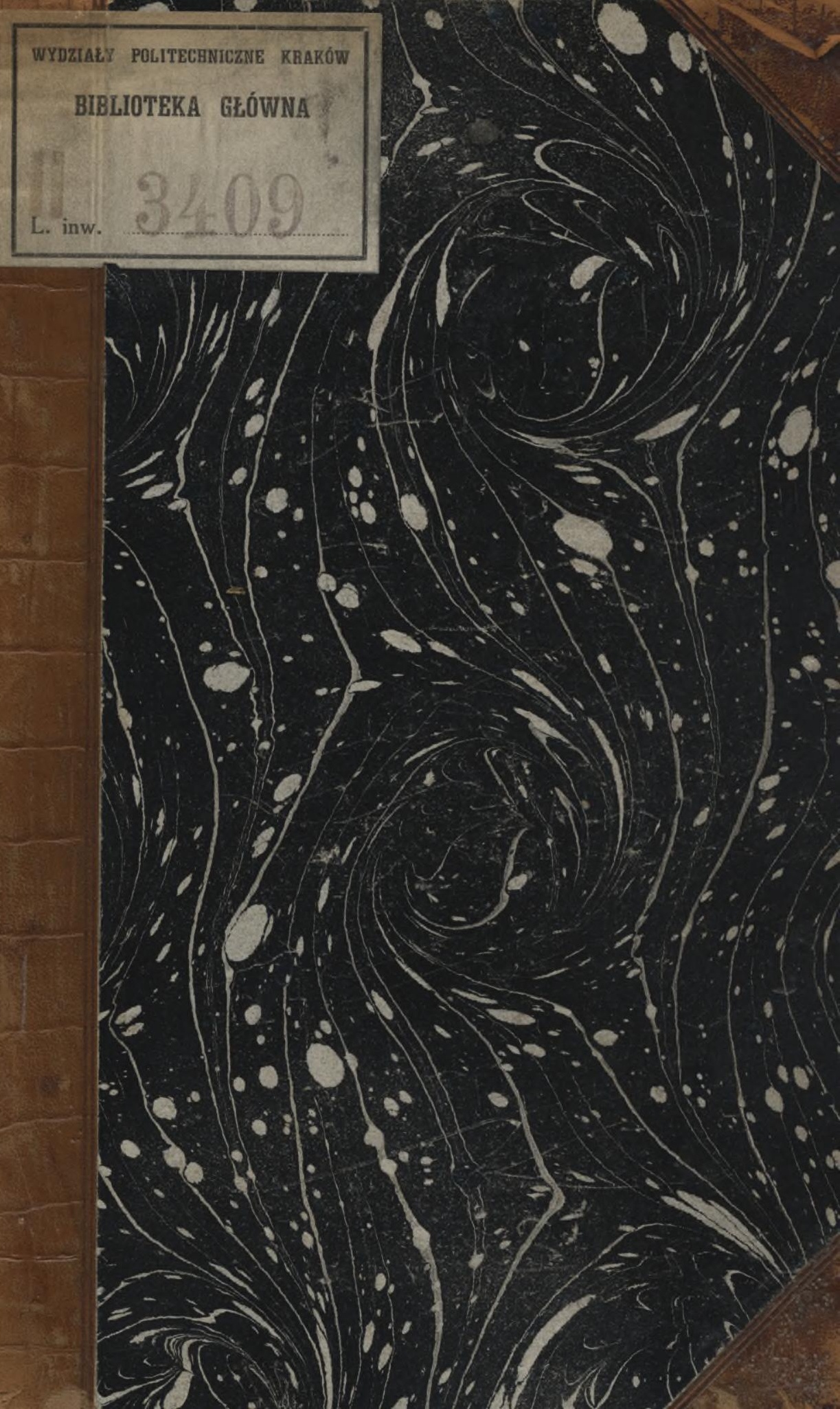




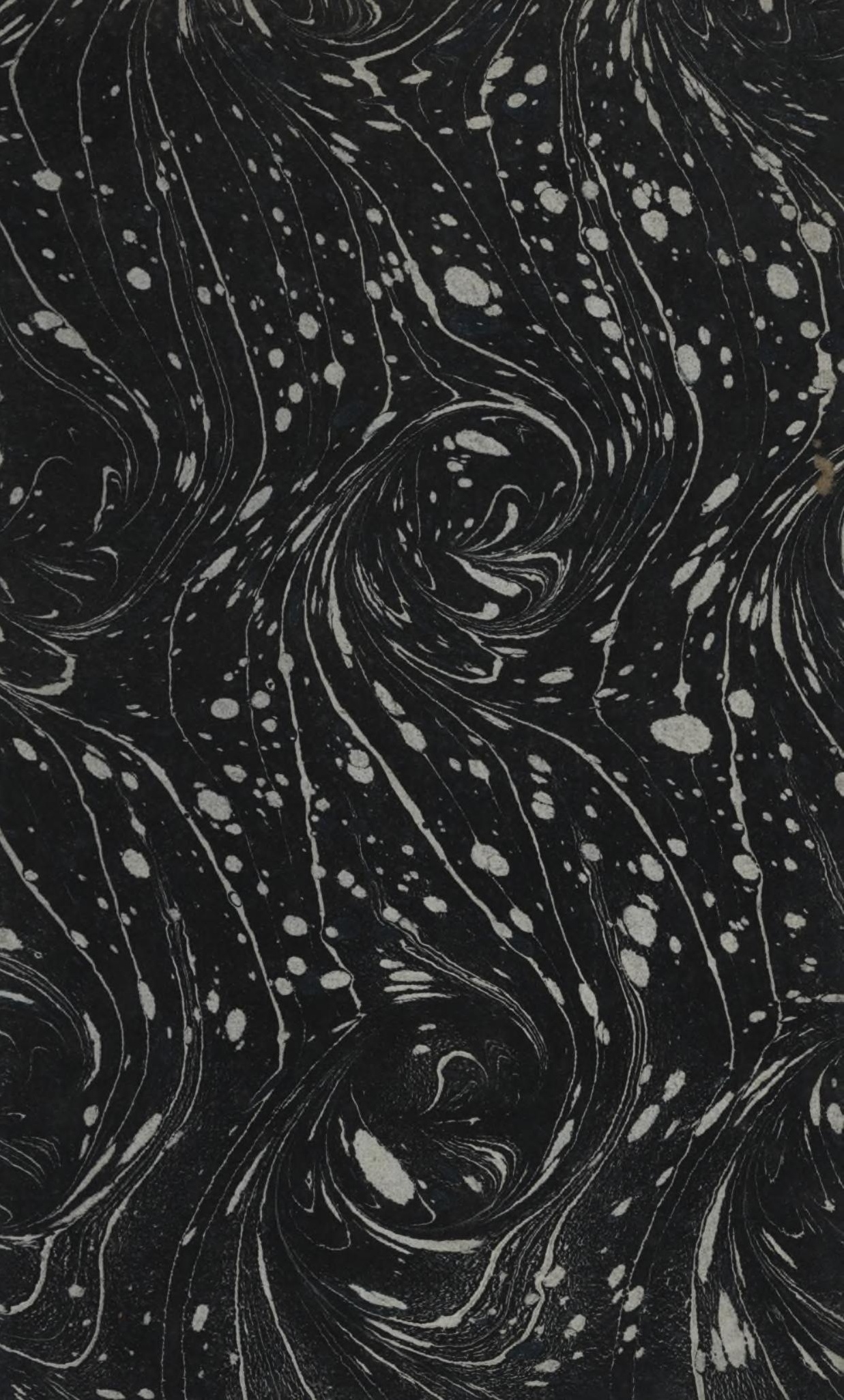





\title{
GRUNDZÜGE
}

DER

\section{PHYSISCHEN ERDKUNDE}

\author{
VON
}

\section{DR. ALEXANDER SUPAN}

- PROFESSOR DER GEOGRAPHIE AN DER UNIVERSITÄt BRESLAU

FÜNFTE, UMGEARBEITETE UND VERBESSERTE AUFLAGE

MIT 270 ABBILDUNGEN IM TEXT UND ZWANZIG KARTEN IN FARBENDRUCK

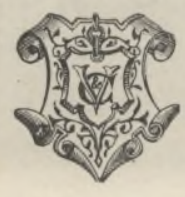

LEIPZIG

VERLAG VON VEIT \& COMP. 
Alle Rechte vorbehalten.

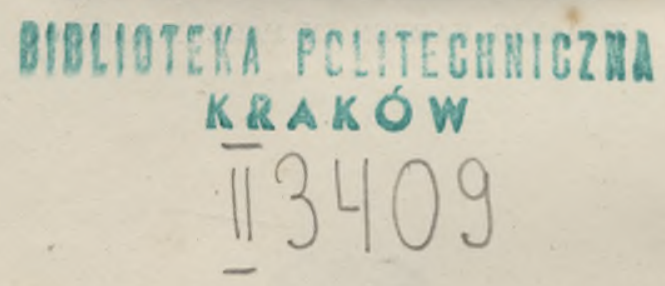

Druck von Metzger \& Wittig in Leipzig.

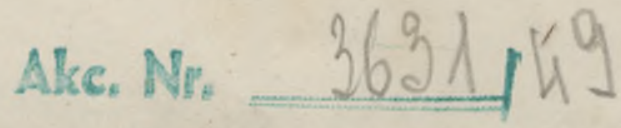




\section{Vorwort.}

Wenn auch seit dem Erscheinen der vierten Auflage erst wenige Jahre verflossen sind, so machte sich mir doch das Bedürfnis nach Umarbeitung dieser und jener Abschnitte immer mehr fühlbar. Zur akademischen Lehrtätigkeit zurückgekehrt, erfuhr ich an mir von neuem die Wahrheit des Satzes „docendo discimus“. Anordnung und Gliederung des Stoffes schienen mir hier und da eine Umgestaltung zu fordern, und manchen Problemen mußte nähergetreten werden. $\mathrm{DaB}$ es dabei ohne eine Vermehrung des Textes nicht abging, muß ich zu meinem Bedauern gestehen, aber bis auf zwei Druckbogen, die hinzugekommen sind, gelang es doch, das Mehr auf der einen Seite durch eine gedrängtere Fassung auf der anderen Seite auszugleichen. Daß der Erosionsfrage und der Peneplaintheorie besondere Aufmerksamkeit geschenkt wurde, liegt in den Zeitumständen begründet.

Von den Karten wurde die der Niveauveränderungen beseitigt, denn ich bin immer mehr zur Überzeugung gelangt, daß dieser Fragenkomplex zu einer kartographischen Darstellung, besonders im kleinen Maßstab, noch nicht reif ist. Dafür wurden die thermischen Isanomalen, die uns den Schlüssel zum Verständnis der mittleren Isobaren liefern, für Januar und Juli besonders gegeben.

Zu großem Dank bin ich meinem Herrn Kollegen KRÜмmeL dafür verpflichtet, daß er die Güte hatte, mir die Bogen des zweiten 
Bandes seines grundlegenden Handbuches der Ozeanographie noch während der Drucklegung mitzuteilen, denn nur dadurch wurde es mir ermöglicht, den Abschnitt über das Meer dem neuesten Stand der Wissenschaft entsprechend umzugestalten. Wärmster Dank gebührt auch meinem Herrn Kollegen Vouz, der mit unermüdlichem Eifer die Korrektur besorgte und mir dabei manche wertvolle Fingerzeige gab, und endlich sei auch der Verlagsbuchhandlung der Dank für ihr stets gleichbleibendes opferwilliges und verständnisvolles Entgegenkommen öffentlich ausgesprochen.

Breslau, den 31. Juli 1911.

A. Supan. 


\section{In halt.}

\section{Erster Abschnitt. Der Erdkörper und die Grundzïge seiner Oberflächengestaltung.}

Die Gestalt und Größe der Erde. S. 1. Entwicklung der Erde. S. 2. - Gestalt der Erde. S. 4. - Dimensionen der Erde. S. 6. - Flächenberechnung. S. 7. Literaturnachweise S. 7.

Die Teile des Erdkörpers. S. 8. Der Erdkern. S. 8. - Die Erdkruste. S. 15. Literaturnachweise S. 17.

Die Energiequellen. S. 18 Die Wirkungen der unterirdischen Kräfte. S. 18. Die solaren Wirkungen. S. 19. - Die Anziehung von Sonne und Mond. S. 21. - Die Rotation der Erde. S. 22. - Literaturnachweise S. 23.

Geschichte der Erde. S. 24. Literaturnachweise S. 28.

Die Grundzüge der Gestaltung der Erdoberfläche. S. 28. Verhältnis von Wasser und Land. S. 28. - Einteilung des Ozeans. S. 32. - Einteilung des Festlandes. S. 34. - Oberflächengestaltung des Festlandes. S. 36. - Das Gestaltungsgesetz. S. 42. - Vertikaler Aufbau der Erdkruste. S. 45. - Mittlere Höhen und Tiefen. S. 47. - Literaturnachweise S. 51.

\section{Zweiter Abschnitt. Die Lufthülle.}

Allgemeine Vorbemerkungen. S. 53. Die Schwankungen. S. 53. - Höhe der Lufthülle. S. 54. - Zusammensetzung der Luft. S. 54. - Literaturnachweise S. 56 .

Die Erleuchtung und Erwärmung der Erdoberfläche. S. 56. Wärmequellen. S. 56. Die Bestrahlungsgesetze. S. 57. - Das Grundgesetz des solaren Klimas. S. 60. - Einfluß der Lufthülle. S. 62. - Verteilung der Wärmemengen. S. 63. - Dauer des Sonnenseheins. S. 64. - Das Polarlicht. S. 65. Literaturnachweise S. 69.

Die Änderung der Temperatur mit der Höhe. S. 69. Wärmequellen der oberen Luftschichten. S. 69. - Freie Atmosphäre. S. 70. - Gebirge. S. 75. - Thermische Verschiedenheiten des Höhenklimas. S. 79. - Plateaus. S. 81. Reduktion der Temperatur auf das Meeresniveau. S. 82. - Literaturnachweise S. 83.

Die horizontale Verteilung der Temperatur. S. 84. Normale Temperaturverteilung. S. 85. - Abweichungen. S. 86. - Temperaturverteilung in den extremen Monaten. S. 90. - Durchschnittstemperatur der Parallelkreise, Meridiane, Erdteile und Meere. S. 94. - Isanomalen. S. 97. - Temperaturzonen. S. 98. - Literaturnachweise S. 102. 
Die Schwankungen und die mittlere Veränderlichkeit und Abweichung der Temperatur. S. 103. Die tägliche Temperaturschwankung. S. 103. - Die jährliche Temperaturschwankung. S. 106. - Temperaturveränderlichkeit. S. 110. Mittlere Abweichung. S. 113. - Literaturnachweise S. 114.

Windsysteme und Windgebiete. S. 114. Windgesetze. S. 114. - Antizyklonen. S. 117. - Zyklonen. S. 118. - Passate. S. 123. - Allgemeine Luftzirkulation. S. 125. - Literaturnachweise S. 129.

Luftdruck und Windverteilung in den extremen Jahreszeiten. S. 129. Die Isobarenkarten. S. 129. - Die südliche subtropische Hochdruckzone und das subantarktische Windsystem. S. 130, - Das Passatgebiet und die nördliche Halbkugel im nördlichen Winter. S. 131. - Das Passatgebiet und die nördliche Halbkugel im nördlichen Sommer. S. 135. - Mittlere monatliche Barometersehwankungen. S. 138. - Die periodischen Luftmassenverschiebungen und die Breitenschwankungen. S. 139. - Literaturnachweise S. 140.

Lokale Winde. S. 140. Lokale Windsysteme. S. 140. - EinfluB lokaler Verhältnisse auf die Winde. S. 142. - Literaturnachweise S. 146.

Der Wasserdampf in der Atmosphäre und die Ursachen seiner Kondensation. S. 147. Verschiedene Maße der Luftfeuchtigkeit. S. 147. - Die Winde als Verbreiter des Wasserdampfes. S. 150. - Kondensátion des Wasserdampfes. S. 150. Literaturnachweise S. 153.

Die Verteilung der jährlichen Niederschlagsmengen. S. 153. Gesetze der Verbreitung der Niederschläge. S. 153. - Die warme Zone. S. 161. - Der regenarme Gürtel. S. 163. - Die gemäBigten Zonen. S. 164. - Mittlere Regenwahrscheinlichkeit. S. 167. - Literaturnachweise S. 169.

Die jahreszeitliche Verteilung der Niederschläge. S. 170. Winter- und Sommerregen. S. 170. - Die jährliche Niederschlagssehwankung. S. 172. - Die gemäBigten Zonen. S. 173. - Die subtropischen Regengebiete. S. 174. Tropenzone. S. 176. - Schwankungen des Regenfalls. S. 179. - Gewitter. S. 179. - Hagel. S. 180. - Literaturnachweise S. 181.

Verbreitung des Schnees. S. 181. Verbreitung. S. 181. - Die Schneegrenze. S. 183. - Verteilung der Schneegrenze. S. 188. - Literaturnachweise S. 190.

Gletscher. S. 191. Begriff und Einteilung der Gletscher. S. 192. - Die Gletscherzunge. S. 194. - Das Leben des Gletschers. S. 196. - Gletschertheorie und Gletscherstruktur. S. 200. - Theorie des stationären Gletschers. S. 207. - Moränen. S. 209. - Gletscherschwankungen. S. 213. - Literaturnachweise S. 217.

Die geographische Verteilung der Gletscher. S. 218. Die Tropen, S. 218. - GemäBigte Zonen. S. 221. - Polare Zonen. S. 225. - Eisberge. S. 228. - Literaturnachweise S. 230.

Das Klima. S. 230. Klimaprovinzen. S. 230. - Die 35jährigen Schwankungen. S. 234. - Säkulare Perioden. S. 240. - Geologische Perioden. S. 242. Klimaänderungen. S. 251. - Einfluß des Waldes. S. 254. - Literaturnachweise S. 255.

\section{Dritter Abschnitt. Das Meer.}

Morphologie des Meeres. S. 258. Gliederung des Weltmeeres. S. 258. - Unterseeische Bodenformen. S. 261. - Vertikalgliederung des Weltmeeres. S. 266. - Bedeckung des Meeresbodens. S. 270. - Literaturnachweise S. 275.

Das Meerwasser. S. 277. Das Meeresniveau. S. 277. - Salzgehalt und spezifisches Gewicht. S. 282. - Gasgehalt. S. 287. - Farbe. S. 287. - Literaturnachweise S. 290. 
Die Wellenbewegung. S. 291. Windwellen. S. 291. - Brandung. S. 295. - Benthonische Wellen. S. 297. - Stehende Wellen. S. 299. - Interne Wellen. S. 300. - Literaturnachweise S. 301.

Die Gezeiten. S. 302. Theoretische Gezeiten. S. 302. - Wirkliche Gezeiten. S. 307. - Wellentheorien. S. 310. - Die harmonische Analyse. S. 315. Gezeitenströme. S. 316. - Differentialtiden. S. 316. - Literaturnachweise S. 317.

Die Meeresströmungen. S. 317. Bedingungen. S. 317. - Ozeanische Strömungen. S. 319. - Theorie. S. 321. - Nordatlantischer Ozean. S. 327. - Die übrigen Ozeane. S. 334. - Das Auftriebwasser. S. 335: - Literaturnachweise S. 337 .

Die Temperaturverteilung im Wasser. S. 339. Die Oberflächentemperatur des Meeres. S. 339. - Tiefentemperatur in Süßwasserseen. S. 341. - Tiefentemperaturen im Salzwasser. S. 346. - Ozeane. S. 348. - Die Polarmeere. S. 354. Das Meereis. S. 358. - Literaturnachweise S. 363.

\section{Vierter Abschnitt. Dynamik des Landes.}

Die Hauptformen der Dislokationen. S. 365. Theorien. S. 368. - Literaturnachweise S. 375.

Die vulkanischen Ausbrüche. S. 376. Eruptionsprodukte. S. 377.-Die vulkanischen Ausbrüche. S. 379. - Überblick der Vulkanformen. S. 389. - StüBEL's Einteilung. S. 390. - Erlösehen der Vulkane. S. 392. - Geographische Verbreitung der Vulkane. S. 394. - Theorie des Vulkanismus. S. 401. Schlammsprudel. S. 407. - Literaturnachweise S. 410.

Erdbeben. S. 412. Bodenbewegungen. S. 412. - Die seismischen Wellen. S. 413. - Die Teile des seismischen Feldes. S. 418. - Dauer. S. 421. - Intensität und Wirkungen. S. 422. - Areal. S. 425. - Ursachen. S. 427. - Einteilung der Beben. S. 434, - Periodizität. S. 434. - Literaturnachweise S. 437.

Moderne Niveauveränderungen. S. 438. Einteilung. S. 438. - Litorale Niveauveränderungen. S. 439. - Theorien. S. 441. - Skandinavien. S. 443. - Höhere arktische Breiten. S. 451. - Die angebliche Meeresverschiebung zwischen Pol uud Äquator. S. 453. - Mittelmeerländer. S. 456. - Binnenländische Niveauveränderungen. S. 459. - Schlußfolgerungen. S. 462. - Literaturnachweise S. 463.

Ubersicht der exogenen Wirkungen. S. 466.

Die Verwitterung. S. 470. Der VerwitterungsprozeB. S. 470. - Bodenarten. S. 474. - Gebiete vorherrschender Denudation. S. 475. - Gebiete säkularer Verwitterung. S. 481. - Literaturnåchweise S. 483.

Das Bodenwasser. S. 484. Der Kreislauf des Wassers. S. 484. - Das Grundund Schichtwasser und ihre Quellen. S. 485, - Das Kluftwasser und seine Quellen. S. 489. - Einteilung der Quellen. S. 493. - Geysir. S. 495. Literaturnachweise S. 498.

Das fließende Wasser. S. 498. Wassermenge. S. 498. - Bewegung des Wassers. S. 506. - Die Arbeit der Flüsse. S. 510. - Flußablagerungen. S. 511. Literaturnachweise S. 516.

Die Erosionsarbeit des fließenden Wassers. S. 517. Das Wesen der Erosionsarbeit. S. 517. - Der Typus des Erosionstales. S. 518. - UngleichmäBige Erosion. S. 520. - Moderne Talbildung. S. 522. - Klammen und Cañons. S. 524. - Variation des Erosionstypus. S. 527. - Der geographische Zyklus. S. 530. - Das Karstphänomen. S. 533. - Genetische Einteilung der Täler. S. 541. - Terminologie von W. M. Davis. S. 545. - Literaturnachweise S. 546 . 
Die Frage der Gletschererosion. S. 547. Ansichten darüber. S. 547. - Kare. S. 551. - Die Talformen. S. 553. - Talterrassen. S. 558. - Ergebnis. S. 562. Literaturnachweise S. 563.

Deltabildungen. S. 564. Mündungsformen der Flüsse. S. 564. - Bau, Gestalt und Oberflächenform der Deltas. S. 566. - Wachstum der Deltas. S. 568. Geographische Verbreitung der Deltas. S. 569. - Literaturnachweise S. 571.

Die Arbeit des Windes. S. 571. Winderosion. S. 571. - Äolische Sandablagerungen, S. 575. - Dünen. S. 576. - Staubablagerungen. S. 580. - Literaturnachweise S. 582.

Die Arbeit des Meeres. S. 583. Begriff der Küste. S. 583. - Charakter der Küste. S. 584. - Die Brandung. S. 585. - Steilküsten. S. 586. - Zerstörung der Flachküsten. S. 592. - Erosion durch Gezeitenströmungen. S. 594, - Anschwemmung. S. 595. - Literaturnachweise S. 599.

Die geographische Verbreitung der exogenen Wirkungen. S. 600. Bodentypen. S. 600.Faciesgebiete. S. 605. - Gebirgsfacies. S. 608. - Literaturnachweise S. 610.

\section{Fünfter Absehnitt. Morphologie des Landes.}

Ubersicht. S. 611. Orographisches System. S. 612. - Hypsometrische Systeme. S. 613. - Hypsometrie. S. 614, - Orometrie. S. 617. - Genetisches System. S. 617. - Literaturnachweise S. 619.

Die Oberflächenformen der Flachschichtung. S. 619. Das Tafelland. S. 619. - Ausgefüllte Landsenken. S. 622. - Peripherische Flachböden jugendlichen Alters. S. 626. - Ergebnis. S. 629. - Umformung durch Destruktion (Destruktionsformen). S. 629. - Umformung durch Bruch (Frakturformen). S. 638. - Übersicht der Umwandlungsformen der Flachschichtung. S. 642. - Literaturnachweise S. 643.

Faltengebirge. S. 645. Terminologie. S. 645. - Faltenzonen und Geosynklinalen. S. 652. - Tangentialkraft. S. 654. - Der Faltungsvorgang. S. 655. - Nachträgliche (postume) Bodenbewegungen. S. 656. - Literaturnachweise S. 657.

Haupttypen der Faltengebirge. S. 658. Sattelgebirge oder Monoantiklinalen. S. 658. - Querprofil einfacher Faltengebirge. S. 660. - Querprofil zusammengesetzter Gebirge. S. 662. - Längserstreckung. S. 670. - Beziehungen der Faltengebirge zueinander. Ihre Abgrenzung und Einteilung. S. 672. Beziehungen der Kettengebirge zum ungefalteten Vorland, S. 675. - Literaturnachweise S. 676 .

Umformung der Faltengebirge. S. 678. Leitsatz. S. 678. - Umformung dureh Bruch. S. 679. - Umformung durch Destruktion. Landstufen. S. 681. - Rumpfflächen. S. 682. - Rumpfgebirge. S. 685. - Rumpfschollengebirge. S. 693. - Genetische Einteilung des Faltenlandes. S. 700. - Literaturnachweise S. 702 .

Vulkanische Berge. S. 703. Einteilung. S. 704. - Aufgesetzte Stratovulkanberge. S. 706. - Aufgesetzte homogene Vulkane. S. 709. - Einfluß der Lage der Eruptionsstellen. S. 709. - Umwandlung durch Destruktion und aufgedeckte Vulkanberge. S. 710. - Literaturnachweise S. 712.

Gliederung der Gebirge. S. 713. Alter und Anordnung der Täler. S. 713. - Längsund Quertäler. S. 714. - Wasserseheide. S. 718. - Durchgangstäler. S. 719. - Talwasserscheiden. S. 725. - AufschlieBung der Gebirge. S. 729. Literaturnachweise S. 730.

Die Flüsse. S. 731. Einteilung. S. 731. - Verteilung der Flüsse. S. 732. - Flußvermischung und Wasserteilung. S. 735. - Bau der Flubsysteme. S. 736. Größe der Flüsse. S. 738. - Veränderungen der Flüsse. S. 739. - Literaturnachweise S. 745 . 
Die Seen. S. 745. Hauptkategorien. Mündungsseen. S. 745. - Beckenformen. S. 746. - Dimensionen der Seebecken. Depressionen. S.751. - Seengebiete. S. 753, - Süß- und Salzwasserseen. S. 758. - Erlöschen der Seen. S. 760. Sumpf und Moor. S. 762. - Literaturnachweise S. 764.

Die horizontale Gliederung des Festlandes. S. 765. Die Halbinseln. S. 765. - Inseln. S. 769. - Genetische Einteilung. S. 769. - Kontinentalinseln. S. 771. Ursprüngliche Inseln. S. 773. - Koralleninseln. S. 774. - Theorie der Korallenriffe. S. 779. - Flora und Fauna der Kontinentalinseln. S. 784. Flora und Fauna der ursprünglichen Inseln. S. 788. - Literaturnachweise S. 791.

Küstenformen. S. 792. Haupttypen. S. 792. - Detailformen. S. 794. - Talbuchten. S. 796. - Natürliche Seehäfen und Meeresstraßen. S. 804. - Küstenentwicklung und mittlerer Küstenabstand. S. 806. - Literaturnachweise S. 809 .

\section{Sechster Abschnitt. Die Pflanzendecke und die geographische Verbreitung der Tiere.}

Die geographischen Bedingungen des Pflanzenlebens. S. 810. Abhängigkeit vom Klima. S. 810. - Abhängigkeit vom Boden. S. 813. - Pflanzenformationen. S. 815. - Literaturnachweise S. 817.

Die Hauptzonen und Hauptregionen der Vegetation. S. 817. Tropische Pflanzenzone. S. 817. - GemäBigte Zone. S. 822. - Polare Waldgrenzen. S. 824. - Polare Pflanzenzone. S. 826. - Pflanzenregionen. S. 827. - Literaturnachweise S. 833.

Die wichtigsten Vegetationsformationen innerhalb der Waldgrenzen. S. 833. Tropenwald. S. 834. - Der Wald mittlerer und höherer Breiten. S. 837. - Buschland. S. 839. - Savane. S. 842. - Wiesen und Weiden. S. 844. - Grassteppen. S. 844. - Wüstensteppen und Wüsten. S. 846. - Ausdehnung der Formationen. S. 849 . - Literaturnachweise S. 850.

Die Nutzpflanzen. S. 850. Zerealien. S. 851. - Andere Kulturpflanzen. S. 854. Literaturnachweise S. 857.

Die Lebensbedingungen der Tierwelt. S. 857. Beziehungen zwischen der Tier- und der Pflanzenwelt. S. 858. - Färbung. S. 860. - Abhängigkeit der Tiere vom Klimu. S. 861. - Tropische Tierwelt. S. 863. - Polare Tierwelt. S. 864. - Vertikale Verteilung. S. 865. - Periodizität im Tierleben. S. 866. - Beziehungen der Tiere zueinander und zu dem Mensehen. S. 867. - Literaturnachweise S. 868.

Die Flora und Fauna der Tropen und der südlichen Halbkugel. S. 868. Verbreitungstypen. S. 868. - Die Tropen der Alten und der Neuen Welt. S. 872. Provinzielle Unterschiede in den tropischen Reichen. S. 875. - Die alten Kontinentalinseln. S. 876. - Australien. S. 877. - Der malaiische Archipel und Polynesien. S. 879. - Das Problem der südhemisphärischen Kontinentalzusammenhänge. S. 883. - Literaturnachweise S. 886.

Flora und Fauna der mittleren und höheren Breiten der Nordhalbkugel. S. 888. Klimaänderung. S. 888. - Die südlichen Übergangsgebiete. S. 888. - Zentralasien. S. 891. - Die holoarktische Zone. S. 891. - Rückblick auf die Theorie der Landbrücken. S. 894. - Hochgebirge. S. 897. - Veränderungen in der Jetztzeit. S. 900. - Literaturnachweise S. 904.

Die pflanzen- und tiergeographischen Einteilungen der festen Erdoberfläche. S. 905. Literaturnachweise S. 909.

Register S. 910.

Berichtigungen S. 970 . 


\title{
Verzeichnis der Kartenbeilagen.
}

\author{
Tafel I. Höhen und Tiefen der Erde. \\ II. Die morphologische Dreiteilung des Landes. \\ III. Jahres-Isothermen. \\ IV. Januar-Isothermen. \\ V. Juli-Isothermen. \\ VI. Isanomalen der Lufttemperatur im Januar. \\ VII. Isanomalen der Lufttemperatur im Juli. \\ VIII. Die Temperaturzonen der Erde. \\ IX. Linien gleicher jährlicher Temperaturschwankung. \\ $\mathrm{X}$. Isobaren und Winde im Winter. \\ XI. Isobaren und Winde im Sommer. \\ XII. Jährliche Niederschlagsmengen. \\ $" \quad$ XII. Jährliche Niederschlagsmengen.
$" \quad$ XIII. Jahreszeitliche Verteilung der Niederschläge. \\ $" \quad$ XIV. Verbreitung der Gletscher und des Treibeises. \\ " XV. Die Klimaprovinzen. \\ " XVI. Die Oberflächenströmungen des Meeres. \\ " XVII. Korallenbauten, Vulkane und Erdbeben. \\ $"$ XVIII. Vegetationskarte. \\ " XIX. Die Florenreiche. \\ " XX. Faunengruppen und reiche.
}




\section{Erster Abschnitt.}

\section{Der Erdkörper und die Grundzüge seiner Oberflächengestaltung.}

\section{Die Gestalt und Größe der Erde.}

Die einfache Naturanschauung betrachtet die Erde als ruhenden Körper, den die Sonne in kreisförmiger Bahn umwandelt. Der alexandrinische Gelehrte PтоцемӓUs gab dieser Anschauung zuerst einen wissenschaftlichen Ausdruck und schuf damit ein Weltsystem, das bis zum Anfang der Neuzeit seine Geltung bewahrt hat. Er machte die Erde zum Zentrum des Weltalls, und die von der Theologie beherrschte Wissenschaft des Mittelalters fand in diesem System eine Bestätigung ihres Grundsatzes, daß der Mensch der Mittelpunkt und Zweck der Schöpfung sei. Erst Copernicus verbannte die Erde aus ihrer usurpierten Stellung und wies ihr einen bescheideneren Platz im Sonnensystem an. Die Erde ist ein Planet, der sich in 24 Stunden einmal um seine Achse und, vom Monde begleitet, in einem Jahr einmal um die Sonne bewegt, von der er Licht und Wärme empfängt.

Die Fortschritte in der Erforschung des Erdkörpers, seines organischen Lebens und seiner Entwicklung hatten eine gänzliche Umwandlung der Weltanschauung im Gefolge. Wir sehen in der Natur nicht mehr eine Aufeinanderfolge wunderbarer Schöpfungstaten, die jede Form fertig und unabänderlich aus dem Nichts oder aus dem Chaos hervorriefen, sondern einen nach ewigen Gesetzen wirkenden Mechanismus, in dem die Formen in beständiger Umwandlung begriffen sind. An diesem Grundgedanken der Entwicklung müssen wir festhalten, wenn auch der Streit über das Wie der Entwicklung wohl noch lange, vielleicht für immer, ungeschlichtet bleiben wird. Welche Bedeutung wir aber auch den verschiedenen Entwicklungshypothesen zuerkennen mögen, so unter- 
liegt es doch keinem Zweifel, daß sie unendlich befruchtend auf die Wissenschaft gewirkt haben. Wenn wir annehmen, daß jede Form durch einen unerforschlichen und uns daher willkürlich erscheinenden Schöpfungsakt entstanden ist, dann bleibt uns am Ende nichts übrig, als diese Formen zu beschreiben und zu klassifizieren; nehmen wir aber an, daß sich alles auf natürlichem Wege entwickelt hat, so können wir diesem Prozeß nachspüren. Die Naturwissenschaft schreitet von der Systematik zur Genetik fort, und damit erwachsen auch der Geographie ganz andere Aufgaben, als sie früher zu lösen hatte.

Entwicklung der Erde. ${ }^{1}$ Die von Laplace entwickelte Nebulartheorie verknüpft auch die einzelnen Teile unseres Sonnensystems genetisch miteinander. Alle seine Körper bildeten einst einen großen kugelförmigen, rotierenden Nebelfleck, dessen hohe Temperatur spätere Forscher entweder auf den Zusammenstoß dunkler Massen oder (nach FrIEDEL ${ }^{2}$ ) auf die Vereinigung der Elektronen zu Atomen zurückführten. Indem er sich infolge der Abkühlung im kalten Weltenraum zusammenzog, erhöhte sich die Rotationsgeschwindigkeit, die Abplattung an den Polen und die Ausbauchung am Äquator wurden immer größer, und so lösten sich mit der Zeit am Äquator Teile los, die einen Ring bildeten. Dieser zerriß infolge ungleicher Beschaffenheit und Erkaltung und veranlaBte so die Entstehung planetarischer Nebelballen. Derselbe ProzeB wiederholte sich auch hier: erst Ringbildung, wie sie noch am Saturn beobachtet werden kann, $\times$ dann Zerreißung des Ringes und Bildung der Monde. So erscheinen nach dieser geistvollen Hypothese alle Glieder des Sonnensystems als eine große Familie, deren Mutter die Sonne ist, wie sie auch noch jetzt alles Leben auf der Erde ernährt und erhält.

Durch fortgesetzte Abkühlung und Zusammenziehung wurde die Erde aus einem glühenden Nebelball ein glühendflüssiger Körper, der sich endlich mit einer Erstarrungskruste umhüllte. Nach einer anderen Ansicht, die sich darauf stützt, daß der Schmelzpunkt der vulkanischen Laven mit steigendem Drucke hinaufrückt, begann die Verfestigung dort, wo der Druck am gröBten ist, d. h. im Mittelpunkt, und schritt nach außen fort. Die Wasserdämpfe wurden kondensiert und sammelten sich in den Vertiefungen der Erdkruste als Meer an, über das die Erhöhungen als Kontinente emporragen. Der Gegensatz von Land und Wasser ist seit dieser Zeit ein bleibender Charakterzug unseres Planeten, wenn auch die

$\times$ Nach den neuesten Beobachtungen ist der Saturnring kein homogenes Ganzes, sondern ein Aggregat gesonderter kleiner, starrer Massen. 
geographische Verteilung dieser beiden Grundformen dem Wechsel unterworfen ist.

Schon KanT, der Vorgänger von LapLace, hatte angenommen, daß sich die Planeten selbständig aus der in ihre Grundstoffe aufgelösten Materie entwickelten, indem dichtere Elemente dünnere anzogen. Verwandt damit sind die verschiedenen Anhäufungstheorien, sowohl die älteren Meteoritentheorien G. DARwis's und N. Lockyer's, wie die neue Planetesimaltheorie von C. Chamberlin ${ }^{3}$, die die Entstehung der Planeten auf die Anhäufung kleiner kosmischer Massen zurückführen. Die letztere gewinnt, wie es scheint, jetzt immer mehr Boden und darf daher auch an dieser Stelle nicht übergangen werden. Sie leitet unser Sonnensystem von einem Spiralnebel ab, den sie sich aus unzähligen kleinen Körperchen (Planetesimals) gebildet denkt. Diese drehen sich um eine zentrale Gasmasse ebenso, wie es die Planeten tun. Das Vorhandensein von Knoten zeigt an, daß die Nebelmasse nicht gleichartig verteilt ist. Aus der Zentralmasse entstand die Sonne, die Knoten waren die Embryonen der Planeten, die übrige Nebelmasse wurde teils von der Sonne, teils von den. Knoten absorbiert, die sich dadurch zu Planeten entwickelten. Daraus ergeben sich nach FAIRCHILD ${ }^{4}$ folgende wichtige Unterschiede zwischen der Planetesimal- (P-Th.) und der Nebulartheorie (N-Th.): 1. Nach der N-Th. hat die Erde von ihrem ehemaligen Zustand Wärme zurückbehalten, während nach der P-Th. schon die kleinen kosmischen Urkörper ihre Wärme verloren haben. Die Erde war an ihrer Oberfläche immer kalt, und ihre innere Wärme ist eine Folge der Verdichtung, der Zusammenballung der kosmischen Massen, wobei sich ihre Bewegung in Wärme umsetzte. 2. Nach der N-Th. hat die Erde durch Abkühlung stetig an Umfang abgenommen, nach der P-Th. hat sie sich zuerst stetig durch Anhäufung von Planetesimals vergrößert, dann aber durch Zusammensackung der Massen wieder verkleinert. 3. Nach der N-Th. schieden sich die flüchtigen Stoffe der Erdmasse als Wasser und Luft aus, nach der P-Th. waren Luft und Wasser ursprüngliche Bestandteile der Planetesimals, und die gegenwärtige Luft- und Wasserhülle wurde durch Hitze und Druck aus dem Innern der Erde herausgepreßt.

Die beglaubigte Erdgeschichte beginnt erst spät; nur soweit uns ihre Zeugnisse in den aufeinander folgenden Gesteinsschichten, in deren vielfachen Störungen und in den begrabenen Lebewesen noch erhalten sind, stehen wir auf sicherem Boden. Aber auch hier hat sich eine richtige Deutung erst allmählich herausgearbeitet. Zwar konnten es sich auch die älteren Geologen nicht verhehlen, 
daß der Erdkörper und sein organisches Leben verschiedene Stadien durchlaufen haben, aber sie meinten noch, daß die einzelnen Perioden der Erdgeschichte durch allgemeine Katastrophen, die das Bestehende vernichteten, und ebenso viele Neuschöpfungen voneinander getrennt seien. Dagegen lehrten HoFF ${ }^{5}$ und LxelL ${ }^{6}$, daB sich die Veränderungen der Erdoberfläche allmählich vollzogen haben, in derselben Weise, wie wir sie auch in der geologischen Gegenwart beobachten, und durch dieselben Kräfte, die noch jetzt tätig sind, wenn auch zugegeben werden mag, daß die Kraftäußerungen in früheren Epochen eine größere Intensität besaßen. LAMARCK und Charles Darwin ${ }^{7}$ wendeten diese Theorie auch auf die organische Welt an, die, von niederen zu höheren Formen fortschreitend, endlich im Menschen gipfelt. Es mag aber dahingestellt bleiben, ob sich der Entwicklungsprozeß gleichmäßig oder sprungweise abspielte, d. h. ob Perioden erhöhter Tätigkeit - sogen. „kritische Perioden“, wie Le Conte $^{8}$ sie nannte - mit relativen Ruhepausen wechselten, Perioden, die sich auch in der Umgestaltung der organischen Welt widerspiegeln.

Gestalt der Erde. ${ }^{9}$ Als ein sicheres Zeugnis für die einst flüssige Beschaffenheit des Erdkörpers wird dessen Gestalt angesehen, aber mit Unrecht, denn jeder rotierende kugelförmige Körper, der nicht absolut starr ist, muß sich an den Enden der Rotationsachse, d. h. an den Polen abplatten und am Äquator ausbauchen: mit anderen Worten: die Kugel muß sich zu einem Ellipsoid umgestalten. Die ellipsoidische Gestalt der Erde ist direkt durch Pendelbeobachtungen und Gradmessungen erweisbar, indirekt auch auf astronomischem Wege.

Die Pendelbeobachtungen ergaben, daß die Länge des Sekundenpendels (d. h. eines Pendels, das in einer Sekunde eine Schwingung ausführt) vom Äquator nach den Polen zunimmt.× Diese Tatsache kann ihre Erklärung nur darin finden, daß die Schwerkraft an den Polen am größten, am Äquator am kleinsten ist. Der Grund hierfür ist doppelt. Einerseits erreicht die Fliehkraft, die der

$\times$ Zur Illustration dieses Gesetzes greifen wir aus Hecmert's Tabelle einige Stationen in Abständen von ungefähr $10^{\circ} \mathrm{B}$, heraus:

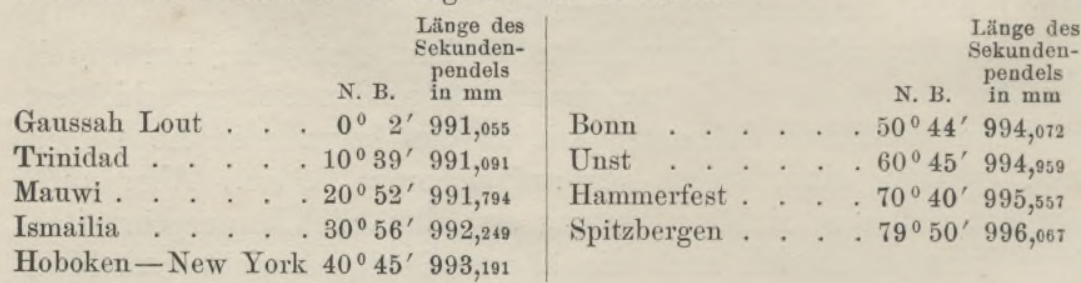


Schwerkraft direkt entgegenwirkt, am Äquator ihren größten Wert während sie an den Polen gleich Null ist; anderseits ist man wegen der Abplattung dem Erdmittelpunkte, dem Sitze der Schwerkraft, an den Polen am nächsten, und am Äquator am weitesten davon entfernt.

Einen noch augenfälligeren Beweis für die Abplattung der Erde liefern die Gradmessungen. In Fig. 1 ist rechts ein halber kreisförmiger, links ein halber elliptischer Meridian dargestellt;

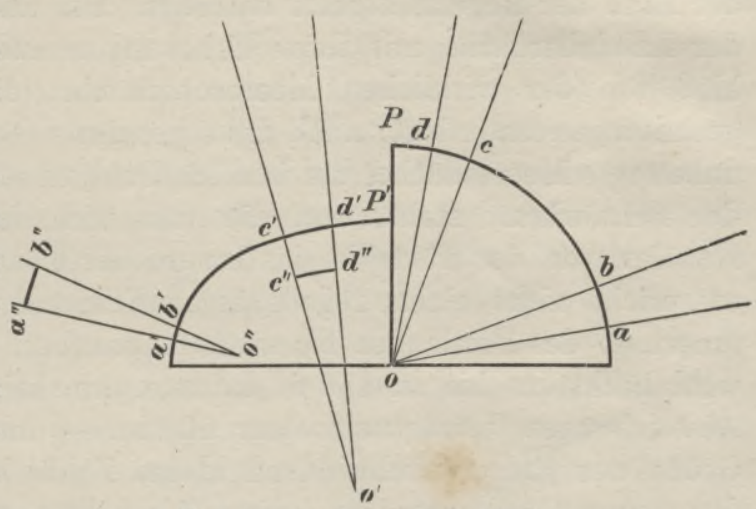

Fig. 1. Abplattung der Erde.

$P$ beziehungsweise $P^{\prime}$ ist der Pol, und die Horizontallinie der Durchschnitt der Äquatorialebene. Wählen wir auf dem Kreisquadranten zwei Paare von Punkten, von denen sich $a$ und $b$ nahe dem Äquator, $c$ und $d$ nahe dem Pole befinden. Die Vertikalen (oder Normalen), die wir in diesen Punkten errichten, sind Halbmesser und schneiden sich daher in $o$; der Winkel $a o b$ ist $=c o d=10^{\circ}$, ebenso ist der Bogen $a b=c d$, oder mit anderen Worten: auf einer Kugel entsprechen gleichen Winkelabständen der Normalen gleiche Meridianbogen.

Anders auf dem Ellipsoid. Die Normalen schneiden sich nicht mehr im Zentrum, die Winkelabstände von $a^{\prime}$ und $b^{\prime}, c^{\prime}$ und $d^{\prime}$ sind zwar gleich $\left(=10^{\circ}\right)$, wovon wir uns sofort überzeugen können, wenn wir mit dem Radius $a o$ von $o^{\prime}$ und $o^{\prime \prime}$ aus Kreise beschreiben (die Bogen $a^{\prime \prime} b^{\prime \prime}=c^{\prime \prime} d^{\prime \prime}=c d=a b$ ); aber die ihnen entsprechenden Meridianbogen sind ungleich $\left(a^{\prime} b^{\prime}<c^{\prime} d^{\prime}\right)$, weil sich die Krümmung der Ellipse gegen den Pol hin verflacht. Auf dem Ellipsoid nimmt also die Länge eines Meridiangrades rom Äquator gegen die Pole zu.

Indem die große französische Gradmessung in der Mitte des 18. Jahrhunderts für die Länge eines Meridiangrades in Lappland $\left(66^{\circ} 20^{\prime}\right.$ N) 111947 , in.Frankreich $\left(49^{\circ} 13^{\prime}\right.$ N) 111212 , auf der Hochfläche von Ecuador $\left(1^{\circ} 31^{\prime}\right.$ S) $110614 \mathrm{~m}$ fand, erbrachte sie den unumstöBlichen Beweis für die ellipsoidische Gestalt der Erde. ${ }^{\times}$Als

$\times$ Diese epochemachende Arbeit wird jetzt durch Gradmessungen in Eeuador und auf Spitzbergen wiederholt. 
aber die folgenden, in verschiedenen Gegenden ausgeführten Gradmessungen und Pendelbeobachtungen verschiedene Werte für die Abplattung ergaben, gelangte man zu der Erkenntnis, daß die Gestalt der Erde der Regelmäßigkeit entbehrt. Und dies gilt nicht bloß von der Landoberfläche mit ihren Erhebungen und Vertiefungen, nicht bloß von der wirklichen Meeresoberfläche, die wechselnden Umgestaltungen unterliegt; auch das sogenannte Geord, d. h. die ideelle, unbewegte Meeresfläche, die in allen Punkten senkrecht zur Richtung der Schwerkraft steht, und die man sich durch ein System von Kanälen von der Küste in das Innere der Kontinente geführt denkt, entspricht nicht einem regelmäBigen Ellipsoid, sondern erhebt sich innerhalb des Festlandes bis zu $50 \mathrm{~m}$ darüber, während es im Ozean wohl höchstens bis zu $150 \mathrm{~m}$ darunter hinabsinkt. Die Summe der Abweichungen beträgt also nur $200 \mathrm{~m}$ - eine in Anbetracht der Größe der Erde verschwindend kleine Zahl. ${ }^{10}$ Es ist die Aufgabe der neuen Gradmessungen, diese Abweichungen in bezug auf verschiedene Teile der Erde festzustellen und zugleich ihre Ursachen zu erforschen.

Dimensionen der Erde. Die nächste praktische Folge dieser Unregelmäßigkeit ist die, daß man, um Dimensionen der Erdoberfläche zu berechnen, ein ideelles Ellipsoid zugrunde legen muß, das sich den Ergebnissen der Grad- und Pendelmessungen möglichst anschmiegt. Unter diesen Berechnungen hat die von Besses, ${ }^{11}$ obgleich sie sich nur auf zehn zuverlässige Gradmessungen stützt, die größte Verbreitung gefunden und kann auch heute noch für geographische Zwecke als ausreichend erachtet werden. Daneben hat sich auch die Berechnung CLARKE's Eingang verschafft. Die Hauptwerte sind folgende:

$$
\begin{array}{lll}
\text { Äquatorialhalbmesser }(a) & =6377,4 & \\
\text { Polarhalbmesser }(b) & =6356,1 & 6378,2 \mathrm{~km} \\
\text { Abplattung }=\frac{a-b}{a} & =\frac{1}{299} & \frac{1}{293} \\
\text { Umfang des Äquators } & =40070 & 40076 \mathrm{~km} \\
\text { Umfang im Meridian } & =40003 & 40007 \mathrm{~km} \\
\text { Oberfläche der Erde } & =509950714 & 510062854 \mathrm{qkm} .
\end{array}
$$

Clarke's Abplattungswert ist zu groß; HeLmert hält $1 /{ }_{296}$ für die oberste Grenze und gelangt an der Hand der neuesten Messungen und Rechnungen zu einem dem BesseL'schen sehr ähnlichen Resultat $(1 / 298,3 \pm 1,1) \cdot{ }^{12}$ Dagegen steht es ziemlich fest, daß der Clarke'sche Wert für $a$ vorzuziehen ist. Die sich daraus ergebenen Veränderungen des Oberflächeninhalts des Erdellipsoides sind so geringfügig, daß wir die runde Zahl von 510 Millionen $q \mathrm{~km}$ beibehalten können. 
Flächenberechnung. ${ }^{13}$ Die Fläche eines Landes kann entweder durch direkte Vermessung oder auf planimetrischem Wege, d. h. auf der Karte mit Hilfe des Planimeters ermittelt werden. Die letztere Methode wird weitaus am häufigsten angewendet, ja für halb oder ganz unzivilisierte Länder ist sie die einzig mögliche. Dabei kommt es in erster Linie darauf an, welche Dimensionen des Ellipsoids der Messung zugrunde gelegt werden, ob z. B. die Bessel'schen, wie es in der Geographischen Anstalt von Justus Perthes in Gotha geschieht, oder die Clakke'schen, die Streibitzkx bei seinen bekannten Flächenberechnungen Europas und des Russischen Reiches angewendet hat. Unter sonst gleichen Umständen $m u B$ für ein und dasselbe Land die Fläche nach CLakke stets größer sein, als die nach Bessec; aber der Unterschied, der sich daraus ergibt, ist in den meisten Fällen geringfügig gegenüber der Unsicherheit der Messung, die durch das mangelhafte Kartenmaterial, den Maßstab der Karte, die Dehnung des Papieres bei verschiedener Feuchtigkeit und die Beschaffenheit des Instrumentes bewirkt wird. Selbst bei Ländern mit so vortrefflichen Karten, wie Frankreich oder Italien sie besitzen, haftet den Flächenzahlen noch ein wahrscheinlicher Fehler von $1 / 2$ bis 1 Prozent des Areals an; und man mag danach ermessen, wie es selbst mit den besten Flächenzahlen dort bestellt ist, wo noch verhältnismäBig wenige Punkte durch gute Breiten- und Längenbestimmungen festgelegt sind, und jede neue größere Forschungsreise Verschiebungen des Kartenbildes zur Folge hat. Solche Länder werden daher meist in kleinerem Maßstab abgebildet, und daraus erwächst wieder ein neuer Fehler, der sich bei sonst größter Sorgfalt bis zu 3Prozent der Fläche steigern kann.

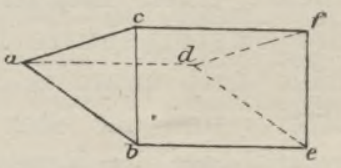

Fig. 2.

Überdies ist auch zwischen der auf die Karte projizierten Fläche und der wahren Oberfläche zu unterscheiden. Dies wird sofort klar aus Fig. 2, die ein schematisches Gebirgsprisma darstellt. Auf der Karte, erscheint nur die Grundfläche $a b d e$ und nur ihr Areal wird ermittelt, die wahre Oberfläche ist aber $a c f d+b c f e$. Dieser Unterschied verschwindet nur auf völlig horizontalen Flächen und nimmt mit dem Böschungswinkel zu, so daß er in Gebirgsländern einen ziemlich hohen Wert erreicht. Für ein Gebirge vom Typus des Böhmerwaldes hat z. B. Beneš ${ }^{14}$ berechnet, daß die wahre Oberfläche um 3,8 Prozent größer ist als die projizierte.

Literaturnachweise. ${ }^{1}$ Svante Arrhenius, Das Werden der Welten; Leipzig 1907. Aьв. GоскеL, Sehöpfungsgeschichtliche Theorien; Köln a. Rh. 1907; gute Übersieht. - ${ }^{2}$ Joh. Friedel in Petermanx's Mitteilungen, 1905, 
S. 43. $-{ }^{3}$ Tн. C. Chamberhin u. R. D. Salisbury, Geology, New York 1906, Bd. II. - ${ }^{4}$ H. L. FatrohlLd im Ameriean Geologist, 1904, Bd. XXXII, S. $94 .-{ }^{5}$ K. E. A. Horf, Geschichte der dureh die Überlieferung nachgewiesenen natürlichen Veränderungen der Erdoberfläehe. Gotha 1822-40. - ${ }^{6}$ Сн. LxкLL, Principles of Geology, London 1830-33. 12. Aufl. 1876. - ${ }^{7}$ Сн. Darwis, The Origin of Species, London 1859. Letzte deutsche Ausgabe von CARus, Stuttgart 1883. - ${ }^{8} \mathrm{~J}$. LE Conte, Critical Periods in the History of the Earth, im Bulletin of the Department of Geology of the University of California, Bd. I, 1895. - ${ }^{9}$ Hauptwerk F. R. Hewsert, Die mathematisehen und physikalisehen Theorien der höheren Geodäsie, Berlin 1880-84. S. Güxther, Handbuch der mathematisehen Geographie, Stuttgart 1890. Der beste Leitfaden für mathematische Geographie, den wir besitzen, ist H.WAGNER's Lehrbuch der Geographie, 8. Aufl. Hannover 1908. - ${ }^{10}$ J. B. Messerschmit, Über den V́rlauf des Geoïds auf den Kontinenten und auf den Ozeanen, in den Annalen der Hydrographie und marit. Meteor., 1900. - ${ }^{11} \mathrm{H}$. Wagner, Die Dimensionen des Erdsphäroids nach Bessel; in Beнм's Geographisehem Jahrbuch, Bd. III, 1870. — ${ }^{12}$ F. R. HeLMERT in den Sitzungsberiehten der Preußischen Akademie der Wissenschaften 1906, Bd. XXVII/XXVIII, S. 525. - ${ }^{13}$ W. Schmedebera, Zur Geschichte der geographischen Flächenmessung bis zur Erfindung des Planimeters; in der Zeitschrift der Gesellschaft für Erdkunde, Berlin 1906. - ${ }^{14}$ J. BExEš, Die wahre Oberfläche des Böhmerwaldes, in dem Bericht des Vereins der Geographen an der Universität Wien, 1888.

\section{Die Teile des Erdkörpers.}

Wenn wir von den Dimensionen der Erde sprechen, so verstehen wir darunter nur die des festen Erdkörpers, schließen aber seine gasförmige Umhüllung, die Atmosphäre, aus, obwohl diese ebenso einen integrierenden Bestandteil des Erdkörpers bildet, wie die Gesteinshülle (Lithosphäre) und der Erdkern. Die Gesteinshülle tritt entweder als Festland zutage oder ist als Grund des Meeres und der Seen unseren Blicken entrückt, so daß wir, ausgehend von den Erscheinungen der Oberfläche, von einer Gesteinshülle im engeren Sinne und einer Wasserhülle sprechen können.

Der Erdkern. ${ }^{1}$ Ob eine so scharfe Grenze, wie zwischen der Luft- und Gesteinshülle, auch zwischen der letzteren und dem Erdkern besteht, wissen wir nicht, denn selbst das tiefste Bohrloch der Erde, das Czuchower Bohrloch in Oberschlesien, durchfuhr sie nur bis $2240 \mathrm{~m}$ Tiefe, und es ist also auch an dieser Stelle vom Erdinnern nur der dreitausendste Teil des mittleren Halbmessers bekannt.

So unnahbar das Erdinnere auch der direkten Beobachtung ist, so sind uns doch zwei Tatsachen bekannt, die geeignet sind, etwas Licht über seine Beschaffenheit zu verbreiten.

Für seine hohe Temperatur legen die Laven und heißen Quellen Zeugnis ab. Die schwer schmelzbaren Laven erforderten $\mathrm{zu}$ ihrer Flüssigmachung Wärmegrade bis zu 1700. Daß sich die 
Stoffe des Erdinnern in glühend-flüssigem Zustand befinden, und daß die Erdkruste verhältnismäßig dünn sei, war daher eine Annahme, die sich von selbst aufdrängte, und die mit den kirchlichen Vorstellungen von der Hölle ebenso harmonierte, wie mit den Ansichten über die Entwicklung der Erde nach der herrschenden Nebulartheorie.

Eine genauere Kenntnis von der Verteilung der Temperatur im Erdinnern verdanken wir aber nur den Beobachtungen bei den zahlreichen vertikalen und horizontalen Tiefbohrungen, die in allen Kulturländern zu technischen und industriellen Zwecken ausgeführt werden. Die Temperaturschwankungen der Oberfläche dringen nur bis zu einer geringen Tiefe in die Gesteinshülle ein; schon in einer Tiefe ron etwa $1 \mathrm{~m}$ wird die tägliche Schwankung nicht mehr fühlbar, und die jährliche erlischt je nach ihrer Größe und der Leitungsfähigkeit des Gesteins in hohen Breiten in ungefähr 25, in den mittleren in 20-15 und in den Tropen wahrscheinlich schon in $6 \mathrm{~m}$ Tiefe. Unterhalb dieser Schicht konstanter Temperatur, ${ }^{\times}$ die etwas höher ist als die mittlere Jahrestemperatur an der Oberfläche, nimmt die Temperatur in allen Jahreszeiten und überall mit der Tiefe zu.

Aber die geothermische Tiefenstufe, d. h. die Tiefe, die einer Temperatursteigerung von $1^{\circ} \mathrm{C}$ entspricht, ist nicht überall gleich groB. $\times \times$ Sie wird durch die Nähe vulkanischer Herde und durch chemische Prozesse gesteigert, durch die abkühlende Einwirkung benachbarter Wassermassen herabgedrückt, und hängt unter sonst gleichen Bedingungen von der Wärmeleitungsfähigkeit des Gesteins ab. Indes

$\times$ Dieser Ausdruck ist nicht genau, Schwankungen sind auch hier nicht ganz ausgeschlossen, aber sie übersteigen nicht mehr den Betrag von $0,1^{\circ} \mathrm{C}$.

$\times \times$ Kösigsberger ${ }^{2}$ hat eine Reihe zuverlässiger Beobachtungen nach folgenden Gesichtspunkten geordnet:

Geothermische Mittel Tiefenstufen

1. Ebene, dessen Gestein nicht jungeruptiv und chemisch unter dem EinfluB der Atmosphärilien nicht veränderlich ist (23 Proben) .

$29-37,9 \mathrm{~m}$

$39,8-130$,

$11,3-24,1$,

$20-28,5$,

$13,9-29,6$,

$10-17,1$,

$31-55$
24,3,

$33,3 \mathrm{~m}$

65,3,

16,3,

22,1,

13,5,

40,2,

6. Erzbergwerke (2 Proben) Bergwerke, durch Ventilation ganz abgekühlt
7. 
kann man nach den bisherigen Erfahrungen als normale Tiefenstufe unter der Ebene 33-34 m betrachten. Gehen wir in den Tunneln von der Talsohle nach dem Innern der Berge, so wird sie größer So z. B. im St. Gotthardtunnel:

$\begin{array}{lllll}\text { Tiefe des Tunnels } & 301 & 558 & 1026 & 1165 \mathrm{~m} \\ \text { Geothermische Stufe } & 24,0 & 42,3 & 51,8 & 52,5 \quad \text {, }\end{array}$

Die Flächen gleicher Erdwärme (Geoisothermen) wiederholen also die Konturen der Oberfläche, indem sie im Innern der Gebirge ansteigen, aber unter einem flacheren Winkel als die Böschungen. Die Erfahrungen im Simplontunnel haben uns auch über die abkühlende

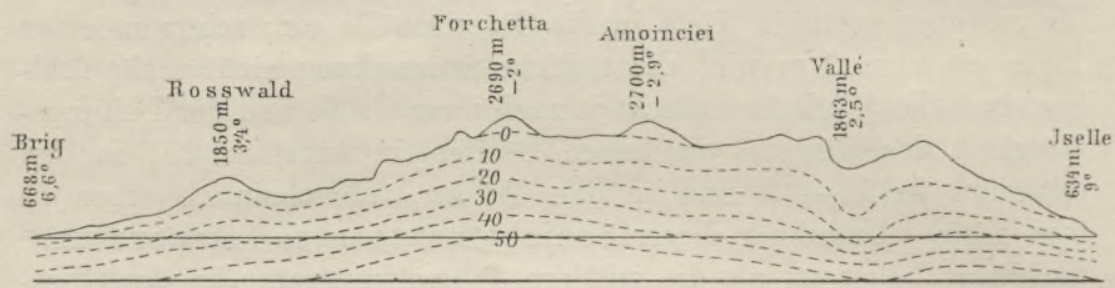

Fig. 3. Die Geoisothermen des Simplontunnels nach ScHARdT.

Wirkung geneigter Schichtenstellung und des Bodenwassers aufgeklärt. Die höchste Temperatur liegt dort nicht unter den höchsten Gipfeln, sondern nördlich davon, wo die flache Schichtenlagerung die Wärmeleitungsfähigkeit verringert, und die großen Einbuchtungen der Isothermen unter Vallé sind nicht durch das Relief, sondern durch die starke Wasserzirkulation bedingt. Die hohe Gesteinstemperatur in diesem Tunnel stellte sogar seine Ausführung in Zweifel, da der menschliche Körper trockene Wärme nur bis $50^{\circ}$ und feuchte nur bis $40^{\circ}$ längere Zeit ertragen kann. Nur die Anwendung komprimierter Luft, die sich bei der Ausdehnung stark abkühlt, hat über diese Schwierigkeit hinweggeholfen.

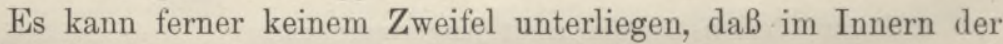
großen Massenerhebungen der Gesteinshülle, die wir Kontinente nennen, die Isothermenflächen in ähnlicher Weise ansteigen, wie im Innern der Gebirge. So fand z. B. die „Challenger"-Expedition im südatlantischen Ozean in $4160 \mathrm{~m}$ Tiefe Wasser von nur $1^{\circ}$, während, wie wir annehmen müssen, unter dem afrikanischen Boden in gleicher Tiefe bereits eine Temperatur von ungefähr $150^{\circ}$ herrscht.

Da aber die geothermischen Tiefenstufen unter den Erhebungen größer sind, als unter der Ebene, so muß allmählich ein Ausgleich erfolgen, indem die Geoisothermen, wie Fig. 4 versinnlicht, mit zunehmender Tiefe immer flacher werden, und dieser Ausgleich muß 
sich um so schneller vollziehen, je größer der Unterschied der Tiefenstufen ist. Nehmen wir an, unter dem Gipfel eines $2000 \mathrm{~m}$ hohen Berges (Jahrestemperatur $0^{\circ}$ ) betrage die geothermische Tiefenstufe 52,5, unter der Ebene (Jahrestemperatur $10^{\circ}$ ) aber $34 \mathrm{~m}$, so ist bereits in $2700 \mathrm{~m}$ unter dem Niveau der Ebene die Temperatur überall gleich, und man darf annehmen, $d a \beta$ von $d a$ an keine weitere Störung im gleichmäBigen Verlauf der Geoisothermen

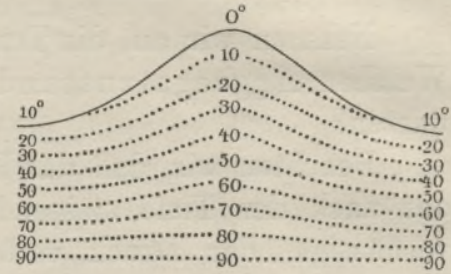

Fig. 4. Geoisothermen. eintritt, und die geothermische Tiefenstufe nicht mehr von den Reliefverhältnissen der Erdoberfläche beeinflußt wird. ${ }^{\times}$

$\mathrm{DaB}$ die Temperaturzunahme auch über die unserer Messung zugängliche Zone hinabreicht, ist gewiß, aber bis zu welchen Tiefen und nach welchen Gesetzen, ist unsicher. Haben diejenigen recht, die annehmen, daß die Erde eine sich durch Wärmeleitung und Wärmeausstrahlung abkühlende Kugel ist, dann müssen die geothermischen Tiefenstufen gegen den Mittelpunkt zu immer größer werden. F'ourien's Rechnung und Bischof's Experiment mit einer Basaltkugel führen zu dem nämlichen Schlusse. Letztere zeigte 48 Stunden nach dem Gusse folgende Temperaturen:

$\times$ Nachstehende Tabelle gibt die Vorstellungen WoErkow's ${ }^{3}$ von der Verteilung der Bodentemperaturen in versehiedenen Teilen der Erde im Vergleich zur Luft- und Meerestemperatur und unter der Annahme einer gleichmäBigen Temperatur von $530^{\circ}$ in $20000 \mathrm{~m}$ Tiefe wieder (Meerestemperaturen kursiv, Bodentemperaturen fett):

\begin{tabular}{|c|c|c|c|c|}
\hline $\begin{array}{l}\text { Höhen über }(+) \\
\text { und Tiefen unter } \\
\text { dem Meeresniveau } \\
(-) \text { in m }\end{array}$ & $\begin{array}{l}\text { Polarland } \\
300 \mathrm{~m} \text { hoeh }\end{array}$ & $\begin{array}{l}\text { Tropische } \\
\text { Wüste } \\
300 \mathrm{~m} \text { hoch }\end{array}$ & $\begin{array}{l}\text { Tropisches } \\
\text { Plateau } \\
4000 \mathrm{~m} \text { hoch }\end{array}$ & $\begin{array}{c}\text { Äquatorialer } \\
\text { Ozean }\end{array}$ \\
\hline+5000 & - & - & $-2,7$ & - \\
\hline+4000 & - & - & & - \\
\hline+1200 & $-19,2$ & 23,1 & 67,5 & 20,5 \\
\hline+300 & $\begin{array}{l}-16,5 \\
-12,5\end{array}$ & $\left.\begin{array}{l}28,5 \\
33,5\end{array}\right\}$ & & - \\
\hline 0 & $-4,4$ & 40,8 & 93,7 & $\begin{array}{l}26,5 \\
27,5\end{array}$ \\
\hline-1000 & - & - & - & 6,5 \\
\hline-5000 & 129,9 & 163,3 & 202,7 & 2,0 \\
\hline-8000 & 210,8 & 236,8 & 268,1 & 1,0 \\
\hline-9000 & 237,7 & 261,2 & 289,4 & 45,1 \\
\hline-20000 & 530 & 530 & 530 & 530 \\
\hline
\end{tabular}




$\begin{array}{lcccc}\text { Entfernung vom Mittelpunkte } & 0 & 4,5^{\prime \prime} & 6,75^{\prime \prime} & 9^{\prime \prime} \\ \text { Temperatur } & 192,5^{\circ} & 170,0^{\circ} & 165,3^{\circ} & 137,5^{\circ} \\ \text { Thermische Stufe } & 0,200^{\prime \prime} & 0,164^{\prime \prime} & 0,120^{\prime \prime} .\end{array}$

Nehmen wir an, die Temperatur steige bis zum Erdmittelpunkt. Welchen Aggregatzustand haben wir dann im Erdinnern zu erwarten?

Beachten wir, daß das Erdinnere sich auch unter dem Einflusse des nach der Tiefe steigenden Druckes befindet. Die Temperatur verflüssigt, der Druck verfestigt, oder mit anderen Worten: der Schmelzpunkt (d. h. die Temperatur, bei der Schmelzung eintritt) rückt mit zunehmendem Druck in die Höhe. Es könnte also immerhin auch unter der obigen Annahme an ein festes Erdinnere gedacht werden. Aber aus den neuen Experimenten von TammanN ${ }^{4}$ geht hervor, daß jenes Gesetz nur beschränkte Geltung hat. Der Schmelzpunkt steigt langsảmer als der Druck, und bei einem gewissen Druck, der für verschiedene Körper verschieden ist, tritt sogar eine Wendung ein, d. h. der Schmelzpunkt sinkt nun mit zunehmendem Druck. Es kann also trotz des gewaltigen Druckes der auflagernden Massen der Erdkern flüssig bleiben, ja es ist sogar denkbar, daß sich eine feste Zone zwischen zwei flüssigen einschiebt.

Ferner ergab sich aus den Untersuchungen von A. Ritter, daB eine Reihe von Körpern - und es läßt sich auch von den andern annehmen - oberhalb einer für jeden Körper bestimmten, sogenannten kritischen Temperatur nur mehr als Gase existieren und durch keinen noch so hohen Druck in einen andern Aggregatzustand übergeführt werden können. Nimmt man eine stetige Zunahme der Temperatur nach dem Erdmittelpunkt an, so sind im Innern unseres Planeten 10000 bis $20000^{\circ}$ nicht unwahrscheinlich; jedenfalls müssen hier sämtliche Körper die kritische Temperatur weit überschritten haben, und Zöppritz ${ }^{5}$ leitete daraus in folgerichtiger Weise die Hypothese $\mathrm{ab}$, daB sich das Erdinnere in gasförmigem Zustand befinde. GÜNTHER ${ }^{6}$ hat diese Hypothese weiter entwickelt, indem er den Satz aufstellte, daß der Erdkörper alle Aggregatzustände in ganz allmählichen Übergängen in sich vereinige. Die feste Erdkruste geht in eine plastische Zone, diese in eine zähflüssige, diese in eine flüssige, diese endlich in einen gasförmigen Kern über. Aber auch der letztere erscheint in diesem System noch zweigeteilt. Die äußere Zone nehmen Gase ein, die ihre Individualität noch beibehalten haben (GüNTHER's Zone der „gemischten“ Gase); im innersten Kerne ist aber der molekulare Zusammenhang in Atome aufgelöst, und an die Stelle der "gemischten" treten die einatomigen Gase. Auch der schwedische Physiker Arrhenius ${ }^{7}$ bekennt sich zu dieser 
Lehre. Er gibt der festen Erdkruste eine Dicke von etwa $40 \mathrm{~km}$ und der feurig-flüssigen Masse oder dem Magma eine solche von $100-200 \mathrm{~km}$, so daß von dem Gesamtdurchmesser der Erde $(12740 \mathrm{~km})$ nicht weniger als ungefähr $12200 \mathrm{~km}$ auf den Gaskern ${ }^{\times}$entfallen (s. Fig 5).

Die Einwürfe, die gegen die Annahme eines flüssigen oder gar gasförmigen Erdkerns von Astronomen und Physikern erhoben worden sind, gründen sich darauf, daß sich die Erde als Ganzes gegenüber den kosmischen Kräften wie ein fester Körper verhält. ${ }^{8}$ Besonders deutlich lehrt uns dies das Flutphänomen. Schon die englischen Forscher Thomson und G. DARwin ${ }^{9}$ haben darauf hingewiesen, daB jene Bewegungen des Meeres, die unter dem Namen Ebbe und Flut allgemein bekannt sind, nicht zustande kommen könnten, wenn das Erdinnere flüssig und die Kruste dünn wäre, denn dann müßte sich auch die Kruste heben und senken, also Land und Wasser, und wir würden die Gezeiten ebensowenig wahrnehmen, wie die Bewegung der Erde. Da aber das Wasser sich erfahrungsgemäB anders verhält, als die Kruste, so müsse die Erde mindestens den Starrheitsgrad des Stahles besitzen. Das ist durch die neuesten Untersuchungen HEckeR's ${ }^{10}$ vollauf bestätigt worden. Auch die feste Erde verändert unter dem Einfluß von Mond und Sonne ihre Form, ist als̈o nicht absolut starr, aber auch nicht nachgiebiger als eine Stahlkugel von gleicher Größe. Um trotzdem den Gaskern zu retten, schreibt ihm ARrhenius die Eigenschaften fester Körper zu; die Gasmoleküle haben unter dem Druck ihre Bewegungsfähigkeit eingebüßt und erlangen sie erst wieder, wenn der Druck nachgibt. Darin liegt ein schwer zu beseitigender Widerspruch.

In neuester Zeit rücken dị Physiker die Dichteverhältnisse der Erde in den Vordergrund ihrer theoretischen Erwägungen. Die mittlere Dichte der Erde ${ }^{11}$ beträgt nach den zuverlässigsten Untersuchungen (von Richarz und Krigar-Menzes) 5,5, d. h. die Erde ist 5,5 mal schwerer als eine gleich große Wasserkugel. Da die Gesteine, die sich hauptsächlich an der Zusammensetzung der Erdoberfläche beteiligen, nur ein spezifisches Gewicht von 2,6 bis 2,8 besitzen, so muß die Dichte des Erdkerns beträchtlich über dem Mittelwert liegen, und Suess hat ihn daher mit Recht die Bary= sphäre ( $\beta$ cov́s $=$ schwer) genannt.

Wie haben wir uns nun die stoffliche Beschaffenheit des Erdinnern zu denken? Nur zwei Annahmen sind möglich. Entweder

× Mrune nennt den problematischen Erdkern Geïte (nicht zu verwechseln mit Geoïd, das nur die Form des Erdkörpers bezeichnet). 
besteht die ganze Erde aus denselben Stoffen wie die Oberfläche, und dann ist die größere Dichte des Kerns lediglich eine Funktion des Druckes. Man hat berechnet, daß in diesem Fall die Dichte von ungefähr 2,7 an der Oberfläche bis 11 im Mittelpunkt steigt; die Körper müßten also erheblich mehr zusammendrückbar sein, als sich mit unsern, allerdings lückenhaften Anschauungen von dem molekularen Bau der Materie verträgt. Oder - und dies ist die zweite mögliche Annahme - Erdkruste und Erdkern sind chemisch verschieden. WreCHERT ${ }^{12}$ denkt sich eine Metallkugel von ungefähr $10000 \mathrm{~km}$

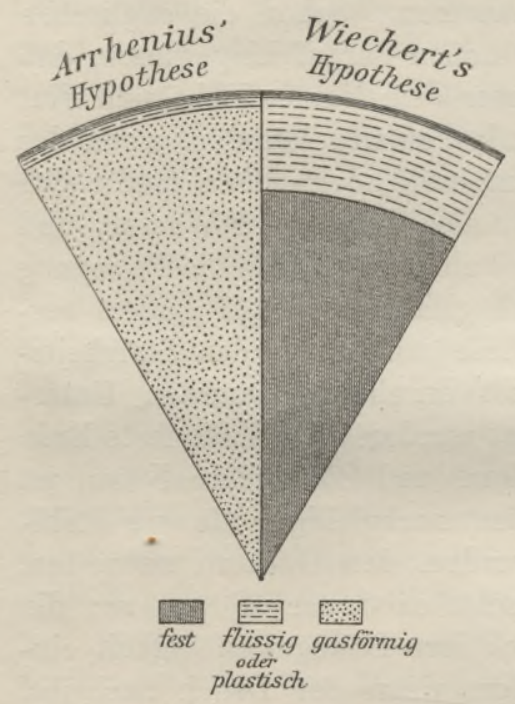

Fig. 5. Durchmesser und von 8 bis 8,15 Dichte, entsprechend dem komprimierten Nickeleisen, von einem etwa $1500 \mathrm{~km}$ dicken Steinmantel von der mittleren Dichte von 3-3,4 umschlossen. Eine solche Erde wäre nur ein größeres Abbild eines Meteoriten, der ebenfalls aus Stein und Eisen besteht. Eine Stütze findet Wiechert in den instrumentellen Erdbebenbeobachtungen. Die elastischen Wellen, die als Vorboten eines fernen Bebens das Pendel der Beobachtungsstation in Bewegung setzen, nehmen - wie wir später erörtern werden - ihren Weg durch das Innere der Erde, und man hat aus den Variationen der Geschwindigkeit in verschiedenen

Das Erdinnere nach den beiden wichtigsten Hypothesen der Gegenwart.

Teilen des Schüttergebiets berechnet, daß sie bis zu einer Tiefe von $1521 \mathrm{~km}$ (nach BENNDORF aber bis zu einer noch größeren Tiefe) stetig zunimmt, dann aber nahezu konstant bleibt. × Anderseits hat ARrHenius aus ihrer geringen Intensität geschlossen, daß der Erdkern nicht fest sein könne, denn nur die beträchtliche innere Reibung, die Flüssigkeiten und Gasen bei hohem Druck und hoher Temperatur eigen ist, erkläre die außerordentliche Abschwächung des Stoßes. Nun schließt aber die Annahme einer überkritischen Temperatur im Erdinnern die Annahme eines Eisenkerns aus. Im ersten Fall konnten

$\times$ Es muß übrigens hervorgehoben werden, daß die nach ähnlichen Methoden gefundenen Rechnungsergebnisse von Oцdнам und Batemax sehr erheblich von den Wiechers'schen abweichen. Von einem völlig gesicherten Resultat kann also noch nicht gesprochen werden. 
sich die Stoffe nicht nach ihrem Gewicht scheiden, weil in allen sich berührenden Gasen Diffusion eintreten muß, die Mischung zur Folge hat. In der Tat erkennen die Verfechter des Eisenkerns dem Erdinnern nur eine Temperatur von etwa 3000 bis $4000^{\circ} \mathrm{zu}$. Das Gesetz der Isostasie, von dem. wir sogleich sprechen werden, und die geologischen Tatsachen nötigen sie aber doch, zwischen dem festen Metallkern und der iesten Erdkruste eine flüssige oder wenigstens plastische Magmaschicht einzuschieben, so daß der Steinmantel nun aus zwei T'eilen besteht: einer festen Kruste von 100-200 km und einer Magmaschicht von $1300-1400 \mathrm{~km}$ Dicke.

Die Erdkruste. $\times$ Soweit die Erdkruste der unmittelbaren Beobachtung zugänglich ist, besteht sie aus Gesteinen, die sich aus mehreren Mineralien zusammensetzen; nur wenige, wie Quarzfels, Schwefel, Graphit und einige andere, sind einfache Gesteine. Die Unterlage scheinen überall Gneis und kristallinische Schiefer $\mathrm{zu}$ bilden, doch treten sie auch an vielen Stellen auf weite Erstreckungen zutage. Darauf ruhen mit wechselnder Mächtigkeit die geschichteten oder Sedimentgesteine, von denen Schiefer, Kalksteine, Dolomite, Sandsteine und Konglomerate die verbreitetsten sind. Eruptive Massengesteine durchbrechen vielfach die kristallinische Grundmauer, wie den sedimentären Oberbau. ${ }^{13}$

Über die Massenverteilung in der Lithosphäre geben uns die Messungen der Schwerkraft ebenso exakten AufschluB, wie über die Erdgestalt (s. S. 4). ${ }^{1+}$ Es läßt sich für jede Breite die normale Schwerkraft berechnen, und die Abweichung von den gemessenen Schwerkräften gibt uns einen Anhaltspunkt für die Berechnung der Störungsgrößen. Voraussetzung ist, daB der schweremindernde Einfluß der Seehöhe durch die Reduktion auf das Meeresniveau beseitigt wird. Man sollte nun erwarten, daß die Schwere auf den Bergen größer ist, als in der Ebene, denn dort wirkt die Anziehung einer größern Masse; wenn sie aber trotzdem normal ist, so muß der Einfluß der größern Masse durch deren lockeres Gefüge ausgeglichen werden. Schon 1869 hatte J. H. PRATT auf Grund der Beobachtungen in Indien den Satz aufgestellt, daß sich die Erhebungen der Erdkruste, die Kontinente und ${ }^{*}$ Gebirge, durch geringere, die großen Vertiefungen aber, die den Boden der Meere bilden, durch höhere Dichte auszeichnen, daß also zwischen beiden Gleichgewicht oder Isostasie bestehe. Seit den 80 er Jahren haben

$\times$ Die Bezeichnung Erdkruste bringt in deutlicherer Weise als die Erdrinde zum Ausdruck, daß die darunter befindliche Magmaschicht von lockererer Beschaffenheit ist, was - wie wir gesehen haben - auch von den Anhängern der Lehre vom Festkern zugestanden wird. 
diese Untersuchungen einen mächtigen Aufschwung genommen, besonders seit v. STERNECK ein bequem zu handhabendes Halbsekundenpendel konstruiert hatte, und sie haben im großen und ganzen die Prattr'sche Regel für die Gebirge bestätigt. Lokale Ausnahmen sind jedoch nicht selten, wie z. B. der Harz, der übernormal, oder der Thüringer Wald, der unternormal ist, und manche Tieflandstrecken zeigen einen Überschuß an Schwere, so daß hier dichtere Massen unter dem Erdboden angenommen werden müssen. Ja die positive Anomalie verbreitet sich auch über ausgedehnte Gebiete. Für das Meer mußte man sich lange Zeit mit Pendelmessungen auf kleinen ozeanischen Inseln begnügen, wo die Schwere durch die dichten vulkanischen Gesteine überhöht wird, erst die Framexpedition (1893 bis 96) gab Gelegenheit, solche Messungen im Polareis vorzunehmen. Auf dem beweglichen Schiff ist aber das Pendel nicht zu gebrauchen, und es mußte erst eine neue Methode ersonnen werden, ehe HEcker seine epochemachenden Beobachtungen auf dem Atlantischen (1901) und dem Indischen und Pazifischen Ozean (1904-05) ausführen konnte. Seine Methode beruht darauf, daß die Luftdruckmessungen mittels des Quecksilberbarometers und des Siedethermometers verschiedene Werte ergeben, da nur das erstere unter dem Einfluß der Schwerkraft steht, so daß die Differenz der Luftdrucke zur Ermittlung*der Schwere führt. Das Ergebnis ist folgendes: im Innern der Kontinente ist die Schwere normal, an den Küsten und in der sich daran schließenden Flachsee (Tiefe bis $200 \mathrm{~m}$ ) ist sie übernormal, weiter draußen, wo die Tiefsee beginnt, unternormal, und über den tiefen Meeresbecken selbst wieder normal. Daß diese Becken mit einer Wassermasse angefüllt sind, die beträchtlich leichter ist als die das Land aufbauenden Gesteine, bleibt also ohne Einfluß, weil der Unterschied dadurch ausgeglichen wird, daß die Becken selbst aus dichtern Stoffen bestehen, als die Kontinente. Damit ist das Pratt'sche Gesetz der Isostasie für die ganze Erde erwiesen. Freilich gibt es auch im Meere Störungszonen; im Bereich des $9000 \mathrm{~m}$ tiefen Tongagrabens z. B. herrscht Massendefekt, auf dem anstoßenden, $3000 \mathrm{~m}$ tiefen Tongaplateau aber Massenüberschuß.

Zwischen Hoch und Tief bestehen also betreffs des spezifischen Gewichts ebenso Gegensätze, wie betreffs der Temperatur, und es ist wohl möglich, daß zwischen Dichte und Temperatur ein innerer Zusammenhang vorhanden ist. Die Temperaturbeobachtungen haben uns auf dem Wege der Extrapolation zu der Annahme geführt, daß sich der thermische Gegensatz nach der Tiefe zu verflacht und endlich ausgleicht, und ebenso wird angenommen, daß in der Tiefe von ungefähr $100 \mathrm{~km}$ die Dichteunterschiede verschwinden. Diese sogenannten 
„Ausgleichsfläche“ liegt also vielleicht schon in der Magmazone. Die Existenz einer solchen Zone ist eine Forderung, die sich aus der Isostasie ergibt. Die Geologie erzählt uns von gewaltigen Massenumlagerungen, die sich in vergangenen Zeiträumen vollzogen haben, indem die Zerstörungsprodukte des Festlandes in das Meer hinausgetragen wurden - ein Vorgang, den wir noch heute beobachten können. Wenn trotzdem das Gleichgewicht im großen und ganzen gewahrt blieb und bleibt, so müssen in der Tiefe Massenumlagerungen im entgegengesetzten Sinne vor sich gehen und die Materie muß dort eine größere Bewegungsfähigkeit besitzen. Die $1200-3700 \mathrm{~m}$ mächtigen mesozoischen und tertiären Ablagerungen im westlichen Hochland von Nordamerika haben, wie sich aus der Gesteinsbeschaffenheit und den organischen Einschlüssen ergibt, nicht allmählich ein tiefes Meeresbecken ausgefüllt, sondern sind alle, die tiefsten wie die höchsten, im seichten Wasser entstanden. Der Boden dieses Wassers hat sich also allmählich unter der sich auftürmenden Last gesenkt, und dies ist nicht anders denkbar, als wenn die feste Lithosphäre auf einer flüssigen oder wemigstens plastischen Unterlage gewissermaßen schwimmt.

Literaturnachweise. ${ }^{1}$ Herm. Thiene, Temperatur und Zustand des Erdinnern; Jena 1907; ein historischer Überblick über die darauf bezüglichen Theorien. - ${ }^{2}$ Јон. Königsberger im Zentralblatt für Mineralogie usw. 1907, S. 673. $-{ }^{3}$ A. Woerkow in der Meteorologischen Zeitschrift 1905, S. 50 u. 399. ${ }^{4}$ G. Tammann, Kristallisieren und Schmelzen; Leipzig $1903 .-{ }^{5}$ K. Zöppritz in den Verhandlungen des I. Deutsehen Geographentages, Berlin 1882, S. 15. ${ }^{6}$ S. Günther, Entwicklung der Lehre vom gasförmigen Zustand des Erdinnern im XIV. Jahrsbericht der Geographischen 'Gesellschaft in München 1892. Eine sehr anschauliche bildliche Darstellung dieser Hypothese nach WoLDRIcH s. Globus, 1899, Bd. LXXVI, S. 175. - ${ }^{7}$ S. Arrhenrus, Zur Physik des Vulkanismus in den Verbandl. d. Geol. Ges. in Stockholm, 1900. - ${ }^{8}$ Vgl. H. Benndorf, Über die physikalische Beschaffenheit des Erdinnern, in den Mitteilungen der Geologischen Gesellsehaft, Wien 1908, Bd. I. - ${ }^{9}$ Die Arbeiten von W. Thomson (Lord Kelvin) und G. Darwin sind nur dem gewiegten Mathematiker verständlich, einen elementaren Beweis für die Starrheit der Erde versuchte G. F. Becker im Ameriean Journal of Science, 1890, Bd. XXXIX, S. 336. ${ }^{10}$ O. Hecker, Beobachtungen an Horizontalpendeln über die Deformationen des Erdkörpers unter dem Einfluß von Sonne und Mond; Berlin 1907. - ${ }^{11}$ Einen guten Überblick über die verschiedenen ,Methoden zur Bestimmung der mittleren Dichtigkeit der Erde" gibt unter diesem Titel E. WAWRzIK in der wissensehaftlichen Beilage zum Jahresbericht des Gymnasiums zu Oppeln, 1898. 12 E. Wiechert, Über die Massenverteilung im Innern der Erde, in den Nachrichten der Gesellschaft der Wissenschaften zu Göttingen, Math.-phys. Klasse, 1897; Über Erdbebenwellen, ebenda 1907; Was wissen wir von der Erde unter uns? Populäre Darstellung in der Deutschen Rundschau, Berlin 1907, Bd. XXXIII. - ${ }^{13}$ F. Löws, Die gebirgsbildenden Felsarten, Stuttgart 1893 (ein vortreffliches, aber elementares Hilfsbüchlein), E. W Eгnschenк, Grundzüge der Gesteinskunde, 2. Aufl.; 1906-07. - 14 O. Hecker, Die Schwerebestim-

Supan, Physische Erdkunde. 5. Aufl. 
mung an der Erdoberfläche n. s. w., in der Zeitschrift der Gesellschaft für Erdkunde, Berlin 1908.

\section{Die Energiequellen.}

Die Veränderungen, denen die Erdoberfläche seit dem Beginn ihrer Geschichte fortwährend unterliegt, lassen sich unmittelbar oder mittelbar auf vier Energiequellen zurückführen: auf die Erdwärme, die Sonnenwärme, die Drehun der Erde und die Anziehungskraft von Sonne und Mond. Wenn ie Schwerkraft hier nicht besonders genannt wird, so erklärt es sich daraus, daß sie zunächst nur potentielle Energie ist und erst durch die anderen primären Energiequellen in kinetische Energie umgewandelt wird. Sie würde fortbestehen, auch wenn alle Bewegung auf Erden erlöschen würde.

Hier handelt es sich nur darum, das Gewebe von Ursachen und direkten und indirekten Wirkungen, die das Erdenleben ausmachen, in seinen- Grundzügen darzulegen und damit das Verständnis der nachfolgenden Betrachtungen anzubahnen.

Die Wirkungen der unterirdischen Kräfte." Wenn wir als erste Energiequelle die Eigenwärme der Erde genannt haben, so ist dies so zu verstehen, daß ein völlig erkalteter Körper nicht mehr imstande wäre, aus eigener Kraft Veränderungen an der Oberfläche hervorzurufen. ${ }^{\times}$Solche Veränderungen haben sich aber im Laufe der geologischen Zeiträume wiederholt ereignet und ereignen sich noch fortwährend. Ihnen verdanken wir in erster Linie die abwechslungsreichen Formen der Landoberfläche und höchstwahrscheinlich auch den Gegensatz von Land und Meer.

Die meisten Schichten, welche die Oberfläche des Festlandes zusammensetzen, sind ursprünglich auf dem Boden des Meeres horizontal oder mit sehr sanfter Neigung abgelagert worden. Es gibt zwar Ausnahmen, wo schon die ursprüngliche Lagerung unter einem größeren Winkel erfolgte, aber sie treten in der Regel nur in örtlich beschränkter Weise auf. Wo immer nun ehemaliger Meeresboden in Festland umgewandelt wurde, oder wo das Meer erobernd über weite Flächen in das Land eindrang, oder wo die Schichten in ihrer ursprünglichen Lagerung oder in ihrem Zusammenhang gestört wurden, muß eine Niveauveränderung angenommen werden. Ausgehend von den Erscheinungen auf dem Lande können wir aktive und passive Niveauveränderungen unterscheiden. Im ersteren Falle

$\times$ In letzter Zeit sind ein paar miBglückte Versuche gemacht worden, die Eigenwärme der Erde zu eliminieren und auch die geologischen Prozesse auf die Sonnenwärme zurückzuführen. ${ }^{1}$ 
ist es der betreffende Landesteil, der seine Entfernung vom Erdmittelpunkt verändert hat. Da es sich dabei immer nur um begrenzte Gebiete handelt, so können wir uns einen solchen Vorgang nicht ohne Schichtenstörungen oder Dislokationen denken. Es treten Verbiegungen mit großer Spannweite oder Faltung ein, oder die Schichten werden durch Brüche in Schollen zerlegt, und diese werden in horizontaler (Verschiebung) oder vertikaler Richtung (Verwerfung) gegeneinander verschoben. Alle diese Veränderungen liegen klar zutage. Daneben gibt es aber auch solche, die anscheinend mit Dislokationen nicht in Verbindung stehen. Vorausgesetzt, daß hier der Schein nicht trügt, können wir solche Niveauveränderungen nur auf Bewegungen des Meeresspiegels zurückführen, und wir nennen sie daher passive. Verschiebungen der Wassermasse könnten nur infolge von Gestaltveränderungen des Erdkörpers oder größeren Polschwankungen eintreten, und von derartigen Vorgängen, die wohl oft theoretisch erwogen werden, haben wir keine unmittelbare Kunde; wohl aber sind Anzeichen vorhanden, daß auch der Boden des Meeres in bezug auf seine Entfernung vom Erdmittelpunkt nicht konstant bleibt. Verschiedene Bodenproben zeigen deutliche Schichtung, und solche beruht stets auf Unterbrechung oder Veränderung des Sedimentabsatzes. Einige dieser Vorkommnisse mögen sich aus klimatischen Ursachen erklären lassen, wie PHILIPPI ${ }^{2}$ meint, aber selbst dieser vorsichtige Forscher kann nicht umhin zuzugestehen, daß der wechselnde Kalkgehalt der Bodenproben aus dem atlantischen Romanchetief auf vertikale Bodenbewegungen hindeute. Suess hat diese marinen Bodenbewegungen eustatische genannt; sie äußern sich auf dem Lande stets im entgegengesetzten Sinne: Hebung des Meeresbodens bewirkt scheinbare Senkung des Landes, Senkung des Meeresbodens bewirkt scheinbare Hebung des Landes. Da das Meer eine geographische Einheit bildet, so haben diese Wirkungen stets eine universelle Verbreitung.

Eine andere Äußerung der unterirdischen Kräfte sind die vulkanischen Ausbrüche. Dagegen fassen wị die Erdbeben jetzt nicht mehr als ein selbständiges Phänomen auf, sondern nur als eine Begleiterscheinung des Vulkanismus und der Bodenbewegungen.

Die solaren Wirkungen. Für die Gestaltung der Oberfläche ist aber die Erdwärme nicht der einzige Faktor. Die Sonnenwärme tritt ihr als zweite Energiequelle ebenbürtig an die Seite. Ja auch das organische Leben ist im Grunde genommen nichts anderes als umgewandelte Sonnenwärme.

Abgesehen von der Pflanzendecke wirkt die zugeführte Sonnenwärme auf jeden Punkt der Landoberfläche zerstörend, und dieser Einfluß wird wesentlich erhöht durch ihre periodischen Schwankungen, 
zunächst durch die thermischen Gegensätze von Tag und Nacht, Sommer und Winter. Allerdings beruht der V erwitterungsprozeB zunächst nur auf der chemischen Einwirkung der Lufthülle auf das Gestein, und er würde nicht sofort zum Stillstand gebracht werden, wenn die Sonne plötzlich erlöschte. Nicht sofort, aber doch schon bald. Die Lockerung des Gesteins durch die Temperaturunterschiede würde aufhören, und das Wasser würde seinen Kreislauf einstellen.

Dazu kommt aber noch die ungleiche Verteilung der Temperatur. Sie setzt das Luftmeer in ununterbrochene Bewegung, es entstehen die Winde.

Die Winde erzeugen wieder zweierlei Bewegungen innerhalb der Wasserhülle: Wellen und Strömungen. Das bewegte Meer zerstört die Küsten, und das Zerstörungsprodukt wird entweder im Meer abgelagert oder an anderen Stellen zur Vergrößerung des Landes verwendet. Auf dem Lande bewirkt der Wind direkt eine Umlagerung des losen Materials, wodurch er untev Umständen auch indirekt an der Abtragung des Gesteins mitarbeitet; eine noch eingreifendere Rolle spielt er als Verbreiter des Wasserdampfes.

Alles Wasser verdunstet unter dem Einfluß der Sonnenwärme, am meisten natürlich das Meer. In die Höhe geführt, verdichtet sich der Wasserdampf wieder und kehrt als Regen oder Schnee zur Erde zurück. Das Wasser dringt zum Teil in den Erdboden ein und fördert und unterhält den VerwitterungsprozeB; zum Teil fließt es oberflächlich ab, schafft Täler durch seine eigene zerstörende Kraft und durch die Fortführung fremder Zerstörungsprodukte, und entledigt sich an anderen Stellen dieser fremden Stoffe wieder, durch die es das Land erhöht oder auf Kosten des Meeres und der Seen vergrößert. In großen Höhen und unter polaren Breiten tritt das Wasser vorwiegend in der festen Form, als Eis auf, aber auch dieses wirkt, wenn auch in etwas anderer Weise wie das Wasser, zerstörend und neuschaffend.

Wenn wir also die geologische Tätigkeit der Sonnenwärme, die ebenfalls periodischen Schwankungen, wie die Wärme selbst, unterliegt, noch einmal überblicken, so haben wir zu unterscheiden:

1. Förderung des Verwitterungsprozesses;

2. Wirkungen des Windes;

3. Wirkungen des Wassers, und zwar

a) des Meeres und der Seen,

b) des fließenden Wassers;

4. Wirkungen des Eises, und zwar

a) des Meereises,

b) des Landeises. 
Jede dieser Wirkungen ist zugleich zerstörend und schaffend; beide Seiten ergänzen sich notwendigerweise, denn ebensowenig, wie aus dem Nichts ein Etwas, kann aus dem Etwas ein Nichts werden. Aber die änßere Erscheinungsform ändert sich. LAPPARENT ${ }^{3}$ schätzt das durchschnittliche jährliche Ergebnis der kontinentalen Zerstörung auf 10,43 , das der marinen auf 0,30 und das der chemischen auf 4,92 cbkm, die gesamte jährliche Abtragung also auf rund $16 \mathrm{cbkm}$. Um soviel verliert das Land und gewinnt das Meer; das erstere wird um $0,110 \mathrm{~mm}$ erniedrigt, der Spiegel des letzteren um $0,044 \mathrm{~mm}$ erhöht; die Höhe des Landes, die wir ja vom Meeresniveau aus rechnen, nimmt also jährlich um $0,110+0,044=0,154 \mathrm{~mm}$, oder in ungefähr 6500 Jahren um $1 \mathrm{~m}$ ab. Die Sonnenwärme wirkt somit der Erdwärme entgegen; die Erhöhungen und Vertiefungen, die die unterirdischen Kräfte schaffen, werden durch die Oberflächenkräfte wieder ausgeglichen. Aber diese Umlagerung von Material muß, wie aus dem Gesetz der Isostasie hervorgeht, selbst wieder Niveauveränderungen hervorrufen, indem das erleichterte Land in die Höhe steigt und der beschwerte Meeresboden sich senkt:

$\mathrm{Zu}$ den Ablagerungen irdischen Ursprungs gesellen sich überdies noch kosmische Bruchstücke, von denen die Meteorsteine die bekanntesten sind. Nachgewiesen ist auch eine kosmische Beimengung der Tiefsee-Ablagerungen in Gestalt von braungelben Körnchen von $1 / 2 \mathrm{~mm}$ mittlerem Durchmesser (Bronzitchondrite) und Kügelchen von Magneteisen $;^{4}$ dagegen ist es unwahrscheinlich, daß kosmischer Staub in genügenden Mengen auf die Erde gelangt, um, wie NordenskiöLD ${ }^{5}$ meinte, unseren Planeten im Laufe geologischer Zeiträume merkbar $\mathrm{zu}$ vergrößern. Was beglaubigt ist, sind nur vereinzelte und örtlich beschränkte Fälle kosmischen Niederschlags, die auf die Entwicklung des Erdballs keinen nennenswerten Einfluß ausüben.

Die Anziehung von Sonne und Mond: Durch die Anziehungskraft von Sonne und Mond erleidet die Erde periodische Gestaltveränderungen, die zunächst allerdings nur in der Ebbe und Flut des Meeres einen sichtbaren Ausdruck finden. Auch diese Bewegung wird unter Umständen ein bedeutsamer Faktor in dem Umgestaltungsprozesse der Küsten. Daß auch die feste Erdkruste jener Anziehung unterliegt, war schon theoretisch vorauszusetzen; aber erst mit Hilfe eines so empfindlichen Instrumentes, wie es das Horizontalpendel von Rebeur-Paschwitz ${ }^{6}$ ist, gelang es diesem sowohl auf Tenerife, wie in Potsdam Bewegungen der Lotlinie nachzuweisen, die auf sehr geringe körperliche Gezeiten zurückzuführen sind. HeckeR's ${ }^{7} \mathrm{Be}-$ obachtungen an zwei Horizontalpendeln, die fortlaufend von Dezember 1902 bis Mai 1905 in Potsdam in einem $25 \mathrm{~m}$ tiefen Raum an- 
gestellt wurden, haben die Existenz solcher Gezeiten über allen Zweifel erhoben.

Die Rotation der Erde. Alle in horizontaler Richtung sich bewegenden Körper werden durch die Rotation der Erde auf der nördlichen Hemisphäre nach rechts, auf der südlichen nach links abgelenkt. ${ }^{8}$ Die Ursache dieser Ablenkung ist zweifach; zunächst die Beibehaltung der absoluten Bewegungsrichtung. In Fig. 6, die einen Erdquadranten vorstellt, bewegt sich ein Körper in einer gewissen Zeit von $a$ nach $b$, während er in derselben Zeit infolge der Rotation von $a$ nach $a^{\prime}$ gelangt. Die Wirkung dieser Doppelbewegung ist dieselbe, als wenn auf der stillstehenden Erde die Bewegung von $a^{\prime}$ ausginge und parallel mit der ursprünglichen Richtung $(a b)$ nach $b^{\prime}$ gerichtet wäre. Die dadurch hervorgerufene Ablenkung nach rechts tritt in der Zeichnung hervor, indem der Winkel $\alpha^{\prime}$ gröBer ist als $\alpha$. Die Bewegungsrichtung ist dabei ganz gleichgültig, und es $\mathrm{muB}$ besonders betont

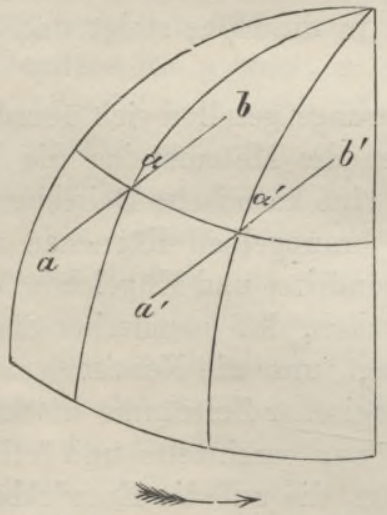

Fig. 6. Ablenkung durch die Beibehaltung der absoluten Bewegungsrichtung.

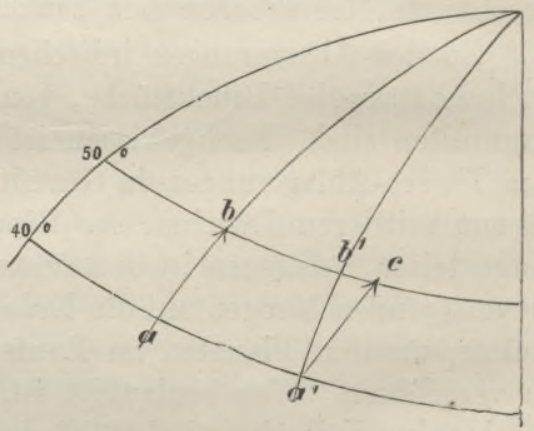

Fig. 7. Ablenkung durch die Beibehaltung der Rotationsgeschwindigkeit.

werden, daß auch die äquatoriale (d. h. ostwestliche oder westöstliche) dieser Ablenkung unterliegt.

Eine zweite Ursache der Ablenkung liegt in der Beibehaltung der Rotationsgeschwindigkeit und in dem sog. Prinzip der Erhaltung der Flächen (Fig. 7). Ein Körper bewege sich z. B. vom 40. zum 50. Breitengrad, also in meridionaler Richtung nach Norden. Er würde von $a$ nach $b$ gelangen, wenn sich nicht inzwischen $a$ nach $a^{\prime}$ und $b$ nach $b^{\prime}$ fortbewegt hätte. Der Einfàchheit wegen setzen wir voraus, daß die erstgenannte Ursache der Ablenkung nicht vorhanden sei. Wird dann der Körper in $b^{\prime}$ anlangen? Nein, denn die Geschwindigkeit des Punktes $a$ ist größer als die von $b(b: a=1: 1,2$,$) ,$ 
und mit dieser größeren Geschwindigkeit erreicht $a$ den 50. Parallel. Gesteigert wird die Geschwindigkeit noch dadurch daß der Körper in $50^{\circ} \mathrm{B}$. der Erdachse näher ist, also eine gröBere Rotationsgeschwindigkeit besitzt, als diesem Parallel eigen ist (Prinzip der Erhaltung der Flächen). Er wird daher dem Punkte $b^{\prime}$ vorauseilen und den Punkt $c$ treffen, d. h. die aus Süd kommende Bewegung wird in eine aus $\mathrm{SW}$ kommende verwandelt. Würde sich $b$ nach $a$ bewegen, so würde es aus denselben Gründen hinter $a$ zurückbleiben. Stets erhalten Bewegungen aus höhern in niederen Breiten eine westliche, und Bewegungen aus niederen in höhere Breiten eine östliche Komponente. Die gesamte Ablenkung ist proportional der Geschwindigkeit und dem Sinus der geographischen Breite, ${ }^{\times}$sie erreicht somit an den Polen ihr Maximum und ist am Äquator gleich Null.

Die Ablenkung der Bewegungen erfolgt demnach im Sinne der Pfeile:

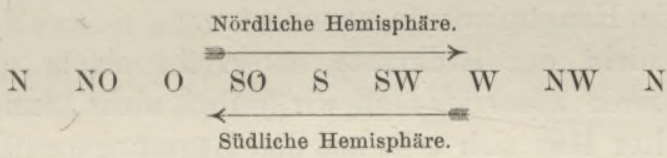

Wenn auch , alle horizontalen Bewegungen dieser Ablenkung unterliegen, so leisten ihr doch nur die Luft- und Meeresströmungen, solange sie nicht auf einen kräftigen Widerstand stoßen, in so sichtbarer Weise Folge, daß jeder Zweifel ausgeschlossen ist. In bezug auf die Flüsse sind.aber die Meinungen geteilt; d. h. die Ablenkung kann zwar nicht geleugnet werden, wohl aber ihre geologische Bedeutung.

Streng genommen ist die Rotation der Erde nicht als eine Energiequelle zu betrachten. Sie bewirkt an sich keine Bewegung, sondern beeinflußt nur schon vorhandene Bewegungen. Aber sie gibt ihnen neue Impulse, lenkt sie nach Stellen hin, die sie sonst nicht berührt hätten, und kann dadurch indirekt zu Veränderungen der Erdoherfläche Veranlassung geben.

Literaturnachweise. ${ }^{1}$ F. Tredrent, Die Somne als Ursache der hohen Temperatur in den Tiefen der Erde, der Aufrichtung der Gebirge und der vulkanischen Erscheinungen, München 1904. L. JAszewski, Über das thermische Regime der Erdoberfläche im Zusammenhang mit den geologischen Prozessen; in den Verhandlungen der Kais. Mineralogischen Gesellschaft in St. Petersburg, Bd. XLII, 1905. Vgl. dazu die kritischen Bemerkungen von M. Rudzki im Literaturbericht zu Petermans's Mitteilungen, 1906, Nr. $409-$

$\times$ Ist $w$ die Winkelgeschwindigkeit der Erde $(2 \pi: 86164$ Sekunden $=$ $0,00007292), v$ die Geschwindigkeit in Metern pro Sekunde und $\varphi$ die geographische Breite, so ist die Ablenkung oder Rotationskraft (A)

$$
A=2 v v \sin \varphi \text {. }
$$


${ }^{2}$ E. Phintpri in den Verhandlungen der Deutschen Geologischen Gesellschaft 1908, Bd. LX, S. 346. - ${ }^{3}$ A. de Lapparent, La mesure du temps par les phénomènes de sédimentation, im Bulletin de la Société géologique de France, Bd. XVIII. - ${ }^{4}$ John Murray et A. F. Renard, Les earactères microseopiques des cendres voleaniques et des poussières cosmiques, im Bulletin du Musée R. de l'histoire naturelle de Belgique, Bd. III, 1884. - ${ }^{5}$ A. E. v. Nordenskiöld, Studien und Forschungen, Leipzig 1885. - ${ }^{6}$ E. v. Rebeur-Paschwitz, Über Horizontalpendel-Beobachtungen in Wilhelmshaven usw., in den Astronomischen Nachrichten 1892, Bd. CXXX. - ${ }^{7}$ O. Hecker zit. S. 17, Anm. 10. $-{ }^{8}$ Einen Apparat zur experimentellen Darstellung dieser Erseheinung hat K. Ehrenuero konstruiert und als ,Trägheitsbahnglobus" in GerLand's Beiträgen zur Geophysik, 1897, Bd. III beschrieben.

\section{Geschichte der Erde.}

Die Geschichte der Erde ist Gegenstand einer eigenen Wissenschaft, der Geologie, ${ }^{1}$ die aber zur physischen Geographie in so engen Beziehungen steht, daß wir es uns nicht versagen können, hier wenigstens die Hauptmomente anzudeuten.

Jede Schicht der Erdkruste entspricht einem gewissen Zeitabschnitte, dessen absolutes $\mathrm{MaB}$ wir freilich nicht kennen. $\times$ Nur ihr relatives Alter läßt sich teils aus den Lagerungsverhältnissen, teils aus den organischen Einschlüssen ermitteln. Schichten mit Überresten gleichartiger Lebewesen fassen wir zu Stufen oder Etagen, die Etagen zu Serien, die Serien zu Formationen oder Systemen, die Formationen wieder zu Formationsgruppen zusammen. Zeitlich entspricht die Formation einer Periode, die Formationsgruppe einem Zeitalter.

Solcher Zeitalter unterscheidet die Geschichte der Erde vier. Aus der Urzeit oder dem archäischen Zeitalter stammen die Gneise und die kristallinischen Schiefer und Kalksteine, die nur zweifelhafte Spuren organischen Lebens enthalten. Mit dem Auftreten einer reichen Tierwelt, der sich später echte Landpflanzen zugesellen, beginnt das Altertum der Erde, das primäre oder paläozoische Zeitalter, aber eine weite Kluft trennt die organischen Typen jener fernen Epoche von denen der Gegenwart. Fische und Amphibien sind fast bis zum Schluß die einzigen Vertreter des Kreises der Wirbeltiere; die Meere belebten zahllose Armfüßer (Brachiopoden), besonders aus den ausgestorbenen Familien Spirifer und Productus. Im Mittelalter der Erde, im sekundären oder mesozoischen Zeitalter, erscheinen schon die Vorläufer der jetzigen Lebewelt, aber unter den Landtieren spielen noch die Reptilien, unter den See-

$\times$ Alle derartigen Berechnungen, die sich häufig den Ansehein absoluter Zuverlässigkeit geben, beruhen auf der Annahme, da B der Zerstörungsproze $B$ immer in gle icher Weise vor sich geht, aber diese Voraussetzung ist durchaus willkürlich. ${ }^{2}$ 
tieren die Ammoniten und ihre Verwandten die erste Rolle. In der Neuzeit der Erde, im tertiären oder känozoischen Zeitalter, nehmen Tier- und Pflanzenwelt modernen Charakter an, und die Säugetierfauna gelangt zu immer reicherer Entwicklung. Die geologische Gegenwart oder die quartäre Periode endlich kann kurzweg als das Zeitalter des Menschen bezeichnet werden.

Zum bequemen Nachschlagen in zweifelhaften Fällen lassen wir hier eine Übersicht der wichtigsten geologischen Haupt- und Unterabteilungen von den ältesten bis zu den jüngsten folgen.

I. Arehäische Formationsgruppe.

II. Paläozoische Formationsgruppe:

1. Kambrium;

2. Silur;

3. Devon;

4. Karbon oder Steinkohlenformation:

a) Unter-Karbon (Kulm),

b) Ober-Karbon (produktive Steinkohlenformation);

5. Perm oder Dyas:

a) Rotliegendes,

b) Zechstein.

III. Mesozoische Formationsgruppe:

1. Trias:

a) Buntsandstein,

b) Muschelkalk,

c) Keuper (oberste Stufe: Rhät);

2. Jura:

a) Lias,

b) Dogger oder brauner Jura,

c) Malm oder weißer Jura;

3. Kreide oder kretacelsche Formation:

a) Untere Kreide:

a) Neocom und Wealden,

ß) Gault;

b) Obere Kreide:

a) Cenoman,

$\beta$ ) Turon,

$\gamma$ ) Senon.

IV. Känozoische Formationsgruppe:

1. Alt-Tertiär oder Eogen:

a) Eocän,

b) Oligocän; 
2. Jung-Tertiär oder Neogen:

a) Miozän,

b) Pliozän.

3. Quartär:

a) Diluvium (Pleistozän),

b) Alluvium.

Diese Formationen sind weder überall in lückenloser Reihe, noch dort, wo sie vorkommen, in gleicher Weise entwickelt. Es herrschten zu allen Zeiten ähnliche Verschiedenheiten, wie in der Periode, in der wir leben: im Alluvium. Die eigentlichen alluvialen Ablagerungen sind in den Meeren zu suchen, aber auch hier sind sie im offenen Meer anderer Art, als in der Nähe der Küste. Das Land ist vorwiegend eine Stätte der Zerstörung; die Ablagerungen der Flüsse, Gletscher, Seen und des Windes und die vulkanischen Neubildungen sind von verhältnismäßig geringer Ausdehnung. Es geht daraus auch hervor, daß Ablagerungen innerhalb gleicher Zeiträume sehr verschiedene Mächtigkeit besitzen können. So besteht z. B. das oberste Triasglied, der Keuper, in Deutschland aus sandigen, tonigen und mergeligen Gesteinen, die eine Gesamtmächtigkeit von etwa $300 \mathrm{~m}$ erreichen, während in den Ostalpen in derselben Periode Kalksteine und Dolomite bis zu ein paar tausend Meter Mächtigkeit zur Ablagerung gelangten. Und anderseits, während in Deutschland und in den Alpen alle drei Glieder der Trias entwickelt sind, fehlt in England der Muschelkalk, und der Keuper ruht unmittelbar auf Buntsandstein, so daB man es hier vorzieht, die ganze Formation als New Red Sandstone zu bezeichnen.

Trotzdem läßt sich, wenn man die Maximalmächtigkeiten der Formationen miteinander vergleicht, der Gedanke nicht abweisen, daß das, was wir geologische Perioden nennen, Zeiträume von sehr verschiedener Dauer repräsentiert. In noch höherem Grade gilt das von den geologischen Zeitaltern, und man darf mit einiger Sicherheit die Behauptung aussprechen, daß sie um so kürzer werden, je jünger sie sind. In der sog. „Weltgeschichte“ ist es ja auch nicht anders. Da umfaßt das Altertum jedenfalls über 4000, das Mittelalter aber nur etwa 1100 Jahre. Auch in einer anderen Beziehung finden wir eine Analogie zwischen der „Welt-“ und der Erdgeschichte. Wie die Gliederung der ersteren nur auf den europäisch-mediterranen Kulturkreis anwendbar ist, aber nicht auf die Geschichte anderer Kulturvölker, so paßt das herrschende geologische System zunächst nur auf die Verhältnisse in Mittel- und Westeuropa, d. h. im Heimatland der geologischen Wissenschaft. Zwar läßt es sich auch auf 
das übrige Europa und auch auf Nordamerika übertragen, aber jenseits des Äquators versagt es stellenweise. Die mächtige Karruformation Südafrikas ${ }^{3}$ und das ihr entsprechende GondwanaSystem der vorderindischen Halbinsel ${ }^{4}$ umfassen, in die Sprache der europäischen Geologie übertragen, den ungeheuern Zeitraum vom oberen Karbon bis zum Rhät, in Vorderindien sogar bis zur untern Kreide, also paläozoische wie mesozoische Formationen, und die bedeutungsvolle Grenze zweier europäischer Formationsgruppen trennt hier nur zwei Etagen einer zusammenhängenden Serie. Steigen wir in tiefere Horizonte hinab, so löst sich der südhemisphärische Zusammenhang wieder auf, und es ist bisher weder gelungen, die indischen, die Kap- und Transvaalschichten untereinander, noch mit den paläozoischen Systemen der Nordhalbkugel zu identifizieren.

Es ist oben gesagt worden, daß unsere gebräuchliche geologische Einteilung auf den organischen Einschlüssen beruht. Nun tritt aber, dank den epochemachenden Untersuchungen von Suess, ${ }^{5}$ immer deutlicher hervor, daß die Umgestaltungen im Bereich der Lebewelt mit wichtigen geographischen Veränderungen der Vorzeit nicht zusammenfallen. Solche Veränderungen sind die Transgressionen oder Überflutungen und die Gebirgsfaltungen.

$\mathrm{Zu}$ wiederholten Malen ist der Boden der heutigen Festländer trocken gelegt und wieder vom Meer überflutet worden. So liegt die obere Kreide nicht überall normal auf der unteren Serie, sondern vielfach auf Jura, Trias, ja sogar auf paläozoischen und archäischen Formationen. In der Mitte der Kreideperiode trat also das Meer über seine bisherigen Ufer hinaus und eroberte weite Landgebiete. Transgressionen von beschränktem Umfange gehören zu den gewöhnlichen Ereignissen der Erdgeschichte, ausgedehnte sind aber verhältnismäßig selten; die mitteldevonische, unterkarbonische, mitteljurassische und oberkretaceische sind die bekanntesten. Die letztere scheint die größte gewesen zu sein, denn ihre Spuren lassen sich über die ganze Erde verfolgen.

$\mathrm{Zu}$ wiederholten Malen war das Festland auch ein Schauplatz gewaltiger Gebirgsfaltungen. Zwar sind die Äußerungen der inneren Erdkräfte an keine bestimmten Perioden gebunden und, wie die Erdbeben uns lehren, eine geradezu alltägliche Erscheinung, aber trotzdem hat es uns SuEss in hohem Grad wahrscheinlich gemacht, $\mathrm{da} B$ sie in gewissen Zeitabschnitten eine größere Intensität erlangten. Solche Faltungsepochen waren in nacharchäischer Zeit das jüngere Silur, das jüngere Karbon und das Tertiär. Die meisten unserer Kettengebirge stammen aus der letzten Epoche, aber wiederholt werden wir auch den Überresten älterer Faltungen begegnen. 
Das Ergebnis des sicher Millionen von Jahren dauernden geologischen Entwicklungsprozesses sind die heutigen Formen der Erdoberfläche, deren Grundzüge wir im nächsten Kapitel zu schildern versuchen werden. Aber nicht als ein endgültiges Ergebnis sind sie aufzufassen, sondern auch nur als ein Durchgangsstadium. In Anbetracht der ungeheuern Länge geologischer Zeiträume sind unsere Karten kaum mehr als Momentphotographien.

Literaturnachweise. ${ }^{1}$ Besonders empfehlenswerte Lehrbücher der Geologie sind H. Credner, Elemente der Geologie, 10. Aufl., Leipzig 1906; M. Neumayr, Erdgesehichte, 2. Aufl., Leipzig 1895; Em. Kayser, Lehrbuch der Geologie, Bd. I, 3. Aufl., Stuttgart 1909; Bd. II, 2. Aufl. 1905. Speziell für Geographen berechnet ist F. LöwL, Geologie, Leipzig 1906. Von fremdsprachigen Lehrbüehern seien besonders genannt A. de Lapperent, Traité de Géologie, 5. Aufl., Paris 1905, wegen seiner außerordentlichen Reichhaltigkeit und steten Rücksichtnahme auf die Bedürfnisse der Geographen, die besonders auf die zahlreichen paläogeographischen Kärtchen aufmerksam zu machen sind, und J. D. Dana, Manual of Geology, 4. Aufl., New York und London 1895, wegen der Berücksichtigung amerikanischer Verhältnisse. - ${ }^{2}$ Die Unhaltbarkeit aller geologisehen Zeitbestimmungen hat W. Busman (The Geologieal Chronometer, im Geological Magazine, 1903, Bd. X) dargetan. $-{ }^{3}$ F. H. Hatcu und G. S. Constorphrine, The Geology of South Africa, 2. Aufl., London 1909. ${ }^{4}$ E. W. Vredenberg, A Summary of the Geology of India; Caleutta 1907. ${ }^{5}$ Ev. Suess, Das Antlitz der Erde, Wien 1885-1909.

\section{Die Grundzüge der Gestaltung der Erdoberfläche.}

(Siehe Karte I und II.)

\section{Verhältnis von Wasser und Land. ${ }^{1}$ Die bekannten Landmassen} schätzt man nach den neuesten Quellen auf rund 135 Mill. qkm. Diese Zahl ist beständigen und ziemlich beträchtlichen Veränderungen unterworfen, da sich das Kartenmaterial, worauf sich die Flächenberechnungen gründen, mit dem Fortschreiten unserer geographischen Kenntnisse fortwährend verbessert. Es gibt ja noch große Räume, die, soweit die historische Kunde reicht, noch kein Mensch betreten hat. Die ausgedehntesten liegen an den Polen. Von dem arktischen Gebiet ist nur die atlantische, den Kulturländern zunächst liegende Hälfte etwas genauer bekannt, und auf der westgrönländischen Route gelang es endlich auch dem Amerikaner Robert Peary am 6. April 1909 den Nordpol zu erreichen. Im Norden von Sibirien durchkreuzten die unglückliche amerikanische „Jeanette“- (1881) und die norwegische „Fram"-Expedition (1893-96) das Eismeer, aber nur zwei: Nansen (1905: $86^{\circ} 13^{\prime}$ unter $96^{1} /{ }^{\circ} \mathrm{O}$ ) und CAGNI (1900: $86^{0} 34^{\prime}$ unter $64^{1} /_{2}{ }^{0}$ O) überschritten ein wenig den 86. Parallel. Ganz unbekannt ist noch die amerikanische Seite zwischen dem Meridian der Beringstraße und den Parry-Inseln, wo die wenigen 
Vorstoßversuche nicht einmal bís zum 74. Parallel gelangten. $\times$ Noch weniger wissen wir von der südpolaren Kalotte; über den 80. Parallel kam man nur in Viktorialand, und selbst an den 70. nur an einigen Stellen der westlichen Hälfte; die höchsten erreichten Breiten sind hier: unter $22^{\circ} \mathrm{W} 74^{\circ} 1^{\prime}$ (BRdCe 1904), unter $34^{\circ} \mathrm{W}$ $74^{\circ} 15^{\prime}$ (WEDDELL 1823), unter $88^{\circ} \mathrm{W} 71^{\circ} 36^{\prime}$ (die belgische Expedition 1998) und unter $162^{\circ} 088^{\circ} 23^{\prime}$ (ShackLeton 1909). Gänzlich unerforscht sind um den Nordpol etwa 4 und um den Südpol 19 Mill $\mathrm{qkm}$. Indes lassen sich auch für diese unbekannten Gebiete Vermutungen aufstellen, die von der Wahrheit nicht allzu weit abweichen dürften. Durch NANSEN wissen wir, daß die östliche Hälfte der Arktis tiefes Meer ist. Daß sich dieses auch über den Nordpol erstreckt, geht aus zwei wichtigen Lotungen hervor, die wir PEARY verdanken. Wie es sich weiter im W verhält, ist allerdings noch unsicher; hier hat Sverdrup noch 1898-1902 Inseln mit einer Gesamtfläche von ungefähr $64500 \mathrm{qkm}$ entdeckt, und nördlich davon glaubte Peary Land gesehen zu haben. Aber wenig wahrscheinlich ist es, daB sich der arktische Archipel Nordamerikas weiter nach W fortsètzt, denn in diesem Falle wäre es jener Boje, die am 24. Juli 1900 nördlich von Kap Bathurst $\left(128^{\circ} \mathrm{W}\right)$ ausgesetzt wurde, wohl nur durch ein seltsames Zusammentreffen günstiger Umstände gelungen, ihren Weg nach Norwegen zu finden, wo sie am 3. November 1908 bei Sörö (westlich von Hammerfest) aufgefischt wurde. Auch die Lotungen, die Mrkkelsen 1907 unter $150^{\circ} \mathrm{W}$ ausführte, sprechen dafür, daß der Meeresboden hier schnell zu größern Tiefen hinabsinkt. Wir können also wohl das ganze unbekannte Nordpolargebiet dem Meere zuweisen. Daß der Südpol auf einem eisbedeckten Hochland liegt, kann seit SHackLeTon's Expedition als sicher angenommen werden, und wenigstens wahrscheinlich ist es, daß sich dieses antarktische Land nach $\mathrm{O}$ bis zum Wilkes-, Kemp- und Enderbyland

$\times$ Folgende Zahlen geben eine ungefähre Vorstellung von der Größe des unbekannten Gebietes in den einzelnen Teilen der arktischen Welt (70 bis $90^{\circ} \mathrm{N}$.);

\begin{tabular}{l|c|c|c}
\hline \hline & $\begin{array}{c}\text { Fläche } 70-90^{\circ} \mathrm{N} . \\
\text { Mill. qkm }\end{array}$ & \multicolumn{2}{|c}{ Davon unbekannt } \\
\cline { 3 - 5 } & Mill. qkm & Prozente \\
\hline \hline Grönländischer Teil $20^{\circ}-110^{\circ} \mathrm{W}$ & 3,88 & 0,18 & 4,8 \\
Atlantischer Teil . $20^{\circ} \mathrm{W}-70^{\circ} \mathrm{O}$ & 3,88 & 0,42 & 10,8 \\
Sibirischer Teil . $70^{\circ} \mathrm{O}-170^{\circ} \mathrm{W}$ & 5,16 & 1,48 & 28,7 \\
Westamerikanischer & & & \\
Teil . . . . . $110-170^{\circ} \mathrm{W}$ & 2,58 & 1,85 & $\mathbf{7 1 , 4}$ \\
\hline Arktisches Gebiet & 15,50 & 3,93 & 25,4
\end{tabular}


erstreckt; ob aber auch nach W bis zum Coats- und Grahamland, muß noch als fraglich bezeichnet werden. Vereinigt man alle diese peripherischen Länder zu einer großen Landmasse, so ist ein Flächeninhalt von 14 Mill. qkm nicht zu hoch gegriffen. Wir erhalten dann rund für das Land 149 Mill. qkm oder 29 Prozent und für das Meer 361 Mill. $\mathrm{qkm}$ oder 71 Prozent der Erdoberfläche, woraus sich ein Verhältnis von Land zu Wasser $=1: 2,4$ ergibt.

Land und Wasser sind ungleichmäBig verteilt. Die nördliche Halbkugel hat 39, die südliche im günstigsten Falle nur 19 Prozent Land, und in demselben Gegensatze stehen die östliche Hemisphäre mit 35 und die westliche mit 20 (nach Trulo mit 19) Prozent Land. Die nachstehende Tabelle zeigt uns ein Übergewicht des Landes zwischen 70 und $40^{\circ}$ n. B. Dann be-

Tabelle der Verteilung der Landflächen innerhalb der $10^{\circ}$ Zonen in Prozenten der Gesamtflächen.

\begin{tabular}{|c|c|c|c|c|c|}
\hline & \multicolumn{3}{|c|}{ Nach Heiderich } & \multirow{3}{*}{$\begin{array}{c}\begin{array}{c}\text { Nach } \\
\text { WAGNER }\end{array} \\
\text { Erde }\end{array}$} & \multirow{3}{*}{$\begin{array}{c}\begin{array}{c}\text { Nach } \\
\text { KrüMMEL }\end{array} \\
\text { Erde }\end{array}$} \\
\hline & \multirow{2}{*}{$\begin{array}{c}\text { Westl. } \\
\text { Halbkugel }\end{array}$} & \multirow{2}{*}{$\begin{array}{c}\text { Östl. } \\
\text { Halbkugel }\end{array}$} & \multirow{2}{*}{$\begin{array}{l}\text { Ganze } \\
\text { Erde }\end{array}$} & & \\
\hline & & & & & \\
\hline $90-80^{\circ} \mathrm{N}^{-}$ & - & - & - & 10 & 8,9 \\
\hline $80-70$ & 39,8 & 25,6 & 32,7 & 29,3 & 26,6 \\
\hline $70-60$ & $58,9^{*}$ & $83,4^{*}$ & $71,5^{*}$ & $71,4^{*}$ & $71,8^{*}$ \\
\hline $60-50$ & 40,9 & $73,2^{*}$ & $57,0^{*}$ & $56,9^{*}$ & $56,6 *$ \\
\hline $50-40$ & 33,8 & $70,7^{*}$ & $52,2^{*}$ & $52,3^{*}$ & $52,2^{*}$ \\
\hline $40-30$ & 27,2 & $59,7^{*}$ & 43,5 & 42,8 & 42,9 \\
\hline $30-20$ & 17,1 & $57,5^{*}$ & 37,3 & 37,6 & 37,5 \\
\hline $20-10$ & 15,6 & 37,7 & 26,7 & 26,3 & 26,4 \\
\hline $10-0$ & 16,4 & 29,5 & 23,0 & 22,8 & 22,7 \\
\hline $0-10^{\circ} \mathrm{S}$ & 23,7 & 21,0 & 22,8 & 23,6 & 23,6 \\
\hline $10-20$ & 20,5 & 24,5 & 22,5 & 22,1 & 22,0 \\
\hline $20-30$ & 13,4 & 32,5 & 22,8 & 23,1 & 23,2 \\
\hline $30-40$ & 9,1 & 11,2 & 10,1 & 11,4 & 11,5 \\
\hline $40-50$ & 4,8 & 1,7 & 3,3 & 3,2 & 3,1 \\
\hline $50-60$ & 2,1 & 0,0 & 1,0 & 0,8 & 0,8 \\
\hline $60-70$ & 1,8 & 4,6 & 3,2 & (10) & 9,4 \\
\hline $70-80$ & - & - & - & $\left(78^{*}\right)$ & $73,0^{*}$ \\
\hline $80-90$ & - & - & - & $\int\left(10^{\circ}\right)$ & $100^{*}$ \\
\hline
\end{tabular}

ginnt die Herrschaft des Meeres; zunächst freilich nur allmählich, und zwischen $10^{\circ} \mathrm{N}$ und $30^{\circ} \mathrm{S}$ bleibt das Verhältnis von Wasser und Land nahezu konstant. Zwischen 30 und $60^{\circ} \mathrm{S}$ liegt die eigentliche Wasserzone; zwischen 50 und $60^{\circ} \mathrm{S}$ herrscht das Meer viel entschiedener vor, als zwischen 60 und $70^{\circ} \mathrm{N}$ das Land. Die Ab- 
nahme des Landes nach S bis zur Grenze der antarktischen Welt ist auch der gemeinsame Charakterzug beider, durch den Meridian von Greenwich getrennten Halbkugeln, in beiden tritt aber ein doppeltes Maximum deutlich hervor: das Hauptmaximum fällt zwischen 70 und $60^{\circ} \mathrm{N}$, das sekundäre liegt im W zwischen 0 und $10^{\circ} \mathrm{S}$ und im $\mathrm{O}$ zwischen 20 und $30^{\circ} \mathrm{S}$. Eine eigentliche Landzone (mit mehr als 50 Prozent Land) hat, immer abgesehen von der südpolaren Zone, die Westhemisphäre nur zwischen 70 bis $60^{\circ} \mathrm{N}$, während sie sich auf der Ost-Halbkugel über 50 Breitengrade, von 70 bis $20^{\circ} \mathrm{N}$ erstreckt. Nur in drei Zonen, 80 bis $70^{\circ} \mathrm{N}, 10$ bis $0^{\circ} \mathrm{N}$ und 40 bis $60^{\circ} \mathrm{S}$ übertrifft die westliche Landfläche die östliche, am meisten steht sie hinter der letzteren zurück zwischen 20 und $30^{\circ}$ nördlicher und südlicher Breite.

Nach den gemeinsamen Charakterzügen der $5^{0}$-Zonen KrüMmeL's läßt sich die Erde in folgende Gürtel einteilen:

\begin{tabular}{cc||r|r|r|r|r}
\hline & & \multicolumn{2}{c}{$\begin{array}{c}\text { Land } \\
\text { in Mill. }\end{array}$} & $\begin{array}{c}\text { Wasser } \\
\text { qkm. }\end{array}$ & \multicolumn{2}{|c|}{$\begin{array}{c}\text { Land } \\
\text { in Prozenten }\end{array}$} \\
\hline \hline 90 & $-70^{\circ} \mathrm{N}$ & 3 & 12 & 22 & $\mathbf{7 8}$ \\
70 & $-45^{\circ} \mathrm{N}$ & 37 & 23 & 61 & 39 \\
45 & $-20^{\circ} \mathrm{N}$ & 39 & 54 & 42 & 58 \\
$20^{\circ} \mathrm{N}-35^{\circ} \mathrm{S}$ & 54 & 179 & 23 & $\mathbf{7 7}$ \\
35 & $-65^{\circ} \mathrm{S}$ & $\mathbf{2}$ & 83 & 3 & $\mathbf{9 7}$ \\
65 & $-90^{\circ} \mathrm{S}$ & 14 & 10 & 59 & 41
\end{tabular}

Man hat die Erde auch in eine Land- und eine Wasserhalbkugel geteilt; der Pol der ersteren liegt in der Nähe der Loiremündung in $47^{1} /{ }^{0} \mathrm{~N}, 2{ }^{1} /{ }^{0} \mathrm{~W}$, der der letzteren fällt in das Meer östlich von der neuseeländischen Südinsel; es ist aber bemerkenswert, dẳ selbst bei dieser Teilung das Meer auch auf der Landhalbkugel noch mit 52 Prozent der Fläche vorherrscht. Auf der Wasserhalbkugel nimmt es 94 Prozent ein. ${ }^{2}$ Kreisförmig umlagern die großen Kontinentalmassen das arktische Binnenmeer: Amerika -dringt bis $71^{\circ} 50^{\prime}$, Europa bis $71^{\circ} 10^{\prime}$, Asien bis $77^{\circ} 42^{\prime} \mathrm{B}$. vor; von da an strecken sie mit abnehmender Breitenentwicklung polypenartig ihre Arme nach Süden aus, um auf der südlichen Hemisphäre in drei Spitzen zu enden: Südamerika in $56^{\circ}$, Australien mit Tasmanien in $43^{\circ} 40^{\prime}$, Afrika sogar schon in $34^{\circ} 51^{\prime}$ B. Dagegen hat der Ozean seine Heimat auf der südlichen Halbkugel, wo das Antarktische Eismeer, die Südsee und der Indische Ozean den Stamm einer zusammenhängenden Wasserfläche bilden, die in zwei Armen, dem nordpazifischen und dem Atlantischen Ozean mit dem Arktischen Meer, auf die Nordhemisphäre übergreift. So sind Ozean und Fest- 
land antipodisch angeordnet, nur die Südhälfte von Südamerika macht davon eine Ausnahme, denn auf der entgegengesetzten Erdseite liegt auch wieder Land (Ostasien).

Im Gegensatz zu der ununterbrochenen Meeresfläche erscheint das Trockene in der Form getrennter Massen, Kontinente und Inseln,

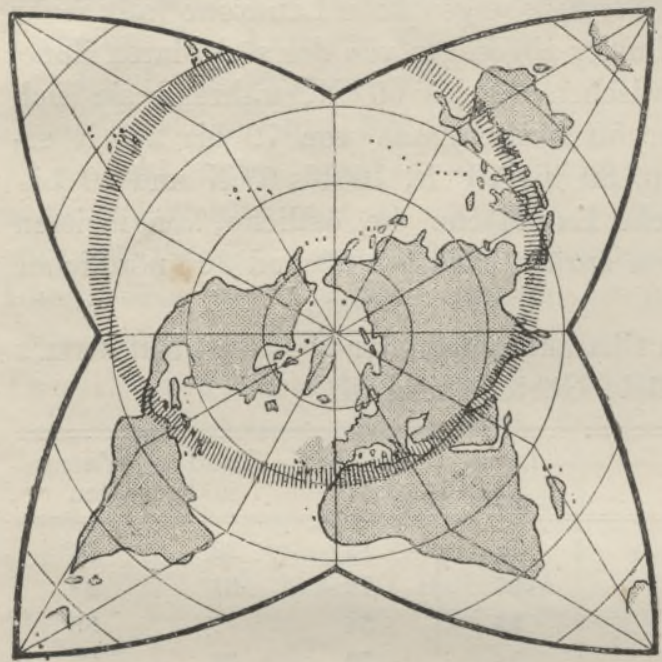

Fig. 8. Erdkarte in Steinhadsen's Sternprojektion. von denen aber die letzteren - nur 7,2 Prozent der ganzen bekannten Landfläche eine verhältnismäßig untergeordnete Rolle spielen. Indes ist es, dank der nahen Áneinanderrückung der Kontinente an ihrer arktischen Breitseite, möglich, von jeder Südspitze eines Südkontinentes zu den beiden anderen $\mathrm{zu}$ reisen, ohne das Land aus den Augen zu verlieren. Die Beringstraße, die Asien von Amerika trennt, ist nur $1 \frac{3}{4}$ Längengrade $(92 \mathrm{~km})$ breit. Zwischen Neufundland und Irland erstreckt sich allerdings der Ozean über 47 Längengrade oder $3300 \mathrm{~km}$, aber zwischen Grönland und Norwegen engt er sich schon auf $1500 \mathrm{~km}$ ein. Wie ganz anders gestalten sich die Verhältnisse an den Ausläufern der Kontinente! Das Kap Hoorn ist vom Kap Agulhas 87, das letztere vom South Cape 127, und dieses vom Kap Hoorn 146 Längengrade entfernt.

Einteilung des 0zeans. Gewöhnlich unterscheidet man fünf Kontinente und fünf Ozeane. Untersuchen wir, ob dies in der Natur begründet ist. Die offizielle Einteilung des Weltwassers grenzt zunächst die beiden Eismeere von den übrigen Ozeanen durch die Polarkreise $\mathrm{ab}$; und da die südlichen Festländer schon in niederen Breiten enden, so werden die kontinentalen Grenzen des Atlantischen, Indischen und Großen oder Pazifischen Ozeans durch die Meridiane der drei Südspitzen (und $67^{\circ} \mathrm{W}, 20^{\circ}$ und $147^{\circ} \mathrm{O}$ Gr.) zum südlichen Polarkreis ergänzt.

Aber Meridiane und Polarkreise sind keine natürlichen Grenzen, und doch finden sich solche streckenweise auch außerhalb des festländischen Rahmens. So ist die Südgrenze des Arktischen Meeres 
durch eine Reihe von unterseeischen Bodenanschwellungen gegeben und wir werden in einem späteren Kapitel nachweisen, welchen EinfluB sie auch auf die Verteilung der Tiefentemperaturen haben. Auf der pazifischen Seite ist die BeringstraBe schon oberflächlich eine gute Grenze, ihre Bedeutung wird aber noch verstärkt durch ein unterseeisches Plateau, das sich vom asiatischen Kap Deschnew über die Diomedes- und Krusenstern-Insel zum Kap Prinz von Wales hinüberzieht. Auf der atlantischen Seite finden wir solche Bodenschwellen unter dem Polarkreis zwischen Baffinland und Grönland, und eine zweite, besonders wichtige, die von der grönländischen Ostküste über Island und die Färöer zu den Shetland-Inseln hinüberstreicht; von hier bis zur Südwestspitze Norwegens ist die Grenze freilich nur eine künstliche.

Indes hat KRÜмmes mit Recht die Selbständigkeit des nördlichen Eismeeres bestritten. Morphologisch ist es nur eine Fortsetzung des atlantischen Tales, und ebenso ist es durch seine Strömungen auf das innigste mit dem Atlantischen Ozean und nur mit diesem verbunden. Für die Aufstellung eines antarktischen Ozeans sprechen dagegen manche Gründe. Verbindet man die Südspitzen der drei südlichen Kontinente durch Loxodromen miteinander, so tritt sein wichtigster Charakterzug scharf hervor. Er ist das einzige Meer, das ohne kontinentale Schranken, und wahrscheinlich nur von kleineren Inseln unterbrochen, die ganze Erde umgibt, er ist der zirkumterrane Ozean im Gegensatz zu den interkontinentalen. Ratzes hat als Nordgrenze des antarktischen Meeres den 40. Parallel S vorgeschlagen, und sie empfiehlt sich nicht nur durch ihre Bequemlichkeit, sondern gewinnt auch dadurch Berechtigung, daß südlich von ihr die große östliche, die ganze Erde umkreisende Meeresströmung zur Herrschaft gelangt. Morphologisch läßt sich aber weder diese, noch die Loxodromengrenze aufrecht erhalten, seit man weiß, daß die Eigenart der atlantischen Bodengestaltung viel weiter im S wurzelt. Da keine Einteilung allen Gesichtspunkten gerecht wird, so mag es - wenigstens vorläufig - bei der von KRÜMMEL vorgeschlagenen sein Bewenden haben. Hier verschwinden beide Eismeere aus der Liste der Ozeane, das nördliche wird zum Atlantischen Ozean geschlagen, und das südliche unter die drei Ozeane in der Weise verteilt, daß die obengenannten Grenzmeridiane der offiziellen Einteilung bis $\mathrm{zu}$ den, allerdings noch hypothetischen Küsten des antarktischen Festlandes verlängert werden. Von den

$\times$ Die Loxodromen, die alle Meridiane unter gleichem Winkel schneiden, erscheinen nur auf Karten in Mercator's Projektion als Gerade.

Supan, Physische Erdkunde, 5. Aufl, 
361 Mill. qkm der Meeresfläche entfallen dann 180 auf den Großen oder Pazifischen, 106 auf den Atlantischen und 75 auf den Indischen Ozean. Der Pazifische Ozean ist also fast um das Areal Asiens, des gewaltigsten Kontinents, größer als das gesamte Festland der Erde. Er bedeckt am Äquator die Hälfte unseres Planeten, ist unter $44^{\circ} \mathrm{S}$ noch $11300 \mathrm{~km}$ breit, verengt sich aber am Nordende auf $92 \mathrm{~km}$. Der Indische Ozean wiederholt im abgeschwächten Maße die Gestalt der Südsee, während der Atlantische talförmig zwischen der Alten und Neuen Welt eingebettet ist. Seine Breite erscheint ziemlich gleichmäßig, wenn man sie nach Parallelgraden mißt; nach Kilometern gemessen, zeigen sich aber erhebliche Unterschiede. So beträgt die Breite unter $35^{\circ} \mathrm{S} 6800$, unter $25^{\circ} \mathrm{N} 7300$, unter $65^{\circ} \mathrm{N}$ aber nur $3800 \mathrm{~km}$, und außerdem wird hier die Meeresfläche noch durch Grönland unterbrochen.

Einteilung des Festlandes. Das Festland erscheint in vier zusammenhängenden Massen: die Alte Welt, die Neue Welt oder Amerika, Australien und Antarktika. Sie sind die geographischen Individuen höchster Ordnung, jedes mit einer eigenartigen Geschichte, die ebenso in seiner Oberflächengestaltung, wie in seiner organischen Welt zum Ausdruck kommt. Durch die Vermittelung von Inselketten gruppieren sie sich zu zwei Paaren: einerseits schließt sich Australien an die Alte Welt, andrerseits Antarktika an die Neue Welt an, vorausgesetzt, daß die Länder um den Südpol zusammenhängen. Neben diesem Gegensatz der West- und Ostfeste, wovon die erstere 37, die letztere 63 Prozent alles Trockenen umfaßt, fällt uns noch ein zweiter sofort in die Augen: der zwischen den Nord- und Südkontinenten; sie werden durch Gurot's Bruchzone (s. Fig. 8, S. 32), die vom europäischen Mittelmeer zu den west- und ostindischen Inselmeeren hinüberführt, voneinander geschieden. Das Zusammenspiel dieser beiden Gegensätze führt uns zunächst zur Auflösung der Alten und der Neuen Welt in je zwei Kontinente.

Am deutlichsten ist die Natur eines Doppelkontinents in Amerika ausgeprägt. Das verbindende Mittelglied beginnt an der Landenge von Tehuantepec, wo die Wasserscheide nur eine Höhe von $262 \mathrm{~m}$ besitzt, und endet streng genommen erst an der Mündung des San Juanflusses in $4^{0}$ n. B.; doch ist dieser östlichste Ausläufer, die Cordillere von Chocó, jetzt an Südamerika angeschweißt. Die Tehuantepecenge ist nicht bloß eine geographische, sondern auch eine scharfe geologische Grenze. ${ }^{3}$ Die Gebirge von Mittelamerika ${ }^{4}$ sind weder eine Fortsetzung der nord- noch der südamerikanischen Cordilleren; die miozänen Faltenzüge streichen nördlich vom Nicaraguasee in leicht nach Süd gekrümmtem Bogen quer durch das Land, südlich von 
jenem See bis Panama bilden sie mit gleicher Streichrichtung, aber größerem Krümmungsradius den Rückgrat des immer mehr sich verengenden Landes. Im Pliozän versanken wenigstens Teile von Zentralamerika wieder unter das Meer; in Chiapas fand SAPPER jungtertiäre Schichten mit Austern in fast horizontaler Lagerung auf den Andesiten in 2200-2400 m Seehöhe. Seit dem Ende der Tertiärzeit besteht die Landverbindung zwischen den amerikanischen Kontinenten, aber doch vielleicht noch zeitweilig von Bodenbewegungen unterbrochen, wie sie HaYes an der Furche des Nicaraguasees annimmt, und worauf auch der pazifische Charakter der Korallen hindeutet, die die jüngsten Bänke von Barbados aufbauten. ${ }^{5}$ An zwei Stellen sinkt die Wasserscheide des zentralamerikanischen Isthmus unter $100 \mathrm{~m}$ : zwischen Colon und Panama auf 87 und bei dem Hafen von Brito auf $45 \mathrm{~m}$ (13 m über dem Spiegel des Nicaraguasees). Beide Stellen wurden für Kanalanlagen in Aussicht genommen; jetzt hat das Panamaprojekt den Sieg davongetragen, und in nicht $\mathrm{zu}$ ferner Zeit wird hier eine Wasserstraße statt der nur 72,5 $\mathrm{km}$ langen Eisenbahn beide Ozeane verbinden.

Das Seitenstück zu Südamerika bildet in der Alten Welt Afrika, aber hier fehlt ein Mittelglied von der Größe Zentralamerikas, und Afrika hat in seiner heutigen Gestalt seine Selbständigkeit nicht durch Angliederung, sondern durch einen Doppelprozeß von An- und Abgliederung jungen Datums gewonnen. Erst gegen Ende der Pliozänperiode wurde die Furche des Roten Meeres geschaffen; vorübergehend stand es über Suës mit dem Mittelländischen Meer in Verbindung, bis im Diluvium ein Nilarm durch seine Ablagerungen die Trennung herbeiführte, und so der heutige Isthmus von Suës entstand. ${ }^{6}$

Die konventionelle Einteilung des Festlandes nennt unter den Kontinenten auch Europa. Wohl ist Europa von Afrika durch das Mittelmeer geschieden, mit Asien aber so innig verwachsen, daß man es nicht mit Unrecht als eine asiatische Halbinsel bezeichnet hat. Fügen wir noch hinzu, daß es die Flora und Fauna mit den benachbarten Gegenden Asiens teilt, so scheint es jede Berechtigung seiner kontinentalen Selbständigkeit eingebüßt zu haben. In der Tat verdankt dieser Kontinent seine Würde nur der eigenartigen und hohen Kultur seiner Bewohner, aber es wäre ebenso kleinliche Pedanterie wie vergebliche Mühe, wollte man ihn nur als asiatisches Anhängsel gelten lassen. Die Landgrenze, die mit der Kultur immer weiter nach Osten rückte, ist freilich schwankender Natur. Eine gute Marke bildet nur das Uralgebirge, während der Uralfluß lediglich eine konventionelle Grenze ist und durch das Mugodschargebirge 
und das Ust-Urt-Plateau zu ersetzen wäre. Im Südosten ragt zwar auch ein Gebirge empor, aber mit besseren Gründen, als auf den Kamm des Kaukasus, verlegen wir die Grenze in die Manytschniederung, wo die Wasserscheide zwischen dem Schwarzen und Kaspischen Meere nur $10 \mathrm{~m}$ über dem Spiegel des ersteren liegt, und noch in junger geologischer Vergangenheit ein natürlicher Kanal beide Wasserbecken verband.

Um die Selbständigkeit Europas auch morphologisch $\mathrm{zu}$ begründen, hat man darauf hingewiesen, daB es, wie Asien, in drei Halbinseln ausläuft. Man hat dies überhaupt als einen gemeinsamen Zug der Nordkontinente bezeichnet, aber schon die Ungleichheit des Baues und der Entwicklungsgeschichte der asiatischen und europäischen Halbinseln belehrt uns, daß die Dreizahl nichts mehr als Zufall ist - abgesehen davon, daB sie bei Nordamerika nur dadurch zu retten ist, daß man Mexico erst durch den Zusammenschluß mit Südamerika seine Halbinselnatur einbüßen läßt. Auffallender ist die Zuspitzung Südamerikas und Afrikas; nur bei Australien wurde durch die Abtrennung Tasmaniens diese Eigentümlichkeit etwas verwischt. Auch sonst haben die Südkontinente manche gemeinsame Züge. So entspricht die flache Bucht von Arica dem Busen von Guinea und dem Australischen Golf, und es ist bemerkensmert, wie die Größe dieser Einschnitte gegen Osten stetig zunimmt.

Sehen wir von dem insularen Zubehör und Antarktika vorläufig $\mathrm{ab}$, so erhalten wir für die Areale der Kontinente folgende abgerundete Zahlen:

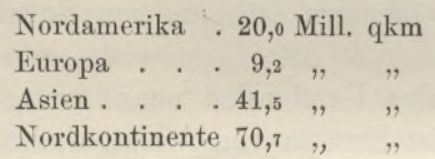

(56 Prozent). $\times$
Südamerika . . 17,6 Mill. qkm

Afrika . . 29,2, , ,

Australien . . 7,6, , ,

Südkontinente. 54,4, , ,

(44 Prozent). $\times$

In bezug auf die geographische Lage entspricht stets ein Nordkontinent einem Südkontinent. Aber in ihren gegenseitigen Größenverhältnissen weicht jedes Paar von den anderen, ab. Europa-Afrika und Asien-Australien stellen die Extreme dar, zwischen denen die fast gleich großen amerikanischen Zwillinge vermitteln.

Oberflächengestaltung des Festlandes (s. Karte II). Nach seiner Entwicklungsgeschichte, die sich noch im Bau widerspiegelt, läßt sich das gesamte Festland in drei große Gruppen gliedern: den Falten-

$\times$ Ist die von uns angenommene Flächenzahl Antarktikas (14 Mill. qkm) annähernd richtig, so sind die Nord- und die Südkontinente nahezu gleich groB. 
gürtel, die boreale und die australe Gruppe. Nach einer oberflächlichen Berechnung umfaßt der Faltengürtel 42, die boreale Gruppe 37 und die australe Gruppe 70 Mill. qkm.

1. Der Faltengürtel ist eine mehr oder weniger zusammenhängende Zone von Gebirgen, deren Entstehung mit wenigen Ausnahmen in die beiden jüngsten Faltungsperioden gegen Ende des paläozoischen und im tertiären Zeitalter fällt. Einige von ihnen haben spätere Umwandlungen erlitten; aber im Großen und Ganzen ist der ursprüngliche Bauplan noch formbestimmend oder schimmert wenigstens durch die neue Form noch wohl erkennbar hindurch. Dieser Faltengürtel umschließt den Großen Ozean im N, O und W, und sendet einen großen Zweig nach W, der die borealen und australen Gebiete der Alten Welt trennt und vielleicht noch in einem Ausläufer nach Nordamerika hineinreicht.

a) Der eurasiatische Faltengürtel beginnt im $\mathrm{O}$ mit dem zentralasiatischen Hochland. Die ältesten Gebirge liegen nur im $\mathrm{N}$, die jüngsten im $\mathrm{S}$, und in gleicher Richtung nimmt die Höhe zu. Im Pamir, dessen Talsohlen noch in mehr als $3000 \mathrm{~m}$ Seehöhe liegen, vereinigen sich die gewaltigsten Gebirgssysteme der Alten Welt: der Tiënschan, der Kwenlun, der Karakorum, der sich vielleicht in dem von HEDIN jüngst entdeckten Transhimalaya ${ }^{7}$ fortsetzt, und der Himalaya, das höchste Gebirge der Erde. Nördlich vom Kwenlun dehnen sich weite, wüsten- oder steppenartige Hochflächen aus; zwischen den Kwenlun und dem Transhimalaja liegt die größte Bodenanschwellung unseres Planeten, Tibet, wahrscheinlich ein Faltenland, dessen wenig bekannte Bergketten sich vielleicht ebenso zu sanft bogenförmig. gekrümmten, durch breite Talmulden voneinander geschiedenen Systemen zusammenschließen, wie es Hedis rom Transhymalaja nachgewiesen hat. In $70^{\circ}$ ö. $\mathrm{L}$. verengt sich der Faltengürtel zu dem schmalen Gebirgsisthmus des Hindukusch, der das zentralasiatische mit dem vorderasiatischen Hochland verknüpft. Auch hier wieder eine ähnliche Anordnung, wie im $\mathrm{O}$, nur in beträchtlich kleinern vertikalen und horizontalen Dimensionen: Randgebirge schließen Hochflächen ein, die selbst wieder von mehr oder weniger langen Falten durchzogen werden. Iran, Armenien, Kleinasien sind die Teile dieses Hochlandes; ein selbständiges Glied ist der Kaukasus.

Das europäische Hochland unterscheidet sich von den beiden asiatischen in wesentlichen Zügen. An die gebirgsumschlossenen Flachländer unseres Nachbarkontinents erinnert nur noch die ungarische Ebene. Die großen Kettengebirge erscheinen in seltsamen Verschlingungen, und ihre Bögen sind nach N gerichtet. Ihrem Alter 
nach sind die Gebirge in zwei Zonen geordnet: eine spätpaläozoische im $\mathrm{N}$ und eine tertiäre im $\mathrm{S}$. Die letztere beginnt im $\mathrm{O}$ mit dem dinarischen System der Balkanhalbinsel, dann folgt das Alpensystem, das sich von den Alpen einerseits über die Karpathen bis zum Balkan, anderseits über die Appeninnen und den Atlas bis zur Sierra Nevada verzweigt, endlich die Pyrenäen. Das ältere, nur noch bruchstückweise erhaltene Gebirge umfaBt die spanische Meseta, das französische Zentralplateau, die Bretagne, Cornwallis und das deutsche Mittelgebirge.

Als den letzten Ausläufer des eurasiatischen Faltengürtels betrachtete Marcel Bertrand das appalachische Gebirgssystem

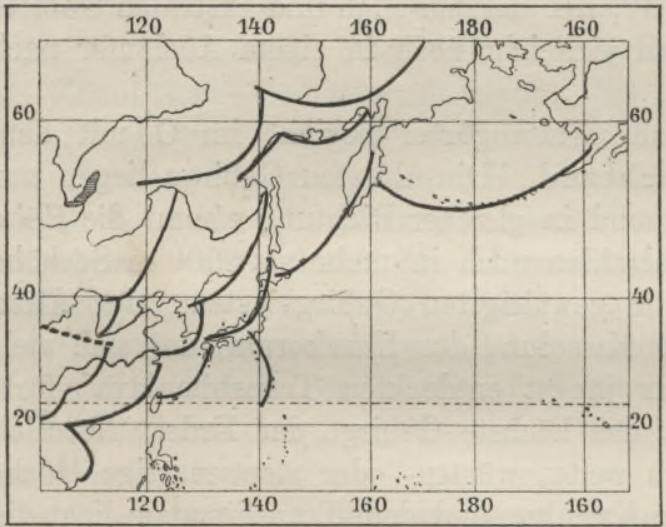

Fig. 9. Die tektonischen Bogenlinien Ostasiens. (Punktierte Linie das Tsinling-Gebirge.) Nach F. v. RICHTHOFEN.

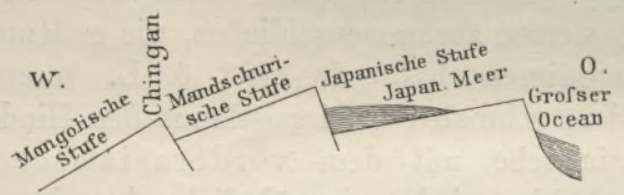

Fig. 10. Schematischer Durchschnitt durch das mittlere Ostasien mit Berücksichtigung der Erdkrümmung nach F. v. RICHTHOFEN. von Nordamerika, das sich von Neufundland über Neuengland und die Alleghanies in einzelnen Bruchstücken bis Arkansas verfolgen läßt. Suess hat sich dieser Auffassung angeschlossen.

b) Am Ostrand Tibets beginnt eine andere Anordnung der Leitlinien, indem die Gebirge sich bogenförmig nach $\mathrm{S}$ wenden und über Hinterindien, die Andamanen und Nikobaren in den großen Bogen der Sundainseln übergehen. Nach VoLz ${ }^{8}$ macht sich schon in Sumatra jenes Gesetz geltend, das v. RICHTHOFEN ${ }^{9}$ im orographischen Bau der ostasiatischen Bögen erkannt hat. Nur darüber sind die Ansichten geteilt, ob die Bogenform lediglich auf Brüche oder wenigstens z. T. auch auf Faltung (Suess) zurückzuführen sei. In Ostasien treten uns drei Reihen von Bögen entgegen, die ohne Ausnahme ihre konvexe Seite dem Großen Ozean zukehren. In jeder Reihe fügen sie sich derart aneinander, daß stets die nahezu westöstlich verlaufende Komponente des einen Bogens von der annähernd süd- 
nördlich streichenden Komponente des nächsten südlichen Bogens unter einem steilen Winkel getroffen wird(Fig. 9). Die binnenländische Bogenreihe wird durch die beiden Flügel des Stanowoigebirges, das Chingangebirge, das Taihanggebirge und die Steilabfälle der Hochländer von Kweitschou und Yünnan gebildet; zwischen den Flüssen Hwangho und Han ragt der Ausläufer des zentralasiatischen Kwenlun, der Tsinling, nach China hinein, um dann plötzlich abzubrechen. Die zweite Bogenreihe bestimmt den größten Teil des Küstenverlaufs von der Gischigabucht $\left(62^{\circ} \mathrm{N}\right)$ bis zum Kap St. Jacques $\left(10^{\circ} \mathrm{N}\right)$, die dritte setzt sich aus den Inselgirlanden zusammen, die im Verein mit der Halbinsel Kamtschatka von Alaska bis Südchina eine fast ununterbrochene Vorpostenkette des größten Festlandes gegen den größten Ozean bilden. Durch diese drei Bogenlinien wird die pazifische Randzone in drei Stufen zergliedert, von denen, wie Fig. 10 darstellt, jede östliche tiefer liegt als die benachbarte westliche. Weiter im S ist der litorale Bogen in der Küste von Annam noch deutlich erkennbar, in den Inselbögen aber treten verwickeltere Verhältnisse auf, die erst noch der Klarlegung bedürfen. $\mathrm{Zu}$ einem innern Inselbogen scheint sich noch ein äußerer zu gesellen, bestehend aus den Bonininseln, den Marianen und den Palauinseln, aber vorläufig können wir ihre Zusammengehörigkeit nur damit begründen, daß sie ebenso, wie die andern Inselbögen, an ihrer Ostseite von tiefen ozeanischen Gräben begleitet werden. Jedenfalls beginnt vom 30. Parallel an eine zunehmende Zerstückelung und Auflösung; sie erreicht ihren Höhepunkt

c) in den insularen australischen Bögen. Auch hier ist die Zusammenfassung der Inseln zu Bögen noch vielfach problematisch, und es empfiehlt sich, die zahlreichen Eilande W. L. vorläufig ganz aus dem Spiel zu lassen, bis wir über die Gestalt des Meeresbodens in diesen Gegenden besser unterrichtet sind.

d) Die asiatischen Faltenzüge streichen über die Beringenge nach der Neuen Welt hinüber, die mit der Halbinsel Alaska und den Alëuten noch Teil nimmt an den ostasiatischen Bögen. Was den amerikanischen Faltengürtel vor Allem charakterisiert, ist seine Geschlossenheit, die selbst in Zentralamerika nur durch verhältnismäßig schmale Einsenkungen unterbrochen wird. Ein Vergleich mit dem eurasiatischen Gürtel liegt nahe. In beiden schwillt durch Einschaltung von Hochflächen die Erhebungszone zu beträchtlicher Breite an, aber in der Alten Welt nimmt die Breite regelmäBig nach W ab, (Zentralasien unter $90^{\circ} \mathrm{O} 3200 \mathrm{~km}$, Iran unter $60^{\circ} \mathrm{O}$ $1300 \mathrm{~km}$, Kleinasien unter $35^{\circ}$ O $670 \mathrm{~km}$ ), während in der Neuen Welt Verschmälerung und Erweiterung wechseln und zwei Maximal- 
breiten, die aber beträchtlich hinter den asiatischen zurückstehen, zu beiden Seiten des Äquators auftreten: die nordamerikanische unter $40^{1} /{ }^{0} \mathrm{~N}$ ist $1600 \mathrm{~km}$, und die südamerikanische unter $20^{\circ}$ B. $730 \mathrm{~km}$ breit. Den amerikanischen, besonders den nordamerikanischen Hochflächen eigentümlich sind die scharenweise auftretenden und in der Längsrichtung des ganzen Gürtels angeordneten kurzen Bergketten, die auf der Karte wie ein breiter Zug von Raupen erscheinen und daher Raupengebirge genannt werden mögen. In Zentralasien finden sich solche in der Gobi und vielleicht in Tibet. Solche seltsame Bogenkrümmungen, wie im europäischen Faltengürtel fehlen in Amerika; langgestreckte und am Ende kulissenförmig gegen einander verschobene Gebirgszüge herrschen vor, mit Ausnahme von drei Stellen mit reiner Bogenform, die aber z. g. T. erst aus den insularen Bruchstücken wiederhergestellt werden muß. Es sind dies der Alaskabogen im N, der westindische, der durch die Cordilliere von Merida mit dem südamerikanischen Faltengürtel in Verbindung steht und sich anderseits an die ostwestlich streichenden Gebirge von Zentralamerika anschließt (vgl. S. 34), und endlich der westantarktische, der. Feuerland vielleicht über Südgeorgien und die Südorkney-Inseln mit dem echten Faltengebirge des Grahamlandes verbindet. ${ }^{10}$ Es deutet unzweifelhaft auf ein bisher noch dunkles Gesetz hin, daß die beiden zuletzt genannten Bögen ebenso wie die westpazifischen, ihre konvexe Seite nach Ost wenden. Ein ferneres Unterscheidungsmerkmal zwischen dem eurasiatischen und amerikanischen Faltengürtel kann man darin erblicken, daß sich an dem Aufbau des letztern Eruptivgesteine in beträchtlich größerem Umfang beteiligen. Endlich ist auch die geographische Lage verschieden. Der eurasiatische Faltengürtel scheidet mit Ausnahme von Ostiran denn der Persische Golf und das Mittelmeer kommen als Binnenmeere hier nicht in Betracht - Land von Land, der amerikanische aber in seiner ganzen Ausdehnung Meer von Land. Hierin gleicht er zwar den ostasiatischen Bögen, aber diese sind viel breiter und geben großen Flächen Raum. Daher hat Eurasien drei Hauptabdachungen, die Neue Welt aber nur eine: die zum Atlantischen Ozean.

2. Im Faltengürtel dauerte die faltende Bewegung bis in das Spättertiär an, während sie in der borealen und australen Gruppe schon in der Frühzeit der paläozoischen Periode erlosch. Nur zwei größere Gebirge machen davon eine Ausnahme: der Ural und das Kapgebirge, das vom Olifantsflu $B$ bis $28^{\circ} \mathrm{O}$ reicht und nach Suess im Pondoland wieder auftaucht. Das Alter dieser Gebirge dürfte jungpaläozosich sein, im südlichen Ural wahrscheinlich noch jünger. Alle ältern Faltengebirge sind aber durch die zerstörenden 
Kräfte des Wassers, des Eises und des Windes in Rumpfflächen verwandelt, haben also ihren tektonischen Charakter eingebüßt. Allerdings gibt es auch hier noch Gebirge, aber sie verdanken ihr Dasein entweder Brüchen und Verwerfungen oder der Flußerosion oder der Widerstandskraft des Gesteins oder dem Vulkanismus. In weitaus dem größten Teil dieser Länder liegen schon die kambrischen Schichten horizontal, und die Oberflächenform des Tafellandes ist daher weit verbreitet. Einen fast ebenso großen Raum nehmen die Tiefländer ein, die durch Aufschüttung junger lockerer Massen entstanden sind. Dieses Vorherrschen des Flachlandes kommt auch darin zum Ausdruck, daß mit Ausnahme von Afrika und Dekan das Land nur an wenigen Stellen von größerer Ausdehnung die Seehöhe von $500 \mathrm{~m}$ übersteigt.

Im Vergleich zum Faltengürtel mag man die borealen und australen Länder wohl einförmig nennen, aber sie sind es nicht völlig. Schon auf Grund des geologischen Baues lassen sich verschiedene Hauptglieder unterscheiden. So im borealen Eurasien die britischen Inseln, das große archäische Massiv Fennoskandia (Skandinavien, Finnland, Kola), das norddeutsche Tiefland, die russische Tafel, die ihr Gegenstück in der ostsibirischen Tafel hat, von der sie durch die Tieflandsmulden von Westsibirien und Turkestan geschieden ist. In Nordamerika entspricht der die Hudsonbai um. gebende archäische Landgürtel dem baltischen Fennoskandia, nach W steigt das Prärienplateau zum Felsengebirge an, im S breitet sich die appalachische Tafel aus, an die sich dann junge Tiefländer anschließen. In Südamerika ist die Form des Tieflandes vorherrschend aber im $\mathrm{O}$ erheben sich zwei alte Massive, die von Guayana und von Brasilien. Im australen Teil der Ostfeste tritt uns zunächst die Wüstentafel entgegen, die die Sahara, Arabien und Syrien umfaßt. Das übrige, geologisch allerdings noch sehr unvollständig bekannte Afrika bis zum südlichen Faltengebirge ist eine archäische Rumpffläche mit ausgedehnten Sandsteindecken, die sich nach innen zu dem Becken des Niger, des Tschadsees, des oberen Nil, des Kongo und zum Sambesi-Kalahari-Becken senkt. Madagaskar und Dekan verraten in ihrem Bau Verwandtschaft mit Afrika. In Australien ${ }^{11}$ haben die altpaläozoischen Faltungen den Charakter eines zusammenhängenden Gebirges nur im Osten bewahrt, aber schon westlich davon bis ungefähr zum 137. Meridian und dann wieder westlich vom 130. Meridian sind sie nur noch bruchstückweise erhalten. Alte Eruptivgesteine setzen jene Ketten zusammen, die in ost-westlicher Richtung das zentrale Tafelland durchschneiden. Wenn wir, abgesehen vom Grahamland, auch Antarktika in die australe Gruppe 
einreihen, so stützen wir uns auf die Erfahrungen im Viktorialand, wo einer Unterlage von kristallisohen Gesteinen eine mächtige Sandsteindecke in horizontaler Lagerung aufruht. ${ }^{12}$

Das Gestaltungsgesetz. ${ }^{13}$ Der erste Versuch, die Mannigfaltigkeit der Oberflächengestaltung einem geometrischen Gesetz unterzuordnen, ging von EuIE de Beaumont aus (1852). Nach seiner Annahme muß dieses Gesetz in irgend einem symmetrischen System seinen Ausdruck finden. Auf einer Kugeloberfläche gehen durch jeden Punkt unendlich viele größte Kreise, und es gilt nun, diejenigen aufzufinden, die die Kugeloberfläche in gleiche und regelmäßige Figuren teilen, und unter den möglichen Fällen denjenigen zu wählen, der die größte Übereinstimmung zwischen den Richtungen der größten Kreise und den beobachteten orographischen Linien darstellt. Auf diese Weise entstand ein Pentagonalnetz, wodurch die Erdoberfläche in 120 gleiche rechtwinklige sphärische Dreiecke zerlegt wurde, Wir brauchen uns bei diesem Versuch nicht länger aufzuhalten, denn er ist verdientermaßen schon längst der Vergessenheit anheimgefallen. Gregory sagt treffend, Beaumont's System sei nur auf eine symmetrisch gebaute Welt anwendbar; in seinem Netze sind die antipodischen Flächen immer ähnlich, aber gerade die antipodische Ungleichheit ist der Grundzug der heutigen Erdoberfläche.

Dieser Tatsache trägt Green's Tetraëdersystem (1875) Rechnung. ${ }^{14}$ Seine Hypothese beruht auf der mathematischen Erwägung, daß unter den regelmäBigen Körpern bei gegebener Oberfläche die Kugel das gröBte und das Tetraëder das kleinste Volumen besitzt. Indem sich die Erde durch Abkühlung zusammenzieht, muß sie die tetraëdische Form anstreben, weil sich nur so die größte Verkleinerung des Inhalts mit der geringsten Veränderung der Oberfläche vereinigt. Anderseits strebt aber die rotierende Erde die sphärische Gestalt an, und die wirkliche Oberfläche resultiert aus dem Kampfe dieser beiden entgegengesetzten Tendenzen. Daher kommt hier nicht das regelmäBige Tetraëder, die von vier gleichen Dreiecken eingeschlossene Pyramide, in Betracht, sondern das Hexakistetraëder, das dadurch entsteht, daß man jeder Tetraëderfläche eine flache sechsseitige Pyramide aufsetzt. Denkt man sich noch die Kanten abgestumpft, so ist die Oberfläche eines solchen Körpers nahezu sphärordal. Green orientiert nun sein Tetraëder in der Weise, daß die erste Ecke mit dem Südpol zusammentrifft; die zweite kommt etwas westlich vom mittlern Niltal, die dritte ungefähr an die Yukatanküste und die vierte in die Gegend der Marianen zu stehen. Auf diese Weise entsprechen die Kanten des tetraëdrischen Grundkörpers den Kontinenten und die Flächen den Ozeanen; freilich trifft dies, 
von den unbekannten Polargebieten abgesehen, einigermaßen genau nur bei Europa-Afrika und dem Großen Ozean zu. Die Anordnung der Festländer und Meere erklärt sich daraus, daß das Wasser stets die sphärische Gestalt annehmen, also über den Tetraëderflächen sich ansammeln mub.

Nachdem Green's Hypothese mehr als 20 Jahre fast unbeachtet geblieben war, wurde sie um die Wende des Jahrhunderts mit einem Mal von französischen und englischen Geologen wieder auf die Tagesordnung gesetzt. Doch mußte sie sich verschiedene Umänderungen gefallen lassen. De LAPPARENT und ARLDT nehmen unregelmäBige Tetraëder an, letzterer gibt ihm auch gekrümmte Kanten und Flächen. Die Achse fällt, wie bei Green, mit der Drehungsachse zusammen, eine Ecke bildet daher den Südpol, die drei anderen werden in die archäischen Massivs von Canada, Finnland und Ostsibirien verlegt. Michel-Levy verrückte das Tetraëder etwas, um seine vulkanischen Bruchzonen auf sechs größte Kreise zu bringen, und Bertrand nimmt zwei Tetraëder, ein nördliches und ein südliches, mit gekrümmten Kanten an. Schon diese Unsicherheit zeigt, daß das Tetraëdersystem von Willkürlichkeiten ebensowenig frei ist und der Natur ebensoviel Zwang antut, wie das Pentagonalsystem. Aber der Grundgedanke ist nicht ohne weiteres von der Hand zu weisen. Manche charakteristische Erscheinungen der gegenwärtigen Erdgestaltung finden in GreEn's Hypothese eine befriedigende Erklärung, wie die antipodische Anordnung der Festländer und Meere, von der nur das südliche Südamerika eine Ausnahme macht; die Gestalt der Kontinente, die ihre breite Seite dem Nordpol zukehren und im Süden mit Zuspitzungen enden; die von LA CaILle und MaĆLEAN behauptete geringere Abplattung der Südhalbkugel und die langsamere Zunahme der Schwere auf derselben, endlich auch eine gewisse Anordnung der vertikalen Maße, auf die wir später (S. 50) die Aufmerksamkeit lenken werden. Aber die Verteilung von Wasser und Land hat sich im Lauf der geologischen Zeiträume geändert, und es ist bezeichnend, daB sich Gregory, um die Theorie damit in Einklang zu bringen, zur Vermutung gedrängt sah, daß das Tetraëder in frühern geologischen Perioden umgekehrt orientiert war, d. h. seine Spitze dem Nordpol zuwandte. Es leuchtet ein, daß ein wanderndes Tetraëder nichts mehr erklären würde, wenn man nicht zugleich auch das Gesetz der Verschiebung aufdecken könnte.

Als ein zweiter Grundzug im Antlitz der Erde wird die große Bruchzone (vgl. Fig. 8, S. 32) betrachtet. Nach Green's Meinung lag sie einst in der Ebene der Ekliptik; Ebbe und Flut im Erd- 
innern mußten hier die größten Spannungsänderungen hervorrufen, die endlich zum Einbruch führten, gerade so wie ein Draht, der hin- und hergebogen wird, endlich bricht. Dagegen verlegt Emerson, sonst ein warmer Anhänger GreEn's, die Bruchzone nach dem Äquator und stützt sich dabei auf die Annahme verschiedener Geologen, daB der Nordpol früher in der Nähe der Beringstraße lag. Demzufolge fiel damals der Äquator annähernd in die Ebene der Ekliptik. Die Erde drehte sich schneller und die Abplattung war größer als heutzutage, aber unter dem Einflusse der von Ost nach West fortschreitenden Gezeitenwelle verlangsamte sich die in entgegengesetzter Richtung erfolgende Rotation, die Abplattung mußte sich den geänderten Verhältnissen anpassen, und der äquatoriale Wulst brach zusammen. Auch da muß man die Frage aufwerfen, ob wir wirklich berechtigt sind, die westindischen, mediterranen und ostindischen Einsturzfelder zu einer Zone zu vereinigen. Nicht nur, daß diese Zone in Vorderasien über hohe Tafelländer und Bergketten verläuft, sie müßte auch noch in dem Relief des Meeresbodens zu erkennen sein, aber soweit unsere, allerdings mangelhafte Kenntnis desselben reicht, lassen sich dort Spuren einer Bruchzone nicht entdecken.

Ähnlich verhält es sich mit der Anordnung der Gebirge. Es gilt, ihre annähernd äquatoriale Streichrichtung in der Alten Welt und ihren annähernd meridionalen Verlauf auf der pazifischen Erdhälfte zu erklären. KREICHGAUER ${ }^{15}$ verlegt die Gebirgsbildung durch Faltung in die Zone des mathematischen Äquators. Da die Abplattung der Erde als eine konstante Größe betrachtet wird, so muB der äquatoriale Durchmesser, der durch die Auffaltung vergrößert wurde, wieder verkleinert werden, und dies geschieht durch den Zusammenschub der Erdrinde in der dazu senkrechten Richtung. Dem primären Äquatorialgebirge entspricht also stets ein sekundäres Meridionalgebirge. Auch diese Theorie verlangt eine Verschiebung der Pole, um den altweltlichen Gebirgsgürtêl in äquatoriale Breiten zu rücken, und auch hier gilt derselbe Einwurf, den wir oben gemacht haben, nämlich daß der Boden jener Meeresteile, die der hypothetische Tertiäräquator durchschneidet, keine Spur von Auffaltung verrät. Da in verschiedenen Erdperioden Gebirge in verschiedenen Gegenden entstanden sind, muß Kreichgauer zu einer phantastischen Wanderung des Nordpols vom südlichen Polarkreis durch den Großen Ozean seine Zuflucht nehmen, wobei er der Erdrinde die Fähigkeit zuschreibt, bei unveränderter Lage der Drehungsachse im Weltraum wie ein Überzug über eine feste Kugel hinwegzugleiten.

Charakteristisch für die gegenwärtige Erdoberfläche ist ferner 
die Verschiebung der südlichen Kontinente gegenüber den nördlichen; GREeN erklärt sie als eine Torsionserscheinung längs der Bruchzone. Infolge der Orientierung des Tetraëders mit der Spitze gegen den Südpol und der Grundfläche gegen den Nordpol hat die südliche Halbkugel einen etwas kleineren Radius und rotiert schneller, sie eilt der Nordhalbkugel nach $O$ yoraus. Prinz, ${ }^{16}$ der hierin ein allgemeines planetarisches Gesetz erblickt, hat auf seiner Erdkarte eine Menge solcher nach NW abschwenkender Linien eingezeichnet, und seine Darstellung verdient insofern Beachtung, als sie zeigt, zu welchen Willkürlichkeiten alle derartigen geometrischen Konstruktionen führen. Eine seiner Linien verläuft an den Westküsten Australiens und der hinterindischen Halbinsel und findet ihre Fortsetzung im Himalaya; das dazu gehörige, nach W verschobene Stück ist der Ural! So werden zwei Gebirge von ganz verschiedenem Alter miteinander in Beziehung gesetzt, und gerade das, was die Alte Welt auszeichnet, der große ostwestliche Hochlandgürtel, als etwas Nebensächliches behandelt. Emerson macht gegen die Torsionshypothese geltend, daß von den drei Festlandpaaren die beiden Amerika und Asien-Australien ungleichmäBig gegeneinander verschoben sind, und Europa-Afrika gar nicht, und führt das ganze Bhänomen auf Niveauveränderungen zurück. Nordamerika und Asien haben im Laufe der geologischen Geschichte im O Land verloren, im W Land gewonnen, während Australien auf dieselbe Weise scheinbar nach $\mathrm{O}$ gewandert ist. Aber auch in dieser Auffassung steckt viel Unsicheres, und keine Sache wird klarer, wenn man Hypothesen auf Hypothesen häuft. Auch das Gestaltungsgesetz, das die großen Züge im Antlitz der Erde unzweifelhaft beherrscht, gehört $\mathrm{zu}$ jenen naturwissenschaftlichen Fragen, auf die wir, vorläufig wenigstens, mit einem ignoramus antworten müssen.

Vertikaler Aufbau der Erdkruste. Die neuen Erdkarten mit Linien gleicher Höhe (Isohypsen) und gleicher Tiefe (Isobathen) (vgl. Karte I) eröffnen uns einen lehrreichen Einblick in den Aufbau der Erdkruste. Setzen wir die ganze Erdoberfläche $=100$, so erhalten wir für die einzelnen Höhen- und Tiefenstufen folgende Prozentzahlen:

$$
\begin{array}{cc}
\text { nach PENCK } & \text { nach WAGNER } \\
(1889)^{17} & (1908)^{1}
\end{array}
$$

\begin{tabular}{|c|c|c|c|c|c|}
\hline $8840-4000$ & über & len & & 0,5 & 1 Proz. \\
\hline $4000-3000$ & $"$ & $"$ & & 0,6 & \\
\hline $3000-2000$ & $"$ & " & $"$ & 1,2 & 1,2 \\
\hline $2000-1000$ & $"$ & $"$ & $"$ & 4,3 & 4,1 \\
\hline $1000-200$ & $"$ & " & " & 13,0 & 12,9 \\
\hline $200-\quad 0$ & , & , & , & 10,5 & 10,0 \\
\hline
\end{tabular}




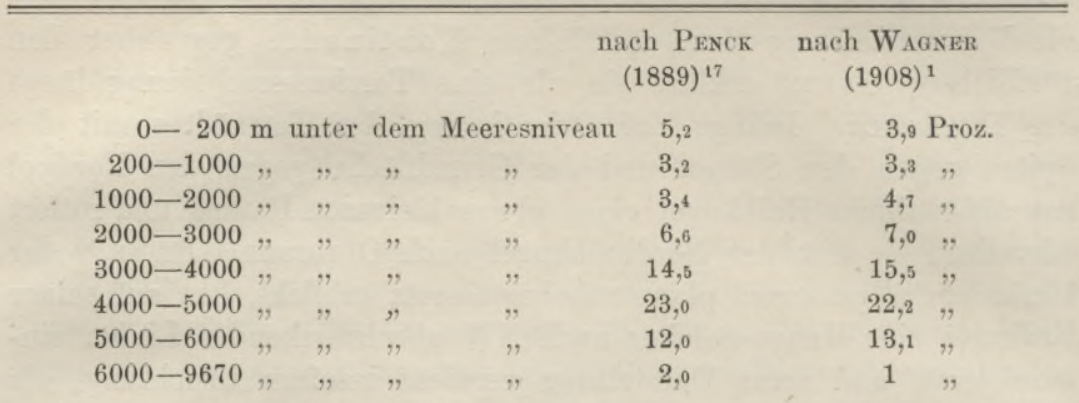

Wir können diese Zahlen in der Weise graphisch darstellen, daB wir den Meeresspiegel als Abzissenachse nehmen und darauf die den einzelnen Stufen entsprechenden Strecken auftragen. Dann

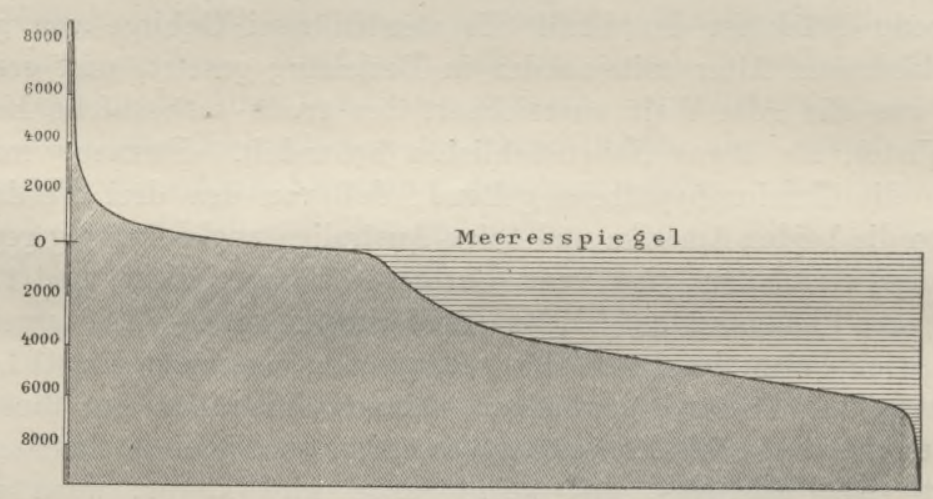

Fig. 11. Hypsographische Kurve der Krustenoberfläche.

errichten wir in jedem Teilpunkt Ordinaten, für das Land nach oben, für das Meer nach unten, geben ihnén die betreffenden Höhen (8844, 4000, 3000 usw.) und verbinden endlich ihre Endpunkte mit einer Kurve, die den allmählichen Übergang, wie er in der Natur Regel ist, zum Ausdruck bringen soll. Die Endpunkte dieser hypsographischen Kurve sind die gröBte Landhöhe (Mt. Everest $8840 \mathrm{~m}$ und die größte bekannte Meerestiefe $(9636 \mathrm{~m})$. Ihr Verlauf ist sehr wechselnd: von $8840 \mathrm{~m}$ bis $2000 \mathrm{~m}$ Seehöhe steil, dann sich verflachend, besonders zwischen $200 \mathrm{~m}$ und dem Meeresspiegel, und sich in derselben Weise bis $200 \mathrm{~m}$ Tiefe fortsetzend. Hier erst hört die Kontinentaltafel auf. Dann folgt bis etwa $3000 \mathrm{~m}$ Tiefe ein Steilabfall, den wir als Kontinentalböschung (aktische Region) auffassen können, endlich die Tiefenregion (abyssische Region), flach bis $6000 \mathrm{~m}$, dann wieder steil. In Prozenten der Erdoberfläche kommen diesen drei Hauptteilen der Kruste folgende Werte zu: 
nach Penck nach Wagner

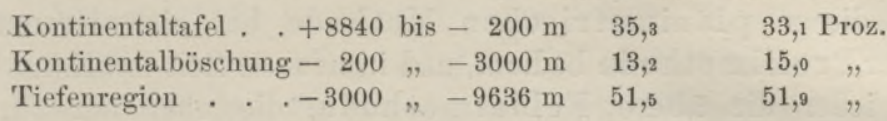

Mehr als die Hälfte der Erde nimmt also der Tiefboden des Weltmeeres ein.

Den vertikalen Aufbau der einzelnen Kontinente und Ozeane nach den drei Höhen- und den drei Tiefenstufen zeigt in Prozenten der betreffenden Einheiten die nachstehende Tabelle. ${ }^{18}$

\begin{tabular}{|c|c|c|c|c|c|c|c|}
\hline Höhenstufen & 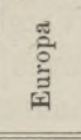 & $\frac{.}{\frac{0}{4}}$ & $\frac{\pi}{2}$ & 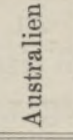 & 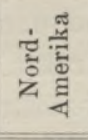 & 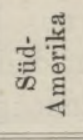 & 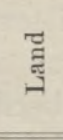 \\
\hline Hochstufe (über $2000 \mathrm{~m}$ ). & 1,5 & 14,1 & - 2,4 & 0,8 & 6,0 & 9,0 & 7,7 \\
\hline Mittelstufe $(200-2000 \mathrm{~m})$ & 41,7 & 60,5 & 82,2 & 63,2 & 61,6 & 48,4 & 62,5 \\
\hline Unterstufe (unter $200 \mathrm{~m}$ ) & 56,8 & 25,4 & 15,4 & 36,0 & 32,4 & 42,6 & 29,8 \\
\hline
\end{tabular}

\begin{tabular}{l||r|r|r|r}
\hline \multicolumn{1}{c||}{ Tiefenstufen } & $\begin{array}{c}\text { Atlanti- } \\
\text { scher } \\
\text { Ozean }\end{array}$ & $\begin{array}{c}\text { Indischer } \\
\text { Ozean }\end{array}$ & $\begin{array}{c}\text { Großer } \\
\text { Ozean }\end{array}$ & Meer \\
\hline \hline Kontinentalstufe od. Sehelf $(0-200 \mathrm{~m})$ & 11,5 & 4,6 & 5,4 & 7,1 \\
Kontinentalböschung $(200-3000 . \mathrm{m})$. & 25,5 & 21,2 & 14,5 & 19,2 \\
Tiefenregion (über 3000 m). . . . & 63,0 & 74,2 & 80,1 & 73,7 \\
\hline
\end{tabular}

Auf dem Festland herrscht überall die Mittelstufe vor, mit Ausnahme von Europa, dem nur Südamerika nahe kommt. Die Hochstufe ist am meisten in Asien und Südamerika entwickelt. Der massige, auch vertikal wenig gegliederte Bau Afrikas findet in obigen Zahlen einen treffenden Ausdruck. Die ozeanischen Becken sind noch gleichartiger als die Festländer, doch tritt die Eigenart des Atlantischen Ozeans in der relativ großen Ausdehnung der beiden oberen Stufen deutlich hervor.

Mittlere Höhen und Tiefen. Die Ausmessung der Flächen zwischen den Isohypsen und Isobathen bildete in neuester Zeit auch vielfach die Grundlage von Berechnungen der mittleren Höhe des Festlandes und der mittleren Tiefe des Meeres, sei es, daß man dabei nur rechnerisch verfuhr, wie MurraY ${ }^{19}$ und der Verfasser, ${ }^{17}$ oder sich der hypsographischen Kurve bediente, wie Penck. ${ }^{17}$ Diese Kurve schließt eine unregelmäßige Fläche $a b$, die an den geraden Seiten von den Ordinaten der höchsten Erhebung und der größten Tiefe und von der, der Ausdehnung des betreffenden Kontinentes oder Ozeans entsprechend langen Abszisse (dem Meeresspiegel) begrenzt wird (vgl. Fig. 11). Der Quotient dieser Fläche und der 
Länge der Abszisse ist die gesuchte mittlere Höhe bzw. Tiefe. Neben dieser planimetrischen Methode hat sich Heiderich ${ }^{1}$ auch der Profilmethode bedient, und in neuerer Zeit hat KaRstens ${ }^{20}$ auch wieder die ältere Feldermethode, die aber nur für die Ozeane angewandt wird, zu Ehren zu bringen gesucht. Uns scheint Penck's Methode den Vorzug zu verdienen, schon deshalb, weil sie auf kontinentale und ozeanische, auf große und kleine Gebiete in gleicher und einfacher Weise anwendbar ist, wenn sie auch bei der Konstruktion der Kurve Willkürlichkeiten nicht ganz ausschließt. Doch dürfen wir von diesen Mittelwerten nicht zuviel verlangen; sie bieten uns bequem zu handhabende Vergleichszahlen, führen aber nur auf indirekte Weise zu Vorstellungen über die Hauptzüge der Oberflächengestaltung und die Ausdehnnng der Gebirge, Hoch- und Tiefebenen. Wie große Fortschritte unsere Kenntnis von den Reliefverhältnissen des Landes in den letzten fünfzig Jahren gemacht hat, ersieht man am besten aus einem Vergleich der HuмвоLDT'schen Schätzung der mittleren Höhe mit den neueren Ermittlungen. HumBOLDT hatte $300 \mathrm{~m}$ gefunden, jetzt nimmt man rund $700 \mathrm{~m}$ als wahrscheinlichsten Wert an, jedoch mit Ausschluß von Antarktika. Für diese hat jüngst MeINardus ${ }^{21}$ auf Grund der Luftdruckverteilung eine mittlere Höhe von $2000 \mathrm{~m}$ herausgerechnet, und die Zahl klingt

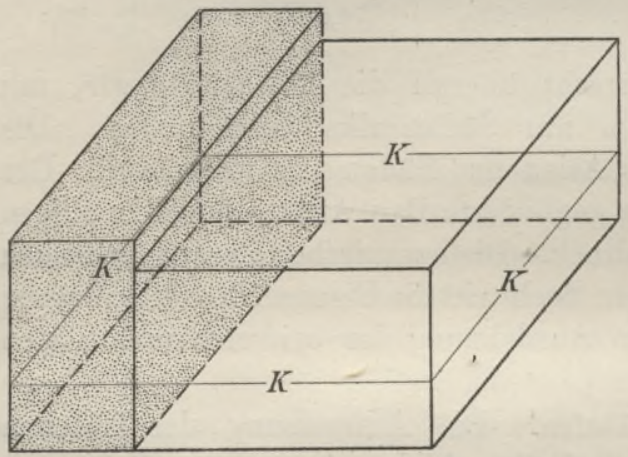

Fig. 12. Landblock (punktiert) und Wasserblock. nach den Erfahrungen der ShakLeton'schen Expedition, die bereits eine Seehöhe von $3000 \mathrm{~m}$ erreicht hat, nicht unwahrscheinlich. Die mittlere Landhöhe würde sich dadurch auf rund $800 \mathrm{~m}$ erhöhen; die entsprechende Zahl für das Meer ist $3700 \mathrm{~m}$.

Wir können uns, wie Fig. 12 zeigt, alles Land und alles Wasser zu je einem Block vereinigt denken; das Volumen des Landblocks ist $=148823000 \mathrm{qkm} \times(3,7+0,8) \mathrm{km}=670$ Mill. cbkm, das Volumen des Wasserblocks $=361128000 \mathrm{qkm} \times 3,7 \mathrm{~km}=1336$ Mill. cbkm, und der Landblock verhält sich somit zum Wasserblock wie $1: 2$. Das ist annähernd dieselbe Verhältniszahl, die wir für die beiden Oberflächen gefunden haben.

Denken wir uns den Landblock gleichmäßig über die Erde aus- 
gebreitet, so würde der Meeresboden um $1300 \mathrm{~m}$ erhöht werden. Dieses Niveau, $2400(=3700-1300) \mathrm{m}$ unter dem gegenwärtigen Meeresspiegel, nennen wir die mittlere Krustenhöhe ( $K$ in Fig. 12). Das Meer selbst, das nun die ganze Erde überflutet, hätte eine mittlere Tiefe von (1336 Mill. cbkm: 510 Mill. qkm) 2600 m, und der Erdhalbmesser würde dann um $2600-2400=200 \mathrm{~m}$ größer sein als jetzt.

Obwohl die mittlere Meerestiefe fünfmal größer ist als die mittlere Landhöhe, sind die größten bekannten Tiefen und Höhen doch annähernd gleich. Schon daraus müßte man den Schluß ziehen, daß auf dem Land die geringen Höhen und im Meer die

Nördliche Breite

Südliche Breite

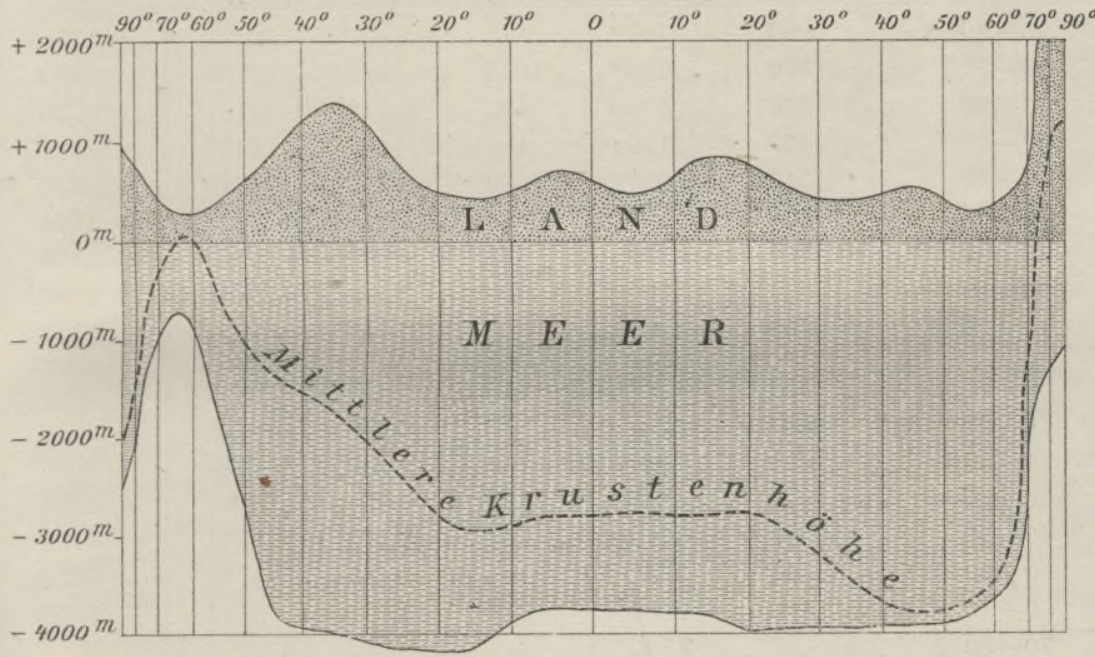

Fig. 13. Mittlere Höhe des Landes und mittlere. Tiefe des Meeres.

(Die Breiten sind in orthographischer Projektion dargestellt, der Abstand zwischen den Parallelkreisen wird polwärts in demselben $\mathrm{Ma} \beta$ kleiner wie die dazwischen liegenden Flächen.)

großen Tiefen vorherrschen, und wir haben bereits gesehen, daß dieser Schluß den Tatsachen völlig entspricht.

Nach Breitenzonen sind die mittleren Höhen und Tiefen von HeIDERICH $^{1}$ und TrLLo ${ }^{22}$ und in der neuesten Zeit die mittleren Tiefen von KRÜMMEL ${ }^{1}$ berechnet worden. Aus den Höhenzahlen v. Tiulo's und den Tiefenzahlen KrüMmel's haben wir die mittlere Krustenhöhe der Zonen von je $10^{\circ}$ Breitengraden abgeleitet und das Diagramm in Fig. 13 entworfen. Es ist in manchen Beziehungen lehrreich. Die mittleren Landhöhen sind beträchtlicherem Wechsel unterworfen, als die mittleren Meerestiefen, offenbar eine Folge davon, 
daß das Land den zerstörenden und modellierenden Einflüssen vielmehr ausgesetzt ist, als der Tiefseeboden. Ferner ist beachtenswert, daß die mittlere Krustenhöhe zweimal positiv wird, und zwar dort, wo annähernd die Ecken des Green'schen Tetraëders liegen. Durch diese Anordnung der vertikalen Maße erscheint die Abplattung der Kruste gemildert.

In den Grundzügen dürfte sich dieses Bild kaum mehr ändern, im einzelnen aber sind, wie nachstehende Tabelle zeigt, die Berech-

\begin{tabular}{|c|c|c|c|c|c|c|}
\hline & \multicolumn{2}{|c|}{ Nach v. Truso } & \multicolumn{2}{|c|}{ Nach Heiderich } & \multirow{2}{*}{$\begin{array}{c}\begin{array}{c}\text { Nach } \\
\text { KRÜMMEL }\end{array} \\
\begin{array}{c}\text { Mittlere } \\
\text { Meeres- } \\
\text { tiefe }\end{array}\end{array}$} & \multirow{2}{*}{$\begin{array}{c}\text { Mittlere } \\
\text { Krusten- } \\
\text { höhe }\end{array}$} \\
\hline & $\begin{array}{l}\text { Mittlere } \\
\text { Land- } \\
\text { höhe }\end{array}$ & $\begin{array}{l}\text { Mittlere } \\
\text { Meeres- } \\
\text { tiefe }\end{array}$ & $\begin{array}{l}\text { Mittlere } \\
\text { Land- } \\
\text { höhe }\end{array}$ & $\begin{array}{c}\text { Mittlere } \\
\text { Meeres- } \\
\text { tiefe }\end{array}$ & & \\
\hline $90-80^{\circ} \mathrm{N}$ & 860 & $740 \times$ & - & - & 2221 & -1950 \\
\hline $80-70$ & 550 & $630 \times$ & 1044 & $510 \times$ & 860 & $-\quad 440$ \\
\hline $70-60$ & $360^{*}$ & 890 & 492 & 718 & $767^{*}$ & $+\quad 50$ \\
\hline $60-50$ & 470 & 2130 & $480^{*}$ & 1801 & 2197 & -680 \\
\hline $50-40$ & 770 & 3650 & 652 & 3762 & 3845 & -1430 \\
\hline $40-30$ & 1350 & 4150 & 1472 & 3986 & 4025 & -1720 \\
\hline $30-20$ & 740 & 4150 & 750 & 3647 & 4059 & -2250 \\
\hline $20-10$ & $520^{*}$ & 4100 & $576^{*}$ & 3872 & 4124 & -2900 \\
\hline $10-0$ & 690 & $4020^{*}$ & 618 & $3489^{*}$ & $3800^{*}$ & -2780 \\
\hline $0-10^{0} \mathrm{~S}$ & 550 & 4100 & 622 & 3535 & 3854 & -2810 \\
\hline $10-20$ & 830 & 4200 & 907 & 3789 & 3919 & -2870 \\
\hline $20-30$ & 600 & 4420 & 735 & 3898 & 3945 & -2890 \\
\hline $30-40$ & 470 & 4120 & 528 & 3666 & 3906 & -3400 \\
\hline $40-50$ & 540 & 4210 & 623 & 3732 & 3892 & $-3750^{*}$ \\
\hline $50-60$ & $400^{*}$ & 3690 & $393^{*}$ & 2945 & 3764 & -3730 \\
\hline $60-70$ & 510 & 2850 & 843 & 2651 & 3352 & -2970 \\
\hline $70-80$ & 2000 & 1580 & - & - & 1337 & +1300 \\
\hline $80-90$ & & - & - & & & \\
\hline
\end{tabular}

nungen noch immer etwas problematisch. Die Maxima und Minima fallen zwar meist in die gleichen Zonen, aber die Zahlen selbst weichen doch noch erheblich voneinander ab. Es erklärt sich zur Genüge aus der Ungleichheit des Kartenmaterials und der Berechnungsmethode, sowie aus abweichenden Grenzbestimmungen. Wenn man dies im Auge behält, so wird man von der Übereinstimmung der neueren Ergebnisse betreffs der mittleren Höhe des Festlandes überrascht sein, während inbezug auf die einzelnen Kontinente die Angaben zum Teil noch schwankend sind. (Siehe nebenstehende Tabelle).

Vertikale und horizontale Ausdehnung scheinen im geraden Verhältnis zueinander $\mathrm{zu}$ stehen, ${ }^{33}$ obwohl wir den ursächlichen

$\times$ Diese Werte stammen aus der Zeit vor der ersten „Fram“-Expedition, die sehr beträchtliche Tiefen jenseits des 80 . Parallels lotete. 


\begin{tabular}{|c|c|c|c|c|c|c|c|c|}
\hline Autoren & 范 & 总 & $\frac{\pi}{5}$ & 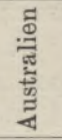 & 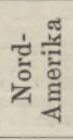 & 总营 & 选泀 & 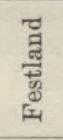 \\
\hline Huмвоцdт (1844). . & 205 & 351 & - & - & 228 & 345 & - & 307 \\
\hline (Einzelberechnungen) & $297^{23}$ & $940^{24}$ & $662^{25}$ & 一 & - & $582^{26}$ & $2000^{21}$ & - \\
\hline DE LAPPARENT $(1883)^{27}$ & 292 & 879 & 612 & 362 & 595 & 537 & - & 646 \\
\hline Murray $(1888)^{19}$. & 286 & 972 & 616 & 245 & 575 & 633 & - & 686 \\
\hline SUPAN $(1889)^{17}$. & 290 & 940 & 620 & 260 & 610 & 610 & - & 680 \\
\hline Penck $(1889)^{17}$. & 280 & 950 & 650 & 280 & 600 & 630 & - & 705 \\
\hline v. Tillo $(1889)^{28}$ & 317 & 957 & 612 & 240 & 622 & 617 & - & 693 \\
\hline HEIDERICH $(1891)^{1}$. & 375 & 920 & 602 & 470 & 830 & 760 & - & 744 \\
\hline Penck $(1893)^{18}$. . & 330 & 1010 & 660 & 310 & 650 & 650 & - & 735 \\
\hline WAGNER $(1895)^{29}$. . & 300 & 950 & 650 & 300 & 700 & 650 & - & 700 \\
\hline W AGNER $(1900 \mathrm{u} .1908)^{1}$ & 300 & 950 & 650 & 350 & 700 & 650 & - & 700 \\
\hline PeNCK $(1909)^{30}$. . . & 300 & 940 & 670 & 360 & 730 & 580 & - & 710 \\
\hline
\end{tabular}

Als mittlere Tiefe der Ozeane wird angegeben:

\begin{tabular}{|c|c|c|c|c|}
\hline Autoren & $\begin{array}{c}\text { Atlantisches } \\
\text { Gebiet }\end{array}$ & $\begin{array}{c}\text { Pazifisches } \\
\text { Gebiet }\end{array}$ & $\begin{array}{c}\text { Indisches } \\
\text { Gebiet }\end{array}$ & Weltmeer \\
\hline KRÜMMEL $(1879) \times{ }^{31}$. & 3180 & 36500 & 3310 & 3440 \\
\hline de Lapparent $(1883)^{27}$. & - & - & - & 4260 \\
\hline KRÜMMEL $(1886) \times 32 .$. & 3070 & 3650 & 3310 & 3320 \\
\hline Murray $(1888) \times 19$ & 3510 & 4140 & 3820 & 3800 \\
\hline SUPAN $(1889)^{17}$ & 3330 & 3870 & 3600 & 3650 \\
\hline PencK $(1889)^{17}$ & 3290 & 3870 & 3590 & 3650 \\
\hline v. Thllo $(1889)^{28}$. & 4020 & 4380 & 3670 & 3800 \\
\hline HeIDERICH $(1891)^{1}$ & - & - & - & 3440 \\
\hline KaRstens $(1894)^{20}$ & 3160 & 3830 & 3590 & 3500 \\
\hline KRÜMMEL 1907) $\times 1$. & 3260 & 3860 & 3860 & 3680 \\
\hline
\end{tabular}

Zusammenhang nicht aufzudecken vermögen. Einige Zahlen widersprechen übrigens zum Teil dieser Vermutung.

Literaturnachweise. ${ }^{1}$ F. R. Herderich, Die mittleren Erhebungsverhältnisse der Erdoberfläche, Wien 1891. Nach Breitenzonen geben neue Zahlen $\mathrm{H}$. WAgner in seinem Lehrbuch und $\mathrm{O}$. KrüMmes im Handbuch der Ozeanographie, Bd. I., Stuttgart 1907, nach Längszonen A. v. Thuso in Petermans's Mitteilungen 1895, S. 96. $-{ }^{2}$ H. Bexthien, Eine neue Bestimmung des Poles der Landhalbkugel, Kiel 1898. Vgl. dazu die kritischen Bemerkungen von A. Penck in der Geographisehen Zeitsehrift 1899, S. 121, und von O. Krümmei in Petermann's Mitteilungen, Literaturbericht 1899, Nr. $5699 .-{ }^{3}$ G. W. v. Zahn, Der Isthmus von Tehuantepec, in der Zeitschrift der Gesellschaft f. Erdkunde,

× Die Zahlen für die Einzelozeane habe ich, um Vergleichbarkeit zu erzielen, nach den Zahlen der betreffenden Autoren und nach deren Methoden berechnet. 
Berlin 1907. - 4 Über den Gebirgsbau Zentralamerikas s. die zusammenfassenden Arbeiten von K. SAPPER in den Ergänzungsheften Nr. 127 u. 151 zu Petermann's Mitteilungen. $-{ }^{5}$ A. J. Jukes-Brown und J. B. Harrison, The Coral Rocks and Oceanic Deposits of Barbados, im Quarterly Journal of the Geological Society, Bd. XLVII (1891) u. Bd. XLVIII (1892). - ${ }^{6}$ M. BlanckenноR,, Neues zur Geologie und Paläontologie Ägyptens, in der Zeitschrift der Deutschen Geologischen Gesellschaft, 1900 u. 1901 (auch gesammelt u. d. T. Geologie Ägyptens, Berlin 1901). — ${ }^{7}$ Sven Hedrs, Transhimalaya, Leipzig 1909. Vgl, dazu die Karte von Tibet von H. Навеnicht in Petermans's Mitteilungen 1910, Taf. 2. - 8 W. Vouz, Die geomorphologische Stellung Sumatras, in dè Geographischen Zeitschrift 1909. - 9 F. v. Ricнтноғел, Geomorphologische Studien aus Ostasien. Fünf Abhandlungen in den Sitzungsberichten der Berliner Akademie der Wissenschaften 1900-03. - ${ }^{10} \mathrm{~J}$. G. Anderssox, On the Geology of Graham Land, im Bulletin des Mineral.-geolog. Instituts in Upsala 1906, Bd. VII. - ${ }^{11}$ H. Basedow, Beiträge zur Kenntnis der Geologie Australiens, in der Zeitschrift der Deutschen Geologischen Gesellschaft, Bd. LXI, 1910. 12 National Antaretic Expedition 1901-04, Natural History, Bd. I, Geology, London 1907. - ${ }^{13} \mathrm{O}$. BEvL, Frühere und spätere Hypothesen über die regelmäBige Anordnung der Erdgebirge nach bestimmten Himmelsriehtungen; München 1905. - ${ }^{14}$ Lowtminan Green's Werk: Vestiges of the molten Globe (1. Bd. London 1875 ; 2. Bd. Honolulu 1887) ist selten, man findet aber alle notwendigen Aufschlüsse darüber in J. W. Gregory, The Plan of the Earth and its Causes (im Geographical Journal, 1899, Bd. XIII), W. Prinz, L'hypothèse de la déformation tétraédrique de la terre (im Annuaire astronomique pour 1902, Brüssel), B. K. Emerson, The Tetrahedral Earth and Zone of the Intercontinental Seas (im Bulletin of the Geological Society of America 1900, Bd. XI), und in Th. Arrdt, Die Gestalt der Erde, in Gertand's Beiträgen zur Geophysik 1905, Bd. VII. - ${ }^{15}$ D. Kreichqader, Die Äquatorialfrage in der Geologie, Steyl 1902. Die Theorie von J. Golfrer (Esquisse d'un système orthogonal, im Bulletin de la Société géologique de France, 1903) stimmt im wesentlichsten Punkt mit der Auffassung Kreichander's überein. - ${ }^{16}$ W. Prisz, Sur les similitudes que présentent les cartes terrestres et planétaires, im Annuaire de l'observatorie Royal de Bruxelles pour 1891. - ${ }^{17}$ In Petermans's Mitteilungen 1889, S. 17. (Daselbst auch die Berechnung von A. Supan.) - ${ }^{18}$ A. Penck, Morphologie der Erdoberfläche, Bd. I. - ${ }^{19}$ Sir John Murrax im Scottish Geographical Magazine, 1888, S. 1. - ${ }^{20}$ K. Karstens, Eine neue Berechnung der mittleren Tiefen der Ozeane, Kiel 1894. - ${ }^{21}$ W. Mernardus in Petermany's Mitteilungen 1909, S. 304 und 355. - ${ }^{22}$ A. v. Trulo in Petermans's Mitteilungen, 1889, S. 48. - ${ }^{23}$ G. Lerpond, Die mittlere Höhe Europas, Plauen i. V. 1874. 24 O. Lonentzen, Die mittlere Höhe von Asien, Leipzig 1906. - ${ }^{25}$ J. Chavanne, Die mittlere Höhe Afrikas, in den Mitteilungen der Wiener Geographisehen Gesellschaft, 1881. - ${ }^{26}$ H. HAack, Die mittlere Höhe von Südamerika, Halle a.S. 1896. - ${ }^{27}$ A. de Lapparent, Traité de Geologie, Paris 1883. - ${ }^{28}$ A. v. Tillo, in den Iswesstijä der Russischen Geographischen Gesellschaft, 1889, S. 113. ${ }^{29}$ Herm. Wagner, Areal und mittlere Erhebung der Landflächen, sowie der Erdkruste; in Gerland's Beiträgen zu Geophysik 1894. Bd. II. - ${ }^{30}$ A. Реncк, Die Erdoberfläche, in A. Scoвen's Geographischem Handbuch, Bielefeld 1909, Bd. I. - ${ }^{31}$ O. KrÜмmen, Versuch einer vergleichenden Morphologie der Meeresräume, Leipzig 1879. - ${ }^{32}$ O. Krüмmes, Der Ozean, Leipzig 1886. - ${ }^{33}$ A. v. TrLlo in Petermann's Mitteilungen 1889, S. 49. 


\section{Zweiter Abschnitt. Die Lufthülle.}

\section{Allgemeine Vorbemerkungen.}

Die Schwankungen. Alles auf Erden ist steten Veränderungen unterworfen. Sie vollziehen sich umso rascher, je beweglicher die Teilchen sind: in der Regel langsam und nur in größern Zeiträumen zu merklichen Wirkungen sich summierend in der festen Erdoberfläche, schon deutlich wahrnehmbar in der flüssigen, und am schnellsten in der gasförmigen Lufthülle, die in der Form eines Hohlsphäroids die Erde umgibt. Ein Teil dieser Zustandsschwankungen kehrt annähernd regelmäßig zu bestimmten Zeiten wieder - wir nennen sie die periodischen -; andere, die unperiodischen, sind an kein Zeitgesetz gebunden und erscheinen uns daher überhaupt als willkürlich, ja der naiven Anschauung geradezu als Eingriffe höherer Mächte in die Ordnung der Dinge, und die Wissenschaft arbeitet unablässig daran, auch sie in den gesetzmäBigen Zusammenhang der Erscheinungen einzureihen.

Um periodische und unperiodische Veränderungen voneinander zu scheiden und die ersteren zum klaren Ausdruck zu bringen, gibt es einen bequemen Weg: die Bildung mathematischer Mittel aus längeren, ununterbrochenen Beobachtungsreihen. Die ganze Meteorologie beruht auf dieser Methode. Sie führt uns zur Erkenntnis einer täglichen und einer jährlichen Periode, und schon treten, wenn auch noch nicht in so scharfen Umrissen, Perioden höherer Ordnung in unsern wissenschaftlichen Gesichtskreis.

Indes darf man von der Methode der Mittelbildung nicht zuviel erwarten. Sie beruht auf der Voraussetzung, daß die Störungen der Periode - d. h. die unperiodischen Veränderungen - eben so oft im negativen wie im positiven Sinn auftreten, und diese Voraussetzung trifft nirgends in vollem $\mathrm{Maß} \mathrm{zu}$, und umso weniger, je komplizierter ein Phänomen ist. Auch die meteorologischen Elemente, wie Temperatur, Luftdruck, Winde, Feuchtigkeit, Niederschlag, ver- 
halten sich in dieser Beziehung verschieden; bei manchen sind die unperiodischen Veränderungen so übermächtig, daß selbst in langjährigen Mittelwerten die eine oder andere Periode nur schwach durchschimmert oder gar völlig verdeckt wird. Die jährliche Periode wird verhältnismäßig am wenigsten dadurch betroffen, und ihr kommt auch in der geographischen Klimalehre die gröBte Bedeutung $\mathrm{zu}$.

Höhe der Lufthülle. ${ }^{2}$ Die Luft bildet einen Bestandteil der Erde, aber ihre äußere Grenze ist unsicher. Man hat ihre Höhe nach dem ersten Aufleuchten der Sternschnuppen, nach dem Verschwinden der blauen Himmelsfarbe bei Eintritt der Dämmerung und nach anderen Anzeichen auf rund 200-250 km berechnet, also nur auf den 30. Teil des Halbmessers der festen Erde. Darüber hinaus erfüllen verdünnte Gase den Raum zwischen dem Planeten und der Sonne: Gase, die man im Gegensatz zur Erdenluft als Himmels luft bezeichnet hat, und die sehr wohl zu unterscheiden sind ron dem Äther, jenem angenommenen Medium, das alle Zwischenräume zwischen der ponderablen Materie erfüllt und uns die elektrischen, Wärme- und Lichterschęinungen vermittelt. Während die Erdenluft noch an der Bewegung der Erde teilnimmt, verharrt die Himmelsluft in relativer Ruhe oder bewegt sich nach verschiedenen Richtungen, begleitet aber zugleich das ganze Planetensystem auf seiner Wanderung durch den Weltenraum. Eine ziffermäßige Grenze zwischen der Himmels- und Erdenluft läßt sich noch nicht angeben, aber aus der Beobachtung der ,silbernen Wolken (Jesse'schen Nachtwolken)" wissen wir, daß sich schon in $82 \mathrm{~km}$ Höhe die Luftschichten nicht mehr in völliger Abhängigkeit von der Drehung der Erde befinden. Die meteorologischen Erscheinungen beschränken sich aber auf eine verhältnismäßig geringe Höhe. Die Atmosphäre ist, wie alle Körper, schwer; eine bis zum Meeresniveau herabreichende Luftsäule hält im Mittel einer $760 \mathrm{~mm}$ hohen Quecksilbersäule das Gleichgewicht. Mit zunehmender Höhe nimmt der Luftdruck $a b$, denn die auf dem Barometer lastende Luftsäule wird kleiner. Dem Luftdruck ist aber auch die Dichte proportional, denn jede Schicht drückt auf die untere und preßt sie zusammen. Schon in $5513 \mathrm{~m}$ Seehöhe ist die Luft um die Hälfte dünner als im Meeresniveau (Dichte $=1$ ), und in einer Höhe von $59400 \mathrm{~m}$ ist der Barometerstand schon auf $1 / 4 \mathrm{~mm}$ und die Dichte auf 0,0003 gesunken.

Zusammensetzung der Luft. Die trockene Atmosphäre, ist ein Gemenge von Gasen, von denen folgende fünf die wichtigsten sind: Stickstoff 78,03 Prozent des Volumens, Sauerstoff 20,99 Prozent, Argon, ein dem Stickstoff verwandtes, aber schwereres Element 0,94 Prozent, 
Kohlensäure 0,03 und Wasserstoff 0,01 Prozent. Diese Zusammensetzung kann für alle Breiten und für Höhen bis ungefähr $6000 \mathrm{~m}$ als konstant betrachtet werden. Darüber hinaus gewinnen die leichten Gase die Oberhand, und es ist berechnet worden, daB jenseit $70-80 \mathrm{~km}$ Höhe ein Wasserstoffmantel die eigentliche Lufthülle umschließt.

Unter den genannten Bestandteilen sind der Sauerstoff, der den AtmungsprozeB des tierischen Organismus unterhält, und die Kohlensäure, die Ernährerin der Pflanzenwelt, am wichtigsten. Die Existenzfähigkeit des Menschen hört auf, wenn sich der Sauerstoffgehalt auf 17,2 Prozent vermindert. Da dünnere Luft weniger Sauerstoff enthält als dichtere, so ist dem tierischen Leben eine Höhengrenze gesetzt die $13000 \mathrm{~m}$ nicht übersteigen dürfte. Die sogenannte „Bergkrankheit“, die fast jeden in bedeutender Seehöhe befällt, wird nicht durch die geringe Dichtigkeit der Atmosphäre, sondern durch die Abnahme des Sauerstoffgehaltes verursacht; erhielt sich doch Berson noch in $9155 \mathrm{~m}$ Höhe (4. Dez. 1894) durch künstliche Zufuhr von Sauerstoff frisch bei Kräften. Bei der Fahrt am 31. Juli 1901 blieb das Befinden der beiden Luftschiffer, Berson und Süring, ebenfalls bis $9000 \mathrm{~m}$ Höhe normal, und bis $10250 \mathrm{~m}$ Höhe konnten die meteorologischen Instrumente noch regelmäßig abgelesen werden; auch damit scheint aber die äußerste Höhengrenze für den menschlichen Organismus noch nicht erreicht worden zu sein, denn die Italiener Mrna und Piacenza sollen am 12. August 1909 bis $11700 \mathrm{~m}$ Höhe aufgestiegen sein. Da Sauerstoff bei der Verwitterung einiger Mineralien verbraucht wird, so ist die Frage berechtigt, ob er sich nicht im Lauf der Zeit vermindere. Aber diese Gefahr scheint nicht drohend zu sein; da durch die Zersetzung der Kohlensäure, von der die Pflanzen nur den Kohlenstoff aufnehmen, immer wieder Sauerstoff der Luft zugeführt wird, so brauchen nur die Vorräte an Kohlensäure vermehrt zu werden, und dafür sorgen die vulkanischen Ausströmungen in ausreichender Weise. Von den zufälligen Bestandteilen der Luft ist der Wasserdampf als eine wesentliche Bedingung des organischen Lebens am wichtigsten. Er ist zwar immer und überall vorhanden, aber seine Menge ist außerordentlichen Schwankungen unterworfen. Staub, gasförmige Fäulnisprodukte und mikroskopische Organismen, die häufig die Träger ansteckender Krankheiten sind, verunreinigen überall die Luft, besonders in Fabrikbezirken und Großstädten. In Palermo beträgt der Gehalt an organischen Substanzen vom Februar bis Mai 0,102 und steigert sich im trockenen Sommer auf 0,160 Volumprozente. Der Regen wäscht also gleichsam die Atmosphäre und ist daher von eminenter sanitärer Bedeutung. 
Literaturnachweise. ${ }^{1}$ Hier sind zunächst von den unfangreicheren Darstellungen der physisehen Geographie zu nennen: S. Günther, Handbuch der Geophysik, 2. Aufl., Stuttgart 1899, mit einer unerreichten Fülle von Literaturangaben in steter Rücksichtnahme auf die geschichtliche Entwicklung; Haxs, Hochstetter, Poкorny, Allgemeine Erdkunde, 5. Aufl. (bearbeitet von J. Haxx, E. Brǘckner u. A. Kтrсhноғf), Wien 1896-99; F. Ratzer, Die Erde und das Leben, Leipzig 1901-02; S. Arrhenius, Lehrbuch der kosmischen Physik, Leipzig 1903; E. de Martonne, Traité de géographie physique, Paris 1909. Allgemeine Werke über Meteorologie und Klimatologie: J. Hans, Lehrbuch der Meteorologie, Leipzig 1901, 2. Aufl. 1906 (die zweite Auflage ersetzt die erste nicht völlig, da manche Partien kürzer behandelt und die literarisehen Nachweise weniger zahlreich sind). Eine ausgezeichnete geschichtliche Darstellung gibt das im Erscheinen begriffene Werk von H. Hindebrandssox und L. Teisserenc DE Bont, Les bases de la météorologie dynamique, Paris seit 1898. Die umfangreichsten klimatologischen Darstellungen sind: J. Haxx, Handbuch der Klimatologie, 2. Aufl., Stuttgart 1897, (1. u. 2. Band in dritter erweiterter Auflage 1908 u. 1910), und A. Worrкow, Die Klimate der Erde, Jena 1887. Kartographische Darstellungen bieten Haxn's Atlas der Meteorologie in Berghaus' Physikalisehem Handatlas, Gotha 1887, und noch vollständiger J. G. Bartholomew u. A. J. Herbertson, Atlas of Meteorology (Bd. IV von Bartholomew's Physical Atlas), London 1899. - ${ }^{2}$ W. Förster, Von der Erdatmosphäre zum Himmelsraum, Berlin 1906.

\section{Die Erleuchtung und Erwärmung der Erdoberfläche.}

Wärmequellen. Licht und Wärme, die uns die Sonne spendet, bedingen das organische Leben. Gegenüber der Sonne verschwinden alle andern Wärmequellen. Die Eigenwärme unseres Planeten trägt nach TRABERT nur $0,1^{\circ}$ zurErhöhung der Oberflächentemperatur bei und könnte im Laufe eines Jahres nur eine Eisschicht von 7,4 mm Dicke schmelzen; und wäre die Erde allein auf die Wärme, die die Fixsterne uns zusenden, angewiesen und ohne Lufthülle, so würde ihre Oberflächentemperatur, wie HavN meint, den absoluten Nullpunkt $\left(-273^{\circ}\right)$ nicht übersteigen.

Die Sonne ist ein glühender Körper, umgeben von einer ebenfalls glühenden Atmosphäre, die für uns allein sichtbar ist. Auf ihrer Oberfläche bemerkt das bewaffnete Auge wechselnde Flecken, über deren Wesen die Meinungen noch geteilt sind. Rudolf WoLf erkannte in ihrem Auftreten eine gewisse RegelmäBigkeit, indem von einem Maximum bis zum nächsten durchschnittlich ein Zeitraum von 11 Jahren verstreicht. Wir werden sehen, wie sich diese Fleckenperiode auch in einigen irdischen $\mathrm{Phänomenen} \mathrm{widerspiegelt.}$

Die Sonne sendet leuchtende und dunkle oder Wärmestrahlen aus; ${ }^{\times}$

$\times$ Langley gibt für die Verteilung der Energie im Sonnenspektrum folgende Werte:

Wellenlänge in

Mikron....

Spektrum ...

Licht ......

Wärme .....

$\begin{array}{cccc}0,35 & 0,40 & 0,45 & 0,50 \\ \text { violett } & \text { blau } & \text { grün } \\ -\quad 0,8 & 2,8 & 25,0 \\ 1,8 & 5,3 & 11,9 & 17,3\end{array}$

$\begin{array}{ccr}0,55 & 0,60 & 0,65 \\ \text { gelb } & \text { orange } & \text { rot } \\ 82,0 & 66,5 & 12,3 \\ 20,7 & 21,9 & 22,2\end{array}$

$0,70 \quad 0,75$

0,77

dunkelrot

$21, \overline{0}+\overline{2}$

20,2 
einige davon zeichnen sich auch durch ihre chemischen Wirkungen aus. Diese Unterscheidung ist wichtig, wie wir später sehen werden.

Die Bestrahlungsgesetze. Nicht die Bestrahlung an sich, sondern ihre ungleichmäBige Verteilung ist die letzte Ursache aller meteorologischer Prozesse; sie ist begründet in der Kugelgestalt der Erde, in ihrer Rotation und in der Schiefe und elliptischen Gestalt ihrer Bahn.

1. Die Kugelgestalt bewirkt, daß die Sonnenstrahlen die Erdoberfläche unter verschiedenen Winkeln treffen, Aus Fig. 14 ist ersichtlich, daß die Fläche, auf die ein Strahlenbündel unter einem schiefen Winkel $(\varepsilon)$ auffällt $(A B)$, größer ist, als die, die von demselben Strahlenbündel senkrecht getroffen $\operatorname{wird}(A C)$; die Wirkung ist im erstern Fall, weil sie sich über eine weitere Fläche verteilt, schwächer als im zweiten, wo sie sich auf die kleinste Fläche konzentriert. Die Erleuchtung und Erwärmung wächst mit dem Sinus des

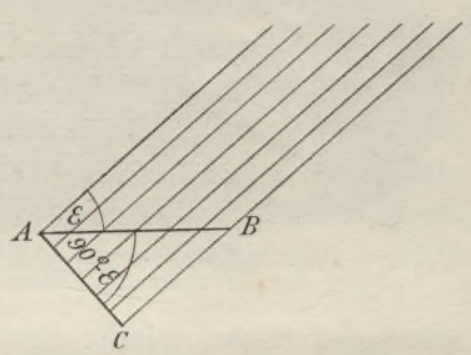

Fig. 14. Einfallswinkels der Sonnenstrahlen. $\times$

2. Infolge der Achsendrehung der Erde ist immer nur eine Erdhälfte den Sonnenstrahlen ausgesetzt, während die andere die empfangene Wärme in den kalten Weltraum ausstrahlt. An jedem Punkt der Erdoberfläche wechseln also Tag und Nacht, eine Zeit der Erwärmung und eine Zeit der Abkühlung, und die Temperatur ist somit einer 24 stündigen Perigde unterworfen. Sie stejgt mit zunehmendem Einfallswinkel vom Morgen bis zum Mittag, nimmt dann entsprechend der Verringerung des Einfallswinkels bis zum Sonnenuntergang $a b$, und die Abnahme setzt sich während der Nacht bis zum nächsten Sonnenaufgang fort.

3. Würde die Bahn, auf der die Erde die Sonne umwandelt, mit der Äquatorialebene zusammenfallen, so würde jeder Punkt der Erdoberfläche das ganze Jahr hindurch die Sonnenstrahlen unter dem gleichen Winkel empfangen, Tag und Nacht wären immer und überall von gleicher Dauer, und es gäbe keine Jahreszeiten und keine jährliche Temperaturperiode. Nun bildet aber die Erdbahn mit

$\times$ Die Bestrahlungsintensität in $A B(=I)$ verhält sich zu der in $A C$ (=1) umgekehrt wie die Flächen.

$$
\begin{gathered}
I: 1=A C: A B \\
I=\frac{A C}{d B}=\cos \left(90^{\circ}-\varepsilon\right)=\sin \varepsilon .
\end{gathered}
$$


der Äquatorialebene einen Winkel von $23^{1} /{ }^{0}$ (genauer $23^{0} 27^{\prime}$ ), und die Erdachse, die während des ganzen Umlaufes mit sich selbst parallel bleibt, ist unter einem Winkel von $66^{1} /{ }^{0}$ (genauer $66^{0} 33^{\prime}$ ) gegen die Erdbahn. geneigt. Die nachstehenden Figuren zeigen die Stellung der Erde zur Sonne in den vier Epochen des Jahres. Die Sonnenstrahlen können wegen der großen Entfernung beider Himmelskörper voneinander als parallel gedacht werden.

Fig. 15 stellt die Erde am 22. Dezember dar. Der Wendekreis des Steinbocks, $23{ }^{1} /{ }^{0}$ südl. vom Äquator, wird. von senkrechten

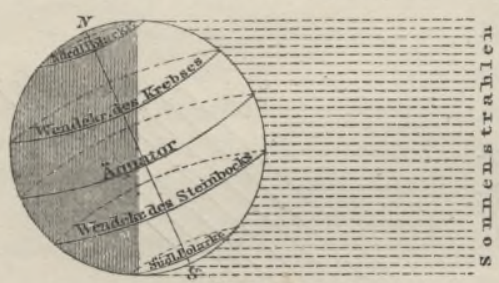

Fig. 15 .

Stellung der Erde am 22. Dezember. Strahlen getroffen. Die ganze Kalotte innerhalb des nördlichen Polarkreises $\left(66^{1} / 2\right.$ B.) fällt in die unbeleuchtete, die ganze Kalotte innerhalb des südlichen Polarkreises in die beleuchtete Erdhälfte. Die südliche Hemisphäre hat den längsten, die nördliche den kürzesten Tag; auf jener beginnt der astronomische Sommer, auf dieser der Winter, und zwar einerseits wegen der Kürze des Tages, anderseits weil jeder Punkt der Nordhalbkugel die Sonnenstrahlen unter einem spitzeren Winkel empfängt, als ein unter gleicher Breite befindlicher Punkt auf der südlichen Hemisphäre.

Am 21. März und 23. September steht die Erde in den Schnittpunkten der Bahn und der Äquatorialebene (s. Fig. 16). Senkrechte

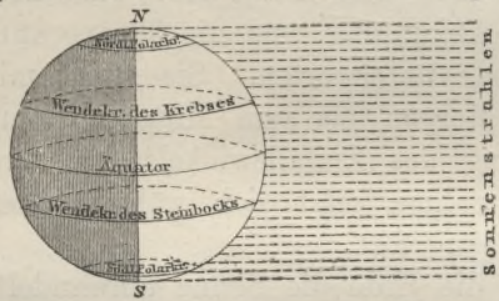

Fig. 16. Stellung der Erde am 21. März und 23. September.

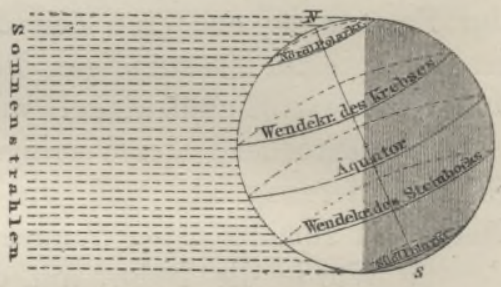

Fig. 17. Stellung der Erde am 22. Juni.

Strahlen treffen nur den Äquator; der Winkel, unter dem die Strahlen auf die beiden Hemisphären einfallen, ist unter gleicher geographischer Breite gleich. Ebenso ist auf der ganzen Erde (mit Ausnahme der Pole) Tag und Nacht gleich lang. An diesen beiden Tagen beginnen die astronomischen Übergangsjahreszeiten Frühling und Herbst.

Fig. 17 zeigt die Stellung der Erde zur Sonne am 22. Juni. Senkrechte Sonnenstrahlen fallen auf den Wendekreis des Krebses $\left(23^{1} / 2^{0}\right.$ n. B.). Die nördliche Hemisphäre hat den längsten Tag und 
Sommeranfang, die südliche den kürzesten Tag und Winteranfang; und ebenso verhalten sich die beiden polaren Kalotten gerade umgekehrt wie am 22. Dezember.

Von den vier astronomischen Jahreszeiten weichen die meteorologischen in bezug auf die Begrenzung und Dauer etwas ab:

$\begin{array}{lll}\text { Dezember-Februar } & \begin{array}{c}\text { Nordhemisphäre } \\ \text { Winter }\end{array} & \begin{array}{c}\text { Südhemisphäre } \\ \text { Sommer }\end{array} \\ \text { März-Mai . . . . Frühling } & \text { Herbst } \\ \text { Juni-August . . . . Sommer } & \text { Winter } \\ \text { September-November } & \text { Herbst } & \text { Frühling. }\end{array}$

4. Die Länge der astronomischen Jahreszeiten ist etwas verschieden, und die nördliche Halbkugel erscheint dadurch bevorzugt, denn $\mathrm{ihr}$ Winterhalbjahr (23. September bis 21. März) dauert nur 179 Tage, während es auf der südlichen 7 Tage länger ist. Der Grund dieser Ungleichheit liegt in der elliptischen Gestalt der Erdbahn, die allerdings sehr wenig von der Kreisform abweicht, denn die Exzentrizität (Abstand der Brennpunkte vom Mittelpunkt) beträgt nur $1 / 60$ der großen Achse.

Die Sonne steht, wie Fig. 18 schematisch zeigt, in einem Brennpunkt, und die Erde befindet sich daher einmal im Jahr in der Sonnennähe (Perihel) und einmal in der Sonnenferne (Aphel). Während die Erde im Mittel in 24 Stunden einen Bogen von 59' 8" zurücklegt, rückt sie im Perihel um 61'10" und im Aphel nur um $57^{\prime} 12^{\prime \prime}$ vor. Da die Erde jetzt am 1. Januar im Perihel und am 2. Juli im Aphel stêht, so gelangt sie rascher vom Herbst- zum Frühlingspunkt, als vom Frühlings- zum Herbstpunkt, woraus sich die längere Dauer des südlichen Winters und nördlichen Sommers erklärt.

Das Perihel hat aber keine konstante Lage, sondern verschiebt sich jährlich um $61,7^{\prime \prime}$ in der Richtung gegen den Frühlingspunkt, und dementsprechend das Aphel gegen den Herbstpunkt, so daß die Sonne im Sommersolstitium (22. Juni) nicht mehr im Zeichen des Krebses steht, wie vor 2000 Jahren zur Zeit Hipparch's, des Begründers der wissenschaftlichen Astronomie, sondern $30^{\circ}$ westlich davon. Wenn das Perihel den Frühlingspunkt erreicht haben wird, werden Sommer- und Winterhälfte des Jahres gleich sein. Von da an wird die Südhemisphäre begünstigter sein, und in ungefähr 10500 Jahren werden Perihel und Aphel ihre Plätze gewechselt haben, und der nördliche Winter wird länger sein als der südliche. In einem Zeitraum von $\left(360^{\circ}\right.$ oder $\left.1296000^{\prime \prime}: 61,7=\right)$ ungefähr 21000 Jahren vollführt somit die Apsidenlinie ( $P A$ in Fig. 18) einen Umlauf. Man nennt diesen Vorgang die Präzession. 
Auf die Wärmezufuhr haben jedoch diese Veränderungen keinen Einfluß, auch wenn einmal der Unterschied von Sommer- und Winter-

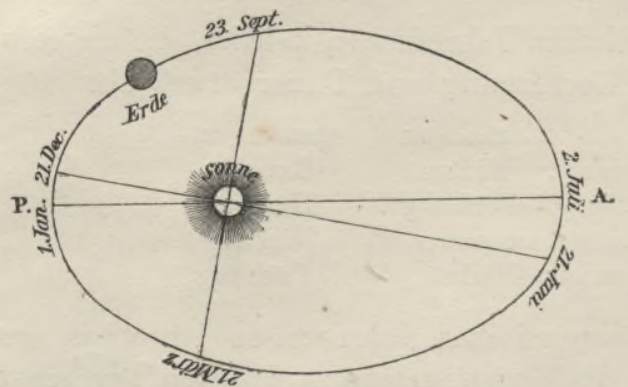

Fig. 18. Die Erdbahn.

halbjahr seinen äußersten Grenzwert von 36 Tagen erreicht haben wird. Unter allen Umständen erhält jede Halbkugel im Winterhalbjahr37 und im Sommerhalbjahr 63 Prozent der jährlichen solaren Strahlen. menge, und nur darin besteht ein Unterschied, daß sich die konstante Wärmezufuhr auf verschieden lange Perioden verteilt, daß also, wenn die Zahl der Tage eines Halbjahrs größer ist, durchschnittlich weniger Wärme auf einen Tag entfällt als im entgegengesetzten Fall.

Das Grundgesetz des solaren Klimas. Die Erleuchtung und Erwärmung jedes Punktes der Erdoberfläche hängt in erster Linie von der Sonnenhöhe, d. h. dem Einfallswinkel der Sonnenstrahlen, und von der Dauer der Bestrahlung, d. h. der Tageslänge ab. Beide sind eine Funktion der geographischen Breite.

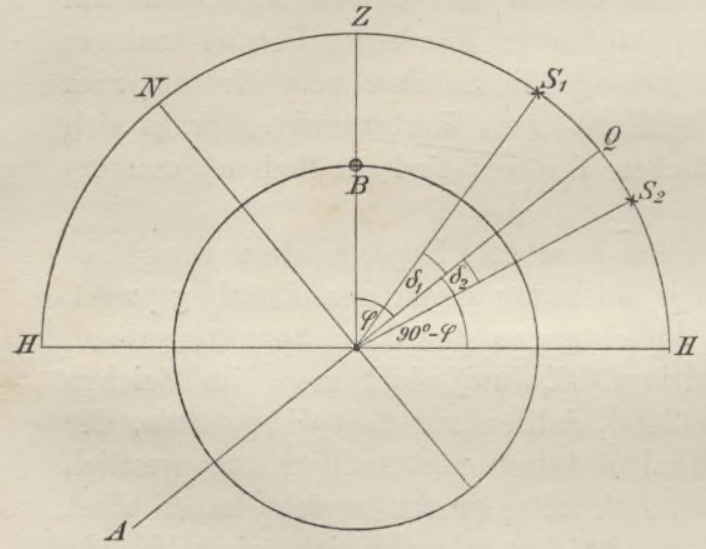

Fig. 19.

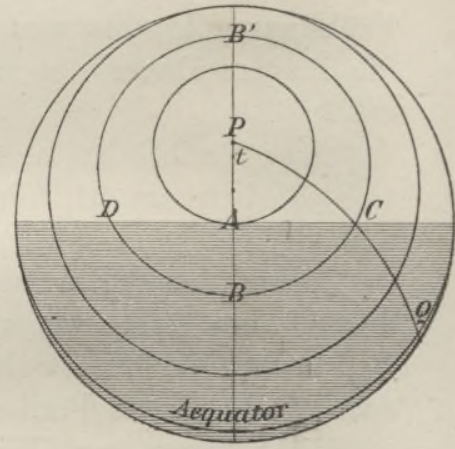

Fig. 20.

In Fig. 19 steht für den nordhemisphärischen Punkt $B$ die Sonne an einem Sommertag am Mittag in $S_{1}$ und an einem Wintertag in $S_{2}$. Im erstern Fall ist ihr Abstand vom Äquator $(A Q)$ oder ihre Deklination (Winkel $\delta_{1}$ ) positiv, im zweiten (Winkel $\delta_{2}$ ) negativ. Bezeichnen wir die geographische Breite von $B$ mit $\varphi$ (entsprechend dem 
Bogen $Z Q$ ), so ist die Höhe dẹ Sonne über dem Horizont $(H H)$ im ersten Fall $=\left(90^{\circ}-\varphi\right)+\delta_{1}$, und im zweiten $=\left(90^{\circ}-\varphi\right)-\delta_{2}$. Für die südliche Hemisphäre ist die nördliche Deklination der Sonne negativ und die südliche positiv.

Fig. 20 stellt uns eine Halbkugel in der Epoche ihres Sommeranfangs dar. Die Grenze zwischen der beleuchteten und unbeleuchteten Hälfte geht durch den Punkt $A, 66^{1} /{ }^{0}{ }^{0}$ vom Äquator, $23^{1} /{ }^{0}$ vom Pol $(P)$ entfernt. Ein Punkt in der Breite $\varphi$ befindet sich Mittags in $B^{\prime}$, tritt bei $D$ in die Nachthälfte ein und verläBt diese bei $C$; der Tagbogen $C B^{\prime} D$ ist augenscheinlich beträchtlich größer als der Nachtbogen $D B C$ : Die Größe des halben Nachtbogens $B C$ entspricht dem Winkel $t$; wir können ihn aus dem rechtwinkligen sphärischen Dreieck $P A C$, worin $A P 23^{1} /{ }_{2}{ }^{0}$ und $P C=P Q-C Q$ oder $90^{\circ}-\varphi$ ist, nach der Formel $\cos t=\operatorname{tang} 23^{1} / 2^{0} \times$ cotang $\left(90^{\circ}-\varphi\right)$ berechnen und das Bogenmaß dann in Zeitmaß $\times$ übertragen.

So entscheidend auch die geographische Breite für die Wärmezufuhr ist, so ist sie für die endgültige Temperaturverteilung doch nicht der einzige Faktor, und es widerstreitet daher durchaus den tatsächlichen Verhältnissen, wenn man die aus den Zeiten der griechischen Naturphilosophie uns überkommene Einteilung jeder Hemisphäre in drei Klimazonen, die durch die Wende- und Polarkreise voneinander getrennt werden, noch aufrecht erhalten will. Dagegen behalten diese Zonen noch ihren vollen Wert, wenn man sie ausschlieBlich auf die Beleuchtungsverhältnisse anwendet; nur muß man ihnen dann andere als die üblichen Namen beilegen. Wir nennen den Gürtel zwischen Äquator und Wendekreis die Tropen-, den zwischen Wende- und Polarkreis die mittlere, und den Kugelabschnitt innerhalb des Polarkreises die polare Zone. Nur bis zur Grenze der Tropenzone treffen senkrechte Strahlen die Erdoberfläche, und zwar zweimal im Jahr und nur an den Wendekreisen einmal. Die mittlere Zone hat mit der tropischen nur den regelmäBigen Wechsel von Tag und Nacht innerhalb 24 Stunden gemein.

Vom Äquator, wo Tag und Nacht immer gleich sind, bis zu den Polen, wo ein halbjähriger Tag mit einer halbjährigen Nacht wechselt, nimmt im Sommer die Tages- und im Winter die Nachtlänge stufenweise $\mathrm{zu}$ :

Tropische und mittlere Zone:

G. B.

$0^{\circ} \quad 10^{\circ} \quad 20^{\circ}$

$30^{\circ}$

$40^{\circ}$

$50^{\circ} \quad 60^{\circ} \quad 66^{1 / 2} 2^{\circ}$

Längster Tag . $12^{\mathrm{h}} 0^{\mathrm{m}} 12^{\mathrm{h}} 35^{\mathrm{m}} 13^{\mathrm{h}} 13^{\mathrm{m}} 13^{\mathrm{h}} 56^{\mathrm{m}} \quad 14^{\mathrm{h}} 51^{\mathrm{m}} \quad 16^{\mathrm{h}} 9^{\mathrm{m}} \quad 18^{\mathrm{h}} 30^{\mathrm{m}} \quad 24^{\mathrm{h}} 0^{\mathrm{m}}$

$\begin{array}{llllllllllllllll}\text { Kürzester Tag } & 12 & 0 & 11 & 25 & 10 & 47 & 10 & 4 & 9 & 9 & 7,51 & 5 & 30 & 0 & 0\end{array}$

$\begin{array}{llllllllllllllllll}\text { Unterschied } . & 0 & 0 & 1 & 10 & 2 & 26 & 3 & 52 & 5 & 42 & 8 & 18 & 13 & 0 & 24 & 0\end{array}$

$\times 360^{\circ}=24$ Stunden, $1^{\circ}=4$ Minuten, $1^{\prime}=4$ Sekunden. 
Nordpolare Zone:

\begin{tabular}{|c|c|c|c|c|}
\hline & G. B. $\quad 66^{1} / 2^{0}$ & $70^{\circ}$ & $80^{\circ}$ & $90^{\circ}$ \\
\hline Die Sonne gel & unter. 1 & 65 & 134 & 186 \\
\hline e ge & auf & 60 & 127 & 179 \\
\hline
\end{tabular}

Für die südliche Hemisphäre sind die Zahlen umzukehren. Am antarktischen Pol geht z. B. die Sonne 179 Tage nicht unter und 186 Tage nicht auf.

Einfluß der Lufthülle. Wir haben bisher von der Lufthülle abgesehen, durch die die Zufuhr von Licht und Wärme wesentlich modifiziert wird. Nicht alle Sonnenstrahlen gelangen bis zur Erdoberfläche, besonders die roten werden von der Atmosphäre gleichsam verschluckt, und die Abhängigkeit der Belichtung und Erwärmung von der Sonnenhöhe wird dadurch noch erheblich verschärft, denn je schiefer die Strahlen einfallen, desto länger ist ihr Weg durch die Lufthülle. $\times$ Namentlich sind es Kohlensäure und Wasserdampf, die die dunklen Wärmestrahlen absorbieren; es ist jedermann bekannt, wie sehr dichter Nebel oder eine ununterbrochene Wolkendecke die Bestrahlung verhindern. Diese atmosphärische Eigenschaft selektiver Wärmedurchlässigkeit oder Diathermanität kommt uns aber insofern wieder zugut, als sie auch die nächtliche Wärmeausstrahlung der Erdoberfläche vermindert; sie mildert die tägliche wie die jährliche Temperaturperiode.

Andere Strahlen, besonders die blauen, werden, vielleicht von feinsten Stäubchen, die die Atmosphäre trüben, nach allen Seiten zerstreut, und diesem Vorgang ist die blaue Farbe des Firmaments zuzuschreiben. Der Diffusion haben wir es auch zu danken, daß der ganze Himmel uns Licht und Wärme zustrahlt, und daß die beschatteten Teile der Erdoberfläche nicht finster und kalt sind.

Solange die Sonne nicht tiefer als $18^{\circ}$ unter dem Horizont steht, wird ihr Licht von der Atmosphäre reflektiert; so entsteht die Dämmerung, die die astronomische Dauer der Nächte beschränkt. Jener. Grenzwert wird am Abend um so später und am Morgen um so früher erreicht, je kleiner der Winkel ist, den die scheinbare Sonnenbahn mit dem Horizonte bildet; die Dauer der Dämmerung wächst daher mit der geographischen Breite. In der Tropenzone gehen Tag und Nacht fast unvermittelt ineinander über. Dagegen gibt es von $50^{1} /{ }^{0} \mathrm{~B}$. an zur Zeit des höchsten Sonnenstandes keine eigentlichen Nächte mehr, indem Abend- und Morgendämmerung ineinander fließen. In der Breite von St. Petersburg z. B. dauern diese hellen Nächte vom 27. April bis 15. August. Für

$\times$ Strahlungsintensität in Prozenten auf einer horizontalen Fläche:

$\begin{array}{llllllllllll}\text { Sonnenhöhe } & . & 90^{\circ} & 80^{\circ} & 70^{\circ} & 60^{\circ} & 50^{\circ} & 40^{\circ} & 30^{\circ} & 20^{0} & 10^{\circ} & 0^{0} \\ \text { Prozente } & . & 78 & 76 & 72 & 65 & 55^{\circ} & 44 & 31 & 17 & 5 & 0\end{array}$


die polare Zone erweist sich die Dämmerung, die die monatelange Nacht verkürzt, als eine besondere Wohltat. Unter $70^{\circ} \mathrm{B}$. währt der Tag vom 20. Mai bis 23. Juli, aber die Nächte vorher vom 30. März angefangen und nachher bis zum 12. September werden ganz von der Dämmerung erfüllt. Am Nordpol beginnt die Morgendämmerung am 4. Februar, die Sonne geht am 21. März auf und am 23. September unter, und am 6. November erlischt auch die Abenddämmerung. So wird die volle Nacht auf 90 Tage eingeschränkt.

Verteilung der Wärmemengen. Die Wärmemenge, die senkrechte Sonnenstrahlen an der Grenze der Atmosphäre der Erde zuführen, beträgt nach LANGLEY 3 Kalorien pro Quadratzentimeter und Minute. $\times$ Man nennt diesen Wert die Solarkonstante, ohne damit sagen zu wollen, daß er wirklich konstant ist. Nimmt man den Verlust, den die Wärmestrahlen bei ihrem Durchgang durch die Lufthülle erleiden, zu 40 Prozent an und wählt man, um zu große Zahlen zu vermeiden, als Einheit diejenige Wärmemenge, die der Äquator bei mittlerer Sonnenferne in den Äquinoktien erhält, so gestaltet sich nach Angot ${ }^{1}$ die Wärmeverteilung auf der Erdoberfläche, wie folgt:

\begin{tabular}{|c|c|c|c|c|c|c|c|c|}
\hline & \multirow{2}{*}{$\begin{array}{l}\text { Dez. bis } \\
\text { Febr. }\end{array}$} & \multirow{2}{*}{$\underset{\text { Mai }}{\text { März bis }}$} & \multirow{2}{*}{$\begin{array}{l}\text { Juni bis } \\
\text { Aug. }\end{array}$} & \multirow{2}{*}{$\begin{array}{l}\text { Sept. bis } \\
\text { Nov. }\end{array}$} & \multirow{2}{*}{ Jahr } & \multicolumn{2}{|c|}{ Monatliches } & \multirow{2}{*}{$\begin{array}{l}\text { Sehwan- } \\
\text { kung }\end{array}$} \\
\hline & & & & & & $\begin{array}{c}\text { Maxi- } \\
\text { mum }\end{array}$ & $\begin{array}{l}\text { Mini- } \\
\text { mum } \\
\end{array}$ & \\
\hline $90^{\circ} \mathrm{N}$ & - & 8,1 & 20,2 & 0,1 & 28,4 & 9,9 & - & 9,9 \\
\hline 80 & - & 10,4 & 22,6 & 0,5 & 33,5 & 10,3 & - & 10,3 \\
\hline 70 & 0,1 & 16,5 & 28,6 & 2,5 & 47,7 & 11,8 & - & 11,8 \\
\hline 60 & 1,1 & 24,1 & 35,6 & 6,6 & 67,4 & 13,8 & - & $13, \mathrm{~s}$ \\
\hline 50 & 4,9 & 31,5 & 41,3 & 12,9 & 90,6 & 15,3 & 0,7 & 14,6 \\
\hline 40 & 11,7 & 37,6 & 45,3 & 20,6 & 115,2 & 16,2 & 2,7 & 13,5 \\
\hline 30 & 20,0 & 42,2 & 47,2 & 28,2 & 137,6 & 16,4 & 5,3 & 11,1 \\
\hline 20 & 28,4 & 44,6 & 47,0 & 35,1 & 155,1 & ${ }_{15,9}$ & 8,2 & 7,7 \\
\hline 10 & 36,2 & 45,1 & 44,6 & 40,6 & 166,5 & 15,3 & 11,1 & 4,2 \\
\hline 0 & 42,5 & 43,4 & 40,1 & 44,2 & 170,2 & 15,3 & 12,8 & $2,5^{*}$ \\
\hline $10^{\circ} \mathrm{S}$ & 47,3 & 39,6 & 34,0 & 45,6 & 166,5 & 15,8 & 10,4 & 5,4 \\
\hline 20 & 49,7 & 33,9 & 26,5 & 45,0 & 155,1 & 17,0 . & 7,7 & 9,3 \\
\hline 30 & 49,9 & 27,0 & 18,5 & 42,2 & 137,6 & 17,5 & 5,0 & 12,5 \\
\hline 40 & 47,8 & 19,3 & 10,6 & 37,5 & 115,2 & 17,3 & 2,4 & 14,9 \\
\hline 50 & 43,4 & 11,9 & 4,4 & 30,9 & 90,6 & 16,3 & 0,7 & 15,6 \\
\hline 60 & 37,2 & 5,8 & 0,9 & 23,5 & 67,4 & 14,6 & - & 14,6 \\
\hline 70 & 29,8 & 2,0 & - & 15,9 & 47,7 & 12,5 & - & 12,5 \\
\hline 80 & 23,3 & 0,4 & - & 9,8 & 33,5 & 11,0 & - & 11,0 \\
\hline 90 & 20,9 & - & - & 7,5 & 28,4 & 10,5 & - & 10,5 \\
\hline
\end{tabular}

$\times$ D. h. diese Wärmemenge würde die Temperatır von 1 Kubikzentimeter Wasser in 1 Minute um $3^{\circ}$ erhöhen. W. Wundr hält 2,1 Kalorien für den wahrscheinlichsten mittleren Wert. 
Deutlich tritt uns in diesen Zahlen der Einfluß der Exzentrizität vor Augen: der südhemisphärische Sommer ist wärmer als der nordhemisphärische, und umgekehrt verhält es sich mit dem Winter. Daher sind in den südlichen Breiten auch die Extreme schroffer und die jährliche Schwankung ist größer. Ferner ist $\mathrm{zu}$ beachten, $\mathrm{da} B$ die höchsten Monatstemperaturen vom Äquator bis über $30^{\circ} \mathrm{B}$. hinaus zu- und dann erst wieder abnehmen: die gegen die Pole zu sich steigernde sommerliche Tageslänge ist also bis über die mittleren Breiten hinaus ein mächtigerer Faktor als die Sonnenhöhe. In der Jahressumme aber gleichen sich alle Unterschiede aus, und ganz gleichmäßig nimmt die Wärme vom Äquator gegen beide Pole ab.

Dauer des Sonnenscheins. Die jährliche Dauer des möglichen Sonnenscheins, d. h. der Zeit, während der die Sonne über dem Horizont steht oder $\mathrm{zu}$ stehen scheint, läßt sich leicht berechnen. Sie wächst mit der atmosphärischen Strahlenbrechung, d. h, mit der Breite. Das gilt aber nur für die Ebene. Im Gebirgstal ist der Horizont beschränkt, und PEuCKER ${ }^{2}$ hat eine Methode angegeben, mit deren Hilfe man den Einfluß des Bergschattens zahlenmäßig ermitteln kann. So wird z. B. die mögliche Dauer des Sonnenscheins in Innsbruck täglich im Durchschnitt um $1^{\mathrm{h}} 25^{\mathrm{m}}$, in Hallstatt um $4^{3} / 4$, in der Großen Schneegrube im Riesengebirge sogar um volle 7 Stunden verkürzt. Steigen wir dagegen auf einen freien Berggipfel, so sehen wir die Sonne länger als in der Ebene, weil wir einen weiteren Horizont überblicken. Mit der wirklichen Dauer des Sonnenscheins verhält es sich aber wesentlich anders. Wir sind über diesen wichtigen Punkt allerdings nur mangelhaft unterrichtet, weil erst in neuester Zeit brauchbare Beobachtungsmethoden gefunden wurden, und nur für Europa und die Vereinigten Staaten besitzen wir jetzt eine übersichtliche, wenn auch aus dem genannten Grund noch lange nicht erschöpfende Zusammenstellung der Resultate. ${ }^{3}$ Das Wichtigste ist der Nachweis, daß die wirkliche jährliche Sonnenscheindauer im geraden Gegensatz zur möglichen mit wachsender Breite abnimmt. $\times$ Sie beträgt in Südeuropa über 2000 , in Norddeutschland aber nur 16-1700 Stunden. KöNıg führt es auf die nach Norden abnehmende Sonnenhöhe zurück, oder mit anderen Worten, auf die zunehmende Länge des Weges, den die

$\times$ Beispiele:

\begin{tabular}{|c|c|c|c|c|}
\hline & ${ }^{\circ} \mathrm{B}$. & $\begin{array}{l}\text { Mögliche Dauer: } \\
\text { Stunden }\end{array}$ & Stunden & $\begin{array}{l}\text { liche Dauer: } \\
\text { Proz, der möglichen Dauer }\end{array}$ \\
\hline Paulowsk & 59,7 & 4490 & 1684 & 38 \\
\hline Kassel . . & 51,3 & 4458 & 1582 & 35 \\
\hline Sonnblick (3100 m) & 47,0 & 4465 & 1531 & 34 \\
\hline Pola & 44,9 & 4412 & 2546 & 57 \\
\hline
\end{tabular}


Sonnenstrahlen durch die Atmosphäre zurückzulegen haben. Daneben spielt natürlich auch der verschiedene Grad der Bewölkung eine entscheidende Rolle; aus diesem Grund ist Rußland sonniger als die britischen Inseln, und erreicht die Sonnenscheindauer ihren höchsten bekannten Wert (über 3200 Stunden) auf den trockenen Hochflächen von Arizona und Neu-Mexico. Die Gebirgsstationen unserer Alpen haben im Herbst und Winter mehr Sonnenschein als die Niederungen, im Sommer aber beraubt sie die Wolkenbildung über den dominierenden Höhen dieser Begünstigung. ${ }^{4}$ EтснноRN's Sonnenscheinkarte von Deutschland ${ }^{5}$ zeigt deutlich den Einfluß des Mittelgebirgs auf die Verkürzung der Sonnenscheindauer und deren Zunahme in östlicher Richtung. In unseren Kulturländern kommt noch ein anderes einschränkendes Moment hinzu: die Trübung der Luft durch den Rauch der großen Städte und Fabrikorte. London mit seinem schweren Nebel ist ein schlagendes Beispiel hierfür.*

Das Polarlicht. ${ }^{6}$ Die polare Winternacht wird zeitweise von jenen eigentümlichen und rätselhaften Lichterscheinungen erhellt, die wir unter dem Namen Polarlichter zusammenfassen und je nach der Hemisphäre, auf der sie aufteten, als Nord- und Südlichter bezeichnen. Das Nordlicht, das natürlich häufiger beobachtet und eingehender studiert wurde, ist besonders in einem 5-10 Meridiangrade breiten Grütel in der Nähe des Polarkreises heimisch, wo es ein fast tägliches Phänomen ist, und wird nach Norden wie nach Süden immer seltener. Fig. 21 verbindet die Orte gleicher Häufigkeit der Nordlichter durch Linien von entsprechender Breite, die sich in kreisähnlicher Gestalt um einen Punkt zwischen dem geographischen und dem magnetischen Nordpol gruppieren. Da sich letzterer im arktischen Archipel von Nordamerika unter ungefähr $70^{\circ}$ B. und $96^{\circ}$ w. L. befindet, so erklärt es sich, daß die Linien gleicher Häufigkeit in der Neuen Welt viel weiter gegen den Äquator hinabsinken als in der Alten, und somit die Parallelkreise schneiden. Auf der südlichen Halbkugel finden wir eine ähnliche Anordnung. Die Zone häufigerer Südlichter wird durch einen Kreis abgeschlossen, der ungefähr $44^{\circ}$ vom magnetischen Südpol entfernt ist. Infolgedessen reicht hier das Phänomen in der Osthemisphäre weiter nach dem Äquator, und berührt der Grenzkreis im östlichen Australien noch den 30. Parallel, während er südlich von Amerika in ungefähr $55^{\circ} \mathrm{B}$. vorüberzieht.

$\times$ Aus Nachstehendem ist ersichtlich, wie sehr die westlichen Vororte von London begünstigt sind gegenüber den östlichen, denen die vorherrschenden Westwinde den Rauch der Hauptstadt zuführen:

$\begin{array}{lccc} & \text { Kew } & \text { London City } & \text { Greenwich } \\ \text { Dauer des Somnenscheins, Stunden } & 1389 & 1026 & 1214 \\ \text { Prozente der möglichen Dauer . . . } & 31 & 23 & 27\end{array}$

Supan, Physische Erdkunde. 5. Aufl. 
Die spektralanalytischen Untersuchungen haben gelehrt, daß selbst in den Tropen das Polarlicht nicht selten ist, aber nur ausnahmsweise erreicht es hier eine solche Stärke, daß es sichtbar wird. Das große Nordlicht vom Jahr 1859 reichte fast bis zum Äquator, und auch von der südlichen Hemisphäre wissen wir, daß den Bewohnern der alten Inkastadt Cuzko unter $12^{1} / 2$ B. dieses Phänomen nicht unbekannt ist. Am glänzendsten zeigt es sich aber stets nur in der Maximalzone, wo es hauptsächlich in zwei Grundformen, als

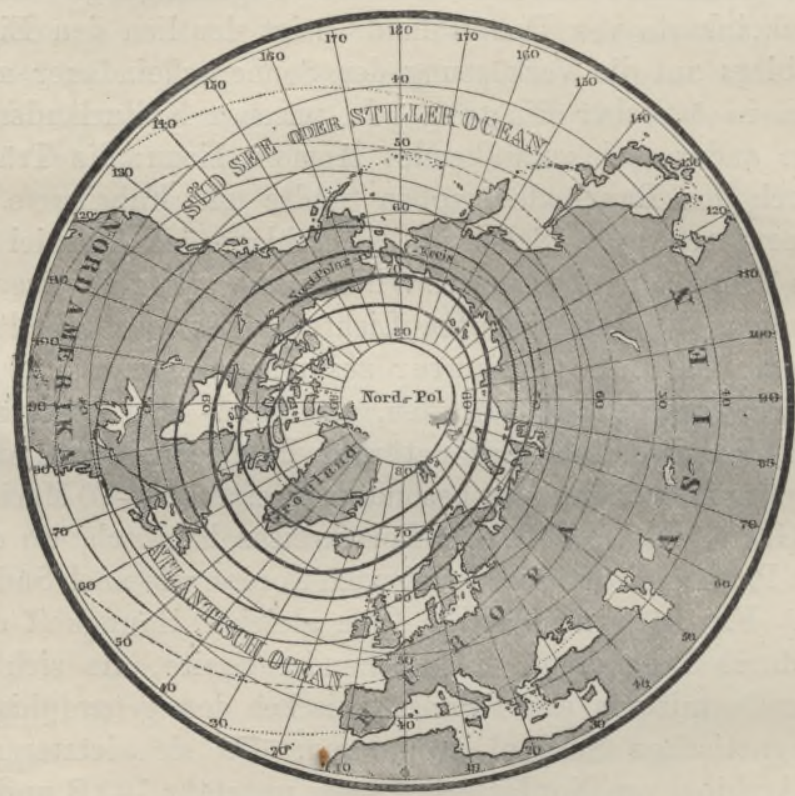

Fig. 21. Geographische Verbreitung des Nordlichts nach Fritz.

Band - und Strahlenlicht, auftritt. Das erstere besteht aus nebeneinander gereihten senkrechten Lichtstreifen, die den Eindruck von in der Luft fliegenden Bändern oder herabhängenden Draperien machen (Fig. 22). Die zweite Form ist ein leuchtender Bogen am nördlichen Himmel, dessen Enden sich auf den Horizont stützen (Fig. 23). Er umsäumt ein völlig dunkles Kreissegment, das man für einen grauen oder bräunlichen Nebel hält. Aus dem Lichtbogen schießen Strahlen in den mannigfachsten Farben hervor, um sich nicht selten über dem Scheitel des Beobachters zu einer glänzenden Krone zu vereinigen. Manchmal erscheint auch ein Bogen über dem anderen. Nur eine Modifikation des Strahlenlichts ist der gewöhnliche Nordlichtbogen ohne Bewegung und ohne Strahlen, 
der in den höheren Breiten jenseits der Maximalzone am häufigsten ist; manchmal erscheint hier aber noch ein zweiter Bogen im Süden,

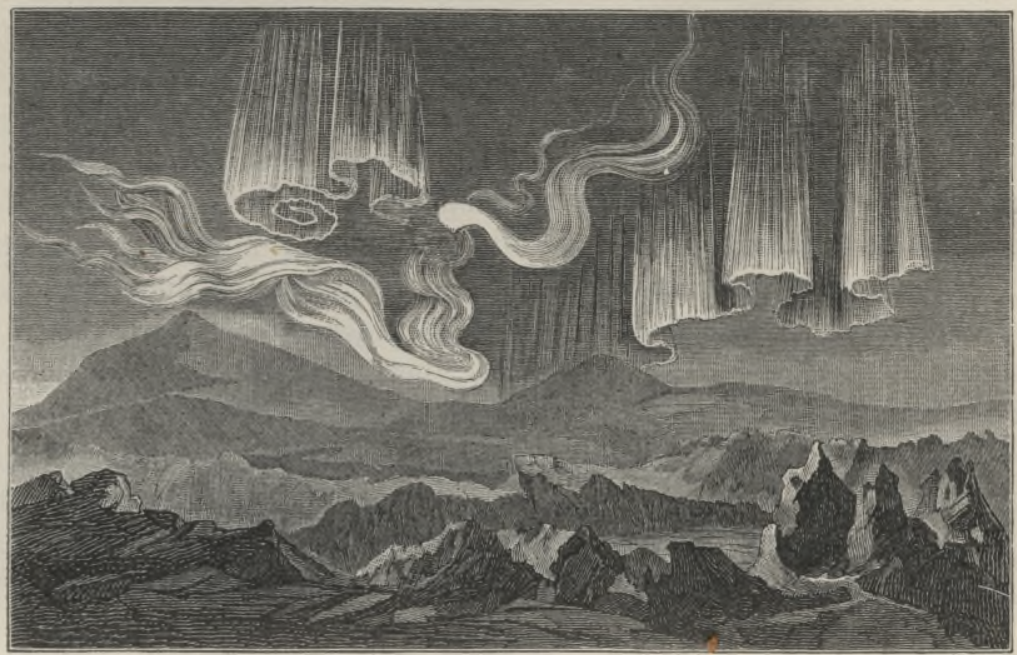

Fig. 22. Band-Nordlicht nach J. PAYER.

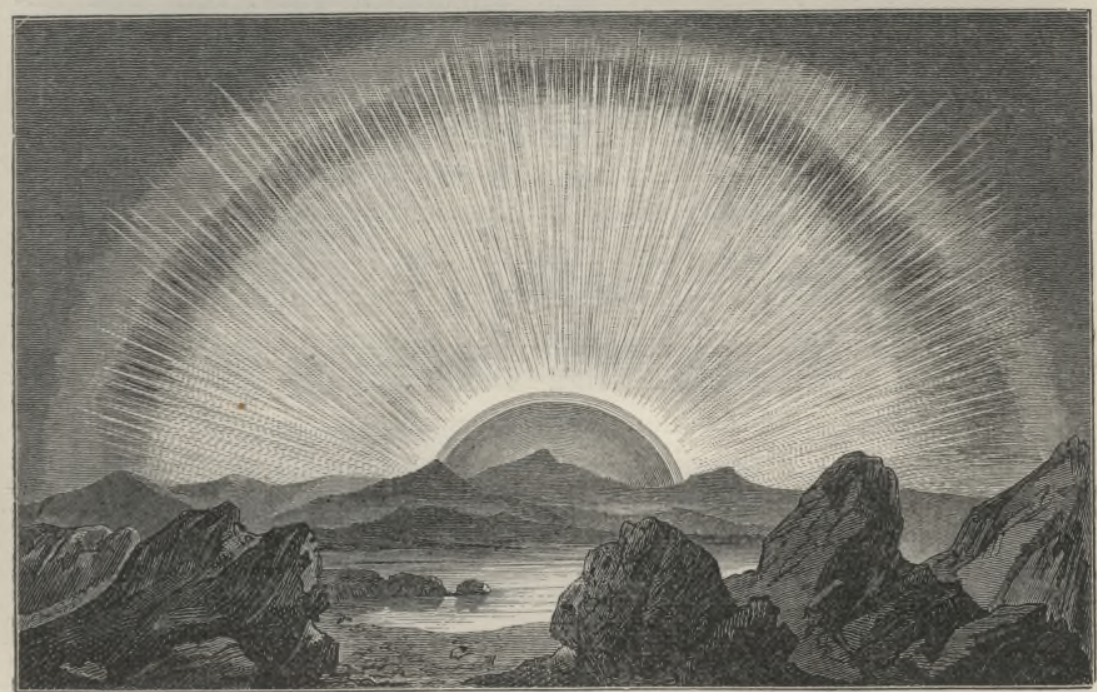

Fig. 23. Strahlen-Nordlicht zu Bergen in Norwegen nach H. Sattuer.

und beide tauschen Strahlen aus. In der innersten Arktis wird meist nur ein heller Nebel am südlichen Horizont sichtbar, und die geringe Lichtentwickelung erklärt es, daß man hier Nordlichter nur 
selten beobachtet hat. In unseren Breiten wird zumeist nur eine helle, zuweilen rötliche Wolke von strahligem Bau oder ein diffuser weißlicher Schein am nördlichen Himmel wahrgenommen; doch ist das Licht in den Perioden gröBter Häufigkeit intensiv genug, um das Lesen zu gestatten und Schattenwurf zu erzeugen. Gewöhnlich ist aber die Lichtstärke auch in höheren Breiten so gering, daß Sterne I. und II. Größe durchschimmern, und selten wird die Leuchtkraft des Vollmonds übertroffen, daher auch die Häufigkeit der beobachteten Polarlichter zur Vollmondzeit ein Minimum erreicht.

Wie die Erscheinungsweise und die Intensität, ist auch die Höhe der Polarlichter verschieden, auf Spitzbergen wird sie auf 55, auf Island sogar auf $400 \mathrm{~km}$ geschätzt, aber ohne Zweifel gehören sie noch der Lufthülle an. Bald sind sie nur innerhalb enger Grenzen sichtbar, bald beleuchten sie einen beträchtlichen Teil der Hemisphäre; bald dauern sie nur wenige Minuten, bald ganze Nächte,

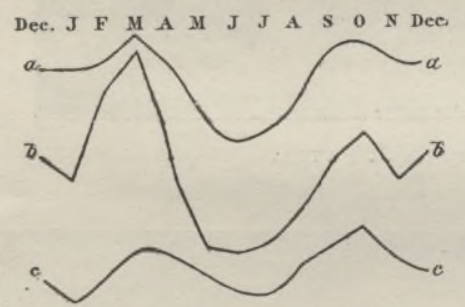

Fig. 24, Jährliche Periode des Polarlichts. ja manchmal erstrecken sie sich sogar über einen größeren Zeitraum, wie das Nordlicht, das vom 28. August bis 7. September 1859 dauerte. Es gilt als Regel, daß große Erscheinungen sich allmählich entwickeln und allmählich verschwinden.

Über die Natur des Polarlichts haben Lemströn's Experimente den lange gewünschten Aufschluß gebracht.

Am 29. Dezember 1882 gelang es ihm durch ein mit Spitzen versehenes Drahtnetz, das auf dem Gipfel der kegelförmigen Pietarintunturi bei Kultala in Finnland aufgestellt wurde, ein wirkliches Nordlicht zu erzeugen, und die Untersuchungen der folgenden Jahre haben die Theorie wesentlich vervollständigt. Damit war die elektrische Natur des Polarlichts außer Zweifel gestellt; es ist, wie sich aus der Untersuchung seiner Spektrallinien durch PAULSEN ergibt, nichts anderes als der Effekt eines elektrischen Entladungsvorgangs. Nur darüber sind noch die Meinungen geteilt, wie dieser Vorgang zustande kommt, ob die Ursache in der Sonne oder in den obersten Schichten der Atmosphäre zu suchen sei. ${ }^{7}$

Am häufigsten sind die Polarlichter 1 bis 2 Stunden vor Mitternacht, nur in der Nähe des magnetischen Nordpols verspäten sie sich etwas. Über die jährliche Periode gibt Fig. 24 Aufschluß. Die Kurve $a a$ stellt die Periode der Nordlichter dar, $b b$ die der Südlichter (beide in Prozenten der Jahresmengen) und $c c$ die mittlere tägliche Variation der Deklinationsnadel in München und Hobart (in 
Minuten). Alle drei Kurven zeigen Maxima zur Zeit der Nachtgleichen (März und Oktober) und Minima zur Zeit des höchsten und des tiefsten Sonnenstandes. (Juni und Januar). Darin zeigt sich unleugbar ein Zusammenhang mit dem Erdmagnetismus. Ebenso ist die elfjährige Periode mit dem Maximum zur Zeit der größten und dem Minimum zur Zeit der kleinsten Häufigkeit der Sonnenflecken beiden Erscheinungen gemeinsam. In Island und Grönland zeigen die Polarlichter allerdings, aber nur zeitweise, ein anderes Verhalten, und es hat den Anschein, als ob die Periodizität um so schärfer zum Ausdruck komme, je weiter der Beobachtungsort von der Maximalzone entfernt ist. ${ }^{8}$

Literaturnachweise. ${ }^{1}$ A. Axqor, Recherches théoriques sur la distribution de la chaleur à la surface du globe, in den Annales du Bureau central météorologique de France, Année 1883, I, Paris 1885. In streng mathematischer Weise behandelt neuerdings „Die Verteilung der solaren Wärmestrahlung auf der Erde" F. Hoprner in den Sitzungsberichten der Wiener Akad. d. Wiss., math.-naturwiss. Klasse, 1905, Bd. CXIV, Abteil. IIa. - ${ }^{2}$ K. Peucker, Der Bergsehatten, in den Verhandlungen der XII. Deutschen Geographentages zu Jena, 1897. - ${ }^{3}$ H. Kösı, Dauer des Sonnenscheins in Europa, in den Nova Acta der Leopoldina, Halle 1896; J. vax Bebber, Der Sonnensehein in Europa und Nordamerika, in Natur und Offenbarung, 1896. - ${ }^{4} \mathrm{H}$. ВАсн, der EinfluB der Alpen auf die Sonnenseheindauer, in "Natur" 1908. - ${ }^{5}$ A. Еiснноr, Entwurf einer Sonnenscheindauerkarte für Deutschland, in Petermaxs's Mitteil. 1903. - ${ }^{\circ}$ H. Fritz, das Polarlicht, Leipzig 1881; W. Boller, Das Südlicht, in Gerland's Beiträgen zur Geophysik, Bd. III, 1896; S. Lemströм, L'aurore boréale, Paris 1886; zur Orientierung dient am besten A. Nippoldt Jun., Erdmagnetismus, Erdstrom und Polarlicht, Leipzig 1903 (Sammlung Göscнen). ${ }^{7}$ A. Paulsen, Über die neuern Theorien der Polarlichter, in Danske Videnskabernes Selskab Forhandlinger 1906. - ${ }^{8} \mathrm{~S}$. Arrhenrus, Die Nordlichter in Island und Grönland, in Meddelanden från Vetenskaps akademiens Nobelinstitut, 1906.

\section{Die Änderung der Temperatur mit der Höhe.}

Wärmequellen der oberen Luftschichten. Wir haben eine solare und eine terrestrische Wärmequelle zu unterscheiden; man kann jene auch die direkte, diese die indirekte nennen. Die Luft absorbiert, was häufig übersehen wird, einen beträchtlichen Teil der Wärmestrahlen, die sie passieren, aber nach Maßgabe ihrer Dichte. Je dünner die Luft, desto geringer die Absorptionsfähigkeit und desto größer der Verlust durch Ausstrahlung. Da nun die Dichte mit der Höhe abnimmt, so muß schon aus diesem Grund auch die Temperatur in gleicher Richtung abnehmen.

Die indirekte Wärmequelle ist die erwärmte Erdoberfläche, und nur für diese gilt der Satz, daß mit der Entfernung von ihr die Temperatur abnimmt. Auch tritt diese Wärmequelle nicht immer 
in Wirksamkeit. Wenn die Erdoberfläche mit Schnee oder Eis bedeckt ist, wird alle Sonnenwärme zur Schmelzung verwendet, ohne die Temperatur der Oberfläche zu erhöhen, und diese wirkt dann als Kälte-, nicht als Wärmequelle.

Die Erdoberfläche teilt die empfangene Sonnenwärme zunächst durch Leitung und Strahlung den untersten Luftschichten mit. Wäre aber das der einzige Vorgang, so würde der Erwärmungsprozeß nur sehr langsam in die Höhe vorrücken. Von gröBter Bedeutung ist daher die aufsteigende Luft. Indem die untersten atmosphärischen Schichten erwärmt werden, dehnen sie sich aus und steigen in die Höhe, während kältere Luft von oben ihren Platz einnimmt. So schreitet allmählich — wie HANN sich ausdrückt — die Erwärmung der Luft durch das Spiel aufsteigender wärmerer und niedersinkender kälterer Luftsäulchen von unten nach oben fort, und das Werk des einen Tages wird nach nächtlicher Unterbrechung am folgenden weiter fortgesetzt.

Nach den Prinzipien der mechanischen Wärmetheorie kühlt sich aufsteigende trockene Luft infolge Volumensvergrößerung um $1^{\circ} \mathrm{C}$. für je $100 \mathrm{~m}$ Erhebung ab, und es ist sowohl die Anfangstemperatur, wie die Höhe, von wo aus das Aufsteigen stattfindet, ohne EinfluB. darauf. Umgekehrt wird herabsinkende trockene Luft um $1^{0}$ für je $100 \mathrm{~m}$ erwärmt. Anders verhält sich die mit Wasserdampf gesättigte Luft. Einerseits kühlt sie sich bedeutend weniger ab, weil der Wärmeverlust zum Teil durch die bei der Kondensation des Wasserdampfs frei werdende Wärme ersetzt wird; anderseits ist die Temperaturabnahme um so geringer, je höher das Niveau, von wo das Aufsteigen stattfindet, und je höher die Anfangstemperatur ist. $x$

Ist die aufsteigende Luft nicht mit Wasserdampf gesättigt, so verhält sie sich bis zum Zeitpunkt, wo Kondensation eintritt, wie trockene, dann wie gesättigte Luft.

Freie Atmosphäre. ${ }^{1}$ Durch die Einrichtung des bekannten Eiffelturms in Paris für den meteorologischen Dienst ist zum ersten Mal die Möglichkeit geboten worden, regelmäBige Beobachtungen über den Zustand der freien Atmosphäre anzustellen. Die Instrumente sind in 2, 123, 197 und $302 \mathrm{~m}$ über dem Boden aufgestellt und an den drei letzteren Stellen somit völlig dem unmittelbaren Einflu $B$ des Bodens entrückt, während anderseits die luftige Bauart

$\times$ Anfangstemperatur

Seehöhe

, 3300

$$
-20^{\circ}
$$

Temperaturabnahme für $100 \mathrm{~m} \mathrm{H}$.

$\begin{array}{lllll}0,86^{\circ} & 0,76^{\circ} & 0,63^{\circ} & 0,54^{\circ} & 0,45^{\circ}\end{array}$

$\begin{array}{lllll}0,80 & 0,68 & 0,55 & 0,46 & 0,38\end{array}$ 
des Turms selbst eine Störung der Instrumente durch Strahlung ausschlieBt. Bei Tag erreicht die Temperaturabnahme einen überraschend hohen Wert, besonders bis $200 \mathrm{~m}$ Höhe im Frühjahr und Sommer, wo sie sogar über den Maximalwert für aufsteigende trockene Luft hinausgeht. Das erklärt sich dadurch, daß in den Mittagsstunden der Erdboden überhitzt ist und seine Wärme nicht rasch genug den oberen Luftschichten mitteilen kann. In der Nacht tritt der umgekehrte Fall ein; der Boden kühlt sich rascher ab als die Luft, die noch einen Wärmefond vom vorhergehenden Tag bewahrt hat. Daher nimmt nachts in allen Jahreszeiten die Temperatur bis $200 \mathrm{~m}$ $\mathrm{zu}$, und wenn auch dann Abnahme eintritt, so ist es doch auf der Höhe des Eiffelturms immer noch wärmer als auf dem Erdboden. Aber die Abnahme bei Tag ist größer als die Zunahme bei Nacht, die mittlere Tagestemperatur nimmt also ab, und zwar im Sommer rascher als im Winter. Gleichzeitig verschieben sich auch die Eintrittszeiten der täglichen Maxima und Minima, die in der Höhe ungefähr 1 Stunde später eintreten, und ähnliches gilt auch von dem jährlichen Gang der Temperatur.

Mittlerer täglicher Temperaturgang an der Bodenstation und auf dem Eiffelturm.

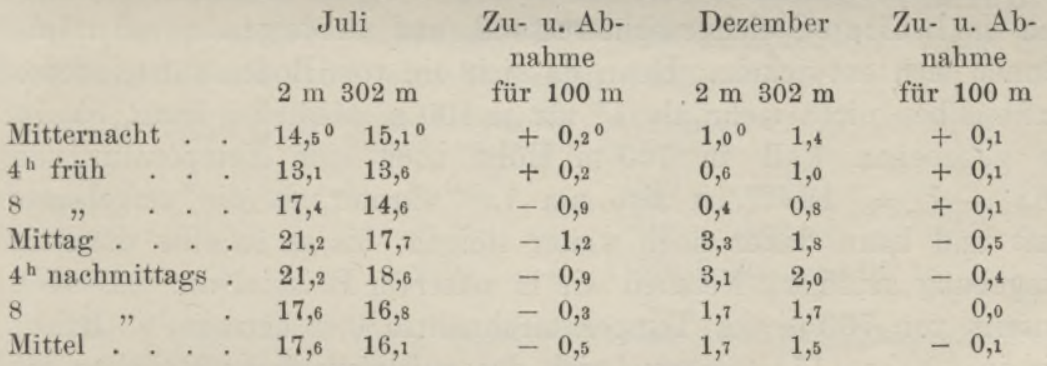

Einen Einblick in die Mechanik der vertikalen Temperaturverteilung in den untersten Luftschichten gewähren uns die Untersuchungen Hergesell's mittels eines Fesselballons in Straßburg am 7. und 8. Juni 1898. Wir betrachten hier nur die wichtigsten Epochen:

\begin{tabular}{|c|c|c|c|c|c|}
\hline $\begin{array}{c}\text { Höhe } \\
\text { m }\end{array}$ & $\begin{array}{l}9^{\mathrm{h}} 32^{\mathrm{m}} \\
\text { abends }\end{array}$ & $\begin{array}{l}3^{\mathrm{h}} 29^{\mathrm{m}} \\
\text { früh }\end{array}$ & $\begin{array}{l}5^{\mathrm{h}} 25^{\mathrm{m}} \\
\text { früh }\end{array}$ & $\begin{array}{l}7^{\mathrm{h}} 25^{\mathrm{m}} \\
\text { früh }\end{array}$ & $\begin{array}{c}1^{\mathrm{h}} 25^{\mathrm{m}} \\
\text { nachmittags }\end{array}$ \\
\hline 700 & $16,2^{0 *}$ & $15,4^{0}$ & $16,0^{\circ}$ & $16,3^{0 *}$ & $18,8^{0 *}$ \\
\hline 600 & 17,2 & 15,3 & 15,6 & 16,4 & 19,4 \\
\hline 500 & 18,1 & 15,2 & 15,3 & 16,4 & 20,0 \\
\hline 400 & 19,0 & 15,2 & 15,1 & 16,4 & 20,8 \\
\hline 300 & 19,9 & 15,1 & 14,8 & 16,4 & 21,6 \\
\hline 200 & 20,6 & 15,1 & 14,6 & 16,4 & 22,4 \\
\hline 100 & 20,2 & 14,9 & $14,5 *$ & 16,5 & 24,4 \\
\hline 0 & 18,4 & $14,5^{*}$ & 14,6 & 16,7 & 26,9 \\
\hline
\end{tabular}


Um $9^{1} / 2$ Uhr abends hatte die Erkaltung des Erdbodens bereits einige Fortschritte gemacht, während in den untersten Luftschichten noch Wärme aufgespeichert war, daher bis $200 \mathrm{~m}$ Temperaturzunahme, dann erst Abnahme. Diese Anordnung erhielt sich bis in die ersten Morgenstunden. Natürlich sank die Temperatur in allen Schichten, aber in den unteren und am Boden mehr als in den oberen - ein Beweis, daß die Luft nicht durch Ausstrahlung nach oben, in den Weltraum, sondern nach unten, nach dem erkalteten Boden, Wärme verloren hat. Die Temperatur nimmt nun bis $700 \mathrm{~m}$ zu. Ebenso zwei Stunden später, aber erst von $100 \mathrm{~m}$ an, da sich der Boden unter den Strahlen der aufgehenden Sonne bereits etwas erwärmt hat. Um $7 \frac{1}{2}$ Uhr stellt sich die thermische Tagschichtung ein, die Temperatur nimmt nach oben $a b$, aber so geringfügig, daß man sagen darf, die ganze Luftsäule von $700 \mathrm{~m}$ Höhe habe eine gleichmäBige Temperatur. Je höher die Sonne steigt, desto schärfer bildet sich der Gegensatz von oben und unten aus. War um $7 \frac{1}{2}$ Uhr der Temperaturunterschied zwischen 0 und $700 \mathrm{~m}$ nur $0,4^{0}$, so ist er um $1 \frac{1}{2}$ Uhr mittags $8,1^{\circ}$. Die Temperatur nimmt bis $100 \mathrm{~m}$ um 2,5 , von $100-200 \mathrm{~m}$ um 2,0 , von $200-500 \mathrm{~m}$ um 0,8 für je $100 \mathrm{~m}$, von $500-700 \mathrm{~m}$ um je $0,6^{\circ} \mathrm{ab}$. Im ganzen übersteigt die Temperaturabnahme für $100 \mathrm{~m} 1^{\circ}, \mathrm{d}$. h. die Luftsäule befindet sich im labilen Gleichgewichtszustand, und aufsteigende Luftströme können sich entwickeln. Denn da sich ein rom Boden aufsteigendes Luftteilchen nicht mehr als $1^{0}$ für je $100 \mathrm{~m}$ abkühlen kann, hat es im gégebenen Fall in $700 \mathrm{~m}$ Höhe noch eine Temperatur von $\left(26,9^{\circ}-7^{\circ}=\right) 19,9^{0}$, ist also um $1,1^{\circ}$ wärmer als die umgebende Luft und kann daher noch weiter steigen, bis es in eine wärmere Umgebung gelangt. Nehmen wir in unserem Beispiel an, daß auch jenseits von $700 \mathrm{~m}$ die Temperaturabnahme $0,0^{\circ}$ betrage, so haben wir in $1000 \mathrm{~m} 17^{\circ}$, während sich das aufsteigende Luftteilchen bis $16,9^{\circ}$ abgekühlt hat. In dieser Höhe muß also die Bewegung zum Stillstand kommen. Stabil ist der Gleichgewichtszustand der Luft, wenn die Temperatur um weniger als $1^{0}$ abnimmt, und selbstverständlich auch dann, wenn sie mit der Höhe zunimmt, denn dann liegen die schwersten, d. h. die kältesten Schichten zu unterst, und es ist keine Veranlassung zu freiwilligem Aufsteigen vorhanden.

In einzelnen polaren Gegenden, wo der Boden dauernd mit Schnee oder Eis bedeckt ist, ist die umgekehrte Temperaturschichtung der normale Zustand, wie uns die Beobachtungen der dänischen Expedition in Nordost-Grönland (1906-08) lehren, die bis $300 \mathrm{~m}$ Höhe stete Temperaturzunahme im Winter und Sommer ergaben.

Für die Kenntnis der Temperaturverhältnisse in den höheren 
Schichten der freien Atmosphäre ist erst durch das Assmann'sche Aspirationspsychrometer eine sichere Grundlage geschaffen worden; alle alten Ballonbeobachtungen waren fehlerhaft und alle daraus gezogenen Schlüsse sind falsch.

Die Überzeugung, daß ein Einblick in den ursächlichen $\mathrm{Zu}$ sammenhang der Witterungserscheinungen ohne Kenntnis der Vorgänge in den hohen Luftschichten unmöglich ist, hat, besonders seit dem Anfang der $90 \mathrm{er}$ Jahre des 19. Jahrhunderts, einen gewaltigen Aufschwung der wissenschaftlichen Aëronautik in Europa und Nordamerika veranlaßt. Besonders erfolgreich sind die unbemannten Registrierballons, die in Höhen dringen, die dem Menschen sonst verschlossen blieben; am höchsten stieg der Brüsseler Ballon am 5. Januar 1908: bis $29040 \mathrm{~m}$. ${ }^{\times}$Auch ein allbekanntes Kinderspielzeug, der Drache, wurde - natürlich mit zweckmäBiger Änderung seines Baus und mit Registrierapparaten versehen - in den Dienst der Wissenschaft gestellt, und seit einigen Jahren werden bereits an mehreren Wetterwarten tägliche Aufstiege von Drachen und Drachenballons veranstaltet.

Das übereinstimmende Ergebnis dieser Untersuchungen ist die Zweiteilung der freien Atmosphäre in eine untere Troposphäre mit vertikaler Temperaturabnahme und eine gleichmäßig temperierte obere Stratosphäre. ${ }^{4}$ Als Beispiel diene uns die Straßburger Balionfahrt vom 3. August $1905 .^{3}$

\begin{tabular}{|c|c|c|c|c|}
\hline Höhe & Temperatur & $\begin{array}{l}\text { Mittlere Temperatur- } \\
\text { änderung auf } 100 \mathrm{~m}\end{array}$ & $\begin{array}{l}\text { Mächtigkeit. } \\
\text { der Luftsäule }\end{array}$ & \\
\hline $140 \mathrm{~m}$ & $\left.16,8^{0}\right\}$ & $-0,33^{\circ}$ & $4990 \mathrm{~m}$ untere & \\
\hline 5130, & 0,1 & $-0,67$ & 9360 , oberen & Troposphäre \\
\hline $\begin{array}{l}14490 \text { " } \\
25800 \text {, }\end{array}$ & $\begin{array}{l}-62,7 \\
-40,0\end{array}$ & $+0,20$ & 11310, Stratosp & 1äre \\
\hline
\end{tabular}

Die Troposphäre gliedert sich wieder in zwei Etagen. Die untere reicht durchschnittlich bis $4000 \mathrm{~m}$ Höhe; es ist die Region der Wolkenbildungen, in der durch Kondensation des Wasserdampfs Wärme frei wird, daher die mittlere Temperaturabnahme in mäßigen Grenzen bleibt. Sie ändert sich oft sprungweise von Schicht zu Schicht und schlägt nicht selten in Temperaturzunahme (Inversion) um. Auf- und absteigende Luftströmungen herrschen hier vor, wie uns Assmans's Diagramm ${ }^{5}$ der Berliner Luftsäule i. J. 1903 in sinnfälliger Weise veranschaulicht. Die Höhenisothermen verlaufen in steilen Zickzacklinien, bald steigt warme Luft in die Höhe, bald senkt sich kalte Luft zu Boden. Die obere Troposphäre enthält

$\times$ Die Höhenangaben über $20 \mathrm{~km}$, vielleicht auch schon von $15 \mathrm{~km}$ an sind unsicher und wahrscheinlich etwas zu hoch (vgl. A. WAgner in der Meteorologischen Zeitschrift 1910, S. 170). 
nur wenig Wasserdampf, und die Temperaturabnahme, selten von einer Inversion unterbrochen, nähert sich immer mehr dem Wert, der für aufsteigende trockene Luft Geltung hat.

Fast ohne Übergang folgt nun die Stratosphäre; alle Temperaturdiagramme der hohen Ballonfahrten zeigen in $10000 \mathrm{~m}$ oder darüber einen scharfen Knick. Auch das plötzliche Abflauen des Windes kündet an, daß der Ballon hier in eine ganz anders geartete Luftschicht eingetreten ist. Man hat sie nicht ganz zutreffend die isotherme Schicht genannt, aber wenn auch Temperaturunterschiede vorkommen, so sind sie doch gering. Inversion ist Regel, sie erfolgt jedoch nicht gleichmäßig, und auch schwache Temperaturabnahme kommt vor. Das deutet darauf hin, das die aufsteigenden Luftströme der Troposphäre hier eine Grenze finden, und daß die Luft nur mehr in horizontaler Bewegung begriffen ist. So deutlich ist die atmosphärische Zweiteilung ausgeprägt, daß es den Eindruck macht, als schwimme die Strato- über der Troposphäre. Über den Gebieten niederen Luftdrucks senkt sie sich nach den französischen Erfahrungen bis 8 oder $9 \mathrm{~km}$ herab, über den Gebieten hohen Luftdrucks erhebt sie sich bis zu 14 oder $15 \mathrm{~km}$. Am überraschendsten ist aber, daß sie vom Äquator gegen die Pole in immer tiefere Niveaus hinabsteigt. Im arktischen Meer erreichte Hergeselu sie schon in $7 \mathrm{~km}$, auf dem Atlantischen Ozean fanden Teisserenc DE BORT und Rотсн sie unter $25^{\circ} 18^{\prime} \mathrm{N}$ erst in $14 \mathrm{~km}$ Höhe und im äquatorialen Teil erreichten selbst die über $15 \mathrm{~km}$ aufsteigenden Ballons sie noch nicht. $\mathrm{DaB}$ sie aber auch in diesen Breiten vorhanden ist, beweisen die Versuche BERson's am Viktoriasee in Ostafrika. Diese geographische Anordnung erklärt die scheinbar paradoxe Tatsache, daß es im Äquatorialgürtel kälter ist als im nordpolaren im gleichen Höhenniveau. Eine so tiefe Temperatur, wie sie Berson am Viktoriasee in $19800 \mathrm{~m}$ Höhe maß $\left(-84^{\circ}\right)$, ist in Europa niemals und in den Vereinigten Staaten nur einmal gefunden worden. $\times$

Aus allen bisherigen Beobachtungen in Mitteleuropa hat HavN folgende Jahresmittel abgeleitet:

\begin{tabular}{lcc|ccc} 
Höhe Temperatur & $\begin{array}{c}\text { Abnahme auf } \\
100 \mathrm{~m}\end{array}$ & Höhe Temperatur & $\begin{array}{c}\text { Abnahme auf } \\
100 \mathrm{~m}\end{array}$ \\
$1 \mathrm{~km}$ & $+5,0^{\circ}$ & $0,45^{\circ}$ & $6 \mathrm{~km}$ & $-22,0^{\circ}$ & \\
2, & $+0,5$ & 0,45 & $7, "$ & $-29,0$ & $0,70^{\circ}$ \\
$3, "$ & $-4,0$ & 0,52 & $9, "$ & $-36,2$ & 0,72 \\
$4, "$ & $-9,2$ & 0,62 & 10, & $-43,2$ & 0,70 \\
$5, "$ & $-15,4$ & 0,66 & &
\end{tabular}

$\times$ Am 25. Januar 1905 in St. Louis $-85,8^{\circ}$ in $14800 \mathrm{~m}$ Höhe; die Wiener Messung vom 2. März $1905,-85,4^{\circ}$ in $9717 \mathrm{~m}$ Höhe, wird mit Recht angezweifelt. 
Den mittleren jährlichen Gang der Lufttemperatur ersieht man aus Fig. 25. Die Grenze zwischen der Tropo- und Stratosphäre verschiebt sich etwas im Lauf des Jahres $(9700 \mathrm{~m}$ im März und $11100 \mathrm{~m}$ im Juli, und dies hängt damit zusammen, daß die Temperatur in allen Niveaus eine jährliche Schwankung erleidet. Auch unperiodische

Temperaturveränderungen von betfächtlicher Höhe kommen in allen Niveaus vor, überall kämpfen warme und kalte Luftströme um die Herrschaft, und ohne Zweifel wird auch der Zustand der unterstenLuftschichten, d. h. unser Wetter, durch solche Veränderungen in den Höhen mitbestimmt, wenn auch der Zusammenhang noch nicht klar zutage liegt.

Gebirge. Bisher haben wir den thermischen Zustand verschie-

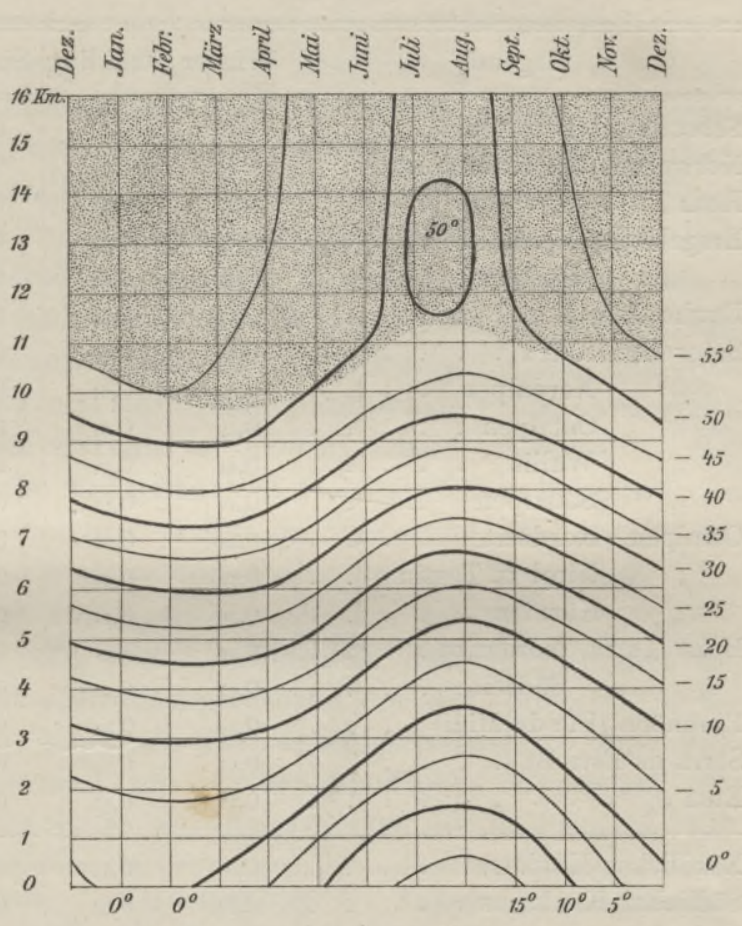

Fig. 25. Thermoisoplethen der freien Atmosphäre nach den Tabellen von A. WAGNER ${ }^{6}$. Die punktierte Fläche ist die Stratosphäre.

dener Luftschichten über einer und derselben Erdstelle betrachtet, die Temperaturabnahme im Gebirge bezieht sich aber auf die unterste, dem Einfluß der terrestrischen Wärmequelle unmittelbar unterworfene Luftschicht an Orten von verschiedener Höhe. Es ist dabei nicht zu umgehen, daß das Ergebnis häufig durch klimatische Eigentümlichkeiten getrübt wird, die mit der absoluten Höhe nichts zu tun haben. Namentlich drückt die in den Niederungen stagnierende kalte Winterluft den Durchschnittswert für die Temperaturabnahme manchmal erheblich herab. Dies ist im Auge zu behalten, wenn man nachstehende Tabelle durchmustert, welche die vertikale Temperaturabnahme für je $100 \mathrm{~m}$ 
in einigen Gebirgen Europas, Asiens, Amerikas und der Insel St. Helena zeigt.

Man ersieht aus dieser Zusammenstellung, daß die Abnahme der mittleren Jahrestemperatur der untersten Luftschicht auf der ganzen Erde ziemlich gleichmäßig ist, im Mittel $0,5^{\circ}$ für $100 \mathrm{~m}$, wenn wir St. Helena von der Rechnung ausschließen. Der jährliche

\begin{tabular}{|c|c|c|c|c|c|c|c|}
\hline Gegend & & & Winter & Frühling & Sommer & Herbst & Jahr \\
\hline Sehottland (Ben-Nevis). & . & . . & $0,60^{\circ}$ & $0,72^{0}$ & $0,68^{0}$ & $0,63^{\circ}$ & $0,66^{\circ}$ \\
\hline Norwegen (bei Kristiania & & . . & 0,05 & 0,72 & 0,91 & 0,52 & 0,55 \\
\hline Harz . . . . . . . & . & . . & 0,43 & 0,67 & 0,70 & 0,51 & 0,58 \\
\hline Erzgebirge, Nordseite . & . & . . & 0,46 & 0,60 & 0,60 & 0,53 & 0,54 \\
\hline , Südseite . & . & . . & 0,41 & 0,66 & 0,70 & 0,54 & 0,58 \\
\hline Rauhe Alb . . . . & . & . . & 0,26 & 0,53 & 0,55 & 0,42 & 0,44 \\
\hline Sehweizer $^{7}$ Jura . . . & . & . . & 0,28 & 0,58 & 0,55 & 0,41 & 0,46 \\
\hline , Nordalpen . & . & . . & 0,43 & 0,61 & 0,55 & 0,46 & 0,51 \\
\hline " Ostalpen . . & . & . . & 0,42 & 0,61 & 0,54 & 0,48 & 0,51 \\
\hline "Wallis . . & . & . . & 0,44 & 0,64 & 0,62 & 0,52 & 0,56 \\
\hline " Südalpen . & . & . . & 0,49 & 0,66 & 0,66 & 0,55 & 0,59 \\
\hline Ostalpen, ${ }^{7}$ Nordseite . & . & . . & 0,34 & 0,60 & 0,62 & 0,47 & 0,51 \\
\hline " Tirol u. Tessin & $a$ & . . & 0,50 & 0,66 & 0,67 & 0,57 & 0,60 \\
\hline " Kärnten . . & . & $\cdot$. & 0,26 & 0,57 & 0,58 & 0,42 & 0,46 \\
\hline Hohe Tatra, Nordseite. & . & . . & 0,40 & 0,55 & 0,57 & 0,51 & 0,51 \\
\hline$" \quad$ " Südseite . & . &. & 0,27 & 0,65 & 0,62 & 0,43 & 0,49 \\
\hline Pyrenäen (Pic du Midi) & . & . . & 0,50 & 0,61 & 0,56 & 0,55 & 0,56 \\
\hline Serra da Estrella . . . & . & . . & 0,57 & 0,65 & 0,49 & 0,57 & 0,57 \\
\hline Etna . . . . . . & . & . . & 0,59 & 0,61 & 0,65 & 0,63 & 0,61 \\
\hline Nördlicher Kaukasus . & . & . . & 0,26 & 0,48 & 0,51 & 0,38 & 0,41 \\
\hline Südlicher Kaukasus . . & . & . . & 0,39 & 0,54 & 0,58 & 0,48 & 0,49 \\
\hline Bengalen . . . . . & . & . . & 0,56 & 0,52 & 0,47 & 0,57 & 0,52 \\
\hline Indische Nordwest-Provil & nzen & . & 0,47 & 0,64 & 0,57 & 0,59 & 0,56 \\
\hline Ceylon . . . . . . & . & . . & 0,57 & 0,58 & 0,62 & 0,59 & 0,59 \\
\hline Insel Hongkong . . · & . & . . . & 0,62 & 0,47 & 0,67 & 0,66 & 0,60 \\
\hline Mt. Washington (New Ham & apsh & hire) & 0,40 & 0,59 & 0,67 & 0,52 & 0,55 \\
\hline Felsengebirge . . . & . & . . & 0,55 & 0,71 & 0,69 & 0,59 & 0,64 \\
\hline Peru $16^{\circ} \mathrm{S}$, West-Andes & . & . $\cdot$ & 0,62 & 0,60 & 0,59 & 0,62 & 0,61 \\
\hline St. Helena . . . . . & . & . . & 0,84 & 0,99 & 0,97 & 0,88 & 0,93 \\
\hline
\end{tabular}

Gang ist in den Gebirgen der gemäBigten Zone derselbe, wie in der freien Atmosphäre. Der Winter ist überall die Jahreszeit der langsamsten Abnahme, der Sommer in der Regel die Jahreszeit, in der der thermische Gegensatz von hoch und tief am grellsten hervortritt, und der Herbst schließt sich in dieser Beziehung meist dem Winter, 
der Frühling dem Sommer an. Daß wir in den Tropen Abweichungen von diesem Typus finden, darf uns nicht wundernehmen. In Bengalen z. B. ist die Abnahme im Winter viel gröBer als im Sommer, offenbar deshalb, weil dort der Sommer den Winter an Feuchtigkeit übertrifft. Sehr lehrreich sind auch die abnormen Verhältnisse auf St. Helena. Die untere Station, Jamestown, ist außerordentlich trocken, und die von hier aufsteigende Luft befolgt im Frühjahr und Sommer (Regenmenge 6 und $22 \mathrm{~mm}$ ) nahezu das Gesetz der Temperaturabnahme dampfleerer Luft. Im Herbst steigt die Regenmenge auf $49 \mathrm{~mm}$, und dementsprechend sinkt die Temperaturabnahme auf $0,88^{\circ}$; im Winter endlich erreicht die Niederschlagshöhe ihr Maximum $(68 \mathrm{~mm})$ und die Temperaturabnahme ihr Minimum. Dieses Beispiel beweist, daß für isolierte Anhöhen die aus den tieferen Regionen aufsteigende Luft die hauptsächlichste Wärmequelle ist, während sie in ausgedehnten Gebirgen gegenüber der Wärmeaufnahme und Ausstrahlung der Abhänge und Talflächen naturgemäß etwas zurücktritt.

Auch die tägliche Periode ist überall scharf ausgeprägt. Aus dem Vergleich der nahe benachbarten, frei gelegenen Bergstationen Sonnblick und Kolm-Saigurn ermittelte TraberT ${ }^{8}$ für die Nachthälfte eine mittlere Abnahme von $0,50^{\circ}$, für die Tageshälfte eine solche von $0,65^{\circ}$ für je $100 \mathrm{~m}$.

Die folgende Tabelle gibt als Beispiele des Bergklimas die mittleren Monats- und Jahrestemperaturen der drei höchsten, unter verschiedenen Breiten gelegenen Beobachtungsstationen. Zum Vergleich fügen wir Upernivik an der grönländischen Westküste, die nördlichste Station der Erde mit langjährigen. Beobachtungen, bei.

\begin{tabular}{|c|c|c|c|c|c|c|}
\hline & & & $\begin{array}{c}\text { Alpen. } \\
\text { Sonnblick }\end{array}$ & $\begin{array}{c}\text { Felsengebirge. } \\
\text { Pikes Peak }\end{array}$ & $\begin{array}{c}\text { Andes. } \\
\text { Antisana }\end{array}$ & $\begin{array}{l}\text { Grönland. } \\
\text { Upernivik }\end{array}$ \\
\hline \multicolumn{3}{|c|}{$\begin{array}{l}\text { Geogr. Breite } \\
\text { Höhe m }\end{array}$} & $\begin{array}{c}47^{0} 3^{\prime} \mathrm{N} . \\
3106\end{array}$ & $\begin{array}{c}38^{0} 50^{\prime} \mathrm{N} \\
4308\end{array}$ & $\begin{array}{c}0^{0} 21^{\prime} \mathrm{S} . \\
4060\end{array}$ & $\begin{array}{c}72^{0} 47^{\prime} \mathrm{N} \\
-\end{array}$ \\
\hline $\begin{array}{l}\text { Dezember } \\
\text { Januar } \\
\text { Februar }\end{array}$ & . & $\dot{.}$ & $\begin{array}{l}-12,2^{0} \\
-13,0 \\
-13,6^{*}\end{array}$ & $\begin{array}{l}-14,3^{0} \\
-16,4^{*} \\
-15,6\end{array}$ & $\begin{array}{l}6,0^{0} \\
\mathbf{6 , 2} \\
5,1\end{array}$ & $\begin{array}{l}-17,0^{\circ} \\
-20,9 \\
-23,4\end{array}$ \\
\hline $\begin{array}{l}\text { März } \\
\text { April } \\
\text { Mai }\end{array}$ & : & . & $\begin{array}{r}12,1 \\
-\quad 8,5 \\
-\quad 4,2\end{array}$ & $\begin{array}{r}-13,4 \\
-10,4 \\
-\quad 5,3\end{array}$ & $\begin{array}{l}5,6 \\
5,9 \\
5,5\end{array}$ & $\begin{array}{r}22,7 \\
-14,9 \\
-\quad 4,4\end{array}$ \\
\hline $\begin{array}{l}\text { Juni } \\
\text { Juli . } \\
\text { August }\end{array}$ & : & $\dot{.}$ & $\begin{array}{r}1,5 \\
\mathbf{1 , 3} \\
0,9\end{array}$ & $\begin{array}{l}0,4 \\
\mathbf{4 , 4} \\
3,6\end{array}$ & $\begin{array}{l}4,5 \\
3,0 * \\
3,0\end{array}$ & $\begin{array}{l}1,5 \\
5,0 \\
4,5\end{array}$ \\
\hline $\begin{array}{l}\text { September } \\
\text { Oktober } \\
\text { November }\end{array}$ & r & . & $\begin{array}{l}-1,4 \\
-\quad 5,0 \\
-\quad 8,7\end{array}$ & $\begin{array}{l}-\quad 0,3 \\
-\quad 5,8 \\
-11,8\end{array}$ & $\begin{array}{l}4,0 \\
5,0 \\
5,5\end{array}$ & $\begin{array}{r}0,4 \\
-\quad 4,2 \\
-\quad 9,8\end{array}$ \\
\hline Jahr & . & . & $-6,5$ & $-7,1$ & 4,9 & $-8,8$ \\
\hline
\end{tabular}


Es ist eine landläufige Vorstellung, da $B$ das Bergklima in größeren Höhen einen polaren Charakter annehme. Nun findet man allerdings die mittleren Jahrestemperaturen des Sonnblick oder des Pikes Peak in der arktischen Zone wieder, aber selbst das durchschnittlich kältere Upernivik hat einen wärmeren Sommer und Herbst als die Hochgipfel der Alpen und des Felsengebirges. Ebenso auffällig ist der Kontrast von Antisana und Westerås am Mälarsee unter $59^{\circ} 37^{\prime}$. Die Jahrestemperatur ist an beiden Orten die gleiche, aber die tiefste Monatstemperatur ist in Westerås $-4,6^{\circ}$ und die höchste $16,3^{\circ}$. Das Höhenklima unterscheidet sich also vom polaren wesentlich durch kühle Sommer und verhältnismäBig milde Winter.

Es besitzt aber noch einen anderen Vorzug, der selten entsprechend gewürdigt wird. Die mittleren Temperaturen einer Beobachtungsstation sind Schattentemperaturen; in den alpinen Hochtälern ist aber bei vorwiegend heiterem Himmel (s. S. 65) und Windstille die Insolation außerordentlich kräftig, und daher im Winter der Unterschied zwischen Sonnen- und Schattentemperatur, der in der polaren Nacht natürlich wegfällt, sehr bedeutend. In Davos (1650 m hoch) stieg z. B. die Lufttemperatur am 30. Dezember 1873 nicht über $-12,9^{\circ}$, aber in der Sonne zeigte das Thermometer um $9 \mathrm{Uhr}$ morgens $25,5^{\circ}$ und um $1 \frac{1}{2}$ Uhr nachmittags $38,5^{\circ}$ Von dem bekannten Kurort Meran sagt Fuchs, daß vom Dezember bis März die Nächte Winter, die Tage aber sommerliches Frühjahr seien. Auch im Sommer ist der Unterschied zwischen Sonnen- und Schattentemperatur größer als in der Ebene. Er beträgt nach H. Hoffmann ${ }^{9}$ im Juli und August in den Alpen $16,4^{\circ}$, in Gießen (an den gleichen Tagen gemessen) dagegen nur 4,9 ${ }^{\circ}$. Im Gebirge ist die Luft trockener und reiner, während im Tiefland der größere Dampfgehalt, die größere Dichtigkeit und die Trübung der untersten Luftschichten einen beträchtlichen Teil der eingestrahlten Sonnenwärme absorbieren. $\times$

$\times$ Messungen von E. Frankland, Sonnenhöhe konstant $60^{\circ}$.

Seehöhe Thermometer

\begin{tabular}{|c|c|c|c|c|c|c|c|}
\hline Whitby . & & . & . & 20 & $32,2^{0}$ & $37,8^{\circ}$ & $5,6^{\circ}$ \\
\hline Oatland Parl & & . & . & 46 & 30,0 & 41,5 & 11,5 \\
\hline Pontresina . & . & . & . & 1800 & 26,5 & 44,0 & 17,5 \\
\hline Bernina . & . & . & . & 2330 & 19,1 & 46,4 & 27,3 \\
\hline Riffelberg & . & . & . & 2570 & 24,5 & 45,5 & 21,0 \\
\hline Hörnli . & . & . & . & 2890 & 20,1 & 48,1 & 28,0 \\
\hline Diavolezza & . & . & . & 2980 & 6,0 & 59,5 & 53,5 \\
\hline Gornergrat . & . & . & . & 2140 & 14,2 & 47,0 & 32,8 \\
\hline
\end{tabular}


Thermische Verschiedenheiten des Höhenklimas. Die Beobachtungen am Wendelstein in Bayern haben dargetan, daß Berggipfel im Sommer nachts kälter und bei Tag wärmer sind, als die freie Atmosphäre in gleicher Höhe. Wenn die Bodenfläche eines Gipfels auch verhältnismäßig klein ist, so beeinflußt sie doch durch Ausstrahlung die ihr unmittelbar aufliegende Luft. Je massiger das Gebirge ist, desto größer ist dieser Einfluß. Aus A. DE Quenvarn's Untersuchung der Temperaturverteilung in der Schweiz, bezogen auf das Niveau von $1500 \mathrm{~m},{ }^{10}$ geht die thermische Begünstigung der geschlossensten Alpenteile, des Monterosagebiets und Engadins, gegenüber dem übrigen Gebirge deutlich hervor. Sie gründet sich auf die stärkere Erwärmung in den Mittagsstunden, die sich von Februar bis November bemerkbar macht, während in den Morgenstunden mit Ausnahme des Sommers der umgekehrte Fall eintritt. Daher das scheinbar paradoxe Resultat, daß mittags im gleichen Niveau die höchsten Gebirge um ein paar Grade wärmer sind als die Ebene.

Es muß auch zwischen dem Klima der isoliert aufragenden Gipfel und dem der großen, breiten Täler unterschieden werden. Rigikulm (1795 m h.) und Sils-Maria im Engadin $(1811 \mathrm{~m} \mathrm{~h}$.) bilden vortreffliche Vergleichsobjekte. Im Winterhalbjahr ist das Bergklima,

\begin{tabular}{|c|c|c|c|c|c|c|c|c|c|c|c|c|c|}
\hline & Dez. & Jan. & Feb. & März & April & Mai & Juni & Juli & Aug. & Sept. & Okt. & Nov. & Jahr \\
\hline igi . & & & $-4,0^{\circ}$ & $-3,4^{\circ}$ & $0,2^{\circ}$ & $3,9^{\circ}$ & $7,5^{\circ}$ & $9,9^{\circ}$ & $9,4^{0}$ & $7,5^{\circ}$ & $2,7^{\circ}$ & $-0,8^{0}$ & $2,0^{\circ}$ \\
\hline Sils . . & $-6,8$ & $-8,0$ & $-6,8$ & $-4,0$ & 0,6 & 5,0 & 9,1 & 11,3 & 10,4 & 7,4 & 2,4 & $-2,4$ & 1,8 \\
\hline Tal-Berg . & $-2,9$ & $-3,5$ & $-2,8$ & $-0,6$ & $+0,4$ & $+1,1$ & $+1,6$ & $+1,4$ & $+1,0$ & $-0,1$ & $-0,3$ & $-1,6$ & $-0,4$ \\
\hline
\end{tabular}

im Sommerhalbjahr das Talklima wärmer. In unserem Fall ist der Gegensatz durch ein anderes Phänomen noch beträchtlich verschärft. Die Beobachtungen auf dem Eiffelturm haben uns schon gelehrt, daB in der Nacht der Boden regelmäBig so stark erkaltet, daß eine vertikale Temperaturzunahme eintritt, die aber viel geringfügiger ist als die Abnahme in den Tagesstunden. In Gebirgsländern kann sie jedoch im Winter ein dauernder Zustand werden, der bei Tag wie bei Nacht wirksam ist. Grundbedingung ist ein hoher Barometerstand, der heiteres, ruhiges Wetter erzeugt; günstig wirkt auch eine dichte Schneedecke, da diese durch Ausstrahlung außerordentlich intensiv erkaltet. Diese Temperaturerniedrigung teilt sich nur den untersten Luftschichten mit, die sich bei vorherrschender Windstille ruhig über dem Talboden lagern. Zwar erkalten auch die Berggehänge und Gipfel, aber hier ist die Luft immer etwas bewegt, und die dem Boden unmittelbar auflagernden kalten Schichten können sich mit den wärmeren der freien Atmosphäre mischen. Dann ragen die Berge als Wärmeinseln aus 
dem kalten Meer der Täler und Ebenen hervor, und es können Wochen vergehen, bis der normale Zustand wieder hergestellt ist. Solche Umkehrperioden tragen natürlich auch dazu bei, die mittlere winterliche Temperaturabnahme zu erniedrigen, wenn wir ihrer Berechnung die Beobachtungen an Ebenen- und Talstationen zugrunde legen.

Geographisch bedeutsam wird die Wärmeumkehr aber nur dort, wo sie auch in langjährigen Mittelwerten zum Ausdruck kommt, also zum habituellen klimatischen Charakter gehört. In den Alpen sind, wie $\mathrm{HANN}^{7}$ ziffermäßig nachwies, alle Täler, die gegen die herrschende Windrichtung abgeschlossen sind, durch diese Abnormität ausgezeichnet, und daraus erklärt es sich, daß die menschlichen Wohnstätten mit auffallender RegelmäBigkeit selbst breite, fruchtbare Talsohlen meiden und sich auf die Gehänge zurückziehen. Das Engadin und das kärntnerische Drautal sind schon lange bekannte klassische Beispiele der winterlichen Wärmeumkehr. Sils im Engadin $\left(1810 \mathrm{~m} \mathrm{~h}\right.$.) ist im Januar $\left(-8,0^{\circ}\right)$ fast ebenso kalt wie der St. Bernhard in $2478 \mathrm{~m} \mathrm{H} .\left(-8,3^{\circ}\right)$, und Bevers, nur $1715 \mathrm{~m}$ hoch gelegen, hat sogar $-9,7^{\circ}$, ist also um $4,6^{\circ}$ kälter als der $75 \mathrm{~m}$ höhere, aber isolierte Rigi. Im Drautal nimmt in der Regel die Temperatur normal mit der Höhe ab, im Winter sind aber noch die Stationen in $1600 \mathrm{~m} \mathrm{H}$. wärmer als die $1000 \mathrm{~m}$ tieferen Talsohlen. $\times$ Im Gebiet des ostsibirischen Kältezentrums rufen dieselben Ursachen dieselbe Wirkung hervor. Auf der einzigen sibirischen Höhenstation, Werchnjaja Mischikha im ostbaikalischen Chamar-Daban-Gebirge (ungefähr $1300 \mathrm{~m} \mathrm{~h}$.), war, obwohl sie in einer Paßeinsenkung gelegen ist, die Temperatur im Januar 1897 um $3,8^{\circ}$ höher als in der benachbarten Talstation Werchne-Udinsk (521 $\mathrm{m} \mathrm{h}$.), dagegen im Juli in normaler Weise um $4,7^{0}$ und im Jahresmittel um $0,8^{0}$ tiefer. $^{11}$ Im nordöstlichen Grönland haben die Ballon- und Drachenaufstiege fast regelmäßig eine Temperaturzunahme bis $200 \mathrm{~m}$ Höhe ergeben. ${ }^{12}$

$\times$

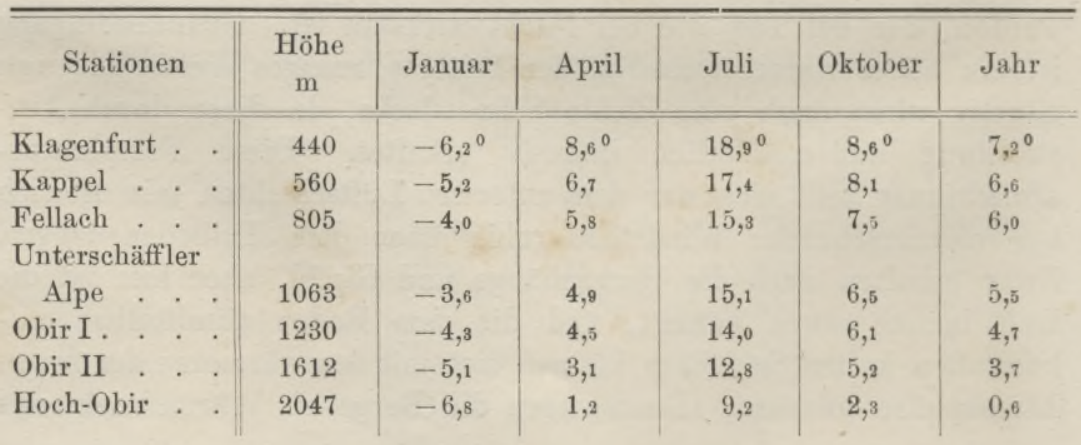


Plateaus. Über ausgedehnten Plateaus, die stellenweise, wie z. B. im südlichen Zentralasien, zu alpiner Höhe ansteigen, werden die untersten Luftschichten in derselben Weise erwärmt wie über dem Tiefland. Von einer Wärmevermittlung durch aufsteigende Luftmassen aus der Tiefebene kann keine Rede sein, am wenigsten bei den großen, gebirgsumschlossenen Hochtlächen der Erde. Trotzdem besteht hier dasselbe Gesetz der vertikalen Temperaturabnahme zu Recht, wie im Gebirge. Es ist die geringere Dichtigkeit der Luft, die einerseits die Wirkung der solaren Wärmequelle schwächt und anderseits die Wärmeaufnahme des Bodens beeinflußt. Er erwärmt sich und erkaltet schneller als im Tiefland. An hellen Sommertagen mag es hier ebenso heiß sein, wie wenige Meter über dem Meeresniveau, aber die Nächte sind bedeutend kälter, und dieser Gegensatz steigert sich mit der Seehöhe. Daher muß der Höheneinfluß auch in der Tagestemperatur zum Ausdruck kommen, denn diese ist ein. 24stündiges Mittel oder wenigstens auf ein solches reduziert.

Es wäre für den Geographen von höchster Wichtigkeit, das $\mathrm{MaB}$ der Temperaturabnahme auf den Hochebenen festzustellen. Leider stoßen wir hier auf zwei bedeutende Hindernisse. Von den großen Hochflächen der Erde besitzen wir - mit Ausnahme der nordamerikanischen - nur spärliche und kurze Beobachtungen. Wir sind ferner meist darauf angewiesen, Plateau- und Tieflandstationen miteinander $\mathrm{zu}$ vergleichen, aber diese liegen häufig weit entfernt voneinander und stehen unter verschiedenen klimatischen Bedingungen. Wie die Wahl der Vergleichstationen die höchste Vorsicht erfordert, zeigt folgendes Beispiel. Valparaiso und das um $489 \mathrm{~m}$ höher gelegene Santiago, nur $110 \mathrm{~km}$ voneinander entfernt, scheinen zu einer Untersuchung über die vertikale Temperaturänderung vollkommen geeignet zu sein. Santiago ist im Juli (Winter) um $3,8^{\circ}$ kälter als Valparaiso, von Norember bis März dagegen wärmer, im Januar sogar um $2,8^{0}$. Ist da der Schluß gestattet, daß die Temperatur im Sommer mit der Seehöhe zunimmt? Keineswegs, denn Valparaiso repräsentiert das unter dem Einfluß der kalten Meeresströmung stehende Küstenklima, Santiago das Binnenklima; sie sind daher nicht miteinander vergleichbar. Santiago wäre jedenfalls noch viel wärmer, wenn es tiefer läge. Nördlich vom $27 .^{\circ} \mathrm{B}$. zeigen die chilenischen Inlandstationen auch im Winter eine scheinbare vertikale Temperaturzunahme, die in der Wärmeausstrahlung der kahlen Felsen und in der Abwesenheit der Küstennebel begründet ist.

Bigelow ${ }^{13}$ hat bei seinen eingehenden Untersuchungen über die vertikale Temperaturabnahme in Nordamerika diese Schwierig- 
keiten durch die Bildung von Gruppenmitteln, die auf einen einheitlichen Parallel und einen einheitlichen Meridian reduziert wurden, zu umgehen gesucht. Mit Hilfe einer äußerst komplizierten Methode fand er für das Jahresmittel eine Abnahme von $0,33^{\circ}$ für $100 \mathrm{~m}$. Daß der jährliche Gang sehr unregelmäBig ist, macht gegen das Ergebnis mißtrauisch; die Schwankung ist gering, die Extreme sind $0,27^{\circ} \mathrm{im}$ März und $0,39^{\circ}$ im Juni. Hier geht also die vertikale Abnahme langsamer vor sich als im Gebirge, ist aber wie dort in der kalten Jahreszeit kleiner als in der warmen. Ganz anders sind die Verhältnisse im russischen Zentralasien. ${ }^{14}$ Legt man die Stationen Samarkand $(719 \mathrm{~m})$ und Pamirski Post $(3640 \mathrm{~m})$ zugrunde, so erhält man für den Winter $0,69^{\circ}$, den Frühling $0,45^{\circ}$, den Sommer $0,39^{\circ}$, den Herbst $0,13^{0}$ und das Jahr $0,49^{\circ}$ auf $100 \mathrm{~m}$. Diese jährliche Periode der Temperaturabnahme, die auch in andern Kombinationen wiederkehrt, entspricht in der Tat für Hochflächen mit intensiver winterlicher Ausstrahlung und beträchtlicher sommerlicher Erwärmung unsern Voraussetzungen besser als die BigeLow'sche.

Reduktion der Temperatur auf das Meeresniveau. Von den großen Faktoren, die die mathematische, d. h. die allein von der geographischen Breite abhängige Temperaturverteilung auf der Erdoberfläche modifizieren, haben wir den am meisten wechselnden, die Seehöhe, soeben kennen gelernt. Wir können ihn ausschließen, indem wir die beobachteten Temperaturen auf das Meeresniveau reduzieren; wenn wir dann die Orte mit gleicher Temperatur durch Linien (Is othermen) miteinander verbinden, so gewinnen wir ein einfaches und übersichtliches Bild, das uns die Ursachen der tatsächlichen Temperaturverteilung sofort verrät. Es ist eines der gröBten wissenschaftlichen Verdienste Alexander v. Humbolidt's, die erste Isothermenkarte der Erde entworfen zu haben.

Die Frage nach dem besten Reduktionsfaktor kann erst dann mit Aussicht auf Erfolg gelöst werden, wenn man über das $\mathrm{MaB}$ der Temperaturabnahme auf Hochflächen ins Klare gekommen sein wird. HanN hat sich für $0,5^{\circ}$ entschieden und wendet diesen Wert auch für die Monatstemperaturen an. Vielleicht ist er etwas zu hoch, weil für Isothermenkarten großer Länderräume die Plateau-, nicht die Gebirgsstationen ins Gewicht fallen. Jedenfalls muB daran festgehalten werden, daß jede Isothermenkarte nur für den betreffenden Reduktionsfaktor gilt. Das muß besonders bei Karten in großem Maßstab und von Gegenden mit unruhigen Geländeverhältnissen im Auge behalten werden. Anscheinend ist die Forderung berechtigt, daß für jeden Monat ein eigener Reduktionsfaktor gebraucht werde, und doch muß man sie zurückweisen, weil 
dadurch einer der wichtigsten klimatischen Charakterzüge, die jährliche Temperaturschwankung, gefälscht werden würde. Pamirski Post z. B. hat im Januar $-18,5^{\circ}$, im Juli $13,9^{\circ}$, also eine jährliche Schwankung von $32,4^{\circ}$. Diese würde auf $25,2^{\circ}$ erniedrigt werden, wenn man mit Zugrundelegung der Vergleichsstation Samarkand für den Januar den Reduktionsfaktor $0,6^{0}$ und für den Juli $0,4^{6}$ in die Rechnung einführen würde, und die Pamirhochtäler erhielten dadurch einen thermischen Charakter wie das turanische Flachland. Ebenso gerechtfertigt ist ein einheitlicher Maßstab für die ganze Erde. Wollte man für jeden einzelnen Fall ein eigenes Reduktionsmaß berechnen, so käme man $\mathrm{zu}$ demselben Resultat, wie wenn man alle Stationen mit größerer Seehöhe ausschließen würde. Ein einheitlicher Maßstab liefert zwar nur ein ideales, aber jedenfalls ein einheitliches Bild. Er muß auch dann zur Anwendung kommen, wenn tatsächlich die Temperatur mit der Höhe zunimmt; denn nur auf diese Weise wird z. B. die Kälte des Talbodens im Draugebiet auf der Isothermenkarte des Januar hervortreten, während eine umgekehrte Reduktion alle örtlichen Eigenschaften verwischen würde. Man muß sich nur stets vor Augen halten, was das Isothermenbild eigentlich darstellen will. Es sagt uns nicht: so würde sich die Temperaturverteilung gestalten, wenn die ganze Erdoberfläche eine ununterbrochene Ebene im Meeresniveau wäre; sondern es setzt die wirklichen Terrainverhältnisse mit allen ihren modifizierenden Einflüssen voraus und elimiert nur die thermische Wirkung der Seehöhe.

Literaturnachweise. ${ }^{1} \mathrm{H}$. Hergesell, Die Temperatur der freien Atmosphäre, in Petermann's Mitteilungen, 1900. $-{ }^{2}$ R. Assmann und A. Berson, Wissenschaftliche Luftfahrten, Berlin 1899-1900. Ein Werk von grundlegender Bedeutung. $-{ }^{3}$ S. das Diagramm in Petermans's Mitteilungen 1907, S. 139. 4 Zur Orientierung empfiehlt sich A. Schmauss, Die obere Inversion, in der Meteorologischen Zeitschrift 1909. - ${ }^{5}$ R. Assmans, Die Temperatur der Luft über Berlin in der Zeit vom 1.Okt. 1902 bis 31. Dez.1903, Berlin 1904. - ${ }^{6}$ ARthuR Wagner in der Meteorologischen Zeitschrift 1910 S. $97 .{ }^{7}$ Die für "die Schweiz (J. Maurer, Die Wärmeabnahme mit der Höhe in den Schweizer Alpen; in der Meteorologischen Zeitschrift 1908) und die Ostalpen (J. Hanv. Die Temperaturverhältnisse der, österreichischen Alpenländer; in d. Sitz.-Ber. d. Wien. Akad. d. Wiss., Math.-naturw. Kl. 1884-85, Bd. XC, XCI uud XCII) aus der Kombination sämtlicher Temperaturmittel nach der Methode der kleinsten Quadrate gewonnenen Werte sind wohl die zuverlässigsten, die jemals für ein Gebirge berechnet wurden. $-{ }^{8}$ W, Trabert, Der tägliche Gang der Temperatur und des Sonnenseheins auf dem Sonnblickgipfel; in den Denkschriften der Wiener Akademie der Wissenschaften, Math.-naturwiss. Kl. Bd. LIX, 1892. Die Arbeit bietet auch in theoretischer Beziehung viel Beachtenswertes. ${ }^{9} \mathrm{H}$. Hoffmann in der Zeitschrift der österreichischen Gesellschaft für Meteorologie, 1882 , S. $123 .-{ }^{10}$ A. DE QUERvaIN, Die Hebung der atmosphärischen 
Isothermen in den Schweizer Alpen, in GerLand's Beiträgen zur Geophysik, 1903, Bd. VI. - ${ }^{11}$ A.Woвıкоw in der Meteorologischen Zeitschrift 1900, S. 28. - ${ }^{12}$ A. Wegener in Danmarks Ekspeditionen til Grenlands Nordestkyst, Bd. II, Kopenhagen 1909. - ${ }^{13}$ F. H. Bigecow, Report on the Barometry of the United States, Canada, and the West Indies; im Report of the Chief of the Wheather Bureau, 1900-1901, Bd. II, Washington 1902. - ${ }^{14}$ H. v. Frскеr, Zur Meteorologie von Westturkestan, in den Denksehriften der Akademie der Wiss. in Wien, Math.-naturwiss. Kl., Bd. LXXXI, 1908.

\section{Die horizontale Verteilung der Temperatur.}

(Vgl. Karten III bis VIII.)

Wir haben oben (S. 63) die relativen Wärmemengen kennen gelernt, welche die verschiedenen Breiten von der Sonne empfangen, und es muß nun einen Schritt weiter gegangen und festgestellt werden, wie sich die verschiendenen Erdoberflächen zu derjenigen Wärmemenge, die bis auf den Boden gelangt, verhalten. Denn Land und Wasser empfangen, wenn sie auch unter gleicher Breite liegen, wegen der ungleichen Reflexion der Sonnenstrahlen verschiedene Wärmemengen, und zwar, wie ZENKER ${ }^{1}$ nachgewiesen hat, das Wasser überall weniger als das Land. Mit der Polhöhe steigert sich dieser Gegensatz, weil die Reflexion mit dem Einfallswinkel der Sonnenstrahlen wächst. Daß die Luft über dem Land in der Regel trockener ist als über dem Meer und daher mehr Wärme durchläßt, kommt noch als weiterer Umstand hinzu. Die höhere spezifische Wärme des Wassers bewirkt ferner, daß es sich langsamer erwärmt als das Land. ${ }^{\times}$Die Zufuhr von einer Kalorie erhöht die Temperatur von $1 \mathrm{ccm}$ Wasser um $1^{\circ}$, die eines gleichen Volumens Land aber um $2^{\circ}$. Wenn umgekehrt das Wasser sich um $1^{0}$ abkühlt, gibt es 1 , das Land aber nur 0,5 Kalorien ab, und durch diesen Vorgang wird im ersten Fall die Temperatur von $(1: 0,00031=) 3226$, im zweiten aber nur von $(0,5: 0,00031=) 1613 \mathrm{ccm}$ Luft um $1^{0}$ erhöht. Von noch größerer Bedeutung ist die Art der Wärmeaufspeicherung. Auf dem Land kann sich die Wärme nur durch Leitung nach der Tiefe fortpflanzen, nur eine dünne Schicht wird bei Tag und im Sommer erwärmt, und daher rasche Erkaltung in der Nacht und im Winter. Das Wasser wird dagegen schon direkt bis zu größeren Tiefen von der Sonne durchstrahlt, ${ }^{2}$ und außerdem gestattet die Beweglichkeit der einzelnen Teile den während der Nacht und im Winter erkalteten oberen Schichten,

$\times$ Unter spezifischer Wärme versteht man die Wärmemenge, die notwendig ist, um die Temperatur eines cem eines Körpers um $1^{\circ}$ C. zu erhöhen. Wenn wir die des Wassers $=1$ setzen, so kann die des Landes in seiner mittleren Zusammensetzung auf nur 0,5 und die der Luft auf 0,00031 veransehlagt werden. 
als den schwereren, zu Boden zu sinken und ihren Platz wärmeren Schichten einzuräumen. Das Land erhält viel Wärme, aber es geht verschwenderisch damit um; das Wasser hält seinen geringen Vorrat sparsam zusammen und speichert Wärmemengen für die kalten Perioden auf. $\times$ Daraus folgt unmittelbar: 1 . da B die Temperatur über dem Wasser bei Nacht und im Winter höher und bei Tag und im Sommer niedriger ist als auf dem Land, oder mit anderen Worten, daß das Landklima größeren täglichen und jährlichen Schwankungen unterworfen ist als das Seeklima; 2. daß die mittlere Jahrestemperatur in höheren Breiten, wo die kalten Perioden lange andauern, auf der See, in niederen Breiten a dem Land höher ist.

Normale Temperaturverteilung. Wir haben bisher nur von relativen Wärmemengen gesprochen, aber diese müssen erst in die gemeinverständliche Sprache der Temperaturgrade übersetzt werden, um sie für die klimatologische Betrachtungsweise brauchbar zu machen. Das ist der heikle Punkt der modernen Methode, denn es gibt kaum eine meteorologische Station, von der wir mit Bestimmtheit behaupten können, daß sie reines See- oder Landklima besitze; und es ist daher begreiflich, wenn ZENKER, der mit diesen Untersuchungen hauptsächlich beschäftigt war, im Lauf der Zeit zu verschiedenen Werten gelangte. Die zuletzt gefundenen sind folgende: ${ }^{4}$

$\begin{array}{crcc}\text { Breite } & \text { Landklima } & \text { Seeklima } & \begin{array}{c}\text { Unterschied } \\ \text { (Landklima-Seeklima) }\end{array} \\ 0^{0} & 34,6^{\circ} & 26,1^{0} & +8,5 \\ 10 & 33,5 & 25,3 & +8,2 \\ 20 & 30,0 & 22,7 & +7,3 \\ 30 & 24,1 & 18,8 & +5,3 \\ 40 & 15,7 & 13,4 & +2,3 \\ 50 & 5,0 & 7,1 & -2,1 \\ 60 & -7,7 & 0,3 & -8,0 \\ 70 & -19,0 & -5,2 & -13,8 \\ 80 & -24,9 & -8,2 & -16,7 \\ 90 & -26,1 & -8,7 & -17,4\end{array}$

$\times$ Der jährliche Wärmeumsatz, d. h. die im Lauf eines Jahres aufgespeicherte und wieder an die Luft abgegebene Wärmemenge beträgt nach Schubert $^{3}$, Krümmel und Hañ in Tausenden $\mathrm{kg}$-Kalorien für ein qm:

Sandboden mit Kiefernwald in Eberswalde . 12,9

Sandboden mit Gras in Eberswalde . . . . 18,5

Hintersee in Westpreußen bis $24 \mathrm{~m}$. . . . 280

Genfer See . . . . . . . . . 370

Ostsee . . . . . . . . . . . . . 505

Östliches Mittelmeer. . . . . . . . . 426

Schwarzes Meer . . . . . . . . . . 482 
Am Äquator ist das Landklima dem maritimen am meisten überlegen; dann nähern sich beide Klimate immer mehr, bis sie unter $45^{\circ} \mathrm{B}$. einander gleich werden; von da ab ist das Seeklima wärmer, und es wird relativ immer wärmer, je mehr wir uns dem Pol nähern, - freilich unter einer Voraussetzung, die in der Natur nicht erfüllt wird: daß nämlich das Wasser nicht gefriert. Wir nennen die Zone zwischen 0 und $45^{\circ} \mathrm{B}$. die innere und die Zone zwischen 45 und $90^{\circ} \mathrm{B}$. die äuBere. Die mittlere Temperatur der Erde würde ihren höchsten Grad erreichen, wenn die innere Zone nur aus Land und die äußere nur aus Wasser bestünde, und im umgekehrten Fall ihren niedrigsten Wert erlangen. Es ist leicht einzusehen, daß beide Extreme für die Bewohnbarkeit der Erde durch Landorganismen gleich ungünstig wären.

In Wirklichkeit liegen zwischen $80^{\circ} \mathrm{N}$ und $50^{\circ} \mathrm{S}$ Land und Wasser in meridionalen Streifen nebeneinander, und nun tritt ein Wärmeaustausch nicht bloß, wie unter allen Umständen, in meridionaler, sondern auch in ostwestlicher Richtung ein, denn stets müssen verschieden temperierte Räume, die miteinander korrespondieren, einen Ausgleich anstreben. Selbst wenn wir annehmen, daß sich im innersten Teil der Land- und Meeresstreifen reines Landbezw. reines Seeklima noch erhalten könnte, so wird doch gegen die Ränder hin stets eine Mischung eintreten und die beiden Klimate immer mehr einander nähern. Dieser einfachste Fall ist in Fig. 26 dargestellt. Land und Meer sind als regelmäBige Streifen zwischen $80^{\circ} \mathrm{N}$ und $50^{\circ} \mathrm{S}$ gedacht. Im mittleren Meridian dieser Streifen sind den Temperaturen von $5 \mathrm{zu} 5^{0}$ diejenigen Stellen angewiesen, die ihnen nach dem Solarklima zukommen, und die Orte gleicher Temperatur sind durch Linien (Isothermen) miteinander verbunden. Das sind die Normalisothermen unter der Voraussetzung, daß Land und Wasser in meridionalen Streifen nebeneinander lagern; sie weichen mit Ausnahme der Isotherme in $45^{\circ} \mathrm{B}$. (in der Figur annähernd die $10^{\circ}$-Isotherme) überall von den Parallelkreisen ab, indem sie in der inneren Zone vom Meer gegen das Land, in der äußeren vom Land gegen das Meer polwärts ansteigen. Auf dem Land treten in der äquatorialen und der polaren Zone sogar in sich geschlossene Isothermensysteme auf. Aber obwohl sich Wärmeänderungen auch in ostwestlicher Richtung vollziehen, so bleibt doch stets das Grundgesetz des solaren Klimas gewahrt, indem in jedem Meridian die Temperatur vom Äquator gegen die Pole hin stetig abnimmt.

Abweichungen. Vergleichen wir dieses Normalbild mit der Karte der Jahresisothermen (Karte III), so werden wir von dem hohen Grad der Übereinstimmung beider überrascht, soweit es die 
Grundgesetze der Temperaturabnahme mit wachsender Breite und der Isothermenkrümmung betrifft. Aber neben der Übereinstimmung gewahren wir auch auffallende Abweichungen von dreierlei Art. Die Winde und Meeresströmungen bewirken Temperaturverschieebungen, abnorme Erwärmungen auf der einen und damit notwendigerweise Erkaltungen auf der anderen Seite. Es ist eine der wichtigsten physikalischen Tatsachen und auch für die Entwicklung des Menschengeschlechtes von weitest tragender Bedeutung, daß fast die ganze nördliche gemäBigte und kalte Zone wärmer ist, als ihr der Breite nach zukommt, und daß die heiße Zone, vor allem die südliche, diesen uns so erwünschten Wärmezuschuß deckt. In die nördlichsten

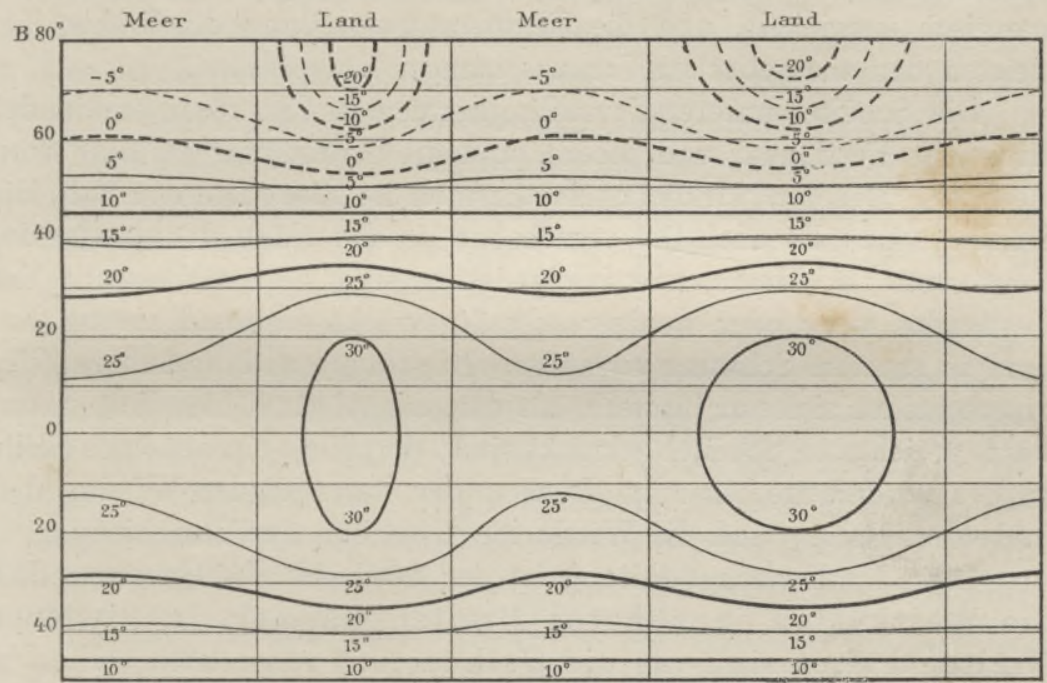

Fig. 26. Normalisothermen.

Teile der Kontinente dringt das Seeklima so weit ein, daß mit Ausnahme des inneren eiserfüllten Grönlands selbst die niedrigsten Jahrestemperaturen höher sind, als die den betreffenden Breiten entsprechenden Werte des solaren Landklimas: offenbar eine Folge davon, daß das Land in den höheren Breiten abbricht. Würde Asien über den Pol mit Amerika zusammenhängen, so würden in 60 und $70^{\circ} \mathrm{B}$. viel niederere Temperaturen auftreten, als es tatsächlich der Fall ist. Auch in der Tropenzone löst sich das Land auf, auch hier siegt das See- über das Landklima, und selbst die höchsten beobachteten Jahrestemperaturen erreichen kaum die Wärmegrade des reinen solaren Landklimas, das einen großen Teil der Kontinente unbewohnbar machen würde. Auf dem Indischen Ozean be- 
wirkt die große kontinentale Umrahmung eine deutliche Temperaturerhöhung; hier hat sich der Ausgleich zwischen Land- und Seeklima wirklich vollzogen, indem das erstere erniedrigt, das letztere erhöht wird, während im südtropischen Teil des Atlantischen Ozeans die Strömungen den Einfluß des umgebenden Festlandes so sehr unter drücken, daß er entschieden als zu kalt erscheint. Dagegen ist der ganze atlantische Norden zu warm, und diese Abnormität tritt besonders in den höheren Breiten schärfer hervor. Die Isothermen dringen hier mit den warmen Meeresströmungen durch eine offene Pforte viel weiter gegen Norden vor, als in dem abgeschlossenen Pazifischen Ozean. Diese gröBte Meerestläche endlich wird von dem Landklima nur wenig beeinflußt, die Strömungen sind nicht sehr energisch entwickelt, und die Temperaturverteilung dürfte hier am meisten den theoretischen Voraussetzungen entsprechen.

Die Scheitel unserer Normalisothermen in Fig. 26 liegen in der Mitte der Festländer und Meere, und die Krümmung verläuft symmetrisch. Bei den wirklichen Isothermen ist dies nicht der Fall, die Scheitel sind alle nach Ost verschoben, in die Nähe der Ränder der Kontinente und Meere, und infolgedessen sind sie am Westrand des Festlandes mehr oder weniger scharf geknickt, während sie am Ostrand in sanftem Schwung verlaufen. Die innere und die äußere Zone unterscheiden sich nur insofern, als dort die polwärts, hier die äquatorwärts gerichteten Scheitel geknickt sind; dort liegt die abnorme Stelle an der Vorderseite, hier im Rücken der herrschenden Winde, aber in beiden Fällen sind die Winde die Ursachen der Verschiebung.

Diese Isothermengestaltung ist der Ausdruck des Gesetzes, da B die Westküsten in höheren Breiten wärmer, in niederen Breiten kälter sind als die Ostküsten. Theoretisch sollten ja beide Küsten nahezu gleich warm sein, unter dem Einfluß der Westwinde schiebt sich aber in der äußeren Zone unserer Halbkugel das Seeklima im Westen weit in das Land hinein, und ebenso verschiebt sich das Landklima gegen die Ostküste und macht seinen erkältenden Einfluß noch weit in das Meer hinaus geltend. Auch in der Zone der Passate sind die von diesen Seewinden getroffenen Küsten wärmer, aber die Verkettung von Ursache und Wirkung ist hier eine andere. Hier schiebt sich ein Zwischenglied ein, das wir erst später genauer kennen lernen werden: die Erkaltung des Meerwassers an den Westküsten Afrikas und des tropischen Amerikas durch Aufsteigen von Tiefenwasser und Zufluß kälteren Wassers. Wo dieses kalte Küstenwasser fehlt, wie in Australien, da ist die Ostküste kälter, weil sie vom Ostwind überweht wird.

Die dritte UnregelmäBigkeit besteht endlich in der stellenweisen 
Temperaturzunahme mit wachsender Breite. Der Grund liegt in der horizontalen und vertikalen Gliederung des Festlandes, im Wechsel von Land und Wasser längs eines Meridians, in Vegetationsverhältnissen, in Meeresströmungen usw.

Verbindet man, wie es auf Karte VIII geschehen ist, die heißesten Punkte der Meridiane miteinander, so erhält man den thermischen Äquator, der in höchst unregelmäBiger Weise zwischen $26^{\circ} \mathrm{N}$ und $9^{\circ} \mathrm{S}$ hin und her schwankt. Daß er im Pazifischen Ozean auf die Südhemisphäre übertritt, ist wohl in den Strömungsverhältnissen begründet, sonst liegt er aber fast durchaus auf unserer Halbkugel und bewegt sich auf den Festländern am weitesten polwärts. Warum er sich in Afrika, wo am wirklichen Äquator doch auch breites Land ist, so weit nach Norden verschiebt, mag auffallen, ist aber ohne weiteres erklärlich, wenn man erwägt, daß er eine Wüste durchzieht, die sich im Sommer außerordentlich erhitzt und ihre Wärme den untersten Luftschichten mitteilt, während am Gleicher das Land mit Vegetation bedeckt ist. Deshalb liegt auch in Amerika die heißeste Stelle nicht im üppig bewaldeten Äquatorialstreifen, sondern im trockenen Binnenland Mexicos.

$\mathrm{Ob}$ die mathematischen Pole die kältesten Punkte der Erdoberfläche sind, wie es das solare Klima verlangt, wissen wir zwar nicht, es spricht aber manches gegen diese Annahme. Der kälteste Ort unserer Halbkugel und der Erde überhaupt, von dem wir die mittlere Jahrestemperatur mit einiger Sicherheit feststellen können, ist die Lady-Franklin-Bai an der Ostküste von Grinnel-Land $\left(81^{\circ} 44^{\prime} \mathrm{N}\right)$; $\mathrm{H}_{\text {ANN }}$ hat dafür eine Mitteltemperatur von $-20^{\circ}$ berechnet. $\times$ MонN ${ }^{5}$

$\times$ Beispiele für das polare Klima; die drei arktischen Landstationen liegen in ungefähr derselben Breite, für die Frambeobachtungen im östlichen Eismeer wurden die mittleren Koordinaten eingestellt. Im arktischen Gebiet vertritt das Eismeer das ozeanische, NW-Grönland das streng kontinentale Klima, Spitzbergen das Klima im Bereich der warmen Atlantischen Strömung.

\begin{tabular}{|c|c|c|c|c|c|c|c|}
\hline & & & & \multicolumn{3}{|c|}{ Arktisches Klima } & \multirow{2}{*}{$\begin{array}{l}\text { Antark- } \\
\text { tisches Klima } \\
\text { Viktorialand }\end{array}$} \\
\hline & & & & $\begin{array}{l}\text { 1. Östliches } \\
\text { Eismeer }\end{array}$ & $\begin{array}{l}\text { 2. NW- } \\
\text { Grönland }\end{array}$ & $\begin{array}{l}\text { 3. Spitz- } \\
\text { bergen }\end{array}$ & \\
\hline B. & : & . & . : & $\begin{array}{l}82,7^{\circ} \mathrm{N} \\
89,2 \mathrm{O}\end{array}$ & $\begin{array}{l}79,5^{\circ} \mathrm{N} \\
68,2 \mathrm{~W}\end{array}$ & $\begin{array}{l}78,5^{\circ} \mathrm{N} \\
15,7 \mathrm{O}\end{array}$ & $\begin{array}{r}77,8^{\circ} \mathrm{S} \\
166,80\end{array}$ \\
\hline Winter & . & . & . & $-34,5^{\circ}$ & $-32,6^{\circ}$ & $-14,3^{\circ}$ & $-26,3^{0}$ \\
\hline Frühling & . & . & & $-21,4$ & $-22,1$ & $\begin{array}{r}-9,6 \\
-\quad 1\end{array}$ & $-19,5$ \\
\hline Sommer & . & . & . & $-1,2$ & $+1,9$ & $+3,6$ & $-6,0$ \\
\hline Herbst. & . & . & . & $-19,8$ & $-16,8$ & $-4,5$ & $-22,0$ \\
\hline Jahr. . & . & . & . & $-19,2$ & $-17,4$ & $-6,2$ & $-18,4$ \\
\hline Wärmster & Mona & & . & $+0,05$ & $+3,8$ & $+4,6$ & $-4,0$ \\
\hline Kältester & Mona & & . & $-35,8$ & $-34,1$ & $-18,5$ & $-26,9$ \\
\hline Sehwankı & & & . & 35,85 & 37,9 & 23,1 & 22,9 \\
\hline
\end{tabular}


verlegt den thermischen Nordpol in ungefähr $86^{\circ} \mathrm{N}$ und $170^{\circ} \mathrm{O}$ und umschlieBt ihn mit der Isotherme von $-24^{\circ}$. Daneben finden wir noch ein zweites Kältezentrum auf dem grönländischen Inlandeis, wo die Jahrestemperatur bis $-22^{\circ}$ sinken soll.

Temperaturverteilung in den extremen Monaten. ${ }^{6}$ Die mittlere Jahrestemperatur ist eigentlich ein imaginärer Wert, denn die Sonne wandert im Verlauf eines Jahres von einer Hemisphäre zur anderen, und mit ibr das ganze Isothermensystem, der Wärmeäquator sowohl wie die beiden Grenzlinien zwischen der inneren und den äußeren Zonen. ${ }^{\times}$Nur in den Übergangsjahreszeiten nähert sich die Temperaturverteilung dem mittleren Zustand, im Januar und Juli weicht sie am meisten davon ab. Aber nicht im gleichen Sinn. Alles was wir früher als Abweichung vom Normalen bezeichnet haben, gelängt in der inneren Zone im Sommer, in der äußeren im Winter zur höchsten Entfaltung. In diesen Jahreszeiten bleibt für die betreffende Zone der Charakter der Jahresisothermen zwar gewahrt, ist aber bis zum Extrem verzerrt. Man ersieht das am besten aus der Knickung der Isothermen, die immer einen schroffen Übergang vom See- zum Landklima unter gleicher Breite anzeigt. Im Sommer schwächt sich in der äußeren und im Winter in der inneren Zone der Gegensatz von Wasser und Land $a b$, und der Einfluß der Polhöhe gewinnt an Bedeutung.

Der thermische Äquator liegt im Januar (s. Karte IV) zum größten Teil in der Südhemisphäre, am weitesten ausgebuchtet auf den Kontinenten, wo in den trockenen Gebieten die Hitze über $30^{\circ}$ steigt, in Südamerika allerdings nur im westlichen Argentinien, während das innere Australien ein wahrer Glutofen ist, ähnlich wie die Wüstendistrikte Nordafrikas und Vorderasiens im Juli. Die innere Zone umfaßt alle südlichen Festländer, auf unserer Halbkugel beginnt die äußere Zone aber schon zwischen $10^{\circ}$ und $20^{\circ} \mathrm{B}$. Unsere Aufmerksamkeit wird hier hauptsächlich durch die Verhältnisse im Umkreis des Atlantischen Ozeans vom Felsengebirge bis zum Ostrand Asiens gefesselt. Hier wirken die mit dem Golfstrom zusammenhängenden Strömungen in der Tat als Warmwasserheizung, aber nur das europäische Gestade überfluten die herrschenden Westwinde mit lauen atlantischen Lüften, an der Ostküste der Alten und der Neuen Welt kommen sie als kalte Landwinde an. Der Gegensatz von West und Ost wird noch dadurch verschärft, daß die Seewinde

$\begin{array}{llcccc}\quad \text { Normalisothermen: } & & \text { Jahr } & \text { Januar } & \text { Juli } \\ \text { Grenze zw. d. nördl. äußeren u. imneren Zone } & . & 45^{\circ} \mathrm{N} & 22^{\circ} \mathrm{N} & 68^{\circ} \mathrm{N} \\ \text { Mathematischer Wärmeäquator . . . . . . . . } & 0 & 23 \mathrm{~S} & 23 \mathrm{~N} \\ \text { Grenze zw. d. südl. inneren u. äuBeren Zone } & . & 45 \mathrm{~S} & 68 \mathrm{~S} & 22 \mathrm{~S}\end{array}$

Grenze zw. d. südl. inneren u. äußeren Zone . . 45 S 68 S 22 S


an den Westküsten feucht sind; der bewölkte Himmel hindert die Ausstrahlung, die bei der Kondensation des Wasserdampfes frei werdende Wärme erhöht die Temperatur. Die entgegengesetzte Wirkung hat das trockene, klare Wetter an der Ostküste Asiens. Dagegen sind die kalten Meeresräume an den Ostseiten der Nordkontinente von geringerer thermischer Bedeutung. Sie sind schmal, und ihre Temperatur wird nicht durch die herrschenden Winde den benachbarten Küstenstrichen mitgeteilt, wie die der warmen Strömungen den westlichen Gestaden. Nur in der nordostasiatischen Inselwelt, die an der Westküste von einem Zweige des warmen Kuroschio und an der Ostküste von einer kalten Strömung aus dem Ochotskischen Eismeer berührt werden, entstehen Gegensätze, die im kleinen den Kontrast zwischen den West- und Ostseiten der Kontinente wiederholen. Noch gewaltiger ist der Unterschied zwischen dem winterlichen Land- und Seeklima. Der Ostschenkel der atlantischen Isothermenknickung nimmt einen meridionalen Verlauf, ja wendet sich zum Teil sogar widersinnig nach Südwest und West. Die Temperatur nimmt in der Alten Welt von West nach Ost stärker ab als von Süd nach Nord, so zwischen der südlichsten und der nördlichsten Stadt Europas, Tarifa und Hammerfest, durchschnittlich für $100 \mathrm{~km}$ um $0,14^{\circ}$, dagegen zwischen Europa und Westsibirien, auf das gleiche Maß reduziert, im 56. Parallel um $0,51{ }^{\circ}$ und im 63. sogar um $0,82{ }^{\circ}$. Die $0^{0}$-Isotherme überschreitet an der norwegischen Küste den Polarkreis, sinkt im östlichen Asien bis zum 34. Breitengrad herab, steigt dann in Japan wieder bis $40^{\circ}$ und an der amerikanischen Westküste bis $59^{\circ}$, um im Inneren der Union bis $38^{\circ}$ herabzusinken und die Ostküste unter ungefähr $40^{\circ} \mathrm{B}$. zu erreichen. Schanghai unter der Breite von Alexandrien hat dieselbe mittlere Januartemperatur wie Thorshaven auf Färöer unter $62^{\circ} \mathrm{B}$. und die amerikanische Ostküste in der Breite von Sizilien. Am schroffsten sind die Gegensätze an den atlantischen Gestaden, wo in Kristiansund und Aalésund an der norwegischen Küste die mittlere Tagestemperatur nie unter $0^{\circ}$ sinkt, während an der amerikanischen selbst die mittlere Monatstemperatur auf $-20^{\circ}$ und darunter fällt.

Alle Isothermenkarten verzeichnen in Ostsibirien ein Kältezentrum von enormer Tiefe. In Breiten, wo sich die Lufttemperatur auf dem Atlantischen Ozean über dem Gefrierpunkt hält und die norwegische Küste so warm ist wie das pontische Gestade Südrußlands, beträgt die mittlere Januartemperatur in Jakutsk $\left(62^{\circ} \mathrm{N}\right)$ $-43,3^{\circ}$, sie sinkt in Werchojansk am Janafluß auf $-50,8^{\circ}$ und steigt im Ustjansk an der arktischen Küste wieder auf $-41,4^{0}$. Dies ist die Gegend, wo überhaupt die tiefsten Temperaturen beobachtet 
wurden: ${ }^{\times}$so in Irkutsk $-64,4^{\circ}$, und in Werchojansk $-67,8^{\circ}$, während als absolutes Minimum auf der westlichen Hemisphäre (am Floeberg Beach) bisher nur $-58,7^{\circ}$ notiert wurde. Indes hat WовIкоw Zweifel an der Richtigkeit der üblichen Darstellung, der auch wir gefolgt sind, ausgesprochen. Er hat darauf aufmerksam gemacht, $\mathrm{da} B$ die Stationen hier alle in den Tälern liegen, und daß - wie wir bereits auf S. 80 gezeigt haben - aller Wahrscheinlichkeit nach die Temperatur im Winter mit der Höhe zunimmt. Die tiefsten geschlossenen Isothermen müßten also schmale Kältebänder längs der Flußläufe umsäumen, anstatt in weiter Ausdehnung Berg und Tal zu umschließen. Aber selbst wenn wir uns dieser Auffassung anschließen, eines ist unzweifelhaft: die außergewöhnliche Erkaltung Ostsibiriens im Vergleich zu den Binnenlandschaften Nordamerikas unter gleicher Breite. Wir werden bei Besprechung der Luftdruckverteilung in Ostsibirien ebenso abnorme Verhältnísse ausgebildet finden, und unzweifelhaft besteht zwischen beiden meteorologischen Elementen eine Wechselbeziehung. Schon an der Grenze zwischen West- und Ostsibirien sinkt das Thermometer bei Windstille im Winter außerordentlich tief, während alle stärkeren Winde die Temperatur erhöhen, gleichgültig aus welcher Himmelsrichtung sie wehen. Bei Windstille stagnieren die durch die heftige Ausstrahlung des schneebedeckten Bodens erkalteten unteren Luftschichten, und es kommt, um sehr tiefe Temperaturgrade zu erzeugen, nur darauf an, daß Kalmen vorherrschen. Das ist nun in Ostsibirien der Fall. Die hügelige Natur des ganzen Landes und die ziemlich hohe Scheidewand, die das Stanowoigebirge zwischen Ostsibirien und dem Pazifischen Ozean aufrichtet, hindern den Abfluß der kalten Tiefenluft zu den umgebenden Gebieten niederen Barometerstandes; während die Luft des canadischen Mackenziebeckens, das sonst unter ähnlichen Bedingungen steht wie Ostsibirien, nach Norden, Osten und süden freie Bahn findet.

Ein zweites Kältezentrum bildet die Eiswüste Grönlands, wo NANSEN in Seehöhen von über $2000 \mathrm{~m}$ schon im September 1888 Nächte erlebte, in denen sein nur bis $-30^{\circ}$ gehendes Thermometer völlig versagte. МонN ${ }^{7}$ berechnete auf konstruktivem Weg ein Minimum von $-45^{\circ}$ ! Das grönländische Kältezentrum dürfte also dem ostsibirischen nicht viel nachgeben, ja es vielleicht sogar über-

$\times$ Das Maximum-Minimum-Thermometer, das wahrscheinlich die österreichische Expedition am Matotschkin Scharr auf Nowaja Semlja zurückgelassen hatte und das von Bonissow wieder anfgefunden wurde, zeigte $-70^{\circ}$; da aber nicht mitgeteilt wird, ob es auch geprüft wurde, so ist diese Angabe wissenschaftlich nicht verwertbar. 
treffen. Ein drittes liegt nach Mons's neuesten Karten ${ }^{5}$ am Nordpol. Man kann jetzt alle diese drei Zentren als Kältepole bezeichnen, wenn auch nach Moнn's Darstellung der sibirische Pol im Dezember und Januar der kälteste ist. Dafür ist er aber auch vergänglich, er erscheint erst im November und verschwindet im März, während sich die beiden anderen das ganze Jahr hindurch erhalten.

Im Juli (s. Karte V) steigt der Wärmeäquator weit in unsere Hemisphäre hinauf, besonders in Asien und Nordamerika, wo er sich dem 30. Parallel nähert, vielleicht ihn sogar überschreitet. Auch hier sind Mitteltemperaturen über $30^{\circ}$ an die vegetationsarmen Gebiete gebunden; am heißesten ist die Sahara. Die Grenze zwischen der inneren und äußeren Zone liegt in Australien und Südamerika in etwa $20^{\circ} \mathrm{B}$., auf der nördlichen Halbkugel umfaßt die innere Zone die Kontinente bis über $70^{\circ} \mathrm{B}$, mit Ausnahme von Grönland. Überall ist das Meer kälter als das Land, die Isothermen steigen auf dem Festland polwärts an und senken sich auf der See äquatorwärts, aber die Temperaturunterschiede sind im allgemeinen doch nicht so groß wie die entgegengesetzten im Januar. Nur im westlichen Nordamerika zeigen die dichtgedrängten meridionalen oder sogar überkippten Isothermen eine beispiellos rasche Temperaturzunahme von der Küste nach dem Innern des Landes an. San Diego am californischen Gestade, das unter dem Einfluß einer kühlen Meeresströmung und vorherrschender Seewinde steht, hat eine mittlere Julitemperatur von $21,3^{\circ}$, das nur $250 \mathrm{~km}$ davon entfernte Fort Yuma in der Coloradowüste dagegen $34,1^{\circ}$. Das ergibt in östlicher Richtung eine Steigerung von $1^{0}$ für nicht ganz $19 \mathrm{~km}$.

Im schroffen Gegensatz zu der thermischen Anordnung im Januar ist nun Ostsibirien, wo selbst Werchojansk eine mittlere Julitemperatur von $15,1^{\circ}$ hat, beträchtlich wärmer als Nordamerika unter gleicher Breite, das schutzlos den polaren Winden preisgegeben ist. Man beachte besonders, wie die tief eindringende Hudsonbai, die erst spät ihr Eis verliert, die Isothermen nach Süden drängt. So wird Labrador, in der Breite von England und Norddeutschland, eines der unwirtlichsten Länder, denn nicht die mittlere Jahrestemperatur und die Winterkälte ist entscheidend für den Kulturwert eines Landes, sondern die Sommerwärme.

Auf der südlichen Halbkugel nehmen die Isothermen einen einfacheren Verlauf als im Sommer, weil die Kontinente nicht in hohe Breiten hineinreichen. Die West- und Ostküsten von Afrika und Südamerika zeigen dasselbe thermische Verhalten wie im Januar, nur ist die Temperaturdifferenz in der Nähe des Äquators größer, weiter gegen Süden aber kleiner als im heißesten Monat. Den 
schärfsten Gegensatz bilden die brasilianische und die peruanische Küste. Lima unter $12^{\circ} \mathrm{B}$. und $172 \mathrm{~m}$ ü. M. hat eine mittlere Julitemperatur von $15^{\circ}$, die im Osten erst unter $27^{\circ} \mathrm{B}$. erreicht wird. Der Unterschied von 15 Breitengraden wird zwar auf der Nordhemisphäre übertroffen, aber nirgends finden wir wieder eine so niedere Temperatur so nahe dem Äquator.

Man sollte voraussetzen, daß sich im zirkumterranen Meer der höheren südlichen Breiten die Isothermen den Parallelkreisen anschmiegen. In Wirklichkeit finden wir aber auch hier Abweichungen, die direkt auf die Verbreitung des polaren Treibeises, indirekt wahrscheinlich auf Meeresströmungen zurückzuführen sind. Bemerkenswert ist namentlich die südatlantische Kältezunge; Südgeorgien ist kälter als Kap Hoorn, und noch kälter muß die völlig vereiste Bouvetinsel sein, so daß man wohl annehmen darf, daß hier alle Isothermen von W nach $\mathrm{O}$ in äquatorialer Richtung ansteigen. ${ }^{8}$ Sicher sind innerhalb des zirkumterranen Meeres die Winter wärmer und die Sommer kälter, als durchschnittlich in gleicher Breite auf unserer Landhalbkugel, aber dieser Charakterzug darf nicht, wie es früher geschah, in seiner ganzen Schärfe auch auf die polare Zone übertragen werden. Am Rand der eisbedeckten Landmassen sind auch die antarktischen Winter streng. Das Charakteristische dieser Zone bleibt allerdings die tiefe Sommertemperatur. Die Nullisotherme des wärmsten Monats dürfte nicht weit südlich vom Polarkreis liegen, während auf unserer Halbkugel nicht nur auf eisfreiem Land, $\times$ sondern sogar mitten im Eismeer bis zum 85. Parallel wenigstens ein Monat eine positive Mitteltemperatur besitzt. Nur im Inneren des grönländischen Eisplateaus stoßen wir auf eine negative Mitteltemperatur des wärmsten Monats, also auf antarktische Verhältnisse. Alles Eis verbraucht im Tauprozeß einen großen Teil der ihm zugeführten Wärme, aber Landeis, wie es scheint, mehr als marines - vielleicht deshalb, weil sich letzteres im Sommer in Schollen auflöst, so daß auch Wasser mit der Luft in Berührung tritt. Wir dürfen daraus schließen, daß auch die niedere antarktische Sommertemperatur von einem großen Landeis herstammt; und wenn sich hier die beiden temperaturerniedrigenden Faktoren, Landeis und Polnähe, in höchster Potenz vereinigen, so ist in der Nähe des Südpols der absolute Kältepol der Erde zu erwarten.

Durchschnittstemperatur der Parallelkreise, Meridiane, Erdteile und Meere. Nach den Isothermenkarten hat zuerst Dove die "Normaltemperaturen“, richtiger gesagt, die Durchschnitts-

$\times$ Lady-Franklin-Bai $87^{\circ}$ B., $+2,8^{\circ}$. 
temperaturen der Parallelkreise berechnet, und in neuester Zeit haben Spitaler, Batchelder und Hopfner mit Zuhilfenahme des inzwischen reichlich angewachsenen Beobachtungsmaterials, wie es in HanN's und Buchan's Isothermenkarten niedergelegt ist, diese Operation wiederholt. ${ }^{9}$

Durchschnittstemperaturen der Breitenkreise.

\begin{tabular}{|c|c|c|c|c|c|c|c|c|c|}
\hline & \multicolumn{3}{|c|}{ Spitaler (Mohn, HanN $\times$ ) } & \multicolumn{3}{|c|}{ BatCHELDER } & \multicolumn{3}{|c|}{ Hopfner (Meinardes $\times \times$ ) } \\
\hline & Jahr & Januar & Juli & Jahr & Januar & Juli & Jahr & Januar & Juli \\
\hline $90^{\circ} \mathrm{N}$ & $-22,7^{0}$ & $-41,0^{0}$ & $-1,0^{\circ}$ & - & - & - & - & - & - \\
\hline 80 & $-18,1$ & $-32,2$ & 2,0 & $-16,9^{0}$ & $-34,9^{0}$ & $0,2^{0}$ & $-16,4^{0}$ & $-33,3^{0}$ & $1,9^{\circ}$ \\
\hline 70 & $-10, \bar{i}$ & $-26,3$ & 7,3 & $-10,2$ & $-26,5$ & 6,7 & $-9,6$ & $-26,4$ & 6,7 \\
\hline 60 & $-1,1$ & $-16,1$ & 14,1 & $-1,2$ & $-15,6$ & 13,8 & $-0,8$ & $-16,1$ & 14,0 \\
\hline 50 & 5,6 & $-7,2$ & 18,1 & 5,8 & $-6,7$ & 18,1 & 6,2 & $-7,3$ & 17,9 \\
\hline 40 & 14,0 & 3,9 & 23,8 & 13,9 & 6,1 & 24,1 & 14,5 & 5,9 & 24,2 \\
\hline 30 & 20,3 & 13,9 & 27,4 & 20,2 & 15,3 & 27,2 & 20,7 & 15,0 & 27,2 \\
\hline 20 & 25,7 & 21,7 & 28,1 & 24,9 & 22,1 & 28,0 & 25,2 & 21,9 & 27,9 \\
\hline 10 & 26,4 & 25,7 & 26,7 & 27,1 & 25,8 & 27,1 & 26,8 & 25,8 & 27,0 \\
\hline 0 & 25,9 & 26,2 & 25,5 & 26,6 & 26,7 & 25,7 & 26,3 & 26,5 & 25,7 \\
\hline $10 \mathrm{~S}$ & 25,0 & 25,9 & 24,0 & 25,7 & 26,7 & 23,8 & 25,4 & 26,7 & 23,8 \\
\hline 20 & 22,7 & 25,5 & 20,5 & 23,3 & 25,3 & 19,4 & 22,9 & 25,2 & 19,4 \\
\hline 30 & 18,5 & 22,6 & 15,3 & 18,3 & 21,1 & 13,9 & 18,3 & 21,2 & 14,3 \\
\hline 40 & 11,8 & 16,1 & 9,7 & 12,2 & 15,1 & 8,3 & 11,7 & 15,1 & 8,4 \\
\hline 50 & 5,9 & 8,1 & 3,2 & 5,3 & 8,6 & 2,7 & 5,1 & 8,6 & 3,1 \\
\hline 60 & $-2,0$ & 3,2 & $-7,6$ & - & - & - & $-3,5$ & 2,3 & $-10,6$ \\
\hline 70 & $-11,5$ & $-0,8$ & $-22,2$ & - & - & - & $-12,8$ & $-1,3$ & $-22,0$ \\
\hline 80 & $-19,8$ & $-6,5$ & $-31,5$ & - & - & - & $-20,6$ & $-4,3$ & $-28,7$ \\
\hline 90 & $-24,0$ & - & - & - & - & - & $-25,0$ & $-6,0$ & $-33,3$ \\
\hline
\end{tabular}

Auffallenderweise weichen die Tabellen gerade in Zonen mit verhältnismäßig zahlreichen meteorologischen Stationen (30 und $40^{\circ} \mathrm{N}$ und $20-40^{\circ} \mathrm{S}$ ) beträchtlich voneinander ab - ein Beweis, wie ungenau selbst unsere besten Isothermenkarten noch sind. Aber abgesehen davon, springt der Gegensatz zwischen den beiden Halbkugeln aus allen Zahlenreihen sofort in die Augen, nur muß man den nördlichen Januar mit dem südlichen Juli und umgekehrt vergleichen. Im wärmsten Monat ist die ganze nördliche Hemisphäre wärmer als die südliche, im kältesten aber nur vom Äquator bis

$\times$ Für die nördlichen Breiten von $60-90^{\circ}$ setzen wir die neuen Zahlen von $\mathrm{MoHN}^{5}$ ein, für die höheren südlichen Breiten $\left(60-80^{\circ}\right)$ hat HaNN (Meteorologie, 2. Aufl., S. 114) Mitteltemperaturen berechnet.

$\times \times$ Zahlen für $60-90^{\circ} \mathrm{S}$ siehe A. Scoвer, Geographisches Handbuch, Leipzig, S. 74. 
$30^{\circ}$ B., und im Jahresmittel besitzt die südliche Halbkugel nur im zirkumterranen Meer der gemäßigten Zone $\left(50^{\circ} \mathrm{B}\right.$.) ein thermisches Übergewicht. Man hat früher angenommen, daß sich die Gegen-

Nördliche Breite Südliche Breite

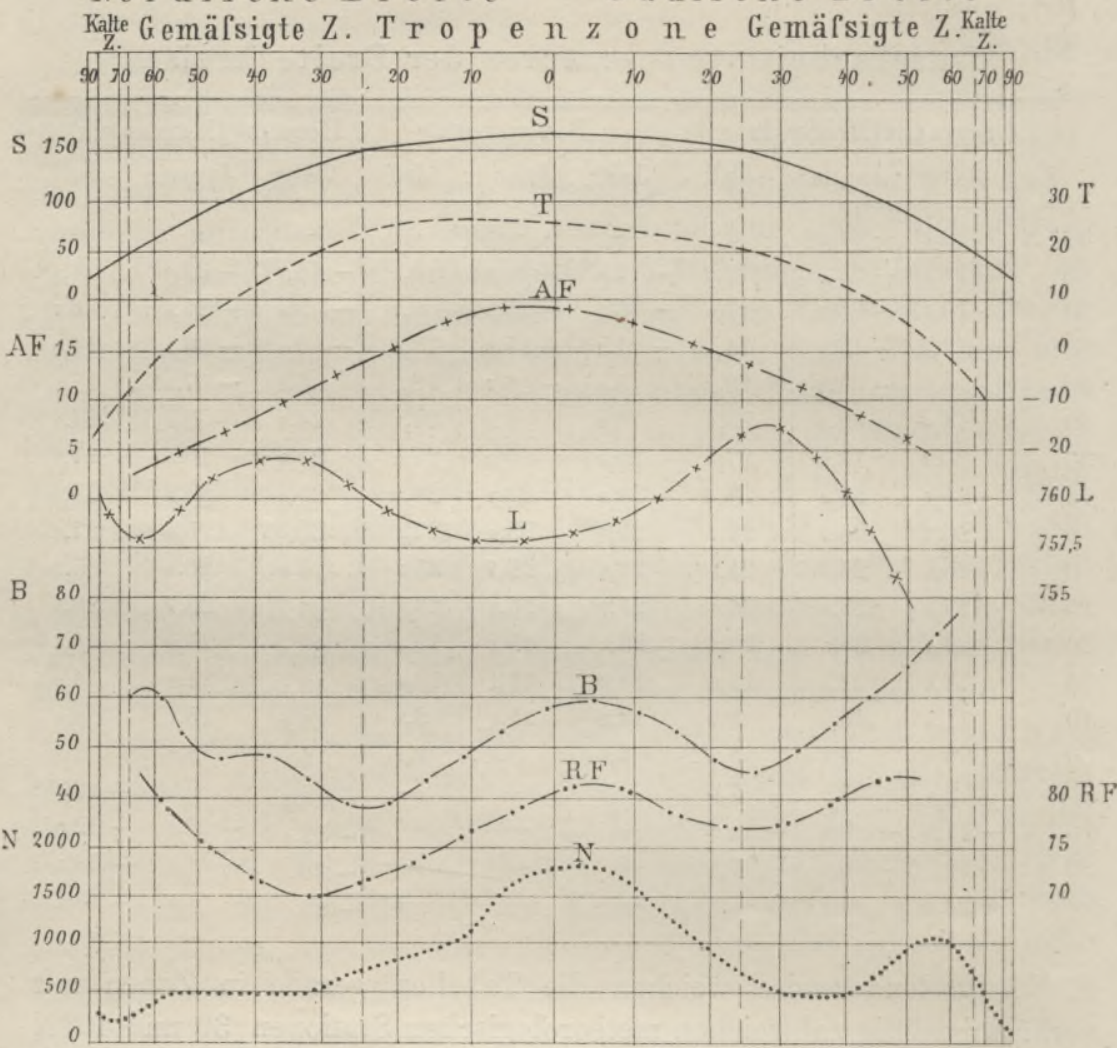

Fig. 27. Verteilung der klimatologischen Elemente nach der geographischen Breite (vgl, dazu die Bemerkung zu Fig. 13, S. 49).

S. = Sonnenstrahlen in Äquatorialtagen, T. = Mittlere Jahrestemperatur in ${ }^{0} \mathrm{C}$, AF. = Absolute Feuchtigkeit in Gramm in $1 \mathrm{cbm}$ Luft, L. = Luftdruck in mm, B. = Bewölkung $0-100$, RF. $=$ Relative Fenchtigkeit in Prozenten, N. = Nieder schlag auf dem Land in $\mathrm{mm}$.

sätze in höheren Breiten ausgleichen, und daß beide Halbkugeln eine gleiche Durchschnittstemperatur von ungefähr $15^{\circ}$ besitzen, die neuesten Erfahrungen im Südpolargebiet haben aber diese Ansicht berichtigt. HANN hat neuerdings folgende Mitteltemperaturen berechnet: 


\begin{tabular}{|c|c|c|c|c|c|c|c|}
\hline & & & t & $\begin{array}{l}\text { Nördliche } \\
\text { Halbkugel }\end{array}$ & $\begin{array}{l}\text { Südliche } \\
\text { Halbkugel }\end{array}$ & $\begin{array}{c}\text { Ganze } \\
\text { Érde }\end{array}$ & $\begin{array}{c}\text { Unterschied } \\
\text { beider Halbkugeln }\end{array}$ \\
\hline Jahr . & . & . & . & $15,1^{\circ}$ & $13,6^{\circ}$ & $14,4^{\circ}$ & $+1,5^{\circ}$ \\
\hline Januar & . & . & . & 7,8 & 17,3 & 12,6 & $-9,5$ \\
\hline Juli . . & . & . & . & 22,5 & 10,3 & 16,4 & $+12,2$ \\
\hline
\end{tabular}

Man vergleiche damit die Tabelle Angot's auf S. 63. Die südliche Halbkugel erhält in ihrem Sommer mehr Wärmemengen als die nördliche im nördlichen Sommer und ist doch kälter als diese. Im Winter liegen die Verhältnisse gerade umgekehrt: ein klarer Beweis, daß für die Verteilung der Temperatur die irdischen Verhältnisse maßgebender sind als die solare Wärmezufuhr.

Man hat auch sogenannte Durchschnittstemperaturen der einzelnen Breitenzonen (Spitaler, v. Thllo ${ }^{10}$ ), der Meridiane (Buys-Ballot ${ }^{11}$ ) und der Erdteile und Meere (v. Truso ${ }^{10}$ ) ermittelt; alle diese Zahlenreihen variieren nur das Grundgesetz von dem Gegensatz des Landund Seeklimas. Noch deutlicher kommt es auf den Isanomalenkarten zum Ausdruck.

Isanomalen. Die Berechnung der fälschlich sogenannten Normaltemperaturen führte Dove zur Aufstellung des Begriffes der thermischen Anomalie. Man versteht darunter die Abweichung der Temperatur eines Ortes von der Durchschnittstemperatur seiner Breite. Ist die Anomalie positiv, so gilt der betreffende Ort als zu warm, im entgegengesetzten Fall als zu kalt. In unserer Zeit haben auch Spitaler, Batchelder und Hopfner Karten entworfen, auf welchen die Orte gleicher Anomalie durch Linien, sogenannte Isanomalen, miteinander verbunden sind. Auf Taf. VI und VII ist die Anomalie in beiden extremen Monaten nach Hopfner und MoHN zur Darstellung gebracht.

Konstant zu warm sind die Westseiten der nordhemisphärischen Festländer, aber aus orographischen Gründen in sehr verschiedener Ausdehnung. Denn während in Amerika das Cordillerensystem der Seeluft nicht gestattet, über den schmalen pazifischen Küstenstrich binnenwärts vorzudringen, werden im offen liegenden Westeuropa ausgedehnte Länder der Wohltat der atlantischen Winterwärme teilhaftig. Dauernd zu kalt sind die Ostseiten, und auch darin zeigt sich wieder die Bevorzugung der Alten Welt. In den übrigen Gebieten wechselt die thermische Anomalie im Lauf des Jahres ihr Zeichen: die Meere sind im Winter zu warm und im Sommer zu kalt, das Innere der Kontinente ist im Sommer zu warm und im Winter zu kalt. So ordnen sich etwa nördlich von $20^{\circ} \mathrm{N}$ die vier Arten der thermischen Anomalie in meridionalen Streifen an (Fig. 28), jedoch sind 
die winterlichen Anomalien viel größer als die sommerlichen. Umgekehrt verhält es sich in den Tropen (vgl. Fig. 29), wo die Erhitzung des Festlandes durch die senkrechten Sonnenstrahlen entscheidend wirkt. Auch hier wechseln die vier Arten der Anomalien miteinander $\mathrm{ab}$, aber die permanent kalten Gebiete liegen nun im Westen, die permanent warmen Gebiete im Osten der Festländer, Australien ausgenommen. Im großen und ganzen entspricht die Temperaturverteilung in den Tropen viel mehr dem solaren Klima

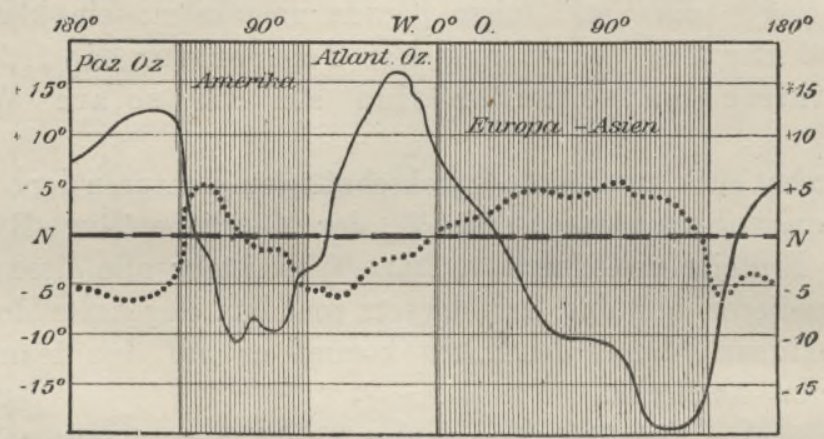

Fig. 28. Thermische Anomalie in $50^{\circ} \mathrm{n} . \mathrm{B}$.

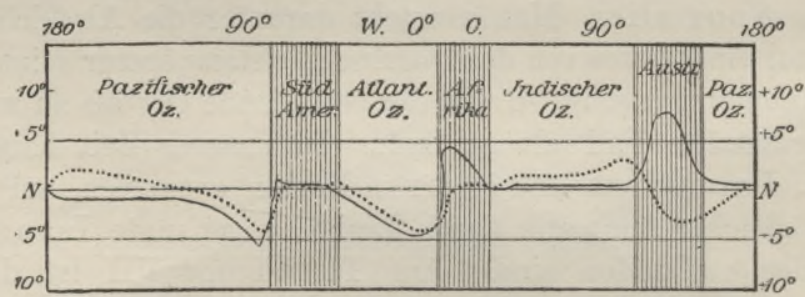

Fig. 29. Thermische Anomalie in $20^{\circ} \mathrm{s} . \mathrm{B}$.

In Fig. 28 und 29 bedeutet $N$ die Durchschnittstemperatur des betreffenden Breitenkreises, + bedeutet positive, - negative Anomalie. Anomalie im Januar. Anomalie im Juli.

als in unseren Breiten; es gilt der allgemeine Satz, daß die Anomalie um so größer ist, je mehr die Isothermen von den Parallelkreisen abweichen. Innerhalb des zirkumterranen Ozeans können nur Meeresströmungen geringere Anomalien hervorrufen.

Temperaturzonen. Wenn wir das, was über die horizontale Temperaturverteilung bisher gesagt wurde, überblicken, so ergibt sich, daß das wirkliche Klima zwar auf dem solaren beruht, aber stellenweise mehr oder minder beträchtlich davon abweicht. Die alten Klimagürtel (s. S. 61) aufrecht zu erhalten, ist unter solchen Umständen vergebliches Bemühen, denn was nützt eine Regel, wenn die Ausnahmen überwiegen? An die Stelle von Wende- und 
Polarkreisen, die die mathematischen Zonen begrenzen, sind also Isothermen zu setzen (s. Taf. VIII).

Für die Polargrenzen der warmen Zone eignen sich am besten die Jahresisothermen von $20^{\circ}$. Sie fallen im großen und ganzen mit den Polargrenzen der Palmen zusammen, die Grisebach den reinsten Ausdruck des Tropenklimas nennt, und auch mit den Polargrenzen der Passatwinde, die - wie wir später sehen werden für die warmen Erdgegenden so sehr charakteristisch sind. Für die Abgrenzung der gemäBigten Zonen von den kalten habe ich ursprünglich die Jahresisotherme von $0^{0}$ vorgeschlagen. Sie hat allerdings zunächst nur theoretische Bedeutung, aber praktisch doch auch insofern, als innerhalb der $0^{\circ}$-Isotherme beständiges Bodeneis vorkommt. Nach WILD's Annahme tritt es, da die Bodentemperatur etwas höher ist als die der Luft, dort auf, wo die letztere im Jahresmittel $-2^{0}$ beträgt; in der Tat ist aber seine Verbreitung von einer Reihe anderer Umstände abhängig, unter denen, wie Wokiкow gezeigt hat, der Schnee am wichtigsten ist. Als schlechter Wärmeleiter schützt die Schneedecke den Boden vor Ausstrahlung, und Eisboden entwickelt sich erst dort, wo die Jahrestemperatur unter $-5^{0}$ sinkt; während dort, wo Schnee fehlt, wie z. B. in weiten Gebieten Zentralasiens, der Boden schon bei höheren Mitteltemperaturen in einer gewissen Tiefe dauernd gefriert. Es ist aber mit Recht der Einwurf erhoben worden, daß jenseits der Nullisotherme sehr verschiedene Klimate existieren, verschieden nämlich, wenn wir den Einfluß des Klimas auf die Pflanzenwelt und damit auch auf den Menschen berücksichtigen. Allen Anforderungen einer guten Grenze entspricht dagegen die $10^{\circ}$-Isotherme des wärmsten Monats. Die Sommerwärme ist für die Vegetation entscheidend, die Winterkälte ist ohne Einfluß. Wo die Mitteltemperatur des wärmsten Monats $10^{\circ}$ nicht mehr erreicht, da sind Waldwuchs (mit alleiniger Ausnahme des Feuerlandes) und Getreidebau ausgeschlossen, und damit nehmen die menschlichen Kulturformen eine andere Gestaltung an.

Den Unterschied der mathematischen Klimagürtel und unserer Temperaturzonen entnimmt man aus folgenden Zahlen:

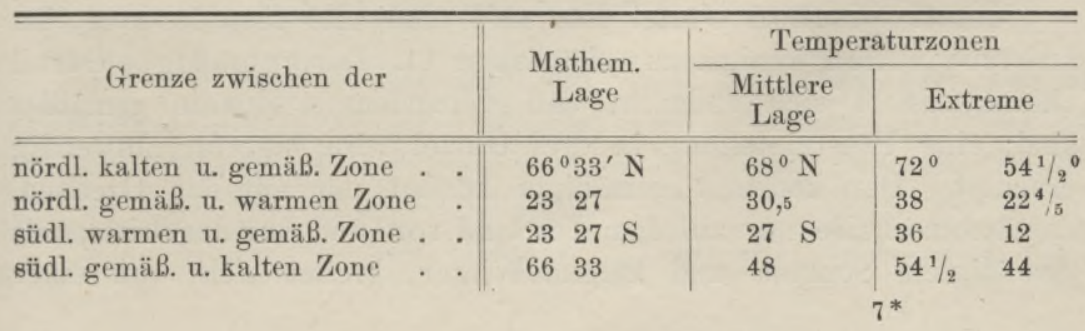


Aus der mittleren Lage der Grenzisothermen können wir die Flächen der Temperaturzonen berechnen:

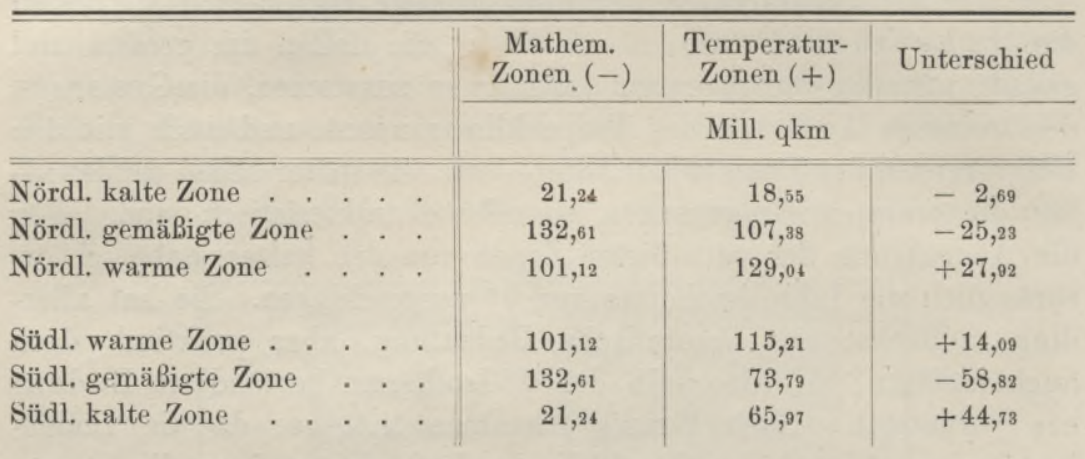

Die warmen Temperaturzonen sind ausgedehnter als der Gürtel zwischen den Wendekreisen, eine Folge der großen Entwicklung der Kontinentalmassen zu beiden Seiten des Äquators. Aus demselben Grund nimmt auch die südliche warme Zone eine kleinere Fläche ein als die nördliche. Das Entscheidende ist aber die gewaltige Ausdehnung der südlichen kalten Zone. Das ist die Wirkung des zirkumterranen Meeres. Wo Südamerika weiter in dieses Meer hineinragt, da springt auch die $10^{\circ}$-Isotherme weiter als irgendwo sonst in der antarktischen Welt gegen den Pol vor. Nun haben wir allerdings Grund anzunehmen, daß sich um den Südpol ein Festland lagert, aber für die Temperaturzonen bleibt dies gleichgültig. Kontinente sind machtlos, wenn sie nicht in einem breiten Zusammenhang mit dem Festland der gemäßigten und warmen Zone stehen. Wenn ein großes Südpolarland existiert, so ist es unter einer Eisdecke begraben wie das Innere Grönlands. -

Von wesentlich anderen Gesichtspunkten ging KöPPEN ${ }^{12}$ bei der Aufstellung seiner Wärmezonen aus. Er begrenzt sie nicht durch Isothermen, sondern berücksichtigt nur die Dauer gewisser Temperaturen, und zwar ohne Reduktion auf das Meeresniveau. Als Schwellenwerte sind $20^{\circ}$ und $10^{\circ}$ angenommen; über $20^{\circ}$ nennt KöPPEN heiB, $10-20^{\circ}$ gemäBigt, unter $10^{\circ}$ kalt.

Im tropischen Gürtel Köppen's sind alle Monate heiß, im subtropischen wenigstens 4 , höchstens 11 . Der gemäBigte Gürtel charakterisiert sich dadurch, $\mathrm{da} B$ wenigstens 4 Monate gemäßigt sind; eine Untereinteilung in drei Gürtel wird hier für notwendig erachtet. Der konstant gemäBigte kommt nur auf den Ozeanen, der sommerheiße nur auf dem Festland vor, und nur der dritte, mit gemäßigtem Sommer und kaltem Winter, breitet sich, von einer 
großen Unterbrechung in Sibirien abgesehen, rings um die Erde aus. Auf den gemäßigten Gürtel folgt der kalte, in dem höchstens 4 Monate gemäßigt, die übrigen kalt sind; endlich der polare Gürtel: alle Monate kalt.

Der polare Gürtel Köppen's fällt also mit unserer kalten Zone zusammen, die $20^{\circ}$-Isotherme durchschneidet aber verschiedene Dauergebiete. Zwischen der einen und der anderen Einteilung zu wählen, liegt kein Grund vor; man kann beide mit Nutzen nebeneinander gebrauchen. Unsere Einteilung hat den, besonders in didaktischer Beziehung nicht zu unterschätzenden Vorzug der Einfachheit, sie schließt sich den althergebrachten Klimazonen möglichst an, und endlich kommt den Grenzlinien, wie wir gesehen haben auch eine reelle Bedeutung zu. Dagegen ist KöpPEN's Gesichtspunkt für viele, namentlich für pflanzengeographische Untersuchungen in hohem Grad fruchtbringend, wenn wir uns auch nicht verhehlen können, daß seine Einteilung einer viel größeren Spezialisierung fähig ist und diesem Schicksal auch nicht entgehen wird, freilich um sich damit immer mehr von der Forderung klarer Übersichtlichkeit zu entfernen. Man wird dann anfangen, Karten für die Dauer verschiedener Schwellenwerte gesondert zu entwerfen, wie das für Europa bereits geschehen ist. ${ }^{13}$ Überhaupt sucht man jetzt in der Klimatologie nach neuen Methoden. Es möge hier nur eine erwähnt werden. Wir arbeiten jetzt ausschließlich mit arimethischen Mitteln der Temperatur, des Regens usw. Daneben lassen sich aber aus den meteorologischen Beobachtungen noch andere Werte ableiten, und unter diesen dürfte dem Scheitelwert, d. h. dem vorherrschenden oder wahrscheinlichsten Wert, eine Zukunft nicht abzusprechen sein. ${ }^{14}$ Aber die Schwierigkeit liegt darin, daß er sich in zuverlässiger Weise nur aus sehr langen Beobachtungsreihen ermitteln läßt, und daß, um verschiedene Stationen miteinander zu vergleichen, an der Forderung der Gleichzeitigkeit noch strenger festgehalten werden $\mathrm{mu} B$ als bei dem Mittelwert. Daher ist diese Methode noch nicht in dem Umfang angewendet worden, um geographisch bedeutsame Ergebnisse zu liefern. Hier einige Beispiele:

Scheitelwert minus Mittelwert.

Dez. Jan. Febr. März April Mai Juni Juli Aug. Sept. Okt. Nov.

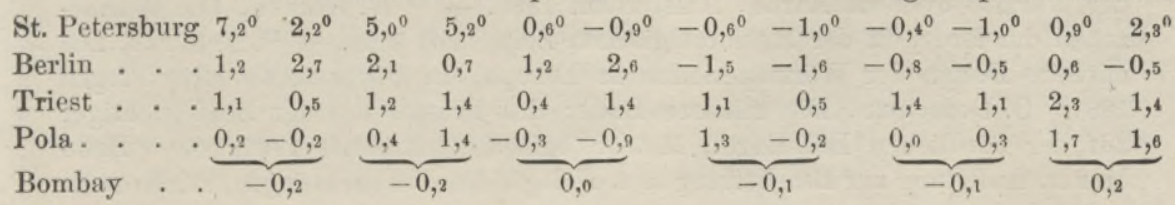


In unseren Breiten sind also die Scheitelwerte in der kalten, die Mittelwerte in der warmen Jahreszeit höher. In Berlin z. B. ist im Januar nicht die Mitteltemperatur die wahrscheinlichste, sondern eine um $2,7^{\circ}$ höhere, im Juli dagegen eine um $1,6^{\circ}$ tiefere. In Triest liegt der Scheitelwert das ganze Jahr hindurch über dem Mittelwert, in dem nicht weit davon entfernten Pola aber nicht; da nicht streng gleichzeitige Beobachtungen zugrunde liegen, so wissen wir nicht, ob dieser Unterschied reell ist. In den Tropen scheinen beide Werte nahezu zusammenzufallen.

Eine kartographische Darstellung der mittleren Maxima und Minima hat van BEBBER ${ }^{15}$ versucht. Sie wiederholt das Bild der Januar- und Juli-Isothermen, nur in verschärfter Weise. Mittlere Maxima von $40^{\circ}$ und mittlere Minima von $-50^{\circ}$ kommen ausschlieBlich auf dem Festland vor.

Literaturnachweise. ${ }^{1} \mathrm{~W}$. ZenKER, Die Verteilung der Wärme auf der Erdoberfläche, Berlin 1888. - ${ }^{2}$ Wнн. Sснмпт in den Sitzungsberichten der Wiener Akademie d. Wiss., Math.-naturwiss. Klasse, 1908, Bd. CXVII, Abteil. IIa, S. 237. - ${ }^{3}$ J. Scuubert, Der Wärmeaustausch im festen Erdboden, Berlin 1904. - ${ }^{4}$ W. Zenker, Der thermische Aufbau der Klimate, Halle 1895. $-{ }^{5}$ The Norwegian North Polar Expedition, 1893-96. Scientific Results, edited by Fridtjof Nansen; Bd. VI, London 1905. - ${ }^{6}$ Isothermenkarten für alle Monate hat seit H. W. Dove erst wieder A. Buchan (im Challenger-Werk, Physics and Chemistry, II. Bd., London 1889), leider im Fahrenheit-MaB, veröffentlicht. - ${ }^{7} \mathrm{H}$. MoHN und F. NANSEN, NANSEN's Durehquerung von Grönland, Gotha 1892 (105. Ergänzungsheft zu Petermaxs's Mitteilungen.) 8 A. Supan, Das antarktische Klima, in Petrrmans's Mitteilungen, 1901. 9 R. Sittaler, Die Wärmeverteilung auf der Erdoberfläche, in den Denkschriften d. Wiener Akademie d. Wissenschaften, Math.-naturwiss. Kl., 1886, Bd, LI. Isanomalenkarte des Jahres in Pemtermann's Mitteilungen 1887, des Januar und Juli ebendas. 1889. S. F. BatcheLDER, A new Series of Isanomalous Temperature Charts, based on Buchas's Isothermal Charts, im American Meteorological Journal 1894. F. Hopfner, Die thermisehen Anomalien auf der Erdoberfläche, in Petermanx's Mitteilungen 1906 (zum erstenmal seit Dove sind hier die Durchsehnittstemperaturen für alle Monate, und zwar auf Grund der Buснау'schen Karten berechnet und danach Isanomalenkarten gezeichnet worden). Neue "Normaltemperaturen" hat W. Pвеснт (Meteorologische Zeitschrift 1894, S. 81) unter der Voraussetzung berechnet, daß Land und Wasser überall gleich verteilt sind. Es sind dies also völlig imaginäre Werte. Auf die Bezeichnung Normaltemperaturen haben nur die auf S. 81 mitgeteilten Anspruch. - ${ }^{10}$ A.v. TruLo, Recherches sur la répartition de la température et de la pression atmosphérique à la surface du globe, St. Petersburg 1887. - ${ }^{11} \mathrm{C}$. H. Buys-Ballot, Verdeeling der Warmte over de Aarde, Amsterdam 1888. - ${ }^{12}$ W. Köppen, Die Wärmezonen der Erde, in der Meteorologischen Zeitschrift 1884. - ${ }^{13}$ A. Supan, Die mittlere Dauer der Wärmeperioden in Europa, in Petermans's Mitteilungen 1887. O. Donsonerd, Die mittlere Dauer des Frostes auf der Erde (richtiger auf der nördlichen Halbkugel; Meteorologisehe Zeitschrift 1907). - ${ }^{14}$ Hvgo Meyer, Anleitung zur Bearbeitung meteorologiseher Beobachtungen, Berlin 1891. 
E. Mazelle, Beziehungen zwischen den mittleren und wahrscheinlichsten Werten der Lufttemperatur, in den Denkschriften der Math.-naturwiss. Klasse der Wiener Akademie der Wissenschaften, Bd. LXII, 1895. - ${ }^{15}$ W. J. van Bebber in Petermann's Mitteilungen 1893, S. 273.

\section{Die periodischen und unperiodischen Veränderungen der Temperatur.}

(Siehe Karte IX.)

Die tägliche Temperaturschwankung. Das Klima eines Landes wird nicht bloß durch die mittleren Temperaturen des Jahres und der Monate, sondern auch durch die Schwankungen und die Veränderlichkeit der Wärme charakterisiert. Wie alle meteorologischen Elemente hat auch die Temperatur eine dreifache Periode, eine tägliche, eine jährliche und eine zyklische; von der letzteren werden wir bei einer anderen Gelegenheit sprechen.

Das tägliche Minimum und Maximum fällt nicht mit dem tiefsten und höchsten Sonnenstand zusammen, sondern verspätet sich um ein paar Stunden. Das Minimum tritt ein, wenn die Ausstrahlung der tagsüber empfangenen Wärme ihren Höhepunkt erreicht hat, im Seeklima $1-2^{\mathrm{h}}$ vor Sonnenaufgang, an kontinentalen Orten dagegen bei Sonnenaufgang oder einige Minuten nachher. Ihr Maximum erreicht die Temperatur auf dem Meer und an den Küsten zwischen 12 und $1^{\mathrm{h}}$ mittags und im Sommer etwas früher als im Winter, auf den Kontinenten dagegen zwischen 2 und $3^{\text {h }}$ nachmittags und im Sommer etwas später als im Winter.

Den mittleren Unterschied zwischen der höchsten und der tiefsten Tagestemperatur, wie sie am Maximum-Minimum-Thermometer abgelesen werden können, nennt man die unperiodische tägliche Temperaturschwankung (A mplitude), die Differenz zwischen der größten und kleinsten Ordinate der mittleren Tageskurve dagegen die periodische. $\times$ Unmittelbar läßt sich diese nur durch wenigstens stündliche Beobachtung finden, mittelbar durch geeignete Interpolation der fehlenden Beobachtungen. Die unperiodische Schwankung ist stets größer als die periodische, und der Unterschied wächst mit der geographischen Breite; wir kennen sie von vielen Stationen, da sie leicht zu ermitteln ist, während die periodische nur für verhältnismäßig wenig Orte berechnet wurde. ${ }^{1}$ Die Schwierigkeit besteht nun in der Vermengung des nicht streng miteinander vergleichbaren Materials, daher auch die Lehre von der geogra-

$\times$ Zur Darstellung des täglichen Ganges der Temperatur eines Ortes im Lauf eines Jahres bedient man sich der von L. LaLanne erfundenen Thermoisoplethen. Das Prinzip dieser flächenhaften Darstellungsweise, die die Veränderungen nach zwei Richtungen zu verfolgen gestattet, wird aus unseren Fig. 25 anf S. 75 und Fig. 30 anf S. 107 ersichtlich. 
phischen Verbreitung der täglichen Temperaturschwankung leider noch auf keiner allseitig gesicherten Grundlage ruht. Doch treten jetzt schon die Hauptzüge deutlich hervor.

Im allgemeinen steigt die tägliche Temperaturschwankung mit abnehmender und fällt mit zunehmender Bewölkung, da diese sowohl die Insolation wie die Ausstrahlung vermindert. Sie ist daher in unseren Breiten im Winter kleiner als im Sommer, verhält sich aber in Ostindien, soweit die Winter trocken sind, gerade umgekehrt. Auf dem Meer beträgt sie infolge der größeren Bewölkung und der geringen thermischen Leitungsfähigkeit des Wassers nur $1-2^{0}$; an den Küsten ist sie etwas größer, und noch größer im kontinentalen Tiefland. So steigert sie sich im Jahresmittel auf dem 55. Breitengrad von $3,7^{\circ}$ in Kopenhagen auf $4,8^{\circ}$ in Moskau und $5,1^{0}$ in Kasan. In der turanischen Niederung, wo sich der vegetationslose Boden rasch erwärmt und abkühlt, erreicht sie unter $41-42^{\circ}$ B. $12^{\circ}$ und darüber. Noch größer ist sie in den australischen Ebenen, selbst in geringer Entfernung vom Meér. So hat z. B. Hollow in Queensland, nur $40 \mathrm{~km}$ von der Küste entfernt und etwa $60, \mathrm{~m}$ hoch, eine unperiodische Schwankung von $13,1^{\circ}$, und Deniquil im Murraygebiet eine solche von $19,2^{\circ}$; es ist also auch die periodische im letzteren Fall unzweifelhaft größer als in Turan. Die höchsten Werte erreicht sie auf regenarmen Hochebenen, wo die dünne, trockene Luft die Ein- und Ausstrahlung der Wärme außerordentlich befördert. So groß auch die Temperaturschwankung in der aral-kaspischen Steppe ist, so ist sie doch im August und September um 9 bis nahezu $12^{\circ}$ kleiner als auf den Plateaus und in den Hochtälern der Pamir. Auch auf dem Karakorumplateau fand Shaw im September eine durchschnittliche Amplitude von $19,5^{\circ}$, im Karakaschtal aber bei trübem Wetter nur $13^{\circ}$. Im westlichen Tibet beobachtete Przewalski selbst noch im Dezember eine mittlere Differenz von $17,3^{0}$ zwischen den Temperaturen um $8^{\mathrm{h}}$ früh und $1^{\mathrm{h}}$ nachmittags und eine maximale von $26,5^{\circ}$. Die Sand- und Steinwüsten der Sahara genossen lange Zeit den Ruf, die Gegend der extremsten Temperaturschwankungen zu sein. 'In der Tat steht auch Timbuktu mit einer mittleren Tagesschwankung von $16,2^{\circ}$ (im April $18,5^{\circ}$, im August $13,8^{\circ}$ ) unter allen Orten, von denen wir regelmäBige Beobachtungen haben, obenan, und im Wadi Affatakha $\left(25^{\circ} \mathrm{N}, 7,7^{\circ} \mathrm{O}\right.$, $1200 \mathrm{~m}$ hoch) beobachtete Foureau im Januar 1899 an drei aufeinanderfolgenden Tagen Nachttemperaturen von $-8,4^{\circ},-10,2^{\circ}$ und $-8,7^{\circ}$, während um Mittag das Thermometer 16 bis $19^{\circ}$ zeigte. Dagegen erreichte in der libyschen Wüste die Amplitude nach JoRDAN im. Mittel von 21 Tagen im Dezember und Januar nur $13,6^{\circ}$, während 
sie in Kairo in derselben Zeit sogar nur $10,1^{\circ}$ betrug, und zwischen Mursuk und Schimmedru fand NaChtigaL selbst zur Zeit des Zenitalstandes der Sonne und bei heiterem Himmel nur eine mittlere Schwankung von $22,4^{\circ}$. Die größte Differenz in der afrikanischen Wüste, die BARTH unter $27,8^{\circ}$ B. und in $300 \mathrm{~m}$ Seehöhe erlebte, war $34^{\circ}$, aber sie wird in Schatten gestellt durch die Beobachtungen auf den westlichen Plateaus von Nordamerika. So betrug die Schwankung $\mathrm{zu}$ Wickenburg in Arizona $\left(34^{\circ} \mathrm{N}, 112,7 \mathrm{~W}, 620 \mathrm{~m}\right.$ hoch) am 28. Juli $187738,9^{\circ}$, am 31. $42,2^{\circ}$ und am 1. August $40^{\circ}$. Vielleicht die schnellste je beobachtete Temperaturänderung wird aus dem Felsengebirge in $2000 \mathrm{~m}$ Höhe gemeldet, wo vom 27. bis 28. Dezember 1894 das Thermometer in 7 Stunden von $-40^{\circ}$ auf $7,2^{0}$ stieg. Das sind einzelne Fälle; aber auch die stündlichen Beobachtungen der amerikanischen Vermessungsingenieure auf den Plateaus des Felsengebirges zwischen 35 und $42^{\circ} \mathrm{B}$. ergaben für die Seehöhe von $1500-1600 \mathrm{~m}$ so enorm hohe monatliche Mittelwerte (Juli $24,2^{\circ}$, August 20,8 und November 19,2), wie sie kaum noch irgendwo vorkommen dürften. Auch auf den tropischen Hochebenen ist die Temperaturschwankung größer als im benachbarten Tiefland; so beträgt sie z. B. auf dem Plateau von Guatemala $(1480 \mathrm{~m} \mathrm{H}$.) $10^{\circ}$, in Belize an der Küste aber nur $2,9^{\circ}$.

Im Gebirge ist die tägliche Temperaturschwankung in den Hochtälern größer als in der Ebene, auf den Berggipfeln dagegen kleiner; und der Satz, daß sie mit der Höhe abnimmt, findet daher nur auf die letzteren Anwendung. Nachstehende, von WoEIKow entlehnte Tabelle ist in dieser Beziehung sehr lehrreich. Man vergleiche nur Altstätten mit dem benachbarten Gäbris, oder Bevers mit dem nur wenig höheren Rigi. Nicht bloß die größere Trockenheit der Atmosphäre in den Tälern, sondern auch die stärkere Abkühlung in den Winternächten, wenn die schwere kalte Luft an den

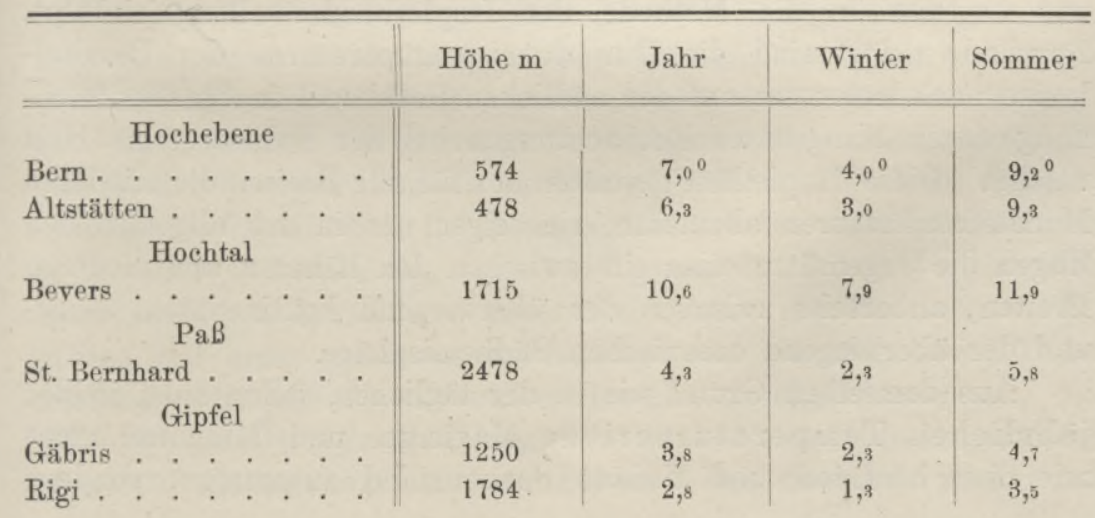


Gehängen hinabfließt, um sich ruhig über dem Talboden zu lagern, begünstigt die Steigerung der Temperaturschwankung. Die Pässe, nicht so frei wie die Berggipfel, aber auch nicht so eingeschlossen wie die Täler, vermitteln zwischen diesen Extremen.

Zunächst ist also die tägliche Temperaturschwankung von den topographischen Verhältnissen abhängig. Der Einfluß der Polhöhe kommt erst in zweiter Linie in Betracht. An den Küstenstationen in der Nähe des Äquators ist die Amplitude nicht größer als in unseren Breiten, und nur darin besteht ein wesentlicher Unterschied, daß sie sich dort — wie die Tageslänge — das ganze Jahr hindurch ziemlich gleich bleibt. In St. Thomé $\left(0^{\circ} 20^{\prime} \mathrm{N}\right)$ beträgt sie $6,5^{\circ}$, in Tschinschoscho $\left(5^{0} 9^{\prime} \mathrm{S}\right) 6,4^{\circ}$, in Sansibar $\left(6^{0} 10^{\prime} \mathrm{S}\right)$ $4,1^{\circ}$, in Batavia $\left(6^{\circ} 11^{\prime}\right.$ S) $6,0^{\circ}$, und auf Ascension $\left(7^{\circ} 55^{\prime} \mathrm{S}\right) 5,1^{\circ}$. Auf den Kontinenten tritt unter übrigens gleichen Verhältnissen ihre Abnahme mit der Breite schärfer hervor. So ist sie z. B. in Lugan um $2,9^{\circ}$ größer als in Moskau, und selbst noch in Odessa um $1,4^{\circ}$, trotz der Nähe des Meeres. Ihr Maximum erreicht sie auf den Hochplateaus zwischen 30 und $50^{\circ}$ B., während weiter im Norden die Insolation in den kurzen Wintertagen und die Ausstrahlung in den kurzen Sommernächten zu geringfügig ist, als daß die Temperatur innerhalb 24 Stunden beträchtlich variieren könnte. Im polaren Gürtel mit seinen monatelangen Winternächten und ebenso langen Sommertagen ist sie naturgemäß sehr gering. So auf Nowaja Semlja unter $73^{1} / 2^{0}$ und auf der Sabine-Insel unter $74^{1} / 2^{0}$ B. $2,5^{\circ}$, in der Mosselbai $\left(79,9^{\circ}\right.$ B. $) \quad 0,9^{\circ}$ und in Grantland $\left(81,7^{\circ}\right.$ B.) $1,4^{\circ}$. An den Polen, wo ein halbjähriger Tag mit einer halbjährigen Nacht wechselt, fällt die tägliche Schwankung mit der jährlichen zusammen.

Die jährliche Temperaturschwankung. Der jährliche Gang der Temperatur auf der Erdoberfläche ist aus Fig. 30 ersichtlich, die uns zugleich in die Methode der Isoplethendarstellung einführt. Zugrunde gelegt sind die Durchschnittstemperaturen der Parallelkreise nach Hopfner; auf der südlichen Halbkugel mußte die Zeichnung wegen Mangels an Beobachtungen bei der Nullisotherme Halt machen. Diese Isoplethen gestatten uns für alle Breiten die mittleren Monatstemperaturen abzulesen, sie zeigen uns in den allgemeinsten Zügen die Gegensätze einerseits zwischen den höheren und niederen Breiten, anderseits zwischen der überwiegend kontinentalen Nordund der überwiegend ozeanischen Südhemisphäre.

Aus demselben Grund wie in der täglichen, fallen auch in der jährlichen Temperaturperiode Maximum und Minimum nicht mit dem höchsten und tiefsten Sonnenstand zusammen, sondern 
treten etwas später ein. In den mittleren und höheren Breiten des nördlichen Festlandes ist der Juli der wärmste und der Januar der kälteste Monat, auf dem Meer sind dagegen im allgemeinen Februar und August die extremen Monate. In der tropischen Zone steigt das Thermometer am höchsten, wenn die Sonne den Scheitelpunkt erreicht; so ist in Columbia der März, in Zentralamerika der April, und in Mexico der Mai der wärmste Monat. Während sonst überall die mittleren Monatstemperaturen eine Kurve mit nur einem Maximum darstellen, zeigt diese in der Äquatorialzone, wo die beiden Zenitstände der Sonne weit auseinander liegen, zwei Erhebungen. Doch ist dies keineswegs eine allgemeine Erscheinung. Deutlich ausgeprägtistdas doppelte Maximum z. B.im südäquatorialen Teil des malaiischen Archipels, dagegen in Singapore nur in einer leisen Hebung der Kurve im Oktober angedeutet. In Westafrika tritt die Doppelhebung scharf an der Elfenbeinküste und in T'schinschoscho, also unter $5^{\circ} \mathrm{N}$ und

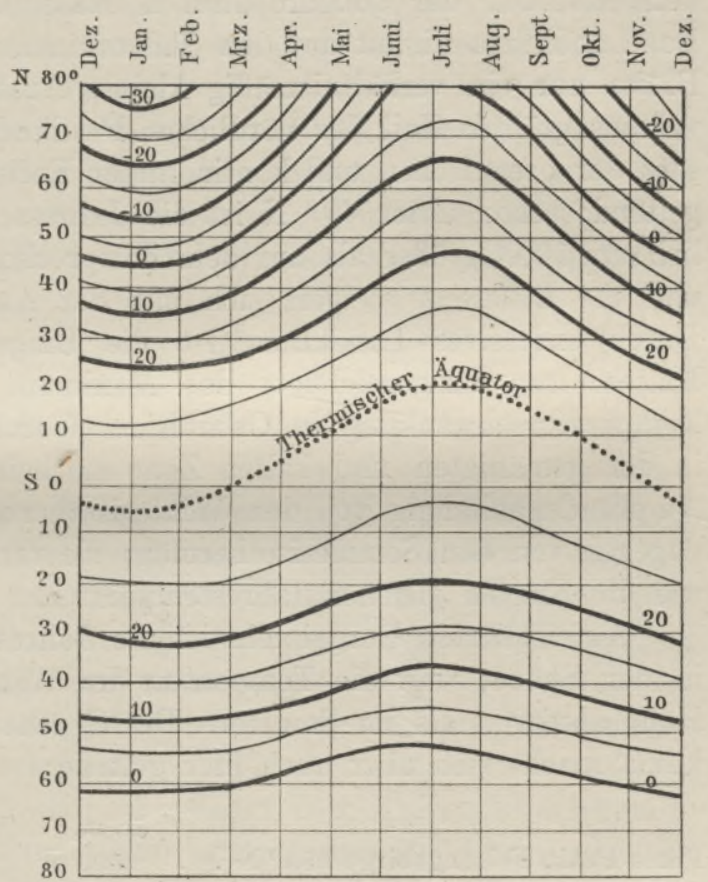

Fig. 30. Thermoisoplethen der Erde.

$\mathrm{S}$ hervor, aber undeutlich am Äquator, und im Osten ist schon in Sansibar unter $6^{\circ} \mathrm{S}$ die einfache Kurve wieder hergestellt.

Die Differenz der extremen Monatstemperaturen nennen wir die jährliche Temperaturschwankung ${ }^{2}$ (s. Karte IX). Vom Äquator, wo sie durchschnittlich $1,3^{\circ}$ beträgt und auf den ostindischen Inseln sogar auf $0,8^{0}$ herabsinkt, nimmt sie gegen die Pole $\mathrm{zu}$, gleichzeitig aber auch von den Küsten gegen das Innere der Kontinente. Ein Klima mit einer mittleren Jahresamplitude bis höchstens $15^{0}$ bezeichnen wir als Åquatorial-, beziehungsweise Seeklima, von $15-20^{\circ}$ als Übergangsklima, von $20-40^{\circ}$ als Landklima und über $40^{\circ}$ als exzessives Landklima. Das Seeklima wird durch 
warme Winter und kühle Sommer, das Landklima durch kalte Winter und warme Sommer charakterisiert. Das erstere ist auf unserer Hemisphäre nördlich vom 30. Parallel auf die Westküsten beschränkt, während die Ostküsten wegen der bedeutenden Winterkälte Landklima haben. Auch in den höheren Breiten, mit Ausnahme von Grönland, und in den mittleren Breiten der Südhalbkugel ist die jährliche Schwankung an den Westküsten kleiner als an den östlichen, und dem gleichen Gesetz begegnen wir an den Gestaden der südeuropäischen Halbinseln und Vorderindiens. Das Landklima nimmt auf den Südkontinenten wegen ihrer niederen Breite nur ein verhältnismäßig kleines Areal ein, während es den weitaus größten Teil der nördlichen Festländer umfaßt. Der Gegensatz der ozeanischen und kontinentalen Erdhälfte macht sich wieder geltend; schon unter $40^{\circ} \mathrm{N}$ ist die Jahresschwankung durchschnittlich um $10,4^{\circ}$ größer als auf dem entsprechenden südlichen Parallel, und die Differenz steigert sich mit der Annäherung an die Pole. Durch exzessives Landklima ist die Umgebung der winterlichen Kältezentren ausgezeichnet; das Maximum erreicht die jährliche Temperaturschwankung in Ostsibirien (Werchojansk 65,9\%). Überall in der gemäßigten und kalten Zone erscheinen die Linien gleicher Amplitude abhängig von den Winterisothermen, im warmen Gürtel dagegen von den Sommerisothermen; sie verhalten sich also ebenso wie die Kurven gleicher Jahrestemperatur.

Auf isolierten Berggipfeln ist die Jahresschwankung kleiner als in der Ebene, weil die Temperatur im Winter langsamer mit der Höhe abnimmt als im Sommer. Der Gegensatz von Land- und Seeklima macht sich aber auch hier geltend:

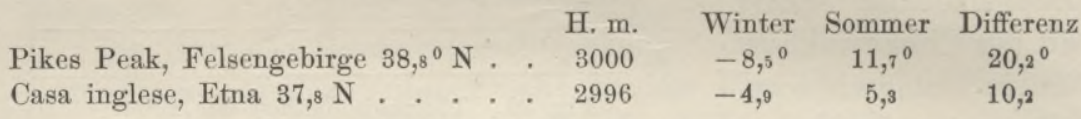

In den Hochtälern ist die jährliche Schwankung nicht nur beträchtlicher als auf freien Berggipfeln in gleichem Niveau, sondern auch größer als in der Ebene. F'olgende Tabelle gibt auch die Ursache dieser Erscheinung an:

\begin{tabular}{|c|c|c|c|c|c|}
\hline & & $\begin{array}{l}\text { H. m } \\
1790\end{array}$ & $\begin{array}{c}\text { Kältester M. } \\
-4,8^{\circ}\end{array}$ & $\begin{array}{c}\text { Wärmster M. } \\
9,7^{\circ}\end{array}$ & $\begin{array}{c}\text { Differenz } \\
14,5^{\circ}\end{array}$ \\
\hline & & 1715 & $-9,7$ & 11,9 & 21,6 \\
\hline Basel & . & 278 & 0,4 & 19,2 & 18,8 \\
\hline
\end{tabular}

Für die Plateaus läßt sich ein genaues Gesetz noch nicht aufstellen. Auf einigen differieren die extremen Monatstemperaturen etwas mehr, auf anderen etwas weniger als im kontinentalen Tiefland, aber nirgends 
ist der Unterschied so bedeutend, daß man auf eine bestimmte $\mathrm{Ab}$ hängigkeit von der Seehöhe schließen könnte.

Vergleichen wir die Verteilung der jährlichen Temperaturschwankung mit der der täglichen, so gelangen wir zur Aufstellung folgender klimatischer Typen:

1. Das Äquatorialklima. Auf dem Meer und auf dem Land in nicht beträchtlicher Seehöhe sind beide Schwankungen gering, aber die tägliche ist größer als die jährliche. Erstere beträgt im Mittel der auf S. 106 angeführten Stationen 5,8 ${ }^{0}$, letztere nur 2,8 und lediglich in diesem Sinn ist der bekannte Satz aufzufassen, daß die Nacht der Winter der Tropen sei.

2. Im Seeklima der mittleren und höheren Breiten sind beide Schwankungen gering, aber die jährliche ist größer als die tägliche. Landeinwärts nehmen beide zu. Die jährliche Variation nimmt unter übrigens gleichen Verhältnissen auch mit der Breite $\mathrm{zu}$, die tägliche aber $\mathrm{ab}$.

3. Das Polarklima mit großer jährlicher und kleiner täglicher Schwankung.

Mit Bezug auf die Seehöhe lassen sich folgende Typen unterscheiden:

1. Das Bergklima. Beide Schwankungen sind kleiner als im benachbarten. Tiefland. Das Bergklima gleicht somit dem Seeklima.

2. Das Plateau- und Hochtälerklima hat dagegen einen streng kontinentalen Charakter. Die tägliche Temperaturschwankung ist unter allen Umständen und unter allen Breiten größer als im Tiefland, während sich die jährliche von der in den Niederungen nicht beträchtlich unterscheidet.

Eine andere Seite des Klimas gelangt in v. KenNER's ${ }^{3}$ Thermoisodromen zur Darstellung. Man versteht darunter Linien gleichen Wärmeüberschusses des Oktober über den April in Prozenten der Jahresschwankung. Durch die Berücksichtigung des Gegensatzes zwischen den extremen Monaten wird der jährliche Gang der Temperatur charakterisiert; je größer der Prozentsatz oder der thermodromische Quotient, desto gleichmäßiger die Temperatur. ${ }^{\times}$Aus der Karte der gemäBigten Zone der nördlichen Halbkugel ergibt sich, 1. daß auf dem Atlantischen Ozean der relative Wärmeüberschuß mit der Breite abnimmt, und 2. daß er sich auch von der Küste

$\times$ Valentia an der Südwestküste von Irland und Groningen in Holland haben gleichen absoluten Wärmeüberschuß des Oktober, nämlich $1,7^{\circ}$, dort beträgt aber die Jahresamplitude nur $7,9^{\circ}$, hier dagegen $17,3^{\circ}$. Der relative Wärmeüberschuß beider Stationen ist also sehr versehieden: Valentia 21,5, Groningen 9,8 Proz. 
landeinwärts verringert, bis er in den streng kontinentalen Gebieten negativ wird. Das zeigt an, daß der Frühling wärmer ist als der Herbst. Der Satz, daß sich das Land bei steigender Sonne rascher erwärmt als das Meer, daß aber das Meer seinen Wärmevorrat länger bewahrt, erfährt dadurch eine umfassende Bestätigung.

Temperaturveränderlichkeit. Neben den periodischen Veränderungen müssen auch die unperiodischen in Betracht gezogen werden. Ein klimatologisches Moment von eminent geographischer Bedeutung, aber noch nicht genug gewürdigt, ist die mittlere Veränderlichkeit der Temperatur von einem Tag zum anderen. Schon HanN, ${ }^{4}$ dessen bahnbrechende Untersuchungen bereits in mehreren Ländern Nachahmung gefunden haben, machte darauf aufmerksam, wie die größere Temperaturvariabilität in Nordamerika, Australien und Neuseeland auf den körperlichen Habitus und den Charakter der europäischen Einwanderer merklich einwirkt, und wir fugen die Vermutung hinzu, daß der erschlaffende Einfluß des Tropenklimas hauptsächlich in der geringen Veränderlichkeit begründet ist. Einen Einfluß auf die Sterblichkeit, die sowohl in der geographischen Verteilung, als auch im jährlichen Gang mit der Temperaturveränderlichkeit wächst, hat KERMsER ${ }^{5}$ wenigstens für Norddeutschland sehr wahrscheinlich gemacht. Es liegt ferner auf der Hand, daß auch die Verbreitung der Pflanzen zum Teil von diesem Moment abhängt, und es ist nur zu bedauern, daß Untersuchungen in dieser Richtung noch nicht eingeleitet worden sind.

Infolge des Wechsels der Jahreszeiten nimmt die Tagestemperatur bis zum Maximum zu und dann wieder ab. Das ist das periodische Element in der Veränderlichkeit. Daneben wirken aber auch Winde, Bewölkung, Niederschläge usw., und das ist das unperiodische Element, das sich schon dadurch als das maßgebendere erweist, daß sich die Werte für die mittlere Veränderlichkeit nicht erheblich ändern, wenn man den Einfluß des periodischen Elementes eliminiert. Daraus erklärt es sich, daß in der Zone der regelmäBigen Winde, in den Tropen, die Tagestemperatur weniger variiert (in Georgetown in Guayana z. B. durchschnittlich nur um $\left.0,6^{0}\right)$, als im Gebiet der wechselnden Luftströmungen. Die mittlere Veränderlichkeit nimmt daher mit der Breite zu, aber in ganz unregelmäßiger Weise, wie nebenstehende Tabelle zeigt. Die nördliche Hemisphäre hat zwei Maximalbezirke, von denen nach allen Seiten, auch gegen den Pol hin, die Veränderlichkeit abnimmt. Der eine liegt im Innern von Nordamerika und umfaßt wahrscheinlich die nördlichsten Teile der Vereinsstaaten und den südlichen und mittleren Teil der Hudsonbai-Länder; der andere liegt in West- 


\begin{tabular}{|c|c|c|c|c|c|c|}
\hline $\begin{array}{l}\text { Östliches Eismeer (Fram- } \\
\text { trift) . . . . . . . }\end{array}$ & $\begin{array}{l}\text { Mittlere } \\
\text { Breite }\end{array}$ & 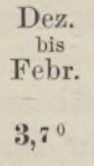 & $\begin{array}{c}\text { März } \\
\text { bis } \\
\text { Mai } \\
2,7^{0}\end{array}$ & $\begin{array}{c}\begin{array}{c}\text { Juni } \\
\text { bis } \\
\text { Aug. }\end{array} \\
0,8^{0 *}\end{array}$ & $\begin{array}{c}\text { Sept. } \\
\text { bis } \\
\text { Nov. } \\
3,3^{0}\end{array}$ & $2,7^{\circ}$ \\
\hline Arktisehes Nordamerika . & 71,9 & 3,4 & 2,4 & $1,3^{*}$ & 2,5 & 2,4 \\
\hline Amerikanische Westküste & 47,4 & 2,0 & 1,4 & $1,1^{*}$ & 1,5 & 1,5 \\
\hline Westliches Plateau. . . & 40,3 & 3,2 & 2,9 & $2,3^{*}$ & 2,6 & 2,8 \\
\hline Inneres von Nordamerika & 43,0 & 4,7 & 3,5 & $2,4^{*}$ & 3,3 & 3,5 \\
\hline Östliches Nordamerika . & 42,8 & 4,1 & 2,8 & $2,1 *$ & 2,7 & 2,9 \\
\hline Südöstliches Nordamerika & 30,6 & 2,9 & 1,9 & $1,1^{*}$ & 1,8 & 1,9 \\
\hline Plateau von Mexico. . . & 19,2 & 1,1 & 1,6 & $0,7^{*}$ & 0,7 & 1,0 \\
\hline England . . . . & 53,7 & 2,1 & 1,6 & $1,5^{*}$ & 1,9 & 1,8 \\
\hline Mitteleuropa . . . . & 49,3 & 2,2 & 1,9 & 1,9 & $1,7^{*}$ & 1,9 \\
\hline Europäisches RuBland . & 56,8 & 3,7 & 2,5 & $2,0^{*}$ & 2,3 & 2,6 \\
\hline Westsibirien . . . . & 56,0 & 4,6 & 3,1 & $2,2 *$ & 3,1 & 3,2 \\
\hline Ostsibirien . . . . . & 57,1 & 3,2 & 2,6 & $2,1 *$ & 2,7 & 2,6 \\
\hline Ostasien . . . . . . . & 50,2 & 2,8 & 2,1 & $1,7^{*}$ & 2,2 & 2,2 \\
\hline Westliches Mittelmeer. & 42,1 & 1,3 & 1,3 & 1,4 & $1,2^{*}$ & 1,3 \\
\hline Östliches Mittelmeer . & 35,5 & 1,5 & 1,7 & 1,2 & $1,1^{*}$ & 1,4 \\
\hline Südliche Halbkugel. . & 33,8 & 1,9 & $1,5 *$ & 1,7 & 2,0 & 1,8 \\
\hline Antarktis . . . . . & 65,6 & $0,9^{*}=$ & 3,4 & 4,8 & 2,9 & 3,0 \\
\hline
\end{tabular}

sibirien, etwas nördlicher als der amerikanische, und ist etwas schwächer ausgebildet. Der Gegensatz der Ost- und Westküsten tritt auch hier wieder zutage, indem jene eine etwas variablere

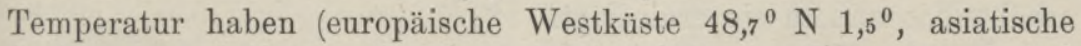
Ostküste $47,8^{0} \mathrm{~N}^{\circ}{ }^{\circ}$; dies ist wahrscheinlich eine Folge davon, daB dort die Temperatur im Winter rasch mit der Breite zunimmt. Wenn sich auch die Veränderlichkeit in der Regel landeinwärts steigert, so darf man doch nicht dem Seeklima als solchem einen mildernden Eintluß zuschreiben, denn in diesem Fall müßte sie auf der südlichen Halbkugel geringer sein als auf der nördlichen, während doch tatsächlich das Umgekehrte stattfindet. Den durchschnittlichen Wert von $1,8^{\circ}$, der jenseits des Äquators schon in $33,8^{\circ}$ B. erreicht wird, finden wir auf unserer Erdhälfte im Mittel erst unter $49,3^{\circ} \mathrm{B}$., und wir sind daher nicht erstaunt, in der antarktischen Zone, für die uns Meinardus Werte geliefert hat, auf einen dritten Maximalbezirk zu stoßen, der den beiden nordhemisphärischen nichts nachgibt. Mit der Höhe wächst die Veränderlichkeit, und zwar zum Unterschied von den Schwankungen gleichmäßig auf Berggipfeln wie auf Plateaus. In Zürich $(480 \mathrm{~m})$ beträgt sie im Jahresmittel $1,8^{\circ}$, auf dem Ütliberg $(874 \mathrm{~m}) 2,0^{\circ}$ und auf dem Rigi $(1784 \mathrm{~m}) 2,4^{\circ}$. In Stuttgart $(270 \mathrm{~m})$ beträgt sie $1,8^{0}$, in München 
$(479 \mathrm{~m})$ dagegen $2,1^{\circ}$. Im Erzgebirge nimmt sie durchschnittlich um $0,03^{0}$ für je $100 \mathrm{~m} \mathrm{zu}$.

In den mittleren und höheren Breiten unserer Halbkugel erreicht die Veränderlichkeit ihr Maximum im Winter und ihr Minimum im Sommer. Die geographische Anordnung ändert sich aber das ganze Jahr nicht, nur sind im Sommer die Unterschiede beträchtlich kleiner als im Winter. Die winterlichen Werte sind also für das Jahresmittel das Entscheidende, und das gibt uns den Schlüssel zur Erklärung der Maximalbezirke an die Hand. Sie liegen an den Grenzen der winterlichen Regionen hohen Luftdruckes, wo eine häufige Verschiebung der Windgebiete stattfindet. So gelangt z. B. Westsibirien bald unter die Herrschaft warmer Winde vom Atlantischen Ozean, bald unter die der kalten Luftströmung vom asiatischen Kältezentrum. Nordamerika, der kleinere und daher wärmere Kontinent, dessen meridionale Gebirge ein AbflieBen der kalten Luft zu den Meeren im Osten und Süden gestatten, erfährt aus diesem Grund (wie wir später ausführlicher erörtern werden) auch raschere Windwechsel, und die Tagestemperatur ist daher größerer Veränderlichkeit unterworfen. Man muß sich auch stets vor Augen halten, da $B$ die Winde nicht nur direkt die Temperatur beeinflussen, sondern auch indirekt, indem warme Winde im Winter, weil sie meist von der See kommen, auch Bewölkung und Niederschläge bringen, die kalten Landwinde aber Heiterkeit und trockene Luft; und wir haben schon gehört, daß das eine die Temperatur erhöht, das andere sie erniedrigt.

Örtliche Einflüsse spielen im Sommer eine viel größere Rolle als im Winter. Namentlich wird die Variabilität gesteigert, wenn sich in der Nähe eines erhitzten Landstriches ein höheres Gebirge oder eine größere Wasserfläche befindet, wie an der Hudsonbai und im canadischen Seengebiet oder auf der bayerischen Hochebene und im oberitalienischen Tiefland. Besonders auffallend ist im Sommer die geringe Veränderlichkeit in beiden Polargegenden, wo sie nicht größer ist als in den Mittelmeerländern. In den subtropischen Breiten der südlichen Hemisphäre sind Frühling und Herbst die veränderlichsten Jahreszeiten, und der Sommer ist sowohl an den Küsten wie im Binnenland veränderlicher als der Winter.

Klimatologisch wichtig ist auch die Häufigkeit der Veränderungen von bestimmter Größe. Auch hier wiederholt sich die geographische Verteilung, die wir soeben kennen gelernt haben, wenn auch mit einigen Unterschieden. So sind z. B. Veränderungen von mehr als $6^{\circ}$ in Ostsibirien seltener als im europäischen Rußland, geringere Änderungen aber häufiger. In beiden Maximalbezirken 
sind Änderungen von $20^{\circ}$ und darüber nicht sehr selten, und auch solche von $25^{\circ}$ kommen noch vereinzelt vor, aber der westsibirische Bezirk scheint öfter als der inneramerikanische bedeutenden Schwankungen unterworfen zu sein. Dagegen reichen in Amerika die großen Temperaturwechsel viel weiter nach Süden als in der Alten Welt, was HanN mit Recht den „Northers" zuschreibt, jenen von Norden kommenden Winterstürmen, die manchmal bis in den Golf von Mexico, also bis in die warme Zone hinein die binnenländische Kälte tragen.

Mittlere Abweichung. Wie in der mittleren Veränderlichkeit, so können wir auch in der mittleren Abweichung der Monatsund Jahrestemperaturen der einzelnen Jahrgänge von dem Mittelwert ohne Rücksicht auf das Vorzeichen, wie sie Dove ${ }^{6}$ für zahlreiche Stationen berechnet hat, einen Ausdruck für die unperiodischen Störungen sehen, wenn auch - wie aus späteren Erörterungen hervorgehen wird - ein periodisches Element darinnen steckt, das aber aller Wahrscheinlichkeit nach von dem unperiodischen verdunkelt wird. Ihre geographische Verteilung ist von großer klima-

\begin{tabular}{|c|c|c|c|c|c|c|c|}
\hline \multicolumn{5}{|l|}{ Länder } & $\begin{array}{c}\text { GröBte } \\
\text { Abweichung }\end{array}$ & $\begin{array}{c}\text { Kleinste } \\
\text { Abweichung }\end{array}$ & \multirow{2}{*}{$\frac{\text { Jahr }}{1,19^{\circ}}$} \\
\hline Italien . . . & . & . & . & & Dez. $1,44^{0}$ & Aug. $\quad 0,90^{\circ}$ & \\
\hline England. . & . & . & . & . & Jan. $\quad 1,46$ & Sept. 0,89 & 1,24 \\
\hline Westeuropa . . & . & . & . & . & Jan. $\quad 2,26$ & Sept. 1,07 & 1,44 \\
\hline Schweiz . . . . & . & . & . & . & Dez. $\quad 2,02$ & Okt. $\quad 1,11$ & 1,46 \\
\hline Süddeutschland . & . & . & . & . & Jan. $\quad 2,51$ & Sept. 1,16 & 1,65 \\
\hline Norddeutschland. & . & . & . & . & Jan. & Sept. 1,09 & 1,72 \\
\hline Baltische Länder & . & . & & . & Jan. & Sept. 0,87 & 1,47 \\
\hline Nordosteuropa . & . & . & * & . & Jan. $\quad 3,18$ & Sept. 1,01 & 1,84 \\
\hline Inneres RuBland & . & . & & . & Dez. $\quad 3,50$ & Mai $\quad 1,41$ & 2,00 \\
\hline Ural und Sibirien & . & . & & . & Dez. 3,12 & Juli $\quad 1,17$ & 1,97 \\
\hline Westliches Nordam & eril & & & . & Jan. $\quad 2,19$ & Sept. 0,66 & 1,22 \\
\hline Inneres Nordameri & & . & & . & Febr. $2, e 2$ & Aug. 1,12 & 1,70 \\
\hline Östliches Nordame & rika & & & . & Febr. 1,59 & Juli $\quad 0,90$ & 1,27 \\
\hline Polarländer & . & . & . & . & Dez. $\quad 1,95$ & Sept. 1,19 & 1,59 \\
\hline
\end{tabular}

tologischer Bedeutung. Es zeigt sich, daß Abweichung und Veränderlichkeit nicht parallel laufen. Zwar gilt auch für jene im allgemeinen das Gesetz, daß sie vom Äquator gegen die Pole und von den Küsten landeinwärts zunimmt. In der Alten Welt wie in Nordamerika liegt das Gebiet der gröBten Abweichung im Inneren, und sind die Monats- und Jahrestemperaturen an der Ostküste variabler als an der westlichen, aber damit hört auch der Parallelis- 
mus auf. Die Neue Welt hat die größte Veränderlichkeit, die Alte die größte Abweichung; die störenden Elemente, die die Temperaturkurve von einem Tag zum anderen beeinflussen, sind in Amerika mächtiger, aber sie treten auch regelmäBiger von Jahr zu Jahr auf, als auf unserer östlichen Feste. Die Abweichung im amerikanischen Binnenland ist nicht größer als im nördlichen Deutschland, und in den östlichen Vereinsstaaten sogar geringer als in Westeuropa. Ebenso ist die Abweichung auf der südlichen Hemisphäre kleiner als auf der nördlichen unter gleicher Breite. Alles das beweist, daß sie von der Kontinentalität des Klimas weit abhängiger ist als die Veränderlichkeit. Dagegen nehmen beide mit der Höhe zu, aber die Abweichung nur um $0,007^{\circ}$ für $100 \mathrm{~m}$. In den einzelnen Monaten ist sie verschieden. Am größten ist sie im Winter, wo die Temperatur am meisten von den Winden abhängt, am kleinsten im Spätsommer; nur in Gegenden mit strengerem Landklima fällt das Minimum in den Anfang oder in die Mitte des Sommers.

Literaturnachweise. ${ }^{1}$ J. Hann, Der tägliche Gang der Temperatur in der äußeren Tropenzone (Denkschriften der Wiener Akad. d. Wiss., Math.naturwiss. Kl. 1905 u. 1907, Bd. 78, 80 u. 81; eine Zusammenstellung der wichtigsten Daten s. Petermans's Mitteilungen 1908, Literaturbericht S. 11). ${ }^{2}$ A. Supan, Die Verteilung der jährlichen Wärmeschwankung, in der Zeitschrift für wissenschaftliche Geographie, 1880, Bd. I. $-{ }^{3}$ F. v. Kerner, Thermoisodromen, Wien 1905 (Abhandlungen der Wiener Geographischen Gesellschaft, Bd. VI, Nr. 3). 4 J. Hans, Untersuchungen über die Veränderlichkeit der Tagestemperatur, in den Sitzungsberichten der Wiener Akademie der Wissenschaften, Math.-naturwiss. Kl. 1875, Bd. LXXI, II; Die Veränderlichkeit der Temperatur in Österreich, in den Denkschriften der Wiener Akademie der Wissenschaften, Math.naturwiss. Kl. 1891, Bd. LVIII. - ${ }^{5}$ V. Kremser, Die Veränderlichkeit der Lufttemperatur in Norddeutschland, in den Abhandlungen des PreuBisehen Meteorologischen Instituts, Bd. I, 1888. - ${ }^{6} \mathrm{H}$. W. Dove, Die mittlere und absolute Veränderlichkeit der Temperatur, in den Abhandlungen der Berliner Akademie der Wissenschaften 1867.

\section{Windsysteme und Windgebiete.}

Windgesetze. $\mathrm{Zu}$ wiederholten Malen hatten wir schon Gelegenheit, den Einfluß der Winde auf die Temperaturverteilung kennen zu lernen. In einem späteren Kapitel werden wir erfahren, daß der Wind einer der wichtigsten Faktoren ist, der die Verteilung der Niederschläge regelt. Es ist daher nicht Überschätzung, wenn man den Wind als den eigentlichen Träger des Klimas. bezeichnet, und zugleich - da die klimatischen Verhältnisse das organische Leben und damit auch die Entwicklung der Menschheit bedingen - als eine Kulturmacht ersten Ranges. 
Direkt erscheinen die Winde von der Verteilung des Luftdruckes abhängig. Ein ungleich verteilter Luftdruck zeigt an, daß das Gleichgewicht der Atmosphäre gestört ist, und die Winde haben das Bestreben, es wieder herzustellen. Dieses Grundprinzip der modernen Meteorologie ergab sich unmittelbar aus den sogenannten synoptischen Witterungskarten, die den Zustand der Atmosphäre über einem größeren oder kleineren Teil der Erdoberfläche (Europa, nordatlantischer Ozean, Vereinigte Staaten von Amerika) in einer bestimmten Stunde (meist $7^{\text {h }}$ früh nach Ortszeit) darstellen. Auf diesen Karten sieht man die Orte gleichen Luftdruckes durch Linien, die sogenannten Isobaren, miteinander verbunden. $\mathrm{Um}$ die beobachteten Barometerstände miteinander vergleichbar zu machen, muß man sie auf das Meeresniveau reduzieren; und außerdem muß man, da das Gewicht aller Körper, somit auch der Luft, mit der Polhöhe zunimmt, eine Schwerekorrektur anbringen, d. h. die unter verschiedenen Breiten beobachteten Barometerstände auf einen gemeinsamen Parallel (gewöhnlich den 45.) reduzieren. Der Vergleich der Isobaren mit den Winden ergibt nun folgende zwei Gesetze, die nach ihren Entdeckern benannt werden:

1. Das Buys-Ballot'sche Gesetz: Die Luft strömt von der Gegend höheren Luftdruckes nach der niederen Luftdruckes und wird dabei durch die Erdrotation auf der nördlichen Hemisphäre nach rechts und auf der südlichen nach links abgelenkt. Man kann noch den Satz hinzufügen, daß jedes Windsystem aus zwei Strömungen besteht, aus einer unteren vom höheren Luftdruck zum niederen und einer oberen in entgegengesetzter Richtung. Beide werden durch die Achsendrehung der Erde abgelenkt, die untere aber außerdem noch durch die verschiedenen Reibungswiderstände an der Erdoberfläche. Ozeanische Winde unterliegen einer größeren Ablenkung als kontinentale, weil die letzteren auf dem unebenen Boden des Festlandes nicht völlig dem Einfluß der Rotation zu folgen vermögen. Stets bildet die Windrichtung mit dem Gradienten einen Winkel, der aber nie $90^{\circ}$ erreicht.

2. Das Stevenson'sche Gesetz lautet: Die Windstärke wird bedingt durch den barometrischen Gradienten, d. h. durch die Druckdifferenz, die in der Richtung senkrecht zu den Isobaren gemessen und auf eine Längeneinheit (jetzt allgemein $1^{0}$ am Äquator $=111 \mathrm{~km}$ ) bezogen wird. Je steiler der Gradient, desto dichter gedrängt die Isobaren, desto größer auch die Windgeschwindigkeit. Nach WEGEMANN's Untersuchungen ${ }^{1}$ nimmt sie bei gleichen Gradienten mit der Breite $a b$ und ist in gleicher Breite auf dem Meer größer als im Flachland. Sie wird also durch die Reibung wesentlich modifiziert. 
LоoмIs $^{2}$ ermittelte die Windgeschwindigkeit in Kilometer pro Stunde für folgende Gebiete, die wir in der Richtung $\mathrm{W}-\mathrm{O}$ anordnen.

\begin{tabular}{|c|c|c|c|c|c|c|c|c|c|}
\hline & & & & & \multicolumn{2}{|c|}{ Vereinigte Staaten } & \multirow{2}{*}{$\begin{array}{l}\text { Nord- } \\
\text { atlant. } \\
\text { Ozean }\end{array}$} & \multicolumn{2}{|c|}{ Europa } \\
\hline & & & & & $\begin{array}{l}\text { Bimnen- } \\
\text { land }\end{array}$ & $\begin{array}{l}\text { Ost- } \\
\text { küste }\end{array}$ & & $\begin{array}{l}\text { West- } \\
\text { küste }\end{array}$ & $\begin{array}{l}\text { Binnen- } \\
\text { land }\end{array}$ \\
\hline Winter. & . & . & . & . & 13,7 & 18,0 & 53,1 & 22,3 & 14,1 \\
\hline Frühling & . & . & . & . & 15,2 & 17,0 & 49,6 & 20,3 & 13,5 \\
\hline Sommer & . & . & . & . & 11,2 & 12,6 & 41,0 & 18,5 & 10,6 \\
\hline Herbst. & . & . & . & . & 12,5 & 16,1 & 47,8 & 20,9 & 12,5 \\
\hline Jahr . . & . & . & . & . & 13,1 & 15,9 & 47,9 & 19,8 & 12,7 \\
\hline
\end{tabular}

In allen Jahreszeiten sehen wir hier die Windgeschwindigkeit vom Ozean gegen die Küste und von der Küste gegen das Binnenland abnehmen, also genau in der Richtung, in der die Reibungswiderstände wachsen. Aus demselben Grund nimmt die Windstärke mit der Höhe zu, und schon geringe Höhenunterschiede fallen da schwer ins Gewicht; ist doch schon auf dem $300 \mathrm{~m}$ hohen Eiffelturm die Windstärke durchschnittlich $4 \mathrm{mal}$ größer als auf dem $1 / 2 \mathrm{~km}$ davon entfernten Turm des Meteorologischen Zentralbureaus in $21 \mathrm{~m}$ Höhe. Auch darüber hinaus wächst sie stetig und zwar ungefähr in demselben $\mathrm{Maß}$, in dem die Dichte der Luft abnimmt. Reduziert man, wie Axeu Egnelu ${ }^{3}$ getan hat, die oberen Strömungen auf die Dichte an der Erdoberfläche, so erhält man nahezu konstante Geschwindigkeiten, oder mit anderen Worten: oberhalb $300 \mathrm{~m}$, wo die Reibung am Boden keinen Einfluß mehr ausübt, bis an die Wolkengrenze von $12000 \mathrm{~m}$ werden durch den Wind in allen Schichten gleiche Luftmassen transportiert. In der täglichen Periode unterscheiden sich Meer, Land und freigelegene Berggipfel wesentlich voneinander. Auf dem Meer ist eine tägliche Periode der Windgeschwindigkeit so gut wie gar nicht bemerkbar, Tag und Nacht weht es mit gleicher Stärke. Auf dem Festland erreicht sie unter allen Breiten ihr Minimum in den ersten Morgenstunden und ihr Maximum ein paar Stunden nach Mittag; sie steigt und fällt also mit der Temperatur, und dieser Parallelismus kommt auch darin zum Ausdruck, daß sie an heiteren Tagen schärfer ausgeprägt ist als an trüben. In den höheren Luftschichten ist dagegen der Wind bei Nacht bedeutend stärker als bei Tag, wie die Beobachtungen nicht nur auf Berggipfeln, sondern auch schon auf dem Eiffelturm zeigen. Die unteren Schichten werden also am meisten zur Zeit der größten Erwärmung in die allgemeine Luftzirkulation hineingezogen, während sich diese in der Nacht hauptsächlich nur 
auf die oberen Schichten beschränkt. KöPPEN erklärt dies dadurch, daß sich in den Mittagsstunden die unteren Luftschichten ausdehnen und in die Höhe steigen, während die oberen, stärker bewegten hinabsinken. Infolgedessen findet ein stärkerer Austausch zwischen den verschiedenen Niveaus statt, und die horizontale Geschwindigkeit der ganzen Luftmasse wird gleichförmiger.
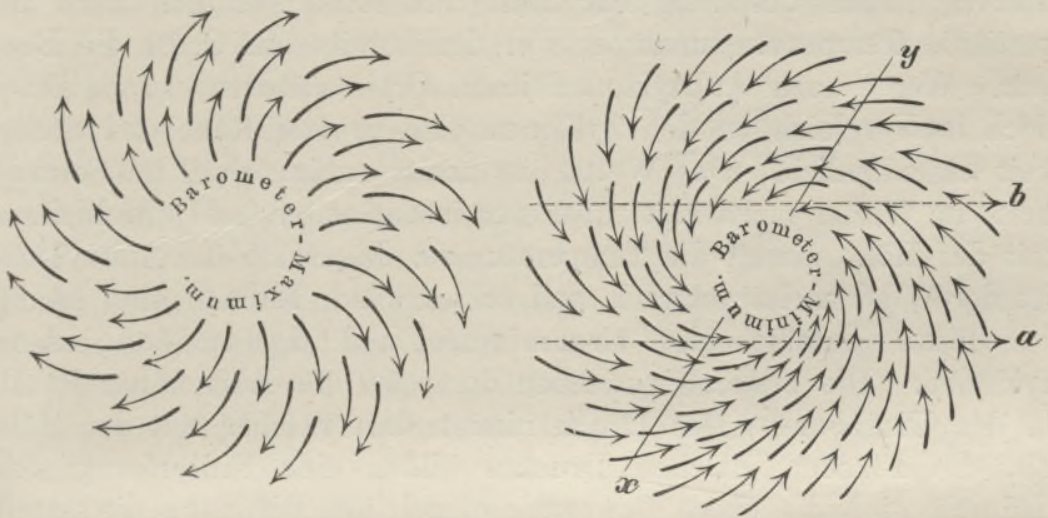

Fig. 31 a. Antizyklonen und Zyklonen auf der nördlichen Halbkugel.
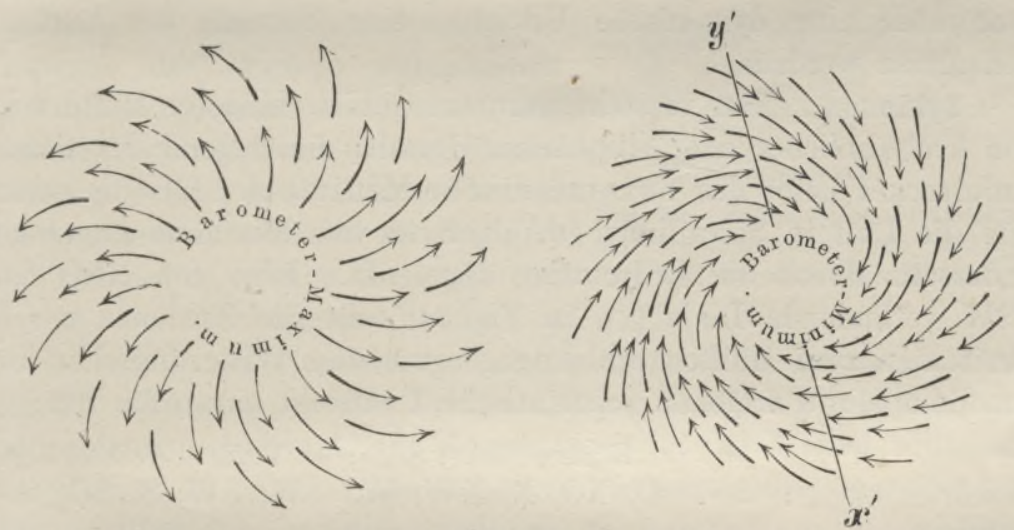

Fig. 31b. Antizyklonen und Zyklonen auf der südlichen Halbkugel.

Antizyklonen. Betrachten wir synoptische Witterungskarten von größerer Ausdehnung, etwa die der nordatlantischen Welt, so erkennen wir eine dreifache Art der Luftbewegung: eine passatische, eine zyklonische und eine antizyklonische. Doch bestehen sie nicht unabhängig nebeneinander, sondern Passate und Zyklonen treten stets in Verbindung mit Antizyklonen auf. In typischer Ausbildung erscheinen die Antizyklonen (Fig 31) als kreisähnliche oder elliptische Gebiete hohen Barometerstandes, aus denen die Luft 
allseits von der Gegend des höchsten Luftdruckes, dem sogenannten barometrischen Maximum, ausströmt. Innerhalb des Gebietes steigt die Luft hinab, und dieser vertikale Strom wird durch horizontalen Zufluß in der Höhe ernährt. Dafür spricht außer der Wolkenrichtung, die gegen das Maximum gekehrt ist, die große Dauerhaftigkeit der Antizyklonen, die sich natürlich bald auflösen müßten, wenn beständig nur Luft ausströmte; endlich auch die vertikale Temperaturzunahme, von der bereits auf S. 79 die Rede war. Wenn auch Antizyklonen ihren Ort verändern, so ist ihnen doch im Vergleich zu den Zyklonen eine gewisse Ruhe und Stetigkeit eigentümlich. Das Wetter ist meist ruhig, klar, im Sommer heiß, im Winter meist kalt, aber nur in den untersten Luftschichten; mit der Höhe nimmt die Temperatur zu. Innerhalb der Antizyklone ist der Wind meist schwach und schwankend; Kalmen sind häufig.

Hans unterscheidet thermische und dynamische Antizyklonen. Die ersteren entstehen dort, wo die Luft kälter ist als in der Umgebung. Der Druck nimmt dort rascher mit der Höhe ab, die Flächen gleichen Druckes bilden eine Einsenkung, und dadurch wird die obere Bewegung eingeleitet, die dann die untere Bewegung nach sich zieht. Für Antizyklonen in warmen Gegenden muß aber eine dynamische Ursache, eine Stauung der Luft angenommen werden.

Zyklonen. Man versteht darunter Gebiete niederen Luftdruckes von kreisähnlicher oder elliptischer Gestalt; die Gegend des tiefsten Luftdruckes heißt das barometrische Minimum. Allseitig strömt ihm die Luft in Spirallinien zu, einerseits vom Minimum angezogen, anderseits durch die Erdrotation abgelenkt. Eine von NNO nach SSW verlaufende Linie ( $x y$ in Fig. 31) teilt die Zyklonen unserer Breiten in zwei Hälften mit entgegengesetztem Witterungscharakter, von dem Монм folgende schematische Übersicht entworfen hat:

$$
\text { Hintere (linke) Seite: }
$$

Windrichtung . . O, NO, N, NW, W.

Barometer

Temperatur, Feuchtig-

keit und Bewölkung Niederschlag

$$
\text { steigt }
$$

Vordere (rechte) Seite: $\mathrm{W}, \mathrm{SW}, \mathrm{S}, \mathrm{SO}, \mathrm{O} . \times$ fällt

Die hintere Seite wird also durch kalte Polar-, die rechte durch warme Äquatorialwinde ausgezeichnet. Doch bezeichnen diese, für beide Hemisphären gleichmäßig anwendbaren Ausdrücke nicht etwa den Ort der Entstehung, sondern lediglich die Richtung, aus der

× Für die südliche Hemisphäre ist Süd statt Nord zu setzen und umgekehrt. 
die Winde wehen. Wir werden im folgenden die hintere Seite der

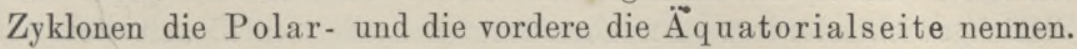
Im Zentrum der barometrischen Depression sind die Winde veränderlich und Windstillen häufig. Der Gradient (und damit auch die Windgeschwindigkeit) ist nicht in allen Teilen der Zyklonen gleich; der größte liegt im nördlichen und westlichen Europa meist im südlichen, der kleinste im nördlichen Quadranten; auf den ersteren sind daher die meisten europäischen Stürme beschränkt. Aber auch innerhalb eines Quadranten nimmt der Gradient vom Zentrum gegen die Peripherie erst zu, dann wieder ab. Bei gleichem Gradienten sind in unseren Breiten die nördlichen und östlichen Winde stärker als die südlichen und westlichen, und im Sommer sind alle Winde stärker als unter gleichen Verhältnissen im Winter.

Der zyklonalen Bewegung an der Erdoberfläche entspricht eine antizyklonale in der Höhe, die die im Zentrum des Wirbels aufsteigende Luft aus demselben hinausführt. Beide bilden zusammen einen Körper. Über seine vertikale Mächtigkeit lauten die Angaben verschieden; in England und Schweden reichen die Zyklonen
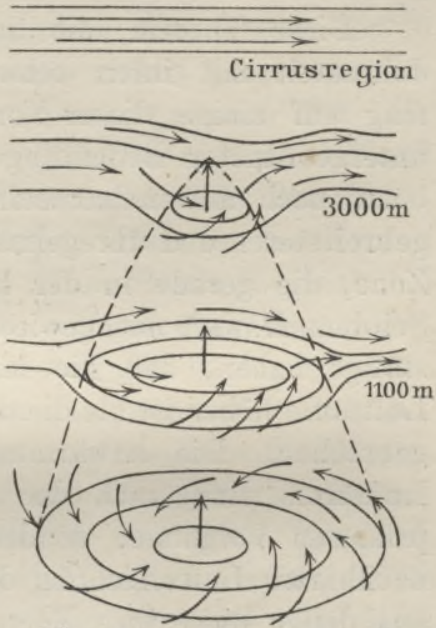

Me eresnive au

Fig. 32. Schematische Darstellung der nordamerikanischen Zyklonen in vier Niveaus nach BIGELOw, ${ }^{6}$ bis in die Cirrusregion hinein, in Nordamerika und Frankreich enden sie schon in geringerer Höhe. Fig. 32 zeigt uns, wie der Zyklonenkörper keilförmig in die höheren Luftschichten eindringt. Im Meeresniveau ist der Wirbel vollständig ausgebildet. In $1100 \mathrm{~m}$ Höhe bemerken wir bereits eine antizyklonische Bewegung, aber - und dies scheint ein wenigstens für unsere gemäßigte Zone allgemein gültiges Gesetz zu sein - nicht mit allseitiger Entwicklung, denn nur an der Vorderseite strömt Luft aus, im westlichen und südlichen Quadranten aber noch ein, und der nördliche Quadrant ist im Verschwinden begriffen; die Isobaren weichen hier nur wenig von ihrem normalen geradlinigen Verlauf ab und die regelmäßige Westbewegung der Wolken ist nur wenig gestört. In $3000 \mathrm{~m}$ Höhe ist der Prozeß der Auflösung noch weiter fortgeschritten, die Cirrusregion endlich bleibt von der Zyklone völlig unbeeinflußt.

Die ältere Theorie (Konvektions- oder thermische Theorie) er- 
blickte in der Zyklonenbildung die erste Phase der atmosphärischen Gleichgewichtsstörung. An überwärmten Stellen entwickelt sich ein aufsteigender Luftstrom; sein Dampfgehalt wird dabei kondensiert, und die dadurch frei gewordene Wärme verstärkt den Auftrieb. Oben fließt er nach allen Seiten ab, und sinkt dann erkaltet zu Boden und erzeugt Antizyklonen. So speist in den oberen Schichten die Zyklone die sie umgebenden Antizyklonen, und in den unteren Schichten ernährt die Antizyklone die sie umgebenden Zyklonen.

Diese Theorie, die auf die tropischen Zyklonen der heißen Jahreszeit mit ihren schweren Niederschlägen zugeschnitten war, mag auf einige dieser Vorkommnisse, sowie auch auf einige von untergeordneter Bedeutung in unsern Breiten (wie z. B. Gewitterböen) noch anwendbar sein ${ }^{4}$, versagt aber völlig für die viel ausgebreiteteren und unregelmäßiger gestalteten Zyklonen der gemäßigten Zone, die gerade in der kälteren Jahreshälfte am häufigsten sind. Seitdem HanN ${ }^{5}$ nachgewiesen hat und die Berliner Luftschiffer bestätigt haben, daB die mittlere Temperatur der antizyklonischen Luftsäule höher ist als die der zyklonischen, war ihre Alleinherrschaft gebrochen. Die Erwärmung des Erdbodens und der aufsteigende Luftstrom sind nach der neueren dynamischen Theorie nicht die primären Vorgänge, sondern es sind Temperaturunterschiede benachbarter Luftschichten, die zur zyklonalen Bewegung führen, und aus denen diese ihre Energie schöpft. In den Vereinigten Staaten, die uns die meisten unserer europäischen Zyklonen herübersenden, entsteht der Wirbel nach BigeLow's ${ }^{6}$ Wolkenbeobachtungen in einer Höhe von durchschnittlich $2500 \mathrm{~m}$, wo die warmen Luftströmungen aus dem mexicanischen Golf und die kalten aus dem Norden zusammenstoßen, und senkt sich dann zu Boden. Ist die zyklonale Bewegung einmal eingeleitet, so wird unter günstigen Umständen das barometrische Minimum durch den Luftwirbel immer mehr vertieft. Je mehr das Barometer im Zentrum sinkt, desto steiler wird der Gradient, desto heftiger der Wirbel, desto geringer auch der Luftdruck im Mittelpunkt. So trägt die Zyklone in sich selbst die Bedingungen ihres Wachstums, das aber erfahrungsgemäß zeitlich beschränkt ist.

Von ihrer Geburt bis zu ihrem Erlöschen sind die Zyklonen in beständiger, bald schnellerer, bald langsamerer Wanderung begriffen. In der tropischen Zone bewegen sie sich nach Westen, biegen dann an der Polargrenze der Passate nach Norden beziehungsweise Süden um, wobei sie an Tiefe verlieren, aber an Ausdehnung gewinnen, und schlagen in den mittleren und höheren 
Breiten einen östlichen Weg ein. Das letztere gilt auch von jenen Depressionen, die in den außertropischen Gegenden entstehen. Die Zyklonen bewegen sich also, seltene Ausnahmen abgerechnet, im Sinn der allgemeinen Luftzirkulation; sie sind Wirbel, die von den großen Ost- und Westströmen weiter getragen werden. Genauer kennen wir bisher allerdings nur ihre mittleren Zugstraßen zwischen dem Felsengebirge und dem Ural. In Nordamerika wandert die Mehrzahl unter ungefähr $45^{\circ} \mathrm{B}$. durch die Seenregion, während andere aus dem SW auf den Atlantischen Ozean gelangen. Mehr als die Hälfte der nordamerikanischen Minima durchkreuzt ihn in 4-5 Tagen und erreicht Europa. Die einen ziehen über Labrador oder längs der Küste nach Grönland und von da nach Ost; die Bahnen der anderen teilen sich in der Nähe von Neuschottland und führen dann entweder über Island oder quer über den Ozean oder nördlich von den Azoren nach Europa. Hier ist der Norden das Hauptdurchzugsgebiet der Minima. Eine Straße beginnt bei Island, zieht dem norwegischen Gestade entlang über den Polarkreis hinaus und führt von da entweder nordwärts in das Eismeer, oder zum Weißen Meer, oder nach SO in das Innere von Rußland. Von den britischen Inseln und ihrer Umgebung wandern die Minima entweder über die Nordsee, Südschweden und die mittlere und südliche Ostsee nach den baltischen Provinzen und nach Finnland, oder - jedoch nur in selteneren Fällen und im Sommer fast nie über Frankreich nach dem Mittelmeer. Hier vereinigt sich diese Zugstraße mit der vom westlichen Mittelmeer kommenden, um im weiteren Verlauf teils nach SO, teils in das Schwarze Meer, teils nach NO in das innere Rußland zu führen. Besonders ausgezeichnet sind die Kreuzungspunkte der Zugstraßen, wie die Lorenzomündung, die Gegenden in der Davisstraße, südwestlich von Island und bei den Lofoten, das südliche Schweden und der Atlantische Ozean zwischen 50 und $52^{\circ} \mathrm{N}$ und 34 und $38^{\circ} \mathrm{W}$ Gr. Hier pflegen die Minima länger zu verweilen und schlagen häufig auf kurze Zeit sogar eine rückläufige Bewegung ein; hier bilden sich auch die meisten so einflußreichen stationären Depressionen. Gebirge bilden für Zyklonen von geringer Höhe ein Hindernis, das sie nur selten zu übersteigen vermögen. Indes gelangen, wie es jetzt erwiesen zu sein scheint, pazifische Zyklonen in das östlich vom Felsengebirge gelegene Gebiet der Vereinigten Staaten, wenn sie auch erst auf dem westlichen Hochland ihre ausgebildete Form erhalten. ${ }^{7}$ Anderseits wird freilich behauptet, daß diese Verknüpfung pazifischer und ostamerikanischer Luftdruckverhältnisse nur scheinbar sei, indem in derselben Zeit, wenn eine pazifische Zyklone am 
Westabhange des Felsengebirges gleichsam zerschellt, eine neue sich am Ostabhang bildet.

In den Vereinigten Staaten legen die Minima durchschnittlich $41,8 \mathrm{~km}$ in der Stunde zurück. Auf dem nordatlantischen Ozean sinkt ihre mittlere Geschwindigkeit auf $29 \mathrm{~km}$ und in Westeuropa sogar auf 26,9 km herab, steigert sich dan aber wieder in Rußland auf $33,9 \mathrm{~km}$. Daraus ergibt sich ein bedeutungsvoller Unterschied zwischen dem nordamerikanischen und dem europäischen Klima. Denn die direkte Folge der fortschreitenden Zyklonen ist die Veränderlichkeit des Wetters; je rascher sie wandern, desto größer auch die Veränderlichkeit. Die Punkte $a$ und $b$ in Fig. 31 a (S. 117) gelangen, wenn die Zyklone nach rechts fortschreitet, von der Äquatorial- auf die Polarseite, wobei sich in $a$ der Wind im Sinn eines Uhrzeigers von SO über SW nach NW, in $b$ aber im entgegengesetzten Sinn von SO über NO nach NW dreht.

Innerhalb einer größeren Depression können sich auch sekundäre oder Teilminima bilden, in unseren Gegenden am häufigsten auf der Südseite. Im ersten Stadium ihrer Entwicklung verraten sie sich durch eine seitliche Ausbuchtung der Isobaren. Unter günstigen Bedingungen lösen sie sich vom Hauptminimum los und verfolgen selbständig ihren Weg.

Die eigentliche Heimat der Zyklonen sind die mittleren und höheren Breiten. $\times$ In einem schmalen Gürtel zu beiden Seiten des Äquators fehlen sie ganz, denn hier ist die ablenkende Wirkung der Erdrotation zu schwach, als daß Störungen des Gleichgewichtszustandes der Luft nicht bald ausgeglichen würden. In dem übrigen Teil der Tropenzone fehlen sie zwar nicht und sind insofern wichtig, als sie meist von verheerenden Stürmen begleitet werden, aber sie sind nur auf einige Monate beschränkt. Genauer bekannt sind die Hurrikane des nordatlantischen Tropenmeeres, die Taifune der Chinasee und die Zyklonen des Indischen Ozeans. Von den erstgenannten kommen nach Looms 88 Prozent auf die Monate August bis Oktober, in denen sich der thermische Äquator am weitesten von dem mathematischen entfernt. Die niederste Breite ihres Vorkommens ist $10,3^{\circ} \mathrm{N}$, das Umbiegen der Bahn erfolgt im Sommer im Mittel in $30,6^{\circ}$, im September in $29,7^{\circ}$ B.; die durchschnittliche

$\times$ Zahl der Stürme in Prozenten aller Beobachtungen auf dem nordatlantischen Ozean:

\begin{tabular}{rl|lr|ll}
$0-5^{0} \mathrm{~N}$ & 0,06 & $20-25^{0} \mathrm{~N}$ & 1,9 & $40-45^{0} \mathrm{~N}$ & 10,5 \\
$5-10$ & 0,1 & $25-30$ & 3,2 & $45-50$ & 14,0 \\
$10-15$ & 0,8 & $30-35$ & 7,7 & $50-55$ & 16,0 \\
$15-20$ & 1,1 & $35-40$ & 13,1 & $55-60$ & 20,5
\end{tabular}


tägliche Geschwindigkeit beträgt $460 \mathrm{~km}$. Auch die Taifune sind in der warmen Zeit am häufigsten (72 Prozent in den Monaten Juli bis Oktober). Von den Wirbelstürmen im Pazifischen und Indischen Ozean kommen 52 Prozent auf den Herbst (September bis November) und 43 Prozent auf den Frühling (April bis Juni): das sind die Zeiten des sogenannten Monsunwechsels, wovon wir im nächsten Kapitel hören werden. Ihre niederste Breite ist $6,1^{\circ}$, die Umbiegung ihrer Bahn nach Norden vollzieht sich im Durchschnitt schon unter $19,8^{\circ}$ B., die mittlere Geschwindigkeit in 24 Stunden beträgt $310 \mathrm{~km}$. Im südindischen Ozean sind die Monate Januar bis April die Sturmzeit. Den tropischen Zyklonen verwandt sind die unter dem Namen Tornados bekannten, verheerenden Luftwirbel der Vereinigten Staaten, die am häufigsten im Frühsommer auftreten.

Wir haben oben gesagt, Zyklonen seien hauptsächlich eine Erscheinung der gemäBigten Breiten, und wir hatten dabei unsere nördlichen besonders im Auge. Hier gelangt jeder Ort auf der Erdoberfläche bald in eine antizyklonische, bald in eine zyklonische Luftbewegung, bald auf die äquatoriale, bald auf die polare Seite der wandernden Zyklonen und erleidet dadurch beständige Witterungsveränderungen. Aber nicht immer lagern wohlausgebildete Zyklonen und Antizyklonen nebeneinander, manchmal trennt nur ein schmaler Rücken hohen Luftdrucks zwei Zyklonen oder eine schmale Furche tiefen Barometerstandes zwei Antizyklonen. In Australien ist das letztere geradezu Regel: von W nach $\mathrm{O}$ wandernd, folgt Antizyklone auf Antizyklone mit wenig ausgedehnten V-förmigen Depressionen dazwischen. ${ }^{8 \times}$

Passate. Das nur der warmen Zone eigentümliche Passatsystem unterscheidet sich von bisher besprochenen Windsystemen zunächst durch die ostwestlich gerichtete bandartige Gestalt der äquatorialen Barometerdepression einerseits und der subtropischen, etwas polwärts von den beiden Wendekreisen gelagerten Hochdruckgebiete anderseits. Von diesen fließen die unteren Luftschichten als NO-Passat auf der nördlichen und als SO-Passat auf der südlichen Halbkugel zum Äquator. Ein zweites unterscheidendes Merkmal der Passate ist ihre Beständigkeit, denn beständig ist auch die äquatoriale Depression, wenn sie sich auch mit dem Gang der Sonne verschiebt und dadurch ebenfalls Verrückungen der beiden subtropischen Hochdruck-

$\times$ Eine solche barometrische Rinne im kleinen MaBstab hat M. C. Engel. in der westlichen Küstenzone Grönlands entdeckt (Meteorologische Zeitsehrift 1903, S. 274). Im Sommer wehen an der Küste Südwinde, weiter landeinwärts, am Rande des Inlandeises, flieBt die Luft von diesem herab und erwärmt sich dabei durch Niedersinken, so daB diese Winde verhältnismäBig warm und trocken sind. 
zonen bewirkt. In beistehender Figur (33), wo die Kurven die mittleren Barometerstände der Breitenkreise (nach der Berechnung von Teisserenc $\mathrm{DE}$ BoRT $^{9}$ ) in ihren positiven und negativen $\mathrm{Ab}$ weichungen von dem als normal geltenden Luftdruck im Meeresniveau $(760 \mathrm{~mm})$ zur Darstellung bringen, sind diese jahreszeitlichen Verschiebungen durch die punktierten Linien angedeutet. In der Nähe des mathematischen Äquators kann also ein Punkt zeitweise im Depressionsgürtel mit seinen variablen Winden und Stillen (Kalmengürtel) liegen und zeitweise unter die Herrschaft bald des NO-, bald des SO-Passates gelangen. Aber auch abgesehen davon

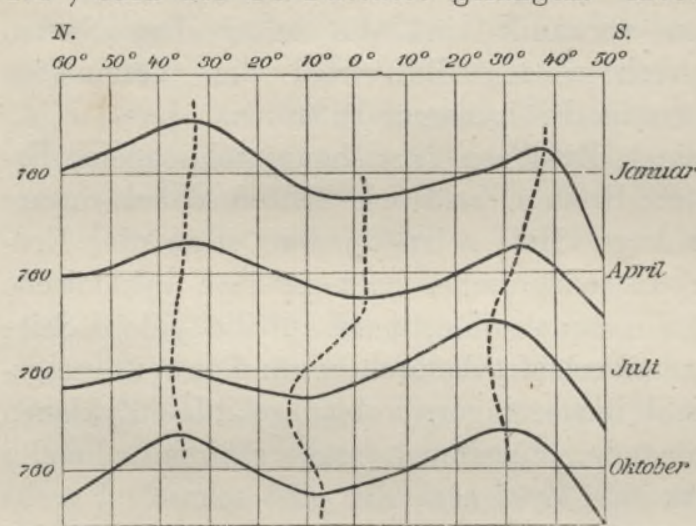

Fig. 33. Verteilung des Luftdruckes. (Die Abstände vom mittleren Luftdrucke $760 \mathrm{~mm}$ in $\mathrm{mm}$ entsprechend dem Barometerstande.) bedarf die Vorstellung von der Gleichmäßigkeit undRegelmäBigkeit der Passate einiger Einschränkung. Das Nebeneinander von Wasser und Land wirkt störend. Von einem ununterbrochenen Passatband kann man daher auf der nördlichen Hemisphäre niemals und auf der südlichen nur im Winter sprechen. Auch auf den Meeren ist der SO-Passat, entsprechend der bedeutenderen barometrischen Höhe des südsubtropischen Maximums, besser entwickelt als der NO-Passat. Die äquatorialen Depressionen bilden hier keine gleichmäßig breiten Bänder, sondern verschmälern sich von $\mathrm{O}$ nach W beträchtlich, und ebensowenig ist der Luftdruck in den subtropischen Hochdruckzonen gleichmäßig verbreitet, sondern verdichtet sich in der Nähe der Westküsten der Kontinente zu scharf umrissenen Antizyklonen. Daher kommt es, daß wir den Passat nur in den Osthälften der Meere ganz regelmäßig ausgebildet finden, während er im Westen eine rückläufige Bewegung annimmt. Der SO der Südhemisphäre, wo diese Erscheinung besonders kräftig ausgebildet ist, geht allmählich in $\mathrm{O}, \mathrm{NO}, \mathrm{NW}, \mathrm{W}$ über, so daß dadurch ein vollkommen geschlossener antizyklonischer Kreislauf um die subtropischen Maxima entsteht, und die Passate selbst nur als ein verlängerter Zweig desselben erscheinen. Daß auch die Passatzonen zeitweilig von Zyklonen durchfurcht werden, wurde schon oben erwähnt, und endlich unterliegen auch ihre polaren Grenzen häufigen unperiodischen Verschiebungen. 
Der in der höheren Atmosphäre von den Zyklonen nach den Antizyklonen ausströmenden Luft entspricht im Passatsystem der Antipassat, der als SW- (auf der südlichen Halbkugel NW) bis W-Wind von der äquatorialen Depression nach den subtropischen Hochdruckzonen zieht. Hohe Berggipfel, wie der Pic von Tenerife $(3700 \mathrm{~m})$, der Mauna Loa auf Hawaii $(4170 \mathrm{~m})$ und der Vulkan Misti in Peru $(6100 \mathrm{~m})$ ragen erfahrungsgemäß schon in die antipassatische Region hinein. Indes so einfach, wie man sich die tropische Windschichtung früher vorstellte, ist sie nicht. Aus den Ballonbeobachtungen geht hervor, daß sich auf dem offenen Atlantischen Ozean zwischen dem Passat, der nur bis $1000 \mathrm{~m}$ Höhe reicht, und dem Antipassat eine Zone von NW-Winden einschiebt, die von $8^{\circ} \mathrm{N}$ an nach $\mathrm{N}$ an Mächtigkeit zunimmt. Am thermischen Äquator fand man in der Höhe nur O-Wind. ${ }^{10}$

Allgemeine Luftzirkulation. Aus dem Wirrwarr der von Tag zu Tag wechselnden Luftdruckverteilung kann nur die Betrachtung der mittleren Zustände der Atmosphäre zur Erkenntnis der einfachen, leitenden Gesetze führen.

In letzter Linie ist der Luftdruck, d. h. das Gewicht der Luftsäule, die einer Quecksilbersäule von entsprechender Höhe (als normal nimmt man im Meeresniveau $760 \mathrm{~mm}$ an) das Gleichgewicht hält, eine Funktion der mittleren Temperatur der Luftsäule. Allerdings auch des Dampfgehaltes, denn Wasserdampf ist leichter als eine gleiche Quantität Luft, aber dieser Faktor hängt selbst unter sonst gleichen Umständen lediglich von der Wärme ab. Der Zusammenhang zwischen Luftdruck und Temperatur bedarf indes noch einer weiteren Erörterung. Am Äquator - wir lassen hier überall der Einfachheit wegen den thermischen und den mathematischen Äquator zusammenfallen - am Äquator tritt unter dem Einfluß beständiger hochgradiger Erwärmung eine Auflockerung der ganzen Luftmasse ein; die Flächen gleichen Druckes steigen in die Höhe, d. h. sie entfernen sich weiter von der Erdoberfläche als an den Polen. Dadurch wird der Luftdruck noch nicht vermindert, sondern erst durch die Folgeerscheinung. Es entsteht nämlich in den oberen Luftschichten eine Strömung, die der Abdachung vom Äquator zum Pol folgt. Vom Äquator wird Luft weggeführt - und nun sinkt hier der Luftdruck; an den Polen wird Luft angehäuft - und nun steigt hier der Luftdruck. Damit ist die Gleichgewichtsstörung aus den oberen Schichten in die unteren verlegt und erfordert nun einen Ausgleich durch eine Rückströmung. Auf der ruhenden Erde entstehen also zwei Meridionalströme: ein primärer Oberstrom vom Äquator zu den Polen und ein sekundärer Unterstrom von den Polen zum 
Äquator, beide durch Vertikalströme miteinander verbunden. In den höheren Breiten geht der Oberstrom durch eine absteigende Bewegung in den Unterstrom über, in den niederen Breiten der Unterstrom durch eine aufsteigende Bewegung in den Oberstrom. Damit ist der Kreislauf geschlossen.

Auf der ruhenden Erde mit homogener Oberfläche würde sich also die Luftdruckverteilung genau an die Temperaturverteilung anschließen, nur in umgekehrter Weise. Die Temperatur nimmt gegen die Pole hin stetig ab, der Luftdruck stetig zu.

Wenn wir aber aus den mittleren Jahresisobaren die Durchschnittsbarometerstände der Breitenkreise in derselben Weise ableiten, wie aus der Isothermenkarte die entsprechenden Durchschnittstemperaturen, so erhalten wir ein ganz anderes Bild (vgl. Fig. 27, S. 96). Statt einer barometrischen Depression am Äquator und zwei Hochdruckgebieten an den Polen bestehen in den untersten Luftschichten vier Hochdruckgebiete und drei Depressionen. ${ }^{\times}$

\begin{tabular}{|c|c|c|c|}
\hline Nordpolares (arktisches) Hochdruckgebiet & & $\begin{array}{r}\text { Breite } \\
\text {. } \quad\left(9^{\circ} \mathrm{N}\right.\end{array}$ & $\begin{array}{c}\text { Luftdruck } \\
\mathbf{7 6 0 , 7} \mathrm{mm})\end{array}$ \\
\hline Nördl. subpolare (subarktische) Depressionszone . & . & 66 & 758,2 \\
\hline Nördl. subtropische Hochdruckzone. . & . & 34 & 762,4 \\
\hline Äquatoriale Depressionszone . . . . . & & 8 & 757,8 \\
\hline Südl. subtropische Hochdruckzone. & . & $28 \mathrm{~S}$ & 763,7 \\
\hline üdl. subpolare (subantarktische) Depressionszone & & ? & ? \\
\hline üdpolares (antarktisches) Hochdruckgebie & & ? & ? \\
\hline
\end{tabular}

DaB die äquatoriale Depression auf der nördlichen Halbkugel liegt, kann nicht auffallen, wenn man erwägt, daß der thermische Äquator ebenfalls nach Norden verrückt ist. Auch die polaren Hochdruckgebiete sind thermisch begründet, umso rätselhafter erscheinen uns aber die subtropischen Hochdruck- und die subpolaren Depressionszonen. Zu ihrer Erklärung hat FerReL ${ }^{11}$ die Ablenkung durch die Erdrotation, also eine dynamische Kraft, zu Hilfe gerufen. Ihren Einfluß mag folgendes Beispiel erläutern.

Jeder Punkt am Äquator bewegt sich mit einer Geschwindigkeit von $(40070 \mathrm{~km}: 24 \times 3600=) 465 \mathrm{~m}$ in der Sekunde von West nach Ost. Jeder Körper mit dieser Geschwindigkeit verharrt hier in relativer Ruhe. Wird er aber, ohne durch Reibung an seiner Geschwindigkeit einzubüßen, nach $30^{\circ} \mathrm{B}$. versetzt, wo die Rotationsgeschwindigkeit nur $(34731 \mathrm{~km}: 24 \times 3600=) 402 \mathrm{~m}$ in der Sekunde beträgt, so behält er nicht nur seine ursprüngliche Geschwindigkeit bei, sondern er steigert sie noch bis zu $537 \mathrm{~m}$, weil er sich nun in

$\times$ Abgeleitet aus den Ferres'schen Zahlen durch graphische Interpolation. 
einem kleineren Kreis bewegt als am Äquator (vgl. S. 23). × Er bleibt nun nicht mehr in relativer Ruhe, sondern eilt mit einer Übergeschwindigkeit von $537-402=135 \mathrm{~m}$ in der Sek. den autochtonen Körpern des 30. Parallelkreises voraus. In $60^{\circ} \mathrm{B}$. würde diese sekundliche Übergeschwindigkeit $930-232=698 \mathrm{~m}$ betragen.

Wenden wir dieses Ergebnis auf den vom Äquator zu den Polen fließenden atmosphärischen Oberstrom an, so muß zunächst darauf aufmerksam gemacht werden, daß Reibung und Mischung verschieden bewegter Luftmassen dafür sorgen, daß sich keine solche Übergeschwindigkeiten entwickeln können, wie sie unsere Rechnung ergeben hat. Ein reiner westöstlicher Wirbel kann sich nicht herausbilden. Jedes Luftteilchen des Oberstroms bleibt unter dem Zwang zweier nach verschiedenen Richtungen wirkender Kräfte: der Gradient zieht es zum Pol, seine Übergeschwindigkeit lenkt es nach Ost ab, zieht es also gleichsam wieder zum Äquator zurück. Die Rechnung ergibt, daß sich diese beiden Komponenten in ungefähr $30-35^{\circ}$ B. das Gleichgewicht halten. Hier tritt also eine Stauung ein, eine Anhäufung von Luft (subtropische Hochdruckzonen). Weiter polwärts, wo die Übergeschwindigkeiten rasch wachsen, siegt die Ablenkungskomponente über die polare Anziehung, die Wirbelbewegung gelangt zu größerer Entfaltung, es entsteht gewissermaßen ein atmosphärischer Trichter, und auf dessen Grund muß der Luftdruck sein Minimum erreichen. Dieses Minimum ist die subpolare Depressionszone. Eigentlich sollte es mit den Polen zusammenfallen, hier aber greifen die thermischen Verhältnisse störend ein, jedoch nur in den untersten Luftschichten, in denen die Steigerung der Luftdrucks polare Winde hervorruft. Nach den Beobachtungen von DE Quervatn in Godthaab (1909) reicht der Nordwind nur einige hundert Meter hinauf und dann folgt bis $20000 \mathrm{~m}$ Höhe Südwind, und im antarktischen Viktorialand herrschen bereits auf dem Mt. Erebus (3890 m) Westwinde.

Von den vier Gliedern der Luftdruckverteilung sind also zwei die äquatoriale Depressionszone und das polare Hochdruckgebiet thermischen und zwei - die subtropische Hochdruckzone und die subpolare Depressionszone - dynamischen Ursprungs.

Aus dieser Anordnung ergeben sich in den untern Luftschichten drei fundamentale Windsysteme: ein äquatoriales oder passatisches zwischen $34^{\circ} \mathrm{N}$ und $28^{\circ} \mathrm{S}$ und zwei subpolare, wie es

$\times$ Die so erhaltene Geschwindigkeit $\left(G_{\varphi}\right)$ in der Breite $\varphi$ verhält sich zu der am Äquator umgekehrt wie die Halbmesser der betreffenden Parallelkreise:

$$
G_{\varphi}: 465=R \cdot r=R: R \cos \varphi ; G_{\varphi}=465: \cos \varphi .
$$


Fig. 34 darstellt. Nach der Ansicht von HiLdebrandsson ${ }^{12}$ ist das äquatoriale in sich geschlossen; dem Passat in den unteren Schichten entspricht der Antipassat in den oberen, und zwischen beiden vermitteln vertikale Luftbewegungen: eine aufsteigende in der äquatorialen Depressionszone und eine absteigende in beiden subtropischen Hochdruckzonen. Diese Gebiete sind an der Erdoberfläche durch Windstillen oder schwache, veränderliche Winde ausgezeichnet. DaB aber der Antipassat wenigstens zeitweise die Nordgrenze des Passats überschreitet, erhellt daraus, daß der vulkanische Staub des Krakatau

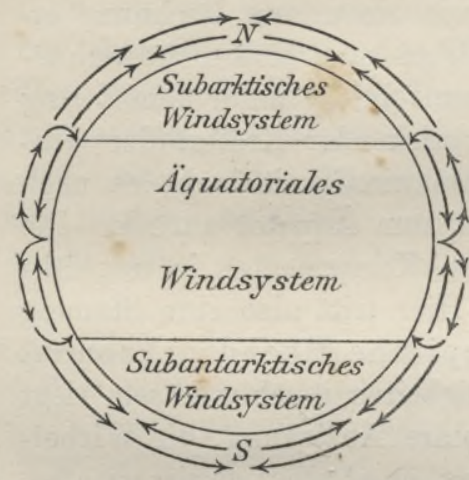

Fig. 34. Die meridionalen Komponenten der allgemeinen Luftzirkulation und ihre vertikalen Verbindungsglieder. und westindischer Feuerberge bis in unsere Breiten geführt wurde. In den höhern Luftschichten über den subpolaren Windsystemen herrscht aber, wie uns der Zug der Cirruswolken verrät, ausnahmslos Westbewegung, wie es der Theorie entspricht. Die Frage, wie die zu den Polen abströmende Luft wieder in die niederen Breiten zurückgelangt, hat noch keine völlig befriedigende Antwort gefunden. Aus Wolkenbeobachtungen schloB Hudebrandsson, daß auf unserer Halbkugel eine NW-Strömung über der Cirrusregion die Luft zur subtropischen Hochdruckzone zurückführt; vielleicht ist der NW-Wind über dem nordatlantischen Passat, von dem wir auf S. 125 gesprochen haben, eine Fortsetzung desselben, und dann wäre der Zirkulationsring zwischen Äquator und Pol geschlossen.

Bemerkenswert ist der Gegensatz der beiden subpolaren Depressionszonen, der in den von FERREL berechneten durchschnittlichen Barometerständen in drastischer Weise zutage tritt:

\begin{tabular}{|c|c|c|c|c|c|c|c|}
\hline Breite & $35^{\circ}$ & $40^{\circ}$ & $45^{0}$ & $50^{\circ}$ & $55^{0}$ & $60^{\circ}$ & $65^{0}$ \\
\hline & & & Luftdr & k 70 & $\mathrm{~mm}+$ & & \\
\hline & 62,4 & 62,0 & 61,5 & 60,7 & 59,7 & 58,7 & 58,2 \\
\hline Sü & 62,4 & 60,3 & 57,5 & 53,2 & 48,2 & 43,4 & 39,7 \\
\hline
\end{tabular}

Wir erblicken in diesem Gegensatz einen Ausdruck der verschiedenen Reibungswiderstände in den mittleren und höheren Breiten beider Halbkugeln, denn über der südhemisphärischen Wasserfläche muß der polare Wirbel zu viel kräftigerer Entfaltung gelangen als bei uns, wo Land und Wasser mehrfach wechseln.

Unsere bisherigen Erörterungen hatten eine homogene Erdoberfläche zur Voraussetzung. Nur auf einer solchen könnten De- 
pressions- und Hochdruckzonen ringförmig die ganze Erde umspannen. In Wirklichkeit wechseln aber mit Ausnahme des zirkumterranen Südmeers Land und Wasser in ostwestlicher Richtung miteinander $a b$, und daraus ergeben sich tiefgreifende Störungen der theoretischen Luftdruck- und Windsysteme.

Literaturnachweise. ${ }^{1}$ G. Wegrmann, Erweiterungen des barisehen Windgesetzes, in den Annalen der Hydrographie u. marit. Meteorologie 1904. ${ }^{2}$ E. Looms, im American Journal of Seience 1885, Bd. XXX, S. 9. Die ausführlichste Arbeit über die geographische Verteilung der Windgesehwindigkeit ist G. Hellmann, Untersuchungen über die jährliche Periode der Windgeschwindigkeit in der Meteorologisehen Zeitschrift 1897. - ${ }^{3}$ Meteorologische Zeitschrift 1903, S. 135. - ${ }^{4}$ Vgl. W. Trabert in der Meteorologisehen Zeitsehrift 1908 , S. 103. - ${ }^{5}$ J. HANN, Das Luftdruckmaximum vom November 1889, in den Denkschriften der Wiener Akademie der Wissenschaften, Math.-naturwiss. Kl. Bd. LVII, 1890. W. v. Bezowd, Zur Theorie der Zyklonen, in den Sitzungsberichten der Berliner Akademie der Wissensehaften 1890. - ${ }^{6} \mathrm{~F}$. H. BigeLow, The Mechanism of Countereurrents of different Temperatures in Cyclones and Anticyclones, im Monthly Weather Review, Washington 1903, Bd. XXXI. ${ }^{7}$ A. J. Henry, Climatology of the United States, Washington 1906. $-{ }^{8}$ R. ABERcrombx, Three Essays on Australian Weather; Sydney 1896. - ${ }^{9}$ L. Teisserenco DE BoRT, Répartition dè la pression atmosphèrique à la surface du globe, in Comptes rendus de l'Académie des Sciences, Paris 1889 (S. 878). ${ }^{10}$ L. Teisserenc DE Bort und L. Roton, Étude de l'atmosphère marine par sondages aériens, Paris 1909. - ${ }^{11}$ Zur Einführung (ohne Zuhilfenahme der höheren Mathematik) dient W. Ferres, A Popular Treatise on the Winds; London 1889. Für die Theorie der allgemeinen Luftzirkulation sind ferner wichtig H. v. Нецмногтz, Über atmosphärisehe Bewegungen, in den Sitzungsberichten der Berliner Akademie der Wissenschaften 1888 u. 1889; M. Mörıer, Zur Dynamik der Atmosphäre, in der Meteorologisehen Zeitschrift 1893; W. Köppes, Über den Rücktransport der Luft nach niedrigen Breiten in den gemäBigten Zonen, in den Annalen der Hydrographie 1899. Eine gute Zusammenstellung ist M. Brillourn, Mémoires originaux sur la eireulation générale de l'atmosphère, Paris 1900. - ${ }^{12} \mathrm{H}$. Hudebrandsson, Rapport sur les observations internationales des nuages; Upsala 1903.

\section{Luftdruck- und Windverteilung in den extremen Jahreszeiten. ${ }^{1}$}

(Siehe Karte X und XI. Vgl, auch Tafel VI und VII.)

Die Isobarenkarten. In derselben Weise, wie einst Dove die mittlere Temperaturverteilung in den Monaten und im Jahresdurchschnitt kartographisch durch Isothermen darstellte, hat Buctan Isobaren- und Windkarten entworfen, die uns die mittleren Druckund Bewegungszustände des Luftmeeres vor Augen führen. Dieser Versuch ist für das Jahr und die extremen Monate (Januar und Juli) von verschiedenen Seiten, für alle Monate aber nur noch einmal, und zwar von Buchan ${ }^{2}$ selbst wiederholt worden. Indes leiden diese Karten an verschiedenen Mängeln. HaNN mußte-1886 das Geständnis 
ablegen, daß „die Kurven (mittleren Isobaren), die mit vorhandenem guten Material konstruiert werden können, so umfassender Interpolationen bedürfen, daß sie eigentlich mehr eine Darstellung unserer Vorstellungen von der Verteilung des Luftdruckes sind, als der Ausdruck von Tatsachen". Trotz dieses skeptischen Urteils dürfen wir aber wohl sagen, daß die Isobarenkarten wenigstens im großen und ganzen der Wirklichkeit entsprechen, wenn wir auch genaue, ganz zuverlässige Darstellungen nur von sehr wenigen Gegenden ${ }^{3}$ besitzen. Ein weiterer Übelstand liegt darin, daß wir die mittlere Luftdruckverteilung mit den vorherrschenden Winden in Vergleich setzen, also einen Mittelwert mit einem Scheitelwert. Die bisherigen Versuche, die mittlere Windrichtung eines Ortes festzustellen, haben zu keinem befriedigenden Ergebnis geführt, und ebensowenig sind wir imstand, die sehr maßgebenden örtlichen Einflüsse auf die Drehung der. Windfahne zu beseitigen. Indes treten diese Übelstände mehr in Detailuntersuchungen störend zutage, als bei der Feststellung' der Hauptwindgebiete in den extremen Jahreszeiten, womit wir es hier zu tun haben.

Die südliche subtropische Hochdruckzone und das subantarktische Windsystem. Es empfiehlt sich, mit demjenigen Teil der Erde zu beginnen, der sich am meisten der Voraussetzung einer homogenen Oberfläche nähert. Von Februar bis November (s. Taf. XI) umschlingt die subtropische Hochdruckzone bandartig Land und Meer, aber in der Nähe der abnormal kältesten Gebiete entwickeln sich Kerne höhern Luftdrucks mit antizyklonischen Winden. Dagegen ist sie in den Sommermonaten Dezember und Januar auf die Meere beschränkt, während über den wärmeren Kontinenten flache Zyklone lagern: das erste Beispiel einer thermischen Störung der fundamentalen Luftdruckzonen (s. Taf. X).

Entsprechend der jahreszeitlichen Verschiebung der subtropischen Hochdruckzone beginnt das subantarktische Windgebiet in etwa 45 , im Winter in $40^{\circ}$ B. Hier scheint in der Tat die Depressionszone, wenn auch nicht durchwegs, die Form einer Mulde oder Rinne beibehalten zu haben. Die Südgrenze der W- und NWWinde wurde von der deutschen „Valdivia“-Expedition im Jahr 1898 südlich vom Kapland in $55^{\circ}$ und südlich von Kerguelen in $56^{1} /{ }^{0}$ B. überschritten. Dann folgte bis $60^{\circ} \mathrm{B}$. eine Kalmenzone mit flauen, veränderlichen Winden, und südlich vom 60. Parallel betrat die „Valdivia“ bereits das Gebiet der polaren Antizyklone mit östlichen und südöstlichen Luftströmungen. Weiter östlich durchquerte die „Gauß"-Expedition die barometrische Rinne erst in $65^{1} / 4\left(85^{1} /{ }^{0} \mathrm{O}\right)$ und $63{ }^{1} / 2{ }^{0} \mathrm{~S}\left(96^{\circ} \mathrm{O}\right)$. Die deutsche Beobachtungsstation in Kaiser- 
Wilhelm II.-Land $\left(66^{\circ} \mathrm{S}, 89,6^{\circ} \mathrm{O}\right)$ und die englischen Stationen sowohl am Kap Adare $\left(71,3^{\circ} \mathrm{S}, 170^{\circ} \mathrm{O}\right)$ wie im Discoveryhafen $\left(77,8^{0} \mathrm{~S}, 166,8^{\circ} \mathrm{O}\right)$ standen das ganze Jahr unter der Herrschaft der polaren Antizyklone; dagegen zeigen die Tabellen der „Belgica“ in durchschnittlich $70^{1} /{ }^{0} \mathrm{~S}, 86^{\circ} \mathrm{W}$ im Jahr $1898-99$ vorwaltende Polarwinde im Sommer und ebenso überwiegende Äquatorialwinde im Winter. Die Grenze zwischen den beiden Gliedern des subantarktischen Windsystems lag hier im Sommer nördlich, im Winter aber südlich vom 70. Parallel, dagegen in den Meridianen des KaiserWilhelm II.- und des Viktorialandes immer nördlich von dem genannten Breitenkreis. Die südpolare Antizyklone mit der sie umschließenden barometrischen Rinne erleidet also jahreszeitliche Verschiebungen, ihr Kern verrückt sich im Sommer gegen den Pol, im Winter gegen die östliche Halbkugel, und hier ist der eisbedeckte antarktische Kontinent $\mathrm{zu}$ suchen, denn erfahrungsgemäß entwickeln sich winterliche Barometermaxima abseits vom Pol nur auf größeren, intensiv erkaltenden Landmassen. ${ }^{4}$

Südlich von Amerika springt das westantarktische Land meridional nach $\mathrm{N}$ vor, und überall, wo solches vorkommt, erleidet die bandartige Anordnung der Luftdruckzonen Störungen. Hier treten, wie MeckIng $^{5}$ es wahrscheinlich gemacht hat, an die Stelle der barometrischen Rinne zyklonale Gebilde, im Sommer zu beiden Seiten des eisbedeckten Landes, im Winter aber nur in dem wärmeren Weddellmeer.

Das Passatgebiet und die nördliche Halbkugel im nördlichen Winter (s. Karte X). Der charakteristische Zug dieser Jahreszeit ist die Auflösung der subarktischen Depressionszone.

Im Band hohen Luftdruckes, das sich vom Dezember bis zum März um unsere Halbkugel schlingt, liegen vier antizyklonische Zentren: zwei, von denen die NO-Passate ausgehen, am Rande der Tropenzone, und zwar das atlantische im S der Azoren, das pazifische nordöstlich von Hawaii, die beiden anderen dagegen auf den Kontinenten in der Nähe der Gebiete gröBter negativer Wärmeanomalie. Das ostsibirische Maximum ist um $10 \mathrm{~mm}$ höher als das nordamerikanische, denn dort sinkt die Temperatur um $24^{\circ}$, hier nur um $10^{\circ}$ unter den Breiter.lurchschnitt. Die Isobaren von 775 bis $765 \mathrm{~mm}$ buchten sich auf der Ostfeste scharf nach W aus, und ähnliche Krümmungen zeigen auch die Isanomalen.

Das äquatoriale Minimum liegt auf dem Atlantischen und dem Pazifischer Ozean nördlich vom Gleicher, nur auf dem warmen Indischen Ozean ist es mit der Sonne etwas nach $\mathrm{S}$ gewandert.

Hoher Luftdruck breitet sich über die ganzen Nordkontinente 
aus und schließt sich im nördlichen Polarmeer zu der allmählich nach W sich verschiebenden arktischen Windscheide ${ }^{6}$ zusammen. Auf diese Weise werden zwei subpolare Gebiete niederen Barometerstandes, deren Minima bei Island und den Alëuten, also in der Nähe der relativ wärmsten Gegenden unserer Hemisphäre liegen, vollständig abgegrenzt. Auch hier ist wieder der Zusammenhang mit der Temperaturverteilung deutlich ausgeprägt. Die größere Tiefe des nordatlantischen Minimums ist durch den höheren Grad der positiven Anomalie bedingt, und auch die Biegungen der Isobaren sind in den Isanomalen vorgezeichnet, wie beispielsweise das wichtige Teilminimum in der Davisstraße.

Der thermische Gegensatz von West und Ost, der das Winterklima unserer Halbkugel beherrscht, kommt auch darin zum Ausdruck, daß in derselben Richtung Windsysteme von entgegengesetztem Charakter einander ablösen. Auf die nordatlantische Zyklone folgt die ostasiatische Antizyklone, dann die nordpazifische Zyklone und endlich die nordamerikanische Antizyklone. Eine Linie, die auf den Meeren ungefähr mit dem 30. Parallel zusammenfällt, auf den Kontinenten aber - wie Karte X zeigt - beträchtlich höher ansteigt, bildet, gleichsam wie ein barometrisches Gebirge, die Hauptwindscheide zwischen den vier nördlichen und den südlichen Systemen.

Von jenen ist die nordatlantische Zyklone für uns am wichtigsten, überdies auch am eingehendsten erforscht. Eine von den Bermudas gegen Island gezogene Linie trennt die Polar- von der Äquatorialseite. Auf der letzteren herrschen südliche und westliche Winde vor, welche die höhere Lufttemperatur über der Atlantischen Strömung, größere Feuchtigkeit und reichlichere Niederschläge über das mittlere und polare Europa bis nach Westsibirien verbreiten, aber natürlich in immer geringerem $\mathrm{MaB}$, je weiter sich die ozeanischen Winde von ihrer Ursprungsstätte entfernen, und je mehr kontinentale Luftmassen in den Wirbel hineingezogen werden. Die umstehende Tabelle, welche die mittlere Differenz der Polar- (-)

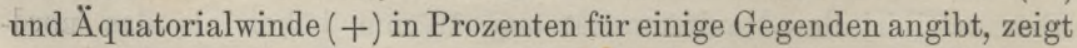
uns am besten den Kontrast zwischen den beiden Seiten der Zyklone.

Man ersieht aus dieser Tabelle, daB in Europa nicht alle Gegenden gleichmäßig begünstigt sind. England und das südliche und östliche Skandinavien haben im Osten und Süden wärmere Meeresflächen, die häufig der Schauplatz von Zyklonenbildungen sind, aber ohne auf unseren Isobarenkarten als Teilminima klar hervorzutreten. Jene Lokalitäten liegen daher oft auf der Polarseite von Barometerdepressionen. In Nordamerika nimmt die Häufigkeit 
Neu-England

Küste von New York bis zur Chesapeakebai .

Küste von der Chesapeakebai bis Savannah

Hudsontal

Seenregion

Ohio und Tennessee . . . . +11,0

Oberes Mississippital.

$-31,4$
$-21,1$
$-9,0$
$-9,2$
$+4,6$
$+11,0$
$-4,0$

Irland

$+20,0$

Schottland . . . . . $+26,8$

England . . . . . . . + 7,5

Norwegische Westküste . . . $+33,6$

Norwegische Südküste . . . $-\mathbf{1 5 , 0}$

Südsehweden . . . . . $+9,5$

Baltische NW-Küste . . . . + $+3,0$

Belgien und Nordfrankreich . $+22,2$

Französische Westküste . . + 8,3

Niederlande, Deutschland und

Dänemark . . . . . . . $+26,2$

Nordalpen (Rigi und Schafberg) . . . . . . $+21,5$

Inneres Böhmen . . . . . $+15,0$

Nordabhang der Karpathen : $+10,3$

Ostseeprovinzen und Finnland $+27,3$

NordruBland . . . . . . $+21,0$

Zentralrußland . . . . . $+23,5$

Westsibirien . . . . . $+20,0$

der nördlichen Winde nach Süden rasch ab (und infolgedessen die Temperatur ebenso rasch zu), ja stellenweise herrschen sogar die Äquatorialwinde, wenn auch nicht bedeutend vor. Dies erklärt sich aus der regelmäßigen Wanderung von Zyklonen aus dem Innern der Vereinsstaaten gegen Osten, wodurch ihre Zugstraßen, sowie die südlich davon gelegenen Landstriche häufig der Wohltat äquatorialer Winde teilhaftig werden.

Die nordpazifische Zyklone unterscheidet sich von der atlantischen in einigen wesentlichen Punkten. Sie umfaßt auf der einen Seite die Ostabdachung Asiens, auf der anderen den schmalen pazifischen Rand von Nordamerika. Ihre kontinental abgeschlossene Nordseite ist viel ausgebildeter als die offene der atlantischen Zyklone; überall in der Umgebung der Beringstraße herrschen Polarwinde vor, wie die Vega-Expedition bestätigen konnte. Aus dem gleichen Grund liegt das Minimum hier wenigstens 10 Breitengrade südlicher als im Atlantischen Ozean; Alaska befindet sich schon auf der Polarseite, während Skandinavien noch auf der Äquatorialseite liegt. Die letztere ist also in der Neuen Welt in nordsüdlicher Richtung beschränkter als in der Alten Welt, aber auch gegen Osten hin, weil Gebirge ein tieferes Eindringen nicht gestatten. Ein ebenso bemerkenswerter Unterschied liegt in der gleichförmigen Entwicklung der Polarseite bis an den Wendekreis. Eine Linie von den Bonininseln zu den Alëuten trennt sie yon der äquatorialen. 
Polarseite,

Ochotskische Küste und Kamtsehatka

Sachalin, Japan und China
$-41,5$ $-46,7$
Äquatorialseite.

Pazifische Küste von Nordamerika $+15,7$ $+18,0$

Ein Vergleich mit den auf S. 133 mitgeteilten Zahlen zeigt uns deutlich, daß das östliche Nordamerika in den mittleren Breiten ungleich begünstigter ist als das östliche Asien. Hier nimmt die Temperatur nicht so rasch nach Süden zu; Schanghai hat nur eine mittlere Januartemperatur von $2,8^{0}$. Noch schärfer tritt der Gegensatz in den Niederschlagsverhältnissen hervor, wie wir später sehen werden. Woher dieser Unterschied? Offenbar findet in Ostasien keine so lebhafte Zyklonenbewegung statt wie in den Vereinigten Staaten. Alle Bewegung nimmt in diesen Breiten eine östliche Richtung, und in dieser stößt sie auf hohe Gebirge. Ebensolche verhindern auch den Abfluß der Luft nach Süden. So gewinnt die sibirische Antizyklone eine größere Festigkeit als die nordamerikanische, und dadurch ist wohl auch zum Teil die abnorme Höhe des Luftdruckes bedingt. $\times$

Außer den beiden genannten Antizyklonen dürfte sich noch eine dritte im Gebiet des arktischen Kältepols befinden. Darauf deuten die sehr beständigen NW-Winde hin, die das ganze arktische Amerika bis in die Baffinbai und Davisstraße überwehen.

An der Hauptwindscheide finden wir schwankende Strömungsverhältnisse, da sich die Grenzen der Windgebiete, der Beweglichkeit des Elementes entsprechend, beständig verschieben. Je weiter wir aber gegen Süden vordringen, desto mehr nimmt die Luftzirkulation einen passatischen Charakter an. Die Polargrenze des eigentlichen NOPassates liegt im Osten und Westen des Atlantischen Ozeans in ungefähr $26^{\circ} \mathrm{B}$. und sinkt in der Mitte auf etwa $18^{\circ}$ herab; die westliche Sahara auf der einen Seite, und Zentralamerika und der nördliche Teil von Südamerika auf der anderen gehören noch diesem Gebiet an. Auch im Pazifischen Ozean treffen wir den ausgebildeten Passat erst jenseits des 30. Parallels im Osten und des 21.-25. im Westen an. In der östlichen Sahara, in Arabien und in Mesopotamien zieht eine sehr beständige NW-Strömung zum Indischen Ozean. In Zentralasien beginnt das passatische System erst jenseits des Himalaya, der weit in die Region der antipassatischen Strömung hineinragt; diesseits desselben bis zum 50. Breitengrad ist ein Über-

× Der höchste Luftdruck, der bisher überhaupt auf der Erde verzeichnet wurde, wurde nach WoErkow am 23. Januar 1900 in Barnaul beobachtet: $\mathbf{7 8 9 , 2} \mathrm{mm}$, oder auf das Meeresniveau reduziert $808,7 \mathrm{~mm}$. 
gangsgebiet mit schwankenden Winden, unter denen jedoch die polaren vorherrschen. Wie hier das Relief des Erdbodens die Passatgrenze nach Süden schiebt, so rückt im Westen das Mittelmeer die Hauptwindscheide nach Norden. Auch hier nimmt der Luftdruck vom Festland gegen die See ab; aber das vielfach gegliederte Mittelmeer beherbergt mehrere Minima, und die Windverhältnisse sind daher ziemlich komplizierter Natur. Doch herrschen an den nördlichen und westlichen Küsten im allgemeinen nördliche und an den südlichen südliche Winde vor.

Jenseits des Himalaya fließt die Luft durch die großen Täler des Ganges und Brahmaputra zum Indischen Ozean, wo die Strömung erst die regelmäßige passatische Richtung annimmt. Überall wo der Kalmengürtel im Süden des Äquators liegt, also im ganzen Indischen Ozean und in der westlichen Südsee, dringt der NO-Passat auf die Südhemisphäre hinüber bis ungefähr $10^{\circ} \mathrm{B}$. und in Australien noch weiter. Er wird hier durch die Rotation in einen NW- bis W-Wind umgewandelt, und daher im malaiischen Archipel und in Australien als NW- oder Australmonsun bezeichnet. Unter dem Ausdruck Monsun (vom arabischen mausim = Jahreszeit) versteht man einen semesterweise wechselnden Wind; so führt auch der indische Passat den Name NO-Monsun, nur weil er im Sommer vom SW-Monsun abgelöst wird.

Der SO-Passat überschreitet in dieser Jahreszeit (Sommer) nur in den östlichen Teilen des Atlantischen und Pazifischen Ozeans den Äquator, während er sonst von dem nördlichen Passat bis etwa $10^{\circ} \mathrm{s}$. B. zurückgedrängt wird. Er erreicht seine höchste Breite $\left(33-34^{\circ}\right)$ im Gebiet der subtropischen Maxima, und von da nähert sich seine Polargrenze immer mehr dem Äquator. Im Osten wird er durch die benachbarten kontinentalen Minima in SW umgewandelt (besonders deutlich ist diese Ablenkung an der afrikanischen Westküste ausgebildet), im Westen vollzieht sich (ebenfalls unter dem Einfluß jener Minima) die schon auf S. 124 geschilderte Umkehrung, wodurch die antizyklonische Bewegung um die subtropischen Maxima geschlossen wird. Nirgends und niemals ist dieses Phänomen kräftiger ausgebildet, als in dieser Jahreszeit auf der Südhemisphäre. Wir finden sie sogar mitten in der Südsee wieder, wo das östliche Passatgebiet von dem schwächer entwickelten westlichen durch ein Band des rückkehrenden Passats getrennt ist.

Das Passatgebiet und die nördliche Halbkugel im nördlichen Sommer. (Karte XI.) Der April ist für die nördliche Halbkugel ein Übergangsmonat. Im Mai weicht schon die Zone hohen Luftdruckes gegen N zurück, und der äquatoriale Gürtel niederen Lufdrucks 
dringt von $\mathrm{S}$ aus vor. Im Juli und August ist die sommerliche Verteilung des Barometerstandes, von der wir sogleich sprechen werden, zur höchsten Ausbildung gelangt.

Lassen wir die Alte Welt vorläufig außer Betracht. Die Südgrenze des Passatgürtels liegt in ungefähr $30^{\circ} \mathrm{S}$, etwas nördlicher als im Januar. Das äquatoriale Minimum ist mit dem thermischen Äquator allenthalben nach Norden gerückt, im Mittel bis $10^{\circ} \mathrm{N}$, nur an den Westseiten der Festländer bis $15-20^{\circ} \mathrm{N}$. Überall folgt ihm der SO-Passat auf unsere Hemisphäre und wird in der Nähe der erhitzten östlichen Festländer in SW umgewandelt. Auch die subtropischen Maxima liegen nördlicher als im Winter, unter ungefähr $40^{\circ}$ B., und damit verschiebt sich die Hauptwindscheide in höhere Breiten. Auf den Kontinenten, die wärmer als das Meer in gleicher Breite sind, biegen sich die Isobaren nach Süden um, und der Luftdruck nimmt landeinwärts ab; daher sinkt die Hauptwindscheide in Amerika bis zum 20. Parallel, und in der Alten Welt verschwindet sie völlig.

Die nordhemisphärische Passatzone reicht im Sommer nur von der Saharaküste westwärts ungefähr bis zum Meridian von Sachalin. Thre Polargrenze liegt auf den Meeren durchschnittlich in $28^{\circ}$ B., steigt aber im Osten über $30^{\circ}$ an. Die Nähe der erhitzten Kontinentalflächen erzeugt eine vollständige antizyklonische Bewegung um die subtropischen Maxima, wie wir sie bisher nur auf der Südhemisphäre beobachten konnten.

In den mittleren und höheren Breiten lagern vier zyklonische Windgebiete nebeneinander, nur das der Alten Welt reicht auch in die Tropenzone hinein. Eine strenge Scheidung durch ausgedehnte antizyklonische Systeme findet nur in den mittleren Breiten statt, in den höheren treten die Windscheiden nur auf sehr detaillierten Isobarenkarten deutlich hervor. Außerdem sind die Winde nicht so stark wie im Winter, denn die Druckdifferenzen sind nach allen Richtungen kleiner, ebenso wie die Temperaturunterschiede. Sie sind auch in den höheren Breiten von geringerer klimatologischer Bedeutung als im Winter, weil die Verteilung der Temperatur hauptsächlich durch die Insolation bedingt wird, und es genügt daher eine nur flüchtige Betrachtung derselben.

Im nordatlantischen. Zyklonengebiet liegt das Minimum östlich von Island. Amerika östlich vom Mississippi und von einer Linie, die man sich zwischen der Seeregion und der Hudsonbai nach Nordwesten gezogen denkt, ferner der Atlantische Ozean nördlich einer Linie von Florida bis Frankreich, die britischen Inseln, Frankreich und das westliche Deutschland gehören dazu. Im Norden 
der Linie Jamesbai-Island herrschen Polar-, südlich davon Äquatorialwinde vor. Die Nähe der großen ostkontinentalen Barometerdepression macht sich auch hier insofern geltend, als in Westeuropa die Polarströmung häufiger ist als im Winter. Über die Lage des Minimums in der pazifischen Zyklone ist nichts Genaues bekannt. Die amerikanische Zyklone zieht S- und SO-Winde aus dem Golf von Mexico an, die das ganze Prärienplateau überströmen, und erzeugt anderseits NW-Winde an der pazifischen Küste. Weitaus am wichtigsten ist aber das Zyklonengebiet der Alten Welt. Das Hauptminimum verlegt HaNN nach Iran und in das Indusgebiet, aber die Biegungen der Isobare von $755 \mathrm{~mm}$ verraten nicht minder wichtige Teilminima im östlichen Sibirien und in der Sahara. ${ }^{x}$ Überall ist in den weiten erhitzten Ebenen Gelegenheit zur Bildung barometrischer Minima vorhanden, an allen Seiten saugt der Kontinent Luft ein, wie er im Winter Luft ausatmet. Im Süden wird das einzige Beispiel dieser Art - der indische NO-Passat völlig unterdrückt, und der SO-Passat über den Äquator herübergezogen und durch die Erdrotation in den SW-Monsun verwandelt. Talaufwärts strömt dieser in Hindustan bis zur großen Himalaya-Barriere, ja in tieferen Einschnitten vielleicht auch darüber hinweg. Nach Westen herrscht er bis Arabien, nach Osten bis zu den Philippinen. In der Sahara dringt der SO-Passat bis gegen $20^{\circ} \mathrm{N}$ vor; in China, Japan und auf dem benachbarten Festland löst der SO-Wind den winterlichen NW ab. Auf der anderen Seite des großen Depressionsgebietes herrschen von dem östlichen Deutschland und der Balkanhalbinsel bis Sibirien und Turan polare Strömungen vor.

Dasselbe Gesetz, das hier die Luftzirkulation über einem Drittel der Erdoberfläche regelt, macht sich auch im kleinen geltend. Skandinavien und die iberische Halbinsel sind ebenfalls abgeschlossene Zyklonengebiete, wie im Winter kleine antizyklonische Zentren. Auch Italien zieht Seewinde an, während im südlichen Mittelmeer nördliche Winde zur Sahara ziehen.

Überblicken wir noch einmal die Luftdruckverteilung in den extremen Jahreszeiten. Überall, wo in ostwestlicher Richtung Land und Meer wechseln, ist die fundamentale Ordnung nur auf den Meeren zu suchen. Nur hier folgen stets äquatoriales Minimum, subtropisches Maximum, subpolares Minimum und polares Maximum

$\times$ In Asien unterscheidet A. WoErkow, der die übliche Isobarendarstellung mit Reduktion des Luftdrucks auf das Meeresniveau im Gebiet der großen Hochflächen für unstatthaft erklärt, drei Depressionszentren: das indische im $\mathrm{S}$ des Himalaya, das zentralasiatische im Tarimbecken und das turkestanische (Meteorologische Zeitschrift 1904,' S. 502). 
aufeinander. Sie sind permanent, wandern aber mit der Sonne. Die Festländer beherbergen dagegen in der warmen Jahreszeit Minima und in der kalten Maxima. Diese zyklonischen und antizyklonischen Gebilde sind thermischer Natur und daher periodisch.

Die Änderungen vom Winter zum Sommer zeigt folgende schematische Übersicht der Hauptwindgebiete:

\begin{tabular}{|cccc|}
\hline \multicolumn{4}{|c|}{ Nördlicher Winter. } \\
\hline \hline $\begin{array}{c}\text { Nordpazifische } \\
\text { Zyklone }\end{array}$ & $\begin{array}{c}\text { Nordamerik. } \\
\text { Antizyklone }\end{array}$ & $\begin{array}{c}\text { Nordatlantische } \\
\text { Zyklone }\end{array}$ & $\begin{array}{c}\text { Ostasiatische } \\
\text { Antizyklone }\end{array}$ \\
\hline $\begin{array}{c}\text { Nordpazifisches } \\
\text { Passatgebiet }\end{array}$ & $\begin{array}{c}\text { Nordatlantisches } \\
\text { Passatgebiet }\end{array}$ & $\begin{array}{c}\text { Mittelmeer- } \\
\text { Gebiet) }\end{array}$ & $\begin{array}{c}\text { Nordindisches } \\
\text { Passatgebiet }\end{array}$ \\
\hline $\begin{array}{c}\text { West- u. Ostpazif. } \\
\text { Passatgebiet }\end{array}$ & $\begin{array}{c}\text { Südamerik. Südatlant. Südafrikan. Südindisches Austral. } \\
\text { Zyklone }\end{array}$ & Passatgebiet Zyklone & Passatgebiet Zyklone \\
\hline \multicolumn{4}{c}{ Subantarktisches Windgebiet. } \\
\hline
\end{tabular}

\begin{tabular}{|ccc|}
\hline $\begin{array}{c}\text { Nordpazifische } \\
\text { Zyklone }\end{array}$ & $\begin{array}{c}\text { Nordamerikanische } \\
\text { Zyklone }\end{array}$ & $\begin{array}{c}\text { Nordatlantische } \\
\text { Zyklone }\end{array}$ \\
Nordpazifisches & Nordatlantisches & Zyklonengebiet \\
Passatgebiet & Passatgebiet & \\
der Alten Welt \\
Südpazifisches & Südatlantisches & Südindisehes \\
Passatgebiet & Passatgebiet & Passatgebiet \\
\hline & Subantarktisches Windgebiet. & \\
\hline
\end{tabular}

Mittlere monatliche Barometerschwankungen. Wie die Wärmeschwankungen, so sind auch die mittleren Schwankungen des Luftdrucks ein bedeutungsvolles klimatisches Element, und es ist das Verdienst KöPPEN's ${ }^{8}$, sie zuerst kartographisch dargestellt zu haben. Je größer sie sind, desto unruhiger ist durchschnittlich das Wetter, desto steiler ist wahrscheinlich der Gradient, und desto stärker sind die Winde. Auf der Nordhemisphäre nimmt die durchschnittliche monatliche Barometerschwankung vom Äquator bis zum 60. Parallel, der Gegend der subpolaren Minima, zu, dann wieder ab. Überall ist sie im Winter größer als im Sommer, aber die Differenz der winterlichen und sommerlichen Schwankung ist in der Tropenzone auf den Kontinenten, und von $30^{\circ}$ B. ab auf dem Meer beträchtlicher. Vergleichen wir Meer und Festland miteinander, so ergibt sich ein sehr bemerkenswerter Gegensatz. Bis zum 20. Parallel ist das Wetter auf dem Meer im Gebiet des regelmäBigen Passats 
stets beständiger als auf den Kontinenten, nördlich vom $30^{\circ} \mathrm{B}$. ist umgekehrt das maritime Wetter schwankender. Zwischen 20 und $30^{\circ}$ ist eine Übergangszone. Mit der Polargrenze des Passats steigt im Sommer der tropische Typus bis zu $30^{\circ}$ B., und sinkt im Winter der Typus der gemäBigten Zone bis $20^{\circ} \mathrm{B}$. hinab.

Für die Südhemisphäre ist das Beobachtungsmaterial noch ganz unzureichend, jedoch ist der Schluß gestattet, daß hier dasselbe Gesetz der Abhängigkeit von der Breite wirksam ist, wie auf der nördlichen Halbkugel. Die Schwankungen scheinen aber beträchtlicher zu sein, namentlich wenn wir die Sommer miteinander vergleichen. Es zeigt sich also auch hier wieder, daß die barometrischen Gradienten der mittleren und höheren südlichen Breiten steiler sind, und in der Tat berichten alle, die die antarktische See durchfahren haben, von dem stürmischen Charakter der dort herrschenden Westwinde.

\section{Die periodischen Luftmassenverschiebungen und die Breiten-} schwankungen. Vergleicht man die wirklichen (nicht auf das Meeresniveau reduzierten) Barometerstände der extremen Monate miteinander, so ergibt sich das überraschende Resultat, daß sich die Unterschiede auf keiner von beiden Halbkugeln ausgleichen. Auf der nördlichen ist der mittlere Luftdruck im Januar nur 0,75 mm höher als im Juli, während auf der südlichen das Gegenteil stattfindet. Dieses Plus entspricht einer Luftmasse von $2600 \mathrm{cbkm}$ (oder Billionen $\mathrm{kg}$ ), die in unserm Winter von der südlichen Hemisphäre auf die nördliche und in unserm Sommer in der umgekehrten Richtung wandert. ${ }^{8}$

Auf diese Verschiebungen führt SpItaLer die kleinen Schwankungen der Erdachse zurück, deren Kenntnis sich uns erst in den letzten Jahrzehnten des 19. Jahrhunderts erschlossen hat. ${ }^{9}$ Bis dahin nahm man die geographische Breite als unveränderlich oder mit anderen Worten, die beiden Pole als Fixpunkte an. In Wirklichkeit führt aber der Nordpol in durchschnittlich 14 Monaten einen Umlauf um seine mittlere Lage aus, entfernt sich aber davon nach den bisherigen Beobachtungen nur bis auf etwa $\pm 0,15$ Bogensekunden oder $5 \mathrm{~m}$. In dieser Bewegung steckt aber noch eine, von Krmuka entdeckte kleine, jährliche Welle, die jedenfalls nicht durch meteorologische Prozesse hervorgerufen wird. ${ }^{10}$ Es möge nur noch bemerkt werden, daß so geringfügige Schwankungen der geographischen Breiten natürlich ohne merklischen Einfluß auf die physikalischen Verhältnisse der Erdoberfläche sind, wenigstens soweit sie für den Geographen in Betracht kommen; sie haben nichts zu tun mit jenen gewaltigen Polverschiebungen, mit denen spekulative Geologen in neuester Zeit in so verschwenderischer Weise operieren. 
Literaturnachweise. ${ }^{1}$ A. Supan, Statistik der unteren Luftströmungen; Leipzig 1881. - ${ }^{2}$ A. Buchan, Monats- und Jahresisobaren im Challenger-Werk zit. S. 102, Anm. 6, und in"Bartholmew's Physical Atlas zit. S. 56. $-{ }^{3}$ Noch unerreichtes Muster ist J. HaNn, Die Verteilung des Luftdruckes über Mittelund Südeuropa; Wien 1887. Für die Methode der Bearbeitung mariner Beobachtungen ist G. RuNG, Répartition de la pressure atmosphèrique sur l'océan atlantique septentrional, Kopenhagen 1894, maBgebend. $-{ }^{4}$ A. SuPAN, zit. S. 102, Anm. 8. - ${ }^{5}$ L. Mecking, Zum antarktischen Klima, in Petermann's Mitteilungen 1909. - ${ }^{6}$ A. Supax ebenda 1891, S. 191. - ${ }^{7}$ W. Köppen, Die monatlichen Barometerschwankungen, in den Annalen der Hydrographie und maritimen Meteorologie 1882. $-{ }^{8}$ R. Spitaler, Die periodischen Luftmassenverschiebungen und ihr Einfluß auf die Lagenänderungen der Erdachse; Gotha 1901 (Ergänzungsheft 137 zu Petermann's Mitteilungen). O. Baschin in der Zeitschrift der Gesellschaft für Erdkunde, Berlin 1907; und in den Annalen der Hydrographie usw. 1907. W. Meinardus zit. S. 52, Anm. 21. - 9 Tе. Albrecht, Resultate des internationalen Breitendienstes, Bd. I; Berlin 1903. Eine populäre Übersicht über diese Frage gibt A. Kınмaатsch, Über die Änderung der Polhöhen: Graz 1904. - ${ }^{10}$ R. Sprtaler, Periodische Verschiebungen des Schwerpunktes der Erde, in den Sitzungsber. d. Wiener Akad. d. Wiss., Math.-naturwiss. Kl. 1905, Bd. CXIV, Abteil. II a. Tн. Aцввеснт in den Astronomisehen Nachrichten 1908, Bd. 178, Nr. 5 .

\section{Lokale Winde.}

Die lokalen Winde können wir in zwei Hauptarten teilen. Zur ersten gehören die lokalen Winde in des Wortes strengster Bedeutung, die nicht durch die allgemeine geographische Verteilung des Luftdrucks, sondern durch örtlich beschränkte barometrische Unterschiede hervorgerufen werden. Es ist selbstverständlich, daß solche lokalen Druckdifferenzen nur dann zur Geltung gelangen können, wenn die Atmosphäre nicht von beträchtlichen Störungen heimgesucht wird. Die Winde dieser Kategorie sind daher nicht nur örtlich, sondern auch zeitlich beschränkt. Die zweite Hauptart bilden jene Winde, die zwar Teile der allgemeinen Luftzirkulation sind, aber in bestimmten Gegenden oder unter bestimmten Umständen eine lokale Färbung erhalten.

Lokale Windsysteme. Zur ersten Art gehören die Land- und See-, Berg- und Talwinde. Die ersteren, deren Theorie Blanford ${ }^{1}$ ausgebildet hat, finden wir an den Gestaden aller gröBeren Wasserflächen, hauptsächlich an den Meeresküsten. Wenn sich in den Vormittagsstunden das Land erwärmt, steigen die Luftsäulen über ihm zu einer größeren Höhe an als über dem kühleren Meer; es entsteht infolgedessen eine obere Strömung vom Land zur See und zum Ausgleich in den unteren Luftschichten der Seewind. Die Zirkulation reicht in ziemlich bedeutende Höhen, wie die Beobachtungen mittels eines befestigten Ballons in der Bucht der Coney- 
insel (New York) lehren. ${ }^{x}$ In den Abendstunden gleichen sich die Druckunterschiede aus, und nach Mitternacht, wenn sich das Land mehr abgekühlt hat als das Meer, entwickelt sich die umgekehrte Bewegung: in den oberen Schichten ein Seewind, in den unteren der Landwind. Über die Ausbreitung dieses Windregimes liegen nur wenige Beobachtungen vor. An der Ostsee liegt der Ursprung der Seebrise $7 \frac{1}{2}$ bis $9 \mathrm{~km}$ von der Küste, und der Landwind dringt ziemlich weit, bis zu $15 \mathrm{~km}$, seewärts vor. ${ }^{2}$ Die innere Grenze des Seewindes liegt an der Küste von Neuengland $20-40 \mathrm{~km}$ landeinwärts. ${ }^{3}$

Ein echter Tagesmonsun sind auch die Berg- und Talwinde, ${ }^{4}$ ein allen Gebirgsländern gemeinsames Phänomen, wenn auch kaum irgendwo großartiger und regelmäßiger, entwickelt, als in Tibet und Kaschgarien. Wenn sich

mit steigender

Sonne die Luft im Tal und an den Berghängen erwärmt, dehnen sich

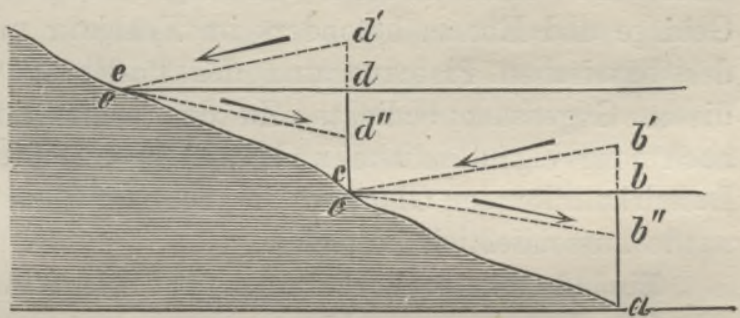

Fig. 35. Berg- und Talwinde. die Luftsäulen (Fig. 35) $a b$ und $c d$ bis $b^{\prime}$ und $d^{\prime}$ aus, und nun entsteht ein Gradient von der freien Atmosphäre gegen den Bergesabhang hin. Dazu kommt noch, daß sich die Luft am Abhang mehr erwärmt, als in der freien Atmosphäre im gleichen Niveau; jene strebt als spezifisch leichter in die Höhe, und muß durch zuströmende Luft ersetzt werden. So entwickelt sich bei Tag ein Steigungswind die Gehänge hinan (Talwind), und zum Ersatz fließt Luft aus der Ebene talaufwärts. Bei Nacht ziehen sich die Luftsäulen $a b$ und $c d$ bis $b^{\prime \prime}$ und $d^{\prime \prime}$ zusammen, und dem neuen Gradienten folgt ein Fallwind an den Gehängen hinab und talabwärts zur Ebene hinaus (Bergwind).

Wo die Berghänge mit Schnee und Eis bedeckt sind und erkaltend auf die Luftschichten wirken, da entsteht auch bei Tag ein kalter Fallwind. Dieser Art sind z. B. die Nevados oder Schneestürme auf dem mit hohen Bergen gekrönten Plateau von Quito.

Obere Grenze des Landwindes. Untere Grenze des Landwindes . Obere Grenze des Seewindes
10. Aug. 1879

$1^{\text {h }} 19^{\mathrm{m}}$ p. m.

$270 \mathrm{~m}$ 150

120
10. Aug. 1879

$3^{\text {h }} 10^{\mathrm{m}}$ p. m.

$330 \mathrm{~m}$

150

150
13. Aug. 1879

$11^{\mathrm{h}} 50^{\mathrm{m}}$ a. m. $320 \mathrm{~m}$ (?) 210 200 
Im oberen Engadin weht der Wind im Sommer bis nach Scanfs auch bei Tag talabwärts. Diese Anomalie bereitete der Theorie einige Schwierigkeiten, bis sie BLLwLLER durch die eigentümlichen orographischen Verhältnisse des Tals befriedigend erklärte. Auch hier finden wir den regelrechten Steigungswind, aber der Ersatz dafür kommt nicht von dem stark eingeengten unteren Tal, sondern von dem offenen oberen Ende.

Enge Nebentäler, die von hohen und steilen Felswänden eingeschlossen und daher nur wenige Stunden von der Sonne beschienen werden, senden oft, besonders im Sommer, kalte Winde in das viel wärmere Haupttal. Bekannt ist der Wisperwind, der, aus dem Taunus kommend, manchmal das um $12-18^{\circ}$ wärmere Rheintal heimsucht. Eine ähnliche Wirkung erzeugt die Nachbarschaft von Gebirge und Ebene, besonders im Frühjahr und Herbst; das Klima des bayrischen Plateaus und der Po-Ebene wird zum Teil durch diesen Gegensatz bedingt. $\mathrm{Zu}$ den echten lokalen Winden gehört auch jene eigentümliche und, wie es scheint, ganz abgeschlossene Luftzirkulation im Ghôr, wo im Sommer Süd- und im Winter Nordwinde ausschließlich herrschen.

Einfluß lokaler Verhältnisse auf die Winde. Zweige der allgemeinen Luftbewegung können durch bestimmte lokale Verhältnisse in ihrer ursprünglichen Richtung oder Stärke verändert werden, oder auch einen eigentümlichen klimatischen Charakter erhalten. So werden im meridionalen Champlain-Hudsontal im Staat New York die winterlichen NW-Winde in N- und die sommerlichen SW-Winde in S-Winde umgewandelt. Das von Nordwesten nach Südosten ziehende Ebrotal kennt eigentlich nur zwei Luftströmungen: den Cierzo (NW) und den Bochorno (SO). Ein großartiges Beispiel dieser Art liefert auch Hindustan, wo der Wintermonsun talabwärts und der Sommermonsun talaufwärts fließt, und selbst die antipassatische Strömung in $2000 \mathrm{~m}$ Höhe im Winter genau den Bahnen des Sommermonsuns folgt. Auf wie weite Strecken hin ein Gebirge die Windrichtung zu bestimmen vermag, beweisen die Gegenden an der Ostseite der Karpathen, wo NW- und SO-Winde von Bessarabien bis in die Nähe von Lemberg entschieden vorherrschen.

In noch höherem Grad als die Richtung unterliegt die Stärke des Windes der lokalen Beeinflussung, besonders durch Temperaturunterschiede, wie zwischen dem Meer und einem gebirgigen Hinterland im Winter, oder zwischen einem solchen und einer erhitzten Küstenebene im Sommer. Auf diese Weise erhält der Mistral, ${ }^{5}$ ein stürmischer N- oder NW-Wind, der die Küstengegenden von der Ebromündung bis in den innersten Winkel des genuesischen 
Golfs - so häufig heimsucht, seinen eigentümlichen Charakter. Besonders heftig ist er in der Provence und im Languedoc, wo die Gebirgsmauern der Cevennen und Alpen fast aufeinander stoßen, und wo er regelmäßig auftritt, wenn sich ein Minimum im Süden oder Südosten der Provence befindet, während eine Antizyklone über dem mittleren und südwestlichen Frankreich lagert. Diese Druckverteilung ist im Winter die normale, daher auch der Mistral in dieser Jahreszeit am häufigsten. Seine Heftigkeit erklärt sich dadurch, daß die Gegensätze nicht sofort ausgeglichen werden, indem sich die von Norden kommende Luft einige Zeit hinter dem Gebirge staut. $\ddot{A}$ hnlich verhält sich die Bora ${ }^{6}$ an den gebirgigen Küsten von Triest, Dalmatien und Albanien. Man versteht darunter NO- und O-Winde, die besonders im Winter durch Minima auf dem Adriatischen Meer erzeugt werden. Die zeitweise Stauung und das plötzliche Hereinbrechen über die Pässe des Gebirges kommt in dem stoßweisen Wehen dieser oft gefährlichen Stürme zum Ausdruck, die am wütendsten dort sind, wo der Gebirgskamm mindestens 300 -600 m hoch und zugleich in horizontaler Richtung nur ein paar Kilometer von der warmen See entfernt ist. Solche Borastürme kommen übrigens auch bei Noworossiisk am NO-Ufer des Schwarzen Meeres und an der ochotskischen Küste vor.

Diese Fallwinde sind relativ kalt und trocken; ein anderer Fallwind, der Föhn, ist relativ warm und trocken. Sie bringen diese Eigenschaften nicht aus ihrem Ursprungsgebiet mit, sondern erhalten sie erst durch die Veränderungen, die sie auf ihrem Weg erleiden. Nehmen wir an, ein Gebirge von $1000 \mathrm{~m}$ Höhe trenne die Orte $a$ mit $8^{\circ}$ und $b$ mit $12^{\circ}$ Temperatur, und die Luft setze sich von $a$ nach $b$ in Bewegung. Beim Aufstieg zum Kamm erkaltet sie, beim Abstieg nach $b$ erwärmt sie sich. Das Maß der Erkaltung ist verschieden, das der Erwärmung aber stets $1^{\circ}$ auf $100 \mathrm{~m}$, und die Endtemperatur des Luftstroms hängt von der Differenz von Erwärmung und Erkaltung ab, also einerseits von der Fallhöhe, anderseits von der Temperaturabnahme beim Aufstieg. Beträgt diese $0,8^{0}$ auf $100 \mathrm{~m}$, so ist in unserem Beispiel die Endtemperatur $=8^{\circ}$ (ursprüngliche Temperatur) $+\left(10^{0}-8^{0}\right)=10^{\circ}$; beträgt sie $0,4^{\circ}$, so ist die Endtemperatur $=8^{\circ}+\left(10^{\circ}-4^{\circ}\right)=14^{\circ}$. Im ersten Fall wird der Wind in $b$ als relativ kalt, im zweiten als relativ warm empfunden. In Castasegna im Bergelltal kommt in der Tat der über den Maloggiapaß herüberwehende Wind bald alș Bora, bald als Föhn an. Stets aber ist, solange der Abnahmekoëffizient kleiner als $1^{\circ}$ ist, der Luftstrom an der Endstation wärmer als am Ursprungsort, und daher auch trockener, selbst wenn sich sein ab- 
soluter Feuchtigkeitsgehalt nicht geändert hat. Denn maßgebend ist die relative Feuchtigkeit (s. S. 148), und diese steht im umgekehrten Verhältnis zur Temperatur.

Der $\mathrm{F}_{\text {öhn }}{ }^{8}$ ist eine zahlreichen Gebirgsländern gemeinsame Erscheinung, während man ihn früher nur auf die Nordalpen beschränkt glaubte. Hier ist dieser warme und trockene Südwind (SW-SO), der sich zeitweise zum Sturm steigert, von Besançon am Jura bis Vorarlberg zu Haus, erreicht aber in seinen östlichen Ausläufern auch das untere Inntal und manchmal sogar die Täler Salzburgs und des Salzkammergutes. Er erzeugt, besonders im Frühling, oft plötzliche und gefährliche Schneeschmelzen und Überschwemmungen, , ist aber auch von dauerndem EinfluB auf das Klima× und ermöglicht die Maiskultur in Gegenden, von denen sie sonst ausgeschlossen wäre.

Nach Hann tritt der typische Föhn auf der Nordseite der Alpen dann auf, wenn sich eine tiefere Barometerdepression auf dem Atlantischen Ozean zwischen dem Golf von Biscaya und Nordschottland einstellt. Der Luftdruck ist dann am Nordfuß der Alpen viel tiefer als am Südfuß, und die Luft wird durch jenes Minimum aus den nördlichen Tälern gleichsam ausgepumpt, und zum Ersatz strömt Luft vom Südabhang über die Pässe auf die Nordseite, wobei durch die Abkühlung der aufsteigenden Luft am Südabhang häufig Niederschläge erzeugt werden. Ist der Luftdruck im Süden beträchtlich tiefer als auf der Nordseite, so erscheint der Nordföhn in den südlichen Tälern.

Auch die niedersinkende Luft in Antizyklonen gibt Veranlassung zu föhnartigen Erscheinungen, und das Bodenrelief kann dabei insofern mitwirken, als der Fallwind in Gebirgstälern infolge der Verengung seiner Bahn an Intensität und Geschwindigkeit gewinnt. Manchmal treten unter solchen Umständen in den Alpen Nord- und Südföhn gleichzeitig auf, ebenso wie in Grönland Föhn an beiden Küsten. Auch antizyklonische Fallwinde, die über weite Ebenen Trockenheit und Wärme verbreiten, werden von BILLwLLLer sEN. ${ }^{9}$ zu den Föhnwinden gerechnet, und BLLLwWLER JuN. unterscheidet zwischen Gradientföhn, d. h. horizontalen Strömungen, die durch orographische Hindernisse zum Auf- und Absteigen genötigt werden, und antizyklonalen Föhn. Die Beschränkung des Föhnbegriffs

\begin{tabular}{ccccccc}
\hline$\times$ & Höhe & Winter & Frühling & Sommer & Herbst & Jahr \\
Zürich & $470 \mathrm{~m}$ & $-0,3^{\circ}$ & $8,9^{\circ}$ & $17,6^{\circ}$ & $8,8^{\circ}$ & $8,7^{\circ}$ \\
Altdorf(Föhngebiet) & 454 & 1,1 & 9,5 & 17,3 & 10,0 & 9,5
\end{tabular}

Pernter hat die Mitteltemperatur der Föhn- und föhnlosen Tage in Innsbruck besonders berechnet und gefunden, daß der Föhn die mittlere Temperatur im Winter um 0,85 und im Jahr um $0,6^{\circ}$ erhöht. 
auf die erstere Kategorie hat sich in der Praxis als unmöglich erwiesen und ist von den meisten Meteorologen jetzt aufgegeben worden.

Heutzutage weiß man, daß der Föhn ein allgemein verbreitetes - Phänomen ist. Der sogenannte Scirocco auf der Nordseite der Pyrenäen und in Algier ist nach HéвERT nichts anderes als Föhn. In Modena nimmt der SW-, in Simferopol auf der Krimhalbinsel der SO-, in Trapezunt und im Kurtal der SW-, in Kutais dagegen der ONO-Wind zeitweise einen föhnartigen Charakter an. Für die Westküste Japans hat KNIPPING das Vorkommen des Föhns nachgewiesen. In Nordamerika ist diese Windart sowohl in den Alleghanies wie auch im westlichen Hochland häufig; im letztern ist sie unter dem Namen Chinook bekannt und erstreckt sich (wahrscheinlich als antizyklonale Begleiterscheinung) weit in die Prärien hinein, angeblich sogar bis Wisconsin. ${ }^{10}$ In Neuseeland ist sie besonders entwickelt auf der Ostseite der Südalpen. Die auffallend hohen Julitemperaturen mancher Jahre an der SW-Küste Afrikas in Port Nolloth und an der Walfischbai führt v. Danckelman auf föhnartige Ostwinde zurück. In Grönland ist der Föhn an beiden Küsten heimisch, sowohl bei antizyklonischer Wetterlage, wie auch dann, wenn ein tiefes barometrisches Minimum westlich oder östlich von dieser Kontinentalmasse erscheint, nur daß in diesem Fall nicht ein Überwehen des ganzen innern Eisplateaus vorausgesetzt werden darf, sondern ein Abströmen der Luft von demselben genügt, um ähnliche thermo-dynamische Wirkungen zu erzeugen, wie in schmalen Gebirgszügen. Von großer klimatischer Bedeutung ist er an der Westküste, wo er im Winter und Frühjahr die Temperatur häufig über den Gefrierpunkt hebt. In Jakobshavn z. B. ist die durchschnittliche Zahl der Föhntage 16 (in der Schweiz 40) im Jahr. In Nischne-Kolymsk erwähnt schon WrangeLI einen trocknen und warmen Wind aus Südosten, wo ein Ausläufer des Stanowoigebirges liegt. WoErkow hat auch den Föhn herangezogen, um manche Eigentümlichkeiten des ostasiatischen Winterklimas zu erklären. Wo der Gebirgsrand unterbrochen ist, bringt der herrschende Nordwest die Temperatur des sibirischen Kältezentrums bis an die Küste; wo er aber ein Gebirge übersteigen muß, erwärmt er sich beim Herabsinken. Daher ist z. B. Ajan im Januar um $2,8^{0}$ wärmer als Nikolajewsk, und Peking um 4,8 ${ }^{0}$ wärmer als Niutschwang. Auch im antarktischen Viktorialand nehmen die von der polaren Antizyklone ausgehende Winde unter Umständen, sobald sie sich über die $2000 \mathrm{~m}$ hohe Admiralitätskette herabstürzen, echten Föhncharakter an und erhöhen die Sommertemperatur an der Robertson-Bai. 
Die Trockenheit und die Wärme hat der Föhn mit den Wüsten winden ${ }^{11}$ gemein, und lange Zeit hielt man ihn auch für einen solchen. Er erhält aber seinen Charakter in der Regel durch lokale Verhältnisse und verliert ihn auch wieder, sobald diese zu wirken aufhören; während die Wüstenwinde ihn aus der Wüste, in der sie entstehen oder die sie passieren, mitbringen. So sendet die Sahara den Khamsin nach Ägypten, den Harmattan ${ }^{12}$ nach Oberguinea, und sogar über breite Meeresstrecken den Leste nach Madeira und den Canarischen Inseln, den Leveche an die spanische Ostküste von Kap Gata bis zum Kap Não, und den Scirocco (nicht $\mathrm{zu}$ verwechseln mit den ebenso genannten feucht-warmen Winden in Italien und auf dem Adriatischen Meer) nach Sizilien. Ein Wüstenwind ist ferner der bekannte Samum im mittleren und nördlichen Arabien. Auch von der Mohavewüste im westlichen Nordamerika sind solche Winde bekannt. Aber keine sind heißer und trockener als die aus dem Inneren von Australien kommenden. Neumayer beobachtete einmal in Melbourne, wie durch einen solchen Wüstenwind die Äpfel an den Bäumen buchstäblich gebraten wurden.× In Neu-Süd-Wales schwankt die Temperatur dieses Windes zwischen 27 und $43^{\circ}$, im Binnenland ist sie aber viel höher. So beobachtete StuRT in Zentralaustralien am 21. Januar $184555^{\circ} \mathrm{im}$ Schatten, und im Dezember 1828 zerstörte ein heißer Wind am Hunt River auf eine Strecke von nahezu $50 \mathrm{~km}$ allen Weizen.

Literaturnachweise. ${ }^{1}$ H. F. Blanfort, Land- und Seewinde an der Küste von Bengalen, in der Zeitschr, d. österr. Gesellschaft f. Meteorologie, 1877. - 2 M. KaIser, Land- und Seewinde an der deutsehen Ostseeküste, Halle a. S., 1906. - ${ }^{3}$ An Investigation of the sea breeze, in den Annals of the Astronom. Observat. of the Harvard College 1890, Bd. XXI. - ${ }^{4}$ J. Hans, Zur Theorie der Tal- und Bergwinde, in der Zeitschr. d. österr. Ges. f. Meteorologie 1879. - ${ }^{5}$ O. Derscir, Der Ursprung des Mistral, ebendaselbst 1881. ${ }^{6}$ J. v. Lorenz, Physikalische Verhältnisse des Quarnero; Wien 1863. - ${ }^{7}$ R. BruLwibler Jun., Der Bergeller Nordföhn, in den Annalen der Schweiz. Meteorologischen Zentralanstalt, 1904. - ${ }^{8}$ Hans's Klimatologie und Meteorologie zit. S. 56. - ${ }^{9}$ R. Brllwiller sEn., Über verschiedene Entstehungsarten und Erscheinungsformen des Föhns; in der Meteorol. Zeitsehrift 1899. Über den Vorsehlag WшD's zur Einschränkung des Begriffs Föhn, ebenda 1903. — ${ }^{10}$ Geographische Zeitschrift 1903, S. 575. - $" 1$ J. Nremeyer, Die heißen Winde der Wüstengebiete; Meldorf 1891. - ${ }^{12}$ Über die Herkunft des Harmattan sind die Meinungen noch geteilt. Vgl. darüber „Mitteilungen aus den deutschen Schutzgebieten" 1899, S. 1-37.

$\times$ Nach R. v. Lendenfeld (Petermann's Mitteilungen 1905, S. 118) wird die Wärme des Melbourner Nordwindes noch durch das Übersteigen eines niederen Bergrückens erhöht. 


\section{Der Wasserdampf in der Atmosphäre und die Ursachen seiner Kondensation.}

Verschiedene Maße der Luftfeuchtigkeit. Alle Wasserflächen und die Pflanzendecke entsenden fortwährend Wasserdampf in die Atmosphäre. Ess besteht aber ein Unterschied zwischen Süß- und Meerwasser; ihre Verdunstungsmengen in gleicher Zeit und unter gleichen Umständen verhalten sich nach MazeLLe wie $100: 82,5$, nach OKaDA wie 100:95. ${ }^{1}$ Man mißt den absoluten Feuchtigkeitsgehalt der Luft als Dampfdruck; die Höhe einer Quecksilbersäule (ausgedrückt in Millimeter), die der Expansivkraft des Wasserdampfes das Gleichgewicht hält, gilt noch allgemein als Maßstab dafür, obwohl die Angabe des Gewichtes des Wasserdampfes in einem Kubikmeter Luft (ausgedrückt in Gramm) vorzuziehen wäre. Die folgende Tabelle zeigt aber, daß beide Ausdrücke nicht sehr voneinander abweichen. Als spezifische Feuchtigkeit bezeichnet v. BezowD das Gewicht des Wasserdampfes in einem Kilogramm feuchter Luft — ein Maß, das bei theoretischen Untersuchungen Vorteile bietet.

Die Erfahrung lehrt, daß die Luft bei einer bestimmten Temperatur nur eine bestimmte Menge Wasserdampf aufnehmen kann:

$\begin{array}{rrrrrrrrr}\text { Temperatur } & -10^{0} & -5^{0} & 0^{0} & 5^{0} & 10^{0} & 15^{0} & 20^{0} & 25^{0} \\ \text { Maximaldampfdruck (mm) } & 2,2 & 3,2 & 4,6 & 6,5 & 9,1 & 12,7 & 17,4 & 23,5 \\ \text { Maximalgewicht (gr) . . . . } & 2,3 & 3,4 & 4,9 & 6,9 & 9,3 & 12,7 & 17,1 & -22,8\end{array}$

Es ergibt sich daraus, daß die Verdunstung mit der Temperatur steigt. Sekundäre Faktoren sind der Luftdruck, zu dem die Verdunstung im umgekehrten Verhältnis steht, und der Wind, der die feuchte Luft immer wieder fortführt und dadurch eine rasche Sättigung verhindert. Je größer die Verdunstung, desto größer ist die absolute Feuchtigkeit der Luft; sie muß sich daher, wie sie an jedem Ort mit der Temperatur steigt und fällt, auch in ihrer geographischen Verteilung an die der Temperatur anschließen. Die Linièn gleichen Dampfdrucks wiederholen in der Tat alle Biegungen der Isothermen, und nur die regenarmen Gebiete der Kontinente machen begreiflicherweise davon eine Ausnahme. Die jährliche Schwankung des Dampfdruckes steigert sich, wie die der Temperatur, vom Äquator gegen die Pole und von den Küsten landeinwärts, wobei in unseren Breiten der Gegensatz von Ost- und Westküsten in derselben Weise hervortritt wie auf der Karte der jährlichen Temperaturschwankung. Ebenso nimmt die absolute Feuchtigkeit mit der Höhe $a b$, und zwar in der freien Atmosphäre rascher als im Gebirge, und hier (mit Ausnahme des Pic von Tenerife und vielleicht der ganzen Passatzone) unter höheren Breiten schneller als unter niederen. 
Schon in einer Höhe von $1500 \mathrm{~m}$ hat sich der Feuchtigkeitsgehalt um die Hälfte vermindert, und über $5000 \mathrm{~m}$ Höhe finden wir nur mehr $1 / 10$ des atmosphärischen Dampfgehaltes. $\times$

Wenn auch für die Charakteristik des Klimas einer Gegend der Dampfdruck ein entscheidendes Element ist, so bedarf er doch stets zu seiner Erläuterung der Temperaturangabe und eignet sich daher wenig zu klimatologischen Vergleichen. Wenn wir auf die untenstehende Tabelle $\times \times$ einen Blick werfen, so finden wir bei Königsberg und Breslau die gleichen Jahresmittel der absoluten Feuchtigkeit, aber trotzdem ist die Luft in beiden Städten nicht durchschnittlich gleich feucht, denn die Temperatur ist verschieden. Um bequeme Vergleichswerte zu schaffen, berechnet man daher entweder das prozentische Verhältnis des wirklichen Dampfdruckes $(d)$ zu dem der Temperatur entsprechenden Maximum $(m)$, d. h. die relative Feuchtigkeit $(f)$, die in der Meteorologie schon lange eine hervorragende Rolle spielt; oder, nach WriD's Vörgang, das Sättigungsdefizit $(s)$, d.h. die Dampfmenge, die der Luft unter den gegebenen Temperaturverhältnissen zur Sättigung noch fehlt. In Formeln ausgedrückt ist also $f=100 \frac{d}{m}$ und $s=m-d$. Nun wird sofort klar, daß Königsberg feuchter ist als Breslau. Aus den Formeln ergibt sich auch, warum die jährliche Periode des Sättigungsdefizits denselben Verlauf nimmt wie die des wirklichen Dampfdruckes, während die relative Feuchtigkeit das gerade entgegengesetzte Verhalten

$\times$ J. Schubert, hat für Mitteleuropa folgende Werte berechnet:

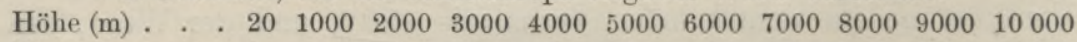
$\begin{array}{lllllllllll}\text { Dampfmenge (gr) } 6,92 & 4,61 & 3,03 & 1,97 & 1,26 & 0,79 & 0,46 & 0,26 & 0,10 & 0,02 & 0\end{array}$ $\begin{array}{llllllllll}\text { Abnahmef.100m } \quad 0,24 & 0,16 & 0,11 & 0,07 & 0,05 & 0,03 & 0,02 & 0,01 & 0,01 & 0,00\end{array}$

$x \times$

$\begin{array}{ll}\text { Königsberg } & 3,5^{*} \\ \text { Breslau . } & 3,7^{*} \\ \text { Borkum . } & 4,9^{*} \\ \text { Trier . . } & 4,5^{*} \\ & \\ \text { Königsberg } & \mathbf{8 7} \\ \text { Breslau . } & \mathbf{8 3} \\ \text { Borkum . } & \mathbf{9 1} \\ \text { Trier . . } & \mathbf{8 5}\end{array}$

Königsberg

Breslau .

Borkum .

Trier

83

91

85
Winter Frühling Sommer Herbst Jahr Absolute Feuchtigkeit (mm)

$\begin{array}{lllll}3,5^{*} & 5,3 & \mathbf{1 0 , 4} & 6,2 & 6,5 \\ 3,7^{*} & 5,6 & \mathbf{1 0 , 2} & 6,8 & 6,5 \\ 4,9^{*} & 6,5 & \mathbf{1 1 , 5} & 8,2 & 7,8 \\ 4,5^{*} & 6,0 & \mathbf{1 0 , 3} & \mathbf{7 , 3} & \mathbf{7 , 0}\end{array}$

Relative Feuchtigkeit (Proz.)

\section{7}

$$
\begin{aligned}
& 0,5^{*} \\
& 0,7^{*} \\
& 0,5^{*} \\
& 0,9^{*}
\end{aligned}
$$

$74^{*}$
$69^{*}$
$82^{*}$
69

83

78

87

80

\section{0}

\section{Sättigungsdefizit (mm)}

$\begin{array}{llll}1,8 & \mathbf{3 , 7} & 1,3 & 1,8 \\ 2,4 & \mathbf{4 , 6} & 2,0 & 2,4 \\ 1,3 & \mathbf{2 , 5} & 1,2 & 1,4 \\ 2,8 & \mathbf{4 , 6} & 2,0 & 2,6\end{array}$


zeigt. In unseren Gegenden ist die Luft im Sommer absolut am feuchtesten, relativ aber am trockensten. Welches Element, die relative Feuchtigkeit oder das Sättigungsdefizit, sich besser für die Zwecke der Klimalehre eignet, ist noch eine offene Frage; es unterliegt aber keinem Zweifel, da $B$ die erstere manchmal irreleitet. Sie erweckt z. B. den Schein, als ob in Trier der Frühling trockener sei als der Sommer, während doch, wie sich aus dem Sättigungsdefizit ergibt, gerade das Umgekehrte der Fall ist. Trotzdem hält die Mehrzahl der Fachautoritäten an der relativen Feuchtigkeit fest. Wenn wir oben sagten, daß ihre jährliche Kurve im entgegengesetzten Sinn verlaufe wie die der Temperatur, so bedarf dies insofern einer Einschränkung, als sie im asiatischen Monsungebiet und in den Polargegenden, wo die Winter sehr trocken sind, mit der Temperatur steigt und fällt, obwohl dieser Parallelismus nicht auf eine direkte Abhängigkeit zwischen beiden Elementen hindeutet. Wie die absolute Feuchtigkeit nimmt auch die relative von den Küsten (mit Ausnahme der asiatischen Ostküste) gegen das Innere des Landes ab und ist am kleinsten in den Wüsten und Steppen, aber im Gegensatz zu der absoluten ist sie in höheren Breiten durchschnittlich größer als in niederen. In der freien Atmosphäre nimmt auch sie mit der Höhe ab, aber so unregelmäßig, daß sich ein so bestimmtes Gesetz wie für die absolute Feuchtigkeit aus den bisherigen Beobachtungen noch nicht ableiten läßt. Im Gebirge machen sich lokale Einflüsse geltend. Am Antisana und in den Andes von Quito, $4060 \mathrm{~m}$ hoch, sinkt die relative Feuchtigkeit selten bis 74 und erreicht meist den Sättigungspunkt. Doch war MüHRY's SchluB, $\mathrm{daß}$ sich die ganze Äquatorialzone durch große Feuchtigkeit bis zu einer Höhe von $5700 \mathrm{~m}$ auszeichne, voreilig, denn JunghuHN belehrt uns, daß auf Java die relative Feuchtigkeit in $3400 \mathrm{~m}$ Höhe 48 und in $3700 \mathrm{~m}$ Höhe nur mehr 10 Prozent beträgt. Das ist bedeutend weniger als auf dem Gipfel des Montblanc $(4810 \mathrm{~m})$, wo im August 55 Prozent gemessen wurden. Jedenfalls ist die relative Feuchtigkeit im Gebirge größer als im gleichen Niveau der freien Atmosphäre, weil dort aufsteigende Luftströme, die wir als Talwinde kennen gelernt haben, beständig Wasserdampf hinauftragen.

Fig. 27 auf S. 96 zeigt die mittlere Verteilung der Feuchtigkeit über die Erde nach den Berechnungen von ArrHenrus. Die absolute Feuchtigkeit stellt eine einfache Kurve dar, die sich von dem Äquator gegen die Pole senkt, parallel mit ihr verläuft die Kurve der relativen Feuchtigkeit in der warmen Zone, in der gemäBigten und kalten aber im entgegengesetzten Sinn. Thren tiefsten Stand erreicht sie auf jeder Halbkugel in den subtropischen 
Gürteln hohen Luftdrucks und den absolut tiefsten auf der Nordhemisphäre wegen der weiten Ausdehnung der Wüstengebiete der Alten Welt. Mit andern Worten: die geographische Kurve der absoluten Feuchtigkeit hat einen streng thermischen, die der relativen Feuchtigkeit einen gemischt thermischbarischen Charakter.

Die Winde als Verbreiter des Wasserdampfes. Da die Luft in fortwährender Bewegung ist, so kann der an einem Ort erzeugte Wasserdampf auch anderen, oft weit entfernten Orten zugute kommen. Die Regelung der Verteilung des Wasserdampfes und damit der Niederschläge ist die zweite Hauptaufgabe der Winde im Haushalt der Natur. Seewinde sind selbstverständlich feuchter als Landwinde, büBen aber ihren Charakter immer mehr ein, je weiter sie landeinwärts vorrücken. Winde, die aus kälteren in wärmere Gegenden kommen, sind relativ trocken, weil sich ihr Dampfgehalt immer weiter vom Sättigungspunkt entfernt; umgekehrt sind Luftströmungen (mit Ausnahme der von Natur trockenen Wüstenwinde) relativ feucht, wenn sie aus wärmeren in kältere Gegenden versetzt werden. Auf diese einfachen Sätze werden wir uns berufen, wenn wir von der geographischen Verteilung der Niederschläge sprechen werden.

Kondensation des Wasserdampfes. Es entsteht nun die Frage: unter welchen Bedingungen schlägt sich die Luftfeuchtigkeit nieder? Offenbar kann nur so lange Wasserdampf aufgenommen werden, als die Luft noch nicht gesättigt ist, d.h. so lange die relative Feuchtigkeit 100 Prozent noch nicht erreicht hat. Sobald aber ganz oder nahezu gesättigte Luft mehr oder weniger rasch abgekühlt wird, muß ein Teil des Wasserdampfes ausgeschieden werden. Wir haben uns also die Frage vorzulegen: unter welcher Bedingungen kann rasche Abkühlung der feuchten Luft eintreten?

Berührung feuchter Luft mit Körperu, deren Temperatur durch nächtliche Ausstrahlung unter die der ümgebenden Atmosphäre herabgesunken ist, oder starke Verdunstung des Bodens und der Pflanzen in hellen, windstillen Nächten, wenn die unterste-Luftschicht kälter ist als der Boden - eine von diesen Ursachen, meist aber beide zusammen erzeugen den Tau und Reif (gefrorenen Tau). ${ }^{2}$ Messungen in Europa ergaben für diese Niederschlagsform eine jährliche Höhe von $8-41 \mathrm{~mm}$; in regenarmen Gegenden kann also der Tau eine nicht ganz unbedeutende Rolle spielen. Eine andere Ursache der Kondensation ist die Vermischung ungleich temperierter Luftmassen. Daher sind die warmen, feuchten Winde in unseren Gegenden meist Regenbringer, besonders in der kälteren Jahres- 
hälfte; aber auch kalte Winde können zu Niederschlägen Veranlassung geben, wenn sie plötzlich in eine dampfgeschwängerte Atmosphäre einbrechen. Die Quelle der reichlichsten Niederschläge sind aber die freiwillig oder gezwungen emporsteigenden Luftströme. $\mathrm{Zu}$ den ersteren gehören die aufsteigenden Luftströme im Zentrum einer Barometerdepression, der Talwind im Gebirge, und alle jene emporsteigenden Luftströme, die sich in den heißen Nachmittagsstunden windstiller Sommertage lokal über größeren und kleineren Ebenen entwickeln. Die Überhitzung des Bodens erzeugt im letzteren Fall einen labilen Gleichgewichtszustand der Atmosphäre, wofür die Ballonfahrten der letzten Jahre zum ersten Mal den tatsächlichen Beweis erbracht haben. Die zweite Art bilden horizontale Luftströmungen, die durch orographische Hindernisse, besonders durch Gebirge gezwungen werden, sich aufwärts zu bewegen, wodurch selbst relativ trockene Winde in Regenwinde verwandelt werden können. Entsprechend diesen verschiedenen Arten aufsteigender Luft hat CuRtis zyklonale, konvektive (in der wärmeren Tageszeit erfolgende) und orographische Niederschläge unterschieden.

Auch jede Abnahme der Geschwindigkeit eines horizontalen Luftstromes muß, solange er sich nicht verbreitern kann, seinen Querschnitt erhöhen, also ein Aufsteigen bewirken. Solche Veränderungen vollziehen sich nicht bloß dort, wo die Reibung zunimmt, wie bei dem Übergang eines Luftstromes von dem Meer auf das Land, oder von einer nackten Fläche auf eine mit Vegetation bekleidete, oder von einer Grasfläche in den Wald, sondern auch mitten auf dem Ozean. ${ }^{3}$

Nach einem Versuche von AITKEn schlägt sich der Wasserdampf reiner Luft an den Wänden eines Rezipienten nieder, ohne die Durchsichtigkeit zu trüben, während er in der nicht von Staubteilchen befreiten Luft Nebel bildet. Auf Grund dieser Erfahrung hat Plumandon das Vorhandensein von Staubteilchen, die als Kondensationszentren wirken, als notwendige Vorbedingung zur Entstehung von Niederschlägen erklärt. ${ }^{4}$ Das ist sicher zu weit gegangen, denn sonst müBte der Regen in den Fabrikbezirken mit ihren stets sich vermehrenden Schloten stetig zunehmen, und die Wüsten mit ihrer stauberfüllten Luft müßten besonders günstige Kondensationsbedingungen bieten. Als ein Moment von sekundärer Bedeutung mag aber der Staub in der Luft wohl wirken; auf seine Abwesenheit in den Polargebieten ist es vielleicht zurückzuführen, daß hier die Kondensation mehr in der Form von Reif als in der meBbarer Niederschläge erfolgt.

Solange der Wasserdampf gasförmig in der Atmosphäre ver- 
teilt ist, ist er vollkommen durchsichtig; kondensiert er sich aber zu Tröpfchen, so erzeugt er Trübung und eine weißliche Färbung des Firmamentes. Eine örtliche Anhäufung von Wassertröpfchen verschiedener Größe oder - in bedeutenden Höhen - von Eisnadeln nennt man Wolken. ${ }^{5}$ Nebel ist nichts anderes als Wolkenbildung in den untersten Luftschichten. Er tritt als eine beständige und daher geographisch wichtige Erscheinung besonders an den Berührungsstellen kalter und warmer Meeresströme (z. B. an der Bank von Neufundland ${ }^{6}$ ) auf, desgleichen auch an den tropischen Küsten mit kaltem Auftriebwasser.

Ein geographisch wichtiges Element, dem aber bisher verhältnismäBig wenig Beachtung geschenkt wurde, ist der mittlere Grad der Bewölkung, $\times$ da von ihr die Verbreitung mancher Pflanzenarten (z. B. der Dattelpalme) ebenso abhängt, wie von der Temperatur. ${ }^{7}$ Welch ein gewaltiger, tiefgreifender Gegensatz besteht z. B. in dieser Beziehung zwischen den Wüsten und unseren heimatlichen Gegenden! Biskra am Nordrand der Sahara hat im Jahr durchchnittlich 264,4 heitere Tage, dagegen Berlin nur 30,5. Und der letztere Ort stellt nicht etwa ein Extrem dar, denn die Bewölkung nimmt in Europa in nordwestlicher Richtung $\mathrm{zu}$ und erreicht ihr Maximum auf den britischen Inseln und in Skandinavien. ARrHentus hat die durchschnittliche Bewölkung der Breitengrade ermittelt, und seine Zahlen sind im Diagramm Fig. 27, S. 96, verwertet. Die Bewölkungskurve hat denselben gemischt thermisch-barischen Charakter wie die Linie der relativen Feuchtigkeit. Wo die Luft in die Höhe steigt und sich abkühlt, wie im Bereich der äquatorialen Depressionszone, da erreicht die Bewölkung einen hohen Betrag; dann folgen in der Breite des subtropischen Hochdruckgürtels, wo die Luft herabsinkt, Zonen mit heiterem Himmel; dann verfinstert er sich wieder, um sich gegen die Pole hin wieder etwas aufzuklären. Daß die Bewölkung der vorwiegend ozeanischen Südhemisphäre $e_{\AA}$ die der nördlichen übertrifft, ist ohne weiteres verständlich. Auf ELfent's Bewölkungskarte von Mitteleuropa ${ }^{8}$ tritt neben dem allgemeinen Gesetz der Zunahme nach Norden auch der Einfluß des Geländes deutlich hervor, indem die Luvseiten der Gebirgszüge immer bewölkter sind als die Leeseiten, und gebirgsumschlossene Gebiete sich meist eines verhältnismäßig heiteren Himmels erfreuen.

Der KondensationsprozeB des atmosphärischen Wasserdampfes, der mit der Wolkenbildung beginnt, führt in seiner weiteren Entbewölkt).

$\times$ Ausgedrückt in Zahlen von 0 (ganz heiter) bis 10 oder bis 100 (ganz 
wicklung zu Niederschlägen in der Form von Regen, Schnee oder Hagel. Sie sind neben der Temperatur und den Winden das dritte klimatologische Hauptelement, von dem nicht bloB das organische Leben, sondern auch die Formen der Erdoberfläche zum großen Teil abhängen.

Literaturnachweise. ${ }^{1}$ E. Mazelue, Verdunstung des Meerwassers und des SüBwassers, in den Sitzungsberichten der Wiener Akademie der Wissenschaften, Math.-naturwiss. Klasse, 1898 (Bd. CVII, Abt. IIa). T. ОкарA in der Meteorologischen Zeitschrift 1903, S. 380. - ${ }^{2}$ C. Chistoni, Sulle cause della formazione della rugiada, in den Annali di Meteorologia, I. Teil 1880. ${ }^{3}$ A. Woвгкоw in der Meteorologischen Zeitschrift 1894, S. 401. - ${ }^{4}$ „Das Wetter", 1899, S. 67. - ${ }^{5}$ C. LEx, Cloudland, a Study on the Structure and Characters of Clouds, London 1894. Internationaler Wolkenatlas, herausgegeben von H. Hildebrandsson, A. Riggenabach und L. Teisserenc de Bort, Paris 1896. ${ }^{6}$ G. Sснотт, Die Nebel der Neufundlandsbänke, in den Annalen der Hydrographie usw. 1897. - ${ }^{7}$ L. Teisserenc de Bort, Etude sur la distribution moyenne de la nébulosité à la surface du globe, in ,den Annales du Bureau central météorologique de Paris, Bd. IV, 1884. Erster Versuch von Bewölkungskarten der ganzen Erde für alle Monate und das Jahr. $-{ }^{s}$ P. Erfers, Die Bewölkung in Mitteleuropa, in Petermann's Mitteilungen 1890.

\section{Die Verteilung der jährlichen Niederschlagsmengen. ${ }^{1}$}

(Siehe Karte XII.)

Gesetze der Verbreitung der Niederschläge. Kein zweites meteorologisches Element ist so sehr von örtlichen Verhältnissen abhängig, keines wechselt so sehr von Jahr zu Jahr, als die Niederschlagsmenge, und zwar - zum Unterschiede von der Temperatur - in den Tropenländern ebenso wie in der gemäBigten Zone. Zur Feststellung verläßlicher Mittelwerte sind daher langjährige Beobachtungsreihen nötig, und wie wenig solche besitzen wir außerhalb Europas! Die Vereinigten Staaten, Algier und Kapland, BritischIndien, Java, Japan und einige. Teile von Russisch-Asien und Ostaustralien - das sind die einzigen außereuropäischen Länder, deren Niederschlagsverhältnisse genauer bekannt sind. Für die Vergleichbarkeit ist auch die Aufstellung der MeBinstrumente wichtig, namentlich muß Schutz gegen den Wind verlangt werden, da dieser das Auffangen des Regens und noch mehr des Schnees ungünstig beeinflußt. ${ }^{2}$ Auf dem Meer gibt es feste Stationen natürlich nur auf den Inseln, aber die Regenmengen, die hier gemessen werden, bieten uns keine zuverlässigen Anhaltspunkte für die der benachbarten Wasserflächen. Sie sind auf der Windseite hoher Inseln stets beträchtllich größer als auf dem Meer selbst, und können auf der Leeseite wesentlich kleiner sein. Wohl könnten uns Beobachtungen auf flachen Inseln, wie auf den Atollen der Südsee, gute Dienste 
leisten, wenn sie nicht gar so spärlich wären, aber selbst in diesem Fall wäre Vorsicht geboten; berichtet doch Hague von der Bakerinsel, daB die vom erhitzten Land aufsteigende Luft wiederholt den herannahenden Regen in zwei Teile spaltete, die nördlich und südlich vorüberzogen. Indes läßt sich mit Hilfe meiner Methode doch eine ungefähre Vorstellung von der Verteilung der jährlichen Regenmengen (aber vorläufig auch nur dieser!) über dem Atlantischen und Teilen des Indischen Ozeans gewinnen. Man hat nur nach den wenigen Messungen an Bord die durchschnittliche tägliche Regendichte für Gradfelder von größerer oder geringerer Ausdehnung zu bestimmen und mit der uns viel genauer bekannten mittleren jährlichen Anzahl von Regentagen zu multiplizieren.

So mangelhaft aber auch das Beobachtungsmaterial ist, einige Hauptgesetze sind doch schon jetzt erkennbar. Zunächst die Abhängigkeit der jährlichen Niederschlagsmengen von der geographischen Breite, über die nachstehende Tabellen Ausdruck geben:

\begin{tabular}{|c|c|c|c|c|c|}
\hline & $\begin{array}{c}\text { Land nach } \\
\text { MurraY }{ }^{3} \\
\text { mm }\end{array}$ & $\begin{array}{l}\text { Land nach } \\
\text { BEzDEK }^{3} \\
\text { mm }\end{array}$ & $\begin{array}{c}\text { Land nach } \\
\text { FrITzSCHE }^{3} \\
\text { mm }\end{array}$ & $\begin{array}{c}\text { Atlantiseher } \\
\text { Ozean } \\
\mathrm{mm}\end{array}$ & $\begin{array}{c}\text { Indische } \\
\text { Ozean } \\
\text { mm }\end{array}$ \\
\hline $90-80^{\circ} \mathrm{N}$ & - & - & 340 & - & - \\
\hline $80-70$ & 380 & - & 259 & - & - \\
\hline $70-60$ & 400 & 407 & 348 & - & - \\
\hline $60-50$ & 590 & 572 & 504 & - & - \\
\hline $50-40$ & 610 & 677 & 508 & 2180 & - \\
\hline $40-30$ & $590^{*}$ & 732 & 522 & 460 & - \\
\hline $30-20$ & 730 & $705^{*}$ & 786 & 160 & - \\
\hline $20-10$ & 1020 & 1037 & 947 & $150^{*}$ & - \\
\hline $10-0$ & 2120 & 1702 & 1716 & 3680 & 3030 \\
\hline $0-10 \mathrm{~S}$ & 2030 & 1735 & 1812 & 1530 & 2250 \\
\hline $10-20$ & 1320 & 1325 & 1100 & $520^{*}$ & 2750 \\
\hline $20-30$ & $710^{*}$ & 987 & 638 & 780 & $450^{*}$ \\
\hline $30-40$ & 750 & 747 & $573^{*}$ & 850 & 1250 \\
\hline $40-50$ & 1130 & $745^{*}$ & 870 & - & \\
\hline $50-60$ & 1120 & 795 & 1021 & - & - \\
\hline $60-90$ & - & - & 300 & - & - \\
\hline
\end{tabular}

Für die Parallelkreise haben Bezdek, PlLGRIM ${ }^{3}$ und v. Kerner ${ }^{3}$ folgende Werte (in $\mathrm{mm}$ ) berechnet:

\begin{tabular}{|c|c|c|c|c|c|c|c|c|c|c|c|c|c|}
\hline & \multicolumn{7}{|c|}{ N } & \multirow[b]{2}{*}{$0^{0}$} & \multicolumn{5}{|c|}{$\mathrm{S}$} \\
\hline & $80^{\circ}$ & ${ }^{0} 70^{\circ} 60^{\circ}$ & $50^{\circ}$ & $40^{\circ}$ & $30^{\circ}$ & $20^{\circ}$ & $10^{\circ}$ & & $10^{\circ}$ & $20^{\circ}$ & $30^{\circ}$ & $40^{\circ}$ & $50^{\circ}$ \\
\hline Bezdek (Land) . . & - & 305510 & 635 & 720 & 745 & $665^{*}$ & 1410 & 1995 & 1475 & 1175 & 800 & $695^{*}$ & 795 \\
\hline Pilarim (Land u. Meer) & 120 & 0270640 & 1000 & 910 & $690^{*}$ & 890 & 1330 & 2420 & 1520 & 1170 & $650^{*}$ & 1250 & 1420 \\
\hline v. Kerner (Land) . . & - & 210440 & 484 & 4557 & 510 & 524 & 1320 & 1933 & 1510 & 787 & 515 & 506 & 793 \\
\hline v.Kerner(Land u.Meer) & 200 & 0300600 & 1000 & 850 & 500 & $450 *$ & 1500 & 2000 & - & - & - & - & - \\
\hline
\end{tabular}


Aus allen diesen Tabellen dürfen wir den Schluß ziehen, daß das Meer, abgesehen von den Passatzonen, regenreicher ist als das Land. Auf dem Meer fehlen zwar die orographischen Hindernisse, die die Niederschlagsmengen " auf dem Land örtlich außerordentlich erhöhen, aber auch diejenigen, in deren Windschatten Trockengebiete entstehen, und die Verdunstung ist jedenfalls intensiver als auf dem Festländ unter gleicher Breite. Wir entnehmen ferner aus den Tabellen, daß die südliche, überwiegend marine Hemisphäre, wenigstens bis $50^{\circ}$ Breite, regenreicher ist als die nördliche. ${ }^{\times}$

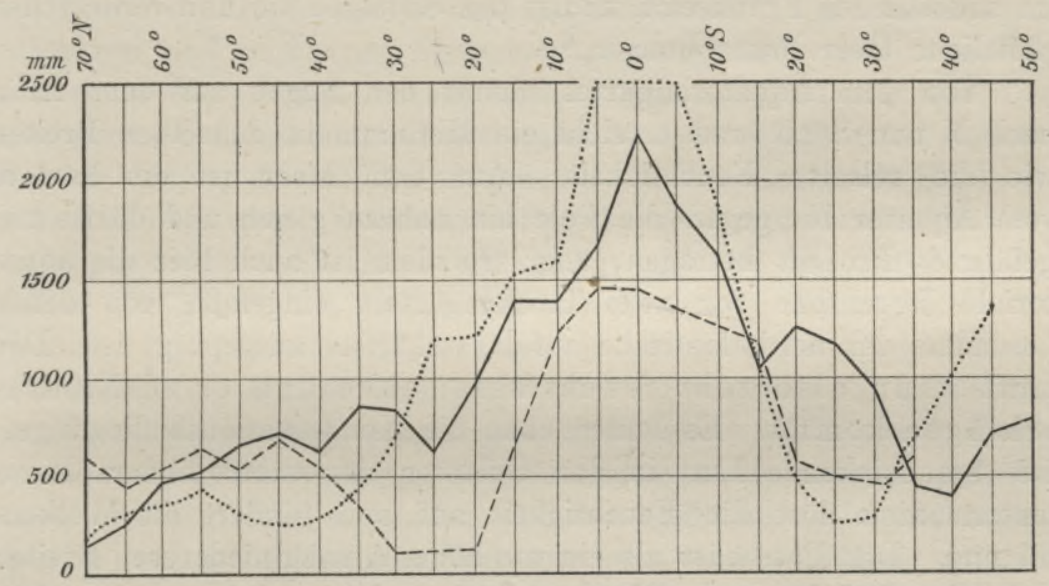

Fig. 36. Verteilung des Niederschlages nach der Breite in Amerika (- $\longrightarrow$, in der

Westhälfte (...) und der Osthälfte der Alten Welt (...) nach F. v. KERNER.

Die meridionale Verteilung des Regens auf dem gesamten Land ersieht man aus Fig. 27, S. 9 i. Die Kurven der relativen Feuchtigkeit, der Bewölkung und der Niederschläge bilden zusammen die Gruppe der thermisch-barischen Kurven, in seinem äquatorialen Maximum schließt sich der Regen aber mehr der absoluten Feuchtigkeit an. Nicht bloß die jährlichen Niederschlagssummen, sondern auch die durchschnittliche Intensität des Regenfalles erreicht in der Äquatorialzone den höchsten Wert. Sie beträgt nach WIESNER in Buitenzorg (Java) 0,3 $\mathrm{mm}$ pro Minute, in Brüssel selbst in den regnerischen Monaten nur $0,04 \mathrm{~mm}$. Hatten aber schon die Unter-

$\times$ Dem widerspricht nicht, daß BEzDEK für das Land der nördlichen Halbkugel (mit AusschluB der Zirkumpolargebiete) eine gesamte Regenmenge von 90644 und für das der südlichen eine solche von 39338 ebkm gefunden hat, denn das Übergewicht unserer Halbkugel beruht nur darauf, daß hier viel mehr Land ist. PrLarim berechnete für die Nordhalbkugel 1010 und für die südliche $1230 \mathrm{~mm}$ mittlere Niederschlagshöhe. 
suchungen WresneR's die Legende zerstört, daß der Tropenregen in Wasserfäden falle, so wissen wir nun auch durch FigeE, daß er nach Intensität und Eintrittszeit des Maximums sehr verschieden ist. Selbst das, was wir Landregen nennen, ist vielen Tropengegenden nicht fremd. Auch sind die intensivsten Platzregen bisher nicht im Äquatorialgürtel, sondern in den mittleren Breiten beobachtet worden, und die größten täglichen Regenmengen $(800-1000 \mathrm{~mm})$ lieferten einige asiatische Stationen in der nördlichen Nachbarschaft der warmen Zone. ${ }^{4}$ Solche von $200 \mathrm{~mm}$ und darüber sind auch in den Tropen nicht allgemein und kommen anderseits auch in England, im südöstlichen Frankreich und in den Südalpen vor und verursachen plötzliche Überschwemmungen. ${ }^{5}$

Von dem Äquatorialgürtel nimmt der Regen auf dem Land nach $\mathrm{N}$ und $\mathrm{S}$ ab und erreicht ein Minimum in denselben Breiten wie die relative Feuchtigkeit. Auf dem Meer ist die letztere vom Äquator bis gegen die Pole hin nahezu gleich und dürfte ungefähr 80 Prozent betragen, aber trotzdem ist auch hier die äquatoriale Regenzone von zwei Trockengürteln eingefaßt, von denen besonders der nordatlantische auf das schärfste ausgeprägt ist. Die Luft kann also sehr feucht sein, ohne daB es zu Niederschlägen kommt. Es fehlen eben die Kondensationsbedingungen. Die herabsinkende Luft in den Gebieten der subtropischen Barometermaxima löst die Feuchtigkeit auf und hindert die Wolkenbildung. Der Passat ist als ein von höheren nach niedereren Breiten wehender Wind seiner Natur nach trocken, und vieles spricht für die Annahme, da $\beta$ er auch eine absteigende Tendenz besitzt. $\times$ Wenn es in den ozeanischen Passatzonen trotzdem manchmal regnet, so erklärt sich dies daraus, daß ihre Polargrenzen von einem Tag zum andern nicht unbedeutenden Schwankungen unterliegen, daß sich auch ihre Äquatorialgrenzen mit der Sonne verschieben, und $\mathrm{da} B$ sie gelegentlich von Zyklonen durchquert werden. Aber anhaltender Regen kommt nicht vor, sondern nur vorübergehende „Passatschauer“, wie sie der deutsche Seemann nennt.

In den mittleren Breiten erreicht der Niederschlag ein zweites Maximum, in dem der Gegensatz von Wasser und Land am schärfsten zum Ausdruck kommt. Auf der Südhalbkugel ist die Lage dieses

$\times$ Bei reinen Ost- und Westwinden äuBert sich die Ablenkung durch die Erdrotation auch im vertikalen Sinn; sie ist bei Westwinden nach oben, bei Ostwinden nach unten gerichtet. Es ist anzunehmen, daß dieses Gesetz auch für Luftbewegungen, die nur eine westliche ơder östliche Komponente besitzen, natürlich in abgeschwächtem Grad, gültig ist. 
ozeanischen Maximums unbekannt, doch dürfte es auch hier das terrestrische Maximum übertreffen, obwohl die Landstationen, die in diesen Breiten in Betracht kommen, selbst unter der Herrschaft des Seeklimas stehen. Für die Beurteilung der Niederschläge in den höheren Breiten liefern uns nur Land̉beobachtungen Anhaltspunkte, es ist aber anzunehmen, daß überall Abnahme gegen die Pole stattfindet, $\mathrm{da} \beta$ sich also die Niederschläge ebenso verhalten wie die absolute, und umgekehrt wie die relative Feuchtigkeit. Trotzdem ist Nansen der Ansicht, daß auch im eigentlichen Polargebiet die Kondensation die Verdunstung überwiegt, nur erfolgt sie mehr in der Form von Reif, der überall das Eis bedeckt, als in der von sichtbaren und meßbaren Niederschlägen. Ähnlich verhält es sich ja auch in der Gletscherregion unserer Alpen. GERLand ${ }^{6}$ hat dies sehr anschaulich erklärt. „Läßt man,“ so sagt er, ,in einer Retorte Wasser sieden, die mit einer anderen, in der ein-Stück Eis liegt, in Verbindung steht, so strömt aller Wasserdampf durch das Verbindungsrohr zum Eis hin und schlägt sich als Eis auf dem Eis nieder. So ist es im großen auf der Erde: die Retorte mit dem warmen, verdunstenden Wasser ist die Tropengegend, das Überleitungsrohr die höhere Atmosphäre, das verdichtende Eis haben wir am Pol. Auch ohne daß Regen und Schnee fällt, wird durch dasselbe alle Feuchtigkeit, aller Wasserdampf der Atmosphäre entzogen und in feinen Kristallen auf der Eisfläche niedergeschlagen, und da der Luftzufluß ein fortwährender und allseitiger ist, so haben wir in ihm das dauernde Ernährungsmittel der Polarübereisung, die am Südpol infolge der größeren Luftfeuchtigkeit wohl mächtiger, gleichmäßiger ist als am Nordpol." Möglicherweise trägt, wie schon oben bemerkt wurde, auch die Staubfreiheit der polaren Luft dazu bei, Regen und Schnee seltener zu machen. Auf dem Meer wird die Verteilung der jährlichen Niederschläge in erster Linie von dem Gesetz der Breite beherrscht, auf dem Land wird aber dieses Gesetz unter dem Einfluß anderer mächtigerer Faktoren zum Teil völlig verdeckt. Als Regel, aber nicht als ausnahmsloses Gesetz darf es gelten, daß die Niederschläge von der Küste nach dem Innern abnehmen, und man hat daraus den Schluß gezogen, daß auch für das Land die Ozeane der tropischen und gemäBigten Zone die Hauptquelle des Regens bilden. Doch hat es WoEIKow schon vor Jahren für unwahrscheinlich erklärt, daß die reichlichen Niederschläge des Amazonasgebietes nur vom Meer herstammen, und in jüngster Zeit hat BRÜCKNER $^{7}$ den Anteil, den die Verdunstung der Landgewässer und der Vegetationsflächen liefert, ziffermäßig festzustellen versucht. Da 
sich der Wasserstand des Meeres nicht ändert, so müßte, wenn aller Regen auf dem Land von marinem Wasserdampf ernährt würde, die Gesamtsumme unserer Niederschläge, soweit sie nicht dauernd dem Kreislauf des Wassers entzogen wird, dem Meer wieder zurückerstattet werden. Von dieser Summe gelangen durch die Flüsse nur 22 Proz. in das Meer, 78 Proz. müßten also durch die Atmosphäre zurückgeführt werden, was völlig ausgeschlossen erscheint.

Fritzsche hat folgende Bilanz des Kreislaufs des Wassers× aufgestellt, deren Zahlen zwar nur rohe Näherungswerte sind, aber doch auf Wahrscheinlichkeit Anspruch machen können.

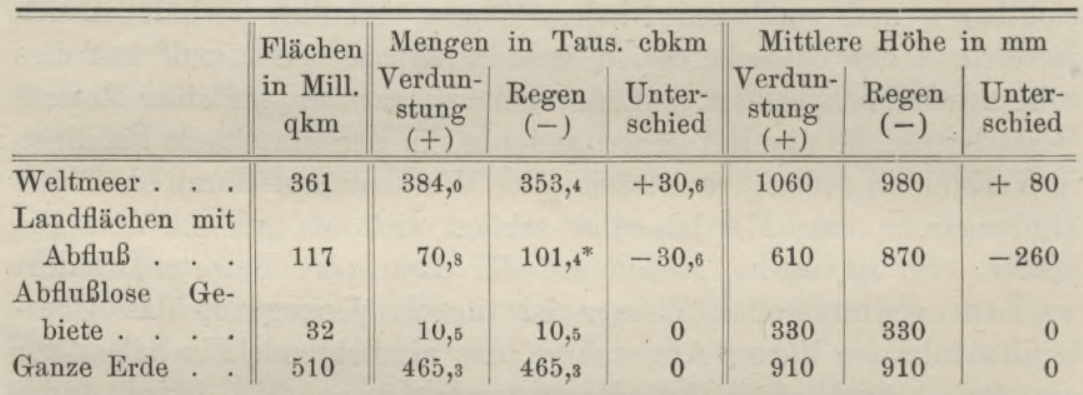

Demnach würde das Land 70 Proz. seines Niederschlages durch seine eigene Verdunstung decken und nur 30 Proz. vom Ozean beziehen.

Einen tieferen Einblick in dieses Problem erschließen uns nur die Karten der jahreszeitlichen oder der monatlichen Regenverteilung. Im Winter empfangen im großen und ganzen nur die meernahen Gegenden reichlichere Niederschläge. Abgesehen von den echten Wüsten und den subtropischen Gebieten an den "Westseiten der Kontinente, dringen die Regenwellen, allerdings sich immer mehr verflachend, immer weiter gegen den Pol vor, je mehr sich die

$\times$ Wenn man von der Voraussetzung ausgeht, daB Niederschlag $=$ Verdunstung ist, da sonst die Luftfeuchtigkeit stetig zu- oder abnehmen müBte, und wenn man den Niederschlag auf dem Meer mit $N_{m}$ und den auf dem Land mit $N_{l}$ und in gleicher Weise die Verdunstung auf dem Meer und dem Land mit $V_{m}$ und $V_{l}$ bezeichnet, so besteht die Gleichung $N_{m}+N_{l}=V_{m}+V_{l}$. Von diesen vier Gliedern sind zwei ihrem Wert nach direkt ermittelt worden: $N_{l}=750 \mathrm{~mm}$ $=112000 \mathrm{cbkm}$, und $V_{m}=1060 \mathrm{~mm}=384000 \mathrm{cbkm}$ (allerdings ziemlich unsicher!). Aus dem im Text angeführten Grund ist $V_{m}=N_{m}+F$, worin $F$ die Menge des jährlich in das Meer abgeführten Flußwassers sbedeutet, und wofür man 30640 ebkm gefunden hat. Aus obiger Gleichung läßt sich nun der Wert von $N_{m}$ und dann aus der ersten Gleichung der Wert von $V_{2}$ rechnerisch ableiten (vgl. auch W. Mrenardus in den Sitzungsberichten der Medizinisch-naturwissenschaftlichen Gesellsehaft zu Münster i. W. vom 18. Dez. 1908). 
Sonne dem Wendekreis der betreffenden Halbkugel nähert. Im Sommer breiten sich die Niederschläge über Binnen- und Küstenland aus, und die Anordnung der Regenstufen entspricht im allgemeinen dem Gesetz der Breite. Mit der Sonne wandern dann auch die Regenwellen nach dem Äquator zurück, aber auf jedem Parallel ist im Durchschnitt der Herbst feuchter als der Frühling, denn im Herbst wirkt noch die Sommerwärme nach, wie im Frühling die Winterkälte. Wir wollen diese jahreszeitlichen Gegensätze an einem Beispiel im kleinen illustrieren, und wählen zu diesem Zweck vier skandinavische Stationen unter ungefähr $63^{\circ}$ B.: Kristiansund am äußersten atlantischen Rand, Trondhjem im Innern eines Fjordes der Westküste, Östersund im Binnenland jenseits der Wasserscheide, und Hernösand an der Ostsee:

Kristiansund Trondhjem Östersund Hernösand In $\mathrm{mm}$

$\begin{array}{lrrrr}\text { Winter . . } \quad 286 & 251 & 73 & 101 \\ \text { Frühling . . } 207 & 179 & 74 & 89 \\ \text { Sommer. . . } 216 & 194 & 174 & 177 \\ \text { Herbst . . . } 348 & 281 & 111 & 194 \\ \text { Jahr. . . . } 1057 & 905 & 432 & 561\end{array}$

Kristiansund Trondhjem Östersund Hernösund In Prozenten von Östersund

\begin{tabular}{|c|c|c|c|c|c|}
\hline Winter . & & 392 & 344 & 100 & 138 \\
\hline Frühling & . & 289 & 228 & 100 & 120 \\
\hline Sommer & . & 124 & 113 & 100 & 102 \\
\hline Herbst . & . & 313 & 253 & 100 & 175 \\
\hline Jahr . & . & 245 & 209 & 100 & 130 \\
\hline
\end{tabular}

Aus diesen Zahlen geht deutlich hervor, daß die Sommerregen anderen Ursprungs sind als die Winterregen, denn kämen sie wie die letzteren vom Westen, so wäre nicht einzusehen, warum das skandinavische Gebirge im Sommer seine schützende Wirkung verlöre. Allerdings mag ein gut Teil Feuchtigkeit auch von der Ostsee kommen, denn eine flache barometrische Depression bedeckt im Juli das innere Skandinavien und zieht von allen Seiten Seewinde in das Land, aber sehr reichlich kann der baltische $\mathrm{Zu}$ schuß nicht sein, sonst müßte Hernösand beträchtlich mehr Regen haben als Östersund. Die skandinavischen Sommerregen müssen also zum größten Teil durch die im Land selbst erzeugte Feuchtigkeit ernährt werden. Im Winter versiegt diese Quelle in den mittleren und höheren Breiten nahezu ganz, der Regen kommt dann tatsächlich vom Meer und nimmt mit der Entfernung von der Küste rasch ab. Je wärmer es wird, desto mehr entwickelt sich 
die Verdunstung der Landflächen, und desto weiter breiten sich die Niederschläge auch über Binnengebiete aus, wohin nur wenig Meerfeuchtigkeit dringt. In der Tropenzone kann allerdings das ganze Jahr hindurch Landfeuchtigkeit produziert werden, aber das genügt nicht, es müssen auch günstige Kondensationsbedingungen vorhanden sein. Nennen wir diese $K$ und die Feuchtigkeit $F$, so ist der Regen $=F K$, und wenn $K=O$ ist, so ist auch das Produkt $=O$.

Die Bevorzugung der Küsten gegenüber den Binnenlandschaften beruht also, wie aus obigem Beispiel hervorgeht, nicht bloB darauf, da $\beta$ es dort reichlicher, sondern auch darauf, da $\beta$ es dort häufiger regnet. Aber nicht alle Küsten sind gleichmäßig begünstigt, sondern vor allem diejenigen mit vorherrschenden Seewinden, in unseren Breiten also die Westküsten und in den Tropen die Ostküsten.

Ebenso entscheidend wie die Entfernung vom Meer sind die orographischen Verhältnisse. Wenn der Boden ansteigt, steigt auch die Regenmenge; daher kann sie im bergigen Gelände innerhalb kurzer Entfernungen sehr variieren. Ganz beispiellos ist in dieser Hinsicht die Umgebung von Honolulu, der Hauptstadt der Hawaiigruppe. Wenn man gesagt hat, daß hier fast jede Straße eine andere Regenmenge habe, so ist dies durch Hann's Bearbeitung der Messungen nahezu bestätigt worden. Das dreijährige Mittel 1890-92 schwankt in der Stadt selbst zwischen $612 \mathrm{~mm}$ im Kapiolanipark in $3 \mathrm{~m}$ Seehöhe, und $982 \mathrm{~mm}$ in der $15 \mathrm{~m}$ hoch gelegenen Nuuanustraße. Im-oberen Nuuanutal $(76 \mathrm{~m}$ hoch) steigt es auf $1782 \mathrm{~mm}$, auf der elektrischen Station $(123 \mathrm{~m})$ auf 2295 , am Half Way House $(224 \mathrm{~m})$ auf 2974 , in Luakaha $(260 \mathrm{~m})$ auf $3652 \mathrm{~mm}$ - auf eine Entfernung von nur $8 \mathrm{~km}$ also auf das Sechsfache des Betrages am Strand! Aber die Zunảhme erreicht endlich auch eine Grenze. In Hindustan liegt nach HuL die Maximalregion des Sommerregens in $1270 \mathrm{~m}$ Höhe, d. h. dort, wo im Mittel eine von der Ebene aufsteigende Luftmasse den Sättigungspunkt des Wasserdampfes erreicht. Der Mt. Owen Stanley auf Neuguinea, nur $8^{0}$ vom Äquator entfernt, ist bis $2400 \mathrm{~m}$ feucht, dann trocken. Auf den Hochländern Zentralasiens schlagén die Eingeborenen in der schneearmen Region über der Maximalgrenze ihre Winterlager auf; Woop fand solche im Pamir in 4880 und Sven Hedin im tibetanischen Arkatag in $4356 \mathrm{~m}$ Höhe. Am Montblanc lag die winterliche Maximalzone 1903-04 in ungefähr $2500 \mathrm{~m}$ Höhe, dagegen erreicht sie in den bayrischen Alpen nur eine Höhe von 600 bis $1000 \mathrm{~m}$, steigt aber mit zunehmender Temperatur immer höher. 
Es ist daher einleuchtend, welche wichtige Rolle die Gebirge besonders in sonst regenarmen Gegenden spielen. Selbst in der Sahara vermögen sie noch zeitweise kräftige Flüsse zu entsenden, im regenlosen Sommer Südeuropas werden die Gebirge immer noch benetzt, und in der Sandwüste am oberen Hoangho ist der Alaschan mit einem Waldgürtel bekleidet.

Wenn ein Gebirgszug mehr oder weniger senkrecht steht zur Richtung der feuchten Luftströmungen, so ist die Windseite regenreicher als die Leeseite, und dieser Kontrast steigert sich mit der Höhe des Gebirges. Sein Einfluß reicht auch noch weit über seine orographischen Grenzen hinaus, indem es kleineren oder größeren Strecken des im Windschatten gelegenen Flachlandes Regen entzieht, bis eine abermalige Erhebung des Bodens eine abermalige Steigerung der Niederschläge hervorruft. Darauf beruht die Bedeutung so vieler Gebirge als Wetter- und Klimascheiden.

Die warme Zone. Halten wir uns die eben erörterten drei Hauptsätze der Abhängigkêit der jährlichen Regenmenge von der Breite, von der Verteilung von Wasser und Land und von dem Relief des Erdbodens vor Augen, und erinnern wir uns daran, was früher über die Verbreitung der Winde gesagt wurde, so wird uns die Regenkarte auf Taf. XII sofort verständlich. Wir unterscheiden drei Stufen: regenarm unter $250 \mathrm{~mm}$, mäBige Niederschläge von 250 bis $1000 \mathrm{~mm}$ und regenreich über $1000 \mathrm{~mm}$.

Die äquatoriale Zone gehört fast ihrer ganzen Ausdehnung nach der letztgenannten Stufe an, denn hier vereinigt sich höchster Feuchtigkeitsgehalt der Luft mit günstigsten Kondensationsbedingungen in den beiden Perioden des Zenitstandes der Sonne, so daß wenigstens in der unmittelbaren Nähe des Äquators, aber auch noch an der Küste von Oberguinea keine Trockenzeit im strengeren Sinn des Wortes vorkommt. Namentlich sind es zwei Gebiete, die durch ihren Regenreichtum hervortreten: die ostindische Inselwelt und der von mächtigen Strömen durchzogene Urwaldgürtel am Amazonas und dessen Nebenflüssen. ${ }^{8}$ Das äquatoriale Afrika ist entschieden trockener, und wir haben keinen Grund anzunehmen, daß uns eine detailliertere Kenntnis von dem Klima dieses Erdteils, als wie sie jetzt besitzen, einst eines anderen belehren würde. Der Gegensatz zwischen den hochgelegenen Steppenlandschaften im Osten und dem weiten, fluß- und waldreichen Kongobecken darf schon jetzt als erwiesen angenommen werden. Aber sicher wird sich mit fortschreitender klimatologischer Erforschung auch die Regenkarte der Tropenzone bunter gestalten, und viel mehr regenreiche Gebirge (z. B. in Ostafrika ${ }^{9}$ ) und trockene Windschattengebiete (z. B. in Südamerika) aufweisen. 
Wenn irgendwo unsere Theorie von der mächtigen Anteilnahme der Landfeuchtigkeit an dem kontinentalen Regen durch das Kartenbild unmittelbare Bestätigung findet, so ist es im südäquatorialen Gürtel Afrikas. Das regenreiche Gebiet des Kongobeckens ist von beiden Meeren durch höher gelegene und trotzdem regenärmere Striche getrennt. $\times$ Vom Atlantischen Ozean kann der Kongoregen nicht herstammen, denn hier nimmt der Niederschlag nach der Küste rasch $\mathrm{b}$, aber auch der Indische Ozean liefert nur der Ostküste reichlichen Regen, und sein Einfluß erstreckt sich nicht weit landeinwärts, denn sonst müßte das Seenhochland feuchter sein als das Kongobecken auf der Leeseite des Passates. In Südamerika liegen die Verhältnisse ähnlich, das Regengebiet, das die $2000 \mathrm{~mm}-$ Linie umschließt, erstreckt sich am Amazonas beträchtlich weiter nach $\mathrm{N}$ und $\mathrm{S}$, als an der Küste.

In Südafrika, Australien und Amerika ist normalerweise die Ostküste regenreicher als die Westküste, im nordäquatorialen Afrika findet aber das umgekehrte Verhältnis statt. Die nach NO verlaufende Küste des Somalihorns wird sowohl vom NO- wie vom SWMonsun mehr gestreift als direkt getroffen, und es ist bezeichnend, daß Regenmengen von mehr als $1000 \mathrm{~mm}$ erst bei Mombas beginnen, wo die Küste in die südliche Richtung umbiegt. Der Golf von Guinea ist infolge meridionaler Lagerung von Wasser und Land ein kleines Monsungebiet, der SO-Passat wird in der warmen Zeit über den Äquator herübergezogen und in einen SW-Wind verwandelt, der namentlich den maritimen Abhang des Kamerunberges mit gewaltigen Regengüssen überschüttet. Debundja, nur $5 \mathrm{~m}$ über dem Meer, hat hier einen jährlichen Niederschlag von $10469 \mathrm{~mm}$.

Im großartigsten Maßstab ist das Monsunphänomen in Indien entwickelt. Seine Eigentümlichkeit besteht darin, daß gerąle in der warmen Jahreszeit, wenn die Verdunstung auf dem Land ihren Höhepunkt erreicht, auch Meerfeuchtigkeit durch den Seemonsun weit landeinwärts getragen wird. Wir haben also hier an den Westküsten, die den $\mathrm{SW}=$ Monsun aus erster Hand empfangen, be-

$\times$ Als Beispiel dienen folgende Stationen, die unter ungefähr gleicher Breite liegen:

Jährliche

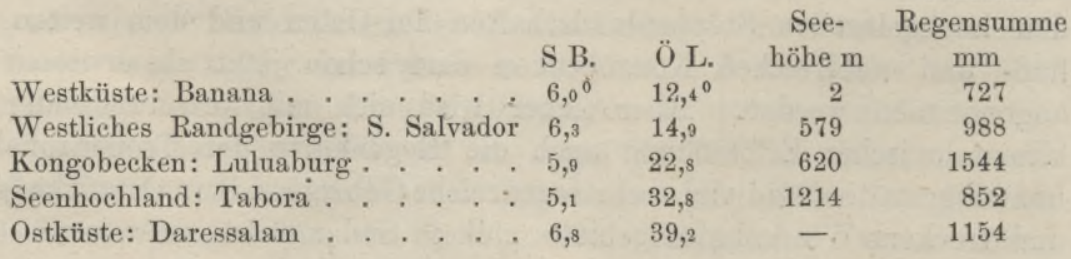


deutende Regenmengen zu erwarten. Und das ist in der Tat auch der Fall. Leider hat Dekan seinen hohen Rand im W, das Innere liegt daher im Schatten des regenspendenden Monsuns, und wenn dieser nicht kräftig entwickelt ist, leidet es an Dürre und Hungersnot. In Hindustan weht der Sommermonsun aus dem bengalischen Golf talaufwärts und in gleicher Richtung nehmen die Niederschläge ab. Im östlichen Bengalen beträgt ihre jährliche Höhe überall über $2000 \mathrm{~mm}$; am Südabhang des Khasigebirges liegt in $1250 \mathrm{~m}$ Höhe Cherrapundji, die regenreichste Beobachtungsstation der Erde, mit $11627 \mathrm{~mm}$ Niederschlag. Im westlichen Bengalen schwankt die Niederschlagshöhe zwischen 1000 und $2000 \mathrm{~mm}$, in der Ebene am mittleren Ganges und an der Djumna beträgt sie durchschnittlich $850 \mathrm{~mm}$, im südlichen Pandjab und am mittleren Indus sinkt sie schon unter $200 \mathrm{~mm}$. Im östlichen Asien weht der Sommermonsun aus SO, und die Regenmenge nimmt nach W ab. Soweit wir über das Klima von China unterrichtet sind, reicht das regenreiche Gebiet bis an den Jangtsekiang.

Der regenarme Gürtel. Für die tropischen Festländer, abgesehen von dem asiatischen Monsungebiet, bilden ungefähr $20^{\circ} \mathrm{N}$ und $\mathrm{S}$ bedeutsame Grenzen. Wir nennen die Zone, die sich von da (auch nur ungefähr) bis $32^{\circ} \mathrm{N}$ und $\mathrm{S}$ ausdehnt, den regenarmen Gürtel, nicht als ob hier überall Regenarmut herrschte, sondern weil sie hier zum ersten Mal als ein Phänomen von regionaler Bedeutung auftritt. Regenreichtum bildet hier nicht wie in der warmen Zone die Regel, sondern die Ausnahme.

Auf der südlichen Halbkugel fällt diese Zone mit der mittleren Lage des subtropischen Hochdruckgürtels zusammen. Hoher Barometerstand mit absteigender Luft ist unter allen Umständen für die Kondensation der ungünstigste Zustand. Im Sommer entwickeln sich über den Festländern allerdings flache Zyklonen, die wohl auf der Ostseite den Passat verstärken, auf der Westseite aber, wo sich die subtropischen Antizyklonen eng an die Küste anschmiegen, keinen Einfluß auf die Windrichtung ausüben. Daher reicht hier die Wüste bis an das Meer heran - eine eigentümliche Erscheinygg: Landstriche, die im Angesicht des Ozeans verdursten! Diese Küstenw üsten erstrecken sich in Australien vom Dampierarchipel (210 $\mathrm{S})$ bis zur Murchisonmündung $\left(28^{\circ} \mathrm{S}\right)$, in Südafrika von 19 bis $29^{\circ} \mathrm{B}$., in Südamerika sogar vom Äquator bis zum 32. Parallel. Auch die regelmäBigen Seewinde vermögen das Schicksal nicht zu wenden; sie bringen wohl Feuchtigkeit, die hier tatsächlich sogar noch höher ist als in unseren norddeutschen Niederungen, aber sie haben offenbar eine absteigende Tendenz und hindern dadurch die Kondensation, 
wenigstens die Kondensation in tropfbarer Form, $\times$ denn Nebel ist hier eine allgemeine Erscheinung, wenn er sich auch nur auf die untersten Luftschichten beschränkt. Unzweifelhaft wirkt hier auch das kalte Küstenwasser mit, denn in Australien, wo es fehlt, ist das Phänomen der Küstenwüste am schwächsten entwickelt. Die hohen Ostränder Australiens und Südafrikas werden von dem aufsteigenden Passat getränkt; in Australien ist die Ostmauer geschlossener als in Südafrika, und das regenarme Binnengebiet daher ausgedehnter. Den schroffsten Gegensatz dazu bildet Südamerika, das nach Osten offen liegt; die innerkontinentale Regenarmut besehränkt sich daher in diesen Breiten auf das schmale Hochland zwischen den Andesketten. IndeB muß betont werden, $\mathrm{da} \beta$ auch in Südafrika und in Australien die dauernde Regenarmut nicht soweit verbreitet ist als diejenige, die in der Jahressumme zum Ausdruck kommt. In der Kalahhari z. B. sind die Sommerregen genügend, um den strengen Wüstencharakter fernzuhalten.

So einfach und klar, wie auf den südlichen Festländern, ist die Regenverteilung auf unserer Halbkugel nicht. Die große Mannigfaltigkeit der horizontalen und vertikalen Gliederung schafft hier grelle Gegensätze. Die kompakte saharisch-arabische Tafel, im N von einem beständig kälteren Meer oder von Land begrenzt, daher das ganze Jahr von kondensationsfeindlichen, trockenen polaren Luftströmungen überweht, ist die größte zusammenhängende Wüste der Erde. Dagegen in der Neuen Welt in denselben Breiten Auflösung der Kontinentalmasse, daher im Sommer Zunahme der Temperatur und Abnahme des Luftdrucks nach NW und die Möglichkeit feuchter Seewinde aus dem Golf; endlich auch ein wechselvolleres Relief. Ganz fehlt allerdings auch hier die Regenarmut nicht; sie beginnt an der Westküste in der Gegend von S. Diego und reicht wahrscheinlich nur bis zum Kap S. Eugenio, wo eine scharfe Vegetationsgrenze einen Klimawechsel anzeigt, erstreckt sich also nur über fünf Breitengrade $\left(33-28^{\%}\right.$ ). Nach innen verbreitet sie sich über die Gila- und Mohavewüste, während das regenarme Gebiet im 0 der Sierra Nevada trotz seines räumlichen Zusammenhangs mit dem subtropischen Trockengebiet schon einer anderen Kategorie angehört.

Die gemäßigten Zonen. Die Äquatorialgrenze der gemäßigten Regenzonen läßt sich nur an den Westküsten genau feststellen; sie liegt dort, wo die Küstenwüsten aufhören. Die Niederschläge nehmen dann rasch polwärts zu, und von durchschnittlich $40^{\circ} \mathrm{B}$. ab ist der Vorrang der Westküsten über die Ostküsten überall entschieden.

$\times$ Walfischbai mit 7 und Copiapó (Chile) mit $8 \mathrm{~mm}$ sind die regenärmsten Stationen, von denen wir Messungen besitzen. 
In ungefähr $60^{\circ}$ B. begegnen wir den ersten Anzeichen polarer Regenarmut am Ochotskischen Meer und im Innern Nordamerikas.

Auf der südlichen Halbkugel gelangt die gemäBigte Regenzone nur auf Neuseeland, Tasmanien und in Südamerika zur typischen Ausbildung. Sobald wir in das Gebiet der Westwinde gelangen, vertauschen hier beide Küsten wie mit einem Zauberschlag ihre Rollen; besonders auffallend und ohne Seitenstück auf den nördlichen Festländern ist die Regenarmut der patagonischen Küste.

Auch in Nordamerika gestaltet sich die Regenverteilung zu einem einfachen und klaren Bild. Der regenreiche Westgürtel ist wie in Chile schmal; die westliche Randstellung der Hochgebirge, die in der Tropenzone so außerordentlich günstig wirkt, gereicht hier zum Nachteil. Man vergleiche damit nur unseren Erdteil mit seinem aufgeschlossenen Westrand, wie weit dringt hier die $500 \mathrm{~mm}$ Linie landeinwärts vor! Nur das nördliche Skandinavien mit seinem westlichen Steilabfall bietet ein Seitenstück zu Nordamerika. Aber dafür hat dieser Kontinent einen anderen, schwer wiegenden Vorzug gegenüber Eurasien: ein ausgedehntes regenreiches Gebiet im Osten, das er dem tief eindringenden mexicanischen Golf verdankt. In Ostasien finden wir Regenhöhen über $1000 \mathrm{~mm}$ nur an den Küsten, die noch von den Ausläufern des SO-Monsuns berührt werden: an den Ostküsten von Korea und Kamtschatka, und vor allem auf den japanischen Inseln, die aber auch von W Regen empfangen. Im schlanken, bis auf den Westen vorwiegend flachen Nordamerika dringt dagegen der Einfluß des Atlantischen Ozeans sehr weit in das Innere; ein größeres regenarmes Windschattengebiet ist nur die Hochfläche zwischen dem Felsengebirge und der californischen Sierra Nevada. Viel mächtiger entwickelt ist diese Kategorie in Asien: Teile vom inneren Kleinasien und die inneren Hochflächen von Iran und Zentralasien sind der Jahressumme nach regenarm, dauernd allerdings sicher nur das Tarimbecken und das westliche Tibet. Eigenartig - ist dagegen das regenarme Gebiet von Turan. Nach $\mathrm{S}$ und $\mathrm{O}$ ist es wohl durch hohe Gebirge abgesperrt, nach W und NW liegt es aber offen, und außerdem senden die großen Seeflächen selbst viel Feuchtigkeit in die Luft. Es müssen hier außer der Entfernung vom Meer noch sehr ungünstige Kondensationsbedingungen wirksam sein, und es liegt nahe, diese den stetigen nördlichen Luftströmungen zuzuschreiben. So schließen sich auf der Ostfeste regenarme Gebiete von verschiedener Entstehung zu einem, nur von feuchteren Gebirgen unterbrochenen Wüsten- und Steppengürtel zusammen, der sich durch 135 Längengrade von dem atlantischen Gestade bis zu dem oberen Hoangho ausdehnt und auf die Geschicke der Mensch- 
heit einen so ungünstigen Einfluß ausgeübt hat. Nichts derartiges weist die Westfeste auf, Amerika ist mit viel reichlicheren Niederschlägen gesegnet und schon deshalb zu einer noch größeren weltgeschichtlichen Rolle berufen, als es bisher gespielt hat.

Zum Schluß noch ein paar Worte über Europa. ${ }^{10}$ Den einfachen Schlüssel zum Verständnis der Regenkarte bietet das Gesetz der Abnahme der Niederschläge nach Ost, das auch für den ganzen Umkreis des Mittelländischen Meers und des Pontus Geltung hat, und ebenso zutage tritt, wenn wir den Erdteil als Ganzes betrachten, wie wenn wir die West- und Ostküsten der Inseln und Halbinseln oder die West- und Osthänge der Gebirge miteinander vergleichen. $\times$ Die Westhälfte gehört im großen und ganzen der zweiten Stufe der mäßigen Niederschläge $(500-750 \mathrm{~mm})$ an. Aber die große Mannigfaltigkeit der Geländegestaltung erzeugt ein viel bunteres Bild, als es der kleine Maßstab unserer Karte wiederzugeben vermag. Nicht bloß die Hochgebirge, auch die höheren Teile der meisten Mittelgebirge sind regenreich. Die größten Mengen finden wir an den westlichen Küstengebirgen: in Skandinavien, vor allem an der Küste zwischen Stadtland und dem Hardangerfjord (Domsten $1954 \mathrm{~mm}$ ), im westlichen Großbritannien (Glencoe in Schottland $3242 \mathrm{~mm}$, der Styehead-Paß in Cumberland $4720 \mathrm{~mm}$ ), und in der Serra da Estrella $(3900 \mathrm{~mm})$ trotz ziemlicher Entfernung vom Meer. Durch großen Regenreichtum sind ferner die Alpenländer ausgezeichnet, besonders der südliche Abhang (Hermsburg in Krain $3173 \mathrm{~mm}$ ), aber sie werden noch von dem dalmatinischen Gebirge übertroffen, wo sich außer dem schon genannten Styehead-Paß die einzige europäische Station mit $4 \mathrm{~m}$ Niederschlag findet (Crkvice $4642 \mathrm{~mm}$ ). ${ }^{11}$ Unter $500 \mathrm{~mm}$ sinkt die jährliche Regenhöhe allerdings auch in Mitteleuropa hier und da in besonders geschützten Lagen, wie z. B. im gebirgsumschlossenen Bỏhmen, auf weite Strecken aber nur in den östlichen Teilen der skandinavischen und der pyrenäischen Halbinsel. Jedenfalls ist die SO-Küste Spaniens das niederschlagsärmste Gebiet von Westeuropa, wo nach WлцLкомм drei und mehr Jahre ohne einen einzigen an-

$\times$ Ein lehrreiches Beispiel bieten die Stationen am Arlberg:

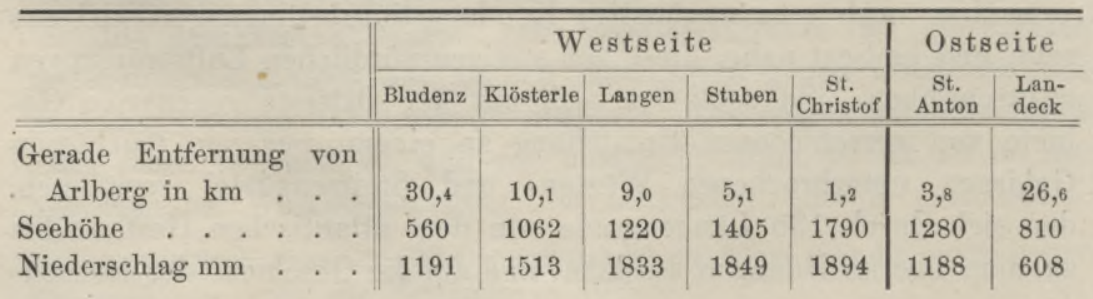


haltenden Regen vergehen, die Bewölkung saharisch gering ist, und die Dattelpalme ihre Früchte reift. Osteuropa hat natürlich einfachere Regenverhältnisse. Der weitaus größere Teil hat weniger als $500 \mathrm{~mm}$ im Jahr. Interessant ist das Vorspringen der $500 \mathrm{~mm}$ Linie im mittleren Rußland, das sicher unterbleiben würde, wenn an Stelle der Ostsee Land wäre.

Mittlere Regenwahrscheinlichkeit. ${ }^{12}$ Wir haben bisher nur von den jährlichen Regenmengen gesprochen, ohne auf die Regenhäufigkeit oder Regenwahrscheinlichkeit× Rücksicht zu nehmen. Da Menge und Dauer der Niederschläge aber nicht gleichmäßig wachsen und abnehmen, so müssen wir - soweit es das Beobachtungsmaterial gestattet - wenigstens einen flüchtigen Blick auf die geographische Verteilung der Regenwahrscheinlichkeit werfen. $\mathrm{Zu}$ beachten ist dabei nur, daß dieser Begriff bisher einer strengen Präzision entbehrt, indem noch immer nicht Übereinstimmung darüber herrscht ob auch Tage, an denen nur einige Tropfen fallen, zu den Regentagen zu rechnen seien.

Auf den Meeren ist die Anordnung der Dauer und der Menge der Niederschläge in den wesentlichen Zügen dieselbe, nur mit dem wichtigen Unterschied, daß es in der äquatorialen Kalmenzone zwar stärker aber seltener regnet als in den mittleren Breiten. Mit allem Vorbehalt, der durch die Dürftigkeit des Beobachtungsmaterials geboten erscheint, sei die Bemerkung gestattet, daß der Atlantische

\section{Mittlere Regenhäufigkeit auf den Ozeanen. ${ }^{13}$}

$\begin{array}{ccccc} & \begin{array}{c}\text { Atlantiseher } \\ \text { Ozean }\end{array} & \begin{array}{c}\text { Westpazifischer } \\ \text { Ozean }\end{array} & \begin{array}{c}\text { Ostpazifischer } \\ \text { Ozean }\end{array} & \begin{array}{c}\text { Indischer } \\ \text { Ozean }\end{array} \\ \text { über } 40^{\circ} \mathrm{N} & \mathbf{0 , 5 8} & \mathbf{0 , 6 1} & - & - \\ 40-30 & 0,47 & 0,46 & - & - \\ 30-20 & 0,34 & 0,43^{*} & - & - \\ 20-10 & 0,32 * & 0,55 & - & - \\ 10-0 & \mathbf{0 , 5 2} & \mathbf{0 , 5 6} & - & \mathbf{0 , 5 8} \\ 0-10 & 0,48 & 0,32 & - & 0,58 \\ 10-20 & 0,48 & 0,50 & 0,38 & 0,50 \\ 20-30 & 0,41 * & 0,43^{*} & 0,32^{*} & 0,46 * \\ 30-40 & 0,45 & 0,57 & 0,38 & \mathbf{0 , 6 2} \\ \text { über } 40 & \mathbf{0 , 6 0} & \mathbf{0 , 8 2} & -\end{array}$

Ozean verhältnismäßig am regenärmsten ist, vielleicht aber doch noch von dem Ostpazifischen Ozean übertroffen wird. Ein Gegen-

$\times$ Der Quotient aus der Anzahl der Regentage einer Periode (Monat, Jahr usw.) dividiert durch die Gesamtzahl der Tage der betreffenden Periode. Eine Regenwahrscheinlichkeit von 0,50 sagt also, daß von 100 Tagen 50 Regentage sind. 
satz zwischen den beiden Hälften des Stillen Ozeans tritt auch in der Regendichtigkeit zutage. Merkwürdig ist die Zweiteilung des äquatorialen Regengürtels durch eine Trockenzone in der westlichen Südsee.

Auf den Kontinenten finden wir den marinen Typus der mit der Breite erst ab-, dann zu- und endlich wieder abnehmenden Regenwahrscheinlichkeit nur an den Westseiten vollkommen ausgebildet, während an den Ostseiten eine ziemlich gleichmäßige Abnahme gegen die Pole stattfindet. Zwischen $40^{\circ} \mathrm{N}$ und etwa ebensoviel S sind eben die regenarmen Küstengebiete nur auf die Westseite beschränkt.

Auch auf dem Festland ist die Äquatorialzone durch eine Regenwahrscheinlichkeit von mehr als 0,40 , stellenweise von über 0,50 ausgezeichnet. Dann folgt in der Alten Welt eine Zone von $0,30-0,40$ Regenwahrscheinlichkeit, wozu die oberen Nilgegenden, die Malabarküste, das östliche Hinterindien und Südchina gehören. In Oberguinea, Bengalen und Nippon schwankt die Regenwahrscheinlichkeit zwischen 0,20 und 0,30 und sinkt in Senegambien, in Vorderindien mit Ausnahme der genannten Teile und des Pandjab und in den Ebenen von Peking auf $0,10-0,20$ herab. Im Wüstengebiet beträgt sie weniger als 0,10 , steigt aber von da wieder in nordwestlicher Richtung. Die Zone $0,10-0,20$ umfaßt Syrien, Kleinasien, Mesopotamien und Turan; die von $0,20-0,30$ das mediterrane Europa, Südrußland, die Kirgisensteppe und Sibirien; die Zone $0,30-0,40$ das mittlere und südliche Frankreich, den Nordrand der Alpen und die Karpathen, ferner Nord- und Zentralrußland; endlich die Zone $0,40-0,50$ Britannien, fast ganz Deutschland und Norwegen.

Eine ähnliche Anordnung finden wir an der schmalen Westabdachung Nordamerikas, eine wesentlich andere aber im Osten. In Zentralamerika und an der Golfküste von Mexico beträgt die Regenwahrscheinlichkeit $0,30-0,40$, auf dem mexicanischen Tafelland und in den Vereinigten Staaten östlich vom Felsengebirge 0,20-0,30, stellenweise, wie in Virginien, Georgia und Carolina, sogar weniger als 0,20. Unter diesem Mittelwerte bleibt sie auch im ganzen arktischen Gebiet. Auf den Südkontinenten erreicht sie nur in der Zone der Äquatorialwinde (Chile und westliches Neuseeland) 0,40 und mehr, sonst hält sie sich fast überall unter 0,30 und in den regenarmen Gegenden unter 0,10.

Schon aus dieser kurzen Beschreibung ergeben sich zwei wichtige Gesetze: 1. Zwischen ungefähr $35^{\circ} \mathrm{N}$ und $\mathrm{S}$ ist der Regen an der Westküste seltener als an der Ostküste, jenseits dieser Grenzparallelen werden aber die Westküsten häufiger von Regen heim- 
gesucht. Die beiden Küsten verhalten sich also in bezug auf die Häufigkeit (wie im allgemeinen auch bezüglich der Menge) der Niederschläge ebenso zueinander wie im bezug auf die Erwärmung. 2. Die Regenwahrscheinlichkeit ist im allgemeinen auf dem Meer größer als auf dem Festland in gleicher Breite, Ganz besonders gilt dies von der ozeanischen Passatzone im Vergleich zu den Wüsten. Auch in diesem Punkt nimmt der nordatlantische Ozean eine Sonderstellung ein; ebenso ausgedehnt wie die Passatzone, ist hier die Regenarmut, und zwar sowohl nach Menge wie nach Dauer gibt es doch auch nirgends eine so ausgedehnte Wüste, wie die ihm benachbarte Sahara. Intensiver ist die Regenarmut vielleicht an der Westküste des tropischen Südamerika, aber sie reicht hier nicht weit in die See hinaus; nach KöPPEN im Sommer bis 79, im Winter nur bis $76^{\circ} \mathrm{W}$; ja ausnahmsweise wurde sogar schon in $70^{1} / 2^{\circ} \mathrm{W}$ Regen notiert.

Literaturnachweise. 1 A. Supan, Die Verteilung der Niederschläge auf der festen Erdoberfläche; Gotha 1898 (erste Regenkarten für die Jahreszeiten!); Die jährlichen Niederschlagsmengen auf den Meeren, in Petermann's Mitteilungen 1898. A. J. Hersertson, The Distribution of Rainfall over the Land; London 1901 (erste Monatskarten der Niederschläge!). — ${ }^{2}$ J. Schubert verlangt in der Zeitschrift für Forst- und Jagdwesen 1906, S. 728, Reduktion der Messungen auf gleichen Windschutz. - ${ }^{3} \mathrm{Sir}$ John Murray, The Total Annual Rainfall on the Land of the Globe, im Scottish Geographical Magazine 1887. Die Berechnung fußt auf der älteren Regenkarte von Looms, dagegen hat J. Bezpex (im Abrégé du Bulletin de la Société hongroise de Géographie 1904, S. 94) meine Regenkarte zugrunde gelegt. Desgleichen auch L. Pragrm (Versuch einer rechnerischen Behandlung des Eiszeitproblems, in den Jahresheften des Vereins für vaterländische Naturkunde in Württemberg 1904), R. Fritzsche (Niederschlag, AbfluB und Verdunstung auf den Landflächen der Erde, Halle a. S. 1906), dessen Methode vor der Bezdek's den Vorzug verdient, und F. v. Kerner (Revision der zonalen Niederschlagsverteilung, in den Mitteilungen der Wiener Geographischen Gesellschaft 1907), der die detailliertesten Zahlen gibt. Die Ergänzung für die ganze Nordhalbkugel gab er in der Meteorologisehen Zeitschrift 1910 , S. 307 . Über Prlarim's Methode ist nichts bekannt. $-{ }^{4}$ A. Woerkow, Regenintensität und Regendauer in Batavia, in der Meteorologischen Zeitsehrift 1906. - ${ }^{5}$ H. Ziemer, Die gröBten Regenmengen eines Tags; Petermanx's Mitteilungen 1881. - ${ }^{6}$ G. GERLAND, Über Ziele und Erfolge der Polarforsehung; StraBburg 1897. - ${ }^{7}$ E. Brückner, Über die Herkunft des Regens, in den Verhandlungen des VII. Internationalen Geographenkongresses; Berlin 1901. Die Bilanz des Kreislaufes des Wassers auf der Erde, in der Geographischen Zeitsehrift 1905. - ${ }^{8} \mathrm{Vgl}$. die neue Regenkarte von Südamerika, in E. L. Voss, Die Niederschlagsverhältnisse von Südamerika, Ergänzungsheft Nr. 157 zu Petermans's Mitteilungen, Gotha 1907. - ${ }^{9} \mathrm{Vgl}$. die neue Regenkarte von Afrika von G. Fraunberger in Petermann's Mitteilungen 1906. - ${ }^{10}$ J. Reger, Regenkarte von Europa, ebenda 1903. - ${ }^{11}$ K. Kassner, ebenda 1904, S. 281. Meteorologisehe Zeitschrift 1910, S. 427. - ${ }^{12}$ W. Köppen, Die jährliche Periode der Regenwahrscheinlichkeit in der nördlichen Hemisphäre, in der Zeitschrift der 
Österreichischen Gesellschaft für Meteorologie 1876. - ${ }^{13}$ Die Tabelle beruht auf dem Material, das in den Arbeiten von W. Köppen und A. Sprung (in den Annalen der Hydrographie und maritimen Meteorologie 1880, S. 225), KöPPEN (ebendas. 1895, S. 440), A. v. Danckelman (in der Zeitschrift der Gesellschaft für Erdkunde in Berlin 1886, S. 316) und von P. SchleE (im Archiv der Deutschen Seewarte 1892, Nr. 3) mitgeteilt ist.

\section{Die jahreszeitliche Verteilung der Niederschläge.}

(Siehe Karte XIII.)

Winter- und Sommerregen. Neben der mittleren Menge und Dauer der Niederschläge ist ihre jahreszeitliche Verteilung, namentlich für das Pflanzenleben, von gröBter Bedeutung. Da Verdunstung und absolute Feuchtigkeit mit der Temperatur steigen, so ist $\mathrm{zu}$ erwarten, daß das Sommerhalbjahr ${ }^{\times}$regenreicher ist als das Winterhalbjahr. In der Tat ist das auch für das Festland die Regel, während für die Meere, mit Ausnahme der niederen Breiten, gerade das Entgegengesetzte gilt. Zwar wird auch hier im Sommer mehr Feuchtigkeit der Luft zugeführt, aber die Kondensationsbedingungen sind ungünstiger, weil sich die Luftdruckdifferenzen mehr ausgleichen und der barometrische Gradient verflacht, während Winter und Herbst als die Hauptzeit der Zyklonenbildungen Veranlassung zu mächtigen aufsteigenden Luftströmen bieten. Winterregen sind also der ozeanische, Sommerregen der kontinentale Typus. Im Norden gibt es, entsprechend der Anordnung von Wasser und Land, zwei Gebiete der Winterregen, das atlantische und das pazifische, im Süden umschlingt im zirkumterranen Ozean ein Gürtel mit Winterregen die ganze Erde und dringt in breiten Zungen weit gegen den Äquator vor, am weitesten an der Westküste von Südamerika, wo er sogar den Äquator erreicht. Nach beiden Seiten greift der ozeanische Typus auf das Festland über, aber (mit Ausnahme von Afrika zwischen 9 und $18^{\circ} \mathrm{N}$ ) an den Westküsten, besonders im Bereich der westlichen Winde, weiter als an den Ostküsten. Es gibt also auf jeder Halbkugel eine Zone, wo die beiden Festlandsküsten verschiedenen Regimes angehören; auch in Japan finden wir diesen Gegensatz ausgeprägt.

Nur an einer Erdstelle hat der ozeanische Typus weite Festlandsräume erobert; er herrscht im ganzen Umkreis des Mittelmeeres, auf der Wüstentafel, in Iran und in einem großen Teil von Turan. Es ist indes fraglich, ob diese Erscheinung überall einheitlich begründet, oder ob der räumliche Zusammenhang von Gebieten, wo verschiedene Ursachen wirksam sind, gleichsam nur

$\times$ Das nordhemisphärische Sommerhalbjahr zählt man von April bis September, das südhemisphärische von Oktober bis März. 
zufällig ist. Unzweifelhaft sind hier überall die Kondensationsbedingungen im Winter günstiger als im Sommer, in dem die polare Luftströmung fast ausschlieBlich herrscht, aber die winterlichen Zyklonen, die das Mittelmeergebiet nach $\mathrm{O}$ durchwandern, reichen nicht bis nach Iran, sondern hier befindet sich, wie aus ELIoT's Untersuchungen hervorgeht, ${ }^{1}$ eine zweite Geburtsstätte flacher Depressionen, die auch nach $\mathrm{O}$ ziehen, Hindustan durchqueren und sich bis Burma verfolgen lassen, und die im Hochgebirge von Afghanistan und im Himalaya gewaltige Schneemassen entladen. Auch kann man nicht sagen, daß hier überall der ozeanische Typus ungetrübt herrsche. Dazu gehört auch, daß der Frühling relativ trockener ist als der Herbst; und an den Küsten ist dieser Gegensatz besonders ausgebildet, weil der Wärmeüberschuß des Meeres über das Land im Herbst am größten und im Frühjahr am kleinsten ist. Die westlichen Südwinde sind im Herbst daher verhältnismäßig am wärmsten und bedürfen zur Kondensation nur eines geringen Anstiegs. Dem großen Subtropengebiet der Alten Welt sind zwar Winterregen und trockene Sommer gemeinsam, in den übrigen Jahreszeiten verhalten sich aber die Küsten- und die Binnenlandschaften ganz abweichend voneinander. Die ersteren haben, wie alle Küsten-mittlerer und höherer Breiten, Herbstregen, die letzteren Frühjahrsregen, und wir glauben in diesen ein Äquivalent der Sommerregen höherer Breiten gefunden zu haben. ${ }^{2}$ In Vorderasien, im Innern der pyrenäischen Halbinsel, von Algerien usw. steigt die Temperatur im Frühjahr sehr rasch; die Luft hat noch vom Winter her einige Feuchtigkeit bewahrt, und damit ist die Möglichkeit zu Gewitterregen gegeben, wie wir sie in unseren Gegenden meist nur im Sommer erleben. Dagegen dörrt die heißeste Jahreszeit dort die Luft so aus, daß diese selbst bei aufsteigender Bewegung keinen Regen mehr zu erzeugen vermag, und die gleichmäßig wehenden Polarwinde führen keine neue Feuchtigkeit zu.

Noch ist zweier vereinzelter Vorkommnisse von vorherrschenden Winterregen im Gebiet der Sommerniederschläge zu gedenken. Eine solche Ausnahme bilden einige Ostküsten der Passatzone, auf die wir später noch zu sprechen kommen werden; die andere Ausnahme wurde beobachtungsmäBig bisher zwar nur in unseren Mittelgebirgslandschaften und in den südlichen Vereinigten Staaten nachgewiesen, ist aber sicher eine viel weiter verbreitete Erscheinung. Im Winterhalbjahr erfolgt die senkrechte Zunahme der Niederschläge rascher als in der Sommerhälfte, die Maximalzone liegt aber, wie bereits auf S. 160 erwähnt wurde, tiefer. Ein lehrreiches Beispiel bietet das dichte Beobachtungsnetz in Belgien: 


\begin{tabular}{|c|c|c|c|c|c|c|c|c|}
\hline \multirow{2}{*}{$\begin{array}{l}\text { Höhe m } \\
\text { unter } 100\end{array}$} & \multicolumn{2}{|c|}{$\begin{array}{l}\text { Niederschlag m } \\
\text { Winter- Sommer- } \\
\text { hälfte }\end{array}$} & \multirow{2}{*}{$\begin{array}{l}\text { m. } \\
\text { Jahr } \\
700\end{array}$} & \multicolumn{2}{|c|}{$\begin{array}{l}\text { Relativzahlen } \\
\text { Winter- Sommer- } \\
\text { hälfte }\end{array}$} & \multirow{2}{*}{$\begin{array}{c}\text { Jahr } \\
100\end{array}$} & \multicolumn{2}{|c|}{$\begin{array}{c}\text { In Prozenten } \\
\text { der Jahressumme. } \\
\text { Winter- Sommer- } \\
\text { hälfte }\end{array}$} \\
\hline & 332 & 368 & & 100 & 100 & & 47 & 53 \\
\hline $100-200$ & 371 & 415 & 786 & 112 & 112 & 112 & 47 & 53 \\
\hline $200-300$ & 435 & 449 & 884 & 131 & 122 & 126 & 49 & 51 \\
\hline $300-400$ & 455 & 459 & 914 & 137 & 125 & 131 & 50 & 50 \\
\hline $400-500$ & 505 & 452 & 957 & 152 & 123 & 137 & 53 & 47 \\
\hline über 500 & 485 & 525 & 1010 & 146 & 140 & 144 & 48 & 52 \\
\hline
\end{tabular}

Hier haben wir zwei Umkehrungsniveaus; in ungefähr 350 und $450 \mathrm{~m}$ Höhe. Orte unter $350 \mathrm{~m}$ Seehöhe haben Sommerregen, zwischen 350 und $450 \mathrm{~m}$ Winterregen, über $450 \mathrm{~m}$ wieder Sommerregen. Unsere meisten Mittelgebirge ragen in die Zone der Winterregen hinein, aber nur in West- und Mitteldeutschland, weil nur hier auch am $\mathrm{FuB}$ der Gebirge die Sommerregen nicht sehr überwiegen. Im östlichen Deutschland ist der hydrometeorische Unterschied der Jahreshälften schon beträchtlicher, er mildert sich zwar auch mit der Höhe, aber das untere Umkehrungsniveau liegt höher als die Schneekoppe, der höchste Punkt unseres Mittelgebirgs.

Die jährliche Niederschlagsschwankung. Wir verstehen darunter den Unterschied der größten und kleinsten Monatsmenge, ausgedrückt in Prozenten der Jahresmenge. Auf Karte XIII unterscheiden wir vier Kategorien:

1. Niederschläge zu allen Jahreszeiten mit einer Schwankung unter 10 Prozent. Dieser Ausdruck ist nicht so zu verstehen, als ob es jedes Jahr das ganze Jahr hindurch regnen würde, sondern es ist damit nur gesagt, daß Maxima und Minima in verschiedenen Jahren in verschiedene Jahreszeiten fallen. Die mittlere Schwankung ist kleiner als die in den einzelnen Jahren, weil sich in langjährigen Monatsmitteln ein Ausgleich vollzieht. Regellosigkeit ist der eigentliche Charakter der hierher gehörigen Gegenden.

2. In den Gebieten mit mäBig-periodischen Niederschlägen, d.h. mit einer mittleren Schwankung von 10-20 Prozent sind Maxima und Minima schon fester an bestimmte Jahreszeiten gebunden, der Gegensatz von nassen und trockenen Monaten ist schon schärfer ausgeprägt, aber es fehlen noch länger andauernde Trockenperioden.

3. Streng-periodische Niederschläge nennen wir solche, die eine mittlere Schwankung von 20 Prozent und darüber aufweisen. Jahraus jahrein herrscht mit geringen Schwankungen die gleiche Periodizität. Maxima und Minima verschieben sich zwar auch von 
einem Monat zum andern, aber es kommt (mit seltenen Ausnahmen) nicht mehr vor, daß in einem und demselben Monat in dem einen Jahre das Minimum, in dem andern das Maximum eintritt. Also nicht völlige, aber doch verhältnismäßig größte RegelmäBigkeit, und damit auch die Ausbildung längerer Trockenund Regenperioden, auf die die Bewohner der Tropenzone, in der die gleichmäBige Temperatur den Gegensatz von Winter und Sommer verwischt, die klimatische Einteilung des Jahres gründen.

4. Als vierte Kategorie haben wir die Gebiete mit dauernder Regenarmut ausgeschieden, weil es hier praktisch von keinem Wert ist, die Periodizität festzustellen. Wir empfehlen einen Vergleich der dauernd regenarmen Gebiete auf Karte XIII mit den nach der Jahressumme als regenarm bezeichneten Landstrichen auf Karte XII. Man wird sehen, daß die ersteren eine erheblich geringere Fläche einnehmen. Dauernd nennen wir die Regenarmut, wenn die Niederschläge in keiner Jahreszeit $60 \mathrm{~mm}$ erreichen; das hindert aber nicht, daß sich hier und da, freilich nach oft jahrelanger Regenlosigkeit, schwere Wolkenbrüche ereignen. Nicht bloß in der australischen Wüste kommen solche vor, sondern auch in der Sahara, und sie erzeugen sogar plötzliche Überschwemmungen, wie z. B. am 12. April $1899 \mathrm{im}$ Wadi Urirlu, wo innerhalb weniger Sekunden eine Fläche von $800 \mathrm{~m}$ im Durchmesser mannshoch unter Wasser gesetzt wurde, und sechs Mann einer französischen Militärabteilung dabei ihr Leben verloren. Im Hoggar erlebte die französische Strafexpedition im Oktober 1902 mehrtägige Platzregen. Genetisch können wir diese dauernd regenarmen Gebiete einteilen 1. in polare, 2. in innerkontinentale, 3. in Windschattengebiete und 4. in passatische Wüsten mit beständigen Polarwinden.

Die gemäßigten Zonen. Wenn wir in der Alten Welt vom atlantischen Gestade nach Ost fortschreiten, so sehen wir die Niederschlagsverteilung ganz allmählich aus dem ozeanischen in den kon-

Prozente der Jahresmenge

\begin{tabular}{|c|c|c|c|c|c|c|c|}
\hline & & & Winter & Frühling & Sommer & Herbst & Sehwankung \\
\hline Irland . . & . & . & . 28 & $21^{*}$ & 24 & 27 & 5 \\
\hline Westengland. & . & . & 28 & $19^{*}$ & 24 & 29 & 5 \\
\hline Ostengland. . & .. & . & 23 & $19^{*}$ & 28 & 30 & 5 \\
\hline Nordwestdeutse & ehlar & & . 23 & $22^{*}$ & $\mathbf{3 1}$ & 24 & 5 \\
\hline Mitteldeutsehlar & and & . & . $20^{*}$ & 23 & 34 & 23 & 6 \\
\hline Ostdeutsehland & . & . & . $19^{*}$ & 22 & 37 & 22 & 7 \\
\hline WestruBland . & . & . & . $16^{*}$ & 21 & 39 & 24 & 10 \\
\hline MittelruBland . & . & . & $16^{*}$ & 22 & 37 & 25 & 10 \\
\hline Westsibirien . & . & . & . $13 *$ & 13 & 42 & 32 & 14 \\
\hline Ostsibirien . & . . & . & $9^{*}$ & 12 & 58 & 21 & 21 \\
\hline
\end{tabular}


tinentalen Typus übergehen. In Irland herrscht der erstere noch unbedingt. Im westlichen England verschiebt sich das Maximum schon auf den Herbst. Im mittleren und östlichen England übertrifft der Sommerregen bereits den winterlichen. Im nordwestlichen Deutschland ist der Sommer die Hauptregenzeit, aber das Minimum fällt noch in den Frühling. In Mitteldeutschland ist der kontinentale Typus hergestellt, aber noch strömt auch in der kalten Zeit genug atlantische Feuchtigkeit in das Land, um eine große Schwankung nicht aufkommen zu lassen, und das sommerliche Maximum ist selbst in Brandenburg und an der deutschen Ostseeküste nur eine Folge der Gewitterregen. ${ }^{3}$ Erst in den östlichsten Binnengegenden Deutschlands, in Rußland und in Westsibirien tritt die maritime gegen die Landfeuchtigkeit zurück, und die Niederschläge konzentrieren sich immer mehr auf die warme Jahreshälfte. Ostsibirien ist das ganze Winterhalbjahr hindurch in den Gürtel hohen Luftdruckes eingeschlossen und damit allseitig von der Zufuhr ozeanischer Feuchtigkeit abgeschnitten. Die pazifischen Randländer teilen dasselbe Schicksal, denn die winterliche Bodenständigkeit der ostasiatischen Antizyklone bewirkt eine ebenso große, nahezu passatische Konstanz trockener nordwestlicher Landwinde, die weit auf das Meer hinaus vordringen, und nur über dem Japanischen Meer etwas Feuchtigkeit aufnehmen, um sie der vorgelagerten Inselkette zuzuführen. Im Sommer herrscht hier aber bis über die Amurmündung hinaus der regenbringende SO-Monsum. So entsteht ein schärferer Gegensatz zwischen Winter und Sommer als irgend wo anders in den höheren Breiten, und eine strenge Periodizität der Niederschlagsverteilung, die an die Tropen gemahnt. Man vergleiche damit Nordamerika. Der ganze Osten hat hier Regen zu allen Jahreszeiten, weil die den Kontinent durchziehenden Zyklonen auch im Winter Seewinde aus dem Mexicanischen Golf in das Land ziehen. Dagegen ist diese Kategorie im W wenig entwickelt, einerseits, weil hier die Cordilleren dem Einfluß der pazifichen Westwinde bald ein Ziel setzen, anderseits weil die subtropische Antizyklone im Sommer im nordpazifischen Ozean weiter nach $\mathrm{N}$ rückt als im nordatlantischen. Der letztere Umstand hat zur Folge, daß der Sommer in Britisch-Columbien und Washington relativ trockener ist, als in den entsprechenden europäischen Küstenländern.

Die subtropischen Regengebiete. Wenn wir von Mitteleuropa nach Süd fortschreiten, so vollzieht sich ebenfalls ein Übergang in der jährlichen Regenverteilung, aber im gerade entgegengesetzten Sinn wie bei dem Fortschreiten nach Ost. In Nordtirol haben wir noch den normalen mitteleuropäischen Typus. In Südtirol ver- 
schiebt sich das Maximum schon auf den Herbst. In der Po-Ebene zeigt sich bereits im Sommer ein sekundäres Minimum, das in Mittel- und noch mehr in Süditalien zum Hauptminimum wird; zu-

\begin{tabular}{|c|c|c|c|c|c|c|c|}
\hline & & & & rozente der & ahresmen & & \\
\hline & & & Winter & Frühling & Sommer & Herbst & Schwankung \\
\hline Nordtirol . & . & . & $16^{*}$ & 24 & 37 & 23 & 9 \\
\hline Südtirol . & . & . & . $14^{*}$ & 26 & 28 & 32 & 8 \\
\hline Po-Ebene. & . & . & . $20 *$ & 26 & 24 & 30 & 6 \\
\hline Mittelitalien & . & . & . 25 & 24 & $17^{*}$ & 34 & 9 \\
\hline Süditalien & . & . & . 31 & 25 & $11^{*}$ & 33 & 11 \\
\hline Sizilien . & . & . & . 39 & 22 & $3^{*}$ & 36 & 15 \\
\hline Malta . & . & . & . 48 & 14 & $2^{*}$ & 36 & 22 \\
\hline
\end{tabular}

gleich ist die jährliche Schwankung beträchtlich gestiegen. In Sizilien fällt das Maximum in den Winter, und der Sommer ist beinahe regenlos; mit anderen Worten: der subtropische Typus ist zur völligen Ausbildung gelangt. Gehen wir noch weiter nach S, z. B. nach Malta, so sehen wir diesen Typus immer schärfer ausgeprägt, und es tritt strenge Periodizität ein. Nicht das winterliche Maximum ist charakteristisch, denn das finden wir ja auch in den höheren ozeanischen Breiten, sondern das tiefe sommerliche Minimum, das sich bis zur völligen Regenlosigkeit steigert.

Diese völlige Umkehr der kontinentalen Regenkurve beruht auf den jahreszeitlichen Verschiebungen des Passates und $\mathrm{muB}$ im Zusammenhang mit den tropischen Verhältnissen betrachtet werden. Dazu eignet sich am besten die atlantische Ostküste, weil nur hier alle Glieder deutlich ausgebildet sind. Wie Fig. 37 zeigt, wandert das ganze Passatsystem mit der Sonne und damit auch das kalte Küstenwasser auf der Lurseite der NO- und SO-Winde, das die Temperatur des Seewindes erniedrigt. Im Bereich der subtropischen Antizyklonen und des strengen Passats herrscht Trockenheit, im Bereich der tropischen Luftauflockerung und der westlichen Winde regnet es. Auf diese Weise entsteht eine regelmäßige Folge:

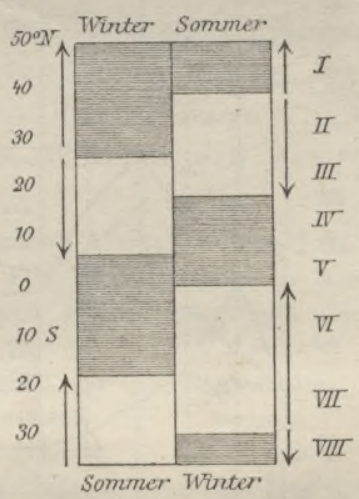

Fig. 37. Regenzonen(dunkel) und regenlose Zonen (hell) an der atlantischen Ostküste im Winter und Sommer. Die Pfeile zoigen die Richtung der Winde.

I. Nördlich von $40^{\circ} \mathrm{N}$ dauernd Regen.

II. $40-27^{\circ} \mathrm{N}$ regenarm im Sommer (subtropisehe Regen).

III. $27-19^{\circ} \mathrm{N}$ dauernd regenarm.

IV. $19-7^{\circ} \mathrm{N}$ regenarm im Winter (tropische Regen).

V. $7-1^{\circ} \mathrm{N}$ dauernd Regen (Äquatorialgürtel). 
VI. $1^{0} \mathrm{~N}-17^{\circ} \mathrm{S}$ regenarm im Winter (tropische Regen).

VII. $17-30^{\circ} \mathrm{S}$ dauernd regenarm.

VIII. Über $30^{\circ} \mathrm{S}$ regenarm im Sommer (subtropische Regen).

(IX. dauernd Regen nur auf dem Ozean, da die afrikanische Westküste in diese Zone nicht mehr hineinreicht).

Subtropische Regen herrschen auch in Californien, in Nordchile und in Westaustralien, also stets nur an den Westküsten, während die Ostküsten gerade durch den Passat Niederschläge empfangen. Überall sind sie, ebenso wie die sich daran anschließenden passatischen Wüsten, eine litorale Erscheinung, nur in der Alten Welt sind beide zonenartig entwickelt. Subtropisch ist hier die Regenverteilung im ganzen Umkreis des Mittelmeers und in ganz Vorderasien!, vielleicht nur mit Ausnahme des Gebirges von Jemen. Wir haben uns über dieses auffallende und noch immer nicht ganz aufgeklärte Phänomen schon an einer früheren Stelle (S. 170) ausgesprochen.

Tropenzone. Ombrometrisch ist nach dem Gesagten eine scharfe

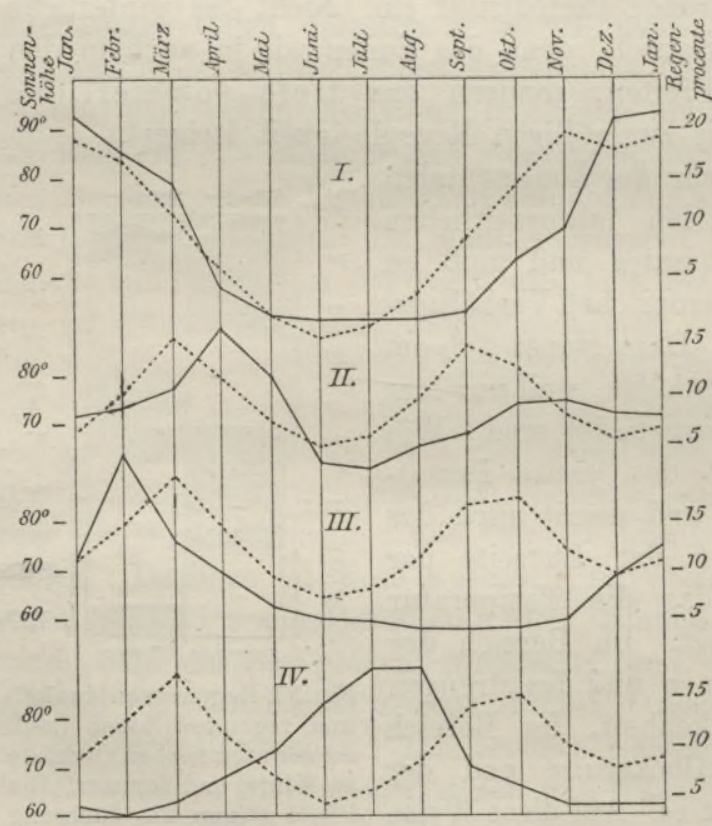

Fig. 38. Regentypen der Tropenzone.

Regenkurve (Prozente der Jahresmenge)

Jährlicher Gang der Sonnenhöhe nach dem Stand in den Monatsmitten.
I. Tropischer Grenz typus (Antananarivo, Madagaskar, $\left.18,9^{\circ} \mathrm{S}\right)$.

II. Äquatorialtypus (Quito, Ecuador, $0,{ }_{2}{ }^{\circ} \mathrm{S}$ ).

III. Monsuntypus (Wahaai an der Nordküste von Ceram, Molukken. $\left.2,8^{\circ} \mathrm{S}\right)$.

IV. Passattypus (Amahei an der Südküste von Ceram, $\left.3,3^{\circ} \mathrm{S}\right)$.

Abgrenzung der Tropenzone nur an den Westseiten der Kontinente möglich. Tropenregen sind diejenigen, die bei dem Zenitstand 
der Sonue eintreten. In der Nähe der Wendekreise (s. Fig. 38) erreicht die Sonne allerdings auch zweimal, aber rasch hintereinander ihren höchsten Stand, und die beiden Regenzeiten verschmelzen infolgedessen zu einer einzigen. So ensteht eine einfache Regenkurve mit strenger Periodizität, entsprechend der großen Schwankung der Sonnenhöhe; mit ihrem regnerischen Sommer und regenlosen Winter bildet der tropische Grenztypus den geraden Gegensatz zum subtropischen.

Je mehr wir uns dem Äquator nähern, um so mehr treten die beiden Zenitstände der Sonne auseinander, es entwickelt sich eine Doppelkurve mit zwei Regen- und zwei Trockenzeiten, $\times$ und der Grenztypus geht allmählich in den Äquatorialtypus über. Aus Fig. 38 ist ersichtlich, daß die Regenmaxima den Zenitständen etwas nachfolgen, und daB sie, ebenso wie die Minima, ungleich entwickelt sind. Auch kann man hier nur von relativen Trockenzeiten sprechen, da auch sie nicht völlig regenlos sind. Die jährliche Niederschlagsschwankung sinkt im Äquatorialgürtel fast überall unter 20, am oberen Amazonas und im westlichen malaiischen Archipel sogar unter 10 Prozent. Wir haben also hier, wo die Luft das ganze Jahr mit Feuchtigkeit geschwängert ist, und kein Passat zeitweise die Kondensation hindert, ebenso Regen zu allen Jahreszeiten, wie im ozeanisch modifizierten Klima der höheren Breiten, mit denselben Unregelmäßigkeiten in dem Auftreten der Maxima und Minima.

Eine andere jahreszeitliche Regenverteilung finden wir in den Ländern mit semesterweisem Windwechsel. Der Monsuntypus unterscheidet sich vom Tropentypus dadurch, daß nur ein Zenit-

$\times$ Als Beispiel diene Loanda an der Westküste Afrikas unter $8^{\circ} 49^{\prime}$ s. B., wo mehrjährige Beobachtungen vorliegen. Die Sonne steht hier am 26. Februar und 17. Oktober im Zenit; dem ersteren Stand entspricht die kleine, dem letzteren die große Regenzeit.

$\begin{array}{ccccc}\text { Beginn der } & \begin{array}{c}\text { Beginn der } \\ \text { kleinen } \\ \text { großen }\end{array} & \begin{array}{c}\text { Beginn der } \\ \text { großen } \\ \text { Trockenzeit }\end{array} & \begin{array}{c}\text { Beginn der } \\ \text { kleinen } \\ \text { Trockent }\end{array} \\ 1879 & \text { ? } & \text { 6. Mai } & \text { 5. Okt. } & \text { 21. Dez. } \\ 1880 & \text { 18. Febr. } & \text { 29. April } & \text { 4. Sept. } & \text { 29. Dez. } \\ 1881 & \text { 5. Febr. } & \text { 10. April } & \text { 2. Dez. } & \text { 27. Dez. } \\ 1882 & \text { 8. Febr. } & \text { 23. Mai } & \text { 8. Okt. } & \text { - } \\ 1883 & - & \text { 5. Mai } & \text { 29. Nov. } & \text { ? }\end{array}$

Die mittlere Dauer der vier Perioden berechnet sich folgendermaßen: Große Trockenzeit 164, groBe Regenzeit 107, kleine Trockenzeit 35, kleine Regenzeit 59 Tage. Man beachte besonders die große Unregelmäßigkeit im Beginn der Hauptregenzeit, den zeitweiligen Wechsel beider Regenzeiten (1881 dauerte die "große" Regenzeit nur 25 Tage, die darauf folgende „kleine" aber 104) und das vollständige Fehlen der kleinen Perioden im Jahre 1882-83. Das alles zeigt deutlich, welehen Schwankungen der Tropenregen unterworfen ist.

Supar, Physische Erdkunde. 5. Aufl, 
stand der Sonne von Niederschlägen begleitet ist. Hier entsteht ebenfalls eine einfache Kurve wie im tropischen Grenztypus, und daher können beide Typen nur in der Nähe des Äquators streng auseinander gehalten werden. Das größte Monsungebiet ist das asiatische, das sich von Indien bis über die Amurmündung hinaus erstreckt; im indischen Bereich ist SW mit seinen Abzweigungen, im pazifischen SO der Regenwind, der ozeanische Feuchtigkeit tief in das Land hineinträgt. Daher die gewaltigen Wassermassen, die hier überall niedergehen, wo der Sommermonsun auf eine Bodenerhebung stößt, und zwar - was besonders beachtenswert ist - trotz strenger Periodizität, während sonst in der Regel die jährliche Niederschlagsmenge im umgekehrten Verhältnis zur Schwankung steht.

Im Gebiet des Australmonsuns lernen wir eine Mischform von Monsun- und Tropentypus kennen. Batavia z. B. hat noch reine Monsunregen, das benachbarte Buitenzorg aber zwei Maxima: ein Monsunmaximum im Januar, das zwei Monate vor dem ersten Zenitstand der Sonne eintritt, und ein Tropenmaximum im Oktober zur Zeit des zweiten Zenitstandes. Für Fig. 38 sind die Monsunregen an der Nordküste von Ceram gewählt worden, um zu zeigen, wie in den Tropen die Extreme oft nahe beieinander liegen. Der Nordküste bringt der NW-Monsun, der Südküste der SO-Monsun, d. h. der Passat, Regen; ihre Regen- und Trockenzeiten fallen somit in die entgegengesetzten Jahreszeiten. Der Passattypus mit dem Maximum zur Zeit des tiefsten Sonnenstandes ist der gerade Gegensatz des Tropentypus; er ist zwar dem subtropischen ähnlich, unterscheidet sich aber dadurch von ihm, daß auch der Sommer nicht regenlos ist. Die warme Jahreszeit bringt, wie überall in den Tropen, zyklonale und konvektive Regen, der Wintèr aber orographische. Während Tropen- und Monsuntypus über weite Gebiete herrschen, tritt der Passattypus nur an den Ostküsten auf, aber auch hier selten rein, sondern in mannigfache Mischung mit dem Tropentypus. In Sansibar z. B. erreicht die Sonne ihren höchsten Stand im März und Oktober, ihren tiefsten im Juni und Dezember; das Hauptregenmaximum im April ist echt tropisch, das sekundäre im Dezember aber passatisch. Überall wird durch die passatischen Steigungsregen die Periodizität gemildert, und nur dem Umstand, daß Südamerika dem Passat offen liegt, ist es zuzuschreiben, daß hier, mit Ausnahme einiger weit entlegener oder vom Wind geschützter Gegenden, der Gegensatz von Regen- und Trockenzeit nicht so schroff ist wie in Afrika und in Australien.

Aus dem Gesagten geht hervor, daß die Regenverhältnisse der Tropen viel mannigfaltiger sind als die der gemäBigten Zone, wo 
mehr die Temperaturunterschiede in den Vordergrund treten. Einförmigkeit herrscht nur in der Polarwelt.

Schwankungen des Regenfalls. Die Regenschwankungen von Jahr zu Jahr besitzen selbstverständlich nicht bloß theoretisches Interesse, sondern auch größte wirtschaftliche Bedeutung. Das Wenige, was wir darüber wissen, verdanken wir Hellmann. ${ }^{4}$ Unter sonst gleichen Umständen stehen sie im geraden Verhältnis zur Periodizität des Regenfalls und im umgekehrten zur durchschnittlichen jährlichen Regenmenge. Tropen- und Subtropengebiete sind also auch besonders großen Niederschlagsschwankungen von Jahr zu Jahr unterworfen. Wir betonen aber nochmals: unter sonst gleichen Umständen, denn an der Luvseite der Regenwinde sind die Schwankungen überall sehr mäBig.

Gewitter. Aus der geographischen Verteilung ${ }^{5}$ und jährlichen Periode der Gewitter kann man den Schluß ziehen, daß sie Begleiterscheinungen des Kondensationsprozesses des Wasserdampfes sind. Wie die Regenmenge, nehmen auch sie mit der Breite ab. Nirgends tritt dieses Phänomen, das in seiner schauerlichen Schönheit auf den Menschengeist stets einen tiefen Eindruck gemacht hat, häufiger und großartiger auf als in den Tropen. In Abessinien gibt es jährlich im Mittel 424 Gewitter, die sich auf 216 Tage verteilen. Auf den Hochebenen von Mexico, Bogota und Quito ist durchschnittlich jeder dritte Tag ein Gewittertag. Auch die tropischen Meere sind gewitterreich, jedoch mit Ausnahme der regenarmen Passatgürtel ${ }^{6}$. In der gemäßigten Zone erscheint - soweit man jetzt die Sachlage zu überblicken vermag - das kontinentale Klima vor dem ozeanischen durch größere Gewitterhäufigkeit ausgezeichnet zu sein. Auf dem Meer sind die Gewitter nach der allgemeinen Ansicht des Seefahrers an die warmen Meeresströmungen gebunden. Landeinwärts nehmen sie $\mathrm{zu}$, aber in so unregelmäBiger Weise, daß sich daraus noch keine allgemeinen Gesetze ableiten lassen. Man kann nicht einmal sagen, daß sie in den Gebirgen stets häufiger seien als in den Ebenen, oder in trockenen Gegenden stets seltener als in feuchten. Es sind hier Faktoren mit im Spiel, über die man nur Vermutungen aufstellen kann, wie z. B. die Bodenbeschaffenheit. Wüsten und polare Gegenden scheinen verhältnismäßig am seltensten von Gewittern heimgesucht $\mathrm{zu}$ werden, aber ganz frei davon sind auch sie nicht.

- Auf dem Meer der mittleren und höheren Breiten wiegen die Winter-, auf dem Festland die Sommergewitter vor. Doch zeigt sich eine solche Übereinstimmung mit der jährlichen Niederschlagsperiode nicht in jedem einzelnen Fall. Madrid und Biskra mit regenarmen Sommern haben doch in dieser Jahreszeit am meisten 
Gewitter, und dasselbe gilt von Schottland, trotzdem auch hier das Maximum der Niederschläge in die kälteste Jahreszeit fällt. Anderseits nehmen die Wintergewitter entschieden $a b$, je weiter wir uns vom atlantischen Gestade in das Gebiet der Sommerregen begeben, und in Osteuropa und Sibirien sind sie bereits ganz verschwunden.

Die Unterscheidung von Wärme- und Wirbelgewittern, wie siе Монм aufgestellt hat, muß auch jetzt noch aufrecht erhalten werden ${ }^{7}$ wenn auch bei jenen auf sehr detailliert gezeichneten Wetterkarten manchmal eine örtlich beschränkte zyklonale Anordnung der Isobaren hervortritt. Die Wärmegewitter sind Folgeerscheinungen des labilen Gleichgewichtszustandes der Luft; ihnen gehört die überwiegende Mehrzahl der Sommergewitter des Festlandes an, die weitaus am häufigsten in den Nachmittagsstunden eintreten und sich in der Regel nicht weit über ihren Ursprungsort verbreiten. Dagegen sind alle Wintergewitter und überhaupt alle elektrischen Phänomene in den außertropischen Teilen des Ozeans Begleiter der großen Zyklonen, mit denen sie wandern, und durch die sie oft zu einer weiten Verbreitung gelangen.

Hagel. Nur kurz sei der Verteilung des Hagels gedacht, da er wegen seiner verderblichen Wirkungen auch geographisches Interesse bietet. Freilich ist seine Statistik ziemlich mangelhaft, und überdies werden nur von wenigen Beobachtern Hagel (Eiskörner) und Graupen (kleine Schneeballen) auseinander gehalten, was freilich auch schwer möglich ist, da beide Formen vielfach ineinander übergehen. So ist es noch nicht einmal mit Sicherheit festgestellt, ob die mittleren Breiten die eigentliche Heimat dieses Phänomens sind, denn auch in den Tropen ist es nicht selten. HumboudT's Ansicht, daß der Hagel hier nur in größerer Höhe vorkomme, da in den tieferen Niveaus die Eiskörner von der Hitze rasch aufgezehrt werden, hat wohl für das äquatoriale Südamerika Gültigkeit, aber weder für die Küstenebene von Guatemala, noch für die tiefer gelegenen Flußtäler der brasilianischen Provinz Minas Gerães, noch endlich für Java und den Sudan (die heißeste Gegend der Erde), oder für das innere Australien im. Sommer.

- Als die Hauptbedingung der Hagelbildung erscheint eine größere Menge von Wasserdampf. Daher schließt sich die jährliche Periode des Hagels eng an die des Regens-an, enger sogar als die der Gewitter. Daher nimmt auch in Europa der Hagel- und Graupenfall mit dem Regen von West nach Ost ab, aber die Zahl der reinen Hagelfälle steigt in derselben Richtung. Selten ist dieses Phänomen in den polaren Gegenden und in den Wüsten. Lokale Einflüsse sind ganz besonders maßgebend, daher in jeder Gegend neben den Hagel- 
strichen Land liegt, das nur selten unter dieser Heimsuchung zu leiden hat. Das Beobachtungsmaterial genügt noch nicht zur Feststellung allgemein gültiger Gesetze, doch läßt es sich jetzt schon aussprechen, daß es im Gebirge häufiger hagelt als in der Ebene, und im Mittelgebirge häufiger als im Hochgebirge. Vom Kaukasus (vielleicht der hagelreichsten Gegend der Erde) sagt Авгсн, daß alle zum Gebirge herbeiziehenden Ungewitter den Charakter verheerender Hagelstürme erst dort annehmen, wo die weiten Täler in die Ebene münden, und von da ab gerne der Zone der niedrigen Vorberge folgen. Ähnlich ist es auch in den Alpen. In der Schweiz wird die Hochebene und der Jura am meisten durch Hagelfälle geplagt, in Kärnten das niedrige Bergland der Osthälfte, und ebenso in Steiermark das Hügelland gegen die ungarische Grenze hin.

Literaturnachweise. ${ }^{1} \mathrm{~J}$. Eurot, An Account of the more important Cold Weather Storms in India 1876-91, in Indian Meteorological Memoirs, Bd. IV, Calcutta 1893. - ${ }^{2}$ A. Supan, Die jahreszeitliche Verteilung der Niederschläge in Europa, Westasien und Nordafrika; in Petermans's Mitteilungen 1890. $-{ }^{3}$ G. Schwalbe, Über Niederschlagstypen, in der Meteorologiseben Zeitsehrift 1907. - ${ }^{4}$ G. Hellamans, Untersuchungen über die Schwankungen der Niederschläge, in den Abhandlungen des Meteor. Inst. in Berlin 1909. ${ }^{5}$ A. Kuossowskx, Distribution annuelle des orages à la surface du globe terrestre, Odessa 1894, mit der ersten Karte der Verteilung der Gewitter auf der Erde, die aber wegen des mangelhaften Materials noch sehr unvollkommen ist. Für die Vereinigten Staaten s. die Karte in A. J. Hennx, zit. S. 129, Anm. 7, für Europa mit Aussehluß der Mittelmeerländer s. E. Alt in Petermans's Mitteilungen 1910 , S. 5 und Taf. 1 . Alle diese Karten berücksichtigen nur die Häufigkeit, nicht die Intensität der Gewitter. - ${ }^{6}$ A. v. Danckelman, Regen, Hagel und Gewitter im Indischen Ozean, im Archiv der Deutschen Seewarte 1880. ${ }^{7}$ W. v. BEzoLd in der Meteorologisehen Zeitsehrift 1895, S. 121.

\section{Verbreitung des Schnees,}

Verbreitung. ${ }^{1}$ Unsere Gegenden gehören der Zone der ge mischten Niederschläge an: in der kälteren Jahreszeit schneit es, in der wärmeren regnet es. Schon im mittleren Italien sind Schneefälle in den Niederungen selten, aber immerhin hat noch Rom durchschnittlich 1,4 Schneetage im Jahr. Jenseits des Atlasgebirges und des Nefud, wo Nolde am 2. Februar 1893 einen starken Schneefall erlebte, ist der Schnee in der Ebene unbekannt, an der Ostseite der Alten Welt aber rückt seine Äquatorialgrenze, den Winterisothermen folgend, weiter nach Süden, bis über Canton hinaus $\left(23^{\circ}\right.$ B.), und eine ähnliche Anordnung wiederholt sich auch in Nordamerika.

Begeben wir uns nach Norden, so wird die feste Niederschlagsform in der Ebene immer häufiger. Mit Ausnahme von Norwegen 
dürfte sich die Grenze der sommerlichen Schneefälle in der Nähe des Polarkreises halten; schon auf Boothia Felix unter $70^{\circ} \mathrm{B}$. betragen sie von Juni bis August 40 Proz. der Niederschläge, und auf ähnliche Verhältnisse deuten die Beobachtungen NordenskiöLD's in der Nähe der Beringstraße. Auf der Südhemisphäre scheint die Grenze des Sommerschnees schon in der Nähe des 50. Parallels zu liegen. Aber überall, soweit man auf den Polarkalotten vorgedrungen ist, regnet es auch in den warmen Monaten, und es ist ganz ungewiß, ob eine Zone des festen Niederschlags überhaupt existiert. ${ }^{2}$

Wie in horizontaler, so verändert sich auch in vertikaler Richtung mit der abnehmenden Temperatur die Form der Niederschläge. Im Gebirge fällt Schnee auch innerhalb der Åquatorialgrenzen seines Vorkommens in der Ebene, sogar in der Sahara, z. B. auf den über $1500 \mathrm{~m}$ hohen Gipfeln des Asdjer in jedem Winter, und hier und da auch in dem noch südlicher gelegenen Hoggar. Während in unseren Gegenden die steigende Sonne den winterlichen Schnee in der Ebene und in den unteren Gebirgsregionen aufzehrt, bleibt er in den höheren Partien das ganze Jahr liegen und wird noch durch gelegentliche sommerliche Schneefälle vermehrt. Über die Veränderungen, die die Schneedecke eines Gebirges im Laufe eines Jahres erleidet, haben wir langjährige Beobachtungen nur vom Säntis in der Schweiz, vom Inntal bei Innsbruck, von der Sonnblickgruppe in den Hohen Tauern und rom Hohen Priel in den oberösterreichischen Kalkalpen. ${ }^{3}$ Die letzteren sind insofern wichtiger, als sie sich sowohl über die Nord- wie Südgehänge ausdehnen, doch berücksichtigen die Tiroler nur die steilen Böschungen, wo der Schnee leichter schmilzt als in den Mulden des Hochgebirges. Im Winter sind alle Talgründe mit Schnee bedeckt, dann zieht sich seine-untere Grenze bis zum Spätsommer in immer größere Höhen zurück, um im Herbst sich rasch wieder zu Tal zu senken. ${ }^{\times}$

$\times$ Temporäre Schneegrenze in den Ostalpen:

März April Mai Juni Juli Aug. Sept. Okt. Nov. Inntal

\begin{tabular}{|c|c|c|c|c|c|c|c|c|c|}
\hline Südabhang . . & 960 & 1270 & 1700 & 2190 & 2680 & 3130 & 3210 & 2150 & $1300 \mathrm{~m}$ \\
\hline Nordabhang & 720 & 1110 & 1540 & 2030 & 2470 & 2930 & 2760 & 1890 & $1010 \mathrm{~m}$ \\
\hline Unterschied. & 240 & 160 & 160 & 160 & 210 & 200 & 450 & 260 & $290 \mathrm{~m}$ \\
\hline \multicolumn{10}{|c|}{ Sonnblick-Gruppe } \\
\hline Südabhang . & - & 1600 & 2300 & 2650 & 2700 & - & 2650 & 2450 & 1400 \\
\hline \multicolumn{10}{|l|}{ Nordabhang und } \\
\hline $\begin{array}{l}\text { Nordexposition } \\
\text { des Südabhanges }\end{array}$ & - & 1500 & 1800 & 2150 & 2450 & 2700 & 2300 & 1950 & \\
\hline Untersehied... & & 100 & 500 & 500 & 250 & - & 350 & 500 & 150 \\
\hline
\end{tabular}

Aus den Messungen am Säntis ist besonders der Einfluß des Föhns im November interessant: Oktober 1620, November 1340 , Dezember $660 \mathrm{~m}$. 
Im heißesten Monat (Juli) kommen Schneefälle in der Schweiz nur oberhalb $1000 \mathrm{~m}$ vor, aber auch in der oberen Region regnet es noch ziemlich häufig. Die meteorologische Station auf dem Sonnblickgipfel in den Tauern (3100 m Höhe) verzeichnete im Durchschnitt der Jahre 1886-1906 in den Monaten Juni bis Oktober $126 \mathrm{~mm}$ Regen, d. h. 6 Proz. der gesamten Niederschlagsmenge $(1800 \mathrm{~mm})$. Es ist also auch zweifelhaft, ob irgend ein Gebirge in die Region beständig fester Niederschläge hineinragt; nur für das grönländische Inlandeis über $800 \mathrm{~m}$ Seehöhe nimmt es v. Drygalski an.

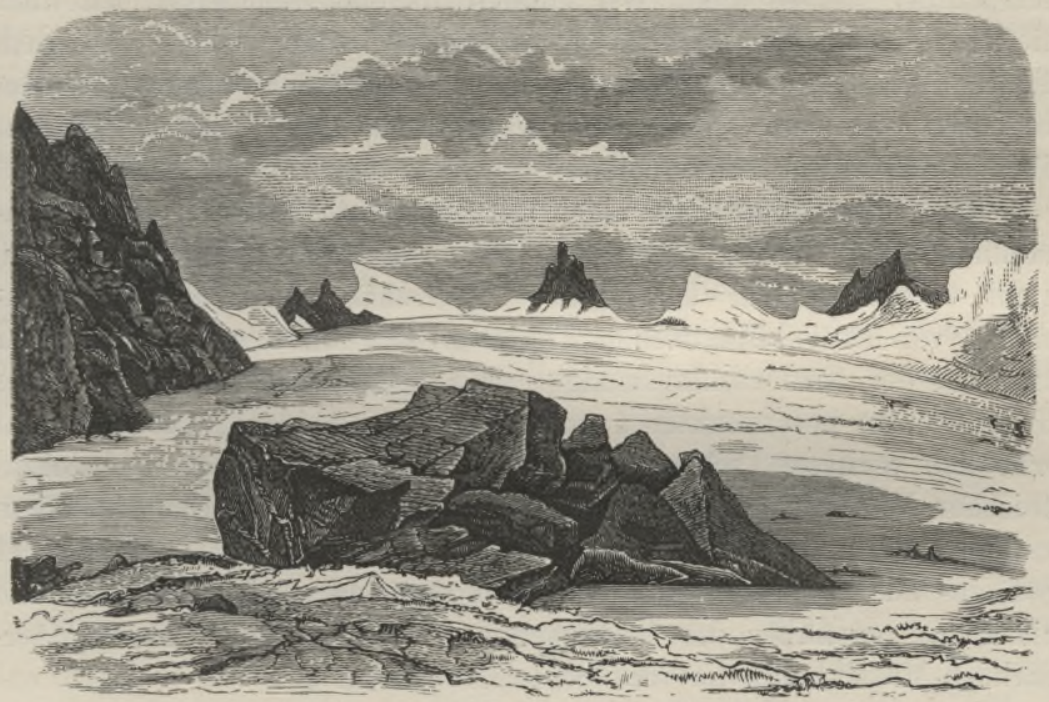

Fig. 39. Firnfeld des Gurgler Gletschers.

Die Schneegrenze. ${ }^{4}$ Der pulverig trockene Schnee, der in den höchsten Regionen unserer Alpen fällt, bleibt auf den steilen Graten und Abhängen nicht lange haften. Das Spiel der Winde und die eigene Schwere führen ihn jenen großen Mulden und kesselförmigen Vertiefungen zu, mit denen die Täler nach oben enden, und häufen ihn hier, zusammen mit dem an Ort und Stelle gefallenen Schnee, zu gewaltigen Massen an, die an den sanfteren Böschungen des umgebenden Höhenkranzes stellenweise bis an den Kamm hinaufziehen, jedoch so, daß aus der weißen Fläche noch immer schneefreie Felseninseln aufragen (Fig. 39). Der Hochschnee nimmt hier unter dem Einfluß wechselnden Auftauens an Sommertagen und nächtlichen Wiedergefrierens eine graupenförmig-körnige Beschaffenheit an, er wird zum Firn. Nach unten geht dieser durch den Druck seiner eigenen Masse in Eis über; die Schneedecke, die darüber lagert, 
wird talabwärts immer dünner und endet an jener Linie, wo die Sommerwärme hoch genug ist, um die Schneemenge des vorigen Winters und gelegentlichen Neuschnee aufzuzehren. Diese Linie ist die Schnee- oder Firnlinie; beide Begriffe können in unseren Hochgebirgen tatsächlich als identisch betrachtet werden, denn die Schneegrenze wird immer an den Firnfeldern gemessen. Oberhalb derselben herrscht Anhäufung, unterhalb Abschmelzung vor. ${ }^{\times}$

Firnfeld reiht sich an Firnfeld; es ist selten eine auf weite Strecken zusammenhängende Schneedecke, aber es sieht, von ferne betrachtet, fast so aus. Wir können die einzelnen Firnlinien über die trennenden Kämme hinweg zu einer einzigen Linie verbinden, die dem Gebirge entlang laufend, im Sommer das vorwiegend schneebedeckte von dem vorwiegend schneefreien Land trennt. Das ist die klimatische Schneelinie.

Aber diese Linie fällt nicht mit einer bestimmten Isohypse zusammen, denn die Bedingungen zu dauernder Schneeanhäufung sind nicht überall gleich. Die Höhe der Grenze hängt allerdings zunächst von zwei klimatischen Faktoren ab: von der Sommerwärme und von der Niederschlagsmenge; aber selbst wenn innerhalb eines Gebirges von beschränkter Ausdehnung diese beiden Faktoren nicht erheblich variieren, schwankt doch die Schneegrenze infolge orographischer Verschiedenheiten, die in der Lage und im Bau der Firnmulden begründet sind. Maßgebend ist vor allem die Lage an der Sonnen- oder Schattenseite eines Gebirges, der Neigungswinkel und die Lage gegenüber der herrschenden Windrichtung. Am Finsteraarhorn-Massiv z. B. hat die Schneegrenze an der

$\begin{array}{lcccc}\text { Nordabdachung eine Seehöhe von } & 2850 \mathrm{~m} \\ \text { Ostabdachung } & , & , & & 2860 \\ \text { Südabdachung } & " & , & , & 3010 \\ \text { Westabdachung } & " & , & , & 2900\end{array}$

$\times$ MACHAČEK $^{3}$ hat die mittlere jährliche Anhäufung $(+)$ und Abschmelzung (-) in der Sonnblickgruppe rechnerisch bestimmt. Die Schneegrenze liegt in $2700 \mathrm{~m}$ Höhe.

$$
\left.\begin{array}{rl}
\text { Höhe } & 3100-3000 \mathrm{~m}+1,4 \mathrm{~m} \\
& 3000-2900+1.1 \\
2900-2800 & +0,8 \\
2800-2700 & +0,4 \\
2700-2600 & -0,1 \\
2600-2500 & -0,7 \\
2500-2400 & -1,25 \\
2400-2300 & -1,9 \\
2300-2200 & -2,4
\end{array}\right\} \text { Firnregion }
$$


Der Gegensatz von Nord- und Südabdachung tritt in den Alpen überall deutlich hervor, obwohl im allgemeinen der Niederschlag auf der Südseite größer sein dürfte. Daß aber auch der Einfluß des letzteren nicht $\mathrm{zu}$ gering $\mathrm{zu}$ achten ist, geht aus folgendem Beispiel hervor. Die Bestrahlungsstärke einer unter der Breite $\varphi$ gelegenen und unter dem Winkel $\alpha$ geneigten Fläche ist bei nördlicher Exposition gleich der Bestrahlungsstärke auf einer horizontalen Fläche in der Breite $\varphi+\alpha$, und bei südlicher Exposition gleich einer solchen in der Breite $\varphi-\boldsymbol{c}$. Nach der Berechnung von МaCHačEK ${ }^{3}$ hat der Weißenbachkees in der Sonnblickgruppe ein solares Klima wie ein Ort in $62^{\circ}$ B., und der Große Zirknitzkees in demselben Gebirge ein solches wie ein Ort in $32^{\circ}$ B. Die Beschattungsverhältnisse sind bei beiden Gletschern nahezu dieselben und ihr Einfluß ganz geringfügig, man sollte also bei so gewaltigen Unterschieden in der Bestrahlungsstärke auch eine entsprechende Differenz der Schneegrenze erwarten, und doch liegt sie in beiden Fällen nahezu gleich hoch $(2715$ und $2710 \mathrm{~m})$. Hier müssen also noch andere klimatische Faktoren eingreifen, und wir dürften nicht fehlgehen, wenn wir dazu auch den Niederschlag rechnen. Sein Einfluß tritt am deutlichsten in tropischen Gebirgen hervor, die keine dauernde Schattenseite haben. Am Kilimandscharo z. B. liegt die Schneegrenze nach Hans Meyer im Osten und Norden in 5800, im Westen in 5430 und im Süden in $5380 \mathrm{~m}$ Höhe.

Selbst bei benachbarten Gletschern von gleicher Lage kann die Höhe der Firngrenze sehr verschieden sein. Wählen wir wieder ein Beispiel aus dem Finsteraarhorn-Massiv. Dem Großen Aletschgletscher fließen rechts der Mittelaletsch-, der Triest- und der Oberaletschgletscher zu; bei dem ersten liegt die Schneegrenze in 3060, bei dem zweiten in 3210 , bei dem dritten in $2830 \mathrm{~m}$ Seehöhe. Sie alle fließen nach SO, und doch schwankt die Schneegrenze um volle $380 \mathrm{~m}$ ! Ein näheres Eingehen auf den Bau der Firnmulden erklärt uns freilich diese Unterschiede; die Triester Mulde liegt der Mittagssonne ganz offen, während der Ober-Aletschfirn durch hohe Kämme beschattet wird (s. Fig. 41, S. 195).

Als klimatisches Phänomen ist die Firngrenze natürlich auch Schwankungen von Jahr zu Jahr unterworfen. Eine einzige Messung hat daher nur beschränkten Wert. Aber Messungen sind in den alpinen Gebirgen überhaupt schwierig und bieten nicht im entferntesten jene Gewähr, wie an den Vulkankegeln des tropischen Südamerika, wo die Schneelinie durch RegelmäBigkeit und Beständigkeit schon früh die Aufmerksamkeit der Forschungsreisenden auf sich gelenkt hat. Man versuchte daher, die Seehöhe der Firngrenze 
zu berechnen, zunächst auf direktem Wege durch Einstellung klimatischer Mittelwerte, wie es v. SonkLar getan hat. Aber diese Methode konnte zu keinem befriedigenden Resultat führen, weil die Grundlagen nicht gesichert sind. Die ältere Vorstellung, daß die Schneegrenze mit der Höhenisotherme von $0^{0}$ zusammenfalle, wurde bald als unhaltbar erkannt. In den letzten Jahren sind vier indirekte Methoden mit Erfolg angewendet worden. Die geographische, von PARTSCH eingeführte Methode ${ }^{5}$ gibt eigentlich nur Grenzwerte; die obere Grenze stellen die Gipfelhöhen jener Bergmassen dar, die Gletscher entsenden, die untere bezeichnen jene benachbarten Gipfelhöhen, die trotz günstiger Lage keine großen Schneefelder mehr beherbergen. Man kann die Frage auch so stellen: welche Isohypse muB ein Berg übersteigen, um Gletscher bilden zu können? Diese Isohypse ist dann annähernd die Schneegrenze innerhalb eines größeren Gebirgsabschnittes. Die orometrische Methode BRÜCKNER's ${ }^{6}$ geht von der Annahme aus, daß mindestens $3 / 4$ einer Gletscherfläche über der Schneegrenze, d. h. im Sammelgebiet liege, und bestimmt nun, welcher Isohypsenfläche dieses Firnareal an Größe gleichkommt. Die betreffende Isohypse stellt die Maximalhöhe der Schneelinie dar; die Maximalhöhe insofern, als das Verhältnis der Eiszunge zum Firnfeld mit Ausnahme der großen Talgletscher "sicher überschätzt ist, und weil sich innerhalb des ewigen Schnees schneefreie Partien befinden, die nicht in das Gletscherareal einbezogen werden. Die Ausdehnung dieser Partien, die ihre Schneefreiheit nur ihrer Steilheit verdanken, kann aber unter Umständen sehr beträchtlich sein; für den Ankogel z. B. fand RichteR ${ }^{7}$ innerhalb der Höhenlinie von $2700 \mathrm{~m} 41$ Prozent schneefrei. Die dritte Methode rührt von KURowski ${ }^{8}$ her. Wenn - so schließt er - der schneeige Niederschlag proportional der Höhe wächst und die Abschmelzung in gleichem Verhältnis abnimmt, so muß die mittlere Höhe der Gletscheroberfläche (Eiszunge und Firn) diejenige Linie sein, wo sich beide Faktoren das Gleichgewicht halten, d. h. die Schneegrenze. Da unser positives Wissen von dem Klima der Hochalpen außerordentlich lückenhaft ist, so schwebt die gemachte Voraussetzung ganz in der Luft, und die nahe Übereinstimmung der berechneten und beobachteten Grenzhöhen in den gewählten Beispielen mag zufällig sein. Diese Methode ist neben der geographischen mit Erfolg angewendet worden, um zu Vorstellungen über die Höhe der eiszeitlichen Schneegrenze zu gelangen.

Als vierte Methode gesellt sich endlich die von Hess ${ }^{9}$ hinzu. Sie beruht auf der Tatsache, daß die Form der Isohypsen oder Linien gleicher Höhe im Firngebiet eine andere ist als im Ab- 
schmelzungsgebiet; dort gehen sie ohne schroffe Richtungsänderung vom Firn in die Felsumrahmung über, hier bilden sie an der Grenze von Gletscher und Fels eine scharfe Einknickung. Die Höhe, wo die eine Form in die andere übergeht, ist die gesuchte Firnlinie. Sie liegt in der Schweiz durchschnittlich $180 \mathrm{~m}$ tiefer als die Schneegrenze nach Kunowski's Methode. Gemeinsam ist allen diesen Methoden mit Ausnahme der ersten, daB sie nur auf diejenigen Gebirge anwendbar sind, von denen wir genaue Höhenschichtenkarten besitzen. Man kann von ihnen nur Näherungswerte erwarten, aber sie haben vor Messungen in der Natur den Vorzug, daß sie mittlere Zustände zum Ausdruck bringen.

Indem man die einzelnen Bestimmungen der klimatischen Schneegrenze innerhalb eines Gebirgsabsehnittes zu einem Mittelwert vereinigt, setzt man voraus, daß sich die Gunst und die Ungunst örtlicher Verhältnisse ausgleichen. Nur wenn die Zahl der Bestimmungen groß ist und alle Lagenverhältnisse berücksichtigt sind, ist diese Voraussetzung einigermaßen berechtigt. Auf diese Weise gelangt man zum Begriff der mittleren klimatischen Schneegrenze eines Gebirges; man definiert sie als die Schneegrenze auf einer supponierten horizontalen Fläche, wo der Gegensatz von Sonnen- und Schattenseite, von Wind- und Leeseite, von feuchter und trockener Seite wegfällt. In der Finsteraarhorngruppe z. B. schwanken nach KURowsKI die klimatischen Firngrenzen zwischen 2490 und $3210 \mathrm{~m}$. Der Mittelwert ist $2950 \mathrm{~m}$, und man nimmt an, daß hier ein Hochplateau mit ewigem Schnee bedeckt wäre, wenn es sich über diese Grenze erhöbe. Das ist natürlich eine Fiktion, weil sich dann die Niederschlagsverhältnisse anders gestalten würden. Es liegt auf der Hand, daß die Mittelwerte um so reeller sind, je geringer die Schwankungen; man wird sich also auf kleine Gebirgsabschnitte mit möglichst gleichartigen Niederschlagsverhältnissen beschränken müssen.

Unterhalb der klimatischen Schneegrenze finden sich in den Vertiefungen der meisten Gebirge noch vereinzelte Firnflecken, die ihre dauernde Erhaltung nur abnorm günstigen orographischen Bedingungen verdanken, und deren untere Grenze RATZEL ${ }^{10}$ daher als orographische Schneegrenze bezeichnet hat. Über die Lage beider Grenzlinien zueinander geben M. Fritzsch's Messungen am Ortler Auskunft:

$$
\text { Lage } \quad \mathrm{N} \text { NW W } \text { SW } \mathrm{S} \text { SO } \mathrm{O} \text { NO Mittel }
$$

Klimatische Firngrenze. 2855* $2900 \quad 300030703090298029702855^{*} 2965 \mathrm{~m}$

Orographische Firngrenze 2535* 2535* $2630 \quad 2745 \quad 2755 \quad 2725 \quad 26302570 \quad 2630$

Unterschied . . . . . $\begin{array}{llllllllll}320 & 365 & 370 & 325 & 335 & 255^{*} & 340 & 285 & 335\end{array}$ 
Verteilung der Schneegrenze. Die Liste der gemessenen und geschätzten Schneegrenzen in verschiedenen Teilen der Erde ist ziemlich reichhaltig, aber so außerordentlich ungleichmäßig, daß man am besten tut, auf ihre Reproduktion zu verzichten. Daß vereinzelte Messungen nur problematischen. Wert haben, wurde schon oben erörtert, und die schätzungsweisen Angaben lassen sich nicht immer auf den Grad ihrer Zuverlässigkeit prüfen. Noch bedauerlicher ist die Verwirrung, die bis in die neueste Zeit in bezug auf den Begriff der Schneegrenze bestand, so daß man oft nicht weiß, ob sich eine Zahl auf die orographische oder die klimatische Schneegrenze bezieht, und in welcher Weise. die klimatische Schneegrenze aufgefaßt wurde. Ja bei manchen Gebirgen ist es überhaupt schwer zu entscheiden, ob man es mit rein orographisch oder mit klimatisch bedingtem Firn zu tun hat. Aber trotz aller Mängel des Zahlenmaterials lassen sich doch schon einige allgemeine Gesetze aufstellen.

Wenn wir von den Niederschlägen vorerst ganz absehen, so müssen wir voraussetzen, daß sich die Schneegrenze von dem thermischen Äquator nach beiden Polen senkt, und zwar rascher nach dem Südpol, weil auf der Südhemisphäre die Sommertemperatur niedriger ist als unter entsprechenden nördlichen Breiten. Das ist auch in der Tat der Fall. Im Kaskadengebirge Oregons liegt die Schneegrenze in 2100-2400 m, in den südchilenischen Andes unter $44^{\circ}$ B. aber schon in $1400 \mathrm{~m}$. Im streng ozeanischen Klima Kerguelens, das in gleicher Breite wie das fruchtbare Neckartal von Heidelberg liegt $\left(49^{1} / 2^{\circ}\right)$, reicht die Schneegrenze bis ungefähr $600 \mathrm{~m}$ herab, auf dem grönländischen Inlandeis unter $70^{\circ} \mathrm{B}$. versetzt sie v. Drygalski aber erst in die Höhenzone zwischen 700 und $800 \mathrm{~m}$. Die Heardinsel $\left(53^{\circ} 8^{\prime} \mathrm{S}, 73^{\circ} 34^{\prime} \mathrm{O}\right)$ ist das einzige bekannte Land, wo die klimatische Schneegrenze wahrscheinlich das Meeresniveau erreicht $^{11}$ - man beachte in der Breite von Bremen! -; nur für die orographische gilt dies allgemein in den Polarzonen.

Die höchste Seehöhe erreicht die Schneegrenze zwar stets innerhalb der inneren Zone, wo das Landklima wärmer ist als das Seeklima, aber nicht unter dem Äquator, sondern in den trockensten Gegenden. Im westlichen Hochgebirgswall Amerikas, ${ }^{12}$ der sich wegen seiner Erstreckung durch alle Klimagürtel am besten zu Gletscherstudien eignet, aber in dieser Beziehung leider noch wenig bekannt ist, liegt die Schneegrenze in Ecuador in $4700-4800 \mathrm{~m}$ Höhe, ${ }^{13}$ sie hält sich in Nordperu in $12^{\circ} \mathrm{B}$. noch in ungefähr derselben Höhe $(4700 \mathrm{~m}),{ }^{14}$ und erst unter $13^{0} 10^{\prime} \mathrm{S}$ erreicht sie ihren Scheitelpunkt in $6120 \mathrm{~m}$ über dem Meeresspiegel. Die gemessene 
Stelle befindet sich am Nordostabhang des Vulkans Pauchata; der benachbarte Vulkan Sajama $\left(18^{\circ} 7^{\prime} \mathrm{S}\right)$ hat seine Firngrenze in $5925 \mathrm{~m}$, so daß wir rund $6000 \mathrm{~m}$ als maximalen Näherungswert für die südamerikanische Westcordillere annehmen dürfen.× Auf der Ostcordillere aber, die schon dem subtropischen Wüstenklima entrückt ist, liegt die Schneegrenze um etwa $1000 \mathrm{~m}$ tiefer, trotzdem der Sommer hier heißer ist. In der Alten Welt steigt die Schneelinie um so höher an, je mehr wir uns den trockenen Gebieten Zentralasiens nähern. Pyrenäen, Kaukasus und Tiënschan liegen in derselben Breite; im Hauptkamm des spanischen Grenzgebirges hat die Firnlinie eine Höhe von $2800 \mathrm{~m}$, im Kaukasus schwankt sie zwischen 2700 und $3500 \mathrm{~m}$, im Tiënschan erreicht man sie erst in $4800 \mathrm{~m}$ Höhe - also ein Unterschied von $2000 \mathrm{~m}$, wie zwischen den Pyrenäen und Grönland! Die Maximalhöhe der Schneegrenze auf der östlichen Halbkugel $-6000 \mathrm{~m}^{15}$ wie auf der westlichen - finden wir im zentralen Gebirge Hochasiens, im Kwenlun. Von da an senkt sie sich äquatorwärts im Karakorumgebirge auf $5300-5600 \mathrm{~m}$, in Kaschmir auf 5000 und in den südlich daranstoßenden Ketten des Himalaya auf $4600 \mathrm{~m}$. Aus dem Gegensatz des nördlichen und südlichen Himalaya schließt man auf ein Übergewicht des Niederschlags- über den Temperaturfaktor; wir werden aber sehen, daß auch der letztere eine gleiche Anordnung bedingen kann.

Genauer bekannt ist uns die Verteilung der klimatischen Schneegrenze nur im Kaukasus, im norwegischen Gebirge und in den Schweizer und österreichischen Alpen. Für die letzteren hat Hess ${ }^{9}$ die Messungen Richter's und die Schweizer Karte JegerLenneR's ${ }^{16}$ zu einem lehrreichen Bilde vereinigt (Fig. 40). Das stetige Ansteigen der Firngrenze von dem Nordrand nach dem Innern der Alpen könnte man wohl der Abnahme der Niederschläge in gleicher Richtung zuschreiben, obwohl wir darüber nicht genau unterrichtet sind, aber für die auffallende Tatsache, daß die Firngrenze in den Gebirgsteilen größter Massenerhebung am höchsten liegt, kann dieser klimatische Faktor nicht verantwortlich gemacht werden. Dafür geben uns nur die schon auf S. 79 erwähnten Isothermenkarten von A. DE Quervatn eine ausreichende Erklärung. Die SchneegrenzenIsohypsen folgen genau den Mittagsisothermen in $1500 \mathrm{~m}$ Höhe, und denselben Verlauf nehmen in der Schweiz auch die Isohypsen der Wald- und Siedelungsgrenzen. ${ }^{17}$ Je massiger ein Gebirge ist,

$\times$ Diese Ziffern sind im Gletscherwerk von Hess auffallenderweise sowohl im Text wie auf der Karte der Verteilung der Gletscher und Schneegrenzhöhen unberücksichtigt geblieben. Allerdings wäre eine Nachprüfung dieser 1838 von Pextland ausgeführten trigonometrisehen Messungen sehr wünsehenswert. 
desto intensiver wird es in den Mittagsstunden erwärmt, und desto höher steigen die Höhengrenzen. Eine Bestätigung findet dieses Gesetz durch Hansen's Karte der Schneegrenzen in Norwegen. ${ }^{18}$ Auch hier ein allmähliches Ansteigen der Firnlinie nach dem Innern, wobei ihre Isohypsen getreu den Konturen der Küste folgen; nach REKstaD ${ }^{19}$ liegt sie ungefähr, aber im ganzen etwas tiefer, als die $0^{\circ}$-Isotherme des Sommerhalbjahrs (April bis September). Die Abnahme der Niederschläge nach dem Innern mag diese Anordnung noch verschärfen. Dagegen decken sich im zentralen Kaukasus, von dem wir ebenfalls eine Karte von Hess ${ }^{9}$ besitzen,

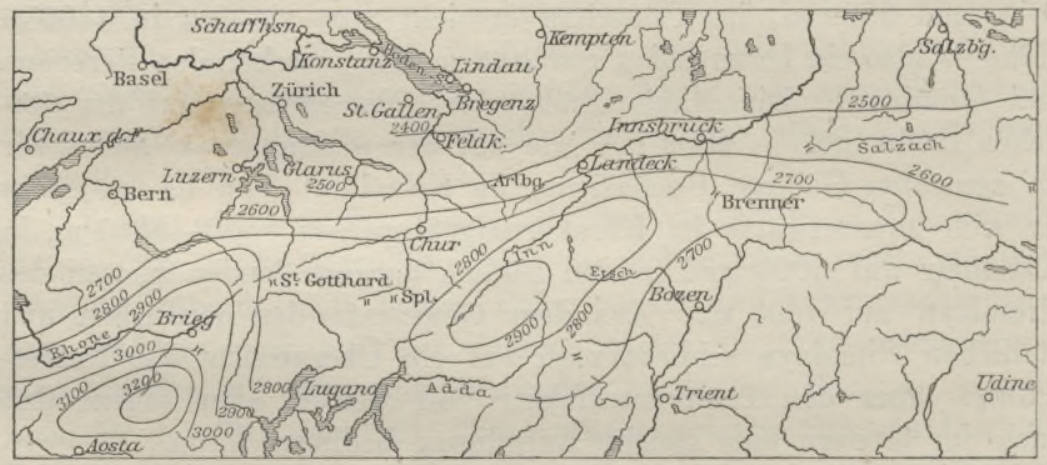

Fig. 40, Verteilung der Schneegrenze in den Alpen nach Hess.

(und nach v. Dе́сну ${ }^{20}$ auch im westlichen Kaukasus) beide Faktoren nicht völlig. Im Gegensatz zu den Alpen liegt hier die Schneegrenze an den Nordabhängen höher als an den südlichen, aber auf beiden Seiten steigt sie um so höher an, je höher der Kamm ist. Die erste charakteristische Eigenschaft ist offenbar in den Niederschlagsdie zweite in den Temperaturverhältnissen begründet.

Literaturnachweis e. ${ }^{1}$ Hass Fischer, Die Äquatorialgrenze des Schneefalls; Mitteilungen d. Vereins für Erdkunde, Leipzig 1888. - 2 M. FriEdrich, Niederschläge und Schneelagerung in der Arktis; Leipzig 1891. - ${ }^{3} \mathrm{~F}$. v. Kerner, Die Schneegrenze im Gebiet des mittleren Inntales; in d. Denkschr. d. Wiener Akad. d. Wiss. 1887. F. МАснас̌EK, Zur Klimatologie der Gletscherregion der Sonnblickgruppe; im Jahresbericht des Sonnblickvereins für 1899. F. SснwaB, Über die Schneeverhältnisse im Gebiet von Stoder, (Verein für Naturkunde) Linz, 1907. J. Mauren in der Meteor. Zeitschrift 1909, S. 539. - ${ }^{4}$ F. KLenger, Die historische Entwieklung des Begriffs der Sehneegrenze; Mitteilungen d. Vereins für Erdkunde, Leipzig 1889. $-{ }^{5}$ E. BRÜокNER, Die Vergletscherung des Salzachgebiets; Wien 1886. - ${ }^{6}$ E. Brückner, Die Hohen Tauern und ihre Eisbedeckung; in der Zeitschrift d. D. u. Ö. Alpenvereins 1886. - ${ }^{7}$ E. RicнтеR, Die Gletscher der Ostalpen; Stuttgart 1888. - ${ }^{8}$ L. Kunowsкi, Die Höhe der 
Sehneegrenze; in den Arbeiten des geographisehen Instituts der Universität Wien, 1891. - ${ }^{9}$ H. Hess, Die Gletscher; Braunschweig 1904. - ${ }^{10} \mathrm{~F}_{\mathrm{R}}$. RAtzeL. Zur Kritik der natürlichen Schneegrenze; in der Leopoldina, 1886. - ${ }^{11}$ Nach E. v. Drygarski im Bd. II der „Deutsehen Südpolarexpedition" 1901-03. ${ }^{12}$ G. Sonwarze, Die Firngrenze in Amerika; wissenschaftlicher Jahresberieht des Vereins für Erdkunde in Leipzig 1890. - ${ }^{13}$ Hans Mexer, In den Hochanden von Ecuador, Berlin 1907. - ${ }^{14} \mathrm{Vgl}$. C. R. Exock, The Andes and the Amazon, London 1907. - ${ }^{15}$ Nach G. SandBerg (Tibet and the Tibetans, London 1906) schwankt die Schneegrenze in Tibet zwischen 4700 und über $6000 \mathrm{~m}$. - ${ }^{16}$ J. Jegerlehner, Die Schneegrenze in den Gletschergebieten der Sehweiz; in Gerland's Beiträgen zur Geophysik, 1902, Bd. V. - ${ }^{17}$ E. Brückner, Höhengrenzen in der Schweiz; in der Naturwissenschaftlichen Wochenschrift, Bd. IV, 1905. - ${ }^{18}$ A. M. Haxsen, Snegraensen i Norge; im Norske Geografiske Selskabs Aarbog, Bd. XIII, 1901-02. - ${ }^{19}$ J. Reкstap, Die Abhängigkeit der Lage der Schneegrenze von den Sommerisothermen in Norwegen, in Forhandlingar Videnskabselskabet i Christiana 1907. - ${ }^{20}$ M. v. Déchy, Kaukasus, Berlin 1905-07.

\section{Gletscher, ${ }^{1}$}

Wenn auch in der Region des ewigen Schnees der Verdunstungsproze $B$ nicht stillsteht, so fällt ihm doch nur ein geringer Bruchteil der jährlichen Niederschlagsmenge zum Opfer, und das Wachstum der Schneemassen wird dadurch wenig gehindert. Es gibt aber ein wirksameres Gegenmittel: die Bewegungsfähigkeit des Schnees. Er wird dadurch den wärmeren Regionen zugeführt und hier aufgelöst, um entweder in den mütterlichen Schoß des Meeres zurückzukehren oder in Dampfform seinen Kreislauf von neuem zu beginnen. Die übliche Bezeichnung „ewiger Schnee“ ist demnach insofern unrichtig, als nicht die einzelne Schneelage, sondern nur die Schneebedeckung dauernd ist.

Plötzlich gleitende Schneemassen nennt man Lawinen. ${ }^{2}$ Namentlich im Frühjahr sind sie häufig, wenn der erweichte Schnee an den steileren Hängen nicht mehr haften kann. Der Schuß eines Jägers, der Pfiff einer Lokomotive, das Jauchzen eines sangfrohen Älplers genügt dann, um den auf das äußerste gespannten Gleichgewichtszustand aufzuheben. Der trockene, pulverige Schnee im Winter erzeugt die Staublawinen, der alte, zusammengebackene, schwere Schnee die viel gefährlicheren Grundlawinen, die in der Regel nicht direkt zu Tal gehen, sondern sich in den von Wildbächen geschaffenen Tobeln sammeln und diese dann als Sturzbahn benutzen. $\times$ Aber so gewaltige Massen auch dadurch dem Tal zugeführt werden, so verheerend auch eine solche Katastrophe wirken

× Für die wichtigeren Lawinenzüge des Taminatales in der Schweiz gibt iSprecher ${ }^{3}$ genaue Ausmessungen, aus denen ich zur bequemeren Orientierung Mittelwerte berechnet habe: 
kann, so trägt doch die langsame, aber stetige Talbewegung des Gletschers unendlich mehr zur Entlastung der Hochgebirge bei und ist auch in ihren sonstigen Wirkungen eines der wichtigsten erdphysikalischen Phänomene.

Begriff und Einteilung der Gletscher. Wir müssen uns zunächst über den Begriff des Gletschers verständigen, denn dieser Ausdruck wird in sehr verschiedener Weise gebraucht, und das gibt zu Mißverständnissen Veranlassung. Überall, wo dauernde Schneeansammlungen vorhanden sind, kommt es auch zur Eisbildung, denn der Schnee geht in seinen unteren Schichten schon vermöge seiner eigenen Schwere in Eis über, und verschieden ist nur die Tiefe, in der sich dieser Übergang vollzieht. Aber nicht überall tritt das Eis aus der Schneehülle zutage, oder mit anderen Worten, nicht überall dringt das Eis aus der Region des ewigen Schnees, wo es sich dauernd in der Tiefe befindet, in diejenige Region ein, wo die winterliche Schneehülle im Sommer schmilzt. Firn- und Eisgrenze fallen dann zusammen, und wenn wir auch auf diese Eisbildung die Bezeichnung Gletscher anwenden, so können wir sie passend Firngletscher nennen. Solche Firngletscher finden wir überall, wo nur einzelne regelmäßig gestaltete, ungegliederte Gipfel in die Schneeregion hineinreichen, vorausgesetzt, daß die Abhänge sanft genug sind, um überhaupt eine Schneedecke tragen zu können. Doch tragen, wie wir später hören werden, auch Kegelberge echte Gletscher. Zu ihrer vollen Entwicklung gelangen diese aber in Gebirgen, die mit einem langgestreckten Kamm über die Schneegrenze emporragen. Wir haben da große, hochgelegene Sammelbecken, wie wir sie in den Firnmulden kennen gelernt haben, und ein ausgebildetes Talsystem, das den Eisströmen den Weg in die Tiefe weist. Deutliche Scheidelinien grenzen hier die einzelnen Gletscher voneinander ab, jeder Gletscher ist ein Individuum für sich, eine hydrographische Einheit; jeder besteht aus zwei Teilen, aus Firn und Eiszunge,

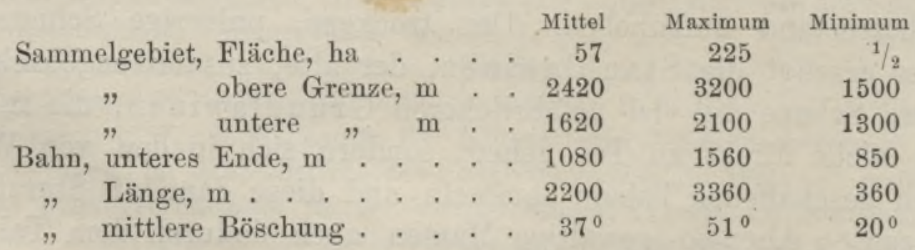

Die Längen sind aus der vertikalen und der horizontalen Projektion der Bahn berechnet und wegen des ungleichmäBigen Gefälles zu klein. Der Körperinhalt der abgelagerten Lawinenmasse, die man nicht ganz zutreffend als Lawinenkegel bezeichnet, beziffert sich durehschnittlich auf ungefähr $700000 \mathrm{cbm}$. 
die durch die Schneegrenze geschieden sind. Je nachdem die Eiszunge entwickelt ist, unterscheiden wir Gletscher erster und zweiter Ordnung. Jene können wir als Talgletscher bezeichnen, denn ihre ausgebildete Eiszunge bewegt sich stromartig talabwärts oft bis in die Wald-, ja sogar bis in die Kulturregion. Die anderen besitzen keine oder eine nur wenig entwickelte Eiszunge, sie scheinen hoch oben, an den Talgehängen, zu kleben oder sind in deren muldenförmige Vertiefungen (Kare) eingebettet, und man hat sie daher Hängegletscher genannt. Diese und die Talgletscher sind Unterarten der alpinen Gletscher.

Wieder eine andere Gestaltung gewinnt das Gletscherphänomen, wenn sich eine breite, plateauartige Gebirgsmasse mit ewigem Schnee bedeckt. Hoch- und Firnschnee verschmelzen dann zu ausgedehnten Schneefeldern, die entweder in gleicher Weise, wie die Firngletscher, als Eismauer abbrechen oder sich mit gelapptem Rand allmählich verflachen oder Eiszungen in der Form von Tal- und Hängegletschern nach verschiedenen Seiten entsenden. Das ist die Erscheinungsform des Inlandeises. Der Unterschied vom alpinen Typus besteht darin, $\mathrm{da} B$ jener sich den Unebenheiten der Unterlage anschmiegt, während das Inlandeis sie ausfüllt und sich dadurch von der Skulptur des Landes bis zu einem gewissen Grad unabhängig macht. v. DRYGALSKI hat es treffend als eine Eisüberschwemmung ganzer Erdräume bezeichnet. Man kann es sich aus alpinen Gletschern entstanden denken, die sich bei ihrem Wachstum über die freien Kämme hinweg zu einer einheitlichen Masse verschmelzen, wobei jede Individualisierung verloren geht.

Ein Mittelglied zwischen dem alpinen und dem Inlandeistypus bilden jene völlig verfirnten Gebirgskämme, von denen nach beiden Seiten Gletscher ausgehen. In unseren Alpen kommen solche

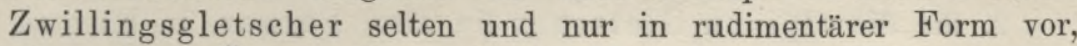
wie z. B. am Ötztaler Hochjoch; dagegen haben uns die Forschungen der letzten Jahre in den Alpen Alaskas zwischen dem Mount Newton und Mont $\operatorname{Logan}{ }^{4}$ und in den patagonischen Andes zwischen Ultima Esperanza $\left(51^{1} /{ }^{\circ} \mathrm{S}\right)$ und dem Fitz-Roy-Gipfel $\left(49^{\circ} \mathrm{S}\right)$ großartige Beispiele solcher zusammenhängenden alpinen Gletscherkomplexe kennen gelehrt.

Eine andere Mittelform zwischen dem alpinen Gletscher und dem Inlandeis ist der Vorlandgletscher des Mount Elias in Alaska. ${ }^{4}$ Die Gletscherzungen verschiedener alpiner Firnfelder erstrecken sich hier über den $\mathrm{FuB}$ des Gebirges hinaus und verschmelzen im Vorland zu einem 3900 qkm großen Eisfeld, dem Malaspinagletscher. Sein Nährgebiet hat also alpinen Bau, er selbst 
aber gleicht dem Inlandeis. In kleinem Maßstab wiederholt der Wenkchemnagletscher ${ }^{5}$ im Felsengebirge, nahe der canadischen Pazifikbahn, diese Form, die einst in der Eiszeit weit verbreitet war.

$\mathrm{Zu}$ einer selbständigen Gruppe, die wir als orographische Gletscher bezeichnen wollen, können wir alle gletscherartigen Bildungen zusammenfassen, die zwischen der klimatischen und der orographischen Schneegrenze ihren Ursprung nehmen und daher mit den großen Firnlagern nicht zusammenhängen. Ein bekannter Vertreter dieser Kategorie in unseren Alpen ist das Blaueis am Hochkalter bei Berchtesgaden. Vielleicht sind auch die „halbausgebildeten" Gletscher Tibets, die A. Schuster als zusammengefrorene Schneemassen mit äußerst geringer Bewegung charakterisiert, hierher zu rechnen. Durch SALisBury ${ }^{6}$ haben wir die „Kliffgletscher" an der östlichen Steilküste (Kliff) von Grönland, nördlich vom Kap York, kennen gelernt; es sind Anhäufungen von Schnee, der von dem Inlandeis herabgeweht wurde und sich in dem Winkel zwischen dem steileren oberen und dem sanftern unteren Teil des Kliffes sammelte. Die größeren dieser Firnfelder erzeugen Miniaturgletscher von höchstens $30 \mathrm{~m}$ Länge. Nur im kalten Klima können sie sich erhalten, während in unseren Alpen Eismassen, die aus Schueelawinen hervorgehen, meist nach einer Reihe von Jahren wieder verschwinden.

Nach diesen Erörterungen können wir zu unserem Ausgangspunkt zurückkehren. Der Ausdruck „Gletscher" wird für drei verschiedene Dinge gebraucht:

1. Für alle aus dem Schnee hervorgehenden dauernden oberflächlichen Eisbildungen auf dem Land. In diesem Sinn spricht man z. B. von einer Vergletscherung Grönlands oder Norddeutschlands zur Eiszeit usw.;

2. für die alpinen Gletscher (in Tirol Ferner, in Kärnten Kees) und setzt dann Gletscher in bestimmten Gegensatz zum Inlandeis. Unsere Firngletscher werden dann nicht als Gletscher angesehen und in diesem Sinn ist es zu verstehen, wenn z. B. vereinzelten hohen Vulkankegeln Gletscher abgesprochen werden;

3. für die Eiszungen der alpinen Gletscher und des Inlandeises und man unterscheidet dann streng zwischen Gletscher und Firn.

Aus unseren Auseinandersetzungen dürfte schon hervorgegangen sein, das wir uns für den weitesten Begriff entschieden haben; wir werden aber der nachfolgenden Schilderung hauptsächlich die alpinen Verhältnisse zugrunde legen, weil diese am besten bekannt und am eingehendsten erforscht sind.

Die Gletscherzunge. Wenn man Gletscher als Eisströme be- 
zeichnet, so denkt man dabei zunächst an die großen Talgletscher. Wie die Flüsse vereinigen sich oft ihrer mehrere zu einem einzigen Eisstrom. So besteht der Aletschgletscher in den Berner Alpen (Fig. 41) aus drei Strömen: dem Großen, Mittleren und Oberen Gletscher; der letztere erreicht freilich nicht mehr den Hauptstrom. Der GroBe Aletschgletscher durchzieht mit einer mittleren Neigung von $7^{0}$ das obere Massatal von $2730-1382 \mathrm{~m}$ Seehöhe: er ist $16,5 \mathrm{~km}$ lang und durchschnittlich $1,5 \mathrm{~km}$ breit. Sein Nährgebiet, das mit einer mittleren Neigung von $20^{\circ}$ bis an die Kämme des Fiescherhorns, des Mönchs und der Jungfrau hinaufreicht, besteht aus vier

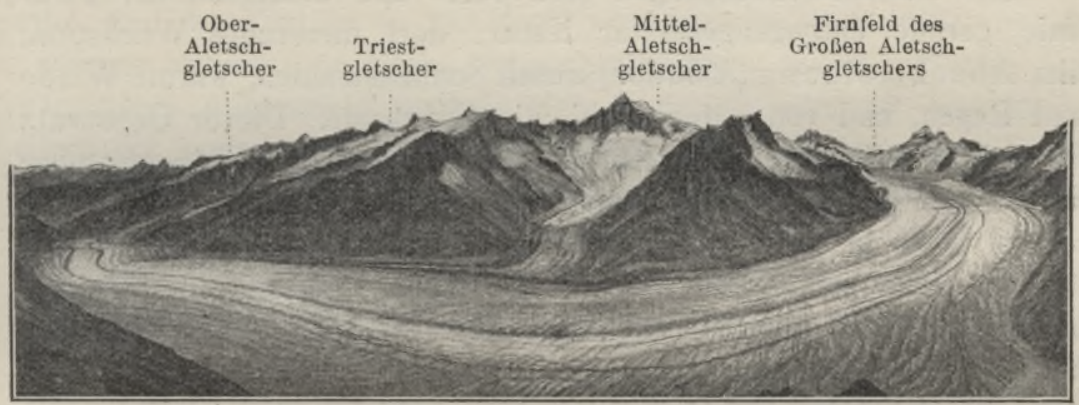

Fig. 41. Aletschgletscher, vom Eggishorn aufgenommen.

Eismulden und bedeckt $99,54 \mathrm{qkm}$. Da die Zunge 29,45 $\mathrm{qkm}$ groß ist, so verhält sie sich zum Firn wie $1: 3$, und dies darf auch als das durchschnittliche Verhältnis bei allen großen Talgletschern der Alpen angesehen werden, wenn auch Schwankungen innerhalb ziemlich weiter Grenzen selbst bei benachbarten Gletschern vorkommen. Bei Hängegletschern ist das Verhältnis natürlich ein anderes. Man kann hier 1:8 als Regel annehmen.

Meist ist der Eisstrom in der Mitte etwas höher als an den Ufern, wo er unter dem Einfluß der erwärmten Berggehänge rascher schmilzt. Bei dem Aletschgletscher betrug die Erhöhung der Mitte über dem Rand, die auch in Fig. 41 deutlich wahrzunehmen ist, im August 1872 nahezu $60 \mathrm{~m}$. Wo aber die Ränder eine dichte Schutzdecke tragen, während der mittlere Teil schutzlos der Wirkung der Sonnenstrahlen preisgegeben ist, da ist die Mitte tiefer eingesenkt, wie z. B. bei dem Vernagtgletscher in Tirol. In unseren Alpen beträgt die Mächtigkeit des Gletschers in seinen oberen Partien mehrere hundert Meter, am Ende aber, besonders wenn er in die Kulturregion hineinreicht, übersteigt sie kaum Baumeshöhe. In der Regel läuft der Gletscher nicht allmählich aus, sondern bricht als eine mehr 
oder weniger hohe Eismauer ab, die aus einem gewölbten Tor den Schmelzwasserbach entläßt. Am reichlichsten ist dieser natürlich in der heißen Jahreszeit, aber bei den großen Gletschern der Alpen versiegt er selbst im Winter nicht und ist in Grönland sogar kaum schwächer als im Sommer. Auch auf der Oberfläche des Gletschers ruft die Sommersonne zahlreiche Bäche und Seen hervor, aber die Nacht legt sie wieder in Eisfesseln, die erst der folgende Tag wieder sprengt.

Das Leben des Gletschers. Das, was wir als Leben des Gletschers bezeichnen können, besteht aus zwei Vorgängen: Massenveränderungen und Bewegung.

Die Massenveränderungen sind ober- und unterhalb der Firnlinie gerade entgegengesetzter Natur: dort dauerndes Wachstum, hier Abschmelzung (Ablation) durch Sonnenstrahlen, warme Winde und Regen, und von unten durch die Erdwärme. Dieser Gegensatz ist nicht bloß theoretisch vorausgesetzt, sondern am Rhônegletscher durch unmittelbare Beobachtung festgestellt. Während die Steinreihen noch in 2400-2500 m Höhe durchschnittlich jährlich um 3-4 $\mathrm{m}$ einsanken, zeigte sich an den Stangen jenseits der Firnlinie in $2700 \mathrm{~m}$ Höhe nur Zunahme, die stellenweise bis zu $4 \mathrm{~m}$ im Jahr betrug. Die Abschmelzung steigert sich von der Mitte zum Rand, wo auch die Rückstrahlung der erhitzten Talwände einwirkt, und selbstverständlich talabwärts. ${ }^{\times}$Durch sie werden Gegenstände, die in eine Spalte gefallen oder sonstwie in das Innere des Gletschers gelangt sind, an einem talabwärts gelegenen Punkt wieder an die Oberfläche befördert, und insofern ist die in den Alpenländern herrschende Überzeugung, daß der Gletscher fremde Körper ausstoße, richtig.

Für den Hintereisgletscher in den Ötztaler Alpen wurde der jährliche Eisverlust durch Abschmelzung auf $10180000 \mathrm{cbm}$ berechnet, die zu ihrer Deckung eine jährliche Niederschlagsmenge von $1000 \mathrm{~mm}$ im Firngebiet erfordern. In einer Höhe von ungefähr $400 \mathrm{~m}$ unter der Schneegrenze schätzt Hess die durchschnittliche

$\times$ Messungen von BLüMcke und Hess ${ }^{7}$ am Hintereisferner (Ötztaler Alpen) $1894-95$ (1 Jahr)

\begin{tabular}{|c|c|c|c|c|}
\hline \multirow[b]{2}{*}{ Höhe, m } & \multicolumn{2}{|c|}{ Abschmelzung, m } & \multicolumn{2}{|c|}{ Bewegung, $\mathrm{m}$} \\
\hline & Rand & Mitte & Rand & Mitte \\
\hline $2750-2700$ & 3,06 & 1,95 & 46,6 & 49,8 \\
\hline $2700-2650$ & - & - & 45,0 & 49,4 \\
\hline $2650-2600$ & 4,06 & 2,08 & 45,4 & 48,0 \\
\hline $2600-2550$ & 4,00 & 3,73 & 37,0 & 41,2 \\
\hline $2550-2500$ & - & - & 36,5 & 40,7 \\
\hline $2500-2450$ & 6,41 & 4,90 & 28,4 & 29,5 \\
\hline Ende, 2300 & & & - & - \\
\hline
\end{tabular}


jährliche Abtragung in den Alpen auf 4, in Skandinavien auf 3,3 und in Grönland auf $2 \mathrm{~m}$. Die Abschmelzung auf der Unterfläche der Gletscher durch die Erdwärme kann nur auf indirektem Weg, durch Messung der winterlichen Wassermenge der Gletscherbäche, ermittelt werden. Sie beträgt $6-7 \mathrm{~mm}$ im Jahr.

Firn und Eiszunge befinden sich in ununterbrochener $\mathrm{Be}$ wegung talabwärts. Diese einseitige Bewegung setzt eine Neigung des Bettes voraus, die wir aber in der Regel nicht messen, sondern nur nach der Neigung der Gletscheroberfläche beurteilen können. Jedenfalls ist die letztere größer, weil die Mächtigkeit nach unten abnimmt. Sie scheint um so größer zu sein, je kleiner die Gletscher sind, und der Firn ist in der Regel etwas steiler. ${ }^{\times}$In außeralpinen Gebirgen scheinen geringere Neigungen häufiger zu sein. Wie in den Flubtälern unterbricht auch in den Gletschertälern oft eine steile Stufe die sanfte Abdachung; der Eisstrom löst sich bei seinem Sturz anscheinend in einen Trümmerhaufen auf, aber unterhalb schließen sich die Spalten wieder, und in majestätischer Ruhe zieht er weiter. Daß dabei der innere Zusammenhang des Eiskörpers nicht verloren geht, lehrte das Verhalten der Steinreihen, die man quer über den Rhônegletscher oberhalb des Sturzes'legte. Sie verschwanden im Sturz völlig, tauchten aber unterhalb nach vier Jahren wieder auf, und zwar genau in ihrer ursprünglichen Reihenfolge und genau in derselben Kurve wie vorher. Hängegletscher haben eine viel größere Neigung als Talgletscher, und es kommt nicht selten vor, daß große Eisstücke abbrechen und als Gletscherlawine in das Tal hinabstürzen. Geschieht dies regelmäBig, und ist die Materialzufuhr ausreichend, so wachsen die Eistrümmer am $\mathrm{FuB}$ der Gletscherwand wieder zusammen und bilden einen bewegungsfähigen regenerierten Gletscher, der keinen Zusammenhang mit der Firnregion hat. Aber trotz ihrer größeren Neigung bewegen sich die Hängegletscher langsamer als die Talgletscher, offenbar deshalb, weil die letzteren mächtiger sind und die Reibung am Untergrund wie auch die innere Reibung leichter überwinden. Es kommt neben der Neigung also auch auf die Größe und Gestalt des Querschnittes an.

$\times$ Aus den Listen der gröBeren alpinen Talgletscher von Hess habe ich folgende Mittelwerte berechnet:

\begin{tabular}{ccc} 
Länge & $\begin{array}{c}\text { Neigung } \\
\text { des Firns }\end{array}$ & $\begin{array}{c}\text { Neigung } \\
\text { der Eiszunge }\end{array}$ \\
$\begin{array}{c}\text { Anzahl der Gletscher) } \\
\text { über 20 km (1) }\end{array}$ & $20^{\circ}$ & $7^{\circ}$ \\
$15-20 \#(3)$ & 25 & 13 \\
$10-15,(7)$ & 24 & 15 \\
$5-10,(51)$ & 24 & 21 \\
unter 5 " (12) & 28 & 24 \\
\hline Summe (74) und Mittel & 25 & 21
\end{tabular}


Der älteste Erklärungsversuch, đie sog. Dilatationstheorie, nimmt an, daß sich die Gletscher durch die Aufnahme von Schmelzwasser, das wieder gefriert und sich dabei ausdehnt, vergrößern, daB also die Bewegung im Grund genommen nur scheinbar ist. Indes erkannte man bald, daß wirklich Bewegung besteht, und man konnte nicht im $Z_{\text {weifel }}$ sein, daß dabei das leitende Motiv die Schwerkraft ist. Aber man sah das Eis noch als einen starren Körper an und konnte daher die Bewegung nur auf ein Hinabgleiten der ganzen Masse auf dem geneigten Boden zurückführen. Der größte Alpenforscher des 18. Jahrhunderts, Saussure, hat sich für diese naheliegende Theorie ausgesprochen. Sie mußte weichen, als um die Mitte des 19. Jahrhunderts Louis Agassiz und J. D. Forbes die Gesetze der Gletscherbewegung feststellten, die eine auffallende Analogie mit den Gesetzen des fließenden Wassers zeigen. Im Gegensatz zur Abschmelzung nimmt die Geschwindigkeit an der Oberfläche der Eiszunge gegen das Ende $a b$ und vom Rand gegen die Mitte zu. $\times$ Wird die Eismasse in dem sich verengenden Bett zusammengepreßt, so wird die Reibung vermindert, während der Querschnitt sich gleich bleibt, und die Geschwindigkeit steigert sich. Zahlreiche Beobachtungen haben ferner gelehrt, daß sie in gekrümmten Tälern am konvexen Rand stärker ist als am konkaven, und daß dann die Linie größter Geschwindigkeit nicht genau in der Mitte, sondern näher dem konvexen Rand liegt; doch kommen auch Ausnahmen vor, wie z. B. am Gepatschferner. Über die Geschwindigkeit im Innern des Gletschers haben erst die Bohrungen von BlÜMCKE und Hess im Hintereisferner, die 1904 die Grundmoräne in einer Tiefe von $214 \mathrm{~m}$ erreichten, ${ }^{8}$ Aufschluß gegeben. Die mittlere Querschnittsgeschwindigkeit beträgt hier 0,77 der Oberflächengeschwindigkeit, die Geschwindigkeit nimmt also, wie im fließenden Wasser, unter dem Einfluß der Reibung nach der Tiefe ab. Für die Grönlandgletscher hat v. DRyGaLski ${ }^{9}$ allerdings das Gegenteil angenommen, aber es ist bemerkenswert, daß die einzige direkte Messung, die am Asakakgletscher, für die Oberfläche eine tägliche Geschwindigkeit von $16,1 \mathrm{~cm}$, für die Tiefe aber nur eine solche von 0,3 cm ergab. Aus seinen Messungen am Karajakgletscher folgerte er neben der Horizontalbewegung in der Mitte auch eine Vertikalbewegung in den Randpartien und konstatierte damit einen fundamentalen Unterschied zwischen Fluß und Gletscher; die Bewegung des ersteren strebt den Ausgleich des Niveaus, die des letzteren den Ausgleich des Druckes an. Diese Beobachtung wurde 
angezweifelt, aber nun haben sie BlüMCKe und FinsterwaLder ${ }^{10}$ auch am Hintereisgletscher bestätigt gefunden. Merkwürdig sind auch die Beobachtungen Hedis's ${ }^{11}$ im Mustagata, dem östlichen Randgebirge des Pamir, wo er an einem Ufer den Gletscher in rückläufiger Bewegung talaufwärts fand; auch sie sind in Zweifel gezogen worden, aber es wäre sonderbar, wenn sich derselbe Beobachtungsfehler an zwei Gletschern wiederholt haben sollte.

Auch sonst bestehen Unterschiede zwischen FluB und Gletscher. Zunächst ein quantitativer. Man kann im allgemeinen sagen, das Wasser bewegt sich unter gleichen Umständen 1 Million mal schneller als die Gletscher. In den Alpen wie in Norwegen rücken sie durchschnittlich in 24 Stunden nur 0,1 bis höchstens $0,4 \mathrm{~m}$ vor. HeIm hat berechnet, daß ein Schneeteilchen etwa 450 Jahre braucht, um vom Gipfel der Jungfrau his zum Ende des Aletschgletschers $\mathrm{zu}$ gelangen! Die gewaltigen Gletscher des Himalaya bewegen sich allerdings viel schneller, im Sommer $2-3,7 \mathrm{~m}$, doch übersteigt in dieser Jahreszeit - wie wir sehen werden - auch die Geschwindigkeit mancher ảlpinen Eisströme $1 \mathrm{~m}$. Die lebhafteste Bewegung herrscht im nordwestlichen Grönland; Geschwindigkeiten, wie sie von Steenstrup, Helland, Hammer, v. Drygalski u. a. an den Ausläufern des Inlandeises nordwärts der Diskobai gemessen wurden, übersteigen noch weit das himalayische Maß, wenn sie auch noch immer nicht größer sind als die Geschwindigkeit kleiner Schnecken! Ein Fortschreiten von 10, 20 bis $32 \mathrm{~m}$ in der Mittellinie für je 24 Stunden ist sonst noch nirgends im normalen Zustand beobachtet worden. Unter außergewöhnlichen Bedingungen nehmen aber auch manche alpine Gletscher plötzlich eine unheimliche und verderbliche Geschwindigkeit an, um dann wieder in ihre gemächliche Gangart zurückzufallen. Der Vernagtgletscher in Tirol und der Dewdarokgletscher im Kaukasus sind durch derartige Ausbrüche bekannt. Der erstere rückte z. B. in der Zeit vom 19. Mai bis 1 . Juni 1845 täglich um $12,7 \mathrm{~m}$ vor, am 1 . Juni sogar um $1,9 \mathrm{~m}$ in der Stunde! Einiges Licht auf diese rätselhaften Vorgänge werfen Hess' Versuche mit Eiszylindern, die durch eine enge Röhre gepreBt wurden. ${ }^{12}$ Das konnte nur geschehen, wenn der Druck eine gewisse Höhe erreicht hatte, dann aber bewegte sich das Eis, obwohl der Druck nicht zunahm, mit steigender Geschwindigkeit bis zu einem Höchstbetrag, worauf Bruch erfolgte. Es hängt also von der Größe der einwirkenden Kraft ab, ob die innere Reibung mit der Zeit zu- oder abnimmt. Am Vernagtgletscher liegen die Verhältnisse so, daß ein sehr ausgedehntes Firngebiet durch einen verhältnismäBig engen Kanal seinen $A b f l u B$ findet. Wächst der Firn in niederschlagsreichen Jahren, so 
erreicht sein Druck auf die Gletscherzunge endlich einen Betrag, der die innere Reibung des Eises überwindet, und dann nimmt die Geschwindigkeit des Gletschers mit der Zeit von selbst zu, bis der Überschuß an Firn erschöpft ist. Ähnlich liegen die Verhältnisse im westlichen Grönland, auch hier enge Abzugskanäle und ein gewaltiger und permanenter Druck von oben. Orographische Bedingungen sind es also, die die große Geschwindigkeit der grönländischen Gletscher erzeugen. Wo sie fehlen, wie im antarktischen Inlandeis des Kaiser Wilhelm II.-Landes, herrscht alpine Langsamkeit. Nach v. Drygalski's Messung rückte dieses durchschnittlich täglich nur $1 / 3 \mathrm{~m}$ vor.

Die ruckweise Bewegung mit rasch wechselnder Geschwindigkeit ist bei den Gletschern überhaupt Regel. Der Betrag, um den sie in einer bestimmten Zeit vorrücken, ist die Resultierende eines Kampfes entgegengesetzter Kräfte: des Druckes von oben und des Widerstandes durch die Reibung. Daraus erklären sich auch die überraschenden Ergebnisse der jüngsten Messungen BuÜMcke's und FinsterwalddeR's auf dem Hintereisferner (1899-1904).10 Man hatte bisher angenommen, daß sich der Gletscher im Sommer schneller bewege als im Winter; die Steine, die man zu den Messungen verwendete, rutschten nämlich im Sommer auf der schmelzenden Gletscheroberfläche ab und ergaben so falsche Geschwindigkeitszahlen. Blümcke und Finsterwalder vermieden diese Fehlerquelle; sie arbeiteten nur mit Bohrlöchern, in die Holzstangen eingefügt waren, und fanden, daß die sommerliche Geschwindigkeit nur im unteren Teil der Eiszunge die winterliche übertrifft, im oberen Teil aber kleiner ist. $\times$ Hier ist die Beschleunigung in der kalten Jahreszeit eine Folge des durch Schneeanhäufung sich vermehrenden Firndruckes, dort wirkt die Abnahme des Reibungswiderstandes im Sommer infolge der Durchtränkung des Eises mit Schmelzwasser.

Gletschertheorie und Gletscherstruktur. Einerseits erscheint uns der Gletscher als ein fester Körper, denn an seiner Unterseite sind Steine eingebacken, mit denen er den Felsboden ritzt und abscheuert; anderseits setzt seine Bewegungsfähigkeit einen hohen Grad von Plastizität voraus. Diese Eigenschaft befähigt ihn auch, sich den wechselnden Formen seines Bettes anzuschmiegen. An der Westküste Grönlands reicht unter $62^{\circ} 40^{\prime}$ B. ein Ausläufer des Binneneises in einen schmalen, nordöstlich streichenden See, den er

$\times$ Setzen wir die mittlere jährliche Geschwindigkeit $=1$, so war die sommerliche in folgenden Entfernungen vom Gletscherende:

$\begin{array}{llllllll}300 \mathrm{~m} & 400 \mathrm{~m} & 700 \mathrm{~m} & 1750 \mathrm{~m} & 2700 \mathrm{~m} & 4000 \mathrm{~m} & 4800 \mathrm{~m} \text { - } \\ 1,337 & 1,329 & 1,173 & 0,890 & 0,773 & 0,637 & (?) & 0,693\end{array}$


in T-Form ausfüllt. Von den Gletschern des Franz-Josef-Landes berichtet PAYER, daß die durch Bergvorsprünge geteilten Arme am Fuße jener wieder zusammenfließen. Den augenscheinlichsten Beweis für die Plastizität liefert der kleine norwegische Gletscher von Kaagan $\left(70^{\circ}\right.$ B. $)$, in dem Fonbes die Form einer herabrinnenden Träne so schön ausgebildet fand. Dieser bahnbrechende Forscher verglich das Gletschereis mit zähflüssigen (viskosen) Massen und gründete darauf seine Viskositätstheorie, dagegen zählt es HЕIм zu den dickflüssigen Körpern, die auf Druck plastisch ausweichen und auf Zug zerreißen. Die talabwärts gerichtete Komponente der Schwerkraft äußert sich in jedem Querschnitt des Gletschers von oben als Druck, von unten als Zug; wirkte Druck allein, so wäre der Gletscher ein ebenso zusammenhängender Körper wie ein Fluß; wirkte Zug allein, so würde er in Trümmer zerfallen. In der Spaltenbildung haben wir den Ausdruck des Kampfes der Kohäsion mit der Streckung zu erblicken; sie ist daher stets senkrecht zur Spannungslinie. Vom Bergschrund an, jener Spalte die die Schneemasse des Firns von der des Gipfelkörpers trennt, bis zum Gletscherende sind Firn- und Eiskörper in allen Gegenden vielfach zerklüftet, wenn

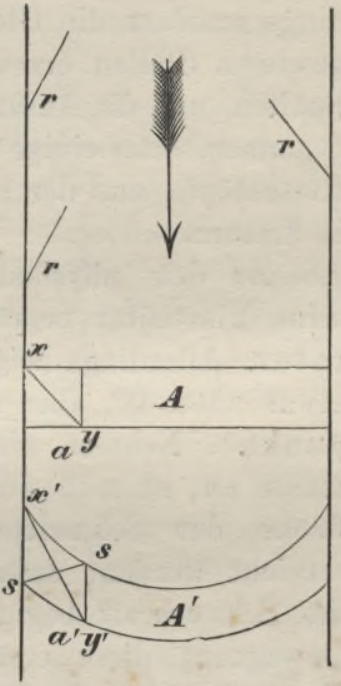

Fig. 42. Randspalten. auch im allgemeinen die nordischen Gletscher elastischer erscheinen als unsere alpinen. Querspalten werden durch die verschiedene Neigung des Bettes hervorgerufen, vernarben aber wieder, wenn sich das Gefälle vermindert. Eine eigentümliche Art der Querspalten sind die Randspalten ( $r$ in Fig. 42), die einen Winkel von 30 bis ungefähr $45^{\circ}$ mit den Seiten einschließen und durch die schnellere Bewegung der Mitte erzeugt werden. Infolgedessen nimmt in Fig. 42 das Stück $A$ nach einer gewissen Zeit die Form $A^{\prime}$ an, und das Quadrat $a$ wird $\mathrm{zu} a^{\prime}$ verzerrt. Dadurch erfährt die Linie $x y$ eine Streckung $\left(x^{\prime} y^{\prime}\right)$, der das Eis nicht folgen kann. Es muß reißen und zwar senkrecht zur Linie der größten Spannung (Spalte $s s$ ). Ist das Bett gekrümmt, so ist die Spaltung an der konvexen Seite stets größer als an der konkaven. Längsspalten bilden sich, wenn der Gletscher aus einem engen in ein weites Bett tritt, denn dann wirkt die Spannung in der Querrichtung des Gletschers. Wenn im Sommer die an der Oberfläche des 
Gletschers entstehenden Bäche in eine Spalte hinabstürzen (sog. Gletschermühlen), so höhlen sie mit der Zeit tiefe und beinahe zylindrische Löcher im Eis aus, die manchmal bis auf den Grund reichen. Gelangen Steine in ein solches Loch, so werden sie von den Sturzbächen in kreisende Bewegung gesetzt und können unter günstigen Verhältnissen in dem Boden Vertiefungen, sog. Riesentöpfe ausschleifen. Berendt fand zwei solche von 0,8 und $1,2 \mathrm{~m}$ Durchmesser im verlassenen Bett des Rosenlauigletschers. Allerdings wandert die Gletschermühle mit der Spalte abwärts, aber an gewissen Stellen erzeugt die Unebenheit des Bodens immer wieder Spalten, und die Ausarbeitung des Riesentopfes, die die eine Kaskade begonnen, setzt einige Tage nachher eine andere fort. Die schönsten Riesentöpfe, aus der Eiszeit stammend, sieht man im Gletschergarten in Luzern.

$\mathrm{Zu}$ den physikalischen Eigenschaften des Gletschereises, die seine Plastizität begründen, gehört in erster Linie seine Temperatur. Allerdings zeigt das Thermometer im Innern des Gletschers etwas unter $0^{\circ}$, aber mit dem Druck sinkt auch der Schmelzpunkt. ${ }^{\times}$Nehmen wir mit CRAMmeR ${ }^{14}$ eine ursprünglich starre Eismasse an, so muß durch den jährlichen Firnzuwachs an der Oberfläche der Schmelzpunkt an der Unterseite des Eises einmal erreicht werden; dadurch wird hier der Zusammenhang gelockert, die Schwerkraft beginnt zu wirken, die unterste Schicht gerät in Bewegung, diese erzeugt Reibungswärme, die sich der nächsten oberen Schicht mitteilt, und so erfaßt nach und nach die Bewegung die ganze Gletschermasse. Auch sonst ist Gelegenheit zu Verflüssigung gegeben; gelangt z. B. das Wasser in Hohlräume, so wird der Druck vermindert, das Wasser gefriert, dabei wird aber Wärme frei, die nun nach anderer Seite hin wieder zum Schmelzen verwendet werden kann. Die Temperaturbeobachtungen gelten zunächst allerdings nur für den Sommer, aber die Tatsache, daß die Gletscherbäche auch im Winter nicht gefrieren, weist schon darauf hin, daß das ganze Jahr hindurch im Innern der Alpengletscher Schmelztemperaturen vorhanden sind. BLÜMCKE und Hess ${ }^{7}$ haben dies auch theoretisch begründet. Der winterliche Wärmeverlust durch Leitung

$\times$ Beobachtungen von Вцёмске und $\mathrm{Hess}^{7} \mathrm{im}$. Hintereisgletscher im August 1899:

\begin{tabular}{|c|c|c|c|c|c|c|c|}
\hline Tie & $\mathrm{m}$ & 18 & 30 & 42 & 54 & 66 & 82 \\
\hline & Beobachtet & $-0,012^{\circ}$ & $-0,023^{\circ}$ & $-0,038^{\circ}$ & $-0,046^{\circ}$ & $-0,055^{\circ}$ & $-0,062^{\circ}$ \\
\hline punkt & $\begin{array}{l}\text { Grund der } \\
\text { mechanischen } \\
\text { Witrmetheorie }\end{array}$ & $-0,015$ & $-0,020$ & $-0,029$ & $-0,037$ & $-0,045$ & $-0,056$ \\
\hline
\end{tabular}

Der mittlere Fehler der Beobachtung beträgt also $\cap, n_{07}{ }^{\circ}$. 
wird durch die Wärme, die die bei der Fallbewegung des Eises auftretende Energie liefert, ausgeglichen, und ein Verlust durch Strahlung findet überhaupt nicht statt. Gegen die kalte Luft schützt die Schneedecke, $x$ und die Erkaltung des Bodens verhindert der Gletscher selbst.

Auch eine andere Eigenschaft des Eises, die Regelation, verdient Beachtung. Zwei tauende Eisstücke frieren an der Berührungsstelle sofort wieder zusammen. Es leuchtet ein, wie sehr der Gletscher dadurch an Deformierbarkeit gewinnt; selbst eine weitgehende Zertrümmerung gefährdet nicht auf die Dauer den Zusammenhang.

Darauf beruht Trndall's Regelationstheorie: Thr zufolge ist die Plastizität gewissermaßen nur scheinbar; die Bewegung erzeugt fortwährend Risse und Sprünge, aber die Regelation heilt sofort wieder die Wunden. In veränderter Form hat v. Drygalski ${ }^{9}$ diese

Theorie wieder aufgenommen. Er er- Stï. 43. Durchschnitt durch ein klärt die Bewegung durch partielle innere Verflüssigungen undWiederverfestigungen

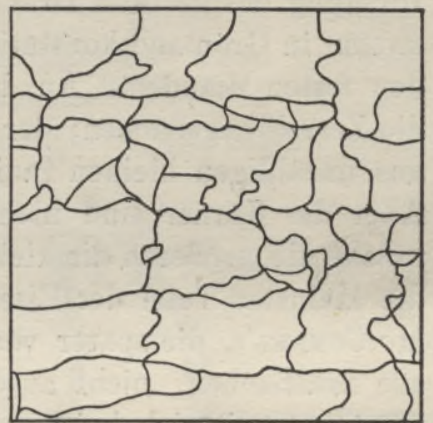
de Glace nach DeELizy und Fletcher. und setzt dabei eine so durchgreifende Lockerung des Gefüges voraus, daß der Gletscher durch den Druck seiner Masse, der sich von den Partien größerer nach denen geringerer Mächtigkeit fortpflanzt, in der Richtung dieses Druckes gewissermaßen ausgequetscht wird. Eine einseitige Neigung des Gletscherbodens braucht gar nicht vorhanden zu sein. Ja es kommen, wie wir schon erwähnt haben, sogar selbständige, d. h. nicht bloß lokal durch Hindernisse im Bett bedingte aufwärts gerichtete Bewegungen vor.

Bei der Regelationstheorie spielt die Struktur des Gletschereises eine wichtige Rolle. Es ist von einem dichten Netz von Haarspalten durchzogen und zerfällt in unzählige kantige, eckige Brocken, die von eigentümlich gerillten, meist krummen Flächen begrenzt sind, und die man Gletscherkörner nennt (Fig. 43). Man war einst der Meinung, daß das Gletschereis allein durch eine solche regellose Anordnung von Kristallkörnern ausgezeichnet sei; aus Emden's Untersuchungen ${ }^{15}$ geht aber hervor, daß jedes Eis diese Struktur annimmt, nur sind im Wassereis die Körner als Prismen

$\times$ Nach den Messungen von ОкарA betrug im Februar die tägliche Schwankung an der Oberfläehe des Schnees $18,9^{\circ}$, in $30 \mathrm{~cm}$ Tiefe aber nur mehr $0,6^{\circ}$ (Zeitschrift für Gletscherkunde, Bd. III, S. 71). 
von bedeutender Länge ausgebildet. Dagegen unterscheiden sich die Körner des Gletschereises von denen des Schneeeises nur durch ihre GröBe $(1-10 \mathrm{~cm}$ und mehr). VALLOT beobachtete auf dem Montblanc schon in $15 \mathrm{~m}$ Tiefe Körner von 0,2 cm im Durchmesser, und in den untersten Partien des Firneises sind schon recht ansehnliche Gletscherkörner vorhanden. × In den arktischen Gletschern sind die Körner viel kleiner als in den alpinen, in beiden wachsen sie aber gegen die Ränder und den Untergrund zu, also anscheinend in der Richtung des gröBten Druckes, und dabei stellen sie sich, wie v. DRYGALSKI in Grönland konstatiert hat, mit ihren Basisflächen parallel zu den festen Wänden. An die Grenzflächen der Körner verlegte man die Zerreißungsflächen; der Gletscher besteht nach dieser Auffassung aus unzähligen kleinen Individuen, die die Regelation zusammenhält. Aber die Körner sind nicht starr und unveränderlich, sie wachsen, indem die größeren die kleineren aufsaugen; und sie sind auch nicht die kleinsten Teile des Eises, sondern bestehen nach der Entdeckung Mc Connel's, die später von MÜGGE ${ }^{16}$ bestätigt und erweitert wurde, aus zahlreichen, nicht ausdehnbaren, aber sehr biegsamen dünnen Blättchen, die sich bei Druck in ihrer Ebene nicht bloB aufeinander verschieben, sondern sogar übereinander hinausschieben lassen, bei Druck senkrecht zu ihrer Ebene sich aber spröde verhalten. In dieser Eigenschaft der Translation sehen MÜGGE und EmDen die Plastizität und Bewegungsfähigkeit des Eises begründet.

Ein höheres Element der Gletscherstruktur ist das Band oder Blatt. Das Eis besteht aus wechselnden, mehr oder weniger dicht gedrängten Bändern oder Streifen von blasenreichem und luftfreiem Eis. Das erstere schmilzt wegen seiner größeren Porosität leichter und bildet an der Oberfläche Vertiefungen, das letztere dagegen Erhöhungen. Überblickt man den Eisstrom von einem erhöhten Standpunkt aus und bei günstiger Beleuchtung, so scheinen die zahllosen kleinen Erhebungen zu Linien (Ogiven) zu verschmelzen, die quer

× Eine Vorstellung von der Kornstruktur geben J. J. Buchanax's Wägungen von Eisblöcken des Glacier des Bossons und des Aletschgletschers (Nature, 1901 Bd. LXIV, S. 399). In einem Block fand er:

\begin{tabular}{ccc}
$\begin{array}{c}\text { Zahl } \\
\text { der Körner }\end{array}$ & $\begin{array}{c}\text { Gesamtgewicht } \\
\text { g }\end{array}$ & $\begin{array}{c}\text { Durehschnitts- } \\
\text { gewicht eines } \\
\text { Korns, g }\end{array}$ \\
16 & 1045 & 65,3 \\
10 & 110 & 11,0 \\
4 & 25 & 6,25 \\
10 & 25 & 2,5 \\
\hline 40 & 1205 & 30,1
\end{tabular}

Von andern Blöcken war das mittlere Korngewicht 16,8, 25,3, 28,5, 48,0, 58,3 und $102,0 \mathrm{~g}$. 
über den Gletscher hinlaufen und in der Nähe des Firns kaum merkbar gekrümmt sind, nach abwärts aber, entsprechend der schnelleren Bewegung der Gletschermitte, immer spitzere Bogen beschreiben. Jeder Zufluß bringt sein eigenes Ogivensystem mit sich, so daß nach der Vereinigung mehrere solche Systeme nebeneinander herlaufen (s. Fig. 44). Die Breite eines solchen Bandes schwankt zwischen einigen Millimetern und mehreren Zentimetern. Verfolgen wir es in seiner Längsrichtung, so bemerken wir bald, das es sich auskeilt; aber ehe es noch sein Ende erreicht, tritt ein anderes Blatt genau in derselben Richtung an seine Stelle. An den Spaltenwänden erscheint diese Struktur als farbige Bänderung von weißem (blasenreichem) und blauem (luftfreiem) Eis. Schon die Ogiven zeigen an, daß die Blätter nicht horizontal liegen; an allen

Rändern fallen sie gegen den Gletscher ein, am Ende talaufwärts und an den Ufern gegen die Achse, und je näher sie dieser liegen, desto steiler stellen sie sich auf (Fig. 45).

Durch diese löffelförmige Blätterstruktur unterscheidet sich die Eiszunge wesentlich von dem geschichteten Firn. Die flachen Firnschichten entsprechen den einzelnen Schneefällen und sind durch Staublagen, die von den Felswänden der Umrahmung herstammen, voneinander getrennt. In welcher Beziehung stehen nun diese beiden Strukturen zueinander? AGASsIZ hatte erklärt, die

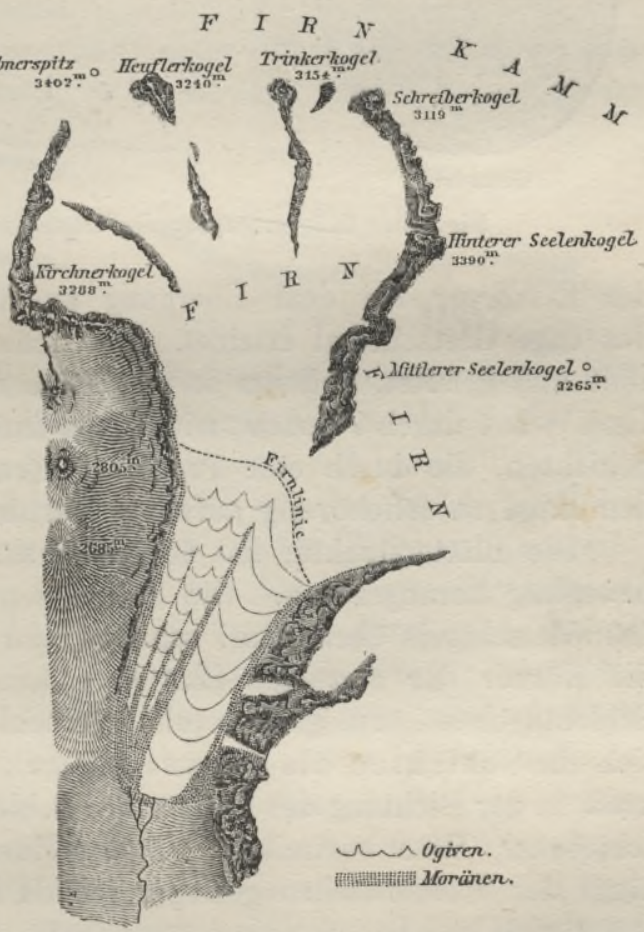

Fig. 44. Rotmoosgletscher nach v. SonkLaR.

Blätter gingen aus den Firnschichten hervor. TrndsLL hatte auf Grund seiner Beobachtungen am Aletsch- und Gornergletscher, wo er horizontale Schichten durch lotrechte blaue Bänder gekreuzt fand, die Blätterstruktur für unabhängig von der Schichtung und für eine Wirkung des Druckes erklärt. Erst in der jüngsten Zeit kehrte man wieder zur älteren Ansicht zurück. CraMmer ${ }^{17}$ hat den Zusammenhang 
der Blätter mit den Firnschichten am Marzel-, Vernagt- und Obersulzbachgletscher und H. F. REID am Fornogletscher festgestellt, und die internationale Gletscherkonferenz im September $1905^{18}$ hat sich dieser Auffassung angeschlossen. Die Umformung der einen Struktur in die andere ist allerdings eine Folge des seitlichen Druckes, den

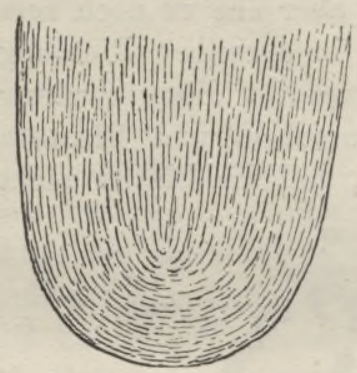

Grundriß
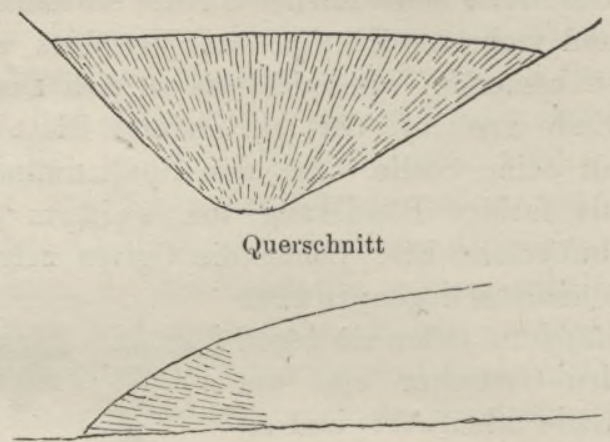

Längsschnitt

Fig. 45. Blätterstruktur des Gletschers nach Crammer. ${ }^{17}$

der Eiskörper bei dem Übergang aus dem weiten Firnbecken in das enge Gletschertal erleidet. Die Schichten werden dadurch zerteilt und gefaltet, und um so steiler, je näher sie der Achse liegen. Hess $^{19}$ hat durch Versuche mit Wachs dargetan, daß sich horizontale Schichten, die durch eine Preßform herausgedrückt werden, gegen den Rand zu löffelförmig aufwärts krümmen.

Die Blätterstruktur hat CrAmмer zur Erklärung der Gletscherbewegung herangezogen. Die Staublagen der Firnschichten, die in das Gletschereis übergehen, schaffen hier durchlaufende Fugen, die die Körner der einzelnen Blätter voneinander trennen, und diese Schichtflächen ,ermöglichen eine Verschiebung in der Weise, daß sich die Schichten als Ganzes infolge der Einwirkung der Schwerkraft in der Richtung des Fallens der Schichten übereinander hinwegschieben". Hess bestreitet, daB der Zusammenhang der Eismasse längs der Schichtflächen geringer sei als in der übrigen Masse, und stützt sich auf Laboratoriumsversuche ${ }^{20}$, die aber Crammer ${ }^{21}$ nicht als beweiskräftig anerkennt. Ähnliche Ansichten, wie der letztere, haben schon früher CHAMBERLIN ${ }^{22}$ in bezug auf das nördliche Grönland und Haмвеrg ${ }^{23}$ betreffs der Spitzbergengletscher geäußert. Die Mehrzahl der Gletscherforscher neigt indes der reinen Strömungs theorie zu, die in der Bewegung der Gletscher einen molekularen Vorgang, eine fortwährende Lagenveränderung der kleinsten Massenteilchen, wie beim fließenden Wasser, erblickt, ohne den Struktur- 
verhältnissen und der Regelation einen maßgebenden Einfluß einzuräumen. Nur ist damit, wie Crammer mit Recht hervorhebt, die Erhaltung der Kristallstruktur bis an das Ende der Gletscher schwer vereinbar. So ringen die Meinungen noch miteinander: ein Beweis, wie beschränkt noch unser Einblick in der Sachverhalt ist.

Theorie des stationären Gletschers. Man kann von den Ursachen der Gletscherbewegung absehen und sich zunächst auf die Frage nach der Art dieser Bewegung beschränken. Man muß dabei von vereinfachenden Voraussetzungen ausgehen, um das Phänomen der mathematischen Behandlung zugänglich zu machen; der Vergleich des rechnerischen Ergebnisses mit der Beobachtung muß dann lehren, ob und inwiefern jene Voraussetzungen zutreffen. Diesen Weg hat FinsterwaLder ${ }^{24}$ eingeschlagen.

Fig. 46a stellt den Längsschnitt einer Röhre dar, durch die sich eine Flüssigkeit von links nach rechts bewegt. Diese Bewegung ist

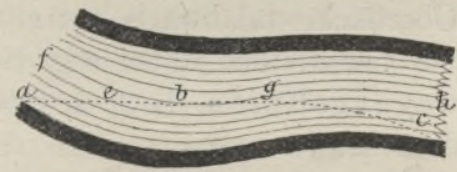

Fig. 46 a.

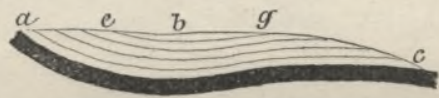

Fig. $46 b, \times$

stationär und stetig. Die erste Eigenschaft besteht darin, daß die Strömung nach Richtung und Größe unverändert bleibt, also von der Zeit unabhängig ist; die Stetigkeit besagt, daß benachbarte Teilchen immer benachbart bleiben, also nicht aus dem Innern nach der Wand oder umgekehrt gelangen können. Jedes Teilchen beschreibt eine Stromlinie, benachbarte Teilchen also benachbarte Stromlinien.

Nun denken wir uns durch die Röhre eine Fläche $a b c$ gelegt und den oberen Teil entfernt. Es entsteht die Frage: kann die Strömung im unteren Teil ihren ursprünglichen Charakter noch aufrecht erhalten? Die Antwort lautet: ja, wenn - wir nehmen eine Stromlinie heraus - die entfallenden Stücke of und $g h$ anderweitig ersetzt werden, ef durch Zufuhr und $g h$ durch Wegnahme.

So entsteht die Fig. 46 b. Sie stellt uns einen stationären und stetigen Gletscher im Längsschnitt dar. Die Trennungsfläche $a b c$ ist die Oberfläche des Gletschers, der verbleibende Röhrenteil das Gletscherbett. $b$ bezeichnet die Firnlinie. Das Wesen der stationären Gletscherbewegung besteht nun darin, daß die Stromlinien des Firns talabwärts, die der Eiszunge talaufwärts einfallen, daß also jedes Teilchen der Firnoberfläche untertaucht, sich im Innern

$\times$ Es muß davor gewarnt werden, die Stromlinien, von denen ja nur einige eingezeichnet sind, als Schichtung aufzufassen. 
des Gletschers talabwärts bewegt und dann an einer bestimmten Stelle der Eiszunge wieder auftaucht $(e$ z. B. in $g$ ). Je weiter es von der Firnlinie entfernt ist, desto länger ist seine Stromlinie, nur in der Firnlinie kehrt diese Stromlinie in sich selbst zurück. Oberhalb der Firnlinie herrscht Auftragung, unterhalb Abschmelzung; Zufuhr und Abfuhr des Materials müssen sich das Gleichgewicht halten.

Eine weitere Erläuterung bietet uns Fig. 47. FF ist die Firnlinie, die Nähr- und Zehrgebiet scheidet. Legen wir im Nährgebiet

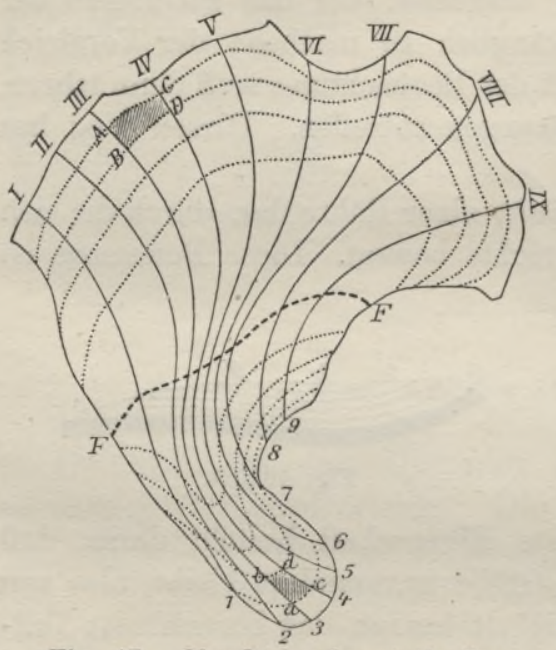

Fig. 47. Oberfläche des stationären Gletschers (nach FinsterwaLDER) einen Stein auf die Oberfläche, so wird er von dem sich bewegenden Eis in die Tiefe gezogen; Steine aber, die auf der Firnlinie oder im Zehrgebiet gelegt werden, entgehen diesem Schicksal und werden passiv an der Oberfläche talabwärts getragen. Sie beschreiben dabei sog. Bewegungslinien (1, 2, 3, usw.), die man experimentell bestimmen kann, wie es z. B. von BlüMCKe und Hess auf dem Hintereisgletscher geschah. Nach unten gehen sie strahlenförmig auseinander, so daß die seitlichen Bewegungslinien schon am oberen Rand der Eiszunge, also an der Talböschung enden. Verlängert man sie nach oben bis zum hintersten Rand des Firnfeldes und verbindet man ferner das Ausgehende der Stromlinien miteinander (die punktierten Linien in Fig. 47), so erhält man ein Liniennetz, von dem jede Masche im Nährgebiet einer bestimmten Masche im Zehrgebiet entspricht. Das Teilchen $A$ z. B. kommt in $a$ wieder zum Vorschein, $B$ in $b$ usw., soda $B$ die Fläche $A B C D$ im Firnfeld der Fläche $a b c d$ in der Eiszunge entspricht. Nun sind alle Bedingungen einer streng mathematischen Behandlung erfüllt. $\times$ Um zu praktischen Ergebnissen zu gelangen,

$\times$ Nennen wir

$\begin{array}{lcc}\text { die entsprechenden Flächen } & \text { im Firngebiet } & \text { auf der Eiszunge } \\ \text { die Auftragung bezw. Abschmelzung } & d \mathrm{~F} & d f \\ \text { den Einfallswinkel der Stromlinie } & A & \Phi \\ \text { ihre Geschwindigkeit . . . . . . . . } & V & \varphi \\ \end{array}$

so bestehen die Gleichungen

$$
d F \cdot A=d F \cdot V \cdot \sin \Phi=d f \cdot a=d f \cdot v \cdot \sin \varphi .
$$


muß man freilich noch eine Reihe anderer Hypothesen zu Hilfe ziehen, da man wohl die Bewegungslinien, den Betrag der Abschmelzung und die Oberflächengeschwindigkeiten durch Beobachtung feststellen kann, aber nicht die Verteilung der Geschwindigkeiten innerhalb der Querșchnitte, und bei den vorhandenen Gletschern auch nicht die Form der Querschnitte selbst. Es liegt nicht in der Tendenz dieses Buches, näher darauf einzugehen; es sei nur erwähnt, daß eine Probe günstig ausfiel. Die Bohrungen, die BLÜMCKE und Hess ${ }^{25}$ seit 1899 im Hintereisgletscher ausführten, und bei denen man den Grund oder wenigstens die Grundmoräne an 13 Stellen (bis zu $224 \mathrm{~m}$ Tiefe) erreichte, ergaben mit einer einzigen Ausnahme zwischen der erbohrten und berechneten Eismächtigkeit nur Differenzen von durchschnittlich $7-8 \mathrm{~m}$.

Moränen. An der Bewegung des Gletschers nimmt passiv auch aller Schutt teil, der von den eisfreien Talgehängen auf den Gletscher fällt, oder den dieser auf dem Grund vorfindet, oder den er sich durch seine eigene, allerdings noch immer nicht allseitig anerkannte erosive Kraft schafft. Er häuft [sich entweder als Oberflächenmoräne an den Seiten oder in der Mitte des Gletschers an (Fig. 44 und 48) oder gelangt in den Eiskörper selbst und bildet dann Innenmoränen, odẹ wird als Grundmoräne talabwärts befördert. ${ }^{x}$

Die Entwicklung und Mächtigkeit der Oberflächenmoränen hängt zum größten Teil von der Ausdehnung und der Schuttproduktivität des den Gletscher überragenden Geländes ab. Fortwährende Felsstürze haben den Baltorogletscher im Karakorumgebirge so mit Trümmern überschüttet, daß auf eine Länge von $50 \mathrm{~km}$ kein Eis mehr sichtbar ist. Dagegen ist die Oberfläche des Bismarckgletschers in den südpatagonischen Andes nach der Schilderung HaUthaL's völlig schuttfrei. Ein allen Gletschern gemeinsamer Begleiter ist nur die Grundmoräne. Dringt man durch die Höhle, aus der der Gletscherbach kommt, unter die Eismasse ein, so findet man, daß diese nicht unmittelbar auf dem Felsboden aufruht, sondern daB sich eine Lage von Sand, Grus und Schlamm mit eingebetteten Gesteinsblöcken von verschiedener Größe dazwischenschiebt. Die Gesteine sind mehr oder weniger gerundet, ihre Oberfläche ist geglättet und

$\times$ Wir folgen in der Nomenklatur den Vorschlägen der Gletscherkonferenz im August $1899,{ }^{26}$ die für bewegte und abgelagerte Moränen verschiedene Bezeichnungen empfohlen hat, jedoch mit der auch von Hess angewendeten Änderung, daß wir im Einklang mit der ganzen bisherigen Literatur die Untermoräne Grundmoräne nennen. Ein anderes, kompliziertes System hat v. Böнм²7 aufgestellt, und noch viel weiter ging $\theta_{\mathrm{YEN}}{ }^{29}$ der 27 Moränentypen unterscheidet.

Supan, Physische Erdkunde. 5. Aufl. 
- wenn sie nicht besonders hart sind - mit Schrammen und Kritzen bedeckt. In gleicher Weise findet man, wenn man die Moräne entfernt, den Felsboden poliert und mit geradlinigen Kritzen in der Richtung der Gletscherbewegung bedeckt. Dasselbe Phänomen

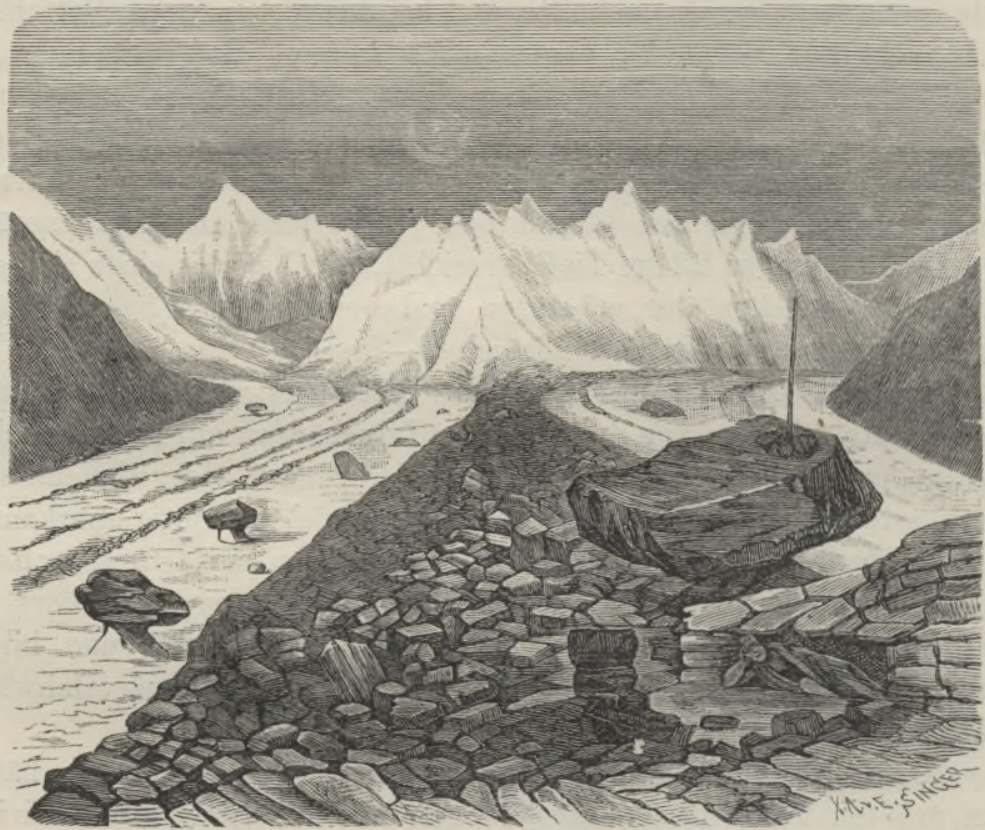

Fig. 48. Moränen und Gletschertische.

beobachtet man auch an den Seitenwänden des Eisstromes; ihre ursprünglichen Unebenheiten sind abgerundet, und ihre Oberfläche

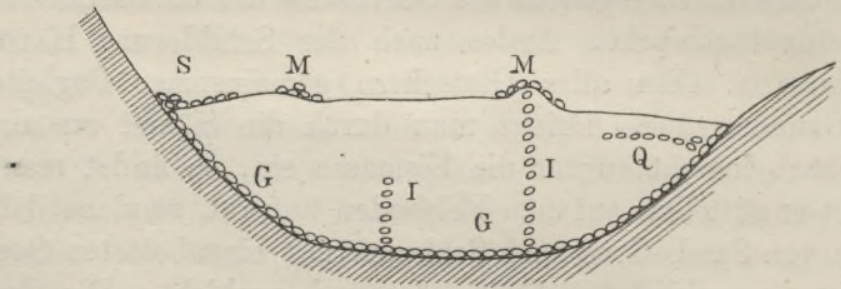

Fig. 49. Querschnitt durch einen Gletscher nach Hess.

$G$ Grundmoräne. I Innenmoräne, $(Q$ Quermoräne, eine seltenere Abart von Innenmoränen). $M$ Mittelmoräne, $S$ Seitenmoräne.

ist blank gescheuert und geschrammt. Aber selbst diejenigen, die dem Gletscher die Kraft zuschreiben, Seebecken auszuschaufeln, sprechen ihm ausdrücklich die Fähigkeit ab, selbst abschleifend zu wirken. Dieses Geschäft besorgt vielmehr nach einer weit- 
verbreiteten Ansicht die Grundmoräne. Man denkt sich die Seitenflächen und die Unterfläche des Gletschers mit eingebackenen Gesteinsblöcken wie mit Zähnen besetzt, und diese polieren und kritzen die Felsen und werden dadurch selbst zermalmt. Das Endprodukt dieses Prozesses ist eine schlammigsandige Masse, die zum Teil als Grundmoräne abgelagert, zum Teil durch den Gletscherbach („Gletschermilch“ wegen seiner trüben Farbe) herausbefördert wird.

Die Finsterwalder'sche Theorie wirft neues Licht auf die Entstehung und Zusammensetzung der verschiedenen Moränen aus Randund Grundschutt. Nur der Randschutt, der unterhalb der Firnlinie seinen Ursprung nimmt, bildet Oberflächenmoränen, und zwar entweder Seiten- oder Mittelmoränen, von denen die letzteren entweder von einer Felseninsel im Gletscherbett ausgehen oder durch Vereinigung der inneren Seitenmoränen zweier zusammenfließender Gletscher entstehen. In dem Firngebiet wird aber aller Randschutt von den Stromlinien in die Tiefe gezogen, der Grundmoräne einverleibt und quillt mit den Stromlinien am Rand der Eiszunge wieder empor (also z. B. Schutt von I in Fig. 47 in 1, von IV in 4, von IX in 9). Denselben Weg nimmt auch der Grundschlamm, jedoch nur in einem ganz regelmäßig gestalteten Gletscherbett; wird aber dieses von Aufragungen unterbrochen, so kommen nicht bloß die untersten, sondern alle Stromlinien, die diese Aufragungen umfließen und sich unterhalb wieder vereinigen, mit Grundschlamm in Berührung, der dann eine Innenmoräne bildet und dort, wo die Stromlinien ausgehen, durch die Abschmelzung als Mittelmoräne zutage gefördert wird, entweder allein oder in Verbindung mit Randschutt, der unter den schon genannten Bedingungen an der Oberfläche verbleibt. Solche Mittelmoränen, die im Eis wurzeln, unterscheiden sich von denjenigen, die nur aus Randschutt bestehen, dadurch, daß sie talabwärts ¡immer breiter werden, ohne an Höhe abzunehmen, indem ihnen durch die sukzessive ausmündenden Stromlinien immer neues Material zugeführt wird. Diese Tatsache, ferner das plötzliche Auftreten von Mittelmoränen, deren Herkunft an der Oberfläche nicht zu ermitteln ist, das Vorkommen von Grundschutt in den Seitenmoränen, und endlich die Mächtigkeit der Grundmoräne finden durch Finterwalder's Theorie eine ungezwungene Erklärung. Eine schöne Bestätigung hierfür liefert der durch die Meereswogen bloßgelegte Querschnitt des Barrygletschers in Alaska, der den Zusammenhang zwischen Mittel- und Innenmoräne deutlich erkennen läBt.

Unterliegt der Gletscher starker Abschmelzung, so kann die Seitenmoräne ganz oder zum Teil auf Felsgrund zu liegen kommen 
und wird dadurch dem Transport entzogen; in diesem Stadium bezeichnet man sie als Ufermoräne. Auch die Grundmoräne kann zum Teil in Höhlungen unter dem Gletscher (wie z. B. unter dem Gletschertor) zur Ablagerung gelangen und bildet hier eine Grundmoränendecke. Aller andere Schutt aber wird bis an den Ausgang verfrachtet und setzt hier die End-oder Stirnmoräne zusammen, die uns bald als schmaler Steinwall von wechselnder Höhe, bald als weite Schlamm- und Kiesfläche entgegentritt, in der mächtige Felstrümmer zwischen kleinen, unregelmäßigen Schutthügeln zerstreut liegen. Der Gletscherbach bearbeitet die abgelagerte Moräne und vermehrt sie mit seinen eigenen Schlammassen; manchmal vermischt sich damit auch der vom Gletscher zusammengeschobene lockere Boden des Vorlandes. Ist der Boden schwach geneigt, wie vor den Gletschern Islands und Alaskas, so ist der Bach, nachdem er die Endmoräne durchbrochen hat, genötigt, einen großen Teil seines Schuttmaterials abzulagern, zuerst den groben Schotter, dann immer feinere Bestandteile. Auf diese Weise entsteht außerhalb der Endmoräne ein wachsender Schwemmkegel, für den sich der in Island gebräuchliche Name Sandr einzubürgern beginnt.

Die ehemalige Ausdehnung schwindender Gletscher verrät die Grundmoränendecke, in der Reste der Oberflächen- und Innenmoränen in streifenförmiger Anordnung als Längsmoränen auftreten.

Auf die Abschmelzung übt der Oberflächenschutt einen großen Einfluß aus, teils hemmend, teils fördernd. Massenanhäufungen schützen Teile des Gletschers vor diesem ZerstörungsprozeB. Die Mittelmoräne liegt auf einem Eiswulst; einzelne größere Steinblöcke scheinen gleichsam aus dem Eis hervorzuwachsen. So entstehen die bekannten, stets nach der Mittagsseite geneigten Glets chertische (Fig. 48), denen freilich nur eine vergängliche Existenz beschieden ist. Die Sandkegel, die oft eine Höhe von mehreren Metern erreichen, ruhen ebenfalls auf geschützten Eiserhöhungen. Dagegen sind dünne Sand- und Schlammlagen, wie solche von den Abhängen herabgeschwemmt oder durch den. Wind herbeigeführt werden, nicht nur kein Schutzmittel, sondern geradezu Beförderer der Abschmelzung. Sie sammeln sich als sogenannte Schmutzbänder in den Ogiven und in den Vertiefungen, welche die zusammengewachsenen Querspalten unterhalb eines Gletscherfalles bezeichnen, und verharren in ihrer Lage, indem sie sich immer tiefer in das Eis hineinfressen, oder sie schaffen selbständig Löcher, die an ähnliche Erscheinungen auf Kalkplateaus erinnern. Das ist übrigens nicht die einzige Ähnlichkeit zwischen den Oberflächenformen schwach 
geneigter, sich langsam bewegender und spaltenarmer Gletscher und den sogenannten Karsterscheinungen, die wir an einer späteren Stelle kennen lernen werden. Die Ursachen sind in beiden Fällen dieselben: Löslichkeit des Materials im Wasser, Zerklüftung und unterirdische Wasserzirkulation. SIEGER ${ }^{29}$ hat diese Analogien systematisch verfolgt; die schon erwähnten Gruben, die sog. Firnschalen und Wasserlöcher, die Trichter, die teils Gletschermühlen in größerem Maßstab sind, teils durch den Einsturz innerglazialer Hohlräume entstehen und dann bis auf den Grund reichen, ferner die Höhlen. und die unterglȧzialen Wasserläufe werden hierher gerechnet.

\section{Gletscherschwankungen. Als ein klimatologisches Phänomen} ist der Gletscher in seiner Existenz und in seinen Lebensäußerungen von den wechselnden Witterungsverhältnissen abhängig, von der Temperatur im Abschmelzungs- und von der Höhe des Niederschlages im Nährgebiet. Der stationäre Zustand kann nur dadurch annähernd aufrecht erhalten bleiben, daß zwischen Mächtigkeit und Bewegung eine Art Gleichgewicht hergestellt wird. Das trifft, wie die Erfahrungen am Rhônegletscher zeigen, in der Tat auch zu: die Geschwindigkeit wächst mit der Mächtigkeit, einer Erhöhung des Eisstandes um $1 \mathrm{~m}$ entspricht ungefähr eine Geschwindigkeitszunahme um $2 \mathrm{~m}$ im Jahr. Von der Geschwindigkeit hängt aber direkt die Länge des Gletschers ab.

Länge und Mächtigkeit sind einer deutlichen jahreszeitlichen Periode unterworfen, die sich eng an die Temperaturkurve anschließt. Im Durchschnitt der Jahre 1895-97 zeigte der Untere Grindelwaldgletscher folgendes Verhalten: Minimum der Länge und Mächtigkeit im September, von September bis Mai VorstoB und Anschwellung, im Mai Maximum der Länge und Mächtigkeit, von Mai bis September Rückzug und Abzehrung. $\times$

Diese jahreszeitlichen-Veränderungen sind aber nur von ganz untergeordneter Bedeutung gegenüber jenen von langer Dauer, denen, soweit geschichtliche Nachrichten reichen oder alte Moränen anzeigen, alle Gletscher unterliegen. Über die Schweizer Alpen sind wir am besten unterrichtet, sie sind seit 1880 unter strenge Aufsicht gestellt, die in der Folge auch auf die übrigen Alpen ausgedehnt wurde, und seit 1894 besteht eine „Commission internationale

$\times$ Abstand der Gletscherzunge vom Fixpunkt 14 (= A) und Höhe der Marke am Rauftbodenband $(=\mathrm{H})$, beides in Metern nach der Tabelle von Baltzer: ${ }^{30}$

Jan. Febr. März April Mai Juni Juli Aug. Sept. Okt. Nov. Dez.

A $\quad 21,6 \quad 19,3 \quad 17,8 \quad 15,6 \quad 13,3 \quad 14,4 \quad 18,4 \quad 24,5 \quad 29,0^{*} \quad 28,6 \quad 28,2 \quad 22,6$

$\mathrm{H} \quad 10,0 \quad(10)-6,6 \quad 5,3-11,4 \quad 11,4 \quad 13,0^{*} \quad 13,0 \quad 12,6 \quad 10,5$ 
des glaciers", die Nachrichten von der ganzen Erde zu sammeln bemüht ist.

Im 19. Jahrhundert erreichten die Alpengletscher zwei Maximalstände, um 1820 und 1855. 1856 begann ein allgemeiner Rückzug von Savoyen bis Tirol, der dann auch die übrigen Alpen ergriff. 1875 trat eine neue, aber nicht allgemeine Vorstoßphase ein, die sukzessive von W nach $\mathrm{O}$ fortschritt und in der Schweiz schon 1898 ein Ende erreichte, während sie in Südtirol 1884 und in den übrigen österreichischen Alpen erst 1890 begann, um bald, schon in den ersten Jahren des neuen Jahrhunderts wieder zu erlöschen. Was wir jetzt im wissenschaftlichen Sprachgebrauch eine Gletscherperiode

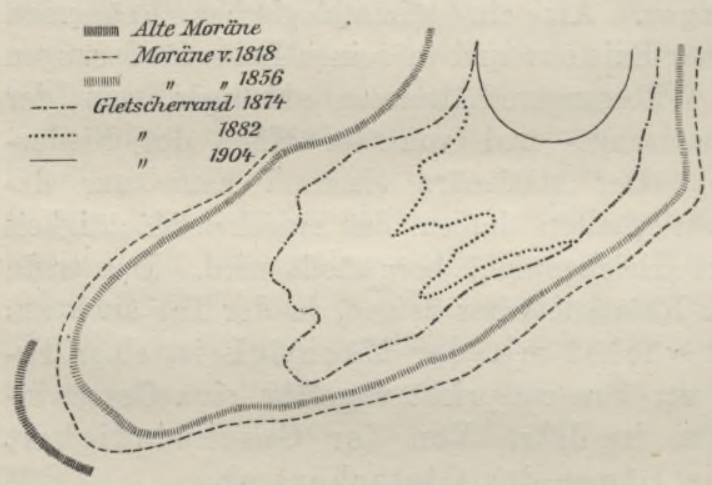

Fig. 50. Rückgang des Rhônegletschers (nach A. HЕгм, mit Fortsetzung bis 1904). nennen, setzt sich aus einer verhältnismäBig kurzen Vorstoß- und einer langen Rückzugsphase zusammen.

Ein besonders anschauliches Bild gewähren uns die Vermessungen des Rhônegletschers, die seit 1874 regelmäßig durchge. führt werden. Den älteren Stand zeigen die Moränen an; wir ersehen aus Fig. 50, wie beträchtlich der Gletscher seit 1856 zurückgegangen, und eine wie große Fläche nun eisfrei geworden ist. Die Unregelmäßigkeit des Randes erklärt sich manchmal aus rein zufälligen Ursachen, manchmal aber auch aus einer Unregelmäßigkeit der Bewegung. Der Suphellengletscher z. B. zog sich 1899-1903 in der Mitte um $32 \mathrm{~m}$ zurück, während der eine Rand stationär blieb und der andere um $42 \mathrm{~m}$ vorrückte. ${ }^{31}$ Aber nicht die Längen- und die Arealabnahme sind entscheidend für das Maß des Rückganges, sondern nur der Volumverlust, und dieser nimmt - einige Ausnahmen abgerechnet - absolut mit der Größe des Gletschers zu. ${ }^{\times}$

Mit den Schwankungen der Gletscher scheinen auch Schwankungen der Firngrenze in Verbindung zu stehen, wenigstens hat es Mougin ${ }^{32}$ für die savoyischen Alpen wahrscheinlich gemacht, dal3

$\times$ Nach der Tabelle in Hess, Die Gletscher, S. 290, habe ich, um vergleichbare Zahlen zu schaffen, den durchschnittlichen Jahresverlust berechnet. Die Flächenzahlen stammen von Richter. 
die Firnlinie jetzt $400 \mathrm{~m}$ höher liegt, als zur Zeit der Herausgabe der Carte de France (1864).

Der klimatologischen Seite dieses Problems werden wir an einer späteren Stelle näher treten, hier wollen wir nur die Ansichten der Forscher darüber hören, wie es zu erklären sei, daß eine einseitige Bewegung lange Zeit anhält, obwohl indessen der Witterungscharakter der Jahre wiederholt wechselt.

Eine ausgebildete Theorie verdanken wir FoneL ${ }^{33}$. Er geht dabei von dem Satz aus, daß. die Länge des Gletschers von seiner Geschwindigkeit, und diese wieder von der Mächtigkeit des Eises abhängt. Wir haben also nach den Ursachen der wechselnden Mächtigkeit des Gletscherkörpers zu fragen, und diese sind offenbar die Abschmelzung und die Speisung durch den Firn. Die erstere wird zwar durch die Mitteltemperatur des Sommers bedingt, aber diese wirkt nicht sogleich auf die Dicke des ganzen Eisstromes ein. Ist sie nur vorübergehend sehr groß oder sehr gering, so wird sie auf die Lage des Gletscherendes am Schluß des betreffenden Sommers wenig Einfluß haben; vielmehr entscheidet darüber unter sonst gleichen Verhältnissen der durchschnittliche Gesamtcharakter einer größeren Reihe früherer Sommer.

In zweiter Linie kommt die Niederschlagsmenge in Betracht, denn von ihr hängt die Mächtigkeit des Firns und damit der Betrag der Zufuhr ab. Fones zeigte, daß diese Ursache von oben nach unten ihre Wirkung steigert. Nur mit wenig geminderter Mächtigkeit gelangt z, B. das Firneis bis zu einem gewissen Punkt des oberen Gletschertales. Die Folge davon ist Abnahme der Geschwindigkeit und Zunahme der Abschmelzung. Schon stärker vermindert flieBt die betreffende Eispartie weiter talabwärts, und zwar

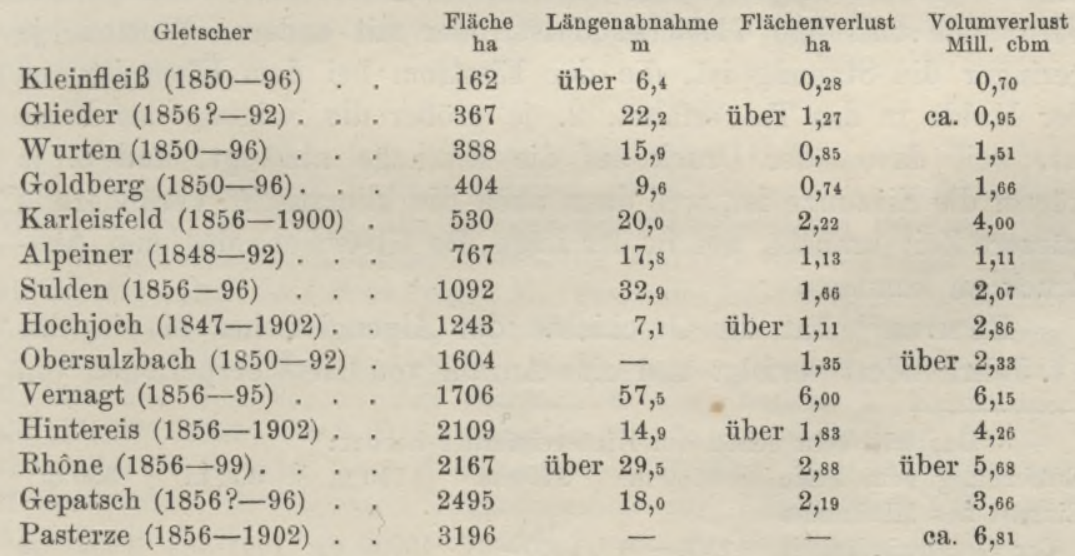


mit noch geringerer Geschwindigkeit und daher noch mehr dem Abschmelzungsprozeß preisgegeben. In einer gewissen Anzahl von Jahren kann diese eine Ursache die ganze Länge des Gletschers durchwandert haben $\times$ und dann erst auf die Lage des Gletscherendes bestimmend einwirken. Nicht die Niederschlagsmenge des betreffenden Jahres ist also dafür maßgebend, ob der Eisstrom vorrückt oder zurückgeht, sondern das Mittel der Schneemassen, die in den letzten Jahrzehnten gefallen sind.

Wenn - so schlieBt Forel weiter - eine kleine Abnahme der Eiszufuhr durch allmähliche Summierung ihrer Wirkungen eine große Abnahme des Gletschers zur Folge hat, so muß auch eine kleine Steigerung der Niederschläge genügen, um in einer längeren Periode einen großen Gletschervorstoß zu erzeugen. Die Zulässigkeit dieser Schlußfolgerung wurde von RICHTER ${ }^{34}$ bestritten, denn wenn auch oben die Geschwindigkeit wachse, so könne sie sich doch erst dann nach unten fortpflanzen, wenn sie den Widerstand der trägen unteren Masse überwunden habe. Gelingt dies, so wird die Eiszunge durch Zusammenschub dicker und kommt dadurch rasch in eine schnellere Bewegung. Auf diese Weise erklärte RICHTER den baldigen Eintritt des Vorstoßes nach naßkalten Jahren, wie auch das ungleiche Verhalten selbst benachbarter Glets cher. So zeigte im Montblanc-Massiv der Glacier des Bossons schon 1875 den Beginn der VorstoBperiode an, aber 15 Jahre dauerte es, bis alle Gletscher dieses Gebirges von der neuen Bewegung ergriffen wurden, und zuletzt sein größter, der Glacier des Bois. Hess ${ }^{1}$ findet nach genauer Untersuchung diese auffallende Tatsache in orographischen Verhältnissen begründet. Die Empfindlichkeit eines Gletschers gegenüber den wechselnden klimatischen Bedingungen ist um so größer, 1. je geringer der Breitenunterschied zwischen der Firnmulde und dem Gletschertal ist, oder mit anderen Worten, je geringer die Staunng ist, die der Eisstrom bei dem Übertritt aus der Mulde in das Tal erfährt, 2. je größer die Neigung des Firns ist, weil davon der Druck auf die Eiszunge abhängt, und 3. je kürzer die Eiszunge ist, weil dann auch die klimatische Veränderung kürzere Zeit braucht, um in der Lage des Gletscherendes zum Ausdruck zu kommen.

RICHTER $^{35}$ hat die Geschichte der Alpengletscher bis in das 17. Jahrhundert verfolgt und eine Anzahl von Gletscherperioden von

$\times$ Das tritt sehr schön am Hintereisferner hervor: ${ }^{13}$

Entfernung vom Ende $4800 \mathrm{~m} \quad 2700 \mathrm{~m} \quad 1750 \mathrm{~m} \quad 600 \mathrm{~m} \quad 350 \mathrm{~m}$

Eintritt des Minimums

der Geschwindigkeit $\quad 1900-01 \quad 1900-01 \quad 1900-02 \quad 1901-03 \quad 1902-04$ 
durchschnittlich 35 jähriger Dauer festgestellt und sie - wie wir später sehen werden - mit klimatischen Schwankungen in Verbindung gebracht. Für die älteren Zeiten fließen natürlich die Geschichtsquellen spärlich, und bedeutende Ereignisse, wie Gletscherausbrüche und Gletscherstürze, fallen nicht immer mit einem allgemeinen Vorsto B zusammen. RABOT ${ }^{36}$ unterscheidet dreierlei Schwankungen: mehrhundertjährige, primäre und sekundäre. Die ersteren sind problematisch, dagegen hat die Unterscheidung von primären und sekundären viel für sich. Die primären Schwankungen sind allgemein und intensiv (Längenänderungen von mehr als $1 \mathrm{~km}$ ), die sekundären sind partiell und schwach und nur untergeordnete Unterbrechungen der primären Schwankungen. Für die Alpen können wenigstens die Vorstöße $1660-1720$ und $1814-1855$ und der Rückzug seit 1856 als primär angesehen werden, der Vorstoß seit 1875 aber nur als eine sekundäre Erscheinung. Die Nachrichten über die übrigen Gebirge sind dürftig. Der Rückzug um die Mitte des 19. Jahrhunderts scheint eine weit verbreitete, vielleicht allgemeine Erscheinung gewesen $\mathrm{zu}$ sein, wenn er sich auch stellenweise etwas verspätet eingestellt hat, so z. B. am Vatna Jökull auf Island erst nach 1880. ${ }^{37}$ Vom Ende des 18. Jahrhunderts bis zu diesem Zeitpunkt war das isländische Inlandeis in beständigem Wachstum begriffen, die älteren Perioden sind also hier nicht zur Geltung gekommen. Ähnlich verhielten sich die norwegischen Gletscher. ${ }^{38}$ Auf einen großen Vorstoß von 1700 bis 1743 folgte ein ebenso starker und allgemeiner Rückzug, nur unterbrochen von kurzen Vorstößen (1807/12 und 1835-40); ob das Vorrücken, das man an einigen Gletschern seit der Mitte dieses Jahrzehnts beobachtet hat, eine neue Periode einleitet, muß erst die Zukunft lehren. Vielleicht machen, wie Hess vermutet, orographische Gründe die skandinavischen Gletscher für weniger tief eingreifende Klimaschwankungen unempfindlich.

Literaturnachweise. ${ }^{1}$ Neuestes Hauptwerk H. Hess, Die Gletscher, zitiert S. 191. Ferner E. Richter, Ostalpen, zit. S. 190. - ${ }^{2}$ Das umfassendste Werk darüber ist J. CoAz, Die Lauinen der Schweizeralpen; Bern 1881. ${ }^{3}$ F. W. Sprecher, Grundlawinenstudien, im Jahrbuch des Schweizer Alpenklubs, 1899-1902. - 4 F. DE Frurpri, Die Forschungsreise S. K. H. des Prinzen Ludwig Amadeus von Savoyen, Herzogs der Abruzzen, nach dem Eliasberg in Alaska i. J. 1897; Leipzig 1900. $-{ }^{5}$ W. H. Sherzer, Glaciers in the Canadian Rockies and Selkirks, in den Smithsonian Contributions to Knowledge, Bd. XXXIV, 1907. - ${ }^{6}$ R. D. Salisbury in The Journal of Geology, Chicago 1895, Bd. III, S. $887 \mathrm{ff} .-7$ A. BцёмcкE und H. Hess, Untersuchungen am Hintereisferner, 2. Wissensch. Ergänzungsheft zur Zeitschrift des D. u. Ö. Alpenvereins, 1899. $-{ }^{8}$ A. Bцӥмске und H. Hess in den Mitteilungen des D. u. Ö. 
Alpenvereins, 1905, S. $45 .-{ }^{9}$ E. v. Drygatski, Grönland-Expedition der Gesellschaft für Erdkunde zu Berlin, 1891-93, I. Bd.; Berlin 1897. - ${ }^{10}$ A. BцӥмскE und S. Finsterwalder, Die Gletscherbewegung mit Berücksichtigung ihres senkrechten Anteils, in der Zeitschrift für Gletscherkunde 1906, Bd. I. - ${ }^{11}$ Sven Hedrs, in der Zeitschrift der Berliner Gesellschaft für Erdkunde, 1895, S. 127. - ${ }^{12}$ H. Hess in Petermany's Mitteilungen, 1902, S. 113. - ${ }^{1 y}$ A. Bü̈mcke und S. Finsterwalder in den Sitzungsberichten der math.-physik. Klasse der Bayerisehen Akademie der Wissenschaften, 1905, Bd. XXXV, S. 109. - ${ }^{14} \mathrm{H}$. Crammer in der Zeitschrift für Gletscherkunde, 1906, Bd. I, S. 225. - ${ }^{15}$ Empen, Über das Gletscherkorn, in den Denkschriften der Allgemeinen Schweizerischen Gesellschaft für die gesamten Naturwissenschaften, 1893. - ${ }^{16}$ O. MüGGE im Neuen Jahrbuch für Mineralogie usw., 1895, Bd. II, S. 211, u. 1899, Bd. II, S. 123. - ${ }^{17}$ H. Crammer, Eis- und Gletscherstudien, im XVIII. Beilageband zum Neuen Jahrbuch für Mineralogie usw., 1903. Zur Entstehung der Blätterstruktur der Gletseher aus der Firnschichtung, in der Zeitschrift für Gletseherkunde 1907, Bd. II. Struktur und Bewegung des Gletschereises, in den Mitteilungen der Geogr. Gesellschaft in München 1909, Bd. IV. - 18. Protokoll in Petermann's Mitteilungen, 1905, S. 256. - ${ }^{19}$ H. Hess, Über den Zusammenhang zwischen Schichtung und Bänderung der Gletscher, im Neuen Jahrbuch f. Mineralogie usw., 1902, Bd. I. - ${ }^{20}$ H. Hess in den Annalen der Physik, 1902 Bd. VIII, S. 405. - ${ }^{21}$ H. Crammer im Neuen Jahrbuch für Mineralogie usw., 1905, Bd. II. S. 33. - ${ }^{22}$ T. C. Chambertin, Recent Glacial Studies in Greenland, im Bulletin of the Geological Society of Ameriea, 1905. - ${ }^{23}$ A. Hanrberg im Ymer, 1894, S. 25. - 24 S. Finsterwalder, Der Vernagtferner. Wissenschaftliche Ergänzungshefte zur Zeitschrift des D. u. Ö. Alpenvereins, Nr. 1, 1897. - ${ }^{25}$ A. BцÜмоке und H. Hess in der Zeitschrift für Gletscherkunde 1909, Bd. IV, S. 66. - ${ }^{26}$ Bericht von E. Richter in Petersans's Mitteilungen, 1900, S. 77. - ${ }^{27}$ A.v. Böнм, Geschichte der Moränenkunde; Wien 1901. - ${ }^{23}$ P. A. Өxen, Versuch einer glazialgeologischen Systematik, in Kristiania Videnskabs Selskabs Förhandlinger, 1904. - ${ }^{99}$ R. Sreger, Karstformen der Gletscher, in der Geographischen Zeitschrift 1895.- - ${ }^{30}$ A. Battzer, Studien am Unter-Grindelwaldgletscher, in den Denkschriften der Sehweizerischen Naturforschenden Gesell-

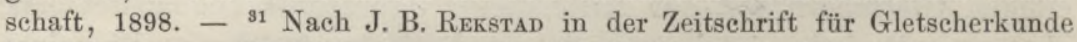
Bd. III, S. 45. - ${ }^{32}$ P. Movgrn, ebenda, Bd. II, S. 285. - ${ }^{33}$ F. A. Forer, Essai sur les variations périodiques des glaciers, in d. Archives des seiences physiques et naturelles, Genf 1881; Lecture sur les variations périodiques des glaciers, ebendaselbst, 1900. In streng mathematischer Weise unter vereinfachenden Voraussetzungen hat S. Frnsterwalder „die Theorie der Gletscherschwankungen“ in der Zeitschrift für Gletscherkunde, Bd. II, S. 81, behandelt. - ${ }^{34}$ E. RIсnтER, Ergebnisse und Probleme der Gletscherforschung, in den Abhandlungen der Geographischen Gesellschaft in Wien, Bd. I, 1899. - ${ }^{35}$ E. Richter, Geschichte der Schwankungen der Alpengletscher, in der Zeitschrift dés D. u. Ö. Alpen-

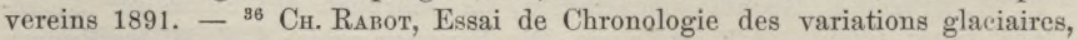
im Bulletin de géographie historique et descriptive, 1902. - ${ }^{37}$ Сн. Raвот in der Zeitschrift für Gletscherkunde, Bd. I, S. 132. — ${ }^{38}$ P. A. Oren, ebenda, S. 46.

\section{Die geographische Verteilung der Gletscher.}

(Siehe Karte XIV.)

Die Tropen. Die angeheftete Karte XIV zeigt, daß die Gletscher vorzugsweise ein polares Phänomen sind. HEss schätzt die 
vereisten Gebiete auf $15156000 \mathrm{qkm}$, wovon nahezu 2 Mill. auf Grönland und 13 Mill. auf den antarktischen Kontinent gerechnet werden. $\times$ Aber die Gletscher sind an keine Zonen gebunden; man kann nur sagen, daß ihre orographischen Ansprüche um so größer werden, je höher sich die klimatische Schneegrenze erhebt. Auch in den Tropen fehlen sie nicht; da aber hier nur einzelne Vulkanriesen in die Region des ewigen Schnees hineinragen, so ist das Gletscherphänomen hauptsächlich in der Form der Firngletscher entwickelt. In Afrika sind die Eisbildungen des Kenia, Kilimandscharo und Ruwenzori genauer studiert worden. Der erstere (5240 $\mathrm{m}$ hoch) entsendet nicht weniger als 15 Gletscher, aber nur einer davon erreicht eine Länge von $1 \frac{1}{2} \mathrm{~km}$ und die tiefste Eiszunge endet schon in $4400 \mathrm{~m}$ Seehöhe. ${ }^{1}$ Ein Eismantel hüllt den $6000 \mathrm{~m}$ hohen Westgipfel des Kilimandscharo, den Kibo, ein und reicht auf der Nordostflanke bis 5650 , im W bis 4700 , im SW bis 4400 und im SO bis $5350 \mathrm{~m}$ herab. Hoch- und Firnschnee vereinigen sich zu einem einzigen Gürtel, von dem im W und SW die kleinen Gletscher fingerförmig auslaufen. ${ }^{2}$ Die Eisbedeckung des Ruwenzori ist über-

$\times$ Hess hat folgende Flächenzahlen der Vergletscherung der Erde aufgestellt, denen wir Relativzahlen beifügen:

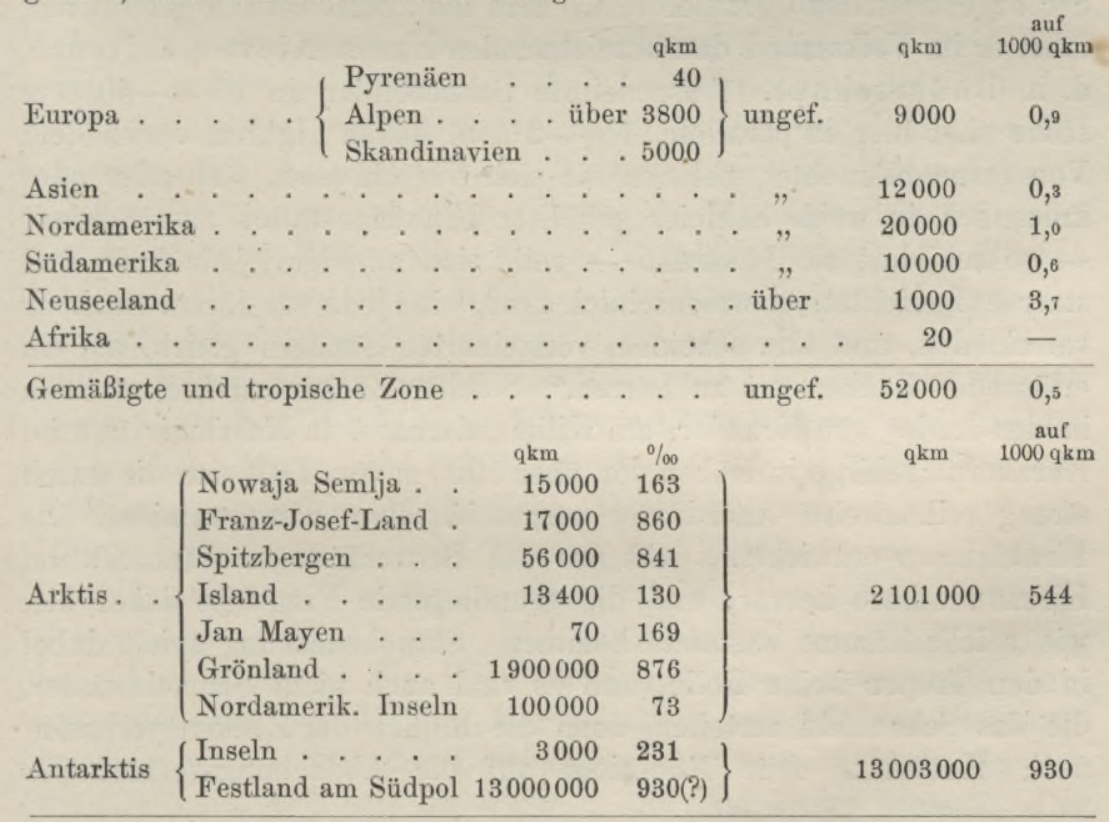

Kalte Zone .

15104000

802 
schätzt worden, auch hier finden sich nur Hängegletscher. Einer ähnlichen Ausbildungsweise begegnen wir im tropischen Amerika. ${ }^{4}$ Die Forschungen von Reiss, Stübel, Whymper, Hans Meyer u. a. haben uns auch hier eine verhältnismäßig reiche Schneewelt enthüllt, aber meist sind es nur Eismäntel, die sich den höchsten Vulkankegeln anschmiegen, zum Teil geschützt durch eine Aschendecke; ferner kleine Hängegletscher und nur unter besonders günstigen orographischen Verhältnissen Eisströme von echt alpinem Typus, wie am nicht vulkanischen Sara-urcu in Ecuador, wo sie bis $4200 \mathrm{~m}$ Seehöhe herabsteigen.

Als eine charakteristische Eigentümlichkeit der tropischen Schneefelder und Gletscher hat Hans Meyer ${ }^{2}$ die tiefe und zugleich regelmäßige Zerfressenheit ihrer Oberfläche bezeichnet. Rudimentäre Schmelzformen des Schnees wurden auch in den Alpen und auf Island ${ }^{5}$ beobachtet, vereinzelte Schmelzkegel oder regelmäBige Kämme, die in der Richtung des Abfalls ziehen und dem schützenden Staub ihren Ursprung zu verdanken scheinen (vgl. auch S. 212). Ihnen verwandt, aber nicht wesensgleich sind die Schmelzformen der warmen Zone zwischen $40^{\circ} \mathrm{N}$ und $\mathrm{S}$, die man jetzt unter der Bezeichnung Zackenfirn ${ }^{\times}$zusammenfäßt. $^{6}$ An den Ostabhängen der argentinischen Cordilleren, wo man ihn zuerst kennen gelernt hat, führt er im Volksmund den bezeichnenden Namen Nieve penitente, d. h. BüBerschnee. Ausgedehnte Schneefelder in $3500-5000 \mathrm{~m}$ Höhe sind hier in parallele, $1^{1} / 2-2^{1} / 2 \mathrm{~m}$ hohen Figuren verwandelt. Von ferne betrachtet, nehmen sie sich wie ein Chor stehender oder knieender, in weiße Schleier gehüllter Frauengestalten aus. „Figur - so schildert sie Güssfeld - reiht sich an Figur, jede hoch und starr aufgerichtet, übermenschlich groB, eine jede von ihrem Nachbar verschieden, und alle scheinen, versteinerten Sündern gleich, auf ein erlösendes Zauberwort zu harren." Solcher Zackenfirn kommt auch in den Andes von Ecuador, am Kilimandscharo, in Kaschmir und im Karakorumgebirge in Höhen von über $5000 \mathrm{~m}$ vor. Daß sich die durch streng reihenweise Anordnung ausgezeichneten Firnpyramiden aus Firnkämmen entwickeln, geht aus den Beobachtungen JAEGER's am Kilimandscharo hervor, und die grundlegende Frage ist daher die, wie solche Kämme zustande kommen. Staubbedeckung spielt dabei in den Tropen keine Rolle, und es sind auch nicht Schmelzwässer, die das Schneefeld zerteilen, denn die Reihen der Zacken verlaufen nach HaUthaL ohne Rücksicht auf die Abdachungsverhältnisse

$\times$ Der Ausdruck „Kerzenfelder" hat sich glücklicherweise nicht eingebürgert. 
NW-SO oder W-O. Es scheint also der Schnee selbst aus härteren und weicheren Streifen zu bestehen, und eine interessante Beobachtung von Hess ${ }^{7}$ bei einem Schneefall in Ansbach gibt wenigstens einen Fingerzeig, wie unter dem Einfluß des Windes eine solche Ungleichmäßigkeit enstehen kann. Nach $\mathrm{J}_{\mathrm{AEGER}}{ }^{8}$ sind die Spitzchen der Schneeflocken widerstandsfähiger als der übrige Schnee, zwar nicht an sich, sondern nur weil sie emporragen und andere Teile beschatten. Es ist also die Sonnenstrahlung selbst, die eine reihenweise Anordnung in ostwestlicher Richtung hervorruft. In den längeren Trockenzeiten der Tropen und in Höhen, wo die Lufttemperatur dauernd unter dem Gefrierpunkt bleibt, kann dann durch die Strahlung der hochstehenden Sonne oder durch warme Winde der SchmelzprozeB innerhalb der weicheren Firnpartien seinen ungehinderten Fortgang nehmen, während die härteren Partien erhalten bleiben.

Gemäßigte Zonen. In den gemäßigten Zonen sind schon viele Kammgebirge mit ewigem Schnee bedeckt, und der alpine Gletschertypus gelangt dadurch zu fast ausschließlicher Herrschaft. Dies gilt wenigstens für die Hochländer bis in die Nähe des 60. Parallels; darüber hinaus entwickeln sich Übergangsformen, von denen später die Rede sein soll. Der Alpengürtel, der die Alte Welt durchzieht, ist in allen seinen höheren Teilen eine Stätte hervorragender Gletscherbildungen. Auf der iberischen Halbinsel finden wir allerdings erst rudimentäre Anläufe. Selbst die Pyrenäen beherbergen mit Ausnahme eines Talgletschers nur Hängegletscher und vorwiegend nur auf der Nordseite; der Maladettagletscher endet hier in $2300 \mathrm{~m}$ Höhe. Ein kleines Eisfeld soll auch die Sierra de Gredos besitzen. Der südlichste Eisstrom unseres Erdteiles ist der Corralgletscher am Nordabhang der Sierra Nevada in 2800 bis $2900 \mathrm{~m}$ Höhe. Unser herrlichstes Schneegebirge sind; von Skandinavien abgesehen, die Alpen. In der Schweiz und den angrenzenden italienischen Alpen sind 2029, in den Ostalpen $1462 \mathrm{qkm}$ vergletschert $;^{9}$ die kristallinische Zone, als das höchste und kompakteste Gebirge, ist die eigentliche Heimat der Eiswelt, $\times$ vor allem die Montblanc-Gruppe, das Berner Oberland, die Penninischen und die Ötztaler Alpen. Allen voran steht der Aletschgletscher mit 129 qkm (doppelt so groß wie die Republik San Marino!), dann folgen der Gornergletscher mit 67, die Mer de Glace mit 55, der Fietschergletscher mit 41 und der Unteraargletscher mit 39 qkm. In den Ostalpen kann sich nur die Pasterze (32 qkm) damit messen. Der

$\times$ In den Schweizer- und Ostalpen entfallen auf die kristallinisehe Zone 3398, auf die nördlichen Kalkalpen 76, und auf die südlichen $17 \mathrm{qkm}$ Gletscherareal. 
Untere Grindelwaldgletscher hat den Ruhm, unter allen alpinen Eisströmen am tiefsten in die Kulturregion hinabzusteigen; er endet jetzt in der Nähe des Dorfes Grindelwald in 1080 Seehöhe, 1818 reichte er noch bis zur Höhenlinie von $983 \mathrm{~m}$. Sonst liegt das Ende der großen alpinen Talgletscher durchschnittlich schon in $2000 \mathrm{~m}$ Höhe. ${ }^{\times}$

Das nächste Gletschergebirge ist der Kaukasus, von dem einer seiner gründlichsten Kenner, Merzbacher ${ }^{10}$, sagt, „daß kein Teil der europäischen Alpen eine mehr ausgedehnte, ununterbrochene Eisbedeckung trägt, wie derjenige der kaukasischen Hochalpen, dessen Eckpfeiler Elbrus und Kasbek bilden, und daß kaum eine Einzelgruppe der europäischen Alpen in bezug auf Ausdehnung des gesamten Gletschermantels eine der bedeutenderen kaukasischen Hochalpengruppen übertrifft." Trotzdem sucht man auch im zentralen Kaukasus vergebens ein so imposantes Gebilde wie den Aletschgletscher, und die beiden größten Gletscher (Bezingi 64 und SeriKitlod $62 \mathrm{qkm}$ ) erreichen nicht einmal ganz den Gornergletscher. Entsprechend der Lage der Schneegrenze enden hier die Eiszungen auf der Nordseite in durchschnittlich 2320 und auf der Südseite erst in $2100 \mathrm{~m} \times \times$ Seehöhe - am tiefsten steigt der Tschalaat herab: bis $1628 \mathrm{~m} \mathrm{-;}$; aber wenn auch die Gletscherenden hier höher liegen als in den Alpen, so sind sie doch von einer reichlicheren Vegetation umgeben anstatt von öden Felsen und Geröllfeldern. Am gewaltigsten entwickelt sich das Gletscherphänomen in den hohen Randgebirgen Zentralasiens, im Himalaya, Karakorum, Hindukusch, Tiënschan, und schon bedeutend schwächer im Altaĩ. Im Himalaya enden die meisten Talgletscher in $3400-4200 \mathrm{~m}$, der des Nanga Parbat in Kaschmir sogar erst in $2900 \mathrm{~m}$ Höhe. Noch gletscherreicher ist der Karakorum, wo die Eisströme nicht nur den Hintergrund der Quertäler einnehmen, sondern auch in die Längstäler hinabsteigen und in diesen sogar flache Wasserscheiden überfluten. Das merkwürdigste Beispiel hat uns Conway's Expedition i. J. 1892,genauer kennen gelehrt (Fig. 51). ${ }^{11}$ Wenn wir yon Nagar in einem Seitental des Gilgit aufwärts gehen, so erreichen wir bei Hispar in $3145 \mathrm{~m}$

$\times$ Berechnung des mittleren Glets cherendes nach den Listen von Hess: Lage . . . . . . . $\mathrm{N}$ NO O $\mathrm{SO}$ S $\mathrm{SW}$ W $\mathrm{NW}$ $\begin{array}{lllllllll}\text { Zahl der Gletseher . . . } & 35 & 9 & 10 & 5 & 6 & 4 & 6 & 6\end{array}$

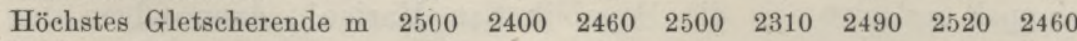
$\begin{array}{lllllllllll}\text { Tiefstes } & \text { " } & & 1080 & 1800 & 1640 & 1500 & 1360 & 1770 & 2150 & 1350\end{array}$

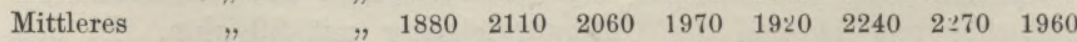
Die Unregelmäßigkeit in der Verteilung der Mittelwerte zeigt schon, daB weniger die Lage als der Bau des Gletscherbettes für die Höhe des Gletscherendes maßgebend ist.

$\times \times$ Berechnet nach der Tabelle auf S. 86 von Hess „Die Gletscher“. 
Seehöhe das Ende des gleichnamigen Gletschers (60 km lang), der am Hisparpass (5380 $\mathrm{m}$ hoch) ohne Unterbrechung in den nach der entgegengesetzten Seite abfließenden Biafogletscher (51 km lang) übergeht. Dieser endet bei Korofan in $3000 \mathrm{~m}$ Seehöhe. Die Gesamtlänge dieses gewaltigen Zwillingsgletschers entspricht dem Rhônetal vom Rhônegletscher bis Martigny. Das Hauptfirngebiet des Biafogletschers bezeichnet CoNWAY wegen seiner anscheinend völligen Flachheit als „Firnsee" (Schneesee in Fig. 51); er bedeckt ein Areal von etwa $300 \mathrm{qkm}$, auf dem das Fürstentum Reuß ä. L. oder das Gebiet der Hansastadt Lübeck bequem Platz hätten. Die tibetanischen Gebirge sind, mit Ausnahme des zentralen Kwenlun, zu trocken, um

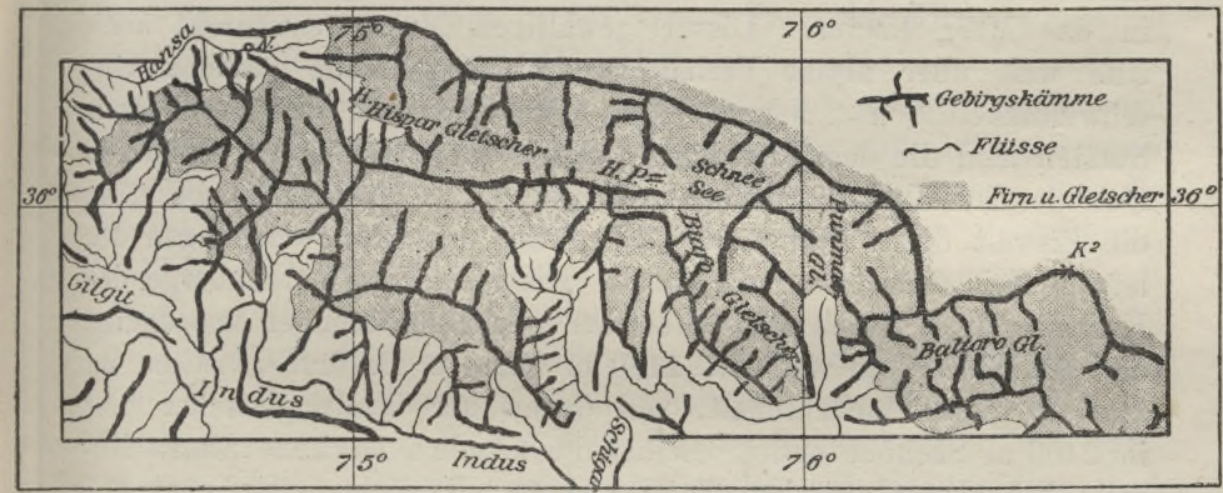

Fig. 51. Die Gletscher des Karakorum-Gebirges.

$N=$ Nagar, $H=$ Hispar, $H . P .=$ Hisparpa $\beta, K=$ Korofan, $K^{2}=$ Dapsang, $8620 \mathrm{~m}$ hoch.

große Eisströme zu erzeugen, aber in jenem Teil des Tiënschan, der im Khan Tengri $(7200 \mathrm{~m})$ gipfelt, hat uns Merzbacher ${ }^{12}$ in den Jahren 1902 und 1903 eine gewaltige Gletscherwelt erschlossen, in der z. B. der Inyltschekgletscher $(70-75 \mathrm{~km})$ sechsmal länger ist, als man ihn bisher schätzte, und dreimal länger als der Große Aletschgletscher. Ausgedehnte und mächtige Oberflächenmoränen bedecken das Eis sowohl im Tiënschan, wo sie sich bis zu kleinen Gebirgen anhäufen, wie im Karakorumgebirge; diese Eigentümlichkeit ist ohne Zweifel eine Folge des trockenen Klimas, das die Schneegrenze in die Höhe rückt und dadurch eine breite Felszone am Abhang der Eistäler der Zerstörung preisgibt. Am pazifischen Rand Asiens sind die orographischen Verhältnisse der Gletscherbildung nirgends günstig; wie es scheint, selbst in Kamtschatka nicht, wo sich doch gewaltige Vulkankegel erheben. Kleine Firnfelder werden von dem nördlichen Korea und von dem Ostabhang des japanischen Berges Tateyama ( $36^{\circ} 35^{\prime} \mathrm{N}, 2900 \mathrm{~m}$ hoch) gemeldet. 
Wir müssen uns auf die amerikanische Seite begeben, um wieder echte Gletschergebirge zu finden. ${ }^{13}$ Die pazifische Küstenkette wird von Alaska bis zur Südgrenze von Britisch-Columbia durch reichliche Niederschläge benetzt, die die Schneegrenze stark herabdrücken. Noch im Takufjord in $58^{\circ} \mathrm{B}$, gehen die Eisströme bis an das Meer herab, und unter $55^{\circ} \mathrm{B}$, also in der Polhöhe des südschottischen Gebirges, endet einer erst bei $400 \mathrm{~m}$ Seehöhe. Ein Hauptzentrum sind die St. Elias-Alpen an der Ostgrenze Alaskas; des Malaspinagletschers haben wir schon auf S. 193 gedacht. Würdig reiht sich ihm der Muirgletscher an, den REID eingehend studiert hat. Er bedeckt ein Areal von $900 \mathrm{qkm}$, das Siebenfache der Aletschfläche, und tritt mit einer Gesamtmächtigkeit von $280 \mathrm{~m}$ in das Meer hinaus. Dieser gewaltigen Masse entspricht auch eine weit über alpine Verhältnisse hinausgreifende tägliche Geschwindigkeit von $2,19 \mathrm{~m}$ in der Mittellinie. In den Vereinigten Staaten sind die dem pazifischen Gestade zunächst liegenden höheren Gebirge das Kaskadengebirge und die Sierra Nevada. Auch über die Eiswelt dieser Höhenzone haben uns erst die Forschungen der letzten Zeit Aufklärung verschafft. Die mächtigen Vulkanberge des Kaskadenzuges tragen echte Gletscher in strahlenförmiger Anordnung, der Mt. Shasta (in $41^{\circ}$ B., $4400 \mathrm{~m}$ hoch) z. B. fünf zwischen 2,7 und $0,3 \mathrm{qkm}$ Flächeninhalt, von denen der Wintungletscher erst in $2400 \mathrm{~m}$ Seehöhe endet. Selbst die ziemlich trockene Sierra Nevada beherbergt zwischen $36^{1} / 2$ und $38^{\circ} \mathrm{B}$. nicht wenigẹr als 17 Gletscher, freilich alle sehr klein und unentwickelt und nur bis $3500 \mathrm{~m}$ hinabreichend. Nach Osten nehmen Niederschläge und Eisentwicklung rasch ab. Jeff Davis Peak im Großen Becken hat nur einen kleinen Firnfleck in besonders günstiger Lage, und auch das Felsengebirge scheint innerhalb der Vereinigten Staaten in der Gegenwart nur unbedeutende Hängegletscher zu erzeugen. Die südlichsten, die man bisher kennt, liegen in der Sangre de ChristoKette in $37^{\circ} 35^{\prime} \mathrm{N}$ und in $4000 \mathrm{~m}$ Höhe. ${ }^{14}$ Erst auf canadischem Boden, in den Quellgebieten des Saskatchewan und Athabaska treten echte Talgletscher von alpinen Dimensionen auf, und auch die inneren Parallelketten, das Selkirk- und das Goldgebirge, entbehren dieses Schmuckes nicht.

Das niederschlagreiche Seeklima der südlichen Hemisphäre ist der Gletscherentwicklung besonders günstig. In den Breiten von Triest bis Hamburg steigen von den kaum $2600 \mathrm{~m}$ hohen Andes Eisströme bis zum Meeresspiegel herab, an den Abhängen begleitet von Hochwäldern der antarktischen Buche und Birke. Kolibris und Papageien, die wir als tropische Vögel zu betrachten gewohnt sind 
bewohnen hier Gletscherlandschaften. An der Westseite der neuseeländischen Alpen enden der Franz-Josef- und der PrinzAlfred-Gletscher in der Breite von Florenz erst in 215 (bezw. 114) $\mathrm{m}$ Höhe, wo die mittlere Jahrestemperatur $\left(10^{\circ}\right)$ der von Wien gleicht und eine üppige Tieflandvegetation von Nadelhölzern, Buchen, Baumfarnen und Fuchsiabüschen gedeiht. An der trockeneren Ostseite liegt das Gletscherende durchschnittlich in $1200 \mathrm{~m}$ Höhe, also auch hier noch immer $700 \mathrm{~m}$ tiefer als in unseren Alpen. Auf den Kerguelen-Inseln in der Breite von Nürnberg und Prag nimmt das Richthofeneis schon den Charakter. des Inlandeises an, und die südatlantische Bouvet-Insel, in der Breite von Rügen gelegen und nur $935 \mathrm{~m}$ hoch, ist völlig vereist.

Polare Zonen. ${ }^{15}$ Wie in der heißen Zone der Firngletscher, in der gemäBigten der alpine Gletscher, so herrscht auf der polaren Kalotte das Inlandeis vor. Trotzdem sind diese verschiedenen Formen zunächst orographisch bedingt, und nur daß sich die Schneegrenze gegen die Pole senkt, hat zur Folge, daß zuerst nur die höchst ragenden Gipfel, dann auch die Kämme der Hochgebirge, endlich auch niedriger gelegene Plateaus Eis erzeugen. Unter günstigen Ụmständen fehlt der alpine Typus auch im Polarland nicht, wie z. B. im westlichen Spitzbergen, ebensowenig wie die Form des Inlandeises, allerdings in sehr bescheidenen Dimensionen, den mittleren Breiten (z. B. auf dem Ewigen Schneeberg in den Salzburger Alpen.) Schärfer ausgeprägt finden wir sie allerdings erst im skandinavischen Hochland von $60^{\circ} \mathrm{B}$. an. Das mächtigste Gletschergebiet ist hier der Jostedalsbrä von $61^{1} / 2$ bis gegen $62^{\circ} \mathrm{B}$. hin. Am Nordabhang des Sognefjords erhebt sich dieser flachgewölbte Bergrücken, ein Fjeld, wie man ihn hier nennt; an den Rändern, wo die Täler einzuschneiden beginnen, $1400-1800$, in der Mitte $2038 \mathrm{~m}$ hoch. Den ganzen Rücken bedeckt ein ununterbrochenes Firnfeld, erst an den Rändern sehen einige steile Gipfel daraus hervor; $1076 \mathrm{qkm}$ liegen hier unter Schnee begraben. Nach allen Seiten steigen Eiszungen herab; man zählt allein 24 Gletscher erster Ordnung. Sie enden in $300-600 \mathrm{~m}$ Seehöhe, der Boiumgletscher aber erst in $151 \mathrm{~m}$, der Suphellagletscher sogar erst in $42 \mathrm{~m}$ Seehöhe. Der Gletscher des Jökelfjords $\left(68^{\circ} \mathrm{B}\right.$.) ist der einzige in Europa, der das Meer erreicht. Die gesamte Gletscherfläche Skandinaviens schätźt RABOT auf 5000 qkm (4600 in Norwegen und 400 in Schweden).

Die denkwürdige Reise Nansen's ${ }^{16}$ im Jahr 1888 hat uns die Geheimnisse der grönländischen Eiswelt, der umfangreichsten unserer Halbkugel, enthüllt. Da finden wir das Inlandeis in seiner 
typischesten Ausbildung. Nur die Ränder sind eisfrei, oder eigentlich nur der Westrand, denn im Osten tritt das große Binneneis, das Sermerssuak der Eskimos, vielfach bis an den Küstenrand heran und bricht hier in Steilmauern ab. Nach Westen sendet es große Eisströme bis in das Meer hinaus; von ihrer außerordentlichen Geschwindigkeit haben wir bereits an anderer Stelle gesprochen. In der Polhöhe der Nansen'schen Durchquerung ist diese eisfreie Zone etwa $100 \mathrm{~km}$ breit. Auf das Sermerssuak entfallen $445 \mathrm{~km}$, davon 50 auf die westliche, 15 auf die östliche Randzone, 380 auf das innere Schneeplateau in Höhen von mehr als $1000 \mathrm{~m}$; NANSEN überschritt die Scheide zwischen beiden Abdachungen in $2716 \mathrm{~m}$ Höhe. Das Eismeer wölbt sich also flach von einer Küste zur anderen, und wie man vermuten darf, auch von Süden nach Norden. Sein Ende hat Peary in ungefähr $82^{\circ} \mathrm{N}$ erreicht.

In den beiden Randzonen ist der Schnee grobkörnig, nach innen zu wird er immer feiner, endlich so ,fein wie Staub“. Bei

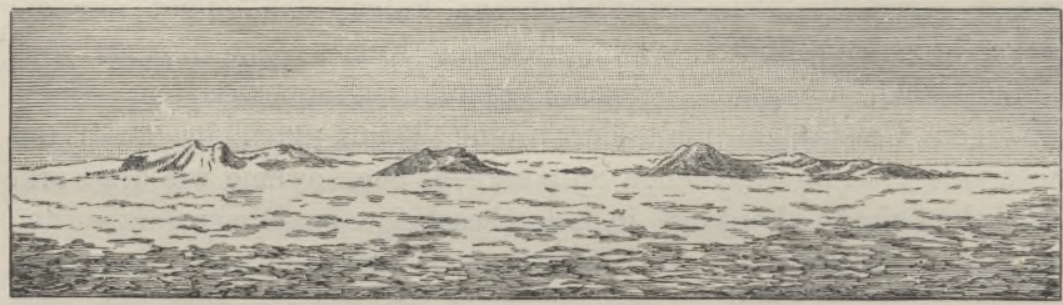

Fig. 52. Grönländisches Inlandeis nach Jensen.

Tag taut nur die Oberflächenschicht etwas auf, um bei Nacht wieder zu einer dünnen Eiskruste zu gefrieren; kein Bächlein entsteht, nichts geht durch Abschmelzung verloren, alles wird durch den Nachtfrost wieder festgehalten. Die Trockenheit des Schnees verhindert in Höhen von mehr als $2300 \mathrm{~m}$ sein Zusammenballen, er kann daher erst in sehr großer Tiefe in Eis übergehen. Dieser innerste Teil war auf einer. Strecke von etwa $150 \mathrm{~km}$ so glatt wie ein Spiegel, ohne andere Unebenheiten als die Spuren, die die Reisenden zurückließen; eine urübersehbare Schneefläche ohne Staub, ohne Schmutz, ohne irgend einen fremden Körper. Mit einem Wort: der innere Teil des Sermerssuak entspricht dem alpinen Hochschnee, die Randzonen entsprechen den alpinen Firnmulden. Nicht bloß der Schnee ist hier firnartig, es treten auch schon Spalten auf, die auf lebhaftere Bewegung hinweisen; einzelne Berggipfel, hier Nunatakker genannt, ragen inselartig aus dem Schnee hervor (s. Fig. 52). Was das Inlandeis von dem alpinen Gletscher unterscheidet, ist nicht bloß die völlige Überdeckung der Geländeformen, 
sondern auch die ungeheuere Ausdehnung der Hochschnee- im Vergleich zur Firnregion und zu derjenigen Zone, wo individualisierte Eisströme in das eisfreie Land vordringen. Faßt man aber das Gletschergebiet im engeren Sinn des Wortes als das Gebiet der sommerlichen Abschmelzung auf, so ist es hier nicht mit der Zone der Eiszungen identisch, sondern umfaßt auch jene unter $70^{\circ} \mathrm{B}$. $40-50 \mathrm{~km}$ breite, weiter nach $\mathrm{N}$ aber bis zu $100 \mathrm{~km}$ sich erweiternde Randzone des Inlandeises, in der im Sommer Wasserläufe und Löcher mit dunklem Kryokonitstaub vorkommen. Die Eiszungen sind zwar ungleich länger, breiter und mächtiger als die alpinen Talgletscher, aber doch nur zwergartige Anhängsel im Vergleich zu den Dimensionen des Inlandeises, das mit seinem Flächeninhalt von rund 2 Mill. qkm ganz Mittel- und Westeuropa überfluten würde. An und für sich sind sie aber gewaltige Gebilde; der größte, der Humboldtgletscher, hat eine Länge von $110 \mathrm{~km}$ und endet mit einer $100 \mathrm{~m}$ hohen Eiswand.

Was das Inlandeis ferner vom alpinen Typus unterscheidet, ist der Mangel an Oberflächenmoränen, die höchstens in den Randgebieten, aber auch da nur selten, von den Nunatakkern erzeugt werden können. Dagegen fehlt die Grundmoräne nicht, ein deutlicher Beweis dafür, daß fließendes Eis seine Unterlage zu erodieren vermag.

Die Form des Inlandeises verbreitet sich über alle größeren Inseln, die in der atlantischen Öffnung der arktischen Kalotte liegen, allerdings in beschränktem Grad. Auf Island bedeckt es nur die Tafelberge, ohne in das tiefere Land hinabzusteigen ${ }^{17}$ und auf Spitzbergen ist es typisch nur im Nordostland entwickelt, während die Gletscher von Westspitzbergen den Untergrund nicht völlig verhüllen. In der Umgebung des Eisfjords treten, anscheinend unmotiviert, schneefreie zwischen schneebedeckten Landstrichen auf; ANDERsson vermutet hier eine verschiedene Wärmeempfänglichkeit des Gesteins. In Franz-Josef-Land sind manche Inseln völlig unter Eis begraben, und ein Abschmelzungsgebiet scheint ganz zu fehlen. Dagegen ist westlich von Grönland, wo keine warme Meeresströmung reichlichere Niederschläge erzeugt, das Gletscherphänomen dürftiger entwickelt; nach SvERDRUP's ${ }^{18}$ Schilderungen scheint in Ellesmereland der alpine Typus vorzuherrschen, und nur in Nord-Lincoln-Land nimmt die Vergletscherung annähernd den Charakter des Inlandeises an.

Das wenige, was wir bisher vom antarktischen Inlandeis wissen, stimmt mit den Erfahrungen in Grönland überein $;^{19}$ merkwürdig ist nur, daß die meisten seiner Abflüsse im Viktorialand bewegungslos der allmählichen Verdunstung und Abschmelzung zu 
erliegen drohen. Kuppeleis nennt O. NondenskJöLD ${ }^{20}$ jene Form des Inlandeises, das niedrige Inseln völlig bedeckt; Übergänge zum alpinen Typus, wie in Westspitzbergen, kommen auch hier vor, aber im Gegensatz zur Arktis vereinigen sich alle antarktischen Talgletscher zu Vorlandgletschern. Manche Eigentümlichkciten der Eisverteilung lassen sich auf orographische Einflüsse zurückführen, denn in dem stürmischen Klima der Antarktis kommt es wesentlich darauf an, ob sich der Schnee in windgeschützten Lagen anhäufen kann. Über die Entstehung des Barriereeises sind die Ansichten geteilt. Zwischen dem Viktoria- und dem König-Eduard-VII.-Land wird die Roßsee im $\mathrm{S}$ in einer Länge von etwa $850 \mathrm{~km}$ von einer Eismauer begrenzt. Ihre ebene, $50 \mathrm{~m}$ hohe Oberfläche erstreckt sich im W $500 \mathrm{~km}$ weit landeinwärts und steht durch den shackletongletscher mit dem Inlandeis in Verbindung. Diese gewaltige Eistafel schwimmt auf dem Meer und bewegt sich täglich etwas über $1 \mathrm{~m}$ vorwärts.

Noch nicht völlig aufgeklärt ist die Natur des Schelfeises, das, wie der Name besagt, auf seichtem Meeresgrund aufliegt. Die niedere Eisterrasse am König-Oskar-Land ist nach O. NoRdEnskJöLd an Ort und Stelle durch Anhäufung von Schnee aut festsitzendem Meereis entstanden, und das Westeis am Kaiser-Wilhelm-II.-Land hält v. DryGalski ${ }^{21}$, obwohl es auch mit dem Inlandeis verbunden ist, für ein Konglomerat von marinem Scholleneis und Eisbergen, das sich unter dem Einflub der Winde nach $\mathrm{N}$ bewegt.

Eisberge. Wenn ein polarer Gletscher in tieferes Meer hinaustritt, so erfolgt an der Stelle, wo das Eis leichter wird als das von ihm verdrängte Wasser, ein Bruch von unten nach oben, und die abgerissenen Gletscherstücke setzen nun als Eisberge ihren Weg im Meer fort, häufig auch Erde und Felsblöcke - Bruchstücke der Moränen" - mit sich führend. Zahlreiche Luftblasen verringern ihr spezifisches Gewicht, sodaß meist nur $1 / 5-1 / 6$ der ganzen Masse aus dem Meer hervortaucht. Eisberge von 50-70 m Höhe - höhere sind in der Arktis selten - haben also eine Gesamtmächtigkeit von $300-500 \mathrm{~m}$. Trotzdem kann es geschehen, daß sich ihr Schwerpunkt nach oben verrückt, und daB sie sich umwälzen und dann statt der ursprünglichen wild zerklüfteten GletscheroberHäche die mehr oder weniger ebene Sohle nach oben kehren. Durch die polaren Meeresströme nach mittleren Breiten entführt, werden diese großen Klötze mit meist senkrechten Wänden von der Sommersonne, den Schmelzwässern und der Meeresbrandung zu phantastischen Gestalten umgeformt, bis sie endlich, in Trümmer zerfallen, mit dem Meereis verschmelzen oder im offenen Ozean zergehen.

Grönland und Franz-Josef-Land sind die Hauptgeburtsstätten 
der großen arktischen Eisberge, dagegen fehlen sie an der ganzen West- und Nordküste von Nowaja Semlja und an der Südspitze von Spitzbergen, weil hier das Meer an den Küsten zu seicht ist, und nur kleine Stücke von den Gletschern abbröckeln.

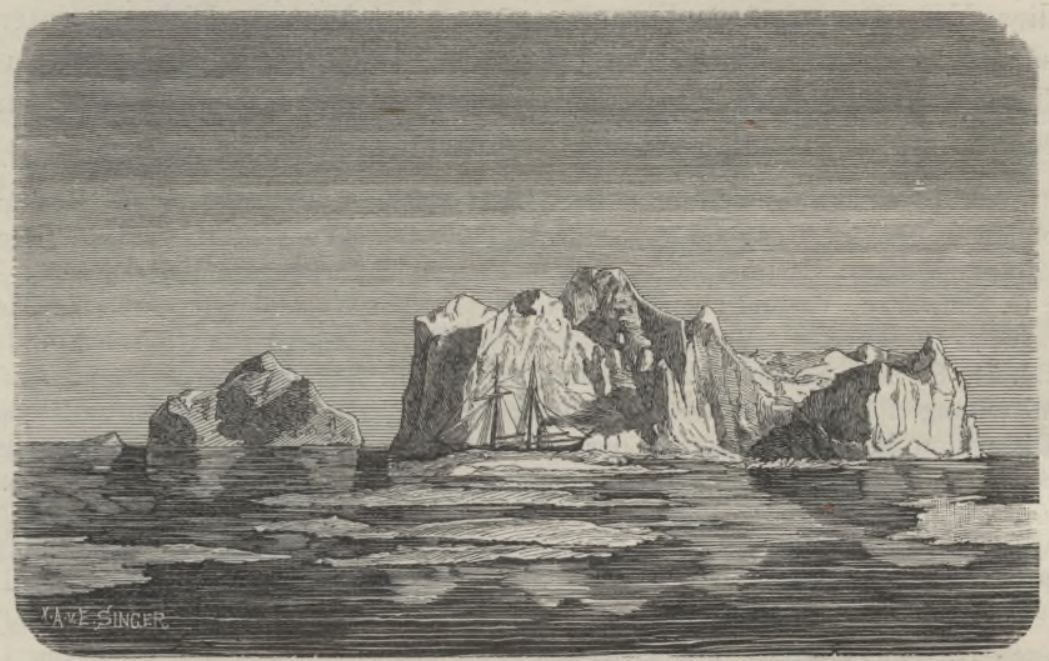

Fig. 53. Arktischer Eisberg nach PAYER.

Weitaus häufiger und größer, auch anders gestaltet als im Nordpolarmeer, sind die. Eisberge in der antarktischen See. Nicht in enge Fjordtäler eingezwängt, wie im westlichen Grönland, tritt das südliche Inlandeis frei in das Meer hinaus, und seine

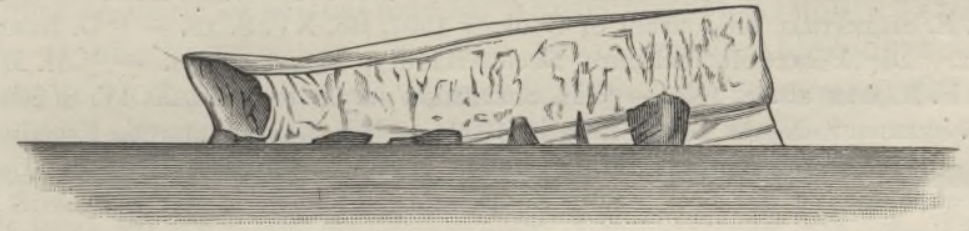

Fig. 54. Antarktischer Eisberg nach Arkтowski.

Schichten bewahren die ursprüngliche flache Lagerung. Die Eisberge sind daher gewaltige Tafeln, häufig von dem Umfang der Insel Helgoland, manchmal aber viel größer - auf dem vom Jahr 1854 hätte das ganze Großherzogtum Hessen Platz gefunden! - und solche können dann wohl für Land gehalten werden. Die ebene horizontale oder geneigte Oberfläche ist von zahlreichen Spalten durchschnitten, die senkrechten Seitenwände zeigen wechselnde Lagen von blauem und weißem Eis in deutlichster Schichtung. Nach unten werden die Schichten dünner und sind horizontal, die oberen, die keinen 
Druck erlitten haben, sind häufig leicht gebogen. Im Lauf der Zeit werden durch Schneefall und Verdunstung die eckigen Formen abgeschliffen und abgerundet, und da das kompaktere, luftleere Eis den zerstörenden Kräften länger Stand hält, hat von v. DRYgalski diese Verwitterungsform Blaueis genannt. Gekenterte Eisberge unterscheiden sich von denen in ursprünglicher Lage durch mannigfaltigere Formen, geneigte Schichtung und den Einschluß von Sand und Gesteinschutt, der als Grundmoräne zu betrachten ist.

Literaturnachweise. ${ }^{1}$ H. J. MAckinder, A Journey to the Summit of Mt. Kenia, im Geographical Journal 1900, Bd. XV. - ${ }^{2}$ Hans Meyer, Der Kilimandscharo; Berlin 1900. - ${ }^{3}$ F. DE FilIPPI, Il Ruwenzori, Mailand 1908. ${ }^{4}$ G. Sohwarze, Verbreitung der Gletseher in den Westgebirgen Amerikas, im „Ausland" 1891. - ${ }^{5} \mathrm{Vgl}$. H. Spethmann in der Zeitschrift für Gletseherkunde, Bd. II, S. 296; E. Brücrner, ebenda, S. 301; R. Lanaenbeor in Petermanx's Mitteilungen 1908, S. 285. - ${ }^{6}$ Wichtig für die Frage des Zackenfirns ist die Diskussion in der Zeitschrift der Berliner Gesellschaft für Erdkunde 1908, S. 95. Eine Systematik der Schmelzfiguren versuchte W. H. Wовкмамм in der Zeitschrift für Gletscherkunde, Bd. III, S. 241. - ${ }^{7}$ H. Hess in Petermanx's Mitteilungen 1908, S. 188. - ${ }^{8}$ F. J JEGER, in der Zeitschrift für Gletscherkunde 1910, Bd. IV, S. 351. - 9 J. Jegerlehner und E. Richter, zit. S. 190 f. ${ }^{10}$ G. Merzbacher, Aus den Hochregionen des Kaukasus; Leipzig 1901. Vgl. auch D. W. Freshrield, The Peakes, Passes and Glaciers of the Cancasus, in den Proceedings of the R. Geographical Society, London 1888, und M. v. DÉcHy zit. S. 191. - ${ }^{11}$ W. M. Coxwax, Climbing and Exploration in the Karakorum Himalayas; London 1894. Die Karte wurde 1894 von der R. Geographical Society in London herausgegeben. Unsere Fig. 51 ist nach einem Kärtchen im Alpine Journal entworfen. - ${ }^{12} \mathrm{G}$. Merzbacher, Vorläufiger Bericht über die Forschungsreise in dem zentralen Tian-Schan; 149. Ergänzungsheft zu Petermans's Mitteilungen, 1904. - ${ }^{13}$ C. Russert, Glaciers of North America; Boston 1897. ${ }^{14}$ C. E. Siebenthal im Journal of Geology 1907, Bd. XV, S. $15 .-{ }^{15}$ O. NordenskJöLD, Die Polarwelt und ihre Nachbarländer, Leipzig 1909. - ${ }^{16}$ H. МонN und F. Nansen zit. S. 102. $-{ }^{17}$ H. Spethmana im Globus, Bd. XCIV, S. 200. ${ }^{18}$ O. Sverdrup, Neues Land, Leipzig '1903. - ${ }^{19}$ National Antaretic Expedition, 1901-04; Natural History, Bd. I, London 1907. E. PHinIPrI, Über die Landeisbeobachtungen der fünf letzten Südpolarexpeditionen, in der Zeitschrift für Gletscherkunde, Bd. II. - ${ }^{20}$ O. Nordensksö̈Ld ebenda, Bd. III, S. $321 .-$ ${ }^{21}$ E. v. Drygalski, Das Schelfeis der Antarktis am Gaußberg, in den Sitzungsberichten der Bayerisehen Akademie der Wissenschaften, Math.-physik. Klasse, 1910. - ${ }^{22}$ E. v. Drygatski, Zum Kontinent des eisigen Südens; Berlin 1904.

\section{Das Klima.}

Klimaprovinzen (s. Karte XV). Unter dem Klima eines Ortes verstehen wir den mittleren Zustand der Atmosphäre, wie er sich uns durch langjährige meteorologische Durchschnittswerte darstellt. Als die Hauptfaktoren haben sich Temperatur und Niederschlag erwiesen, indirekt auch die Winde und die orographischen Verhältnisse, da sie die Verteilung der beiden ersteren Elemente wesentlich mit- 
bedingen. $\times$ Es ist nun die Aufgabe der physischen Geographie, das Zusammenspiel dieser vier Faktoren an den einzelnen Örtlichkeiten zu untersuchen, gemeinsames zusammenzufassen und nach dem vorherrschenden Witterungscharakter Klimatypen oder Klimaprovinzen aufzustellen. Den ersteren Weg hat KöPPEN ${ }^{1}$ eingeschlagen und ist dabei hauptsächlich von pflanzengeographischen Gesichtspunkten ausgegangen. Er unterscheidet sechs Haupttypen: das tropische Tieflandklima, das Xerophilenklima, das sich durch Trockenheit auszeichnet, das mittelwarme, kühle und kalte Klima und endlich den Typus des ewigen Frostes. Jede Abteilung zerfällt wieder in mehrere Untertypen, die meist nach charakteristischen Pflanzen benannt sind, so daB im ganzen 24 Klimatypen unterschieden und auf ihre geographische Verbreitung hin untersucht werden. Dabei geht KöPPEN weniger von Mittel- als von Schwellenwerten aus und betätigt auch hier wieder seine Yorliebe für den Ausdruck der Niederschlagsverhältnisse durch Regentage - eine Vorliebe, die wir nicht teilen können. Auf ähnlichen Prinzipien beruhen die Einteilungen von HuLL ${ }^{2}$ und DE MARTonne ${ }^{3}$, dagegen können wir von PeNcK's Einteilung ${ }^{4}$ (humides, nivales und arides Klima) hier absehen, denn er betrachtet das Klima nur in dessen Beziehungen zur Gestaltung der Erdoberfläche, nicht zur Gesamtheit der geographischen Erscheinungen und berücksichtigt daher hauptsächlich nur die Verteilung des Niederschlags.

Geht man vom geographischen Gesichtspunkt aus, d. h. stellt man die Frage, welche Erdräume ein mehr oder wẻniger gleichartiges Klima besitzen, so gelangt man zur Aufstellung von Klimaprovinzen, wie es hier versucht ist. In jeder dieser großen Abteilungen lassen sich noch eine Reihe von Klimabezirken, oder wie man sie sonst nennen will, unterscheiden, und in manchen Gegenden wird das Beobachtungsmaterial noch eine weitere Untereinteilung gestatten. Es liegt in der Natur der Sache, daß über die Zahl und die Grenzen der Haupt- und Unterabteilungen wohl niemals eine, alle Zweifel ausschließende Übereinstimmung erzielt werden dürfte; und auch Karte XV, die sich nur auf die Darstellung der Provinzen beschränkt, ist lediglich als ein Versuch aufzufassen.

-Von den 35 Klimaprovinzen - unter diese Zahl dürfte keine

$\times$ Nur ist dabei wohl zu beachten, daB unser Wärmegefühl nicht bloB von der Temperatur der Luft, sondern auch von der Verdunstung, daher indirekt von der Feuchtigkeit und der Windstärke abhängt. Einen Versuch, wenigstens Temperatur und Windgeschwindigkeit zu einem einzigen Zahlenausdruck zu verbinden, hat G. Bopmax in den „Wissensehaftlichen Ergebnissen zur schwedischen Südpolarexpedition 1901-03“(Bd. II, Stockholm 1908) gemacht. 
Einteilung herabgehen - entfallen 21 auf die östliche Landfeste mit Polynesien, 12 auf die Neue Welt und 2 auf die Polarzone. Wir müssen uns, um Wiederholungen zu vermeiden, auf kurze, aphoristische Schilderungen beschränken.

\section{1. Östliche Kontinente und Inseln.}

1. Westeuropäische Provinz. Milde Wintertemperatur unter dem EinfluB der westlichen Winde und der warmen atlantischen Strömungen. Jährliche Temperaturschwankung unter $15^{\circ}$. Reichliche Niedersehläge mit ziemlich gleichmäBiger Verteilung über die Jahreszeiten. Summen sehr variabel, da die Terraingestaltung außerordentlich wechselvoll ist. Überhaupt wechseln die klimatischen Verhältnisse oft auf kurze Distanzen, und es wird daher eine eingehende Untersuchung zur Aufstellung zahlreicher Unterabteilungen führen.

2. Osteuropäische Provinz. Hier beginnt schon das Gebiet des Landklimas. Vorherrsehen der Ebene, daher Unterschiede hauptsächlich von der geographischen Breite, aber auch von der Länge abhängig, weil das Klima nach $\mathrm{O}$ immer kontinentaler wird. Die Niedersehläge sind geringer als in der westlichen Provinz und nehmen nach SO ab; ausgeprägtes Sommermaximum.

3. Westsibirische Provinz. Die Grenze gegen die osteuropäische Provinz liegt dort, wo die positive thermische Jahresanomalie, die Europa auszeichnet, aufhört; und es ist zu betonen, daß sie die Urallinie nur wenig überschreitet. Im übrigen unterscheidet sich diese Provinz von der vorhergenannten nur durch ein schärferes Hervortreten aller Charaktereigentümlichkeiten. Große Temperaturveränderlichkeit.

4. Ostsibirische Provinz. Jenseits des Jenissei beginnt eine allgemeine Hebung des Landes, Tiefebene nur an den Flüssen. Gebiet eineswinterlichen Kältezentrums. Jährliche Temperaturschwankung am größten. Niederschläge im allgemeinen gering.

5. Kamtschatka-Provinz. Das Meer mildert die Temperaturextreme und führt reichlicheren Regen zu.

6. Chinesisch-japanische Provinz. Auf dem Festland relativ bedeutende Winterkälte und streng periodische Regen. In Japan treten diese Eigentümlichkeiten etwas gemildert auf.

7. Die asiatische Hochlandprovinz umfaßt alle gebirgsumsehlossenen Hochländer, die im allseitigen Windschatten liegen; daher sehr trocken. Winterkälte durch die bedeutende Seehöhe gesteigert, Son̂merwärme dureh die kontinentale Lage. Tägliche Temperaturschwankung sehr bedentend.

8. Aral-Provinz. Trockenes Tiefland; Niederschlagsmaximum im Norden im Sommer, im Süden im Winter. In Turan strenge Winter und sehr heiße Sommer.

9. Indus-Provinz, durch Trockenheit und Hitze ausgezeichnetes Tiefland.

10. Mittelmeer-Provinz. Große Mannigfaltigkeit wegen reicher horizontaler Gliederung und wechselnder Oberflächenbesehaffenheit. Mild ist das Klima überall mit Ausnahme der inneren Hochländer. Vorherrschend Winterregen.

11. Sahara-Provinz, bis nach Mesopotamien reichend, Gebiet der trockenen Nordwinde, wahrscheinlich regenärmste Provinz der Erde. Kontinentalität und vegetationsarmer Boden steigern die Sommerhitze außerordentlich, jährliche und tägliche Temperaturschwankung beträchtlich.

12. Tropische Provinz von Afrika. Temperatur auf dem inneren Hochland durch die Seehöhe gemildert, desto größer aber in den schmalen Küstenebenen. Tropenregen nach Westen abnehmend. 
13. Kalahari-Provinz, umfaßt das ganze regenarme Gebiet von Südwestafrika.

14. Kap-Provinz, subtropisch.

15. Ostindiseh-australisehe Monsunprovinz. Mit Ausnahme einiger Gegenden im Archipel streng periodischer Regen mit SW-Wind bezw. NWWind: Temperatur ziemlich gleichmäBig trotz beträehtlieher Ausdehnung der Provinz; Jahressehwankung sehr mäßig.

16. Australisehe Binnenprovinz. Große Temperaturextreme; unregelmäBige Niederschläge, vorherrschend trocken.

17. Australische Südwest-Provinz, subtropisch.

18. Australische Ost-Provinz bis an die Wasserseheide, auch die SO-Küste und Tasmanien umfassend. Niederschläge ergiebig und ziemlich gleichmäBig. Temperaturschwankung mäBig.

19. Neuseeländische Provinz, wahrscheinlich auch die kleineren Inseln in der Umgebung umfassend. Mildes Klima mit ziemlich gleichmäBigem Regen.

20. Polynesische Tropenprovinz. Tropenklima durch die See gemildert, eigentlich das ganze Jahr ein milder Sommer. Regen auf den hohen Inseln reichlich und mit tropischer Periodizität.

21. Hawaii-Provinz. Temperatur ebenfalls gleichmäBig mild. Regen subtropiseh.

\section{Amerika.}

1. Hudson-Provinz. Zum gröBten Teil extremes Landklima und wenig Niederschläge.

2. Nordwestliche Küstenprovinz. Regenreiches, mildes, gleichmäBiges Klima.

3. Californische Provinz. Verhältnismäßig kühl, besonders im Sommer. Streng subtropische Regenperiode.

4. Hochlandprovinz. Trocken, große jährliche und tägliche Temperatursehwankung.

5. Atlantische Provinz. Im Winter großer Temperaturgegensatz zwischen Norden und Süden, Landklima auch an der Küste. Regen reichlich und gleichmäBig über das Jahr verteilt. Große Temperaturveränderlichkeit.

6. Westindische Provinz, auch den Südrand von Nordamerika umfassend._GleichmäBige Temperatur, Niederschläge zu allen Jahreszeiten, aber mit ausgesprochenem Sommermaximum.

7. Tropische Cordillerenprovinz. Im inneren Tafelland wegen beträchtlicher Seehöhe ewiger Frühling. In Mexico und Zentralamerika ausgeprägte Zenitalregen, in Südamerika gleichmäBige Niederschläge.

8. Tropenprovinz von Südamerika. Der Gegensatz von Gebirgsund Tiefland dürfte eine ziemliche Mannigfaltigkeit des Klimas hervorrufen, doch wissen wir darüber nichts Genaueres.

9. Peruanische Provinz, auch einen Teil von Chile bis zum $300^{\circ} \mathrm{B}$. umfassend. Regenlos und abnorm kühl.

10. Nordehilenische Provinz, subtropisch.

11. Südehilenische Provinz, außerordentlich niederschlagsreich. Temperatur gleichmäBig, Sommer kühl.

12. Pampas-Provinz. Regen nicht reichlich; jährliche Temperaturschwankung, wenigstens im Norden, ziemlich groß.

Arktische Provinz. Die Eigentümlichkeiten des polaren Klimas wurden schon mehrfach erörtert. Auch hier lassen sich viele Unterabteilungen unter- 
scheiden. Als Südgrenze auf den Kontinenten kann man die $10^{\circ}$-Isotherme des wärmsten Monats, die annähernd mit der Baumgrenze übereinstimmt, annehmen.

Die antarktische Provinz gleicht der arktischen, soweit wir bis jetzt beurteilen können, in der Winterkälte, unterscheidet sich von ihr aber durch eine sehr niedrige Sommertemperatur, durch eine regelmäBige Verteilung des Luftdruckes und der Winde und durch heftige Luftbewegung.

Die 35jährigen Schwankungen. Man hat schon lange darüber gestritten, ob das Klima eines Ortes konstant oder veränderlich sei. Der Begriff der Veränderlichkeit muß aber schärfer gefaßt werden; wir haben zwischen dauernden Veränderungen nach einer Richtung und periodischen Schwankungen zu unterscheiden, und es ist auch die Frage zulässig, ob Bewegungen beider Art nebeneinander stattfinden.

Belehrt durch vielerlei Erfahrungen, sind wir jetzt zu der Auffassung geneigt, $\mathrm{daB}$ die meteorologischen Prozesse regelmäßigen Schwankungen unterliegen, und zwar in der Weise, daß jede Periode wieder in eine Reihe von Perioden kürzerer Dauer zerfällt. Wenn wir diese Schwankungen im Sinn ihrer gewöhnlichen graphischen Darstellung als Wellen auffassen, so können wir auch sagen, daß jede Welle sich in kleinere auflöst, diese wieder in kleinere usw., daß aber dabei niemals ganz regelmäBige Gestalten entstehen.

Wir haben die tägliche und die jährliche Periode der Temperatur bereits kennen gelernt. Wir können die erstere unterdrücken, wenn wir die mittleren Tagestemperaturen berechnen, und die Aneinanderreihung dieser Mittel läßt uns die jährliche Periode erkennen. Wir können auch diese ausschalten, wenn wir das Jahresmittel berechnen. Das zweite maßgebende Klimaelement, der Regen, ist in seiner Periodizität schwieriger zu behandeln, weil er kein Zustand, sondern ein Ereignis ist, doch ist auch er deutlichen jährlichen Schwankungen unterworfen, wenn diese auch in verschiedenen Gegenden bald stärker, bald schwächer hervortreten.

In der täglichen wie in der jährlichen Temperaturkurve sind zwei Elemente deutlich zu unterscheiden. Das periodische bewirkt stetige Zunahme vom Minimum zum Maximum und dann wieder ebenso stetige Abnahme, und nur die unperiodischen, nicht an bestimmte Zeiten gebundenen Veränderungen rufen in dem streng regelmäBigen Verlauf der Temperaturkurve Störungen hervor. In noch höherem Grad ist das bei der Regenkurve der Fall. Gerade dieses unperiodische Element suchen wir durch Bildung langjähriger Mittelwerte zu beseitigen, indem wir - wenn auch nicht ganz zutreffend - annehmen, daB es ebenso oft im positiven wie im negativen Sinn wirke.

Reihen wir nun die klimatologischen Jahresmittel eines Ortes aneinander. Kalte und warme, nasse und trockene Jahre wechseln 
miteinander ab, scheinbar ohne GesetzmäBigkeit. Sind diese Schwankungen von Jahr zu Jahr nur unperiodischer Art, oder steckt darin auch ein periodisches Element?

$\mathrm{DaB}$ man das letztere so lange vergeblich suchte, hat seinen Grund offenbar darin, daß die unperiodischen Veränderungen mit der Länge der Periode an Bedeutung wachsen. Zunächst suchte man Beziehungen zu der elfjährigen Sonnenfleckenperiode, ${ }^{5}$ die auf den Erdmagnetismus und die Polarlichter von so entscheidendem Einfluß ist. Gleichen Schritt mit der Häufigkeit der Sonnenflecken halten die Protuberanzen am Sonnenrand, zeigen aber noch eine Unterperiode von 3,7 Jahren mit sekundären Maxima und Minima, und ihre Zunahme fällt mit der Abnahme der Breite der Sonnenflecken zusammen. Diese kleinste unter den längeren Perioden der Sonnentätigkeit spiegelt sich, wie LOcKYER ${ }^{6} 1902$ gezeigt hat, in Luftdruckänderungen wider. In Indien, das hohen Barometerstand von Oktober bis März und niederen im Sommerhalbjahr hat, steigt in den. Jahren der Protuberanzenmaxima der Luftdruck, und dieser EinfluB läßt sich fast über die ganze Ostfeste der Erde verfolgen, während sich die Stationen in Nordwest-Afrika und in Amerika westlich bis $\mathrm{zu}$ den Hawaiischen Inseln entgegengesetzt verhalten.

Was die Fleckenperiode selbst betrifft, so sind die Ergebnisse der bisherigen Untersuchungen folgende: 1. Ohne Zweifel steigert sich die Häufigkeit der Wirbelstürme in Ost- und in Westindien mit der Häufigkeit der Flecken. 2. Fleckenarme Jahre sind in den Tropen trockener als fleckenreiche, aber diese Regel erleidet Ausnahmen, und in der gemäBigten Zone ist ein Zusammenhang nicht mehr allgemein nachweisbar. 3 . Auch in bezug auf die Temperaturänderungen ergaben nur die tropischen Stationen ein greifbares Resultat. KöPpen $^{7}$ hat sie für die Zeit $1820-70$ und NoRdmanN ${ }^{8}$ für die Periode 1870 - 1900 untersucht, und beide stimmen darin überein, daß die fleckenreichen Jahre kalt und die fleckenarmen warm sind; doch ist der Unterschied mehr theoretisch interessant als praktisch fühlbar, da die Schwankung nicht ganz ${ }^{1 / 2}{ }^{0}$ beträgt. Dieses Verhalten ist deshalb auffallend, weil die Sonnentemperatur mit der Fleckenhäufigkeit zunimmt, und man hat es dadurch erklärt, daß in den fleckenreichen Jahren, die zugleich die nassen sind, die Bewölkung zunimmt, und diese nachweisbar die Temperatur in den Tropen hinabdrückt.

Die Schwankungen der Gletscher und des Niveaus abflußloser Seen weisen auf meteorologische Perioden höherer Ordnung hin, die anscheinend keine Beziehungen zu den Sonnenflecken haben. Hier setzte E. BRÜCKNER ${ }^{9}$ den Hebel an. Er untersuchte die Wasser- 
standsschwankungen einer größeren Zahl von abflußlosen Seen, Flußseen und Flüssen aus allen Gegenden der Erde; die Temperatur- und Regenmessungen, die bis in die Mitte bzw. den Anfang des 18. Jahrhunderts hinaufführen; die Eisverhältnisse der russischen Flüsse, deren Aufzeichnungen ebensoweit (betreffs der Düna bei Riga sogar bis 1556) hinaufreichen; die sorgfältigen Aufzeichnungen über das Datum der Weinernte in Westeuropa, die sich bis zum Ende des 14. Jahrhunderts zurückverfolgen lassen, und, endlich die Nachrichten über besonders kalte Winter, die das Material bis ungefähr 1000 n. Chr. ergänzen.

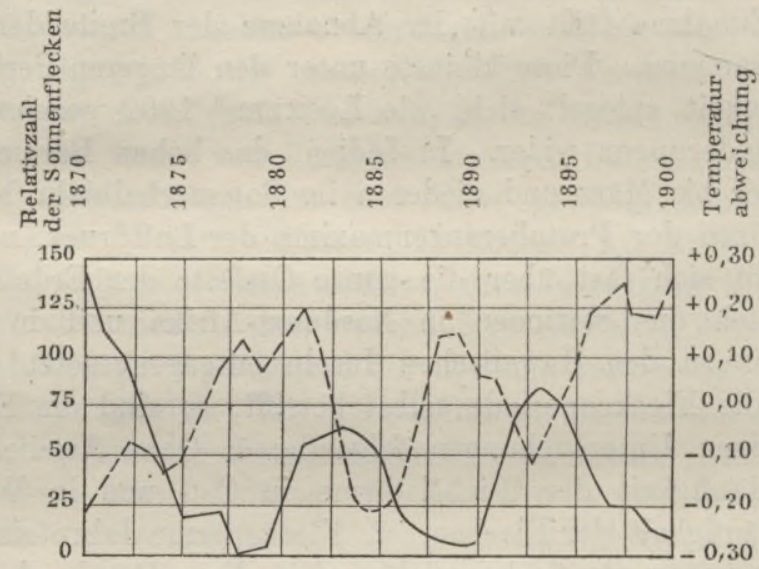

Fig. 55. Häufigkeit der Sonnenflecken $(\longrightarrow \rightarrow$ ) und der Temperaturabweichung ) an 13 tropischen Stationen nach NoRdManN.

Das Ergebnis war die Entdeckung einer durchschnittlich 35jährigen Periode. Jede Periode zerfällt in eine kalte und eine warme Hälfte; die Jahrestemperaturen steigen bis zu einem Maximum an und sinken dann bis zu einem Minimum hinab, freilich noch unregelmäBiger als die Tagestemperaturen innerhalb der Jahresperiode, weshalb es BRÜckner vorgezogen hat, fünfjährige Durchschnittszahlen zu verwerten, die in ihrem Wesen genau den Monatsmitteln entsprechen. Die Zeit zwischen zwei Temperaturminima schwankt zwischen 20 und 50 Jahren, ebenso wie auch die Zeit zwischen zwei jährlichen Minima nicht immer 365 Tage beträgt; das Mittel von 35 Jahren ergibt sich aber aus verschiedenen Ansätzen, sodaß es wenigstens vorläufig als' wahrscheinlichster Wert festgehalten werden muß.

Auch diese Schwankung erscheint auf den ersten Blick nicht beträchtlich, nach der Tabelle auf S. 237 nur höchstens $1^{\circ} \mathrm{C}$., in 
Klimaschwankungen. ${ }^{x}$

\begin{tabular}{|c|c|c|c|c|c|}
\hline Jahre & $\begin{array}{l}\text { Tem- } \\
\text { peratur }\end{array}$ & $\begin{array}{c}\text { Regen } \\
\text { (Prozente) }\end{array}$ & Seen & $\begin{array}{l}\text { Beginn der } \\
\text { alpinen } \\
\text { Gletscher- } \\
\text { bewegungen }\end{array}$ & $\begin{array}{l}\text { Häufigkeit } \\
\text { der Sonnen- } \\
\text { flecken } \\
\text { nach LrzNAR }\end{array}$ \\
\hline $1731-1735$ & $-0,34^{0}$ & -4 & & 1735 Vorsto $B$ & \\
\hline $\begin{array}{l}1736-1740 \\
1741-1745 \\
1746-1750 \\
1751-1755\end{array}$ & $\begin{array}{l}-0,43^{*} \\
-0,35 \\
+0,45 \\
+0,16\end{array}$ & $\begin{array}{l}+9 \\
-6 * \\
+5 \\
+5\end{array}$ & 1740 Max. & 1750 Rückzug & \\
\hline $\begin{array}{l}1756-1760 \\
1761-1765 \\
\end{array}$ & $\begin{array}{l}-0,08 \\
-0,10 \\
\end{array}$ & $\begin{array}{l}-3 \\
+0 \\
\end{array}$ & 1760 Min. & & \\
\hline $\begin{array}{l}1766-1770 \\
1771-1775\end{array}$ & $\begin{array}{l}-0,42^{*} \\
+0,24\end{array}$ & $\begin{array}{l}-4 * \\
+7\end{array}$ & & 1767 VorstoB & \\
\hline $\begin{array}{l}1776-1780 \\
1781-1785 \\
1786-1790 \\
1791-1795 \\
1796-1800 \\
1801-1805\end{array}$ & $\begin{array}{l}+0,15 \\
+0,18 \\
-0,11 \\
+\mathbf{0 , 4 6} \\
+0,07 \\
+0,26 \\
\end{array}$ & $\begin{array}{l}-2 \\
-2 \\
+2 \\
-2 \\
-1 \\
-4^{*}\end{array}$ & $\begin{array}{c}1780 \text { Max. } \\
1800 \text { Min. }\end{array}$ & 1800 Rückgang & \\
\hline $\begin{array}{l}1806-1810 \\
1811-1815 \\
1816-1820\end{array}$ & $\begin{array}{l}-0,18 \\
-0,46 * \\
-0,35\end{array}$ & $\begin{array}{l}+3 \\
+0 \\
+0\end{array}$ & 1820 Max. & 1814 Vorstoß & \\
\hline $\begin{array}{l}1821-1825 \\
1826-1830 \\
1831-1835 \\
\end{array}$ & $\begin{array}{l}+0,56 \\
+0,14 \\
+0,03 \\
\end{array}$ & $\begin{array}{l}-2 \\
-0 \\
-8^{*}\end{array}$ & 1835 Min. & 1823 Rückgang & \\
\hline $\begin{array}{l}1836-1840 \\
1841-1845 \\
1846-1850 \\
1851-1855\end{array}$ & $\begin{array}{l}-0,39^{*} \\
-0,00 \\
-0,08 \\
+0,11\end{array}$ & $\begin{array}{l}-5 \\
+1 \\
+3 \\
+1\end{array}$ & 1850 Max. & 1840 Vorstob & 1840,5 Max. \\
\hline $\begin{array}{l}1856-1860 \\
1861-1865 \\
1866-1870 \\
1871-1875 \\
\end{array}$ & $\begin{array}{l}+0,06 \\
-0,06 \\
+0,11 \\
-0,04 \\
\end{array}$ & $\begin{array}{l}-4 \\
-5^{*} \\
-1 \\
+2 \\
\end{array}$ & 1865 Min. & $\begin{array}{l}1856 \text { Rüekgang } \\
1875 \text { Vorsto } B\end{array}$ & $\begin{array}{l}\text { 185̌,0 Min. } \\
1872,5 \text { Max. }\end{array}$ \\
\hline $\begin{array}{l}1876-1880 \\
1881-1885\end{array}$ & $\begin{array}{l}-0,07 \\
-0,08 *\end{array}$ & $\begin{array}{r}+7 \\
+6\end{array}$ & 1880 Max. & & 1886,0 Min. \\
\hline
\end{tabular}

× Mittel aus sämtlichen Gruppen der Erde; die positiven und negativen Werte stellen Abweichungen von der mittleren Temperatur bezw. Jahresmenge des Regens dar, im letzten Fall in Prozenten der mittleren Jahresmenge. Die dicken Striche scheiden die nach den Schwankungen der Weinernte aufgestellten Perioden, die feinern die kalt-feuchten und warm-trockenen Phasen. 
der Periode $1836-70$ sogar nur $0,5^{\circ}$. Aber man muß beachten, daß sich bei der Zusammenfassung der Beobachtungsreihen einzelner Orte $\mathrm{zu}$ Gruppenmitteln und dieser wieder zu einem Mittel für die ganze Erde viele Gegensätze ausgleichen. Wir können vermuten, daß im kontinentalen Klima die Amplituden größer werden (im südwestlichen Rußland z. B. bis $2^{\circ}$, und möglicherweise findet auch eine Steigerung mit der Breite statt. Die Dove'schen Werte für die mittlere Abweichung (s. S. 113) geben vielleicht auch hierfür einen Anhaltspunkt, wenn sie auch für unsere Frage nur mit großer Vorsicht zu benutzen sind.

Diese Temperaturschwankungen treten gleichzeitig auf der ganzen Erde ein, die Ursache muß daher außerhalb der Erde liegen, und wir sind geneigt, auch sie in periodischen Veränderungen des Strahlungsvermögens der Sonne zu suchen. Über diesen Punkt hat erst in jüngster Zeit WILLIAM LockYeR ${ }^{10}$ einiges Licht verbreitet. Die nachstehende Tabelle zeigt, daß neben der im Durchschnitt 11,3jährigen Periode der Fleckenhäufigkeit noch eine zweite Periode höherer Ordnung besteht, die sich einerseits in der Wachstumsdauer der Fleckenhäufigkeit vom Minimum zum Maximum, anderseits - und dies ist besonders wichtig - in der Fleckenbedeckung der Sonnenscheibe kund tut. Diese Periode dauert (1ऽ43,5-1879,0) 35,5 Jahre, stimmt also mit der BRÜCKNER'schen Periode überein. Leider enthält unsere Temperaturtabelle auf S. 237

\begin{tabular}{|c|c|c|c|c|c|c|c|}
\hline Periode & $\begin{array}{r}\text { Minimum } \\
\text { der }\end{array}$ & $\begin{array}{c}\text { Daten } \\
\text { Maximum } \\
\text { leckeuhäufig }\end{array}$ & $\underset{\text { Minimun }}{\text { Meit }}$ & $\begin{array}{c}\text { Dauer } \\
\text { Im der } \\
\text { Periode }\end{array}$ & $\begin{array}{l}\text { Dauer des } \\
\text { Wachstums } \\
\text { vom Mini- } \\
\text { mum zum } \\
\text { Saximum }\end{array}$ & $\begin{array}{l}\text { Fleckenbedeck- } \\
\text { ung in Pro- } \\
\text { mille der sicht- } \\
\text { baren Sonnen- } \\
\text { hemisphäre }\end{array}$ & $\begin{array}{l}\text { Mittlere } \\
\text { Häufigkeit } \\
\text { der Sonnen- } \\
\text { flecken } \\
\text { nach LIZNAR }{ }^{11}\end{array}$ \\
\hline I & 1833,9 & 1837,2 & 1843,5 & $5 \quad 9,6$ & - $3,3^{*}$ & 86 & $65,2 \quad(1833-43)$ \\
\hline II & 1843,5 & 1848,1 & 1856,0 & 12,5 & 4,6 & $85^{*}$ & $53,6 \quad(1843-56)$ \\
\hline III & 1856,0 & 1860,1 & 1867,2 & 11,2 & 4,1 & 112 & $49,6^{*}(1856-67)$ \\
\hline IV & 1867,2 & 1870,6 & 1879,0 & 11,8 & $3,4 *$ & 126 & $56,6 \quad(1867-78)$ \\
\hline V & 1879,0 & 1884,0 & 1890,2 & 11,2 & 5,0 & $78^{*}$ & $34,6^{*}(1878-89)$ \\
\hline VI & 1890,2 & 1894,0 & ? & - & 3,8 . & 97 & $41,4 \quad(1889-1900)$ \\
\hline
\end{tabular}

gerade für diese Zeit Unregelmäßigkeiten; berücksichtigt man aber nur das zweite Maximum, so herrscht leidliche Übereinstimmung: Minimum 1836-40, Maximum 1866-70, Minimum 1881-85: jedenfalls fallen die Minima in die Perioden geringer Fleckenbedeckung. Wenn man statt dieser die Zahl der Sonnenflecken in Betracht zieht, wie es LiznaR ${ }^{11}$ getan hat, so verschiebt sich zwar das erste Minimum etwas, aber das Endresultat bleibt dasselbe, wie besonders aus den Häufigkeitsepochen, die Liznar auf graphischem Weg gefunden hat, und die der Tabelle auf S. 237 beigefügt sind, hervorgeht. Mit der Temperatur schwankt auch der Niederschlag, aber im Gegensatz zu jener nicht überall in dem gleichen Sinn. In warmen Perioden- 
hälften muß die Verdunstung größer sein, und man sollte daher auch reichlichere Niederschläge erwarten, aber nur auf den Meeren und in den ozeanischen Randpartien scheint diese Voraussetzung erfüllt zu sein, während im Binnenland die warme Zeit entschieden die trockene ist. Es müssen also - und das gleiche gilt auch für die fleckenarmen Jahre (S. 235) - die Kondensationsbedingungen auf dem Land ungünstigè sein. BRÜCKNER hat auf die periodischen Veränderungen des Luftdruckes hingewiesen. Dieser sinkt in der trocken-warmen Hälfte auf dem nordatlantischen Ozean und steigt über Europa; dort vertieft sich das subpolare Minimum, hier entsteht eine Antizyklone, die uns von der Zufuhr feuchter Meeresluft abschneidet. In der feucht-kühlen Hälfte gleichen sich die Gegensätze etwas aus; über dem nordatlantischen Ozean steigt das Barometer, über Europa sinkt es. Diese Erklärung reicht jedoch nicht aus, denn gerade in der sommerlichen Hauptregenzeit ist die Zufuhr ozeanischer Feuchtigkeit von untergeordneter Bedeutung. Nur detaillierte Untersuchungen der jahreszeitlichen Regenverteilung in den beiden Periodenhälften können eine Lösung dieser Frage anbahnen. ${ }^{\times}$

Die feuchten und trockenen Periodenhälften decken sich nicht genau mit den kalten und warmen, namentlich scheint sich die Periode 1756-1805 durch fast permanente Trockenheit ausgezeichnet zu haben. Wir können aber noch nicht entscheiden, ob diese Anomalie tatsächlich ist, oder ob sie nur in der bedauerlichen Mangelhaftigkeit des Beobachtungsmaterials ihre Erklärung findet. $\times \times$ Von der Größe

$\times$ Brǘckner ${ }^{12}$ hat für beide Periodenhälften eine Bilanz des Regens von kontinentalem und ozeanischem Ursprung aufgestellt, aber unter der ganz willkürlichen Voraussetzung, daß das prozentische Verhältnis beider Niederschlagsquellen konstant bleibt.

$\times \times$ Wenn man nur längere Beobachtungsreihen in Betracht zieht, ist die Übereinstimmung leidlicher. $\mathrm{H}_{\mathrm{ANN}}{ }^{13}$ hat die Regenbeobachtungen von Padua (1725-1900), Mailand (1764-1900) und Klagenfurt (1813-1900), und LockYeR ${ }^{14}$ die der britischen Inseln, Brüssels, Madras', Bombays, Kapstadts und des oberen Ohiotals'daraufhin untersucht und folgende ungefähre Epochen gefunden. Wir fügen das mittlere Jahr der Temperaturepochen-Quinquennien nach der Tabelle auf S. 237 hinzu.

$$
\begin{array}{ccc}
\text { Hegen } & \text { Temperatur } \\
\text { HaNN } & \text { BockYER } & \text { BrüCKNER }
\end{array}
$$

Max. 1738

Min. 1753

Max. 1773

Min. 1788

Max. 1808

Min. 1823

Max. 1843

Min. 1859

Max, 1878

Min. 1893

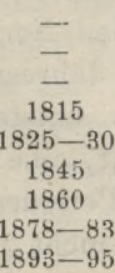

Min. um 1738

Max. „ 1748

Min. , 1768

Max. „ 1793

Min. " 1813

Max. , 1823

Min. " 1838

Max. ." 1853

Min. ., 1883 
der Regenschwankungen gibt uns jene Tabelle kein richtiges Bild, weil in dem Mittel für die ganze Erde die europäischen Stationen wegen ihrer großen Anzahl naturgemäß dominieren, und auch die nordatlantischen Gebiete einbezogen sind. In Europa beträgt die Schwankung nur 14-20 Prozent, in den echt kontinentalen Gebieten Asiens aber schon bis 36 Prozent, in Barnaul in Sibirien über 100 Prozent der mittleren Jahressumme (1861-1865 durchschnittlich 150, 1881-85 $460 \mathrm{~mm}$ !). Solche Gegenden, die ja an und für sich schon an Wasserarmut leiden, verändern in der Trockenzeit in der Tat ganz ihr Aussehen, und hier greifen die Klimaschwankungen noch viel tiefer als bei uns in die menschlichen Verhältnisse ein. Und doch fühlen wir ihren Einfluß selbst in Deutschland schon schwer genug.

Von den in die physische Geographie einschlägigen Erścheinungen werden die Wasserstände der Seen und Flüsse, das Meeresniveau, die Eisbildung auf den nordischen Flüssen und die Bewegung der Gletscher am meisten beeinflußt; der Zusammenhang tritt schon in der Haupttabelle deutlich hervor, noch besser aber, wenn wir die Alpengletscher-Epochen mit den Schwankungen in Süddeutschland in Vergleich setzen. Wir legen auf das Verhalten der Seen und Gletscher das Hauptgewicht, weil sich darin auch noch größere Klimaperioden widerspiegeln. Ehe wir aber darauf eingehen, wollen wir noch eine wichtige Schlußfolgerung ziehen.

Wir haben schon wiederholt über die UngleichmäBigkeit der klimatologischen Mittelwerte geklagt. Aus unseren Erörterungen über die 35̄jährige Periode geht klar hervor, erstens daß nur gleich. zeitige Mittelwerte miteinander vergleichbar sind, zweitens daß kurze Beobachtungsreihen selbst in den Tropen ganz ungenügende Werte ergeben, weil sie dem auf- oder dem abwärtssteigenden Ast der Klimawelle angehören können. Mittel, die wirklich das Klima repräsentieren, sog. Normalwerte, müssen eine ganze Klimaperiode umfassen, also auf etwa 30-35jährige Beobachtungen sich stützen. Aber wir werden noch sehr lange warten müssen, bis diese Forderung auf der ganzen Erde erfüllt ist; bis dahin müssen wir alle unsere Isothermen-, Isobaren-, Wind- und Regenkarten als ziemlich rohe Skizzen betrachten.

Säkulare Perioden. Aus den Normalmitteln ist die 35̃jährige Periode eliminiert, wie aus den Jahresmitteln die jährliche, aus den Tagesmitteln die tägliche. Es entsteht nun die Frage, ob die Normalmittel, aneinander gereiht, eine ähnliche Schwankung zeigen wie die Jahresmittel, ob noch Perioden höherer Ordnung bestehen. ZiffernmäBig lassen sich diese nicht mehr nachweisen, denn wenn 
auch manche Temperaturreihen bis in die Mitte oder den Anfang des 18. Jahrhunderts hinaufreichen, so sind sie doch selten homogen und überdies zu spärlich verteilt, um Rückschlüsse auf Bewegungen über die ganze Erde zu gestatten. Beachtenswert ist indes die Entdeckung Heldmann's, da $B$ in Berlin in der Periode 1848-1907 die Winter im Durchschnitt wärmer und die Sommer kälter waren als im Zeitraum 1756-1847, denn ähnliche Erfahrungen hat man auch in Wien und Stockholm gemacht. ${ }^{15}$ Mancherlei Anzeichen haben wir in den Aufzeichnungen über die Wasserstände des Kaspisees, die Eisbedeckung der Flüsse, die Weinernte, die Gletschervorstöße, daß die 35jährigen Perioden nur Auszackungen größerer Wellen sind, die sich vielleicht über ein Jahrhundert und mehr ausdehnen und daher mit mehr Recht als die BRÜCKNER'schen säkulare genannt zu werden verdienen. Auch das, was auf S. 217 über primäre und sekundäre Gletscherschwankungen gesagt wurde, kann zugunsten dieser Annahme angeführt werden.

Über Klimaänderungen zwischen den Anfängen der geschichtlichen Kunde und dem Ende jenes großen Klimaabschnitts, den wir Eiszeit nennen, geben uns nur pflanzengeographische Untersuchungen Aufschluß. Aber in der Deutung der Funde stehen sich zwei Ansichten schroff einander gegenüber.

„Die Torfmoore des südlichen Norwegens,“ sagt BLYtr, ${ }^{16}$, ,bestehen, wenn sie über der höchsten marinen Stufe liegen, aus vier Torfschichten mit drei zwischengelagerten. Waldschichten, und sie sind, seit sie anfingen sich zu bilden, jetzt zum vierten Mal mit Wald bewachsen. Auf eine ähnliche Anzahl wechselnder Perioden deuten auch die dänischen Torfmoore mit ihren vier Torfschichten, welche zuweilen von Wurzelschichten geschieden werden. Torfmoore mit allen drei Wurzelschichten sind aus Dänemark bekannt, gleichfalls aus einzelnen Teilen Schwedens: Södermanland, Smaaland und Dalsland. Moore mit drei Wurzelschichten kennt man aus Schlesien, aus England und Schottland und aus dem Juragebirge." Wir haben hier nach BLYTT's Auffassung einen wiederholten Wechsel von langen trockenen und feuchten Zeiträumen, und die Resultate, zu denen Sernander ${ }^{17}$ in Schweden, Lorie in Holland und Lewis in Schottland ${ }^{18}$ gekommen sind, stehen damit in guter Übereinstimmung. Drei solche Klimaperioden nimmt August Schulz ${ }^{19}$ für das mittlere Europa im Norden der Alpen an.

Ein so regelmäBiges Auftreten von Schichten mit. Waldresten wie BuytT annahm, hat J. Hоцмвов in den norwegischen Torfmooren nicht finden können. Er steht auf Seiten G. Andersson's, der die Annahme von Klimaperioden zurückweist und die Wechsel- 
lagerung von Torf- und Wurzelschichten auf das eigene Wachstum der Moore, das durch verschiedene, meist örtliche Ursachen bedingt war, zurückführt. Die Altersfolge der Bäume in Schweden läßt nach seiner Auffassung nur erkennen, daß seit der Eiszeit die Temperatur stetig zu- und dann wieder abnahm. ${ }^{20}$ Als sie den Höhepunkt erreichte, war der Haselnußstrauch weit über seinen gegenwärtigen Bezirk hinaus verbreitet. Seine heutige Nordgrenze fällt mit der August-September-Isotherme von $12^{\circ}$ zusammen, an seiner ehemaligen beträgt die Temperatur im Spätsommer jetzt $9,5^{\circ}$, und man schließt daraus auf eine sommerliche Wärmeabnahme von ungefähr $2^{1} / 2^{0}$. Solche horizontale Verschiebungen der Pflanzengrenzen mußten auch vertikale zur Folge haben, und in der Tat hat sich die Waldgrenze im südlichen Norwegen nach ReKstAD ${ }^{21}$ um $350-400$, im mittleren Schweden um 150 bis über 200 und in Lappland um $200-250 \mathrm{~m}^{22}$ gesenkt. Für Island hat Thoroddsen eine größere Ausbreitung der Birkenwälder in nachglazialer Zeit nachgewiesen. Auch in Mitteleuropa schob sich nach Briquex zwischen die Eiszeit und die gegenwärtige Waldperiode eine „xerothermische“ Periode mit wärmerem und trockenerem Klima ein, und diese Ansicht vertritt auch der Erforscher der Pflanzenwelt der Schwäbischen Alb, Gradmann.

Die Frage ist also: füllen den geologischen Zeitraum, den wir Alluvium nennen, eine oder mehrere große Klimawellen aus? Und ferner: waren diese Klimawellen allgemeine oder nur lokale Erscheinungen? denn auch das letztere muß als möglich bezeichnet werden, da die Verteilung von Wasser und Land in Nordeuropa damals etwas von der heutigen abwich, und die Ostsee in offener Verbindung mit dem warmen nordatlantischen Ozean stand.

Geologische Perioden. Eine scharfe Grenze zwischen der Gegenwart und jener großen Epoche in der Erdgeschichte, die wir Eiszeit nennen, gibt es nicht. Es ist möglich, daß die warme Zeit, von der wir eben gesprochen haben, noch in die Glazialperiode fällt, jedenfalls aber war der europäische Mensch schon Zeuge der großen Vergletscherung. Wie heutzutage Grönland, war damals ganz Nordeuropa ${ }^{23}$ unter einer Eisdecke begraben, deren mächtigster Ausgangspunkt Skandinavien war (vgl. Taf. XIV). Im nördlichen Asien sandten nach Кворотктм alle Bodenerhebungen über $1000 \mathrm{~m}$ Höhe Gletscher aus, die die Täler bis $300 \mathrm{~m}$ Seehöhe erfüllten, während die Ebenen unter $600 \mathrm{~m}$ Seehöhe eisfrei blieben. Dies gilt jedoch nicht für die Küste des Eismeeres, wo NANsEN von der Karasee bis zur Taimyrbucht unzweifelhafte Glazialspuren entdeckte. v. ToLL ${ }^{24}$ hielt auch das merkwürdige òstsibirische Steineis, d. h. wirkliche Eislager innerhalb eines Schichtensystems, für Reste ehe- 
maliger Inlandeismassen, doch ist die Deutung jetzt wieder zweifelhaft geworden. ${ }^{25}$ In Nordamerika füllte den Raum zwischen der canadischen Küstenkette und dem Felsengebirge ein gewaltiger Gletscher aus, der von etwa $52-59^{\circ} \mathrm{N}$ nach Nordwesten und Südosten floß. Östlich vom Felsengebirge strahlte das Inlandeis von der Gegend zwischen dem Mackenzie und der Hudsonbai und von Labrador aus und ergoß sich sogar bis in die nördlichsten Vereinsstaaten, in Ohio und Indiana bis über den 40. Parallel, also weiter als in der Alten Welt, wo selbst in RuBland der 49. Breitenkreis wohl nirgends überschritten wurde. Alle Gebirge der gemäBigten Zonen, die jetzt noch Gletscher tragen, waren damals bis in die Haupttäler herab vereist; unsere alpinen Gletscherströme rückten bis in die nördlichen und südlichen Ebenen vor und lagerten hier ihre gewaltigen Moränenmassen ab, nur im $O$ waren auch damals die Bedingungen weniger günstig, so daß der Murgletscher nach den Untersuchungen v. Böнм's schon in der Gegend von Judenburg sein Ende fand. In dem deutschen Mittelgebirge trugen wenigstens der Harz, die Vogesen, der Schwarzwald und das Riesengebirge ansehnliche Gletscher; Steinmann meint sogar, es habe hier keinen Fleck eisfreien Landes gegeben. Die Glazialzeit des Karpathensystems haben Partsch, Paul Lehmann, de Martonne und Lucerna, die der Balkanhalbinsel CvıлÍ́ u. a. eingehend studiert. Gegen Westen können wir ihre sicheren Spuren über die Zentralappenninen, Corsica und die Pyrenäen bis Estremadura verfolgen. In den Hochgebirgen Zentralasiens - tritt die großartige Entfaltung des eiszeitlichen Gletscherphänomens mit jedem Jahr deutlicher hervor. Auch die Tropen blieben von der Klimaänderung nicht verschont. ${ }^{26}$ Auf den Vulkanriesen des ëstlichen Äquatorialafrika (Ruwenzori, Kenia und Kilimandscharo) wie in den Andes von Columbia, Ecuador, Nordperu und Bolivia reichten die Gletscher $900-1000 \mathrm{~m}$ tiefer als jetzt herab. In den jetzt schneefreien Australalpen sind Gletscher am Mt. Kosciusko und Mt. Bogong nachgewiesen, auf Tasmanien findet man Glazialablagerungen schon in 120-210 m Seehöhe. An der Westseite Neuseelands stiegen die Gletscher bis an das Meer hinab. Kerguelen und Patagonien waren ganz mit Eis bedeckt. Mit einem Wort: Überall auf der Erde findet man Spuren einer Eiszeit, soweit Land über die damalige Schneegrenze ${ }^{27}$ hinausreichte. Nach den auf S. $186 \mathrm{f}$. beschriebenen Methoden hat man ermittelt, daß die klimatische Schneegrenze damals in den Alpen 12-1300, in den Pyrenäen 1100, in dem Großen Becken Nordamerikas 1000, in den Australalpen ungefähr ebensoviel, in den Tropen aber nur 5-600 m unter der gegenwärtigen lag. Das läßt 
sich durch die Annahme reichlicherer Niederschläge allein nicht erklären. Auch eine Temperaturerniedrigung muB hinzugetreten sein. Man hat sie auf $2-3^{0}$ geschätzt, aber sie braucht nicht einmal so groß gewesen zu sein, wenn nur eine niedere Sommertemperatur den Schmelzprozeß unterband. ${ }^{*}$ Jedenfalls konnten sich die gewaltigen Eismassen in mittleren und niederen Breiten nur in einer feuchten Periode entwickeln. Ein solcher Klimacharakter in so relativ naher Vergangenheit mußte auch in den tiefer gelegenen Landstrichen Spuren hinterlassen, und in der Tat sind auch solche vorhanden. HuLL ${ }^{29}$ nannte die Zeit, in der das Tote Meer so anschwoll, daß es das ganze Ghôr erfüllte, die Pluvialzeit. Einer solchen begegnen wir auch in den Wadis der Arabischen Wüste, wo BlANCKENHORN ${ }^{30}$ drei gewaltige Schotterablagerungen entdeckte, und aus den ägyptischen Gräberfunden aus dem vierten vorchristlichen Jahrtausend erfahren wir, daß damals in der benachbarten Wüste noch auf Giraffen, Elefanten und Löwen gejagt wurde, woraus man wohl auf einen mehr steppenartigen Charakter schließen darf. Das Stauwerk, das die alten Ägypter im Wadi Geraui errichtet haben, wäre zwecklos gewesen, wenn es damals nicht mehr geregnet hätte als heutzutage. ${ }^{31}$ Wir wissen auch, đă $B$ die Sahara einst wasserreicher war, daß Flüsse damals Täler ausfurchten, und in der Oase Chargeh Steineichen wuchsen. GaUtien, der kürzlich die Wüste zwischen Algerien und dem Niger durchquerte, fand zahlreiche Beweise, daß diese Gegenden noch in der jüngeren Steinzeit verhältnismäßig dicht bevölkert waren. Auch für Südafrika hat PASSARGE ${ }^{32}$ eine Pluvialzeit nachgewiesen. In Turan hatten sich die Seen mächtig ausgebreitet, der Kaspisee stand noch mit dem Schwarzen Meer in Verbindung. Schlagendere Gründe für die Annahme der Gleichzeitigkeit der Pluvial- und Eisperioden liefern aber die großen Seen auf dem trockenen Hochland der westlichen Vereinigten Staaten, der Bonneville-See, ${ }^{33}$ dessen kümmerlicher Überrest der Große Salzsee ist, der Lahontan-See ${ }^{34}$ am Fuß der Sierra

$\times$ An der Magalhāesstraße liegt die Sehneegrenze jetzt ebenso hoch wie in der Eiszeit in den nördlichen Alpen, nämlich in $1100 \mathrm{~m}$ Seehöhe, trotzdem der Winter wärmer ist als jetzt in Salzburg:

\begin{tabular}{|c|c|c|c|c|c|c|c|}
\hline & Winter & Frühling & Sommer & Herbst & $\begin{array}{c}\text { Kältester } \\
\text { Monat }\end{array}$ & $\begin{array}{c}\text { Wärmster } \\
\text { Monat }\end{array}$ & Jahr \\
\hline Salzburg $(+)$. & $-1,5^{0}$ & $8,0^{\circ}$ & $17,0^{\circ}$ & $8,3^{0}$ & $-2,4^{0}$ & $17,8^{\circ}$ & $7,9^{0}$ \\
\hline Punta Arenas (-) & 2,1 & 6,6 & 10,5 & 7,0 & 1,0 & 11,0 & 6,5 \\
\hline
\end{tabular}

Entscheidend ist also die Temperatur der wärmeren Jahreshälfte. Auch BrockMANN-JEROSCH ${ }^{28}$ gesteht aus botanischen Gründen nur eineTemperaturerniedrigung von $1,5^{\circ} \mathrm{zu}$ und bezeichnet das Klima der Eiszeit als ein ozeanisches mit reichlichen Niederschlägen. 
Nevada u. a., die so deutliche Strandlinien hinterlassen haben, daB man ihre einstige Fläche - $109300 \mathrm{qkm}$ gegen $15400 \mathrm{qkm}$ in der Gegenwart - ziemlich genau ermitteln konnte. Entscheidend ist, daß hier zwei Schwellungsperioden, entsprechend den beiden Eiszeiten der höheren amerikanischen Breiten, deutlich erkennbar sind, und $\mathrm{da} B$ in $\operatorname{der}$ Zwischenzeit die Seenbedeckung wahrscheinlich noch unter das gegenwärtige $\mathrm{Maß}$ herabsank. Ein anderes Zeichen für die Gleichzeitigkeit ist darin $\mathrm{zu}$ erblicken, daß in Nordindien, wo die diluviale Schneegrenze in etwa $3600 \mathrm{~m}$. Seehöhe gelegen sein mochte, der südliche Himalaya Gletscher bis $2000 \mathrm{~m}$ hinabsandte, während im Salt Range, der in $1530 \mathrm{~m}$ gipfelt, die Diluvialzeit nach E. KoKen durch reichlichere Niederschläge als jetzt und große Ströme ausgezeichnet war. In den großen Talterrassensystemen, die VoLz ${ }^{35}$ in Sumatra beobachtet hat, sieht er einen Beweis, da $B$ auch die feuchteren Tropengebiete zum Beginn des quartären Zeitalters eine regenreichere Periode erlebt haben.

Zwingende Beweise sind weder für noch gegen die Gleichzeitigkeit der Eis- und Pluvialperioden auf der ganzen Erde geliefert worden, $\times$ aber Wahrscheinlichkeitsgründe, vor allem die Eiszeit der Äquatorialzone, sprechen dafür. Auch folgte die Verteilung der Schneegrenzen den gleichen Gesetzen wie in der Gegenwart. Sie senkte sich von den Tropen gegen die Pole, wenn auch nicht um den gleichen Betrag, wie man früher vermutet hatte. Doch läßt sich auch dafür eine Erklärung geben, wenn man annimmt, daßi das $\mathrm{MaB}$ ihrer Erniedrigung in der warmen Zone die Norm war, und der höhere Betrag in den mittleren Breiten auf Rechnung des erkältenden Einflusses der benachbarten großen Inlandeismassen zu setzen ist. Soweit unsere Kenntnisse reichen, hob sich die diluviale Schneegrenze in allen Breiten in der Richtung von der Küste landeinwärts; $\times \times$ die Verteilung von Wasser und Land dürfte also damals nicht wesentlich anders gewesen sein als heutzutage.

Daß auch die diluviale Eisdecke starken Oszillationen unterworfen war, wird allgemein anerkannt, aber die Mehrzahl der gegenwärtigen Glazialforscher neigt auch der Ansicht zu, daß die Rückzugsphasen nach Dauer und Intensität völlige Unterbrechungen der

$\times$ Die Eiszeit auf Neuseeland halten Hutron u. a. für älter, und die Eiszeit in Kamtschatka und im nordöstlichen Asien hält Bogdanowrrson für jünger als die europäische. Selbst die Inlandeismassen Nordamerikas hält TrrReLt nicht für streng gleichzeitig, sondern meint, der Hauptvorstoß habe sich in der Richtung W-O immer mehr verspätet.

$\times \times$ Sehr deutlich zeigt sich dies auf der Balkanhalbinsel ${ }^{36}$, z. B.:

Orjen (Dalmatien) Höhe 1895, Schneegrenze 12-1400, Gletscherende unter $1000 \mathrm{~m}$ Rila (Bulgarien) , 2930 
Eiszeit waren. In den warmen und trockenen Interglazialzeiten soll die Eisbedeckung nicht größer, ja z. T. sogar kleiner gewesen sein als in der Gegenwart. So unterscheiden Penck und BRÜCKNER ${ }^{37}$ in den Alpen vier Eiszeiten, denen im nördlichen Vorland ebensoviele Schotterablagerungen entsprechen, und drei Interglazialzeiten, die sich dort durch Zwischenschichten aus Löß dokumentieren. ${ }^{\times}$Die deutlichsten Spuren hat selbstrerständlich die letzte Eiszeit hinterlassen; auch während derselben machten sich Schwankungen bemerkbar, und ihr Übergang zur Gegenwart vollzog sich etappenweise mit einem deutlichen Rückfall. Auf den britischen Inseln hat J. GEIKIE sechs Eiszeiten unterschieden, während Laмplugh hier die Hypothese der Interglazialzeit ablehnt. Unsere Geologen nehmen für die norddeutsche Ebene drei Eiszeiten an, Leverett für Nordamerika vier. Für die Einheitlichkeit der Eiszeit, die noch GEINITz ${ }^{38}$ und FrECH ${ }^{39}$ verfechten, sprachen lange Zeit die Verhältnisse in Skandinavien, bis es gelang, auch hier - in den Bohrprofilen von Jaederen - interglaziale Ablagerungen festzustellen. ${ }^{40}$

Aber nicht genug, daß sich die quartäre Eiszeit in eine Vielheit spaltet, auch in den älteren Perioden der Erdgeschichte treten Spuren von Eiszeiten auf. Wir lassen es dahingestellt, ob die Beweise für die unterkambrische, die silurische und die devonische Eiszeit stichhaltig genug sind, aber gewisse permische Ablagerungen verraten deutliche Anzeichen glazialen Ursprungs. Man kannte sie bisher nur von dem Umkreis des Indischen Ozeans (Australien, Vorderindien, Südafrika), jetzt hat man sie auch im Kongobecken und in Togo entdeckt, und man darf daraus, auch wenn man mit PHILIPPI ${ }^{41}$ das Vorkommen in Westfalen als fragwürdig ausschaltet, den Schluß ziehen, daß die permische Eiszeit ein ebenso allgemeines Phänomen war wie die quartäre.

Wir gelangen damit zur Erkenntnis von Klimawellen höchster Ordnung. In der Diluvialzeit war das Klima in Mittel-

$\times$ Einteilung mit Angabe der Sehneegrenze unter (-) und über $(+)$ der gegenwärtigen.

IX. Gegenwart .

VIII. Übergangsperiode

4. Daunstadium .

$\pm 0$

3. Gschnitzstadium . . -600

2. Bühlstadium . . . -900

1. Achenschwankung . -700

VII. Würmeiszeit
3. Zweites Maximum
$-1200$
2. Laufenschwankung
$-1000$
1. Erstes Maximum.
$-1200$

VI. Würm-Riß-Interglazialzeit . . . . . +300

V. RiB-Eiszeit . . . . . -1300

IV. Riß-Mindel-Interglazialzeit

III. Mindel-Eiszeit * . . . -1300

II. Mindel-Günz-Interglazialzeit

I. Günz-Eiszeit . $-1200$ 
europa glazial, in der Pliozänzeit gemäßigt wie jetzt, im Miozän halb tropisch, im ältesten Tertiär tropisch. Die tertiäre Waldflora von Spitzbergen und Grönland trägt einen gemäßigten, die ebenfalls tertiäre Flora der antarktischen Seymourinsel $\left(64^{\circ} \mathrm{B}\right)$ einen fast halbtropischen Charakter. Wir können diese Welle nicht mit gleicher Sicherheit weiter rückwärts verfolgen, aber wir können den ganzen Zeitraum zwischen der permischen und der quartären Eiszeit als eine große Klimaperiode auffassen. Dies macht das Glazialproblem verwickelter. Früher dachte man sich die Eiszeit - man kannte nur eine einzige - als eine extreme Episode im stetigen Abkühlungsprozeß, jetzt ist sie eine im ganzen Entwicklungsgang der Erde begründete wiederkehrende Erscheinung. Früher fragte man sich, welche abnormen Bedingungen haben die nordische Eiskappe im Diluvium geschaffen?, jetzt frägt man: wie kommen die großen Klimawellen zustande? Damit verengt sich der Kreis der möglichen Ursachen. Als solche sind Verschiebungen der Pole (womit man jetzt so freigebig umgeht!), Veränderungen in der Verteilung von Wasser und Land und Abnahme der Seehöhen schon durch die Allgemeinheit der letzten Eiszeit ausgeschlossen. Verlegt man die Ursache in die Erde, so ist man zur Annahme geologischer Zyklen gezwungen. Die Klimaschwankungen werden in diesem Fall aufgefaßt als Folgeerscheinungen des an- und abschwellenden Vulkanismus, der die Zusammensetzung und damit die thermische Durchlässigkeit der Lufthülle beeinflußt. DE MARCHI ${ }^{42}$ legt dabei das Hauptgewicht auf die Zufuhr von Wasserdampf, Arrenenius ${ }^{43}$ auf die Zufuhr von Kohlensäure, SARAsiN ${ }^{44}$ auf die Erzeugung von Höhenstaubwolken nach Art jener, die den Krakatau-Ausbruch begleiteten, und Hofmmann ${ }^{45}$ auf das Zusammenwirken aller drei Momente. Ein größeres Ansehen hat nur die Theorie von ArRHenrus gewonnen. Die Bedeutung der Kohlensäure besteht darin, daß sie die Rückstrahlung der der Erde zugeführten Wärme in den Weltraum durch ihre Absorptionsfähigkeit vermindert. Man hat berechnet. daB eine Verarmung der Luft an Kohlensäure um 54 Prozent ihres gegenwärtigen Gehaltes hinreichen würde, um die mittlere Temperatur um $4-5^{0}$ zu erniedrigen, und da $\beta$ eine Steigerung des Gehaltes um das̀ Vier- bis Sechsfache die gegenwärtige Temperatur um $8-9^{\circ}$ erhöhen würde. Der Gehalt an Kohlensäure wechselt, er wird gesteigert durch vulkanische Eruptionen und durch die kohlensauren Gas- und Wasserquellen, vermindert hauptsächlich durch Kohlenund Kalkbildung und durch den ZersetzungsprozeB der Silikate. $\mathrm{FRECH}^{46}$ findet diese Theorie in der Erdgeschichte bestätigt: „Jede Eiszeit fällt mit dem völligen oder annähernd völligen Aufhören 
der vulkanischen Tätigkeit zusammen; jeder Höhepunkt vulkanischer Ausbrüche schlieBt Eiszeiten aus." Daß die permische und die quartäre Eiszeit auf Perioden starker Kohlenanhäufung folgen, ist sehr beachtenswert. Aber eine Erklärung der Interglazialzeiten fehlt, da sich diese durch keine lebhaftere vulkanische Tätigkeit auszeichneten. Um diesem Mangel abzuhelfen, haben ChamberLin und SAurssbury ${ }^{47}$ die Ansicht $\mathrm{zu}$ begründen versucht, daß in den Interglazialzeiten die warmen, in den Eiszeiten die kalten Meeresströmungen vorherrschten; aber müssen sich diese Strömungen nicht stets kompensieren?

Man kann die Ursache der geologischen Klimaperioden auch in den Veränderungen der Stellung der Erde zur Sonne suchen. Diese sind dreierlei Art. Die Schiefe der Ekliptik, die jetzt $23^{0-27}$ beträgt, schwankt innerhalb von etwa $40000 \mathrm{Jahren}$ höchstens zwischen $22^{\circ} 6^{\prime}$ und $24^{\circ} 50^{\prime}$. Der Einfluß dieser Schwankung auf die Erwärmung der Erdoberfläche ergibt sich ohne weiteres aus dem Grundgesetz des solaren Klimas (s. S. 60).

Mit zunehmender Schiefe der Ekliptik wächst (mit Ausnahme des Äquators) Sonnenhöhe und Tageslänge im Sommer und nimmt im Winter ab, $\times$ aber die von Eкноцм ${ }^{48}$ berechneten Abweichungen der Temperatur von der gegenwärtigen $\times \times$ reichen an sich nicht aus, um Eiszeiten zu erzeugen, eine Verkleinerung der Schiefe könnte aber nach der Ansicht von Herz ${ }^{49}$ wohl an irgend einer Stelle die Eisbildung einleiten, diese würde eine Abweichung des Rotationsvom Trägheitspol und diese wieder Verschiebungen des Meeres zur Folge haben. Anderseits stimmen die Sommertemperaturen für die Maximalschiefe vor 9100 Jahren gut mit denjenigen, die sich aus

$\times$ Aus den Formeln (S. 61) ergibt sich z. B. für $60^{\circ}$ B.:

\begin{tabular}{|c|c|c|c|c|c|}
\hline \multirow[b]{2}{*}{$\begin{array}{c}\text { Schiefe } \\
\text { der Ekliptik }\end{array}$} & \multicolumn{2}{|c|}{ Sonnenböhe } & \multicolumn{3}{|c|}{ Tageslänge } \\
\hline & $\begin{array}{l}\text { Sommer- } \\
\text { Solstitiumm }\end{array}$ & $\begin{array}{l}\text { Winter- } \\
\text { Solstitium }\end{array}$ & & Bte & kleinste \\
\hline $23^{0} 27^{\prime}$ & $53^{0} 27^{\prime}$ & $6^{0} 33^{\prime}$ & $18^{\mathrm{h}}$ & $30^{\mathrm{m}}$ & $5^{\mathrm{h}} 30^{\mathrm{m}}$ \\
\hline $24 \quad 50$ & $54 \quad 50$ & $5 \quad 10$ & 19 & 6 & $4 \quad 54$ \\
\hline 22 & 52 & 54 & 17 & 54 & 6 \\
\hline
\end{tabular}

$x \times$ Positive und negative Abweichungen der Temperatur von der gegenwärtigen im Winter- (WH) und Sommerhalbjahr (SH) und im Jahresmittel (J).

Vor 9100 Jahren, Sch, d, E. $=24,24^{0}$

$\begin{array}{rrrr}\text { NB. } & \text { WH. } & \text { SH. } & \text { J. } \\ 90^{\circ} & 0,0^{\circ} & 3,2^{\circ} & 1,0^{\circ} \\ 70 & -0,4 & 2,4 & 1,0 \\ 50 & -1,0 & 1,1 & 0,05 \\ 30 & -0,7 & 0,5 & -0,1 \\ 10 & -0,4 & 0,0 & -0,2 \\ 0 & -0,2 & -0,2 & -0,2\end{array}$

Vor 28300 Jahren, Sch, d. E, $=22,13^{\circ}$

$\begin{array}{ccc}\text { WH. } & \text { SH. } & \text { J. } \\ 0,0^{\circ} & -5,1^{\circ} & -2,55^{\circ} \\ 0,7 & -3,8 & -1,55 \\ 1,7 & -1,6 & -0,05 \\ 1,3 & -0,6 & 0,35 \\ 0,7 & 0,1 & 0,4 \\ 0,4 & 0,4 & 0,4\end{array}$


der Verbreitung der Haselnuß in Schweden in der nachglazialen Wärmeperiode ergeben (vgl. S. 242).

Eine zweite Störung. haben wir unter dem Namen Präzession bereits kennen gelernt (S. 59). Gegenwärtig liegt die Schneegrenze auf der südlichen Halbkugel tiefer als auf unserer. Ein aphelischer Winter scheint also der Vereisung günstig zu sein, wir haben jedoch bereits auf S. 60 und 97 darauf aufmerksam gemacht, daß die Verteilung von Wasser und Land jetzt ein viel wichtigerer Faktor ist, als die Entfernung der Erde von der Sonne. Aber auch diese ändert sich. Die Exzentrizität der Erdbahn $(\varepsilon)$ die jetzt nur 0,0167 beträgt, ist einer Periode von 91800 Jahren unterworfen und schwankt zwischen den allerdings nur in den seltensten Fällen erreichten Extremen 0,0745 (oder 0,0778) und nahezu Null. Bei hoher Exzentrizität steigert sich der Unterschied zwischen dem Winterund Sommerhalbjahr $(=465 \varepsilon)$, der jetzt nur 7,8 Tage beträgt, auf 34,6 (oder 36,2) Tage, und darauf gründete CroLL ${ }^{50}$ seine berühmte Theorie, die sich lange Zeit hindurch des größten Ansehens erfreute. Bei hoher Exzentrizität hat diejenige Halbkugel Eiszeit, deren Winter in das Aphel fällt, und die Vereisung ist nicht so sehr eine Folge der direkten klimatischen Veränderungen, als der dadurch bedingten Verschiebungen der Meeresströme. Aber die Tatsachen sprechen für die Gleichzeitigkeit der Eiszeit auf beiden Halbkugeln, nicht für abwechselnde Eiszeiten auf der einen, dann auf der andern Halbkugel. Um diesem Umstand Rechnung zu tragen, hat PILGRIM ${ }^{51}$ auch die Schwankung der Schiefe der Ekliptik in die Rechnung eingeführt und das Zusammenwirken-aller drei Störungen für eine Million Jahre in der Vergangenheit berechnet. Aus diesen Ergebnissen leitete er dann die Schwankungen der Schneegrenze in den Alpen ab (vgl. Fig. 56). Das geschah unter Voraussetzungen, die freilich noch problematisch sind. Die durch die astronomischen Verhältnisse bedingten Schwankungen sind verhältnismäBig klein und reichen nicht im entferntesten aus, die Erscheinungen der diluvialen Glazialperiode zu erklären. Ist aber einmal eine Inlandeisdecke zustande gekommen, so wirkt sie ebenfalls abkühlend, und dieser Faktor fällt mehr ins Gewicht als der astronomische. Ja sein EinfluB dehnt sich noch bis in die folgende Interglazialzeit aus und bewirkt, daB Inlandeismassen auch Interglazialzeiten überdauern können. Das grönländische Inlandeis z. B. ist nach dieser Auffassung ein Überbleibsel aus der früheren Glazialzeit, das die gegenwärtigen interglazialen Temperaturverhältnisse wohl zurückdrängen, aber nicht vernichten konnten. Wir sehen in Fig. 56 ein fortwährendes Auf- und Abschwanken der alpinen Schneegrenze. Das 
sind die alle 10000 Jahre wechselnden astronomischen Glazialund Interglazialzeiten. In ihrer Anordnung zeigen sich aber Perioden höherer Ordnung, die durch die durchgelegte Kurve versinnlicht werden. Das sind die geologischen Eis- und Interglazialzeiten. Die gesamte Glazialperiode dauerte nach Pilgrim über eine Million Jahre. Aber wir dürfen dieser Chronologie kein großes Gewicht beilegen, wie ja überhaupt die ganze hier vorgetragene Theorie vorderhand nur als ein geistreicher und beachtenswerter Versuch, nicht als eine Lösung zu betrachten ist.

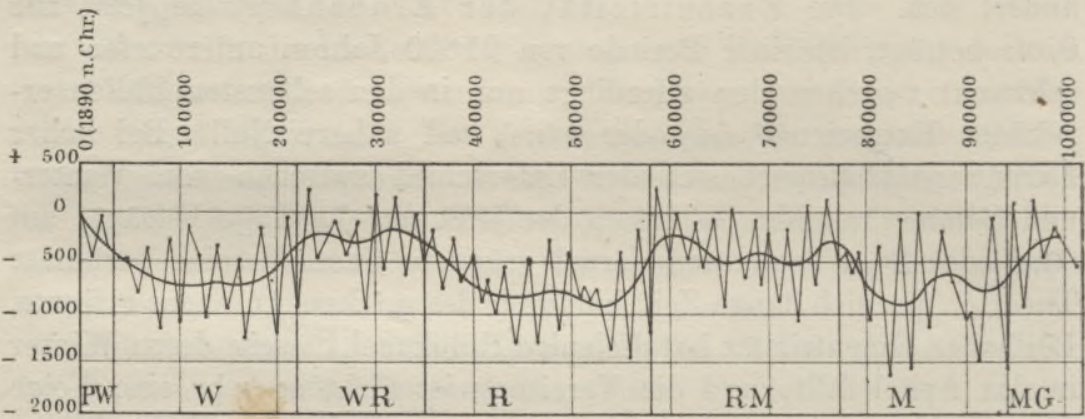

Fig. 56. Die Schwankungen der Schneegrenze in den Alpen nach PILGRIM,

Die Schneegrenzenhöhen in Abweichung von der gegenwärtigen. In der Höhe ist $1 \mathrm{~mm}=100 \mathrm{~m}$, in der Länge $=10000 \mathrm{Jahre}$, d. h. eine halbe Präzessionsperiode. $P W=$ Postwürmzeit, $W=$ Würmeiszeit, $W R=W$ ürm-Ri $\beta$-Interglazialzeit, $R=$ Ri $\}$ Eiszeit, $R M=$ Riß-Mindel-Interglazialzeit, $M=$ Mindel-Eiszeit, $M G=$ Mindel-GünzInterglazialzeit.

Eine dritte Gruppe von Theorien verlegt die Ursache der geologischen Klimaschwankungen ganz außerhalb der Erde. Ausgehend von der Beobachtung, daß sich das Sonnensystem im Weltenraum fortbewegt, nimmt NöLKE ${ }^{52}$ an, daß die Sonne zeitweise kosmische Nebel passierte, die einen Teil ihrer Licht- und Wärmestrahlung absorbierten; der Wechsel von Glazial- und Interglazialzeiten könnte durch den Wechsel dichterer und dünnerer Stellen in der Nebelmasse erklärt werden. Nahe liegt die Annahme langperiodiger Schwankungen der Sonnenstrahlung selbst, aber leider wissen wir darüber noch nichts Sicheres. Während LANGLEY 1903 eine ausgesprochene Abnahme der Sonnenstrahlung zu erkennen glaubte, leugnet Nеwсомв alle solche Schwankungen mit Ausnahme der elfjährigen und hält auch diese für ganz geringfügig.

Für uns hat die Frage der geologischen Klimaschwankungen ein mehr als nur theoretisches Interesse. Befinden wir uns in einer Interglazialzeit oder gehen wir einer neuen Tertiärperiode entgegen? Schuster ${ }^{53}$ hat sich für letzteres ausgesprochen, indem er 
auf verschiedene tiergeographische Änderungen, unter anderen auf das immer häufiger beobachtete Überwintern einzelner Zugvögel und das seltenere Auftreten nordischer Wandergäste hinwies. Kann man eine so weittragende Beweiskraft diesen Argumenten auch nicht zuerkennen, so sind sie doch immerhin beachtenswert.

Klimaänderungen. Unter dem Gesichtspunkt der Klimaschwankungen betrachtet, gewinnen auch die verschiedenen, immer wieder auftauchenden Nachrichten über die Änderung des Klimas einzelner Gegenden eine ganz neue Beleuchtung. Es wurde darüber ein zeitweise erbitterter Streit geführt, aber Gegner und Verteidiger können sich heute die Hand reichen, ohne ihre Ansichten gänzlich ändern zu müssen. Nur müssen die ersteren zugeben, daß das Klima in der Tat nichts Konstantes ist, daß Änderungen von verschiedener Dauer stattfinden, und daß jede Generation solche Änderungen erfährt, die ihr bei oberflächlicher Betrachtung als dauernd erscheinen können. Früher sagte man, das Klima ändere sich lokal, aber dauernd; jetzt sagen wir: die Klimaänderungen sind zeitlich beschränkt, aber allgemein. Da wir nur mit Normalwerten operieren, so können wir die Grenzen der Klimaprovinzen im großen und ganzen als konstant ansehen, vom Standpunkt der säkularen Schwankungen betrachtet, sind sie es aber wahrscheinlich nicht. Nur muß man in dieser Beziehung größte Vorsicht walten lassen, weil die Nachrichten, aus verschiedenen Zeiten stammend, sehr leicht nur die BRÜCKNeR'schen Perioden widerspiegeln können und daher nicht einfach aneinander gereiht werden dürfen. Es könnte dabei geschehen, daß wir nur die absteigenden Äste aufeinander folgender Klimawellen wahrnehmen, nicht aber die dazwischen liegenden aufsteigenden, und dies könnte zu ganz falschen Schlüssen führen. Selbst wenn man diese Klippe vermeidet, wie das bei Екноцм's Vergleich der Beobachtungen in Uranienborg 1582-97 (durch Tұсно Вrahe) und 1881-98 der Fall ist, sind weittragende Scĥlüsse nicht zulässig, denn die Abweichungen sind nicht so auffällig, da $B$ sie nicht auch in Beobachtungs- und Instrumentalfehlern oder in anderen Zufälligkeiten begründet sein könnten. Mit großer Bestimmtheit tritt die Behauptung einer zunehmenden Austrocknung auf. Daß die Eiszeit in eine wasserreichere Periode, die Göтz ${ }^{54}$ als Regenzeit und KвороткіN ${ }^{55}$ als Seenperiode bezeichnet, ausklang, ist möglich; auch die auf S. 244 erwähnten ägyptischen Gräberfunde sprechen dafür. Die Frage ist aber die: nehmen die Niederschläge seit jener Zeit beständig ab, und sind die längeren Perioden, z. B. die BRÜCKNFR'schen, nur als untergeordnete Schwan- 
kungen zu betrachten? Selbst langjährige Aufzeichnungen $\times$ liefern keinen Anhaltspunkt dafür, aber man kann einwenden, daß sie zur Beantwortung dieser Frage nicht ausreichen. Man beruft sich auf die Zeugnisse der Geschichte. Aber wie schwer ist es hier, die Ursachen einer Veränderung reinlich voneinander zu scheiden! Hat, wie man von Zeit zu Zeit immer wieder behauptet, stetige Regenabnahme Griechenland, Kleinasien, Syrien und andere Kulturstätten des Altertums zur Verödung und Barbarei verurteilt, oder ist nur die Untüchtigkeit der jetzigen Bewohner dafür verantwortlich zu machen? Wahrscheinlich das letztere, denn einerseits hat UNGER schon vor Jahren nachgewiesen, daß jene-Länder auch im Altertum an Wassermangel litten, und anderseits blüht die alte Fruchtbarkeit wieder auf, wenn - wie bei Urfa, Aintab, Mess'r und a. a. O. der Boden durch ein ausgebreitetes Kanalsystem genügend benetzt wird. Für Nordafrika hat kürzlich Leitnen ${ }^{56}$ die Frage der Klimaänderung in geschichtlicher Zeit sorgfältig untersucht und ist $\mathrm{zu}$ einem verneinenden Ergebnis gekommen. Es ist bezeichnend, daß alle neueren Nachrichten über Austrocknung aus Gebieten stammen, die von Natur aus regenarm sind, wie aus Zentralasien, wo die Entdeckung buddhistischer Ruinenstätten in der Wüste Taklamakan berechtigtes Aufsehen erregt hat, ${ }^{57}$ aus dem östlichen Iran, ${ }^{58}$ aus Südamerika, ${ }^{59}$ und aus Südafrika. Das Seichterwerden von Flüssen, das Versiegen von Quellen und Brunnen sind Veränderungen, die hier tief in das menschliche Wirtschaftsleben einschneiden und daher einwandfrei festzustellen sind. Aber alle diese Erscheinungen können auch andere Ursachen haben, als eine Abnahme der Niederschläge. Sandverwehung durch den Wind kann die Grenzen der Wüste verschieben. Die Vernichtung von Waldbeständen kann die Bodenfeuchtigkeit vermindern, namentlich in Ländern ohne Schneedecke und mit kurzer Regenzeit. PAssarge ${ }^{32}$ hat auch betont, daß der aus der Pluvialzeit stammende Vorrat von unterirdischem Wasser in Ländern, die von Natur aus trocken sind, auch ohne Regenabnahme einer allmählichen Erschöpfung entgegengehen muß, besonders wenn der Mensch sie ausnutzt. Übrigens ist auch die Möglichkeit zunehmender Austrocknung solcher Länderräume, die von der Zufuhr maritimer Feuchtigkeit abgeschnitten sind, nicht von

$\times$ 35jährige Normalmittel nach $\mathrm{H}_{\mathrm{AHN}}:^{13}$

$\begin{array}{lccccc} & 1726-60 & 1761-95 & 1795-1830 & 1831-65 & 1865-1900 \\ \text { Padua . . . } & 880 & 923 & 835 & 836 & 835 \mathrm{~mm} \\ \text { Mailand. . . } & - & 920 & 1010 & 1080 & 1020 \quad " \\ \text { Klagenfurt. . } & - & - & - & 950 & 1020 \quad "\end{array}$


der Hand zu weisen, braucht aber nichts mit einer allgemeinen Klimaänderung zu tun zu haben, weil jede zufällige Verminderung der im Land erzeugten Luftfeuchtigkeit eine Verminderung des Niederschlages, diese eine weitere Verminderung der Feuchtigkeitsquelle usw. zur Folge hat, die Wirkung also die Ursache steigert. Das Hauptgewicht legte man auf die Zusammenschrumpfung der Seen, aber dieses Argument erwies sich als wenig stichhaltig, und nichts ist geeigneter, vor voreiligen Schlüssen in dieser Frage zu warnen, als die Tatsache, daß der Aralsee seit ungefähr 1880 wieder im Steigen begriffen ist. Eine Wasserstandsmarke vom Jahr 1874 war 1903 bereits um 2,75 m überschritten, und das nordöstliche Ufer ist ein paar Kilometer weit überschwemmt. Nach WoErkow's Schätzung enthielt der Aralsee 190820 Proz. mehr Wasser als 1880. Eine ähnliche Zunahme wurde auch an anderen Seen benachbarter Gegenden, z. B. im Gouvernement der Steppe, am Issykkul, Balkaschsee, Saissan-nor u. a. beobachtet und steht in völliger Übereinstimmung mit dem gleichzeitigen Anschwellen der Flüsse und dem Vorrücken der Gletscher des Tiënschan. ${ }^{60}$

Wie REICHELT ${ }^{61}$ urkundenmäBig nachgewiesen hat, hatte der Weinbau in Deutschland um das Jahr 1300 seine größte Ausbreitung erreicht, selbst nach Niederbayern, Thüringen und Brandenburg war er vorgedrungen. Hat sich seitdem das Klima verschlechtert? Nichts zwingt uns zu diesem Schluß. Der kirchliche Gebrauch des Weines bei der Messe ließ es, besonders den Klöstern, wünschenswert erscheinen, ihn überall anzubauen, wo er in günstigen Jahren eben noch fortkommt; die Güte des Erzeugnisses spielte dabei keine Rolle. Je mehr sich aber der Geschmack und die Verkehrsmittel verbesserten, desto mehr zog sich der Weinbau in Gegenden zurück, wo er noch als ein lohnender Zweig der Landwirtschaft betrieben werden kann. Sehr oft werden Kulturen aufgegeben, weil sich ihr Erträgnis aus äußeren Gründen vermindert. So verschwindet allmählich der Maulbeerbaum aus Südtirol, weil die Konkurrenz der ostasiatischen Seide zu mächtig geworden ist, und in einigen Jahrhunderten könnte ein Gelehrter daraus eine Klimaänderung folgern, wenn ihn nicht die zahlreichen Geschichtsquellen der Gegenwart über die wahren Ursachen belehren würden. Ganz in das Gebiet der Sage gehören die Nachrichten von dem einstigen Kornreichtum Islands, von skandinavischen Ansiedlungen an der Osküste Grönlands, von der Gangbarkeit alpiner Pässe, die jetzt vergletschert sind uswे. Sie sind alle teils durch Untersuchungen an Ort und Stelle - wie in Grönland -, teils durch die historische Kritik widerlegt worden, was natürlich nicht verhindern wird, daß man sie 
von Zeit zu Zeit immer wieder einem leichtgläubigen Publikum aufzutischen versuchen wird.

Einfluß des Waldes. Die schwierigste und am meisten umstrittene Frage ist die nach dem Einfluß des Waldes auf das Klima. Daß er als Windbrecher wirkt, ist eine tägliche Erfahrung; er bietet dadurch ebenso Schutz wie ein Gebirge, nur in geringerem Grad. Alle seine anderen Einflüsse werden aber vielleicht überschätzt. Jedenfalls haben die verschiedenen Untersuchungsmethoden verschiedene Ergebnisse geliefert. Wenn man, wie es z. B. WorIkow tat, große Waldgegenden mit unbewaldeten vergleicht, so scheinen sich überall die ersteren durch niederere Jahrestemperatur, geringere Wärmeschwankungen und reichlichere Niederschläge vor den letzteren auszuzeichnen. Diese Methode ist aber nicht einwandfrei, weil man möglicherweise dem Wald zuschreibt, was in der Tat eine Wirkung anderer Faktoren ist. Es ist doch auffallend, daB die forstlich-meteorologischen Beobachtungen in Deutschland, Österreich und Schweden einen so weit reichenden Einfluß nicht erkennen lassen, ${ }^{62}$ und für Sachsen ist Schreiber durch eine eingehende Analyse zu demselben Resultat gelangt. Betreffs der Lufttemperatur ist zwar festgestellt, daß sie unter den Baumkronen etwas niederiger ist als in den Lichtungen, und hier wieder etwas niederiger als an den benachbarten Freilandstationen, aber im Jahresmittel höchstens um einige Zehntel Grad. Auch sind die Schwankungen im eigentlichen Wald geringer als in der Lichtung und im Freiland, denn das Laubdach schützt namentlich in der Vegetationszeit vor intensiver Ein- und Ausstrahlung, und das echte Waldklima nähert sich in dieser Beziehung dem Seeklima. Gerade die Eigenschaft des Windbrechers hindert aber das Innere des Waldes, in klimatische Wechselbeziehung zum entfernten Freiland zu treten; nur die Temperaturverhältnisse der Baumkronen können durch Vermittelung von Luftströmungen auf größere Entfernung wirken, und zwar, wie die Erfahrung gelehrt hat, besonders in der kälteren Tageshälfte, wenn die Baumkronen bei klarem Himmel rascher erkalten als der nackte Boden. Im großen und ganzen ist also der Einfluß des Waldes auf die Temperaturverteilung, wenigstens in den Kulturländern unserer Breiten, sehr mäßig; und niemand wird behaupten wollen, daß sich das Isothermensystem gänzlich umgestalten würde, wenn Europa und Asien von Ozean zu Ozean ein einziger Wald wäre. Der Einfluß auf die Regenmenge kann theoretisch nicht geleugnet werden, seitdem man auch die Landfeuchtigkeit als eine Quelle der Niederschläge erkannt hat, und man darf auch nicht vergessen, daß der Wald indirekt den Regen begünstigt, indem er 
horizontale Luftströmungen zum Aufsteigen nötigt. Trotzdem haben auch in diesem Punkt die Beobachtungen nur ein zweifelhaftes Resultat ergeben. SchubERT ${ }^{63}$ fand $\mathrm{zwar}$ in waldreichen Gegenden im Sommerhalbjahr einen Mehrniederschlag von 6 Proz., davon sind aber 3 Proz. auf Rechnung der Aufstellung des Regenmessers zu setzen, weil ein geschütztes Instrument mehr Regen auffängt als ein ganz frei stehendes, und die übrigen 3 Proz. sind noch mit einer Unsicherheit von 2 Proz. behaftet. In Schlesien ist die Regenmenge im Waldland $25 \mathrm{~mm}$ höher als im Freiland, der Einfluß des Waldes ist also nur gleichzuachten einer Bodenerhebung von $44 \mathrm{~m}$. Man muß eben berücksichtigen, daß die Feuchtigkeit, die ein Waldgebiet erzeugt, durch Winde entführt und ferner liegenden, vielleicht waldarmen Gegenden zugute kommen kann. $\times$ Ein schlagenderer Beweis für die regenerhöhende Kraft des Waldes scheint aus folgendem hervorzugehen. BLANFoRd hat die Regenverhältnisse eines Gebietes von ungefähr $160000 \mathrm{qkm}$ in den indischen Zentralprovinzen vor und nach der Bewaldung, die 1875 begann, untersucht, und um den Einfluß der Perioden dritter Ordnung auszuschließen, mit den Niederschlägen von ganz Indien verglichen. Das Ergebnis war folgendes:

$\begin{array}{lcl} & 1869-75 & 1875-83 \\ \text { Wald der Zentralprovinzen . . . } 1215 & 1369 \mathrm{~mm} \\ \text { Ganz Indien . . . . . . . } 1072 & 1074 \text { " }\end{array}$

Das betreffende Gebiet war vor der Bewaldung um 13, nach derselben aber um 27 Proz, regenreicher als Indien im Gesamtdurchschnitt. 14 Proz. könnten also auf Rechnung der Bewaldung gesetzt werden. Aber auch das erscheint uns noch nicht ganz sicher, denn schon 1874, also vor der Wiederbewaldung, begann dort die Regenkurve stark anzusteigen, und außerdem ist die mittlere Regenmenge eines Landes von so gewaltigen Gegensätzen, wie Indien, ein zu schematischer Wert, als daß er als Vergleichsobjekt ein befriedigendes Gefühl der Sicherheit in uns erwecken könnte.

Literaturnachweise. ${ }^{1}$ W. Köppen, Versuch einer Klassifikation der Klimate, in der Geographischen Zeitschrift 1901. ${ }^{2}$ R. HuLt in den Vetenskapliga Meddelanden af geografiska föreningen i Finland, I, 1892-93. 3 E. de Martonne, Traité de géographie physique, Paris 1909. - ${ }^{4}$ A. Penck, Versuch einer Klimaklassifikation auf physiogeographischer Grundlage, in den Sitzungsberichten der Preußischen Akademie der Wissenschaften 1910. ${ }^{5}$ Eine knappe Übersicht gibt J. N. Lockyer, Simultaneous Solar and Terrestrial Changes; in Nature 1904, Bd. LXIX, S. 351. - ${ }^{6}$ Norman und Wrlliam Lockyer

$\times$ Nach den Untersuchungen von E. Marchand wird dureh die Verdunstung der Wälder der französischen Landes die Regenmenge im Umkreis von $240 \mathrm{~km}$, also auf einem Gebiet, das $7-8 \mathrm{mal}$ so grob ist als der Waldbezirk, um $60 \mathrm{~mm}$ vermehrt. 
in der Meteorologisehen Zeitsehrift 1902, S. 423, und 1903, S. 88. W. Lockyer, A Discussion of Australian Meteorology, London 1909. C. Braak hat den EinfluB einer Luftdruekperiode anf die Temperatur und den Regen in Niederländisch-Indien untersucht (Meteorol. Ztschr. 1910 S. 121). $-{ }^{7}$ W. KöpPEN, Über mehrjährige Perioden der Witterung, in der Zeitschrift der Österr. Gesellschaft f. Meteorologie, 1881. - ${ }^{8}$ Ch. Nordmans in den Comptes rendus der Pariser Akademie der Wiss. 1903, Bd. CXXXVI, S. 1047. - 9 E. Brückner, Klimaschwankungen seit 1700; Wien 1890. Nachträge in Petermans's Mitteilungen 1902, S. $173 .-{ }^{10}$ W. Lockyer, Die Sonnentätigkeit 1833-1900. Übersetzung aus den Proceedings of the Royal Society, 1901, in der Meteorologischen Zeitschrift, 1902. - ${ }^{11}$ J. Liznar, ebenda S. 237. - ${ }^{12}$ E. Brückner, 1905, zit. S. 169. 13 J.HANs, Die Schwankungen der Niederschlagsmengen in größeren Zeiträumen, in den Sitzungsberichten der Wiener Akademie der Wiss., math.-naturwiss. Klasse, 1902, Bd. CXI, Abteil. IIa. - ${ }^{14}$ W. Lockyer in Nature 1903, Bd. LXVIII, S. 8. - ${ }^{15}$ Zeitschrift der Gesellschaft für Erdkunde, Berlin 1910, S. 395. ${ }^{16}$ A. Blytт, Zwei Kalktuffbildungen in Gudbrandsdalen; Beiblatt 36 zu Evgler's Botanischem Jahrbuch 1892. - ${ }^{17}$ G. DE Geer und R. Sernander, On the Evidences of Changes of Climate in Scandinavia, in den Geologiska föreningens i Stockholm förhandlingar, Bd. XXX, 1908. - ${ }^{18}$ J. GEIKIE in der Zeitschrift für Gletseherkunde, Bd. I, S. 21. - ${ }^{19}$ Avg. Schulz, Entwieklungsgeschichte der phanerogamen Pflanzendecke Mitteleuropas nördlich der Alpen; Stuttgart 1899. - ${ }^{20}$ G. Axdersson, The Climate of Sweden in the Late-quaternary Period, im Arsbok 1909 von Sveriges geologiska undersökning. - ${ }^{21}$ G. REкstaD im Zentralblatt für Mineralogie ete. 1903, S. 469. - ${ }^{22}$ A. GAvalin in der Skogsvårdsfören. Tidskrift, Stockholm 1909, S. 133. - ${ }^{23}$ E. Geinitz, Das Quartär von Nordeuropa; Stuttgart 1904. - ${ }^{24}$ E. v. ToLL, Die fossilen Eislager und ihre Beziehungen zu den Mammutleichen, in den Mémoires de l'Académie imper. des Sciences de St. Pétersbourg, 1895, Bd. XLII. Über Vorkommnisse in Nowaja Semlja u. Spitzbergen s. La Géographie 1910, Bd. XXII. S. 282. - ${ }^{25}$ A. Bunge in den Verhandlungen der Kais. Russisehen Mineralogischen Gesellschaft 1903, Bd. XL, S. 203: J. P. Tomatschew, ebenda S. 415; J. B. Trrenel im Journal of Geology 1904, Bd. XII, S. 232. - ${ }^{26}$ Hans Meyer, Die Eiszeit in den Tropen, in der Geographischen Zeitschrift, 1904. - ${ }^{27}$ A.Penck, Höhenkarte der Sehneelinie in Europa während der Gegenwart und Eiszeit, in den Verhandlungen des IV. Deutschen Geographentages 1884 ; z. T. veraltet, aber noch immer interessant. $-{ }^{28} \mathrm{H}$. Вrocкmann-Jerosch, Die fossilen Pflanzenreste des glazialen Deltas bei Kaltbrunn, im Jahrbuch der St. Gallischen Naturwissenschaftlichen Gesellschaft 1909. 29 E. Huld, The Survey of Western Palestine; London 1886. - ${ }^{30}$ M. BlanckenHorn, zit. S. 52. - ${ }^{31}$ H. Burmester im Globus 1910, Bd. XCVIII, S. 149. 32 S. Passarge, Die Kalahari; Berlin 1904. - ${ }^{33}$ G. K. Gilbert, Lake Bonneville; Washington 1890. - ${ }^{34}$ J. C. Russeld, Geologieal History of Lake Lahontan; Washington 1885. - ${ }^{35}$ W. Vouz, Nordsumatra, Bd. I, Berlin 1909. - ${ }^{36}$ J. Cvisí́, Neue Ergebnisse über die Eiszeit auf der Balkanhalbinsel, in den Mitteilungen der Wiener Geographischen Gesellschaft, 1904. - ${ }^{37}$ A. Prenck und E. BrǘckNER, Die Alpen im Eiszeitalter; Leipzig 1901-09, ein fundamentales Werk! Eine übersichtliche Darstellung der Resultate gab H. Lautensach im Geographischen Anzeiger, 1909, S. 85 u. 101 (mit Karte, die im Original fehlt) und in der Zeitschrift für Gletscherkunde Bd. IV, S. 1. - ${ }^{38}$ E. Gersirz, Wesen und Ursache der Eiszeit, im Archiv des Vereins der Freunde für Naturgeschichte in Mecklenburg, Bd. LIX, 1905. - ${ }^{\mathbf{9}}$ F. FreCr in der Zeitschrift der Gesellschaft für Erdkunde 1906, S. 543. - 40 O. Bлөrцгкке, Jaederens Geologie, 
Kristiania 1908. - ${ }^{41}$ E. PHuıPPI, Über einige paläoklimatische Probleme, im Neuen Jahrbuch für Mineralogie usw. Beilageband XXIX, 1910. - ${ }^{42}$ L. DE Marchi, Le cause dell' Era glaciale, Pavia 1895. - ${ }^{43}$ Svante Arrhenius, On the Influence of Carbonic Acid in the Air upon the Temperature of the Ground, im Philosophical Magazine, 1896, Bd. XLI. Die vermutliche Ursache der Klimaschwaukungen, in den Meddellanden from K. Vetenskapsakademiens Nobelinstitut, Bd. I, 1906. Die physikalisehen Grundlagen der Kohlensäuretheorie der Klimaveränderungen, im Zentralblatt für Mineralogie usw., 1909. 44 P. und F. SArasin, Über die mutmaBliche Ursache der Eiszeit, in den Verhandlungen der Naturforsehenden Gesellschaft in Basel, Bd. VIII, 1901. 45 J. F. Hofrmann, Grundlinien einer Theorie der Eiszeiten, in den Beiträgen zur Geophysik, 1908, Bd. IX. - ${ }^{46}$ F. Freor, Studien über das Klima der geologischen Vergangenheit, in der Zeitschrift der Gesellschaft für Erdkunde, Berlin, 1902, Die wichtigsten Ergebnisse der Erdgeschichte, in der Geographischen Zeitschrift 1905. Über das Klima der geologischen Perioden, im Neuen Jahrbuch für Mineralogie usw. 1908, Bd. II. - ${ }^{47}$ Tн. C. Сhamberlin u. R. D. SalisBury, Geology, New York 1907, Bd. II u. III. - ${ }^{48}$ N. Eкноцм, On the variations of the Climates of the Geological and Historical Past, and their Causes, im Quarterly Journal of the R. Meteorological Society, Bd. XXVII, 1901. 49 N. Herz, Die Eiszeiten und ihre Ursachen, Leipzig 1909. - 50 J. Croll, Climate and Cosmology, Edinburgh 1885. - ${ }^{51}$ Zit. S. 169, Anm. 3. - ${ }^{52}$ Fr. NöLke, Die Entstehung der Eiszeiten, in den Deutschen geogr. Blättern, Bd. XXXII, Bremen 1909. Neue Erklärung der Entstehung der irdischen Eiszeiten, in den Abhandlungen des naturwissenschaftlichen Vereins in Bremen 1909, Bd. XX. - ${ }^{53}$ W. Schuster im Journal f. Ornithologie; Leipzig 1902, S. 331. ${ }^{54}$ Wнн. Göтz, Historische Geographie; Leipzig 1904. Das Klima am Beginn der neolithischen Zeit, in den Verhandlungen des 16. Deutschen Geographentags, Berlin 1907. - ${ }^{55}$ P. Kropotкrn, The Dessiceation of Eurasia, im Geographical Journal, London 1904, Bd. XXIV. - ${ }^{56}$ H. Lertner, Die Frage der Klimaänderung während geschichtlicher Zeit in Nordafrika, in den Abhandlungen der Geogr. Gesellschaft in Wien, Bd. VIII, 1909. - ${ }^{57}$ Eursworth Hunrington, The Rivers of Chinese Turkestan and the Dessiceation of Asia, im Geographical Journal, Bd. XXVIII, London 1906. M. A. Stern Land-Buried Ruins of Khotan, London 1903. - ${ }^{58}$ R. Pumpeluy, W. M. Davis and Eulsw. HunTIngton, Explorations in Turkestan, Washington 1905. - ${ }^{59}$ I. Bowsan, Man and Climatic Change in South America, im Geographical Journal, Bd. XXXIII, London 1909. - ${ }^{60}$ L. Berg, Trocknet Zentralasien aus? in den Iswestijä der K. Russisehen geographischen Gesellschaft, 1905, Bd. XLI. Auszug in Peterrans's Mitteilungen 1906, Literaturbericht Nr. 491. Vgl. aueh J. de Schokalsky in den Annales de géographie, 1909, Bd. XVIII, S. 407, und A. Woerкow, Der Aralsee, in Petermans's Mitteilungen 1909. - ${ }^{61}$ K. Reichent, Beiträge zur Geschichte des ältesten Weinbaues in Deutschland; Reutlingen 1886. - ${ }^{62} \mathrm{~J}$. Schubert, Der Einflub der Wälder auf das Klima, in der Meteorologisehen Zeitschrift, 1900. - ${ }^{63}$ J. Schubert, Wald und Niedersehlag in Schlesien; Eberswalde 1904. 


\section{Dritter Abschnitt.}

\section{Das Meer.}

\section{Morphologie des Meeres.}

Mit der Luft teilt das Wasser die Eigenschaften der Beweglichkeit seiner Teilchen, aber diese Beweglichkeit findet eine Schranke in der Gestaltung des Gefäßes, das das Wasser umschließt.

Gliederung des Weltmeeres. Die Verschiedenheiten in der Gestalt und Gliederung der Ozeane finden in ihrer mittleren und größten Küstenentfernung den kürzesten ziffernmäßigen Ausdruck. JEAN DE WINDT ${ }^{2}$ ermittelte folgende Werte, wobei er die Grenzen der drei Hauptozeane nach $\mathrm{S}$ bis zu dem hypothetischen Südpolarkontinent verlängerte:

\section{Mittlerer GröBter}

Küstenabstand

\begin{tabular}{|c|c|c|c|c|c|c|}
\hline Atlantischer Ozean & . & & - & & & \\
\hline Indischer Ozean. & . & . & . & & 62 & \\
\hline Großer Ozean . . & . & . & . & & 76 & \\
\hline Gesamtes Weltmeer & & & . & & & \\
\hline
\end{tabular}

Daß der Große Ozean die höchsten Werte aufweist, ist selbstverständlich; überraschend ist dagegen, daß sich der Indische und der Atlantische Ozean in bezug auf die mittlere und die größte Küstenentfernung ganz verschieden verhalten. Das erklärt sich aus ihrer Gestalt: der Indische Ozean ist, wie der Pazifische, eine große Bucht mit immer weiter auseinander fliehenden Landgrenzen, der Atlantische Ozean dagegen ein Tal mit ein- und ausspringenden Winkeln.

Die Gliederung des Meeres spiegelt sich nur zum Teil in der des Landes wieder. Wohl entspricht das Adriatische Meer der langgestreckten Gestalt Italiens und der Bengalische Busen der Dreiecksform Vorderindiens, aber zwischen der arabischen Halbinsel und den sie begrenzenden Meereseinschnitten finden wir keine morpho- 
logischen Beziehungen mehr. Ein so rudimentäres Glied wie die Somalihalbinsel und der nordwestliche Vorsprung des afrikanischen Festlandes ist der Golf von Guinea. Schärfer ausgeprägt sind schon der Arabische und der Bengalische Meerbusen; wir können sie vergleichen mit jenen Halbinseln, deren Bergzüge sich ohne Unterbrechung im Festlandsrumpf fortsetzen. Während sich aber der Boden der genannten Golfe allmählich zur Tiefsee absenkt, ist er in der Baffinbai trogförmig gestaltet, und eine Schwelle trennt ihn von dem Becken des offenen Atlantischen Ozeans. Ein Gegenstück dazu finden wir in jenen gebirgigen Halbinseln, die sich mittels eines Tieflandstreifens an den Festlandsrumpf angliedern. Macht sich die Trennung auch oberseeisch geltend, indem sich die Verbindungsstelle zwischen dem offenen Ozean und seinem Nebenraum zu einer schmalen Pforte verengt, so entsteht ein Binnenmeer, das unter den großen Halbinseln der Gegenwart nur ein typisches Seitenstück findet: die Krim. Im übrigen sind auch die Binnenmeere sehr verschieden. Bald ist die Verbindungsstelle ein einziger schmaler Kanal, wie bei dem europäischen Mittelmeer und dem Persischen Golf, bald ist sie durch insulare Mittelpfeiler in mehrere Eingänge geteilt, wie bei der Ostsee, der Hudsonbai und dem Roten Meer; bald füllen diese Meere tiefe Einstürze der Erdkruste aus, wie im Roten und Mittelländischen Meer, bald flach schüsselförmige Einsenkungen, wie in der Ostsee und Hudsonbai. Der Persische Golf ist das einzige Binnenmeer, dessen Tiefe nach dem Ausgang zu wächst. Ganz eigenartig sind die inselabgeschlossenen Meere in dem Bereich zertrümmerter Faltenzüge. Sie sind eine charakteristische Eigentümlichkeit der pazifischen Welt, die sie am West- und Nordrand umsäumen: das Bering-, Ochotskische und Japanische Meer, die Ostchinesische See und das Australasiatische Mittelmeer bilden eine ununterbrochene Übergangszone zwischen dem gröBten Festland und dem gröBten Meer. Der Atlantische und der Indische Ozean haben nur je ein Glied dieser Art: das Amerikanische Mittelmeer und das Andamanische Meer.

Die 'Binnen- und die inselabgeschlossenen Meere fassen wir unter dem Namen Nebenmeere zusammen. In der Regel sind sie trogartig gestaltet, indem die ozeanischen Ausgangspforten flacher sinid als der innere Raum: ein Umstand, der sich für die vertikale Temperaturverteilung als wichtig erweist. Am typischsten ist die Trogform im Roten Meer ausgeprägt; die tiefste Stelle liegt fast genau in der Mitte. Diese morphologische Eigenschaft verleiht den Nebenmeeren im Gegensatz zu den offenen Busen eine gewisse Selbständigkeit, und zwar den Binnenmeeren in noch höherem Grad 
als den inselabgeschlossenen, weil jene von den großen Meeresströmungen nicht berührt werden. Sie gleichen geschlossenen Häusern mit einem einzigen Tor, während die Meere, die durch Inselketten vom Ozean geschieden werden, offenen Säulenhallen ähnlich sind, durch deren zahlreiche Eingänge die Meeresströme ungehindert einund ausfließen können, sofern nicht die Tiefenverhältnisse Hindernisse bereiten. Die Nordsee zählen wir nur aus konventionellen Gründen zu diesen Nebenmeeren, in Wirklichkeit ist sie nur ein Meerbusen mit durchbohrter Rückwand, der auch in seinem unterseeischen Relief keine Spur von Selbständigkeit verrät.

Das Beringmeer und das Australasiatische Mittelmeer unterscheiden sich von den übrigen Nebenmeeren dadurch, daß sie als Durchgangsmeere zwei Ozeane miteinander verbinden. Der Suës-

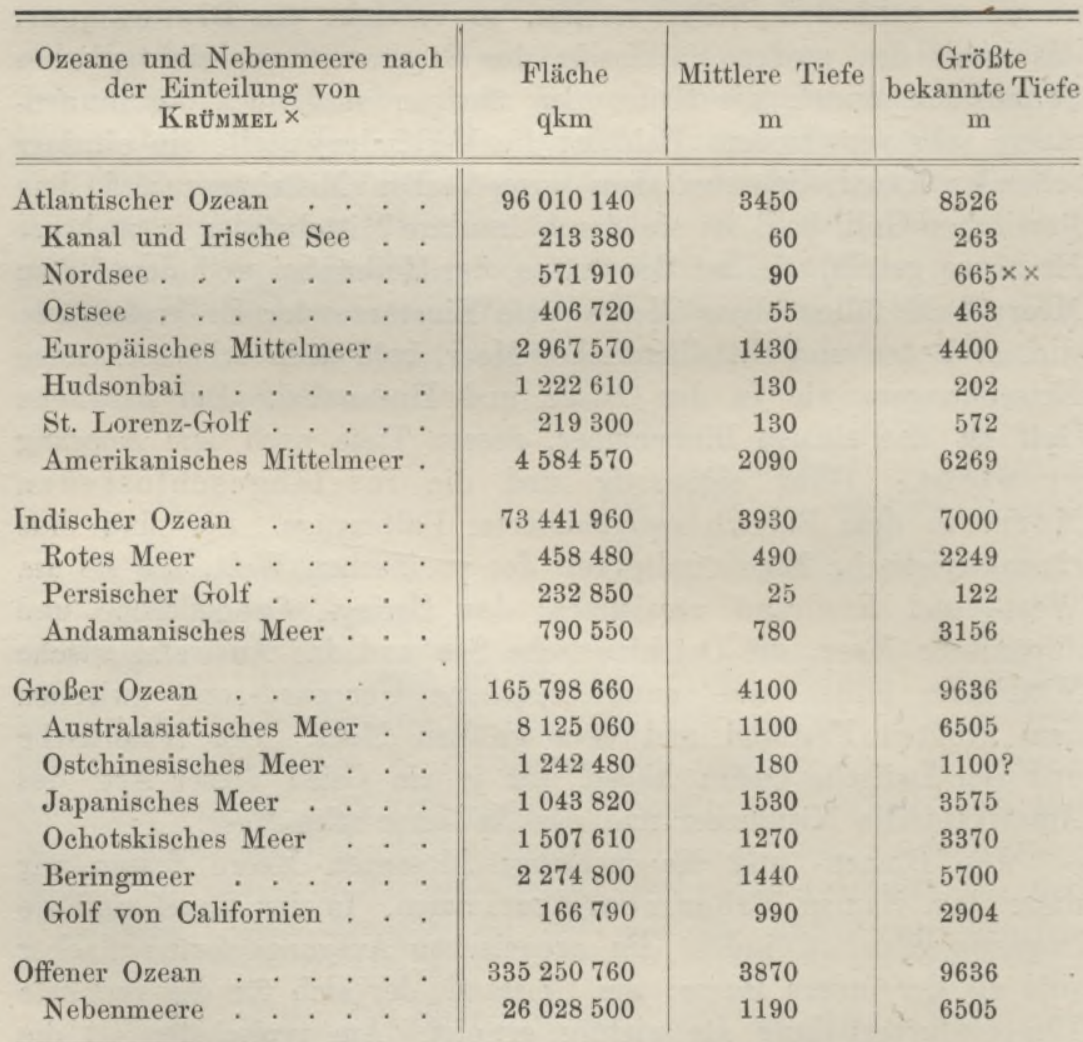

$\times$ Die Ozeane sind bis zum südpolaren Festland ausgedehint (vgl. S. 33). Wir weichen aber von Krümmel darin ab, daß wir das nördliche Eismeer zum Atlantischen und das Tasmanische Meer zum Großen Ozean rechnen. $\times \times \operatorname{Im}$ Skagerrak. Eine ältere Messung, die $809 \mathrm{~m}$ ergeben hatte, ist nun zweifelhaft geworden. 
kanal hat diese Eigenschaft auch dem europäischen Mittelmeer wieder zurückgegeben und dadurch dessen Bedeutung außerordentlich erhöht. Überhaupt muß man zugestehen, daß die Nebenmeere, so sehr sie auch räumlich hinter dem Ozean zurücktreten — sie machen nur 7,2 Prozent des Weltmeeres aus - und nur als geringfügige Anhängsel desselben erscheinen, die menschliche Entwicklung in viel höherem $\mathrm{MaB}$ beeinflußt haben. Gerade ihre verhältnismäßig kleinen Dimensionen befähigten sie dazu, die völkerverbindende Kraft des Meeres früher zur Geltung zu bringen als die ungeheure, Wasserwüste des offenen Ozeans. Je gegliederter diese Nebenmeere sind, um so besser konnten sie ihre Kulturaufgabe erfüllen. In dieser Beziehung wird das europäische oder das Mittelmeer schlechtweg von keinem übertroffen. Durch die italienische Halbinsel zerfällt es in zwei Hauptbecken; das östliche besitzt im Adriatischen und Ägäischen Meer zwei weit vorgreifende Glieder und spielt dem Schwarzen Meer gegenüber selbst wieder die Rolle eines Ozeans. Einen ganz anderen Typus repräsentiert das Australasiatische Mittelmeer. Ohne hervorragende Gliederung zeichnet es sich durch weitgehende Individualisierung seiner Teile aus; namentlich die östliche Hälfte gleicht einem Zellengewebe, was uns noch deutlicher wird, wenn wir die Tiefenverhältnisse berücksichtigen. Die senkrechten und die wagrechten Dimensionen müssen eben stets im Zusammenhang betrachtet werden.

Unterseeische Bodenformen. Der ozeanographische Zweig der physischen Erdkunde war bis in die letzten Jahrzehnte ein seltsames Gemisch von wahren und falschen Vorstellungen, guten Beobachtungen und willkürlichen Annahmen; und erst die wissenschaftlichen, mit zuverlässigen Apparaten ausgerüsteten Seeexpeditionen, die seit den sechziger Jahren begannen, und unter denen die des britischen Kriegsschiffes „Challenger" $(1872-76)^{3}$ besonders hervorragt, haben eine wissenschaftliche Meereskunde begründet. Ihnen sowie den zahlreichen Kabellegungen verdanken wir zunächst eine richtigere Vorstellung von der Tiefe und Beschaffenheit des Meeresbodens. Ein wesentliches Verdienst erwarb sich dabei BRooke durch die Erfindung des ablösbaren Lotes (1854), denn nur dadurch wurde es möglich, in tiefer See genau den Zeitpunkt zu bestimmen, wann das Lot den Boden berührt, und das weitere Abwickeln der Leine durch den Seegang zu verhüten. ${ }^{\times}$Aber selbst unsere neuesten und

$\times$ Daß selbst die hochentwickelten Lotungsmaschinen der Gegenwart dies nicht immer verhüten, zeigt ein Vorfall auf dem Vereinigten Staaten-Dampfer ,Dolphin“ im Januar 1902. In $19^{\circ} 46^{\prime} \mathrm{N}, 68^{\circ} 10^{\prime} \mathrm{W}$ rollten $12679 \mathrm{~m}$ Lottau ab, wobei ein großer Teil davon verloren ging. 
besten Isobathenkarten ${ }^{4}$ lassen mehr ahnen, als sie wirklich darstellen, da die Lotungen nicht bloß verhältnismäßig spärlich, sondern auch sehr ungleichmäßig verteilt sind. Sie drängen sich dichter in der Nähe der Küsten, wo das praktische.Bedürfnis der Schiffahrer schon früh zu Tiefenuntersuchungen geführt hat, während die weiten Flächen des offenen Ozeans nur von vereinzelten Lotungsreihen durchfurcht sind. Glücklicherweise wird dieser Übelstand dadurch gemildert, daß der Meeresboden im großen und ganzen ebener ist als die Oberfläche des Festlandes. Ein Profil durch den verhältnismäßig unebenen Teil des Atlantischen Ozeans zwischen den Azoren und dem Kanal zeigt nach KRÜMmEL einen mittleren Abstand zwischen zwei aufeinander folgenden Erhebungen (Muldenbreite) von $120 \mathrm{~km}$, das mitteleuropäische dagegen einen solchen von nur $1 / 2$ bis $1 \frac{1}{2} \mathrm{~km}$. Nur ausnahmsweise, wo Land untergetaucht ist, erinnert das marine Bodenrelief an die Mannigfaltigkeit unserer Gebirgslandschaften. ${ }^{\times}$Die Einförmigkeit des Meeresbodens ist leicht verständlich; zwar sind auch dort die unterirdischen Kräfte tätig und schaffen Erhebungen und Vertiefungen, aber jene anderen Faktoren, die die Details der oberseeischen Bodenformen herausmodellieren, die Verwitterung und die Erosion, fehlen ihm ganz oder wirken doch in anderer Weise. Die Verwitterung fehlt, denn der Meeresboden ist gänzlich vor dem Einfluß der Atmosphärilien geschützt; und wenn auch das Seewasser eine zersetzende und auflösende Wirkung auf den festen Meeresgrund ausübt, so geht dieser chemische Prozeß doch außerordentlich langsam vor sich, und seine Produkte werden nicht durch Winde und flieBendes Wasser nach fernen Gegenden entführt, sondern lagern sich an Ort und Stelle wieder ab. Zwar ist auch das Meerwasser bewegt, aber seine mechanischen Wirkungen reichen nicht tiefer als bis $200 \mathrm{~m}$ und sind auch anderer Art als die der Flüsse, sie gehen in die Breite und schaffen keine Rinnen, oder sie gehen, wenn das Wasser an orographischen Hindernissen in wirbelnde Bewegung gerät, auch in die Tiefe, erzeugen aber dann Kolke. $\times \times$ Von einer anderen Art von Veränderungen haben wir erst durch die Beschädigungen der Kabel Kenntnis erhalten, nämlich von Rutschungen, denen alle steileren unterseeischen Böschungen ausgesetzt sind, und die zum Teil auf

$\times$ Vgl, das Kärtchen des Nordrandes des Biskayagolfs in Krüмmé's Ozeanographie, Bd. I, S. 100, den ersten Versuch in Schraffenmanier.

$\times \times$ Einen solehen, dureh Gezeitenströme erzeugterf Kolk in Porto di Malamoceo in der Lagune von Venedig beschrieb O. Marinelli. Die Tiefe beträgt $50 \mathrm{~m}$ und die mittlere Böschung $13^{\circ} 50^{\prime}$, doch kommen auch Abstürze bis $45^{\circ}$ vor. 
Seebeben, zum Teil, aber nur in den Tropen, auf unterseeisches Hervortreten des Grundwassers in der Regenzeit zurückgeführt werden. Wie häufig sie sind, geht aus MrLne's ${ }^{5}$ Zusammenstellung hervor, die innerhalb eines Zeitraumes von 20 Jahren an 38 Kabellinien 245 Brüche verzeichnet. Aber diese Veränderungen verringern den Böschungswinkel und tragen somit zum Ausgleich der Tiefenunterschiede bei. Den gleichen Erfolg haben im großen und ganzen auch die Ablagerungen der Flüsse, der Eisberge, der staubführenden Winde, der unterseeischen Vulkanausbrüche und der Überreste der Meeresorganismen - mit einem Wort: der Meeresboden ist ein Reich der Aufschüttung, nicht der Zerstörung.

An das Festland schließt sich zunächst der Strand an, jener amphibische Gürtel, der bei Hochwasser Meeresboden und bei Niederwasser Land ist. RATzEL schätzt die Länge aller Küsten einschließlich der engen Talbuchten (Fjorde und Rias) auf 2 Mill km; nimmt man mit Murray als mittlere Strandbreite $0,8 \mathrm{~km}$ an, so bedeckt der Strand eine Fläche von 1,6 Mill. qkm oder etwa 0,4 Proz. der Meeresfläche in ihrer weitesten Ausdehnung. Dann folgt das Schelf oder die Flachsee bis $200 \mathrm{~m}$ Tiefe, endlich die Tiefsee jenseits der Isobathe von $200 \mathrm{~m}$. Diese Tiefenlinie (entsprechend der 100 Fadenlinie) ist in dreifacher Beziehung wichtig: als Grenze der Kontinentaltafel (vgl. S. 46), der erosiven Wirkungen des bewegten Seewassers und des Eindringens des Lichtes, wodurch in der Flachsee ganz andere Lebensbedingungen für Pflanzen und Tiere geschaffen werden, als sie in der Tiefe vorhanden sind.

Soweit sich vom Strand aus die Küste langsam senkt, soweit rechnen wir das Schelf, ${ }^{6}$ wie man es in neuester Zeit bezeichnet. Seine Breite ist sehr verschieden, seine Grenze fällt in der Regel ungefähr mit der $200 \mathrm{~m}$-Linie zusammen. Dann folgt in mehr oder minder scharfer Weise eine Knickung des Bodens. Gehen wir von der Westküste Irlands unter $55^{\circ}$ B. nach Westen, so finden wir den Rand der Flachseeplatte, auf der die Britischen Inseln ruhen, erst in $102 \mathrm{~km}$ Entfernung, was einem Abfallswinkel von kaum 0,7 entspricht; zwischen 200 und $500 \mathrm{~m}$ Tiefe steigert er sich aber schon auf $1^{\circ} 43^{\prime}$ und zwischen 1000 und $2000 \mathrm{~m}$ Tiefe sogar auf $5^{0} 43^{\prime}$ - erreicht also schon die Gefällswerte im deutschen Mittelgebirge (Erzgebirge vom Keilberg bis Annaberg $1^{0} 45^{\prime}$, NO-Abdachung des Thüringer Waldes $5^{0} 37^{\prime}$ ). Weiter im S, im Umkreis des Golfs von Biscaya, ist der Abfall noch steiler. E. HuLL ${ }^{7}$ berechnet den mittleren Böschungswinkel des ganzen westeuropäischen Schelfs auf $13-14^{\circ}$, bei Kap Toriñana $\left(43^{\circ} 4^{\prime} \mathrm{N}\right)$ maß er sogar $36^{\circ}$, also schon eine echt alpine Böschung. Auch die von den Konti- 


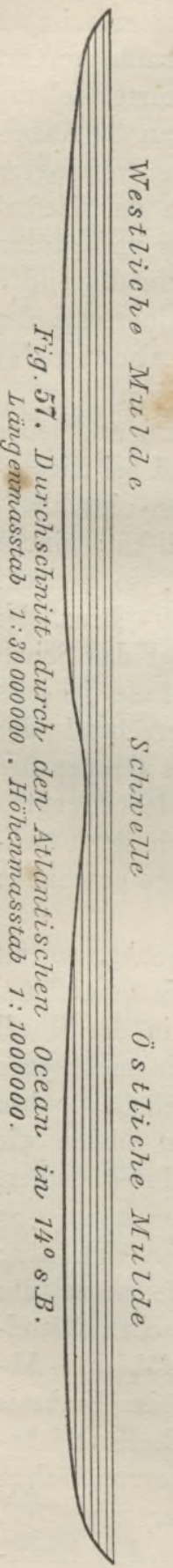

nenten durch Bruch abgetrennten Inseln senken sich rasch in das Meer. ${ }^{8}$

Sofern das Schelf eine untergetauchte Küstenebene ist, bildet es einen integrierenden Bestandteil des Festlandes, nicht des eigentlichen Meeresbodens, und seine ununterbrochene Erstreckung über weite Küstengebiete und das Vorkommen benachbarter abgetrennter Schelfstücke, die jetzt Bänke bilden, sprechen deutlich für seine kontinentale Zugehörigkeit. Ausnahmsweise kann es aber auch durch Anhäufung von Sedimenten zustande gekommen sein. Eísberge können grobe Gesteinsmassen weithin verfrachten, und in der Glazialzeit mag sich dieser Prozeß im großen Maßstab abgespielt haben. Nach BLAKE's ${ }^{9}$ Annahme ist auch das Wasser bei der Ausbildung des Schelfs beteiligt. Wenn es sich von der Küste wegbewegt, lasse es die von ihm mitgeführten festen Teilchen in dem Maß zu Boden sinken, in dem die Stromkraft erlahmt. Daher häufen sich die Sedimente nicht, wie man bisher annahm, hauptsächlich in der unmittelbaren Nähe der Küste an - dies gilt aber wohl von den gröberen Bestandteilen —, sondern ihre Mächtigkeit wachse mit der Entfernung von der Küste, und sie brechen dort schroff ab, wo der seewärts gerichtete Strom erlischt. Durch diese Aufschüttung soll die ursprünglich gleichmäßige Kontinentalböschung zuerst gemildert und dann gesteigert werden.

Dort, wo sich der Gefällswinkel dauernd auf wenige Bogenminuten ermäBigt, hört die Kontinentalböschung auf und beginnt der Flachboden der Tiefsee. Über die hier auftretenden Formen ${ }^{10}$ wird uns ein Durchschnitt durch den Atlantischen Ozean unter $44^{\circ} \mathrm{S}$ belehren (Fig. 57).

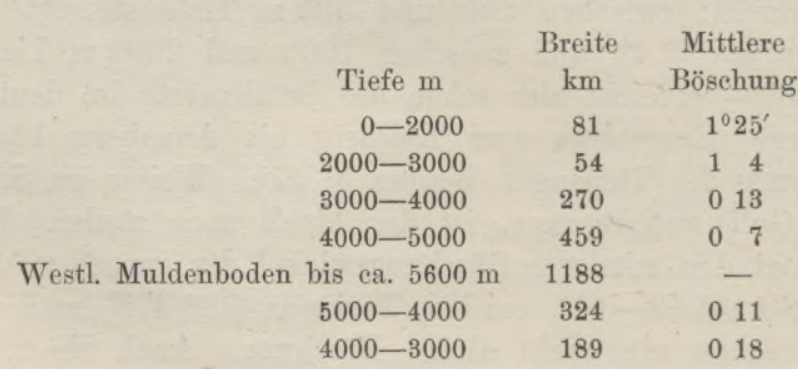




$\begin{array}{ccc}\text { Tiefe m } & \begin{array}{c}\text { Breite } \\ \mathrm{km}\end{array} & \begin{array}{c}\text { Mittlere } \\ \text { Böschung }\end{array} \\ \text { Schwellenhöhe bis } 2740 \mathrm{~m} & 351 & - \\ 3000-4000 & 216 & 0^{\circ} 16^{\prime} \\ 4000-5000 & 757 & 05 \\ \text { Östl. Muldenboden bis ea. } 5600 \mathrm{~m} & 1188 & - \\ 5000-4000 & 162 & 021 \\ 4000-3000 & 216 & 016 \\ 3000-0 & 108 & 135\end{array}$

Trotz Tiefenunterschieden von nahezu $3000 \mathrm{~m}$ gewinnt man doch den Eindruck eines Flachbodens, und selbst die 30 fache Überhöhung unseres Profils kann ihn nicht verwischen. Das Gefälle gleicht dem unserer Ebenen; so senkt sich beispielsweise die Münchener Ebene von Holzkirchen bis Moosburg unter einem Winkel von $0^{\circ} 1^{\prime}$, die Poebene vom Alpenrand nach der mittleren FluBrinne unter $0^{\circ} 8^{\prime}$, und die norddeutsche Tiefebene zwischen dem Wiehengebirge und der Hadelnküste unter kaum $0^{0} 1^{\prime}$. Eine so völlige Horizontalität mögen wohl auch die Muldenböden besitzen, von denen jeder so breit ist wie Mitteleuropa von Genua bis Schleswig, und auch die Schwellenplatte zeigt auf einer Strecke, die ungefähr der Entfernung Basel-Köln gleichkommt, nur geringfügige Niveauunterschiede. In ihren Abdachungsverhältnissen ist die Schwelle den norddeutschen Landrücken vergleichbar; das Gefälle des pommerischen Rückens zwischen Lauenburg und Preußisch-Stargard z. B. beträgt im NW $0^{\circ} 19^{\prime}$ und im SO $0^{\circ} 17^{\prime}$.

In der Folge wollen wir den Ausdruck MuJde für alle flachen, langgestreckten Einsenkungen beibehalten; sind die beiden Horizontaldimensionen annähernd gleich, so werden wir von Becken sprechen. Die ganz flachen Erhebungen des Meeresbodens nennen wir Schwellen und die etwas steileren Rücken, wenn sie eine ausgesprochene lineare Erstreckung besitzen, sonst Plateaus. Ausdrücklich bemerken wir aber, daß wir uns in unserer Nomenklatur nicht auf bestimmte Tiefenstufẹn beschränken. Es kommt vielmehr, gerade so wie in der Orographie der festen Erdoberfläche, lediglich auf die Bodenform an. Man hat diesen Grundsatz bisher nur bei der Gliederung des Atlantischen Ozeans befolgt, und auch da nicht konsequent, ihn bei den übrigen Meeren aber gänzlich außer acht gelassen. Sir JoHn Murray vertritt sogar die Ansicht, daB man nur die Tiefen unter 3000 Faden durch besondere Namen auszuzeichnen habe. Vom biologischen Standpunkt aus mag das eine gewisse Berechtigung haben, der Geograph hat aber die Gliederung in ihrer Gesamtheit zu erfassen. 
Innerhalb der Flachformen, die der Hauptsache nach den Meeresboden charakterisieren, treten aber auch vereinzelte Steilformen auf, Erhebungen sowohl wie Vertiefungen. Die ersteren sind vulkanische Aufschüttungen oder Bauten von Meeresorganismen oder beides zusammen. Die Kuppen haben Tiefen von mehr als $200 \mathrm{~m}$, verbergen sich also noch ganz unter dem Wasser; als Beispiel mögen die felsigen Faradayhügel $(49,7 \mathrm{~N}, 29,2 \mathrm{~W})$ genannt sein, die $1143 \mathrm{~m}$ unter dem Meeresniveau liegen und steile Böschungen von $15-35^{\circ}$ besitzen. Die Bänke nähern sich schon in bedrohlicher Weise dem Meeresspiegel zwischen 200 und $11 \mathrm{~m}$; auch sie sind zum Teil sehr steil. So erhebt sich z. B. die Alexabank in der Südsee $\left(11,7^{\circ} \mathrm{S}\right.$, $175,5^{\circ} \mathrm{O}$ ) unter einem Winkel von $51^{0}$ aus dem $4000 \mathrm{~m}$ tiefen Becken

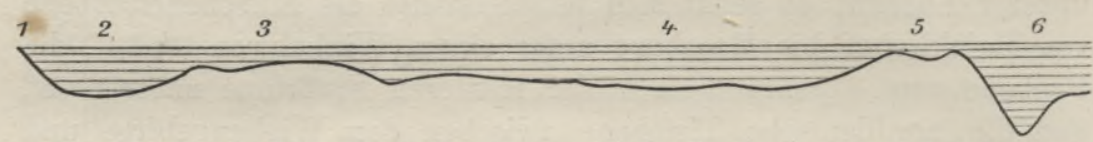

Fig. 58. Durchschnitt durch das Ostaustralische Randmeer in $30^{\circ} \mathrm{S}$. Längenmaßstab 1:30000000, Höhenmaßstab 1: 1000000 .

1. Australien, 2. Ostaustralische Bucht, 3. Neuealedonischer Rücken, 4. Fidschi becken, 5. Tongarïcken, 6 . Kermadecgraben.

bis zu $24 \mathrm{~m}$ Tiefe. Erhebungen von höchstens $11 \mathrm{~m}$ Tiefe, die daher der Schiffahrt gefährlich sind, nennen wir Riffe oder Gründe. Sie bilden den Übergang zu den vulkanischen und korallinischen Inseln, die in der Regel steil abfallen; Böschungen von mehr als $50^{\circ}$, wie sie hier vorkommen ${ }^{8}$, zählen selbst in unseren Gebirgen zu den Seltenheiten. Von den Hohlformen nennen wir die Kessel, mehr oder weniger steile Einstürze von verhältnismäßig geringer Ausdehnung, wie der Monacokessel auf dem Azorenplateau, und die Gräben, lange, schmale Einsenkungen mit hohem Innen- und tieferem Außenrand (s. Fig. 58), denen die meisten bisher gemessenen Maximaltiefen der Ozeane angehören. Neigungswinkel bis zu $7^{\circ}$ sind hier schon nachgewiesen - das erinnert an die Form der Kontinentalböschung, und wir werden sehen, daß hier auch ein genetischer Zusammenhang wahrscheinlich ist. Soweit wir bisher den Tatbestand überblicken können, sind die Gräben als tektonische Formen aufzufassen, die an Küsten von Faltengebirgen oder Zerrungsbögen gebunden sind. Ob sie selbst zu den Bruch- oder zu den Faltenbildungen gehören, muß vorläufig noch dahingestellt bleiben.

Vertikalgliederung des Weltmeeres (vgl. Karte I). Jeder der drei Ozeane, die sich zwischen die Festlandsmassen einschieben, hat 
auch in seiner Vertikalgliederung Eigentümlichkeiten, die hier nur in aller Kürze geschildert werden können.

Soweit der Indische Ozean von Festländern umschlossen ist, ist er einseitig gebaut. Der Boden senkt sich gegen Ost und erreicht seine größte Tiefe $\left(7000 \mathrm{~m}\right.$ in $\left.10^{\circ} 1^{1} / 2^{\prime} \mathrm{S}, 108^{0} 5^{\prime} \mathrm{O}\right)$ in jenem merkwürdigen Doppelgraben, zu dem der Sunda-Inselbogen mit der sich im Norden daran anschließenden weitgedehnten Flachsee schroff abstürzt. Schließt man jenen Teil des zirkumterranen Ozeans, der im $\mathrm{S}$ des Indischen Ozeans liegt, in die Betrachtung ein, so ergibt sich eine Zweiteilung. In der Westhälfte zwischen Afrika, Vorderindien und Kerguelen liegen die größten Tiefen am Rand der Antarktis und der Boden steigt gegen $\mathrm{N}$ an, mehrfach unterbrochen durch Schwellen und Rücken, über die sich Inseln erheben. Dagegen ist in der inselleeren Osthälfte im großen und ganzen eine entschiedene Tiefenzunahme in nördlicher Richtung bemerkbar.

Im GroBen Ozean lassen die, allerdings noch recht ungleichmäßig verteilten Lotungen eine Dreiteilung erkennen. Im südhemisphärischen Teil senkt sich der Boden von der Antarktis nach Norden, aber nicht gleichmäBig. Durch die gegen die Galapagosinseln sich hinziehende Osterschwelle erhält er einen flachgewölbten Bau mit kurzer Abdachung nach $\mathrm{O}$ und langer nach $\mathrm{W}$, und bricht an beiden Seiten längs der südamerikanischen Küste und des inselgekrönten Tongarückens mit steilen Gräben ab. Nördlich vom Äquator sind zwar an der Küste von Mexico und Niedercalifornien auch Gräben, jedoch beträchtlich seichtere als im Süden zu erkennen, aber sonst senkt sich der Boden von Nordamerika nach den großen Inselgirlanden, wo das Grabenphänomen wieder in schönster Weise entwickelt ist. Aus dem 4-5000 m tiefen pazifischen Becken, diesem ausgedehntesten Flachboden der Erde, erheben sich vereinzelte Rücken und Plateaus, die die zahlreichen Eilande Polynesiens tragen. Sie bilden eine charakteristische Eigentümlichkeit des Großen Ozeans, ebenso wie die ihn umkränzenden Gräben.

Auf der amerikanischen Seite findet sich eine ausgesprochene Grabenbildung - der Atacamagraben (tięfste bekannte Stelle $7635 \mathrm{~m}$ ) - nur dort, wo die Cordillere einen großen Bogen beschreibt; der dann folgende Mexicanische $(5428 \mathrm{~m})$ und noch mehr der Niedercalifornische Graben (4396 m) sind nur undeutlich entwickelt. Anders auf der westlichen Seite. Wir können hier eine äußere und eine innere Grabenreihe unterscheiden. Mit Ausnahme von dreien liegen sie alle an der Konvexseite der Inselbögen. Die äußere Reihe beginnt im N mit dem Alëutengraben $(7383 \mathrm{~m})$, dann folgen der Japanische (8513 m) und der Mariạnengraben, 
in dem das amerikanische Vermessungsschiff "Nero" 1899 in $12^{\circ}$ $43^{\prime} \mathrm{N}$ und $145^{\circ} 49^{\prime} \mathrm{O}$ die größte bekannte Tiefe des Weltmeeres, $9636 \mathrm{~m}$, lotete, der Yap- (7583 m) und der Palaugraben $(8138 \mathrm{~m})$. Den Abschluß der äußern Reihe bilden nach einer langen Unterbrechung der Tonga- (9184 m) und der Kerma decgraben (9427 m).

Die innere Grabenreihe besteht aus dem Liukiu- (7481 m), dem Philippinen- (über $8900 \mathrm{~m})$, dem Kei- $(6505 \mathrm{~m})$ und dem Bougainville-Graben $(9140 \mathrm{~m})$, der sich in der Fortsetzung des Huongolfs bogenförmig bis zur Bougainville-Insel hinzieht, und endlich der Neuhebriden-Graben $(7520 \mathrm{~m}){ }^{11} \quad$ Es ist eine bemerkenswerte Tatsache, daß sich die drei letztgenannten Gräben an der Innenseite der Bögen befinden, gerade so wie der Atacamagraben.× Die äußere Grabenreihe trennt die Zone der ostpazifischen Randmeere von dem eigentlichen pazifischen Becken. Von jenen Randmeeren sind die nördlichen: das Bering-, Ochotskische und Japanische Meer unsymmetrische Becken; einen ganz anderen Charakter tragen aber die beiden südlichen. Schon im ostaustralischen Randmeer zwischen dem Tonga-, Neuhebriden-, Queensland- und Neucaledonischen Rücken ist das Relief sehr mannigfaltig, denn nicht weniger als drei Becken unterbrechen die Bodenanschwellungen, die die Inseln miteinander verbinden. Seine höchste Ausbildung erreicht aber dieser Typus der unterseeischen Orographie im Austral-asiatischen Mittelmeer zwischen Formosa, Borneo und Neuguinea. Die Zahl der Becken steigert sich hier auf wenigstens zehn; es sind becherförmige Einsenkungen, fast durchweg von mehr als $4000 \mathrm{~m}$ Tiefe, während die trennenden Rücken nur 700 bis $1800 \mathrm{~m}$ tief sind.

Der Atlantische Ozean sondert sich durch seine Talform von dem übrigen Weltmeer ab; im innigsten Zusammenhang damit steht auch seine Bodengestaltung (vgl. Fig. 57). Genau in der Mitte, also ebenfalls S-förmig gekrümmt, durchzieht ihn die Atlantische Schwelle, die die meisten vulkanischen Inselbildungen trägt, von der Bouvetinsel im S bis Island im N. Unter dem Äquator verengt sie sich beträchtlich oder ist vielleicht völlig durchbrochen; das Romanchetief $\left(0^{0} 11^{\prime} \mathrm{S}, 18^{\circ} 15^{\prime} \mathrm{W}, 7370 \mathrm{~m}\right)$, dessen Existenz die deutsche Südpolarexpedition bestätigt hat, läßt darauf schließen, daß hier auf kurze Entfernungen beträchtliche Tiefenunterschiede vorkommen. Sonst ist die Schwelle nur eine flache Wölbung, die beiderseits in breite Mulden übergeht, deren Boden sich hebt und senkt, so daß sie in mehrere Becken zerfallen. Die

× Suess' Auffassung der Gräben als Vorstufen der Faltungsbögen wird dadurch völlig hinfällig. 
westatlantische Mulde scheint durch größere Tiefen ausgezeichnet zu sein; die größte bekannte Tiefe $(8526 \mathrm{~m})$ ist auch hier an eine Grabensenkung im N von Portorico gebunden. In der Grönländischen Bucht setzt sich die Mulde weit nach $\mathrm{N}$ fort. Im $\mathrm{S}$ finden beide Mulden ihr Ende an zwei von der Schwelle ausgehenden Querrücken (Rio Grande- und Walfisch-Rücken), die für die Temperaturverteilung von größter Bedeutung sind; jenseits derselben setzt sich die Muldenform jedenfalls im $\mathrm{O}$ fort (Kapmulde), vielleicht auch im W, falls sich die Hypothese Sснотт's bestätigt, daß das Argentinische Becken mit dem Atlantisch-indischen Südpolarbecken in ununterbrochener Verbindung steht. Auch im N ist ein solcher, nur noch viel deutlicher markierter Abschluß vorhanden, indem der Isländische Rücken mit weniger als $600 \mathrm{~m}$ Tiefe die Kontinentaltafel der Britischen Inseln mit Grönland verbindet. Aber jenseits dieses Querriegels erscheint wieder die atlantische Furche in den beiden Nordmeerbecken, im Spitzbergenbecken, das nach NANSEN unter $81^{\circ}$ B. durch einen unterseeischen Rücken abgesperrt wird, und in der arktischen Mulde, die sich wahrscheinlich weit in das Eismeer hinein fortsetzt, denn die ganze Trift der norwegischen „Fram"-Expedition bewegte sich wenigstens von $80^{\circ} \mathrm{N}, 135^{\circ} \mathrm{O}$ bis $83^{\circ} \mathrm{N}, 14^{\circ} \mathrm{O}$ über Tiefen von $3000-3900 \mathrm{~m} .^{12}$ Auch der Nordpol liegt in dieser Mulde; auf Peary's Route in $70^{\circ} \mathrm{W}$ reicht das Schelf bis ungefähr $84^{\circ} \mathrm{B}$., ganz in der Nähe des Poles wurde eine Tiefe von 2700 m gelotet. ${ }^{13}$ Dạs nördliche Eismeer ist also morphologisch eine Dependenz des Atlantischen Ozeans, und diese ganze atlantisch-arktischeTiefenfurche ist die wahre Grenze zwischen der Alten und Neuen Welt, während im Beringmeer eine Flachsee beide Landfesten verbindet. Die größte Tiefe der Beringstraße beträgt auf DALL's Messungslinie nur $52 \mathrm{~m}$, und damit hängt wohl auch ihre geringe Breite zusammen, gering wenigstens im Vergleich zu den Kanälen zwischen Grönland und Britannien.

Von den atlantischen Nebenmeeren sind die beiden nördlichen, die Ostsee und die $\mathrm{Hudsonbai,} \mathrm{flach,} \mathrm{und} \mathrm{es} \mathrm{ist} \mathrm{wohl} \mathrm{möglich,}$ daß sie, wie $\mathrm{H}_{\mathrm{AHN}}$ auseinandergesetzt hat, durch den Moränenschutt der eiszeitlichen Gletscher und Eisberge aufgefüllt wurden. Die beiden südlichen, das amerikanische und das europäische Mittelmeer, gleichen sich, obwohl verschiedenen Kategorien angehörig, in der Mannigfaltigkeit ihrer horizontalen und vertikalen Gliederung. Das amerikanische besteht aus vier Hauptgliedern. Das Caribische Becken umschlieBt ein Inselkranz: die Kleinen Antillen, die Jungferninseln, Hairti, Jamaica und eine Reihe von Bänken, die zum Landvorsprung von Honduras hinüberleiten. Eine zweite Boden- 
anschwellung geht von der Sierra Maestra auf Cuba aus, ihre Fortsetzung bilden die Caymaninseln und einige Bänke, und zwischen diesem Cayman- und dem südlichen Jamaicarücken stürzt der Meeresboden zu dem bis $6269 \mathrm{~m}$ tiefen Caymangraben ab, in dessen Verlängerung jenseits des Windwärtskanals die tiefe Rinne im N von Harti und der schon erwähnte Portoricograben liegen. Eine abermalige Abschnürung findet zwischen den Vorgebirgen S. Antonio (Cuba) und Catoche (Yucatan) statt, sie trennt das südliche Yucatanbecken von dem viel seichteren Mexicanischen Golf. Dieser Gegensatz ist sehr lehrreich: im Bereich der Faltenbildungen nur Tiefbecken und ein Graben, im Bereich des Flachlandes das mexicanische Hochbecken.

Das europäische Mittelmeer ist ein kleines Abbild des Ozeans mit seinen Randbildungen. Das Eingangstor zwischen den Kaps Trafalgar und Spartel ist meist weniger als $200 \mathrm{~m}$ tief, und nur einige Durchfahrten reichen unter $400 \mathrm{~m}$ hinab; aber schon zwischen Gibraltar und Ceuta erreicht die Tiefe $800 \mathrm{~m}$ und darüber. Das Mittelmeer selbst gliedert sich in drei Becken von mehr als $2000 \mathrm{~m}$ Tiefe; das westliche erreicht eine Maximaltiefe von $3149 \mathrm{~m}$, das tyrrhenische eine solche von $3731 \mathrm{~m}$, die orientalische Mulde eine solche von $4400 \mathrm{~m}$. Corsica mit Sardinien und Italien mit Sizilien und dem tunesischen Landvorsprung bilden die Scheidewände; in der sizilischen Straße beträgt selbst die größte Tiefe nur $454 \mathrm{~m}$. Das zur Hälfte flache Adriatische Meer (Maximaltiefe $1590 \mathrm{~m}$ ) und der Pontus $(2618 \mathrm{~m}$ ) sind echte Binnenmeere, das Marmarameer (größte Tiefe $1403 \mathrm{~m}$ ) ein solches mit zwei Ausgängen, das Ägäische Meer (größte Tiefe $2250 \mathrm{~m}$ ) eine durch Inseln abgeschlossene Randbildung. Auch hier bestätigt sich das Gesetz, daß die Randmeere flacher sind als das Hauptmeer.

Bedeckung des Meeresbodens. ${ }^{14}$ Nur an wenigen Stellen berührt das Lot Felsboden, meist ist der Grund des Meeres mit lockerem Material bedeckt. Die geologische Arbeit nimmt eben ungestörten Fortgang; die Ablagerungen in den Meeren sind die eigentlichen Alluvionen. Nach Ursprung und Beschaffenheit unterscheidet man kontinentale und pelagische Ablagerungen. ${ }^{\times}$Das Material zu den ersteren liefert teils die von den Meereswogen beständig benagte Küste, teils das Innere der Festländer, deren Zerstörungsprodukte die Flüsse dem Meer zuführen. Dabei ist von Bedeutung, daß im Salzwasser alle festen Bestandteile schneller zu Boden sinken als im Süßwasser, wenn auch die allerfeinsten Trübungen sich noch

$\times$ Krümmer teilt die kontinentalen Ablagerungen in litorale und hemipelagische und nennt die pelagischen eupelagische Ablagerungen. 
längere Zeit schwebend erhalten können. Stets wird das Material einem natürlichen SchlemmprozeB unterworfen. Die gröberen Stücke bleiben in der nächsten Nachbarschaft der Küste, der Sand wird etwas weiter hinausgeführt, der Schlamm am weitesten. Die Küsten werden also in der Regel von Sandablagerungen begleitet. Dort, wo sich zwei einander entgegenkommende sand- und schlammbeladene Strömungen treffen, lassen sie ihre Last zu Boden fallen und bauen jene für die Schiffahrt so gefährlichen Sandbänke oder Barren auf, dîe oft auf viele Kilometer Erstreckung den Küsten entlang ziehen. In den höheren Breiten liefern auch die Eisberge und das treibende Küsteneis mit seinem eingefrorenen Detritus namhafte Beiträge; so befindet sich die über $700 \mathrm{~km}$ lange Neufundlandbank genau an der Stelle, wo das von der polaren Meeresströmung mitgeführte Grönlandeis und das Treibeis aus dem St. Lorenzgolf mit dem warmen Golfstrom zusammenstoßen. ${ }^{15}$ Manche Bänke steigen dauernd über den Seespiegel empor, manche nur zur Ebbezeit, manche - und diese sind die gefürchtetsten - verbergen sich stets unter dem Meeresspiegel. Häufig werden sie von Einsenkungen unterbrochen, die den Schiffen als Durchfahrten dienen, aber die Lage und Tiefe dieser Kanäle ist vielfachen Veränderungen unterworfen. Andere Barren sind nur zur Flutzeit und auch dann oft nur mit kleinen Fahrzeugen passierbar.

Kies, Sand und Schlamm bedecken den Strand und die Flachsee, die feinsten erdigen Massen oder der Schlick, $\times$ an deren $\mathrm{Zu}$ sammensetzung sich bereits auch Meeresorganismen in heryorragendem Maß beteiligen, treten aber schon in die Tiefsee hinaus, umsäumen die submarinen Abdachungen der Festländer und Inseln und erfüllen den Boden der tieferen Nebenmeere mit Ausnahme des amerikanischen. Es ist besonders beachtenswert, daß nicht bloß im nördlichen Eismeer, soweit es flach ist, sondern auch im südlichen nur solcher Schlick gefunden wird, denn er kündet deutlich die Nähe eines antarktischen Festlands an. Weitaus am verbreitetsten ist der blaue Schlick, der seine Farbe der Beimengung von organischer Substanz und Eisensulfid verdankt. Große Mengen von Glaukonitkörnern, die meist Steinkerne von Foraminiferen bilden, färben den Schlick grün; die eisenoxydhaltigen Sedimente, die die großen südamerikanischen Ströme in das Meer führen, geben den Schlickablagerungen an der brasilianischen Küste eine rote Farbe. Vulkanische Gestade liefern grauen Schlamm und Sand, Korallen-

$\times$ Die Engländer unterscheiden Ooze und Mud. Die meisten Schriftsteller übersetzen ersteres mit Schlamm, letzteres mit Schlick, jedoch kommt auch das Umgekehrte vor. Andere bezeichnen Oore als Erde und Mud als Schlamm. 
riffe eine amorphe kalkige Masse, in der organische Bestandteile in der Form von Korallentrümmern und Schalen größerer und kleinerer Meerestiere bereits überwiegen (vgl. Tab. S. 275).

Den eigentlichen Boden der Ozeane - eine Fläche, doppelt so groß wie das gesamte Festland - bedeckt organischer Schlamm und roter Ton. Auch in bezug auf die Verbreitung der marinen Lebewesen haben die Untersuchungen in den letzten Jahrzehnten zu überraschenden Resultaten geführt. Allerdings erlischt das Pflanzenleben mit dem Sonnenlicht schon $200-250 \mathrm{~m}$ unter dem Seespiegel, aber das Tierleben kennt keine Tiefengrenzen, wenn es auch am reichlichsten in der obersten und in der untersten Region entwickelt ist. Die Tierleichen fallen zu Boden, und ihre festen Bestandteile schichten sich hier in so enormen Massen auf, daß z. B. der "Travailleur" an der tiefsten Stelle des Biscayischen Meerbusens $(5100 \mathrm{~m})$ in einem Kubikzentimeter Schlamm 116000 Foraminiferen und Radiolarien fand. Diese mikroskopischen Wurzelfüßer sind auch hauptsächlich die Baumeister des organischen Tiefseeschlammes, an dessen Zusammẹnsetzung sich aber auch unorganische Massen, Mineralpartikelchen und feinster Schlamm, beteiligen. Diese Massen stammen zum Teil noch vom Festland, ja nach GüMBEL's Untersuchungen der von der "Gazelle"16 mitgebrachten Bodenproben scheint sogar noch feinster Flußdetritus mit Hilfe der Meeresströmungen weit in den offenen Ozean hinaus zu gelangen. Auch den Winden fällt eine wichtige Vermittlerrolle $\mathrm{zu}$, indem sie Staub und vulkanische Asche weit über die Ursprungsstätte hinaus verbreiten. Wohl nirgends spielen die ozeanischen Staubfälle eine größere Rolle, als im Gebiet der Capverdischen Inseln, aber gelegentlich werden auch westlichere Gegenden heimgesucht. Der küstenfernste Punkt, von dem bisher roter Passatstaub gemeldet wurde, liegt in $40,9^{\circ} \mathrm{N}$ und $37,6^{\circ} \mathrm{W}$; der Staubfall am 12. Februar 1882 bedeckte ein Areal von $527300 \mathrm{qkm}$, fast von der Ausdehnung des Deutschen Reiches, und der Staub, der am 19. Februar 1902 bei den Canarischen Inseln beobachtet wurde, verbreitete sich in den folgenden drei Tagen bis $40^{\circ} \mathrm{W}, 50^{\circ} \mathrm{N}$ und $5^{\circ} \mathrm{N}$. Wirkliche Staubfälle kommen allerdings durchschnittlich nur acht- bis neunmal im Jahr vor, aber häufig ist die Luft über den capverdischen Gewässern mit Staub erfüllt, und weiter gegen die afrikanische Küste zu sind die unerwünschten trockenen Nebel eine beständige Erscheinung. Seit Helmmann's und DinkLage's ${ }^{17}$ Untersuchungen kann es keinem Zweifel mehr unterliegen, daß der nordatlantische Passatstaub aus der Sahara stammt, nicht, wie seinerzeit EHrenberg annahm, aus Südamerika.

Einer noch größeren Verbreitung ist die feine Asche fähig, die 
bei vulkanischen Ausbrüchen oft in kolossalen Mengen in die Luft geschleudert wird. Man schätzt die Totalmenge der Auswurfstoffe bei dem berühmten Krakatau-Ausbruch im Jahr 1883 auf 18 Millionen cbkm. Der Aschenfall, der bis zu $60 \mathrm{~mm}$ Mächtigkeit anschwoll, erstreckte sich von Singapore im Norden bis zu den Cocosinseln im Süden, und von Benkulen (Sumatra) im Westen bis Patuha (Java) im Osten, d. h. über ein Gebiet von 827000 qkm. Ganz unvergleichlich ausgedehntere Wanderungen unternahmen aber jene Mengen feinster Asche, die in die oberen Luftströmungen gelangten und von diesen zunächst über den ganzen Äquatorialgürtel und dann polwärts getragen wurden. Namentlich auf der Nordhalbkugel war die Luft nahezu vollständig mit Asche durchsetzt und erzeugte dadurch die prächtigen Dämmerungserscheinungen und sonstigen optischen Phänome im Herbst und Frühwinter 1883, wie ähnliche auch schon früher nach großen vulkanischen Ausbrüchen (1818 und 1831) beobachtet worden waren. ${ }^{18}$

Solche gelegentliche kontinentale Spenden stehen aber in ihrer Bedeutung für die pelagischen Ablagerungen jedenfalls zurück gegen die Stoffmengen, die die vulkanischen Ausbrüche auf dem Meeresboden selbst liefern. Aus RUDoLPH's Untersuchungen, ${ }^{19}$ von denen wir bei einer anderen Gelegenheit ausführlicher sprechen werden, geht mit Bestimmtheit hervor, daß solche submarine Ausbrüche überall vorkommen, in der Flach- wie in der Tiefsee, auf den Rücken und Plateaus wie in den Becken des Meeresgrundes. Asche und Bimsstein bedecken oft weithin die Meeresfläche, manchmal in solchen Massen, daß sie Schiffe am Weiterfahren hindern, und sinken nur sehr langsam zu Boden. Erwähnt wurde schon, daß das Seewasser den Felsengrund des Meeres chemisch zersetzt; auch diese Zerstörungsprodukte, die der Verwitterungserde des Festlandes entsprechen, beteiligen sich am Aufbau der anorganischen pelagischen Ablagerungen; und endlich gesellt sich dazu auch noch etwas kosmischer Staub in der Form kleiner Kügelchen mit metallischem Kern oder kristallinischer Struktur. Das Wachstum dieser Sedimente geht äußerst langsam for sich, jedenfalls viel langsamer als das der kontinentalen Ablagerungen, und langsamer auch als die Aufschüttungen auf den Erhebungen des Tiefseebodens. Denn hier tritt ja noch das organische Element hinzu. Allerdings bevölkern jene Myriaden winziger Organismen, die man jetzt unter dem Namen Plankton zusammenfaßt, $\times$ gleichmäßig die tiefsten wie die seichteren

$\times$ Нӥскец teilt die Salzwasserorganismen nach ihrer Lebensweise in drei Klassen; das Benthos ( $\beta \varepsilon ́ v \vartheta o s=$ die Tiefe) umfaßt alle festliegenden, laufenden und kriechenden Organismen, die also an den Meeresboden gebunden sind; das 
Gewässer, und ununterbrochen geht ein Regen von Kalkgehäusen zu Boden. Aber je tiefer sie gelangen, desto rascher fallen sie der Zerstörung anheim, da der Kohlensäuregehalt des Meerwassers mit der Tiefe zunimmt, und außerdem kohlensäurehaltiges. Wasser unter hohem Druck mehr kohlensauren Kalk aufnimmt als unter dem gewöhnlichen Luftdruck. Daraus erklärt es sich, daß der Kalkschlamm nur die mäßiger tiefen Abgründe des offenen Ozeans bedeckt. Die größte Verbreitung hat der Globigerinenschlamm, besonders im Atlantischen Ozean (44 Mill. qkm); auch im Indischen Ozean, wo er den Westen und Norden einnimmt, herrscht er noch vor, während er im Großen Ozean der Hauptsache nach auf die polynesischen Plateaus beschränkt ist. Seinen Namen führt er von der Foraminiferengattung Globigerina, deren Schalen weitaus überwiegen. Besonders gerne folgt sie den warmen Meeresströmungen, und ihre weite polare Verbreitung im Atlantischen Ozean verdankt sie nur der Golfstromtrift.

Auf der mittleren Schwelle des südatlantischen Ozeans nimmt der Globigerinenschlamm durch die massenhafte Anhäufung von Molluskenschalen, besonders von Pteropoden und Heteropoden, einen besonderen Charakter an. Man hat diese lokal beschränkte Abart des Kalkschlammes als Pteropodenschlamm bezeichnet.

In den höheren antarktischen Breiten spielen die feinen Kieselpanzer der mikroskopischen Algenordnung der Diatomaceen dieselbe Rolle wie die Globigerinenschalen in den übrigen Meeren, und der Diatomeenschlamm, der übrigens auch einen großen Prozentsatz kohlensauren Kalkes enthält, scheint, soweit man jetzt beurteilen kann, ein ununterbrochenes, breites Band um das südliche Eismeer zu schlingen. Sonst hat man ihn nur noch in der Nähe der Kurilen gefunden.

In allen diesen Ablagerungen bilden die anorganischen Bestandteile nur ungefähr $1 / 3$, im roten oder Tiefseeton aber $\% / 10$ der Proben. Im Atlantischen Ozean bedeckt dieser die tiefsten Einsenkungen der Becken, die Rücken und Plateaus dagegen - wie schon erwähnt - Globigerinenschlamm; im Indischen Ozean nimmt der rote bis schokoladenbraune Ton den tieferen Osten ein; im Pazifischen Ozean gewinnt er aber seine größte Verbreitung (106 Mill. qkm), im Norden und Osten herrscht er nahezu aus-

Plankton $(\pi \lambda \alpha \nu \alpha \omega=$ umherschweifen) alle schwimmenden Organismen, die widerstandslos den Bewegungen des Meeres folgen; das Nekton ( $\nu \eta \varkappa \tau$ ć $=$ schwimmend) endlich die kräftigeren Schwimmer, die sich auch gegen die Strömung bewegen können. $\mathrm{Zu}$ den pelagischen Ablagerungen trägt das Plankton am meisten bei. 
schlieBlich. Er besitzt alle physikalischen und chemischen Eigenschaften eines echten Tones; er ist weich, plastisch, schmierig; seinem Hauptbestandteil nach kann man ihn als ein TonerdeSilikat-Hydrat bezeichnen, wie es aus der chemischen Zersetzung vulkanischer Auswürflinge hervorgeht. An einigen der tiefsten Stellen des Indischen Ozeans und im östlichen Großen Ozean mischen sich ihm die kugeligen Kieselgerüste der Radiolarien oder Gittertierchen in solchen Mengen bei, daß man sich genötigt gesehen hat, ihn als eigene Art unter dem Namen Radiolarienschlamm auszuscheiden.

Übersicht der Meeresablagerungen.×

\begin{tabular}{|c|c|c|c|c|c|}
\hline \multirow[b]{2}{*}{ Ablagerungen } & \multicolumn{3}{|c|}{ Bestandteile in Prozenten } & \multirow[b]{2}{*}{$\begin{array}{c}\text { Tiefengrenze } \\
\mathrm{m}\end{array}$} & \multirow[b]{2}{*}{$\begin{array}{c}\text { Areal } \\
\text { Mill.qkm }\end{array}$} \\
\hline & $\begin{array}{c}\text { Kalk- } \\
\text { haltige } \\
\text { Organismen }\end{array}$ & $\begin{array}{c}\text { Kieselsäure- } \\
\text { haltige } \\
\text { Organismen }\end{array}$ & $\begin{array}{c}\text { Anorgan. } \\
\text { Ab- } \\
\text { lagerungen }\end{array}$ & & \\
\hline Roter Ton ..... & 7 & 2 & 91 & $4100-7200$ & 130,3 \\
\hline Radiolarienschlamm . & 4 & 54 & 42 & $4300-8200$ & 12,2 \\
\hline Diatomeenschlamm . & 23 & 41 & 36 & $1100-3600$ & 23,2 \\
\hline Globigerinenschlamm & 64 & 2 & 34 & $700-5400$ & 105,6 \\
\hline Pteropodenschlamm. & 79 & 3 & 18 & $700-2800$ & 1,4 \\
\hline Summe d. pelag. Ablag. & - & - & - & - & 272,7 \\
\hline Blauer Schliek . . . & 13 & 3 & 84 & $200-5100$ & \\
\hline Roter Schliek . . . & 32 & 1 & 67 & $200-2200$ & \\
\hline Grüner Schlick . . & 25 & 14 & 61 & $200-2300$ & \\
\hline Grüner Sand . . . & 50 & 8 & 42 & unter 1600 & \\
\hline Vulkanischer Sehlamm & 20 & 2 & 78 & $500-5100$ & 55,7 \\
\hline Vulkanischer Sand . . & 29 & 1 & 70 & $200-800$ & \\
\hline Korallenschlick . . & 86 & 1 & 13 & $200-3300$ & \\
\hline Korallensand . . . . & 87 & 5 & 8 & unter 500 & \\
\hline Litorale Ablagerungen. & 一 & 一 & 二 & $0-200$ & 33,0 \\
\hline Summe d. kontin. Ablag. & - & - & - & - & 88,7 \\
\hline
\end{tabular}

Literaturnachweise. ${ }^{1}$ Hauptwerk O. Krünmes, Handbueh der Ozeanographie; neue Ausgabe Stuttgart 1907 und 1911. Gedrängtere Darstellungen in O. Krüмmer, Die Ozeane, 2. Aufl.; Leipzig 1902; G. Sснотт, Physische Meereskunde; Leipzig 1903, und K. Rösscer, Grundzüge der Ozeanographie; Fiume 1903. Von fremdsprachigen ist besonders J. Thобцет, L'Océan, ses lois et ses problèmes; Paris 1904, zu nennen. Herm. Berghaus, Atlas der Hydro-

$\times$ Die Analyse und die Tiefengrenzen beziehen sich nur auf die Bodenproben, die John Murray und Renard zur Prüfung vorlagen. Die Areale sind der neuen Auflage von Krümmel's Ozeanographie entnommen. In bezug auf den großen Ozean weichen die neuen Zahlen von John Murray und G. W. Laen ${ }^{14}$ nicht nnerheblich ab. 
logie und Teile des Atlas der Geologie (in Berghaus' Physikalischem Atlas; Gotha 1891 u. 92). Von der Deutschen Seewarte sind drei umfangreiche Kartenwerke herausgegeben worden: Atlas des Atlantischen Ozeans; Hamburg 1882 (2. Aufl. 1902), des Indischen Ozeans, 1891, und des Stillen Ozeans, 1896. Eine neue Bearbeitung fand der Indische Ozean in Bd. I der wissenschaftlichen Ergebnisse der deutsehen Tiefsee-(„Valdivia")Expedition: G. Sснотт, Ozeanographie und maritime Meteorologie; mit Atlas; Berlin 1902. — ${ }^{2}$ JEAN DE Wind, Sur les distances moyennes à la côte dans les Océans, in den Mémoires couronnés et mémoires des savants étrangers de l'Académie R. des seiences de Belgique, Bd. LVII; Brüssel 1889. - ${ }^{3}$ Das Challenger-Werk (Report on the Scientific Results of the Voyage of H. M. S. Challenger; herausgegeben von C. W. Thomson und J. Murrax); 1882-95, umfaßt 50 Bände, von denen 40 zoologischen Inhalt haben. Die geographisch wichtigen Teile werden an den geeigneten Stellen zitiert werden. - 4 A. Supan, Die Bodenformen des Weltmeeres, in Petermann's Mitteilungen 1899 mit Tiefenkarte in MetermaB; eine Reproduktion derselben in großem Maßstab (26 Blätter) mit Berücksichtigung der neuesten Lotungen und sämtlichen Tiefenzahlen ist Thoulex's Carte générale bathymétrique des Océans; Monaco 1905. Für die südlichen Breiten ist sie überholt durch die Karte von G. Sснотт (Die Bodenformen und Bodentemperaturen des südlichen Eismeeres, in Petermanx's Mitteilungen 190j). Sir John Murray, Oceanography, im Geographical Journal, Bd. XIV, 1899 (Tiefenkarte in englisehem Fadenmaß). - 5 J. Mrine, Suboceanic Changes, im Geographieal Journal, Bd. X, 1897. - ${ }^{6}$ G. Ziemendonff, Der kontinentale Schelf des nordatlantisehen Ozeans, in den „Beiträgen zur Geophysik", Bd. X, 1910. Von dem arktischen Schelf handelt F, Naxsen (s. u. Anm. 12). - ${ }^{7}$ E. Huls, On the Sub-oceanic Terraces and River Valleys of the Coast of Western Europe; London 1899. - ${ }^{8}$ F. Diernich, Untersuchungen über die Böschungsverhältnisse der Sockel ozeaniseher Inseln; Greifswald 1892. - ${ }^{9}$ J. F. Buake, On the Original Form of Sedimentary Deposits, im Geologieal Magazine, 1903, Bd. X. $-{ }^{10}$ A. Supan, Terminologie der wichtigsten unterseeischen Bodenformen, in Petermann's Mitteilungen, 1903. - 11 Über die jüngeren Gräbenentdeckungen s. G. Sснотт und P. Perlewitz, Lotungen I. M. N. S. „Edi" und des Kabeldampfers „Stephan" im westlichen Stillen Ozean, Arehiv der Deutschen Seewarte 1906, Nr. 2; W. Brennecre in Bd. III der Forschungsreise S. M. S. „Planet" 1906/07, Berlin 1909; die Lotungen desselben Dampfers 1909 in den Annalen der Hydrographie und maritimen Meteorologie 1910, Taf. 19 u. 20, und 1911, Taf. 1 u. 2. - ${ }^{12}$ F. Nanses, The Norwegian North Polar Expedition, 1893-96, Scientific Results, Bd. IV, London 1904. - ${ }^{13}$ R. E. Peary im Geographical Journal 1910, Bd. XXXVI, S. 129. - ${ }^{14}$ J. Murray und A. F. Renard, Deep-Sea Deposits (Challenger Report); London 1891. J. Murrax, On the Distribution of the Pelagie Foraminifera, im Natural Science, 1897; J. Murray und G. W. Lee, The Depths and Marine Deposits of the Pacific, in den Memoirs of the Museum of Comparative Zoology at Harvard College, Bd. XXXVIII, 1909. Eine detaillierte Darstellung der mannigfaltigen Bodenbedeckung des Schelfs gibt J. Thooler, Carte lithologique sous-marine des côtes de France, in 22 Blättern; Paris 1899-1901. - ${ }^{15} \mathrm{H}$. Rodman, Report on Ice and Ice Movements in the North Atlantie Ocean; Washington 1890. (Nr. 93 der Publikationen des U. S. Hydrographic Office). - ${ }^{16}$ Die Forschungsreise S. M. s. "Gazelle"; Berlin 1889 u. 1890. Bd. II enthält die ozeanographischen Ergebnisse. - ${ }^{17}$ L. E. Dinkqage in den Aunalen der Hydrographie und maritimen Meteorologie 1886, S. 63 u. 113, und 
1898, S. 246. - ${ }^{18}$ G. J. Sxmoss, The Eruption of Krakatoa; London 1888. J. Kıessling, Untersuchungen über Dämmerungserscheinungen; Hamburg 1888. - ${ }^{12}$ E. Rudolph, Über submarine Erdbeben und Eruptionen, in Gerland's Beiträgen zur Geophysik, Bd. I, 1887; Bd. III, 1897.

\section{Das Meerwasser.}

Das Meeresniveau. Abgesehen von der Wellenbewegung, die immer nur ein vorübergehender Zustand ist, den wir durch eine zweckmäBige.Aufstellung des Pegels an der Küste ausschalten können, ordnen sich die leicht verschiebbaren Teilchen des Meeres nach dem Verhältnis von Schwerkraft und Fliehkraft. Nur die Meeresoberfläche repräsentiert die wahre Erdgestalt (das Geold), während die Landoberfläche unter dem Einfluß ganz anderer Kräfte in unregelmäßigen Erhebungen und Vertiefungen verläuft.

Das Meeresniveau ist aber nicht konstant, es hebt und senkt sich unter der Anziehungskraft von Mond und Sonne. Es ist auch nicht rein ellipsordisch, weil Meer und Land nebeneinander lagern. Jedes Wasserteilchen erleidet eine doppelte Anziehung, einerseits zum Mittelpunkt der Erde, anderseits seitlich zu den 2,6 mal schwereren Landmassen hin. Aus der Differenz der astronomisch und geodätisch gemessenen Entfernungen zweier Oberflächenpunkte läßt sich diese seitliche Ablenkung des Bleilotes, das uns die Richtung der Schwerkraft anzeigt, ermitteln. Das ungestörte Meeresniveau, das sich stets senkrecht zur Lotlinie stellt, wird in der Nähe des Landes in die Höhe gezogen, und zur Ausgleichung müssen entferntere Teile der Meeresoberfläche sich senken. Denken wir uns der Einfachheit wegen alle Kontinente entfernt bis auf Europa-Asien und das Meer durch Kanäle unter dieses Festland fortgesetzt. Im Zentrum des Kontinentes $\left(48^{\circ} \mathrm{N}, 73^{\circ} \mathrm{O}\right)$ würde das Geold oder der Meeresspiegel am höchsten ansteigen, aber auch an dem entgegengesetzten Punkt würde eine Niveauerhöhung eintreten, denn hier wirkt die Anziehungskraft der Festlandsmasse am wenigsten; gleichzeitig wird auch der Schwerpunkt der Erde von dem Mittelpunkt gegen das kontinentale Zentrum hin verschoben, so daß in dem entgegengesetzten Meridian der Abstand zwischen Oberfläche und Schwerpunkt größer wird, als er vor Einschaltung des Festlandes war., Zwischen den beiden Erhebungen liegen die Senkungen der Meeresfläche. HeLment ${ }^{1}$ fand hierfür folgende Werte:

× Eine Folge davon ist auch, daB das Meer durch sein eigenes Gewicht zusammengedrückt wird und dadurch eine Niveauerniedrigung von durchschnittlich $30 \mathrm{~m}$ erleidet. 


\begin{tabular}{|c|c|c|}
\hline $\begin{array}{l}\text { Abstand } \\
\text { vom } \\
\text { Festlandszentrum }\end{array}$ & $\begin{array}{c}\text { Meridian } \\
\text { (Greenwich) }\end{array}$ & $\begin{array}{c}\text { Lage der deformierten } \\
\text { Niveaufläche über }(+) \\
\text { und unter }(-) \text { dem nor- } \\
\text { malen Niveau }\end{array}$ \\
\hline 00 & $73^{\circ} \mathrm{O}$ & +504 \\
\hline 700 & $\begin{array}{r}143^{\circ} 0 \\
3^{\circ} 0\end{array}$ & -188 \\
\hline 1800 & $107^{\circ} \mathrm{W}$ & +201 \\
\hline
\end{tabular}

In Wirklichkeit liegen mehrere Festländer unregelmäBig zerstreut im Meer, und ihre Wirkungen auf das Geold interferieren miteinander. Hesmert hat nach seinen Berechnungen eine Karte der Geolddeformationen entworfen, die aber nur ein theoretisches Interesse in Anspruch nehmen darf. Unsere Kenntnis von der Massenverteilung ist viel zu gering, als daß sich daraus schon ziffermäßige Ermittelungen jener Deformationen ableiten ließen; und da die Zahlen aller reellen Bedeutung entbehren, so schweben natürlich auch alle jene weittragenden Schlüsse, die man vor ein paar Jahrzehnten darauf baute, in der Luft. Die Pendelbeobachtungen, auf die schon einmal (S. 4) hingewiesen wurde, haben es nach Anwendung der Kondensationsmethode HeLmerT's im höchsten Grad wahrscheinlich gemacht, daß durch Massendefekte in den Kontinenten einèrseits, durch gröBere Dichtigkeit der ozeanischen Kruste anderseits eine Ausgleichung angestrebt, wenn auch vielleicht noch nicht erreicht wird. Aus den Lotablenkungen hat man für die Kontinente eine Maximalerhöhung des Geords von ungefähr $50 \mathrm{~m}$ herausgerechnet; für die Ozeane kann man nach Messerschimt ${ }^{2}$ nur Depressionen von höchstens $150 \mathrm{~m}$ unter dem Ellipsoid erwarten, so daß die Gesamtabweichung $200 \mathrm{~m}$ nicht überschreitet - ein ganz minimaler Wert gegenüber der Größe der Erde.

Welche Gestaltveränderungen auch immer der Meeresspiegel dadurch erleiden möge, sein Charakter als Niveaufläche wird nicht berührt. Wohl geschieht dies aber durch eine Reihe anderer von außen her wirkender Einflüsse, und alle Störungen dieser Art müssen durch Strömungen vom höhern zum niederern Niveau wieder ausgeglichen werden. Soweit die Störungen dauernd sind, müssen sie auch dauernde Strömungen hervorrufen. Die Erwärmrung, die alle Körper ausdehnt, hebt das Niveau der Tropenmeere nach Zöppritz' Rechnung nur $6 \mathrm{~m}$ über das der Polarmeere. Die Veränderungen des Luftdrucks machen sich mit ihrem 13 fachen Betrag, aber im entgegengesetzten Sinn geltend; steigt z. B. das Barometer um $10 \mathrm{~mm}$, so sinkt der Meeresspiegel an der betreffenden Stelle um $130 \mathrm{~mm}$. Nach dem Gesetz der kommunizierenden Röhren nehmen verschieden dichte Flüssigkeiten verschiedene Niveaus ein, und zwar 
die dichteste das tiefste. Die Dichte des Meerwassers hängt nun von zwei variablen Faktoren, der Temperatur und dem Salzgehalt, ab. Einmündende Flüsse, Niederschläge und die Schmelzwässer des Eises verringern den relativen Salzgehalt und damit auch die Dichte. Die Winde endlich wirken mittel- und unmittelbar auf das Meeresniveau ein; unmittelbar, indem auflandige Winde das Wasser an der Küste aufstauen, , ablandige es von der Küste wegtreiben; ${ }^{\times}$mittelbar, indem sie Strömungen erzeugen, die, durch die Erdrotation abgelenkt, auf der nördllichen Halbkugel nach den rechts, auf der südlichen nach den links gelegenen Küsten hindrängen und hier das Niveau erhöhen.

Aus den Ablesungen des wechselnden Wasserstandes am Pegel oder aus den fortlaufenden Aufzeichnungen des selbstregistrierenden Mareographen berechnet man das mittlere Niveau oder das Mittelwasser an der betreffenden Küstenstelle in gleicher Weise wie meteorologische Mittelwerte. Die periodischen Schwankungen der störenden Einflüsse kommen in dem Mittelwasser klar, wenn auch abgeschwächt zum Ausdruck. An der niederländischen und schwedischen Küste steht das Niveau von Januar bis Juni unter, von Juli bis Dezember über dem Jahresmittel, an der deutschen Ostseeküste fallen die positiven Wasserstände in die Zeit von Juni bis Oktober. Hier ist jedenfalls die jährliche Verteilung der Niederschläge, sowol unmittelbar wie auch mittelbar durch ihren Einfluß auf die Wasserstände der Flüsse der maßgebende Faktor. Aber die jährliche Schwankung ist gering: an der schwedischen Küste 21,3, an der niederländischen 20,7, an der deutschen nur 12,5 cm. BRÜCKNER ${ }^{3}$ fand auch seine 35jährige Periode in den Pegelablesungen in der Ostsee und im Schwarzen Meer wieder, ja selbst das Küstenwasser des offenen Ozeans steigt, wie die Beobachtungen an nordwestlichen Hafenplätzen Frankreichs zeigen, in der feuchten Periodenhälfte an (in Havre bis $0,05 \cdot \mathrm{m}$ ) und senkt sich in der trockenen. Hier ist offenbar die Verringerung des Salzgehaltes durch das Flußwasser das entscheidende Moment. Noch rätselhaft ist jene lange Periode, die man an der atlantischen Küste von Frankreich beobachtet hat: 1857-71 sank das Niveau um ungefähr $2 \mathrm{~mm}$ im Jahr und stieg dann von 1821 an wieder um den gleichen Betrag. ${ }^{4}$

Wenn wir von Mittelwasser schlechtweg sprechen, so verstehen wir darunter einen vieljährigen Mittelwert, etwa entsprechend der mittleren Jahrestemperatur. Dieser Vergleich ist auch insofern zu-

$x$ In Aden schwankt der mittlere monatliche Wasserstand zwisehen $+104 \mathrm{~mm}$ bei NO-Monsun und $-137 \mathrm{~mm}$ bei SW-Monsun. An der deutsehen Ostseeküste steigt das Mittelwasser infolge der vorherrschenden Westwinde nach $\mathrm{O}$ etwas an (Wismar $-0,053$, Memel $+0,138 \mathrm{~m}$ bezogen auf den normalen Nullpunkt). 
treffend, als aus beiden Werten nicht alle Störungen eliminiert sind. Daher liegt das Mittelwasser nicht an allen Küstenpunkten im gleichen Niveau. MoнN's ${ }^{5}$ Untersuchungen im europäischen Nordmeer zwischen Norwegen, Grönland, Island und Spitzbergen sind in dieser Beziehung von bahnbrechender Bedeutung. Er berechnete die Deformationen des Meeresspiegels durch die Dichteverschiedenheiten und die Windtriften und leitete daraus durch Summierung die Stromfläche ab, $\times$ die nach einer kleinen Korrektur mit Rücksicht auf den Luftdruck die wirkliche Meeresoberfläche darstellt. Sie bildet eine Mulde, deren tiefster Punkt in $68^{1} / 2^{0} \mathrm{~N} 1^{0} \mathrm{~W}$ liegt, und die dann nach allen Seiten zuerst langsam, dann schneller ansteigt. Das Küstenwasser bei den Färöer liegt 0,4, bei Island, Jan Mayen und Spitzbergen 0,6, bei Finmarken 0,9 , bei Schottland $1-1,1$, bei Nowaja Semlja 1,1, bei Grönland, Jütland und im südlichen Norwegen $1,4 \mathrm{~m}$ über jener tiefsten Einsenkung.

Die Tatsache, daß das Mittelwasser an den Küsten in verschiedenen Niveaus liegt, hat auch eine große praktische Bedeutung. $\mathrm{Da}$ die Höhenmessungen der einzelnen Staaten sich auf das Mittelwasser eines Küstenpunktes innerhalb ihrer Grenzen beziehen, liefern sie nicht streng vergleichbare Werte. Ja sogar innerhalb eines und desselben Staates können sich diese Unstimmigkeiten fühlbar machen. In Preußen wurden vor 1866 alle Höhenangaben in den östlichen Provinzen auf den Nullpunkt des Pegels zu Swinemünde und in den westlichen Provinzen auf den Nullpunkt des Amsterdamer Pegels bezogen. Als sich nun Preußen durch die Einverleibung Hannovers zu einer kompakten Ländermasse zusammenschloB, war jener hypsometrische Dualismus unhaltbar geworden. Man verlegte den Ausgangspunkt des Nivellements der Landesaufnahme seit 1879 in die Berliner Sternwarte, wo auf dem tief fundierten Nordpfeiler der "Normalhöhenpunkt" angebracht ist; genau $37 \mathrm{~m}$ unter ihm befindet sich die ,Normalnull“, auf die alle neuen Höhenmessungen bezogen werden. Man glaubte ursprünglich, daß sie genau in dem Niveau des Nullpunktes des Amsterdamer Pegels liege, in der Tat liegt sie aber nach den letzten Berechnungen 0,003 $\mathrm{m}$ darüber und $0,066 \mathrm{~m}$ über der Swinemünder Null. Die schwedische

$\times$ Als Beispiele dienen folgende Stationen:

Beobachtungsstation $\left\{\begin{array}{llll}69^{\circ} 18^{\prime} \mathrm{N} & 64^{\circ} 36^{\prime} & 68^{\circ} 21^{\prime} \mathrm{N} \\ 14^{\circ} 33^{\prime} \mathrm{O} & 10^{\circ} 22^{\prime} & 2^{\circ} & 5^{\prime} \mathrm{W}\end{array}\right.$

Höhe über bez. unter $(-)$ dem Normalniveau

$\begin{array}{llrr}\text { Windfläche . . . } & 0,580 \mathrm{~m} & 0,196 \mathrm{~m} & 0,015 \mathrm{~m} \\ \text { Dichtigkeitsfläche . . } & 0,213, & -0,112, & -0,016, \\ \text { Stromfläche - . . . } 0,793, & 0,084, & -0,001,\end{array}$


Normálnull befindet sich 11,8 m unter dem Normalhöhenpunkt an der Nordostseite des Generalstabsgebäudes in Riddarsholmen (Stockholm). Die Sehweiz, die keine Meeresgrenzen hat, wählte als Basis ihres Nivellements die Pierre du Niton bei Genf, deren mittlere Seehöhe noch nicht mit Sicherheit ermittelt ist; man nimmt jetzt als solche $373,6 \mathrm{~m}$ an. Die Aussicht auf eine gemeinsame europäische Normalnull dürfte sich nicht so bald verwirklichen, da sich auch die internationale Erdmessungskommission dagegen ausgesprochen hat. Denn unter allen Umständen müßte diese Normalnull an das Meer verlegt werden, sonst würde man auf jeden Vergleich der europäischen Höhen mit jenen anderer Festländer und der Inseln verzichten; aber mit der Wahl eines einzigen Pegelnullpunktes würde man für die entfernteren Länder noch größere Fehlerquellen eröffnen, als diejenigen sind, unter denen man jetzt leidet. Selbst unsere feinsten Nivellements unterliegen nach BöRsch norch einem mittleren Fehler von $\pm 4,42 \mathrm{~mm}$ auf das Kilometer, und anderseits sind die Niveauunterschiede des Mittelwassers an den verschiedenen Küsten jedenfalls nicht so groß, wie man früher annahm. Sie dürften in den europäischen Meeren wohl selten $0,5 \mathrm{~m}$ überschreiten und in den meisten Fällen nicht einmal 0,1 erreichen, doch lassen sich genauere Zahlen bis jetzt nur für wenige Punkte geben. ${ }^{\times}$Zwischen den Ozeanen ist zum erstenmal 1904 durch das Feinnivellement quer durch die Vereinigten Staaten eine geodätische Verbindung hergestellt worden. Sie ergab, daß der Spiegel des Mittelwassers des Großen Ozeans um 0,187 m höher liegt als der des Atlantischen ${ }^{7}$ - ein höchst geringfügiger Unterschied, der wohl ganz den Nivellementsfehlern zur Last gelegt werden darf. Zum Unterschied von den Höhenmessungen gehen die Tiefenmessungen in den flachen Küstengewässern gezeitenbewegter Meere von dem sog. Kartenniveau aus. Man versteht darunter in England und Deutschland (mit Ausnahme der Ostsee) das Niedrigwasser der Springzeit, in Frankreich das tiefste bisher beobachtete Niedrigwasser und in Amerika das mittlere Niedrigwasser. Die Tiefen sind daher nicht nur nicht mit den Höhen des Küstenlandes, sondern

$\times$ Helmert $^{6}$ sagt darüber: „Das Resultat dieser Arbeit (Kritik von 48 Nivellementspolygonen in Mittel- und Westeuropa) hat gezeigt, daB das mittlere Niveau im Mittelländischen und Ádriatischen Meer ungefähr $13 \mathrm{em}$ tiefer liegt als in der Ostsee, Nordsee und im Kanal, aber auch, daß Differenzen von derselben Ordnung entlang den nördlichen und südlichen Küsten vorkommen. Ein Teil dieser Differenzen ist sicherlich reell, wie z. B. die bis zu $15 \mathrm{~cm}$ betragenden für die Punkte an der holländischen Küste. Allein sobald es sich um große Entfernungen von Stationen handelt, kann diese Realität noch nicht als erwiesen betrachtet werden," Als sichergestellt darf jetzt nach Rosén die Höhenlage der Ostsee um ungefähr 0,19 m über dem Kattegat gelten. 
auch nicht untereinander vergleichbar, weil das Niedrigwasser an verschiedenen Stellen verschiedene Niveaus einnimmt. An der Südküste Englands zwischen Selsea Bill und Brighton beträgt der Unterschied zwischen dem Mittelwasser, das der englischen Landvermessung zugrunde liegt, und dem Niedrigwasser 2,4-3 m, mit der Entfernung von der Küste vermindert er sich aber uød dürfte in einem Abstand von $19 \mathrm{~km}$ nur mehr auf $1,8 \mathrm{~m} \mathrm{zu}$ veranschlagen sein. $^{8}$ In der küstenfernen Tiefsee beziehen sich die Lotungen auf das augenblickliche Meeresniveau. Die daraus entspringende Ungleichheit der Tiefen ist indes ohne Belang, weil der Unterschied zwischen Hoch- und Niedrigwasser im offenen Ozean äußerst gering ist.

Salzgehalt und spezifisches Gewicht. 32 Elemente sind bisher im Meerwasser nachgewiesen worden, und es unterliegt keinem Zweifel, daß künftige Untersuchungen diese Zahl noch vermehren werden. Sie erscheinen als Bestandteile teils des Wassers selbst, teils dér absorbierten Luft und Kohlensäure, zum größten Teil aber der aufgelösten chemischen Verbindungen. Die letzteren bezeichnet man in ihrer Gesamtheit als Salzgehalt; dieser ist es, der dem Meerwasser den eigentümlich salzig bittern Geschmack und das hohe spezifische Gewicht verleiht. Im allgemeinen kann man 35 Promille als den normalen Salzgehalt des offenen Ozeans betrachten. Seine Zusammensetzung ist, wie auch die zahlreichen Analysen der Challengerprobén neuerdings wieder bestätigten, unter allen Breiten und Längen die gleiche, und nur der Kalkgehalt nimmt mit der Tiefe etwas zu. Ditrmar berechnete im Durchschnitt für $1000 \mathrm{~g}$ Wasser:

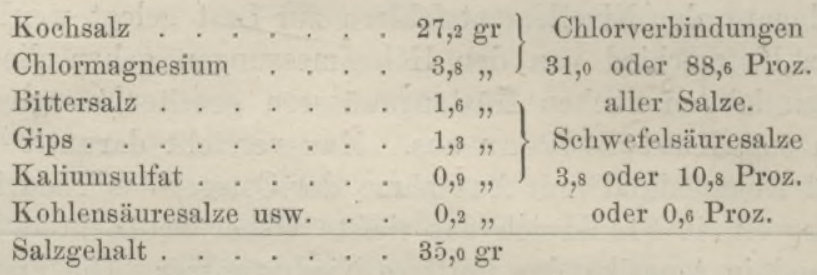

Der Unterschied zwischen dem Meer- und dem Flußwasser besteht aber nicht nur in dem weitaus größeren Salzgehalt des ersteren, sondern auch in dessen Zusammensetzung. Im Meerwasser herrschen die Chlorverbindungen, im Flußwasser die Kohlensäuresalze entschieden vor; der Salzgehalt des ersteren kann also nicht von dem letzteren abgeleitet werden.

Die direkte Ermittlung des Salzgehaltes durch Wägung der nach dem Eindampfen übrig gebliebenen Rückstände kann in genauerer Weise nur im Laboratorium bewerkstelligt werden und führt selbst dann nicht völlig zum Ziel, weil Kohlen- und Salzsäure miţ 
dem Wasser fortgehen. An Bord des Schiffes ist man im wesentlichen auf drei indirekte Methoden angewiesen: auf die Bestimmung des spezifischen Gewichtes mittels des Aräometers, auf die chemischanalytische Feststellung des Chlorgehalts, der in einem konstanten Verhältnis zu dem ganzen Salzgehalt steht, und endlich auf die Untersuchung des optischen Brechungsexponenten des Seewassers, der ebenfalls vom Salzgehalt abhängt. Von diesen Methoden hat die zweite den Sieg davongetragen. Bezeichnen wir mit $S$ das Salzgewicht in Gramm in $1000 \mathrm{~g}$ Meerwasser und mit $\mathrm{Cl}$ die entsprechende Gewichtsmenge Chlor, so ist

$$
S=0,03+1,805 \mathrm{Cl} \text {. }
$$

Der so ermittelte Salzgehalt ist etwas kleiner als der wirkliche, aber der Unterschied ist so gering, $\mathrm{da} B$ er in der Praxis vernachlässigt werden kann. ${ }^{10}$

Das in der deutsehen Marine und auch sonst gebräuchlichste Aräometer gibt unmittelbar das spezifische Gewicht des Seewassers bei seiner augenblicklichen Temperatur $\left(l^{0}\right)$, bezogen auf destilliertes Wasser von $17,5^{\circ}\left(14^{\circ} \mathrm{R}\right.$.), oder, um es kurz auszudrücken, $s\left(\frac{t^{0}}{17,5^{\circ}}\right)$. Das spezifische Gewicht des Meerwassêrs, das man gewöhnlich, wenn auch nicht ganz korrekt, mit seiner Dichte identifiziert, hängt

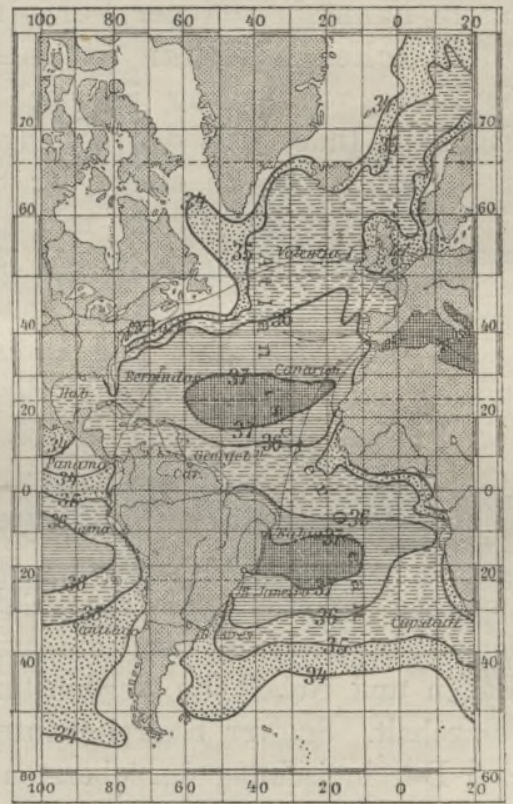

Fig. 59. Salzgehalt des Atlantischen Ozeans nach ScHотт. ${ }^{9}$ außer von dem. Salzgehalt auch von der Temperatur ab, da das Meerwasser, wie alle Körper, sich bei steigender Temperatur ausdehnt und dadurch leichter wird. Das spezifische Gewicht ist daher periodischen und unperiodischen Schwankungen unterworfen, wie die Temperatur selbst. Wir können den Einfluß der Temperatur ausscheiden, wenn wir alle Aräometerangaben auf gleiche Temperatur reduzieren, z. B. auf $17,5^{\circ}$, wie es bei uns üblich ist. $\times$ Dieses

$\times$ Die Engländer berechnen, um wieviel mal Seewasser von der Temperatur $15,56^{\circ}\left(60^{\circ} \mathrm{F}\right.$.) sehwerer ist als ein gleich großes Volumen destillierten Wassers von $4^{0}$, also $s\left(\frac{15,6^{\circ}}{4^{0}}\right)$. Andere Reduktionen sind $s\left(\frac{0^{\circ}}{4^{0}}\right)$ und $s\left(\frac{20^{\circ}}{4^{0}}\right)$. Eine internationale Regelung ist dringend erwünseht. 
reduzierte spezifische Gewicht $s\left(\frac{17,5^{\circ}}{17,5^{\circ}}\right)$ wird allein vom Salzgehalt bestimmt und kann direkt in denselben verwandelt werden, ${ }^{\times}$doch ziehen es manche Darsteller vor, in ihre Karten nur Linien gleicher Dichte oder gleichen reduzierten spezifischen Gewichts einzuzeichnen. ${ }^{11}$

Obwohl sich das Aräometer auch schon auf Handelsschiffen eingebürgert hat, so haben doch eigentlich nur die wenigen wissenschaftlichen Expeditionen wirklich brauchbares Material geliefert und unsere Kenntnis von der Verteilung des Salzgehaltes in den Oberflächenschichten ist daher noch recht mangelhaft; selbst die Karte von Sснотт ist noch für viele Gegenden hypothetisch (Fig. 59). Indes tritt das Grundgesetz doch schon deutlich hervor. Im offenen Ozean steigt der Salzgehalt von der Äquatorialzone bis gegen $15-30^{\circ}$ Breite und sinkt dann wieder polwärts, wobei wir es natürlich unentschieden lassen müssen, ob sich dieses Verhalten bis in die innersten Polarkalotten fortsetzt. Man erkennt sofort, daB Salzgehalt und Luftdruck im inneren Zusammenhang stehen, wenn auch nicht im direkten, sondern durch Vermittlung der Winde. Daher fallen die Maximalgebiete des Salzgehaltes und des Luftdruckes nicht zusammen, sondern jene liegen in der Zone lebhaftester passatischer Luftbewegung, weil hoher Salzgehalt durch starke Verdunstung bedingt ist, und nichts so sehr die Verdunstung befördert, als regelmäßige, frische, trockene Winde. In demselben $\mathrm{MaB}$, in dem die atmosphärischen Niederschläge (Regen und Nebel) die Verdunstung überwiegen, verringert sich der Salzgehalt. Sснотт bestreitet ihren Einfluß, weil der Seegang sofort eine Durchmischung der obersten Wasserschichten mit dem Regenwasser einleite; aber gerade dieser ProzeB ist es, der den Salzgehalt jener Schichten verringert. Infolge dessen nimmt im Äquatorialgürtel, entgegen der allgemeinen Regel, der Salzgehalt mit der Tiefe etwas zu. Wäre, wie Sснотт meint, der äquatoriale Salzgehalt der normale, der nur deshalb keine Steigerung erfährt, weil unregelmäBige, schwache Winde und Stillen und feuchte Luft die Verdunstung verhindern, so müBte er auch in den mittleren und höheren Breiten zu finden sein, weil hier die Verdunstung stetig gegen die Pole abnimmt. Im Bereich des Polareises, wo die Niederschläge gering sind, bewirken die Schmelzwässer die Aussüßung des Oberflächen-

$\times$ Die hydrographischen Tabellen von KNudsen ${ }^{10}$ gestatten die unmittelbare Ablesung des Salzgehalts in Promille aus dem Wert

$$
1000\left(s\left[\frac{17,5}{17,5}\right]-1\right) \text {. }
$$


wassers. Die Meeresströmungen durchbrechen das Grundgesetz nicht' völlig, rufen aber Störungen hervor, die sich in starken Krümmungen der Linien gleichen Salzgehaltes kundgeben. Wo polare Ströme, wie an den Ostküsten Amerikas, weit in niedere Breiten vordringen, verringern sie den Salzgehalt merklich, während warme Ströme ihr salzreicheres Wasser mehr oder minder weit in höhere Breiten führen - am weitesten die Atlantische Strömung, in deren Bereich ein Salzgehalt von 35 Promille noch den 70. Parallelkreis überschreitet. Nichts Ähnliches weist sonst die Meereskunde unserer Tage auf. Im südatlantischen Ozean reicht die 35 Promille-Linie nur im Brasilstrom bis $43^{\circ}$. B. und zieht sich sonst bis gegen $36^{0}$ B. zurück, und ein gleiches Verhalten zeigen, soweit unsere Kenntnisse reichen, auch die übrigen Südozeane. Im nordpazifischen Ozean liegt die äußerste Polargrenze dieses Salzgehaltsgrades ebenfalls in $39^{\circ} \mathrm{B}$. Schon dies vermag uns eine Vorstellung zu geben von der Macht der Atlantischen Strömung, der in der Tat keine andere gleichkommt.

Wir haben bisher die Küstenzone von unserer Betrachtung ausgeschlossen. Wo große Ströme münden, zeigt sich ihre verdünnende Wirkung oft noch in ziemlich großer Entfernung von der Küste. Oft, aber nicht immer. Daß das äquatoriale Minimum im Atlantischen, Ozean an der afrikanischen Seite so weit nach Süden hinabreicht, ist, wenigstens zum Teil, dem Niger und noch mehr dem Kongo zuzuschreiben; aber Orinoco und Amazonas führen noch größere Mengen Süßwassers dem Meer zu, und doch erlahmt ihr Einfluß schon knapp an der Küste, gegen die die Passatströmungen salzreiches Wasser hinwälzen. In den polaren Zonen gelangt das festländische Süßwasser in der Form von Eisbergen noch weiter in das Meer hinaus, aber auch das schmelzende Meereis ist nur schwach salzig und kann zur Verdünnung der Oberflächenschichten beitragen.

Die geographische Verbreitung des Salzgehaltes im Indischen und Pazifischen Ozean weicht in den Grundzügen von dem atlantischen Bild nicht ab. Auch daB der Indische Ozean nur ein Maximalgebiet, zu beiden Seiten des 30 . Südparallels, besitzt, kann uns nicht überraschen, wenn wir beachten, daß er nur in seinem südhemisphärisehen Teil von beständigem Passat überweht wird. Die Verteilung ist also in allen Ozeanen dieselbe, aber in den absoluten Werten bestehen große Unterschiede. Der nordatlantische Ozean ist weitaus der salzreichste, der nordpazifische sicher der salzärmste Ozean. Als Maxima werden angenommen im nordatlantischen Ozean 37,9, im südatlantischen 37,6, im Indischen 36,4, im nordpazifischen 35,9 , im südpazifischen 36,9 Promille. 
Die Nebenmeere zeigen ein sehr verschiedenes Verhalten. Zunächst ist entscheidend, ob sie von den großen Meeresströmungen berührt werden oder nicht. Im ersteren Fall ist der Salzgehalt von dem Charakter der Strömung abhängig, aber immer etwas geringer als im benachbarten offenen Ozean, weil Nebenmeere verhältnismäBig mehr Flußwasser empfangen. Die inselabgeschlossenen Meere am Ostrand Asiens haben 34-34,5 Promille Salzgehalt, wenn sie von warmen, und 30-32 Promille, wenn sie von kalten Strömungen durchzogen werden. Im Australasiatischen Mittelmeer ist der Unterschied zwischen der verhältnismäßig salzarmen Bandaund Javasee und den salzreicheren Gewässern im Norden und Nordosten besonders auffallend, und die Annahme'Schoтt's, daß die letzteren noch pazifisches Wasser erhalten, scheint uns das Richtige zu treffen. Dagegen ist der geringe Salzgehalt der Javasee (ungefähr 32 Promille) auffallend, wenn man die niedere Breite berücksichtigt, und wahrscheinlich eine Folge reichlicher Zufuhr von Begenwasser. In den Binnenmeeren regelt sich der Salzgehalt der Oberflächenschichten ausschließlich nach dem Verhältnis von Verdunstung und Süßwasserzufluß. In einem warmen und trockenen Klima erreicht er eine Höhe, wie selbst im Ozean nicht. Das Rote Meer ist wohl das salzreichste (bis 41 Promille), aber selbst das europäische Mittelmeer hat noch über 37 Promille. Das Schwarze Meer wird dagegen schon stark durch die einmündenden großen Flüße ausgesüßt (15-18 Promille), und noch weit mehr die Ostsee, wo auch die niedere Temperatur der Verdunstung hinderlich ist. Während die Nordsee, die mit dem Ozean in offener Verbindung steht, noch im Osten 32,5 Promille Salzgehalt besitzt, sinkt dieser im Skagerrak schon auf 30 , im westlichen Teil der Ostsee auf 8 , im nördlichen Bottnischen Busen unter 3, jm Finnischen sogar unter 1 Promille. Auch noch in einem anderen Punkt unterscheiden sich die Binnenmeere wesentlich von dem offenen Ozean: dort nimmt der Salzgehalt. mit der Tiefe zu, hier aber ab, und zwar - wie aus den Beobachtungen der deutschen Südpolarexpediton hervorgeht - in ebenso raschem Tempo wie die Temperatur bis $900 \mathrm{~m}$ Tiefe; und wenn er dann auch wieder etwas steigt, so ist er doch stets am Grund kleiner als in den Oberflächenschichten. Die Konzentration des Seewassers unter dem Einfluß der Verdunstung vollzieht sich ja nur an der Oberfläche; aber da das Wasser dadurch schwerer wird, so sinkt es unter und kann in den Binnenmeeren unter den hier obwaltenden Temperaturverhältnissen (von denen später ausführlicher die Rede sein soll) wirklich bis zum Boden gelangen, während im kalten Ozean schon in Tiefen von etwa $200 \mathrm{~m}$ eine Dichtigkeit herrscht, 
die kein weiteres Einsinken des salzreichen Oberflächenwassers gestattet.

Indem wir von dem Salzgehalt sprachen, sprachen wir zugleich auch von den Verbreitungsgesetzen des reduzierten spezifischen Gewichts. Anderen Gesetzen unterliegt das absolute spezifische Gewicht, das nicht nur von dem Salzgehalt, sondern auch von der Temperatur abhängt und auf destilliertes Wasser von $4^{0}$ bezogen wird (also $\left.s\left[\frac{t^{0}}{4^{0}}\right]\right)$. Der einzige Versuch einer kartographischen Darstellung ist von Sснотт in dem „Valdivia“-Werk gemacht worden; die subtropischen Maxima des Salzgehaltes sind hier verschwunden, und nur in der Abnahme des Gewichts von W nach $O$ innerhalb der Äquatorialzonen des Atlantischen und Indischen Ozeans macht sich der Salzgehalt noch bemerkbar. Im übrigen nimmt aber das Gewicht von der Äquatorialzone gegen die Pole und an jedem Ort mit der Tiefe zu. Die Wirkungen des sich verringernden Salzgehaltes werden also durch die Temperaturerniedrigung mehr als ausgeglichen.

Gasgehalt. Die Oberflächenschicht des Meeres nimmt atmosphärische Luft auf, und zwar um so mehr, je niedriger die Temperatur ist, und die vertikalen Bewegungen des Wassers führen dann die Luft auch den tieferen Schichten zu. Aber die Absorptionsfähigkeit des Wassers ist für Sauerstoff größer als für Stickstoff, und die im Meer enthaltene Luft unterscheidet sich daher von der atmosphärischen durch einen höhern Prozentsatz von Sauerstoff (33-35 Proz. neben $67-65 \%$ Stickstoff). Das ist von größter Bedeutung für die Tierwelt, namentlich für die Fische. Während die Stickstoffmenge durch alle Tiefen nahezu die gleiche bleibt, ist die Sauerstoffmenge an der Oberfläche am gröBten, sinkt dann bis zur Tiefe von $700-800 \mathrm{~m}$ auf $11,4-15,5$ Proz. und steigt dann wieder auf 23-24 Proz. Die bekannte Tatsache, daß das Oberflächenwasser kalter Meeresräume besonders fischreich ist, scheint durch das erörterte, Verhalten des Wassers zum Sauerstoff hinreichend erklärt zu sein. Freie Kohlensäure ist bisher noch nicht beobachtet worden, sie tritt nur in chemischen Verbindungen auf.

Farbe. Wenn man absieht von allen jenen Reflexerscheinungen an der Oberfläche des Seespiegels, die die Himmelsfarbe, die wechselnde Bewölkung, die Sonnenhöhe und das Mondlicht hervorrufen, so kann man die Meeresfarbe als blau bis grün bezeichnen. Weiße Gegenstände erscheinen, wenn man sie in das Meer taucht, zuerst grün und nehmen eine immer blauere Färbung an, je tiefer man sie versenkt, bis sie dem Auge gänzlich entschwinden. Die größte 
Sichttiefe, die man bisher beobachtet hat, betrug $77 \mathrm{~m}$ (in dem Schwarzen Meer). DaB aber die chemisch wirksamsten Strahlen der blauen und violetten Seite des Spektrums noch tiefer eindringen, lehren Untersuchungen mittels der photographischen Kamera. Blaue Strahlen waren auf der „Michael SaRS"-Expedition (1910) in der atlantischen Sargassosee bis $550 \mathrm{~m}$ Tiefe deutlich und bis $910 \mathrm{~m}$ Tiefe noch in abgeschwächtem Grad nachweisbar ${ }^{12}$. Dagegen werden die roten und gelben Strahlen sehr bald vom Wasser absorbiert, und dies ist unzweifelhaft der Grund, weshalb Meer und Seen, wenn sie nicht verunreinigt sind, blau oder grün erscheinen. In der Verteilung der Nuancen herrscht eine gewisse geographische Ordnung, das lehren die Farbenkarten, die zuerst KRÜмmeL gezeichnet, und die jetzt Sснотт in dem mehrfach erwähnten „Valdivia"-Werk für den ganzen Atlantischen und Indischen Ozean entworfen hat. Möglich wurde eine solche Darstellung erst durch die FonEL'sche Skala, die alle Abstufungen vom tiefen Kobaltblau bis zum dunkelsten Grün durch das prozentische Verhältnis einer blauen und einer gelben Lösung in exakter Weise unterscheiden läßt. Allerdings reicht sie nicht für alle natürlichen Färbungen aus; ULE und LuKsch haben sie daher erweitert, und v. LonENz hat mit Zugrundelegung von 19 Mineralfarben eine neue Skala aufgestellt, die aber auf allgemeine Gültigkeit ebenfalls nicht Anspruch erheben darf. Gegenüber diesem Verfahren hat O. v. u. z. Aursess ${ }^{13}$ die unmittelbare Untersuchung von Wasserproben mittels eines Taschenspektroskops empfohlen, und er unterscheidet nur vier Abstufungen: blau, grün, gelblichgrün und gelb oder braun.

Im allgemeinen sind die Ozeane zwischen $40^{\circ} \mathrm{N}$ und $\mathrm{S}$ blau, doch bestehen Ausnahmen. Blaugrün sind z. B. die Küstengewässer um die Canarischen Inseln und der mittlere und östliche Tẹil der atlantischen Äquatorialzone, in den noch Ausläufer des kalten Benguelastromes einzudringen scheinen. Kobaltblau und von größter Transparenz ist die sog. Sargassosee und der südatlantische und der südindische Ozean etwa zwischen 10 und $30^{\circ} \mathrm{S}$, also Gebiete, die nur zum Teil mit dem Maximalgebiet des Salzgehaltes zusammenfallen. In mittleren und höheren Breiten geht die Meeresfarbe, je weiter wir polwärts fortschreiten, über blaugrün und grünblau in grün über. Dieselben Abstufungen finden wir im nordatlantischen Ozean unter $50^{\circ} \mathrm{Br}$. in der Richtung von Ost nach West nebeneinander gelagert, also in derselben Richtung, in der Temperatur. und Salzgehalt abnehmen. Anscheinend ist ein Zusammenhang zwischen den verschiedenen physikalischen Eigenschaften des Meerwassers vorhanden, aber jedenfalls ist er nicht durchgreifender Natur. 
Wohl ist die Ostsee grün und das Mittelmeer blau, aber das viel salzreichere Rote Meer ist vorwiegend blaugrün. DaB auch die Temperatur nicht unmittelbar mit der Farbe zusammenhängt, beweisen die kalten und trotzdem blauen Süßwasserseen. Mittelbare Beziehungen sind aber wohl anzunehmen. Erwiesen ist, einerseits daß die Intensität des Blau mit der Durchsichtigkeit des Wassers zunimmt, und anderseits daß die trübenden Bestandteile um so rascher zu Boden sinken, je salzreicher und wärmer das Wasser ist. Ferner ist daran zu erinnern, daß das Plankton besonders in kühlen Gewässern gedeiht, und daß diese vorwiegend grün sind, so daß Sснӥтт mit einigem Recht Blau als die Wüstenfarbe des Meeres bezeichnen konnte.

Die physikalische Erklärung der Wasserfärbung ist noch streitig. Nach der Diffraktionstheorie, die Sonet begründet hat und in neuester Zeit besonders ABEGG ${ }^{14}$ vertrat, ist das Wasser an sich ebenso farblos wie die Luft. Aber in der Natur ist es niemals völlig rein, sondern stets ein trübes Medium, d. h. es enthält äußerst kleine, undurchsichtige Teilchen, deren Dimensionen die Länge der Lichtwellen nicht überschreiten. Sie zerstreuen die kurzwelligen blauen und violetten Strahlen, während die langwelligen roten und gelben durchgelassen werden. Gegen diese Auffassung spricht die Tatsache, daß, wenn man im chemischen Laboratorium auch die feinste Trübung zum Sinken bringt, eine größere Menge Wasser noch immer blau erscheint. Blau ist also die Naturfarbe des Wassers, und es sind nur die Abweichungen nach grün zu erklären. SPRING ${ }^{15}$ führt nur sie auf Trübungen zurück, entweder indirekt auf die Reflexion gelber Strahlen oder direkt auf die Eisenoxydhydrate, deren gelbe Farbe mit dem Blau des Wassers grün in verschiedenen Abstufungen ergibt, die aber nur so lange wirken, als sie nicht durch Huminstoffe in andere Verbindungen übergeführt werden. Einige Schwierigkeiten bereiten die farblosen oder - wenn sie tief genug sind - dunkeln Gewässer (wie z. B. der Wetternsee in Schweden); Spring erklärt diese Erscheinung durch die Anwesenheit mikroskopischer Eisenoxydkörperchen, deren rötliche Farbe mit der blauen, des Wassers komplementär ist. In neuester Zeit hat v. u. z. Aufsess ${ }^{13}$ auf Grund der Untersuchungen verschiedener Seen nur die im Wasser gelösten Substanzen für die Abweichungen von der blauen Farbe verantwortlich gemacht, und zwar hauptsächlich die organischen humösen Stoffe, die das Wasser je nach ihrer Menge grün, gelb und braun färben; dann den gelösten Kalk, der, wenn er in großer Menge vorhanden ist, eine grüne Farbe erzeugt; und endlich die Eisensalze. Da diese chemischen Bestand- 
teile nicht veränderlich sind, so hat nach dieser Theorie jeder See seine spezifische Eigenfarbe. Die dunkle Farbe des Torfwassers und der sog. "schwarzen" Flüsse des brasilianischen Berglandes und anderer Gegenden erklärt REINDL ${ }^{16}$ aus dem Reichtum an Huminsäure und deren Verbindungen bei gleichzeitiger Armut an gelösten Bestandteilen. Das Experiment zeigt, daß ein größerer Zusatz von doppeltkohlensaurem Kalk Entfärbung und einen bräunlichen Schlammniederschlag hervorruft; daher kommen schwarze Flüsse im Kalkgebirge nicht vor. Auch für mehr oder minder abgeschlossene Meeresteile scheint dieser Satz von der chemischen Natur der Färbung, wenn auch nicht in aller Strenge, zu gelten, und der Gegensatz zwischen dem offenen Ozean und den Küstenzonen läßt sich wahrscheinlich auch auf Trübungen oder chemische Unterschiede zurückführen.

Außergewöhnliche Meeresfärbungen, wie milchweiß, blutrot, gelblich- oder schiefergrau, olivenbräunlich, nennt der Seemann bezeichnenderweise „Miß“- oder „Verfärbung“. Sie treten immer nur sporadisch und örtlich begrenzt auf, und werden meist von massenhaft auftretendem Plankton erzeugt. 'Mancher Meeresname mag damit zusammenhängen. Das Gelbe Meer heißt sicher so von den Lößmassen, die der Hoangho ihm zuführt, während andere Namen, wie Weißes und Schwarzes Meer, ebenso sicher mit der Färbung nichts zu tun haben. In bezug auf das Rote Meer sind die Ansichten geteilt. Milliarden mikroskopischer Tierchen sind es auch, die jenes wunderbar schöne, besonders den Tropenmeeren eigentümliche Phänomen erzeugen, das als Meeresleuchten bekannt ist.

Literaturnachweise. ${ }^{1}$ F. R. Helmert zit. S. $9 .-{ }^{2}$ J. B. Messersснмттт zit. S. 9. Ein ausgezeichneter orientierender Artikel. $-{ }^{3}$ E. Brückner zit. S. 256, Anm. 9. - ${ }^{4}$ La Géographie, Paris 1909, Bd. XIX, S. 63. - ${ }^{5}$ H. Монм, Nordhavets Dybder, Temperatur og Ströminger; Kristiania 1887. - ${ }^{6}$ F. R. HeLMerT, Le Zéro des altitudes, in den Verhandlungen der permanenten Kommission der internationalen Erdmessung in Florenz 1891. - ${ }^{7}$ J. Harford im Science, 1905, Bd. XXI, S. 673. - ${ }^{8}$ E. G. Ravenstein, On Bathy-hypsographical Maps, in den Proceedings of the R. Geographical Society, London 1886, Bd. VIII. - 9 G. Sснотт, Die Verteilung des Salzgehalts im Oberflächenwasser der Ozeane; in Petermann's Mitteilungen, 1902. - ${ }^{10} \mathrm{M}$. Knddsen, Berichte über die Konstantenbestimmung zur Aufstellung der hydrographischen Tabellen, in den Denkschriften der Akademie der Wissenschaften in Kopenhagen, 1902; die hydrographisehen Tabellen selbst, die bequeme Ablesungen gestatten, sind 1901 in Kopenhagen und Hamburg erschienen. - ${ }^{11}$ A. Buchas, Report on the Oceanic Cireulation (Appendix zum Challenger-Report), 1895. - 12 Geographical Journal, London 1910, Bd. XXXVI, S. $362 .-{ }^{13}$ Orto Frhr. von U. zU Aursess, Die Farbe der Seen; München 1903. - ${ }^{4}$ R. Abeqg, Über die Farbe der Meere und Seen, in der Naturwissenschaftlichen Rundschau, 1898. 
${ }^{15}$ W. Spring in den Bulletins de l'Académie Royale de Belgique, 1883 (Bd. V, S. 55), 1886 (Bd. XII, S. 814), 1896 (Bd. XXXI, S. 94) u. 1897 Bd. XXXIV, S. 578) und im Neuen Jahrbuch für Mineralogie usw., 1899, Bd. II, S. 47. - ${ }^{16}$ J. Rernd, Die sehwarzen Flüsse Südamerikas, in der Naturwissenschaftlichen Wochensehrift, Bd. XX, 1905.

\section{Die Wellenbewegung.}

Windwellen. Von der strömenden unterscheidet sich die Wellenbewegung dadurch, daß nur die Form der Bewegung, der Wechsel von Berg und Tal, fortschreitet, während das einzelne Wasserteilchen seine Lage im Raum wenig oder gar nicht verändert. Wir können uns durch den Augenschein davon überzeugen, wenn wir irgend einen leichten Gegenstand auf das Wasser werfen: während Berg und Tal unter ihm hinwegeilen, hebt er sich und bewegt sich zugleich ein wenig nach vorwärts, dann senkt er sich und kehrt zugleich an seine ursprüngliche Stelle zurück. Eine solche Bewegung in einer kreisähnlichen Vertikalbahn nennt man eine Orbitalbewegung. Das Profil fortschreitender Wellen ist am besten mit einer Trochoide $\times$ zu vergleichen, und die Erfahrung hat gelehrt, daß sich die Trochoidenformeln auch auf die Wellen, wenigstens auf solche in tiefem Wasser, anwenden lassen. Die Hauptmaße: die Wellenlänge $(L)$ oder die Entfernung von einem Wellenkamm zum andern, die Periode $(T)$ oder die Zeitdauer zwischen zwei aufeinanderfolgenden Wellenbergen, und die Fortpflanzungsgeschwindigkeit der Welle in der Sekunde $(C)$ stehen in innerem Zusammenhang, so daß, wenn eines dieser Elemente durch die Beobachtung gegeben ist, sich die anderen durch die Trochoidengleichungen rechnungsmäBig ableiten lassen. $\times \times$ Nur ist dabei nicht $\mathrm{zu}$ vergessen, daß Beobachtungen auf einem fahrenden Schiff die eigene Geschwindigkeit und den Winkel zwischen Kiellinie und Wellenrichtung berücksichtigen müssen. Das vierte der Hauptmaße, die Wellenhöhe oder der Vertikalabstand zwischen Berg und Tal, kann

$\times$ Rollt ein Rad auf einer horizontalen Fläche weiter, so beschreibt ein beliebiger Punkt der Peripherie eine Zykloide, ein soleher an einer Radspeiche aber eine flachere Kurve oder eine Trochoide.

$$
\times \times \quad T=\frac{L}{C}=\sqrt{\frac{2 \pi}{g}} L=\frac{2 \pi}{g} C .
$$

Fügen wir für $\pi(=3,142)$ und $g$ (Beschleunigung der Schwere $=9,806$ ) die Werte ein, so erhalten wir nach Sснотт folgende einfache Gleichungen:

$$
\begin{aligned}
& C=1,25 \sqrt{L}=1,56 T \\
& L=0,6 i C^{2}=1,56 T^{2} \\
& T=0,80 \sqrt{L}=0,64 C .
\end{aligned}
$$


dagegen nur durch unmittelbare Beobachtung festgestellt werden, und da man dafür leider noch kein sicheres Meßverfahren ausfindig gemacht hat, so ist begreiflicherweise auch der geübteste Seemann vielfachen Täuschungen ausgesetzt, und es erklärt sich daraus zur Genüge, daß H.öhe und Steilheit der Meereswellen in Wort und Bild so häufig übertrieben werden.

Es ist nicht schwer zu erklären, warum um irgend einen Gegenstand, der die Wasserfläche trifft, konzentrische Wellen entstehen. An dieser Stelle wird das Wasser hinabgedrückt, seine leicht verschiebbaren Teilchen weichen aus, und indem sie dadurch einen Druck auf alle benachbarten Wasserteilchen ausüben, wird um die Depressionsstelle eine Erhöhung des Wasserspiegels, ein Wellenberg erzeugt. Dieser sinkt wieder in sich zusammen, schwingt aber vermöge des Gesetzes der Trägheit noch über seine Gleichgewichtslage hinaus, und so entsteht an der Stelle des früheren Wellenberges ein kreisförmiges Wellental, das an seiner äußeren Peripherie wieder einen Wellenberg erzeugt. Auf diese Weise pflanzt sich die Bewegung fort, bis die Reibung die bewegende Kraft aufgezehrt hat. Der Wind dagegen ist eine kontinuierlich und horizontal wirkende Kraft und sollte die Wasserteilchen vor sich herschieben. Und dies ist in der Tat auch der Fall, der Wind erzeugt ebenso Strömungen wie Wellen, und die Frage ist nur die, wann erzeugt er die eine, wann die andere Bewegungsart, und wie gehen beide ineinander über? Sobald die völlig ruhige See von einem Wind mit mehr als $0,2 \mathrm{~m}$ Geschwindigkeit in der Sekunde getroffen wird, entsteht eine leichte Kräuselung des Wasserspiegels. Die Oberflächenschicht, die sich bei jeder Flüssigkeit in mancherlei Hinsicht wie eine selbständige Membran verhält, legt sich in Falten, wie die Haut am Handrücken, wenn man mit dem Finger darüber hinwegștreicht. Die Entstehung dieser Fältchen oder kapillaren Welleñ, wie Scott Russelu sie nannte, erklärt sich aus der Theorie von HeLmноLтz. Wenn zwei Flüssigkeiten von verschiedener Dichte, wie hier Luft und Wasser, übereinander lagern, so ist die Trennungsfläche nur bei völliger Ruhe eine Ebene. Gerät die obere Flüssigkeit (hier die Luft) in Bewegung, so wird diese durch Reibung an der ruhenden Flüssigkeit in den untersten Schichten gehemmt, während nach oben die Geschwindigkeit zunimmt. Damit vermindert sich der Druck, den in unserem Fall die Luft auf das Wasser ausübt; dieses wird gleichsam emporgezogen, sein Niveau hebt sich an einer Stelle und muß daher an der benachbarten sinken, oder mit anderen Worten: die Trennungsfläche nimmt eine wellige Gestalt an. Zähere Flüssigkeiten als das Wasser widerstreben länger dem Einfluß des Druckes; 
darauf beruht wohl die seit dem Altertum bekannte glättende Wirkung des Öles. Die kapillaren Wellen sind es nun, die dem Wind neue Angriffspunkte bieten und immer höher zu wirklichen Wellen anwachsen. Je größer der Raum und die Wassermasse ist, desto ungehinderter kann diese Entwicklung vor sich gehen; das Meer ist daher der eigentliche Schauplatz großer Wellenbildungen. Dabei wird, wenn der Wind lange genug aus einer und derselben Richtung weht, die Tendenz immer größer, die Wasserteilchen in dieser Richtung auch wirklich weiterzubewegen, so daß die Orbitalbahnen nicht mehr geschlossene Kurven bilden, und jedes Wasserteilchen am Ende einer Schwingung von seiner früheren Lage etwas abgerückt ist. Daraus entstehen die Triftströmungen, auf die wir bei einer anderen Gelegenheit noch zurückkommen werden.

Aus Scнотт's ${ }^{1}$ Wellenmessungen heben wir folgende beobachtete Werte hervor:

\begin{tabular}{c|c|c|c|c|c|c|c}
\hline \hline Geogr. & Geogr. & $\begin{array}{c}\text { Wind- } \\
\text { stärke } \\
\text { Breite }\end{array}$ & $\begin{array}{c}\text { Geschwin- } \\
\text { digkeit } \\
\text { Länge }\end{array}$ & $\begin{array}{c}\text { Länge } \\
\mathrm{m}\end{array}$ & $\begin{array}{c}\text { Periode } \\
\text { Sek. }\end{array}$ & $\begin{array}{c}\text { Höhe } \\
\mathrm{m}\end{array}$ & Böschung \\
\hline \hline
\end{tabular}

\section{Atlantisches Passatgebiet.}

\begin{tabular}{r|rr|r|r|r|r|r|r}
$7^{\circ} \mathrm{S}$ & $15^{0} \mathrm{~W}$ & 5 & 7,4 & 36,4 & 4,9 & 1,0 & $5^{0}$ \\
11 & 10 & & $4-5$ & 7,8 & 37,5 & 5,0 & $1,8-2,0$ & 9 \\
29 & 9 & 0 & 5 & 8,8 & 58,8 & 6,6 & 4,0 & 11 \\
29 & 9 & & 5 & 10,2 & 61,6 & 6,0 & 4,5 & 13
\end{tabular}

Indisches Passatgebiet.

\begin{tabular}{l|l|l|l|r|r|r|r}
$26^{\circ} \mathrm{S}$ & $48^{\circ} \mathrm{O}$ & 5 & 7,2 & 32,8 & 4,6 & 0,8 & $4^{0}$ \\
26 & 48 & 6 & 8,2 & 44,2 & 5,4 & 2,5 & 10 \\
17 & 72 & $8-9$ & 14,7 & 130,4 & 8,8 & $7-8$ & 10
\end{tabular}

Je stärker der Wind ist, desto größer sind alle Wellendimensionen, aber auch bei gleichbleibender Windstärke entwickeln sie sich immer voller, wofür die beiden Beobachtungen Sснотт's in $29^{\circ} \mathrm{S} 9^{\circ} \mathrm{O}$, die am gleichen Tag gemacht wurden, ein gutes Beispiel bieten. Diese Abhängigkeit tritt jedoch bei den einzelnen Dimensionen in verschiedenem Grad zutage. Am veränderlichsten ist jedenfalls die Höhe, aber sie bildet sich nicht ruhig bis zu dem der Windstärke entsprechenden Maximum aus, weil bei zunehmender Luftbewegung die Kämme abbrechen und sich in das vor ihnen liegende Tal stürzen. Auf stürmischem Meer sind diese „Sturzseen" den Schiffen äußerst gefährlich. Gleichzeitig verändert sich mit der Windstärke auch das Verhältnis von Höhe und Länge oder mit anderen Worten der Böschungswinkel der Wellenberge, der um 
so steiler wird, je heftiger der Wind weht. $\times$ Uber das Verhältnis der Wind- und Wellengeschwindigkeit sind die Ansichten geteilt; die Lösung dieses Widerspruchs findet Krüмmen in der Energieformel. $\times x$ Die Energie der Wellenbewegung hängt von der Höhe und der Länge, bzw. der Geschwindigkeit ab; da die Höhe erfahrungsgemäß nur bis zu einem Maximum wächst, so muß, wenn dieses erreicht ist und die Energie trotzdem in ihrer früheren Stärke erhalten bleiben soll, die Geschwindigkeit zunehmen. Junge Wellen laufen daher langsamer, alte schneller als der Wind. Bei mäBigem Wind bewegen sich die Wellen nicht schneller als die großen Segelschiffe und die meisten Dampfer, und selbst bei Sturm erreichen sie nur selten die Geschwindigkeit von Schnellzügen (ungefähr $19 \mathrm{~m}$ pro Sekunde im deutschen Flachland). In Scнотт's Beispielen sind freilich nur die ruhigeren Passatgebiete vertreten, und es unterliegt keinem Zweifel, daß die Zonen der Westwinde, besonders die südliche, viel ausgebildetere Wellen besitzen, wie aus den zahlreicheri Messungen von PÂRIS ${ }^{2}$ hervorgeht. $\times \times \times$ Als höchste beglaubigte Dimensionen können folgende angesehen werden:

Geschwindigkeit . . $35,8 \mathrm{~m}$ in der Sek.
Länge . . . $824 \mathrm{~m}$
Periode . . . $23 \mathrm{Sek}$.
Höhe . . . . $15 \mathrm{~m}$, selten über $10 \mathrm{~m}$.

$\times$ Nach Sснотт beträgt bei

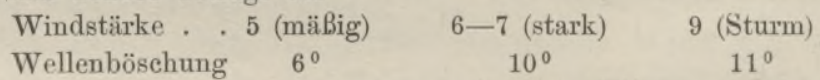

$\times \times \quad$ Energie $=\frac{1}{8} m L H^{2}\left(1-\frac{\pi^{2}}{2} \cdot \frac{H^{2}}{L^{2}}\right)$.

$m=$ Gewicht eines Kubikmeters Wasser, der Ausdruck in der Klammer ist nahezu $=1$ und kann daher meist vernachlässigt werden. Für $L$ kann man nach der Trochoidenformel (S. 291) die Geschwindigkeit $O$ einführen und erhält dann

$$
\text { Energie }=\frac{2 \pi}{8 g} C^{2} H^{2} .
$$

$\times \times \times$ Beobachtete Mittelwerte:

\begin{tabular}{l|c|c|c|c|c|c}
\hline & $\begin{array}{c}\text { Geschw. } \\
\mathrm{m}\end{array}$ & $\begin{array}{c}\text { Länge } \\
\mathrm{m}\end{array}$ & $\begin{array}{c}\text { Periode } \\
\text { Sek. }\end{array}$ & \multicolumn{2}{|c|}{$\begin{array}{c}\text { Höhe m } \\
\text { Mittel }\end{array}$} & $\begin{array}{c}\text { Maximum } \\
\text { Böschung }\end{array}$ \\
\hline \hline Atlantisches Passatgebiet & 11,2 & 65 & 5,8 & 1,9 & 6 & $5^{0}$ \\
Indisches Passatgebiet . & 12,6 & 96 & 7,6 & 2,8 & 5 & 5 \\
Südatlantische Westwinde & 14,0 & 133 & 9,5 & 4,3 & 7 & 6 \\
Indische Westwinde . . & 15,0 & 114 & 7,6 & 5,3 & 11,5 & 8 \\
Ostchinesisches Meer . . & 11,4 & 79 & 6,9 & 3,2 & 6,5 & 7 \\
Westpazifischer Ozean . & 12,4 & 102 & 8,2 & 3,1 & 7,5 & $5^{1 / 2}$
\end{tabular}

Es darf indes nicht verschwiegen werden, da $\mathrm{B}$ in neuerer Zeit gegen die allgemeine Zuverlässigkeit der Messungen von PÂ RIs 'schwerwiegende Bedenken erhoben worden sind. 
Die Wellenbewegung ist nicht gleichmäßig; nach dem Glauben der Seeleute kommen die großen Wellen immer in Gruppen zu je drei, und Consish ${ }^{3}$ fand das im nordatlantischen Ozean bestätigt. Die bewegte See schied sich deutlich in breite Streifen von verhältnismäBig flachen Wellen, zwischen die sich schmale Bänder mit - ungefähr drei großen Wellen einschoben. In anderen Gegenden ist bei stürmischer See erst die vierte oder fünfte oder eine noch spätere Welle die höchste.

Wie das Wasser, in das wir einen Stein geworfen haben, zufolge seines großen Trägheitsmomentes und seiner geringen inneren Reibung erst allmählich zur Ruhe kommt, so wogt das Meer auch dann noch, wenn sich der Wind schon gelegt hat. Diese Bewegung nennt der Seemann Dünung, im Gegensatz zu den unmittelbaren Windwellen oder "Seen". Nichts bietet dem Neuling ein geheimnisvolleres Schauspiel, als wenn auf windstiller Fläche Welle auf Welle heranrollt, von den Seen durch nichts unterschieden als durch sanftere Böschung und abgerundete Form der Kämme. Die alte Bewegung dauert manchmal noch fort, wenn sich schon neuer Wind aus anderer Richtung erhoben hat; alte und neue Wellen durchkreuzen sich dann nach den Gesetzen der Interferenz, als ob jede nur für sich da wäre; und es steigert sich bis zum tollen Wirrwarr, wenn eine tiefe Zyklone mit ihrer rasch wechselnden Windrichtung über das Meer zieht. Dann kann die Dünung dem Schiffer schon einige Zeit vorher den kommenden Sturm verkündigen. Am reinsten und großartigsten gelangt die Dünung in den Zonen der regelmäßigen Passate und im äquatorialen 'Kalmengürtel zur Ausbildung; die gewaltigen Wellen, die die Weststürme höherer Breiten erregen, dringen . sogar nicht selten von einer Halbkugel in die andere vor. ${ }^{\times}$

Brandung. Nach den experimentellen Untersuchungen der Gebrüder WẸER reicht die Wellenbewegung bis zu einer Tiefe, die dem 350 fachen Betrag der Wellenhöhe gleichkommt. Bei den höchsten Wellen würde also erst das Wasser jenseits der Isobathe von $5200 \mathrm{~m}$ in Ruhe verharren. Aber mit der Tiefe nimmt die Wellenhöhe rasch $a b$, die Orbitalbahnen nehmen eine elliptische Gestalt mit immer mehr sich verkürzender Vertikalachse an, so daß

× Beispiele zweier starker Dünungen nach den Beobachtungen von Scнотт:

\begin{tabular}{|c|c|c|c|c|c|c|c|c|c|}
\hline \multirow{2}{*}{$\begin{array}{l}\text { Südl. } \\
\text { Breite }\end{array}$} & \multirow{2}{*}{$\begin{array}{c}\text { Östl. } \\
\text { Länge }\end{array}$} & \multicolumn{2}{|c|}{ Wind- } & \multirow{2}{*}{$\begin{array}{l}\text { Dünung } \\
\text { aus }\end{array}$} & \multirow{2}{*}{$\begin{array}{l}\text { Geschw. } \\
\text { m pro Sek. }\end{array}$} & \multirow{2}{*}{$\begin{array}{c}\text { Länge } \\
\text { m }\end{array}$} & \multirow{2}{*}{$\begin{array}{l}\text { Periode } \\
\text { Sek. }\end{array}$} & \multirow{2}{*}{$\begin{array}{c}\text { Höhe } \\
\text { m }\end{array}$} & \multirow{2}{*}{ Böschung } \\
\hline & & Richtung & Stärke & & & & & & \\
\hline $19^{\circ}$ & $0^{0}$ & - & 0 & $\mathrm{SW}$ & 17,0 & 174,0 & 10,0 & 4,0 & $4^{0}$ \\
\hline 28 & 39 & $\mathrm{SO}$ & 5 & $\mathrm{SW}$ & 23,5 & 341,7 & 14,5 & 7,5 & 4 \\
\hline
\end{tabular}


in größeren Tiefen die Wellenbewegung eigentlich nur mehr in einem Hin- und Herschieben der Wasserteilchen beträgt. Schon in einer Tiefe, die gleich der Wellenlänge ist, beträgt nach der Theorie die Wellenhöhe nur mehr den 500 sten Teil der oberflächlichen. Indes genügt diese Bewegung um den festsitzenden Tiefentieren fortwährend Nahrung zuzuführen, ja sie ist in mäBiger Tiefe bis ungefähr $200 \mathrm{~m}$ noch imstande, feste Teilchen in Bewegung zu setzen, wie man aus den Kräuselungen des Sandes nachweisen kann. Auf seichtem Grund wird also ein Teil der lebendigen Kraft in Arbeit umgesetzt, und dieser Vorgang wird noch dadurch gefördert, daß hier die Orbitalgeschwindigkeit nicht bloß mit der Wellenhöhe, sondern auch mit der Verminderung der Wassertiefe zunimmt, wenn

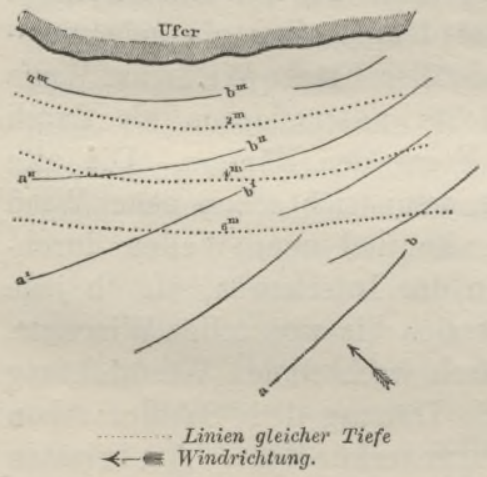

Fig. 60. Wellen am Ufer.

sie wohl auch kaum jemals ihr theoretisches Maximum, den halben Wert der Fortpflanzungsgeschwindigkeit der Wellenform, erreichen dürfte. Zugleich wird die Welle, wenn sie aus tiefem Wasser in flaches tritt, kürzer, ${ }^{\times}$und diese doppelte Umgestaltung macht sich auch schon geltend, wenn die Seen über eine Bank im offenen Ozean rollen. Wenn sie dagegen an sanft ansteigenden Küstenabdachungen hinauflaufen, so werden die Horizontalachsen der Orbitalbahnen hauptsächlich an der Vorderseite verkürzt, die Kämme verlieren ihre symmetrische Form, neigen sich nach vorn und stürzen über. Man bezeichnet diesen Vorgang als Brandung; sie tritt an allen Küsten auf, die allmählich in das Meer verlaufen, am großartigsten wohl an der Guineaküste Afrikas, wo sie unter dem Namen Kalema bekannt ist und durch die heftige und häufige Westdünung des südatlantischen Ozeans erzeugt wird. Das Wasser, das die überstürzenden Wellenkämme am Strand aufhäufen, wird in der Tiefe durch eine Strömung, den sog. Soog, wieder in das Meer zurückgeführt. Aber nicht bloß die Form, sondern auch die Richtung der Wellen ändern sich etwas infolge ungleicher Reibung, wie es Fig. 60

$\times$ Die Formeln von Lagrange (manchmal auch als Arry's Formeln bezeichnet) für flaches Wasser, in denen ein neuer Faktor $h=$ Wassertiefe auftritt, lauten:

$$
C=\sqrt{g h}, \quad L=T \sqrt{g h}, \quad T=\frac{L}{\sqrt{g h}} .
$$


schematisch darstellt. Die Wellen $a b$, die in einiger Entfernung vom Ufer in der Richtung des Windes verlaufen, machen in der Nähe des Landes eine Schwenkung, weil die $a$-Hälften sich auf tieferem Grund und daher rascher bewegen als die $b$-Hälften. Bei heftigen und lange andauernden gegen das Land gerichteten Stürmen verbindet sich mit der Brandung der Windstau, eine Erhebung des Wasserspiegels, die besonders in trichterförmig sich verengenden Buchten den Betrag von mehreren Meter erreichen.kann und die Flüsse oft zwingt, aufwärts zu fließen. Solche Sturmfluten setzen, flache Küstenländer weithin unter Wasser und gehören zu den verheerendsten Phänomenen.

Wesentlich verschieden von der Strandbrandung ist die Klippenbrandung. Trifft die Woge eine steil bis zu größerer Tiefe abfallende Wand, so wird sie von dieser zurückgeworfen, d. h. sie erfährt eine Gegenwirkung, als ob eine Welle von gleicher Form und Geschwindigkeit ihr entgegenliefe. Dadurch wird sie gleichsam zusammengepreBt; sie erhebt sich, da sie nur nach aufwärts ausweichen kann, zu beträchtlicher Höhe (bis zu $30 \mathrm{~m}$ ), und ein Wogenchaos macht dann das Ufer oft unnahbar. Einsame Felseninseln und Leuchttürme sind vor allem dieser Klippenbrandung ausgesetzt, aber nur wenn der Wind stark und auflandig ist, entfaltet sie sich in ihrer ganzen furchtbaren Größe.

Benthonische Wellen nennt KRÜмMEL alle diejenigen, die im Gefolge seismischer oder vulkanischer Ereignisse auf dem Boden des Meeres entstehen. RUdoLPH ${ }^{4}$ hat alle Phänomene dieser Art einer kritischen Prüfung unterworfen, und man ersieht daraus, daß sie zwei verschiedenen Kategorien angehören. Es ist durch zahlreiche Beobachtungen, besonders im äquatorialen Teil des Atlantischen Ozeans erwiesen, daß Schiffe plötzlich einen Stoß verspürten, als ob sie auf Grund aufgefahren wären, auch daß sie emporgehoben wurden und dann wieder einsanken, ohne daß der Meeresspiegel irgendwelche Veränderung erlitt. Wir haben es in diesem Fall mit longitudinalen Wellen zu tun, die sich vom Meeresboden durch die ganze Wassermasse fortpflanzten, aber keine Oberflächenwellen erzeugten, und man darf annehmen, daß sich das Schiff über der Stelle befand, von dem das Seebeben, d. h. die Erschütterung des Meeresbodens ausging. In anderen Fällen aber wurde auch die Oberfläche durch gewaltige Erdbebenfluten, also transversale oder Travitationswellen in Mitleidenschaft gezogen. Bekannte Vorkommnisse dieser Art knüpften sich an die beiden peruanischen Beben von Arica (13. August 1868) und Iquique (9. Mai 1877); mehrere Wellen durcheilten den Pazifischen Ozean von Amerika bis nach Australien, im Jahr 1877 sogar bis zu den 
japanischen Inseln, und richteten stellenweise bedeutende Verwüstungen an. Von den Windseen unterscheiden sie sich durch ihre Dimensionen; die Geschwindigkeit steigert sich auf $150-200 \mathrm{~m}$ und darüber, die Länge auf 150 bis über $1000 \mathrm{~km}$, die Periode erweitert sich auf eine viertel Stunde bis ein oder zwei Stunden, nur die Höhe ist verhältnismäBig gering und übersteigt jedenfalls nicht beträchtlich die der Windseen. Dieser eigentümliche Charakter gestattet nicht mehr die Anwendung der Trochoidenformeln; da die Wellenlänge die Wassertiefe bedeutend übertrifft, so ist hier, wie im flachen Wasser, die Geschwindigkeit nur von der Tiefe abhängig. ${ }^{\times}$Einen Einblick in

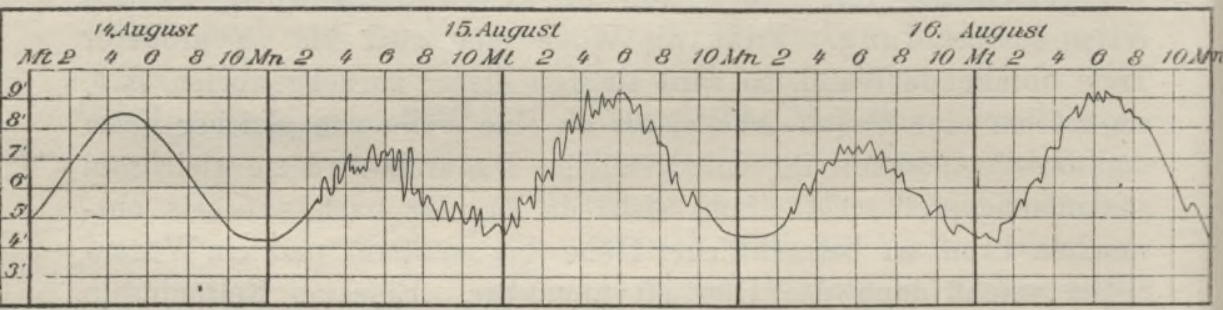

Fig. 61. Wasserstandsveränderungen in Sydney 14.-16. August 1868 nach den Aufzeichnungen des selbstregistrierenden Flutmessers. (Reduktion nach d. Taf. in den Sitz.-Ber. d. Wien. Akad. d. Wiss., Math.-nat. Kl. Bd. LX. 1869.) (Höhen in engl. Fuß.)

das Wesen dieser Wasserbewegung gewähren die Aufzeichnungen selbstregistrierender Flutmesser, die durch ihre Aufstellung ja nur dem FinfluB der kurzen Windwellen entrückt sind. Wir ersehen aus der Flutkurve von Sydney (Fig. 61), daß die in Frage stehenden Wellen durchaus nicht mächtig genug sind, den Wechsel der Gezeiten zu unterdrücken, sondern nur als untergeordnete Störungen erscheinen, die der Kurve ein gezähntes Aussehen verleihen. Am 14. August war die Kurve noch ziemlich regelmäßig; am 15. August nach $2 \mathrm{Uhr}$ morgens begann die Wellenbewegung, gegen $7 \mathrm{Uhr}$ trat die Hauptstörung ein: eine Welle von etwa $1 / 2 \mathrm{~m}$ Höhe und einer Periode von 40 Minuten. Dann folgten bis zum 19. August noch eine ganze Reihe von Oszillationen mit gelegentlichen Ruhepausen; die Zahl sämtlicher Wellen belief sich auf ungefähr 170. Das großartigste Ereignis dieser Art, das die Geschichte kennt, was die Krakatauwelle im August 1883. Sie folgte dem Ausbruch des Krakatauvulkans in

$\times$ F. v. Hochstetrer ${ }^{5}$ und Geinitz ${ }^{6}$ haben die Lagrange'sche Formel benutzt, um aus den Flutwellen von Arica und Iquique die damals noch ganz unbekannte mittlere Tiefe des Großen Ozeans zu berechnen. Das Ergebnis scheint nicht weit von der Wahrheit abzuweichen, weil der Meeresboden zwischen Amerika und Hawaii ziemlich flach ist. Bei wechselnder Tiefe muB es nach Davison stets zu klein ausfallen. 
der Sundastraße und überschwemmte nicht bloß vorheerend alle benachbarten Küsten und machte sich im ganzen Umkreis des Indischen Ozeans bemerkbar, sondern trat auch in den Atlantischen Ozean ein, wo sie an so entfernten Orten, wie in Südgeorgien, an der Panamaenge und an der französischen Küste (Rochefort) von den Flutmessern verzeichnet wurde.

Da nicht alle Erdbeben in Küstengegenden und auch nicht alle Seebeben von derartigen benthonischen Transversalwellen begleitet werden, so müssen diese an besondere Bedingungen geknüpft sein. Man hatte früher an plötzliche Einstürze auf dem Meeresgrund gedacht, nach denen das Wasser von allen Seiten hindrängt, aber kein einziger zuverlässiger Schiffsbericht läßt eine derartige Deutung ungezwungen zu: RUDOLPH, der sich auf Beobachtungen bei den großen Sprengarbeiten im Hafen von San Francisco stützt, sieht die Ursache in vulkanischen Eruptionen auf dem Meeresboden und in den damit verbundenen Gas- und Dampfexplosionen, während KRüмmeL derartige Vorkommnisse zwar nicht leugnet, aber die Mehrzahl jener großen Wellen oder Wogen, wie er sie zu nennen vorzieht, auf unterseeische Bergschlipfe und ähnliche Folgeerscheinungen von Seeund Erdbeben zurückführt.

Stehende Wellen. Plötzliche Anschwellungen des Wassers an den Ufern ohne sichtbare Ursache kommen in Binnenseen aller Größen ${ }^{7}$ und in mehr oder weniger abgeschlossenen Meeresteilen häufig vor. Man nennt sie im Genfer See Seiches - ein Name, der sich jetzt allgemein für diese Erscheinungen eingebürgert hat $\times$-, an der Ostsee Seebär (Verstümmelung von Bare $=$ Woge), an der sizilianischen Küste Marrobbio, in Nordspanien Resaca, in den engen dalmatinischen Gewässern Gaiola usw. Soweit es sich um die Seiches der Binnenseen handelt, kann das Problem - dank besonders den Bemühungen Forel's ${ }^{8}$ und ChrystaL's ${ }^{9}-$ als gelöst betrachtet werden. Rasche Veränderungen des Luftdruckes, plötzliche Windstöße von den Fig. 62. Stehende Wellen. Bergen herab, Stürme und andere gewaltsam, aber lokal wirkende atmosphärische Störungen rufen sowohl in derLängswie in der Querachse des Genfer Sees stehende Wellen hervor, eine eigentümliche Schaukelbewegung des Wassers, so daß das Niveau, während es an dem einen Ufer steigt, an dem entgegengesetzten fällt.

$\times$ Graf E. Zeppenin hat in der Geographisehen Zeitschrift (1901, S. 104) dafür den deutschen Ausdruck ,Laufen" vorgeschlagen. Ich würde, wenn man sehon verdeutsehen will, den Ausdruck, Schaukelwelle" vorziehen. 
Wird bei $B$ in Fig. 62 ein plötzlicher Druck ausgeübt, so nimmt der Seespiegel $(A K B)$ die Form $A^{\prime} K B^{\prime}$, dann die Form $A^{\prime \prime} K B^{\prime \prime}$ an, wie die Wasseroberfläche in einem Gefäß, das man bald auf die eine, bald auf die andere Seite neigt. Dieses Spiel kann sich stundenlang wiederholen. $K$ ist der Ruhepunkt oder Knoten; die Mehrzahl der Seiches sind wohl einknotige (uninodale) Wellen von dem oben beschriebenen Typus, doch kommen auch zweiknotige (binodale) vor, bei denen sich der Spiegel $A C B$ in $A^{\prime} C^{\prime} B^{\prime}$, dann in $A^{\prime \prime} C^{\prime \prime} B^{\prime \prime}$ usw. deformiert.

$\mathrm{Ob}$ auch auf jene marinen Flutwellen, die ihrem ganzen Wesen nach nicht als Dünung gedeutet werden können, entweder weil ihre Periode zu lang ist, oder weil sie (wie der baltische Seebär) nach kurzer Zeit ebenso plötzlich verschwinden, wie sie erschienen waren, - ob, sage ich, auch auf diese Wellen die Seichestheorie in ihrem ganzen Umfang Anwendung findet, muß noch als offene Frage gelten. Nur so viel darf als sicher betrachtet werden, daß jene Wellen nicht Erdbeben, sondern ebenfalls atmosphärischen Einflüssen ihr Dasein verdanken. Für den Seebär hat R. CREDner diese Ursache wenigstens sehr wahrscheinlich gemacht. ${ }^{10}$

Eine befriedigende Erklärung haben durch die Seichestheorie die rätselhaften Bewegungen im Euripus gefunden. ${ }^{11}$ Nach den Wasserstandsbeobachtungen im Nordhafen von Chalkis treten zur Zeit der Mondviertel anstatt der regelmäßigen Gezeiten innerhalb 12 Stunden 8-9 Wellen mit einer Durchschnittshöhe von 5-6 $\mathrm{cm}$ und einer mittleren Periode von $1^{\mathrm{h}} 25^{\mathrm{m}}$ auf; diese letztere stimmt, wie die Seichestheorie es verlangt, mit den Dimensionen des talantischen Euripus gut überein. $\times$ Im Südhafen sind die Niveauschwankungen permanent; man zählt in 12 Stunden $7-8$ Wellen von $8-18 \mathrm{~cm}$ Höhe und einer mittleren Periode von $1^{\mathrm{h}} 36^{\mathrm{m}}$. Sind auch diese letzteren stehende Wellen, so muß man sich den chalkidischen und eretrischen Euripus als ein einheitlich bewegtes Becken vorstellen, um die nötigen Maße zu erhalten.

Interne Wellen. ${ }^{12}$ Mit diesem seltsamen Phänomen haben uns erst die Untersuchungen der letzten Jahre in den nordischen Gewässern bekannt gemacht, obwohl die Klagen der norwegischen Seeleute über das "Totwasser", das ohne sichtbare Ursache den Gang des Schiffes verlangsamt und die Steuerung unmöglich macht, schon alt sind. Auch in diesem Fall haben wir es mit echten

$\times$ Nach der Seichesformel ist die halbe Schwingungsdauer (in Sekunden) $t=\frac{l}{\sqrt{g h}} ; l=$ Länge des Beckens (in $\mathrm{m}$ ), $h=$ seine mittlere Tiefe (in $\mathrm{m}$ ), $g$ (Beschleunigung der Schwere) $=9,806$. 
Gravitationswellen $\mathrm{zu}$ tun, aber sie bewegen sich nur in den tieferen Meeresschichten und verraten sich durch einen deutlichen wellenförmig auf- und absteigenden Verlauf der Linien gleichen Salzgehalts und gleicher Temperatur. An der Oberfläche sind sie kaum merkbar, und das Tal befindet sich hier stets über dem internen Berg; der Oberflächenberg stets über dem internen Tal. Auch auf die internen Wellen findet die Theorie von Нецмноцтz Anwendung, denn sie treten nur dort auf, wo sich das Wasser durch rasche Temperaturabnahme

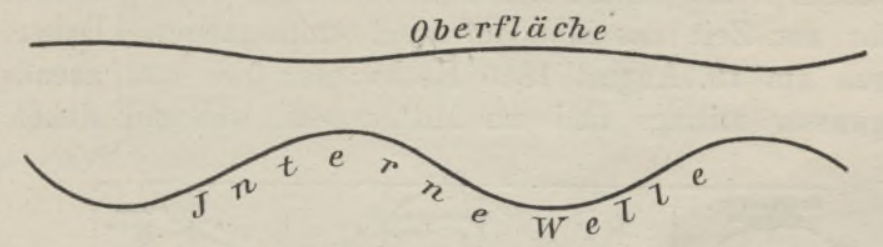

Fig 63. Interne Wellen nach W. EkMaN.

oder Salzgehaltszunahme deutlich schichtet, und Ober- und Unterschicht sich wie verschiedene Flüssigkeiten verhalten. Tritt eine plötzliche Störung des hydrostatischen Gleichgewichts ein, so nimmt ihre Trennungsfläche (wie bei den kapillaren Wellen der Oberfläche, vgl. S. 292) eine wellige Gestalt an. Auch interne stehende Wellen sind nachgewiesen worden; vielleicht stehen damit manche Wellenfurchen oder Rippelmarken auf dem Boden von Binnenseen und seichter Litoralzonen der Meere in ursächlicher Verbindung.

Literaturnachweise. ${ }^{1}$ G. Sснотт, Wissenschaftliche Ergebnisse einer Forschungsreise zur See 1891 und 1892; Gotha 1893 (109. Ergänzungsheft zu Petermans's Mitteilungen). $-{ }^{2}$ A. PÂrIs in der Revue maritime et coloniale; Paris 1871, Bd. XXXI, S. 111. - ${ }^{3}$ V. Connish in Symons' Meteorological Magazine 1901, S. 56. - ${ }^{4}$ E. Rudolph, zit. S. 277. - ${ }^{5}$ F. v. Hochstetter in Petermans's Mitteilungen 1869, S. 222. - ${ }^{6}$ E. Geinitz, ebenda 1877, S. 454. 7 Vgl. A. Endrös, Vergleichende Zusammenstellung der Hauptseichesperioden der bis jetzt untersuchten Seen, in Petermann's Mitteilungen 1908. - ${ }^{8}$ F. A. Forer, Die Formel der Seiches, in den Archives des Sciences; Genf 1876 und 1885. 9 G. Chrystal, On the Hydrodynamical Theory of Seiches, in den Transactions of the R. Society of Edinburgh 1905. W. Halbfass hat den heutigen Stand der Seichesforschung in der Zeitschrift der Gesellschaft für Erdkunde zu Berlin 1907, S. 5, dargelegt. - ${ }^{10}$ R. Credner, Über den Seebär der westlichen Ostsee, im Jahrbuch der Geographischen Gesellschaft in Greifswald 1887-88. S. Günther, Über die rhythmischen Schwankungen des Spiegels geschlossener Meeresbecken, in den Mitteilungen der Geographischen Gesellschaft in Wien 1888. B. Doss, Über ostbaltische Seebären, in GerLand's Beiträgen zur Geophysik, Bd. VIII, 1907. - ${ }^{11}$ O. Krümmer, Das Problem des Euripus, in Petermans's Mitteilungen 1888. - ${ }^{12}$ V. W. Eкman, On Dead-Water, in F. Nansen, The Norwegian North Polar Expedition, Bd. V. 


\section{Die Gezeiten. ${ }^{1}$}

Das Meeresniveau ist einem periodischen Schwanken unterworfen, indem es innerhalb eines Mondtages von $24^{\mathrm{h}} 50^{\mathrm{m}}$ zweimal fällt und zweimal steigt. Nachstehende Fig. 64 versinnlicht uns Beobachtungen am Pegel von Cuxhaven zwischen $5^{\text {h }}$ früh und $8^{\text {h }}$ abends. Der höchste Wasserstand (Hochwasser) tritt ein, wenn der Mond den Meridian des Ortes passiert (obere Kulmination) und wenn er $180^{\circ}$ davon entfernt ist (untere Kulmination), das Niedrigwasser aber ungefähr zur Zeit des Mondauf- und -unterganges. Daher hatte Cuxhaven am 19. August 1866 Hochwasser früh und abends, und Niedrigwasser mittags und um Mitternacht, während sieben Tage

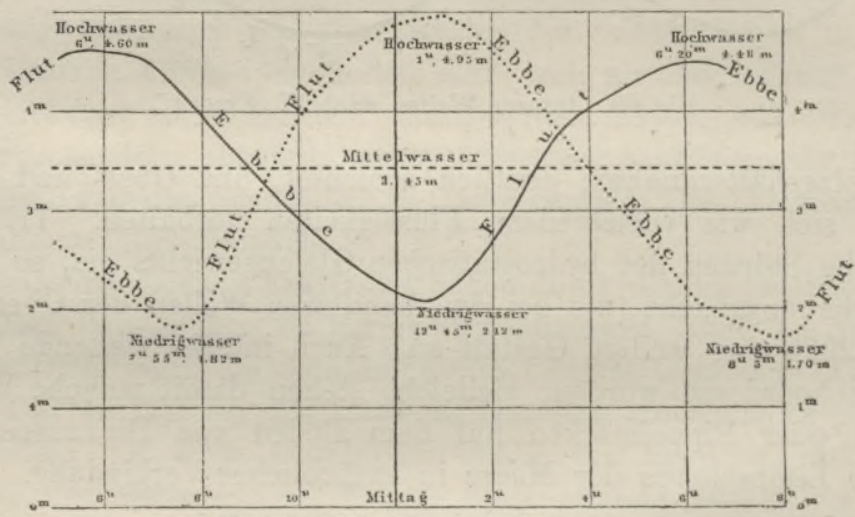

Fig. 64. Gezeiten zu Cuxhaven.

später der umgekehrte Fall eintrat. Das Steigen des Wassers nennt man Flut, das Fallen Ebbe; beide Bewegungen zusammen Tiden oder Gezeiten. Aus dem angeführten Beispiel ersieht man, daB die Zeitdauer von Ebbe und Flut nicht immer gleich ist, und daB Hoch- und Niedrigwasser nicht immer den gleichen Punkt am Pegel berühren. Ebenso ändert sich der Hub oder der Höhenunterschied zwischen Hoch- und Niedrigwasser.

Theoretische Gezeiten. Nach Newton's Gravitationsgesetz üben alle Körper Anziehungskraft aus, die im geraden Verhältnis zu ihrer Masse und im umgekehrten zum Quadrat ihrer Entfernung steht. So wird nicht bloß der Mond von der Erde, sondern auch die Erde vom Mond angezogen; und die Gezeitenbewegung wäre eine ebenso einfache wie regelmäßige Erscheinung, wenn die Erde flüssig oder von einem Meer von gleichmäßiger Tiefe bedeckt wäre, das den anziehenden Kräften sofort Folge zu leisten vermöchte. Fig. 65 
stellt diesen Fall dar. Der Mond $(M)$ befindet sich $15^{0}$ nördlich vom Äquator, und es ist zunächst seine Wirkung auf den Erddurch-

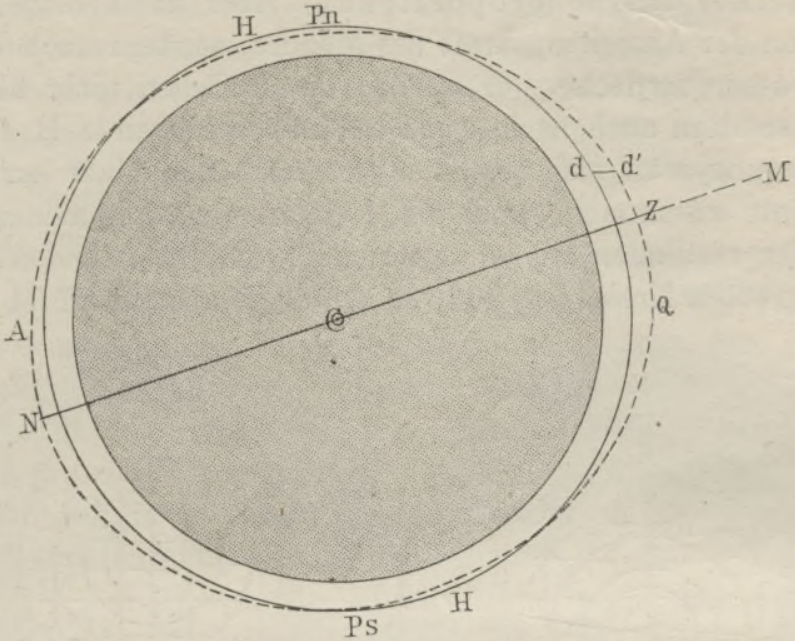

Fig. 65. Erddurchschnitt zur Erläuterung der Entstehung der Gezeiten. $P n=$ Nordpol, $P s=$ Südpol, $A Q=$ Äquator.

messer $Z C N$ zu untersuchen. Da er 60 Erdradien von dem Mittelpunkt der Erde entfernt ist, so ergeben sich für seine Anziehungskraft folgende Maße:

$$
\begin{aligned}
& \text { Für } C \frac{1}{60^{2}}=0,00027778 \\
& \text { " } Z \frac{1}{59^{2}}=0,00028727 \\
& \text { "N } N \frac{1}{61^{2}}=0,00026875 \text {. }
\end{aligned}
$$

Die Unterschiede $Z-C$ und $C-N$ betragen 0,00000949 bzw. 0,00000903, sind also nahezu gleich groß und können dem Wert $\frac{2}{60^{3}}$ oder allgemein $\frac{2}{d^{3}}$ (wenn $d$, die Entfernung der Erde von dem fluterzeugenden Himmelskörper, in Erdhalbmessern ausgedrückt wird) gleich gesetzt werden. Unter der Einwirkung des Mondes tritt im Durchmesser $Z C N$ eine Streckung ein, indem $Z$ ebensoweit von $C$, wie $C$ von $N$ entfernt wird; da aber der starre Erdkörper an dieser Streckung nicht teilnimmt, so entfällt das ganze Plus auf die Wasserhülle, und ihre höchste Erhebung über ihr früheres Niveau findet an zwei Punkten statt: an jenem, der den Mond im Zenit hat $(Z)$, und an dem antipodischen Punkt (Nadir, $N$ ). Auf der Ungleichheit der Anziehung, d. h. auf der Differenz $\frac{2}{d^{3}}$ beruht also die fluterzeugende 
Kraft jedes Himmelskörpers; sie ist umgekehrt der dritten Potenz seiner Entfernung, anderseits aber, wie die Anziehung, direkt seiner Masse proportional. Aber nicht bloB $Z$ und $N$ unterliegen der Anziehungskraft des Mondes, sondern auch die ganze übrige Wasseroberfläche, nur werden ihre Teilchen nicht bloB von $C$ entfernt, sondern auch nach $Z$ und $N$ hinübergezogen (z. B. $d$ nach $d^{\prime}$ ); ihre Bewegung setzt sich aus einer vertikalen und einer horizontalen Komponente zusammen, und die letztere nimmt immer mehr auf Kosten der vertikalen zu, je weiter man sich von $Z$ und $N$ entfernt. In dem größten Kreis, der $90^{\circ}$ von $Z$ und $N$ absteht $(H H)$, scheiden

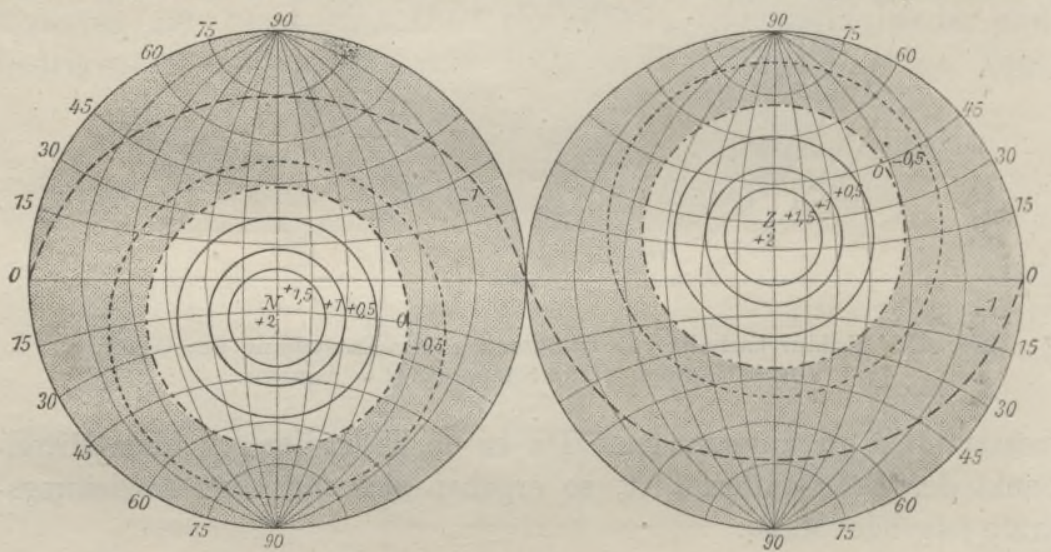

Fig. 66. Karte der Gleichgewichtsgezeiten nach G. H. DARwIN. ${ }^{1}$

\section{Linien gleicher Niveauerhöhung.}

Null-Linie (keine Niveauveränderung).

Linien gleicher Niveauerniedrigung.

sich die Horizontalbewegungen nach $Z$ und $N$ hin, hier tritt also nur Niveausenkung, d. h. eine rein vertikale Bewegung ein, die aber im Gegensatz zu $Z$ und $N$ nach abwärts gerichtet ist. Das Endergebnis ist die Umformung der ursprünglichen Kugeloberflächę - von der Abplattung sehen wir hier ab -- in ein Flutellipsoid, dessen größte Achse in die Ebene der Erd- und Mondmittelpunkte fällt. Setzen wir die Maximalerhöhung des Wasserspiegels über das ursprüngliche Niveau $=2$, so beträgt die Maximalerniedrigung unter jenes Niveau 1; dieser Unterschied erklärt sich daraus, daß sich die erstere nur auf zwei Punkte $(Z$ und $N$ ) beschränkt, während die letztere längs eines größten Kreises stattfindet. - Der absolute Wert der Maximalerhöhung ist aber sehr gering, denn sie findet naturgemäß dort ihre Grenze, wo sich die Anziehungskraft des Mondes und die Schwerkraft der Erde das Gleichgewicht halten. Sie berechnet sich auf $375 \mathrm{~mm}$, die Maximalerniedrigung somit auf 
$188 \mathrm{~mm}$ und die gesamte Hubhöhe auf $375+188=563 \mathrm{~mm}$. In unserer Fig. 65 ist die Darstellung, um deutlich zu sein, enorm übertrieben; das Meer ist 200 mal zu tief, und die Deformation durch die Mondflut 1 millionmal zu groß. Eine richtige Vorstellung von der Umformung gewinnt man erst aus Fig. 66. Die Linien gleicher Niveauerhöhung und gleicher Niveauerniedrigung sind hier in $\mathrm{Ab}$ ständen von $1 / 2$ eingezeichnet, die Erhöhung in $Z$ und $N$ zu 2 angenommen. Auf jeder Halbkugel sehen wir zwei flache Wasserkegel, deren Gipfel $Z$ und $N$ sind, und die, dem scheinbaren Mondumlauf folgend, in $24^{\mathrm{h}} 50^{\mathrm{m}}$ einmal die Erde umkreisen. Wir können uns auch das System ruhend vorstellen und annehmen, in dem genannten Zeitraum umwandere ein Beobachter beispielsweise im 30. nördlichen Parallel die Erde (vgl. Fig. 66). Er beginne im W in der tiefsten Depression 1, steigt dann den Kegel der Nadirflut $(N)$ hinan bis zur Höhenlinie $1 / 2$, dann wieder abwärts bis zur Depression 1, dann aufwärts auf dem Kegel der Zenitflut $(Z)$ bis zur Höhe von ungefähr $1 \frac{1}{4}$, endlich wieder abwärts zur Depression, von der er ausgegangen war. In jedem Parallel stellen die Gezeiten eine flache Doppelwelle dar, deren absolute Höhen sich aus den angeführten Relativwerten ergibt:

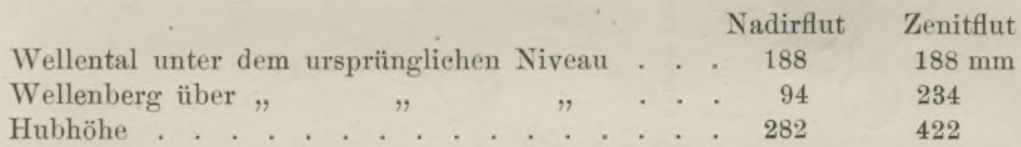

Die Hubhöhe der Zenitflut ist also in dem angenommenen Fall $140 \mathrm{~mm}$ höher als die der Nadirflut; man nennt diesen Unterschied die tägliche Ungleichheit. Infolge der Neigung der Mondbahn gegen die Äquatorialebene verschieben sich die Zenit- und Nadirfluten im Lauf eines Monats zwischen $28^{\circ} \mathrm{N}$ und $28^{\circ} \mathrm{S}$, und damit wechselt auch die tägliche Ungleichheit. Sie verschwindet nur dann, wenn der Mond im Äquator steht.

Außer dem Mond übt auch die Sonne eine fluterzeugende Kraft aus, die aber um mehr als die Hälfte kleiner ist als die unseres zwar viele millionenmal kleineren, aber beträchtlich näheren Trabanten $\times$ Die Sonnenkegel steigen nur $164 \mathrm{~mm}$ über das ursprüngliche Niveau an und die Depression senkt sich nur $82 \mathrm{~mm}$ darunter hinab; die Hubhöhe der Sonnenflut beträgt somit $246 \mathrm{~mm}$.

$\times$ Setzen wir die Masse der Erde $=1$ und drücken wir die Entfernungen der beiden Himmelskörper in Erdradien aus, so verhält sich ihre fluterzeugende Kraft

$$
\text { Mond : Sonne }=\frac{0,01235}{60^{3}}: \frac{328500}{23312^{3}}=0,000000057: 0,000000026=2,2: 1 .
$$


In $24^{\mathrm{h}}$ umkreisen zwei Sonnenwellen und in $24^{\mathrm{h}} 50^{\mathrm{m}}$ zwei Mondwellen von Ost nach West die Erde. Mond- und Sonnenwelle vereinigen sich zu einer einzigen Welle, deren Höhe und Eintrittszeit von der wechselnden Stellung beider Gestirne zueinander abhängt (Fig. 67). In der Phase des Neumondes passieren sie gleichzeitig den Meridian, und das Sonnenhochwasser tritt gleichzeitig mit dem Mondhochwasser ein. Das wirkliche Hochwasser stellt die Summe beider dar, und ebenso das wirkliche Niedrigwasser die Summe beider Niedrigwasser. Der umgekehrte Fall tritt im ersten Viertel

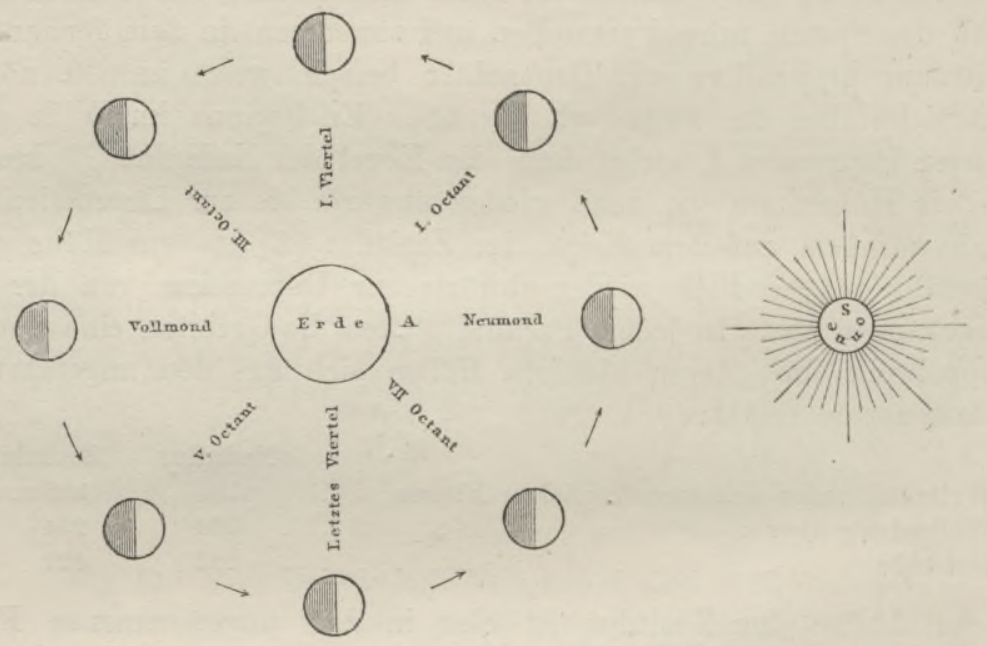

Fig. 67. Mondphasen.

ein; wenn $A$ Sonnenhochwasser hat, hat es Mondniedrigwasser und umgekehrt, und die wirklichen Gezeiten sind gleich dem Unterschied der Mond- und Sonnentiden. Zur Zeit des Vollmondes trifft die untere Kulmination des Mondes mit der oberen der Sonne zusammen, und das Resultat ist dasselbe wie bei Neumond. Innerhalb eines Monats erreicht also die Hubhöhe zweimal ihren höchsten (Springtiden) und zweimal ihren niedrigsten Wert (taube oder Nipptiden $\times$ ); die Übergänge zwischen diesen Extremen stellt Fig. 68 dar. Die Springflut steigt zu $563+246=809 \mathrm{~mm}$, die taube Flut aber nur bis $563-246=317 \mathrm{~mm}$ an. Den Unterschied zwischen den Hubhöhen zur Zeit der Syzygien und Quadraturen nennt man die halbmonatliche Ungleichheit.

$\times$ Der Ausdruck „Nipptiden“ ist eine Verstümmelung der englischen Bezeichnung neap tides. Die ursprüngliche Bedeutung der neap zugrunde liegenden niederdeutsehen Wurzel ist ,sehwach". 
Wie die lunaren, so verschieben sich auch die solaren Flutkegel, aber nur zwischen $23^{1} /{ }^{0} \mathrm{~N}$ und S, und dieser Wechsel vollzieht sich erst im Lauf eines Jahres. Endlich hängt die fluterzeugende Kraft beider Himmelskörper auch von ihrer wechselnden Entfernung von der Erde ab. Die Mondflut schwankt nach der theoretischen Berechnung zwischen 647 und $465 \mathrm{~mm}$, die Sonnenflut nur zwischen 259 und $234 \mathrm{~mm}$. Die höchste Springflut ist also 906, die niedrigste

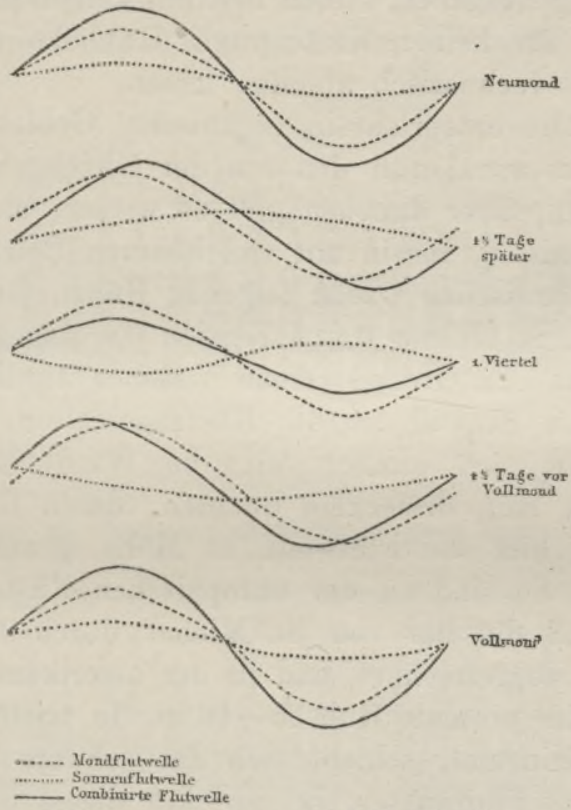

Fig. 68. Sonnen- und Mondwelle.

taube Flut $231 \mathrm{~mm}$. Diesen Unterschied nennt man die parallaktische Ungleich/heit.

Fassen wir das bisher Gesagte noch einmal in Kürze zusammen. Die Hubhöhe und die Eintrittszeit des Hochwassers hängen ab: 1. von der Stellung des Mondes zur Sonne, 2. von der Deklination beider Gestirne, und 3. von ihrer Entfernung von der Erde. Die theoretischen Gezeiten ändern sich ferner mit der Breite. Am Äquator findet keine tägliche Ungleichheit statt, unter den übrigen Breiten aber nur dann nicht, wenn die Deklination von Mond und Sonne $=0$ ist. Jenseits der Breiten $28^{\circ} \mathrm{N}$ und $\mathrm{S}$ nimmt die Hubhöhe stetig gegen die Pole ab. An den Polen selbst wechseln Ebbe und Flut innerhalb eines halben Monats einmal.

Wirkliche Gezeiten. Die Bedingungen, die die Gleichgewichtstheorie stellt, werden in der Natur nicht erfüllt. Die Trägheit ge- 
stattet dem Wasser nicht, den anziehenden Kräften sofort Folge zu leisten. Die UngleichmäBigkeit der Meerestiefen erlaubt es ferner der Flutwelle nicht, mit dem scheinbaren täglichen Umlauf der Sonne und des Mondes gleichen Schritt zu halten. Von noch entscheidenderem Einfluß ist die Unterbrechung der ozeanischen Fläche durch Festlandsmassen, und die theoretischen Entwicklungen von Newton und Laplace, die von der Voraussetzung einer allgemeinen Meeresbedeckung ausgehen, haben insofern keinen praktischen Wert, als sich daraus für keinen Küstenpunkt Hubhöhe und Eintrittszeit des Hochwassers rechnerisch ableiten lassen.

Die Hubhöhe entspricht im ozeanischen Gebiet nur an einigen landfernen Inseln annähernd den von der Gleichgewichtstheorie geforderten Werten, aber daneben gibt es wieder, anscheinend unter gleichen Verhältnissen, Inseln mit viel höheren Beträgen. So finden wir z. B. im Atlantischen Ozean folgende Höhen für die Springflut: Südgeorgien 0,8 , St. Helena 0,9, Ascension 0,6, dagegen Madeira 2,1, Azoren 1-1,5 m. Im Großen Ozean bestehen ähnliche Gegensätze. Von wesentlichem Einfluß ist die Küstengestaltung; die Gezeitenbewegung verhält sich ähnlich wie die Windwellen. Besonders günstig erweisen sich dreieckige Buchten, deren Boden allmählich ansteigt, indem hier die Flutwelle an Höhe gewinnt, was sie an Breite verliert. So sind an der europäischen Küste besonders der Bristolkanal und die Bai von St. Michel durch hohe Flutwellen $(15,9$ bzw. $11 \mathrm{~m})$ ausgezeichnet, und in der amerikanischen Fundybai erreicht sogar der normale Hub 15-16 m. In trichterförmige.Flußmündungen eindringend, schiebt sich das schwere Salzwasser keilförmig unter das Flußwasser ein, so daß dieses tatsächlich einige Stunden aufwärts fließt. Die Vorderseite der Flutwelle ist hier besonders steil, so daß die Flut kürzer dauert als die Ebbe. Schwellen günstige orographische Verhältnisse die Fluthöhe beträchtlich an und finden sich ausgedehnte Untiefen vor, so entwickelt sich die imposante, aber gefährliche Flutbrandung× (Bore des Ganges, Mascaret der Seine vor ihrer Regulierung, Pororoca des Amazonenstroms: besonders großartig im chinesischen Tsientangkiang bei Hangtschou). In mächtiger Brandung stürzt sich das Wasser über die flachen Uferbänke, während in der Mitte des Stromes die Flutwelle als ungebrochener mauerartiger Wall aufwärts fortschreitet. Die Flutgrenze, an der die Gezeitenbewegung aufhört, ist die eigentliche Grenze zwischen FluB und Meer; an ihr haben sich zahlreiche der bedeutendsten Handelsstädte entwickelt. Die Länge

$\times$ Auch Sprungwelle oder Stürmer genannt. 
der Flußstrecke zwischen der Flutgrenze und der Mündung, des sogenannten Flußgeschwelles, beträgt z. B. bei der Weser 67, bei der Elbe 148, in den Hauptarmen des Ganges ungefähr 250, am Jangtsekiang 500, am Amazonas sogar $870 \mathrm{~km}$.

An den Gezeiten nehmen aber nur die ozeanischen Flüsse teil. In den Binnenmeeren ist die Hubhöhe so gering, daß man ihnen dies Phänomen früher sogar ganz abgesprochen hat. Im Mittelländischen Meer sinkt sie z. B. von 1,2 m in Gibraltar auf 0,14 in Genua, 0,3 in Lipari und 0,06 $\mathrm{m}$ in Korfu; nur in den Syrten erreicht

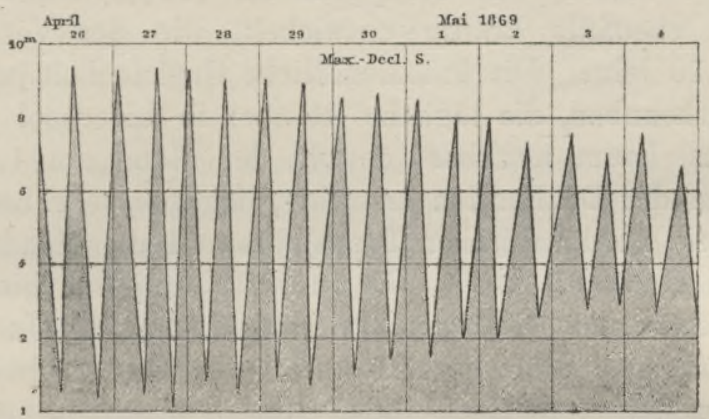

Fig. 69. Gezeiten zu Liverpool nach Lentz. ${ }^{2}$

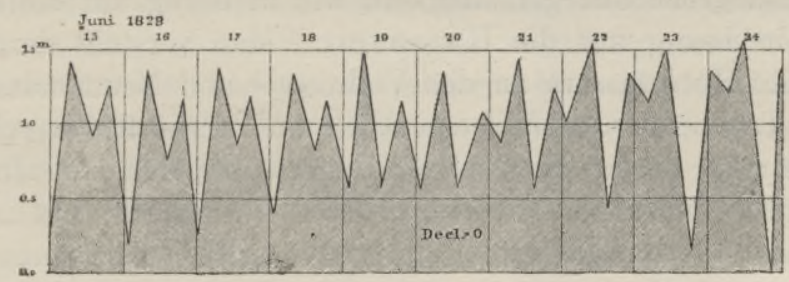

Fig. 70. Gezeiten zu Petropawlowsk nach Lentz. ${ }^{2}$

sie $1,83 \mathrm{~m}$. Am Eingang in die Ostsee beträgt sie noch $0,3 \mathrm{~m}$, in Kiel aber nur mehr $0,07 \mathrm{~m}$ und jenseits Rügen sogar nur einige mm, erhebt sich jedoch im Finnischen und Bottnischen Busen wieder bis auf $0,05 \mathrm{~m}$. Bei Chicago am Michigansee erreicht die Springflut $0,07 \mathrm{~m}$. Es muß übrigens nochmals betont werden, daß auch Stürme den Wasserstand wesentlich beeinflussen, indem sie Wasser zur Küste hintreiben (Windstau) oder von ihr entfernen; die beobachtete mittlere Hubgröße ist also nicht allein das Resultat der Gezeitenbewegung.

Auch die periodischen Veränderungen der Hubhöhe vollziehen sich nicht überall in gleicher Weise. So ist z. B. im nordatlantischen Ozean die halbmonatliche Ungleichheit an der ameri- 
kanischen Seite nur halb so groß als an der europäischen. Die tägliche Ungleichheit ist an beiden Gestaden gering; am amerikanischen wächst sie aber rasch nach $\mathrm{S}$ zu, und im Golf von Mexico ist die kleine Ebbe schon völlig verschwunden, und innerhalb 24 Stunden wechseln Flut und Ebbe nur einmal. Solche Ein tagstiden haben auch die Golfe von Tongking und Siam und das Meer von Formosa bis Java und Sumatra; anderseits gibt es auch Küstenpunkte, wo sich die Hochwässer in Zwischenräumen von weniger als 12 Stunden wiederholen, wie z. B. an der Taymündung an der schottischen Ostküste. Im nordpazifischen Ozean ist die tägliche Ungleichheit ebenfalls kräftig entwickelt, wie der Vergleich der Fig. 69 und 70 lehrt. Die halbmonatliche Ungleichheit ist an beiden Orten gut erkennbar, die tägliche ist aber in Liverpool (nordatlantischer Typus) kaum merkbar, obwohl der Mond am 1. Mai 1869 das Maximum der Deklination erreichte, dagegen sehr bedeutend in Petropawlowsk (nordpazifischer Typus), obwohl die Monddeklination am 21. Juni $1828=0$ war, $\times$ Bis zum 19. Juni war hier das vormittägige Hoch- und Niedrigwasser größer, vom 19. Juni an aber das nachmittägige. Man beachte auch, wie sich an beiden Orten die Eintrittszeiten von Hoch- oder Niedrigwasser allmählich verschieben.

Ebenso große Unregelmäßigkeit, wie in bezug auf die Hubhöhe, herrscht in bezug auf die Hafenzeit. Man versteht darunter die Uhrzeit des Hochwassers an den Vollmond- und Neumondtagen, also an jenen Tagen, an denen es eigentlich um $12^{\mathrm{h}}$ eintreten sollte. Wir werden einige dieser Unregelmäßigkeiten sogleich kennen lernen; hier sei nur darauf hingewiesen, daB - wie J. P. van DER STok bemerkt hat - von Hafenzeit nur dort die Rede sein kann, wo der Theorie gemäß die Mondflut stärker als die Sonnenflut ist. Gerade das Entgegengesetzte trifft aber für die meisten Teile des Pazifischen und für viele Teile des Indischen Ozeans zu. Wie Hochwasser und Mondkulmination, so differieren zeitlich auch Springfluten und Syzygien; die ersteren verspäten sich im Atlantischen Ozean um $1 / 2$ bis $2^{1 / 2}$ Tage, in Toulon treten sie aber um $4^{3} / 4$ Stunden zu früh ein.

Wellentheorien. Wheweli war der erste, der seine Theorie den beobachteten Hafenzeiten anzupassen suchte. Wenn man die gleichen Hafenzeiten, bezogen auf den Meridian von Greenwich, durch Linien (Cotidal lines, Flutstunden- oder bloß Flutlinien) mit-

$\times$ Die tägliche Ungleichheit ist nach der Theorie proportional dem Sinus der doppelten Deklination. 
einander verbinde, so müssen diese - das war WHEwELL's Ansicht die Kämme der fortschreitenden Flutwellen darstellen. Für seichtes Meer ist diese Annahme zulässig, aber die Verlängerung der Flutlinien in das offene Meer hinaus ist - wie der Autor später selbst zugab - lediglich ein Phantasiegemälde. Auch war WHewell der Ansicht, daß die Südsee die eigentliche Geburtsstätte der Gezeitenbewegung sei, und die Flutwelle erst von da aus in den Atlantischen Ozean eindringe, und suchte damit die Verspätung der Springtiden zu erklären. Aber auch diese Hypothese ist durch die Erfahrung widerlegt, daß nicht nur Binnenmeere, wie das Mittelländische und die Ostsee, sondern auch von aller ozeanischen Verbindung abgeschlossene große Becken, wie der Michigansee, Ebbe und Flut besitzen.

Einen bedeutsamen Fortschritt bezeichnet ArRY's Kanaltheorie (1842), die uns zuerst den maßgebenden EinfluB der Reibung auf das Gezeitenphänomen würdigen gelehrt hat. In einem gleichmäßig tiefen Kanal erzeugt die Anziehungskraft des Mondes eine Welle von der Periode eines halben Mondtages und von der Länge eines halben Erdumfangs, die Höhe ist aber abhängig von der Tiefe des Kanals und steht $\mathrm{zu}$ dieser im geraden Verhältnis. Je nachdem der Kanal in einem größten Kreis am Aqquator oder in meridionaler Richtung oder in einer Zwischenrichtung oder in einem kleinen Kreis, z. B. längs eines Parallelkreises verläuft, gestalten sich die Wellen verschieden, und die tatsächliche Meeresbedeckung läßt sich annäherungsweise auf ein System solcher verschiedener Kanäle zurückführen. Sobald sich an irgend einer Stelle des Kanals die Breite oder Tiefe ändert, so daß die primäre Welle und ihre Fortbewegung gehemmt ist, entsteht als Ausdruck der neuen Gleichgewichtsstörung eine sekundäre Welle von derselben Periode wie die primäre, aber von verschiedener Länge, die, weil sie unter allen Umständen die Tiefe weit übertrifft, nach der LagrangE'schen Formel im direkten Verhältnis zur Tiefe steht. $\times$

Die Annahme regelmäßiger Kanäle ermöglicht die Rechnung, entspricht aber natürlich nicht den Formen der Meeresbecken. Trotzdem läßt sich diese Theorie bis zu einem gewissen Grad auch auf die natürlichen Verhältnisse anwenden; jedenfalls ist sicher, daß die an den Küsten beobachteten Gezeiten, wenn sie wirklich fortschreitende Wellen sind, nur sekundäre Wellen sein können.

× Man nennt die primären Wellen auch gezwungene, weil sie unter der unmittelbaren Herrsehaft der wellenerzengenden Kraft stehen, die sekundären dagegen freie. Windseen sind z. B. gezwungene, Dünungen freie Wellen. 
Darauf baute BöBgen weiter (1884). Die atlantischen Hafenzeiten $\times$ deuten an, daß die Flutwelle von $\mathrm{S}$ nach $\mathrm{N}$ fortschreitet. Zwei Orte im N und S mit gleicher oder ähnlicher Hafenzeit, wie z. B. S. Francisco in Brasilien und Barra Head in Schottland, sind dann, wie man annehmen darf, nur eine Wellenlänge voneinander entfernt. Stimmt die wirkliche Entfernung mit der aus der Periode und der mittleren Tiefe berechneten überein oder doch wenigstens nahezu überein, so wird man für jene Annahme eine wesentliche Stïtze gewonnen haben. KREIDEL ${ }^{3}$ glaubte sogar, daß es einst möglich sein werde, aus den Tiefen und Hafenzeiten die Lage der Flutlinien im offenen Ozean zu berechnen; für die südatlantische 12 UhrLinie hat er einen solchen Versuch bereits gewagt, der aber wegen unzulänglicher Beobachtungen, und weil der Begriff der Hafenzeit nicht allgemein anwendbar ist, als gescheitert betrachtet werden muB.

Im Gegensatz zu dieser Theorie fortschreitender Gezeitenwellen faßt eine neuere die Gezeiten als stehende Wellen auf. Sie suchte zunächst der eigenartigen Entwicklung des Tidenphänomens im nordatlantischen Ozean $\times$ gerecht zu werden. Die Hubhöhe ist selbst unmittelbar am ozeanischen Gestade überraschend hoch, und auf der Ostseite höher als an der westlichen, während in der südhemisphärischen Hälfte das umgekehrte Verhältnis stattzuhaben scheint. Die Hafenzeit verspätet sich an der Ostküste von Süd nach Nord immer mehr, als ob die Flutwelle in dieser Richtung fortschreiten

× Aus den Gezeitentafeln für 1909 wurden nur Orte mit möglichst freier Lage gewählt. Die Hafenzeiten sind, um vergleichbar zu sein, auf Greenwicher Zeit reduziert. Die Hubhöhe bezieht sich auf die Springzeit.

Westküste

Ostküste

\begin{tabular}{|c|c|c|c|c|c|c|c|c|c|c|}
\hline Breite & Ort & & $\begin{array}{r}\text { Haf } \\
\text { ze }\end{array}$ & & $\begin{array}{c}\mathrm{Hub} \\
\mathrm{m}\end{array}$ & Ort & & $\begin{array}{r}\text { Haf } \\
\text { ze }\end{array}$ & $\begin{array}{l}\text { fen- } \\
\text { eit }\end{array}$ & $\begin{array}{c}\text { Hub } \\
\mathrm{m}\end{array}$ \\
\hline $56,{ }^{\circ} \mathrm{N}$ & Nain. & . & $11^{\mathrm{h}}$ & $16^{\mathrm{m}}$ & 2,0 & Barra Hd. & & $6^{\mathrm{h}}$ & $15^{\mathrm{m}}$ & 3,4 \\
\hline 51 & Kripon . & . & 10 & 47 & 1,5 & Valentia. . & . & 4 & 23 & 3,4 \\
\hline 47 & St. John's . . & . & 11 & 01 & 1,2 & Insel Hoedic & . & 3 & 40 & 4,6 \\
\hline 43 & Sable Island & . & 10 & 30 & 1,2 & Socoa... & . & 3 & 35 & 3,8 \\
\hline 41 & Blockinsel . . & . & 0 & 27 & 1,1 & Oporto. . & - & 3 & 04 & 3,0 \\
\hline $5-37$ & Hatteras Inlet. & . & 0 & 17 & 0,8 & Lagos (Portugal & & 2 & 23 & 3,5 \\
\hline 28 & Kap Canaveral & . & 1 & 41 & 1,3 & Gran Canaria & . & 2 & 07 & 3,0 \\
\hline $3-14$ & Barbados . . & & 6 & 58 & 0,9 & Kap Verde. & . & 8 & 53 & 1,5 \\
\hline 6 & Surinam . & & 8 & 41 & $2,7-3,0$ & Monrovia . . & . & 6 & 43 & 1,8 \\
\hline 4 & Cayenne. . . & & 8 & 01 & $1,5-2,1$ & Kap Palmas & . & 5 & 00 & 1,2 \\
\hline$-5 \mathrm{~S}$ & Kanal S. Roque. & & 6 & 37 & 2,3 & Loango . . & - & 3 & 26 & 2,1 \\
\hline $12-13$ & Bahia. . . & & 6 & 49 & 2,2 & Benguela. . & . & 2 & 51 & $1,5-1,8$ \\
\hline 26 & S. Franciseo do $\mathrm{S}$ & & 5 & 44 & 2,0 & Lüderitzbucht & - & 1 & 27 & 2,0 \\
\hline $4-36$ & Kap S. Antonio & . & 1 & 47 & 1,7 & Tafelbai . . & . & 1 & 26 & 1,5 \\
\hline
\end{tabular}


würde, oder vielmehr als ob $\mathrm{zwei}$ Wellen sich nach Norden bewegten, denn Orte, die um 60-70 Breitengrade voneinander entfernt sind, haben gleiche Hafenzeit. An der Westküste begegnen wir einer ähnlichen Anordnung nur bis zu den Antillen, an der Küste der Vereinigten Staaten tritt aber die Springflut überall nahezu gleichzeitig ein. Auf die ungleichmäBige Ausbildung der periodischen Gezeitenschwankungen an beiden Gestaden ist schon früher aufmerksam gemacht worden.

Nach Fitzroy, Dove (1854) und Ferrec (1874) lassen sich die Ġezeiten des nordatlantischen Ozeans durch die Annahme einer meridionalen stehenden Welle, einer Seiche im großartigsten Maßstab, erklären. Eine solche könnte unter günstigen Umständen durch Interferenz zustande kommen, indem die ursprüngliche, von den Gestirnen erzeugte Flutwelle von den Küsten zurückgeworfen würde. Das Wesen einer solchen stehenden Welle besteht - wie schon dargelegt wurde - darin, daß beide Ufer abwechselnd Hochund Niedrigwasser haben. Das amerikanische Gestade hat in der Tat nahezu überall gleichzeitig Flut, am europäischen aber müßte sich nach der Ansicht FERREL's die stehende Welle infolge der wechselnden Tiefenverhältnisse in eine fortschreitende verwandeln.

Wir haben oben (S. 300) die Seichesformel kennen gelernt. Wir können berechnen, ob die Länge und die mittlere Tiefe des atlantischen Beckens mit der Periode der Flutwelle $\left(12^{\mathrm{h}} 25^{\mathrm{m}}\right)$ übereinstimmt, und danach den Wert der Theorie bemessen. Die Prüfung, die BörGen vorgenommen hat, ergab kein günstiges Resultat.

In neuester Zeit (1900) hat HARRIS ${ }^{4}$ die Theorie der stehenden Gezeitenwellen auf das ganze Weltmeer ausgedehnt, indem er dieses in durchaus willkürlicher Weise in eine Reihe verschieden gestalteter Schwingungsgebiete zerlegte, die sich zum Teil nicht einmal einseitig an das Festland anlehnen, so daß - wie KRÜMmeL bemerkt gerade die Grundbedingung aller Seichesentwicklung, die festen Wände fehlen. Damit soll aber nicht gesagt sein, daß stehende Wellen im Gezeitenphänomen überhaupt fehlen; sie können sich wohl infolge von Interferenzen aus fortschreitenden Wellen entwickeln und örtlich sogar eine große Bedeutung gewinnen. Dieses im einzelnen nachgewiesen zu haben, ist als ein bleibendes Verdienst von HARRIS anzuerkennen.

Außer der Tiefe unterliegt die Flutwelle auch noch anderen Einflüssen. Zunächst der Ablenkung durch die Erdrotation, und es mag wohl damit zusammenhängen, daß im südatlantischen Ozean das Westufer, im nordatlantischen das Ostufer die bedeutendere Hubhöhe aufweist. Noch entscheidender, namentlich auf die Hafenzeit, 
wirken die verschiedenen Interferenzen ein. Solche entstehen dadurch, daß Mond- und Sonnenwelle durch die unregelmäBige Gestalt der Meeresräume in verschiedenen Richtungen einerseits abgelenkt, anderseits zurückgeworfen werden. Ein lehrreiches Beispiel bieten die britischen Gewässer und die Nordsee; die Verteilung der Hafenzeiten in diesen Gegenden (Fig. 71) hatte WHEwell zuerst Veranlassung gegeben, Flutstundenlinien zu konstruieren, die allerdings jetzt überholt sind. Die Flutwelle erreicht zuerst die iberische, dann die französische Küste, dringt dann einerseits in den britischen

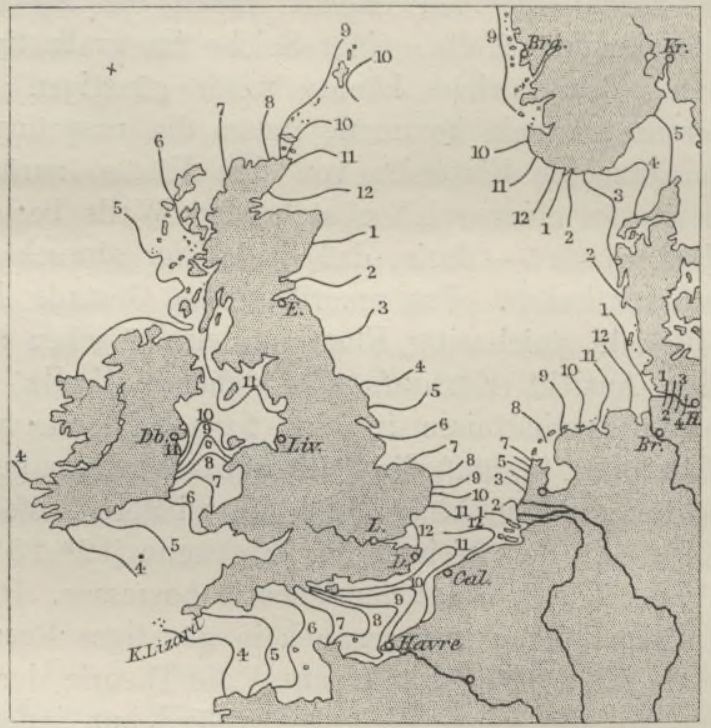

Fig. 71. Flutstundenlinien der Nordsee und der britischen Gewässer nach der Darstellung der Deutschen Seewarte. Die Flutstundenlinien geben die Hafenzeit nach Greenwicher Zeit an.

Kanal und in den St. Georgskanal ein, anderseits läuft sie um Irland und Schottland herum und gelangt so auch von $\mathrm{N}$ her teils durch den Nordkanal in die Irische See, teils durch die Nordsee in das Meer zwischen England und Holland. So stoßen in der Irischen See und im Kanal Flutwellen aus entgegengesetzten Richtungen zusammen, und dazu kommt noch, daß die von W kommende Welle im Kanal durch die-meridional streichende Küste von Artois an das englische Gestade zurückgeworfen wird. Das Ergebnis sind vielfache Interferenzen, die sich als solche schon dadurch dokumentieren, daB die Flutstundenlinien in keiner Beziehung zu der Meerestiefe stehen. In der Irischen See bilden sich zwei stehende Wellen, deren Knoten an den beiden Ausgängen liegen, desgleichen auch im Kanal im 
Meridian von Cherbourg und zwischen Holland und England. An der letztern Stelle kommt es zur Interferenz zweier stehender Wellen; dort, wo die Schwingungsknoten sich schneiden, herrscht Ruhe, und die Flutstundenlinien gehen von da strablenförmig aus. HARRIs hat eine solche Anordnung eine Amphidromie genannt.

Im flachen Küstenwasser erleidet die Flutwelle Umgestaltungen, die denen der akustischen Schwingungen völlig analog sind. Den Obertönen entsprechen die Oberfluten, den Kombinationstönen die Kombinationsfluten. Außerdem zeigen an manchen Orten die von den Mareographen gezeichneten Flutkurven eigentümliche Kräuselungen, ähnlich denjenigen, die in Fig. 61 (S. 298) dargestellt sind, ohne daß seismische oder meteorologische Vorgänge dafür verantwortlich gemacht werden könnten. In ihrer Erklärung gehen die Meinungen auseinander, man führt sie auf Kombinations- oder Oberfluten oder auf sehr verwickelte Interferenzerscheinungen zurück.

Als allgemeinstes Ergebnis seiner ebenso umfassenden wie tiefgründigen Untersuchungen des Gezeitenphänomens nennt KRÜMMEL die wahrscheinliche Existenz zweier Hauptwellen oder Hauptwogen, die jedes der drei ozeanischen Becken, die eine im Sinn des Uhrzeigers, die andere im entgegengesetzten Sinn umkreisen und durch vielfache Interferenzen eine Gleichzeitigkeit der Hafenzeiten auf weite Küstenstrecken hervorrufen. Als eine Wirkung der Erdrotation ist es $\mathrm{zu}$ betrachten, daß die erste jener beiden Hauptwellen in den Südbreiten, die zweite in den Nordbreiten gegen die in $\mathrm{O}$ und $\mathrm{W}$ begrenzenden Küsten abgelenkt wird, und daß infolge davon dort die erste, hier die zweite über die andere die Oberhand gewinnt. Ein weiterer Ausbau der Theorie ist nur zu erwarten einerseits von Gezeitenbeobachtungen im offenen Ozean, anderseits von einer allgemeinen Anwendung der harmonischen Analyse.

Die harmonische Analyse. Aus keiner der bisher aufgestellten Theorien lassen sich die beiden Gezeitenkonstanten, die Hafenzeit und die Höhe der Springflut, für irgend einen Küstenpunkt auf mathematischem Weg ableiten. Das kann nur durch unmittelbare Beobachtung geschehen, wohl aber können die von den Pegeln auf. gezeichneten Kurven in ihrer GesetzmäBigkeit nachgewiesen und daraus die Eintrittszeiten und die Hubhöhen für das ganze Jahr berechnet und die sog. Gezeitentafeln für den betreffenden Hafenpunkt hergestellt werden, - wie auf der Hand liegt, ein Werk von größter praktischer Wichtigkeit. Die Schwierigkeit besteht nur darin, daß sich die beiden fluterzeugenden Himmelskörper in Bahnen bewegen, die mit der Äquatorialebene einen Winkel einschließen. Man umgeht sie, indem man Mond- und Sonnenflut gesondert berechnet, 
und statt des einen Mondes und der einen Sonne eine Anzahl von Himmelskörpern annimmt, die entweder still stehen oder sich in Bahnen parallel zum Äquator bewegen und im Raum so verteilt sind, daß die Summe ihrer Wirkungen gleich ist der der beiden wirklichen Gestirne. Man nennt diese, zuerst (1868) von Sir William Thomson auf die Flutrechnung angewandte Methode die harmonische Analyse.

Gezeitenströme. Wenn die Auffassung des Gezeitenphänomens als einer fortschreitenden Welle richtig ist, so ergibt sich daraus die Erklärung der Gezeitenströme. Man braucht sich nur vor Augen zu halten, daß jedes Wasserteilchen eine Orbitalbewegung ausführt, und dazu genau so vielZeit braucht, als dieWellenperiode beträgt, in unserem Fall also sechs Stunden nach vorn und sechs Stunden nach rückwärts sich bewegt. Die gleichzeitige Bewegung nach oben und unten macht sich nicht fühlbar; überdies nimmt auch die Orbitalbahn um so mehr die Gestalt einer flachen Ellipse an, je länger die Welle ist.

In einem Punkt scheinen aber die Gezeitenströme der Wellentheorie $\mathrm{zu}$ widersprechen. Man muß nämlich voraussetzen, daß der Stromwechsel oder das Kentern des Stromes jedesmal stattfindet,

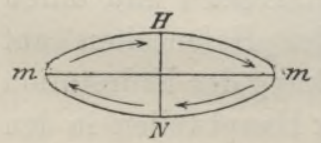

Fig. 72. Bahn der Wasserteilchen in der Flutwelle. wenn das Niveau des Mittelwassers $(\mathrm{m} m$ in Fig. 72) erreicht ist; in Wirklichkeit aber vollzieh er sich aber meist bald nach Hochund Niederwasser ( $H$ und $N$ in Fig. 72), nachdem eine kurze Zeit völliger Stillstand geherrscht hat. Dieses abnorme Verhalten läßt sich auf den Einfluß des ansteigenden seichten Meeresgrundes zurückführen, wodurch der vordere Schenkel der Welle eine Verkürzung erleidet. Das Einsetzen des Ebbestromes unmittelbar nach Hochwasser entspricht dem Branden der Windseen. Wo günstige Verhältnisse obwalten, nähert sich der Zeitpunkt des Kenterns auch mehr der theoretischen Forderung.

Wie wir ebenfalls im vorigen Kapitel schon hervorgehoben haben schwenkt der Wellenkamm, wenn er eine sanfte Böschung hinaufläuft, parallel zur Küste ein. Daher geht der Flutstrom stets senkrecht auf das Land $\mathrm{zu}$ und flieBt der Ebbestrom * ebenso vom Land ab, welche Richtung sie auch immer in größerer Entfernung von der Küste verfolgen mögen.

Differentialtiden. Daß wir das Wasser an den Küsten steigen und fallen sehen, beweist schon, daB es der Anziehungskraft des

$\times$ Die Küstenbewohner gebrauchen dafür kurzweg die Ausdrücke Flut und Ebbe. 
Mondes unendlich leichter folgt als die feste Erde. Aber deshalb darf die letztere doch nicht als gänzlich gezeitenlos betrachtet werden, wie sehon auf S. 21 erörtert wurde, und der Nullpunkt des Pegels, auf den man Hoch- und Niedrigwasser bezieht, ist daher selbst kein fixer Punkt. Wenn am 26. August 1866 der Wasserstand zu Cuxhaven von 1,82 auf $4,95 \mathrm{~m}$ stieg (s. Fig. 64, S. 302), so entfernte sich das Meeresniveau nicht bloB um 3,13 m vom Erdmittelpunkt, sondern um 3,13 m plus dem Betrag, um welchen der Pegelnullpunkt selbst gestiegen war.

Die beobachtete Flutgröße ist also gleich der wirklichen Fluthöhe des Wassers weniger der Fluthöhe der festen Erde, oder mit anderen Worten: die beobachteten Tiden sind Differentialtiden. Wie groß die Erdflut ist, läßt sich vielleicht einmal in bezug auf die halbmonatlichen Schwankungen ermitteln; bedeutend ist sie jedenfalls nicht und kann nur theoretisches Interesse beanspruchen.

Literaturnachweise. 1 G. H. Darwin, The Tides and Kindred Phenomena in the Solar System; London 1898; ausgezeichnete, auch für Nicht-Mathematiker verständliche Darstellung. (Unter dem Titel „Ebbe und Flut" übersetzt von A. Pockers, Leipzig 1902). Aloys Müller, Elementare Theorie der Entstehung der Gezeiten, Leipzig 1906; Zur Theorie der Entstehung der Tiden, in Gertand's Beiträgen zur Geophysik, Bd. X. Die ausführlichste Analyse der wirklichen Gezeiten findet sich in O. Krüмmer, Ozeanographie (zit. S. 275), Bd. II. Einen Apparat zur Veranschaulichung von Ebbe und Flut hat F. S. Archenнold in der Zeitschrift für Schulgeographie 1904, Bd. XXV, S. 353, beschrieben. - ${ }^{2}$ H. Lentz, Flut und Ebbe; Hamburg 1879. a W. Kreidel, Untersuchungen über den Verlauf der Flutwellen in den Ozeanen; Frankfurt a. M. 1889. - ${ }^{4}$ R. A. Haris, Manual of Tides, Report of the U. S. Coast and Geodetic Survey for 1900; Washington 1901.

\section{Die Mleeresströmungen. ${ }^{2}$}

(S. Karte XVI.)

Bedingungen. Strömungen können aus verschiedenen Ursachen entstehen. Von den sogenannten Gezeitenströmungen wurde bereits gesprochen; sie beherrschen das Meer oft bis in beträchtliche Entfernung von der Küste, wie in den britischen Gewässern, in der Hudsonstraße und im Lorenzgolf, in den seichten Gebieten des Australasiatischen Mittelmeers oder im Golf von Carpentaria. In einigen Meeresstraßen geben sie Veranlassung zu Wirbelbildungen, von denen der Maelstrom bei den Lofoten und die Scylla und Charybdis in der Meerenge von Messina die bekanntesten Beispiele sind.

Viel wichtiger sind die Ausgleichsströmungen. Zwischen benachbarten Meeresteilen von ungleicher Dichte entwickelt sich eine Zwillingszirkulation, bestehend aus einem Oberflächenstrom, der von dem Gebiet geringerer nach dem höherer Dichte geht, und einem 
unterseeischen Ersatzstrom in entgegengesetzter Richtung. Zwischen den beiden Horizontalströmungen vermitteln zwei vertikale Verbindungsströmungen: eine absteigende vom Ober- zum Unterstrom und eine aufsteigende vom Unter- zum Oberstrom. Solche Ausgleichsströmungen treten an den Toren auf, die vom Ozean in die Binnenmeere führen. Ein atlantischer Ober- und ein mediterraner Unterstrom passieren die Straße von Gibraltar, ${ }^{2}$ dagegen strömt das salzarme Ostseewasser oberflächlich durch die Belte und den Sund in den Kattegat, und darunter finden wir in mäßiger Tiefe einen nach SO sich bewegenden Unterstrom. Auch im offenen Ozean gibt es solche Dichteunterschiede; sie werden in der warmen Zone hauptsächlich durch Unterschiede der Temperatur und in den polaren Breiten durch solche des Salzgehaltes bedingt.

Eine dritte Kategorie bilden die durch die Winde erzeugten Triftströmungen.

Sehr lehrreich sind in dieser Beziehung die Beobachtungen auf dem deutschen Feuerschiff „Adlergrund“ zwischen Rügen und Bornholm, die ersten Beobachtungen dieser Art von einem festen Punkt aus und in genügender Entfernung vom Land. ${ }^{3}$ In 86 Prozent aller Fälle lief die Strömung mit dem Wind des betreffenden Tages, und der Einfluß des Windes erstreckte sich schon in kurzer Zeit bis $5 \mathrm{~m}$ Tiefe. Die Stromrichtung fiel aber nicht genau mit der Windrichtung zusammen, sondern wich im Durchschnitt um $28^{\circ}$ nach rechts ab. Eine ebensolche Ablenkung hat Wrтtis ${ }^{4}$ auch auf den übrigen Feuerschiffen der Ostsee nachgewiesen. Waren die Winde veränderlich, so war die Strömung für den ganzen Tag (24 Stunden) die Resultante aller Winde; und nur dann, wenn die Luftbewegung schwach war, konnte es vorkommen, daß der Strom nicht mit dem Wind oder sogar gegen ihn lief.

Man hat früher auch die Erdrotation für die Meeresströmungen verantwortlich gemacht. Denken wir uns, eine von Meer bedeckte Erde ohne atmosphärische Hülle und ohne Temperaturunterschiede beginne sich um ihre Achse zu drehen. In diesem Moment werden unzweifelhaft Strömungen beginnen, aber nur so lange dauern, bis überall das Gleichgewicht zwischen Schwer- und Fliehkraft hergestellt ist. Das Endergebnis ist die ellipsoidische Gestalt; es ist aber nicht einzusehen, wie die heutigen Strömungen mit der Erdrotation als primärer Ursache zusammenhängen sollten. Ihr Einfluß beginnt erst wieder, sobald aus irgendeiner anderen Ursache das Gleichgewicht gestört wird, und äußert sich nach dem auf S. 22 erörterten Gesetz in der Ablenkung von der ursprünglichen Stromrichtung. Theoretisch beträgt bei reiner Windwirkung der Ab- 
lenkungswinkel nach EkмaN ${ }^{5}$ unter allen Breiten mit Ausnahme des Äquators $45^{\circ}$, also erheblich mehr, als bei den baltischen Feuerschiffen. Aus Fig. 73 ist ersichtlich, daß ein nach $\mathrm{S}$ gerichteter barometrischer Gradient je nach seiner Lage auf der nördlichen oder südlichen Halbkugel und je nach der Breite NO- bzw. WNW-Winde erzeugt, und diese wieder W- bzw. ONO-Strömungen $\times$ hervorrufen.

Ozeanische Strömungen. Von den großen ozeanischen Strömungen, die im Haushalt der Natur eine so bedeutsame Rolle spielen, macht man sich, verführt -durch schematisierende Kartenbilder, vielfach falsche Vorstellungen. Man muß sich vor allem der Meinung entschlagen, daß überall auf dem Meer nur bestimmte Stromrichtungen herrschen. Ganz abgesehen von kleinen Schwankungen, kann man in einer und derselben Gegend zu verschiedenen Zeiten ganz verschiedene Richtungen finden. Nur ein Beispiel. In dem atlantischen Fünfgradfeld $45-50^{\circ} \mathrm{N}$ und $10-15^{\circ} \mathrm{W}$ beobach-

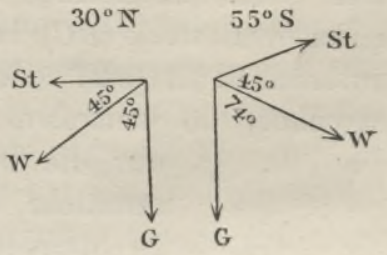

Fig. 73. Beziehungen zwischen den Richtungen des barometrischen Gradienten(G), des Windes (W) und der Meeresströmung(St).

tete man nach KRÜмmes in 538 Fällen, nach den Quadranten geordnet, folgende Strömungen: 35 Prozent nach SO, 25 nach SW, 24 nach NO und 16 Prozent nach NW. Hier kann also an der Oberfläche nicht von einer konstanten, sondern nur von einer vorherrschenden Stromrichtung gesprochen werden. Noch schwankender ist die Geschwindigkeit, und meist werden wir nur durch indirekte Anzeichen belehrt, daB die Wasserteilchen in einer bestimmten Richtung fortschreiten. Polare Eisberge werden in die gemäßigte Zone entführt; amerikanisches Treibholz gelangt nach Norwegen und zu den arktischen Inseln; Flaschen, die einen Zettel mit genauer Angabe der Stelle und Zeit des Aussetzens enthalten, werden an weit entlegenen Orten wieder aufgefunden. ${ }^{6}$ Die Geschichte erzählt uns, daß Cabral im Jahr 1500, als er nach Ostindien segeln wollte, von den Strömungen nach Westen entführt und so der unfreiwillige Entdecker Brasiliens wurde. Vor allem aber ist die Temperatur und Salzgehaltsverteilung im Meer ein sicherer Beweis für das Vorhandensein von Strömungen sowohl an der Oberfläche wie in der Tiefe des Ozeans.

Auf dem offenen Meer ermittelt man die Stromversetzung des Schiffes durch Vergleichung des aus dem Kurs und der Fahrgeschwindigkeit berechneten (,gegißten“, d. h. geschätzten) Standortes

× Im Gegensatz zur Richtung der Winde bezeichnet man die der Meeresströmungen nach der Himmelsgegend, nach der sie fließen. 
mit dem astronomisch bestimmten („Besteck“) im Verlauf eines „Etmals" (Zeitraum von einem Mittag zum anderen). Folgendes Beispiel, einer Abhandlung von Sснотт ${ }^{7}$ entnommen, wird uns über das Wesen dieser Bestimmung aufklären. Ein Schiff befindet sich an einem Mittag in $\mathrm{O}$ (Fig. 74), $\left.31^{\circ}\right\lrcorner 5^{\prime} \mathrm{N}, 136^{\circ} 20^{\prime} \mathrm{O}$. Am nächsten Mittag sollte es sich nach der Schiffsrechnung in A $\left(29^{\circ} 29^{\prime} \mathrm{N}\right.$, $134^{\circ} 20^{\prime}$ O) befinden, ist aber, wie die astronomische Beobachtung zeigt, tatsächlich in B $\left(29^{\circ} 48^{\prime} \mathrm{N}, 134^{\circ} 47^{\prime} \mathrm{O}\right)$, wurde also während seiner Fahrt durch eine Strömung $(A B)$ etwas nach NO abgelenkt. Der Breitenunterschied zwischen dem gegißten und dem astronomischen Besteck $(B C)$ beträgt $19^{\prime}$ oder 19 Seemeilen, der Längenunterschied $(A C) 27^{\prime}$ oder (nach der mittleren Breite von $A$ und $B$ berechnet) 23 Seemeilen. In dem rechtwinkligen Dreieck $A B C$ sind

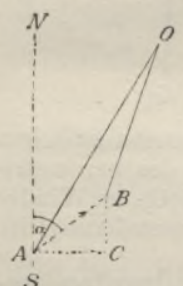

Fig. 74.

Die Stromversetzung.

nur die beiden Katheten bekannt; daraus läßt sich ermitteln 1. der Weg $A B$, den die Strömung in 24 Stunden zurückgelegt hat, oder ihre Geschwindigkeit, 2. der Winkel $A B C=\operatorname{dem}$ Winkel $a$, den die Stromrichtung mit dem Meridian (NS) einschließt. Im vorliegenden Fall ergibt sich für die Strömung die Richtung $N 52{ }^{\circ} \mathrm{O}$ und eine Geschwindigkeit von 30 Seemeilen pro Tag $=0,6 \mathrm{~m}$ pro Sek., also eine bedeutend geringere als die Wellengeschwindigkeit. Eben dadurch hatte sie sich der direkten Beobachtung entzggen.

Es ist klar, daß diese Methode, die Stromversetzung zu bestimmen, an großen Übelständen leidet, denn das Resultat hängt ganz von der Zuverlässigkeit der Schiffsrechnung und der astronomischen Positionsbestimmung ab. Direkte instrumentelle Messungen mittels Propellerapparate, die durch die Umdrehung einer Flügelschraube, oder mittels Pendelapparate, die durch den Ausschlagswinkel eines durch Wasserdruck verschobenen Pendels Stromrichtung und -geschwindigkeit anzeigen, werden erst seit kurzer Zeit ausgeführt, und über ihre Ergebnisse läßt sich noch kein Urteil fällen. Übrigens besitzen wir in den Temperatur- und besonders in den Salzgehaltsmessungen ein sicheres Mittel, um über die polare oder äquatoriale Herkunft einer Wasserprobe $\mathrm{zu}$ entscheiden, und die skandinavischen Forscher legen darauf das Hauptgewicht. Sie haben überdies auch den Kreis der Untersuchungen beträchtlich erweitert. Von großer Wichtigkeit sind die Stickstoffbestimmungen, denn daraus läßt sich mit Hilfe von Hamberg's Tabellen die sogenannte Absorptionstemperatur $\left(\tau^{0}\right)$ ermitteln, $d . h$. diejenige Temperatur, die eine Wasserschicht hatte, als sie zum letzten Mal mit der Luft in Berührung stand, und der Vergleich von $\tau^{0}$ mit der augenblicklichen 
Temperatur gibt uns darüber AufschluB, ob die betreffende Wasserschicht sich seit ihrem Untersinken erwärmt oder abgekühlt hat. Auch die Verbreitung des Plankton $\times$ wird jetzt in der Strömungsfrage immer mehr herangezogen. Aber jede Beobachtung gilt zunächst nur für die Zeit, in der sie gemacht wurde; eine Zusammenstellung der Beobachtungen im Golfstrom vom 10. Mai bis 15. Juni $1904^{8}$ zeigt wesentliche Veränderungen innerhalb weniger Tage, und betreffs seltener besuchter Meeresräume sind wir daher durchaus nicht sicher, ob die Monats- oder Jahreszeitenkarten der Strömungen ${ }^{9}$ wirklich mittlere Zustände darstellen, wie sie beabsichtigen. Aufgabe der systematischen Meeresforschung auf internationaler Grundlage, die im Sommer 1901 ihre Tätigkeit begonnen hat, ist, die periodischen und unperiodischen Schwankungen im einzelnen klarzulegen; und obwohl sie sich vorläufig nur auf die nordeuropäischen Gewässer beschränkt, so hat sie, wie wir sehen werden, doch schon eine Fülle neuer Erkenntnisse zutage gefördert.

Einen rein deduktiven Weg schlug zuerst $\mathrm{MoHN}^{10}$ ein, indem er auf die Fundamentalsätze der Mechanik zurückgriff. Er berechnete die Druckverteilung innerhalb des europäischen Nordmeeres mit Hilfe der beobachteten Wasserdichte und leitete daraus mit Berücksichtigung des Einflusses der Winde und der Erddrehung die Meeresströmungen ab. Eine Vereinfachung dieser Methode verdanken wir BJERKNEs, ${ }^{11}$ und darauf fußend haben SANDStröm und Helland-HANSEN ${ }^{12}$ Tabellen zur Berechnung der Meeresströmungen aufgestellt; jedoch sind von dieser einseitigen Behandlung des komplizierten Phänomens befriedigende Ergebnisse nicht zu erwarten, und das entscheidende Wort kommt auch hier nur der Beobachtung zu.

Theorie. ${ }^{13}$ Daß zwischen Wind und Meeresströmungen ein ursächlicher Zusammenhang bestehe, war zwar schon längst die Überzeugung der Seefahrer und seekundigen Männer, aber ihrer allgemeinen Anerkennung stand die Ansicht, daß der Wind nur die Oberflächenschicht in Bewegung setzen könne, hindernd im Weg. Diesem Irrtum trat ZöPPRITZ entgegen. In seiner 1878 erschienenen. Abhandlung ${ }^{14}$ gelangte er - allerdings unter der Voraussetzung eines unbegrenzten und gleichmäßig tiefen Ozeans - zu folgendem Ergebnis. Wenn sich die oberste Wasserschicht aus irgendeinem Grund mit gegebener Geschwindigkeit in ihrer eigenen Ebene fortbewegt, so erhält die zweite Schicht infolge der inneren Reibung mit der obersten einen Antrieb zur Bewegung in gleicher Richtung,

× Man unterscheidetPlankton tropischer Gewässer oder Desmo plankton, P. mäBig warmer Gewässer oder Styliplankton, und arktisehes oder Trichoplankton.

Supan, Physische Erdkunde. 5. Aufl. 
und ihre Geschwindigkeit muß sich der der ersten Schicht immer mehr nähern, wenn die gleichförmige Bewegung fortdauert. In gleicher Weise pflanzt sich die Bewegung bei genügend langer Dauer auf die dritte, dann auf die vierte Schicht fort, und endlich bis zum Boden. In einem $4000 \mathrm{~m}$. tiefen Ozean wird unter der Voraussetzung, daß der Wind an der Oberfläche mit konstanter Richtung und Geschwindigkeit weht, die Schicht in $100 \mathrm{~m}$ Tiefe in 41 Jahren $1 / 10$ und in 239 Jahren die halbe Oberflächengeschwindigkeit erreichen. In ungefähr 200000 Jahren wird der stationäre Zustand hergestellt sein, in welchem die Geschwindigkeit von der Oberfläche bis zum Boden proportional der Tiefe abnimmt.

In Wirklichkeit bleibt sich allerdings weder die Richtung noch die Geschwindigkeit des Windes immer gleich. Aber auch die Veränderungen pflanzen sich nur mit großer Langsamkeit nach der Tiefe fort, so daß rasch vorübergehende nur die obersten Schichten beeinflussen. Die tieferen Schichten werden dagegen im Lauf der Zeit eine Bewegung in der Richtung der vorherrschenden Winde annehmen, und ihre Geschwindigkeit wird durch die mittlere Geschwindigkeit an der Oberfläche bestimmt. Mit anderen. Worten: die großen Meeresströmungen der Gegenwart sind ein Produkt aller Winde, die seit ungezählten Jahrtausenden über die betreffenden Gegenden des Ozeans hinweggestrichen sind.

NANSEN ${ }^{15}$ erhob gegen Zöppritz den berechtigten Vorwurf, daß in dessen Theorie die Ablenkung durch die Erdrotation nicht berücksichtigt und für die innere Reibung ein zu kleiner Wert eingesetzt worden sei. Indem er aber nach beiden Richtungen falsche Korrekturen seiner Rechnung zugrund legte, kam er zu dem Resultat, daß die bewegende Kraft des Windes nach unten bald erlahme, daß der Wind wohl ein beschleunigendes oder verzögerndes Moment bilde, daß aber die Hauptursache der ozeanischen Zirkulation in den Dichteunterschieden zu suchen sei. ${ }^{\times}$

In diesen wissenschaftlichen Streit haben nun EкмаN's ${ }^{5}$ theoretische Untersuchungen klärend eingegriffen.

Es steht zunächst fest, daß sich die durch den Wind erzeugte Oberflächenbewegung nur durch Reibung von Schicht zu Schicht nach unten fortpflanzen kann, und daB sie dadurch eine stetige Einbuße an Geschwindigkeit erleidet. Nur ist die Frage, was man unter Reibung zu verstehen habe. Spricht man von der innern Reibung,

$\times$ Noch weiter geht Jors S. Solex (Annalen der Hydrographie usw. 1907, S. 84), wenn er als "Naturgesetz" den Satz aufstellt: „Eine Strömung ist nur eine Frage der Dichtigkeit. Winde verursachen keine Strömung. Sie bewirken nur Wellen." 
so setzt man voraus, daß Schicht an Schicht vorübergleitet, und jedes Wasserteilchen dabei innerhalb seiner Schicht verbleibt. Experimentell ist von KRÜMMEL und RupPIN nachgewiesen worden, daß sie mit der Dichte, d. h. mit zunehmendem Salzgehalt und abnehmender Temperatur größer wird, aber es lassen sich nur Relativzahlen mit Bezug auf reines Wasser bei $0^{\circ}$ aufstellen, und ein absolutes $\mathrm{Maß}$ ist auch für dieses noch nicht mit Sicherheit ermitteit worden. Indes kommt die innere Reibung, auf die Zöppritz seine Rechnung gründete, bei der Bewegung von Wassermassen überhaupt nicht in Betracht, da sich diese stets unter Wirbelbildungen vollzieht, wobei die Wasserteilchen aus ihrem Zusammenhang losgerissen werden. Diese virtuelle Reibung ist viel größer als die innere, aber sie entzieht sich völlig der Berechung. Thr entgegen wirkt nach KRÜMMEL's Ansicht der Seegang mit seinen abbrechenden Wellenköpfen, die Oberflächenwasser in die Tiefe schleudern und damit die Triftimpulse rascher in die Tiefe fortpflanzen.

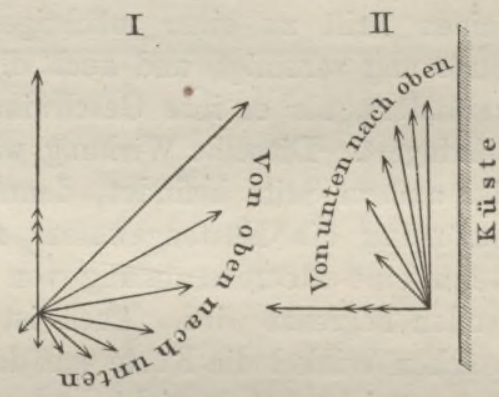

Reiner Triftstrom
Staustrom

Fig. 75. Triftströmung nach EkMaN.

Eine zweite Veränderung erleidet die vertikal fortschreitende Triftbewegung durch die Erdrotation. Die Oberflächenschicht wird um $45^{0}$ von der Windrichtung abgelenkt; sie sucht die nächste Schicht in der gleichen Richtung fortzuschieben, aber vergeblich, da auch da wieder die Ablenkung durch die Erdrotation Platz greift. So nimmt im reinen Triftstrom nach der Tiefe die Geschwindigkeit in geometrischer Progression ab und die Ablenkung gleichmäBig zu, wie aus Fig. $75 \mathrm{I}$ zu ersehen ist. Der gefiederte Pfeil stellt die Windrichtung dar, die übrigen die Bewegung der 1., 2., 3. Schicht usw. nach Geschwindigkeit und Richtung. In einer gewissen Tiefe erreicht die Ablenkung $180^{\circ}$, d. h. die Bewegung erfolgt in der der Oberflächenströmung genau entgegengesetzten Richtung, und die Geschwindigkeit ist bis auf ein Minimum herabgesunken. Hier endet der reine Triftstrom. Ekman nennt dieses Niveau die Reibungstiefe und ersetzt damit den unberechenbaren Reibungskoëffizienten. Sie wächst mit der Geschwindigkeit, d. h. mit der Windstärke, und nimmt mit dem Sinus der geographischen Breite ab, aber ein absolutes $\mathrm{MaB}$ ist damit nicht gegeben. Immerhin kann man annehmen, daß reine Triftströme seicht sind. 
Das gilt indes nur für einen unbegrenzten Ozean. Nehmen wir aber an, daß sich in der Richtung des Windes eine unendlich lange Küste hinzieht (Fig. $75 \mathrm{II}$ ), so entwickeln sich Folgeerscheinungen von größter Tragweite. Indem der reine Triftstrom gegen die Küste hingetrieben wird, staut sich hier das Wasser und am Boden entsteht ein Gradient von den Küste meerwärts (der gefiederte Pfeil in Fig. 75 II), der eine neue Bewegung einleitet. Indem sie sich durch Reibung nach oben fortpflanzt, wird sie durch die Erdrotation immer weiter abgelenkt, soweit es die feste Wand an der rechten Seite gestattet, und die Geschwindigkeit nimmt nach oben zu, weil die Reibung abnimmt. So entsteht ein Staustrom, der sich mit der reinen Trift zu einer mächtigen, bis zum Boden reichenden Strömung vereinigt, und auch die oberflächliche Bewegung insofern verändert, als er ihre Geschwindigkeit steigert und die Ablenkung verringert. Dieselbe Wirkung wird erzielt, wenn sich die Küste auf der andern Seite befindet, denn dann werden durch die ablandige Strömung die Küstengewässer nachgesogen, und es genügt auch, wenn eine Meeresströmung von einer in anderer Richtung verlaufenden begrenzt wird. Auch ist es in der Hauptsache gleichgültig, welchen Winkel die Küste mit der Windrichtung einschließt, solange er nur nicht $90^{\circ}$ erreicht, und maßgebend bleibt stets die mittlere Windrichtung. Vorübérgehende Windänderungen können wohl die Oberfläche beeinflussen, haben aber nicht Zeit, nach der Tiefe vorzudringen. Man sieht, EkMan kommt auf Umwegen zu sehr ähnlichen Resultaten wie ZöpprITz.

In landumschlossenen Meeren nimmt die Triftströmung den Charakter einer geschlossenen Zirkulation an. Das an der Leeküste aufgestaute Wasser fließt nach der Luvküste wieder zurück. Liegt nur diese Hälfte des Beckens im Windstrich, so nimmt die Gegenströmung die andere Hälfte ein, überweht aber der Wind die ganze Oberfläche, so fließt der Gegenstrom unter dem Oberstrom, genau so wie es bei den Ausgleichsströmungen der Fall ist. Mit diesen haben ja die Windstauströmungen gemein, daß sie Gefällströme sind. Die Aufstauung des Wassers an der Leeseite hat, wenn ein Ausweichen nach der Seite nicht möglich ist, zur Folge, daß sich die Oberfläche nach der Lurseite senkt.

Wenn auch Eкмам's Theorie den wirklichen Verhältnissen insofern nicht entspricht, als sie homogenes Wasser oder solches, in dem die Dichte allmählich mit der Tiefe zunimmt, voraussetzt, so hat sie doch der Trifttheorie gegenüber der Ausgleichstheorie eine starke Stütze gegeben. Die Inhomogenität des Meerwassers kompliziert unzweifelhaft das Phänomen, jedoch konnte sich Ekмan mit Recht 
darauf berufen, daß tatsächlich verschieden dichtes Wasser nebeneinander in entgegengesetzter Richtung und zwar hauptsächlich in der der vorherrschenden Winde fließt. Ein solches Verhalten läßt sich durch die Ausgleichstheorie allein nicht erklären. Für streng geschichtetes Wasser hat SANDSTRöm ${ }^{16}$ auf experimentellem Weg eine Trifttheorie entwickelt, die aber auf den freien Ozean keine Anwendung finden kann, weil hier die Mischung durch den Seegang die Schichtung, wenn auch nicht völlig aufhebt, so doch in der Regel stark verwischt.

Die durch den Wind an Ort und Stelle erzeugten Strömungen nennt Krümmel gezw ungene. ${ }^{x}$ Infolge der ihm eigenen Be-

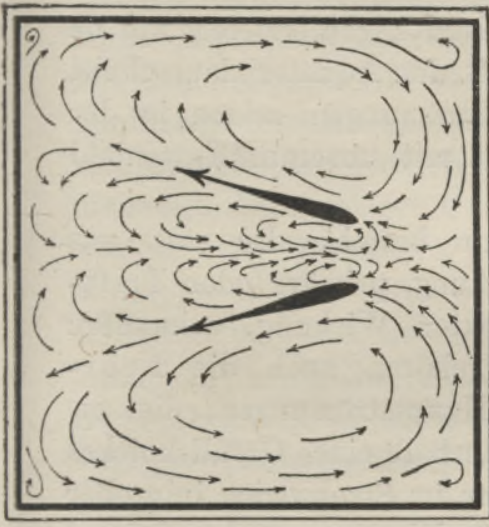

Fig. 76 a.

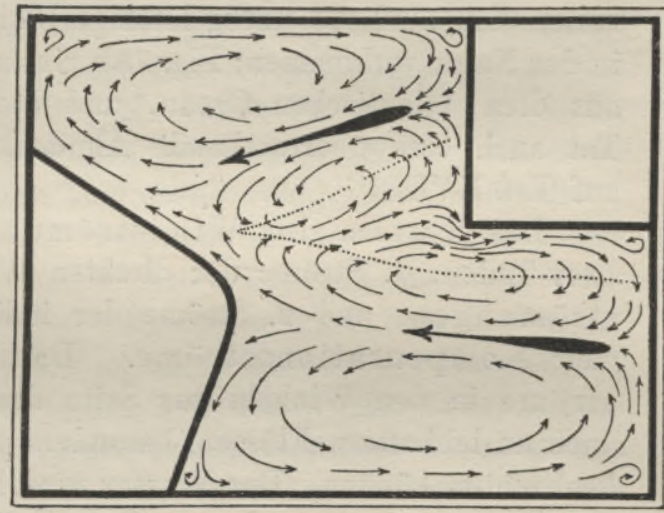

Fig. 76 b.

KRÜMMEL's Stromexperimente.

wegungsenergie setzt aber jedes Wasserteilchen seinen einmal eingeschlagenen Weg fort, solange die Reibung mit den ruhigen Wasserteilchen, die es ebenfalls in Bewegung setzen muß, seine Geschwindigkeit nicht aufgezehrt hat. Die durch einen bestimmten Wind, z. B. den Passat, erzeugte Bewegung kann sich also auch außerhalb seines Bereiches fortsetzen. Dieser Fall tritt ein, wenn der Strom auf ein festes Ufer stößt. Nehmen wir mit Zöppritz der Einfachheit wegen eine Vertikalwand an, so muß sich der Strom in zwei teilen, die dieselbe Geschwindigkeit wie die Mutterströmung, aber nur deren halbe Breite besitzen. Diese Ströme nennt KRÜмmeL freie. Umgekehrt vereinigen sich zwei gleiche Ströme, die längs einer Wand einander zufließen, zu einem einzigen, der mit der Geschwindigkeit und doppelten Breite der Stammströmungen im rechten Winkel von der Wand abflieBt. 
Damit ist aber die Fülle des Gegebenen noch nicht erschöpft. Das Wasser ist eine zusammenhängende, unelastische Flüssigkeit, die jeden Mangel an einer Stelle durch Zufluß von allen Seiten auszugleichen strebt. Der Satz des alten Varenius: wenn ein Teil des Ozeans sich bewegt, so bewegt sich der ganze Ozean, gilt in seinem vollen Umfang. Hier knüpfte KrüMmeL mit seinen ebenso einfachen wie sinnreichen Experimenten an. In dem viereckigen Wassergefäß in Fig. 76a rufen die beiden Triftströme, die durch kräftige Pfeile dargestellt sind, ein ganzes System anderer Ströme hervor, die alle nach der Stelle hineilen, wo Wasser weggeblasen wurde. Der Gegenstrom in der Mitte und die Stromringe zu beiden Seiten der Triftströme sind deutlich zu erkennen. Durch eingesetzte Blechwände lassen sich ähnliche unregelmäBige Ufergestaltungen erzielen, wie sie in der Natur vorkommen; Fig. 76 b gibt z. B. den Äquatorialausschnitt aus dem Atlantischen Ozean, und die Strömungen zeigen in der Tat auch eine überraschende Ähnlichkeit mit unserem Kartenbild auf Taf. XVI.

Das System der Windströmungen besteht also stets aus zwei Teilen: 1. Ströme der direkten Wirkung, primäre oder Triftströmungen, und 2. Ströme der indirekten Wirkung, sekundäre oder Kompensationsströme. Dazu gehören auch die Neerströme in den Winkeln zur Seite der Hauptströmungen, die wir auch an lebhaftern Flüssen, besonders unterhalb eines Gefällsknickes beobachten können. Das Wasser wird hier im Stromstrich in großer Menge fortgerissen und zum Ersatz fließt Wasser aus den Seitenbuchten talaufwärts. Wenn die Kompensation durch oberflächlichen ZufluB nicht ausreicht, steigt auch Wasser aus der Tiefe auf. Es ist klar, daß diese sekundären Strömungen, die ebenfalls der Ablenkung durch die Erdrotation unterliegen, eine nicht minder große Rolle spielen, wie die primären.

Sehen wir von den Gezeitenströmen ab, da sie nur an den Küsten und in engen Meeresstraßen auftreten, so können wir folgende Strömungskategorien unterscheiden:

I. Gefällsströmungen:

1. Ausgleichsströmungen,

2. Windstauströmungen;

II. Windströmungen:

1. primäre oder Triftströmungen,

a) gezwungene,

b) freie,

2. sekundäre oder Kompensationsströmungen.

Es wird nun unsere Aufgabe sein zu zeigen, wie sich diese 
fünf Strömungsarten geographisch verteilen. Unsere Karte (XVI), die uns dabei leiten soll, kann aber wegen ihres kleinen Maßstabes nur ein schematisches Bild geben, und auch dieses bezieht sich im wesentlichen nur auf die nördliche warme Jahreszeit. Der winterliche Zustand ist zum Teil weniger bekannt, zum Teil nur von sekundärer Bedeutung. Eine Ausnahme macht der Indische Ozean, sie hat auch auf unserem Kärtchen in einem Karton Berücksichtigung gefunden. $\times$

Nordatlantischer 0zean. Den schlagendsten Beweis für die Trifttheorie liefert die Aquatorialzone der Ozeane. Ausgleichsströmungen würden hier vom Äquator nach $\mathrm{N}$ und $\mathrm{S}$ fließen und nach $\mathrm{O}$ abgelenkt werden. Anstatt dessen fließen die nördliche und die südliche Äquatorialströmung nach W im Stromstrich der Passate. Mit den Passatgürteln verschiebt sich ihre Äquatorialgrenze; die der nördlichen Strömung zwischen $3^{\circ} \mathrm{N}$ im Februar und $13^{\circ} \mathrm{N}$ im August, die der südlichen zwischen $0^{\circ}$ und $6^{\circ} \mathrm{N}$ in denselben Monaten. Ihre polaren Grenzen sind ebensowenig scharf ausgebildet, wie die der Passate. Ebenso entspricht es der Anordnung der Winde, daß die südliche Äquatorialströmung den Äquator überschreitet, und daß sie an mittlerer Geschwindigkeit $(0,42$ in der Sekunde) die nördliche $(0,32$ bis $0,36 \mathrm{~m})$ übertrifft. In der Kalmenzone biegen beide Strömungen nach $\mathrm{O}$ um, und das Wasser fließt, fächerförmig sich ausbreitend, zum afrikanischen Gestade. Diese äquatoriale Gegenströmung, hier Guineastrom genannt, ist eine echte Kompensationserscheinung von dem Charakter der Neerströme; je breiter der Zwischenraum zwischen den beiden Äquatorialströmen wird, desto mehr verschiebt sich ihre Wurzel nach W, von ungefähr $20^{\circ} \mathrm{W}$ im Winter bis $40^{\circ} \mathrm{W}$ im Sommer.

Über den weiteren Verlauf der Äquatorialströmungen und ihren

× Erklärung der Nummern anf Taf. XVI. Atlantischer Ozean. $I$ Nördliche Äquatorialströmung, 2 südliche Äquatorialströmung, 3 Guineaströmung, 4 Antillenströmung, 5 karibische Strömung, 6 Golfstrom, 7 nordatlantische Verbindungsströmung, 8 eanarische Strömung, 9 irischer Strom, 10 Irmingerstrom, 11 Labradorstrom, 12 westgrönländische Strömung, IS Mitteleisströmung, 14 atlantische Strömung, 15 ostgrönländischer Polarstrom, 16 ostisländischer Polarstrom, 17 Jan Mayen-Polarstrom, 18 Nordkapströmung, 19 Spitzbergenstrom, 20 Brasilstrom, 21 südatlantische Verbindungsströmung, 22 Benguelastrom, 23 Falklandstrom. Indischer Ozean. 1 Nördliche Äquatorialströmung, 2 südliche Äquatorialströmung, 3 Gegenströmung, 4 Agulhasstrom, 5 südindische Verbindungsströmung, 6 westaustralische Strömung. Pazifischer Ozean. 1 Nördliche Äquatorialströmung, 2 südliche Äquatorialströmung, 3 Gegenstrom, 4 ostaustralische Strömung, 5 Perustrom, 6 Kuroschio, 7 nordpazifischer Verbindungsstrom, 8 ealifornischer Strom, 9 Amur-Liman-Strömung, 10 Sachalinströmung, 11 Kurilenströmung. 
Zusammenhang mit dem Golf- oder Floridastrom $\times$ haben die systematischen Untersuchungen der amerikanischen Marine seit 1883, die an verschiedenen Punkten von einem verankerten Schiff aus vorgenommen wurden, Licht verbreitet. ${ }^{17}$ Am südamerikanischen Kap St. Roque teilt sich der südliche Äquatorialstrom, der nördliche Zweig vereinigt sich mit der nördlichen Äquatorialströmung, und beiden fließen teils als Antillenströmung an der Außenseite des westindischen Inselbogens nach NW, teils dringen sie durch die tiefen Passagen zwischen den Inseln Antigua und St. Vincent in das amerikanische Mittelmeer ein. Dieser Zweig, die Karibische Strömung, läßt sich bis zur Straße von Yucatan verfolgen; ihre Fortsetzung ist der Golfstrom. Er trägt diesen Namen, weil man ihn früher mit den Strömungen, die von der Yucatanstraße zuerst in westlicher, dann in östlicher Richtung den Golf von Mexico außerhalb des Schelfs umkreisen, in Verbindung brachte, und SoLEx ${ }^{18}$ ist neuerdings wieder für diesen Zusammenhang eingetreten. Wenn ein solcher besteht, so kann er aber, wie KRÜмmeL aus der Temperaturverteilung nachweist, nur oberflächlich stattfinden. Die beträchtliche Mächtigkeit des warmen Golfstroms stammt aus dem Karibischen Meer.

Die Floridastraße durcheilt der $50 \mathrm{~km}$ breite Golfstrom mit der Geschwindigkeit von $1,5 \mathrm{~m}$ in der Sekunde, die sich zeitweise bis auf $2,5 \mathrm{~m}$ steigert. $\times \times$ In den Ozean hinaustretend, bewegt er sich, durch tiefblaue Färbung und hohe Temperatur $\times \times \times$ von der Umgebung, besonders im W, scharf sich abhebend und mit zunehmender Breite längs des nordamerikanischen Schelfrandes nach NO bis Kap Hatteras. Von da ab entfernt er sich immer weiter vom Festland, schlägt endlich eine östliche Richtung ein, wird seichter und breitet sich fächerförmig aus, wobei er sich in Streifen von verschiedener Temperatur zerfasert. In ungefähr $45^{\circ} \mathrm{W}$ ist sein stromartiger Charakter, der durch den Gegensatz zu den be-

$\times$ Der Name Floridastrom war bis FrankLin (1772) allein üblich, und KRÜмmeL versucht, ihn wieder einzubürgern, weil man unter dem Namen Golfstrom vieles zusammenfaßt, was nicht streng zusammengehört.

$\times \times$ Rhein bei Mannheim 1,5, Donau bei Wien bei Hochwasser $1,9 \mathrm{~m}$. $\times \times \times$ Temperaturen nach $v$. Boguslawski:

\begin{tabular}{|c|c|c|c|c|}
\hline N. B. & . & $\begin{array}{c}\text { Floridastraße } \\
25^{0}\end{array}$ & $\begin{array}{c}\text { Kap Hatteras } \\
35^{\circ}\end{array}$ & $\begin{array}{l}\text { Sudl. v. Neuschottland } \\
43^{\circ}\end{array}$ \\
\hline Winter . & . & $25,0^{\circ}$ & $22,2^{\circ}$ & $16,7^{0}$ \\
\hline Frühling & . & 25,6 & 22,8 & 19,4 \\
\hline Sommer. & . & 28,3 & 26,7 & 25,6 \\
\hline Herbst . & . & 27,8 & 24,4 & 20,0 \\
\hline Jahr . & . & 26,7 & 24,0 & 20,4 \\
\hline
\end{tabular}


nachbarten Gewässern bedingt ist, verschwunden. Er taucht mit seinem östlichen Begleiter, der Antillenströmung, in andere Zirkulationssysteme unter. Zwischen dem nördlichen und dem südlichen System läßt sich nur im mittleren Teil des Ozeans auf Grund von Flaschenposten eine einigermaßen scharfe Grenze ziehen. Sie verläuft nach Sснотт von $42^{\circ} \mathrm{N}, 47^{\circ} \mathrm{O}$ bis $47^{\circ} \mathrm{N}, 12^{\circ} \mathrm{O}$ und ist ungefähr auch die Grenze zwischen dem Desmo- und dem Styliplankton. Im $\mathrm{S}$ durchquert die nordatlantische Verbindungsströmung den Ozean, trifft die französische Küste im Meerbusen von Biscaya und biegt dann nach S um, um als Kanarische Strömung längs der iberischen und nordafrikanischen Küste in die nordatlantische Äquatorialströmung einzulaufen. Damit ist der subtropische Stromring des nordatlantischen Ozeans geschlossen. Innerhalb dieses großen Wirbels breitet sich eine verhältnismäßig ruhige See aus. Hier sammeln sich die von den westindischen und karibischen Felsküsten losgerissenen und von Flüssen herbeigeführten Tange vom Sargassumgeschlecht an, die sich vermöge ihres Reichtums an Luftblasen in ihren oberen Teilen im Wasser aufrecht erhalten. Jene beiden Krautbänke, die nach HumboLDT's Ansicht seit Jahrhunderten an ihrer Stelle verharren, sucht der Seefahrer freilich vergebens, aber ebensowenig entspricht es den Tatsachen, wenn Kuntze die Existenz eines Sargassomeeres ( $S$ auf Taf. XVI) kurzweg leugnet. KRÜMмrL ${ }^{19}$ wendet diesen Namen auf jenes Gebiet an, wo treibende Tangmassen in 10 und mehr Prozent aller untersuchten Fälle angetroffen wurden; es erstreckt sich von 39 bis $75^{\circ} \mathrm{W}$ und von 21 bis $34^{\circ} \mathrm{N}$, umfaßt also eine Fläche von nahezu $4 \frac{1}{2}$ Mill. qkm. Etwas ähnliches findet man nirgends sonst im Weltmeer.

In diesem subtropischen Stromsystem bewegt sich das Wasser im Sinn des Uhrzeigers, ebenso wie in der subtropischen Antizyklone, aber die Sargassosee fällt nicht mit dem Luftdruckmaximum zusammen. Schon das beweist, daß Wind und Strömung sich nicht völlig decken. Gezwungene Triften sind nur die beiden Äquatorialströmungen, ihr freier Ausläufer sind der Antillen-, der Karibische und der Golfstrom. Das mit der nördlichen Äquatorialströmung nach W abfließende Wasser wird ersetzt durch die Canarische Strömung, diese wirkt wieder aspirierend auf die nordatlantische Verbindungsströmung und diese wieder auf den Golfstrom zurück. Mit der Kompensationsbedingung vereinigt sich im mittlern und östlichen Ozean aber auch die vorherrschende Windrichtung als stromerzeugendes Moment. Reiner Kompensationsstrom ist nur die Guineaströmung. 
Nördlich von ungefähr $45^{\circ} \mathrm{B}$. beginnt die Herrschaft der subpolaren Zyklone in der Gegend von Island, und ihr entspricht eine Wasserbewegung im entgegengesetzten Sinn des Uhrzeigers, der subpolare Stromring. Aber die Winde sind hier nicht mehr so beständig in Richtung und Stärke wie in der Passatzone, und die Meeresströmungen sind daher, wenigstens an der Oberfläche, vielfach wechselnd und schwach (durchschnittlich unter $0,2 \mathrm{~m}$ in der Sekunde).

Von der Ostströmung in den mittleren Breiten des Ozeans löst sich ein durch die Erdrotation immer weiter gegen NO gedrängter Stromzweig ab, den KrüMmel den Irischen Strom genannt hat. Ohne Zweifel steht er mit dem Golfstrom in Verbindung - das bezeugen die westindischen Treibgegenstände, die man gelegentlich in den westeuropäischen Gewässern auffischt, das bezeugt auch die relativ hohe Temperatur, der Frankreich und die britischen Inseln indirekt ihr mildes Winterklima verdanken. In der Nähe des isländischen submarinen Rückens biegt er nach W um und führt nun nach seinem Erforscher den Namen Irmingerstrom. Bei Kap Farvel öffnet sich eine breite Pforte ins arktische Meer, und hier wird das Strombild verwickelter. ${ }^{20}$ In der Davisstraße und Baffinbai wehen nördliche bis westliche Winde, und ihnen ist der von Nord kommende Labradorstrom zuzuschreiben, der, eng an die Westküsten sich anlehnend, Ersatzströme aus den Meeresstraßen der polaramerikanischen Inselwelt heranzieht. Am gegenüberliegenden Gestade aber bewegt sich die warme Westgrönländische Strömung nach N und hält die Häfen nördlich von $64-65^{\circ} \mathrm{B}$. eisfrei, während die südlichen Häfen von dem um Kap Farvel umschwenkenden Ostgrönländischen Eisstrom blockiert werden. Durch amerikanisches Treibholz ist unzweifelhaft nachgewiesen, das die Westgrönländische Strömung ein Zweig des Irmingerstroms ist; KRÜMmEL bringt ihn mit dem sekundären Barometerminimum in der Davisstraße und mit dem durch den Labradorstrom bedingten Kompensationsbedürfnis in Verbindung. Auch Dichteunterschiede können dabei mitwirken, wie Wegemann nachgewiesen hat. Zwischen dem Labrador- und dem Westgrönländischen Strom schiebt sich noch eine von N kommende Eistrift ein, und es ist noch nicht recht klar, wie diese zustande kommt. Auch über das Endschicksal des Labradorstroms sind die Ansichten noch geteilt. Ohne Zweifel stöBt er bei der Neufundlandbank mit dem Golfstrom zusammen ${ }^{21}$ und schließt damit den subpolaren Strömungsring; daß er aber hier untertaucht, hält KRÜммeL mit Grund für unwahrscheinlich; er führt ihn an der Ostküste von Canada weiter nach SW, bis er sich mit dem später zu erwähnenden 
„kalten Wall“ an der Ostküste der Vereinigten Staaten vereinigt. Ist dies richtig, so spielt sein äußerster Ausläufer die Rolle eines Kompensationsstromes im Gefolge des von der Küste wegstrebenden Golfstromes.

Betreffs der oberflächlichen Wasserzirkulation im europäischen Nordmeer müssen wir uns vorläufig nur auf eine kurze Schilderung beschränken, weil hier auch das Verhalten der tiefern Schichten in Frage kommt, das erst im nächsten Kapitel erörtert werden kann. Irischer und Irmingerstrom überschreiten den isländischen Rücken zwar zu beiden Seiten von Island, die Hauptmasse des atlantischen Wassers aber benutzt die tiefe Einsenkung zwischen dem FäröerPlateau und dem britischen Schelf und flieBt als Atlantischer Strom $\times$ parallel mit der norwegischen Küste nach NNO. Sein Gegenstück an der grönländischen Seite ist der aus dem arktischen Becken kommende und nach S und SW sich bewegende seichte Ostgrönländische Strom, der den Ostisländischen Polarstrom nach SO entsendet und damit im $\mathrm{S}$ den Nordmeerring schlieBt. Dieser Ring entspricht der im N von Island lagernden Barometerdepression, und es wäre demnach auch diese Stromzirkulation in erster Linie ein Werk der Winde; nach der neuesten Darstellung durch HeuLAndHANSEN und NANSEN ${ }^{22}$ geht aber an der Stelle, wo ein ungefähr $2300 \mathrm{~m}$ tiefer Rücken die beiden über $3000 \mathrm{~m}$ tiefen Nordmeerbecken trennt, ein zweiter Ausläufer vom Ostgrönländischen Strom nach 0 , der Jan-Mayen.Polarstrom. Es bestehen demnach zwei Nordmeerringe, und es zeigt sich hier, wie ja auch schon am isländischen Rücken, da $\mathrm{B}$ auch die Bodengestaltung für die Meereszirkulation nicht gleichgültig ist.

Die Atlantische Strömung läßt sich im Sommer bis in die echt arktischen Gewässer hinein verfolgen. Der östliche Stromarm, der sog. Nordkapstrom, bewegt sich zuerst parallel mit der Murmanküste nach $\mathrm{SO}$ und dann nach $\mathrm{O}$ und endet im $\mathrm{N}$ der Petschorabucht. Ein Ausläufer wendet sich nach Nowaja Semlja, berührt aber deren Westküste nicht, weil sich kalte Oberflächen- und unterseeische Polarströmúngen einschieben. ${ }^{23}$ Von einer Ostströmung längs der sibirischen Küste, die man auch mit dem Atlantischen Strom in Verbindung gebracht hat, hat NAxSEN ${ }^{2+}$ auf seiner epochemachenden „Fram"-Expedition nichts bemerkt; und wenn im Spätsommer, wenigstens im September, eine eisfreie Rinne die Schiffahrt

$\times$ Die Terminologie ist schwankend. Meist wird der Name der Atlantischen Strömung auch auf die Irische ausgedehnt. Zu vermeiden ist die populäre Bezeichnung Golfstrom für die Irische und Atlantische Strömung. 
vom Jenissei bis zum Kap Tscheljuskin ermöglicht, so verdankt man dies lediglich den großen sibirischen Flüssen. Der Hauptarm der Atlantischen Strömung wendet sich vielmehr nach jener Seite, wo sich die atlantische Tiefsee in das arktische Meer fortsetzt, d. $\mathrm{h}$. westlich von Spitzbergen, wo er im Sommer, wenn auch meist von salzärmerem und daher leichterem Polarwasser überflutet, bis über $80^{\circ} \mathrm{N}$ hinaus eine eisfreie Rinne schafft. Daß auch diese Spitzbergenströmung noch mit dem echten Golfstrom in Verbindung steht, beweist der Fund einer Bohne der westindischen Entada gigalobium in $80^{\circ} 8^{\prime} \mathrm{N}, 17^{\circ} 40^{\prime} \mathrm{O}$.

Die äußersten Ausläufer der Atlantischen Strömung werden wir später als Unterstrom wiederfinden. Unzweifelhaft fogt daraus, da B das nördliche Eismeer nicht blob morphologisch, sondern auch hydrographisch eine Dependenz des Atlantischen Ozeans ist. Aber auch die Polarströme stellen eine Verbindung her. Sie finden nur einen einzigen Ausweg: durch die atlantischen Tore zu beiden Seiten von Grönland, und die von ihnen im Sommer mitgeführten Eismassen werden bei der Berührung mit den warmen nordatlantischen Strömungen aufgelöst. Den Labradorstrom haben wir schon kennen gelernt. Der Ostgrönländische Strom hat seine Wurzeln tief im innerarktischen Becken. Über dieses breitet sich das von den sibirischen und nordamerikanischen Flüssen herbeigeführte Wasser aus, das wegen seiner geringen Dichte ein höheres Niveau als der Atlantische Ozean einnimmt. Die Polarströme sind also z. T. Gefällsströme, aber auch die Winde haben einen Anteil daran. Ich habe seinerzeit die Hypothese aufgestellt, daß die östliche Hälfte des arktischen Beckens den größten Teil des Jahres hindurch von einem Rücken hohen Luftdruckes durchquert wird, der als Wịdund Strömungsscheide funktioniert und erheblichen jahreszeitlichen Verschiebungen unterworfen ist. ${ }^{25}$ Die Framtrift hat diese Auffassung bestätigt; es gibt nordwestlich von den Neusibirischen Inseln eine Zone, wo die Stromrichtung zwischen W und O schwankt, westlich von $120^{\circ} \mathrm{O}$ gewinnt aber die Westtrift entschieden die Oberhand. In der Barentssee schiebt sich der polare Bäreninselstrom weit nach SW vor, atlantisches und arktisches Wasser greifen hier fingerförmig ineinander, und an den Grenzen entstehen Wirbel, geradeso wie im Nordmeer. Man $\mathrm{muB}$ dabei im Auge behalten, daß die Dichte des Meerwassers von der Temperatur und dem Salzgehalt abhängt. „So hat arktisches Wasser, dessen Salzgehalt durch Zumischung von etwas atlantischem auf 34,7 Promille erhöht ist, bei $-1^{0}$ dieselbe Dichte wie reines atlantisches Wasser von 35,0 Promille bei $+2^{1} /_{2}{ }^{0}$, nämlich 1,02795 . So kann es kommen, daß die 
Äste des Atlantischen Stroms unter die Flächen des arktischen Wassers untertauchen, aber auch, weit ins Polarmeer hinein vorgedrungen, wieder inselartig an die Oberfläche hinaufreichen und Warmwasserflecke bilden können, wenn die arktische Decke unter $-1^{0}$ abgekühlt und damit schwerer wird, oder wenn sich dem in der Tiefe bewegten warmen Wasser ein mechanisches Hindernis entgegenstellt“ (KRÜмMEL). Wie sich dieser Kampf im Winter gestaltet, ist nur unvollständig bekannt; im Nordmeer scheint die Atlantische Strömung nachzulassen und wird gegen die norwegische Küste verschoben. Immerhin ist sie kräftig genug, um die nordischen Gestade Europas wie mit einem warmen Mantel zu umhüllen. Den Veränderungen von Jahr zu Jahr hat man erst in letzter Zeit Aufmerksamkeit geschenkt, und Petrensson hat daraus auch die meteorologischen Folgerungen gezogen. ${ }^{26}$ NANSEN $^{22}$ hält es für wahrscheinlich, daß die Temperatur der norwegischen See im Mai die mittlere Temperatur in Norwegen im darauffolgenden Winter bestimmt, und aus seinem Diagramm der Jahre 1901-05 ist ersichtlich, daß die Ernte in Norwegen um so ergiebiger ausfällt, je größer der Unterschied zwischen der Temperatur des Atlantischen Stromes an der Oberfläche und in $200 \mathrm{~m}$ Tiefe im Mai ist. In Mittel- und Westeuropa wird, wie aus den Untersuchungen von Mernardus ${ }^{27}$ und BRENNECKE ${ }^{28}$ hervorgeht, die Witterung im Frühjahr hauptsächlich von der Intensität der nordatlantischen Zirkulation bedingt. Ist diese schwach, so findet sich im Frühjahr wenig Eis bei Neufundland, viel bei Island ein, die Temperatur steht in unseren Gegenden unter der normalen, und die Weizen- und Roggenernten fallen in der Regel schlecht aus. Eine starke Zirkulation ruft gerade die umgekehrten Erscheinungen hervor. Die Eisverhältnisse bei Island, die als Hauptsymptom des gesamten meteorisch-hydrographischen Zustandes im nordatlantischen Gebiet gelten können, zeigen ein periodisches Verhalten. ${ }^{29}$ Abgesehen von einer 4-5 jährigen Periode, nimmt der Eisreichtum mit der Sonnenfleckenhäufigkeit zu und ist in den trocken-warmen Hälften der BRÜCKNER'schen Perioden größer als in den feucht-kühlen. -

Unsere bisherigen Betrachtungen können wir in Kürze dahin zusammenfassen, daB die Hauptströmungen in der Weise sich anordnen, daß sie zu beiden Seiten des Äquators Streifen, und it den übrigen Breiten Ringe bilden, und daß sie sich somit ähnlich wie die Winde verhalten. Die Stromringe des nordatlantischen Ozeans hängen kettenartig zusammen, das verbindende Glied ist der Golfstrom, der auch an der Irischen und der Atlantischen Strömung teilnimmt. 
Die übrigen 0zeane. Diese Anordnung finden wir mit einigen Modifikationen, die sich hauptsächlich aus der Lage des Landes und der Küstengestaltung ergeben, auch in den übrigen Ozeanen wieder. Äquatorialströmungen mit jahreszeitlichen Verschiebungen beherrschen auch den Pazifischen Ozean zwischen $20^{\circ} \mathrm{N}$ und $10^{\circ} \mathrm{S}$, und eigentümlich ist hier nur die streifenartige Ausbildung des Gegenstroms im Gegensatz zur keilförmigen im Atlantischen Ozean. ${ }^{30}$ Den schlagendsten Beweis für die Triftnatur dieser Strömungen liefert der Indische Ozean, denn nur zur Zeit des NO-Monsuns gelangt das Äquatorialsystem zur vollen Entfaltung, und die ausnahmsweise Lage des Gegenstroms südlich vom Äquator entspricht genau der der Kalménzone. Im Sommer aber verschwinden Gegenstrom und nördliche Äquatorialströmung mit dem NO-Passat, und der südliche Äquatorialstrom tritt auf die nördliche Hemisphäre hinüber und verwandelt sich hier unter dem Zwang des SW-Monsuns in eine östliche bis nordöstliche Strömung. Von den beiden Armen, in die er sich an der ostafrikanischen Küste teilt, erreicht der nördliche eine sekundliche Geschwindigkeit von $2,8 \mathrm{~m}$, die gröBte, die man bisher im Ozean beobachtet hat.

Dem subtropischen Stromring im nordatlantischen Ozean entspricht genau ein ebensolcher in der südatlantischen Hälfte. Der südliche Arm der Äquatorialströmung fließt nach den Untersuchungen von KrÜмmeL als Brasilstrom vom Kap. St. Roque zunächst der Küste von Südamerika entlang, dann immer mehr nach $\mathrm{O}$ sich entfernend bis $48^{\circ} \mathrm{S}$, biegt dann als südatlantische Verbindungsströmung nach 0 um, um vereint mit gelegentlichen Ausläufern der antarktischen Ostströmung als Benguelastrom in die Äquatorialströmung einzumünden. Zwischen dem Brasilstrom und der Küste bis Rio Janeiro schiebt sich ein Arm der antarktischen Ostströmung, der Falklandstrom ein: ein Gegenstück des Labradorstroms und wie dieser eine Kompensationsströmung. Im Indischen Ozean fehlt der nördliche Ring wegen Raummangels, um so regelmäBiger ist aber der südliche entwickelt. Der freie Ausläufer der Äquatorialströmung, der Agulhasstrom, trifft am südafrikanischen Schelf mit der kalten Ostströmung zusammen und verzahnt sich mit ihr in eigentümlicher Weise, soda B das Meer hier aus wechselnden Bändern von kaltem und warmem Wasser besteht. In einem Abstand von $15 \mathrm{~km}$ hat man schon Temperaturdifferenzen von $7^{\circ}$ angetroffen. Das Gegenstück der Benguelaströmung, die Westaustralische, unterscheidet sich von jener dadurch, daß sie keinen $\mathrm{Zu}$ schuß vom antarktischen Oststrom empfängt. Im Pazifischen Ozean schmiegt sich der südliche subtropische Stromring eng an die 
Windverteilung an, indem er sich in einen Doppelring auflöst; die Ostaustralische freie Windströmung geht von dem westlichen, der Peruanische Kompensationsstrom von dem östlichen Ring aus. Im nördlichen Ozean sind der Kuroschio, der nordpazifische Verbind ungsstrom und der Californische Strom ${ }^{31}$ die Glieder des subtropischen Ringes. Der Kuroschio ist der pazifische Golfstrom, wenn er auch seinem atlantischen Genossen an Mächtigkeit nachsteht. Die asiatischen Randmeere nötigen ihn zur Zersplitterung; er umspült Formosa, die Liu-Kiu-Inseln und Japan, wird aber von der Kontinentalküste durch die kalte nach $\mathrm{S}$ ziehende AmurLiman-Strömung und durch eine in gleicher Richtung sich bewegende, kühle Strömung aus dem Gelben Meer ferngehalten. Diese letztern Strömungen fließen also im Sommer gegen den Wind und mögen wohl zum Ausgleich von Dichteunterschieden dienen. Das gleiche gilt auch von der Sachalinströmung an der Ostküste dieser Insel.

Für die Entwicklung eines subpolaren Stromrings bleibt im nordpazifischen Ozean wenig Raum. Immerhin lassen sich auch hier Ansätze dazu finden. Aber es fehlt die Verbindung mit dem arktischen Becken. Die Kurilenströmung (Oyaschio) ist wohl kalt, aber nicht polar, und erreicht die Ostküste von Nippon nur im Winter.

Ganz eigenartig sind die Stromverhältnisse im zirkumterranen Südmeer. Wie hier ein Ring von Westwinden die ganze Erde umspannt, so auch eine zusammenhängende Ostströmung, die nur an der südchilenischen Küste und durch Neuseeland zu Teilungen gezwungen wird. Nur insofern unterscheiden sich Wind und Strom, als bei jenem die südliche, bei diesem die nördliche Komponente vorherrscht, aber dieser Unterschied kann auch auf Rechnung der Rotationsablenkung gesetzt werden. Daß hier aber der Wind nicht allein als Stromerzeuger in Frage kommt, schließt KrüMmeL daraus, daß die jährliche Periode der Stromgeschwindigkeit den entgegengesetzten Verlauf nimmt, wie die der Windstärke. Auch ist ein Zusammenhang mit den Strömungen der höheren antarktischen Breiten unzweifelhaft, sonst könnten nicht die Eisberge soweit nach Norden vordringen. Wir werden auf diesen Punkt noch einmal zurückkommen, als Schlußergebnis unserer Umschau können wir aber schon jetzt feststellen, daß innerhalb der Zone zwischen ungefähr $48^{\circ} \mathrm{N}$ und $40^{\circ} \mathrm{S}$ Windströmungen nahezu allein herrschen, da $B$ aber in höheren Breiten wohl auch andere Ursachen z. T. bedingend, z. T. modifizierend mitwirken.

Das Auftriebwasser. ${ }^{32}$ DaB polares Wasser aus dem antarktischen Ozean längs der Westküsten der Festländer bis in die äquatoriale 
Zone gelangt, ist eine traditionelle Vorstellung, die auf allen Strömungskarten Ausdruck findet. Allerdings sind, wie die Isothermen der Meeresoberfläche zeigen (vgl. z. B. Fig. 77 auf S. 339), innerhalb des tropischen Stromwirbels die Ostseiten kälter als die Westseiten, aber dies gilt auch für die nördliche Hemisphäre, obwohl wir doch bestimmt wissen, daß weder der Canarische noch der Californische Strom vom Pol kommen. Sie sind die Fortsetzungen der relativ warmen östlichen Verbindungsströme, verändern aber ihren thermischen Charakter, sobald sie sich aus höheren in niedere Breiten bewegen, insofern als sie dann im Vergleich zu ,ihrer Umgebung als kühl erscheinen. Groß kann aber dieser Unterschied nicht sein, weil die Ströme sich langsam bewegen und dadurch Zeit gewinnen, sich den neuen Wärmeverhältnissen anzupassen. Auch der Peruund der Benguelastrom stehen mit dem passatischen Stromsystem in Verbindung; der erstere nimmt aber wohl auch Wasser aus der antarktischen Osttrift auf, sonst könnte der Salzgehalt in den südchilenischen Gewässern nicht ebenso gering sein wie auf der andern Seite Südamerikas, im Bereich des polaren Falklandstromes. Dagegen zeichnet sich die Benguelaströmung an der Westküste Südafrikas durch hohen Salzgehalt aus (35-36 Promille), und es ist daher anzunehmen, daß sich ihr, wenn überhaupt, so doch nur wenig antarktisches Wasser beimischt (vgl. Fig. 59 auf S. 283).

Es gibt aber für die Westküsten zwischen $40^{\circ} \mathrm{N}$ und $\mathrm{S}$ eine viel wirksamere Kältequelle: das aufsteigende Tiefenwasser. Es ist ein allgemeines Gesetz, daß im Rücken des Windes Wasser aus der Tiefe aufsteigt, um das vom Wind weggetriebene Wasser zu ersetzen. In der Passatzone liegen die kontinentalen Westküsten auf der Rückseite; eine Kompensation findet nicht nur oberflächlich von den Seiten her statt, sondern auch von unten. So leicht verständlich auch dieser Vorgang ist, so wenig wurde er beachtet, obwohl Witte schon 1871 und DinkLAGE 1875 darauf aufmerksam gemacht hatten. Vollgültige Beweise brachten erst die Beobachtungen an Uferstellen mit zeitweise ablandigen Winden, wie wir solche in den letzten Jahren an der afrikanischen Ostküste kennen gelernt haben. Zur Zeit des Südwestmonsuns haben hier weite Küstenstrecken auffallend kaltes Wasser, wie zwischen Warschekh und dem Kap Guardafui, im N und $\mathrm{O}$ der Insel Sokotra und an ein paar Stellen der arabischen Südküste. Bei Nordostmonsun verschwinden diese kalten Zonen, aber im Golf von Aden, wo die Strömung nach W und NW geht, erscheint eine neue zwischen Kap Guardafui und Bandar Alula. An polares Wasser ist in allen diesen Fällen natürlich nicht zu denken. 
Eine kalte Küstenzone zeichnet die Ostseiten aller Passatmeere aus, mit einziger Ausnahme derjenigen von Westaustralien. KRÜMMEL erklärt sie durch die geringe meridionale Ausdehnung dieses Erd. teiles, die das fortgeführte Meerwasser durch eine Strömung von N her zu ersetzen gestattet. An der californischen Küste gelangt das Auftriebwasser nur im Sommer zur vollen Entwicklung, weil, wie THORADE ${ }^{31}$ gezeigt hat, die Strömung nur in dieser Jahreszeit eine scharfe ablandige Richtung einschlägt. In diese Kategorie gehört auch der „kalte Wall" zwischen dem Golfstrom und der Ostküste der Vereinigten Staaten, wenn er auch vielleicht mit dem Labradorstrom in Verbindung steht. Selbst abseits von den Küsten treten solche Kaltwasserflecke auf, wenn die Trift besonders kräftig entwickelt.ist; im Pazifischen Ozean westlich von den Galapagos ist dies eine so regelmäßige Erscheinung, daß sie sogar auf den Isothermenkarten der Meeresoberfläche zum Ausdruck kommt. Wahrscheinlich sind auch die rätselhaften Stromkabbelungen, heftige und geräuschvolle, kurzwellige Wasserbewegungen, auf Aufsteigen von Tiefenwasser zurückzuführen.

In seinen klimatischen und sonstigen Eigenschaften unterscheidet sich das kalte Auftriebwasser durchaus nicht von kalten Oberflächenströmungen. Es erzeugt ebenfalls ein rauhes, wenn auch ziemlich gleichmäBiges Küstenklima, indem es besonders die Sommertemperatur stark herabsetzt; es hüllt sich in dichte Nebel, während es gleichzeitig die Regenbildung hindert. Wie alles kühlere Meerwasser, beherbergt es auch eine ungeheure Planktonfülle,. die eine reiche Fischfauna ernährt. Das „Dunkelmeer" an der afrikanischen Nordwestküste ist wahrscheinlich ein nicht minder ergiebiger Fischereigrund wie die Neufundlandbank oder das Gebiet der Falklandströmung.

Literaturnachweise. ${ }^{1} \mathrm{G}$. Sснотт, Weltkarte zur Übersicht der Meeresströmungen, 3. Aufl., Berlin 1909; einzige Wandkarte, die speziell diesem Zweeke gewidmet ist. - ${ }^{2}$ Vgl. den instruktiven Querschnitt von G. Braun in Petermans's Mitteilungen 1910 , II, S. $74 .-^{3}$ L. E. Dinkuage, Die Oberflächenströmungen im südwestlichen Teil der Ostsee, in den Annalen der Hydrographie und maritimen Meteorologie, 1888. - ${ }^{4}$ R. Wrtring, ebendaselbst 1909, S. $193 .-$ ${ }_{5}^{5}$ V. W. Eкмах, Zur Theorie der Meeresströmungen, ebendaselbst 1906. ${ }^{6}$ G. Scнот, Die Flaschenposten der Deutsehen Seewarte bis Ende 1896, im Archiv der Deutschen Seewarte 1897, Bd. XX. $-{ }^{7}$ G. Sснотт zit. S. 301. ${ }^{8}$ In den Annalen der Hydrographie usw., 1905, S. 314. - ${ }^{9}$ Das Hydrographic Office of the Admirality in London gab bisher folgende detaillierte Kartenwerke heraus: Monthly Current Charts for the Indian Ocean, 1896; Monthly Current Charts for the Atlantic Ocean, 1897; Quarterly Current Charts for the Pacific Ocean, 1897. Für den Indischen Ozean s. die vom niederländischen meteorologischen Institut herausgegebenen Monatskarten unter dem Titel 
„Waarnemingen in den Indischen Ocean", $1889 \mathrm{ff} .-{ }^{10}$ H. Монх, zit. S. 290. Nach dieser Methode haben R. Engelhardt die Strömungen der Ostsee (Archiv der Seewarte Bd. XXII, 1899), G. WEgemann die Oberflächenströmungen des nordatlantischen Ozeans nördlich von $50^{\circ} \mathrm{N} B$ (ebenda), Castens die Strömungen des Atlantischen Ozeans (Kiel 1905) und W. Wrssemans die Oberflächenströmungen des Sehwarzen Meeres (Annalen d. Hydrographie, 1906) bearbeitet. - ${ }^{11}$ V. BJERKnes, Über einen hydrodynamischen Fundamentalsatz und seine Anwendung auf die Mechanik der Atmosphäre und des Weltmeeres, in den Kongl. Svenska Vetenskaps-Akademiens Handlingar, 1898, Bd. XXXI. BJerknes und J. W. Sandström, Über die Darstellung des hydrographischen Beobachtungsmaterials durch Schnitte, die als Grundlage der theoretischen Diskussion der Meereszirkulationen und ihrer Ursachen dienen können (in P. T. Cleve, G. Ekman und O. Pettersson, Les variations annuelles de l'eau de surface de l'Océan Atlantique; Göteborg 1901). - ${ }^{12}$ J. W. Sandströn und B. Helland-Hansen, Über die Berechnung von Meeresströmungen; Bergen 1903 (im Report on Norwegian Fishery- and Marine-Investigations, Bd. II). - ${ }^{13}$ Eine gute Übersicht über die ältere Geschichte gibt A. PAHDE, Die theoretischen Ansichten über die Entstehung der Meeresströmungen, im.Jahresbericht des Realgymnasiums zu Krefeld, 1888. - ${ }^{14}$ K. Zöppritz, Zur Theorie der Meeresströmungen, in den Annalen der Physik, 1878, Bd. III. - ${ }^{15}$ F. NAnsen, Die Ursachen der Meeresströmungen, in Petermans's Mitteilungen, 1905. 16 J. W. SAndström, Dynamische Versuche mit Meerwasser, in den Annalen für Hydrographie usw. 1908. - ${ }^{17}$ J. E. Pillsbury, The Gulf Stream, im Report der U. S. Coast and Geodetic Survey für 1889-90; Washington 1892. Eine wichtige Ergänzung bietet G. Sснотт, Salzgehalt und Dichte der Meeresoberfläche in den westindischen Gewässern, in Petermans's Mitteilungen 1908. 19 J. S. Solex in den Annalen der Hydrographie usw. 1907, S. 84. - ${ }^{19}$ O. KrümmeL, Die nordatlantische Sargassosee, in Peternans's Mitteilungen, 1891. 20 L. Mecking, Die Eistrift aus dem Bereich der Baffinsbai, Berlin 1906. ${ }^{21}$ G. Sснотт, Die Gewässer der Bank von Neufundland, in Petermans's Mitteilungen, 1897. - ${ }^{22}$ B. Helland-Hansen u. F. Nansen, The Norwegian Sea, Kristiania 1909. - ${ }^{23}$ L. Breitruss, Ozeanographische Studien über das Barentsmeer, in Petermann's Mitteilungen, 1904. N. Knipowitsch, Hydrologisehe Untersuchungen im Europäischen Eismeer, in d. Annalen d. Hydrographie usw., 1905. F. Nansen, Northern Waters, Kristiania 1906 (Videnskabs-Selskabets skrifter, Math.-naturw. Kl. 1906, Nr. 3). - ${ }^{24}$ F. NAnsen im 3. Bde. von The Norwegian North Polar Expedition, 1893-96. Scientific Results, London 1902. - ${ }^{25}$ A. SuPAN, Die arktische Windscheide, in Petermann's Mitteilungen, 1891. - ${ }^{26}$ O. Petrersson, Über die Beziehungen zwisehen hydrographischen und meteorologisehen $\mathrm{Phäno-}$ menen, in der MeteorologischenZeitschrift, 1896. — ${ }^{27}$ W. Mernardus, DerZusammenhang des Winterklimas in Mittel- und Nordwesteuropa mit dem Golfstrom, in der Berliner Zeitschrift der Gesellschaft für Erdkunde, 1898; Über Schwankungen der nordatlantischen Zirkulation und damit zusammenhängende Erscheinungen, in der Meteorologischen Zeitschrift, 1905. - ${ }^{28}$ W. Brennecke, Beziehungen zwischen der Luftdruckverteilung und den Eisverhältnissen des Ostgrönländischen Meeres, in den Annalen d. Hydrographie usw., 1904. - 29 W. Mernardus, Periodische Schwankungen der Eistrift bei Island; ebenda, 1906. - ${ }^{30}$ C. PuLs, Oberflächentemperatur und Strömungsverhältnisse des Äquatorialgürtels des Stillen Ozeans, im Arehiv der Deutschen Seewarte, Bd. XVIII, 1896. ${ }^{31}$ H. Thorade in den Annalen der Hydrographie usw. 1909, S. 17 und 63. ${ }^{32}$ A. Puff, Das kalte Auftriebwasser; Marburg 1890. 


\section{Die Temperaturverteilung im Wasser.}

Die Oberflächentemperatur des Meeres. ${ }^{1}$ Die Oberflächentemperatur.des Meerwassers ist im allgemeinen etwas höher als die der untersten Luftschichten, und zwar über warmen Strömungen stets und im Winter auch meist über kalten. ${ }^{2 \times}$ In einzelnen Tages- und Jahreszeiten kann dieser Unterschied ziemlich beträchtlich werden, weil die Wassertemperatur viel geringeren Schwankungen unterworfen ist als die Lufttemperatur; im Jahresdurchschnitt ist er aber doch gering, wie bei der innigen Berührung von Luft und Wasser und bei der großen Wärmekapazität des letzteren nicht anders $\mathrm{zu}$ erwarten ist. Genügt doch die Temperaturerniedrigung eines cbm Wasser um $1^{0}$, um die Temperatur von $3000 \mathrm{cbm}$ Luft um $1^{0}$ zu erhöhen. $\times \times$. Die Luftisothermen haben daher überall das Bestreben, sich

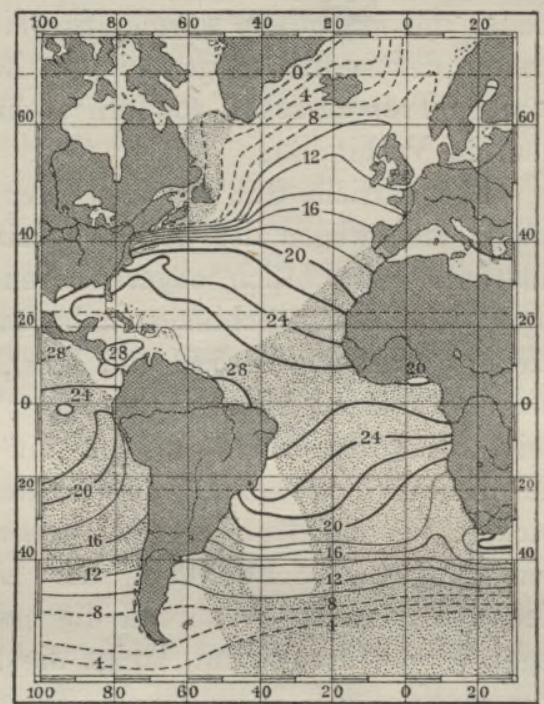

Fig. 77. Isothermen der Oberfläche des Atlantischen Ozeans nach KöPPEN und KRÜMMEL. Die punktierten Flächen sind anomal kalt. möglichst eng den Wasserisothermen anzuschließen; die letzteren hängen aber, außer von der geographischen Breite, auch von der horizontalen und vertikalen Wasserzirkulation ab (vgl. Fig. 77). Daher ist zwischen ungefähr $40^{\circ} \mathrm{N}$ und $40^{\circ} \mathrm{S}$ das Meer im Osten kälter und jenseits dieser Parallelen wärmer als im Westen. Die Mächtigkeit der Atlantischen Strömung verrät sich durch die weit nach Norden geschwungenen Isothermenkurven, und das Zusammenrücken der Wärmelinien an der Neufundlandbank ist ein Werk der Labradorströmung. Für alle Ozeane gilt das Gesetz, daß die nörd-

$\times$ Als Mittel der Differenz Luft minus Wasser aus je vier Beispielen können angeführt werden:

$\begin{array}{lrcccc} & \text { Winter } & \text { Frühling } & \text { Sommer } & \text { Herbst } & \text { Jahr } \\ \text { Warme Strömungen } & -2,1^{0} & -0,9^{0} & -0,3^{0} & -1,7^{0} & -1,3^{0} \\ \text { Kalte } & -0,4 & +0,3 & +0,6 & +0,1 & +0,05\end{array}$
$\times \times$ Vgl. S. 84 . 
lichen Partien wärmer sind als die entsprechenden südlichen. ${ }^{\times}$Dieser Gegensatz ist in letzter Linie eine Folge der stärkeren Entwicklung des Südostpassates. Die südliche Äquatorialströmung, die im Atlantischen und im Großen Ozean beständig, im Indischen aber nur zur Zeit des Südwestmonsuns den Äquator überschreitet, führt unserer Hemisphäre eine Menge erwärmten Wassers zu, und dieses ernährt wieder die mächtigen warmen Ströme der nördlicheren Breiten. Die Ozeane der südlichen gemäßigten Zone erhalten dagegen nicht-nur weniger Tropenwasser, sondern stehen überdies noch mit dem Eismeer in Verbindung.

Die jährliche Schwankung der marinen Oberflächentemperatur ${ }^{3}$ bewegt sich wegen der hohen spezifischen Wärme des Wassers $\times \times$ innerhalb beträchtlich engerer Grenzen als die der Lufttemperatur. In den englischen Schiffsjournalen fand Sir John Murray im offenen Ozean als Extreme $-3,3^{\circ}$ und $32,2^{\circ}$, ja selbst wenn wir die Nebenmeere, wo ein Maximum von $35,6^{\circ}$ verzeichnet ist, berücksichtigen, steigt die absolute Schwankung nur auf $39^{\circ}$. Man'vergleiche damit die absolute Schwankung der Lufttemperatur, die nahezu $100^{\circ}$ erreicht! Verschiedene Gesetze beherrschen auch die geographische Verteilung der Schwankung der Luft- und der Schwankung der Meerestemperatur. Während die erstere auf dem Meer vom Äquator gegen die Pole zunimmt, steigt die letztere nur bis ungefähr $40^{\circ} \mathrm{B}$.

$\times$ Mittlere Oberflächentemperatur nach KRüMmé:

\begin{tabular}{|c|c|c|c|c|c|c|c|c|}
\hline \multirow[b]{2}{*}{ Zonen } & \multicolumn{2}{|c|}{$\begin{array}{c}\text { Atlantischer } \\
\text { Ozean }\end{array}$} & \multicolumn{2}{|c|}{$\begin{array}{c}\text { Indischer } \\
\text { Ozean }\end{array}$} & \multicolumn{2}{|c|}{$\begin{array}{c}\text { Großer } \\
\text { Ozean }\end{array}$} & \multicolumn{2}{|c|}{$\begin{array}{c}\text { Ganizes } \\
\text { Weltmeer }\end{array}$} \\
\hline & $\mathrm{N}$ & s & $\mathrm{N}$ & $\mathrm{S}$ & $\mathrm{N}$ & S & $\mathrm{N}$ & $\mathrm{S}$ \\
\hline $90-80^{0}$ & - & - & - & - & - & - & $-1,7^{0}$ & - \\
\hline $80-70$ & - & $-1,7^{0}$ & - & $-1,7^{0}$ & - & $-1,7^{\circ}$ & $-1,0$ & $-1,7^{\circ}$ \\
\hline $70-60$ & $4,3^{0}$ & $-1,3$ & - & $-1,5$ & - & $-1,3$ & 3,1 & $-1,4$ \\
\hline $60-50$ & 8,9 & 1,9 & - & 1,6 & $5,7^{0}$ & 5,0 & 6,1 & 3,1 \\
\hline $50-40$ & 12,9 & 9,5 & - & 8,7 & 10,0 & 11,2 & 11,0 & 9,8 \\
\hline $40-30$ & 20,3 & 17,1 & - & 17,0 & 18,6 & 17,0 & 18,4 & 17,0 \\
\hline $30-20$ & 23,9 & 21,2 & $26,1^{0}$ & 22,5 & 23,4 & 21,5 & 23,7 & 21,7 \\
\hline $20-10$ & 25,6 & 23,2 & 27,2 & 25,9 & 26,4 & 25,1 & 26,5 & 25,1 \\
\hline $10-0$ & 26,8 & 25,7 & 27,8 & 27,4 & 27,2 & 26,0 & 27,3 & 26,5 \\
\hline \multirow{2}{*}{ Mittel } & 20,1 & 14,1 & 27,5 & 15,3 & 22,2 & 16,3 & 19,2 & 16,0 \\
\hline & \multicolumn{2}{|c|}{16,9} & \multicolumn{2}{|c|}{17,0} & \multicolumn{2}{|c|}{19,1} & \multicolumn{2}{|c|}{17,4} \\
\hline
\end{tabular}

$\times \times$ Über den Begriff der spezifisehen Wärme s, S. 84 . Sie beträgt:

\begin{tabular}{lcccccc} 
& \multicolumn{5}{c}{ Wasser } & Luft \\
Salzgehalt, Promille & 0 & 13 & 26 & 30 & - \\
Spez. Wärme . . . & 1,000 & 0,963 & 0,914 & 0,926 & 0,237
\end{tabular}


und nimmt dann polwärts wieder $a b$; doch muB die Frage, ob in den höheren Breiten nicht abermals eine Steigerung erfolgt, noch offen gelassen werden. Die verhältnismäßig große Schwankung in den Roßbreiten schreibt- Sснотт der geringen Bewölkung und der schwachen Luftbewegung zu, die den jährlichen Wechsel der Sonnen'strahlung zur vollen Geltung gelangen läßt. Die Maxima der Schwankung finden wir einerseits dort, wo warme und kalte Strömungen zusammentreffen, anderseits in der Nähe des Festlandes und daher auch in den Nebenmeeren. Für die maritime Temperaturverteilung sind die Landwinde ein ebenso wichtiger Faktor wie die Seewinde für das Landklima, und am gleichmäßigsten hält sich, abgesehen von der Äquatorialzone, die Meerestemperatur das ganze Jahr hindurch dort, wo der kontinentale Einfluß völlig aufhört, nämlich in den mittleren südlichen Breiten.

Legt man die Mitteltemperatur des ganzen Weltmeeres der Beurteilung zugrunde, so ergibt sich eine zonale Dreiteilung, und jedem. der drei Ozeane kommt in einer Zone das Maximum der positiven, in einer andern das Maximum der negativen Zone zu. Nördlich von $30^{\circ} \mathrm{N}$ ist der Atlantische Ozean zu warm; KRÜMmeL's Isanomalenkarte zeigt im Bereich des Golfstroms und der Irischen und der Atlantischen Strömung die höchsten Werte der positiven Anomalie, die überhaupt auf dem Meer vorkommen. Zwischen $30^{\circ} \mathrm{N}$ und $30^{\circ} \mathrm{S}$, also in der Tropenzone, ist dagegen der Atlantische Ozean relativ am kältesten und der Indische am wärmsten. Südlich von $30^{\circ} \mathrm{S}$ fällt das positive Maximum in den Großen und das negative in den Indischen Ozean, wahrscheinlich eine Folge davon, daß die Antarktika auf der indischen Seite am weitesten und geschlossensten nach $\mathrm{N}$ vordringt, und die Produktion von Eisbergen hier viel beträchtlicher ist, als auf der pazifischen Seite.

Tiefentemperatur in Süßwasserseen. ${ }^{4}$ Wie in der Lufthülle unseres Planeten die Temperatur nach der Höhe abnimmt, so in der Wasserhülle nach der Tiefe. In derselben Richtung vermindert sich auch ihre Schwankung; die tägliche, die in unseren Breiten selbst an der Oberfläche der Seen $2^{\circ}$ nicht übersteigt, sinkt nach HaNn schon in einer Tiefe von $5 \mathrm{~m}$ auf $0,1^{\circ}$, während die jährliche erst in $100-200 \mathrm{~m}$ Tiefe nahezu erlischt. Völlig gleichmäBig ist die Temperatur auch in größeren Tiefen nicht; im Genfer See $(310 \mathrm{~m}$ tief) schwankt sie selbst am Boden noch um ein paar Zehntelgrade innerhalb eines Jahres, und in zwölf Jahren betrug der Unterschied der Extremé sogar 1,40. Nach ForeL sind es hauptsächlich die trüben Gewässer der Zuflüsse, die infolge größerer Dichte zu Boden sinken und ihre höhere Temperatur den Tiefen des.Sees mitteilen. 
Während die Atmosphäre hauptsächlich von unten erwärmt wird, empfängt das Wasser seine Wärme von oben, und die Temperaturverteilung in einer Wassersäule gestaltet sich daher wesentlich anders als in einer Luftsäule von gleicher Höhe. Die SüBwasserseen erwärmen sich am Tag und im Sommer durch Durchstrahlung und Leitung und kühlen sich nachts und im Winter durch Leitung und vertikale Wasserzirkulation ab. Die direkte Sonnenwirkung beeinflußt nur einewdünne Oberflächenschicht; nach Grissinger's Messungen im kärtnischen Weißensee ${ }^{5}$ reichte sie anfangs September nur bis $12 \mathrm{~m}$ Tiefe. Die vertikale Zirkulation wird dadurch hervorgerufen, daß das Oberflächenwasser sich abkühlt, dadurch schwerer wird und untersinkt, bis es eine Schicht von gleicher Temperatur und Dichte erreicht hat. Wärmere Tiefenschichten steigen auf, kühlen sich wieder $a b$, sinken wieder unter, und dieses Spiel dauert so

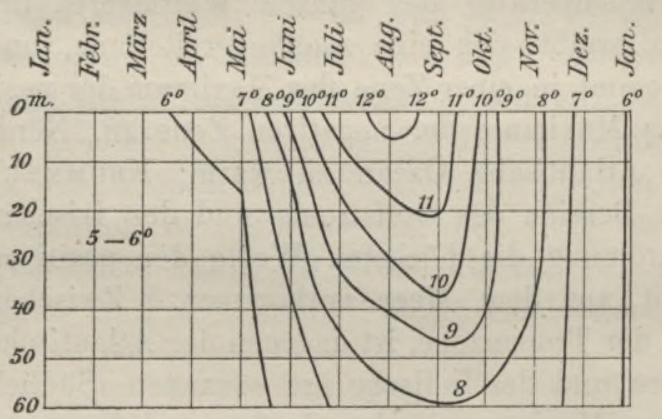

Fig. 78. Thermoisoplethen des Loch Neß. lange, bis das gestörte Gleichgewicht wieder hergestellt ist. Würde die Dichte des Süßwassers mit fallender Temperatur stetig steigen, so müßte in jenen Tiefen unserer mitteleuropäischen Seen das Wasser eine Temperatur besitzen gleich dem mittleren Temperaturminimum der betreffenden Gegend. Bekanntlich erreicht aber das Süßwasser seine größte Dichte schon bei $+4^{0}$ (bei hohem Druck allerdings etwas darunter), und in der Tat finden wir diese Temperatur auch in den meisten unserer tieferen Alpenseen, vorausgesetzt, da $B$ sie nicht durch warme Quellen auf dem Grund gespeist werden. Wenn das Bodenwasser ein wenig wärmer gefunden wird als die benachbarten Schichten, so ist dies dem Einfluß der Erdwärme, vielleicht auch dem wärmeerzeugenden Fäulnisproze $B$ der auf dem Boden lagernden Organismen oder den falschen Angaben eines gegen Druck nicht genügend geschützten Thermometers ${ }^{6}$ zuzuschreiben.

Längere, regelmäßige Beobachtungen besitzen wir nur vom Loch NeB im caledonischen Graben Schottlands. ${ }^{7}$ Sie erstrecken sich über 22 Monate (1903-1905), und die mittleren Monatstemperaturen (2 jährige Mittel, nur für Mai und Juni einjährige) finden sich in nachfolgender Tabelle zusammengestellt. 


\begin{tabular}{ccccccccccccc}
\hline \hline & Jan. & Feb. März & Apr. & (Mai) & (Juni) & Juli & Aug. & Sept. & Okt. & Nov. & Dez, \\
$\begin{array}{c}\text { Luft } \\
\text { Tiefe }\end{array}$ & $4,3^{0}$ & $3,0^{0 *}$ & $4,4^{0}$ & $6,4^{0}$ & $8,8^{0}$ & $12,3^{0}$ & $13,3^{0}$ & $\mathbf{1 2 , 7 ^ { 0 }}$ & $\mathbf{1 1 , 7 ^ { 0 }}$ & $8,4^{0}$ & $5,1^{0}$ & $3,0^{0}$ \\
$0,0 \mathrm{~m}$ & 5,9 & 5,5 & $5,3^{*}$ & 6,6 & 6,4 & 9,2 & 11,7 & $\mathbf{1 2 , 7}$ & $\mathbf{1 1 , 5}$ & 9,7 & 8,1 & 6,6 \\
$-15,2$ & 5,9 & 5,4 & $5,2^{*}$ & 5,4 & 6,0 & 8,0 & 10,3 & 11,1 & $\mathbf{1 1 , 2}$ & 9,5 & 8,1 & 6,6 \\
30,5 & 5,9 & 5,4 & $5,2^{*}$ & 5,3 & 5,9 & 7,4 & 9,2 & 9,9 & $\mathbf{1 0 , 6}$ & 9,3 & 8,1 & 6,6 \\
45,7 & 5,9 & 5,4 & $5,1^{*}$ & 5,3 & 5,8 & 6,7 & 8,1 & 8,6 & $\mathbf{9 , 1}$ & 8,8 & $\mathbf{7 , 9}$ & 6,6 \\
61,0 & 5,8 & 5,3 & $5,1^{*}$ & 5,3 & 5,7 & 6,2 & 7,3 & 7,6 & 7,7 & $\mathbf{7 , 8}$ & $\mathbf{7 , 6}$ & 6,6
\end{tabular}

Daß die Seeoberfläche im Winterhalbjahr wärmer ist als die Luft, erklärt sich aus dem allgemeinen thermischen Verhalten des Wassers. Vom Dezember bis März ist die Temperatur bis $61 \mathrm{~m}$ Tiefe nahezu gleichmäBig. Vom Juni ab beginnt sie mit der Tiefe abzunehmen, und im wärmsten Monat, im August, erreicht die Abnahme ihren höchsten Wert. Sie vollzieht sich nicht gleichmäßig; es gibt eine Stelle, wo die Temperatur gleichsam einen Sprung macht, und ihr Entdecker, ED. RICHTER, hat sie daher auch passend Sprungschicht genannt. Man erkennt sie auch in obiger Tabelle; sie liegt von Juni bis August in den obersten Schichten und senkt sich dann in die untersten Schichten, bis sie im November verschwindet, $\times$ Außer jahreszeitlichen unterliegt sie auch täglichen Verschiebungen. Ihre obere Grenze bezeichnet den Endpunkt der vertikalen Zirkulation, die durch die nächtliche Abkühlung der Oberflächenschicht erzeugt wird und sich bis zu jener Tiefe erstreckt, in der die Temperatur gleich ist der nächtlichen Oberflächentemperatur. Die auf- und absteigenden Schichten vermischen sich so innig, daß sie am darauffolgenden Morgen eine gleichmäßige Temperatur annehmen. Diese ist natürlich an der oberen Grenze der Zirkulationsschicht tiefer als die Temperatur des vorhergehenden Tages, an der unteren aber höher, und statt der früheren gleichmäßigen Abnahme findet nun ein Sprung statt. So trägt, so paradox es auch klingen mag, die nächtliche Abkühlung die Wärme in die Tiefe, und zwar um so tiefer, je größer die tägliche Temperaturschwankung ist.

Neben vertikalen Temperaturunterschieden greifen innerhalb eines Süßwassersees auch horizontale Platz. Wichtig ist der Einfluß

$\times$ Die genaue Lage der Sprungsehicht kann nur durch Messungen in kurzen Abständen festgestellt werden. Selbst solehe von $1 \mathrm{~m}$ sind noch zu grob. Das ersieht man aus der Beobachtung Ed. Richter's im Wörther See am 17. Sept. 1890, mittags:

$\begin{array}{lccccccc}\text { Tiefe m . . . . . } & 0 & 10 & 11 & 12 & 15 & 20 \\ \text { Temperatur . . . . . } & 17,8^{0} & 17,5^{0} & 15,2^{0} & 10,7^{0} & 8,0^{0} & 6,8^{0}\end{array}$

Die genaueren Messungen in Abständen von $20 \mathrm{~cm}$ zeigten, daß nicht die ganze Schicht zwischen 10 und $11 \mathrm{~m}$ Tiefe der Sprungschicht angehört, denn in $10,8 \mathrm{~m}$ betrug die Temperatur noch $17,4^{\circ}$. 
des Windes, besonders in Seen, deren ausgesprochene Längsachse mit der Hauptrichtung der Winde übereinstimmt. Das warme Oberwasser wird von dem Wind nach der Leeseite getrieben, und zum Ersatz dafür steigt kälteres Unterwasser an der Luvseite in dié Höhe. Die Isothermen der oberen Wasserschichten neigen sich in diesem Falle in der Richtung des Windes. $\times$ Aber auch dann, wenn der Wind abgeflaut ist, erlischt sein EinfluB nicht, wie WATson und WedDERBURN zum ersten Mal am Loch NeB nachgewiesen haben. In der Umgebung der Sprungschicht führen die Isothermen, ganz unabhängig von dem Verlauf der. Isothermen in den obern Wasserschichten, eine eigentümliche Schaukelbewegung aus; sie neigen sich nach dem SW-Ende des langgestreckten Sees, dann nach dem NO-Ende, und kehren endlich wieder in ihre frühere Lage zurück. In einer bestimmten Tiefe tritt also gleichzeitig mit dem Temperaturmaximum an dem einen Ende ein Temperaturminimum am andern Ende auf, und die Amplitude wird um so kleiner, je mehr man sich der Mitte des Sees nähert. Solche Oszillationen, die man zutreffend thermische Seiches genannt hat, können sich mehrmals wiederholen; ihre Periode ist umso größer, je tiefer die Sprungschicht liegt, und schwankt nach den Berechnungen zwischen $2^{1} / 4$ und $3 \frac{1}{2}$ Tagen. Sie treten nur dann auf, wenn die Sprungschicht deutlich entwickelt ist, denn nur in diesem Fall besteht ein schärferer Gegensatz zwischen einer relativ warmen Ober- und einer relativ kalten Unterschicht, die in ihrem Verhalten voneinander bis $\mathrm{zu}$ einem gewissen Grad unabhängig sind. Eine weitere Bedingung scheint zu sein, daB die Längsachse des Sees in die Richtung der vorherrschenden Winde fällt. ${ }^{9}$

Nach ihren Wärmeverhältnissen unterscheidet FonEu tropische, gemäßigte und polare Seen. Diese Bezeichnungsweise kann irreführen. Zum tropischen Typus gehört z. B. der Genfersee, zum

$\times$ Ein Beispiel bieten die Messungen Murray's ${ }^{8}$ im Loch Lochy, der, von NO nach SW sich erstreckend, den südwestlichen Teil des caledonischen Grabens erfüllt:

\begin{tabular}{|c|c|c|c|c|c|}
\hline \multirow{3}{*}{$\begin{array}{c}\text { Tiefe } \\
\text { m }\end{array}$} & \multicolumn{3}{|c|}{ 7. September 1887} & \multicolumn{2}{|c|}{ 9. September 1887} \\
\hline & $\begin{array}{l}\text { Nähe des } \\
\text { SW-Endes }\end{array}$ & Mitte & $\begin{array}{l}\text { Nähe des } \\
\text { NO-Endes }\end{array}$ & $\begin{array}{l}\text { Nähe des } \\
\text { SW-Endes }\end{array}$ & $\begin{array}{l}\text { Nähe des } \\
\text { NO-Endes }\end{array}$ \\
\hline & \multicolumn{3}{|c|}{ Wind $\longleftarrow$} & \multicolumn{2}{|c|}{ Wind $\longrightarrow$} \\
\hline 0 & $13,7^{0}$ & $13,3^{0}$ & $12,6^{0}$ & $12,7^{0}$ & $12,9^{0}$ \\
\hline 9 & 13,4 & 13,2 & 12,4 & 12,7 & 12,8 \\
\hline 18 & 13,4 & 12,9 & 12,1 & 11,5 & 12,8 \\
\hline 37 & 8,4 & 8,4 & - & 9,0 & - \\
\hline 55 & 7,2 & 7,3 & - & 7,3 & - \\
\hline
\end{tabular}


polaren der Baikalsee, und der gemäBigte Typus kommt auch in den Tropen in beträchtlichen Seehöhen und in der polaren Zone (z. B. der Enaresee in Lappland) vor. Wir sprechen daher besser von warmen, gemäBigten und kalten Seen. Die geographische Lage ist nicht allein maßgebend, wie HaLBFASS ${ }^{10}$ betont hat, sondern auch die Gestaltung des Seebeckens. Ob seiner weiteren Schlußfolgerung, daß unter sonst gleichen Verhältnissen die Mitteltemperatur der Seen mit der geographischen Breite und die Tiefentemperatur mit der Meereshöhe des Seebodens abnimmt, gesetzmäBige Gültigkeit zukommt, müssen erst weitere Untersuchungen lehren.

In den warmen Seen nimmt die Temperatur das ganze Jahr mit der Tiefe ab; sie sind - nach FoneL's Ausdruck - durch regelmäBige Wärmeschichtung $\times$ ausgez $e i c h n e t . ~ D i e ~ t i e f s t e$ Temperatur kann daher niemals unter $4^{0}$ sinken.

Die gemäBigten Seen haben nur im Sommer regelmäßige, im Winter aber verkehrte Wärmeschichtung, d. h. ihre Temperatur nimmt mit der Tiefe zu. Im Moment des Überganges hat die ganze Wassersäule ungefähr $4^{0} \times \times$ Werden die oberflächlichen Schichten kälter, so sinken sie nicht mehr unter. Die Temperatur der tieferen Schichten erniedrigt sich nur durch Ausstrahlung; sie nimmt nach der Tiefe zu, bis die konstante Schicht von $4^{0}$ erreicht ist. $\times \times \times$ Die Eisbildung ${ }^{11}$ beginnt daher stets an der Oberfläche ${ }^{+}$und schreitet

$\times$ Kвӥмmé hat folgende Terminologie empfohlen:

Homotherm: gleiehmäBige Temperatur,

Heterotherm: ungleichmäBige Temperatur, und zwar: anotherm: Temperatur nach der Tiefe abnehmend, katotherm: Temperatur nach der Tiefe zunehmend, mesotherm: kalt, warm, kalt, dichotherm: warm, kalt, warm, poikilotherm: unregelmäßige Abwechslung verschieden temperierter Schichten.

Analoge Benennungen lassen sich auch für die vertikale Verteilung des Salzgehaltes anwenden, z. B. homohalin usw.

$\times \times$ Dieser Fall ist tatsächlich einmal von HacbFass im pommerischen Dratzigsee (am 1. Januar 1901) beobachtet worden.

$\times \times \times$ Die Temperaturverteilung im Züricher See war am 25. Januar 1880 nach Forel folgende:

$\begin{array}{ccccccccc}\text { Tiefe . } . & 0 & 20 & 40 & 60 & 80 & 100 & 120 & 133 \\ \text { Temperatur } & 0,2^{0} & 2,9^{\circ} & 3,5^{\circ} & 3,7^{0} & 3,8^{0} & 3,9^{\circ} & 4,0^{\circ} & 4,0^{\circ}\end{array}$

+ Bisher hatte man neben dem Eis immer Wasser mit positiver Temperatur beobachtet. Wasser mit $0^{0}$ bildet im Moment des Gefrierens nur eine wenige Millimeter dicke Schicht, deren Vorhandensein erst K. Schun (s. PeterManN's Mitteilungen 1901, S. 57) mit seinem neu konstruierten Thermometer nachgewiesen hat. 
langsam nach unten fort. Aber niemals können unsere tieferen Landseen bis auf den Grund gefrieren, und so kann ihr organisches Leben auch den Winter überdauern.

In den kalten Seen herrscht das ganze Jahr hindurch verkehrte Wärmeschichtung, die Oberflächentemperatur ist daher stets unter $4^{\circ}$.

Namentlich für die Seen von gemäBigtem Typus ist nach BRÜCKNER's ${ }^{12}$ Untersuchungen die Größe des Abflusses ein entscheidender Faktor. Der AbHluß entführt Oberflächenwasser, das im Sommer durch kälteres, im Winter durch wärmeres Tiefenwasser ersetzt wird. Je größer also der Abfluß, desto geringeren jahreszeitlichen Schwankungen ist die Oberfl̈̈chentemperatur ausgesetzt. Überträgt man diese Erfahrung auch auf die beiden andern Kategorien, so ergibt sich der Satz, daß das ganze Jahr hindurch warme Seen um so wärmer, und kalte Seen um so kälter sind, je geringer ihr $A b f l u B$ ist. Indes sind die Untersuchungen auf diese Kategorien noch nicht ausgedehnt worden.

Tiefentemperaturen im Salzwasser. In zwei Punkten unterscheidet sich hinsichtlich seines thermischen Verhalten das Salzwasser von dem Süßwasser. Mit steigendem Salzgehalt verschiebt sich nämlich der Gefrierpunkt und das Dichtigkeitsmaximum nach abwärts, ${ }^{-}$und damit ändert sich das Minimalmaß der Tiefentemperatur. Die erkaltete Oberflächenschicht sinkt in die Tiefe, nicht bloß, wie im Süßwasser, weil sie erkaltet ist, sondern auch, weil sie durch die Ausscheidung von Salz bei der Eisbildung salzreicher geworden ist. Während sich die Tiefentemperatur in Süßwasserseen immer über dem Nullpunkt erhält, kann sie schon in Wasser von nur mäßigem Salzgehalt darunter sinken, wenn die klimatischen Verhältnisse die Erzeugung so niedriger Wärmegrade gestatten. Sobald aber und dieser Fall tritt schon bei einem Salzgehalt von 25 Promille ein - das Dichtigkeitsmaximum tiefer liegt als der Gefrierpunkt, wird die untere Temperaturgrenze der Tiefenschichten nur mehr von dem letzteren bestimmt. Vor intensiverer Erkaltung schützt die

$\begin{array}{lcccccc}\times \text { Salzgehalt (Promile) } & 0 & 10 & 20 & 30 & 40 \\ \text { Gefrierpunkt . . } & 0^{0} & -0,6^{\circ} & -1,1^{\circ} & -1,7^{\circ} & -2,3^{\circ} \\ \text { Dichtigkeitsmaximum } & +4,0 & +1,9 & -0,3 & -2,5 & -4,5\end{array}$

H. J.Hansen drückt das Verhältnis zwischen Salzgehalt und Gefrierpunkt $\left(t_{0}\right)$ durch folgende Formel aus:

$$
t_{0}=-0,0086-0,064633 \sigma_{0}-0,0001055 \sigma_{0}{ }^{2} \text {. }
$$

$\sigma_{\lrcorner}=1000\left(s \frac{0^{0}}{4^{0}}-1\right)$ (vgl. S. 284). Ist der Salzgehalt bekannt, so kann der dazu gehörige Wert von $t_{0}$ unmittelbar Knudsen's hydrographisehen Tabellen entnommen werden. 
Eisdecke als schlechter Wärmeleiter die Tiefe, und daher kann selbst das Bodenwasser polarer Meere nicht kälter sein als - 2 bis $-3^{0}$.

Der zweite Unterscheidungspunkt ist folgender. Die tieferen Süßwasserschichten erwärmen sich hauptsächlich durch Leitung, da die vertikale Zirkulation nicht weit hinabreicht. Um Wasser von der Oberfläche in die Tiefe zu führen, gibt es hier nur ein Mittel: die Abkühlung, im Salzwasser dagegen noch ein zweites: die Erwärmung. Indem das erhitzte Oberflächenwasser verdunstet, wird es relativ salzreicher, schwerer, und sinkt unter. Auch frische, trockene Winde steigern die Verdunstung. Um die ungeheuere Bedeutung dieser Faktoren zu würdigen, vergleiche man nur die Temperaturen im Mittelmeer und in den oberitalienischen Seen. Hier unter $150 \mathrm{~m}$ Tiefe schon überall Temperaturen von 5 bis $7^{\circ}$, dort selbst an den tiefsten Stellen noch eine Temperatur von $13^{\circ} ! \times$ Dieser Wärmegrad entspricht ungefähr der mittleren Januartemperatur der Luft in diesen Gegenden und herrscht mit geringen Schwankungen in der ganzen, mehrere $1000 \mathrm{~m}$ mächtigen Wasserschicht unterhalb $500 \mathrm{~m}$ Tiefe. Die vertikale Temperaturabnahme beträgt hier nur ein paar Zehntel Grad.

Das Mittelmeer ist ein nahezu abgeschlossenes Becken; die Gibraltarschwelle ist zu seicht, als daß das kalte ozeanische Tiefenwasser eintreten könnte. Maßgebend für die Tiefentemperatur der Nebenmeere ist also die Tiefe und auch die Breite der Kanäle, die sie mit dem Hauptmeer verbinden. Daß wir auch die Breite als einen Faktor für den Grad der Vermischung zweier Gewässer anführen, bedarf keiner weiteren Erörterung.

Im Gebiet des Schwarzen Meeres ist das Klima, besonders das winterliche, beträchtlich kälter als im Mittelmeer, und dementsprechend müssen wir dort Tiefentemperaturen von nahe an $6^{\circ}$ erwarten. Solche finden wir auch in der Tat. In dem Längsprofil zwischen Varna in Bulgarien und Pizunda am kaukasischen Gestade, das die russische Forschungsexpedition $1890 / 91$ aufnahm ${ }^{14}$, liegt durchschnittlich zwischen 40 und $90 \mathrm{~m}$ Tiefe eine Kälteschicht von weniger als $8^{\circ}$. In ungetähr $60 \mathrm{~m}$ Tiefe sank das Thermometer im Mittel auf $7,2^{\circ}$, die Extreme schwanken nur zwischen 6,2 und $7,6^{\circ}$. Von da ab

× Zwischen Korfu und Ben Ghâsi (Tripolis) war die durchschnittliche vertikale Temperaturverteilung nach den Messungen der „Pola“ im September 1891 folgende:

Tiefe $m$ $\begin{array}{llllll}0 & 10 & 50 & 100 & 500\end{array}$

Temperatur $\quad 24,8^{\circ} \quad 23,8^{\circ} \quad 18,9^{\circ} \quad 15,5^{\circ} \quad 14,1^{\circ}$ Boden (bis $3700 \mathrm{~m}$ )

An der tiefsten bekannten Stelle des Mittelmeeres $(4400 \mathrm{~m})$ fand die "Pola" $13,5^{0}{ }^{13}$ 
nimmt aber die Temperatur bis zum Boden wieder um $2^{\circ} \mathrm{zu}, \times$ offenbar erwärmt durch Mittelmeerwasser, das als Unterstrom durch den Bosporus in das Schwarze Meer flieBt. Auch die auffallend rasche Temperaturabnahme in den obersten Schichten ist lehrreich; je geringer die Verdunstung ist, desto matter ist die vertikale Zirkulation. Sie erlischt hier schon in $55 \mathrm{~m}$ Tiefe, d. h. in der Schicht der niederigsten Temperatur.

+Dichotherm ist im Sommer auch die Schichtung in der eigentlichen Ostsee zwischen der Darßer Schwelle und den ÅlandsInseln. ${ }^{15}$ Wir unterscheiden hier eine gleichmäßig warme Oberschicht von $10-20 \mathrm{~m}$ Mächtigkeit, die unten durch eine Sprungschicht begrenzt ist, dann langsame Abnahme bis ungefähr $50 \mathrm{~m}$ Tiefe, dann wieder Zunahme. Die kalte Zwischenschicht liegt zwischen 40 und $70 \mathrm{~m}$ Tiefe, die Unterschicht ist wie im Pontus nahezu gleichmäßig warm und durch höheren Salzgehalt ausgezeichnet; sie stammt offenbar aus der Nordsee und füllt alle Einsenkungen des baltischen Beckens aus. $\times \times$ Also auch in der Ostsee dringt der Konvektionsproze $B$ nur in mäBige Tiefe, etwa bis $50 \mathrm{~m}$, und man sollte hier ungefähr $2,5^{\circ}$ erwarten, d.h. diejenige Temperatur, bei der Wasser von 7,5 Promille Salzgehalt seine gröBte Dichte erreicht. Statt dessen finden wir aber mehrfach tiefere Temperaturen, die nicht durch Konvektion, sondern nur durch mechanische Vermischung der Wasserschichten in die Tiefe gelangt sein können. Die Wellenbewegung spielt dabei wohl die Hauptrolle; aber auch der Windstau, der an der Rückseite Tiefenwasser aufsteigen läßt und an der Vorderseite Oberflächenwasser in die Tiefe hinabdrückt, und die mit Wasser getränkten Planktonleichen, die jedes Frühjahr in ungezählten Milliarden in die Tiefe sinken, sind bei diesem Vorgang beteiligt.

Ozeane. $^{16}$ In der vertikalen Temperaturschichtung der Ozeane ist mit Ausnahme der polaren Breiten fast überall eine Dreiteilung bemerkbar (s. Tab. S. 349): eine ungefähr $200 \mathrm{~m}$ mächtige Oberschicht mit rascher Abnahme, eine $700-800 \mathrm{~m}$ mächtige Mittelschicht mit langsamerer, aber immerhin noch bemerkbarer Abnahme, die nach v. DRYGalski's Beobachtungen mit der Abnahme des Salzgehaltes gleichen Schritt hält, und endlich eine mehrere tausend Meter mächtige.

$\times$ Als Beispiel wählen wir die Station in $43^{\circ} 38^{\prime} \mathrm{N}, 35^{\circ} 18^{\prime} \mathrm{O}$ (August 1891)

$\begin{array}{lllllllll}\text { Tiefe } \mathrm{m} & 0 & 9 & 18 & 37 & 55 & 73 & 91 & 1463\end{array}$

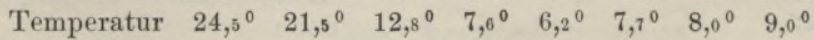

$\times \times$ Als Beispiel führe ich eine Lotungsreihe östlich von Gotland im Juli 1877 an:

$\begin{array}{lclllllllllll}\text { Tiefe m }^{\mathrm{m}} & 0 & 10 & 20 & 30 & 40 & 50 & 60 & 70 & 80 & 90 & 160 & 210 \\ \text { Temp. }^{0} & \mathbf{1 4 , 4} & 14,7 & \mathbf{7 , 8} & 3,2 & 2,8 & 1,8 & 2,0 & 3,0 & 3,5 & 3,9 & 3,8 & 3,1\end{array}$


Vergleichende Übersicht der Temperatur der Ozeane (nach Sснотт).

-Breite

Tiefe:

$0 \mathrm{~m} \quad 100 \mathrm{~m} \quad 200 \mathrm{~m} \quad 400 \mathrm{~m} \quad 600 \mathrm{~m} \quad 800 \mathrm{~m} \quad 1000 \mathrm{~m} \quad 2000 \mathrm{~m} \quad 3000 \mathrm{~m} \quad 4000 \mathrm{~m}$

Atlantischer Ozean, $30^{\circ} \mathrm{W}$

\begin{tabular}{|c|c|c|c|c|c|c|c|c|c|c|}
\hline $60^{\circ} \mathrm{N}$ & $8,3^{0}$ & $7,3^{0}$ & $7,2^{0}$ & $6,4^{0}$ & $5,5^{0}$ & $5,0^{0}$ & $4,6^{\circ}$ & - & - & - \\
\hline 50 & 13,0 & 10,9 & 9,2 & 8,3 & 5,3 & 4,8 & 3,8 & $3,0^{\circ}$ & $2,5^{\circ}$ & - \\
\hline 40 & 18,1 & 14,9 & 14,0 & 12,4 & 10,7 & 8,6 & 7,0 & 3,7 & - & - \\
\hline 50 & 21,6 & 19,2 & 17,3 & 14,8 & 11,3 & 8,5 & 7,5 & 3,6 & 2,9 & $2,5^{\circ}$ \\
\hline 20 & 23,6 & 20,5 & 17,9 & 13,5 & 10,0 & 7,5 & 6,6 & 3,8 & 2,7 & 2,4 \\
\hline 10 & 25,9 & 17,8 & 12,0 & 9,4 & 6,8 & 5,5 & 4,8 & 3,3 & 2,6 & 2,5 \\
\hline 0 & 26,3 & 16,3 & 12,6 & 7,7 & 5,1 & 4,4 & 4,1 & 3,3 & 2,5 & 1,5 \\
\hline 10 & 26,3 & 24,3 & 14,0 & 8,4 & 5,4 & 3,8 & 3,6 & 3,0 & 2,5 & 1,6 \\
\hline 20 & 24,7 & 21,9 & 16,6 & 12,5 & 6,0 & 3,9 & 3,7 & 2,8 & 2,4 & 1,5 \\
\hline 30 & 20,3 & 17,5 & 15,0 & 11,5 & 8,3 & $\check{b}, 5$ & 3,7 & 2,8 & 2,1 & - \\
\hline 40 & 13,7 & 10,0 & 8,1 & 4,8 & 4,4 & 3,8 & 2,9 & 2,6 & 2,2 & 1,1 \\
\hline
\end{tabular}

Indiseher $\mathrm{Ozean}, 70^{\circ} \mathrm{O}$

$\begin{array}{rrrrrrrrrrrr}20 & \mathrm{~N} & 26,6 & 20,5 & \mathbf{1 7 , 0} & \mathbf{1 3 , 2} & \mathbf{1 2 , 0} & \mathbf{1 1 , 8} & - & - & - & - \\ 10 & & 28,0 & 22,8 & 14,2 & 11,7 & 10,4 & 8,9 & \mathbf{7 , 8} & \mathbf{3 , 3} & \mathbf{2 , 7} & \mathbf{1 , 9} \\ 0 & & \mathbf{2 8 , 3} & \mathbf{2 4 , 0} & 14,5 & 10,1 & 8,6 & 7,5 & 6,2 & 2,5 & 2,3 & 1,9 \\ 10 & \mathrm{~S} & \mathbf{2 6 , 7} & 22,5 & 17,1 & 10,9 & 9,4 & 6,9 & \mathbf{5 , 7} & 2,4 & 1,8 & 1,5 \\ 20 & & 24,3 & 22,6 & \mathbf{2 0 , 2} & \mathbf{1 4 , 0} & 9,5 & 7,0 & 4,8 & 2,4 & 1,7 & 1,3 \\ 30 & & 20,4 & 17,9 & 15,0 & 12,7 & \mathbf{1 0 , 8} & \mathbf{8 , 7} & \mathbf{6 , 0} & 2,4 & 1,7 & 1,3 \\ 40 & & 13,7 & 15,5 & 11,7 & 10,6 & 9,5 & 6,5 & \mathbf{5 , 0} & 2,4 & 1,6 & -\end{array}$

GroBer Ozean, $180^{\circ}$

$\begin{array}{rrrrrrrrrrrr}60 & \mathrm{~N} & 1,4 & 0,4 & 2,2 & 3,5 & (2,0) & (1,8) & (1,7) & (1,9) & - & - \\ 50 & 5,2 & 5,1 & 4,7 & 4,0 & 3,6 & 3,4 & 3,2 & 2,1 & 1,7 & 1,6 \\ 40 & 13,7 & 11,6 & 9,3 & 5,7 & 4,9 & 3,7 & 3,7 & 2,1 & 1,6 & 1,5 \\ 30 & 22,0 & 17,8 & 15,2 & \mathbf{1 1 , 3} & 6,2 & \mathbf{4 , 6} & 3,8 & 2,2 & 1,7 & 1,7 \\ 20 & & 25,8 & 23,1 & \mathbf{1 9 , 5} & 10,7 & 6,5 & 4,3 & 4,1 & 2,2 & 1,8 & - \\ 10 & & 27,3 & 19,0 & 10,6 & 8,8 & \mathbf{6 , 5} & 5,3 & 4,2 & 2,4 & 2,2 & 2,0 \\ 0 & & \mathbf{2 7 , 7} & \mathbf{2 7 , 5} & 16,7 & 8,9 & \mathbf{7 , 3} & 5,6 & \mathbf{4 , 6} & 2,4 & 2,1 & 2,0 \\ 10 & \mathrm{~S} & \mathbf{2 7 , 5} & 27,2 & \mathbf{2 2 , 5} & 11,6 & \mathbf{7 , 8} & 5,8 & 4,5 & 2,6 & 2,2 & - \\ 20 & & 25,1 & 23,8 & 21,1 & \mathbf{1 4 , 6} & \mathbf{8 , 5} & 6,5 & 4,4 & 2,6 & 2,2 & - \\ 30 & 20,7 & 17,1 & 16,0 & 12,2 & \mathbf{9 , 2} & \mathbf{7 , 8} & 5,5 & 2,5 & - & - \\ 40 & 16,1 & 13,4 & 12,4 & 9,3 & 8,1 & 6,4 & \mathbf{5 , 6} & \mathbf{2 , 7} & 1,8 & -\end{array}$

Aus diesen Tabellen ergibt sich für die Zone $40^{\circ} \mathrm{N}$ bis $40^{\circ} \mathrm{S}$ folgende mittlere Temperaturabnahme für je 100 Meter:

$\begin{array}{lllllllll}0 & 100 & 200 & 400 & 600 & 800 & 1000 & 2000 & 3000\end{array}$

$\begin{array}{cccccccccc}\text { Tiefenstufen m } & - & - & - & - & - & - & - & - & -\end{array}$

$\begin{array}{llllllllll}\text { Atlantischer Ozean } \quad 4,2^{0} & 3,7^{0} & 1,8^{0} & 1,5^{0} & 0,9^{0} & 0,4^{0} & 0,16^{\circ} & 0,07^{0} & 0,06^{0}\end{array}$

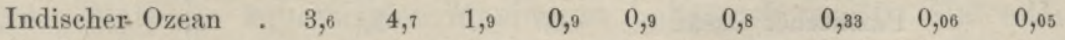

$\begin{array}{lllllllll}\text { Großer Ozean } \begin{array}{c}* \\ 2,8\end{array} \quad 4,1 & 2,8 & 1,6 & 0,8 & 0,5 & 0,1 & 0,05 & 0,01\end{array}$ 
Unterschicht von nahezu gleicher Temperatur und - fügen-wir hinzu - nahezu gleichem Salzgehalt. Innerhalb der Oberschicht liegt eine Sprungschicht, und zwar durchschnittlich (nach Sснотт) im Atlantischen Ozean in 25-80, im Indischen in 90-140 und im Großen Ozean in 110-180 m Tiefe; doch ist sie hier keineswegs eine so allgemein verbreitete Erscheinung wie in den Landseen, und gelangt nur dort zur Ausbildung, wo keine erhebliche Wellen- und Strombewegung eine Mischung der Wasserschichten herbeiführt. Jedenfalls beruht auch die ozeanische Sprungschicht auf vertikaler Wasserzirkulation; aber diese ist weniger eine Folge der täglichen Temperaturschwankung, die im Meer gering ist, als der jährlichen, vor allem aber eine Folge der Verdunstung, die das schwere Oberflächenwasser in die Tiefe führt.

Das Gesetz der Dreischichtung beherrscht den freien Ozean wie die Nebenmeere. Aber zum Unterschied von diesen erstreckt sich der Ozean über alle Klimagürtel, und seine einzelnen Teile stehen in mehr oder minder freier Verbindung miteinander. Diese beiden Momente wirken sich entgegen; an der Oberfläche herrscht noch der Unterschied der Breite, und die Temperatur bewegt sich noch in Differenzen von $35^{\circ}$, zwischen $32^{\circ}$ in einigen wenigen Teilen des tropischen Ozeans und $-3^{0}$ im Polarmeere. Das Bodenwasser der tieferen Becken ist dagegen überall nahezu gleich kalt und schwankt nur zwischen +3 und $-2,5^{\circ}$.

In der Ober- und Mittelschicht ist der südatlantische Ozean beträchtlich kälter als der südpazifische und der Indische Ozean, dagegen ist der nordatlantische in höherem Grad wärmer als der nordpazifische, ja zwischen 10 und $60^{\circ} \mathrm{N}$ ist er, wenn man die Durchschnittstemperatur der ganzen Wassermasse berücksichtigt; entschieden der wärmste Teil des ganzen Weltmeeres. $\times$ Nord- und südatlantischer Ozean stehen also in scharfem thermischen Gegensatz zueinander, wie aus Fig. 80 klar hervorgeht. Im Pazifischen Ozean ist dagegen der südhemisphärische Teil wärmer, was nach BRENNECKE's Vermutung mit seinem höhern Salzgehalt insofern in Verbindung steht, als salzreiches Oberflächenwasser rascher und tiefer untersinkt und einen energischen Konvektionsprozeß unterhält. Auch innerhalb eines und desselben

× Krüмmé hat folgende Mitteltemperaturen der gesamten Wassermaße berechnet:

Atlantischer Ozean

Indiseher Ozean

Pazifischer Ozean

Weltmeer

$90-0^{0} \mathrm{~N}$
$5,4^{\circ}$
6,6
3,7
4,3

4,3

$\begin{array}{cc}0-80^{\circ} \mathrm{S} & 90^{\circ} \mathrm{N}-80^{\circ} \mathrm{S} \\ 3,0^{\circ} & 4,0^{\circ} \\ 3,4 & 3,8 \\ 3,7 & 3,7 \\ 3,5 & 3,8\end{array}$


Parallels bestehen Gegensätze, wie' Fig. 79 versinnlicht. In der Richtung, in der sich die Strömungen bewegen, senken sich die Isothermen in die Tiefe, innerhalb der Tropen also nach Westen und innerhalb der gemäßigten Breiten nach Osten. Im nordatlantischen Ozean ist diese Erscheinung, am schärfsten ausgeprägt und nach KRÜммгеL dem aus dem Mittelländischen Meer kommenden Unterstrom zuzuschreiben, dessen Bahn sich nach den Salzgehaltsmessungen in
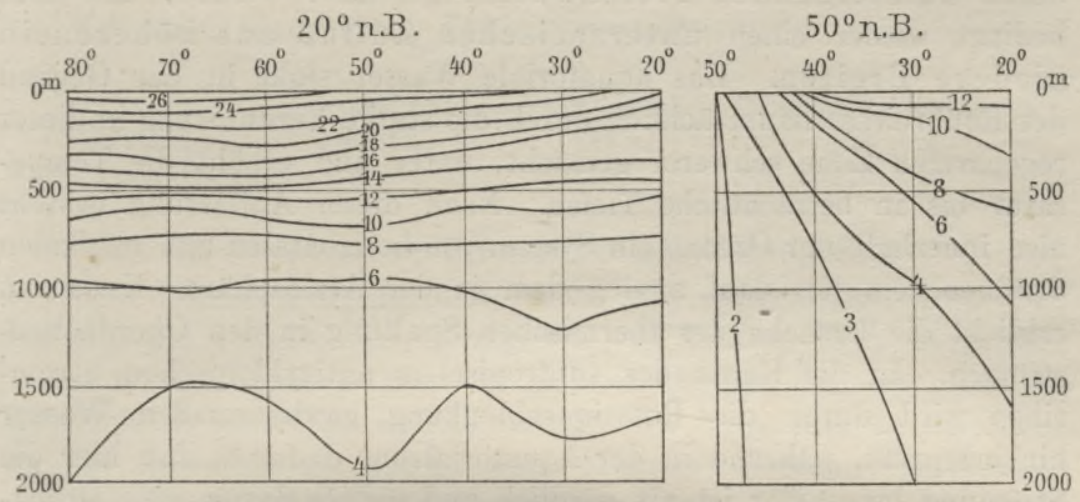

Fig. 79. Tiefenisothermen des nordatlantischen Ozeans in 20 u. $50^{\circ} \mathrm{B}$.

Nördiche Breite

Südliche Breite

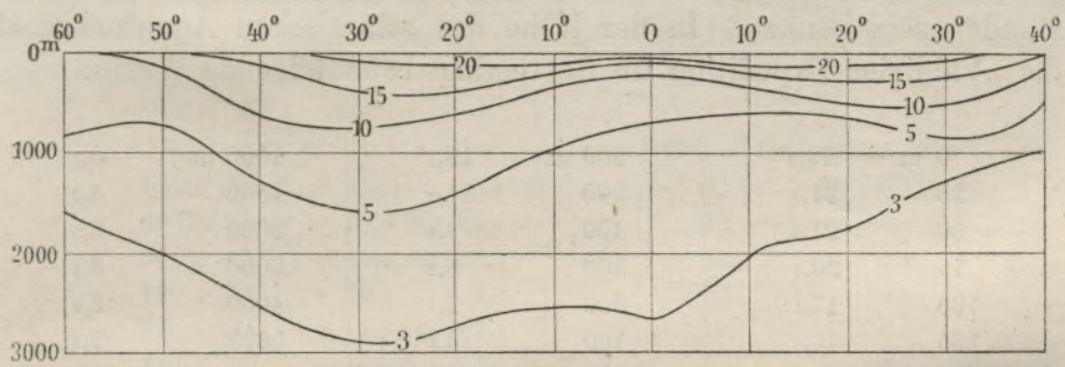

Fig. 80. Tiefenisothermen des Atlantischen Ozeans in $30^{\circ} \mathrm{W}$. L.

800 bis $1000 \mathrm{~m}$ Tiefe entlang der portugiesischen Küste und im Golf von Biskaya bis $53^{\circ} \mathrm{N}$ verfolgen läßt.

Im meridionalen Durchschnitt erreicht die Temperatur in der obersten Schicht ihr Maximum selbstverständlich in der Äquatorialzone, die tieferen Isothermen zeigen aber ein ganz anderes Verhalten. Sie senken sich vom Äquatorialgürtel bis in die Gegend der RoBbreiten und steigen erst dann in normaler Weise polwärts an. Statt des äquatorialen Maximums haben wir in 50-800 oder $1000 \mathrm{~m}$ Tiefe zwei Maxima, getrennt durch ein sekundäres 
äquatoriales Minimum. In der Unterschicht ist die Spaltung des Maximums überall verschwunden.

Sснотт, der auf diese Erscheinung mit dem größten Nachdruck aufmerksam gemacht hat, erklärt sie dadurch, daß die nach höheren Breiten umbiegenden Passatströmungen mehr Wasser vom Äquator fortführen, als durch die. schwachen nach dem Äquator fließenden Oberflächenströme ersetzt wird; es muß also noch weiterer Ersatz durch aufsteigendes Tiefenwasser geschafft werden, und dies bedingt wieder einen unterseeischen $\mathrm{ZufluB}$ aus höheren in niedere Breiten. Das äquatoriale Wasser sinkt in der Gegend der Roßbreiten, hauptsächlich durch die starke Verdunstung in dieser regenarmen Zone schwerer gemacht, unter und erhöht die Temperatur bis in beträchtliche Tiefen. Nach dieser Auffassung besteht also innerhalb der Ozeane ein System von horizontalen und vertikalen Strömen, ein Kreislauf analog dem in der Atmosphäre. KRÜMмEL erblickt die Ursache der thermischen Spaltung in den Oberflächenströmen. In die Kerne der subtropischen antizyklonischen Stromringe wird durch die Rotationsablenkung gewissermaßen Wasser hineingepreßt, während in der Äquatorialzone dadurch, daß hier die Strömung langsamer ist als nördlich und südlich davon, eine Druckentlastung eintritt und so das Tiefenwasser zum Aufsteigen veranlaßt wird. Wie dem auch sei, soviel ist gewiß, daß die niederen Tiefentemperaturen der tropischen Ozeane nicht an Ort und Stelle entstanden sein können. In der Nähe des atlantischen Äquators fand die „Valdivia“-Expedition im September 1898 folgende Werte:

\begin{tabular}{rl|lr|ll}
$0 \mathrm{~m}$ & $23,0^{0}$ & $200 \mathrm{~m}$ & $13,1^{0}$ & $1000 \mathrm{~m}$ & $5,2^{0}$ \\
25 & 21,9 & 300 & 11,0 & 1500 & 4,2 \\
50 & 21,6 & 400 & 9,4 & 2000 & 3,8 \\
75 & 20,1 & 500 & 8,2 & 3000 & 3,3 \\
100 & 17,1 & 600 & 7,4 & 4000 & 2,9 \\
125 & 16,0 & 700 & 6,8 & 5695 & 2,1 \\
150 & 15,1 & 800 & 6,1 & & \\
175 & 14,2 & 900 & 5,6 & &
\end{tabular}

Wir haben hier eine Wassermasse von $5600 \mathrm{~m}$ Mächtigkeit, deren Temperatur niederiger ist, als die tiefste hier mögliche Lufttemperatur, die nicht erheblich unter $20^{\circ}$ liegen dürfte. Wir schließen daraus, daß das Tiefenwasser aus höheren Breiten stammt, und daB es durch eine dauernde unterseeische Strömung beständig erneuert wird, da es sonst bereits eine höhere Temperatur hätte annehmen müssen. Sicher ist diese Strömung außerordentlich langsam und verrät sich nur dem Thermo- 
meter, aber trotzdem verdient sie diesen Namen, denn sie bewirkt eine Wasserversetzung.

Es kann auch keinem Zweifel unterliegen, daß das tropische Tiefenwasser antarktischen Ursprungs ist. Für den Indischen Ozean ist dies selbstverständlich, auch der Große Ozean ist im N so gut wie abgeschlossen, und wenn der Atlantische Ozean auch oberflächlich nach dieser Seite hin offen ist, so liegen doch die Verhältnisse hier viel ungünstiger als nach $\mathrm{S}$ zu. Das beweisen die von KrÜмmeL berechneten Zugangsdimensionen:

$\begin{array}{lccc} & \text { Zugangsbreite } & \text { Zugangstiefe } & \text { Zugangsquerschnitt } \times \\ \text { Arktische } & 1521 \mathrm{~km} & 585 \mathrm{~m} & 890 \mathrm{qkm} \\ \text { Antarktische. } & 9186 & 2740 & 25170\end{array}$

Noch viel bequemer ist der antarktische Zugang zu dem Großen und dem Indischen Ozean, und darauf mag es zurückzuführen sein, daß hier die Unterschicht, wenigstens von $2000 \mathrm{~m}$ Tiefe an, kälter ist als im Atlantischen Ozean in gleichen Breiten, trotzdem sich die Mittelschicht zum Teil anders verhält. In bezug auf das Bodenwasser verweisen wir auf Sir John Murray's Berechnungen, ${ }^{3}$ wenn sie auch zum Teil auf unsicheren Grundlagen beruhen. Innerhalb der gemäBigten und warmen Zonen, jedoch mit Ausschluß der Flachsee, verteilen sich die Areale der gesamten Meere der nördlichen und der südlichen Halbkugel, ausgedrückt in Prozenten der entsprechenden Gesamtflächen, auf die verschiedenen Bodentemperaturen, wie folgt:

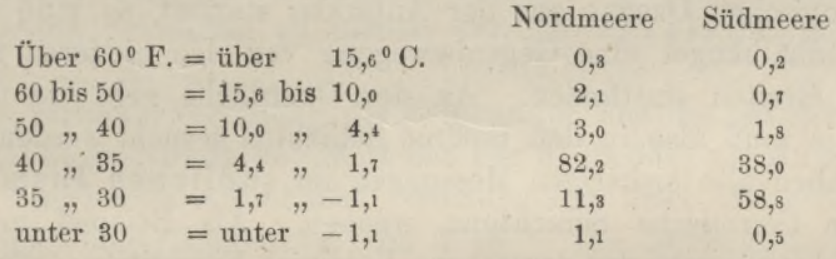

Deutlich geht daraus hervor, daß das kalte Bodenwasser vorwiegend ein Phänomen der südlichen Halbkugel ist.

Für die Verteilung der Bodentemperaturen ist das unterseeische Relief von größter Bedeutung. Im südatlantischen Ozean gliedern sich die beiden, durch die mittlere Schwelle getrennten Mulden in je zwei Depressionen, die ganz verschiedene Bodentemperaturen besitzen:

$\times$ Die Breite multipliziert mit der Tiefe. 
Westen: s. B.

Brasilianisches Becken (16 Messungen) $1-37^{\circ}$ Argentinisches Becken ( 9 Messungen) $\quad 34-42$

Osten:

Südafrikanische Mulde (13 Messungen) $4^{0} \mathrm{~N}-24$ Kap-Mulde (9 Messungen) . . . . . 26-42

Mittlere Mittlere Boden-

Tiefe, $m$ Temperatur $4600 \quad 1,0^{\circ}$ $4800 \quad 0,3$

$\begin{array}{ll}4600 & 2,4 \\ 4800 & 0,8\end{array}$

Solch eine Verteilung ist nur möglich, wo Querriegel dem antarktischen Tiefenwasser hemmend in den Weg treten. Die Existenz des Walfischrückens war schon durch die Temperaturmessungen außer Zweifel gestellt, ehe er auch durch Lotungen nachgewiesen wurde. Ja sogar die Höhe solcher Bodenanschwellungen können wir aus den Bodentemperaturen annähernd erschließen, denn nur das Wasser jener Schicht, die mit den unterseeischen Rücken in gleicher Höhe liegt, kann in die geschützten Becken eindringen. Das auffallendste Beispiel bieten die isolierten Bodensenkungen der westlichen Südsee und des Australasiatischen Mittelmeeres. In der Celebessee (zwischen dem Sulu-Archipel und Celebes) beträgt z. B. die Temperatur von $1460 \mathrm{~m}$ bis zum Boden (in $4755 \mathrm{~m}$ Tiefe) gleichmäßig $3,8^{\circ}$. Eine Barriere von $1190 \mathrm{~m}$ Tiefe sperrt nämlich das kältere Tiefenwasser des offenen Ozeans von dieser Bodensenkung ab. In der benachbarten, allseitig abgeschlossenen Sulusee, die nur indirekt durch die China- und die Celebessee mit dem Ozean in Verbindung steht, hat die Wassersäule von $730-4664 \mathrm{~m}$ Tiefe (Boden) sogar eine konstante Temperatur von $10,3^{\circ}$.

Die Polarmeere. Wenn es richtig ist, daB das Bodenwasser der tropischen Ozeane aus der Antarktis stammt, so muß auch auf der Südhalbkugel eine Gegenbewegung von den niederen nach den hohen Breiten stattfinden. An der Oberfläche geht sie nicht vor sich, sie muß also in den tieferen Schichten gesucht werden. In der Tat haben alle bisherigen Messungen im südlichen Eismeer eine strenge thermische Schichtung ergeben. Als Beispiel möge eine Beobachtungsreihe der deutschen „Valdivia“-Expedition (1898) in dem abnorm kalten Meeresgebiet bei der Bouvetinsel $\left(56^{\circ} \mathrm{S}, 14-16^{\circ} \mathrm{O}\right)$ dienen. Auf eine kalte Oberschicht (ungefähr $170 \mathrm{~m}$ ) folgt eine $1600 \mathrm{~m}$ mächtige warme Mittelschicht, und auf diese eine $2300 \mathrm{~m}$ mächtige kalte Bodenschicht, die aber im ganzen doch wärmer ist als die Oberschicht, $\times$ deren Temperatur durch Ausstrahlung und Eisbildung bestimmt wird. Die Mittelschicht ist eingewandert. Pettersson ${ }^{17}$

$\begin{array}{ccccccccccc}\times & & & & & & & & \text { (Boden) } \\ \text { Tiefe } \mathrm{m} & 0 & 50 & 100 & 175 & 300 & 400 & 1000 & 2000 & 3000 & 4090\end{array}$

Temp. ${ }^{0}-1,5-1,5 \quad-1,5 \quad+0,2 \quad+0,5 \quad+0,6 \quad+0,8 \quad+0,2 \quad-0,3 \quad-0,3$ 
sieht als das leitende Agens dieser Bewegung die Eisschmelze an und stützt sich dabei auf folgendes Experiment. Wird in ein GefäB mit Salzwasser an einem Ende ein Stück Eis eingetaucht, so entsteht eine dreifache Strömung: eine obere vom Eis weg, eine mittlere zum Eis hin und eine untere wiederum vom Eis weg. Dieser Vorgang wiederholt sich in der Natur am Rand des wenigstens $23000 \mathrm{~km}$ langen antarktischen Eisgürtels, von dem angenommen werden kann, daß er stellenweise in die warme Mittelschicht hinabreicht. DaB hier eine Oberflächenströmung vom Eis weg vorhanden ist, bezeugt die Trift des „Gauß". Sie ist zunächst bedingt durch den Dichteunterschied zwischen dem Polarwasser, dessen Salzgehalt durch das Eisschmelzwasser vermindert wird, und dem eisfreien Wasser der niederen Breiten. Die warme Mittelschicht entspricht dem zum Eis hinziehenden Strom, sie schmilzt das Eis, erkaltet dadurch, sinkt zu Boden und bewegt sich langsam als Kompensationsstrom nach Norden. Nach dieser Auffassung geht die kalte Bodenschicht aus der warmen Mittelschicht hervor, auch sie ist nicht autochthon. Wo unterseeische Bodenschwellen die Verbindung mit dem Ozean absperren, müssen wir andere Temperaturen finden, und in der Tat scheinen ein paar Messungen der schwedischen Südpolarexpedition darauf hinzudeuten. Am 24. November 1902 ergab eine Messung im Bransfieldsund zwischen der Deception- und der Livingston-Insel (ca. $62^{0} 50^{\prime} \mathrm{S}, 60^{1} /{ }^{0} \mathrm{~W}$ ) eine Bodentemperatur von $-1,65^{\circ}$ in $977 \mathrm{~m}$ Tiefe, am 15. Dezember fand man dagegen in $61^{\circ} 35^{\prime} \mathrm{S}, 53^{\circ} \mathrm{W}$ in $1631 \mathrm{~m}$ Tiefe nur $-0,4^{\circ}, \mathrm{d} . \mathrm{h}$. die normale Bodentemperatur des antarktischen Ozeans. Für die antarktischen Verhältnisse scheint Petrensson's Theorie somit eine befriedigende Erklärung zu bieten, für die arktischen versagt sie aber.

Die vertikale Verteilung der Temperatur und des Salzgehalts im e uropäischen Nordmeer führt uns Fig. 81 (S. 356) vor Augen. Die nach $\mathrm{O}$ abgelenkte Atlantische Strömung hat einen Salzgehalt von $35 \%$ und eine Temperatur von 4-8". Am norwegischen Rand wird sie von salzarmem Küstenwasser überlagert. Den Westen nimmt der Ostisländische Polarstrom mit geringerem Salzgehalt und niederer Temperatur ein. Den ganzen Bodenraum von 800 oder $1000 \mathrm{~m}$ Tiefe an erfüllt eine $3000 \mathrm{~m}$ mächtige Schicht von gleichmäßiger Temperatur $\left(-1,2\right.$ bis $\left.-1,3^{\circ}\right)$ und gleichmäBigem Salzgehalt $\left(34,9^{\%} \%\right.$. Stammt sie, wie man früher annahm, und wie Pettersson auf Grund seiner Eisschmelztheorie auch jetzt noch meint, aus dem innern Polarbecken und wird durch den Ostgrönländischen Polarstrom in das Nordmeer gebracht, wo sie sich unter die atlantische Schicht einschiebt? Dagegen spricht ihr hoher Salzgehalt, der entschieden auf 
atlantischen Ursprung hindeutet. Aber woher dann die tiefe Temperatur? NANSEN ${ }^{18}$ fand die Lösung des Rätsels in den Beobachtungen
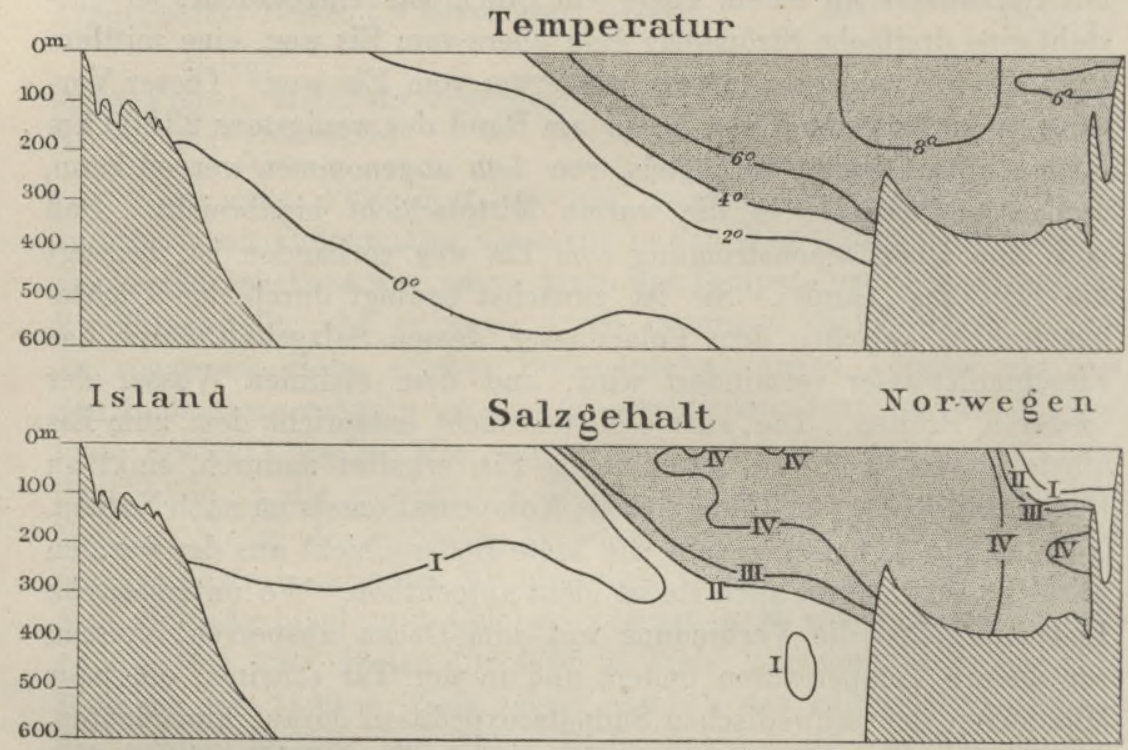

Fig. 81. Temperatur und Salzgehalt im europäischen Nordmeer zwischen Island und dem Sognefjord im Mai und Juni 1903 nach Helland-Hansen und Nassen. Isohalinen I $=34,9, \mathrm{II}=35,0, \mathrm{III}=35,1, \mathrm{IV}=35,2$ Promille Salzgehalt.

von Amundsen i. J. 1901. In dem wegen seiner eigentümlichen Eisverhältnisse den Walfischfängern schon lange bekannten Meeresraum zwischen 73 und $76^{\circ} \mathrm{N}$ und zwischen $4^{\circ} \mathrm{W}$ und $4^{\circ} \mathrm{O}$ ist das Wasser im Winter und Frühling von der Oberfläche bis zum Boden nahezu gleichmäßig kalt und salzig, und Temperatur und Salzgehalt entsprechen genau dem Bodenwasser des Nordmeeres (Station I in Tab. auf S. 357). Hier wird das durch die Atlantische Strömung nach N geführte Wasser einerseits durch Beimischung von Schmelzwasser der westlichen Polarströmung etwas verdünnt, anderseits erkaltet es durch Ausstrahlung an der Oberfläche, die kalten Schichten sinken unter, und das fortgesetzte Spiel auf- und absteigender Ströme verwandelt endlich die ganze Wassersäule in eine homotherme und homohaline Masse. Von da aus verbreitet sie sich über den Boden des Nordmeeres südlich von Jan Mayen, und über ihr breiten sich die leichteren polaren und atlantischen Wässer aus. Im $\mathrm{N}$ dieses merkwürdigen Kältegebiets fand Herzog Philipp von OrLĖans ${ }^{19}$ ähnliche Verhältnisse wie im Nordmeer (Station II in Tab. auf S. 357). Aber in das eigentliche arktische Becken gelangt die Amundsen'- 
Tabelle arktischer Beobachtungsreihen.

I.

$\begin{array}{lr}\text { G. B. } & 74^{\circ} 48^{\prime} \mathrm{N} \\ \text { G. L. } & 4^{\circ} 00^{\prime} \mathrm{W} \\ \text { Zeit } & \text { Juni } 1901 \\ \text { Autor } & \text { A A } 19 \text { Nose }\end{array}$

Temp. ${ }^{\circ}$ Salzgeh. $\%$

$\begin{array}{rcccc}0 \mathrm{~m} & +0,85 & \mathbf{3 4 , 3 4} & +0,88 & 32,77 \\ 20 & +0,26 & 34,37 & +3,26 & 34,82 \\ 50 & -0,92 & 34,79 & +2,07 & 34,89 \\ 100 & -1,10 & 34,88 & +1,62 & 35,00 \\ 200 & -1,01 & 34,90 & +1,11 & 34,99 \\ 300 & -1,07 & 34,90 & +0,66 & 34,98 \\ 400 & -1,07 & 34,89 & +0,24 & 34,95 \\ 500 & -1,21 & 34,90 & -0,59 & 34,92 \\ 600 & -1,24 & 34,90 & -0,77 & 34,94 \\ 700 & -1,25 & - & - & - \\ 800 & -1,25 & 34,91 & -0,84 & 34,93 \\ 1000 & -1,29 & 34,91 & -0,95 & 34,90 \\ 1200 & -1,30 & 34,89 & -1,10 & 34,92 \\ 1800 & - & - & -1,16 & 34,92 \\ 2000 & -1,30 & 34,90 & - & - \\ 2925 & - & - & -1,30 & -\end{array}$

II.

$77^{\circ} 25^{\prime} \mathrm{N}$

$4^{\circ} 03^{\prime} \mathrm{W}$

Juli 1905

Herzog v. OrLÉANS

Temp. ${ }^{\circ}$ Salzgeh. $\%$

Temp. ${ }^{\circ}$ Salzgeh. $\%$

$-1,70 \quad 32,05$

$-1,77 \quad 32,39$

$-1,90$

$-1,88 \quad 34,26$

$+0,78 \quad 34,87$

$+1,04 \quad 35,1+$

$+0,87 \quad 35,18$

$+0,64 \quad 35,14$

$+0,58 \quad 35,23$

$+0,28 \quad 35,23$

$+0,08 \quad 35,31$

$-0,23 \quad 35,18$

$-0,40 \quad 35,24$

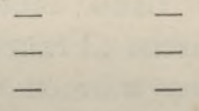

sche Tiefenströmung nicht, vielleicht gehindert durch einen Querriegel, wie ihn NANSEN in $81^{\circ}$ B. annimmt (vgl. S. 269). Station III in obiger Tabelle zeigt eine große Ähnlichkeit mit der antarktischen „Valdivia“-Reihe, die wir auf S. 354 angeführt haben. Trotzdem kann die Petrensson'sche Theorie hier keine Anwendung finden, weil die Grundbedingung, ein bis in die warme Mittelschicht hinabreichender Eisrand, fehlt. Diese Schicht ist, wie ihr Salzgehalt erweist, nichts anderes als der wegen seiner höheren Dichte untergetauchte Ausläufer des Atlantischen Stromes, dem wir als Oberflächenströmung zum letzten Mal an der Westküste von Spitzbergen begegnet sind. Nach unten nimmt seine Temperatur ab und sinkt sogar unter $0^{\circ}$, aber sein Salzgehalt zeugt unzweifelhaft für seine atlantische Herkunft. Selbst in den größten Tiefen von 2100 bis $3800 \mathrm{~m}$ fand Nansen nur Temperaturen von $-0,7$ und $-0,8^{0}$, also viel wärmeres Wasser als nördlich von Island. Immerhin bleibt es ein Problem, wie sich das atlantische Wasser in diesen Tiefen, abgeschlossen von dem Einfluß des Polarklimas und trotz der Erdwärme soweit abkühlen konnte. Diese Temperaturen müssen, wie NANSEN $^{18}$ jetzt vermutet, irgendwo an der Oberfläche entstanden sein, in gleicher Weise wie die des Nordmeer-Bodenwassers im 
AxundSEN'schen Gebiet. Als Ursprungsstätten nimmt er das Meer nördlich von Spitzbergen und in der Nachbarschaft des nördlichen Teiles von Nowaja Semlja an. Eine völlig befriedigende Lösung aller dieser polaren Rätsel muß man indes der Zukunft überlassen. -

Aus unseren Betrachtungen der vertikalen Temperaturverteilung haben wir die Überzeugung gewonnen, daß die Oberflächenströmungen nur ein Zweig der großen ozeanischen Wasserzirkulation sind, und daB ein anderer Zweig in den Tiefen des Weltmeeres liegt. Wie sie sich zu einem großen Ganzen zusammenschließen, auch das kann uns erst die Zukunft enthüllen.

Das Meereis. ${ }^{20}$ Während die übrigen Meere die Kontinente mehr verbinden als trennen, sind die Polarmeere, als der Schauplatz einer ausgedehnten und regelmäBigen Eisbildung, auch für das tauglichste Schiff ein ernstliches Verkehrshindernis, das jeder Berechnung spottet. Traurige Erfahrungen haben den Glauben an ein offenes arktisches Meer zerstört, und wenn NoRDENskiöLD noch daran festhielt, daß es kaum jemals bis in bedeutendere Tiefe und abseits vom Land dauernd gefriere, so wissen wir jetzt durch die norwegische „Fram"-Expedition, daß sich auch der offene Ozean trotz seines warmen Unterstroms mit Eis bedeckt. Allerdings wurden jenseits des sibirischen Küsteneises auch im Winter breite eisfreie Stellen (sog. Polynja) beobachtet, aber von praktischem Wert sind weder diese noch die sommerlichen Kanäle, denn launenhaft verschließen sie sich dem einen Schiff, während sie sich dem anderen öffnen. Wie viele Opfer hat es gekostet, ehe man den Gedanken aufgab, durch die Nordwestpassage in den Stillen Ozean zu gelangen; und wenn auch die Nordostpassage von NordenskiöLD glücklich überwunden wurde, so bleibt doch auch diese ruhmreiche Tat ohne praktische Folgen für den atlantisch-pazifischen Verkehr. Wohl ist NANSEN als Sieger aus dem Kampf mit dem Schrecken des inneren Polarmeeres hervorgegangen, aber nur durch eine sinnreiche Schiffskonstruktion, die es ihm ermöglichte, sich ohne Schaden passiv der Eistrift zu überlassen. Ob Makanow's Eisbrecher, ${ }^{21}$ der in der Ostsee gute Dienste leistet, sich auch im Herzen des Eismeeres bewähren würde, bleibt wenigstens zweifelhaft, aber auch im bejahenden Fall würde er ebenso wie ein Schiff von der Bauart des „Fram". nur zu wissenschaftlichen Zwecken verwendbar sein.

Die marine Eisbildung ist auch von hoher klimatischer Bedeutung, denn das Eis verhält sich gegen die Wärme annähernd wie Land, erkaltet also im Winter durch Ausstrahlung rasch und intensiv und ruft Barometermaxima und polare Winde hervor, während es 
in der sommerlichen Tauperiode Wärme verbraucht und dadurch ebenfalls abkühlend auf die Umgebung wirkt.×

Eisbildung von polarem Charakter findet auch im Beringund im Ochotskischen Meer und in der Hudsonbai statt. Auch das Asow'sche Meer und die Ostsee nördlich von der Linie Stockholm-Ösel gefrieren jeden Winter teilweise oder ganz, was offenbar durch den geringen Salzgehalt begünstigt wird. Küsteneis ist eine häufigere und verbreitete Erscheinung, z. B. im nördlichen Schwarzen Meer und im Bosporus; im Winter 1903 blockierte es sogar die Bucht von Saloniki. ${ }^{22}$

Das Eis der Polarmeere besteht aus Eisbergen, Flußeis, das aber nur in den sibirischen Küstengegenden einige Bedeutung gewinnt, und Eisfeldern. Die ersteren stammen fast ausschließlich von Gletschern her (s. S. 288), doch können auch Teile der aufgebrochenen Eisdecke eines Flusses durch Aufeinanderpressung wahre Berge bilden und wie das Gletschereis Gesteinsmaterial mit sich führen. Das Eisfeld ist marinen Ursprungs, kann aber, besonders im südlichen Eismeer, durch Schneefälle noch bedeutend verstärkt werden; Stücke davon nennt man je nach ihrer Größe Flarden, Schollen oder Brocken. Die Vorposten gegen das offene Meer bilden lose Eismassen, das sog. Treibeis, während das innere Polarmeer mit schwerem Packeis besetzt ist, das jedoch auch keine ununterbrochene Eismasse bildet. Vielmehr werden die einzelnen größeren und kleineren Felder durch Stellen offenen Wassers, sog. Waken, voneinander getrennt.

Verfolgen wir nun die Bildung und Umformung des Polareises an der Hand der klassischen Schilderungen von Weyprecht, ${ }^{23}$ Nansen, ${ }^{24}$ v. DrygaLski ${ }^{25}$ u. a. Beim Beginn der kalten Jahreszeit ist noch altes Eis vorhanden, dazu kommt nun neue Eisbildung. Vom Sommer her besitzt das Polarmeer ein gewisses Wärmequantum, das ihm durch warme Strömungen, durch das Schmelzwasser des Eises, und (auf unserer Hemisphäre) durch die Flüsse zugeführt wurde. Die erkalteten Oberflächenschichten sinken unter, die warmen steigen in die Höhe. Eigentlich könnte die Eisbildung erst beginnen,

$\times$ Die Naxsex'sche Nordpolarexpedition hat interessante Temperaturmessungen im Eis veranstaltet, über die in Bd. VI der ,Seientific Results" berichtet wird.

$\begin{array}{cccccc} & \text { Winter } & \text { Frühling } & \text { Sommer } & \text { Herbst } & \text { Jahr } \\ \text { Luft . . . } & -36,7^{\circ} & -19,5^{\circ} & -2,5^{\circ} & -19,7^{\circ} & -19,6^{\circ} \\ \text { Eis, Oberfläche } & -28,3 & -16,9 & -1,7 & -13,1 & -15,0 \\ \text { " } 3 \text { m Tiefe . } & -5,9 & -7,0 & -2,3 & -1,2 & -4,1\end{array}$

Die Wassertemperatur an der Oberfläche des Polarmeeres war selbst im Winter nur $-1,6^{\circ}$. 
wenn die ganze Wassermasse unter $-2{ }^{1} / 2^{0}$ abgekühlt ist, aber in der Tat gefriert das Wasser an der Oberfläche schon, ehe die warmen Schichten heraufkommen. Bei rascher Eisbildung an der Oberfläche wird nur ein Teil des Salzgehaltes ausgeschieden; bei langsamer, nach unten fortschreitender aber nahezu der ganze; dadurch werden die nächsten Schichten salzreicher, ihr Gefrierpunkt wird herabgesetzt und die vertikale Zirkulation geht rascher vor sich. In den ersten Stunden wächst das Eis schnell, dann immer langsamer. ${ }^{26}$ Erfahrungsgemäß beträgt die gröBte Dicke des in einem arktischen Winter gebildeten Eises nur 2-3 m, in der Antarktis, wo das Wasser wärmer und salziger ist, sogar nur 1

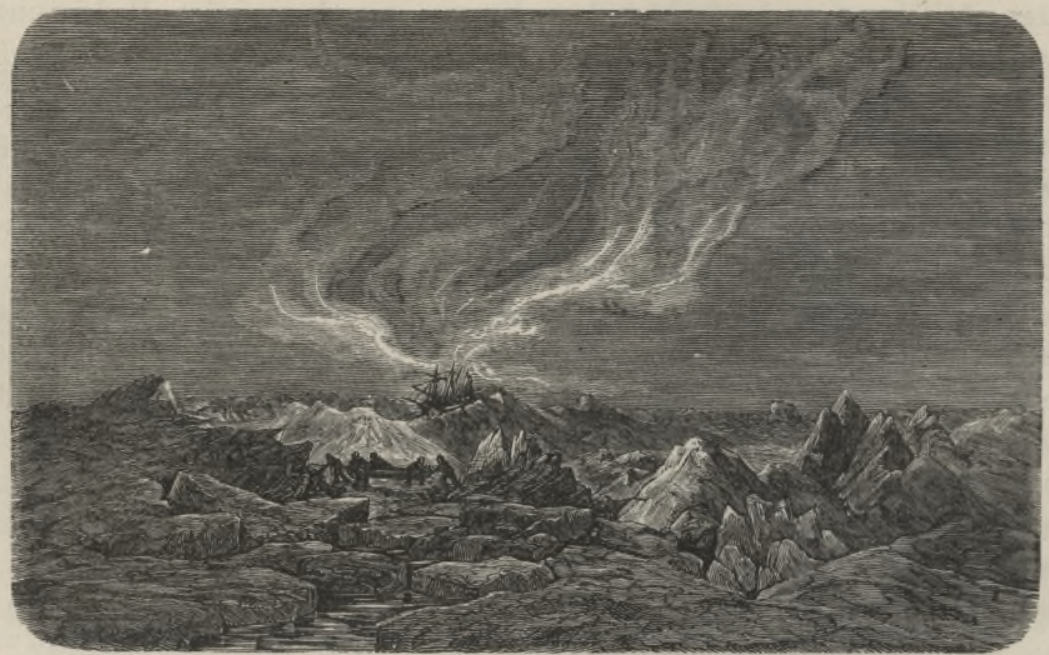

Fig. 82. Eispressung nach PAYER.

bis $1^{1} / 2 \mathrm{~m}$. Ursprünglich hat es eine glatte Oberfläche, aber bald entstehen infolge der Bewegung der Felder durch Wind und Gezeiten, infolge von Gleichgewichtsstörungen und Temperaturdifferenzen zwischen Luft und Wasser Risse und Sprünge. Sofort schieBt in den Öffnungen Wasser empor und treibt die Stücke der Felder auseinander, wird aber bald selbst von jungem Eis bedeckt. Das Meerwasser hat die Eigentümlichkeit, sich beim Erkalten auszudehnen, und gewinnt nach Pettersson erst bei $-20^{\circ}$ ein 'stabiles Volumen. Dadurch und durch das Über- und Untereinanderschieben der hin und her getriebenen Felder entstehen die gefürchteten Eispressungen (Fig. 82), denen besonders in der Arktis schon viele Schiffe zum Opfer gefallen sind, während die Antarktis, wo keine Landumrahmung den freien Abfluß des Eises hindert, in dieser Beziehung weniger gefährlich ist. Durch Regelation und Ausfüllung der 
Zwischenräume mit Schnee verwachsen die aufeinandergepreßten Stücke zu kompakten Massen von mehreren Meter Höhe, die man in Sibirien ToroB nennt. Aber auch jetzt sind dem Wachstum Grenzen gesteckt: nach unten, wenn das Eis den Taupunkt erreicht, und auch nach oben, denn je massenhafter es wird, desto seltener werden Brüche und Überschiebungen. Gewachsenes (nicht aufgetürmtes) Eis, das NANSEN beobachtete, erreichte höchstens eine Mächtigkeit von 4,21 m und im Durchschnitt nur eine solche von $3-3^{1} / 2 \mathrm{~m}$. WEXPRECHT hält eine Maximalmächtigkeit von $10 \mathrm{~m}$ für möglich. Westlich von Grönland kommt allerdings dickeres Eis vor, z. B. $15 \mathrm{~m}$ dickes an der Westküste der Prinz-Patrick-Insel und sogar $25 \mathrm{~m}$ dickes im Smithsund, und die englischen Polarforscher halten noch an der Vorstellung fest, daß ein fundamentaler Unterschied zwischen den Eisbildungen im westlichen und östlichen Polarbecken bestehe. Zwar ist die Behauptung, daß es auf der amerikanischen Seite keine offenen Kanäle gäbe, durch PEARY's Erfahrungen widerlegt worden, aber man beruft sich darauf, daB keine Strömung das Eis in Bewegung setze, daB es jahraus jahrein am Außenrand des Parry-Archipels verharre und dadurch eine enorme Mächtigkeit gewinne. NANSEN erklärt dagegen die Entstehung dieses sog. paläokrystischen Eises lediglich durch 'Aufeinanderhäufung gestauter Schollen, als eine Erscheinung also, die nur an die Küstenzone des inselreichen amerikanischen Polarmeeres mit seinem mangelhaften $A b f l u B$ gebunden ist. Auch IsACHSEN ${ }^{27}$ ist dieser Ansicht und verweist besonders auf die stauende Wirkung der gewaltigen Eisberge, die die Gletscher am Petermann- und Sherard-Osborn-Fjord in den Kennedy- und Robeson-Kanal entsenden.

Von dieser Art ist also das winterliche Packeis: ein beständig sich bewegender und umformender Trümmerhaufen aus altem und jungem Eis, dessen Oberfläche außerdem durch Schneestürme fortwährend verändert wird. Ihre Unebenheit macht auch weite Schlittenreisen schwierig.

Ende Mai beginnt es in den arktischen Gegenden zu tauen. Die steigende Temperatur, vor allem aber Nebel und Regen beschleunigen diesen ProzeB. Seen und Flüsse entstehen, die dem Meer Süßwasser zuführen. Indem sich dieses über dem schwereren Salzwasser, dessen Temperatur noch ungefähr $-1,5^{\circ}$ ist, ausbreitet und die Spalten erfüllt, gefriert es, so daß das Eis durch Ansatz von unten noch bis Mitte August wächst. Dagegen erleidet.es andere wichtige Veränderungen. Die Waken erweitern sich zu Kanälen, und Schollen und Brocken schwimmen darin herum. Die Polarströmungen führen die losen Massen in wärmere Gegenden. 
Die äquatoriale Treibeisgrenze (s. Karte XIV) schwankt auf der südlichen Halbkugel zwischen $56^{\circ}$ B. im Süden von Amerika und $35^{\circ}$ B. am Kap der guten Hoffnung, Scholleneis gelangt jedoch nach KrÜмmes nur im Gebiet der Bouvetinsel bis $53^{\circ}$ B., und das Eis, denen die Schiffe in niederern Breiten begegnen, sind wahrscheinlich nur verkümmerte Eisberge. Jedoch überschreitet selbst das Packeis unter dem Greenwicher Meridian den 50. Parallel, d. h. die Breite von Prag! ${ }^{28}$ Echtes arktisches Treibeis betritt nur den westlichen Atlantischen Ozean, ${ }^{29}$ während kein Eisstück die Atlantische Strömung bis über den 70 . Breitengrad hinauf zu passieren vermag. $\times$

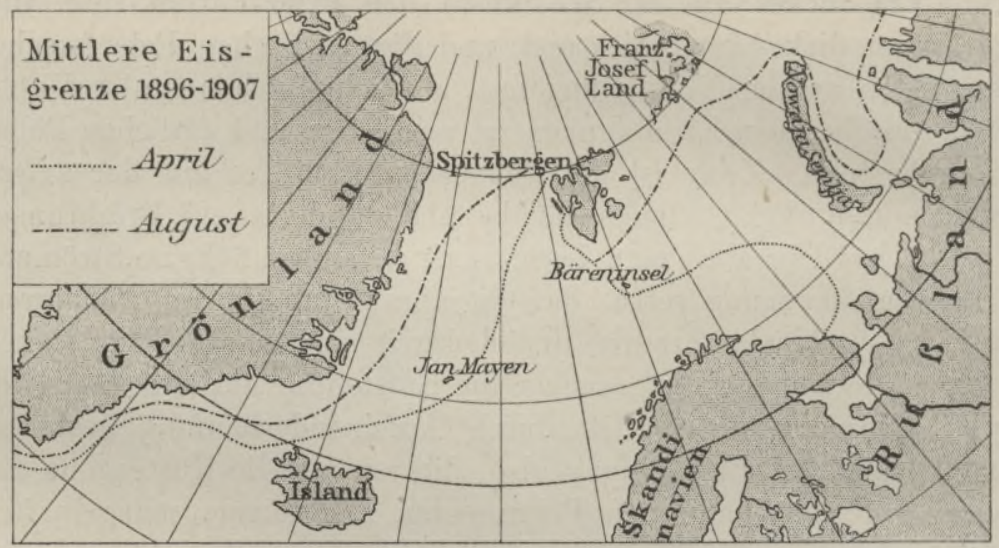

Fig. 83. Verschiebung der Eisgrenze im nordatlantischen Ozean von Ende Winter (April) bis Ende Sommer (August) nach Mossman. ${ }^{30}$

Nach einer allerdings nicht ganz sicheren Berechnung von BöRGEN ist am Ende der warmen Jahreszeit $1 / 3$ der Gesamtoberfläche des Eisgebietes eisfrei (vgl. Fig. 83). Aber der kurze Sommer vermag nicht alles zu zerstören, was der lange Winter geschaffen hat. Es müßte sich daher in den Polarmeeren immer mehr Eis anhäufen, wenn es nicht tatsächlich nur so lange wachsen würde, bis die winterliche Zunahme dem sommerlichen Verlust das Gleichgewicht hält.

Die Erfahrung lehrt, daß die Eisgrenzen von Jahr zu Jahr großen Schwankungen unterworfen sind. Das dänische Meteorologische Institut hat sich die Aufgabe gestellt, alle darauf bezüglichen Nachrichten systematisch zu sammeln und kartographisch zu

$\times$ Unter der Annahme einer mittlern Eismächtigkeit von $5 \mathrm{~m}$ hat KrüмmEL berechnet, daß jährlich rund $20000 \mathrm{ckm}$ Scholleneis aus dem nördlichen Eismeer herausgeführt werden, und zwar $12700 \mathrm{ckm}$ durch den Ostgrönländischen Polarstrom, 5000 aus der Baffinbai und 2000 aus der Barentssee. 
verarbeiten, so daß wir hoffen dürfen, in einigen Jahren einen tieferen Einblick in die wechselnden Bedingungen der arktischen Werkstatt zu gewinnen. Jetzt können wir nur im allgemeinen sagen, daß die Schwankungen weniger von der Sommerwärme, als von den Windund Strömungsverhältnissen innerhalb des ganzen Polarbeckens abhängen; daher sind auch im arktischen Meer die Ostküsten stärker belagert als die westlichen, die Nordküsten stärker als die südlichen.

Literaturnachweise. ${ }^{1}$ Die umfangreichsten thermischen Karten- und Tabellenwerke sind das Valdiviawerk, Bd. I, (G. Sснотт, s. S. 276, Anm. 1) und als Ergänzung dazu G. Sснотт und F. Scно, Die Wärmeverteilung in den Tiefen des Stillen Ozeans, in den Annalen der Hydrographie usw. 1910. W. KöPPEN, Jahresisothermen und -isanomalen der Meeresoberfläche, in den Annalen der Hydrographie und marit. Meteorologie, 1898. $-{ }^{2}$ W. Köppen, Das Verhältnis der Temperatur des Wassers und der Luft an der Oberfläehe des Ozeans, in den Annalen der Hydrographie u. maritimen Meteorologie, 1893. ${ }^{3}$ G. Sснотт, Die jährliche Temperaturschwankung des Ozeanwassers, in PeterMaNs's Mitteilungen, 1895 (Karte des Unterschiedes der extremen Monatsmittel). Sir John Murrax, On the Annual Range of Temperature in the Surface Waters of the Ocean, im Geographical Journal, Bd. XII, 1898 (Karte des Untersehieds der absoluten Extreme in den Monaten Februar und August. Die Ergänzung bilden die Karten der Verteilung dieser Extreme in Sir John Murrax, On the Temperature of the Floor and of the Surface Waters of the Ocean, im Geographical Journal, Bd. XIV, 1899). - ${ }^{4}$ F. A. Fores, Handbuch der Seenkunde; Stuttgart 1901. $-{ }^{5} \mathrm{~K}$. Grissinger in Petermanx's Mitteilungen, 1892, S. 153. 6 O. Frhr. v. v. z. Aursess in Petermann's Mitteilungen, 1905, S. 258. ${ }^{7}$ E. M. Wedderburn, The Temperature of the Fresh-Water Lochs of Scotland, in den Transactions of the Royal Society of Edinburgh, Bd. XLV, 2. Teil, 1907. - ${ }^{8}$ Sir John Murray, im Seottish Geographical Magazine, 1888, S. 345. ${ }^{9}$ E. M. WEDDERBURN, An Experimental Investigation of the Temperature Changes occuring in Fresh-Water Lochs, in den Proceedings of the Royal Society of Edinburgh, Bd. XXVII, 1907. - ${ }^{10}$ W. Halbrass, Die Thermik der Binnenseen und das Klima; in Petermans's Mitteilungen, 1905. - ${ }^{11}$ Wichtiges Werk über die Eisbildung in Binnenseen: A. HoLMsen, Isforholdene ved de norske indsjer; Kristiania 1902. - ${ }^{12}$ Ed. Brückner, Thermik der Alpenseen, in der Geographischen Zeitschrift 1909. - ${ }^{13}$ Berichte der Kommission für Erforschung des östlichen Mittelmeeres, in den Denkschriften der Wiener Akademie der Wissenschaften, Mathem.-naturwiss. Klasse, Bd. LIX-LXI, 1892-94. - ${ }^{14} \mathrm{~J}$. B. SPINDLER und F. F. Wranger, Materialien zur Hydrographie des Schwarzen und Asow'schen Meeres; St. Petersburg 1899 (Russisch). $-{ }^{15}$ O. KrüMmrer, Zur Physik der Ostsee, in Petermann's Mitteilungen, 1895. - ${ }^{16}$ A. Buchan, Report on Oceanic Circulation, Appendix zum Challenger-Report, 1895. Temperaturkarten von 0-1000 Faden Tiefe für je 100 Faden, dann für 1500 und 2200 Faden und größere Tiefen. Zuverlässiger sind die Tiefentemperaturkarten von G. Sснотт s. o. Anm. 1. - ${ }^{17}$ 0. Petrersson, Über Meeresströmungen, Berlin 1908. ${ }^{18}$ F. Nansen, zit. S. 338, Anm. 23; vgl. auch Anm. 22. - ${ }^{19}$ Due d'Orléans, Croisière océanographique acemplie à bord de la Belgica dans la mer du Grönland 1905, Brüssel 1907. - ${ }^{20}$ L. Mecking, Das Eis des Meeres, Berlin 
1909. - ${ }^{21}$ J. Makarow, Der „Jermak“ im Eis; St. Petersburg 1901 (russisch). ${ }^{22}$ Über dieses merkwürdige Ereignis vgl. A. Philrppson in Petermann's Mitteilungen, 1903, S. 91. - ${ }^{23}$ K. Wexprecht, Die Metamorphosen des Polareises; Wien 1881. - ${ }^{24}$ F. Naxsen, In Nacht und Eis, Leipzig 1897. Eine Zusammenstellung der Ergebnisse in Petermanx's Mitteilungen, 1897 S. 158. - ${ }^{95}$ E. v. Drygalski, Zum Kontinent des eisigen Südens, Berlin 1904. - ${ }^{96}$ H. Arctowski, Die antarktischen Eisverhältnisse (Ergänzungsheft Nr. 144 zu Pemermanx's Mitteilungen; Gotha 1903), S. 74. - ${ }^{27}$ G. Isachsen, Das paläokrystische Eis, in Petermann's Mitteilungen, 1906; eine zusammenfassende Darstellung dieses Gegenstandes. - ${ }^{28}$ K. Fricker, Die Entstehung und Verbreitung des antarktischen Treibeises; Leipzig 1893. - ${ }^{29}$ W. Mernardus, zit. S. 338, Anm. 29; L. Mескілg, Die Treibeiserscheinungen bei Neufundland in ihrer Abhängigkeit von Witterungsverhältnissen, in den Annalen der Hydrographie usw. 1907. ${ }^{30}$ R. C. Mossman, The Greenland Sea, im Scottish Geographical Magazine 1909. 


\section{Vierter Abschnitt. \\ Dynamik des Landes. ${ }^{1}$}

Die Hauptformen der Dislokationen. ${ }^{2}$

Als endogene Wirkungen, d. h. als Wirkungen von Kräften, die ihren Sitz im Erdinnern haben, wurden auf S. 18 Niveauveränderungen und vulkanische Ausbrüche genannt.

Die Niveauveränderungen, oder um genauer zu sprechen, die endogenen Niveauveränderungen können wir nach verschiedenen Gesichtspunkten einteilen:

1. der Zeit nach in instantane, die plötzlich eintreten, und in säkulare, deren Wirkungen erst nach längeren Zeiträumen zur Wahrnehmung gelangen;

2. der Ausdehnung nach in regionale oder ausgedehnte und in lokale oder örtlich beschränkte. Eine scharfe Grenze ist zwischen beiden in der Theorie nicht zu ziehen, in der Praxis wird man aber selten im Zweifel sein, welcher Kategorie man die beobachtete Niveauveränderung zuzuzählen hat.

Alle diese Veränderungen müssen mit Verschiebungen der oberen Krustenteile oder Dislokationen verbunden sein, wenn wir auch, diese nicht immer nachweisen können. Die Dislokationen können in horizontaler oder vertikaler Richtung erfolgen. Die letztern, die eigentlichen formenbildenden Vorgänge, sind wieder zweierlei Art: Verwerfungen oder Biegungen.

1. Unter Verwerfung versteht man jede Vertikalschiebung ursprünglich zusammenhängender Schichtenteile längs einer Bruchspalte (Fig. 84). Sie kann in horizontalen wie in geneigten Schichten vorkommen; die Verwerfungs-

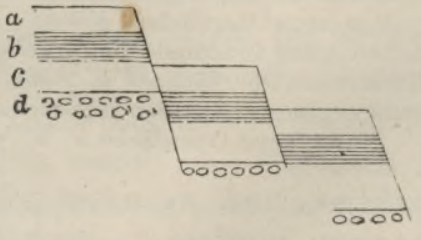

Fig. 84. Verwerfungen. spalte kann verschiedene Lagen zum Horizont einnehmen, die Art der Verschiebung wie ihr $\mathrm{MaB}$ - die sogenannte Sprunghöhe - kann eben- 
falls sehr verschieden sein. Häufig treten Verwerfungsspalten in beträchtlicher Ausdehnung und in großer Zahl auf und zerlegen einen Schichten-

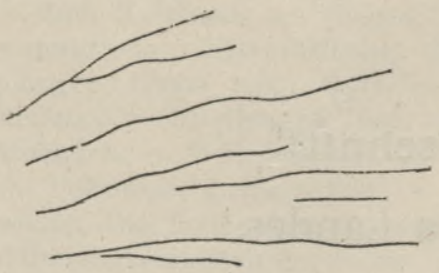

Fig. 85 .

Tafelbrïche nach HerM.

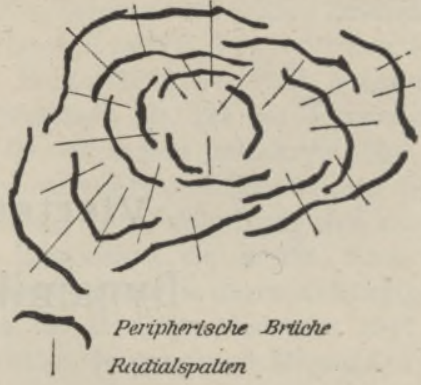

Fig. 86.

Bruchnetze nach Hегм.

komplex in einzelne Schollen. Sie verlaufen dabei mehr oder weniger parallel, als sogenannte Tafelbrüche (Fig. 85), oder sie bilden

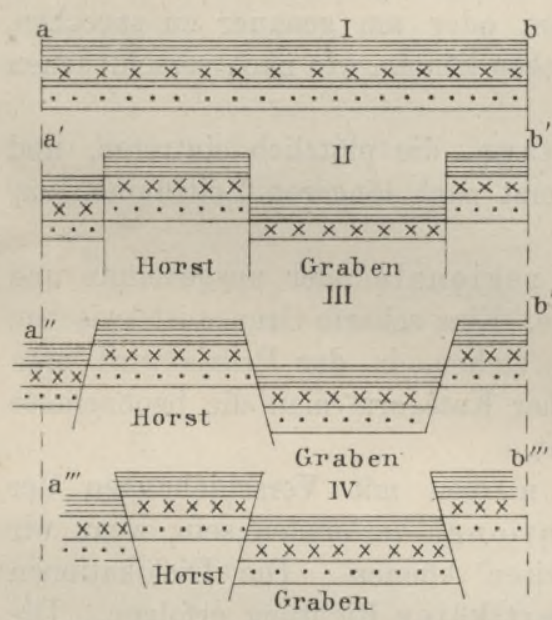

Fig. 87. Schema der Schollenbewegungen. $I$ Ursprüngliche Lagerung ( $a b$ Oberfläche), II Schollenbewegung an senkrechten Bruchspalten (neue Oberfläche $a^{\prime} b^{\prime}=a b$ ), $I I I$ Schollenbewegung an ausfallendenBruchspalten am Horst (neue Oberfläche $a^{\prime \prime} b^{\prime \prime}>a b$ ), $I V$ Schollenbewegung an einfallendenBruchspalten am

Horst (neue Oberfläche $a^{\prime \prime \prime} b^{\prime \prime \prime}<a b$ ). Bruchnetze, die aus einem System sich durchkreuzender peripherischer Brüche und $\mathrm{Ra}$ dialsprünge bestehen (Fig. 86). Auch die einzelnen Schollen können sich verschieden verhalten. In Fig. 84 fallen sie b" z. B. gleichsinnig nach einer Richtung ab, und wir sprechen dann von einem Staffelbruch; häufig ragt aber eine Scholle als sogenannter Horst über die Umgebung hervor oder senkt sich als Graben unter die Nachbarschollen hinab (Fig. 87). Diese Erscheinungen gehören hauptsächlich den Gebieten der Tafelbrüche an, während die Einstürze von rundlichem oder polygonalem Umrib, die man, wenn sie klein sind, als Kesselbrüche, und, wenn sie größeren Umfang besitzen, als Senkungsbecken bezeichnet, durch Bruchnetze erzeugt werden.

Manchmal kommt es nicht zum Bruch, obwohl die Teile eines Schichtenkomplexes ebensolche oder ähnliche Niveauveränderungen erleiden wie bei der Verwerfung. Statt des Bruches entsteht dann 
eine Schichtenbiegung, weshalb man diese Form der Vertikaldislokation als Flexur bezeichnet (Fig. 88). Sie tritt mit Verwerfungen vergesellschaftet auf, und zwischen beiden Arten bestehen

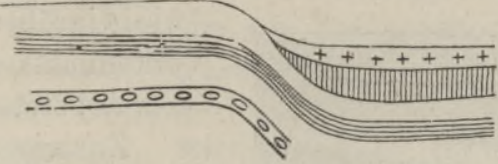

Fig. 88.

Flexur nach Herm.

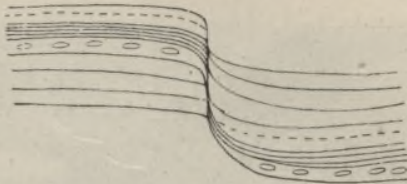

Fig. 89.

Zerrissene Flexur nach Heiм.

mannigfache Übergänge, von denen Fig. 89 die häufig vorkommende zerrissene Flexur mit „geschleppten“ Schichtenenden an der Biegungsstelle vorführt.

2. Die Flexur bildet den Übergang zu der zweiten Kategorie vertikaler Niveauveränderungen, den Biegungen, unterscheidet sich aber von diesen wesentlich durch ihre Einseitigkeit. Sie bildet eine Landstufe, die sich oben in einer Ebene oder wenigstens in einem flacheren Gelände fortsetzt, während die echte Biegung eine allseitige Erhebung über das Umland bewirkt. Ihre bekannteste, aber auch komplizierteste Form ist die Faltung (Fig. 90), von der wir an einer späteren Stelle ausführlicher sprechen werden. Die Schichtenbiegung wiederholt sich hier mehr-

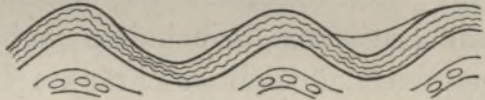

Fig, 90. Falten. mals hintereinander, vereinzelt bildet sie eine Sattelwölbung (Monoantiklinale) und wenn diese eine so große Spannweite besitzt und so allmählich ansteigt, daß sich die Biegung selbst unserer unmittelbaren Wahrnehmung entzieht, und wir nur auf indirektem Weg zu ihrer Kenntnis gelangen, so sprechen wir von einer Verbiegung.

3. Von den Horizontaldislokationen ist die häufigste das Blatt. Man versteht darunter eine Horizontalverschiebung der Schichten entlang einer Bruchspalte, ein Vorkommen, das schon bei einigen Erdbeben beobachtet worden ist. So schnitt z. B. bei dem zentraljapanischen Erdbeben vom 28. Oktober $1891^{3}$ bei Midori die Spalte eine Chaussee entzwei, und die Osthälfte wurde um $4{ }^{\circ} \mathrm{m}$ nach $\mathrm{N}$ verschoben; damit verband sich auch eine Senkung oder Verwerfung des Westflügels um $6 \mathrm{~m}$ (Fig. 91). Besonders auffällig tritt das Blatt dann hervor, wenn sich entlang der Spalte ein Tal entwickelt hat und die Gehänge nun nicht mehr zusammenpassen. Wir erwähnen diese Dislokationsform hier nur nebenbei, da sie keine 
Niveauveränderung erzeugt; wohl ist dies aber der Fall bei der Überschiebung, die wir als die extremste Form der Faltung aufzufassen haben, und die darin besteht, daß hochgewachsene Falten sich nach einer Seite umlegen und fremden Boden bedecken. Wenn

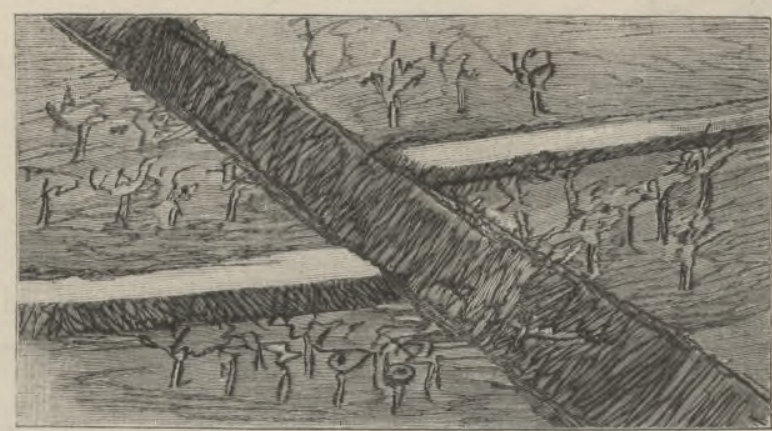

Fig. 91. Verschiebung (Blatt) und Verwerfung bei Midori, nach Kото.

-- wie beigrößeren Vorkommnissen dieser Art stets der Zusammen. hang zwischen den Decken und ihrer Wurzel zerstört ist, so kann auch dieseDislokationsform, geradeso wie die Verbiegung, nurauf indirektem Weg erschlossen werden, und es darf uns daher nicht wundernehmen, wenn über beide noch die Meinungen geteilt sind.

In der Regel treten die Dislokationsformen regional auf. Es gibt weite Gebiete, wo die Schichten ihre ursprüngliche horizontale Lagerung beibehalten haben, und Störungen nur eine untergeordnete, örtlich beschränkte Rolle spielen. Es gibt weite Gebiete, wo die Schichten in Falten gelegt, und wieder andere, wo sie in Schollen aufgelöst sind. Wohl kommen neben Falten auch Verwerfungen, neben Verwerfungen auch Falten vor, aber immer ist es eine dieser beiden Hauptformen, die einer bestimmten Gegend ihr Gepräge verleiht, so daß wir mit Recht von Falten- und Schollenländern sprechen dürfen. Dieser regionalen Anordnung der Schichtenstörungen ist es zu danken, daß Berge und Ebenen nicht wirr durcheinander, sondern in geschlossener Weise auftreten, und daß geographische Provinzen entstehen, die durch ihren einheitlichen Bau auch die Entwicklung ihrer menschlichen Bewohner beeinflussen.

Theorien. Dem Geographen genügt es, wenn es ihm gelingt, eine bestimmte Oberflächenform aus ihrer Bauart zu erklären; den letzten Grund der endogenen Erscheinungen aufzusuchen, überläßt er neidlos den Geschichtsschreibern der Erde. Aber ganz können auch wir den theoretischen Erörterungen nicht aus dem Weg gehen, wir können nun einmal nicht des geistigen Bandes entbehren, das die beobachteten Tatsachen zusammenhält. Doch beschränken wir uns hier nur auf einige allgemeine Gesichtspunkte, die uns später das Verständnis der Einzelphänomene erleichtern sollen. 
Die tektonischen Theorien lassen sich in drei Gruppen einfügen: 1 . in solche, die alle hierher gehörigen Phänomene: Dislokationen, vulkanische Ausbrüche und Erdbeben als oberflächliche Außerungen einer Umbildung des ganzen Erdkörpers auffassen, 2. in solche, die sie auf Vorgänge im Erdkern, und 3. in solche, die sie auf Veränderungen in der Kruste selbst zurückführen. Jahr zehnte hindurch herrschte die plutonistische Theorie, die dem heißflüssigen Erdinnern eine aktive Wirksamkeit zuschrieb und alle tektonischen und vulkanischen Phänomene als Reaktion des explosiven Erdkerns gegen die erstarrte Kruste auffaßte. Das genauere Studium der Faltengebirge hat diese Anschauung erschüttert und der Kontraktionstheorie den Weg gebahnt. G. DARwIN hat, von allerdings sehr unsicheren Voraussetzungen ausgehend, berechnet, daß die Erdoberfläche infolge der säkularen Abkühlung in 10 Millionen Jahren um 590000 qkm kleiner geworden sei. Man stellt sich diesen Prozeß in der Weise vor, daß das unstarre Erdinnere sich durch Erkaltung rascher zusammenziehe als die starre Kruste, so daß zwischen beiden Hohlräume entstehen. Wie ein Gewölbe sich an seiner schwächsten Stelle senkt und endlich zusammenbricht, so auch die Kruste; aber da ihr Umfang zu groB ist für den zusammengeschrumpften Erdkern, so muß durch Zusammenpressung oder Faltung schwacher Partien erst Raum geschafft werden für die starreren Schollen, die nun ebenfalls dem Zug der Schwerkraft folgen können. SuEss hat übrigens die Notwendigkeit der Annahme von Hohlräumen geleugnet. Auf einen anderen Vorgang, der zur Verkürzung des Erdradius führt, hat vaN $\mathrm{HISE}^{4}$ die Aufmerksamkeit gelenkt, nämlich auf die Verlangsamung der Rotation durch die in entgegengesetzter Richtung, von $\mathrm{O}$ nach W fortschreitende Flutwelle. Man nimmt an, daß ursprünglich ein Erdentag nur $5^{1 / 2}$ Stunden gehabt habe. Die Wirkung dieser Veränderung war eine doppelte. Erstens verminderte sich die Abplattung, der mittlere Radius wurde um $7 \mathrm{~km}$ kürzer und die Oberfläche um $540000 \mathrm{qkm}$ kleiner. Zweitens nahm die Fliehkraft ab und die Wirkung der Schwerkraft zu. In einer homogenen $/$ Erde stieg infolgedessen nach SLICHTER's Berechnung der Druck im Mittelpunkt von 1688000 auf 1772000 Atmosphären, also um 4,8 Prozent; in einer heterogenen/Erde, in der die Dichte von 2,7 an der Oberfläche auf 10,74 im Zentrum zunimmt, würde die Druckvermehrung nur 2,5 Prozent (von 2920000 auf 3000000 Atmosphären) betragen. Viel größer ist die Drucksteigerung, wenn man annimmt, daß sich der heterogene Zustand aus dem homogenen herausgebildet habe; die Grenzwerte sind dann 1688000 und 3000000 Atmosphären. Auch dieser Prozeß führt zu

Supas, Physische Erdkunde. 5, Aufl. 
einer Reduktion der Erdoberfläche, die auf 4,4 Millionen qkm geschätzt wird. Eine große Rolle spielt nach vaN HISE auch der Vulkanismus. Indem geschmolzenes Gestein in die Erdkruste eindringt und hier erstarrt, wird diese erweitert, gleịchzeitig aber der Erdkern kleiner, und die Kruste muß sich in der oben geschilderten Weise den neuen Verhältnissen anpassen. Wir übergehen die Kontraktionsursachen von untergeordneter Bedeutung - soviel steht jedenfalls fest, daß, wenn man gewisse Voraussetzungen anerkennt, eine allmähliche Schrumpfung des Erdkörpers sehr wahrscheinlich ist.

Suess hat die Kontraktionstheorie bis in ihre äußersten Konsequenzen ausgebildet. Er kennt nur einen Fundamentalakt: die Senkung. Ungleichmäßige Senkung der Krustenstücke schuf Festländer und Meere. Es gibt nur eine Art der Hebung, die durch Faltung, aber auch diese ist nur eine Wirkung der Schwerkraft, die sich örtlich in eine tangential wirkende Kraft umsetzt. Dabei kommt es in den obersten Krustenpartien zu Zerreißungen, die bald den Falten folgen, bald unabhängig von solchen auftreten. Die vulkanischen Ausbrüche sinken zu untergeordneten Begleiterscheinungen des großen Zusammenbruches der Erdrinde herab, denn dieser Vorgang öffnet die Spalten, durch die die Dämpfe und die Lava ihren Weg nach der Oberfläche finden. Im Gegensatz zu Suess hält DE Lapparent die Faltung für die erste Folge der Erdkontraktion und den Bruch und die Schollensenkung für den sekundären Vorgang. ${ }^{5}$

An Großartigkeit der Konzeption und Einheitlichkeit der Durchführung wird die Schrumpfungstheorie von keiner anderen erreicht, aber es gibt Tatsachen, die sich nicht leicht mit ihr vereinen lassen. Verliert die Erde stetig Wärme und zieht sie sich daher stetig zusammen, warum war dann die Faltung kein dauernder, sondern ein periodisch wiederkehrender Prozeß? AMPfeneR ${ }^{6}$ wies darauf hin, daß die Festigkeit der die Oberfläche zusammensetzenden Gesteine verschwindend klein sei in Anbetracht der Dimensionen unseres Planeten, und daß es daher undenkbar sei, daß sich die Faltung infolge einer allgemeinen Kontraktion des ganzen Erdballs über starre Schollen hinweg auf einige weniger starre Zonen beschränkt habe. Es mehren sich ferner immer mehr die Anzeichen von Hebungen ohne Faltung. Die Kuppelstruktur der amerikanischen Lakkolithen (Fig. 92) macht auf jeden Unbefangenen den Eindruck, daß hier eine vertikal aufwärts wirkende Kraft tätig gewesen ist. Matteucci will einen derartigen Vorgang in kleinem Maßstab an einer kuppelförmigen Lavaansammlung im Atrio del Cavallo des 
Vesur beobachtet haben, die sich von 1895-98 um $15 \mathrm{~m}$ gehoben habe, doch wird diese Darstellung von Mercalui als irrtümlich bestritten. $^{7}$ Wie dem auch sei, die Möglichkeit einer Bildungsweise, wie sie amerikanische Geologen 'von den Lakkolithen annehmen, wird dadurch nicht erschüttert. Branca, FraAs ${ }^{8}$ und v. KNebel $^{9}$ haben mit Hilfe dieser Theorie das Riesrätsel gelöst; vulkanische Auftreibung und spätere. Senkung haben hier höchst merkwürdige Lagerungsverhältnisse geschaffen, und wenn auch $\mathrm{KoKEN}^{10}$ zu etwas abweichenden Ergebnissen gelangt ist, so hält doch auch er an verti-

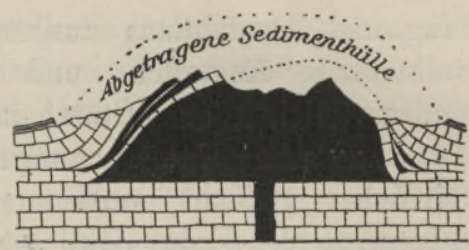

Fig. 92. Mount Hillers in den Henry Mountains (schwarz Trachyt, hell Sedimentgestein).

kalen Hebungen fest. $\times$ Solche vulkanische Dislokationen lassen sich indes als sekundäre Vorgänge auffassen, wenn man annimmt, daB niedersinkende Schollen das Magma emporpressen. Schwerèr kann sich die Kontraktionstheorie mit der Hebung starrer Schollen mit oder ohne Verbiegung abfinden, bei der der Vulkanismus nicht nachweisbar beteiligt ist. Die moderne Schule der Physiogeographen legt gerade darauf das größte Gewicht, ja $P_{\text {ENCK }}{ }^{12}$ geht sogar so weit, zu erklären: „es spielt unseres Erachtens überhaupt in der Physiognomie der Erdoberfläche die für die Tektonik der Kruste so wichtige Faltung eine geringere Rolle als die Krustenbewegung im vertikalen Sinn“. Mögen auch, wie wir sehen werden, manche Fälle nur als hypothetisch betrachtet werden, so gibt es doch auch unzweifelhafte Hebungsvorgänge, die man nicht dadurch beiseite schieben kann, daß man sie als nur scheinbar erklärt. "In unlösbarem Widerspruch stehen aber auch sie nicht zur Schrumpfungstheorie. Es läßt sich denken, daß, wenn in den tieferen Schichten Faltung eintritt, die oberflächlichen ohne wahrnehmbare Biegung gehoben werden. Ferner konnten Horste an einfallenden Bruchflächen (Fig. 87, IV) schon dadurch, daß die benachbarte Scholle sich grabenartig senkt, in die Höhe getrieben werden, während sie nach Suess' Ansicht einfach stehen blieben. Die gröBten Schwierigkeiten bereiten die disjunktiven Dislokationen, wie sie v. RICHTноFEN in größtem Maßstab für Ostasien nachgewiesen hat (vgl. S. 38). Alle Verwerfungen an ausfallenden Bruchflächen (Fig. 87, III) be-

$\times$ Im Gegensatz zu all diesen Erklärungsversuchen hält L. REgeLManN ${ }^{11}$ daran fest; daß die Riesstörungen auf gebirgsbildende Vorgänge seit dem Tertiär, d. h. auf Druck von S (Alpen) und O (Bayriseher Wald) zurückzuführen sei. 
dingen eine Zerrung und Streckung der Erdrinde, also gerade das Gegenteil von dem, was die Schrumpfungstheorie verlangt. Um diesen Fall mit ihr in Einklang zu bringen, müßte man annehmen, daß an anderen Stellen eine Überkontraktion stattgefunden hat. RothPLETz ${ }^{13}$ hat sich für einen periodischen Wechsel von Schrumpfung und Ausdehnung ausgesprochen: jene bewirke Faltung, diese vulkanische Ausbrüche und biegungslose Hebung. Die Ansicht findet vielleicht eine Stütze in den erst später bekannt gewordenen TAMmanN'schen Untersuchungen, deren an anderer Stelle (S. 407) ausführlicher gedacht werden soll. SchlieBlich muß man sich auch fragen, ob die Erde wirklich stetig erkalte. Die Schrumpfung selbst erzeugt wieder soviel Wärme, daß der Verlust durch die Ausstrahlung in den kalten Weltenraum mehr als gedeckt wird, und im Radium hat man in jüngster Zeit eine Wärmequelle von allergrößter Bedeutung entdeckt. Nach STRUTt genügt bei gleichmäßiger Verteilung des Radiums durch die Erdkugel schon $1 / 5700$, nach DUTHERFORD sogar schon $1 / 6600 \mathrm{mg}$ pro $\mathrm{cbm}$, um den thermischen Ausstrahlungsverlust zu ersetzen, und die untersuchten Gesteine enthalten ein beträchtliches Vielfache dieser notwendigen Menge. Vielleicht findet sich aber Radium nur in einem verhältnismäBig kleinen Teil der Erdmasse, immerhin ist schon aus diesem Grund eine abwartende Haltung gegenüber der Schrumpfungstheorie geboten.

v. BöHM ${ }^{14}$ griff wieder auf die Abnahme der Abplattung zurück und erörterte die Formveränderung der Erdoberfläche und des Geoïds, die sich daraus ergeben. Würde sich das heutige Sphärord in eine inhaltsgleiche Kugel verwandeln, so würde sich die große Achse um $7 \mathrm{~km}$ verkürzen und die kleine um $14 \mathrm{~km}$ verlängern. Der Flächeninhalt würde bis $35^{\circ}$ B. zu- und dann abnehmen und das Maximum dieser Abnahme würde zwischen 60 und $65^{\circ}$ B. eintreten. Ferner würden die Meridiangrade bis $55^{\circ}$ B. stetig verlängert und dann bis zum Pol stetig verkürzt werden. Daraus werden folgende Deformationen der Erdkruste abgeleitet: zuerst, weil im Sinn der Schwerkraft erfolgend, eine äquatoriale Senkung, dann erst, gleichsam zögernd nachfolgend, eine polare Hebung. Die Grenze beider Bewegungen liegt in $35^{\circ} \mathrm{B}$. Von da an tritt auch eine Verschiebung aller Teilchen nach dem Pol zu ein, die vertikale Bewegung verwandelt sich in einen tangentialen Druck, der zwischen 35 und $55^{\circ} \mathrm{B}$. besonders intensiv ist und in $45^{\circ} \mathrm{B}$. seinen Höhepunkt erreicht. Aber früher noch, als die Kruste, paßt sich das leicht bewegliche Meer den neuen Bedingungen an, sein Niveau senkt sich im Tropengürtel und hebt sich in den höheren Breiten. Von dieser Art, nur noch gewaltiger, müssen die Veränderungen gewesen 
sein, seit sich die Abplattung bis auf die Gegenwart um das zehnfache verringert hat. Es ist ein Vorzug dieser Theorie, daB sie auch Veränderungen des Meeresspiegels mit einbezieht und so Transgressionen und Faltungen miteinander verknüpft. Auch stimmt die Lage der großen Kettengebirge der Alten Welt im großen und ganzen mit ihr überein, aber für die südliche Halbkugel versagt sie. Hier fehlt die große Faltungszone zwischen 35 und $55^{\circ} \mathrm{B}$.

Im folgenden seien noch einige andere Theorien erwähnt, die in der Literatur eine gröBere Rolle spielen oder gespielt haben, und deren Kenntnis daher wünschenswert erscheinen dürfte.

FISHER $^{15}$ denkt sich die Erdkruste als eine verhältnismäßig dünne Schicht auf einer leichtflüssigen Unterlage (Magma genannt), und zwar in der Weise, daß alle Hervorragungen an der Erdoberfläche in ebensolchen an der Unterseite der Kruste, wie im Wasser, sich abspiegeln.

Ozeanische Becken und kontinentale Massen sind von Anfang an geschieden, wenn auch mancherlei Grenzverschiebungen im Lauf geologischer Zeiträume stattgefunden haben. Die ozeanische Kruste sinkt tiefer in das Magma ein und ist dichter als die kontinentale, wobei die Dichte mit der Tiefe zunimmt. Dagegen ist das Magma unter den Ozeanen weniger dicht als unter den Festländern. Diese Unterschiede geben Veranlassung zu Ausgleichsströmungen, die fortwährend Wärme von unten nach oben führen und eine Umlagerung der Massen bewirken. Unter den Ozeanen, gegen deren kalte Tiefen eine starke Wärmeabgabe stattfindet, steigen im Magma fortwährend Ströme auf, um jenen Wärmeverlust zu ersetzen; unter den Kontinenten befinden sich absteigende Ströme. Dieses Spiel auf- und absteigender Ströme erfordert einen Ausgleich durch horizontale Ströme; in den oberen Schichten der Magmas geht eine solche Strömung von den Ozeanen gegen die Ränder der Kontinente, in den unteren Schichten von den Kontinenten zu den Ozeanen. Die ersteren können vermöge der Reibung an der Unterseite der Kruste, besonders dort, wo die unteren Ausbauchungen des Festlandes Widerstand leisten, die Kruste zusammenpressen, falten - so entstehen Gebirge an der Grenze von Land und Meer (die amerikanischen Cordilleren!). Stellenweise muß die ozeanische Kruste dem Anprall des aufsteigenden Magmas nachgeben, es bilden sich Spalten und Vulkane mitten im Weltmeer. Auch die Ungleichmäßigkeit jener Ströme gibt zu vulkanischen Erscheinungen Veranlassung. Unter gewissen Erdstellen werden sie energischer und schmelzen die Unterseite der Kruste ab; diese wird dünner, es entstehen Spalten, und die betreffende Gegend wird von vulkanischen Ausbrüchen heimgesucht. 
Neben den Strömungen des Magmas wirkt noch die ungleiche Belastung als formbildendes Element. In DutTon's isostatischer Theorie ${ }^{16}$ ist sie sogar das einzige. Da die Erde nicht homogen ist, müssen sich infolge der Rotation die leichteren und die schwereren Bestandteile scheiden; die ersteren folgen leichter der Fliehkraft und streben nach oben; damit ist der erste $A$ nlaß zur Bildung von Kontinenten und Meeresbecken gegeben. Indem sich die schwereren Bestandteile in den Depressionen, die leichteren in den Erhebungen der Kruste sammeln, herrscht Gleichgewicht (Isostasie), und die neueren Schweremessungen (vgl. S. 16) haben dies auch bestätigt. Das Gleichgewicht erleidet fortwährende Störungen, indem das Land abgetragen wird, und die Erzeugnisse seiner Zerstörung im Meer angehäuft werden. Aber unablässig wird dieses Gleichgewicht auch wieder hergestellt: die belastete ozeanische Kruste sinkt immer tiefer ein, das entlastete Festland steigt, aber nicht ins Unendliche, da die zerstörenden exogenen Kräfte dem stets entgegenarbeiten. Voraussetzung ist natürlich, daß die Kruste auf einer plastischen Grundlage ruht, wie wir schon auf S. 15 dargetan haben. Dutron will seine Theorie vor allem auf die Faltengebirge angewendet wissen, andere, wie Mc GeE, sehen dagegen ihre Bedeutung darin, daß sie die großen Niveauveränderungen des Festlandes ungezwungen erklärt.

Bei solcher theoretischen Zerfahrenheit liegt es nahe, auf eine einfache Formel zu verzichten. Schon GILBERT hielt orogenetische oder gebirgsbildende und epirogenetische Niveauveränderungen scharf auseinander. Dies ist auch die Ansicht READE's. ${ }^{17}$ Nur die Faltengebirge entstehen durch seitliche Massenverschiebungen, die epirogenetischen Bewegungen aber durch Volumveränderungen innerhalb der Magmazone, wobei die Masse keine Veränderung erleidet, sondern nur das spezifische Gewicht. READE-erinnert an das interessante Experiment von Sir RoBerts-Austen mit Blei und Gold, wodurch die Diffusion auch bei festen Körpern nachgewiesen wurde, und schlieBt daraus, daß, wenn solche mineralogische und chemische Veränderungen schon bei gewöhnlicher Temperatur und gewöhnlichem Druck vor sich gehen, sie sich noch in weit höherem Grad in den Tiefen der Erde vollziehen müssen. Wenn das Volumen wächst, muB Hebung, wènn es sich vermindert, Senkung eintreten. Auch v. D. Borse ${ }^{18}$ sieht das Wesen aller tektonischen Prozesse darin, daß die verschiedenen Teile des Körpers, der eine Gestaltsveränderung erleidet, in verschiedener Weise ihr Volumen ändern. LE ConTe ${ }^{19}$ unterscheidet vier Gruppen von Bodenbewegungen. Die erste beruht auf ursprünglichen Dichteunterschieden der Erdkruste; 
die dichteren Teile sanken ein, und damit entstand der Gegensatz von Festland und Ozean. Dieser Gegensatz vertiefte sich im Lauf der Erdgeschichte immer mehr, weil die ozeanischen Krustenteile als die dichteren auch besser die Wärme leiten und sich daher stärker kontrahieren. Die zweite Gruppe sind die orogenetischen Bewegungen, die die Gebirgsketten schufen, und auf die Kontraktion der Kruste zurückgeführt werden. Die dritte Gruppe, deren Ursache LE Conte noch als offene Frage behandelt, bilden die oszillatorischen Bewegungen, die in der Erdgeschichte die größte Rolle spielen, die vierte endlich die isostatischen oder Ausgleichsbewegungen, denen aber Le Conte im. Gegensatz zu Dutton und anderen nur eine untergeordnete Bedeutung zuschreibt.

$\mathrm{Ob}$ wir auf diesem Weg sicherer zum Ziel gelangen, ist zweifelhaft. Als Hauptaufgabe erscheint uns zunächst die einwandfreie Feststellung der Periodizität tektonischer Vorgänge, wie der Faltungen und Transgressionen, denn periodische Erscheinungen müssen sich stets auf eine verhältnismäBig einfache Ursache zurückführen lassen.

Literaturnachweise. ${ }^{1}$ Hauptwerke: E. Suess, Das Antlitz der Erde zit. S. 28; F. v. Richthofen, Führer für Forschungsreisende; Berlin 1886. A. Pexck, Morphologie der Erdoberfläche; Stuttgart 1894. A. de Lapparent, Leęons de Géographie physique, 3. Aufl.; Paris 1907. J. E. Marr, The Seientific Study of Seenery; London 1900 (hauptsächlich für Engländer bestimmt). J. GEгкіE, Earth Senlpture or the Origin of Land-Forms; London 1902. O. Pescher, Neue Probleme der vergleichenden Erdkunde, 3. Aufl.; Leipzig 1878, zwar inhaltlich z. T. veraltet, aber in der Darstellung noch immer unerreichtes Muster. Zu den auf S. 28 genannten Lehrbüchern der Geologie sind hier noch hinzuzufügen; E. Reyer, Theoretische Geologie; Stuttgart 1888. St. Meunier, La géologie expérimentale; Paris 1899. J. Wat.ther, Lithogenesis der Gegenwart; Jena 1894. Herm. Berghaus, Atlas der Geologie; Gotha 1892, z. T. auch Atlas der Hydrographie, 1891, in Berghaus' Physikalischem Atlas. Sehr lehrreich sind die vom Geologieal Survey of the United States herausgegebenen Topographic Folios. Viele Folio-Hefte enthalten Karten charakteristischer Gegenden der Vereinigten Staaten: Folio 1 und 2 physiographische Typen von H. Gannetr, Folio 3 Karten zur physikalischen Geographie des Texasgebietes von R. T. HıL. Auch andere,Teile des Geologischen Atlas der Vereinigten Staaten können zum Studium nicht warm genug empfohlen werden, besonders das Yellowstone-Folio (Nr. 30) und das Pueblo-Folio (Nr. 36). Als ein reichhaltiges und instruktives Bilderwerk ist A. RoвIs, La Terre; Paris 1902, zu empfehlen. - ${ }^{2}$ E. de Maraerie u. A. Heim, Die Dislokationen der Erdrinde (französischer u. deutscher Text; Synonyma in französischer, deutseher und englischer Sprache; unentbehrliches Hilfsbuch); Zürich 1888. - ${ }^{3}$ B. Koто, The Cause of the Great Earthquake in Central Japan, 1891, im Journal of College of Science, University of Japan, 1893. - ${ }^{4}$ C. R. van Hise, Estimates and Causes of Crustal Shortening, im Journal of Geology, Chicago 1898, Bd. VI. $-{ }^{5}$ A. de Lappare,st, Le sens des mouvements de l'écorce terrestre, im Bulletin 
de la Société géologique de France 1887, Bd. XV; Soulévements et affaissements, in Revue des questions scientifiques, 1898. - ${ }^{6} \mathrm{O}$. A Mrferer, Über das Bewegungsbild von Faltengebirgen, im Jahrbuch der Geologischen Reichsanstalt, Wien 1906, Bd. LVI. - ${ }^{7}$ R. V. Matteucor in den Comptes rendus de l'Académie des Sciences, Paris 1899, Bd. CXXIX, S. 65, und im Bolletino della Società geologiea italiana, 1902, Bd. XXI, S. 413; G. Mercalli ebenda 1902, Bd. XXI, S. 197; und 1903, Bd. XXII, S. 421. - ${ }^{8}$ W. Branca u. E. Fraas, Das vulkanische Ries bei Nördlingen, in den Abhandlungen der Preubischen Akademie der Wissenschaften, 1901; Beweis für die Richtigkeit unserer Erklärung, in den Sitzungsberichten derselben Akademie, 1901; Die Lagerungsverhältnisse bunter Breccie an der Bahnlinie Donauwörth-Treuchtlingen, in den Abhandlungen derselben Akademie, 1907. - ${ }^{9}$ W. v. Kneber, Weitere geologische Beobachtungen am vulkanischen Ries bei Nördlingen, in der Zeitschrift der Deutschen Geologischen Gesellschaft, 1903, Bd. LV. - ${ }^{10}$ E. KoKen, Geologische Studien im fränkischen Ries, im Neuen Jahrbuch für Mineralogie usw., 1902, Beilageband XV. - ${ }^{11}$ C. Regenmann, im Bericht über die 42. Versammlung des Oberrheinischen Geologisehen Vereins, Karlsruhe 1909, S. 43. 12 A. Penck, Die Physiographie als Physiogeographie in ihren Beziehungen zu anderen Wissenschaften, in der Geographischen Zeitschrift, 1905. - ${ }^{13}$ A. RотнPLETz, Ein geologischer Querschnitt durch die Ostalpen; Stuttgart 1884 (Aufstellung der Expansionstheorie); Über die Möglichkeit, den Gegensatz zwischen der Kontraktions- u. Expansionstheorie aufzuheben, in den Sitzungsberichten der bayrischen Akademie der Wissenschaften, Mathem.-physikalische Klasse, Bd. XXXII, 1902. - ${ }^{14}$ A. v. Böнм, Abplattung und Gebirgsbildung, Leipzig 1910. - ${ }^{15}$ O. Fisher, Physies of the Earth's Crust, 2. Aufl., London 1889. 16. C. E. Dutron, Some of the greater Problems of Physical Geology, im Bulletin of the Philosophical Society; Washington 1892, Bd. XI. Vgl. dazu den Artikel von E. Hammer in Petermann's Mitteilungen, 1906, S. 190. -17 T. Melcard READE, The Evolution of Earth Structure with a Theory of Geomorphic Changes; London, 1903. - ${ }^{18}$ G. v. D. Borne, Die physikalischen Grundlagen der tektonischen Theorien, in GerLand's Beiträgen zur Geophysik 1908. Bd. IX. 19 J. Le Conte, Earth Crust Movements and their Causes, im Bulletin of the Geological Society of America, 1897.

\section{Die vulkanischen Ausbrüche. ${ }^{1}$}

Kein Phänomen führt uns deutlicher vor Augen, daß die Kräfte des Erdinnern noch immer tätig sind, als der Ausbruch eines Vulkans. Aber so großartig dieses Schauspiel auch ist, so steht es doch in seinen Wirkungen weit zurück hinter den langsam, unmerkbar sich vollziehenden Veränderungen, denen die Erdoberfläche unausgesetzt unterworfen ist. Für die geologische Gegenwart wenigstens gilt der Satz, daß der Vulkanismus nur eine Erscheinung von örtlicher Bedeutung ist. Aber in einem Punkt unterscheidet er sich von allen anderen Phänomenen: er schafft, wo er zu voller Entfaltung gelangt, wirkliche Neubildungen, während sonst überall nur eine Umformung oder Umlagerung schon vorhandener Oberflächenmassen stattfindet. Aus unbekannten Tiefen wird neues Material, im Schmelzfluß befindliches Silikatgestein oder Magma, wie man es 
jetzt allgemein nennt, zutage gefördert. Den Ort, wo dieses Magma bereitet wird, bezeichnet man als Lavaherd. Wo zwischen einem Lavaherd und der Erdoberfläche durch einen Kanal eine Verbindung hergestellt ist, entsteht ein Vulkan. Zahlreiche solcher Kanäle aus früheren geologischen Perioden, mit Eruptivgesteinen ausgefüllt und durch die Denudation bloßgelegt, sehen wir die geschichteten Gesteine durchbrechen. Nicht immer erreichten sie die Oberfläche, und die Eruption spielt sich dann in der Tiefe ab: ein. Vorgang, den wir als Kryptovulkanismus bezeichnen können. Seine Bildungen gewinnen erst dann geographische Bedeutung, wenn ihre Decke zerstört ist, und sie nun unverhüllt zutage treten. Aber auch oberirdische Ausbrüche führen nicht immer zu Neubildungen. Auf der jurassischen Kalkdecke der Schwäbischen Alb treten in der Umgebung des Rieses inselartig sog. Grießbreccien auf, die alle Merkmale gewaltsamer Einwirkung an sich tragen. BRANCA ${ }^{2}$ betrachtet sie als Erzeugnisse unterirdischer Explosionen, die nicht stark genug waren, einen Schlot zu öffnen, sondern nur die oberen Schichten zertrümmerten. Gelingt es ihnen aber auch, einen Kanal herzustellen, so reicht doch manchmal ihre Kraft nicht aus, das Magma an die Oberfläche zu schaffen, und sie müssen sich damit begnügen, die Trümmer der durchbrochenen Kruste auszuwerfen; an der Oberfläche bildet sich ein kreisförmiges oder ovales Loch, die Trümmergesteine verstopfen den Kanal und nach diesem einmaligen Versuch stellt der Vulkan seine Tätigkeit ein. So entstehen die unter dem Namen Maare bekannten Vulkanembryonen, über deren Bau erst die Untersuchungen BrancA's ${ }^{3}$ im Schwäbischen Jura helles Licht verbreitet haben, obwohl man solche Gebilde in der Eifel, der Auvergne, Zentralamerika, Ostindien und Japan schon lange gekannt hatte. ${ }^{4}$ Nur heftigere oder wiederholte Eruptionen erzeugen oberirdische Anhäufungen von magmatischem Material.

Eruptionsprodukte. Das Magma ist eine Mischung verschiedener Verbindungen, unter denen die Kieselsäure stets die erste Rolle spielt. Aber in verschiedenen Mischungen in verschiedenem Grad, so daB man danach saure und basische Eruptivgesteine unterscheiden kann. Die tertiären und die der Gegenwart angehörigen ordnen sich in folgende Reihe:

Liparit oder Rhyolith, Kieselsäuregehalt mindestens 75 Proz.,

Trachyt,

Andesit,

Basalt,

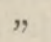

,

,

65 Proz. und darüber,

über 50 Proz.,

40-50 Proz.

In dieser Reihenfolge erniedrigt sich auch der Schmelzpunkt. 
Basalt schmilzt unter gewöhnlichem Luftdruck schon bei einer Temperatur von $1100-1370^{\circ} \mathrm{C}$.

An der Oberfläche erscheint das Magma entweder in zusammenhängenden, heißflüssigen Massen als Lava, oder in lockeren Auswürflingen, die auf ihrem Weg durch die Luft einen großen Teil ihrer Wärme einbüßen und meist erkaltet zu Boden sinken. Je

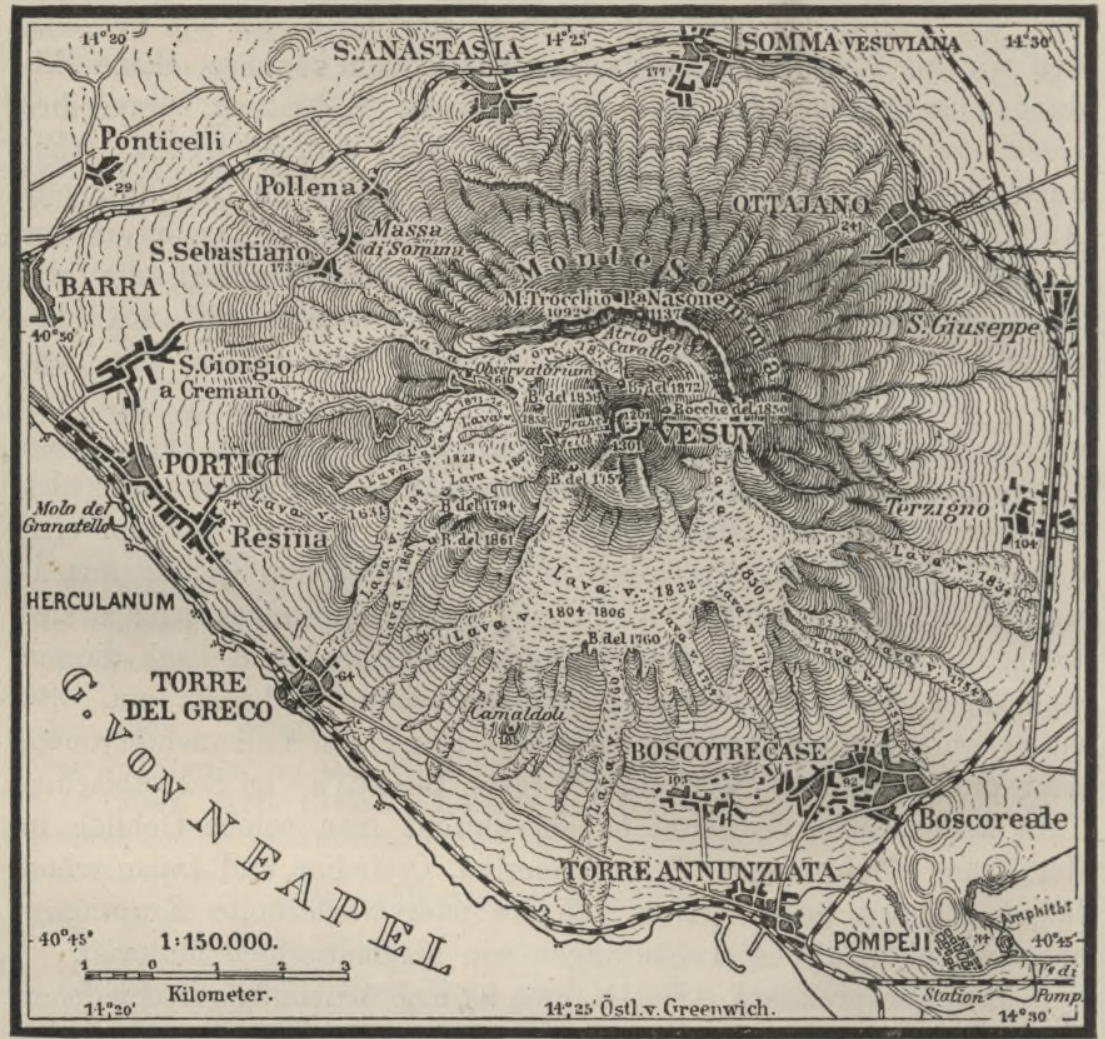

Fig. 93. Karte des Vesuv (vor 1906).

nach der Größe unterscheidet man Blöcke, die bis zu $1 \mathrm{~m}$ Durchmesser erreichen; Bomben, die durch Drehung in der Luft oder durch Umklappen der Ränder des Lavafetzens und Verschiebung des Schwerpunktes eine kugelige, keulen- oder Hadenförmige Gestalt annehmen; Lapilli von Hasel- oder Walnußgröße, vulkanischen Sand und endlich Asche. Die letztere, ein feines Pulver, vermischt sich mit Wasser zu Schlamm, der in erhärtetem Zustand die sog. Tuffschichten bildet; besser ist es indes, diese Bezeichnung nur 
für die unterseeischen Schlammablagerungen zu gebrauchen, für die Schlammströme des Landes aber - wie Löws rät - den in der Eifel gebräuchlichen Namen Tra B anzuwenden.

Das Magma ist kein trockener Schmelzfluß, sondern mit zahlreichen Gasen imprägniert. Daß unter ihnen, wenigstens in der Mehrzahl der Fälle, Wasserdampf die hervorragendste Rolle spielt, ist eine unantastbare Erfahrung; ob er aber zu den wesentlichen Bestandteilen gehört, wie man bisher allgemein angenommen hat, oder zu den rein zufälligen, wie in neuester Zeit BRuN ${ }^{5}$ behauptet hat, muß noch zu den offenen Fragen gezählt werden. Nach BRus sind die eigentlichen Erzeuger der vulkanisclfen Gase Chlor, Stickstoff und Kohlenwasserstoffe, und das Wasser kommt nur durch Einsickern von der Oberfläche mit dem Magma in Berührung. Demgegenüber hat die ältere Auffassung namentlich in GAUTIER $^{6}$ einen energischen Verteidiger gefunden.

Die vulkanischen Ausbrüche. Es darf als Regel gelten, daß die Vulkane intermittierend tätig sind, sei es, daß sich der Kanal zeitweise verstopft, sei es, daß sich das Eruptionsmaterial inta erschöpft oder auch, daß nicht immer diejenigen Kräfte wirksam sind, die das Magma zum Aufsteigen nötigen. ${ }^{\times}$Man hat im Gegensatz dazu von einer Strombolitätigkeit gesprochen, so genannt nach einer der Äolischen Inseln, die sich wenigstens lange Zeit hindurch durch eine ruhige, gleichmäßige Förderung lockern Materials ohne Lavaergüsse auszeichnete; aber in der Tat besteht zwischen dieser Art vulkanischer Kraftäußerung und der intermittierenden nur ein gradueller Unterschied, denn einerseits hatte auch Stromboli nachweisbar Ruhepausen, während er 1889 und 1891 Lavaströme bis zum Meer hinabsandte, ${ }^{7}$ anderseits nehmen auch streng intermittierende Vulkane zeitweise echten Strombolicharakter an, wie z. B. der Vesuv in der Mitte des 18. Jahrhunderts oder im Jahr 1894. Der Charakter der Eruption hängt im wesentlichen einerseits von der chemischen Zusammensetzung und dem Dampfgehalt des Magmas, anderseits von der Beschaffenheit des vulkanischen Kanals ab. Wir können verschiedene Typen unterscheiden, aber wir können noch nicht sagen, welcher der normale ist. Indes darf man doch den Vesurtypus ${ }^{8}$ als denjenigen bezeichnen, wo die einzelnen Akte des Eruptionsdramas am vollständigsten und gleichmäßigsten entwickelt sind.

$\times$ Man hat die explosiv-intermittierende Tätigkeit die plinianische genannt - einer jener vielen und nichtssagenden technischen Ausdrücke, mit denen man die Geographie unnötigerweise beschwert. 
Der Vesuv ist ein charakteristisches Beispiel der weitverbreiteten vulkanischen Doppelberge, die aus zwei ungleichalterigen Vulkanen bestehen (s. Fig. 93). Die wallartige Erhebung im N, die Somma, ist der Rest eines vorgeschichtlichen Tuffkegels, in dessen ausgeweitetem Krater sich seit 79 n. Chr. der neue Kegel, der eigentliche Vesuv, aufgebaut hat, gekrönt von einer trichterförmigen Einsenkung (Krater), in die der gegenwärtige Haupteruptionskanal

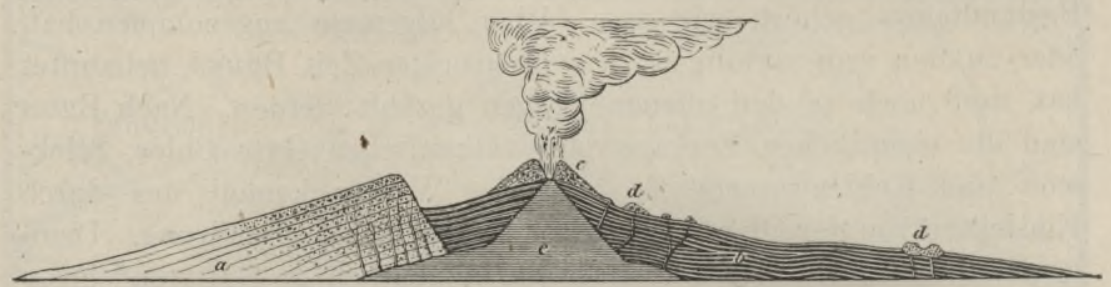

Fig. 94. Idealer Durchschnitt des Vesuvs nach von Hochstetrer.

$a$ die Somma, $b$ gemischter Kegel, $c$ Aschenkegel, $d$ kleine parasitische Schuttkegel (Bocca), $e$ hypothetischer innerer Lavaraum.

ausmündet. $\times$ Einen idealen Durchschnitt zeigt Fig. 94, nur muB bemerkt werden, daß das unaufgeschlossene Innere des Vulkans lediglich hypothetisch als ein weiter, mit Lava erfüllter Raum eingezeichnet ist. Man kann sich an dessen Stelle auch einen schlotförmigen Eruptionskanal vorstellen.

Bis zu der furchtbaren Katastrophe im Jahre 79, der die Städte Pompei, Herculaneum und Stabiae zum Opfer fielen, galt der Vesuv für erloschen. Bis 1631 meldet die Geschichte nur 17 Ausbrüche, wiederholt blieb der Berg mehr als ein Jahrhundert, zweimal sogar mehr als zwei Jahrhunderte ruhig; seit dem 12. Jahrhundert bedeckte er sich wieder mit reicher Waldvegetation. Der Ausbruch von 1631 übertraf an Schrecklichkeit noch jenen zur Zeit des Kaisers Titus, und seit 1694 hat der Vulkan seinen Charakter verändert. Die Ruhepausen wurden kürzer, aber die Tätigkeit verlor an Intensität, wenn sich auch heftige explosive Ausbrüche - Paroxysmen, wie Scrope sie nennt - zeitweise noch immer ereignen $(1760,1794$, $1822,1872,1906)$. Auch bei anderen Vulkanen hat man diese Erfahrung gemacht; es kann als Regel gelten, daß je länger die Ruhe, desto heftiger die darauf folgende Eruption ist. Es muß sich, wie

× Man hat auf Grund eines pompeianischen Wandgemäldes behauptet, daB der eigentliche Vesuv schon vor 79 bestand, und Eastmax meint, die bekannten Ausbrüche seien zu unbedeutend gewesen, um einen so großen Aschenkegel, wie es der Vesuv ist, zu schaffen. Indes ist es doch wahrscheinlicher, $\mathrm{daB}$ die pompeianische Darstellung auf einer Verwechslung mit dem im Hintergrund aufsteigenden Appennin beruht. 
man vermuten darf, eine gewaltige Dampfmenge im Lavaherd entwickeln, um sich durch den in der Ruhezeit verstopften Kanal oder an anderer Stelle einen neuen Weg zu bahnen. Erdbeben leiten meist als äußere Zeichen dieses Kampfes die bevorstehende Katastrophe ein, ja manchmal hebt sich der Boden, um dann wieder zu sinken, wie durch Beobachtungen bei den Vesuvausbrüchen im Dezember 1861 und April 1906 festgestellt wurde. Immer mächtigere Dampfmassen entsteigen dem Krater, bis dieser berstet und eine hohe Aschensäule, die sich oben pinienartig ausbreitet, emporsteigt. Ein feiner Aschenregen beginnt, der durch den Wind oft weithin geführt wird; so bei dem Ausbruch des Coseguina (in Nicaragua) am 20. Januar 1835, einem der schrecklichsten $\mathrm{Phänomene} \mathrm{dieser}$ Art in den letzten Jahrhunderten, $2000 \mathrm{~km}$ in die See hinaus und bis zu dem über $800 \mathrm{~km}$ entfernten Chiapas. Nachts erscheint an der Stelle der Rauchpinie eine imposante Feuersäule von wechselnder Helle. Da sie auch im heftigsten Sturm unbeweglich bleibt und selbst Sterne von schwacher Leuchtkraft durchscheinen läBt, so ist das Licht offenbar nur der Widerschein der glutflüssigen Lava im - Kanal. Aber auch wirkliche Flammen, erzeugt von brennbaren Gasen, wurden manchmal beobachtet, doch sind sie schwach und von geringer Höhe. Gewaltige Schlackenraketen verkünden das Aufsteigen der Lava. Der Cotopaxi schleuderte i. J. 1533 Felsstücke von $3 \mathrm{~m}$ Dicke $900 \mathrm{~m}$ hoch und über $22 \mathrm{~km}$ weit. Heftige Eruptionen werden von Gewittern begleitet. Die Wasserdämpfe erhalten nämlich — wie PaLmieri nachwies - durch schnelle Verdichtung positive, die Asche aher beim Fallen in diesem Medium negative Elektrizität; wahrscheinlich ist auch der ganze Berg elektrisch geladen. Gewöhnliche meteorologische Begleiterscheinungen sind. Sturm und Regengüsse; diese oder geschmolzener Schnee oder entleerte Kraterseen erzeugen, mit Asche vermischt, die Schlammströme, die oft verheerender wirken als die Lavaströme.

Den SchluB des Eruptionsaktes bildet meist der Austritt von Lava, seltener aus dem Gipfelkrater als an den Abhängen, wo sich eine radial auf die Achse des Kegels stehende Spalte öffnet; ja oft spielt sich die ganze Eruption am Abhang ab, wie 1861 am Vesur, während der Hauptkrater nur durch eine intensivere Gasentwicklung daran teilnimmt. Meist fließ̉ die Lava in ruhigen Strömen, die auch bei starker Neigung noch zusammenhängende Gesteinsschichten zu bilden vermögen. Das hängt wesentlich von ihrer chemischen Beschaffenheit und dem Grad ihrer Durchtränkung mit Wasserdampf ab; sie kann bei $35^{\circ}$ Neigung schon erstarren und bei $10^{\circ}$ noch fließen. Die Masse der ausgeworfenen Lava ist sehr bedeutend; sie 
betrug z. B. bei der Eruption des Etna i. J. 1886 im Lauf einer Woche (19.-27. Mai) 48. Mill. cbm, denen dann bis 8. Juni noch 6 Mill. cbm folgten. Der Strom näherte sich Nicolosi mit einer mittleren stündlichen Geschwindigkeit von $50 \mathrm{~m}$, die aber zeitweise bis zu $300 \mathrm{~m}$ stieg, um dann dicht vor der bedrohten Stadt stehen zu bleiben. Die Lava, die 1783 dem Laki auf Island entströmte, bedeckte $565 \mathrm{qkm}$ und erreichte eine mittlere Mächtigkeit von über $20 \mathrm{~m}$. Das ergibt die erstaunlich große Masse von 12320 Mill. cbm. Geht der EruptionsprozeB rasch und unter bedeutender Dampfentwicklung vor sich, so zerfällt der Lavastrom in einen Trümmẹrhaufen (Block- oder Schollenlava); im anderen Fall geht er durch das Zwischenstadium der Zähflüssigkeit aus dem flüssigen in den festen Zustand über und bildet dann die zusammenhängende Fladen- oder Gekröslava.

Aus manchen Vulkanen, wie aus einigen javanischen oder aus dem Demawend in vorgeschichtlicher Zeit, tritt die Lava nicht in flüssigem Zustand, sondern halb erkaltet als ein Gewirr von Blöcken aus. Dagegen beruht nach Тн. WoLf die Nachricht von den südamerikanischen „Kotlaven“ nur auf ungenauer Beobachtung; es sind einfache Schlammströme, die am Cotopaxi neben echten Lavaströmen vorkommen.

Erdbeben, Aschenauswurf, Lavaerguß sind die drei Akte, in die gewöhnlich das Eruptionsschauspiel bei dem Vesurtypus vom Beginn bis zu seinem Höhepunkt zerfällt.' Sie können sich in verhältnismäßig kurzer Zeit abspielen, aber auch wochen- und monatelang mit kurzen Ruhepausen wiederholen, und wir sprechen im letzteren Fall von einer Eruptionsperiode, wie z. B. der Vesuv eine solche vom Januar 1871 bis zum April 1872 durchlebte.

Das veränderlichste Moment sind die Erdbeben. Sie fehlen oft ganz, wie bei den meisten Ausbrüchen des Cotopaxi, oder stehen wenigstens in keinem Verhältnis zu der nachfolgenden Katastrophe, wie bei der Krakatau-Eruption i. J. 1883. Der Etnaausbruch i. J. 1865 wurde durch gelinde Erschütterungen eingeleitet, aber - gegen alle Regel - durch eine sehr heftige abgeschlossen.

Von viel größerer Wichtigkeit ist es, ob das Magma überhaupt und in welcher Form es an die Oberfläche gelangt. Bei dem Vesurtypus geschieht dies, wie wir gesehen haben, sowohl in der Form lockerer Auswürflinge, wie in der von Lavaströmen. Aber gerade die Geschichte der letzten Jahrzehnte hat uns eine Reihe anderer Typen kennen gelehrt.

Der Bandaisan in Japan, seit Menschengedenken erloschen, hatte am 15. Juli 1888 eine furchtbare Dampfexplosion, die die 
ganze Nordseite des Gipfels wegsprengte und an deren Stelle einen gewaltigen Krater von 383 ha Flächeninhalt schuf. Nachstehendes Profil (Fig. 95), in dem die alte Gestalt durch eine punktierte Linie angedeutet ist, veranschaulicht diese Veränderung. Magma trat nicht zutage; das ausgeworfene Material, das man auf 1213 Mill. cbm schätzt, entstammt nicht der Tiefe, sondern dem abgesprengten Teil

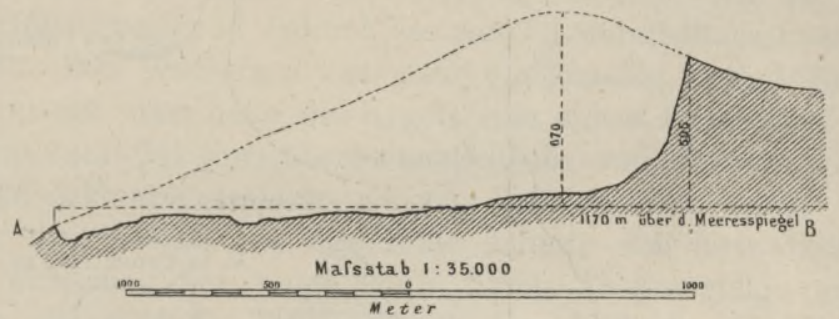

Fig. 95. Profil des Bandaisan vor und nach der Eruption nach Sekrya.

des Berges, dessen Gesteine schon vorher durch Gasausströmungen zersetzt worden waren. ${ }^{9}$

Dem Wasserdampf wird auch die Hauptrolle bei zwei anderen Katastrophen der 80 er Jahre zugeschrieben: bei den Ausbrüchen des Krakatau, ${ }^{10}$ eines Inselvulkans der Sundastraße, am 27. August 1883, und des Tarawera ${ }^{11}$ auf der Nordinsel Neuseelands am 10. Juni 1886. Der erstere hatte seit 1680 geruht, der letztere war, soweit die Tradition reicht, nicht mehr tätig gewesen. In beiden Fällen hatte die Eruption einen explosiven Charakter; zum Unterschied vom Bandaisan wurden gewaltige. Mengen von Asche und Bimsstein (schaumig aufgeblähte Lavafetzen) ausgeworfen, aber kein Lavastrom ergoß sich aus den Spalten.

Reich an Überraschungen waren die denkwürdigen Ereignisse, die sich 1902 und 1903 auf den westindischen Inseln Martinique und St. Vincent abspielten ${ }^{12}$. Die alte Montagne Pelée im nördlichen Martinique baut sich vorzugsweise aus aufgeschichteten lockeren vulkanischen Produkten auf und war, da sie in geschichtlicher Zeit nur ein paar leichte Ausbrüche erlebt hatte, schon stark abgetragen. Der Kraterboden (Étang sec) lag $700 \mathrm{~m}$ über dem Meer, der Kraterrand war ungleichmäßig erhalten; gegenüber dem höchsten Punkt, Morne la Croix $(1350 \mathrm{~m})$, öffnete sich ein tiefer Einschnitt, der zum Tal der Rivière Blanche führte. Durch diese Lücke ergoB sich am 8. Mai 1902 eine dunkle, von tausend Blitzen durchzuckte Wolke mit rasender Geschwindigkeit zur Westküste. Binnen wenigen Minuten war die reiche Stadt St. Pierre zerstört, 
und alle Bewohner bis auf einen, mehr als 30000 Menschen, fanden dabei ihren Tod - eine Katastrophe, die, wenn auch nicht durch ihre Intensität, so doch durch ihre Plötzlichkeit in der Geschichte des Vulkanismus einzig dasteht. Offenbar war diese Wolke, ein Gemisch von Gasen und glühender Asche, zu schwer, um in

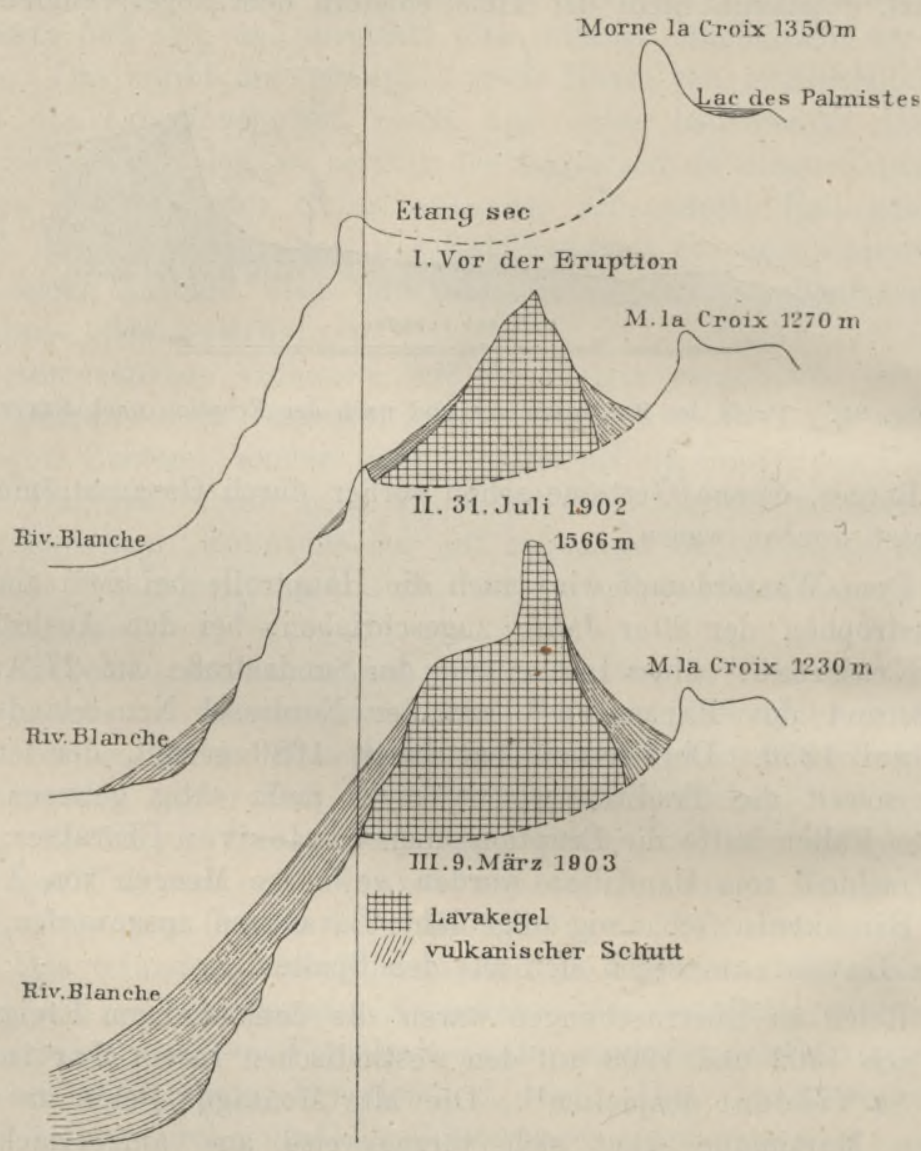

Fig. 96̆. Die Umgestaltungen der Montagne Pelée nach Lıcrörx.

die Höhe zu steigen, und muBte sich nach Art einer Lawine wie ANDERson sich treffend ausgedrückt hat - abwärts bewegen. Auf Martinique wurde sie durch die topographischen Verhältnisse nach einer Seite gedrängt, auf St. Vincent aber, wo der Krater auf dem Gipfel liegt, ergoß sie sich am 7. Mai über den ganzen Bergkegel. Ein derartiger Eruptionstypus, den man als ein Mittelglied zwischen Aschensäulen und Lavaströmen auffassen kann, war bisher 
noch niemais unmittelbar beobachtet worden, wenn auch vielleicht nicht völlig neu. ${ }^{x}$

Bald nach der einleitenden Katastrophe begann die vulkanische Tätigkeit der Pelée einen anderen Charakter anzunehmen. Andesitische Lava trat aus dem Krater hervor, aber ihre Zähflüssigkeit gestattete ihr nicht einen Strom zu bilden, sondern nötigte sie, sich über dem Krater zu einem steilen Felskegel aufzustauen, der sichtbar in die Höhe wuchs und dadurch das ganze Landschaftsbild veränderte (Fig. 96). Das Wachstum war nicht gleichmäBig, am 3. November 1902 trat auf einer Seite des Kegels eine spitze Felsnadel hervor. die schon am 24. November eine Seehöhe von $1575 \mathrm{~m}$ erreichte. Ihre Entwicklungsgeschichte ist von Tag zu Tag. genau verfolgt worden; ihre Gestalt wie ihre Höhe änderte sich fortwährend teils durch Nachschub von unten, teils durch Absprengung von Felsstïcken, die sich als Trümmerhalde am Fuß des Kegels bis in das Tal der Rivière Blanche hinein aufhäuften. Die Hauptepochen waren der 6. Februar 1903, wo die Nadel nurmehr 1424 m hoch war; dann der 31. Mai 1903, wo sie ihre Maximalhöhe von $1617 \mathrm{~m}$ erreichte, und der 10. August 1903, wo sie verschwand. Der Kegel war damals nur noch $1380 \mathrm{~m}$ hoch; er wuchs zwar wieder, aber nicht mehr so stark, und erhielt sich vom September an auf einer nahezu gleichmäßigen Höhe von $1450 \mathrm{~m} . \times \times$

Der Peléetypus ist in der Reihenfolge der Erscheinungen dem Vesuvtypus verwandt, aber die einzelnen Akte sind wesentlich anders entwickelt. Mit seinem Staukegel bildet er den Übergang zu den seltenen mehr oder weniger reinen Lavaeruptionen. Hawaii stellt den basaltischen, Santorin den andesitischen Typus vor.

Die Inselgruppe Santorin ${ }^{14}$ in den ägäischen Gewässern besteht aus vulkanischen Bildungen verschiedenen Alters. Die Hauptinseln Thera und Therasia mit dem Eiland Aspronisi sind die Trümmer eines zerbrochenen Kraterwalles aus vorgeschichtlicher Zeit. Inner-

$\times$ Von den Ausbrüchen des Gunung-Gedé Ende 1840 und des Tangkubanprahu am 10. Juni 1846 berichtet F. Junghuнn (Java, Leipzig 1854, Bd. II, S. 31 u. 46), daß Wälder nach einer Seite und zwar vom Krater abwärts umgelegt wurden, und führt dies auf den durch niederstürzende Aschenmassen erzeugten Luftdruck zurück.

$x \times$ In der Deutung des neuen Peléekegels stimmen alle Beobachter überein mit Ausnahme von HeiLPris ${ }^{13}$, der ihn anfangs in gewöhnlicher Weise durch Aufschüttung entstehen läßt und in der Nadel die emporgepreBte Säule des alten Lavakerns des Vulkanschlotes erblickt. Analoge Bildungen glaubt man in den Felssäulen des Dekan und im Gipfelfelsen der Insel FernandoNoronha gefunden zu haben, es ist aber sehr fraglich, ob sie ursprüngliche oder Destruktionsformen sind.

Supan, Physische Erdkunde. 5. Aufl. 
halb desselben entstanden durch neue Ausbrüche die kleinen Kaymeni-Inseln: 198 v. Chr. die Palaea-Kaymeni, 1573 die Mikra-Kaymeni, 1707-12 die Nea-Kaymeni, 1866 die Inseln Georgios und Aphroessa, die rasch anwachsend mit der Nea-Kaymeni verschmolzen. Diese

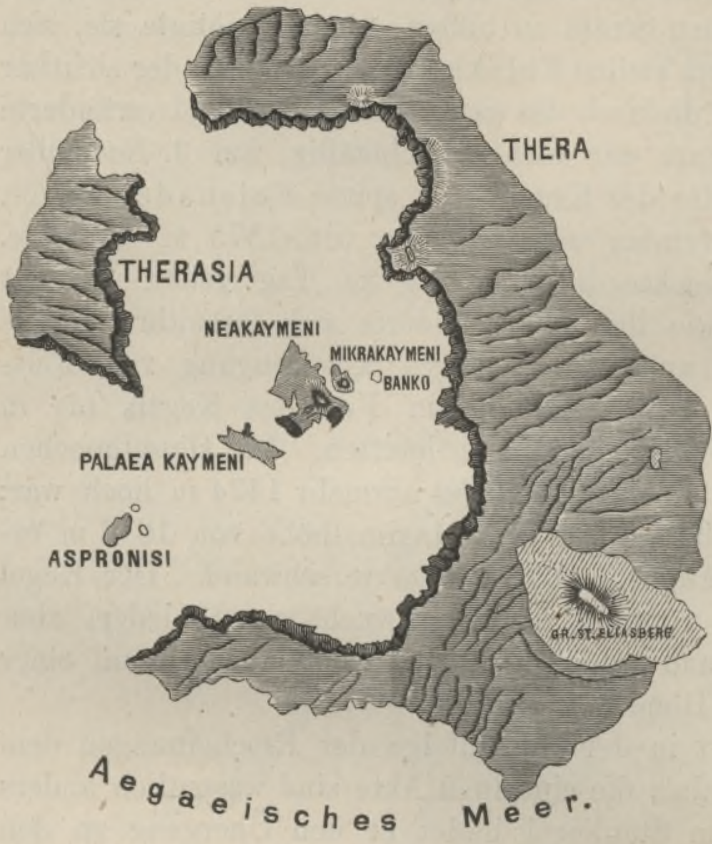

Fig. 97. Santorin im Jahr 1866 nach v. SEEBACH.

letzte Eruption bot zum ersten Mal die erwünschte Gelegenheit, die Entstehung von Andesitbergen $\mathrm{zu}$ beobachten. Am Beginn vollzog sich das Schauspiel in größter Ruhe, ohne Explosionen, ohne unterirdisches Geräusch. Erst später nahm die Eruption einen heftigeren Charakter an. Steine wurden emporgeschleudert und mächtige, mit Asche geschwängerte Dampfsäulen erhoben sich, aber dies alles sind nur nebensächliche Momente; der eigentliche Charakterzug des Santorinausbruches bestand darin, daß sich über der unterseeischen Öffnung des Kanals der zähe Lavabrei wulstartig anhäufte, indem immer neue Massen sich aus der Spalte hervordrängten und die alten in die Höhe und zur Seite schoben. Sehr passend wurden die neugebildeten Inseln mit „riesigen Schwämmen“ verglichen. „Mit eigenen Augen,“ schreiben Reiss und StüBel,, ${ }^{15}$ „haben wir eine, an manchen Stellen bis zu $200 \mathrm{~m}$ mächtige, von steilen Böschungen begrenzte Lavamasse entstehen sehen, deren Oberfläche kaum irgendwelche Schlackenbildung zeigte, und der jeder Aschen- oder Schlackenkegel fehlte." „Diese Lava,“ heißt es an einer anderen Stelle, ,war so zähflüssig und von einer so mächtigen, in große glasige Blöcke zerteilten Erstarrungskruste bedeckt, daß die flüssige Lava selbst niemals an der Oberfläche sichtbar wurde." Während lockere Massen sich wallartig um die Ausbruchsöffnung anhäuften, wurde diese verdeckt, daher war auch anfangs 
ein Krater nicht bemerkbar; erst nach der Explosion am 18. Juli, die den mittleren Teil der Georgsinsel zerstörte, entstand an dieser Stelle eine kraterähnliche Vertiefung, wo sich Lava ansammelte und Ausbrüche stattfanden. „Die anfangs Hach gewölbte Gestalt der Insel formte sich allmählich zu einem regelmäBigen stumpfen Kegel.“

Hawaii ${ }^{16}$ ist eine aus vier oder fünf Basaltkegeln zusammengeschweißte Insel. Das nordwestliche Horn bildet die Kohalakette (1678 $\mathrm{m} \mathrm{h.),} \mathrm{der} \mathrm{Überrest} \mathrm{des} \mathrm{ältesten} \mathrm{Vulkans;} \mathrm{im} \mathrm{Westen} \mathrm{erhebt}$ sich der Hualalai (2522 $\mathrm{m} \mathrm{h}$.), seit 1801 ruhig; die Mitte nehmen die beiden Bergriesen, der seit langem erloschene Kea (4208 m) und der noch tätige Loa $(4168 \mathrm{~m})$, ein. Am Ostabhang des letzteren öfnet sich, in $1231 \mathrm{~m}$ Seehöhe, der ungeheure Krater Kilauea, der ebenso, wie der Krater Mokuaweoweo auf dem Loagipfel, von den senkrecht abstürzenden Bruchrändern nahezu horizontal geschichteter Lavaströme eingeschlossen ist. DutroN ${ }^{17}$ hält diese großen Vertiefungen nicht für echte Krater, sondern für Einsturzbecken und will dafür den Namen Caldera angewendet wissen. Innerhalb des Kilanea liegen die berühmten, mit flüssiger Lava gefüllten Seen, ein einzig dastehendes Phänomen. Es muß eine gewaltige und vor allem eine stetig wirkende Kraft sein, die die Magmasäule beständig in dieser Höhe zu erhalten vermag. Allerdings wirkt sie nicht gleichmäßig; auch die hawaiischen Vulkane sind intermittierend tätig. Aber da ihre basaltische Lava sehr dünnflüssig ist, so staut sie sich nicht, wie die andesitische Santorins oder der Pelée, über der Ausbruchsöffnung an, sondern fließt ruhig über. Der See entleert sich und der Boden des Kraters stürzt über dem Hohlraum ein. Der Dampf kann ohne viel Widerstand entweichen, er vermag daher die Projektile nur wenige Meter in die Höhe zu werfen, und diese fallen, ohne sich abzukühlen, an der gleichen Stelle wieder nieder und bauen Miniaturkegel von 4-18 m Höhe auf, „Dribbletcones", wie Dana sie bezeichnend nennt. Manchmal finden allerdings heftigere Eruptionen statt, und dann werden glühende Lavafontänen $60-200 \mathrm{~m}$ hoch emporgeschleudert. Asche, Lapilli, Bomben spielen auch.hier nur eine untergeordnete Rolle.

Ein Vulkan ist aber durchaus nicht dauernd an einen bestimmten Eruptionstypus gebunden. Der Kilauea hatte i. J. 1789 einen gewaltigen Aschen- und Steinausbruch; der Krakatau ist aus wechselnden Lagen von Aschen- und Lavaschichten aufgebaut ein Beweis, daß er sich früher genau nach dem Vesuvtypus verhielt. Richtig ist es aber, daß, wenn auch ein Vulkan zeitweise seinen Eruptionscharakter ändert, er doch in der Regel einen bestimmten Typus bevorzugt. 
Ferner haben wir zu beachten, daß alle diese verschiedenen Eruptionsarten ein Moment gemeinsam haben, indem sie nämlich alle von einem Zentrum ausgehen, um das sie die Auswurfsmassen mehr oder weniger kreisförmig anhäufen. Das Endprodukt ist in diesem Fall immer ein Berg. Daneben kennen wir aus früheren Erdepochen aber auch Lavaergüsse aus langgestreckten, lippenförmigen Spalten, die teils Gebirgszüge, teils - wenn die Lava dünnflüssig war und in großen Mengen ausfloß - ausgedehnte Tafeln schufen. Die Hargita in Ungarn ist ein Beispiel eines solchen Gebirgszuges, die Basaltdecke im nordwestlichen Dekan, die das. Königreich Preußen an Flächeninhalt übertrifft, ein Beispiel einer vulkanischen Tafel.

Es ist nicht notwendig anzunehmen, daß zwischen den Zentralund Labialeruptionen ein fundamentaler Unterschied bestehe. Wir erinnern nur an die denkwürdige Tarawera-Eruption i. J. 1886, bei der eine von Nordost nach Südwest ziehende Spalte von $14 \mathrm{~km}$ Länge entstand, und innerhalb dieser eine Reihe von Kratern, die ebensovielen Eruptionszentren entspraćhen. Auch die dazwischenliegenden unzerstörten Brücken wurden von engen Vertikalspalten durchsetzt. Wir dürfen also mit Thomas ${ }^{11}$ annehmen, daß sich zuerst der Boden längs einer Linie spaltete, und daß dann die unterirdischen Kräfte an denjenigen Punkten einsetzten, wo entweder die Gesteinsbeschaffenheit den Ausweg erleichterte, oder größere Dampfzufuhr die Explosionskraft vermehrte. Würde sich aus den eng benachbarten Kratern Lava ergossen haben, so hätten sich die Ströme leicht zu einer Gesamtmasse vereinigen können, die die einzelnen Ausbruchsstellen verdeckt hätte, oder es hätten auch die einzelnen Zentren selbst, wenn sie noch näher aneinander gerückt wären, miteinander verschmelzen können. Man sieht also, zwischen Zentralund Labialeruptionen sind Übergänge vorhanden, beide beruhen im wesentlichen auf demselben Vorgang.

Besonders lehrreich ist in dieser Beziehung Island, dessen Erforschung wir in neuester Zeit hauptsächlich Thonoddsen verdanken. ${ }^{18}$ - Hier finden wir verschiedene Typen vertreten: echte geschichtete Vulkane, aus wechselnden Tuffen und Lavaströmen bestehend, wie der Vesuv; Lavavulkane, ganz nach hawaiischem Muster, nur kleiner; flache schildförmige Erhebungen mit einer tellerartigen Vertiefung am Gipfel; endlich Labialbildungen in verschiedenen Stadien ihrer Entwicklung. Am häufigsten ist die Anfangsform: einer Spalte entlang treten eine Reihe noch wohl indiviidualisierter länglicher Krater auf; seltener sehen wir längs der Spalte lange, aber doch noch an vielen Stellen durchbrochene Wälle von Schlacken 
und Làvastücken; am seltensten ist die ausgebildete Form einer völligen Vereinigung der Zentren, die nach beiden Seiten dünnflüssige Lava ergossen haben.

Überblick der Vulkanformen. Jeder Vulkan ist das Produkt seiner eigenen Tätigkeit, und da diese Tätigkeit sich in so mannigfacher Art äußert, so müssen auch die Produkte mannigfach sein. Lediglich von diesem Gesichtspunkt aus die Vulkanformen einmal zusammenzufassen, empfiehlt sich deshalb, weil die spätere morphologische Betrachtungsweise noch andere Momente zu berücksichtigen haben und damit auch zu einem anderen System gelangen wird.

Wo der Ausbruch lediglich in einer Dampfexplosion besteht, wie bei dem Bandaisan, kann natürlich von Neubildungen keine Rede sein, sondern findet nur Zerstörung statt. Wo die Eruption zwar einen explosiven Charakter zeigt, zugleich aber auch neues Material zutage fördert, wird sowohl zerstört wie geschaffen, und es hängt ganz von den näheren Umständen ab, welche Wirkung die Oberhand gewinnt. Bei dem Ausbruch des Tarawera wurden zwar 1500 Mill. cbm Asche ausgeworfen, aber etwa 230 Mill. wurden in das Meer getragen, und 1270 Mill. verteilen sich auf eine Fläche von der Größe Badens. Die Heftigkeit der Explosion war so groß, und es fand eine so vollständige Zerstäubung statt, daß es nicht zur Bildung eines Aschenkegels kommen konnte. Indes ist nicht bloß die Explosion an sich für die Zerstörung verantwortlich zu machen. Indem Material aus der Tiefe entfernt wird, entstehen hier Hohlräume, und der darüber befindliche Boden stürzt ein. Die vier Inseln der Krakataugruppe hatten vor der Katastrophe von 1883 ein Areal von 4020 ha; durch Einsturz verloren sie 2291 ha, durch Neubildung gewannen sie 1305 ha; das ergibt ein Defizit von 986 ha. Ein kleines Eiland, das den sonderbaren Namen „Der polnische Hut“ trug, verschwand ganz, die Hauptinsel wurde um die Hälfte kleiner, Verlaten Eiland wuchs dagegen auf das Dreifache.

Die Eruptionen können wir in einfache und gemischte einteilen. Die einfachen produzieren entweder nur oder doch vorherrschend nur lockeres oder nur festes Material. Wir unterscheiden demnach Locker- und Lavaeruptionen.

1. Bei zentralen Lockereruptionen ist der Grad der Feinheit des Auswurfsmaterials von Wichtigkeit. Asche kann, wie beim Tarawera, lediglich zur Erhöhung des Bodens beitragen, während die Ausbrukhsstelle selbst nur durch eine Vertiefung im Boden gekennzeichnet wird. Dasselbe ist der Fall, wenn nur eine einzige Eruption an der betreffenden Stelle stattfindet, und dabei nicht beträchtliche Mengen von Lockermaterial ausgeworfen werden. Das 
Resultat ist also eine negative Bodenform. Dazu gehören auch die Maare.

Als positive Bodenformen gehen aus diesen Eruptionen auf dem festen Land Aschen- oder Schlackenkegel, auf dem Boden des Meeres Tuffkegel hervor.

2. Als Erzeugnisse labialer Lockereruptionen sind die langen Schlackenwälle in Island zu betrachten.

3. Gemischte Zentraleruptionen schaffen ebenfalls auf dem Land oder auf dem Meeresgrund geschichtete Kegel, die sich von den Aschenkegeln nur dadurch unterscheiden, daß die Beteiligung von Lavaströmen ihnen größere Festigkeit verleiht. Beiden ist ferner gemeinsam, daß sie einen Krater auf ihrem Gipfel besitzen. - Gemischte Labialeruptionen sind nicht bekannt.

4. Zentrale Lavaeruptionen erzeugen homogene Berge ohne Krater oder nur mit kraterförmigen Vertiefungen am Gipfel. Ihre Böschungsverhältnisse hängen wesentlich von dem Flüssigkeitsgrad der Lava ab.

5. Labiale Lavaeruptionen führen zur Bildung langgestreckter Gebirgszüge, wenn die Lava zähe, und zu der von Tafeln oder Plateaus, wenn die Lava dünnflüssig ist.

Stübel's Einteilung. ${ }^{19}$ STÜBEL hat die Behauptung aufgestellt, daß zwischen der vulkanischen Tätigkeit der Vergangenheit und der der Gegenwart ein fundamentaler Unterschied bestehe. Er unterscheidet monogene und polygene Vulkane;/die ersteren sind auf nichtvulkanischem Boden durch einen einmaligen Ausbruch entstanden, der sich zwar über eine lange Zeit erstrecken konnte, aber nur unter der Voraussetzung, daß in den Pausen die Lava nicht bis in ihren innersten Kern erkaltete. Die/polygenen Vulkane sind das Erzeugnis wiederholter, durch lange Ruhepausen voneinander getrennter Ausbrüche. Alle tätigen Vulkane gehören dieser Kategorie an, als monogene Schöpfungen der Gegenwart werden der Kaymeni auf der griechischen Halbinsel Methana und der Monte nuovo unweit von Neapel, die seit ihrer Bildung erloschen sind, angesehen. In der Vergangenheit soll aber die monogene Entstehungsweise die allgemeine gewesen sein; nicht nur die erloschenen Vulkanberge, sondern auch der Unterbau der tätigen sind monogen, wie z. B. die Somma, während der Vesurkegel polygen ist. Diese Ansicht hängt innig zusammen mit STÜBEL's Vulkantheorie, von der später ausführlicher die Rede sein soll. Es werden selbständige Lavaherde angenommen, deren Magma sich ausdehnt und endlich die Decke zerreißt. Ist der Überschuß abgegeben, so bedarf es längerer Zeit, ' um den Magmarest wieder ausbruchsfähig zu machen, und aù die 
erste monogene Schöpfung folgt eine lange Pause, die STÜBEL nicht nach Jahrtausenden, sondern nach Jahrmillionen bemißt. Daß die Ausbrüche nur periodenweise erfolgen und verhältnismäßig wenig Màgma an die Oberfläche bringen, soll anzeigen, daß der Vulkanismus seinem Erlöschen entgegengeht.

Fragen wir ñach Beweisen für die Monogenesis, so läßt uns StÜBEL völlig im Stich. Die Idee ist ihm angesichts der gewaltigen Ecuadorvulkane gekommen, sie haben auf ihn den Eindruck einheitlicher, streng geschlossener Bauten gemacht, gewissermaßen von Werken wie aus einem GuB, aber diese Auffassung ist doch nur eine subjektive und wird von seinem Reisegenossen ReIss ${ }^{20}$ durchaus nicht geteilt. Alle polygenen Vulkane sind geschichtete Kegelberge,

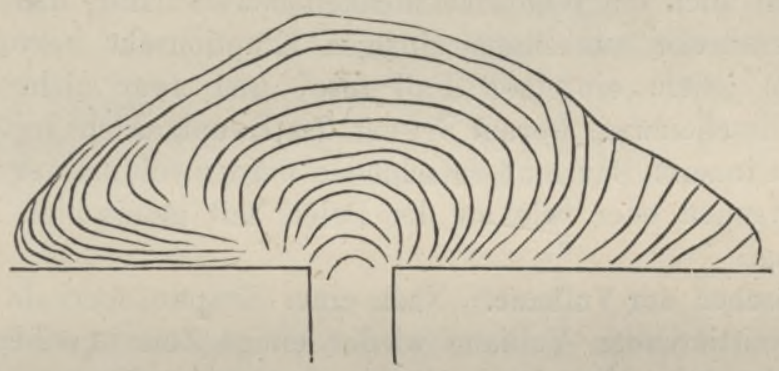

Fig. 98. Profil eines Lavakegels nach REYER.

aber auch monogene können in dieser Form auftreten. Durchgreifende Unterschiede, die sofort das Urteil leiten könnten, gibt es nicht; um z. B. den monogenen Charakter der Somma zu retten, muß StüBel zu einer willkürlichen Veränderung des geologischen Profils seine Zuflucht nehmen. Daß vulkanische Domberge, die sich nach oben verflachen, Calderaberge mit weiten Kratern, Rückengebirge und Plateaus nur auf monogenetische Weise entstehen können, ist nichts als eine Behauptung ohne objektive Beweise, die, soweit sie die Calderaberge betrifft, also in einem wesentlichsten Punkt, nicht einmal die Zustimmung seiner getreuesten Anhänger gefunden hat. Die Unterscheidung von mono- und polygenen Vulkanen verliert aber dadurch nicht allen Wert. Als monogen dürfen wir Lavakegel mit allseitiger Zwiebelstruktur betrachten, wie sie Fig. 98 im Durchschnitt darstellt. Diese Art der plattenförmigen Absonderung des erkalteten Gesteins läßt sich in der Tat am einfachsten erklären, wenn man annimmt, daß das zähe und dampfarme Magma sich über dem Eruptionskanal aufstaute, ganz in derselben Weise, wie wir es bei dem Pelée- und Santorinausbruch geschildert haben. Solch ein Berg wächst nicht durch Aufschüttung, also von 
oben, sondern von unten; und eine solche Anschwellung kann nur so lange vor sich gehen, als die ältere, $d . h$. obere Lava noch ihre Beweglichkeit bewahrt hat. Auch für Bauten anderer Art hat GRosseR $^{21}$ die monogene Entstehung wenigstens wahrscheinlich gemacht, wie z. B. für den Chimborazo, wo die verschiedene Färbung der Lavabänke deutliche Schichtung zeigt, aber ihre pseudoparallele Lagerung vermuten läBt, „daß zwischen den einzelnen Ergüssen keine beträchtliche Abkühlungspause lag“. Bei anderen Ecuadorvulkanen, z. B. am Imbabura, liegt über einem Unterbau aus solider Lava eine geschichtete Decke aus fest miteinander verbundenen Felsblöcken und -brocken, die von Absonderungsklüften von oben bis unten durchsetzt ist - ein Beweis für eine einheitliche Abkühlung und damit auch ein Wahrscheinlichkeitsbeweis dafür, daß Lava und Agglomeratdecke aus einem einzigen Eruptionsakt hervorgegangen sind. In jedem einzelnen Fall also, und zwar nicht nach der äußeren Erscheinung, worauf STÜBEL das Hauptgewicht legte, sondern nach dem inneren Bau muß entschieden werden, ob man es mit monooder polygenen oder (wie an der Pelée) mit gemischten Bildungen zu tun hat.

Erlöschen der Vulkane. Nach einer Eruptionsperiode versinken die intermittierenden Vulkane wieder einige Zeit in einen Zustand der Erschöpfung, der durch die sogenannte Solfatarentätigkeit charakterisiert wird. Man versteht darunter das Ausströmen von Wasserdampf und anderen Gasen in der Gestalt kleiner Säulen (Fumarolen) sowohl aus dem Krater, wie aus den Rissen der Abhänge. Manche Vulkane, wie die Solfatara von Pozzuoli, der Demawend in Persien u. a., verharren seit Menschengedenken in diesem Zustand. Fluor und Chlor, die das intensivste Eruptionsstadium charakterisieren, sind aus den Gasexhalationen verschwunden; endlich verschwinden auch die schwefligen Gase, die Temperatur nimmt ab, die Fumarolen hören auf; und nur die Kohlensäure, die entweder als Gas ausströmt (Mofetten) oder mit Wasser vermischt erscheint (Sauerquellen), und manchmal auch Thermen erinnern an die einstige vulkanische Tätigkeit der betreffenden Erdstellen.

Da aber - wie die Geschichte lehrt - selbst jahrhundertelange Ruhe keine Gewähr für die Zukunft bietet, so ist es nicht statthaft, alle jene Vulkane, die seit einem willkürlich gewählten Termin von ein paar Jahrhunderten kein Zeichen einer Tätigkeit mehr verraten, als erloschen zu bezeichnen. Das gilt wenigstens für Gegenden, wo neben ruhenden auch tätige Vulkane vorkommen. Hier ist die Ruhe vielleicht nur Schlaf, nicht Tod. Dagegen können wir den Puy de Dôme der Auvergne oder den Förmerich der Eifel 
mit einigem Recht erloschene Vulkane nennen, weil die vulkanischen Gebiete, in denen sie liegen, seit Menschengedenken keinen Ausbruch mehr erlebt haben. Statt tätigen und erloschenen Vulkanen unterscheiden wir also besser tätige und erloschene Vulkangebiete; die ersteren enthalten zuweilen nur tätige, in der Regel aber tätige und schlafende Kulkane, die letzteren dagegen nur erloschene Vulkane.

Die genaue Zahl der tätigen Vulkane ist unbekannt, eine kritische Geschichte des Vulkanismus in der historischen Zeit muß erst noch geschrieben werden. Nach der Statistik von Mercalli ${ }^{1}$ hat die Geschichte von 415 Vulkanen Ausbrüche verzeichnet, und von diesen waren noch 231 seit 1800 tätig. $\times$ Diese Zahlen sind gering-

$\times$ Mercali. $^{1}$ hat folgende Tabelle aufgestellt:

\section{Europa}

W-, Zentral- u. S-Asien .

Tätig seit 1800 Ruhend sammen

Kontinentales Asien . . . . . . . . . . . . . .

Unterseeische Vulkane in S-Asien . . . . . . 2

Ostasien .

Kamtsehatka

Kurilen

Japan .

Unterseeische Vulkane bei Japan .

Formosa und unterseeische Vulkane

Malaiischer Archipel

Philippinen

Celebes und die Molukken

Kleine Sundainseln

Java und Sundastraße

Sumatra und Golf von Bengalen

Afrika

Afrika und Rotes Meer

\section{7}

Comoren und Réunion .

Siidsee

Marianen und Hawaii

Neuguinea und Neue Hebriden .

Samoa, Tonga und unterseeisehe Vulkane . . .

Galapagos

Neuseeland

Südlicher Pazifischer Ozean

Amerika .

Alëuten und Alaska.

Nordamerika und Mexico .

Zentralamerika .

Antillen

Südamerika .

Atlantische Inseln

Island und Jan Maven

Azoren, Canarische Inseln, Kapverden

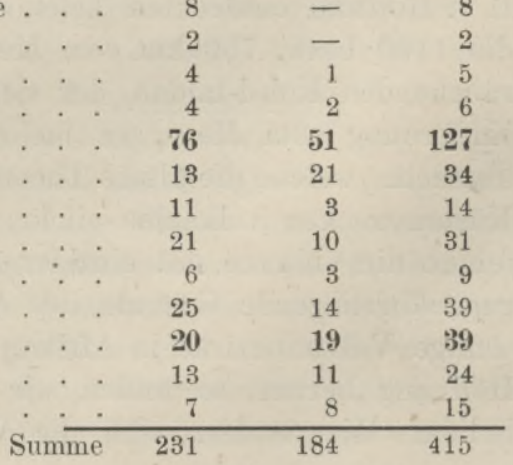


fügig im Vergleich mit der Zahl der erloschenen Vulkane. Man hat daher behauptet, daß die vulkanische Kraft überhaupt im Erlöschen begriffen sei; dieser Schluß wäre aber nur dann gerechtfertigt, wenn wir die relative Förderung von Eruptivgestein, bezogen auf eine Zeiteinheit, in der tertiären und quartären Periode abschätzen könnten. Absolut sind in der Geschichte der Erde zwei 2 Perioden durch intensive vulkanische Tätigkeit ausgezeichnet: die permokarbonische und die tertiäre; es sind dies diejenigen Perioden, in denen große Faltengebirge entstanden, und schon diese eine Tatsache legt den Gedanken nahe, daß zwischen den beiden Äußerungen der endogenen Kräfte ein Zusammenhang bestehe.

Geographische Verbreitung der Vulkane (s. Karte XVII). Von den oben genannten 415 Vulkanen kommen 173 auf die asiatische und 127 auf die amerikanische Seite des Stillen Ozeans, und 37 sind in diesem zerstreut. Das ergibt eine Summe von 337 (81 Proz.); die pazifische Welt ist somit in der Gegenwart der Hauptsitz der vulkanischen Tätigkeit.

Die älteren Theorien legten besonders darauf Gewicht, daß die meisten Vulkane sich im Meer oder in dessen Nähe befinden, und brachten dies mit der Annahme, daß Wasserdampf stets eines der Hauptprodukte der Ausbrüche sei, in ursächliche Verbindung. Meerwasser, so folgerte man, müsse zu den unterirdischen Feuerherden dringen, um das Magma eruptionsfähig zu machen. Diese Theorie läßt aber zweierlei unerklärt. Erstens die Tatsache, daß Vulkane auch fern vom Meer vorkommen. Abgesehen von den nicht ganz einwandfreien Vorkommnissen im Tiënschan, $2300 \mathrm{~km}$ vom Meer entfernt, können wir anführen die mandschurischen Feuerberge südöstlich von Mergen, also über $800 \mathrm{~km}$ von der Küste gelegen, die nach der Angabe v. Richthofen's noch am Anfang des 18. Jahrhunderts in Tätigkeit waren; ferner die noch tätigen Vulkane Ostafrikas: die beiden Kirunga, nördlich vom Kiwusee, und den von L. v. HöHNeL entdeckten Telekivulkan am Südende des Rudolfsees, die 1100 bezw. $750 \mathrm{~km}$ vom Meer entfernt sind; endlich den noch rauchenden Koh-i-tafdan, der sich im östlichen Persien, in $390 \mathrm{~km}$ Entfernung vom Meer, zu mehr als Etnahöhe erhebt. Die zweite Tatsache, welche die ältere Theorie ignoriert, ist die, daB ausgedehnte Küstenstrecken vulkanlos sind. Von Grönland bis zum. Feuerland fehlen die Vulkane mit einziger Ausnahme von Westindien, und das gegenüberliegende Gestade des Atlantischen Ozeans hat nur einige wenige Vulkanbezirke in Afrika. Gehen wir um das Kap der guten Hoffnung herum, so finden wir dieselbe Armut bis nach' Hinterindien. Hier ändern sich die Verhältnisse mit einem Mal. Der 
große vulkanische Sundabogen leitet uns in den Stillen Ozean hinüber. $^{22}$ Nirgends drängen sich die Feuerberge enger aneinander als an seiner Westseite. Von der Nordinsel Neuseelands über die Neuen Hebriden, den Bismarckarchipel, die Philippinen, Formosa, die LiuKiu, Japan, die Kurilen, Kamtschatka reiht sich fast ununterbrochen Bogen an Bog̀en. Den Norden schließt die Alëutenreihe ab, dann folgen im Osten die' amerikanischen Vulkane innerhalb des Hochlandgürtels. ${ }^{23}$ Das Alaskagebiet reicht im 0 bis zum Mt. Wrangell; von da $\left(62^{\circ} \mathrm{N}\right)$ bis zum 22..$^{\circ} \mathrm{N}$ sind vulkanische Gesteine zwar weit verbreitet, aber aus der geschichtlichen Zeit, die hier nicht sehr weit zurückreicht, kennen wir nur Eruptionen vom Mt. Edgecombe bei Sitka, von einigen Vulkanen des Kaskadengebirges und von den Tres Virginies in Nieder-Californien. Mit dem Ceboruco im mexicanischen Territorium Tepic beginnen dann die großen, noch tätigen Vulkangebiete der Neuen Welt, die durch breite vulkanlose Zonen voneinander geschieden sind. Es gibt deren mindestens sechs: das mexicanische $\left(22-18^{\circ} \mathrm{N}\right)$, das zentralamerikanische $\left(15-9^{0} \mathrm{~N}\right)$, das Gebiet von Columbia und Ecuador $\left(5^{\circ} \mathrm{N}-3^{\circ} \mathrm{S}\right)$, das Gebiet von Peru und Bolivien $\left(15-22^{\circ} \mathrm{S}\right)$, das chilenisch-argentinische $\left(22-42^{\circ} \mathrm{S}\right)$ und das patagonische $\left(42-56^{\circ} \mathrm{S}\right)$.

Diese Verteilung der Vulkane an den Festlandsrändern wurde uns erst verständlich, seit Suess den inneren Zusammenhang der vulkanischen Erscheinungen mit den großen Dislokationen aufgedeckt hat. Die pazifischen Ränder werden von jungen Faltengebirgen gebildet, die atlantischen und indischen von abgebrochenen Schollen. Nur Westindien und Hinterindien mit den Sundainseln machen eine Ausnahme im pazifischen Sinn, und wir haben gesehen, daß diese Gebiete auch durch lange Vulkanreihen ausgezeichnet sind. Wir können somit den Satz aussprechen, daß der pazifische Randtypus den Vulkanismus fördert, der atlantische ihn hemmt.

Tätige und erloschene Vulkane - letztere allerdings in der Mehrzahl - begleiten auch jene jugendlichen Faltengebirge, die die Alte Welt in westlicher Richtung durchsetzen, aber gerade die höchsten asiatischen Ketten, vor allem der Himalaya, sind frei davon. Im Osten beginnen diese Reihen mit dem Demawend des Elbursgebirges, dann folgen die kaukasischen, armenischen, kleinasiatischen und griechischen Vulkane, endlich die der einzelnen Zweige des Alpensystems.

Die Beziehungen zwischen den Vulkanen und den Faltenzügen sind sehr mannigfaltig. Die meisten Andesvulkane sind dem Gebirgskamm aufgesetzt, doch gibt es in Ecuador auch solche, die zwischen beiden Cordilleren liegen und sie dadurch verbinden, während der Ilaló isoliert aus der Talsohle aufsteigt. Beziehungen zwischen der 
Verteilung der quartären Vulkane und der des alteruptiven Porphyrs werden von TH. WoLF vermutet. Auch in Zentralamerika besteht eine innige Gemeinschaft zwischen den modernen Vulkanen und den tertiären Eruptivgesteinen, beide schließen im südlichen Chiapas nahezu an der gleichen Stelle ab. Die Vulkane bedecken in Costarica die atlantische Abdachung, steigen dann auf die Hauptwasserscheide hinauf und treten in Honduras auf die pazifische Seite hinüber; SAPPER hat sie in fünf Reihen gruppiert, von denen jede im Vergleich zu der nördlich benachbarten etwas nach SW verschoben ist. Doch kommen auch abseits von diesen Reihen Vulkane vor, in besonders großer Zahl östlich von Guatemala. In Mexico durchqueren sie das Plateau, stehen also anscheinend in keinen Beziehungen zum Gebirgsbau. In Nordamerika liegen Lassen Peak und Mount Shasta zwar im Streichen der Sierra Nevada, aber nicht auf dem Kamm, sondern an jenen Stellen, wo das ganze Gebirge einen Einbruch erlitten hat.

Ähnliche Beispiele liefert auch die Alte Welt. Die kaukasischen Vulkane sind ebenso dem Gebirge aufgesetzt, wie die Demawend-Solfatara dem Elburs; letzteres Gebirge wird aber nach Tretze auch an seinem südlichen Bruchrand von trachytischen Hügelreihen begleitet. Das vulkanische Gebiet des Hegau liegt in einem Einsturzfeld des Jura zwischen Thaingen und Arftingen. Auch die Canarischen Inseln liegen im Streichen des Atlas. Die mehr als 100 Vulkane Sumatras ordnen sich in 11 und die ungefähr ebenso vielen Javas in 9 Gruppen, die sich zu einer Zone vereinigen lassen, die dem heutigen Bruchrand am Indischen Ozean parallel läuft. ${ }^{22}$

In Europa waren die inneren Senkungsfelder jener Kettengebirge, deren kristallinische Zonen nur mehr in Bruchstücken vorhanden sind, ein Hauptschauplatz der vulkanischen Tätigkeit. Am inneren Rand der Appenninen ziehen Vulkane von Toskana bis Sizilien. Solche sind die Trachytberge Monte Amiata und Monte Cimino, die Kraterseen von Bolsena, Vico und Bracciano, das Albanergebirge bei Rom, das vielleicht noch in geschichtlicher Zeit tätig war; die acht Vulkane des Hernikerlandes bei Frosinone, deren Entstehung nach Branca in die vor- oder die altalluviale Periode fällt; die Rocca monfina, die tertiären Vulkane der Pontinischen Inseln, die phlegräische Gruppe mit der Solfatara und dem Monte nuovo, die Inseln Procida, Vivara und Ischia mit dem Epomeo, der 1302 den letzten Ausbruch erlebte; der Vesur und endlich die Liparischen Inseln, von denen Stromboli, Vulcano und Lipari noch tätig sind. Nur der Etna und der erloschene Vultur liegen an der Außenseite 
der Appenninen und bilden nach Suess die Endpunkte radialer Erdbebenlinien. Am mediterranen Bruchrand des Atlas finden sich ebenfalls insulare und kontinentale Vulkane, und in gleicher Weise ist die Innenseite des andalu sischen Gebirgssystems von Cabo de Gata bis Cabo de.Palos mit jungen Eruptivbildungen besetzt. Den inneren Rand der Karpathen begleiten die vorwiegend trachytischen Gebirge von Schemnitz und Kremnitz, von Gran, der Matrastock, die weinberühmte Hegyalja, der Vihorlat-Gutin-Zug und die kettenförmige Hargita. Auf der östlichen Bruchseite der Alpen mangeln trachytische und basaltische Ausbruchsstellen nicht gänzlich, und die Wiener Thermenlinie ist ein anderer Zeuge des gewaltigen Einsturzes dieser Gebirgskette. An der Südseite des böhmischen Erzgebirges fanden mächtige Basaltergüsse in der Neogenzeit statt (Böhmisches Mittelgebirge, Duppauer Gebirge), und hier liegen auch die weltberühmten Thermen von Teplitz und Karlsbad. Der Balkan hat ebenfalls an seiner Bruchseite junge Eruptivgesteine und warme Quellen. In ähnlichen Beziehungen steht wohl die erloschene Vulkanreihe vom Argäus bis zum Kara-Dagh zum Taurus, und stehen vielleicht die armenischen Feuerberge zum Kaukasus.

Genauere Beziehungen zwischen dem Auftreten von Vulkanreihen und den orographisch-geologischen Verhältnissen lassen sich auch im griechischen und westindischen Archipel nachweisen. Die griechischen Vulkane aus jungtertiären Eruptivgesteinen ziehen von einem von Philippson entdeckten Punkt am Isthmus von Korinth über Methana, Poros, Ägina und die Milosgruppe nach Santorin, also am Außenrand des zu Inseln zerstückelten Gebirges, wo das seichte Ägäische Meer zu bedeutenden Tiefen absinkt. In den Kleinen Antillen folgen von $O$ nach W. 1. Bruchstücke einer tertiären Außenzone (Barbados, Barbuda, Sombrero, Anegada), 2. eine Inselreihe von Anguilla bis zur Osthälfte von Guadeloupe, wo unter tertiären Laven und Sedimenten ein Unterbau alter Felsarten sichtbar wird, der als Rest einer ehemaligen Gebirgskette gedeutet werden kann, und endlich 3. der große Bogen junger Vulkane von Saba bis Grenada. Ein genaues Seitenstück zu dieser Anordnung sieht SuEss in den Liu-Kiu-Inseln. Schon diese Beispiele zeigen uns, wie neben Faltungszonen auch Bruchfelder von vulkanischen Kanälen durchzogen werden. Aber auch jugendliche Senkungen allein, ohne Faltung erweisen sich als günstig.

Eines der interessantesten Ergebnisse der jüngeren Afrikaforschung ist die Entdeckung der großen ostafrikanischen Grabeneinstürze, die Suess in genialer Weise mit den erythräischen und syrischen Brüchen verknüpft hat. ${ }^{24}$ Diese Bruch- 
zone, die größte, die wir kennen, erstreckt sich über 60 Breitengrade, vom Nordende Syriens bis zum Njassa, vielleicht bis zum Sambesi (Fig. 99). Das syrische Glied beginnt mit den Bekaâ zwischen dem Libanon und Antilibanon, setzt sich dann fort in der typischen

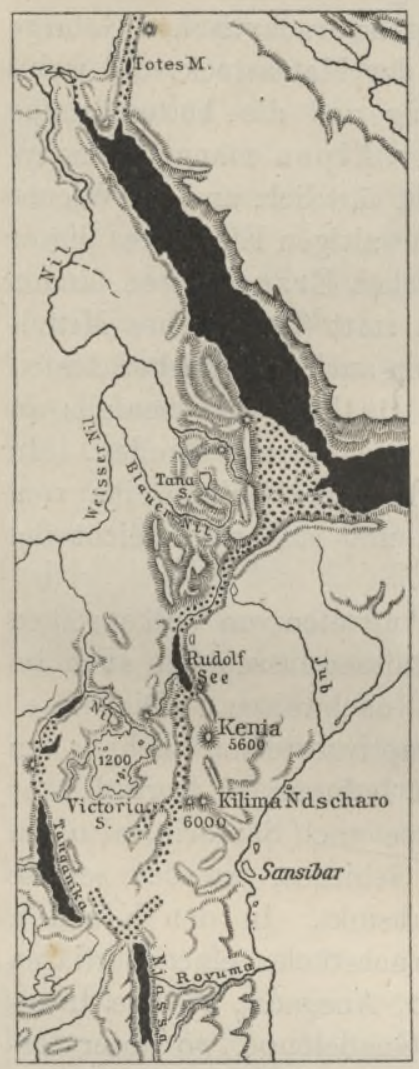

Fig. 99. Schematische Darstellung der syrischen, erythräischen u. ostafrikanischen Brüche. $(\because$ Gräben, $\equiv$ mit Wasser bedeckte Grabenteile, 。Vulkane).

Grabensenke des Ghôr, die unter dem Spiegel des Meeres liegt, und endet mit dem Golf von Akaba. Hier stößt der SSW streichende syrische Graben auf den NW streichenden erythräischen, der durch den Golf von Suës und das Rote Meer ausgefüllt ist. Dazu rechnet Suess auch noch die niedrige Landschaft Afar, die neben erloschenen auch noch mehrere tätige Vulkankegel besitzt. Auch die Inseln sind hier vulkanische Schöpfungen, und die gegenüberliegende Küste Jemens, sowie die Hadramauts an dem Grabeneinbruch des Golfes von Aden sind ebenfalls umfangreiche, wenn auch zum gröBten Teil erloschene Vulkangebiete. Mit steilem Bruchrand stürzt das abessinischeHochland nach Afar ab; vom Vulkan Dofane bei Ankober führt SuEss dieBruchzone hypothetisch weiter bis zum Rudolfsee, wo die Entdeckungen v. НöHNEL's beginnen, die weiter im Süden durch die Gregory's und Baumann's ergänzt werden. Der große ostafrikanische Graben reicht mindestens von $5^{0} \mathrm{~N}$ bis $6^{0} \mathrm{~S}$ und ist durch eine Reihe abflußloser Seebecken ausgezeichnet, hat aber den orographischen Charakter einer Grabensenke zum Teil dadurch eingebüßt, daß er mit jungeruptiven Gesteinen ausgefüllt wurde. Der tätige Telekivulkan ist schon früher genannt worden; östlich davon, an der Marsabitkette (ungefähr $2^{\circ} \mathrm{N}, 38^{\circ} \mathrm{O}$ ) hat Graf WICKENBURG drei Kraterberge entdeckt; erloschene Vulkandome, wie Ngai, Meru und die beiden Bergriesen Kenia und Kilimandscharo erheben sich innerhalb oder auf Seitenzweigen des Einsturzgrabens. Deutlicher prägt sich der zentralafrikanische Graben in der Bodengestaltung aus; er enthält die Seen Tanganika, Kiwu, Albert Edward- und Albert-See, 
und zwischen dem zweiten und dritten liegen in drei Gruppen angeordnet acht gewaltige $3000-4500 \mathrm{~m}$ hohe Vulkanberge, ${ }^{25}$ von denen wir die beiden noch tätigen Kirunga ebenfalls schon kennen gelernt haben.

Das häufige Vorkommen von Vulkanreihen führte zu der Annahme, daß die Vulkane wie Essen gemeinsamen Spalten aufsitzen. Die ältere Theorie L. v. Buch's, v. HuмвоцDт's u. a. betrachtete die Spalten als Erzeugnisse der vulkanischen Kraft selbst, die neuere Kontraktionstheorie, die die vulkanischen Erscheinungen zu Begleitern der Dislokationen herabdrückte, bedurfte aber vorher bestehender Spalten, die dem Magma den Weg nach der Oberfläche bahnen. Bei ihrer Konstruktion ging es nicht ohne Gewalttätigkeit ab; reichten Längsspalten nicht aus, so griff man zu Querspalten, und es kann nicht wundernehmen, wenn man auf diesem Weg alle vulkanischen Vorkommnisse in Spaltensysteme unterbrachte. Gegen dieses willkürliche Verfahren hat sich nun eine gesunde Reaktion erhoben. LöwL ${ }^{26}$ hat zuerst auf Grund allgemeiner Erwägungen die Spaltentheorie verworfen; Branca ${ }^{27}$ ist durch das Studium der schwäbischen Maare, BückING ${ }^{28}$ durch die nicht minder lehrreichen Vorkommnisse in der Rhön, A. GEikıЕ ${ }^{29}$ durch seine Untersuchung der alten Vulkane Großbritanniens und STÜBEL ${ }^{19}$ auf seinem ecuadorischen Forschungsfeld zu dem gleichen Ergebnis gelangt, und DAUBREE ${ }^{30}$ hat experimentell nachgewiesen, daß hoher Gasdruck von unten allein Kanäle öffnen könne. Selbst auf Island; wo der Zusammenhang von Spalten und Vulkanen augenscheinlich ist, sitzen diese nicht immer größeren Bruchlinien und Verwerfungen auf, sondern parallel damit streichenden Klüften ${ }^{31}$ - ein, wie es uns scheint, deutlicher Hinweis, daB diese Spaltenbildungen Wirkungen, nicht Ursachen der Eruptionen sind. Aber trotzdem bleibt die Tatsache der eigentümlichen geographischen Verbreitung der Vulkane bestehen, und sie fordert eine Erklärung. Wir finden diese in der Annahme, daB das Magma dort aufsteigt, wo es den geringsten Widerstand findet, in der Regel also dort, wo durch Dislokationen das Gefüge der Erdkruste zerrüttet ist. Vielleicht genügt schon, wie MrLcH ${ }^{32}$ annimmt, die Massenauflockerung unter Faltengebirgen (vgl. S. 15), vielleicht reichen auch, wie HrbscH ${ }^{33}$ meint, die Spalten nicht bis an die Oberfläche, sondern sind hier durch Sedimente verdeckt. Wo Schichten auf weite Strecken niemals eine Störung erlitten haben, wie in der russischen Ebene, oder wo junge Tiefländer allmählich in das Meer verlaufen, wie an den arktischen Küsten, da fehlen auch Vulkane. Selten sind sie auch in älteren Dislokationsgebieten, wo die meisten Wunden schon vernarbt sind, wie uns die atlantischen 
und die indischen Küsten zeigen. Beispiele, wie die Vulkane der Eifel und des französischen Zentralplateaus, deren Ausbrüche bis in die geologische Gegenwart hineinreichen, zum Teil noch vom prähistorischen Menschen miterlebt wurden, dürfen nicht als Ausnahmen betrachtet werden, denn wir wissen, daß diese Massive, obwohl Bruchstücke alter Gebirge, noch in der T'ertiärperiode vielfachen Bewegungen unterworfen waren.

Wir haben bisher die ozeanischen Vulkane außer acht gelassen, weil uns ihre Beziehungen zu der Tektonik des Untergrundes natürlich verborgen bleiben. Aber so wenig wir auch von ihnen

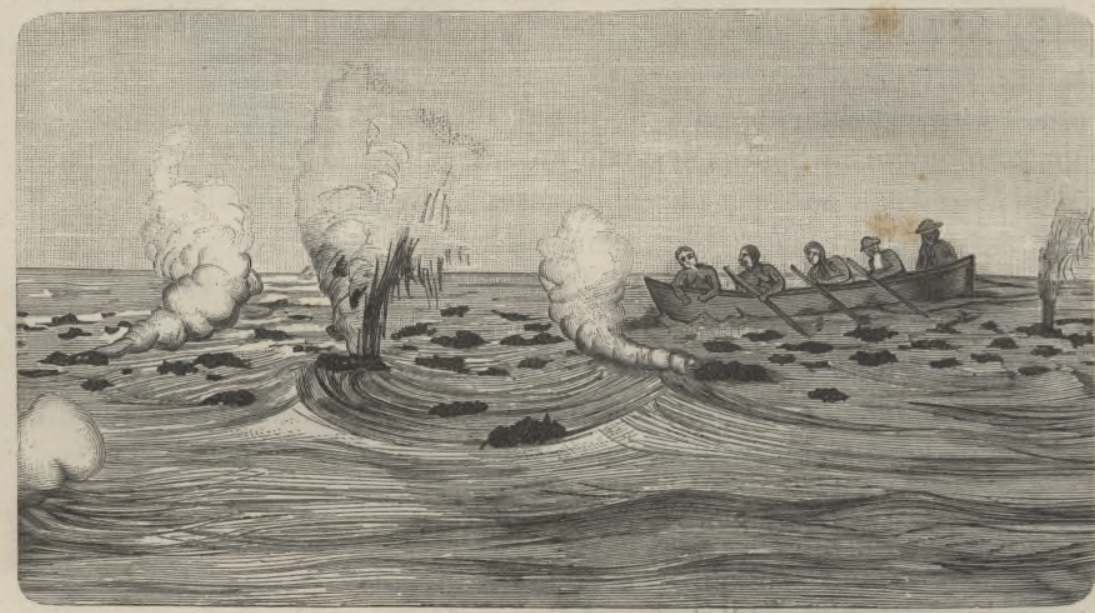

Fig. 100. Unterseeischer Ausbruch bei Pantellaria in der Straße von Sizilien im Oktober 1891, nach Ricco.

wissen, so dürfen sie in einem Gemälde der vulkanischen Erscheinungen-doch nicht fehlen, denn schon der gewaltige Anteil, den lockere Eruptivmassen an der Zusammensetzung der Tiefseeablagerungen nehmen, spricht für ihre Häufigkeit. Wenn sie trotzdem auf unseren Karten sehr in den Hintergrund treten, so.erklärt sich dies einfach daraus, daß wir von unterseeischen Ausbrüchen nur zufällig durch vorüberfahrende Schiffe Kenntnis erhalten. Die spärlichen Beobachtungen in dieser Beziehung hat RuDOLPH gesammelt. ${ }^{34}$ Wir ersehen daraus, daß sich diese Ereignisse unter dem Meer in gleicher Weise abspielen wie auf dem Land; die eigentümlichste Erscheinung, die mehr oder weniger hohen Wassersäulen, die sich über der Ausbruchsstelle erheben, ist durch die Besonderheit des Schauplatzes bedingt. Auch Bodenerschütterungen fehlen nicht, die sich dem Schiff als Stöße fühlbar machen; dumpfes Brüllen macht 
sich vernehmbar, Rauch und Flammen erheben sich über das Wasser, Asche und Bimssteinmassen werden herausgeschleudert, manchmal sieht man auch große Stücke Lava umhertreiben (Fig. 100).

Auch auf dem Boden des Meeres bauen die zentralen Ausbrüche Kegel auf, die - wenn die Auswurfsmassen in einem günstigen Verhältnis zur Wassertiefe stehen - endlich als Inseln über den Meeresspiegel emporsteigen. Aschen- und Schlackenhaufen fallen freilich bald wieder der Brandung zum Opfer, wie beispielsweise die Insel Ferdinandea im Jahr 1821, und nur eine Untiefe erinnert dann noch an ihren einstigen Bestand. Lavaergüsse verleihen ihnen aber größere Festigkeit und sichern ihre Dauer. Von den Inseln der liparischen Gruppe (bei Sizilien) entstanden wahrscheinlich mehrere in geschichtlicher Zeit; mit Bestimmtheit weiß man dies freilich nur von der Insel Vulcanello (ungefähr 200 v. Chr.), die im Mittelalter mit Vulcano verwuchs. Andere Beispiele sind Didica nördlich von den Philippinen (1856), die 1885 entstandene Falkeninsel in der Südsee $\left(20^{\circ} 19^{\prime} \mathrm{S}, 175^{0} 21^{1} /_{2}^{\prime} \mathrm{W}\right)$, die 1898 verschwunden war, aber 1900 wieder auftauchte, Niischima in der zu Japan gehörigen Gruppe der kleinen Vulkaneilande (1904) und vor allem die Bogoslovinseln in den Alëuten, die seit 1796 bis 1907 wiederholt der Schauplatz vulkanischer Ereignisse waren, und besonders deshalb lehrreich sind, weil ihre vielfachen Umgestaltungen durch die Bildung neuer Inseln, ihr Zusammenwachsen und ihre Zerstörung genauer verzeichnet wurden, als irgend welche Vorgänge dieser Art. $^{35}$.

GerLand hat in . seinen „Vulkanischen Studien“ 36 nachzuweisen versucht, daß sich die vulkanischen Kräfte auf dem Meeresboden in anderer Weise äußern als auf dem Festland. Seine Ausführungen beruhen auf der Annahme, daß alle Koralleninseln auf unterseeischen Vulkanbergen ruhen. Das mag in den meisten Fällen zutreffen, aber der weiteren Voraussetzung von der Allgemeingültigkeit der DARwIN'schen Rifftheorie können wir nicht mehr zustimmen, und damit entfällt auch die Folgerung, daß die Vulkane des Meeresbodens in einer anderen Beziehung zu dem Erdinnern stehen als die kontinentalen. Auch die Frage, ob der Grund des offenen Ozeans oder die Ränder der Festlandsmassen mit ihren insularen Vorposten in der Gegenwart der Hauptschauplatz der vulkanischen Tätigkeit seien, muß noch als völlig unentschieden dahingestellt bleiben.

Theorie des Vulkanismus. Über zwei Punkte hat die Theorie Auskunft zu geben: über die Herkunft des Magmas und über die Kraft, die es zum Aufsteigen nötigt.

Die erste Frage läßt sich so formulieren: hat das Magma einen 
gemeinsamen Ursprung, sei es in einem heißflüssigen Erdkern, sei es in einer heißflüssigen Zwischenschicht zwischen der festen Erdkruste und dem festen Erdkern, oder stammt es aus verschiedenen Quellen? Wie man sieht, verträgt sich die erstere Annahme mit verschiedenen Ansichten vom Erdinnern, nur ein allmählicher Übergang vom festen Zustand an der Erdoberfläche durch die Zwischenstufen des plastischen und flüssigen zum gasförmigen $\mathrm{Zu}$ stand im Kern würde die heißflüssige Schicht von jedweder Verbindung mit der Oberfläche abschließen. Wohl können sich in der oberen Grenzzone des flüssigen Aggregatżustandes, wo der Druck noch nicht zu übermäßig ist, Prozesse explosiver Natur abspielen, indem die dissoziierten Gase bald sich vereinigen, bald auseinandertreten, und wir können uns auch vorstellen, daß dabei hier oder da die plastische Schicht durchrissen wird, und das Magma des Erdinnern in den obersten klüftigen Krustenteil gelangt; aber unmöglich ist es, daß sich eine solche Verbindung mit dem Erdkern dauernd erhält, wie es doch bei permanent tätigen Vulkanen der Fall sein müßte. GüNTHER $^{37}$ verlegt daher folgerichtig die Lavaherde in die Erdkruste selbst. StüBEL ${ }^{19}$ fordert die Annahme abgesonderter Lavaherde aus dem Grund, weil die Magmaergüsse in keinem Verhältnis zu den gewaltigen Dimensionen des Zentralherdes stehen. Dieser Einwurf hätte aber nur dann Geltung, wenn das heißflüssige Erdinnere unmittelbar von einer dünnen Kruste bedeckt wäre; denn ist die letztere sehr dick, so kann man sich wohl vorstellen, daß das Magma nur unter besonders günstigen Umständen zum Ausbruch gelängen kann. Auch die weitverbreiteten Doppelvulkane (Sommatypus) zwingen nicht zu der Annahme, daß der Herd nach dem ersten Ausbruch erschöpft war und lange Zeit brauchte, um abermals eruptionsfähig zu werden, denn die große Pause zwischen der Bildung der beiden Berge lieBe sich auch auf SchlieBung und Wiedereröffnung einer Spalte zurückführen.

Zur Erklärung solcher peripherischer Herde hat STÜBEL eine geistreiche Hypothese aufgestellt. Die erste Phase im Erkaltungsprozeß des feurig-flüssigen Erdballs war die Entstehung einer Erstarrungsrinde. Diese wurde von dem Magma- des Zentralherdes an unzähligen Stellen und zu wiederholten Malen durchbrochen, die Lava ergoß sich in gewaltigen Strömen über die ursprüngliche Rinde und bildete im Lauf von Aeonen eine zweite, viel mächtigere Rinde: die Panzerung. Diese ist es, die unter der Einwirkung der exogenen Kräfte den Stoff für die metamorphischen und Sedimentgesteine lieferte; und die Erdkruste in ihrer heutigen Entwicklung nimh besteht demnach von oben nach unten aus vier Teilen: 1. Sedimente, 
2. metamorphische Gesteine, 3. Panzer, wozu vielleicht der Gneis zu rechnen ist, 4. Erstarrungsrinde. Innerhalb des Panzers liegen die peripherischen Herde verschiedenen Alters und in verschiedenen Stockwerken. Sie haben sich als flüssige Nester innerhalb einer erstarrten Masse in derselben Weise erhalten, wie wir solche Vorgänge noch jetzt bei erkaltenden Lavaströmen beobachten können. Auch diese bergen noch vulkanische Herde in sich, deren Ausbrüche manchmal sogar die Entstehung ${ }^{\dagger}$ parasitischer Kegel, wie der Boccas des Vesur oder der Hornitos des Jorullo in Mexico veranlassen. Ihre Lebensdauer ist freilich kurz und nicht zu vergleichen mit der der Panzerherde, die die Millionen Jahre, seit sich organisches Leben auf unserem Planet eingebürgert hat, im Schmelzfluß verharren. Freilich nicht alle; viele erloschene Vulkangebiete mögen über erloschenen Herden liegen, andere Herde mögen aber durch Verbindung mit dem Zentralherd ihre Verluste decken. STÜBEL unterscheidet also drei Ordnungen vulkanischer Herde: 1 . den Zentralherd, der die Panzerung schuf, 2. die peripherischen Herde, von denen die oberflächlichen Lavaergüsse ausgehen, 3 . die Herde innerhalb dieser Lavaergüsse.

LonEnzo ${ }^{38}$ hat eine Methode angegeben, um die Tiefe der vulkanischen Herde zu berechnen. Er geht dabei von der Annahme aus, daß die Umrahmung der Maare und das Baumaterial der Tuff- und Aschenkegel einst den Schlot ausfüllten; und da man die Masse dieses Materials berechnen kann und den Durchmesser des Schlotes kennt, so läßt sich auch die Länge des Schlotes ermitteln. Auf diesem Weg fand er für den Monte Nuovo eine Herdtiefe von $1248 \mathrm{~m}$ und für andere Vulkane der Phlegräischen Felder eine solche von $1000-2500 \mathrm{~m}$. Diese Ziffern sind als Maximalwerte zu betrachten, wenn dem Auswurfsmaterial auch magmatische Bestandteile beigemischt sind; anderseits sind aber diejenigen Auswürflinge, die in den Schlot wieder zurückgefallen sind, vernachlässigt. Für die gemischten und Lavaeruptionen kommt die Beschaffenheit der fremden Einschlüsse in Betracht. Am Vesuv bestehen sie aus älteren Eruptivgesteinen und aus tertiären, kretazeischen und triadischenSedimentgesteinen; die letzteren sind stark metamorphosiert, scheinen sich also in unmittelbarer Nachbarschaft des Magmas befunden zu haben. Die Mächtigkeit dieses ganzen durchbrochenen Schichtenkomplexes kann auf $3000 \mathrm{~m}$ veranschlagt werden; in dieser Tiefe muß sich also nach Lonenzo's Ansicht der Herd befinden. Damit käme man aber zu einer geothermischen Tiefenstufe von ein paar Meter, die allen Erfahrungen widerspricht, und man müßte mit DutтoN ${ }^{39}$ zu radioaktiven Wirkungen seine Zuflucht nehmen - eine Annahme, gegen die LouderBack ${ }^{40}$ energisch protestiert hat. 
Welche Bewandtnis es mit der Magmaquelle hat, können uns nicht theoretische Erwägungen, sondern einzig und allein Beobachtungen an Vulkanen und vulkanischen Gesteinen lehren. Zunächst lehrt die Erfahrung, daß selbst benachbarte Vulkane sich in ihrer Tätigkeit gegenseitig nicht beeinflussen. Ein drastisches Beispiel bieten der Loa und Kilauea, die, wie wir gesehen, doch völlig zu einem einzigen Berg verschmolzen sind. Von neun Eruptionen, die jeder Vulkan seit 1832 hatte, waren nur drei, der im Jahr 1868 streng und die in den Jahren 1832 und 1855 nahezu gleichzeitig. Dagegen wechselten die Eruptionen der beiden Kamtschatka-Vulkane, des Kljutschewskaja Sopka und des Schiweljutsch, im Jahr 1854 trotz ihrer beträchtlichen Entfernung so exakt miteinander ab, daß man keinen Zweifel hegen kann, daB dieselbe Lava bald durch den einen, bald durch den anderen Schlot einen Ausweg fand. Augenscheinlich ist auch der Zusammenhang zwischen den Ausbrüchen auf St. Vincent und Martinique im Jahr 1902, aber das dazwischenliegende St. Lucia zeigte keine Spur größerer Erregung, und nur westlich davon soll am 9. Mai 1902 ein leichter unterseeischer Ausbruch stattgefunden haben.

Für die Annahme gesonderter Lavaherde wurde auch die Verschiedenheit der Laven ins Feld geführt. „Erinnern wir uns,“ sagt v. Fritsch, „da $\beta$ in den Jahren 1865 - 67 auf dem engbegrenzten Gebiet des Mittelmeeres viererlei Lava floß, jede von der anderen wesentlich abweichend, jede aber im allgemeinen dem Charakter der letzten Ausbrüche desselben vulkanischen Gebietes entsprechend, nämlich die Etnalava von 1865, die Santorinlava von 1866, die Vesuvlava vom März 1866 und von $1867-68$, und gleichzeitig mit allen diesen die fortdauernden kleinen Ergüsse des Stromboli.“ Der Vesur hat basaltische, die Phlegräischen Felder haben trachytische Lava; von den beiden eng benachbarten Eruptionspunkten des Monte Cimino förderte der eine augitandesitische, der andere nephelinund leucithaltige Gesteine zutage. Die Beweiskraft solcher Tatsachen wird indes vermindert durch die andere Tatsache, daß auch der Lavacharakter eines und desselben Vulkans in manchen Fällen dem Wechsel unterworfen ist. Der Vesuv z. B. hatte früher eine trachytische Periode, ja Hekla und Krafla auf Island werfen abwechselnd saure und basische Laven aus, und es ist Bunsen gelungen, nachzuweisen, da $\beta$ die auf Island neben normaltrachytischen und normalbasaltischen Gesteinen vorkommenden Übergänge sich in der Tat auf Mischung der beiden Normallaven zurückführen lassen. Nach IDDINGs' Gesetz soll eine Eruptionsreihe mit Gesteinen mittlerer Art beginnen und mit extremen enden, und in der Tat wiederholte 
sich in den Berkeley Hills im californischen Küstengebirge die Aufeinanderfolge von Andesit, Basalt und Liparit nicht weniger als sechsmal. ${ }^{41}$ Ganz anders ist dagegen das Verhalten des Vulcanokraters auf den Liparischen. Inseln, denn nicht nur wechselt die chemische Zusammensetzung der Lava bei verschiedenen Ausbrüchen regellos, sondern sie schwankt auch bei den Auswürflingen einer und derselben Eruption. Einem allgemein gültigen Gesetz unterliegen also die Veränderungen der Laven nicht, wohl aber läßt sich, wie Bergeat ${ }^{7}$ betont, innerhalb von Vulkangruppen ,ein bestimmter, gleichgerichteter Gang im Wechsel der Magmabeschaffenheit" erkennen. Desgleichen zeigen auch die verschiedenen Laven benachbarter Vulkane trotz petrographischer Verschiedenheit chemische Verwandtschaft, und wir gelangen auf diese Weise zur Aufstellung „petrographischer Provinzen" oder "Gaue“. So ist z. B. den Basalten des Vesuv und den Trachyten der Phlegräischen Felder ein hoher Kali- und Natrongehalt gemeinsam. ${ }^{42}$ Ja nach den Untersuchungen von $\mathrm{BECKE}^{43}$ lassen sich alle bekannten vulkanischen Gesteine chemisch in zwei große „Sippen" vereinigen: die atlantische, charakterisiert durch größeren Reichtum an Alkalien und relative Armut an Kieselsäure und Tonerde, umfaßt die afrikanischen, mitteleuropäischen und atlantischen Vulkane mit Ausnahme der westindischen, während zur pazifischen Sippe, die durch relativ hohen Gehalt an Calcium und Magnesium ausgezeichnet ist, die Vulkangebiete am Großen Ozean gehören. Diese wichtige Erkenntnis spricht nicht für gesonderte Lavaherde, sondern für große Zusammenhänge in den unbekannten Tiefen unseres Planeten.

Auch in bezug auf die zweite theoretische Grundfrage sind die Meinungen geteilt. Ohne Zweifel sind die Explosionserscheinungen, wenigstens in der Mehrzahl der Fälle, eine Wirkung des Wasserdampfes; ist dieser aber, wie BRUN meint, nur ein zufälliger Bestandteil der vulkanischen Gase, so fällt damit auch die alte, noch von Arrhenius gestützte Theorie, daß das aus dem Meer in das Erdinnere gelangende. Wasser das Magma ausbruchsfähig mache. Aber auch dann, wenn Brun's Ansicht sich als unrichtig herausstellen sollte, würde sich jene Theorie kaum mehr zum Leben erwecken lassen, denn abgesehen davon, daß die geographische Verteilung der Vulkane ihr nicht günstig ist, sprechen, wie schon Tschermak ${ }^{44}$ betont hat, noch andere Gründe dagegen, wie die UnregelmäBigkeit und Seltenheit der Eruptionen, die sich mit einer dauernd wirkenden Ursache nicht vereinen läßt, und die große Menge anderer Gase, die im Magma enthalten sind und sich nicht nicht vom Meer ableiten lassen. Sie, sowie der Wasserdampf, sind nach seiner An- 
sicht (die, wie wir später hören werden, auch von SuEss vertreten wird) zum größten Teil ursprüngliche Bestandteile des Magmas; und in der Tat läßt sich schon aus ihrem Verhalten beim Erstarren der Lava, der sie in einer bestimmten Reihenfolge entweichen, folgern, $\mathrm{da} B$ sie sich nicht indifferent gegen das Magma verhalten, sondern von diesem absorbiert sind. Der Vulkanismus ist nach dieser Auffassung nichts anderes als ein Detailphänomen im EntgasungsprozeB des Erdinnern. Beachtung verdienen indes auch die neuen Experimente GaUtien's, ${ }^{45}$ der die vulkanischen Gase aus den zu Rotglut erhitzten kristallinischen Gesteinen, wie Granit, Gneis u. a., in großen Mengen erhalten hat. Wie immer es sich aber auch mit der Herkunft der Gase verhalten möge, stets bedarf es einer Druckverminderung, um sie explosiv zu machen. Dafür sprechen die geographischen Beziehungen der Vulkane zu den Dislokationen, aber man darf nicht vergessen, daß nicht alle Laven reich an Wasserdampf, ja daß vielleicht gerade die gewaltigsten Vulkanberge Schöpfungen eines dampfarmen Magmas sind. Das deutet darauf hin, daB der Wasserdampf wohl den Charakter der Eruption bestimmen mag, aber nicht deren eigentliche Ursache ist. Als solche werden isostatische Bewegungen der Erdkruste genannt; dadurch soll das Magma gleichsam ausgequetscht werden. Aber warum sind dann nicht alle ozeanischen Senkungsfelder mit Feuerbergen umgürtet, und warum funktionieren am Rand des pazifischen immer nur einige wenige Vulkane? Nach Löws ${ }^{46}$ verursachen zeitweilige physikalische oder chemische Prozesse da und dort eine, den Vorgängen auf der Sonne vergleichbare sprunghafte Wärmeentwicklung innerhalb des Magmas, und Hitzestrahlen stellen nach Art der Stichflamme, die durch den Tiegel ein Loch bohrt, durch Aufschmelzung einen Kanal durch die Erdkruste her. LöwL, der diese Hypothese für die einzig stichhaltige erklärt, macht aber selbst darauf aufmerksam, daß die Erfahrung $\mathrm{ihr}$ insofern widerspricht, als die Zusammensetzung der Laven von dem Gesteinscharakter der Aufschmelzungsstelle. völlig unabhängig ist. Angesichts der Vulkanberge Ecuadors drängte sich STÜBEL die Überzeugung auf, daß der "Zweck der vulkanischen Ausbrüche" nur darin bestehe, Magma zutage zu fördern, und daß dessen Ausdehnungsbedürfnis die eigentliche Ursache der Eruptionen sei. Auf Grund von Beobachtungen an Metallen in Laboratorien und Schmelzöfen nahm er an, daß bei der Erkaltung des Magmas wenigstens vorübergehend ein Stadium der Volumvermehrung eintrete. Diese Voraussetzung wurde, soweit sie sich auf die Silikatgesteine bezieht, von DoELTER ${ }^{47}$ auf das entschiedenste bestritten, von 
FLEISCHER $^{48}$ dagegen auf Grund experimenteller Beobachtungen am Basalt für zutreffend erklärt. Man hat sich oft darauf berufen, daß erkaltete Lavaschollen auf flüssiger Lava schwimmen, aber dies ist noch kein Beweis dafür, daß sie weniger dicht sind. Alle festen Gesteine, auch die schwersten, beobachten, wie BARUs ${ }^{49}$ gezeigt hat, das gleiche Verhalten; sie drücken sich wohl in den SchmelzfluB ein, aber dieser erkaltet und verfestigt sich an der Berührungsstelle und bildet so gleichsam ein Boot, das das Gesteinsstück trägt. Eine neue Perspektive eröffnen TAмmann's ${ }^{50}$ Untersuchungen. Er zeigte an einer Reihe von Körpern, daß sie sich allerdings beim Schmelzen ausdehnen, und daß infolgedessen der Schmelzpunkt mit steigendem Druck hinaufrückt; aber je größer der Druck, desto geringer ist die Ausdehnung, und man gelangt endlich zu einem Punkt, wo der Körper in fester und flüssiger Form das gleiche Volumen hat. Steigert sich der Druck noch mehr, so rückt der Schmelzpunkt wieder herab, und der flüssige Zustand ist durch ein kleineres Volumen als der feste ausgezeichnet. Eis verhält sich so schon bei dem Atmosphärendruck an der Erdoberfläche, andere Körper erreichen aber erst unter mehr oder weniger starkem Druck ihren maximalen Schmelzpunkt. Darf - was noch nicht erwiesen ist dieses Gesetz auf Allgemeingültigkeit Anspruch machen, so muB der ErkaltungsprozeB des Magmas in geringeren Tiefen mit Zusammenziehung, in größeren mit Ausdehnung verbunden sein. Die Ausdehnung könnte wohl die Kruste heben, aber kaum Gesteinsdecken von mehreren Kilometer Mächtigkeit durchbrechen. Denn nicht durch langsame Bohrarbeit, sondern durch Zerreißen werden neue Kanäle geöffnet, und wir kommen immer wieder zu dem Schluß, daß Dislokationen den ersten Anstoß zu Ausbrüchen geben.

L. DE MARCHI ${ }^{51}$ will herausgefunden haben, daß die vulkanische Tätigkeit im umgekehrten Verhältnis zur Häufigkeit der Sonnenflecken stehe. Auch Jensen ${ }^{52}$ verlegt das Hauptmaximum auf die Zeit der Fleckenminima, ein sekundäres aber in die Epoche der Fleckenmaxima. JoHnston-Lavis ${ }^{53}$ will in der Tätigkeit des Vesuv Einflüsse des Luftdrucks und gezeitenartige Wirkungen erkannt haben. Bei der Mangelhaftigkeit der zugrunde gelegten Statistiken empfiehlt es sich, diese überraschenden Entdeckungen mit größter Zurückhaltung aufzunehmen.

Schlammsprudel. Neben den echten Vulkanen nennt der.Sprachgebrauch auch "Schlammvulkane", für die GüMBEL ${ }^{54}$ die passendere Bezeichnung Schlammsprudel (Fig. 101) vorgeschlagen hat. Man versteht darunter Hügel, die, wie die echten Vulkane, das Produkt ihrer eigenen Tätigkeit sind, aber nur aus tonigem Schlamm 
bestehen, der bei starkem Regen oft so völlig erweicht wird, daß der ganze Hügel zerfließt. Auf dem Gipfel befindet sich der, zur Zeit der Ruhe meist mit schlammigem Wasser gefüllte Krater mit den Eruptionsöffnungen. Die Höhe ist in der Regel außerordentlich gering im Vergleich zum Umfang, auf Trinidad z. B. nur 1,3 m; bei Jenikale (Krim) ist der größte Kegel nur $1 \mathrm{~m}$ hoch, die anderen aber nur 29-35 cm, und vielen der kleinen Öffnungen fehlt jede Umwallung. $\mathrm{Zu}$ den höchsten gehören der Macaluba auf Sizilien $(49 \mathrm{~m})$ und vor allem die Schlammvulkane der kaspischen Region, wo dieses Phänomen am großartigsten entwickelt ist. Neben Hunderten von kleinen Eruptionspunkten zählt man zwischen Baku und der Kurmündung etwa 30 große Schlammberge und 6 solche Inseln. Der Kegel des Osman-Dagh mißt sicher 300 m Höhe und der Krater des $150 \mathrm{~m}$ hohen Agh-Sibyr hat einen Durchmesser von $900 \mathrm{~m} .^{55}$ Perioden der Ruhe, in denen nur Gas ausströmt, wechseln mit solchen heftiger Tätigkeit. Dann steigen in dem breiartigen Schlamm des Kraters große Blasen auf und zerspringen unter donnerartigem Getös, wobei Schlamm, manchmal auch Steine ausgeworfen werden. Der Ausbruch des Lok-Botan im Bakugebiet am 5. Januar 1887 war von einer prächtigen Lichterscheinung begleitet, indem sich die entzündeten Gase zu einer Feuersäule von $600 \mathrm{~m}$ Höhe erhoben. Der Schlammstrom, der sich aus dem Krater ergoB, war $300 \mathrm{~m}$ lang, $200 \mathrm{~m}$ breit und durchschnittlich $2 \mathrm{~m}$ mächtig. Erdbeben sind als Begleiterscheinung nicht selten, auch spaltet sich manchmal der Boden, und es tritt sogar Senkung ein.

Schlammausbrüche finden auch auf dem Boden von Seen und des Meeres statt und geben dann, wie die vulkanischen, Veranlassung zur Inselbildung, die aber in der Regel nicht von langer Dauer ist. Aus den letzten Jahrzehnten sind uns vier Fälle bekannt: am 26. Juli 1841 entstand eine Insel unweit der Insel Cheduba an der Küste von Arakan, und dieser Vorgang wiederholte sich am 15. Dezember $1906^{56} ; 1861$ ist das Geburtsjahr des Kumani im Kaspisee, und am 21. September 1897 tauchten, offenbar im Zusammenhang mit dem gleichzeitigen heftigen philippinischen Erdbeben, zwei Schlamminseln an der Küste von Borneo, bei Labuan und bei Balambangan auf. Die erstere, die man Ruby getauft hat, besuchte KARL Schmid' $^{57}$ zwei Jahre später; ihre ursprüngliche Länge von $250 \mathrm{~m}$ war damals schon auf $140 \mathrm{~m}$ zurückgegangen.

Unter dem Begriff ,.Schlammsprudel" hat man zwei, in ihrer orographischen Erscheinung zwar gleiche, genetisch aber verschiedene Phänomene zusammengefaßt. Die eine Art, die man als warme Schlammsprudel bezeichnen kann, wird durch eine beständig hohe 
Temperatur und durch das Ausströmen großer Mengen von Wasserdampf charakterisiert. Sie sind nur vulkanische Begleiterscheinungen, Solfataren in der tonreichen Umgebung von Feuerbergen, namentlich im Gebiet der Tuffschichten, und als solche nur auf vulkanische Gegenden (Island, Zentralamerika, Celebes, Luzon, Neuseeland) beschränkt. Die kalten Schlammsprudel oder Salsen stehen dagegen mit dem Vulkanismus in keinem direkten Zusammenhang. Ihre Temperatur erhöht sich nur zur Zeit heftiger Eruptionen, und auch nur dann wird Wasserdampf in größerer Menge ausgestoßen. Sonst aber bildet Kohlenwasserstoff $90-95$ Prozent aller exhalierten Gase.

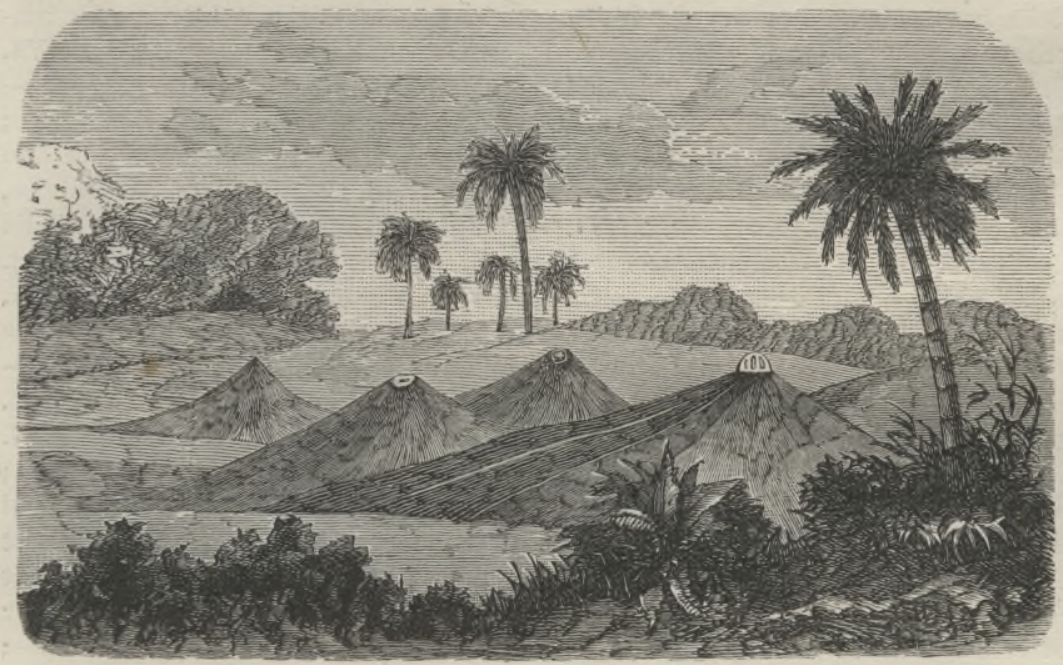

Fig. 101. Die Schlammsprudel von Turbaco bei Cartagena (Columbien) nach A. von Humboldt.

Solche Schlammsprudel sind die unter dem Namen „Mudlumps“ bekannten Inselchen an den Mündungen des Mississippi, die der Zersetzung der in den Deltaablagerungen aufgehäuften organischen Substanzen und der damit Hand in Hand gehenden Gasentwicklung ihre Existenz rerdanken. Andere Schlammsprudel sind in ihrem Vorkommen an das Vorhandensein von Naphta und Tonschichten gebunden; ihr Hauptgebiet finden wir am Südabhang des Kaukasus, auf den Halbinseln Taman und Kertsch und in der Umgebung von Baku.

Das Naphta, ein Gemisch flüssiger Kohlenwasserstoffe, entsteht nach der herrschenden Anschauung durch die Verwesung organischer, zumeist tierischer Reste. ${ }^{58}$ Die Erfahrungen in den Petroleumdistrikten der Alten und Neuen Welt haben gelehrt, daß im ge- 
falteten Gelände die Aussichten für die Erbohrung von Naphtaquellen auf den Schichtensätteln viel günstiger sind als in den Schichtenmulden, und damit steht die Tatsache in Verbindung, daß die kaspischen Schlanmvulkane mit Ausnahme eines einzigen reihenweise auf Sattellinien liegen. So stehen also auch die Salsen wie die echten Vulkane und die solfatarischen Schlammsprudel in innigen Beziehungen zu den Dislokationen.

Literaturnachweise. ${ }^{1}$ G. P. Scrope, Über Vulkane; Berlin 1872 (noch immer ein klassisches Werk). J. D. DaNA, Characteristies of Voleanoes; New York 1890. H. HaAs, Der Vulkan; Berlin 1904. G. Mercaldi, I vuleani attivi della terra, Mailand 1907. - ${ }^{2}$ W. Branco in den Sitzungsberichten der Preubischen Akademie der Wissenschaften, Physik.-math. Klasse, 1903, Bd. XXXVI, S. 748. - ${ }^{3}$ W. Branco, Schwabens 125 Vulkan-Embryonen; Stuttgart 1894. ${ }^{4} \mathrm{~K}$. Schmelzle, Über das Wesen u. die geographische Verbreitung der Maare; Erlangen 1902. - ${ }^{5}$ A. Brun, Quelques recherches sur le voleanisme, in den Archives des sciences physiques et naturelles, Genf 1905-09; Le voleanisme, im Le Globe, Genf 1907, Bd. XLVI. - ${ }^{6}$ Vgl. A. Gautier, Intervention réelle de l'eau dans les phénomènes eruptifs, in dem Arch. des sciences phys, et nat. Bd. XXIV. - ${ }^{7}$ A. Bergeat, Die Äolischen Inseln; Münehen 1899. - ${ }^{8}$ M. Baratta, Il Vesuvio e le sue eruzioni; Rom 1897. - 9 S. Sekixa u. J. Kıкuchi, The Eruption of Bandai-san, im Journal of the College of Science; Tokio 1889. ${ }^{10}$ R. D. M. Verbeek, Krakatau; Batavia 1884 (vgl. auch Petermans's Mitteil. 1886, S. 10). - ${ }^{11}$ S. P. Sмrт, The Eruption of Tarawera; Wellington 1887. A. P. W. Thomas, Report on the Eruption of Tarawera and Rotomahana; Wellington 1888. J. M. BeLL, The great Tarawera Voleanic Rift, im Geographical Journal 1906, Bd. XXVII. - ${ }^{12}$ Hauptwerk der reichen Pelée-Literatur ist A. LAcrorx, La Montagne Pelée et ses eruptions; Paris 1904. Die beste Arbeit darüber in deutscher Sprache lieferte K. SAPpen im Neuen Jahrbuch für Mineralogie usw. 1904, Bd. II, S. $1 .{ }^{13}$ A. Heilprin, The Tower of Pelée; Philadelphia 1904. The shattered obelisk of Mt. Pelée, in The National Geographical Magazin 1906, Bd. XVII. - ${ }^{14}$ F. Fouqué, Santorin et ses éruptions; Paris 1879. - ${ }^{15}$ W. Reiss u. A. Stüвex, Geschichte u. Beschreibung der vulkanischen Ausbrüche bei Santorin; Heidelberg 1868. - ${ }^{16}$ DANA, s. o. Anm. ${ }^{1}$. 17 C. E. Dutron, Hawaian Voleanoes, im 4. Jahresbericht des U. S. Geological Survey; Washington 1884. - ${ }^{18}$ Тн. Тноворdsen, Island; Gotha 1906 (Ergänzungsheft 152 u. 153 zu Petermann's Mitteilungen). - ${ }^{19} \mathrm{~A}$. Stüвel, Die Vulkanberge von Ecuador; Berlin 1897. Ein Wort über den Sitz der vulkanischen Kräfte in der Gegenwart; Leipzig 1901 (mit einer prächtigen bildlichen Darstellung der allmählichen Entwieklung des Vulkanismus nach STüвEL's Auffassung). Über die genetische Verschiedenheit vulkanischer Berge; Leipzig 1903. Die Vulkanberge von Columbia; Dresden 1906 (mit vortrefflichen Bildern!). ${ }^{20}$ W. ReIss, Ecuador 1870-74, Heft I; Berlin 190I. - ${ }^{21}$ P. Grosser, Reisen in den Ecuadorianischen Anden, in den Sitzungsberichten der Niederrheinischen Gesellschaft für Natur- u. Heilkunde in Bonn, 1904. - ${ }^{22}$ Genauer bekannt sind die Vulkane von Java und Sumatra, s. R. D. M. Verbeex u. R. Fennema, Geologische Beschryving van Java en Madoera; 'Amsterdam 1896 (auch in französischer Ausgabe. Auszug in Petermann's Mitteilungen 1898, S. 25). W. Volz, Zur Geologie von Sumatra; Jena 1904, vgl. dazu A. Wichmans 
in der Zeitschrift der Deutsehen Geologischen Gesellschaft 1904, Bd. LVI, S. 227. - ${ }^{23}$ J. C. Russele, Voleanoes of North America; New York 1897. K. SAPPER, Über die räumliche Anordnung der mittelamerikanischen Vulkane, in der Zeitschrift der Deutschen Geologischen Gesellschaft 1897. A. StüвEL, Über die Verbreitung der hauptsäehlichsten Eruptionszentren und der sie kennzeichnenden Vulkanberge in Südamerika, in Petermans's Mitteilungen 1902; ergänzt und berichtigt durch R. HAUTHAL, Die Vulkangebiete in Chile und Argentinien, ebenda 1903. - ${ }^{24}$ L. v. Höhnel, A. Rosrwal, F. Toula und E. Soess, Beiträge zur geologischen Kenntnis des östl. Afrika, in den Denkschriften d. Wiener Akad. d. Wiss. 1891. O. Baumans, Durch Massailand zur Nilquelle; Berlin 1894. J. W. Gregory, The great Rift Valley; London 1896. - ${ }^{25}$ K. Herrmann, Das Vulkangebiet des zentralafrikanischen Grabens, in den Mitteilungen für die deutsehen Schutzgebiete 1904. - ${ }^{26}$ F. LöwL, Spalten und Vulkane, im Jahrbuch der Geologischen Reichsanstalt; Wien 1886. - ${ }^{27}$ BraxcA, s. 0. Anm. ${ }^{3}$ und ferner im Nenen Jahrbuch für Mineralogie usw. 1898, Bd. I, S. 175; in den Sitzungsberichten der PreuBischen Akademie der Wissenschaften, Physik.-math. Klasse, 1903, Bd. XXXVI, S. 757; Zentralblatt für Mineralogie usw. 1909, S. 97 u. 129. - ${ }^{28}$ H. Bücking in Gerland's Beiträgen zur Geophysik, 1903, Bd. VI, S. 267. - ${ }^{29}$ A. GEIKIE, The ancient Voleanoes of Great Britain; London 1897. ${ }^{30}$ A. Daubrée, in Nature, London 1893, Bd. XLVIII, S. 226. - ${ }^{31}$ Tн. Thoroddsen, Die Bruchlinien Islands u. ihre Beziehungen zu den Vulkanen, in Petermans's Mitteilungen 1905: - ${ }^{32}$ L. Мгсн, Über den möglichen Zusammenhang zwischen der Dichtigkeitsverminderung (den Massendefekten) in der Erdrinde und der Entstehung von Tiefengesteinsmassiven, im Zentralblatt für Mineralogie usw., 1903. - ${ }^{33}$ J. E. Нrвscr im Zentralblatt für Mineralogie 1909, S. 526. ${ }^{84}$ E. Rudolph, zit. S. 277. - ${ }^{35}$ T. A. JAGGAR, The Evolution of Bogoslof Voleano, im Bulletin of the American Geographical Society 1908, Bd. XXXII. Die Abbildungen sind reproduziert im Geographischen Anzeiger, Gotha 1909, Sonderbeilage 10. - ${ }^{36}$ G. Geriand, Vulkanische Studien, in den Beiträgen zur Geophysik 1894. - ${ }^{37}$ S. Günther, Gedanken über das Wesen des Vulkanismus, im "Ausland" 1892. - ${ }^{85}$ G. DE Lonenzo, Considerazioni sull' origine superficiale dei vulcani, in den Atti della R. Accademia delle scienze fisiche etc.; Neapel 1902 , Bd. XI. - ${ }^{39}$ C. E. Dutron im Journal of Geology 1906, Bd. XIV, S. 259. 40 G. D. Louderback, ebenda S. 747. - ${ }^{41}$ A. C. Lawson und Ch. Palache, The Berkeley Hills, in dem Bulletin of the Department of Geology, University of California, 1901. - ${ }^{42}$ A. Bergeat, Betrachtungen über die stoffliche Inhomogenität des Magmas im Erdinnern, Erlangen 1908 (auch in den Mitteilungen der Münchener Geographischen Gesellschaft, Bd. III.). — ${ }^{43}$ F. BEскE, Die Eruptivgebiete des böhmischen Mittelgebirges und der amerikanischen Anden; in 'Tschermak's mineralogischen und petrographischen Mitteilungen 1903, Bd. XXII. - ${ }^{44}$ G. Tschermaк, Über den Vulkanismus als kosmische Erscheinung, in den Sitzungsberichten der Wiener Akad. d. Wiss., Math.-phys. Klasse, 1877, Bd. LXXV, I. Abteilung. - ${ }^{45}$ A. Gavtier, Théorie des Voleans, im Bulletin de la Société Belge de Géologie, 1903, Bd. XVII. - ${ }^{46}$ F. LöwL, Geologie, S. 230. - ${ }^{47}$ C. Doelter, Die Dichte des flüssigen und festen Magmas, im Neuen Jahrbuch f. Mineralogie usw., 1901, Bd. II. Zur Physik des Vulkanismus, in den Sitzungsberichten der Wiener Akademie der Wissenschaften, Mathem.naturw. Klasse, 1903, Bd. CXII, Abteil. I. - ${ }^{48}$ A. Fleischer, in den Monatsberichten der Deutschen Geologischen Gesellschaft 1907, S. 122 und 320. 49 C. Barus im Bulletin of the U. S. Geological Survey, 1903, Nr. 103. ${ }^{50}$ G. Tammann, zit. S. $17 .-{ }^{51}$ L. de Marchi zit. S. $257 .-{ }^{52}$ H. J. Jensen, 
Possible Relation between Sunspots and Voleanie and Seismic Phenomena and Climate, in den Proc. of the Royal Society of New South Wales, 1904. ${ }^{53}$ H. J. Johnston-Lavis im Bulletin de la Société Belge de Géologie, Brüssel 1907, Bd. XXI, S. 303. — ${ }^{54}$ K. W. GÜMBEL, Das Eruptionsmaterial der Schlammvulkane von Paterno, in den Sitzungsberichten der bayrischen Akad. der Wissenschaften, Mathem.-physik. Klasse, 1879. - ${ }^{55}$ Hл. S J̈̈̈ren, Die Tätigkeit der Schlammvulkane in der kaspischen Region 1885-87, in den Verhandlungen der russischen mineralogischen Gesellschaft; St. Petersburg 1887. - ${ }^{56}$ E. J. HedDLAM, im Geographical Journal 1907, Bd. XXIX, S. 430, - ${ }^{57}$ KarL Schmidt, in Gerland's Beiträgen zur Geophysik, Bd. VII, S. 120. - ${ }^{\text {E8 }}$ H. Höfer, Geologie, Gewinnung und Transport des Erdöls, Leipzig 1909.

\section{Erdbeben. ${ }^{1}$}

Bodenbewegungen. Die landläufige Vorstellung betrachtet den Erdboden als etwas starres und selbst wenn sie durch ein Beben aus diesem Irrtum aufgerüttelt wird, beruhigt sie sich bei dem Gedanken, daß Bodenbewegungen nur einen Ausnahmezustand bilden. "Nicht bloß der Laie" - sagt August Schmidt - „sondern gerade derjenige Forscher, welchem eine mangelnde Festigkeit des Standortes am ersten zum Bewußtsein kommen muß, der Astronom, verschließt sich so lange als möglich der Annahme von Veränderungen in der Lage des Standortes und von Bewegungen der Erdkruste, indem er viel lieber die kleinen und kleinsten UnregelmäBigkeiten in der Richtung der Fernrohrbilder, welche ihm die Erfahrung zeigt, ganz aus UnregelmäBigkeiten des optischen Verhaltens der Atmosphäre ableitet." Indes konnte sich die Astronomie doch nicht auf die Dauer mit dieser Erklärung begnügen, und ein deutscher Astronom, der der Wissenschaft leider viel $\mathrm{zu}$ früh entrissene E. v. Rebeur-Paschwitz war es, der seit 1889 mit Hilfe seines verbesserten, außerordentlich empfindlichen Horizontalpendels systematische Untersuchungen über Bodenschwankungen anstellte. Das Ergebnis war überraschend. Der Erdboden befindet sich nie in völliger Ruhe; molekulare Bewegungen, die die Physik als elastische Wellen $\times$ bezeichnet, sind ein dauernder Zustand unseres Planeten.

$\times$ Die elastischen Wellen unterscheiden sich von den Gravitationswellen des Wassers dadurch, daß sich das Molekül nicht in einer elliptischen (vgl. S. 291), sondern in einer geradlinigen Bahn bewegt, und zwar entweder in der Richtung der fortschreitenden Welle (longitudina le Wellen) oder senkrecht dazu (transversale Wellen). Die ersteren beruhen auf Veränderungen des Volumens oder der Dichte und sind in allen Aggregatzuständen möglich, die letzteren beruhen auf Veränderungen der Gestalt und können daher nur in festen Körpern auftreten. Die longitudinalen Wellen heiBen auch normale oder Kondensationswellen, die transversalen auch Distorsionswellen; namentlich in der englischen Erdbebenliteratur sind diese Ausdrücke sehr gebräuchlich. 
In den Diagrammen, die das Horizontalpendel durch selbsttätige mechanische oder photographische Registrierung auf einem gleichmäBig fortschreitenden Papierstreifen zeichnet, lassen sich zwei wesentlich voneinander verschiedene Bewegungen erkennen. Die einen sind periodische Ablenkungen der Lotlinie, die das Pendel nicht in Schwingungen versetzen, sondern aus seiner ostwestlichen Lage nach Norden und Süden ablenken. Sie sind aller Wahrscheinlichkeit nach zum größten Teil Wirkungen atmosphärischer Vorgänge, wie schon ihre deutliche Sonnentagsperiode verrät; aus der halbtägigen Mondtagsperiode hat man aber auch mit Recht auf kosmische Gravitationseinflüsse, d. h.. auf eine Gezeitenbewegung der festen Erdkruste geschlossen, wovon schon auf S. 21 die Rede war. Die zweite Gruppe bilden die Störungen, die das Pendel selbst zu Schwingungen veranlassen und den ruhigen Verlauf der Linie in den Diagrammen durch mehr oder minder große Auszackungen unterbrechen. Die geringeren werden auf atmosphärische Veränderungen, wie des Luftdruckes und der Windstärke, zurückgeführt, und insofern ist die übliche Bezeichnung als mikroseismische Unruhe völlig irreleitend, weil wir unter seismisch nur endogene Bewegungen ver- Hith stehen. Die Zitterungen (tremors der Engländer) treten ganzw אu unregelmäBig auf und lassen sich deutlich von den noch rätselhaften Pulsationen unterscheiden, die im Winterhalbjahr in der Form regelmäBiger, flacher Wellen, ähnlich der Dünung, in langen, zusammenhängenden Reihen erscheinen. Sie sind nach OmoRI die Vorboten herannahender barometrischer Depressionen, während sie nach WiECHERT ihre Ursache in der rhythmischen Bewegung der von der Brandung getroffenen Meeresküste haben.

Die zweite Kategorie der Störungen bilden die seismischen, mit denen wir uns ausführlicher zu beschäftigen haben.

Die seismischen Wellen. Obwohl auch der Fall schwerer Körper, z. B. ein Bergsturz, in der nächsten Umgebung eine Bodenerschütterung bewirken kann, so beschränken wir doch im gewöhnlichen und wissenschaftlichen Sprachgebrauch die Bezeichnung Erdbeben auf jene Fälle, wo der AnstoB zur Bewegung unzweifelhaft von einer Stelle unter der Erdoberfläche ausgeht. Wir nennen diese Stelle das Hypozentrum des Erdbebens oder den Erdbebenherd $(H$ in Fig. 102). Der Ort der Erdoberfläche, der gerade oberhalb des Hypozentrums liegt, heißt Epizentrum.

Einen tieferen Einblick in das Wesen der seismischen Bewegung gewannen wir erst durch die instrumentelle Beobachtung. Die älteren Instrumente beruhten auf der Bewegung von Flüssigkeiten; sie waren nur Seismoskope, d. h. Instrumente, die lediglich die Tat- 
sache, daß ein Erdbeben stattgefunden hat, und dessen Richtung anzeigen. Dagegen geben die Seismometer die wichtigsten $\mathrm{Be}$ wegungsmomente an, und sind in der Regel mit einem Seismographen verbunden, der die aufeinanderfolgenden Bewegungen selbsttätig aufzeichnet. ${ }^{2}$ Den Hauptbestandteil bildet das Pendel in horizontaler oder vertikaler Aufstellung, und das Bestreben der Seismometrie geht dahin, die Aufzeichnungen des Seismographen von der Eigenbewegung des Pendels möglichst unabhängig zu machen, was man durch große Massen und große Schwingungsdauer

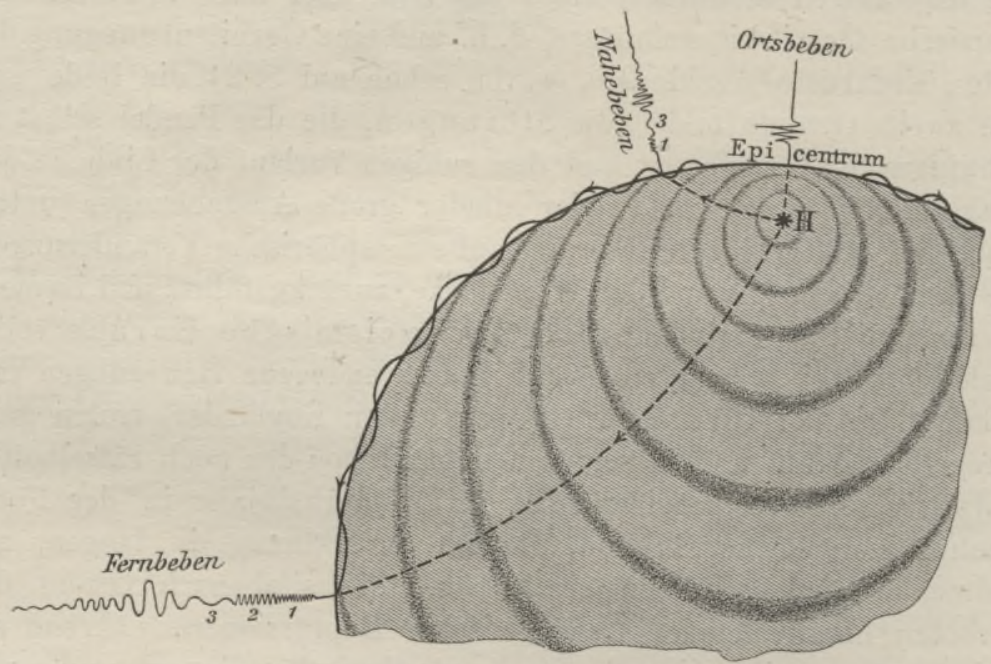

Fig. 102. Die verschiedenen Arten und Wege der Erdbebenwellen und die von ihnen hervorgerufenen Diagramme, nach A. Sikberg.

zu erreichen sucht. Automatische Vorrichtungen an Uhren dienen dazu, die Eintrittszeit der Beben genau zu fixieren. Da Seismometer teurer sind und unter beständiger Aufsicht stehen müssen, so ist ihre Verbreitung natürlich beschränkt, $\times$ und Stationen mit einfachen Hilfsmitteln und die Sammlung nicht instrumenteller Beobachtungen müssen ergänzend hinzutreten. İtalien, Japan und die Schweiz waren die ersten Länder, die sich mit einem Netz seismischer Beobachtungsstationen überzogen, und jetzt ist die systematische Erdbebenforschung, dank den Bemühungen GerLand's, auf eine internationale Grundlage gestellt.

$\times$ Von den anfangs 1904 mit Horizontalpendeln ausgerüsteten 108 Stationen entfielen 60 auf Europa, 25 auf Asien (mit Hawaii), 7 auf Australien, 4 auf Afrika, 8 auf Nord- und 4 auf Südamerika. Anfangs 1907 war die Zahl der Stationen bereits auf 126 getiegen. 
Je nach der Lage der Beobachtungsstation liefert das Horizontalpendel verschiedene Diagramme (s. Fig. 102). Im epizentralen Gebiet wird es sogleich in heftige Bewegung versetzt, die nach kurzer Zeit erlischt. Im Diagramm des Nahbebens wird die Bewegung bereits durch Zitterungen eingeleitet, dann folgen große Wellen, die allmählich verlaufen. Im Diagramm des Fernbebens (an Stationen, die wenigstens $500 \mathrm{~km}$ vom Epizentrum entfernt sind) sind die drei Phasen: Vor-, Haupt- und Nachstörung, schon vollständig ausgebildet, und innerhalb der Phasen. selbst sind wieder Unterschiede in bezug auf die Amplitude und die Wellenperiode deutlich bemerkbar, so daß man daraus auf einen Wechsel im Charakter der Bewegung schließen muß. Freilich bezieht sich das zunächst nur auf die horizontalen Komponenten, die das Horizontalpendel allein in Schwingung versetzen, aber aus den Untersuchungen mit SchLÜteR's Seismographen, der auch die Vertikalkomponente der Fernbeben verzeichnet, geht hervor, daß sich diese ähnlich verhält wie die horizontalen, nur daß sie in der Vorstörung früher eintritt und sich kräftiger geltend macht.

Da man die Tiefe des Erdbebenherdes und den Zeitpunkt des ersten Anstoßes nicht kennt, muß man bei der Berechnung der Fortpflanzungsgeschwindigkeit die Entfernung der Station vom Epizentrum zugrunde legen. BENNDORF ${ }^{3}$ hat für verschiedene Entfernungen folgende mittlere Eintrittszeiten (in Minuten) abgeleitet

Entfernung vom

Epizentrum, km

0

1000

4000

8000

12000

16000
Vorstörung

1. Phase 2. Phase

$0 \quad 0$

$2,1 \quad 4,2$

$6,5 \quad 12,1$

$11,3 \quad 20,5$

$14,8 \quad 26,5$

$16,9 \quad 30,1$
Haupt-

störung

0

4,4

17,6

35,2

52,3

70,4

Daraus ergeben sich folgende (scheinbare) Fortpflanzungsgeschwindigkeiten in Kilometer pro Sekunde:

\begin{tabular}{cccc} 
& \multicolumn{2}{c}{ Vorstörung } & Haupt- \\
Entfernung, km & 1. Phase & 2. Phase & störung \\
$0-1000$ & 8,0 & 4,0 & 3,8 \\
$1000-4000$ & 11,4 & 6,3 & 3,8 \\
$4000-8000$ & 13,9 & 7,9 & 3,8 \\
$8000-12000$ & 19,0 & 11,1 & 3,8 \\
$12000-16000$ & 31,7 & 18,5 & 3,8
\end{tabular}

Es besteht demnach ein fundamentaler Unterschied zwischen der Vor- und der Hauptstörung. Die einleitenden Wellen bewegen sich scheinbar um so schneller, je weiter sie sich von dem Epi- 
zentrum entfernen, sie können also nicht vom Epizentrum ausgehen und sich an der Oberfläche fortpflanzen, sondern sie laufen direkt vom Hypozentrum durch das Innere der Erde zu der betreffenden Station. Da in der ersten Phase die scheinbare Geschwindigkeit nahezu doppelt so groß ist als in der zweiten, so werden die ersten Wellen (1 in Fig. 102) als longitudinale, die zweiten (2 in Fig. 102) als transversale aufgefaßt. Nur die Wellen der Hauptstörung pflanzen sich gleichmäßig fort, verlaufen also an der Oberflâche.

Wir gewinnen aus diesen Beobachtungen folgendes Bild des seismischen Vorgangs: Von dem Hypozentrum pflanzt sich die Bewegung in Kugelwellen, die wir nach BeLaR Erdwellen nennen wollen, nach allen Seiten fort. Man dachte sie sich früher als konzentrisch und die Fortpflanzung als gleichmäBig, weil die unvollkommenen Beobachtungen die Annahme eines nahezu homogenen Erdkörpers als gerechtfertigt erscheinen ließen. Erst die von August Schmidt ${ }^{4}$ i. J. 1888 aufgestellte und später von Rudzki ${ }^{5}$ mathematisch begründete Theorie hat eine richtigere Auffassung angebahnt. Die Erdwellen pflanzen sich, wie Fig. 102 zeigt, exzentrisch und zwar nach dem Innern schneller fort, weil sich mit zunehmender Dichte auch die Elastizität nach der Tiefe steigert: Die vom Zentrum ausgehenden Stoßstrahlen, die die Richtung der Bewegung darstellen, sind nicht gerade Linien, wie man früher annahm, sondern erleiden, indem sie Schichten von verschiedener Dichte durcheilen, ebenso wie die Lichtstrahlen eine Brechung und nehmen eine nach dem Erdmittelpunkt konvexe Gestalt an.

In der „neuen geometrischen“ Theorie von KövesLigethrY ${ }^{6}$ erscheint indes der Schmidt'sche Stoßstrahl nur als ein Spezialfall. Nach dieser Theorie sind die Erbebenstrahlen Kegelschnitte, deren Gestalt (ob Ellipse, Parabel oder Hyperbel) durch den Brechungsindex der durchlaufenen Erdschichten bedingt ist. $\mathrm{Zu}$ ihrer $\mathrm{Be}$ rechnung dient eine Gleichung mit folgenden Gliedern: 1. der Brechungsindex, 2. die Tiefe des Erdbebenherdes, 3. die Zeit des Eintreffens des Stoßes im Epizentrum, 4. die Zeit des Eintreffens des Stoßes an der Beobachtungsstation, 5. die Fortpflanzungsgeschwindigkeit der seismischen Welle, und 6. und 7. die geographischen Koordinaten des Epizentrums. Von allen diesen Gliedern ist nur das vierte bekannt; es müssen also sechs Gleichungen aufgestellt werden, $d$. h. es muß die Zeit des Eintreffens des Stoßes von wenigstens sechs Beobachtungsstationen bekannt sein. Es liegt auf der Hand, daß diese Theorie, wenn sie sich bewährt, einen gewaltigen Fortschritt bedeutet, denn sie gibt uns über die wichtigsten unbekannten Momente ziffermäßigen Aufschluß. 
Im Epizentrum, das nur in der Theorie als ein Punkt betrachtet wird, in Wirklichkeit aber wohl stets eine kleinere oder größere Fläche ist, treffen die Erdwellen zuerst und daher mit größter Wucht die Oberfläche und erzeugen hier, entsprechend dem sog. Huyghens'schen Prinzip, eine neue Bewegung, die sich in der Form von Oberflächenwellen mit gleichmäßiger Geschwindigkeit, aber rasch abnehmender Intensität ausbreitet und in den Diagrammen des Nah- und Fernbebens die Hauptstörung (3 in Fig. 102) hervorruft. Über ihren Charakter sind die Ansichten noch geteilt. Sind es transversale Wellen, ähnlich den Wasserwellen, mit wirklichem Berg und Tal, so sind die Neigungen jedenfalls so gering, daß sie sich nicht einmal dem eigens zu ihrer Registrierung konstruierten Klinographen von SchLÜTER ${ }^{7}$ fühlbar machen. OMORI ${ }^{8}$ läßt keine Neigungen gelten, sondern nimmt nur ein horizontales Hin- und Herschwingen der Oberflächenteilchen an, also ebenfalls eine longitudinale Bewegung wie bei den Erdwellen der ersten Phase. Wie dem auch sei, jedenfalls nimmt die seismische Bewegung, entsprechend den verschiedenen Elastizitätsverhältnissen, in den obersten Schichten andere Formen an, als in den Tiefen. Im epizentralen Gebiet äußert sie sich vielfach stoßförmig oder sukkussorisch; je weiter davon, desto mehr wächst die horizontale Komponente auf Kosten der vertikalen, und die Bewegung nimmt an der Oberfläche einen wellenförmigen oder undulatorischen Charakter an. Die Wellen schreiten nach einer bestimmten Richtung fort, manchmal dem Auge direkt sichtbar, meist aber nur erkennbar aus der Richlung der Risse und Spalten in Gebäuden, aus der Lage umgeworfener Gegenstände und dgl. Einfache Horizontalbewegung versetzt aufgehängte Gegenstände in pendelnde Schwankungen. Aus der drehenden Verschiebung der Steine an Pfeilern, Obelisken usw. schlieBt man auf eine rotatorische oder Wirbelbewegung. In Fällen, wo der Schwerpunkt und der Haftpunkt der Steine nicht in einer senkrechten Linie liegen, muß allerdings schon ein seitlicher StoB eine Drehung der Steine bewirken, aber nach den Beobachtungen bei dem ostindischen Erdbeben i. J. 1897 glaubt OLDHaм ${ }^{9}$ auch eine wirklich drehende Bewegung des Bodens annehmen zu dürfen, sei es, daß die Wellenbewegung selbst einen mehr oder weniger kreisförmigen Weg einschlägt, sei es, daß Hin- und Herbewegungen, jede in einer etwas anderen Richtung, aufeinander folgen. Wie kompliziert die seismische Bewegung an der Oberfläche ist, mag man aus folgendem Beispiel entnehmen. Bei dem Beben in Tokio am 15. Januar 1887 waren alle drei Komponenten deutlich entwickelt, aber die vertikale und die horizontalen er- 
reichten nicht gleichzeitig ihren Höhepunkt, ja die vertikale Bewegung hörte nach 72 Sekunden beinahe ganz auf, während die horizontalen noch fortdauerten; von diesen erlosch zuerst die ostwestliche und erst nach längerer Zeit auch die nordsüdliche. Auch ihre Maxima fielen nicht immer in die gleiche Zeit, und die östliche bezw. westliche Bewegung war bald mit der nördlichen, bald mit der südlichen verbunden. SEKIYA ${ }^{10}$ hat nach den Aufzeichnungen des Seismographen die Bahn eines Erdteilchens während der ersten 72 Sekunden des Bebens durch ein Modell in großem Maßstab dargestellt; es bildet einen höchst verschlungenen Knoten, an dem alle ins einzelne gehenden Erklärungsversuche scheitern müssen.

Die Teile des seismischen Feldes. Das Epizentrum ist in vielen Fällen nicht durch unmittelbare Beobachtung festzustellen, namentlich dann nicht, wenn es in unzivilisierten oder wenig bewohnten Ländern oder im Meer liegt. In solchen Fällen leisten aber die Diagramme der Fernbeben ausgezeichnete Dienste. Da - wie aus Fig. 102 und der Tabelle auf S. 415 ersichtlich ist die Dauer der Vorstörung mit der Entfernung vom Epizentrum wächst, so genügt schon ein einziges Diagramm, um über diesen Punkt Aufschluß zu geben. ${ }^{\times}$Die Aufzeichnungen von Wrechert's astatischem Pendelseismometer in Leipzig lassen sogar erkennen, ob das Epizentrum jenseits des Atlantischen Ozeans oder jenseits des Himalaya oder im östlichen und südöstlichen Kontinent lag. ${ }^{12}$ Zur genaueren Lokalisierung des Epizentrums; d. h. zur Feststellung seiner geographischen Koordinaten sind aber Diagramme von wenigstens drei Stationen erforderlich. Mancherlei Schwierigkeiten ergeben sich dabei, denn die Aufzeichnungen verschiedener Instrumente, die für die einzelnen Arten der Bodenbewegungen nicht gleich empfindlich sind, lassen sich nicht unmittelbar miteinander vergleichen, und besonders schwierig ist es, den eigentlichen Beginn des Bebens festzustellen.

Die zerstörenden Wirkungen im Epizentrum lassen vermuten,

× Die Berechnung geschieht in der Regel nach der ersten LásкA'schen Regel:

$$
V_{2}-V_{1}-1=D
$$

worin $V_{1}$ und $V_{2}$ die Eintrittszeiten der ersten und zweiten Vorstörung in Minuten und $D$ die Distanz der betreffenden Station vom Epizentrum in Megameter $(=1000 \mathrm{~km})$ bedeutet. RosentraL ${ }^{11}$ hat zu den so gefundenen Distanzeu folgende Korrekturen ermittelt:

\begin{tabular}{ll|ll|lc|cr}
$\mathrm{D}$ & Korr. & $\mathrm{D}$ & Korr. & $\mathrm{D}$ & Korr. & $\mathrm{D}$ & Korr. \\
1 & $-0,1$ & 4 & $-0,6$ & 7 & $-0,5$ & 10 & $+0,5$ \\
2 & $-0,3$ & 5 & $-0,6$ & 8 & $-0,3$ & 11 & $+1,5$ \\
3 & $-0,5$ & 6 & $-0,6$ & 9 & 0 & 12 & $+2,8$
\end{tabular}


daß hier die Bodenbewegung nicht rein molekular ist, sondern da $B$ auch körperliche Versetzungen $\times$ Platz greifen. Diese beschränken sich nicht bloB auf die Erdbebenachse (zwischen Zentrum und Epizentrum), sondern kommen auch in deren Umgebung bis zu dem Emersionswinkel $\times \times$ von $45^{0}$ vor. OLDHaM ${ }^{9}$ nennt diesen Ausschnitt der Erdkruste den Erdbebenkern. Hauptsächlich im epizentralen Gebiet wird das Beben häufig durch Schallphänomene angekündigt oder begleitet. Jedenfalls stammen die Geräusche zum größten Teil aus dem Erdboden, es ist aber nicht ausgeschlossen, daß die austretenden Schallwellen auch die Luft in Schwingungen versetzen.

An den Erdbebenkern schließt sich der Gürtel reiner Molekularbewegung an. Nur in der Innenzone macht sich die Wellenbewegung noch fühlbar, in der AuBenzone dagegen wird sie nur mehr in den Aufzeichnungen der Seismometer wahrgenommen.

Erdbebenkern und Innenzone bilden zusammen das makroseismische Feld im Gegensatz zur mikroseismischen Außenzone. Liegt der Erdbebenherd in größerer Tiefe, so erstreckt sich die Außenzone bis zu den Antipoden des Epizentrums und zieht die ganze Erdoberfläche in Mitleidenschaft. CANCANI hat solche Beben Weltbeben genannt.

Das makroseismísche Feld. Verbindet man auf einer Karte die Orte gleichzeitiger Erschütterung durch Linien (Homoseisten), so erhält man verschiedene Gestalten je nach der Oberflächenbeschaffenheit der betreffenden Gegend und der Form des Epizentrums:

1. Sind die Homoseisten mehr oder weniger kreisförmig, so nennen wir das Beben zentrales.

2. Bei linearen Beben ist das Epizentrum eine Linie, in der die Erschütterung gleichzeitig eintritt, wie z. B. am 26. März 1872 an der Ostseite der californischen Sierra Nevada vom 34. bis zum 38. Parallel. $\mathrm{Zu}$ beiden Seiten griff die Bewegung nach den benachbarten Gegenden über, und die Homoseisten erhielten dadurch eine langgestreckte, ovale Form. In Pandjab hatte 1878 die Linie gleichzeitiger Erschütterung eine Länge von $730 \mathrm{~km}$. In dieser Kategorie unterscheidet man wieder

a) Längsbeben, parallel mit dem Streichen der Schichten und Gebirge;

$\times$ Die Engländer bezeichnen sie als „Molar Movement". Wenn man einen Stein in das Wasser wirft, so bewirkt er an dieser Stelle ein „Molar Movement", während in den sich konzentrisch ausbreitenden Wellen „Molecular Movement" herrscht.

$\times \times$ Emersionswinkel heißt der Winkel, den der StoBstrahl mit der Ebene des Horizonts einschlieBt. 
b) Querbeben, die die Streichrichtung in einem spitzen bis rechten Winkel durchschneiden.

3. Bei Flächenbeben wird die ganze seismische Fläche gleichzeitig oder nahezu gleichzeitig erschüttert. Hier kann innerhalb des eigentlichen Erdbebengebietes, wo die Bewegung sich fühlbar macht, weder von einem Epizentrum noch von Homoseisten mehr die Rede sein. Viele schweizerische Beben der letzten Jahrzehnte scheinen dieser Kategorie anzugehören, denn noch bei keinem ist es gelungen, ein annähernd punktförmiges oder lineares Epizentrum in ungezwungener Weise zu finden.

HARBOE $^{13}$ hat das Vorkommen zentraler Beben angezweifelt, da in allen Erdbebenberichten Zeitangaben vorkommen, die im Vergleich zu denen benachbarter Orte als zu früh erscheinen und daher bei der Konstruktion der Homoseisten unberücksichtigt bleiben. Fügt man auch diese ein, so erhält man statt einer annähernd kreisförmigen epizentrischen Fläche mehrere Linien (Herdlinien), und das zentrale Beben stellt sich dann als eine komplizierte Form des linearen Bebens dar. Berücksichtigt man aber, daß solche Verfrühungen unter den Angaben seismologischer Stationen nur ganz ausnahmsweise auftreten, und daß alle anderen Zeitangaben, selbst die der Eisenbahn- und Telegraphenuhren, nur mit Vorsicht zu benutzen sind, so wird man es den genaueren Daten der Zukunft überlassen müssen, über HaRBoE's Hypothese zu entscheiden. Es ist auch zu beachten, daß man von den Homoseisten keine streng regelmäßige Gestalt verlangen darf, weil die Erdkruste nicht homogen ist. Unzweifelhaft erleiden die elastischen Wellen in ihr tiefgreifende Veränderungen. Zahlreiche Versuche haben gelehrt, daB sich die Geschwindigkeit bei dem Übertritt der Welle aus einem in das andere Gestein ändert. NAGAOKA hat die japanischen Gesteine daraufhin untersucht; das Ergebnis war, daß die Fortpflanzungsgeschwindigkeit im großen und ganzen mit der Dichte und damit auch mit dem Alter der Gesteine steigt. Doch kommt einem bestimmten Gestein nicht etwa eine bestimmte Fortpflanzungsgeschwindigkeit zu, sondern diese ist wieder abhängig von der Intensität des Stoßes und wächst mit ihr. Von großem Einfluß ist auch die Zerklüftung des Bodens. In Gebieten mit geneigten Schichten pflanzt sich die Welle in der Streichrichtung der Schichten schneller fort als senkrecht dazu, und hier können die Homoseisten eine elliptische Gestalt annehmen, selbst wenn das Beben ein zentrales ist. Namentlich hohe Gebirge stellen sich der seismischen Bewegung häufig als fester Wall entgegen; so bewähren sich die mittleren und nördlichen Andes von Südamerika als Schutz der östlichen Abdachung gegenüber den 
häufigen Erschütterungen der pazifischen Küste, während sie sich in Chile als machtlos erweisen. Das große Beben von Valparaiso vom 16. August 1906 verbreitete sich ohne Rücksicht auf die Gebirgsschranke bis an den Paraná. ${ }^{14}$

Daner. Die Dauer eines Stoßes, der sich, wie wir gesehen haben, für Instrumente in größerer Entfernung in drei Phasen von langer Dauer auflöst, beträgt meist nur wenige Sekunden, aber es vergehen oft mehrere Minuten, bis-das Zittern des Bodens aufhört und die Ruhe völlig wiederhergestellt ist. Im innersten Kerngebiet des großen Laibacher Bebens vom Jahr $1895^{15}$ dauerte die Erschütterung höchstens 10 Sekunden, in größerer Entfernung aber beträchtlich länger, bei etwa $600 \mathrm{~km}$ sogar einige Stunden. Selten besteht das Erdbeben aus einem einzigen StoB, wie das rheinische im Jahr 1846; auch das berühmte Beben von Caracas am 26. März 1812, wo nur drei Stöße unmittelbar aufeinander folgten, gehört zu den seltensten Ausnahmen. Bei einigen gröBeren Beben in Japan und Formosa wurde der Hauptstoß durch einige Vorstöße angekündigt. ${ }^{16}$ Ein in England häufig beobachteter Typus sind die Zwillingsbeben, bei denen sich der Hauptstoß nach einer Pause von 2 bis $3^{1} / 2$ Sekunden wiederholt; jedoch schiebt sich manchmal ein Streifen ein, wo sich beide Stöße zu einem einzigen vereinigen. DAvIsoN ${ }^{17}$ führt sie auf zwei Erdbebenherde zurück, die in der Regel 16 bis $17 \mathrm{~km}$ voneinander entfernt sind. Meist treten zahlreiche sekundäre Erschütterungen ein, die dem Hauptbeben teils vorangehen, teils folgen. Erstrecken sie sich über eine größere Zeitdauer, so spricht man von einer Erdbebenperiode (auch Erdbebenšchwarm). Eine solche war das Jahr 1783 für Calabrien, ja die schwachen Erschütterungen dawerten noch über ein Jahrzehnt fort. Das Großgerauer Beben am Mittelrhein dauerte von 1869-1873; vom Oktober bis Ende 1869 zählte man 600 Stöße. In Yokohama traten vom 1. bis 6. Mai 1870123 Stöße ein, und in Hawaii betrug im März 1868 allein die Zahl der stärkeren Stöße über 2000. Die Nachstöße folgen einem bestimmten Gesetz, dem OмоRI ${ }^{18}$, mit Erfolg nachgespürt hat. Je stärker das Hauptbeben und je kleiner die Schütterfläche, desto größer ihre Zahl, die mit der Zeit so regelmäßig abnimmt, daß sie sich rechnerisch ermitteln läßt.

Über die Abgrenzung einer Erdbebenperiode können Zweifel entstehen. In Agram erwachte z. B. die seismische Tätigkeit nach fünfjähriger Ruhe am 12. November 1877. Das darauffolgende Jahr rerfloB ohne Erschütterung, 1879 brachte aber schon drei Beben. Am 9. November 1880 trat der HauptstoB ein; darauf folgten in demselben Monat noch zehn Erdbebentage. Der Dezember hatte 
deren acht, der Januar 1881 sieben, der Februar zwei, der März drei, der April einen. Vom 9. November bis zum 12. April dauerte die längste Pause nur 23 Tage, nachher traten solche von mehreren Monaten ein, aber zeitweise schwoll die unterirdische Erregung wieder an, wie im August, September und Oktober 1883. Man kann in diesem Fall die Periode mit dem 12. April 1881 abschließen oder sie auch auf die nächsten Jahre ausdehnen; beide Auffassungen lassen sich verteidigen, aber die erstere ist unzweifelhaft die strengere und darf daher auf allgemeinere Zưstimmung rechnen. Das Agramer Beispiel lehrt uns auch, daß innerhalb einer Periode die Intensität mehrfach wechseln kann.

Intensität und Wirkungen. Meßbar ist die Intensität nur an den Kurven, die der Seismograph zeichnet; für gewöhnlich muß man sich auf eine rohe Schätzung nach dem Gefühl und nach den Wirkungen auf bewegliche und unbewegliche Gegenstände beschränken. Diesem Zweck dient die Rossi-ForeL'sche Skala, die zehn Intensitäten unterscheidet. Der erste Grad kommt den mikroseismischen Bewegungen $\mathrm{zu}$, auch der zweite macht sich meist nur an Instrumenten bemerkbar. Grad 3 wird von dem Menschen nur unter besonders günstigen Verhältnissen, Grad $\underline{4}$ aber auch mitten in die Tätigkeit beobachtet. Beben von der Intensität $\underline{5}$ sind schon imstande, hier und da bewegliche Gegenstände zu verschieben, und bei Intensität 6 geschieht dies allgemein; der siebente Grad äußert sich im Umwerfen solcher Gegenstände und in der Erzeugung von Rissen an den Wänden und Decken der Häuser. Steigert sich die Intensität bis zum achten Grad, so werden Gebäude in ernstlicherer Weise beschädigt, und Kamine stürzen ein. Bei Erschütterungen vom neunten Grad werden Hütten und Stadeln umgeworfen, bei solchen vom zehnten Grad auch festgebaute Häuser demoliert. Hier liegt der wunde Punkt der Skala. Zunächst ist die zerstörende Kraft des Bebens allerdings durch seine Intensität oder, genauer gesprochen, durch die Beschleunigung, ${ }^{*}$ d. h. durch den raschen Wechsel in der Fortpflanzungsgeschwindigkeit der Wellen, nicht durch diese selbst bedingt; in Japan hat man z. B. die Erfahrung gemacht, daß bei einer horizontalen Beschleunigung von 2,6 $\mathrm{m}$ in der Sek. 2 bis 3 Proz. aller Holzhäuser einer Ortschaft zerstört wurden, bei $3,4 \mathrm{~m} 15$,

$\times$ Ist $a$ die instrumentell ermittelte Amplitude der Bebenwelle in Millimetern und $t$ die Wellenperiode in Sekunden, so sind die sekundlichen Werte der Geschwindigkeit $V$ (Velocitas) und der Beschleunigung $A$ (Acceleration) in Millimetern:

$$
V=\frac{2 \pi a}{t} ; \quad A=\frac{V^{2}}{a}=\frac{4 \pi^{2} a}{t^{2}}
$$




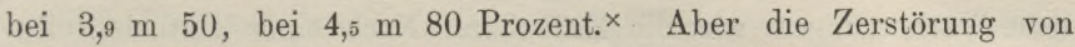
Gebäuden - ein Merkmal, das überdies nur auf bewohnte Gegenden Anwendung findet - hängt auch von dem Material und der Orientierung der Gebäude, sowie von der Beschaffenheit des Untergrundes ab. Indem durch jede Erdbebenwelle, wịe WäHNER dargetan hat, der Boden deformiert wird, neigen und heben, neigen und senken sich auch alle mit ihm fest verbundenen Gegenstände, wie ein ruhendes Schiff auf dem wellig bewegten Wasser. Diese Bewegung der festen Gegenstände, sagen wir z. B. eines Turmes, unterscheidet sich von der pendelförmigen dadurch, daß die Geschwindigkeit mit derEntfernung von der Gleichgewichtslage wächst. In dem Augenblick, da der nach rechts geneigte Turm nach links in seine Gleichgewichtslage wieder zurückkehren soll, hat er das größte Bestreben, sich weiter nach rechts zu bewegen, und dieser Widerstreit kommt in der Lockerung des Baumaterials, in Spaltenbildung oder, wenn die Bewegung intensiv genug ist, im Einsturz des Gebäudes zum Ausdruck. Je höher die Bauwerke sind, desto mehr sind sie gefährdet, vorausgesetzt, daß sie nicht durch ihre Konstruktion zu einem festen Ganzen verbunden sind, wie die fünfstöckigen Tempel Japans oder manche „Wolkenkratzer" der Neuen Welt. Es ist ferner ein durch zahlreiche Erfahrungen gestütztes Gesetz, daß Erdbeben in lockerem Boden viel zerstörender wirken als in festem, vorausgesetzt, daß die Aufschüttungsmassen nicht eine bedeutende Mächtigkeit besitzen. Ist letzteres der Fall, so wird der Stoß gleichsam gedämpft und dringt nur abgeschwächt an die Oberfläche. Das zeigte sich z. B. ganz klar bei dem Charlestoner Erdbeben vom 31. August 1886, einem der größten, die die Vereinigten Staaten seit ihrem Bestehen erlebt haben. Sobald die seismischen Wellen das Alluvialland des Mississippi erreicht hatten, nahm die Intensität rasch ab. Ist die Erschütterung schwach, so genügt auch eine leichte Decke lockeren Materials, um den StoB aufzuhalten, so daß man sagen kann: unter sonst gleichen Verhältnissen hat Felsboden mehr, aber schwächere Beben als seichter Aufschüttungsboden, Aufschüttungsboden von großer Mächtigkeit dagegen wenig und schwache Beben. ${ }^{19}$

Nur die tropischen Zyklonen und plötzliche Überflutungen der Küsten und viel seltener die vulkanischen Ausbrüche bewirken ähn-

$\times$ Omori n. Cancani haben absolute Bebenskalen aufgestellt. Nach letzterem beginnen die Beben sich fühlbar zu machen, wenn $A 2,5 \mathrm{~mm}$ übersteigt, und zerstörend zu wirken, wenn A $250 \mathrm{~mm}$ erreicht. Es ist klar, daB solche Skalen sich nur für Länder eignen, wo die Erdbebenforschung in ganz modernem Sinn organisiert ist, also für einen sehr kleinen Teil der Erde. 
liche Verheerungen wie die Erdbeben. Nach einer amtlichen $\mathrm{Zu}$ sammenstellung wurden in Italien selbst im verhältnismäBig ruhigen Jahr 1870 durch Erdbeben 2225 Häuser zerstört, 98 Menschen getötet und 223 verwundet. In Südamerika verloren 1868 ungefähr 70000 Menschen bei Erderschütterungen das Leben. Genaue Ausweise besitzen wir von jener furchtbaren Katastrophe, die am 28. Oktober 1891 die gartenähnliche Ebene von Owari-Mino in Zentraljapan betraf. 7279 Menschen wurden getötet, 17393 verwundet, 197350 Gebäude ganz, 78296 halb zerstört, und 6379 gingen dabei durch Feuer zugrunde. Der Gesamtschaden bezifferte sich auf mehr als 90 Millionen Mark, und das alles war das Werk weniger Sekunden! ${ }^{20}$ Das Zerstörungsgebiet des nordindischen Bebens vom 4. April 1905 übertraf den Umfang des Königreichs Sachsen. Noch frisch ist die Erinnerung an das süditalienische Erdbeben vom 28. Dezember 1908, dem das volkreiche Messina zum Opfer fiel; dagegen ist der Untergang von San Francisco weniger dem allerdings heftigen Beben vom 18. April 1906, als dem Feuer und der Zerstörung der Wasserwerke zuzuschreiben.

Erdbeben von hohen Intensitätsgraden lassen auch dauernde Spuren im Boden zurück. Spaltenbildung ist im lockeren Boden eine gewöhnliche Erscheinung. Grundwasser, Sand und Schlamm brechen häufig aus den Spalten hervor und bauen Sand- und Schlammkegel auf, die bei Laien die Meinung erwecken, es handle sich hier um vulkanische Eruptionen. Längsspalten, oft von beträchtlichen Dimensionen, sind am häufigsten; bei Einstürzen unterirdischer Hohlräume bilden sich auch Radialspalten. Wind und Wasser füllen diese Öffnungen zum Teil wieder aus; manchmal schließen sie sich von selbst, wobei eine Horizontalverschiebung der Ränder bemerkbar wird. Die obersten Alluvialschichten werden zusammengedrückt, Flußläufe dadurch eingeengt, und Eisenbahnschienen gekrümmt und geknickt. Auf geneigtem Boden kommen die lockeren Auflagerungen ins Rutschen und geben zu Bergstürzen Veranlassung. Das Beben von Wernoje im Jahr 1887 entkleidete die Talgehänge ihrer Verwitterungsdecke, die sich bei den heftigen Regengüssen in mächtigen Schlammströmen über den Talboden ausbreitete, so daß nicht bloB die Vegetation vernichtet, sondern auch die Physiognomie der Täler völlig verändert wurde. In noch viel großartigerem Maßstab wiederholte sich dieses Phänomen bei dem ostindischen Beben am 12. Juni 1897, dessen epizentrales Gebiet südlich vom Brahmaputra im Khasiund Jaintiagebirge lag. Die tiefgründige Verwitterungsrinde dieses regenreichsten Gebietes der Erde wurde einfach abgehoben und sammelte sich zu ungeheueren Schuttmassen am Fuß der Berge, 
wodurch Flußläufe verlegt und Seen aufgestaut wurden. Die hohen Sandsteinberge, die die Ebenen des westlichen Sylhet im N begrenzen, einst vom Gipfel bis zum Fuß mit Wald bekleidet, sind nun auf eine Strecke von $30 \mathrm{~km}$ völlig nackt. Aber auch der Felsboden wird in Mitleidenschaft gezogen. Auch hier entstehen Sprünge, Klüfte und kilometerlange Spalten; und daß sich auch in der Tiefe solches vollzieht, beweist die Tatsache, daß häufig Quellen versiegen oder neue hervorbrechen, und daß selbst Thermen ihre Temperatur verändern. Hier aber drängt sich schon die Frage auf, ob die Spaltenbildung Wirkung oder Ursache des Bebens ist. Sind damit, wie in neuerer Zeit häufig festgestellt werden konnte, auch Dislokationen verbunden, so kann jene Frage nur im zweiten Sinn entschieden werden. Wir werden später noch darauf zurückkommen.

Manche Beobachtungen sprechen dafür, daß die Intensität mit der Tiefe abnimmt, wahrscheinlich deshalb, weil der Druck der oberen Schichten große Schwingungen verhindert. In den Bergwerken von Essen spürte man das rheinische Beben vom Jahr 1828 nicht; das große Agramer Beben im Jahr 1880 machte sich in den Gruben von Wies in Steiermark nur bis zu einer Tiefe von $28-30 \mathrm{~m}$, aber nicht mehr in Tiefen von 60-120 m fühlbar; dagegen reichte das ungefähr ebenso starke Laibacher Beben von 1895 in einer Entfernung von $40 \mathrm{~km}$ bis $200 \mathrm{~m}$ Tiefe. Das ostindische Beben (1897) blieb in den Kohlengruben von Bengalen unbeachtet, wohl aber richtete es in dem Kohlenbergwerk von Makum in Oberassam einigen Schaden an, doch geht dieses flach in das Gebirge hinein und nicht in die Tiefe. Systematische Beobachtungen, die sich aber nur auf die Horizontalkomponenten beziehen, wurden 1887-1890 an der Station Tokio und in einer unmittelbar daneben befindlichen Grube von $5^{1} / 2 \mathrm{~m}$ Tiefe angestellt. Bei schwachen Erschütterungen verhielten sich die Instrumente an der Oberfläche und in der Tiefe ganz gleich, und auch die Hauptwellen bei stärkeren Beben machten sich an beiden Stellen in gleicher Weise bemerkbar. Ein Unterschied bestand nur in bezug auf die kleinen und raschen Vibrationen, die den Hauptstößen vorangehen, indem sie die Tiefe viel weniger berührten als die Oberfläche. ${ }^{21}$

Areal. Wie die homoseistischen Linien die Orte gleichzeitiger Erschütterung, so verbinden die Isoseisten die Orte gleicher seismischer Intensität miteinander. $\overline{\text { Das Gebiet }}$ größter Intensität nennt man das pleistoseiste; von da ab nimmt die Stärke mehr oder minder regelmäBig nach allen Seiten ab. Als Beispiele mögen folgende Beben dienen: 
Zentraljapanisches Beben 1891 Laibacher Beben $1890^{\circ}$

\begin{tabular}{|c|c|c|c|}
\hline Intensität & 10 & $11111 \mathrm{gkm}$ & 570 \\
\hline & 9 u. 8 & & 8400 \\
\hline & 7 & 44907 & \\
\hline & 6 & 52315 & 47000 \\
\hline & 5 u. 4 & 134722 & 97000 \\
\hline & 3 & ? & 160000 \\
\hline & 2 & ? & 400000 \\
\hline & $\mathrm{Si}$ & 243055 & 712970 \\
\hline
\end{tabular}

Man sieht, die Areale wachsen mit abnehmender Intensität. Da aber die zerstörende Wirkung, wie wir gesehen haben, von verschiedenen Umständen abhängt, so kann es uns nicht wundernehmen, daß selbst nahe benachbarte Orte in verschiedener Weise betroffen werden, und daß auch im pleistoseisten Gebiet verhältnismäßig ruhige Stellen vorkommen können. Man nennt solche Örtlichkeiten, wo sich die Gewalt der seismischen Wellen infolge felsiger Bodenbeschaffenheit oder vielleicht infolge von Interferenzerscheinungen gleichsam bricht, Erdbebeninseln oder -brücken.

Auch die Grenzen des makroseismischen Feldes lassen sich nicht mit Sicherheit ziehen, denn außerhalb der deutlich erschütterten Fläche gibt es immer vereinzelte Orte, wo das Beben noch wahrgenommen wurde. Diese Unsicherheit macht es erklärlich, daß man sich früher in bezug auf die Ausdehnung mancher Beben übertriebenen Vorstellungen hingab. Das gilt besonders von dem berühmten Lissaboner Erdbeben vom Jahr 1755, das angeblich ein Gebiet von $38 \frac{1}{2}$ (nach WoErLe 35) Millionen qkm betroffen haben soll. Scheidet man die amerikanischen und isländischen Küsténgegenden, wo nur große Flutwellen beobachtet wurden, und England, wo das gleichzeitige Beben in den Bleibergwerken von Derbyshire entschieden selbständig war, aus, so reduziert sich das Areal auf 2,6 Millionen qkm. ${ }^{9}$ Aus gleichen Gründen verdient auch die Angabe von ungefähr 20 Millionen $q \mathrm{~km}$ für das Neuseeländer Beben von 1855 kein Vertrauen. Das größte Erdbeben in geschichtlicher Zeit war das ostindische im Jahr 1897. Beschränkt man sich nur auf diejenigen Gegenden, von denen sichere Nachrichten vorliegen, so ist das Gebiet, in dem Gebäude ernstliche Beschädigungen erlitten, auf $377000 \mathrm{qkm}$ (so groß wie Preußen), und das ganze makroseismische Gebiet auf 3,12 Millionen $\mathrm{qkm}$ zu veranschlagen. Bezieht man aber noch die Gegenden in Tibet und Westchina, wo das Beben sicher gefühlt wurde, aber von wo Nachrichten nicht erhältlich waren, in die Rechnung ein, so erhöhen sich die genannten Ziffern mindestens auf 416000 , bzw. 4,55 Millionen qkm. 
Areal und Intensität einer Erschütterung stehen nicht immer, wie man vermuten könnte, in geradem Verhältnis zueinander. Oft sind schwache Beben ausgedehnter als starke. Jenes von Ischia am 28. Juli 1883 , das Casamicciola vollständig zerstörte, reichte nicht über die kleine Insel hinaus, während das mitteldeutsche Erdbeben von 1872 , das kaum irgendwo den 6 . Intensitätsgrad überschritt, eine Fläche von 170000 qkm in Mitleidenschaft zog.

Ursachen. Die Erkenntnis der Verschiedenheit der Erdbeben ist eine der wichtigsten Errungenschaften der modernen Forschung. Nur die oberflächliche Betrachtungsweise früherer Zeiten, die allein an den gleichartigen Wirkungen haftete, konnte annehmen, daß alle Erdbeben einander gleich seien, und daß sie daher auch alle eine gleiche Ursache haben müßten; und es lag nichts näher, als sie auf den Vulkanismus zurückzuführen. Sie erscheinen in dieser Auffassung, die in neuerer Zeit wieder in STüBEL einen Anhänger gefunden hat, gewissermaßen als mißglückte Eruptionen.

VolgER war der erste, der den modernen Grundsatz aussprach, daß Erdbeben durch verschiedene Vorgänge im Innern der Erde erzeugt werden können. Als solche Ursachen hat man jetzt drei erkannt: den Vulkanismus, den Einsturz unterirdischer Hohlräume, die durch die auslaugende Tätigkeit des Wassers in Kalk, Salz und Gips entstanden sind, und Dislokationen.

Damit sind wir aber erst einen Schritt weiter gekommen. Eine volle praktische Bedeutung erhält die genetische Einteilung in vulkanische, Einsturz- und tektonische oder Dislokations. beben erst dann, wenn man in jedem einzelnen Fall mit Bestimmtheit die Ursache angeben kann. Von diesem Ziel sind wir einstweilen noch ziemlich weit entfernt.x

Wenn ein Vulkan und seine nächste Umgebung vor einem Ausbruch erschüttert wird, so können wir diesen Vorgang mit Sicherheit als vulkanisches Beben bezeichnen. Aber schwankender wird unser Urteil, wenn ein Erdbeben von gleichen Eigenschaften, d. h. ein zentrales und örtlich beschränktes, zwar auch in einer vulkanischen Gegend auftritt, aber ohne gleichzeitigen Ausbruch, oder gar in einer Gegend, wo die vulkanische Tätigkeit schon als erloschen gelten darf. Jene beiden Eigenschaften, mit verschiedenen Intensitätsgraden verbunden, kommen auch den Einsturzbeben zu, von denen wir als Beispiel die mit Erschütterungen und Detona-

× Ein sicheres Mittel zur Feststellung tektonischer Beben würden die Seismogramme liefern, wenn sich Schlüter's Hypothese der Kompressionswellen bestätigen wïrde. 
tionen verbundenen Bodensenkungen in Eisleben nennen wollen. In der Tat sind die Erdbeben auf Ischia in der ersten Hälfte der 80 er Jahre von Lasaulx und Palmieri als Einsturz-, von MerCALLI u. a. als vulkanische Beben gedeutet worden. Ja, es ist nicht einmal ausgemacht, ob nicht auch Dislokationen lokale Zentralbeben hervorrufen können, und es wird uns daher nicht wundernehmen, wenn z. B. Neumayr das Kaiserstuhl-Erdbeben vom Jahr 1882 für ein vulkanisches, KNoP dagegen für ein Dislokationsbeben hielt, oder wenn das Großgerauer Beben (1869) von Lasaulux auf Einsturz und von anderen Forschern auf Schichtenstörung zurückgeführt wurde. Seitdem wir wissen, daß vulkanische Eruptionen manchmal gar nicht bis zur Oberfläche gelangen, sondern in der Tiefe stecken bleiben, und wir vermuten dürfen, daß auch diese Vorgänge Erdbeben erzeugen, müssen wir mit R. Hoernes den vulkanischen Beben noch kryptovulkanische anreihen, aber in der Praxis fehlt uns dafür jedes Erkennungszeichen.

Die zentralen Beben von großer Ausdehnung und die linearen und Flächenbeben sind dagegen so eigenartig, so gänzlich verschieden von den nachweisbar vulkanischen und Einsturzbeben, daß man sie einer anderen Ursache zuschreiben muB. Die heutige Wissenschaft sieht in diesen Erscheinungen einen Beweis dafür, daß Verschiebungen in der Erdkruste noch immer ihren Fortgang nehmen. Begründet wird diese Annahme 1. durch tatsächliche Dislokationen bei Erdbeben, 2. durch die Existenz von StoB-oder Schütterlinien, die wiederholt den Ausgangspunkt von Erdbeben bilden, 3. durch die geographische Verbreitung der Erdbeben.

Betreffs der seismischen Dislokationen könnte man allerdings einwenden, daß man Ursache und Folge verwechsele, aber gesetzt auch den Fall, daß es jemals gelänge, den Nachweis zu führen, daß die Dislokation später eintrat als die Erschütterung, so wäre damit der tektonische Ursprung der letzteren noch nicht widerlegt. Die Dislokation ist ja nichts anderes als der äußere Ausdruck dér Auslösung von Spannungen innerhalb der Erdkruste. Der unterirdische Prozeß ruft das Beben hervor, nicht der Aufriß einer Oberflächenspalte; daher kommt es auch oft, wie z. B. bei dem Agramer und dem Laibacher Erdbeben, zu gar keinen wahrnehmbaren tektonischen Veränderungen.

Die Achse langgestreckter Epizentralgebiete schwerer Beben fällt meist mit Verwerfungen zusammen, die HoBBs ${ }^{22}$ als seismotektonische Linien bezeichnet; und wenn sie nicht oberflächlich sichtbar sind, so könne man nach seiner Ansicht annehmen, daß 
sie nur durch eine Decke lockern Materials unsern Augen entzogen seien. Die streng zonenartige Anordnung von ackerfurchenartigen Rissen und kleinen Sand- und Schlammkratern bei dem Charlestoner Erdbeben von 1886 deute z. B. auf eine solche verborgene Störungslinie hin. Einen sichereren Anhalt gewähren die habituellen StoBoder Schütterlinien. In den Ostalpen und in Unteritalien sind zwei Arten solcher Stoßlinien erkannt worden. Eine peripherische Linie zieht an der Südseite der Alpen vom Gardasee über Udine und Görz bis Fiume; Erschütterungen sind in diesen Gebieten sehr häufig und hängen offenbar mit der, auch im Gebirgsbau klar zu-

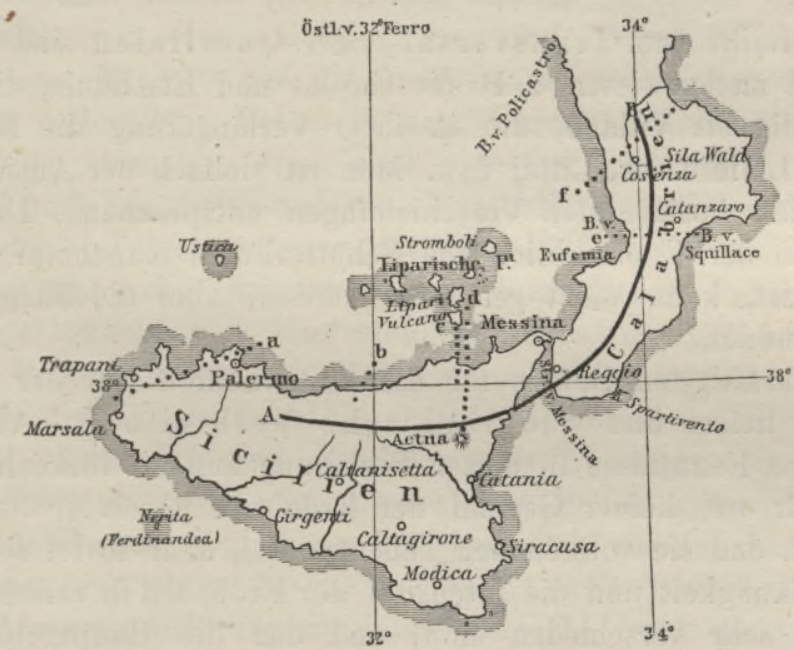

Fig. 103. Die Erdbebenlinien in Unteritalien nach E. Suess.

tage tretenden allmählichen Absenkung der Südalpen zusammen. Noch schärfer tritt der tektonische Charakter der peripherischen Erdbebenlinie in Calabrien und Sizilien $(A B$ in Fig. 103) hervor. Wir werden später ausführlicher auseinandersetzen, wie die ganze kristallinische Innenzone der Appeninnen bis auf wenige Reststücke zerbrochen und versunken ist. Dort, wo das Gebirge um das tyrrhenische Bruchfeld einen großen Halbbogen beschreibt, liegt die Schütterlinie zwischen dem Monte Cocuzzo, den vatikanischen Bergen und dem Scyllafelsen im Westen und dem Silawald und Aspromonte im Osten; in Sizilien umzieht sie das Peloritanische Gebirge. Innerhalb des kreisförmigen Senkungsfeldes, dessen Peripherie jene Stoßlinie bildet, liegen die liparisehen Vulkane; ob aber von da transversale (radiale) Schütterlinien ausgehen ( $a-f$ in Fig. 103), wie Suess annahm, ist durch Mercalui's Untersuchungen zweifelhaft ge- 
worden. Charakteristisch für die peripherische Linie ist das Wandern der Stoßpunkte. Während des calabrischen Erdbebens im Jahr 1783 befand sich das Epizentrum am 5. Februar in Oppido, am 7. in Soriano, am 28. in Polia und am 28. März in Girifalco, war also langsam nach Norden vorgerückt. Dann sprang es nach Süden zurück und befand sich am 5. Juni wieder in der Nähe von Oppido, bei Radicena. 1894 wiederholte sich derselbe Vorgang. Das Beben vom 8. September 1905 scheint seinen Ausgang vom südlichen Teil der Eufemiabucht (Pizzo, Monteleone) genommen zu haben, dasjenige vom 28. Dezember 1908 hatte sein Epizentrum an der Straße von Messina.

Eine Reihe vom Transversal- oder Querlinien sind auch in den Alpen nacligewiesen, z. B. die Garda- und Etschlinie, die Linie von Venedig bis Villach, die in ihrer Verlängerung die Mürzlinie trifft, die Linie Triest-Littai usw. Man ist vielfach der Ansicht, daß diese Linien horizontalen Verschiebungen entsprechen. DaB man übrigens in der Konstruktion von Schütterlinien manchmal zu weit gegangen ist, kann nicht geleugnet werden, aber die Mehrzahl ist wohl begründet.

Den kräftigsten Beweis für die tektonische Natur der meisten Erdbeben liefert ihre geographische Verbreitung. Allerdings sind unsere Kenntnisse in dieser Beziehung äußerst lückenhaft und können wir von keiner Gegend der Erde mit absoluter Sicherheit behaupten, da $\mathrm{B}$ sie vollkommen bebenfrei sei, aber soviel steht fest, daß die Häufigkeit und die Intensität der Erdbeben in verschiedenen Gegenden sehr verschieden sind, und daß die Hauptgebiete der seismischen Tätigkeit gerade diejenigen sind, die in verhältnismäßig junger Vergangenheit großen tektonischen Umwälzungen unterworfen waren. Wohl sind auch die Vulkane vorzugsweise an diese Gebiete gebunden, aber die Erdbebenzonen umfassen viel größere Flächen, ja manche der intensivsten Erschütterungsgebiete sind gänzlich frei von vulkanischer Tätigkeit. Dies geht aus Montessus' ${ }^{23}$ Darstellung der Hauptschüttergebiete, der wir auf Karte XVII gefolgt sind, augenscheinlich hervor. Von den 171434 Beben, auf die dieser unermüdliche Forscher seine seismologische Geographie aufgebaut hat, entfallen auf

1. die nordatlantischen Kontinente zwischen dem Felsengebirge und Ural mit Ausschluß der Autillen, des Alpensystems, der Sierra Nevada und des Kankasus

2. Sibirien, Zentralasien, China, Indochina, Siam, Borneo

3. Dekan und Australien

4. Arabien, Syrien, Afrika mit AussehluB des Atlas und das außerandine Südamerika

$$
\begin{aligned}
& 8939=5,2 \text { Prozent } \\
& 3479=2,0 \quad \text { " } \\
& 374=0,2 \quad, \\
& 457=0,3 \quad n
\end{aligned}
$$


5. Polynesien ohne den australischen Inselbogen von Neuguinea bis Neuseeland.

$2033=1,2$ Prozent

6. Die tertiäre Faltenzone der Alten Welt (Sierra Nevada, Atlas, Alpen, Karpathen, Appenninen, Balkanhalbinsel, Kleinasien, Kaukasus, Iran, Himalaya, westliches Hinterindien und Sundainseln)

7. Die pazifische Faltenzone (Antillen, westamerika$90126=52,6 \quad$, nisches Hochland, Kamtschatka, ostasiatischer Inselbogen, australischer Inselbogen von Neuguinea bis Neuseeland)

$66026=38,5 \quad$,

Ohne Zweifel ist diese Statistik mangelhaft, weil wir nicht über die Beben aller Länder gleichmäBig unterrichtet sind; daher möge eine zweite, von diesen Zufälligkeiten freie Darstellung ergänzend hinzutreten. Mrune ${ }^{24}$ hat die instrumentell ermittelten Epizentren der weit verbreiteten Beben in den Jahren 1899, 1900 und 1901 zu Gruppen vereinigt; diese sind auf der Karte XVII mit punktierten Linien umzogen, und die eingeschriebenen Ziffern geben die Zahlen der von dort ausgegangenen Erschütterungen an. Auch hier tritt das seismische Übergewicht der jugendlichen Faltenzüge und der ihnen benachbarten Meeresteile (77 Proz.) deutlich hervor.

In Europa liegen die Hauptschauplätze seismischer Tätigkeit innerhalb der alpinen Zone bis zum Atlasgebirge und zu der Sierra Nevada. Namentlich sind die Alpen, der Appennin und vor allem Griechenland durch häufige und starke Beben ausgezeichnet, ja Griechenland scheint in dieser Beziehung nur von Japan übertroffen zu werden. Wichtig ist die aus GerLand's Erdbebenkarte von Italien ${ }^{25}$ anschaulich hervortretende Tatsache, da $B$ die vulkanische Westseite der Halbinsel nicht nur weniger seismisch ist als das appenninische Faltengebirge, sondern auch weniger als die adriatische Abdachung, wie ja auch auf der Balkanhalbinsel nicht die Umgebung der östlichen Vulkane, sondern der adriatisch-jonische Rand am häufigsten erschüttert wird. Rrcco will auch einen $\mathrm{Zu}$ sammenhang zwischen den Beben und den Schwereanomalien in Süditalien erkannt baben, der aber von Montessus mit Recht bezweifelt wird, weil ebensolche Anomalien auch in dem seismisch ruhigen Apulien bestehen. In Deutschland sind die Sudeten, das Erzgebirge und der oberrheinische Graben die wichtigsten Bebengebiete. Im allgemeinen verzeichnet die Statistik von Montessus 69315 Erdbeben in Europa; davon kommen 86,4 Proz. auf die Zone der tertiären, 4,8 auf die der karbonischen;, 0,4 auf die der nachsilurischen Faltenzüge und 8,6 auf die ungefalteten Gebiete. Dieses Ergebnis ist sehr wichtig, es zeigt uns die Abhängigkeit der größeren oder geringeren Stabilität der Erdkruste von dem Alter der Faltung. 
Auch in Asien fällt eine seismische Hauptzone in den Hochlandgürtel vom Kaukasus bis zum Himalaya. Häufige Erschütterungen suchen auch die Umgebung des syrischen Grabens heim, und es ist beachtenswert, da $B$ die einzigen namhaften Erdbeben, die uns in letzter Zeit aus Afrika südlich vom Atlas gemeldet wurden, im zentralafrikanischen Graben, am Tanganika, vorkamen.

Anderseits ist es ebenso beachtenswert, daß auf der ungestörten russischen Tafel, besonders in der jungen arktischen Tiefebene und in Westsibirien Erschütterungen selten und schwach sind.

Der indisch-pazifische Faltenrand, der - wie wir sahen - der Hauptträger der vulkanischen. Tätigkeit in der Gegenwart ist, ist zugleich auch der Hauptschauplatz seismischer Erschütterungen. Japan, wo man im Mittel jährlich auf 600 Erdbeben rechnen kann, und zerstörende Katastrophen durchschnittlich alle $2^{1} / 2$ Jahre wiederkehren; Zentralamerika, wo das Tal von San Salvador bezeichnenderweise die Hängematte heißt; der pazifische Küstenstrich im tropischen Südamerika haben ihresgleichen nur in Griechenland. Aber gerade in der pazifischen Welt tritt die Unabhängigkeit der Erdbeben von den tätigen Vulkanen vielfach in prägnanter Weise zutage. In Japan ist diese Tatsache schon lange bekannt; die vornehmsten Schüttergebiete, unter denen die Gegenden westlich und nördlich von Tokio den ersten Platz behaupten, liegen an der Ostseite, dort, wo das Land steil zum japanischen Graben abstürzt. ${ }^{26}$ Große Niveauunterschiede benachbarter Schollen scheinen also die Unruhe des Bodens zu erhöhen. Im vulkanreichen Zentralamerika sind nach Montessus die Städte in der Nähe tätiger Feuerberge minder bedroht als die in der Nachbarschaft erloschener, und für Chile hat Doмєxко nachgewiesen, daß gerade der nördliche Teil, wo es keine tätigen Vulkane gibt, am schwersten unter dem seismischen Ungemach zu leiden hat.

Die atlantischen Seiten der beiden Landfesten sind zwar durchaus nicht bebenfrei, stehen aber in dieser Beziehung doch weit hinter den pazifischen zurück.

Um den tektonischen Ursprung der Erdbeben zu erweisen, berief man sich auch auf die geringe Tiefe des Herdes, wie sie sich aus den ältern Berechnungen nach den Methoden Mallet, v. SeEBACH, Dutton u. a. ergab. Es lohnt sich aber nicht, auf diesen Gegenstand näher einzugehen, denn trotz allen Scharfsinns, den man zur Auffindung geeigneter Berechnungsmethoden aufgewendet hat, sind die Ergebnisse recht zweifelhafter Natur. Manchmal scheint der Herd ganz nahe der Oberfläche zu liegen, manchmal Tiefen bis zu ungefähr $200 \mathrm{~km} \mathrm{zu}$ erreichen. Auf die Natur der seismischen 
Störung lassen sich daraus um so weniger Schlüsse ziehen, als sie notwendigerweise von unsern Ansichten über die Beschaffenheit des unbekannten Erdinnern beeinflußt werden. Auch nur mit aller Reserve läßt sich der Satz aufstellen, daß die Tiefe des Herdes keinen Einfluß auf die Intensität hat, daß sie aber im geraden Verhältnis zur Ausdehnung des Schüttergebietes steht. ${ }^{27}$

Viel weniger als über die Verbreitung der Erdbeben sind wir über die der Seebebęn, d. h. der seismischen Erschütterungen des Meeresbodens unterrichtet. Das wenige, was wir darüber wissen, hat RUDOLPH ${ }^{28}$ in übersichtlicher Weise - auch kartographisch zusammengestellt und einige wichtige Folgerungen daraus abgeleitet. Threr Wirkung nach sind zwei Kategorien zu unterscheiden: Seebeben mit und ohne Flutbewegung. Die ersteren treten nach RUDoLPH's Ansicht nur in Gesellschaft unterseeischer Explosionen auf und wären demnach vulkanischer Natur (vgl. S. 297); die letzteren erzeugen keine sichtbare Bewegung, aber der StoB pflanzt sich durch das Wasser fort und wird von einem zufällig daselbst befindlichen Schiff auch als solcher empfunden. Nur wenn er senkrecht zur Meeresfläche gerichtet ist, vermag er Wasserstrahlen emporzuschleudern. DaB viele Seebeben dieser zweiten Kategorie durch Dislokationen verursacht werden, scheint daraus hervorzugehen, daB es auch Seebeben mit ausgesprochen linearer Verbreitung gibt; RudolpH hat einen dieser Fälle, das Seebeben zwischen den Azoren und Madeira am 22. Dezember 1884, eingehender erörtert. Manchmal greift das Seebeben auf das Land über, das Epizentrum liegt dann im Meer, wie so häufig bei den japanischen Beben.

Ebenso wie die Seebeben fügen sich auch die Simultanbeben der genetischen Dreigliederung ein. Diese von REYER glücklich gewählte Bezeichnung besagt nichts anderes, als daB in zwei oder mehreren entlegenen Gegenden gleichzeitig Erdbeben eintreten, ohne da $B$ in den dazwischenliegenden Gegenden Erschütterungen wahrgenommen werden. Drei Fälle sind hier denkbar: 1. Die Simultanbeben sind völlig unabhängig voneinander, und die Gleichzeitigkeit ist lediglich Zufall, 2. das eine Erdbeben wird durch das andere erzeugt, 3 . beide werden durch eine gemeinsame Ursache hervorgerufen. Der häufig gebrauchte Ausdruck Relaisbeben paßt ausschließlich für den zweiten Fall; aber auch zugegeben, daß manche Simultanbeben Relaisbeben sind, so dürfen diese doch keineswegs als eine vierte Kategorie in die genetische Einteilung eingefügt werden. An dem Ort des sekundären oder Relaisbebens war die Disposition zu einem vulkanischen Ausbruch, einem Einsturz oder einer Dislokation 
jedenfalls schon vorhanden, und das primäre Beben gab nur den letzten AnstoB zur Lösung einer Spannung, die sich ohne ihn noch längere Zeit erhalten hätte. Dasselbe gilt von OLdHaM's sympathetischen Nachbeben, die von einem sekundären Epizentrum innerhalb des Verbreitungsgebietes des Hauptbebens ausgehen.

Einteilung der Beben. Wir wiederholen nochmals die Einteilung der Beben nach den verschiedenen Einteilungsprinzipien:

1. Nach dem Ort: Erd- und Seebeben.

2. Nach der Form der Erdbebenfläche, bezw. des Epizentrums: zentrale, lineare und Flächenbeben.

3. Nach der Ursache: vulkanische, Einsturz- und Dislokationsbeben.

4. Nach der Intensität: schwache (Grad 2-4 der Rossi-FoneLschen Skala), mittelstarke (Grad 5) und starke Beben (Grad 6-10). Es muB aber nochmals betont werden, daß diese Einteilung nur auf Kulturländer Anwendung findet.

5. Beben, die dauernde Spuren im Boden hinterlassen, und solche, bei denen dies nicht der Fall ist. $\times$ Diese Einteilung wäre die geographisch wichtigste, wenn es nur immer möglich wäre, jene Spuren einwandfrei festzustellen.

Kombinieren wir die ersten drei Einteilungen, wobei wir von den beiden ersten, als den am leichtesten erkennbaren, ausgehen, so erhalten wir als bisher beachtete Formen:

\section{Zentrale Beben:}

a) Zentrale vulkanische Erdbeben, $\alpha$ ) Zentrale vulkanische Seebeben;

b) Zentrale Einsturz-Erdbeben,

c) Zentrale Dislokations-Erdbeben,

2. Lineare Beben:

d) Lineare Dislokations-Erdbeben, $\beta$ ) Lineare Dislokations-Seebeben.

\section{Flächenbeben :}

e) Flächen-Dislokations-Erdbeben,

Jede Kategorie kann man dann wieder weiter in schwache, mittelstarke und starke Beben einteilen, wobei man aber, wenn es sich um die Charakteristik eines Erdbebens in seiner Gesamtheit handelt, stets nur die Intensität im pleistoseisten Gebiet zu berücksichtigen hat.

Periodizität. Lange Zeit glaubte man, wie zum Teil auch heute noch, der Statistik der Erdbeben die Gesetze dieses Phänomens entnehmen zu können. Unglücklicherweise leidet auch diese Methode an einigen erheblichen Mängeln. Nur aus den dichter bevölkerten

$\times$ Ŏdнам $^{29}$ unterscheidet geradezu zwei seismische Störungsformen: die vorübergehende Bodenbewegung (Orehesis) und die dauernde Deformation (Mochleusis). 
Kulturländern, die ja nur einen kleinen Prozentsatz der ganzen Landfläche ausmachen, erhielten wir bisher auch von schwächeren Beben Kunde, aus den übrigen Ländern aber nur von den heftigsten Erscheinungen dieser Art, und die Seebeben entzogen sich fast ganz unserer Beobachtung. Die Nachrichten aus den früheren Jahrhunderten sind nicht nur außerordentlich mangelhaft, sondern in manchen Fällen geradezu gefälscht, wie Tн. WoLF in bezug auf alle sogenannten vulkanischen Ereignisse in Südamerika nachgewiesen hat. Erst seit der Errichtung zahlreicherer seismischer Stationen kann von einer annähernd vollständigen Erdbebenstatistik die Rede sein.

Wenn schon, oft die Behauptung aufgestellt worden ist, daß kein Tag ohne Erdbeben vergehe, so ist der Beweis dafür doch erst durch RUDOLPH's Katalog für $1903^{30}$ erbracht worden. Er verzeichnet 4760 makroseismische Stöße, also durchschnittlich 13 pro Tag. Die Schwankung ist nicht sehr bedeutend: im bebenreichsten Monat (März) entfielen 26,8, im bebenärmsten (Oktober) 6,4 Stöße auf den Tag. Auch wem man die älteren Statistiken durchmustert, erhält man den Eindruck, daß es sich mit den seismischen Erscheinungen ebenso verhält, wie mit den Niederschlägen in den Gebieten gleichmäßiger Verteilung: die Ursachen sind immer vorhanden, aber in manchen Zeiten kommt ein gewisses Plus dazu, das die Häufigkeit steigert.

Dieses Plus schiebt man auf kosmische und meteorologische Einflüsse. Perrex suchte nachzuweisen, daß die Beben bei den Syzigien häufiger seien als bei den Quadraturen des Mondes, und gründete darauf die Theorie, daB sie nichts anderes seien als Fluterscheinungen des heißflüssigen Erdkerns. J. Sснмгdт kam aber zu einem wesentlich anderen Schluß. Das Maximum tritt allerdings bei Neumond ein, aber ein zweites Maximum auch zwei Tage nach dem ersten Viertel; zur Zeit des Vollmondes (also ganz im Gegensatz zu dem Flutphänomen) nehmen die Beben ab und sind am Tag deș letzten Viertels am seltensten. In den japanischen Beben erkennt Knотт mit Bestimmtheit eine lunare Periodizität, besonders eine deutliche Ausprägung der halbtägigen Mondperiode, und Iмaмura's Ergebnisse stimmen im wesentlichen damit überein. Im Hinblick auf die Gezeitenbewegung der festen Erde (s. S. 21), die bei besonderer Stärke der fluterregenden Kräfte Spannungen in den oberen Teilen der Erdkruste zur plötzlichen und gewaltsamen Auslösung bringen kann, ist die Fluttheorie zwar nicht kurzweg von der Hand zu weisen, aber ein alle Zweifel ausschließender Beweis ist dafür noch nicht erbracht worden.

Milne, Cancani und Omori haben gefunden, daß außergewöhnliche 
seismische Erscheinungen, wie Beben von hoher Intensität oder allgemeiner Verbreitung, am häufigsten dann eintreten, wenn der Pol auf seiner Wanderung (vgl. S. 139) die Richtung ändert. Was hier Ursache oder Wirkung ist, ist noch völlig unaufgeklärt; v. KövEsLIGETHY meint, daß die nur im Innern der Erde verlaufenden Beben wesentlich $\mathrm{zu}$ den Breitenschwankungen beitragen.

Eine jahreszeitliche Periode der Beben tritt zwar überall hervor, aber nicht überall gleich scharf und in gleichem Sinn. Nach Montessus de BALLORE ${ }^{31}$ tritt das Wintermaximum nur in den Ländern höherer Breiten schärfer hervor, aber er geht wohl zu weit, wenn er es lediglich als ein scheinbares erklärt, indem er darauf hinweist, daB leichte Beben am wenigsten der Beobachtung entgehen, wenn sich Bewohner der betroffenen Gegend in ihren Häusern und in relativer Ruhe befinden. Auch in einem und demselben Land ist die Periode nicht stabil, wie der Vergleich der älteren (FucHs) und neueren Statistik von Italien (ErEdIA und CANCANI, 1891-1900 ${ }^{32}$ ) zeigt:

Verteilung der italienischen Erdbeben in Prozenten:

\begin{tabular}{|c|c|c|c|c|c|c|c|c|}
\hline & & $\begin{array}{c}\text { Zahl } \\
\text { der Beben }\end{array}$ & Winter & Frühling & Sommer & Herbst & $\begin{array}{l}\text { Winter- } \\
\text { halbjahr }\end{array}$ & $\begin{array}{l}\text { Sommer- } \\
\text { halbjahr }\end{array}$ \\
\hline Fühs & - & 1158 & 23,8 & 26,3 & $21,0^{*}$ & 28,8 & 53,1 & 46,8 \\
\hline Eredia . & . & 3886 & 21,3 & $20,3^{*}$ & 33,1 & 25,3 & 47,0 & 53,0 \\
\hline Cancani & . & 3361 & $22,4^{*}$ & 23,0 & 31,7 & 22,9 & 46,5 & 53,5 \\
\hline
\end{tabular}

Überdies geht aus den Untersuchungen OMonI's ${ }^{33}$ auch hervor, daß es nicht immer statthaft ist, Mittelwerte für ganze Länder zu berechnen, wie man es bisher getan hat. In Japan fallen die Maxima und Minima für verschiedene Gegenden in verschiedene Jahreszeiten.

Mittlere Erdbebenzahl einer Station in Japan.

$\begin{array}{lrrrrrrr} & \text { Winter } & \text { Frühling } & \text { Sommer } & \text { Herbst } & \begin{array}{r}\text { Winter- } \\ \text { halbjahr }\end{array} & \begin{array}{r}\text { Sommer- } \\ \text { halbjahr }\end{array} & \text { Jahr } \\ \text { West-Jesso } & 2,1 & 2,2 & 1,9^{*} & \mathbf{2 , 8} & \mathbf{5 , 1} & 3,9 & 9,0 \\ \text { Ost-Jesso } & 11,4^{*} & \mathbf{1 3 , 0} & \mathbf{1 4 , 1} & 13,7 & \mathbf{2 4 , 7} & \mathbf{2 7 , 5} & 52,2 \\ \text { Nord-Nippon } & \mathbf{8 , 8 ^ { * }} & \mathbf{1 1 , 3} & \mathbf{1 3 , 9} & \mathbf{1 0 , 8} & \mathbf{1 9 , 8} & \mathbf{2 5 , 0} & 44,8 \\ \text { Süd-Nippon } & 11,0 & \mathbf{1 3 , 5} & 8,6^{*} & 9,2 & \mathbf{2 1 , 6} & 20,7 & 42,3 \\ \text { Ost-Schikoku } & \mathbf{1 , 5} & 1,2 & 1,3 & 1,1^{*} & \mathbf{2 , 8} & 2,3 & 5,1 \\ \text { Kiuschiu } & 10,2 & \mathbf{1 1 , 5} & 8,6^{*} & 9,8 & \mathbf{2 0 , 6} & 19,5 & 40,1\end{array}$

Man hat hier an einen Einfluß der Luftdruckverteilung gedacht, insofern als die vorwiegend winterlichen Erdbeben meist binnenländischen und die vorwiegend sommerlichen meist submarinen Ursprungs sind. Die Bodenerschütterungen nehmen also wie der Luftdruck auf dem Meer vom Winter zum Sommer und auf dem Land vom Sommer zum Winter zu. Das letztere gilt auch für einige Gebiete Europas, die, wie die Schweiz und das sächsische Erzgebirge 
(Vogtland), eine genauere Bebenstatistik besitzen. Von Wichtigkeit ist der Nachweis Thomassen's, ${ }^{34}$ daß für die norwegischen Erdbeben nicht der örtliche Luftdruck maßgebend ist, sondern die Größe des barometrischen Gradienten am Epizentrum oder in dessen Nähe. Damit scheint man in der Tat einer der sekundären Bebenursachen auf die Spur gekommen zu sein.

Literaturnachweise. ${ }^{1}$ J. Mitne, Seismology; London 1898. W. Branco, Wirkungen und Ursachen der Erdbeben; Berlin 1902. A. Stererg, Handbuch der Erdbebenkunde; Braunschweig 1904, enthält vieleLiteraturangaben. C.E.Duтros, Earthquakes in the Ligth of the New Seismology; London 1904. F. de Montessus de Batlore, La scienee séismologique, Paris 1907. W. H. Hoвbs, Earthquakes, New York 1907; Erdbeben, übersetzt von J. Ruska, Leipzig 1910. - ${ }^{2}$ C. Mainka, Kurze Übersicht über die modernen Erdbebeninstrumente, Berlin 1907. ${ }^{3}$ H. Benndorf, Über die Art der Fortpflanzung der Erdbebenwellen im Erdinnern, Nr. XXIX der Mitteilungen der Erdbebenkommission der Akademie der Wissensehaften in Wien, 1905. - ${ }^{4}$ Avg. Scrмidr, Wellenbewegung und Erdbeben, in den Jahresheften des Vereins für vaterländische Naturkunde in Württemberg, 1888. - ${ }^{5}$ M. P. Rudzkr, Über die scheinbare Geschwindigkeit der Yerbreitung der Erdbeben, in GerLand's Beiträgen zur Geophysik, Bd. III. - ${ }^{\circ}$ R. DE Kövesligethy, Seismonomia; Modena 1906; eine deutsche Bearbeitung mit Ausschluß der höhern Mathematik lieferte A. Pécsı im Abrégé du Bulletin de la Société Hongroise de Géographie, 1906, Bd. XXXIV (die dazu gehörigen Figuren s. im ungarischen Bulletin). Die Berechnung des Cerambebens v. 1899 s. ebenda, 1905, S. 25. $-{ }^{7}$ W. Schü̈trer, Schwingungsart und Weg der Erdbebenwellen, in GrerLand's Beiträgen zur Geophysik, Bd. V. $-{ }^{8}$ F. Omori in den Publications of the Earthquake Investigation Committee, Nr. 5 ; Tokio 1901, S. $42 .-{ }^{9}$ R. D. Oldнaм, Report on the Great Earthquake of $12^{\text {th }}$ June 1897 , in den Memoirs of the Geological Survey of India, 1899, Bd. XXIX (eine der wichtigsten Monographien). ${ }^{10}$ S. Seriya, A Model showing the Motion of an Earth Particle during an Earthquake, im Journal of the College of Science; Tokio, Bd. I. - ${ }^{11}$ E. RosentHaL, Katalog der im Jahre 1904 registrierten seismischen Störungen, StraBburg 1907. 12 F. Etzold, in den "Berichten der Mathem.-physik. Klasse der Sächsischen Gesellschaft der Wissenschaften, 1903, S. 22. - ${ }^{13}$ E. G. HARвoE, Erdbebenherdlinien, in Gerrand's Beiträgen zur Geophysik, Bd. V. u. VI. Mikrohomoseismen, ebenda, Bd. X. $-{ }^{14} \mathrm{H}$. Stefrex's Bericht in Petersians's Mitteilungen 1907, S. 132. - ${ }^{15}$ Franz Surss, Das Erdbeben von Laibach am 14. April 1895, im Jahrbuch der Geologischen Reichsanstalt, Wien 1896. - ${ }^{16} \mathrm{~F}$. Omori im Bulletin of the Imp. Earthquake Investigation Committee 1908, Bd. II, S. 89. ${ }_{17}$ Сн. Davison, Twin Earthquakes, im Quarterly Journal of the Geological Society, Bd. LXI, 1905. - ${ }^{13}$ F. Osrors in den Publications of the Earthquake Investigation Committee; Tokio, Nr. 4 (1900), S. 39 und Nr. 7 (1902), S. 27. $19 \mathrm{Vgl}$. die Beobachtungen in Tokio in den Transactions of the Seismological Society of Japan, 1890 , Bd. XIII, S. 41. $-{ }^{20}$ B. Koro, zit. S. 375. - ${ }^{21}$ Transactions of the Seismological Society of Japan, 1892, S. 19. - ${ }^{22}$ W. H. Новвs, On some Prineiples of the Seismic Geology, in Gertand's Beiträgen zur Geophysik, Bd. VIII; The Charleston Earthquake of August 31, 1907, im Geological Magazine 1907, Bd. IV. - ${ }^{23}$ F. De Montesses de Ballore, Les tremblements de terre; Paris 1906 (ein Hauptwerk, namentlich für den Geographen). Vgl. 
auch F. Frech, Gebirgsbau und Erdbeben, in Petermann's Mitteilungen 1907. Seine Karte zeigt besonders scharf den Zusammenhang von Beben und Dislokationen. - ${ }^{24}$ J. Mrlne, Seismological Observations and Earth Physics, im Geographical Journal, Bd. XXI, 1903. - ${ }^{25}$ G. GerLand, Taf. 20 u. S. 265 in Petermann's Mitteilungen, 1901. - ${ }^{26}$ A. Supan ebendaselbst 1893, S. 15 und Taf, 2; J. Murse's Kärtchen in seinem Catalogue of 8331 Earthquakes recorded in Japan between 1885 u. 1892 (im Seismological Journal of Japan 1895, Bd. IV; beiläufig bemerkt wegen seiner knappen, alles geographisch Wichtige zusammenfassenden Darstellung unerreichtes Vorbild für übersichtliche Erdbebenkataloge.) D. KIкuснг, Recent Seismological Investigations in Japan, in Publieations of the Earthquake Investigation Committee, Nr. 19; Tokio 1904. - ${ }^{27}$ A. RÉthly, Die Erdbeben in Ungarn im Jahre 1906, Budapest 1907. - ${ }^{28}$ E. RudocpH, zit. S. 277. - ${ }^{29}$ R. D. Oldнам im Geographical Journal 1909, Bd. XXXIV, S. 156. - ${ }^{\text {so }}$ E. Rudolph, Katalog der im Jahr 1903 bekannt gewordenen Erdbeben; Leipzig 1905. E. Rosenthal, s. o. Nr. 11. E. Oddone, Les tremblements de terre ressentis pendant l'année 1904, StraBburg 1907. - ${ }^{\text {\$1 }}$ F. DE Montessus DE Ballore im Bulletin de la Société Belge de Géologie 1906, Bd. XX, S. 183. 32 F. Eredia im Bolletino della Società sismologica Italiana, 1904, Bd. X, S. 253. - ${ }^{33}$ F. Omori, Annual and Diurnal Variation of Seismic Frequency in Japan, in den Publications of the Earthquake Investigation Committee, 1902, Nr. 8. - ${ }^{34}$ T. Сн. Thomassen, Erdbeben in ihrer Beziehung zum Luftdruck, in Bergens Museums Aarbog for 1893.

\section{Moderne Niveauveränderungen.}

Einteilung. Endogene Niveauveränderungen nehmen, wie wir sehen werden, auch heute noch ihren Fortgang. Andere ereigneten sich zu einer Zeit, da das heutige Relief der Erdoberfläche in seinen Großformen schon vollendet war, und sind dann zum Stillstand gekommen, haben uns aber in gewissen Kleinformen noch sichtbare Spuren hinterlassen. Nur diese beiden Niveauveränderungen gehören in den Kreis der geographischen Betrachtung.

Die Unterscheidung von instantanen und säkularen Niveauveränderungen hat auch hier ihre Gültigkeit, aber sie ist nur auf diejenigen anwendbar, die sich unter unseren Augen vollziehen, oder von denen wir sichere historische Kunde besitzen. Ihnen gegenüber steht eine weitaus größere Gruppe von Erscheinungen, die wir nur in seltenen Fällen und nur vermutungsweise der einen oder der anderen Kategorie zuweisen können.

Wir haben ferner die binnenländischen Niveauveränderungen von den litoralen $\mathrm{zu}$ trennen. Jene bewirken nur Umgestaltungen im Relief der Oberfläche, diese verändern nicht nur die Gestalt der Küste, sondern auch die Verteilung von Wasser und Land. Jene sind meist nur durch sorgfältige Messungen, wie sie erst mit den Hilfsmitteln unserer Zeit ausgeführt werden können, festzustellen, für die Verschiebungen der Strandlinie bietet aber der Meeresspiegel 
einen bequemen Maßstab, den das Binnenland entbehrt, und es erklärt sich daraus, daß bis in die neueste Zeit fast nur Küstenveränderungen Beachtung gefunden haben. Sofern es sich um Krustenbewegungen handelt, ist zwischen binnenländischen und litoralen Niveauveränderungen genetisch kein Unterschied, und wohl in derm Regel greifen sie ineinander ein; nur bei Verschiebungen des Meeres $\eta$ ut spiegels wird die Strandlinie allein unmittelbar in Mitleidenschaft gezogen, und das Hinterland wird nur indirekt dadurch beeinflußt.

Litorale Niveauveränderungen. ${ }^{1}$ Sichere instantane Veränderungen dieser Art sind erst aus der letzten Zeit bekannt geworden. Das Gebiet der tief in die Südküste von Alaska einschneidenden Yakutatbai hat bei dem Erdbeben von 1899 sowohl Senkungen als auch Hebungen erlitten. Am obern Ende wurden Hebungen von 10-15 m gemessen: die größte seismische Deformation, die man je beobachtet hat. ${ }^{2}$ Bei dem Erdbeben von Valparaiso vom Jahr 1906 beschränkte sich die Hebung auf die chilenische Küstenstrecke zwischen $31^{1} / 2$ und $35^{\circ} \mathrm{S}$. und überstieg nirgends den Betrag von $80 \mathrm{~cm}^{3}$ Südlich davon, bei Conception, wurde nach DARwIN die Küste bei dem Erdbeben von 1835 bis zu $1 \mathrm{~m}$ gehoben, und auf der benachbarten Insel St. Maria soll diese Verschiebung $3 \mathrm{~m}$ erreicht haben. Weniger beglaubigt ist die Senkung von Callao durch die Erschütterung von 1746 .

Sehr viel schwieriger ist der Nachweis §äkularer Küstenveränderungen. Das Land kann nicht nur durch Hebung in das Meer hinauswachsen, sondern auch durch Anschwemmung; Inseln können dadurch landfest werden, Häfen versanden, einstige Seestädte, wie Ravenna, werden vom Meer, ihrem Lebenselement, abgeschnitten. Wenn das Meer gegen das Land vorrückt, so ist man noch immer nicht ohne weiteres zu dem Schluß berechtigt, daß das Land sinke. Die sturmbewegte See hat oft Küstenstriche und flache Inseln verschlungen, ohne daß eine Niveauveränderung stattgefunden hätte. Lange Zeit hindurch galten unterseeische Wälder und Torfmoore als untrügliche Zeichen der Landsenkung, aber sie können auch durch einfache Abrutschung, durch Einbrüche der Sturmfluten und Zerstörung natürlicher Deiche in ihre gegenwärtige Lage versetzt worden sein. An Schwemmlandküsten, besonders in Deltas, wird häufig wirkliche Senkung beobachtet, aber diese kann auch nur eine Folge der Zusammensackung der lockeren Massen sein und mit eigentlichen Krustenbewegungen nichts zu tun haben.

Wo wir aber Spuren der Zerstörung durch das brandende Meer oder Ablagerungen mit marinen Organismen außerhalb der Grenze der Sturmfluten finden, werden wir auf eine Niveauver- 
änderung schließen dürfen. Freilich auch da ist Vorsicht nötig, denn manche Muschelhaufen sind nichts anderes als Reste menschlicher Mahlzeiten aus vorgeschichtlicher Zeit. Auf Kerguelen findet man Meeresmuscheln bis zu $100 \mathrm{~m}$ Höhe, aber die Möglichkeit ist nicht ausgeschlossen, daß sie durch Seevögel dahin verschleppt wurden. Und am Ende werden wir noch immer vor die Frage gestellt sein, welches Element sein Niveau verändert habe, die Oberfläche des Landes oder der Spiegel des Meeres.

Auch das Mittelwasser des Meeres ist, wie wir erfahren haben, eine veränderliche Größe. Lassen wir selbst die Geơdveränderungen durch die Anziehungskraft des Festlandes, auf die man einige Zeit so großes Gewicht gelegt hat, als einen noch nicht abschätzbaren Faktor beiseite, so müssen wir doch jene Niveauveränderungen berücksichtigen, die im Gefolge der Klimaschwankungen nicht nur in Binnenmeeren, sondern auch an ozeanischen Küsten auftreten. Das sind Ursachen, die den Meeresspiegel lokal beeinflussen; Verminderung der Wassermenge und räumliche Veränderungen der Meeresbecken sind dagegen Ursachen, die sich im ganzen Weltmeer gleichzeitig geltend machen. Verminderung der Wassermenge muB überall eine Senkung des Spiegels bewirken. Es kann nicht geleugnet werden, daß durch die Hydratisierung der Eruptivgesteine, durch das Eindringen von Wasser in die Haarspalten der Felsen und durch dauernde Eisbildung viel Wasser teils für immer, teils auf lange Zeit dem Meer entzogen wird; aber es unterliegt ebensowenig einem Zweifel, daß TrautschoLd ${ }^{4}$ diese Faktoren in ihrer Bedeutung ganz außerordentlich überschätzt hat. Kommt der vulkanische Dampf nicht aus dem Meer oder der Atmosphäre, so führen-überdies die Ausbrüche der Feuerberge dem Meer auch wieder Wasser zu. Die räumlichen Veränderungen der Meeresbecken hat SuEss als eustatische Bewegungen bezeichnet. Senkt sich der Meeresboden oder verschwindet Festland unter dem Meer, so sinkt überall der Meeresspiegel, während ihn die Aufhäufung von Sedimenten am Meeresgrund überall hebt.

Wir haben eine Reihe von möglichen Ursachen kennen gelernt, die bei der säkularen Verschiebung der Strandlinie mitwirken, und jede kann entgegengesetzte Wirkungen, sowohl Landgewinn -wie Landverlust erzeugen. Wir haben zunächst diejenigen Verschiebungen auszuscheiden, die nur auf mechanische Ursachen, auf die Tätigkeit des Meeres und der Flüsse, zurückzuführen und mit keiner eigentlichen Niveauveränderung verbunden sind. Wir haben ferner auszuscheiden die oberflächlichen Niveauveränderungen durch Gleitung von Küstenschollen und Zusammensackung angeschwemmter 
Massen, und erst das, was übrig bleibt, können wir als wirkliche litorale Niveauveränderung in Anspruch nehmen. Und nun haben wir zu untersuchen, ob die Niveauveränderung auf senkrechter Verschiebung des Meeresspiegels oder des Landes beruht.

Diese Unterscheidung ist aber in vielen Fällen so schwierig, daß man überhaupt darauf verzichten muß. Man wird dann eine Entscheidung nur auf Grund seiner theoretischen Ansichten treffen können, und diese Ansichten sind verschieden und haben im Lauf der letzten 150 Jahre schon mehrfach gewechselt. Suess schlug daher vor, für die beiden Arten der litoralen Niveauveränderung neutrale Bezeichnungen zu gebrauchen: negativ für Senkung des Meeresspiegels oder Hebung des Landes, positiv für Steigung des Meeresniveaus oder Senkung des Landes. $\times$ Diese Namen haben seitdem in der wissenschaftlichen Literatur vielfach Eingang gefunden, obwohl sie nicht ganz so neutral sind, wie sie aussehen, und keine sinnlichen Vorstellungen erwecken. Jedenfalls dürfen sie nur auf Küstenbewegungen von genetisch zweifelhafter Natur Anwendung finden.

Theorien. Als man im 18. Jahrhundert zuerst dem Problem der schwedischen Niveauveränderungen näher trat, nahm man an, der Wasserspiegel sinke und das Land fest bleibe. Diese Theorie vertrat besonders Celsius. Zu Beginn des 19. Jahrhunderts, als die plutonistische Schule ihre Siegeslaufbahn begann, wurde die entgegengesetzte Theorie, hauptsächlich gestützt durch die gewaltige Autorität LEopold v. Buch's, herrschend; nun wurde der Meeresspiegel konstant und das Land beweglich. Die dritte Phase knüpft sich hauptsächlich an den Namen Sukss. Die Veränderlichkeit des Meeresniveaus wird wieder anerkannt, aber auch das Land ist beweglich. Nur Hebung ohne Faltung sei undenkbar, und was wir bisher als Küstenhebung gedeutet haben, müsse in Wirklichkeit auf eine Senkung des Meeresspiegels zurückgeführt werden. Er vermutete eine Oszillation des Ozeans zwischen den Polen und dem Åquator und fügte beiläufig hinzu, daß sie vielleicht mit periodischen Schwankungen der Fliehkraft zusammenhänge. ${ }^{5}$ Auch BuYTT

× In neuester Zeit bürgern sich wieder die Ausdrücke Hebung und Senkung auch in jenen Fällen ein, wo eine Krustenbewegung nicht zweifellos ist. Man hat sich darauf berufen, daB man auch vom Auf- u. Untergang der Sonne spricht, obwohl wir wissen, daß sich nicht die Sonne, sondern die Erde bewegt. Aber dieser Vergleich ist nicht zutreffend. Der Sprachgebrauch von der Sonnenbewegung erklärt sich aus der sinnlichen Wahrnehmung, Hebung und Senkung der Küste aber nehmen wir nicht wahr, sondern nur Verschiebungen des Meeresspiegels. 
vertritt diese Ansicht. ${ }^{6}$ Es sei daran erinnert, daß die Gestalt der Erde das Produkt von Schwerkraft und Fliehkraft ist. Je größer die Drehungsgeschwindigkeit, desto größer die Fliehkraft, desto abgeplatteter die Erde. Die Drehung von W nach $O$ wird aber verzögert durch die Flutwelle, die sich von $\mathrm{O}$ nach $\mathrm{W}$ bewegt. In den Perioden hochgradiger Exzentrizität der Erdbahn soll die Flutwelle verstärkt werden, dadurch wird die Drehung verlangsamt, die Fliehkraft vermindert, und die Gestalt der Erde nähert sich der Kugel. Der deformierenden Kraft folgt zunächst das Meer, sein Spiegel

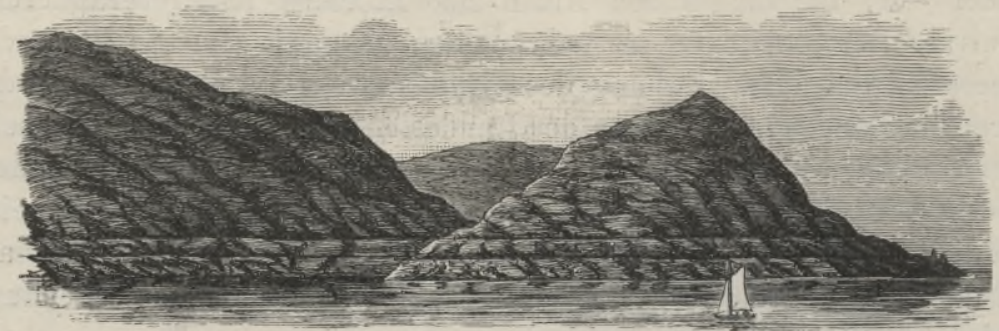

Fig. 104. Doppelte Strandlinie bei Grötnes mit entsprechenden Terrassen an dem Talausgang in der Mitte nach MoHs.

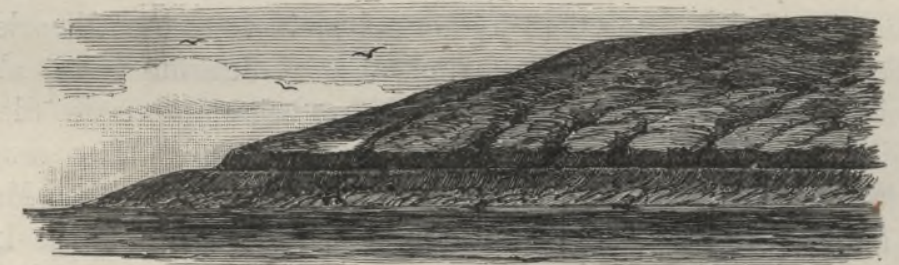

Fig. 105. Strandlinie zwischen Vang und Skaarliodden nach Moнs.

sinkt in der Äquatorialzone und hebt sich gegen die Pole hin. In den Perioden intensiv entwickelter Fliehkraft wächst dagegen die Abplattung, dann erniedrigt sich das Meeresniveau in den Polargegenden und steigt im Äquatorialgürtel. BLYTT hält es für möglich daß mit der Zeit auch die feste Erdkruste der Deformation unterliege. v. Böнм's Theorie, deren Grundzüge wir schon auf S. 372 dargelegt haben, unterscheidet sich von der BLYTT'schen darin, daB sie den Übergang von der sphäroidalen zur kugelförmigen Gestalt als einen einmaligen und stetig verlaufenden Prozeß auffaßt.

Zugegeben, daß die Flutwelle die oben geschilderte Wirkung ausübe, so kann dieser Vorgang, da der Sterntag sich als eine nahezu konstante Größe erwiesen hat, nur so langsam verlaufen, daß die in geschichtlicher Zeit beobachteten Küstenveränderungen nicht in ursächliche Beziehungen dazu gesetzt werden dürfen. $\mathrm{Ob}$ 
aber auch die ältern, muß vorderhand noch dahingestellt bleiben. Wenn ZiemendoRFF ${ }^{7}$ meint, „die Ausdehnung eines ungefähr gleichen Schelfplateaus $\mathrm{zu}$ beiden Seiten des Atlantik lasse nur die Deutung $\mathrm{zu}$, daß es sich um eine Änderung der Meereshöhe bei gleichbleibendem Stand der Kontinente handelte“, so findet diese Ansicht in seinen verdienstvollen Untersuchungen keine Stütze. Von einer GleichmäBigkeit ist keine Rede; vielmehr spricht gerade der an verschiedenen Stellen nachgewiesene stufenweise Aufbau des Schelfs und das Vorkommen von Schelfbänken an seiner Außenseite für eine Schollenbewegung.

Für die isostatische Theorie haben aufsteigende Bewegungen des Festlandes, wie auf S. 374 dargetan wurde, nichts Auffallendes. Eustatische Bewegungen, denen SuEss nur eine nebensächlichere Bedeutung zuerkannte, machte LöwL zum Mittelpunkt seiner oqu Theorie. $^{8}$ Die ozeanischen Becken seien durch Einbruch entstanden, und ihre Sohle sinke fortwährend tiefer ein. Wenn trotzdem der Meeresspiegel nicht an allen Küsten gleichmäßig sinke, an manchen in Ruhe verharre, an anderen sogar zu steigen scheine, so sei dies dadurch zu erklären, daß nicht bloß jene Scholle, die den Meeresgrund bildet, sondern auch die benachbarte Küstenscholle sich senke, und $\mathrm{da} B$ beide Bewegungen sich nicht im gleichen Tempo vollziehen. Es ist klar, daß das Vorhandensein solcher Küstenschollen und ihr eigenartiges Verhalten in jedem einzelnen Fall festzustellen ist, ehe man zu LöwL's Theorie seine Zuflucht nehmen darf.

Skandinavien. Skandinavien ist das klassische Land der Strandverschiebungen; hier wurden die ersten und bis auf den heutigen Tag sorgfältigsten Beobachtungen angestellt, hier wurden alle Theorien zuerst erprobt.

An der steilfelsigen ozeanischen Westküste ${ }^{9}$ finden wir Muschelbänke, Terrassen und "Seter", was man im Deutschen mit der sonst im allgemeineren Sinn gebrauchten Bezeichnung "Strandlinien“ übersetzt hat. Man versteht darunter horizontale wegeartige Einschnitte im festen Gestein, die sich an den Steilwänden der Fjorde

\begin{tabular}{|r|c|c|c|c|c|}
\hline $\begin{array}{c}\text { Stufen } \\
\text { von } \\
\text { Kverve }\end{array}$ & $\begin{array}{c}\text { Seehöhe des } \\
\text { unteren Randes } \\
\text { der Stufe }\end{array}$ & $\begin{array}{c}\text { oberen Randes } \\
\text { der Stufe }\end{array}$ & Mittlere Seehöhe & $\begin{array}{c}\text { Ungefähre } \\
\text { Breite } \\
\text { der Stufe }\end{array}$ & $\begin{array}{c}\text { Abfallswinkel } \\
\text { zur } \\
\text { nächsten Stufe }\end{array}$ \\
\hline \hline I. & $28,1 \mathrm{~m}$ & $31,1 \mathrm{~m}$ & $29,9 \mathrm{~m}$ & $66 \mathrm{~m}$ & $30^{\circ}$ \\
II. & 19,7 & 21,7 & 20,7 & 40 & 27 \\
III. & - & - & 14,5 & 12,6 & 26 \\
IV. & - & - & 9,4 & 13 & 40 \\
V. & 4,2 & 5,2 & 4,7 & 35 & ziemlich steil zur \\
See hin.
\end{tabular}


und Sunde und an freiliegenden Inseln hinziehen. Thre Länge schwankt zwischen ${ }^{4} / 5$ und $22 \mathrm{~km}$, ihre Seehöhe reicht bis $180 \mathrm{~m}$. Häufig treten mehrere übereinander auf. RichaRd Lemmann zählte deren bei Kverve (nördlich von Aalesund, $62^{1} /{ }^{0} \mathrm{~N}$ ) nicht weniger als fünf, die er genau gemessen hat (s. Tab. S. 443). ${ }^{10}$ Von der Gesteinsbeschaffenheit und Schichtenstellung zeigen sie sich völlig unabhängig, im Norden sind sie aber im allgemeinen häufiger und besser ausgebildet als im Süden. Während die Gehänge, an denen sie auftreten, mit Gletscherstreifen und -schrammen bis zum Meeresspiegel bedeckt sind, tragen sie selbst keine Spuren eiszeitlicher Abschleifung, sind also jedenfalls zu einer Zeit entstanden, da sich die ununterbrochene Inlandeisdecke bereits aufzulösen begonnen hatte.

In inniger Gesellschaft mit den Seter erheben sich stufenförmig an den Flußmündungen die Terrassen, ebene, sanft gegen das Meer

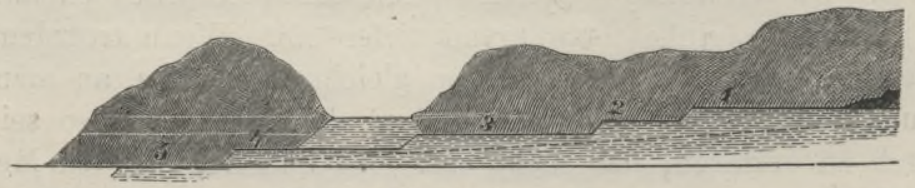

Fig. 106. Norwegische Terrassen nach KJERULF.

sich neigende Flächen, aus Sand- und Tonschichten aufgebaut. Die schematische Darstellung in Fig. 106 macht die Beziehung der Terrassen des Haupttales 1 und 2 zu der des Nebentales und den weißen Strandlinien klar. KJERULF deutet sie als submarine Deltas, deren Bildung sich noch unter dem gegenwärtigen Meeresspiegel als Stufe 5 fortsetze. Die Erosion des Flußlaufes (die gestrichelte Linie in Fig. 106) hat die Terrassen entzweigeschnitten, so daß wir sie vom heutigen Talboden aus hoch oben an den Gehängen erblicken.

Strandlinien und Terrassen sind alte Wasserstandsmarken, aber unter eigenartigen Verhältnissen entstanden. Denn einerseits fehlen sie an der freien Ozeanküste und beschränken sich auf die Fjorde und Sunde, anderseits treten sie selbst in benachbarten Fjorden in verschiedenen Seehöhen auf; ja HANSEN ${ }^{11}$ entdeckte 1885 im südnorwegischen Binnenland echte Seter sogar in Seehöhen zwischen 657 und $1090 \mathrm{~m}$, also außerhalb des höchsten Meeresstandes. Er erklärte sie für Uferlinien eines Sees, der durch Eis abgedämmt war, und diese Hypothese wandte dann Suess auch auf die Seter an der Küste an. Die Fjorde und Sunde bildeten danach in der zweiten Eiszeit Seen, eingeschlossen im W durch die Gletscher, die von den hohen Inseln und Küstengebirgen ausgingen, im $\mathrm{O}$ durch 
das Inlandeis, dessen Ausläufer die inneren Enden der Fjorde berührten. Ähnliche Verhältnisse zeigt noch jetzt die Westküste Grönlands, doch finden sich hier nur an einer einzigen Stelle Terrassen. Für den Romsdalsfjord hält SANDLER ${ }^{12}$ die Suess'sche Hypothese nicht für zutreffend und ersetzt den Eisdamm durch eine Anhäufung von Glazialschutt. Hält man an dem marinen Ursprung der Strandlinien fest, so läßt sich ihre Verteilung dadurch erklären, daß sie durch den Eisfu $B$ gebildet wurden, d. h. durch die Eisdecke längs der Fjord- und Sundgestade, die durch die Wellenbewegung hinund hergeschoben wurde und dadurch den Fels, den schon der Spaltenfrost gelockert hatte, abscheuerte. In der Brandung der ozeanischen Küste konnte sich ein Eisfuß wahrscheinlich nicht bilden.

Die Fossilien der südnorwegischen Muschelbänke, der Terrassen $^{13}$ und der quartären Ablagerungen der baltischen Länder ${ }^{14}$ geben uns sicheren Aufschluß über die Aufeinanderfolge und das relative Alter 'der nordischen Strandverschiebungen. Die ältesten, unter denen Yoldia aretica besonders wichtig ist, zeigen ein polares Klima an; dieses spätglaziale Yoldiameer bedeckte Skandinavien bis zu einer Höhe von mehr als $200 \mathrm{~m}$. In den tiefer liegenden marinen Ablagerungen mischen sich immer mehr und mehr südliche Tierformen bei, ein Beweis, daß während der nun folgenden negativen Niveauveränderungen das Klima immer milder wurde. Das Meer wich so weit zurück, daß die Ostsee ihren Zusammenhang damit verlor und in einen Binnensee mit Süßwasser verwandelt wurde (Ancylussee nach dem Hauptfossil Ancylus fluviatilis oder Gemeine 2 Flußnapfschnecke). Dann trat wieder eine positive Strandverschiebung ein, an die Stelle des Ancylussees trat das Litorinameer (Litorina litorea oder Gemeine Uferschnecke), das auch die südlichen baltischen Gestadeländer überflutete, denn nach KLose ${ }^{15}$ liegt die Sohle der alten Täler Vorpommerns unter dem heutigen Spiegel der Ostsee. Die Litorinaepoche fällt mit dem Höhepunkt der nachglazialen Temperaturkurve zusammen (vgl. S. 242), ohne Zweifel war das südliche Skandinavien damals schon bevölkert.

Für Skandinavien und das Ostseegebiet (vielleicht mit Ausnahme von Finnland) ${ }^{16}$ sind also seit der letzten Eiszeit folgende Niveauveränderungen nachgewiesen: 1. eine positive (Yoldiaperiode), 2. eine negative (Ancylusperiode), 3. eine positive (Litorinaperiode), 4. eine negative (Nachlitorinazeit). Welcher Art waren diese Veränderungen?

Die anscheinend unregelmäßig verteilten Strandlinien und Terrassen Norwegens lassen sich, wie schon BravaIs vor mehr als einem halben Jahrhundert erkannt hat, und wie aus den neuen Untersuchungen von Hansen ${ }^{17}$ und ReKstad ${ }^{18}$ mit Bestimmtheit 
hervorgeht, in zwei Linien einreihen, die gegen das Innere des Landes ansteigen, und zwar die obere Linie unter einem steileren Winkel als die untere (Fig. 107). $\times$ Dasselbe gilt auch für Kola. ${ }^{19}$

In Schweden hat DE GEer eine neue Methode angewendet, die zu überraschenden Resultaten führte. Er stellte nicht nur - womit man sich bisher begnügt hatte - die Verbreitung der Meeres-

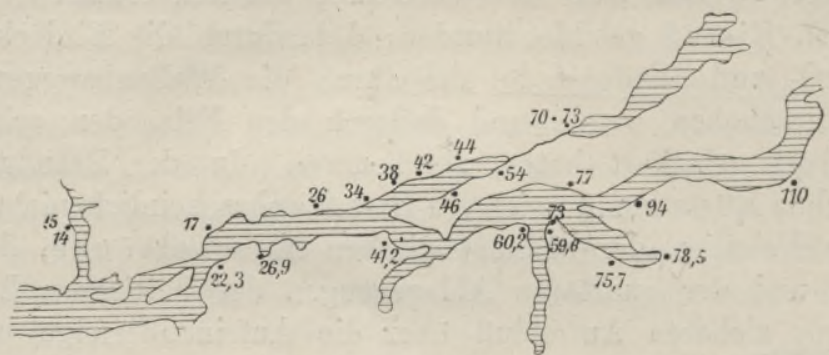

Fig. 107. Seehöhen (in Meter) der obersten spätglazialen Meeresgrenzen am Nordfjord nach REKstad.

ablagerungen mit quartären Fossilien fest, sondern auch die Höhe des Meeresspiegels an den, den betreffenden Fossilfunden benachbarten Hügeln, deren Moränendecke noch unverkennbare Spuren der einstigen Meereswirkung trägt. Auch die auf diese Weise ermittelte spätglaziale Strandlinie steigt gegen das Innere des Landes an, aber - und dies ist der entscheidende Punkt - ohne Rücksicht auf die heutigen Isohypsen. An der baltischen Küste von Schweden liegt sie z. B. bei:

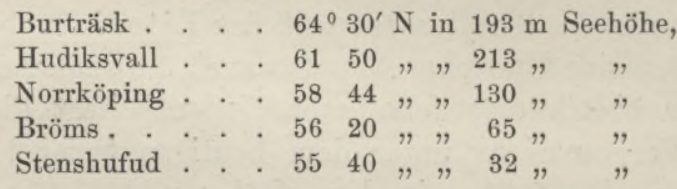

Nach dem Beispiel GubenT's wurden die Punkte gleicher Strandhöhe mit Linien verbunden, die DE GEER Isobasen oder

$\times$ Es gibt allerdings noch viele Seter, die sich dem Liniensystem nicht fügen. A. Helland (Jahrb. d. norweg. geolog. Untersuchung für 1896-99, Nr. 2) hat eine Methode angegeben, um den Fallwinkel der als zusammengehörig gedachten Seter zu ermitteln. Wir wählen ein Beispiel aus dem Vaagsfjord, wo die Zusammengehörigkeit der vereinzelt auftretenden Seter einen hohen Grad von Wahrscheinlichkeit besitzt.

Westseite des Fjords Ostseite des Fjords

$\begin{array}{lccc} & \text { Lundenes } & \text { Aanstad } & \text { Vinje } \\ \text { Obere Seter } & 44,4 \mathrm{~m} & 62,7 \mathrm{~m} & 60,8 \mathrm{~m} \\ \text { Untere Seter } & \mathbf{1 8 , 3} & 22,7 & \mathbf{2 1 , 6}\end{array}$

Fall nach

West

$150^{\prime \prime}$ 
Linien gleicher Deformation nannte. Sie sind wahrscheinlich noch verwickelter, als unsere Fig. 108 darstellt, denn nach SJöGreN ${ }^{20}$ folgen in ostwestlicher Richtung auf das Maximum in der Nähe der Grenze zwischen Norwegen und Schweden ein Minimum, das ungefähr rom Storsee nach NO streicht, dann das Hauptmaximum am Westrand des Bottnischen Busens (die höchste marine Grenze von ganz Nordeuropa liegt nach HöGвoм ${ }^{21}$ in Ângermanland: $284 \mathrm{~m}$ ), dann ein zweites Minimum an der bottnischen Ostküste und endlich ein drittes Maximum in Zentralfinnland. Die Isobase von $0 \mathrm{~m}$ schließt sich ziemlich enge den Grenzen der skandinavisch-finnischen Urgebirgsmasse(Ramsay'sFennoskandia) an, in Dänemark reicht sie etwas weiter südlich, als die Karte angibt, bis zu einer Linie, die von Nordfalster nach NW zum Nisumfjord zieht. ${ }^{22}$

Es entsteht nun die Frage: ist die ungleiche Höhe der Strandlinie ursprünglich, oder war die Strandlinie ursprünglich horizontal und

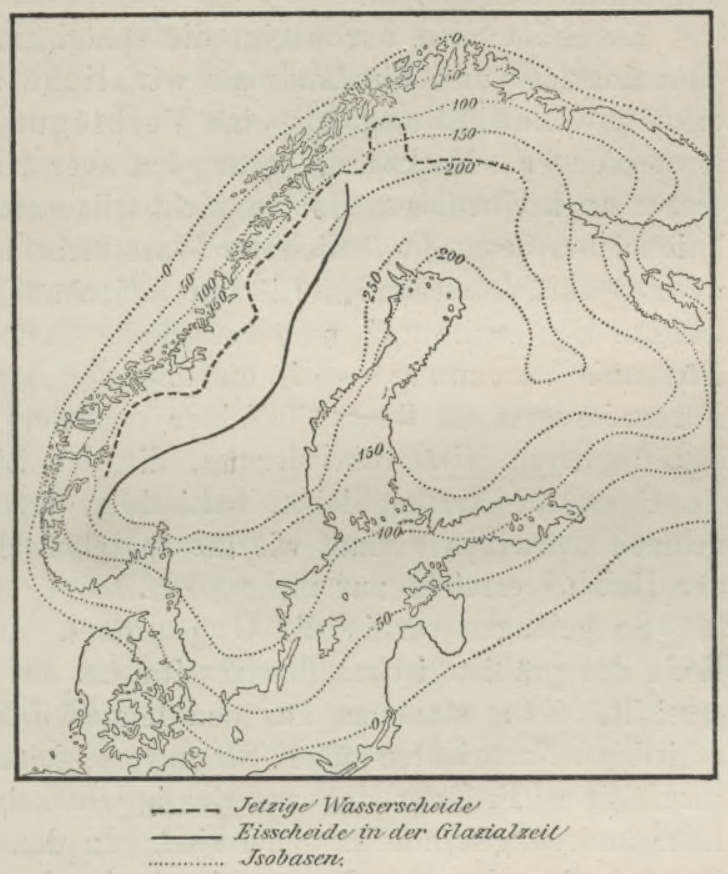

Fig. 108. Spätglaziale Isobasen von Fennoskandia in Abständen von $50 \mathrm{~m}$ nach RAMSAX ${ }^{19}$ u. DE GEER ${ }^{23}$. erlitt erst später Verbiegungen? Im ersteren Fall muß sich der Meeresspiegel ungleichmäßig gesenkt, im letzteren das Land ungleichmäßig gehoben haben.

Den ersteren Fall hatte PENck schon 1882 ins Auge gefaßt, indem er behauptete, daß die Attraktion der skandinavischen Eismassen eine ungleichmäßige Anschwellung des Meeresspiegels an den Küsten bis zu $200 \mathrm{~m}$ bewirkt habe. Wir brauchen uns bei dieser Hypothese nicht länger aufzuhalten, weil ihre Unhaltbarkeit fast gleichzeitig von Hergeselu ${ }^{24}$ und von v. Drygalski ${ }^{25}$ auf Grund der neuen HeLmert'schen Untersuchungen dargetan wurde. Beide 
gelangten zu dem Schluß, daß auf dem Höhenpunkt der Eiszeit das Meeresniveau durch Bindung beträchtlicher Wassermengen eine Senkung (nach Hergeseli um $70 \mathrm{~m}$ ) erfahren, und daB es sich an den Küsten der Inlandeisflächen zwar gehoben habe, aber nur um einen nicht nennenswerten Betrag (bei einer Mächtigkeit des Eises von $1000 \mathrm{~m}$ an der skandinarischen Küste nach Hergeselu um $4 \mathrm{~m}$, nach v. DrYgalski um $6 \mathrm{~m}$ und an der nordamerikanischen Küste um etwa $12 \mathrm{~m}$ ). Damit stimmen auch die Ergebnisse der Arbeiten WOODWARD's 26 überein.

Es bleibt also nur übrig, die spätglaziale Strandverschiebung Skandinaviens und Finnlands als wirkliche und zwar ungleichmäßige Landhebung, als eine Verbiegung dieses Krustenteiles anzuerkemnen. Merkwürdig genug hat aber das zentrale Jemtland an dieser ungleichmäßigen Hebung nicht teilgenommen, denn die Strandlinien jener Seen, die östlich der Wasserscheide durch den allmählich nach 0 zurückweichenden Eisrand aufgestaut wurden, haben keine Deformation erlitten, ${ }^{27}$ und es scheint fast so, als ob - nach Нӧєвом's Vermutung - die aufsteigende Bewegung längs gewisser Formationsgrenzen ihren Charakter verändert hätte. Die Isobasen der negativen Niveauveränderung, die der Litorinazeit folgte, hat DE GEER für die südlichen baltischen Gegenden gezeichnet; sie nehmen denselben Verlauf wie die spätglazialen, aber das Maximum der Hebung erreicht nur mehr $60 \mathrm{~m}$.

So gelangen wir in die Gegenwart. In Norwegen war ám Ende des prähistorischen Bronzezeitalters das heutige Niveau bereits erreicht. Zwar stammen aus den letzten Jahrhunderten noch verschiedene Nachrichten über Strandverschiebungen, aber bei einer sorgfältigen Prüfung der zuverlässigsten zeigt es sich, daß hier Klimaänderungen mit im Spiel sind. In den feuchtkalten Perioden BRÜCKNER's stieg der Meeresspiegel, in den trockenwarmen sank er. Der Zusammenhang ist noch dunkel, aber aus den Aufzeichnungen der selbstregistrierenden Wasserstandsmesser geht hervor, daß einer Luftdruckänderung von $1 \mathrm{~mm}$ eine Veränderung des mittleren Meeresniveaus von ungefähr $10 \mathrm{~cm}$ entspricht. 1835 wurden an der südnorwegischen Küste Wasserstandsmarken angebracht; ihre Revision im Jahr 1865 ergab einen tieferen Stand des Seespiegels um durchschnittlich $9 \mathrm{~cm}$, und die Revision im Jahr 1890 ein weiteres Sinken um $1 \mathrm{~cm}$. Diese Werte liegen aber noch innerhalb der Grenzen der unperiodischen Schwankungen des Meeresspiegels in einem und demselben Monat verschiedener Jahresgänge (im Juni z. B. 5-24 cm) und sind daher für die Frage säkularer Strandverschiebung belanglos. Man darf also das Meeresniveau an 
der norwegischen Küste in "geschichtlicher Zeit als konstant betrachten. Ganz anders verhält es sich aber mit der schwedischfinnischen Ostseeküste. Der Landzuwachs in geschichtlicher Zeit erreicht hier Beträge, die durch Flußanschwemmung nicht erklärt werden können; die Gemeinde Hvittisbofjärd nördlich von Björneborg an der finnischen Küste hat z. B. 1784-1894 667 ha gewonnen! Kein Wunder, daß man schon im 18. Jahrhundert auf diese Erscheinung aufmerksam wurde und durch Anbringung von Wassermarken an geeigneten felsigen Küstenstellen ein ziffermäßiges $\mathrm{Maß}$ für diese Bewegung zu erlangen suchte. ${ }^{28}$ Mehr Gewicht legt Sieger ${ }^{29}$ mit Recht auf die Pegelaufzeichnungen, $\times$ mit denen die Höhen der alten, meist aus dem 18. Jahrhundert stammenden Wassermarken über dem jetzigen Seespiegel eine leidliche Übereinstimmung zeigen. SiEger verarbeitete das ganze kritisch gesichtete Beobachtungsmaterial $\mathrm{zu}$ einer lehrreichen Isobasenkarte, aus der wenigstens für Schweden und Finnland südlich von $62^{\circ} \mathrm{B}$. mit großer Wahrscheinlichkeit hervorgeht, daß die Hebung von der Mitte der Ostsee und des Kattegats nach der Küste zunimmt. Die Isobasen schmiegen sich allen Biegungen der Küste an und wenden sich im Finnischen Meerbusen nach O, ähnlich den Isobasen DE GEeR's. Betreffs Südschwedens sind die Meinungen allerdings noch geteilt. HANSEN ${ }^{30}$ betrachtet es als stationär, RoseN ${ }^{31}$ zieht dagegen aus der Diskussion der Wasserstandsbeobachtungen folgende Schlüsse. Die durchschnittliche jährliche Hebung beträgt bis $62^{1} / 2^{0} \mathrm{~N}$ etwas über $1 \mathrm{~cm}$, dann verringert sie sich bis $58{ }^{3} /{ }^{0} \mathrm{~N}$ auf $5 \mathrm{~mm}$ und sinkt in $57 \frac{1}{3^{\circ}} \mathrm{N}$ auf $2 \mathrm{~mm}$ herab. Die Südküste Schwedens und die Westküste bis $56^{\circ} 3^{\prime}$ zeigen keine Veränderung, dagegen stellt sich im Kattegat wieder Hebung ein, die nach den Messungen von Fineman etwas südlich vom 59. Parallel denselben Wert $(3-4 \mathrm{~mm})$ wie an der Ostküste erreicht. Auch aus diesen Zahlen geht hervor, daß, wie in älteren Zeiten, der Hauptsitz der Bewegung im nördlichen Schweden liegt; und daraus erklärt sich

$\times$ Streng vergleichbar sind nachfolgende aus der Periode 1852-75 (wir beginnen mit der schwedischen Westküste und gehen dann, von $\mathrm{S}$ nach $\mathrm{N}$ fortschreitend auf die Ostküste über. Die beigesetzten Zahlen geben das Sinken des Meeresspiegels in Zentimeter in der ganzen Periode).

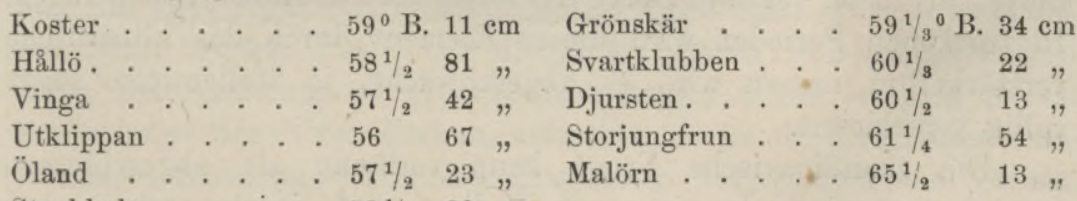

Stockholm . . . . $58^{1 / 3} 30$, 
nach HoLLender ${ }^{32}$ in ungezwungener Weise, daß die ältesten Niederlassungen in Südschweden in unmittelbarer Nähe des jetzigen Standes liegen, während sie sich nach Norden immer weiter von der Küste entfernen. Indes scheint jetzt im nördlichsten Fennoskandia Ruhe eingetreten zu sein, ${ }^{33}$ und auch an der finnischen Küste scheint sich die Bewegung zu verlangsamen. ${ }^{34}$

Der Verbiegungstheorie gegenüber steht die ältere, von SuEss wieder aufgenommene Hypothese von der Entleerung der Ostsee.

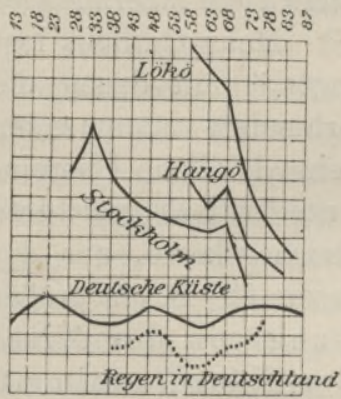

Fig. 109. Wasserstandskurven von Stockholm, Hangö und Lökö und der deutschen Ostseeküste nach BRÜCKNER. (Ein Ansteigen der Kurve um einen Teilstrich entspricht einem Steigen des Wassers um $25 \mathrm{~mm} u$. einer Zunahme des Regenfalles um 5 Prozent. Die oberen Zahlen bedeuten die Jahre 1813-1887.) Eine solche könnte nur durch eine Klimaänderung bewirkt werden, aber keine Anzeigen deuten darauf hin. Die schwedischen Seen zeigen entweder gar keine Strandverschiebung, oder wo eine solche vorhanden ist, eine beträchlich geringere als die Meeresküste. Ferner, wenn der baltische Spiegel sinkt, warum nur an der schwedischen und finnischen und nicht auch an der deutschen Küste?

BRÜCKNER $^{35}$ hat die Pegelbeobachtungen $\mathrm{zu}$ Stockholm, an zwei finnischen und acht deutschen Stationen, zu Lustrenmitteln vereinigt, graphisch dargestellt (Fig. 109). In Übereinstimmung mit der von ihm entdeckten Periode schwankt der Wasserstand an der deutschen Küste entsprechend dem Regenfall in Deutschland und der Zufuhr von Fluß. wasser. Ganz anders geartet sind die schwedischen und finnischen Kurven, sie senken sich, wenn auch nicht gleichmäBig, so doch fast kontinuierlich. Damit ist der Beweis erbracht, daß die Wasserstandsschwankungen hier nicht allein vom klimatischen Element abhängig sind wie an der deutschen Küste, sondern daß noch ein anderes, fremdartiges hinzutritt. Man könnte ja zunächst an eine Zunahme des Salzgehalts an der schwedischen und finnischen Küste denken, aber um jenen Effekt zu erzielen, müßte hier die Ostsee seit dem Ende der 50 er Jahre mehr Salz aufgenommen haben, als sie im ganzen besitzt. Es bleibt also nichts übrig, als eine selbständige Hebung des Landes anzunehmen. In trockenen Perioden wird dieses Element durch das klimatische verstärkt, in nassen wird es abgeschwächt, ja stellenweise sogar völlig verschleiert.

Die skandinavische Frage kann vorläufig als abgeschlossen betrachtet werden. In ein neues Stadium wird sie erst treten, wenn 
das neue, durch Nivellement verknüpfte und mit selbstregistrierenden Instrumenten ausgerüstete Pegelnetz eine genügende Reihe von Jahren funktioniert haben wird.

Höhere arktische Breiten. Erhöhte Bedeutung gewinnt das skandinavische Phänomen durch seine weite Verbreitung in den höheren Breiten unserer Halbkugel. Aber nur an zwei Stellen läßt sich der Charakter der Strandverschiebung als säkulare Verbiegung feststellen: in der Nordhälfte der britischen Inseln ${ }^{36}$ und mit größerer Sicherheit im nordöstlichen Amerika, wo DeLABARRE ${ }^{37}$ und Low ${ }^{38}$ einen wellenförmigen Verlauf der höchsten Strandlinien in Labrador feststellten, und DE GEER die ihm aus seiner schwedischen Heimat bekannten Erscheinungen in Canada so genau wiederfand, daß er seine Methode auch hier anwenden und wenigstens Bruchstücke von Isobasen in die Karten einzeichnen konnte. ${ }^{39}$ Die Bodenbewegung begann fast genau an der Südgrenze des diluvialen Inlandeises und nahm sowohl nach Norden wie auch vom Atlantischen Ozean gegen das Innere des Landes rasch an Intensität zu. Nördlich vom Ottawa erreicht die Hebung bereits einen Wert von $218 \mathrm{~m}$.

Strandlinien sind nahezu allen arktischen und subarktischen Felsküsten eingeschnitten, und durch Fossilfunde ist die nachglaziale Meerestransgression in Nordrußland bis zu einer Seehöhe von $150 \mathrm{~m}^{40}$ und auch am untern $\mathrm{Ob}$ und Jenissei nachgewiesen. Aber alle diese Strandverschiebungen gehören in unsere Verlegenheitskategorie der negativen Schwankungen, und wir wissen auch nicht, ob sie noch gegenwärtig wirksam sind. Von Bedeutung ist aber, daß in ungefähr $40^{\circ} \mathrm{N}$ ihre Spuren verschwinden. Sollten sie daher nicht in direkten Beziehungen zum Inlandeis stehen?

T. F. JAMIESON sprach schon 1865 die Vermutung aus, daB das diluviale Inlandeis die Landmassen, die es bedeckte, hinabgedrückt habe, und daß sie dann, durch das Schwinden des Eises von einer schweren Last befreit, wieder in die Höhe gestiegen seien. Diese Hypothese fand in englischen und skandinavischen Fachkreisen viel Beifall, und RUDZKI ${ }^{41}$ hat sogar den Versuch gemacht, sie mathematisch zu begründen. Die Wirkung des Inlandeises ist dreifach: 1. Verringerung des Volumens des Meerwassers um so viel, als durch das Eis gebunden ist; infolgedessen 2. Verschiebung der Belastung, die auch in dem Fall, daß die Erde nahezu so starr wie Stahl wäre, Deformationen der Oberfläche erzeugen würde; endlich 3. Deformationen der Niveauflächen, einerseits durch die Krustendeformationen, anderseits durch die Anziehung des Inlandeises bewirkt. Wenn die Eisdecke schwindet, hebt sich der Boden, aber wegen 
mangelhafter Elastizität nicht sogleich, und das Meer hat Zeit genug, in die Senkung einzudringen und hier Spuren seiner Anwesenheit zu hinterlassen. Es erklärt sich auch daraus, daß die Strandlinien nach dem Innern zu ansteigen, denn die Senkung nahm mit der Eislast nach dem Innern zu. Auch die Erhebung Grönlands würde damit nicht im Widerspruch stehen, denn sein Inlandeis war einst wohl um vieles mächtiger. Aber warum sank Skandinavien in der ausgesprochen warmen Litorinazeit? Warum hebt sich der Umkreis des nordbaltischen Meeres, während das norwegische Gestade in Ruhe verharrt? An diesen Tatsachen scheitert auch die Hypothese v. Drygalski's ${ }^{42}$, der die Hebung der Glazialgebiete einer Änderung der Wärmeverhältnisse der obersten Erdschichten seit dem Rückzug des Inlandeises zuschrieb. Die Oberfläche eines vereisten Landes nimmt nämlich die konstante Temperatur von $0^{\circ}$ an, die Geoisothermen senken sich, die Erkaltung bewirkt Zusammenziehung, der Boden senkt sich. Nach dem Verschwinden des Eises tritt der umgekehrte Vorgang ein: die Ausstrahlung der Erdkugel ist an dieser Stelle nun nicht mehr gehemmt, die Geoisothermen steigen an, und die allgemeine Erwärmung bewirkt Ausdehnung und Hebung. Auch diese Erklärung fand eine mathematische. Behandlung durch BADOUREAU ${ }^{43}$, der unter der Annahme einer Temperaturerhöhung von $3^{n}$ eine Hebung Skandinaviens um $229 \mathrm{~m}$ herausrechnete. Dieses Resultat stimmt ungefähr mit dem Betrag der spätglazialen Hebung, aber nachdem sich die Bodentemperatur den gegenwärtigen klimatischen Verhältnissen angepaßt hat, fehlt jeder weitere Anlaß zur Hebung, und vor allem zu einer einseitigen Hebung des Ostens. Gerade dieser Tatsache suchte $\mathrm{H}_{\text {ANSEN }}{ }^{30}$ durch eine Erweiterung der isostatischen Theorie JAMIESoN's gerecht $\mathrm{zu}$ werden. Skandinavien stieg, als die Eisdecke sich auflöste; aber nur im W und S, wo die Schmelzwässer bequemen AbfluB fanden, kam die Bodenbewegung bald zur Ruhe, im $\mathrm{O}$ aber, wo sie sich in den Vertiefungen des Bottnischen Busens und in den Seebecken Mittelschwedens und Finnlands ansammelten, wurde die Belastung nur verrückt, und ist daher das Gleichgewicht noch nicht erreicht. Ist diese Erklärung zutreffend, so muB sie sich auch auf Nordamerika anwenden lassen. Auch hier haben wir in der Hudsonbai und den canadischen Seen gewaltige Wasserlasten, die - entsprechend der Auffassung Hansen's - als Überbleibsel der glazialen Schmelzwässer ánzusehen sind. In der Tat hat R. BELL auch eine rezente Hebung der Küste der Hudsonbai um 2-3 m im Jahrhundert behauptet, aber TrRReLL ${ }^{44}$ bestritt dies und konnte nachweisen, daß eine eingehende Beschreibung des Churchillhafens vom Jahr 1619 genau auf die heutigen 
Verhältnisse paßt. An den canadischen Seen hat GILBERT ${ }^{45}$ im Jahr 1896 sorgfältige Wasserstandsbeobachtungen angestellt und aus dem Vergleich mit älteren den Schluß gezogen, daß sich der Boden auf je $100 \mathrm{~km}$ Entfernung um $8 \mathrm{~cm}$ im Jahrhundert nach $\mathrm{SW}$ senke, also gewissermaßen eine Schaukelbewegung ausführe. Die Geringfügigkeit dieses Resultates und die Kürze der Beobachtung verbieten es jedoch, die optimistische Ansicht GILBERT's von der Beweiskraft seiner Untersuchung zu teilen. Aber der Weg ist gewiesen, auf dem man in Zukunft zu sicheren Ergebnissen wird gelangen können.

Die angebliche Meeresverschiebung zwischen Pol und Äquator. Es ist eine bemerkenswerte Tatsache, daß auch in der gemäßigten Zone der Südhalbkugel Anzeichen einer negativen Niveauschwankung häufig sind. So in Ostaustralien und im Staat Viktoria, in Neuseeland, in Chile und Patagonien und auf den Falklandinseln. In der Belgicastraße fand zwar ARcTowski Anzeichen einer positiven Strandverschiebung, aber im Viktorialand konstatierte SHACKLETON eine entgegengesetzte Bewegung bis zum Betrag von $50-55 \mathrm{~m}$.

Indes ist gerade gegenüber den antarktischen Vorkommnissen Vorsicht geboten. Man hat z. B. den ausgeprägten Stufenbau Patagoniens durch ruckweise Landhebung zu erklären versucht, und damit die Tatsache in Verbindung gebracht, daß Schalen rezenter Muscheln auf der Oberfläche der Terrassen noch in großer Entfernung von der Küste und bis zu einer Höhe von $125 \mathrm{~m}$ gefunden wurden; aber die Stufen sind, wie aus Mercerat's Profilen hervorgeht, Verwerfungserscheinungen, und in bezug auf die hochgelegenen Muschelreste hat der Erforscher der Magalhãesländer, OтTо NORDENSKJöLD ${ }^{46}$, die Ansicht geäußert, daß sie wohl durch den Wind oder durch Menschen an ihre gegenwärtige Lagerstätte gebracht worden sein könnten, und daß das Meer höchstens $30-60 \mathrm{~m}$ höher gestanden habe als jetzt. Wir halten es zwar für Hyperkritik, wenn VIDaL GoRMaz ${ }^{47}$ behauptet, die hochgelegenen chilenischen Muschelanhäufungen seien durch den Menschen oder durch gewisse Vogelarten dahin verschleppt worden, aber richtig mag es sein, daß die seit 300 Jahren zunehmende Verflachung der Buchten des südchilenischen Archipels auf Versandung, nicht auf Niveauveränderung beruhe. Auch dürfen wir nicht aus dem Auge verlieren, daß die pazifische Westküste von Südamerika in dem Verdacht instantaner Hebung steht. Wir haben es aber hier nur mit säkularen Vorgängen zu tun.

Das unleugbare Vorherrschen negativer Niveauschwankung in den höhern Breiten hatte SuEss zu der Idee einer großartigen Meeresoszillation zwischen dem Äquator und den Polen geführt. 
In den niederen Breiten hätten wir demnach vorwiegend positive Strandverschiebungen zu erwarten. Anstatt dessen finden wir aber hier, ja auch schon in den mittleren Breiten unserer Halbkugel nur einen verwirrenden Wechsel der Erscheinungen. Das mag zum guten Teil wohl darauf zurückzuführen sein, daß es die Beobachter an der nötigen Kritik fehlen ließen und endogenen Ursachen zuschrieben, was in Wirklichkeit nur ein Werk der zerstörenden und aufbauenden Tätigkeit des Meeres ist. Andere Fälle sind noch dunkel, und die Ansichten darüber sind geteilt. Versunkene Wälder und Torfmoore mit Kulturresten aus der jüngeren Stein- und der Bronzezeit, z. T. sogar aus der römischen Periode, begleiten die Küste der Nordsee und des Kanals von Jütland bis zur Normandie. SuEss hat alle diese Vorkommnjsse auf Entwässerung der Moore, die infolgedessen zusammensinken, auf Rutschungen und Sturmfluten zurückgeführt, und sich zum Beweis dafür auf die Tatsache berufen, daß zwischen der Scheldemündung und Vlieland außerhalb der Dünen römische Bauwerke in Gegenden vorkommen, wo Torfmoore, die mit Meeressand bedeckt sind, römische Münzen bis $270 \mathrm{n}$. Chr. bergen. Auch meint er, daß bei langsamem Vorrücken des Meeres die Brandung den Torf zerstört und die Bäume entwurzelt hätte, aber die Veränderungen, die die belgische Küstenebene zwischen Ostende und Brügge in der geschichtlichen Zeit erfahren hat, sprechen nicht dafür. Zweimal ist hier das Meer in das Land eingedrungen, zwischen 300 und $840 \mathrm{n}$. Chr. und im 11. und 12. Jahrhundert, aber die Lagerungsverhältnisse seiner Sedimente zeigen deutlich, daß der Vorgang in der ersten Periode, ganz im Gegensatz zu der späteren, langsam und ohne katastrophenartige Ereignisse erfolgte, und doch ist die untere, aus der gallo-römischen Zeit stammende Torfschicht erhalten geblieben. ${ }^{48}$ SснӥтTE ${ }^{49}$ glaubte Beweise gefunden zu haben, daß die deutsche Nordseeküste auch jetzt noch um durchschnittlich $7 \mathrm{~mm}$ im Jahr sinke, ist aber bei deutschen, wie bei holländischen Forschern auf Widerspruch gestoßen, und hält jetzt selbst seine Berechnung für übertrieben. Unterseeische Moore und Wälder kommen auch an der atlantischen Flachküste der Vereinigten Staaten häufig vor. Wie an der Nordsee- und Kanalküste hat auch hier das Meer stellenweise weite Bezirke erobert, aber die Frage, ob wirklich eine positive Niveauveränderung dabei im Spiel sei, $\mathrm{muß}$ noch offen gelassen werden. Denn neben diesen 'Senkungsspuren begegnet man auch, wie schon $\mathrm{CooK}^{50}$ zugibt, trocken gelegten Austernbänken; und CHEsteR ${ }^{51}$, der sonst der Senkungshypothese zustimmt, macht für die Delaware-Halbinsel eine entschiedene Ausnahme, da hier die Strandlinie noch jetzt landeinwärts wandere. 
Die Aufzeichnungen des selbstregistrierenden Flutmessers im Hafen von New York, die bis 1853 zurückreichen, lassen erst von 1875 an eine konstante Hebung des Meeresspiegels um durchschnittlich 4,4 mm im Jahr erkennen. ${ }^{52}$ Doch genug der Beispiele. Das Endergebnis der Untersuchung ist stets, daß auch in den mittleren und niederen Breiten, die zweifelhaften Fälle ausgeschlossen, die negativen Bewegungen vorzuherrschen scheinen. Wir betonen: scheinen, denn wir dürfen nicht vergessen, daß die negativ verschobene Strandlinie, soweit sie nicht durch Wind und Wetter zerstört ist, offen zutage liegt, während sich die positiv verschobene unter dem Meer verbirgt. Wir müssen also die Beweisführung durch Heranziehung neuer Argumente erweitern. Da bietet sich uns zunächst die DARwIs'sche Rifftheorie dar. Stünde sie noch heute fest, so hätten wir in den Atollgebieten der Südsee und des Indischen Ozeans gewaltige Erd. räume mit positiver Niveauveränderung zu erblicken. Jetzt aber wissen wir, daß hier auch entgegengesetzte Bewegungen Platz gegriffen haben, ja daß sich noch in der jüngsten Vergangenheit der Meeresspiegel um $1-6 \mathrm{~m}$ gehoben zu haben scheint. Auch in der Frage der sogenannten unterseeischen Täler stehen wir noch nicht auf sicherem Boden. Es sind

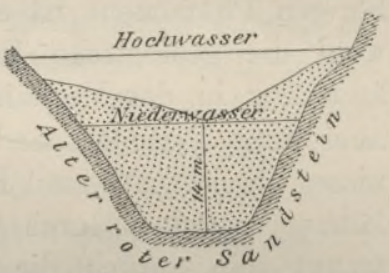

Fig. 110. Versunkenes Tal, Neyland Pill in der Nähe von Pembroke. dies mehr oder minder scharf eingeschnittene Rinnen im Meeresboden, die genau in der Fortsetzung überseeischer Täler liegen. ${ }^{53}$ Man kennt sie z. B. am Adour, am Hudson, am Kongo, an der 'Ganges- und Indusmündung, an der ligurischen Küste, aber auch in Süßwasserseen, wie im Genfer- und Bodensee. Die einen führen sie auf Strömungen zurück, die das Flußwasser nach seinem Eintritt in das Meer oder in den See verhindern, gerade in seinem Stromstrich Sedimente abzulagern, die anderen fassen sie als untergetauchte Talstücke auf. ${ }^{7}$ Daß solche wirklich vorkommen, ist durch die Bohrungen an der Südwestküste von England erwiesen. Fig. 110 stellt uns ein typisches Beispiel nach CoDrIngton ${ }^{54}$ dar: das steilwandige Tal ist in alten roten Sandstein eingeschnitten und zunächst mit Glaziallehm angefüllt, worauf Torf und moderne Meeresablagerungen folgen. Aber unstreitig geht $\mathrm{HuLL}^{55} \mathrm{zu}$ weit, wenn er die ganzen westeuropäischen Kontinentalstufen mit solchen unterseeischen Tälern bedeckt, und ganz phantastisch sind die Rekonstruktionen SpEnCER's ${ }^{56}$, der auf dem Boden des amerikanischen Mittelmeeres die Täler seines alten „Antillenkontinentes“ gefunden zu haben glaubt. An der califor- 
nischen Küste gibt es nach DAvidson ${ }^{57}$ zahlreiche solche unterseeische Rinnen, aber keine einzige liegt in der Fortsetzung eines überseeischen Tales., Wir könnten unsere Beweisführung noch dadurch erweitern, daß wir auf die Fjorde und die ihnen verwandten Erscheinungen, auf die Schelfs, soweit sie der zerstörenden, nicht der aufbauenden Tätigkeit des Meeres ihre Entstehung verdanken, ferner auf die abgegliederten Halbinseln, und endlich auf diejenigen Inseln hinweisen, die vermöge ihres geologischen Baues und ihrer Lebewelt als einstige Zugehörige des Festlandes zu betrachten sind. Sie sind alle ohne Zweifel Folgen einer positiven Niveauveränderung, aber für unseren Zweck doch ohne Beweiskraft. Denn die Suess'sche Theorie verlangt, da $B$ die negative Bewegung in den höheren Breiten durch eine gleichzeitige entgegengesetzte Bewegung in den niederen Breiten ausgeglichen werde. Mit der Chronologie aller hierher gehörigen Phänomene ist es aber sehr unsicher bestellt. Wir können wohl die geologische Periode angeben, in der eine solche Veränderung in der Verteilung von Wasser und Land eingetreten ist, aber diese Perioden sind von ungeheyerer Länge, und zwei Ereignisse, die wir z. B. mit Bestimmtheit als pliozän bezeichnen können, können trotzdem durch viele Tausende von Jahren voneinander getrennt sein. Auch die Zeitbestimmung junger negativer Küstenveränderungen leidet unter dieser Unsicherheit. Wir finden z. B. weit über dem heutigen Meeresspiegel eine Ablagerung rezenter Konchylienreste, aber wir kennen nicht den Zeitpunkt, wann die Küstenfaunen ihr heutiges Gepräge erhielten, und wahrscheinlich vollzog sich die letzte Wandlung in verschiedenen Meeren in verschiedenen Epochen. Nur für die arktische Kalotte bietet die Eiszeit eine feste Marke.

Mittelmeerländer. Die Mittelmeerländer sind für die vorliegende Frage in mehrfacher Beziehung von größter. Wichtigkeit. Hier haben sich noch bis in das quartäre Zeitalter hinein gewaltige Veränderungen in der Verteilung von Wasser und Land vollzogen. ${ }^{58}$ Pliozäne Schichten marinen Ursprungs liegen jetzt in verschiedenen Seehöhen bis zu $1800 \mathrm{~m}$, das adriatische Tiefseebecken ist erst zwischen Miozän und Pliozän entstanden ${ }^{59}$, das Ägäische Meer hat erst im Quartär seine heutige Gestalt erhalten - alle diese Veränderungen sind ohne Zweifel durch Krustenbewegungen zustande gekommen.

Im Jahr 1904 entdeckte DE Laмотне ${ }^{60}$ an der Küste von Oran auf einer Strecke von mehr als $400 \mathrm{~km}$ eine Reihe von konkordanten Strandlinien, deren Bildung nach seiner Ansicht vom älteren Pliozän bis in das oberste Quartär reicht. Zum Teil stimmen damit nach 
Höhe und Alter jene Strandlinien überein, die DepÉret ${ }^{61}$, CAziot und MAURY ${ }^{62}$ an der französischen Mittelmeerküste gemessen haben. An verschiedenen Punkten des Golfs von Korinth, der peloponnesischen Westküste und auf der Insel Siphnos ziehen sich nach NEGRIS $^{63}$ Bohrlöcher von Seemuscheln von den älteren Gesteinen herab bis in pliozäne und vielleicht noch jüngere Schichten. $\times$ Solche regelmäßige negative Niveauverschiebungen mit Pausen, denen die Strandlinien entsprechen, mußten weit in das Land hinein einen Widerhall hervorrufen, indem die Flüsse, dem sinkenden Meeresspiegel folgend, sich immer tiefer in den Boden eingruben. In der Tat will dE Lамотне ${ }^{64}$ Terrassen in der Höhe der Strandlinien im Rhônethal gefunden haben, aber auch am Rhein und an der Mosel; auch die Maasterrassen bei Lüttich scheinen nach BRIQUET ${ }^{65}$ im allgemeinen damit übereinzustimmen. Sollte sich dies bestätigen, so würde jene negative Bewegung auch die atlantischen Küsten ergriffen haben. Einer solchen noch wenig gestützten Verallgemeinerung muß indes widersprochen werden. Selbst die mediterranen Küsten haben sich verschieden verhalten, wenn anders GRUND's ${ }^{59}$ Schlußfolgerung, daß die nordadriatische Flachsee bis $90 \mathrm{~m}$ Tiefe erst in der nachglazialen Zeit überschwemmt wurde, richtig ist.

Noch mehr Vorsicht ist bei der Prüfung der Ansichten über die mediterranen Niveauveränderungen in geschichtlicher Zeit geboten. Das Hauptgewicht wird da auf die Lage alter Bauwerke gelegt, Ruinen unter Wasser sind aber nur dann beweiskräftig, wenn sie auf festem Fels stehen, und wenn man ihrer Bestimmung nach voraussetzen kann, daß sie auf dem Land erbaut wurden. Die so häufig zitierten „versunkenen“ Molen?z. B. sind nichts anders als die unterseeischen Fundamente von Molen, deren obere Teile die Brandung zerstört hat. Ebensowenig hat es etwas mit Niveauveränderungen $\mathrm{zu}$ tun, wenn griechische Städte, die auf Schwemmland erbaut waren, bei Erdbeben mit ihrer Unterlage in die Tiefe

$\times$

\section{Oranküste}

(LAMотне)

$350 \mathrm{~m}$ (?)

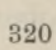

265

200

140

100

55

30

17

Seehöhen der Strandlinien usw.

Französische Mittelmeerküste

(CAzIOT)

350

(DEPÉret)

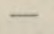

300

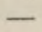

180
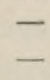

-

30

8
Griechische Küste (NEGrIs)

bis 352 (Terrassen von Messenien und Patras)

335 (Bohrlöeher)

275 (Bohrlöcher)

50-125 (Bohrlöcher)

bis 45 (Bohrlöcher) 
der See hinabrutschten. Anderseits macht PHILIPpson darauf aufmerksam, daß in den mediterranen Kulturschichten häufig marine Muscheln und Schnecken an Stellen gefunden werden, wo eine rezente Meeresbedeckung ausgeschlossen ist. Man ist also auch an den klassischen Stätten des Mittelmeers vielen Täuschungen ausgesetzt. Lange Zeit galt die negative Strandverschiebung an der Westküste von Kreta für unumstöBliche Tatsache. Hier glaubte SpratT nach alten Bauten den künstlichen Hafen von Phalasarna, den der Periplus von Skylax im 4. Jahrhundert v. Chr. erwähnt, entdeckt $\mathrm{zu}$ haben; diese Stelle liegt jetzt $98 \mathrm{~m}$ von der Küste entfernt und $7 \mathrm{~m}$ über dem Meeresspiegel. Aber mit seiner Deutung, die in der Fig. 111 zum Ausdruck kommt, läßt sich das. Vorkommen von antiken Gräbern in dem Boden zwischen dem alten Hafen und der jetzigen Küste nicht vereinen. $\mathrm{C}_{\mathrm{AYEUX}}{ }^{66}{ }^{66}$ dem wir diese Berichtigung verdanken, leugnet in Übereinstimmung mit SuEss überhaupt Niveauveränderungen von größerer Ausdehnung im Bereich des Mittelmeers

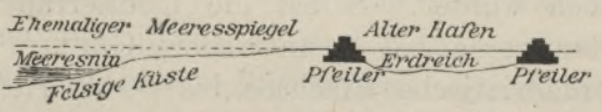

Fig. 111. Ruinen von Phalasarna nach SpRAtT. in historischer Zeit; ihm gegenüber stehen NEGRIs ${ }^{67}$ und GNIRs, ${ }^{68}$ die eine allgemeine positive Niveauveränderung wenigstens im östlichen Teil des Mittelmeers, von der Westküste von Italien angefangen, behaupten. GNIRS spricht bestimmt von einem Ansteigen des Meeresspiegels um $1 \frac{1}{2}-2 \mathrm{~m}$ in den letzten 2000 Jahren. Die Wahrheit dürfte auch hier in der Mitte liegen. Zunächst ist die Verallgemeinerung noch schwach begründet, selbst für den Osten; hier spricht manches für Ruhe. Die Niederungen der Krim und am Asowschen Meer haben seit der Zeit, da Polybius und Strabo sie beschrieben, keine nennenswerte Veränderung erlitten, und die Küstenverlandung am Mäander beruht nach GRUND ${ }^{69}$ auf Anschwemmung, nicht auf Hebung. Anderseits haben sich die Küsten stellenweise jedenfalls verschoben, aber nichts nötigt zu der Annahme einer gleichmäßigen Meerestransgression, selbst nicht die von Grins erwähnte Beobachtung, daß der Meeresspiegel in Pola von 1875-1904 um $32 \mathrm{~mm}$ gestiegen sei. Palmarola, die westliche Insel der italienischen Ponzagruppe, hat sich ohne Zweifel gehoben. Vergleicht man die Kartenbilder und Beschreibungen von Scrope i. J. 1822 mit denen von DoeLter i. J. 1875 , so wird man von dem außerordentlichen Wachstum dieses nur gelegentlich besuchten, steilen Felseneilandes überrascht sein. Емmons konstatierte 1892 eine Hebung von $64 \mathrm{~m}$, d. h. von ungefähr $1 \mathrm{~m}$ pro Jahr. ${ }^{70}$ Dieser auffallend hohe Betrag läBt vermuten, daB hier wiederholte instan- 
tane Bewegungen stattgefunden haben. Auch das vielbesprochene Phänomen des Serapistempel von Pozzuoli am Golf von Neapel, dessen drei noch aufrechtstehende Säulen in einer Höhe von 3 oder $3^{1} / 2-6 \mathrm{~m}$ über dem Boden des Gebäudes ringsum von Bohrmuscheln angenagt sind, hielt Suess für vulkanischer Natur. Seitdem haben die Untersuchungen R. T. GüNTHER's ${ }^{71}$ die nicht nur den ganzen Golf von Neapel umfassen, sondern auch über die südwestitalienische Küste einerseits bis Paestum, anderseits bis Rom hinübergreifen, neues Licht verbreitet. Etwa zur Zeit der Ansiedlung der Griechen stand die Küste um wenigstens $6 \mathrm{~m}$ über dem heutigen Niveau. Schon in der Römerzeit trat Senkung ein, wenn auch das Land noch immer um $5 \mathrm{~m}$ höher lag als jetzt; im Mittelalter schlug sie ein rascheres Tempo ein, so daß sich der Meeresspiegel um $5^{1} / 2-6 \mathrm{~m}$ über den gegenwärtigen Nullpunkt erhob. Der Gesamtbetrag der Bewegung ist also auf wenigstens $12 \mathrm{~m}$ zu veranschlagen. Am Ende des 15. Jahrhunderts begann sich die Küste langsam zu heben, doch nicht so weit, daß der ganze römische Saum trocken gelegt wurde, und dann folgte wieder eine Senkung, die bis zum heutigen Tag andauert. Wir haben hier ein ausgezeichnetes Beispiel einer Oszillation aus der geschichtlichen Zeit, das sehr geeignet ist, die Ansichten von CAYEux sowohl wie von Ginss zu berichtigen. Die Entdeckung eines noch drastischeren Beispiels verdanken wir FraAs. ${ }^{72}$ An den Trümmern eines 1696 zerstörten Befestigungswerkes in Mombasa an der Küste von Britisch-Ostafrika, das 4-5 m über der Flutzone liegt, sind Austern in ungeheuren Mengen angewachsen und es $\mathrm{muB}$ daraus auf eine Oszillation von $10-12 \mathrm{~m}$ innerhalb der letzten drei Jahrhunderte geschlossen werden.

Binnenländische Niveauveränderungen. Instantane Veränderungen bei Erdbeben, sowiohl Lage- wie auch Niveauveränderungen, sind in den letzten Jahrzehnten wiederholt beobachtet und einwandfrei festgestellt worden. Bei dem Belutschistaner Erdbeben am 20. Dezember 1892 entstand parallel mit dem Khadschakgebirge, an dessen Westfuß, eine über $20 \mathrm{~km}$ lange Spalte, die gleichzeitig mit Verschiebung und Verwerfung verbunden war. Man konnte dies umso genauer feststellen, als die Spalte die Eisenbahn kreuzte. Diese neue Dislokationslinie fällt nahe zusammen mit einer alten, die durch eine Bodensenkung und das Hervortreten zahlreicher Quellen markiert ist. ${ }^{73}$ Die $112 \mathrm{~km}$ lange Spalte, die sich bei dem großen, schon mehrfach erwähnten japanischen Erdbeben am 28. Oktober 1891 öffnete, durchschneidet quer das Gebirge und war ebenfalls mit Verwerfung und Verschiebung verbunden (s. Fig. 91 auf S. 368). Dagegen sind die-Verwerfungsspalten, die sich bei dem Erdbeben 
vom 31. August 1896 im nördlichen Nippon bildeten, symmetrisch $\mathrm{zu}$ beiden Seiten der tertiären Mahirukette verteilt; in der östlichen, $15 \mathrm{~km}$ langen Spalte sank der Ostflügel um $2 \mathrm{~m}$, in der westlichen, $60 \mathrm{~km}$ langen der Westflügel um $1-3 \mathrm{~m}^{74}$ Bei dem lokrischen Erdbeben im April 1894 entstand eine etwa $60 \mathrm{~km}$ lange Spalte, an der eine ausgedehnte Scholle des mittelgriechischen Festlandes gegen den Kanal von Atalante absank. Die Sprunghöhe der Verwerfung schwankt zwischen einigen Zentimetern und $2 \mathrm{~m}^{75}$ Dieses schwere Erdbeben war also nur eine kleine Episode in dem großen ZerstückelungsprozeB, der im südöstlichen Europa schon seit vorgeschichtlicher Zeit im Gang ist.

Für Flächensenkungen ist eines der hervorragendsten Beispiele das Erdbeben von Katsch im Jahr 1819, das eine Fläche von ungefähr $520 \mathrm{qkm}$ in einen See verwandelte.

Seismische Lagen- und Niveauveränderungen abseits von den Spalten lassen sich, weil es sich da nur um kleine Beträge handelt, nur auf geodätischem Weg feststellen. Die erste sichere Nachricht darüber stammte aus Sumatra, wo bei dem Erdbeben am 17. Mai 1892 Triangulationspfeiler bis zu $1 \mathrm{~m}$ verschoben wurden. ${ }^{76}$ Noch beträchtlicher waren die Folgen des ostindischen Bebens von 1897. Niveauveränderungen sind in dem Garo- und Khasigebirge nicht nur indirekt durch Änderung des Gefälles der Flüsse, die zur Seenbildung führte, sondern auch direkt durch eine neue trigonometrische Aufnahme nachgewiesen. Die Dreiecksseiten sind im Vergleich zur Aufnahme von 1860 bis zu 2,8 m länger geworden, und die Hauptstationen haben dadurch eine Verschiebung von $1 / 2-31 / 2 \mathrm{~m}$ erlitten, zugleich ist aber auch (mit einer einzigen Ausnahme) ihre Seehöhe um ${ }^{1} / 2-7 \mathrm{~m}$ gewachsen. Freilich ist dabei vorausgesetzt, daß die Basislinie unverändert geblieben ist, und möglicherweise ist die Streckung der trigonometrischen Linien auf eine Verkürzung der Basis zurückzuführen, aber auch in diesem Fall wäre eine Niveauveränderung außer Zweifel gestellt.' Genaue Daten besitzen wir von dem schon erwähnten japanischen Erdbeben vom 28. Oktober 1891, dessen Epizentrum zufällig mit einem wichtigen Nivellementsknotenpunkt zusammentraf. Die 1899 abgeschlossenen Nachmessungen ergaben Höhenveränderungen in einem Gebiet von $160 \mathrm{~km}$ größter Länge, und zwar vorwiegend Hebungen bis zum Betrag von $0,8 \mathrm{~m}$, aber auch Senkungen bis $0,4 \mathrm{~m}$, im ganzen also eine Höhenveränderung von 1,2 m. ${ }^{77}$ Endlich gab auch das verheerende californische Erdbeben von 1906, dem St. Francisco zum Opfer fiel, Veranlassung zu außerordentlich sorgfältigen Nachmessungen. Es ging, wie auch schon sein Vorläufer von 1868, von einer der gröBten Bruchlinien 
aus, die wir kennen, der San-Andreas-Linie. Sie erstreckt sich von San Juan in der Grafschaft Benito (östlich von der Montereybai) $435 \mathrm{~km}$ weit nach N $30-40^{\circ} \mathrm{W}$ bis Punta Delgada. 1868 wurde ein Krustenstück von $2600 \mathrm{qkm}$ als Block (mit Ausnahme eines einzigen Punktes) um 1,6 $\mathrm{m}$ nach $\mathrm{N} 11^{\circ} \mathrm{W}$ verrückt, während die Verschiebungen von 1906, die eine Fläche von über $10000 \mathrm{qkm}$ betrafen, an der Westseite der Spalte nach NW, an der Ostseite nach SO erfolgten, wobei die Intensität, die zwischen $1 \frac{1}{2}$ und $7 \mathrm{~m}$ schwankte, von der Bruchlinie nach außen abnahm. Damit war im nördlichen Teil eine Hebung des SW-Flügels um $0,7-1 \mathrm{~m}$ und weiter im $\mathrm{N}$ eine noch unbedeutendere Hebung des NO-Flügels verbunden. ${ }^{78}$

Einige Senkungserscheinungen in unserem Vaterland lassen es als zweifelhaft erscheinen, ob man sie als instantane oder als säkulare Bewegungen aufzufassen hat. Wir neigen der letzteren Ansicht zu, besonders betreffs der Senkungen des Bodenseebeckens, die sich bei Konstanz bis in das Jahr 1817 zurückverfolgen lassen und hier bis 1890 den Betrag von $317 \mathrm{~mm}$ erreicht hatten. Die Senkung ist allgemein, und die des südlichen Ufergeländes stärker als die des Seespiegels. ${ }^{79} 1906$ wurde das Feinnivellement auf der Strecke Freilaßing-Laufen a. d. Salzach, das 1887 stattgefunden hatte, mit aller Genauigkeit wiederholt und ergab, daß FreilaBing in bezug auf die Nachbarmarken stationär geblieben war, während sich Laufen um $84 \mathrm{~mm}$ gesenkt hatte. In der Nähe von Laufen befindet sich eine Bruchlinie, und 1904 hatte hier ein Erdbeben stattgefunden. Rätselhaft sind die durch Nivellements festgestellten Bodenbewegungen des Telegraphenbergs bei Potsdam, die den Betrag von $1 \mathrm{~cm}$ erreichen. ${ }^{80}$ Dagegen mögen sich die Bewegungen der Festpunkte des Nivellements an der Deime (Arm der Pregel, der in das Kurische Haff mündet), die zwischen 1898 und 1901 teils bis $47 \mathrm{~mm}$ sich gesenkt haben, teils bis $\mathrm{zu}$ $57 \mathrm{~mm}$ in die Höhe gestiegen waren, wohl auf Zusammensacken des Bodens zurückführen lassen, denn nur die auf Pfählen im Moorboden zeigten sich unruhig, während sich die an Bauten angebrachten nicht veränderten. ${ }^{81}$ Manche Täuschungen sind auch hier untergelaufen. So machte vor einigen Jahren eine scheinbar exakte Beobachtung von Bewegungen des französischen Bodens großes Aufsehen. Aus dem Vergleich der älteren BouRdalouk'schen Nivellierung, dem sog. Nivellement général de la France, und dem neuen Präzisionsnivellement glaubte man schließen zu dürfen, daß der Boden sich in der Richtung von Marseille nach Calais bis zu $78 \mathrm{~mm}$ gesenkt habe; jetzt sind aber alle beteiligten Kreise darüber einig, daß 
diese Differenz systematischen Fehlern zuzuschreiben ist. Auch in der Schweiz glaubte man aus den bisherigen Aufnahmen kleine Verschiebungen innerhalb des Gebirgsdreiecks Rigi-Lägern-Napf zu erkennen, aber auch diese sind in den Messungen nicht begründet. ${ }^{82}$ Zur Kritik fordern auch alle Nachrichten über Veränderungen der Aussichtsweite heraus, wie z. B. in der Umgebung von Jena, ${ }^{83}$ im Aintal im französischen Jura, ${ }^{84}$ im Waadt ${ }^{85}$ und auf der schwedischen Skagerrakinsel Orust. ${ }^{86}$ Einen gleichen Fall in der piemontesischen Provinz Cuneo konnte SAcco lediglich auf Gleitung und Rutschung, zurückführen. ${ }^{87}$ Als echt säkular dürfen wir dagegen eine kleine Senkung betrachten, die im Clausthaler Bergwerk in $730 \mathrm{~m}$ Tiefe beobachtet wurde, und die 1895-1901 30 und 1901 bis $190625 \mathrm{~mm}$ betrug $^{88}$ - also eine nahezu gleichmäßige $\mathrm{Be}$ wegung.

Schlußfolgerungen. Auf eine sichere Grundlage kann die Lehre von den modernen Niveauveränderungen nur durch systematische Beobachtung gestellt werden. Das Beispiel, daß man jetzt in Indien gibt, wo man von einem hohen Turm in der Nähe von Roorke aus die im Verdacht der Hebung stehenden Siwalikberge einer dauernden Beaufsichtigung unterworfen hat, verdient Nachahmung. Noch wichtiger wäre es, wenn sich die Regierungen dazu entschlössen, nach LaLlemand's ${ }^{89}$ Vorschlag alle 30 Jahre die Festpunkte der Feinnivellementsnetze von neuem einzuwägen. Indes lassen sich doch auch schon aus den bisherigen Erfahrungen einige Sätze ableiten:

1. Die Dislokationen der Gegenwart umfassen Verwerfungen, Verschiebungen und Verbiegungen.

2. Soweit man überhaupt instantane und säkulare Bodenbewegungen unterscheiden kann, sind die ersteren anscheinend zahlreicher; und wenn man erwägt, daß kein Tag ohne Erdbeben vergeht, so kann man wohl auch die Behauptung aufstellen, daß instantane Dislokationen eine alltägliche Erscheinung sind. Nur die Geringfügigkeit ihres Ausmaßes entzieht sie meist der unmittelbaren Wahrnehmung, und nur im Lauf unendlich langer Zeiträume können sie sich zu reliefumgestaltenden Wirkungen summieren.

3. Es ist nicht ganz sicher, ob zwischen instantanen und säkularen Bewegungen ein wesentlicher Unterschied besteht. Erfolgen die säkularen ruckweise, so kann man sie als eine Reihe instantaner Bewegungen mit gleicher Tendenz auffassen. Wechsel der Tendenz innerhalb langer Zeiträume oder Oszillationen scheinen den säkularen Niveauveränderungen eigentümlich zu sein.

4. Die Mehrzahl der beobachteten Niveauveränderungen läßt 
sich nicht genauer definieren, und es ist kein Fall bekannt, wo mit Sicherheit auf eine Bewegung des Meeresspiegels geschlossen werden kann. Positive und negative Schwankungen zeigen weder eine deutliche regionale, noch eine zeitliche Anordnung, $\times$ wie man bei Geoïd veränderungen voraussetzen sollte. Es ist aber trotzdem nicht ausgeschlossen, daß örtliche Hebungen und Senkungen des Meeresspiegels eine Verschiebung der Strandlinie innerhalb mäßiger Grenzen bewirken können.

Literaturnachweise. ${ }^{1}$ F. HAHN, Untersuchungen über das Aufsteigen und Sinken der Küsten, Leipzig 1879. A. Issse, Le oseillazioni lente del suolo, Genua 1883. $-{ }^{2}$ R. S. TARR und L. Martin, Recent Changes of Level in the Yakutat Bay Region, Alaska, im Bulletin of the Geological Society of America, 1906, Bd. XVII. - ${ }^{3}$ H. Steffen in Petermann's Mitteilungen, 1907, S. 132. $-{ }^{4} \mathrm{H}$. Trautschold, Über säkulare Hèbungen und Senkungen, im Bulletin de la Soeiété des Naturalistes de Moseou, 1869, - ${ }^{5}$ Vgl. E. Suriss' erste Schrift über „die vermeintlichen säkularen Schwankungen“" usw., in den Verhandlungen der Wiener Geologisehen Reichsanstalt, 1880. - ${ }^{6}$ A. BLytr zit, S. $256 .-{ }^{7}$ G. ZremendorfF zit. S. 276. $-{ }^{8}$ F. LöwL, Die Ursache der säkularen Versehiebungen der Strandlinie; Prag 1886. - ${ }^{9}$ Тн. KJerulf, Die Geologie des südlichen und mittlerén Norwegen; Bonn 1880, - ${ }^{10}$ R. Lemmans, Über ehemalige Strandlinien in Norwegen; Halle a. S. 1879. - ${ }^{11}$ A. M. Hansex, On 'Seter in Central Norway, in Nature, London 1886, Bd. XXXIII. 12 Chr. Sandler, Strandlinien und Terrassen, in Petermans's Mitteilungen, 1890. - ${ }^{13}$ Für das Gebiet des Kristianiafjords, wo die drei Endmoränen des sich etappenweise zurückziehenden Inlandeises gute Altersbestimmungen zulassen, s. W. C. Bregaer, Om de senglaeiale og postglaciale Nivåforandringer i Kristianiafeltet; Kristiania 1900 u, 1901. Strandliniens beliggenhed under stenalderen i det sydöstlige Norge, in Norges geologiske undersögelse, 1905. Auf das Gebiet von Jäderen beziehen sich die Untersuchungen von J. Ноцмвов (in Nyt. Magazin for Naturvidenskaberne, 1901, Bd. XXXIX, S. 1) u. P. A. Öyex (in den Abhandlungen der norwegisehen Akademie der Wissenschaften, Mathem.-naturwiss. Klasse 1903, Nr. 7), auf das Gebiet von Bergen die Arbeit von C. F. Kolderer (in Bergens Museums Aarbog 1907, Nr. 14). Für Nordnorwegen hat erst J. Ноцмвов (om faunaen i nogle skjaelbanker og lerlag ved Norges nordlige Kyst, in Norges geologiske undersögelse 1904) Nachweise geliefert. - ${ }^{14}$ G. DE GEER, Om Skandinaviens geografiska utveckling, Stockholm 1896, bietet einen vortrefflichen, durch Karten veranschaulichten Überblick über die glaziale und nachglaziale Entwicklungsgesehichte Skandinaviens. Vgl, auch E. Geisitz, Das Quartär von Nordeuropa, Stuttgart 1904. - ${ }^{15}$ H, KLose, Die alten Stromtäler Vorpommerns, im 9. Jahresbericht der Geographischen Gesellschaft in Greifswald, 1904. - ${ }^{16}$ J. Lervisкä, Zu den Küstenfragen, in Fennia, Bd. XXVII, 1909. - ${ }^{17}$ A. M. Haxsen, Strand-

$\times$ Wenn H. W. Pearson in seinem Artikel „Oscillations in the SeaLevel" (Geological Magazin 1901) zu dem Schluß kam, daß sich in Perioden von durchschnittlich 580 Jahren höchste und tiefste Wasserstände wiederholen, so war dies nur durch eine völlig willkürliche und kritiklose Zusammenstellung von Notizen möglich. 
linje-Studier, im Archiv for Mathematik og Naturvidenskab, Bd. XIV (1890) und XV (1892). - ${ }^{18} \mathrm{~J}$. REKsTAD, Jagttagelser fra terrasser og strandlinjer i det vestlige Norge, in Bergens Museums Aarbog 1905. - ${ }^{19}$ W. Rassax, Über die geologische Entwicklung der Halbinsel Kola in der Quartärzeit, in Fennia, Helsingfors 1898. - ${ }^{20}$ O. SJöGReN, in Ymer 1908, S. 17. - ${ }^{21}$ A. G. НӧGвoм, Norrland, Upsala 1906. - ${ }^{22}$ N. V. Ussing, Dänemark (Handbueh der regionalen Geologie), Heidelberg 1910, - ${ }^{23}$ G. DE GEer, Om de senkvartäre landhöjningen kring: Bottniska viken, in den Verhandlungen der Stockholmer geologisehen Gesellschaft, 1898, Bd. XX. $-{ }^{24}$ H. Hergeselt, Die Änderung der Gleichgewichtsflächen der Erde durch die Bildung polarer Eismassen, in GERLand's Beiträgen zur Geophysik, Bd. I, 1887. - ${ }^{25}$ E. v. Drygatski, Die Geoiddeformationen der Eiszeit, in der Zeitschrift der Berliner Gesellschaft für Erdkunde, 1887. - ${ }^{26}$ R. S. Woodward, On the form and position of the Sea Level, im Bulletin of the U. S. Geological Survey, Nr. 48, 1888. - ${ }^{27}$ G. Axdersson, Den Centraljämtska issjön, im Ymer 1897. А. G. Нӧявом, Några anmärkningar om de isdämda sjöarne i Jemtland, in den Verhandlungen der Stockholmer Geologischen Gesellschaft, 1897. - ${ }^{28}$ L. Ноцмsтвöм, Om strandliniens förskjutning a Sveriges kuster, in den Abhandlungen der schwedischen Akademie der Wissenschaften, Bd. XXII, 1888. - ${ }^{29}$ R. SregER, Seeschwankungen und Strandversehiebungen in Skandinavien, in der Zeitschrift der Berliner Gesellschaft für Erdkunde, 1893. - ${ }^{30}$ A. M. HANSEN, Seandinaviens stigning, im Jahrbuch der Norwegischen geologisehen Untersuchungen für 1896-90. ${ }^{31}$ Roséx's Resultate finden sich nach brieflicher Mitteilung in A. WestphaL, Das Mittelwasser der Ostsee bei Travemünde usw.; Berlin 1900. - ${ }^{39}$ A. How LENDER in den Geologiska föreningens förhandlingar, 1901, Bd. XXIII, S. 231. $-{ }^{33} \mathrm{~V}$. TANNER, Studier öfver Kvartärsystemet i Fennoskandias nordliga delar, Nr. 18 des Bulletin de la Commission géologique de Finlande, 1907. ${ }^{34}$ A. Bonsdorff, Über die Hebung der Küste Finnlands, in Fennia, Bd. XXI. - ${ }^{35}$ E. BRückNer, Über Schwankungen der Seen und Meere, in den Verhandlungen des Deutsehen Geographentages zu Wien, 1891. - ${ }^{36}$ Das geht aus den Untersuchungen von D. WooLAcotr (im Quarterly Journal of the Geological Society, London 1905, Bd. LXI, S. 64), T. F. JAMIEson (im Geologieal Magazine, 1906, S. 22) und von G. Coffey u. R. L. Praeger (The Larne Raised Beach, in den Proceedings of the Royal Irish Academy, Bd. XXV, 1904) hervor. - ${ }^{37}$ E. B. Defabarre im Bulletin of the Geographical Society of Philadelphia 1902, Bd. III, Nr. 4. - ${ }^{35}$ A. P. Low im Annual Report of the Geological Survey of Canada, 1902, Bd. XIII, part D. - ${ }^{39}$ G. DE GEER, Pleistocene Changes of Level in Eastern North America, in the Proceedings of the Boston Society of Natural History, 1892. - ${ }^{40}$ Тн. Tschernyschew, Aperęu sur les dépots posttertiaires au nord et à l'est de la Russie d'Europe; in d. Schriften d. kais. Gesellschaft für Naturwissenschaften in Moskau 1892. - ${ }^{41}$ M. P. RedzkI, Deformationen der Erde unter der Last des Inlandeises, im Bulletin international de l'Académie des Sciences de Cracovie, 1899, S. 169 u. 445; Zeitschrift für Gletscherkunde, Bd. I, S. $182 .-{ }^{42}$ E. v. DexgaLsKI, Über Bewegungen der Kontinente zur Eiszeit, in den Verhandlungen des VIII. deutschen Geographentages zu Berlin, 1889. - ${ }^{43}$ A. Badodreav, Etude sur le soulèvement lent actuel de la Seandinavie, in den Annales de mines, 1894, Bd. VI. ${ }^{44}$ J. B. Trrrell, im Geological Magazine 1900, S. $266 .-{ }^{45}$ G. K. Gilbert, Recent Earth Movements in the Great Lakes Region, im Annual Report of the United States Geological Survey, 1898, Bd. XVIII, 2. Teil. - ${ }^{40}$ Отто NordenskJöLd, Svenska Expeditionen till Magellans länderna; Stockholm 1899, 
Bd. I. - ${ }^{47}$ F. Vidal Gormaz, Hundimiento o solevantamiento de los archipélagos australes de Chile. Santiago de Chile, 1901. - ${ }^{48}$ A. Rutot, Sur les antiquités découvertes dans la partie belge de la plaine maritime, in den Mémoires de la Société d'ańthropologie de Bruxelles, 1903, Bd. XXI. ${ }^{49} \mathrm{H}$. Scнütте, im Jahrbuch für die Geschichte des Herzogtums Oldenburg 1908, Bd. XVI, S. 397. Dagegen J. Martin in Bd. XVII. - ${ }^{50}$ G. H. Cook, Subsidence along the Sea Coast of New Jersey, im American Journal of Science 1857, Bd. II. - ${ }^{51}$ F. D. Chester, The Gravels of the Southern Delaware Peninsula; ebendas. 1885 , Bd. I. $-{ }^{52}$ G. W. Tutrle, Recent Changes of Land and Sea in the Vicinity of New York City, im American Journal of Seience, 1904, Bd. XVII. - ${ }^{53}$ E. Linhardt, Unterseeische Flubrinmen, im Jahresbericht der Geographischen Gesellsehaft in München, 1892. - ${ }^{54} \mathrm{~T}$. CoDRINGton, On some submerged Rockvalleys in South Wales, Devon, and Cornwall, im Quarterly Journal of the Geological Society, 1898, Bd. LIV. ${ }^{55}$ E. Hull, zit S. 276 . - ${ }^{56}$ J. W. Spencer, Reconstruction of the Antillean Continent, im Bulletin of the Geological Society of America, 1895, Bd. VI. - ${ }^{57}$ G. Davidson, The submerged Valleys of the Coast of California and of Lower California, in den Proceedings of the California Academy of Science, 1897, Bd. I. - ${ }^{58}$ A. Phmiprson, Das Mittelmeergebiet, Leipzig 1904. -59 A. Grund, Die Entstehung und Geschichte des Adriatischen Meeres, im Geographischen Jahresbericht aus Österreich, Bd. IV. - ${ }^{60}$ L. DE Lamothe, in den Comptes rendus der Pariser Aeadémie des Sciences vom 26. Dez. 1904 u. 13. Juni 1905. - ${ }^{61}$ С . Depéret, im Bulletin de la Société géologique de France, 1906, Bd. VI, S. 207. - ${ }^{62}$ E. Caziot und E. Mavry, ebenda, 1907, Bd. VII, S. 72. - ${ }^{63}$ Ph. Negris, ebenda, Bd. VI, S. 519. - 64 L. de Lamothe, in den Comptes rendus der Pariser Académie des Sciences 1906, Bd. CXLII, S. 1103. - ${ }^{65}$ A. Briquer, Note préliminaire sur quelques points de l'histoire plio-pleistocène de la région gallo-belge, in den Annales de la Société géologique du Nord 1907, Bd. XXXVI. - ${ }^{6}$ L. Cayeux, Fixité du niveau de la Mediterranée, in den Annales de Géographie 1907, Bd. XVI. - ${ }^{67}$ PH. Negris in den Comptes rendus der Pariser Académie des Sciences vom 20. Juli 1903 u. 1. August 1904; in der Revue universelle des Mines; Liège 1903, Bd. III; und in den Mitteilungen des Kaiserl. Deutschen Archäologischen Instituts in Athen, Bd. XXIX; Délos et la transgression actuelle des mers, Athen 1907. - ${ }^{68}$ A. Gsirs, in den Mitteilungen der Wiener Geographischen Gesellsehaft, 1908, Bd. LI, S. 1. Vgl. dazu W. Kranz, Hebung oder Senkung des Meeresspiegels? im XXVIII. Beilageband zum Neuen Jahrbuch für Mineralogie usw., 1909. - ${ }^{69}$ A. Grund, in Sitzungsberichten der Wiener Akademie der Wissenschaften, Math.-Nat. Klasse, 1906, Bd. CXV, S. 241 u. 1757. - 70 H. Emmons, im Neuen Jahrbuch für Mineralogie usw., 1892, Bd. II, S. 83. - ${ }^{71}$ R. T. Günther, Contributions to the Study of Earth Movements in the Bay of Naples; Oxford 1903. - ${ }^{72}$ E. FraAs, Geologische Streifzüge in Ostafrika, Vortrag, Stuttgart 1909. - ${ }^{73} \mathrm{Vgl}$. den Bericht C. L. Griesbach's in den Records of the Geological Survey of India, 1893, S. 57. - ${ }^{74}$ N. Yamasaki in Petermann's Mitteilungen, 1900, S. 249. - ${ }^{75}$ Тн. Sкupноs, Die zwei griechischen Erdbeben in Lokris 1894, in der Zeitschrift der Gesellschaft für Erdkunde in Berlin, 1894. - ${ }^{76}$ Seismische Bodenverschiebung, in Petermans's Mitteilungen 1895, S. 97. — ${ }^{77} \mathrm{Vgl}$. E. Hamrmer's Bericht ebenda 1903, S. 284. — ${ }^{78}$ The California Earthquake of April 18, 1906. Report of the State Earthquake Commission, Washington 1908. - ${ }^{79}$ C. Regelmann, Neuzeitliche Schollenverschiebungen der Erdkruste im Bodenseegebiet, in dem Bericht über die 40. Versammlung 
des Oberrheinischen geologischen Vereins zu Lindau, 1907. - ${ }^{80}$ J. B. Messersснмгт, Über Höhenmessungen und Höhenänderungen, in der Schweizerischen Bauzeitung, Bd. XXXIV. - ${ }^{81}$ W. Sегвт, Höhenverschiebungen von Nivellementfestpunkten an der Deime, im Zentralblatt für Bauverwaltung, 1902. 82 Е. ВвӥскмеR, Über die angebliche Änderung der Entfernung zwischen Jura und Alpen, im Jahresbericht der Geographischen Gesellschaft in Bern 1893. 83 Beriehte von P. Kahle, E. Pfeiffer u. Gerke in den Mitteilungen der Geographischen Gesellschaft in Jena, Bd. V u. VI, 1887 u. 1888. Vgl. auch P. Kahle in Petermann's Mitteilungen, 1899, S. 218. - ${ }^{4}$ Berichte von L. A. Girardot und A.Romiedx im Bulletin géographique, historique et descriptive, 1890. - ${ }^{85}$ J. Jegerlehner im XIII. Jahresbericht der Geographischen Gesellschaft in Bern, 1894. - ${ }^{86}$ R. Kjellén im Ymer 1903, S. 387. - ${ }^{87}$ F. Sacco, Des phénomènes altimétriques dans l'intérieur des continents, im Bulletin de la Société géologique de France 1885/86, Bd. XIV. - ${ }^{8 s}$ H. Baumgärtel, in Gerland's Beiträgen zur Geophysik, Bd. VIII, S. 494. - ${ }^{89}$ CH. Lar.Lemand, in den Comptes réndus der Pariser Académie des Seiences 1908, Bd. CLXVI, S. 64.

\section{Übersicht der exogenen Wirkungen.}

Die endogenen Erscheinungen, die wir bisher kennen gelernt haben, sind zwar auch vielfach mit Zerstörung verbunden, aber hauptsächlich wirken sie doch aufbauend und halten damit jenen Agentien das Gleichgewicht, die, von außen auf die Oberfläche wirkend, die Erhöhungen abzutragen, die Unebenheiten auszugleichen trachten.

Dieser ProzeB zerfällt in drei Akte: Zerstörung, Abfuhr, Ablagerung. Zerstörung und Abfuhr sind aber zum Teil notwendig miteinander verbunden, und wir fassen sie in dem Begriff $\mathrm{De}$ struktion zusammen. Die destruktiven Agentien sind die Wärme, die Luft, das Wasser und die organische Welt.

Der allgemeinste zerstörende Vorgang ist die Verwitterung; ·ihr verfällt alles, wenn auch in verschiedenem Grad, am langsamsten wohl der mit Wasser bedeckte Boden. Die Verwitterungsprodukte bleiben entweder an Ort und Stelle liegen oder werden fortgeführt. Auf ihre Abfuhr beschränken wir den Ausdruck Denudation, wie er auch seiner Etymologie entspricht. Schon die Schwerkraft bringt überall, wo eine Böschung vorhanden ist, den Verwitterungsschutt in Bewegung, namentlich dort, wo durchtränkende Feuchtigkeit die Reibung vermindert. Wir nennen diesen Vorgang Bodenversetzung. $\times$

Es greifen aber auch andere Kräfte in diesen Prozeß ein: das bewegte Wasser in flüssiger und fester Form und die bewegte Luft. Aber ihre Arbeitsleistung, die wir als Erosion bezeichnen,

$\times$ Den von Braun eingeführten Ausdruck Bodenbewegung vermeiden wir nur deshalb, weil er auch auf endogene Vorgänge angewendet wird. 
beschränkt sich nicht bloB auf die Abfuhr der Verwitterungsprodukte. Sie wirken auch selbständig an dem Destruktionsprozeß mit und schaffen damit neue Oberflächenformen.

Die Erosion wirkt teils + chemisch, teils mechanisch. An der chemischen Erosion beteiligt sich nur das Wasser, sie steht im allgemeinen an Bedeutung weit hinter der mechanischen zurück. Die mechanische Erosion löst sich bei genauerer Betrachtung in zwei Phasen auf: ${ }^{A}$ Ablation und Korrossion. Zunächst greifen Wasser und Luft nur lockeres Material an, teils Verwitterungschutt, teils andere lockere Bestandteile des Bodens (Ablation), und diese dienen ihnen nun als Feile, um durch Reibung auch das feste Gestein, das in ihrer Bahn liegt, abzuschleifen und zu zerstören (Korrosion). Im Gegensatz zur Verwitterung läßt die Erosion ihre Zerstörungsprodukte niemals an Ort und Stelle liegen; auf die Loslösung folgt unmittelbar die Abfuhr, und bestünde diese auch nur in einer Verschiebung um wenige Millimeter.

Daraus ergibt sich für die Kehrseite der Zerstörung oder die Ablagerung eine Zweiteilung in Eluvium oder Verwitterungsboden auf ursprünglicher Lagerstätte und in Alluvium, d. h. Ablagerung der Denudations- und Erosionserzeugnisse, sobald die Transportkraft erlischt.

Wir können die Vorgänge, von denen bisher die Rede war, in folgendes Schema zusammenfassen, wobei ihre Mitwirkung an dem Umgestaltungsproze $B$ mit + angezeigt wird:

\begin{tabular}{|c|c|c|c|}
\hline & Zerstörung & Abfuhr & Neubildung \\
\hline Verwitterung & + & - & + (Eluvium) \\
\hline Denudation . & - & + & + (Alluvium \\
\hline Erosion . . & + & + & (Alluvium \\
\hline
\end{tabular}

Wir haben nun das Wesen der Destruktion etwas näher ins Auge zu fassen. Sie wirkt in dreifacher Weise: punktweise, linear und flächenhaft.

1. Das Ergebnis der punktweisen Destruktion sind allseitig geschlossene Bodenvertiefungen in verschiedenen Formen von topfartigen Löchern bis zu großen, aber verhältnismäßig flachen Becken und Wannen. Indes ist hier noch manches unklar und streitig, wie z. B, die Beteiligung der Gletschererosion an diesem Vorgang. Als sicher kann die Bildung von Töpfen durch stürzendes und strudelndes Wasser angesehen werden. Auch dem Wind kann unter gewissen Bedingungen eine ähnliche Tätigkeit zugeschrieben werden, und nach Passarge haben in Südafrika auch die großen Säugetiere an der Schaffung flacher Vertiefungen mitgewirkt.

2. Das allgemein anerkannte Hauptagens der linearen Destruktion, der wir die weitaus größte Zahl der Täler verdanken, ist das 
fließende Wasser; viele Forscher stellen ihm das fließende Eis oder die Gletscher als gleichwichtig an die Seite. Unter Umständen kann auch der Wind durch Ausräumung vorhandener Furchen die Talbildung fördern.

3. An der flächenhaften Destruktion sind eine Menge Faktoren beteiligt. Nur flächenhaft wirkt das brandende Meer und hauptsächlich flächenhaft der Wind. Die Bedeutung des spülenden Regens ist erst in letzter Zeit mehr gewürdigt worden. Leichter Regen dringt in den Boden ein und fließt in selbstgeschaffenen oder schon vorhandenen Rinnen ab, heftige Regengüsse aber, wie solche in den Tropen besonders häufig sind, breiten sich flächenhaft aus, besonders dort, wo die tonige Beschaffenheit des Bodens oder harte Krusten oder Gerölldecken das Einsickern verhindern. Dichte Vegetation legt die denudierende Tätigkeit des Regens überall lahm. Auch das fließende Wasser arbeitet flächenhaft, wenn es durch seitliche Erosion seinen Talboden zu erweitern bestrebt ist, und wer den Gletschern lineare Destruktionskraft zutraut, wird nicht umhin können, dem Inlandeis wenigstens bis $\mathrm{zu}$ einem gewissen Grad die Fähigkeit zuzuerkennen, seine Unterlage flächenhaft zu bearbeiten. Endlich sind auch die Bodenversetzungen als fast ausschließlich flächenhafte Destruktionsvorgänge zu bezeichnen.

Eine Übersicht über die wichtigsten dieser Prozesse gibt folgendes Schema, worin + dieselbe Bedeutung hat wie auf S. 467. (+) zeigt an, daß die Mitwirkung zweifelhafter oder untergeordneter Natur ist.

Destruktion

Schwerkraft

Agens

FlieBendes Wasser

Stürzendes, sprudelndes

Wasser

Spülendes Wasser

Brandendes Wasser

FlieBendes Eis

Wind

Vorgang $x$
Bodenversetzung . .
FluBerosion $x \times$

Evorsion (GeINITz)

Flächenspülung (Passarge, Volz), Schichtflut

(PENCK nach d. engl. sheet flood)

Abrasion (v. Richthofen) .

Exaration (WALTHER) . .

Deflation (W ALther)

\section{Punkt- Linear Flächen- weis haft}

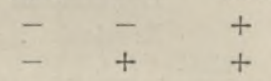

$+$

$-$

$-$

$\begin{array}{ccc} & & \\ - & - & + \\ - & - & + \\ (+) & (+) & (+) \\ (+) & (+) & +\end{array}$

Alle destruktiven Vorgänge sind periodischen und unperiodischen Veränderungen unterworfen, die einen in höherem, die anderen in geringerem Grad. Sie vollziehen sich anders bei Tag

× In Klammern die Namen der Autoren, die den betreffenden Ausdruck zuerst eingeführt haben.

$\times \times$ Lineare Fluberosion oder Tiefenerosion, flächenhafte oder Seitenerosion. 
als in der Nacht, anders im Winter als im Sommer, anders in den feucht-kühlen Perioden als in den trocken-warmen. Tiefgreifender als diese zeitlichen sind die räumlichen Unterschiede, in denen sich die großen klimatischen Gegensätze der Länder widerspiegeln Tropen- und Polargürtel, Regengebiete und Wüsten werden in verschiedener Weise destruiert, und verschieden gestaltet sich danach ihre Oberfläche. Penck schließt aus der Tatsache, daß die höchsten Gebirge den Tropen angehören, auf das Vorhandensein eines absoluten oberen Denudationsniveaus, über das kein Gebirge hinauswachsen könne, weil es dann sofort der Abtragung unterliege und verlegt dieses Niveau in eine Höhe von 2-3000 $\mathrm{m}$ über der Schneelinie. Klimaperioden von langer Dauer oder völlige Veränderung des Klimas eines Landes sind daher von gröBter morphologischer Bedeutung. Aber wenn auch die Art der Destruktionsarbeit sich rasch ändert, so braucht es doch lange, bis der ihr entsprechende Relieftypus den alten verdrängt. Noch begegnen wir allenthalben in höheren Gebirgen und unter großen Polhöhen den Spuren der Eiszeit, in Wüsten den Spuren einstiger Regenfülle, in niederschlagreichen Gegenden den Spuren ehemaliger Trockenheit.

Als absolutes unteres Denudationsniveau bezeichnet Peńck das Meeresniveau, und in der Tat kann (die Depressionen ausgenommen!) kein Fluß, kein Gletscher eine Erhebung unter den Meeresspiegel erniedrigen, nur dem Wind kann man unter besonders günstigen Umständen eine solche Fähigkeit zuerkennen. Auch jede Veränderung der Meereshöhe muß daher die Denudationsarbeit beeinflussen. Von den absoluten Denudationsniveaus sind die wirklichen zu unterscheiden, die durch den höchsten und den tiefsten Punkt einer bestimmten Landerhebung repräsentiert werden; aber stets bleiben die wirklichen Denudationsniveaus innerhalb der absoluten.

Je kürzer der Weg zum Meer ist, desto schneller gehen die Destruktionsprodukte dem Land verloren, und das Endziel der zerstörenden Kräfte, die Einebnung, wird in kleinen Räumen früher erreicht als in großen. „Wenn man die Stoffmenge" - sagt SAPPER —, „die einem bestimmten Raum von der Natur zugewiesen ist, mit einem Kapital vergleichen darf, so darf man sagen, daß der engräumige Haushalt damit wesentlich verschwenderischer umgeht als der weiträumige, der denselben Stoff häufiger zu verwerten pflegt, ehe er ihn nach mehrmaligem Absatz und Wiederaufnehmen endlich ans Meer abgibt. Die engräumigen Insel- und Halbinselgebiete werden dagegen erst sparsam, wenn sie den größten Teil ihres Kapitals verloren haben, also stark abgetragen sind." 
Es liegt in der Natur der Sache, daß sich die Destruktion um so mehr verlangsamt, je näher sie ihrem Endziel kommt, voraușgesetzt, daß die äußeren Bedingungen nicht wechseln. Es werden ferner nicht bloB den in vertikaler, sondern auch manchen der in horizontaler Richtung wirkenden Agentien Schranken gesetzt. Endlich kann auch die mit der Zerstörung Hand in Hand gehende Ablagerung den Destruktionsprozeß unterbinden. Man vergleicht ihn am besten mit einer Kurve, die zuerst steiler, dann immer allmählicher ansteigt; Davis hat ihn, wenig zutreffend, einen Zyklus genannt, und seine verschiedenen Stadien als Jugend-, Reife- und Greisenzustand bezeichnet. Damit sind aber nicht absolute Altersunterschiede gemeint, denn die Destruktion ist nicht bloß eine Funktion der Zeit, sondern auch des Gesteinswiderstandes, und zwei Erdstellen im gleichen Stadium der Zerstörung können trotzdem sehr verschieden alt sein. Um Mißverständnissen vorzubeugen, gebrauchen wir daher die Ausdrücke: Unreife, Reife und Überreife.

\section{Verwitterung und Denudation. ${ }^{1}$}

Der Verwitterungsprozeß. Die Widerstandsfähigkeit der Gesteine gegen die Einflüsse der Atmosphärilien hängt zunächst von der Art der Kornbindung ab. Bei den Trümmergesteinen wird diese durch ein besonderes Zement bewirkt; und sind die Körner nicht dicht aneinander gelagert und ist das Zement nicht wetterhart, so zerfällt das Gestein bald in Stücke. Daher kann jedes Sedimentgestein in harten und weichen Varietäten auftreten, im allgemeinen sind sie jedoch verwitterbarer als die kristallinischen Silikatgesteine, deren Körner unmittelbar miteinander verbunden sind.

Die Verwitterungskräfte dringen nicht nur von der Oberfläche allmählich in das Innere einer Gesteinsmasse vor, sondern finden ihren Weg auch durch zahlreiche Spalten und Risse, die in verschiedenster Ausdehnung jedes Gestein durchsetzen. Bei Felsmassen, die durch Ablagerung im Wasser entstanden sind, werden nicht nur die einzelnen Schichten durch mehr oder minder weite Klüfte voneinander getrennt, sondern sie neigen häufig, besonders Sandsteine, Kalke und Dolomite, auch zu vertikaler Zerklüftung. Zahlreich sind die Spältchen zwischen den dünnen Lagen der geschieferten Gesteine, und namentlich dann eröffnen sich den zersetzenden Agentien viele Eingangstore, wenn die Schieferung die Schichtung schneidet. Eruptivgesteine werden von Absonderungsklüften durchzogen, und ebenso werden sie, wie die Sedimentgesteine, häufig von Dislokationsspalten durchsetzt. Infolge von Temperaturschwankungen dehnen sich 
die Massenteilchen aus und ziehen sich dann wieder zusammen, und zwar um so intensiver, je dunkler die Farbe und je rauher die Oberfläche ist. Risse und Sprünge sind das Resultat dieser Volumveränderungen; ja in wärmeren Wüstengebieten erweist sich die große tägliche Temperaturschwankung, die nach OBRUTschew selbst noch in Zentralasien $40-55^{\circ}$ beträgt, als kräftig genug, große Gesteinsmassen völlig $\mathrm{zu}$ zertrümmern. $\mathrm{DaB}$ Talgehänge die sich der Mittagsseite zuwenden, rascher verwittern als die entgegengesetzten, hat Culbertson ${ }^{2}$ durch genaue Messungen festgestellt, und ähnliche Beobachtungen hat Thoroddsen ${ }^{3}$ von Island mitgeteilt, wo die Basaltberge an der Südseite in der Regel unter $20-25^{\circ}$, an der Nordseite aber unter $30-35^{\circ}$ geböscht sind. In den höheren Breiten und in dên Hochgebirgen der warmen Zone spielt der Frost eine ähnliche Rolle. Das gefrierende Wasser in den Spältchen und Klüften des Gesteins dehnt sich aus und zersprengt es in scharfkantige, unzersetzte Fragmente, oft von kolossalen Dimensionen. Der Einfluß des Blitzes wird gering angeschlagen, da er nur Löcher und Schrammensterne erzeuge; $\mathrm{da} B$ er sich aber manchmal auch an der Zertrümmerung der Felsen beteiligt, wird durch eine Beobachtung G. ANDERsson's ${ }^{4}$ bestätigt.

Hand in Hand mit dieser mechanischen Auflösung geht die chemische Zersetzung, d. h. die Veränderung der Substanz des Gesteins durch die Einwirkung von Sauerstoff, Kohlensäure und Wasser. Wir nennen diesen Vorgang mit Rотн ${ }^{5}$ die einfache Verwitterung. Reine Kalksteine und Dolomite, Anhydrit und Gips, Salz (Chlornatrium) und andere Mineralien, die sich am Bau der Erdrinde nicht in so hervorragender Weise beteiligen, werden durch kohlensäurehaltiges Wasser vollstänidig gelöst und fortgeführt. Von den anderen Mineralien werden nur einige Bestandteile entweder direkt aufgelöst oder in lösliche Verbindungen umgewandelt, während ein unlöslicher Rest als Verwitterungserde zurückbleibt und dann unter Umständen der mechanischen Abtragung verfällt. Diesem Prozeß unterliegen vor allem die tonerdehaltigen Silikatgesteine, die neben den kalkigen Gesteinen einen Hauptbestandteil der Erdkruste bilden. Der Rückstand ist mehr oder weniger reine Tonerde, die allein der Vegetation eine dauernde Wohnstätte bieten kann. Es muß übrigens betont werden, daß auch der Kalkstein in zahlreichen Fällen Beimengungen von Tonerde enthält, die bei der Verwitterung zurückbleibt.

Die durch die einfache Verwitterung erzeugten Lösungen wirken ebenfalls zersetzend auf die Gesteine ein. Rотн nennt diesen Vorgang die komplizierte Verwitterung. Auch die Pflanzen be- 
teiligen sich in hervorragendem $\mathrm{MaB}$ an dem Zerstörungsprozeß. Im lebenden Zustand sind ihre Wurzeln imstande, vermöge ihrer organischen Säuren durch Endosmose mineralische Bestandteile zur Nahrung in sich aufzunehmen. Beim Absterben entwickeln sie die sog. Humussäuren, die sich mit den im Pflanzenkörper vorhandenen Alkalien zu humussauren Alkalien verbinden und ebenfalls lösend und zersetzend auf das Gestein einwirken. Auch scheinbar nackte Felsen unterliegen ihrem Einfluß. In den Alpen und Pyrenäen, in den Vogesen und in der Auvergne fand Mustz ${ }^{6}$ nicht bloß die Felsflächen, sondern sogar die feinsten Gesteinsporen mit mikroskopischen Organismen bedeckt, die ihren Kohlen- und Stickstoffbedarf unmittelbar der Luft entnehmen und bei ihrem Absterben diese Stoffe dem Gestein überlassen. Das Faulhorn in der Schweiz ist von solchen nitrifizierenden Organismen bis in den Kern hinein durchfressen. Auf diese Pioniere der Humusbildung folgen dann niedere Pflanzen, die ihren Stickstoffbedarf aus dem Boden beziehen. Winde führen die Keime von Schorfflechten herbei, die an der befeuchteten Felsfläche kleben bleiben und ohne eigentliche Wurzeln festen Fuß fassen. Bald bedecken sie den Felsen mit farbigen, staubartigen Überzügen und zerstören allmählich durch ihre Verwesungsprodukte den mütterlichen Boden. So arbeiten viele Generationen mikroskopischer Organismen an der Herstellung einer Erdkrume, die endlich auch weniger genügsame Pflanzengeschlechter ernähren kann, während die ursprüngliche Vegetation immer mehr an Boden verliert. Je mächtiger die Erdkrume wird, desto dichter und mannigfaltiger wird die Pflanzendecke, bis sich endlich auch Bäume ansiedeln, die durch ihre tieftreibenden Wurzeln teils mechanisch, teils chemisch das Zerstörungswerk vollenden.

So arbeiten Luft, Wasser und Pflanzen seit ungezählten Jahrtausenden gemeinsam an der Umgestaltung der Erdoberfläche. Modifiziert wird aber dieser Prozeß durch die verschiedenen klimatischen Bedingungen und durch die Lagerungsverhältnisse des Gesteins. Je geneigter die Schichten, je reicher die Eruptivgesteine an Absonderungsklüften sind, desto rascher geht die Verwitterung vor sich. Die Gebirge sind daher vor allem der Sitz der zerstörenden Kräfte, auch deshalb, weil sie unter allen Umständen regenreicher sind als die angrenzenden Ebenen. In den Eisregionen der Hochgebirge und in der Polarzone schützt nicht einmal die Gletscherdecke völlig vor den Angriffen der Atmosphärilien, in noch höherem Grad unterliegen aber die nackten Felsen der zertrümmernden Gewalt des Frostes. In den tieferen Regionen der warmen Zone fehlt dieses Agens, aber um so kräftiger wirken die tropischen Regengüsse und 
die dichte Vegetation; und im großen und ganzen gilt der Satz, daß die Zerstörung des festen Gesteins und die Mächtigkeit des Verwitterungsschuttes nach den Polen abnimmt. In den Gebieten mit subtropischer Regenverteilung bewirkt die Sonnenstrahlung in der Trockenzeit ein kapillares Aufsteigen der Bodenfeuchtigkeit, und diese überzieht in Kalkgebieten den Boden mit einer Kalkkruste, wie $\mathrm{MAW}^{7}$ in Marokko und PASsARgE ${ }^{8}$ im algerischen Küstenatlas beobachtet haben. Theовald Fischen ${ }^{9}$ schreibt den kurzen Regengüssen, worauf schnell Sonnenschein mit starker Verdunstung folgt, eine entscheidende Rolle bei diesem Vorgang zu, durch den einerseits das Gestein chemisch zersetzt, anderseits aber vor Abtragung geschützt wird. In den Wüsten der Tropenund Subtropenzone ${ }^{10}$ überziehen sich alle, der Sonne ausgesetzten Gesteinspartien mit einer, meist nur Bruchteile eines Millimeters dicken. Haut von Eisen- und Manganoxyd, deren Farbe um so dunkler ist, je mehr Kieselsäure das Gestein enthält. Sie ist härter als das Gestein selbst und trägt daher mit Recht den Namen Schutzkruste, aber sie gewährt nicht absoluten Schutz, denn die Verwitterung ergreift die beschatteten Partien, erzeugt Höhlungen und zersetzt den Stein von innen nach außen. ${ }^{\times}$Das zweite Agens in den Wüsten sind die grellen Temperaturwechsel des Bodens. Bei Askabad an der transkaspischen Bahn wurde der Lößboden an einem Julitag auf $71^{\circ}$ erhitzt und kühlte sich in der darauffolgenden Nacht auf $26^{\circ} \mathrm{ab}$, während die Lufttemperatur nur zwischen 40,5 und $27^{\circ}$ schwankte. Es kann daher nicht wundernehmen, wenn gewaltige Steinblöcke unter dem Einfluß der Insolation bersten; auch die Abschuppung der Gesteine ist als eine unmittelbare Wirkung der Sonnenstrahlen erkannt worden. Anderseits macht aber die Trockenheit der Luft stellenweise die Erhaltung der feinsten Oberflächenformen möglich. Тн. FucHs fand z. B. auf dem Isthmus von Suës noch Wellenschlagspuren in der Umgebung der Bitterseen, Räderspuren im Sand des Kabretplateaus waren noch nach zwölf Jahren unverwischt, und Fouread konnte in der Sahara 1892 die Spuren von Kamelen, die nachweisbar 1877 die betreffende Stelle passiert hatten, noch deutlich erkennen. So hat jedes Klimagebiet seine eigentümliche Verwitterungsform, die dem Relief ein charakteristisches Gepräge verleiht.

$\times$ Die Schutzrindenbildung ist übrigens nicht, wie man angenommen hat, auf die Wüste beschränkt, denn Du Bors fand sie auch im feuchten Surinam, selbst im dichtesten Urwald, und Vouz in den Battakländern Sumatras, sowohl im Urwald, wie in offenen Grasfluren. 
Bodenarten. ${ }^{11}$ Unter allen Umständen ist es aber das Ziel der Verwitterungskräfte, den festen Felsen in Steinschutt (Blöcke, Geröll, Grus und Sand) aufzulösen. Dieser bildet den sog. Gerölloder Schuttboden. Schreitet die chemische Zersetzung weiter fort, so entsteht die pulverartige Erdkrume, das letzte Verwitterungsprodukt aller tonerdehaltigen Mineralien. Steinschutt in Verbindung mit Erdkrume gibt den sog. Mineral- oder Rohboden, der nach seiner Zusammensetzung und daher auch nach seiner landwirtschaftlichen Brauchbarkeit in mehrere Arten eingeteilt wird. Besteht die ganze Bodenmasse aus mindestens 80 Prozent Sand, so nennt man ihn Sandboden. Tonboden enthält wenigstens 65 Prozent Tonsubstanz, Lehmboden ist ein Gemenge von Ton und sehr feinem Sand, und Mergelboden ein Gemisch von höchstens 75 Prozent Ton und wenigstens 15 Prozent Kalk nebst verschiedenen anderen Beimengungen. Mit dem Rohboden vermischen sich mehr oder weniger Pflanzenreste; besteht wenigstens die Hälfte des Bodens aus festen Humussubstanzen und der Rest aus anderen Erdarten, so wird er als Humusboden bezeichnet. Bei seiner Bildung sind - wie DARwiN ${ }^{12}$ nachgewiesen hat - die Regenwürmer in hervorragender Weise beteiligt. Indem sie unglaubliche Mengen Erde, mit Vegetabilien gemischt, verschlingen und wieder ausscheiden, werden immer neue Oberflächen der Einwirkung der Kohlen- und Humussäuren preisgegeben, und die Zersetzung wird dadurch außerordentlich gefördert. ${ }^{\times}$In den Tropen geht dieser ProzeB mindestens dreimal so schnell vor sich wie in England. Ameisen in Verbindung mit zahlreichen anderen im Boden lebenden Tieren sind die eifrigsten Helfershelfer der Regenwürmer, namentlich in trockenen Gegenden, und auf den Koralleninseln üben verschiedene Krebse dieselbe geologische Tätigkeit aus. ${ }^{13}$ Die Kulturfähigkeit des Boden hängt von der Art und Menge jener unorganischen Bestandteile ab, die, wie Tonerde, kohlensaurer Kalk u. a., die Nährstoffe der Pflanzenwelt bilden. Die landwirtschaftliche Benutzung wird wesentlich erleichtert, wenn der Untergrund der Ackerkrume locker ist, und in diesem Punkt sind trockene Länder den feuchten überlegen. HILGARD ist auf Grund umfassender Studien in den Vereinigten Staaten überhaupt zum Schluß gelangt, daß trockenes Klima nicht kulturfeindlich ist, wie man gewöhnlich urteilt, natürlich stets unter der Voraussetzung künstlicher Bewässerung. So ist z, B. Sandboden nur im feuchten Klima unfruchtbar, im trockenen aber enthält er neben Quarz auch andere Mineralpartikelchen, und sein Humusgehalt ist

× So wurde z. B. in der Nähe von Maer-Hall innerhalb zehn Jahre ein sandiges Grasfeld mit einer $50 \mathrm{~mm}$ dicken Humusschicht überkleidet. 
zwar gering, aber reich an Stickstoff, weil er hauptsächlich von den Wurzeln herstammt, nicht von den oberirdischen Pflanzenteilchen, wie in regnerischen Gebieten. Die Mächtigkeit des Gesamtbodens (Humus- und Rohbodens) ist sehr verschieden; für die meisten Kulturgewächse sind nur die obersten $30-60 \mathrm{~cm}$ maBgebend, nur die Waldbäume treiben ihre Wurzeln beträchtlich tiefer.

Gebiete vorherrschender Denudation. Auf völlig horizontalem Felsboden häufen sich die Verwitterungsprodukte an; nur die feinsten können vom Wind weit fortgeführt werden. Ist der Boden aber wie dies in der Regel der Fall ist - geneigt, so bemächtigt sich das fließende Wasser (und das Eis) des Schuttes. Daneben wirkt auch die Schwerkraft, je nach dem Böschungswinkel, bald unscheinbar langsam, bald katastrophenartig. Schon Davison ${ }^{14}$ hatte ein langsames Abwärtskriechen des Gehängeschuttes beobachtet, das er auf Ausdehnnng und Zusammenziehung infolge wechselnder Temperatur zurückführte; GöTzINGER ${ }^{15}$ hat diese Feinbewegung, als deren wesentliche Vorbedingung er die Durchtränkung des Bodens erkannte, im Wiener Wald gemessen, und Andersson ${ }^{16}$ hat sie auf der Bäreninsel studiert und dafür den Ausdruck Solifluktion vorgeschlagen. Man kann daher eine nasse nnd eine trockene Abfuhr unterscheiden, wenn auch in der Natur gewöhnlich beide zusammenwirken. Das Endziel des Denudationsprozesses ist die BloBlegung des' verwitterten Felsbodens, wodurch den Atmosphärilien wieder neue Angriffspunkte geboten werden.

Es gibt Gebiete, in denen die Abtragung der Verwitterung das Gleichgewicht hält, und wo es daher niemals zur Bildung eines Verwitterungsbodens kommt. Reichliche Niederschläge und starke Neigung des Bodens sind notwendige Vorbedingungen dieses Vorganges, der daher hauptsächlich nur auf die steilen Abhänge der Gebirge beschränkt ist. In den gebirgigen Teilen des Festlandes finden die zerstörenden Kräfte den freiesten Spielraum. ${ }^{17}$ Schafft die Erosion die Gegensätze von Berg und Tal, so

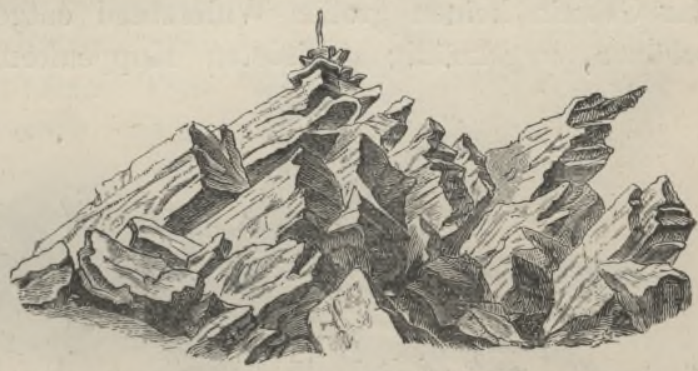

Fig. 112. Schwarzhorn im Wallis (3207 m) nach Herm. arbeitet die Verwitterung vorwiegend an der Form der Gipfel und Gehänge. Je steiler die Schichten aufgerichtet sind, je zahlreicher die Spalten, je verwitterbarer die Gesteine, desto ruinenhafter erscheinen die 
Kämme und Gipfel. Bei der unendlichen Mannigfaltigkeit ihrer Formen muß man freilich auf einfache morphologische Gesetze verzichten, nur

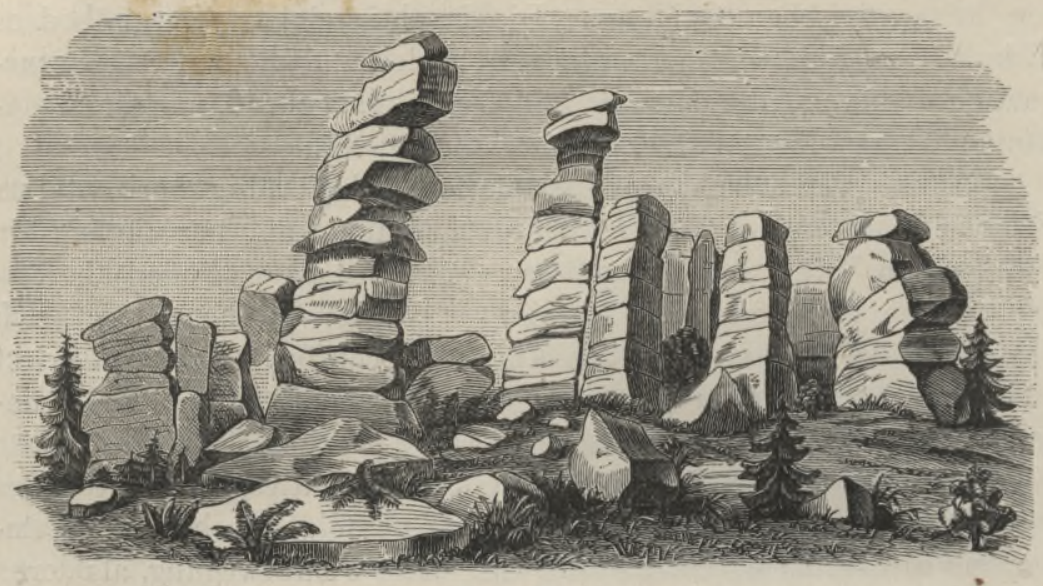

Fig. 113. Königstein.

von einigen besonders auffallenden Typen kann hier die Rede sein. Wirkt die Verwitterung gleichförmig nach allen Richtungen, und setzt ihr

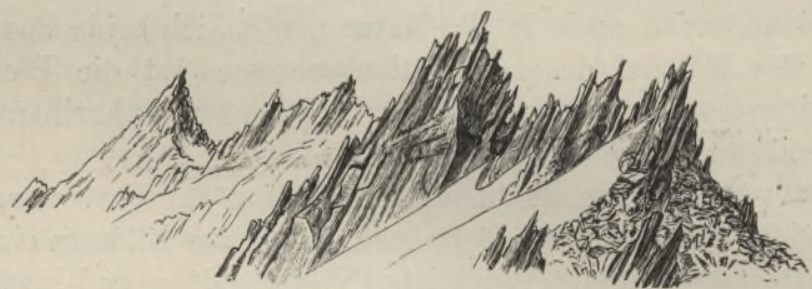

Fig. 114. Aclettagrat nach HEIM.

das Gestein keinen großen Widerstand entgegen, so entstehen die schönen, regelmäßig gebildeten Kuppenformen, wie sie manche

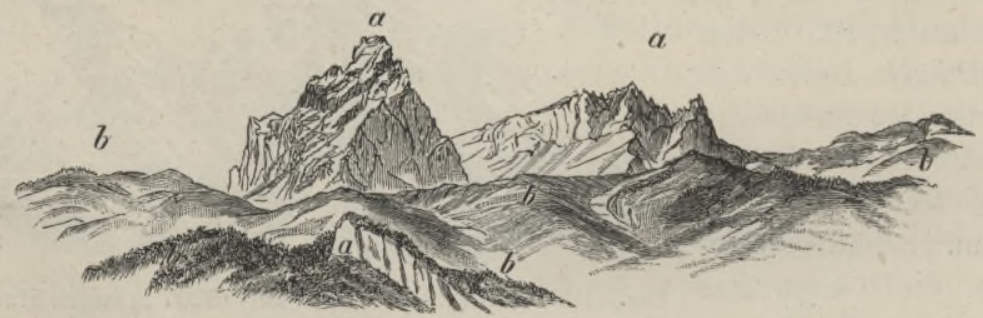

Fig. 115. Mythen nach Herm. ( $a$ fester Kalkstein, $b$ Schiefer oder Flysch.)

Massengesteine (Porphyre, Granit, Gabbros usw.) zeigen. Sind die Klüfte aber zahlreich, so lösen sich die Gipfel häufig in unförmliche 
Blockhaufen auf (Fig. 112). Felsenmeere nennt man sie, wenn sie eine größere Ausdehnung erreichen. Die große Mehrheit der Pyrenäengipfel sind nach LEYMERIE solche Trümmerhaufen, und zwar nicht blob die Granit-, sondern auch die Kalkberge; ebenso schildert Deckert die Gipfel des Felsengebirges als ein Haufwerk scharfkantiger Blöcke. Werden im Lauf der Zeit Blöcke weggeführt, so bildet der Rest oft Säulenruinen, wie z. B. der Plöckensteingranit im Böhmer Wald (s. Fig. 113) oder der Sandstein in den Vogesen und der. Sächsischen Schweiz. Manche Bergspitzen sind so verwittert, daß man - um mit Heim zu reden - ,mittelst Hebeeisen den ganzen Gipfel schleifen könnte, ohne einen, zusammenhängenden festen Block von einem Meter Durchmesser zu finden". Mit

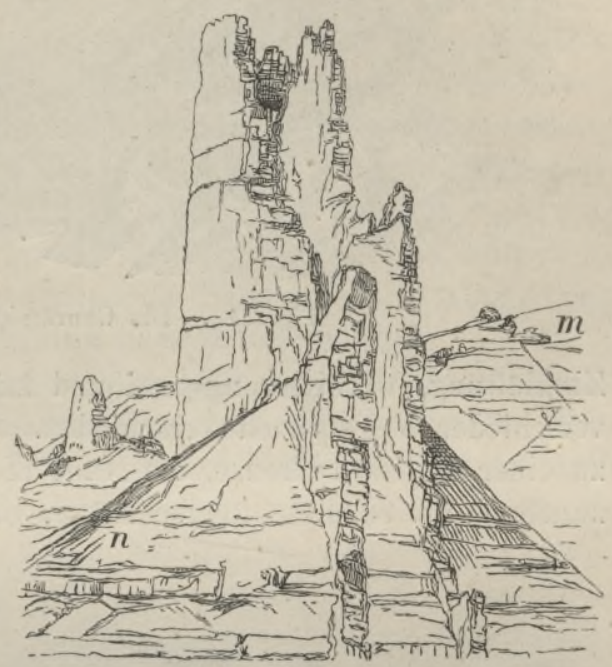

Fig. 116.

Aus dem Coloradogebiet (zwei Trachytgänge im horizontalen Sandstein $n$ ) nach HaYDEN.

Recht tragen viele Gipfel Namen, wie „Fauler“, „Faulberg“, „Faulhorn“ und dergleichen. In den Zonen der oft senkrecht stehenden kristallinischen Schiefer sind wild zerrissene Kämme und kühn geformte Gipfel sehr häufig (Fig. 114), aber es fehlt auch nicht an Beispielen vom entgegengesetzten Extrem. So bildet der leicht verwitterbare Tonschiefer in der spanischen Sierra Nevada langgezogene Rücken, über die sich die beiden höchsten Punkte (Veleta und Mulhacen) kaum merklich erheben. Wechseln Gesteine von ver-

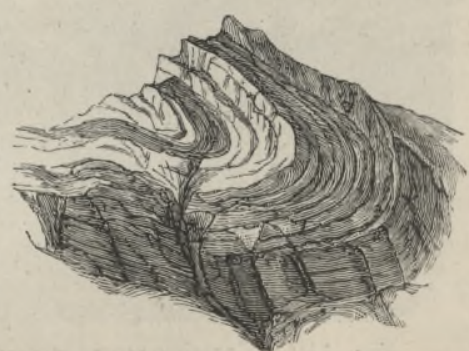

Fig. 117. Sichelkamm nach Herm. schiedener Widerstandskraft miteinander $a b$, so werden die härteren durch die Verwitterung gleichsam herausmodelliert, wie zwei drastische Beispiele aus der Natur in Fig. 115 und 116 zeigen. Fig. 117 belehrt uns endlich, welche Kammform gebogene Sedimentschichten annehmen können.

In bezug auf die Gehängeform unterscheiden sich die Sedi- 
mentgesteine wesentlich von den kristallinischen Schiefern. Der Böschungswinkel ist unter sonst gleichen Umständen — wie Lagerung,

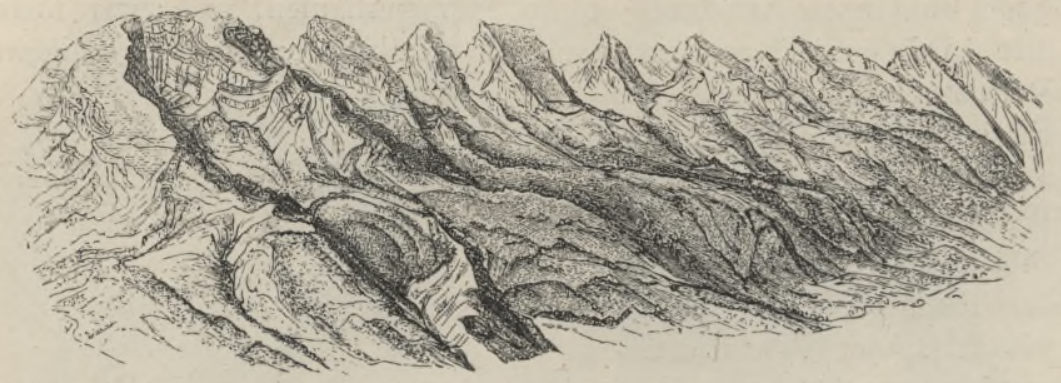

Fig. 118. Die Churfirsten nach Herm.

Zerklüftung, Verwitterungsgrad und klimatische Verhältnisse - bei verschiedenen Felsarten verschieden. Seine Steilheit kann nur bis zu einer gewissen Grenze, die Heıм die Maximalböschung nennt, zunehmen; wird diese überschritten, so brechen die oberen Massen

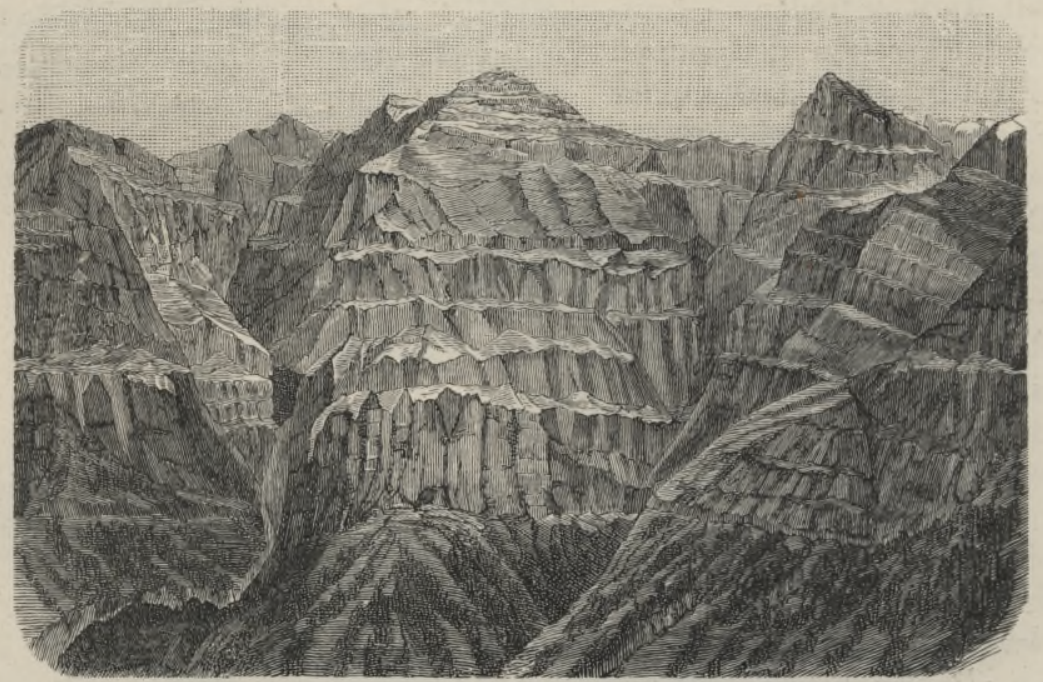

Fig. 119. Verwitterungsterrassen im Glärnisch-Gebirge nach BaLtzer.

schneller oder langsamer nach, stürzen hinab, und Kamm und Gipfel werden erniedrigt. So haben die nach oben fortschreitenden Schluchten den ursprünglich gerade verlaufenden Grat der Churfirsten in 9-11 Zacken zerschnitten (Fig. 118).

Im allgemeinen ist die Maximalböschung am gröBten bei Kalksteinen und Dolomiten, kleiner bei Sandsteinen und Quarziten, am kleinsten bei Schiefern. Da bei einem aus verschiedenen Sediment- 
gesteinen bestehenden Berg die Maximalböschung von Schicht zu Schicht wechselt, so entstehen ungleichmäßig geneigte Abhänge mit sog. Bandstruktur, d. h. mit flach geneigten Denudationsterrassen, die den weicheren Schichten entsprechen (Fig. 119). Bei den kristallinischen Schiefern bleibt dagegen in der Regel die Maximalböschung. den ganzen Abhang entlang gleich. Als eines der schönsten Beispiele nennt Heim den Bristenstock (in der Schweiz), wo mit Ausnahme einer ganz unbedeutenden Einbiegung der ganze Abhang unter einem Winkel ron $36^{\circ}$ geneigt ist. Die kristallinischen Schiefer nehmen übrigens, wenn sie flach gelagert sind, eine ähnliche Verwitterungsform an wie die Sedimentgesteine, anderseits tritt auch bei den Sedimentgesteinen die Bandstruktur zurück, wenn sie steil aufgerichtet, dünnschichtig oder schieferig sind.

Es $m u B$ übrigens bemerkt werden, daß die wirkliche Böschung nicht immer der Maximalböschung entspricht. Sie ist größer, wenn das fließende Wasser durch Abtragung und Unterwaschung so rasch arbeitet, daß die Verwitterung nicht gleichen Schritt halten kann; sie ist kleiner im umgekehrten Fall. Senkrechte oder überhängende Wände sind verhältnismäßig selten und stets örtlich beschränkt; wenn trotzdem häufig solcher Erwähnung geschieht, so kommt dies daher, daß das ungeübte Auge nichts so sehr überschätzt : wie Böschungswinkel. Die abgestürzten Steine sammeln sich am Fuß der Berggehänge zu.Schutthalden an, die um so steiler sind, je massiger, eckiger, grobkörniger und rauhbrüchiger die Trümmer sind. PIWOWAR $^{18}$ hat eine große Zahl solcher auf trockenem Weg gebildeten Ansammlungen gemessen und Maximalböschungen von 20 bis $43^{\circ}$ gefunden. Der Böschungswinkel der vom Wasser abgelagerten Schuttkegel nimmt von ungefähr $30^{\circ}$ im obersten Teil nach unten ab.

Die außerordentliche Gewalt des spülenden Regens in lockeren Massen illustrieren am besten die gruppenweise oder vereinzelt auftretenden Erdpyramiden (Fig. 120), deren Entstehung Fig. 121 erläutert. KITTLER ${ }^{19}$ hat die allgemeine Verbreitung dieser einst für eine Seltenheit geltenden Erosionsform nachgewiesen, und auch seine Aufzählung erhebt noch nicht Anspruch auf Vollständigkeit. Wo Regengüsse, die ungleichmäßig über das Jahr verteilt sind, auf leicht zerfallende und doch wieder fest zusammenhaltende Schuttmassen einwirken, und Bäche für die rasche $\mathrm{Abfuhr}$ des Materials sorgen, da sind die Bedingungen für Erdpfeiler gegeben. GüNTHER ${ }^{20}$ unterscheidet in Tirol, dem klassischen Land der Erdpyramiden, drei Typen: in Südtirol sind die Obelisken mit einem Steinblock oder einem Rasenstück oder einem Baum gekrönt, Nordtirol hat ein- 
fache Spitzsäulen ohne ein Schutzmittel, und in Osttirol treten lange, scharfschneidige Kämme an ihre Stelle. Diesen östlichen Typus betrachtet GüNTHER als die Embryonalform, die noch der Auflösung in Pfeiler harrt, und findet dies dadurch bestätigt, daß man bei genauerem Zusehen stets eine lineare Anordnung der Pyramiden entdeckt, so daß die vorderen die hinteren verdecken. Nur darüber gehen die Meinungen auseinander, ob das Vorkommen von Steinblöcken im Schutt eine notwendige Vorbedingung zur Entstehung

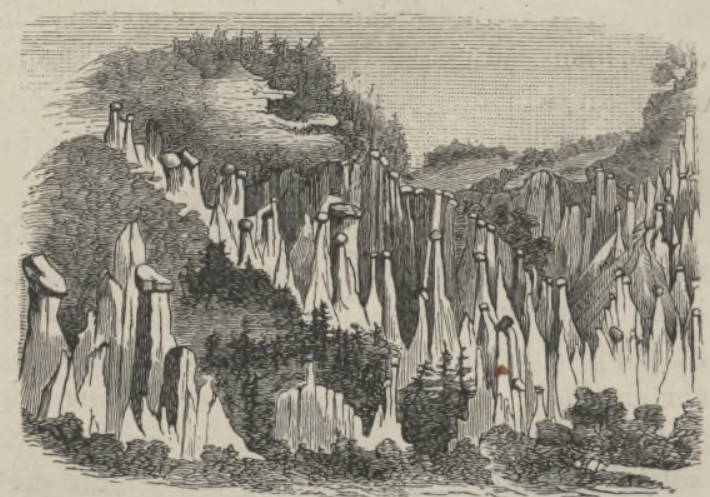

dieser merkwürdigen Erosionsgebilde sei. SAUER $^{21}$ bejaht es; die Steine, ob groß oder klein, schützten den Schutt vor Abspülung; war aber einmal der erste Schnitt hinter dem Stein gemacht, so war dessen Aufgabe beendet, under wurde Fig. 120. Erdpyramiden bei Bozen in Südtirol $(8-30 \mathrm{~m} \mathrm{H}$.). überflüssig. Nicht bloß Schuttmassen, besonders glaziale, auch Talwände aus mürbem Gestein, das in trockenem Zustand einen gewissen Zusammenhalt besitzt, im nassen aber zerfällt, lösen sich in Pyramiden auf, wie CAPEDER ${ }^{22}$ aus der

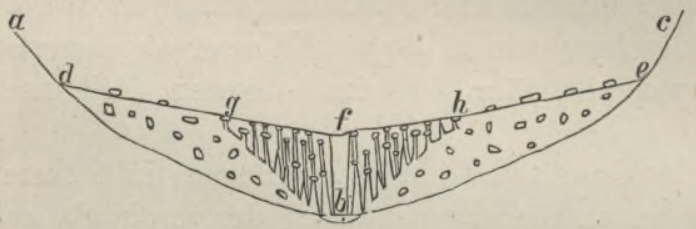

Fig. 121. Durchschnitt zur Erklärung der Bildung der Erdpyramiden nach LyelL. $a b c$ die Wände und die Sohle des im Porphyr ursprünglich ausgewaschenen Tales. $d f e$ die Ausfüllung des Tales durch den Moränensehutt eines alten Gletschers. $g b h$ jetziger Taleinschnitt mit Erdpyramiden zu beiden Seiten.

Umgegend- von Bra und Castellamonte in Piemont und RIKLI ${ }^{23}$ aus Corsica berichten. In der Umgebung von Melbourne wird der lehmige Sandstein in ähnlicher Weise ausgewaschen, so daß nur noch vertikale Säulen unter vorspringenden Teilen der Kalkdecke stehen bleiben.

Neben der regelmäBigen Denudationsarbeit, die den Verwitterungsschutt zu Tal führt, um ihn allmählich mit Hilfe des fließenden Wassers in die Ebene hinauszuschaffen, gibt es auch katastrophenartige Ereignisse, die große Massen auf einmal von den Anhöhen in das Tal befördern. Nach lange andauernden Regengüssen ver- 
wandeln sich die Wildbäche nur allzuhäufig in gewaltige Schlammund Schuttströme (sog. Muren), die weite Talstrecken überschütten. ${ }^{24}$ Durch solche Muren wurden z. B. in den Jahren 1874 und 1875 bei Ried im Oberinntal 320000 cbm Schutt angehäuft. Seltener, aber noch verheerender sind die Berg- und Felsstürze, ${ }^{25}$ wodurch das oft jahrhundertelang angehäufte Verwitterungsmaterial, hier und da auch kolossale, durch den Frost losgelöste Felsblöcke, manchmal durch unbekannte Ursachen aus dem Gleichgewicht gebracht, in stürzende Bewegung geraten. Erdbeben geben häufig Veranlassung dazu; dies war der Fall beim Absturz der Schlaggendorfer Spitze in der Tatra (1662), wodurch sie ungefähr $300 \mathrm{~m}$ an Höhe verlor, und bei dem Einsturz der Südseite der Villacher Alp (25. Januar 1348), durch den 13 Dörfer begraben wurden. Längs der Schichtoder Klufttlächen, die gegen das Tal einfallen, können nicht nur lose Anhäufungen, sondern auch ganze Felsmassen abrutschen, wenn ihre Kohäsion durch Spaltenbildung gelockert und ihre Unterlage durch starke Regengüsse oder abgelenkte Quellen durchweicht ist. Der Sturz des RoBberges am 2. September 1806, der vier Dörfer verschüttete, ist eine der bekanntesten Katastrophen dieser Art. Leider treten sie in nassen Jahren im Gebirge häufig ein. Nach Aretin schweben in Tirol 300000 Menschen in steter Lebensgefahr, und Simony veranschlagte den jährlichen Schaden auf durchschnittlich eine Million Mark. Der Unverstand der Menschen unterstützt noch die zerstörenden Kräfte, indem natürliche Widerlager, welche die zum Rutschen geneigten Massen stauen, leichtsinnigerweise weggeräumt werden. So veranlaßte z. B. die Anlage von Steinbrüchen bei Elm jenen furchtbaren Bergschlipf am 11. September 1881, der nicht bloB den Talboden, sondern auch den unteren Teil der gegenüberstehenden Lehne mit einer Schuttmasse von zehn Millionen Kubikmetern bedeckte. In manchen Gegenden setzen sich kleinere Rutschungen durch Jahrhunderte hindurch fort. In Tälern, die das Wasser in lockerem Material ausgegraben hat, sind Bewegungen der Massen infolge ihrer eigenen Schwere eine regelmäßige Erscheinung.

Gebiete säkularer Verwitterung. Neben diesen Gebieten einer kräftigen Denudation, wo die Verwitterung stets neue Angriffspunkte findet, gibt es auch weite Erdräume mit warmfeuchtem Klima, wo unter dem Schutz einer dichten, tiefgreifenden Waldvegetation, welche die Abfuhr der Verwitterungsprodukte hindert, der ZersetzungsprozeB von den Klüften und Fugen konzentrisch gegen das Innere des Felsbodens fortschreitet und ihn im Lauf langer Zeiträume bis zu bedeutender Tiefe in ein Haufenwerk von eckigen Gesteinsfragmenten, Grus und sandigen und tonigen 
Massen verwandelt, während der Denudationsprozeß sich hauptsächlich auf die Fortführung der Karbonate beschränkt. Pumpelly, der auf diesen Vorgang besonders aufmerksam gemacht hat, bezeichnete ihn als säkulare Verwitterung. Ihre Gebiete teilt von Richthofen in Regionen der Lateritbildung und in solche der lehmigen Zersetzung. Der Begriff Laterit ist schwankend, doch stimmen alle darin überein, daB diese Verwitterungserde nur in den Tropen vorkommt. ${ }^{\times}$Sie unterscheidet sich nach BAUER, ${ }^{26}$ dem sich Holuand ${ }^{27}$ anzuschließen scheint, von den lehmigen Verwitterungsprodukten der gemäBigten Zone oder der ihr entsprechenden Gebirgsregionen der warmen Zone durch die Abwesenheit von Kieselsäure und durch fast regelmäBige Verunreinigung von Eisenhydroxyd, das ihm die charakteristische ziegelrote Farbe verleiht. Dagegen fand $\mathrm{Du} B \mathrm{Brs}^{28}$ die eluvialen Laterite in Surinam reich an Kieselsäureverbindungen, die nur in den alluvialen Vorkommnissen zugunsten der Hydrate zurücktreten. VoLz ${ }^{29}$ unterscheidet zwischen Bunterden und Laterit und beschränkt die letztere Bezeichnung nur auf die leuchtend roten bis gelben Vorkommnisse mit schlackigen Eisenkonkretionen. Er ist auch der Ansicht, daB die Lateritbildung der geologischen Vergangenheit angehört, und daß die nahe verwandten alluvialen Bunterden als eine Vorstufe dazu anzusehen seien. Nach anderen sind auch gegenwärtig noch die Bedingungen zur Lateritbildung vorhanden. Du Bors weist die wichtigste Rolle dabei der Schwefelsäure zu, die den Pyriten des Muttergesteins entstammt, und das tropische Klima wirke nur insofern mit, als es eine energische Zersetzung des Gesteins * begünstigt.. Dagegen meint J. WALther, daß bei den zahlreichen Gewittern dieses Erdgürtels in der Luft genügend viel Salpetersäure entstehe, um in hohem Grad oxydierend auf die Gesteine einzuwirken; und in der Tat bat die Analyse des Regenwassers von Caracas den hohen Salpetersäuregehalt tropischer Gewitterregen bestätigt. ${ }^{30}$ In den Anschnitten, z. B. in den Gräben, überzieht sich der Laterit mit einer schlackenartigen, glänzenden Rinde, die im Verein mit seiner Porosität den Boden unfruchtbar macht. In Vorder- und Hinterindien, im brasilianischen Gebirge und in Afrika von Senegambien bis zum Kapland ist er außerordentlich häufig und erreicht stellenweise eine Mächtigkeit bis zu $60 \mathrm{~m}$; sein Vorkommen im mittleren und südlichen China deutet auf eine Klimaänderung hin. In der gemäBigten Zone sind hauptsächlich die östlichen Staaten der Union im Süden der dilu-

$\times$ Der dem Laterit nahe verwandte Bauxit unserer Breiten stammt entweder aus einer früheren wärmeren Klimaperiode oder bildet sich jetzt noch unter ganz ausnahmsweisen Bedingungen. 
vialen Gletschergrenze von einer mächtigen Verwitterungsrinde, dem Produkt des einstigen Urwaldes, bedeckt.

In einigen Gebieten säkularer Verwitterung wurde das Felsgerüst infolge von Klimaschwankungen in vorgeschichtlicher Zeit oder von Niveauveränderungen, die eine erhöhte Erosionstätigkeit hervorriefen, wieder bloßgelegt und zeigt nun eigentümliche unregelmäßige Oberflächenformen, einen Wechsel von Erhöhungen und Vertiefungen, die der Verbreitung widerstandsfähiger und leicht zerstörbarer Gesteine entsprechen. In der Mongolei gab wahrscheinlich eine starke Verminderung der Niederschläge die Veranlassung dazu. Die Vegetation starb infolgedessen $\mathrm{ab}$, und der Wind bemächtigte sich der feineren Verwitterungsprodukte, während der gröbere Schutt zurückblieb. Sogar die Grundmoränen diluvialer Gletscher hält Pumpelux für umgearbeiteten Verwitterungsschutt. ${ }^{31}$ Hier betreten wir aber bereits das Gebiet der reinen Hypothese, wie ja überhaupt in bezug wauf die Eluvialbildungen die Ansichten noch sehr der Klärung bedürfen.

Literaturnachweise. 1 G. P. MerriL, A Treatise on Rocks, RockWeathering, and Soils; New York 1897. J. G. Russell, Subaëral Decay of Rocks, Nr. 52 des Bulletin of the U. S. Geological Survey, 1889. N. S. Shaler The Origin and Nature of Soils, im XII. Annual Report of the U. S. Geological Survey, Part I, mit lehrreichen Abbildungen. J. Hraschwald, Die Prüfung der natürlichen Bausteine auf ihre Wettêrbeständigkeit, Berlin 190s. Einen Auszug des Wichtigsten gab der Verfasser in der Zeitschrift für praktische Geologie 1908, Bd. XVI, S. 257, 375 und 464. - ${ }^{2}$ G. Culbertson in den Proceedings of the Indiana Academy of Science, 1899, S. 167. - ${ }^{3}$ Тн. Thoroddsen, Island, S. 7. -4 G. Andersson, in den Verhandlungen der Stockholmer Geologisehen Gesellschaft, 1901, Bd. XXIII, S. 521. - ${ }^{5}$ J. Rотн, Lehrbuch der chemischen Geologie, Bd. I, Berlin 1879. - ${ }^{6}$ Muntz, in den Comptes rendus de l'Aeadémie des Sciences, Paris 1890 , Bd. CX, S. 1370. - ${ }^{7}$ J. D. Hooker, Journal of a Tour in Maroc, London 1878. - ${ }^{8}$ S. PAssarge, Verwitterung und Abtragung in den Steppen und Wüsten Algeriens, in den Verhandlungen des XVII. Deutschen Geographentages, Berlin 1910. - 9 Theoвald Fischer, Wissensehaftliche Ergebnisse einer Reise im Atlasvorland von Marokko, Gotha 1900. ${ }^{10} \mathrm{~J}$. Walther, Das Gesetz der Wüstenbildung; Berlin 1900. - ${ }^{11}$ E. Ramann, Bodenkunde, 2. Aufl.; Berlin 1905. E. W. Hrlgard, Soils, New York 1906. F. H. Krna, The Soils, New York 1907. - ${ }^{12}$ Сн. Darwin, Die Bildung der Ackererde durch die Tätigkeit der Würmer; Stuttgart 1882. - ${ }^{13}$ C. Keller, Reisebilder aus Ostafrika und Madagaskar; Leipzig 1887. W. НАAскE, Über die geologische Tätigkeit der Ameisen, in ,Zoologischer Garten“; Frankfurt a. M. 1886. O. Lenz, Die Bedeutung der Termiten für Erdbewegung, in den Mitteilungen der Wiener Geographischen Gesellschaft 1894. J. C. Branner, Ants as Geologieal Agents in the Tropies, im Journal of Geology 1900. - ${ }^{14}$ CH. Davison, im Geological Magazine 1889, S. 255. - ${ }^{15}$ G. Götzisaer, Beiträge zur Entstehung der Bergrückenformen, Leipzig 1907. - ${ }^{16}$ J. G. Andersson, Contributions to the Geology of the Falkland Islands, in den Wissenschaftlichen Ergebnissen der Schwedischen Südpolarexpedition, Stockholm 1907. - ${ }^{17}$ A. Нвгм, Über die Verwitterung im Gebirge; Basel 1579. - ${ }^{18}$ A. Prwowar, in der Vierteljahrs- 
schrift der Naturforschenden Gesellschaft in Zürich, 1903, Bd. XLVIII, S. 335. -

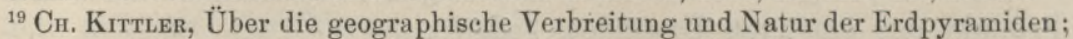
München 1897. Ergänzungen und Berichtigungen bot A. v. Вӧнм in seinem Referat in Petermans's Mitteilungen 1899, Literaturbericht Nr. 42. S. anch die Mitteilung von C. R. Exock im Geographieal Journal, 1908, Bd. XXXI, S. 684. - ${ }^{20}$ S. Günthen in den Sitzungsberichten der Bayerisehen Akademie der Wissenschaften, Mathem.-physik. Klasse, 1902, Bd. XXXII, S. 459; und 1904, Bd. XXXIV, S. 397. - ${ }^{21}$ L. Sauer, Die Erdpyramiden in den Alpén, im Jahresbericht des Friedrich-Wilhelm-Realgymnasiums in Stettin, 1904. ${ }^{22}$ G. Capeder im Bolletino de la Società Geologica italiana, 1899, Bd. XVIII, S. 309. - ${ }^{23}$ M. RIKLI in der Vierteljahrsschrift der Naturforschenden Gesellschaft in Zürich, 1902, Bd. XLVII, S. 243. - ${ }^{24}$ J. Strsx́, Das Murenphänomen, in den Mitteilungen des Deutschen Naturwissenschaftlichen Vereins beider Hochschulen, Graz 1907. - ${ }^{25}$ A. Негм, Über Bergstürze; Zürich 1882. M. Nedmayr, Über Bergstürze, in der Zeitschrift des D. und Ö. Alpenvereines, 1889. 26 M. Bauer, Über die Natur des Laterits in Petermans's Mitteilungen 1898. ${ }^{27}$ T. H. Holland, im Geological Magazine, 1903, Bd. X, S. 59. - ${ }^{23}$ G. C. Du Bors, in Tschermak's. Mineralogischen und petrographisehen Mitteilungen, 1903, Bd. XXII, S. 1. - ${ }^{29}$ W. Vouz, Nordsumatra, Bd. I, Berlin 1909. - ${ }^{30}$ Muntz und Marcano, Über den Salpetersäuregehalt tropischer Regen, in der Meteorologischen Zeitschrift 1889. - ${ }^{31}$ R. Pumpeluy, im American Journal of Seience 1879, Bd. I, S. 133.

\section{Das Bodenwasser. ${ }^{1}$}

Der Kreislauf des Wassers. Von den Niederschlägen fließt ein Teil oberflächlich $a b$, ein Teil verdunstet, ein Teil wird von den Organismen aufgenommen und kehrt erst nach deren Tod wieder in den Kreislauf des Wassers zurück, und etwa ein Drittel versinkt in den Erdboden, um an anderen Stellen wieder zutage zu treten.

Gegenüber dieser wohlbegründeten Theorie versuchen sich von Zeit zu Zeit immer wieder andere Anschauungen zur Geltung zu bringen. Nachdem Volger, der das Bodenwasser allein auf die Kondensation des durch die "Grundluft" in das Erdinnere eindringenden Wasserdampfes zurückführte, von $\mathrm{HANN}^{2}$ gründlich widerlegt worden war, hat in neuerer Zeit KoENI ${ }^{3}$ wieder ähnliche Ansichten ausgesprochen, zugleich aber auch dem Meer einen wichtigen Anteil an der Entstehung des Bodenwassers zugeschrieben. Nach dieser Auffassung, die auch KutPERs ${ }^{4}$ teilt, soll das Meerwasser in die Lithosphäre gelangen und hier in Dampf verwandelt werden, und indem dieser in die Höhe steigt, soll er durch Kondensation das Bodenwasser ernähren. Was grundsätzlich dagegen einzuwenden ist, ist bereits an einer früheren Stelle (S. 405) erörtert worden.

Der Kreislauf des Wassers ist nicht vollständig. Ein Teil wird ihm bei der Umwandlung wasserfreier in wasserhaltige Mineralien auf lange Zeit, vielleicht dauernd entzogen. Unser Planet würde einer völligen Austrocknung entgegengehen, käme ihm nicht Ersatz 
aus seinem Innern, ein Ersatz, der freilich auch nicht von ewiger Dauer ist. Von den Quellen sind die einen in ihrer Wassermenge und in der Menge und im Mischungsverhältnis ihrer gelösten Stoffe von den Schwankungen der Niederschläge abhängig, während sich die anderen das ganze Jahr hindurch gleich bleiben. Das deutet auf verschiedenen Ursprung. Die ersteren, die man jetzt mit E. Suess ${ }^{5}$ vados nennt, stammen aus der Atmosphäre, die zweiten, die juvenilen, sind ein Ergebnis des allmählichen Entgasungsprozesses des Magmas, dessen Wasserstoff sich mit dem Sauerstoff der Atmosphäre verbindet. Alles vadose Wasser war einst juvenil, kann aber niemals wieder in den juvenilen Zustand zurückkehren.

Das Grund- und Schichtwasser und ihre Quellen. Obwohl keine Bodenart absolut wasserundurchlässig ist, da selbst feste Gesteine von mikroskopischen Poren und Haarspältchen durchzogen werden, so ist doch das Verhalten der verschiedenen Bodenarten gegenüber

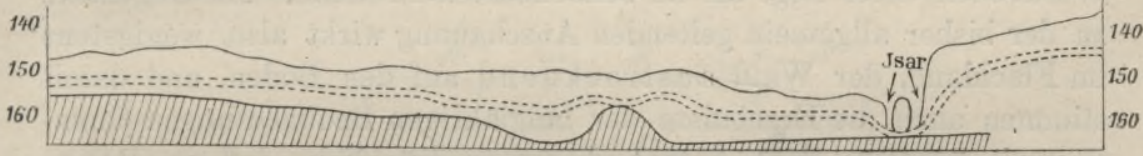

Fig. 122. Profil des Bodens von München nach Sorka.

Über dem undurchlässigen Flinz (schraffiert) liegt Schotter, der das Grundwasser (punktiert) führt.

dem Wasser sehr ungleichmäßig. Undurchlässig sind Ton, Mergel und Lehm, wenn sie erst einmal Wasser aufgenommen haben. Liegen sie an der Oberfläche, so kommt es zu keiner Quellbildung. Ist solcher Boden eben, so versumpft er; ist er geneigt, so fließt das Wasser rasch ab; bei Dürre versiegen die Bäche und Flüsse, bei heftigen Niederschlägen schwellen sie zu Wildströmen an.

Der höchste Grad der Durchlässigkeit kommt lockerem, porösem oder zerklüftetem Boden zu. In ihm versinkt das Wasser, nachdem es die Kapillarräume der obersten Schicht gefüllt hat, in die Tiefe, bis es auf eine undurchlässige Schicht stößt, und es kann als Regel gelten, daß heftige Niederschläge weniger Nahrung zuführen, als schwacher Regen oder schmelzender Schnee. Wesentlich verschieden verhält sich aber lockerer und poröser Boden einerseits, zerklüfteter anderseits. Jener saugt wie ein Schwamm das Wasser auf und wird in seinen untersten Teilen, über der undurchlässigen Schicht, mehr oder weniger durchtränkt. Flächenhafte Ausbreitung ist für diese Art des Bodenwassers charakteristisch. Wenn sich ihm ein Ausweg als Quelle bietet, so setzt es sich nach dieser Seite in langsame Bewegung. Das oberste Bodenwasser unter den 
Aufschüttungsmassen der Alluvialtäler in den Gebirgen und der weiten Ebenen nennen wir Grundwasser. ${ }^{\times}$Im großen und ganzen schmiegt es sich den Oberflächenformen an, es erhebt sich auf den höher gelegenen Flächen und senkt sich zu den Taleinschnitten hinab. Wo die Decke abbricht, erscheint es als Quelle; bei hohem Stand erfüllt es die oberflächlichen Vertiefungen völlig

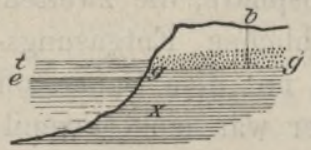

Fig. 123. Grundwasser an der Küste. (e Meeresniveau bei Ebbe, $t$ bei Flut; $g g^{\prime}$ Grundwasser, $b$ Brunnen, $x$ undurchlässige Schicht). und bildet Quelltümpel oder Seeaugen Ein solcher Quelltümpel in großartigem Maßstab ist der Neusiedler See, der infolge trockener Jahre 1865 ganz verschwand, aber seit 1867 sich wieder zu füllen begann.

Sehr bemerkenswert ist die zuerst von Ототвкіл in verschiedenen Klimadistrikten Rußlands, dann auch von HenRy in Frankreich festgestellte Tatsache, daß das Grundwasser im Waldboden tiefer liegt als im benachbarten Freiland. Im Gegensatz $\mathrm{zu}$ der bisher allgemein geltenden Anschauung wirkt also, wenigstens im Flachland, der Wald austrocknend auf den Boden, und damit stimmen auch die Ergebnisse der langjährigen Beobachtungen EBERMAYER's überein; doch betont dieser ausdrücklich, daß an Bergabhängen der Wald nach allen Erfahrungen den Grundwasserstand und den Quellenreichtum erhöht. ${ }^{6}$

In den Brunnen erscheint das Grundwasser als Wasserspiegel, dessen Höhe sich von einer Jahreszeit zur anderen, von einem Jahr zum anderen ändert. Diese Schwankungen sind vor allem von zwei Faktoren abhängig, die einander entgegenarbeiten: von dem Niederschlag und der Verdunstung; und ihre jährliche Periode richtet sich nach demjenigen Faktor, der größeren jahreszeitlichen Schwankungen unterworfen ist. $\times \times$ Die Niederschläge sind aber nicht ausschließlich

$\times$ Dieser Ausdruck wird in sehr verschiedenem Sinn gebraucht. Manche verstehen darunter alles Bodenwasser, andere nur das flächenhaft ausgebreitete und trennen die oberste Etage, auf die wir den Namen Grundwasser beschränken, als phreatische Schicht (von фøé $\varrho=$ Brunnen) ab. Dieses bedauerliche Schwanken gibt zu vielen Mißverständnissen Veranlassung.

$\times \times$ Als Repräsentanten der beiden Typen führt SoyкA ${ }^{7}$ München und Berlin an. In nachstehender Tabelle ist die Verdunstung durch das Sättigungsdefizit ausgedrückt, die Grundwasserhöhe ist die Höhe des.Wasserspiegels über dem Meer. Die jahreszeitlichen Werte sind als Abweichungen vom durehschnittlichen Monatsmittel gegeben, um den Parallelismus klarer hervortreten zu lassen. Man beachte besonders das gegenteilige Verhalten der Stationen im Winter und Sommer; in München steigt und fällt das Grundwasser mit dem Regen, in Berlin ist es dagegen von der Verdunstung abhängig. Im Frühling schwillt es durch die Schneeschmelze an. 
die Ernährer des Grundwassers, denn in den Klüften und Poren des Gesteins zirkuliert auch Luft und kondensiert hier im Sommerhalbjahr, in dem der Boden bis $30 \mathrm{~m}$ Tiefe kälter ist als die Luft, ihren Gehalt an Wasserdampf. Außer der atmosphärischen Feuchtigkeit dringt auch Fluß- und Seewasser in die durchlässigen Ufer-

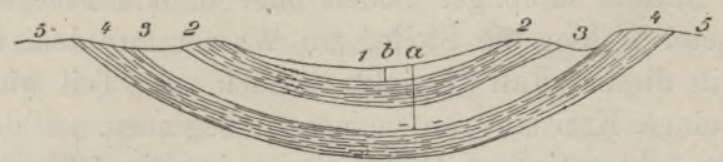

Fig. 124. Becken mit zwei Bodenwasserschichten (in 1 u. 3) und zwei undurchlässigen Schichten (2 u. 4). $\quad a$ artesischer Brunnen. $b$ gewöhnlicher Brunnen.

wandungen ein und durchnäßt ein größeres oder kleineres Gebiet. In manchen Küstengegenden fällt und steigt das Brunnenniveau'mit Ebbe und Flut; Fig. 123 zeigt uns, wie das Grundwasser, das bei Ebbe einen Ausfluß zum Meer hat, durch die Flut gestaut wird.

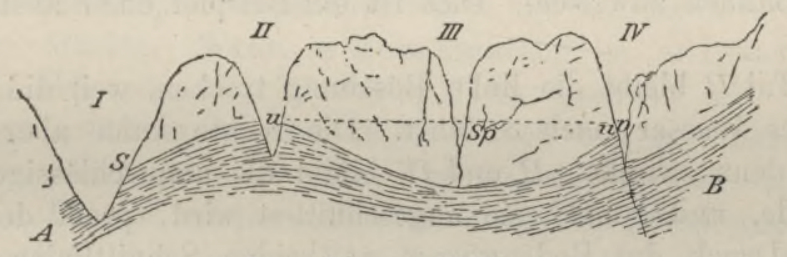

Fig. 125. Quellbildung.

Wo die Schichten auch nur leise Neigung zeigen, tritt Bodenwasser auch in tieferen Horizonten auf. In Fig. 124, die die Lagerungsverhältnisse eines Beckens schematisch darstellt, führen die Schichten 1 und 3 Wasser, denn die letztere, die unter $a$ und $b$ tief im Boden begraben liegt, streicht an anderen Orten zutage und erhält hier direkt atmosphärische Niederschläge. Dieses tiefere Schichtwasser - wie man es zum Unterschied vom Grundwasser

\begin{tabular}{|c|c|c|c|c|c|c|c|}
\hline & & \multicolumn{3}{|c|}{ München $1856-85$} & \multicolumn{3}{|c|}{ Berlin $1870-85$} \\
\hline & & $\begin{array}{l}\text { Nieder- } \\
\text { schlag }\end{array}$ & $\begin{array}{c}\text { Ver- } \\
\text { dunstung }\end{array}$ & $\begin{array}{c}\text { Grund- } \\
\text { wasser- } \\
\text { höhe }\end{array}$ & $\begin{array}{l}\text { Nieder- } \\
\text { sehlag }\end{array}$ & $\begin{array}{c}\text { Ver- } \\
\text { dunstung }\end{array}$ & $\begin{array}{l}\text { Grund- } \\
\text { wasser- } \\
\text { höhe }\end{array}$ \\
\hline Monatsmittel & . & $66,1 \mathrm{~mm}$ & $1,60 \mathrm{~mm}$ & $515,46 \mathrm{~m}$ & $47,6 \mathrm{~mm}$ & $2,71 \mathrm{~mm}$ & $32,64 \mathrm{~m}$ \\
\hline Winter. & . & $-29,5$ & $-1,33$ & $-0,07$ & $-7,2$ & $-1,97$ & $+0,03$ \\
\hline Frühling. & . & $-5,5$ & $+0,11$ & $+0,04$ & $-8,1$ & $+0,03$ & $+0,27$ \\
\hline Sommer . & . & $+42,4$ & $+1,69$ & $+0,12$ & $+15,3$ & $+2,49$ & $-0,08$ \\
\hline Herbst . & .. & $-7,3$ & $-0,46$ & $-0,08$ & $-0,0$ & $-0,54$ & $-0,22$ \\
\hline
\end{tabular}


genannt hat - ist der eigentliche Ernährer unserer Flüsse, die sich bis in den undurchlässigen Untergrund eingeschnitten haben. An dessen Grenze tritt es - oft weit von seinem Ursprungsort - als Quelle wieder zutage. ${ }^{8}$ Freilich nicht immer als scharf markierter Wasserfaden. Häufig bezeichnen nur ein intensiveres Grün der Vegetation, Binsen, sumpfiger Boden oder dunkle Flecken inmitten ausgetrockneter Felder die Stelle, wo Wasser aus dem Boden hervordringt; in diesem Fall versinkt es auch zum Teil wieder in die Erde, um seinen Kreislauf von neuem zu beginnen.

An dem schematischen Durchschnitt in Fig. 125 sollen einige Arten der Quellbildung erläutert werden. $A B$ ist die undurchlässige Schicht mit flachwelliger Lagerung. Thr entlang bewegt sich das Bodenwasser dem Tale $I$ zu und tritt auf dessen rechter Seite in $S$ als Schichtquelle hervor. Daß dies nicht gleichmäBig am ganzen Gehänge geschieht, hat seinen Grund in den Unebenheiten der Unterlage oder in Spaltengängen, die dem Wasser bestimmte Bahnen anweisen. Dies ist ein Beispiel einer absteigenden Quelle.

Im Tal II bleibt die linke Böschung trocken, weil die Schwerkraft alles Wasser nach $S$ führt. Die rechte kann aber Quellen besitzen, denn zwischen $I I$ und $I V$ bildet die undurchlässige Schicht eine Mulde, und sobald sie angeschnitten wird, preßt der hydrostatische Druck das Bodenwasser an beiden Schnittlinien als sog. Überfallsquellen heraus. Solche finden sich in den Tälern II und $I V(u)$. Im Tal $I V$ kann es auch zur Entstehung einer Verwerfungsquelle $(v)$ kommen. Die undurchlässige Schicht ist hier längs einer Spalte derart verschoben, daß ihr linker Flügel-vor die durchlässige Schicht des rechten Flügels gebracht ist. Das Bodenwasser, das auf der rechten Talseite abwärts fließt, wird dadurch plötzlich gehemmt und gezwungen, längs der Verwerfungsspalte in die Höhe zu steigen. Es bedarf übrigens nicht einmal einer Verwerfung, um das Bodenwasser zum Aufsteigen zu veranlassen, es genügt, daß es in seinem Niveau auf eine Decke aus undurchlässi-gem Material stößt (GärtneR's Barrierenquellen). Endlich kann auch im Tal III, obwohl es den Untergrund noch nicht erreicht hat, das Schichtwasser zutage treten, wenn der Talboden tiefer liegt, als die Muldenränder der undurchlässigen Schicht, und eine Spalte ihm den Weg öffnet. Solche Quellen nennt man daher Spaltquellen $(S p)$. Dazu gehören auch die artesischen Brunnen, bei denen die Spalte künstlich durch Bohrung erzeugt wird (s. a in Fig. 124). In diesem Fall wird das Wasser durch den hydrostatischen Druck in die Höhe getrieben; in anderen Fällen wird 
diese Kraft durch komprimierte Gase (Kohlensäure oder Kohlenwasserstoff ${ }^{\times}$) oder durch Wasserdampf ersetzt.

Dies sind nur einige der einfachsten Beispiele von ab- und aufsteigenden Quellen. Viel komplizierter liegen die Verhältnisse in stark disloziertem Boden, wo ein weitverzweigtes Netzwerk von Spalten die Quellen zutage fördert.

Das Kluftwasser und seine Quellen. Wesentlich anders wie in lockerem und porösem Boden gestaltet sich die unterirdische Wasserzirkulation im zerklüfteten Boden. Auch hier wandert das Wasser in die Tiefe, bis es durch eine zusammenhängende undurchlässige Schicht gehemmt wird, aber es breitet sich nicht flächenartig aus, sondern bewegt sich durch die Spalten und Schichtungsfugen wie in Kanälen. Darin besteht die Eigentümlichkeit des Kluftwassers gegenüber dem Grund- und Schichtwasser.

Kluftwasser findet sich in verschiedenen Gesteinen. Ohne Zweifel war es solches, das in den Tunnels des Col di Tenda bei Cuneo und des Simplon angebohrt wurde und den Ingenieuren soviel zu schaffen machte. Wenn v. NoRDENskiöLd im archäischen Gelände von Schweden in $30-35 \mathrm{~m}$ Tiefe Brunnen mit reinstem Trinkwasser erbohren konnte, so sind auch hier reichliche Kluftwasseradern vorauszusetzen. Man darf annehmen, daß das Kluftwasser überall seine erodierende Kraft durch die Erweiterung seiner Kanäle betätigt, aber größere Veränderungen ruft es nur dort hervor, wo sich zu der mechanischen Wirkung eine ausgiebige chemische gesellt. Das ist der Fall in Salz, Gips, Kalkstein und vielfach auch im Dolomit, d. h. in allen Gesteinen, die durch kohlensäurehaltiges Wasser aufgelöst und fortgeführt werden. Hier können sich die ursprünglichen Klüfte, Spalten und Schichtenfugen $\mathrm{zu}$ mehr oder minder großen Gängen und Hohlräumen entwickeln. Am weitesten fortgeschritten ist dieser Prozeß im Karst, jenem Kalkgebirge, das sich von der Laibacher Ebene über Istrien, Dalmatien, Bosnien, die Herzegowina und Albanien bis nach Griechenland erstreckt, und man pflegt deshalb alle hierher gehörigen Erscheinungen unter dem Namen Karstphänomen zusammenzufassen. Wir werden es bei einer passenderen Gelegenheit im Zusammenhang betrachten, hier handelt es sich nur darum, das Charakteristische jener Abart des Kluftwassers, die in der neuesten Literatur den Namen Karstwasser führt, zu erfassen.

Betreffs seiner Verteilung stehen sich zwei Theorien, trotz gegenseitiger Annäherung, kampflustig einander gegenüber. Nach

$\times$ Die Kohlenwasserstoffquellen haben wir als Schlammsprudel schon kennen gelernt (s. S. 409). 
GRUND $^{9}$ ist das Ziel alles oberflächlich eindringenden Wassers die undurchlässige Unterlage. Er unterscheidet scharf zwischen dem vertikal in die Tiefe sich bewegenden Sickerwasser und dem über jener Unterlage sich ansammelnden Karstgrundwasser, das durch die Erdwärme eine höhere Temperatur empfängt. Das Karstgebirge gliedert sich also in zwei Stockwerke, das obere ist trocken oder nur von Sickerwasser benetzt, während in dem unteren alle Hohlräume bis zur undurchlässigen Unterlage mit Wasser gefüllt sind. GRund nimmt an, daß sie untereinander zusammenhängen; dadurch bildet sich ein gemeinsames Niveau aus, und der Unterschied zwischen dem Karstgrundwasser und dem übrigen Bodenwasser besteht eigentlich nur darin, daß jenes, weil es sich auf verhältnismäBig wenige Adern verteilt, anstatt sich über Flächen auszubreiten, größeren Niveauschwankungen unterliegt. Im Kameniti-Schlundloch des Livnopolje steht es im trockenen Sommer in $669 \mathrm{~m}$ und zur Zeit des Hochwassers in $710 \mathrm{~m}$ Meereshöhe; die Schwankung beträgt also nahezu $40 \mathrm{~m}$. Wo das Kalkgebirge an niedrigeres Gelände mit undurchlässigem Gestein oder an das Meer grenzt, und auch im Innern, wo es von normalen Tälern durchschnitten wird, oder wo sich wannenartige Vertiefungen, die sog. Poljes, tief in die Oberfläche einsenken, eröffnen sich dem Karstgrundwasser Austrittsstellen, und nach diesen bewegt es sich seitlich hin. Sein Niveau erhebt sich also im allgerneinen von den Grenzen des Gebirges nach dem Innern.

Die Grundwassertheorie bietet für die Mehrzahl der hydrographischen Karstprobleme eine befriedigende Erklärung, reicht aber doch nicht für alle aus. KATzER hat z. B. auf folgenden Fall hingewiesen. ${ }^{10}$ Im nordwestbosnischen Polje von Lužci-Palanka und Tukkobija versiegt das Höhlenwasser bei Praštala im Poljeboden im Sommer, während die $20-40 \mathrm{~m}$ über dem Boden befindlichen Quellen das ganze Jahr hindurch Wasser spenden. Bestünde zwischen den Klüften eine Verbindung, so müßte gerade umgekehrt die tiefere Kluft länger Wasser halten als die höhere. KATZER ${ }^{11}$ läßt die Grundwassertheorie nur für den seichten Karst gelten, in dem die undurchlässige Unterlage in mäBiger Tiefe liegt, nicht aber für den tiefen. Für diesen nimmt er vielmehr eine regellose Verteilung der wasserführenden Klüfte oder Karstgerinne, wie er sie nennt, in verschiedenen Tiefen an; sie vereinigen sich zum Teil zu weitverzweigten Systemen, die aber untereinander in keiner Verbindung stehen. Das Karstwasser bewegt sich nicht nur abwärts, sondern nach dem Prinzip der kommunizierenden Röhren und des Hebers auch aufwärts. Der Anwendung des Heberprinzips 
widerstrebt übrigens, wie GRUND bemerkt, die Tatsache, daß luftleere Röhren nicht vorhanden sind. Einen besonders schlagenden Beweis für die Richtigkeit der Katzen'schen Auffassung sieht WAAGEN $^{12}$ in den unterseeischen Quellen, denen wir an allen Kalkküsten begegnen, und die aus beträchtlichen Tiefen $\times$ und zum Teil mit solcher Gewalt aufsteigen, daß sie die Meeresoberfläche in Wallung versetzen, in anderen Fällen aber sich nur durch eine lokale Verminderung des Salzgehalts verraten. Anderer Art sind die Quellen an den Karstküsten von SO-Europa, die zum Teil durch Brunnenbohrungen schon in geringer Tiefe erschlossen werden und mehr oder weniger brackisches Wasser führen. WAAGEN meint, daß hier das Sickerwasser des Meeres in seiner Abwärtsbewegung aufgehalten werde. Ám Nordende der Halbinsel Argastoli (an der Westküste von Kephallenia) tritt das Meerwasser in die Klüfte des Kalksteines ein; hier ergieBen sich Tag für Tag $58300 \mathrm{cbm}$ Meerwasser in das Land, kräftig genug, um Mühlen zu treiben. Ï̉ber den weiteren Verlauf dieser gewaltigen Wassermassen weiß man nichts Bestimmtes, wahrscheinlich kehren sie in einem tieferen Niveau wieder in das Meer zurück. v. Lonenz hat eine solche Meeresschwinde, die man nach der Art der praktischen Ausnutzung in Argastoli auch Meermühle getauft hat, auch in Istrien

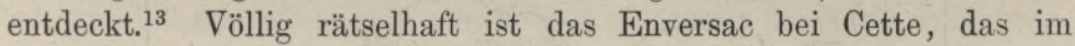
Sommer eine Meeresschwinde und im Winter eine Quelle ist.

Nicht alle Karstquellen entstammen ausschließlich dem Karstwasser, viele stehen auch mit oberirdischen Flüssen in Verbindung. Ein bekanntes Beispiel ist die Reka, die zuerst die eozäne Flyschmulde in einem offenen Tal durchflieBt und dann, sobald sie das Gebiet der Kreidekalke erreicht hat, bei St. Canzian in einer Höhle verschwindet. Man war früher der Ansicht, daB sie am Golf von Triest als Timavoquelle wieder zutage trete. Aber erst die Versuche von Vortmans und G. Trmeus i. J. $1907^{14}$ erbrachten dafür den Beweis, jedoch in einer anderen Weise, als man erwartet hatte. Das Lithiumchlorür, das man dem Rekawasser bei St. Canzian beigemengt hatte, erschien nicht nur im Timavo wieder, sondern auch in andern Karstquellen am Golf auf einer Strecke von $22 \mathrm{~km}$. Die unterirdische Reka bleibt also nicht ein zusammenhängender Fluß, sondern teilt sich in viele Adern. In neuester Zeit wurde durch dieselbe Methode auch ein Zusammenhang der Timavoquelle mit der Wippach festgestellt. ${ }^{15}$

× Die Quelle von Cannes liegt 162, die von S. Remo 190, die am Kap St Martin sogar $700 \mathrm{~m}$ unter dem Meeresniveau. 
Anderseits gibt es aber auch unterirdische Flüsse, die sich nicht nach Art der Reka verzetteln, sondern ihre Individualität bewahren. Die Poik tritt bei Adelsberg in eine Höhle ein; von ihrem $8900 \mathrm{~m}$ langen unterirdischen Lauf bis Planina sind $5900 \mathrm{~m}$ erforscht. Wohl scheint sie manchmal im Gebirge völlig zu verschwinden, die Höhlendecke senkt sich bis zum Wasserspiegel herab, und es entsteht ein unpassierbarer sog. Siphon, aber es ist gelungen, durch trockene Grottengänge diese Siphone zu umgehen,

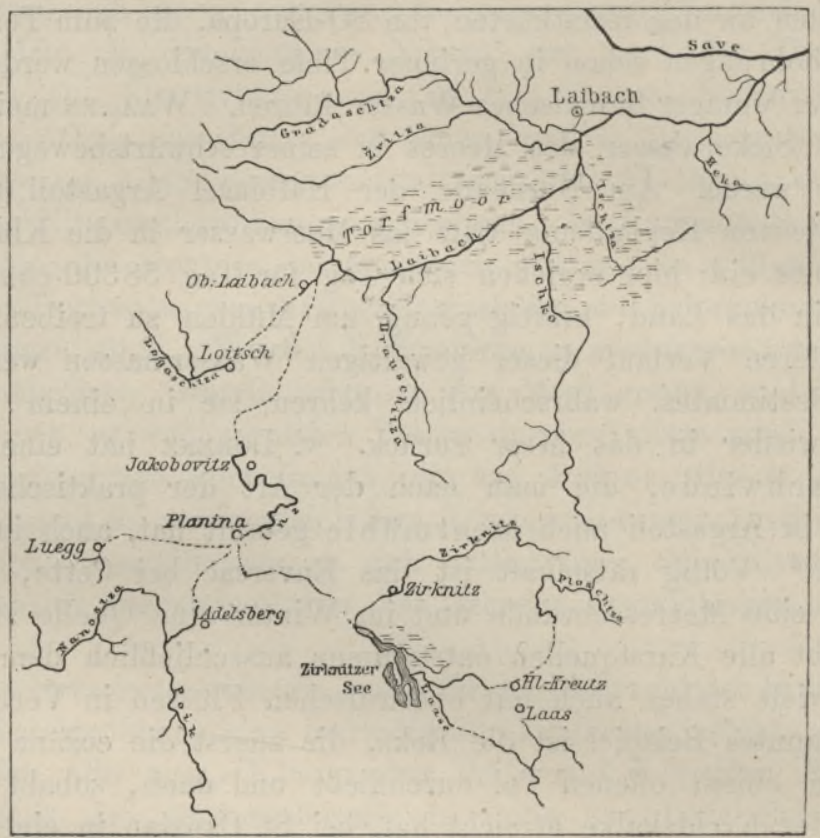

Fig. 126. Flußsystem der Laibach in Krain, nach UrBas u. a. Oberirdische, Unterirdische Flußläufe.

und man hat jenseits derselben die Poik wieder gefunden. Ebenso kennt man von dem unterirdischen Lauf ihres vom Zirknitzer See kommenden Nebenflusses $(11600 \mathrm{~m})$ bereits $8900 \mathrm{~m}$. Die Poik durchfließt das Polje von Planina unter dem Namen Unz; auch diese verschwindet wieder in noch unerforschte Tiefen, jedoch ist hier wohl die Vermutung gerechtfertigt, daß auch sie bis zu der Stelle, wo sie als Laibach wieder erscheint, ihren Flußcharakter beibehält (s. Fig. 126). Solche Flußquellen zeichnen sich in der Regel durch Wasserreichtum aus; ob aber alle Riesenquellen der Kalkgebirge dieser Kategorie angehören, bleibt fraglich. Dies gilt z. B. für die berühmte Vauclusequelle im südlichen Frankreich, die der Sorgue ihren Ursprung gibt. 
Einteilung der Quellen. Die wichtigsten Eigenschaften der Quellen sind ihre Wassermenge, ihr Gehalt an festen Bestandteilen und ihre Temperatur.

Wie das Bodenwasser, so hängen auch die vadosen Quellen von den Niederschlägen ab. Spalten, die unter normalen Verhältnissen trocken sind, ergießen in sehr nassen Jahren die sog. Hungerbrunnen, die diese Bezeichnung deshalb führen, weil sie als Anzeichen einer schlechten Ernte betrachtet werden. In Gegenden mit periodischem Regen fließt auch die Mehrzahl der Quellen periodisch, überhaupt besitzen nur solche Quellen, die mit großen unterirdischen Wasseransammlungen (z. B. in der Nähe von Seen) in Verbindung stehen, eine gleichmäBigere Wassermenge. Je ausgedehnter das Quellengebiet eines Ortes ist, desto unabhängiger ist er in den Wasserverhältnissen von seinem eigenen Klima. In regenlosen Gegenden treten die Quelien in weiter Entfernung von ihrem Ursprung hervor. In den Oasenketten der Libyschen Wüste, von denen die eine parallel mit dem Nil zieht, während die andere den Südabhang des Plateaus von Barka umsäumt, stammen sie nach ZiтteL aus dem tropischen Regengebiet Afrikas. Auf den wasserdichten Schichten der nubischen Sandsteinformation flieBt das Schichtwasser nach Nordosten und sammelt sich in einer seichten Mulde westlich vom Nil an, indem eine schwache Aufbiegung der Kreideschichten unter der nördlichen Oasenreihe den Abfluß zum Mittelmeer verhindert. Die ägyptischen Natronseen werden nach Schwersforth durch das Sickerwasser des Nil gespeist. Den erstaunlichen unterirdischen Wasservorrat der algerischen Sahara, von dem die Franzosen durch artesische Brunnenbohrungen den ausgiebigsten Gebrauch machen, führt RoLLAND auf das Regen- und Schmelzwasser des Atlas zurück, das zwischen undurchlässigen Schichten der aufgebogenen Kreidebildungen in den südlichen Wüstenboden gelangt. Im allgemeinen liegt der Bodenwasserspiegel in den Wüsten sehr tief, nur in den Wadis und Depressionen kommt er der Oberfläche nahe, und allein darauf beruht die Möglichkeit, die Wüsten zu durchqueren.

Je weitere unterirdische Bahnen eine Quelle durchwandert. desto mehr belädt sie sich mit festen Bestandteilen, unter denen Karbonate, Sulfate und Chloride die wichtigsten sind. Denn überall, nicht bloß in direkt löslichen Gesteinen, wirkt die chemische Erosion des kohlensäurehaltigen Wassers. Der Mineralgehalt der Quelle hängt zunächst von der Beschaffenheit des Muttergesteins ab. In England sind jene Quellen am reinsten, die dem Granit- und Gneisboden entspringen; ihnen zuñächst kommen die aus dem Silur und 
Kohlensandstein stammenden; am meisten verunreinigt sind jene, die ihren Weg durch den Dyaskalk und durch das Diluvium und Alluvium nehmen. Unter sonst gleichen Umständen sind Thermen reicher an festen Bestandteilen als kalte Quellen, weil warmes Wasser eine größere Lösungskraft besitzt; doch gibt es auch verhältnismäBig reine Thermen, wie die von Pfävers, Gastein, Plombières und Bormio.

Je nach dem vorherrschenden Mineralgehalt unterscheidet man Kalk-, Kiesel-, Stahl-, Natron-, Schwefel-, Soolquellen usw.; sind die Quellen sehr kohlensäurereich, so nennt man sie Sauerquellen. Viele von ihnen haben wegen ihrer Heilkraft große Bedeutung, einige wirken sogar auf die Oberflächengestaltung ein. Das gilt hauptsächlich von den kalk- und den kieselsäurereichen Quellen; letzterer, die stets heiße Quellen sind, werden wir weiter unten gedenken. Die kalkreichen Gewässer lagern Travertin, oft in großer Mächtigkeit, ab. Aus Italien sind viele derartige Fälle bekannt; am berühmtesten sind die Ablagerungen des Anio bei Tivoli. Das an den Ufern wachsende Rohr wird inkrustiert, der Schaum des Wasserfalles bildet Stalaktiten, und die Wände der tiefen Schlucht, in die er sich stürzt, bestehen aus horizontalen Schichten von Tuffen und Travertin von $120-150 \mathrm{~m}$ Mächtigkeit, sind also zum großen Teil selbst ein Ablagerungsprodukt des Flusses. Noch weit großartiger sind die Travertinbildungen der Quellen auf dem kleinasiatischen Plateau Pambuk-Kalesi in der Nähe der alten Stadt Hierapolis.

Die Temperatur der vadosen Quellen, die aus mäBiger Tiefe kommen, entspricht im allgemeinen der mittleren Jahrestemperatur des betreffenden Ortes, zeigt aber doch eine jährliche Schwankung, die nach Martel um so größer ist, je länger das Wasser vor seinem Einsickern der Luft ausgesetzt war. Kälter sind die absteigenden Quellen im Gebirge, die durch Schnee- und Gletscherwasser gespeist werden, ${ }^{\times}$und die unterirdischen Abflüsse tieferer Seen, deren Bodenschicht bekanntlich nur eine Temperatur von $4^{0}$ besitzt. Als warme Quellen oder Thermen bezeichnet man jene, deren Temperatur die mittlere Jahrestemperatur der Luft an der Ausflußstelle übersteigt. Man kann relativ und absolut warme Quellen unterscheiden, und als Grenzwert das höchste thermische Jahresmittel im Meeresniveau $\left(30^{\circ}\right)$

× Die höchsten, bisher bekannt gewordenen kalten Quellen liegen nach einer. Zusammenstellung von Sohuagrntwert in Tibet 5379, im Himalaya 4852, in den Andes 4732 und in den Alpen $3182 \mathrm{~m}$ hoch (Petermans's Mitteilungen 1865, S. 367.) 
annehmen. $\times$ Sie sind nach der von SuEss vertretenen Auffassung juvenilen Ursprungs und daher in der Regel an ein tief hinabreichendes, vertikales Spaltensystem gebunden, also ebenso, wie die Vulkape, eine Begleiterscheinung beträchtlicher Schichtenstörungen. ${ }^{16}$ Daher entspringen heiße Quellen auch dort, wo es nicht zu vulkanischen Ausbrüchen kam. Daraus erklärt es sich auch, daß die in stark dislozierten Gegenden häufigen Erdbeben oft dauernd die Temperatur der Thermen verändern, indem sie tiefere Spalten entweder öffnen oder schließen. Durch das Lissaboner Erdbeben (1755) wurde z. B. die Temperatur der Königinquelle zu Bagnères-de-Luchon in den Pyrenäen von ungefähr 8 auf $50^{\circ}$ erhöht, und anderseits verwandelte das Erdbeben von 1660 die Thermen zu Bagnères-deBigorre in kalte Quellen. Auch der ziemlich gleichmäBige Wasserreichtum der Thermen weist darauf hin, daß ihr Sammelgebiet dem Einfluß der meteorologischen Schwankungen fast ganz. entrückt ist.

Geysir. ${ }^{17}$ Kochend heiße Quellen kommen nur in vulkanischen Gegenden vor. Steigt ihre Temperatur über den Siedepunkt, so verwandeln sie sich zum Teil oder ganz in Dampf, wie die Karapiti auf Neuseeland. Die interessantesten Erscheinungen dieser Art sind die Geysire, intermittierende Springquellen, die in der Regel große Quantitäten Kieselsinter um ihre Mündungsstelle absetzen. Dadurch entstehen meist allmählich ansteigende Kegel mit einem flachen Becken in der Mitte, auf dessen Boden ein zylindrischer Kanal mündet. So gebaut ist der Große Geysir auf Island (Fig. $127 \mathrm{u}$. 128), der dem Phänomen den Namen gab und bisher auch am eingehendsten studiert worden ist. Vor der Eruption ist sein Becken

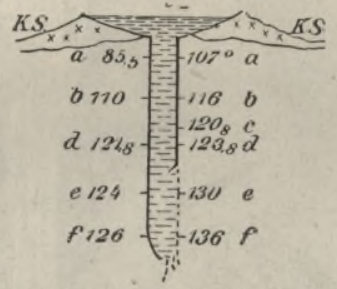

Fig. 127. Durchschnitt des Großen Geysirs auf Island in 1: 1000 nach den Messungen von Coles (1881). Die Zahlen links sind beobachtete Tem. peraturen, die rechts die der Tiefe entsprechenden Siede. punkte. $K S=$ Kieselsinter. mit kristallhellem, bläulichgrünem Wasser gefüllt, dessen Temperatur nach unten zunimmt und sich gleichzeitig in jeder Schicht bis zum Zeitpunkt der Eruption steigert, ohne irgendwo den Siedepunkt zu erreichen. Heftiger unterirdischer Donner kündigt den

$\times$ Dampfquellen $\left(100^{\circ}\right)$ hat Europa nur eine: die Soffioni in Toskana. Über $80^{\circ}$ haben die Bäder auf den Liparen $\left(97-100^{\circ}\right)$, Gurgitello auf Isehia $\left(90^{\circ}\right)$, die Nerobäder $\left(86^{\circ}\right)$ und Piseiarelli $\left(84^{\circ}\right)$ bei Pozzuoli, Albano in den Euganeen $\left(84,5^{\circ}\right)$, Chaudesaigues in Frankreich (Cantal, $\left.88^{\circ}\right)$ und die Petersquelle im Terektal $\left(89^{\circ}\right)$. Berühmte Thermen in Mitteleuropa sind Burtscheid $\left(78^{\circ}\right)$, Karlsbad $\left(74^{\circ}\right)$, Gastein $\left(71,5^{\circ}\right)$, Wiesbaden $\left(69^{\circ}\right)$, Baden-Baden $\left(67^{\circ}\right)$, Ofen $\left(61^{\circ}\right)$, Mehadia $\left(55^{\circ}\right)$, Aachen $\left(55^{\circ}\right)$, Leuckerbad $\left(51^{\circ}\right)$, Teplitz $\left(49^{\circ}\right)$, Ems $\left(47,5^{\circ}\right)$ usw. 
Ausbruch an, das Wasser beginnt zu wallen, kleinere Eruptionen erfolgen, endlich schießt ein Strahl heißen Wassers, ungefähr $3 \mathrm{~m}$ stark und über $30 \mathrm{~m}$ (einmal sogar $70 \mathrm{~m}$ ) hoch, von Dampfwolken umgeben und manchmal auch von Steinen begleitet, hervor. Von Zeit zu Zeit scheint der Strahl einzusinken, aber immer wieder erhebt er sich. Nach ungefähr 10 Minuten fällt er endlich in sich zusammen, das Becken ist leer und nur die Steigröhre ist noch bis $2 \mathrm{~m}$ unter der Oberfläche gefüllt. Nach langer Pause wiederholt sich

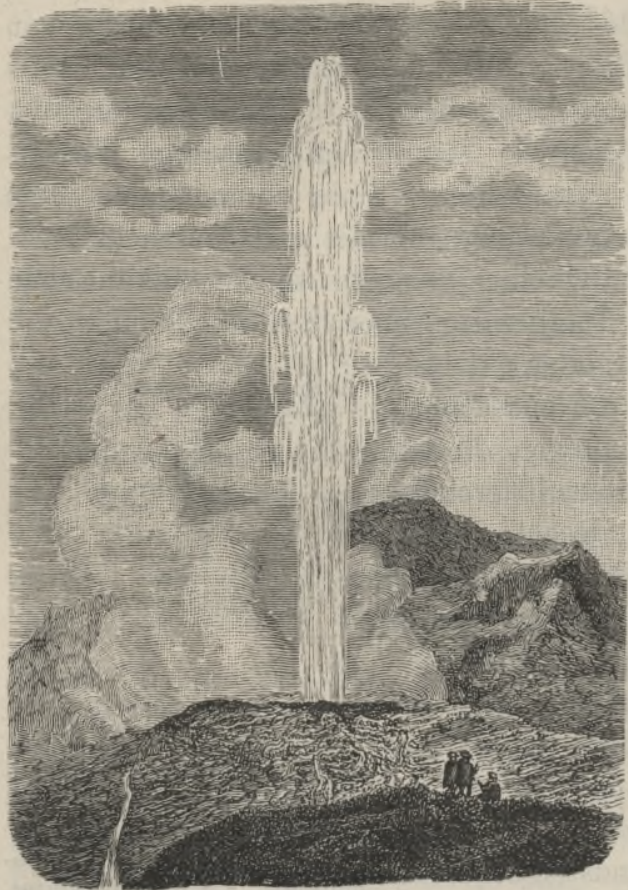

Fig. 128. Der Große Geysir nach K. Fuchs. dieses imposante Schauspiel in der eben geschilderten Reihenfolge.

Es ist klar, daß Dampf die Wassermasse im Kanal emporschleudert, und die verschiedenen Erklärungsversuche weichen nur in der Angabe der Örtlichkeit, wo die erste Dampfentwickelung stattfindet, voneinander ab. Ältere und neuere Theorien verlegen sie in Hohlräume, die mit der Steigröhre in Verbindung stehen,Bunsen dagegen in die Mitte der Steigröhre selbst. Für den Großen Geysir ist diese Annahme auch durch Beobachtung erhärtet, denn Steine und ein Thermometer, die auf den Boden derRöhre versenkt wurden, wurden nicht ausgeschleudert, ja letzteres blieb sogar bei einer heftigen Eruption völlig unversehrt. In der Tat ersehen wir auch aus den Zahlen in Fig. 127, daß sich gerade in der Mitte des Kanals die Temperatur des Wassers am meisten dem Siedepunkt nähert; hier muß ein besonderer Wärmeherd liegen, und damit stimmt auch . der Bau der Röhre, die nach BRyson's Entdeckung in $13 \frac{1}{2} \mathrm{~m}$ Tiefe eine einspringende Leiste besitzt. Die Wasserschicht $d$ mit $121,8^{0}$ braucht nur um $2 \mathrm{~m}$, bis zum Niveau $c$, wo der Siedepunkt schon bei $120,8^{\circ}$ liegt, gehoben zu werden, um sich sofort in Dampf zu verwandeln. Diese Hebung wird durch die Erhitzung des ganzen 
Röhreninhalts von unten her bewirkt; die Abkühlung von oben und die Zufuhr kalten meteorischen Wassers wirken entgegen, und darauf beruht die Periodizität der Ausbrüche und ihre allmähliche Steigerung $\mathrm{zu}$ einer Haupteruption.

Es ist keineswegs ausgemacht, ob diese Theorie für alle Fälle ausreicht, da die Geysire und zwar selbst benachbarte, in vielen wichtigen Merkmalen voneinander abweichen. So greift z. B. WAItz ${ }^{18}$ zur Erklärung der Vorkommnisse von Ixtlan in Mexico auf die alte Theorie von MackenzIE zurück. Jedenfalls ist Bunsen's Annahme, daß ein Sinterbecken notwendig sei, nicht zutreffend, denn der Steamboot-Geysir im Yellowstonegebiet zeigt erst Ansätze zu einer solchen Umrandung. $\mathrm{J}_{\mathrm{AGGAR}}{ }^{19}$ hat experimentell den Unterschied zwischen überfliebenden und stehenden Geysiren erläutert, die er nach hervorragenden Vertretern im Nationalpark als Excelsiorund Old Faithful-Typus bezeichnet. Jene stehen unter hydrostatischem Druck, indem beständig von größeren Höhen kaltes Wasser zuströmt, das den Abfluß von heißem Wasser ersetzt. Daher überfließt der Schlot beständig, und zu Eruptionen kommt es nur in der Jahreszeit, in der sich der Zufluß vermindert. Bei dem Old Faithful-Typus steht das Wasser im Schlot; sobald es zum Kochen kommt, erfolgt ein Ausbruch; dann erst tritt kaltes Wasser hinzu, das in einem bestimmten Zeitraum zum Ausbruch reif wird - daher die periodische Wiederholung der Eruptionen. Beachtenswert ist es auch daß es MaLfroy in Neuseeland gelang, durch Ableitung einer Wasserschicht von $60 \mathrm{~cm}$ Mächtigkeit die Puia-Therme in eine Springquelle von $9-12 \mathrm{~m}$ Höhe zu verwandeln. ${ }^{20}$

In Island ist neben dem schon genannten Großen Geysir der Strokkr, der erst 1784 während eines Erdbebens entstand, am bekanntesten, auch dadurch, daß man ihn durch hineingeworfene Steine und Erde zur Eruption zwingen kann. Noch großartiger ist dieses Phänomen im Nationalpark im Felsengebirge (am oberen Yellowstone und Madison) entwickelt. Zahlreich sind hier die Dampfquellen, Geysire und heißen Quellen; im oberen Geysirgebiet am Feuerlochfluß werden Wasserstrahlen von $70-80 \mathrm{~m}$ und Dampfsäulen v.on $300 \mathrm{~m}$ Höhe emporgeschleudert, doch hat hier BARBouR eine entschiedene Abnahme der Geysirtätigkeit festgestellt. Diesen beiden Bezirken kann sich nur noch die Nordinsel von Neuseeland an die Seite stellen. Einen wunderbaren Anblick boten einst die terrassenförmig aufgebauten, marmorweißèn Kieseltuffablagerungen des Tetarata, bis sie durch den Tarawera-Ausbruch im Jahr 1886 völlig zerstört wurden. Dafür schufen die vulkanischen Ereignisse des letzten Jahrzehnts eine neue Merkwürdigkeit: die kleinen Geysire 
verschwanden, und an ihre Stelle trat Ende 1899 der gewaltige Waimangu-Geysir, der Wassermassen von $800000 \mathrm{~kg}$ Gewicht bis $460 \mathrm{~m}$ hoch schleuderte, aber seit November 1904 seine Tätigkeit eingestellt hat. ${ }^{21}$ Sonst finden sich Geysire nur noch vereinzelt, wie in Californien, nördlich von San Francisco, in Mexico und in Japan, wo Honda und Terada ${ }^{22}$ das interessante Vorkommen von Atami beschrieben haben.

Literaturnachweise. ${ }^{1}$ Hauptwerk: A. DaUbrÉE, Les eaux souterraines à l'époque actuelle; Paris 1887. $-{ }^{2} \mathrm{~J}$. $\mathrm{H}_{\mathrm{ANN}}$ in der Zeitschrift der Österreichischen Gesellschaft für Meteorologie, 1880, S. 482. $-{ }^{3}$ Fr. KoenıG, Die Verteilung des Wassers über, auf und in der Erde; Jena 1901. - ${ }^{4}$ R. KoIPERs, Grondwater of Rijnwater voor Amsterdam? Amsterdam 1903. - ${ }^{5}$ Ed. Surss, Über heiße Quellen, in den Verh. der Ges. deutscher Naturforscher und Ärzte, 1902. - ${ }^{6}$ Vgl. den Bericht von H. Gravelius in Petermans's Mitteilungen 1901, S. 64 . E. Henry, Sur le rôle de la forêt dans la circulation de l'eau à la surface des continents; Paris 1902. - ${ }^{7}$ J. Sorka, Die Schwankungen des Grundwassers; Wien 1888. $-{ }^{8}$ H. J. HAAs, Quellenkunde; Leipzig 1895. ${ }^{9}$ A. Grund, Die Karsthydrographie; Leipzig 1903 (in Penck's Geogr. Abhandlungen). In den „Beiträgen zur Morphologie des Dinarischen Gebirges", Leipzig 1910 (ebenda), berichtigt und vervollständigt er seine Theorie. Vgl. auch seine Bemerkungen in den Mitteilungen der Wiener Geogr. Gesellschaft 1910, S. 606. - ${ }^{10}$ F. KATZER in der Zeitschrift der Deutschen Geologischen Gesellschaft, 1905, Protokoll, S. 239. - ${ }^{11}$ F. KATzER, Karst und Karsthydrọgraphie, Serajevo 1909. - ${ }^{12} \mathrm{~L}$. W ${ }_{\triangle A G E N}$, in der Geographischen Zeitschrift 1910, S. 398. - ${ }^{13}$ F. J. Frscher, Meer und Binnengewässer in Wechselwirkung, in den Abh. der Wiener Geograph. Ges., Bd. IV, 1902. - ${ }^{14}$ N. Krebs, in Petermann's Mitteilungen 1908, S. 166. - ${ }^{15}$ L. K. Moser, im Globus 1910, Bd. XCVIII, S. 20. - ${ }^{16}$ Eine Variante der Scess'schen Theorie findet sich in A. GaUtier, La genèse des eaux thermales et ses rapports avec le volcanisme, in den Annales des mines, Paris 1906. Gegen die Sunss'sche Theorie sprach sich E. H. L. Schwarz aus: Hot Springs, im Geological Magazine 1904, Dec. V, Bd. I; er hält auch die Thermen für vadoses Wasser. - ${ }^{17}$ Hauptwerk: W. H. Holmes und A. C. Peale, Yellowstone National Park; Washington 1883 (im 12. Annual Report of the U. S. Survey of the Territories). - ${ }^{18}$ G. WAItz, Les geysirs d'Ixtlan, im Guide des excursions du X. Congrès géologique international, Mexico 1906; Algunos experimentos en geyseres arteficiales, im Boletin der Sociedad geológica Mexicana, Bd. II. - ${ }^{19}$ T. A. JAGGAR, im American Journal of Science 1898 , Bd. I, S. $323 .-{ }^{20}$ C. Matrrox, in den Transactions of the New Zealand Institute 1891, Bd. XXIV, S. 579. - ${ }^{21}$ J. M. Maclaren, im Geological Magazine 1906, S. 511. - ${ }^{22}$ In den Publications of the Earthquake Investigation Committee 1906, Nr. 22 B.

\section{Das fließende Wasser. ${ }^{1}$}

Wassermenge. Die Quellen, das oberflächlich abfließende Regenwasser und das Schmelzwasser des Schnees und des Eises vereinigen sich schließlich zu Wassertäden, die wir je nach ihrer Größe als Bäche, Flüsse oder Ströme zu bezeichnen gewohnt sind. Dem Gesetz der Schwere folgend, streben sie insgesamt dem tiefsten 
Niveau der Erdoberfläche, dem Meeresniveau zu, wenn auch nicht alle das Ziel erreichen. In regenarmen Gegenden ist ihre Wassermenge zu gering, als daß sie der Verdunstung Widerstand leisten könnten, und so finden sie ein vorzeitiges Ende, indem sie entweder in einen See münden oder in den Boden einsickern oder, von der Sonne aufgezehrt, spurlos verschwinden. Nur größere Ströme, wie der ägyptische Nil oder der Euphrat und Tigris, deren Quellgebiete in einer niederschlagsreichen Zone liegen, oder die durch die Schmelzwässer schneereicher Hochgebirge ernährt werden, dringen sieghaft durch Wüstendistrikte bis zum Meer durch.

Die Wassermenge, die den Ozean erreicht, schätzt WoEIkow auf $600000 \mathrm{cbm}$ in der Sekunde.

Die Abflußmenge eines Flusses wird mittels des einer Schiffsschraube ähnlichen hydrometrischen Flügels oder mittels „Schwimmer“ gemessen; bei eisführenden Flüssen muß man dabei stets den Eisstau berücksichtigen, da sich sonst in die Zahlen für den winterlichen Abfluß die gröbsten Fehler einschleichen. ${ }^{2}$ Im Durchschnitt mehrerer Jahre ist der AbfluB gleich der Differenz von Niederschlag und Verdunstung, denn das Regenwasser, das in den Boden eindringt, kommit ja an einer anderen Stelle dem AbfluB wieder zugute. Doch ist das Verhältnis von AbfluB und Niederschlag kein konstanter Faktor, vielmehr wächst der Abfluß nicht bloB absolut, sondern auch relativ mit der Niederschlagsmenge. Dieses Gesetz bewährt sich, mögen wir die Niederschlagsmengen eines größeren Gebietes in verschiedenen Jahren oder Gebiete mit verschiedenen Regenmengen miteinander vergleichen, und das hydrographische Übergewicht der Gebirge gewinnt dadurch noch eine wesentliche Verstärkung. Für Mitteleuropa ergeben sich nach einer Tabelle von KELLER ${ }^{3}$, die 60 Flußgebiete umfaßt, folgende mittlere Abflußfaktoren (=AbfluB in Prozenten des Niederschlags):

$\begin{array}{ccccc}\begin{array}{c}\text { Niederschlag } \\ \text { mm }\end{array} & \begin{array}{c}\text { Flach- } \\ \text { land }\end{array} & \begin{array}{c}\text { Flach- und } \\ \text { Hochland }\end{array} & \begin{array}{c}\text { Mittel- } \\ \text { gebirge }\end{array} & \text { Alpen } \times \\ 400-500 & 20,1 & - & - & - \\ 500-600 & 30,7 & - & - & - \\ 600-700 & 38,4 & 30,1 & 28,1 & - \\ 700-800 & 39,9 & 40,2 & 35,7 & - \\ 800-900 & - & 47,3 & 37,3 & - \\ 900-1000 & - & - & 48,5 & 58,2 \\ 1000-1100 & - & - & 60,9 & - \\ \text { über } 1100 & - & - & 68,0 & 67,4\end{array}$

$\times$ Die AbfluBfaktoren der.Alpenflüsse sind unsicher, weil wir die Niederschlagshöhe im eigentlichen Hochgebirge, wo wir nur wenige Beobachtungsstationen haben, wahrseheinlich beträchtlich unterschätzen. 
Wenn Keller das Verhältnis von Niederschlag und AbfluB in Mitteleuropa in folgender Formel (worin $A$ AbfluB und $N$ Niederschlag in Millimetern bedeuten) zusammenfaßte:

$$
A=0,942 N-405 \text {, }
$$

so ist dagegen einzuwenden, daß solche Formeln nur einen sehr geringen praktischen Wert besitzen. Denn das oben ausgesprochene Gesetz gilt nur für Gruppenmittel, und auch innerhalb derselben ist die Zunahme des Abflusses mit dem Niederschlag in Gebieten von verschiedener Oberflächenbeschaffenheit verschieden. Vergleicht man die einzelnen Flußgebiete miteinander, so begegnet man großen Abweichungen, und die Abflußfaktoren der einzelnen Jahre innerhalb eines und desselben Flußgebietes kehren sich durchaus nicht an das genannte Gesetz. Der AbfluB ist also keine einfache Funktion der mittleren jährlichen Niederschlagsmenge. Es kommen noch eine Menge anderer Faktoren in Betracht: die Form und jahreszeitliche Verteilung der Niederschläge, die Temperatur, nach der sich die Verdunstung regelt, die Abdachungsverhältnisse, die Durchlässigkeit des Bodens und die Pflanzenbedeckung. Es ist daher auch verfehlt, aus der Extrapolation von Abflubformeln weitgehende Schlüsse zu ziehen, wie z. B. wenn Penck ${ }^{4}$ auf diesem Weg dasjenige $\mathrm{MaB}$ des Niederschlags zu ermitteln suchte, bei dem sich in Böhmen Verdunstung und Niederschlag das Gleichgewicht halten und Abflußlosigkeit eintreten müßte. Nach obiger Formel wäre $A=0$, wenn der Niederschlag $430 \mathrm{~mm}$ betrüge; die Regenmenge des Gebietes der oberen Netze $(460 \mathrm{~mm})$ kommt diesem Wert schon sehr nahe, und doch fließen $94 \mathrm{~mm}$, d. h. 201/2 Prozent ab.

Um einen Einblick in den Wasserhaushalt eines mitteleuropäischen Flusses zu gewinnen, betrachten wir nachstehende, einer

\section{Gebiet der Sächsischen Saale}

a) Niederschlag

b) Verlust $\left\{\begin{array}{l}\text { durch unmittelbare Verdunstung } \\ \text { durch }\end{array}\right.$

c) Aufspeicherung $\left\{\begin{array}{l}\text { im Bodenwasser } \\ \text { in der Schneedecke }\end{array}\right.$

d) Bleiben somit für den $\mathrm{AbfluB}(=a-[b+c])$

e) Wirklicher AbfluB .

f) Deckung des Defizits $(e-d)$ durch anfgespeicherte Feuchtigkeit

\begin{tabular}{|c|c|c|c|}
\hline $\begin{array}{l}\text { Winter } \\
\text { mm }\end{array}$ & $\begin{array}{c}\text { Frühling } \\
\mathrm{mm}\end{array}$ & $\begin{array}{c}\text { Sommer } \\
\mathrm{mm}\end{array}$ & $\begin{array}{c}\text { Herbst } \\
\text { mm }\end{array}$ \\
\hline 108 & 144 & 216 & 146 \\
\hline 45 & 96 & 112 & 66 \\
\hline - & 21 & 40 & 10 \\
\hline 3 & 4 & 47 & 37 \\
\hline 35 & 10 & - & 2 \\
\hline 25 & 13 & 17 & 31 \\
\hline 48 & 60 & 28 & 32 \\
\hline
\end{tabular}

47
11

1

Aufstellung ULE's ${ }^{5}$ entnommene Zahlen, von denen freilich einige nur auf Schätzung beruhen. In allen Jahreszeiten verbleibt nur ein 
verhältnismäßig kleiner Teil des Niederschlags für den sofortigen Abfluß disponibel $(d)$, und mit Ausnahme der Monate Oktober, November und Dezember ist er stets kleiner als der wirkliche AbfluB. Von Januar bis September müssen also die von früheren Niederschlägen herrührenden und als Bodenwasser oder Schneedecke aufgespeicherten Feuchtigkeitsschätze in Anspruch genommen werden, um die Verluste wenigstens teilweise zu decken. Am besten gelingt das im Frühling, wenn der Winterschnee schmilzt, und der AbfluB erreicht daher in dieser Jahreszeit seinen Höhepunkt. Am kleinsten ist er im Sommer, trotzdem die Niederschläge zu dieser Zeit am reichlichsten sind. Aber auch die Verdunstung, der Verbrauch durch die Vegetation und die Aufnahmefähigkeit des Bodens sind dann am größten, und von dem aufgespeicherten Wasser steht nur noch das unterirdische zur Verfügung. Der Abflubfaktor ist daher in unserem Klima überall starken, aber nicht ganz gleichzeitigen Schwankungen unterworfen. ${ }^{x}$ Im Sommer erreicht er überall seinen niedrigsten Wert, ist aber in den Alpen, wo noch die Schneeund Gletscherschmelze des Hochgebirges Wasser liefert, beträchtlich größer als in jenen Gegenden, wo der sommerliche Abfluß nur durch Regen und Bodenwasser gespeist wird. Die sommerlichen Niederschläge sind im deutschen Mittelgebirge und

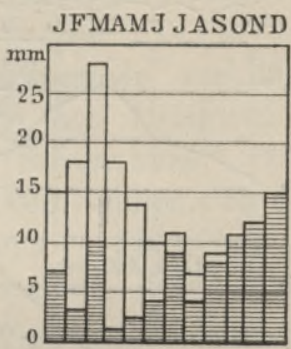

Fig. 129. Abflußhöhen derSächsischenSaale und ihre Zusammensetzung aus gleichzeitigen Niederschlägen (schraffiert) und aufgespeichertem Wasser (weiß). im Dnjeprgebiet nahezu gleich, aber in Osteuropa ist die Verdunstung größer und dementsprechend der Abflußfaktor kleiner. Sein Maximum erreicht dieser im Mittelgebirge im März, im Djneprgebiet im April und in den Alpen im April oder Mai, d. h. überall zur Zeit der Schneeschmelze. Es ist besonders beachtenswert, daß er im Frühling in Osteuropa sogar etwas größer ist als in den Alpen, obwohl sich die entsprechenden Niederschläge nahezu wie $1: 3$ verhalten — wieder ein Beweis, daB das im Eingang erwähnte Gesetz nicht auf allgemeine Gültigkeit Anspruch machen kann. Auf der russischen Ebene werden eben die winterlichen Niederschläge fast ganz als

$\times$

Deutsches Mittelgebirge (Mittel von 3 Flüssen)

Nordalpen (Mittel von 2 Flüssen)

Osteuropa (Oberer Dnjepr nach

E. Oppoкоw)
Winter Frühling Sommer Herbst Jahr AbfluBfaktor (Proz. des Niederschlags)

$\begin{array}{lllll}44,4 & 43,6 & 13,8 & 22,7 & 28,3 \\ 54,4 & 76,0 & 42,3 & 51,9 & 53,3 \\ 28,5 & 76,2 & 11,2 & 11,9 & 27,3\end{array}$


Schneedecke aufgespeichert und dann im Frühjahr mit einem Mal den Flüssen zugeführt. Nun wird auch die eigentümliche Gestaltung der Jahreskurve des Wasserstandes der Flüsse in unseren Breiten (vgl. Fig. 130) verständlich. Im Mittelgebirge und im Flachland tritt das Hochwasser schon im März, in den Alpen erst im Juni ein. Der Vorrat der alpinen Gletscher reicht auch aus, um den Ausfall durch die sommerliche Verdunstung zu decken, so daß der tiefste Wasserstand sich vom September auf den Februar verschiebt. Die Jahresperiode am Niederrhein weicht von der der östlichen

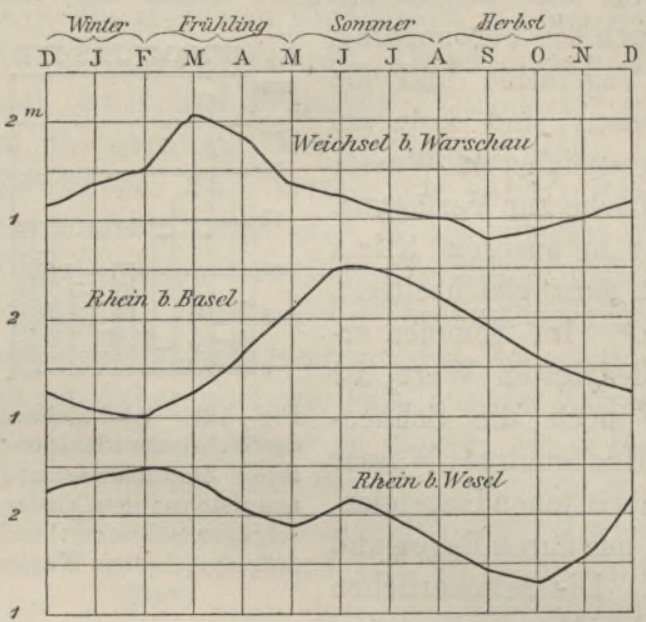

Fig. 130. Wasserstand der Weichsel bei Warschau $(1871-95)$ u. des Rhein $(1851-86)$ bei Basel und Wesel. Maßstab 1: 100 .

Flüsse etwas $a b$, denn in Westdeutschland sind die Winter milder und bringen mehr Regen als Schnee, so daß bereits im Februar das Maximum eintritt. Zugleich macht sich auch die sommerliche Anschwellung des Oberrhein bis an die holländische Grenze in einem sekundären Maximum bemerkbar. Dieses Beispiel zeigt uns auch, daß bei großen Strömen mit komplizierten $A b f l u ß-$ gebietenHoch-und Nieder wasser nicht an allen Orten gleichzeitig auftreten.

Die Schwankungen des Wasserstandes werden in unseren Gegenden, wo kein Monat ohne Niederschläge vergeht, durch örtliche Verhältnisse stark beeinflußt. Unter diesen ist in erster Linie die Bewaldung der Berghänge zu nennen, denn der Wald erhöht hier - wie wir schon auf S. 486 erwähnt haben - ohne Zweifel die Bodenfeuchtigkeit, und mit seiner Beseitigung nimmt die Menge des oberflächlich abfließenden Wassers zu und die Zahl der Quellen ab. Zur Zeit heftiger Regengüsse schwellen dann die Flüsse mächtig an, während in der Periode des Niedrigwassers die Ernährung durch die Quellen gering ist. An den französischen Gebirgsflüssen, besonders an der Loire, machen sich die Folgen rücksichtsloser Entwaldung in starken Wasserstandsschwankungen geltend, und auf ein besonders drastisches Beispiel auf der Balkanhalbinsel (Ergene, Nebenfluß der Mariza) hat kürzlich Schaffer ${ }^{6}$ 
aufmerksam gemacht. Als Regulatoren wirken auch die Flußseen, indem sie zur Zeit großer Wasserfülle einen Teil des Wassers zurückbehalten, um ihn in der Trockenzeit langsam wieder abzugeben. Daher verhalten sich die Wassermengen des Rhein bei tiefstem und bei höchstem Stand oberhalb des Bodensees in Graubünden wie 1:70, bei Basel aber nur wie 1:14, und der Wasserstand der Newa bei St. Petersburg ist so gleichmäßig, daß nur anhaltende starke Seewinde Überschwemmungen hervorrufen können. Eine ähnliche Rolle, wie den Seen, schrieb man auch den Sümpfen zu; dagegen behauptet Opрокоw, ${ }^{7}$ daß sie gegen die Flüsse nahezu geschlossen sind und durch ihren Wasservorrat nur den Verdunstungsprozeß ernähren.

Je schärfer sich die jährliche Niederschlagsperiode ausbildet, desto mehr treten die örtlichen Einflüsse hinter den klimatischen zurück, und desto größer wird die jährliche Schwankung. ${ }^{8}$ Das zeigt sich schon bei den russischen und sibirischen Flüssen, wo das Frühlingshochwasser eine viel höhere Bedeutung gewinnt als in Mitteleuropa, und die kräftig entwickelte Jahresperiode des Wasserstandes bereits an die der subtropischen und tropischen Länder gemahnt. Die spanischen Plateauflüsse, die im Frühjahr zu brausenden Fluten anschwellen, ziehen sich im Sommer zu unscheinbaren Wasserfäden zusammen; und in den Gebieten regenloser Sommer verschwinden in dieser Jahreszeit viele von den kleineren Flüssen (i ntermittierende Flüsse oder Fiumaren) ganz. Weniger schwankt der Wasserstand jener subtropischen Flüsse, die aus dem Hochgebirge kommen, wie beispielsweise des Guadalquivir.

Für die Wasserverhältnisse der Tropenzone haben die Untersuchungen von Merk $^{9}$ in Zentralamerika und von Pietsch ${ }^{10}$ im Nilgebiet neue Aufschlüsse gebracht. In Zentralamerika sind die Flüsse weniger wasserreich, als man bei den hohen Niederschlagsmengen erwarten sollte, da die starke Verdunstung - nicht die üppige Vegetation, wie man vielfach annahm - viel Wasser entzieht. In Mitteleuropa entspricht einer Niederschlagshöhe von $1500 \mathrm{~mm}$ ein Abflußfaktor von ungefähr 67, in Nicaragua aber nur ein solcher von 27 Prozent. Im Gebiet des Blauen Nil fließen von der jährlichen Regenmenge von $1300 \mathrm{~mm}$ nur 20,1, in dem des Weißen Nil bis Gondokoro von $1240 \mathrm{~mm}$ sogar nur 7,5 Prozent ab. Dieser erstaunlich kleine Abflußfaktor erklärt sich daraus, daß der äquatoriale Nilarm im Gegensatz zum abessinischen ein schwaches Gefälle besitzt und viel Wasser an die Ufersümpfe abgibt. Die jährliche Periode des Abflußfaktors nimmt in Zentralamerika ungefähr denselben Verlauf wie in unseren Gegenden, aber aus einem anderen 
Grund. Dort ist die Regenkurve, hier die Temperaturkurve entscheidend, dort wird das Maximum in unseren Wintermonaten durch das Übermaß, hier durch die Geringfügigkeit der Verdunstung bedingt. Von November bis April ist in Nicaragua der Abfluß größer als der Niederschlag, es müssen also die in der sommerlichen Regenzeit im Boden aufgespeicherten Wasserschätze in Anspruch genommen werden. Wäre dieses Kapital nicht zur Verfügung, so müßten die Tropenflüsse größeren Schwankungen unterliegen, als es in Wirklichkeit der Fall ist. Immerhin sind diese beträchtlicher, als in unseren Breiten, besonders dort, wo die Regenzeit mit der alpinen Schneeschmelze zusammentrifft. Ein-Beispiel ist der Blaue Nil (Fig. 131). Der Weiße Nil reicht dagegen in die Zone der Äquatorialregen hinein, auch wirken hier die Seen als Regulatoren. Der ägyptische Nil wird in der ersten Jahreshälfte hauptsächlich durch den Weißen, in der zweiten durch den Blauen Nil gespeist, seine fruchtbringenden Überschwemmungen verdankt er aber nur den abessinischen $\mathrm{Zu}$ flüssen, und ohne ihre Hilfe wäre er nicht imstande, den Kampf mit dem verzehrenden Wüstenklima aufzunehmen. Die Wasserstandsschwankungen des Ganges werden dadurch gemildert, das sein und seiner nördlichen Nebenflüsse Quellgebiet, der Himalaya, auch im Winter durch den Antipassat Niederschläge erhält. Eine Ausnahmestellung nehmen ferner die Äquatorialströme ein. Im Gebiet des Amazonas selbst vergeht kein Monat ohne Regen, während seine Nebenflüsse in den entgegengesetzten Jahreszeiten, die nördlichen im nordhemisphärischen und die südlichen im südhemisphärischen Sommer anschwellen; und die Gleichmäßigkeit der Wassermenge des Hauptflusses wird nur dadurch etwas gestört, daß die südlichen Zuflüsse größer sind als die nördlichen. Es erklärt sich daraus, daß in der Nähe der Mündung das Verhältnis von Niedrig- und Hochwasser nach J. Huber nur 1:2,3 beträgt. Ähnliche Bedingungen finden beim Kongo statt, so daB man schon lange vor StanLey's Entdeckung die Existenz des nördlichen Kongobogens aus den Wasserständen im Unterlauf des Stromes erschlossen hatte.

Die Wassermenge der Flüsse wechselt von Jahr zu Jahr mit den Niederschlägen; Fig. 132 lehrt uns, daß das Mittelwasser dem niedrigsten Wasserstand näher liegt als dem höchsten, oder mit anderen Worten, daß die Hochwässer verhältnismäBig rasch vorübergehende Episoden sind. Die gröBten Schwankungen finden wir in den Gegenden der unregelmäßigen Regen, besonders im Innern Australiens. Die sog. Creeks bestehen gewöhnlich nur aus einer Reihe unzusammenhängender Teiche, die sich nur nach andauerndem Regen zu Flüssen zusammenschließen. In den Jahren 1817 und 
1870 breiteten sich Murray und Darling seeartig aus, und das Hochwasser brauchte Monate, um abzufließen, während in trockenen Jahren zahlreiche Nebenflüsse nur ausnahmsweise den Hauptstrom

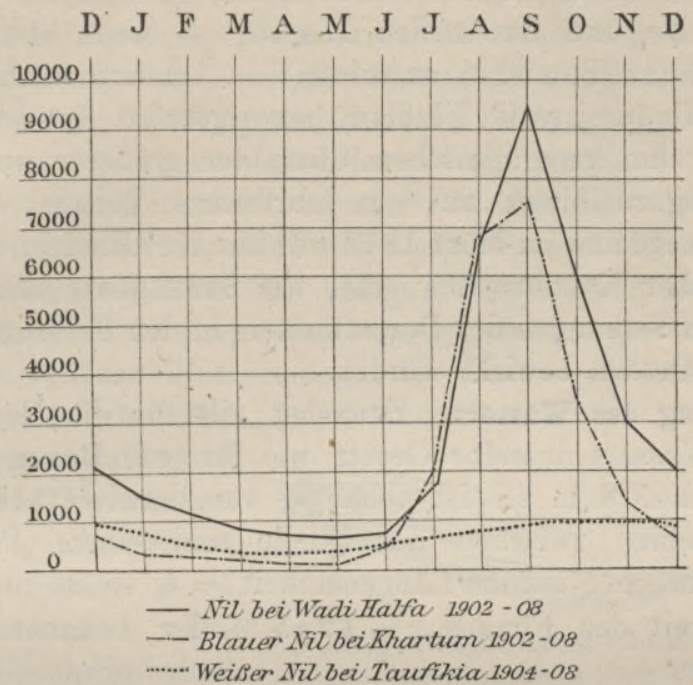

Fig. 131. Mittlere Wassermengen des Nil in cbm in der Sekunde.

erreichen. Für unsere Gegenden glaubte man aus Pegelbeobachtungen den Schluß ziehen zu dürfen, da $\beta$ die Wassermenge der

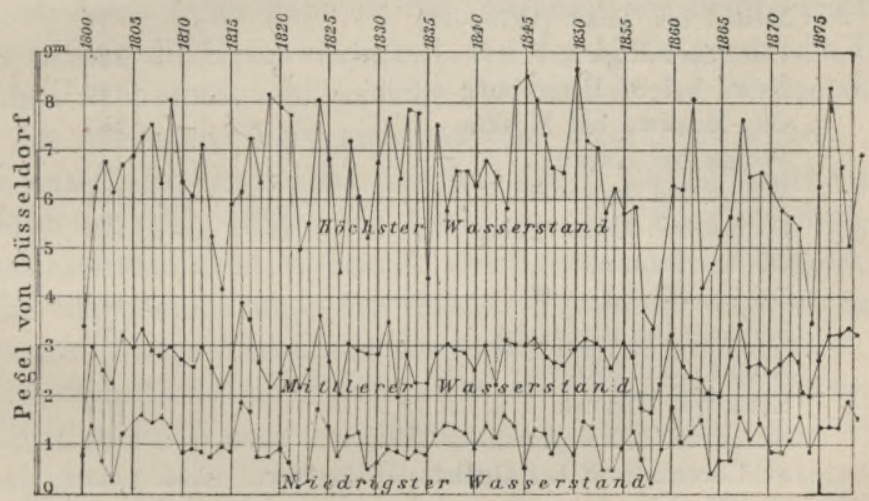

Fig. 132. Wasserstände des Rhein bei Düsseldorf, 1800-1879.

Flüsse abnehme; andere 'behaupteten, daß wenigstens der mittlere und niedere Wasserstand sinke, während die.Hochwässer steigen; wir wissen aber jetzt, daß sich in diesen Schwankungen nur die 35 jährigen Klimaperioden ${ }^{11}$ widerspiegeln, ebenso wie in der Dauer 
der Eisbedeckung, die die Flüsse höherer Breiten oft monatelang in Fesseln schlägt und dem Verkehr entzieht. $\times$

Außergewöhnliche Hochwässer, die Überschwemmungen verursachen, werden nicht nur durch heftige Regengüsse, plötzliche Schneeschmelze und durch den Eisgang - wenn die treibenden Schollen sich zu Barrieren aufstauen -, sondern auch durch orographische Hindernisse im Flußlauf hervorgerufen. Im letzteren Fall gehören sie zum geographischen Charakter größerer und kleinerer Gebiete. Ungarn bietet uns ein lehrreiches Beispiel dafür. Der Untergang Szegedins im März 1879 war nur ein Glied in einer langen Reihe ähnlicher Katastrophen, die, wie Stefanović nachwies, insgesamt durch Stauungen des Donauwassers in den Felsengen zwischen Bazias und Orsova bewirkt wurden.

Bewegung des Wassers. Zunächst gilt für die Bewegung des fließenden Wassers dasselbe Gesetz wie für jede Bewegung auf der schiefen Ebene, d. h. sie ist abhängig von dem Gefälle. Ist der Höhenunterschied zwischen der Quelle und einem Punkt $a$ des Flußlaufes, bezogen auf die Längeneinheit $=h$, so ist in $a$ die Endgeschwindigkeit des Flusses $v=\sqrt{2 g h}(g$ der bekannte Wert für

× Für folgende Flüsse beträgt die mittlere Dauer der Eisbedeckung in Tagen:

\begin{tabular}{|c|c|c|c|c|c|c|c|c|}
\hline & & & & & & & & \\
\hline be bei Hamburg (1816- & & & & . & & & & \\
\hline eichsel bei Warsehau. & & & & . & & & & \\
\hline emel bei Tilsit (1870-9? & & & & & & & & \\
\hline ina bei Riga . . . . & & . & & . & & & & \\
\hline ewa bei St. Petersburg & & & & & & & & \\
\hline ka-Moskwa bei Moskau & & & & & & & & \\
\hline ei Kasan . . . & & & & & & & & \\
\hline han . . & & & & . & & & & \\
\hline bei Arehangelsk. & & & & & & & & \\
\hline Barnaul. . . & & & & : & . & & & \\
\hline i Tomsk . . . & & & & : & & & & \\
\hline ei bei Jenisseisk . & & & & & & & & \\
\hline bei Irkutsk . . & & & & & & & & \\
\hline ei Kirensk . . & & & & . & & & & \\
\hline jewsk : & & & & . & & & & \\
\hline ei Quebe & & & & & & & & \\
\hline & & & & & & & & \\
\hline 1817 & & & & & & & & \\
\hline
\end{tabular}

$\mathrm{Zu}$ beachten ist, daB sich diese Mittelwerte auf verschiedene Zeiträume beziehen und daher nicht unmittelbar miteinander vergleichbar sind. In Sibirien hat man festgestellt, daß die kleinen Flüsse zuerst gefrieren und zuerst eisfrei werden. Die großen Flüsse gefrieren später als die Seen, tauen aber früher auf. 
die Beschleunigung der Schwere). $\mathrm{Da}$ a aber diese Geschwindigkeit niemals erreicht wird, ist eine Folge der Reibungswiderstände. Und zwar,ist eine äußere und eine innere Reibung zu überwinden: die äußere vollzieht sich an der festen Begrenzung des Flusses, die innere entsteht durch das Vorübergleiten der einzelnen Flüssigkeitsfäden aneinander, oder - wie Boussivesq ${ }^{12}$ für alle Fälle nachwies, wo die Geschwindigkeit groß oder das Bett etwas unregelmäBig ist - dadurch, daß der molekulare Zusammenhang zwischen den einzelnen Wasserschichten, besonders in der Nähe der unebenen Wände, zerrissen wird, und abgelöste Wasserteilchen sich fortwährend wirbelartig durch die übrige Flüssigkeit hinbewegen. Nun ist aber klar, daß in einem Bett von gegebenem Gefälle und Querschnitt eine größere Wassermenge den Reibungswiderstand leichter besiegen kann als eine. kleinere; ferner daß unter sonst gleichen Umständen die Reibung in einem breiten Bett größer ist als in einem schmalen. Die wirkliche Geschwindigkeit

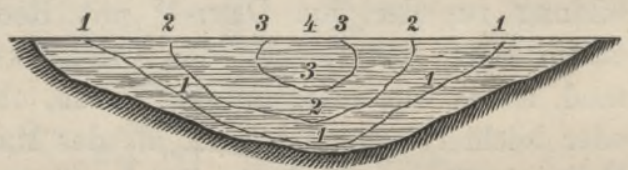

Fig. 133. Linien gleicher Geschwindigkeit innerhalb des Querprofils eines Flusses. eines Flusses steht also im geraden Verhältnis zum Gefälle und zur Wassermenge und im umgekehrten zur Breite des Bettes.

Je weiter ein Wasserfaden von der reibenden Außenfläche entfernt ist, desto freier kann er der Wirkung der Schwerkraft folgen. Daher nimmt die Geschwindigkeit von der Mitte gegen die Ufer und von oben nách unten $a b$, erreicht aber wegen des Widerstandes der Luft den höchisten Wert nicht an der Oberfläche selbst, sondern etwas unterhalb, und zwar in der Regel um so tiefer, je tiefer der Fluß ist (Fig. 133). Die Linie, die die Punkte gröBter Oberflächengeschwindigkeit verbindet, der Stromstrich genannt, bewegt sich im allgemeinen über der tiefsten Furche des Bettes, dem Talweg. Aus dieser Verteilung der Geschwindigkeiten erklärt es sich, daß die Oberfläche der Flüsse nicht eben ist. Bei Hochwasser wird der Mitte mehr Wasser zugeführt als den Rändern, und der Flußspiegel nimmt eine konvexe Gestalt an. Sinkt der Wasserstand, so fließt in der Mitte die größte Wassermenge ab, und die Oberfläche wird konkav, bis wieder normale Verhältnisse eintreten, und der Spiegel sich ein wenig über die Horizontalebene emporwölbt. Beim Mississippi betragen diese Oszillationen bis $\mathrm{zu} 2 \mathrm{~m}$.

Die Reibung durch die innere Bewegung des Wassers steigert sich, wenn bedeutendere Hindernisse, wie Ufervorsprünge, große 
Sand- und Kiesablagerungen oder Felsriffe vorhanden sind. Sie erzeugen Seiten- und Gegenströme, die unter Umständen zur Wirbelbildung führen und erst allmählich wieder in die normale Richtung einlenken.

Würden sich die Flüsse vom Ursprung bis zur Mündung auf glatten schiefen Ebenen bewegen, so wäre ihr Lauf völlig geradlinig. Aber diese Bedingung wird in der Natur nicht erfüllt. Mannigfache Hindernisse, oft unscheinbarer Art, sind vorhanden, und da das flieBende Wasser stets den tiefsten Punkt aufsucht, so wird es häufig von seinem geraden Lauf abgelenkt und gezwungen, sich in schlangenartigen Windungen (Serpentinen oder Mäander, so genannt nach einem Fluß an der Westküste Kleinasiens) zu bewegen. Diese sind um so zahlreicher, je geringer das Gefälle ist. CALLAWAY ${ }^{13}$ und ElusIs ${ }^{14}$ schreiben, ohne in der Begründung übereinzustimmen, den Nebenflüssen einen entscheidenden Anteil an der Serpentinenbildung zu; der von Davis ${ }^{15}$ mit Recht bestritten wurde. Nach einem Satz von Lóczy, den CHoLnokx ${ }^{16}$ an der Theiß bestätigt fand, ist es von wesentlichem Einfluß, ob die Flußgeschiebe schwerer oder leichter beweglich sind, als das Material der Ufer; im ersteren Fall schafft der Fluß Sandbänke, im zweiten Mäander. In jeder Biegung werden die sich am schnellsten bewegenden Wasserfäden gegen das konkave Ufer ( $a$ in Fig. 134) hingetrieben, tauchen hier in die Tiefe hinab, wobei sie durch Reibung einen Teil ihrer Bewegungsenergie einbüßen, und steigen am konvexen Ufer ( $b$ in Fig. 134) wieder in die Höhe. Der Stromstrich ( $s$ in Fig. 134) befindet sich daher nicht mehr in der Mitte, sondern schwankt von einem Hohlufer zum anderen. Die unmittelbare Folge dieser Bewegungsart ist die Vertiefung des Flußbettes in der Nähe des konkaven Ufers und dessen Unterhöhlung und Abnagung, während in dem verhältnismäßig ruhigen Raum an der entgegengesetzten Seite (bei $b$ ) Sinkstoffe abgelagert werden. Diese Doppeltätigkeit vergrößert die Krümmung immer mehr, besonders wenn der herrschende Wind das Wasser gegen das Hohlufer treibt und die Versandung des Konvexufers durch Treibmassen unterstützt. Ist der Isthmus zwischen den Bogenenden sehr eng geworden, so wird er häufig bei Hochwasser durchbrochen; auf diese Weise entstand z. B. die Insel Budsak bei Zenta (Fig. 135). In der Mehrzahl der Fälle muß aber der Mensch dieses Regulierungswerk ausführen. Die Kurve, die dann anfangs noch als Nebenkanal dient, versandet wegen des schwachen Gefälles und der geringen Wasserzufuhr immer mehr, besonders an der Aus- und der Eingangsstelle, und wird endlich völlig vom Fluß abgeschnitten. Solche sichelförmige Seen (Altwasser), die nur noch bei Hochwasser vorübergehend mit dem FluB in Verbindung treten, sind in Tief- 
ebenen sehr häufig (s. Fig. 136). Da in dem Mäanderfluß eine doppelte Strömungstendenz-herrscht, die eine gegen das Konkavufer, die andere

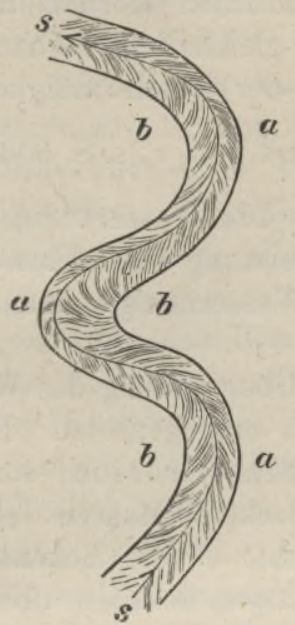

Fig. 134. Serpentinen.

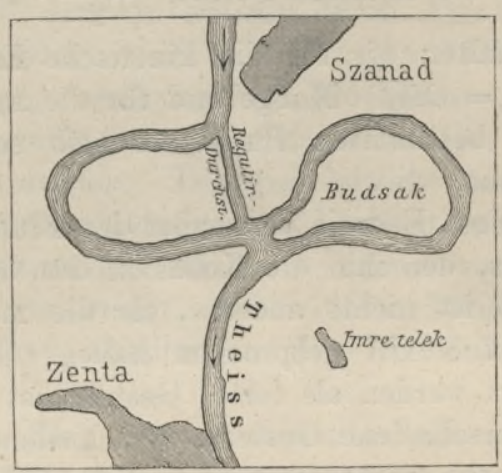

Fig. 135. Theiß bei Zenta.

talabwärts, so entwickelt sich daraus das Bestreben, die Mäander flußabwärts zu verschieben. Dadurch werden die nächsten unterhalb liegenden Konvexufer ron der Seitenerosion angegriffen, und wenn auch sie in Hohlufer umgewandelt werden, so entsteht ein breites Bett, in dem sich der FluB dahinschlängelt.

Von großer Bedeutung für den Verkehr, besonders in unzivilisierten Ländern, sind diejenigen Stellen eines Flußbettes, wo das Wasser eine so geringe Tiefe - meist unter

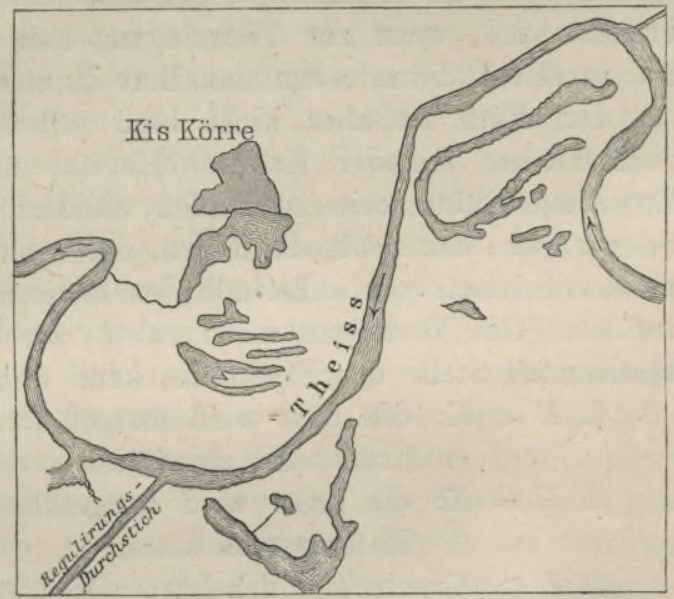

Fig. 136. Altwasser der Theiß bei Kis-Körre. $1 \mathrm{~m}$ - besitzt, daß es ohne Gefahr durchschritten werden kann. Tronnien ${ }^{17}$ unterscheidet genetisch zwei Hauptarten von Furten: solche, die durch Barren, seien es Fels- oder Sandbarren, und solche, die durch Verbreiterung und daher Verseichterung des Flusses zustande kommen. 
Die Arbeit der Flüsse. Die Betrachtungen über die Serpentinen haben uns schon mitten in die geologische Arbeit der Flüsse hineingeführt. Wie alle in Bewegung befindlichen Körper, besitzt auch das fließende Wasser lebendige Kraft, gleich dem halben Produkt aus der Masse $(M)$ und dem Quadrat der Geschwindigkeit $(v)$. Setzen wir in diese Formel $\left(\frac{M v^{2}}{2}\right)$ den Wert von $v$ (s. S. 506) ein, so erhalten wir für die kinetische Energie des Wassers den Ausdruck $=$ Mhg. Maßgebend für die Arbeitsleistung eines Flusses an einem bestimmten Punkt ist also seine Wassermenge und seine Fallhöhe.

Diese Energie verwèndet der Fluß zur Überwindung des Widerstandes, den ihm die Kohäsion des Gesteins entgegensetzt. Dieser Prozeb ist nichts anderes, als die mechanische Erosion, von der wir auf S. 467 gesprochen haben. Daß lockere Massen leichter erodiert werden als festes Gestein, ist bekannt; ebenso bekannt ist, daß verschiedene Gesteine verschiedene Kohäsion besitzen, aber wir sind noch nicht imstande, diese ziffernmäßig abzuschätzen. Die Erosion geht entweder in die Breite oder in die Tiefe oder nach beiden Richtungen zugleich. Es ist aber noch wenig erforscht, in welchem Verhältnis die Seiten- und Tiefenerosion zueinander stehen, denn die Erfahrung lehrt; das manchmal das Bett noch verbreitert wird, wenn zur Tieferlegung keine Kraft mehr vorhanden ist, ja selbst dann, wenn das Bett durch Ablagerung erhöht wird.

Der Fluß ist aber nicht bloB selbständiger Arbeiter, er ist auch Diener fremder Kräfte. Er hat nicht bloß seine eigenen Erosionsprodukte weiterzuschaffen, sondern auch das, was ihm die Schwerkraft, der spülende Regen, der schmelzende Schnee an Verwitterungsschutt von außerhalb des Bereiches seiner Erosionssphäre zuführt. Das Verhältnis der Last $(L)$ zur Wasserkraft $(K)$ an einer bestimmten Stelle des FluBlaufes kann dreifach sein:

1. $L<K$ : die Last wird fortgeführt und der Überschuß an Kraft wird zur Erosion verwendet;

2. $L=K$ : die Last wird fortgeführt, es findet aber keine Tiefenerosion statt;

3. $L>K$ : ein Teil der Last wird transportiert, der Überschuß wird abgelagert.

Beide Momente, die die geologische Arbeit des Flusses bedingen, Last und Kraft, sind nach Ort und Zeit veränderlich. Wo Hochwasser eben noch erodieren kann, kann das folgende Niedrigwasser nur ablagern. Manchmal wird durch Bergstürze eine solche Menge Schutt auf einmal in das FluBbett geworfen, daß jahrelang 
an seiner Beseitigung gearbeitet werden muß, und die Erosion auf ebenso lange Zeit brach gelegt ist. Bei Flüssen, die im Gebirge entspringen und dann durch Hügelland und Tiefebene ihren Lauf nehmen, hängt die Energie mehr von der nach unten abnehmenden Geschwindigkeit als von der in gleicher Richtung zunehmenden Wassermenge $a b$, und in diesem Fall wird im großen und ganzen der Oberlauf durch Erosion, der Unterlauf durch Ablagerung charakterisiert. Im Zwischenstück oder im Mittellauf ist die Geschwindigkeit im allgemeinen, wenigstens bei Hochwasser, eben noch groß genug, um die Sinkstoffe fortzuschaffen, reicht aber nicht mehr hin, um das Bett zu vertiefen. Dagegen bewirkt hier die seitliche Erosion durch Serpentinenbildung eine Verbreiterung des Bettes. Einschneiden, Verbreitern und Erhöhen folgen also talabwärts aufeinander, doch ist, wie gesagt, keine dieser Tätigkeiten ausschließlich auf eine der drei Abteilungen des Flußlaufes beschränkt.

Flußablagerungen. ${ }^{18}$ Der Fluß führt Sedimente teils in gelöstem Zustand, teils mechanisch mit sich fort. Die chemisch gelösten Mineralstoffe (kohlensaurer und schwefelsaurer Kalk, etwas kohlensaure Magnesia und untergeordnet Kochsalz) bilden zwar nur ungefähr 1/6000 der Wassermenge, können aber im Lauf geologischer Zeiträume einen hohen Betrag erreichen. Ein Teil dieser Stoffe wird bei Hochwasser im Inundationsgebiet abgelagert, ein anderer durch das Sickerwasser dem Boden zugeführt, der größte Teil aber gelangt in das Meer. Warum das Meer trotzdem keine konzentrierte Lösung von kohlensaurem Kalk und Gips ist, erklärt sich aus dem Verbrauch dieser Stoffe durch die marine Tierwelt. Das mechanisch mitgeführte Material wird einem Schlemmprozeß unterworfen. Größere Felsstücke können höchstens durch angeschwollene Wassermassen fortgeschleppt werden; so vermag z. B. die Linth bei Hochwasser $50 \mathrm{~kg}$ schwere Blöcke weiterzubewegen, und bei der Überschwemmung von Bozel (Savoyen) im Juli 1904 lagen an Stelle der zerstörten Häuser Blöcke von zehn und mehr cbm Inhalt, ohne eine Spur des Rollens aufzuweisen. ${ }^{19}$ Aber in die Ebene gelangen sie nicht, sondern bleiben, ebenso wie grobes Geröll, im Gebirge zurück. Weiter hinab werden Kies, Sand und am weitesten Schlamm geführt. $\times$ Der letztere wird schwebend erhalten, der Sand aber nur

$\times$ Diese Bezeichnungen haben keine petrographisehe Bedeutung, sondern beziehen sich nur auf die Korngröße. Eine einheitliehe Terminologie besteht leider noch nicht. Deutsehe Autoritäten nennen Körner von mehr als $3 \mathrm{~mm}$ Durehmesser Kies, 3-2 mm Grand, 2-0,5 mm groben Sand, 0,5-0,05 mm Sand und unter $0,05 \mathrm{~mm}$ Staub bzw. Schlamm. 
solange, als die innere Bewegung des Wassers bedeutend ist. Im entgegengesetzten Fall sinkt er zu Boden und wird hier stromabwärts geschleppt. In geradlinigen Flußstrecken bilden sich wandernde Sandbänke (Untiefen), so daß das Flußprofil sich beständig verändert (vgl. Fig. 137), während die Ablagerungen an den konvexen Ufern der Serpentine verhältnismäBig stabil sind. Auch wenn sich die Geschwindigkeit des Wassers nicht ändert, entstehen Sandablagerungen an den Stellen, wo sich das Bett verbreitert. Ist das Gefälle beträchtlich, so können sich die Sedimente nur dort am Boden anhäufen, wo Rückstau eintritt - also hinter einem festen Gegenstand im Flußbett und an den toten Stellen in den Biegungswinkeln eines sich plötzlich verengenden Bettes - , oder infolge von Scharung, d. h. beim Zusammentreffen zweier konvergierender Strömungen. So kann eine Insel nach oben durch Rückstau und nach unten durch Scharung vergrößert werden. Sandinseln bilden sich nach den Erfahrungen der

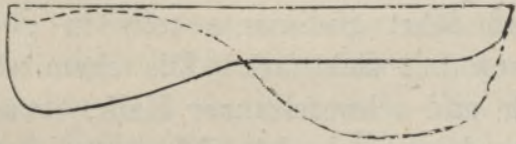

Fig. 137. Profil des Donaubettes unterhalb der Reichsbrücke bei Wien, nach Penck. 1884. Hydrotechniker in den meisten Fällen aus stromabwärts gerichteten Landzungen, deren Verbindung mit dem Ufer dann durchrissen wird, oder bei dem Durchbruch einer Serpentine (S. 508). Diese aus losem Material aufgehäuften Gebilde können natürlich wieder vom Wasser verschlungen werden, wenn nicht der Pflanzenwuchs, namentlich tiefer wurzelnde Bäume Halt gewähren. Die Pflanzendecke hält auch das immer neu herbeigeschaffte Material fest, so daß sich die Insel endlich auch über den Hochwasserstand erhebt. In tropischen Flüssen veranlassen häufig auch Treibholz und andere Pflanzenansammlungen die Entstehung von Inseln oder gar geschlossenen Wehren, da die Bäume wegen des größeren spezifischen Gewichtes des. Wurzelendes eine schiefe Stellung im Wasser einnehmen und sich leicht im Grund festsetzen können. ${ }^{20}$

In den beschriebenen Fällen wird entweder das Flußbett erhöht, oder eine Insel gebildet, oder das Ufer vergrößert. Ähnlicher Art ist die Ablagerung im sog. Inundationsbett seicht eingeschnittener Ströme, das sie nur bei Hochwasser überschwemmen. Setzt der Mensch - wie z. B. im unteren Poland - der Ausbreitung des Hochwassers durch Dammbauten Schranken, so wird alles Material im Flußbett zurückbehalten und erhöht es stetig, so daB das Flußniveau oft mehrere Meter hoch über der umgëbenden. Niederung liegt. Natürlich müssen auch die Dämme immer höher wachsen, 
aber leider können sie das Kulturland zu ihren Füßen nicht immer vor dem Einbruch des Wassers schützen.

Gebirgsbäche, die aus steilen Seitentälern kommen, lagern fast ihr gesamtes, Material beim Eintritt in das sanfter geneigte Haupttal in der Form von Schuttkegeln ab. Nebenflüsse, die ihre Sinkstoffe bis zur Mündung mitführen, werden hier gestaut und gezwungen, das Material im inneren Winkel der Mündungsstelle fallen zu lassen. Je mehr die Ablagerung wächst, desto weiter wird die Mündungsstelle nach abwärts verschoben. Die Nebenflüsse des $\mathrm{Po}$ zeigen diesen Vorgang in besonders prägnanter Weise; ja die Landzunge zwischen der Etsch und dem Po ist so rasch gewachsen, daß der tirolische FluB aus der Klientel seines einstigen Hauptstromes entlassen wurde und nun parallel mit ihm in das Meer flieBt. ${ }^{21}$

Eine andere Erklärung dafür geben BoussinesQ und GÜNTHER. ${ }^{22}$ In einem Hohlraum von streng geometrischer Regelmäßigkeit liegt nur eine Abflußlinie, den sie Talweg (hier identisch mit Haupt$\mathrm{fluB}$ ) nennen, in ihrem ganzen Verlauf in einer Vertikalebene, während alle anderen asymptotisch zu dieser verlaufen, indem sie mit dem Hauptlluß einem gemeinsamen, unendlich weit entfernten Tiefpunkt zustreben. In Wirklichkeit nähern sie sich aber nicht nur immer mehr dem Hauptfluß, sondern vereinigen sich auch mit ihm, aber in der Weise, daß sie ihre Mündung möglichst weit abwärts verlegen.

Die Sedimente, die am Land keine Ruhestätte finden, werden endlich in einem See oder im Meer abgelagert. Daß selbst die langsam fließenden Ströme der Tiefebenen noch imstande sind Material fortzuschaffen; hat seinen Grund darin, daB sie in der Regel bis zu ihrem Ende Zuflüsse empfangen, und daß zwei Flüsse nach ihrer Vereinigung niemals ein Bett von doppelter Breite einnehmen. Das Bett des Hauptflusses behält entweder seine frühere Breite bei oder verengt sich sogar, wie z. B. das des Mississippi von $1400 \mathrm{~m}$ in der Nähe der Ohiomündung bis $750 \mathrm{~m}$ zwischen Carrollton und der Deltagabelung. Tritt aber auch keine Verschmälerung ein, so $m u B$ sich doch die größere Wassermenge jetzt rascher bewegen als vor Aufnahme des Nebenflusses, um so mehr als nur mehr die Reibung von zwei statt von vier Ufern zu überwinden ist. Mit der Geschwindigkeit wird aber auch die Transportkraft des Wassers gesteigert.

Die Menge der Sedimente, die die Flüsse teils in gelöstem Zustand, teils mechanisch mitführen, gibt uns eine Vorstellung von der allmählichen Zerstörung dẹs Festlandes. Tägliche Messungen besitzen wir leider nur von zwei Alpenflüssen, von der Arve ${ }^{23}$ und der Rhône, ${ }^{24}$ und nur die letzteren erstrecken sich lückenlos über ein ganzes Jahr. Wir entnehmen daraus, daß die Sedimentführung - 
wie nicht anders zu erwarten war - mit der. Wassermenge steigt und fällt, also im Sommer ungleich größer ist als in der kalten Jahreshälfte, daß aber - und dies ist überraschend - die Flüsse im Winter relativ mehr gelöstes Material mit sich führen als im Sommer, $\times$ Das Endergebnis ist ein Abtrag von 0,29 $\mathrm{mm}$ im Jahr im oberen Rhônegebiet. Nach anderen Methoden hatten HeIм für das Reußgebiet 0,24 und Steck für das Kandergebiet 0,43 $\mathrm{mm}$ gefunden. Die Schlammessungen im Oeschinensee ergaben 0,3 mm. Die Zahlen für die Schweizer Alpen stimmen also leidlich überein, bringen aber nicht den ganzen Destruktionsbetrag zum Ausdruck. Zum Teil vernachlässigen sie die gröberen Abtragungsprodukte, und alles Gerölle, das die Flüsse oberhalb der Messungsstelle in ihrem Bett liegen lassen, und alle Schuttkegel, die ihre Zuflüsse aufbauen, bleiben unberücksichtigt. Ausgehend von der Erwägung, daß der Abtrag von dem Böschungswinkel, dem Niederschlag und dem Frostwechsel abhängt, hat Hess ${ }^{25}$ versucht, die Destruktionsarbeit auf die einzelnen Höhenstufen zu verteilen, und gefunden, daß sie bis zu einer Höhe von ungefähr $2000 \mathrm{~m}$ zu- und dann wieder abnimmt. $\times \times$ Als Hauptfaktor erweist sich also die Häufigkeit des Überganges vom Frost zum Auftauen; gerade dadurch wird die Zerstörung am meisten gefördert. Aus diesem Grund unterliegt unter sonst gleichen Umständen

× Messungen an der Rhône bei Pont-du-Scex, 6 km oberhalb des Genfersees.

\section{Absolute Zahlen \\ Winter- Sommer- \\ halbjahr halbjahr Jahr}

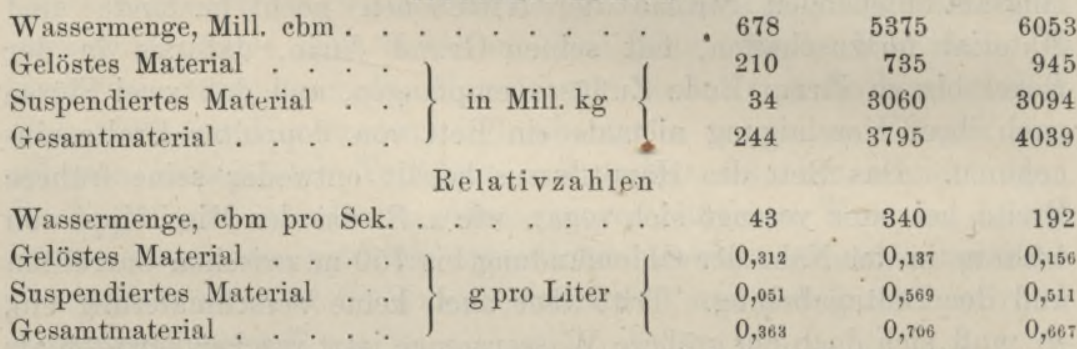

$\times \times$ In allen untersuchten Gebieten lassen sich drei Hauptstufen unterscheiden, von denen nur die mittlere durch einen höheren Abtrag ausgezeichnet ist, als dem ganzen Gebirge zukommt. Die durehsehnittliche jährliche Abtragung beträgt in $\mathrm{mm}$ :

\begin{tabular}{|c|c|c|c|}
\hline & ReuB & Rhône & Kander \\
\hline unter $1500 \mathrm{~m}$ & 0,17 & 0,15 & 0,25 \\
\hline $1500-2700$, & 0,27 & 0,39 & 0,57 \\
\hline über $2700 "$. & 0,19 & 0,19 & 0,32 \\
\hline Ganzes Gebirge & 0,24 & 0,29 & 0,43 \\
\hline
\end{tabular}

Es ist aber dabei wohl im Auge zu behalten, dab die klimatologischen Daten für die oberste Stufe, namentlich die Regenmengen, sehr unsicher sind. 
das Mittelgebirge beträchtlich langsamer der Abtragung als das Hochgebirge:

\begin{tabular}{|c|c|c|c|c|c|}
\hline & & $\begin{array}{l}\text { Jährlieh } \\
\text { Suspendiertes } \\
\text { Material }\end{array}$ & $\begin{array}{l}\text { Gelöstes } \\
\text { Material }\end{array}$ & Zusammen & $\begin{array}{l}\text { Abtragung } \\
\text { von } 1 \mathrm{~mm} \\
\text { in Jahren }\end{array}$ \\
\hline Elbe. & . & 0,002 & 0,015 & 0,017 & 58,8 \\
\hline Maas . . & . & 0,005 & 0,022 & 0,027 & 37,0 \\
\hline Seine u. Marne & . & 0,004 & 0,016 & 0,020 & 50,0 \\
\hline Themse. . . & : & 0,0015 & 0,015 & 0,0165 & 60,6 \\
\hline
\end{tabular}

Diese Beispiele sind auch dadurch interessant, daB hier durchaus die chemische Abtragung die mechanische überwiegt, und den gleichen Gegensatz zwischen Flüssen von sehr verschiedenem Gefälle finden wir nach PietseH ${ }^{10}$ auch im Nilgebiet. Durch das suspendierte Material trägt der Blaue Nil von seinem Gebiet jährlich 0,063, der Weiße $0,0005 \mathrm{~mm} \mathrm{ab}$, durch das gelöste Material der Blaue Nil 0,01 , der Weiße $0,0013 \mathrm{~mm}$. Jener bedarf zu einer Abtragung von

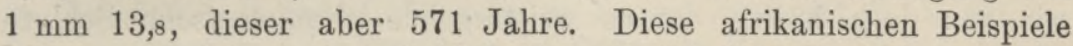
geben uns auch noch Aufschluß über die jährliche Periode der Sedimentführung in den Tropen; wir haben dabei nur im Auge zu behalten, daß der Weiße Nil noch an den äquatorialen Regen teilnimmt, der Blaue aber unter der strengen Herrschaft der Tropenregen steht.

Monatsmittel: $g$ in 1 Liter Wasser

Dezember bis Mai Suspendiert

Weißer Nil

Blauer Nil
0,061

0,032
Gelöst

0,170

0,132

\section{Juni bis November} Suspendiert

Gelöst

$\begin{array}{ll}0,063 & 0,159 \\ 0,566 & 0,116\end{array}$

Die umfassenden Messungen in den Vereinigten Staaten, die BAULIG $^{26} \mathrm{zu}$ einem interessanten Gesamtbild vereinigt hat, zeigen eine außerordentliche Veränderlichkeit der Destruktionsarbeit nach Bodenart und Klima, d. h. Wasserreichtum.× Ihre höchsten Werte

$\times$ Aus Baulig's Kärtchen entnehmen wir folgende Beispiele. Die Zahlen bedeuten den jährlichen Transport in Tonnen auf $1 \mathrm{qkm}$ des betreffenden FluBgebiets.

\begin{tabular}{|c|c|c|}
\hline & $\begin{array}{c}\text { Mecha- } \\
\text { nisch }\end{array}$ & Gelöst \\
\hline Savannah & . 90 & 38 \\
\hline Potomack (Washington) & 36 & 49 \\
\hline II. Glazialgeb & iet. & \\
\hline Kennebee . . . & 2,8 & 32 \\
\hline Hudson (Albany). . . & . 11 & 74 \\
\hline White River (Indiano & & \\
\hline polis) . . . . . & 11 & 138 \\
\hline Mississippi (St. Paul) . & & 61 \\
\hline
\end{tabular}

\begin{tabular}{|c|c|c|}
\hline & $\begin{array}{c}\text { Mecha- } \\
\text { nisch }\end{array}$ & Gelös \\
\hline Ohio (Cineinnati). . . & 142 & 74 \\
\hline Mississippi (St. Louis) . & .114 & 17 \\
\hline , (N.-Orleans) . & .129 & 45 \\
\hline Missouri (Kansas C.) . & .112 & 23 \\
\hline Arkansas (Little Rock) & . 56 & 47 \\
\hline
\end{tabular}

Colorado (Yuma) . . . 181 18

Sacramento . . . . 33 67 
erreicht sie dort, wo tiefgründige Verwitterungserde oder mächtige feinlockere Ablagerungen den Felsboden bedecken; wo diese fehlen, wie im Gebiet des alten Inlandeises an den canadischen Seen und im Nordosten der Union, ist die mechanische Abtragung auffallend gering. Auch daß der Mississippi trotz seines langen Unterlaufes noch reich mit Sedimenten beladen das Meer erreicht, ist ein interessantes Ergebnis. Auf die chemische Abtragung scheinen die klimatischen Verhältnisse einen größeren Einfluß auszuüben als auf die mechanische; im trockenen Westen ist sie verhältnismäßig geringfügig. Außerdem hängt sie, wie selbstverständlich, von der Löslichkeit des Gesteins ab und steht unter sonst gleichen Bedingungen, wie auch die Beispiele aus der Alten Welt bestätigen, im umgekehrten Verhältnis zum Gefälle der Flüsse.

Wenn wir uns jetzt auch eine annähernde Vorstellung von dem Umfang der kontinentalen Zerstörung machen können, so müssen wir uns doch hüten, daraus weittragende chronologische Schlußfolgerungen zu ziehen, wie es z. B. Penck getan hat, indem er berechnete, „da $B$ unter Voraussetzing ihrer heutigen Tätigkeit die Flüsse fast 9 Millionen Jahre brauchten, um das Land bis zum Meeresspiegel abzutragen.“ Jene Voraussetzung ist eben unrichtig, denn je weiter die Abtragung fortschreitet, desto langsamer wirkt sie. „Schließlich bleiben wir“, sagt Нетм, „nach solchen Messungen und Betrachtungen unentschieden, ob wir sagen sollen: die Verwitterung und Erosion ist ein Vorgang, der mit staunenerregender Schnelligkeit und Gewalt an der Umformung der Gebirge arbeitet, oder sollen wir sagen: sie ist ein Vorgang, der fast unmerklich langsam arbeitet. Beides ist wahr - den ,ersteren Eindruck erlangen wie bei Betrachtung des Schutttransportes durch die Ströme, den letzteren im Anblick der viel gewaltigeren Masse des Gebirges."

Literaturnachweise. ${ }^{1} \mathrm{Am}$ ausführlichsten werden die Flüsse in hydrotechnischen Werken behandelt. Besonders zu empfehlen sind G. HAGEN, Handbuch der Wasserbaukunst, Berlin $1871 ;$ L. Franzius und E. Sonne, Wasserbau, Leipzig 1884; J. F. Bubendey, P. Gerhardt u. R. Jasmund, Die Gewässerkunde, Leipzig 1905-06. Ausführlich auch in A. PEnck's Morphologie, zit. S. 375. J. C. Russels, River Development as illustrated by the Rivers of North Ameriea, London 1898, behandelt nur die geologische Seite des Problems. Von großer Wichtigkeit ist die amtliche Strombeschreibung des Deutschen Reichs: Der Rheinstrom, Berlin 1889; Der Oderstrom, Berlin 1896; Der Memel-, Pregel- und Weichselstrom, Berlin 1889; Das Maingebiet (M. v. Teıs), Berlin 1901; Weser und Ems, Berlin 1901. $\rightarrow{ }^{2}$ Für die Methodik der Wasserstandsmessungen ist wichtig $\mathrm{H}$. A. Pressex, Dbservations on the Flow of Rivers in the Vicinity of New York City; Washington 1903 (Water Supply and Irrigation Paper, Nr. 76) $-{ }^{3}$ H. KelLer, Nièdersehlag, Abfluß und Verdunstung in Mitteleuropa; Berlin 1906; auch in der Geographischen 
Zeitsehrift 1907, S. 611 u. $682 .-{ }^{4}$ A. PENck, Untersuchungen über AbfluB und Verdunstung von größeren Landflächen, in Pesck's Geographischen Abhandlungen, 1896, Bd. V. $-{ }^{5}$ W. Ule, Niedersehlag und AbfluB in Mitteleuropa; Stuttgart 1903 (in den Forsehungen zur deutschen Landes- und Volkskunde, Bd. XIV). - ${ }^{6}$ F. X. Schaffer, in den Mitteilungen der Wiener Geographisehen Gesellschaft, 1903, S. 126. - ${ }^{7}$ E. Opрокоw in La Pèdologie 1901, S. 225 und Semlewedenje 1905. - ${ }^{8}$ A. Woeikow, Klimate, zit. S. 56. ${ }^{9}$ A. Merz, Beiträge zur Klimatologie und Hydrographie Mittelamerikas, Leipzig 1907. - ${ }^{10}$ W. Pietsch, Das Abflußgebiet des Nil, Berlin 1910. - ${ }^{11}$ E. Brǘcrner, Klimaschwankungen, zit. S. 256. - ${ }^{12}$ Boussinese, Essai sur la théorie des eaux courants, in den Mémoirs der französischen Akademie der Wissenschaften 1877. - ${ }^{13}$ C. Callaway, im Geologieal Magazine, 1902, Bd. IX. S. 450. - ${ }^{14}$ T. S. Ellis, ebenda 1903, Bd. X, S. 350. - ${ }^{15}$ W. M. DAvis, ebenda S. $145 .-{ }^{16}$ J. v. ChoLNoкx, Über die Lagenveränderungen des Tiszabetts, im Abrégé du Bulletin de la Société Hongroise de Géographie 1907. - ${ }^{17}$ R. Tronsier, Über Furten, in Petermans's Geographischen Mitteilungen 1905. - ${ }^{18}$ E. Fugger und K. Kastner, Die Geschiebe der Salzach, in den Mitteilungen der Geographischen Gesellschaft in Wien 1895, eine eingehende, sehr lehrreiche Studie. - ${ }^{19}$ L. Carez, im Bulletin de la Société géologique de France, 1905, Bd. V, S. 519. 20 K. Frauenfelder, Über Entstehung der FluBinseln; München 1897. O. DeuerLıNG, Die Pflanzenbarren der afrikanischen Flüsse, München 1909. - ${ }^{21}$ Von einem Ausnahmefall handelt L. Henkel in Petermann's Mitteilungen 1889, S. 176. - ${ }^{22}$ S. GÜnther, Über gewisse hydrologisch-topographisehe Grundbegriffe, in den Sitzungsberichten der Bayerischen Akademie der Wissensch., Mathem.-phys. Klasse, 1902, Bd. XXXII. - ${ }^{23}$ B. BÄ̈Ff, Les eaux de l'Arve; Genf 1891. - ${ }^{24}$ E. Uetrecht, Die Ablation der Rhône in ihrem Walliser Einzugsgebiet im Jahr 1904-05; Bern 1906. - ${ }^{25}$ H. Hess, Der Abtrag in den Sehweizer Alpen, in Petermans's Mitteilungen 1909. - ${ }^{26}$ H. Baulig, Eeoulement fluvial et dénudation, in den Annales de géographie 1910, Bd. XIX.

\section{Die Erosionsarbeit des fließenden Wassers.}

Das Wesen der Erosionsarbeit. Das Endergebnis der Erosionsarbeit des Wassers sind lineare Vertiefungen, aber sie erreicht dieses Ziel nicht bloB, wie man bisher meinte, durch einfaches Einschneiden oder Durchsägen der Unterlage, sondern auch auf Umwegen. Es ist ein Verdienst von BronHes, ${ }^{1}$ auch auf den wichtigen Anteil der Wirbelbewegung des Wassers hingewiesen zu haben, wenn er ihn auch unserer Ansicht nach überschätzt. Wo immer das Wasser nicht glatt abfließen kann, gerät es in wirbelnde Bewegung und erzeugt, wenn ihm Schleifmaterial zu Gebot steht, mehr oder minder kreisähnliche Löcher, sogenannte Riesentöpfe. Man glaubte früher, sie seien auf Gletscherbetten beschränkt (vgl. S. 202), BRunHES hat aber nachgewiesen, $\mathrm{daB}$ sie auch in den in festes Gestein eingeschnittenen Flußbetten, man darf wohl sagen, allgemein vorkommen. Wie rasehe Fortschritte diese Bohrarbeit macht, zeigte sich 1897 , als eine ungewöhnliche Trockenheit das Bett eines 1872 angelegten künstlichen Kanals bei Freiburg i. Sch. zugänglich machte. Ein 
Vierteljahrhundert hatte genügt, um im Molassegestein zahlreiche Riesentöpfe auszuhöhlen, von denen die größten $1 / 2$ bis $3 / 4 \mathrm{~m}$ im Durchmesser hatten und $1 \frac{1}{5} \mathrm{~m}$ tief waren. Ein besonders ergiebiges Feld für Beobachtungen bietet eine der zahlreichen Granitinseln im ersten Nilkatarakt; man sieht hier Töpfe in verschiedenen Stadien der Entwicklung, von rinnenförmigen Vertiefungen um eine konische Erhebung, ähnlich dem Boden der Weinflaschen, bis zum völlig ausgefeilten Loch mit konkavem Grund. Fourtau ${ }^{2}$ bemerkt aber ausdrücklich, daß Wirbel nur dort entstanden, wo die Strömung auf Hindernisse stie $B$, und betont auch gegenüber BRunHEs, da $B$ das Schleifmaterial aus Mahlsteinen, nicht aus Sand bestand. Benachbarte Töpfe können miteinander verschmelzen, dünne Scheidewände werden zerstört, und aus rosenkranzartig aneinandergereihten Löchern entsteht so eine zusammenhängende Tiefenlinie. ${ }^{3}$ Die Erosion besteht also in Einschneiden und Bohren, und es hängt von verschiedenen Umständen $a b$, welche Art der Tätigkeit die Oberhand gewinnt. In lockerem Gestein findet nur Einschneiden statt.

Der Typus des Erosionstales. ${ }^{4}$ Die ersten Anfänge der Talbildung durch Erosion können wir nach jedem Regenguß im Gebirge beobachten. Das abfließende Wasser hat sich Rinnsale im lockeren Boden ausgegraben, die, wenn die Böschung nicht allzusteil ist, nicht direkt von der Höhe ins Tal hinunterziehen, sondern diagonal einander zulaufen, um sich endlich zu einer einzigen Rinne zu vereinigen. Die Produkte seiner Zerstörung lagert es als Schuttkegel am $\mathrm{FuB}$ des Gehänges ab und fließt in weit verzweigten Wasserfäden darüber hin. Der Schuttkegel bildet den Unterlauf, alles übrige den Oberlauf des Wildbaches, während der Mittellauf nur auf einen Punkt zusammengedrängt ist. Nąch den nächsten Regengüssen finden wir das Bett im Oberlauf vertieft, den Schuttkegel erhöht, und gleichzeitig hat sich das Quellgebiet nach rückwärts erweitert. Die Erosion bewirkt also nicht nur eine Vertiefung des einmal entstandenen Bettes, sondern auch seine Verlängerung nach rückwärts.

Die Erfahrung lehrt ferner, daß Täler unter einfachen Verhältnissen im Längsprofil die Form einer nach unten verflachenden Kurve annehmen, und es ist auch leicht einzusehen, warum dies geschehen muB. Selbst wenn sich ein FluB ursprünglich in einem Kanal mit gleichmäBigem Gefälle bewegen würde; kæönnte dieser Zustand nicht erhalten bleiben, denn die Wassermenge nimmt nach unten zu, und damit auch die Arbeitsfähigkeit. Im untersten Teil beginnt der Fluß einzuschneiden, und die Erosion schreitet stetig nach oben fort, aber nach MaBgabe der Wasserkraft. 
Sie arbeitet unten erfolgreicher als oben, und dies kommt dadurch zum Ausdruck, daß das neue Gefälle stetig nach oben zunimmt. Indem sich oben 'mit geringster Wassermenge ein stärkstes Gefälle, unten mit größter Wassermenge ein schwächstes Gefälle paart, entsteht ein Gleichgéwichtszustand. Das Wasser besitzt dann nur mehr die Kraft, den ihm zugeführten Verwitterungsschutt talauswärts zu schaffen, ist aber nicht mehr imstande, sein Bett $\mathrm{zu}$ vertiefen. In diesem Sinn darf man die Gleichgewichtskurve mit PHILIPpson wohl als Erosionsterminante bezeichnen, aber nur als zeitweilige. Fig. 138 führt uns eine solche typische Kurve vor Augen; können wir aber annehmen, daß hier, bei einem Gefälle von $36^{\circ} 43^{\prime}$ in der obersten und von $14^{0} 56^{\prime}$ in der untersten Partie die Erosionskraft lahmgelegt sei, während doeh erfahrungsmäBig - wie Penck ${ }^{5}$ hervorhebt - noch Ströme unter einem Neigungswinkel von $0^{0} 17^{\prime}$

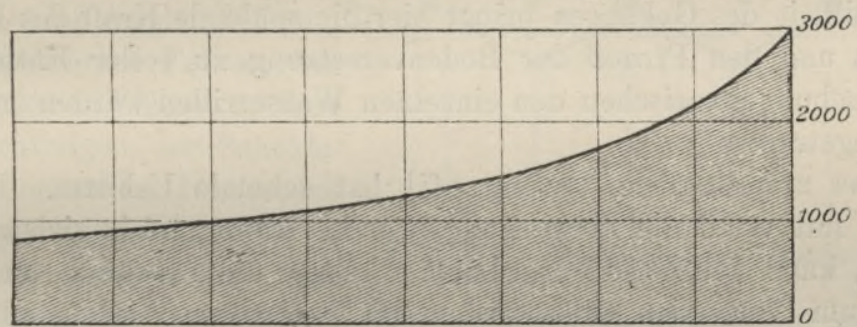

Fig. 138. Längsprofil des Litzerbachtales bei Laas (Tirol).

Länge und Höhe im gleichen Maßstab (Meter).

„erstaunliche Sandmassen transportieren und oft große Löcher auskolken“? „Die Erosion,“ sagt er, „hört erst dann auf, wenn die Gewässer so träge dahinschleichen, daß sie nicht mehr die feinsten Partikel zu verschleppen vermögen, welche sich im Lauf der Zeiten durch das Zusammenwirken der verschiedensten Kräfte aus ihrem Boden loslösen.“ Die Lösung dieses Widerspruchs scheint uns Davis gegeben zu haben. Nur so lange ist die Tiefenerosion sistiert, solange sich Wasserkraft und Last das Gleichgewicht halten. Die Last nimmt aber $a b$, die Talgehänge nnd die Wasserscheide erniedrigen sich, und ihre Verwitterungsprodukte werden nicht nur an Masse geringer, sondern auch feiner. Nun wird ein Teil der Wasserkraft frei, der zu neuer Erosionsarbeit verwendet wird, um einen den neuen Bedingungen entsprechènden Gleichgewichtszustand herzustellen. Dieses Spiel kann sich mehrmals wiederholen, die Gleichgewichtskurve senkt sich immer tiefer in den Boden hinein und nähert sich dabei immer mehr der Geraden, ohne sie jemals erreichen zu können. Erst die letzte ist die wahre Erosionsterminante; wann sie erreicht wird, hängt von der Beschaffenheit 
des Bodens, der Wassermenge und der Dauer der Arbeit ab. Die erste Bedingung ist für jedes Tal ein für allemal gegeben, die zweite wechselt mit den Jahreszeiten. Nur das regelmäBige Hochwasser ist für die Gestaltung der Endkurve maßgebend, außergewöhnliche Hochwässer bringen nur vorübergehende Störungen, die Perioden des Niedrigwassers sind Perioden des Stillstandes; ja stellenweise kann sogar Ablagerung eintreten, die das nachfolgende Hochwasser erst beiseite schaffen muß, ehe es an die Fortführung seiner Erosionsarbeit gehen kann.

Mit der Gestaltung des Längsprofils hängt auch die des Grundrisses zusammen. Gehen wir ein junges Erosionstal hinauf, so gelangen wir durch einen kanalartigen Einschnitt, die Klamm, in eine trichterförmige Erweiterung, wo sich die einzelnen, radial einander zulaufenden Quellarme zu dem Bach vereinigen (Quelltrichter). Die Steilheit des Gehänges bringt hier die spülende Kraft des Regenwassers und den ProzeB der Bodenversetzung zu voller Entfaltung, die Erhebungen zwischen den einzelnen Wasserrillen werden mit der Zeit abgetragen.

Das ursprüngliche Querprofil hat schmale U-Form. In Gesteinen mit vertikaler Zerklüftung, wie in Granit und in vielen Sandsteinen, kann sich diese Form lange erhalten; die Talwände, an denen Platte um Platte sich loslöst und in die Tiefe stürzt, treten von selbst zurück, und das Tal verbreitert sich, ohne daß der Fluß direkt etwas dazu beiträgt. In Gesteinen von anderer Beschaffenheit nehmen aber die Talwände durch die fortschreitende Destruktion endlich eine Neigung an, die der Maximalböschung des betreffenden Materials entspricht; die U-Form geht in die V-Form über. Auch diese ist nur ein Zwischenstadium und wird, sobald die Seitenerosion kräftig zur Geltung kommt, und die Flußmäander die Talsohle erweitern (vgl. S. 508), in die Form \übergeführt. Auch der Umwandlungsprozeß des Querprofils schreitet von unten nach oben fort.

Diese hier entwickelten Gesetze gelten für alle Abdachungen, auf denen fließendes Wasser allein in Tätigkeit tritt, mit Ausnahme der Kalkgelände mit Karsttypus, wovon später die Rede sein wird.

Ungleichmäßige Erosion. Wir sind von zwei Fixpunkten ausgegangen: der Wasserscheide und der Mündung. Die letztere kann wohl auf dem Schuttkegel horizontal hinausgeschoben werden, unterliegt aber unter normalen Verhältnissen keiner vertikalen Verrückung; sie bildet die Erosionsbasis, unter die auch der kräftigste Fluß nicht hinabgehen kann. Die Wasserscheide erniedrigt sich aber unter allen Umständen, weil hier, solange sich keine schützende Pflanzendecke darüber ausbreitet, die flächenhafte Destruktion fort- 
während tätig ist, auch wenn die Erosion erlahmt. Sie kann auch horizontal insofern nicht als fix angesehen werden, als sie in der Regel ein mehr oder minder breiter Rücken oder bei einem Einzelberg ein abgeflachter Kegel oder eine Platte ist, und innerhalb einer solchen Fläche die wasserscheidende Linie durch die rückschreitende Erosion sehr wohl verrückt werden kann. Es kommt dabei vor allem auf die Verteilung der Täler an. Sind sie an beiden Seiten einer Erhebung wechselständig angeordnet, wie in Fig. 139, so ist ihnen nach oben ein freies Feld geöffnet, jeder FluB drängt die ursprünglich gerade Scheidelinie $(a b)$ zurück, so daß sie die zickzackförmige Gestalt $A B C$ annimmt. Sind die Verhältnisse auf beiden Seiten gleieh, so wird die Endgestalt mehr oder minder regelmäBig sein, im umgekehrten Fall werden den stärkeren Flüssen größere Ausbuchtungen der Scheidelinie entsprechen. Ist die eine Seite sehr regenreich im Vergleich zur anderen, so kann

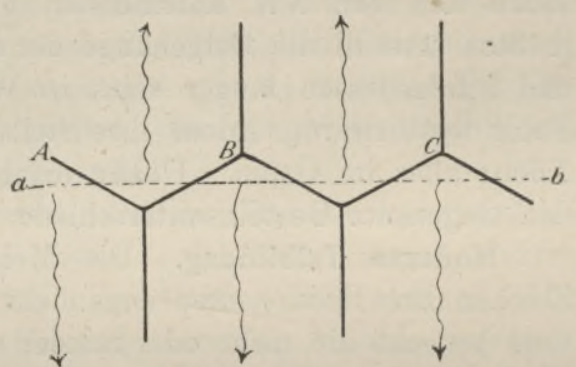

Fig. 139. Zickzackförmige Wasserscheide. eine allgemeine Verschiebung der wasserscheidenden Linie nach der Trockenseite erfolgen. Bei gegenständiger Talanordnung, d.h. wenn zwei entgegengesetzt verlaufende Täler mit ihren Sammelbecken an der Wasserscheide zusammenstoßen, kann das kräftigere Tal in das Quellgebiet des anderen übergreifen und sich dieses dienstbar machen. Man muß sich dabei vor Augen halten, daß in diesem Fall der wasserscheidende Rücken durch die beiderseitige Erosion immer mehr zugeschärft wird, und dadurch der Verwitterung und der Erniedrigung durch die Schwerkraft, das spülende Wasser, den schmelzenden Schnee usw. rascher zum Opfer fällt.

\section{Auf ungleiche Erosion} führt HILBER ${ }^{6}$ auch die so häufige Asymmetrie der Talgehänge zurück, vorausgesetzt, daß sie nicht in der Schichtenstellung begründet ist, (wie in den Isoklinaltälern

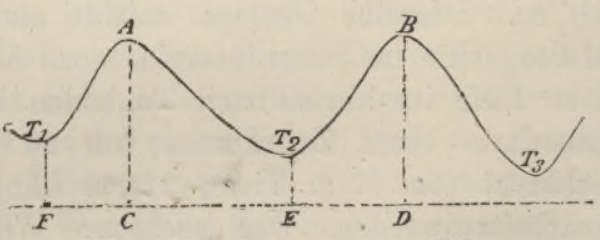

Fig. 140. Asymmetrische Täler. wovon später die Rede sein soll). Fig. 140 stellt das Querprofil durch eine Reihe von Paralleltälern dar, von denen jedes folgende tiefer eingeschnitten ist, als das vorhergehende. Tal $T_{2}$ hat einen sanften Abhang auf der linken, einen steileren auf der rechten Seite 
$(C E>E D) ; \operatorname{der}$ Rücken $A$ senkt sich steil zu $T_{1}$, allmählicher zu $T_{2}$. Dort liegt die Erosionsbasis höher als hier $\left(T_{1} F>T_{2} E\right)$, auf dem Abhang $A T_{2}$ wird daher kräftigere Denudation herrschen, und die Wasserscheide $A$ gegen $T_{1}$ verrückt werden. Das ist ganz der gleiche Vorgang, wie wir ihn oben bei den gegenständigen und wechselständigen Tälern kennen gelernt haben; in beiden Fällen rückt die Wasserscheide nach der Seite, der schwächeren Erosion. Indes ist die Asymmetrie nicht immer só einfach zu erklären. Sie ist besonders schön in dem Talfächer entwickelt, der sich nördlich von den Pyrenäen zur Garonne ausbreitet. $\mathrm{FABRE}^{7}$ nimmt als Ursache den von NW kommenden Regenwind an; in diesem Fall müßten überall die Ostgehänge der Meridionaltäler stärker erodiert und infolgedessen länger sein, in Wirklichkeit haben aber nur die Täler westlich vom Adour ihre Steilseite im Westen, die östlich vom Adour aber im Osten. FABRE macht für diesen schwer zu deutenden Gegensatz Gesteinsunterschiede verantwortlich.

Moderne Talbildung. Die Mehrzahl der Täler kann direkte Zeichen ihres Erosionsursprungs nicht mehr aufweisen. Verwitterungserde bedeckt die mehr oder minder sanft ansteigenden Gehänge, und Flubsedimente, Schutthalden, Ablagerungen von Bergstürzen usw. verhüllen die felsige Unterlage der Talsohle, die der Fluß höchstens bei auBerordentlichem Hochwasser noch in der ganzen Breite überschwemmt. Wir wären bei der genetischen Deutung solcher Formen auf Mutmaßungen angewiesen, hätte uns nicht die Geschichte Beispiele der Entstehung von Tälern durch Erosion aufbewahrt. Im Visptal wurde am rechtsseitigen Gehänge zwischen Visp und Salden 1855 eine eisenhaltige Quelle eröffnet, die sich zwei Jahre darauf bereits eine Schlucht ausgegraben hatte. 1865 war diese nach LyelL's Bericht schon beträchtlich erweitert und hatte sich gleichzeitig rückwärts bis in einen Weingarten verlängert, den sie nun entzweischnitt. Ihre Breite betrug hier $37 \mathrm{~m}$ und ihre Tiefe etwa $4^{1 / 2} \mathrm{~m}$. Derselbe Geologe erzählt auch von einer Talbildung bei Milledgeville im Staat Georgia, wozu allerdings Klüfte von ungefähr $1 \mathrm{~m}$ Tiefe im abgeholzten Tonboden Veranlassung gegeben haben. Innerhalb eines Zeitraumes von 20 Jahren waren sie zu einer Schlucht von $17 \mathrm{~m}$ Tiefe, $274 \mathrm{~m}$ Länge und 6-55 m Breite ausgearbeitet worden. Der furchtbare Wildtobel Runcsrüfi, der in den Jolfertobel (ein Seitental des Plessur östlich von Chur) mündet, ist nach TARnuzzer erst innerhalb der letzten 80 Jahre entstanden. Häufig wurden auch Auswaschungen in losen vulkanischen Massen beobachtet; auf diese Weise entstand 1824 am Vesuv in drei Tagen ein Tal von $7 \frac{1}{2} \mathrm{~m}$ Tiefe, und auf Krakatau und Langeiland in 
der Sundastraße fand Muller 1896 in den aus dem Jahr 1883 stammenden Aschenablagerungen 40 und $50 \mathrm{~m}$ tiefe Regenschluchten mit fast lotrechten Wänden ausgewaschen. In Südrußland sind viele Fälle bekannt, wo Karrengeleise zu Schluchten von 3()-50 m Tiefe und mehreren Kilometer Länge erweitert wurden. Das sind Talbildungen in lockerem Boden; seltener sind natürlich historische Nachrichten von solchen Erscheinungen im festen Gestein. Ungefähr $5 \mathrm{~km}$ oberhalb Aderno am Westabhang des Etna versperrte ein Lavastrom 1603 dem Simeto den Weg. Bis zu LxeLL's Besuch im Jahr 1828 hatte der Fluß im verfestigten Gestein ein neues Tal von 15 bis ungefähr $100 \mathrm{~m}$ Breite und $12-15 \mathrm{~m}$ Tiefe ausgehöhlt. Nach HoFr hat sich auch das Flüßchen Caltabianco in einem 396 v. Chr. ergossenen Lavastrom ein 4,3 m tiefes Tal eingegraben, und ähnliche Fälle werden von den vorgeschichtlichen Lavaergüssen in Zentralfrankreich erzählt.

Es ist oben erwähnt worden, daß die Erosion hauptsächlich bei Hochwasser erfolgt. Was dieses zu leisten vermag, lehren folgende denkwürdige Fälle aus den letzten Jahrzehnten. Der Kanabcañon, ein Nebental des Coloradocañons in Arizona, wurde in den Jahren 1883-85 wiederholt von starken Fluten heimgesucht, und der FluB entführte dabei den Alluvionen, die sein Tal ausfüllten, mindestens 9 Millionen cbm. Die neue Taleinsenkung ist ungefähr $18 \mathrm{~m}$ tief, $21 \mathrm{~m}$ breit und $24 \mathrm{~km}$ lang - ein Beweis, welche Veränderungen die seltenen reichlichen Niederschläge in einem trockenen Wüstenland erzeugen können. ${ }^{8}$ Der Värdalsfluß, der sich in den Trondhjemfjord ergießt, durchzog oberhalb des Härfos ein verhältnismäßig breites Tal in marinen Tonschichten, umging diese dann mit östlicher Biegung und stieß dabei auf festen Fels, über den er mit kataraktartiger Schnelligkeit dahinschoß. Die Tonmassen innerhalb der Biegung hatten schon lange unter den Angriffen des Flusses zu leiden; als am 12. September 1893 ungewöhnliches Hochwasser eintrat, wurden sie völlig durchbrochen und damit das Katarakttal des Härfos trocken gelegt. Dieses Ereignis ist nicht allein als ein modernes Beispiel einer Talverlegung lehrreich, sondern auch deshalb, weil es uns die rückwirkende Kraft der Erosion vor Augen führt. Im neuen Talstück, wo kein Fels mehr zu überwinden war, ging nämlich die Vertiefung außerordentlich rasch vor sich, und dieser Vorgang machte sich noch $5 \mathrm{~km}$ aufwärts fühlbar; auf dieser ganzen Strecke wurde der Fluß zu lebhafter Erosionstätigkeit angeregt. ${ }^{9}$ Einen dritten Fall hat uns Doss ${ }^{10}$ geschildert. Bei Schmarden in Kurland, westlich von Riga, mündet die unansehnliche Schlocke in den Rigaischen Meerbusen. Am 14. und 
15. April 1900 schwoll sie durch wiederholte Eisstauungen mächtig an und wurde gezwungen, einen neuen Weg einzuschlagen. Auf diesem grub sich das Wasser in devonischen Dolomit-, Mergel- und Tonschichten eine Hauptschlucht von $98 \mathrm{~m}$, eine Nebenschlucht von $30 \mathrm{~m}$ und eine Seitenschlucht von $14 \mathrm{~m}$ Länge; die Hauptschlucht war oben $5 \frac{1}{2} \mathrm{~m}$ breit und $3,7 \mathrm{~m}$ tief, und unten $8 \mathrm{~m}$ breit und $1^{3} / 4 \mathrm{~m}$ tief. Wenigstens $2250 \mathrm{cbm}$ Gesteinsmaterial wurden dabei ausgenagt und fortgeführt, und das alles war das Werk von nur 34 Stunden! $\times$

Klammen und Cañons. Auch in Tälern, deren Anfänge weit jenseits der Grenzen geschichtlicher Erinnerung liegen, treten uns noch vielfach sichtbare Spuren der Erosion entgegen, und wir können

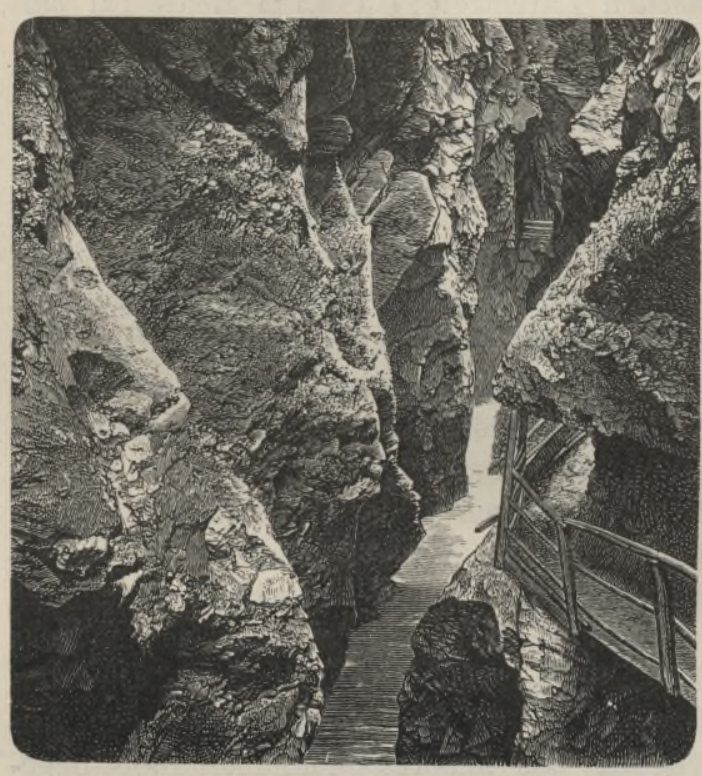

Fig. 141. Liechtensteinklamm. das fließende Wasser bei seiner Zerstörungsarbeit belauschen. Von den zahlreichen Rinnen mit spiegelglatt polierten Wänden und von verschiedener Tiefe, die unscheinbare Wasserfäden in der harten Nagelfluh des Rigi bei Vitznau ausgemeißelt haben, und die RütIMEYER $^{12}$ so anschaulich beschrieben hat, bis zu den tiefen Klammen unserer Alpen, Montenegros, des Thüringer Waldes bei Eisenach usw., gibt es alle möglichen Übergänge. Eine der lehrreichsten Bildungen dieser Art ist die Liechtensteinklamm, die der GroßArlbach vor seinem Eintritt in das Salzachtal durchströmt (Fig. 141). Bis über $300 \mathrm{~m}$ steigen die nur $2-4 \mathrm{~m}$ voneinander entfernten Wände über die Talsohle, die zugleich Flußbett ist, empor. In den polierten Nischen, die sich bis weit über den Hochwasserstand

$\times$ Derartige Katastrophen machen alle Berechnungen des Alters der Täler, wie z. B. die von SoкоL ${ }^{11}$, illusoriseh. Wer weiß, wie oft solche gewaltige Hochwässer den normalen Gang unterbrochen haben, und wer kann dafür bürgen, daß die Mittelwerte der Abtragung ein konstanter Faktor sind? 
hinaus verfolgen lassen, erblickte BRUNHEs Überreste durchsägter Riesentöpfe, und dafür scheint zu sprechen, daß manchmal noch ein Teil des konkaven Bodens erhalten ist und man stellenweise noch Gerölle auf ihm findet. Dagegen spricht die echte Nischenform, da man nicht annehmen kann, daß die Öffnung der Riesentöpfe kleiner war als der Boden. Auch FlevrY ${ }^{13}$ hält die Nischen für eine Schöpfung der Seitenerosion, und man kann noch beobachten, wie der Fluß an diesen Stellen einen Wirbel bildet und durch rückläufige Strömung an der Vertiefung der Nischen arbeitet. Hindernisse im Stromstrich sollen nach FLEURY die erste Veranlassung zu Wirbelbildungen gegeben haben. Nicht immer erhalten sich solche Spuren der allmählichen Tieferlegung; früher oder später, je nach der Gesteinsart, fallen sie der Verwitterung anheim, und endlich faßt auch die Vegetation auf den einst spiegelglatten Wänden Fuß, die letzten Spuren verwischend und verhüllend. Die Böschung der Abhänge nähert sich immer mehr ihrem natürlichen Grenzwert, und kein direktes Zeichen verrät uns mehr den Ursprung des Tales. Glücklicherweise hat uns die Natur auch Übergangsformen zwischen der Klamm und dem fertigen Tal erhalten. Die Kitzlochklamm befindet sich im ersten Verwitterungsstadium, und die Steilwände der Gasteinerklamm (zwischen jener und der Liechtensteinklamm) tragen bereits eine Pflanzendecke, aus der aber hier und da, freilich nur dem aufmerksamen Beobachter sichtbar, eine Erosionsspur hervorlugt. In der Kranabetter Klamm bei Innsbruck sieht man alle drei Stadien nebeneinander.

Gleiche Gebilde wie hier in aufgerichteten Schichten, schafft die Erosion auch in flach gelagerten. Der Große Cañon des westlichen Colorado ${ }^{14}$ ist in leicht nach Süd geneigte feste Gesteinsschichten eingeschnitten. Die Erosion begann in der Tertiär-, nach LeE sogar erst in der Quartärzeit; die Tertiär-, Kreide-, Juraund Triasschichten wurden durch Denudation entfernt, und nun begann der Colorado sein Bett in Karbon einzuschneiden und ist bereits bis zur granitischen Unterlage fortgeschritten. Das $1800 \mathrm{~m}$ tiefe Tal ist im Querschnitt trichterförmig, d. h. es besteht aus einem breiten oberen und einem schmalen unteren Teil, wie auch manche Klammen der Alpen. Die steilen, oft senkrechten Wände zeigen Glättung und Nischenbildung, die Sohle ist oft so schmal, daß sie vom Fluß ganz überschwemmt wird, und wie bei den Klammen hat die Tallinie die Serpentinenform mit aus- und einspringenden Winkeln (Fig. 142). Die Cañons sind aber nicht bloß dem Colorado eigentümlich. Auch der obere Missouri, der Rio grande del Norte, der Red River und der Arkansas flieBen teil- 
weise durch solche gigantische Klammen, und endlich finden wir solche (1500-1800 m tief) auch im Scottgebirge nordwestlich der Sierra Nevada. Dutron betrachtete die Cañons ursprünglich als die Talform regenarmer Gebiete; als er aber später dieselben Bildungen auf den Hawaiischen Inseln kennen lernte, mußte er selbst seine Einschränkung fallen lassen. Üb̈erall wo die Tiefenerosion viel intensiver arbeitet, als die Seitenerosion, entstehen Schluchten,

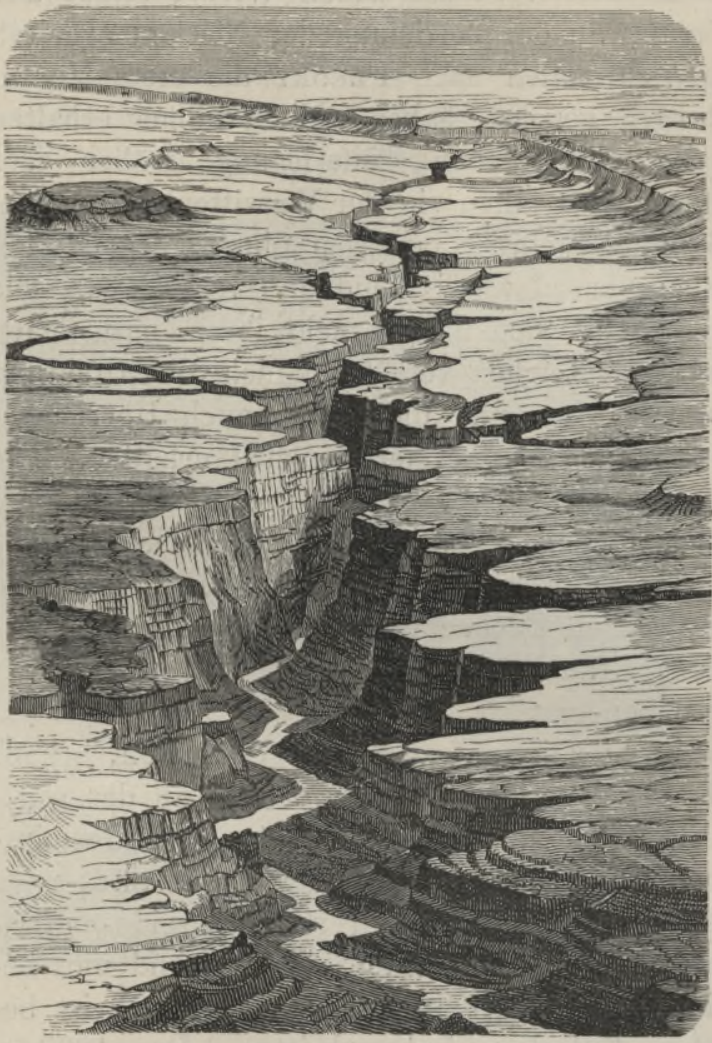

Fig. 142. Marble Cañon. Klammen, Cañons; aber die Steilheit der Talwände erhält sich nur dort, wo diese vor Abspülung bewahrt bleiben. Das ist der Fall in trockenen Erdstrichen, wie im westlichen Nordamerika, aber - wie Penck mit Recht betonte - auch in durchlässigem Gestein, besonders in klüftigen Sand- und Kalksteinen, die den Regen verschlucken. Das Verdontal in den südfranzösischen Kalkalpen bezeichnet Martel als einen typischen Cañon, dem schönen Elbtal der Sächsischen Schweiz spricht aber v. ŁoZINskI $^{14}$ diesen Charakter $a b$, weil die Steilwände nicht durch Erosion, sondern durch Absturz des Quadersandsteins an Kluftflächen geschaffen wurden.

Vereinzelten Erosionsspuren in verschiedenen Höhen über dem heutigen Flußspiegel begegnen wir häufig, sowohl im gefalteten wie im flachgeschichteten Gelände. Im Himalaya kann man sie bei kleineren Flüssen bis $400 \mathrm{~m}$, selbst bis über $600 \mathrm{~m}$ und im oberen Lauf des Ganges, Sutlej und Indus bis zu $900 \mathrm{~m}$ über dem jetzigen Wasserniveau verólgen. An den Gehängen des Elbtales 
oberhalb Dresden liegen Schotterbänke in verschiedenen Höhen, und im Niltal kommen Reste der Cyrena fluvialis, die noch jetzt den Strom bewohnt, $37 \mathrm{~m}$ über dem höchsten Wasserstand vor. Das sind unmittelbare Beweise dafür, daß sich die Flüsse ihre Täler ausgehöhlt haben, und man muß dies besonders betonen, weil noch vor einigen Jahrzehnten die Meinung herrschte, die Gebirgstäler seien ursprüngliche Spalten, und DAUBRÉE selbst im nicht dislozierten Gelände in den Flußläufen nur ein Netz sich kreuzender Spalten zu erkennen glaubte.

Variation des Erosionstypus. Nachdem wir so die Überzeugung gewonnen haben, daß auch große Talbildungen der geologischen Vorzeit Werke der Wassererosion sind, können wir denjenigen Formen näher treten, die mit den von uns erörterten Gesetzen der Erosion in scheinbarem. Widerspruch stehen. Wir sind oben. von der vereinfachenden Voraussetzung eines nahezu homogenen Bodens ausgegangen, in Wirklichkeit ist aber in einem größeren Tal die Widerstandskraft des Gesteins selten überall gleich, und anders vollzieht sich die Erosionsarbeit im horizontal geschichteten Boden als in aufgerichteten Schichten, anders wenn der Fluß die letzteren durchquert, als wenn er sich in ihrer Streichrichtung bewegt. Wo das Regenwasser nicht oberflächlich abfließen kann, wie in klüftigen Kalk- und durchlässigen Sandsteinen, kann sich ein Quelltrichter nicht völlig entwickeln, und ebenso fehlt er im Tafelland, wo sich das Wasser zuerst über den Rand hinabstürzt, hier einen Einschnitt erzeugt und diesen dann immer weiter nach rückwärts verlängert. Noch wenig erforscht ist der Einfluß des Härtegrades des Gesteins auf die Talbildung, nur das läßt sich behaupten, daß er die Talbildung verzögern, aber nicht aufhalten kann. Ist nur genügend Zeit gegeben, so siegt die Erosion unter allen Umständen, aber die Übergangsformen bis zur Erreichung des Endgefälles werden durch die Verschiedenheit des Gesteins außerordentlich mannigfaltig. Eine der merkwürdigsten Erscheinungen ist die diagonale Stromzerlegung, die nach GrLbert's und v. Richthofen's Ansicht dadurch entsteht, daß der FluB ein aus aufgerichteten härteren und weicheren Schichten bestehendes System diagonal durchschneidet, wobei er das Bestreben hat, in den weicheren Schichten möglichst lange zu verharren und die harten Schichten auf möglichst kurzem Weg zu durchqueren, so daß der Grundriß einen zickzackförmigen, aus vielen kurzen Längs- und Querstrecken bestehenden Tallauf zeigt (Fig. 143). In der Régel kommt der Gesteinswechsel sowohl im Längs- wie im Querprofil zum Ausdruck. Die harten Zonen zeichnen sich durch steilere Gehänge und größeres Gefälle vor den 
weichen Zonen aus; in jenen verengt sich das Tal, in diesen erweitert es sich; in jenen ringt der FluB noch nach der Gleichgewichtskurve, während er sie in diesen schon erreicht hat.

Seen und Wasserfälle ${ }^{15}$ stellen die Gefällsextreme dar und sind daher charakteristische Merkmale unfertiger Talbildung. Im See

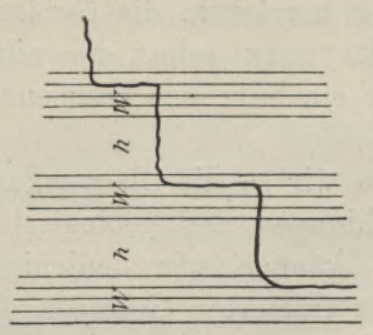

Fig. 143. Diagonale Stromzerlegung nach v. RichthofEN. ( $h=$ harte, $W=$ weiche Schichten.) wird das Gefälle negativ, denn der Boden senkt sich und steigt dann wieder an, im Wasserfall erreicht es dagegen seinen denkbar größten positiven Wert. Der Lage nach unterscheidet man Mündungs- und Talfälle; der untere Gasteinerfall in dem durch seine Thermen weltbekannten Tal der Hohen Tauern gehört z. B. der ersten, der obere der zweiten Kategorie an. In den Alpen sind viele Haupttäler übertieft, wie PeNcK sich ausdrückt, d. h. in ihrer Erosion den Nebentälern weit vorgeschritten die letzeren enden daher häufig nicht am Boden des Haupttales, sondern oben am Gehänge, über das sich der Nebenbach herabstürzt. Jeder Mündungsfall schreitet zurück, wird in ein hinteres Talstück verlegt und dadurch $\mathrm{zu}$ einem Talfall. An dem unteren Gasteiner Fall kann man die Anfänge dieses Prozesses gut beobachten. Aber nicht alle Talfälle waren einst Mündungsfälle, sondern sie können auch mit der Bildung tektonischer oder Ausfüllungsstufen zusammenhängen.

Das Rückschreiten der Wasserfälle hängt damit zusammen, daß das fließende Wasser stets bestrebt ist, die Gleichgewichtslinie der Talsohle herzustellen. Stark geneigte Schichten setzen ihm in der Regel kein Hindernis entgegen. Indem es einersseits in den Boden einschneidet, anderseits den Rand abschleift und abbröckelt, wird der Neigungswinkel der Sohle immer kleiner. Das Wasser, das sich früher in einem einzigen Strahl über die senkrechte Felswand hinabstürzte, löst sich in eine stufenförmige Reihe von Fällen Kaskaden - auf, und da sich bei jedem einzelnen Fall dieselbe Arbeit wiederholt, entstehen aus Kaskaden Katarakte. Haben sich endlich die Böschungen soweit gemildert, daß das Wasser nicht mehr fällt, wohl aber noch pfeilschnell dahinschießt, so ist der einstige Wasserfall bei dem letzten Akt seiner Entwickelungsgeschichte angelangt: bei dem Stadium der Stromschnellen. Solche können übrigens auch selbständig entstehen durch Felsstürze, deren gewaltige Trümmer sich im Flußbett verbreiten.

In horizontalen oder schwach geneigten Schichten findet der 
geschilderte Umwandlungsprozeß nur dann statt, wenn das Material gleichmäßig ist, oder die Härte der Gesteine von oben nach unten zunimmt. Der Geneseefall bei Rochester in Nordamerika (Fig. 144) ist bereits in das Stadium der Kaskaden eingetreten. Dagegen besteht die $49 \mathrm{~m}$ hohe Felswand, über die sich der Niagara stürzt, in den oberen Partien aus hartem Kalkstein und in den unteren aus weichen Schiefern (Fig. 145.) Diese werden durch die wirbelnden Wassermassen am Fuß des Falles ausgewaschen, der Kalkstein bricht stückweise $a b$, und der Wasserfall schreitet langsam talaufwärts fort. Bis jetzt hat er einen Weg von ungefähr $11 \mathrm{~km}$ zurückgelegt und sich dadurch aus einem Mündungsfall (bei Queenston, in den einst ausgedehnteren Ontariosee) in einen Talfall verwandelt. $\times$ Analoge Erscheinungen weist das esthländische Kalkplateau auf: die Fälle

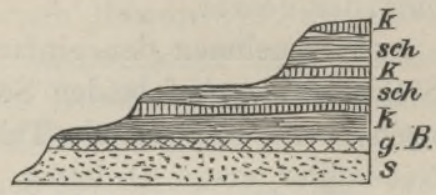

Fig. 144

Profil des Genesee-Fallesnach $\mathrm{D}_{\mathrm{ANA}}$ $k=$ Kalk, $s c h=$ Schieferton, g. $B .=$ graues Band, $s=$ Sandstein der Narowa, des Jagowal u. a. sind seit einem Menschenalter schon beträchtlich talaufwärts gerückt.

Einige Wasserfälle zeichnen sich durch ihre Höhe aus (als höchster gilt der Yosemitefall in der californischen Sierra Nevada $680 \mathrm{~m}$ hoch), andere, wie der Rheinfall bei Schaffhausen, der Niagarafall, der Viktoriafall des Sambesi, durch ihre Wassermasse. Nord.

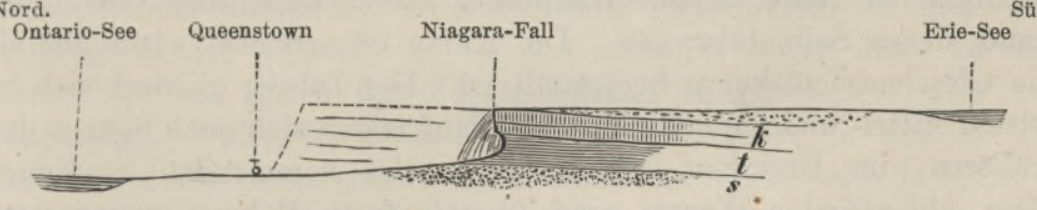

Fig. 145. Der Niagarafluß und seine Fälle.

$s$ Weiche Oneida- und Medina-Sandsteine und Clintongruppe. $t$ Weiche Niagara-

Schiefer. $k$ Harter Niagara-Kalkstein.

Häufig greift die Erosion nicht gleichmäßig die Gesteinsunterlage an, Felsreste bleiben dann im Bett zurück, und der Fall teilt sich in Arme (z. B. der Rheinfall). Unzählig sind solche Felsklippen in

$\times$ Genauere Ermittlungen sind erst seit 1842 möglich, wo die Fälle zum erstenmal sorgfältig aufgenommen wurden. Der Fall teilt sich durch die Ziegeninsel in zwei Arme, von denen der eanadische 95 Proz. der ganzen Wassermasse führt. Er war 1842-75 im Jahresdurchschnitt 1,6, 1875-90 1,65 und 1890-1905 0,7 m zurückgegangen. Spencen ${ }^{16}$ hat daraus das Alter des Niagara auf 39000 Jahre berechnet; diese Zahl, so problematisch sie auch sein mag, verdient doch den Vorzug vor andern, z. T. recht abweichenden Rechnungsergebnissen, weil Spencer alle wahrscheinlichen Verzögerungs- und Beschleunigungsmomente berücksichtigt hat.

SuPaN, Physische Erdkunde. 5. Aufl. 
den Katarakten des Nil oder in den Stromschnellen des Orinoco bei Maipure.

Der geographische Zyklus. In der normalen Entwicklungsgeschichte der Täler und Talsysteme unterscheidet DAvis ${ }^{17}$ drei Perioden: die Jugendzeit, das Stadium der Reife und das Greisenalter. Aus schon erörterten Gründen setzen wir dafür die Bezeichnungen: Unreife, Reife und Überreife. Behalten wir dabei im Auge, daß Erosion und Verwitterung stets Hand in Hand miteinander gehen.

Wir nehmen den einfachsten Fall an: ein dachförmig gestaltetes Stück Land. Auf beiden Seiten entstehen annähernd parallele, sich nach oben verzweigende Talfurchen. An ihren Gehängen entstehen Nebentäler erster Ordnung, an deren Abhängen Nebentäler zweiter Ordnung usw.; mit einem Wort: der Prozeß der Zertalung beginnt. Überall sind Erosion und Verwitterung in lebhaftem Gang, überall strebt die Oberfläche den durch die Regenmenge und die Gesteinsbeschaffenheit bedingten Gleichgewichtskurven und Maximalböschungen zu, ohne sie erreichen zu können. Manche Talwege steigen stufenförmig auf und sind von Seen und Wasserfällen unterbrochen, überall herrscht noch unentschiedener Kampf um die Wasserscheide. Das sind die Merkmale der Unreife, wie wir sie noch vielfach in unseren Hochgebirgen beobachten können.

Threm Alter entsprechend treten die Täler nacheinander in das Stadium der Reife ein, die Haupttäler zuerst, dann ihre Nebentäler, dann deren Seitentäler usw. Die Reife ist erreicht, wenn überall die Gleichgewichtskurve hergestellt ist. Der Talweg gliedert sich in Ober-, Mittel- und Unterlauf; im Oberlauf zeigen sich noeh Spuren des früheren, im Unterlauf schon Spuren des kommenden Stadiums. Dem abfließenden Wasser sind überall feste Bahnen angewiesen, die ganze Talanlage und die Wasserscheiden sind festgelegt, die Auflösung des Geländes durch Zertalung ist vollendet, in regenreichen Gegenden natürlich in größerem Umfang als in niederschlagarmen. Durch die Abtragung der Höhen haben die relativen Niveauunterschiede abgenommen und die Umrisse der Berge haben ihre Schärfe verloren. In dem größten Teil des Pariser Beckens herrscht schon solcher Reifezustand.

Der Grundzug der Überreife ist die allgemeine Abschwächung der Funktionen und die Formenverarmung. Die Talvertiefung geht noch langsamer vor sich als die Erniedrigung der Wasserscheiden, nur die seitliche Erosion der sich in Schlangenwindungen hin und her bewegenden Flüsse wirkt noch fort und erweitert die Talflächen auf Kosten der sie trennenden Bodenschwellen. Sind auch diese 
soweit als möglich weggeräumt, so ist der geographische Zyklus beendet, und wie immer auch die ursprüngliche Geländeform gewesen sein mag, das Endergebnis bleibt stets dasselbe: ein unmerklich zum Quellgebiet ansteigendes, von flachen Tälern unterbrochenes welliges Gelände mit- gerundeten, eintönigen Formen, nur hier und da überragt von einzelnen Partien widerstandsfähigeren Gesteins, die DAvis nach einem Berg in New Hampshire Monadnocks× getauft hat, und eingehüllt in Verwitterungsschutt, den die gealterten Flüsse nicht mehr wegzuschaffen vermögen, - ein Peneplain, wie Davis es nennt, oder eine Fastebene, wie wir im Deutschen sagen können. Davis ist auf deduktivem Weg zu seinen Anschauungen gekommen, ähnlich wie DARwin einst zu seiner Korallenrifftheorie. Die der Naturwissenschaft angemessenere induktive Methode versagt hier, weil ein geographischer Zyklus sich nur in geologischen Zeiträumen abspinnen kann. Aber die Beobachtung lehrt doch, daß unreife, reife und überreife Formen in der Natur wirklich vorhanden sind, und nur, daß sie Entwicklungsstadien eines und desselben Prozesses sind, ist theoretische Zutat. Der strittigste Punkt ist das Peneplain. Diesem Begriff haftet noch Unklarheit an. Sind es die Härtlinge allein, die die Fastebene von der Ganzebene scheiden? Dann müBten die Täler verschwunden sein, weil die sie trennenden Bergrücken verschwunden sind. In der Tat hat man angenommen, sie seien durch die seitliche Flußerosion hinweggeräumt worden, als ob Flußmäander unbegrenzt nach der Seite fortschreiten könnten! Die Abtragung des Geländes ist - und auch Davis hat diese kürzlich betont - nur durch das Zusammenspiel verschiedener linear und flächenhaft wirkender Destruktionskräfte denkbar; in diesem Fall kann aber aus einem Gebirge wohl ein flachwelliges Gelände (Penck's Wellungsebene), aber niemals eine völlige Ebene entstehen. Selbst wenn die Täler unter Schutt begraben liegen, müssen ihre Linien noch nachweisbar sein, und ein neu einsetzender Zyklus muß, z. T. wenigstens, an das alte Netz anknüpfen. Nur eine völlige Auflösung durch tektonische Vorgänge könnte die ursprünglichen Züge bis zur Unkenntlichkeit verwischen.

Es ist nicht ausgeschlossen, daß wir die Rolle der Flußerosion im Gesamtbild des fluviatilen Zyklus überschätzen; ist doch unsere Kenntnis der destruktiven Vorgänge noch recht lückenhaft! Noch vor wenigen Jahren sprach LöwL die Ansicht aus, daß ein reich bewaldetes Gebirge niemals bis zu einer Fastebene abgetragen werden könne, weil die Flächenspülung hier außer Betracht bleibe; jetzt hat

$\times$ Man hat dafür die zutreffende deutsche Bezeichnung Härtling vorgeschlagen. 
uns Götzinger gerade an dem Beispiel eines Waldgebirges den nivellierenden Einflu $B$ der kriechenden Bodenversetzung kennen gelehrt (vgl. S. 466). Für Davis und seine Anhänger gilt es als ein Dogma, daB der geographische Zyklus erst dann sein Ende finde, wenn die Abtragung bis nahe an das Meeresniveau vorgerückt sei, und es werden daraus die kühnsten Schlüsse gezogen; ja man spricht sogar, wie wir auf S. 516 anführten, von der Möglichkeit einer so extremen Erniedrigung der gesamten Landfläche durch die Flüsse. $\mathrm{DaB}$ es aber eine allgemeine Zyklusterminante nicht geben kann, lehrt folgende Erwägung. Ein Gebirge, das unmittelbar aus dem Meer aufsteigt, wird sich anders verhalten als eines, das weit landeinwärts liegt und vom Meer durch eine sich allmählich abdachende Ebene getrennt ist. Im letzteren-Fall bildet für jedes Flußgebiet die Seehöhe des Austrittes des Hauptflusses in die Ebene die Erosionsbasis, über die die Abtragung nicht hinausgehen kann. Sie bestimmt die Taltiefe. Ihr paßt sich zuerst das Haupttal, dann sukzessive die Nebentäler an. Nun wird aber vorausgesetzt, daß die Erosionsbasis selbst erniedrigt, daß die schiefe Ebene bis nahe an den Meeresspiegel abgetragen wird, oder mit andern Worten, daB vertikale Flußerosion auch noch bei dem denkbar kleinsten Gefälle stattfinde. Dem widerspricht aber die Erfahrung, die uns lehrt, daß Aufschüttung und Tieferlegung sich gegenseitig ausschließen. Sind die Tieflandsflüsse in die Phase der Aufschüttung eingetreten, so verändert sich die Erosionsbasis des angrenzenden Gebirges nicht mehr. Daß die Seehöhe eines Peneplain von der Taltiefe abhängt, hat neuerdings auch Penck durch seine Diagramme in ScoBeL's Geographischem Handbuch (Bd. I. S. 144) anerkannt.

Der Einfachheit wegen mochte es wohl gestattet sein, die Erosionsgesetze an einem fertigen Gelände zu entwickeln, in der Natur spielt sich aber der Vorgang anders ab. In demselben Moment, in dem Land aus dem Wasser aufzutauchen beginnt, beginnt auch die Zerstörung. Erst wenn die Niveauverhältnisse konstant geworden sind, kann die Talentwicklung ihren letzten Zielen zustreben. Aber häufig treten Störungen ein: die Bewegung lockerer Massen, die Abdämmungsstufen veranlassen; vulkanische Ausbrüche; große Klimaschwankungen oder Klimaänderungen, wie die Eiszeit eine war. ${ }^{18}$ Aber selbst dann, wenn der geographische Zyklus wirklich zum Abschluß gelangen kann, ist noch keine Gewähr für die Dauer dieses Zustandes geboten. Jede einseitige Hebung der Wasserscheide, jede Senkung der Erosionsbasis belebt den gealterten Fluß wieder, und ein neuer Zyklus beginnt. Die letzte Erosionsbasis sämtlicher Flüsse (mit Ausnahme der Depressionen) ist der Meeres- 
spiegel; jede Niveauveränderung weckt mit der Zeit auch ein Echo in den entferntesten Gegenden an der Hauptwasserscheide des Festlandes oder der Insel. Erst paßt sich ihr der Hauptfluß an, dann dessen Nebenflüsse, dann deren Zuflüsse usw. Geht die Niveauveränderung allmählich vor sich, so kommt die Talbildung niemals zur Ruhe, denn jeder Tag schafft neue Bedingungen, die freilich nur in ihrer Summierung große Wirkungen erzielen können.

Auf alle diese von außen kommenden Eingriffe lassen sich die in der Natur so häufigen gemischten Formen zurückführen, in denen sich reife und überreife Charakterzüge mit unreifen paaren, und bald die einen, bald die anderen überwiegen.

Das Karstphänomen. ${ }^{19}$ Eigentümliche Formen schafft die Erosion im löslichen Gestein, vor allem in dem weitverbreiteten Kalkstein: Formen, die auf dem Vorhandensein von Kluftwasser und dem Überwiegen der chemischen Erosion beruhen. Oberflächengebilde, wie die Karren und Dolinen, Höhlen und blinde Täler sind diejenigen Erscheinungen, die hier zu erörtern sind.

Nicht nur die Plateaus, sondern auch die Abhänge der Berge sind im Karst mit schüssel- oder trichterförmigen Vertiefungen bedeckt, für die sich in der deutschen Wissenschaft die slovenische Bezeichnung Dolinen eingebürgert hat. Sie treten vereinzelt oder gesellig auf und sind häufig so dicht nebeneinander (oft $40-50$ auf $1 \mathrm{qkm}$ !),

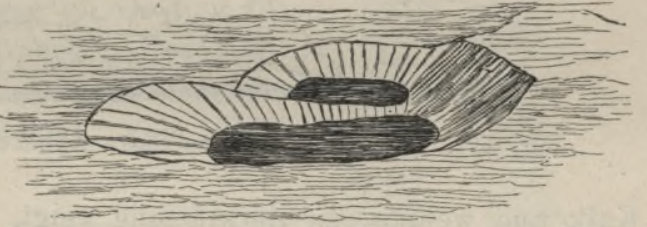

Fig. 146. Doppeldoline bei Lesetsche im Karst nach REYER.

daß die Karstoberfläche in der Tat einem blatternarbigen Gesicht, womit man sie so oft verglichen hat, ähnlich sieht. Die Form dieser Löcher ist bald kreisrund, bald unregelmäBig, ihre Tiefe variiert zwischen 2 und $20 \mathrm{~m}$, ihr Durchmesser von 10 bis $120 \mathrm{~m}$. Selten besteht der Boden aus nacktem Fels, meist ist er mit Zersetzungslehm bedeckt, manche Löcher sind mit Wasser oder in den höheren Regionen auch mit dauerndem Schnee gefüllt. Von diesen geschlossenen Felsdolinen sind die Naturschachte und Schwemmlanddolinen zu unterscheiden. Die ersteren sind Felsdolinen, die entweder mittels einer verbreiterten Spalte zu einer blinden Höhle oder mittels eines breiten Schlotes zu einem unterirdischen Flußtal führen (Fig. 147). Die Schwemmlanddelinen treten im lockeren Boden auf, auf dem Lehmboden großer Felsdolinen oder auf Talböden. Nur von ihnen gilt, was PrLaR vom kroatischen Grenzbezirk berichtet, nämlich daß die Neubildung von Dolinen so rasch 
vor sich gehe, daß mancher Bewohner, der nach einigen Jahrzehnten in seine Heimat zurückkam, diese kaum mehr zu erkennen vermochte, denn Häuser waren infolge von Einstürzen verlegt, neue Wege waren gebahnt, Obstgärten waren verschwunden. Hier finden, das liegt auf der Hand, Einstürze über breiten Spalten im Untergrund statt. Dieselbe Entstehungsweise schrieb man auch den Felsdolinen und Naturschachten zu, und in manchen Fällen dürfte diese Erklärung zutreffend sein. Zwischen dem Tartarusarm der Adelsberger Grotte und der Höhle von Ottok breitet sich ein großes Trümmerfeld aus, und gerade über ihm befindet sich die Doline Stara Apnenca. Hier ist offenbar, wie aus Fig. 147 erhellt, die Decke des ehemaligen Hohlraumes, der den Tartarus mit der Ottokgrotte verband, eingestürzt. In Gips, der leichter löslich ist als der

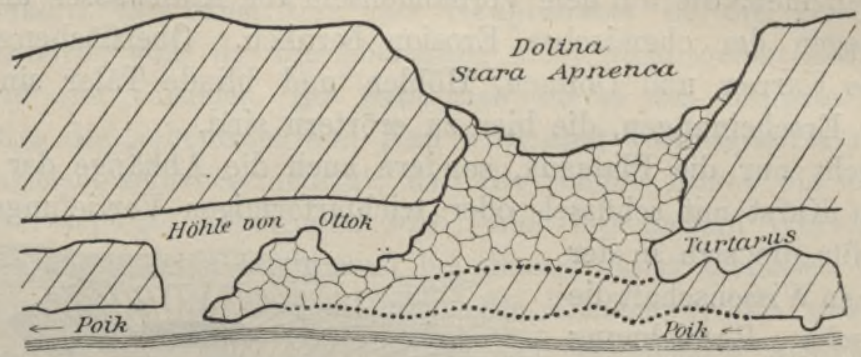

Fig. 147. Die Einsturzdoline Stara Apnenca in Krain, nach Martel.

Kalk und weniger zu Zerklüftung neigt, sind nach ŁozıŃski nahezu alle Dolinen durch Einsturz entstanden. Dagegen können wir in anderen Fällen direkt nachweisen, daß ein derartiger Vorgang nicht stattgefunden hat. Der Bau einer $3 \mathrm{~m}$ tiefen Doline̊ bei Unterloitsch ist durch einen Eisenbahneinschnitt völlig aufgedeckt (Fig. 148). Hier ist die Doline in festen Fels eingesenkt, der Boden ist - wie die Zeichnung durch Punktierung andeutet - bis zu einer gewissen Tiefe durch Verwitterung mürbe gemacht oder aufgelöst, besonders unter dem Boden der Doline, von wo enge Spalten sich nach der Tiefe ziehen. Hier kann von Einsturz keine Rede sein; die einzige Erklärung, die uns übrig bleibt, ist die durch chemische Erosion des Kalksteins, die das Wasser längs vorhandener Spalten bewirkte. Wir dürfen annehmen, daß sich dieser Prozeß auf diejenigen Stellen konzentrierte, wo besonders viele Vertikalspalten der Zersetzung vorgearbeitet hatten und die Abfuhr der Zersetzungsprodukte nach der Tiefe begünstigten. Mit der Zeit wurden diese Spalten verstopft, und die Verwitterungserde konnte sich nun auf dem Boden der Doline ansammeln. Auch viele Naturschachte 
sind nichts anderes als durch chemische Erosion erweiterte Vertikalspalten; ein nicht mißzuverstehendes Beispiel dieser Art aus dem französischen Karstgebiet bietet uns Fig. 149.

Den Dolinen nahe verwandt sind die geologischen Orgeln, kleine, kaminartige Löcher in tonigem Kalkstein, die aber stets mit lockeren Massen bedeckt und ausgefüllt sind und daher nur in Einschnitten zutage treten. Ein Oberflächengebilde anderer Art wie die Felsdolinen, aber wie diese vorwiegend durch chemische Erosion entstanden, sind die in den Kalkalpen, besonders in der Höhenzone zwischen 1600 und $2300 \mathrm{~m}$ wohlbekannten Karren oder Schratten (Fig. 150). ${ }^{20}$ Sie treten bald allein, bald in Gesellschaft von Dolinen auf, und zwar nur auf vegetationslosen Kalkflächen, wo Regen- und Schmelzwasser oberflächlich abfließen können. Statt Löcher bilden sich dann zahlreiche lange und parallele Furchen, die der Abdachung folgen oder durch Klüfte und Risse im Gestein zu gewundenem Lauf abgelenkt werden. Zwischen ihnen erheben sich Rippen von verschiedener Breite, zum Teil abgerundet, zum. Teil

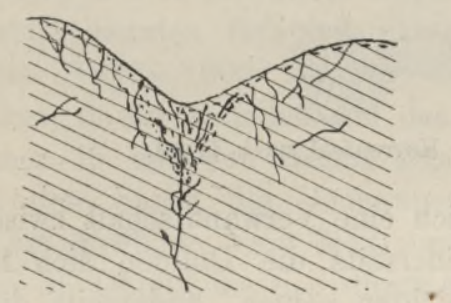

Fig. 148. Erosionsdoline bei Unterloitsch in Krain, nach CviлIć.

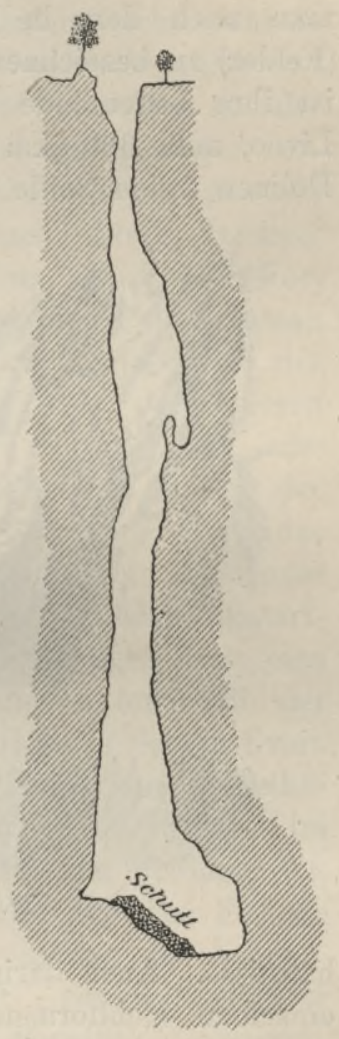

Fig. 149. Naturschacht Fontlongue bei dem Dorf Bidon, Dep. Ardêche, nach Martex.

mit messerscharfer Kante und dann sehr gefährlich für den Wanderer. Besitzt die Oberfläche geringe Neigung, so herrschen unregelmäßige tiefe Löcher und kurze Furchen vor. Stets entsprechen die Vertiefungen den leichter, die Erhebungen den schwerer löslichen Partien; ist der Kalkstein unrein, so bilden sich zwar rauhe Oberflächenformen, aber keine Karren. ${ }^{\times}$

$\times$ In neuerer Zeit wurde vielfach die Ansicht laut, daß die Karren dureh die Schmelzwässer eiszeitlicher Gletscher geschaffen wurden, allein sie sind 
Kehren wir nun zum Karst zurück. Eine höhere Ordnung deı oberflächlichen Hohlformen bilden die Uvalas, umfangreichere Einsenkungen mit breiter, unebener Sohle, die von Wasserläufen durchschnitten wird. Wie es zwischen den Dolinen und den Uvalas zahlreiche Übergangsformen gibt, so auch zwischen den Uvalas und den breiten, ebenen, von allen Seiten eingeschlossenen Talwannen, die man nach dem in Bosnien gebräuchlichen Namen als Poljen (Felder) zu bezeichnen pflegt. Was sie vor den Uvalas auszeichnet, ist ihre bedeutende Ausdehnung - eines der gröBten, das von Livno, mißt $380 \mathrm{qkm}$-, ihre tiefere Lage, die Ebenheit ihrer von Dolinen freien Sohle und ihre komplizierten hydrographischen Ver-

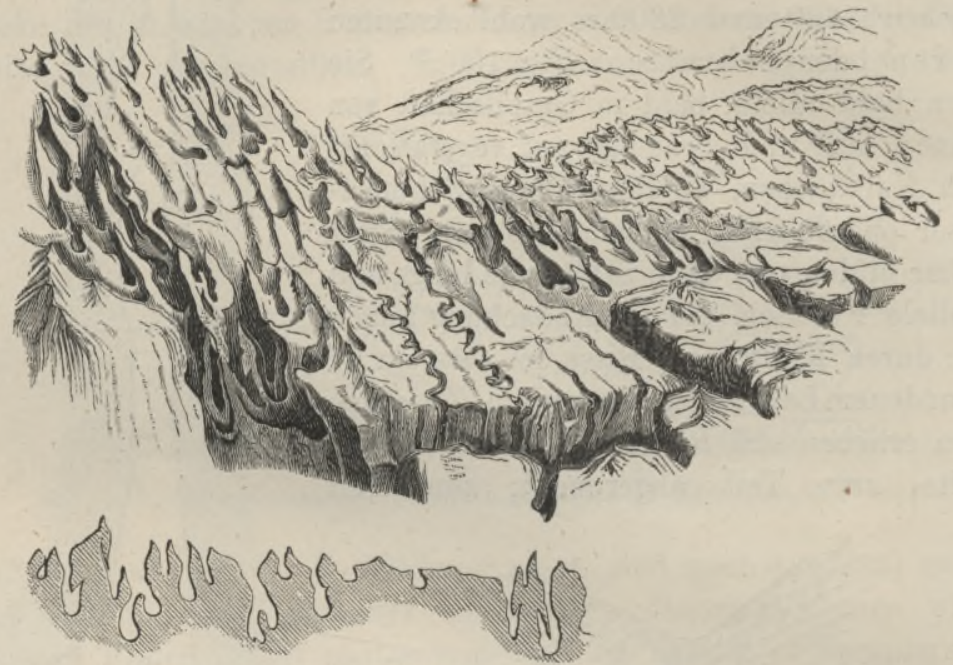

Fig. 150. Ein Karrenfeld nach Herm.

hältnisse. Auch darin zeigt sich eine Verwandtschaft zwischen den einzelnen Hohlformen, daß einerseits die Dolinen *sích längs der Fugen der aufgerichteten Schichten häufen, anderseits die Uvalas und Poljen im großen und ganzen parallel mit den Gebirgsfalten angeordnet sind, wenn auch die Längsachse einiger Poljen von dieser Richtung abweicht. In der Regel treten die Uvalas in der Fortsetzung der Poljen auf, und manche unfertige Poljen lassen ihre Entstehung aus dem ZusammenschluB früher getrennter Uvalas

keineswegs auf alte Glazialgebiete beschränkt, sondern kommen in allen Klimaten und in den verschiedensten Höhenlagen vor. Jedoch mag, wie E. RichteR meint, die Eiszeit insofern mitgewirkt haben, als die Gletscher die Kalkflächen vom Schutt befreiten und bloßlegten. Katzer hat sogar die Dolinen des Karstes als Überreste der Eiszeit angesprochen, obwohl hier von einer völligen Vereisung nicht die Rede sein kann. 
noch deutlich erkennen. Wenn aber CviJI'́21 die oberflächlichen Karstformen als eine einheitliche Entwicklungsreihe auffaßt, so daß sich durch fortschreitende Erosion Karren in Dolinen, Dolinen in Uvalas, Uvalas in Poljen verwandeln, so dürfte er wohl zu weit gegangen sein, wie anderseits auch KATzER, wenn er jeden möglichen genetischen Zusammenhang zwischen diesen Formen leugnet. In bezug auf die Poljen hält auch CvıJIć seine Ansicht nicht mehr in ganzer Strenge aufrecht, und in der Tat ist es wahrscheinlich, daß sie zum großen Teil Grabeneinbrüche sind, wie ja solche auf der westlichen Balkanhalbinsel auch außerhalb des Kalkgebirges vorkommen (z. B. das Becken von Üsküb). Kleine Poljen, wie die Rekamulđe westlich von Zirknitz, mögen auch durch Deckeneinbrüche unterirdischer Hohlräume entstanden sein. Die Verschiedenheiten in den Bewässerungsverhältnissen der Poljen lassen sich ungezwungen auf ihre verschiedene Lage zu dem Niveau des Karstwassers zurückführen. Liegt ihr Boden über dem oberen Niveau, so sind sie von der Zirkulation des Karstwassers ausgeschlossen, können aber Flüsse vom undurchlässigen Boden des benachbarteń Geländes erhalten. Reicht ihre Sohle bis unter das untere Niveau des Karstwassers hinab, so bildet sich ein dauernder See, wie der von Janina in Epirus, der montenegrische Skutarisee oder der Vranasee auf der Insel Cherso. Dagegen tritt eine periodische Wasserfüllung ein, wenn der Poljeboden innerhalb der Schwankungen des Karstwassers liegt. Der Zirknitzer See in Krain ist ein weltbekanntes Beispiel dieser Art. $x$ Nach den Pegelbeobachtungen 1896-1902 war er durchschnittlich 49,6 Tage im Jahr trocken, davon entfallen auf den Winter 11, den Frühling 0,3, den Sommer 15 und den Herbst 23,3 Tage. Die jährliche Periode entspricht dem Stand des Bodenwassers, der infolge der Schneeschmelze im Frühjahr sein Maximum erreicht. Durch Speilöcher tritt es an die Oberfläche und durch zahlreiche Sauglöcher (Ponoren, Katavothren) am Boden oder am Rand verschwindet es wieder in die Erde. Wieder andere Löcher, die sog. Estavellen, fungieren nur bei starkem und anhaltendem Regen als Spei-, sonst als Sauglöcher. $^{22}$ Verstopfen sich die Abzugskanäle, so wird der See permanent, sinkt aber aus irgend einem uns unbekannten Grund das Niveau des Karstwassers dauernd, so hört die Seebildung ganz auf, wie.in der Ebene von Verdoletsch in Kroatien und auch in manchen Poljen Innerkrains. Nun liegt das Polje, wenn auch noch gelegent-

× Ein Seitenstück dazu ist der Bauerngraben oder Hungersee am Südabhang des Harzes (vgl. Petermann's Mitteilungen, 1864, S. 43 u. 192). 
lichen Überschwemmungen ausgesetzt, trocken, und es hängt ganz von der Beschaffenheit des ehemaligen Seebodens, von der Verteilung der Sauglöcher und von den Beziehungen zu benachbarten Höhlen $a b$, ob es von einem oder mehreren verschwindenden Flüssen bewässert wird oder ganz des Wassers entbehrt. Es unterliegt keinem Zweifel, daß die meisten Poljen des Karstes, von denen viele in der jüngsten Tertiärzeit nachweisbar Seen waren, eine solche Entwicklung durchgemach haben. Möglicherweise ist durch eine negative Niveauveränderung das Karstwasser in die Tiefe gezogen worden.

Die lückenhafte Talbildung ist eine charakteristische Eigenschaft des Karstes. Nicht nur die Flüsse der Poljen verschwinden, auch diejenigen, die aus den Zonen undurchlässigen Gesteins kommen,

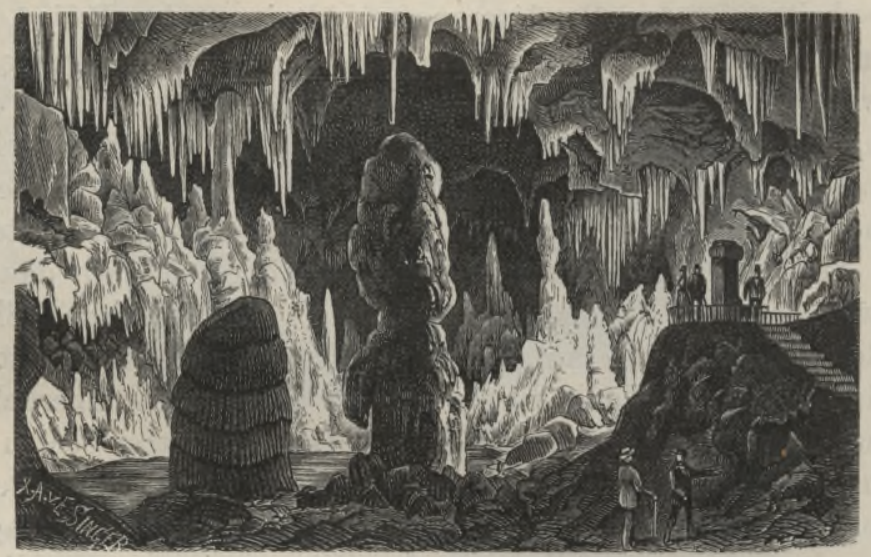

Fig. 151. Aus der Adelsberger Grotte in Krain.

wie z. B. die der Flyschmulde Istriens. Das oberirdische Tal hört plötzlich auf, aber manchmal setzt es sich unterirdisch in einer Flußhöhle fort. Auch hier wechseln oft Engen und Weitungen, auch hier findet man oft Seen und Wasserfälle. Seitenhöhlen münden in die Haupthöhle, wie Nebentäler in das Haupttal; manche Zweiggänge eines Grottensystems sind nur verlassene Wege des Hauptflusses. Wenn viele kanalartige Grotten keine Flüsse beherbergen, so erklärt sich dies daraus, daß die Öffnung neuer Klüfte, z. B. infolge von Erdbeben, das Wasser aus seiner ursprünglichen Bahn abgelenkt hat, oder daß das Niveau des Karstgrundwassers gesunken ist. Manche Grotten bestehen aus mehreren etagenartig übereinander liegenden Höhlen, deren unterste in der Regel von einem Bach durchflossen wird. Ein berühmtes Beispiel dieser Art ist die Lueger-Grotte in Krain. 
Auch in ihrer unvollständigen Entwicklung gleichen die unterirdischen Karsttäler den oberirdischen. Am Ende senkt sich das Gewölbe bis zum Flußspiegel hinab, manchmal nur auf eine kurze Strecke (Siphons, vgl. S. 492); einige Höhlen laufen endlich in eine Anzahl von Klüften aus, wie das z. B. jetzt von der St. Canzianer erwiesen ist (vgl. S. 491).

Außer den Flußhöhlen, die durch horizontal fließendes Wasser entstanden sind, gibt es auch Sickerhöhlen, in die das Wasser von oben her gelangt, und die in der Regel keine große Ausdehnung besitzen. Beide sind Schöpfungen der chemischen Erosion, die unter der Erde kräftiger wirkt als an der Oberfläche, ${ }^{\times}$aber eine weitgehende Zerklüftung muß ihr vorgearbeitet haben, sonst wären Höhlen 'in zerkarsteten Gebirgen weiter verbreitet, als sie es in Wirklichkeit sind. Sie sind aber auch ein Schauplatz von Neubildungen. Kies und Lehm werden vom flieBenden Wasser abgelagert, während das durch die Decke der trocken gelegten Flußund der Sickerhöhlen eindringende Regenwasser Tropfsteine bildet. Es scheidet den Kalk, mit dem es sich auf seinem Weg beladen hat, bei der Verdunstung zum Teil an der Decke, zum Teil an dem gerade darunter liegenden Punkt des Bodens aus. Die herabhängenden Tropfsteine oder Stalaktiten und die vom Boden aufsteigenden Stalagmiten vereinigen sich endlich bei ungestörtem Wachstum zu Säulen (Fig. 151). Neben den Zapfen und Kegeln, die dem tropfenden Wasser ihre Entstehung verdanken, gibt es auch schwammartige Kalkbildungen, die aus größeren Wassermengen abgelagert sind und oft einen zauberhaften Anblick gewähren, wie z. B. die Draperien an den Wänden, die durch Niederschläge aus den Überrieselungen der Wandflächen entstehen. Ist der Kalk rein, so sind alle diese Bildungen wasserhell; häufig werden sie aber durch Beimengung von Metalloxyden, besonders von Eisen, gefärbt.

In den sog. Eishöhlen oder natürlichen Eiskellern vertritt Eis die Stelle des Tropfsteins. Sie sind stets Sackhöhlen, d. h. ihr Eingang liegt höher als der übrige Höhlẹnraum. In ihnen sammelt sich die schwere kalte Winterluft wie in einem Gefäß und wird, da sie nicht abfließen kann, von der wärmeren Luft im Frühjahr und Sommer nicht verdrängt. Eishöhlen können daher nur in

$\times$ Den Beweis dafür liefert die Lesse in Belgien, die auf ihrem unterirdischen Lauf von nur $1 \mathrm{~km} \mathrm{0,02}$ g pro Liter löst (im ganzen $1879000 \mathrm{~kg}$ im Jahr), während sie auf ihrem oberirdischen Lauf von $250 \mathrm{~km}$ nur fünfmal mehr gelöste Substanzen enthält. ${ }^{23}$ Einen viel größeren Erosionsbetrag gibt v. KNEBEL für den Timavo (nordwestlich von Triest) an: $0,25 \mathrm{~g}$ pro Liter, im Jahr also 210 Mill. kg, was einem Würfel von $43 \mathrm{~m}$ Seitenlänge gleichkommen würde. 
Gegenden vorkommen, wo die winterliche Temperatur dauernd unter den Gefrierpunkt sinkt. ${ }^{24}$

Daß gelegentliche Deckeneinbrüche der Höhlen auch für die Oberflächengestaltung Bedeutung gewinnen, wurde schon bei der Besprechung der Dolinen und Poljen erwähnt. Auf diesem Weg kann sich auch das unterirdische Tal in ein oberirdisches verwandeln, wie z. B. das der Ardêche in Südfrankreich, wo sich ein Überrest der Decke noch als natürliche Brücke in $34 \mathrm{~m}$ Höhe über den Fluß wölbt. Doch werden Brücken dieser Art auch durch herabgestürzte große Felsblöcke gebildet, die sich zwischen den unteren Talwänden einklemmen; und eine dritte Entstehungsart, durch Überwucherung mit Travertinablagerungen, haben KELLER ${ }^{25}$ und $\mathrm{LA}_{\mathrm{A}} \mathrm{Touche}^{26}$ an Beispielen aus Umbrien und Burma erläutert.

In Europa sind neben dem Karstgebirge (im weitesten Sinn des Wortes) die Kalkplateaus der Causses im französischen Zentralmassiv das ausgedehnteste und - dank den jahrelangen Forschungen Martel's - bestbekannte Karstland. Weit verbreitet sind nach Kruber die Dolinen, Grotten, blinden Täler und periodischen Seen in Rußland. Von den zahlreichen außereuropäischen Vorkommnissen wollen wir nur zwei nennen: Jamaica, ein echtes Karstland, dem auch die Poljen nicht fehlen, und das umfangreiche Höhlengebiet der Vereinigten Staaten zwischen dem Alleghanygebirge und dem Mississippi. Die Mammuthöhle in Kentucky besteht aus zahlreichen Gängen mit einer Gesamtlänge von 60 (nach anderen 48) km, und die nächst gröBte Höhle der Welt, die Wyandotthöhle in Indiana, mißt $37,6 \mathrm{~km}$. Dagegen haben die längsten Grotten des Karstes nur $5-7 \mathrm{~km}$.

Von den Höhlen der gehobenen Koralleninseln gehören sicher viele (wie z. B. die Auswaschungen im äolischen Kalkstein der Bahamas und Bermudas) in die Kategorie des Karstphänomens, ob aber alle, mag noch dahingestellt bleiben, da schon die lebenden Riffé nicht massive Bauten sind. Kraus zählt sie, ebenso wie die Blasenräume in Eruptivgesteinen, zu den ursprünglichen Höhlen.

Nicht alle Elemente des Karstphänomens sind überall in gleicher Weise ausgebildet, am seltensten, wie es scheint, die Poljen. Die Causses in Frankreich sind z. B. verhältnismäßig wenig höhlenaber sehr dolinenreich, während umgekehrt der Wüstenkalk des Antilibanon zahlreiche Grotten birgt, der Dolinen aber gänzlich entbehrt. Sieht man von der Vollständigkeit ab, so kann man sagen, daB das Karstphänomen eine allgemeine Verbreitung besitzt. Weder das geologische Alter noch die Lagerungsverhältnisse der Kalksteine haben darauf Einfluß. Es kommt ebenso in Faltengebirgen wie in 
horizontal geschichteten Plateaus (z. B. in Livland oder in den Causses) vor. Maßgebend ist nur die größere oder geringere Reinheit des Kalksteines, und ob die unreinen Kalksteine als Zersetzungsprodukte Ton oder Grus und Sand liefern; es hängt eben alles davon ab, in welchem Umfang und in wie viel Zeit die Klüfte mit den Überresten der chemischen Erosion verkleistert werden können. Sogar in einem und demselben Gebirge, wie z. B. auf dem Nanosplateau in Krain, können nahe bei einander Gegenden mit ganz verschiedener Entwicklung des Karstphänomens vorkommen. ${ }^{27}$ Das macht auch den Destruktionszyklus des Karstes verwickelter als den des offenen, undurchlässigen Geländes. Unzweifelhaft findet auch dort Abtragung statt, aber nicht bloß an der Oberfläche, sondern auch im Innern; sie schreitet nicht bloß von oben nach unten, sondern auch von unten nach oben fort. Auf den Karstebenen in Dalmatien und Montenegro fanden CviJI'́ ${ }^{28}$ und Schubert in der tonigen Ablagerung der Terra rossa Tropfsteine, wohl ein sicheres Anzeichen, daß hier die alte Oberfläche tiefer gelegt, und ehemalige mit Terra rossa ausgefüllte Höhlen aufgedeckt wurden. Auch die Karstdestruktion strebt einen Ausgleich der Niveauunterschiede an, kann dieses Endziel aber nach der Ansicht von CviJIó nur unvollkommen erreichen. Die chemische Erosion sucht nämlich immer nur einige günstige Punkte auf, während die dazwischen liegenden Partien langsamer der Zerstörung anheimfallen. Reste der alten Oberfläche bleiben als Einzelberge stehen; in der Herzegowina, wo man sie Hum nennt, sind sie so häufig, daß das Land einst davon den Namen führte. Sie sind also wesentlich andere Erscheinungen als die Härtlinge der Fastebene. Ein zweiter Unterschied besteht darin, daß für das $\mathrm{MaB}$ der Abtragung nicht die Erosionsbasis, wie bei oberirdischen Flüssen, sondern das Niveau des Karstgrundwassers bestimmend ist. Ist dieses erreicht, so erlischt das Karstphänomen und die Gesetze der Oberflächenerosion treten nunmehr allein in Kraft. Eine solche Umwandlung kann sich aber auch auf anderem Weg vollziehen. Die lehmigen Rückstände des aufgelösten Kalkes breiten sich von den Dolinen allmählich über die Oberfläche aus, auch die Fugen und Klüfte können damit, wie $\mathrm{SAWICKI}^{29}$ mit Nachdruck hervorgehoben hat, verkleistert werden, und so verliert die Oberfläche den Charakter eines Karstgeländes, wenn dieser auch in der Tiefe noch nicht völlig erloschen ist. Das südliche Istrien und der Schwäbische Jura sind bereits in dieses Stadium der Überreife eingetreten.

Genetische Einteilung der Täler. Die Allgewalt der Erosion findet ihren prägnantesten Ausdruck darin, daß die Talbildung an 
den Regenseiten der Kettengebirge entwickelter ist und tiefer in das Gebirge eindringt als auf der Leeseite. ${ }^{30}$ Je schärfer der klimatische Gegensatz, desto ausgeprägter der Gegensatz der Gliederung, und nur Plateaus, die, wie das von Dekan, sich nach der Trockenseite neigen, machen davon eine bemerkenswerte Ausnahme. Während der Nordabhang des Elbursgebirges von tiefen Tälern durchfurcht ist, ist der südliche ein einziger schroffer Abhang ohne eigentlichen FluB. Auf Tenerife ist nach Hans Meyer unter sonst gleichen Umständen die feuchtere Nordseite regelmäBiger und stärker erodiert als das im Passatschatten liegende Südgehänge. Das schlagendste Beispiel für diese Regel sind aber die Andes von Südamerika, wo im Gebiet des Passats die Wasserscheide westlich und im Gebiet der Westwinde östlich von den Hauptketten liegt. In Skandinavien deutet schon die gekerbte Gestalt der Hauptwasserscheide mit ihren Ausbuchtungen nach Ost und Süd darauf hin, daß sie von der feuchten atlantischen Seite nach der trocknen baltischen verrückt wurde, und einen unmittelbaren Beweis dafür erblickt REvSCH $^{31}$ in den auffallenden Widerhakentälern der oberen Nebenflüsse des Sundalselven, der Örkla, Gula u. a., die nicht, wie die anderen Nebentäler, nach West, sondern in einer Richtung verlaufen, die dem allgemeinen Gefälle entgegengesetzt ist.

Die Frage nach dem Ursprung der Täler ist aber häufig mit der Frage nach ihrer Ausbildung verwechselt worden. Ursprüngliche Täler, d. h. Hohlformen, die lediglich durch den Bau des Bodens bedingt sind, und an deren Ausgestaltung die Erosion nur einen geringfügigen Anteil hat, sind verhältnismäßig selten. Wir kennen nur drei Arten: Mulden-, Graben- und interkolline Täler. Die ersteren, in den Mulden der Schichtenfalten gelegen, sind wohl kaum irgendwo in ihrer ursprünglichen Gestalt erhalten, so daß man im Zweifel sein kann, ob man sie zu den ursprünglichen Tälern rechnen darf. Grabentäler, $\times$ durch Einsenkung entstanden, sind nach den neuesten Forschungen der russischen Geologen ${ }^{32}$ dem Bergland von Transbaikalien eigentümlich und zeichnen sich durch beträchtliche Breite aus. Nehmen sie, wie beispielsweise das Oberrheintal, eine Mittelstellung zwischen Tal und Ebene ein, so werden sie besser der letzteren morphologischen Kategorie zugezählt. Interkolline Täler liegen zwischen zwei selbständigen Gebirgen, die niemals oder wenigstens nie vollständig zusammengehangen haben. Sie sind also im Gegensatz zu allen andern Tälern primäre Gebilde wie die

$\times$ Onnutschew nennt sie Disjunktivtäler und ist der Ansicht, daB nicht die Täler sich senkten, sondern das begrenzende Gebirge sich hob. 
Gebirge selbst, die sie einschließen. So ist in der Wetterau ein Teil der hessischen Senke als Tal übriggeblieben, als im Osten des Taunus vulkanische Ausbrüche das Vogelsgebirge schufen. Auch in diesen Fällen ist es manchmal schwierig, zwischen Tal und Ebene $\mathrm{zu}$ unterscheiden.

Alle übrigen Täler können wir als Erosionstäler bezeichnen, insofern wir darunter Täler verstehen, die ihre heutige Ausbildung der Erosion verdanken. Als solche verraten sie sich namentlich durch drei Merkmale: 1. Durch ein Längsprofil, das sich mehr oder weniger der Gleichgewichtskurve nähert. Gebrochene Kurven sind nur Übergangsstadien; das Fehlen der Rückwand im Quellgebiet deutet, wie wir bei einer andern Gelegenheit ausführen werden, auf gewisse Vorgänge in der Entwickelungsgeschichte des Tales hin. 2. Durch den mehr oder weniger gewundenen Lauf des Tales, so daß in der Regel das kulissenartige Ineinanderschieben der Seitengehänge uns hindert, das ganze Tal zu überblicken. Solch ein Verlauf entspricht ganz der Tendenz der Flüsse zu Umwegen, sie kommt zum schärfsten Ausdruck in den Mäandertälern, ${ }^{33}$ wie z. B. in dem der Mosel unterhalb Trier. Diese in das Gebirge eingesenkten Mäander gleichen den Flußmäandern im Flachland in allen charakteristischen Eigenschaften; es kommt auch dort gelegentlich

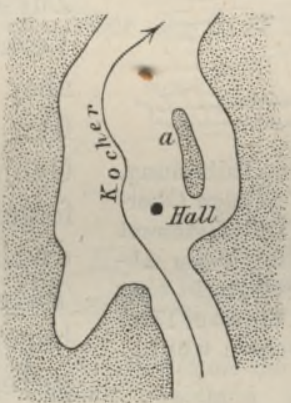

$I$

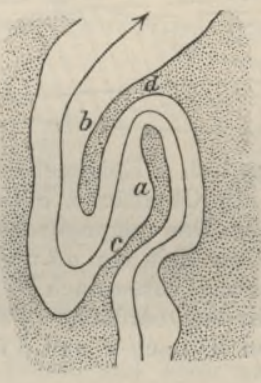

II

Fig. 152. Das Kochertal bei Hall nach Sched. $I$ stellt die gegenwärtige Gestalt des Tales (weiß) dar. II ist der Versuch einer Rekonstruktion des früheren Zustandes. Bei $c$ und $d$ erfolgten die Durchbrïche; von den dadurch isolierten Umlaufbergen ist $a$ noch erhalten, $b$ aber zerstört.

zum Durchbrueh eng eingeschnürter Talpartien, die dann als isolierte Berge (ScheU ${ }^{3+}$ hat sie Umlaufberge genannt) noch längere Zeit der Zerstörung trotzen (Fig. 152). Die Talmäander beginnen in der Regel dort, wo ein Fluß aus weicherem in härteres Gestein übertritt, wo also die Tiefenerosion auf Hindernisse stößt und dafür die Seitenerosion sich stärker entfalten kann. Eine langsame Hebung des Landes kann diesen Vorgang unterstützen, ist aber nicht unter allen Umständen erforderlich. Häufig findet man noch über dem harten Gestein Lappen einer einst weit verbreiteten Decke aus weicherem Gestein, und man kann mit $V_{A C H E R}{ }^{35}$ annehmen, daß die Flüsse einst auf dieser Decke ihren Lauf begannen. Das 3. Merkmal 
der Erosionstäler ist die Verästelung im obersten Talgebiet. Ein Tal löst sich am oberen Ende in zwei unter einem spitzen Winkel zusammenstoßende Quelltäler auf, diese wieder in zwei, diese abermals usw. Ein solches Tal endigt also nicht mit einem, sondern mit mehreren Quelltrichtern, aber die Verzweigung ist genau derselbe Vorgang wie derjenige, der zur Bildung eines Quelltrichters führt. Keines dieser Merkmale läBt sich durch die Annahme erklären, daß die Täler tiefe Spaltenaufrisse seien.

Anders gestaltet sich aber das Problem, wenn wir die Frage stellen, warum sich ein Erosionstal gerade an dieser Stelle entwickelt hat. Es unterliegt keinem $Z_{\text {weifel, }} \mathrm{da} \beta$-die ursprüngliche Anlage zahlreicher Täler im Bodenbau begründet war, der den erodierenden Kräften bestimmte Richtungen anwies. Neben diesen tek-

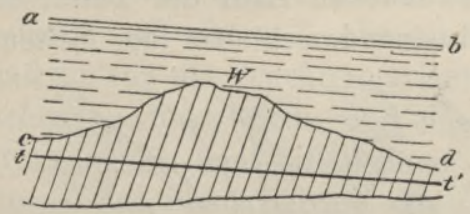

Fig. 153. Epigenetische Talbildung. $a b$ alte Oberfläche, $c W d$ jetzige Oberfläche. Das epigenetische Tal $t t^{\prime}$ stammt aus der Zeit von $a b$ und folgte der Abdachung von $a$ nach $b$, entspricht aber nicht der Oberfläche $c W d$, die zwei Täler von $W$ nach $c$ und $d$ fordern würde. tonischen Tälern gibt es aber viele andere, bei denen sich kein Zusammenhang mit geologischen Verhältnissen nachweisen läßt, wohl aber mit hypsometrischen, insofern sie der Hauptabdachung eines Gebirges oder einer schiefen Ebene folgen. Wir nennen sie $\mathrm{Ab}$ dachungs- oder orographische Täler. Es bleibt jedem unbenommen sich vorzustellen, daB gelegentliche Risse und Klüfte die ersten atmosphärischen Niederschläge da oder dort zu Wasserfäden gesammelt haben, aber es $\mathrm{mu} \beta$ betont werden, daß bei dem gänzlichen Mangel an oberflächlichen Klüften das flieBende Wasser die gleiche Richtung nehmen und in ihr Täler aushöhlen mußte. Es gibt aber endlich auch unzweifelhafte Erosionstäler, die sowohl mit den tektonischen als auch mit den hypsometrischen Bedingungen im Widerspruch stehen. Zur Erklärung dieser rätśelhaften Gebilde nimmt v. RichтноғeN an, daß sie zu einer Zeit entstanden sind, als das heutige Gebirge noch mit einer flachen Sedimentdecke verhüllt war. Die Flüsse folgten der Abdachung der alten Oberfläche und konnten sich in der ursprünglichen Richtung erhalten, wenn sie sich zu der Zeit, da die Sedimentdecke der. Destruktion zum Opfer fiel, schon genügend tief in den alten Untergrund, d. h. in die jetzige Oberfläche eingefressen hatten (s. Fig. 153). v. Richthofen nannte diese Talbildung die epigenetische.

Das System der Täler ist also folgendes: 
1. Ursprüngliche Täler:
a) Muldentäler,
b) Grabentäler,
c) Interkolline Täler;

2. Erosionstäler:
a) Orographische Täler,
b) Tektonische Täler,
c) Epigenetische Täler,
d) Einsturztäler (vgl. S. 540).

Es gibt vielleicht noch eine Kategorie, die wir Verwitterungstäler nennen können, weil angenommen wird, daß hier eine Spalte, längs der die Verwitterung der Erosion vorgearbeitet hat, für die Talanlage richtunggebend war. ${ }^{36}$ Wir lassen sie indes als problematisch vorläufig außer Betracht.

Terminologie von W. M. Davis. Davis unterscheidet die Flüsse und die von ihnen geschaffenen Täler nach ihrem Alter und nach ihren Beziehungen zum Schichtenbau. Er geht dabei von der Ansicht aus, daß die ursprünglichen Abdachungen eines Landes durch den Fall der Schichten bedingt waren, ihnen folgten die ältesten Flüsse, diedaherkonsequente

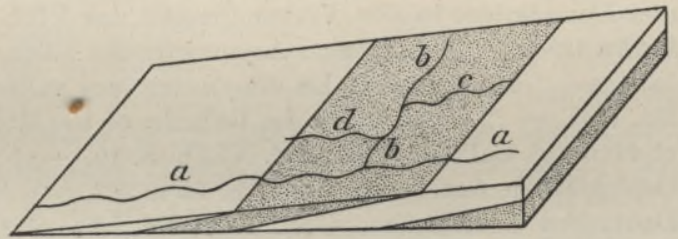

Fig. 154. Klassifikation der Flüsse und Täler nach Davıs. Harte Schichten weiß, weiche gekörnt, $a$ konsequenter, $b$ subsequenter, $c$ resequenter. $d$ obsequenter Fluß. genannt werden. In den Faltengebirgen gehören dazu neben den Abdachungsflüssen auch diejenigen, die die Muldentäler einnehmen. An den Abdachungen der konsequenten Täler entwickeln sich Nebenflüsse, vor allem dort, wo das Gestein geringeren Widerstand leistet. Nur auf diese beschränkt Davis den Namen subsequente Flüsse und Täler; sie geben wieder Veranlassung zur Bildung neuer Flüsse und Täler, von denen die einen, die resequenten in der Fallrichtung der Schichten, die auf der anderen Seite, die obsequenten, in der entgegengesetzten Richtung verlaufen. Flüsse und Täler, die keiner dieser Bedingungen entsprechen, werden als insequente bezeichnet.x Für einfache

$\times$ Bei der heutigen Neigung der Geographen, unsere schöne und reiche deutsche Sprache mit fremden Namen zu belasten, wäre jeder Verdeutschungsversuch der DAvis'schen Benennungen, denen KRÜMmEL mit Recht Unanschaulichkeit vorgeworfen hat, willkommen, wenn er geglückt wäre. Das kann man aber leider von den bisherigen nicht sagen. Vorgesehlagen wurden: für kon- 
tektonische Verhältnisse reicht diese Terminologie aus und ist nützlich, bei einem komplizierten Gebirge, wie den Alpen, versagt sie aber, und mit der umfassenderen genetischen Einteilung läßt sie sich nur zum Teil vereinen.

Literaturnachweise. ${ }^{1} \mathrm{~J}$. Bronhes, Le travail des eaux courantes, in den Mémoires de la Société des sciences naturelles, 1902, Géologie et Géographie, Bd. II; Nouvelles observations sur le rôle et l'action des tourbillons, in Le Globe 1904, Bd. XLIII. - ${ }^{2}$ R. Fourtad, La eataracte d'Assouan, im Bulletin de la Société Khédiviale de Géographie 1905. $-{ }^{3} \mathrm{~S}$. dazu die lehrreichen Abbildungen zu E. Chaix-Du Bors, Le pont des Oulles, in La Géographie 1903, Bd. VIII. ${ }^{4}$ L. Rütrmeyer, Über Tal- und Seebildung; Basel 1869. A. Supan, Talbildungen des östlichen Graubündens und der Tiroler Zentralalpen, in den Mitteilungen der Wiener Geographischen Gesellschaft 1877. F. LöwL, Über Talbildung; Prag 1884. A. Philippson, Ein Beitrag zur Erosionstheorie, in Petermann's Mitteilungen 1886; Studien über Wasserscheiden, in den Mitteilungen des Vereins für Erdkunde in Leipzig 1886. G. DE LA NoË und E. DE Margerie, Les formes du terrain; Paris 1888 (handelt hauptsächlich von der Erosion und enthält sehr lehrreiche Abbildungen). A. Hetraer, Die Arbeit des fließenden Wassers, in der Geographischen Zeitschrift 1910. - ${ }^{5}$ A. Penck, Das Endziel der Erosion und Denudation, in den Verhandlungen des VIII. deutschen Geographentages; Berlin 1889. - ${ }^{6}$ V. Hilber, Asymmetrische Täler, in Petermann's Mitteilungen 1886. - ${ }^{7}$ L.-A. Fabre, La dissymetrie des vallées, in La Géographie, 1903, Bd. VIII. - ${ }^{8}$ W. M. Davis im Bulletin of the Museum of Comparative Zoology at Harvard College, 1903, Bd. XLII, S. 10. - ${ }^{9}$ H. Reúsch, im norwegischen Geologischen Aarbog for 1900, S. 13 u. 223. - ${ }^{10}$ B. Doss, in der Ztschr. der Deutschen Geologisehen Ges., 1902, Bd. LIV, S. 1. - ${ }^{11}$ R. SoкоL, im Zentralblatt für Mineralogie usw. 1907, S. 429. - ${ }^{12}$ L. Rütmmeyer, Der Rigiberg; Basel 1877. - ${ }^{13}$ E. Fleury, Le chaudron latéral, in La Géographie, Paris 1907, Bd. XV. - ${ }^{14}$ C. E. Dutron, Tertiary History of the Grand Cañon District, Washington 1882. W. M. Davis, An Exeursion to the Grand Cañon of Colorado, im Bulletin of the Museum of Comparative Zoology at Harvard College, 1901. W. T. Lee, Geological Reconnaissance of a part of Western Arizona, Bulletin of the U.-S. Geological Survey, 1908. W. v. Łozinski, Versuch einer Charakteristik der Cañontäler, im Jahrbuch der Geologischen Reichsanstalt, Wien 1909, Bd. LIX. - ${ }^{15}$ F. Sturs, Die Entstehung der Wasserfälle, in der Festschrift des Geographischen Seminars der Universität Breslau, 1901. E. FAsolt, Wasserfälle und Stromschnellen, im Jahresbericht des I. Deutschen Staatsgymnasiums in Brünn 1905/06. - ${ }^{16} \mathrm{~J}$. W. W. Spencer, The Falls of Niagara; Ottawa 1907. - ${ }^{17}$ W. M. Davis hat seine wiederholt erörterte Theorie in Kürze zusammengefaßt im Aufsatz "The Geographical Cycle" im Geographical Journal, 1899, Bd. XIV. - ${ }^{18}$ M. R. Campbell, Drainage Modification and their Interpretation, im Journal of Geology, Chicago 1896, Bd. IV. W. M. DAvIs, Complications of

sequente Flüsse Folge- und Hangflüsse, für subsequente Nachfolge- und Schichtflüsse (beide Namen bringen gerade das Hauptmoment, die Lage in weichen Schichten, nicht zum Ausdruck), für obsequente Gegen-, Stirn-, Abkehrflüsse, für resequente Folgeflüsse zweiter Ordnung, Nachfolge- und Einkehrflüsse, für insequente Kürflüsse. Vgl. dazu Geographischer Anzeiger 1910 , S. 10,121 u. 196. 
the Geographical Cycle, im Report of the VIII ${ }^{\text {th }}$ International Geographical Congress, 1904; Washington 1905. - ${ }^{19}$ J. CvıJé, Das Karstphänomen, Wien 1893. E. A. Martel, Les abîmes, Paris 1894; La spéléologie ou science des eavernes, Paris 1900; L'évolution souterraine, Paris 1908. F. Kraus, Höhlenkunde, Wien 1894. L. K. Moser, Der Karst und seine Höhlen, Triest 1900. A. GRUnd, zit. S. 498. A. Penck, Über das Karstphänomen, in den Schriften des Vereins zur Verbreitung naturwissenschaftlicher Kenntnisse in Wien, Bd. XLIV, 1904. W. v. Knebel, Höhlenkunde, Braunschweig 1906. F. Katzer, zit. S. 498. H. Hilpert, Die historische Entwicklung der Frage nach dem Wesen des Karstphänomens, Würzburg 1907. - ${ }^{20}$ M. Eckert, Die Karren oder Schratten, in Petermann's Mitteilungen 1898. Durch Abbildungen und Karte sehr lehrreich ist E. Charx, La topographie du désert de Platé, in Le Globe, Genf 1895. - ${ }^{21}$ J. Cvisré, Morphologische und glaziale Studien aus Bosnien usw., in den Abhandlungen der Geographischen Gesellschaft, Wien 1900/01, Bd. II u. III. - ${ }^{22}$ A. Gavazzi, Die Seen des Karstes, ebenda 1904, Bd. V. - ${ }^{23}$ J. Du Fref und E. Rahir, im Bulletin de la Société de Belge de géologie 1901, Bd. XV, S. 11. - ${ }^{24}$ E. S. BALch, Glacières or Freezing Caverns, Philadelphia 1900 (Hauptwerk). E. Richter, Über Eishöhlen, in Petermans's Mitteilungen 1889. H. Crammer, Eishöhlen- und Windröhren-Studien, in den Abhandlungen der Geographischen Gesellschaft in Wien, Bd. I, 1899. 25 Ph. Keller, in Petermann's Mitteilungen 1881, S. 329. - 26 T. D. La Touche, in den Records of the Geological Survey of India, 1906, Bd. XXXIII, S. 49. 27 N. Krebs, Offene Fragen der Karstkunde, in der Geographischen Zeitsehrift 1910. - ${ }^{28}$ J. Cvisıć, Bildung und Dislozierung der Dinarischen Rumpffläche, in Petermann's Mitteilungen 1909. - ${ }^{29}$ L. Sawicki, Skizzen des slowakischen Karstes, im Kosmos, Lemberg 1908, Bd. XXXIII. - ${ }^{30}$ O. KrümmeL, Einseitige Erosion, im „Ausland" 1882. E. v. Сноцкоку, Die Verteilung des Niedersehlags als Ursache eines wichtigen geophysischen Vorganges, im Abrégé des Bulletins der Ungarischen Geographischen Gesellschaft, 1903. - ${ }^{31}$ H. Reusch, En eiendommelighed ved Skandinaviens Hovedvandskille, in Norsk Geologisk Tidskrift, 1905, Bd. I. - ${ }^{32}$ W. A. Oвrutschew, Orographie und Tektonik Transbaikaliens, in den Verhandlungen des VII. internationalen GeographenKongresses, Berlin 1899 (1901, Bd. II). - ${ }^{33}$ W. M. Davis, Incised Meandering Valleys, im Bulletin of the Geographical Society of Philadelphia 1906. 34 E. Sched, Zur Morphologie der Schwäbisch-Fränkischen Stufenlandsehaft, Stuttgart 1909. - ${ }^{35} \mathrm{~A}$. VAcher, Rivières à méandres encaissés et terrains à méandres, in Annales de géographie, 1909. - ${ }^{36}$ E. v. Drygalski, Ein typisches Fjordtal, in der Richthofen-Festschrift 1893. Vielleicht gehört auch das Transkei Gap in diese Kategorie (A. W. Rogers und E. H. L. Schwarz, in den Transactions of the South African Philosophical Society 1903, Bd. XIV, S. 66).

\section{Die Frage der Gletschererosion.}

Ansichten darüber. In der Region des ewigen Schnees sind andere zerstörende Kräfte tätig, als wir sie bisher kennen gelernt haben. Spülendes und fließendes Wasser fehlen, die chemische Verwitterung tritt in den Hintergrund, aber gründlicher und schneller als diese arbeiten der Spaltenfrost und die grellen Temperaturwechsel an den nackten Felswänden. Der Verwitterungsschutt fällt auf den Firn und wird als Moräne talabwärts getragen. Diese Vor- 
gänge liegen offen zutage, anders aber verhält es sich mit der viel umstrittenen Frage, ob fließendes Eis auch erodiere. Innerhalb beschränkter Grenzen wird dies allgemein zugestanden. An jedem verlassenen Gletscherbett kann man beobachten, daß die Eisströme die Tendenz haben, die Unebenheiten zu beseitigen und die Ecken abzurunden, und an Talvorsprüngen kann man nach $\mathrm{CHAIx}^{1}$ genau erkennen, ob sie durch Wasser- oder Gletschererosion angegriffen wurden; im ersteren Fall ist die talabwärts gelegene Seite am meisten in Mitleidenschaft gezogen worden, im zweiten wurde die talaufwärts gelegene Seite zu Rundhöckern umgestaltet, während die andere unverletzt und kantig blieb. Nichts anderes zeigt auch das Experiment von Simonx, der im Jahr 1846 nahe am untersten Eisrand des Karleisfeldes (am Dachstein) in dem kompakten Felsboden ein ungefähr $3 \mathrm{~mm}$ tiefes Kreuz ausmeißelte. Zur Zeit seines Maximalstandes i. J. 1856 schritt der Gletscher über diese Marke hinweg und zog sich dann wieder zurück, und als die betreffende Stelle freigelegt war, war das Kreuz verschwunden, und die Platte in der Richtung der Gletscherbewegung gekritzt. ${ }^{2}$ Einen Beweis für wirkliche Tiefenerosion wird erst der Versuch von BaLtzer und Voskule liefern, die auf dem Boden des untern Grindelwald- und des Hüfigletschers Bohrlöcher anlegen und mit Gips ausfüllen ließen, denn dadurch wurde jede Unebenheit beseitigt. Um zu einer Vorstellung von der Größe der Gletschererosion zu gelangen, hat man den Schlammgehalt der milchigtrüben Gletscherbäche gemessen, und aus Ören's ${ }^{3}$ Zusammenstellung $\times$ scheint hervorzugehen, daß mit der Ausdehnung der Eisbedeckung die Schlammführung auch relativ wächst, also die Erosionskraft zunimmt. Indes ist dabei zu berücksichtigen, daß nach Finsterwalden's Theorie (s. S. 207) ein großer Teil der Grundmoräne von dem Oberflächenschutt des Firnfeldes

$\times$

\section{Alaska, Muirgletseher}

Grönland, Isortok .

Alangordlek .

Island, Jökulsá

Vatnajökull .

Norwegen, Jostedalsbrae

" Hardangerjökel

„ Leira.

Galdhötind
Schlamm

pro Liter Wasser

g

12,980

9,744

2,374

1,876

-

0,523

0,345

0,092

Jährliche

Abtragung

$\mathrm{mm}$

(19, ReID;

jedenfalls unrichtig)

Vgl. dazu die Zahlen für die Rhône auf S. 514 
stammt, also nicht nur Erosions-, sondern auch Verwitterungsprodukt ist. Um das letztere auszuscheiden, hat Hess ${ }^{4}$ den Schuttgehalt der mittleren Innenmoräne einiger Ötztaler Ferner durch Messung annähernd $\mathrm{zu}$ bestimmen versucht, und daraus auf einen jährlichen Erosionsbetrag von $0,027 \mathrm{~mm}$ geschlossen. Man sagt wohl, auch minimale Wirkungen können sich im Lauf unendlich langer Zeiträume zu großen summieren, aber mit solchen Zeiträumen können wir nicht rechnen, da selbst nach der Schätzung von Penck die ganze Eisperiode nur ungefähr eine Million Jahre dauerte, und davon wenigstens die Hälfte auf die Interglazialzeiten entfiel, Berücksichtigt man ferner, daß die talbildende Kraft der Gletscher nicht, wie die des fließenden Wassers, durch geschichtliche Beispiele belegt ist, so kann es nicht wundernehmen, daß sie von vielen Forschern noch geleugnet wird. Man fragt sich, wie es möglich sei, daß die eiszeitlichen Gletscher der Alpen Riegel und kleine Berge von 100-200 m Höhe nicht weggeräumt haben, während sie Täler von viel beträchtlicherer Tiefe ausgehöhlt haben sollen. Wenn sich trotzdem die neue Lehre von der Gletschererosion immer mehr Bahn bricht, so geschieht es mehr unter dem Zwang der Logik als der Tatsachen, denn unbestreitbar ist der Satz, daß jeder in Bewegung befindliche Körper auf seine Unterlage zerstörend einwirken muß. Es ist unwahrscheinlich, daß die Gletschererosion aufhört, sobald die Unebenheiten des Bettes beseitigt sind. Man beruft sich auch auf die große Mächtigkeit und die ihr entsprechende große Geschwindigkeit der eiszeitlichen Alpengletscher, denen man ganz andere Wirkungen zutrauen dürfe, als ihren kümmerlichen Überresten in der Gegenwart. Die physikalische Erklärung des Wie der Gletschererosion bereitet freilich noch Schwierigkeiten. Ohne Zweifel zerfällt auch sie in Ablation und Korrosion, sollte sich aber die letztere in Glättung erschöpfen, so wäre sie gering anzuschlagen. Nach BALTzER ${ }^{5}$ gilt das aber nur für massige Gesteine, während in schieferigen Gesteinen oder in solchen, deren Gefüge anderweitig gelockert ist, der untere Grindelwaldgletscher eckige Bruchstücke bis $\mathrm{zu} 1 \mathrm{cbm}$ absplitterte. Ähnliche Beobachtungen hat v. Drygalski in Grönland gemacht. DeELex ${ }^{6}$ weist darauf hin, daß der Gletscher infolge des Druckes überkältetes Wasser führt; wenn es am Boden austritt und in poröses Gestein eindringt, wird dieses am Eis anfrieren und kann losgerissen werden. Aus den Experimenten yon BLÜMCKE und FINSTERWALDER ${ }^{7}$ geht hervor, daB in Eis gebettete Gesteine sich unter wechselndem Druck, der bald Gefrieren, bald Verflüssigung des Eises bewirkt, genau so verhalten wie Gesteine an der Oberfläche, d. h. es erfolgt nicht nur eine Zersprengung der Gesteine unter der Einwirkung des 
Gefrierens und Wiederauftauens des Spaltenwassers, sondern es werden auch, wie bei der gewöhnlichen Verwitterung, feine Partikelchen losgelöst. Nimmt man an, daß ein und derselbe Punkt des Gletscherbodens unter dem darüber hinwegschreitenden Eisstrom wechselnden Druck erleidet, so muß man zugestehen, daß die Verwitterung auch unter dem Gletscher noch fortarbeitet. SALOMON $^{8}$ legt auf dieses Moment das Hauptgewicht; wie in der Schneeregion, so wird auch am Gletscherboden das Gestein durch Spaltenfrost zertrümmert und kann vom Gletscher fortgeführt werden; und wahrscheinlich ist das, was BALtzer im Gegensatz zur abschleifenden die splitternde Erosion nannte, auf diesen Vorgang zurückzuführen. Demnach wäre die Gletschererosion der Hauptsache nach Ablation, der nicht bloB von oben, sondern auch von unten immer neues Material zugeführt wird. Seltsam mutet die von $\mathrm{DE}$ Martonne $^{9}$ aufgestellte Theorie an, der zufolge die Gletschererosion proportional den Stauungen ist, die durch die Unebenheiten des Bettes dem Fortschreiten des Eisstroms entgegengestellt werden, denn es folgt daraus, daß über eine gewisse Neigung hinaus die Gletschererosion sich vermindert, wenn die Neigung wächst, und daß sie ihre höchste Kraft ober- und unterhalb der Gefällsbrüche und Einschnürungen des Tales entfaltet. De Martonne weist darauf hin, daß in den flachen Teilen des Bettes sich zưrückziehender Gletscher die ganze Oberfläche abgescheuert ist, während die steilen Stufen verhältnismäßig wenig Gletscherstreifen zeigen. Als im Sommer 1900 ein großer Teil des Katarakts des Rhônegletschers als Eislawine herabstürzte, eröffnete sich uns ein Einḅlick in die Granitwand, über die sich der Gletscher seit der Eiszeit mit der ungewöhnlichen Geschwindigkeit von etwa $150 \mathrm{~m}$ im Jahr bewegt. Trotzdem ist sie, wie Forer feststellte, so wenig abgenutzt, daß sie kaum hinter die Flucht der eisfreien Felspartien rechts und links vom Gletscher zurücktritt. Freilich ist der Eisstrom hier nur 5-10 m dick.

Wie immer es sich auch mit der Erosion der Gletscher verhalten möge, unzweifelhaft arbeiten sie anders wie fließendes Wasser. Sie bewegen sich ungleich langsamer, aber sie entfalten über einem Punkt eine größere Masse, wenn auch an eine Zerquetschung und Zertrümmerung der Gesteinsunterlage selbst durch den mächtigsten Eisstrom nicht gedacht werden darf. Thre Reibungsfläche ist viel gröBer, als die der Flüsse, sie wirken in erster Linie flächenhaft, und es unterliegt keinem Zweifel, daß eine Eismasse, die sich nach Art des grönländischen Inlandeises über eine schiefe Fläche bewegt, nicht fähig ist, ein Tal auszuhöhlen, wenn nicht gerade besonders widerstandschwache Linien, z. B. Verwitterungszonen längs Spalten 
(vgl. S. 545), vorhanden sind. $\mathrm{DaB}$ der Gletscher auf dem Frostismassiv am norwegischen Ofotenfjord noch keine Talrinne geschaffen hat, ist also nicht, wie $\mathrm{R}_{A B O T}$ meint, ein Beweis gegen seine Erosionskraft. Aber überall, wo Gletscher in bestehende Täler eintreten, kommt auch lineare Erosion zur Geltung. Sie sind also nicht in so allgemeiner Weise, wie das fließende Wasser, Talbildner, aber sie wirken umgestaltend. Nur über das Maß dieser Umformung gehen die Ansichten noch weit auseinander. Nach der Meinung von ALbert Herm u. a. beschränkt sie sich auf Glättung des Bettes; ist diese Arbeit getan, so wirke der Gletscher geradezu konservierend. Dagegen verdanken nach der Ansicht von Hess ${ }^{10}$ die Täler unserer Alpen ihre Existenz fast ganz den Eisströmen der Glazialzeit. Eine Mittellinie halten Penck, BrÜCKNeR, ${ }^{11}$ DAvIs $^{12}$ u. a. ein, indem sie die Anlage der'Alpentäler im wesentlichen zwar der Flußerosion in vorglazialer Zeit zuschreiben, in den gegenwärtigen Formen aber ein Werk der eiszeitlichen Gletschererosion erblicken.

Kare. In den Tälern

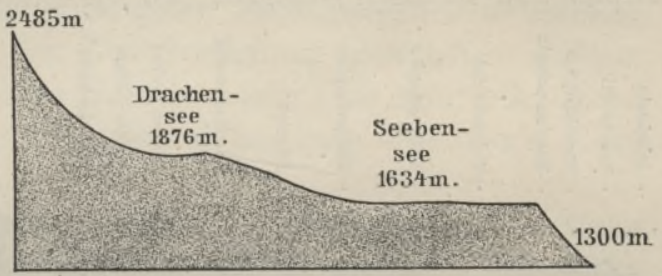

Fig. 155. Stufenkare mit Seen am Nordabhang der Miemingerkette in Tirol.

Länge und Höhe in 1:50000.

der Hochalpen steigt das

Gehänge nicht gleichmäßig von der Sohle bis zum Kamm an, sondern scheidet sich in drei Regionen: die untere oder Gehängeregion mit steiler Böschung (Fig. 155), die Karregion mit sanftem Bodenanstieg und die Kammregion mit sehr steilem Abfall. Einen Einblick in die Kar- und die Kammregion des östlichen Ausläufers der Hohen Tauern (nordöstliche Seite des Maltatales) gewährt uns Fig. 156; sie zeigt uns, daß die Karregion durch steil aufragende Felsrippen in Nischen geteilt ist. Auf diese in den Gipfelkörper eingesenkten Nischen mit breitem Boden, die man anschaulich mit Lehnstühlen verglichen hat, beschränken wir im Einklang mit v. Böнм und Richter den Namen Kar. ${ }^{*}$ Sie kommen nur über der Schneegrenze vor oder dort, wo die eiszeitlichen Gletscher über die Schneegrenze anstiegen, über dem oberen Gletscherrand, aber in den Alpen auch nur dort, wo die Kämme wenigstens dreimal breiter als hoch und nicht über

$\times$ Andere Schriftsteller gebrauchen dafür den in Norwegen heimischen Namen Botner und nennen Kare die Quelltrichter, die auch nischenförmig in den obersten Kamm eindringen, aber einen trichterförmigen Boden haben. Unsere Kare haben im Querprofile U-Form, die Quelltrichter V-Form. 
$31^{0}$ geneigt sind. ${ }^{13}$ Vielleicht ist aus diesem Grund das Schweizerische Hochgebirge ärmer daran, aber auch in den Ostalpen sind manche höchste Erhebungen der Zentralalpen und die Kalkplateaus frei von Karen, und PencK schließt daraus, daß eine völlige Eisbedeckung des Gebirges ihrer Entwicklung nicht günstig war. Viele Kare tragen noch Firnfelder oder Hängegletscher, andere sind schneefrei, weisen aber noch Spuren ehemaliger Eisbedeckung auf. Kleine Seen sind häufig. Die Mehrzahl ist jetzt durch Seitenbäche in das Talsystem einbezogen, andere aber nicht, und das beweist schon, daß die Karbildung mit dem fließenden Wasser nichts zu tun hat. Noch deutlicher sprechen die norwegischen Kare, insofern hier jeder Zusammenhang mit den Tälern fehlt. Rrchter faßt sie als glaziale Umformungen bestehender Bodensenkungen auf; in den Alpen und in allen Gebirgen, wo die Eiszeit schon ein ausgebildetes

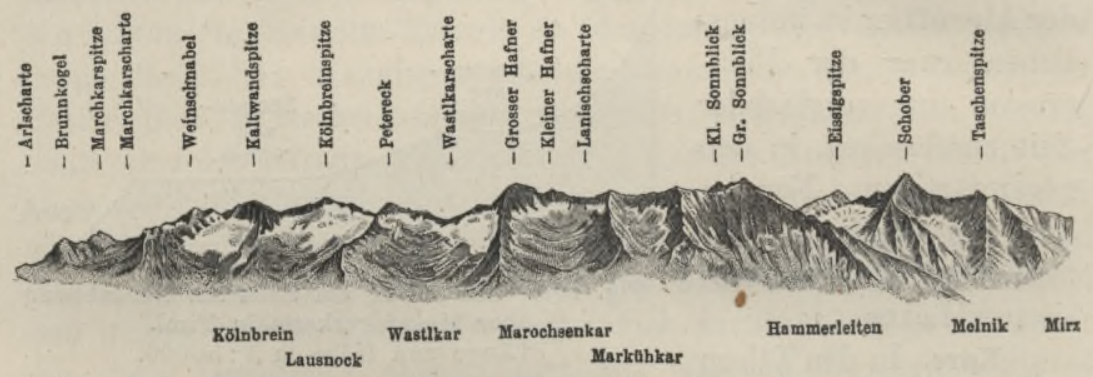

Fig. 156. Die Hafnergruppe vom Hochalmkees gesehen, nach F. Kordon (Zeitschrift des D. u. Ö. Alpenvereins 1898).

Talnetz vorfand, boten die Quelltrichter für solche Umgestaltung die geeignetsten Objekte. Der wegen seiner Steilheit größtenteils schneefreie Rahmen wurde durch hochgradige Verwitterung immer weiter zurückgedrängt und zu Steilwänden umgeformt, der Schutt fiel auf die Firndecke des Bodens und wurde fortgeführt; der Boden selbst wurde durch das sich bewegende Eis geglättet und ausgeebnet. De Martonne ${ }^{14}$ ist in den Transsylvanischen Alpen zu derselben Anschauung gelangt, obwohl er sich die Schwierigkeiten dieser Theorie nicht verhehlt, die namentlich darin bestehen, daß man dem Gletscher schon an seinem Ursprung eine bedeutende Erosionstätigkeit zumutet. DaB Kare aus Quelltrichtern hervorgehen, zeigen deutlich die Übergangsformen in der Adamello-Gruppe, ${ }^{8}$ aber anderseits ist es seltsam, daß auf dem schlesischen Abhang des Riesengebirges in unmittelbarer Nähe eines so typischen Kars, wie es die Schneegruben sind, und in nahezu gleicher Höhe völlig intakte Quelltrichter sich erhalten haben. NUSsBaum ${ }^{15}$ erwähnt die an Trichter erinnernden Kare in den südlichen Tessiner Alpen und an den 
südlichen Kämmen der Bernina-Alpen, die er auf Umgestaltung durch fließendes Wasser zurückführt, und meint, daß nur jene Kare ihre Form bewahrt haben, die auch in den Interglazialzeiten unter Schnee und Eis begraben waren. Aus Beobachtungen im trocknen Westen der Vereinigten Staaten sind die Erklärungsversuche von JoHnson und Matthes hervorgegangen, die auch HoBBs ${ }^{16}$ sich zu eigen gemacht hat. Darnach habe sich, als die Eiszeit herannahte, in der ursprünglichen Vertiefung zunächst ein unbewegliches Schneefeld angesammelt, das durch exzessiven Spaltenfrost an den im Sommer zurückweichenden Rändern den Boden bearbeitete und einebnete; als dann die Mächtigkeit des Firns wuchs, geriet er in Bewegung, zwischen ihm und dem Fels entstand eine Spalte (die JoHnson als Bergschrund bezeichnet), und hier seien durch die beständige Feuchtigkeit die günstigsten Bedingungen zur raschen und intensiven Zerstörung der Felsumrahmung geschaffen worden. Diese Theorie mag auf trockne Gebiete anwendbar sein, aber nicht auf unsere Alpen, wo ein Bergschrund im Sinn JoHnson's nicht vorkommt (vgl. S 201).

Die von beiden Seiten in die Bergrücken eindringenden Kare sind es, denen wir die echt hochalpinen Formen, die schroffen Grate und die vielgestaltigen Gipfel, verdanken.

Die Talformen. Als charakteristische Glazialformen der alpinen

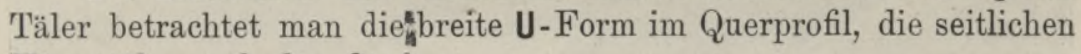
Hängetäler und den Stufenbau im Längsprofil. Man beruft sich darauf, daß die unvergletscherten Täler der Ost- und Südalpen dieser Merkmale entbehren.

Von dem Rand der Karregion senkt sich das Gehänge mehrere hundert Meter steil zu

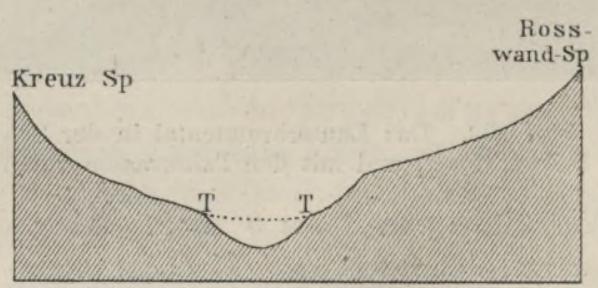

Fig. 157. Querprofil des Stilluppgrundes in den Zillertaler Alpen. $T T=$ Trogrand. demTalboden hinab; RichteR hat diese breite U-Form der unteren Talböschung den Taltrog genannt, und diese Bezeichnung rechtfertigt sich besonders dadurch, daß sich die beiderseitigen Trogränder meist im Hintergrund des Tals im sogen. TrogschluB vereinigen. Über den Trogrand stürzen sich die Seitenbäche als Wasserfälle herab (vgl. den Staubbach bei Lauterbrunnen in Fig. 158) oder sie durchschneiden ihn in steil ansteigenden Klammen. Augenscheinlich hat die Erosionsarbeit in diesen seitlichen Hängetälern mit der im Haupttal nicht gleichen Schritt gehalten, das Haupttal ist nach dem Ausdruck Penck's übertieft. 
Nur große Nebentäler machen davon eine Ausnahme; so münden z. B. das Ötz- und das Zillertal gleichsohlig in das Inntal und ebenso das Drance- und das Visptal in das Walliser Rhônetal.

Die herrschende Glazialtheorie betrachtet den Taltrog und die Talübertiefung als ein Ergebnis der eiszeitlichen Gletschererosion, und zwar in den Ostalpen als eine Schöpfung der gesamten Eiszeiten, in der Schweiz aber nur als ein Erbstück aus den beiden letzten Eiszeiten. $\times$ Es fällt auf, daß nicht entlang der ganzen Reibungsfläche Erosion stattgefunden hat; die Übertiefung ist stets kleiner als die Mächtigkeit des Eises und steht zu ihr ungefähr in dem

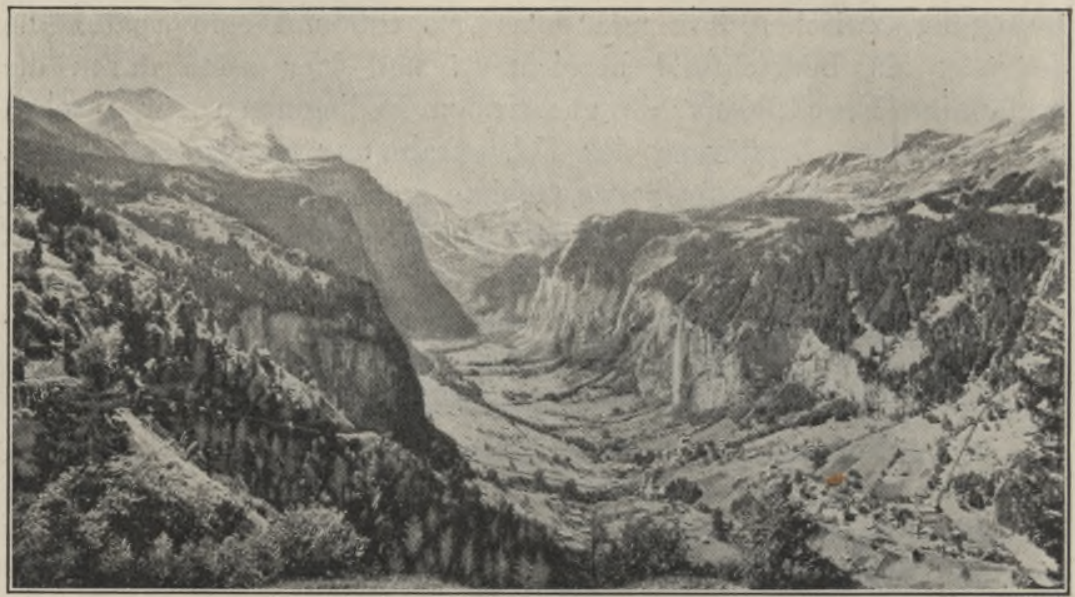

Fig. 158. Das Lauterbrunnental in der Schweiz mit charakteristischer breiter U-Form (Trog) und mit den Talterrassen von Wengen (links) .und Mürren (rechts).

Verhältnis von 2 bis 3 zu 5 . Aber dieses Bedenken ist jetzt beseitigt, denn aus den Tiefbohrungen von Blümcke und Hess' auf dem Hintereisferner geht hervor, daß auch sein Boden sich trogförmig einsenkt und daß die Kanten dieses Troges 70-100 $\mathrm{m}$ unter der Gletscheroberfläche liegen. ${ }^{17}$ Es ist bereits erwähnt worden, daß Hess ${ }^{10}$ über Penck hinausgeht; er konstruierte nach den Karten aus den Gefällsknicken der Rippen, die sich von den Gehängen aus gegen die Talmitte vorschieben, drei alte Taltröge, die er, einschließlich des gegenwärtigen, den vier alpinen Eiszeiten zuschrieb.

Gegen die Glazialtheorie wird geltend gemacht, daB die U-Form nicht ausschließlich an ehemals vergletscherte Täler gebunden ist,

$\times$ Das schematische Profil von Lautensach in Petermann's Mitteilungen 1911, Bd. I, S. 12, entspricht nicht der Auffassung von Penck und Brückner in deren großem Alpenwerk und ist daher irreführend. 
und daß sie diesen auch manchmal fehlt. Selbst $D_{A v I S}{ }^{18}$ muB das zugeben. Flußerosion ist also auch im alpinen Taltrog nicht grundsätzlich auszuschließen, anderseits erkennen selbst die Gegner der Glazialtheorie einen bescheidenen modifizierenden Einfluß der eiszeitlichen Gletscher auf die Talbildung an. Nach Brunhes ${ }^{19}$ sind Taltrog und Übertiefung ein Werk der unter dem Eis fließenden Gletscherbäche. Kilian ${ }^{20}$ sprach sich dahin aus, daß die heutigen Haupttäler durch die Ströme der Interglazialzeiten ausgehöhlt wurden, während die Nebentäler unter Eis begraben lagen und dadurch ihr altes Niveau behaupten konnten. Diese Ansicht vertritt noch GARwood, ${ }^{21}$ während KuLIAN die Voraussetzung einer längeren Eisbedeckung der Nebentäler aufgegeben hat und einen neuen Faktor einführte: die Erniedrigung der Erosionsbasis durch negative Niveauveränderungen. Dadurch wurden die Hauptflüsse zu

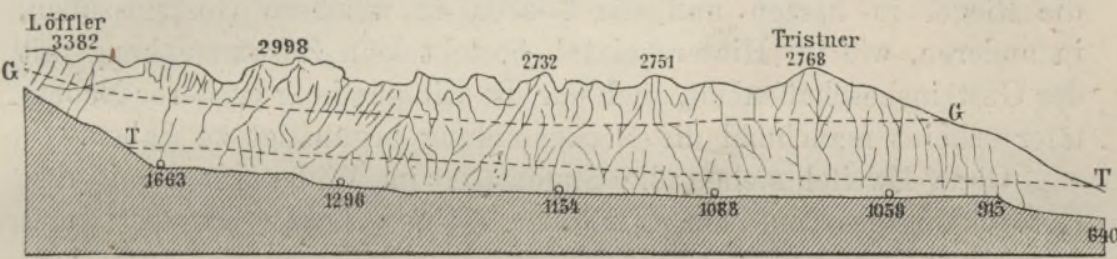

Fig. 159: Längsprofil des Stilluppgrundes nach Richter.

( $T T=$ Trogrand, $G G=$ der obere Rand der eiszeitlichen Gletscher.)

energischer Talvertiefung veranlaßt, mit der die schwächeren Nebenflüsse nicht gleichen Schritt zu halten vermochten.

Die meisten Trogtäler haben ein gebrochenes Längsprofil (Fig. 159), in dem sich das normale gleichsam mehrmals wiederholt. Fast horizontale Weitungen wechseln mit steil abfallenden Engen oder gar mit völligen Gefällsbrüchen. Wir haben es hier mit wirklichen Felsstufen zu tun, und diese sind scharf $\mathrm{zu}$ unterscheiden von den ebenfalls häufig vorkommenden Abdämmungsstufen. Alte Endmoränen, Bergstürze oder rasch wachsende Schuttkegel der Nebenbäche stauten den Hauptfluß zu einem See auf: ein Ereignis, von dem uns die Geschichte der Hochgebirgsländer wiederholt erzählt. Ist der Damm solid genug, um dem Wasserdruck dauernd Widerstand $\mathrm{zu}$ leisten, so wird der See allmählich ausgefüllt und bildet dann eine Talebene, die durch eine steile, in den Damm eingerissene Schlucht mit der nächsten Stufe in Verbindung steht. Im Vintschgau wiederholte sich dieser Prozeß nachweisbar viermal und erzeugte dadurch einen scharf ausgeprägten Stufenbau. Beruhen somit die Abdämmungsstufen auf äußeren Eingriffen in die Talentwicklung, so gehören die Felsstufen zur ursprünglichen Talanlage. Sie zeigen 
stets an, daß das fließende Wasser noch nicht Zeit gehabt hat, eine regelmäßige Gefällskurve herzustellen. Daß die Stufen in anstehenden Fels eingegraben sind, sieht man in der Regel nur an ihren Absätzen, und über ihre ursprüngliche Gestalt lassen sich nur Vermutungen aussprechen. Da ihre Kante meist höher liegt als der Boden, so kann man sich diesen als eine wannenartige Vertiefung denken, in der sich das Wasser zu einem See sammelte, der dann durch den Fluß zugeschüttet und in eine Ebene verwandelt wurde. Über die Tiefe dieser Wannen gibt uns vielleicht der plötzliche Einsturz des Lötschenbergtunnels (Berner Oberland) am 24. Juli 1908 AufschluB, denn der Verdacht ist begründet, daß hier die Sprengarbeiten in die Ausfüllungsmasse des Gasternbeckens eindrangen, deren Mächtigkeit demnach mindestens $180 \mathrm{~m}$ betragen würde. ${ }^{22}$ In manchen Stufentälern, wie z. B. im Simmental, liegen die Riegel in harten und die Becken in weichern Gesteinszonen, in anderen, wie im Hinterrheintal, besteht kein Zusammenhang mit der Gesteinsbeschaffenheit, und nur die Einmündung größerer Nebentäler scheint manchmal die Beckenbildung begünstigt zu haben.

Ohne Zweifel stehen die Stufentäler im Widerspruch mit den Entwicklungsgesetzen der Flußtäler. Zwar haben $\mathrm{PENCK}^{23}$ und neuerdings BRUnHes ${ }^{19}$ darauf hingewiesen, daß man das Gletscherbett nicht mit der Kurve des Stromstrichs, also mit der Flußoberfläche, vergleichen dürfe, sondern mit dem Flußbett, und daß auch dieses kein kontinuierliches Gefälle besitze, sondern aus einem Wechsel von Kolken und Schwellen, Wannen und Riegeln bestehe, aber die vertikalen und horizontalen Dimensionen der Eintiefungen eines durch Flußaufschüttung noch nicht nivellierten Stufentals sind doch unvergleichlich größer. Auch die Glazialtheorie steht diesem Phänomen ziemlich ratlos gegenüber. Nach MaRTionne ${ }^{24}$ waren die vorglazialen Täler noch unreife Bildungen; in den flacheren T'eilen entwickelte (seinen Gesetzen zufolge) der Gletscher seine ganze Erosionskraft, während er in steileren Partien erlahmte und das Einschneiden vorzugsweise dem Gletscherbach überlieb. Wír erinnern hier an die Bemerkung von BRunhes, da $B$ die Felsriegel sich meist nach beiden Seiten erniedrigen, und daB manchmal ihre Verbindung mit den Talgehängen völlig aufgehoben ist, wodurch isolierte Riegelberge entstehen; er nimmt an, daß sich die Schmelzwässer an den Seiten der Eisströme zu Gletscherbächen vereinigen. AMPFERER ${ }^{25}$ betont besonders den Gewölbedruck des Gletschers. In ein enges Tal hineingepreBt, ist der Eisstrom vor allem bestrebt, sein Bett zu erweitern, und erst wenn dies geschehen ist, oder wenn er aus einer Talenge in eine Talweitung eintritt, gewinnt die Tiefenerosion über 
die seitliche die Oberhand. Er schiebt also, geradeso wie Martonne, die erste Anlage der Stufentäler in die vorglaziale Zeit zurück, aber wie verhält er sich dann in jenen Fällen, wo der Stufenbau nicht an Gesteinsunterschiede geknüpft ist? Was konnte hier die jungtertiären Flüsse zu einer selektiven Erosion veranlassen?

Das hier erörterte Problem hängt eng zusammen mit der Frage: können Gletscher Seebecken aushöhlen? Seen sind ja eine sehr häufige Errscheinung in den alten Glazialgebieten; wir finden sie in den Tälern, auf den Talterrassen, in den Karen (s. Fig. 155), und viele davon sind echte Felsbecken. Wir werden diesem Gegenstand in einem anderen Zusammenhang näher treten, hier sei nur auf eines aufmerksam gemacht. Man beobachtet an Gletschern, die sich zurückgezogen haben, vor ihrem gegenwärtigen Ende eine flache schalenförmige Vertiefung, die oft nach unten durch eine mehr oder weniger abgeschliffene Felsbarre, begrenzt wird. Penck hat sie Zungenbecken genannt. Als solche Zungenbecken faßt Nussbaum ${ }^{15}$ die Becken der Stufentäler auf und verlegt ihre Entstehung in die Interglazialzeiten, während welcher sich die Gletscher in das Innere der Täler zurückzogen - eine Ansicht, die mit den Ergebnissen von Penck und Brückner in scharfem Widerspruch steht (vgl. S. 246). In der Altersbestimmung der Stufen berührt sich Garwood's ${ }^{21}$ Theorie mit der von Nussbaum. Als Gegner der Glazialerosion betrachtet Garwood die Eiszeiten als Perioden völligen Stillstandes der Tiefenerosion, die er ausschlieBlich in die Interglazialzeiten verlegt. Wir erläutern seine Theorie an

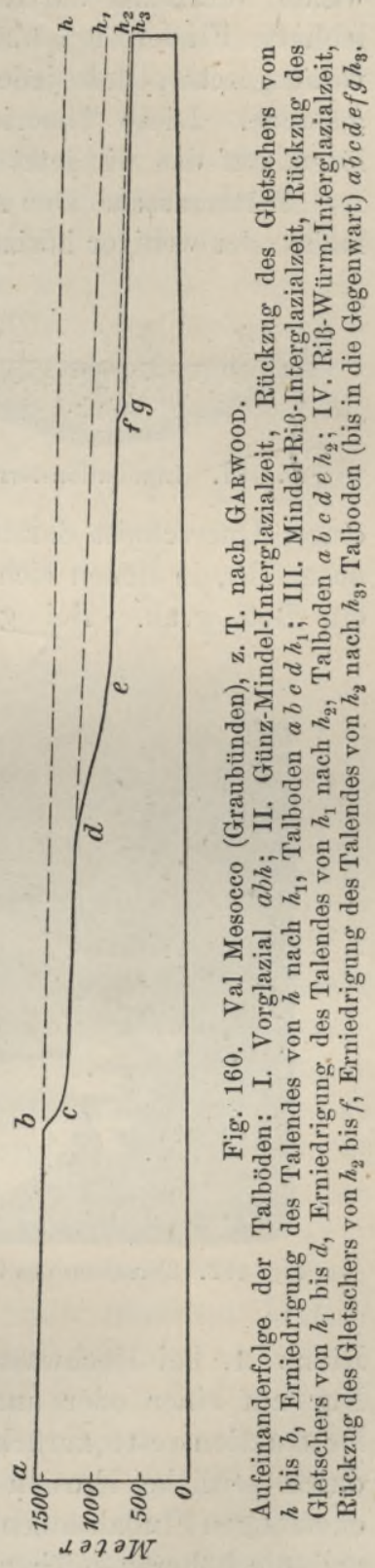
dem Beispiel des Val Mesocco in Fig. 160; die Becken sind danach Reste alter Talböden, die ihre Erhaltung der schützenden Eis- 
decke verdanken. Was in den Interglazialzeiten eisfrei wurde, wurde, veranlaßt durch eine sukzessive Hebung der Alpen, durch lebhafte Flußerosion übertieft. Außer der Hebung wird dabei noch vorausgesetzt, daß jede Interglazialzeit kälter war als die vorhergehende. Diese Theorie will auch das Problem der Talterrassen lösen, auf das wir jetzt zu sprechen kommen.

Talterrassen. Den Ausdruck „Terrasse“ beschränken wir auf die mehr oder weniger horizontalen Stufen der Talgehänge. Sie treten in zwei genetisch verschiedenen

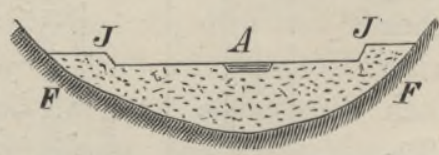

Fig. 161. Inundationsterrassen. Formen auf: als Ausfüllungsund als Felsterrassen. Die einfachste Art der erstgenannten Kategorie sind die Inundationsterrassen, wie sie Fig. 161 in einem Querschnitt darstellt. Das Felsbett war einst mit Sedimenten ausgefüllt, in denen sich der zu neuer Erosionsarbeit angeregte FluB ein Bett grub. Bei gewöhnlichem Wasserstand benutzt er die

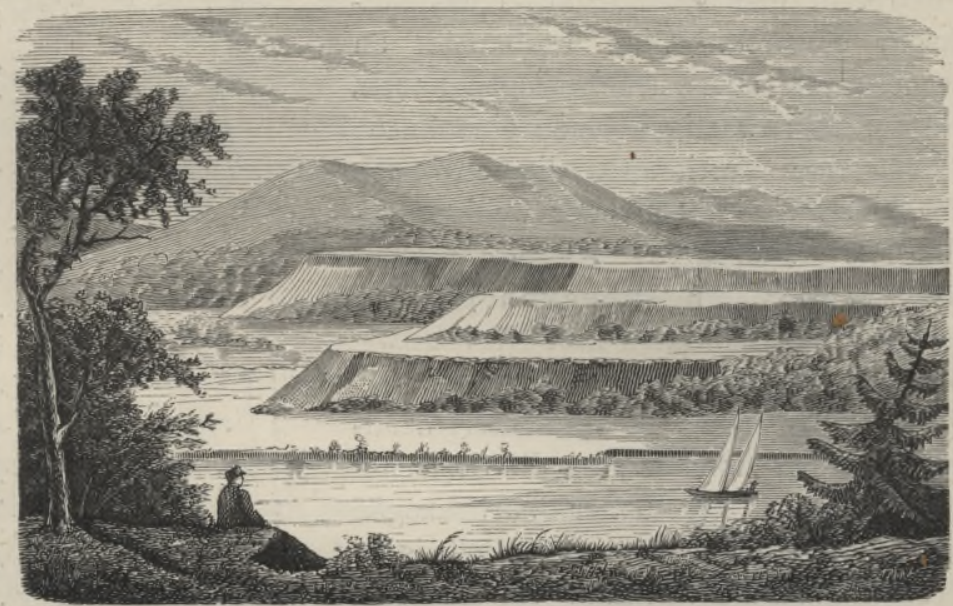

Fig. 162. Terrassen des Connecticut, südl. von Hannover (New Hampshire), nach Dana.

Rinne $A$, bei Hochwasser aber füllt er das Tal bis $J$ und $J^{\prime}$ aus. Nur auf einer oder auch auf beiden Seiten blieben Terrassen als Destruktionsreste zurück, bald durch neue Absätze erweitert, bald durch seitliche Erosion verkleinert. In vielen Tälern sind in den ehemaligen Flußabsätzen mehrere Terrassen übereinander ausgegraben, und die höheren reichen weit über die höchsten jetzt vorkommenden Wasserstände des Flusses hinaus. Das Ausfüllungsmaterial dieser Diluvialterrassen stammt aus der Eiszeit, und sie sind auch nur 
auf ehemals vergletscherte oder ihnen benachbarte Gebiete beschränkt. In einem großen Teil von Nordamerika wurden innerhalb der Glazialgrenze und etwas südlich davon in der Champlainperiode, die die zweite Eiszeit abschloß, die Täler (mit Ausnahme derer im Hochgebirge) mit großen Massen von Sand und Schotter, die die Schmelzwässer des Inlandeises herbeiführten, angefüllt. Die darauffolgende negative Niveauveränderung verlegte die Mündungsstellen der Flüsse in ein tieferes Niveau und zwang dadurch die Flüsse, ihr Bett immer tiefer einzuschneiden. Solche Terrassen, wie sie Fig. 162 zeigt, erstrecken sich viele Kilometer weit an den Ufern der nordamerikanischen Flüsse, freilich nicht immer mit gleicher Regelmäßigkeit, sei es, daß die Ausfüllungsmasse schon ursprünglich ungleichmäßig verteilt war, sei es, daß die Erosion an einigen Stellen mehr zerstörte als an anderen. Auch in Mitteleuropa sind diluviale Schotterterrassen eine weitverbreitete Erscheinung. Sie sind nach Penck in den wasserreichen Perioden des Gletschervorstoßes abgelagert und in Perioden geringerer Transportfähigkeit wieder erodiert worden. Diese Terrassen stellen uns also eine Episode in der Talentwicklung dar. Durch die neubelebte Erosion wurde das frühere

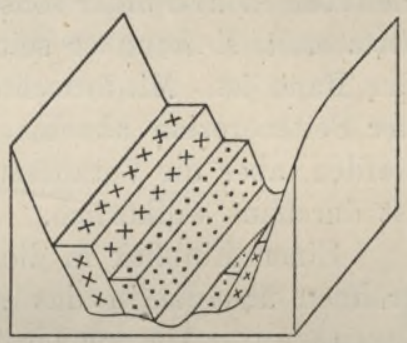

$\times \times$ ältere …jü̈ngere Terrasse

Fig. 163. Schematischer Ausschnitt aus einem Tal mit einge. schachtelten Ausfüllungsterrassen.

Niveau der Sohle zurückgewonnen, oder

dieses Ziel wenigstens angestrebt. Dieses Spiel konnte sich mehrmals wiederholen: auf die Auffüllung folgte Ausgrabung, dann wieder Auffüllung, dann wieder Ausgrabung usw., jedoch so, daß keine Erosionsperiode das Werk der vorhergehenden Ablagerungsperiode völlig zerstören konnte. In diesem Fall sind die Terrassen nicht aus einer einheitlichen Masse herausgeschnitten, sondern ineinander hineingeschachtelt (Fig. 163).

Wie diese Terrassen durch seitliche Erosion des hin- und herwandernden Flusses zustande gekommen sind, unterliegt keinem Zweifel; oft genug verrät noch ihre Bogenform, daß hier einmal die Konvexseite einer Flußserpentine lag. Wohl aber bedarf es einer weiteren Erklärung, warum sich der Abstand zwischen den einander entsprechenden Terrassen auf beiden Talseiten mit der Tiefe stetig vermindert, oder mit andern Worten: wodurch die Treppenform entstanden ist. Augenscheinlich hat der Fluß seine Neigung zu mäandrischen Bewegungen mehr und mehr eingebüßt, nach ältern Ansichten, weil die Wassermenge abgenommen hat, oder weil die 
Ruhepausen zwischen den einzelnen Hebungen, die den Fluß zu erneuter Tieferlegung seines Bettes anregten, immer kürzer wurden. Eine derartig stetig fortschreitende Veränderung der Erosionsbedingungen ist aber durch nichts sonst bezeugt. Die Theorie von HugH Miller D. J. ${ }^{26}$ zur Erklärung der schottischen Vorkommnisse, die $D_{A v I S}{ }^{27}$ auch in Neuengland bestätigt fand, besagt, daß die Erosion in den tieferen Horizonten immer mehr auf Hindernisse im anstehenden Gestein oder in der Beschaffenheit des Ausfüllungsmaterials stoße, und daß sich diese der Verbreiterung des Talbodens entgegenstellen. Auf die Talterrassen der Alpen findet diese Theorie keine Anwendung, und ebensowenig kann folgende Theorie von WeTtstein 28 Anspruch auf Allgemeingültigkeit erheben. Da ein Fluß in gleichen Zeiträumen und unter sonst gleichen Verhältnissen gleichviel Material fortschafft, so kann er sein Bett umso weniger verbreitern, je höher der Rand ist. Mit fortschreitender Tiefenerosion muB die Amplitude der Seitenerosion abnehmen. Das mag im allgemeinen zugegeben werden, aber die Voraussetzung gleich langer Verbreiterungsperioden ist durchaus willkürlich.

Einen Einblick in die ältere Entwickelungsgeschichte der Täler eröffnen uns die in das anstehende Gestein eingegrabenen Felsterrassen. Am genauesten kennt man sie in den Alpen, und unsere Erörterungen werden sich auch ausschließlich mit diesen Vorkommnissen beschäftigen. Man hat zwischen Denudations- und Erosions- oder Talterrassen zu unterscheiden, und nur die letzteren können als Reste höher gelegener, alter Talböden in Anspruch genommen werden, aber es ist häufig sehr schwer, beide Arten auseinanderzuhalten. Berücksichtigt man ferner, daß sie nur noch in einzelnen Bruchstücken erhalten sind, und daß Verwittertfng, Seitenbäche, Muren, Bergstürze, Lawinen usw. fortwährend an ihrer Zerstörung arbeiten, so kann es uns nicht wundernehmen, daß in bezug auf ihre Deutung und ihren einstigen Zusammenhang die Ansichten noch recht weit auseinandergehen. Vortrefflich erhalten ist aber noch in vielen Tälern die unterste Felsterrasse (Fig. 158); 'sie senkt sich allmählich gegen die Talmitte und ist oft so breit, daß sie ganze Dörfer trägt; ja in manchen Fällen, wo die jetzige Talsohle schmal und von Hochwasser bedroht ist, ist sie die einzige Stätte menschlicher Besiedlung.

Heim $^{29}$ hat im Reußtal die Beobachtung gemacht, daß sich jede Talstufe talabwärts in Talterrassen fortsetzte, und BoDMre ${ }^{30}$ fand dies auf Grund seiner Kartenstudien für die ganze Schweiz bestätigt. Jede Talstufe reichte nach dieser Auffassung einst bis zum Ende des Tales, und auf diese Weise erhielt Herm für das 
Reußtal, wie Fig. 164 zeigt, vier Talböden, die in Perioden ruhiger Entwickelung in die Breite wuchsen und in Perioden erwachter Erosioñskraft zerschnitten wurden. Ist diese Deutung richtig, so haben wir in den Talterrassen und -stufen eine Aufeinanderfolge geographischer Zyklen zu erblicken. Der Talboden $I$ entspricht mit seinem sanften Gefälle nahezu einer Erosionsterminante, dann erfolgte durch Tieferlegung der Erosionsbasis eine Wiederbelebung, und das Ergebnis des zweiten Zyklus war der Talboden II, der wenigstens das Stadium der Reife erreichte. Dagegen fanden der dritte und vierte Zyklus ein vorzeitiges Ende, so daß sie den Gefällsbruch der Schellenenschlucht nicht aus dem Weg zu räumen vermochten. ' GoGARTEN, ${ }^{31}$ der in seiner Erklärung durchaus auf der Seite Heтm's steht, hat die Terrassenreste des Linthtales zu nicht weniger als 17 Talböden vereinigt! Auf GARwood's Theorie, die

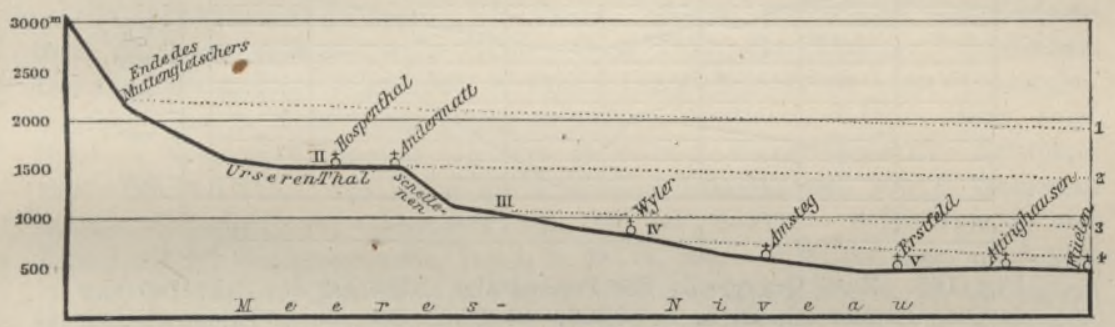

Fig. 164. Längsprofil des Reußtales.

Höhenmaßstab fünfmal größer als der Längenmaßstab.

mit jener der Schweizer Forscher einige Verwandtschaft zeigt, ist schon oben hingewiesen worden.

Penck und BrÜCKNer stellen den Sachverhalt ganz anders dar. In den Ostalpen kennt PeNcK nur einen alten Talboden; der Trogrand scheidet das glaziale von dem durch Flußerosion geschaffenen vorglazialen Tal. Im Etsch- und im Isèretal treten zwar zwei Talterrassen auf, aber die höhere hält PeNck für pliozän. In der Schweiz fand BRÜCKNER nur zwei alte Talböden in durchschnittlich $300 \mathrm{~m}$ Abständen voneinander und von dem jetzigen. Beide betrachtet er als Flußschöpfungen, das obere aus der vorglazialen, das untere aus der Mindel-Riß-Interglazialzeit. Zwischen den Darstellungen eines BrÜCKNER und eines GOGARTEN klafft ein unversöhnlicher Gegensatz, der uns den Wunsch einer Revision in dieser wichtigen Streitfrage nahelegt.

LöwL, Richter und in neuester Zeit Nussbaum haben sich gegen die Deutung der Talterrassen als Überreste alter Talböden aus. gesprochen. Der Letztgenannte hat ein vollständiges System des glazialen Erosionszyklus aufgestellt; im Taltrog und in den von einander 
getrennten Karen sieht er die Züge einer reifen Glaziallandschaft, im Stadium der Überreife sind die Seitenwände der Kare abgetragen und die Karböden vereinigen sich $\mathrm{zu}$ ausgedehnten Talterrassen. Woran man besonders AnstoB nahm, war die auffallende Breite der rekonstruierten Talböden, aber man hat bisher übersehen, daB solche in zusammenhängenden Resten noch vorhanden sind. Im Hintergrund der Alpentäler öffnet sich ein weiter Zirkus, an den Seiten von Karen umgeben; Rгснтев hat ihn treffend mit einem gothischen Chor mit seinem Halbkranz von Seitenkapellen verglichen. Die Firnmulden der großen Gletscher liegen in diesen Zirkussen; mit Absicht haben wir aber in Fig. 165 ein nunmehr gletscherfreies Tal gewählt, um zu zeigen, daß uns nicht die Schneedecke die flache

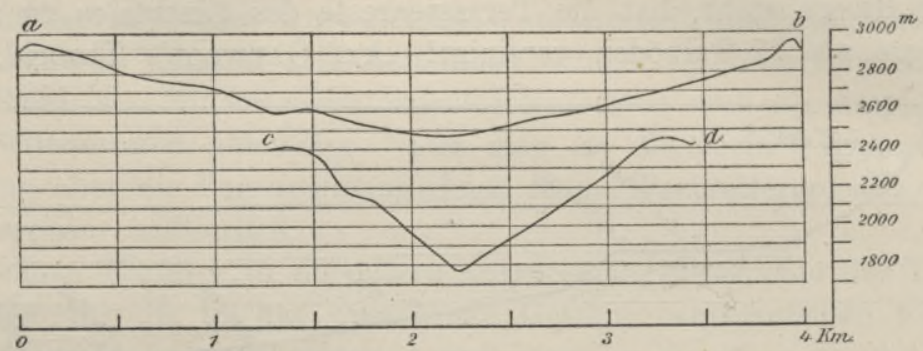

Fig. 165. Zwei Querprofile des Penaudtales (Nebental des Schnalsertales in den Ötztaler Alpen) in 1:50000. $a b$ Profil des oberen Tales zwischen der Murzollspitze und dem Kar an der Schwarzen Wand, cd Profil des unteren Tales oberhalb des Penaudhofes.

Muldenform vortäuscht. Der Gegensatz beider Profile springt in die Augen ${ }^{\times}$das untere ist ein typisches noch unreifes Erosionstal, das obere betrachten wir als den Rest des vorglazialen Tales, das seiner Durchsägung durch die rückschreitende Flußerosion enst entgegensieht. Der Boden dieser Talmulde ist freilich etwas höckerig, aber das erklärt sich leicht aus der Einwirkung der eiszeitlichen Gletscher.

Ergebnis. Das Problem der Gletschererosion kann noch nicht als gelöst betrachtet werden. Manche der sog. Glazialformen haben noch von keiner Seite eine befriedigende Erklärung gefunden, wie der Karboden und der TrogschluB. Andere kommen auch in Gegenden vor, die niemals vergletschert waren. Die U-Form des Querprofils der Täler wurde schon als eine solche genannt. Kare und ähnliche Formen finden sich auch in der Sächsischen Schweiz, im Cañongebiet des Colorado und in der afrikanisch-arabischen Wüste; Richter legt auch hier das Hauptgewicht auf die Verwitterung der

$\times$ Diesen Gegensatz zeigt auch das prächtige Modell des obern Reintales von H. Hess, Ansbach 1908. 
Wände, deren Steilheit im trockenen Klima nicht durch fließendes und spülendes Wasser gemildert wird. Auf der podolischen Platte nimmt das Gefälle aller Nebentäler talabwärts zu, und v. ŁozıNsкI ${ }^{32}$ schließt daraus mit Recht auf eine Übertiefung des Dnjestrtales. In den Batakländern Nordsumatras ist nach den Beobachtungen von VoLz ${ }^{33}$ die Übertiefung der Haupttäler sogar die Regel, und fast alle Wildbäche haben Stufenmündungen. Was also die alten Gletschergebiete charakterisiert, ist nicht so sehr diese oder jene Form, die auch anderwärts vorkommt, sondern ihr gemeinsames und gehäuftes Auftreten. Dieses geographische Argument ist die Hauptstütze der Glazialtheorie, und die fortschreitende Erforschung der Erdoberfläche muß ergeben, ob es wirklich allen Glazialgebieten und nur diesen eigen ist.

Literaturnachweise. ${ }^{1}$ E. CHAIx, Erosion torrentielle post-glaciaire dans quelques vallées, in Le Globe, Genf 1902, Bd. XLI. - ${ }^{2}$ F. Srmony, Das Dachsteingebiet; Wien 1895, S. 149 f. Dieses Bilderwerk kann für morphologische Studien nicht warm genug empfohlen werden. $-{ }^{3}$ P. A. Ören, Varitions of Norwegian Glaciers, in Nyt Magazin f. Naturvidenskab; Kristiania 1901, Bd. XXXIX. Vgl. dazu die kritischen Bemerkungen von E. Gogartan in der Zeitschrift für Gletscherkunde, Bd. III, S. $271 .-{ }^{4}$ H. Hess in der Zeitschrift für Gletscherkunde, Bd. I, S. 287 u. $355 .-{ }^{5}$ A. BaLtzer, zit. S. 218. - ${ }^{6}$ R. M. Deeley, The Erosive Power of Rivers and Glaciers, im Geological Magazine 1897. - ${ }^{7}$ A. BuÜmcke und S. Finsterwalder, Zur Frage der Gletschererosion, in den Sitzungsberichten der bayerischen Akademie d. Wissenschaften, Math.-physik. Klasse 1890. - ${ }^{8}$ W. SALomon, Können Gletseher im anstehenden Fels Kare, Seebecken und Täler erodieren? im Neuen Jahrbuch f. Mineralogie usw. 1900, Bd. II. - ${ }^{9}$ E. DE Mantonne, Sur la théorie mécanique de l'erosion glacière, in den Comptes rendus de l'Académie des Sciences, 1910, Bd. CXXX. - ${ }^{10}$ H. Hess, Der Taltrog, in Petermans's Mitteilungen 1903; Alte Talböden im Rhônegebiet, in der Zeitschrift für Gletseherkunde 1907, Bd. II. - ${ }^{11}$ A. Penck und E. Brückner, Die Alpen im Eiszeitalter, zit. S. 256. Für die Frage der Gletschererosion von grundlegender Bedeutung. - ${ }^{12}$ W. M. Davis, The Seulpture of Mountains by Glaciers, im Seottish Geographical Magazine 1906. - ${ }^{13}$ E. Richter, Geomorphologische Untersuchungen in den Hochalpen; Gotha 1900 (Ergänzungsheft 132 zu Petermann's Mitteilungen). 14 E. DE Martonne, Sur la formation des cirques, in den Annales de Géographie 1900. - ${ }^{15}$ F. Nussbaum, Die Täler der Schweizeralpen, Bern 1910. ${ }_{16}$ W. H. Hoввs, The Cycle of Mountain Glaciation, im Geographical Journal 1910, Bd. XXXV. - ${ }^{17}$ H. Hess, Fortschritte der Gletseherkunde, in „Gaea“ 1909. - ${ }^{18}$ W. M. Davis, Glacial Erosion in North Wales, im Quaterly Journal of the Geological Society, London 1909, Bd. LXV. - ${ }^{19}$ J. Bronhes, Erosion fluviatile et érosion glaciaire, in Revue de géographie annuelle, Bd. I, 1906-1907. - ${ }^{20}$ W. Kinian, Le surcreusement des vallées alpines, in den Annales de l'Université de Grenoble 1901, Bd. XIII. L'érosion glaciaire et la formation des terrasses, in La Géographie, Bd. XIV, 1906. - ${ }^{21}$ E. J. GArword, Features of Alpine Scenery due Glacial Protection, im Geographical Journal, Bd. XXXVI, London 1910. - ${ }^{22}$ G. FrüH, im Compte rendu des travaux du 
IX. Congrès international de géographie, II. Bd. (Genf 1910), S. 326 . ${ }^{23}$ A. Penck, Die Übertiefung der Alpentäler, in den Verhandlungen des VII. internationalen Geographen-Kongresses, Berlin 1899 (1901, Bd. II). 24 E. de Martonne, Sur la genêse des formes glaciaires alpines, in den Comptes rendus de l'Académie des Sciences 1910 , Bd. CL. L'érosion glaciaire et la formation des vallées alpines, in Annales de géographie, 1911. - ${ }^{25} \mathrm{O}$. A mprerer, Studien über die Inntalterrassen, im Jahrbuch der Österr. Geologischen Reichsanstalt 1904. - ${ }^{26}$ Hбgh Mruser, River Terracing, in den Proceedings of the R. Physical Society, Bd. VII, Edinburgh 1883. - ${ }^{27}$. W. M. Davis, River Terraces in New England, im Bulletin of the Museum of Comparative Zoölogy at Harvard College, Bd. XXXIII, 1902. - ${ }^{2 s}$ A. Wetrstern, Geologie von Zürich und Umgebung, Zürich 1885. - ${ }^{29}$ A. Herm, Die Erosion im Gebiete der ReuB, im Jahrbuch des Sehweizer Alpenklub 1878-79. - ${ }^{30}$ A. Bopmer, Terrassen und Talstufen der Sehweiz; Zürich 1880. - ${ }^{31}$ E. Gogarten, Über alpine Randseen und Erosionsterrassen (Ergänzungsheft Nr. 165 zu Petermann's Mitteilungen), Gotha 1910. - ${ }^{32}$ W. v. Łozınski, im Abrégé du Bulletin de la Société géographique de la Hongrie 1908, Bd. XXXVI, S. 97. - ss W. Vouz, Nordsumatra, Bd. I, Berlin 1909.

\section{Deltabildungen. ${ }^{1}$}

Mündungsformen der Flüsse. Wie sich in der Talbildung die zerstörende Kraft des fließenden Wassers geographisch am wirksamsten äußert, so in der Deltabildung seine aufbauende Kraft. Wenn ein Fluß in ein ruhendes Wasser mündet, so tritt nicht sogleich eine Vermischung ein, sondern er behält vermöge seiner StoBkraft noch einige Zeit den Charakter einer selbständigen Masse bei. Im Meer und in Salzseen kommt noch der Umstand hinzu, daß das süße Flußwasser wie Öl auf dem schweren Salzwasser schwimmt. Allmählich vermengen sich beide Flüssigkeiten zu sogenanntem Brackwasser, bis endlich unter fortdauerndem Einfluß der Wasserbewegung das Flußwasser völlig absorbiert wird. Vor der Kongomündung ist das Oberflächenwasser noch bis zu einer Entfernung von $23 \mathrm{~km}$ süß, und die Zone des brackischen Wassers reicht noch $40-50 \mathrm{~km}$ weiter.

Mit der Geschwindigkeit des Flusses erlischt auch seine Tragkraft, und die Sinkstoffe lagern sich am Boden des Meeres oder Binnensees ab, und bilden entweder Sandbänke, Untiefen und Barren, oder wachsen unter günstigen Verhältnissen über den Seespiegel empor. Es gibt also nach den eingehenden Untersuchungen von R. Credner nur zwei Mündungsformen: offene Mündungen mit unterseeischen Ablagerungen und Deltamündungen, wobei sich das Land auf Kosten des Meeres oder eines Sees vergrößert. Man kann daher ozeanische und Binnendeltas unterscheiden.

Die Bezeichnung Delta wurde ursprünglich nur auf den Unterlauf des Nil angewendet (Fig. 166). Das Hauptgewicht legte man, 
dem Namen entsprechend, auf die Gabelung des Flusses in zwei oder mehrere Arme, und in diesem Sinn sprach man auch von

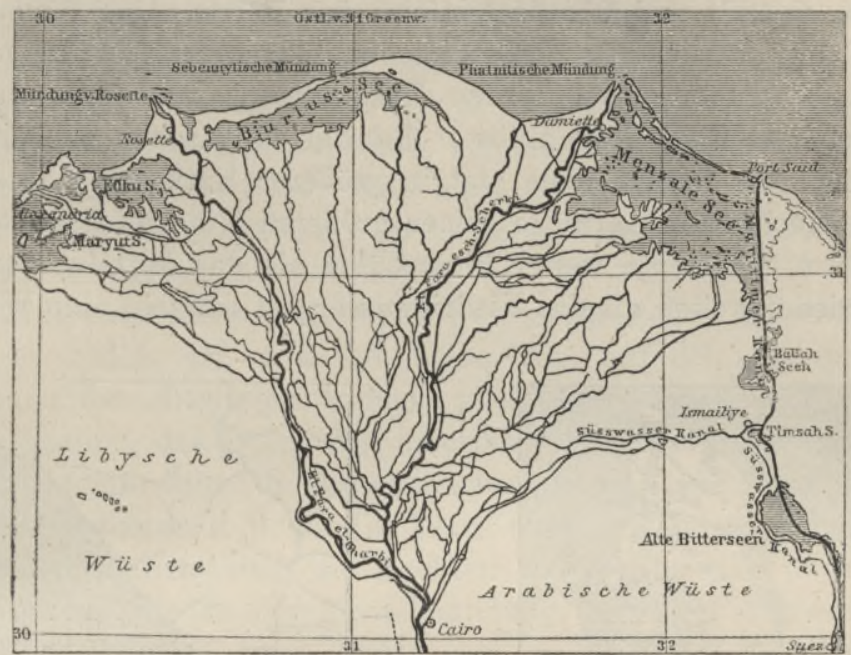

Fig. 166. Nildelta nach R. CREDNER.

einem Delta des Cooper Creek oder des Amazonas, obwohl in keinem dieser Fälle eine Schöpfung von Neuland durch Flußabsätze, die

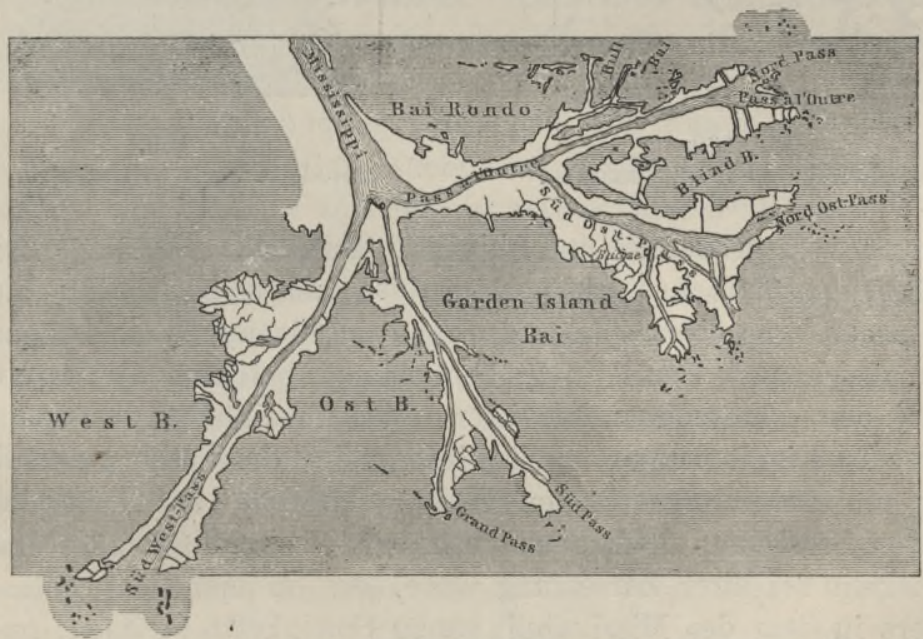

Fig. 167. Mississippidelta nach R. CRedner.

von rezenten Bildungen stehender Gewässer unterlagert werden, stattgefunden hat. Gerade das betrachtet aber der moderne Deltabegriff als das Wesentliche. Die Gabelung ist dagegen ein nebensächlicher Vorgang, der keineswegs immer mit dem Beginn des 
Deltalandes zusammenfällt, ja bei einigen echten deltabildenden Strömen, wie z. B. beim Ebro (Fig. 169), gänzlich fehlt.

Bau, Gestalt und Oberflächenform der Deltas. Das Baumaterial liefern hauptsächlich die Flußsedimente, bei größeren Flüssen feiner Sand und Schlamm, bei kurzen Küstenflüssen (besonders an Steilufern) auch Geröll. Das gröbste Material fällt schon zunächst der Mündung, das feinere aber erst in größerer Entfernung zu Boden. $\mathrm{Da}$ das Hochwasser vermöge seiner größeren Transportfähigkeit die schwereren Sedimente weiter hinausführt als das Mittelwasser, und dieses wieder weiter als das Niedrigwasser, so entsteht eine Wechsel-

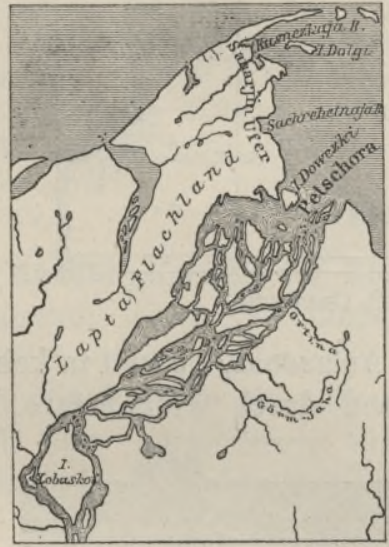

Fig. 168.

Petschoradelta nach R. CREDNER.

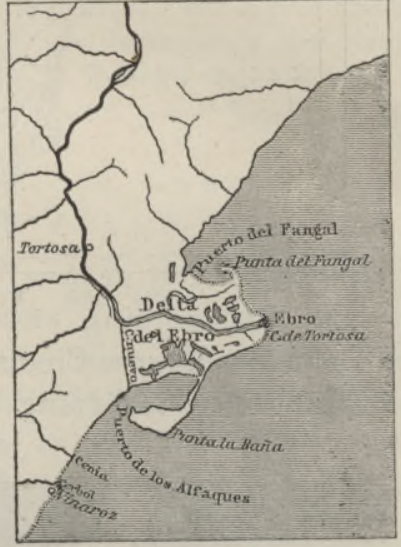

Fig. 169.

Ebrodelta nach R. CREDNER.

lagerung von gröberem und feinerem Material. Die Lagerung ist im Meer gewöhnlich flach geneigt bis nahezu horizontal; nur in Binnenseen kann die Böschung des Schuttkegels, an dessen Zusammensetzung sich auch Geröll in größerer Menge beteiligt, $35^{\circ}$ erreichen. Neben den Flußsedimenten liefern auch Treibholz, das später in Torf oder Lignit umgewandelt wird, und animalische Bestandteile (aber nur in untergeordneter Weise) Baustoffe zur Deltabildung. Die von Sand- und Schlammassen bedeckten organischen Substanzen entwickeln bei ihrer Zersetzung Gase, die in manchen Deltas (besonders in dem des Mississippi) genug Spannkraft besitzen, um die Decke zu sprengen und kleine Schlamm- und Gasvulkane (sogenannte Mudlumps) zu erzeugen.

Die Mächtigkeit der Deltabildungen, über die uns Bohrungen Aufschluß geben, ist sehr verschieden. Beim Rhein beträgt sie über 60 , bei der Rhône über 100 , beim Po $173 \mathrm{~m}$. Die Bohrung bei 
Venedig ergab bis $85,5 \mathrm{~m}$ Tiefe sandige und tonige Flußablagerungen, $\mathrm{zu}$ unterst Torf, dann folgten bis $105 \mathrm{~m}$ Tiefe brackische Ablagerungen, endlich bis $121 \mathrm{~m}$ Tiefe marine Schichten. Das Nildelta erwies sich viel mächtiger, als man früher annahm, denn das Bohrloch bei Sagasig erreichte bei $105 \mathrm{~m}$ Tiefe (97 m unter dem Meer) noch nicht den festen Untergrund. ${ }^{2}$ Nicht in allen Fällen läßt sich die Grenze zwischen Fluß- und Meeressedimenten mit Sicherheit ziehen, daher die Angaben z. B. in bezug auf das Mississippidelta beträchtlich voneinander abweichen.

Häufig entstanden Deltas in tief eingeschnittenen Meeresbuchten. Wenn es richtig ist, daß der blaue Ton, auf dem die modernen Alluvionen des Mississippi ruhen, nicht rein fluviatilen Ursprungs ist, so beginnt das Delta des amerikanischen Riesenstromes schon bei der Ohiomündung. In der Gegenwart können wir die Ausfüllung von Meeresbuchten z. B. an La Plata oder am Dnjestr beobachten. In manchen Fällen sind die Buchten durch Uferwälle (Nehrungen) abgeschlossen, wie an der Memelmündung, beim Nil dagegen durch eine Inselreihe, die nach $J_{\text {ANKó aus jungmarinem Kalk besteht. }{ }^{3}}$ Die Bucht ist hier bis auf einige Lagunen schon ausgefüllt. Die Poanschwemmung ist sogar über die Uferwälle hinausgewachsen und hat sich damit aus einem Ausfüllungsdelta in ein vorgeschobenes Delta verwandelt. Besonders drastische Beispiele der letzteren Art sind die Deltas des Ebro (Fig. 169), der Lena und des Mississippi (Fig. 167).

An jeder Deltamündung spielt sich ein Kampf zwischen Fluß und Meer ab. Der Fluß sucht das Delta hinauszurücken, die Brandung und die Flut schieben es zurück, und die Küstenströmung hat die Tendenz, eine geradlinige Küste herzustellen. GULLIver ${ }^{4}$ hat eine Formenreihe aufgestellt, die die Ergebnisse dieses Kampfes zum Ausdruck bringt. Vorgeschobene Deltas sind stets ein Zeichen, daB der FluB sich siegreich behauptet. Auch der Tagliamento dringt vor, aber das Meer verhindert die lappige Ausbildung des Deltas. Die Arnomündung verrät sich nur noch durch eine sanfte Küstenausbuchtung, das Tiberdelta ist durch eine Küstenströmung von wechselnder Richtung scharf zugespitzt, und der Cavone ist so schwach, daß seine Anschwemmung den geradlinigen Verlauf des Westgestades des Tarenter Golfes kaum noch unterbricht.

Die Deltaländer sind völlig horizontale Ebenen, die sich bei Hochwasser stetig erhöhen und gegen das Meer hin in ein sumpfiges Litorale übergehen. Nur wo das Delta nicht allseitig wächst, wie das der Rhône, werden am Strand Dünenreihen aufgeworfen, die aber mit den schon erwähnten präexistierenden Uferwällen nicht zu 
verwechseln sind. Da das Gefälle sehr gering ist, so ist der Flußlauf fortwährenden Veränderungen unterworfen, indem alte Kanäle verșanden und neue sich bilden. Wenn die Gabelung unter einem spitzen Winkel erfolgt, wie am Nil, so erleidet die Spitze des dreieckförmigen Landes beständigen Abbruch und verschiebt sich talabwärts.

Wachstum der Deltas. Am raschesten scheint das Delta des Terek zu wachsen, denn es rückt jährlich durchschnittlich $495 \mathrm{~m}$ in den Kaspisee vor. Unter den großen Stromdeltas dürfte sich das des Mississippi am schnellsten vergrößern, aber - wie dies auch bei anderen Flüssen der Fall ist - nicht gleichmäßig an allen Mündungsstellen, wofür jedoch nicht die Wassermenge der einzelnen Arme (hier Pässe genannt) verantwortlich gemacht werden kann.×

Das Wachstum erfolgt nicht gleichmäßig, so daß sich daraus kein Schluß auf das Alter der Deltas ziehen läßt. Der Arno z. B. rückte seit dem Beginn unserer Zeitrechnung bis $933 \mathrm{um} \mathrm{2,37} \mathrm{m}$ im Jahr vor, 933-1406 aber um 5,67 und 1406-1841 sogar um 8,65 m. Pisa, um das Jahr 1000 v. Chr. als Mündungsstadt gegründet, liegt jetzt $12 \mathrm{~km}$ vom Strand. Der Einfluß des Menschen läBt sich am Podelta erkennen. Es vergrößerte sich nach Lombakdini 1600-1830 jährlich um 135 ha, 1300-1600 aber nur um 53 ha, weil damals noch nicht ein umfassendes Deichsystem den Fluß gezwungen hatte, den gröBeren Teil seiner Sinkstoffe in das Meer zu führen. Wenn der Landzuwachs zwischen 1823 und 1893, den G. MarineliLi auf 76 ha im Jahr berechnet hat, wieder eine Abnahme zeigt, so erklärt sich dies daraus, daß die Front des Deltas bereits tieferes Meer erreicht hat. Das Nildelta rückt jährlich nur um $4 \mathrm{~m}$ vor, denn die regelmäßigen Überschwemmungen entziehen dem Fluß eine Menge Sedimente, die im Binnenland liegen bleiben. Wo eine positive Niveauveränderung stattfindet, oder das stürmische Meer besonders heftig die Neulandbildungen bekämpft, können Deltas sogar wieder zerstört werden. Das Narentadelta an der dalmatinischen Küste verliert immer mehr an Umfang, und das Rheindelta, das schon zum großen Teil unter dem Seespiegel liegt, würde demselben Schicksal verfallen, wenn es nicht durch Dämme geschützt wäre. Das Emsdelta, das noch zur Römerzeit bestand, ist ganz verschwunden, und wir haben Ursache anzunehmen, daß auch die

$\times$

Wassermenge in Prozenten Jährliches Wachstum in Metern
SW-PaB

$\mathrm{S}-\mathrm{PaB}$
NO-Paß PaB à l'Outre

$\begin{array}{rrrr}34 & 8 & 22 & 23 \\ 103 & 85 & 40 & -\end{array}$

Die übrigen 13 Proz. der Wassermenge werden durch Nebenkanäle abgeführt. 
Weser, die Elbe und die Eider, und desgleichen der Hudson und der Connecticut an der Ostküste der Vereinigten Staaten einst Deltas besessen haben.

Infolge des Wachstums können Deltas benachbarter Flüsse miteinander verschmelzen, wie das des Rheins, der Maas und der Schelde und das des Ganges und des Brahmaputra; oder zwei Flüsse können sich zu einem Hauptkanal vereinigen, wie Euphrat und Tigris; oder ursprünglich selbständige Flüsse sinken zu Nebenflüssen herab. So wurde der Pruth derDonau und der Red River dem Mississippi tributär. Das Landfestwerden von Inseln, die Zweiteilung langgestreckterSeen durch seitlich einmündende Flüsse, die endliche Ausfüllung der Seen sind alles Folgeerscheinungen des Wachstums der Deltas.

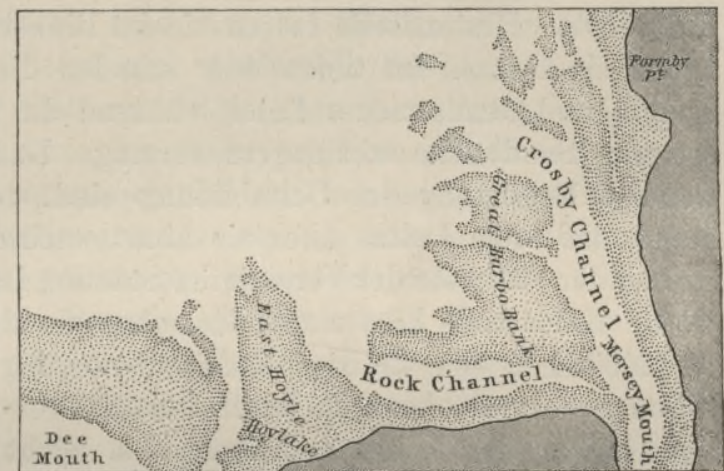

Fig. 170. Unterseeisches Delta des Mersey, 1847.

Geographische Verbreitung der Deltas. Die unterseeischen Ablagerungen an offenen Flußmündungen zeigen häufig eine so ausgesprochene Deltaform, daß wir sie geradezu als unterseeische Deltas bezeichnen können (vgl. Fig. 170 mit Fig. 168). Jedes Oberflächendelta $m u B$ als solches begonnen haben und kann wieder unter besonderen Umständen in ein solches verwandelt werden; zwischen beiden Formen besteht also kein genetischer Gegensatz. Es entsteht nun die Frage, unter welchen Bedingungen die Flußablagerungen unterseeisch bleiben, unter welchen sie über den Meeresspiegel emporwachsen. Daß allgemein wirkende Ursachen dabei im Spiel sind, ergibt sich schon aus dem geselligen Auftreten beider Mündungsformen. Deltaküsten sind z. B. die russische und die ostsibirische Eismeerküste, die südostasiatische Küste vom Gelben Meer bis zum Golf von Bengalen, der nördliche Teil der Ostküste von Südafrika, das Gestade des Golfes von Guinea, die Küsten des Schwarzen und Mittelländischen Meeres, die Südostküsten der Baltischen See, die Küsten des amerikanischen Mittelmeeres usw. Dagegen haben der Djuba, die Kerka, der Bug u. a. offene Mündungen, obwohl sie sich an Deltaküsten in das Meer ergießen, und anderseits geben uns die Mündungen des Indus, des Schat el Arab, der La 
Plata, des Rheins usw. Beispiele von Deltabildungen an sonst deltafreien Küstenstrecken.

Es ist bisher kein einziger Faktor gefunden worden, der allein und überall die Mündungsform bedingt. Die Gironde, die $66 \mathrm{mal}$ mehr Sedimente in das Meer führt als die deltabildende Weichsel, hat trotzdem eine offene Mündung. Elbe und Weser haben ein stärkeres Gefäll als zahlreiche Deltaflüsse und können daher'mehr Material an der Mündung ablagern, aber trotzdem ohne sichtbaren Erfolg. Träg schleichen Nil und Donau dahin, einen großen Teil ihrer festen Bestandteile lassen sie im Binnenland zurück und doch bauen sie Deltas. Im tiefen Meer schaffen die Küstenflüsse zwischen Toulon und Genua neues Land, während die Themse in einer Flachsee nur Sandbänke abzulagern vermag. Daß Uferwälle keine notwendige Bedingung der Deltabildung sind, beweist schon der Umstand, daß viele Deltas über sie hinauswachsen. Anderseits gibt es, wie an der Ostküste der Vereinigten Staaten, Lagunen mit Nehrungen, in die bedeutende Flüsse münden, ohne sie auszufüllen. Viele waren der Meinung, eine kräftige Gezeitenbewegung verhindere die Deltabildung, aber sie konnten durch den Hinweis auf die großen Deltas des Ganges, des Indus, des Niger u. a. leicht widerlegt werden. Im Gegensatz zu den genannten Flüssen haben Murray und Columbia offene Mündungen, obwohl diese von Ebbe und Flut nur schwach bewegt werden. Wohl aber beeinflussen die Gezeiten die Form der Ästuarien, d. h. der Mündungsarme, in die sie eindringen. Indem das Flußwasser, durch die keilartig eindringende, spezifisch schwerere Flut nach oben gedrängt, an Breite zu gewinnen sucht, was es an Tiefe verliert, wird das Ästuarium trichterförmig erweitert, gleichgültig ob die Mündung eine offene oder eine Deltamündung ist. Nur darf man nicht alle trichterförmigen Buchten (wie beispielsweise die La Plata-Bai) als Flutschöpfungen betrachten und als Ästuarien bezeichnen.

Auch Küstenströmungen verhindern weder Deltabildungen, noch rufen sie sie hervor. Im Bereich des Mozambiquestromes mündet der Sambesi mit und der Limpopo ohne Delta, und ebenso verhalten sich Orinoco und Amazonas an der von der südäquatorialen Strömung bespülten Küste. Der Einfluß der Strömungen beschränkt sich darauf, daß unter Umständen die Flußablagerung durch Sedimente, die von fernher stammen, vergrößert wird. Winde verstärken die Strömung des Flusses und damit auch dessen Transportkraft, wenn sie talabwärts wehen, während sie im umgekehrten Fall auf das Wachstum des Deltas verzögernd einwirken, ohne es verhindern zu können. Auch die Richtung der Mündungsarme ist oft eine Folge 
der vorherrschenden Windrichtung; die östliche Ablenkung der Rhônearme durch den Mistral (s. S. 142) mag als Beispiel angeführt werden.

R. Credner glaubte in den Niveauveränderungen den Schlüssel zur Erklärung der geographischen Verbreitung der Deltas gefunden zu haben. Es ist auch einleuchtend, daß positive Niveauveränderungen die Entstehungen offener Mündungen und negative die Deltabildungen im hohen Grad begünstigen müssen. Aber nicht immer gehen beide Phänomene Hand in Hand. Im Po-, Memel-, RheinGanges- und Mississippidelta fand man bei Bohrungen in mehr oder minder beträchtlichen Tiefen und wiederholt Torflager und Baumstämme in angestörter Stellung. Diese Tatsachen lassen sich kaum anders als durch die Annahme einer positiven Niveauveränderung erklären. Zwar ist es wahrscheinlich, daß wir es hier nur mit örtlich beschränkten Sackungsvorgängen zu tun haben, aber immerhin sind negative Niveauschwankungen ausgeschlossen. Das schon erwähnte Nil-Bohrloch bei Sagasig durchfuhr von $38 \mathrm{~m}$ unter dem Meer angefangen grobe Sande und Geröll; zur Zeit ihrer Ablagerung waren also die Verhältnisse ganz anders als heutzutage, und es ist wahrscheinlich, daß damals das ganze Land 30-90 m höher lag. ${ }^{2}$ Anderseits sind unzweifelhafte Hebungsgebiete frei von Deltas, wie die pazifische Küste der Neuen Welt oder das Mündungsgebiet des Amur.

Das Zusammenwirken verschiedener Faktoren, unter denen die Niveauveränderungen jedenfalls auch eine Rolle spielen, bedingt also die geographische Verbreitung der Deltas, ohne daß wir jetzt schon in jedem einzelnen Fall die Haupt- und Nebenursachen, die fördernden und die hemmenden Momente zu'sondern vermöchten. Vielleicht werden uns eingehende Einzelstudien der Lösung des Rätsels näher bringen, aber derzeit läßt sich noch nicht einmal die Vermutung aussprechen, ob es jemals gelingen werde, die Anordnung der offenen und der Deltamündungen auf eine einfache Formel zurückzuführen.

Literaturnachweise. $-{ }^{1}$ R. Credner, Die Deltas; Gotha 1878 (Ergänzungsheft Nr. 56 zu Petermans's Mitteilungen). $-{ }^{2}$ J. W. Judd, Second Repord on a Series of Specimens of the Deposits of the Nile Delta, in den Proceedings of the Royal Society; London 1897, Bd. LXI. $-{ }^{3}$ J. JANkó, Das Delta des Nil, im Jahrbuch der Ungarischen Geologischen Anstalt 1890. ${ }^{4}$ F. P. Gulurver, Shoreline Topography, in den Proceedings of the American Academy of Arts and Sciences, 1899, Bd. XXXIV.

\section{Die Arbeit des Windes.}

Winderosion. Die geologische Bedeutung des Windes erkannt zu haben, ist das epochemachende Verdienst v. Riснтноғen's, und 
sie in ihrem ganzen Umfang klar dargelegt zu haben, ist das Verdienst von Johannes Walther. ${ }^{1}$ Daß diese Entdeckung erst so spät reifte, hat seinen Grund darin, daß der Wind in Kulturländern eine verhältnismäßig untergeordnete Rolle spielt, eine untergeordnete jedenfalls im Vergleich zu der des fließenden Wassers. Wo der lockere Boden durch eine Vegetationsdecke geschützt ist, ist er der Ablation des Windes ebenso entrückt, wie dort, wo er mit Schnee oder Eis bedeckt ist, oder wo seine Teilchen durch Feuchtigkeit fester miteinander verbunden sind. Die.Wü ste, wo nackter, trockener Lockerboden weite Flächen einnimmt, ist das eigentliche Reich des Windes, hier herrscht er beinahe unumschränkt. Es kommt noch hinzu, daß über baumlosen Ebenen die untersten Schichten der bewegten Luft eine verhältnismäßig geringe Reibung erleiden, und die Windstärke schon unmittelbar am Boden einen hohen Grad erreicht. Welche Mengen Materials von der Luft transportiert werden, kann jeder ermessen, der eine Schilderung jener gewaltigen die Sonne verfinsternden Staub- und Sandstürme in Wüsten und Steppen gelesen hat; ja in manchen Gegenden Zentralasiens ist die Luft so mit Staub erfüllt, daß sie sogar bei völliger Windstille den Sonnenstrahlen den Durchgang verwehrt. Der große Staubfall, der sich vom 9. bis 12. März 1901 über Nordafrika, Süd- und Mitteleuropa ausbreitete, gab Veranlassung zu einem eingehenderen Studium dieses wichtigen Phänomens durch Helmmann und Meinardus. ${ }^{2}$ Der Ursprung lag in der algerischen Sahara; Tunis war in einen dichten Staubnebel von braungelber Farbe eingehüllt, und eine Staubschicht von $1 / 2 \mathrm{~mm}$ Mächtigkeit bedeckte den Boden, so daß das Gesamtgewicht des niedergefallenen Staubes allein im Küstengebiet Nordafrikas auf mindestens 150 Mill. Tonnen (à $1000 \mathrm{~kg}$ ) zu veranschlagen ist. Eine südliche Strömung in den oberen Luftschichten führte den Wüstenstaub weit nach Norden. In Süditalien fiel sogenannter Blutregen, in den Ostalpen roter Schnee, und die äußersten Ausläufer des Staubfalleš erreichten Dänemark. Man schätzt das Gewicht des Staubniederschlags in Italien auf 1314000 , in ÖsterreichUngarn auf 375500 , in Norddeutschland und Dänemark auf 92700 Tonnen, und nicht unberechtigt erscheint die Frage, die Hellmann und Meinardus aufwerfen, ob solche Massenversetzungen in kurzer Zeit und innerhalb eines relativ beschränkten Gebietes ohne EinHuß auf die Lage der Erdachse bleiben können.

Anders als die Erosionskraft des Wassers wirkt die des Windes. Das Wasser transportiert abwärts und nur ausnahmsweise auch aufwärts; der Wind weht auf- und abwärts, er ist bis zu einem gewissen Grad unabhängig von der Schwerkraft wie von der Beschaffen- 
heit des Geländes. Daher ist er auch an keine Erosionsterminante gebunden, er kann durch Ausräumung des Verwitterungsschuttes die Oberfläche bis unter das Meeresniveau aushöhlen, und rein theoretisch darf man mit WaLTHER wohl die Möglichkeit zugeben, da $B$ die Depressionsoasen der Sahara ein Werk der Windablation sind. Das Wasser ist an gewisse Seehöhen gebunden und muß darüber dem Eis weichen, das Reich des Windes erstreckt sich über die ganze Erde, über alle Breiten, über alle Höhen. Das fließende Wasser wirkt linear und schafft Rinnen, der Wind denudiert Flächen und erzeugt nur ausnahmsweise Rinnen, indem er Straßen mit gelockertem Boden in Hohlwege verwandelt.

WALther hielt die Ablation durch den Wind, die er Deflation nannte, für ungleich wirkungsvoller als die Korrosion, und auf seinem Beobachtungsfeld, der ägyptischen Sahara, hat auch PEnck ${ }^{3}$ ähnliche Wahrnehmungen gemacht. Dagegen tritt in der algerischen Sahara nach PASsARge ${ }^{4}$ die Ablation ganz hinter der Korrosion zurück. Eine korrodierende Tätigkeit übt der Wind nur mit Hilfe von Quarzsand aus. Er rollt ihn am Boden weiter und schleudert ihn gegen Felsen. Thoulet hat auf experimentellem Weg die Bedingungen der Zerstörung durch Sandgebläse untersucht; sie hängt von der Sandmenge, der Windstärke, der Härte des angegriffenen Gesteins im Vergleich mit derjenigen der Angriffswaffe, von seiner Beschaffenheit - homogene Gesteine sind widerstandsfähiger als zusammengesetzte - ferner von dem Winkel ab, unter dem der Luftstrom auffällt, und der $60^{\circ}$ übersteigen muß, wenn bedeutendere Wirkungen erzielt werden sollen; usw. BRUnHes ${ }^{5}$ legt dabei das Hauptgewicht auf die Wirbelbewegung der Luft. Ist einmal eine kleine Vertiefung zustande gekommen, so bleibt der benutzte Sand darin liegen, um bei dem nächsten Windstoß sofort wieder in Tätigkeit zu treten; ja die Vertiefung kann nach BRunHes' Ansicht durch ihre Gestalt auch wechselnde Luftströmungen zur Wirbelbewegung nötigen.

An der Zerstörung der Felswüste arbeiten unausgesetzt Insolation und chemische Verwitterung (vgl. S. 471), und indem der Wind einerseits die feinsten Verwitterungsprodukte fortträgt, anderseits korrodiert, schafft er die seltsamsten Felsformen. „Hier scheinen" schreibt WaLther - „Pilze oder Kohlköpfe von rotem Granit aus dem Boden zu wachsen, dort bilden riesige Blöcke ein gewaltiges Haufwerk. Tiefe Höhlen kriechen in die Felsen hinein, als ob riesige Wühltiere sie ausgegraben hätten. Hier liegt ein großer Block, der innen so hohl ist, daß ein Eremit leicht seine Wohnung darin aufschlagen könnte, überall erkennen wir mit ein wenig Phan- 
tasie grinsende Menschenköpfe und abenteuerliche Tiergestalten." An den Felswänden erblicken wir taschen- oder wabenförmige Vertiefungen, unregelmäBige Steingitter, manchmal zu förmlichen Säulengängen ausgearbeitet, und Girlanden von Steinzapfen. Vereinzelte Felsen nehmen häufig die Pilzform an, manche Blöcke ruhen nur noch mit einer kleinen Fläche auf ihrer Unterlage (sog. Wackelsteine). Ist das Gestein spröde oder durch eine Kalkkruste geschützt (s. S. 473) oder mangelt es an Sand, so entsteht aus der reinen Felswüste die Hammada, d. h. ein Felsboden, der mit zahllosen kantigen Absplitterungsstücken übersät ist. Die Hammada kann aber auch nur ein Übergangsstadium zur Serir - wie man die Kieswüste in der Sahara nennt - darstellen. Ist genügend viel Sand vorhanden, so wird auch der Hammadaschutt von dem Wind korrodiert, die weicheren Bestandteile werden entfernt, und nur der härteste unter den Hauptbestandteilen der Gesteine, der Quarz, bleibt zurück. Aber auch dieser geht nicht ganz siegreich aus dem Kampf mit den zerstörenden Kräften hervor; er wird durch das Sandgebläse abgeschliffen und erhält jenen Firnisglanz, der ihn merklich vom Flußgeröll unterscheidet. Die Kieswüste, bedeckt mit gerundeten oder kantig zugeschliffenen Quarzstücken und dazwischen mit Quarzsand, ist das Endprodukt der Destruktion der Felswüste. Ein drastisches Beispiel ist die Kalanscho-Serir zwischen Audjila und Djibbena, wo man nach RoHLFs stundenlang über linsen- und erbsengroße, dann wieder stundenlang über nußgroße Kiesel wandern muß.

Einen rein äolischen Erosionszyklus gibt es nicht, denn selbst in der Wüste wirken gelegentliche, oft sehr ergiebige Regenfälle an der Zerstörung mit. ${ }^{6}$ Außerdem ist die destruktive Wirkung des Windes unbegrenzt, und es fehlt demnach gerade das Charakteristische des Zyklus, nämlich daß er sich selbst sein Grab gräbt. In Wirklichkeit sind aber auch dem Wind meist Schranken gezogen, denn Erosionswannen können durch die Ablagerungen der Regenfluten ausgefüllt werden. Ein Feind aller Erhebungen ist der Wind ebenso wie das bewegte Wasser, die Herstellung einer Destruktionsfläche ist auch sein Ziel. PASSARGE ${ }^{7}$ erblickt in den sog. Inselberglandschaften des tropischen Afrika äolische Erzeugnisse des Wüstenklimas. Das Flachland geht über die Köpfe aufgerichteter Schichten hinweg; es ist eine wirkliche Ebene, keine Fastebene. Sie reicht bis unmittelbar an den Fuß der „Inselberge", die bald niedere Kuppen, bald ausgedehnte und hohe Massive sind, und auch in dem letzteren Fall tritt keine Hügelzone vermittelnd ein. Seichte, abgeschlossene Hohlformen, Breccien- und Kieselsäurebildungen und Sanddecken 
sind außerdem charakteristische Eigenschaften dieser wahrscheinlich äolischen Destruktionsflächen.

Äolische Sandablagerungen. Die Transportkraft des Windes ist demselben Gesetz unterworfen wie die des Wassers. Je leichter das Material, desto weiter der Transport. ${ }^{\times}$Schreiten wir von der Serir in der Richtung des herrschenden Windes fort, so betreten wir zuerst Gebiete, wo Sand, dann erst solche, wo die feinsten Partikelchen verschiedener Gesteinsarten, die wir unter dem Namen Staub zusammenfassen, zur Ablagerung gelangen. Wechselt der Wind häufig, so kommt es zu keiner so strengen Sonderung der Denudations- und der Ablagerungsgebiete; aber gerade in den Wüsten scheint - nach «den spärlichen Beobachtungen, die uns vorlieger, zu schließen - die Windrichtung ziemlich beständig zu sein.

Der Flugsand breitet sich entweder flächenartig aus oder wird zu Hügeln und Hügelketten, den sogenannten Dünen, aufgeworfen. Wir unterscheiden Strand- und Binnenlanddünen. GÜNTHER $^{8}$ legt besonders Nachdruck auf die Beschaffenheit des Sandes, ob infolge der Feuchtigkeit die Körner noch etwas aneinander haften, oder ob er ganz trocken ist. Da eine dichtere Vegetation der Hauptfeind der Dünenbildung ist, so sind die Stranddünen in der Regel auf eine schmale Zone beschränkt, während die Wüstendünen ausgedehnte Länderstrecken bedecken. Auch die Herkunft des Baumaterials ist verschieden. Am Strand liefert es das Meer, woher aber stammen die ungeheueren Sandmassen der Wüste? Auch da dachte man an das Meer; und wo in jüngster geologischer Vergangenheit die Wüste vom Meer bedeckt oder bespült war, wie es z. B. die indischen Geologen von der Thar behaupten, mag diese Ansicht auch richtig sein. Aber gerade für die größten Sandwüsten der Erde muß man nach andern Sandquellen suchen, und man glaubt sie in der Zersetzung von Sandsteinen gefunden zu haben. $\mathrm{DaB}$ auch kristallinische Gesteine dabei stark beteiligt

$\times$ UDDEN hat darüber folgendes ermittelt:

Kies .

Grober Sand

Feiner Sand .

Feinster Sand

Grober Staub

Feiner Staub

Feinster Staub

Durehmesser
$8-1 \mathrm{~mm}$
$1-1 / 4 "$
$1 / 4-1 / 8 "$
$1 / 8-1 / 16 "$
$1 / 16-1 / 32 "$
$1 / 32-1 / 64 "$
unter $1 / 64 "$

Transport
einige FuB
mehrere Meter
über $1 \mathrm{~km}$
mehrere km
$100 \mathrm{~km}$
$500 \mathrm{~km}$
unbegrenzt.

Nach L. Carez (Bulletin de la Société géologique de France, Bd. XX, S. 519) können dureh heftige Stürme auch größere Blöcke ziemlich weit fortbewegt werden. 
sind, wie WALTHER meinte, wird bezweifelt. In Zentralasien gelten die mürben Sandsteine der Kreideformation als hauptsächliche Sandlieferanten, die Decke des Erg in der westlichen Sahara leitet Foureau von den devonischen Sandsteinen des Tuareghochlandes $a b$, die Dünen der Libyschen Wüste führt BeAdnelL ${ }^{9}$ auf die sandigen Tertiärgesteine im N. zurück.

Dünen. ${ }^{10}$ Um die Dünenbildung zu beobachten, begeben wir uns an den Strand. Der ausgespülte Sand wird, sobald er trocken geworden, vom Seewind landeinwärts gerollt oder getragen. Die Erfahrung an unsern Küsten, die Cockayse auch in Neuseeland vollinhaltlich bestätigt fand, lehrt, daß gewisse Pflanzen die erste Veranlassung zur Bildung von Stranddünen geben. Sie wirken aber nicht bloB, wie auch leblose Gegenstände, als stauende Hindernisse, vor denen sich der Triebsand ansammelt, sondern fördern außerdem noch die Dünenbildung, wie aus den Beobachtungen von REINKE ${ }^{11}$ an der Westküste von Schleswig-Holstein hervorgeht. Die Dünen sind hier nur auf die durch Salzwasser befeuchteten Sandfelder beschränkt, auf denen die Binsenquecke (Triticum junceum) gedeiht; ist die Urdüne $2-3 \mathrm{~m}$ in die Höhe gewachsen, so siedelt sich auf ihr das Sandschilf (Psamma arenaria) an, und nun erst schlägt das Wachstum ein rascheres Tempo ein. Schon wenn das Sandhäufchen kaum $1 \mathrm{~cm}$ hoch ist, nimmt die Leeseite die natürliche Böschung an; die Luvseite ist stets sanfter geneigt, an ihr bewegen sich die Sandkörnchen aufwärts, um auf der Leeseite hinabzufallen. In den Landes steigen die Dünen unter einem Winkel von $5-12^{\circ}$, höchstens von $25^{\circ}$ an der Seeseite an und fallen unter einem Winkel von $28-32^{\circ}$, der sich stellenweise sogar auf $50-60^{\circ}$ steigert, gegen das Land ab. An der Westküste der Sahara, wo der Passat Dünen aufwirft, ist natürlich die Seeseite steiler. Dicht gedrängte Sandhügel vereinigen sich zu Dünenwällen von ansehnlicher Länge. Daneben treten niedere Bogendünen (in Turkestan Barchane genannt) auf, die ihre halbmondförmige Krümmung der Leeseite zukehren. BASCHIN führt sie darauf zurück, daß unter sonst gleichen Umständen kleine Sandanhäufungen sich leichter verschieben als große, die. Seiten eines Sandkegels also rascher als die Mitte. Menge und Korngröße des Sandes einerseits, die mittlere Windstärke anderseits bestimmen das Wachstum der Dünen. Die französischen Landes, Europas bedeutendstes Dünengebiet bedecken mit einer Länge von $230 \mathrm{~km}$ und einer Breite von $2-8 \mathrm{~km}$ eine Fläche von $900 \mathrm{qkm}$. Die Höhe schwankt hier beträchtlich und ist in der Mitte am größten, wo Lescours sogar $89 \mathrm{~m}$ erreicht, während sie an der Nord- und Ostsee meist unter 30 oder $40 \mathrm{~m}$ bleibt; nur die Kurischen Dünen er- 
reichen $70 \mathrm{~m}$. Solange noch die Luvseite kahl bleibt, kommt der Sand hier nicht zur Ruhe, jeder stärkere Seewind trägt ihn auf die Leeseite und so wandert die Düne landeinwärts. Weite Strecken werden dadurch versandet, die menschlichen Wohnsitze zurückgedrängt und Wälder verschüttet, die, wenn sie auch ein günstiges Geschick wieder von ihren Fesseln befreit, ihre Lebenskraft doch unwiederbringlich eingebüßt haben. In den Landes rückten die Dünen früher im Durchschnitt jährlich 1-2 $\mathrm{m}$ landeinwärts, an manchen Stellen aber - wie die Dünen von Teste und Lége - 20 bis $25 \mathrm{~m}$; ferner in Schleswig 7 und auf der Frischen Nehrung $3 \frac{3}{4}$ bis $5^{1 / 2} \mathrm{~m}$; an zwei Wanderdünen zwischen Rügenwalde und Stolpmünde beobachtete KeILHack ein jährliches Vorrücken von $10^{1 / 2}$ und $17 \mathrm{~m}$. Für die Kurische Nehrung ergab der Vergleich der Aufnahmen in den Jahren 1837/39 und 1859/61 nach GerHaRdT eine durchschnitt-

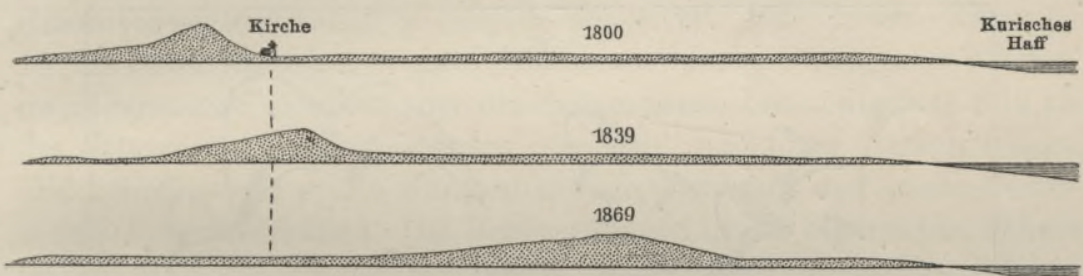

Fig. 171. Die Wanderdüne bei Kunzen auf der kurischen Nehrung in den Jahren 1800, 1839 und 1869, nach BERENDT.

liche Verschiebung der Luvseite um 4,4, des Kammes um 6,2 und der Leeseite um 7,9 m. Auf diese Weise entstehen mehrere Hügelreihen hintereinander, landeinwärts stetig an Höhe zunehmend. In der Tropenzone, wo sogleich Pflanzen, darunter auch Bäume, von den Dünen Besitz nehmen, ist deren Beweglichkeit gering, und auch in Europà scheinen sie ehemals natürliche Wälder getragen zu haben, denn Montaigne berichtet im 16. Jahrhundert, sie hätten erst seit kurzer Zeit zu wandern angefangen. In unseren Tagen sucht man sie durch Anpflanzung von Gewächsen mit langen Wurzeln, wie Strandhalm, Strandhafer, Strandroggen und Strandweide, zu befestigen; hat sich dann aus deren Abfällen eine dünne Humusschicht gebildet, so siedeln sich auch andere Pflanzen an, die die Seeluft vertragen. Werden die Ränder der Wanderdüne früher als die Mitte durch die Vegetation festgehalten, so entsteht die Form der Parabeldüne, eine umgekehrte Bogendüne, die ihre Hohlseite dem herrschenden Wind zukehrt, mit langen Haken und allseitig steilen Böschungen.

In Binnenländern mit trockenem, warmem Sommer, wie im südlichen Rußland, finden wir in offenen, sandigen Flachtälern die 
niedrigen Flußdünen. Am gewaltigsten tritt das Dünenphänomen in der Wüste auf. Höhen von $100 \mathrm{~m}$ und darüber sind keine Seltenheit, der Sandberg am Natronsee von Fessan soll $160 \mathrm{~m}$ erreichen. Eine unendliche Zahl von Einzeldünen, unter denen die Barchanform vorherrscht, ordnen sich zu großen, langgestreckten Sandrücken mit konvexer Böschung an der Windseite und scharfem Grat, der sich nach der Leeseite mit konkaver Böschung allmählich verflacht. Nach BASCHIN ${ }^{12}$ ist dies das Normalprofil, und der an der Leeseite häufig vorkommende kurze Steilabsturz unter dem Grat nur eine Folge von Abrutschungen, während man sich ihn früher durch die erodierende Wirkung des Luftwirbels entstanden dachte. Rücken auf Rücken folgen aufeinander, durch Längstäler getrennt, „die“ - um Hedis's Worte zu gebrauchen - „geradeso aussehen, wie die Wellen eines Meeres, über das ein beständiger, heftiger

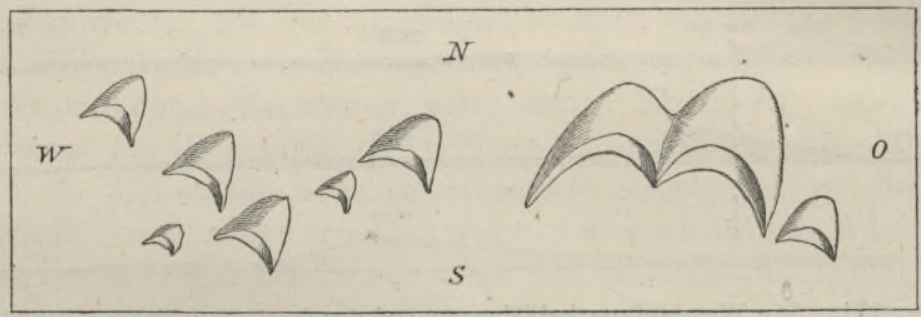

Fig. 172. Aus dem Gebiet der Bogendünen bei Buchara (1:3000) nach J. WALTHER.

Wind hinstreicht." Da hier stauende Vegetationshindernisse fehlen, so ist man in Verlegenheit, welcher Ursache man die erste Anlage der Dünenbildung zuschreiben soll. BAschin ${ }^{13}$ verwies auf die HeLmнoltz'sche Wellentheorie, von der schon auf S. 292 die Rede war. In unserem Fall kommt die Wellenbewegung in periodischen Luftdruckänderungen zum Ausdruck; wo der Druck stärker ist, werden die Sandkörnchen fortgeblasen, wo er schwächer ist, häufen sie sich in langgestreckten Linien an, nach Art der Wellenfurchen, die bei heftigem Wind auf trockenen Schneeflächen entstehen. Schwierigkeiten bereiten aber diejenigen Sandrücken, die in der Richtung der vorherrschenden Winde verlaufen. Solche Strichdünen mit beiderseitigem Steilabfall bedecken den südlichen Teil der Indischen Wüste, nach N folgen normale Dünen senkrecht zur Windrichtung, und zwischen beiden Gebieten vermittelt ein gemischter Typus. ${ }^{14}$ Ebenso seltsam ist der $6-7 \mathrm{~km}$ breite Strichdünengürtel Abu Moharik, der sich in der Libyschen Wüste von $29^{\circ} 45^{\prime} \mathrm{N}$ wenigstens $650 \mathrm{~km}$ weit nach SSO erstreckt. Eine befriedigende Erklärung dieser Vorkommnisse ist noch nicht -gegeben worden. 
WALther's Ansicht, daß der Barchan die Urform ist, aus der sich durch Verwachsung die langen Dünen entwickeln, scheint für die Wüste zuzutreffen. In vielen Wüsten tritt er aber auch noch vereinzelt auf, nach W WLTHER aber nur in Monsungegenden, und auch nur dann, wenn die Windrichtung der einen Jahreszeit nicht genau der der anderen entgegengesetzt ist, so daß, was in der einen Jahreszeit vereinigt, in der andern wieder zerschnitten wird. v. Сноцnокт ${ }^{15}$ fügt auf Grund seiner Beobachtungen in der ungarischen Pußta noch hinzu, daß wandernde Dünenwälle, wenn sie genug Raum haben und nicht unter der Herrschaft allzu veränderlicher Winde stehen, sich schließlich wieder in Barchane auflösen. Über die Bewegung der Wüstendünen wissen wir wenig. In der Kysyl-Kum schätzt sie WALther auf $6 \mathrm{~m}$ im Jahr; bei Buchara wandern die Dünenkämme im Winter $12 \mathrm{~m}$ nach $\mathrm{N}$ und im Sommer $18 \mathrm{~m}$ nach $\mathrm{S}$, woraus eine Gesamtbewegung von $6^{\prime \prime} \mathrm{m}$ nach S resultiert. Eine höhere Ziffer 15 bis $16 \mathrm{~m}$ im Jahr - fand Beadnell ${ }^{9}$ für die Libysche Wüste, $\times$ im allgemeinen scheinen aber die Saharadünen beständiger zu sein als die Stranddünen, sonst würden sie nicht besondere Namen tragen, und könnten sich uralte Karawanenwege, Brunnen und ganze Oasenarchipele nicht erhalten. Die Beobachtungen in der algerischen Sahara lehren, daß die Dünen im Innern feucht sind; diese Feuchtigkeit kommt nach CourBis von unten und gibt die erste Veranlassung zur Anhäufung von Sand an einer bestimmten Stelle, während RoLLAND die erste Ursache der Dünenbildung in der Unebenheit des Geländes erblickt, die den Flugsand an der Fortbewegung hindert, und die Feuchtigkeit von den atmosphärischen Niederschlägen ableitet. Möge die eine oder die andere Ansicht richtig sein, jedenfalls ist die innere Feuchtigkeit ein vortreffliches Verfestigungsmittel. ${ }^{16}$ Die Unbeweglichkeit der Ergdünen erklärt sich nach Foureau aus dem Widerstreit der heftigen Südwinde mit den herrschenden Nordwinden. In der westlichen Sahara ist indes eine äußerst langsame Verschiebung der Sandmassen nach $\mathrm{O}$ und $\mathrm{S}$ aus verschiedenen Anzeichen zu erschließen.

Klimatische Änderungen haben in der Form alter oder fossiler Dünen - wie Solger ${ }^{17}$ sie nenint - ihre Spuren hinterlassen. Im norddeutschen Flachland findet man u. a: Barchane, die ihre konvexe Seite nach Ost wenden, also zu einer Zeit entstanden sein müssen, als die Windverhältnisse wesentlich von den heutigen ab-

$\times 1908$ betrug die Fortbewegung der Dünen in der Oase Kharga im Winter 2,7, im Frühling 3,3, im Sommer 4,6 und im Herbst 6,6 m, zusammen also $17,2 \mathrm{~m}$. Es scheint damit zusammenzuhängen, daB sich die Herrschaft der nördlichen Winde in gleicher Weise vom Winter zum Herbst steigert. 
wichen. SoLGER denkt an Ostwinde, die von dem Rand des zurückweichenden Inlandeises ausgingen. Die jetzt herrschenden westlichen und südwestlichen Winde haben zwar den Grundriß der Barchane nicht verwischen können, aber ihr Profil völlig verändert, so daß die nördlichen und östlichen Abhänge jetzt steiler sind als die südlichen und westlichen.

Staubablagerungen. Staubniederschläge finden zwar überall statt, aber nur auf grasbedeckten Ebenen oder in abfluBlosen Becken in der Nähe von Wüstenräumen, deren zerfallende kristallinische Gesteine viel Staub liefern, erreichen sie einen nennenswerten Betrag und wirken oberflächengestaltend. Auf stark geneigtem Boden spült sie der Regen wieder $a b$, und auf nacktem Boden erfaßt sie wieder der nächste Windstoß und trägt sie weiter.

$\mathrm{Da}$ der Staub verschiedenartige mineralische (besonders tonige) und organische Bestandteile in sich vereinigt, so ist der äolische Aufschüttungsboden in der Regel sehr fruchtbar, vorausgesetzt, daB die klimatischen Bedingungen günstig sind. Ist die Trockenheit aber so groß, daß die Flüsse das. Meer nicht erreichen, so beschränkt sie nicht bloß direkt den Pflanzenwuchs, sondern auch indirekt, indem die Salze, die derselben Quelle entstammen wie der Staub selbst und durch Wind und fließendes Wasser überallhin verbreitet werden, den Aufschüttungsboden imprägnieren. So entsteht die Salzsteppe nicht bloß dort, wo sich das Meer erst vor kurzer Zeit zurückgezogen hat, oder wo Salzseen austrocknen, wenn auch in dem letzteren Fall der Salzgehalt des Bodens in der Regel am größten ist, oft so groß, daß Salzkrusten wie frisch gefallener Schnee den Boden weithin bedecken.

Tritt eine Klimaänderung ein, so daß der Niederschlag den Betrag der Verdunstung übersteigt, so bahnen sich die erstarkten Flüsse einen Weg zum Meer oder zu den nächsten ozeanischen Flüssen, graben tiefe Erosionsschluchten in das Becken der Salzsteppe ein, tragen die äolischen Ablagerungen dem Meer zu, befreien den Boden von seinẹm Salzgehalt und machen ihn dadurch dem Ackerbau zugänglich. Die Steppengebilde werden auf diese Weise, nach v. RichтноғEN's Theorie, in LöB verwandelt.

Man unterscheidet zwei Arten von Löß: Land- und SeelöB. Jener, die weitaus verbreitetste Art, ist eine nahezu homogene Masse aus lehmiger gelber Erde mit etwas Sand, etwas kohlensaurem Kalk und einigen leicht löslichen alkalischen Salzen. Feine Kanälchen, die Hohlräume ausgewitterter Wurzelfasern, durchziehen ihn, saugen das Wasser begierig auf und verhindern dadurch die Bildung von Seen und Sümpfen; wahrscheinlich bedingen sie auch den Hang 
des Lößes zu vertikaler Zerklüftung, die - wie wir bei einer andern Gelegenheit sehen werden - landschaftlich so bedeutungsvoll wirkt. Wirkliche Schichtung fehlt; eine scheinbare Schichtung wird durch die lagenartig horizontale Anordnung von Mergelknollen (den sog. Lößmännchen) hervorgerufen; doch beweist deren vertikale Stellung, daß sie an Ort und Stelle entstanden sind. Dieser Umstand sowie die eigentümliche Verbreitung des Lößes, die sich an kein Niveau bindet, und das fast ausschlieBliche Vorkommen von Landschnecken darin werden als Beweise für den äolischen Ursprung dieser, durch außerordentliche Fruchtbarkeit ausgezeichneten Ackererde angeführt. Der Seelöß wurde dagegen in Salzseen abgelagert; er ist geschichtet und ermangelt der Kapillarstruktur.

In Europa spielt der Löß eine verhältnismäßig untergeordnete Rolle, wenigstens in morphologischer Beziehung. Am verbreitetsten ist er im Rhônetal, im Rhein- und Donaugebiet (im letzteren von Bayern bis Rumänien), in Thüringen, im nördlichen Böhmen und besonders in Galizien und der Bukowina, von wo er sich über das wolhynisch-podolische Plateau bis in die Ukraine fortsetzt. In Zentraleuropa stammt er von den mächtigen Schlammassen, die die Schmelzwässer des diluvialen Inlandeises ablagerten; in den Alpen ist er, wie Penck und Du Pasquier dargetan haben, eine interglaziale Bildung und auf das nördliche Vorland beschränkt; im Süden vertritt ihn der rote Ton (terra rossa oder Ferretto). Die Mächtigkeit des Lößes beträgt bei uns nur $30-60 \mathrm{~m}$, dagegen erreicht er im nordwestlichen China, wo er ein Areal von der Größe des Deutschen Reiches fast ununterbrochen bedeckt, stellenweise eine Mächtigkeit bis zu $600 \mathrm{~m}$; und wenn man von Loczy hört, daß die 2000 Jahre alten Gräber in Singanfu erst von einer $2 \mathrm{~m}$ dicken LöBschicht bedeckt sind, so gewinnt man eine Vorstellung von der Länge der Zeit, die die Bildung des ganzen chinesischen Lößes in Anspruch nahm. Kaum weniger verbreitet ist diese Bodenart auf dem nordamerikanischen Prärienplateau von Missouri bis Texas, wo noch Salzseen und weite sandige Strecken an den einstigen Zustand erinnern; ferner auf der gebirgsumschlossenen Hochebene der westlichen Union, wo ihn Russelu unter dem Namen Adobe beschrieben hat ${ }^{18}$ endlich in der südamerikanischen Pampasebene, die sich vom mittleren Bolivia bis Patagonien erstreckt.

Die Frage, ob alle Bodenarten, die man unter dem Namen LöB zusammenfaßt, äolischen Ursprungs sind, harrt noch der Entscheidung. Für Nordchina darf sie durch FutTekek's ${ }^{19}$ Beobachtungen als gelöst betrachtet werden. Der Umstand, daß im oberen Tauhogebiet nur 
die Südgehänge der westöstlich streichenden Täler mit mächtigen Lößterrassen bedeckt sind, läßt sich nur dadurch erklären, daß die in der kalten Jahreszeit herrschenden NW-Winde den Staub aus den nördlichen Wüsten hierher geführt haben, während die den sommerlichen SO-Winden zugekehrten Abhänge frei blieben, weil diese Winde keine Wüstenstriche passieren. DAvison's ${ }^{20}$ Erklärung, die den LöB als Beimengung des treibenden Schnees transportiert werden läßt, ist im Grund genommen nur eine Modifikation der Windtheorie und auch nur auf gewisse Vorkommnisse anwendbar. In bezug auf den deutschen wie auf den PrärienlöB finden sich unter den Geologen noch immer energische Verteidiger der Ansicht, daß er ein wässeriger Niederschlag sei, und im Eöß von St. Joseph wurden in der Tat auch Flußmollusken gefunden. ${ }^{21}$ Für Turkestan, wo ein allmählicher Übergang des Lö́ßes der Ebene in die Verwitterungsrinde der Gebirge zu beobachten ist, hält PAwLOw ${ }^{22}$ nur die Annahme einer fluviatilen Ablagerung für zulässig. Auch über die Entstehung der russischen und indischen Schwarzerden, die sich durch reichen Humusgehalt und daher durch große Fruchtbarkeit auszeichnen, sind die Meinungen noch immer geteilt. v. RicнтноғEN betrachtet sie nur als Abarten des Lößes, d. h. als äolische Ablagerungen, die die intensive Humifizierung ihrer oberen Schichten dem Einfluß örtlicher Bedingungen verdanken, und THеовацы Fischen schlieBt sich ihm betreffs des marokkanischen Tirsbodens rückhaltlos an. Dagegen wird die russische Schwarzerde oder das Tschernosjom, das ein weites Gebiet vom Pruth bis zur Wolga in einer Mächtigkeit von $1-20 \mathrm{~m}$ bedeckt und auch im westlichen Sibirien wieder auftritt, von seinem ausgezeichnetsten Kenner, DокUтsсналеw, für eine Eluvialbildung erklärt, entstanden durch die Verwitterung der darunter liegenden Urgesteine. ${ }^{23}$ Genau dieselbe Beschaffenheit hat auch die Schwarzerde in den nördlichen Zentralstaaten der Union und in Manitoba. Auch die unter dem Namen Regur oder Cottonsoil bekannte Schwarzerde, die in Südindien nahezu ein Drittel des Bodens einnimmt, halten einige indische Geologen für eluvial, andere dagegen für eine Süßwasserablagerung, indem sie darauf hinweisen, daß auch jetzt noch zahllose Sümpfe und Wasserlachen die östliche Küstenebene, besonders im Süden, bedecken.

Literaturnachweise. ${ }^{1}$ Eine weitere Ausführung der auf den Wind bezüglichen Auseinandersetzungen in F. v. Riснтноғем's Führer usw. gibt JoH. W Alther, zit. S. 483. - ${ }^{2}$ In den Abhandlungen des PreuBischen Meteorologisehen Instituts; Berlin 1901, Bd. II. - ${ }^{3}$ A. Penck, Die Morphologie der Wüsten, in den Verhandlungen des XVII. Deutschen Geographentages, Berlin 
1910. $-{ }^{4}$ S. Passarge, Verwitterung und Abtragung in den Steppen und Wüsten Algeriens, ebenda. - ${ }^{5} \mathrm{~J}$. BRunhes, in den Comptes rendus de l'Académie des Sciences; Paris 1902, Bd. CXXXV, S. 1132. - ${ }^{6}$ W. M. DAvis, The Geographical Cycle in an Arid Climate, im Journal of Geology, Chicago 1905; Geographical Journal 1906, Bd. XXVII. - ${ }^{7}$ S. Passarge, Rumpfflächen und Inselberge, in der Zeitschrift der Deutschen Geologischen Gesellschaft 1904, Bd. LVI, Protokoll. Vgl. auch sein „Kalahari“, Berlin 1904. - ${ }^{8}$ S. Günther, Ein Naturmodell der Dünenbildung, in den Sitzungsberichten der math.-phys. Klasse der Bayerischen Akademie der Wissensehaften, Bd. XXXVII, 1907. - ${ }^{9}$ H. J. L. Beadnell, The Sand-Dunes of the Libyan Desert, im Geographical Journal, Bd. XXXV, London 1910. - ${ }^{10}$ N. Sokolów, Die Dünen; Berlin 1894. P. Gerhardt, Handbuch des deutschen Dünenbaues; Berlin 1900. - ${ }^{11}$ J. REINKE, in den Sitzungsberichten der PreuBischen Akademie der Wissenschaften 1903, S. 281. - ${ }^{12}$ O. Baschrs, Dünenstudien, in der Zeitschrift der Gesellschaft für Erdkunde in Berlin, 1903. 13 O. B Aschrs, Die Entştehung wellenähnlicher Oberflächenformen, ebenda 1899, Bd. XXXIV. - ${ }^{14}$ V. Connssh, On the Formation of Sand-Dunes, im Geographieal Journal, Bd. IX, London 1897. - ${ }^{15}$ E. v. Сноцмоку, Die Bewegungsgesetze des Flugsandes, in Földtani Közlöny; Budapest 1902, Bd. XXXII. - ${ }^{16}$ A. Свогsy, Documents relatifs à la mission dirigée au sud de l'Algérie, Paris 1890. Vgl. auch die zahlreichen Artikel über die Saharadünen von E. Courbis, G. Roltand, E. Buanc usw. in den Comptes rendus der Pariser Geographischen Gesellschaft, 1890. - ${ }^{17}$ F. Solger, Studien über norddeutsche Inlanddünen, Stuttgart 1910. 18 J. C. Russer, Subaërial Deposits of the Arid Region of North America, im Geological Magazine 1889. - ${ }^{19}$ K. Futrerer, Durch Asien; Berlin 1901, Bd. I, S. $430 .-{ }^{20}$ Сн. Davison, im Quarterly Journal of the Geological Society, 1894, Bd. L, S. 472. - ${ }^{21}$ L. A. Owen, im American Geologist, 1905, Bd. XXXV, S. 291. - ${ }^{22}$ A. P. Pawlow in den Comptes rendus de la Société Impériale des Naturalistes de Moscou, 1905, Nr. 4-9, S. 4. - ${ }^{23}$ W. Dokutschajew, Die russische Sehwarzerde; St. Petersburg 1883.

\section{Die Arbeit des Meeres. ${ }^{1}$}

Begriff der Küste. ${ }^{2}$ Unter Küste versteht man zunächst die Grenzlinie zwischen Meer und Land. Aber da das Męer ein bewegliches Element ist, so - erleidet diese Linie beständig. Verschiebungen. Nur dort, wo die Küste senkrecht in die See abstürzt, erscheint sie in der Horizontalprojektion als feste Linie, die aber in Wirklichkeit auf- und abwärts schwankt, so daß streng genommen die Küste auch hier nicht eine Linie, sondern ein mehr oder weniger breites Band ist. In allen Fällen aber, wo sich das Land unter einem spitzen Winkel in das Meer senkt, ist die Küste eine Fläche, und in diesem Sinn wird auch der Ausdruck Strand gebraucht, wenn er auch in der Regel nur auf breitere, sandbedeckte Küstenstriche Anwendung findet.

Zwischen Land und Meer schiebt sich also eine Zone ein, die, obwohl dem Festland angehörig, doch der umgestaltenden Arbeit durch das bewegte Meer unterliegt. Thre Grenze gegen das Meer 
liegt dort, wo dauernde Wasserbedeckung stattfindet, die Grenze gegen das Land aber noch weiter landeinwärts als die Küstenlinie zur Zeit des höchsten Wasserstandes, weil die Brandung Gesteinsmaterial weiter, als sie selbst dringt, vorwärts zu schleudern vermag. In Meeren mit ausgeprägten Gezeiten wird der äußere Saum der Küstenzone regelmäBig bei Flut von Wasser bedeckt und zur Ebbezeit wieder trockengelegt.

Neben dem Meer wirken in der Küstenzone natürlich auch die übrigen exogenen Kräfte, besonders aber sind zwei Vorgänge wichtig: die Deltabildungen der Flüsse und die ebenfalls schon besprochenen Dün enbauten durch den Wind, wozu allerdings das Meer das Material liefert. Ein kombinierter ProzeB ist es auch, wenn das Meer als Transportmittel für Flußsedimente dient.

Charakter der Küste. Im allgemeinen wird der Charakter der Küste durch das Hinterland bedingt. Wir werden bei einer andern Gelegenheit noch ausführlicher darauf zurückkommen, hier handelt es sich nur um die Umgestaltung der Küste durch das Meer, und dafür ist in erster Linie das Querprofil der Küste maßgebend. Wir unterscheiden in dieser Beziehung Flach- und Steilküsten. Wohl gilt im großen und ganzen die Regel, daß Tiefebenen mit Flachküsten enden und Gebirge mit Steilküsten an das Meer herantreten, aber im einzelnen gibt es doch viele Ausnahmen. Die Kreideküste zwischen der Seine- und der Sommemündung gehört nach hypsometrischen Begriffen einem Tiefland an und ist trotzdem eine Steilküste mit ungefähr $100 \mathrm{~m}$ hohen senkrechten Wänden. Ebenso ist das östliche Gestade von Rügen eine prächtige Steilküste, obwohl das Vorgebirge Arkona nur $46 \mathrm{~m}$ über den Meeresspiegel ansteigt; auch die samländische Niederung endigt mit einer $30-50 \mathrm{~m}$ hohen Steilküste. Reine Steilküsten sind indes verhältnismäBig selten, meist. geht der Steilabfall des Landes oder das Kliff in einen schmalen Strand über, der allmählich in das Meer verläuft. Manchmal schieben sich auch etwas breitere Küstenebenen zwischen das Meer und den Gebirgsrand ein. So begleitet beispielsweise der sandige Küstenstrich Germesir den südlichen Steilabfall des iranischen'Hochlandes und schafft ein flaches Gestade. Es ist ferner auch nur im großen und ganzen richtig, daß der Küstencharakter sich auch unter dem Meer fortsetzt, oder mit andern Worten, daß die unterseeische Böschung an Flachküsten flacher ist als an Steilküsten. Wo z. B. die norwegische Steilküste südlich von Stavanger durch die ausgedehnte Ebene Jäderen unterbrochen wird, ändert sich der unterseeische Steilabfall nicht im geringsten, und schon in einer Entfernung von $3-4 \mathrm{~km}$ lotet man eine Tiefe von $235 \mathrm{~m}$. Wohl ist die Zone 
der Flachsee gewöhnlich nur an ebenen Küsten sehr breit, aber vergessen wir nicht, daß sich auch die Steilufer Dalmatiens und der britischen Inseln aus sehr seichten Meeren erheben.

Die Brandung. Jede Küste befindet sich nach Pfaff's trefflichem Ausspruch im Belagerungszustand, aber trotzdem finden wir überall neben Küstenstellen, die vorwiegend unter Zerstörung leiden, andere, deren Veränderung hauptsächlich durch Anschwemmung erfolgt. Wie sich das Endergebnis gestaltet, hängt von der Widerstandsfähigkeit des Gesteins ab, ferner davon, wie die Atmosphärilien vorgearbeitet haben, in erster Linie aber von der Lage gegen die Brandung, denn unter den zerstörenden Kräften ist sie jedenfalls die mächtigste. Wie groß ihre Gewalt ist. läßt sich daraus entnehmen, daß sie bei dem Oststurm im Dezember 1872 im Hafen von Wick (Schottland) einen Block mit seinen Fundamenten im Gesamtgewicht von 1370 Tonnen 10 bis $15 \mathrm{~m}$ weit fortbewegte. Auf den Leuchtturm von Bell Rock übt sie einen Druck von 14700 und auf den von Skerryvore einen Druck von $29700 \mathrm{~kg}$ pro Quadratmeter aus. Selbstverständlich wächst ihre Kraft mit der Windstärke, und ihren Höhepunkt erreicht sie, wenn der Sturm senkrecht die Küste trifft, denn die Wellenbewegung vereinigt sich dann mit dem Windstau. Daher bieten uns die steilen Westküsten höherer Breiten ein Bild völliger Zerrissenheit dar. Mit gleichmäBiger Stärke tobt die Brandung gegen die tropischen Gestade, teils durch die regelmäBigen Passate, teils durch die Westdünung erzeugt.× Nicht bloß durch ihre Arbeitsleistung zeichnet sich die Brandung aus, sondern auch durch ihre Allgegenwart. Wir finden sie nicht bloB in allen Meeren sondern auch in den Seen, allerdings geringer an Intensität, aber dem Wesen nach gleich. Was daher im folgenden über die Umgestaltung der Meeresküsten gesagt wird, kann - wenn man sich nur des Unterschiedes von groß und klein bewußt bleibt - auch auf die Seeufer angewendet werden. ${ }^{3}$ Auch jenes wichtige Agens, das man gewöhnlich als Küstenstrom bezeichnet, wird von neueren Forschern vorzugsweise aus der Wellenbewegung abgeleitet, doch nehmen in gewissen Gegenden auch die Gezeitenströme daran teil. In den polaren Meeren wird die Dynamik der Küstenveränderung durch das Treibeis etwas modifiziert; ${ }^{4}$ wo es in heftiger Bewegung ist, wie in der Klippenbrandung, wirkt es wie schweres Belagerungsgeschütz und fördert die Zerstörung; wo es sich aber anhäuft, schützt es die Küste und verhindert die Abfuhr der Erosionsprodukte.

Über die chemische Erosion hat $\mathrm{JOLY}^{5}$ interessante Experimente

$\times$ Vgl. dazu den Abschnitt über Brandung auf S. 295. 
veranstaltet, aus denen hervorgeht, daß die lösende Kraft des Salzwassers beträchtlich größer ist als die des süßen, daß sie sich aber verschiedenen Gesteinen gegenüber verschieden verhält.

Steilküsten. Denken wir uns eine steil ins Meer abfallende Felswand. Indem die Woge an sie schlägt, preßt sie die in den Spalten befindliche Luft zusammen und lockert dadurch das Gefüge. Zieht sie sich zurück, so wird die Luft nachgesogen und kleine Gesteinspartikelchen werden dadurch herausgeführt. Ablation und Korrosion wirken beständig zusammen; durch den Stoß der Brandung werden kleine Teilchen vom Felsen losgelöst, die Ecken werden abgebrochen, und größere Gesteinsstücke, in höheren Breiten auch Treibeis, werden als Geschosse gegen die Felsenfestung geschleudert. Dabei ist $\mathrm{zu}$ beachten, daß die Brandung stets flächenhaft wirkt wie der Wind, aber doch wieder grundverschieden von

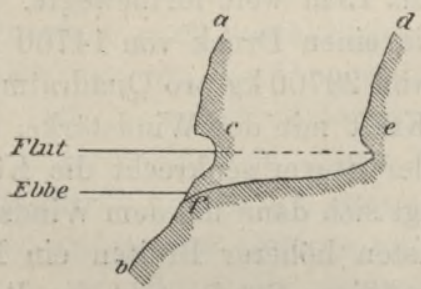

Fig. 173.

Umgestaltung der Steilküste.

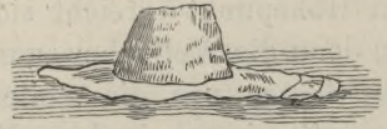

Fig. 174 .

„Der alte Hut", Neuseeland, nach Dava.

diesem. Die Meereswoge ist an ein gewisses Niveau gebunden, der Wind an keines, aber dafür arbeitet jene viel gründlicher. Der Wind führt nur das lockere Material fort und schafft damit Unebenheiten, die im Lauf der Zeit allerdings verschwinden, die Brandung arbeitet aber von Anfang an auf Nivellierung hin, und man hat daher diesen Erosionsproze $B$ sehr passend als Abrasion bezeichnet. Zunächst entsteht an der Steilküste innerhalb der Zerstörungszone eine hohlkehlenartige Vertiefung, deren untere Grenze etwas über dem Niveau des Niedrigwassers, und deren obere Grenze etwas über dem Niveau des Hochwassers liegt ( $c$ in Fig. 173). $\mathrm{Z}_{\mathrm{AHN}}{ }^{6}$ betont jedoch mit Recht, daß das Bereich der unmittelbaren Brandungswirkung noch über die Prallstelle hinaus soweit reicht, wie der Gischt der Wogen, nur daB in der oberen Spritzzone die Felsoberfläche rauhere Formen annimmt, als in der unteren Schliffzone. Mittellbar reicht aber die Wirkung der Brandung noch höher hinauf, indem die von ihr unterwaschenen Kliffpartien bald nachbrechen, so daß gut ausgebildete Hohlkehlen in der Natur verhältnismäBig selten zu beobachten sind. Die feineren Zerstörungsprodukte werden fortgeführt, 
die gröberen schichten sich am FuB der Steilküste auf und bilden meistens einen schmalen Schuttwall, der unter Umständen die Küste vor weiteren Angriffen schützt. Nur solch einem natürlichen Wellenbrecher verdankt es z. B. der waldgekrönte Kreidefelsen der Stubbenkammer auf Rügen, daB er nicht schon längst in den Fluten versunken ist. Fig. 173 führt uns die Umgestaltung einer Steilküste schematisch vor Augen. Die Küste ist zurückgetreten, das ursprüngliche Profil $a c b$ hat sich in defb verwandelt. Das Endergebnis der Abrasion ist eine Strandterrasse (Strandriff), deren Plattform als sanft geneigte, vielfach durchfurchte Ebene vom Niveau der Ebbe gegen die Rückwand ansteigt (s. ef in Fig. 173). Die Bildung solcher Terrassen hat Tн. WoLf an der Küste von Ecuador, ${ }^{7}$ Rich. Lehmann bei der Poststation Bolgen in Norwegen ${ }^{8}$ und TH. Studer am basaltischen Gestade der Kergueleninsel ${ }^{9}$ beobachtet. Ob das Meer schneller oder langsamer an Terrain gewinnt, hängt von der Stärke der Brandung und der Widerstandsfähigkeit des Gesteins ab. Aus den Berechnungen des Landverlustes in England ${ }^{10}$ scheint hervorzugehen, daß die Brandung der maßgebendere Faktor ist, denn an der Westküste haben in geschichtlicher Zeit Cornwall 588, Nordwales 236 und Cheshire 122 qkm Land verloren, an der Ostküste aber Kent nur 49 und Suffolk $116 \mathrm{qkm}$. Diese Vergleichszahlen sind um so bedeutungsvoller, als an den Küsten des unruhigen Kanals das jährlich vom Meer fortgeführte Material auf 10 Millionen Kubikmeter geschätzt wird. Rasch brechen hier die unterwaschenen Kreidefelsen zusammen, während z. B. der feste Kalkstein der ligurischen Küste überhängende Wände bildet. Granit, Gneis, Syenit, Basalt usw. können länger der Brandung Trotz bieten, aber auch sie sind nicht gegen die Zerstörung gefeit, denn fast überall finden sich Schwächelinien, wie $Z_{\mathrm{AHN}}$ sie genannt hat: Absonderungs- und Schichtungsfugen, Spalten und Gänge weicherer Gesteine, ja oft auch Zonen schwacher Widerstände, und von da aus beginnt das Meer seine Arbeit. Besonders leichtes Spiel haben die Wogen, wo sie eine aus lockerem Material aufgebaute Steilküste bespülen; so dringt in Holderness in Yorkshire, wo Geschiebelehm das schroff abstürzende Gestade bildet, das Meer auf einer Länge von $58 \mathrm{~km}$ jährlich 2,3-3 m landeinwärts vor und hat seit den Römerzeiten bereits einen Weg von 5,6 $\mathrm{km}$ zurückgelegt, und der Landverlust, den allein die steilen Partien der mecklenburgischen Küste im 19. Jahrhundert erlitten haben, wird von Gernitz auf $30637000 \mathrm{ebm}$ geschätzt. Auch die Lagerungsverhältnisse sind von Bedeutung; jedenfalls geht die Zerstörung leichter vor sich, wenn der Küstenabbruch aus Schichtenköpfen, als wenn er aus Schichtenflächen be- 
steht, und dieser Umstand mag wohl auch zum enormen Landverlust an der englischen Westküste mit beigetragen haben.

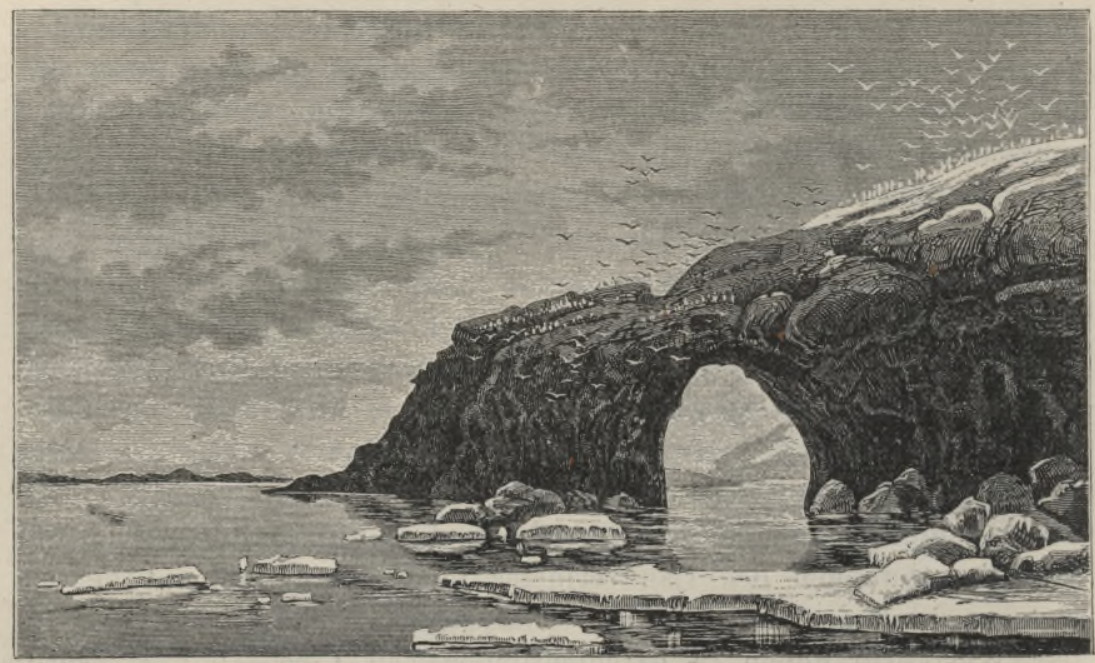

Fig. 175. Das Bürgermeistertor auf der Bäreninsel 1864 nach G. ANdERsson.

Riesentöpfe wurden mehrfach auf ehemaligem Meeresboden beobachtet, und die nischenartigen Vertiefungen in den Wänden enger

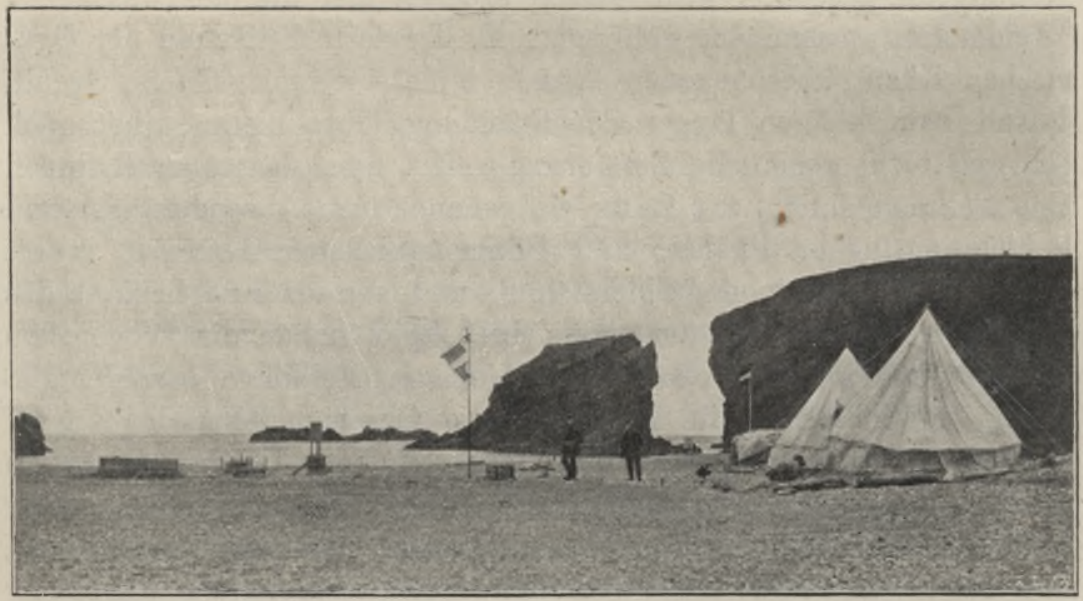

Fig. 176. Das Bürgermeistertor auf der Bäreninsel 1899 nach G. AndERssov,

Sunde sind vielleicht nur emporgehobene Reste solcher Topf́bildungen. Doch wohl nicht alle, denn eine Beobachtung von Gersitz ${ }^{11}$ an der 
mecklenburgischen Küste belehrt uns, daß das brandende Wasser, wenn es sich nicht ungehindert zurückziehen kann, in einem Kliff, das Schleifmaterial liefert, auch seitliche Riesentöpfe einzubohren vermag. In leicht löslichem Kalkstein gräbt die Woge durch chemische Erosion tiefe Höhlen, Kammern und Gänge ein, vorausgesetzt daß die Decke fest genug ist, um nicht einzustürzen. Von solcher Bildung ist beispielsweise die Küste der australischen Kolonie Viktoria in der Nähe des Kaps Otway. In anderen, nicht löslichen Gesteinen scheint die Höhlenbildung an das Vorhandensein von Spalten gebunden zu sein, die vom Meer allmählich erweitert werden. Von solchen Erosionserscheinungen am norwegischen Steilufer, die jetzt freilich infolge der Niveauveränderung dem Bereich der Brandung entrückt sind, berichtet Reusch. ${ }^{12}$ Die SjonghellerGrotte auf Valderö ist $142 \mathrm{~m}$ lang und am Eingang $38 \mathrm{~m}$ hoch,

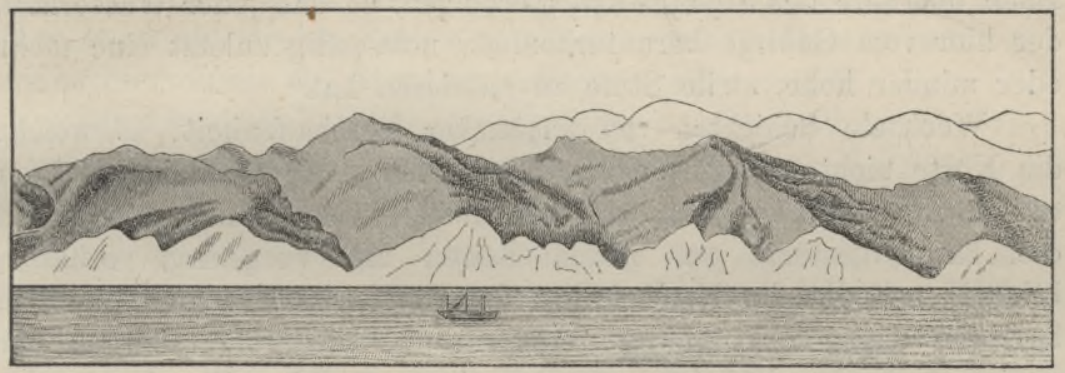

Fig. 177. Abrasionsküste am Schwarzen Meere zwischen Poti und Noworossijsk nach HerM.

wird aber gegen die Tiefe zu immer niederer. Dieser Umstand, sowie die Glätte der Wände beweist, daß sie vom Meer ausgewaschen wurde. Weltberühmt ist die Insel Torghatten $\left(6 \tilde{5}, 4^{0} \mathrm{~B}\right.$.), deren Felsenkappe in einer Seehöhe von $110-125 \mathrm{~m}$. von einem gewaltigen Loch durchquert wird. Seine Länge beträgt $160 \mathrm{~m}$, seine Höhe ungefähr $35 \mathrm{~m}$. und seine Breite 11-12 m. Die glatten Wände dieses Riesentores weisen mit Bestimmtheit darauf hin, daß es ein Werk der Meereserosion ist. Weitaus am interessantesten ist aber das „Bürgermeistertor" auf der Bäreninsel, das NoRdeNSKIöLD 1864 entdeckte und nach den sich dort zahlreich aufhaltenden Eismöven benannte (Fig. 175). 1870 fanden es NaTHorst und WILANDER scheinbar unversehrt wieder, aber 1898 suchte die schwedische Expedition vergebens danach, und erst 1899 gelang es GunAR ANDERsson es wiederzufinden, aber die Wölbung war verschwunden (Fig. 176). ${ }^{13}$ Dies ist wohl das denkwürdigste Beispiel der Meereserosion an Steilküsten, das die Geschichte kennt. 
Treten Schichten von gleichmäBiger Beschaffenheit an das Meer heran, so werden gerade verlaufende Steilwände geschaffen. Eines der ausgezeichnetsten Beispiele hat Herm's Meisterstift im Jahr 1897 festgehalten (Fig. 177). Die bis $100 \mathrm{~m}$ hohen Steilhänge des tertiären Kalksteingebirges, „die sich durch ihre helle gelbliche Farbe äußerst scharf von dem waldbedeckten Hintergrund abhoben, gewährten“ - wie KeILHAck berichtet - „vom Meer aus erblickt, ein Bild, als wenn ein Gipsmodell einer Landschaft durch einen Vertikalschnitt zerlegt wäre. Das Merkwürdigste aber ist, daß die Abrasion hier mit einer solchen Geschwindigkeit voranschreitet, daß die Talbildung, die erodierende Tätigkeit der Flüsse und Bäche mit ihr nicht gleichen Schritt halten kann. Unsere kleine Skizze schon zeigt deutlich, daß die einzelnen vom Gebirge herabkommenden Täler nicht am Strand endigen, sondern daß sie ihr eigentliches Ende oberhalb des Steilabsturzes erlangen, so daß jeder Wasserlauf, der hier vom Gebirge herunterkommt, notwendig zuletzt eine mehr oder minder hohe, steile Stufe zu passieren hat."

Wechseln Schichten von ungleicher Beschaffenheit, so weicht die Küste nicht überall gleichmäßig zurück. Die St. Brides-Bai im südwestlichen Wales ist in Karbonschichten eingeschnitten, während die Eruptivgesteine zu beiden Seiten als Vorgebirge erbalten blieben; und dieselbe Erscheinung, daß weicheren Schichten Buchten, härteren dagegen Vorgebirge entsprechen, wiederholt sich an der ganzen britischen Westküste, soweit sie aus solidem Gestein besteht.

Ein schönes Beispiel einer bogenförmigen Abrasionsküste hat Theовадd Fischer ${ }^{14}$ bei Tipaza in Algier beobachtet. Fast auf jedes Kilometer Küstenlänge kommt hier eine Bucht, in jede mündet ein Gießbach, und die Größe der Buchten steht in genauem Verhältnis zu der Lauflänge und dem Wasserreichtum der betreffenden Bäche. Hier hat offenbar die Erosion des fließenden Wassers der Abrasion vorgearbeitet, was sich auch dadurch erweist, daß dort, wo keine Bäche münden, die Küste geradlinig verläuft.

Die Abrasionskraft arbeitet nicht blo $B$ in horizontalem Sinn, sondern auch in die Tiefe. Sie korrodiert die Oberfläche der Terrasse; und da die Wellenbewegung noch bis $200 \mathrm{~m}$ Tiefe imstande ist, loses Steinmaterial hin und her zu schieben, so darf man annehmen, daß die Korrosion erst in dieser Tiefe völlig erlischt, vorausgesetzt, daB die Terrasse nicht durch eine Schutt- oder Sanddecke geschützt ist. Daraus erklärt sich wahrscheinlich, daß die Tiefenlinien bis zu $200 \mathrm{~m}$ die Gestalt der Küstenlinie wiederholen. Mit der Tieferlegung wächst auch die Breite der Terrasse, bis endlich die Welle auch zur Zeit des höchsten Wasserstandes, indem 
sie die schiefe Ebene hinaufläuft, durch Reibung ihre Kraft völlig einbüßt. Nur eine positive Niveauveränderung kann die zerstörende Tätigkeit wieder beleben, wie eine negative ihr vorzeitig Halt gebieten kann, indem sie die Strandterrasse dauernd trocken legt. Die Reste einer solchen Abrasionsterrasse umsäumen die Westküste Norwegens vom Kap Lindesnäs bis zum Nordkap in Gestalt von ausgedehnten Untiefen mit vereinzelten Felseneilanden am äußeren Rand, dann mehr dem Land $\mathrm{zu}$ in Gestalt von vielen Tausenden kleiner, ungefähr gleich hoher Schären, die meist durch ganz seichtes Wasser voneinander getrennt sind. In Helgeland hat diese alte, aus vorglazialer oder glazialer Zeit stammende Strandebene, die nur an wenigen Stellen das heutige Festland berührt, eine Breite von ungefähr $45 \mathrm{~km}$; am Außenrand liegt sie $10-30 \mathrm{~m}$ unter dem Meeresspiegel, im Innern erhebt sie sich 20-60 m darüber, und unmittelbar daran steigt der Felsboden bis zu $500 \mathrm{~m}$ an. Man kann aus diesen Zahlen entnehmen, welche Massen festen Gesteins hier durch die Abrasion entfernt worden sind. ${ }^{15}$

Die Lage der Endlinie der Abrasion - der Abrasionsterminante, wie Phimippson sie nennt - hängt nur von der Stärke der Brandung ab, die Dauer des Abrasionsprozesses aber auch von der Beschaffenheit der Küste. Über kurz oder lang siegt jedoch das Meer über jedes Hindernis, ebenso wie das fließende Wasser. Höhlen verwandeln sich meist durch Deckeneinsturz in offene, schluchtartige Einschnitte und indem diese entlang einer Schwächelinie immer tiefer eindringen und sich manchmal mit ähnlichen Bildungen an der entgegengesetzten Seite des Kliffvorsprungs begegnen, lösen sich Inselpfeiler los, die die einstige Küstenausdehnung verraten. Namentlich die steilen Westküsten der höheren Breiten werden von dichten Schwärmen solcher Felseneilande und Klippen begleitet. Aber auch diese Vorposten werden mit der Zeit vom Meer weggeräumt, um als blinde Klippen den Schiffen nur noch gefährlicher zu werden. So sieht man bei Arbroath an der schottischen Ostküste eine lange Riffreihe aus festem Gestein bei Ebbe bloßgelegt. Ein anderes ausgezeichnetes Beispiel ist das Sandsteinriff, das die Küste Brasiliens durch acht Breitengrade vom Cabo Frio bis zum Cabo do Calcanhar begleitet.

Eine noch höhere Bedeutung gewinnt die Abrasion, wenn sie sich mit einer positiven Niveauveränderung verbindet. Halten sie ungefähr das gleiche Tempo ein, so rückt die Abrasionsterminante immer weiter ins Land hinein, und ihr folgt die alles nivellierende Brandungswelle. Hochragendes. Gelände verwandelt sich in eine einförmige Abrasionsebene, die durch eine negative Niveau- 
veränderung trocken gelegt werden kann. RAMSAY und v. RICHTHOFEN haben mit Nachdruck auf die Wichtigkeit dieser marinen Destruktion hingewiesen.

Zerstörung der Flachküsten. Auch Flachküsten fallen der Meereserosion zum Opfer, wie die Geschichte des deutschen und des englischen Nordseestrandes beweist. Aber nicht unablässig wirkt hier die Brandung zerstörend wie an den Steilküsten, sondern hauptsächlich nur bei Windstau, wenn das Meer weite Gebiete überschwemmt; dann aber mit furchtbarer Gewalt. Sehr lehrreich ist in dieser Beziehung die Geschichte des Zuidersee ${ }^{16}$ (Fig. 178). Etwa $3 / 4$ davon, von der Inselreihe Wieringen-Ameland bis ungefähr zur

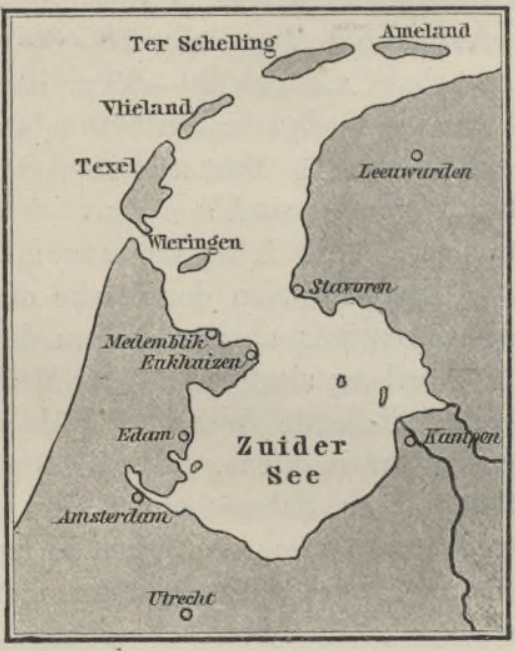

Fig. 178. Zuidersee.

Linie Edam-Kampen, waren noch zur Römerzeit Land. Der südliche Teil bildete den Binnensee Flevo; ihn durchfloß der Rheinarm Ijssel, der wahrscheinlich zwischen Vlieland und Ter Schelling mündete. Vom 4. Jahrhundert unserer Zeitrechnung an beginnt das große Zerstörungswerk, das besonders durch Überflutungen bei Nordweststürmen gefördert wurde. Am Ende des 7. Jahrhunderts waren Ter Schelling und Ameland schon Inseln. Im Jahr 1170 wurde alles Land zwischen Texel, Medemblik und Stavoren verschlungen, mit Ausnahme der insularen Reste. 1237 erweiterte sich der Flevosee beträchtlich, indem eine große Fläche zwischen Enkhuizen, Stavioren und Kampen dauernd überflutet wurde. Im Jahr 1395 verschwand auch der schmale Isthmus zwischen Medemblik und Stavoren, und die nördliche Meeresbucht Ferband sich mit dem südlichen Binnensee. Den Landverlust seit der Zeit Cäsars schätzt man auf wenigstens $5813 \mathrm{qkm}$, wovon nur $3635 \mathrm{qkm}$ durch Eindeichung dem Meer wieder abgewonnen wurden. Der Jadebusen erhielt seinen heutigen Umfang erst zwischen 1219 und $1511,{ }^{17}$ und der Katastrophe i. J. 1413 fiel das fruchtbare Reiderland an der Stelle des heutigen Dollart zum Opfer. ${ }^{18}$ Auch den friesischen Inseln, dem alten Küstenrand Deutschlands, ist eine vergängliche Existenz beschieden. Noch zur Zeit ADAM's voN Bbemen, um 1100, waren Borkum, Juist und Norderney miteinander 
vereinigt, und diese große Insel Bant, wie man sie damals nannte, erstreckte sich auch noch weit nach S. Die Auflösung erfolgte jedenfalls vor 1398, wahrscheinlich durch die sog. Marcellusflut im Jahr 1362; zwei kleinere Trümmer, die Eilande Bant und Buise sind seitdem völlig verschwunden. ${ }^{19}$ Das Dorf auf der Insel Wangeroog wurde durch die Sturmfluten des Dezembers 1854 zerstört, und Kirchturm wie Leuchtturm werden jetzt von der Flut bespült. Auch das steile Helgoland hat an Umfang verloren, wenn auch nicht soviel, als man früher, verleitet durch tendenziöse Erfindungen des 15. Jahrhunderts, geglaubt hatte. ${ }^{20}$ Die Verluste der flachen nordfriesischen Inseln sind ebenfalls übertrieben worden, wenn sie auch noch groß genug sind. Man betrachte nur die Entwicklung Nordstrands, wie sie Fig. 179 darstellt. Für das 13. Jahrhundert fließen allerdings die Geschichtsquellen zu dürftig, als daß sich die Umrisse der Inseln und des Festlandes genau zeichnen ließen. Aber noch vor der großen Sturmflut in der Nacht vom 11. zum 12. Oktober 1634 be$\mathrm{saB}$ Nordstrand eine ansehnliche Ausdehnung. Diese Katastrophe, die alle Deiche hinwegfegte und 6408 Men-
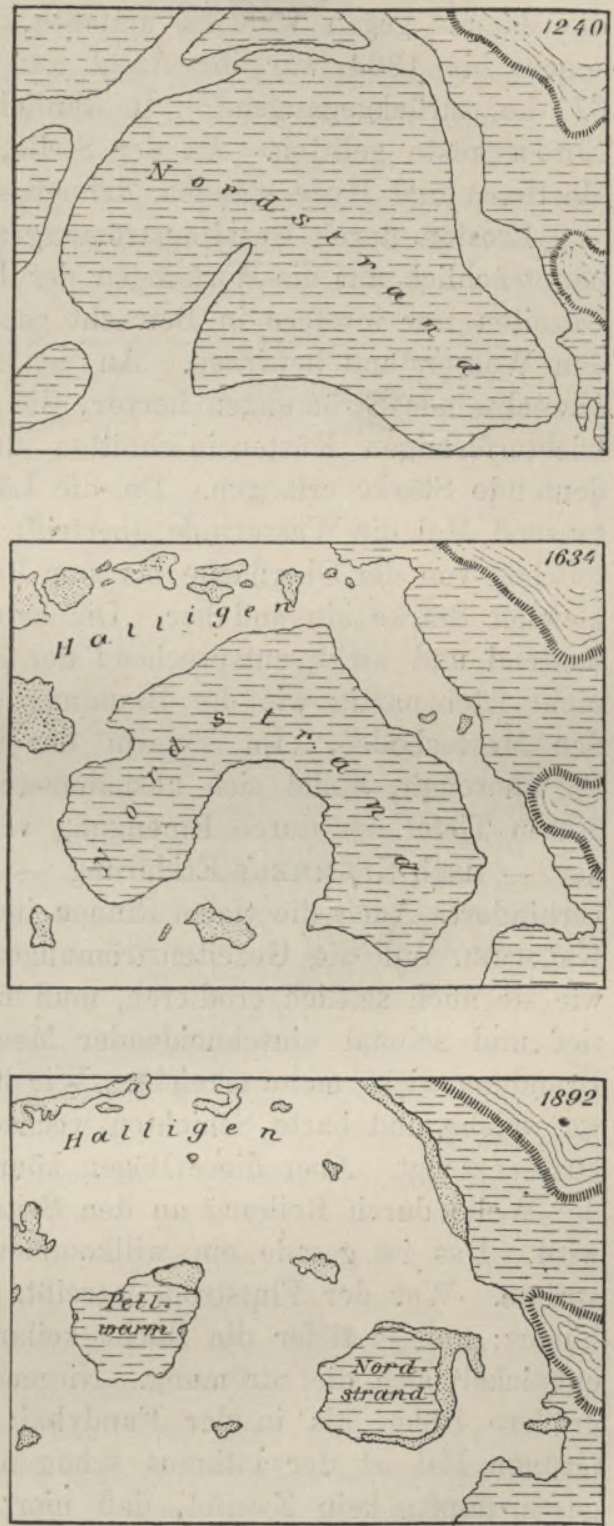

Geest, =1- eingedeichtes Land it. unbedeichtesLand

Fig. 179. Nordstrand um 1240, 1634 und 1892 nach R. HANSEN. 
schen das Leben kostete, ließ nur drei Eilande übrig; allerdings hätte - wie man nicht verschweigen darf - rechtzeitige Hilfe noch manches Stück Land retten können. ${ }^{21}$ Auch die benachbarte Hooge, die damals gegen 1200 ha umfaßte, wurde in Mitleidenschaft gezogen; bis 1804 war ihr Areal auf 860 und bis 1873 sogar auf 677 ha zurückgegangen. ${ }^{22}$ In ähnlicher Weise hat die englische Nordseeküste gelitten. An der Stelle, wo einst die Orte Autburn, Hartburn und Hyde standen, dehnen sich jetzt Sandbarren aus.

Erosion durch Gezeitenströmungen. ${ }^{23}$ Wir haben uns bisher hauptsächlich auf die Wirkungen der Brandung beschränkt und die Gezeiten nur insofern in Betracht gezogen, als sie einen wechselnden Wasserstand bewirken. An den Küsten rufen sie aber auch abwechselnde Strömungen hervor, die zwischen Inseln, in Kanälen, trichterförmigen Küsteneinschnitten und Flußmündungen eine bedeutende Stärke erlangen. Da die Länge der Flutwellen um viele tausend Mal die Wassertiefe übertrifft, so bewegen sich die Wasserteilchen von der Oberfläche bis zum Boden fast gleichzeitig und mit gleicher Stärke hin und her. Die Erosionskraft ist daher sehr bedeutend und wirkt, entsprechend der Art ihres Auftretens, linear, nicht flächenartig wie die Brandung. Die Tiefenerosion beeinflußt den Meeresboden. Im Südarm der Fundybai, in der Enge von Parrsborough, findet sich ausnahmsweise Felsboden von mehr als $200 \mathrm{~m}$ Tiefe; der durch Einengung verstärkte Gezeitenstrom ist es, der — nach KRÜмmeL's Erklärung - hier jede Sedimentablagerung verhindert. Auch die tiefen Rinnen im friesischen Wattenmeer führt KвüмmeL auf die Gezeitenströmungen zurück. Um zu erfahren, wie sie auch seitlich erodieren, $m u B$ man sich in die innersten Teile tief und schmal einschneidender Meeresbuchten begeben, die die Brandung nicht mehr erreicht. Wir haben oben gesehen, daß dort, wo weiche und harte Schichten wechseln, die Abrasion eine Bogenküste erzeugt. Aber diese Bögen können nicht tief eindringen, weil die Welle durch Reibung an den Seitenwänden zu sehr geschwächt wird. Das ist gerade ein willkommenes Arbeitsfeld für Gezeitenströme. Was der Flutstrom losreißt, führt der Ebbestrom ins Meer hinaus; und je tiefer die Bucht keilartig eindringt, desto kräftiger entwickelt sich die Strömung. Nirgends erreicht die Flutwelle eine größere Höhe, als in der Fundybai; zwischen Sackville und der Grünen Bai ist der Isthmus schon auf $20 \mathrm{~km}$ Breite zusammengeschrumpft; kein Zweifel, daß hier an der völligen Lostrennung Neuschottlands gearbeitet wird. Angesichts solcher Wahrnehmungen läßt sich der Gedanke nicht abweisen, daß auf diese Weise auch England einst zur Insel geworden ist; haben doch die Untersuchungen 
anläßlich der Tunnelprojekte den ungestörten Schichtenzusammenhang zwischen Dover und Calais ergeben.

Die übrigen Meeresströmungen berühren selten unmittelbar die Küsten und sind auch in der Regel zu langsam, um merkbare Erosionswirkungen ausüben zu können. Nur vom Bosporus vermutet KrÜмmeL, daß er seit dem Altertum durch den Oberflächenstrom erweitert worden sei.

Anschwemmung. Zerstörung und Neubildung gehen auch an der Küste Hand in Hand. Das lehren am deutlichsten die Gezeitenströme in engen Einfahrten und Flußmündungen, wo sie kräftig genug entwickelt sind. Die tiefe Fahrrinne liegt nicht in der Mitte, sondern ist nach links verschoben; rechts dehnen sich die Anschwemmungen aus. Nach KRÜMMEL's Erklärung haben wir hierin eine Doppelwirkung der Gezeiten unter dem Einfluß der Erdrotation zu erblicken. Flut- und Ebbestrom werden nach rechts abgelenkt; jener erodiert, dieser, beladen mit den Sedimenten des zurückgestauten Wassers, lagert

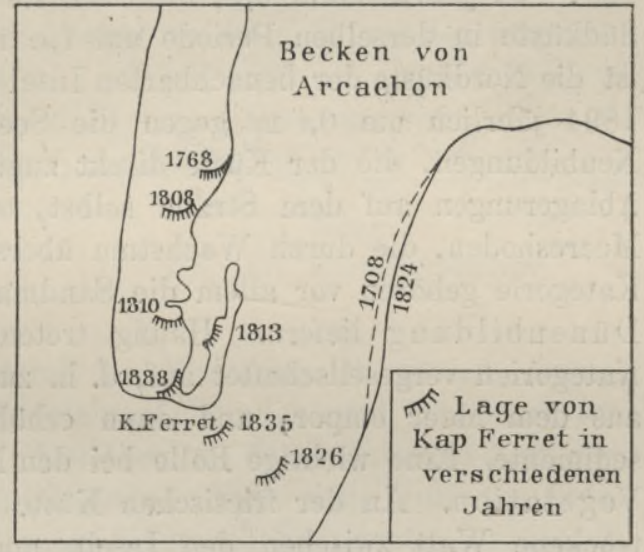

Fig. 180. Wanderungen des Kap Ferret am Eingang in die Bucht von Arcachon (Département Gironde), nach GIRARD. ${ }^{24}$

ab. An den Vorsprüngen der Buchtenwände gerät der Flutstrom in Wirbelbewegung, und dort, wo die vor- und die rückläufige Bewegung sich begegnen, entsteht aus den mitgeführten Sanden ein dreieckförmiger Landansatz. Derselbe Vorgang wiederholt sich auch noch außerhalb der Küste und führt zur Bildung einer Reihe von Sandbänken, die an der deutschen Küste fälschlich Riffe genannt werden. Anschwemmung und Zerstörung, die oft auf kurze Strecken miteinander abwechseln, können die Gestalt flacher Küsten in kurzen Zeiträumen völlig verändern (vgl. Fig. 180), und von ihnen gilt dann im strengsten Sinn der Satz, daß unsere Karten nur Augenblicksbilder sind. ${ }^{25}$ Zuverlässige ziffermäßige Daten über diesen Doppelprozeß finden sich in der Literatur selten, regelmäßige Beobachtungen werden nur an der niederländischen Dünenküste gemacht. An der Westküste Nordhollands von: Helder bis Bergen (28,2 km) ist die Hochwasserlinie in der Periode $1843-97$ um 44,4 $\mathrm{m}$ und die 
Niedrigwasserlinie um 22,2 m landeinwärts gerückt, von Bergen südwärts $(37,7 \mathrm{~km})$ hat aber eine Verschiebung nach dem Meer zu stattgefunden, und zwar bei Hochwasser um 21,5 und bei Niedrigwasser um 66,7 m. Daraus ergibt sich für die Nordhälfte ein Landverlust von 126 ha bei Hoch- und von 63 ha bei Niedrigwasser und für die Südhälfte ein Landgewinn von 81 bezw. 251 ha. ${ }^{26}$ Beachtung verdienen auch die Arbeiten Marindin's ${ }^{27}$ über die Küstenveränderungen der Insel Nantucket (Massachusetts) zwischen 1846 und 1891 bezw. 1894. Von den $42 \mathrm{~km}$ Küste haben 32 Land verloren und 10 Land gewonnen. Im großen und ganzen ist die Nordküste 1887-94 jährlich um 0,18, die Ostküste 1846-91 um 0,19 und die Südküste in derselben Periode um 1,42 m zurückgewichen. Dagegen ist die Nordküste der benachbarten Insel Martha's Vineyard 1887 bis 1894 jährlich um 0,2 m gegen die See vorgerückt. Die marinen Neubildungen, die der Küste direkt zugute kommen, sind entweder Ablagerungen auf dem Strand selbst, oder Ablagerungen auf dem Meeresboden, die durch Wachstum überseeisch werden. Zur ersten Kategorie gehören vor allem die Sandmassen, die das Material zur Dünenbildung liefern. Häufig treten die Ablagerungen beider Kategorien vergesellschaftet auf, d. h. zunächst wächst das Neuland aus dem Meer empor, und dann erhöht es sich durch Übergußsedimente. Eine wichtige Rolle bei den Neulandbildungen spielt die Vegetation. An der friesischen Küste wird das bei Niedrigwasser trockene Watt zwischen den Inseln und dem Festland bei jeder neuen Flut durch hinzugeführte Schlammteilchen etwas erhöht. Zwischen den Pflanzen, die sich darauf ansiedeln, bleibt immer mehr Schlamm zurück, bis endlich die gewöhnliche Flut die Fläche nicht mehr zu überschwemmen vermag. Neue Gräser und Kräuter erhöhen und verfestigen immer mehr den Boden, der schon als Weide benützt wird (Kelter), bis er, durch Eindeichung völlig vor dem Meer geschützt, als Polder ein fruchtbares Ackerland liefert. ${ }^{28}$ In noch höherem Grad wirken die Mangrovebäume mit ihrem weit ausgesponnenen Wurzelgeflecht als Schlamm- und Sandfänger, sie sind die wahren Pioniere des Landes im Kampf gegen das Meer. Wir finden sie überall am tropischen Gestade, wo der Boden tonreich und die Brandung nicht $\mathrm{zu}$ heftig ist.

Von größter Wichtigkeit ist der Prozeß der Küstenversetzung, wie ihn Philtppson nennt, d. i. der Transport der Zerstörungsprodukte von einer Küstenstelle nach einer anderen, oft weit entfernten. Den Vorgang, der diese Umsetzung bewirkt, bezeichnet man als Küstenströmung, ${ }^{29}$ er ist aber meist nur eine Wirkung schräg auflaufender Wellen, die Gerölle und Sande vor sich herstoßen (von $a$ 
nach $b$ in Fig. 181), während die rücklaufende Welle sie wieder zurückführt (von $b$ nach $c$ in Fig. 181). Auf diese Weise können die Sedimente immer weiter geschoben werden (in Fig. 181 z. B. von $a$ bis $d$ ), wobei sie eine stetige Verkleinerung erleiden. Thoules ${ }^{30}$ hat diesen Vorgang an den Küsten der Bretagne und Normandie beobachtet und gefunden, daß ein Korn auf seiner Zickzackwanderung einen 8000 mal längeren Weg zurücklegt, als wenn es den direkten Weg eingeschlagen hätte. Feineres Material kann aber wohl auch in Küstenströmungen gelangen und von diesen dem Land wieder zugeführt werden, nur kann es nicht weit gelangen, da es im Salzwasser früher zu Boden sinkt als im süBen. Auch die Gezeitenströmungen wirken in dieser Weise; so ist z. B. an der britischen Kanalküste nach WHEELER ${ }^{31}$ nur der Flutstrom die bewegende Kraft, denn die Geschiebe wandern nur im Niveau unmittelbar unterderHochwasserlinie und umgehen nicht die

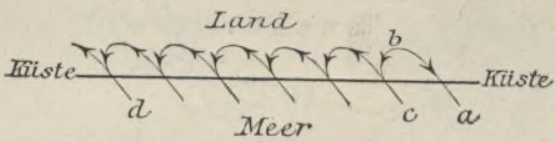

Fig. 181. Küstenversetzung.

Küstenvorsprünge, sondern

bleiben innerhalb der Buchten. Der Flutstrom ist es auch, der die Abrasionsprodukte der Kalkküste von Calvados nach der Seinebucht westlich von Honfleur führt. Der Detritus der spanischen Nordküste wandert an den. Strand der Gironde. Eine vom Golf von Triest nach Westen fließende Strömung fängt die Sedimente auf, die die Flüsse vom Isonzo bis zum Po von den Alpen bringen, und füllt damit die Lagunen aus. Mit den Sinkstoffen des Dnjepr, des Dnjestr und der Donau vergrößert eine Litoralströmung die Küste der Dobrudscha; und in gleicher Weise kommt das Material, das die Rhône den Alpen entführt, der Küste des Languedoc zugute; HoFF gibt ihr Wachstum auf $1-2 \mathrm{~m}$ pro Jahr an.

Die Transportkraft der Wellen und Küstenströmungen sinkt unter das der Last entsprechende $\mathrm{MaB}$, wenn sie mit Strömungen von entgegengesetzter Richtung zusammentreffen, oder durch Reibung auf seichtem Grund. Im ersteren Fall, besonders in der Nähe von Flußmündungen, entstehen häufig Inseln, d. h. freie Anschwemmungen im Gegensatz zu den Ansatzanschwemmungen, zu denen der zweite Fall Veranlassung gibt. Ist der Grund tief genug, so tritt die Strömung bis an die Küste heran, an deren äußerstem Saum die Ablagerung erfolgt. Dies, ist der Strandsaum, wie Philippson ihn nennt. Dagegen bildet sich der Strandwall in einiger Entfernung von der Küste, sei es, daß der Grund zu seicht ist, sei es, daß die Küste ursprünglich eingebuchtet ist, und die darauf 
gerichtete Strömung durch Reibung an den Seitenwänden verhindert wird, das Innerste der Bucht zu erreichen. Unter den verschiedenen Formen der Strandwälle sind namentlich drei besonders auffallend und häufig: die Nehrung, der Haken und der Hals.× Die Danziger Bucht zeigt uns die beiden erstgenannten Bildungen nebeneinander. In sanftem Bogen schwingt sich die Frische Nehrung von der einen Seite der Bucht zur anderen und trennt deren innersten Teil als Strandsee (hier Haff genannt) von dem Meer. Manche Nehrungen

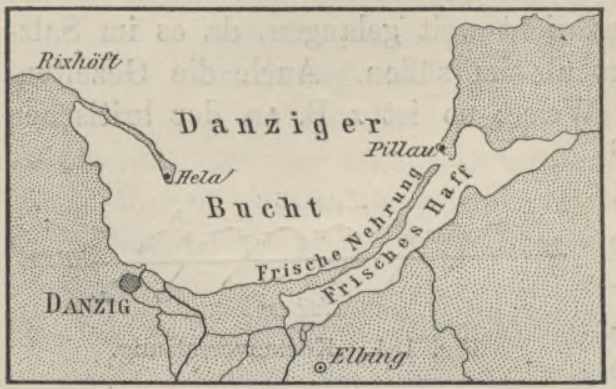

Fig. 182. Nehrung, und Haken in der Danziger Bucht. sind völlig geschlossen, andere hat eine gelegentliche Sturmflut oder der Mensch geöffnet. Ein Haken erstreckt sich im Osten von Rixhöft bis Hela; das sind frei in das Meer hinausragende schmale Landzungen, die von irgend einem festen Punkt an der Küste, oder von einer Insel aus zu wachsen beginnen, zuerst in einer geraden Linie und dann sich hakenförmig umbiegend, genau wie die Strömung, der sie ihre Entstehung verdanken. Es ist wahrscheinlich, daß auch manche Nehrungen als Haken begonnen haben, jedenfalls gibt es zwischen beiden Formen mancherlei Übergänge. Neben der langen, schmalen Gestalt ist ihnen auch die glatte Außenund die zerfranzte Innenseite gemeinsam; jene wird durch die Strömung abgeschnitten, an dieser nagt ein unregelmäßig bewegtes Meer. Gemeinsam ist ihnen auch die allmähliche Erhöhung durch Dünenbildung. In den Strandseen finden die Sedimente der einmündenden Flüsse eine völlig geschützte Ablagerungsstelle; sie füllen sie allmählich aus, ${ }^{32}$ und Seestädten, wie Ravenna, wird dadurch der Lebensnerv abgeschnitten. An der Außenseite des jungen Landes können wieder neue Nehrungen entstehen, und so schreitet die Landbildung siegreich gegen das Meer vor; solch ein Schicksal traf die Hafenstadt Ephesus, deren Trümmer jetzt $8 \mathrm{~km}$ landeinwärts liegen. ${ }^{33}$ Häufig aber wird dieser Prozeß unterbrochen durch Perioden mariner Reaktion, besonders wenn diese durch eine positive Niveauveränderung unterstützt wird. An der Stelle des Mensalehsees im Nildelta standen einst die Städte Tanis und Tennis, und der See

$\times$ Wir halten diese Bezeichnung für zutreffender, als den italienischen Terminus „Tombolo", den GulLIver einführen will. 
von Abukir entstand erst 1784. Dagegen kann eine negative Niveauveränderung das angeschwemmte Land dauernd vor Überflutungen schützen. Inseln werden durch Strandwälle in Halsform landfest gemacht, wie beispielsweise Portland an der südenglischen, Giens an südfranzösischen, oder der Mte. Argentario an der toskanischen Küste (Fig. 183). Aber die Neubildungen, so bedeutend sie auch an manchen Stellen erscheinen mögen, ersetzen nicht den Verlust; das beweist die große Ausdehnung der submarinen Küstenablagerungen von denen auf S. 270 die Rede war. Das Ringen zwischen Meer und Land endet stets zuungunsten des letzteren.

GULLIVER ${ }^{1}$ hat den Versuch unternommen, die Zyklentheorie auch auf die Küsten anzuwenden. Grundsätzlich ist dagegen nichts einzuwenden, denn auch die Küstenformen sind Entwicklungsprodukte, und jede Entwicklung ist begrenzt, jede verläuft zyklisch. Aber die Küstenerosion ist ein ungleich verwickelteres Problem als die Talerosion. Diese strebt unter allen Umständen die Gefällskurve an, und danach läßt sich das Reifestadium bemessen, aber was ist die Endform der Küstenerosion? Man kann höchstens die Abrundung aller eckigen Formen und die Ausfüllung aller abgetrennten Meeresteile nennen, aber innerhalb dieser Grenze ist noch eine große Mannigfaltigkeit von Einzelformen möglich. Das fließende Wasser

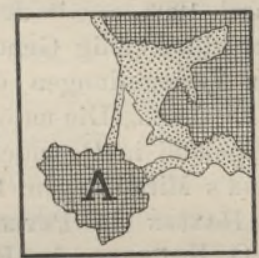

Fig. 183. Hals des Mte.Argentario (A) in 1:1 Mill.

Berge gewürfelt, Alluvialebene punktiert. ist eine einfache Größe, die Energieäußerungen des Meeres sind komplizierter Natur. Die Katastrophen, die die Küste betreffen, sind nachhaltiger und folgenschwerer als die, die den normalen Entwicklungsgang eines Tales unterbrechen können, abgesehen von den geologischen Klimaänderungen. Die säkularen Niveauveränderungen machen sich allerdings auch in den Tälern des Binnenlandes fühlbar, aber erst spät und ganz allmählich, während das Gestade unmittelbar davon betroffen wird. Das alles erklärt zur Genüge, daß es, wenigstens derzeit, noch aussichtslos ist, sämtliche Küstenformen in das Schema einer Altersreihe einzugliedern.

Literaturnachweise. ${ }^{1}$ A. Phimppson, Über Typen der Küstenformen, in der v. Richthofen-Festschrift 1893. F. P. Gulliver, zit. S. 571. - ${ }^{2}$ W. Grosse, Die Entwicklung des Küstenbegriffs; Leipzig 1904. - ${ }^{3}$ G. K. Grcbert, The Topographic Features of Lake Shores, im Jahresbericht des U. S. Geological Survey $1883-84 .-{ }^{4}$ G. Hartmann, Der EinfluB des Treibeises auf die Bodengestalt der Polargebiete, in den Beiträgen zur Geographie des festen Wassers; Leipzig 1891. - ${ }^{5} \mathrm{~J}$. JoLY, in den Comptes rendus des VIII. internationalen Geologenkongresses, S. 774. - ${ }^{6}$ W. v. ZAHN, Die zerstörende Arbeit des Meeres an Steilküsten, in den Mitteilungen der Geographischen Gesellschaft in Hamburg, 
Bd. XXIV, 1909. Vgl, dazu die Bemerkungen von E. Werth in der Zeitschrift der Gesellschaft für Erdkunde, Berlin 1911, S. 35. — ${ }^{7}$ Rich. Lenmann, Zur Strandlinienfrage, in der Zeitschrift für die gesamten Naturwissenschaften 1880. 8 Rich. Lenmann, Neue Beiträge zur Kenntnis der ehemaligen Strandlinien, ebendas. 1881. $-{ }^{9}$ Tн. Studer, Geologisehe Beobachtungen auf Kerguelensland, in der Zeitschrift der Deutschen Geologischen Gesellschaft 1878. - ${ }^{10}$ The Lost Land of England, im Strand Magazine 1901, auszugsweise in La Géographie 1903, Bd. VII, S. 117. - ${ }^{11}$ E. Gernitz, im Zentralblatt für Mineralogie usw., 1903, S. 414. - ${ }^{12}$ H. REusch, im Neuen Jahrbuch für Mineralogie usw. 1879, S. $244 .-{ }^{13}$ G. Andersson, im Ymer 1900, S. 423. - ${ }^{14}$ Theob. Fischer, in Petermann's Mitteilungen 1887, S. 1, und in der Zeitschrift der Gesellschaft für Erdkunde 1906, S. 554. - ${ }^{15}$ H. Reusch, The Norwegian Coast Plain, im Journal of Geology, 1894. J. H. L. Vogt, Sendre Helgeland; Kristiania 1900 (Norges Geologiske Undersögelse, Nr. 29). - ${ }^{16}$ J. Kuyper, in Petermann's Mitteilungen 1876, S. 284, und in der Zeitschrift für wissenschaftliche Geographie 1883, Bd. IV, S. 105, mit lehrreicher Karte. - ${ }^{17}$ G. Sello, Der Jadebusen; Varel 1903. - ${ }^{18}$ J. C. RAMAer, in der Tijdschrift van het K. Nederlandseh Aardrijkskundig Genootschap 1909, Bd. XXXVI, S. 1. - ${ }^{19}$ K. Kretschmer; in den Verhandlungen der Gesellschaft für Erdkunde; Berlin 1901, S. 172. ${ }^{20}$ E. Trтté, Die natürlichen Veränderungen Helgolands; Leipzig 1894. Ввонм, Helgoland in Geschichte und Sage, Cuxhayen 1907. - ${ }^{21}$ R. Hansen, in PeterManN's Mitteilungen 1893, S. 177. - ${ }^{22}$ Vgl. die kritischen Bemerkungen von R. Hansen in Petermann's Mitteilungen 1902, Literaturbericht Nr. 51. 23 O. Krümmes, in Petermans's Mitteilungen 1889, S. 129. - 24 J. Girard, Evolution comparée des sables; Paris 1903. - ${ }^{25}$ Lrerad, Der Dünendurchbruch der Weichsel bei Neufähr von 1840-90, in der Zeitschrift für Bauwesen, 1892, Bd. XLII. Die 15 Karten dieser Abhandlung gehören zu den lehrreichsten Anschauungsmitteln der Küstengeographịe. — ${ }^{26}$ Nach der Tijdschrift in Petermann's Mitteilungen 1899, S. 40. Die Mittelwerte sind für unseren Text mit Berücksichtigung der Längen berechnet worden. - ${ }^{27}$ H. L. Marindin, in den Reports of the U. S. Coast and Geodetic Survey für 1891/92 (Bd. II, S. 243) und für 1895/96 (Appendix 8). - ${ }^{28}$ Vgl. R. HANsen, Küstenänderungen in Süddithmarschen im 19. Jahrh., in Petermans's Mitteilungen 1905. - ${ }^{29} \mathrm{~A}$. RüHL, Beiträge zur Kenntnis der morphologischen Wirksamkeit der Meeresströmungen (Heft 8 der Veröffentlichungen des Instituts für Meereskunde; Berlin 1906); reichhaltige Literaturangaben. - ${ }^{\text {so }} \mathrm{J}$. Thоuцet, in den Comptes rendus de l'Académie des Sciences, Paris 1907, Bd. CXLIV, S. 938. - ${ }^{31}$ W. H. Wheeler, im Nature, 1900, Bd. LXII, S. 400. - ${ }^{32}$ Vgl. Сн. Duffart, Nouvelle preuve de l'existence des baies ouvertes sur le Littoral Gascon pendant les temps quartairs, im Bulletin de Géographie historique et descriptive, 1902. — ${ }^{33}$ A. Grund, Bericht über physiographische Untersuchungen im Deltagebiet des kleinen Mäander, in den Sitzungsberichten der Wiener Akademie der Wissenschaften, math.-naturwiss. Klasse, Bd. CXV, 1906.

\section{Die geographische Verbreitung der exogenen Wirkungen.}

\section{Bodentypen. Nach dem Schema v. Richthofen's hat RoHRBACH} in Berghaus' Physikalischem Atlas eine Bodenkarte der festen Erdoberfläche entworfen, und $\vee$. Truso hat danach den prozentischen Anteil der Bodentypen nach Kontinenten und Breitenzonen planimetrisch bestimmt. ${ }^{1}$ 
Etwas abweichend von der dort beliebten Einteilung unterscheiden wir vier Hauptbodentypen: Eis-, Fels-, Wechsel- und Lockerboden. Den Korallenboden können wir nicht als einen selbständigen Typus gelten lassen, da er sich ungezwungen dem Lockerboden einreiht.

Das Eis tritt bodenbildend nur in den Regionen ewigen Schnees auf. Die oben genannten Autoren haben es nicht berücksichtigt, wir können aber nach einer Schätzung v. TruLo's sein Areal auf etwa 2 Prozent der Festlandsoberfläche veranschlagen, wobei wir von dem hypothetischen Südpolarkontinent gänzlich absehen. Das einzige bekannte Land, wo der Eisboden nach allen Dimensionen eine große Mächtigkeit erreicht, ist Grönland.

Da das feste Gestein überall den zersetzenden Kräften der Verwitterung, des Frostes und der Insolation unterliegt, so kann Felsboden nur dort zutage treten, wo die Denudation die Zersetzung überflügelt. Je nach der Denudationsart haben wir marinen, fluviatilen, glazialen und äolischen Felsboden zu unterscheiden; die beiden ersten Untertypen werden auf RoHRBACH's Karte nicht ausgeschieden, weil der Maßstab zu klein ist; die beiden anderen nehmen 11 Prozent des Festlandes ein, und zwar 6 Prozent der äolische, 5 Prozent der glaziale Felsboden.

Der äolische Felsboden ist der Wüste eigentümlich, sein Hauptverbreitungsgebiet ist die Sahara, so daß er nicht weniger als 14 Prozent von Afrika einnimmt. Der glaziale Felsboden ist, wenn man von den Gletscherregionen der Hochgebirge aller Zonen absieht, auf die gegenwärtigen und diluvialen Binneneislandschaften beschränkt. Im weiten Umkreis umgibt er die Hudsonbai, dasjenige Gebiet, wo auch heute noch die kalte Zone in unserem thermischen Sinn (s. S. 93) am weitesten äquatorwärts herabsteigt. Ein volles Viertel des nordamerikanischen Festlandes ist glazialer Felsboden. Freilich dürfen wir dabei nicht vergessen, daß der Kartenzeichner rein schematisch verfahren mußte. Wenn hier die Riesenfläche von etwa 5 Mill. qkm (das halbe Europa!) mit der Farbe der glazialen Denudation bedeckt wurde, so ist damit nicht gesagt, daß jeder andere Bodentypus ausgeschlossen sei. Entbehren ja doch jene Gegenden keineswegs gänzlich des Waldwuchses, und dieser setzt eine Bodenkrume voraus. Die Farbe soll nur das Vorherrschen eines bestimmten Bodentypus andeuten.

Es gibt aber Gegenden, wo keine Bodentypen vorherrschen, oder wo nach v. RichтноFEN's Ausdruck ein „Ebenmaß von Zerstörung und Fortschaffung" besteht. Als solche führt uns RoHRBACH's Karte die höheren Gebirge aller Zonen vor. Das geforderte 
„Ebenmaß“ besteht aber hier nicht in dem Sinn, daß sich an jedem einzelnen Punkt die einander entgegenwirkenden Kräfte das Gleichgewicht halten; vielmehr finden wir da eine Reihe von Bodentypen vertreten, aber in buntem Wechsel, so daß keiner auf weite Strecken das Übergewicht erhält. Daher nennen wir diesen Typus den Wechselboden. v. Tisuo hat dafür ein Areal von 4 Prozent berechnet. Relativ am meisten vertreten finden wir ihn in Südamerika (Andes) und in Europa (alpiner Gürtel, Mittelgebirge).

Übersicht der Verteilung der Bodentypen nach Erdteilen und Breitengürteln nach v. Truso (in Prozenten der betreffenden Erdteile bzw. Breitenzonen).

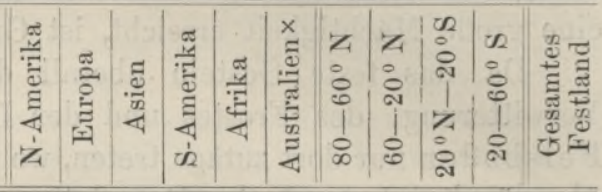

\section{Eisboden}

\section{Felsboden}

1. Dureh glaziale Denudation

2. Dureh äolische Denudation

\section{Wechselboden}

\section{Lockerboden:}

1. Eluvialboden.

a) Lehm

b) Laterit

e) Gebirgssehutt

2. Aufschüttungsboden

a) Marine Aufschüttung $\times x$

b) Gletsehersehutt .

c) Alluvionen

d) Äolische Aufschüttung:

a) Flugsand .

$\beta$ ) Feinerdige Ablagerung

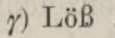

e) Vulkanische Aufschüttung nicht berücksichtigt

\begin{tabular}{|c|c|c|c|c|c|c|c|c|c|c|}
\hline & 9 & 7 & 1 & 14 & 2 & 24 & 16 & 1 & \pm & \\
\hline & 9 & 0 & 1 & - & - & 24 & 5 & 0 & 1 & \\
\hline & - & 7 & - & 14 & 2 & - & 11 & 1 & 3 & \\
\hline & 8 & 3 & 9 & 3 & 0 & 0 & 5 & 4 & 6 & \\
\hline & 22 & 54 & 45 & 50 & 31 & 52 & 31 & 63 & 27 & \\
\hline & 22 & 37 & 2 & 1 & 15 & 52 & 24 & - & 12 & \\
\hline & - & 16 & 43 & 49 & 16 & - & 6 & 63 & 15 & \\
\hline & - & 1 & -1 & - & - & - & 1 & - & - & \\
\hline & 61 & 36 & 45 & 33 & 67 & 24 & 48 & 32 & 63 & \\
\hline & - & 0 & 0 & 0 & 5 & -1 & - & 1 & 1 & \\
\hline & 36 & 1 & 4 & - & - & 23 & 9 & - & 5 & \\
\hline & 5 & 3 & 27 & 2 & - & - & 3 & 12 & 3 & \\
\hline & 0 & 8 & 1 & 13 & 19 & 0 & 7 & 5 & 20 & \\
\hline & 13 & 20 & 1 & 18 & 41 & - & 23 & 13 & 20 & \\
\hline & 7 & 3 & 10 & - & 0 & - & 5 & - & 12 & \\
\hline & & & 2 & 0 & & & & 1 & 2 & \\
\hline
\end{tabular}

Mehr als vier Fünftel des gesamten Festlandes ist mit Schutt, Geröll, Kies, Sand, Erde bedeckt. Alles das fassen wir unter dem Namen Lockerboden zusammen.

Genetisch zerfällt er in zwei Hauptunterabteilungen. Die Decke des Felsgerüstes ist entweder an Ort und Stelle durch kumulative Verwitterung, Frostwirkung und Insolation entstanden und blieb liegen, weil die denudierenden Mächte ihr nicht gewachsen waren -

$\times \times$ Mit Hinzurechnung des Korallenbodens. 
das ist der Eluvialboden - , oder sie ist von anderswo herübergeführt - das ist der Aufschüttungsboden. In die genannten vier Fünftel teilen sich diese beiden Böden nach der Karte ungefähr zu gleichen Hälften; es mag aber fraglich bleiben, ob der Aufschüttungsboden dabei nicht zu kurz gekommen ist.

Unter den Eluvialbildungen sind Lehm und Laterit die wichtigsten; jener ist-den mittleren und höheren Breiten, dieser den Tropen eigentümlich. Der größte Verbreitungsbezirk des Lehms ist Sibirien; auch das südliche China, das ostaustralische Gebirge, die Vereinigten Staaten östlich vom Mississippi treten als Lehmböden augenfälliger hervor, als uns begründet erscheint. Laterit bedeckt Mexico und Zentralamerika, die kristallinischen Massengebirge im östlichen Südamerika, das äquatoriale Afrika, Madagaskar, Ostindien; mit einem Wort: ein volles Viertel des ganzen Festlandes.

$\mathrm{Zu}$ den Eluvialbildungen ist ferner auch der Gebirgsschutt abflußloser Becken zu zählen. Mächtige Schutthalden umsäumen hier die Gebirge, ja in manchen Gegenden, wie z. B. in Persien, hüllt sie ein Schuttmantel bis an den Kamm ein. Die Karte verzeichnet diesen Bodentypus nur in Zentralasien. Im strengen Sinn des Wortes muß auch die Hammada dazu gerechnet werden.

Aufschüttung lockerer Massen kann einerseits durch die denudierenden Kräfte, anderseits durch vulkanische Ausbrüche erfolgen. Den letzteren wird nur eine Fläche von 1 Prozent zuerkannt. Von den Ablagerungen der ersten Kategorie kommen die marinen auf RoHRBaCH's Karte so wenig zur Geltung, daß sie auf v. TrLlo's Liste nicht einmal 1 Prozent erreichen. ${ }^{x}$ Auch die FluB- und Seeanschwemmungen, auf die man gewöhnlich die Bezeichnung Alluvium anwendet, sind nach der Karte weniger verbreitet,'als man erwárten sollte. Ihre Hauptdomäne ist Südamerika, die ungeheuere Ebene des Amazonasgebietes. Es ist ein interessantes, aber vielleicht anfechtbares Ergebnis der Karte, daß das Gletscherschuttland mehr Raum einnimmt als die Alluvionen. Und doch ist es nur auf wenige Gegenden beschränkt. Moderne Glazialablagerungen finden sich nur dort, wo Gletscher sich zurückziehen, und das sind verschwindend kleine Flächen. Alle andern stammen aus der Eiszeit; wieder ein Beweis dafür, welch' gewaltigen Einfluß jene Klimaepoche auf die gegenwärtige Gestaltung der Erdoberfläche ausübt. In Nordamerika sind 23, in Europa sogar 36 Prozent des Areals mit Glazialablagerungen bedeckt. Zum Unterschied von anderen vgl. S. 451 .

$\times$ Sicher ist z. B. Nordrußland als marine Ablagerung zu betrachten, 
Aufschüttungen (die Dünen ausgenommen) verebnen sie nicht immer, sondern schaffen auch Niveauunterschiede. KeILHACK ${ }^{2}$ unterscheidet im Gebiet der norddeutschen Vereisung drei Landschaftsformen: die ausgedehnte horizontale oder schwach wellenförmige Ebene (Grundmoränenlandschaft), die Drumlin- und die Moränenlandschaft (im engeren Sinn oder Endmoränenlandschaft), und im großen und ganzen dürfte sich diese Einteilung auch auf den ganzen Bereich der nord- und mitteleuropäischen und der nordamerikanischen Diluvialgletscher anwenden lassen. Die Drumlins ${ }^{3}$ sind gesellig auftretende, mehr oder wenig elliptisch gestaltete, niedere und flachgeböschte Hügel, die sich durch einen ausgesprochenen Parallelismus auszeichnen, indem ihre Längsachsen nachweisbar in die Stromrichtung der alten Gletscher fallen. Dagegen besteht die Moränenlandschaft aus unregelmäßig verteilten Hügeln und Hügelwällen, die bald durch enge Schluchten, bald durch gröBere Depressionen mit Seen und Mooren getrennt sind und ein außerordentlich wechselvolles Relief bilden. Man kann auch noch den allerdings weniger hervortretenden Typus der Kameslandschaft hinzufügen, der mit der Moränenlandschaft die regellose Anordnung der Hügel teilt, aber sanftere Formen zeigt und in Norddeutschland wegen der Durchlässigkeit des Bodens nicht durch Seen belebt wird. Bei der Bildung der Kames, wie auch bei der der langgestreckten, linearen Åsaroder Eskerrücken war das fließende Wasser in hervorragender Weise beteiligt, denn beide bestehen aus geschichteten Sanden und Granden. Nach außen schließen die wallartigen, oft noch vorzüglich erhaltenen Endmoränen die Grundmoränenlandschaften ab, dann folgen die weitgedehnten einförmigen Sandebenen. Im Gegensatz zu dem nördlichen Alpenvorland, wo die Grundmoränenlandschaften typisch entwickelt sind, umgeben den Austritt der südalpinen Täler große Endmoränenwälle in konzentrischem Halbbogen. Das Südende des Gardasees wird von einem solchen Moränen-Amphitheater umrahmt, dem die in den österreichisch-italienischen Kriegen viel umkämpften Höhen von Custozza und Solferino angehören; noch schöner ist der Bogen bei Ivrea, denn hier steigen die Hügel bis zu $330 \mathrm{~m}$ über die Ebene empor.

Überraschend ist die ungeheuere Ausdehnung der äolischen Ablagerungen, zu denen allerdings, wie wir an anderer Stelle bemerkt haben, manches gezählt sein mag, was nicht dazu gehört. Das gilt weniger von den Sandwüsten (7 Prozent des Festlandes), als von den feinerdigen Ablagerungen, die mit 17 Prozent, und vom LöB, der mit 4 Prozent vertreten ist. Die beiden ersteren Arten charakterisieren vor allem die Alte Welt, wo sie eine breite Zone 
von Zentralasien bis zur Sahara einnehmen. Beweglicher Sand bedeckt Flächen, die zusammen so groß wie Rußland und Mitteleuropa sind, und Staub ein Areal von der anderthalbfachen GröBe unseres Erdteiles. Australien ist mit 60 Prozent seiner Fläche ein äolisches Ablagerungsgebiet. Dagegen übertrifft in bezug auf den LöB Amerika die Ostfeste nicht bloß relativ, sondern auch absolut. Mit den Pampäs und dem westlichen Mississippigebiet kann sich nur das chinesische Lößland an Ausdehnung messen.

Faziesgebiete. ${ }^{4}$ Die endogenen Kräfte sind überall die gleichen; ob sie in ihren Äußerungen einem zeitlichen Wandel unterworfen sind, mag noch dahingestellt bleiben. Die exogenen Kräfte variieren dagegen nach bestimmten, zum Teil schon klar erkannten Gesetzen örtlich wie zeitlich. Es ergeben sich daraus für die Umgestaltung des Bodens verschiedene Faziesgebiete, von denen nur die fundamentalen hier kurz skizziert werden mögen.

Zunächst tritt uns die Küstenzone entgegen, und zwar die Küstenzone aller Breiten, obwohl klimatische Unterschiede auch hier zu weiterer Einteilung Veranlassung geben können; jedenfalls steht die polare Küste unter etwas anderen Bedingungen als die eisloser Gewässer. Das Charakteristische ist das Vorhandensein von Agentien, die dem übrigen Festland gänzlich fehlen: der Brandung und der Gezeiten. Abrasion und marine Anschwemmung sind Prozesse, die sich nur hier vollziehen. Daneben sind nur noch die Verwitterung, die Deltaablagerung und die Dünenbildung durch den Wind von besonders formgebender Bedeutung.

Das Festland außerhalb der Küstenzone steht vor allem unter der Herrschaft des Klimas, von dem wir wissen, daß es örtlich und zeitlich wechselt. Doch kommen hier nur die langen Klimaperioden in Betracht, durch die beträchtliche, in ihren Wirkungen weit in die folgende Periode hinübergreifende Verschiebungen der Faziesgebiete hervorgerufen werden. Wir können in dieser Beziehung geradezu Dauer- und Wechselgebiete unterscheiden. Beide haben seit dem Beginn der Quartärzeit Klimaänderungen durchgemacht, aber in den ersteren blieben die geologischen Oberflächenprozesse im wesentlichen immer die gleichen und erfuhren nur eine zeitweise Abschwächung oder Steigerung, während sie in den Wechselgebieten totale Umwandlungen erlitten. Ein Wechselgebiet ist z. B. die norddeutsche Ebene, denn sie gehörte einst der glazialen und gehört jetzt der fluviatilen Fazies an, aber Nordsumatra ist es nicht, obwohl es nach der Ansicht von Vouz in der Diluvialzeit stärkere Niederschläge empfing, denn der Faziescharakter hat sich nicht geändert. In den Wechselgebieten mischen sich 
alte und neue Formen; je mehr man sich ihrer Peripherie nähert, desto mehr treten die Reliktenformen zurück. Am längsten scheinen sie sich unter den Kleinformen erhalten zu haben, besonders von gewissen Sandsteinen, deren auffallende Verwitterungs- und Korrosionserscheinungen OBST ${ }^{5}$ und $\mathrm{v}$. ŁozIŃsKI ${ }^{6}$ dem trockenen, windreichen und rauhen Klima am Rand des diluvialen Inlandeises zuschreiben. Die Kanzel bei Pirmasens ist eine so typische Pilzform, wie sie unter den gegenwärtigen klimatischen Verhältnissen der Rheinpfalz nicht entstanden sein kann. ${ }^{7}$

Als erstes Faziesgebiet haben wir die Polarländer zu nennen, und zwar im Sinn unserer Temperaturzonen (s. Karte VIII). Die Verwitterung erfolgt hier hauptsächlich durch Spaltenfrost, und wie tatkräftig sie wirkt, zeigt der mächtige Gehängeschutt in Grönland und Baffinland, der sicher erst nach der Eiszeit entstanden ist. Auch die Erosion des fließenden Wassers darf man nicht zu gering anschlagen; sie ist. zwar nur auf den Sommer beschränkt, aber in dieser Jahreszeit wird, wie $\mathrm{TARR}^{8}$ bemerkt, alles Regen- und Schmelzwasser den Flüssen zugeführt, weil der Boden an der Oberfläche mit Wasser gesättigt und in der Tiefe gefroren ist. Die vorherrschenden Bodentypen sind Eisboden, glazialer Felsboden und Gebirgs- und Gletscherschutt.

Die Regengebiete der gemäßigten und warmen Zone, soweit sie nicht früher von Eis bedeckt waren, haben miteinander gemein, daß Wasser und Pflanzen überall an der Verwitterung des Gesteins arbeiten. Felsboden tritt daher nicht mehr auf weite Erstreckung zutage und wird weit mehr durch Eluvialbildungen als durch Aufschüttungsmassen verhüllt. In zwei Punkten unterscheiden sich aber die beiden Zonen sehr wesentlich: 1. der Eluvialboden ist in der gemäßigten Zone Lehm, in der warmen Bunterde und Laterit; 2. in der warmen Zone sind, entsprechend dem größeren Regenreichtum, die fluviatilen Anschwemmungen beträchtlich ausgedehnter als in der 'gemäßigten. Wir nennen diese Fazies die fluviatile.

Zwischen die polare und die gemäßigte Zone schieben sich die glazialen Übergangsgebiete ein, die aus der Eiszeit noch glazialen Felsboden und Gletscherschuttland in die gegenwärtige Klimaperiode herübergerettet haben: Typen, die jetzt freilich der Verwitterung, Verwaschung und Zuschüttung allmählich anheimfallen.

Ein scharf gezeichnetes Faziesgebiet ist die Wüste. ${ }^{9}$ Auch hier fehlt die Pflanzendecke wie im Polargürtel, aber es fehlt auch das Eis; fließendes Wasser tritt abseits von den wenigen Wüstenströmen nur sporadisch auf, und die Temperaturverbältnisse sind 
andere. Die wichtigste destruktive Kraft ist hier die Insolation, die wichtigste denudierende Kraft der Wind. Aber nicht die einzige, denn gelegentlich kommt es auch in der Wüste zu heftigen Niederschlägen, und nach den Beobachtungen von PeNcK ${ }^{10}$ in der Gebirgswüste des nordamerikanischen Westens gewinnt das fließende und spülende Wasser sogar éine größere Bedeutung als der Wind. Alluvionen sind nur die Ablagerungen der ephemeren Seen und Flüsse, aus denen die Tonwüste ${ }^{\times}$hervorgeht; die vorherrschenden Bodentypen sind aber, soweit sie der Gegenwart angehören, äolischer Felsboden, Gebirgsschutt und Flugsand. Wir betonen ausdrücklich: soweit sie der Gegenwart angehören, weil WALTHER ${ }^{11}$ in neuerer Zeit die Hypothese aufgestellt hat, daß die Wüsten seit ihrer Trockenlegung Wüste gewesen seien, und daß man ihre Bodenarten wie ihre Oberflächenformen auf diejenigen Kräfte zurückführen müsse, die wir heute noch daselbst tätig sehen. Die entgegengesetzte Ansicht erblickt in der Sahara eine junge Wüste, die sich einst eines viel feuchteren Klimas erfreut und noch Dokumente jener glücklicheren Periode bewahrt hat. Es sind dies zunächst die Täler und die gewaltigen Schottermassen, zu deren Erklärung uns die heute vorhandenen Wasserkräfte, selbst die gelegentlichen Wolkenbrüche nicht auszureichen scheinen. Überdies besitzen wir auch positive Beweise für einen Klimawechsel. Am weitesten fortgeschritten ist die geologische Forschung in der algerischen und tunesischen Sahara. ${ }^{12}$ Vielleicht schon seit der Kreidezeit, jedenfalls aber seit der jüngsten Eozänperiode ist dieses Wüstengebiet Festland, die jüngeren Schichten sind $S$ üßwasserablagerungen untermiozänen, pliozänen und quartären Alters. Die ersteren treten nur an wenigen Stellen im Norden zutage, um so ausgedehnter sind aber die beiden anderen. Sie erstrecken sich in einer Breite von ungefähr $350 \mathrm{~km}$ von Biskra bis El-Biodh (700 km) und senden noch Ausläufer einerseits bis in die Kleine Syrte, anderseits bis gegen Figig. Erinnern wir uns daran, daß genau zur Eiszeit auch in dem trockenen Landbecken der westlichen Vereinigten Staaten gewaltige Seen existierten, so werden wir nicht fehlgreifen, wenn wir auch dem Quartärsee der Sahara ein glaziales Alter zuweisen. Aber auch nach seinem Verschwinden blieb das Klima noch feucht genug, um dauernde Flüsse zu ernähren, und diese Flüsse schufen jene großen, in die Süßwasserbildungen eingeschnittenen Täler: die Wadis Mya und Igharghar, die sich im Wadi Rirh vereinigen, Wadi Suf, Wadi Djedi.

x Man nennt diese Lehmflächen in der Turkmenenwüste Takyr, in Zentralasien Schala, in Afrika Sebcha. 
Die Anordnung dieser Täler, die gegen den tiefsten Punkt, das Schott Melghir, konvergieren, die Verzweigung nach oben und die häufigen Serpentinen sprechen deutlich für fluviatilen Ursprung. Das Längsprofil hat freilich durch die Deflation eine Umwandlung erfahren; ein ununterbrochener Talweg ist nicht mehr vorhanden, sondern nur mehr eine stufenförmige Aufeinanderfolge länglicher Becken, die durch Schwellen getrennt sind. Diese Umgestaltung gehört einer Zeit an, da die Flüsse vertrockneten und der Wind Alleinherrscher wurde, und nun gehen alle Vertiefungen der allmählichen Zuschüttung durch Flugsand entgegen.

Diese Ergebnisse sind durch Roluand völlig sichergestellt, und durch die Untersuchungen BLANCKENHORN's ${ }^{13}$ und BuRMESTER's ${ }^{14}$ in Ägypten bestätigt worden. Letzterer schildert uns in anschaulicher Weise, wie zuerst in den kleinen Nebentälern und allmählich auch in den Hauptwadis die Wüstenfazies durch Bildung von Schutzkrusten die fluviatile verdrängt. Umwandlungen feuchter Landstriche in trockene sind auch sonst vielfach bekannt geworden. $\mathrm{Zu}$ den amerikanischen Beispielen, deren wir mehrfach gedachten, gesellen sich u. a. auch Südafrika und das große aralkaspische Becken.

Kehren wir wieder zu den Faziesgebieten zurück. An die Wüsten schließen sich als Übergangsform zu den feuchten Gebieten die Steppen an. Der äolische Denudationsboden tritt zurück, der äolische Aufschüttungsboden herrscht aber noch vor. Nur ist es nicht mehr Flugsand, sondern Tonstaub, der die felsige Unterlage verhüllt. In der algerischen Steppe fand indes Passarge ${ }^{15}$ die $\mathrm{Ab}$ tragung durch Flächenspülung größer als die Aufschüttung. Wir müssen übrigens nochmals darauf aufmerksam machen, daß über die Deutung mancher hierher gehöriger Gebilde Zweifel bestehen, wie dasselbe ja auch von den LöBgebieten gilt. Ist RiснтноғEN's Theorie allgemein gültig, so gehören auch die Lößlandschaften zu den Wechselgebieten, nur da $\beta$ die Klimaänderung sich hier im entgegengesetzten Sinn wie in den Wüsten vollzog.

Gebirgsfazies. Die Fazies des Karstgebirges, die durch die unterirdische Erosion gekennzeichnet wird, haben wir bereits ausführlich besprochen, auch des Schuttgebirges in regenarmen Gegenden auf S. 603 bereits flüchtig gedacht. Niedere Gebirge hüllen sich hier ganz in Schutt ein, im höheren Gebirge Zentralasiens lassen sich aber, wie OBRUTsCHEw anschaulich schildert, deutlich zwei Zonen unterscheiden: über einen breiten, sanft abfallenden Sockel, die Region der Schuttanhäufung, erheben sich wilde, zackige Gipfel: die nackte Verwitterungsregion. Im feuchteren Klima ist die Höhe noch maßgebender für die Gebirgsformen, und wenn wir 
von Hoch- und Mittelgebirge sprechen, so denken wir dabei nicht bloß an hypsometrische, sondern auch an Faziesunterschiede. ${ }^{16}$ Indes empfiehlt es sich, um allen Mißverständnissen vorzubeugen, die Ausdrücke fluviatile und glaziale Fazies zu gebrauchen, denn entscheidend ist ja, ob das Wasser in flüssiger oder in fester Form auftritt. Soweit der Regen dauernd fließendes Wasser ernährt, soweit ist das Gebirge in seinem natürlichen Zustand auch mit Vegetation bekleidet, und soweit herrschen auch abgerundete Formen. Zwischen die obere Grenze der zusammenhängenden Pflanzendecke und die Schneelinie schiebt sich eine Trümmerregion ein, in der Wildbäche, Lawinen und Steinschläge an der Modellierung arbeiten. Je trockener das Klima ist, desto breiter ist diese Region, wie z. B. in den Apdes von Südamerika oder in den Gebirgen Zentralasiens. Jenseits der Schneelinie sind die Bedingungen wesentlich andere. Hier herrschen die scharfen Formen, die dachähnlichen Grate, die schroffen Gipfel in ihren mannigfaltigen Verwitterungsgestalten, denn die schnelle Abfuhr des Schuttes legt immer wieder neue Felstlächen bloß; und nur dort, wo dauernde Verfirnung seit Beginn der Eiszeit auch die höchsten Höhen vor dem zerstörenden Einfluß greller Temperaturwechsel geschützt hat, haben sich Massive, wie der Montblanc und der Monterosa, erhalten. Ein charakteristisches, wenn auch nicht allgemein verbreitetes Merkmal dieser Glazialfazies ist das reihenweise Auftreten von Karen.

In den Alpen fehlt die Trümmerregion, über der Waldgrenze beginnt sofort die glaziale Fazies. Unterhalb der heutigen Schneelinie ist sie eine Hinterlassenschaft der Eiszeit, und manche Teile der Alpen, wie z. B. die Niedern Tauern, haben dadurch ein Gepräge erhalten, das dem gegenwärtigen Klima nicht entspricht. Aber schon beginnt sich dieses geltend zu machen. Die Vegetation dringt siegreich in die Höhe vor, rundet die Formen und befestigt den Schutt, und die Kare werden allmählich in das Entwässerungssystem einbezogen. Im deutschen Mittelgebirge ist dieser Prozeß schon sehr weit vorgeschritten. Auch hier hatte die Eiszeit Kare geschaffen - REgeLmann zählt in den Vogesen 75, im südlichen Schwarzwald 136, im nördlichen 101 -, aber trotzdem hat die fluviatile Fazies schon völlig die glaziale verdrängt. In tropischen Hochgebirgen, wie im Himalaya, oder in solchen, in denen das eiszeitliche Gletscherphänomen schwach entwickelt war, wie am Pikes Peak im nordamerikanischen Felsengebirge, liegt die obere Grenze der fluviatilen Fazies sehr hoch, während sie z. B. auf den Lofoten schon in geringer Seehöhe den glazialen Formen Platz macht. Aus diesem Grund haben wir hier von den üblichen Bezeichnungen 
Mittel- und Hochgebirge, die sich nur in unseren Gegenden mit den Faziesunterschieden völlig decken, Abstand genommen.

Literaturnachweise. ${ }^{1}$ A. v. Tillo in Petermann's Mitteilungen 1893, S. 17. $-{ }^{2}$ K. KerLнack, Die Drumlinlandsehaft in Norddeutschland, im Jahrbuch der preußisehen geologisehen Landesanstalt 1896. Vorzüglich zur Orientierung geeignet ist F. W AнNSCHAFFE, Die Ursachen der Oberflächengestaltung des norddeutschen Flachlandes, 2. Aufl.; Stuttgart 1901. - ${ }^{3}$ J. FrüH, Die Drumlinlandschaft, im Jahresberieht der St. Gallensehen naturwissensehaftlichen Gesellschaft für 1894/95. - ${ }^{4}$ J. WALTHER, Lithogenesis zit. S. 375. ${ }^{5}$ E. Овsт, Die Oberflächengestaltung der schlesisch-böhmischen Kreideablagerungen, in den Mitteilungen der Geographischen Gesellschaft in Hamburg, Bd. XXIV, 1909. - ${ }^{6}$ W. v. Łozı́sski, Über die mechanische Verwitterung der Sandsteine im gemäBigten Klima, im Bulletin de l'Académie des Sciences de Cracovie, 1909, - ${ }^{7} \mathrm{~S}$. die Abbildung im Wanderbüchlein des PfälzerwaldVereins 1911 (Abhandlung von D. HäвERLE). $-{ }^{8}$ R. S. TARR, im American Geologist 1897, Bd. XIX, S. 131. $-{ }^{9}$ Ein getreues Bild der Wüstendenudation gibt zum ersten Male G. Schweinfurth's Karte der Umgebung von Heluan $(1: 30000)$; Berlin 1899. - ${ }^{10}$ A. Penck, zit. S. $582 .-{ }^{11}$ J. Walther, zit. S. $483 .-{ }^{12}$ A. Chorsy, zit. S. $583 .-{ }^{13}$ M. BlanckenhorN, zit. S. $52 .-$

${ }^{14} \mathrm{H}$. Burmester, Einige Beobachtungen über tropische Schutzkrusten und Wadibildungen im Globus 1910, Bd. XCVIII. - ${ }^{15}$ S. Passarge, zit. S. 583. - ${ }^{16}$ Vgl. E. Richter, zit. S. 563. 


\section{Fünfter Abschnitt.}

\section{Morphologie des Landes. ${ }^{1}$}

\section{Übersicht.}

Nachdem wir die einzelnen-Kräfte kennen gelernt haben, gehen wir zur Betrachtung der Formen über, oder richtiger gesagt, zur Systematik der Formen, die wir als Endergebnis jener teils mit-, teils gegeneinander wirkenden Kräfte verstehen zu lernen haben. Dieser genetische Gesichtspunkt in der Morphologie ist es hauptsächlich, der die moderne geographische Auffassung von der früher herrschenden unterscheidet. Es ist derselbe UmwandlungsprozeB, den auch die übrigen beschreibenden Naturwissenschaften durchgemacht haben.

Jedwede Oberflächenform ist ein Individuum. Wie jeder Kontinent und jedes Meer seine eigentümlichen Züge hat, so auch jedes Gebirge, jede Ebene; denn sicherlich haben nicht zwei Erdstellen, trotz Übereinstimmung im Grundcharakter, im Verlauf ihrer Entwicklungsgeschichte genau dieselben Schicksale erfahren. Es ist auch leicht erklärlich, daß der Individualismus mit der Schichtenstörung zunimmt, und daß er daher am meisten in den Kettengebirgen ausgebildet ist. Diese Abwesenheit von allem Schematischen bedingt zum großen Teil die Mannigfaltigkeit des Völkerlebens.

In dieser Eigenschaft der Oberflächenformen ist auch die Zweiteilung der Geographie in eine allgemeine und eine spezielle begründet. Diese hat gerade die individuellen $\mathrm{Züge} \mathrm{zu}$ erfassen, jene sieht von ihnen ab und sucht das Gemeinsame. Die Aufgabe der geographischen Morphologie ist die Klassifizierung der Oberflächenformen auf genetischer Grundlage. Aber dies ist ein ideales Ziel, dessen Erreichung einer fernen Zukunft überlassen bleibt. So groß ist noch die Lückenhaftigkeit unserer geographischen und noch mehr unserer geologischen Kenntnis, daB wir uns mit der Aufstellung von Typen begnügen müssen. 
Die Morphologie betrachtet 1. die Landmassen als Einzelwesen in ihren Beziehungen zueinander und zum Meer (Kontinente, Kontinentalinseln, ursprüngliche Inseln; Küstengliederung), 2. die Landmassen als Komplexe verschiedener Oberflächenformen. Methodisch empfiehlt es sich, den zweiten Abschnitt zuerst zu behandeln.

Orographisches System. Die Reliefformen des Landes lassen sich nach drei Gesichtspunkten einteilen: nach der äußeren Erscheinung, nach der Höhenlage und nach dér Entstehungsweise. Wenn wir auch den letzteren Gesichtspunkt -jetzt obenan stellen, so muß man doch daran festhalten, daß jedes dieser Systeme seine Berechtigung hat, und daß es der Übersicht dienlicher ist, sie nebeneinander zu stellen als eines in das andere einzuschachteln. Besonders der Reisende, der unbekannte Gegenden flüchtig durcheilt, wird gut daran tun, sich nur der orographischen Terminologie zu bedienen, denn die äußere Form ist dem geübten Auge leicht erkennbar, während der innere Bau intensive Forschung fordert.

Die orographischen Grundbegriffe sind Ebenheit und Unebenheit; sie beziehen sich auf das Maß der Niveauunterschiede benachbarter Punkte. In ihrer räumlichen Anordnung gewahren wir eine große Mannigfaltigkeit: bald beherrschen sie als Flach-oder Gebirgsland ausgedehnte Erdräume, bald durchdringen sie sich gegenseitig, indem hier ein Berg oder ein auch äußerlich scharf individualisiertes Gebirge sich aus der Ebene, wenn auch nicht immer, mit einem ganz deutlichen $\mathrm{FuB}$ erhebt, dort eine Ebene als Landsenke von Gebirgen eingeschlossen erscheint.

I. Der geographische Begriff der Ebenheit ist bekanntlich viel weiter als der geometrische, weil Änderungen des Gefälles einen gewissen, aber nicht für alle Menschen gleichen Schwellenwert erreichen müssen, um von dem Auge bemerkt zu werden. Wo die Fläche langsam ansteigt und sich nach der andern Seite ebenso langsam wieder senkt, so daß eine Wasserscheide entsteht, da sprechen wir von einer Landschwelle.

II. Einen viel größeren Formenreichtum zeigen die Unebenheiten. Einzelerhebungen nennt man Berge, ausgedehntere Erhebungen Gebirge, aber der Sprachgebrauch schwankt sehr häufig, und es wäre vergebliche Mühe, wollte man ihn durch feste Maße in ein künstliches System zwängen. Nur die Gepflogenheit, auch hervorragende Punkte innerhalb eines Gebirges als Berge zu bezeichnen, wollen wir aus der Sprache des Geographen verbannen.

Man kann folgende orographische Kategorien unterscheiden:

1. Kammgebirge zeichnen sich durch deutliche Längserstreckung und eine scharf ausgesprochene Kammlinie aus, sie ent- 
behren jedoch, im Gegensatz zum Kettengebirge, einer reichlicheren Gliederung durch Längstäler. Unter den Einzelerhebungen entsprechen ihnen die Kegelberge.

2. Linear entwickelt ist auch das Rückengebirge, aber statt eines scharfen Kammes krönt es ein breiter Rücken. Einen gleichen Gegensatz bildet der Kuppenberg zum Kegelberg.

3. Das Plateaugebirge $\times$ hat eine breite, wenigstens in einzelnen Teilen ebene Oberfläche. Unter den Einzelerhebungen kann ihm der Tafelberg zur Seite gestellt werden, aber eine scharfe Grenze läßt sich nicht ziehen, weil auch bei Plateaugebirgen häufig die Ausdehnung nach der einen Horizontaldimension nicht erheblich von der nach der andern abweicht.

4. An Masséngebirge oder Massive stellen wir nur die Forderung, daß Breite und Länge nahezu gleich seien, die Gestaltung der höchsten Teile kann aber sehr verschieden sein. Das Ötztaler Alpenmassiv besteht z. B. aus Kämmen, in anderen ist die Oberfläche wellig, und nur dort, wo sie vorherrschend eben ist, werden wir die Bezeichnung Massiv besser mit der des Plateaugebirges vertauschen.

5. Kettengebirge bestehen zwar vorwiegend aus einer Aneinanderreihung mehr oder weniger paralleler Kammgebirge, die durch Längstäler getrennt sind, aber sie können auch, wie die Alpen, Massive und Plateaugebirge enthalten. Indes zeigen auch diese eine deutliche Anordnung in der Längsrichtung des ganzen Gebirges.

6. Unregelmäßige Anhäufungen von Bergen bilden ein Bergland, und je nach ihrer Form kann man Kuppen- und Tafelgebirge unterscheiden.

7. Geht eine Fläche mit scharfer Biegung in eine andere, tiefer liegende über, so entsteht eine Landstufe, die im gewöhnlichen Sprachgebrauch häufig als Gebirge bezeichnet wird und daher hier nicht übergangen werden darf.

Hypsometrische Systeme. Dem System der absoluten Höhe liegt der Gedanke zugrunde, daß die Temperatur mit der Höhe abnimmt, und sich damit die Lebensbedingungen der Organismen, wie Wesen und $\mathrm{Maß}$ der zerstörenden Kräfte ändern. Für die Wahl der Grenzisohypsen ist natürlich ein weiter Spielraum offen gelassen, denn selten bezeichnet eine bestimmte Höhenlinie auch einen Wechsel der Oberflächenform. Ob wir die Grenze zwischen Nieder- und Mittelgebirge bei $600 \mathrm{~m}$, zwischen Mittel- und Hoch-

× v. Richtнofen sprach sich gegen die Beibehaltung des Ausdruckes Plateau aus. Dieser ist aber so sehr eingebürgert, daB man ihn durch einen Machtspruch kaum wird entfernen können. 
gebirge bei $1300 \mathrm{~m}$ ansetzen oder bei irgend einer andern Seehöhe, ist in der Natur nicht begründet. In letzter Linie sind diese Einteilungen, wie schon auf S. 609 bemerkt wurde, nur unseren europäischen Verhältnissen angepaßt, aber Seehöhen von $1000 \mathrm{~m}$ oder $2000 \mathrm{~m}$ haben hier eine ganz andere Bedeutung als im polaren oder im tropischen Klima. Trotzdem können die Bezeichnungen Mittel- und Hochgebirge beibehalten werden, aber nicht die Seehöhe, sondern der Abstand der beiden wirklichen Denudationsniveaus, der Unterschied zwischen Gipfel- und Talhöhe ist ein entscheidendes Moment für die Gebirgsformen, denn in ihr kommt die Intensität der zerstörenden Kräfte zum Ausdruck. An die Stelle des Systems der absoluten Höhen setzen wir daher mit Penck ein solches der relativen Höhen; die Grenze von Mittel- und Hochgebirge mag um den Höhenunterschied von etwa $1000 \mathrm{~m}$ schwanken, denn auch sie variiert mit dem Klima.

Dagegen hat sich von den absoluten Werten die Seehöhe von $200 \mathrm{~m}$ als Grenze zwischen Tief- und Hochland allgemein eingebürgert. Der Grund liegt darin, daß über $1 / 3$ der gesamten Landfläche unter $200 \mathrm{~m}$ liegt, und diese Höhenstufe selbst auf kleinen Karten deutlich zur Geltung kommt. Selbstverständlich ist das Tiefland vorwiegend Flachland; viele Flachländer steigen aber ganz unmerkbar zu beträchtlichen Seehöhen empor, wie z. B. die nordamerikanischen Prärien im 39. Parallel von 30 bis über $2000 \mathrm{~m}$, ohne daß irgendwo ein Gefällsbruch sich bemerkbar machte, oder der Abstand zwischen zwei Isohypsen auf GANNETT's schöner Relief Map (1892) irgendwo einem größeren Böschungswinkel als $0^{0} \quad 16^{\prime}$ entspräche. Solch ein geographisches Individuum in eine bestimmte Kategorie des absoluten Höhensystems einzureihen, ist natürlich unmöglich. Dasselbe gilt auch von dem relativen System Penck's, soweit es das Flachland betrifft. " Er unterscheidet 1. Ebenen mit seichten Flußeinschnitten, 2. Platten mit Tälern upter $200 \mathrm{~m}$ Tiefe, 3. Tafelländer mit tieferen Tälern. Es liegt auf der Hand, daß Tafelländer in Platten, Platten in Ebenen übergehen können. Der Verengerung des Begriffes Ebene ist nur zuzustimmen, aber die Grenze zwischen Platte und Tafelland ist ganz willkürlich gewählt. Außerdem drücken die Namen Platte und Tafel keineswegs eine Zerschnittenheit des Geländes aus, sie sind im Gegenteil konzentrierte Namen für ebenes Land, abgesehen davon, daß Tafelland in der modernen Morphologie einen ganz bestimmten Begriff bezeichnet.

Hypsometrie. Wenn auch hypsometrischen Systemen eine gewisse Willkürlichkeit anhaftet, so ist doch die Höhenmessung eine der unentbehrlichsten Grundlagen der geographischen Erkenntnis, 
ebenso unentbehrlich, wie die Bestimmung der räumlichen Lage durch Breite und Länge.

Es gibt drei Methoden der Höhenmessung: die nivellitische, die trigonometrische und die barometrische. Diese Reihenfolge entspricht auch ihrer Rangordnung in bezug auf die Genauigkeit. ${ }^{2}$

Bei dem Nivellement wird der Höhenunterschied benachbarter Punkte durch horizontales Zielen nach senkrechten Maßstäben (Latten) bestimmt. Diese sind 2-4 $\mathrm{m}$ lange, geteilte Stäbe ( $a$ in Fig. 184); das Nivellierinstrument ( $b$ in Fig. 184) besteht aus einer Libelle und einem Fernrohr, deren Achsen unter sich,parallel und beim Gebrauch horizontal sind. Eine besondere Berücksichtigung

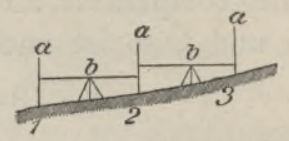
der Erdkrümmung ist unnötig, weil die Ziellinien sich ihr an und für sich als Tangenten anschmiegen. Diese genaueste hypsometrische Methode ist, wenn sie sich über größere Räume erstrecken soll, äußerst zeitraubend und kostspielig, und kann auch nur in Kulturländern zur Anwendung kommen. $\times$

Trigonometrisch mißt man Höhen mittels des Theodoliten, eines Instrumentes, das sich ebenso zur Bestimmung von Horizontalwie von Höhenwinkeln eignet und daher in der wissenschaftlichen Ausrüstung eines Forschungsreisenden eine wichtige Rolle spielt. Haben wir die Höhe des Berges $D$ (in Fig. 185), die durch die Vertikale $D C$ repräsentiert wird, zu bestimmen, so genügt es nach den Gesetzen der Trigonometrie, eine Basis $(A B)$ auf ebenem Boden und von ihren beiden Endpunkten die Höhenwinkel $\alpha$ und $\beta$ zu messen. $\times \times$ Dabei macht

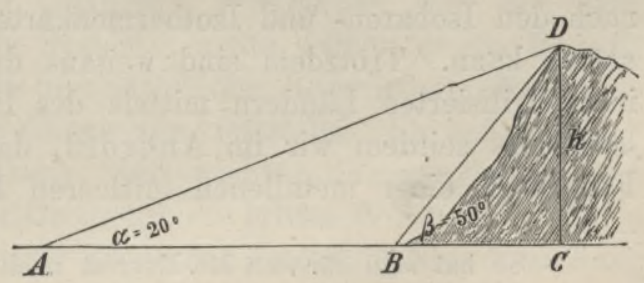

Fig. 185. Trigonometrische Höhenmessung. man allerdings die Voraussetzung, daß die Linien $A B, A D$ und $B D$ Gerade seien, und dies trifft ja in Wirklichkeit nicht zu. $A B$ wird durch die Erdkrümmung, $A D$ und $B D$ werden durch die Strahlenbrechung gebogen, und namentlich letztere ist eine nicht zu unterschätzende Fehlerquelle für die trigonometrische Höhenmessung, weil sich der Brechungskoëffizient nach einer uns nicht genau bekannten Skala mit der Höhe des Beobachtungspunktes

$\times$ Vgl. dazu S. 281.

$\times \times$ Die Höhe $C D$ ist dann $=A B \frac{\sin \alpha \sin \beta}{\sin (\beta-\alpha)}$. 
ändert. $\times$ Begnügt man sich mit Höhenzahlen, die noch in ihren Einheiten (in Metern) richtig sind, so kann man den Einfluß von Erdkrümmung und Refraktion vernachlässigen, solange die Entfernung von der Höhenlinie ( $A C$ in Fig. 185) $5 \mathrm{~km}$ nicht übersteigt.

Die barometrische Höhenmessung gründet sich auf das Gesetz, daß der Luftdruck mit wachsender Höhe in geometrischer Progression abnimmt. Ist in einer bestimmten Zeit der Barometerstand und die Temperatur an der unteren Station $B$ und $T$ und an der oberen $b$ und $t$, so ist nach RÜHumann die Höhendifferenz (in Metern)

$$
=18400\left(1,00157+0,00367 \frac{T+t}{2}\right) \log \frac{B}{b} \cdot \times \times
$$

Allein diese Formel hat einen Mangel. Sie setzt fälschlich voraus, daß die mittlere Temperatur der Luftsäule zwischen beiden Stationen gleich sei $\frac{T+t}{2}$. Daher liefern die Barometerablesungen zu verschiedenen Tages- und Jahreszeiten bald zu hohe, bald zu niedere Werte, und nur die Jahresmittel der meteorologischen Beobachtungen geben Höhen, die sich von den wahren Werten wenig entfernen. Es ist klar, daß Höhenbestimmungen auf Grund von einigen wenigen, ja oft nur von einer einzigen Ablesung sehr unsicher sind, besonders dann, wenn die Beobachtungen an beiden Stationen nicht gleichzeitig erfolgten, oder wenn die Seehöhe der unteren Station nicht völlig sichergestellt ist. Noch zweifelhafter wird das Resultat, wenn das Meeresniveau als untere Station angenommen wird, für die man nach den Isobaren- und Isothermenkarten nur ganz vage Werte einsetzen kann. Trotzdem sind weitaus die meisten Höhenmessungen in unzivilisierten Ländern mittels des Barometers gemacht worden, besonders seitdem wir im AneroId, das den Luftdruck durch die Federkraft einer metallenen luftleeren Büchse anzeigt, ein außer-

x So hat man für den Mt. Everest rach Messungen von der Ebene aus eine Seehöhe von $8840 \mathrm{~m}$, nach Messungen von dem Darjilinghochland aus aber eine solche von $8882 \mathrm{~m}$ gefunden.

$\times \times$ In dieser vereinfachten Formel sind die weiteren Glieder, die die Korrektionen wegen des in der Luft enthaltenen Wasserdampfes, wegen der Schwere und der Höhe über dem Meeresspiegel enthalten, weggelassen. Man bedient sich bei Berechnungen der für alle Glieder gültigen Tabellen, wie sie z. B. Jeurnek's Anleitung zur Ausführung meteorologischer Beobachtungen (4. Aufl.; Wien 1895) enthält. Die neueren Ansichten über die Schwerekorrektion entwickelte HANn in Petermann's Mitteilungen 1903, S. 163. Eine einfache Formel ohne Logarithmen, die zu schneller Berechnung wenigstens bis zu Höhenunterschieden von $2000 \mathrm{~m}$ gute Dienste leistet, stammt von BaBINET:

$$
\text { Höhe (in Metern) }=16010(1+0,002[T+t]) \frac{B-b}{B+b} \text {. }
$$

Für Barometerstände ohne-Schwerekorrektion lautet der erste Faktor 16035 . 
ordentlich bequemes Instrument besitzen. ${ }^{x}$ Leider reicht der Grad seiner Zuverlässigkeit bei weitem nicht an den des Quecksilberbarometers heran, und eignet sich dieses wegen seiner Zerbrechlichkeit wenig zur Mitnahme auf Reisen. Eine gute Kontrolle bieten die Kochthermometer aus Jenaer Glas, die in ihren Angaben konstanter sind als die Aneroide. ${ }^{3}$ Auch dieses Instrument dient zur barometrischen Höhenmessung; sie beruht in diesem Fall darauf, daß der Siedepunkt mit abnehmendem Luftdruck herabrückt; so befindet er sich z. B. bei einem Barometerstand von $760 \mathrm{~mm}$ bei $100^{\circ}$, von $700 \mathrm{~mm}$ bei $97,7^{\circ}$, von $600 \mathrm{~mm}$ bei $93,5^{\circ}$.

Im allgemeinen ist das Urteil berechtigt, dab unsere Kenntnisse von den Höhegnverhältnissen nicht bloß sehr lückenhaft, sondern auch sehr unsicher sind. Indes ist ein kräftiger Fortschritt nach beiden Richtungen unverkennbar.

Orometrie. $^{4}$ Wir haben schon an früherer Stelle der Versuche gedacht, die mittlere H.öhe bzw. Tiefe größerer Erdräume zu berechnen, Versuche, die bis auf LAPLACE zurückreichen, aber erst unter Номвоцрт's Meisterhand eine greifbare Gestalt annahmen. Aus dieser Volumberechnung entwickelte sich die Orometrie, die es sich zur Aufgabe stellt, alle charakteristischen Formen- und Größenverhältnisse der Gebirge durch Mittelwerte zum ziffermäßigen Ausdruck zu bringen. Was man bisher mit Worten schilderte, soll nun mit Zahlen kurz, prägnant und ohne jeden subjektiven Beigeschmack zur Darstellung gelangen. v. SoNKLAR war der erste, der dieses Programm in ein System brachte, indem er die Begriffe der mittleren Kamm-, Gipfel- und Sattelhöhe, der mittleren Neigungswinkel der Talböden und Gehänge usw. feststellte. Es bedarf keiner weitläufigen Auseinandersetzung, daß wir für das vergleichende Studium der Gebirge aus der Orometrie die größte Belehrung schöpfen können, aber leider steckt dieser Zweig der geographischen Forschung noch ganz in den Kinderschuhen. Solange sieh noch jeder seine Methode selbst zurechtschneidet, können streng vergleichbare Werte nicht geliefert werden. Dazu kommt noch, daB der Orometer ausschlieBlich mit Karten arbeitet und in seinen Resultaten von ihrer Zuverlässigkeit abhängig ist.

Genetisches System. Um zu einem genetischen System zu gelangen, müssen wir den entwicklungsgeschichtlichen Weg betreten; dieser Aufgabe sollen die nächsten Kapitel gewidmet sein. Die verschiedenen Formen, die die Natur uns bietet, fassen wir als Glieder einer Entwicklungsreihe auf, das räumliche Nebeneinander verwandeln

$\times$ Das Aneroïd oder Federbarometer wurde 1847 von Vidr erfunden. 
wir in zeitliches Nacheinander. Dabei gehen wir von zwei tektonischen Grundformen aus: den flach gelagerten und den gefalteten Schichten. Jene bedingen Ebenheit, diese Unebenheit. Eine fremdartige Zutat liefern die vulkanischen Ergüsse.

Indem diese Grundformen in verschiedenen Höhenlagen aneinander stoßen, entsteht zunächst eine orologische Gliederung. Als orologische Einheit bezeichnen wir ein Stück Land von größerem oder kleinerem Umfang, das sich durch seine Höhenverhältnisse mehr oder weniger scharf von seiner Umgebung abhebt. Die meisten dieser Einheiten sind tektonische Formen, deren Begrenzung durch Schichtenwölbung (Faltung, Flexur) oder Brüche bedingt ist. Als orologische Destruktionsformen sind jene zu bezeichnen, die durch zerstörende Vorgänge über ihre Umgebung scheinbar emporgehoben werden, während in Wirklichkeit die Umgebung abgetragen wird. $\mathrm{Zu}$ ihnen gehören die Überreste alter Oberflächen oder die Zeugenberge und die aufgedeckten Eruptivmassen. Eine dritte Kategorie bilden die aufgesetzten Berge, von denen aber nur die vulkanischen eine hervorragende Rolle spielen, während Moränen (s. S. 604), Dünen (s. S. 576) und andere Anhäufungen wegen ihrer geringen Höhe nur örtliche Bedeutung besitzen.

Die morphologische Erscheinungsweise im engern Sinn ist die Oberflächenform. Eine orologische Einheit kann auch eine morphologische Einheit sein, kann aber auch verschiedene Oberflächenformen in sich vereinigen, wie z. B. der Schweizer Jura. In den Strukturformen wird die Gestaltung der Oberfläche durch das innere Gefüge bestimmt. Aber auch hier greifen schon andere Faktoren ein: Brüche und vertikale Schollenverschiebungen einerseits und die nie rastende Destruktion anderseits. Sobald dadurch wesentliche Eigenschaften der Strukturformen verloren gehen, entstehen Umwandlungs- oder Mutationsformen. Wir haben unter diesen zunächst Bruchoder Fraktur- und Destruktionsformen zu unterscheiden. Die äußerste Grenze ist erreicht, wenn Ebenheiten in Unebenheiten, Unebenheiten in Ebenheiten verwandelt sind. Letztere können aber wieder durch Brüche und Verbiegungen in Unebenheiten zurückgeführt werden. Diese sind die Rekonstruktionsformen, die wir als dritte Unterart der Mutationsformen anzusehen haben.

So erzählen uns nicht bloß, wie uns die Geologen lehrten, die Zusammensetzung, die Lagerungsverhältnisse und die fossilen Einschlüsse der Schichten eine Geschichte, sondern - wie die moderne Geographie hinzufügt - auch die Oberflächenformen. Aber ihre Sprache ist noch schwerer verständlich als die geologische. Die Zyklenlehre von Davis leistet bei ihrer Entzifferung unstreitig sehr 
nützliche Dienste, aber ihre Überschätzung und einseitige Anwendung birgt auch eine Gefahr für die Wissenschaft in sich, wie immer, wenn das Schema zur Herrschaft gelangt. ${ }^{5}$ Schon der Ausgangspunkt der morphologischen Geschichtsschreibung ist meist unsicher. Es handelt sich dabei darum, die ursprüngliche Strukturform wiederherzustellen. Nur in seltenen Fällen gleicht sie den einfachen Modellen, an denen die Zyklentheorie entwickelt worden ist; man denke nur an die strukturelle Mannigfaltigkeit eines Überschiebungsgebirges vom Typus der Schweizer Alpen! Auch die Destruktion selbst ist kein eindeutiges Problem; es können zu verschiedenen Zeiten verschiedene Faktoren maßgebend gewesen sein, und in Wechselgebieten muB man das von vornherein erwarten. Endlich ist die Destruktionslehre noch so reich an Streitfragen, daß sie an und für sich keinen ganz sicheren Standpunkt gewährt. In vielen Fällen wird man daher gut daran tun, sich mit einer Lösung des morphologischen Rätsels in den gröbsten Umrissen zufrieden zu geben, anstatt sich in bestechende, aber unfruchtbare und irreführende Details einzulassen.

Literaturnachweise. ${ }^{1}$ Hauptwerke wie für die Dynamik s. S. 375 2 W. Jordan, Vermessungskunde, Bd. II, 1893. - ${ }^{3}$ Vgl. A. v. Danckelman, in den Verhandlungen der Berliner Gesellschaft für Erdkunde, 1888, S. 594. ${ }^{4}$ K. Peucker, Beiträge zur orometrischen Methodenlehre, Breslau 1890, woselbst die ziemlich ausgedehnte Literatur übersichtlich zusammengestellt ist. $-{ }^{5} \mathrm{Vgl}$. W. M. Davis, The Systematic Description of Land-forms, im Geographical Journal 1909, Bd. XXXIV.

\section{Die Oberflächenformen der Flachschichtung.}

Den Ausdruck Flachschichtung haben wir gewählt, weil völlig horizontale Lagerung verhältnismäßig selten ist. Selbst dort, wo man eine solche voraussetzte, hat sich häufig bei erweiterter Beobachtung eine leise Neigung nach einer bestimmten Himmelsgegend herausgestellt. Solange diese Neigung aber keinen hohen Wert erreicht, erzeugt die Flachschichtung als Urform stets Flachland.

Das Tafelland. Wir mögen bezweifeln, ob es irgend eine Gegend der heutigen Landoberfläche gibt, die stets flach war, aber wir wissen bestimmt, daß ausgedehnte Räume seit langen geologischen Perioden Flachland sind. Das sind die Tafelländer.

$\mathrm{Zu}$ den ausgedehntesten Tafelländern gehört die Wüstentafel der Alten Welt. Soweit die Sahara ${ }^{1}$ nicht mit modernen Ablagerungen bedeckt ist, und abgesehen von den Durchbrüchen der altkristallinischen Unterlage, besteht sie zum großen Teil aus pälaozoischen Schichten, ferner im Osten aus Afrikasandstein, in der 
Mitte aus Gebilden der mittleren und oberen Kreide, und nur im Nordosten aus tertiären Ablagerungen. Die frühere Annahme, daB alle Sedimente durchaus flach liegen, hat sich zwar durch die neueren französischen Forschungen ${ }^{2}$ in der zentralen und westlichen Sahara als irrtümlich erwiesen, da im Süden nachsilurische und weiter im Norden jungkarbonische Faltungen vorkommen, aber selbst das Karbon ist nicht überall von der Dislokation ergriffen, und die horizontale Lagerung der jüngeren Schichten ist mit Ausnahme einiger, orologisch unwichtiger Brüche nirgends erheblich gestört worden. Die saharische Tafel setzt sich nach Arabien fort, wo eine gewaltige Sandsteindecke Granit und alte Eruptivgesteine verhüllt. ${ }^{3}$ Auch sonst ist in Afrika die Tafellagerung weit verbreitet, unzählig sind die Schollen horizontaler Sandsteine, die wahrscheinlich der jüngeren Primär- und älteren Sekundärperiode, zum Teil wohl auch, wie in Deutsch-Ostafrika, den jüngsten mesozoischen Bildungen angehören. Das Innere von Australien darf ebenfalls als Tafelland bezeichnet werden. In Nordamerika breitet sich von den Alleghanies bis über den Mississippi eine paläozoische Tafel aus, und daran schließt sich im Westen bis zum Felsengebirge die schräge Kreidetafel der Prärien. Südamerika hat seine brasilianische Tafel, die sich allerdings auch mit Strichen von wesentlich anderem Charakter zu einer orologischen Einheit verbindet, wie wir an einer späteren Stelle ausführlicher zu erörtern haben werden.

SuEss spricht auch von einer russischen Tafel. ${ }^{4}$ Die granitische Unterlage der Sedimentformationen tritt in Finnland und in SüdruBland zutage und ist in St. Petersburg in $200 \mathrm{~m}$ und in Moskau in $600-1000 \mathrm{~m}$ Tiefe erbohrt worden. Sie bildet also eine schüsselförmige Einsenkung mit einem flachen Neigungswinkel von $0^{0} 4^{1} / 2$ bis $4^{3} / 4^{\prime}$. Das nach $\mathrm{O}$ sich senkende Wolgabecken bringt diese Anordnung durch seine zentrale Lage zum Ausdruck. Ihr entspricht auch, daß in $\mathrm{O}$ und $\mathrm{W}$ immer ältere Formationen von der Kreide bis zum Kambrium an der Oberfläche erscheinen. Die flache Lagerung der Schichten bedingt in Zentral- und wahrscheinlich auch in dem noch wenig bekannten Nordrußland den Charakter eines Tafellandes. Wohl haben sie, wie der Lauf der Flüsse zeigt, in den Ostseeprovinzen und im N eine seewärts gerichtete Verbiegung erlitten, wohl kommen auch örtliche Dislokationen vor, aber die Flachlagerung im großen und ganzen wurde dadurch nicht gestört. Selbstverständlich war auch die Destruktion tätig, und von jüngeren Sedimentdecken sind nur mehr Reste vorhanden. Am einschneidendsten wirkte das diluviale Inlandeis, indem es mit seinen Moränen einerseits Uneben- 
heiten ausfüllte, anderseits Unebenheiten schuf (z. B. die Waldaihöhe). Nord- und Zentralrußland ist also als ein wenig verändertes Tafelland aufzufassen.

Anders Südrußland. Von den Karpathen bis zur Wolga erstreckt sich eine kompakte Schwelle von mehr als $200 \mathrm{~m}$ Höhe, nur von den Erosionssenken des Don und des Dnjepr unterbrochen. In diese Senken rückte das diluviale Inlandeis in zwei mächtigen Zungen nach S vor; hier ist also das heutige Relief älter als in Zentralrußland, wo es sich erst in der nachglazialen Zeit entwickelt hat. Im Gouvernement Cherson reicht es sogar bis in die Neogenperiode zurück. ${ }^{5}$ Der Untergrund ist stark disloziert, im Donezrücken hat die faltende Bodenbewegung vom Ausgang des paläozoischen bis zu dem des mesozoischen Zeitalters wenigstens fünfmal eingesetzt, jedesmal schwächer als das vorige Mal, und jedesmal folgte der Faltung eine Meeresüberflutung, die das Gebirge einebnete. $^{6}$ Trotzdem ist auch hier der Boden flach. Welchem Umstand ist dies zuzuschreiben? Soweit sich über dem alten Gebirge eine mächtige Decke horizontaler Tertiärablagerungen ausbreitet, wohl dieser; wo aber die Decke dünn und zerrissen ist, wie im nördlichen Cherson, geht das Tafelland in eine marine Destruktionsebene über.

Die wesentliche Eigenschaft des Tafellandes ist seine Zusammensetzung aus festem Schichtgestein höheren Alters. Daß sein morphologischer Charakter nur durch die Lagerungsverhältnisse bedingt ist, zeigt sich am deutlichsten dort, wo es an ein Gebirge von gleicher geognostischer Zusammensetzung grenzt, und die bisher flach gelagerten Schichten sich nun aufrichten. Soweit sich die Tafelländer aus Sedimentgestein aufbauen, in denen wohl auch manchmal Eruptivmassen eingelagert sind, können wir sie auch ursprüngliche Ebenen nennen, und stellen sie jenen Flachländern gegenüber, die mit lockerer Aufschüttung jugendliche Störungsgebiete verhüllen, und die wir als aufgesetzte Ebenen bezeichnen können. Nur jene mächtigen Lavadecken, wie wir sie am Columbia im Westen der Vereinigten Staaten in einer Ausdehnung von über $500000 \mathrm{qkm}$ und im nordwestlichen Dekan finden, machen davon eine Ausnahme. Der sog. Dekantrapp bedeckt eine Fläche von mehr als $400000 \mathrm{qkm}$ und erreicht stellenweise eine Mächtigkeit von $1800 \mathrm{~m}$. Der Untergrund ist uneben, alte Täler von mehr als $300 \mathrm{~m}$ Tiefe sind mit Lava ausgefüllt. Die Schichtung ist horizontal, die feste Gesteinsbeschaffenheit macht das Trappplateau zu einem echten Tafelland, seine Oberfläche zeigt alle charakteristischen Eigenschaften eines solchen, und trotzdem müssen wir es zu den 
aufgesetzten Ebenen rechnen. Man hat diese Flachländer Übergußtafeln im Gegensatze zu den Schichtungstafeln genannt.

Ausgefüllte Landsenken. Sie sind ohne Ausnahme jugendliche Oberflächenformen, die ältesten reichen in das Tertiär zurück. Ihrer Umgebung gegenüber verhalten sie sich meist völlig fremd, wenn sie auch hier und da durch den fortschreitenden FaltungsprozeB in die Gebirgsbildung einbezogen und ihr Baumaterial dadurch verfestigt wurden.

Man hat zwischen Anschwemmungsflächen und äolischen A ufschüttungen zu unterscheiden. Jene zeichnen sich vielfach durch schüsselförmigen Bau aus, am Rand lagern sich die Schichten schräg an und gehen gegen die Mitte des Beckens in schwebende Lagerung über (Fig. 186). Daher kommt es, daß von der Mitte nach dem Rand immer ältere Bildungen an die Ober-
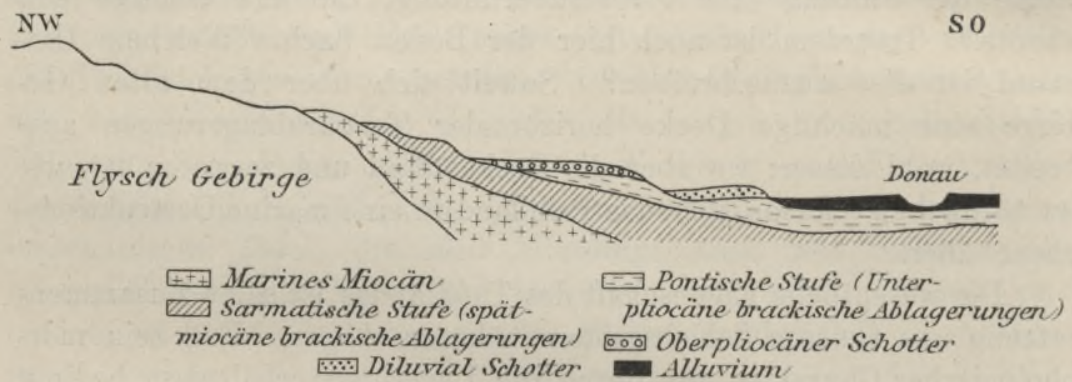

Fig. 186. Das Wiener Becken nach Hassrvgen ${ }^{7}$, Miozän bis Unterpliozän sind Ablagerungen in stehendem Wasser, die jüngern Bildungen sind Flußablagerungen. 3 fache Überhöhung.

fläche treten, und da die ältesten am höchsten liegen, sind sie häufig durch Erosion zu einem Hügelland aufgelöst. Die Donauebenen, die sich seit dem jungen Tertiär über gewaltigen Kesseleinbrüchen aufbauten, gehören diesem Typus an. Die Senkung vollzog sich aber ungleichmäßig; eine Reihe von Gebirgshorsten ragen noch aus der ungarischen Ebene auf. ${ }^{8}$ Westlich von Altofen erhebt sich der Dreihotterberg etwas über $400 \mathrm{~m}$ über das Meeresniveau, aus dem ältesten Gestein in dieser Gegend, dem triadischen Hauptdolomit, bestehend. Thm lagert sich im Osten oligozäner Mergel an, der sich von 200 bis $100 \mathrm{~m}$ Seehöhe senkt und dann unter der Donau verschwindet. Auf der Margareteninsel fand man ihn unter der alluvialen Decke wieder und verfolgte ihn bis $19 \mathrm{~m}$ unter dem Meeresspiegel. Nur 2,s km davon entfernt, im Stadtwäldchen, durchfuhr der Bohrer zunächst jüngere Tertiärschichten, erreichte erst in $450 \mathrm{~m}$ unter dem Meeresspiegel das Oligozän und in $700 \mathrm{~m}$ den 
Dolomit des Dreihotterberges. Das ergibt auf eine Entfernung von $7 \mathrm{~km}$ eine Niveaudifferenz von $1100 \mathrm{~m}$ ! Auf den neogenen Rand folgen nach dem Innern des Alföld diluviale Ablagerungen, überdeckt mit Löß und Flugsand und durchfurcht von alluvialen Flußniederungen. Die Sohle der diluvialen Tonablagerungen mit sandigen Zwischenschichten und mit Arten von Süßwasserschnecken und -muscheln, die noch heute im Alföld leben, senkt sich beckenförmig nach dem Innern und steigt nach Süd ebenso an wie nach West. $\times$ Niveauunterschiede von reichlich $200 \mathrm{~m}$ sind dadurch bis auf wenige Meter ausgeglichen. In der Diluvialzeit vollzog sich die Ausfüllung der Seen, ihre Umwandlung in Sümpfe und endlich die Ausbildung des heutigen Flußsystems, gleichzeitig dauerte aber die Senkung noch fort. Der Prozeß spielte sich also nicht in zwei zeitlich getrennten Akten: erst Senkung und dann Ausfüllung, ab, sondern die Aufschüttung hielt, wenigstens bis zu einem gewissen Grad, gleichen Schritt mit der Senkung. Das scheint auch der allgemeine Vorgang bei der Entstehung von Ebenen, die sich aus Flußalluvionen zusammensetzen, gewesen zu sein, und soweit er sich in mäßigen Grenzen hält, erklärt er sich ungezwungen aus dem Nachsacken der lockeren Massen. So wurde bei Portovecchio in der Poebene in $215 \mathrm{~m},{ }^{9}$ bei Lucknow in der Gangesniederung in $284 \mathrm{~m}$ unter dem Meeresniveau der Untergrund der modernen Anschwemmung noch nicht erreicht, ${ }^{10}$ wenn man ihm auch im letzteren Fall schon ziemlich nahe gekommen zu sein scheint, Es unterliegt natürlich keinem Zweifel, daB, als jene Tiefalluvionen abgelagert wurden, der Boden sich wie heute über dem Meeresspiegel befand. Erderschütterungen in jungen Schwemm-

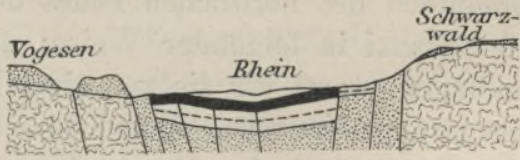

$\square$ Grundgebinge $\square$ Trias - Jura - Tertiär $\square$ Quartär

Fig. 187. Schematisches Profil des Rheingrabens. 5 fache Überhöhung. gebieten weisen übrigens darauf hin, daß die Senkung auch jetzt noch fortdauert.

Manchmal wird uns ein schüsselförmiger Bau nur vorgetäuscht. Dies ist z. B. der Fall in der oberrheinischen Tiefebene, die

$\times$

\begin{tabular}{|c|c|c|}
\hline & & Seehöhe \\
\hline Szentes . . . . & & $+85 \mathrm{~m}$ \\
\hline Hód-Mezö-Vasárhely & & 81 \\
\hline Szegedin . . . & & +82 \\
\hline Theresiopel. . . & & +112 \\
\hline Zombor . . . & & +87 \\
\hline
\end{tabular}

Seeböhe der Sohle des Diluviums

$-90 \mathrm{~m}$

$-98$

$-72$

$+16$

$+54$

Seeböhe der Sohle der Ablagerungen des jüngsten tertiären Süßwassersees unbekannt

$"$,
$-\quad 164$
$-\quad 63$


uns zugleich als ein ausgezeichnetes Beispiel eines Grabenbruches dienen mag (Fig. 187). ${ }^{11}$ Die große mesozoische Tafel, die einst von Schwaben bis Lothringen reichte, sank dort am tiefsten ein, und der Graben wurde in mitteloligozäner Zeit vom Meer und im jüngern Tertiär von einem Süßwassersee eingenommen und mit ihren Ablagerungen angefüllt, endlich im Diluvium vom Rhein erobert, der seine Schotter und Sande darüber ausbreitete. Auch hier liegen die älteren Schichten am Rand, aber lediglich infolge ungleichmäßiger Schollensenkung.

Ausgefüllte Seebecken, die einen unebenen Untergrund verhüllen, sind außerordentlich häufig und ebenso verschieden in bezug auf Ausdehnung wie auf Seehöhe. In Europa nennen wir die Hochflächen beider Castilien; in Afrika gehört das große Kongobecken hierher, das nach ConNET erst in verhältnismäßig junger Zeit durch Durchbrechung des westafrikanischen Schiefergebirges einen AbfluB zum Meer gewann; in Amerika sind die Hochflächen des südlichen Mexico und der Andes zugeschwemmte Landsenken. Daneben gibt es auch Landsenken, die durch Steppengebilde ausgefüllt sind. Ihre Verbreitung ist an klimatische Grenzen gebunden: nur dort kommen sie vor, wo die geologische Kraft des Windes zur unumschränkten Herrschaft gelangt, d. h. in trockenen Gegenden oder in solchen, die früher regenärmer waren als jetzt (vgl. S. 580). Eigentümlich ist ihnen die Beckenform. v. RicнтноғEN ${ }^{12}$ schildert die Lößmulden des nördlichen Teiles der chinesischen Provinzen Tschili und Schansi in folgender Weise: „Fast eine jede der großen Einsenkungen, wenn wir sie von einer Höhe überblicken, hat die Gestalt eines Steppenbeckens, indem eine Vertikalebene die Oberfläche in einer Kurve von der Form eines zwischen den beiden Gehängen. schlaff gespannten Seiles durchschneiden würde (s. 2 und 3 in Fig. 188). Der Höhenunterschied zwischen den Rändern und der Mitte beträgt oft mehrere tausend $\mathrm{FuB}$; aber die Abdachung ist so allmählich, daß das Auge sich keine Vorstellung von der GröBe dieser Differenzen machen kann. Zunächst den Gehängen ist der Neigungswinkel am gröBten; gegen die Mitte hin nimmt er immer langsamer $a b$, bis sich der diesseitige mit dem jenseitigen Abfall in einer Ebene begegnet. Der obere Muldenrand geht bald unmittelbar durch Anhäufungen von eckigem Schutt in den aus festem Gestein bestehenden trennenden Gebirgsrücken über, bald lehnt er sich an Felswände, welche noch hoch darüber aufragen.... Neben diesen normalen Formen treten auch einseitige Lößmulden $(1,4$ und 5 in Fig. 188) auf, bei denen die lange, geschwungene Abdachung sich nur von einer Flanke herabzieht, und wo von dem tiefsten Teile 
derselben entweder eine durch Seeausfüllung entstandene, beinahe vollkommene Ebene bis an das jenseitige Gehänge hinanreicht, oder eine schmale Lößaufschüttung den zweiten Muldenflügel gewissermaßen nur andeutet. In allen solchen Fällen, soweit ich deren beobachtet habe, ruht der ausgebildete Muldenflügel auf einer im Durchschnitt sanft geneigten Fläche des unterliegenden Gesteins, während der rudimentäre Teil oder der ebene Boden an eine steile und im Verhältnis sehr hohe Felswand grenzt." Solche LöBländer sind in China die Provinzen Schansi, Nord-Tschili und Honan, aber noch allgemeiner ist der Löß in Schensi und Kansu, wo er den eigentlichen Boden bildet und ihm Form und Farbe gibt. Eine Fläche von der Größe des Deutschen Reiches trägt hier eine fast ununterbrochene Lößdecke. Wir müssen indes die Frage offen lassen, ob

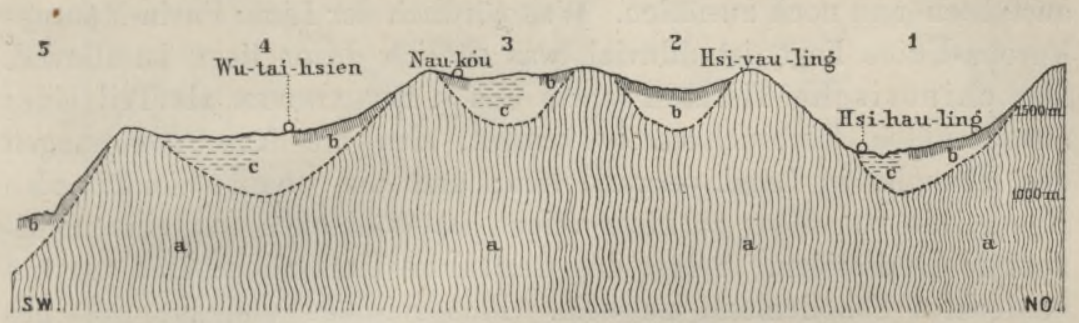

Fig. 188. Querschnitt der Lößbecken am Südfuß des Wutai-schan nach v. RichтHOFEN. Länge zur Höhe $=1: 8$.

$a$ festes Gebirge, $b$ Löß, $c$ Seeablagerungen.

es Flächen gibt, die ausschlieBlich äolischer Aufschüttung ihre Entstehung verdanken, wenn wir auch nicht daran zweifeln, daß der windbewegte Staub in trockenen Gegenden Mächtigkeit genug besitzt, um sich an der Gestaltung von Geländeformen $\mathrm{zu}$ beteiligen. Am wenigsten wäre solcher Zweifel in bezug auf die ausgedehnten Hochflächen Zentralasiens berechtigt, doch bezeichnet GrIEsBaCH ${ }^{13}$ Tibet als ein Faltenland, dessen breite Mulden mit jung- und nachtertiären Seenblagerungen (im Hundés-Plateau über $600 \mathrm{~m}$ mächtig) ausgefüllt sind. Von dem Tarimbecken und der Gobi nahm man an, daß hier seit dem Ende der Kreideperiode ein Meer flutete, das durch die Dsungarei mit dem aral-kaspischen Meer in Verbindung stand und dann, als das Klima immer trockener wurde, der Verdunstung anheimfiel; in den letzten Jahren sind hier aber auch unzweifelhafte Beweise der Existenz jungtertiärer Süßwasserseen gefunden worden, ${ }^{14}$ und jedenfalls bilden wässerige Sedimente die Unterlage, über die sich atmosphärische Ablagerungen ausḅreiten. In seinem Werk über die Wüstenbildung teilt uns J. WALtHer ein $600 \mathrm{~m}$ tiefes Brunnenprofil bei Askabad an der transkaspischen Bahn 
mit, in dem Lehm, Sand, Kies und Geröll beständig wechseln; unzweifelhaft nehmen also auch hier lakustrische und fluviatile Bildungen großen Anteil an dem Aufbau des Bodens. In den viele Kilometer breiten Flachmulden des westlichen Hochlandes von Nordamerika sind ebenfalls Seengebilde nachweisbar.

Peripherische Flachböden jugendlichen Alters. Wir haben bisher nur die aufgesetzten Ebenen innerhalb der Festländer in den Kreis unserer Betrachtung gezogen, und es entsteht nun die Frage, ob sich jene jugendlichen Flachlandgebilde, die an das Meer grenzen, auf gleiche Vorgänge zurückführen lassen. Wir antworten: ohne Zweifel in einzelnen Fällen, wo solche Ebenen buchtenförmig in das Festland eindringen. Ein solches Senkungsfeld ist der alte $\mathrm{Po}_{0}$ Golf, den Alpen- und Appenninenflüsse mit ihren Geröllmassen ausfüllten und noch ausfüllen. Was nördlich der Linie Pavia-MantuaVerona-Udine liegt, ist diluvial, was südlich davon liegt, ist alluvial. Das chinesische Tiefland lehrte uns v. Richтногеn als Teil eines ausgedehnten Einbruchkessels kennen, den die Anschwemmungen des Hoangho in Land verwandelten; und die vorderindische Ebene, die von Meer zu Meer reicht, ist wohl auch nur eine kontinentale Depression. Selbst das deutsche Tiefland scheint nur ein verdecktes Schollenland zu sein. Paläozoisches und mesozoisches Grundgebirge mit gestörtem Schichtenbau tritt noch mehrfach zutage, Rügen und Helgoland sind ebenfalls solche stehengebliebenen oder gehobenen Schollen. In der jüngeren Tertiärzeit nahm das Meer von diesem Senkungsfeld Besitz, seine Ablagerungen verwischten die Höhenunterschiede, wenn auch nicht ganz, weil am Ende der Miozänperiode wieder neue Störungen eintraten. Daraus erklärt es sich, daß selbst nahe beieinander liegende Bohrungen sehr beträchtliche Niveauverschiedenheiten des tertiären Untergrundes verraten. Im Weichbild Berlins schwankt - wie man aus den 33 Messungen in W AHNSCHAFFE's Zusammenstellung ${ }^{15}$ entnehmen kann - die Mächtigkeit der Diluvialdecke zwischen 34 und $126 \mathrm{~m}$, die Seehöhe der tertiären Basis zwischen +2 und $-90 \mathrm{~m}$, die Niveauunterschiede der gegenwärtigen Oberfläche betragen an den Bohrlöchern aber nur $16 \mathrm{~m}$. So sehr hat die Eiszeit mit ihren Ablagerungen, die sie über den Norden Deutschlands ausbreitete, ausgleichend gewirkt. Aber eine völlige Ebene ist auch dadurch nicht geschaffen worden. Am jeweiligen Rand des sich etappenartig nach N zurückziehenden Inlandeises erodierten die Schmelzwässer breite, sich von $\mathrm{O}$ nach W senkende. Talfurchen, die zum Teil auch heute noch von Flüssen benutzt werden; dadurch wurden die Diluvialablagerungen mannigfach zerschnitten, und es entstand jener flachwellige Bau, der das 
deutsche Tiefland von der Weser bis über die Elbe hinaus charakterisiert. Zwischen einem südlichen Landrücken, der sich von der schlesischen Platte über die Niederlausitz, den Fläming und die Lüneburger Heide nach Nordwest erstreckt, und der großen baltischen Seenplatte, die zuerst nach Südwest zieht und dann ebenfalls nach Nordwest umbiegt, liegt eine breite von Längstälern durchfurchte Mulde, und die äußersten Höhenunterschiede betragen noch immer

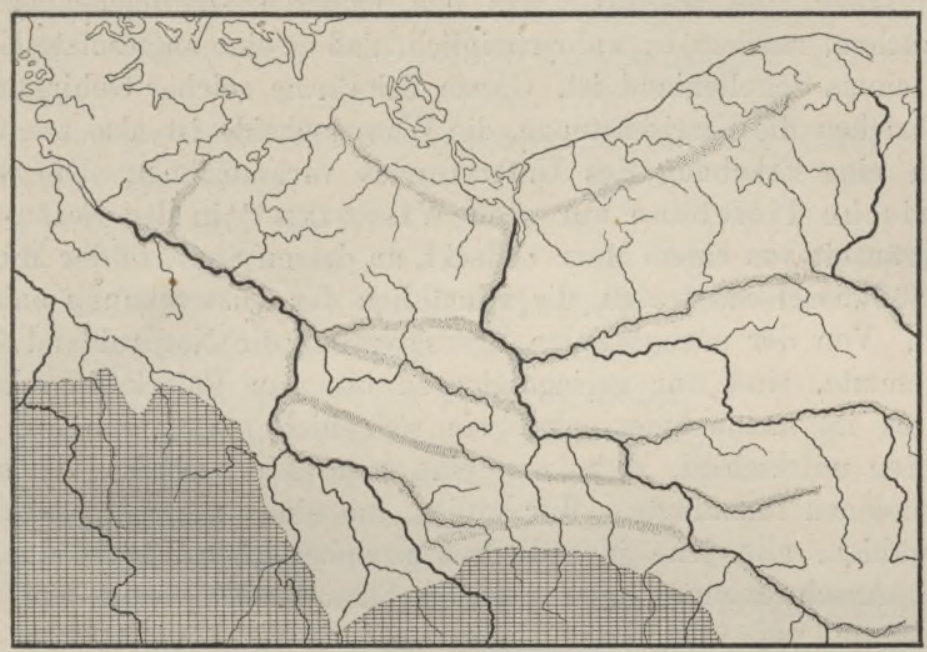

涼曲 Bergland

Nachglaziale Täler.

Fig. 189. Die Stromtäler des norddeutschen Tieflandes am Schluß der Eiszeit nach KEILHACK.

ein paar hundert Meter, ${ }^{\times}$wenn auch Schwellen und Mulde sich allmählich ineinander verlieren. Man hat in den Schwellen unterirdische Gebirgszüge erblicken wollen, und diese Meinung hat viel für sich, wenn auch der Fläming an den Bohrstellen keinen tertiären Kern über dem Meeresniveau besitzt.

Von den Gestaden des sibirischen Eismeeres zieht das Flach-

$\times$ Höchste Punkte der südl. Landschwelle $\mathrm{m}$

LüneburgerHeide 170

Fläming . . . 200

Niederlausitz . . 230

TarnowitzerPlatte

(Mesozoisch) $\quad 400$
Täler der Muldenmitte.

Hamburg . . . . 3

Berlin . . . . . 37

Küstrin . . . . 13

Bromberg . . . 37
Höchste Punkte der nördl. Landschwelle

m

Holstein . . 160

Mecklenburg . . 180

Pommern (Turm-

berg) . . . 330

Preußen . : . 310 
land über die Obniederung bis in das Herz des asiatisch-europäischen Kontinents. Aber der Lauf der Gewässer zeigt eine Zweiteilung an. Tobolsk im Obgebiet liegt $114 \mathrm{~m}$ über See, die wasserscheidende Kirgisensteppe steigt $300-500 \mathrm{~m}$ an, auf der anderen Seite liegt der Aralsee $48 \mathrm{~m}$ über, der Kaspisee $26 \mathrm{~m}$ unter dem Spiegel des Schwarzen Meeres. Das junge aral-kaspische Tiefland ist also ohne Zweifel eine Landsenke, und die aus altem Gestein bestehenden Gebirgszüge, die inselartig aus den lockeren Oberflächengebilden auftauchen, machen es wahrscheinlich, daß es eine aufgesetzte Ebene über einem Schollenland ist. Ganze Schwärme solcher Gebirgsinseln durchziehen die Kirgisensteppe, die Wasserscheide ist also zweifellos durch eine Erhebung des Untergrundes vorgezeichnet. Die westsibirische Tiefebene war nach WrssotzkiJ ${ }^{16}$ in der Eozän- und Oligozänzeit von einem Meer bedeckt, an dessen Stelle in der Miozänzeit Süßwasserseen traten, die allmählich der Austrocknung anheimfielen. Von der nachglazialen Transgression, die Nordrußland überschwemmte, sind nur geringe Spuren bis zum Polarkreis bekannt, und es ist anzunehmen, daß sie sich nicht wesentlich von den früheren unterschied, d. h. nur eine neue Flachschicht den schon vorhandenen hinzufügte. Wir wollen, um einen neutralen Ausdruck zu wählen, alle jene jugendlichen peripherischen Flachböden, die durch Anschwemmung oder negative Strandverschiebung dem Land zuwuchsen, und über deren Untergrund wir nicht unterrichtet sind, als angefügte Ebenen bezeichnen. Wir finden solche an den meisten Küsten, wenn auch oft nur auf einen schmalen Streifen beschränkt. Die sich sanft zum Meer abdachenden Ebenen, die die Vereinigten Staaten an der atlantischen und Golfseite umsäumen und von New Jersey bis Georgia von 50 auf $300 \mathrm{~km}$ Breite anwachsen, sind ein ausgezeichnetes Beispiel dieser Kategorie. Seit der Kreideperiode hat hier das Land trotz mannigfacher Schwankungen eine stetige Vergrößerung erfahren. ${ }^{17}$ Nirgends ist die Form der Tieffläche ausgedehnter als in Südamerika; sie erreicht $11^{1 / 2}$ Mill. qkm und nimmt $2 / 3$ des Kontinents ein. Aber wenn auch das ganze Flachland zusammenhängt, so bildet es doch keine genetische Einheit. Die Llanos des Orinoco sind tertiäre Meeresablagerungen, die in jeder Regenzeit durch neue Flußanschwemmungen erhöht werden. Die Amazonas-Ebene war seit der Miozänzeit ein See, der durch die Cordillerenflüsse zugeschüttet wurde. ${ }^{18}$ In der argentinischen Ebene lagert unter dem ungefähr $1 \mathrm{~m}$ mächtigen Alluvium die sogenannte Pampasformation, eine Mergel- oder Lehmschicht mit Resten von Landsäugetieren, die ihrem ganzen Charakter nach dem Löß entspricht. Nach Santiago Roth ${ }^{19}$ wechseln äolischer LöB, Fluß- 
löß und Seemergel wiederholt miteinander $a b$, und umfassen diese Bildungen, die man bisher für ausschließlich quartär hielt, den ganzen Zeitraum vom Diluvium bis in das früheste Tertiär. Marine Ablagerungen unter dem Löß wurden nur bei Buenos Aires gefunden. An verschiedenen Stellen tauchen kristallinische Gebirgsinseln aus den jüngeren Schichten empor; es ist möglich, daß auch hier ein altes Schollenland begraben liegt.

Ergebnis. Unsere bisherigen Erörterungen ergeben folgendes genetische System der Flachläñder (Strukturformen der Flachschichtung):

I. Ursprüngliche Ebenen oder Schichtungstafelländer (Hoch- und Tiefflächen).

II. Aufgesetzte Ebenen:

1. ÜberguBtafeln.

2. Locker geschichtete Flächen.

a) Landsenken (Hoch- und Tiefland).

c) Landsenken im Schollenland,

$\beta$ ) Landsenken im Faltenland.

b) Peripherische Tiefländer.

«) Buchtenländer,

$\beta)$ Angefügte Ebenen.

Natürlich ist dieses System noch einer weiteren Gliederung fähig - so z. B. die Kategorie der aufgesetzten Ebenen nach der Art der Aufschüttung -, aber uns kommt es nur darauf an, einige Haupttypen herauszugreifen und systematisch aneinander zu reihen. Einteilungen, die sich zu weit in Einzelheiten verlieren, erschweren die Übersicht, statt sie zu erleichtern.

Umformung durch Destruktion (Destruktionsformen). Überall, wo das fließende Wasser größere Kraft erlangt, wird das flachgeschichtete Land von Tälern durchschnitten. Die Wasserkraft hängt bekanntlich von dem Gefälle und der Wassermenge ab; Siebenbürgen und die niederungarische Ebene mögen uns den Einfluß des erstgenannten Faktors vor Augen führen. Zwei meridionale Flüsse durchziehen Niederungarn: die Donau senkt sich von $103 \mathrm{~m}$ (bei Budapest) auf $83 \mathrm{~m}$ (bei Vukuvar), die Theiß von $113 \mathrm{~m}$ (bei Tokaj) auf $79 \mathrm{~m}$ (bei Semlin); das Gefälle ist bei beiden ungefähr das gleiche 1:12000, wenn man von den Krümmungen absieht. Zwischen Donau und Theiß erhebt sich die diluviale Kumanierschwelle durchschnittlich $30-40 \mathrm{~m}$ über die alluvialen Talflächen; nur im Westen wird sie von einem Steilrand, offenbar dem alten Donauufer, begrenzt; gegen die Theiß hin senkt sie sich unmerklich. Ebenso unmerklich steigt das Gelände von der Theiß nach Siebenbürgen 
hin um $20-30 \mathrm{~m}$. Niveauunterschiede sind also wohl vorhanden, aber nur an wenigen Stellen werden sie dem Auge wahrnehmbar, sonst empfängt der Beschauer überall den Eindruck einer horizontalen Ebene. Anders in Siebenbürgen. Das Innere ist mit flachgelagerten Sanden, lockeren Sandsteinen und Mergel der jüngeren Tertiärformation erfültt; hier, wie im ungarischen Tiefland, ist der Straßenbau durch den Mangel an festen Steinen gehemmt. Szamos und Maros, die nach Ungarn entweichen, erreichen aber ein Gefälle von etwa 1:800, bzw. 1:1100, und dem entsprechen Taltiefen von $200 \mathrm{~m}$ und darüber. Die Ausfüllungsmasse ist in eine Reihe von Höhenzügen zerschnitten; nichts erinnert mehr an das ursprüngliche, sich nach Westen senkende Flachland, als die in dieser Richtung ziemlich regelmäßig abnehmende Seehöhe der Berge.

Maßgebend für den Grad der Erosionskraft ist aber nicht die Seehöhe eines Flachlandes, sondern die Höhe über der Erosionsbasis. Die Täler der Szamos und der Maros können nicht tiefer werden als das Theißtal, und dessen Tieferlegung hängt wieder von der Ausgestaltung des engen Durchbruchstales von Orsova ab, das bei Hochwasser die Theiß oft genug staut und dadurch Überschwemmungen verursacht. Für Gebiete mit $A b f l u B$ ist freilich in letzter Instanz der Meeresspiegel die Erosionsbasis, die, wenn auch nicht jetzt, doch in Zukunft einmal zur Geltung kommen muB. Tiefländer sind daher in der Regel weniger durchfurcht, einförmiger, ungegliederter als Hochflächen. Aber abflußlose Hochflächen sind es nicht minder. Es ist ganz gleichgültig, daß der Westrand des Tarimbeckens in Kaschgar und Jarkent $1300 \mathrm{~m}$ über dem Meer liegt, denn seine Erosionsbasis, der Lop-nor, hat selbst eine Seehöhe von $800 \mathrm{~m}$, und für das Gefälle kommt nur die Höhendifferenz von $500 \mathrm{~m}$ in Betracht. Noch entscheidender ist hier freilich, daß es an Wasser selbst mangelt. Nur unter besonders günstigen Verhältnissen überwindet ein Fluß die Gefahren der Wüste, wie der Nil, dessen Tal die ganze Saharatafel entzwei scheidet. Auch stammt in der Wüste noch manches Tal aus der früheren feuchteren Klimaperiode, das nun der Umformung durch den Wind unterliegt, bald weiter ausgearbeitet, bald mit Sando verschüttet wird.

Welche Formen die Destruktionskraft des Wassers schlieBlich erzeugt, hängt von der Gesteinsbeschaffenheit der Hochflächen, von dem Neigungswinkel der Schichten, von der Zahl der Tüler, von der Dauer der Erosionsarbeit ab. Bis zu $200 \mathrm{~m}$ tiefe Täler, von denen einige jetzt trocken liegen, durchfurchen den schwäbischen Teil der oberdeutschen Hochebene, aber die breiten Zwischenstücke, die PEncK Riedel nennt, haben ihren ursprünglichen Charakter gewahrt (Fig. 190). 
So gewaltig sich auch die Destruktion im Tafelland des Colorado entfaltet hat - so gewaltig, daß durchschnittlich 16-1800 m mächtige Deckschichten bis auf wenige Reste verschwunden sind - , so ist

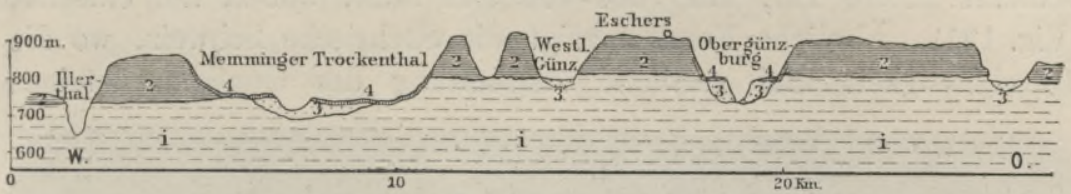

Fig. 190, Profil eines Teiles "der schwäbischen Hochebene nach Pevck. 1 Tertiär, 2 diluviale Nagelfluh, 3 unterer Glazialschotter, 4 Moränen.

es doch noch immer eine geschlossene Masse. Wir haben seiner Cañons schon gedacht; es sind deren verhältnismäßig wenige, weil das Klima an Trockenheit leidet, aber die wenigen lassen an Großartigkeit alle ähnlichen Bildungen der Erde weit hinter sich zurück.

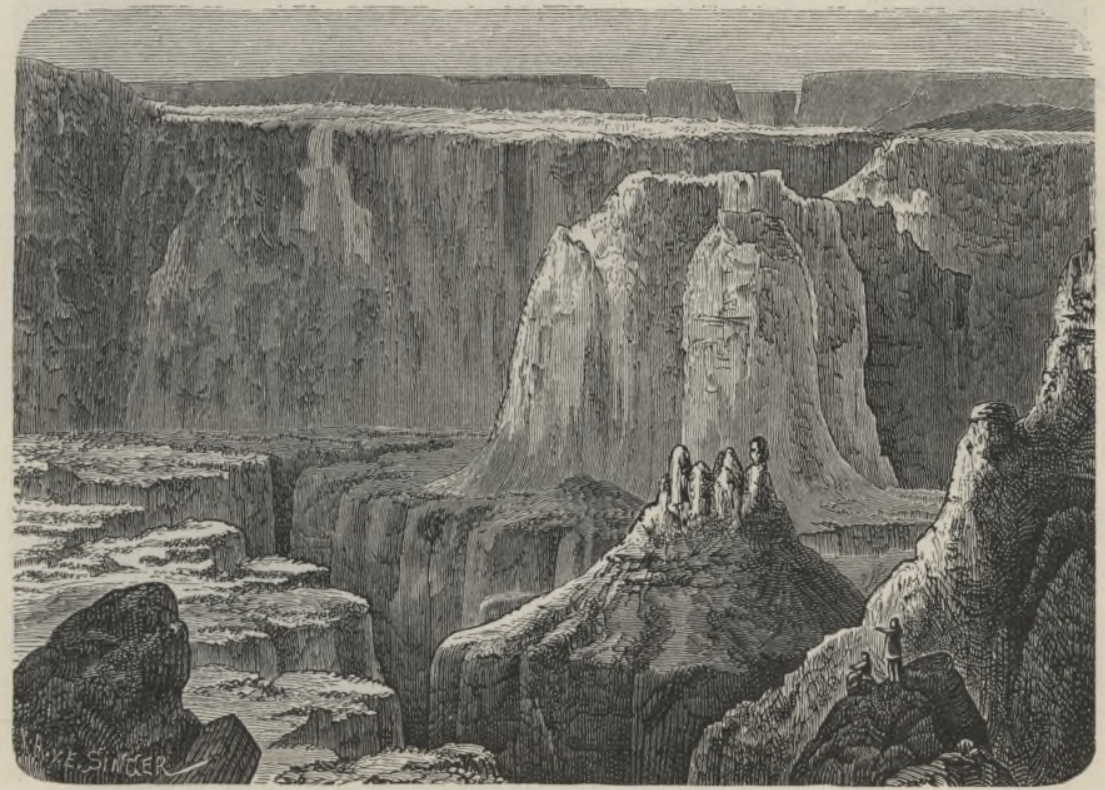

Fig. 191. Seitencañons des Colorado.

Je nach der Widerstandskraft der Schichten sind sie in U- oder V-Form bis zu $2000 \mathrm{~m}$ Tiefe in das Tafelland eingeschnitten. Sind die oberen Schichten härter als die unteren, so entstehen steilwandige Schluchten, die im Vergleich zur Ausdehnung des Plateaus nur als unbedeutende Risse erscheinen (s. Fig. 142. S. 526), während sich im umgekehrten Fall die Gehänge sanfter-und meist stufen- 
förmig abdachen. Manchmal bestehen die Cañons aus zwei Stockwerken, im Großen Cañon ist das obere $8-9000 \mathrm{~m}$ breit und $600 \mathrm{~m}$ tief und endet unten mit einer rauhen Fläche, in die sich das schmale untere Tal, nur $1000-1200 \mathrm{~m}$ breit, $900 \mathrm{~m}$ tief einsenkt (Fig. 191). Ähnliche Formen zeigt die Sächsische Schweiz, wo die Durchlässigkeit und vertikale Zerklüftung des Quadersandsteines

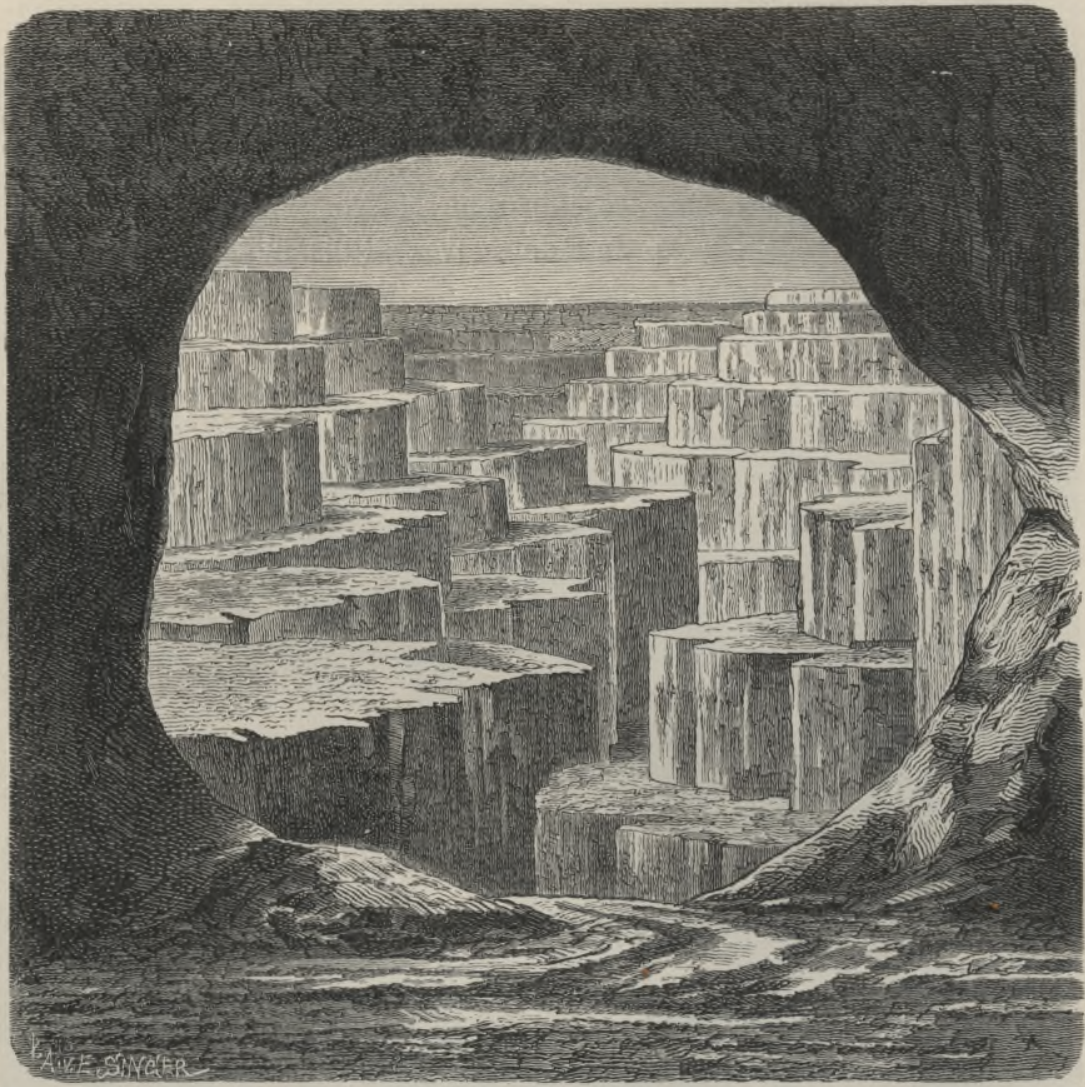

Fig. 192. Aussicht auf Lößschluchten durch eine Öffnung in der Wand eines Hohlweges am $\mathrm{Pa} \beta$ Hansinling in Schansi nach v. Rrohthofen.

die Erhaltung der mauergleichen Eelswände fördert (vergl. S. 526). Selbst der lockere Löß eignet sich infolge seiner Neigung zu senkrechter Spaltung zu dieser Talform. Ein labyrinthartiges System von Tälern durchschneidet die chinesischen LöBplateaus nach allen Richtungen; die Wände sind senkrecht oder sogar überhängend, und verlaufen dort, wo horizontale Lager von Mergelknollen eine scheinbare Schichtung hervorrufen, in regelmäßig zugehackten Terrassen 
(Fig. 192), ja einzelne Pfeiler lösen sich von den Lößmassen völlig los. Auch der Wind schafft Hohlwege längs der Verkehrsstraßen, wo Karrenräder oder der Huf der Tiere den Boden gelockert haben. So geht aus der monotonen Hochfläche abflußloser Gebiete, sobald mit einer Klimaänderung das flieBende Wasser seine Tätigkeit zu entfalten beginnt, eine Landschaft hervor, in der sich die größte Einförmigkeit, die im Baumaterial begründet ist, mit einer „endlosen Mannigfaltigkeit der Ziselierung" verbindet. ${ }^{\times}$

Sind die Täler zahlreich im Verhältnis zur Ausdehnung der Fläche, so schrumpfen die Zwischenstücke zu schmalen Rippen oder vereinzelten Erhebungsmassen zusammen: die zerschnittene Fläche hat sich in ein Erosionsgebirge aufgelöst.

In lockeren Ausfüllungsmassen flachen sich die Böschungen der Berge und Bergzüge $a b$; im Neogenbecken Siebenbürgens nehmen sie stellenweise eine kammartige Gestalt an, und gerade dadurch ist die-ursprüngliche Oberflächenform völlig verwischt worden.

Anders im Tafelland. Mit steilen, sich oft stufenförmig aufbauenden Abhängen erheben sich darüber Tafelberge oder umfangreichere Plateaus, oben flach abgeschnitten. In der Regel ist die oberste Schicht widerstandsfähiger, als die darunter liegende. Auf der Kreidetafel Südaustraliens sind sie stets mit einem gelben Feuerstein-Jaspisgestein oder mit einem harten porzellanähnlichen Sandstein und Quarzit gekrönt. ${ }^{20}$ Quarzitischer Sandstein deckt in Südafrika die Tafelberge der Kapformation, Diabas die der Karruformation. Gesellig treten sie hier in den bogenförmig angeordneten Karree- und Prambergen südlich vom Oranje auf. Kluftartige Täler scheiden diese Hunderte von Bergen, deren Gipfel ohne Ausnahme etwa $300 \mathrm{~m}$ über der Hochebene liegen, und deren Abhänge mit kolossalen Trümmern herabgestürzter Gesteinsmassen bedeckt sind. Lavadecken schützen besonders häufig die Tafelberge, so in Arabien und in dem altpaläozoischen Tafelland Ostsibiriens, das sich vom Jenissei bis zur Lena und oberhalb Jakutsk darüber hinaus bis an den Aldan erstreckt, ferner die Ambas Abessiniens (s. Fig. 193) und die Mesas (Tische) des Coloradoplateaus (Fig. 201 S. 640). Hier ist die Auflösung durch Destruktion stellenweise außerordentlich weit fortgeschritten, besonders im Gebiet der leicht zerstörbaren eozänen Sandsteine und Mergel, wo das Seltsame jener phantastisch ruinenhaften Oberflächengestaltung, die unter dem Namen der „bad land

× Ein europäisches Seitenstück zur chinesischen LöBlandschaft ist nach W. v. Łozısski (Globus 1909, Bd. XCVI, S. 330) die Gegend von Sandomierz und Opatów in der Provinz Radom. 
erosion" berühmt geworden ist, noch durch die lebhaften, häufig wechselnden Gesteinsfarben erhöht wird. ${ }^{21}$

Die Tafelberge stellen ein altes Niveau des Tafellandes dar, und in diesem Sinn hat man sie auch "Zeugen" $\times$ genannt. Die Steilabhänge sind entweder vertikale Kluftflächen, wie im Elbsandsteingebirge der Sächsischen Schweiz, oder sie sind dadurch entstanden, daß die Zerstörung durch die Atmosphärilien oder durch die Insolation und den Wind in der weichen Unterschicht weiter nach innen fortschreitet als in der harten Oberschicht, und diese dann über der Hohlkehle nachbricht. Bedingung ist nur, daß die Unterschicht allseitig entblößt sei, und dies kann durch Talbildung oder durch Zerklüftung bewirkt werden.

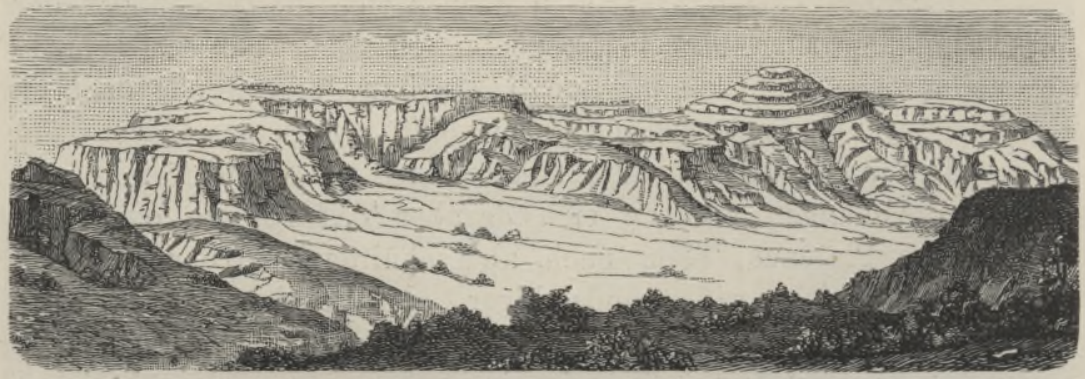

Fig. 193. Ambas in Abessinien.

Größere Schwierigkeiten bietet die Erklärung jener Landstufen, die wir als Destruktionsstufen bezeichnen wollen. Ein lehrreiches Beispiel ist die Schwäbische Alb, und sie ist doppelt lehrreich durch die Untersuchungen BRANCA's ${ }^{22}$ geworden.

Von dem Donautal in der oberdeutschen Hochebene erhebt sich das Plateau der Schwäbischen Alb "ganz allmählich um etwa $300 \mathrm{~m}$ und stürzt im Norden steil $4-500 \mathrm{~m}$ zu den welligen Flächen des Neckarlandes ab, wo sich über triadische Ablagerungen eine leichte Decke von Lias ausbreitet (Fig. 194). Über dem Lias folgt an den Abhängen der Alb der Braune Jura (Dogger), ebenso wie jener vorwiegend aus tonigen und mergeligen Gebilden bestehend, dann, mit einer Steilmauer endend, der. massige Kalkstein des Weißen Jura oder Malm. Die Schichten neigen sich sanft nach Süd und tauchen unter das Tertiär der oberdeutschen Hochebene unter, ${ }^{23}$ auch im Norden ist kein Bruch bemerkbar. $\mathrm{DaB}$ hier die $\mathrm{Alb}$ einst weiter

× Für Erhebungen, die durch Erosion des Wassers oder des Windes von der Hauptmasse abgetrennt wurden, gebrauchen die englisehen Geologen den Ausdruck Outlier (Auslieger). 
in das Neckarland hineinreichte und durch Destruktion nach Süden gedrängt wurde, war schon lange Überzeugung, aber ein positiver Beweis dafür wurde erst von Branca gefunden. Die Tuffgänge der miozänen Maare, von denen wir schon auf S. 377 gesprochen haben, enthalten eine Sammlung aller durchbrochenen Gesteine; Dogger und Malm kommen selbstverständlich in den Tuffgängen der Alb vor, aber sie fehlen ebensowenig im Vorland, wo sie nicht mehr anstehen; und ein Transport von fernher erscheint nach dem ganzen Sachverhalt als ausgeschlossen. Auch das nördlichste Tuffmaar, bei Scharnhausen im Kerschtal gelegen ( $K$ in Fig. 194), macht von dieser allgemeinen Regel keine Ausnahme; der Steilrand der Alb $\mathrm{mu} ß$ also in der Miozänzeit wenigstens in der Gegend von Stuttgart ( $M$ in Fig. 194) gelegen haben und hat sich seitdem um etwa $23 \mathrm{~km}$ zurückgezogen: eine sehr bescheidene Leistung der Destruktion, wenn man die ungeheuere Länge der Zeit in Betracht zieht. DaB der isolierte Jurafetzen von Langenbrücken im Rheintal, den seine
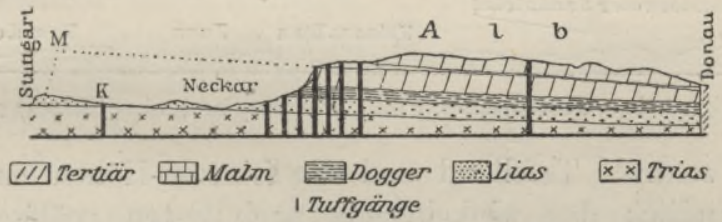

Fig. 194. Die Schwäbische Alb.

Maßstab der Länge 1:1000 000, der Höhe 1: 100000.

Versenkung vor Denudation geschützt hat, einst mit der Alb zusammenhing, ist nun keine waghalsige Vermutung mehr.

Die Steilwand der Alb ist keine Talwand, sie steht mit der Bildung des Neckartales. in keinem unmittelbaren Zusammenhang, denn sie setzt sich nach Nordost fort, während der Neckar nach Nordwest umbiegt. Wie alle Denudationsstufen schneidet sie den Lauf der Flüsse senkrecht oder unter einem spitzen Winkel. Die Entstehungsweise ist dieselbe wie bei den Tafelbergen: Auswaschung der weichen Unterschicht und Abbröckelung der harten Oberschicht. Auf Karten größeren Maßstabes erscheint der Steilrand keineswegs als eine gerade verlaufende Mauer, sondern zerfranst. Zwischen den Tälern, die von der Alb ausgehen, springen Gebirgssporne halbinselartig vor, manchmal breit und abgerundet, manchmal schmal und spitz zulaufend. Nun kann die Erosion diese gefährdeten Vorposten auch von rückwärts angreifen; Taleinschnitte trennen sie vom Mutterkörper ab, der Gebirgsvorsprung wird ein Tafelberg, und schutzlos preisgegeben verfällt er nun den allseitig eindringenden zerstörenden Kräften. Wie ein solcher Steilrand 
immer weiter zurückweicht, läßt sich beobachten, aber seine ersten Anfänge sind noch rätselhaft.

Östlich vom Neckar finden wir drei Stufen, die an widerstandsfähigere Gesteine gebunden sind: im Süden an die mächtigen Kalke des weißen Jura, weiter nördlich an die Sandsteine und Kalke des unteren Lias und endlich, in der nördlichsten Stufe, an den Stubensandstein des oberen Keuper. ${ }^{24}$ Ein anderes ausgezeichnetes Beispiel bietet das englische Tiefland, das seine reizvolle $\mathrm{Ab}$ wechslung nur dem Stufenbau verdankt. Mit wenigen Ausnahmen sind hier die Lagerungsverhältnisse der Schichten von der Triasformation angefangen ungestört (Fig. 195). In westöstlicher Richtung folgen aufeinander: das aus primären Gesteinen bestehende Gebirge, die aus Trias und Lias zusammengesetzten Ebenen, die vom Severn und Mersey einerseits, Trent und Ouse anderseits entwässert werden; dann das Juraplateau, das sich von den Cotswold Hills über das

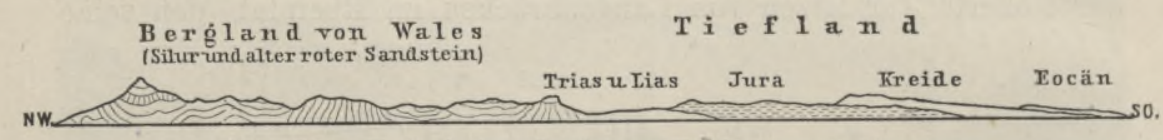

Fig. 195. Geologisches Profil von Fingland nach Ramsay.

sogenannte zentrale Tafelland und die Lincoln-Höhen nach Norden erstreckt; endlich das winkelförmig nach Osten geöffnete Kreideplateau (Marlborough- und Chilternhügel, die ostanglikanischen Höhen, die Lincoln und York Wolds), das das Eozänbecken von London einschlieBt. Beide Plateaus, die steil nach W, sanft nach $\mathrm{O}$ abfallen, sind nur durch die Festigkeit ihres Materials vor völliger Abtragung bewahrt geblieben. Der Humber durchbricht die Juraund Kreidestufe, die Themse nur

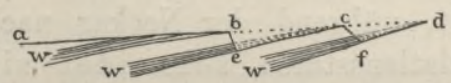

Fig. 196. Hypothetische Entstehung der Landstufen. $w$ weiche Schichten, $a b c d$ ursprüngliche Oberfläche, $a b e c f d$ jetzige Oberfläche. die Kreidestufe; beide folgen dem östlichen Schichtenfall.

Darüber sind alle einig, daß die heutige Stufenentwicklung ein Werk der fluviatilen Destruktion ist, und daß die Flüsse älter sind, als die Stufenbildungen, die sie durchbrechen. Um das zu erklären, gingen Nö̈ und DE MARgerie ${ }^{25}$ von der Annahme aus, daß der oberflächliche Wechsel von mehr und weniger widerstandsfähigen Gesteinen ursprünglich sein müsse, oder mit andern Worten, daß die ursprüngliche Oberfläche sich sanfter neigte als die Schichten, etwa in der Weise, wie es HuLL's Profile der Texas. prärien vor Augen führen. ${ }^{26}$ Die weitere Entwicklung ist nach DAvIs $^{27}$ und seiner Schule leicht verständlich. Es entstanden zu- 
nächst konsequente Flüsse, dann innerhalb der leichter zerstörbaren Zonen subsequente, endlich obsequente Flüsse, die die Stufen zurückdrängten. Nur darf das, was wohl für England gelten mag, nicht verallgemeinert werden, denn in der scharf ausgeprägten nordfranzösischen Stufenlandschaft spielen die subsequenten Flüsse nur eine untergeordnete Rolle (Fig. 197). Aber richtig ist, daß innerhalb der weichen Zonen die Destruktion rascher und kräftiger arbeitet als innerhalb der harten, daB Erniedrigung und Einebnung dort schnellere Fortschritte machten als hier.

Aber wie kam jene ursprüngliche Oberfläche zustande? Die befriedigendste und einfachste Antwort wäre offenbar: durch Abrasion. Für das nordöstliche England ist sie auch begründet; das Meer der oberen Kreide hat durch seine Brandungswirkung eine sanft an-

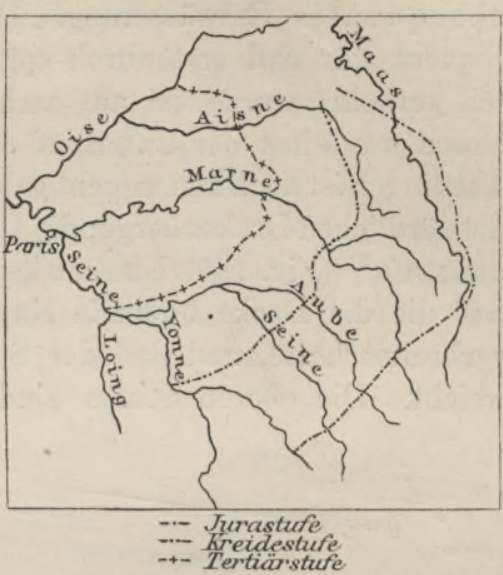

Fig. 197. Nordfranzösische Stufenlandschaft in $1: 5000000$. steigende Fläche geschaffen (Fig. 198). Die Kreidedecke konnte im oberen Teil, wo sie dünner war, leicht zerstört werden, und dadurch wurden die unteren Schichten von wechselnder Widerstandskraft bloßgelegt. Wo aber transgredierende Meeresablagerungen fehlen, hängt auch die Abrasionstheorie in der Luft. ScHeU ${ }^{24}$ nennt jene hypothetische ursprüngliche Oberfläche ein Peneplain, ohne sich weiter darüber aus-

Karbon Perm Trias Jura Obere Kreide

Fig. 198. Ursprüngliche Oberfläche des östlichen Yorkshire nach REED. ${ }^{28}$

zusprechen, wie durch subaërische Einflüsse aus einer mit den Schichten gleichfallenden schiefen Ebene eine die Schichten schneidende entsteht, ohne daß es schon in jenem Stadium zur Stufenbildung kommt. Jene schichtenschneidende Ebene ist aber überhaupt in vielen Fällen eine unstatthafte Voraussetzung. Im fränkisch-schwäbischen Stufenland zeigt nur ScHeu's Karte Reste der Liasstufe bis an den Rand der Keuperstufe. Im englischen Tiefland bedeckten Jura und Kreide einst auch die Triaszone im W, und RAMsaY ${ }^{29}$ erklärt dadurch die Talbildung der Themse, deren Quellgebiet niedriger liegt, als das Kreideplateau, das sie durchbricht. Die Erosion begann schon damals, als die Kreide noch bis an den 
Ursprung des Flusses hinaufreichte, und die Differenzierung der Stufen durch Bloßlegung der dazwischen liegenden Weichzone ist in beiden Beispielen erst späteren Datums. ${ }^{30}$.

Das östliche England ist eine Stufenlandschaft mit konsequenter, die Gegend im N. der Schwäbischen Alb eine solche mit obsequenter Entwässerung. Daß diese aber einst auch hier konsequent war und erst durch spätere Bodenbewegungen in ihr Gegenteil verkehrt wurde, ist aus mehreren Anzeichen zu schließen. Die Brenz war einst der Unterlauf der Kocher, und die Donau oberhalb Tuttlingen ist noch konsequent geblieben. In dieselbe Kategorie gehören die nördlichen Drakenberge; die Deutung des lehrreichen Profils MolexGRAAFF's $^{31}$ (Fig. 199) bereitet keine Schwierigkeiten, denn es ist klar, daß die die Decke bildende Kapformation sich einst weiter nach 0 verbreitet hatte, und daß der Steilrand allmählich nach W zurückweicht. Die oberen Stufen sind durch das Ausgehen widerstands-

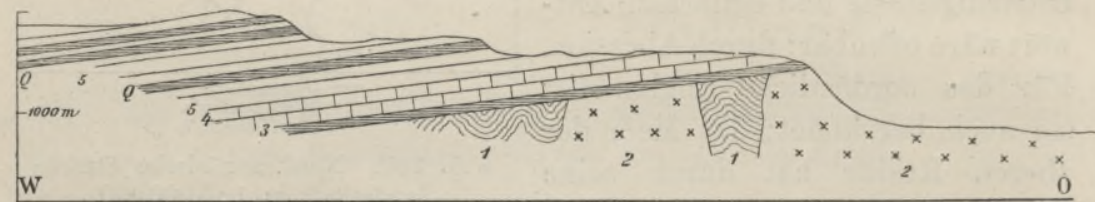

Fig. 199. Profil der Drakenberge an der Bahn von Lourenço-Marquez nach Pretoria, nach Molengraaff.

Primärformation: 1 kristallinische Schiefer, 2 Granit. Kapformation: 3 Sandstein, 4 Dolomite, 5 Schiefer usw. mit Quarzitbänken (Q).

fähiger Quarzitbänke bedingt. Nur beiläufig sei erwähnt, daß die Nieuwveld-, Schnee- und südlichen Drakenberge, die die Große Karru von den inneren Hochflächen Südafrikas abgrenzen, zu den großartigsten Destruktionsstufen der Erde gehören. Die wenig widerstandsfähigen Beauford-Schiefertone und Stormberg-Sandsteine werden durch Diabasdecken geschützt, wie die Tafelberge im Innern ${ }^{32}$ hier wird besonders deutlich, daß Landstufen und Tafelberge aus demselben Destruktionsprozeß hervorgehen.

Umformung durch Bruch (Frakturformen). Aber nicht alle Landstufen haben den gleichen Ursprung; neben Destruktionsstufen gibt es auch Bruchstufen. Eine solche ist der Ostrand der abessinischen Tafel, die sich nach AuBRY's ${ }^{33}$ Forschungen aus Triassandsteinen, Jurakalken und gewaltigen vulkanischen Auswurfsmassen über dem niederen Danakilland ein paar tausend Meter hoch aufbaut. Wir haben dieses Bruches schon gedacht als eines Gliedes jener Grabenversenkungen, die sich von Syrien bis zum Njassa erstrecken (S. 398). Manchmal geht der Bruch in eine Flexur über; das Elbsandsteingebirge bricht gegen das kristallinische Gebirge der Lausitz mit 
einer Verwerfungsspalte ab, während es sich im Süden mit einer Schichtenneigung von $20^{\circ}$ unter das böhmische Mittelgebirge senkt. Eine mächtige Flexurstufe ist das Nankou-Gebirge, das die Tiefebene von Peking im Nordwesten abschlieBt (Fig. 200), und solcher Beispiele finden sich noch viele in v. RIснтноғеN's klassischem Chinawerk. Manchmal löst sich die Senkung in Staffelbrüche auf; in dem Karbonplateau von Süd-Schansi zählt man deren vom Rand des Tieflandes bis Pingting-tschou nicht weniger als neun, die ebenso vielen Landstufen entsprechen; die Schichten neigen sich etwas gegen "das Plateau, so daß am Rand jeder Stufe der Kohlenkalk unter der produktiven Steinkohlenformation, die sonst die Oberfläche bildet, zutage tritt: $^{34}$ Auch unser Erdteil bietet eine Fülle von Beispielen ähnlicher Art, wenn auch in bescheidenerem Maßstab; man erinnere sich nur an die Steilabstürze, die die Nordhälfte des oberrheinischen Grabenbruches begleiten.

Aberwohl kaum irgendwo ist ein frischer Bruchrand zu beobachten, stets hat er durch die nie rastende

Destruktion Veränderungen erlitten, und oft

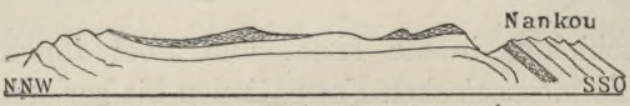

Kalksteine der Sinischen Formation Gischieferthone

Fig. 200. Nankou-Gebirge in Nordehina nach v. Richthofen.

können nur genauere geologische Untersuchungen entscheiden, ob man es mit einer Destruktions- oder einer Bruchstufe zu tun hat. Vorgelagerte Zeugenberge fehlen der letıteren in der Regel.

Allein Verwerfungen beschränken sich nicht auf die Ränder flachgeschichteter Teile der Erdkruste, sie greifen auch in das Innere ein und können große Partien der Flachländer in Schollen zerlegen. Die unterste Scholle im Coloradoplateau längs des Großen Cañons, der uns alle Geheimnisse der Tiefe aufschließt, ist die des Grand Wash, die durch die gleichnamige Spalte im Osten $(G W$ in Fig. 201) begrenzt wird. Hier hat eine Versenkung von 1800 bis 2100 m Sprunghöhe stattgefunden; die Denudation hat diese Differenz gemildert, aber noch immer muß man $1000 \mathrm{~m}$ steigen, um auf das Shearwitsplateau zu gelangen (1600 m ü. M.). Hier herrscht schon der mächtige, widerstandsfähige Kohlenkalkstein. Reste der permischen Schiefer haben sich nur erhalten, wo Lavaauflagerungen sie schützten; ein paar ausgedehnte Plateaus erheben sich bis $2100 \mathrm{~m}$. Nun folgt die Hurricanespalte $(H)$ mit leiser Flexurbeugung, und abermals steigen wir eine Stufe empor, zum Uinkaretplateau (2100 m), das den $2700 \mathrm{~m}$ hohen Tafelberg Mt. Trumbull (Tb) trägt. Die Toroweaspalte $(T)$ macht sich orographisch nicht sehr bemerkbar; das Kanabplateau, die umfangreichste aller Schollen dieses Profils, 
verharrt ebenfalls in Seehöhen von $1800-2100 \mathrm{~m}$. Der Anstieg nach Osten ist aber unverkennbar, besonders in der vorkarbonischen Unterlage, die der Kanab-Cañon (K.C.) bereits erreicht. Nun folgt die höchste Scholle, das Kaibabplateau $(2700 \mathrm{~m})$, nach West durch zwei Brüche (West-Kaibab-Spalten - WK 1 u. 2) vom Kanab geschieden, nach Ost sich in einer sanften Flexur (O.K.) $\times$ zur Marble Cañonplatte $(1500 \mathrm{~m})$ senkend. Noch einmal beugen sich die Karbon-

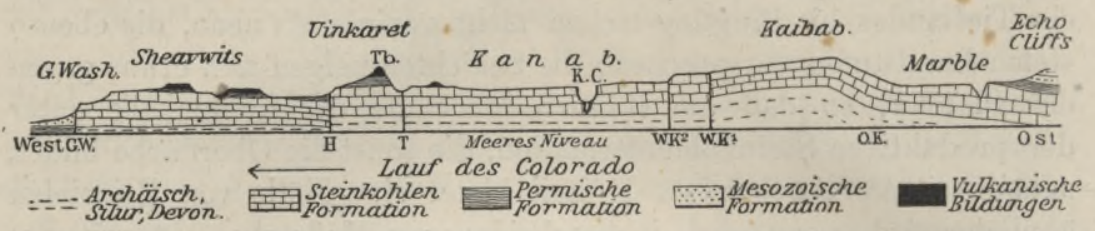

Fig. 201.

Profil des Colorado-Plateaus im Parallel des Großen Cañon nach Dutron reduziert. Maßstab der Länge 1:2000000, der Höhe 1:400000.

schichten in die Tiefe, und über ihnen erscheinen nun Perm und die mesozoischen Formationen bis zur Kreide, die vom ganzen Westen bis auf die genannten Permreste abgeschwemmt sind. Die Echo Cliffs $(2300 \mathrm{~m})$ sind eine Destruktionsstufe.

Alle diese tektonischen Veränderungen müssen sich vollzogen haben, als die Coloradotafel schon Land war und der Coloradofluß sein herrliches Tal schon zu vertiefen begonnen hatte, denn unbekümmert setzt er seinen Weg fort, wenn auch die Schollenbewegung seiner Laufrichtung widerspricht.

In diesem Teil des Tafellandes sehen wir eine sich sanft neigende Ebene durch vertikale Niveauveränderungen der Schollen in ein Stufenland verwandelt. Einen kleinen Schritt weiter in der Auflösung zeigen uns Mercerat's ${ }^{35}$ Profile von Südpatagonien. Die Verwerfungen haben zwar keine bedeutende Sprunghöhe, beherrschen aber trotzdem infolge ihrer Häufigkeit den orographischen Charakter. Einzelne Schollen erheben sich als Tafelberge über die Umgebung, aber noch bedeutungsvoller treten im Landschaftsbild die annähernd meridional verlaufende Brüchen hervor, an denen in der Regel die östliche Stufe abgesunken ist, und die den ausgeprägten nach W ansteigenden Terrassenbau bedingen. Aber noch ist im großen und ganzen der Charakter der Fläche gewahrt. Auch dieser kann verschwinden. Um das darzulegen, folgen wir zunächst Russelu, ${ }^{36}$ dem wir einen lehrreichen Bericht über die geologischen Verhältnisse von Süd-Oregon verdanken.

$\times$ Man beachte, daß in Fig. 201 wegen der fünffachen Überhöhung alle Neigungen übertrieben sind! 
Das "Große Becken" zwischen dem Felsengebirge und der Sierra Nevada ist ein echtes Schollenland, aber die Südhälfte ist, wie wir später sehen werden, von wesentlich anderer Beschaffenheit wie die nördliche. Hier breiten sich die großen vulkanischen Tafeln aus Basalten, Rhyolithen und deren Tuffen aus, und diese sind durch spätere Dislokationen vielfach zerstückelt worden. Fig. 202a stellt uns den Bau im mittleren Alvordtale $\left(42{ }^{1} /{ }^{0} \mathrm{~N}, 118^{1} /{ }^{0} \mathrm{~W}\right)$ dar. Es ist ein einfacher Grabenbruch, ausgefüllt mit Ablagerungen eines einst viel größeren Sees; das Steingebirge, das sich zu der ansehnlichen Höhe von 14-1500 m über die Talsohle erhebt, ist eine einfache Bruchstufe, die nur an der Ostseite als Gebirge erscheint, während sich nach West die Schichten ganz allmählich neigen. Die entgegengesetzte Neigung herrscht an der Ostseite des Grabens. Am nördlichen Ende des Alvordtales (Fig. 202b) werden die tektonischen Verhältnisse aber verwickelter. Die Bruchstufe der Stein Mountains ist zwar noch vorhanden, aber innerhalb des Grabens liegen noch
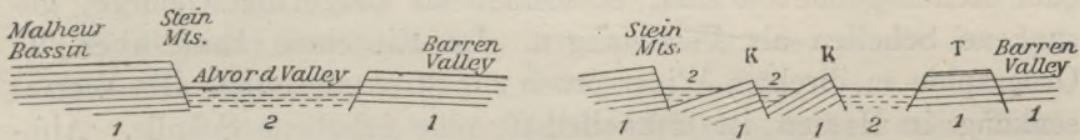

Fig. 202. Profile aus dem südöstlichen Oregon nach Russelu. a Mittleres Alvordtal, $b$ nördliches Alvordtal. 1 Vulkanische Ablagerungen, 2 moderne Ausfüllungsmassen.

zwei Schollen mit steiler Schichtenneigung nach West ( $K$ in Fig. $202 b$ ), die wir als Keilschollen bezeichnen wollen, und am Ostrand löst sich von der Tafel des Barren Valley eine andere Scholle los $(T$ in Fig. 202b), die ihre Flachschichtung noch bewahrt hat, aber sich beiderseits als Berg über die Umgebung erhebt. Das ist eine Tafelscholle, man kann auch sagen Tafelhorst, wenn festgestellt ist, daß sie allseitig von Brüchen begrenzt wird. Daß Tafel- und Keilscholle in typischer Ausbildung sich orographisch sehr wesentlich voneinander unterscheiden, lehrt ein Blick auf Russelu's Profil. Jene gleicht mit ihrer Platte völlig einem durch Destruktion herausgearbeiteten Tafelberg, diese erzeugt, wenn sie ausgedehnt genug ist, ungleichseitige Kammgebirge, mitunter, wenn die Schichten keine große Widerstandskraft besitzen, auch Rückengebirge; aber stets ist die Ungleichartigkeit der Böschungen ein charakteristisches Merkmal dieser Geländeform.

Daß der Zusammenhang der Schollen hier oberflächlich durch jugendliche Ablagerungen verhüllt ist, ist ein nebensächliches Moment. Im hessischen Bergland (Fig. 203) ist eine solche Maskierung nur in untergeordneter Weise bemerkbar, aber auch hier sind die Schollen 
so stark gegeneinander verschoben, da $\mathrm{B}$ - und dies ist das Wesentliche - die einstige Fläche sich in ein Bergland verwandelt hat. Indem die Gesteine in verschiedene Niveaus gerückt sind, wird der Destruktionsprozeß außerordentlich verwickelt. Im Großen und

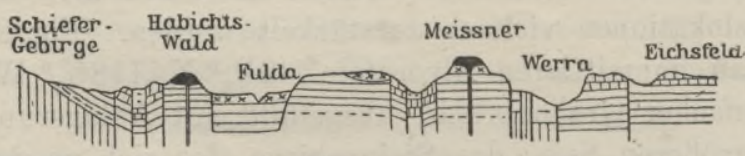

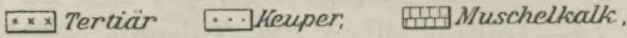

$\exists$ Bundsandstein. $\quad-\rightarrow$ Zechstein,

떼엑 gefaltetes Grundgebirge,

Basalt.

Fig. 203. Westöstlicher Durchschnitt durch das hessische Bergland nach Penck. Maßstab der Länge 1:250000, der Höhe 1:25000.

Ganzen bleibt das tektonische Bild gewahrt; Schollen, die gehoben oder stehen geblieben sind, erscheinen als Berge und Gebirge, gesunkene Schollen als Vertiefungen. Im Einzelnen kann aber die Orographie in direkten Widerspruch zur Struktur treten. Die Werrasenkung in Hessen ist unzweifelhaft eine gehobene Scholle. Ähn-

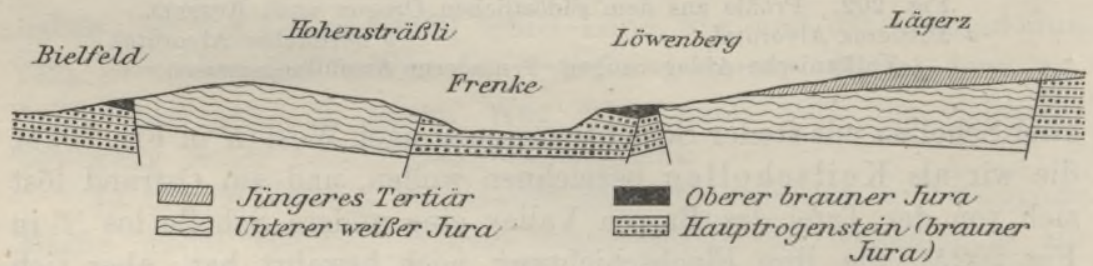

Fig. 204. Profil des Frenketals im Baseler Tafeljura in 1:25000 nach Cloos.

lichen Umkehrungen begegnen wir im Baseler Tafeljura. Das Homburger, das Diegtener und das Frenketal (s. Fig. 204) liegen in Horsten, während die dazwischen liegenden Gräben Erhebungen bilden. Der Destruktion kann das nicht zugeschrieben werden, sie kann höchstens Horst und Graben nivellieren. CLoos ${ }^{37}$ macht darauf aufmerksam, daß die tektonischen Gräben hier durch konvergierende Bruchspalten begrenzt werden, und meint, da $B$ sie beim Sinken zusammengeschoben und auf diese Weise über die Horste hinausgeschoben wurden.

\section{Übersicht der Umwandlungsformen der Flachschichtung.}

I. Der ursprüngliche Charakter der Fläche wird verändert, aber nicht aufgehoben: 
1. durch Erosion: zerschnittenes Flachland.

a) Im Tafelland,

b) im aufgesetzten Flachland (castilianischer Typus);

2. durch Bruch: Tafelschollenland (Coloradotypus).

II. Die Fläche kann als solche ihren Charakter wahren oder verändern, stellt sich aber durch eine Landstufe in scharfen orologischen Gegensatz zum Vorland:

3. Destruktionsstufe (Albtypus).

4. Tektonische Stufe:

a) Bruchstufe (abessinischer Typus),

b) Flexurstufe (Nankou-Typus).

III. Die Fläche löst sich auf und wird Gebirge:

5. Durch Erosion: Erosionsgebirge.

a) Im Tafelland, Plateaugebirge (Elbsandstein-Typus),

b) in der aufgesetzten Ebene, Rücken- und Kammgebirge (siebenbürgischer Typus).

6. Durch Bruch: Tafelschollen gebirge (hessischer Typus). IV. Einzelformen sowohl in den zerschnittenen, wie in den aufgelösten Hauptformen:

7. Durch Destruktion: Destruktionsberge, teils Tafelberge, teils aber auch abgerundete oder zugespitzte Erhebungen.

8. Durch Bruch: Schollenberge.

a) Tafelschollenberge,

b) Keilschollenberge.

Die äußersten Umwandlungsformen sind jedenfalls die Flexurstufe und die Keilscholle, ${ }^{\times}$insofern als hier die Flachschichtung vollständig aufgehoben ist. Ihre innigen Beziehungen zur Flachschichtung lassen es aber doch gerechtfertigt erscheinen, sie an dieser Stelle in' das genetische System einzufügen.

Literaturnachweise. ${ }^{1}$ G. Rothand, Géologie du Sahara algérien, in Cногsх, zit. S. 583; L'histoire géologique du Sahara, in den Comptes rendus de l'Académie des sciences $1890 .-{ }^{2} \mathrm{E}$. Havg, in den Comptes rendus de l'Académie des sciences 1905, Bd. CXLI, S. 374. R. Chudeau, ebenda, S. 566. E. F. Gautier, Le Sahara algérien, Paris 1908. - ${ }^{3}$ C. M. Dovahty, Travels in Arabia Deserta; Cambridge 1888. $-{ }^{4}$ A. Karpinskx, Übersicht der physiko-geographischen Verhältnisse des europäischen RuBland während der verflossenen geologischen Perioden, in den Beiträgen zur Kenntnis des Russischen Reiches, 1887; Sur les mouvements de l'écorce terrestre dans la Russie d'Europe, in Annales de géographie, Bd.V. A. v. Truso's hypsometrische Karte von Rußland 1889

$\times$ Dieser Begriff ist hier enger gefaßt als in v. Ricнтноғем's Führer, wo auch einseitige Rumpfschollen dazu gezählt werden. 
(vgl. Petermans's Mitteilungen 1890, S. 156). Neue geologische Karte 1892, in Reduktion in Petermann's Mitteilungen 1895. A. Philippson, Das russische Flachland, in der Zeitschrift der Berliner Gesellschaft für Erdkunde, 1898; Zur Morphologie des europäischen Rußland, in Petermans's Mitteilungen 1898. A.v. Krassnow, Rußland. 3. Teil von A. Kirohноrf's Länderkunde von Europa, Leipzig 1907. $-{ }^{5} \mathrm{~N}$. Soкоцоw, Hydrogeologische Untersuchungen im Gouvernement Cherson, in den Mémoires du Comité géologique, Bd. XIV, 1896. - ${ }^{6}$ A. Borissjak, Geologisehe Skizze des Kreises Isjum, ebenda, N. S. 1905. - ${ }^{7}$ H. Hassinaer, Geomorphologische Studien aus dem inneralpinen Wiener Becken und seinem Randgebirge, Leipzig 1905 (Bd. VIII von PENck's Geographischen Abhandiungen). $-{ }^{8}$ Bericht von E. Zsigmondy im Jahrbuch der Wiener Geologischen Reichsanstalt, 1878, S. 659. J. HaLaVíts, Die geologischen Verhältnisse-des Alföld zwischen Donau und Theiß, im Jahrbuch der ungarischen geologischen Anstalt, 1897. P. Treirz, Agrogeologische Besehreibung des Gebietes zwischen Donau und Theiß, in Bd. XXXIII des Földtani Közlöny; Budapest 1903. ${ }^{\circ}$ D. Pantanelui, Le aeque sotteranee nella Provincia Modenese, in den Atti della Società dei naturalisti di Modena 1888. - ${ }^{10} \mathrm{R}$. D. Oldнaм, in d. Records of the Geological Survey of India 1890, S. 261. - ${ }^{11}$ R. Lepsits, Die oberrheinische Tiefebene; Stuttgart 1885. - ${ }^{12}$ F. v. RicнтноғеN, China, Bd. II, S. 337. $-{ }^{13}$ C. L. Griessach, Geology of Central Himalaya, in den Memoirs of the Geological Survey of India 1891. - ${ }^{14}$ M. Friederichsen in Petermanx's Mitteilungen 1900 , S. $22 .-{ }^{15} \mathrm{~F}$. Wahnschaffe, zit. S. $610 .-{ }^{16} \mathrm{~N}$. WrssotzkiJ, in Explorations géologiques et minères le long du chemin de fer de Sibérie, Lief. V. 1896. - ${ }^{17}$ Von der Geschichte dieser Küstenebene handelt ausführlich W. J. McGEe, The Lafayette Formation, im 12. Annual Report of the U. S. Geological Survey, 1890-91. - ${ }^{18}$ F. Katzer, Grundzüge der Geologie des unteren Amazonasgebietes; Leipzig 1903. - ${ }^{19} \mathrm{~S}$. Rотн, in der Zeitsehrift der Deutschen Geologischen Gesellschaft, 1888, S. 375. - ${ }^{20}$ H. Y. L. BRown, The Mesozoic Plains of South Australia, 1888. - ${ }^{21}$ Um eine Vorstellung von diesen wunderbaren Formen zu gewinnen, betrachte man die meisterhaften Zeichnungen C. E. Dutrox's, die er seiner "Physieal Geology of the Grand Cañon District" (im 2. Annual Report of the U. S. Geological Survey, 1882) beigab, besonders des Panorama von Point Sublime. - ${ }^{22}$ W. Branco (Branca), zit. S. 410, Anm. 3. - ${ }^{23}$ C. Regelmann, Bericht über die 41. Versammlung des Oberrheinischen Geologischen Vereins zu Ulm, Karlsruhe 1909. - ${ }^{24}$ E. Schev, zit. S. 547. ${ }^{25}$ G. de la NoË und E. de Margerie, zit. S. $546 .-{ }^{26}$ R. T. Hull, Geography and Geology of the Black and Grand Prairies; Texas (XXIt Annual Report of the U. S. Geological Survey, Bd. VII, Washington 1901). - ${ }^{27}$ W. M. DAvis, The Development of certain English Rivers, im Geographical Journal, 1895, Bd. V. $-{ }^{23}$ F. R. Cowper Reed, The Geological History of the Rivers of East Yorkshire; London 1901. - ${ }^{29}$ A. C. RAMSAY, Physical Geology and Geography of Great Britain; London 1878. - ${ }^{30}$ Eine allerdings auch nicht ganz befriedigende Erklärung der Destruktionsstufen mit Umgehung des ursprünglichen

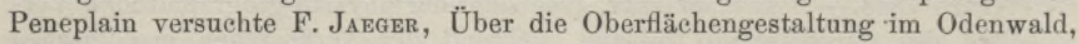
Stuttgart 1904 (Forschungen zur deutschen Landes- und Volkskunde). - ${ }^{31}$ G. A. Molengraaff, Géologie de la République Sud-Africaine, im Bulletin de la Société géologique de France 1901. - ${ }^{32}$ A. Scienck, Die geologische Entwicklung Südafrikas, in Perermann's Mitteilungen 1888. - ${ }^{33}$ A. A Arri, im Bulletin de la Société géologique de France 1885-86, Bd. XIV, S. 201. ${ }^{34}$ Siehe das Profil in F. v. Richthofen, China II, S. 442. - ${ }^{35}$ A. Mercerat, Coupes géologiques de la Patagonie australe, in den Anales del Museo nacional 
de Buenos Aires, 1897, Bd. V. - ${ }^{36}$ J. C. Russell, im 4. Annual Report of the U. S. Geological Survey, 1884. - ${ }^{37}$ H. Croos, Tafel- und Kettenland im Basler Jura, im Neuen Jahrbuch für Mineralogie usw., Beilageband XXX, 1910.

\section{Faltengebirge. $^{1}$}

Terminologie. Man hat streng zu unterscheiden zwischen Faltenland und Faltengebirge; jenes ist der weitere, dieses der engere Begriff. Faltung ist ein weitverbreitetes Phänomen, aber nur dort, wo sie über das embryonale Stadium hinausgewachsen, und wo

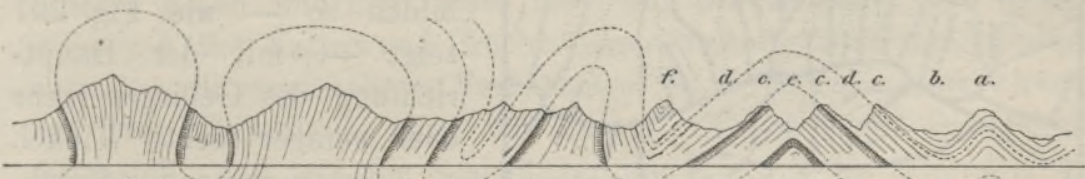

Fächer-Fitien

a Antiklinalkamm

$b$ Synklinaltal c Isoklinalkamm

$d$ Isoklinaltal
Jormale Falten.

e Antiklinaltal

$f$ Synklinalkamm

Fig. 205. Form und Orographie der Falten nach Hвгм.

sie in ihrer Ursprünglichkeit noch soweit erhalten ist, daß sie der Erdoberfläche die ihr eigentümliche Form langgestreckter Wellen, die sich deutlich von ihrer Umgebung abheben, verleiht, kann man von einem Faltengebirge sprechen. Im Großen und Ganzen deckt sich der Begriff Faltengebirge mit dem Begriff Kettengebirge. Jedenfalls sind die meisten jener gewaltigen Kettengebirge, die die Hochlandzonen beider Welten zusammensetzen, durch Faltung entstanden, und dasselbe gilt von den drei Kettengebirgen außerhalb jener Zonen, dem Ural, den Alleghanies und dem südafrikanischen Kapgebirge.

Die einfachste Form ist die normale, stehende Falte. Sie besteht aus zwei Teilen: dem Sattel, von dem die Schichten beiderseits abfallen (daher Antiklinale genannt), und der Mulde, zu

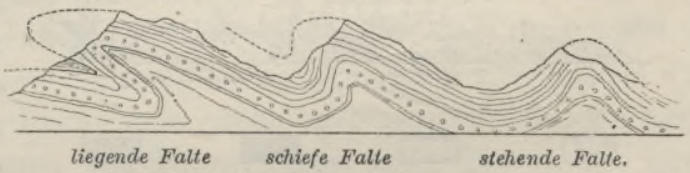

Fig. 206. Lage der Falten nach Hеiм. der sich die Schichten beiderseits zuneigen, und die man daher auch als Synklinale bezeichnet. In seiner einfachsten Form schafft der Faltungsprozeß mehr oder minder langgestreckte Antiklinalkämme und Synklinaltäler ( $a$ und $b$ in Fig. 205). Aber nur sehr selten ist diese ursprüngliche Form noch erhalten, wie in vielen Teilen des Schweizer Jura. Die Destruktion kann die natürliche Anordnung des Faltenwurfes geradezu umkehren, so daß Synklinalkämme 
und Antiklinaltäler ( $f$ und $e$ Fig. 205) entstehen. Ein anderes Produkt der Zerstörung sind die Isoklinalkämme und Isoklinaltäler ( $c$ und $d$ in Fig. 205), in denen die Schichten beiderseits nach der gleichen Richtung fallen.

Die genannten Kämme und Täler verlaufen in der Richtung der Falten und des Gebirges und sind daher Längskämme und Längstäler. Dagegen durchschneiden die Quertäler und Quer-

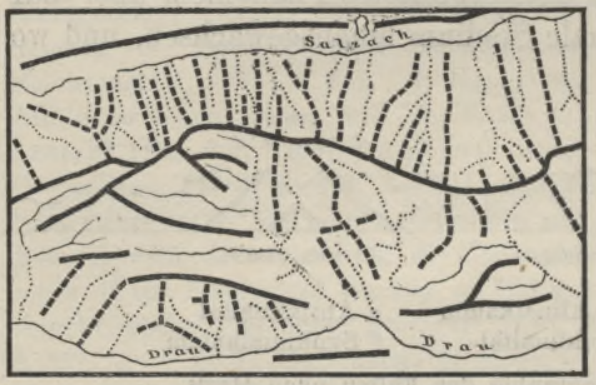

- Längskiämn?

-n-s-n-m Qnerkümme

Längstaler

Fig. 207. Längs- und Quergliederung der Hohen Tauern. kämme die Schichten in ihrer Streichrichtung und bilden so - wie Fig. 207 zeigt - mit der Hauptrichtung des Gebirges mehr oder weniger rechte Winkel. Neben stehenden Falten kommen auch schiefe und liegende Falten vor (s. Fig. 206). In letzterem Fall können - wie z. B. am Glärnisch - die Schichten vollkommen horizontal liegen, und nur durch eingehende Untersuchungen ist dann die Dislokation nachweisbar. Beí gröBerer Faltungsintensität entstehen die sogenannten Is oklinalfalten (Fig. 205), in denen die zusammengedrückten Mulden und Sättel im gleichmäBigen Schichtenfall verschwinden. Selbstverständlich ist hier auch die Längsgliederung nur auf isoklinale Kämme und Täler beschränkt. In der Fächerstruktur (Fig. 205), die der kristallinischen Zone der Alpen und auch anderer Gebirge eigentüm-

NW

so

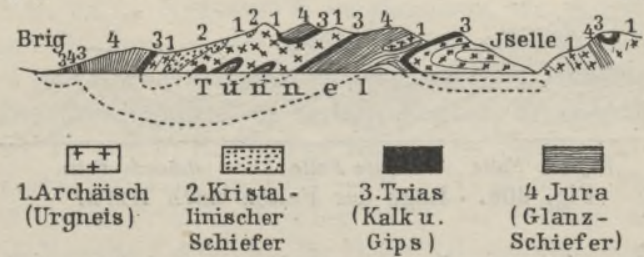

Fig. 208. Profil des Simplon nach Schardt. lich ist, erscheint die natürliche Ordnung geradezu umgekehrt, indem die Sattelkämme synklinalen und die Muldentäler antiklinalen Bau besitzen.

Nicht alle Gesteine verhalten sich der faltenden Kraft gegenüber

gleichmäßig. Schiefer zeigen oft die merkwürdigsten -Windungen, während massige Sandsteine und Kalksteine sich häufig spröde verhalten und lieber brechen als sich biegen. Anderseits sehen wir aber auch wieder mächtige Schichtenkomplexe bruchlos umgeformt und zu äußerster Dünne ausgewalzt. Das setzt nicht nur einen 
äußerst langsamen Fortschritt des Faltungsprozesses, sondern auch eine große Plastizität der Gesteine voraus. Heim führt sie auf den gewaltigen Druck zurück, und die Versuche von Adams und Niçolson am Marmor haben diese Annahme bestätigt. Sehr lehrreich ist in dieser Beziehung der Bau des Simplon, von dem erst der Tunnelbau eine richtige Vorstellung gab (Fig. 208). Man betrachte nur die große liegende Falte der Trias- und Juraschichten und ihre oberen Ausbuchtungen; ein solches Ineinanderkneten ist nur in plastischem Zustand denkbar. Jedoch kommt man, je mehr man in das Studium unserer Alpen eindringt, umso mehr zur Überzeugung, daß in den meisten Fällen Falten und Brüche vergesellschaftet auftreten. Daraus entstehen die verwickeltsten Verhältnisse. So die Schuppenstruktur, zu deren Erläuterung Fig. 209 dient. Es sei durch Petrefakten festgestellt, daß von der Schichtengruppe $a b c d a$ die älteste, $d$ die jüngste ist. Ihre wiederholte Aufeinanderfolge sucht man dadurch zu erklären, daß in der Sattelbiegung der ursprünglichen Isoklinalfalten Brüche entstanden, und die Falten an den Bruchflächen (B) hinaufgeschoben wurden, wobei der ganze Muldenschenkel (zwischen Sattel und Mulde) durch Auswalzung verloren ging oder vielmehr unkenntlich gemacht wurde.

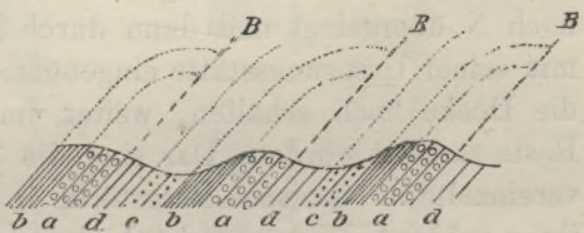

Fig. 209. Schuppenstruktur.

Schon dieses Beispiel zeigt, welche verwickelten Probleme die Tektonik der Hochgebirge darbietet. Nur was über die Talsohlen aufragt, ist unmittelbar $\mathrm{zu}$ beobachten, und davon ist ein großer Teil durch Pflanzenkleid und Eis- und Schneedecken unseren Blicken entzogen. Die oberen Partien sind durch Zerstörung verschwunden. Die Verbindungslinien, die der Geologe in seinen Profilen nach oben in die Luft, und im Innern der Erde zeichnet, und durch die er die ursprünglichen Falten herzustellen sucht, sind Kombination. Die unterirdischen Linien kann man noch gelegentlich durch bergmännische Untersuchungen und Tunnelbauten kontrollieren, die Luftlinien aber niemals. Man muß dies im Auge behalten, wenn man an die neueste Phase der Faltungstheorie, die Deckentheorie (Nappismus), herantritt.

In den Glarner Alpen sah man zuerst ein aus permischen und mesozoischen Bildungen bestehendes Schichtensystem auf tertiärem Flysch liegen. Dann lenkten die sogenannten Voralpen, d. h. die Chablais- und Stockhornalpen zwischen den Tälern der Aare und Arve, die Aufmerksamkeit auf sich. Auch hier fallen tertiäre Schichten 
unter einen mächtigen, in sich selbst gefalteten mesozoischen Gebirgskomplex ein, und dieser unterscheidet sich durch seine petrographische Zusammensetzung und seine fossilen Einschlüsse wesentlich von den gleichalten Schichten im Juragebirge und am Nordrand der Berner Hochalpen. Besonders beachtenswert ist die jurassische Kalkbreccie, die erst im Süden des Montblancmassivs wiederkehrt. Hier fand die Theorie der Überdeckungsschollen, die Marcel BERTRAND $^{2}$ schon früher für ähnliche Verhältnisse im provençalischen Gebirge aufgestellt hatte, zuerst durch SchardT (1893) Anwendung und weitere Entwickelung. Das mesozoische Gebirge der Chablaisund Stockhorngruppe steht danach nicht unterirdisch mit der Kalkzone des Berner Oberlandes in Verbindung, sondern ruht wurzellos auf tertiären Schichten. Es stammt aus den südlichen Alpen und ist nach der ursprünglichen Annahme ScHARDT's ${ }^{3}$ durch Rutschung als ungeheuere Scholle in das nordschweizerische Tertiärmeer gelangt und dann mit seiner Unterlage gefaltet worden, nach der Annahme Lugeon's ${ }^{4}$ aber hat es sich in Falten von gewaltigen Dimensionen nach N übergelegt und dann durch Destruktion den Zusammenhang mit seiner Ursprungsstätte eingebüßt. Nur in den Voralpen hat sich die Decke noch erhalten, weiter im Osten ist sie bis auf wenige Reste zerstört worden. Das sind die berühmten Schweizer Klippen: vereinzelte mesozoische Bergstöcke in tertiärer Umgebung, die wegen ihrer größeren Widerstandsfähigkeit landschaftlich scharf hervortreten (vgl. die Mythen, Fig. 115 S. 476). Stellenweise konnte man durch Beobachtung nachweisen, daß sie nicht aus dem Flysch hervorragen, wie man früher glaubte, sondern ihm aufruhen, und da sie petrographisch den Voralpen gleichen, so verlegt man auch ihren Ursprungsort in die Alpen südlich vom St. Gotthard. Die Überfaltungstheorie wurde aber dann auch auf alle Kalkalpen vom Thunersee bis zum Rheintal ausgedehnt, wie am folgendem Beispiel erläutert werden soll.

Fig. 210 stellt uns einen Durchschnitt durch die nördlichen Schweizer Alpen längs der Ostseite des Reußtales und des Vierwaldstätter Sees dar. Wir sehen nördlich vom Maderanertal drei Kreideketten (Axenkette, Frohnalpstock, Rigihochfluh) durch breitere und schmälere Zonen aus alttertiärem Flysch voneinander geschieden. Man nahm - und das ist ja das nächstliegende - früher allgemein an, daß die Kreideablagerungen, die die drei Kalkketten zusammensetzen, an Ort und Stelle entstanden und durch den Faltungsprozeß nur auf eine geringere Breite reduziert worden seien, daB man also, wenn man tief bohren würde, unter ihnen auf die nächst ältere Formation, den Jura, stoßen würde. Aber ihr verwickelter Bau 
bereitete Schwierigkeiten. Die Überlagerung tertiärer Schichten durch ältere ist an vielen Stellen deutlich zu beobachten. Die Einfaltung von Jura und Eozän in der Axenkette stellt die ursprünglichen Verhältnisse geradezu auf den Kopf: der Jura erscheint in

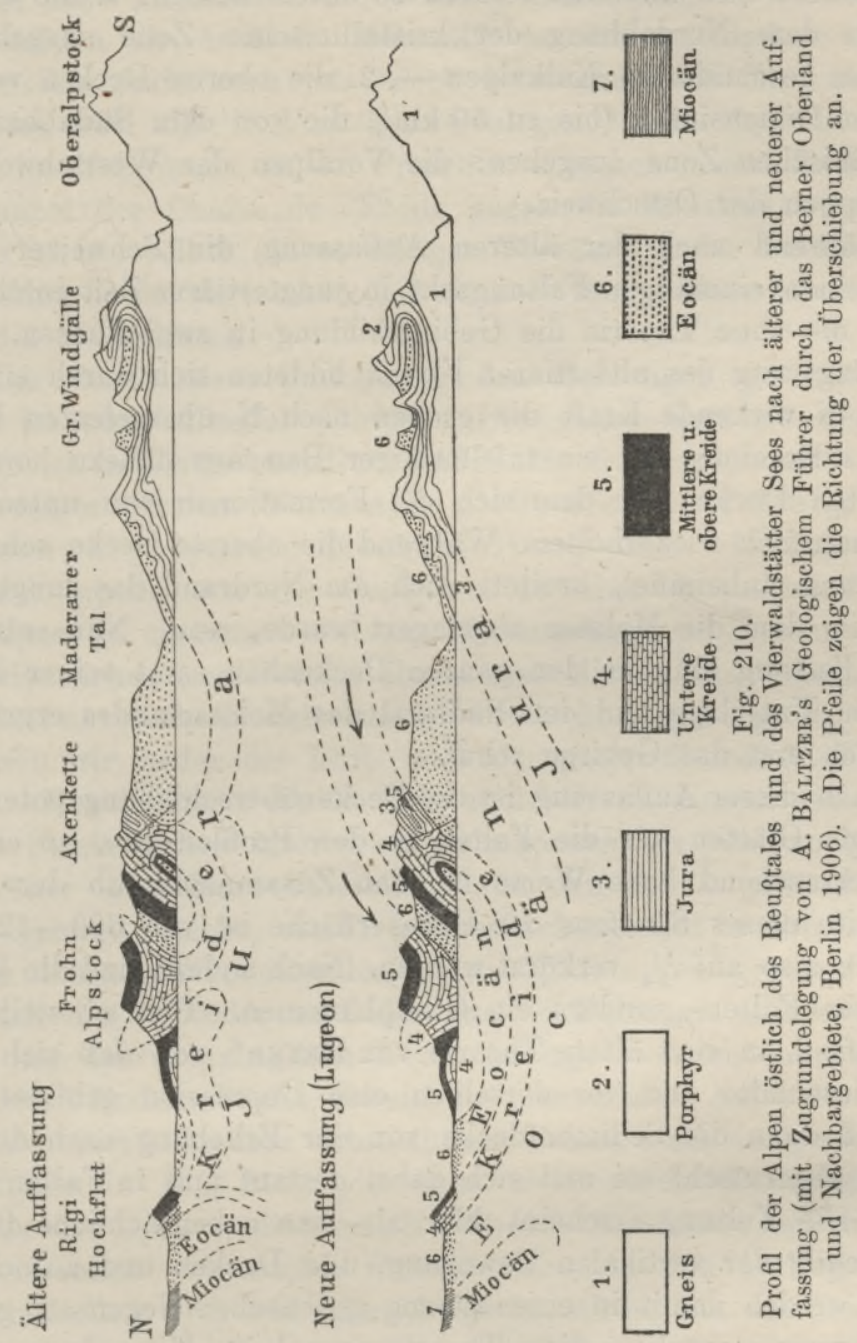

einer Synklinale anstatt in einer Antiklinale, das Eozän als Sattel statt als Muldenkern. Die neuere Auffassung sucht diese Schwierigkeiten zu lösen, indem sie annimmt, daß das Kreidegebirge wurzellos in Eozän eingebettet ist. Die petrographische Übereinstimmung dieser mesozoischen Bildungen mit denen am Nordabhang der 
kristallinischen Alpen (Windgälle) führte zu der Annahme, daB sie hier ihre Wurzeln hatten und in zwei großen Falten nach Norden übergelegt wurden, von denen uns aber nur die Stirnenden erhalten geblieben sind.

Es sind also zweierlei Decken zu unterscheiden: 1. die unteren, die von dem Nordabhang der kristallinischen Zone ausgehen die eben geschilderten Kalkalpen - , 2. die oberen Decken von viel größeren Dimensionen (bis zu $50 \mathrm{~km}$ !), die von dem Südabhang der kristallinischen Zone ausgehen: die Voralpen der Westschweiz und die Klippen der Ostschweiz.

Während nach der älteren Auftassung die Schweizer Alpen durch einen einmaligen Faltungsakt in jungtertiärer Zeit entstanden, zerlegt die neue Theorie die Gebirgsbildung in zwei Phasen. Nach der Ablagerung des alttertiären Flysch bildeten sich durch eine von $\mathrm{S}$ nach $\mathrm{N}$ wirkende Kraft die großen nach $\mathrm{N}$ übergelegten Falten, und das Ergebnis war ein tafelförmiger Bau aus nahezu horizontal gelagerten Decken, in dem sich die Formationen von unten nach oben mehrfach wiederholten. Während die oberste Decke schon der Zerstörung anheimfiel, breitete sich am Nordrand das jungtertiäre Meer, in dem die Molasse abgelagert wurde, aus. Nun setzte die zweite Faltung ein, die den ganzen Deckenbau samt seiner kristallinischen Unterlage und den Südrand des Molasselandes ergriff und eigentlich erst das Gebirge schuf.

Nach dieser Auffassung ist die Deckenüberschiebung potenzierte Faltung. Glätten wir die Falten in den Profilen aus, so erhalten wir überraschend hohe Werte für den Zusammenschub der Alpen; die Breite dieses Streifens der Erdoberfläche ist von $600-1200 \mathrm{~km}$ auf 150 , also auf $1 / 4$ verkürzt worden. Nach andern sind die Decken nicht ein Falten-, sondern ein Gleitphänomen. PENCK ${ }^{5}$ stellt sich, anknüpfend an eine ältere Theorie von REYER ${ }^{6}$, vor, daB sich zuerst eine Riesenfalte und vor derselben eine Depression gebildet habe, und daß dann die Sedimentdecke von der Erhebung nach der Vertiefung abgerutscht sei und sich dabei gestaut und in Falten gelegt habe. Die Faltung erscheint hier als eine nebensächliche Begleiterscheinung der vertikalen Bewegung, und Decken und autochthone Falten werden damit in einen streng genetischen Gegensatz gestellt. Würde man versuchen, diese Theorie einmal im Einzelnen auf die beobachteten Lagerungsverhältnisse anzuwenden,' so würden wahrscheinlich unübersteigliche Schwierigkeiten zutage treten.

Wir haben also nach der neuen Auffassung in der Schweiz zwei Arten von Faltengebirgen: ein autochthones, den Jura, und ein Deckengebirge, die Alpen. 
Die Deckentheorie beansprucht aber auch allgemeine Gültigkeit und wurde bereits auf die Ostalpen ${ }^{7}$, die Karpathen ${ }^{8}$, Apenninen ${ }^{9}$, den Atlas ${ }^{10}$, die Pyrenäen ${ }^{11}$, das ostiberische Gebirge ${ }^{12}$ u. a. ausgedehnt. Freilich blieb dies nicht ohne Widerspruch. FreCH ${ }^{13}$, der die neue Theorie für die Westalpen anerkannte, lehnte sie für die Ostalpen ab, und die Mehrzahl der österreichischen Geologen dürften ihm darin auch jetzt noch beistimmen. Ebenso abweisend verhalten sich die italienischen Geologen. ${ }^{14}$ In dem klassischen Land des Nappišmus, in der Provence, sprechen neuere Erfahrungen im Tunnel der Chaîne de l'Étoile gegen die Konstruktionen BerTRAND's ${ }^{15}$, und selbst ein so eifriger Vorkämpfer der Deckentheorie, wie UhLIG, mußte zugestehen, daß sie noch immer einen wunden Punkt hat: die Wurzelfrage.

Der durch diese Umwälzung der Meinungen geschaffene $\mathrm{Zu}$ stand ist ohne Zweifel peinlich. Die ganze Geologie der Hochgebirge ist in Frage gestellt. ${ }^{\times}$Aber die Geographie wird dadurch viel weniger berührt. Für uns ist nicht die Überfaltung selbst, sondern die spätere Deckenfaltung der wichtigste Akt. Dadurch wurde erst der Gegensatz zwischen kristallinischen und Kalkalpen, ja eigentlich erst das Kettengebirge geschaffen. Um die landschaftlichen Kontraste in ihrem ursächlichen Zusammenhang mit der Gesteinsbeschaffenheit und der Schichtenlagerung zu erfassen, bedürfen wir weder der Luft- noch der unterirdischen Verbindungslinien. Nur in einem Punkt sind auch wir an diesem wissenschaftlichen Streit lebhaft interessiert: wir können uns jetzt noch weniger als früher eine klare Vorstellung von dem Anfangsstadium der Faltengebirge machen, von ihrer Oberflächengestalt in dem Zeitpunkt, da sie den zerstörenden subaërischen Kräften preisgegeben wurden. Geschah das vor oder nach der zweiten Faltung? und im ersteren Fall, war das ursprüngliche Deckengebirge vielleicht nur eine ungegliederte Bodenschwelle, die sich langsam erhob? Auf weite Strecken sind die einst bedeckten autochthonen Falten bloßgelegt, wie an der Windgälle in Fig. 210, oder man sieht durch die ausgedehnten Lücken der Decken, die man als Fenster bezeichnet hat (die Hohen Tauern sollen ein solches Fenster sein), in den Untergrund; an andern Stellen sind, wie schon bemerkt wurde, von den Decken nur mehr vereinzelte „Klippen“ übrig geblieben. Ist diese gewaltige

$\times$ Wir haben, um nur ein Beispiel anzuführen, in der 4. Auflage dieses Werkes die fortschreitende Faltung an dem Bau der Karpathen, und zwar an der Hand von Uhuig's Darstellung erörtert. Nun hat Uнцi selbst seine frühere Auffassung verworfen, und damit sind alle daraus gezogenen Schlüsse hinfällig geworden. 
Zerstörung lediglich ein Werk der Verwitterung, Denudation und Erosion? Eine Reihe neuer Probleme rollt sich auf, und die für uns so wichtige Frage der Talanordnung ist durch diese Unsicherheit ganz ins Dunkle gerückt.

Faltenzonen und Geosynklinalen. Am Ende des archäischen Zeitalters scheint die ganze Erdkruste gefaltet worden zu sein, denn überall, wo die kristallinische Unterlage der Sedimentärformationen der Beobachtung zugänglich ist, sind die Schiefer mehr oder weniger steil aufgerichtet. $\times$ Seit jener Zeit blieb aber der FaltungsprozeB nur auf gewisse Zonen beschränkt, und es entstand der Wechsel zwischen Flachland und Gebirge. Wenigstens für Europa und auch für andere genauer bekannte Gegenden hat das Bertrand'sche Gesetz Gültigkeit, daß Falten immer wieder an denselben Stellen entstanden oder wenigstens in der Fortsetzung älterer Falten.

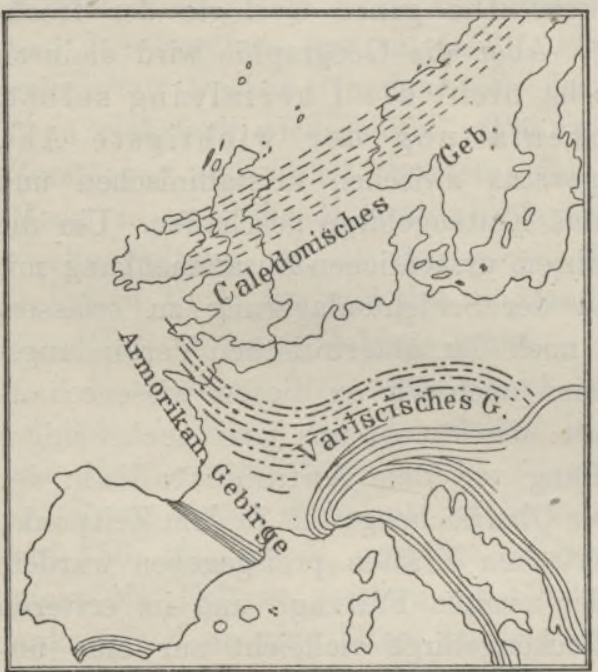

Fig. 211. Die drei Faltengürtel von Westund Mitteleuropa nach M. BouLE.

- - - Silurische Falten, _.- - . karbone Falten, tertiäre Falten.

Ein ausgezeichnetes Beispiel ist der südrussische Donezrücken, dessen wir schon auf S. 621 gedacht haben.

Wenn es auch gewisse Zonen gibt, in denen die Faltung wiederholt einsetzte, so gibt es doch auch solche, in denen sie erloschen ist. Dazu gehört jene Gebirgszone, die Suess den alten Scheitel Eurasiens genannt hat. Sie erstreckt sich vom Großen Chingan über Transbaikalien bis zum Baikalsee, und tritt jenseits des letzteren mit veränderter Streichrichtung in den Gebirgen vom Ostsajan bis zum Gobi-Altai wieder hervor. Seit dem Ende der archäischen Zeit hat hier keine Faltung mehr stattgefunden. In Europa kennen wir, wie an späterer Stelle ausführlicher besprochen werden soll, seit der paläozoischen Zeit drei Faltungsepochen: die Bruchstücke der silurischen liegen in Wales, Schottland und Norwegen; die der karbonen in Cornwall, in

$\times$ Man bestimmt das Alter einer Dislokation nach dem von Élie de BEAUMoNт aufgestellten Grundsatz, wonach die Dislokation einer Schicht jünger ist als die Schicht selbst und älter als die nächste ungestörte Schicht. 
der Bretagne, in Zentralfrankreich und in Mitteldeutschland; die tertiären Falten sind unsere heutigen Kettengebirge (Fig. 211). Die gebirgsbildende Bewegung schritt also von $\mathrm{N}$ nach $\mathrm{S}$ fort, aber völlig unberührt blieb auch der Norden von der tertiären Faltung nicht. HaARManN ${ }^{16}$ hat Bewcise für eine alttertiäre Gebirgsbildung im nordwestlichen Deutschland erbracht, durch das ganze Pariser Becken bis nach Belgien hinein ziehen sanfte Faltenwellen ${ }^{17}$, und in ihrer Fortsetzung liegt der englische Weald, den wir noch kennen lernen werden. In Asien nimmt man ein Fortschreiten der Gebirgsbildung vom Alten Scheitel nach S und nach O wahr. In der mittleren Sahara lassen die neuesten Untersuchungen französischer Geologen ${ }^{18}$ zwar die gleichen Faltungsepochen wie in Europa, aber in umgekehrter Anordnung erkennen. Silurische Falten herrschen von Adrar bis ungefähr zum 26. Parallel $\mathrm{N}$, karbone von Tidikelt bis Marokko, und den AbschluB bilden im $\mathrm{N}$ die tertiären Atlasfalten. In der marokkanischen Schauja wurden die paläozoischen Schichten in variskisch (NNO) streichende Falten gelegt: nördlich davon biegen sie plötzlich nach NW, d. h. in die armorikanische Richtung um. ${ }^{19}$

Ohne Zweifel besteht die Erdkruste aus Streifen von größerer und von geringerer Biegsamkeit. In den tertiären Faltengebirgen beobachtet man eine mächtigere und vollständigere Entwicklung der mesozoischen Formationen als in den ungefalteten Nachbargebieten, und auch die Gesteinsbeschaffenheit und die organischen Einschlüsse deuten auf eine Verschiedenheit der physikalischen Bedingungen hin. An Stelle der Faltenzonen befanden sich einst nach der Annahme der amerikanischen Geologen Geosynklinalen, d. h. trogförmige Einsenkungen des Meeresbodens, die unter dem Druck der sich anhäufenden Ablagerungen in immer größere Tiefen gelangten. Man verlegt sie an den Rand des Festlandes, denn hier erheben sich in Amerika die Faltengebirge. In Asien schlug aber, wie SuEss ${ }^{20}$ gezeigt hat, die Gebirgsbildung einen anderen Weg ein, und die Faltenwellen dringen bogenförmig vom Festland in das Meer hinaus. Diese Verhältnisse hat $\mathrm{H}_{\mathrm{AvG}}{ }^{21}$ im Auge, wenn er die Geosynklinalen als Kanäle zwischen Kontinentalmassen auffaßt; aber wenn dies auch hier und da zutrifft, so ist doch seine Verallgemeinerung ebenso willkürlich wie die der amerikanischen Theorie und führt zu einem schwindeligen Hypothesenbau. Ansprechender ist der Erklärungsversuch Bertrand's. ${ }^{22}$ Eine Geosynklinale entsteht dort, wo sich in der Erdkruste schwerere Bestandteile anhäufen. Von dem im N gelegenen Festland wird ihr Destruktionsschutt zugeführt, sie sinkt infolgedessen immer tiefer ein, und ihre plastische Unterlage wird 
samt der schweren Tiefenzone zum Ausweichen nach S veranlaßt. So entsteht an ihrem Südrand eine Anschwellung, die sich in Falten über sie hinausschiebt. Die Bewegungen sind also sukzessive folgende: 1. vom nördlichen Festland nach der südlichen Mulde, 2. in der Mulde von oben nach unten, 3. im Süden davon von unten nach oben, 4. Überfaltung von S nach N. Endlich folgt 5. Hebung dieses so gebildeten unterirdischen Bauwerkes, und nun kann südlich davon der ganze Prozeß sich wiederholen. Diese Theorie, die ebenfalls auf isostatischer Grundlage ruht, ist vor allem auf die europäischen Verhältnisse zugeschnitten.

Tangentialkraft. Über die Ursache der Faltenbildung herrschen, wie schon in einem früheren Abschnitt (S. $368 \mathrm{ff}$ ) erörtert wurde, verschiedene Ansichten, aber darin stimmen die meisten überein, daß Geosynklinalen nur durch einen seitlichen Druck zu Faltengebirgen aufgetürmt werden können. Suess, der von dem Studium des Alpenbogens ausgegangen ist, läßt nur einseitigen Druck von der konkaven nach der konvexen Seite hin zu. „Das beste Bild,“ sagt er, „das ich von der Entstehung eines großen Gebirges $\mathrm{zu}$ geben weiß, besteht darin, daß ich mir vorstelle, es würde meine Hand durch eine Verletzung aufgeschürft, dabei die Haut nach einer Seite in Falten zusammengeschoben, auf der andern reiße sie und es dringe etwas Blut hervor. So sehen wir ein großes Gebirge immer nach einer Seite zusammengeschoben, in große Falten gelegt; auf der andern Seite zerreißen sie, und wo sie aufgerissen sind, da treten aus dem Innern der Erde Vulkane hervor." Die großen, nach NW gerichteten Überschiebungen scheinen auch in der Tat für diese Auffassung zu sprechen. Indem Suess den schweizer und französischen Jura nur als einen Teil des Alpensystems betrachtete, zeigte er, wie die aus $\mathrm{S}$ vorrückenden Faltenwellen sich an alten Gebirgsmassen, des Serre bei Dôle (am Doube), dem Schwarzwald und dem böhmischen Massiv stauten und hier zusammengepreBt wurden, um sich dann, nachdem dieses letzte Hindernis überschritten war, im Karpathenbogen frei nach $\mathrm{N}$ zu entfalten. Diese, durch ihre Einfachheit bestechende Auffassung stößt aber auf Widersprüche. Wohl neigen sich die alpinen Falten im $\mathrm{N}$ nach außen, aber im $\mathrm{S}$ nach innen, als ob der Druck vom Inneren des Gebirges nach beiden Seiten auswärts gewirkt hätte, und man kann dieser Deutung nur durch die Hilfshypothese ausweichen, daß am italienischen Rand eine nachträgliche Rückfaltung eintrat, als das adriatische Festland in die Tiefe sank. Wie kam es ferner, daß das schweizerische Molasseland zwischen den Alpen und dem Jura der Faltung entging? Der Jura wird am schweizerischen Rand von 
NO-, am französischen von N- und am Nordrand von W-streichenden Faltenzügen begrenzt, die nördlich und südlich von Salins zwei Gebiete ohne oder mit schwacher Faltung einschließen; auch diese Anordnung läßt sich mit einem von den Alpen herkommenden Druck schwer vereinigen. RoLLIER ${ }^{23}$ führt die Druckwirkung auf das Versinken der, den Jura umgebenden Depressionen im Schweizer Molasseland, an der Saôn und am Oberrhein zurück; es hat nach dieser Auffassung ein Zusammenschub von drei Seiten stattgefunden.

Der Faltungsvorgang: Um die Plastizität der Gesteine zu erklären, nimmt man an, daß sich der Faltungsvorgang in der Tiefe vollzieht, es ist aber fraglich, ob dazu nicht auch ein langsamer und stetiger seitlicher Druck genügt. Unzweifelhaft gibt es auch Falten, die an der Oberfläche entstanden sind, wie die der miozänen Molasse am Nordrand der Schweizer Alpen oder die Vorketten des Himalaya, die sich Tiefenfalten anschmiegten, und das gleiche gilt von den in Falten gelegten jungen terrestrischen Ablagerungen in den zentralasiatischen Gebirgen. Wie sich autochthone Gebirge nach der Art des Schweizer Jura verhalten haben, ist wenigstens noch zweifelhaft. Jedenfalls entstehen Faltungsgebirge nicht durch einen einheitlichen Akt, sondern nach und nach, und der ProzeB setzte auch innerhalb eines Gebirges nicht an allen Stellen gleichzeitig ein und hörte gleichzeitig auf. In den Ostalpen begann die Hauptfaltung schon in der zweiten Hälfte der Oligozänperiode und dauerte in der älteren Miozänzeit fort; nur im Südosten reichte sie noch in jüngere "Zeiten hinein. Dagegen ist in den Westalpen das jüngere Miozän die Epoche der Hauptfaltung. Auch betreffs des Himalayagebirges sprach sich GrIEsBacH in bestimmtester Weise dahin aus, daB es nicht das Erzeugnis einer einzigen Faltungsepoche, sondern periodisch wiederkehrender Dislokationen sei, die allerdings am Ende der Miozänzeit ihren Höhepunkt erreicht haben, aber auch heute noch nicht abgeschlossen sind. In den Alpen hat man auch noch ältere Faltungen nachgewiesen, aber soweit sie nur in einer ungleichförmigen Lagerung der Schichten zum Ausdruck kommen, sind sie geographisch belanglos, und die Alpen gelten mit Recht als ein tertiäres Gebirge, weil diese letzte Hauptfaltung ihnen die gegenwärtige Gestalt gegeben hat.

Freilich auch sie nur zum Teil. Vom ursprünglichen Gebäude ist nur eine Ruine übrig geblieben. Aber trotzdem darf sie als eine Strukturform bezeichnet werden, sofern sich in ihrer Anlage der alte Bauplan noch deutlich verrät. Die Strukturform wird durch zwei Momente bedingt: die Hebungsintensität, d. h. die Seehöhe, bis zu der eine bestimmte Tiefenzone emporgepreßt wurde, und durch 
die Faltungsintensität oder den Fallwinkel der Schichten, der, von der Richtung des Zusammenschubes aus gemessen, über $90^{\circ}$ hinaus und in den liegenden Falten bis $180^{\circ}$ und darüber wachsen kann. Brüche und Senkungen können die ursprüngliche Ordnung stören, und die Destruktion, deren Kraft sich nach oben steigert, mildert die hypsometrischen Unterschiede, aber im großen und ganzen ist die Hebungsintensität doch der maßgebende Faktor für die Höhenverhältnisse der Faltengebirge. Sie war in den Alpen ungleich größer als im Jura, sie nahm im Jura selbst im allgemeinen nach Nordwesten $a b$ und bewirkte in derselben Richtung eine Erniedrigung der Ketten. Die Faltungsintensität ist in anderer Beziehung wichtig. Flache F'alten geben dem Gebirge einen plateauartigen Charakter, aber anderseits können auch breite stehende und noch mehr liegende Falten die orographischen Eigentümlichkeiten der Flachschichtung hervorrufen. Werden die Falten stark zusammengepreßt, so unterliegen sie in ihren oberen Teilen leichter den zerstörenden Kräften, Schichten von verschiedener Gesteinsbeschaffenheit werden nahe aneinander gerückt, und die ursprünglichen Unebenheiten werden durch den raschen Wechsel der Destruktionswirkungen |gesteigert. Indes unterliegen solche allgemeine Regeln natürlich mannigfachen Modifikationen; der Individualismus der Gebirge kann nicht stark genug betont werden. Jedenfalls ist ohne weiteres klar, daB sich schon aus dem wechselnden Verhältnis der genannten Momente zueinander eine åußerordentlich große Mannigfaltigkeit in der äußeren Erscheinung der Gebirge ergibt.

Nachträgliche (postume) Bodenbewegungen. Wir haben oben erwähnt, daß Faltungen sich wiederholen, aber auch Bodenbewegungen anderer Art können eintreten, denen gegenüber das Faltengebirge sich ebenso wie ein flacher Schichtenbau als einheitlicher, starrer Körper verhält. In den französischen Alpen steigt das marine Pliozän von Valence nach $\mathrm{O}$ an und am Südrand der Alpen erreicht es Seehöhen bis $300 \mathrm{~m}$. An einigen Stellen, wie am Montellohügel am Ausgang des Piavetals und bei Castenedolo am Gardasee wurden sogar schwache Ansätze einer quartären Faltung in der Form von Antiklinalen beobachtet. Die St. Elias-Alpen in Alaska wurden in nachglazialer Zeit wenigstens $1500 \mathrm{~m}$ hoch gehoben, und dieser Vorgang setzt sich bis in die Gegenwart fort (vgl. S. 439). Die hohe Lage mariner Pliozänschichten in Zentralamerika (s. S. 35), solcher und auch noch jüngerer Meeresablagerungen in den Mittelmeerländern (s. S. 456) beweisen, daß die jüngsten Krustenbewegungen die Form von Verbiegungen annahmen, und berücksichtigen wir ferner, daß auch im Ostindischen Archipel nach Ablauf der Tertiärzeit aus- 
gedehnte Niveauverschiebungen von beträchtlicher Sprungweite eintraten, so ist wenigstens für den Bereich der großen Bruchzone der Erde durch die geologische Methode der Beweis tiefgreifender nachpliozäner Landveränderungen erbracht.

Die morphologische Methode kann noch ein anderes Argument hinzufügen. Überall, wo in einem Tal über dem heutigen Talboden Felsterrassen auftreten, die nicht als Verwitterungsstufen zu deuten sind, haben wir es, mit verschiedenen Erosionszyklen zu tun, denn es ist klar, daß zur Zeit der Ausbildung von $a a$ in Fig. 212 andere Zustände geherrscht haben

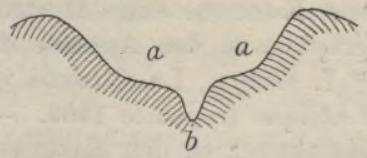

Fig. 212. Querschnitt von Felsterrassen im anstehenden Gestein. müssen, als zu der Zeit, da der schluchtenförmige Einschnitt $b$ entstand. Die Wiederbelebung der Tiefenerosion setzt eine Tieferlegung der Erosionsbasis voraus, sei es durch ein Sinken des benachbarten Meeresspiegels oder durch eine Senkung des Vorlandes oder durch eine Hebung des Gebirges. Was die Ursache war, muß die Untersuchung von Fall zu Fall lehren, aber das häufige Vorkommen gestufter Talgehänge in den Gebirgen legt die Vermutung nahe, daß meistens Hebung dabei im Spiel war.

Literaturnachweise. ${ }^{1}$ Betreffs der Mechanik des Faltungsprozesses ist A. Herm, Mechanismus der Gebirgsbildung, Basel 1878, noch immer ein klassisches Werk, wenn auch z. T. schon überholt. Ergänzt wird es dureh sein Werk „Das Säntisgebirge“, Bern 1905, worin den neuen Theorien Rechnung getragen wird. Über Faltungsexperimente siehe B. Willis, The Mechanics of Appalachian Structure, im 13. Annual Report of U. S. Geological Survey 1891-92. - ${ }^{2}$ M. Bertrand, La grande nappe de recouvrement de la BasseProvence, im Bulletin des services de la earte géologique de la France, Nr. 68, 1898. - ${ }^{3}$ H. Schardt, Die exotischen Gebiete, Klippen und Blöcke am Nordrande der Schweizer Alpen; Lausanne 1898. - ${ }^{4}$ M. Lugeon, Les grandes nappes de recouvrement des Alpes du Chablais et de la Suisse; im Bulletin de la Société géologique de France, 1901. Als zusammenfassende Darstellung empfiehlt sich besonders durch musterhafte Klarheit und lehrreiche Abbildungen G. Steinmann, Geologisehe Probleme des Alpengebirgs, in der Zeitschrift des Deutschen u. Österreichischen Alpenvereins, Bd. XXXVII, 1906. - ${ }^{5}$ A. Penck, Die Entstehung der Alpen, in der Zeitschrift für Erdkunde, Berlin 1908. ${ }^{6}$ E. Reyer, Ursachen der Deformationen und Gebirgsbildung Leipzig 1892. ${ }^{7}$ V. UнціG, Über die Tektonik der Ostalpen, in den Verhandlungen der Gesellschaft deutscher Naturforscher und Ärzte 1909. $-{ }^{8}$ V. UnLia, Über die Tektonik der Karpathen, in den Sitzungsberichten der Wiener Akademie 'der Wissenschaften, math.-naturwiss. Klasse, Bd. CXVI, Abteil. I, 1907. - ${ }^{9}$ G. Steinmann in den Monatsberiehten der Deutsehen Geologisehen Gesellschaft 1907, Bd. LIX, S. 177; M. Lugeon und E. Argand in den Comptes Rendus de l'Académie des Sciences v. 23. April und 14. Mai 1906. - ${ }^{10}$ C. Termier, ebenda 1906, Bd. CXLIII, S. 137. - ${ }^{11}$ C. Termer, ebenda 1905, Bd. CXLI, S. 920 und 966. A. Bresson im Bulletin de la Société géologique de France, 1906, Bd. VI, S. 850. L. BEn- 
Trand, ebenda, S. 823. - 12 J. Almera und J. Bergeron, ebenda Bd. IV, S. 705. ${ }^{13}$ F. Fred, Über den Gebirgsbau der Alpen, in Petermans's Mitteilungen 1908. $14 \mathrm{Vgl}$. das Referat von Theoв. Fischer, ebenda, S. 164. - ${ }^{15}$ E. Fournier im Bulletin de la Société géologique de France, 1906, Bd. VI, S. 101. - ${ }^{16}$ E, HaAnMANN, Die geologischen Verhältnisse des Piesbergsattels bei Osnabrück, im Jahrbuch der Preußischen geologisehen Landesanstalt für 1909. - ${ }^{17}$ G. F. DoLLrus, Relations entre la structure géologique du Bassin de Paris et son hydrographie, in den Annales de géographie 1900, - ${ }^{18}$ Zitiert S. 643, Anm. 2. 19 L. Gentí, La Chaouia et le Maroe septentrional, im Bulletin du Comité de l'Afrique française 1909. - ${ }^{20}$ E. Susss, Über die Asymmetrie der nördlichen Halbkugel, in den Sitzungsberichten der Wiener Akademie der Wissensch., mathem.-naturwiss. Klasse, 1898. - ${ }^{21}$ E. HAUG, Les géosynclinaux et les aires continentales, im Bulletin de la Société géologique de France 1900. - ${ }^{22} \mathrm{M}$. BerTRAND, Essai d'une théorie mécanique de la formation des montagnes, in den Comptes rendus de l'Académie des Sciences; Paris 1900, Bd. CXXX; zur Ergänzung dient die ebendaselbst erschienene Abhandlung: Deformation tétraédrique de la terre usw. - ${ }^{23}$ Zur Orientierung eignet sich vortrefflich der Vortrag von V. Uhuig, „Über Gebirgsbildung“', Wien 1904. - ${ }^{24}$ L. Rolliter, Le plissement de la chaîne du Jura, in den Annales de géographie 1903, Bd. XII.

\section{Haupttypen der Faltengebirge.}

Sattelgebirge oder Monoantiklinalen. Sattelgebirge, die aus einer einzigen Antiklinale bestehen, können als die einfachste Form von Faltengebirgen betrachtet werden, und an die Spitze der Formenreihen stellen wir jene domförmigen oder mehr oder weniger langgestreckten Schichtenaufwölbungen im Departement Basses Alpes, die KILIAN ${ }^{1}$ unter dem Namen der Brachyantiklinalen beschrieben hat. In der Nähe von Peyruis, südlich von der Lurekette, erhebt sich eine solche aus Kalken der mittleren Kreide (unteres Aptien), von der allseitig Mergel derselben Stufe und grüne Sandsteine der Gaultstufe (ebenfalls mittlere Kreide) abfallen. Die kleine Achse dieser Erbebung ist ungefähr $1 \mathrm{~km}$, die große, nach NNO gerichtete $2,8 \mathrm{~km}$ lang. Das Auftreten eines so einfachen Baues mitten in einem Faltengebiet und der Umstand, daB in der Fortsetzung seiner Längsrichtung die Lurefalte aus der O- in die NO-Richtung abschwenkt, geben der Vermutung Raum, daß wir es hier mit einer rudimentären Faltung zu tun haben. Wir werden darin noch bestärkt durch die höchst interessanten Beobachtungen BoRIssJak's ${ }^{2}$ im nordwestlichen Grenzgebiet des Donezrückens, wo jede Falte aus einer Kette einzelner in der Hauptrichtung gestreckter, kuppelförmiger Fältchen besteht. Die Stellen, wo diese rudimentären Aufwölbungen miteinander zu Faltenzügen verschmelzen, machen sich noch durch kleine Einsattelungen bemerkbar.

Im embryonalen Zustand befinden sich auch jene jungtertiären 
Falten, die in großer Anzahl das nordfranzösische Becken durchziehen und sich äußerlich nur in der Anordnung der niederen Hügel und im hydrographischen Netz bemerkbar machen. ${ }^{3}$ Kräftiger treten die Sattelgebirge des nord mexicanischen Zentralplateaus zwischen $22^{1} / 2$ und $25^{1} /{ }^{0} \mathrm{~N}$ hervor ${ }^{4}$; sie bauen sich aus Jura- und Kreidcschichten auf, streichen annähernd ostwestlich und sind durch breite Synklinaltäler der obern Kreide voneinander getrennt, über die sich z. B. das Santa Rosa-Gebirge über $700 \mathrm{~m}$ erhebt. Man könnte sie also als ein Faltengebirge auffassen, dessen Zusammenschub ein vorzeitiges Ende gefunden hat. $\mathrm{Ihr}$ antiklinaler Bau wird nur stellenweise durch die Einschaltung von Eruptivmassen gestört. In dieselbe Kategorie gehören die Uinta-Mountains, die das Tafelland des Colorado vom Wahsatch- gegen das Felsengebirge durchqueren. Ihre Länge beträgt $240 \mathrm{~km}$, die Breite $50-60 \mathrm{~km}$, in der Mitte steigen sie bis $4200 \mathrm{~m}$ über den Meeresspiegel, $2300 \mathrm{~m}$ über das Tafelland empor. Es ist also nach allen Dimensionen ein be-

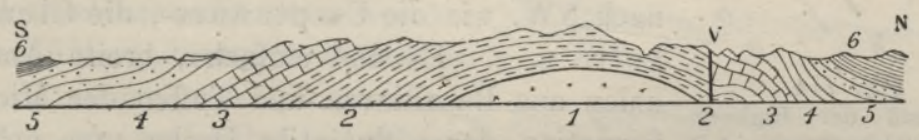

Fig. 213. Profil des Uinta-Gebirges von Poweld.

1 Archäisch, 2 Uinta-Sandstein, 3 Karbon, 4 und 5 Mesozoisch, 6 Tertiär; $V$ Verwerfung.

deutendes Gebirge und doch von wunderbar einfachem Bau, Nur an der Nordseite tritt eine Verwerfung ( $V$ in Fig. 213) störend ein, und am Südschenkel, östlich vom Green River, zeigt sich in dreimaliger flachwelliger Schichtenbiegung ein schwacher Ansatz zu Faltung. ${ }^{5}$ Der tektonischen Einfachheit entspricht die morphologische: Quertäler laufen von dem Sattelkamm nach Norden und Süden aus, und nur dem gewundenen Durchgangstal des Green River verdankt das Gebirge eine reichere Gliederung. Aber auch dieses Tal ist ausschließlich Erosionswerk.

Eine Komplikation des bogenförmigen Sattelgebirges bilden die Kulissenfalten, die meist auf der Außenseite auftreten und von $\mathrm{STAFF}^{6}$ als sekundäre Antiklinalen aufgefaßt werden, die gewissermaßen der Biegung widerstrebten und die Richtung der Tangente $\mathrm{zu}$ bewahren suchten. Ihr Bau ist asymmetrisch, indem die der Hauptachse zugekehrte Seite steiler geböscht ist (Fig. 214).

Den Übergang zum Faltengebirge führen uns die tertiären Jergenihügel im südlichen Rußland vor Augen. Zwischen $48^{\circ} \mathrm{B}$. und dem Elistafluß bilden sie ein asymmetrisches Sattelgebirge mit steilem Ostflügel, Unter $48^{\circ} \mathrm{B}$, gesellen sich im W sekundäre 
Falten dazu, und südlich vom Elistafluß erfolgt die Auflösung der Antiklinale in zwei bis drei nicht parallele Falten. Ebenso ausgeprägt ist der Übergang im Libanon, dessen breite und flache Antiklinale sich im S in eine Doppelfalte spaltet. ${ }^{7}$

Querprofil einfacher Faltengebirge. Im

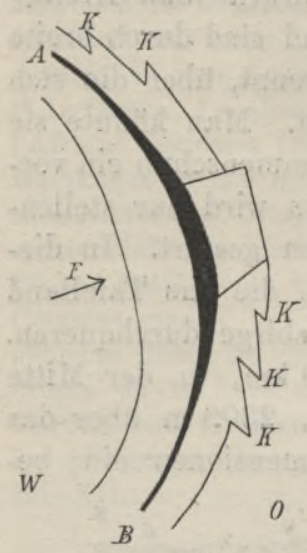

Fig. 214.

Grundriß der Bighorn Mts. nach v. Staff. $A B$ die tektonische Achse, $K$ Kulissen, $F$ Richtung der faltenden Kraft. Querdurchschnitt bestehen sämtliche Faltengebirge aus einer Aufeinanderfolge von Falten, zu denen sich allerdings auch häufig Zonen gesellen, in denen Brüche vorherrschen. ${ }^{\times}$ Dieses Moment wollen wir vorläufig außer acht lassen.

Verlaufen die Falten in sedimentärem Gestein oder in schichtförmigen Lavaströmen, so nennen wir das Gebirge ein einfaches. Südlich von Ellensburg im Staat Washington $\left(47^{\circ} \mathrm{N}\right.$ $120^{1} / 2^{0} \mathrm{~W}$ ) streichen mehrere Bergzüge von SO nach NW, wie die Umptanum-, die Clemankette u. a. Es sind einfache, breite Antikli. nalen aus Basaltlaven und Tuffen der Miozänformation, deren fluviatile Decke zum größten Teil abgetragen ist; die Synklinalen bilden Täler. ${ }^{8}$ Aus sedimentären Gesteinen der mesozoischen und tertiären Formationen (bis zum Miozän) besteht der Schweizer Jura ${ }^{9}$ (Fig. 215), das am besten erforschte unter allen Faltengebirgen der Erde. Man zählt hier 200 Falten, aber keine - und dies scheint ein allgemein

\section{NW}

Blauen-

berg

So

Af:?

Fringeli-K . Beinwyl-K.Passwang-K.Graitiry-K.

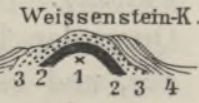

\section{$x^{x}$}

1.Trias

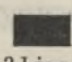

2.Lias
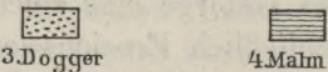

Fig. 215. Profil durch den mittleren Jura nach L. RonLIer. (Die Tertiärdecken in den Synklinalen sind der Deutlichkeit halber nicht berücksichtigt).

gültiges Gesetz zu sein - erreicht die Länge des ganzen Gebirges $(320 \mathrm{~km})$, sondern sie streichen nur $12-90 \mathrm{~km}$ (eine sogar $162 \mathrm{~km}$ ) weit und tauchen dann unter, um andern Platz zu machen.

$\times$ Darauf gründet v. Richtнofen seine Einteilung in homöomorphe oder reine Faltengebirge und heteromorphe oder Faltengebirge mit Bruchzonen. Wir werden die entsprechenden deutschen Ausdrücke gleich- und ungleichförmig in einem wesentlich anderen Sinn gebrauchen. 
Auf dem Weg quer durch das Gebirge durchschneidet man etwa 10-12 stehende oder nordwärts geneigte Falten, die parallel nebeneinander herziehen. Die Hebungsintensität nimmt zwar nach NW ab, wie sich im obigen Profil aus der Seehöhe des triadischen Kerns in der Weißensteinkette ergibt, aber trotzdem unterscheiden sich die einzelnen Glieder nicht wesentlich voneinander; keine Zone hebt sich scharf von den anderen ab, weil sich alle Ketten aus denselben Formationen aufbauen. Das sind die Eigenschaften eines gleichförmigen Gebirges in unserem Sinn. Dies alles gilt jedoch nurivon dem Kettenjura, der auch allein morphologisch ein Gebirge ist.

Ungleichförmig nennen wir dagegen ein Gebirge, wenn es aus deutlich unterseheidbaren Streifen von verschiedener Zusammensetzung besteht. Dieser zonale Aufbau istdas geographisch wichtigste Moment, denn er ist, sofern das Gebirge nicht später tiefgreifende Veränderungen erlitten hat, mit einem großen Wechsel der Szenerie verbunden. Auch einfache Gebirge können ungleichförmig sein. Man betrachte nur umstehendes Profil des Suli-

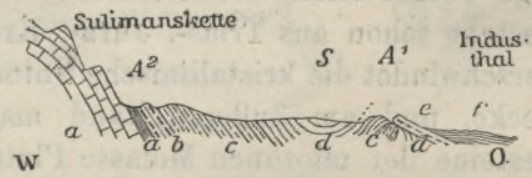

Fig. 216. Querprofil des Suliman-Gebirges nach LA Touche. ${ }^{10} \quad a$ Korallenkalke der Kreideformatios, $b$ Belemnitenschichten der Kreideformation; $c$ mittleres, $d$ oberes Eoeän ; $e$ Siwalikschichten; $f$ Alluvium. mangebirges, das sich zwischen Indien und Afghanistan erhebt (Fig. 216). Der Gegensatz der Hochgebirgszone (Takht-i-Suliman $3370 \mathrm{~m}$ ) und des im Osten vorgelagerten Berglandes, wo nur einige Höhen 1500 bis $1800 \mathrm{~m}$ erreichen, ist so auffallend, daß man sich weitere Worte sparen kann. Aber auch die Ursache dieses Kontrastes ist ohne weiteres erkennbar. Die Tektonik ist ja verhältnismäßig einfach: zwei Antiklinalen $A^{1}$ und $A^{2}$ schließen eine breite Synklinale $(S)$ ein. Und nun vergleiche man die beiden Antiklinalen; $A^{1}$ würde selbst bei vollständiger Erhaltung (wie die punktierte Linie andeutet) kaum ein Drittel so hoch sein, wie das Gewölbe der Sulimanskette $\left(A^{2}\right)$, obwohl hier die ganze eozäne Sedimentdecke durch Denudation schon entfernt ist. Mit anderen Worten: die Hebungsintensität war im Osten viel geringer als im Westen. Solche Unterschiede kommen, wie wir gesehen haben, auch im Jura vor, und in der Tat besteht zwischen gleich- und ungleichförmigen Faltengebirgen in unserem Sinn nur ein gradueller Unterschied; aber dieser ist so bedeutungsvoll, beherrscht so sehr die ganze geographische Erscheinungsweise, daß wir darauf mit vollem Recht eine Klassifikation gründen können. 
Querprofil zusammengesetzter Gebirge. Die Ungleichförmigkeit tritt noch prägnanter in zusammengesetzten Gebirgen hervor, d. h. in Gebirgen, die einerseits aus Zonen kristallinischer Gesteine, anderseits aus Sedimentzonen bestehen. Auch innerhalb der letzteren ist eine stufenartige Anordnung nach dem Alter vielfach bemerkbar.

Begeben wir uns in die Schweizer Alpen (vgl. Fig 210 S. 649). ${ }^{11}$ Von Nord nach Süd treten immer ältere Gebilde zutage, und wird das Gebirge stufenweise höher. Die innere und höchste Zone setzt sich aus kristallinischen Schiefern und Massengesteinen zusammen, und jüngere Sedimente haben sich nur in den Faltenmulden vor der Abtragung gerettet und bilden die Grenzen zwischen den einzelnen „Zentralmassiven“, in die sich diese Zone auflöst. In den sich daran anschließenden Partien der Sedimentzone ist die kristallinische Unterlage noch stellenweise sichtbar, aber die Hauptmasse der Gebirge besteht schon aus Trias-, Jura-, Kreide- und Eozängesteinen. Dann verschwindet die kristallinische Unterlage gänzlich unter der Sedimentdecke, und am äußeren Rand machen auch die älteren Schichtgesteine der miozänen Molasse Platz, die nur noch in der Nähe des Gebirges in Falten gelegt ist. Die Hebungsintensität nimmt also von der kristallinischen Zone nach außen ab, und darauf beruht es, daß diese noch immer die höchste ist, obwohl sie ihre Sedimentdecke bis auf wenige Reste verloren hat. Allerdings erreicht hier auch die Faltungsintensität ihr Maximum, denn Fächerstruktur ist nur dieser Zone eigen; daneben kommen aber auch flache Antiklinalen vor, wie im Tessiner Gebirge, und am niederen Außenrand der Sedimentzone treten noch einmal zusammengepreßte, steile Falten auf, die sich nach außen neigen. In den dazwischen liegenden Kalkalpen sind, wenn die neueste Auffassung Recht behält, die autochtonen Falten von Überfalten bedeckt, und dadurch kommt häufig Hache Schichtenlagerung zustande. Alle Momente vereinigen sich, um das Landschaftsbild $\mathrm{zu}$ einem außerordentlich wechselnden zu gestalten.

Da die Alpen einen Bogen beschreiben, so können wir die kristallinische Zone auch als die innere, die Sedimentzone als die äuBere bezeichnen; man nimmt an, daß die faltende Kraft von innen nach außen wirkte, d. h. von Süd nach Nord, bzw. von Ost nach West. Wir nennen diesen Typus den einseitigen.

In den Ostalpen ${ }^{12}$ tritt uns der Typus eines doppelseitig zusammengesetzten Gebirges entgegen. Die kristallinische Zone wird beiderseits von Sedimentgürteln eingefaßt, und in diesen ist ebenfalls eine zonenweise Altersfolge von innen nach außen bemerkbar: erst paläozoische, dann mesozoische, endlich tertiäre Gesteine. Trotzdem 
darf man nicht von Symmetrie sprechen, denn ihrem Bau nach sind die beiden Kalkzonen völlig verschiedene Gebirge. $\times$ Westlich der Etsch streichen die Falten ganz abnorm nach Nordnordost statt nach Ost oder Ostnordost; schon hier treten große Brüche auf, und diese gewinnen östlich derEtschimmer mehr an Bedeutung, so daß die südlichen Kalkalpen in manchen Profilen mehr einem Schollenals einem Faltengebirge gleichen. Dazu kommt noch, daß hier wiederholt die kristallinische Unterlage in schmalen Streifen an die Oberfläche tritt, eine Erscheinung, die den nördlichen Kalkalpen ganz fremd ist. Nur darin liegt ein symmetrischer Zug, daß die Faltung in beiden Randzonen nach außen gerichtet war; dagegen machte sich

$\times$ Nach Suess sind die Südalpen ein Ausläufer des dinarischen Systems der Balkanhalbinsel; dadureh rettet er auch für die Ostalpen den Charakter eines einseitigen Faltensystems. Das ist eine Auffassung, keine Tatsache, und wäre es auch eine solche, so wäre sie doch für die geographische Betrachtungsweise nur von untergeordneter Bedeutung. Gebirge ist ein geographischer, kein geologischer Begriff, und wir dürfen der Geologie zulieb geographische Einheiten nicht zerreißen. Das Zusammenschweißengeologischverschiedener Stüekezugeographischen Einheiten ist nahezu Regel, ist ein Charakterzug des gegenwärtigen Entwi cklungsstadiums der Erde, mit dem wires allein zu tun haben.

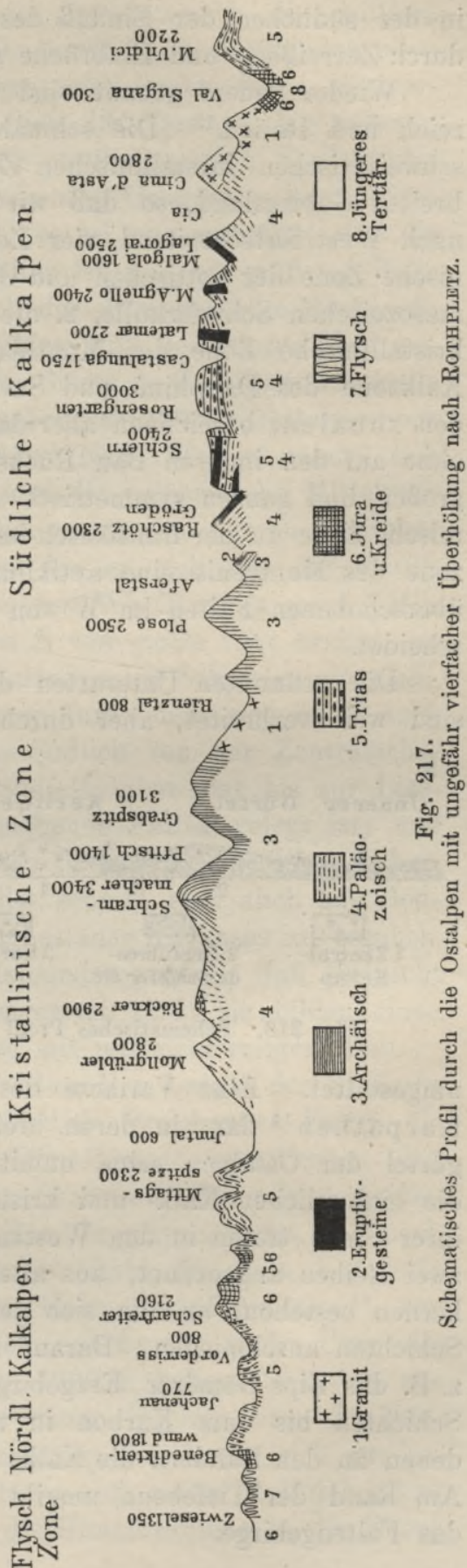


in der südlichen der Einfluß des adriatischen Senkungsfeldes auch durch Zerreißung und Einbrüche geltend.

Wieder anders gebaut sind die Westalpen zwischen Frankreich und Italien. ${ }^{13}$ Die schmalen Sedimentmulden innerhalb der schweizerischen kristallinischen Zone entfalten sich dort $\mathrm{zu}$ einem breiten Gebirgsland, so daß wir von dem italienischen Innenrand nach West fortschreitend vier Zonen durchqueren: 1. die kristallinische Zone der Cottischen und Grajischen Alpen, mit ihrer breiten mesozoischen Schieferhülle, 2. die Kalkzone des Briaçonnais, 3. die kristallinische Zone des Montblanc und des Mt. Pelvoux, 4. die Kalkzone des Dauphiné und Savoyens. Diesen Typus nennen wir den zonalen, bezeichnen aber damit nur eine räumliche Anordnung, ohne auf den inneren Bau Rücksicht zu nehmen, der insofern im großen und ganzen symmetrisch angelegt ist, als die schmale permische Zone an der französisch-italienischen Grenze und die Karbonzone des Montcenis eine antiklinale Achse bilden, die die westlich überschobenen Falten $\mathrm{im} \mathrm{W}$ von den östlich überschobenen im $\mathrm{O}$ scheidet.

Die genannten Unterarten des ungleichförmigen Gebirgsbaues sind weit verbreitet, aber durch Brüche und Destruktion vielfach

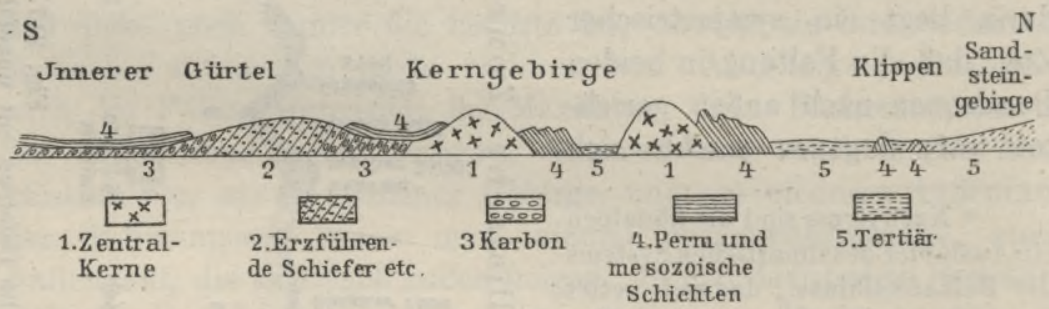

Fig. 218. Schematisches Profil der Westkarpathen nach UHLIG.

umgestaltet. Eine Variante des einseitigen Baues stellen die Karpathen ${ }^{14}$ dar, in deren breitem Sandsteingebirge der Flyschgürtel der Ostalpen seine unmittelbare Fortsetzung findet. Aber die einheitlichen Kalk- und kristallinischen Zonen fehlen, und an ihrer Stelle treten in den Westkarpathen die Kerngebirge, die, in zwei Reihen angeordnet, aus alten, zum Teil granitischen Zentralkernen bestehen, an die sich gefaltete permische und mesozoische Schichten anschmiegen. Darauf folgt ein innerer Gürtel, zu dem z. B. das Zips-Gömörer Erzgebirge gehört; hier sind alle älteren Schichten bis zum Karbon in nordwärts geneigte Falten gelegt, denen an den Rändern die Kalke der Triasformation flach aufliegen. Am Rand der Tiefebene umgibt ein Kranz tertiärer Vulkanberge das Faltengebirge. 
Doppelseitigen Bau besitzen die Pyrenäen ${ }^{15}$; die mittlere Zone besteht aus paliozoischen Gesteinen mit durchbrechenden Gneis- und Granitkernen, dann folgen nach beiden Seiten die verschiedenen mesozoischen Zonen, endlich das Tertiär. Die äußeren Falten neigen 'sich nach außen, die nördlichen nach Norden, die südlichen nach Süden, geradeso wie in den Ostalpen. Aber weiter geht die Symmetrie auch hier nicht; es sei nur erwähnt, daß die südliche Sedimentzone viel entwickelter ist und zu größerer Höhe ansteigt als die nördliche; steht doch der ihr angehörige Montperdu nur um wenige'Meter dem Kulminationspunkt des ganzen Gebirges, dem granitischen Aneto, nach. In der Sierra de Guara am äußersten aragonischen Rand führen sehr verwickelte Strukturverhältnisse noch einmal die mesozoische Reihe zutage. Nach Westen nähern sich beide Sedimentzonen immer mehr, und die paläozoische Mittelzone schrumpft zu einem schmalen Band zusammen. Noch einfacher gebaut ist der zentrale Kaukasus, wie er sich uns auf Hers's Profil längs der großen Heerstraße von Wladikawkas nach Tiflis darstellt. ${ }^{16}$ Die Granitachse wird im $\mathrm{S}$ von einem sehr breiten, im $\mathrm{N}$ von einem sehr schmalen Band paläozoischer Schichten eingefaßt, dann folgen Lias, mittlerer und oberer Jura, dem sich im $\mathrm{N}$ auch Kreide anlagert, endlich Alttertiär. Südlich von-der Zentralachse herrscht durchaus Nordfall, im N Südfall, aber nur bis zur Liaszone, während der Jura in breite stehende Falten gelegt ist, und die nächstfolgenden jüngeren Schichten nach $\mathrm{N}$ fallen. Eine fächerförmige Anordnung des Schichtenfalles scheint sich auch aus BogDanowitsch's ${ }^{17}$ Profilen aus dem Daghestaner Kaukasus zu ergeben. Kaukasus und Pyrenäen haben miteinander gemein, daß sie nicht in ihrem ganzen Verlauf zusammengesetzt sind; sie bilden einen Übergang zu den einfachen Gebirgen mit ungleichförmigem Bau.

Einen wunderbar einfachen zonalen Bau besitzt der-Sichota Alin, der mit seinen steilen nordöstlich streichenden Falten die sibirische Küstenprovinz erfüllt. Die Kämme entsprechen den archäischen Aufbrüchen, von denen Iwanow ${ }^{18}$ auf seinen beiden Durchquerungen fünf gezäblt hat; diese Anordnung setzt sich noch jenseits des Amur im Kleinen Chingan fort. In diese Kategorie gehört auch das höchste Gebirge der Erde, der Himalaya ${ }^{19}$, von dem aber nahezu zwei Drittel noch unerforscht sind. Über die Gangesebene erheben sich die $900-1200 \mathrm{~m}$ hohen. Vorketten aus pliozänen Siwalikschichten, die das ganze Gebirge vom Brahmaputra bis über den Indus hinaus begleiten. Sie bauen sich aus gefalteten Sandsteinen und Konglomeraten auf, einem Material genau von derselben Art, wie noch heute die Himalayaflüsse in der Ebene 


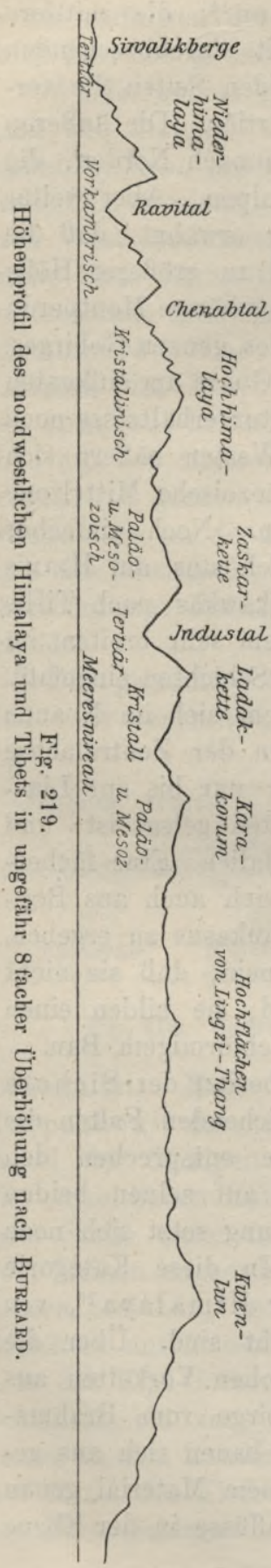

ablagern. Ein scharfer, nach NO einfallender Bruch bildet die Nordgrenze, und die nun folgenden älteren Tertiärschichten (Sirmurschichten) sind über die Siwalik hinübergeschoben. Man kann mit dieser Zone des Vorhimalaya die dem gleichen Zeitalter angehörigen Vorberge am Außenrand der Alpen vergleichen, aber während sich an diese eine mesozoische Zone anschlieBt, folgen im Himalaya Faltenzüge aus Schiefern, Quarziten und Kalksteinen, die wegen völligen Mangels an fossilen Einschlüssen keine genaue Altersbestimmung gestatten und von den indischen Geologen jetzt in das älteste Paläozoikum verwiesen worden. In dieser Zone des Niederhimalaya erreichen die Gipfel schon Höhen von mehreren Tausend Metern; die nächste Zone ist die des Hochhimalaya, eine fortlaufende, wenn auch nicht geschlossene Reihe von Schneegipfeln von 6000 bis $8000 \mathrm{~m}$ Höhe. Sie entspricht der kristallinischen Zone der Alpen, aber alte Gneise und kristallinische Schiefer spielen im Himalaya eine untergeordnete Rolle gegenüber den Graniten und Gneisgraniten, echten Eruptivgesteinen, die erst zum Beginn der Tertiärzeit, als der FaltungsprozeB einsetzte, aus der Tiefe aufstiegen. Gegen $\mathrm{O}$ gewinnt diese kristallinische Zone gewaltig an Breite. Nun erst folgt ein Komplex von Schichten, in dem man sämtliche Formationen vom Kambrium bis zur Kreide nachweisen konnte, also ein Analogon unserer Kalkalpen, auch insofern als massige Kalksteine in erster Linie formgebend auftreten. Am Südrand des Industales erscheint wieder Tertiär, aber genetisch von' anderer Art als die Siwalik- und Sirmurbildungen. Nach der landläufigen Nomenklatur findet der Himalaya hier sein Ende, aber das Profil in Fig. 219 belehrt uns, daß die ganze Massenanschwellung von der Gangesebene bis zum Tarimbecken als eine orologische Einheit anzusehen ist. Auch als eine tektonische Grenze kann das Industal nicht gelten; nördlich davon wiederholt sich 
die Anordnung, die wir im S kennen gelernt haben: eine kristallinische Zone, die Ladakkette, und eine paläozoische und mesozoische Sedimentzone, der Karakorum.

Um eine Vorstellung von der außerordentlichen Mannigfaltigkeit der Gebirgstektonik zu geben, fügen wir noch ein paar Beispiele aus dem westamerikanischen Hochgebirgsgürtel hinzu. Ein Profil in etwa $40^{\circ}$ B. (Fig. 220) diene zur Erläuterung des Baues des Fels eng ebirges. Wir nähern uns ihm von Osten und erreichen in Boulder eine Seehöhe von $1609 \mathrm{~m}$. Hier sehen wir die sonst flachgelagerten Kreideschichten steil 'emporsteigen; ihre Schichtenköpfe bilden parallele Vorketten, von den Amerikanern plastisch Hogbacks (Schweinsrücken) genannt. Dann folgt die breite archäische Coloradokette, deren höchster Punkt in dieser Gegend, der Arapahoe Peak, $4120 \mathrm{~m}$ über dem Meer liegt. Im ıWesten seńkt sich die Kette zu den flachen Depressionen der Parks, die mit Sedimenten ausgefüllt sind; die Talböden haben hier 2200-2500 m Höhe. Von der zweiten archä-

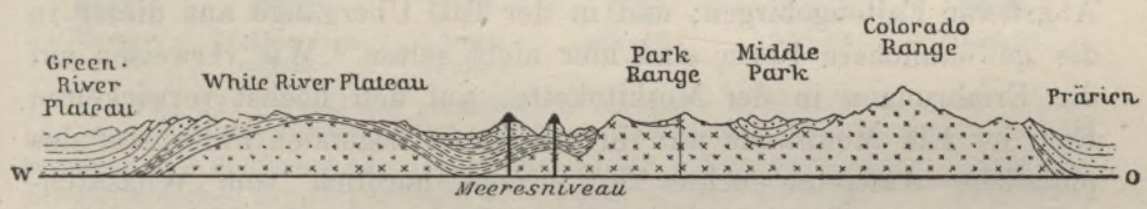

$\square$ Archaisch

塱Paläozoisch

Mesozoisch

Tertiar

Fig. 220. Geologisches Profil des Felsengebirges nach Hayden (Atlas von Colorado).

ischen Kette, der Parkkette (Lone Peak, $3440 \mathrm{~m}$ ), sehen wir in unserem Profil nur einen schmalen Ausläufer. Den westlichen AbschluB macht die Riesenantiklinale des White River-Plateaus (höchster Punkt $3679 \mathrm{~m}$ ); in den Grand Hogbacks biegt sich der paläo- und mesozoische Schichtenmantel in die Tiefe und verschwindet unter den flachen Tertiärschichten des Green River-Plateaus, das hier etwa $2600 \mathrm{~m}$ über dem Meer liegt.

Die amerikanischen Geologen, bisher nur an die regelmäßige Faltenaufeinanderfolge der Alleghanies gewöhnt, standen hier vor einem neuen Problem. Die einfachen Schichtenbeugungen am Rand, die große Ausdehnung der kristallinischen Zonen, die gewaltigen Gewölbe - das alles findet in den übrigen Faltengebirgen kein Analogon. Die Ansichten über die Entstehungsweise dieses Gebirges gehen daher ziemlich weit auseinander. Zunächst erhebt sich die Frage, ob die beiden archäischen Ketten einst ebenso von Sedimenten überlagert waren, wie jetzt noch das White River-Plateau; und wer dieser Ansicht huldigt, wie es die älteren Erforscher, HAYDEN und Powell, getan haben, findet die einfachste Erklärung in der An- 
nahme vertikaler Dislokationen, sei es, daß man im Sinn der Amerikaner die Gebirge durch einfache Hebung über die Umgebung emporwachsen läßt, sei es, daß man sich mit SuEss die Umgebung gesunken denkt, während dre heutigen Gebirge keilförmig stehen blieben. Die neueren Untersuchungen sind aber zu wesentlich andern Ergebnissen gelangt. Namentlich Emmons ${ }^{20}$ vertritt die Ansicht, daß die archäischen Massen der Colorado- und Parkkette und des Sawatch uralte Festländer sind, und daß die Sedimente nur an den Rändern, also als Uferbildungen abgelagert und dann durch seitlichen Schub in Falten gelegt wurden. Nur waren diese Falten einseitig ausgebildet, mit sanft ansteigendem Ost- und steil abfallenden Westschenkel; dies erzeugte Einbrüche mit Senkung des Westflügels, wodurch eine Art Schuppenstruktur entstand. Nach dieser Theorie, die zunächst zur Erklärung der Lagerungsverhältnisse in der Moskitokette diente, ist das Felsengebirge von Colorado eine durch übermächtige Entwickelung der kristallinischen Zone charakterisierte Abart von Faltengebirgen; und in der Tat, Übergänge aus dieser in die gewöhnlichere Form sind hier nicht selten. Wir verweisen auf die Erfahrungen in der Moskitokette, auf den höchst verwickelten Bau der Elk Mountains mit ihrer schönen liegenden Falte; auf das plötzliche Auftreten echter Faltenzüge nördlich vom Whasatchgebirge bis zur Basalttafel des Snake River. Ja, das Felsengebirge selbst nimmt schon in Montana den Typus eines echten Faltengebirges mit antiklinalen Kämmen und synklinalen Tälern an, wie Hayes schon 1871 richtig erkannt und Peale bestätigt hat. ${ }^{21}$

In den Beispielen, die bisher zur Erörterung kamen, bestehen die kristallinischen Zonen aus archäischen Schiefern und Eruptivmassen aus den Familien der Granite und Syenite; in den Andes Südamerikas treten daneben aber auch andere Eruptivgesteine in zonaler Anordnung in den Bau des Gebirges ein, ganz abgesehen von den jungen Vulkanen, die den Kettyen aufsitzen und nicht in den Faltungsproze $B$ mit einbezogen wurden. In Steinmann's ${ }^{22}$ Profil durch die peruanische Cordillere zwischen Lima und dem Chanchamayotal tritt diese Anordnung, klar hervor (Fig. 221). Die Dioritzone der pazifischen Abdachung wird beiderseits von Sedimentzonen, und diese wieder beiderseits von Granitzonen eingefaßt, von denen aber die westliche, die sich nur auf die Inseln und die Küste beschränkt, in unserem Profil nicht zur Darstellung gelangt. Fragt man, wo das Analogon zur kristallinischen Zone der Alpen zu suchen sei, so wird man geneigt sein, auf die östliche Granitzone zu verweisen, denn nur sie tritt in Gesellschaft von kristallinischen Schiefern auf, und nur hier vermitteln paläozoische und Trias- 
schichten den Übergang zu dem breiten Kalkgebirge der jüngeren mesozoischen Formationen. Indes ist diese Frage noch nicht spruchreif. Die kristallinischen Gesteine, die die Ostcordillere von Ecuador zusammensetzen, sollen nach F. v. WoLFF's neuesten Untersuchungen ${ }^{23}$ nicht archäisch, sondern jüngern Ursprungs sein, und weiter südlich, in der chilenisch-argentinischen Cordillere, zieht sich ein breiter Granitstreifen nur der Küste entlang. BURCKHARDT ${ }^{24}$ verdanken wir zwei lehrreiche Profile aus dieser Gegend (in ungefähr 35 und $39^{\circ}$ B. die uns - wie übrigens zum Teil auch Steinmann's Profil - durch die Einfachheit und Regelmäßigkeit des Faltenbaues geradezu überraschen. - Der östliche Teil des Gebirges erinnerte BurckHardT lebhaft an den Schweizer Jura.

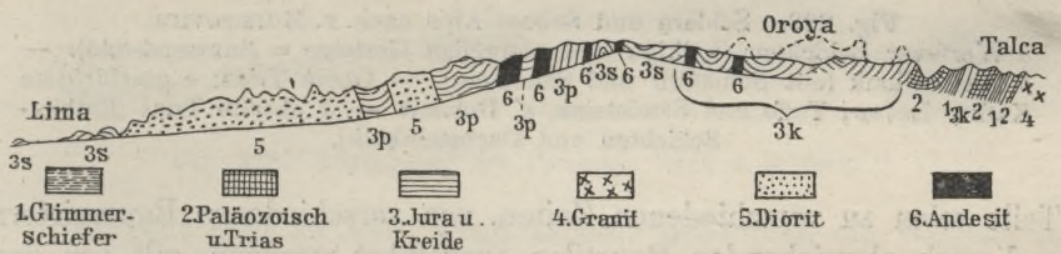

Fig. 221. Profil der peruanischen Cordillere nach G. Sternmann.

Längenmaßstab 1:2000000, Höhenmaßstab 1:500000. (Die Jura- und Kreideformation ist in dreifacher Ausbildung vertreten : $3 p=$ Meeressedimente in Verbindung mit porphyrischen Eruptivgesteinen, $3 s=$ Sandsteine und Schiefer, $3 k=$ Kalksteine.)

Schon aus diesen wenigen und nur dürftig erläuterten Beispielen wird man eine Vorstellung von der schier unübersehbaren Mannig. faltigkeit des Aufbaues der Faltengebirge gewonnen haben. Und nicht bloB der verschiedenen Gebirge, sondern auch der einzelnen Teile eines und desselben Gebirges. Sie steigert sich noch dadurch, daß nicht bloB Falten und Brüche vereinigt auftreten, sondern häufig auch Brüche die Falten ersetzen. Dann werden Schollen von verschiedener Ausdehnung und mit flacher Schichtenlagerung emporgehoben und bilden Plateaus inmitten von Gebirgsketten. 'Das ist der Charakter des südlichen Appennin gegenüber dem mittleren und nördlichen, wo allein Faltung herrscht. Fig. 222 gibt uns ein Beispiel aus den Dolomiten Südtirols, das noch in anderer Beziehung lehrreich ist. Zur Zeit der oberen Trias entstanden unmittelbar nebeneinander geschichtete Ablagerungen $(c)$ und massiger Dolomit $\left(c^{\prime}\right)$, der jetzt von den meisten Forschern als Koralleuriff gedeutet wird; und dieser Gesteinsunterschied gleichzeitiger Bildungen, die - wie man aus der Figur ersieht - zackenartig ineinander eingreifen, beherrscht auch das gegenwärtige Landschaftsbild Mit geisterbleichen, nackten Wänden erhebt sich der Bergstock des Schlern über die üppigen, grünen Matten der Seisser Alpe, und das ist im allgemeinen 
auch der Charakter der übrigen viel gepriesenen Dolomitenwelt Südtirols. In andern Gebirgen gesellen sich spätere vulkanische Ergüsse hinzu, zwar als ein fremdes Element, aber doch als ein solches, das mit dem Faltenbau zu einer oft untrennbaren Einheit verschmilzt. Das treffende Wort, das v. MoJsisovics auf die Alpen anwandte: „ein gemeinsames Dach wölbe sich zwar über dem großen, mit uniformen Schnörkeln ausgestatteten Bau, aber die einzelnen

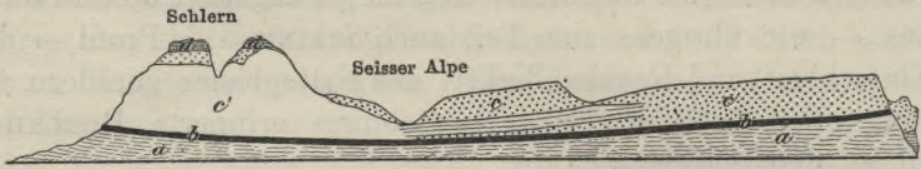

Fig. 222. Schlern und Seisser Alpe nach v. MoJsisovics.

$a$ Werfener Schichten (kalkige und mergelige Gesteine $=$ Buntsandstein). $b$ Muschelkalk (mit Schiefern und Sandstein). - Obere Trias: $c$ geschichtete Kalke, Laven, Tuffe und Sandsteine, $e^{\prime}$ Dolomit. $-d$ oberste Trias (RaiblerSchichten und Dachsteinkalk).

Teile seien $\mathrm{zu}$ verschiedenen Zeiten, von verschiedenen Baumeistern und nach abweichenden Baustilen ausgeführt worden", gilt von den meisten großen Kettengebirgen.

Längserstreckung. In bezug auf die Gestalt ihrer Längsachse kann man die Kettengebirge in geradlinige und bogenförmige teilen; und es muß besonders betont werden, daß die Bogenform durchaus nicht an die Ungleichförmigkeit gebunden ist, denn es gibt auch gleichförmige Bogengebirge, wie den Schweizer Jura, und ungleichförmige mit geradlinigem Verlauf, wie die Pyrenäen oder den Kaukasus. Die Bogenform bietet ein schwieriges Problem, denn wenn sich auch aus der Annahme eines Horizontalschubs unmittelbar ergibt, daß die Falten und Bergketten senkrecht zu der Richtung der faltenden Kraft verlaufen, so entsteht doch die Frage, was diese Kraft zu so auffallenden Drehungen veranlaßt haben kann. Ausgehend von der Voraussetzung eines einseitigen Schubes, dachte Suess an einen Widerstand alter Massen an der Áußenseite der Falten, wie es auf S. 654 dargelegt wurde. FreCH ${ }^{25}$ macht die alten Restgebirge an der Innenseite der Falten, wie er solche in den südlichen Kalkalpen fand, für die Ablenkung des Horizontalschubs verantwortlich. Diesen Staungsbögen stellte voN RICHTHOFEN $^{26}$ die Zerrungsbögen entgegen, die den Bau Ostasiens beherrschen, und von denen wir schon auf S. 38, gesprochen haben. TH. Lonenz ${ }^{27}$ verwirft sie, weil sie sich mit der Kontraktionstheorie schlecht vertragen. Er betrachtet alle Bogenlinien der Erdoberfläche, mögen sie aus Faltung oder Bruch hervorgegangen sein, als 
Torsionserscheinungen. Die Falten, die am Ende des archäischen Zeitalters entstanden, streichen nach seiner Annahme von NW nach SO, alle späteren Falten aber von NO nach SW. Wirkte die Tangentialkraft nicht genau in der Richtung der archäischen Falten, sondern traf sie "unter einem schiefen Winkel, so entstand Interferenz nach dem Gesetz des Kräfteparallelogramms, aber die Resultierende konnte nicht immer eine gerade Linie sein, weil sich der Widerstand, den die archäischen Falten dem neuen Zusammenschub entgegensetzten, wegen ügleicher Gesteinsbeschaffenheit oder verschiedenen Denudationsverlustes in ihrem Verlauf änderte. Auf der chinesischen Hुalbinsel Schantung läßt sich der Kampf beider Richtungen noch in der heutigen Anordnung der Gebirge erkennen.

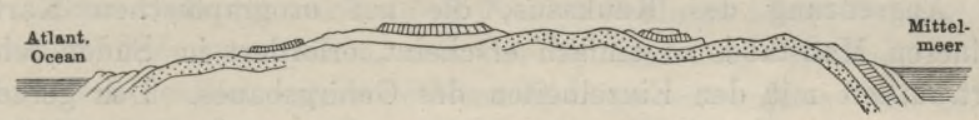

Fig. 223. Längsprofil der Pyrenäen nach J, Roussex. ${ }^{15}$

Es geht aber zu weit, wenn LoRENz behauptet, ein Wechsel in der Streichrichtung habe sich auf der ganzen Erde nur einmal, am Beginn der paläozoischen Periode vollzogen. Die Durchkreuzung zw eier Faltensysteme ist eine sehr häufige Erscheinung. ZüRCHER ${ }^{28}$ hat in den Basses-Alpes, in der Gegend von Castellane, die verschiedenartigsten Komplikationen dieser Art analysiert. Am Fläscherberg beobachtete LoRENz ${ }^{29}$ eine ältere NW streichende Faltung, die die Kammrichtung des Gebirges bestimmt, und jüngere NO streichende Falten, die dem Berg durch die Loslösung von der Alvierkette zu einer selbständigen Existenz verhalfen. Die Pyrenäen ziehen, wie die Longitudinalfalten, von $\mathrm{W}$ nach $\mathrm{O}$, daneben gibt es aber noch sekundäre Transversalfalten (N-S), die in der Aufwölbung des mittleren Gebirges und in der Kammsenkung nach den beiden Meeren hin einen prägnanten Ausdruck finden (Fig. 223). Auch das Taurische Gebirge hat nach Listow's Untersuchungen ${ }^{30}$ einen solchen komplizierten Bau, aber das nordöstliche System bleibt das formgebende Element, das nordwestliche kommt nur in untergeordneter Weise zur Geltung. Im Hohen Altlas von Marokko fand GENTIL ${ }^{31}$ eine karbonische Faltung mit der ungefähren Richtung N $20^{\circ} \mathrm{O}$, aber auch hier war die bis zu $45^{\circ}$ davon abweichende jüngere (tertiäre) Faltung maßgebend für die heutige Gestalt des Gebirges. Im tunesischen Atlas erheben sich die meisten domförmigen Berge, die ihm ein so eigentümliches Gepräge geben, an der Kreuzungsstelle zweier Falten ${ }^{32}$; hier ist die Hebungsintensität durch die Interferenz offenbar gesteigert worden. Dagegen kann man in der mesozoischen 
Randzone der Seealpen Synklinalen beobachten, die sich unter einem rechten Winkel schneiden, ohne sich gegenseitig im geringsten zu beeinflussen. $^{33}$ Die Wirkungen solcher Kreuzfaltungen sind also sehr verschieden, aber stets tritt ein Faltensystem als das maßgebende hervor: dasjenige, das die Hauptrichtung des Gebirges als Ganzes bestimmt.

Beziehungen der Faltengebirge zueinander. Ihre Abgrenzung und Einteilung. Wenn sich ein Gebirge isoliert aus der Ebene erhebt, so kann sich über seine geographische Selbständigkeit und seine Grenzen kein Zweifel erheben. Solche Gebirge gehören aber meist andern Kategorien an; von den echten Faltengebirgen unseres Festlandes nimmt nur der Ural eine isolierte Stellung ein; selbst die Abgrenzung des Kaukasus, die auf orographischen Karten kleineren Maßstabes so einfach erscheint, erfordert im Süden schon Vertrautheit mit den Einzelheiten des Gebirgsbaues. Den geraden Gegensatz zum Ural bilden die westlichen Faltengebirge der Balkanhalbinsel. Im Westen ist natürlich das Meer die Grenze, im Osten treten sie aber ohne Einschaltung einer Ebene so nahe an Gebirge von anderer Struktur heran, da $B$ auf genaue, allseitig befriedigende Scheidung überhaupt verzichtet werden muß. Schwierig ist auch die Aufgabe des Geographen, wenn Faltengebirge miteinander verwachsen, und dies ist innerhalb der Hochlandgürtel beider Welten sogar die Regel. Der Sprachgebrauch bietet einige Anhaltspunkte, aber keineswegs sichere; trotzdem läßt er sich nicht einfach ignorieren, soll nicht eine heillose Verwirrung einreißen.

Hier nur ein paar Beispiele.

Die Alpen zeigen uns zwei verschiedene Arten der Verwachsung oder Kettung, wie v. Richthofen „die Verbindung von je zwei selbständigen orographischen Einzelgebilden" nannte. Der Schweizer Jura schmiegt sich an seinem Südwestende so eng an die Kalkalpen an, da $B$ er geradezu als ein Teil davon erscheint, und erst in seinem weiteren Verlauf gewinnt er Selbständigkeit. Der Appennin und der Karst sind dagegen orographisch einfach Fortsetzungen der Alpen. Im ersteren Fall leitet uns wenigstens der Richtungswechsel und die Veränderung in der geologischen Zusammensetzung bei der Grenzbestimmung, obwohl noch bis zum heutigen Tạg darüber gestritten wird, durch welche Täler und über welchen $\mathrm{PaB}$ am besten die Grenze zu ziehen sei. ${ }^{34}$ Bei der Scheidung zwischen Alpen und Karst lassen uns orographische wie geologische Karten im Stich; hier müssen wir noch tiefer in den Gebirgsbau eindringen, um einige Anhaltspunkte zu gewinnen. Wie noch viele andere Kettengebirge, treten die Alpen im Osten rutenförmig auseinander; der 
Karst ist der Südflügel, die Karpathen sind der Nordflügel; nur ist im letzteren Falle die Trennung auch äuBerlich durch aufgesetzte Ebenen vollzogen. Aber gerade dieses Beispiel lehrt uns, daß die Natur oft äußerlich getrennt hat, was innerlich zusammengehört; und wenn es aụch niemandem einfällt, den Karpathen ihre Selbständigkeit zu rauben, so müssen sie es sich doch gefallen lassen, als ein Glied dem alpinen System eingereiht zu werden (vgl. S 38). Gebirgssysteme repräsentieren also eine höhere Ordnung als Gebirge, und zu einem solchen System fassen wir nicht bloß die äußerlich verbundenen Gebirge zusammen, sondern auch solche, die in entwickelungsgeschichtlichen Beziehungen zueinander stehen, wenn auch jugendliche Oberflächengebilde den Zusammenhang verbergen.

Eine große (umgekehrte) S-förmige Schlinge bildet der Gebirgsrahmen der ungarischen und der walachischen Tiefebene. Drei geologisch deutlich unterscheidbare Gebirge verschmelzen hier nahezu zu einer orologischen Einheit: die Karpathen gehen in der Gegend des Tömöser Passes mit scharfer Knickung in die Transsylvanischen Alpen über, und diese wieder setzen sich in schönem Bogen über die Donau hinüber in dem Balkan fort. Die Grenzen Jiegen also gerade an den Umbiegungsstellen; die erste wird auch orographisch durch das Einsturzbecken von Kronstadt markiert, an der zweiten stellen aber die Andesite des Einsturzbeckens der Tscherna-Reka eine oberflächliche Verbindung her. Einem auffallend ähnlichen Bau begegnen wir am westlichen Ausgang des Mittelmeeres, wo das marokkanische Rîf in das andalusische Gebirge umschwenkt; indes ist hier der Bruch an der Beugestelle, der die Straße von Gibraltar geöffnet hat, noch nicht vernarbt.

Am Westende des zentralasiatischen Hochlandes verschlingen sich Himalaya, Karakorum, Kwenlun, die Pamirerhebung, der Hindukusch, der Tiënschan zu dem gewaltigsten Gebirgsknoten der Erde, von dem sie fast nach allen Himmelsrichtungen ausstrahlen. Diese Art der Kettung ist Scharung, d. h. Zusammendrängung von Faltenzügen, die dann auseinandertreten, wie bei Alpen und Jura, aber zugleich auch Endverkettung, wie zwischen Alpen und Appenninen, indem der Übergang aus dem Himalaya in den Hindukusch durch Beugung und Veränderung der Streichrichtung erfolgt. Eine andere Art von Kettung hat v. Richтногen am Ostende des Kwenlun beobachtet. Starr behält dieser seine Richtung bei und zwingt die auf ihn stoßenden Falten des sinischen Systems sich ihm anzuschließen (Fig. 224). Ein ganz anderes Verhalten befolgen die beiden Richtungssysteme des Atlas, das östliche des Kleinen und das nordöstliche des Großen Atlas; an der algerisch-tunesischen Grenze, wo 
sie sich begegnen, werden die Falten des ersteren von denen des letzteren glatt abgeschnitten. ${ }^{35}$ Wieder anders vollzieht sich der ZusammenstoB in der nordwestlichen Balkanhalbinsel. Von den

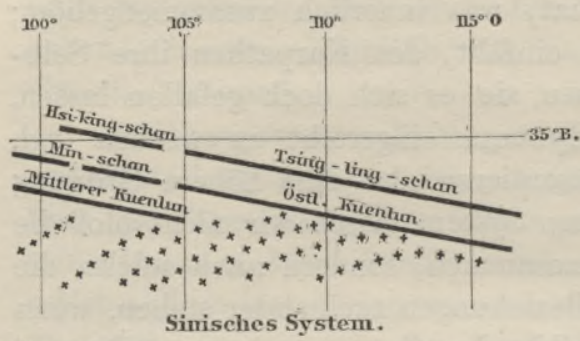

Fig. 224. Das Zusammentreffen des sinischen u. des Kwenlun-Systems nach v. RICHтHOFEN. nach SO ziehenden dinarischen Falten biegen die östlichen nach $\mathrm{O}$ und NO um und stoßen in ihrem weiteren Verlauf auf die archäischen Gebirgsmassen Westserbiens. Hier gestaut, werden sie in der Horizontalen zickzackförmig gebogen; Cviлć nennt sie gew undeneFalten. ${ }^{36}$

Wie wir einerseits Gebirge

zu Systemen zusammenfassen, so lösen wir sie anderseits in Haupt- und Untergruppen auf. Soll eine solche Einteilung über das Niveau eines schulmäBigen Notbehelfs hinausreichen, so muß sie die fundamentalen morphologischen Gegensätze zum Ausdruck bringen. ${ }^{37}$ Diese Gegensätze sind zum Teil durch den innern Bau, zum Teil durch die Gliederung bedingt; beides muß berücksichtigt werden. Die neueste, auf Grund der modernen geologischen Theorien vorgenommene Einteilung der Alpen, wie sie SuEss seinem Werk über „das Antlitz der Erde“ beigegeben hat, kann daher dem Geographen nicht genügen. Durchaus zweckmäßig ist dagegen die Zweiteilung, die v. Mossisovics vorgeschlagen hat. Er war der erste, der den tiefgreifenden Unterschied zwischen der Ost- und Westhälfte der Alpen erkannte und sie durch die sich vom Bodensee zum Lago-Maggiore erstreckenden Tallinien schied. Geographisch besonders wichtig ist die schon erwähnte Tatsache, daß nur die Ostalpen eine südliche Sedimentzone besitzen. Die großen Kalk- und Dolomitmassen, die hauptsächlich die nördliche Sedimentzone zusammensetzen, sind in den Ostalpen obertriadischen Alters, während sie in den Westalpen der Jura- und Kreideformation angehören. Hier nehmen auch die eozänen F́lyschschiefer und Sandsteine hervorragenden Anteil an der Gebirgsbildung, indem sie zonenartig zwischen den mesozoischen Gesteinen auftreten, während sie in den Ostalpen nur auf den äußeren Rand beschränkt sind; das unter dem Namen Nagelfluh bekannte neogene Konglomerat kommt nur in den Westalpen vor. Jeder dieser beiden Hauptteile verlangt aber wieder eine Zweiteilung. In den Westalpen haben wir den Gegensatz des einseitigen Baues der schweizerischen und des zonalen Baues der französischen Alpen schon hervorgehoben (S. 664). In den Ostalpen tritt der hydrographische Gegensatz in den Vorder- 
grund, ein Gegensatz, der dem Geologen als nebensächlich erscheinen mag, für den Geographen aber geradezu fundamentale Bedeutung besitzt. Während westlich von der Dreiherrenspitze nur eine einzige Hauptwasserscheide die Alpen durchzieht, gabelt sie sich im Osten, und statt zwei Abdachungen haben wir nun drei, indem sich zwischen die nördliche und die südliche eine östliche einschiebt. Eine eingehendere Analyse wird außerdem noch in allen drei Zonen tiefgreifende Unterschiede zwischen den beiden Flügeln der Ostalpen aufdecken.

Im Tiënschan vereinigen sich gerade im Kulminationspunkt (Chan-Tengri) zwei Gebirge von verschiedener Entwicklung zu einem anscheinend kompakten Körper. Die Verschiedenheit der Streichrichtung zu beiden Seiten des Musarttales - im W nach NO, im $\mathrm{O}$ nach NW - deutet auch schon äußerlich diesen Gegensatz an. Das westliche Gebirge ist schon in nachkarboner Zeit gefaltet worden, die mesozoischen Ablagerungen fehlen, die tertiären Gobisedimente liegen diskordant, und die gebirgsbildende Tätigkeit der Pliozänzeit äußerte sich nur in Brüchen und Schollenverschiebungen. In allen diesen Punkten verhielt sich das Gebirge östlich vom Musart gerade entgegengesetzt: keine alte Faltung, mächtige limnische oder terrestrische Bildungen des mesozoischen Zeitalters, konkordante Lagerung der Gobisedimente, pliozäne Faltung. Jede Einteilung des Tiënschan, die auf Wissenschaftlichkeit Anspruch macht, muß dieser erst durch die neuesten geologischen Forschungen ${ }^{38}$ ans Licht gebrachten fundamentalen Tatsache in erster Linie Rechnung tragen.

Beziehungen der Kettengebirge zum ungefalteten Vorland. Es ist eine häufig wiederkehrende Erscheinung, daß der eine $\mathrm{FuB}$ eines Kettengebirges tiefer liegt als der andere. Bogenförmige Gebirge werden in der Regel an der konkaven Seite von Tiefebenen, an der konvexen von Hochflächen begleitet, selbst dann, wenn an der Innenseite keine sichtbaren Spuren von Einstürzen vorhanden sind. Die einzelnen Glieder des Alpensystems zeigen hierin eine bemerkenswerte Übereinstimmung, so die Alpen selbst, der Jura, die Karpathen. Der Atlas und das andalusische Gebirge grenzen an der Innenseite an das Meer und an der Außenseite an Land; der Appennin hat das tiefere Meer an seiner konkaven, das flachere an seiner konvexen Seite. Auch bei geradlinigen Gebirgen, wie bei dem Ural und den Alleghanies finden wir tieferes Vorland an der Seite, wo die Hebungsintensität am größten war. Aber es gibt auch Beispiele vom Gegenteil. So begrenzen den Himalaya an seiner Innenseite Ebenen von $4000 \mathrm{~m}$ Seehöhe, an seiner Außenseite aber ein Tiefland, das selbst 
am Fuß des Gebirges nur ein paar hundert Meter über dem Meeresspiegel liegt; und das japanische Gebirge stürzt an seiner konvexen Seite zu gewaltigen Ozeantiefen ab, während es sich an der andern zur flach schüsselförmigen Vertiefung des Japanischen Meeres senkt.

Sehen wir von den beiden letztgenannten Fällen vorläufig ab, so nehmen wir wahr, daß auch die geognostischen und tektonischen Beziehungen zum Hinterland andere sind, als zum Vorland. Dieselben Schichten, die den äußersten Gebirgsgürtel aufbauen, setzen sich mit horizontaler Lagerung in dem flachen Hinterland fort; allmählich erstirbt die faltende Kraft, manchmal tauchen noch vereinzelte Antiklinalen auf, wie die Parmas im Westen des Ural. An der Innenseite dehnt sich junges, fremdartiges Schwemmland aus, der eigentliche Gebirgsfluß liegt in der Tiefe verborgen. Solche

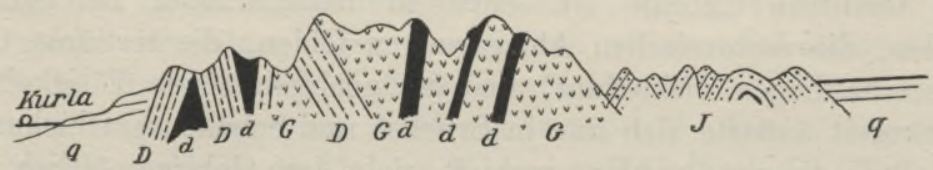

Fig. 225. Profil des Kuruk-tag bei Kurla $\left(41^{\circ} 40^{\prime} \mathrm{N}, 86^{\circ} 35^{\prime} \mathrm{O}\right)$ nach Bogdanowitsch. $G=$ Granit, $D=$ Devon, $d=$ Diabas, $J=$ Jura und Kreide, $q=$ Quartär.

Gebirge nennen wir einseitige Randfaltungen. Im Himalaya liegen die Randfalten ausnahmsweise an der alluvialen Grenze. Es wurde schon auf S. 665 bemerkt, daB das Siwalik mit dem Alluvium der Gangesebene völlig übereinstimmt, es war einst horizontale Anschwemmung, und das heutige Schwemmland wird vielleicht einst Vorkette sein. Solch ein Fortschreiten der Faltung in das Hinterland hat GrIesBaCH auch vom afghanisch-turkestanischen Grenzgebirge behauptet.

Ist ein Gebirge an allen Seiten von jüngeren Schichten umgeben, die an der Faltung keinen Anteil nehmen, so kann man es ein durchgreifendes Gebirge nennen. Ist es nicht durch Brüche begrenzt, so $\mathrm{muB}$ man annehmen, daB die Randfaltungen nur oberflächlich verhüllt sind. Bei dem zentralasiatischen Gebirge, dessen Profil wir hier als Beispiel vorführen (Fig. 225), bedecken rezente Steppenablagerungen den Gebirgsfuß im Norden und Süden.

Literaturnachweise. ${ }^{1}$ W. Kurax, im Bulletin de la Société géologique de France, 1897, S. 483. - ${ }^{2}$ A. Borissjak, Geologische Skizze des Kreises Isjum, St. Petersburg 1905 (Mémoires du Comité géologique). - ${ }^{3}$ G. F. DolLFus, zit. S. 658, Anm. 17. - ${ }^{4}$ K. Burcкнardt, Géologie de la Sierra de Mazapil et Santa Rosa, im Livret-guide des exeursions du $\mathrm{X}^{\mathrm{e}}$ Congrès géologique international, Mexico 1906. - ${ }^{5}$ Сн. A. Wніте, Geology and Physiography of a Portion of Northwestern Colorado, im IX. Jahresbericht des U. S. Geological 
Survey, 1887-88. - ${ }^{6}$ H. v. StafF, Über Kulissenfalten, im Neuen Jahrbuch für Mineralogie usw., Beilageband XXX, 1910. - ${ }^{7}$ M. Blanckenhorn, Die Strukturlinien Syriens, in der Riснтноғек-Festschrift; Berlin 1893. $-{ }^{8}$ G. 0. Sмıтн, im Journal of Geology 1903, Bd. XI, S. 166, u. Geological Atlas of the United States, Nr. 86. - ${ }^{9}$ L. Rollier, zit. S. 658, Anm. 24, E. DE Margerie, La structure du Jura, in den Actes de la Société Helvétique des Sciences naturelles 1909. $-{ }^{10}$ T. D. LA Tovche, in den Records of the Geological Survey of India, 1893. - ${ }^{11}$ E. HAva, Contribution à l'étude des lignes directrices de la chaîne des Alpes, in den Annales de géographie 1896, Bd. V; Études tectoniques sur les Alpes Suisses, im Bulletin de la Société géologique de France, 1896, Bd. XXIV. H. R. ZeLLer, Ein geologisches Querprofil dureh die Zentralalpen; Bern 1895. Ferner s. die auf S. 657 unter ${ }^{1},{ }^{3},{ }^{4}$ angeführten Arbeiten. - ${ }^{12}$ K! Diener, in K. Diener, R. Hoernes, F. E. Suess u. V. Uhuig, Bau und Bild Österreichs, Wien 1903. A. Rothpletz, Ein Querschnitt durch die östlichen Alpen; Stuttgart 1894. - ${ }^{13} \mathrm{~K}$. Diener, Der Gebirgsbau der Westalpen; Wien 1891. S. Franchi, Sull età mesozoica della zona delle pietre verdi nelle Alpi occidentali, im Bollettino del R. comitato geologico, 1898. W. Kutian und J. Révil, Etudes géologiques dans les Alpes occidentales, Paris 1904. - ${ }^{14} \mathrm{~S}$. Anm. ${ }^{12}$ Über die neue Auffassung der Karpathen als Deckengebirge s. V. Uhuig, zit. S. 657 , Anm $8 .-{ }^{15}$ E. DE Margerie und F. Schrader, Aperçu de la structure géologique des Pyrénées; Paris 1892. J. Rousser, Etude stratigraphique des Pyrénées, im Bulletin des services de la earte géologique de la France, 1894, Bd. V. - ${ }^{16}$ A. Hen, Querprofil dureh den Zentral-Kaukasus, in der Vierteljahrschrift der naturforsehenden Gesellschaft in Zürich, 1898, Bd. XLIII. Etwas abweichende Anschauungen vertritt E. Fournier (in den Annales de la faculté des sciences de Marseille, 1896). - ${ }^{17} \mathrm{~K}$. Bogdanowrrsch, Zwei Übersteigungen der Hauptkette des Kaukasus, in den Mémoires du Comité géologique, Bd. XIX, 1902. 18 D. W. Iwanow, in der 16. Lieferung der Explorations géologiques le long du chemin de fer de Sibérie. - ${ }^{19}$ S. G. Burrard und H. H. Hayden, A Sketeh of the Geography and Geology of the Himalaya Mountains and Tibet, Calcutta 1907-08. - ${ }^{20}$ S. F. Emsons, Geology and Mining Industry of Leadville; Washington 1886; Orographic Movements of the Rocky Mountains, im Bulletin of the Geological Society of America, 1890. - ${ }^{21}$ A. C. Peale, im Bulletin of the U. S. Geologieal Survey, Nr. 110, 1893. - ${ }^{22}$ G. SternMasn, im Boletin del Cuerpo de Ingenieros de Minas del Peru, 1904, Nr. 12. ${ }^{23}$ F. v. Wolff in W. Reiss, Eeuador; Berlin 1904, S. 187. - ${ }^{24}$ K. Burckhardt, Profiles géologiques transversaux de la Cordillière Argentino-Chilienne; Coupe géologique de la Cordillière entre Las Lajas et Curacautin; La Plata 1900. 25 F. Frech, Die Tribulaungruppe, in der Richtноғеn-Festschrift; Berlin 1893. - ${ }^{26}$ F. v. Rrchthofen, zit. S. 52. - ${ }^{27}$ Tн. Lonenz, Beiträge zur Geologie u. Paläontologie von Ostasien, in der Zeitschrift der Deutschen Geologischen Gesellschaft, Bd. LVII, 1905. - ${ }^{28}$ P. Zürcher, Note sur la structure de la région de Castellane, im Bulletin des services de la carte géologique de la France, Nr. 48, 1895, Bd. VII. - ${ }^{29}$ Tн. Lorenz, Monographie des Fläscher-

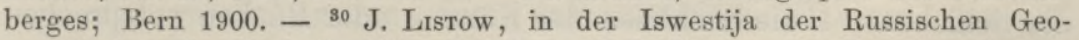
graphischen Gesellschaft 1889, S. 270. - ${ }^{31}$ L. GentiL, in den Annales de Géographie 1907, S. 70. - ${ }^{32}$ L. Pervinquière, Etude géologique de la Tunisie centrale; Paris 1903. - ${ }^{33}$ A. Guébhard, Sur les recoupements et étoilements de plis observés dans les Alpes maritimes, in den Comptes rendus du VIII. Congrès géologique international, 1900. - 34 Vgl. Petermann's Mit- 
teilungen 1893, S. 93. F. SAcco, im Bulletin de la Société Belge de géologie, 1895, Bd. IX, S. $33 .-{ }^{35}$ A. Rothpletz, Das Atlasgebirge Algeriens, in PeterManv's Mitteilungen 1890. - ${ }^{36} \mathrm{~J}$. Cvisı́, in der Zeitschrift der Berliner Gesellschaft für Erdkunde 1902, S. 211. — ${ }^{37}$ Die Grundsätze einer wissenschaftlichen Einteilung erörtert A. v. Böнм, Einteilung der Ostalpen; Wien 1887. ss H. Keides, Geologische Untersuchungen im südlichen Tianschan, im Neuen Jahrbuch für Mineralogie usw., Beilageband XXII, 1906. M. Scruosser, Über fossile Land- und Süßwassergasteropoden aus Zentralasien und China, in den Annales Musei Hungarici 1906.

\section{Umformung der Faltengebirge.}

Leitsatz. Als Mutationsformen haben wir nur diejenigen zu betrachten, bei denen wesentliche Eigenschaften der. Faltengebirge verloren gegangen sind. Welche sind nun diese wesentlichen Eigenschaften?

Man begegnet in der einschlägigen Literatur in der Regel der Ansicht, daß der reine Typus des Faltengebirges in der Aufeinanderfolge von Antiklinalkämmen und Synklinaltälern bestehe, wie ihn der Schweizer Kettenjura in so ausgezeichneter Weise darstellt. Solche einfache Bauformen sind indes seltene Ausnahmen, und das Juraschema ist auf die verwickelteren Architekturen, auf die Isoklinalfalten, die Schuppenstruktur und vor allem auf die Deckengebirge schlechterdings nicht anwendbar. Vollzog sich die Überfaltung in der Tiefe, und waren die Deckengebirge bei ihrem Auftauchen nur einfache Bodenschwellen, so begann die Struktur erst nach der Entfernung der Sedimenthülle wirksam zu werden. Aber auch jene ursprüngliche Struktur blieb nicht maßgebend, sondern erst ihre Umwandlung durch die zweite Faltung. Wir haben von diesen Anfangsstadien keine sichere Anschauung, aber als unzweifelhaft erscheint uns, daB der Wechsel von Antiklinalkämmen und Synklinaltälern nicht die allgemeine Urform der Faltengebirge gewesen sein kann. Schon die weite Verbreitung der Isoklinalfälten verbietet eine derartige Voraussetzung.

Als wesentliche Eigenschaften aller Faltengebirge haben wir dagegen folgende $\mathrm{zu}$ betrachten: 1. die Erhebung über das umliegende Land; 2. die Richtung und die Umrisse der Gebirge werden durch den Zug der Falten bestimmt, die Gebirge reichen soweit, wie die Faltung gereicht hat; 3. der Abfall des Gebirges zu dem angrenzenden Land entspricht im großen und ganzen dem Neigungswinkel der Schichten; 4. die Seehöhen der Kämme oder Rücken entsprechen der Hebungsintensität; 5. innerhalb des Gebirges kommen ausgedehntere Ebenheiten nur dort vor, wo die Schichten flach lagern; 6. die typische Talform ist das Längstal; wir werden uns über diesen Punkt an einer späteren Stelle ausführlicher verbreiten. 
Umformung durch Bruch. Brüche haben wir schon als eine gewöhnliche Begleiterscheinung der Faltung kennen gelernt, ja stellenweise ersetzt geradezu die eine Dislokationsform die andere, wie im östlichen Südtirol. Hier haben wir aber nur diejenigen Fälle ins Auge zu fassen, wo Brüche einen gefalteten Gebirgskörper ergreifen, ihn seiner ursprünglichen Gestalt berauben, endlich ihn völlig auflösen.

Die Innenseite bogenförmiger Kettengebirge unterlag häufig einer weitgehenden Zertrümmerung und Umgestaltung. Ein erstes Stadium führt uns das andalusische Faltensystem vor Augen. ${ }^{1}$ Es gehört der Kategorie der einseitig zusammengesetzten Faltengebirge an. Die kristallinische Zone läBt sich von der Sierra Bermeja im W bis zum Kap Palos im O verfolgen, und eine Reihe von Einbruchskesseln und die breite Talmulde der Sangonera und Segura trennt sie von der Sedimentzone, die im $\mathrm{W}$ mit dem Horst des Gibraltarfelsens beginnt und im $\mathrm{O}$ am Kap Náo endet. Schon die scharf ausgeprägte Depressionszone weist darauf hin, daß Brüche eine hervorragende Rolle in der Tektonik dieses Systems spielen, aber sie dringen auch in die Gebirgszonen ein, in die kristallinische in der Form von Querbrüchen, in die sedimentäre in der Form von Längsbrüchen und lösen sie in eine Reihe von verhältnismäßig kurzen Ketten auf. Aber noch entspricht die hypsometrische Rangordnung der Hebungsintensität und die Sierra Nevada, deren einfachen antiklinalen Bau v. Drasche anschaulich geschildert hat, ist noch immer die Königin der iberischen Gebirge.

In den Karpathen und Appenninen ist dagegen nur noch die Außenzone vollständig erhalten. Der plötzliche Abbruch der Kerngebirge der Karpathen an der Hernadlinie und das Wiederauftauchen eines kristallinischen Innengürtels in den Ostkarpathen deuten darauf hin, daß in dem Zwischenraum mächtige Gebirgsmassen in die Tiefe gesunken sind. Noch größer ist die Zerstückelung der appenninischen Innenzone, die nach den neueren italienischen Forschungen $^{2}$ wenigstens südlich von $41^{1} /_{2}{ }^{\circ} \mathrm{B}$. erst im Lauf der Tertiärzeit begonnen und bis in die geologische Gegenwart hinein gedauert hat, ja wahrscheinlich noch fortdauert. Thre Überreste finden wir in den Apuanischen Alpen, auf den toskanischen Inseln, in der Catena metallifera, im Circekap und auf der Insel Zannone; sie sind spärlich genug, denn das calabrische Gebirge, das nicht in ihrer Fortsetzung liegt, darf ihnen nicht zugezählt werden; es ist lediglich nur das Grundgerüst der Sedimentdecke, die bis auf einige Fetzen verschwunden ist. Während in den Karpathen die Granitkette der Hohen Tatra noch immer ihren hypsometrischen 
Vorrang behauptet hat, ist der Kulminationspunkt in den Appenninen bereits in die Sedimentzone gewandert.

In den bisher erörterten Beispielen hatte die Umformung durch Bruch nur einige Partien des Faltengebirges betroffen. In einem weiter fortgeschrittenen Stadium der Deformation befindet sich das transbaikalische Gebirgsland, ${ }^{3}$ dessen nahezu geometrische RegelmäBigkeit in der Anordnung der ostnordöstlich streichenden Ketten und Täler auf Faltenbau schließen ließ. Wohl ist auch dieses Gebiet gefaltet worden, aber schon in vorkambrischer Zeit, und seit dieser Epoche bis in das Tertiär, ja stellenweise bis in das Quartär traten vertikale Bewegungen ein, die das uralte Festland teils parallel mit den Falten, teils quer zu diesen in eine Reihe von Horsten und Gräben auflösten, von denen jene den heutigen Ketten, diese den Tälern entsprechen. Alle Ablagerungen und vulkanischen Ergüsse, die die paläozoischen und die nachfolgenden. Formationen diesem Gebirgskomplex hinzufügten, ordnen sich dem Bruchsystem ein. Solche Faltengebirge nennen wir gebrochene.

Wenn völlige Auflösung des ursprünglichen Gebirgskörpers eingetreten ist und nur mehr Bruchstücke davon vorhanden sind, so sprechen wir von Faltenschollengebirgen, die dort, wo sie gesellig auftreten, ein Faltenschollenland bilden. Es ist aber nicht immer leicht zu entscheiden, ob solche Gebirge ihr heutiges Aussehen mehr den Vertikaldislokationen oder mehr der Destruktion verdanken, oder mit andern Worten, ob wir es mit Faltenoder mit Rumpfschollen, von denen später die Rede sein soll, zu tun haben. Wir beschränken die Bezeichnung Faltenschollen auf Bruchgebirge jugendlichen Alters, wie solche beispielsweise den Ostrand der Alpen begleiten, oder auf ältere Gebirge, die in ihrem ganzen Charakter noch augenscheinlich vom Faltenbau beeinfluBt sind. Trotzdem verhehlen wir uns nicht, daß auch diese Begriffsbestimmung nicht für alle Fälle ausreicht.

In Griechenland ${ }^{4}$ können wir diesen ProzeB in allen Stadien verfolgen. Den Westen nimmt das dinarische Gebirgssystem mit seinen südöstlich streichenden Falten ein. Auch hier finden sich schon Anzeichen, daß nach der horizontalen eine vvertikale Bewegung eintrat, da das Pliozän ungefaltet, aber gebrochen in verschiedenen Höhen liegt, die im Peloponnes im allgemeinen von N nach S abnehmen. Schon im mittleren Griechenland bilden die nach verschiedenen Richtungen verlaufenden Bruchlinien ein wahres Netzwerk, in Elis ist das Faltenland in der Tat schon in Schollen aufgelöst, aber im großen und ganzen wird das peloponnesische Gebirge doch noch durch die südsüdöstliche Streichrichtung der Falten 
beherrscht. Gehen wir nach Thessalien und in das östliche Mittelgriechenland, so stoßen wir auf östlich streichende Faltensysteme, die sich im Stadium völliger Auflösung befinden. Größere und kleinere Senkungsfelder scheiden die Horste voneizander. Othrys, Oeta, Helikon, Kithaeron, Parnes erwecken gleichsam noch den Schein von Faltengebirgen, weil die Bruchlinien mit dem Streichen der Falten parallel verlaufen, - wir nennen sie Längsschollen —, aber im Pentelikon und Hymettos, auf Euböa und im östlichen Thessalien ist auch dieser Schein geschwunden. Im thessalischen Küstengebirge, das sich vom Pelion bis zur Kampania von Saloniki fortsetzt, ist der Typus der Querscholle auf das schärfste ausgeprägt: die Umrisse des Gebirges werden ausschließlich durch Brüche bestimmt, welche die alten Falten unter senkrechtem oder spitzem Winkel schneiden. Es vist, als wenn wir quer durch die Schweizer Alpen einen Streifen von etwa $20 \mathrm{~km}$ Breite herausschneiden würden und alles andere Gebirge im Westen und Osten in die Tiefe versänke, um von Wasser oder lockeren Ablagerungen bedeckt zu werden. Im Archipel erreicht die Auflösung ihren Höhepunkt. Ein Meer mit Tiefen bis zu $2000 \mathrm{~m}$ bedeckt das Senkungsfeld, und nur vereinzelte Horste ragen als Inseln empor.

Umformung durch Destruktion. Landstufen. Die einfachste Art des Faltengebirges, das Sattelgebirge, bietet auch in seinen Destruktionsformen der Erklärung keine großen Schwierigkeit. Wechseln Schichten von erheblich verschiedener Widerstandskraft, so wird es in Landstufen aufgelöst, und nur in deren Anordnung ist die einstige Gestalt noch wiederzuerkennen. In den "Swells" des Colorado-Tafellandes, einseitigen, flachen Antiklinalen, die aus einem Sedimentmantel und einem Granitkern bestehen, können wir verschiedene Stadien dieses Destruktionsprozesses studieren. ${ }^{5}$ Eine der merkwürdigsten Gebirgsbildungen sind die Black Hills von Süd-Dakota, eine beulenförmige Auftreibung der Erdkruste von $140 \mathrm{~km}$ Länge und $60 \mathrm{~km}$ Breite. Im Innern sehen wir ein altes Gebirge aus Granit und krystallinischen Schiefern entblößt, von dem allseitig kambrischer Sandstein, Kohlenkalk, Trias, Jura und Kreide abfallen, um dann in die flache Lagerung der Prärien überzugehen. Kohlenkalk uud gewisse Granite, die der Denudation den größten Widerstand entgegensetzten, bilden jetzt die höchsten Erhebungen (ungefähr $1000 \mathrm{~m}$ über der Ebene), während die Zerstörung der triadischen Gesteine eine ringförmige Depression schuf, der die Indianer den bezeichnenden Namen "die Rennbahn“ gegeben haben. ${ }^{6}$ Ein bescheidenes europäisches Gegenstück dazu liefert der wohlbekannte Weald im Süden des Londoner Beckens. Die Mitte nimmt 
der unterkretaceissche Hastingssand ( $a$ in Fig. 226), ein niederes Hügelland, ein, dann folgen die Ebenen des wenig widerstandsfähigen Wealdentons $(b)$, dann unterer Grünsand $(c)$, schwach hervortretende Landstufen bildend, endlich oberer Kreidekalk $(d)$, der sich als North und South Downs steil über das zerstörte Gewölbe erhebt. Daß die Downs echte Destruktionsstufen sind, unterliegt keinem Zweifel, aber

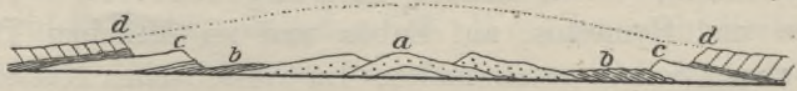

Fig. 226. The Weald nach Ramsay.

die ursprüngliche Öffnung der Antiklinale, wodurch Schichten von wechselnden Härtegraden dem Spiel der Atmosphärilien preisgegeben wurden, ist noch Problem. Ramsay schrieb sie der Abrasion in der Eozänzeit zu, man kann aber auch an eine Berstung des Gewölbes denken, die nur den Weald betraf, nicht aber dessen festländische Fortsetzung, die Schwelle von Amiens, die ihre ursprüngliche Gestalt bis zum heutigen Tag bewahrt hat.

Rumpfflächen. Das Endergebnis der Abtragung großer und komplizierter Faltengebirge ist die Rumpffläche, wie sie uns im canadischen und im baltischen Schild in klassischen Beispielen vorliegt. Die Hudsonbai wird von einem $600 \mathrm{~km}$ und darüber breiten Band stark dislozierter archäischer Gesteine umschlungen. ${ }^{7}$ Eine Reihe großer Seen: der Bären-, der Sklaven-, der Athabaska-, der Winnipegsee und die canadischen Seen bezeichnen den Rand des Tafellandes, das aus flach gelagerten paläozoischen Schichten (vorwiegend Kalksteinen und Dolomiten) besteht und sich unter der kretazeischen Decke bis an den $\mathrm{FuB}$ des Felsengebirges erstreckt. Vereinzelte paläozoische Reste sind auch auf der andern Seite, am Westgestade der Hudsonbai und an ein paạr. Stellen des Binnenlandes erhalten, die dazwischen liegende archäische Zone trägt aber keine jüngeren Ablagerungen, außer hier und da glazialen Schutt oder Fluß- und Seeabsätze der Gegenwart. Sorgfältigen Untersuchungen gelang es, die Altersfolge der kristallinischen Gesteine dieser Zone festzustellen, und damit war ein Anhaltspunkt zur Entwirrung der Lagerungsverhältnisse gewonnen. Alle Forscher stimmen darin überein, daß wir es hier mit den Fundamenten eines alten Faltenlandes zu tun haben. Im Lake of the Woods sah Lawson den Gürtel der Keewatingesteine in Tausende von Inseln und Halbinseln zersplittert, aber noch lassen sich hier die Antiklinalen erkennen, die in bogenförmigem Verlauf ihre konvexe Seite nach Norden kehren. Aber statt mächtiger Gebirge finden wir hier ein 
Flachland, das sich von allen Seiten zur Hudsonbai neigt; Suess hat es treffend mit der Hohlseite eines flachen Schildes verglichen. Wenn wir Flachland sagten, so sind wir uns dabei freilich bewußt, das Charakteristische dieses Geländes nur unvollkommen zum Ausdruck gebracht zu haben. Für eine Ebene wechseln Erhebungen und Vertiefungen zu rasch, für ein Berg- oder auch nur für ein Hügelland sind die Höhenunterschiede zu gering (meist nur $5-30 \mathrm{~m}$ ), für ein Wellenland ist die Gestaltung zu unregelmäBig. Nicht die einstige Anordnung der Schichtensättel und -mulden ist für die heutige Orographie maßgebend, sondern einzig und allein der Härtegrad der Gesteine; Granite, alte Gneise usw. haben der Zerstörung kräftiger widèrstanden und bilden Rücken und kuppelförmige Bergchen, abgerundet und gescheuert durch das Binneneis, das in der Glazialzeit darüber hịwweggeschritten ist.

Kein Zweifel,-wir stehen auf einem Schauplatz gewaltigster Zerstörung, die sich - wie die flache Lagerung der silurischen Schichten beweist - schon im frühesten Altertum der Erdgeschichte vollzogen haben muß. Aber welcher Art waren die zerstörenden Kräfte?

RAMSAx und andere englische Geologen, in Deutschland besonders v. Rrchthofen, führten eine solche totale Umformung von Gebirgen in Flachländer auf Abrasion durch die auf sinkendem Gestade immer weiter landeinwärts schreitende Brandungswelle zurück. Wo Meeresablagerungen horizontal einer abradierten Fläche aufruhen, ist für diese Hypothese ein positiver Anhaltspunkt gegeben; auch die Annahme, daß die paläozoischen Schichten diesseits und jenseits des canadischen Flachfaltenlandes einst zusammenhingen, hat nichts Unwahrscheinliches. Die Untersuchung an den Stellen des Kontaktes zwischen der kristallinischen Unterlage und der paläozoischen Decke liefert aber in Canada kein der Abrasionshypothese günstiges Ergebnis. Die in den untersten Schichten manchmal vorkommenden archäischen Gesteine sind nicht zerrieben, und sandige Lager fehlen. Das spricht dafür, daß die untersilurische Transgression sich mit großer Schnelligkeit ausbreitete, und das Meer verhältnismäßig ruhig war. Für die neue amerikanische Geologenschule, an ihrer Spitze W. M. Davis, ${ }^{8}$ sind alle Rumpfflächen Schöpfungen der Erosion, Peneplains oder Fastebenen. Wenn man dabei auch die Gesamtwirkung der subaërischen Destruktionsarbeit, die lineare wie die flächenhafte (vgl. S. 468) im Auge hat, so legt man das Hauptgewicht doch auf die seitliche Erosion der Flüsse, denn ohne diese könnte in der Tat wohl ein welliges Niederland, aber keine ausgedehnte Verebnung entstehen. Man kann die heutigen Tieflandflüsse als 
Bèispiel heranziehen, z. B. die Theiß, deren Alluvialtal stellenweise bis $54 \mathrm{~km}$ breit ist, freilich arbeitete sie in lockerem Diluvialboden, nicht in hartem Gestein, aber angesichts der viele tausendmal längern Abtragungsperiode in Canada fällt dieser Unterschied nicht ins Gewicht. Wir haben also auf einem Peneplain außerordentlich breite Talböden zu erwarten, aber daß sie nur durch die Seitenerosion $\mathrm{zu}$ großen Ebenen verschmelzen, ist nicht wahrscheinlich, und man muß erwarten, daß die alten Flußsysteme noch nachweisbar sind. Man darf übrigens bei diesen nordischen Rumpfflächen auch nicht vergessen, daß die klimatischen Faktoren wechselten. Wer die Glazialerosion nicht gering achtet, muß einen großen Anteil an der Umformung Canadas und Fennoskandias auch dem Inlandeis zugestehen. So einfach, wie sich die Peneplaintheoretiker die Sache vorstellen, dürfte sich die Zerstörungsarbeit wohl nicht vollzogen haben.

Das Peneplain ist das Schlagwort der Gegenwart, andere Erklärungen werden gar nicht mehr in Erwägung gezogen. Es ist daher ein großes Verdienst von PASSARge, ${ }^{9}$ auch auf eine andere Art von Destruktionsflächen die Aufmerksamkeit gelenkt zu haben. Es sind die Inselberglandschaften $\times$ Afrikas und Westaustraliens. Sie bestehen aus Ebenen, aus denen einzelne Berge wie Inseln aus dem Wasser aufragen. Die Verteilung dieser beider Grundformen ist auch hier an das Vorkommen von leicht zerstörbarem und widerstandsfähigem Gestein geknüpft. Auch hier geht das Flachland über die Köpfe aufgerichteter Schichten hinweg, ist also unzweifelhaft eine Destruktionsform, aber es ist eine wirkliche Ebene, keine Fastebene. Sie reicht bis unmittelbar an den $\mathrm{FuB}$ der Inselberge, die bald niedere Kuppen, bald ausgedehnte und hohe Massive sind; und auch in dem letzteren Fall tritt keine Hügelzone vermittelnd ein. Den südafrikanischen Typus dieser Landschaftsform, den Passarge eingehender studiert hat, betrachtet er als ein Erzeugnis der Wüstendenudation, also hauptsächlich des Windes; und außer den schon berührten Merkmalen haben eine Reihe anderer Yorkommnisse, wie die seichten geschlossenen Hohlformen, die Breccien- und Kieselsäurebildungen und die Sanddecken, ihn in dieser Auffassung be-

$\times$ Wir haben daran nur den Namen Inselberg auszusetzen. Man begegnet ihm jetzt in den verschiedensten Zusammenhängen, während er doch nichts besagt, als daB sich der Berg über das Flachland erhebt, wie eine Insel über das Meer. Daher ist dieser Nane nur auf diejenigen Fälle anwendbar, wo ein Berg ringsum von jungen Aufsehüttungen umgeben ist, die seinen Zusammenhang mit anderen Bergen verdecken. Wir haben solche Berge oder Gebirge auf S. 676 als durehgreifende bezeichnet. 
stärkt. Die Inselberglandschaft tritt aber, wenn auch in etwas veränderter Weise, auch in jenen Teilen Afrikas auf, die kein Wüstenklima haben. Hier muß PAssarge zu großen klimatischen Umwälzungen seine Zuflucht nehmen; er nimmt an, daß zwischen dem Ende des paläozoischen Zeitalters und der oberen Kreide alle drei Südkontinente eine langandauernde, intensive Trockenperiode erlebt haben.

Wir kehren zu unserem früheren Beispiel zurück. Canada wurde nicht nur eingeebnet, sondern auch erniedrigt. Desgleichen die Rumpffläche von Fennoskandia. Die mittlere Höhe von Südfinnland übersteigt kaum $150 \mathrm{~m}$. Trotzdem tragen die Flüsse deutlich den Charakter der Unreife an sich wie in einem Gebirge, Seen schieben sich ein, und Stromschnellen und Wasserfälle unterbrechen den Lauf. Das ist eine Folge der jungen Hebung, die die Flüsse zu erneuter Erosionsarbeit zwang; jene nordischen Rumpfflächen sind damit in ein neues Stadium ihrer Entwicklung getreten. Wir werden nun Beispiele kennen lernen, wo diese Phase schon sehr weit fortgeschritten ist.

Rumpfgebirge. Das dinarische Gebirge ist erst an der Wende der älteren und jüngeren Tertiärperiode gefaltet worden, hat aber trotzdem seinen Strukturcharakter zum guten Teil eingebüßt. In welchem Umfang ist freilich noch Streitfrage, denn merkwürdiger-

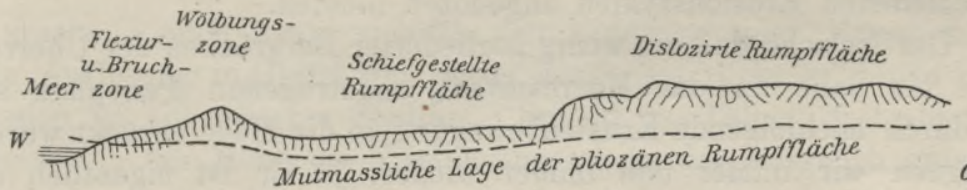

Fig. 227. Dinarische Rumpfflächen nach Cvisı́́.

weise widersprechen sich die Autoren ${ }^{10}$ sogar in den fundamentalen Beobachtungsdaten. Alle sind darin einig, da $B$ die untere Stufe (schiefgestellte Rumpffläche in Fig. 227) eine echte Destruktionsfläche ist, jedoch wird auch sie von ansehnlichen Bergen unterbrochen, die sich nicht durch ihre Gesteinsbeschaffenheit von den eingeebneten Teilen unterscheiden und daher nicht den Härtlingen (vgl. S. 531) zugezählt werden können. Die Destruktion hat also noch nicht volle Arbeit gemacht, jene Erhebungen sind als Restberge zu bezeichnen. $\times \mathrm{Zu}$ diesen rechnet GRUND auch das Küstengebirge und die höheren Karstpartien, während Cvısı́ sie als aufgewölbte und gehobene Teile einer großen Rumpffläche auffaßt (Wölbungszone und

$\times$ Penck nennt den Restberg nach einem dalmatinischen Berg Mosor, Cvisić nach dem dortigen Sprachgebrauch Hum, WiLLis nach einer Gegend in den Alleghanies Unaka. 
dislozierte Rumpffläche in Fig. 227). Ebenso divergieren die Ansichten betreffs der Bildungsweise der Rumpfflächen; CviJić betrachtet sie als eine Folgeerscheinung des Karstphänomens, die anderen Autoren dagegen als Peneplains. Jetzt werden diese Rumpfflächen von schmalen Tälern durchschnitten: ein Beweis dafür, daß die Erosionsbasis tiefer gelegt worden ist. Aber offene Täler gibt es in einem Kalkgebirge wenige, und diesem Umstand ist es zuzuschreiben, daß sich die dinarische Rumpffläche als ein drastisches Schulbeispiel erhalten hat. $\times$

Ist jedoch die Taldichte groß und die neue Erosion sehr weit gediehen, so bleiben von den alten Rumpfflächen nur mehr wenige Reste übrig, und ihrer Deutung und der Herstellung ihres einstigen Zusammenhanges ist ein gefahrvoll weiter Spielraum gelassen. Die Transsylvanischen Alpen, die den Südrand Siebenbürgens bilden, sind ein Faltengebirge aus dem Ende des Mesozoikums. Es besteht zum größten Teil aus kristallinischen Schiefern, Gneisen und Graniten und erreicht Höhen von mehr als $2000 \mathrm{~m}$. Aber statt zerrissener Kämme, wie in der kristallinischen Zone der Alpen, finden wir breite Rücken, über die sich die Gipfel nur wenig erheben, während die tief eingeschnittenen Schluchten an alpine Verhältnisse erinnern. De Martonne ${ }^{11}$ schloß daraus, daß Rücken und Täler verschiedenen Erosionszyklen angehören müssen.

Der Ansicht, daß ein wenig gegliederter Bergrücken der Überrest eines bis nahe an das Meeresniveau abgetragenen Peneplain sei, der durch nachfolgende Krustenbewegung in die Höhe gerückt wurde, begegnen wir immer und immer wieder, ja sie ist eigentlich die Grundlage der modernen Peneplaintheorie. Es braucht nicht einmal ein ziemlich gleichförmiger Rücken zu sein, um solchen Verdacht zu erwecken, es genügt schon, wenn sich nur die durch tiefere Scharten geschiedenen Gipfel in eine „ideale" Ebene mehr oder minder leicht einfügen lassen. Dem gegenüber muß betont werden, daß die Konstanz der Gipfelhöhen eine weit verbreitete Erscheinung ist. Sie hängt schon damit zusammen, daß dem Wachstum der Gebirge klimatisch bestimmte Höhengrenzen gesetzt sind, das obere Denudationsniveau, wie es Penck genannt hat (vgl. S. 469). Penck hat namentlich auf die Bedeutung der Baumgrenze aufmerksam gemacht, denn mit dem Schwinden der Vegetationsdecke ist den zer-

$\times$ Wir könnten noch ein Beispiel aus dem Berner Jura, das Brückner (Penck u. Brückner, Die Alpen im Eiszeitalter S. 475) entdeckt hat, anführen, sehen aber davon ab, weil E. de Margerie gegen die Auffassung Brückner's Widerspruch erhoben hat, und erst das Erscheinen seines großen Jurawerkes abgewartet werden mub. 
störenden Kräften Tür und Tor geöffnet. Nach seiner Tabelle sind in Fig. 228 drei Kurven entworfen worden, aus denen man den Schluß ziehen darf, daß Beziehungen- zwischen Gipfelhöhe und Schnee- und Baumgrenze tatsächlich bestehen. Alle diese Kurven senken sich in höheren Breiten und erreichen ihre höchste Höhe zwischen dem 20. und 40. Parallel; auch die äquatoriale Depression ist überall deutlich ausgeprägt. Selbst in den Alpen unterscheiden sich in der Regel benachbarte Gipfel an Höhe nur wenig voneinander, aber die tieferen Einschnitte dazwischen geben ihnen ein individuelles Gepräge. Wie die Urform der Alpenkämme beschaffen war, wissen wir nicht; in normalen Faltengebirgen dürften die Antiklinalkämme sehr gleichmäßig verlaufen sein, wie der Schweizer Jura, von

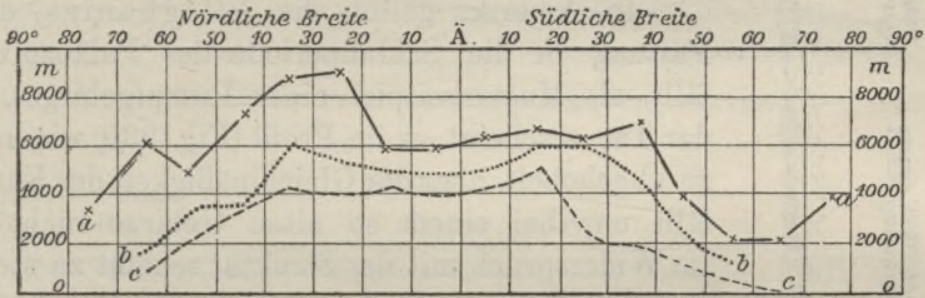

Fig. 228. Graphische Darstellung der größten Gipfelhöhen $(a a)$, der obersten Schneegrenze $(b b)$ und der obersten Baumgrenze $(c c)$ in den $10^{\circ}$-Zonen.

S gesehen, noch heute vielfach den Eindruck einer Mauer macht. Die Auflösung in Gipfel und Sättel durch die rückschreitende Flußerosion ist ein späteres Stadium. Sobald das Talnetz festgelegt ist, beginnt in der Höhe die Nivellierungsarbeit, der Ausgleich zwischen Gipfeln und Sätteln, und, sofern nicht eine schützende Schneedecke sich ausbreitet, schlägt der Zerstörungsprozeß in der Höhe ein rascheres Tempo ein als in der Tiefe, weil die Verwitterung durch den Frost und die Denudation durch die heftigen Winde gefördert wird. Daß die Alpen einst auch Rückenform besaßen, wird vielfach angenommen, und ihre Umwandlung in die Kammform der langen und intensiven Vergletscherung zugeschrieben; in dem transsylvanischen Gebirge konnte sie sich erhalten, da die Eiszeit nicht so verheerend wirkte. An und für sich ist also ein gleichmäBiger Rücken noch kein Beweis dafür, daß er einst eine Fastebene nahe dem Meeresniveau war, und es ist bezeichnend, daß die Verwertung dieses Arguments für die amerikanische Peneplaintheorie selbst in Amerika auf Widerspruch $\mathrm{zu}$ stoßen beginnt. ${ }^{12 \times}$

In den Transsylvanischen Alpen unterscheidet DE MARTONNE noch zwei andere Verebnungsflächen, von denen er die höhere dem Miozän

$\times$ Vgl. zu Obigem auch S. $476 \mathrm{ff}$. 
(Fig. 229), die tiefere dem Pliozän zuschreibt. Sie sind durch jüngere Täler zerschnitten, in die sie sich in der Form von Felsterrassen
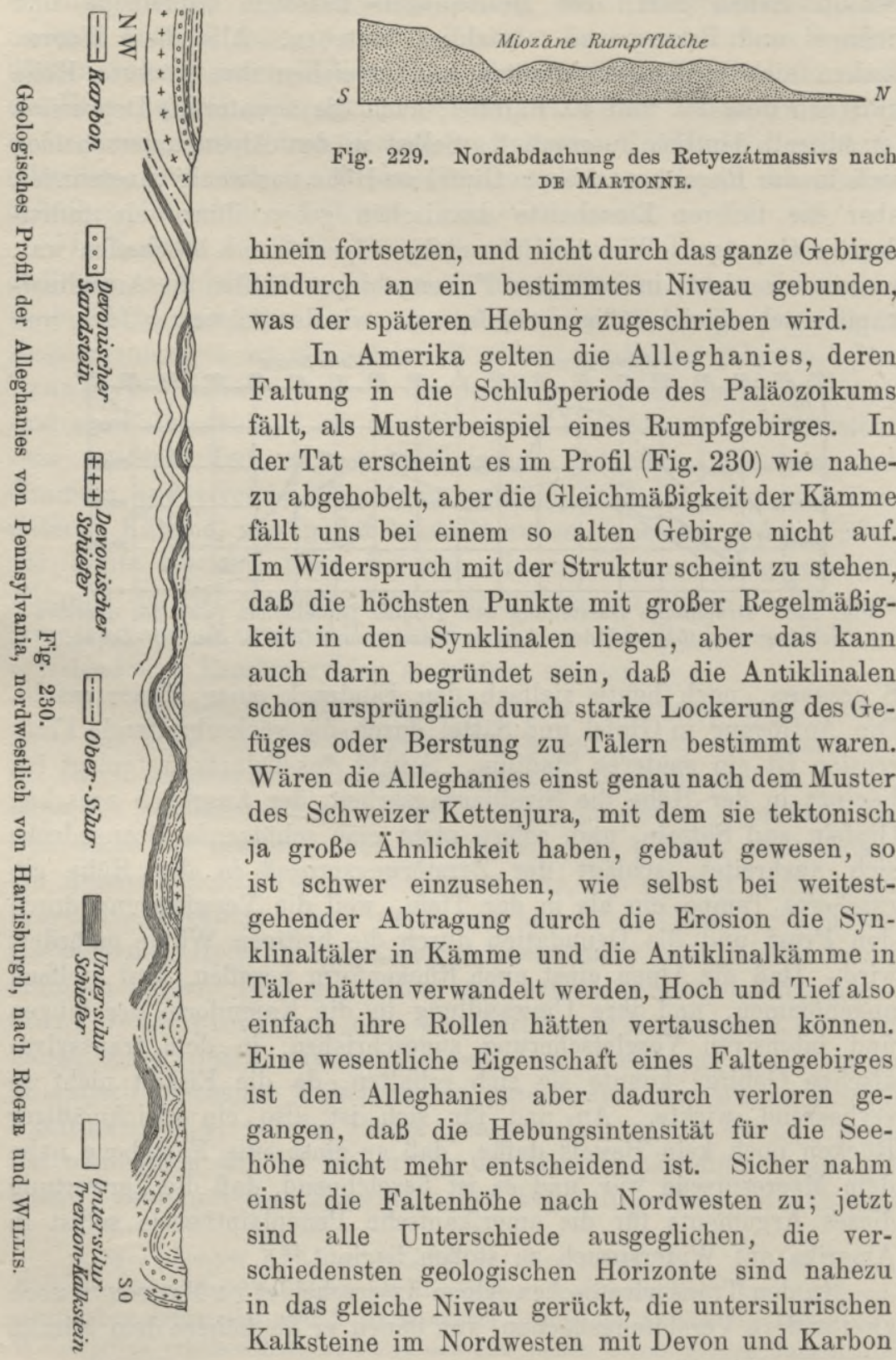

Fig. 229. Nordabdachung des Retyezátmassivs nach de Martonne.

hinein fortsetzen, und nicht durch das ganze Gebirge hindurch an ein bestimmtes Niveau gebunden, was der späteren Hebung zugeschrieben wird.

In Amerika gelten die Alleghanies, deren Faltung in die Schlußperiode des Paläozoikums fällt, als Musterbeispiel eines Rumpfgebirges. In der Tat erscheint es im Profil (Fig. 230) wie nahezu abgehobelt, aber die GleichmäBigkeit der Kämme fällt uns bei einem so alten Gebirge nicht auf. Im Widerspruch mit der Struktur scheint zu stehen, daß die höchsten Punkte mit großer Regelmäßigkeit in den Synklinalen liegen, aber das kann auch darin begründet sein, daß die Antiklinalen schon ursprünglich durch starke Lockerung des Gefüges oder Berstung zu Tälern bestimmt waren. Wären die Alleghanies einst genau nach dem Muster des Schweizer Kettenjura, mit dem sie tektonisch ja große Ähnlichkeit haben, gebaut gewesen, so ist schwer einzusehen, wie selbst bei weitestgehender Abtragung durch die Erosion die Synklinaltäler in Kämme und die Antiklinalkämme in Täler hätten verwandelt werden, Hoch und Tief also einfach ihre Rollen hätten vertauschen können. Eine wesentliche Eigenschaft eines Faltengebirges ist den Alleghanies aber dadurch verloren gegangen, daß die Hebungsintensität für die Seehöhe nicht mehr entscheidend ist. Sicher nahm einst die Faltenhöhe nach Nordwesten zu; jetzt sind alle Unterschiede ausgeglichen, die verschiedensten geologischen Horizonte sind nahezu in das gleiche Niveau gerückt, die untersilurischen Kalksteine im Nordwesten mit Devon und Karbon im Südosten. Als eine große, aber zerstückelte Verebenungszone 
betrachten die amerikanischen Geologen auch jene Depression, die unter dem Namen „das Große Tal" bekannt ist, aber nicht bloß von Tälern, sondern auch von langgestreckten, mauergleichen Bergzügen eingenommen wird. Sie wird im SO begrenzt von der kristallinischen Zone, die ihre ursprüngliche dominierende Stellung noch bewahrt hat und nach HAYES und CAMPBELL ${ }^{13}$ der Umwandlung in ein Peneplain entgangen ist. Aber nur zum Teil, denn dazu gehört auch die Piedmontzone, die die junge Küstenebene bis zum Fuß der Alleghanies fortsetzt, aber von ihr deutlich durch die „Fallinie“ geschieden ist, an der die vom Gebirge kommenden Flüsse unter

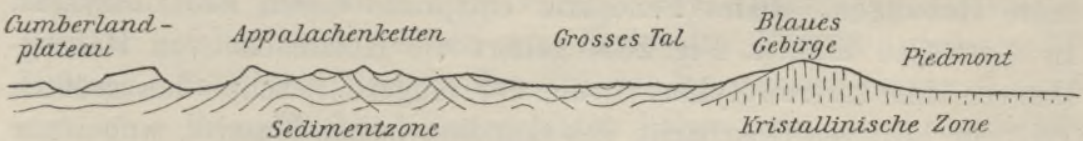

Fig. 231. Profil der Alleghanies nach Hayks.

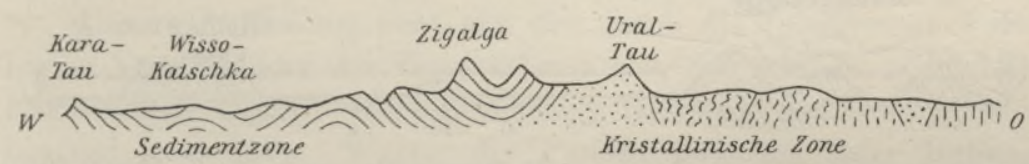

Fig. 232. Profil des südlichen Ural nach Karpinsky und Tschernysohew.

Wasserfällen und Kaskaden den kristallinischen Gürtel verlassen (Fig. 231). Diese ausgezeichnete Destruktionsfläche findet ein Gegenstück im Ural (Fig. 232), dessen Faltung ebenfalls in der permokarbonischen Periode stattgefunden hat. Nur der sibirische Destruktionsrand verleiht ihm den Charakter eines Gebirges, während er auf der russischen Seite fast unmerklich in die Ebene verläuft.

Daß alle diese rekonstruierten Rumpfflächen Peneplains sind, wird als eine nicht weiter zu diskutierende Tatsache vorausgesetzt. Es ist eine Ausnahme, wenn VoLz ${ }^{14}$ zur Erklärung gewisser Erscheinungen in Nordsumatra eine Klimaänderung in Erwägung zieht. Die Opposition, die seinerzeit in Amerika von TARR ${ }^{15}$ ausging und an das nicht gerade glücklich gewählte Beispiel von Neuengland anknüpfte, scheint verstummt zu sein. $\times$ Selbst in Fällen, wo die Anwendung der Peneplaintheorie auf die größten Schwierigkeiten stöBt, blieb man widerspruchslos in ihrem Bannkreis. Auf seiner Forschungsreise im nordwestlichen Himalaya durchquerte Ö streicH $^{16}$ die merkwürdige Hochfläche der Déusi zwischen Srinagar und Skardu. Sie ist nahezu kreisförmig, ungefähr $450 \mathrm{qkm}$ groß, liegt in 3800 bis

× In Amerika wurde TARR's Theorie kurz „The Bevelling Hypothesis" genannt.

Supan, Physische Erdkunde. 5. Aufl. 
$4000 \mathrm{~m}$ Seehöhe und ist rings von Höhen von $5000 \mathrm{~m}$ umgeben. Schon die außergewöhnliche Lage und das Fehlen eines großen Flusses, der diese angebliche Fastebene hätte schaffen können; fielen ÖsTREICH auf, aber trotzdem blieb sie ihm „das Muster einer in jugendlicher Zeit gehobenen, noch fast unverletzten Peneplain", und er beruhigt sich mit der Vermutung, daß bei der Hebung ,ihr beherrschender Fluß zerbrochen, verschwunden ist". Die Theorie verlangt eben, daß ein Peneplain nur in einer sehr tiefen Lage entstehen könne. Jede höhere Lage erfordert eine Hebung, und da man Peneplains in verschiedenen Höhen fand, so schloß man daraus auf wiederholte Hebungen. Jedes Peneplain entspricht einem Erosionszyklus. In Norwegen z. B. (s. Fig. 233) gehört die Hochfläche von Hallingskarven dem älteren Zyklus $(a)$ an, der jüngere $(b)$ schuf den größten Teil der heutigen Oberfläche des skandinavischen Massivs, wobei nur einige Monadnocks $(M)$ der Verebnung entgingen; aus dem jüngsten,

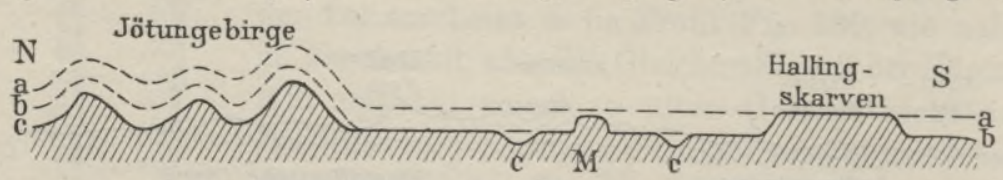

Fig. 233. Norwegische Peneplains nach H. REuscH (Geographische Zeitschrift 1903).

noch unvollendeten Zyklus (c) endlich stammen die in das untere Peneplain eingegrabenen Täler. Über die Destruktionsflächen erhebt sich das echt alpine Jötungebirge, ein Stück der ältesten Oberfläche, das zwar im Lauf der Zeit erniedrigt wurde, jedoch ohne seinen Charakter einzubüßen. Mit einer einmaligen Hebung reichte nur Cvıлí für das dinarische Gebirge aus (vgl. Fig. 227): die Rumpffläche wurde in Schollen zerlegt, und diese wurden staffelförmig gehoben. Ein allmähliches Aufsteigen in drei Etappen nimmt DE Martonne für die Transsylvanischen Alpen an, und zwar eine Hebung des ganzen Gebirgsblocks, aber doch in teilweiser Verbindung mit merkbaren Verwerfungen, Flexuren und Faltungen. Die Geschichte der Alleghanies nach ihrer Faltung spielte sich nach Hayes und CAMPBELL in folgender Weise ab: 1. Mesozoische Einebnung bis auf die kristallinische Zone; 2. Aufwölbung in der Kreidezeit, die ihren Höhepunkt von $1200 \mathrm{~m}$ westlich von Washington erreichte und einen neuen Erosionszyklus einleitete; 3. im Tertiär wird das mesozoische Peneplain zerschnitten, seine letzten Reste sind die Kämme der appalachischen Ketten (s. Fig. 231', aber nur in der Zone des Großen Tales wird das Stadium der Überreife erreicht; 4. neue Aufwölbung in der Jungtertiärzeit; 5. Auflösung des tertiären Peneplain, Erosionstätigkeit der Flüsse in der Gegenwart. Jeder Erosionszyklus ist 
also kürzer als der vorhergehende, sonst hätte er mit dessen Peneplainschöpfungen völlig aufräumen müssen; die Hebungen folgten immer rascher aufeinander, anstatt allmählich auszuklingen. Das ist der dunkle Punkt, auf den wir schon bei der Besprechung der Talterrassen (S. 559) hingewiesen haben.

Es ist nur eine Konsequenz der einseitigen Peneplaintheorie, wenn WrLLIs ${ }^{17}$ die grundstürzende Behauptung aufstellt, kein vortertiäres Gebirge habe sich in seiner früheren Gestalt erhalten, sie alle seien dem Erdboden gleichgemacht und erst in der Tertiäroder Quartärzeit durch Hebung wieder ins Leben zurückgerufen worden. Man geht auch noch weiter. Die Appenninen wurden im Miozän gefaltet und erlitten am Ende des Pliozän wieder eine Hebung. In dieser Periode des Stillstandes, erklärt Braun, ${ }^{18} \mathrm{muB}$ sich eine Rumpffläche herausgebildet haben, sie "wird durch die geologische Geschichte direkt gefordert". So wird das Peneplain zum beherrschenden Prinzip der ganzen geographischen Morphologie.

Unsere Auffassung geht von der durch die Talterrassen beglaubigten Verschiebung der Erosionsbasis aus, die, wie die geologischen Erfahrungen lehren, vielfach in einer Hebung des.Gebirgskörpers bestand (s. S. 657). Waren die Pausen zwischen zwei Hebungen lang oder waren die klimatischen Bedingungen besonders günstig, so trat eine mehr oder weniger weitgehende Destruktion ein. Welcher Art diese Destruktion war, wird sich nicht immer mit Sicherheit ermitteln lassen; jedenfalls muß ${ }^{*}$ man stets den ganzen Umkreis der Möglichkeiten im Auge behalten. Wir halten daher nicht für erwiesen, daß die normale Geschichte der meisten Gebirge in einem beständigen Wechsel von Verschwinden und Wiederauftauchen bestand. Nachweisbar machte die Destruktion niemals völlig tabula rasa, Härtlinge und Restgebirge blieben übrig. Wurde durch sie das ursprüngliche Faltengebirge in einer oder in mehreren wesentlichen Eigenschaften verändert, aber durch die nachfolgende Hebung in seinem früheren Umfang wiederhergestellt, so entstand ein Rumpfgebirge. Solche Rumpfgebirge sind unzweifelhaft die Alleghanies und der Ural; orographisch haben sie ihren ursprünglichen Charakter als Kettengebirge noch bewahrt, aber morphologisch sind sie Zwitterdinge geworden, die Formen in verschiedenen Entwickelungsstadien in sich vereinigen, überreife Hochflächen und unreife Täler. Natürlich gibt es zahlreiche Übergangsformen zwischen Falten- und Rumpfgebirgen, das liegt im Wesen der Entwickelung begründet; alle unsere systematischen Einteilungen sind ja nur Notbehelfe, um der Fülle der Erscheinungen einigermaßen Herr zu werden. 
Die erörterten Gesichtspunkte eröffnen uns auch einen Einblick in die gesetzmäBige Verteilung der Gipfelhöhen,der Kettengebirge. Abgesehen von jenen Fällen, wo die höchsten Gipfel aufgesetzte Vulkankegel sind, wie im Kaukasus oder in den Andes, wird die Höhe durch die ursprüngliche Hebungsintensität, nachträgliche Krustenbewegungen und durch die Dauer und Stärke der Destruktion bestimmt. In den Alpen ist die kristallinische Zone fast überall höher, als die Kalkzone. Die Reihe der 3000 m-Gipfel beginnt im Westen mit der Argentara, der Pelvoux eröffnet den Reigen der 4000 m-Gipfel, der bis zur Bernina reicht. Bis zum Montblanc $(4810 \mathrm{~m})$ ist Zunahme, dann wieder Abnahme bemerkbar. Jenseits des Bernina-Meridians herrschen wieder die $3000 \mathrm{~m}$-Gipfel, sie schließen mit dem Sonnblick am Ostende der Hohen Tauern. Nun macht sich bereits die ungarische Senkung geltend. Die nördlichen Kalkalpen brechen steil $\mathrm{im}^{2}$ Wiener Becken $\mathrm{ab}$ und übertreffen nicht unbeträchtlich die kristallinische Zone, die, sich allmählich senkend, in die ungarische Ebene verläuft. Der östlichste 2000 m-Gipfel, der Schneeberg, gehört dem nördlichen Kalkgürtel an. Hier erscheinen also Hebungsintensität und postume Senkung als die maßgebenden Faktoren. 'Rumpfgebirge sind niedriger als die benachbarten Faltengebirge, aber der Abtragung wirkt die spätere Hebung entgegen, und offenbar hat ein so altes Gebirge, wie der Kwenlun, seine beträchtliche Höhe nur ihr zu verdanken. DaB die alten zentralasiatischen Gebirge noch in jüngster Zeit starke Hebungen erfahren haben, beweisen die jungtertiären Gobischichten, die in der Ebene flach lagern, im Nanschan aber bis zu mehreren tausend Meter Seehöhe emporgetragen wurden.

Einen Übergang zu den Rumpfschollengebirgen bilden die gebrochenen Rumpfgebirge, bei denen die Form der Kettengebirge zwar auch noch erhalten ist, aber die ursprüngliche Gestalt nicht nur durch Destruktion, sondern auch durch Auflösung in Schollen eine Umformung erlitten hat. Ein Beispiel dieser Art ist die Sierra Nevada von Californien, ${ }^{19}$ jenes mächtige Kettengebirge, das das Sacramentotal von dem Großen Becken des amerikanischen Hochlandgürtels scheidet. Die paläozoischen, triadischen und jurassischen Sedimente wurden gegen Ende der Jurazeit, aber noch vor deren völligem $A$ bschluB in enge Falten gelegt, und ungefähr um dieselbe Zeit traten kryptovulkanische Vorgänge ein, die die Tiefen des Faltensystems mit Granitmassen erfüllten. Kreide- und Eozänzeit waren Festlandsperioden; die damalige Sierra unterlag einer ausgedehnten Abtragung, die die Granitinjektionen aufdeckte und damit einen orographisch bedeutungsvollen Gegensatz $\mathrm{zu}$ den gefalteten 
Schieferzonen schuf. Die Täler jener Zeit sind uns durch die Ausfüllung mit jungtertiären Lavaströmen noch erhalten geblieben; ihre Anordnung war anders wie die der heutigen, und sie waren auch nicht so tief eingeschnitten; die Erosionsbasis, d. h. der FuB der Sierra muß also damals höher gelegen haben. In der Neogenperiode setzte die gebirgsbildende Kraft von neuem ein, aber diesmal in der Form von Brüchen und senkrechten Verschiebungen. Im Osten wurde die Sierra von den angrenzenden Gebirgen geschieden, ihr Westfuß wurde gehoben, Brüche durchsetzen nun auch den eigentlichen Gebirgskörper. Die Deutung des westlichen Tiënschan als gebrochenes Rumpfgebirge verdanken wir erst der Merzвacher'schen Expedition. ${ }^{20}$ Zwischen dem Karbon und dem Tertiär fehlen alle Sedimente, das Mesozoikum war also eine Periode starker Abtragung,

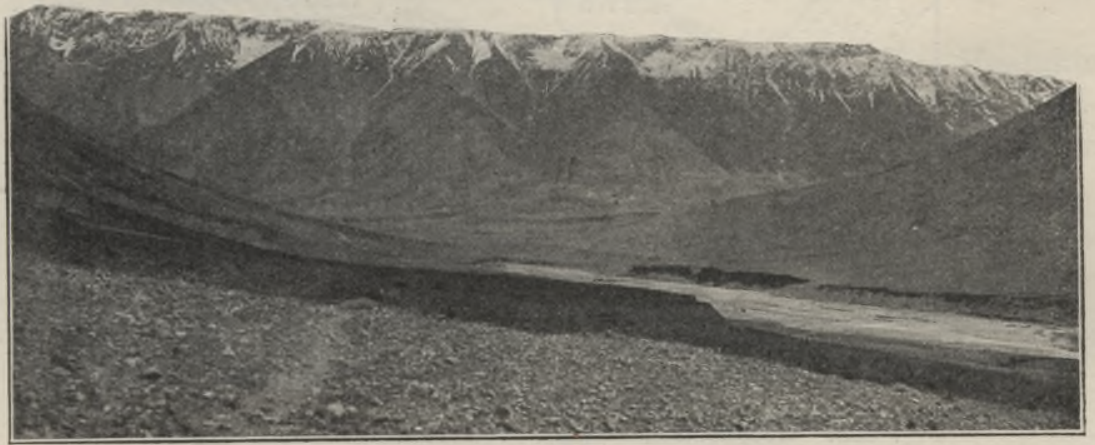

Fig. 234. Die Ischigartkette des Tiënschan südlich der Einmündung des Ischigart in den Irtasch, nach M. FrIEderi ${ }_{\text {HSEN. }}$

und ihr Ergebnis mag wohl die mauergleiche Firstlinie (Fig. 234) sein, die schon Davis aufgefallen ist. Die tertiären Brüche haben sie zum Teil vernichtet, zum Teil in verschieden hohe Lagen gebracht. Auch in den geologischen Profilen, die CviJíc ${ }^{21}$ von dem mazedonischen Gebirge veröffentlicht hat, erkennt man überall das Zusammenwirken von Schollenbewegungen und Destruktion.

Rumpfschollengebirge. In den gebrochenen Rumpfgebirgen bilden die Schollen noch einen einheitlichen Körper, vielfach sind aber Schollen völlig versunken und liegen unter jüngeren Ablagerungen begraben, während andere durch Hebung wiederbelebt wurden. Sie gleichen den Pfeilerüberresten einer längst zerstörten Brücke. Als Beispiel möge uns zunächst der Thüringer Wald dienen. ${ }^{22}$

Auf der Südseite ist der Thüringer Wald fast geradlinig durch eine nach Nordwest verlaufende Linie abgeschnitten, dagegen bildet der Nordrand einen nach Nord geöffneten flachen Bogen von Eisenach 


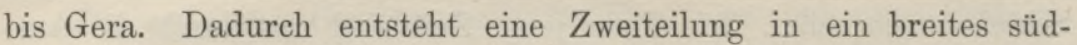
östliches Plateau und ein schmales nordwestliches Kammgebirge. Jenes hängt mittels des Frankenwaldes und des Vogtlandes mit dem Fichtel- und dem Erzgebirge zusammen.

Der südöstliche Teil ist ein Schiefergebirge, dessen Baumaterial der älteren paläozoischen Periode, vom Kambrium bis ins untere Karbon, entstammt. Im Nordwesten treten die archäischen Gesteine, die unter den Schiefern des Südostens verborgen liegen, Gneise, kristallinische Schiefer und Granite, zutage und bilden Erhebungen bis ungefähr $600 \mathrm{~m}$ Seehöhe; dagegen fehlen die paläozoischen Formationen vom Kambrium bis zum Karbon, und kommt das Rot-

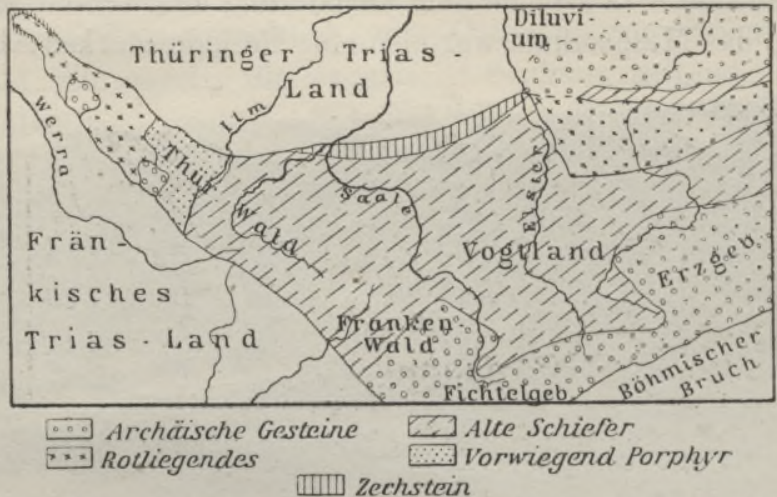

Fig. 235. Geognostische Skizze von Thüringen und Sachsen.

liegende, das im Südostteil nur an einer Stelle am Südwestrand gefunden wurde, zu mächtiger Entwickelung. Es besteht aus Sandsteinen und Konglomeraten einerseits, aus gewaltigen Eruptivmassen, besonders Porphyr und Melaphyr, anderseits. Verschiedene Bausteine setzen also den Nordwesten und den Südosten zusammen, aber darin ist der morphologische Gegensatz nicht begründet, denn der südöstliche Gesteinstypus greift auch noch in den schmalen Teil bis zur Linie Tlmenau-Schleusingen über.

Im südöstlichen Teil enthüllt sich uns der Rest eines alten Gebirges. Die Schichten sind stark gefaltet und streichen nach Nordost, wie im Erzgebirge; aber während in diesem Gebirgs- und Faltenrichtung übereinstimmen, stehen sie im Thüringer Wald senkrecht aufeinander. Solch ein Zustand läßt sich nur durch eine tektonische Umformung erklären. Gehen wir im Streichen der Schichten nach Nordost weiter, so stoßen wir am Rande des Gebirges auf ein Zechsteinband, und kommen dann in das Trias-Flachland. Glücklicherweise haben sich aber auch noch ein paar spärliche Reste von Zech- 
stein und ein Rest von Bunstandstein auf dem Kamm des Thüringer Waldes erhalten; dieser muß also einmal mit dem Vorland in gleichem Niveau gelegen haben, und die jetzige Gestaltung muß jedenfalls erst nach der Ablagerung des Buntsandsteins erfolgt sein. Um ein genaueres Datum zu erlangen, müssen wir die Verhältnisse im Vorland in Betracht ziehen, wo sich auf der herrschenden Trias noch Spuren jüngerer mesozoischer Ablagerungen finden, die ebenfalls durch Brüche Deformationen erlitten haben. Diese tektonischen Bewegungen haben sich in der Tertiärperiode vollzogen. Die Geschichte des Thüringer Waldes ist also in Kürze folgende:

1. Entstehung eines großen, Nordost streichenden Faltengebirges, dessen kristallinische Achsen zum Teil noch im Frankenwald, im Erzgebirge und im nordwestlichen Thüringer Wald sichtbar sind. Die Faltung erreichte ihren Höhepunkt in der jüngeren Steinkohlenperiode.

2. Destruktion in der Zeit des Rotliegenden. Ihre Produkte wurden auf dem untergetauchten kristallinischen Gebirge im Nordwesten abgelagert, zu gleicher Zeit erfolgen in diesem ältesten Bruchgürtel großartige Eruptionen.

3. Das ganze Gebirge senkt sich unter den Meeresspiegel und wird abradiert. Im Saaletal sieht man die steil gefalteten Devon-

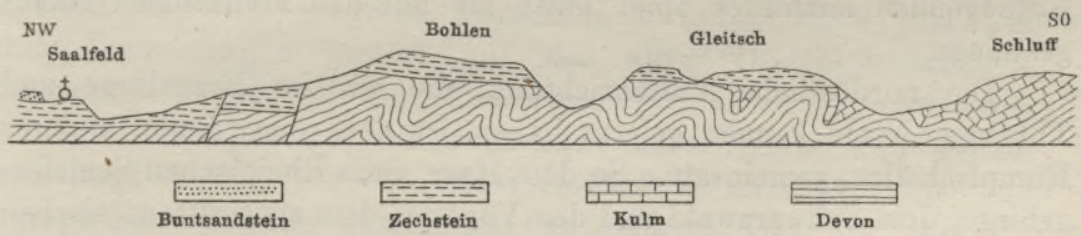

Fig. 236. Profil des östlichen Thüringer Waldes nach J. WALtheR.

und älteren Karbonschichten oben geradlinig abgeschnitten und von nahezu horizontalem Zechstein überlagert (Fig. 236). Diese marine Periode dauerte von der Zechsteinepoche durch die ganze Triasund Jurazeit, vielleicht auch noch in der Kreidezeit.

4. Wiedererstehung des Gebirges in der Tertiärperiode, aber in ganz neuer Form durch nordwestlich verlaufende Brüche, sei es, daB das Gebirge sich hob oder das Vorland sich senkte. Auf der Südwestseite trennen die Brüche das paläozoische Gebirge von der Trias, auf der Nordostseite war die Bewegung intensiver und die Brüche verlaufen in der Triaszone. Zechstein, Buntsandstein und Muschelkalk fallen flexurartig vom Gebirge ab und gehen dann in die flache Lagerung des thüringischen Vorlandes über.

5. Destruktionsperiode der Gegenwart. Zechstein und Trias 
wurden von den Höhen des' Gebirges abgeschwemmt, das dadurch mindestens um $1200 \mathrm{~m}$ erniedrigt worden ist. Im Südosten wurde die alte Abrasionstläche entblöBt, im Nordwesten hat die Denudation die härteren Gesteine, besonders den Porphyr, aus den weicheren herauspräpariert und dadurch mannigfaltigere Formen geschaffen.

Ähnliche Schicksale betrafen das Erzgebirge. Zwei große, nordöstlich streichende Antiklinalen, das eigentliche Erzgebirge im Süden und das sächsische Granulitgebirge im Norden, schließen ein Muldental ein, in dem die produktive Steinkohlenformation - der Reichtum Sachsens - zur Ablagerung gelangte, und das dann in der Periode des Rotliegenden zugeschüttet wurde. Die Tertiärzeit rief auch dies Gebirge wieder in das Leben zurück, aber doch in anderer Weise als den Thüringer Wald. Der Bruch, der es von der böhmischen Scholle trennt, verläuft im Streichen der erloschenen Falten, ist also ein Längsbruch; und damit war vermutlich eine Hebung im Süden verbunden, denn im Norden taucht das Gebirge anscheinend ohne Bruch unter die jüngere Schichtenfolge unter. So entstand eine schiefe Fläche mit Steilabsturz nach Süd, jedenfalls ein Gebilde, das der alten Faltungsoberfläche durchaus widerspricht. Wohl ist das einstige Muldental wieder zum Vorschein gekommen, aber nur dadurch, daß das Wasser mit der Ausfüllungsmasse des Rotliegenden leichteres Spiel hatte als mit den archäischen Randgesteinen.

Die nordöstliche Faltenrichtung, die wir im Erzgebirge und Thüringer Wald kennen gelernt haben, ist noch einer Reihe anderer Rumpfschollen gemeinsam. So dem Harz, dem Rheinischen Schiefergebirge, dem Schwarzwald und den Vogesen, dem zentralfranzösischen Plateau; überall fand die Faltung in der jüngeren Steinkohlenzeit statt. Sukss faßt sie als Trümmer eines einst zusammenhängenden Faltengebirges auf, dem er den Namen des varis̉cischen gab, während es von anderen als mitteldeutsche Alpen bezeichnet wurde (s. Fig. 211, S. 652). Schon im östlichen Erzgebirge vollzieht sich die Schwenkung in die Südostrichtung der Sudeten. Dagegen ist uns im Böhmischen Massiv der Rest eines noch älteren Gebirges erhalten. In einer anderen Gruppe westeuropäischer Rumpfschollen, im südlichen Irland und südlichen Wales, in Cornwall und in der Bretagne, biegen sich die ebenfalls jungkarbonen Falten aus Ostnordost über Ost nach Südost um: Suess nennt sie das armorikanische Gebirge und stellt es den Pyrenäen zur Seite, wie das variscische den Alpen. Die dritte westeuropäische Rumpfschollengruppe endlich umfaßt das nördliche Irland und Wales, Schottland und Skandinavien; das ist Suess' caledonisches Gebirge, das be- 
trächtlich älter ist als die beiden anderen, denn seine Faltung vollzog sich schon zwischen Silur und Devon. Eine Anzahl solcher Rumpfschollengebirge wurden von den jungen Faltenzügen der Mittelmeerzone gleichsam umschlungen, wie die Meseta der Tberischen Halbinsel, die Chaîne des Maures und der Esterel in der Provence, das kristallinische Gebirge von Corsica und Sardinien und das Rhodopemassiv der Balkanhalbinsel.

Von auBereuropäischen Vorkommnissen sind die Massive von Guayana und Brasilien, von Dekan und die Australalpen besonders hervorzuheben. Vielleicht ist ganz Afrika von der Wüstentafel bis zur kapländischen Faltenzone als eine einzige gewaltige Rumpfscholle aufzufassen. Rumpf- und Faltenschollen sind jene fremdartigen Gebirgszüge, die inselartig aus jüngeren Flachländern auftauchen, wie in Zentralaustralien, in der Sahara, in der Gobi, im Great Basin Nordamerikas; wir finden hierin wieder eine Bestätigung, daB in der Gebirgsbildung der gegenwärtigen Landoberfläche Brüche und vertikale Krustenbewegungen eine nicht minder wichtige Rolle spielen als die Faltung.

Als gemeinsamer Charakterzug aller Rumpfschollengebirge kann ihre Zusammensetzung aus archäischen und paläozoischen Gesteinsbildungen bezeichnet werden. Nur diese haben an der Faltung teilgenommen, alle jüngeren Formationen liegen flach oder nur durch Verwerfungen gestört auf den alten Destruktionsebenen. Kommen sie in größerer Ausdehnung und Mächtigkeit vor, so müssen wir sie als aufgesetzte Tafelländer ausscheiden; und gerade hierin zeigt es sich so recht, wie vorteilhaft es ist, tektonische und orographische Begriffe auseinander zu halten. Das brasilianische Bergland ${ }^{23}$ ist unzweifelhaft eine geographische Einheit, für die die orographische Bezeichnung Massiv wie geschaffen erscheint. Tektonisch haben wir es als eine Rumpfscholle mit aufgesetztem Tafelland zu definieren. Rumpfschollengebirge sind nur das Küstengebirge und das wasserscheidende Gebiet zwischen Paraná und Tocantins, die aus Granit, Gneis und kristallinischen Schiefern bestehen, und die wahrscheinlich silurischen Sandsteingebirge zu beiden Seiten des S. Francisco; nur diese haben eine Faltung erfahren. Zwei Drittel der Rumpfscholle ist aber durch eine Decke von horizontal oder nahezu horizontal gelagerten Sand- und Mergelgesteinen devonischen, karbonischen oder mesozoischen Alters verhüllt, und nur die Täler sind zum Teil bis auf die archäische Unterlage eingeschnitten. Solche Vorkommnisse sind weit verbreitet, wenn sie auch häufig nur untergeordnet auftreten und dann den Charakter des Rumpfschollengebirges nur örtlich verändern. Ich erinnere an 
das nordböhmische Kreidegebiet, an die jurassischen Causses des französischen Zentralplateaus, an den Alten roten Sandstein Schottlands, an das mesozoische Gebirge am Ostrand der iberischen Scholle, in dem Duero und Tajo entspringen, an verschiedene Vorkommnisse im Dekan, vor allem an die große Trappplatte, endlich an die Karruformation Südafrikas.

Man kann es als Regel aussprechen, daB, je verwickelter der Umwandlungsprozeß war, desto mannigfacher die daraus hervorgegangenen Geländeformen sind. Für die orographische Erscheinungsweise der Rumpfschollengebirge sind die Anordnung der Verwerfungsspalten, die Unterschiede in der Widerstandsfähigkeit der Gesteine und die Verteilung der Erosionsfurchen in erster Linie bestimmend. Von allen den wesentlichen Eigenschaften der Faltengebirge, die wir auf S. 678 angeführt haben, ist mit Ausnahme der Erhebung keine einzige mehr überall erhalten geblieben.

Wie bei den Faltenschollen gibt es auch hier Quer- und Längsschollen. Wird aus einer alten Destruktionsfläche ein längeres' Stück quer zum Streichen der Schichten herausgeschnitten, so entstehen häufig Kamm- oder Rückengebirge. Den Thüringer Wald haben wir als solchen schon kennen gelernt; die Vogesen und der Schwarzwald sind andere naheliegende Beispiele; das skandinavische Gebirge dürfte wenigstens für seinen südlichen und mittleren Teil hier zu nennen sein; in der australischen Kolonie Viktoria streichen die Falten meridional, während der wasserscheidende Rücken auf eine Länge von ungefähr $500 \mathrm{~km}$ äquatorial verläuft. Die Herausbildung eines fortlaufenden Kammes oder Scheitels ist in diesen Fällen ausschlieBlich das Werk der Erosion seit der Zeit, da sich die Scholle - relativ oder absolut - über die Umgebung zu erheben begann; indem die Talentwickelung immer tiefer in die Scholle eindrang, wurde die Wasserscheide immer schmäler. Für die Anordnung der Täler waren unzweifelhaft die Abdachungsverhältnisse zunächst maßgebend, in manchen Fällen aber wohl auch das Streichen der Schichten, wie man z. B. aus dem wechselnden Verlauf der norwegischen Fjorde zu erkennen glaubt.

Auch der Harz ist eine Querscholle, aber von kleinem Umfang. Hier sind die Täler strahlenförmig angeordnet, daher kam es nicht zur Kamm- oder Rückenbildung, und so tritt der Harz als plateauartiges Massiv in scharfen Gegensatz zu dem benachbarten Thüringer Wald.

Als Längsscholle haben wir schon das Erzgebirge genannt. Vergleichen wir es mit dem Rheinischen Schiefergebirge, so finden wir darin einen gemeinsamen $\mathrm{Zug}$, daß beide ihren Hauptlängsbruch 
im Süden haben und sich daher auch nur hier deutlich als Gebirge abheben, während sie sich nach Nord verflachen. Diese Einseitigkeit kommt aber nur bei dem Erzgebirge auch orographisch zum Ausdruck: die Kammlinie liegt am südlichen Bruchrand, Quertäler gehen nach Nord und Süd aus, jene, sind lang, diese kurz. Dagegen ist das Rheinische Schiefergebirge hydrographisch unselbständig, das Rheintal schneidet es der ganzen Länge nach entzwei, und dadurch entstanden Abdachungen nach Ost und West, denen die Längstäler der Mosel, der Ahr, der Lahn, der Sieg und der Ruhr entsprechen.

Japan ist ein Beispiel eines zusammengeschweißten Rumpfschollengebirges. Quer durch die Hauptinsel, von der Toyamabucht nach SO, verläuft E. NaUmann's Fossa magna, ein breiter Grabenbruch, der zum größten Teil durch vulkanisches Gestein ausgefüllt ist. Was südlich davon liegt, ist eine zonal gebaute, durch das japanische Binnenmeer zerstückelte Längsscholle, während Nordjapan einschließlich Jesso aus drei Querschollen besteht, deren Schichten nach SSO streichen. Wären ihre Fortsetzungen noch erhalten, so würde ihr Gegensatz zu der südlichen Längsscholle auch orographisch deutlich zur Erscheinung kommen; und nur die Inselnatur Japans erweckt den Schein eines zusammengehörigen, die Inseln in ihrer Längsachse durchziehenden Kettengebirges. Diese Auffassung ist auch lange Zeit die herrschende gewesen, bis v. RICHTHOFEN's ${ }^{24}$ Analyse der neuesten geologischen, Aufnahmen den wahren Sachverhalt aufgedeckt hat.

Bau und Umrisse des schottischen Hochlandes erklären sich aus einer Kombination von Bruchlinien, von denen die einen im

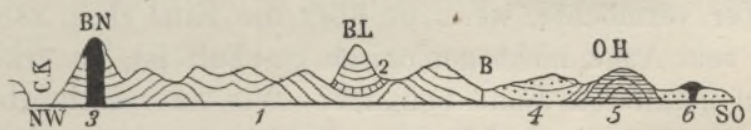

Fig. 237. Profil des mittelschottischen Hochlandes nach A. GeIkIE. ${ }^{25}$ (Länge auf die Hälfte reduziert, Höhe wie im Original.)

1 Altpaläozoische Schiefer, 2 Altpaläozoischer Kalkstein, 3 Granit, 4 Alter roter

Sandstein (Devon), 5 Geschichtete vulkanische Gesteine (Devon), 6 Karbon.

CK Caledonischer Kanal; BN Ben Nevis (1343 m); BL Ben Lawers (1214 m);

B Bruchlinie Stonehaven-Firth of Clyde; OH Ochil Hills.

Sinn der alten Falten von SW nach NO, die anderen von W nach $\mathrm{O}$ streichen; im Moray Firth stoßen sie unter einem Winkel von ungefähr $40^{\circ}$ zusammen. Den NO-Brüchen folgen die Depressionen: der Nordrand des großen Grabens des Lowlands, das Speytal, dessen Richtung sich im Loch Ericht und Loch Awe fortsetzt, und genau parallel damit das Glenmore, eine schnurgerade Furche, die selbst an der Wasserscheide nur $24 \mathrm{~m}$ hoch ist. Quer darüber ziehen 
Kämme und Täler von W nach O. Die Wasserscheide ist ganz an den atlantischen Rand gerückt und liegt im N an oder nahe der Grenze von Gneis und Schiefer. Die höchsten Erhebungen (Ben Nevis u. a.) fallen in die Zone der Granitstöcke. Solche mehr oder minder umfangreiche Eruptivmassen, die die fortschreitende Abtragung aus der Destruktionsfläche herausschält, tragen allenthalben dazu bei, Rumpfgelände mannigfaltiger zu gestalten. Die vier Einzelberge, die sich als weithin sichtbare Landmarken über das Harzplateau erheben, der Brocken (1142 m), der Ramberg (575 m), der Auerberg $(575 \mathrm{~m})$ und der Ravensberg $(660 \mathrm{~m})$, bestehen aus Granit oder Porphyr. Aber auch feste Sedimentbänke treten scharf aus der Umgebung hervor, so die langgestreckten, quarzitischen Acker- und Bruchberge im Harz, die Höhenrücken des Taunusquarzites in dem sonst so eintönigen Rheinischen Schiefergebirge, die phantastischen

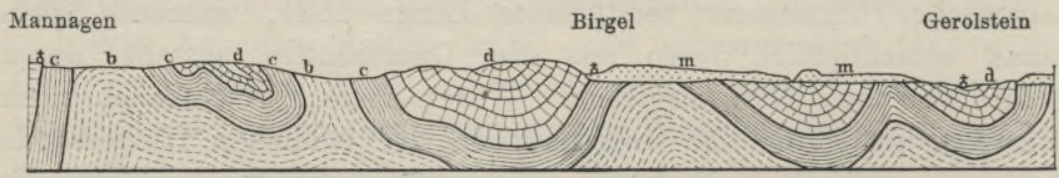

Fig. 238. Profil der Eifel.

$b$ unterdevonische Grauwacke, $c$ Schiefer und Sandstein, $d$ Kalk, $m$ Buntsandstein.

Felsmauern aus mitteldevonischen Konglomeratbänken, die manche Gegenden der Ardennen schmücken, usw. - die Zahl solcher Beispiele ließe sich nach Belieben vermehren. Wo aber das Gesteinsmaterial ziemlich gleichmäßig ist, und die Täler weite Zwischenräume lassen, hat die Destruktionsfläche ihren Charakter noch bewahrt. Wer vermöchte, wenn er über die Eifel (Fig. 238) wandert, und wenn sein Auge nicht geologisch geschult ist, zu erkennen, daß er sich auf gefaltetem Land befindet?: Wie im zerschnittenen Tafelland enthüllt sich auch hier der Gebirgscharakter nicht auf der Höhe, sondern tief unten im Tal. Indes so sehr auch solche Rumpfschollenplateaus den flachgeschichteten ähneln, im einzelnen gewahrt man doch wesentliche Unterschiede. Denn eine völlige Gleichmäßigkeit ist innerhalb eines Schichtenkomplexes niemals vorhanden, und auf einem abgehobelten Faltengebirge sind die Härteunterschiede horizontal nebeneinander, in einem Tafelland vertikal untereinander gelagert.

\section{Genetische Einteilung des Faltenlandes.}

A. Embryonale Formen:

I. Strukturform: Sattelgebirge,

II. Destruktionsform: Landstufen. 
B. Entwickelte Faltenformen:

I. Strukturformen:

1. Gleichförmige,

2. Ungleichförmige.

a) Einfache,

b) Zusammengesetzte.

a) Einseitige,

$\beta$ ) Doppelseitige,

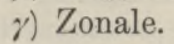

II. Mutationsformen:

1. Frakturformen(Umförmung durch Bruch u. Senkung):

a) Faltengebirge mit zerbrochener Innenzone,

b) Gebrochene Faltengebirge,

c) Faltenschollengebirge,

c) Längsschollen,

B) Querschollen.

2. Destruktionsform (Umformung durch Destruktion): Rumpffläche.

3. Rekonstruktionsformen (Umformung durch Destruktion und Hebung):

a) Rumpfgebirge, $\times$

b) Gebrochene Rumpfgebirge,

c) Rumpfschollengebirge,

c) Längsschollen,

ß) Querschollen.

Wir können auch von orographischen Kategorien ausgehen und erhalten dann:

I. Kettengebirge:

1. Faltengebirge,

2. Faltengebirge mit zerbrochener Innenzone,

3. Gebrochene Faltengebirge,

4. Rumpfgebirge,

5. Gebrochene Rumpfgebirge.

II. Schollengebirge: Kammgebirge, Massive:

1. Faltenschollengebirge,

2. Rumpfschollengebirge.

III. Flachland: Destruktionsflächen.

$\times$ Die Kategorien einfach und zusammengesetzt, gleichförmig und ungleíchförmig sind auch auf die Rumpfgebirge anwendbar. 
Literaturnachweise. ${ }^{1} \mathrm{Vgl}$. Tнеов. Fischer, Wissenschaftliche Orographie der Iberischen Halbinsel, in Petermann's Mitteilungen 1894. - 2 TheoBald Fischer, in Petermann's Mitteilungen 1897, S. $193 .-{ }^{3}$ W. A. Obrutschew, Orographie und Tektonik Transbaikaliens, in den Verhandlungen des VII. internationalen Geographenkongresses; Berlin 1901. Vgl, auch seinen Bericht in Petermann's Mitteilungen 1910, Bd. I, S. 21. $-{ }^{4}$ Von den zahlreichen Arbeiten A. Philippsox's nennen wir hier nur als zusammenfassende Darstellung: La tectonique de l'Egéide, in den Annales de géographie; Paris 1898, Bd. VII. ${ }^{5}$ C. F. Dutron, Mount Taylor and the Zuñi Plateau, im 6. Annual Report of the U. S. Geological Survey, 1885. - ${ }^{6}$ N. H. Darton, Preliminary description of the Geology and Water Resources of the Southern Half of the Black Hills, im Annual Report of the U. S. Geolog. Survey, 1901, Bd. XXI. Part IV. 7 A. W. G. WiLson, The Laurentian Peneplain, im Journal of Geology, Bd. XI, 1903. Für den Osten gibt H. Haas in Petermans's Mitteilungen 1908, S. 123, eine Übersicht der neueren Forschungen. $-{ }^{8}$ Zum erstenmal erörterte W. M. DAvis die Peneplain-Theorie im American Journal of Science 1889, Bd. XXXVII, S. 430. Von allgemeinen Gesichtspunkten aus verteidigte er sie im Artikel "The Peneplain" im American Geologist, 1899, Bd. XXIII, und fast gleichlautend in den Pariser Annales de géographie, Bd. VIII, S. 289. - 9 S. PASsarge, Rumpfflächen u. Inselberge, in der Zeitsehrift der Deutschen Geologischen Gesellschaft, 1904, Bd. LVI, Protokoll. Vgl. auch sein „Kalahari“ zit. S. 256. ${ }^{10}$ A. Penck, Geomorphologische Studien aus der Herzegowina, in der Zeitschrift des D. u. Ö. Alpenvereins 1900. W. M. Davıs, An Excursion in Bosnia, Hercegovina, and Dalmatia; im Bulletin of the Geographical Society of Philadelphia 1901. E. Richter, Beiträge zur Landeskunde Bosniens u. der Herzegowina; in den wissenschaftlichen Mitteilungen aus Bosnien ete., Bd. X, 1907. J. Cvıлé, Bildung und Dislozierung der Dinarischen Rumpfläehe; in Petersanx's Mitteilungen 1909. A. Grund, in der Zeitschrift der Gesellschaft für Erdkunde. Berlin 1908, S. 468, und in den „Beiträgen“ zit. S. 498, Anm. 9. - ${ }^{11}$ E. DE Martonne, Recherches sur l'évolution morphologique des Alpes de Transylvanie, in der Revue de géographie, Paris 1907, Bd. I. - ${ }^{12}$ R. A. DdLY, im Journal of Geology 1905, S. $105 .-{ }^{13}$ C. W. Hayes und M. R. Camprell, Geomorphology of the Southern Appalachians, im National Geographical Magazine 1894. ${ }^{14}$ W. Volz, Jungpliozänes Trockenklima in Sumatra, in ,Gaea" 1909. 15 R. S. TARr, The Peneplain, im American Geologist 1898, Bd. XXI. ${ }^{16} \mathrm{~K}$. Östreich, Die Täler des nordwestlichen Himalaya (Ergänzungsheft Nr. 155 zu Petermans's Mitteilungen), Gotha 1906. - ${ }^{17}$ Research in China: Bd. I. B. Willis, E. Blackwelder und R. H. Sargent, Descriptive Topography and Geology; Bd. II. B. Wrulrs, Systematic Geology; Washington 1907. 18 G. Braun, Beiträge zur Geologie des nördlichen Appennin, in der Zeitschrift der Gesellschaft für Erdkunde, Berlin 1907. - ${ }^{19}$ Über die Geschichte der Sierra Nevada berichten H. W. Turner im U. S. Geologieal Atlas, Folio 43 (1898) u. F. L. Ransome, ebenda, Folio 63 (1899). - ${ }^{20}$ H. Keidel u. St. Richarz, Ein Profil durch den nördlichen Teil des zentralen Thianschan, in den Abhandlungen der Bayerischen Akademie der Wissenschaften, II. Kl., Bd. XXIII, Abteil. II, 1906. - ${ }^{21}$ J. Cvıı́e, Grundlinien der Geographie und Geologie von Mazedonien und Altserbien (162. Ergänzungsheft zu Petermann's Mitteilungen), Gotha 1908. - ${ }^{22}$ H. Pröscholdt, Der Thüringer Wald; Stuttgart 1891. J. Walther, Geologische Heimatskunde von Thüringen; Jena 1902. - ${ }^{23}$ O. A. Derby, Physikalische Geographie und Geologie von Brasilien, in den Mitteilungen der 
Geographisehen Gesellschaft in Jena, 1886. - ${ }^{24}$ F. v. Richtноғеn zit. S. $52 .-$ 25 Авсн. Gerkie, The Seenery of Seottland; London 1887.

\section{Vulkanische Berge.}

Im Gegensatz zu der bescheidenen Rolle, die der Vulkanismus in der Gegenwart spielt, ist die Anteilnahme der Eruptivgesteine an der Zusammensetzung der Erdoberfläche sehr beträchtlich. v. TrLLo ermittelte das Areal nur der jüngeren Eruptivgesteine mit nahezu 4 Mill. qkm, d. h. 4 Prozent der geologisch bekannten Landfläche, und angesichts der Entdeckungen ausgedehnter Lavafelder in Ostasien im Lauf der letzten Jahre kann man wohl behaupten, daß jene Ziffer zu niedrig ist. Der Hauptanteil daran entfällt aber auf die großen Lavatafeln, die wir schon im Kapitel über die Flachschichtung besprochen haben. Die vulkanischen Berge und Gebirge, denen wir jetzt unsere Aufmerksamkeit zuwenden, sind dagegen im Vergleich zu diesen Geländeformen anderen Ursprungs in der Tat nur von untergeordneter Bedeutung. Soweit sie noch tätig sind, unterscheiden sie sich von allen anderen Bodenformen in

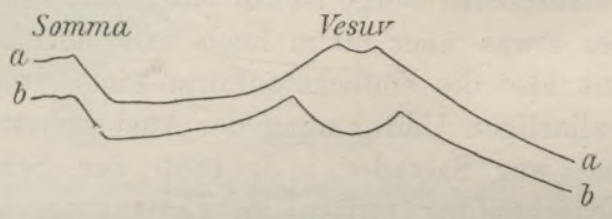

Fig. 239. Nordsüdliches Profil des Vesuvs vor $(a)$ und nach dem Ausbruch v. 1906 (b) nach Greim. ${ }^{1}$ einem wichtigen Punkt. Während wir diese - wenigstens im Vergleich zu unserer Kurzlebigkeit - als etwas Gegebenes, Starres zu betrachten gewohnt sind, an denen nur die destruktiven Kräfte arbeiten, erleiden die tätigen Vulkane fortgesetzt endogene Veränderungen. Am häufigsten kommt dies in ihrer Höhe zum Ausdruck. Bei ruhiger, gleichmäBiger Tätigkeit und genügendem Lavaerguß wachsen sie kontinuierlich; wechseln aber Ruhepausen, in denen die Erosion ungehindert arbeitet, mit Perioden heftiger Ausbrüche, wobei nicht selten der ganze obere Teil des Berges weggeblasen wird, so variiert die Höhe ziemlich stark. Der Vesuv z. B. war 18321140 m und $18551286 \mathrm{~m}$ hoch. und sank am Ende dieses Jahres auf $1235 \mathrm{~m}$ herab, erreichte 1867 eine Höhe von $1387 \mathrm{~m}$ und maß nach 1872 nur mehr 1297 m. Im Mai 1905 betrug seine Höhe 1335 m, im April 1906 aber nur mehr $1223 \mathrm{~m}^{1}$ Auch in der darauf folgenden Ruhezeit hat er durch Erdschlipfe und große Erdlawinen, die den Rand des Kraters erniedrigten und dessen Boden erhöhten, auffällige Veränderungen erfahren. ${ }^{2}$ Eine Höhenabnahme hat Riccò auch am Etna festgestellt: der östliche Gipfel, der bei der geodätischen Aufnahme i. J. 1866 noch $3312 \mathrm{~m} \mathrm{maß,} \mathrm{wird} \mathrm{jetzt} \mathrm{von} \mathrm{dem} \mathrm{nur} 3278 \mathrm{~m}$ 
hohen südlichen Gipfel überragt. Daß auch die Form tätiger Vulkanberge manchmal innerhalb kurzer Zeiträume großen Umgestaltungen unterliegt, lehrt die jüngste Geschichte der Pelée (s. Fig. 96, S. 384).

Sogar von völligen Neubildungen, auch auf dem Land, meldet uns die Geschichte. In die Regierungszeit des mazedonischen Königs Antigonos Gonatas (277-240 v. Chr.) fällt das Geburtsjahr des Vulkans auf der griechischen Halbinsel Methana, der aber nicht mehr tätig ist, und in das Jahr 286 v. Chr. verlegt die Tradition die Entstehung des japanischen Vulkans Fujiyama (3778 m hoch). Viel jünger ist der Monte Nuovo (139 $\mathrm{m}$ hoch) in den Phlegräischen Feldern, der seit seiner Bildung im Jahr 1538 keinen Ausbruch mehr erlebt hat. In das Jahr 1759 fällt die Entstehung des Vulkans Jorulla in Mexico (1220 m hoch); um 1769 (oder 1793?) entstand der Vulkan von Izalco in San Salvador, der sich schon bis zu einer relativen Höhe von $800 \mathrm{~m}$ ausgewachsen hat. Einer der jüngsten vulkanischen Berge ist der von Leon in Nicaragua (14. November 1867), der etwas über $60 \mathrm{~m}$ hoch und dessen Krater ebenso tief ist, der uns also die einfachste Form eines vulkanischen Berges, die einer wallartigen Umrahmung der Ausbruchsstelle, darstellt. Zum zweitenmal war Salvador i. J. 1880 der Schauplatz einer vulkanischen Neuschöpfung mitten im Ilopangosee, von der aber außer zwei isolierten Felsen nichts mehr übrig geblieben ist. Im April 1907 war in den Andes von Südchile, östlich vom Rancosee in ungefähr $49^{\circ} 20^{\prime} \mathrm{S}$, ein neuer Vulkan in Entstehung begriffen, der in den Berichten Riñinahue genannt wird, ${ }^{3}$ doch ist Näheres darüber noch nicht bekannt geworden.

Einteilung. Auf S. 390 haben wir STÜBEL's Einteilung der Vulkane in monogene und polygene erwähnt, aber hinzugefügt, daß es keine sicheren Unterscheidungsmerkmale gebe; schon aus diesem Grund ist sie morphologisch nicht verwendbar. v. Seebach's Einteilung in homogene und Stratovulkane knüpft an den inneren Bau an und hat den Vorteil bequemer Handhabung, ist aber nicht erschöpfend. Ein Faltengebirge kann seinen Ursprung niemals verleugnen; selbst wenn es bis auf die Grundmauern abgetragen ist, kann der ursprüngliche Bau in seinen Hauptzügen wiederhergestellt werden. Nicht so die Vulkanberge. Locker- und gemischte Eruptionen erzeugen allerdingș Stratovulkane, wie Lavaeruptionen homogene Vulkane, aber wir sind durchaus nicht sicher, ob alle homogenen Vulkane aus Lavaeruptionen hervorgegangen sind. Auch bei geschichteten Vulkanen kann sich nämlich der Bau des Kerns wesentlich von der Struktur der Umhüllung unterscheiden; wir verweisen nur auf v. HochstetteR's Idealprofil des Vesurs auf 
S. 380 (Fig. 94). Der große Vulkankegel im nordwestlichen Teil von Tahiti ist durch radiale Erosion bis zu einer Tiefe von $600-1200 \mathrm{~m}$ aufgeschlossen. Während sich in den unteren Tälern die Gehänge aus wenige Meter mächtigen Lavabänken in Wechsellagerung mit Tuffen und Konglomeraten aufbauen, nehmen die Lavabänke talaufwärts an Mächtigkeit zu, und besteht der ganze zentrale Teil aus einer homogenen, ungeschichteten Lavamasse. ${ }^{4}$ Auch im ostafrikanischen Kenia ist die Talerosion hereits bis zur homogenen Schlotausfüllung vorgedrungen. ${ }^{5}$ Prächtige Profile hat der Steinbruchbetrieb im rheinischen Siebengebirge entblößt (Fig. 240). ${ }^{6}$ Die Grenze zwischen dem, flachgeschichteten Grundgebirge und der basaltischen Ausfüllungsmasse fällt steil nach innen ein, so daß die Lavakuppe die Form eines gestielten Pilzes besitzt. Zwischen ihr und dem Grundgebirge haben sich Reste eines Trümmergesteins $(L)$ erhalten, das

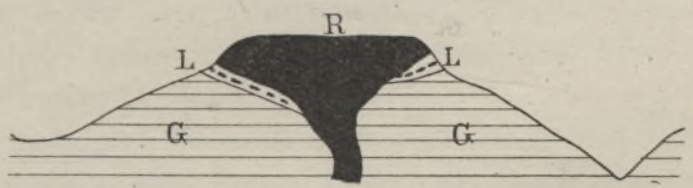

Fig. 240. Eine Basaltkuppe des rheinischen Siebengebirges nach LAsPEYREs. ( $G=$ Grundgebirge, $L=$ Lockerprodukte der Basalteruption, $R=$ Homogene Basaltmasse.)

sich aus Stücken des Grundgebirges und der Basaltlava in der Weise zusammensetzt, daß die ersteren nach oben zu immer mehr gegen die letzteren zurücktreten. Der Ausbruch begann also mit der Bildung eines Kraters; dann folgte eine Lockereruption, die einen Stratovulkan aufbaute; endlich erfüllte die aufsteigende Lava den ganzen inneren Hohlraum und kühlte sich so rasch ab, daß sie sich nicht stromartig über den Kraterrand verbreiten konnte. Als dann die Aschen- und Schlackenhülle beseitigt wurde, trat der blanke Kern zutage und erweckt so den Schein eines ursprünglich homogenen Vulkans, eines Lavakegels. Auch in andern Gegenden dürften zahlreiche steile Basaltkegel als solche Destruktionsformen zu deuten sein. Wahrscheinlich haben Stratovulkane aus vortertiärer Zeit nur unter außergewöhnlich güstigen Umständen ihre Form bewahrt; der älteste dürfte der porphyrische Geitsegubib in der Ebene des Fischflusses in Deutsch-Südwestafrika sein, der seine Erhaltung nur der Verhärtung seiner Tuffe mittels eines kieseligen Zementes verdankt. ${ }^{7}$

Wir haben somit zwischen aufgesetzten und aufgedeckten Vulkanbergen zu unterscheiden. Alle Vulkane im eigentlichen Sinn des Wortes, d. h. alle Erzeugnisse von Oberflächeneruptionen sind 
aufgesetzte Berge, wenn sie auch mittels des Schlotes mit dem Erdinnern in Verbindung stehen; alle Ausfüllungen von Kanälen und Hohlräumen innerhalb der Erdkruste mit Eruptivmassen können dagegen nur durch Aufdeckung, durch Denudation in Oberflächengebilde umgewandelt werden. Mit dieser Einteilung kombiniert sich SeEbach's Einteilung in folgender Weise:

I. Aufgesetzte Vulkanberge:

1. Stratovulkane,

2. Homogene Vulkane;

II. Aufgedeckte Vulkanberge, nur homogene Vulkane.

Aufgesetzte Stratovulkanberge. Ihre naturgemäße Gestalt, sofern sie durch Zentraleruption entstanden sind, ist der Kegel. Mögen sie auch durch spätere Ausbrüche und durch die Erosion Verän-

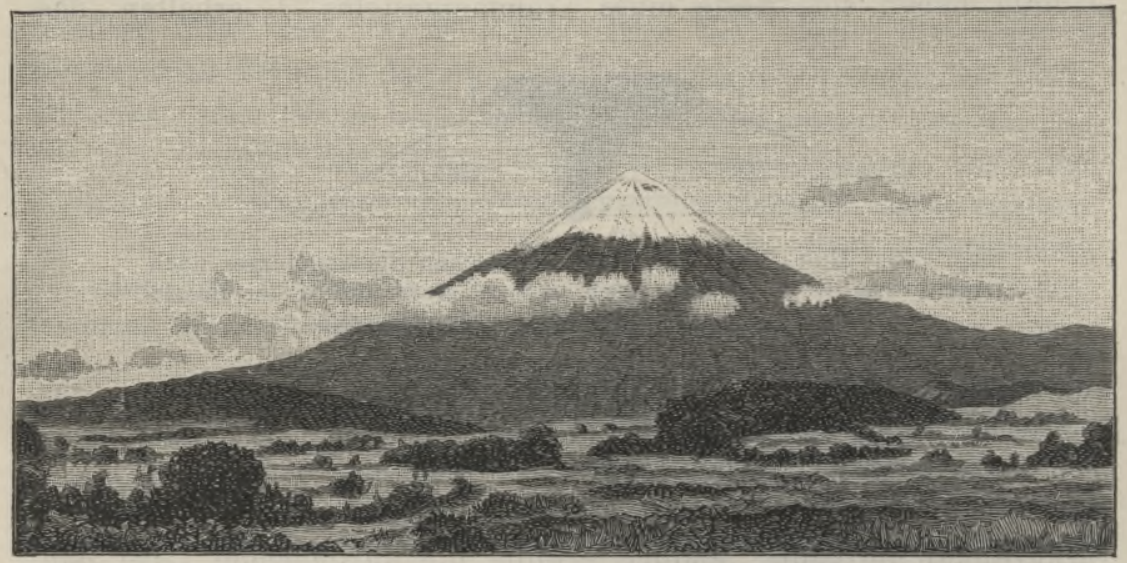

Fig. 241. Popocatepetl bei Puebla (Mexico).

derungen erleiden, so bleibt doch in der Regel im großen und ganzen die ursprüngliche Kegelgestalt gewahrt, ja in vielen Fällen, wie bei dem Cotopaxi, dem Pic von Orizaba, dem Popocatepetl (Fig. 241) u. a. ist sie noch in wunderbarer Reinheit erhalten. In schön geschwungener Linie verflacht sich die Böschung allmählich nach unten; als Beispiel möge der Vulkan von Pico (Azoren) dienen, dessen Gehänge in der Nähe des $2500 \mathrm{~m}$ hohen Gipfels unter $30-35^{0}$ abfallen, während sich weiter unten der Böschungswinkel auf $6-12^{\circ}$ und am Fuße sogar auf $3^{0}$ ermäBigt. $\times$ Natürlich herrscht

$\times$ LrNck hat die äußere Form der Stratovulkane experimentell nachzuahmen versucht, wobei aus einer Röhre Sand durch komprimiertes Gas ausgetrieben wurde. Die Sandkegel hatten oben konvexe, in der Mitte gerade und unten konkave Böschung (Neues Jahrbuch für Mineralogie usw., Festband, 1907. S. 91). 
in dieser Beziehung große Mannigfaltigkeit. Reine Tuffkegel sind am flachsten. Scharf heben sich durch ihre Steilheit moderne Aschenkegel von ihrem massiven Unterbau ab. Auf Island beobachtete SAPPER $^{8}$ Vulkane, die aus zusammengeschweißten Lavafetzen aufgebaut sind und sich durch steile Böschungen auszeichnen, besonders an der Innenseite der Krater, wo sie manchmal überhängende Wände bilden.

Die Höhe der Vulkankegel hängt von ihrem Alter und der Art der Eruptionen ab. Maßgebend ist aber stets nur die relative Höhe, die Erhebung über den nichtvulkanischen Untergrund, und dies ist besonders bei den Vulkanen der Andes und des Kaukasus zu berücksichtigen, die auf einem gewältigen Gebirgssockel ruhen. Absolut dürfte der Chimborazo $(6310 \mathrm{~m})$ der höchste Vulkan der Erde sein, aber der Vulkankegel selbst ist nur $2-3000 \mathrm{~m}$ hoch, steht also weit zurück hinter der Kliutschewskaja Sopka auf Kamtschatka, die als höchste vulkanische Aufschüttung von $4900 \mathrm{~m}$ noch den Montblanc überragt.

Auf dem Gipfel befindet sich eine trichterförmige Einsenkung von kreisähnlicher oder ovaler Form, der Krater, und auf dessen Boden münden die Eruptionskanäle, die in der Zeit der Ruhe verstopft sind. Bestehen die Wände des Kraters nur aus lockerem Material, so neigen sie sich trichterförmig flach dem Innern zu; die der Felskrater dagegen sind steil. ${ }^{8}$ Die Durchmesser sind verschieden und stehen in keinem bestimmten Verhältnisse zur Höhe des Berges. $\times$ Auch der Krater ist fortwährenden Veränderungen unterworfen; heftige Eruptionen können ihn zu einem großen Zirkus mit steilen, immer mehr einstürzenden Wänden erweitern. Von dem Krater unterscheidet sich die unter dem Namen Caldera bekannte Hohlform äußerlich nur dadurch, daß sie im Vergleich zu dem ganzen, sie ringförmig umschließenden Vulkankörper sehr groß ist. ${ }^{9}$ Die berühmte Caldera von Palma schildert v. FrITSCH ${ }^{10}$ als „einen ungeheueren elliptischen Talkessel, der, im Innern von zahlreichen Bächen und Schluchten durchzogen, von fast senkrechten, wild zerrissenen und bunt gefärbten Felswänden umgeben wird. Diese Wände stürzen an $1200 \mathrm{~m}$ steil $\mathrm{ab}$, dann erst breiten sich deren scharfe Vorsprünge in etwas flacher geböschte Rücken aus, die zwischen den Schluchten hinziehen." Alle Bäche des großen Kessels vereinigen sich zu einem großen Fluß, der durch die tiefe Talschlucht des Gran Barranco de las Angustias seinen Ausgang gewinnt. Über die Genesis der Calderen sind die Ansichten auch heute noch geteilt.

$\times$ Stromboli, 670, Etna ungefähr 700, Kilauea ungefähr 4700, Tengger auf Java, der gröBte tätige 'Krater, gegen $4900 \mathrm{~m}$. 
Sind sie ursprüngliche Bildungen oder durch Erosion erweiterte und vertiefte Krater? Für die letztere Erklärung trat seinerzeit LYELL ein, und v. Fritsch, SAPPER ${ }^{11}$ und $\mathrm{G}_{A G E L}{ }^{12}$ haben ihr zugestimmt. Dagegen hielt LeOpoLd v. BucH die Calderen für Erhebungskrater, und diese Ansicht fand noch in neuester Zeit einen Verteidiger in v. KNEBEL, ${ }^{13}$ nur daß dieser die Sprengung des Deckengebirges nicht Gasen, sondern emporgetriebenen Schmelzmassen zuschrieb. Nach STÜBEL ${ }^{14}$ ist, entsprechend der Theorie der homogenen Vulkane, der Calderawall „der stehen gebliebene Rest der Erstarrungsschale einer in die Tiefe des Kraterschachtes zurückgesunkenen, noch einigermaßen flüssig gewesenen Gesteinsmasse“. Er steigt in der Regel schräg an, an der niedrigsten Stelle ist er bis zum Boden talartig geöffnet, und der höchste Punkt liegt meist gegenüber der Öffnung. Für ursprüngliche Anlage spricht die auffallende Übereinstimmung im Bave der benachbarten Calderaberge Ecuadors, Pasochoa und Rumiñahui; aber selbst ein so überzengter Anhänger STÜBEL's, wie es Grosser ${ }^{15}$ ist, kann die Allgemeingültigkeit dieser Theorie nicht anerkennen, ja sogar auf Ecuador findet er sie nicht durchaus anwendbar, denn der Imbabura besitzt einen zentralen Krater und davon getrennt eine große Caldera. Er denkt an Explosionen, wie am Krakatau und Bandaisan (vgl. Fig. 95 auf S. 383), wodurch große Teile des Vulkans in die Luft gesprengt wurden. Eine der interessantesten Calderen ist der nahezu kreisrunde Kratersee (Crater Lake) im Kaskadengebirge Oregons, der $53 \mathrm{qkm}$ mißt und eine mittlere Tiefe von ungefähr $460 \mathrm{~m}$ besitzt. Sein Spiegel liegt $1900 \mathrm{~m}$ über dem Meer und bis zu $600 \mathrm{~m}$ unter dem Steilrand. Die hier aufgeschlossenen Lavabänke weisen durch ihre radiale Anordnung und ihre Neigung darauf hin, daß sie von einem Punkt über dem jetzigen Rand ausgingen; es muß hier einst ein gewaltiger Kegelberg gestanden haben, ähnlich dem Mt. Shasta im californischen Kaskadengebirge, und ebenso hoch oder höher als dieser $(4380 \mathrm{~m})$ gewesen sein, denn in der Eiszeit sendete er nach allen Seiten große Gletscher aus. Auf welche Weise ist dieser Mt. Mazama, wie man ihn genannt hat, verschwunden? Die STüBeL'sche Theorie versagt hier ebenso wie die Erosionstheorie. Man könnte an eine Explosion denken, aber in diesem Fall müBten sich noch Spuren von den gewaltigen Trümmern finden. Es bleibt also, wie Diller ${ }^{16}$ auseinandergesetzt hat, nur die Annahme eines Einsturzes übrig. Die Calderen scheinen somit genetisch sehr verschiedenartige Gebilde zu sein.

AuBer den Krater- und Calderabergen gibt es auch Vulkankegel ohne Krater; es sind entweder monogene Bildungen, die nie einen Krater besaßen, oder Ruinen, deren* Krateraufsatz durch 
Denudation entfernt wurde. Als typisches Beispiel in Ecuador nennt SтÜвеL den Cerro Llimpi. Ferner unterscheidet Stüвel Vulkankegel mit zentraler Gipfelpyramide (z. B. Quilindaña in Ecuador) und Domberge, wie den Chimborazo und den flachgewölbten, weit ausgedehnten Páramo de Pansache.

Aufgesetzte homogene Vulkane. Der Georgiosvulkan von Santorin und die Montagne Pelée haben uns belehrt, daß homogene Vulkane auch heute noch entstehen können, aber es ist schwierig, solche aufgesetzte Vulkane auch in den Schöpfungen der Vergangenheit wiederzuerkennen und sie von den aufgedeckten Eruptivbergen zu scheiden. Als wesentliche Merkmale, die entweder allein oder vereinigt auftreten, betrachtet BERGEAT ${ }^{17}$ die Bedeckung der homogenen Staumasse mit Auswürflingen von derselben Gesteinsbeschaffenheit und das Vorhandensein eines Kraters. Er unterscheidet andesitische und liparitische Staukuppen; jene sind kompakt, ,wie aus einem Guß erstarrt", diese ein Haufenwerk ineinander gekneteter Lavaschollen. Auf den äolischen Inseln finden sich Vertreter beider Arten, Panaria und Filicudi bergen andesitische, Lipari liparitische Vulkane. $\mathrm{Zu}$ den ersteren zählt Bergeat auch die Montagna Grande auf Pantelleria und den Nevado de Toluca in Mexico.

Einfluß der Lage der Eruptionsstellen. Von größter Bedeutung für den Bau eines Vulkans ist es, ob die Eruptionsstellen konstant bleiben oder sich verschieben. Benutzt die neue Eruption den vorhandenen Kanal, so findet sie auf dem Boden des alten Kraters statt, und innerhalb dieses entstehen ein oder mehrere Auswurfskegel, die ebenfalls Krater besitzen, in denen sich unter gleichen Umständen wieder neue Kegel aufbauen können. Im Vulkan von Santa Ana in Salvador, den $\mathrm{SAPPER}^{8}$ besucht hat, verschob sich das Ausbruchszentrum im Lauf der Zeit immer weiter nach SO; auf den Hauptkrater folgen gegen NW noch drei Krater mit wohl erhaltenen Wällen, die ebensovielen älteren Eruptionsperioden entsprechen. Noch erscheint aber der Vulkan als ein einheitlicher Kegel. Findet dagegen die neue Eruption an der Flanke des alten Kraters statt, so wird ein Teil davon zerstört, wie beispielsweise die Somma des Vesur durch den Ausbruch von 79, $\times$ und solche Vulkane erscheinen dann doppelgipfelig (Fig. 93 und 94 auf S. 378 und 380). Häufig suchen sich aber die vulkanischen Gewalten an den Abhängen des Kegels neue Bahnen und bauen hier seitliche Eruptionskegel auf, die mit dem alten eine vielgipfelige Bergmasse bilden. Der Etna hat mehrere hundert und der Galunggung auf Java mehr als tausend

$\times$ Franco und Pammeri vertreten die Meinung, daß die Südseite der Somma als die Wetterseite von jeher niedriger war. 
solcher Kegel. Findet auf beschränktem Terrain jede neue Eruption an einer anderen Stelle statt, so kommt es zwar zur Bildung von vielen, aber nur kleinen Kegeln. Die Phlegräischen Felder bei Neapel zählen auf einer Fläche von etwa 220 qkm 27. (Fig. 242), und der Isthmus von Auckland auf einer ungefähr doppelt so großen Fläche 63 selbständige Ausbruchsstellen. Liegen die Eruptionsstellen nahe beieinander und annähernd in einer Reihe, so können wohl die einzelnen vulkanischen Gebilde zu einem langgestreckten, mehrgipfeligen Gebirge verschmelzen, wie dies z. B. von den Cerros de Yaruquíes

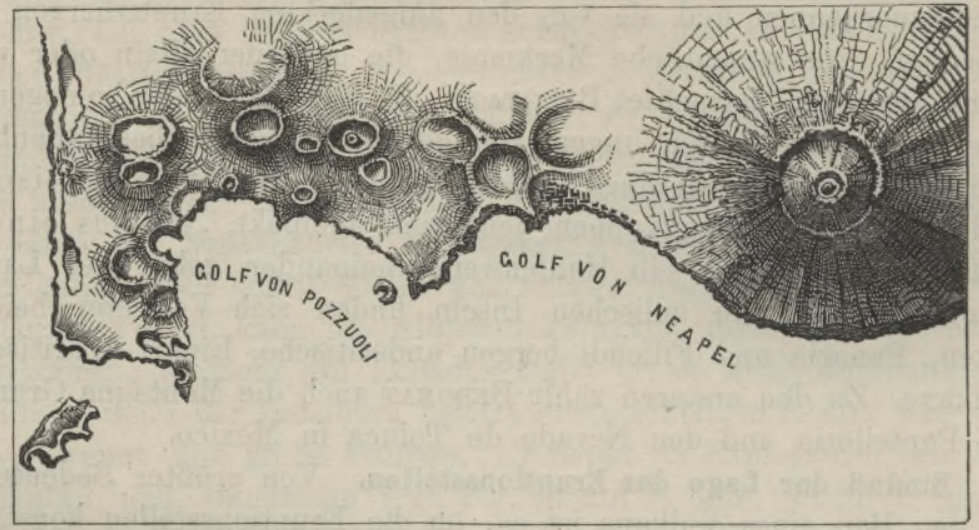

Fig. 242. Neapolitanischer Vulkandistrikt.

in Ecuador angenommen wird; echte vulkanische Kammgebirge sind aber wohl auf Labialeruptionen zurückzuführen. Eines der ausgezeichnetsten Beispiele ist die siebenbürgische Hargita, ein $150 \mathrm{~km}$ langer, $30 \mathrm{~km}$ breiter und $1400-1800 \mathrm{~m}$ hoher Gebirgszug. Den Kamm bildet Andesitlava, die Flanken begleiten aber noch vulkanische Breccien, Konglomerate und Tuffe. Aus einer unregelmäßigen Anordnung von Ausbruchsstellen entstanden die mehr oder minder geschlossenen homogenen Kuppengebirge, von denen das Siebengebirge am Rhein als Beispiel genannt sein mag.

Umwandlung durch Destruktion und aufgedeckte Vulkanberge. Erloschene Vulkane sind fertige Oberflächengebilde wie andere Berge, und nun gelangt die Destruktion zur Alleinherrschaft. Der Krater verfällt von selbst der Abtragung durch den Wind und das fließende Wasser; er wird dadurch erweitert und zugleich verflacht. Die Trichterform geht in die Kessel- und diese in die Tellerform über; die flache Delle, die den Vulkan Masárang auf Celebes krönt, wird von Sarasin mit Recht als das letzte Stadium der Umbildung vor dem völligen Verschwinden gedeutet. Daß Aschenkrater schneller zerstört werden als Felskrater, ist selbstverständlich. 
Das fließende Wasser schafft regelmäßige Rinnen, die mit zunehmender Breite und Tiefe vom Gipfel zum FuB herabziehen und durch ebenso regelmäBige Rippen getrennt werden. Den Gunung Sumbing auf Java, an dem die radiale Talanordnung besonders regelmäBig entwickelt ist, hat man sehr passend mit einem halbgeöffneten Regenschirm verglichen. STÜBEL betrachtet auch diese Einschnitte als ursprüngliche Bildungen, die mit der Entstehung monogener Vulkane gegeben sind, ohne sich deutlich darüber auszusprechen, wie man sich einen so seltsamen Vorgang vorzustellen habe. Verschiedene Etappen des Erosionsprozesses sind übrigens nebeneinander häufig zu beobachten. Sehr anschaulich schildert DANa ${ }^{18}$ die beiden hawaiischen Inseln Oahu und das später erloschene Maui. Jede ist das vereinigte Werk zweier Vulkane, eines westlichen und eines östlichen. Ost-Maui hat durch Destruktion noch wenig eingebüßt; an der Windseite hat es enge Schluchten, an der Leeseite aber nur seichte Rinnen. West-Maui ist schon tiefer eingeschnitten, aber die Kegelform ist dadurch nur wenig verändert worden. Dagegen existiert von dem Kegel Ost-Oahus nur mehr ein Teil, und noch mehr reduziert ist West-Oahu, so daB man über die Lage der Krater nur Vermutungen anstellen kann.

Die Destruktion beschränkt sich aber nicht blob auf die Zerstörung der oberflächlichen Vulkanbildungen, sondern kann, indem sie die alte Oberfläche selbst Schicht für Schicht abträgt, auch die Wurzeln der Vulkane bloßlegen. Viele vulkanische Gangausfüllungen zieren jetzt als steil aufragende Felspartien die Landschaft.(vgl. Fig. 116 auf S. 477). Manche Teile des Tafellandes von Colorado werden von "Necks" geradezu durchschwärmt. Es sind Lavakegel oder Kuppen ohne Lavaströme, ohne Aschenkegel, ohne irgendwelche lockere Auswürflinge, also offenbar aufgedeckte Ausfüllungsmassen vulkanischer Schlote; und von der Richtigkeit dieser Erklärung kann man sich nirgends besser überzeugen, als gerade hier, wo alle Stadien der Ausschälung dieser einst unterirdischen Kerne zu beobachten sind. ${ }^{19}$

Greift die Denudation noch tiefer, so können sogar krypto. vulkanische Bildungen zutage gefördert werden. Trachytische, porphyritische und basaltische Lakkolithen, die in Gestalt unregelmäBiger großer Brote oder Kuchen weite Hohlräume des Erdinnern erfüllen, hat man zuerst im westlichen Hochland von Nordamerika kennen gelernt, ${ }^{20}$ doch ist ihre weite Verbreitung auch außerhalb Nordamerikas jetzt nachgewiesen. Fig. 92 auf S. 371 stellt uns einen aus der Lakkolithengruppe der Henry Mountains in Utah dar; GILBER'T beschreibt sie als „eine Gruppe von fünf Einzelbergen, die durch 
niedere Pässe voneinander getrennt und ohne ein erkennbares System angeordnet sind. Der höchste erhebt sich ungefähr $1500 \mathrm{~m}$ über das Plateau und $3350 \mathrm{~m}$ über den Meeresspiegel. Thre Ausdehnung ist gering. Vom Ellen Peak bis zum Mount Ellsworth, die am weitesten voneinander abliegen, beträgt die Entfernung $45 \mathrm{~km}$, und ein Kreis von $29 \mathrm{~km}$ im Halbmesser würde die ganze Gruppe einschließen." Stets zeigt eine Verflachung des Böschungswinkels den Übergang vom eruptiven zum Sedimentsgestein an. Aus Fig. 92 ist ohne weiteres ersichtlich, daß die Sedimente, die an den Abhängen noch erhalten sind und den Unterbau bilden, einst auch die ganze Magmamasse umhüllten. Die Lakkolithen sind also ebenso wie die Necks und die ehemaligen Gänge a ufgedeckte Vulkanbildungen. SuEss unterscheidet davon die granitischen Batholithen, die ebenfalls Kuchenform zeigen, aber mit der Tiefe an Breite zunehmen; es sind Magmamassen, die durch Aufschmelzung des Deckengesteins in die Erdkruste eingedrungen sind, während in den Lakkolithen das Magma seitliche Hohlräume ausgefüllt hat. Solche nun bloßgelegte Batholithen sind der Drammengranit von Kristiania, die Granite des Erzgebirges, der Brocken im Harz, ${ }^{21}$ vor allem aber der Granitdiorit von Britisch-Columbien, der sich aus Alaska unter ungefähr $63^{\circ} \mathrm{N}$. bis $49^{\circ} \mathrm{N}$. nach $\mathrm{S}$ erstreckt und mit seinen Erhebungen von mehr als $2000 \mathrm{~m}$ die ganze Westhälfte von BritischColumbien erfüllt.

Literaturnachweise. ${ }^{1}$ G. Grems, Die Veränderungen am Vesuv infolge des Ausbruches vom April 1906, in der Geographisehen Zeitsehrift 1910. $-{ }^{2}$ F. A. Perret, Vesuvius, im American Journal of Seience, Bd. XXVIII, 1909. - ${ }^{3} \mathrm{H}$. Stefren, in Petermann's Mitteilungen 1907, S. $160 .-{ }^{4} \mathrm{~J} . \mathrm{D}$. DANA, A dissected voleanic Mountain, im American Journal of Science 1886, Bd. XXXVII. - ${ }^{5}$ J. W. Gregory, im Quarterly Journal of the Geological Society, London 1900 , Bd. LVI, S. 205. $-{ }^{6}$ H. Laspeyres, Das Siebengebirge am Rhein; Bonn 1901. - ${ }^{7}$ A. Schenck, in der Zeitsehrift der Deutschen Geologischen Gesellschaft 1901, Protokoll, S. 54. $-{ }^{8}$ K. SAPPER, Über einige isländische Vulkanspalten und Vulkanreihen, im Neuen Jahrbuch für Mineralogie usw., Beilageband XXVI; Kratertypen von Mexico und Guatemala, in Petermans's Mitteilungen, 1894; Vulkane in Salvador und Südost-Guatemala, ebenda, 1897. - ${ }^{9}$ H. Spethmann, Der Begriff Caldera, im Globus, Bd. XCV, 1909. - ${ }^{10}$ K. v. Fritson, Reisebilder aus den Canarisehen Inseln; Gotha 1867 (22. Ergänzungsheft zu Petermans's Mitteilungen). - ${ }^{11} \mathrm{~K}$. Sapper, Beiträge zur Kenntnis von Palma und Lanzarote, in Petermans's Mitteilungen, 1906. ${ }^{12} \mathrm{~K}$. GAGEL, Die Caldera von Palma, in der Zeitsehrift der Gesellschaft für Erdkunde, Berlin 1908. - ${ }^{13}$ W. v. KNEBEL, im Globus, Bd. XC, S. 312 u. 329, und Bd. XCII, S. 326 u. $343 .-{ }^{14}$ A. StüвEL, zit. S. 410, Anm. 19. Siehe besonders die Abbildungen von Vulkantypen auf S. $406 \mathrm{ff}$. des Ecuadorwerkes. - ${ }^{15}$ P. Grosser, Geologische Betrachtungen auf vulkanischen Inseln, in den Verhandlungen des naturhistorisehen Vereins der preußischen Rheinlande usw., 
1899; Reisen in den ecuatorianischen Anden; ebenda 1904. - ${ }^{16}$ J. S. Dillek und H. B. Patton, The Geology and Petrography of Crater Lake; Washington 1902 (U. S. Geol. Survey, Professional Paper Nr. 3). - ${ }^{17}$ A. Bergeat, Staukuppen, im Festband des Neuen Jahrbuches für Mineralogie usw. 1907. 18 J. D. Dana zit. S. $410 .-{ }^{19}$ C. E. Dutron, Mount Taylor and the Zuñi Plateau, im 6. Annual Report of the U. S. Geological Survey, 1885. 20 Wн. Cross, The Laccolitic Mountain Groups of Colorado, Utah, and Arizona, im XIV. Annual Report of the U. S. Geological Survey, 1894, II. Teil. ${ }^{21}$ O. LUEDEcke, in den Mitteilungen des Vereins für Erdkunde in Halle a. S., 1903 , S. 56.

\section{Gliederung der Gebirge.}

Alter und Anordnung der Täler. Die Talbildung in einem Gebirge ist so alt wie das Gebirge selbst, aber man darf daraus nicht folgern, daß alle heutigen Täler so alt seien. Einige können älter, andere auch jünger sein. Ihre Anordnung ist zunächst durch den Gebirgsbau vorgezeichnet. Auf Vulkankegeln verlaufen sie radial, in vulkanischen Kammgebirgen folgen sie annähernd parallel miteinander den beiderseitigen Abdachungen. Aber schon hier stoßen wir auf Ausnahmen; die siebenbürgische Hargita wird z. B. ihrer ganzen Breite nach von der Maros durchschnitten. Im Schweizer Jura stehen die Synklinaltäler im offenbaren Zusammenhang mit dem Faltenwurf, aber die großen Quertäler widersprechen ihm. Noch verwickelter erscheint uns die Gliederung in komplizierten Faltengebirgen nach der Art der Alpen, aber vielleicht erscheint sie uns nur so, weil wir uns über die ursprüngliche Oberflächenform dieser Deckengebirge gänzlich im Dunkeln befinden. Es läßt sich nicht einmal die Frage beantworten, in welchem Altersverhältnis die Längs- und die Quertäler zueinander stehen. Sogar Teile eines und desselben Tales können von verschiedenem Alter sein. Tallinien aus einer längst vergangenen Epoche der Gebirgsbildung können wieder aufleben, wie z. B. die große Längsfurche am Nordrand der Tauern einem Grabenbruch der Kreidezeit folgt; andere Tallinien können ganz oder teilweise außer Betrieb gesetzt werden. Solche Talverlegungen haben sogar noch in der jüngsten geologischen Vergangenheit stattgefunden. Die Ausfüllung der Alpentäler mit glazialem Schutt nötigte an vielen Stellen die Flüsse, sich ein neues Bett im Fels zu graben ${ }^{1}$, das Silltal in Tirol (Fig. 243) ist eines der zahlreichen Beispiele dieser Art. Ein mit Sand und erratischem Material verschüttetes Tal wurde vor wenigen Jahren anläßlich eines Straßenbaues von Gap nach La Blache im französischen Departement Hautes Alpes bloBgelegt. ${ }^{2}$ Von höchstem Interesse ist die Entdeckung ausgezeichnet erhaltener Talterrassen im Ural unter $60^{\circ}$ B., die sich vom Kamm bis etwa $800 \mathrm{~m}$ Seehöhe hinab er- 
strecken und $\mathrm{zu}$ den heutigen Tälern in keinen Beziehungen stehen. ${ }^{3}$ Die hydrographischen Verhältnisse müssen sich völlig geändert haben, ohne daß eine Einebnung, die auch die Terrassen vernichtet hätte, eingetreten ist. Ein anderer häufiger Vorgang sind die Flußanzapfungen, doch sind dadurch nicht neue Täler geschaffen, sondern es işt nur die hydrographische Verknüpfung der Täler verändert worden. Wir werden daher erst im folgenden Kapitel davon sprechen.

In Rumpfschollengebirgen ist die Geschichte der Talbildung noch viel verwickelter, denn hier scheidet sich deutlich eine ältere Ketten- und eine jüngere Schollenperiode. Sofern die Einebnung des alten Gebirges durch fluviatile Destruktion erfolgte, und eine

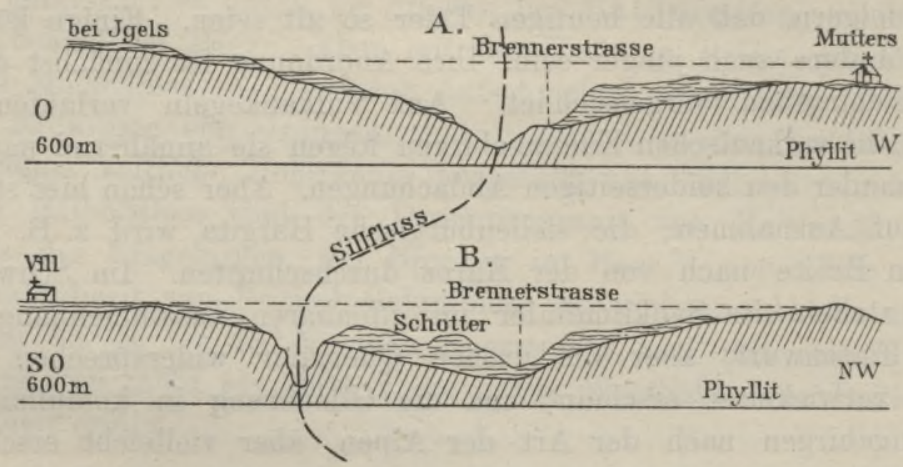

Fig. 243. Profile durch das vordere Silltal nach J. BLAs (Zeitschrift des Deutschen und Österreichischen Alpenvereins 1904, S. 9).

jüngere Sedimentdecke nicht alle früheren Formen verwischte, müssen auch aus jener ersten Periode noch Talrudimente vorhanden sein. Mit ihnen vereinigen sich nun junge Täler aus der Zeit der Wiederaufrichtung der Gebirgsreste, Täler, die durch die neugeschaffenen Höhenunterschiede ins Leben gerufen wurden. Im Unterharz scheint uns eine solche Kombination vorzuliegen. Bode, Selke und Wipper fließen zuerst auf der Plateaufläche nach SO und biegen dann zum Teil mit scharfem Knick nach NO um. Der Unterlauf ist jedenfalls jung, im Oberlauf werden nach unserer Ansicht aber alte Talböden benutzt. Typisch ist namentlich die flache Furche des Hassel- und Selketales (Wasserscheide bei Stiege $482 \mathrm{~m}$ hoch, Abfall nach Günters berge $0^{0} 27^{\prime}$, nach Hasselfelde $0^{0} 21^{\prime}$ ).

Längs- und Quertäler. Voń Längs- und Quertälern im rein topographischen Sinn kann man zwar in allen Gebirgen sprechen, die sich nach einer bestimmten Richtung erstrecken, aber nur in Kettengebirgen verbinden sich mit jenen topographischen $\mathrm{Be}$ - 
griffen auch tektonische, indem die Längstäler nicht bloß in der Streichrichtung des Gebirges, sondern auch in der der Schichten verlaufen, und die Quertäler diese durchschneiden. Ja das Längstal hat auch eine genetische Bedeutung, wenn auch synklinale Täler seltener sind, als antiklinale und isoklinale, die wir als Erosionsbildungen längs tektonischer Linien $\mathrm{zu}$ betrachten haben. Einen solchen, wenn auch nur indirekten Zusammenhang mit der Faltung beweisen die großen Längsfurchen vieler Gebirge, durch die mehrere Flüsse, nur durch niedere Wasserscheiden getrennt, häufig in entgegengesetzter Richtung fließen. In den Alpen sind die bedeutendsten dieser Längsfurchen folgende: 1. die Linie Martigny-Chur (Rhônetal, Furkapaß, Urserental, Oberalppaß, Rheintal); 2. die Linie FeldkirchWörgl (Täler der Ill und Alfens, Arlberg, Täler der Rosanna und des Inn); 3. die Linie Zell am Ziller-Hieflau (Gerlostal und -paß, Salzachtal, Arltal, Sattel von Wagrein, Ennstal); 4. die Mur-Mürzlinie; 5. die Linie Franzensfeste-Marburg (Rienztal, Toblacher Wasserscheide, Drautal). In den Karpathen ist neben der Waag-Hernadlinie besonders jene breite Furche bemerkenswert, die in einem $140 \mathrm{~km}$ langen Bogen von Nameszto bis Nagy-Sáros hinzieht und von der Arva, dem Dunajec, dem Poprad und der Tarcza entwässert wird. Sie fällt mit einem Kreideaufbruch und mit einem der bedeutendsten Juraklippenzüge zusammen. Im Himalaya setzt sich das große Längstal des Brahmaputra über die flache Wasserscheide von Mariam-la im obersten Sutlejtal fort und etwas westlich davon beginnt das zweite große Längstal, das der Indus durchströmt.

Der Bau der Faltungstäler ist verschieden. Die Gehänge der echten Synklinaltäler werden beiderseits von Schichtenflächen gebildet, sie steigen daher sanft an und sind quellenreich. Die Gehänge der Antiklinaltäler werden von Schichtenköpfen gebildet, sie sind steiler, meist von Verwitterungsterrassen unterbrochen und quellenarm. Die Isoklinaltäler vereinigen beide Charaktere, indem die eine Seite Schichtenköpfe, die andre Schichtenflächen dem Tal zukehrt. Sehr oft vereinigt ein Längstal mehrere Formen in sich, wobei der Übergang aus der einen Form in die andere durch kurze Quertalstrecken vermittelt wird.

Neben Faltungslinien gaben auch Brüche Veranlassung zur Talbildung. Schöne Beispiele bietet uns das südwestliche Tirol, wo die sogenannte Judikarienspalte das kristallinische Ortler-Adamellogebirge von dem östlichen Kalkgebirge trennt. Thr entlang haben sich mehrere Täler entwickelt: Valbuona, Val Rendena, Val Meledrio und das Maraun-Ultental. In den wasserscheidenden Rücken, die Höhen von $800-2400 \mathrm{~m}$ erreichen, hängen beide Gebirge zusammen 
- ein Beweis, daß jene Täler nicht primäre Spalten, sondern nur Erosionserzeugnisse längs einer Verwerfungsspalte sind. Grabentäler sind eine typische Erscheinung des Schollenlandes - wir erinnern nur an die oberrheinische Ebene, an die Rhône-Saône-Furche, an das californische Tal, an das syrische Ghôr - dagegen scheinen sie in Faltengebirgen selten $\mathrm{zu}$ sein; vielleicht ist das breite Kaschmirtal ihnen zuzuzählen. ${ }^{4}$ Häufiger sind große Talbecken, die, wie das Laibacher in den Südalpen, durch Kesseleinstürze entstanden sind. Ein intercollines Tal ist das der oberen Maritza und des Alt in Siebenbürgen, das auf der einen Seite von dem Steilrand der Karpathen, auf der anderen von dem später entstandenen, vulkanischen Hargitagebirge begrenzt wird, und wahrscheinlich auch das Kurund Riontal im Süden des Kaukasus.

Daß die Quertäler nicht, wie man früher annahm, Spalten sind, erkennt man daraus, daß die Schichten ohne sichtbare Störung von einer Talseite auf die andere hinüberstreichen, und manchmal kann man auch beobachten - wie Escher in der Taminaschlucht - , daß der Fels einen fugenlosen Talboden bildet. In manchen Fällen entsprechen sich aber in den obersten Partien der Gehänge die Schichten nicht völlig. Im EngpaB des Gultals (südlich von Trondhjem) streichen nach KJERULF die Schichten an der Ostseite in N $30^{\circ} \mathrm{O}$ und an der Westseite in $\mathrm{N} 40^{\circ} \mathrm{O}$ bis $\mathrm{N} 50^{\circ} \mathrm{O}$. Ob diese Anzeichen genügen, um daraus auf das Vorhandensein einer ur. sprünglichen Spalte zu schließen, ist noch fraglich; Heıм nimmt zur Erklärung ähnlicher Abnormitäten nachträgliche Schichtenbewegungen an, und zu einem gleichen Ergebnis gelangte LуDEKKER in bezug auf die Himalayatäler. Unzweifelhaft haben aber, wie wir später noch erörtern werden, auch in manchen Quertälern tektonische Bedingungen den Flüssen teilweise ihren Weg vorgezeichnet.

Im allgemeinen sind die Quertäler steiler und enger als die Längstäler, jedoch ändern sich mit den wechselnden Formationen, die sie durchschneiden, auch Gefälle und Physiognomie. Wo im Schweizer Jura ein Fluß eine Antiklinale mit harter Decke und weichen Kernschichten durchbricht, sind stets Ein- und Ausgang des Tales eng und der dazwischen liegende Teil elliptisch oder kreisförmig erweitert. Durchwandert man das Salzachtal in südlicher Richtung, so kommt man aus der engen, steilwandigen Schlucht zwischen den Kalkmassen des Tennen- und Hagengebirges in die Zone der Grauwackenschiefer, in der der Fluß eine breite Talsohle und die Verwitterung sanfte Gehänge geschaffen hat. Dagegen haben jene Täler, die man orographisch zu den Quer- und geologisch zu den Längstälern zählt, in der Regel den Charakter der letzteren. 
Eine solche Zwitterbildung ist das Etschtal südlich von Bozen, das zur Richtung der Ostalpen senkrecht steht, aber parallel mit den Schichten des sich an seiner Westseite erhebenden Kalkgebirges streicht.

Welche Talformen in einem Kettengebirge vorherrschen und wie sie sich verteilen, hängt zunächst von der Zahl der Abdachungen ab. Hat das Kettengebirge nur Querabdachungen, d. h. nur ein Gefälle senkrecht zum Streichen des Gebirges - wie der Himalaya -, so müssen sich alle Längstäler mit Quertälern verbinden, um ihren Flüssen einen Ausweg zu verschaffen. Bricht aber das Gebirge an den Enden ab, so treten zu den Querabdachungen auch solche in der Längsrichtung. So dachen sich die Ostalpen nicht bloB nach Nord und Süd, sondern auch nach Ost ab, und die Täler der Drau und Save können ihren longitudinalen Charakter durchaus beibehalten. Das Dinarische Gebirge der Balkanhalbinsel hat nur eine Quer- und zwei Längsabdachungen. Auch sonst herrscht große Mannigfaltigkeit in der Gliederung der Kettengebirge. Der T'sinling-Schan im Süden des Weiflusses, ein $140 \mathrm{~km}$ langer und etwa $3000 \mathrm{~m}$ hoher Gebirgszug, besitzt nach v. RichтноғEN's Schilderung trotz vollkommener geologischer Parallelstruktur kein einziges größeres Längstal, und wird nur durch enge und wilde Quertäler gegliedert. Die Pyrenäen haben an der Nordseite fast nur Quertäler, am Südabhang aber eine bedeutende Längs- und Quergliederung; in den Alpen halten sich beide Talformen so ziemlich das Gleichgewicht; im Tiënschan herrscht die Längsgliederung entschieden vor. Mit Ausnahme des tief in das Gebirge eingreifenden Sarydschaß, den erst Merzbacher entdeckt hat, empfängt der Tarim nur einige größere QuerHüsse von der kurzen südlichen Abdachung, während auf der Nordseite die drei großen Längstäler des Naryn, Tschu (mit östlicher Fortsetzung im Tekestal) und Ili nach Westen ziehen.

Die Quergliederung ist entweder fiederförmig mit gleichoder wechselständigen Tälern (vgl. Fig. 207, S. 646) oder strahlenförmig. In ihrer reinsten Form finden wir die strahlenförmige Gliederung in den Vulkanbergen, sonst aber auch in unregelmäBigen Schollen-, ja sogar in Kettengebirgen (s. Fig. 244).

Die Längsgliederung ist entweder parallel oder rostförmig. Die erstere ist an die Längsabdachungen der Kettengebirge gebunden (die Morawa-, Vardar- und Strumatäler der Balkanhalbinsel); vorherrschend ist aber die rostförmige Gliederung, bei der sich in verschiedenster Weise Längs- und Quertäler zu einem Furchennetz verbinden, das das Gebirge nach allen Richtungen 
aufschlieBt. Ein ausgezeichnetes Beispiel dieser nur in Kettengebirgen vorkommenden Gliederungsart bietet uns der Schweizer Jura (Fig. 245).

Wasserscheide. Den Abdachungen eines longitudinalen Gebirges

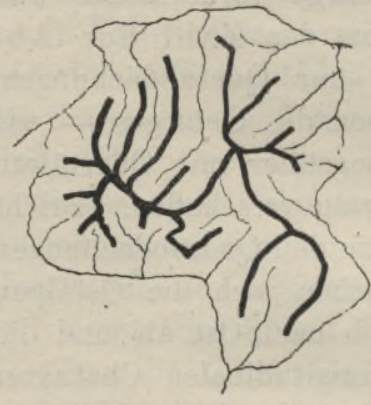

Fig. 244. Ötztaler Alpen (strahlenförmige Gliederung). entsprechen die Wasserscheiden. Sind nur Querabdachungen vorhanden, so gibt es auch nur eine einfache Hauptwasserscheide; sie teilt sich gabelförmig, wenn noch eine Längsabdachung hinzutritt. In den Alpen liegt der hydrographische Knotenpunkt in der Drei-Herren-Spitze, der Nordarm erweist sich aber als die gerade Fortsetzung der einfachen Hauptwasserscheide, die wir von da bis in die Appenninen hinein verfolgen können. Liegt die Hauptwasserscheide ganz oder nahezu in der Mitte des Gebirges, so verteilen sich die Täler symmetrisch auf beide Seiten, doch verläuft auch in diesem Fall die wasserscheidende Linie nur streckenweise ge-

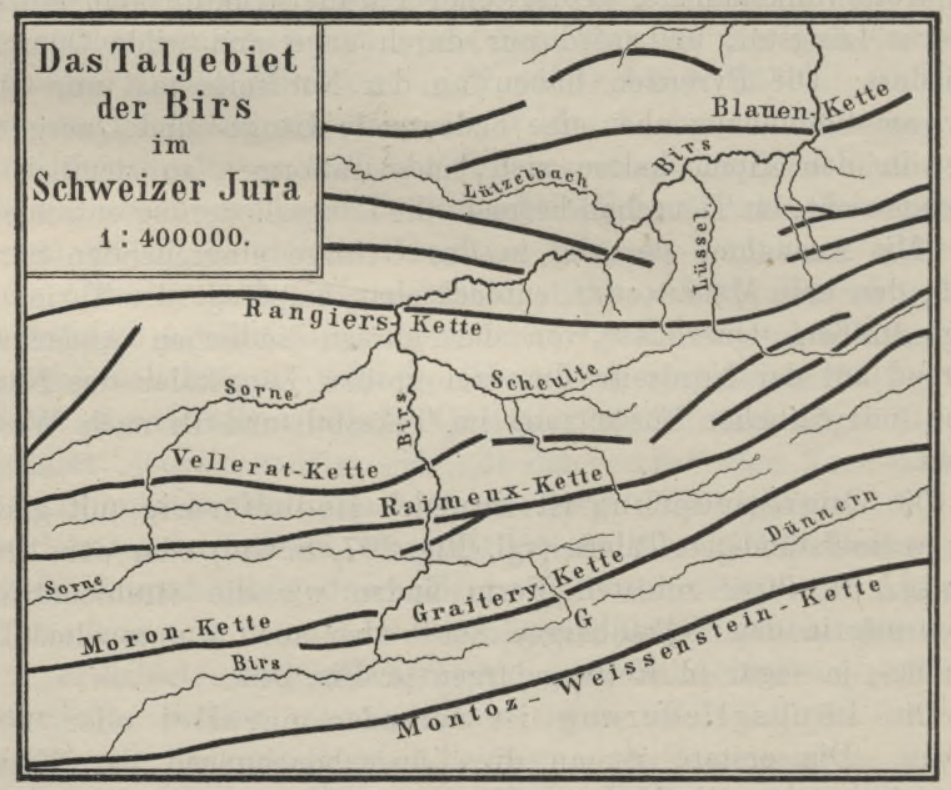

Fig. 245 .

rade. Die Asymmetrie der Talanordnung hängt, wie wir schon auf S. 542 betonten, in vielen Fällen mit der Regenverteilung zu- 
sammen, doch dürfen auch die Ausnahmen nicht übersehen werden. So ist in den Pyrenäen gerade die lange Abdachung (die Südseite) durch Trockenheit ausgezeichnet.

Betrachten wir die Hauptwasserscheide in ihrem Verhältnis zur Höhe, so können wir normale und anomale (durchgreifende nach v. RichтнотеN) Wasserteiler unterscheiden. Der normale ist an die höchste Kette gebunden, und es ändert daran nichts, wenn sich auch hier und da höhere Gipfel auf einem Nebenkamm erheben. Ist dieses aber die Regel, wie im Himalaya oder im Pamir, so hat die Hauptwasserscheide eine anomale Lage. Ja manches Gebirge wird sogar seiner ganzen Breite nach von einem Quertal durchbrochen; es hört dann, wenn auch nicht in seinem ganzen Verlauf, so doch wenigstens stellenweise auf, eine Wasserscheide zu bilden. Damit haben wir eines der schwierigsten Probleme der physischen Geographie, das der Durchbruchs- oder, wie v. Richthofen sie zu nennen vorzog, Durchgangstäler berührt.

Durchgangstäler. In den Kettengebirgen beobachten wir folgende drei Kategorien:

1. Das Quellgebiet des Durchgangsflusses liegt in der höchsten Kette (normale Wasserscheide), und niederere Ketten werden durchbrochen, wie dies in den Alpen der Fall ist (normale Durchgangstäler). Hier entsteht die Frage, warum der Fluß seinen Weg nicht durch die Längstäler zwischen den Ketten genommen hat.

2. Die durchbrochenen Ketten sind höher als das Quellgebiet. Dies ist das Problem der anomalen Wasserscheide (anomale Durchgangstäler).

3. Das ganze Gebirge wird durchbrochen; so z. B. der Balkan vom Isker, das Banatergebirge von der Donau, die Transsylvanischen Alpen vom Alt, das catalonische Gebirge vom Ebro, die Alleghanies vom Susquehanna usw. (Breschetäler).

Die Durchgangstäler sind aber keineswegs auf die Kettengebirge beschränkt, sondern eine ganz allgemeine Erscheinung. Weder Schollengebirge, noch vulkanische Bildungen, noch Landstufen sind davon frei, ja wir finden sie sogar im Tiefland, wo z. B. Oder und Weichsel die ganz ansehnliche Barriere der baltischen Seenplatte durchschneiden.

HrLBER $^{5}$ zählt nicht weniger als neun Theorien auf, die zur Erklärung dieses merkwürdigen $\mathrm{Phänomens} \mathrm{ersonnen} \mathrm{worden} \mathrm{sind.}$ Die einfachste Lösung bietet wohl die Spaltentheorie, die einer Zeit entstammt, in der man überhaupt in allen Tälern nur Spalten sah, die bei der Aufrichtung der Gebirge entstanden waren. Noch Peschel sah in der Tatsache, daß sich manchen Flüssen in un- 
mittelbarer Nähe ihrer schmalen, tiefen Durchbruchstäler viel bequemere Wege darbieten, einen Beweis für die Präexistenz von Talspalten. Der Green River verläßt dreimal flaches Land, um sich ebensoviele Durchgänge durch das Uintagebirge zu erzwingen; und sein Nebenfluß Yampa frißt sich dreimal in hartes Gestein ein, obwohl er es sich wenigstens zweimal durch ganz kurze Umwege hätte ersparen können. Auf gewisse Schwächelinien - nicht offene Spalten - wird auch jetzt noch häufig Gewicht gelegt. Die Durchbrüche des Inn in den Alpen und des Timok und Isker im Balkan erfolgten dort, wo die Faltungsintensität abflaute und eine Verschiebung der Falten eintrat. ${ }^{6}$ Für die zahlreichen Durchbrüche der Birs im Schweizer Jura (s. Fig. 245, S. 718) hat Jenny ${ }^{7}$ Spalten und Risse verantwortlich gemacht, die der Erosion vorarbeiteten, und in der Tat neigt sich in der Klamm der Rangierskette die Antiklinale an der Westseite nach S, an der Ostseite nach $\mathrm{N}$, dagegen wird in der Klamm von Moutier die ,auffallende Übereinstimmung der beiden Talseiten" konstatiert, und ebensowenig konnte im Durchbruch der Blauen-Kette eine Störung gefunden werden, wohl aber kommt hier im W eine Verwerfung vor, die für die Talentwickelung gänzlich belanglos blieb. Anderseits gibt es, wie Diener mit Recht hervorhebt, bedeutende Querstörungen, an die sich keine größeren Talentwickelungen knüpften. „Die Salzach durchschneidet das geologisch einheitliche Plateau des Hagen- und Tennengebirges, während (östlich davon) der Querstörung Strobl-Abtenau-Annaberg-St. Martin, einer der auffallendsten in den nördlichen Kalkalpen, kein Durchbruchstal folgt." Mögen also wohl auch hier und da Zerrüttungszonen die Richtung der Flüsse beeinflußt haben, so tragen doch die meisten Durchgangstäler so sehr den Charakter eines rein erosiven Ursprungs an sich, daß man zu anderen Erklärungen greifen mußte.

Positive Anhaltspunkte sind dort gegeben, wo sich hinter einem allseitig abschließenden Riegel Seeablagerungen finden, wie im Egertal sowohl oberhalb des Tonschieferrückens zwischen dem Kaiserwald und dem Erzgebirge, als auch oberhalb des Basaltstockes zwischen Karlsbad und Kaaden. Hier sind alte Seebecken durch spätere Erosion der trennenden Rücken zu einem Tal verbunden worden. Aber diese Seentheorie findet auf die großen Durchgangstäler keine Anwendung, am wenigsten auf jene schon genannten Fälle, wo ein hypothetischer See nach der heutigen Konfiguration des Bodens unzweifelhaft nach einer anderen Seite hätte überfließen müssen. Es ist nur zweierlei möglich: entweder ist der Fluß älter als die durchbrochene Erhebung oder jünger. Die letztere Annahme 
erscheint auf den ersten Blick als allein zulässig, und ihr trägt LöwL's Regressionstheorie Rechnung. Wie der Name verrät, beruht sie auf dem Gesetz der rückläufigen Erosion; sie läßt die Talbildung am niederschlagsreicheren Außenrand des Gebirges beginnen und allmählich bis $\mathrm{zu}$ der wasserscheidenden Kette, ja über sie hinaus bis an den entgegengesetzten Rand des Gebirges fortschreiten. Namentlich jene Vorkommnisse, wo ein Längstal mit mehr oder weniger scharfer Kniebeuge in ein Quertal übergeht, sollen dadurch erklärt werden; die Längstäler werden als die älteren Bildungen betrachtet, die von außen angezapft wurden.

Wenn man auch die Möglichkeit eines solchen Vorganges zugeben muß, so schwebt doch die Anwendung der Regressionstheorie in speziellen Fällen meist in der Luft. Diesen Übelstand teilt sie übrigens mit der Antecedenztheorie, die zuerst von indischen und amerikanischen Geologen ausgebildet wurde und in Deutschland besonders in TrEтze einen eifrigen Vorkämpfer fand. Sie geht von der Ansicht aus, daß das Gebirge nicht zuerst fertig dastand und dann erst die Erosion einsetże, sondern daß das Wasser gleichzeitig mit der Gebirgsfaltung seine talbildende Tätigkeit zu entfalten begann. Besonders energische Flüsse, die vom älteren Hinterland ausgingen, konnten das anliegende jüngere Gebirge während dessen allmählicher Erhebung durchschneiden, so daß Faltung und Durchsägung gleichen Schritt hielten. PENCK hat diesen Vorgang plausibel zu machen gesucht, indem er zwar zugestand, daß oberhalb der sich hebenden Schwelle der Fluß eine Stauung erfahre und dadurch zur Ablagerung seiner Geschiebe gezwungen werde, zugleich aber scharf betonte, daß am unteren Ende der Schwelle das Gefälle sich steigere und dadurch die Erosionskraft vermehre. Es komme nur darauf an, daß die obere Geschiebeanhäufung nicht über den niedrigsten Punkt in der Umrahmung des oberen FluBgebietes hinauswachse, denn dann würde der Fluß nach einer andern Richtung abgelenkt werden. Noch schärfer drückt - sich LöwL ${ }^{8}$ aus, der die Antecedenztheorie nur in dem Fall gelten läßt, daß der FluB schon früher ein Tal durchzog, das ihn auch während der Bodendeformation gefangen hält. Das sei aber nur möglich, wenn der Betrag der Schollenhebung oder der Faltung die ursprüngliche Taltiefe nicht übersteige. $\times$

Bisher kennen wir nur einen einzigen Fall, wo die Antecedenztheorie erwiesen ist: es sind die südlichen Vorketten des Himalaya, die sich aus den Ablagerungen derselben Flüsse aufbauen, von denen sie jetzt durchbrochen werden. Welche wichtigen Aufschlüsse sich

$\times$ Wir haben es versucht, die Hauptstadien der Durchbruchsbildung nach der modifizierten Antecedenztheorie in Fig. 246 graphisch vorzuführen. 
aus dem Studium der Sedimente ergeben, haben Förstel ${ }^{9}$ für den Berner Jura und FutTeReR ${ }^{10}$ für die Karnischen Alpen dargetan; und letzterer hat uns auch den Weg gezeigt, wie positive Anhaltspunkte für die Wahl zwischen der Regressions- und der Antecedenztheorie zu gewinnen seien. Es sei $W$ die wasserscheidende Kette, der sich später die Vorkette $V$ angeschlossen hat. Ein von $W$ kommender Fluß durchbricht $V$ und gelangt dadurch in die Ebene. Ging die Erosion von $V$ aus und erreichte durch Regression $W$, so müssen in der Ebene über den grobkörnigen Denudationsprodukten von $V$ die feineren (weil von weiterher stammenden) Denudationserzeugnisse von $W$ liegen. Ging aber die Erosion von $W$ aus und überwand die Emporfaltung von $V$, so müssen in der Ebene die feinen $W$-Gesteine von den gröberen $V$-Gesteinen bedeckt werden. Das letztere trifft in den Karnischen Alpen zu.

Verwandt mit der eben erörterten Theorie ist die epigene. tische insofern, als auch sie dem. Durchgangsfluß ein höheres Alter zuschreibt als dem heutigen Relief. Den einfachsten Fall, daß das durchbrochene Gebirge durch Denudation bloßgelegt wird, haben wir schon auf S. 544 durch Fig. 153 erläutert. Auf einen ähnlichen Vorgang läuft auch die Theorie von Jukes hinaus. Dieser machte im südlichen Irland die Wahrnehmung, daß am Knie der sich umbiegenden Längstäler ein von der Hauptwasserscheide kommender Nebenfluß einmündet, dessen Tal die obere Fortsetzung des Durchgangstales ist. Die Betrachtung der Karte lehrt uns, daß diese Anordnung außerordentlich häufig wiederkehrt. So empfängt z. B. die Rhône die Drance, der Rhein den Oberhalbsteinerbach, die Salzach den Groß-Arlbach (Fig. 250, S. 728), die Enns den Radmerund Erzbach, die Mur den Tragößbach, die Adda die Maira und den Liro, die Tiber den Anio, die Moldau den Hainbach usw. Man kann vom morphologischen Standpunkt aus das ganze Quertal als Hauptund das Längstal als Nebental betrachten, ohne sich um den Sprach-

I, Vorstadium vor der Faltung, $A B C D$ Talrand, $a b c d$ Talweg. II. Stadium der Deformation, Bildung einer Antiklinale $B^{\prime} C^{\prime} b^{\prime} c^{\prime}$, Geröllablagerung oberhalb der

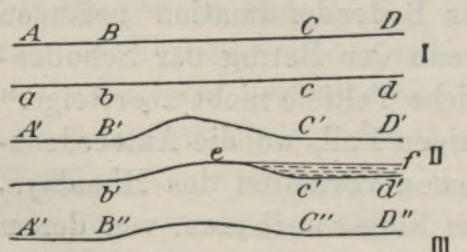

$\overline{a^{\prime \prime}} b^{\prime \prime} c^{\prime \prime} d^{\prime \prime}$

Fig. 246. Durchbruchsbildung.
Falte in $e^{\prime} d^{\prime} e f$; im unteren Faltensehenkel $b^{\prime} e$ verstärkte Erosion, die nach PENck's Annahme bei sehr langsamer Hebung dieser das Gleichgewicht halten kann, so daB keine Geröllablagerung mehr stattfindet, wenn auch die Hebung fortschreitet. III. Endstadium. Der Talrand $A^{\prime \prime} B^{\prime \prime} C^{\prime \prime} D^{\prime \prime}$ zeigt die Deformation, während der alte Talweg $a^{\prime \prime} b^{\prime \prime} e^{\prime \prime} d^{\prime \prime}$ (wenn auch natürlich nicht genau in der füheren Lage) wiederhergestellt ist. 
gebrauch zu kümmern, der überdies inkonsequent verfährt, indem er das Durchbruchstal bald mit dem Namen des Längsflusses (z. B. Salzach), bald mit dem des Querflusses (z. B. Eisack unterhalb Brixen) bezeichnet. Jukes verband mit dieser Auffassung auch eine genetische Vorstellung. Der von der Hauptwasserscheide kommende Querfluß begann bereits zu fließen, als die Längstäler noch ausgefüllt waren, und gab erst Veranlassung zur Drainierung der letzteren, eilte ihnen aber in seiner Erosionsarbeit immer voraus, so da $B$ er keine Ablenkung erfahren konnte. In dieser ursprünglichen Auffassung findet die epigenetische Theorie nur auf die normalen Durchgangstäler Anwendung; sie gewinnt aber eine viel umfassendere Bedeutung, wenn wir auch die Möglichkeit einer Verschiebung der Hauptwasserscheide ins Auge fassen. Für die Praxis ist damit allerdings nicht viel gewonnen, denn wohl nur in den seltensten Fällen wird die epigenetische Entstehung eines Durchgangstales direkt nachweisbar sein. Die Gefahr von Zirkelschlüssen - eine der Hauptklippen der geographischen Morphologie! - liegt besonders hier sehr nahe. Für die zahlreichen Durchgangstäler der Landstufen bietet sich uns wie schon aus unseren Erörterungen auf S. 636 erhellt - wenigstens vorläufig keine andere Erklärung als die Epigenesis, aber auch hier stößt sie auf Schwierigkeiten. Es erscheint zunächst einleuchtend, wenn Penck ${ }^{11}$ den Durchbruch der Donau durch die Schwäbische Alb darauf zurückführt, daß die Trias-, Jura- und Miozänschichten einst den Schwarzwald in Gewölbeform überdeckten, wodurch ein ununterbrochenes südöstliches Gefälle nach der oberdeutschen Hochebene entstand; aber dann wäre das Donautal nachmiozän, und die Veränderungen in der ungeheuer langen Periode von der Kreide bis zum jüngeren Tertiär sind dabei außer acht gelassen.

Ähnlich in ihrem Endergebnis, aber durchaus verschieden in ihrem Entwickelungsgang sind jene Fälle, wo nach Festlegung des Durchgangstales das Hinterland einsank. So erklärt man sich jetzt die merkwürdige völlige Zerschneidung des Rheinischen Schiefergebirges durch den Rhein, die Mosel und die Lahn; für die allmähliche Tieferlegung dieser Täler hat man unzweifelhafte Belege in den Wahrzeichen alter Flußläufe in höheren Niveaus. Auch die auffallenden Durchbrüche des Green und des Yampa River, von denen schon oben die Rede war, führt Emmons auf Einsenkungen zurück; dieselben horizontalen Tertiärschichten, die das Flachland bilden, finden sich auch auf der Höhe des Yampa Peak, und man darf daraus schließen, daß sie einst im gleichen Niveau gelegen haben. Es handelt sich hier also um Breschetäler, die von jeher am rätselhaftesten erschienen sind. Daß der Rhein das Schiefer- 
gebirge und die Donau das Banater Gebirge einst in breiten Tälern durchflossen haben, und daß ihre heutigen romantischen Durchbrüche noch eine Folge postumer Hebung der Gebirgsbarrieren sind, geht aus den Untersuchungen von ÖstreICH $^{12}$ und CviJić ${ }^{13}$ hervor. Völlig unaufgeklärt bleibt noch das Verhalten der Donau in ihrem oberen Lauf. So durchschneidet sie jetzt unterhalb der Marchmündung bei

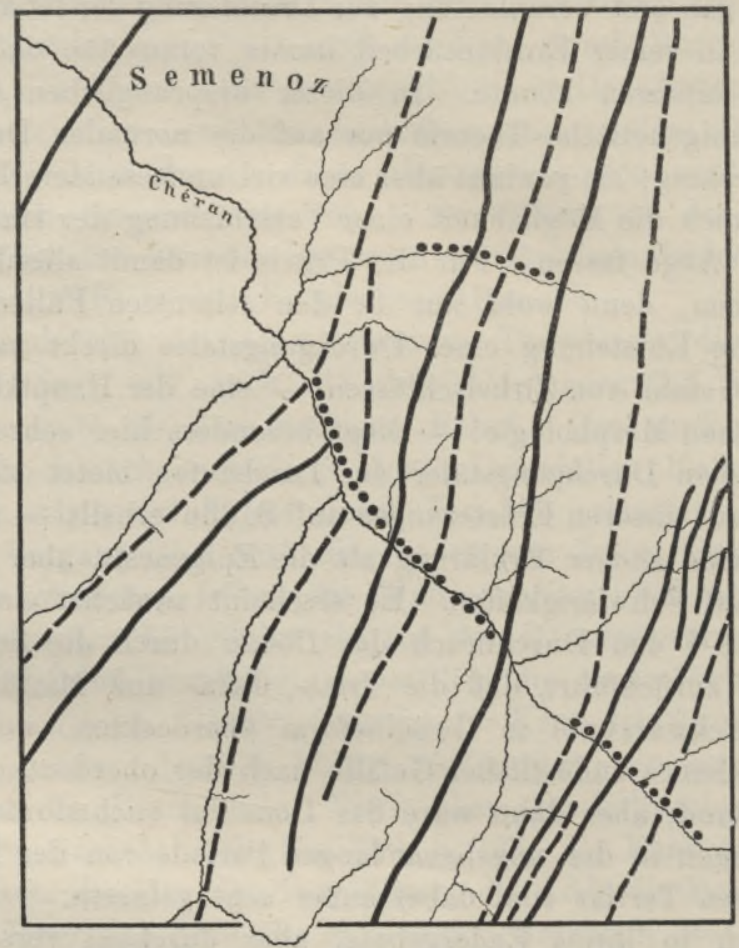

Fig. 247. Talsystem des Chéran in den savoyischen Kalkalpen nach LUGeon. ${ }^{13}$ Autiklinalen, - - - Synklinalen, ........ transversale Synklinalen.

Theben in $139 \mathrm{~m}$ Seehöhe den äußersten Zipfel der kleinen Karpathen, und südlich davon liegen zwei tote Breschen: die Hainburger $(169 \mathrm{~m}$ hoch) und Karnunter (183 $\mathrm{m}$ hoch), von denen jene vielleicht einmal von der March und diese sicher von der Donau benutzt wurde. Was die spätere Öffnung der Thebener Bresche veranlaßt hat, ist auch von HASSINGER $^{14}$. nicht befriedigend erklärt worden.

Die jüngste Theorie - wir können sie die tektonische nennen - stammt von Lugkon. ${ }^{16}$ Wir erläutern sie an dem Beispiel des Chéran (Fig. 247), der die aus Jura und Kreide bestehenden Falten der savoyischen Kalkalpen unter einem Winkel von ungefähr 
$50^{\circ}$ durchschneidet. Außer den Hauptfalten, die annähernd in meridionaler Richtung streichen und sich etwas nach W neigen, macht sich noch eine untergeordnete Querfaltung bemerkbar, so daß jede longitudinale Anti- und Synklinale sich hebt und senkt, und gerade die Senkungen (die transversalen Synklinalen) wurden von dem Chéran und einem nördlichen Querfluß seines Systems benutzt, deren Täler daher in die Kategorie der tektonischen gehören. Aber sowie der Chéran aus der transversalen Synklinale heraustritt, ändert sich sein Talcharakter, und in einer pittoresken Klamm durchbricht er die mächtige Antiklinale der Semenozkette an einer Stelle, wo ihm keine Quermulde den Weg gewiesen hat. Dasselbe ist der Fall im Quertal der Isère unterhalb Grenoble, ja die westlichste Antiklinale wird sogar an der Stelle durchschnitten, wo sie durch die Querfaltung eine Aufwölbung erfahren hat. Noch mehr: in den Chablaisalpen zeigt sich deutliche Querfaltung, aber weder die Arve noch die Giffre kümmern sich darum, und die Rhône lenkt erst unterhalb St. Maurice, aber auch da nicht ganz in eine transversale Synklinale ein. Ebenso haben die Reuß, die Linth und der Rhein solche Einsenkungen aufgesucht, aber nur in der äußersten Sedimentzone. Lugeon ist der Ansicht, daB nur jene Quermulden als Uranlagen der Durchbruchstäler in Betracht kämen, die älter als die Längsfaltung sind, während die jüngeren ohne Einfluß blieben. Bestätigt sich dies auch anderwärts, bestätigt sich vor allem auch diese neue Auffassung von dem Gang des Faltungsprozesses, so wäre damit eine Lösung der Frage der Durchbruchstäler, wenigstens der normalen und vielleicht auch der anormalen, angebahnt, denn darüber herrscht kein Zweifel, daß ein so allgemein verbreitetes Phänomen in Faltengebirgen nicht unter stets wechselnden Bedingungen zustande gekommen sein kann. Voraussetzung ist freilich, daß sich wenigstens die letzte, formgebende Faltung oberìdisch vollzogen hat.

Talwasserscheiden. Wie einerseits die höchsten Kämme ohne Einfluß auf die Verteilung der Gewässer sein können, so können anderseits unmerkliche Bodenanschwellungen in einer Talfurche die wichtigsten Wasserscheiden bilden. Wir nennen sie Talwasserscheiden im Gegensatz zu den Kammwasserscheiden. Auch sie sind eine weitverbreitete Erscheinung, die im Gebirge besonders auffällig hervortritt, aber auch dem Flachland nicht fehlt. In den großen Talzügen des ostdeutschen Tieflandes werden sie jetzt von Kanälen überschritten.

Kammwasserscheiden sind die Regel, aber manchmal werden sie den Talwasserscheiden ähnlich. So das Pfitscherjoch (2248 m) in den Zillertaler Alpen, das zwischen dem Hochpfeiler (3523 m) 
und der Hohen Wand (3284 m) eingesenkt ist und das Pfitschertal vom Zemmtal trennt. Im Reschenscheideck (Fig. 248) erniedrigt sich dagegen die Hauptwasserscheide der Alpen zu einer ganz flachen Bodenschwelle (1510 m ü. M.), von der der Stillebach nach Norden zum Inn und die Etsch nach Süden flieBt. Sie wird durch einen Felsriegel gebildet, während der Talboden zu beiden Seiten aufgeschüttet ist; denken wir uns diese Schuttmassen entfernt, so erhalten wir ein ähnliches Bild wie am Pfitscherjoch. Ein noch bekannteres Beispiel einer Talwasserscheide in der Querrichtung der Alpen ist der Brenner (1370 m ü. M.). In Norwegen fließt aus dem See Lesjeskogs (625 m hoch) nach Nordwesten die Rauma, nach Südost der Laagen; dies ist eines der großartigsten Doppeltäler der Erde, an beiden Seiten von mehr als 2000 m hohen Gebirgsmassen eingerahmt.

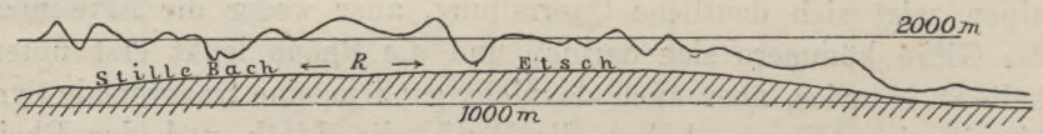

Fig. 248. Profil des Reschenscheideck nach PhIuIPrson.

$R=$ Reschenscheideck. Die obere Profillinie schneidet die östliche Talwand in $2 \mathrm{~km}$ Entfernung vom Fluß.

Häufiger sind die Talwasserscheiden in den Längstälern. Als eine der merkwürdigsten Bildungen dieser Art sei das $1500 \mathrm{~km}$ lange Tal im W des canadischen Felsengebirges erwähnt, das nicht weniger als sieben Flüsse benutzen: der Kootenay, der Columbia, der Canoe, der Fraser, der Parsnip, der Finlay und der Hachika River. Die mittlere Talhöhe ist ungefähr $700 \mathrm{~m}$, die höchste Wasserscheide liegt $950 \mathrm{~m}$ über dem Meer. Mit einer einzigen Ausnahme wird diese lange Furche von Gebirgszügen eingeschlossen, die sich $1000-2000 \mathrm{~m}$ darüber erheben. Auch die Alpen weisen viele, wenn auch bescheidenere Beispiele auf. Aus dem Drautal gelangt man ohne merkliche Steigung über das Toblacher Feld $(1209 \mathrm{~m})$ zur Rienz und damit in das Etschgebiet. Das Tal der Wurzener Save setzt sich bei Ratschach $(850 \mathrm{~m})$ flach und mit unverminderter Breite im Seebachtal fort, das zum Draugebiet gehört; und gehen wir in derselben Richtung nach West weiter, so überschreiten wir bei Saifnitz $(810 \mathrm{~m})$ die ebenso unmerkbare Wasserscheide zwischen der Drau und dem Tagliamento. Solche tiefe Furchen, die entweder durch zwei in entgegengesetzter Richtung fließende oder sogar durch mehrere Flüsse entwässert werden, scheiden die Alpen nicht nur in zwei, beziehungsweise drei Zonen, die den geologischen nahezu entsprechen, sondern lösen auch im Verein mit den Durchgangstälern die Zonen stellen- 
weise in mehrere, völlig individualisierte Gruppen und Bergstöcke auf. Solche sind z. B. die Ötztaler Gruppe in der kristallinischen Zone (s. Fig. 244, S. 718) und die zahlreichen größeren und kleineren Gruppen und Stöcke in der Kalkzone zwischen dem Inn und der Salzach (Fig. 249).

Ursprüngliche Talwasserscheiden darf man nur in Senkungstälern vermuten; eine solche ist sicher die nur $24 \mathrm{~m}$ hohe Wasserscheide im caledonischen Graben Nordschottlands und vielleicht auch die zwischen dem Orontes und der Lita $(1158 \mathrm{~m})$ im Libanon, auf der sich die Ruinen von Heliopolis erheben. Die übrigen Vorkommnisse sind wohl sekundäre Bildungen, wenn wir auch betreffs der Entstehungsweise meist nur auf Vermutungen angewiesen sind.

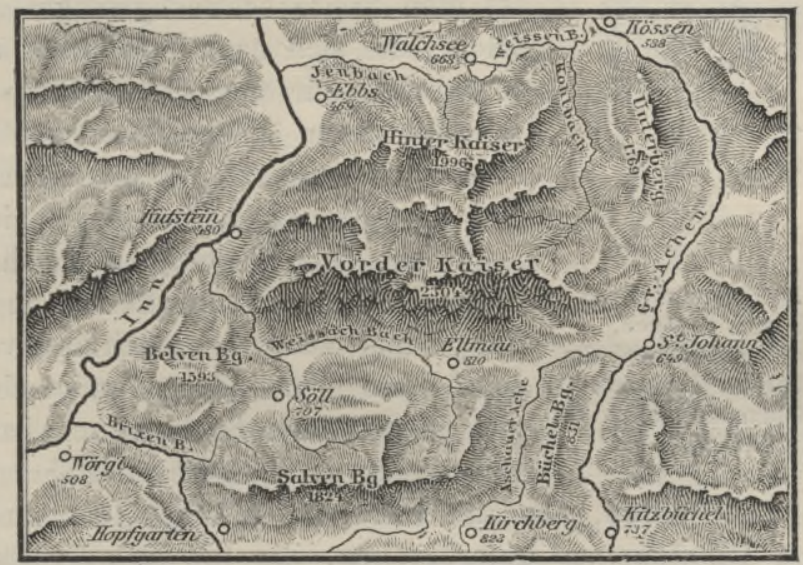

Fig. 249. Das Kaisergebirge im nordöstlichen Tirol.

Folgende Straßen führen über die Talwasserscheiden des Kaisergebirges vom GroßAchen- in das Inntal: 1. Kössen-Walchsee-Ebbs, 2. St. Johann-Elmau-SöllWörgl (das Weissachtal ist zu eng), 3. Kitzbühel-Kirchberg-Wörgl (Eisenbahn), - Höhen in Meter.

Wo sich von einer Talwasserscheide zwei Flüsse nach gerade entgegengesetzten Richtungen bewegen, mögen sie durch rück schreitende Erosion den trennenden. Rücken abgetragen haben, und daraus ließe sich ihr sehr häufiges Vorkommen in tektonischen Tälern, wo wir uns die Erosionsbedingungen als besonders günstig vorzustellen haben, erklären. Arbeitet ein Fluß rascher als der andere, so kann es vorkommen, daß jener diesem einen Teil seines Gebietes entzieht. Auf diese Weise muBte der Oberengadiner Inn, wie Herm und Geiger ${ }^{17}$ aus der Höhe der Talterrassen nachwiesen, sein Sammelgebiet an die rascher fließende Maira abtreten.

Eine andere Bewandtnis hat es jedenfalls mit jenen Talwasserscheiden, die sich zwischen zwei mehr oder weniger senkrecht auf- 
einander stehende Flußläufe einschieben. Sie lassen sich nur als verlassene Talstücke deuten. Bowman ${ }^{18}$ hat einen Fall aus dem südlichen Michigan (südlich von Detroit, westlich vom Eriesee) beschrieben, wo der Oakbach augenscheinlich durch eine nordwärts vordringende Serpentine des Huronflusses entzweigeschnitten und sein Oberlauf in den Huron abgelenkt wurde. Der Unterlauf hat seine Selbständigkeit bewahrt, und zwischen den beiden Oak liegt eine flache Wasserscheide. Derartige Vorgänge können sich nur im Flachland ereignen, ähnliche orographische Abnormitäten kommen aber

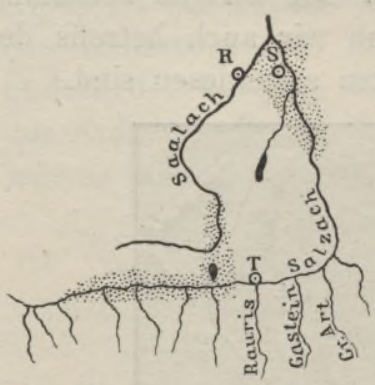

Fig. 250. Talsysteme der Salzach und Saalach.

( $S$ Salzburg, $R$ Reichenhall,

$T$ Taxenbach. Die punktierten Flächen sind alluviale Talflächen.) auch in Gebirgen vor. Eines der lehrreichsten Beispiele bietet das Salzachtal (Fig. 250). Der obere Teil des Längstales ist eine breite schwachgeneigte Alluvialfläche, die sich nach Nord über eine unmerkliche, nur um $15 \mathrm{~m}$ höhere Bodenschwelle zum Zeller See und in das Saalachtal fortsetzt. Kristallinisches Geröll im Glazialschotter bei Reichenhall zeigt an, daß die Saalach noch in der Eiszeit mit den Tauernflüssen in Verbindung stand; was die Salzach aber veranlaßt hat, diese Verbindung aufzugeben und sich in der tiefen Schlucht von Taxenbach einen Weg nach Osten zu bahnen, bleibt dunkel. Das Gebirge, das die Isère im W begleitet, wird sogar durch zwei Talöffnungen unterbrochen, die die savoyischen Eisenbahnen benutzen. Nach Lugeon ${ }^{15}$ wurde das Quertal von Annecy durch die Flüsse Arly und Doron und das Quertal von Chambéry durch die Flüsse Bréda und Gelon zu einer Zeit geschaffen, als das große Längstal der Isère noch nicht bestand. Unser Gewährsmann meint, daß dank der geringen Widerstandsfähigkeit der Liasgesteine, in deren Zone das Isèretal liegt, die Erosion hier so rasche Fortschritte machen konnte, daß die oben genannten Quelltäler des Arly usw. von ihren westlichen Fortsetzungen abgeschnitten wurden. Über die Wasserscheide von Sargans floß einst der Rhein zum Walen- und Züricher See ab. Der einstige Zusammenhang der Wutach mit der Aitrach und des Faulenbaches mit der Prim ist durch Geröllablagerungen erwiesen, wahrscheinlich haben die Senkungsvorgänge im Rheingebiet diese alten Flußläufe zerrissen und Wutach und Prim aus der Gefolgschaft der Donau in die des Rheins hinübergezogen. ${ }^{11}$ Nur die Talwasserscheiden von Blumberg und Spaichingen sind noch als Zeugen ehemaliger Abdachungsverhältnisse zurück- 
geblieben. Viele kleinere Durchbrüche stehen sicherlich mit Talwasserscheiden in ursächlicher Beziehung. Wir verweisen nur auf das Kärtchen in Fig. 249 (S. 727). Was konnte ein so unansehn. liches Gerinne, wie die Weißach, veranlaßt haben, zwischen den Stöcken des Bölvenberges und Vorderkaisers zum Inn durchzubrechen, während sie sich ohne erhebliche Schwierigkeiten über die Elmauer Schwelle hätte nach Ost wenden können? Denken wir uns aber den Osten durch längere Zeit mit Gletschermassen verstopft, so wird uns diese mit den heutigen orographischen Verhältnissen unvereinbare Talanordnung verständlich. Wahrscheinlich hat die Eiszeit in den von ihr betroffenen Gebirgen zahlreiche Stromverlegungen bewirkt, einerseits durch Gletscher, anderseits durch mächtige Geröllanhäufungen, und die überwiegende Mehrzahl der Talwasserscheiden dürfte auf derartige Vorgänge zurückzuführen sein.

Aufschließung der Gebirge. Am aufgeschlossensten von den großen Gebirgen der Erde sind diejenigen, die einen rostförmigen Bau besitzen, am geschlossensten die mit einfacher Quergliederung. Für den Verkehr über das Gebirge von Ebene zu Ebene sind anscheinend die Breschetäler am günstigsten, in Wirklichkeit sind sie aber wegen ihres schluchtartigen Charakters häufig ohne Bedeutung. So blieb der Balkan trotz des Iskerdurchbruchs eine Völker- und Staatenscheide, und bis zur Herstellung des Kuntersweges im 14. Jahrhundert zog man es vor, die schauerlichen Engen des Eisacktales auf den westlichen Berghöhen oder über den Jaufenpaß zu umgehen. Vorherrschende Parallelgliederung ist ungünstig, weil mehrmals Kämme zu übersteigen sind; so muß die Rudolfsbahn in den Ostalpen dreimal Wasserscheiden übersetzen und ist natürlich zu Umwegen gezwungen, um bequemere Anstiege aufzusuchen. Viel bessere Bedingungen bietet die rostförmige Gliederung, wenn die Hauptwasserscheide ein Längstal kreuzt. Die Talwasserscheide wird dadurch zum Wechselpaß. Ein solcher ist der bei Gänsbrunnen ( $G$ in Fig. 245, S. 718) im Schweizer Jura, der das Dünnern(Aare)-Gebiet mit dem der Birs verbindet; man ersieht aber auch aus unserem Kärtchen, daß solche Verkehrsstraßen weite Umẃege zu machen gezwungen -sind. Am vorteilhaftesten ist es jedenfalls, wenn von beiden Seiten des Gebirges korrespondierende Durchgangstäler geradlinig und mit nicht zu starkem Gefälle bis zur Hauptwasserscheide hinaufführen; darauf beruht z. B. die Bedeutung der St.-Gotthard-Straße. Die Brennerlinie steht dagegen zurück, weil man hier erst das Längstal des Inn zu passieren hat, um in die bayerische Ebene zu gelangen; daher schlug man im Mittelalter, um Westdeutschland rascher zu erreichen, von Innsbruck aus lieber den Weg über den 
Seefelder oder den Fernpaß ein. Günstig ist auch eine anomale Lage der Hauptwasserscheide, am unzuträglichsten aber eine Gliederung, wo man zur Hauptwasserscheide durch kurze, steile Täler ansteigen muß, wie im Gebiet der Hohen Tauern. Solche Verhältnisse sind in Gebirgen aller Art sehr häufig, und wo sie die Regel bilden, ist das Gebirge in Wahrheit eine trennende Schranke, die erst die Technik unseres Zeitalters zu überwinden gelernt hat.

Unter allen Umständen sucht der Verkehr die niedrigsten Punkte der wasserscheidenden Kämme und Rücken auf, und auf diese will v. Richthofen die Bezeichnung Pässe beschränkt wissen. Indem wir seine Terminologie anwenden, unterscheiden wir Wallpässe, die über breite Scheitelflächen führen - wie z. B. im skandinavischen Gebirge -, und Kammpässe in Kammgebirgen, und teilen letztere wieder ein in Sattel-, Scharten- und Lückenpässe, je nachdem der Kammeinschnitt gerundet, schneidig oder scharf kerbenartig ist. SöLCH ${ }^{19}$ hat eine genetische Einteilung der Paßübergänge (im Gegensatz zu den Paßdurchgängen in Engtälern) durchgeführt und führt als Hauptkategorien die durch tektonische Verhältnisse bedingten und selten vorkommenden konstruktiven, die fluviatilen und die glazialen Destruktionspässe an. $\mathrm{Ob}$ man die letztgenannten in dieser Ausdehnung, wie SöLCH will, anerkennt, hängt davon ab, wie man über Gletschererosion denkt.

Literaturnachweise. ${ }^{1}$ M. Luaron, Sur la fréquence des gorges épigénétiques dans les Alpes, im Bulletin des laboratoires de géologie etc. de l'Université de Lausanne, Nr. 2, 1901. - ${ }^{2}$ D. Martis, in La Géographie 1906, Bd. XIV, S. $1 .-{ }^{3}$ L. Duparc et F. Pearce, Sur l'existence des hautes terraces dans l'Oural du Nord, in den Comptes rendus de l'Académie des seiences 1905. - ${ }^{4} \mathrm{~K}$. Östreich zit. S. 702. $-{ }^{5}$ V. Hilber, Die Bildung der Durehgangstäler, in Petermans's Mitteilungen 1889 (mit ausführlichen Literaturangaben). ${ }^{6}$ J. Cvısı́, Die Tektonik der Balkanhalbinsel, in den Comptes rendus du IX. Congrés géologique international 1903. - ${ }^{7} \mathrm{~F}_{\mathbf{R}}$. Jenny, Das Birstal; Basel 1897. - ${ }^{8}$ F. LöwL, in den Verhandlungen der Wiener Geologisehen Reichsanstalt 1894, S. $472 .-{ }^{9}$ A. F. Förstle, The Drainage of the Bernese Jura, in den Proceedings of the Boston Society of Natural History, 1892. - ${ }^{10} \mathrm{~K}$. FuTTERER, Durehbruchstäler in den Südalpen, in der Zeitsehrift der Berliner Gesellschaft für Erdkunde 1895. - ${ }^{11}$ A. PExck, Talgesehichte der obersten Donan, in den Schriften des Vereins für Geschichte des Bodensees, 1899, Bd. XXVIII. $-{ }^{12} \mathrm{~K}$. Östreich, Studien über die Oberflächengestalt des Rheinischen Sehiefergebirges, in Petermann's Mitteilungen 1908 und 1909. - ${ }^{13} \mathrm{~J}$. CvijJé, Entwicklungsgesehichte des Eisernen Tores (160. Ergänzungsheft zu Petermans's Mitteilungen) Gotha 1908. $-{ }^{14}$ H. Hassinger, zit. S. $644 .-{ }^{15}$ M. Lugeon, Recherches sur l'origine des vallées des Alpes occidentales, in den Annales de géographie, 1901, Bd. X. - ${ }^{16}$ M. Lugeon, Les dislocations des Bauges; Bulletin des services de la carte géologique de la France, Nr. 77, 1900. — ${ }^{17}$ E. Geraer, Das Bergell, im Jahresbericht der Naturforschenden Gesellschaft von Graubünden, 1902, Bd. XLV. - ${ }^{18}$ J. Bowman im Journal of Geology 1904, Bd. XII, 
S. 326. - ${ }^{19}$ J. SöLcH, Studien über Gebirgspässe mit besonderer Berücksichtigung der Ostalpen'(Forschungen zur deutschen Landes- und Volkskunde), Stuttgart 1908.

\section{Die Flüsse.}

Einteilung. Man kann die Flüsse nach verschiedenen Gesichtspunkten einteilen. Geläufig ist die Unterscheidung von Hauptund Nebenflüssen, auf die wir später noch zurückkommen werden. Die Hauptflüsse sind entweder marin oder kontinental, je nachdem sie das Meer erreichen oder nicht. In bezug auf das Verhältnis der FluBrichtung zur Richtung der Wasserscheide kann man von Quer- und Längsflüssen sprechen. Beispiele von Querflüssen, die mehr oder weniger senkrecht zur Wasserscheide stehen, sind die sibirischen Ströme oder die Flüsse von Norddeutschland; zur zweiten Kategorie gehören z. B. Donau, Po und Ganges, die nahezu parallel mit der Wasserscheide fließen.

Wichtiger ist die Einteilung der Flüsse nach der Art ihres Baues. Wir haben auf S. 511 von Ober-, Mittel- und Unterlauf gesprochen und können diejenigen Flüsse als normale bezeichnen, bei denen diese Abteilungen deutlich und nur je einmal entwickelt sind. Solche Flüsse sind aber verhältnismäBig selten, und für die Praxis eignet sich besser jené Einteilung, die HAAsE vorgeschlagen hat. ${ }^{1}$ Er unterscheidet nur Berg- und Flachlauf; jener ist durch hohe Ufer ausgezeichnet und kommt daher auch im zerschnittenen Flachland vor (z. B. Colorado); anderseits kann man auch da von Flachlauf sprechen, wo nur auf einer Seite das Gelände höher ansteigt, wie auf derDonaustrecke zwischen Bulgarien und der Walachei.

Danach zerfallen die Flüsse nur in zwei Hauptgruppen: gleichartige und ungleichartige, und jede Hauptgruppe wieder in . zwei-Untergruppen. Denn gleichartig sind sowohl jene Flüsse, die nur Flachlauf besitzen, wie die meisten der Niederungen, als auch solche ausschlieBlich mit Berglauf. $\mathrm{Zu}$ diesen gehören nicht bloB zahlreiche Nebenflüsse, sondern auch manche, wenn auch nur kurze Hauptflüsse, nämlich alle diejenigen Bäche, die sich direkt in das Meer stürzen, und deren Schuttkegel die Wasseroberfläche noch nicht erreicht hat. Ungleichartige Flüsse haben Berg- und Flachlauf, und es sind hier zwei Fälle möglich, die auch in der Natur reichlich vertreten sind: Doppellauf und Wechsellauf. Bei jenem folgt auf den Berg- der Flachlauf - solche Flüsse haben wir oben als normale bezeichnet —, bei diesem wiederholen sich Berg- und Flachlauf mehrmals, wie beim Rhein oder bei der Donau, vor allem aber bei den afrikanischen Strömen, die sich durch Wasserfälle in ihrem Unterlauf auszeichnen. Wechsellauf deutet stets darauf hin, 
daß der betreffende Fluß sich aus mehreren, ursprünglich selbständigen Gewässern zusammensetzt und eine komplizierte Entwickelung durchgemacht hat.

Verteilung der Flüsse. Unter den zahlreichen wasserscheidenden Linien, die das Land netzartig überspannen, ist eine, die mit alleiniger Unterbrechung in der Beringstraße das gesamte Festland mit Ausnahme des abseits liegenden Australien in zwei Abdachungen teilt: eine atlantische und eine pazifisch-indische. v. TrLLo ${ }^{2}$ nannte sie die Hauptwasserscheide der Erde $(A B C$

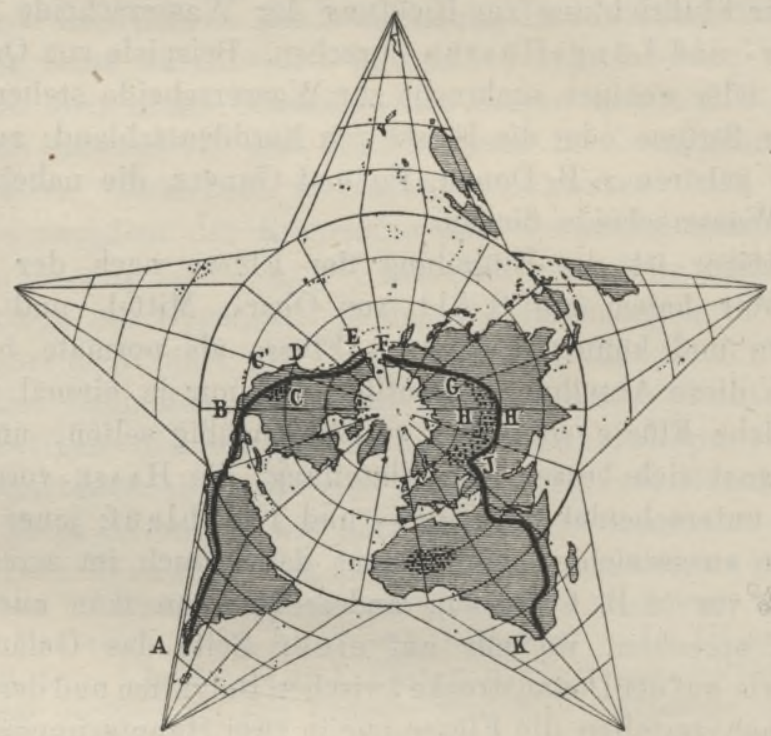

Fig. 251. Die Hauptwasserscheide der Erde nach v. Tilıo.

$D E F G H I K$ in Fig. 251). Innerhalb der beiden Abdachungen liegen aber auch abfluBlose Gebiete, die auf 23 Prozent der Festlandsoberfläche geschätzt werden. Weitaus das größte ist das asiatischeuropäische Zentralgebiet, das mit seinen 10 Mill. qkm Europa an Ausdehnung übertrifft. Afrika hat zwei solche Hauptgebiete: in der Sahara und in der Kalahari, Australien ist mehr als zur Hälfte abflußlos, dagegen ist Amerika arm an solchen trockenen Binnenlandschaften, und darin liegt einer der gewichtigsten Vorzüge der Neuen Welt vor der Alten. $\times$ Aber auch zwischen die marinen Flüsse schieben sich auf sehr durchlässigem Boden kleine Flächen ohne AbfluB ein; hat uns doch KeшHAck ein solches Vorkommen auch auf

$\times$ Abflußlos sind von Australien 53,9, vou Asien 30,6, von Afrika 30,5, von Europa 20,4, von Nordamerika 5,0, von Südamerika 1,7 Proz. des betreffenden Festlandes. 
der baltischen Seenplatte kennen gelehrt. ${ }^{3}$ Auch im Sand des Elbtales versiegen manche Bäche aus dem Lausitzer Gebirge.

Betrachten wir jeden Erdteil für sich, so gewahren wir, daB auch in der Verteilung des fließenden Wassers jeder seine individuellen Eigentümlichkeiten besitzt. Jeden Erdteil durchziehen eine oder mehrere Hauptwasserscheiden, die zum Teil mit der Hauptwasserscheide der Erde zusammenfallen, zum Teil sich von ihr abzweigen. Europa besitzt nur eine einzige Hauptwasserscheide, die am Ural unter $61^{2} /{ }_{3}{ }^{0} \mathrm{~N}$ beginnt, den Festlandsrumpf in südwestlicher und die iberische Halbinsel in südlicher Richtung durchzieht und hier unter $36^{\circ} \mathrm{N}$ endet. Die nordwestliche Abdachung ist die ozeanische, die südöstliche die mediterran-kaspische. In Asien finden wir, entsprechend der östlichen Rutenteilung des Hochlandgürtels, zwei senkrecht aufeinander stehende Hauptwasserscheiden: die äquatoriale, die die großen abflußlosen Gebiete umschließt, scheidet den indischen und den arktischen Bezirk, die meridionale grenzt die pazifischen Systeme gegen Westen ab. Afrika hat zwei primäre Wasserscheiden, von denen die eine meridional zwischen dem Indischen und dem Atlantischen Ozean nach Süden zieht, während die andere sich unter etwa $4^{\circ} \mathrm{S}$ abzweigt und, wie die Verteilung der Wadis erkennen läßt, sich über das Zentralgebirge der Sahara nach Nordwesten wendet, um die mediterrane von der atlantischen Abdachung zu trennen. In Amerika bildet das westliche Hochland die Scheide zwischen den atlantisch-arktischen und den pazifischen Strömen, doch wird diese anscheinend einfache Anordnung durch das Auftreten großer Längsströme (Mackenzie, Mississippi, Paraguay-Paraná) etwas komplizierter, namentlich in Nordamerika, wo ein Querfluß (Saskatchewan) sich zwischen die beiden großen Längsströme einschiebt. Ebenso einseitig, wie in Amerika, ist die Flußverteilung in Australien, wo die Hauptwasserscheide sich an das östliche Bergland knüpft; aber das abflußlose Gebiet ist zentral wie in Asien, nicht exzentrisch wie in Amerika.

Aus der umstehenden Tabelle (nach Strelbitsky und Bludad ${ }^{4}$ ) ersieht man die Ausdehnung der Abdachungsgebiete des Festlandes (in Millionen Quadratkilometer). Das Übergewicht der atlantischen Abdachung tritt mit großer Schärfe hervor; rechnet man noch die Inseln dazu, so erhalten wir für das atlantische Gebiet 53, für das pazifisch-indische 25, für die abflußlosen Binnengebiete 22 Proz. Die entsprechenden mittleren Regenhöhen sind nach Fritzsche ${ }^{5}$ 870,1090 und $330 \mathrm{~mm}$. Nur die abflußlosen Gebiete sind also klimatisch bedingt, die gewaltige Ausdehnung des atlantischen Flußgebietes ist aber ein tektonisches Phänomen. 


\begin{tabular}{|c|c|c|c|c|c|c|c|}
\hline & 范 & $\frac{5}{4}$ & $\frac{\pi}{4}$ & 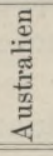 & 它苛 & 突营 & 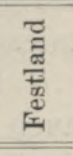 \\
\hline Atlantischer Ozean . . . & 2,6 & - & 10,5 & - & 2,6 & 15,7 & 31,4 \\
\hline Eismeer (und Hudsonbai). & 1,3 & 11,3 & - & - & 6,3 & - & 18,9 \\
\hline Mittelländisches Meer . . & 3,5 & 0,7 & 4,4 & - & - & - & 8,6 \\
\hline Amerikanisches Mittelmeer & - & - & - & - & 5,5 & 0,6 & 6,1 \\
\hline Atlantisches Gebiet. . . & 7,4 & 12,0 & 14,9 & - & 14,4 & 16,3 & 65,0 \\
\hline Großer Ozean . . . . . & - & 9,4 & - & 0,6 & 4,5 & 1,0 & 15,5 \\
\hline Indischer Ozean . . . . & - & 7,4 & 5,4 & 2,9 & - & - & 15,7 \\
\hline Pazifisch-indisches Gebiet & - & 16,8 & 5,4 & 3,5 & 4,5 & 1,0 & 31,2 \\
\hline Marine FluBgebiete. . . & 7,4 & 28,8 & 20,3 & 3,5 & 18,9 & 17,3 & 96,2 \\
\hline Kontinentale Flußgebiete. & 1,9 & 12,7 & 8,9 & 4,1 & 1,0 & 0,3 & 28,9 \\
\hline Festland. . . . . . . & 9,3 & 41,5 & 29,2 & 7,6 & 19.9 & 17,6 & 125,1 \\
\hline
\end{tabular}

Genaue Untersuchungen über die Dichte des FluBnetzes sind bisher nur für wenige Gegenden Europas ausgeführt worden. ${ }^{6}$ Thre Ausdehnung auf alle Länderräume mit zuverlässigen Karten in großem Maßstab ist im höchsten Grad wünschenswert, denn Flußdichte ist zugleich auch Taldichte und daher ein ziffermäBiger Ausdruck für den Grad der Zerschnittenheit des Geländes. Über die Berechnungsmethoden gehen die Ansichten noch auseinander, wir halten uns hier an die einfachste und praktischeste von L. NeuMans, ${ }^{7}$ der diesem Gegenstand zuerst eine größere Aufmerksamkeit gewidmet hat und unter Flußdichte die mittlere Flußlänge (in $\mathrm{km}$ ) auf $1 \mathrm{qkm}$ versteht. Die bisherigen Ergebnisse sind folgende:

\section{Niederschlag $\mathrm{mm}$}

Flachland

Pommersche Seenplatte

Nordschleswig

Mittelgebirge

Eifel

Münstersches Becken

Glatzer Gebirge

Elbsandsteingebirge $u$. a.

Schwarzwald

Hoehgebirge

Berner Oberland

Mittelmeer

Attika

\section{Flußdichte}

Mittlere Jahres-

summe

595

730

615

780

765

820

1180

1200

350
Mittleres Absolutes

Tages- Tages-

Maximum Maximum

$33 \quad 80$

$\begin{array}{ll}34 & 88\end{array}$

31

35

43

45

56

55

133

$\times$ Die meisten Flüsse fließen nur im Winter; die Rinnsale, die nur bei heftigen Niederschlägen Wasser führen, blieben unberücksichtigt. 
Im großen und ganzen wächst hier die Flußdichte mit der Regenmenge, aber rascher als diese. Weniger kommt die mittlere Niederschlagshöhe als die Tagesmaxima, besonders die extremen, in Betracht, und in zweiter Linie die Bodenbeschaffenheit. In Gebieten mit gleichartigen Niederschlägen wird dieser zweiter Faktor ausschlaggebend. Im Elbsandsteingebirge beträgt die Flußdichte 0,99 km auf das Quadratkilometer, im Lausitzer Granitgebirge aber 1,43; sie ist also um so größer, je weniger durchlässig das Gestein ist. Auch andere Momente spielen noch mit, und es bedarf ausgedehnterer Untersuchungen, um uns einen tieferen Einblick in die wie es scheint, ziemlich verwickelten Kausalverhältnisse zu eröffnen.

Flußvermischung und Wasserteilung. ${ }^{8} \mathrm{Im}$ allgemeinen spielen die Hochgebirge bei der Verteilung der Flüsse nur eine untergeordnete Rolle. Der Himalaya steht ganz und die Alpen stehen zum größten Teil außerhalb der Hauptwasserscheide, und selbst in den Andes verläuft sie nicht immer auf dem höchsten Kamm. Ein großer Teil der primären Wasserscheiden liegt in der Ebene, und in manchen Gegenden (z. B. in Rußland) werden sie durch so sanfte Bodenanschwellungen gebildet, daß sie ohne besondere Schwierigkeiten von Verbindungskanälen überschritten werden können. Ja stellenweise werden zur Zeit des Hochwassers solehe Kanäle auf. natürlichem Weg hergestellt, oder Teile verschiedener FluBsysteme treten bei völligem Fehlen der Wasserscheide sogar in dauernde Verbindung. Man nennt diesen Vorgang Gabelung oder Bifurkation; doch versteht man unter diesem. Namen auch eine wesentlich andere Gruppe von Erscheinungen, nämlich die Teilung eines Flusses in zwei oder mehrere Arme, die Inseln einschließen oder sich nicht wieder vereinigen, wie in den Deltas. Diese schwankende Terminologie gibt zu manchen Mißverständnissen Veranlassung, und wir tun daher am besten, wenn wir neue Ausdrücke einführen. Treten zwei Flußsysteme während ihres Laufes miteinander in Verbindung, so nennen wir dies eine Flußvermischung; wird diese Verbindung aber an den Quellen hergestellt, indem Seen oder Sümpfe nach ver. schiedenen Seiten entwässert werden, so nennen wir dies mit BERGнаUs eine Wasserteilung. Das bekannteste Beispiel von Flußvermischung bietet der Orinoco, der einen Arm (Cassiquiare) zum RioNegro, einem Nebenfluß des Amazonas, entsendet. Im kleinen wiederholt sich dieses Phänomen nördlich vom Teutoburger Wald, wo sich die Else, ein Arm der Haase (Emsgebiet), östlich zur Werre wendet; doch ist es fraglich, ob dieser Zustand nicht künstlich hergestellt wurde. Häufiger ist die Wasserteilung; im Staat Maine 
ist sie nach RatzeL eine gewöhnliche Erscheinung. Bei Hochwasser verbindet sich das Mississippisystem in der Seenregion von Minnesota mit dem Red River und dem Oberen See, und der Petit Lake stellt einen Wasserweg zwischen dem Michigansee und dem Illinois her. In Zentralsudan spielt eine solche Mittlerrolle zur Regenzeit der Tuburisumpf zwischen dem Benuë-Niger und dem Logone-Schari. Die Rokitnosümpfe haben Abfluß sowohl zur Weichsel wie zum Dnjepr, und die masurischen Seen im Regierungsbezirk Gumbinnen werden zugleich nach Nord in den Pregel und nach Süd in die Weichsel entwässert. Selbst Gebirgen ist dieses Phänomen nicht fremd, aber natürlich nur an Talwasserscheiden gebunden. Den Lesjeskogs-See haben wir schon auf S. 726 erwähnt. Der kleine See Les Dous in den Pyrenäen hat seinen Namen von den beiden Abflüssen, von denen sich der eine zur Tet, der andere zum Segre (Ebro) wendet. Eine periodische Flußvermischung findet auf dem Two Ocean-PaB im Felsengebirge $(2463 \mathrm{~m})$ statt, indem vom Two Ocean Creek, der dem Mississippisystem angehört, bei vollem Wasserstand schwache Arme zum Pacifik Creek (Columbiagebiet) ausgehen. In Kalkgebirgen kommen auch unterirdische Flußvermischungen vor; zwei solche Fälle in Frankreich wurden von REcLus beschrieben, ein dritter ist die von KNoP nachgewiesene Verbindung zwischen dem Rhein und der Donau, von der ein Arm unterirdisch zur Aachquelle abflieBt.

Bau der Flußsysteme. Ein Gebiet mit gemeinsamem AbfluB zum Meer oder zu einem abflußlosen See bildet ein Flußgebiet, und jedem Flußgebiet entspricht ein Flußsystem, das aus einem HauptfluB, dessen Nebenflüssen, deren Zuflüssen usw. besteht. Welche von den vielen Abflußlinien als Hauptfluß zu betrachten sei, entscheidet zunächst allerdings der Sprachgebrauch; da aber dieser nicht auf wissenschaftlichen Grundsätzen beruht, so darf man die üblichen Flußnamen wohl als Verständigungsmittel benutzen, ohne in jedem einzelnen Fall der Kritik überhoben zu sein. Bei einfach gebauten Systemen hat der Sprachgebrauch in der Regel das Richtige getroffen, wie z. B. im Pogebiet, obgleich man auch hier die Frage aufwerfen kann, ob sich oberhalb Turin der Hauptfluß im Po oder in der Dora Riparia fortsetze, denn die Quelle der letzteren ist am weitesten von der Pomündung entfernt, und der Verlauf des Ripariatales liegt in der Richtung des Hauptflusses. Wenn man aber die ganze Konfiguration der oberitalienischen Ebene in Betracht zieht, so wird man dem Sprachgebrauch Recht geben müssen, denn auch die Ebene vollzieht von Turin ab eine Wendung nach S. Nach Länge und Wasserreichtum hat unzweifelhaft der Missouri Anspruch darauf, 
dem Mississippisystem den Namen zu geben, $\times$ aber der Mississippi kann zu seinen Gunsten anführen, daß er die tiefste Rinne des ganzen Systems einnimmt. Dagegen ist im Elbsystem unzweifelhaft die Moldau und im Rhônesystem die Saône der Hauptfluß. Wenn wir aber nach demselben Gesichtspunkt den Hoangho für eine Fortsetzung des Weiho erklären wollten, so würden wir mit Recht auf Widerspruch stoßen, denn der Weiho kann weder nach Länge noch nach Wasserreichtum den Vergleich mit dem Berglauf des Hoangho aushalten. Insofern hat also Wisotzki ${ }^{9}$ recht, wenn er den Satz aufstellt, daß kein einzelnes Moment, wie Länge, Wassermenge, Breite, Tiefe, Farbe, Richtung $u$. dergl. ausreiche, um in jedem einzelnen Fall mit Bestimmtheit Haupt- und Nebenfluß zu unterscheiden, sondern daß man.das ganze Stromsystem in allen seinen Beziehungen betrachten müsse; nur ist damit keine exakte Regel gegeben, und der Natur der Sache nach kann eine solche auch nicht gegeben werden. Denn außerordentlich mannigfaltig ist der Bau der Flußsysteme, von denen jedes seine individuellen Züge hat, die sich nicht in ein allgemeines Schema einzwängen lassen; ja die meisten größeren Systeme zeigen in verschiedenen Teilen auch verschiedene Anordnung. Nur einige Grundformen sollen hier besprochen werden.

Die einfachsten Systeme bestehen aus einem Hauptstrang, an den sich rechts und links Nebenflüsse rechtwinkelig oder mit abwärts gekrümmter Mündung wie Äste ansetzen. Der Po, der Amazonas, die Moldau, der Oberrhein und die untere Donau sind so gebaut. Meist sind auch in diesem Fall die Nebenflüsse auf beiden Seiten nicht gleichwertig, und zwischen dem symmetrischen und dem einseitigen Bau lassen sich alle möglichen Übergänge beobachten. Dem Jenissei, dem Tigris, der Theiß, der unteren Garonne u. a. sendet die Gebirgsseite begreiflicherweise zahlreichere und größere Nebenflüsse zu als die ebene Seite. Die Rhône empfängt ihre wichtigsten Nebenflüsse von den Alpen, wo nicht nur der Wasserreichtum größer, sondern auch die Wasserscheide viel weiter vom Talweg des Hauptstromes entfernt ist als auf der westlichen Seite, der das französische Massiv seinen Steilabfall zuwendet. Der Lauf der Aare und der oberen Donau bezeichnet die tiefste Rinne am Fuß des Jura, wo die Flüsse, die den Alpen entstammen und durch die Neigung des

$\times$ Auch die Geographen sind in dieser Beziehung schwankend, denn bei der Längenmessung des Mississippi geht man meist von der Missouriquelle aus. Um solche Inkonsequenzen zu vermeiden, sollte man für alle Flüsse, ganz unabhängig von der Nomenklatur, den längsten kontinuierlichen Talweg der Berechnung zugrunde legen.

SUPAN, Physische Erdkunde. 5. Auf,. 
Vorlandes zu nordwestlichem bezw. nördlichem Lauf gezwungen werden, sich sammeln müssen, um in veränderter Richtung einen Ausweg zu finden.

Häufig ist der Fall, daß zwei oder mehrere nahezu gleichgroße Flüsse radial einander zuströmen und erst nach ihrer Vereinigung einen deutlich erkennbaren Hauptstrang bilden. Dieser Typus tritt in zahlreichen Variationen auf. Am einfachsten ist der Bau der Loire und des Allier, des Cauca- und Magdalenenstromes, des ParanáParaguay, des Ganges-Gogra, des Murray-Darling, die selbst wieder nach demselben Gesetz gebaut sind, u. a.m. Aus der Vereinigung mehrerer Hauptarme entstehen der Dnjepr, die untere Seine und der untere $\mathrm{Ob}$; im Mississippisystem läßt sich außer dem Mississippi und dem Missouri auch der Ohio als Hauptarm auffassen. In kleinem Maßstab, aber mit seltener Schärfe ist diese Bauart in der Thaya ausgebildet, besonders da jeder der drei Hauptarme dieselbe Bildungsweise wie der vereinigte Fluß zeigt. Einen etwas komplizierteren Fall bietet das Indussystem, dessen beide Hauptarme (Indus und Sutlej) sich mit einem dritten, kleineren vereinigen. Aus zwei Längsflüssen, die einander zuströmen, entsteht der Querfluß Dwina, und in ähnlicher Weise verbinden sich Trent und Ouse zum Humber.

Die großen Veränderungen der Laufrichtung lassen sich als eine Vereinigung verschiedener Systeme auffassen. Der Kongo und die Loire sind Beispiele der Verwandlung eines Längssystems in ein Quersystem durch einfache Umbiegung. Die Loire zeigt anfänglich die Tendenz, dem Pariser Becken zuzufließen, wie ja auch die übrigen Flüsse, die seinem Rand entspringen. Die Ablenkung nach West, der auch die Bäche der Sologne, wie die größeren Flüsse Cher, Indre und Creuse-Vienne folgen, ist schon miozänen Alters; sie alle benutzen den ehemaligen Abzugskanal der Gewässer des Seinebeckens. Das Quersystem der Wolga setzt sich nach Norden in dem der Kama fort. In der Petschora vereinigen sich zwei Quersysteme (obere Petschora und Ischma mit der unteren Petschora) mit einem Längssystem (Ussa und mittlere Petschora), in der Donau zwei Längssysteme (obere Donau bis Waitzen und Drau-Save-untere Donau) mit einem Quersystem. Diese Beispiele erschöpfen nicht im entferntesten die Zahl der verschiedenen Fälle, aber sie geben uns doch eine Vorstellung von der Mannigfaltigkeit in der Anordnung der Flußläufe innerhalb eines hydrographischen Gebietes.

Größe der Flüsse. Starke Niederschläge und lange Abdachungen sind die Bedingungen für die Entwickelung großer Ströme. Nicht die Länge des Flusses ist maßgebend für seine Bedeutung, sondern die 
Größe seines Gebietes. Der Amazonas ist zwar der mächtigste Strom der Erde, aber an Länge wird er vom Missouri-Mississippi um 1100 und vom Nil um $1000 \mathrm{~km}$ übertroffen. Die Donau ist nur doppelt so lang wie der Rhein, aber sie entwässert ein viermal größeres Areal; und die Dwina hat einen kürzeren Lauf als der Guadalquivir, aber trotzdem ist ihr Gebiet sechsmal größer.

$\mathrm{Zu}$ einer Vorstellung von der hydrographischen Verschiedenheit der Erdteile gelangt man, wenn man berechnet, wie viele Prozente des Gesamtareals auf die Gebiete der großen Ströme (als Grenze haben wir $1 / 2$ Mill. qkm angenommen) entfallen:

\begin{tabular}{|c|c|c|c|c|c|}
\hline Südamerika & $(4$ & & & & \\
\hline Nordamerik & 8 & 8) & & & \\
\hline Asien (11) & . & & & & \\
\hline Afrika (5) & & & & & \\
\hline Europa (3) & & & & & \\
\hline Australien & (1) & & & & \\
\hline
\end{tabular}

Südamerika ist also vor allem das Land der großen Ströme, wie es der Kontinent der Tiefebenen ist. Die beiden kleinsten Erdteile nehmen in obiger Tabelle begreiflicherweise den letzten Platz ein; bei Australien wirkt noch die Trockenheit des inneren Landes mit. Asien besitzt zwar die größte Anzahl von Strömen, aber nur der $\mathrm{Ob}$ steht den amerikanischen würdig zur Seite; die große Ausdehnung und zentrale Stellung des Hochlandes wirkt der Entwickelung eines Amazonas entgegen, während in Südamerika die peripherische Lage der Andes mit der Regenverteilung zusammenwirkt, um den mächtigsten unter den Riesenströmen der Erde zu erzeugen.

Veränderungen der Flüsse. Auch Flüsse und Flußsysteme sind veränderlich. Namentlich dort, wo ein schwach geneigtes und daher sich beständig erhöhendes Bett in lockerem Material liegt, also haupt-

$\times$ Die eingeklammerte Ziffer gibt die Zahl der Hauptströme mit mehr als $1 / 2$ Mill. qkm FluBgebiet. Nach den Messungen von BuddaU ${ }^{4}$ und Strelbitsky (Europa) sind es folgende:

\begin{tabular}{|c|c|c|c|c|c|}
\hline & & & & & \\
\hline & 6000000 & worga & 145900 & Donau & 81700 \\
\hline Longo . & 3690000 & Sambesi . & 1330000 & Mekong & 810000 \\
\hline Mississippi & 3248000 & St. Lorenz & 1248000 & Euphrat- & \\
\hline La Plata & 3104000 & Nelson. & 1080000 & Tigris & 710000 \\
\hline $\mathrm{Ob} .$. & 2915000 & Ganges & 1060000 & Brahmaputra & 670000 \\
\hline Nil . & 2803000 & Hoangho & 980000 & Columbia . & 655000 \\
\hline Jenissei . & 2510000 & Indus. . & 960000 & S. Francisco & 652000 \\
\hline Lena . . & 2320000 & Oranje & 960000 & Colorado . & 590000 \\
\hline Niger. . & 2092000 & Orinoeo & 944000 & Rio grande & \\
\hline Amur. . & . 2010000 & Murray & 910000 & del Norte & 570000 \\
\hline Jangtse-kia & ng 1775000 & Yukon & 817000 & Dnjepr . . & 527000 \\
\hline
\end{tabular}


sächlich im Unterlauf, verändern die Flüsse häufig ihre Richtung. Wohl keiner ist so starken Oszillationen unterworfen wie „Chinas Kummer", der Hoangho. Seine älteste und zugleich nördlichste Mündungsstelle liegt unter $39^{2} /{ }^{0} \mathrm{~N}$, seiné südlichste, die er vom 13. Jahrhundert bis 1852 benutzte, unter $34^{\circ} \mathrm{N}$. In den Jahren 1851 bis 1853 wandte er sich wieder nach Norden, aber 1887 brach er abermals nach Süden durch, wurde jedoch schon 1889 durch Menschenhand gezwungen, sein früheres Bett wieder aufzusuchen. In kleinerem Maßstab sind Veränderungen im Unterlauf, wo die Flüsse nicht durch feste Ufer eingedämmt sind, außerordentlich häufig, wie z. B. BuINK ${ }^{10}$ bezüglich des Rheindeltas dartat; aber obwohl die Geschichtsquellen hier reichlich fließen, gelang es ihm doch nicht, alle dunkelen Punkte aufzuklären. Um so schwieriger ist dies in Ländern, deren Geschichte sich mit Sagen verwebt Bis in die neueste Zeit war die Ansicht verbreitet, daß der Amu (Oxus) sich noch im Mittelalter in den Kaspisee ergossen habe, und man hoffte, diese wichtige Wasserstraße wiederherstellen zu können. Erst die geologischen Untersuchungen und Nivellements der Russen um die Mitte der achtziger Jahre haben dieses Märchen zerstört, ${ }^{11}$ und als direkten Gegenbeweis führt J. WALtheR ${ }^{12}$ an daß sich an der angeblichen Mündungsstelle zwischen den Balchan bergen bis $35 \mathrm{~m}$ Tiefe keine Spur von dem leicht erkennbaren Oxusschlamm finde. Sicher ist nur, daß die Mündung des Amu einst im Sary-Kamysch lag, und daß von hier aus eine Wasserverbindung mit dem Aralsee und durch den Usboi mit dem Kaspisee stattfand (nach BARTOLD 1221-1573); doch war der Usboi kein eigentlicher Flußarm, sondern nur eine zusammenhängende Seenkette mit schwacher Wasserbewegung. 1878 füllte sich das Bett zum Sary-Kamysch wieder, aber dieser Zustand war nur vorübergehend. Auch gegenüber den Nachrichten von einer Verlegung der Indusmündung infolge eines Erdbebens im Jahr 962 ist die größte Skepsis geboten.

Nicht bloß im Unterlauf werden die Flüsse von Veränderungen betroffen. Seit dem Dammbruch bei Mussadjib i. J. 1903 benutzt der Euphrat den Hindiyekanal im Westen, und das alte Bett bis Samawa ist versandet. Der Bodensee endigt im Westen in drei Zipfeln; dem südlichsten entströmt jetzt der Rhein, die beiden anderen sind alte Ausmündungsstellen. Die geologische Untersuchung ergab die Existenz eines alten Rheinlaufes von Radolfszell über Singen und Ramsen, also im jetzigen Bibertal; und ebenso konnte nachgewiesen werden, daß der Rhein einige Zeit von Schaffhausen direkt durch den Klettgau nach Waldshut floB. Diese Terrainfurche benutzt jetzt die Eisenbahn. 
Wie in verhältnismäBig kurzer Zeit durch Ablösung von alten Flüssen neue entstehen, erfahren wir aus FourNiER's ${ }^{13}$ vergleichenden Kartenstudien über die Gegend südwestlich von Lons-le-Saunier im Département Jura. Von den vier Nebenflüssen, die die Vallière hier von Osten empfängt: Sorne, Dérobé, Roi und Sonette, bestand 1658 nur der letztgenannte, denn die Sorne mündete damals noch in die Sonette. 1748 war die Sorne schon selbständig geworden und sandte nun den Roiarm aus. Auf der Cassinikarte hat sich bereits die Ablösung des Roi vollzogen. Dérobé erscheint als ein Arm der Sorne erst auf der Karte von 1841 und hat sich seitdem ebenfalls durch Abtrennung von ihrem MutterfluB zu einem selbstständigen Tributär der Vallière ausgebildet.

Als eine allgemein wirkende Ursache von Laufveränderungen bezeichnete der berühmte russische Akademiker v. BaER die Erdrotation, die auf der nördlichen Halbkugel eine Ablenkung nach rechts und auf der südlichen eine solche nach links zur Folge hat (vgl. S. 22). Soviel auch schon darüber geschrieben worden ist, ${ }^{14}$ so ist doch die Frage noch immer nicht zum Abschluß gebracht und es mag billig bezweifelt werden, ob eine Entscheidung überhaupt möglich sei. Niemand leugnet mehr den Einfluß der Erdrotation, der sich auch nicht, wie v. BAER meinte, auf meridionale Flüsse beschränkt; aber man hält ihn vielfach für $\mathrm{zu}$ geringfügig im Vergleich zu jenen Momenten, die - wie Unebenheiten und Verschiedenheiten in der Härte der Unterlage - die Geschwindigkeit und die Richtung der Bewegung vorzugsweise bedingen.

Die Rotation drängt die schneller bewegten Wasserfäden nach rechts (auf unserer Hemisphäre) und erhöht hier den Wasserspiegel. Aber diese Abweićhung von der Horizontalen erreicht nur ganz minimale Werte; selbst bei einer ansehnlichen Breite von $1000 \mathrm{~m}$ und einer Geschwindigkeit von $3 \mathrm{~m}$ in der Sekunde würde sie am Pol nur 44, unter $50^{\circ}$ Breite nur 34, im 20. Parallel sogar nur $15 \mathrm{~mm}$ betragen. Auch die Länge geologischer Perioden kann die Wirkung der Rotation nicht steigern, ,denn ebenso lange," sagt ZöPPRITZ, „wirken alle Unregelmäßigkeiten und, da sich das Flußbett durch Erosion und Sedimentführung beständig ändert, fortwährend in anderer, völlig unübersehbarer Weise." BRunHes, ${ }^{15}$ der die zerstörende und aufbauende Tätigkeit des fließenden Wassers vornehmlich auf Wirbelbewegungen zurückführt (vgl. S. 517), erblickt den Einfluß der Erdrotation darin, daß sich die Flußwirbel auf unserer Halbkugel in der Regel von links nach rechts bewegen. Als einen Faktor von regionaler Bedeutung hat man auch den Wind erkannt, und KöPpen machte besonders auf die Wichtigkeit der 
Sturmrichtung zur Zeit des Frühlingshochwassers aufmerksam. ${ }^{16}$ Während sich der EinfluB der Rotation mit der Geschwindigkeit des bewegten Körpers steigert, macht sich der des Windes gerade bei schwach fließenden Strömen besonders geltend, indem er eine Wasserversetzung nach dem leeseitigen Ufer bewirkt, namentlich dann, wenn der Flußlauf von dev vorherrschenden Windrichtung unter einem steilen Winkel getroffen wird. So vereinigen sich verschiedene Faktoren, um die Flüsse nach der einen oder anderen Seite abzulenken; bald wirken sie im gleichen Sinn, bald arbeiten sie einander entgegen, und daraus erklärt sich zur Genüge der Widerstreit der Meinungen.

Auffallend konstant ist die Rechtswanderung des Amu, die die Ingenieure auf $5 \mathrm{~km}$ im Jahrhundert schätzen, und hier mögen die sehr häufigen und starken NW- und W-Winde wohl zur Erklärung herangezogen werden. Daß die sibirischen Flüsse nach Osten drängen, hat noch in neuerer Zeit PoLJakow bestätigt; ob dieses Verhalten den Westwinden zuzuschreiben sei, kann noch bezweifelt werden, denn auch in Südrußland herrscht diese Windrichtung vor, ohne die Flüsse an ihrem westlichen Fortschreiten hindern zu können. Die östliche Ablenkung des Nil hatte schon MrnutoLI beobachtet und Hoff das Vordringen des Sandes aus der Libyschen Wüste dafür verantwortlich gemacht. Auch auf andere Flüsse wurde das BAER'sche „Gesetz" angewendet. Dagegen zeigen die norddeutschen Flüsse ein ganz anderes Verhalten, und der Oberrhein wurde von den Anhängern wie von den Gegnern BAER's als Beweis für ihre Ansichten angeführt. Die Donau floß, wie HaLAvTás zeigte, nach Trockenlegung des levantinischen Sees in der Richtung Budapest-Szolnok und dann weiter im Bett der Theiß; erst seit dem Ende der Diluvialzeit hat sie ihre südliche Richtung eingeschlagen, und seitdem drängt sie (wie die Theiß) unablässig gegen das Westufer, das steile LöBabstürze bilden. Auch in den östlich gerichteten Teilen ihres Laufes zeigt sie, soweit sie nicht durch felsige Ufer eingeschlossen ist, das Bestreben, sich nach rechts zu wenden; Suess vergleicht sie daher mit einer zwischen festen Punkten aufgehängteu Kette. Besonders im Unterlauf bilden das walachische Flach- und das bulgarische Steilufer scharfe Gegensätze, * und eine Reihe blinder Arme zeigt den früher nördlicheren Lauf des Flusses an. Für die Strecke Galatz-Reni nimmt Peters die Stoßkraft des Pruth als Ursache dieser Erscheinung in Anspruch, und dieselbe Wirkung läBt sich wohl auch den von den Transsylvanischen Alpen kommenden Flüssen zuschreiben, da sie bedeutend wasserreicher und kräftiger sind als die bulgarischen. In ähnlicher Weise wie die Donau schreiten auch 
der Ganges und die Djumna nach Süden vor, und die indischen Geologen erklären dies durch die größeren Sedimentmassen der Himalayaflüsse, wodurch die nördliche Ebene höher aufgeschüttet wurde als die südliche.

Auch die Flußsysteme erleiden Veränderungen. Der einfachste Fall ist der, daß durch Erweiterung des Deltas mehrere selbständige Flüsse zu einem System verschmelzen. So verbanden sich Euphrat und Tigris erst nach dem 8. Jahrhundert v. Chr, zum Schat-el-Arab und Seihun und Djihar, die sich in den Golf von Alexandretta ergießen, haben sich seit Xenophov's Zeiten dreimal vereinigt und dreimal getrennt. Durch das Fortschreiten des Donaudeltas sank der Pruth zu dem Rang eines Nebenflusses hinab. Erst in verhältnismäßig junger Vergangenheit vergrößerte die Rhône ihr Gebiet durch die Aufnahme der Durance, die in der Zeit ihrer Selbständigkeit das Geröllfeld La Crau schuf und bei Salon mündete. Der Tennessee floß einst mit dem Coosa und dem Alabama direkt in den Mexicanischen Golf, und noch erinnern gemeinsame Züge in der Molluskenfauna dieser drei Flüsse an jene Zeit. Eine Laufveränderung brachte den Sutlej in Abhängigkeit vom Indus; die Reste seines ehemaligen Laufes sind jetzt unter dem Namen Wahand und Nara bekannt. Umgekehrt wurde sein einstiger Nebenfluß Saraswati selbständig, indem ihn die nach rückwärts fortschreitende Djumna eines Teiles seines Quellgebietes beraubte, so da 3 er sich jetzt wegen Wasserarmut in der Wüste verliert. Eine ebenso traurige Selbständigkeit erlangten die einstigen Nebenflüsse des Murray Tyrrell, Yarriambiack und Wimmera. Wie die Sedimentablagerung die Gebiete des Po und der Etsch trennte, wurde schon auf S. 513 berichtet. Der Arno umfließt oberhalb Florenz in einem großen Bogen den Prato magno, in vorgeschichtlicher Zeit mündete aber sein oberer Arm bei Arezzo in den Chianasee und gehörte mit diesem zum Tibersystem. Erst die fortgesetzte Erhöhung seines Schuttkegels nötigte ihn, sich bei Giovi nach West zu wenden und mit dem westlichen Arno zu vereinigen, und seit ungefähr $1500 \mathrm{n}$. Chr. wurden auch die letzten Reste des Chianasees durch einen künstlichen Kanal in das Arnogebiet mit einbezogen. Die großen Mediantäler der norddeutschen Ëbene (s. Fig. 189, S. 627) weisen auf eine, einst wesentlich andere hydrographische Anordnung zurück; die Weichsel floB durch das Netzetal in die Oder, und diese setzte sich durch die Spree- und Havelniederung in der unteren Elbe fort. Dieser große Strom löste sich erst seit der Eröffnung der Durchgangstäler der Weichsel und der Oder durch den nördlichen Land. rücken in drei Flüsse auf. Im Osten löste sich der Pregel von der 
Memel los, die nach BerEndt einst das Instertal benutzte. und nur bei Hochwasser auch einen Seitenarm in das Kurische Haff sandte. In Nordfrankreich wurde die Wasserscheide zwischen der Sambre und der Oise in vorgeschichtlicher Zeit um $12 \mathrm{~km}$ nach $\mathrm{N}$ vor-

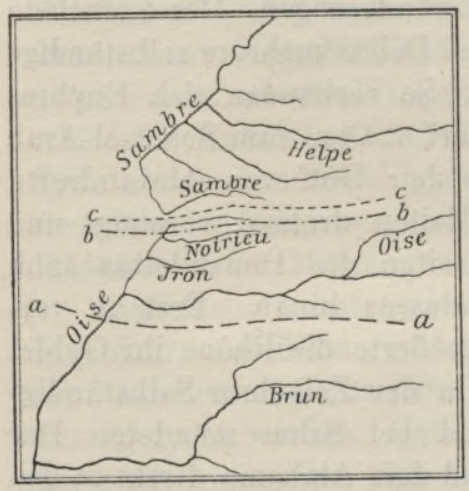

Fig. 252. Alte $(a a)$ und neue $(b b)$ Wasserscheide zwischen Oise und Sambre und Wasserscheide seit 1684 (cc) nach BRIQUET. geschoben, wodurch die Oise ihren heutigen Quellfluß und die Gewässer Iron und Noirieu gewann, und 1684 wurde ihr noch auf künstlichem Weg die alte Sambre beigesellt (Fig. 252). ${ }^{17}$ Wie leicht unter Umständen solche Verschiebungen noch heute stattfinden können, beweist ein Fall aus dem Ohiogebiet, den Tigнт, ${ }^{18}$ erzählt. Der Racoon Creek floß einst nach W zum Pleasant Run, hat aber infolge der Anlage eines Mühlteiches und eines Mühlwehres eine östliche Richtung zum Rush Creek eingeschlagen und sie auch beibehalten, obwohl jene Anlagen längst zerstört sind.

Durch solche Systemveränderungen können selbst wichtige Wasserscheiden Verschiebungen erleiden. Es gab eine Zeit (mittleres und Anfang des oberen Pliozän), da der Rhein mit dem Doubs zusammenhing; zu einer anderen Zeit gehörten Oberrhein und Genfer See zum Donaugebiet, und erst die Eröffnung des Durchgangstales zwischen Bingen und Bonn lenkte den Rhein in die Nordsee ab. Die Breite und der Geröllreichtum des oberen Minnesotatales, die in keinem Verhältnis zur gegenwärtigen Wassermenge stehen, legen die Vermutung nahe, daß der Red River es einst benutzte, und der Winnipegsee zum Mississippigebiet gehörte, bis die negative Niveauveränderung der Hudsonbai den Nelson zu erhöhter Tätigkeit anregte. Das Quellgebiet des Nelson wurde immer weiter nach rückwärts verlegt, erreichte endlich den Winnipegsee und zwang den Red River zur Umkehr. Sichere Beweise für solche Veränderungen lassen sich allerdings nur dort erbringen, wo blinde Talstücke noch erhalten sind, $\times$ wie dies besonders häufig in einigen Kettengebirgen (s. S. 728) der Fall ist, oder wo das Material der

$\times \mathrm{DaB}$ auch bei der Benutzung blinder Täler zu weitgehenden Folgerungen Irrtümer unterlaufen können, haben P. Lemorne und F. JAccard gezeigt (vgl. La Géographie 1910, Bd. XXII, S. 47). Das verdient besonders jetzt Berücksichtigung, da in Amerika und Frankreich derartige Anzapfungsstudien mit Eifer betrieben werden. 
Flußablagerungen über deren Herkunft bestimmten Aufschluß gibt, oder wo geschichtliche Nachrichten vorliegen; aber vermuten können wir wenigstens, da $B$ besonders dort, wo die Wasserscheiden mannigfach gekrümmte Linien bilden, die hydrographischen Grenzen Wandlungen erlitten habęn.

Literaturnachweise. ${ }^{1}$ A. HaAse, in Petermann's Mitteilungen, 1891, S. 49. $-{ }^{2}$ A. v. Trluo, in Petermann's Mitteilungen, 1887, S. $101 .-^{3}$ K. KeilHack, in Petermann's Mitteilungen 1891, S. 38. - ${ }^{4}$ A. Bludad, Die Areale der außereuropäischen Stromgebiete, in Petermann's Mitteilungen 1897 u. 98. Erste zuverlässige Messungen! Von Europa sind bisher erst einige Teile bearbeitet (s. ebendaselbst 1898 u. 1900 ). $-{ }^{5}$ R. Fritzsche zit. S. $169 .-{ }^{6}$ E. Puls, Vergleichende Untersuchungen über Flußdichte, Hamburg 1910. - ${ }^{7}$ L. NeUManN, in Gerland's Beiträgen zur Geophysik, 1900, Bd. IV, S. 219. - ${ }^{8}$ A. HaAse, Über Bifureationen, in Petermann's Mitteilungen 1889. - ${ }^{9} \mathrm{E}$. Wisotzki, HauptfluB und NebenfluB, Stettin 1889. - ${ }^{10} \mathrm{H}$. Burnk, Der Rhein in den Niederlanden, Stuttgart 1889. - ${ }^{11}$ Berieht von A. M. Konschin in Petermann's Mitteilungen 1887, S. 226. Eine Übersicht der russischen Forschungen gibt R. v. Eckert im Ausland, 1892, S. 545. E. Blanc (im Bulletin de la Société géographique de Paris, 1892, S. 281) suchte einen Teil der alten Sagen noch zu retten. Auch im Geographical Journal, 1903, Bd. XXII, S. 328, werden angebliche geschichtliche Beweise dafür angeführt. - ${ }^{12}$ J. Walther, Das Oxusproblem, in Petermann's Mitteilungen 1898. - ${ }^{13}$ E. Fournier, in den Comptes rendus de l'Académie des Sciences, Paris, 13. März 1905. — 14 B. Neumann, Studien über den Bau der Strombetten und das BAER'sche Gesetz, Königsberg in Pr. 1893 (s. dort die Literatur). - ${ }^{15}$ B. und J. Brunhes in den Annales de Géographie 1904, Bd. XIII, S. 1. Über einen bestimmten Fall äuBerte er sich in den Comptes rendus de l'Académie des Sciences, Paris 1910, Bd. CL, S. 567. Vgl. dazu Mark Jefrerson im Bulletin of the Geological Society of America, 1907, Bd. VIII, S. 333. - ${ }^{16}$ W. KöpPEN, in der Meteorologischen Zeitschrift 1890 , S. 34 u. 180 . - ${ }^{17}$ A. Briquet, Sambre et Oise: une Capture, in den Annales de la Société géologique du Nord 1908, Bd. XXXVII. 18 W. G. Tıянт, im Bulletin of Scientific Laboratories, Denison University, Bd. IX, 2. Teil, S. 33.

\section{Die Seen. ${ }^{1}$}

Hauptkategorien. Mündungsseen. Das Wasser sammelt sich dort zu einem See, wo eine gleichsinnige Abdachung von einer Vertiefung unterbrochen wird, oder an der tiefsten Stelle eines weiten Hohlraumes, wie solche aus der Ablagerung von Steppengebilden hervorgehen. Wir unterscheiden dementsprechend als Hauptkategorien die Becken- und die Mündungsseen. Die letzteren sind den abflußlosen Erdgebieten eigentümlich, obwohl auch hier Beckenseen vorkommen. Ein ausgezeichnetes Beispiel ist der Lop-nor Zentralasiens, über den wir von Sven v. $\mathrm{HedIN}^{2}$ ausführliche Nachrichten besitzen. $\mathrm{DaB}$ dieser See keine selbständige Bodenvertiefung füllt, sondern einfach das Ende des Tarimflusses bildet, geht daraus 
hervor, daß er seichter ist als der Fluß oberhalb der Mündung; noch weit hinein ist eine flieBende Bewegung bemerkbar. Wie alle Mündungsseen, ist er nach Lage, Größe, Gestalt und Tiefe großen Schwankungen unterworfen. Er war 1896 beträchtlich kleiner als 20 Jahre vorher, da ihn Przewalsky besuchte, und ist im Lauf der Zeit nach $\mathrm{S}$ gerückt; während sich der alte Mündungssee der chinesischen Karten von W nach O erstreckte, haben seine Überreste jetzt, durch den Ostwind und den Treibsand nach W verschoben, eine nordöstliche Richtung angenommen. Ein Seitenstück zum Lop-nor ist der weiter im Osten gelegene Hoa-hai-tse, dessen letzte Spuren BonIN entdeckt hat. Ähnliche Erfahrungen hat man in den zentralen Teilen Australiens 'gemacht, und wenn uns die Karten hier große Seen zeigen, wie den Lake Eyre, so entspricht das nur in sehr nassen Jahren der Wirklichkeit. Meist sind sie trocken und nur ausnahmsweise und nur auf kurze Zeit mit seichtem, brackischem Wasser überschwemmt. Eine, allerdings nur ephemere Bildung eines Mündungssees konnte man 1906 in Californien beobachten, als der Colorado infolge Kanalanlagen seinen Unterlauf verließ und den Saltonsee schuf. ${ }^{3}$

Beckenformen. Alle Vertiefungen, die von Seen erfüllt sind, lassen sich auf zwei Grundformen zurückführen. Entweder ist das

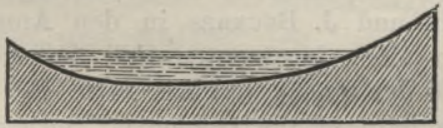

Fig. 253. Profil eines Eintiefungsbeckens.

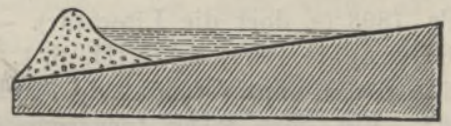

Fig. 254. Profil eines Aufschüttungsbeckens.

Becken in den Boden eingesenkt (Fig. 253), oder die Vertiefung ist gleichsam nur scheinbar, d. h. sie entstand durch Aufschüttung eines Dammes oder Walles aus fremdem Material auf unveränderter Unterlage (Fig. 254). Die erstere Art nennen wir Eintiefungs-, die letztere Aufschüttungsbecken.

Indem wir von Damm und Wall sprachen, haben wir bereits die beiden Arten von Aufschüttung genannt: die einseitige, die einen Fluß zum See aufstaut (Fig. 254) oder einen Meeresteil abschnürt, und die allseitige, wobei durch ungleichmäßige Anhäufung von Gesteinsmaterial Becken entstehen. Wir erhalten also zwei Unterkategorien: Damm- und Wallbecken.

Außerordentlich mannigfaltig sind die Vorgänge, die zu Dammseen Veranlassung geben können, und die jetzt so beliebte systematische Richtung kann sich nicht genug daran tun, immer wieder neue Klassen aufzustellen. Hier sollen nur einige Beispiele an- 
geführt werden, die uns zugleich zeigen, daß die Seenbildung auch in der Gegenwart noch fortdauert. Nur ephemere Bildungen sind die Eisseen. Der Gurgler Eissee entstand 1717-18, indem der rasch vorwärts schreitende Gurgler Gletscher den Abfluß des Langtaler Gletschers abdämmte. 1846 durchbrach er die Barriere und war 1865 ganz ausgetrocknet, sammelte sich aber später wieder. Seine Breite betrug nach v. SonkLan $632 \mathrm{~m}$, und seine Tiefe bei vollem Wasserstand im Frühjahr am unteren Ende 95-126 m. Noch kürzer ist die Existenz jener Seen, die durch Schnee- und Eislawinen gestaut werden; ein solcher See von $210 \mathrm{~m}$ Breite und ungefähr $60 \mathrm{~m}$ Tiefe bildete sich nach LyeLL's Bericht im Jahr 1818 im Val de Bagnes (Drance). Eine Reihe merkwürdiger Dünenseen begleitet das rechte Ufer des Tarim in dessen südöstlichem Unterlauf; sie sind nach $\mathrm{HEDIN}^{4}$ nichts anderes als die Vertiefungen zwischen den Dünenwällen, die von dem höher gelegenen Tarim gespeist werden, und wandern mit den Dünen nach West. Von größerer Dauerhaftigkeit sind jene Dämme, die durch Berg- und Felsstürze, durch die Schuttkegel der Seitenbäche, durch Endmoränen oder durch gewaltige Schotterablagerungen fluviatilen oder glazialen Ursprungs gebildet werden. Der Absturz von zwei Felshörnern der Diablerets im Berner Oberland (1714 und 1749) erzeugte die drei Seen von Derborence, die noch heute bestehen. Einem Bergsturz verdankt auch der Dorfersee im Kalsertal (Tauern) seine Entstehung. Zwei mächtige Schuttkegel, die sich in der Mitte des Antholzer Tales (Tauern) vereinigen, dämmen einen See ab, der ungefähr $1 \mathrm{~km}$ lang und $1 / 2 \mathrm{~km}$ breit ist. Einseitige Schuttkegel lagern dem unteren Ende des Haider- und des Reschensees im Etschtal vor. Im Tauferer Tal in Tirol ergoß der Schwarzenbach infolge heftiger Regengüsse und rascher Schneeschmelze im August 1878 gewaltige Schottermassen, die die Talsohle bei St. Martin auf große Strecken unter Wasser setzten. In allen diesen Fällen - und dies ist in der Gegenwart der gewöhnliche Vorgang - führten mächtige Ablagerungen von Seitenbächen, die von dem Hauptfluß nicht sogleich fortgeschafft werden konnten, zur Seebildung im Haupttal. Den umgekehrten Vorgang hat PENCK im Saalachtal (Salzburger Alpen) beobachtet. Der Damm, den der Hauptfluß aufgeschüttet hat, versperrte ein Seitentälchen bei Kehlbach oberhalb Saalfelden und erzeugte dadurch eine kleine, aber dauernde Wasseransammlung. In der Eiszeit scheinen sich solche Vorgänge häufiger abgespielt zu haben, und manchmal wurde der gestaute Nebenfluß sogar gezwungen, ein fremdes Tal aufzusuchen.

Der Diluvialperiode gehören auch jene zahlreichen Seen an, 
die CH. Martins als Moränenseen bezeichnet hat. Die Seiten- und Endmoränen der einstigen Gletscher erweisen sich als außerordentlich dauerhafte Dämme, die schon Jahrtausende lang dem Druck des Wassers wie der Erosion Trotz bieten. Von diesen Moränendammseen sind die Moränenwallseen zu unterscheiden, die in unregelmäßig angehäuften Endmoränen verteilt, also allseitig von glazialem Material umgeben sind. Von sonstigen Wallseen nennen wir noch besonders die häufigen Kraterseen ruhender oder erloschener Vulkane.

An den Küsten erzeugt der AufschüttungsprozeB die Strandseen, Mitteldinge zwischen Meeresbuchten und Binnenseen; sie sind je nach der Breite und Zahl der Kanäle, die in das Meer führen, bald den einen, bald den anderen zuzuzählen (vgl. S. 598). Doch sind nicht alle Strandseen abgetrennte Meeresteile; sie entstehen auch (wie zum Teil in den Landes oder nach НеHL an der brasilianischen Küste zwischen 21 und $23^{\circ}$ S) durch Ansammlung von Flußwasser hinter den Dünen, und ihr Salzgehalt rührt dann davon her, daB die Düne zeitweise durchbrochen wird und die Flut in die Seen eindringt. Ein ungleichmäßiges Fortschreiten der Deltabildung kann ebenfalls bewirken, daß Meeresreste als Seen zurückbleiben, wie beispielsweise in der Umgebung von New Orleans. Mehrfach wurde in geschichtlicher Zeit die Umwandlung einer Meeresbucht in einen Binnensee durch das Delta eines seitlich einmündenden Flusses beobachtet. So entstand der See Akis an der kleinasiatischen Küste (der latmische Meerbusen der alten Geographie), und der Hafen von Smyrna würde demselben Schicksal entgegengehen, wenn der Hermosfluß nicht künstlich abgelenkt worden wäre.

Die Gruppe der Eintiefungsbecken, die meist im festen Fels liegen, umfaßt genetisch sehr verschiedene Gebilde. Die Eintiefung kann von oben oder von unten bewirkt worden sein, aber die Schwierigkeit einer befriedigenden Erklärung liegt darin, daß solche Vorgänge nur selten und in unzureichender Weise zur Beobachtung gelangen. DaB strudelndes Wasser selbst in hartem Gestein tiefe Becken aushöhlen kann - GeInITz nannte diesen Vorgang Evorsion -, ist nicht zu bezweifeln, aber nach ihren horizontalen Dimensionen sind sie geringfügig im Vergleich zu den großen Seen. Man schreibt den Gletschern die Fähigkeit zu, Wannen auszuhobeln; PENCK beobachtete solche auf dem verlassenen Boden des unteren Grindelwaldgletschers, aber auch das waren zwerghafte Gebilde, die man nicht ohne weiteres mit den Seebecken in Vergleich setzen darf. Pumpelux sah in Zentralasien, wo keine Spuren einer Eiszeit vorhanden sind, echte, mit eckigen Gesteins- 
fragmenten gefüllte Felsbecken, und gründete darauf seine Verwitterungstheorie, der zufolge die Becken durch Zersetzung weicherer Schichten und spätere Entfernung des Verwitterungsschuttes durch den Wind oder in Glazialgebieten durch Gletscher entstanden sind (vgl. S. 483). Als Werke äolischer Ablation sieht Grubert einige Seen in den Prärien des Arkansas an. Alle diese Erklärungsversuche, welche die Felsbecken auf oberirdische Kräfte, d. h. auf Ausräumung zurückführen, erheben sich nicht über das Niveau der Möglichkeiten, aber als solche muß man sie gelten lassen.

Von unterirdischen Vorgängen, die Eintiefungsbecken zu schaffen vermögen, sind Einstürze über Hohlräumen und vulkanische Explosionen zwar auch aus der Gegenwart vielfach bekannt, aber sie scheinen verhältnismäBig selten zur Seebildung Veranlassung zu geben. Im April 1895 entstand bei Leprignano nördlich von Rom durch Bodensenkung ein kleines Seitenstück zum benachbarten Lago di Bracciano, ein nahezu kreisförmiges Loch von $260 \mathrm{~m}$ Durchmesser, das sich alsbald mit Wasser füllte. Daß die Maarseen aller Wahrscheinlichkeit nach in Explosionsbecken liegen, wurde schon auf S. 377 (und 390) erwähnt. Als eine besonders wichtige Ursache von Eintiefungen betrachtet man die Bodenbewegungen, die wir aus tektonischen Veränderungen herzuleiten gewohnt sind. Erdbeben sind bekanntlich häufig von merklichen Niveauveränderungen begleitet. So sank westlich von New Madrid am Mississippi 1811/12 ein ausgedehntes Stück Land, das jetzt mit zahlreichen Seen und Sümpfen bedeckt ist; an der Stelle von Gotachi in Ecuador befindet sich seit dem furchtbaren Beben von 1868 ebenfalls ein See. In Tennessee entstand bei dem Beben von 1811 der Beelfoot Lake, indem durch eine Niveauveränderung der Abfluß eines Baches gestaut wurde. Solche Stauungserscheinungen bringt man auch mit dem Faltungsproze $B$ in Verbindung, aber da bisher nur fertige Faltungen der Beobachtung zugänglich sind, so lassen sich für jene Annahme nur indirekte Beweise beibringen.

Viele Seen enthalten eine marine Fauna, andere sogenannte pelagische Tierformen, über' deren Zugehörigkeit zu der echten Meeresfauna die Ansichten noch geteilt sind. Man schloß daraus, daB alle diese Seen, die man Reliktenseen nannte, einst mit dem Meer im Zusammenhang gestanden haben. Die Bedeutung dieses Beweismittels hat R. CREDNER ${ }^{5}$ gründlich zerstört, indem er zeigte, daß häufig Einwanderungen aus dem Meer in das Süßwasser stattfanden, und daß viele Wassertiere sehr wohl imstande sind, sich veränderten Lebensbedingungen anzupassen. Trotzdem läßt Credner den Begriff der Reliktenseen nicht fallen, ja er setzt sie 
in direkten Gegensatz zu den „Festlands- oder echten Binnenseen“, d. h. solchen, die „nachträglich auf bereits festländischem Boden entstanden", nur verlegt er die Beweisführung von dem biologischen auf das geologische Gebiet. Aber damit ist die ganze Frage verschoben. Für eine genetische Einteilung der Seen ist es gleichgültig, wo die Vertiefungen entstanden sind; die Hauptsache ist, wie sie entstanden sind. In der Geschichte mancher Seebecken war die Senkung unter den Meeresspiegel nur eine Episode, wie Penck mit Recht in bezug auf die südschwedischen Seen hervorhob. Selbst wenn von einer Eintiefung dargetan würde, daß sie ursprünglich eine Senke des Meeresbodens war und als solche bei der Hebung ihre Wasserfüllung behielt, während die Umgebung trockenes Land wurde, wäre damit über die Natur jener Senke noch nichts ausgesagt. In einem genetischen Seebeckensystem können wir daher die Reliktenseen völlig entbehren.

Die wichtigsten Kategorien dieses Systems fassen wir nochmals übersichtlich zusammen:

I. Aufschüttungsbecken:

1. Dammbecken,

2. Wallbecken;

II. Eintiefungsbecken:

1. Ausräumungsbecken,

a) Evorsionsbecken,

b) Glaziale Erosionsbecken,

c) Becken der äolischen Ausräumung;

2. durch unterirdische Vorgänge entstanden:
a) Einsturzbecken,
b) Explosionsbecken,
c) Tektonische Becken:
a) Senkungsbecken,
$\beta)$ Faltungsbecken.

Selbstverständlich erfahren die Seebecken Umwandlungen, ähulich denen des Meeresbodens. Die Wellen greifen das Ufer an und lagern die Trümmer teils am Strand, teils unter Wasser an den Wänden der Wanne ab. An den Mündungen der Zuflüsse entstehen Schuttkegel, die manchmal durch eine Rinne geteilt sind (s. S. 455). Auf diese Weise bedecken sich die Beckenwände mit Schutt- und Schwemmhalden, die den ursprünglichen Böschungswinkel bald verkleinern bald vergrößern, während der feinste Schlamm weit hinausgeführt wird und sich über den Grund des Beckens ausbreitet, dessen zentralen Teil er dadurch zu einer horizontalen Ebene umbildet. 
Dimensionen der Seebecken. Depressionen. Die Fläche sämtlicher Seen schätzt Penck auf 21/2 Mill. qkm, also nur auf 1,8 Prozent des gesamten Landareals. Eine völlig isolierte Stellung nimmt der Kaspisee mit $438690 \mathrm{qkm}$ ein; er würde in Europa nahezu ganz Schweden bedecken. In weitem Abstand folgt dann der Obere See in Nordamerika mit $81380 \mathrm{qkm}$, dann folgen 4 Seen mit $60000 \mathrm{qkm}$ (Viktoria-Nyansa, Aral-, Michigan- und Huronsee), dann nach einer weiteren Lücke folgt der Tanganika mit $35130 \mathrm{qkm}$, und erst von da an läßt sich eine ziemlich zusammenhängende Reihe bis hinunter zu dem kleinsten Weiher verfolgen. Seen mit beträchtlichen Wasserstandsschwankungen und flachen Ufern sind natürlich großen Arealveränderungen unterworfen; so erklären sich z. B. die abweichenden Angaben über den Tschadsee. Eine unendliche Mannigfaltigkeit herrscht in bezug auf die Umrißformen; zwischen runden und langgestreckten, geschlossenen und gelappten Seeflächen gibt es alle möglichen Übergänge.

Viele Seen galten als unergründlich, solange man sie noch nicht ergründet hatte. Soweit die Lotungen reichen, ist nur der Baikalsee $(1522 \mathrm{~m})$ über $1000 \mathrm{~m}$ tief; von unseren Alpenseen senkt sich der tiefste, der Comosee, nur $409 \mathrm{~m}$ in den Boden ein. Nur einige flache Rand- und Binnenmeere können den Seen an die Seite gestellt werden.

Trotzdem reicht der Boden zahlreicher Seen unter den Meeresspiegel hinab. Liegt die Oberfläche über dem Meeresniveau, so nennen wir solche Einsenkungen Kryptodepressionen. Thre Liste vermehrt sich fast von Tag zu Tag, je weiter die jetzt in erfreulichem Aufschwung begriffene Seenforschung fortschreitet. Schon in Europa zählt man jetzt über $100 .^{6}$ Der Baikal-, der Aral-, der Ladoga- und der Onegasee, viele skandinavische und britische Seen, einige der italienischen Alpenseen, die canadischen Seen, der Lake Champlain, der Große Bärensee, mehrere Seen in Chile und Neuseeland mögen hier genannt werden, um eine Vorstellung von der weiten Verbreitung dieses Phänomens zu geben.

Echte Depressionen sind dagegen jene, in denen auch die zutage liegende Fläche unter dem Meeresspiegel liegt. Wir haben hier aber streng zwischen Küsten- und Binnendepressionen zu unterscheiden. Jene finden sich an vielen Flachküsten hinter Dünen und Dämmen und sind meist vom Menschen erobertes Land. An der Ost- und Nordsee sind sie häufig; fast die Hälfte des Königreichs der Niederlande $(14757 \mathrm{qkm})$ würde von der See dauernd überflutet werden, wenn sie nicht durch Dämme geschützt wäre. Teile der toskanischen Maremmen und der bessarabischen Küste und die Umgebung von Georgetown in Guayana gehören auch zu diesen 
Depressionen, die wohl selten mehr als $2 \mathrm{~m}$ eingesenkt sind. . Ta manche würden, wie PENCK bemerkt, überhaupt nicht als Depressionen gelten, wenn man den Nullpunkt der Höhenmessung in das Niedrigwasser verlegen würde. In viel größere Tiefen reichen die Binnendepressionen. In Afrika liegen solche im Süden des Atlassystems und des miozänen libyschen Plateaus. Eine Bodenschwelle von $52 \mathrm{~m}$ Höhe trennt das Schott-el-Djerid, das noch $20 \mathrm{~m}$ über dem Meer liegt, von dem Golf von Gabes; dann folgen gegen Westen die Depressionen der Schotts Gharsa (-21 m), Melghir $(-21 \mathrm{~m})$ und Meruan $(-29 \mathrm{~m})$. Soweit könnte das Meer in die tunesisch-algerische Wüste hineingeleitet werden: ein Projekt, das die französischen Geographen und Techniker einige Zeit lebhaft beschäftigt hat. Auch das zweite saharische Depressionsgebiet besteht nur aus vereinzelten Senkungen, von denen die Areg-Oase $(-75 \mathrm{~m})$ die tiefste ist. Beträchtlich tiefer liegen Teile des Danakillandes, die nördliche Depression in ungefähr $14^{\circ} \mathrm{N}, 40^{\circ} \mathrm{O}$ hat -120 und die Oberfläche des Assalsees, eines abgetrennten Golfes des Roten Meeres sogar $-174 \mathrm{~m}$. In Californien senkt sich das Tote Tal (Death Valley) bis 33 und das Coahuillatal sogar bis $91 \mathrm{~m}$ unter den Meeresspiegel. Erst vor einigen Jahren entdeckte man im zentralasiatischen Hochland südlich von Turfan $\left(43^{\circ} \mathrm{N}, 90^{\circ} \mathrm{O}\right)$ eine Depression von $-130 \mathrm{~m}$. Asien besitzt übrigens das ausgedehnteste und das tiefste Senkungsfeld. Das ausgedehnteste ist der Kaspisee und seine nördliche Umgebung bis zum 50. Parallel (736000 qkm), das tiefste ist das Ghôr, jenes lange und breite Verwerfungstal, das der Jordan durchfließt. Der Hulesee liegt noch $2 \mathrm{~m}$ über dem Spiegel des Mittelländischen Meeres, der Tiberiassee aber bereits 208 und das Tote Meer $394 \mathrm{~m}$ darunter. Dann steigt der Boden im Wadi-el-Araba wieder über das Meeresniveau.

Zwischen Binnen- und Kryptodepressionen besteht, wie R. CREDNER treffend bemerkte, lediglich ein klimatischer Unterschied. Jene sind an trockene Gebiete gebunden; viele waren einst, wie man noch aus den alten Wasserstandsmarken erkennt, bis zu größeren Höhen mit Wasser gefüllt, das aus manchen fast ganz verschwunden ist. Das Birket-el-Kerun im Fayum ( $-45 \mathrm{~m}$ ) hat sich sogar in der kurzen Zeit von 1871-85 aus einer versteckten Depression in eine echte verwandelt, und dasselbe Schicksal würde auch andere Kryptodepressionen treffen, wenn einmal die Verdunstung über den Zufluß die Oberhand gewänne.

Die tiefsten Einsenkungen des Festlandes sind der Boden des Baikalsees 1046 m, der Boden des Kaspisees 971 m, der des Toten Meeres $793 \mathrm{~m}$, und der Grund zweier norwegischer Seen: Hornin- 
dalsvand 435 und Salsvand i Fosnaes $432 \mathrm{~m}$ unter dem Meeresspiegel.

Die vertikalen und die horizontalen Dimensionen der Seebecken $\times$ stehen in keinem genau gesetzmäßigen Verhältnis zueinander. Wohl sind die (absolut) tiefen Seen auch groß, aber nicht alle großen sind tief. Einen ziffermäßigen Ausdruck gewinnen -wir, wenn wir berechnen, wieviel mal die Quadratwurzel der Fläche größer ist als die Maximaltiefe; und wenn wir die nachstehende Tabelle, die nur

\begin{tabular}{|c|c|c|c|c|c|c|c|c|c|}
\hline & & & & & & $F$ & & $t$ & $\sqrt{F}:$ \\
\hline Oberer See & . . & . . & . & . & & $81380 \mathrm{c}$ & $\mathrm{qkm}$ & $307 \mathrm{~m}$ & 923 \\
\hline Kaspisee . & . . & . . . & . . & . & & 438690 & $"$ & 945, & 701 \\
\hline Ladogasee . & . . & . . & . . & . & . & 18129 & $"$ & $256 "$ & 526 \\
\hline Müritzsee . & . . & . . & . . & . & . & 133 & " & $31 \%$ & 12 \\
\hline Wettersee . & . & . . & . & . & . & 1898 & " & $119 "$ & \\
\hline Njassasee . & . & . & . & . & . & 30800 & $"$ & $706 "$ & \\
\hline Baikalsee . & . & . & . . & . & . & 34932 & $"$ & 1522, & 23 \\
\hline Großer Plönerse & ee & . . & . & . & & 47 & $"$ & 60 & 113 \\
\hline Genfer See & . & . . & . & . & & 582 & , & 309, & \\
\hline Totes Meer & . & . & . & . & & 914 & $"$ & 394 & \\
\hline Höftsee . . . & . & . & . & . & & 0,3 & $"$ & 19 & \\
\hline Hallstätter See & & . & & & & 8,6 & $"$ & 125 & \\
\hline Hornindalsvand & (Norn & wegen) & & & & 51 & $"$ & 486 & \\
\hline Karsee . . . & . . & . . & & . & & & $04 \%$ & 21. & \\
\hline
\end{tabular}

einige Beispiele enthält, durchmustern, so finden wir, daß gerade viele kleine Seen einen kleinen Quotienten aufweisen, d. h. verhältnismäßig sehr tief sind.

Wir werden die Bedeutung dieser relativen Tiefen sogleich kennen lernen.

Seengebiete. Das wichtigste Moment für die Beurteilung der Entstehung der Seebecken ist derzeit unstreitig noch ihre geogra-

$\times$ Beide wechseln natürlich mit dem Wasserstand: so z. B. (nach HALBFAss) bei den Vogesenseen

Weißer See $\left\{\begin{array}{lccc}\text { Fläche } & \text { Hochwasser } & \text { Mittelwasser } & \text { Niedrigwasser } \\ \text { Größte Tiefe } & 6,304 & 0,280 & 0,250 \mathrm{qkm}\end{array}\right.$
Schwarzer See $\left\{\begin{array}{llll}\text { Fläche } & 0,166 & 58,7 & 58 \mathrm{~m} \\ \text { GröBte Tiefe } & 45 & 0,154 & 0,122 \mathrm{qkm}\end{array}\right.$

Dagegen steht die mittlere Tiefe im umgekehrten Verhältnis zum Wasserstand, weil das Hochwasser nur flachen Grund übersehwemmt; z. B.:

\section{Bodensee f Fläche}

(Penck) $\{$ Mittlere Tiefe Genfer See f Fläche

(HaLbfass) Y Mittlere Tiefe

$\begin{array}{cc}\text { Hochwasser } & \text { Mittelwasser } \\ 577,55 & 538,52 \\ 86 & 90 \\ 590,65 & 582,46 \\ 153,7 & 154,4\end{array}$

Niedrigwasser $512,75 \mathrm{qkm}$ $93 \mathrm{~m}$ $576,06 \mathrm{qkm}$ $154,9 \mathrm{~m}$.

Wenn den ziffermäßigen Angaben nichts beigefügt ist, so beziehen sie sich (oder sollten sich beziehen) auf den mittleren Wasserstand. 
phische Verbreitung. Denn wenn auch Seen überall vorkommen, so treten sie doch gesellig nur in ganz bestimmten Gegenden auf, und stellenweise häufen sie sich so sehr, daß wir geradezu von Seenlandschaften sprechen können. Nur flüchtig erwähnen wir gewisse Strandgebiete, da hier die Erklärung der Seen keine Schwierigkeiten bereitet. Im Binnenland fällt uns zunächst der außerordentliche Seenreichtum der eiszeitlichen Gletschergebiete auf. Im nordeuropäischen nimmt die Seenfläche $161000 \mathrm{qkm}$ oder nahezu 4 Proz. des Landes ein, am meisten in Finnland, wo sich der Anteil des stehenden. Wassers auf fast 13 Prozent des Areals steigert. Die Zahl der Seen ist überraschend, schätzte sie doch GeInITZ nur in Mecklenburg auf 650! In Nordamerika diesseits des Felsengebirges rückt die nordische Seenzone mit den Grenzen des alten Inlandeises weiter nach Süden als irgendwo sonst. Über die Seenfülle Canadas ist noch zu wenig bekannt, von den Vereinigten Staaten scheint Minnesota mit seinen 10000 Seen ähnliche Verhältnisse aufzuweisen wie Finnland. $\mathrm{Da} B$ die Seenbildung mit der Eisbedeckung in ursächlichem Zusammenhang stehen muß, kann niemand mehr leugnen, aber über das Wie sind die Ansichten noch nicht geklärt. Penck machte auf den Gegensatz der Zentralund Randbezirke der alten Gletschergebiete aufmerksam; die ersteren sind die „Rundhöckerlandschaften“, wo die Erosion vorherrschte, wo abgeschliffener Fels häufig zutage tritt, und viele echte Felsbecken, manchmal parallel angeordnet, wie in Finnland, vorkommen; die letzteren sind die an Seen verhältnismäBig ärmeren Moränengebiete mit ihren Wall- und Dammbecken. Allein gerade die Felsbecken sind noch immer Gegenstand des wissenschaftlichen Streites, besonders die großen südschwedischen Seen, die in die von Gneis umgebenen weicheren silurischen Schichten eingetieft sind. Die Frage, ob sie durch Gletschererosion entstanden sind, muß jedenfalls noch als offen bezeichnet werden. Über die Genesis der canadischen Seen ist schon eine kleine Literatur ${ }^{7}$ erwachsen, aber trotzdem gibt es noch genug dunkle Punkte, und nur soviel scheint sichergestellt zu sein, daß diese gewaltige Seenkette eine lange Entwicklungsgeschichte hinter sich hat, in der neben den Wirkungen der Eiszeit auch Krustenverbiegungen eine große Rolle gespielt haben. Aber das gilt nicht bloß von den großen Seen. Bei seinen eingehenden Untersuchungen des mecklenburgischen Randgebietes des alten Inlandeises kam Gersirz ${ }^{8}$ zu der Überzeugung, daß hier nicht alle Seen in Moränenbecken liegen, sondern daß ganz verschiedene Ursachen, sogar tektonische mitgewirkt haben, wenn er auch die Evorsion durch die Schmelzwässer des Eises für die wichtigste erklärte. Aus 
dér Tabelle auf S. 753 ersehen wir, daß die größeren Seen der Glazialgebiete verhältnismäßig flach sind; daneben gibt es aber kleine Becken, wie den Höftsee, die sich in bezug auf relative Tiefe mit den Gebirgsseen messen können, und auf sie könnte die Evorsionstheorie wohl Anwendung finden. Einen Beweis dafür, daß die Seebecken-Ostholsteins mit der Diluvialablagerung gleichzeitig entstanden sind, sieht ULE ${ }^{9}$ darin, daß ihre Gestaltung im Einklang mit der Oberflächenbeschaffenheit der nächsten Umgebung steht; und dies wird noch durch die Wahrnehmung bestätigt, daß der glaziale Geschiebelehm gleichmäßig Höhen und Tiefen überkleidet und an den Ufern der Seen bis zum Wasserspiegel hinabsinkt.

Für den großen Anteil, den die Eiszeit an der Seenbildung genommen hat, sprechen übrigens auch die Gebirgsseen. $\times$ Es sind teils Moränenseen, teils echte Felsbecken, die hier in Betracht kommen, und die wir in allen Gebirgen finden, die einst vergletschert waren. Wir haben hier zwischen Hoch- und Talseen zu unterscheiden; nur jene meist kleine Becken auf den Berghängen und Pässen und in den Quelltrichtern, sind ein allgemein verbreitetes Phänomen. An relativer Tiefe übertreffen sie, wie uns der Karsee in unserer Tabelle auf S. 753 zeigt, vielfach die großen Seen. Besonders bedeutsam ist aber die Tatsache, daß sie an gewisse Höhenzonen gebunden sind. In den Ostalpen zählte v. Вӧнм ${ }^{10}$ 2460 solcher Hochseen; abgesehen von den 224, deren Seehöhe nicht $\mathrm{zu}$ ermitteln war, liegen in

$$
\begin{array}{ccc}
3000-2500 \mathrm{~m} \text { Höhe } & 389 \\
2500-2000, \quad " & 953 \\
2000-1500, \quad " & 494 \\
\text { unter } 1500, ", & 400 .
\end{array}
$$

Eine Höhenzone mit reichlicherer Entfaltung des Seenphänomens findet sich auch in anderen Gebirgen, und es ist besonders beachtenswert, daß sie sich vom Äquator gegen die Pole, wenn auch nicht regelmäßig, senkt. Sie liegt im mittleren Norwegen in 1000-1600, in der spanischen Sierra Nevada in 2900-3200, im Himalaya in $4-5000$, in den peruanischen Andes in 4300-4600 $\mathrm{m}$ Höhe; dagegen in den höheren südlichen Breiten, entsprechend der Senkung der Schneelinie, viel tiefer: in Patagonien unter 1000, auf Neuseeland in 600-1200 m Seehöhe. Daß auch hier eine ursächliche Verknüpfung mit der Vergletscherung vorliege, ist schwer abzuweisen. Die Anhänger der Lehre von der Gletschererosion führen die untere Grenze des häufigen Vorkommens der Hochseen auf die letzte Phase

$\times$ Der höchste bekannte See der Erde ist der Horpatso in Tibet $5465 \mathrm{~m}$ ü. M. 
der diluvialen Vereisung zurück, während die obere zum Teil durch die gegenwärtige Gletscherbedeckung, zum Teil durch die Steilheit der Gehänge bedingt sein soll.

In den Alpen folgt auf die Zone der Hochseen ein seearmer Gürtel, und auf diesen folgen die großen Tal- und Randseen, im Norden vom Lac du Bourget bis zum Traunsee, im Süden vom Lago d'Orta bis zum Gardasee. Die inneren Talseen zeichnen sich vor den Randseen durch eine 3-4 mal größere relative Tiefe aus (vgl. Hallstätter und Genfer See auf S. 753), anderseits übertreffen die Randseen hierin die Seen des Flachlandes. Daß Tal- und Randseen diluvialen Alters sind, wird jetzt auch von den Gegnern der Glazialtheorie zugestanden; im übrigen stehen sich aber die Meinungen noch schroff gegenüber. Die bedeutendsten Schweizer Geologen, an ihrer Spitze Heıм, ${ }^{11}$ erklären sie für Teile fluviatiler Erosionstäler,

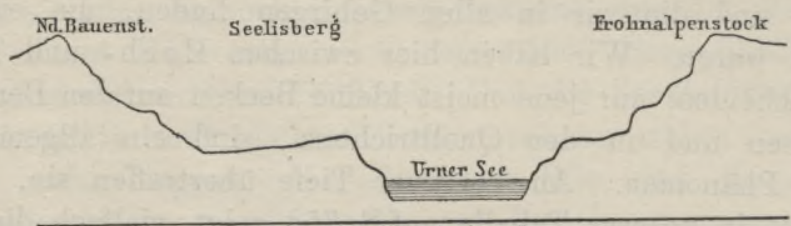

Meeresspiegel

Fig. 255. Profil durch den Urner See nach Herm (in gleichem Verhältnis von Länge und Höhe).

die durch eine postume Rücksenkung des Alpengebirges nach der ersten Eiszeit ein widersinniges Gefälle erhielten. Die so entstandenen Seen wurden in ihren oberen Teilen mit Glazialschotter ausgefüllt, überdauerten aber wenigstens in ihren unteren Teilen die folgenden Eiszeiten, die sie durch Gletscherausfüllung vor $\mathrm{Zu}$ schüttung schützten. In der Tat sind alle diese Randseen mit den Tälern auf das innigste verknüpft; ihr Grund reicht nicht, wie man früher glaubte, in bedeutende Tiefen hinab und stellt eine fast ebene Talsohle dar. Besonders interessant sind in dieser Beziehung die Messungen Herm's im oberen Teil des Vierwaldstätter Sees (Urner See, Fig. 255), wobei sich folgende Zahlen ergaben:

\begin{tabular}{r|c|c|c|c|r}
\multicolumn{3}{c|}{ Entfernung } & \multicolumn{3}{|c|}{ Entfernung } \\
vom westlichen Ufer & Mitte & \multicolumn{2}{|c}{ vom östlichen Ufer } \\
m 65 & 135 & 255 & & 160 & $125 \mathrm{~m}$ \\
Tiefe: $\mathrm{m} 203$ & 204 & 205 & 204 & 196 & $102 \mathrm{~m}$
\end{tabular}

Solch ein ebener Boden macht den Eindruck eines reifen Talgrundes, womit aber die steilen Seitenwände nicht völlig im Einklang stehen. Für das Rücksinken der Alpen wird als Beweis angeführt, daß sich die als alte Talbodenreste gedeuteten Felsterrassen am Züricher, Iseo- und Comosee talaufwärts senken. Die Richtigkeit dieser Be- 
obachtungen ist von PENCK und BRÜCKNER angezweifelt, aber für den Züricher See durch die neuen Untersuchungen von Gogarten ${ }^{12}$ bestätigt worden. Allerdings greift dieser See, wie BrÜckner bemerkt, nicht in die Nebentäler ein, wie es der Fall sein müßte, wenn er ein ertrunkenes Tal wäre, aber solche Buchten kommen am Garda- und am Langen See vor, und doch wird auch für diese Herm's Theorie abgelehnt. Am entscheidendsten ist wohl der Einwurf, daß die tiefste Stelle des Züricher Sees ungefähr mehrere Kilometer unterhalb der Dislokationszone der Felsterrassen liegt, nicht oberhalb, wie man erwarten sollte. HeIM gegenüber vertreten PencK und. BRÜCKNER ${ }^{13}$ mit Energie die Theorie RAMSAY's, der in den großen Alpenseen Erzeugnisse der Gletschererosion erblickte. Die Randseen liegen nach ihrer Ansicht in den Zungenbecken der eiszeitlichen Gletscher. Daß ihre Sohle talabwärts wieder ansteigt, spricht nicht gegen die Gletschererosion, denn die Tiefe ist verschwindend klein im Vergleich zur Länge der Seen, und das Oberflächengefälle der Gletscher talabwärts war jedenfalls größer als das Sohlengefälle talaufwärts, und darauf kommt es an, wenn sich ein Eisstrom über eine wannenförmige Vertiefung weiter bewegen soll. Die ausgebuchtete Gestalt mancher Seen, die drei Endzipfel des Bodensees, die Gabelung des Comosees werden dadurch erklärt, daß sich die alten Gletscher nicht nur am Rand der Alpen fächerförmig ausbreiteten, sondern sich auch innerhalb des Gebirges zu zerteilen bestrebt waren, indem sie in die Täler eindrangen, von denen sie keine Zuflüsse erhielten. Solange sich indes die Meinungen über die Gletschererosion überhaupt noch schroff einander gegenüberstehen, wird auch ihre Anwendung auf die Seen immer Gegner finden, um so mehr als sowohl in den Alpen wie in anderen Gebirgen manche große Eisströme keine Seen hinterlassen haben. Wohl sind Schottland, Norwegen, die Alpen Neuseelands reich an Talseen, aber andere Gebirge mit mächtiger diluvialer Eisdecke, wie die Pyrenäen, der Kaukasus, der Himalaya, entbehren dieses Reizes. Die tektonische Theorie findet eine Erklärung für dieses Verhalten darin, daß seen. bildende Bodenbewegungen und Vergletscherung räumlich und zeitlich nicht zusammenfielen. Sie benötigt also der diluvialen Talgletscher lediglich zur Konservierung der Seebecken.

Mit einem höheren Grad von Wahrscheinlichkeit können wir im syrisch-ostafrikanischen Grabengebiet von tektonischen Seen sprechen. Dies gilt wenigstens von den Seen des Jordantales, dem Rudolfsee, dem Tanganika, dem Njassa und einigen andern, während der in seinen Umrissen ganz davon abweichende und, wie es scheint, flache Viktoria-See nicht in einer Grabenversenkung liegt. Das Tote 
Meer ähnelt nach unserer Angabe auf S. 753 in seiner relativen Tiefe den alpinen Randseen, würde sie aber weit übertreffen, wenn wir die ehemalige Höhe des Wasserspiegels der Berechnung zugrunde legten.

Ein anderes großes Seengebiet, das mit der Eiszeit in keinerlei Verbindung steht, ist das a ral-kaspis che, der letzte Überrest eines ausgedehnten Meeres, das sich in der jüngeren Tertiärzeit bis in das Wiener Becken erstreckt hat und seitdem stetig zusammengeschmolzen ist und noch weiter zusammenschmilzt. Aber noch in der Quartärzeit hingen Kaspisee und Schwarzes Meer zusammen, erst später trat dieses mit dem Mittelmeer in Verbindung. Die tiefe Südhälfte des Kaspisees erklärt Andrussow ${ }^{14}$ für ein Senkungsbecken, die Nordhälfte und die übrigen Becken sind ganz flache tellerförmige Vertiefungen, wie sie in Trockengebieten, z. B. in Zentralasien oder im Innern Australiens, so häufig sind, und viele dieser Wasserflächen sind nur Mündungsseen.

Süß- und Salzwasserseen. Meeresteile, die sich in Binnenseen verwandeln, haben selbstverständlich ursprünglich salziges Wasser; Seen, die nur durch meteorisches Grund- und Flußwasser gefüllt wurden, haben ursprünglich süßes Wasser, vorausgesetzt, daß sie nicht starke Soolquellen aufnehmen, wie die ehemaligen Seen bei Eisleben. Ob aber der ursprüngliche Zustand gewahrt bleibt oder sich verändert, hängt ganz davon $a b$, ob der See Abfluß hat oder nicht. Der $A b f l u B$ kann ober- oder unterirdisch sein oder beides zugleich, wie bei dem Lac de Chaillexon im Jura; er kann permanent sein oder periodisch, wie bei dem Tanganika und Dilolosee. Hört er auf, oder war ursprünglich, wie bei den Mündungsseen, keiner vorhanden, so häufen sich die von den Flüssen herbeigeführten Salze im See an, da die Verdunstung, die den Zufluß paralysiert, nur Wasser entfernt, und der Süßwassersee verwandelt sich in einen salzigen. Umgekehrt werden Salzwasserseen ausgesüßt, wenn Abfluß vorhanden ist. Doch gibt es einige Ausnahmen von dieser Regel. Der Tschadsee, der Balkaschsee, der Lop-nor und ein kleiner See bei Dastarjan, westlich von Schiras, enthalten trotz ihrer Abflußlosigkeit Süßwasser. Daß der jetzige Lop-nor, trotzdem er Mündungssee ist, süßes Wasser führt, erklärt sich aus seiner Jugend, und darauf sind wahrscheinlich auch die übrigen Fälle zurückzuführen. Vom Tschadsee wird angenommen, daß er früher einen $A b f l u ß$ im Bahr-el-Ghasal hatte, der sich in die Wüste verliert. $\times$ Der Passat

$\times$ H. Freydenberger (Édute sur le Tehad et le Bassin du Chari, Paris 1908) hat aus geologischen Gründen den Bahr-el-Ghasal als ZufluB des Tsehad erklärt, was aber mit den Höhenverhältnissen nicht im Einklang steht (vgl. H. Marquardsen in Petermann's Mitteilungen 1910, I. S. 14.) 
drängt den See immer weiter nach West, im Osten ist er versandet und von vielen Inseln unterbrochen, zwischen denen das Wasser schon ganz den Charakter von Natronseen angenommen hat; ja selbst das Wasser des eigentlichen Sees im W beginnt bereits in der Trockenzeit salzig zu schmecken. Der Tschad befindet sich demnach im Stadium des Übergangs aus einem Süß- in einen Salzwassersee. ${ }^{15}$ Auch die Südhälfte des Balkaschsees beginnt sich in einen Salzsumpf umzubilden.

Der Salzgehalt ist nicht nur bei verschiedenen Seen sehr verschieden, $\times$ sondern wechselt auch innerhalb eines und desselben Sees. Er beträgt im Kaspisee ziemlich gleichmäßig 14 Promille, dagegen im flachen Golf Karabugas, der nur durch eine schmale Öffnung mit dem übrigen See in Verbindung steht, 170 Promille. Kein FluB mündet hier, und der große Verdunstungsverlust wird nur durch eine beständige Strömung aus dem Kaspisee ersetzt, der einen großen Teil seines Salzgehaltes hier anhäuft. Doch ist nicht erwiesen, daß sich - wie vielfach behauptet wird - am Boden des Karabugas bereits eine mächtige Steinsalzschicht ausgeschieden habe. ${ }^{16}$

Nicht bloB der Reichtum an Salzen, sondern auch diese selbst sind in verschiedenen Seen verschieden, und wechseln in ihren Verhältniszahlen auch in einem und demselben See, wie AвICH vom Kaspisee nachwies. Man unterscheidet in dieser Beziehung Salzseen im engeren Sinn, Natron- und Boraxseen. Die ersteren sind am zahlreichsten; hier herrscht meist Kochsalz vor, daneben findet man Chlormagnesium, schwefelsaure Magnesia und schwefelsaures Natron. Im Eltonsee und im Toten Meer übertrifft das Chlormagnesium alle anderen Salze. Zu den Natronseen gehören z. B. der Wansee, der Güsgundag, der See bei Ägyptisch-Theben und kleine Seen bei Szegedin und Debreczen. Hauptbestandteile sind hier neben Kochsalz kohlensaures und schwefelsaures Natron, von welchen Verbindungen meist die erste, manchmal aber auch die zweite vorherrscht. In Ungarn kommt nach PETERS der Salzgehalt von den trachytischen Gemengteilen der Tieflandablagerungen. Sehr selten sind die Boraxseen, die neben Borax stets auch Kochsalz

$\times$ Nach Rотн beträgt der Salzgehalt auf 1000 Teile Wasser:

Natronsee Palies (zwischen Szege-

din und Theresianopel) . . . 2,2

Kuku-nor

Aralsee . . . . . . . 10,8

Wansee . . . . . . . 19,1

Bitterseen des Sueskanals(2 Mess.) $\quad 53,7$
Großer Salzsee, Utah (2 Mess.) 186,0 Urmiasee (3 Messungen) . . . 210,5 Totes Meer (4 Messungen) . . 237,5 Eltonsee (3 Messungen) . . . 270,6 Roter See bei Perekop (2 Mess.) 328,7 Güsgundagamkl.Ararat(2Mess.) 368,0 
enthalten. Man kennt solche nur in Zentralasien, Persien, Californien und Nevada.

Erlöschen der Seen. Die Seen gehören zu den vergänglichsten Reizen einer Landschaft. Indem sich der Abfluß immer tiefer ein-

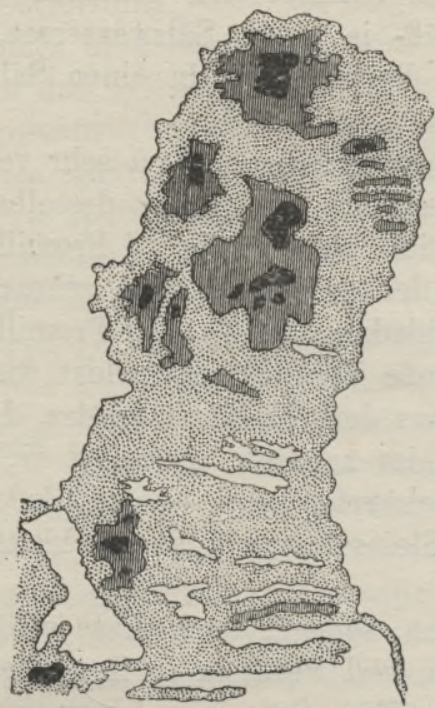

Fig. 256. Veränderungen des Abyschkansees in Westsibirien, nach $\mathrm{J}_{\mathrm{AD}}$ RINZEw. ${ }^{17}$ Die punktierte Seenfläche ist seit $1813-24$, die schraffierte seit $1850-60$ ausgetrocknet; schwarz bedeutet die Seereste i. J. 1880. schneidet, droht ihnen allmähliche Entleerung; und wenn dieser Prozeß auch langsam vor sich geht, so sind ihm doch sicher schon viele Bergseen zum Opfer gefallen. Mit unheimlicher Schnelligkeit, die so manchen zu dem falschen Schluß einer sichtlichen Verschlechterung des Klimas verleitet hat, gehen die Seen der Trokengebiete, wo die Verdunstung die Niederschlagsmenge beträchtlich übersteigt, $\times$ an Abzehrung zugrunde. In Turkestan und im angrenzenden Westsibirien lassen sich diese Veränderungen in der geschichtlichen Zeit gut verfolgen. Das Kärtchen in Fig. 256 überhebt uns weiterer Auseinandersetzungen, nur darauf möge aufmerksam gemacht werden, wie mit der Abnahme der Seenfläche die Zahl der Seen zunimmt. Der Balkaschsee stand noch in ge. schichtlicher Zeit mit dem Alakul in Verbindung; jetzt ist diese große Wasserfläche in fünf Seen aufgelöst, von denen einer schon ausgetrocknet ist. Nach Nrкouski's Beobachtung sank der Spiegel des Balkaschsees in 15 Jahren um $1 \mathrm{~m}$, was einer jährlichen Verdunstung von 1,3 Mill. cbm entspricht; er ist aber jetzt wieder im Steigen begriffen. ${ }^{18}$ Da

$\times$ Folgende Beobachtungen stammen aus den Jahren 1875-79, sie geben aber nur ein ungefähres Bild, da die Verdunstungsmessungen problematischer Natur sind:

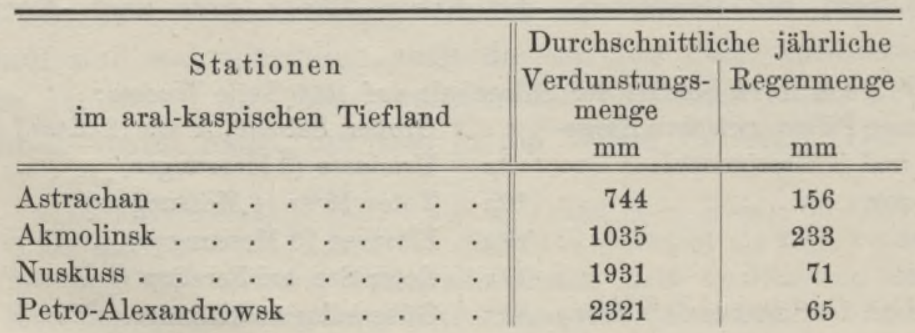


nasse und trockene Perioden von langer Dauer wechseln, so ist es nicht auffallend, daß der Austrocknungsprozeß zeitweise Unterbrechungen erleidet, ja sogar in das Gegenteil umschlägt. Während der Spiegel des Aralsees von 1848 bis in den Anfang der 80 er Jahre jährlich um $70 \mathrm{~mm}$ sank, ist er seit dieser Epoche bis $1901 \mathrm{um}$ $2 \mathrm{~m}$ gestiegen, was bei der Flachheit der Ufer eine enorme Vergrößerung der Wasserfläche zur Folge hatte. Auch an ein paar andern Seen des Gouvernements Akmolinsk und am Issykkul wurde diese Erscheinung festgestellt. ${ }^{19}$ Seit der vorgeschichtlichen Zeit haben auch die großen russischen Seen an Umfang verloren; am Onegasee ist ein altes Ufer noch $20 \mathrm{~m}$ über dem gegenwärtigen Spiegel sichtbar. Noch gewaltigere Veränderungen hat Nordamerika seit der Eiszeit erlebt. Von seinen beiden Riesenseen auf dem westlichen Hochland, dem Lahontan- und dem Bonneville-See (vgl. S. 244), sind nur noch spärliche Reste vorhanden, unter denen der Salzsee von Utah der bedeutendste ist; der Winnipeg- und eine Anzahl kleinerer Seen traten an die Stelle des Agassizsees, und auch die canadische Gruppe bildete einst eine einzige Wasserfläche: den Warrensee.

In regenreichen Gegenden wird die Existenz der Seen durch die Zuflüsse bedroht, die ihre Geschiebelasten im stehenden Wasser ablagern, und dieser ProzeB spielt sich natürlich im Gebirge rascher ab als im Flachland. Breite alluviale Talebenen schließen sich an das obere Ende der meisten Alpenseen an, deren einstige Ausdehnung verratend. So reichte der Genfer See bis Bex, der Brienzer bis Meiringen, der Bodensee bis Bendern, der Urnersee bis Erstfeld, der Lago-maggiore bis Bellinzona usw. Seitwärts mündende Bäche schneiden durch Deltas die Seen entzwei; die Lütschine trennte den Thuner vom Brienzer See, die Adda den Como- vom Mezzolasee, die Linth vielleicht den Züricher vom Walensee. Am St. Wolfgangsee bei Ischl oder an den Engadiner Seen läßt sich dieser Vorgang gut beobachten.

Wenn man aber, wie dies häufig geschehen ist, alle größeren Talebenen für zugeschüttete Seebecken erklärt, so geht man zu weit. Auch die seitliche Erosion schafft Talweitungen, und damit geht Hand in Hand die Auftragung von Alluvionen. Doch ist jene Annahme in zahlreichen Fällen richtig. Manche Gebirgsseen verschwanden erst in geschichtlicher Zeit völlig, wie 1817 der Novaledoșee und 1818 der Lago-morto im Valsugana, oder der Kankersee in Krain seit dem 18. Jahrhundert. Von anderen kennt man zwar nicht das Todesjahr, aber Sagen des Volkes oder Ortsnamen haben ihr Andenken erhalten. Aus einem Vergleich der ANıcH'schen und Hueber'schen Karte von Tirol mit der neuen Spezialkarte ergibt 
sich, da $B$ in diesem Land innerhalb eines Jahrhunderts 118 Seen verschwunden sind. Von den 149 Seen, die Gyger's Karte des Kantons Zürich i. J. 1667 verzeichnet, fehlen jetzt nach WALSER nicht weniger als 73. BREU zählt innerhalb Bayern 64 erloschene Seen, von denen die meisten durch menschliche Eingriffe in Land verwandelt worden sind. Kleine Wasseransammlungen, sumpfige und moorige Stellen, saure Wiesen usw. sind ziemlich sichere Anzeichen eines erloschenen Sees, und nicht minder zuverlässig ist ein orographisches Merkmal, nämlich die rundliche Gestalt eines Talbeckens. Die größte Talfläche innerhalb der Alpen, die nordkrainische Ebene (633 qkm), war in vordiluvialer Zeit ein See, den die Save und die übrigen alpinen Zuflüsse schrittweise von Nordwest nach Südost mit mächtigen Kiesmassen zuschütteten, während die Karstflüsse mit einer einzigen Ausnahme nur Sand und Schlamm herbeiführten. Der südliche Teil blieb daher noch lange See, als der nördliche schon ausgefüllt war; Pfahlbauten wurden dort gefunden, und noch jetzt ist or eine $114 \mathrm{qkm}$ große Moorfläche (s. Fig. 126, S. 492).

Sumpf und Moor. ${ }^{20}$ Bei der Umwandlung der Seen in Land spielen neben den Flußsedimenten und den äolischen Ablagerungen auch die Organismen eine hervorragende Rolle. An zwei Seen am Rigaer Meerbusen hat B. Doss eine bis zu $4 \mathrm{~m}$ mächtige Anhäufung tierischer Exkremente beobachtet, die die Landbildung einleitet. Viel wichtiger ist jedoch der Anteil, der in diesem Prozeß den Pflanzen zufällt. Die Vermoorung der Seen ist eines der hervorstechendsten Ergebnisse der Moorbildung überhaupt.

Die Moorbildung geht entweder in untiefem stehendem Gewässer vor sich oder wird durch Versumpfung des Bodens eingeleitet, wie solche überall entsteht, wo der Boden undurchlässig und das Gefälle zu klein ist, um reichliche Wasserzufuhr rasch abzuleiten. Sümpfe begleiten häufig die Flachufer der Meere, Seen und großen Flüsse, im letzteren Falle besonders dann, wenn das Flußniveau höher liegt als das umliegende Land; andere Sümpfe verdanken ihre Entstehung dem austretenden Grundwasser in einer Bodendepression, wie die Moore des Münchener Beckens. In der Regenzeit verwandeln sich viele Gebiete der tropischen Ebenen in Sumpflandschaften, die aber bald wieder austrocknen, während in den Gegenden mit gleichmäBigen Niederschlägen viele Sümpfe permanent sind.

Die Bezeichnung Moor beschränken wir mit WoLLny auf jene wässerigen oder sumpfigen Örtlichkeiten, wo die abgestorbenen Pflanzenteile unter Wasser infolge mangelhaften Zutritts von atmosphärischem Sauerstoff nicht verwesen, sondern verfaulen, und daraus 
mehr oder weniger mächtige Lager von Torf entstehen. Die Pflanzen können entweder angeschwemmt (allochthoner Torf) oder an Ort und Stelle gewachsen sein (autochthoner Torf); nur mit dem letzteren Fall haben wir es hier zu tun.

Enthält das Wasser mineralische Nährstoffe, namentlich Kalk, wie in der Regel das See-, Fluß- und Grundwasser, so wird der Vermoorungsprozeß durch spelzblütige Pflanzen, besonders Riedgräser (Cyperaceen) eingeleitet. Sie dringen allmählich vom Flachufer nach dem Innern der Wasserstelle vor; andere Pflanzen, wie Algen, Moose und auch einige Phanerogamen siedeln sich auf dem ruhigen Wasser der Uferzone an, und sie alle tragen dazu bei, durch Torfbildung den Boden zu erhöhen, die Wasserfläche mehr und mehr einzudämmen und das Eindringen dauerhafter Gewächse zu ermöglichen. An Stelle der Wasser- oder Sumpflläche tritt endlich flaches Land, das Flachmoor.

Ist dagegen das Wasser arm an Mineralstoffen, wie das Regenwasser, so fällt dem Torfmoos (Sphagnum) die erste Rolle im Ver-

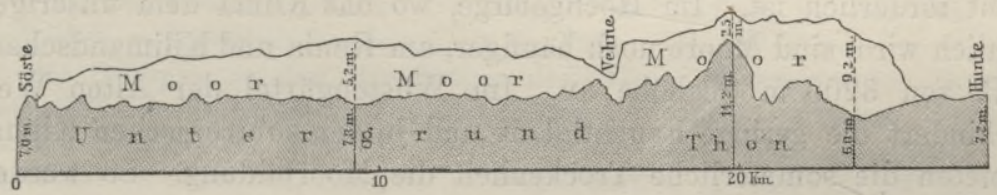

Fig. 257. Profil der östlichen Linie des Hunte-Ems-Kanals (Oldenburg) nach SoHacht.

(Die Zahlen geben die Mächtigkeit des Untergrundes und des Hochmoores.)

moorungsprozeß zu. In dichten Filzlagern beisammen wachsend, saugt es das Wasser wie ein Schwamm auf und hält es fest; es trägt so seine Lebensbedingungen in sich; und hat es einmal, selbst auf sonst trockenem Boden in einem außergewöhnlich nassen Jahr $\mathrm{FuB}$ gefaßt, so breitet es sich unaufhaltsam aus und überzieht bald Berg und Tal (Fig. 257). Indem es in seinen oberen Teilen noch fortvegetiert und sich vermehrt, wenn die unteren schon abgestorben sind, wächst die Polsterdecke in die Höhe und nimmt dabei eine gewölbte Gestalt an, woraus sich die in der Wissenschaft jetzt gebräuchliche Bezeichnung Hochmoor erklärt. In einem ausgewachsenen Hochmoor herrscht das Sphagnum nur mehr in den innersten, höchsten Teilen vor, an dem Abhang gesellen sich Heidesträucher dazu, und am Rand gedeiht bereits eine Waldvegetation.

Von diesen beiden Moorarten ist das Hochmoor wichtiger, weil verbreiteter. Das Flachmoor ist seiner Natur nach vorwiegend auf die wassersammelnden Vertiefungen der Erdoberfläche beschränkt und daher mehr eine lokale Erscheinung, während das Hochmoor 
sich auch in höher gelegenen Gegenden, selbst auf wasserscheidenden Rücken entwickeln kann und dadurch eine regionale Verbreitung gewinnt. Die großen Moore Nordwestdeutschlands und Irlands und die nordamerikanischen Swamps gehören vorwiegend dieser Kategorie an. Die niederschlagsreichen Gegenden unserer Breiten sind wahre Brutstätten des Sphagnums. Manchmal, nach andauerndem Regenwetter, zerreißt seine, durch Gase und Wasser straff gespannte, verfilzte Decke plötzlich, oder das Moor kommt ins Gleiten, und gewaltige Schlammströme stürzen dann hervor, weithin das Land verwüstend. Namentlich in Irland sind solche Ereignisse nicht selten; der Schlammstrom von Kinalady am 25. Juni 1821 riß Häuser und Wälder mit sich fort und bedeckte eine Fläche von mehr als $13 \mathrm{qkm}$, und der Ausbruch des Knocknageehan-Moors bei Killarney am 28. Dezember 1896 dauerte 5 Tage lang. ${ }^{21}$

Seit in Sumatra auch Flachmoore entdeckt worden sind, darf man die Niederungen des Äquatorialgürtels nicht mehr als nahezu moorfrei bezeichnen, wenn auch die hohe Temperatur der Torfbildung nicht förderlich ist. Im Hochgebirge, wo das Klima dem unserigen ähnlich wird, sind Moore noch häufiger, am Kenia und Kilimandscharo z. B. von $3200 \mathrm{~m}$ Seehöhe an. Im Wüstengürtel der Alten Welt verhindert die geringe Feuchtigkeit und in den subtropischen Klimagebieten die sommerliche Trockenheit die Moorbildung. So werden die Äquatorialgrenzen der eigentlichen Moorzone ziemlich weit polwärts verschoben, etwa bis zum 37. bis 40. Parallel, im Innern Nordamerikas sogar bis $50^{\circ}$ und in Westsibirien bis $56^{\circ} \mathrm{B}$. Eine Ausnahme machen nur die atlantische Küste der Vereinigten Staaten und die pazifische Küste Australiens, wo noch bis $30^{\circ} \mathrm{B}$. Moore vorkommen. Eine Polargrenze ist auf Spitzbergen und Grönland nachgewiesen; da aber in hohen Breiten wie in beträchtlichen Seehöhen die Moore nur in Krüppelformen auftreten, so ist anzunehmen, daß niedere Temperatur ihnen ebenso ein Ziel setzt wie hohe.

Literaturnachweise. ${ }^{1}$ F. A. Fonel, Seenkunde, zit. S. 363 . In den letzten Jahren hat die Seenforschung große Fortschritte gemacht. Der Bodensee und der Plattensee sind von wissensehaftlichen Kommissionen eingehend untersucht worden, für den Genfer See hat F. A. Forel (1892-1901), für den Starenberger See W. Ule (1901) gröBere Monographien geliefert. A. Penck und E. Richter $(\dagger)$ geben einen Atlas der österreichischen Alpenseen heraus. Die Seen der norddeutschen Seenplatte und einiger Teile des Mittelgebirges sind besonders von W. Ule, W. Halbfass u. G. Braun untersucht worden. In Frankreich hat sich $\mathrm{A}$. Delebeque um diesen Wissenszweig verdient gemacht, und in Italien arbeitete G. Agostins auf diesem Gebiet. Die englischen Seen haben in H. Mrll und T. J. Jehu, die schottischen in Sir John Murray u. L. Pullar Bearbeiter gefunden. Für Rußland besitzen wir Arbeiten von D. Axurschis, 
für die Balkanhalbinsel von J. Cvısı́c, für Neuseeland von K. Lucas. Eine bibliographische Zusammenstellung findet man in H. WAGNER, Geographisehes Jahrbuch, 1907, Bd. XXX, S. 203. Ein zusammenfassender Seenkatalog wäre sehr wünschenswert; für Europa hat W. HalbFass ein Verzeichnis geliefert: Die Morphometrie der europäischen Seen, in der Zeitschrift der Gesellschaft für Erdkunde, Berlin 1903 u. 1904. - ${ }^{2}$ Sven v. Hedin in Petermann's Mitteilungen 1896, S. 201; ferner: Die geographisch-wissenschaftlichen Ergebnisse meiner Reisen in Zentralasien; Gotha 1900 (Ergänzungsheft 131 zu Petermans's Mitteilungen). - ${ }^{3}$ H. Erdmann, Die Katastrophe von Mansfeld u. das Problem des Coloradoflusses, in Petermann's Mitteilungen 1907. - ${ }^{4}$ Sven v. Hedin in Petermann's Mitteilungen, 1904, S. $159 .-{ }^{5}$ R. Credner, Die Reliktenseen; Gotha 1887-88 (Ergänzungshefte 86 u. 89 zu Petermans's Mitteilungen). ${ }^{6}$ J. Cvisı́, in La Géographie 1902, S. 247. Die norwegischen Seen sind zu berichtigen und zu ergänzen nach Globus, Bd. LXXIX, S. 67. Weitere Ergänzungen für Nordeuropa lieferte P. Stolpe in La Géographie, Paris 1909, Bd. XIX, S. 275. - ${ }^{7}$ Kurzer orientierender Artikel von G. Grem im Globus, Bd. LXXI, S. 8. F. B. TAYLOR, A short History of the Great Lakes, in Studies in Indiana Geography, 1897. R. BecL, The Geologieal History of Lake Superior; Toronto 1899. - 8 E. Gernitz, Über die Entstehung der mecklenburgischen Seen, im Archiv des Vereins d. Freunde der Naturgeschichte in Mecklenburg 1885. Die Seen, Moore und Flußläufe Mecklenburgs; Güstrow 1886. 9 W. Ule, Die Tiefenverhältnisse der ostholsteinischen Seen, im Jahrbuch der preuBischen geologisehen Landesanstalt für $1890-{ }^{10}$ A. v. Вӧнм, Die Hochseen der Ostalpen, in den Mitteilungen der Wiener Geographischen Gesellschaft 1886. - ${ }^{11}$ A. Herm, Die Entstehung der alpinen Randseen, in der Vierteljahrsschrift der naturforschenden Gesellschaft in Zürich, 1894. 12 E. Gogarten zit. S. 564, Anm. 31. - ${ }^{13}$ A. Penck u. E. Brückner zit. S. 256, Anm. ${ }^{37}$. Vgl. auch Penck, Die großen Alpenseen, in der Geographischen Zeitschrift 1905. - ${ }^{14} \mathrm{~N}$. Andrussow, in den Iswestija der Russischen Geographischen Gesellschaft, 1888, S. $91 .-{ }^{15}$ S. PAssarge, Zur Oberflächengestaltung von Kenem, in Petermann's Mitteilungen 1904. - ${ }^{16}$ N. Andrussow, in PeterMANN's Mitteilungen 1897, S. 25 . - ${ }^{17}$ N. JADRINzew, in den Iswestija der Russischen Geographisehen Gesellschaft 1886, S. 53. - ${ }^{18}$ Mitteilung VenJukow's in den Comptes rendus der französ. Akad. d. Wiss. 1886, S. 1045. L. Berq in den Iswestija der Russischen Geographischen Gesellschaft 1903, S. 262. 19 A. Woeikow, in Petermans's Mitteilungen 1901, S. 199, u. 1902, S. 260. L. Berg in Semlevedenie; Moskan 1904, S. 1. - ${ }^{20}$ Hauptwerk: J. FrüH und C. Schröter, Die Moore der Schweiz mit Berücksichtigung der gesamten Moorfrage; Bern 1904. F. Solger, Die Moore in ihrem geographischen Zusammenhange, in der Zeitschrift der Gesellschaft für Erdkunde zu Berlin, 1905. 21 J. FrÜH, Über Moorausbrüche, in der Vierteljahrsschrift der naturforschenden Gesellsehaft in Zürich 1897, Bd. XLII.

\section{Die horizontale Gliederung des Festlandes.}

Die Halbinseln. Wie der vertikale Aufbau, so sind auch die Umrisse der Festländer in ihren Hauptzügen das Produkt einer langen Entwickelungsgeschichte. Strandverschiebungen spielen dabei die Hauptrolle. In zutreffender Weise hat man die Kontinente mit Organismen verglichen, und Halbinseln und küstennahe Inseln als 
Glieder bezeichnet, die in der Tat auch wie Arme nach benachbarten Erdräumen hinübergreifen.

Die Halbinseln, zu deren Betrachtung wir nun übergehen, sind sehr ungleichmäßig verteilt. Ihr Areal beträgt nach H. WAGNER in Prozenten der Gesamtfläche des Erdteiles (ohne die Inseln):

Nördliche Festländer

Europa

Asien

Nord- und Zentralamerika
Südliche Festländer

29,3

Australien .

Südamerika

Afrika
5,5

0,3

0,0

Die Halbinselbildung ist also vorwiegend den nördlichen Festländern eigentümlich und von diesen ist wieder Europa am meisten gegliedert. Es besitzt überdies alle Hauptformen der Halbinseln. Die mit dem Festland innig verwachsene Bretagne, eigentlich nur ein scharf markierter Vorsprung, stellt uns das kontinentale Extrem, die Krim dagegen, die nur durch den $11 \mathrm{~km}$ breiten, sandigen Isthmus von Perekop mit dem Festland zusammenhängt, das insulare Extrem dar. Übergänge finden wir in der Balkanhalbinsel, die sich zwar schon deutlich vom Kontinent abgliedert, aber doch ganz allmählich daraus hervorwächst; in der italienischen, die nur mehr mit einem schmalen Gebirgsstück an das Festland gekettet ist endlich in der orographisch selbständigen pyrenäischen Halbinsel, die als ein fremdes Anhängsel am europäischen Körper erscheint. Nur ist hier, im Gegensatz zur Krim, das Verbindungsglied eine breite Ebene.

Schon aus dieser kurzen Betrachtung ergibt sich, daß Halbinseln sich auf zweierlei Weise bilden können: durch Ab- und durch Angliederung; jene geschieht durch eine positive, diese durch eine negative Niveauveränderung. In den abgegliederten Halbinseln setzt sich stets die Geländeform des benachbarten Festlandsteiles fort. Die beiden unteren Stufen des Karstes bilden die Halbinsel Istrien, und dasselbe Gebirgssystem zieht durch die ganze Westhälfte der Balkanhalbinsel bis in den Peloponnes fort. Ebenso gehören das serbische und das Banater Gebirge wenigstens orographisch zusammen. Zwei Gebirgszüge aus kristallinischem Gestein ziehen aus Armenien in die kleinasiatische Halbinsel hinein, endigen am Kisil-Irmak und tauchen wieder im Westen aus der tertiären Ebene auf. Die Gebirge, die Hinterindien in südsüdöstlicher Richtung durchziehen, beginnen nach v. RicHтHOFEN's Ansicht auf dem Kontinent schon unter $32^{\circ}$ B. Die Zusammengehörigkeit Koreas und des ostasiatischen Rumpfes kommt in den tektonischen Grundzügen deutlich zum Ausdruck; die alten Faltenzüge der südlichen Halbinsel sind eine Fortsetzung der 
chinesischen, und die jüngeren Bruchlinien streichen ohne Unterbrechung in das nördliche Festland hinüber. Betreffs Kamtschatka dürften genauere Untersuchungen wohl zu dem gleichen Ergebnis führen. Das granitisch-vulkanische Gebirge des nördlichen Teiles der californischen Halbinsel endigt auf dem Festlandsrumpf erst bei Los Angeles. Auch die Appenninen Italiens sind ein Teil des alpinen Systems, während die Poebene erst in der Quartärzeit dem Meer abgerungen wurde; Italien gehört also nur scheinbar zu den abgegliederten Halbinseln mit breiter Basis. Noch schmäler als der Appenninenisthmus ist das Verbindungsglied zwischen Neuschottland und Neubraunschweig. Es besteht aus Karbonschichten, die vom Festland auf die Halbinsel hinüberstreichen; und es unterliegt keinem Zweifel, daB die Gezeitenströmungen wesentlich zur Zerstörung der Landenge beigetragen haben (vgl. S. 594). Wo das Hinterland flach oder hügelig ist, finden wir dieselbe Geländeform auch auf den abgegliederten Halbinseln, so auf der jütischen und wahrscheinlich auch in Labrador und Arabien.

Die angegliederten Halbinseln sind geologisch und orographisch selbständige Individuen, und dieser Charakterzug drückt sich auch meist in den geschichtlichen Schicksalen ihrer Bewohner aus. Eine Tiefebene von jugendlichem Alter stellt die Verbindung mit dem kontinentalen Rumpf her. Der Anschluß der iberischen Halbinsel an Frankreich vollzog sich zugleich mit der letzten Aufrichtung der Pyrenäen; die miozänen Schichten, die die südfranzösische Tiefebene bedecken und an der Gebirgsfaltung nicht mehr teilgenommen haben, sind Süßwasserablagerungen. In gleicher Weise gewann Asien das altkristallinische Massiv von Dekan bei der Aufrichtung des Himalaya, also ebenfalls in der Tertiärzeit, und seitdem wurde die Verbindung durch die Aufschüttung von. Flußsedimenten in der hindustanischen Tiefebene immer fester. Erst in der Quartärzeit schlossen sich die Krim mit ihrem isolierten Jailagebirge und das aus altkristallinischen Gesteinen bestehende finnischskandinavische Massiv an das Festland an. Der Ladoga- und der Onegasee sind vielleicht noch Überreste der einst die Ostsee mit dem Weißen Meer verbindenden Wasserstraße.

Florida erregt durch seine Eigenart unsere besondere Aufmerksamkeit. Morphologisch könnte man es für eine abgegliederte Halbinsel halten, und wenigstens in seinem nördlichsten Drittel ist es in der Tat auch nichts anderes als eine Fortsetzung der atlantischen Küstenebene, aber auch in diesem Teil nicht durch Senkung zur Halbinsel geworden, sondern mit der Küstenebene dem Festland angegliedert worden. Das mittlere und südliche Florida ist aber 
ein Stück Westindien, das erst in sehr junger Vergangenheit anwuchs, in so junger, daß es trotz des Mangels jeglicher orographischer Schranke seine ursprüngliche Flora und Fauna noch erhalten hat. Nicht weniger als 360 floridanische Pflanzenarten, 134 Gattungen und 16 Ordnungen reichen nach ChapMan nur bis zum 29. Parallel. An den SuwanneefluB verlegt Cope eine wichtige Grenze für die Reptilien und Amphibien; nur im südlichsten Florida vertritt der südamerikanische Kaiman den nordamerikanischen Alligator. Von den Vögeln der südlichen Halbinsel überschreiten neun Gattungen den 28. Parallel nur wenig, und Insekten und Landschnecken tragen ein echt westindisches Gepräge. Florida ist also eine kombinierte Halbinsel, aber die einzelnen Teile gliedern sich orographisch nicht scharf voneinander ab, wie es sonst die Regel ist. Auch die Stiefelgestalt Italiens ist das Produkt einer solchen Kombination. An drei Stellen (zwischen den Buchten von S. Eufemia und Squillace, zwischen der Serra und dem Aspromonte, und im O des Poromassivs) wird das kristallinische Gebirge der Halbinsel Calabrien von horizonial gelagerten Meeresbildungen tertiären Alters, die von Küste zu Küste reichen, durchschnitten, und diesen geologischen Unterbrechungen entsprechen auch orographische Depressionen. Hier wurden also drei Inseln angegliedert, und von den jungtertiären Meerengen dieser Gegend existiert nur noch eine: die Straße von Messina. Insular waren in der Neogenzeit auch die Kreidetafel von Apulien und der Monte Gargano, und auch jetzt sind sie noch durch weite Ebenen von den Appenninen getrennt; ja vom Gargano mit seiner eigentümlichen Flora und Landschneckenfauna glaubt man sogar ob mit Recht, ist jetzt freilich etwas zweifelhaft geworden - , daß er innigere Beziehungen zu Dalmatien als zu den Appenninen habe. Man kann also wohl sagen, Italien sei ein vielfach geflickter Stiefel. Noch schärfer ausgeprägt sind die sekundären Halbinselbildungen der Balkanhalbinsel. Die mittlere und die östliche Landzunge von Chalkidike sind erst in der jungtertiären Zeit angewachsen, während die westliche eine abgegliederte Halbinsel ist. In die spätere tertiäre Periode fällt auch die Angliederung des Peloponnes, denn zwischen den aus Kreidekalk bestehenden Bergen, der Geraneia in Megara $(1370 \mathrm{~m})$ und dem Oneion in Morea $(582 \mathrm{~m})$, bilden horizontal gelagerte, wenn auch von zahlreichen Verwerfungen durchsetzte Tertiärschichten, die mit marinem Pliozän abschließen, den $5900 \mathrm{~m}$ breiten Isthmus von Korinth, dessen Maximalhöhe nur $79 \mathrm{~m}$ beträgt. Malakka war ebenfalls eine Insel, wie jetzt noch Sumatra, dem es auch in Gestalt und Bau ähnlich ist; und seine Verwandlung in eine Halbinsel hat noch nicht seinen faunistischen Charakter verwischen können, 
denn noch jetzt gleicht seine Tierwelt der der Sundainseln, nicht der Hinterindiens.

Inseln. Im Gegensatz zu den großen Landmassen oder Kontinenten nennt man die kleinen vom Meer umgebenen Landstücke Inseln. ${ }^{\times}$Diese Definition scheint auf den ersten Blick der nötigen Schärfe zu entbehren, in der Tat reicht sie aber aus, denn zwischen dem kleinsten Kontinent mit 7,6 Mill. qkm (Australien) und der gröBten unzweifelhaften Insel mit 0,8 Mill. qkm (Neuguinea) ist doch ein gewaltiger Unterschied. Ein Mittelglied bildet allerdings Grönland mit etwa 2,1 Mill. qkm, und manche mögen es vorziehen, dieses Landstück einen kleinen Kontinent zu nennen, wie man ja auch den Kaspisee, der eine ähnliche isolierte Stellung unter den Seen einnimmt, häufig als Meer bezeichnet. Das Areal aller bekannten Inseln (Grönland ausgenommen) beträgt ungefähr 8,4 Mill. qkm, davon kommen 57 Prozent auf die 23 Inseln mit mehr als $50000 \mathrm{qkm}$ und nur 43 Prozent auf die übrigen ungezählten Tausende von Eilanden, die zusammengenommen nur $2 / 3$ des europäischen RuBland bedecken würden.

Verhältnismäßig selten sind vereinzelte Inseln, wie St. Helena (123 qkm), Ascension (88 qkm) oder Sala y Gomez (4 qkm); meist treten sie gesellig auf. Entweder wird eine Hauptinsel nur von einigen Klippen umgeben, wie Island, oder von größeren Eilanden, wie Madagaskar. Je zwei Hauptinseln enthalten die britische und die Spitzbergengruppe. Doppelinseln sind Neuseeland und Nowaja-Semlja. Eine reihenweise Anordnung zeigen die Antillen, die Alëuten u. a. Eine anscheinend unregelmäßige Anbäufung größerer und kleinerer Inseln, die sich aber meist in mehrere Reihen auflösen läßt, nennt man einen Archipel. Auch hier finden wir bezüglich der Größe wieder dieselben Unterschiede wie bei den einzelnen Inseln. Der malaiische Archipel hat 2,8 und der arktisch-amerikanische 1,4 Mill. qkm; auf beide zusammeñ entfallen also 50 Prozent des gesamten Inselareals. Dagegen sind die 180 Bermudasinseln (50 qkm) nicht einmal so groß wie die Republik San Marino.

Genetische Einteilung. ${ }^{1}$ Nach den Erfahrungen aus der geschichtlichen Gegenwart können Inseln auf zweierlei Weise entstehen: durch Abtrennung vom Festland und durch Wachstum vom Meeresgrund aus. Wir nennen die ersteren festländische oder Kontinentalinseln, die letzteren ursprüngliche Inseln. Beispiele von Abtrennung sind auf S. 591 erwähnt worden; auch jener amphibischen

$\times$ Hier werden nur die Meeresinseln berücksichtigt, da nur diese einen Gegensatz zu den Kontinenten bilden.

Supas, Physische Erdkunde. 5. Aufl. 
Landstücke sei hier gedacht, die, wie der Mount St. Michael in der Mountsbai (Cornwall) oder die friesischen Eilande zur Flutzeit Inseln und zur Ebbezeit Halbinseln sind. Viel zahlreicher sind die Beispiele ursprünglicher Inselbildungen. Wenn wir hören, daß in unseren Tagen an der esthischen Küste zwischen Dagö und Worms die Klippeninsel Harrilaid auftauchte, oder daß man die Golfstrominseln an der Nordseite von Nowaja-Semlja 1871 genau an der Stelle entdeckte, wo 1594 eine Sandbank von $33 \mathrm{~m}$ Tiefe gelotet worden war, so liegt die Annahme nahe, daß hier eine Hebung stattgefunden hat. Ohne Zweifel war dies auch die Entstehungsart jener Inselchen, die Russelu 1905 im Gebiet der Yakutatbai von Alaska entdeckt hat, und die mit dem Erdbeben von 1899 in Verbindung gebracht werden. ${ }^{2}$ In anderen Fällen muß es unentschieden bleiben, ob Hebung oder Aufschüttung der inselbildende Vorgang war, wie bei der Insel Edmondstone zwischen der Mündung des Hugli und dem Kanal de la Baye (Gangesdelta), die nach einem Bericht von 1819 innerhalb fünf Jahren aus einer Sandbank zu einem Eiland von $3 \mathrm{~km}$ Länge und etwa $4 / 5 \mathrm{~km}$ Breite heranwuchs und eine solche Höhe erreichte, daB sie nur noch von den höchsten Sturmfluten überspült wurde. Sicher beglaubigte Fälle vom Auftauchen neuer Inseln infolge von Ausbrüchen von Vulkanen und Schlammsprudeln sind auf S. 401 und 408 angeführt worden, und endlich können wir auch noch die Korallen bei der Herstellung ihrer Riffbauten belauschen. Wir erhalten, wenn wir alle diese Erfahrungen zusammenfassen, ein Schema, dem sich alle genauer bekannten Vorkommnisse einfügen lassen:

I. Kontinentalinseln,

II. Ursprüngliche Inseln:

a) Hebungsinseln,

b) Aufschüttungsinseln,

c) Vulkanische Inseln,

d) Riffinseln.

Daß die Kontinentalinseln zu den Gliedern des Festlandes zu zählen sind, bedarf keiner weitläufigen Erörterung, dagegen muß nachdrücklich betont werden, daß ursprüngliche und ozeanische Inseln nicht identisch sind, wie ältere Einteilungen annahmen. Es gibt ozeanische Kontinentalinseln, wie Neuseeland, und es gibt ursprüngliche Inseln in solcher Festlandsnähe, daß man sie ebenso nur als parasitische Zutaten zu den Kontinenten auffassen muß, wie z. B. Vulkankegel, die auf dem Land selbst entstehen. Den Gegensatz zu den ozeanischen bilden die festlandnahen Inseln, beide Benennungen beziehen sich ausschließlich auf die Lage. 
Kontinentalinseln. Abgesehen von Island, dessen Charakter noch problematisch ist, gehören alle großen Inseln einer Kategorie an, und dazu noch eine ungezählte Menge größerer und kleinerer Felseneilande, die die Fjord- und Riasküsten umschwärmen. Wir erinnern nur an Norwegen, an die Westküste Nordamerikas nördlich von der Juan de Fuca-Straße oder an Südchile. Schon der bloße Anblick der Karte verrät ihre kontinentale Abstammung, und die geologische Untersuchung bestätigt dies. Wir nennen als weiteres Beispiel die dalmatinischen Inseln, die aus demselben Kreidekalk (mit untergeordneten Tertiärbildungen) bestehen wie das dalmatinische Gebirge. Von Veglia bis Zuri streichen sie nach Nordwest, d. h. parallel mit der Küste und dem Streichen der Schichten. Südlich von Sebenico liegt noch ein Stück vollständig erhaltenen Küstenlandes, und genau in seiner Richtung liegt weiter nach Süden die Insel Solta. Dagegen sind die süddalmatinischen Inseln in äquatorialer Richtung gestreckt, bedingt durch eine Wendung im Streichen der Schichten, wie man auf der Halbinsel Sabbioncello beobachten kann. Das Charakteristische der Kontinentalinseln besteht darin, daB sie sich in Gesteinsbeschaffenheit und tektonischem Bau rom Festland nicht unterscheiden. Wir finden hier dieselben sedimentären und kristallinischen Gesteine, dieselben tektonischen Grundformen der Flachschichtung, Faltung und Schollenbildung. Manchmal lassen sich, allerdings mehr oder minder hypothetisch, aus den insularen Bruchstücken noch die ursprünglichen Einheiten herstellen. Wir können die armorikanischen Falten von Irland und Westengland bis in die Bretagne verfolgen (s. Fig. 211. S. 652), und der Parallelismus zwischen dem Londoner und dem Pariser Becken fällt schon bei einem Blick auf die geologische Karte auf. Die Kykladenreihen bis Sikinos, Nios und Naxos sind geologisch die Fortsetzungen von Attika und Euböa, die Spitzen eines untergesunkenen Gebirges. Nach den Forschungsergebnissen der österreichischen Geologen ${ }^{3}$ haben wir es hier mit einer bedeutenden nachpliozänen Niveauveränderung des Landes zu tun, der das Ägäische Meer seine Existenz verdankt. Durch denselben ProzeB, durch den Abgliederungshalbinseln entstehen, werden an ihren Rändern die flachen Teile unter Wasser gesetzt, oder Einsenkungen durch die Erosion des Meeres erweitert und vertieft und dadurch die Erhebungen in Inseln verwandelt. Die jütische und die Balkanhalbinsel, Italien, Hinterindien und das polare Amerika mit Labrador werden von solchen festländischen Inseln begleitet.

Die meisten Kontinentalinseln sind in Bögen angeordnet, die mit gebirgsbildenden Vorgängen in Verbindung stehen. In den 
Antillen läßt sich die Zonengliederung des einstigen einseitigen Faltengebirges noch deutlich erkennen (s. S. 397). Einige Inselbögen sind einfach, andere verketten und verzweigen sich in ähnlicher Weise wie die festländischen Gebirgsbögen. Fig. 258 gibt uns einen Überblick über die westpazifischen Bögen hauptsächlich nach der Auffassung von Suess, doch muß betont werden, daß manche Zusammenhänge noch problematisch sind. Das gilt hauptsächlich für die Linien, die von den Philippinen nach Borneo und Celebes ausgehen, und besonders für die Verbindung Neuseelands mit Tonga einerseits (wofür das Relief des Meeresbodens mit den beiden Gräben spricht)

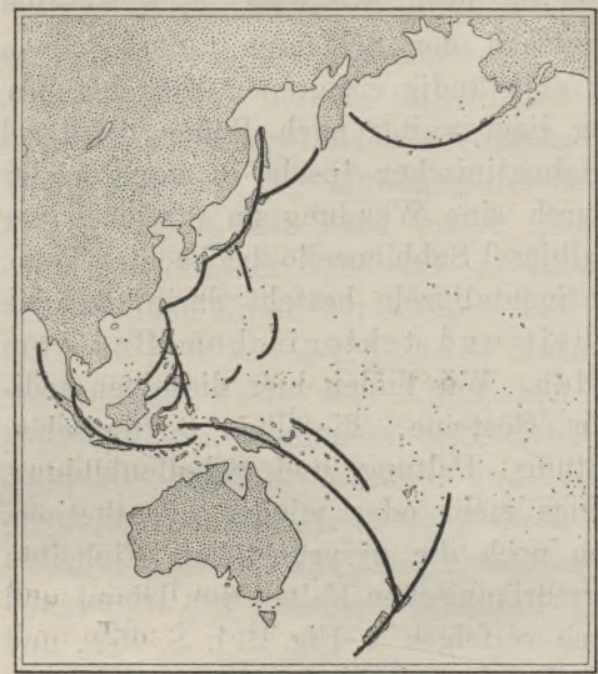

Fig. 258. Die westpazifischen Inselbögen. und anderseits über Neucaledonien mit Neuguinea bis nach Ceram und Buru. Das Zusammentreffen dieser von verschiedenen Seiten kommenden tektonischen Linien im malaiischen Archipel könnte die abenteuerliche Gestalt von Celebes und Halmahera erklären. Selbst der verhältnismäBig am besten bekannte Sundabogen bietet noch Schwierigkeiten. Sein Beginn im $\mathrm{W}$ und seine Abgrenzung gegen den Andamanenbogen ist erst durch VoLz ${ }^{4}$ festgelegtworden; die meridionale Malakka-Streichrichtung setzt nach Sumatra über und schwenkt hier nach SO um. In Java vollzieht sich der Übergang nach $\mathrm{O}$, und dieser Richtung bleiben auch die kleinen Sundainseln treu, aber über den Zusammenhang mit den Bögen des Bandasee sind die Meinungen noch geteilt.

Senkung, Brüche und Meereserosion sind die Vorgänge, die bei der Entstehung der Kontinentalinseln in Betracht kommen. Mit der Senkung geht Hand in Hand aber auch die nivellierende Arbeit der Abrasion, die der Inselbildung feindlich ist. Von den Kykladen Mykonos und Syra im N bis Nios und Sikinos im S breitet sich ein unterseeisches Plateau von geringer Tiefe und fast völlig eben aus, und doch muß es einmal, als es noch Land war, ebenso gebirgig gewesen sein, wie jetzt noch die Inseln. Warum einzelne Teile des sinkenden Geländes, eben die Inseln, der Einebnung entgingen, läßt sich nicht immer erkennen. Jedenfalls darf man an- 
nehmen, daß - wenigstens in Meeren mit stärkerer Brandung die Senkung nicht so langsam erfolgte, daß die Abrasion damit gleichen Schritt halten konnte. Kontinentalinseln, die aus tiefem Meer aufsteigen, sind als Horste aufzufassen; das unterseeische Relief deutet häufig auf Beckensenkungen, Kessel- und Grabeneinbrüche hin. Tafel-, Falten- und Rumpfschollen lassen sich auch hier unterscheiden; die Inseln sind ja nichts anderes als Gebirge der wasserbedeckten Erdkruste. Die Meereserosion spielt jedenfalls bei der Abtrennung kleiner Küsteninseln eine bedeutsame Rolle, ob sie aber auch in größerem Maßstab inselbildend wirkt, ist unsicher. Manche schreiben ihr die Losreißung Großbritanniens vom europäischen. Rumpf zu (vgl. S. 594).

Ursprüngliche Inseln. Die vulkanischen Inseln treten wie die festländischen Vulkane vereinzelt, in Gruppen oder in Reihen auf; die Bogenreihen ordnen sich mit wenigen Ausnahmen den festländischen Inselbögen ein und sind nichts anderes als Krönungen untergegangener Faltenzüge, von denen sich in der Riukiureihe und in den Kleinen Antillen noch einige Lappen an der konvexen Seite erhalten haben. Nicht alle vulkanischen Inseln sind reine Meeresgeburten. So besteht auf Santorin (s. Fig. 97 auf S. 386) der Kern von Thera, der große St. Eliasberg, aus kristallinischen Schiefern und Kalkstein und erweist sich damit als ein echtes Glied der kontinentalen Inselgruppe der Kykladen. Ebenso ist Zannone, eine der Pontinischen Inseln, nach DoELteR ${ }^{5}$ nur ein durch vulkanische Neubildung vergrößertes Reststück der inneren appenninischen Gebirgskette; und derselbe Forscher berichtet, daß die Vulkangruppe der Capverden einst den Westrand von Afrika gebildet habe, da sich, mit Ausnahme der westlichen Insel, auch kristallinische Schiefer und andere Sedimentgesteine an ihrem Bau beteiligen. ${ }^{6}$ Der St. Paulfels im äquatorialen Atlantischen Ozean besteht aus altem Olivingestein, und auf Tristan da Cunha wurde Granit gefunden. ${ }^{7}$ Auch im Großen Ozean erweitert sich der Kreis alter Festlandsreste. So herrschen auf den $z \mathrm{u}$ den Karolinen gehörigen Inseln Yap und Map Amphibolite und Stralsteinschiefer vor, ${ }^{8}$ und auf Viti-Levu in der Fidschigruppe hat A. WICHMANN ${ }^{9}$ neben tertiären Eruptivgesteinen und Tuffen alte massige Gesteine und kristallinische Schiefer nachgewiesen, während die Abwesenheit paläozoischer und mesozoischer Schichten auf eine Festlandperiode hindeutet. Die Marianen sind wieder in anderer Beziehung von Wichtigkeit. Alle sind vulkanisch, aber die sechs südlichen sind bis auf die höchsten Gipfel mit Korallenkalk bekleidet, ${ }^{10}$ also nach unserer Terminologie nicht vulkanische, sondern Hebungsinseln. 
Die größte Anhäufung ursprünglicher Inseln findet sich im Großen Ozean zwischen den Parallelen $30^{\circ} \mathrm{N}$ und $\mathrm{S}$ und zwischen Asien und dem 130. Meridian westlich von Greenwich. Die Kartenbilder dieses Gebietes sind freilich nicht ganz wahrheitsgetreu. Mit Ausschluß der kontinentalen Inseln und der beiden größten ozeanischen (Hawaii und Viti-Levu), haben alle die unzähligen pazifischen Inseln, sowohl hohe als niedere, zusammen nur einen Flächeninhalt von $30000 \mathrm{qkm}$, d. h. nur soviel wie die Provinz Pommern. Da sie sich auf eine Meeresfläche von wenigstens 37 Millionen $q \mathrm{~km}$ verteilen, so kommt durchschnittlich auf $1200 \mathrm{qkm}$ Meer $1 \mathrm{qkm}$ Land, oder - um dies an einem Beispiel klar zu machen - auf ein Meer von der Größe Europas ein Land von der Ausdehnung Kretas. Dana und ARLDT ${ }^{11}$ haben versucht, in diesen Wirrwarr Ordnung zu bringen, indem sie die einzelnen Eilande durch gerade Linien miteinander verknüpften, und sie gelangten so zu der Annahme eines Parallelismus, der - abgesehen von den größeren Inseln im Osten Australiens - in dem Vorherrschen der westnordwestlichen Richtung seinen Ausdruck findet. Wir halten diese Konstruktionen nicht für ganz zutreffend, weil sie die Bodengestaltung des Meeres zu wenig berücksichtigen. Allerdings ist unsere Kenntnis in diesem Punkt noch sehr mangelhaft, aber was wir davon wissen, läßt eher auf das Vorhandensein bogenförmiger als geradliniger Leitlinien schließen.

Die überwiegende Mehrzahl der ursprünglichen pazifischen Inseln sind Korallenbauten, aber nicht alle dürfen wir in die Kategorie der Riffinseln unseres genetischen Systems einordnen. Unter Riffinseln verstehen wir nämlich nur solche, die ihr insulares Dasein ausschlieBlich den riff bildenden Organismen verdanken, während bei den Hebungsinseln eine negative Niveauveränderung das (unterseeische) Riff zutage gefördert hat. Indem wir diesen Gegensatz betonen, berühren wir schon eines der interessantesten, aber auch schwierigsten Probleme der geographischen Morphologie.

Koralleninseln. ${ }^{12}$ Die riffbildenden Korallen, diese unermüdlichen „Arbeiter des Meeres", sind gallertartige Hohltiere, die ein kalkiges Gerüst abscheiden. Die Vermehrung geschieht durch Knospung, wobei keine vollständige Trennung der Individuen eintritt, so daß jede Familie mit ihren lebenden und abgesstorbenen Gliedern einen gemeinsamen Stock bildet. Fester Meeresgrund und ungetrübtes Salzwasser sind in der Regel Bedingungen ihrer Existenz, unerläßlich sind jedenfalls genügende Nahrungszufuhr durch Wellenschlag oder mäBige Strömungen und eine Temperatur, die selbst im Mittel des kältesten Monats nicht unter $20^{\circ}$ sinkt. Aus dem letzteren Grund sind die Riffkorallen einerseits an die Tropenmeere gebunden 
und bleiben auch hier den Gebieten der kalten Meeresströme fern (s. Karte XVII), anderseits sind sie nur auf die oberen Schichten des Meeres beschränkt. Leider ist ihre Tiefengrenze nicht genau festgestellt, man hat riff bildende Korallen (nicht $\mathrm{zu}$ verwechseln mit den Tiefseekorallen!) ausnahmsweise noch in $90 \mathrm{~m}$ Tiefe lebend gefunden, aber im allgemeinen kann man 30 , höchstens $60 \mathrm{~m}$ Tiefe als ihre untere Grenze bezeichnen.

Meistens vereinigen sich in einer Kolonie mehrere Korallenarten, von denen sich die einen, entsprechend ihren besonderen Lebensbedürfnissen, vorzugsweise auf die unteren, die anderen vorzugsweise auf die oberen Wasserschichten beschränken In dem $\mathrm{MaB}$, in dem sich die Ansiedler vermehren und die Individuen an der Basis oder im Innern des Baues absterben, wächst dieser in die Höhe und Breite. Eine Grenze bildet nur das Niveau des Niedrigwassers; aber einige Korallen, die sich einer zeitweisen Besonnung ohne ernste Folgen aussetzen können, wachsen sogar darüber hinaus, etwa bis zu einem Drittel der Fluthöhe. $\mathrm{Zu}$ diesen gehören besonders die Poriten, das widerstandsfähigste aller Polypengeschlechter, das sogar im getrübten Wasser noch leben kann. Die Korallenstöcke bilden aber nur das Skelett des Riffes; der Masse nach überwiegt der Anteil anderer kalkerzeugender Meeresorganismen, wie Foraminiferen und Kalkalgen (Nulliporen, besonders Lithothamnium, Halimeda); und sie sind es vor allem, die dem Bau Festigkeit verleihen. In gleicher Weise wirkt das Meer, aber, wie es scheint, nur in der Zone zwischen Hoch- und Niedrigwasser. Der Kalk löst sich nach KENT im warmen Tropenwasser, und damit werden die Poren verstopft und die Trümmer verkittet. Mechanisch wirkt das Meer, indem es unablässig die Außenseiten des Riffes zerbröckelt und die abgerissenen Stücke zu Sand zerreibt, den es einerseits in den Fugen des Bauwerkes ablagert, anderseits bei heftigen Stürmen auf die Riffoberfläche wirft, so daß der Korallenfels sich allmählich über das Niveau des Hochwassers erhöht. Wir haben dann zwei Teile zu unterscheiden, den unterseeischen oder das Riff, und den oberseeischen, aufgeschütteten insularen Teil. $\times$

Über das Wachstum der Korallen lauten die Angaben verschieden. Eine sehr interessante Tatsache hat v. LeHnerT mitgeteilt. ${ }^{13}$ Das große Bumbum-Riff an der Nordostküste von Borneo, das 1875 ganz nahe der Meeresfläche lag, erscheint auf den Plänen der

$\times$ Die Terminologie ist übrigens schwankend. Manche verstehen unter Korallenriffen die die Küsten der Kontinente und Inseln umsäumenden Korallenbildungen und unter Koralleninseln die isolierten Korallenbildungen auf hoher See. 
Bambum-Inseln, die Sir Edward Belcher 1843 aufgenommen hat, nicht einmal angedeutet; und da die Möglichkeit des Übersehens wohl ausgeschlossen ist, so $\mathrm{mu} B$ das Riff damals mindestens $6 \mathrm{~m}$ tiefer gewesen sein. Das ergibt eine jührliche Höhenzunahme von wenigstens $20 \mathrm{~cm}$, oder, wenn man die Ausdehnung des ganzen

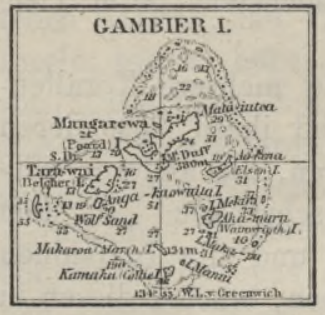

Fig. 259. Wallriff um die Gambier-Inseln (PaumotuGruppe). Höhen und Tiefen in Meter. Korallenfeldes (193 q km) berücksichtigt, eine jährliche Vermehrung der Kalkmasse um etwa 39 Mill. Kubikmeter. Aus den Veränderungen der Breite und Tiefe der Riffkanäle schlieBt GARDINER nur auf eine durchschnittliche Jahreszunahme von $3 \mathrm{~cm}$.

Die überseeischerr Korallenbauten (s. Taf. XVII) sind entweder parasitische Saumriffe oder selbstständige Riffe. Die einfachste Form der Saumriffe - so genannt, weil sie Festländer oder Inseln umsäumen - sind die Küstenriffe, die sich unmittelbar an das Gestade anschließen, mit Ausnahme jener Stellen, wo die Küste zu größeren Tiefen abstürzt, oder wo einmündende Flüsse oder Strömungen das Meerwasser trüben. Der Außenrand des Riffes ist meist etwas erhöht, weil gerade hier, wie GARDINER bemerkt, die Nulliporen

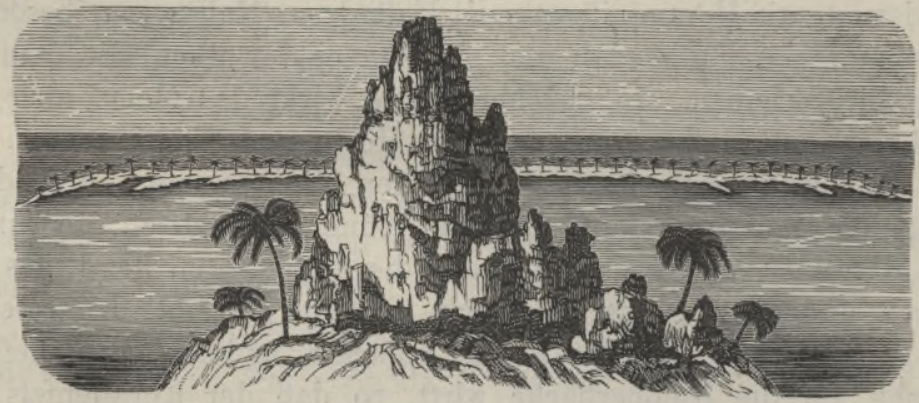

Fig. 260. Borabora-Insel (Tahitigruppe) mit einem Teil ihres Wallriffes nach Darwin.

besonders üppig gedeihen. Gegen das Land hin vertieft sich das Riff etwas und bildet einen schmalen, seichten Kanal, der durch das von den Wogen hineingeschleuderte Material bald ausgefüllt werden würde, wenn nicht die rückläufige Gezeitenströmung für seine Reinhaltung sorgte. Die Breite der Riffe schwankt zwischen etwa 45 und $90 \mathrm{~m}$; ihre bei Ebbe kaum bedeckte Oberfläche ist hart und glatt; Inselbildungen sind selten. Sehr beträchtlich ist die Ent. fernung zwischen der Küste und den Wallriffen, $\times$ die die zweite

$\times$ Andere Benennungen sind: Barriere-, Damm- und Kanalriffe. 
Art der Saumriffe bilden. Besonders bekannt ist das Riff, das die Nordostküste Australiens in einer Entfernung von 30-50, stellenweise von $80-140 \mathrm{~km}$ und in einer Länge von $2000 \mathrm{~km}$ begleitet; die Tiefe des Kanals zwischen Riff und Küste beträgt $20-80 \mathrm{~m}$ und steigert sich im Süden sogar bis $110 \mathrm{~m}$. Meist sind es aber einzelne Inseln oder Inselgruppen aus sedimentären oder vulkanischen Gesteinen, die von Wallriffen umgeben werden (Fig. 259). Die Tiefe des Kanals variiert hier von ein paar bis über hundert Meter. Sein Boden ist mit Korallensand und -schlamm oder mit Riffen bedeckt. Öffnungen in verschiedener Anzahl, oft tief genug, um größeren Schiffen den Eingang zu gestatten, führen aus dem

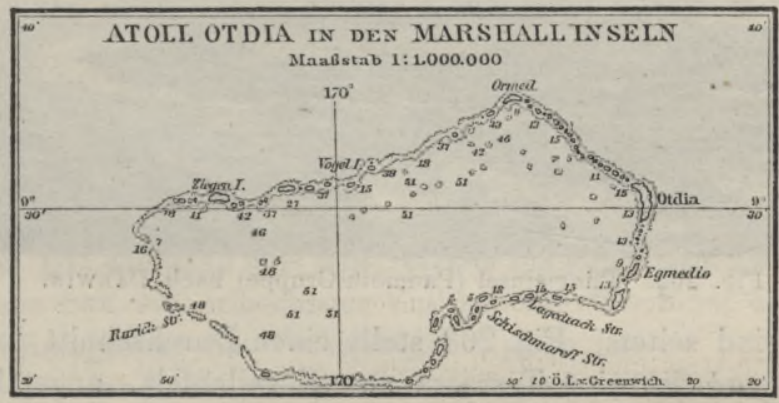

Fig. 261. Atoll Otdia (Marshall-Inseln). Tiefen in Meter.

Meer in die ruhige Lagune, die dann einen natürlichen Hafen bildet. Der Durchmesser des Riffes schwankt zwischen 5 und $47 \mathrm{~km}$. Größere und kleinere Inseln bedecken es, aber nur selten ist (wie in Fig. 260) ein beträchtlicher Teil des Korallenbaues in Land verwandelt.

Die selbständigen Korallenriffe krönen unterseeische Bodenerhebungen. Auf den seichten Bänken der Flachsee überziehen sie krustenartig den Boden; die westindischen Gewässer, die Umgebung der Philippinen, die Javassee, die Gegenden nördlich von Madagaskar und an der Nordwestküste Australiens sind Heimstätten solcher Krustenriffe, wie PENCK sie getauft hat. Die runden oder langgestreckten Atolle (Fig. 261) sind dagegen der Tiefsee eigentümlich. Sie kommen in allen Größen vor; eines der größten, wenn nicht das größte Atoll ist Suvadiva in den indischen Malediven, das $80 \mathrm{~km}$ in der Länge und $65 \mathrm{~km}$ in der Breite mißt und mit seinem Areal (2100 $\mathrm{qkm})$ dem Herzogtum Anhalt gleichkommt. Aber davon entfallen neun Zehntel und darüber auf die vom Riff umschlossene Lagune, die nur bei wenigen kleinen Atollen fehlt, d. h. wahrscheinlich ausgefüllt ist. Das meist von mehreren Öffnungen unter- 
brochene Riff trägt Inseln, die an der Windseite am höchsten sind; in den Malediven sind diese Inseln, die mit fast regelmäßigen Zwischenräumen kranzartig die Lagune umgeben, selbst wieder kleine Atolle (GARDINER ${ }^{14}$ nennt sie mit der einheimischen Bezeichnung Faro), die Seen klaren Salzwassers (Velu nach GARDiner) enthalten. GARDINER ist der Ansicht, daß durch das Zusammenwachsen solcher Faros langgestreckte Riffinseln entstehen. Vollständige Ringinseln

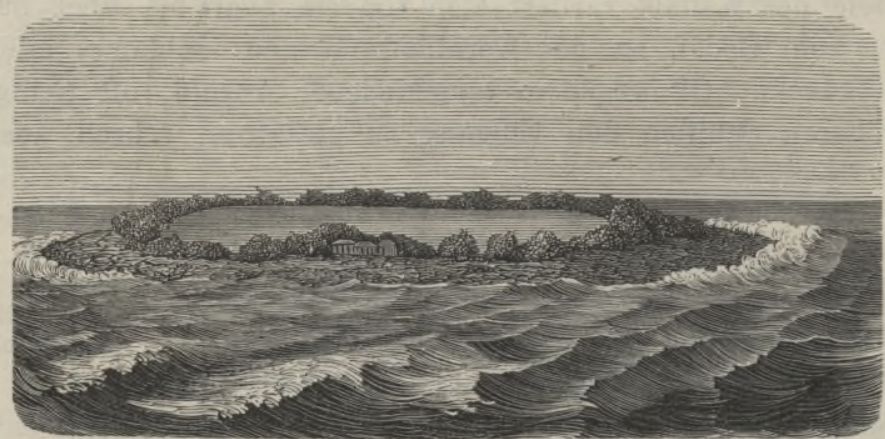

Fig. 262. Pfingstinsel (Paumotu-Gruppe) nach Danwrn.

(Fig. 262) sind selten. Fig. 263 stellt einen Durchschnitt durch eine Insel dar. $a b$ ist eine Terrasse aus Korallenfels, ungefähr $90 \mathrm{~m}$ breit und nur bei Ebbe trocken. Darüber erhebt sich, $2-21 / 2 \mathrm{~m}$ hoch und gewöhnlich $250-360 \mathrm{~m}$ breit, die aus Korallensand und verkitteten oder losen Riffblöcken aufgeschüttete Insel, die die tro-

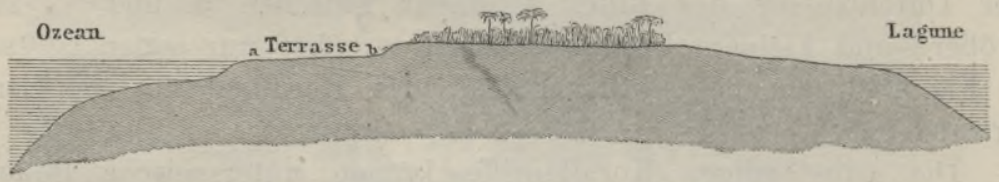

Fig. 263. Querschnitt durch ${ }^{-}$ein Atoll nach DANA.

pische Lebensfülle mit einer dichten Pflanzendecke bekleidet hat. „Die Unendlichkeit des Ozeans,“ sagt Darwin, „die Wut der Wellen im scharfen Gegensatz zur niedrigen Erhebung des Landes und zur Glätte des hellgrünen Wassers innerhalb der Lagune kann man sich kaum vorstellen, ohne dies alles gesehen zu haben." Aber nicht alle Koralleninseln sind flach, manche haben durch eine negative Niveauveränderung eine beträchtliche Höhe erlangt. Daß die Existenz der niederen Inseln beständig gefährdet ist, und daß wohl kein Jahr vergeht, ohne daß eine oder die andere verschwindet, ist verständlich; anderseits leuchtet es ein, daß Sturmfluten hierzu völlig ausreichen, und daß die Annahme einer positiven Niveauveränderung überflüssig ist. ${ }^{15}$ 
Die unterseeischen Berge, denen die Atolle aufgesetzt sind, erheben sich entweder vereinzelt aus dem Tiefboden oder verschmelzen an ihrer Basis zu ausgedehnten Rücken oder Plateaus. Der Tschagosrücken des Indischen Ozeans, ungefähr $54000 \mathrm{qkm}$ (größer als Böhmen!), hat eine mittlere Tiefe von $1300 \mathrm{~m}$ und wird ringsum von Tiefen von mehr als $3700 \mathrm{~m}$ umgeben; die Bänke, die er trägt, werden durch Kanäle von 600 bis $1500 \mathrm{~m}$ Tiefe von einander getrennt; ${ }^{16}$ ein steiler Abfall in den oberen, eine allmähliche $\mathrm{Ab}$ dachung in den unteren Partien ist ihnen allen gemeinsam. Kein Atoll ist in bezug auf die Tiefenverhältnisse genauer bekannt, als Funafuti in der pazifischen Ellice-Gruppe. ${ }^{17}$ Als konischer Berg, der an seiner Basis $48 \mathrm{~km}$ in der Länge und $45 \mathrm{~km}$ in der Breite mißt, erhebt es sich aus einer Tiefe von $5500 \mathrm{~m}$, zuerst ganz allmählich, dann immer steiler. Von $700 \mathrm{~m}$ Tiefe an erreicht der Böschungswinkél $30^{\circ}$, und zwischen 60 und $260 \mathrm{~m}$ Tiefe stürzt das Riff jäh, stellenweise senkrecht $a b$, so daß es BoNNeY mit einer gigantischen Festung auf einem Bergkegel vergleichen durfte. Dieser Bergkegel ist, wie man aus den starken magnetischen Abweichungen geschlossen hat, ein erloschener Vulkan; wir wissen ja, daß die konkave Böschungsform für Vulkankegel typisch ist.

Theorie der Korallenriffe. Der ozeanische Steilabfall der Atolle und Wallriffe wird nach der Annahme DaRwis's von gewachsenen Korallenmauern gebildet. Sie müssen infolgedessen eine Mächtigkeit von vielen hundert Meter erreichen. Bringt man dies in Verbindung mit der Tatsache, daß die Polypen nur bis zu einer gewissen Tiefe leben können, so kommt man notwendigerweise zu dem Schluß, daß hier eine positive Niveanveränderung stattgefunden hat, daß sie aber so langsam war, daß die F'ortführung des Korallenbaues bis an den Meeresspiegel damit gleichen Schritt halten konnte. Jedes Atoll begann nach dieser Theorie seine Laufbahn als Küstenriff um eine Insel, wie es Fig. 264 im Durchschnitt darstellt. Steigt das Meeresniveau von $m^{\prime} m^{2}$ auf $m^{\prime \prime} m^{\prime \prime}$ oder sinkt der Boden um denselben Betrag, so erhöht sich die äußere Korallenmauer, und zwischen ihr und dem Gestade entsteht ein breiter und tiefer Kanal. Dauern diese Vorgänge fort, so verschwindet endlich die zentrale Insel und wird von Korallen überwuchert, aber das Atoll behält die ursprüngliche Form des Wallriffes bei, und der Kanal schließt sich zu einer Lagune zusammen. Jedes Atoll ist also der Leichenstein einer begrabenen Insel.

Was bei dieser Theorie zunächst besticht, ist die genetische Verknüpfung der verschiedenen Riffbildungen, die ja in der Tat alle möglichen. Übergänge selbst in verhältnismäßig kleinem Raum auf- 
weisen. Im Fidschi-Archipel ${ }^{18}$ repräsentiert uns Koro das erste Stadium, das eng sich anschmiegende Küstenriff. Ngau ist im Osten von einem Küsten-, im Westen von einem Wallriff begleitet. Im benachbarten Nairai tritt das Riff schon allseitig von der Küste zurück. In den Exploring Isles ist der nichtkorallinische Kern schon stark zusammengeschmolzen; in Yangasa Cluster sehen aus der Lagune nur noch ein paar Spitzen heraus, Mbukatatanoa oder die Argoriffe u. a. sind endlich reine Atolle. Auch das Nebeneinander verschiedener Entwicklungsstadien ist mit der DARwIN'schen Theorie wohl verträglich, man hat nur eine ungleichmäßige Senkung, eine Verbiegung des Meeresbodens oder eine gleichförmige Niveauveränderung eines in seinen Erhebungen rasch-wechselnden Geländes

1. Stadium.

2.Stadimm.

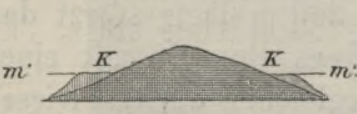

Küstonriff $(K \bar{B})$

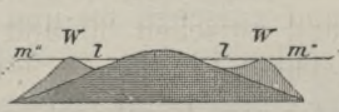

Walliff $(W T)$
3.Stadium.

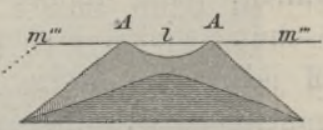

Atoll (AA)

\section{ENin Insel ans altralliconischem Gestein. \\ IIIIIIil Forallenbildungen. \\ $\mathrm{mm}$ Maresspiegel. \\ 2. Lagure.}

Fig. 264. Darwin'sche Riff-Theorie.

anzunehmen. Indes gibt es auch ungeheuere Flächen, wo die Atollform fast ausschlieBlich herrscht. Im Indischen Ozean bilden Lakkadiven, Malediven und Tschagos eine meridionale Kette; abseits liegen die Saya de Malha- und die Nazareth-Bank. In der Südsee erstreckt sich die Atollzone über 35 Breitengrade, von den Karolinen über die Marshall-, Gilbert-, Ellice-, Phönix-, Tokelau- und Manihikigruppe zur Inselwolke des Paumotu. Im Süden wie im Norden werden sie von Gebieten mit vorherrschenden Küstenriffen begrenzt. Auch diese regionale Anordnung ist der DaRwIs'schen Theorie in hohem Grad günstig.

Einigermaßen im Widerspruch damit steht aber die DARwIN noch nicht bekannte Tatsache der regionalen Verbreitung gehobener Korallenriffe. Im mittleren Teil von Polynesien, im Loyalty-, Fidschi-, Tongaarchipel und auf Niue hat die negative Niveauveränderung Werte von mehreren hundert Meter erreicht. Östlich davon sind im Paumotu-Archipel, auf Starbuck, Malden, Jarvis und auf Laysan (Hawaiigruppe) nur Hebungen von $1-6 \mathrm{~m}$ festgestellt worden, und die Korallenbauten haben noch ibren ursprüng- 
lichen Charakter als niedere Inseln bewahrt. Derselbe Vorgang hat auch in der Westhälfte des Indischen Ozeans die Riffe bis zum Höchstbetrag von $8 \mathrm{~m}$ über den Meeresspiegel emporgerückt. Man hat in dieser Übereinstimmung einen Beweis dafür erblickt, daß sich hier das Meeresniveau gesenkt habe; wäre aber dies der Fall, so müßte die Bewegung gleichmäßiger und allgemeiner gewesen sein. Die DarwIN'sche Theorie wird durch diese neueren Erfahrungen zwar stark erschüttert, aber nicht völlig widerlegt, denn der Hebungsperiode könnte ja eine Senkungsperiode vorangegangen sein, in der die Wallriffe und Atolle entstanden sind.

Auch betreffs der Mächtigkeit der Korallenriffe, die den eigentlichen Angelpunkt des wissenschaftlichen Streites zwischen den Anhängern und den Gegnern DaRwin's bildet, haben wir neue Anschauungen gewonnen. Dem unterseeischen Steilabfall der Riffe legen wir keine entscheidende Bedeutung mehr bei. Die Mittelwerte, die Dietrich ${ }^{19}$ berechnet hat, zeigen zwischen unzweifelhaft vulkanischen und korallinischen Inseln keine erheblichen Unterschiede, um so größere aber zwischen diesen beiden Kategorien und den Kontinentalinseln. $\times$ Selbst nichtvulkanische Küsten senken sich da und dort unter steilem Winkel in das Meer hinab; AGAssiz hat scharfsinnig bemerkt, daß die unterseeische Böschung des australischen Riffes nicht steiler ist, als die der rifffreien Ostküste dieses Erdteils. Direkte Aufschlüsse über die Mächtigkeit des Riffkalkes haben uns erst die Messungen an gehobenen Inseln und die Bohrungen verschafft und uns den wichtigen Unterschied zwischen tiefen und seichten Korallenriffen kennen gelehrt. Die Grenze zwischen beiden bildet die untere Grenze der Lebensfähigkeit der riffbauenden Korallen.

$\mathrm{Zu}$ den tiefen Korallenriffen gehört Funafuti. ${ }^{17}$ Die Bohrungen, die Soluas begonnen und DAvid bis zu einer Tiefe von $334 \mathrm{~m}$ fortgeführt hat, haben die Unterlage noch nicht erreicht. Es ist möglich, daß auch die Inseln nördlich davon bis zu den Karolinen dieser

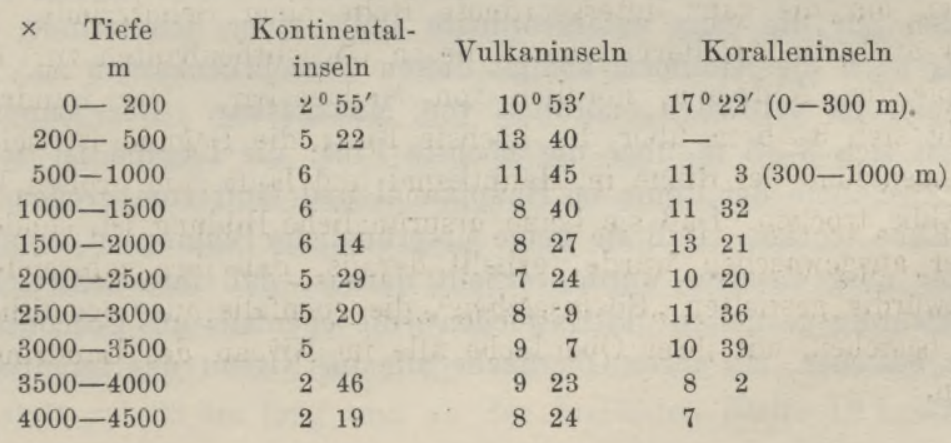


Kategorie angehören, für die wir an DARwin's Senkungshypothese festhalten dürfen. Es gibt aber auch tiefe Korallenriffe, wie beispielsweise die Paumotu-Inseln, die nicht eine einheitliche Masse bilden, sondern wo AGAssiz deutlich zwischen einem unteren tertiären (?) und einem oberen rezenten Kalk unterscheiden konnte. Der letztere ist seicht, die Mächtigkeit des älteren ist unbekannt, und über seine Bildungsbedingungen läßt sich nichts aussagen. Beide Riffperioden waren nach AGassiz' Ansicht durch eine Hebung geschieden; in dieser Zeit wurden die ältern Riffe abradiert und damit der Boden für die rezenten Bauten geschaffen.

Die seichten Korallenriffe der Tiefsee entsprechen den Krustenriffen der Flachsee, die Annahme eines Senkungsvorganges ist hier ausgeschlossen. Nach den Bohrungsresultaten beträgt ihre Mächtigkeit bei Honolulu auf Oahu (Hawaiigrúppe) nur 26 und auf Key West, einer der Florida-Inseln, sogar nur $15 \mathrm{~m}$; die darunter liegenden Kalksteine enthalten nur wenige Korallen und ihr Alter reicht auf Key West bis in das älteste Tertiär zurück. ${ }^{20} \mathrm{Im}$ SalomoArchipel, den Guppr ${ }^{21}$ untersuchte, ruht Korallenkalk mit einer Mächtigkeit von $45-60 \mathrm{~m}$ auf Foraminiferen-Kalkstein oder unmittelbar auf dem vulkanischen Kern. Sehr abwechșlungsreich ist das geologische Profil der Weihnachtsinsel (Christmas Island) südlich von Java, eines über $4600 \mathrm{~m}$ hohen Berges, dessen höchster Punkt $360 \mathrm{~m}$ über dem Meer liegt. Сн. Andrews ${ }^{22}$ fand zu unterst Trachyt und Basalt, darauf folgt eozäner oder oligozäner Kalkstein, dann Tuffe, darauf miozäner Orbitolden-(Foraminiferen)-Kalkstein, endlich Korallenkalk, der auch hier nur einen dünnen Überguß bildet. Noch überraschender sind die Ergebnisse von Voeltzkow's Untersuchungen im westlichen Indischen Ozean. ${ }^{23}$ Viele Riffe, die man ausschlieBlich für korallinische Erzeugnisse hielt, bestehen aus mikroskopischen Coccolithen, organischen Gebilden, die die einen zu den pelagischen Algen, die andern zu den Foraminiferen zählen, und Korallen, die sich auf dem Coccolithenkalk angesiedelt haben, spielen nur die ganz untergeordnete Rolle einer Schutzrinde. Ja sogar auch die Atollform kommt diesen Coccolithenbauten zu. Ein Beispiel ist Aldabra, nördlich von Madagaskar. Der Landring erhebt sich 3-5 m über die höchste Flut; die Lagune ist seicht mit Ausnahme der Rinne im Hauptkanal und läuft zum großen Teil bei Ebbe trocken. Daß sie keine ursprüngliche Bildung ist, sondern später ausgewaschen wurde, erhellt daraus, daß ihre zahlreichen, merkwürdig gestielten „Pilzinselchen“, die ebenfalls aus Coccolithenkalk bestehen, mit ihrer Oberfläche alle im Niveau des Landringes liegen. 
Eigenartige Verhältnisse herrschen im westindischen Korallengebiet. Wallriffe und Atolle sind seltener als in den anderen Ozeanen, und es fehlt die charakteristische Steilböschung am Außenrand. Die Bermudas und Bahamas ${ }^{24}$ bestehen aus Sandstein, der als äolische Bildung, als alte Düne nachgewiesen ist. Er setzt sich auch unterseeisch fort, und lebende Korallen überkleiden ihn nur mit einem dünnen Überzug. Dünen entstehen nur über dem Wasser, die Bermudas und die Bahamas müssen also gesunken sein, und das Material zu dem Sandstein lieferten alte Korallenriffe. Ehemalige Atolle sind bei rascher Senkung zerstört worden, und die jetzigen Bänke sind die alten, nun ausgefüllten Lagunen.

Die DARwin'sche Theorie ist nur auf die tiefen und einheitlichen Korallenbauten anwendbar, aber auch da nur, soweit sie sich auf die Niveauveränderung bezieht. Dagegen fehlt der zwingende Beweis dafür, daß die Wallriffe aus Küstenriffen und die Atolle aus Wallriffen hervorgegangen sind. Die selbständige Entstehung der Wallriffe im Fidschi-Archipel erklärt AGAssiz ${ }^{25}$ in der Weise, daß durch Abrasion längs der gehobenen Inseln eine seichte submarine Plattform geschaffen wurde, auf der sich Korallen ansiedelten, die sich am Rand am üppigsten entfalteten. Für diese Auffassung spricht vor allem die Tatsache, daß auch an solchen Stellen, wo Wallriffe fehlen, die Küste in eine breite, ebene Stufe übergeht, die dann rasch zu größeren Tiefen absinkt, und ferner auch die seitliche Stellung der Insel innerhalb des Riffes statt einer zentralen Lage, wie sie die DARWIN'sche Theorie fordert. Ergriff die Abrasion die ganze Insel, so trat an ihre Stelle ein Atoll. In ähnlicher Weise erklärt GARDINER ${ }^{14}$ die Bildung der Korallenbauten im Indischen Ozean. Wie leicht unterseeische Vulkane der Abrasion zum Opfer fallen können, wurde schon auf S. 401 erwähnt; und ist einmal die vulkanische Kraft erloschen, so ist die Grundlage für Korallen geschaffen. Hat doch auf Krakatau schon sechs Jahre nach dem verheerenden Ausbruch eine Korallenkolonie wieder Fuß gefaßt! Solche Bänke, die sich zur Ansiedelung von Korallen eignen, können auch auf andere Weise in der Tiefsee entstehen. Die ozeanische Forschung der letzten Jahrzehnte hat uns gelehrt, daß sich auch auf dem Meeresboden vereinzelte Berge von gewaltiger Höhe und mit steilen Abstürzen erheben, die wahrscheinlich vulkanischen Ursprung haben, aber niemals oder nur vorübergehend über den Meeresspiegel hinausgewachsen sind. Vier solche Bänke hat das britische Vermessungsschiff „Penguin“ im Jahr $1896460 \mathrm{~km}$ südwestlich von den ElliceInseln entdeckt. Eine davon, die Alexabank, hat eine dreieckförmige Gestalt, ist $33 \mathrm{~km}$ lang und an der breitesten Stelle $19 \mathrm{~km}$ breit; 
die Oberfläche zeigt eine flach-tellerförmige Einsenkung von $44-46 \mathrm{~m}$ Tiefe, über die sich der korallinische Rand ungefähr $13 \mathrm{~m}$ erhebt. ${ }^{26}$ Es ist ein echtes Atoll, das sich von der benachbarten FunafutiInsel nur darin unterscheidet, daß es noch unterseeisch ist. Tiefere Bänke können durch Hebung in die Lebenssphäre der Riffkorallen emporgerückt werden, oder dadurch, daß sich die Kalkschalen der toten Meeresbewohner darüber aufhäufen, während sie ringsum im tiefern Wasser aufgezehrt werden (vgl. S. 274). Durch diesen Vorgang, auf den besonders Murray und Guppy großes Gewicht legten, könnte die oben erwähnte Dreiteilung: vulkanischer Sockel, Mittelschicht aus Foraminiferenkalkstein und korallinischer ÜberguB, erklärt werden. Einige Schwierigkeiten bereiten dieser Theorie nur die tiefen Lagunen vieler Atolle, denn wenn sich auch schon infolge der günstigeren Wachstumsverhältnisse am Rand die Oberfläche jedes Riffs nach innen senkt, so können doch die ursprünglichen Niveauunterschiede nicht bedeutend gewesen sein. Da aber die Lagunen meist durch Kanäle mit dem offenen Ozean in Verbindung stehen, so können sie durch die chemische und mechanische Erosion der Gezeitenströmungen vertieft werden. GARDINER ${ }^{14}$ führt als Beweis an, daß sich die Velus an der Westseite der Maledivenbank seit der Zeit der Aufnahme durch MonesBy (1836) erheblich erweitert und vertieft haben, doch ist noch fraglich, ob die alten Karten völlig zuverlässig sind. Schwerer wiegt seine Beobachtung auf dem Tschagosrücken, wo der Boden zwischen einzelnen Bänken bis zu einer Tiefe von $300 \mathrm{~m}$ von Sand und Schlamm so völlig reingefegt ist, $d a ß$ er einer zementierten Straße gleicht. ${ }^{16}$ Atolle mit tiefen Lagunen können auch alten Kratern aufgesetzt sein, wie schon der erste Erforscher der Koralleninseln, Chaмisso, vermutet hat. Ohne Zweifel waren trotz der Ähnlichkeit der Rifformen ihre Entwicklungsbedingungen verschiedenartig, und nachdem die Herrschaft des DARwIN'schen Schemas glücklicher Weise gebrochen ist, ist die Bahn freigemacht, um jede Möglichkeit vorurteilslos zu prüfen. Wohl darf man voraussetzen, daß überall, wo Atolle óder Wallriffe gesellig auftreten, gleichartige Bedingungen geherrscht haben, aber jedes Gebiet muß für sich auf seine Genesis untersucht werden.

Flora und Fauna der Kontinentalinseln. ${ }^{27}$ Bei der Beurteilung, ob eine Insel kontinental oder ursprünglich ist, können wir der Beihilfe der Pflanzen- und Tiergeographie nicht entraten. Sie ist es allein, die uns AufschluB über das Alter einer Insel geben kann. Die britischen Inseln haben z. B. die Flora und Fauna mit Westeuropa gemein, und wir schließen daraus, daß sie noch in der geologischen Gegenwart mit dem Festland verbunden waren. Denn 
wenn auch die Samen mancher Pflanzen und manche Vögel über die zwar schmale, aber unruhige Meeresstraße von Frankreich nach Britannien gelangen konnten, so hätte diese doch für die überwiegende Mehrzahl der Organismen, namentlich für die Säugetiere ein unüberschreitbares Hindernis gebildet. Die Annahme, daß der Mensch alle Pflanzen und Tiere eingeführt habe, die nützlichen wie die schädlichen, ist - ganz abgesehen von ihrer Unwahrscheinlichkeit - schon deshalb nicht stichhaltig, weil der Reichtum der britischen Fauna in der historischen Zeit abgenommen hat; ja manche Tierformen, wie der Löwe, das Rhinozeros, das Mammut usw., die in der vorgeschichtlichen Periode Britannien bevölkerten, sind gänzlich ausgestorben. Der Landzusammenhang wurde aber früher aufgehoben, ehe die ganze kontinentale Lebewelt in Britannien einwandern konnte, und Irland war schon eine Insel, als die Brücke von Dover noch bestand. ${ }^{\times}$Auch deutet das Vorhandensein einiger eigentümlicher Arten auf längere Isolierung hin. Der insulare Endemismus läßt sich auf verschiedene Weise erklären. In den seltensten Fällen ist er ursprünglich, d. h. die betreffenden Organismen (wohl nur Pflanzen und niedere Tiere) waren nur auf einen kleinen Verbreitungsbezirk beschränkt, und dieser wurde vom Festland abgetrennt. Wahrscheinlich ist der Reichtum der deutschen Insel Borkum an eigentümlichen Pflanzen darauf zurückzuführen. Häufiger ist der Fall, daß organische Formen sich unter günstigen Bedingungen auf einer Insel erhielten, während sie auf dem Festland überhaupt oder wenigstens in dem Mutterland im Kampf ums Dasein zugrunde gingen. In den meisten Fällen haben sich aber die eingewanderten Tiere und Pflanzen den neuen Lebensbedingungen allmählich angepaßt. Veränderte Artenmerkmale konnten sich befestigen, weil eine Vermischung mit der Stammart nicht mehr möglich war. Wie rasch die insulare Abgeschlossenheit unter besonders günstigen Umständen solche Veränderungen erzeugen kann, lehrt uns folgende Tatsache. Auf den Keelinginseln wurden durch ein gescheitertes britisches Schiff Ratten eingeführt, und ihre Nach-

$\times$ Anzahl der Arten nach Wallace:

\begin{tabular}{|c|c|c|c|}
\hline & Festland & England & Irland \\
\hline Säugetiere $\cdot \cdot \cdot \cdot \cdot \cdot \cdot \cdot$ & $\begin{array}{c}\text { etwa } 90 \\
\text { (Deutschland) }\end{array}$ & 40 & 22 \\
\hline Reptilien und Amphibien . . . & (Belgien) & 13 & 4 \\
\hline Landvögel . . . . . . . . . & - & 130 & 110 \\
\hline Phanerogamen und Farne. . . & $=-$ & 1425 & 970 \\
\hline
\end{tabular}

SuPaN, Physische Erdkunde. 5. Aufl, 
kommen unterscheiden sich von den englischen Verwandten bereits dadurch, daß sie kleiner und heller gefärbt sind.

Der größere oder geringere Reichtum einer Insel an eigentümlichen Arten ist also bis zu einem gewissen Grad ein Zeugnis für ihr relatives Alter. Berücksichtigen wir nur den Endemismus in den höheren Tierklassen, so erhalten wir beispielsweise nachstehende Reihenfolge: die britischen Inseln mit 3 Vogelarten, Hainan mit einer Säugetierart und 20 Vogelarten, Formosa mit 14 Säugetierarten, 43 Vogelarten und sogar einem Vogelgeschlecht, endlich Japan mit 25 Landsäugetieren (von 30), aber nur 11 Vögeln (von 165 dort lebenden). Alle übrigen Arten stimmen mit denen des benachbarten Festlandes überein, und auch die endemischen sind mit diesen verwandt. Diese Zahlen, stammen von WaLlace; sie können sich seitdem etwas geändert haben, es ist aber nicht wahrscheinlich, daß in diesem Fall die fortschreitende Erforschung die Schlußfolgerung umstoßen wird. Im übrigen ist aber stets Vorsicht geboten; selbst auf einem so sorgfältig untersuchten Gebiet, wie es der ostindische Archipel ist, brachten die letzten Jahrzehnte umstürzende Entdeckungen. Wir werden darauf an anderer Stelle näher eingehen, hier sei nur eins erwähnt. Borneo und Celebes unterscheiden sich morphologisch in einem wichtigen Punkt voneinander: jenes ist durch eine Flachsee mit Hinterindien verbunden, dieses erhebt sich aus einem tiefen Meer. Die Tiergeographie bestätigt die fundamentale Wichtigkeit dieses Gegensatzes. Borneos Tierwelt trägt einen streng indischen Charakter, in Celebes aber finden wir eine Mischfauna mit altertümlichen Formen. Weitere Aufschlüsse bietet uns aber auch die Biogeographie nicht, und es bleibt unentschieden, ob Celebes von einem Festland abgegliedert wurde, oder ob es gar trotz seines geologischen Kontinentalhabitus eine anomale ursprüngliche Insel ist.

Es ist oben eines Momentes gedacht worden, das uns bei der Bestimmung des relativen Alters einer Kontinentalinsel sicher zu leiten schien, nämlich der Meerestiefe zwischen der Insel und dem Festland. Man ist geneigt, die Inseln der Flachsee als junge Abgliederungen zu betrachten, und in den meisten Fällen dürfte dies auch zutreffen. Trotzdem darf man diesem Moment keine ausschlaggebende Bedeutung - beimessen. Neuguinea und Tasmanien sind beide durch die $200 \mathrm{~m}$-Isobathe mit Australien verbunden, und doch ist Neuguinea unzweifelhaft früher vom Mutterland abgetrennt worden. Wir verdanken diese Erkenntnis ausschließlich der Tiergeographie,

Die ältesten genauer bekannten Kontinentalinseln sind die Antillen, Madagaskar und Neuseeland. KrnchноғF ${ }^{28}$ hat neben 
Abgliederungsinseln, d. h. selbständig gewordenen Randgebieten bestehender Festlandmassen, Restinseln oder Reste untergegangener Festländer unterschieden, und Neuseeland der letzteren Kategorie zugewiesen. Diese Auffassung ist zwar nicht völlig widerlegt, aber zweifelhaft geworden. Dagegen gibt es vielleicht Restinseln in den arktischen Breiten. Die Tiergeographie läßt uns hier fast ganz im Stich. Der Eisbär kommt mit dem Treibeis überall hin, die Renntiere unternehmen weite Wanderungen über gefrorene Meeresstraßen, und auch der Polarfuchs, obwohl nicht so kühn, kann doch gelegentlich mit Treibeis auf eine fern abliegende Insel gelangen. Ob auch der gemeine Fuchs, der in Spitzbergen gefunden wird, und die überall verbreiteten Lemminge ähnliche Reisen ausführen, ist uns nicht bekannt. Dagegen sind das fossile Vorkommen von Mammut und Rhinozeros auf den Neusibirischen Inseln und der Fund eines großen Mammutzahnes im Innern des Wrangellandes stichhaltige Zeugnisse für den einstigen Landzusammenhang. Um die Abstammung des nordamerikanischen Archipels zu erkennen, bedarf es keiner weitläufigen Beweisführung; Nowaja-Semlja ist eine Fortsetzung des Paëchoi-Gebirges; ${ }^{29}$ dagegen bleibt die Entwickelungsgeschichte der anderen Inseln, die durch tiefe Meere yom Festland geschieden sind: Spitzbergens, des König-KarlLandes, des Franz-Josef-Landes, selbst Grönlands noch in Dunkel gehüllt. Nur daß sie kontinentale Inseln sind, erkennen wir daraus, daß sie alle sedimentäre Gesteine, meist von hohem Alter, besitzen. Die silurischen Schichten sind noch gefaltet, die devonischen liegen flach. Suess hält diese. Inseln für Rèste eines alten atlantischen Festlandes. $\mathrm{DaB}$ auch der biogeographische Beweis nicht überschätzt werden darf, sondern stets Hand in Hand mit dem geologischen gehen muB, um uns vor Irrtümern zu schützen, wird aus folgenden Beispielen ersichtlich. Die eigentümlichen Arten der Falklandinseln: der Fuchs, einige Singvögel und etwa 30 Gefäßpflanzen, sind mit den patagonischen Arten sehr nahe verwandt. Trotzdem bezeichnet Suess diese Inseln als „ein dem nahen Festland völlig fremdes, gefaltetes Bruchstück paläozoischer Sedimente". Die drei Inseln im Guineagolf bestehen aus Eruptivgesteinen, wie das Kamerungebirge an der Küste; aber im Gegensatz zu S. Thomè und der Prinzeninsel beherbergt Fernando Po zahlreiche Säugetiere, und von diesen, wie von der übrigen Fauna ist wahrscheinlich keine Art endernisch. Indes liegt kein Grund zu der Annahme vor, daB es nicht auch eine Meeresgeburt ist. Zwischen einer Insel und einem Kontinent kann eine zeitweise Landverbindung bestanden haben, ohne daß die erstere ein Abkömmling des letzteren zu sein braucht. 
Umgekehrt können unzweifelhaft kontinentale Inseln eine Lebewelt beherbergen, die nur ursprünglichen Inseln eigentümlich ist. Wiederholte Sturmfluten können, wie auf den flachen Halligen an der schleswigschen Küste, die vorhandenen Organismen vernichten, oder eine Insel kann ganz oder teilweise versinken und dann wieder auftauchen. Wir haben für die letztere Annahme allerdings keinen geschichtlichen Beweis, aber eigentümliche Verhältnisse in Polynesien legen sie uns nahe. Daß die Gesteinsbeschaffenheit der FidschiInsel Viti-Levu auf ehemaligen Kontinentalzusammenhang hindeutet, wurde schon auf S. 773 erwähnt. Nachklänge an jene Periode fehlen nicht ganz, denn hier bricht das Verbreitungsgebiet der neuguineischen Molluskenfauna, die mit ihren zahlreichen großen Arten einen entschieden kontinentalen Charakter zeigt, plötzlich ab, so daß nach KoBelt's Äußerung das benachbarte Samoa näher mit Tahiti als mit Fidschi verwandt erscheint. Aber größere Tiere mußten schon aus Nahrungsmangel verschwinden, wenn das Land $\mathrm{zu}$ wenigen kleinen Inseln zusammenschrumpfte. Ein solches Ereignis scheint hier eingetreten zu sein, denn die merkwürdige Oberflächenbildung der großen Insel Vanua-Levu läßt sich nach GuPPY ${ }^{30}$ nur dadurch erklären, daß es nicht ein alter Landrest ist, sondern sich erst in spättertiärer Zeit aus der Vereinigung mehrerer vulkanischer Inseln von verschiedener Größe herausgebildet hat. Ein wiederaufgetauchtes kontinentales Reststück ist vielleicht der atlantische St. Paul-Fels (s. S. 773), wo nur Seevögel und ihre Parasiten gefunden wurden und bezeichnender Weise die Flora gänzlich fehlt.

Flora und Fauna der ursprünglichen Inseln. Entsteigt eine Insel dem Meer, so kann eine Besiedlung nur durch Einwanderung erfolgen, und Flora und Fauna müssen daher viel dürftiger ausgestattet sein, als dort, wo ein Stamm ansässiger Organismen in das insulare Dasein hinübergenommen wurde. Von den Tieren sind die Säuger, mit Ausnahme der fliegenden und der schwimmenden, und die Lurche fast völlig von den ursprünglichen Inseln ausgeschlossen. Ratten und Mäuse sind zwar auf den Färöer, den Galapagosinseln und den Andamanen heimisch, aber da sie dem Menschen überallhin folgen, dürften sie wohl eingeführt worden sein. Auf den letztgenannten Inseln wurde auch eine Schweineart gefunden, aber die Andamanen sind wahrscheinlich vom Festland abgetrennt worden, da die südlichen nach KURz geologisch und floristisch ganz mit der Küste von Arakan übereinstimmen. Aus ihrer kontinentalen Vergangenheit stammt wohl auch ihre Amphibienfauna. Sonst bewohnen einheimische Lurche nur noch einige westpolynesische Inseln, aber alle gehören der Baumfroschfamilie der 
Polypedatidae an. Dagegen sind Landvögel allgemein verbreitet. Einige sind mit großer Flugkraft ausgestattet - so besuchen alljährlich 170 nordamerikanische Vögel die $1100 \mathrm{~km}$ entfernten Bermudas - , andere werden durch Stürme weithin verschlagen. Dasselbe widerfährt in noch höherem Grad den Insekten, die überdies noch eine Zeit lang den Wirkungen des Salzwassers widerstehen, und deren Larven und Eier auch auf schwimmenden Pflanzen weithin getragen werden können. Eine genaue Analyse der Käferfauna von Madeira ergab, daß mit wenigen und gut zu erklärenden Ausnahmen nur jene europäischen Käfer fehlen; die flügellos sind oder eine geringe Flugkraft besitzen. Um so auffallender ist hier (wie auf den Kerguelen) die ungewöhnlich große Zahl flügelloser Insekten. DARwIn hat dies durch das Prinzip der natürlichen Zuchtwahl erklärt. Bei jenen Insekten, die die Flügel nicht unbedingt brauchen, trat eine Verkümmerung dieses Organs ein, da sie für den Aufenthalt auf einer stürmereichen Insel förderlich war. Bei den anderen mußte aber aus demselben Grund das Organ sich stärker entwickeln, und in der Tat haben die geflügelten Arten auf Madeira meist größere Flügel als ihre europäischen Verwandten.

Im Gegensatz zu den Vögeln und Insekten werden Kriechtiere und Landschnecken nur zufällig über die See verschleppt; aber ihre weite Verbreitung zeigt, daß diese Zufälligkeiten nicht allzu selten eintreten. Reptilien findet man mit Ausnahme der Azoren, Madeiras, der Canaren, Färöer und der Revillagigedo-Gruppe fast überall. Seltener scheinen Landschnecken Seereisen zu unternehmen, daher gerade in dieser Tierklasse der insulare Endemismus stark ausgebildet ist.

Pflanzen verfügen über verschiedene Transportmittel. Winde und Vögel scheinen dabei die wichtigste Rolle zu spielen. ${ }^{\times}$Manche Samen, die mit borstigen oder stacheligen Fortsätzen versehen sind, bleiben am Gefieder, andere in Verbindung mit erdigen Teilchen an den Füßen der Vögel haften. Noch bedeutungsvoller für die Pflanzenverbreitung erscheint die Eigentümlichkeit dieser Tiere, die Samen genossener Früchte unverdaut wieder auszuscheiden, da deren Keimkraft dadurch nicht nur nicht zerstört, sondern sogar erhöht wird. Sporen und kleine Samen, die oft nur Hunderttausendstel eines Grammes wiegen, können durch die Winde weithin geführt

$\times$ Die Analyse der Krakatauflora scheint dem zu widersprechen, denn 39-70 Proz. der neuen Pflanzen wurden durch Meeresströmungen, 16-30 durch den Wind und 10-19 durch Vögel eingeführt. Aber man beachte, daB Krakatau sehr nahe dem Land liegt, auf weite Strecken dürften die Strömungen ein weniger geeignetes Transportmittel sein. 
werden; diesem Agens ist es zuzuschreiben, daß die Farne in der Flora der ozeanischen Inseln eine so große Rolle spielen. Andere Samen, besonders diejenigen, die durch harte Schalen geschützt sind und daher auch im Salzwasser ihre Lebensfähigkeit bewahren, wandern mit den Meeresströmungen. ${ }^{31}$ Die Äquatorialströmung brachte die ursprünglich amerikanische Kokospalme den Inseln der Südsee und verbreitete sie von da bis nach Madagaskar und den Seychellen. Madeira, die Canaren und die Azoren sind durch den Passat mit Südeuropa verbunden, und von da stammt auch ihre Pflanzenwelt. Die meisten Gewächse der Bermudas sind mit dem Golfstrom aus Westindien eingewandert. Eine lokale Strömung von der Panamabai zur Nordostseite der Galapagosinseln brachte dorthin zentralamerikanische Pflanzen.

Wie rasch die Pflanzenbesiedlung vor sich geht, beweist Krakatau. Schon drei Jahr nach dem verheerenden Ausbruch von 1883 hatte es sich mit Farnen bedeckt, und hier und da traten auch schon Phanerogamen auf. Damals zählte man erst 15, 1897 aber schon 56 und 190692 Spezies von Blütenpflanzen. Schon haben im Innern die Gräser die früher herrschenden Farne auf die steilen Felspartien zurückgedrängt, müssen aber nun selbst den Kampf mit den Waldbäumen aufnehmen, die die feuchten Schluchten bereits erobert haben. ${ }^{32}$ Diese Insel liegt eben günstig zwischen Java und Sumatra, Tier- und Pflanzenwanderungen über weite ozeanische Strecken sind aber jedenfalls nur zufällige Ereignisse. Es genügt auch nicht, daß gelegentlich einmal ein Individuum auf eine Insel verschlagen wird, sondern es muß sich hier auch erhalten und fortpflanzen können. Unter tausend Fällen der Verschleppung, wie solche tatsächlich beobachtet wurden, mag nur einer zur Ansässigkeit führen, aber es bedarf nur langer Zeiträume, damit sich solche seltene Ereignisse wiederholen. Sie werden um so öfter eintreten, je stürmischer ein Meer ist, wie der Reichtum der Azoren oder der Bermudas im Gegensatz zu der Armut der Galapagos (an Pflanzen wie an Vögeln) lehrt. Aber selbst die am besten ausgestattete Flora einer ursprünglichen Insel ist ärmlich im Vergleich mit den Floren der Kontinente und selbst der festländischen Bruckstücke. Der Umstand, daß jene Eilande nur auf spärliche Almosen angewiesen sind, bewirkt einerseits, daß die Geschlechter meist nur durch wenige Arten vertreten sind, und begünstigt anderseits den Endemismus. Dieser ist freilich auch von dem Alter der Insel abhängig, ebenso wie unter übrigens gleichen Umständen auch die Anzahl der Arten. Die Azoren und Madeira besitzen - wie schon oben erwähnt wurde eine mediterrane Flora. Auf jenen kommen durehschnittlich 20, 
auf dieser 85 Gefäßpflanzen auf je $100 \mathrm{qkm}$; auf jenen sind 8,3, auf dieser 15,2 Prozent endemisch, und die eigentümlichen Gewächse der Azoren sind viel näher mit den europäischen verwandt als die Madeiras, trotzdem die Azoren weiter von unserem Erdteil entfernt sind. Wir müssen daraus schließen, daß Madeira älter ist als die Azoren. Die Bermudas sind jung, und ihre organische Welt stimmt fast ganz mit der nordamerikanischen überein. St. Helena ist, wenn überhaupt eine ursprüngliche Insel, jedenfalls eine der ältesten; im Großen Ozean sind Hawaii, die großen Fidschi-Inseln, Tahiti und die Galapagos die ältesten Vulkaninseln. In bezug auf die letzteren sind die Ansichten geteilt. Verschiedene Vögel, die Eidechse Tropidurus, mehrere Pflanzen, wie Scalesia, Euphorbia viminea u. a., kommen auf jeder Insel in einer besondern Art oder wenigstens Varietät vor, und $\mathrm{BAUR}^{33}$. hat daraus geschlossen, daß alle Inseln dieser Gruppe einst untereinander und mit Zentralamerika zusammenhingen, und daß sich die verschiedenen Arten und Varietäten erst nach der Isolierung entwickelt haben. Gegen die kontinentale Abstammung spricht die Lückenhaftigkeit der Fauna, und gegen die Ansicht, daß sich die Galapagos erst nach der Besiedlung in Inseln aufgelöst haben, die Tatsache, daß die Floren entfernter Inseln näher miteinander verwandt sind als die benachbarter. RoBINson ${ }^{34}$ kehrt daher wieder zu der älteren Annahme der Ursprünglichkeit der Galapagos zurück. Wir haben dieses Beispiel deshalb hier angeführt, um zu zeigen, daß auch betreffs der ursprünglichen Inseln noch Streitfragen schweben, die die Biogeographie nicht endgültig $\mathrm{zu}$ lösen vermocht hat.

Literaturnachweise. ${ }^{1}$ F. HaHN, Inselstudien; Leipzig 1883. AuBerordentlich reich an Beobachtungsmaterial, die Ergebnisse in bezug auf die Einteilung können wir jedoch nicht annehmen. $-{ }^{2}$ R. S. TARR und L. Martin zit. S. 463. - ${ }^{3} \operatorname{Im}$ 40. Band der Denkschriften der Akademie der Wissenschaften in Wien, Mathem.-naturwiss. Klasse, 1880. Vgl. auch A. PhiLrppson, Beiträge zur Kenntnis der griechischen Inselwelt; Gotha 1901 (Ergänzungsheft 134 zu Petermans's Mitteilungen). - ${ }^{4} \mathrm{~W}$. Volz, Die geomorphologische Stellung Sumatras, in der Geographisehen Zeitschrift 1909. - ${ }^{5}$ C. Doelter, Die Vulkangruppe der Pontinischen Inseln, im 36. Bd. der Denkschriften der Wiener Akademie der Wissenschaften (Mathem.-naturwiss. Klasse) 1875. ${ }^{6}$ C. Doflter, Die Vulkane der Capverden; Graz 1883, - ${ }^{7}$ E. H. L. Schwarz, The Rocks of Tristan d'Acunha, in den Transactions of the South Afriean Philosophical Society 1905, Bd. XVI. ${ }^{8}$ E. KaIser, im Jahrbuch der Preubischen Geologischen Landesanstalt 1903, Bd. XXIV, S. 91. - 9 A. Wichmann, Petrographie des Viti-Archipels, in Tscнerмak's mineralogischen Mitteilungen, Bd. V, 1883. - ${ }^{10}$ Fritz, in den Mitteilungen aus den Deutschen Schutzgebieten, 1902, S. 96. - ${ }^{11}$ Тн. AвLdт, Der Parallelismus der Inselketten Ozeaniens, in der Zeitschrift der Gesellschaft für Erdkunde in Berlin, 1906. - ${ }^{12}$ Сн. Darwin, 
Structure and Distribution of Coral Reefs; London 1842 (neue Ausgabe in The Camelot Series; London 1890). J. D. Dana, Corals and Coral Islands; London 1875. John Murray, On the Structure and Origin of the Coral Reefs; im X. Bd. der Proceedings of the Royal Society of Edinburgh 1879-80. A. Agassiz, The Coral Reefs of the Tropieal Pacific, in den Memoirs of the Museum of Comperative Zoology at Harvard College, Bd. XXVIII, 1903. Über die weitere Literatur s. R. LANGenbeck, Die Theorien über die Entstehung der Koralleninseln; Leipzig 1890, und sein Referat in der Geographischen Zeitschrift 1907 , S. 24 u. 92. - ${ }^{13}$ J. v. LeHNert, Über Landbildungen im Sundagebiet; Deutsche Rundschau für Geographie, 1883, Bd. V. - ${ }^{14}$ J. St. GarDIner, The Fauna and Geographie of the Maldive and Laccadive Archipelagoes; Cambridge 1901. Ausgezeichnete Karten in A. Agassiz, The Coral Reefs of the Maldives, in den Memoirs of the Museum of Comparative Zoology at Harvard College 1903, Bd. XXIX. - ${ }^{15} \mathrm{Vgl}$. den Bericht von C. Jeschke in Petermann's Mitteilungen 1905, S. 248. - ${ }^{16}$ J. St. Gardiner, The Indian Ocean, im Geographical Journal 1906, Bd. XXVIII. - ${ }^{17}$ The Atoll of Funafuti, London 1904. - ${ }^{18} \mathrm{~S}$. die Karte der Fidschigruppe in Petermann's Mitteilungen 1882 , Taf. $8 .-{ }^{19}$ F. Dietrich zit. S. $276 .-{ }^{20}$ A. Agassiz, The Elerated Reef of Florida, ebenda, Bd. XXVIII, 1896. - ${ }^{21}$ H. B. Guppy, The Salomon Islands; London 1887. - ${ }^{22}$ Сн. W. Andrews, A Monograph of Christmas Island; London 1900. - ${ }^{23}$ A. Voeltzkow, Wissenschaftliche Ergebnisse der Reisen in Madagaskar und Ostafrika in den Jahren 1889-95, II. Bd.; Frankfurt a. M. 1901. Vorläufiger Bericht über die Forschungsreise 1903-05 in den Sitzungsberichten der Preußischen Akademie der Wissenschaften 1906, S. 25. - ${ }^{24}$ A. Agassiz, A Reconnaissance of the Bahamas usw.; a Visit to the Bermudas, im Bulletin of the Comparative Zoology at Harvard College, Bd. XXVI, 1894 u. 1895. - ${ }^{25}$ A. AaAssiz, The Islands and Coral Reefs of Fiji. Bulletin of the Museum of Comparative Zoology at Harvard College, Bd. XXXIII, 1899. E. C. Andrews, Notes on the Limestones and General Geology of the Fiji Islands; ebenda, Bd. XXXVIII, 1900. - ${ }^{26}$ W. J. L. Wharton, im Nature, 1897, Bd. LV, S. 390, mit sehr interessanter Karte. $-{ }^{27}$ A. R. Wallace, Island Life; London 1880. - ${ }^{28}$ A. K Irснноғ, Das genetische Inselsystem, in der Zeitschrift für wissenschaftliche Geographie, Bd. III, 1882. 29 A. Wichmans, Zur Geologie von Nowaja-Semlja, in der Zeitschrift der Deutsehen Geologischen Gesellschaft 1886. - ${ }^{30}$ H. B. Guppy, Observation of a Naturalist in the Pacific; London 1905/06. - ${ }^{31} \mathrm{~S}$. Birger, Über den EinfluB des Meerwassers auf die Keimfähigkeit der Samen, in den Beiheften zum Botanischen Zentralblatt, Dresden 1907, Bd. XXI. - ${ }^{32}$ A. Ernst, Die neue Flora der Vulkaninsel Krakatau. Zürich 1907. - ${ }^{\text {s3 }}$ G. BAUR, im American Naturalist 1891, S. 217 u. 307, und 1897, Bd. XXXI, S. 661; ferner in den Biological Lectures, delivered at the Marine Biological Laboratory of Wood's Holl; Boston 1894, S. 67. - ${ }^{34}$ B. L. RoBısson, Flora of Galapagos Islands, in den Proceedings of the American Academy of Arts and Sciences 1902, Bd. XXXVIII.

\section{Küstenformen.}

Haupttypen. Die Küstenformen hängen in erster Linie von dem Bau des Hinterlandes ab; erst in zweiter Linie kommen jene Vorgänge in Betracht, die wir in Kürze als Kampf um die Herrschaft 
zwischen Land und Meer bezeichnen können. Es sind dies Anschwemmungen der Flüsse, Anschwemmung und Zerstörung durch das Meer, endlich Niveauveränderungen, die sich den Oberflächengewalten bald hemmend, bald fördernd zur Seite stellen.

Verfolgen wir die Umrisse des Landes in ihren Hauptzügen, und beginnen wir mit den pazifischen Gestaden.

Die Westküste Amerikas begleitet ein großes Faltengebirge, das mit allen seinen Biegungen den Verlauf der Küstenlinie bestimmt. Solch eine Küste nennen wir eine konkordante. Auf der asiatischaustralischen Seite haben wir zunächst zwischen einer Außen- und einer Innenküste zu unterscheiden. Die äußere bilden die Inselbogen von den Alëuten bis Neuseeland. Auch sie ist konkordant, und insofern hat Suess recht, wenn er die Konkordanz kurzweg als pazifischen Typus bezeichnet. Aber die kontinentale Innenküste läßBt verwickeltere Verhältnisse erkennen. Am Ochotskischen und Japanischen Meer ist sie vorwiegend konkordant, dann aber tritt die chinesische Tiefebene an die See heran. Wo die Umrisse durch flachgelagerte Schichten oder Massengesteine gebildet werden, kann natürlich von einer bestimmten Streichrichtung nicht die Rede sein; es entsteht eine neutrale Küste. Südlich vom Jangtsekiang herrscht wieder Gebirgsküste, aber die Küstenlinie läuft nicht mehr parallel dem Gebirge, sondern schneidet es unter einem spitzen Winkel, so daß das Meer abwechselnd die Ausläufer der Ketten und die Längstäler bespült. Das ist der Charakter des dritten Haupttypus: der diskordanten Küste.

Im Bereich des Indisch-Atlantischen Ozeans ist die Diskordanz vorherrschend; Suess bezeichnete dies als atlantischen Küstentypus. Die große Gebirgszone der Alten Welt erreicht das indische Gestade nur in Hinterindien und Iran, gegen den Atlantischen Ozean streicht sie senkrecht aus. Senkrecht dazu gestellt sind auch die alten Faltenzüge der europäischen Westhälfte, nur im nördlichen Skandinavien verläuft die Küste nahezu parallel mit dem Streichen der Schichten, und ebenso im nördlichen Spanien, soweit das Cantabrische Gebirge reicht. Vielleicht kann auch die Küste Niederguineas als konkordante aufgefaßt werden. Denselben Charakter trägt auch die Küste Brasiliens zwischen Rio de Janeiro und Pernambuco und die Neuschottlands. In Westindien wiederholt sich die Doppelküste Ostasiens mit einem äußeren konkordanten Faltenrand. Im großen und ganzen werden aber die Grenzen des Atlantischen und des Indischen Ozeans mehr durch Querbrüche, als durch Faltungs- und Zerrungsbögen bestimmt, und geradlinige und geknickte Umrisse herrschen daher vor. Die verschiedenen Typen lösen sich im bunten Wechsel 
ab, im schroffen Gegensatz zu der Einförmigkeit der amerikanischen Westküiste. Im Mittelmeer finden wir konkordante Küsten in größerer Ausdehnung, wie zu beiden Seiten der Adria, das pontische Südgestade, die phönizische Küste, die Atlasküste. Die Westküste Vorderindiens liefert uns ein anderes Beispiel von Konkordanz, aber hier streicht der Küste entlang ein Bruchgebirge.

Im arktischen Gebiet scheint der neutrale Typus vorzuherrschen.

Detailformen. $^{1}$ Wir haben auf S. 584 nach dem Vertikalprofil Steil-, Flach- und Strandküsten unterschieden. Die neutrale Küste kann in allen drei Formen auftreten, und damit kombiniert sich eine große Mannigfaltigkeit in den horizontalen Umrissen. ${ }^{\times}$Als Hauptkategorien betrachten wir die glatte und die gebuchtete Küste. Guldiver sieht darin einen Ausdruck des Kampfes zwischen der Küstenströmung, die der Küste folgt, und der Gezeitenströmung, die die Küste mehr oder weniger senkrecht trifft. Wo jene herrscht, entstehen glatte Küsten, wo diese maßgebenden Einfluß gewinnt, nimmt die Küste eine unregelmäßig gezackte, kleinbuchtige Gestalt an. Jedenfalls deutet die glatte Küste stets auf Anschwemmung, die aber gleichzeitige Zerstörung nicht ausschließt; so ist nach JESSEN $^{2}$ die ursprünglich gebuchtete Nordwestküste von Jütland sowohl durch Fortspülung der Vorsprünge wie durch Ausfüllung der Buchtung geglättet worden. Die einfachste Form ist die geradlinige, wie sie uns in der Flachküste der Landes und in der Steil- und Strandküste der Normandie entgegentritt. In flachen Bogen, girlandenförmig, umsäumt dagegen das deutsche Flachland die Ostsee. Die gebuchtete Form mag wohl in vielen Fällen eine reine Erosionserscheinung sein, in anderen steht sie aber sicher auch mit einer positiven Strandverschiebung in Verbindung. Wahrscheinlich ist darauf die unregelmäßige kleinbuchtige Gestalt, die die französische Küste nördlich der Gironde annimmt, zurückzuführen; dafür sprechen schon die abgegliederten Inseln Oléron und Ré. Welche Bewandtnis es dagegen mit der Entstehung der großbuchtigen Neutralküsten Patagoniens und Sibiriens hat, ist noch unbekannt. Einen Übergang von glatten zu gebuchteten Formen zeigt uns die Boddenküste Vorpommerns und Mecklenburgs. Die Bodden fallen schon auf Karten kleineren Maßstabes durch ihre abenteuerlich gelappte Gestalt auf; sie sind ohne Zweifel Eroberungen des Meeres, aber zum Teil noch recht unvollständige, und in diesem

× Mernhold (Die Küste der mittleren atlantischen Staaten Nordamerikas, Crimmitschau 1904) unterscheidet auf der Strecke vom Eingang der Chesapeakbai bis zur Grenze von Maine nicht weniger als 13 verschiedene „Küstenarten“; wir stehen auch hier, wie in der Seeneinteilung, im Zeichen der Subtilität. 
Fall entstehen Doppelküsten. So bilden die Halbinsel DarB und die kaum davon getrennte Insel Zingst die geradlinige Außenküste, hinter der, nur durch schmale Zugänge erreichbar, die zerfetzte Boddenküste von Barth und Ribnitz liegt. Den umgekehrten Entwickelungsgang nahm die Haffküste Preußens. Die Haffe sind alte Buchten, die durch Nehrungen abgeschlossen wurden. Aus der gebuchteten Küste entsteht eine geradlinige Doppelküste, wenn, wie in Preußen, das Haff vom Meer aus noch zu erreichen ist, oder eine geradlinig geschlossene Küste, wenn, wie in Hinterpommern, die Haffe völlig in Strandseen verwandelt sind. Doppelküsten jener Art gehören zu den häufigsten Erscheinungen. In Oberitalien heißen die abgesperrten Buchten Lagunen, in Südrußland Limane, und man hat den Vorschlag gemacht, den letzteren Namen auf alle jene Buchten $\mathrm{zu}$ übertragen, die im Gegensatz zu den langgestreckten Haffen und Lagunen senkrecht in die Küste einschneiden. Diese Unterscheidung ist, wie wir sehen werden, auch genetisch gerechtfertigt.

Eine andere Form der neutralen Doppelküste, die an ein bewegtes Meer mit kräftigen Gezeiten gebunden ist, ist die Wattenküste. An der Westseite der jütischen Halbinsel können wir den Übergang aus der gebuchteten Doppelküste zur Wattenküste verfolgen. Dünen begleiten sie von der Nordspitze bis Blaavands-Huk, einige bodden- oder limanartige Buchten werden abgesperrt. Von Fanö an ist die Dünenkette zu Inseln zersplittert, die dahinter liegenden Buchten sind geöffnet; das niedrige Marschland, das einst durch die Dünenkette geschützt war, wird zur Flutzeit überschwemmt. Zwischen Heverstron und Wangeroog fehlt die insulare Außenküste, und die geschlitzten Konturen der Festlandsküste zeugen von der Macht der Nordseebrandung. Dann folgt die friesische Doppelküste bis Texel, glatt bogenförmig an dem äußeren, mehrfach gebuchtet an dem inneren Gestade.

Geradlinig oder bogenförmig ist auch die konkordante Küste, zwar wenig gegliedert, wie die cantabrische Küste oder die Ostküste Italiens von Pesaro bis Punta della Penna, aber doch nicht so glatt: wie neutrale Küsten. Kleine rundliche Buchten hat uns Theobald Fischer an der algerischen Küste kennen gelehrt; kleine, zackige Einschnitte finden sich häufig an der japanischen. $\mathrm{Ab}$ und zu dringt das Meer tiefer ein, wo ein Einsturzbecken den Verlauf des Litoralgebirges unterbricht, oder schafft ein sedimentreicher Fluß ein vorspringendes Deltaland. Die ursprüngliche Gestalt kann aber erheblich verändert werden. Die Vorsprünge werden durch die Brandung zerstört, die Buchten mit Hilfe der Küstenversetzung 
oder durch wachsende Deltas ausgefüllt, Flach- und Steilküsten wechseln, die Küstenlinie wird geglättet oder neue Buchten werden durch landfest gewordene Felsinseln gebildet, wie die herrliche Bai von Tokio, an der Japans Hauptstadt liegt. Das ist die Form der Ausgleichs-, oder besser gesagt, der ausgeglichenen Küste. An der toskanischen Küste hat sich diese Umwandlung zum Teil erst im Lauf der geschichtlichen Zeit vollzogen. An die Stelle der großen Buchten von Pisa und Grosseto trat sumpfiges Schwemmland, und der Mte. Argentario (Fig. 183, S. 599), das Gebirge von Piombino und der Monte dell' Uccellina führen uns die verschiedenen Stufen im Verlandungsprozeß von Inseln vor Augen. Dieser Buchtenreichtum könnte an einer konkordanten Küste auffallen, aber man muß beachten, daß die westitalienische Küste an der Innenseite eines Faltengebirges liegt, wo große, kesselförmige Einbrüche nicht selten sind. Die Golfe von Gaeta, Neapel, Salerno und Policastro sind noch erhalten, obwohl an der Ausgleichung gearbeitet wird. Auch in Korea ist die Westküste viel gegliederter als die Ostküste.

Am gegliedertsten ist aber die diskordante Küste. Berge, Täler, selbst größere Ebenen treten im bunten Wechsel an das Meer heran, und in demselben Maß wechselt auch das Spiel von Zerstörung und Landbildung. Im allgemeinen entsprechen die Buchten den Hohlformen des Geländes und die Vorsprünge den abgeschnittenen Gebirgen, doch werden auch durch Einbrüche große Buchten gebildet. Den höchsten Grad der Gliederung erreicht die Küste im Umkreis des jugendlichen Ägäischen Meeres, wo ostwestlich streichende Faltenzüge stückweise in die Tiefe gesunken sind. Aber auch im Bereich der diskordanten Küste kann Ausgleichung eintreten, und dann können glatte Küsten entstehen, wie es die portugiesische ist, oder die Ostküste Vorderindiens, oder die südamerikanische Küste vom Kap S. Roque bis zum Orinoco, wo die Flußsedimente mit Hilfe der Küstenversetzung in merkwürdig gleichmäßiger Weise angeschwemmt werden.

Talbuchten. Unter dieser Bezeichnung fassen wir alle talartigen Buchten zusammen, die unter einem rechten oder einem steilen Winkel in das Land einschneiden, sich meist auch oberseeisch in einem Tal fortsetzen und in der Regel gesellig auftreten. Sie sind nicht an eine von den drei genannten Hauptkategorien gebunden, aber ihre kräftigste Entwickelung finden sie an Gebirgsküsten.

Die bekanntesten Talbuchten sind die Fjorde. ${ }^{3}$ In Verbindung mit dichten Schwärmen von Felseilanden bestimmen sie den Küsten- 
charakter von Falten- und Rumpfgebirgen, von Tafelländern und Destruktionsflächen auf weite Strecken. Die Küstenentwickelung er-

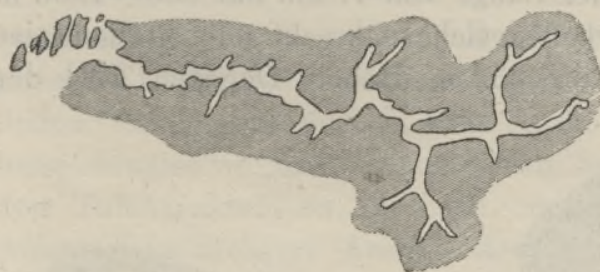

Fig. 265. Sogne-Fjord (Norwegen). reicht hierihren Höhepunkt Die Fjordküste Neuseelands ist nach ScHwind's ${ }^{4}$ Berechnung zehnmal länger als die in gerader Linie gemessene, und für die norwegische Küste zwischen 61 und $62^{\circ} \mathrm{B}$. beträgt dieser Quotient sogar 40.x Ein mehr oder minder scharf ausgesprochener Parallelismus in der Anordnung der Einschnitte und Inseln verleiht zwar der Fjord-

$\times$ Messungen einiger Küstentypen nach Schwind ${ }^{4}$, de Martonne ${ }^{5}$, HentzscheL $^{6}$ und Schröter ${ }^{7}$. Die Küste in gerader Linie verbindet die äußersten Vorsprünge.

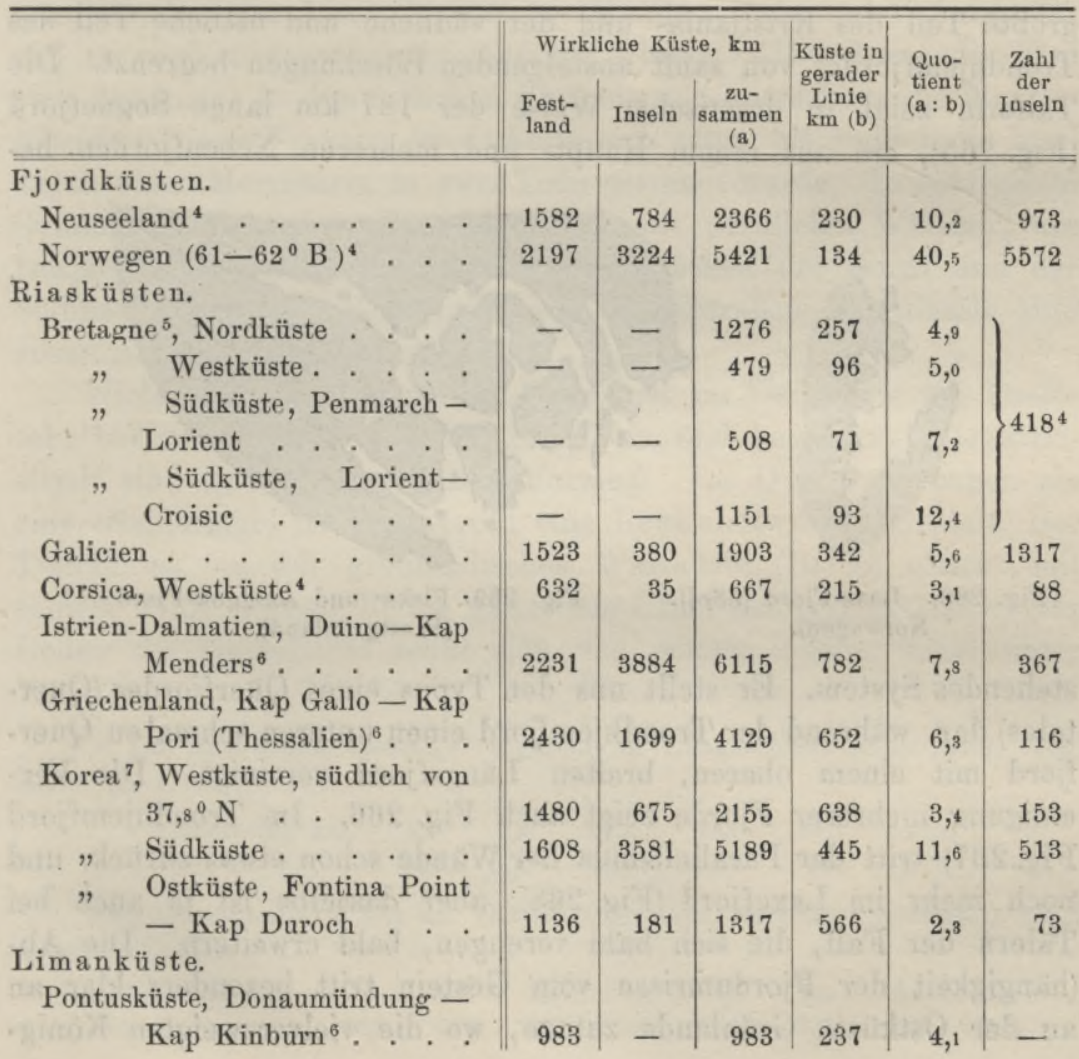


küste eine gewisse Eintönigkeit, im einzelnen aber herrscht große Mannigfaltigkeit. Den extremsten Typus stellt der norwegische Lysefjord dar. Er ist bei einer Länge von $41 \mathrm{~km}$ nur $600-1900 \mathrm{~m}$ breit, und seine Felswände erheben sich senkrecht oder stellenweise sogar überhängend bis ungefähr $950 \mathrm{~m}$ Höhe. Dagegen wird der

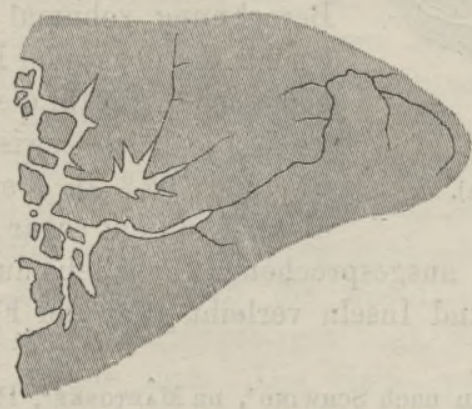

Fig. 266. Fjorde bei Kristiansund (Norwegen).

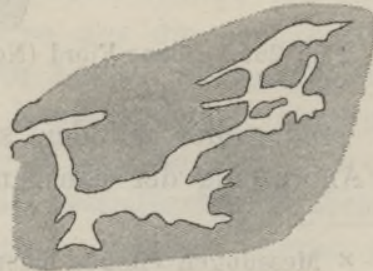

Fig. 267. Trondhjem-Fjord (Norwegen).

gröBte Teil des Kristiania- und der südliche und östliche Teil des Trondhjemfjordes von sanft ansteigenden Böschungen begrenzt. Die Talform zeigt in drastischer Weise der $187 \mathrm{~km}$ lange Sognefjord (Fig. 265), ein aus einem Haupt- und mehreren Nebenfjorden be-

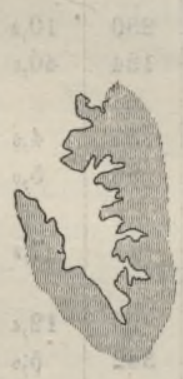

Fig. 268. Laxe-Fjord (nördl. Norwegen).

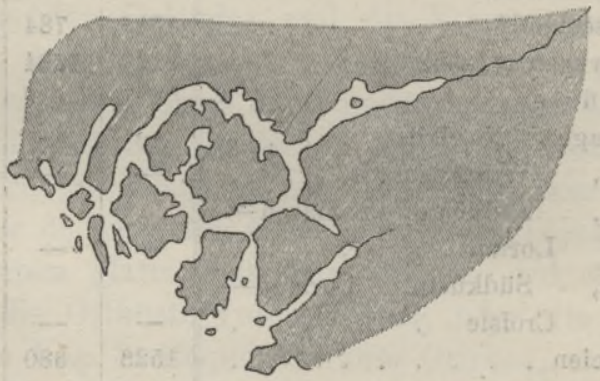

Fig. 269. Fiske- und Aniggok-Fjord (Westgrönland).

stehendes System. Er stellt uns den Typus eines Querfjordes (Quertales) dar, während der Trondhjemfjord einen unteren schmalen Querfjord mit einem oberen, breiten Längsfjord vereinigt. Die Vereinigung mehrerer Fjorde zeigt auch Fig. 266. Im Trondhjemfjord Fig. 267) tritt der Parallelismus der Wände schon etwas zurück, und noch mehr im Laxefjord (Fig. 268); aber dasselbe ist ja auch bei Tälern der Fall, die sich bald verengen, bald erweitern. Die Ab(hängigkeit der Fjordumrisse vom Gestein tritt besonders klar an an der Ostküste Grönlands zutage, wo die vielverzweigten König- 
Oskar- und Franz-Josef-Fjorde zwei verschiedene Formationen durchschneiden. Im Gneis gleichen sie schmalen Klüften, im Gebiet der paläozoischen Sedimente und der Basaltdecke erweitern sie sich beckenartig. Es kann kein Zweifel sein, daß die Fjorde untergetauchte Täler sind. Selbst solche Keilformen wie der Laxefjord finden ihr Seitenstück in den Ausgängen von Gebirgstälern, wie beispielsweise in der Talbucht von Salzburg. Zwar scheint gegen den Talcharakter zu sprechen, daß viele Fjorde sich an ihrem Ausgang in mehrere Arme teilen (s. Fig. 266 und 269), doch hat schon Hartung diese Eigentümlichkeit befriedigend erklärt. Zwischen den $1000 \mathrm{~m}$ und darüber hohen Bergen Norwegens führen tiefeingesenkte flache Pässe (Eide) aus einem Tal in das in entgegengesetzter Richtung verlaufende. Überstieg der Betrag der positiven Niveauveränderung die Seehöhe der Eide, die in manchen Fällen nicht einmal $100 \mathrm{~m}$ beträgt, so mußten mehrere Täler zu einem einzigen Fjordsystem verschmelzen, dessen Arme Gebirgsinseln einschließen. Ein ähnlicher Vorgang ist übrigen schon beobachtet worden. Auf der Insel Caviana im Mündungsgebiet des Amazonas gab es zwei entgegengesetzt laufende Flüsse. 1850 drang die Flut zum erstenmal in den östlichen Fluß ein und überschritt die Wasserseheide. Dieser Vorgang wiederholte sich öfter, bis endlich die Insel durch einen Meeresarm in zwei Teile getrennt wurde. In gebirgigem Gelände entstehen so Fjordstraßen mit parallelen Wänden, wie beispielsweise der Matotschkin-Scharr zwischen der Nord- und der Südinsel von Nowaja-Semlja. Fjorde, Fjordstraßen, Fjordinseln sind zusammengehörige Phänomene.

Nicht bloB die Länge der Fjorde ist im Verhältnis zur Breite sehr bedeutend, sondern auch ihre Tiefe, und besonders charakteristisch sind ihre unterseeischen Formen. Im Querprofil haben sie eine trogförmige, im Längsprofil eine beckenförmige Gestalt. Der Torsukatak an der grönländischen Westküste $\left(70^{\circ} \mathrm{B}\right)$ gleicht mit seinem völlig ebenen Boden ganz dem Urner See (vgl. S. 756).× Der Boden des Sognefjords senkt sich von seinem oberen Ende unter

$\times$ Die Messungen EvaelL's ${ }^{s}$ ergaben im Längsschnitt (Entfernung vom Ende des Inlandgletschers):

$\begin{array}{lcccccc}\text { Entfernung km } & 4,3 & 7,2 & 17,4 & 30,9 & 44,5 & 47,5 \\ \text { Tiefe m } & 230 & 550 & 720 & 740 & 740 & 575\end{array}$

Der Querschnitt in 30,9 km (Entfernung vom Nordufer gemessen) zeigt folgende Tiefen:

Entfernung km

Tiefe $\mathrm{m}$
520
2,3 $640 \div 735$
4,3

735
5,2

740
6,0
735

6,6

725
7,4

725 
einem Winkel von $0^{\circ} 39^{\prime}$ bis zu einer Tiefe von $1242 \mathrm{~m} \times$ und hebt sich dann wieder unter einem Winkel von $1^{\circ} 2^{\prime}$ bis $158 \mathrm{~m}$ Tiefe. Die Schwelle fällt bald mit dem unteren Ende des Fjordes zusammen, bald liegt sie oberhalb im Fjord selbst, bald unterhalb im vorliegenden Meer. In den meisten Fällen sind aber mehrere Becken vorhanden, und in ihrem gegenseitigen Verhältnis zeigt sich eine große Mannigfaltigkeit. Der Howesund in Britisch-Columbia zerfällt in zwei nahezu gleich große und gleich tiefe Becken, der Hardangerfjord in Norwegen in fünf, die ebenso wie die Schwellen nach außen zu immer seichter werden, der Loch Hourn in Schottland beginnt mit einer Reihe kleiner Becken und endet mit einem großen. $\times \times$ Die Tiefenunterschiede sind manchmal nicht bedeutend, aber stets ist das Vormeer seichter als die Fjorde. Wenn wir oben die Fjorde nach ihrer überseeischen Gestalt als untergetauchte Täler bezeichnen konnten, so können wir sie jetzt auf Grund ihrer unterseeischen Formen als untergetauchte Talseen betrachten. In dieser Schlubfolgerung werden wir unterstützt, wenn wir wahrnehmen, daß das Tal, das den Fjord überseeisch fortsetzt, noch Seen beherbergt, die mit ihrer langgestreckten Gestalt und ihren steilen Gehängen völlig den Fjordseen gleichen. Manche solcher Seen sind in Schottland, Norwegen usw. vorhanden, viele sind freilich schon verschüttet. Auch ins offene Meer hinaus können wir manchmal den Fjord als

$\times$ Diese Tiefe wird nur übertroffen von den unter $48^{\circ} \mathrm{S}$, an der chilenischen Küste gelegenen Baker- $(1261 \mathrm{~m})$ und Messierfjord $(1270 \mathrm{~m}$, s. Karte Nr. 19 v. H. Steffen in Petermann's Mitteilungen 1904).

$\times \times$ Tiefen der Becken und Schwellen:

\begin{tabular}{|c|c|c|c|c|c|c|c|c|}
\hline \multicolumn{3}{|c|}{ Howesund } & \multicolumn{3}{|c|}{ Hardangerfjord } & \multicolumn{3}{|c|}{ Loeh Hourn } \\
\hline 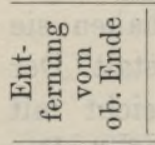 & $\frac{0}{0}$ & $\begin{array}{l}\text { है } \\
\stackrel{0}{0} \\
\frac{1}{0} \\
\text { हn } \\
\text { D. }\end{array}$ & 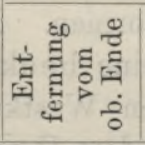 & 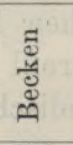 & ᄅี & 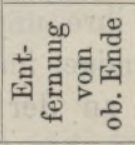 & 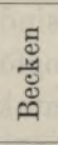 & हี \\
\hline $\mathrm{km}$ & $\mathrm{m}$ & $\mathrm{m}$ & $\mathrm{km}$ & $\mathrm{m}$ & $\mathrm{m}$ & $\mathrm{km}$ & $\mathrm{m}$ & $\mathrm{m}$ \\
\hline 14,2 & 287 & - & 50 & 800 & - & 0,5 & 18 & - \\
\hline 21,7 & - & 174 & 60 & - & 545 & 0,9 & - & 1 \\
\hline 37,0 & 282 & 一 & 86 & 669 & - & 3,1 & 49 & - \\
\hline 46,7 & - & 123 & 91,3 & - & 507 & 3,4 & - & 10 \\
\hline (49,7 Ende) & - & - & 102,3 & 564 & - & 4,9 & 35 & - \\
\hline & & & 113,7 & - & 436 & $\check{5}, 5$ & - & 9 \\
\hline & & & 118,1 & 506 & - & 7,0 & 49 & - \\
\hline & $y=$ & & 124,5 & - & 259 & 7,2 & - & 13 \\
\hline & & & 128,5 & 384 & - & 18,2 & 183 & - \\
\hline & & & (166 Ende) & - & - & 20,7 & - & 101 \\
\hline 207 & e- & & 174,3 & - & 203 & Ende & - & - \\
\hline
\end{tabular}


Rinne verfolgen, und selbst diese läßt noch eine Trennung in Becken erkennen. $\times$

In ihrer strengsten Form ist die Fjordküste auf höhere Breiten beschränkt. Die atlantische Seite des skandinavischen Massivs, WestSchottland und das nordwestliche Irland, die arktischen Inseln, Grönland, Neufundland und Labrador, endlich die Westküste Nordamerikas von Alaska bis zur Juan de Fuca-Straße sind die wichtigsten Fjordbezirke unserer Halbkugel. Auf der Südhemisphäre sind die Westküsten Patagoniens und der neuseeländischen Südinsel und die in höheren Breiten gelegenen Inseln zu nennen. Der Zusammenhang mit der diluvialen Eisverbreitung, den zuerst DANA erkannt hat, liegt auf der Hand und bietet auch nichts Auffälliges, wenn wir uns ins Gedächtnis zurückrufen, daß gerade die alten Gletschergebiete außerordentlich reich an Seen sind. Nur muB man dabei zwei Fragen auseinanderhalten: 1. die Entstehung der Tal- und Beckenform; in dieser Beziehung haben die verschiedenen Theorien über die Genesis der Täler und Seebecken auch auf die Fjorde Anwendung gefunden; 2. das Untertauchen. Dieses steht in keiner Beziehung zur Eiszeit, sondern ist ein Phänomen von allgemeiner Verbreitung.

Als charakteristisches Merkmal der norwegischen Fjorde bezeichnet RICHTER ${ }^{9}$ neben ihrer Steilwandigkeit die geringe Entwickelung des hydrographischen Systems. „Neben dem tiefen Fjord steht unmittelbar das unzerschnittene massive Fjeld; während der eine Bach, der in den Fjord mündet, sich bis auf den Meeresspiegel durchgeschnitten hat - es ist dies allerdings gewöhnlich der Hauptbach —, läuft ein anderer, kaum schwächerer, erst träge in einem flachen Fjeldtal, um dann plötzlich in hoher Kaskade über die Fjordwand hinabzustürzen." Wir haben also hier eine Talübertiefung, genau so wie in den Alpen; Rrchter erklärte sie im Sinn der ältern Theorie von Krlian, Reusch ${ }^{10}$ im Sinn von Penck (vgl. S. 554f):

In Neuseeland sind die Fjorde auf das Dioritmassiv im äußersten Südwesten beschränkt, während das daran stoBende, noch heute gletschertragende Gebirgsland der Südalpen frei davon ist. Diese Tatsache ist aber nicht, wie Heim meint, ein Argument gegen die Glazialtheorie, da in der Eiszeit jedenfalls auch das Dioritgebirge vergletschert war, läßt aber noch nicht näher bestimmbare Beziehungen zwischen dem Fjordphänomen und der Gesteinsbeschaffenheit ahnen. Die typisch entwickelten Fjordlandschaften liegen alle in Massengesteinen, kristallinischen Schiefern und paläozoischen Schichten.

$\times$ Z. B. die Fortsetzung des Stor- und Sulefjords in Norwegen $62^{1} / 2^{0} \mathrm{~B}$. (s. die schöne Karte von Sandler in Petermann's Mitteitungen 1890, Taf. 16). 
Auch die Fjorde sind nicht ein völlig abgeschlossener Gestaltungskreis. Man spricht von Fjorden an der Küste von Maine und Neuschottland und sogar an den Ufern der canadischen Seen, aber die Beckenform ist hier nur schwach ausgeprägt. Das mag zum Teil wohl auf spätere Zuschüttung, wofür hier auch geschichtliche Zeugnisse vorliegen, zurückzuführen sein, denn nur jene Fjorde erhalten sich rein, deren Zuflüsse sich ihrer Sedimente in einem oberhalb gelegenen See entledigt haben. Aber selbst in jenen Teilen, wo das Lot auf felsigen Grund stieß, sind die Mainefjorde meist flach; auch ist zum Unterschied von anderen Fjordgebieten die Umgebung niederes Hügelland, dagegen ist der Parallelismus deutlich entwickelt. Die Ostseeküste der skandinavisch-finnischen Rumpfscholle zeigt eine Art der Gliederung, die sich wieder einen Schritt weiter von den echten Fjorden entfernt. Sie erscheint wie zerschlitzt; zahllose kleine, schmale Einschnitte, die sogenannten Fjärde, dringen mehr oder weniger tief in das niedrig gelegene Küstenland ein, zum Teil mit beckenartigem, zum Teil mit einfach abfallendem Talboden. An vielen Stellen ist der äußere Küstenrand in hunderte von kleinen Felsinseln (Schären) zersplittert, aber meist in regelloser Weise, nicht in paralleler Anordnung, wie die Fjordinseln. Werth ${ }^{11}$ faßt den baltischen Typus als ein Erzeugnis des Inlandeises, den norwegischen als ein Produkt von Talgletschern auf. An den Neutralküsten Ostjütlands und der dänischen Inseln begegnen wir den vielgestaltigen Förden, $\times$ bald breiten, bald schmalen Talbuchten, von denen die ersteren sich dadurch auszeichnen, daß das tiefe Fahrwasser bis an die Spitze der Bucht reicht. DaB auch sie überschwemmte Erosionstäler sind, wird allgemein zugestanden, nur in der geographisch minder wichtigen Altersfrage gehen die Aussichten auseinander; $\mathrm{HAAS}_{\mathrm{A}}{ }^{12}$ verlegt ihre Bildung in die Interglazialzeit, Struck ${ }^{13}$ in die letzte Eiszeit.

Bis jetzt haben wir uns innerhalb der diluvialen Binneneisgrenzen gehalten. Außerhalb davon liegen die teils gewundenen, teils keilförmigen Talbuchten der Küsten des südwestlichen Irlands, Cornwalls, der Bretagne, Corsicas, Galiciens, Südchinas usw., die v. Richthofen unter dem in Galicien gebräuchlichen Namen Rias zusammengefaßt hat. Auch sie sind wie die Fjorde Fortsetzungen oberirdischer Täler, unterscheiden sich aber von jenen nicht nur durch ihre unbedeutenderen horizontalen Dimensionen und die geringere Inselentwickelung, sondern auch dadurch, daB ihr Boden in

× In Dänemark Fjorde genannt. Einige sind aber unzweifelhaft nichts anderes als Bodden, wie z. B. der Albuenfjord auf Laaland. 
der Regel allmählich, ohne Unterbrechung durch beckenartige Einsenkungen in das Meer verläuft. Manchmal ist die Fjordähnlichkeit sehr groß, wie bei der Bocche di Cattaro, die die Gestalt des Eisfjords in Spitzbergen wiederholt und auch am Eingang durch eine kleine unterseeische Schwelle abgeschlossen ist. Überhaupt treten die Rias in so mannigfachen Formen auf, daB DE MARTONnE ${ }^{5}$ nicht ohne Grund die Frage aufwerfen konnte, ob man berechtigt sei, sie zu einer morphologischen Einheit zusammenzufassen. Schon die Küste der Bretagne ist, wie aus den auf S. 797 mitgeteilten Zahlen hervorgeht, ein Beweis dafür. Die gezackte nördliche Granitküste, die tief eingebuchtete diskordante Westküste und die konkordante Südküste mit ihren vielgestaltigen Einschnitten zeigen deutlich die Abhängigkeit der Küstenform von dem Bau des Landes. Desgleichen hat SchneIdeR $^{14}$ auf den Gegensatz zwischen der Flysch- und der Kreideküste in Istrien hingewiesen. Die Rias der fast gezeitenlosen Adria sind noch insofern wichtig, als sie dartun, daß RütIMEYER's ${ }^{15}$ Theorie von der Umgestaltung und Vertiefung der Rias durch die Meereserosion keine allgemeine Anwendung findet. Es soll aber nicht geleugnet werden, daß auch dieser Faktor Bedeutung gewinnen kann. Die sechs Keilbuchten im südwestlichen Irland (Kerry und Cork), die genau den Karbonkalkmulden entsprechen, während der widerstandsfähigere devonische Sandstein die sie trennenden Halbinseln bildet, ähneln auffallend den Flußästuarien, und dies läßt vermuten, daß bei der keilförmigen Erweiterung die Flutwelle mit im Spiel ist.

Den Rias der gebirgigen Küsten entsprechen die Limane am pontischen Flachgestade Südrußlands. So mannigfach auch ihre Umrisse sind, so stimmen sie doch stets mit dem Relief der umliegenden Steppe und mit dem Bau der Täler, deren Fortsetzungen sie sind, überein. Die Tiefe nimmt in der Regel seewärts zu. Am Bugliman konnte SokoLow ${ }^{16}$ durch Bohrungen direkt die Entwickelungsgeschichte nachweisen. Der erodierte Untergrund (neogener Mactrakalkstein) liegt $96 \mathrm{~m}$ vom Ufer in 4 und bei $374 \mathrm{~m}$ Entfernung in 20,5 m Tiefe; die letztere Zahl gibt uns den Betrag der positiven Niveauänderung an. Darauf liegt Sand mit Flußfauna, auf diesem Schlamm mit Meeresfauna, und $\mathrm{zu}$ oberst wieder Sand mit fluviatilen Tierresten. Der Liman ist also in Zuschüttung begriffen; daß dies nicht schon früher geschah, hat, wie bei den Rias, seinen Grund wohl darin, daß die Strandverschiebung zu rasch erfolgte, während die Fjorde (wie die großen Talseen) hauptsächlich durch die Eisausfüllung vor diesem Schicksal bewahrt blieben. 
Indem wir die Talbuchten als untergetauchte Talenden auffassen, erblicken wir in ihnen ein ebenso wichtiges Dokument für positive Niveauveränderungen, wie in den abgegliederten Halbinseln, in den Kontinentalinseln, vielleicht auch in manchen Wallriffen und Atollanhäufungen. Allerdings finden wir gerade in dem Bereich der Fjordküsten auch Anzeichen einer negativen Niveauveränderung, aber diese hat noch nicht einen so hohen Betrag erreicht, um den Effekt der älteren entgegengesetzten Bewegung auszulöschen.

Natürliche Seehäfen und Meeresstraßen. Vom verkehrsgeographischen Standpunkt aus hat v. RichтноғEN die konkordanten Küsten treffend als Abschließungs-, die diskordanten als wahre AufschlieBungsküsten bezeichnet. Das ist ohne weiteres verständlich, wenn man die Verbindung zwischen der Küste und dem Binnenland in den Vordergrund stellt. Aber es gilt auch, wenigstens im großen und ganzen, in betreff des natürlichen Hafenreichtums der Küsten, wenn auch gerade konkordante Küsten manchen ausgezeichneten Hafen besitzen.

Von natürlichen Häfen fordert man einen guten Ankergrund von etwa $10-100 \mathrm{~m}$ Tiefe und Schutz vor Wellenbewegung. Ihre Zahl ist verhältnismäBig nicht sehr groß, so daß der ausgedehnte Verkehr unserer Tage genötigt ist, auch offene Reeden zu benutzen oder sie in künstliche Häfen umzugestalten. Diese fallen natürlich außerhalb des Bereiches unserer Betrachtung.

KRÜMмeL ${ }^{17}$ unterscheidet genetisch drei Hauptarten von Seehäfen, betont aber, daß die meisten Häfen mehrere Typen in sich vereinigen.

Groß ist der Formenkreis der Aufschüttungshäfen, bei denen die Natur durch Anhäufung von Sedimenten, vulkanischen Auswürflingen oder durch korallinische Riffbildung einen Wellenbrecher geschaffen hat. Haffe und verwandte Erscheinungen der Neutralküsten bieten gute Hafenplätze, wenn der Eingang frei gehalten wird; an ausgeglichenen Küsten gibt das Landfestwerden von Inseln manchmal Veranlassung zur Buchtenbildung; durchbrochene Kraterwälle einsamer Vulkaninseln (Fig. 270) und die Lagunen der Wallriffe und Atolle gewähren Schutz auch mitten im Ozean. Häufiger und vielgestaltiger sind die Einbruchshäfen, die dadurch entstehen, daß das Meer infolge einer positiven Niveauveränderung in das Land einbricht. Alle Liman-, Rias- und Fjordhäfen gehören in diese Kategorie; nur muß hinzugefügt werden, daß viele Fjorde wegen $\mathrm{zu}$ großer Tiefe keinen Ankergrund bieten, so daß z. B. die Norweger manche Hafenplätze auf die vorgelagerten Fjordinseln verlegt haben. 
Küsteneilande schützten die alten phönizischen Häfen; an konkordanten Küsten öffnen sich tief eingeschnittene Buchten, von denen manche wohl durch Kesseleinbrüche entstanden sind. S. Francisco,

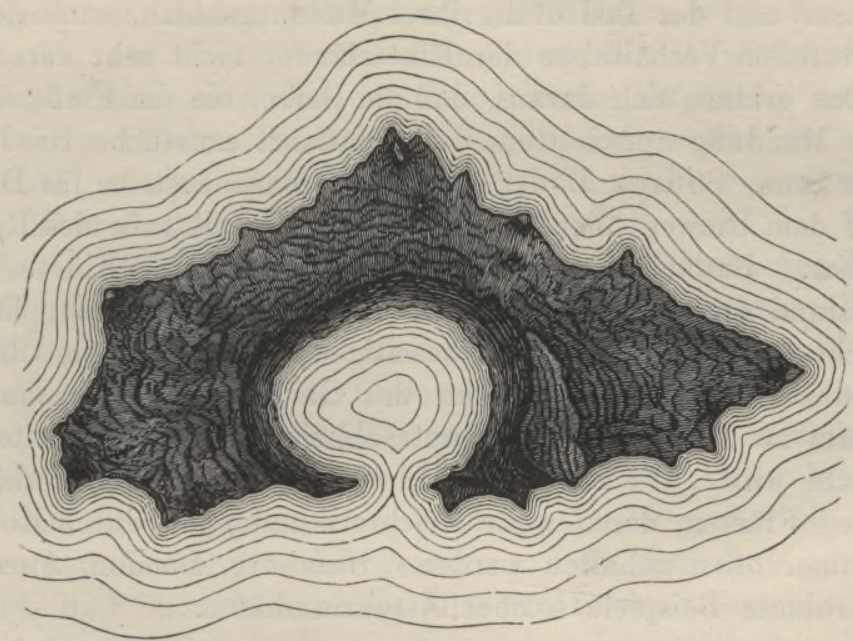

Fig. 270 a.

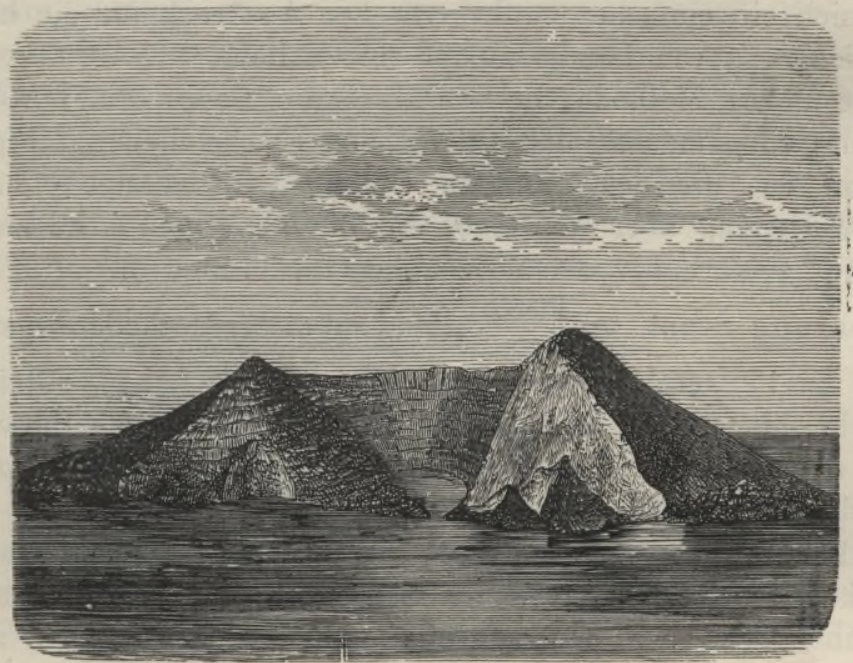

Fig. 270b. St. Paul im Indischen Ozean.

Rio de Janeiro, Sydney verdanken ihren Aufschwung solchen natürlichen Öffnungen an sonst wenig zugänglichen Küstenstrecken. Einen Einschnitt in der Küste verursacht ferner jede Flußmündung, und jeder größere Fluß ist zugleich eine bequeme Verbindungsstraße. 
nach dem Innern. An den meisten neutralen, besonders an Schwemmlandsküsten herrschen in der Tat die Mündungshäfen vor. Aber trotzdem besteht oft ein seltsamer Gegensatz zwischen der Größe der Flüsse und der Bedeutung ihrer Mündungshäfen, auch dort, wo die kulturellen Verhältnisse der Hinterländer nicht sehr verschieden sind. Das erklärt sich daraus, daß die Barre, die die Flußsedimente vor der Mündung aufschütten, der Schiffahrt ernstliche Hindernisse bereiten kann. So ist z. B. der gewaltige Amazonenstrom für Dampfer nur auf dem Umweg über die gewundene Wasserstraße des Rio-Parà erreichbar. Besonders tropische und subtropische Flüsse, deren Wasserstand großen Schwankungen unterliegt, sind in der Trockenzeit nicht fähig, ihre Barre zu beseitigen; und solch ein Übelstand zwang dazu, den Mündungshafen des Ganges, Calcutta, an einen Nebenarm zu verlegen, der hauptsächlich nur vom Gezeitenstrom beherrscht wird. Weitaus am günstigsten liegen die Verhältnisse bei jenen Flüssen, deren weite Trichtermündungen durch Ebbe und Flut immer offen gehalten werden. Hamburg, London, Amsterdam sind berühmte Beispiele solcher Ästuariumbäfen.

Küstenentwicklung und mittlerer Küstenabstand. Schon seit langem beschäftigen sich die Geographen mit der Frage, auf welche Weise sich ein einfacher mathematischer Ausdruck für die horizontale Gliederung von Länderräumen finden ließe.

Die älteste Methode, die von Heinrich Berghaus (1830), geht von dem Gedanken aus, daß bei gleicher Fläche diejenige Figur gegliederter ist, die den größeren Umfang (Küstenlänge ${ }^{\times}$) hat, bei gleichem Umfang aber diejenige, die die kleinere Fläche hat; und Berghaus setzt daher die horizontale Gliederung, die er Küstenentwicklung nennt, $=\frac{\text { Fläche }}{\text { Umfang }}$. Man hat dieser Methode vorgeworfen, daß sie zwei unvergleichbare Werte, Fläche und Länge, miteinander vergleiche, aber schon Reuschue hat das Unberechtigte dieses Vorwurfes dargetan, der nur dann am Platz wäre, wenn man z. B. sagte: der Umfang von Europa verhalte sich zur Fläche wie 1:243, während es durchaus statthaft ist, sich so auszudrücken: auf $1 \mathrm{~km}$ Küste kommen 243 q km Fläche. Schwerer wiegt der Umstand, daB die Zahlen sich nach dem zugrunde gelegten Maß ändern, aber er kann beseitigt werden, wenn man irgend eine Küstenentwicklung,

× Keine der auf den Karten gemessenen Küstenlängen entspricht der wirklichen, sie wachsen mit dem MaBstab der Karten. Sie sind daher auch nur unter der Voraussetzung gleichen Kartenmaßstabs streng vergleichbar. Man könnte im Hinblick auf die zukünftige Erdkarte als Normalküstenlänge diejenige bezeichnen, die auf Karten im MaBstab von 1:1 Mill. gemessen wird. 
z. B. die mittlere aller fünf Kontinente oder die Europas gleich 1 setzt und alle anderen Zahlen in Teilen dieser Einheit gibt. Die späteren Verbesserungsvorschläge fußen auf dem Grundsatz, daß Längen nur mit Längen, Flächen nur mit Flächen verglichen werden dürfen. Um auf diese Weise einen passenden Ausdruck für die Küstenentwicklung zu finden, benutzte man die Erfahrung, daß unter allen Figuren gleicher Fläche der Kreis oder - da wir uns auf einer Kugel befinden - die Kugelkalotte die denkbar regelmäßigste ist und daher den kleinsten Umfang besitzt. Je mehr der Umfang eines Festlandes oder einer Insel den einer inhaltgleichen Kalotte übertrifft, desto größer ist die Küstenentwicklung. ${ }^{\times}$Man übersieht aber bei dieser Methode die für unsere Zwecke sehr fatale Eigenschaft aller Figuren, daß ihr Umfang viel langsamer wächst als ihre Fläche. Nicht nur, daß infolgedessen die Methode kleinen Erdräumen günstiger ist als großen, sie fördert auch den offenbaren Widersinn zutage, daß die Küstenentwicklung Europa-Asiens größer ist, als die Europas und Asiens für sich genommen, die Amerikas größer als die Nord- und Südamerikas, die aller Kontinente zusammen größer als die jedes einzelnen! Noch ein paar andere Methoden kranken an diesem Übelstand und werden dadurch unfähig, wirklich vergleichbare absolute Werte für die Küstenentwicklung oder für die Zugänglichkeit eines Landes zu liefern.

Einen andern Weg schlug RoHRBACH ${ }^{18}$ ein. Er zeichnete in die Erdteile Linien gleichen Küstenabstandes ein und berechnet daraus mit Hilfe der graphischen Methode $\times x$ den mittleren Küstenabstand. In nachstehender Tabelle, die einer neueren Be-

\begin{tabular}{|c|c|c|c|c|c|c|c|c|}
\hline & \multicolumn{6}{|c|}{ Küstenabstand in $\mathrm{km}$} & \multirow{2}{*}{$\begin{array}{l}\text { Mittlerer } \\
\text { Küstenabsta }\end{array}$} & \multirow{2}{*}{$\begin{array}{l}\text { Größter } \\
\text { and in km }\end{array}$} \\
\hline & $0-250$ & $250-500$ & $500-1000$ & $|1000-1500|$ & $|1500-2000|$ & $2000-2500$ & & \\
\hline & \multicolumn{6}{|c|}{ Prozente } & & \\
\hline Europa & 51 & 23 & 19 & 7 & - & - & 340 & 1550 \\
\hline Asien. & 29 & 16 & 23 & 17 & 11 & 4 & 770 & 2400 \\
\hline Afrika & 23 & 19 & 31 & 23 & 4 & - & 670 & 1800 \\
\hline Australien . & 43 & 29 & 28 & - & - & - & 350 & 920 \\
\hline Nordamerika & 41 & 23 & 26 & 9 & 1 & - & 440 & 1650 \\
\hline Südamerika . & 31 & 22 & 31 & 16 & - & - & 540 & 1600 \\
\hline
\end{tabular}

rechnung von PeNcK ${ }^{19}$ folgt, sind die wichtigsten Ergebnisse dieser Methode zusammengefaßt; sie bieten uns einen bequemen, zum Teil

$\times$ Auf Europa und Asien ist diese Methode streng genommen gar nicht anwendbar, weil der Umfang dieser Erdteile größer ist alș ihre Küstenlänge. $\times \times$ Die chorigraphische Kurve Roнrвacr's entspricht der hypsographischen Kurve Pexcr's (vgl. S. 46). 
sogar überraschenden Kommentar zur Karte. Namentlich der Prozentsatz der küstennahen Zone (bis $250 \mathrm{~km}$ ) ist ein guter Maßstab für den Umfang des legitimen Einflusses des Meeres auf das Klima der Erdteile und für die Bedeutung mancher orographischer Hindernisse, die diesen Einfluß abschwächen oder vernichten. Aber weder die Ausdehnung der küstennahen Zone, noch der mittlere Küstenabstand sind ohne Karte ohne weiteres verständlich. Wenn einerseits Asien und Afrika, anderseits Europa und Australien nahezu gleichviel Prozent küstennahes Land haben, so wird das in dem ersten Fall nur durch den Unterschied in der horizontalen Gliederung, im zweiten aber trotz dieses Unterschiedes bewirkt; im ersten Fall ist die Küstenentwickelung, im zweiten die Fläche ausschlaggebend. In dem größeren mittleren Küstenabstand Asiens gegenüber dem Afrikas kommt aber doch die beträchtlich größere Ausdehnung Asiens zur Geltung; dagegen haben Europa und Australien nahezu gleichen mittleren Küstenabstand, obwohl es kaum zwei größere Länderräume gibt, die in ihrer Umrißgestaltung so grundverschieden wären wie sie. Für die Gliederung allein gewinnt man einen exakten Ausdruck, wenn man die Flächen der Halbinseln mit der des Rumpfes in Vergleich setzt (s. S. 766); es ist dabei nur schwierig $\mathrm{zu}$ bestimmen, was alles als Halbinsel $\mathrm{zu}$ betrachten sei, und an welchen Stellen man sie abzutrennen habe. Die Anzahl und die Größe der Glieder ist übrigens für die Küstenentwickelung nicht allein maßgebend. Afrika und Südamerika sind beide Rümpfe ohne Glieder; da aber Südamerika sich sehr stark verschmälert, so kommen hier auf $1 \mathrm{~km}$ Küste nur $698 \mathrm{qkm}$, in Afrika dagegen 1128. Die EhrenburG'sche Methode führt zu einem ganz entgegengesetzten Resultat. Ehrenburg ${ }^{20}$ unterscheidet drei sphärische Kreise: 1. den Außenkreis $(A)$ oder den größten Kreis, der noch alle Glieder des betreffenden Landraumes umfaßt, 2. den Innenkreis $(I)$ oder den kleinsten Kreis, der dem Rumpfe eingeschrieben werden kann, und 3. den inhaltgleichen Kreis $(F)$, und setzt die Flächen dieser Kreise in Beziehung zueinander. Der Quotient $A / I$ ist unter allen möglichen Kombinationen offenbar der reinste Ausdruck der horizontalen Gestaltung, und doch ist er für Afrika größer $(5,6)$ als für Südamerika $(5,1)$. Der Grund liegt in der großen Ausdehnung des Golfs von Guinea, den Afrika halbmondähnlich umzieht; dadurch wird der Außenkreis sehr groB und der Innenkreis sehr klein. Angesichts solcher entgegengesetzten Ergebnisse kann mit Recht die Frage aufgeworfen werden, ob alle diese künstlichen Methoden der Geographie wesentliche Dienste leisten. Nur die Küstenentfernungszonen und bis $\mathrm{zu}$ einem gewissen Grad auch der nittlere Küsten- 
abstand bieten uns reale Werte, die aber auch nur einseitige Verhältnisse zum Ausdruck bringen. Das Kartenbild in eine Formel zu pressen, ist vergebliche Mühe.

Literaturnachweise. ${ }^{1}$ A. Phimmpson zit. S. 599. K. Weule, Beitrag zur Morphologie der Flachküsten; in der Zeitschrift für wissenschaftliche Geographie 1891, Bd. VIII. F. P. Gulliver zit. S. 571. $-{ }^{2}$ A. Jessen, Beskrivelse til Kortbladene Skagen, Hirshals, Frederikshavn, Hjöring og Lökken; Kopenhagen 1899. - ${ }^{3}$ P. DiNSE, Die Fjordbildungen; in der Zeitschrift der Berliner Gesellschaft für Erdkunde 1894. Otтo NordenskJöLd, Topographisch-geologische Studien in Fjordgebieten, im Bulletin of the Geological Institut of Upsala, 1899, Bd. IV. - ${ }^{4}$ F. Schwind, Die Riasküsten; Prag 1901. $-{ }^{5}$ E. DE MARTONNE, Le développement des eôtes bretonnes, im Bulletin de la Société scientifique et médicale de l'Ouest, Rennes 1903, Bd. XII. - ${ }^{6}$ O. Hentzscher, Die Hauptküstentypen des Mittelmeeres; Leipzig 1903. - ${ }^{7}$ W. ScHröтrer, Korea, Leipzig 1904. - ${ }^{8}$ M. C. EngelL, Zur Kenntnis der Fjorde Grönlands, in Petermans's Mitteilungen 1910, Bd. I. - ${ }^{9}$ E. Richter, Geomorphologische Beobachtungen aus Norwegen; in den Sitzungsberichten der Wiener Akademie der Wissenschaften, mathem.-naturwiss. Klasse, 1896, Bd. CV, Abteilung I. ${ }^{10} \mathrm{H}$. Reusch, Some Contributions towards an Understanding of the Manner in which the Valleys and Mountains of Norway were formed; im Jahrbuch 1900 von Norges geologiske undersögelse. - ${ }^{11}$ E. Werth, Fjorde, Fjärde und Föhrden, in der Zeitschrift für Gletscherkunde, Bd. III. - ${ }^{12}$ H. J. HAas, Studien über die Entstehung der Förden; in den Mitteilungen aus dem mineralogischen Institut an der Universität Kiel, 1888. $-{ }^{13}$ R. Struck, Übersicht der geologischen Verhältnisse Schleswig-Holsteins, in der Festschrift zum Geographentag, Lübeck 1909. - ${ }^{14} \mathrm{~K}$. Schnerder, Die Küstenformen der Halbinsel Istrien, in den Mitteilungen der Wiener Geographischen Gesellschaft 1905. ${ }^{15}$ L. RÜтrmeyer, Die Bretagne; Basel 1883, - ${ }^{16}$ N. SokoLów, Über die Entstehung der Limane Südrußlands; in den Mémoires du Comité géologique, St. Petersburg 1895 , Bd. X. $-{ }^{17}$ O. KRüмmeL, Die Haupttypen der natürlichen Seehäfen; im Globus, 1891, Bd. LX. - ${ }^{18}$ C. Roнrвach, Über mittlere Grenzabstände; in PEtermans's Mitteilungen 1890 (mit vollständiger Literaturangabe über das Thema der Küstenentwicklung auf S. 92). - ${ }^{19}$ A. PEncK in ScoBer's Geographischem Handbuch, Bd. I, S. 124. - ${ }^{20}$ K. Ehrenberg, Studien zur Messung der horizontalen Gliederung von Erdräumen; Würzburg 1891 (mit übersichtlicher Angabe sämtlicher bisher angewendeten Formeln.) 


\section{Sechster Abschnitt.}

\section{Die Pflanzendecke und die geographische Verbreitung der Tiere.}

\section{Die geographischen Bedingungen des Pflanzenlebens. ${ }^{1}$}

Glücklicherweise ist der Teil des Festlandes, wo der Boden unverhüllt zutage tritt oder eine Eisdecke trägt, klein im Vergleich zu dem, der mit einem Pflanzenkleid geschmückt ist. Hier bedingen nicht bloß Geländeverhältnisse und Gewässer die Physiognomie der Landschaft, sondern auch die Vegetation, die schon aus diesem Gesichtspunkt das geographische Interesse in Anspruch nimmt, in noch höherem Grad aber deshalb, weil nicht nur die Existenz der Tiere, sondern auch die unsere darauf gegründet ist.

Vegetation und Flora sind verschiedene Begriffe. Der Reichtum der Vegetation hängt von der Anzahl der Individuen, der der Flora von der Anzahl der Arten ab. Es gibt Gegenden, wie die Ebene des Amazonas, wo die Dichtigkeit der Pflanzendecke mit der Fülle der Pflanzenformen wetteifert; aber es gibt auch Gegenden, wo trotz der Ärmlichkeit der Vegetation der sammelnde Botaniker eine reiche Ausbeute findet. So ist es in den vorderasiatischen Steppen, wo das Doppelgeschlecht Astragalus und Oxytropis in mehr als tausend Arten auftritt. Dagegen ist in Neuseeland die Vegetation üppiger als in den Mittelmeerländern, aber die Flora ist ungleich ärmer.

Abhängigkeit vom Klima. Licht, Wärme und Feuchtigkeit bilden die Grundbedingungen des Pflanzenlebens. Wir werden bei unseren Betrachtungen immer wieder darauf zurückkommen, hier beschränken wir uns nur auf allgemeine Bemerkungen.

Licht, und zwar nicht so sehr das direkte als das zerstreute Sonnenlicht, ist unentbehrlich für die Ernährung der Pflanze, denn ohne Licht findet keine Kohlensäureassimilation statt. Wresnen's ${ }^{2}$ 
bahnbrechende Untersuchungen mit Hilfe der photochemischen Methode ergaben, einerseits daß das Lichtbedürfnis verschiedener Pflanzen verschieden ist, und daß sich darnach die Form, GröBe und der histologische Bau der Blätter und die Verzweigungen der Holzgewächse richten, anderseits daß ein und dieselbe Pflanze umso mehr Licht zu ihrem Gedeihen benötigt, je niedriger die Temperatur ist. Auch das Wärmebedürfnis der Pflanzen ist verschieden. Es besteht nicht nur für jede Art eine obere und eine untere Temperaturgrenze und eine ihrer Entwickelung zusagendste Temperatur (das sogen. Optimum), sondern auch für jede Funktion des pflanzlichen Lebens; und es kommt dabei sowohl auf den Mittelwert und die Schwankung der Temperatur, wie auch auf die Dauer gewisser Temperaturgrade an. Birke und Lärche z. B. können weiter gegen den Pol und in höhere Regionen vordringen als Buche und Eiche, denn bei jenen darf die Vegetationsperiode nicht unter drei, bei diesen nicht unter fünf Monate herabsinken. Aber trotzdem bilden die Isothermen keine unübersteiglichen Schranken, insofern Pflanzen kälterer Gegenden einen gewissen Wärmeüberschuß sehr wohl ertragen können, während umgekehrt eine Akklimatisation von Gewächsen wärmerer Gegenden an kältere begreiflicherweise seltener erfolgreich ist.

Die Beleuchtung und Erwärmung der Erdoberfläche ist derart, daß sie überall Pflanzenleben ermöglicht, ausgenommen in den Kratern tätiger Vulkane und in der unmittelbaren Nachbarschaft von Fumarolen, wo die Hitze zu groß ist. Ihr Einfluß zeigt sich hauptsächlich in der geographischen Verteilung der Arten, wenn auch dabei - wie wir sehen werden - noch ein anderer Faktor mitspricht. Da Licht und Wärme von der geographischen Breite und der Seehöhe abhängen, so bewirken sie eine nach gleichen Gesetzen geordnete Florenschichtung, die Ausbildung horizontaler Pflanzenzonen und vertikaler Pflanzenregionen.

Am genauesten erforscht ist die Bedeutung des Wassers für das Pflanzenleben. Die Pflanze ist gegen Feuchtigkeit in hohem Grad empfindlich und paßt sich den gegebenen Bedingungen durch weitgehende Veränderungen an. $\mathrm{Da}$ diese Bedingungen unregelmäßig über die Erde verteilt sind, so gestaltet sich das Pflanzenkleid äußerst mannigfaltig. Durch ein tiefreichendes und weitverzweigtes Wurzelsystem suchen sich die ausdauernden Xerophyten oder Trockenpflanzen die unterirdischen Wasserschätze dienstbar zu machen, und gleichzeitig hemmen sie durch verschiedene Vorrichtungen den Verdunstungsprozeß $\beta$ und schützen sich gegen die übermäßige Lichtfüulle des wolkenlosen Himmels. Viele 
xerophile $\times$ Holzgewächse umgeben Stamm und Wurzelteile mit einem Korkmantel; die Spaltöffnungen der Epidermis, durch welche die in den Zwischenräumen zwischen den Zellen enthaltene Luft mit der äußeren Luft in Verbindung tritt, sind meist in krug- oder rinnenartige Vertiefungen eingesenkt; vor allem aber sind die wichtigsten Transspirationsorgane, die Blätter, durch eigentümliche Strukturen ausgezeichnet. Viele Fiederblätter falten sich bei starker Besonnung zusammen; bei anderen Gewächsen, wie bei den Eukalyptusbäumen Australiens, sind die Blätter in senkrechter Stellung, also parallel zu den Sonnenstrahlen eingesetzt. Stets sind sie dicker als bei den Feuchtpflanzen, manchmal lederartig oder fleischig ausgebildet und stets auch kleiner. Die Nadeln und wahrscheinlich auch die Dornen sind nur durch Trockenheit bedingte Blattreduktionen, ja bei den australischen Casuarinen und dem Besenstrauch (Spartium) ist die Blattbildung völlig unterdrückt. Haarbedeckung, Wachsschichten und Salzkrusten verlangsamen ebenfalls die Verdunstung der Blätter, und dem gleichen Zweck dient auch die Ausscheidung von Harz und ätherischen Ölen.

Den Gegensatz zu den Xerophyten bilden die Hygrophyten oder Feuchtpflanzen, die sich in ihrer typischen Ausbildung durch schwache Wurzeln, langgestreckte Achsen und große, dünne Laubflächen auszeichnen. Zwischen diese beiden extremen Gruppen stellt ScHгмper $\times \times$ die Tropophyten (Wechselpflanzen), die die Eigenschaften beider vereinigen und dadurch den Klimaten mit wechselnden Feucht- und Trockenzeiten angepaßt sind. Achse und Knospen sind xerophil gebaut, das Blatt dagegen hygrophil. Unsere Laubbäume gehören in diese Gruppe; daB sie im Herbst die Blätter verlieren, ist nicht durch die Temperatur bedingt, sondern als Schutz gegen die Trockenheit des Winters aufzufassen. Nur die Nadelhölzer bleiben immer grün, weil auch ihr Blatt xerophil ist. Ferner sind die Zwiebelund Knollengewächse hierher zu rechnen; in der Trockenzeit werden ihre oberirdischen Sprossen abgeworfen, während die unterirdischen als Nahrungs- und Wasserbehälter funktionieren. Durch diese Einrichtung können sie sogar in den Steppen und Wüsten den Kampf mit dem Klima aufnehmen, und mit überraschender Schnelligkeit

$\times$ Xerophile Pflanzen sind solche, die die Trockenheit lieben, also kurz ausgedrückt Xerophyten.

$\times \times$ Anders ist die Einteilung bei Warmna, der Xero-, Hydro-, Meso- und Halophyten unterscheidet. Die Hydrophyten oder Wasserpflanzen gehören zu Schrmpen's Hygrophyten, die Mesophyten verteilen sich auf die Hygro- und Tropophyten, die Halophyten oder Salzpflanzen bilden, wie wir später sehen werden, nur eine Unterabteilung der Xerophyten. 
entwickeln sie ihre Lichtsprossen und Blüten, sobald die ersten Regengüsse eintreten.

HILDEBRAND ${ }^{3}$ stellte eingehende Untersuchungen über den $\mathrm{Zu}-$ sammenhang zwischen dem Klima und der Lebensdauer der Pflanzen an. Er wies nach, daß ein gleichmäßiges Klima nicht nur langlebige Gewächse, sondern auch die Andauer der Vegetationsorgane begünstigt. Die einjährigen Pflanzen treten zurück und die Zahl der Holzgewächse nimmt außerordentlich zu; ja auf den Hawaiischen Inseln und auf St. Helena sind Familien, die sonst nur Kräuter und Stauden enthalten, durch Holzgewächse vertreten. Der Äquatorialzone fehlen einjährige Pflanzen ganz; wenn sie aber auch in tropischen Gegenden mit langer Trockenheit verhältnismäBig selten sind, so erklärt sich dies daraus, daß hier der Boden von Gewächsen mit längerer Lebensdauer zu sehr besetzt ist, um eine reichlichere Entfaltung ephemerer Existenzen zu gestatten. In unserem Klima ist ihre Zahl beträchtlich gewachsen, auch in Wüsten und Wüstensteppen sind sie nicht selten, dagegen nehmen sie im polaren Gürtel und in der alpinen Region $\times$ rasch wieder ab, vielleicht deshalb, weil hier nicht nur Trockenheit, sondern auch Kälte die Vegetationszeit verkürzt.

Überall, wo die klimatischen Elemente eine ausgesprochene jährliche Periode zeigen, verändert sich auch das Pflanzenkleid mit den Jahreszeiten. Der Winter der mittleren und höheren Breiten und die Trockenzeit in den Gegenden mit streng subtropischem und tropischem Regen versenken die Vegetation in längeren oder kürzeren Schlaf. Aus den Beobachtungen über ihr allmähliches Erwachen hat sich sogar ein eigener Wissenszweig, die $\mathrm{Phänologie,} \mathrm{entwickelt,} \mathrm{die}$ besonders H. HoFfmann und InNe große Förderung verdankt; phänologische Karten bilden eine um so erwünschtere Ergänzung unserer Klimakarten, als sie manche Unterschiede enthüllen, die die meteorologischen Mittelwerte nicht mit gleicher Schärfe erkennen lassen. ${ }^{4}$ Manches bleibt freilich noch rätselhaft, wie das Verhalten des Ölbaumes, der im Mittelmeergebiet seine Knospen schon entfaltet, wenn der Winter die Blätter am meisten bedroht, oder die Erscheinung, daß manche Bäume in Venezuela und Brasilien schon vor Beginn der Regenzeit ausschlagen.

Abhängigkeit vom Boden. Der für das Pflanzenleben maßgebende Grad der Feuchtigkeit hängt nicht nur von den Nieder-

$\times$ Die Zahl der einjährigen Pflanzen beträgt im Dauphiné in $\begin{array}{ccc}200-600 \mathrm{~m} & 600-1800 \mathrm{~m} & \text { über } 1800 \mathrm{~m} \text { Höhe } \\ 60 & 33 & 6 \text { Proz., }\end{array}$

ferner in Paris $\left(49^{\circ}\right.$ B. $) 45$, in Kristiania $\left(59,6^{\circ}\right.$ B. $) 30$, in Listad $\left(61,4^{\circ}\right.$ B. $) 26$ Proz. der Gesamtflora. 
schlägen, sondern auch von der Wasserkapazität, der kapillaren Wasserleitung und der Durchlässigkeit des Bodens ab. Unter ganz gleichen klimatischen Bedingungen ernährt hier ein humusreicher, feinkörniger Boden mit durchlässigem Untergrund eine tropo- oder hygrophile Vegetation, dort ein humusarmer Sand- oder Kalkboden ausgesprochen xerophile Gewächse. Ja sogar feuchter Boden ist nur für Trockenpflanzen geeignet, wenn er, wie der Meeresstrand, reich an gelösten Salzen, oder, wie die Torfmoore, reich an Humussäuren ist, die die Absorption des Wassers durch die Wurzeln erschweren. Auch kalter, besonders gefrorener Boden ist trocken; daher wirkt selbst ein schneereicher Winter auf das Pflanzenleben in derselben Weise ein wie die Trockenperiode der Tropen.

Neben den physikalischen Eigenschaften des Bodens kommen auch seine chemischen in Betracht. Ihr Einfluß zeigt sich namentlich in Gebirgen, wo die Felsarten rasch wechseln. In der Schweiz findet man einige Pflanzen (z. B. Androsace lactea) nur auf Kalk, andere nur auf Sandstein, wieder andere, wie gewisse Moose und Farne des Hochgebirges, nur auf kristallinischem Gestein. Als Beispiel absoluter Anpassung führt CHrist das Alpen-Windröschen (Anemone alpina) an, dessen weiße Form nur auf Kalk und dessen gelbe Form nur im Ton- und Quarzgebirge auftritt. Wo das eine Gestein allmählich in das andere übergeht, finden sich auch Farbenübergänge in zahlreichen Abstufungen. Aber schon in den Vogesen hört diese strenge Scheidung auf, und ein ähnliches Verhalten läßt sich auch bei anderen Pflanzen beobachten. Die Lärche, die in der westlichen Schweiz nur das kristallinische Gebirge bewohnt und auf Kalk auch bei künstlicher Anpflanzung nicht gut gedeiht, zeigt sich in Oberbayern und Salzburg, noch mehr aber in den Karpathen völlig gleichgültig gegen die Gesteinsbeschaffenheit ihres Standortes. Desgleichen kommt die Legföhre, die in den Alpen ein entschiedenes Kalkgewächs ist, in den Karpathen auf jeder Unterlage vor. Die Unterscheidung in Kalk- und Kieselpflanzen ist wohl begründet, aber mit Recht warnt Schimper vor dem Irrtum, daß die einen nur des Kalkes, die anderen nur der Kieselsäure bedürfen. Es kommt auf die Summe aller Lebensbedingungen an, und es gibt wohl keine Pflanze, die unter allen Umständen nur auf einer einzigen Bodenart gedeihen könnte. In vielen Fällen sind die physikalischen Eigenschaften des Bodens sicher maßgebender als die chemischen. Die ausgesprochen xerophilen immergrünen Bäume und Sträucher, die den hervorstechendsten Charakterzug der Mittelmeerflora bilden, kommen nach den Beobachtungen von FucHs in Südfrankreich, Italien, Griechenland, Südrußland und im nördlichen Kleinasien nur 
auf trockenem Kalkboden vor, offenbar deshalb, weil sie nur hier den Kampf ums Dasein erfolgreich mit den tropophilen Gewächsen aufnehmen konnten; weiter südlich aber, wo die Regenzeit immer kürzer und die Trockenheit allgemein wird, hatten sie keine Konkurrenten und konnten sich ohne Rücksicht auf die Gesteinsbeschaffenheit über das ganze Land ausbreiten. Aus demselben Grund ist auf der pyrenäischen Halbinsel die Steppe streng an die gipsführende Formation gebunden, denn salzhaltiger Boden ist physiologisch trocken. Anderseits gibt es auch Pflanzen, die sich gegen die Feuchtigkeitsverhältnisse völlig gleichgültig verhalten, aber einige davon, wie die bittere und die schopfige Kreuzblume, wachsen nur auf kalkhaltigem, andere, wie ein paar Grimmia-Arten, nur auf kalkarmem Boden. Hier gibt also unzweifelhaft die chemische Bodenbeschaffenheit den Ausschlag.

Unter den bodenständigen Pflanzen sind geographisch die Halophyten oder Salzpflanzen weitaus am wichtigsten. Im strengen Sinn bodenständig sind auch sie nicht alle, denn es gibt Pflanzen, die auf salzhaltigem Boden wie auf solchem von gewöhnlicher Beschaffenheit vorkommen, aber auch diese verändern auf Salzböden ihren morphologischen und anatomischen Charakter. Die wenigen Pflanzen, die Chloride in größerer Menge vertragen, beherrschen ohne Konkurrenz den Salzboden. Diese Vegetation besteht aus einund mehrjährigen Kräutern, Gesträuchen und Bäumen, die in der Regel im Wachstum etwas zurückgeblieben sind. Die meisten sind Succulenten, Fettpflanzen mit fleischigen, manchmal schuppenartig ausgebildeten Blättern, bald dunkelgrün, bald von matter, ins Grau spielender Farbe - also echt xerophilen Eigenschaften, die sich wahrscheinlich daraus erklären, daß die Wasseraufnahme aus Salzlösungen schwierig ist. Salzboden wirkt als Trockenboden; daher bewohnen die Halophyten sowohl die Meeresküsten wie die binnenländischen Steppen; ja eine und dieselbe Art, wie das gemeine Salzkraut oder das Meerstrands-Milchkraut, lebt unter den anscheinend extremsten klimatischen Bedingungen, sowohl an dem niederschlagsreichen Gestade Norwegens, wie im regenlosen Tibet.

Pflanzenformationen. Der Einfluß des Klimas und des Bodens kommt in der Verteilung jener großen Pflanzengemeinschaften zum Ausdruck, die Grisebach Vegetationsformationen genannt hat. Sie bestimmen die Physiognomie der Landschaft, und mit ihnen hat es daher der Geograph in erster Linie zu tun. Die entwickelungsgeschichtlich begründete Tatsache, daß sich eine und dieselbe Pflanzenformation in verschiedenen Gegenden aus verschiedenen floristischen Bestandteilen zusammensetzt, gewinnt für uns zunächst nur dann Bedeutung, wenn einzelne Formen in charakteristischer 
Weise im Landschaftsbild hervortreten oder wegen ihres Nutzens uns nahestehen.

Schimper hat zwei Formationsgruppen unterschieden: die klimatischen und die edaphischen.

I. Die klimatischen Formationen sind durch das gegenwärtige Klima, in erster Linie durch die Verteilung der Niederschläge bedingt und gliedern sich in drei Untergruppen:

1. Das Gehölz erscheint a) als Wald, b) als Buschwald oder Gebüsch, „wo die Sträucher so reich entwickelt sind, daß die Baumkronen einander nicht berühren“, und c) als Gesträuch.

2. Die Grasflur besteht im wesentlichen aus büschelartig wachsenden perennierenden Gräsern. In der Einteilung fehlt es leider noch an scharfen Begriffsbestimmungen; ScHIMPER nennt die Hygro- und Tropophytenvereine Wiesen und die Xerophytenvereine Steppen oder, wenn sie auch Baumleben gestatten, Savanen. In der Praxis ist die Anwendung manchmal schwierig, namentlich in den zahlreichen Fällen, wo die Flora nicht genau bekannt ist. Wir werden in der Folge von Gras - und Wüstensteppen sprechen, wobei wir mehr den ökonomischen Wert als die botanische $\mathrm{Zu}$ sammensetzung im Auge haben, sind uns aber wohl bewußt, daß wir auch damit nicht alle Schwierigkeiten beseitigen.

3. In der Wüste wird der Boden nur von solchen krautigen und Holzgewächsen eingenommen, die die Ungunst des extremen trockenen Klimas ertragen können. Während Gehölz und Grasflur geschlossene Formationen sind, in denen alle möglichen Stellen von Pflanzen besetzt sind, ist die Wüstenformation offen, da viele Pflanzen vorzeitig absterben oder wenigstens nicht zur Fortpflanzung gelangen. Als Übergangsform zwischen Steppe und Wüste führt Schimper die Halbw üste ein, die im großen und ganzen unserer Wüstensteppe entspricht.

II. Innerhalb der klimatischen Formationen können durch günstige oder ungünstige Beschaffenheit des Bodens wesentliche Modifikationen hervorgerufen werden, die ScHIMPER als edaphische oder Standortsformationen bezeichnet. Örtlich sich anhäufendes Grundwasser ernährt in Grasfluren Wälder, in Wüsten Oasen, oder führt an anderen Stellen zur Bildung von Sümpfen und Mooren. Die Halophytenvegetation ist ebenfalls edaphisch, ferner die Vegetation auf Felsen und in Felsenspalten, die Dünenvegetation usw. ${ }^{\times}$

× Für die wärmeren Gegenden der Erde hat Engler (Die Vegetationsformationen tropischer und subtropischer Länder, Leipzig 1908) eine übersichtliche und streng wissenschaftliche Einteilung in halophile, hydrophile, hygrophile megatherme (in den warmen Niederungen), hygrophile mesotherme (in den 
Literaturnachweise: ${ }^{1}$ Pflanzengeographische Hauptwerke sind: A. Grisebach, Die Vegetation der Erde, Leipzig 1872; A. Engler, Versuch einer Entwickelungsgeschichte der Pflanzenwelt, Leipzig 1879; O. Drude, Die Florenreiche der Erde (Gotha 1884) und Handbuch der Pflanzengeographie (Stuttgart 1890), Atlas der Pflanzenverbreitung, Gotha 1887 (in Berohaus' Physikalischem Atlas); E. W Aвmrna, Lehrbuch der ökologischen Pflanzengeographie, 2. Aufl., Berlin 1902; A. F. W. Schrmper, Pflanzengeographie auf physiologischer Grundlage, Jena 1898 (außerordentlich lehrreich für den Geographen, auch wegen der charakteristischen Abbildungen); H. Graf zu SocmsLашвасн, Die leitenden Gesichtspunkte einer allgemeinen Pflanzengeographie, Leipzig 1905 (gewährt einen bequemen Überblick über die Hauptfragen). Zur raschen Orientierung eignet sich L. Diecs, Pflanzengeographie (Sammlung Goeschen), Leipzig 1908. Seit 1896 geben A. Engler und O. Drude eine Sammlung pflanzengeographischer Monographien unter dem Titel „Die Vegetation der Erde" (Leipzig) heraus. M. Kronfeld, Bilderatlas zur Pflanzengeographie, Leipzig 1899. G. Karsten und H. Schenck, Vegetationsbilder, Jena 1903 (im Erscheinen begriffen, ein lang entbehrtes Hilfsmittel!) - 2 J. Wirsner, Der Lichtgenuß der Pflanzen, Leipzig 1907. $-{ }^{3}$ Hrbdebrand, Lebensdauer und Vegetationsweise der Pflanzen, in Engler's Botanischen Jahrbüchern, Bd. II. - ${ }^{4}$ Als Beispiel diene E. Inve's phänologische Karte von Mitteleuropa, in Petermann's Mitteilungen 1905.

\section{Die Hauptzonen und Hauptregionen der Vegetation.}

\section{(Siehe Karte XVIII.)}

Die Karte der Verbreitung der Vegetationsformationen wird nur verständlich, wenn man sie mit den Isothermen- und den Regenkarten vergleicht. Beide klimatischen Elemente müssen stets im Auge behalten werden, ist doch auch die Veränderung des Pflanzenkleides vom Äquator gegen die Pole nicht bloß eine Wirkung der Licht- und Temperaturabnahme, sondern auch durch die Abnahme der Niederschläge und der absoluten Luftfeuchtigkeit bedingt.

Tropische Pflanzenzone. Als Grenzen der warmen Zone betrachten wir die Jahresisothermen von $20^{\circ}$, und in der Tat fallen damit auch die Polargrenzen der Palmen nahezu zusammen. Die Tropenvegetation im engeren Sinn reicht aber nicht so weit, ihre polaren Grenzen bilden die großen Wüsten- und Steppengebiete, und nur an den Ostküsten Nordamerikas, Asiens, Australiens und Südafrikas, wo das Waldland keine Unterbrechung erleidet, findet ein allmählicher Übergang aus der tropischen Vegetation in die der gemäBigten Breiten statt. Es braucht nicht besonders betont $\mathrm{zu}$

kühleren Hochländern), subxerophile und xerophile Formationen entworfen. Auf diesem Weg kommen wir vielleicht zu einer internationalen Verständigung, besonders wenn die empfohlenen Kartensignaturen allgemeine Annahme finden werden. Trotzdem müssen wir hier davon absehen, solange die Ergänzung für die gemäBigte und die kalte Zone noch fehlt,

Supan, Physische Erdkunde. 5. Auf, 
werden, daß diese Anordnung auf das innigste mit der Verteilung der Niederschläge zusammenhängt.

Mit dem Begriff der Tropenvegetation verbinden wir gewöhnlich die Vorstellung außerordentlicher Formenfülle und üppigen Wachstums. Diese Vorstellung hat aber nur beschränkte Gültigkeit; hohe und gleichmäßige Temperatur und gleichmäßige Lichtintensität $\times$ sind wohl allen Tropenländern mit Ausnahme der Hochgebirge eigen, aber um so ungleichmäßiger ist der Regen verbreitet, und darauf kommt es hier vor allem an. Von dem immergrünen hochstämmigen Regenwald bis zur Wüste vereinigt die Tropenzone alle Vegetationsformationen in sich, und in Gebirgsländern liegen die größten Gegensätze oft räumlich dicht nebeneinander. „Bei Setal $(730 \mathrm{~m})$ oder Tual $(820 \mathrm{~m})$ auf der Nordseite des Kettengebirges von Mittelguatemala befindet man sich" — schreibt SAPPER - „bei einem jährlichen Regenfall von 5-6 m in der üppigsten regenfeuchten Tropenvegetation, und kaum $64 \mathrm{~km}$ weiter südlich beobachtet man auf dem Südabhang desselben Gebirges bei Salamá $(930 \mathrm{~m})$, einem Ort mit nur $0,6-0,8 \mathrm{~m}$ Regenfall, während der Trockenzeit eine halbwüstenförmige Vegetationsformation, indes auf dem zwischen beiden Punkten liegenden Kamm von S. Rosa die Grenze zwischen dem feuchten und dem trockenen Gebiet mit außerordentlicher Schärfe hervortritt."

Unter den Florenbestandteilen der tropischen Vegetation bilden die monokotylen Laubbäume, deren einfaches Holzgerüst eine ausgebreitete, riesige Blattrosette krönt, und unter diesen wieder die Palmen den hervorstechendsten Charakterzug. Die höchsten nördlichen Breiten, die die Palmen in ihrer natürlichen Verbreitung erreichen, sind $35^{\circ}$ in Amerika und $43,7^{\circ}$ in der Alten Welt (Nizza); in Südamerika liegt ihre äußerste Grenze in $38^{\circ}$, in Afrika in $34^{\circ}$, in Australien in $36^{\circ}$ B. Weiter vom Äquator entfernen sie sich auf Neuseeland; östlich von Neuseeland, auf der Pittinsel, erreichen sie in fast $45^{\circ} \mathrm{S}$. ihre größte Polhöhe. Dagegen bleiben sie den Galapagosinseln und den Eilanden Ascension und St. Helena fern, aber wohl nicht aus klimatischen Gründen; die schmale und lange äquatoriale Ausbuchtung ihrer Polargrenze in Südamerika ist da-

$\times$ Nach Schimper werden bei dem Zenithstand der Sonne 19 Proz. der leuchtenden Strahlen, 25 Proz. der Wärmestrahlen und 60 Proz. der chemischen Strahlen von der Atmosphäre absorbiert. Je tiefer der Stand, desto größer die Absorption; nur in bezug auf die leuchtende Energie erleidet die Wirkung dieses Gesetzes insofern eine Ausnahme, als die Lichtzerstreuung mit der Breite zunimmt und dadurch im Sommer, wenn der Tag gegen die Pole zu immer länger wird, die Folgen der Absorption paralysiert werden. 
gegen klimatisch, nämlich durch die gewaltige Erhebung der Andes bedingt.

Während an der antarktischen Grenze verschiedene Palmen, zum Teil von hochstämmigem Wuchs, auftreten und der tropische Vegetationscharakter ziemlich rasch abbricht, gehören die nördlichsten Palmen ausschlieBlich zur Gruppe der Sabaleae, und zwar in der Neuen Welt zum Sabal-, in der Alten Welt zum ChamaeropsGeschlecht. Die Gültigkeit des Hauptgesetzes, daß der Florenreichtum unter sonst gleichen Umständen mit wachsender Breite abnimmt, erwies DRUDE, ${ }^{1}$ dem wir überhaupt die eingehendsten Untersuchungen über die Verbreitung der Palmen verdanken, auch in bezug auf diese Pflanzenfamilie. ${ }^{\times}$Nur das höchste, in äquatorialer Richtung verlaufende Kettengebirge, der Himalaya, bildet eine schroffe Grenze, indem südlich davon die Palmen sogleich in großer Artenzahl auftreten. Am üppigsten entfaltet sich die tropische Vegetation in der Ebene des Amazonas und im malaiischen Archipel, also unter dem Äquator. Wenn Afrika nicht durch eine gleiche Palmenfülle ausgezeichnet ist, so hat man dies, zum Teil wenigstens, der bedeutenden Erhebung über dem Meeresspiegel zuzuschreiben, denn die Palmen lieben vor allem warmfeuchtes Tiefland und steigen nur ausnahmsweise in größere Seehöhen empor (die Wachspalme in den Andes bis $3000 \mathrm{~m}$ ). Daraus erklärt es sich auch, daB in Afrika die Palmen nur in der Guinea-Niederung einen hervorragenden Anteil an der Vegetation nehmen.

Die einzige einheimische Palme Südeuropas, Chamaerops humilis, ist eine Zwergform. Der Stamm ist meist im Boden versteckt, und nur in den günstigsten Fällen erreicht er eine Höhe von 4-6 m. Solche Zwerge finden wir aber auch gelegentlich in der Nähe des Äquators, besonders in höheren Regionen. Die meisten Palmen aber sind hier hochwüchsige Bäume, deren schlanker Stamm sich

$\times$ Die Artenzahl beträgt:

a) in Amerika:

Prärien 3. Südöstliche Vereinsstaaten 6, Mexicanisches Gebiet 80. Westindien 40. Südamerika diesseit des Äquators 90. Amazonasebene 180. Tropische Andes 70. Brasilianisches Gebiet 90. Chile 2. Nördliche Pampas 6.

b) im westlichen Teil der Osthemisphäre;

Mittelmeerländer 1. Sahara und Vorderasien 3. Tropisches Afrika, Westküste 17, Ostküste 11. Madagaskar 10. Südafrika 2.

c) im östlichen Teil der Osthemisphäre:

Südchina 11. Vorderindien 50, Hinterindien 70. Malaiischer Archipel 200. Australische Nordküste bis zum Wendekreis 19. Australische Ostküste 6. 
bei einigen südamerikanischen Arten bis zu $60 \mathrm{~m}$ über den Boden erhebt, oder sie sind Schlinggewächse (Rotangs). Eine Ausnahme von der gewöhnlichen Palmform bilden die afrikanischen Dumpalmen, deren Stamm ein- oder mehrfach gabelförmig geteilt ist. Die Blätter sind oft von erstaunlicher Größe; es gibt Fächer von $3^{1} / 2$ m Durchmesser und Fiederwedel von $15 \mathrm{~m}$ Länge. Das ganzrandige, steife Blatt der Manicaria saccifera besitzt eine Länge von 9 und eine Breite von $1 \frac{1}{2} \mathrm{~m}$. Noch deutlicher zeigt sich die tropische Lebensfülle in den Kletterpalmen, die besonders in Ostindien heimisch sind (die Geschlechter Calamus und Daemonorops), und deren Holzstamm eine Länge von 370-550 m erreicht. Wäre ihr Stamm entsprechend dick, um aufrecht stehen zu können, so würde er viele Berge an Höhe übertreffen.

Aber die Palmen sind nicht bloß ein unvergleichlicher Schmuck der Landschaft, sondern auch von unberechenbarem Nutzen. Ganze Länder ernähren sich von den Früchten der Dattel- und der Kokospalme. Der Stamm der Sagopalme enthält reichliches Stärkemehl, das unter dem Namen Sago in den Handel kommt. Die Blattknospen einiger Arten werden als Gemüse genossen, oder man bereitet aus ihrem Saft den Palmenwein, und durch Zusatz bitterer Kräuter und Wurzeln, die die Gärung zurückhalten, ein bierartiges Getränk. Gekocht und zur Verdunstung gebracht, liefert dieser Saft guten Zucker. Den Assai, ein dem Kaffee oder der Schokolade ähnliches Getränk, liefert die Frucht der südamerikanischen Euterpe oleracea. Die BetelnuB, die Frucht der Arecapalme, ist im ganzen südöstlichen Asien ein beliebtes GenuBmittel. Das Palmöl, dessen Bedeutung für den Welthandel von Jahr zu Jahr steigt, gewinnt man aus dem Sameneiweiß einiger Palmen, besonders der westafrikanischen Ölpalmen; und nur dem Handel mit Kopra, aus der man das KokosnuBöl darstellt, verdanken wir die wirtschaftliche Erschließung der kleinen Südseeinseln. Unendlich mannigfaltig ist endlich die Verwendung der Blätter und des Holzes zu Flechtwerk, Hüten, Matten, Gefäßen, Kästen usw.; und wohl keine Pflanze ist mit den Sitten und Gebräuchen der Tropenbewohner so innig verwachsen wie die Palme; ja in bezug auf die Vielseitigkeit des Nutzens kommt ihr keine andere Pflanzenfamilie der Erde gleich.

Als Nahrungspflanzen sind auch die Musaceen von außerordentlicher Bedeutung. Thre saftreichen, nicht sehr hohen Stämme tragen Blätter von außerordentlicher Größe, schöne Blüten und Fruchtbündel von $1-1^{1} / 2 \mathrm{~m}$ Länge. Die Früchte der Bananen ${ }^{2}$ werden als frisches Obst, die des Pișangs (Paradiesfeige) auch gekocht genossen. Eine beschränktere Verbreitung besitzt der Brot- 
baum, ursprünglich nur vom Sundaarchipel bis $\mathrm{zu}$ den fernsten polynesischen Inseln; aber gerade für diese pflanzenarmen Eilande ist er das wertvollste Geschenk, um so mehr, als er keiner Kultur bedarf, und drei Bäume ausreichen, einen Menschen das ganze Jahr hindurch zu ernähren. Fast unabsehbar ist die Zahl der übrigen Bäume mit eBbaren Früchten. Hier sei nur noch der Banjanen gedacht, die der Hindu als das Symbol unerschöpflicher Naturkraft verehrt. Aus den Zweigen senken sich Luftwurzeln herab, die wieder zu neuen Stämmen heranwachsen, so daß „Krone an Krone wie über einer gemeinsamen Säulenhalle sich ausbreitet", und ein einziges Individuum einen ganzen Wald erzeugen kann. Seltsam erscheinen auch dem an nordische Formen gewöhnten Auge die Gestalten des Pandanus und die Mangrovebäume, an deren Früchten sich lange Keime entwickeln, die nach der Loslösung vom mütterlichen Stamm im Schlamm schnell Wurzeln treiben.

Am meisten fällt uns die Wachstumskraft der Tropen auf, wenn wir innerhalb einer und derselben Familie tropische Vertreter mit denen höherer Breiten vergleichen. Zur Familie unserer Gräser gehört das Bambusrohr, das am $\mathrm{FuB}$ etwa $15 \mathrm{~cm}$ dick ist und sich nach oben zu einer Spitze verjüngt. Die glänzend glatten Stämme vereinigen sich zu dichten Büscheln von 20-30, ja sogar $40 \mathrm{~m}$ Höhe und treten somit in der Physiognomie der südasiatischen Landschaft bedeutsam hervor. Seltener ist der Bambus in Südamerika, und noch weniger verbreitet ist er in Afrika. Unerschöpflich ist seine Verwendbarkeit zu Waffen, Leitern, Masten, Kähnen, Brücken, Matten, Schränken, Gefäßen, Möbeln; ja ganze Häuser werden aus diesem ebenso eleganten als leicht zu verarbeitenden Material erbaut. Die Familie der Liliengewächse hat einige baumartige Repräsentanten, wie Yucca, Aloë und den berühmten Drachenbaum, einen der Riesen der Pflanzenwelt. Aus der Klasse der Farne, die in außerordentlichem Formenreichtum und enormer Artenzahl die feuchten Urwälder bewohnen, ragen besonders die schönen, 6-10, manchmal 15-18 $\mathrm{m}$ hohen Baumfarne hervor. Auch der Ricinus erlangt baumartigen Wuchs und eine Höhe von 6-10 m. Die Familie der Arongewächse, die bei uns nur in kleinen Formen vorkommt, verliert zwar auch in den Tropen ihren krautartigen Charakter nicht, aber Stamm und Blätter erlangen kolossale Dimensionen. Viele Schling- und Schmarotzergewächse des Urwaldes gehören ihr an. Ein noch größeres Kontingent zu den epiphytischen Pflanzen stellen die Orchideen, die an Mannigfaltigkeit und Blütenschönheit alle anderen Familien übertreffen. Aber die prachtvollsten Blumen verschwinden im Dickicht des Ur- 
waldes oder bilden nur einen vergänglichen Schmuck. Die Üppigkeit der tropischen Vegetation äußert sich überhaupt nicht in der Hervorbringung von entsprechend großen Blüten, ja gerade bei den gewaltigsten Pflanzen sind die Blüten verhältnismäßig unscheinbar. Immerblühende Pflanzen sucht man wahrscheinlich auch in gleichmäßig feuchten Gebieten vergeblich; nicht ein und derselbe Stock blüht immer, wohl aber findet man immer blühende Stöcke. Auch die größten Bäume von $\mathrm{mehr}$ als $120 \mathrm{~m}$ Höhe (Sequoia gigantea und Eukalypten) findet man nicht in der Tropenzone; nur in bezug. auf den Umfang des Stammes kann sich der afrikanische Affenbrotbaum und der westindische Wollbaum, dessen Krone tausend Personen Schatten gewährt, und aus dessen Stamm Kanus für 180 Personen hergestellt werden, mit den Riesen Californiens und Australiens messen. Dagegen entwickeln sich einzelne Pflanzenteile in großartigster Weise. Die Kigelia trägt $60 \mathrm{~cm}$ lange, dicke Früchte, und der ebenfalls afrikanische Ensete-Pisang $6 \mathrm{~m}$ lange Blätter. Ungefähr ebenso lang und $3-4 \mathrm{~m}$ im Durchmesser sind die Fächer der Palme Corypha umbraculifera auf Ceylon und in Malabar, die am Schluß ihres Lebens eine Blütenrispe von $10 \mathrm{~m}$ Höhe treibt. Das abgerundete Blatt der Gunnera gigantea, einer Steinbrechart in Columbien, hat 6-8 $\mathrm{m}$ im Umfang. Die kreisförmigen, oben hellgrünen, unten karminroten Blätter der Victoria regia, die im Durchmesser $1 \frac{1}{2}-2 \mathrm{~m}$ groß sind, schwimmen ausgebreitet auf dem Spiegel des Amazonas und seiner Nebenflüsse und rechtfertigen den königlichen Namen dieser herrlichsten aller Wasserpflanzen. Die Aroidee Amorphophallus titanum auf Sumatra genieBt den Ruhm, die größte aller bekannten Blüten zu besitzen; ihr Kolben wird von einer $70 \mathrm{~cm}$ hohen und $83 \mathrm{~cm}$ breiten Blütenscheide umschlossen, die an ihrem oberen freien Rand 2:/2 m mißt. Die Nüsse der Palme Lodoicea Sechellarum erreichen einen Durchmesser von $45-60 \mathrm{~cm}$, und es dauert ein volles Jahrzehnt, bis sie zur völligen Reife gelangen.

Gemäßigte Zone. An den Westseiten und im Innern der Festländer grenzen ausgedehnte Wüsten und Steppen an die tropische Vegetationszone, und daran schließen sich polwärts im Bereich der subtropischen Winterregen eigenartige Vegetationsgebiete an, die sich durch immergrüne Hartlaubhölzer charakterisieren, deren typischer Vertreter in unseren Mittelmeerländern der Ölbaum ${ }^{3}$ ist. Ihre harten, dicken, lederartigen Blätter sind einem Klima angepaßt, in dem die Transspiration gleichzeitig durch Hitze und Trockenheit gesteigert wird. Aus demselben Grund erreichen hier die Zwiebel- und Knollengewächse, wie Tulpen, Narzissen, Aspho- 
dilen usw., eine Entwickelung wie sonst nirgends; und wie sehr auch die Flora der Mittelmeerländer, des Kaps, des südwestlichen Australien, Nordchiles und Californiens verschieden sind, überall herrscht derselbe streng xerophile Charakter.

Stellenweise überschreiten tropische Gewächse, wie die Palmen, die Wüstenschranke, noch leichter aber verbreiten sie sich in den östlichen Waldländern polwärts, wenn auch zum Teil in verkümmerten Formen. Die Bambusen kommen in ganz China vor, aber es ist fraglich, ob sie nördlich vom Tsinling einheimisch sind. In Japan erreichen sie noch baumartigen Wuchs, und Arundarien, die sich zum Bambus in ähnlicher Weise verhalten wie die Zwergpalme zur Baumpalme, bewohnen noch die Kurilen und sind in den Vereinigten Staaten bis Illinois verbreitet. Zwergartige Lilienbäume reichen im westlichen Nordamerika bis $49^{\circ} \mathrm{B}$. und im östlichen bis zur Chesapeakebai $\left(37^{\circ}\right.$ B.). Von tropischem Gepräge sind der Tulpenbaum und der Sassafraslorbeer, die sich bis Canada, der virginische Ebenholzbaum und eine Magnolie, die sich bis New York, und der Trompetenbaum, der sich bis Illinois findet. In den trockenen Gebieten Nordamerikas dringen die Agaven zwar nur bis $35^{\circ} \mathrm{B}$. vor, desto weiter aber die Kakteen, die man noch jenseits des Missouri in $49^{\circ}$ B. antrifft. Aber auch sie nehmen nach Norden rasch an Höhe ab, geradeso wie die Mimosensträucher der südlichen Prärien.

Viel wichtiger als vereinzelte Vorposten der Tropenwelt sind die immergrünen dikotylen Laubbäume, die den südlichsten Gebieten unserer gemäßigten Zone, soweit milde Winter herrschen, also mit Ausschluß der großen Bodenerhebungen, ein charakteristisches Gepräge verleihen. Im Westen der Alten Welt erreichen sie ihre höchste Breite bei Görz $\left(46^{\circ}\right)$, im Osten dringen die immergrünen Eichen nur bis $36^{0}$ vor, werden aber in Nippon noch bis $38^{\circ}$ B. angepflanzt. In Nordamerika liegt ihre Polargrenze im Westen in etwa $47^{\circ} \mathrm{B}$. (Oregon), in Kentucky in $36^{1 / 2}$ und an der Ostküste in $37^{\circ} \mathrm{B}$; hier, wie in der östlichen Hemisphäre, folgt sie also den Winterisothermen. Weiter nach Norden reichen die immergrünen Sträucher, am weitesten an der von der Atlantischen - Strömung bespülten Küste Europas, wo sich z. B. die Erica cinerea von Portugal bis zu den Färöer und bis Bergen in Norwegen, al*o bis zum 62. Parallel verbreitet hat. Nur der Buchsbaum, der in West- und Südeuropa, in China und Japan, ebenso wie in den Steppen und auf den Gebirgen Hochasiens vorkommt, schlingt ein ununterbrochenes immergrünes Band um die Alte Welt.

Auf der Südhemispäre umfaßt die immergrüne Zone, begünstigt durch die große Gleichmäßigkeit des Klimas, das ganze außertropische 
Festland. Auf unserer Halbkugel aber folgt darauf der Gürtel der sommergrünen Laubbäume, der im westlichen Europa bis $60^{\circ}$, im östlichen bis etwa $56^{\circ}$, im mittleren Sibirien bis $48-50^{\circ}$ und in Kamtschatka wieder bis $60^{\circ} \mathrm{B}$. reicht. Für den atlantischen Teil von Nordamerika wird $54^{\circ}$, für das Binnenland etwa $47^{\circ} \mathrm{B}$. als Polargrenze angegeben; darüber hinaus dehnt sich in der Alten wie in der Neuen Welt die Koniferenzone bis zur Waldgrenze aus.

Bei dieser Anordnung der Vegetation nach der Breite ist zu beachten, daß gewisse Hauptelemente bei dem Übergang aus dẹr einen Zone in die andere teils zu-, teils abnehmen. Im Tropengürtel herrschen monokotyle und immergrüne dikotyle Laubbäume, und nur in den Trockengebieten spielt die periodische Belaubung eine größere Rolle. Nadelhölzer sind selten, nur wenige, wie die Araukarien, überschreiten den 20. Parallel, und in den höheren Gebirgsregionen werden sie meist durch Kätzchenbäume vertreten. In der folgenden, durch wärmere Winter begünstigten Zone finden wir noch einige Ausläufer der monokotylen Baumflora; die Aloë in Südafrika, die Yucca in Nordamerika, der gemeine Drachenbaum auf den Canaren, der Ti-Drachenbaum und der Grasbaum in Australien und Neuseeland treten noch bedeutsam im Landschaftsbild hervor. Aber mit den immergrünen Laubbäumen aus der Klasse der Dikotyledonen mischen sich schon sommergrüne; und Koniferen, unter denen sich einige dem Norden fremde Formen, wie die Zypressen und die Pinien, befinden, verleihen der Vegetation schon einen untropischen Charakter. Dann verschwinden die immergrünen dikotylen Bäume und nur solche mit periodischer Belaubung, gemischt mit Nadelhölzern, bilden die Wälder der mittleren nördlichen Breiten, bis endlich in den höheren Breiten die Konifere die Oberherrschaft erlangt. Endlich endet auch der Nadelwald und die polare Vegetation beginnt.

Polare Waldgrenzen. Die arktische Waldgrenze folgt im allgemeinen, mit einigen Ausnahmen an den Ostseiten, der $10^{\circ}$-Isotherme des wärmsten Monats; nicht die Winterkälte ist entscheidend das beweist schon der Wald im Bereich des winterlichen Kältezentrums in Sibirien -, sondern die Sommertemperatur oder mit anderen Worten: die Dauer der Vegetationszeit. Aber damit ist das Problem der arktischen Waldgrenze noch nicht erschöpft. Aus Krnlman's ${ }^{4}$ Untersuchungen in Kola geht hervor, daß auch die trockenen Winde der kalten Jahreszeit den Baumwuchs zurückdrängen; und ferner hat WIEsNer gezeigt, daß das Lichtbedürfnis der Pflanzen mit der Abnahme der Temperatur rapid zunimmt, und daß Bäume, die sich selbst beschatten und im geselligen Zusammen- 
sein von höheren Nachbarn überschattet werden, im Kampf mit den feindlichen Mächten der polaren Welt zuerst unterliegen müssen. Nur in geschützten Flußtälern dringt der Wald erheblich weiter als sonst gegen Norden vor: im Janatal erreicht er z. B. $70^{\circ} 55^{\prime}$, und im Tal der Chatanga im Taimyrland seine höchste arktische Breite: $72^{1} /{ }^{0}$. In Alaska fanden DALL und WHyмper am Fort Yukon $\left(67^{\circ} 10^{\prime} \mathrm{N}\right)$ noch einen stattlichen Wald, und bei Nulato $\left(64^{\circ} 40^{\prime} \mathrm{N}\right)$ noch Bäume von $90 \mathrm{~cm}$ Durchmesser und $30 \mathrm{~m}$ Höhe. Die kalten Seewinde flieht der Baum, daher die Küstengegenden des Beringmeeres waldlos sind, und an der sibirischen Waldgrenze nach den Beobachtungen MrddendorfF's die Bäume in regelmäBiger Stufenfolge kleiner werden, um endlich in verkrüppelten $Z_{w}$ wergformen zu enden. Die Eisströmungen, die von N und W durch die Davisund die Hudsonstraße zum Atlantischen Ozean abfließen, drücken mit der Sommerwärme auch die Waldgrenze an der Ostküste von Labrador bis gegen $52^{\circ}$ B. hinab; die extremsten Grenzen des Baumlebens auf unserer Halbkugel differieren also um volle 20 Breitengrade.

$\mathrm{DaB}$ die Baumgrenze, wenigstens in Sibirien, einst weiter nach Norden reichte, bezeugen die Waldinseln und die stehenden Wurzeln großer Bäume, die man noch in der Tundra findet. Es wäre aber verkehrt, wollte man daraus auf eine dauernde Verschlechterung des Klimas schließen. Ohne daß die mittlere Jahrestemperatur sich ändert, können mehrere aufeinander folgende ungünstige Winter mit trockenen Nordwinden die Waldgrenze rasch zurückdrängen, weil hier die Bedingungen der Existenz größerer Holzgewächse eben noch knapp erfüllt sind, und daher auch vorübergehende Änderungen sich fühlbar machen. Ein noch gefährlicherer Feind ist der Mensch, der z. B. in den Tälern Islands die einstigen Birkenwaldungen bis auf eine einzige (bei Hallormstradur) vernichtet hat. Nirgends ist, wie MrddendorfF treffend bemerkt hat, der Wald so sehr sich selbst Schutz als an seinen äußersten Grenzen; jede Blöße, die das Beil oder der Sturm geschaffen hat, gefährdet hier die Umgebung. Dahêr kommt es, daß hier und da die polare Tundra zungenartig oder in vereinzelten Flecken weit in das Waldland eingreift.

Die südlichen Kontinente liegen ganz innerhalb der Waldgrenze. Auf einigen Inseln, wie auf der Falklandgruppe, gestatten die häufigen Stürme keinen Baumwuchs oder, wie auf Tristan da Cunha, nur das Aufkommen von Krummholz. Die Amsterdam-Insel besitzt einen Wald von Phylica nitida, völlig übereinstimmend mit Tristan da Cunha, aber schon auf St. Paul sucht man vergebens nach einem Holzgewächs und ebenso auf den Kerguelen und der Marioninsel. 
Kerguelens Flora, die nur 21 Phanerogamen enthält, ist dürftiger ausgestattet als die des Franz-Josef-Landes, das doch um $33^{\circ}$ dem Pol näher liegt (23 Phanerogamenarten), und die Vorherrschaft der Kryptogamen gibt ihr schon ein echt polares Gepräge. Die Stürme trocknen die Gewebe aus, und die abnorm tiefe Sommertemperatur verhindert die Tränkung mit der reichlich vorhandenen Bodenfeuchtigkeit. ${ }^{5}$ Ebenso wie in Labrador, greift auch hier die Polargrenze des Baumwuchses zungenartig in die gemäßigte Zone ein, nur erreicht sie hier den 38. Parallel, d. h. die Breite von Calabrien! Erinnern wir uns daran, daB sich in Südamerika bis zu $55^{\circ} \mathrm{B}$. immergrüne Laubbäume an der Zusammensetzung der Wälder in hervorragender Weise beteiligen, und daß im Osten von Neuseeland hochwüchsige Palmen noch in $44^{\circ} \mathrm{B}$. vorkommen, so werden wir zu unserem Erstaunen gewahr, welche Gegensätze innerhalb gleicher Breiten die anscheinend so einförmige, fast nur von Wasser bedeckte Südhemispäre in sich birgt.

Polare Pflanzenzone. Außerhalb des südamerikanischen Festlandes fand man die letzte Phanerogame, ein kleines Gras (Deschampsia antarctica) im Palmerarchipel und Orleanskanal $\left(64^{0} \mathrm{~B}\right.$.), in dem übrigen Teil der Antarktis kann aber rund der 60. Parallel (die Breite von St. Petersburg!) als die Südgrenze der Blütenpflanzen bezeichnet werden. Darüber hinaus ist die Pflanzenwelt nach unserem gegenwärtigen Wissen nur durch die niedersten Formen, nämlich Zellenkryptogamen, wie Moose, Flechten und Algen vertreten; aber solche kommen noch am Eisrand von Kaiser Wilhelm II.- und Viktorialand vor.

Wie ganz anders gestalten sich die Verhältnisse im arktischen Gürtel! ${ }^{6}$ Am ärmlichsten ist die Flora auf den nahezu wagerechten Ebenen, wo das sommerliche Schmelzwasser weder abflieBen noch eindringen kann, und die Bodentemperatur sich wegen der Nähe des unterirdischen Eises nicht über den Gefrierpunkt erhebt. Das sind die Moostundren, die das Festland der Alten Welt jenseits der Waldgrenze umsäumen. Wo festes Gestein der Oberfläche nahe liegt und der Boden einigermaßen trocken ist, wie im größten Teil des polaren Nordamerika, entwickelt sich die Flechtentundra, die mit ihren Flechten, ihren Heidel- und Krähenbeeren ein reicheres Tierleben ernährt. Wiesen mit Kräutern, Weidegestrüpp und Gruppen kleinerer Holzgewächse schmücken die FluBniederungen; und auf geneigtem Boden zaubert der monatelange Sommertag anmutige Matten mit frischem Grün und prächtigen Blumen hervor, denn nur auffällig gefärbte Blüten können die wenigen Insekten, die die Befruchtung vermitteln, herbeilocken. Im östlichen Grönland wurden 
die Mitglieder der deutschen Expedition durch große, gleichmäßig grüne Flächen, die bis zu einer Höhe von $300 \mathrm{~m}$ ansteigen, überrascht. Herden von Renntieren und Bisamochsen belebten die Gegend, und an manchen Stellen labte sich das Auge an dem schönsten Rasen mit Stauden und Erikensträuchern oder niederem Birkengestrüpp. In den höheren Regionen des eisfreien Küstenlandes, wo kein ozeanischer Nebel die Sonne verhüllt, steigt Papaver nudicaule bis $1500 \mathrm{~m}$, viele Blütenpflanzen bis $1250 \mathrm{~m}$ Höhe an, und ein Vaccinium trägt noch in $660 \mathrm{~m}$ Höhe reife Beeren. Selbst auf den Nunatakker des Binneneises (s. S. 226) fand JENSEN grüne, wenn auch spärlich bewachsene Stellen; in beträchtlicher Entfernung von der Küste und in $1250 \mathrm{~m}$ Höhe sammelte er 27 Phanerogamen, und am Rand des Inlandeises bei Julianehaab empfing ihn eine üppige Vegetation von Gräsern und 3-4 $\mathrm{m}$ hohen Birken. Von den 386 Gefäßpflanzen, die Grönland besitzt, erreichen noch 88 den 83. Parallel. Auf Grinnellland $\left(82^{\circ}\right.$ B. $)$ liefert eine mit Stauden gemischte Moossteppe noch genügendes Futter für Tiere, und unter $82^{\circ} 50^{\prime}$ wurden sogar noch 9 Blütenpflanzen gesammelt. Am ärmlichsten dürfte die Vegetation auf Franz-Josef-Land sein, denn vergebens sucht man hier nach einer geschlossenen Rasendecke, aber dichte Moospolster sind nicht selten und Flechten in Menge vorhanden. $\times$ Solche Kontraste schafft der kontinentale Sommer der nördlichen und der ozeanische Sommer der südlichen Polarzone.

Die arktische Flora besitzt einen ausgesprochen xerophilen Charakter und trägt in ihrer Struktur auch dem intensiven Lichtbedürfnis Rechnung. Die Vegetationszeit, die Anfang Juli beginnt, dauert nur ungefähr zwei Monate; wie mit einem Zauberschlag entwickelt sich das ganze Pflanzenleben gleichzeitig, um danu plötzlich, noch mitten in der Tätigkeit, ein Ende zu finden. Daß die dauernde Beleuchtung die Entwickelung fördert, geht daraus hervor, daß die Gerste im nördlichen Norwegen und Finnland, von der Aussaat an gerechnet, nur 89 Tage braucht, um zur Reife zu gelangen, während sie in Schonen dazu 100 Tage benötigt.

Pflanzenregionen. Die vertikale Temperatur- und Feuchtigkeitsabnahme und die Zunahme der Windstärke und damit der Transspiration bewirken eine ähnliche Pflanzenanordnung mit wachsender Höhe wie mit wachsender geographischer Breite. Es ist auf das Beiwort „ähnliche“ besonders Gewicht zu legen, denn nur in bezug auf den allgemeinen Vegetationscharakter entsprechen die einzelnen Pflanzenregionen den Pflanzenzonen; und wenn auch in vielen

$\times$ G. Andersson ${ }^{6}$ nennt diese Vegetationsformation Polsterfeld. 
alpinen Gebirgen arktische Formen wiederkehren, so läßt sich das - wie später gezeigt werden soll — nicht durch die heutigen Temperaturverhältnisse erklären.

Als Beispiel eines äquatorialen Gebirges führen wir den Ruwenzori in Afrika an, wo die Vegetation ihren tropischen Charakter bis $2100 \mathrm{~m}$ Höhe behält, und dann eine Bambuszone den Übergang zu dem gemäßigten Waldgürtel vermittelt. ${ }^{7}$ In den Andes von Columbia liegt die Tropengrenze schon in $1300 \mathrm{~m}$ Höhe, und von da reicht die subtropische und gemäßigte Pflanzenregion bis $3400 \mathrm{~m}$ Höhe. An der Grenze der warmen Zone im westlichen Himalaya reicht der echte Tropenwald nur bis 900 Höhe. Dann nimmt er den Charakter der gemäBigten Zone an, wenn auch mit eingesprengten tropischen Pflanzen, denn erst in $2400 \mathrm{~m}$ Höhe, also nur $1260 \mathrm{~m}$ unter der Waldgrenze, verschwindet die mit Chamaerops verwandte Palme Trachycarpus Martiana. In den Pyrenäen steigt die immergrüne Vegetation nur bis $400 \mathrm{~m}$ an, darauf folgt bis $1600 \mathrm{~m}$ der sommergrüne Laubwald, dann von 1600-2400 m Höhe der Nadelwald, der in einen Knieholzgürtel ausläuft, endlich die alpine Vegetation bis zur Schneegrenze in $2750 \mathrm{~m}$ Höhe. In den Schweizer Alpen, die in der sommergrünen Laubbaumzone liegen, unterscheidet CHRIST ${ }^{8}$ vier Regionen. In der unteren, die auf der Nordseite in 550, im Süden und Westen aber in $700 \mathrm{~m}$ Höhe endet, gedeihen noch Wein, Obst und einige Gewächse von mediterranem Typus. Die zweite Region, die des Laubwaldes, in der die Buche vorherrscht und die Kastanie auf der Südseite bis $900 \mathrm{~m}$ ansteigt, reicht in der Nordschweiz bis $1350 \mathrm{~m}$ Höhe. Dann folgt der Gürtel des Nadelwaldes, der in durchschnittlich $1900 \mathrm{~m}$ Höhe der alpinen Vegetation den Platz räumt.

Von besonderer Wichtigkeit ist die alpine Waldgrenze, über deren Höhen in den Gebirgen der Erde wir die umstehende Tabelle zusammengestellt haben. Es braucht wohl nicht betont zu werden, daß in denjenigen Zonen, wo nur eine Messung vorliegt, die Verteilung auf eine der beiden Kolumnen im Grund willkürlich ist.

Im allgemeinen ist die Höhe der Waldgrenze von denselben Bedingungen abhängig, wie die der Schneelinie (vgl. Fig. 228, S. 687). Sie sinkt vom Äquator gegen die Pole in immer tiefere Niveaus, aber nur unter sonst gleichen Verhältnissen, denn im Bereich des Seeklimas liegt sie überall tiefer als in Gebieten des sommerwarmen Landklimas. Daher endigt das Baumleben auf der südlichen Halbkugel in geringerer Höhe als auf der nördlichen in gleicher Breite; daher steigt es an der Ostseite des norwegischen Gebirges höher 


\begin{tabular}{|c|c|c|c|c|}
\hline \multirow{2}{*}{ Breite } & \multicolumn{2}{|l|}{ Tiefste Waldgrenze } & \multicolumn{2}{|r|}{ Höchste Waldgrenze } \\
\hline & Örtlichkeit & $\mathrm{m}$ & $\mathrm{m}$ & Örtliehkeit \\
\hline $74-70^{\circ} \mathrm{N}$ & Norwegen, Westseite, $70^{1} / 2^{0}$ & 260 & - & - \\
\hline $69-65$ & , $\quad " \quad 67^{\circ}$ & 360 & 700 & Norwegen, Ostseite, $67^{\circ}$ \\
\hline $64-60$ & Ural $64^{\circ}$ & 555 & 1140 & Stanowoigebirge $60^{\circ}$ \\
\hline $59-55$ & Sehottland $57^{\circ}$ & 810 & 1220 & Felsengebirge $56^{\circ}$ \\
\hline $54-50$ & Harz $52^{\circ}$ & 1040 & 2200 & Sajanisches Geb. $50^{\circ}$ \\
\hline $49-45$ & Vogesen $48^{\circ}$ & 1300 & 2900 & Felsengebirge in Montana \\
\hline $44-40$ & (Dalmatien $44^{\circ}$ ) & $(970)$ & & \\
\hline & White Mts. $44^{\circ}$ & 1260 & 3600 & Pamir $40^{\circ}$ \\
\hline $39-35$ & Pindus $39^{\circ}$ & 1800 & 3700 & Felsengebirge $39^{\circ}$ \\
\hline $34-30$ & Libanon, Westseite $34^{\circ}$ & 1950 & 4600 & Tibet ungefähr $30^{\circ}$ \\
\hline $29-25$ & Himalaya-Bhutan $28^{\circ}$ & 3250 & 4040 & Geb. am Mekong $29^{\circ}$ \\
\hline $24-20$ & Formosa $23^{1} / 2^{0}$ & 3000 & - & - \\
\hline $19-15$ & Guatemala, niederste Grenze & 3500 & 3980 & Tajumuleo, Guatemala \\
\hline $14-10$ & Küstengeb. v. Venezuela $10^{\circ}$ & 1500 & 3800 & Abessinien \\
\hline $9-5$ & S. Nevada de S. Marta & 1900 & 3400 & Cordillere v. Bogota \\
\hline $4-0$ & Ruwenzori $0,4^{\circ}$, Westseite & 3000 & 3800 & Ruwenzori, Ostseite \\
\hline $0-4^{0} \mathrm{~S}$ & Pic v. Korintji, Sumatra & 2500 & 3500 & Ecuador, Ostseite \\
\hline $5-9$ & - & - & - & - \\
\hline $10-14$ & - & - & - & - \\
\hline $15-19$ & - & - & 2800 & Pic de Sorata $16^{\circ}$ \\
\hline $20-24$ & - & - & - & $1-$ \\
\hline $25-29$ & - & - & - & - \\
\hline $30-34$ & 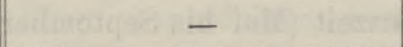 & - & - & - \\
\hline $35-39$ & Mt. Egmont,Neuseeland $39^{1} / 2^{\circ}$ & 1070 & 1900 & Chile $37^{\circ}$ \\
\hline $40-44$ & Südalpen, $\quad \quad \quad 42^{\circ}$ & 1220 & 1460 & Vulkan Osorno $41^{\circ}$ \\
\hline $45-49$ & -1 & - & - & - \\
\hline $50-54$ & Feuerland $54^{\circ}$ & 450 & & 一 \\
\hline
\end{tabular}

als an der Westseite; ${ }^{\times}$daher erhebt sich die Waldlinie in der Alten Welt von Westen nach Osten, erreicht in Zentralasien die größte Höhe, um dann wieder an der pazifischen Seite herabzusinken, und beschreibt in Nordamerika eine ähnliche Kurve. Über $4600 \mathrm{~m}$ Höhe (Tibet) findet man nirgends Bäume, ebensowenig wie jenseits von $72^{1} /{ }^{0}$ B. In den tropischen Gebirgen beschränkt weniger

$\times$ Als Beispiel entnehme ich aus RAвот's Abhandlung über die Waldgrenze im nördlichen Skandinavien ${ }^{9}$ folgende Mittelwerte für die Zone $66^{\circ} \mathrm{B}$.

\section{Norwegen}

$\begin{array}{ccc}\text { Seeseite } & \text { Landseite } & \text { Schweden } \\ 370 \mathrm{~m} & 440 \mathrm{~m} & - \\ 405 & 530 & - \\ 575 & 610 & 718 \mathrm{~m}\end{array}$


die Temperatur als die abnehmende Feuchtigkeit das Baumleben, daher erlischt es in den gletscherlosen Bergen von Sumatra und Borneo schon in einer Höhe, in der es im wasserreichen Himalaya noch fröhlich gedeiht. Auf Java tritt die Abhängigkeit der Waldgrenze von dem Wind besonders scharf zutage, denn ihre auffallend tiefe Lage $(2800 \mathrm{~m})$ ist nach Schimper dadurch bedingt, daß sich in dieser Höhe die Gebirgsmassen in einzelne Kegel auflösen, die beinahe immer von starken Winden umweht werden. In den chilenischen Andes nähern sich Wald- und Schneelinie einander, doch ist hier - gleichsam zum Ersatz für die Einschränkung der baumlosen Pflanzenregion - die alpine Strauchvegetation stark entwickelt; im Feuerland dagegen entfernen sich beide Linien wieder voneinander, weil hier der Wald in den stürmischen Höhen nicht gedeihen kann.

Wie die Schneelinie, ist auch die Waldgrenze zum großen Teil von örtlichen Verhältnissen, von der Besonnung und dem orographischen Charakter des Gebirges abhängig. Je massiger dieses gebaut ist, desto mehr wird es erwärmt, und desto höher dringt die Baumvegetation vor, $\times$ ohne jedoch immer ihre klimatische Grenze zu erreichen. Die Feststellung dieser Grenze ist allerdings mit Schwierigkeiten verknüpft. Für die österreichischen Alpen ermittelte MareK ${ }^{10}$, daß die Waldgrenze auch hier (wie in den polaren Rreiten) ungefähr mit der $10^{\circ}$-Isotherme des wärmsten Monats zusammenfällt. Die mittlere Temperatur der Vegetationszeit (Mai bis September) beträgt dort $8,3^{\circ}$ und um diesen Wert schwankt sie auch in den übrigen mitteleuropäischen Gebirgen. In freier Lage erreicht der Wald aber diese durchschnittliche Klimagrenze nicht, und in geschützter Lage überschreitet er sie um ein paar hundert Meter. Auch der Niederschlag ist von Einfluß. Daß reichliche Niederschläge die Schneegrenze herabdrücken, ist ohne weiteres verständlich, warum aber

$\times$ Deutlich geht dies aus den neueren Untersuchungen über die Waldgrenze in den Alpen hervor. In der Schweiz ist ihre mittlere Lage nach $\mathrm{IMHOF}^{11}$ :

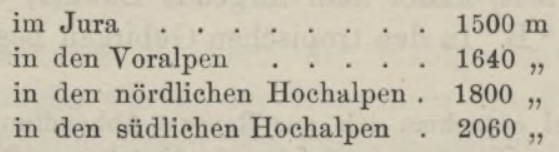

In den österreichischen Alpen besteht nach MAREK ${ }^{10}$ folgender Zusammenhang zwischen der mittleren Massenerhebung (Totalvolumen des Gebirges dividiert durch dessen Fläche) $=\mathbf{M}$ und der mittleren Waldgrenze $=W$.

\begin{tabular}{lc|l|lrl}
\multicolumn{2}{l}{ Ötztaler Alpen $\mathrm{M}=2540 \mathrm{~m}, \mathrm{~W}=2170$} & Hohe Tauern & \multicolumn{2}{l}{$\mathrm{M}=1830 \mathrm{~m}, \mathrm{~W}=2030$} \\
Stubaier ", & 2180 & 2020 & Niedere Tauern & 1440 & 1840 \\
Zillertaler ", & 1940 & 2000 & Hochschwab & 1120 & 1640
\end{tabular}


auch die Waldgrenze, bedarf noch der Aufklärung. In alten Kulturländern machen sich auch die Folgen menschlicher Eingriffe bemerkbar. Wenn der Wald im dalmatischen Gebirge nicht einmal $1000 \mathrm{~m}$ mehr erreicht, so ist dies der unsinnigen Zerstörungswut des Menschen zuzuschreiben. Am Großglockner endet er jetzt in $1970 \mathrm{~m}$ Höhe, aber noch in $2152 \mathrm{~m}$ Höhe entdeckte SEenand einen Holzstrunk. Im 18. Jahrhundert waren am Südrand der Bernina Bäume noch in $2334 \mathrm{~m}$ Höhe zu sehen, wo jetzt echte Alpenpflanzen wachsen; und einzelne Wurzelstöcke oder alleinstehende Tannen, Lürchen und Arven von hohem Wuchs jenseits der Waldgrenze beweisen uns, daß der Wald sich einst bis hierher ausgedehnt hat. Man hat daher streng genommen - was allerdings selten geschieht - zwischen Wald- und Baumgrenze zu unterscheiden; ihre Differenz beträgt in den Schweizer Alpen nach Iмног ${ }^{11} 70-100 \mathrm{~m}$. Auch von dem Zurückweichen der alpinen Walḋgrenze gilt, was oben (S. 825) von der polaren Baumlinie gesagt wurde, und es kann daher nicht ohne weiteres als ausgemacht gelten, daß der unzweifelhafte Rückgang der Waldgrenze im nördlichen Skandinavien, ron dem RABOT ${ }^{9}$ berichtet, mit einer Klimaänderung zusammenhänge, obwohl manches dafür spricht. In anderen Fällen schlieBt die Bodenbeschaffenheit den Wald aus. Am Mauna Loa auf Hawaii, dessen oberer Teil ganz von Lavaströmen bedeckt ist, verschwindet schon in $2140 \mathrm{~m}$ Höhe alle Vegetation; dagegen kommt auf den Mauna Kea, der aus lockeren Eruptionsprodukten besteht, der Manatibaum vereinzelt bis $3350 \mathrm{~m}$ Höhe vor.

Wie an der polaren Waldgrenze häufig zwerghafte Baumformen die äußersten Vorposten bilden, so auch in vielen Hochgebirgen. In den Karpathen und Sudeten tritt das Krummholz als selbständige Formation hervor. Meist vollzieht sich der Übergang zur alpinen Region allmählich, nur in den nordamerikanischen Hochgebirgen trennt ein scharfer Strich, die sogenannte „Timber line", den Hochwald vom Knieholzgürtel. Im Coloradogebirge z. B. endigt der Hochwald in $3350 \mathrm{~m}$ Höhe, und dann folgt ein aus gleichen Arten bestehender Zwergwald bis $3800 \mathrm{~m}$ Höhe.

Ausdauernde Arten mit verkürzten Stengelgebilden, großen Blüten und kleinen Blättern sind für die alpine Region charakteristisch. Kryptogamen herrschen vor, wie in der polaren Flora; die Phanerogamen werden durch Sträucher, Stauden und Gräser vertreten. In einigen Punkten ist aber die alpine Region begünstigter als die arktische Zone. Nach den Polen nimmt die Lichtstärke ab, mit der Höhe aber zu, und außerdem steigert sich die Intensität der direkten Strahlung im Vergleich zu der des diffusen 
Lichtes. Während die Pflanzen im hohen Norden unter Lichthunger leiden, leiden sie in großer Seehöhe unter Lichtüberfluß; während jene durch eine weitgehende Reduktion der Verzweigung soviel als möglich vom Licht zu gewinnen suchen, nehmen die Föhren des Felsengebirges, wo WIESNER seine Untersuchungen angestellt hat, eine zypressenartige Form an, um Licht abzuwehren. Ferner ist zu beachten, daß in der arktischen Zone, wenn auch die Sommersonne nie untergeht, ihre schiefen Strahlen den Boden doch nicht so intensiv erwärmen wie im Hochgebirge, obgleich die mittlere Lufttemperatur der höheren Regionen im Sommer geringer ist als in den entsprechenden höheren Breiten. ${ }^{\times}$Dafür ist aber im Gebirge die Vegetationszeit (Monate über $0^{\circ}$ ) länger, und während derselben taut der Boden bis zur Tiefe auf und gestattet den Wurzeln tiefer einzudringen. Der Unterschied in der Stärke der Insolation erklärt es nach Christ's Ansicht, daß die alpinen Pflanzen in bezug auf Masse des Stoffes, Dicke des Stammes, Zahl und Stärke der Zweige und Laubteile den arktischen so sehr überlegen sind.

An der Schneegrenze hört zwar die zusammenhängende Vegetation auf, aber nicht alles Pflanzenleben erlischt. Etwa $500 \mathrm{~m}$ darüber sammelte BALL am Aletschgletscher noch 40 Arten, und am Montblane fand man zwischen 3400 und 3500 m noch 24 Phanerogamen, ja einige Exemplare kommen noch bis $4000 \mathrm{~m}$ vor. Die höchste bekannte Blütenpflanze, Saussurea tridactyla, wächst im westlichen Tibet noch in $5800 \mathrm{~m}$ Höhe. Auf schneefreien Felsen siedeln sich Flechten an, und auf dem Schnee selbst finden noch Algen ihre bescheidenen Lebensansprüche erfüllt. Eine Algenart von mikroskopischer Größe ruft die bekannte Erscheinung des roten Schnees hervor.

Aus derselben klimatischen Ursache, die eine vertikale Pflanzenschichtung im Gebirge bewirkt, erklärt sich die von v. $\mathrm{BECK}^{12}$ entdeckte Umkehrung der Pflanzenregionen in den großen, tiefen Dolinen des Karstes, auf deren Grund sich lange dauernde Schneemassen sammeln. Aus dem oberen Laubwald steigt man hinunter erst durch Fichtenwald, dann durch Legföhrenbestände und erreicht endlich nahe dem Grund eine ausgesprochen alpine Region mit denselben Pflanzen, die im Hochgebirge die Matten in der Nähe der Schneegrenze schmücken.

$\times \mathrm{H}_{\text {ANN }}$ zitiert in seiner Klimatologie (Bd. I, S. 207) folgendes lehrreiche

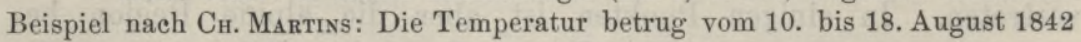
um $9^{\mathrm{h}}$ vormittags

\begin{tabular}{lccc}
\multicolumn{1}{c}{ in } & Höhe & Luft & Bodenoberfläche \\
Faulhorn & $2680 \mathrm{~m}$ & $8,2^{\circ}$ & $16,2^{\circ}$ \\
Brüssel & 50 & 21,4 & 20,1
\end{tabular}


Literaturnachweise. ${ }^{1} \mathrm{O}$. Drode, Die geographische Verbreitung der Palmen, in Petermann's Mitteilungen 1878. $-{ }^{2}$ R. Rung, Die Bananenkultur, Gotha 1911 (Ergänzungsheft 169 zu Petermann's Mitteilungen). — ${ }^{3}$ Theobald Fischer, Der Ölbaum; Gotha 1904 (Ergänzungsheft 147 zu Petermans's Mitteilungen). - ${ }^{4}$ A. O. Kinuman, Pflanzenbiologische Studien aus Russisch-Lappland, in den Aeta societatis pro fauna et flora fenniea, 1890. - ${ }^{5} \mathrm{H}$. Schenck in K. Chun, Wissenschaftliche Ergebnisse der deutschen Tiefsee-Expedition auf dem Dampfer „Valdivia“, II. Bd.; Jena 1905. - ${ }^{6}$ G. Andersson, Zur Pflanzengeographie der Arktis, in der Geographischen Zeitschrift 1902. - ${ }^{7}$ R. B. WoosNAM, Ruwenzori and its Life Zones, im Geographical Journal, Bd. XXX, 1907. $-{ }^{8}$ H. Christ, Pflanzenleben der Schweiz; Zürich $1879 .-{ }^{9} \mathrm{CH}_{\text {H. Raвот, in }}$ Revue générale de botanique; Paris 1896 , Bd. VIII, S. 385 . - ${ }^{10}$ R. Marek, Waldgrenzstudien in den österreichischen Alpen (Ergänzungsheft Nr. 168 zu Petermann's Mitteilungen), Gotha 1910. - ${ }^{11}$ E. Imhof, in Gerland's Beiträgen zur Geophysik, Bd. IV, S. 241. - ${ }^{12}$ G. Beck v. Mannagetta, in den Sitzungsberichten der Wiener Akademie der Wissenschaften, Mathem.-naturwiss. Klasse, 1906, Bd. CXV, Abteilung I, S. 3.

\section{Die wichtigsten Vegetationsformationen innerhalb der Waldgrenzen.}

(Siehe Karte XVIII.)

Innerhalb der Waldgrenzen wechseln, entsprechend der Verteilung der Niederschläge, Wälder, Grasfluren und Wüsten miteinander $a b$.

Der Wald bedarf eines dauernden Wasservorrates im Boden. Er ist daher in der Regel an feuchtere Gegenden gebunden, aber es ist gleichgültig, wann der Regen fällt; ja auch in niederschlagsarmen Gebieten gedeiht er, wenn nur Grundwasser vorhanden ist. Die jährliche Regenmenge der Waldländer schwankt innerhalb sehr weiter Grenzen; in Ostindien z. B. kommen - wie Brandis gezeigt hat - kräftige Wälder nur dort vor, wo der Regen eine jährliche Durchschnittshöhe von mehr als $1000 \mathrm{~mm}$, und Tropenwälder nur dort, wo er eine solche von mehr als $1900 \mathrm{~mm}$ erreicht, während die nördliche gemäßigte Zone ein einziges Waldgebiet ist, obwohl hier die mittlere jährliche Niederschlagshöhe meist nur 250-500, ja in Ostsibirien und im nördlichen Teil von Amerika weniger als $250 \mathrm{~mm}$ beträgt. In der warmen Zone ist das Feuchtigkeitsbedürfnis des Waldes ungleich gröber als in unseren Breiten, weil bei hoher Temperatur der Verdunstungsprozeß der Blätter rascher vor sich geht. Bei gleicher Regenmenge kann sich in der gemäßigten Zone ein Wald aus Hygro- oder Tropophyten entwickeln, während er in den Tropen einen streng xerophilen Charakter annimmt. Überdies kann in den höheren Breiten - worauf WoEıkow aufmerksam gemacht hat - die winterliche Schneedecke eine bedeutende Niederschlagshöhe ersetzen, denn das Schneewasser sickert langsam in den 
Boden ein und eruährt die Vegetation gerade bei ihrem Erwachen im Frühling, während die stärksten sommerlichen Regengüsse zum Teil oberflächlich abfließen.

Man stellt häufig Wald und Grasland als die Vegetationsformationen feuchter und trockener Gegenden einander gegenüber; aber diese Auffassung ist nur teilweise richtig. Zwergbäume und Sträucher sind in jeder Beziehung genügsamer als normal entwickelte Bäume, und auch das Buschland ist ein Ausdruck trockenen Klimas und leitet zur Wüste hinüber. Anderseits gibt es auch hygrophile Grasfluren, nur kommt es hier nicht so sehr auf starke, als auf häufige Niederschläge an, die den Obergrund feucht erhalten, namentlich während der Vegetationszeit, die auch nicht zu warm sein darf. Weun man sich daher die Abstufungen der klimatischen Formationen als eine einfache Reihe (Wald - Grasland - Wüste) vorstellt, so ist dies höchstens für die Tropen zutreffend, und auch da nur, wenn man an das eine Ende den hygrophilen Regenwald setzt; im allgemeinen aber werden sie besser durch eine Doppelreihe repräsentiert, etwa in folgender Weise:

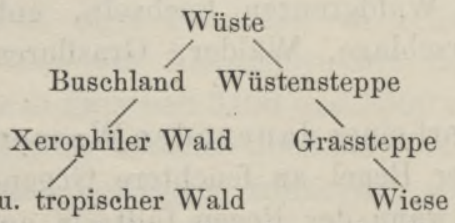

Hygrophiler u. tropischer Wald Wiese

Zwischen Gehölz und Grasflur herrscht beständiger Krieg, besonders dort, wo sich das Klima der unteren Grenze des Gehölzklimas nähert, und es genügt dann manchmal ein Eingriff des Menschen, um bedeutende Formationsverschiebungen hervorzurufen.

Tropenwald. ${ }^{1}$ Die unerschöpfliche Zeugungskraft der tropischen Natur findet ihren üppigsten Ausdruck im Regenwald. Von unseren Wäldern unterscheidet er sich vor allem durch den gemischten Baumschlag. Selten gehören zwei benachbarte Bäume derselben Art an. Dikotyle Bäume mit immergrünen, glänzenden, lederartigen Blättern herrschen vor; Monokotyledonen, besonders Palmen, gesellen sich ihnen zu. Charakteristisch ist der etagenartige Aufbau, „der Wald über dem Wald“. In Ostafrika erreichen die höchsten Bäume mit $1^{1} / 2-2 \mathrm{~m}$ dicken Stämmer $30-50 \mathrm{~m}$ Höhe; ihre Kronen sind so hoch, daß man das Laub selten erkennen kann. Unter und zwischen diesen Riesen stehen Bäume von 15-20 m Höhe, und in ihrem Schatten gedeihen Baumsträucher und Sträucher. Am Amazonas mischen sich stammlose Zwergpalmen, 3-4 m und 20-30 m hohe Palmen, sowie riesige Laubbäume, deren Kronen sich bis 80 und $100 \mathrm{~m}$ erheben. Das Unterholz ist in verschiedenen Gegenden ver- 
schieden; im ostindischen Dschungel z. B. besteht es aus Bambusen und Dorngesträuchen. Ebenso bezeichnend für den tropischen Regenwald sind die Lianen und Epiphyten, die schon in den subtropischen Breiten entschieden zurücktreten und weiter gegen Norden hin allmählich verschwinden. Die Lianen, die sich von Baum zu Baum schlingen und frei von den Kronen herabhängen, sind zum Teil Holzgewächse, wie die Rotangpalmen (S. 820); ihnen hauptsächlich verdankt der Wald seine Unwegsamkeit. Die Epiphyten, zu denen Farne, Orchideen und Arongewächse, in Amerika auch die Ananasgewächse das Hauptkontingent stellen, setzen sich auf den Bäumen fest, ohne sie zu umranken. Der unendliche Reichtum an Schattengewächsen erklärt sich daraus, daß im tropischen Regenwald trotz der Überfülle des Laubwerkes, und trotzdem die Blätter vorherrschend undurchscheinend sind, doch ein mildes, gedämpftes Licht herrscht. Auch dadurch unterscheidet er sich wesentlich nicht nur von unseren finsteren Nadelwäldern, sondern auch von unseren Laubwäldern; denn im Gegensatz zu diesen, deren Laubdach zwar durchscheinend und weniger dicht, aber wegen der großen Anzahl kleiner Zweige zusammenhängender ist, sind die Bestandteile des Tropenwaldes so gebaut, daß überall Zwischenräume den Lichtwellen in den Wald einzudringen gestatten.

Im tropischen Regenwald gibt es, wie WARMing sich ausdrückt, „weder Sommer noch Winter, weder Frühling noch Herbst“. Es gibt immer blühende Pflanzen, und wenn auch manche Bäume zeitweise ihre Blätter verlieren, so verschwinden sie doch in der Menge derjenigen, die nur wenige Tage Ruhe bedürfen oder zu auderer Zeit ihr Laub abwerfen. Darauf beruht der immergrüne Charakter des Tropenwaldes, denn an und für sich gibt es nach G. VoLkens' Beobachtungen in Buitenzorg (Java) auch in den Tropen nur wenige Bäume, die an der Spitze ununterbrochen neue Blätter entfalten, während gleichzeitig die alten abfallen.

Sind auch gewisse Charakterzüge allen tropischen Regenwäldern gemeinsam, so finden sich doch auch sehr bemerkbare individuelle Eigenschaften, die sich nicht nur aus den Eigentümlichkeiten der verschiedenen Florengebiete erklären, sondern auch innerhalb eines solchen durch örtliche Verhältnisse bedingt sind. Der Igapowald im Überschwemmungsgebiet des Amazonas zeichnet sich z. B. durch eine Überfülle von Palmen, durch verhältnismäßig niedrigen Wuchs der Laubbäume und geringe Entwickelung der Lianen und Epiphyten aus. Im Etewald, der auch auf Tonboden steht, aber nicht mehr überschwemmt wird, herrschen die dikotylen Bäume mit lorbeerartigem Blatt entschieden vor, und ihnen gehören auch die höchsten 
Individuen an. Im Sandsteingebiet des Rio Negro endlich werden die Laubhölzer kleiner, Palmen und Lianen seltener, aber die epiphytischen Farne und Arongewächse wuchern in üppigster Fülle. Der Teraiwald, der den Südfuß des Himalaya begleitet, ist im Osten echter Tropenwald, aber gegen Westen, also in derselben Richtung, in der die Regenmenge abnimmt und das Klima kontinentaler wird, verlieren sich die tropischen Charakterzüge, und die Bestände werden einförmiger. Am reinsten ist der Typus des tropischen Regenwaldes in jenen Gegenden ausgeprägt, wo sich gleichmäBige Wärme mit großer, dauernder Feuchtigkeit paart, also besonders im Äquatorialgürtel, wie im malaiischen Archipel und in der Amazonasniederung, wo sich der Urwald von Parnahyba bis Zamora in einer Länge von mehr als $4000 \mathrm{~km}$ (gleich der Entfernung von der Westspitze der Bretagne bis zum Aralsee!) erstreckt. In Afrika haben uns erst die Forschungsreisen der letzten Jahrzehnte über die große Ausdehnung des Urwaldes durch das Kongobecken bis an das östliche Seengebiet unterrichtet, wobei es freilich noch fraglich erscheint, ob er eine völlig zusammenhängende Formation bildet; ${ }^{2}$ auch ist er nach CHevalieR ${ }^{3}$ im Rückgang begriffen. Nächst der Äquatorialzone sind die Windseiten aller tropischen Gebirge mit Regenwäldern bedeckt, so die Westghats, die Westseite von Hinterindien vom Himalaya bis Malakka, die madagassische Ostseite, die Windseiten der hohen polynesischen Inseln, die brasilianische Ostküste bis zur Wasserscheide gegen den St. Franciseo und den Paraná, die östliche Abdachung von Zentralamerika und Mexico, jedoch hier, mit Ausnahme von Tabasco, auf die Region von 1000 bis $2000 \mathrm{~m}$ beschränkt, während auf der pazifischen Seite nur der Küstensaum bis $650 \mathrm{~m}$ Höhe Regenwälder trägt. Nach oben zu verändert der Regenwald, entsprechend der Temperaturabnahme, allmählich seinen Charakter; die Bestände bleiben noch gemischt, aber andere Gattungen mit pinienartig sich ausbreitenden Kronen treten auf, und das Wachstum erreicht nur mehr 4-10 m. In Usambara erscheint dieser Hochwald, wie ihn ENGLer nennt, schon in $1900 \mathrm{~m}$, in den südlicheren Gebirgen Ostafrikas aber erst in $2400 \mathrm{~m}$ Seehöhe. Auch in den Niederungen mit einer ausgesprochenen Trockenzeit nimmt der Tropenwald, ohne sich in seinen Bestandteilen völlig zu ändern, einen anderen Gesamtcharakter an; die unendliche Fülle der Formen macht einer größeren Einförmigkeit Platz, die immergrünen Gewächse versehen sich mit Schutzvorrichtungen gegen den Einfluß der Trockenheit, periodisch belaubte Dikotyledonen gewinnen die Oberhand. Diese regengrünen oder Monsunwälder, wie sie DRODE und Schimper im Gegensatz zu den Regenwäldern genannt haben, 
übertreffen diese wahrscheinlich an Ausdehnung, vielleicht auch im Reichtum an Nutzhölzern. Aber auch in periodisch trockenen Gebieten vermag die Bodenfeuchtigkeit längs der Flußufer Gehölze vom Typus der Regenwälder hervorzuzaubern. Das sind die Galeriewälder, die den edaphischen Vegetationsformationen zuzurechnen sind. „In ihrem Innern" - schreibt ScHweInfurth - „gewahrt man Säulengänge, ägyptischen Tempelhallen ebenbürtig, in ewig tiefe Schatten gehüllt und von aufeinander gelegten Laubdecken oft dreimal überwölbt. Von außen betrachtet, erscheinen sie wie eine undurchdringliche Wand des dichtesten Blattwerkes, im Innern eröffnen sich überall Laubgänge unter den Säulenhallen, roll murmelnder Quellen und Wasseradern."

Eine andere wohlbekannte edaphische Vegetationsformation sind die Mangrovewälder, die den Strand der wind- und wellengeschützten Buchten und Lagunen fast aller Tropenländer mit einem dunkelgrünen Band umsäumen und in einzelnen Ausläufern auch noch $32^{\circ} \mathrm{N}$ (Bermudas, Kagoschima auf Kiuschiu) und $44^{\circ} \mathrm{S}$ (ChathamInsel) erreichen. Die seitlichen Stützwurzeln der Mangrovebäume dienen zum Widerstand gegen die Flut, und mit ihren senkrecht emporstrebenden Atmungswurzeln entziehen sie den notwendigen Sauerstoff der Atmosphäre, da das Innere des Bodens so sehr mit Wasser getränkt ist, daß keine Luft zirkulieren kann. Sie gehören einer einzigen Pflanzenfamilie an, aber in Ostafrika und Asien einerseits und in Westafrika und Amerika anderseits treten verschiedene Arten auf. Diese Wälder sind somit ein Beispiel einförmiger Bestände, aber sie sind nicht das einzige. Selbst die Palme tritt häufig waldbildend auf, wie die Dum- und die Delebpalme in Afrika, die Ölpalmen in Verbindung mit Phoenix spinosa an der westafrikanischen Küste, ein paar Mauritiaarten im Gebiet des Orinoco und des Amazonas, die Wachspalme in Gran Chaco, die Carandapalme in Paraguay, die Yataypalme in Uruguay und verschiedene Arten im malaiischen Archipel. Andere bekanntere Beispiele sind die seltsamen Tjemorowälder in den Gebirgen der SundaInseln, die aus Casuarinen mit blattlosen Zweigen bestehen, die Tekwälder Ostjavas, die Pisangwälder an der Gambiamündung, die aus Hornemann's Trachylobium, einer wichtigen Kopal liefernden Leguminose, bestehenden Wäldern Ostafrikas, die Tamariskenwälder am Blauen Nil, die schattenlosen und doch oft undurchdringlichen Akazienwälder in Südarabien und Afrika, die Araukarienwälder von Brasilien usw.

Der Wald mittlerer und höherer Breiten. Nach Süden verliert sich der tropische Waldcharakter allmählich. Die Küstenwälder 
vom brasilianischen Staat Sa. Catharina bis zur Grenze von Uruguay unterscheiden sich von den tropischen nur durch niedrigeren Wuchs und geringere Mannigfaltigkeit; und ebenso macht sich im chilenischen Waldland zwischen 34 und $44^{\circ} \mathrm{B}$. gegen Süden nur eine zunehmende Einförmigkeit bemerkbar, ohne daß das dichte Unterholz aus bambusartigen Gräsern und das Gewirr von Lianen und Epiphyten zurücktreten und den Wald zugänglicher machen würden. Dagegen ist auf Neuseeland die Baummischung kaum minder groß als zwischen den Wendekreisen, und der Nordinsel fehlen auch die Lianen und Epiphyten nicht. In Australien tragen noch die gemischten Wälder in den Creektälern von Neusüdwales ein tropenähnliches Gepräge. Einen sonderbaren Anblick gewähren die offenen, schattenlosen Eukalyptenwälder, deren Boden ein zusammenhängender Wiesenteppich mit schönen Blumen bedeckt. Zur Zeit der Dürre erhält sich freilich nur in den Creektälern eine üppigere Vegetation. Auf trockenem Untergrund haben sich Akazien und Casuarinen angesiedelt; im Norden gesellen sich zu den Eukalypten indische Holzgewächse, und hier bietet auch der Grasboden stellenweise das Bild einer echt tropischen Savane.

Selbst in den höheren Breiten Südamerikas, an der feuchten chilenischen Abdachung jenseits des 44. Parallels und im Feuerland, herrschen neben sommergrünen immergrüne Buchen und Koniferen, und eine üppige Moosvegetation bedeckt den Boden der Wälder.

In Nordamerika reichen die immergrünen Laubbäume noch bis in die südlichen Staaten der Union hinein, überlassen aber die Herrschaft bereits der langnadeligen Kiefer. In den Mittelmeerländern tritt nur die immergrüne Eiche waldbildend auf; in China und Japan verleiht, soweit die Kultur den Wald noch nicht verdrängt hat, der Ahornbaum der Landschaft ein eigentümliches Gepräge. In Südjapan erinnern die immergrünen Eichenwälder mit ihren Holzlianen und tropischen Epiphyten noch lebhaft an die Waldvegetation der warmen Zone; selbst in Nippon beherbergen die Wälder noch mächtige Lianen und epiphytische Farne. In dem milden und feuchten Klima dieser Inselkette finden wir - allein auf der Nordhemisphäre - ähnliche Verhältnisse wie in Chile oder auf Neuseeland.

Der sommergrüne Laub- und der Nadelholzwald ist auf die Nordhalbkugel beschränkt. In den östlichen Vereinigten Staaten und in Ostasien zeichnen sich die Laubwälder noch durch reichere Artenmischung aus, während in Europa reine Bestände, vorwiegend aus Buchen, Eichen und Birken vorherrschen. Die Buchenwälder die einer milden Wintertemperatur bedürfen, charakterisieren das 
westliche und mittlere, die Eichenwälder das östliche Europa. Entsprechend dem schon erwähnten, von WIEsNER entdeckten Gesetz, $\mathrm{da} \mathrm{B}$ mit abnehmender Temperatur das Lichtbedürfnis der Pflanzen wächst, ist das Unterholz dürftig oder fehlt ganz; nur Moose und Flechten führen noch ein epiphytisches Dasein; die Holzlianen sind gänzlich verschwunden, und nur Heckenkirsche, Efeu, Hopfen und Waldrebe schlingen sich um die Bäume.

Die statistischen Untersuchungen von Asa GraY bestätigen den großen Gegensatz der Ost- und Westseiten der Kontinente, $\times$ dessen Verständnis sich uns später, bei der Betrachtung der geschichtlichen Entwickelung der heutigen Pflanzenwelt, erschließen wird. Die Zahl der Laubbaumarten ist an den Ostseiten fast um das Doppelte größer als in Europa und nahezu viermal größer als im westlichen Nordamerika. Ein anderer Gegensatz besteht zwischen der atlantischen und der pazifischen Seite der beiden Festländer. An dieser erreichen die Nadelhölzer ihre hốchste Entwickelung, und im westlichen Nordamerika bilden sie sogar $56,4 \%$ aller Waldbäume. Tannen sind am häufigsten und meist von hohem Wuchs; die Douglastanne erreicht $60-80 \mathrm{~m}$, wird aber von dem Rotholzbaum, der Zuckerkiefer und vor allem von der bis $150 \mathrm{~m}$ hohen Sequoia gigantea noch übertroffen. Mit Laubhölzern gemischt bilden die Tannen und die Oregonzeder die ausgedehntesten Urwälder, die wenigstens zum Teil noch ihre Jungfräulichkeit bewahrt haben. Sie schließen sich unmittelbar an den nördlichen Koniferengürtel an, an dessen Zusammensetzung in Amerika vorzüglich die Weißtanne, in der Alten Welt aber die Fichte und die Kiefer, und in Ostsibirien die Lärche Anteil nehmen. Eine untergeordnete Rolle spielen die Laubbäume (Pappeln, Erlen, Weiden), die meist nur die Ufer der Flüsse begleiten; nur die Birke kann sich in der Alten Welt den Nadelbäumen ziemlich ebenbürtig an die Seite stellen und dringt auch überall bis oder nahe bis an die Waldgrenze vor. Ein anderer Unterschied zwischen den Wäldern der Alten und der Neuen Welt, und zwar im Koniferen- wie im Laubholzgürtel, besteht darin, daß in Amerika das Unterholz und das Strauchwerk einen höheren Wuchs und eine üppigere Entwickelung erreicht.

Buschland. Wir haben oben gesehen, daß an der arktischen und an den alpinen Waldgrenzen Zwergbäume auftreten. Darüber

$x$

Wälder

des östlichen Nordamerika des pazifischen von Japan und der Mandschurei . von ganz Europa

Anzahl der Arten von

Laubholz

130

34

123

68
Nadelholz 
hinaus entwickeln sich Holzgewächse nur noch in Strauchform. Die Weidengebüsche Grönlands, die Alpenrosengebüsche unserer mitteleuropäischen Hochgebirge sind Beispiele davon.

Dieselbe Verkümmerung tritt auch innerhalb der Waldgrenzen ein, wo die Bodenfeuchtigkeit zur Heranbildung hochstämmiger Bäume nicht mehr ausreicht. In den wärmeren Breiten, wo das Feuchtigkeitsbedürfnis groB ist, ist das Buschland am stärksten entwickelt; ja im tropischen Afrika, das unter allen Ländern der warmen Zone am wenigsten Regen empfängt, ist es, besonders im Osten, soweit eine kurze, aber meist regelmäßige Regenzeit mit einer langen Trockenperiode wechselt, der vorherrschende Formationstypus, und mannigfache Übergänge verknüpfen es einerseits mit dem Wald, anderseits mit der Wüste. Die Charakterpflanze dieser Bestände ist die Akazie, die mit ihren tiefen Wurzeln noch das Grundwasser erreicht und bis zu $5 \mathrm{~m}$ hoch wird; dazwischen sind aber auch bis $15 \mathrm{~m}$ hohe Bäume eingestreut. Ihr Xerophilismus kommt besonders darin zum Ausdruck, daß sie häufig am Grund der Blätter mit Dornen ausgestattet ist, und solche Dornsträucher bilden oft undurchdringliche Dickichte. An andern Stellen stehen die Bäume weit voneinander ab wie in einem Obstgarten. Manche dieser Dornbüsche werfen das Laub ab, andere behalten das ganze Jahr ihre graugrüne Färbung. Daneben spielen auch Fettpflanzen eine hervorstechende Rolle; die kaktusähnliche Kandelabereuphorbie, die bis zu $12 \mathrm{~m}$ Höhe erreicht, und die Aloë sind bekannte ostafrikanische Charakterpflanzen. Auf der obersten Terrasse des Kaplandes, vom Oranje bis zu den Roggeveld- und Nieuwveld-Bergen wird der Boden von niederem Gestrüpp von Korbblütern bedeckt. Auf der großen Karru herrscht zwar der mattgefärbte Rhinozerosbusch, aber die Winterregen rufen ein üppiges, blumenreiches Grün hervor, das diese Hochflächen für einige Wochen $\mathrm{zu}$ einem ausgezeichneten Weideplatz umgestaltet. Am reinsten ist die Form des Búschlandes im australischen Skrub ausgeprägt. Verschlungene Sträucher mit starrem, immergrünem Laub bedecken in dichten Gemeinschaften, nur gelegentlich von Bäumen unterbrochen, aber mit völligem Ausschluß von Gräsern und Kräutern, ausgedehnte Flächen des inneren Australien. Kein Monat vergeht hier ohne Blüten, aber ,jeder Monat sieht“, wie BEHR sich ausdrückt, „dasselbe wüste Gedränge starrer, saftloser und untereinander gröBtenteils übereinstimmender Formen." Trotz seiner Üppigkeit ist der Skrub die eigentliche australische Wüste, die ebenso die Fortschritte der Forschungsreisenden wie der Kultur hemmt, denn mit unbesiegbarer Zähigkeit halten diese einförmigen Dickichte sogar dem Feuer stand. 
Häufig, in Ostafrika sogar in der Regel, tritt das Buschland in Gesellschaft der Steppen auf, im östlichen Südamerika scheiden sich aber beide Formationen zum Teil streng nach der Bodenbeschaffenheit. Soweit in den argentinischen Pampas Lehmboden ist, dehnen sich Grasfluren aus; dort aber, wo der patagonische Kiesboden beginnt, also am Rio negro, ändert sich mit einem Mal das Pflanzenkleid, das nun aus niedrigem Dorngebüsch mit vereinzelten Mimosen und magerem Graswuchs besteht; „nur diejenigen Stellen“, sagt LoREnTz, „die durch ihre niedere Lage besonders fruchtbar sind, vielfache Täler und Vertiefungen zeigen einen eigentlichen Rasen und eine Vegetation, die an die Pampas erinnert." Ähnlich ist die Vegetation westlich von den Pampas, zwischen dem Meridian von Cordoba und den Andes. Dornige Sträucher, besonders der Chanar und eine Akazie, bedecken weite Flächen, aber der Graswuchs ist nicht ganz ausgeschlossen, und reiche Fluren wechseln mit ödem Buschland.

Seltener ist die Buschformation auf unserer Halbkugel. Die dänischen und andere Inseln der regenärmeren Antillen sind nach WARMING "großenteils von einem grauen, trostlosen, nicht nutzbaren, brennend heißen Gebüsch bedeckt, zwischen dessen dornigen, verfilzten Sträuchern und niedrigen Bäumen man ohne Axt nicht vordringen kann". Im nördlichen Mexico, in Texas und in Arizona bestehen die sog. Chaparals vorwiegend aus Mimosen im Verein mit vielen anderen Dornsträuchern. In dem dichten, oft undurchdringlichen Dschungelgebüsch Vorderindiens herrschen Bambusen und Dornsträucher vor; aber es ist fraglich, ob wir es hier mit einer ursprünglichen Formation zu tun haben. WARMING nennt die Gebüsche „verunglückte Versuche der Natur, Wälder zu bilden“; sie können aber auch dort, wo das Klima zu ungünstig ist, um einen verwüsteten Wald schnell $\mathrm{zu}$ regenerieren, an dessen Stelle treten. Das ist z. B. der Fall bei den amerikanischen Palmengebüschen aus Serenaea serrulata, und bei der Maquis, der pflanzenreichen, immergrünen Strauchformation des Mittelmeergebietes, die besonders auf Corsica, im dalmatinischen Archipel und an der Nordküste des Ägäischen Meeres große Flächen einnimmt, hier allerdings auch wesentlich gefördert durch die baumfeindliche Ziegenzucht. Unter ähnlichen klimatischen Verhältnissen erscheint sie an der californischen Küste bei S. Diego und in den Berg- und Hügellandschaften des südlichen China wieder, während auf Neuseeland eigentümliche Farnfluren die Stelle zerstörter Wälder einnehmen. $\mathrm{Ob}$ auch unsere Heiden aus Wäldern hervorgegangen sind, ist durch OцвRICHT's statistische Nachweise sehr zweifelhaft geworden; sie sind eine 
edaphische Formation, die an nahrungsarme und zumeist auch trockene Böden gebunden ist.

Savane. Unser Kärtchen zeigt innerhalb des Tropengürtels als herrschende Vegetationsformation neben dem Wald die Savane. Diese ist aber nur als ein Kollektivbegriff wechselnder Formationen aufzufassen, und es erscheint fraglich, in welcher Ausdehnung sie als ein Erzeugnis frei wirkender Naturkräfte zu betrachten oder der wüsten Raubwirtschaft, die die Bodenkultur niedrig stehender Völker kennzeichnet, zuzuschreiben ist. Vielfach verbreitet ist die Sitte, die bebauten Felder nach kurzer Zeit wieder aufzugeben und durch Vernichtung von Waldstrecken neuen Boden zu gewinnen, während die verlassene Pflanzung sich mit Gras und Buschwerk bedeckt, mitunter auch wieder mit Wald, der aber dann stets im Verhältnis zum ursprünglichen Wald artenarm ist. ${ }^{3}$ Durch solche menschliche Eingriffe erklärte es sich Pechuel-Loesche, daß in Niederguinea auf einem und demselben Boden, unter gleichartigen klimatischen Verhältnissen verschiedenartige Pflanzenformationen auftreten. Auch in Brasilien traten die Campos z. T. an die Stelle des durch Abbrennen vernichteten Waldes oder Busches, z. T. sind sie aber nach der Ansicht von Inering ${ }^{4}$ durch die Bodenbeschaffenheit bedingt. Abgesehen von solchen Fällen darf man jedoch die Savane wohl als einen Ausdruck trockenen Klimas betrachten.

Die meisten Pflanzengeographen sind darin einig, daß Grasland (Kampine) mit eingestreuten Holzgewächsen als Savane zu bezeichnen sei. Nur ENGLER ${ }^{5}$ macht davon eine bemerkenswerte Ausnahme, indem er den Ausdruck Savane auf diejenigen Grasfluren beschränkt, die im wesentlichen nur aus echten Rasen- und Riedgräsern bestehen und auf undurchlässigem, nach der Regenzeit lange versumpftem Boden der Niederungen vorkommen, während er alle mit Büschelgras bedeckten Fluren ohne Rücksicht auf ihre sonstigen Bestandteile unter dem Begriff Steppe zusammenfaßt, und das, was wir Savane nennen, nur als eine Unterart, als Hochgras-, Buschoder Baumsteppe, ausscheidet.

Wird die Savane in unserem Sinn auch von zahlreichen Kräutern, Stauden und Halbsträuchern bevölkert, so ist Gras doch der Hauptbestandteil. Die $1 / 3$ bis $1 \mathrm{~m}$ hohen, harten und steifen Halmgräser wachsen zwar in rasenähnlichen Beständen, jedoch nicht so geschlossen wie die Gräser unserer Wiesen, und der Boden bleibt meist sichtbar. Manchmal ist freilich das Wachstum so dicht, daB man sich künstlich einen Weg bahnen muß. In diesem Fall erreichen die Gräser die ansehnliche Höhe von mehreren Metern und 
gleichen in der Regenzeit, von weitem gesehen, einem wogenden Getreidefeld. Mit den hohen mischen sich aber auch niedere Formen, und gerade dort, wo die niederen vorherrschen, ist die Vegetation mannigfaltiger. So ist in den brasilianischen Campos die Höhe des Grases keineswegs beträchtlich, aber Kakteen, Agaven und hohe und niedrige Sträucher bringen Abwechselung in die offene Landschaft, die in ihrem Blütenschmuck einem Garten gleicht. In der Trockenzeit bieten freilich die Savanen in ihrer gelblich-braunen Färbung nirgends ein freundliches Bild.

Neben solchen üppigeren Grasländern, die zum Teil wohl an die Stelle von Waldland getreten sein mögen, gibt es aber auch echte Steppen mit niedrigem, büschelförmigen Graswuchs, der überall die nackte Erde hervortreten läßt. Sie sind immer ein Merkmal minderwertigen Bodens oder dürttiger Bewässerung, aber mannigfache Übergänge verknüpfen sie mit den Kampinen der Savanenlandschaft, so daß eine kartographische Ausscheidung auf Schwierigkeiten stöBt. Geht man z. B. auf der bekannten Karawanenstraße von Bagamojo auf die ostafrikanische Seenplatte, so kann man alle Abstufungen tropischer Vegetation kennen lernen, von dem Waldland der feuchten Küste bis zur wüstenartigen Landschaft von Ugogo, die auf weite Strecken nur mit Pori, einem dem australischen Skrub ähnlichen Dorngebüsch, bewachsen ist. In Marokko sah Theobald Fischer selbst mitten im reichsten Kulturland öde Steppe, wo der Boden mit einer Kalkkruste bedeckt ist.

Nicht immer gesellt sich zur tropischen Kampine der Baumwuchs; entbehren ihn doch die Alang-Alangfluren der Sunda-Inseln und der Campo vero von Brasilien, ohne sonst den Savanencharakter einzubüßen. Aber das sind Ausnahmen. Bald erheben sich vereinzelte Holzgewächse aus der Grasfläche, bald schließen sie sich zu Buschwerk, Buschwald oder sogar regengrünem Hochwald zusammen. Schon daß ihr Vorkommen an kein allgemeines Gesetz gebunden ist, läßt erkennen, daß menschliche Eingriffe mitbestimmend gewirkt haben. Während z. B. die Loangoküste größtenteils Savane ist und die Wälder erst da beginnen, wo das Land ansteigt, ist umgekehrt an der Kongomündung die Niederung Wald und das hügelige Gelände Savane. Die flachen Llanos von Venezuela sind auf große Strecken baumlos oder werden nur von vereinzelten Proteaceen- oder Malpighiaceenbäumen oder von Gruppen von Fächerpalmen unterbrochen; aber dieser Charakter scheint nicht ursprünglich zu sein, denn Sachs und Jonas berichten, daß seit der Verringerung des Viehstandes die Zahl der Bäume beträchtlich 
zugenommen habe. Waldreicher sind die Savanen von Guayana, und das hängt offenbar mit der bergigen Beschaffenheit des Geländes, mit dem Wechsel der Bodenarten und der Bewässerung zusammen. Die südlichen Campos von Brasilien in $600-1300 \mathrm{~m}$ Höhe werden durch kleine, aber gesellige Lilienbäume belebt, an deren Stelle in den tiefer gelegenen nördlichen Campos eine ähnliche Zwergform aus der Familie der Ananasgewächse tritt. Daneben kommen auch echte Wälder vor; inselartig zerstreut sind die Capoës, in denen die höchsten Bäume die Mitte einnehmen, und immer kleinere Bäume in regelmäßiger Abstufung nach der Peripherie zu folgen; und an den Ufern der Flüsse dehnen sich die periodisch belaubten Catingas aus. In der Regel sind die Savanenbäume nicht höher als unsere Obstbäume, aber aus den Kampinen Afrikas erheben sich auch vereinzelte Riesen, wie der Boabab.

In außertropischen Breiten sind natürlich die floristischen Elemente andere, aber rein physiognomisch betrachtet, findet sich die Savanenformation wieder im californischen Parkland, wo Waldungen mit offenen Flächen wechseln, und in manchen Gegenden am Amur und auf Kamtschatka, wo der Rasenteppich eine außerordentliche Höhe erreicht, und Gebüsche und Bäume die Einförmigkeit der ausgedehnten Grasfluren mildern.

Wiesen und Weiden. Wir schalten hier diese Pflanzenformationen nur der Vollständigkeit halber ein, da sie im Vergleich zu den übrigen eine untergeordnete Rolle spielen. Von Savanen und Steppen unterscheiden sie sich schon dadurch, daß sie nicht Xerophytenvereine sind, ja die Wiesengräser und -kräuter können sogar als hygrophil bezeichnet werden. Die meisten Wiesen und Weiden sind Kulturerzeugnisse, doch gibt es sicher Ausnahmen, z. B. dort, wo längs der Flußufer der Baumwuchs durch Überschwemmungen ausgeschlossen ist. Engler erwähnt wiederholt Wiesen in DeutschOstafrika, und Schimper zählt auch die üppigen Grasfluren in den oben genannten ostasiatischen Parklandschaften, ja sogar die östlichen Prärien zu den Wiesen - wieder ein Beweis, wie schwankend unsere Terminologie ist.

Grassteppen. Wir haben in unserer schematischen Darstellung auf S. 834 die Steppen als Mittelglieder zwischen Wiese und Wüste eingezeichnet, in Wirklichkeit findet aber ein solcher Übergang kaum irgendwo statt, wohl aber von der Savane durch die Steppe zur Wüste. Größere Dürftigkeit des Graswuchses und Baumarmut charakterisieren die Steppe gegenüber der Savane, doch muß man sich stets bewußt bleiben, daß man mit Steppe sowohl physiognomisch wie wirtschaftlich und wahrscheinlich auch genetisch sehr verschiedene 
Formationen bezeichnet. Zum mindesten müssen stets Gras- und Wüstensteppen streng auseinandergehalten werden.×

Auch in der Grassteppe bedeckt der Rasen niemals völlig den Boden; die Zwischenräume nehmen aromatische oder stachelige oder wollige Stauden und Kräuter ein. ${ }^{6}$ Die Vegetation in der niederungarischen Pußta und in den südrussischen Steppen ist üppig und kann im Blütenschmuck des Frühlings sogar reizend genannt werden, aber schnell ermüdet der Anblick des eintönigen Bildes das Auge, das nirgends einen Ruhepunkt findet. Wohl die gröBte ununterbrochene Grasebene der Erde sind die Pampas von Argentinien. Das harte Pfriemengras mischt sich hier mit zarteren und nahrhaften Gramineen; in den Vertiefungen wachsen sie gedrängter, auf den Erhebungen aber in zerstreuten, dichten Büscheln. Gebüsche fehlen und Stauden sind selten. Mannigfaltiger sind die nordamerikanischen Prärien, wo Gramma-, Büffel- und Büschelgräser, die eine treffliche Weide bieten, von Kakteen, Lilienbäumen und geselligen Stauden begleitet werden.

Mit Ausnahme der Pampas entbehren oder entbehrten auch die Grassteppen nicht ganz des Baumwuchses, aber er ist auf bestimmte Örtlichkeiten beschränkt, während in der Savane größere und kleinere Holzgewächse einzeln und in Gruppen durch das ganze Grasland zerstreut sind. Die sogenannte Barabasteppe, eine große Ebene im westlichen Sibirien zwischen dem Irtysch und dem $\mathrm{Ob}$, besteht aus Mooren mit mannshohen Stauden und steppenartigem Graswuchs und aus einzelnen Waldinseln. Eine neuere Karte von TANFILEW $^{7}$ zeigt uns zahllose kleine und gröBere Waldflecke in die südrussische Steppe eingesprengt. $\mathrm{DaB}$ die niederungarische Ebene einst reicher bewaldet war, ist eine gut beglaubigte Tatsache. Die östlichen Prärien haben allerdings weniger als 20 Prozent Wald, aber der Übergang vom Waldland der östlichen Staaten zum baumlosen Land am Fuß des Felsengebirges vollzieht sich allmählich. ${ }^{8}$ Sicher ist, daß hier überall die Steppengewächse im Kampf ums Dasein günstigere Bedingungen finden als die Bäume, aber betreffs der Ursache dieser Erscheinung sind die Ansichten geteilt. Die einen schreiben sie dem trockenen Klima, die anderen dem Boden zu. Die Klimahypothese, deren Hauptvertreter einst GrisebacH war, zählt in RuBland und Amerika kaum noch Anhänger. ${ }^{9} \mathrm{DaB}$ die südrussische Grassteppe auf das Gebiet der Schwarzen Erde beschränkt ist, erklärt TANFILEW durch den Salzgehalt des Bodens;

$\times$ Wir haben dieser Forderung auch auf dem Kärtehen XVIII durch verschiedene Signaturen Rechnung zu tragen versucht. Die Grassteppe ist noch eine geschlossene Formation, daher Flächenkolorit. 
wo dieser durch das fließende Wasser ausgelaugt ist, wie in den Flußniederungen und auf den Wasserscheiden, da gedeiht auch der Wald. In den forstlichen Anpflanzungsversuchen erblickt er einen experimentellen Beweis für die Richtigkeit seiner Ansicht, denn wo solche Waldungen abstarben, erwies sich das Grundwasser schon in geringer Tiefe als salzhaltig. Andere russische Forscher führen die Baumarmut auf die Feinerdigkeit des Bodens zurück, die das atmosphärische Wasser nicht tief genug eindringen läßt, und dieselbe Hypothese wandte WhITNey auf die nordamerikanischen Prärien an. Die östliche Hälfte derselben ist fruchtbar, genügend benetzt, warum sollte hier kein Wald gedeihen können? Diese Frage beantwortet Mrmber Christr ${ }^{10}$ mit dem Hinweis auf die großen Brände, die meist von Menschenhand herrühren und im Frühjahr und Herbst oft ungeheure Flächen heimsuchen. Verbreitete sich doch ein solcher Präriebrand einst von $49-53^{\circ}$ B. und von $98-108^{\circ} \mathrm{L}$., d. h. über ein Areal, nahezu so groß wie das Königreich Preußen! Wo der Baumwuchs vor solchen verheerenden Einflüssen geschützt ist, wie auf den Farmen, findet er alle Existenzbedingungen erfüllt.

Wüstensteppen und Wüsten. In den regenärmeren, zum größten Teil abflußlosen Gegenden kommen Grassteppen nur dort vor, wo der Boden ohne Salzgehalt und mit etwas Humus bedeckt ist. Aber sie sind hier ungleich dürftiger und gestatten abseits von den Flüssen nur nomadische Lebensweise. Wo der nackte Fels zutage tritt oder Sandmeere sich ausdehnen, in denen auch die geringe Feuchtigkeit, die ihnen zuteil wird, ungenützt einsickert, oder wo der Boden mit Salzen geschwängert ist, da entwickelt sich der Graswuchs noch dürftiger oder fehlt ganz, und Dornsträucher mit verkümmertem Laub oder völlig blattlos, ferner Saft- und Zwiebelgewächse sind die einzigen Repräsentanten der Pflanzenwelt. Diese Sand- und Salzsteppen gehen ganz allmählich in Wüsten über, die zwar auch nicht völlig vegetationslos, aber doch im allgemeinen unbewohnbar sind. Die Begriffe Wüste und Wüstensteppen auseinanderzuhalten, ist schwierig, und auch der Sprachgebrauch trifft nicht immer das Richtige. Auch die Wüste enthält stellenweise Weidegründe, die von den Viehherden der Nomaden besucht werden, und Oasen, ${ }^{11}$ in denen sich selbst eine seBhafte Bevölkerung ansiedeln konnte. Abgesehen von den regenreicheren Gebirgsabhängen liegen sie entweder an Flüssen oder in Bodenvertiefungen, wo Grundwasser zutage tritt, und eine tonige Erdkrume sich bilden konnte. In der algerischen Sahara haben die Franzosen durch Anlage artesischer Brunnen manche Strecken in fruchtbare Gefilde verwandelt.

Auch aus der Wüstensteppe ist das Baumleben nicht völlig 
verbannt, wenn auch meist nur an die Flußufer gebunden; ungehener lange Wurzeln und eine streng xerophile Struktur sind die Bedingungen seiner Existenz. Selbst in den Tälern des ödesten Teiles der Gobi fand man Gruppen von Ulmen und Pfirsichgebüsch; in den Wadis der Sahara wohnen neben Gräsern, Stauden und Sträuchern auch Bäume, und vereinzelt erheben sich solche auch aus der trostlosen westaustralischen Sandsteppe, die GrLes durchwandert hat. Aber ausgedehntere Waldungen kommen in der Steppe nicht vor, mit Ausnahme der großen Kondensatoren der atmosphärischen Feuchtigkeit, der Gebirge; und auch diese entbehren zum Teil des Waldschmuckes, wie z. B. die peruanischen Andes an ihrer Westabdachung und die nordchilenischen zwischen 30 und $34^{0} \mathrm{~S}$ sogar auf beiden Seiten. Am Südabhang des Elburs grenzt in $2200 \mathrm{~m}$ Höhe die alpine Region unmittelbar an die Steppe, während die feuchtere Nordseite bis $2400 \mathrm{~m}$ Höhe mit Wald bekleidet ist. Einen ähnlichen Gegensatz bilden die tibetanischen und die indischen Gehänge des Himalaya. An der Nordseite des Kaukasus schiebt sich zwischen Steppe und Wald ein Wiesengürtel als vermittelndes Zwischenglied ein, während auf der den Südwestwinden zugekehrten Seite die Wälder bis zum FuB hinabreichen. Der Tiënschan trägt Wälder nur in der Region der winterlichen Schneewolken zwischen 1500 und $3000 \mathrm{~m}$ Höhe, auf dem Inschan (oder Wulaschan) beginnt die Bewaldung ebenfalls erst in $1500 \mathrm{~m}$ Höhe, auf dem Alaschan sogar erst in $2400 \mathrm{~m}$, und - um ein Beispiel aus der Neuen Welt hinzuzufügen - in Colorado in $2130 \mathrm{~m}$ Höhe.

Ein zusammenhängender Steppen- und Wüstengürtel durchzieht die Alte Welt vom atlantischen Gestade bis nahe an das pazifische Weltmeer. Die gebirgsumschlossenen Hochebenen Asiens, die aralkaspische Niederung, und die von beständigen Nordwinden bestrichene Wüstentafel sind die einzelnen Glieder dieser Zone: ungleich zwar in bezug auf die einzelnen Bestandteile ihrer Flora, ungleich auch in bezug auf die Bedingungen ihrer Wasserarmut, aber durch diese und durch ihren allgemeinen Vegetationscharakter zu einer geographischen Einheit verbunden. Die Sahara gilt als das Prototyp der Wüste, aber völlig pflanzenleer sind nur der bewegliche Dünensand und stellenweise die Serir, wie z. B. zwischen Tuat und Tafilet. Dagegen trägt selbst die Hammada einige Holzgewächse, und die Dünentäler werden von Sträuchern und hochwüchsigen Pfriemengräsern bewohnt. Nach Wolkenbrüchen entfaltet sich ein überraschender Pflanzenwuchs, während ihn gelegentliche leichte Regenfälle nicht merklich fördern. Die sogenannte Syrische Wüste ist vorwiegend Salzsteppe mit Halophyten, kümmerlichen 
Tamarisken und etwas Graswuchs. Noch mehr verdient die Arabische Wüste, vielleicht mit Ausnahme der südöstlichen Sandwüste Dahna, die Bezeichnung Steppe, denn selbst in Nefud trägt der Sandboden nach Buunt's Bericht eine verhältnismäßig reiche Vegetation, die einen großen Teil des Jahres die Herden der Beduinen ernährt. Vielleicht noch trostlosere Einöden als manche Teile der Sahara sind die persischen Wüsten. Die Große Salzwüste ist im strengsten Sinn des Wortes pflanzenlos, nur in der Nähe des Nordrandes erblickte BuHse einmal einen einsamen Halophyten, und eine ähnliche Schilderung gibt Bunge von der Wüste von Kirman. Viel besser sind die zentralasiatischen Hochebenen ausgestattet, obwohl hier die Geographen von ausgedehnten Wüsten sprechen; die Steppennatur der Gobi hat OBRutschew auf das nachdrücklichste betont. In Nordamerika entspricht ihnen das ebenfalls von hohen Gehirgen umrahmte westliche Hochland, dessen Salzwüsten ebenso wie in der Alten Welt von zerstreuten Gänsefußund geselligen Beifußgewächsen bewohnt werden, stellenweise aber auch völlig vegetationslos sind. Die bizarren Formen der Kakteen und die als Nahrungsmittel wertvollen Agaven, deren große, saftige Blattrosette auch dem dürrsten Felsboden entsprießt, geben aber den trockenen Gebieten der Neuen Welt ein eigenartiges Gepräge. Auf den südlichen Festländern greift die Steppen- und Wüstenvegetation im Windschatten des Passates weit in die Tropenzone hinein, am weitesten in der peruanisch-chilenischen

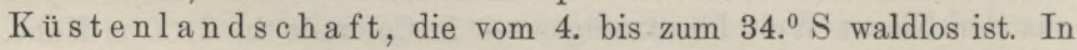
der Regenzeit bekleidet sie sich wohl mit blühenden Stauden, aber die sommerliche Dürre überdauern nur vereinzelte Gruppen von Fettgewächsen und niederem Dorngesträuch. Das hochgelegene Atacamaplateau ist auf weite Strecken hin völlig regetationslose Salzwüste. Aber in einem Punkt unterscheidet sich die peruanische Steppe wesentlich von den Steppen der gemäßigten Zone: durch das allerdings nur zerstreute Vorkommen immergrüner Bäume. Jenseits des 30. Parallels bessert sich die Vegetation zusehends, und reichlicher Graswuchs schafft ein gutes Weideland. Auch die Hochflächen der Cordilleren, die sogenannte Punaregion, nehmen an der Steppennatur teil. Die südwestliche Küste von Afrika ist ebenfalls bis über den Wendekreis hinaus eine traurige Sand- und Steinwüste mit niederem graugrünem Gebüsch (darunter die seltsame Welwitschia und die Narasbüsche) und ärmlichem Graswuchs, und diese Vegetationsformation erstreckt sich mit einigen von der Bodenbeschaffenheit abhängigen günstigen Variationen, die Viehzucht gestatten, über das hochgelegene Damara- und Namaland bis zur 
ausgedehnten Sandsteppe der Kalahari. Im Verhältnis zum Areal des Festlandes nehmen die Steppen und Wüsten in Australien den gröBten Raum ein, denn die östliche Randstellung des Hochlandes beraubt die inneren und westlichen Landschaften der Wohltat regelmäßiger Befeuchtung. Aber so öde auch diese Gegenden in der Regel sind, so rasch belebt sich die Vegetation, wenn einmal, freilich oft nach jahrelanger Dürre, ein wolkenbruchartiger Regen niederfällt. Doch unausgenützt fließen die Wassermassen $a b$, und die blumenreichen Gras- und Kräuterfluren verschwinden wieder wie ein Trugbild der Fata Morgana. Die Eigentümlichkeit Australiens besteht darin, daß der periodische Wechsel des Landschaftsbildes, dem alle Steppen unterworfen sind, sich in völlig regellosen Sprüngen vollzieht. Daher auch die scheinbaren Widersprüche in den Berichten der Forschungsreisen - ein Moment, das übrigens auch bei der Beurteilung der übrigen Steppen und Wüsten in Betracht gezogen werden muß und die Unbestimmtheit dieser Begriffe wesentlich mitverschuldet hat. Streng genommen läßt sich die Vegetation der einzelnen waldlosen Gegenden der Erde nur während der Regenzeit miteinander vergleichen, aber diese Periode ist kurz, und den größten Teil des Jahres lastet selbst auf den begünstigteren Steppen der Fluch der Unfruchtbarkeit.

Ausdehnung der Formationen. In Ermanglung detaillierter Ausmessungen, die auf dem gegenwärtigen Standpunkt unserer Kenntnis von der Erde und bei der Unsicherheit der Begriffsbestimmung der Vegetationsformationen natürlich unlohnende Arbeit wären, möge nachstehende Tabelle von Hermann WAGNer ${ }^{12}$ wenigstens eine ungefähre Vorstellung von der Ausdehnung der benutzbaren Flächen geben.

In Millionen $\mathrm{qkm}$.

In Prozenten.

Wald Kuitur- Steppe Ödland Wald $\begin{gathered}\text { Kultur- Steppe Ödland } \\ \text { land }\end{gathered}$

\begin{tabular}{|c|c|c|c|c|c|c|c|c|c|}
\hline Europa . . & . & 3,0 & 4,4 & 0,6 & 2,0 & 30,0 & 44,0 & 6,0 & 20,0 \\
\hline Asien . & . & - 13,0 & 9,0 & 9,2 & 13,0 & 29,4 & 20,4 & 20,8 & 29,4 \\
\hline Afrika . & . & . $\quad 9,0$ & 5,3 & 8,5 & 7,0 & 30,2 & 17,8 & 28,5 & 23,5 \\
\hline Australien & . & 1,3 & 1,0 & 3,4 & 3,3 & 14,4 & 11,1 & 37,8 & 36,7 \\
\hline Nordamerika & . & 9,0 & 3,5 & 4,0 & 7,5 & 37,5 & 14,6 & 16,7 & 31,2 \\
\hline Südamerika & . & 8,0 & 3,8 & 4,0 & 2,0 & 45,0 & 21,4 & 22,3 & 11,3 \\
\hline Alte Welt & . & . 26,3 & 19,7 & 21,7 & 25,3 & 28,3 & 21,2 & 23,3 & 27,2 \\
\hline Nene Welt & . & . 17,0 & 7,3 & 8,0 & 9,5 & 40,7 & 17,5 & 19,1 & 22,7 \\
\hline Nördl.Festlän & nder & $r \quad 25,0$ & 16,9 & 13,8 & 22,5 & 31,9 & 21,6 & 17,7 & 28,8 \\
\hline Südl. Festlän & nder & 18,3 & 10,1 & 15,9 & 12,3 & 32,3 & 17,8 & 28,1 & 21,8 \\
\hline Polargebiete & . . & - & - & - & 9,6 & - & - & - & 1000 \\
\hline
\end{tabular}

Land . . 43,3 27,0
Supas, Physische Erdkunde. 5. Aut. 
Die außerordentliche Bevorzugung der Neuen Welt springt aus dieser Tabelle deutlich hervor: 58,2 Proz. des Areals sind Waldund Kulturland gegen 49,5 Proz. in der Alten Welt. Indes gestattet auch diese Tabelle keine weitgehenden Schlüsse auf die Kulturfähigkeit der einzelnen Erdteile. Manche Gebiete, die hier unter Steppe und Ödland eingereiht sind, dürften nicht als absolut kulturfeindlich aufzufassen sein. Die Anfänge der menschlichen Gesittung gingen nicht von dem fruchtbarsten Boden, dem Wald, aus, sondern von dem offenen Grasland, und erst allmählich drang die Kultur in das Waldland vor. Sie kann nun den umgekehrten Weg einschlagen, da, wie HILGARD ${ }^{13}$ gezeigt hat, die Bodenverhältnisse auch in vielen trockenen Gebieten günstig sind. Voraussetzung ist natürlich eine ausgedehnte künstliche Bewässerung; die Versuche in den westlichen Vereinigten Staaten haben gelehrt, daß auf diesem Weg schöne Erfolge zu erzielen sind.

Literaturnachweise. ${ }^{1}$ Für die Vegetationsformationen der Tropen sind sehr lehrreich W. Goetze und A. Engler, Vegetationsansichten aus DeutschOstafrika; Leipzig 1902 (64 photographische Aufnahmen in ausgezeichneten Reproduktionen). - ${ }^{2}$ A. Brischin, La forêt tropicale en Afrique, in La Géographie, Paris 1902, Bd. V u. VI. $-{ }^{3}$ A. Chevalier, in den Comptes rendus de l'Académie des Sciences 1909, Bd. CXLIX, S. 458. - ${ }^{4}$ H. v. Ihering, A distribuçâo de campos e mattas no Brazil, in Revista do Museu Paulista, Bd. VII, S. Paulo 1907. - ${ }^{5}$ A. Engler, Die Pflanzenwelt Ostafrikas, Teil A; Berlin 1895. - ${ }^{6}$ Eine ausgezeichnete kartographische Darstellung des zerstreuten Pflanzenwuchses der südrussischen Steppe nach ihren floristischen Elementen gibt P. v. Köppen in den Beiträgen zur Kenntnis des Russischen Reiches, Bd. XI, 1845. - ${ }^{7}$ G. I. Tanfilew, Die Waldgrenzen in SüdruBland (russisch mit deutschem Resumé); St. Petersburg 1894. - ${ }^{8}$ Vgl. die Karte von C. S. Sargent in Petermann's Mitteilungen 1886, Taf. 12. - ${ }^{9}$ And. Krassnow, Die Grassteppen der nördlichen Halbkugel (russ.); Moskau 1894. (Einen ausführlichen Bericht von Woeıкow s. Petermann's Mitteilungen 1895, Literaturbericht Nr. 36.) Vgl. auch seinen Vortrag über die Flora der südrussischen Steppen in den Verhandlungen des VII. internationalen Geographenkongresses, Berlin 1901. - ${ }^{10}$ Mrtuer Christy, in den Proceedings of the R. Geographical Society of London 1892 , S. 78. Seine Erklärung wird bestätigt von A. GaskilL in Science 1905, Bd. XXII, S. 55. - ${ }^{11}$ G. Haennel, Die Morphologie und Hydrographie der Oasen in der Sahara, im Gymnasialprogramm, Bunzlan 1895. - ${ }^{12}$ H. Wagner, Lehrbuch der Geographie, S. 623 . - ${ }^{13}$ E. W. Hilgard, zit. S. 483 .

\section{Die Nutzpflanzen. ${ }^{1}$}

$\mathrm{Zu}$ den folgenreichsten Eingriffen des Menschen in die Natur gehört die Züchtung und Veredlung von Pflanzen, die ihm zur Nahrung und Bekleidung, als Genuß- oder Heilmittel dienen. „Es ist,“ sagt Unger, "2 „eine auf keine Weise in Abrede zu stellende 
Tatsache, daß fast keine einzige jener Pflanzen, deren Teile als Nahrung verwendet werden, in ihrem ursprünglichen Zustand angenehm und wohlschmeckend war. Thr vielfältiger Anbau, die Verbreitung auf Teile der Erde, die ihrer Ursprungsstätte fern lagen, ihre sorgsame Pflege und die der Natur abgelauschten Operationen, wodurch sie selbst Veränderungen in Größe und Beschaffenheit, in Gewebe und chemischer Konstitution hervorbrachte, haben nach und nach eine Anzucht herbeigeführt, die von der ursprünglichen Beschaffenheit in dem Grad abweichen mußte, als die Hand des Menschen über sie wachte. Ihr danken wir es, daB das Getreide und die Knollengewächse nahrhafter, die Gemüsearten und das Obst wohlschmeckender geworden sind."

Allerdings ist es zunächst Aufgabe der Anthropogeographie, sich mit den Kulturgewächsen zu beschäftigen, aber wir können uns nicht versagen, auf einige wichtige Punkte hinzuweisen, die unsere bisherigen Auseinandersetzungen ergänzen sollen. Zwei bedeutungsvolle Gegensätze treten uns da vor Augen: der Kontrast zwischen den Tropen und den Polarländern, der aber durch allmähliche Übergänge ausgeglichen wird, und der Gegensatz zwischen der Alten und der Neuen Welt, den erst die neuzeitliche Kulturentwickelung der europäischen Menschheit verwischt hat.

Zerealien. Weitaus die wichtigsten Nahrungspflanzen sind die Getreidearten, deren Anbau die Grundlage jeder höheren Gesittung ist; unter ihnen sind wieder Reis und Mais, Weizen, Roggen und Gerste am verbreitetsten und die eigentlichen Ernährer der ansässigen Menschheit.

Der Reis, dessen Heimat wahrscheinlich Indien ist, der sich aber schon im hohen Altertum über die Kulturländer Süd- und Ostasiens verbreitet hat, ist nach REIN für wenigstens ein Drittel des Menschengeschlechtes die vorwiegende tägliche Speise. Die Araber brachten ihn nach Vorderasien, Europa und Afrika, und die Engländer und Portugiesen nach Amerika, wo er namentlich in Südcarolina und in Brasilien große Bedeutung erlangt hat. Sein großes Wärmebedürfnis beschränkt ihn auf jene Gegenden, die ihm während seiner halbjährigen Entwickelungszeit eine Mitteltemperatur von wenigstens $20^{\circ} \mathrm{C}$. gewähren können. In der Alten Welt erreicht er daher nur stellenweise den 45. Nordparallel, in Amerika aber nur den 38., und auf der südlichen Hemisphäre überschreitet er nur selten den Wendekreis. Sein auBerordentliches Feuchtigkeitsbedürfnis, das nur eine minderwertige Abart, der Bergreis, nicht teilt, macht überdies seine Kultur nur in den Niederungen möglich, wo die Felder leicht bewässert werden können. Weniger empfindlich ist sein ameri- 
kanischer Vertreter, der Mais, die einzige Getreideart der Neuen Welt, die sich in bezug auf Verbreitung mit den Zerealien der Ostfeste messen kann. Bald nach der Entdeckung Amerikas gelangte er in die Mittelmeerländer, nach Ostasien und nach Afrika, wo er dus einheimische Sorghum (Durrha oder Mohrenhirse) fast zu verdrängen droht. In Europa gedeiht er nur südlich von $50^{\circ} \mathrm{B}$. und nur am Rhein noch unter dem 52. Parallel, während er in seiner Heimat sogar noch am Red River, also unter $55^{\circ}$ B., trotz des rauheren Klimas mit bestem Erfolg angebaut wird. Dieser Vorzug kann Amerika auch durch die Kultur nicht geraubt werden, denn jener nordische Mais besteht aus Abarten mit kürzerer Vegetationsdauer, die eine Verpflanzung in fremde Erdteile nicht dulden. Neben Reis und Mais ist noch der Weizen, die edelste aller Zerealien, auf die wärmeren Gegenden beschränkt, flieht aber anderseits auch große Hitze, daher er in den Tropen nur im Bereich des Seeklimas oder in größerer Höhe angebaut wird. Aus Vorderasien (wahrscheinlich Palästina) stammend, hat er sich schon in vorgeschichtlicher Zeit über die benachbarten Länder verbreitet und in der Neuzeit seinen siegreichen Einzug auch in Amerika gehalten, wo er in den Vereinigten Staaten von 1849-80 um mehr als 9 Längengrade nach Westen vorgerückt ist. Im Mackenziegebiet reicht sein Anbau bis $62^{\circ}$ B. (Fort Simpson), im Westen aber nur bis $50^{\circ} \mathrm{B}$; in der Alten Welt betritt seine Polargrenze die norwegische Westküste unter $65^{\circ}$ B. und durchzieht mit einer zwischen 61 und $64^{\circ}$ auf- und abschwankenden Linie Europa, bis sie am Ural auf $60^{\circ}$ B. hinabsinkt. Auch in den mittleren Breiten der Südhemisphäre begegnen wir seiner Kultur überall, in Viktoria und Südaustralien, im Kapland, bei Buenos Aires, besonders aber in Chile. Weniger Wärme als der Weizen beansprucht der Roggen, der für das nördliche Europa und Asien der wichtigste Brotlieferant ist, und am weitesten gegen die Pole dringt die Gerste vor. Nur an der skandinavischen Westküste fällt unter dem Einfluß der Atlantischen Strömung die Getreidegrenze mit der Baumgrenze $\left(70^{\circ}\right.$ B. $) \times$ zusammen, dann aber entfernen sich beide Linien beträchtlich voneinander, indem jene am Bottnischen Meerbusen bis $67^{\circ}$ sinkt, dann RuBland zwischen 65 und $66^{\circ}$ und Sibirien zwischen 61 und $62^{\circ}$ durchzieht, dann längs der pazifischen Grenzgebirge nach Süden ausbiegt und die östliche Küste, deren Sommertemperatur durch das Auftauen des ochotski-

$\times$ Neuere Anbauversuche von Gerste und Roggen am lappländischen Enaresee unter $69^{\circ} \mathrm{B}$. haben gute Resultate erzielt (Petermans's Mitteilungeu 1888, S. 188), man muß aber noch längere Erfahrungen abwarten. 
schen Meereises stark erniedrigt wird, erst unter $50^{\circ} \mathrm{B}$. berührt, in Kamtschatka aber wieder bis $57^{\circ}$ ansteigt. Im Gebiet des nordamerikanischen Kontinentalklimas reicht die Getreidegrenze bis $65^{\circ} \mathrm{B}$., denn bei Fort Norman am Mackenzie gedeiht die Gerste noch in

\section{Höhengrenze des Getreidebaues:}

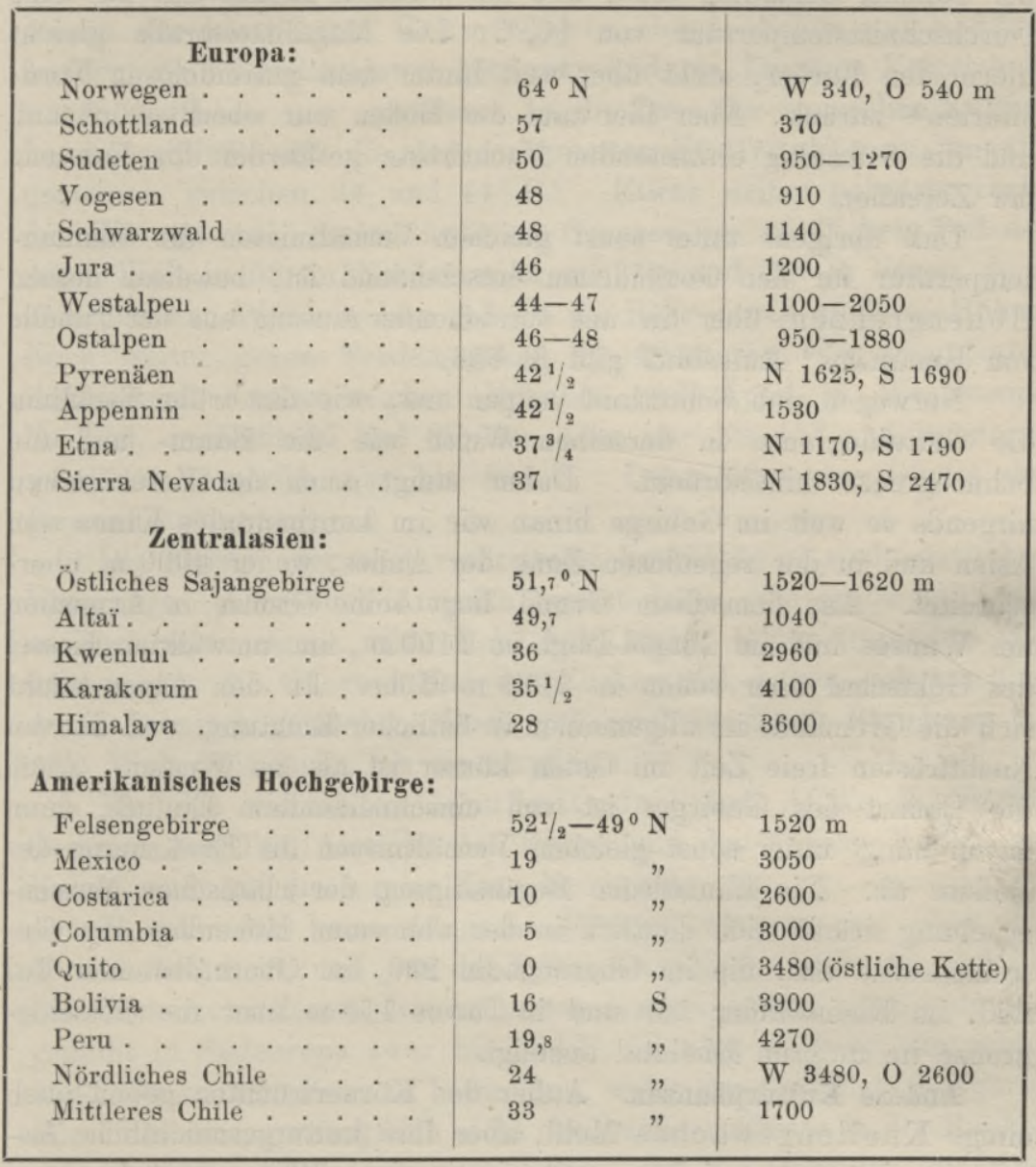

guten Jahren. Der Sommer ist hier kühler als an der sibirischen Getreidegrenze, aber der Boden, dessen felsige Unterlage bald erreicht wird, taut bis zu größeren Tiefen auf und ist daher wärmer. In Labrador schließt dieselbe Ursache, die die Baumgrenze so weit hinabdrückt, auch den Getreidebau nördlich von $51^{\circ} \mathrm{B}$. aus. Dagegen kommt die Kartoffel, die sich sonst überall nicht mehr als die Gerste 
dem Pol nähert, nach Missionsberichten noch in Hebron an der Ostküste von Labrador $\left(58^{\circ}\right.$ B.) vor. Grönland liegt jenseits, die Färöergruppe aber diesseits der Getreidegrenze, und ebenso wahrscheinlich auch Island, wo Gerste im ganzen Mittelalter gebaut wurde, und auch neue Versuche wieder geglückt sind. ${ }^{3}$ In Südamerika werden noch bei Punta-Arenas Roggen und Gerste gebaut, und doch ist hier der Sommer beständig trüb, und der wärmste Monat hat nur eine Durchschnittstemperatur von $10,7^{\circ}$. Die Magalhãesstraße gleicht hierin den Färöer, steht aber weit hinter dem getreidelosen Nordsibirien $\times$ zurück. Aber hier taut der Boden nur oberflächlich auf, und die frühzeitig eintretenden Nachtfröste gefährden die Existenz der Zerealien.

$\mathrm{Da} B$ übrigens unter sonst gleichen Verhältnissen die Sommertemperatur für den Getreidebau entscheidend ist, beweisen dessen Höhengrenzen, über die uns vorstehender Auszug aus der Tabelle von Berghaus ${ }^{4}$ Aufschluß gibt (S. 853).

Norwegen und Schottland zeigen uns, wie das trübe Seeklima die Getreidegrenze in derselben Weise wie die Baum- und die Schneegrenze hinabdrückt. Daher steigt auch der Zerealienbau nirgends so weit im Gebirge hinan wie im kontinentalen Klima von Asien und in der regenlosen Zone der Andes, wo er $4000 \mathrm{~m}$ überschreitet. Aus demselben Grund liegt seine Grenze in Armenien am Wansee und im Bingöl-Dagh in $2100 \mathrm{~m}$, im umwölkten Kessel des Goktschaï aber schon in $1800 \mathrm{~m}$ Höhe. In den Alpen senkt sich die Grenzlinie im allgemeinen in östlicher Richtung, weil die von Nachtfrösten freie Zeit im Osten kürzer ist als im Westen. Auch die Bauart des Gebirges ist von einschneidendem Einfluß, denn davon hängt unter sonst gleichen Verhältnissen die Erwärmung des Bodens ab. Die klimatische Begünstigung der rhätischen Massenerhebung drückt sich deutlich in der abnormen Höhenlage der Getreidegrenze aus, die im Oberengadin 290, im Oberhalbsteiner Tal 200, im Rheinwalder 180 und in Davos $110 \mathrm{~m}$ über die Getreidegrenze im unteren Rheintal ansteigt.

Andere Kulturpflanzen. Außer den Körnerfrüchten geben auch einige Knollengewächse Mehl, aber ihre kulturgeschichtliche Bedeutung ist viel geringer, weil sie weniger Pflege bedürfen und daher nicht im gleichen $\mathrm{MaB}$ wie das Getreide erziehend auf den Menschen einwirken. Nur die Kartoffel, neben dem Mais das wichtigste Geschenk Amerikas, hat eine Weltverbreitung, wenn sie

× Temperatur des wärmsten Monats in Beresow (Westsibirien $64^{\circ}$ B.) $16,7^{\circ}$, in Turuchansk (Mittelsibirien $66^{\circ}$ B.), wo die Gerste nicht mehr reift, $15,5^{\circ}$, und in Werchojansk (Ostsibirien $67^{1} / 2^{\circ}$ B.) $15^{0}$. 
auch nur in den gemäBigten und kälteren Zonen als das „Brot der Armen" eine große Bedeutung erlangt hat. Wichtiger sind die amerikanische Maniokpflanze und Batate und die in der Alten Welt heimischen Arons- und Yamswurzeln, die sich zwar über beide Hemisphären verbreitet haben, aber im allgemeinen auf die Tropenzone beschränkt bleiben. Ziemlich mühelos ernähren sie hier eine träge Bevölkerung, der die Natur überdies noch eine Menge der köstlichsten Baumfrüchte bietet. Schon auf S. $820 \mathrm{f}$. wurden die allerwichtigsten genannt, und ein längeres Verzeichnis würde den Leser nur ermüden. An die Zone der tropischen Kulturbäume schließt sich die der sogenannten Südfrüchte an (im allgemeinen zwischen 34 und $44^{\circ} \mathrm{B}$.). Etwas weiter polwärts rückt der Weingürtel, dessen äußerste Grenzen im nördlichen Teil der Alten Welt in 53 (in Nordamerika nur 43) und $28^{\circ}$ B. liegen, denn zwischen den Wendekreisen gedeiht die Rebe nur in größeren Höhen. Noch weiter gegen Norden gehen die Obstsorten der gemäBigten Zone; nach Jessen reichen Kirschen und Äpfel in Westeuropa bis $65^{\circ}$, in Rußland und Sibirien aber nur bis $45^{\circ}$ und im nordwestlichen Amerika nur bis $50^{\circ}$ B. Dann folgt der Gürtel der Beerensträucher.

Die meisten der weit verbreiteten Fruchtbäume sind asiatischen Ursprungs. Aber auch Amerika besitzt deren eine große Zahl, wie es auch seine eigene wilde Rebe hat; einige seiner tropischen Gewächse, wie die Guayava und der Zuckerapfel, haben sich rasch in Asien heimisch gemacht. Doch gab auch in dieser Beziehung die Alte Welt weit mehr, als sie empfing.

Von den wichtigsten GenuBmitteln lieferte Afrika den Kaffee, Ostasien den Tee, Amerika den Kakao und den Tabak. Kaffee und Kakao sind auf die warme Zone beschränkt; der immergrüne Teestrauch ist zwar keine tropische Pflanze, überschreitet aber den 40. Parallel nicht, und nur der Tabak ist größerer Verbreitung fähig. Das Zuckerrohr, dessen drei Arten aus dem tropischen Asien stammen, gedeiht in Südeuropa zwar bis $38^{\circ}$ B., ist aber doch als ein echtes Kind der warmen Zone zu betrachten, wofür der gemäBigte Erdgürtel allerdings einen, wenngleich nicht ebenbürtigen Ersatz in der Runkelrübe besitzt. Fügen wir noch hinzu, daß die Gewürze, die einst die Menschheit zu ebenso kühnen Unternehmungen anspornten wie Gold und Silber oder die Pelztiere des Nordens, nur den Tropen angehören; daß die Baumwolle, der wichtigste aller Pflanzenfaserstoffe, ursprünglich auch tropisch ist, wenn ihre Kultur auch nach amtlichen Erhebungen in den Vereinigten Staaten bis zum 43. Parallel mit Erfolg ausgedehnt werden könnte; — so wird unsere Vorstellung 
von der überquellenden Produktionskraft der Tropenwelt einigermaßen ergänzt. Allerdings gibt es hier auch traurige Einöden, aber mitten in den Sand- und Steinwüsten der Sahara liegen inselgleich die Oasen, wo sich das Wasser in großen, der Verdunstung entzogenen Vorräten sammelt, und im Schatten der Dattelwälder dichtgedrängt tropische und subtropische Kulturgewächse gedeihen. Diese durch Trockenheit erzeugten Einöden sind von ganz anderer Art als jene der Polarzone, wo nur Treibholz einen unzuverlässigen Ersatz für den Baumwuchs gewährt, wo einige Beeren, Flechten, Algen und Pilze die einzigen Nahrungsmittel sind, die das Pflanzenreich bietet, und der streifende Mensch nur auf die Tierwelt angewiesen ist, die ihm Kleidung, Nahrung und Tran für seine Lampe liefert, die kümmerlich die lange Winternacht erhellt.

Die ursprüngliche Armut der Neuen Welt an Nutzpflanzen, die um so mehr auffällt, als Amerika in bezug auf die Gesamtzahl seiner Pflanzen im Verhältnis zu seiner Größe die Alte Welt vielleicht übertrifft, ist in unserer Darstellung schon zur Genüge hervor-

Zahl und Heimat der Nutzpflanzen.

\begin{tabular}{|c|c|c|c|c|c|c|c|c|c|}
\hline & \multicolumn{5}{|c|}{ Alte Welt } & \multicolumn{4}{|c|}{ Neue Welt } \\
\hline & 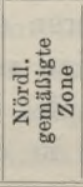 & 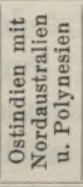 & 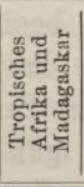 & 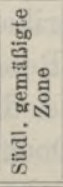 & 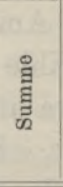 & 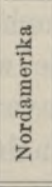 & 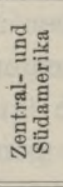 & 离 & \begin{tabular}{|c} 
Mit Berück- \\
sichtigung \\
des Areals $x$ \\
verhält sich \\
die Neae Welt \\
zur Alten \\
Welt $=1$ : \\
\end{tabular} \\
\hline Getreidepflanzen . . & 12 & 4 & 5 & - & 21 & - & 2 & 2 & 4,67 \\
\hline Hülsenfrüchte. . & 9 & 3 & 5 & 一 & 17 & - & 5 & 5 & 1,51 \\
\hline Gemüse . . . . . & 36 & 23 & 14 & 3 & 76 & 2 & 13 & 15 & 2,25 \\
\hline Obstarten . . . & 43 & 34 & 7 & - & 84 & 6 & 44 & 50 & 0,75 \\
\hline Nahrungspflanzen & 100 & 64 & 31 & 3 & 198 & 8 & 64 & 72 & 1,22 \\
\hline GenuBmittel . . & 37 & 12 & 5 & - & 54 & 3 & 11 & 14 & 1,71 \\
\hline Technische Pflanzen & 20 & 22 & 9 & 3 & 54 & - & 12 & 12 & 2,00 \\
\hline Heilpflanzen . . . & 12 & - & 1 & 3 & 16 & 1 & 10 & 11 & 0,65 \\
\hline Nutzpflanzen $\times x$. . & 169 & 98 & 46 & 9 & 322 & 12 & 97 & 109 & 1,30 \\
\hline
\end{tabular}

$\times$ Da die Alte Welt sich der Fläche nach zur Neuen Welt wie 9:4 verhält, so muB man, um ganz gerecht zu sein, die Beiträge beider Welten auf das gleiche Areal reduzieren. Höck tat dies in einer älteren Arbeit in der Weise, daß er die altweltlichen Arten mit 4, die neuweltlichen mit 9 multiplizierte. Dann findet man z. B., daß die Alte Welt an Pflanzen, die erregende Getränke liefern, zwar absolut mehr erzeugt als Amerika, relativ aber weniger $(6 \times 9: 10 \times 4=1: 0,74)$.

$\times \times$ Ohne die Futterpflanzen. 
getreten, trotzdem diese nur auf das Allerwichtigste Rücksicht nahm. Noch prägnanter kommt sie in vorstehender, nach Н̈̈ск $^{5}$ zusammengestellten Tabelle zum Ausdruck.

Auf der östlichen Halbkugel ist der australische Kontinent sehr arm an einheimischen Nutzpflanzen, und auch Afrika kann den Vergleich mit Asien nicht aushalten. Zieht man auf einer Karte in Mercator's Projektion eine gerade Linie von Irland bis zu den Molukken, so häufen sich darum, wie Unger gezeigt hat, die meisten und wichtigsten Nahrungspflanzen an: die des malaiischen Archipels, von Vorder- und Hinterindien, von Persien und Armenien, des Kaukasusgebietes und der Krim, Griechenlands, Italiens und Mitteleuropas. Eine ebensolche, nach Nordwesten gerichtete bromatorische $\times$ Linie wies UNGER auch in Amerika nach. Um sie gruppieren sich Brasilien, Guayana, Peru, Ecuador, Columbia, Zentralamerika, Mexico und Westindien; und nur die atlantischen Vereinsstaaten, die ebenfalls ein ursprüngliches Zentrum von Nahrungsgewächsen sind, liegen abseits von jener Linie.

Literaturnachweise. ${ }^{1}$ Alph. de Candolue, Der Ursprung der Kulturpflanzen; Leipzig 1884. Тн. H. Engelbrecht, Die Landbauzonen der außertropischen Länder; Berlin 1899 (namentlich der Atlas ist von Interesse). ${ }^{2}$ F. Unger, Botanische Streifzüge auf dem Gebiet der Kulturgeschichte; in den Sitzungsberichten der Wiener Akademie der Wissenschaften, Mathem.-naturwiss. Klasse 1857, Bd. XXIII. - ${ }^{3}$ Vgl. Nature 1885, Bd. XXXII, S. 116. ${ }^{4}$ Herm. Berghaus, Höhentafel von 100 bekannteren Gebirgen, in Behm's Geographisehem Jahrbuch, Bd. I, 1866. - ${ }^{5}$ F. Höck, Der gegenwärtige Stand unserer Kenntnis von der ursprünglichen Verbreitung der angebauten Nutzpflanzen, in der Geographischen Zeitschrift, 1899 u. 1900, Bd. V und VI.

\section{Die Lebensbedingungen der Tierwelt.}

Ebenso intim wie die Beziehungen des Menschen zur Pflanzenwelt ist sein Verhältnis zu den Tieren, von denen er sich einige zu Hausgenossen erzogen hat, während er andere der Nahrung oder des Pelzes oder einer anderen Beute wegen verfolgt oder als gefährliche Feinde bekämpft. Im übrigen erregt aber die Fauna in geringerem Grad als die Flora das Interesse des Geographen, denn selten tritt sie im Landschaftsbild so bedeutungsvoll hervor wie in Tibet, wo sich nach Przewalsky die Zahl der Säugetiere, die in großen Herden von einer Weide zur anderen wandern, auf Millionen beläuft, und nicht der Mensch, sondern das Tier der Herrscher ist. In der Regel drängt sich die Fauna nicht unmittelbar wie die Vegetationsformen dem Auge des Beobachters auf, sondern will erst

$\times \beta \varrho \tilde{\omega} \mu \alpha=$ Nahrung. 
gesucht werden. Dagegen ist ein anderes Moment, auf das wir bei unseren Betrachtungen über den Ursprung der Inseln schon wiederholt aufmerksam gemacht haben, von hervorragender geographischer Wichtigkeit. Die Veränderungen der Erdoberfläche spiegeln sich in der Verbreitung der Landtiere getreuer wider als in der Verteilung der Pflanzen, denen sogar die meisten flugfähigen Tiere in bezug auf die Verbreitungsmittel nachstehen. Es wird die Aufgabe der nächsten Kapitel sein, auf diesen Punkt näher einzugehen, während wir uns in diesem nur auf eine kurze Besprechung jener geographischen Momente einlassen wollen, die das Tierleben bedingen. Es sind dies vor allem die Nahrung und die Wärme. Dagegen ist die Tierwelt unabhängig vom Licht, sie bevölkert auch die Tiefen des Weltmeeres, und ihr Verbreitungsbezirk erstreckt sich über die ganze Erde, soweit sie Nahrung findet.

Beziehungen zwischen der Tier- und der Pflanzenwelt. Im Gegensatz zu den Pflanzen sind die Tiere hauptsächlich auf organische Nahrung angewiesen und daher durch die Pflanzenwelt bedingt, entweder direkt, wie die Pflanzenfresser, oder indirekt, wie die Fleischfresser. Dies gilt ebensowohl für die Landtiere wie für die Tiere der hohen See, denn auch die Oberfläche des Meeres entbehrt nicht des Pflanzenlebens, wenn sich dieses auch nur auf die niedrigsten Formen, auf mikroskopische Algen beschränkt. Wenn sich in den polaren Breiten die Sonne senkt, so tauchen unzählige Diatomeenschwärme an der Oberfläche des Meeres auf, das sie in einen dicken Schleim, das „Schwarzwasser“ der Nordpolfahrer, verwandeln. Thnen folgen, wie TH. FucHs ${ }^{1}$ gezeigt hat, die Ruderschnecken und kleine Krebse, diesen wieder zahlreiche Fische, und diesen endlich die Räuber der hohen See, die Delphine und Walfische. In wärmeren Meeren kommen Diatomeen hauptsächlich nur in der Nähe von Flußmündungen vor, meist werden sie aber durch Fadenalgen und Schwingfäden ersetzt, die im Indischen Ozean in so großen Mengen auftreten, daß das Wasser stellenweise einen sumpfigen Geruch annimmt. Ja manche dieser Algen scheinen sogar des Lichtes entbehren zu können, denn die Plankton-Expedition i. J. 1889 fischte solche noch in Tiefen von $1000-2000 \mathrm{~m}$ auf. $^{2}$

Es ist klar, daß zwischen Pflanzen und monophagen Tieren ein bestimmtes Zahlenverhältnis bestehen muß, denn die Nahrung wird nicht völlig in Fleisch verwandelt, sondern zum Teil unverdaut ausgeschieden, zum Teil zur Erzeugung von tierischer Wärme sowie zur Ausübung der tierischen Funktionen verbraucht. „Nehmen wir einmal - sagt SEMPER ${ }^{3}$ - ganz willkürlich an, es sei das Verhältnis zwischen der vom Boden erzeugten Pflanzenmenge und 
der durch Umsetzung dieser ermöglichten Masse von Pflanzenfressern wie $10: 1$, so würden in dem vorhin angenommenen Areal von 1000 Einheiten Pflanzen nur 100 Einheiten (Individuen) pflanzenfressender Tiere leben können. Das Maximum von Nahrung, welche damit den monophagen Fleischfressern geboten wäre, würde nur noch 100 Einheiten betragen. Aber bei der Umsetzung dieser 100 Einheiten tierischer Nahrung in die Organe der Fleischfresser würde abermals ein sehr bedeutender Verlust entstehen; organische Substanz würde verbrannt, das Unverdauliche (Haare, Hufe, Hörner) würde ausgestoßen werden; und wenn das Verhältnis wieder so wäre, daßB 10 Einheiten tierischer Nahrung nur eine Einheit tierischen Körpers bilden könnten, so würden von dem Maximum der Nahrung, wie es durch Pflanzenfresser dargeboten wäre, höchstens 10 Fleischfresser wirklich existieren können." In dem angenommenen Fall ist also das Verhältnis der Pflanzen zu den Pflanzenfressern und Fleischfressern gleich 1000:100:10. Damit stimmt die Tatsache überein, daß unter den Wirbeltieren nur die Pflanzenfresser in großen Herden leben, während die Raubtiere seltener sind und sich meist in kleine Familien absondern. Ferner hängt damit zusammen, daß die Zahl der Pflanzenfresser mit der Üppigkeit der Vegetation gegen den Äquator zunimmt, wenn auch die Entwickelung der tropischen Fauna mit der der Pflanzenwelt nicht gleichen Schritt hielt.

Es leuchtet auch ein, daß streng monophage Tiere von ihrer Umgebung abhängiger sind als die Vielfresser und daher eine beschränktere Verbreitungsfähigkeit besitzen. Einschneidende Veränderungen in der Pflanzenwelt, wie sich solche in der geschichtlichen Zeit in Kulturländern vollzogen haben, haben stets auch faunistische Änderungen im Gefolge, wobei freilich nicht immer der Wechsel der Nahrung das entscheidende Moment ist. Denn abgesehen davon sind die Lebensgewohnheiten vieler Tiere auch an bestimmte Vegetationsformen gebunden. Man kann von Wald-, Steppen-, Wiesen-, Wüsten- und Tundrafaunen sprechen, aber diese Formationen unterscheiden sich von den pflanzlichen in einem wichtigen Punkt. In beiden Reichen setzen sich gleiche Formationen in verschiedenen Erdstrichen aus verschiedenen Bestandteilen zusammen, aber die Speziesunterschiede drängen sich uns in der Tierwelt sinnenfälliger auf als in der Pflanzenwelt. Die Vegetation wirkt als Masse, als mehr oder minder zusammenhängende Bodendecke, die höheren Tiere treten aber vereinzelt oder höchstens in Gruppen gleichartiger Individuen auf. Eine afrikanische Steppe ähnelt auf den ersten Blick einer zentralasiatischen viel mehr als ihre beiderseitigen Tierbestände. Außerdem sind viel Tiere, namentlich jene der höheren Ordnungen in 
hohem Grad anpassungsfähig. Es gibt allerdings Säugetiere, wie das Zebra, das Kamel, die Giraffe, viele Antilopenarten u. a., für die Wälder eine unüberschreitbare Schranke bilden, es gibt aber andere, wie z. B. den Wolf, die den Wald ebenso wie die Steppe durchstreifen. Echte Waldsäugetiere sind in den Tropen z. B. alle Klettertiere, die Affen, der Rüsselbär, aber in unseren Gegenden sind viele erst durch die Kultur in den Wald zurückgedrängt worden. Schon das Geweih des Hirsches zeigt, daß er ursprünglich nicht für das Waldesdickicht geschaffen war. Nur das Eichhörnchen ist im strengsten Sinn auf den Wald angewiesen, und da $B$ es in der Krim fehlt, hat daher v. BAER mit Recht als einen Beweis für das hohe Alter der südrussischen Steppen angesehen.

Färbung. Noch eine andere Beziehung besteht zwischen vielen Tieren und ihrem Wohnort. Es gereicht den Tieren zum Schutz, wenn sie sich durch die Färbung möglichst wenig von ihrer Umgebung abheben, denn dadurch können sie sich am sichersten der Aufmerksamkeit ihrer Feinde entziehen. Die Tierfarbe der Polargegenden ist daher weiß, die der Wüsten isabellgelb, die der Steppen dunkelgelb; auf Felsen lebende Tiere sind grau gefärbt; in gleicher Weise sind die grünen Vögel und Insekten der Tropenwälder geschützt. Selbst die gewaltigen Raubtiere, die außer dem Menschen keinen Gegner zu fürchten haben, tragen die Farbe ihres Wohnortes, denn diese macht es ihnen möglich, sich unerkannt dem arglosen Opfer zu nahen. Der Löwe, der König der Steppe, ist gelb, und der Tiger zeigt sogar die Rohrstengel der Bambusdickichte in den schwarzen Streifen seines Felles. Diese Erscheinungen hat man unter dem Namen der Anpassung an den Wohnort zusammengefaßt.

Die Schutzfarben sind also geographisch bedingt. Das gilt aber nicht von den anderen Farben der Tiere. Die auffallende Menge schön gefärbter Tiere in den Tropen, besonders aus den Klassen der Vögel und Insekten, verleitete zwar ältere Forscher zu der Ansicht, daß die Farbe hauptsächlich vom Licht abhänge, aber die DARwin'sche Theorie hat auch in diesem Punkt, wie in so vielen anderen, $\mathrm{zu}$ richtigeren Anschauungen geführt. Besonders WALLACE ${ }^{4}$ machte auf eine Reihe von Tatsachen aufmerksam, die sich mit der älteren Erklärung nicht vereinbaren lassen, und seine Autorität wird durch zwölfjährige Beobachtungen in den Äquatorialgegenden gestützt. Er gibt zu, daß die heiße Zone an prächtig gefärbten Tieren absolut reicher ist als die gemäßigte, ob aber auch relativ, wagt er nicht zu entscheiden. Denn neben jenen Tieren, die dem Nordländer am meisten auffallen, gibt es dort nicht minder zahlreiche 
einfarbige und mattgefärbte; manche Vögel, wie die Drosseln, die Zaunkönige oder die Falken, erscheinen unter den senkrechten Strahlen der Tropensonne in keinem bunteren Kleid als in unseren Gegenden, ja die arktischen Enten und Taucher sind schöner geschmückt als ihre tropischen Verwandten. $\mathrm{Zu}$ den prächtigsten Tieren gehören unstreitig die Gold- und Silberfasanen, obwohl ihre Heimat außerhalb der Wendekreise, im nördlichen China und in der Mongolei liegt. Anderseits findet sich dort, wo das Licht am intensivsten wirkt, in der Sahara, eine Fauna mit der einfachen Farbe des Wüstensandes, und die buntesten Tiere leben im Halbdunkel des tropischen Urwaldes. Damit entfällt aber auch jeder Zusammenhang zwischen physikalischen Verhältnissen und jenen Farben, die WALLACE als Trutzfarben, geschlechtliche und typische Farben bezeichnet; ihre Erklärung gehört ausschließlich in den Kreis der zoologischen Aufgaben.

Abhängigkeit der Tiere vom Klima. Das Klima beeinflußt die Tierwelt in viel geringerem Grad als die Pflanzen. Die Verteilung der Niederschläge kommt nur insofern in Betracht, als ein Übermaß von Feuchtigkeit vielen Steppentieren verderblich wird. Wichtiger ist der Einfluß der Temperaturverteilung, die sich zunächst, wie bei den Pflanzen, in einer Artenverarmung gegen die Pole zu offenbart. Die nachstehende Tabelle, die sich auf die (allerdings unvollständigen)

$\begin{array}{cccc}\begin{array}{c}\text { Klassen } \\ \text { der Landwirbeltiere }\end{array} & \begin{array}{c}\text { Rein tropisehe } \\ \text { Familien }\end{array} & \begin{array}{c}\text { Rein außer- } \\ \text { tropisehe } \\ \text { Familien }\end{array} & \begin{array}{c}\text { Gemeinsame } \\ \text { Familien }\end{array} \\ & & & \end{array}$

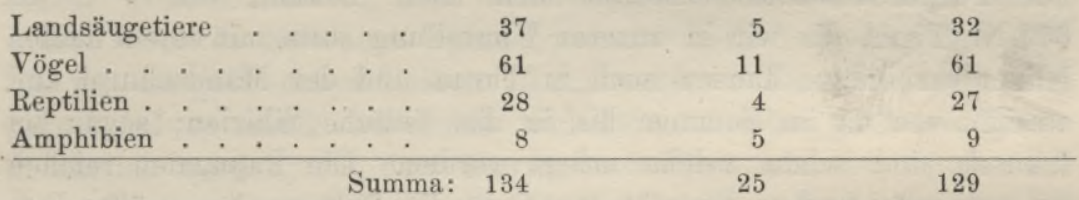

Kataloge von WaLLace stützt, gibt uns von dem faunistischen Gegensatz der Tropen und der höheren Breiten eine bessere Vorstellung, als lange Schilderungen es zu tun vermöchten. Auch auf gleiche Flächen bezogen, ist der Artenreichtum der Tropen ungleich größer als der der gemäBigten und kalten Zone und tritt auch in einigen Ordnungen, die in unseren Breiten gut bekannt sind (wie in denen der Singvögel, Spechte und Tauben), mit überraschender Schärfe zutage. Aber auch hier ist das Problem nicht einfach mit dem Hinweis auf die gegenwärtigen Temperaturverhältnisse zu lösen. Wir wissen nämlich, daß sich in der Tertiärzeit die jetzige tropische Fauna zugleich mit tropischen Pflanzenformen in höhere Breiten erstreckte, daß Europa damals von Elefanten, Nashörnern, Fluß- 
pferden, Affen und Halbaffen, Beuteltieren und zahnarmen Säugetieren (Edentaten) bewohnt war. Die Eiszeit unterbrach hier die normale Entwickelung, die in der warmen Zone, wo sich das Klima seit den früheren geologischen Perioden nicht wesentlich geändert hat, ungestört vor sich gehen konnte. „Der Kampf ums Dasein,“ sagt WALLACE, „sofern er sich gegen die Naturkräfte richtete, war hier stets leicht; Nahrung gab es in Unmasse und in ununterbrochener Zufuhr; Schutz und Obdach waren stets leicht zu haben; die Änderungen der physischen Bedingungen, die nur durch kosmische Gesetze oder geologische Ereignisse veranlaßt wurden, waren notwendigerweise so langsam, daß Variation und Zuchtwahl sich ihnen aubequemen und die üppige Fülle von Organismen in einem schönen, harmonischen Gleichgewicht mit jenen Bedingungen erhalten konnten.“

Noch auf einen anderen wichtigen Punkt muß aufmerksam gemacht werden. Die Tiere sind weniger von der mittleren Temperatur als von den Temperaturschwankungen abhängig, und die kaltblütigen in höherem Grad als die warmblütigen. Leicht bewegliche Tiere können sich aber gegen zu große Schwankungen dadurch schützen, daß sie sich in der ungünstigen Jahreszeit in wärmere Distrikte zurückziehen. Die amerikanischen Kolibris, echte Tropenbewohner, verbreiten sich in einigen Arten an der Westküste bis $61^{\circ} \mathrm{N}$, in Canada bis $57^{\circ}$, auf der südlichen Hemisphäre bis zum Feuerland, wo sie selbst im Schneesturm beobachtet wurden, und steigen auf dem Chimborazo bis zur Schneelinie $(4900 \mathrm{~m})$ empor. Die Purpurschwalbe verbreitet sich nach ToReLl von $9^{\circ} \mathrm{S}$ bis $67^{\circ} \mathrm{N}$. Tiger, die wir in unserer Vorstellung stets mit einem heißen Klima verbinden, hausen noch in Turan und der Mandschurei und streifen von da im Sommer bis in das östliche Sibirien; sogar bei Irkutsk sind schon welche erlegt worden. Die Papageien reichen im neuseeländischen Distrikt, wo auch die Palmen ihre größte Polhöhe erreichen (s. S. 818), bis zum 54. Breitengrad (Insel Macquarie); und ein Experiment von Buxton belehrt uns, daß sie auch in den englischen Wäldern im Freien überwintern und sich fortpflanzen köunen, denn selbst bei einer Temperatur von $-7^{0}$ ging kein einziges Exemplar zugrunde. Es unterliegt also keinem $Z$ weifel, daB einige Tropenbewohner auch kältere Klimate ertragen können, besonders dann, wenn sie keinen großen Temperaturschwankungen ausgesetzt sind. Das ist eben der Charakterzug, den das Seeklima der höheren Breiten mit dem Äquatorialklima gemein hat (vgl. Karte IX). Daher nähern sich tropische Tiere auf der südlichen Halbkugel mehr dem Pol als auf der nördlichen, während anderseits z. B. die Tatsache, daß Westeuropa keine Papageien beherbergt, nicht durch die 
Isothermen bedingt ist, sondern offenbar nur mit der Entwickelungsund Verbreitungsgeschichte dieser Ordnung zusammenhängt.

Tropische Tierwelt. Trotz des faunistischen Reichtums des heißen Erdgürtels wird hier die Tierwelt von der üppigen Vegetationsfülle völlig erdrückt. „Der erste Eindruck, den man in den Tropenwaldungen empfängt,“" sagt WaLLACE, ,ist der, daß fast kein tierisches Leben zu finden ist. Man will das Wild, das Geflügel, die Insekten sehen und späht gar oft vergebens nach ihnen aus." Am meisten fallen nicht die großen Säugetiere, sondern die Tagschmetterlinge auf, die sich durch Arten- und Individuenzahl, durch Größe und Farbenpracht von denen der gemäBigten Zone wesentlich unterscheiden. Bei Para (an der Amazonasmündung) allein hat man über 700 Arten gesammelt, während England nur 54 und Deutschland nur ungefähr 150 besitzt. Ebenso setzt die Größe mancher Arten den Reisenden in Erstaunen, denn einige Papilioniden und Morphiden messen mit angespannten Flügeln $15-20 \mathrm{~cm}$. Von den übrigen Insekten machen sich besonders die Ameisen durch ihre Allgegenwart und Zerstörungswut unangenehm bemerkbar; manche dringen in die Häuser ein und fressen alles Genießbare, so daß man die Möbel auf Klötze oder Steine und diese in wassergefüllte Behälter stellen muß, um sie vor der Invasion der Ameisen zu schützen. Zahlreich, groß und teilweise brillant gefärbt sind auch die übrigen Insekten, wie die Bienen, Wespen, Käfer, und von den ungeflügelten Gliedertieren hauptsächlich die Spinnen, Skorpione und Tausendfüßer. Namentlich von den letzteren sieht man oft riesige Exemplare; aber es gibt auch Spinnen, deren Leib $5 \mathrm{~cm}$ lang ist, und die mit ausgestreckten Beinen $15 \mathrm{~cm}$ messen. Ihre Gespinste sind manchmal so stark wie Seide und können selbst größeren Tieren gefährlich werden; hat doch Bates beobachtet, wie eine Spinne aus dem südamerikanischen Geschlecht Mygale einen Vogel tötete. Die Größe der Insekten ist unstreitig geographisch bedingt, nämlich durch die reichliche Nahrung und die geringe Temperaturschwankung, die das Wachstum der Larven niemals unterbricht.

Nach den Insekten sind die Vögel am zahlreichsten und wie jene durch glänzende Färbung ausgezeichnet. Außerordentlich häufig begegnet man auch den Eidechsen, die sogar in die Häuser dringen, während die Schlangen glücklicherweise nicht in so großen Mengen auftreten und nur in trockenen Distrikten sehr lästig werden. Dafür zeugt aber die Größe mancher Arten aus dieser Klasse von der unerschöpflichen Lebensfülle der Tropenwelt. Ein Schlinger der Alten Welt erreicht eine Länge von $8 \mathrm{~m}$, wird aber weit übertroffen von der südamerikanischen Anakonda, die $12 \mathrm{~m}$ mißt und selbst 
ausgewachsene Rinder bewältigt und verzehrt. $\mathrm{Zu}$ den hervorstechenden Charaktertypen der Tropenfauna können auch die allgemein verbreiteten Krokodile ${ }^{x}$ und ihre beiden Verwandten, der ostindische Gavial und der amerikanische Alligator, gerechnet werden, obwohl letzterer auch im unteren Mississippi und in Texas heimisch ist. Von den Amphibien sind nur die Kröten und Frösche häufiger, und von den Landsäugern sind die Affen und die Flattertiere, die zwischen den Wendekreisen den Höhepunkt ihrer Entwickelung erreichen, als tropische Repräsentanten zu nennen, denn die zahlreichen anderen Familien fallen entweder nicht auf oder sind nur auf kleine Bezirke beschränkt. Hinzuzufügen wären vielleicht noch die Edentaten, insofern diese seltsamen Überreste einer alten Fauna, die sich nur in den warmen Ländern noch erhalten haben, den $\mathrm{Zu}-$ sammenhang der jetzigen tropischen Tierwelt mit der tertiären uns besonders klar vor Augen führen.

Polare Tierwelt. Betrachten wir nun das Gegenstück zu diesem Tropenbild, die arktische Fauna. Die Familienzahl der Landsäugetiere, die in den tropischen Reichen 69 beträgt, ist hier auf $\mathrm{S}$ zusammengeschmolzen, und auch diese sind nur durch ungefähr 16 Arten vertreten. Der König der Eiszone ist der Polarbär, der sich an Größe und Kraft mit den tropischen Katzen wohl messen kann; der Polarfuchs und der Fjällfras (irrtümlich Vielfraß genannt) begleiten ihn durch das ganze Gebiet. Wölfe werden noch stellenweise in arktischen Gegenden angetroffen, wenn sie auch nicht zu den eigentlichen Polartieren gehören, wie ein anderer Vertreter der Familie der Canidae, ein wolfsähnlicher Hund, von dem der Eskimo im nordwestlichen Grönland völlig abhängig ist. Die arktischen Ausläufer der Wiederkäuer sind das Renntier und der Moschusochs, und die Nagetierordnung ist durch die Polarhasen, die niedlichen Lemminge und die kosmopolitischen Mäuse vertreten. Aber so dürftig auch die arktische Säugetierfauna ist, so entbehrt doch, soweit man die Zone kennt, keine Gegend ihrer völlig. Renntiere trafen Kane und Hayes im nordwestlichsten Teil von Grönland, und Fährten dieses Wiederkäuers fand man in Franz-Josef-Land. Der Moschusochse verbreitet sich nach NАTновST von dem polaren Amerika über die Inseln bis zum Grantland und in Grönland, wenn auch jetzt mit vielen Lücken, bis zum 83. Parallel. Die Mitglieder der „Fram“-Expedition erlegten noch unter $82^{\circ}$ B., mitten im Eismeer und wenigstens $500 \mathrm{~km}$ von dem nächsten bekannten Land entfernt, einen Eisbären. Reichhaltiger ist die Vogelfauna; die Familien

$\times$ Im Sinn der Systematik von A. Günther. 
der Möven, Enten, Gänse, Regenpfeifer, Schnepfen und Alken haben in der arktischen Zone ihre Heimat, und im ganzen werden hier nach Reichenow ${ }^{5} 150$ Arten regelmäBig beobachtet. Gegen den Pol hin nimmt die Artenzahl rasch ab, denn während z. B. die Sperlinge südlich vom 68. Parallel noch in 20 Arten vorkommen, werden sie nördlich davon auf 4 und jenseits von $74^{\circ} \mathrm{B}$. auf 2 Arten reduziert. Die meisten Vögel wandern im Winter und kehren im Frühjahr wieder nach dem Norden zurück; um hier in großen Gesellschaften (sogen. „Vogelbergen“) zu brüten. Selten finden sich Reptilien; die Insektenfauna ist besonders nördlich vom 73. Parallel sehr ärmlich. In ihr herrschen die Zweiflügler, die für ihre ersten Entwickelungsstadien nur eine kurze Zeit bedürfen, entschieden vor; Mückenschwärme hinderten JoHN Ross' Mannschaft unter $70^{\circ} \mathrm{B}$. an der Arbeit; sie sind in vielen polaren Gegenden eine wahre Landplage. Das Tierleben tritt also auch hier zurück wie in den Tropen freilich aus einem ganz anderen Grund und in ganz anderer Weise. Kein Laut stört die feierliche Stille der nordischen Einöde, aber das muntere Tierleben des Meeres zeigt uns, daß wir auch hier noch nicht an den Grenzen der organischen Welt angelangt sind.

Auch das antarktische Meer ist reich belebt, um so dürftiger ist aber die Fauna der Inseln. Allerdings nicht an Individuen, denn in Kolonien von vielen tausend Köpfen bedecken dichtgedrängt die Pinguine das Land, jene merkwürdigen Vögel, die nicht fliegen, aber mit den Fischen um die Wette schwimmen können und durch ihre lächerliche Ähnlichkeit mit der menschlichen Gestalt von jeher die Verwunderung der Reisenden erregt haben. Aber sie sind auch die einzigen größeren Bewohner dieser weltabgeschiedenen Eisländer, und außer ihnen wurden nur noch hier und da kleine Insekten gefunden.

Vertikale Verteilung. Die Abnahme der Landtiere gegen die Pole kehrt selbstverständlich auch in vertikaler Richtung im Ge. birge wieder. Nur sind die Höhengrenzen der beweglichen Tiere selten so genau zu fixieren wie die der Pflanzen, die an den Boden gefesselt sind, und es ist erklärlich, daß zeitraubende systematische Untersuchungen in dieser Richtung nur selten angestellt werden. Doch lassen sich aus den vorhandenen Beobachtungen in verschiedenen Teilen der Alpen einige Sätze von allgemeinerer Bedeutung ableiten. Heen ${ }^{6}$ zeigte, daß im Kanton Glarus die vertikale Abnahme der Arten in der Tierwelt viel rascher erfolgt als in der Flora. In der unteren Region (bis $800 \mathrm{~m}$ ) ist die Zahl der Tierarten $2^{3} / 4$ mal größer als die der Pflanzenarten, aber in bedeutenderen Höhen ist das Verhältnis umgekehrt. In der Region der Alpen- 
sträucher kommt nur eine Tierart auf $1 \frac{1}{7}$ Pflanzenarten; dort, wo der Schnee schon sporadisch liegen bleibt, stellt sich das Verhältnis wie $1: 6$, und an der Grenze des organischen Lebens sogar wie $1: 2$ . Die Baumlinie übt auf die Verbreitung der Tiere im Tiroler Hochgebirge einen viel geringeren Einfluß aus als die Grenze zwischen der Region der alpinen Wiesen (1700-2300 m) und der subnivalen Region (2300-2700 m); der faunistische Gegensatz dieser beiden Höhengürtel ist eines der auffallendsten Resultate der Untersuchungen von Heller. ${ }^{7}$ Eine Zusammenstellung aus dessen Verzeichnissen ergibt nämlich, daß von den 90 Hochgebirgsarten (und Varietäten) der Weichtiere in der alpinen Region noch 76 , in der subnivalen aber nur 8 vorkommen; ferner daß von den 785 Schmetterlingen 680 in der alpinen und nur 98 in der subnivalen Region leben; endlich daß von den 738 Käfern 730 in der Wiesen- und nur 106 in der subnivalen Region gefunden werden. Der Zusammenhang mit der Pflanzenwelt tritt hier sehr scharf zutage, wie er sich auch darin zeigt, daß die südlichen Gehänge von einer reicheren und mannigfaltigeren Fauna bevölkert sind als die nördlichen, und daß dort die Höhengrenzen weiter hinaufrücken. Die obere Schneeregion (über $2700 \mathrm{~m}$ ) beherbergt nur wenige flügellose Gliedertiere, die wohl den größten Teil des Jahres, im Winterschlaf zubringen. Vielleicht am höchsten steigt der Weberknecht (Opilio glacialis), der selbst auf der obersten Spitze des Piz Linard $(3480 \mathrm{~m})$ gefunden wurde. Wohl dringen auch geflügelte Tiere, wie Schmetterlinge, Käfer, Fliegen u. a. entweder freiwillig bei ihrem Ausschwärmen oder vom Winde erfaßt in die Firnwelt vor, aber sie gehen hier in der Regel bald zugrunde. Der Sommer sieht hier auch Gestalten aus der höheren Tierwelt, aber der Winter scheucht die meisten bis in den Waldgürtel hinab.

Periodizität im Tierleben. Die Abhängigkeit des Tierlebens vom Klima zeigt sich auch, ähnlich wie bei den Pflanzen, in seiner jährlichen Periode. In den höheren Breiten, wo der Gegensatz zwischen kalter und warmer Jahreszeit schärfer hervortritt, ist der Winter in der Tierwelt die tote Saison. Die Mehrzahl der Vögel ist in wärmere Gegenden abgezogen, viele Säugetiere, Insekten, Mollusken usw. fallen in den Winterschlaf, zahlreiche niedere Tiere sterben ab, nachdem sie ihre Eier, die sich im nächsten Frühjahr entwickeln, gelegt haben. Die Ursache der winterlichen Erstarrung und des Wanderns mag wohl in zahlreichen Fällen ebenso der Mangel an Nahrung wie die Kälte sein; Nahrungssorgen dürften hauptsächlich die nordischen Tiere, wie den Moschusochsen und den Lemming, zwingen, scharenweise ihre Heimat zu verlassen, in die 
sie beim Eintritt der milderen Jahreszeit wieder zurückkehren. Dágegen ist der zeitweilige Kälteschlaf einiger tropischer Tiere, wie mancher Schlangen und Eidechsen, jedenfalls nur klimatisch bedingt, desgleichen die Wanderungen einiger bengalischer Affen oder der Elefanten in Tenasserim oder der Renntiere, die sich in der heißen Zeit in die höheren Gebirgsregionen zurückziehen. In der warmen Zone beschränkt die gleichmäßigere Temperatur (mit Ausnahme der wenigen oben aufgezählten Fälle) das Tierleben ebensowenig wie das Pflanzenleben, wohl aber äußert sich der Einfluß der Trockenzeit in ähnlicher Weise, wie der des Winters in unseren Gegenden. Daß die Einwirkung auf den tierischen Organismus in beiden Fällen gleich ist, beweist schon der Umstand, daß der aus fremden Ländern zu uns gebrachte Siebenschläfer, der in seiner Heimat zurzeit der trockenen Hitze sein aktives Leben unterbricht, in der nordischen Fremde in den Winterschlaf verfällt. Aber die Beispiele einer Einschränkung der Lebenstätigkeit durch die jährliche Regenperiode der Tropen sind in höheren Tierklassen doch nur selten, und selbst von niederen Tieren findet man das ganze Jahr hindurch Eier, Larven und geschlechtsreife Individuen zu gleicher Zeit. Anderseits hat man aber auch häufig die Beobachtung gemacht, daß die Zahl der Larven sich beim Beginn der Regenzeit erheblich steigert, und man weiß auch, da $B$ viele tropische Insekten in der trockenen Periode sterben. In den Mittelmeerländern verfallen die Landschnecken während der regenlosen Sommerzeit in einen Ruhezustand und unterbrechen auch ihr Wachstum, ja in der Sahara führen sie ein aktives Leben überhaupt nur in der Nacht oder am frühen Morgen, wenn Tau den Boden befeuchtet.

Beziehungen der Tiere zueinander und zu dem Menschen. Neben der Einwirkung der toten Natur und der Pflanzenwelt auf das Tierleben ist noch ein anderes Moment zu beachten: die Beziehungen der einzelnen Tiere zueinander. Hier stehen wir aber schon knapp an der Grenze des rein zoologischen Forschungsgebietes, die wir im Interesse unserer Wissenschaft nicht überschreiten werden. Doch können wir uns nicht enthalten, zwei Fälle zu erwähnen, die geographisch von größter Bedeutung sind.

Der erste Fall betrifft die afrikanische Tsetsefliege, die sich nach Austen's Untersuchungen ${ }^{8}$ in Westafrika vom Senegal bis zum Kongo und in Ostafrika vom Jub bis zur Delagoabai verbreitet. Ihr Stich ist nach den Berichten zahlreicher Reisender für Rinder, Pferde, Kamele und Hunde absolut tödlich, dagegen für den Menschen, für alle wilden Tiere, für die Kälber, solange sie saugen, und angeblich auch für Esel und Ziegen unschädlich. Dieser unscheinbare 
Zweiflügler schließt demnach aus seinem Verbreitungsbezirk die Viehzucht aus. Daher war man hier auf den Menschen als Transportmittel angewiesen, und dieser Umstand bildete ein Haupthindernis sowohl der wissenschaftlichen, wie der wirtschaftlichen Erschließung des tropischen Afrika; schon aus diesem Grund sind hier Eisenbahnen eine Lebensfrage allerersten Ranges. Aber nicht an sich ist die Tsetsefliege schädlich, sondern nur als Trägerin eines Parasiten, den sie dem gestochenen Tier einimpft. Auch als Vermittlerin der verheerenden Schlafkrankheit gehört sie zu den Schrecken des tropischen Afrika. Ein gleicher Vorgang ruft in Indien die gefürchtete Surrakrankheit hervor, und an der Küste von Deutsch-Ostafrika sind es nach R. Koch ${ }^{9}$ Rinderzecken, die als Infektionsvermittler die Rinderherden dezimieren. Diese Krankheit entspricht nach КосH völlig dem nordamerikanischen Texasfieber.

Eine noch verhängnisvollere Rolle als diese Insekten spielen in den Tropen gewisse Moskitos. In ihnen hat KocH die hauptsächlichsten Verbreiter des Malariagiftes erkannt, das den größten Teil der heißen Zone für den Weißen unbewohnbar macht. Eine Ausnahme machen nur die Wüsten, die Hochländer und gewisse Gegenden, die aus unbekannten Gründen moskitofrei sind. Wäre es möglich, jene Moskitos zu vernichten oder unschädlich zu machen, so würde das ganze wirtschaftliche Leben der Tropen eine Umgestaltung von ungeheuerer Tragweite erfahren.

Literaturnachweise. ${ }^{1}$ Тн. Fucнs, Die pelagisehe Flora und Fauna, in den Verhandlungen der Wiener Geologischen Reichsanstalt 1882. - ${ }^{2} \mathrm{Be}-$ richt von K. BRANDT in den Verhandlungen der Berliner Gesellschaft für Erdkunde, 1889, S. 515. $-{ }^{3}$ K. Semper, Die natürlichen Existenzbedingungen der Tiere; Leipzig 1880. - ${ }^{4}$ A. R. Wallace, Die Tropenwelt; Braunsehweig 1879. $-{ }^{5}$ A. Reichenow, Die Begrenzung zoogeographischer Regionen vom ornithologisehen Standpunkt, in den Zoologischen Jahrbüchern, 1888, Bd. III. ${ }^{6}$ Historisch-geographisch-statistisches Gemälde der Schweiz, Bd. VII, 1846. ${ }^{7}$ C. Heller, Die Verbreitung der Tierwelt im Tiroler Hochgebirge, in den Sitzungsberichten der Wiener Akademie der Wissenschaften, Mathem.-naturwiss. Klasse; Bd. LXXXIII, 1. Abteil. (1881) und Bd. LXXXVI, 1. Abteil. (1882). ${ }^{8}$ E. E. Austen, A Monograph of the Tse-Tse-Flies; London 1903; The Distribution of the Tse Tse-Flies, in Reports of the Sleeping Sickness Commission of the Royal Society, 1905. Seine hier erschienene Karte der Verbreitung der versehiedenen Glossina-Arten auch in La Géographie, 1905, Bd. XII, S. 433. - ${ }^{9}$ Rовегт Косн, Reiseberichte über Rinderpest, Bubonenpest in Indien und Afrika, Tsetse- oder Surrakrankheit, Texasfieber, tropische Malaria und Schwarzwasserfieber; Berlin 1898.

Die Flora und Fauna der Tropen und der südlichen Halbkugel.

Verbreitungstypen. Die Verbreitung einer Art aus dem Tierwie aus dem Pflanzenreich ist entweder durch aktive Wanderung 
oder passive Verschleppung von ihrem Entwickelungszentrum aus zu erklären. ${ }^{*}$ An einigen Beispielen aus dem PHanzenreich mögen die verschiedenen Typen der geographischen Verteilung erläutert werden.

Am Simplon bewohnt eine Glockenblume, Campanula excisa, einen wohlabgerundeten Bezirk, über den sie noch nicht weiter hinausgedrungen ist. Hier decken sich Entwickelungszentrum und Verbreitungsbezirk, aber derartig genügsamer Gewächse gibt es verhältnismäßig nicht viele. Der Kampf ums Dasein, der ja eigentlich ein Kampf um den Raum ist, drängt zur Ausbreitung, und verschiedene Zufälligkeiten hemmen oder fördern die Organismen in ihrem Bestreben. Das canadische Berufkraut (Erigeron canadensis) wurde angeblich mit einem ausgestopften Vogelbalg nach Europa rerschleppt und neben seinem Entwickelungszentrum in der Neuen Welt entstand nun auch ein Ansiedlungszentrum in der Alten, von dem aus in kurzer Zeit weite Bezirke erobert wurden. 1655 wird es zuerst als Gartenpflanze im botanischen Garten zu Blois erwähnt, aber noch 1763 gibt Linve als Verbreitungsgebiet nur Amerika und Südeuropa an. Seitdem ist es, unterstützt durch die Flugfähigkeit seines mit einem Fallschirm versehenen Samens, nach Norden wie nach Osten vorgedrungen, und hat sich von England bis zum Altai und von Sizilien bis Schweden ansässig gemacht. Manche Arten haben sich nur noch an wenigen, weit voneinander entfernten Gegenden erhalten, wie die Monotropa uniflora und die Phryma Leptostachya, die das östliche Nordamerika, Japan und den Himalaya, letztere auch die Gegenden am Amur und westlich von Peking bewohnen. Diese Verbreitungsart läßt sich durch die Annahme erklären, daß die betreffenden Pflanzen an den Zwischenstationen ausgestorben sind, und ENGLer faßt sie daher als die kümmerlichen Reste einer einst weit verbreiteten Tertiärflora auf. Zu demselben Schluß gelangen wir in bezug auf das Vorkommen mancher nahe verwandter, aber vikariierender Arten an weit entlegenen Punkten. Das Geschlecht Liquidambar ist jetzt durch je eine Art in Kleinasien, in Japan und in den atlantischen Staaten von Nordamerika vertreten, aber in der Miozänzeit lebte es auch im übrigen Nordamerika, in Grönland, in Mitteleuropa und in Italien. Zwei andere Geschlechter liefern uns Beispiele eines noch fortgeschritteneren

$\times$ Die Voraussetzung dabei ist, daß eine Art sich nur einmal und an einem einzigen Ort entwickelt hat. Die entgegengesetzte Theorie, die in der Botanik in neuester Zeit Briquer vertritt, wird von der überwiegenden Mehrzahl der Botaniker abgelehnt und würde in der Tat auch zur Erklärung der pflanzengeographischen Verhältnisse wenig beitragen. 
Verfalles. Das Genus Sequoia gliedert sich in 26 Arten, von denen aber nur noch zwei, S. gigantea (Wellingtonia oder Mammutbaum, die gröBte Konifere der Jetztzeit) und S. sempervirens, im pazifischen Nordamerika von Californien bis Oregon leben, während die fossilen Arten im ganzen nördlichen Waldgürtel und in der arktischen Zone gefunden werden. Die Blüteperiode des Gingko fällt in den mittleren Jura; schon im Tertiär zeigen sich deutliche Spuren des Niedergangs, wenn sich auch der Verbreitungsbezirk noch über den ganzen Norden ausdehnte, und in der Gegenwart ist er nur auf das östliche Asien beschränkt.

Die angeführten Beispiele belehren uns zugleich über die verschiedenen Arten des Endemismus. Endemische Gewächse sind sowohl die Glockenblume am Simplon, wie die Sequoia Californiens, aber in jenem Fall ist die Heimat zugleich das Entwickelungszentrum, in diesem aber nur die Zufluchtsstätte der letzten Vertreter einer untergehenden Form.

Nicht in allen Fällen reicht die Reliktentheorie aus. Die Ölpalme bewohnt das westliche Afrika bis an das Seengebiet und das Mündungsland des Amazonas. Kein greisenhafter Zug macht sich an dieser wichtigen Pflanze bemerkbar, kein paläontologischer Fund deutet auf eine einst weitere Verbreitung im Norden hin. Hier ist die Annahme gerechtfertigt, daß das Entwickelungszentrum in Südamerika liegt, weil sich hier die nächsten Verwandten der Ölpalme befinden, und daß sie entweder durch Verschleppung oder Wanderung nach Afrika gelangt ist. Im letzteren Fall ist man natürlich genötigt, entweder eine Landbrücke über den Atlantischen Ozean zu schlagen oder wenigstens durch eine Reihe jetzt verschwundener Inseln eine Verbindung herzustellen.

In der Tierwelt begegnen wir denselben Verbreitungstypen. Es gibt z. B. Landschneckenarten, die nur auf einen Berg, ja nur auf einen Fels beschränkt sind; es gibt Tiere, wie die Ratten und Mäuse, die man mit vollem Recht als Kosmopoliten bezeichnen kann, und nicht minder häufig als im Pflanzenreich kommt sprungweise Verbreitung vor. Ebenso lassen sich, wie wir später hören werden, zahlreiche Beispiele dafür anführen, daß auch die Verbreitungsgrenzen der Tierarten sich noch beständig verschieben.

Die heutige Verteilung der Floren und Faunen ist, wie alle geographischen Phänomene, das Ergebnis einer langen und noch nicht abgeschlossenen Entwickelung. Beide organischen Reiche bestehen aus Elementen von sehr verschiedenem Alter, geradeso wie die Formen der festen Erdoberfläche. Soweit jene Elemente zurückreichen, immer herrschte das Bestreben nach Ausbreitung, und immer 
setzten klimatische Unterschiede, Gebirge und Hochländer und das Meer ihnen Schranken. Diese Schranken waren aber, wie wir aus der Geologie wissen, selbst Veränderungen unterworfen, und diese spiegeln sich in der Verteilung der Pflanzen und Tiere wieder. Da durch wird die Biogeographie ${ }^{1}$ zu einem erdgeschichtlichen Dokument von unschätzbarem Wert, und der moderne Geograph kann ihrer als Hilfswissenschaft nicht entraten, wenn er auch ihren Ausbau den Botanikern und Zoologen überlassen muß. Für das Studium der großen Klimaschwankungen leistet besonders die Pflanzengeographie ausgezeichnete Dienste nicht nur wegen der Empfindlichkeit der Pflanzen gegen Feuchtigkeit und Temperatur, sondern auch wegen ihrer Anpassungsfähigkeit, über die BonnIER's ${ }^{2}$ Experimente neuerdings Licht verbreitet haben. Dagegen kommen terrestrische Veränderungen am schärfsten in der Verbreitung jener Organismen zum Ausdruck, die am wenigsten der Verschleppung unterliegen und größere Wasserflächen nicht überschreiten können. Diesen Bedingungen entsprechen die Landsäugetiere, soweit sie nicht flugbegabt sind; und da sie sich auch der Beobachtung zuerst aufdrängen und daher am besten gekannt sind, so nahmen sie bis auf die neueste Zeit in den tiergeographischen Untersuchungen die erste Stelle ein. ${ }^{3} \quad$ Fledermäuse und Vögel sind zwar nicht so fest an die Scholle gebunden, aber ihre Transportfähigkeit durch Flug und durch zufällige Ereignisse ist doch von manchem Tiergeographen überschätzt worden. Zahlreiche Vorkommnisse sind nur unter der Annahme erklärbar, daß auch manche dieser flugfähigen Tiere nicht bloß vor weiten Meeren, sondern manchmal auch vor engen Meeresstraßen Halt machen; und daher kommt es auch, daß eine Einteilung der Erde in Vogelgebiete im großen und ganzen mit der Einteilung in Säugetiergebiete zusammenfällt. Gegen die Verwendung dieser höchsten Klassen hat sich indes in letzter Zeit eine scharfe Opposition erhoben. Man hat betont, daß es nicht genüge, die gegenwärtige Verbreitung zu kennen, sondern daß man sie auch in die geologische Vergangenheit zurückverfolgen müsse, um über ihre Wanderungen AufschluB zu erhalten. Zwar ist man über die Stammesgeschichte der Säugetiere am besten unterrichtet, aber ihre Jugend hat sie etwas in Mißkredit gebracht. Beutler erscheinen erst in der oberen Trias, und die Ahnen der heute noch lebenden Familien aus dieser Ordnung treten erst in der oberen Kreide auf. Überreste von plazentalen Säugern liefern zum ersten Male die Eozänschichten, und noch später, im Neogen, beginnen sich diejenigen Formen zu entwickeln, die zu den gegenwärtigen hinüberleiten. Manche bevorzugen daher Tierklassen, deren Stammbaum viel tiefer in der geolo- 
gischen Geschichte wurzelt: IHering ${ }^{4}$ und Ortmann ${ }^{5}$ die Süßwasserfauna, Kobelt ${ }^{6}$ die Landschnecken, Mrchaelsen ${ }^{7}$ die Regenwürmer. Ohne Zweifel werden dadurch ganz neue Beziehungen der Länder zueinander offenbar; alte Landverbindungen, die zur Zeit der Säugetierwanderungen bereits aufgelöst waren, und alte Inselräume, die zu jener 7 git den Kontinenten bereits angeschweißt waren, treten zutage wie eine alte Schrift auf einem Palimpsest. Diese vielversprechenden Anfänge fordern zu weiteren Studien auf dem Gebiete der Mikrofauna auf, aber nur durch die Vereinigung der nicht immer übereinstimmenden Ergebnisse der Spezialforschung wird sich Klarheit in die verwickelten Verhältnisse ehemaliger geographischer Gruppierungen bringen lassen. Noch stehen wir in der Periode der Hypothesen, aber schon diese eröffnen eine weite Perspektive.

Die Tropen der Aiten und der Neuen Welt. Aus Engler's Tabelle der dikotylen Angiospermen geht hervor, daß von den 3617 Gattungen, die in der warmen Zone vorkommen, 931/2 Prozent rein oder doch vorherrschend tropisch und nur $6 \frac{1}{2}$ Prozent in höheren Breiten heimisch sind. Von jenen überschreiten nur etwa 20 Prozent die Tropenzone, und ungefähr 73 Prozent sind nur innerhalb dieser verbreitet. Die Statistik bestätigt also die Eigenart und den Reichtum der tropischen Flora; sie liefert aber auch den Beweis, daB die warmen Gegenden der Alten und der Neuen Welt trotz der Übereinstimmung der klimatischen Verhältnisse in bezug auf die Flora bedeutend voneinander abweichen. Nur $12^{1} / 2$ Prozent der dikotylen Angiospermen sind beiden Hemisphären gemeinsam, während 40 auf die westliche und über 47 Prozent auf die östliche Halbkugel beschränkt sind. Es besteht also ein tiefgreifender floristischer Gegensatz zwischen den Tropen der Alten und der Neuen Welt, wenn er auch durch EngLeR's neueste Untersuchungen über die afrikanische Pflanzenwelt etwas gemildert wird. Was das tropische Amerika vor Afrika voraus hat, ist vor allem die reiche Entwickelung der Ananasgewächse, Kakteen, Agaven, Anthurien, Philodendren und Vochysien. Der Formenreichtum ist in beiden Hemisphären nahezu gleich und auf der östlichen in Indien-entschieden gröBer als in Afrika.

Dieselben Gegensätze treten uns, nur noch verschärft, in der höheren Tierwelt entgegen. Wenn wir die Abkömmlinge dieser Tierklassen aus der Tertiärzeit am vollständigsten beisammen finden wollen, müssen wir nach Ostindien gehen. Dieses Tropenreich besitzt relativ die meisten Säugetiere und Landvögel, und es unterliegt keinem Zweifel, daß es diesen Reichtum seiner dauernden Verbindung mit der großen asiatisch-europäischen Festlandmasse, 
der Geburtssätte der meisten modernen Tierformen, verdankt. Als der eigentümlichste Charakterzug in seiner Säugetierfauna dürfte die bedeutende Menge von Raubtieren anzusehen sein; denn wenn auch in Afrika nahezu gleichviel Arten vorkommen wie in Ostindien, so beträgt doch die mittlere Artendichtigkeit (auf die Mill. qkm bezogen) hier 10 und dort nicht ganz 4. Die ostindische Vogelwelt ist in allen Ordnungen, mit Ausnahme der hier fehlenden Kurzflügler, mannigfaltiger als die afrikanische, und mit Ausnahme der Spechte und Papageien übertrifft sie auch die südamerikanische.

Zwischen Afrika und Europa-Asien bestanden in der jüngeren Tertiärzeit und im Diluvium Zusammenhänge einerseits durch die Landbrücken von Gibraltar und zwischen Tunis und Sizilien, anderseits im Nordosten, wo der Einbruch des Roten Meeres erst spät die Verbindung mit Asien löste. Die Sahara, die sich einst eines günstigeren Klimas erfreute, bildete nur für die Schnecken eine Schranke, gestattete aber einen regen Austausch in der leichter beweglichen Tierwelt. Die Affen, die Löwen, Leoparden und Hyänen, die Einhufer (Zebra und Verwandte), die Elefanten, Nashörner und Flußpferde, die Giraffen, Gazellen und Büffel sind die hervorragendsten osthemisphärischen Typen der afrikanischen Fauna, denn auch von den altmodischen Familien der Giraffen und Flußpferde, die jetzt auf Afrika beschränkt sind, wissen wir, daß sie einst weit über die Alte Welt verbreitet waren. Um so mehr überrascht das Fehlen anderer für Europa-Asien charakteristischer Säugetiergruppen: der Bären und Maulwürfe, der Hirsche, Ziegen und Schafe, des wilden Ochsen (Bos) und des wilden Schweins (Sus), aber einige davon sind fossil gefunden worden, darunter auch das Kamel, das in geschichtlicher Zeit durch den Menschen wieder eingeführt wurde. ${ }^{8}$ Nordund Südamerika trennten sich am Beginn der Tertiärzeit. Die merkwürdige Säugetierfauna der untermiozänen Santa Cruz-Schichten von Argentinien besteht aus Beutlern und Zahnarmen; von den noch lebenden plazentalen Ordnungen sind nur die Nager, die unpaarzehigen Huftiere und die breitnasigen Affen vertreten. Gerade das, was damals den Faunen der nördlichen Festländer ihr charakteristisches Gepräge verlieh: Halbaffen, Fledermäuse, Raubtiere, Insektenfresser, paarzehige Huftiere - fehlt in den Santa Cruz-Schichten völlig. Erst in der Pliozänzeit vollzieht sich der (vorerst vielleicht nur vorübergehende) Zusammenschluß von Nord- und Südamerika, und nun beginnt sofort die faunistische Vermischung. Schon in den Monte-Hermoso-Schichten Südamerikas erscheinen nordische Typen, und in den ungefähr gleichalten Loup-Fork-Schichten Nebraskas treten zum ersten Male südliche Einwanderer auf. In Zentral- 
amerika und in den mexicanischen Küstenländern haben sie den Sieg davongetragen, so daß WALLACE diese Länder zum südamerikanischen Reiche rechnen durfte.

Anders in Südamerika selbst. Seine Fauna ist freilich nur mehr in verkümmerter Form erhalten. Eine erhebliche Zahl von Säugetierarten, die durch Größe ausgezeichnet waren und noch in der Diluvialzeit die Pampas bevölkerten, sind verschwunden, und wahrscheinlich war schon der Mensch Zeuge dieses großen, noch immer rätselhaften Sterbens. Aber der Charakter der Fauna ist dadurch in seinen Hauptzügen nicht verändert worden. Wie durch die spanisch-portugiesische Eroberung dem alten Volkstum nur einige neue Elemente hinzugefügt wurden, ohne es vernichten zu können, so verhält es sich auch im Bereich der Säugetierwelt. Noch lebt hier die Beutelratte; und wenn die Zahnarmen auch schon im Diluvium den Höhepunkt ihrer Entwickelung überschritten haben, so sind sie doch immer noch in ansehnlicher Weise durch die Familien der Ameisenbären, der Faul- und der Gürteltiere vertreten. Die Affen der Neuen und der Alten Welt sind noch immer streng voneinander geschieden, keine einzige Familie ist ihnen gemeinsam. Die Nager nehmen zwar überall mit Ausnahme von Australien in bezug auf Artenzahl den ersten Rang unter den Landsäugern ein, aber Südamerika ist hierin doch allen anderen Kontinenten voraus. Das trifft sogar in der kosmopolitischen Familie der Ratten und Mäuse zu. Die Hufpfötler, die größte Form dieser Ordnung, die Baumstachelschweine und die Chinchillas sind ausschlieBlich südamerikanisch, und Strauchratten und Borstenferkel kommen sonst nur sporadisch vor. Dagegen sind die fremden Typen zu keiner hervorragenden Bedeutung gelangt, ausgenommen die Fledermäuse, von denen die Blattnasen - wozu der berühmte blutsaugende Vampyr gehört - nur auf Amerika beschränkt sind. Am auffallendsten ist das Fehlen der großen Ordnung der Insektenfresser; denn die Familie des Solenodon kommt nur in Westindien vor, und die Spitzmaus betritt eben erst das Reich im Norden. Von den Dickhäutern fehlen die Elefanten, dagegen hat sich der Tapir, ein uralter Typus, der nur noch im malaiischen Archipel wiederkehrt, hier erhalten, und das kosmopolitische Schwein wird durch die schwanzlose Unterfamilie der Pekari ersetzt. Von den Wiederkäuern ist nur noch die Hirschgattung allgemein verbreitet, da die Antilopen ebenso wie die Einhufer ausgestorben sind; und die Raubtiere stehen denen der Alten Welt nicht nur an Artenreichtum, sondern auch an Größe und Kraft nach. Der Jaguar und der Puma sind nur schwächliche Vertreter des asiatischen Tigers und des afrikanischen Löwen. 
Unendlich reich ist die südamerikanische Vogelwelt; in jeder Ordnung der Landvögel mit Ausnahme der Kurzflügler übertrifft der westliche Südkontinent an absoluter Artenzahl Afrika und Ostindien, und nur in bezug auf die Papageien und Tauben steht er Australien nach. Im brasilianischen Schopfhuhn besitzt er wahrscheinlich den letzten lebenden Repräsentanten einer ausgestorbenen Ordnung. Noch mannigfaltiger ist die Insektenfauna mit ihrem unerschöpflichen Reichtum an schönen Formen; und es ist bezeichnend, daß selbst in dieser Tierklasse, die doch über so viele Verbreitungsmittel verfügt, der Endemismus stark ausgeprägt ist.

Provinzielle Unterschiede in den tropischen Reichen. Aus den bisherigen Erörterungen geht hervor, daß wir in den Tropen und auf der Südhalbkugel (abgesehen von Australien und Madagaskar) drei biogeographische Reiche zu unterscheiden haben: das ostindische, das afrikanische und das südamerikanische. In jedem sind wieder teils klimatisch, teils entwickelungsgeschichtlich bedingte provinzielle Unterschiede bemerkbar.

In Südamerika besteht in Flora und Fauna ein Gegensatz zwischen dem trockenen andinen Westen und dem feuchten Osten, und das andine Gebiet erstreckt sich auch über die außertropischen Niederungen des Ostens. Hier fehlen die Affen, dagegen besitzt es die Chinchillas und die wichtigen Auchenien, die Vertreter des osthemisphärischen Kamels, zu denen die einzigen Haustiere Südamerikas (Lama und Alpaka) gehören. Die Insektenfauna und die Flora des chilenischen Gebirges enthält auch Elemente, die auf Wanderungen aus weiten Fernen schließen lassen, und zum Teil von hohem Alter sind. Auch im tropischen Afrika ist die Waldflora im Osten und Westen erheblich verschieden, ${ }^{9}$ und eine scharfe Faunengrenze liegt dort, wo der äquatoriale Urwald der Savane Platz macht. Den Urwald Guineas bewohnen die großen menschenähnlichen Affen, Gorilla und Schimpanse, und diese, sowie das Zwergmoschustier Hyomoschus und einige Schlangen weisen auf Ostindien hin. Dagegen sind Savane und Steppe die wahre Heimat der großen Huftiere und das ergiebigste Jagdgebiet des Löwen. Am merkwürdigsten ist die Kapflora, die auf den äußersten Südwesten des Festlandes beschränkt ist und auf diesem engen Raum eine unendliche Fülle eigenartiger Gewächse in sich vereinigt. Sträucher aus den Familien der Ericaceen, Proteaceen, Diosmeen, Bruniaceen usw. herrschen vor, und eine Menge von Lilien-, Orchideen- und Irisgewächsen mit herrlichen Blüten lassen dies Ländchen fast als einen Ziergarten erscheinen. Von 548 Gattungen kommen nur 256 auch im tropischen Afrika vor, alle anderen sind endemisch. Nicht ganz 
so eigenartig und selbstverständlich auch über einen größeren Raum verbreitet ist die südafrikanische Fauna, aber auch in ihr fallen zahlreiche endemische Formen auf, wie unter den Säugetieren der insektenfressende Goldmull und der hyänenähnliche Erdwolf, ferner der Klippschliefer, ein Mittelglied zwischen Nagern und Dickhäutern, und das zur Familie der Zahnarmen gehörige Erdferkel, die beide auch noch in Ostafrika leben; endlich eine beträchtliche Anzahl von Vögeln, Reptilien und besonders Käfern. Man gewinnt den Eindruck, als seien in Afrika alte Bewohner von jüngeren Einwanderern nach Süden gedrängt worden, wie die Buschmänner und Hottentotten von den Negern.

In Ostindien spielen das südliche Dekan und Ceylon eine ähnliche Rolle wie Südafrika gegenüber dem übrigen Kontinent, nur ist hier die Ursache eine andere, nämlich die späte Angliederung der vorderindischen Halbinsel ån das Festland. Wir werden noch an anderer Stelle darauf zurückkommen, hier genügt der Hinweis auf die bemerkenswerte Tatsache, daB in beiden organischen Reichen nach dem Süden zu eine zunehmende Differenzierung Platz greift.

Die alten Kontinentalinseln. In der Fauna der großen Antillen haben sich einige altertümliche Züge erhalten, die uns sehr wechselvolle Schicksale dieser Inseln ahnen lassen. So charakteristische Typen des südamerikanischen Festlandes, wie die Beutler, Zahnarmen und Breitnasen, fehlen hier völlig, desgleichen auch die nordischen Einwanderer, die Raub- und die Huftiere. Das erklärt sich vielleicht daraus, daß die Abtrennung der Antillen früher erfolgte als die Vereinigung der beiden Amerika. Dagegen hat sich im Solenodon (oder SchlitzrüBler) der Repräsentant einer offenbar sehr alten Familie erhalten, denn ihre übrigen Glieder, die Borstenigel, leben nur noch auf Madagaskar. Eine ehemalige Verbindung der großen Antillen mit Zentralamerika und Mexico wird durch das gemeinsame Vorkommen einer größeren Zahl von Land- und Süßwassermolluskeln bezeugt, während die Weichtiere der Kleinen Antillen auf Südamerika als Ursprungsland hinweisen. Bei den SüBwasserkrebsen finden wir dieselben Verwandtschaftsverhältnisse, und Ortmann ${ }^{5}$ hat daraus Schlüsse auf die Geschichte dieser Länderräume gezogen, die sich nicht völlig mit der Darstellung von HrLL ${ }^{10}$ decken. Darin stimmen beide überein, daß gegen Ende des mesozoischen Zeitalters hier ein Festland bestand, das Zentralamerika und die Großen Antillen vereinigte, und im Laufe der Tertiärzeit zusammenbrach, als das Karibische Meer entstand. Wir haben schon auf S. 34 auf den tektonischen Zusammenhang zwischen den Gebirgen 
Guatemalas und der Antillen hingewiesen, und nun liefert uns die Fauna dafür ein neues Argument.

Die zweite alte Kontinentalinsel, von der wir hier zu sprechen haben, ist Madagaskar. Aus ihrer Flora und Fauna ist ebenso deutlich ihre einstige Verbindung mit Afrika wie ihre frühzeitige insulare Selbständigkeit ersichtlich. Von den ungefähr 4100 einheimischen Pflanzenarten sind nach BARoN nicht weniger als 3000 endemisch. Die heutige Tierwelt ist sowohl durch das, was sie besitzt, wie durch das, was ihr fehlt, so eigenartig, daß Madagaskar und die benachbarten Inseln mit Recht als ein eigenes Faunenreich proklamiert wurden. Charaktertier ist der Halbaffe, der im ältern Tertiär auch Europa und Nordamerika bewohnte, jetzt aber außer dem tropischen Asien (2 Genera mit 4 Spezies) und Afrika (3 Genera mit 16 Spezies) nur noch auf Madagaskar und zwar in 6 endemischen Genera mit 33 Spezies vorkommt, ungerechnet die ihnen verwandte, auf Madagaskar beschränkte Familie der Aye-Aye. Außerdem erhielten sich hier noch andere seltsame Tiergestalten, wie die endemische Familie der Cryptoproctidae, ein Kollektivtypus von Katze und Zibetkatze, die flugunfähigen Riesenrögel und die Riesenschildkröte der Mascarenen. Manche Tiere sind schon ausgestorben, unter ihnen das Rind und das Flußpferd, ${ }^{11}$ ein Beweis, daß die Landbrücke zwischen Madagaskar und dem Festland noch nicht völlig zerstört war, als sich die jüngere Säugetierwelt über Afrika verbreitete. Aber lange konnte die Verbindung nicht mehr bestanden haben, sonst würden nicht die Affen, die meisten Insektenfresser, Raubtiere, Huftiere und Nager auf Madagaskar fehlen, und im Wettbewerb mit diesen mächtigen Gegnern hätte die alte Fauna ohne Zweifel den Kürzern gezogen.

Australien. Australien ist faunistisch eine Welt für sich. Seine Säugetierfauna trug noch bis zur Ankunft der Europäer vor 140 Jahren ein mesozoisches Gepräge, denn während in der Alten Welt die Beutler überall ausgestorben sind und in der Neuen Welt sich nur noch in einer einzigen Familie (Opossum) erhalten haben, haben sie in Australien ihre herrschende Stellung bewahrt und sich ungehindert fortentwickelt. Da unter ihnen sowohl Raubtiere als Insektenfresser und Nagetiere vorkommen, so erfüllen sie alle jene Aufgaben im Haushalt der Natur, die sonst überall verschiedenen Säugetierordnungen zufallen. Fast noch merkwürdiger sind das eierlegende Schnabeltier und sein Verwandter, der Ameisenigel, die nur in Australien vorkommen. Obwohl das Schnabeltier noch nirgends im fossilen Zustande gefunden wurde, ist es jedenfalls ein Typus von sehr hohem Alter, denn es nimmt eine eigentümliche Mittelstellung 
zwischen der Vogel- und Säugetierklasse ein. Aus allem dem müssen wir schließen, daß Australien spätestens schon im Frühtertiär den Zusammenhang mit der Alten Welt verlor. Von den Plazentalen verirrten sich außer Fledermäusen, die an Verbreitungsfähigkeit nahezu mit den Vögeln wetteifern, nur wenige nach dem abgeschiedenen Australien. Die Familie der Mäuse, die fossil nicht vor dem Miozän vorkommt, ist durch einige endemische, also jedenfalls alteingesessene Gattungen vertreten, aber da sie sehr klein sind, so vermutet LYDEKKER, daß ihre Einwanderung auch ohne eine jungtertiäre Landverbindung stattgefunden habe. Rätselhaft ist der Dingo, angeblich ein verwilderter Haushund, obwohl er schon in den diluvialen Ablagerungen mit ausgestorbenen Beutlern vorkommt. Der vermeintlichen Entdeckung von Zähnen einer dem südamerikanischen Pekari verwandten Schweinsart wird von den Zoologen keine Bedeutung beigemessen. ${ }^{12}$

In der australischen Vogelwelt fehlen auch einige sonst allgemein verbreitete Familien, wie Finken, Spechte, Geier und Fasanen, und andere, die in Ostindien besonders reich entwickelt sind. Dafür sind andere Familien nur auf das australische Reich beschränkt oder überschreiten nur in wenigen Arten seine Grenzen, wie die Paradiesvögel, Honigsauger, Leierschwänze, Strauchvögel, Kakadus, Grassittiche, pinselzüngigen Papageien, Großfußhühner und Casuare. Besonders charakteristisch sind die Honigsauger, die durch das ganze Reich verbreitet sind. Die Papageien und Tauben erreichen hier den Höhepunkt ihrer Entwickelung sowohl in bezug auf Artenzahl wie auch auf Schönheit der Formen und Farbenpracht. Namentlich ist die große Menge von Tauben ebenso lehrreich wie die der Beuteltiere, denn beide verdanken ihre ungestörte Entwickelung nur der Abwesenheit gefährlicher Feinde aus der jüngeren Lebewelt des benachbarten Festlandes.

Überblickt man die Gesamtheit der australischen Fauna, so lassen sich in ihr nach Heduex drei Elemente unterscheiden. Das älteste hat seinen Hauptsitz im Südwesten und wird als autochthon betrachtet; das zweite, zu dem die Säugetiere gehören, umfaßt die älteste Einwanderung, deren Herkunft noch streitig ist; das dritte von Ostindien über Neuguinea zugewanderte, beschränkt sich auf den Nordosten. Vergleicht man damit die Flora, so ergibt sich eine bemerkenswerte Übereinstimmung. Auch die australische Pflanzenwelt, zu deren bekanntesten Formen die Eukalypten, Casuarinen oder Keulenbäume, Grasbäume usw. gehören, trägt einen eigenartigen Charakter. Im allgemeinen kommen hier 425 endemische Gattungen von Gefäßpflanzen vor; anderseits fehlen 24 Familien, die sich über 
beide Hemisphären, und 7, die sich nur über die südliche Hemisphäre verbreiten. Auch diese Umstände weisen auf eine frühzeitige Abtrennung Australiens von dem übrigen Festland hin. Der Gesamtcharakter der Flora ist auf dem ganzen Kontinent derselbe, aber in den Details weichen die einzelnen geographischen Provinzen wesentlich voneinander ab. $\mathrm{Zu}$ dem autochthonen Element gesellt sich außer einem antarktischen, von dem später die Rede sein soll, noch ein indisches, das am artenreichsten in den Regenwäldern des Nordostens auftritt, nach Süden und Westen aber immer mehr an Bedeutung verliert. Im Südwesten hat sich dagegen das autochthone Element noch in voller Reinheit erhalten, und so kommt es, daB wir hier auf kleinem Raum eine Flora finden, die an Endemismus sogar noch die Kapflora übertrifft. Der Grund liegt darin, daß der Westen in der Kreide- und vielleicht noch in der Tertiärperiode durch ein Meer von dem Ostland geschieden war, und dann eine Wüstenschranke an Stelle des Wassers trat. Nur die höheren Tiere haben diese Schranke überschritten.

Der malaiische Archipel und Polynesien. Die organische Welt des malaiischen Archipels birgt eine Menge von Problemen, die seit langer Zeit die Wissenschaft beschäftigen. Wenn wir die Säugetiere berücksichtigen, so gehören Sumatra, Java und Borneo unstreitig zu Asien, und ebenso zweifellos müssen Neuguinea, die Aruund die Kei-Inseln zu Australien gerechnet werden. WaLLace verlegte einst die Grenze zwischen Asien und Australien in die Meerenge zwischen Bali und Lombok, in die Makassarstraße und die Celebes-See, aber die neueren Forschungen haben die Unhaltbarkeit dieser Linie erwiesen. Zwischen die echt asiatischen und echt australischen Inselvorposten schiebt sich vielmehr ein Gebiet mit gemischtem Faunencharakter ein. In den Kleinen Sunda-Inseln erkannte WEBER $^{13}$ eine verarmte indische Tierwelt mit einigen australischen Beimengungen. Die westlichsten Ausläufer der Beuteltierfauna aus der Familie der Phalanger erreichen noch Timor und Celebes. Die Fauna der letztgenannten Insel, um deren Erforschung sich die beiden SARASIN ${ }^{14}$ hochverdient gemacht haben, enthält aber noch eine Reihe anderer altertümlicher Typen, und erwägt man alle Vorkommnisse, so gelangt man zu dem SchluB, daß Celebes zeitweilig mit den Philippinen, den Molukken, Flores und Java, aber nie mit Borneo in Landverbindung stand. Damit stimmen die jüngsten geologischen Forschungen ELBERT's ${ }^{15}$ überein. SO-Celebes, Ostflores, Wetar und Timor sind Bruchstücke eines alten Festlandes, das sich bis in das nordwestliche Australien erstreckte, und anderseits ging eine Landbrücke von SO-Celebes über 
Sumbawa nach Java. Der Zusammenbruch dieser Landmassen eröffnete dem Meer beträchtlich größere Räume, als es jetzt einnimmt. Elbert fand im südöstlichen Celebes und auf den benachbarten Inselchen Korallenriffe und Erosionsterrassen bis $1500 \mathrm{~m}$ und WANNER $^{16}$ auf Timor pliozäne und quartäre Korallenkalke bis $1050 \mathrm{~m}$ Seehöhe; eine Hebung hat also erst in der geologischen Gegenwart wieder eingesetzt. Diese Vorgänge im östlichen Archipel erklären es, daß sich in den höheren Tierklassen ein Abklingen des asiatischen Elements nach Ost und des australischen nach West deutlich bemerkbar macht, für andere aber nur nach Maßgabe ihrer Verbreitungsfähigkeit und ihres geologischen Alters. In der Vogelfauna Neuguineas, die sich durch eine größere Anzahl von prächtig gefürbten Arten als irgendwo sonst auszeichnet, überwiegt noch das australische Element bedeutend, in anderen Tierklassen überwuchert aber das asiatische. Die Käferfauna ist nach PAscoE indischen Ursprungs und von der australischen wesentlich verschieden. Die Süßwasserkrabben aus der Unterfamilie der Potamoninae verbreiten sich nach Ortmann von Indien bis Nordaustralien, unter den Regenwürmern hat Australien die älteren Megascolecinen-Gattungen mit Ceylon gemeinsam, sie fehlen aber im ganzen malaiischen Archipel, selbst auf Neuguinea, wo sie nach Michaelsen ${ }^{17}$ von der jüngeren Gattung Pheretima völlig verdrängt wurden. Am auffallendsten ist aber die Tatsache, daß sich der ostindische Florencharakter über den ganzen malaiischen Archipel und ganz Polynesien bis zu den Paumotu-Inseln, d. h. über einen Gürtel von 170 Längengraden verbreitet. Indische Pflanzenformen sind ja, wie wir schon erfahren haben, auch nach Nordaustralien eingedrungen, wie sich anderseits australischer Einfluß auch auf den benachbarten Inseln geltend gemacht hat. Mit der Entfernung vom Stammland schwindet er zusehends, auf den Fidschi-Inseln ist er nur noch wenig bemerkbar, und das eigentliche Polynesien blieb davon unberührt.

Wir haben auf S. 772 den vermutlichen Verlauf der ostaustralischen Inselbögen dargelegt. Ein Teil dieser Inseln ist vulkanischer oder korallinischer Natur, andere sind aber unzweifelhaft kontinental, und wir haben bemerkt, daß auch der Kern der größeren FidschiInseln dazu gehört. Von diesen Bögen scheint sich der östliche am spätesten aufgelöst zu haben, denn Beuteltiere sind noch über Neupommern nach den Salomo-Inseln gelangt. Aber sie erreichten weder Neucaledonien, noch Neuseeland, geschweige denn die unzähligen kleinen Inseln im Osten und Norden. Die Abwesenheit von Säugetieren, ausgenommen die Fledermäuse, ist der zweite 
biogeographische Charakterzug der Südsee-Inseln. Überhaupt ist die Fauna sehr mangelhaft entwickelt und weist vorwiegend auf Australien als Ursprungsland hin. Wir haben also hier den einzigen Fall, daB die Pflanzen- und die Tierbesiedlung eines Gebietes von verschiedenen Festländern ihren Ausgang nahmen.

Eine Sonderstellung nehmen Neuseeland mit den benachbarten Inseln (wenigstens von der Chatham- bis zur Macquarie-Insel) und die Hawaiigruppe ein.

Dab sich eine ihrer Lage nach so echt ozeanische Insel, wie $\mathrm{Neuseeland}$, durch eine durchaus eigenartige Lebewelt auszeichnet, kann nicht befremden, ja es fällt auf, daß der Endemismus in der Flora verhältnismäßig wenig ausgeprägt ist. Er erreicht zwar in den Arten $61^{1} / 2$, in den Gattungen aber nur $6 \frac{1}{2}$ Prozent. Die Verwandtschaft mit der australischen Flora ist zwar unverkennbar, fordert aber nach ENGLER keinen direkten Landzusammenhang. Indische Ausläufer berühren eben noch die Nordinsel. Die Pflanzengeographen rechnen Neuseeland zum antarktischen Florenreich, von dem später die Rede sein soll. In hohem Grad merkwürdig ist die Fauna, aber fast noch mehr im negativen als im positiven Sinn. Ein fruchtbares Land von der Größe Italiens ohne Säugetiere, ohne Schlangen, mit einem einzigen Vertreter der Amphibien (der ende. mischen Unkengattung Liopelma), mit einer höchst dürftigen Insektenwelt - das sind einige negative Charakterzüge, durch die Neuseeland einzig dasteht. Eine Erinnerung an eine längstvergangene Zeit bewahrt es in der eidechsähnlichen Hatteria punctata, dem einzigen Repräsentanten der Ordnung der Rhynchocephalier, die den Urreptilien am nächsten stehen, und einem nahen Verwandten zweier fossiler Tierformen aus den Triasschichten der nördlichen Alten Welt. Ein anderes merkwürdiges Überbleibsel ist die Retropinna aus der Familie der Lachse, denn ihre nächste Verwandte, der Stint, kommt nur auf der nördlichen Halbkugel vor. Ganz eigenartig ist auch die Landschneckenfauna. Von den Vögeln stehen zwar die meisten mit den australischen in verwandtschaftlichen Beziehungen, aber immerhin besitzt Neuseeland vier endemische Familien: den Eulenpapagei und drei Laufvögel, und 21 endemische Gattungen. Für die geologische Geschichte Neuseelands sind wichtig die Süßwasserkrebse, die eine Verbindung mit Australien, und die Regenwürmer, die eine solche mit Südasien, vielleicht über Neuguinea, fordern. Ortmann verlegt diese Landverbindung in die Kreide-, Hotton ${ }^{18}$ schon in die mittlere Jurazeit. Die aus paläozoischen Schiefern bestehenden höchsten Teile der Neuseeländer Alpen mögen damals 
Land gewesen sein. Östlich davon liegt ein Streifen mesozoischer Ablagerungen, die jetzt eine Synklinale zwischen zwei paläozoischen Sätteln darstellen. Jedenfalls haben noch nachkretazeïsche Faltungen stattgefunden. Auch Neucaledonien ist nach Proouter's Untersuchungen ${ }^{19}$ nicht durchaus altes Land, denn an der Südwestküste findet sich eine ziemlich vollständige mesozoische Sedimentfolge, die ebenfalls in Falten gelegt ist. Es scheinen sich also innerhalb der ostaustralischen Inselbögen noch nach der Auflösung gebirgsbildende Vorgänge fortgesetzt zu haben. Aus dieser alten Kontinentalzone sind biogeographisch noch die Fidschi-Inseln bemerkenswert. GUPPY ${ }^{20}$ erkannte in der dortigen Pflanzenwelt eine dreifache Altersschicht: eine mesozoische, eine nachtertiäre und eine moderne. Das spricht dafür, daß Teile von Fidschi seit dem Zusammenbruch der Inselbögen Land geblieben sind, und in dieser Vermutung werden wir durch die Tatsache bestätigt, daß hier das Verbreitungsgebiet der neuguineischen Molluskenfauna, die mit ihren zahlreichen großen Arten einen entschieden kontinentalen Charakter zeigt, plötzlich abbricht, so daß nach KoBeLT's Äußerung Samoa näher mit Tahiti als mit Fidschi verwandt erscheint. Was westlich und nördlich von Tonga liegt, sind ohne Zweifel ursprüngliche Inseln, die nur durch zufällige Verschleppung Organismen erhalten haben. Aus der Zusammensetzung der Flora ist dies, wie Reinecke ${ }^{21}$ dargetan hat, deutlich ersichtlich. Die hohen vulkanischen Inseln haben selbstverständlich eine reichere Pflanzenwelt als die niederen Atolle, und unter jenen ist Tahiti dadurch ausgezeichnet, daB es noch einen Stamm tertiärer Ansiedler besitzt. Unerklärt bleibt nur, warum die Südsee floristisch von Asien statt von Amerika aus besiedelt wurde, denn Winde und Strömungen kommen ja von Ost, und in der Tat ist auf dem östlichen Weg auch die Kokospalme eingewandert. GUPPY legt das Hauptgewicht auf die Vermittlung der Insekten, Fledermäuse und Wasservögel, für die zwei Drittel aller indomalaiischen Pflanzengattungen geeignet erscheinen. Für diese Erklärung spricht, daß zwischen Asien und den Paumotu und Mlarquesas eine bald mehr, bald minder dichte Reihe von Inseletappen liegt, zwischen den Paumotu und Amerika aber ein breites, inselloses Meer.

Nur Hawaii ist von der indischen Pflanzenwanderung weniger berührt worden als von der amerikanischen; IHERING ${ }^{4}$ nimmt auch eine einstige Landverbindung mit der Neuen Welt an. Das hohe Alter dieser Inselgruppe wird nicht nur durch ihre Flora, die noch tertiäre Typen enthält, sondern auch durch so auffallende endemische Tierformen bezengt, wie die Sperlingsfamilie der Drepanididae und 
die Schneckengattung der Achatinellen, einen wahrscheinlich uralten Typus mit spitzkegelförmigem Gehäuse.

Das Problem der südhemisphärischen Kontinentalzusammenhänge. Pflanzengeographisch lassen sich Beziehungen zwischen dem audinen Hochgebirge von Südamerika, Australien, Neuseeland und den zerstreuten Inseln südlich vom 37. Parallel nachweisen. Die Gemeinsamkeit trotz der weiten Entfernungen zwischen diesen Ländern und Inseln beruht zum großen Teil auf Verschleppung durch die vorherrschenden westlichen Winde und die dadurch hervorgerufene Osttrift. Eines der merkwürdigsten Beispiele bietet die floristische Verwandtschaft zwischen Tristan da Cunha und den um einen Erdquadranten davon entfernten, aber in gleicher Breite gelegenen Inseln Neu-Amsterdam und St. Paul. Auf Neu-Amsterdam besteht der Buschwald aus der gleichen Heidenmyrte (Phylica nitida) wie auf Tristan, und das Besengras Spartina arundinacea, das auf Tristan den gröBten Teil der Steppen zusammensetzt, erscheint wieder als ein wesentlicher Bestandteil des Graslandes von St. Paul. Wenn sich aber im Kerguelenbezirk 2 Arten finden, die nur noch auf Neuseeland vorkommen, oder auf den Inseln südlich von Neuseeland 6 Arten, die sie nur mit dem Feuerland gemein haben, ${ }^{22}$ so sind diese Vorkommnisse mit der Wind- und Trifttheorie schwer vereinbar. Außerdem stehen auch Südamerika und Australien-Neuseeland durch 48 gemeinsame Arten - die weit verbreiteten nicht mitgerechnet - und 49 gemeinsame Gattungen floristisch miteinander in Verbindung. Dieses antarktische Element spielt in Australien aber nur in der Hochgebirgsflora Tasmaniens und der Australalpen eine hervorragende Rolle; es ist auch in die polynesische Pflanzenwelt eingedrungen und läßt sich z. B. noch auf . Fidschi und Samoa nachweisen.

Auch nahezu in allen Tierklassen lassen sich verwandtschaftliche Beziehungen zwischen den Randländern der Südsee erkennen. Hooker hatte schon 1847 eine Landbrücke in den höheren südlichen Breiten angenommen. In letzter Zeit traten besonders v. Ihering ${ }^{4}$ und Or'TMANN ${ }^{5}$ auf Grund ihrer Spezialstudien über die Verbreitung der Flußmuscheln und Süßwasserkrebse für diese Hypothese ein; v. Ihering hat diese südpazifische Landverbindung Archinotis genannt. Der Gesteinscharakter der jurassischen Schichten der Andes scheint darauf hinzudeuten, daß sich Südamerika in der mesozoischen Periode weiter nach Westen ausgedehnt habe, denn nur an der Westküste des Gebirges finden sich Konglomerate, während sie am Ostabfall durch feinere sandige und mergelige Gesteine vertreten werden ${ }^{23}$ da aber Polynesien im engeren Sinn wohl stets 
insular war, so muß die archinotische Brücke weiter im Süden gelegen haben. ORtMan identifiziert sie mit dem antarktischen Kontinent und verbindet diesen in der Kreidezeit einerseits über Grahamland, Südorkney und Südgeorgien mit dem Feuerland, anderseits durch einen breiten, von Wilkesland ausgehenden Landstreifen mit Australien. Matтhew ${ }^{24}$ ist auch auf Grund der Säugetierverbreitung dieser Auffassung beigetreten, denn die innige Verwandtschaft der australischen und südamerikanischen Beutlerfauna tritt immer deutlicher hervor, ${ }^{25}$ und damit verliert die WALLACE'sche Annahme eines Austausches über nordhemisphärische Landbrücken sehr an Wahrscheinlichkeit. Die Archinotis-Hypothese findet auch eine kräftige Stütze in den jüngsten Entdeckungen in den hohen südlichen Breiten; es ist nun durch fossile PHanzenfunde festgestellt, daß sich die jetzt unter Eis begrabenen Länder von der Jura- bis in die Tertiärzeit eines milden Klimas erfreuten und somit größere Wanderungen von Lebewesen vermitteln konnten. Dagegen spricht die Verbreitung der Notiodrilusgattung der Regenwürmer, denn die betreffenden Arten vertragen, wie MichaELSEN ${ }^{26}$ nachgewiesen hat, sehr wohl den Wassertransport, und die echten Landregenwürmer fehlen in endemischen Arten auf den subantarktischen Inseln ganz. Lange Zeit führte man zugunsten der Antarktishypothese auch die großen Laufögel an, die zwar im Eozän auch in Europa und Nordamerika und in der Miozänzeit in Vorderindien und im Gebiete des griechischen Archipels lebten, jetzt aber auf die Südkontinente beschränkt sind, und deren Vorkommen auf eine lange Abwesenheit großer Raubtiere hindeutet. In Afrika bewohnt der Strauß nur die nördliche Wüste, wo er von Feinden weniger gefährdet ist; sein nächster Verwandter ist der südamerikanische Nandu. Australien hat den Emu und gemeinsam mit den papuanischen Inseln die Casuare, und Neuseeland den Kiwi. Auf dieser Insel wohnten noch zwei andere Familien gigantischer Laufvögel, von denen die letzten wohl erst vom Menschen ausgerottet wurden. Auch die Riesenvögel Madagaskars dürften erst in der geologischen Gegenwart ausgestorben sein. Solange man alle diese Vögel als eine natürliche Abteilung betrachtete, lag es nahe, sie von einem antarktischen Entstehungsherd ausstrahlen zu lassen; nun hat aber BuRCKHARDT ${ }^{27}$ nachzuweisen versucht, daß die systematische Voraussetzung nicht zutreffe, und daß die Ordnung der Ratitae vielmehr nur ,eine mehr oder minder künstliche Versammiung von ursprünglich heterogenen Vögeln“ darstelle, „welche in alter Vorzeit, die einen früher, die anderen später, aus primitiven und noch unbekannten Flugvögeln unter Reduktion der Flugfähigkeit hervorgegangen sind". Ja gerade 
dieser EntwickelungsprozeB fordert insulare Abgeschlossenheit; da $B$ Festländer dazu nicht günstige Bedingungen boten, beweist - die Artenarmut der kontinentalen Laufvögel. Wir ersehen aus diesem Beispiel, wie innig die tiergeographischen Fragen mit den Fragen der Systematik und der Artenentstehung verquickt sind.

Um die biogeographischen Beziehungen der übrigen südhemisphärischen Erdteile zu verstehen, müssen wir tiefer in die geologische Vergangenheit hinabsteigen. Gegen Ende des paläozoischen Zeitalters entwickelte sich in Südamerika, Südafrika, Vorderindien und Australien eine Flora, die nach der besonders charakteristischen Farngattung als Glossopterisflora bezeichnet wird. Die Schichten, die uns diese Pflanzenreste aufbewahrt haben, sind unzweifelhaft Landbildungen; ihre Ablagerung umfaBt in Vorderindien noch das ganze mesozoische Zeitalter. Daß damals eine Landmasse - man nennt sie das Gondwanaland - von Südamerika ostwärts wenigstens bis Dekan reichte, ist eine Annahme, die auch durch die Tatsache unterstützt wird, daß die Ränder des östlichen Südamerika, Afrikas und Dekans durch Brüche erzeugt sind. In der Jurazeit begann der Einbruch des westindischen Ozeans; nach Lemorne ${ }^{28}$ hat die Landverbindung zwischen Afrika und Vorderindien, deren letzte Reste Madagaskar und die benachbarten Inseln sind, noch bis in die Kreidezeit bestanden, dann aber nicht mehr; und die Annahme einer tertiären Landbrücke, der Lemuria, wird von den Tiergeographen jetzt allgemein zurückgewiesen. ${ }^{29}$ Das zerstreute Vorkommen der Halbaffenfamilie der Lemuren in Madagaskar, Westafrika und Vorderindien ist eine Reliktenerscheinung, ein Nachklang aus der Eozänzeit, in der die Lemuren auch in Europa und Nordamerika gelebt haben. Aus der terrestrischen Periode stammt wohl das indische Element in der Lurchen- und Schneckenfauna Madagaskars, welches das afrikanische überwiegt, und auffallend ist auch, daß die fruchtfressenden Fledermäuse jener Insel nicht einer afrikanischen, sondern einer indischen Gattung der Fledermäuse angehören.

Die Landverbindung zwischen Südamerika und Afrika nennt Ihering Archhelenis, da sie nach seiner Ansicht die Insel St. Helena einschloB. Faunistische Argumente für eine südatlantische Brücke gibt es nach ScHaRfF's Zusammenstellung ${ }^{30}$ in allen Tierklassen, freilich auch manche Fälle, auf die die Reliktentheorie ebensogut anwendbar ist. Eines der seltsamsten Vorkommnisse ist die Boaschlange, die sich außerhalb Zentral- und Südamerikas nur noch in zwei Arten auf Madagaskar findet. Auffallende Beispiele verwandtschaftlicher Beziehungen zu beiden Seiten des südatlantischen Ozeans liefert besonders die niedere Tierwelt, wie die wirbellose Küstenfauna 
von Brasilien und Westafrika, die Muscheln und Krebse des SüBwassers, die Fische, ${ }^{31}$ die Landmollusken und die Käfer. Je weiter die Erforschung der afrikanischen Flora fortschreitet, um so mehr treten auch hierin die südamerikanischen Anklänge hervor. Nach ENGLER $^{32}$ kommen in Afrika außer 30 südamerikanischen Arten, die vielleicht durch den Schiffsverkehr verschleppt worden sind, noch 55 vor, die nur über schmale Meeresarme oder zu Land gewandert sein können, und noch mehr Gewicht legt er auf die überraschend große Zahl korrespondierender Arten und Gattungen, die anderen Erdteilen fehlen. Diese Tatsachen fordern, wie ExGLer fast widerwillig zugesteht, zu ihrer Erklärung die Annahme eines afrikanischamerikanischen Festlandes oder wenigstens das Vorhandensein großer vermittelnder Inseln. Daß diese Verbindung spätestens am Beginn der Tertiärperiode aufgelöst wurde, geht aus den jüngsten Eozänfunden in Westafrika hervor. ${ }^{33}$ Thre Lage ist noch strittig. Die Annahme, daß St. Helena ein Reststück davon sei, wird durch KoBELT's ${ }^{34}$ Analyse ihrer so merkwürdigen, aber leider nur mehr fragmentarisch erhaltenen Lebewelt etwas erschüttert. Die völlige Abwesenheit von Säugetieren, Reptilien und Süßwasserfischen, vielleicht auch von einheimischen Landvögeln deutet darauf hin, daß diese Insel durch einen unterseeischen Vulkanausbruch entstanden ist. Auch die Abwesenheit endemischer Landregenwürmer führt МгснAELSEN $^{26}$ als einen Beweis für ihre Ursprünglichkeit an. Freilich müßte dann ihre Käferfauna und ihre Flora von Nord oder Nordost eingewandert sein, und dies würde eine von der gegenwärtigen verschiedene Wind- und Strömungsverteilung voraussetzen. $\mathrm{Zu}$ denken geben auch ihre typischen Landmollusken, die KoBelt wegen ihres polynesischen Gepräges für Abkömmlinge eines antarktischen Festlandes der Sekundärzeit hält.

Ehe wir die im höchsten Grad interessante Frage der alten Landverbindungen weiter verfolgen, wollen wir noch die biogeographischen Verhältnisse der Nordhalbkugel näher ins Auge fassen.

Literaturnachweise. ${ }^{1}$ Über pflanzengeographisehe Werke s. S. 817 , Anm. 1. Zur Tiergeographie sind zu nennen: A. R. WALLACE, Die geographisehe Verbreitung der Tiere, Dresden 1876. A. HeiLPRIN, The Geographical and Geological Distribution of Animals; New York 1887. A. JACOBI, Lage und Form biogeographiseher Gebiete; in der Zeitsehrift der Gesellschaft für Erdkunde; Berlin 1900. W. Kовецт, Die Verbreitung der Tierwelt; Leipzig 1902 (bezieht sich nur auf die nördliche gemäßigte Zone). W. HAacke u. W. Kunnert, Das Tierleben der Erde; Berlin (beschreibend). A. JАсовг, Tiergeographie; Leipzig 1904 (eine zwar nur skizzenhafte, aber zuverlässige Darstellung des neuesten Standpunktes der Disziplin). W. Marshall, Atlas der Tierverbreitung, Gotha 1887, in Berghaus' Physikalischem Atlas. - 2 G. Bonnier, in den 
Annales de Géographie 1902, Bd. XI, S. 193. - ${ }^{3}$ K. v. Zirté, Rückblick über die geologische Entwickelung, Herkunft und Verbreitung der Säugetiere; in den Sitzungsberichten der bayerischen Akademie der Wissenschaften 1893. R. Lydekker, A Geographical History of Mammals; Cambridge 1896. W. L.u. Рн. L. Sclater, The Geography of Mammals; London 1899. - ${ }^{4}$ H. v. Iherixg, Archhelenis und Archinotis, Leipzig 1907. - ${ }^{5}$ A. E. Ortmann, The Geographical Distribution of Freshwater Decapods and its Bearing upon Ancient Geography, in den Proceedings of the American Philosophical Society, Philadelphia 1902, Bd. XLI. - e W. Koвelt, Studien zur Zoogeographie; Wies. baden 1897 u. 98 . Die geographische Verbreitung der Mollusken in dem paläarktischen Gebiet; Wiesbaden 1904. - ${ }^{7}$ W. Mrchaelsen, Die geographische Verbreitung der Oligochaeten; Berlin 1903. - ${ }^{8}$ E. Stromer, Über die Bedeutung der fossilen Wirbeltiere Afrikas für die Tiergeographie, in den Verhandlungen der Deutschen Zoologisehen Gesellschaft 1906. - 9 A. ExGLer, Pflanzengeographische Gliederung von Afrika, in den Sitzungsber. d. Preuß. Akad. d. Wiss. Bd. XXXVII, 1908. - ${ }^{10}$ R. T. HiLl, Geological Reeonnoissance of Jamaica, im Bulletin of the Museum of Comparative Zoology at Harvard College, Bd. XXXIV, 1899. - ${ }^{11}$ G. Grandidier, Recherches sur les Lémuriens disparus et en particulier sur ceux qui vivaient à Madagasear, in den Nouvelles Arehives du Muséum; Paris 1905, Bd. VII. - ${ }^{12}$ R. Semon, Im australisehen Busch, 2. Aufl.; Leipzig 1903, S. 196. - ${ }^{13}$ MAx WEBER, Der Indoaustralische Archipel und die Geschichte seiner Tierwelt; Jena 1902. - ${ }^{1 t}$ P. u. F. Sarasin, Über die geologische Geschichte der Insel Celebes auf Grund der Tierverbreitung; Wiesbaden 1901. - ${ }^{15}$ Bericht in Petermann's Mitteilungen, 1910, Bd. I, S. 306. - ${ }^{16}$ J. W ANner, im Zentralblatt für Mineralogie usw. 1910, S. 137. 17 W. Mrchaelsen, Die Tierwelt Südwest-Australiens und ihre geographisehen Beziehungen, in den Mitteilungen der Geographischen Gesellschaft in Hamburg 1907. - ${ }^{18}$ F. W. Hutron, The Geological History of New Zealand; in den Transactions of the New Zealand Institute, 1899, Bd. XXXII. ${ }^{10}$ M. Prrodter, im Bulletin de la Société géologique de France, 1903, Bd. III, S. 155 . - ${ }^{20}$ H. B. Guppy zit. S. 792, Anm. 30. - ${ }^{21}$ F. Reinecke, Die SamoaInseln und ihre Vegetation, in Petermann's Mitteilungen 1903. - ${ }^{22} \mathrm{H}$. Schenck zit. S. 833 . - ${ }^{23}$ C. Burckнardt, Traces géologiques d'un ancien continent pacifique, in der Revista del Museo de la Plata 1902, Bd. X. $-{ }^{24}$ W. D. Matriew, Hypothetical Outlines of the Continents in Tertiary Times, im Bulletin of the American Museum of Natural History, Bd. XXII, 1906. - ${ }^{25}$ W. J. Sinclarr, in den Proceedings of the American Philosophical Society 1905, Bd. XLIX, S. 73. G. M. A. Sмiтн, A Naturalist in Tasmania, Oxford 1909. ${ }^{26}$ W. Mrchaelsen, in Bd. IX, Heft 1, des Werkes Deutsche Südpolar-Expedition 1901-03; Berlin 1905. - ${ }^{27}$ R. Burcknand, Das Problem des antarktischen Schöpfungszentrums vom Standpunkt der Ornithologie, im Zoologisehen Jahrbuch, 1902, Bd. XV. - ${ }^{28}$ P. Lemorne, Etudes géologiques dans le Nord de Madagascar; Paris 1906. - ${ }^{29}$ M. Boule, in La Géographie, Paris 1906, Bd. XIII, S. 19. - ${ }^{30}$ R. F. Scharff, Some Remarks of the Atlantis Problem,

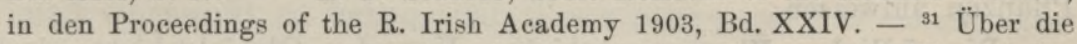
wichtige, aber schwer zugängliche Arbeit von C. H. Eigenmann in The Popular Science Monthly, New York 1906, S. 515, s. ein ausführlicheres Referat in H. WAgner, Geographisches Jahrbuch, Bd. XXXI, S. 254. - ${ }^{32}$ A. Engler, Über floristisehe Verwandtsehaft zwisehen dem tropisehen Afrika und Amerika, sowie über die Annahme eines versunkenen Brasilianisch-äthiopischen Kontinents; in den Sitzungsberichten der PreuBischen Akademie der Wissenschaften, 
physikalisch-mathem. Klasse 1905 , Bd. VI. $-{ }^{33}$ E. Stromer, im Jahrbuch der PreuBischen Geologischen Landesanstalt 1909, S. 511. - ${ }^{34}$ W. Koвelt, in der Geographischen Zeitschrift 1896, S. 199.

\section{Flora und Fauna der mittleren und höheren Breiten der Nordhalbkugel. ${ }^{1}$}

Klimaänderung. Wir haben in dem vorhergehenden Kapitel dargetan, daß die Entwickelung der organischen Welt in den äquatorialen und südlichen Breiten hauptsächlich durch Veränderungen in der Verteilung von Wasser und Land gestört wurde. Dagegen hat das Klima keine tiefergreifende Wandlungen erfahren, wenn auch die mittlere Jahrestemperatur in der Eiszeit um ein paar Grad gesunken sein mag. ,Die Araukarienwälder Südbrasiliens," sagt Palackx, „sind vielleicht seit der paläozoischen Zeit an derselben Stelle." Aus dieser Gleichförmigkeit der klimatischen Lebensbedingungen erklärt sich der große Reichtum an Landpflanzen und Landtieren der warmen Zone. Nördlich davon nahm die Entwickelungsgeschichte einen ganz anderen Verlauf. In Europa können wir an der Hand der paläontologischen Zeugnisse die allmähliche Umgestaltung des Klimas genau verfolgen. In der jungmiozänen Zeit war es noch tropisch, in der pliozänen Zeit glich es schon dem gegenwärtigen. Trotzdem war die Tierwelt damals artenreicher als jetzt; in den Pliozänablagerungen des Chianatales in Mittelitalien findet man noch Reste von Elefanten, Nashörnern, Flußpferden und Affen. $\mathrm{DaB}$ sich diese und andere Tierformen seitdem in niedere Breiten zurückgezogen haben, war die Folge des auf die Pliozänperiode folgenden großen Intermezzos der Eiszeit. Soweit Gletscher das Land bedeckten, wurde die Lebewelt nahezu vernichtet, und als die Eisdecke schwand, mußte hier die Entwickelung von vorn beginnen. Dieser ProzeB mußte sich ebensooft wiederholen, als Interglazialzeiten mit Eiszeiten wechselten, doch lassen sich die einzelnen Stadien nicht mehr unterscheiden. Nach der letzten Vergletscherung war Mitteleuropa ein ptlanzenarmes Land, das den einwandernden Gewächsen Raum genug zur Ansiedlung bot. Seine Flora ist entlehnt, und es ist bezeichnend, $\mathrm{da} B$ das deutsche Tiefland keine endemische Form besitzt, während die atlantischen Küstenländer, wo die Eiszeit nicht so verheerend gewirkt hat, 29 eigentümliche Pflanzen aufweisen.

Die südlichen Übergangsgebiete. Von den Glazialgebieten im engsten Sinu des Wortes sind jene zu unterscheiden, die von der Eiszeit nur mittelbar betroffen wurden, wo die Entwickelung seit der Tertiärzeit zwar nicht so ungehemmt vor sich ging wie in der Tropenzone, aber auch keine völlige Unterbrechung erlitt. Hier be- 
gegnen wir einem ausgeprägten Endemismus. Im Mittelmeergebiet zählt Grisebaci 2700 eigentümliche Pflanzenarten, von denen 816 auf Kleinasien und Syrien und 782 auf die iberische Halbinsel kommen. Im Vergleich zum Areal sind aber Kreta, Corsica, Sizilien und Griechenland am reichsten ausgestattet. Ein zweiter Charakterzug dieser Gebiete besteht in der Erhaltung tropischer Formen, die aus einer Zeit stammen, da das Klima noch wärmer war. Im mediterranen Bezirk haben nicht nur kräftige Holzgewächse, wie die Zwergpalme, der Lorbeer, die Myrte, der Ölund der Granatbaum, der Feigen- und der Storaxbaum u. a. den Klimawechsel überdauert, sondern auch zartere Gewächse, wie der Jasmin oder der Akanthus. Noch zahlreicher finden sich die Reste der Tropenzeit auf den Azoren, Madeira und den Canaren (z. B. der bekannte Drachenbaum, der einer auf Südarabien, Sokotra und Abessinien beschränkten Spezies am nächsten verwandt ist), denn diese Inseln waren dem Einfluß der kontinentalen Klimaveränderungen völlig entrückt.

Den Mittelmeerländern an der Westseite der Alten Welt entsprechen floristisch an der Ostseite die größere Hälfte der Mandschurei, wo sich die mandschurische $\mathrm{NuB}$, ein ausgezeichneter Vertreter der Tertiärflora, bis gegen $50^{\circ} \mathrm{N}$ verbreitet, ferner China und Japan. Japans Pflanzenwelt, die genauer bekannt ist, besitzt nicht weniger als 44 endemische Gattungen - ein Reichtum, der allerdings auch auf Rechnung der Insularität zu setzen ist. Sie beginnt im südlichen Jesso mit vielen, sonst ausgestorbenen Tertiärformen; ungefähr der 35. Parallel scheidet die sommergrüne Vegetation des Nordens von der immergrünen des Südens; die Südspitze von Kiuschiu ist schon ganz tropisch.

In Nordamerika macht sich ein starker Gegensatz zwischen den atlantischen und den pazifischen Ländern bemerkbar. Die größere Hälfte der californischen Arten ist endemisch; auf die außerordentliche Entwickelung der pazifischen Koniferen wurde schon an einer früheren Stelle (S. 839) aufmerksam gemacht. Auch von den Laubhölzern gehören 27 Arten nur dem Osten, 13 nur dem Westen an, und nur 30 sind beiden Teilen gemeinsam. Schon frühzeitige klimatische Unterschiede scheinen auf den Entwickelungsgang beider Floren eingewirkt zu haben, und dazu kommt noch, daß die einstige Wasserbedeckung der westlichen Steppen und später ihr trockenes Klima einen Austausch der Pflanzen verhindert haben.

Die Flora der Vereinigten Staten steht in innigen Beziehungen zu der Ostasiens. Wir sehen hier ab von den identischen Arten in beiden Gegenden, die außerdem auch im arktischen Gebiet leben 
und also auch unter den gegenwärtigen Verhältnissen über die enge Beringstraße gewandert sein könnten. Anders verhält es sich mit jenen 140 Spezies, die einerseits im östlichen Asien oder auch auf dem Himalaya, und anderseits in Nordamerika und zum Teil sogar nur in der östlichen Hälfte dieses Kontinents gefunden werden, und deren Wärmebedürfnis $\mathrm{zu}$ groB ist, als daß sie in der Gegenwart eine Wanderung über die Beringstraße hätten unternehmen können. Ihre Verbreitung muß daher vor der Glazialperiode erfolgt sein, und zu einem ähnlichen Schluß gelangen wir in bezug auf jene (etwa 140) ostasiatischen Pflanzen, deren nächste Verwandte Nordamerika bewohnen, und zwar ungefähr 110 Arten nur das östliche und 7 nur das westliche Gebiet. EngLer nimmt an, daß ihre Urformen einst weiter im Norden lebten, daß ein Austausch über die Beringstraße stattfand, und daß sie dann in der Urheimat ausstarben, während sich in den jetzigen Verbreitungsbezirken vikariierende Arten ausbildeten.

In der Tierwelt begegnen wir ähnlichen Erscheinungen. Im mediterranen Gebiet bildet allerdings das Meer eine scharfe Grenze für die Säugetiere, die nur von wenigen überschritten wird. $\mathrm{Zu}$ den Ausläufern der warmen Zone gehört hier eine kleine Affenart, der Magot, der Nordafrika und den Felsen von Gibraltar bewohnt, ferner mehrere Fledermausgeschlechter, einige Antilopengattungen, darunter die Gazelle, die sich von Nordafrika bis Iran verbreitet, das Stachelschwein in Südeuropa und Palästina, die Zibetkatze (Genette), die in Südeuropa, Nordafrika und Palästina gefunden wird, und mehrere Raubtiere, wie Hyäne, Löwe, Leopard, Serval und Gepard, die Nordafrika und zum Teil auch das mediterrane Asien durchstreifen. Weniger bekannt sind die Vögel, doch weiß man, daß sie in Palästina und Persien einen entschieden außertropischen Charakter tragen. Im ostasiatischen Übergangsgebiet soll sich ungefähr $50 \mathrm{~km}$ östlich von Peking eine Affenart finden, die ein dicker Pelz gegen die Kälte ihrer Heimat schützt. Ein naher Verwandter des Magot, der Macacus, bewohnt Japan nördlich bis zur Tsugarustraße. Andere tropische Ausläufer sind die Zibetkatze und das Stachelschwein, ferner die ostindische Wiederkäuergattung Nemorhedus und das ebenfalls ostindische Flughörnchen. Die chinesisch-japanische Vogelfauna, für die die Fasanen charıkteristisch sind, unterscheidet sich von der mediterranen durch ihr vorwiegend tropisches (ostindisches) Gepräge, und ebenso sind die japanischen Reptilien und Käfer stark mit Elementen der warmen Zone gemischt. In der Neuen Welt ist die californische Fauna durch einige tropische Elemente ausgezeichnet, wie durch die Blatt- 
nasen- und Hundskopf-Fledermäuse, durch mehrere südamerikanische Vogelgattungen und eine Pythonschlange; und sogar die südamerikanische Beutler- und Zahnarmenfauna reicht mit zwei Ausläufern, dem Opossum und dem Gürteltier, in das gemäBigte Nordamerika hinein.

Zentralasien. Das abflußlose Innerasien hat zwar keine Eisdecke getragen, aber große Teile sind erst spät von der Wasserbedeckung befreit worden, und auch hier war, wie in den Glazialländern, Platz für neue Ansiedlungen geschaffen. Das trockene Klima gewährte jedoch nur einer beschränkten Anzahl von Pflanzen die nötigen Existenzbedingungen, und die Einwanderer mußten sich zum Teil den veränderten Verhältnissen anpassen, um sich vor dem Untergang zu bewahren. Daher einerseits die Armut der Steppenflora, andererseits ihr Reichtum an endemischen Formen trotz ihrer Jugendlichkeit, also eine Vereinigung von Charakterzügen der Glazialund der Übergangsgebiete.

Die Gebirgswälle, die Zentralasien im Süden abschließen, haben die Eigenart seiner Tierwelt geschützt. Daher ein scharfer Gegensatz zwischen seiner Fauna und der der Sahara, Arabiens, Vorderasiens, Belutschistans und der indischen Wüste. Die südlichen Gazellen werden im Norden durch andere Antilopenarten (besonders verbreitet die Dscheren) vertreten, der vorderasiatische Wildesel Onager durch den Kulan, das einhöckerige Kamel durch das zweihöckerige. Besondere Züge hat sich die Tierwelt der rauhen tibetanischen Hochsteppen bewahrt; hier ist die Heimat des wilden Yak und der Orongo-Antilope.

Die holoarktische Zone. Nördlich der Übergangsgebiete und der zentralasiatischen Steppen breitet sich über die ganze Alte Welt ein ununterbrochener Waldgürtel aus, der trotz provinzieller Unterschiede als eine floristische Einheit zusammengefaßt werden muß, und ihr gehört auch der nördliche Waldgürtel Nordamerikas an. Jenseits der Baumgrenze hören auch die provinziellen Unterschiede auf. Wanderungen konnten hier längs der Küsten aus der Alten in die Neue Welt und umgekehrt ausgeführt werden, und mit Hilfe der Meeresströmungen konnteu sich die Pflanzen auch leicht über die Inseln des Eismeeres verbreiten. Mit zunehmender Breite schwindet also der Gegensatz der beiden großen Landmassen der Erde immer mehr, und floristisch darf man mit vollem Recht von einer holoarktischen Zone sprechen. Ob auch faunistisch, ist eine viel erörterte Frage.

Wir vergleichen im folgenden die Tierwelt der ganzen gemäBigten und kalten Zonen beider nördlicher Festländer miteinander, 
weil in der Alten Welt die faunistischen Unterschiede zwischen den Übergangsgebieten, der Steppe, dem Waldland und der Tundra weniger ins Gewicht fallen als die gemeinsamen $Z$ üge. $\mathrm{Ob}$ auch in der Neuen Welt, muß die Untersuchung lehren.

In der Jura- und Kreideperiode beherbergten Nordamerika und Europa eine und dieselbe Säugetierfauna, in der Tertiärzeit trat dagegen schon eine Scheidung ein; neben gemeinsamen Geschlechtern gab es solche, die nur die Neue oder nur die Alte Welt bevölkerten, und man schließt daraus, daß eine Landbrücke zwar bestand, daß sie aber verhältnismäßig eng war und einen Austausch der in südlicheren Breiten lebenden Tierformen verhinderte. Der Charakter der gegenwärtigen Fauna ist im großen und ganzen derselbe geblieben und WALLACE unterschied daher zwei arktische Reiche: ein neo- und ein paläarktisches. In jedem setzt sich die Fauna aus drei Elementen zusammen: einem endemischen, einem gemeinsamen oder borealen und einem tropischen, d. h. aus Formen, die den Höhepunkt ihrer Entwickelung in den benachbarten tropischen Faunengebieten erreichen.

Je weiter wir aber gegen Norden fortschreiten, desto mehr gewinnt das gemeinsame Element die Oberhand. Diese Tatsache bewog mehrere Tiergeographen, wie Brauer, Reichenow und Möbius, zur Aufstellung eines zirkumpolaren arktischen Reiches, das im Süden bis zur Baumgrenze, wo die Lebensbedingungen der Tiere eine durchgreifende Veränderung erfahren, reicht. Noch radikðler verfuhr HeILPRIN, der die gemäßigten Zonen beider Nordkontinente zu einem einzigen Reich verschmolz. Einen Mittelweg schlug Merriam ein und scheint uns damit das Richtige getroffen zu haben. CarPenter, Scharfa, Lydekker und JACOBI haben seinen Vermittlungsvorschlag angenommen und nur der jüngere ScLater verharrt noch auf dem WALLACE schen Standpunkt.

Merriam ${ }^{2}$ scheidet Nordamerika in ein nördliches und ein südliches Tiergebiet; die Grenze liegt in ungefähr $45^{\circ} \mathrm{B}$., fällt also annähernd mit der Südgrenze des diluvialen Inlandeises zusammen. Aber von einer scharfen Grenze kann hier noch weniger als sonstwo auf dem Festland gesprochen werden, weil keine ostwestlich streichenden Gebirge der Faunenvermischung hemmend in den Weg treten. Man darf hier noch weniger als sonstwo von einer Grenzlinie sprechen, sondern nur von einer Grenz- oder Übergangszone.

In der nördlichen Hälfte ist die Säugetierfauna überwiegend altweltlich. Von den 40 Geschlechtern, die Sclater jun. in seiner canadischen Subregion zählt, kommen 28 auch auf der östlichen Halbkugel vor, 8 sind amerikanisch und 4 endemisch. $\mathrm{Zu}$ den 
letzteren gehört die bekannte Bergziege, deren nächster Verwandter der Nemorhedus in den asiatischen Gebirgen ist, die übrigen drei sind Nagetiere. Die zirkumpolaren Geschlechter sind z. T. auch durch identische Arten vertreten, besonders in der Ordnung der Raubtiere (Luchs, Wolf, Fuchs, brauner und Eisbär, Seeotter, Marder, Fjällfras, Wiesel); aber auch einige Arten von Nagetieren (Biber, Wühlmaus, Lemming, Hase) und Huftieren (Bison, Schaf, Hirsch, Elentier, Renntier) sind beiden Hemisphären gemeinsam oder wenigstens sehr nahe verwandt. Das amerikanische Element besteht aus Überläufern aus dem südlichen Nordamerika; der Waschbär, das Stinktier, der amerikanische Dachs, der Präriehund, die Gabelantilope, der Sternmaulwurf sind einige bekanntere Beispiele. Im Vergleich zu der Alten Welt ist aber das nördliche Nordamerika arm an Säugetierarten. Am grellsten tritt dieser Gegensatz in der Ordnung der Huftiere hervor. Die Ziegen, die Gazellen und das Kamel fehlen ganz, ebenso viele Antilopen- und Hirschgattungen. Es unterliegt keinem Zweifel, daß hauptsächlich die größere Ausdehnung der Steppen der Alten Welt die Entwickelung einiger dieser Familien gefördert hat; andere Arten sind auf die Mittelmeerländer beschränkt, während die Fauna der Waldzone mit der nordamerikanischen große Übereinstimmung zeigt.

Ártenarmut ist auch der Charakter der Säugetierwelt des südlichen Nordamerika. Der Endemismus ist unbedeutend, außer ein paar Nagetieren ist ihm nur die schwarzschwänzige Hirschgattung Cariacus eigen. Der weitaus größte Teil der Fauna besteht aus borealen und tropischen Elementen, und diese halten sich nahezu die Wage.

$\mathrm{Zu}$ gleichen Ergebnissen kommt die ornithologische Untersuchung. $\mathrm{J}_{\mathrm{ACOBI}}$ analysiert die nordamerikanische Vogelwelt in folgender Weise. Von den borealen Gattungen sind ungefähr die Hälfte in der Alten Welt entstanden, die andere Hälfte sind tropisch-kosmopolitischen, arktischen oder unbekannten Ursprungs, und nur drei können als nordamerikanische Erzeugnisse in Anspruch genommen werden. Von den speziell amerikanischen Gruppen sind $1 / 3$ endemisch und $2 / 3$ Überläufer aus dem südamerikanischen Reich. Das boreale Element bewohnt vorwiegend den Kontinent nördlich von $45^{\circ} \mathrm{B}$, das amerikanische die südliche Hälfte. In anderen Tierklassen tritt das boreale Element mehr zurück, wie bei den Reptilien und Insekten. In der Molluskenfauna zeigt sich ein anderer, geschichtlich wichtiger Gegensatz: im andinischen Westen ist sie sehr nahe der ostasiatischen verwandt, im atlantischen Osten ist sie im Norden holoarktisch, im Süden aber reich an alten Arten Faßt man alles 
zusammen, so erscheint Merriam's Einteilung als die zweckmäBigste. Zum Unterschied von Europa-Asien ist die Südhälfte Nordamerikas als eine selbständige tiergeographische Einheit (Merriam's sonorisches Reich) auszuscheiden, während die Nordhälfte sich in die holoarktische Zone eingliedert.

$\mathrm{DaB}$ die Existenz einer solchen Zone eine ehemalige Landverbindung zwischen der Alten und Neuen Welt zur Voraussetzung hat, liegt auf der Hand. Man darf sie zunächst dort vermuten, wo noch jetzt beide Festländer nahe aneinander herantreten und eine Flachsee beide Gestade verknüpft: in der Beringstraße. Auf Matthew's ${ }^{3}$ Karten erscheint diese Landbrücke vom Oligozän bis ins Quartär, dagegen leugnet dieser Tiergeograph eine nordatlantische Landverbindung in so junger Vergangenheit, wofür besonders $\mathrm{SCHARFF}^{4}$ mit Nachdruck eintritt. Den Beweis dafür findet er in jenen Arten, die in Europa und im östlichen Nordamerika heimisch sind, dagegen im westlichen Nordamerika und in Asien fehlen. Außer 10 Pflanzenarten sind es meist nur Angehörige der niederen Tierwelt, die eine derartige Verbreitung haben, und bei denen eine passive Überführung von einem Erdteil in den andern so gut wie ausgeschlossen erscheint. Als besonders bemerkenswerte Beispiele nennen wir flügellose Insekten, den Flußbarsch, die Flußperlmuschel, den Flußschwamm und die Gartenschnecke, die nun auch in diluvialen Ablagerungen in Maine gefunden, also sicher nicht durch europäische Einwanderer dorthin verschleppt wurde. Es liegt nahe. diese nordatlantische Landbrücke mit dem Isländischen Rücken (vgl. Karte I) zu identifizieren, um so mehr als die alt- bis mitteltertiären Basalte, aus denen Island und die Färöer sich aufbauen, auch an den atlantischen Küsten von Schottland, Irland und Ostgrönland wiederkehren. $\mathrm{DaB}$ sie auch die Eiszeit überdauert habe, ist allerdings sehr unwahrscheinlich ${ }^{5}$, dagegen spricht auch die völlige Abwesenheit von Säugetieren und Reptilien auf den Färöer.

Rückblick auf die Theorie der Landbrücken. So sehr auch diese Theorie im Lauf der letzten Jahrzehnte Anhänger gewonnen hat, so halten doch noch manche an der gegenteiligen Ansicht von der Permanenz der Ozeane fest, einer Ansicht, die auch WALLACE bei seinen berühmten tiergeographischen Untersuchungen geleitet hat. Sie besagt, daß die ozeanischen Becken, wenigstens die von mehr als $4000 \mathrm{~m}$ Tiefe, von jeher mit Meer bedeckt waren, daß sich also der durch die Geologie nachgewiesene Wechsel von Land und Wasser nur auf ungefähr 63 Prozent der Erdoberfläche vollzogen habe. Der Permanenz der Ozeane entspricht die Permanenz des Festlandes; da es aber hier keinen Punkt gibt, der nicht ein oder 
mehrere Male Meeresboden gewesen ist, so kann es sich, wenn jene Ansicht recht hat, nur um verhältnismäßig seichte Überflutungen von Randpartien handeln. In der Tat lassen sich unsere Sedimentgesteine, soweit sie nicht auf festländische Bildungen zurückzuführen sind, nicht nur als alte Strand- und Flachsee-, sondern auch als alte Kontinentablagerungen der Tiefsee ohne Schwierigkeit erkennen. Dagegen sind Schreibkreide und Nummulitenkalke höchstwahrscheinlich alte pelagische Ablagerungen, die sich unter denselben Verhältnissen niederschlugen, wie heutzutage der Globigerinenschlamm. Von dem roten Ton nahm man an, daß er in keiner Formation vertreten sei, bis die Untersuchung der tertiären farbigen Erden von Barbados dartat, då zwischen diesen und pazifischen Tonproben aus $5400 \mathrm{~m}$ Tiefe völlige chemische Übereinstimmung besteht. ${ }^{6}$ Übrigens kennen wir marine Bildungen von vielen tausenden Meter Mächtigkeit, und damit ist der Beweis erbracht, daB sich echt ozeanischer Tiefboden in Festland verwandeln kann. Warum sollte nicht auch eine Verwandlung im umgekehrten Sinn möglich sein? Allerdings scheint im Gesetz der Isostasie (s. S. 16) ein fundamentaler Unterschied zwischen den ozeanischen und kontinentalen Krusténteilen begründet zu sein. Aber dieser Unterschied ist nicht ursprünglich, und die größere Schwere der ozeanischen Kruste ist daher auch keine unveränderliche Eigenschaft. Wäre sie es, so hätte niemals Tiefseeboden in Hochland verwandelt werden können, und die Schwere in den Schelfgebieten, die ohne Zweifel ein oder mehrere Male Festland waren, könnte nicht übernormal sein. Wohl besteht ein unverkennbarer morphologischer Gegensatz zwischen den ungeheueren Flachgründen der Tiefsee und den ozeanischen Randzonen mit ihren Nebenmeeren und Gräben. DaB in diesen Randzonen die innigsten Beziehungen zu dem Relief der angrenzenden Küstengebiete bestehen, ist schon betont worden, und die tiefen Furchen, die ihrem Antlitz eingegraben sind, verraten zu deutlich, $\mathrm{daB}$ sie in die wechselvollen geologischen Schicksale des Landes mitverflochten waren. Aber die geschichteten Bodenproben, die man aus der Tiefsee heraufgeholt hat, haben auch das Vertrauen auf die Stabilität landfernen Meeresbodens erschüttert. Man hat sie früher als Ausnahmen betrachtet, aber nach den Erfahrungen der deutschen Südpolarexpedition, die mit vervollkommneten Instrumenten arbeitete, scheinen sie Regel zu sein. Schichtung beruht stets auf Unterbrechung oder Veränderung des Sedimentabsatzes. Das letztere ist hier der Fall, der Kalkgehalt verändert sich, er nimmt nach oben zu, oder - jedoch seltener - ab. Soweit es sich um Vorkommnisse in höheren Breiten handelt, mag vielleicht 
$\mathrm{PhilippI}^{7}$ recht haben, wenn er die großen klimatischen Veränderungen der Quartärzeit dafür verantwortlich macht, aber auch er kann nicht umhin, die Vorkommnisse mehrfach geschichteter Bodendecken in niederen Breiten mit Niveauveränderungen in Verbindung zu bringen. Besonders interessant ist die Bodenprobe aus der atlantischen Romanchetiefe $\left(0^{0} 11^{\prime} \mathrm{S}, 18^{\circ} 15^{\prime} \mathrm{W}\right.$, Tiefe $\left.7230 \mathrm{~m}\right)$. Die oberste Schicht war, wie zu erwarten, roter Ton, unter demselben aber lagen anders gefärbte Schlammschichten, von denen eine wahrscheinlich mit dem blauen Schlick identisch ist, während die unterste kalkhaltig war. ${ }^{8}$ Dieser Befund weist auf Senkungen hin, zugleich aber auch auf Veränderungen in der Verteilung von Wasser und Land, denn unter den gegenwärtigen Verhältnissen hätte blauer Schlick nicht an diese Stelle gelangen können. Von Seiten der Tiefseeforschung kann also gegen die Annahme alter Landverbindungen kein Veto mehr eingelegt werden.

Wir müssen uns jedoch klar werden, auf welchen Grundlagen diese Annahme beruht und welchen Grad der Sicherheit wir überhaupt der Paläogeographie zuerkennen dürfen. DaB in der Triaszeit die große Bruchzone der Erde (s. S. 43) von Meer bedeckt war, und daß damals Nord- und Südkontinente durch ein breites Meer, dem Suess den Namen Tethys gegeben hat, geschieden waren, dafür besitzen wir positive geologische Beweise. Marine Triasablaǵgerungen finden sich auch in der Arktis und im ganzen Umkreis des Pazifischen Ozeans, fehlen aber an den atlantischen Küsten. ${ }^{9}$ Der SchluB, daB sich damals an Stelle des Atlantischen Ozeans mit Ausnahme jenes Teiles der Tethys, der sich von Westindien nach dem Mittelmeer hinzog, Land befand, fußt also nur auf einem negativen geologischen Beweis, der durch einen neuen Fund umgestoßen werden kann. ${ }^{\times}$Die Biogeographie endlich kann für ihre alten Landverbindungen (genau so wie die Morphologie für die Entwicklung der Oberflächenformen) nur einen Indizienbeweis liefern. $\times \times$ Erkennt man auch diesen als ausreichend an, so gestaltet sich die Entwickelung der Verteilung von Wasser und Land seit dem Mesozoikum folgendermaßen:

Am Beginn scharfer Gegensatz zwischen Nord- und Südkontinenten oder möglicherweise zwischen einem Nord- und einem Südkontinent.

$\times$ Man vergleiche dazu die scharfe und gesunde Kritik, die SEMPER im Zentralblatt für Mineralogie usw. 1908, S. 434, an den paläogeographisehen Karten geübt hat.

$\times \times$ Eine schärfere zeitliche Fixierung, besonders für die vortertiären Perioden, bleibt ausgeschlossen, und die Umrisse der alten Festländer sind vage Phantasiegebilde. Trotzdem hat Tн. ArLdт den Mut gefunden, die Größe der alten Kontinente seit dem Kambrium zu berechnen! (Neues Jahrbuch für Mineralogie usw. 1907, Bd. I, S. 32). 
Der Südkontinent löst sich auf, und ungefähr um den Beginn der Tertiärzeit ist hier der heutige Zustand im großen und ganzen hergestellt. Die Verbindung der Nordkontinente dauert noch etwas länger an. In Asien schließt sich die Tethys, an ihre Stelle tritt der Atlantische Ozean, der in seiner horizontalen wie in seiner vertikalen Gliederung so sehr von den übrigen Ozeanen abweicht. Statt des mesozoischen Gegensatzes von Nord und Süd beherrscht nun der Gegensatz von Ost und West die Erdoberfläche. Was an das frühere Weltbild noch erinnert, sind die Reste der Tethys, alte Landstücke, die sich als Inselpfeiler erhalten oder an fremde Festländer angegliedert haben, (Dekan!), endlich gewisse Züge in der Flora und Fauna, besonders in der niederen Tierwelt.

Hochgebirge. Einer kurzen Auseinandersetzung bedürfen noch die Flora und Fauna der alpinen Region. Erhebt sich ein Gebirge, so wird es zunächst von Pflanzen der umgebenden Niederung besiedelt; den veränderten klimatischen Verhältnissen entsprechend, entstehen Varietäten, oder ältere Varietäten finden im Gebirge besonders günstige Existenzbedingungen und können sich, wie die jungen, im Lauf der Zeit zu Arten befestigen. Jede Hochgebirgsflora - dies ergibt die theoretische Betrachtung - muß also aus zahlreichen endemischen Elementen bestehen, die aber mit der Flora des benachbarten Tieflandes eng verwandt sind. Da sich verhältnismäßig wenige Pflanzen den klimatischen Bedingungen der alpinen Region anzupassen vermögen, so erklärt es sich, daß auf allen Hochgebirgen, die in der Tertiärzeit schon bestanden haben, vorwiegend dieselben Familien und Gattungen vorkommen. Neben diesen Einwanderern aus der Ebene gibt es aber auch Pflanzen, die sich vermöge der langdauernden Keimkraft und der Transportfähigkeit ihrer Samen von Gebirge zu Gebirge verbreiten konnten, die also keine Verwandten im benachbarten Flachland besitzen. Auf diesem alten Standpunkt sind die Floren Abessiniens, des Kamerungebirges, des Kilimandscharo und der Gebirge von Australien, Tasmanien und Neuseeland stehen geblieben.

Eine wesentlich andere Zusammensetzung zeigt die alpine Flora unserer Alpen. MARIE Jerosch ${ }^{10}$ zählt in der Schweiz 420 Alpenpflanzen, die sie in folgender Weise geographisch gliedert: 1. 31 Arten ( 7,4 Prozent), die auch in der Ebene vorkommen und daher keiner weiteren Erörterung bedürfen. 2. 64 Arten (15,2 Prozent), die nur auf die Alpen beschränkt sind oder sich höchstens den benachbarten Gebirgen, wie dem Jura und den Appenninen, mitgeteilt haben. Dieser Gruppe fügen wir 3. noch die 158 Arten (37,6 Prozent) hinzu, die auch noch in den Pyrenäen, in den Karpathen und im Kaukasus 
vorkommen, weil von ihnen, wie von den endemischen Arten, viele als ein Überrest der alten Hochgebirgsflora aus der Tertiärzeit auf. gefaßt werden müssen. Anderseits können manche endemische Arten sich erst in nachglazialer Zeit entwickelt haben. Von der Gruppe 3 müssen aber genetisch viele mit den nun folgenden Gruppen vereinigt werden, nämlich 4. mit dem nordeuropäischen Element (18 Arten $=4,3$ Prozent), 5. mit dem asiatischen (20 Arten $=4,8$ Prozent kommen noch im Altai und 1 Art (0,2 Prozent) noch im Himalaya, aber nicht in der Arktis vor), und 6. mit dem arktischen (128 Arten $=30,5$ Prozent).

Das Vorkommen aller dieser Pflanzen in der alpinen Gebirgsflora deutet auf Wanderungen hin, die zu einer Zeit ausgeführt wurden, als die dazwischenliegenden Landstriche eine ähnliche Flora beherbergten und ein ähnliches Klima besaßen, wie jetzt die Hochgebirgsregionen. Wir begegnen also hier wieder den Spuren der Eiszeit. Damals drang die arktische Flora von Norden, die tertiäre Hochgebirgsflora der Alpen von Süden nach Mitteleuropa vor× und mischten sich hier im eisfreien Gürtel, ja konnten sich sogar mitten im Eis auf Moränen ansiedeln, wie auch jetzt noch die Moränen der Mt. Elias-Gletscher in Alaska Sträucher und sogar Bäume tragen.11 Als das Klima wieder wärmer wurde, drangen von allen Seiten andere Pflanzenelemente in die nordeuropäischen Niederungen vor, und die Glazialflora verschwand endlich aus der Ebene, denn sie scheut nichts so sehr wie die Konkurrenz mit Bäumen, gesellig wachsenden Sträuchern und rasenbildenden Gräsern. Daher reicht sie noch jetzt in Hochgebirgen an jenen Stellen, wo ihre Feinde nicht fortkommen, z. B. in den Kiesbetten der Flüsse, in tiefere Regionen hinab; ja sogar in den Mooren und Heiden der deutschen Ebenen hinterlieB sie noch einige Spuren. Auch im deutschen Mittelgebirge, im Jura, im Schwarzwald und in den Vogesen, im Bayrischen Wald, in den Sudeten und im Harz ist sie von Wald und -Wiese noch nicht völlig verdrängt worden; aber überall, wo die Viehzucht durch Düngung des Bodens den Graswuchs befördert, ist sie ebenso im Verschwinden begriffen wie in den Mooren, wo künstliche Entwässerung den Boden für neue Pflanzenansiedelungen vorbereitet. Nur im arktischen Gebiet einerseits, in den Hochgebirgsregionen anderseits hat sie auf dem vom Eis verlassenen Boden günstige Lebensbedingungen gefunden; aber es ist nun nicht mehr eine rein alpine und eine rein arktische, sondern hüben wie drüben eine aus beiden Elementen gemischte Flora.

$\times$ Nathorst fand 1894 bei Deuben in Sachsen, also am äuBersten Rand des diluvialen Inlandeises, eine fossile Glazialflora. 
Glazialpflanzen, d. h. solche, deren Austausch in der Eiszeit erfolgt ist, bewohnen alle europäischen Hochgebirge, aber je weiter wir nach Süden fortschreiten, desto seltener werden sie. In Griechenland ist die Hälfte der alpinen Flora endemisch, 46 Prozent hat es mit den benachbarten Gebirgen oder mit den Alpen gemeinsam, und 4 Prozent sind glazial. Im marokkanischen Atlas finden sich nur noch sehr wenige für die Alpen und die Pyrenäen charakteristische Pflanzen und nur mehr 1 Glazialpflanze. Die Gebirge des tropischen Afrikas haben, wie bereits bemerkt wurde, ihre eigene Flora:

Glazialpflanzen bewohnen auch die zentralasiatischen Gebirge. 75 finden sich noch auf dem Himalaya, wovon 45 auch in den sibirischen Gebirgen und im arktischen Gebiet und 27 auch in den Pyrenäen vorkommen. Es ist aber nicht in allen diesen Fällen anzunehmen, daß das dazwischen liegende Land (und dasselbe gilt auch von Südeuropa) mit einer arktischen Flora bedeckt war. Alpine Pflanzen können einerseits auch im wärmeren Klima gedeihen, wenn sie nur vor starker Konkurrenz geschützt sind, und anderseits konnten sie auch über nicht allzu weite Zwischenräume von Gebirge zu Gebirge transportiert werden, ohne die Ebene zu berühren. Daraus erklärt sich das zerstreute Vorkommen europäischer Pflanzenarten und -gattungen auf den Höhen von Ceylon und auf den Vulkankegeln von Java; und noch leichter konnten solche Wanderungen auf dem fast ununterbrochenen meridionalen Hochgebirgswall Amerikas ausgeführt werden. Auf den Rocky Mountains finden sich Glazialpflanzen in größerer Anzahl nur bis $37^{\circ} \mathrm{N}$, aber es kommen solche auch in Mexico vor, und auf den südamerikanischen Andes gehören einige Gewächse arktisch-alpinen Gattungen, wenn auch anderen Arten an. Ja sogar einige arktische Arten treten unvermittelt wieder im Feuerland auf, aber es ist möglich, daß, wie in ein paar anderen Fällen, sporadische Vorkommnisse in dem Zwischengebiete noch entdeckt werden. Im östlichen Amerika, wo ein Hochgebirgsvermittler zwischen beiden Hemisphären fehlt, sind die Glazialpflanzen nur bis zu den Weißen Bergen in New Hampshire, also nur bis zum 44. Parallel vorgedrungen, aber hier machen sie noch 77 Prozent der alpinen Flora aus.

Den alpinen Pflanzen entsprechen die alpinen Tiere, die in den Ostalpen die Region von ungefähr 1200 bis $2700 \mathrm{~m}$ Höhe bewohnen. Auch sie sind ein Überrest einer einst auch in der Ebene verbreiteten Fauna, und auch ihre verwandtschaftlichen Beziehungen zu den Tieren des hohen Nordens oder'anderer Hochgebirge führen uns in die Eiszeit zurück.

Nur einige wenige Beispiele aus der Säugetierwelt der Alpen 
mögen hier angeführt werden. Der veränderliche oder der Schneehase unseres Hochgebirges kehrt im Norden der Alten Welt wieder; seine Heimat erstreckt sich hier von Irland und Schottland über Skandinavien, Rußland und Sibirien bis Kamtschatka. Das alpine Murmeltier, das in den Diluvialablagerungen von Mitteleuropa fossil gefunden wird, hat nahe Verwandte in Sibirien, und ebenso findet die Schneemaus ihren Vertreter in der nordasiatischen Wurzelmaus. Der Steinbock, der jetzt freilich nur noch in wenigen Teilen der Alpen erhalten ist, ist sehr nahe dem pyrenäischen, dem kaukasischen und dem sibirischen Steinbock verwandt, mit denen er in bezug auf Lebensweise vollkommen übereinstimmt; andere Arten dieser Untergattung bewohnen auch die Sierra Nevada, die höchsten Felsregionen von Abessinien und die Gebirgsgegenden von Mittelägypten, Syrien und der Sinaihalbinsel. Nicht vergessen dürfen wir endlich des elegantesten unter den alpinen Tieren, der Gemse, die in allen höheren Gebirgen von den Pyrenäen bis zum Kaukasus vorkommt und uns den Lehrsatz von der Vermischung verschiedener Gebirgsfaunen in der Eiszeit noch besser illustriert als der Steinbock, da genau dieselbe Art in all den genannten Gebirgen wiederkehrt. Aus der Vogelwelt sei das Schneehuhn als echter arktischer Einwanderer genannt.

Auch die faunistischen Beziehungen zwischen tropischen Gebirgen Afrikas (Abessinien, Kilimandscharo, Kamerunberg), dem Himalaya und dem Gebirge von Luzon führen uns in eine Periode von allgemein verbreiteter tieferer Temperatur zurück, wenn wir sie auch nicht bestimmt mit der Eiszeit identifizieren können. Das zerstreute Vorkommen solcher Tierformen in der Alten Welt hängt damit zusammen, daß hier die Gebirge in ostwestlicher Richtung streichen, während sich in den meridionalen Andes Amerikas der Guanako vom Äquator bis $55^{\circ} \mathrm{S}$ verbreitet und in der Insektenfauna noch Elemente der 'nördlichen gemäßigten Zone auftreten. Auch in den Alpen birgt die niedere Tierwelt zahlreiche Überbleibsel aus der Glazialzeit. Zsснокке ${ }^{12}$ bezeichnet als solche in der Schweiz die Bergeidechse, verschiedene Insekten und Mollusken und auch Wassertiere, die sowohl die Seen im hohen Norden wie in den Alpen bewohnen.

Veränderungen in der Jetztzeit. Wenn wir unter Jetztzeit die seit dem Abschluß der Glazialperiode verstrichenen Jahrtausende verstehen, so haben wir auch hier mit klimatischen Veränderungen zu rechnen, die sich im Wechsel des Pflanzenkleides widerspiegeln. Aller Wahrscheinlichkeit nach war Mitteleuropa einmal wärmer und trockener als jetzt (vgl. S. 242), und es ist anzunehmen, daß die Steppenpflanzen, die im Hochgebirge und mehr noch im Flach- 
land auftreten und hier entweder der Wald- und Wiesenflora eingestreut sind oder eigene Kolonien bilden, damals nach Mitteleuropa eingewandert sind. Von manchen Botanikern wird ihr Eindringen in eine der Interglazialzeiten oder gar in die vorglaziale Zeit zurückdatiert, aber es ist nicht glaublich, daß sie die Eiszeit oder gar wiederholte Eiszeiten hätten überdauern können. Für viele Gegenden Europas und Asiens ist ein säkularer Waldwechsel außer Zweifel gesetzt. Fast in ganz Mitteleuropa und Skandinavien folgte auf die Birke die Kiefer, auf diese die Eiche, dann die Buche, endlich die Fichte. Im russischen und sibirischen Nadelholzwald erobert die Birke (in Rußland im Vereine mit der Esche) immer größere Areale. Die Ursachen dieser Erscheinung sind noch keineswegs genügend aufgeklärt, doch war wohl nicht immer ein Klimawechsel dabei im Spiel. Waldbrände haben jedenfalls mitgewirkt, namentlich im Norden sind sie verhängnisvoll, weil die Samenreife schwieriger ist. Manchen dieser Vorgänge kann man mit CHRIST als eine natürliche Brachwirtschaft bezeichnen, indem der Boden, jahrhundertelang durch gewisse Pflanzengattungen ausgesogen, diesen endlich nicht mehr die nötigen Existenzmittel gewähren kann, wohl aber anderen Gewächsen, die andere Ansprüche an ihren Standort stellen. Die Ausbreitung der Calluna-Heide in Dänemark und Norddeutschland findet auf diese Weise eine ungezwungene Erklärung.

Die auffallenden Veränderungen, die im Laufe der historischen Zeit in der Verbreitung der Pflanzen stattgefunden haben, sind aber direkt oder indirekt ein Werk des Menschen. ${ }^{13}$ Die Physiognomie alter Kulturländer, wie Chinas, der hindustanischen Ebene und des Mittelmeergebietes, hat sich gründlich verändert, aber kaum minder die jüngerer Kulturländer, wie des übrigen Europa, Westindiens, der östlichen Staaten Nordamerikas u. a., wo die kürzere Dauer des menschlichen Einflusses durch die Energie der Arbeit aufgewogen wird. Fast überall begann die Tätigkeit des Kulturmenschen mit der Ausrodung der Wälder, an deren Stelle aber nicht immer Kulturland, sondern nur zu häufig auch Einöden traten. $\times$ In Europa $\times \times$ ist nur der nordrussische Wald noch zum gröBten Teil unberührt, von einer Fläche von $2134000 \mathrm{qkm}$ sind hier noch

× Über die Fortschritte der Entwaldung ist man wenig unterrichtet; häufig werden sie überschätzt. Für den Kanton Zürich ermittelte WALsER eine Abnahme des Waldes in der. Periode 1640-1891 um $50 \mathrm{qkm}$ oder 10 Proz. Dabei sind manche günstige Lokalitäten, wie z. B. die Überschwemmungsgebiete der Flüsse, vom Wald erobert worden.

$\times \times$ Der gegenwärtige Waldbestand beträgt in Prozenten der Gesamtfläche der betreffenden Staaten: 
67 Prozent bewaldet, und diese Verhältniszahl dürfte wahrscheinlich auch für das sibirische Waldgebiet Geltung haben.

Eine Vermischung der Floren ist die unausbleibliche Folge dər Allgegenwart des Kulturmenschen. In den Mittelmeerländern gedeihen jetzt trefflich die amerikanischen Kakteen und Agaven, die afrikanischen Aloë und die australischen Eukalypten, namentlich die letzteren, die erst 1854 eingeführt wurden und sich jetzt schon über die meisten Küstenstriche, bei deren Entsumpfung sie ausgezeichnete Dienste leisten, verbreiten. Die Savanen von Westindien sind nicht mehr im ursprünglichen Zustand erhalten, seit das Guinea- und das Paragras zur Verbesserung der Weide eingeführt wurden. Südeuropäische Gewächse haben sich zwischen die Gräser der Pampas eingedrängt, so daß in der Umgebung von Buenos Aires die Flora nach O. KunTze schon $\mathrm{zu}^{3} / 4$ aus eingewanderten Pflanzen besteht. Die Artischockendistel, deren Samen zuerst um das Jahr 1769 in den Haaren eines Esels aus Spanien nach Argentinien gelangt ist, bildet bereits auf Flächen von mehreren hundert Quadratkilometern zusammenhängende, undurchdringliche Dickichte von mehr als Manneshöhe. Zahllose fremde Unkräuter sind mit den Kulturgewächsen nach Nordamerika, besonders in die atlantischen Staaten eingewandert; der gemeine Natterkopf z. B. hat in manchen Gegenden von Virginien die einheimische Vegetation völlig verdrängt. Ähnliches ist in Australien der Fall, wo in der Umgebung von Sydney schon über 100 europäische Pflanzenarten, darunter viele schädliche Unkräuter, sich ansässig gemacht haben. ${ }^{14}$ Wie die Kolonisation haben auch die Kriege stets zur Florenvermischung beigetragen, und der rasch pulsierende Verkehr der Jetztzeit beschleunigt diesen Prozeß außerordentlich. Besonders bemerkenswert ist die Tatsache, daß längs der Eisenbahnlinien neue Gewächse auftauchen, und zwar nicht bloB an den Ausladestationen, sondern merkwürdigerweise auch da, wo die Bahn Kurven beschreibt. Welche Dimensionen diese Pflanzenverschleppung annimmt, geht schon daraus hervor, daB auf der Strecke Augsburg-Haspelmoor gelegentlich der Getreidetransporte 1868-80 44 neue Phanerogamen in die Flora eingeführt wurden. ${ }^{15}$

Gewaltig sind auch die Veränderungen in der Tierwelt, die der Mensch durch Ausrottung, Züchtung und durch die Umgestaltung

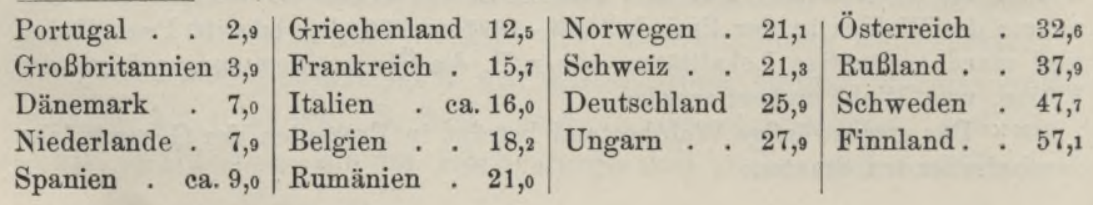


der Vegetation hervorgerufen hat. $\mathrm{Da} B$ er mit den großen Dickhäutern, dem Mammut und dem wollhaarigen Rhinozeros, sowie mit mehreren ausgestorbenen Raubtieren, wie dem Höhlenbären, dem Höhlentiger (fälschlich Höhlenlöwe genannt), dem Höhlenwolf und der Höhlenhyäne, in Europa zusammengelebt hat, ist durch mehrfache Funde sichergestellt; aber ihr völliger Untergang erfolgte schon zu einer Zeit, von der uns keine schriftliche Nachricht Kunde gibt. Viel später erlagen die großen Wiederkäuer, die noch im Nibelungenlied genannt werden: der Wisent (Bison), der Ur oder Auerochs, der Stammvater unseres zahmen Rindes, und der Schelch oder Riesenhirseh. Der europäische Bison kommt nur noch in einem Distrikt des Kaukasus und im Bjelowjescher Wald (russisches Gouvernement Grodno), hier aber nur im gehegten Zustand vor. Der Ur lebte in Frankreich noch im 5. Jahrhundert unserer Zeitrechnung, im Harz noch im 7., in Böhmen noch im 14. und in Polen noch im 16. Jahrhundert; die Ausrottung schritt also mit der Kultur von West nach Ost fort. Das Renntier bewohnte einst ganz Mittel- und Westeuropa, wurde aber aus Frankreich schon in vorgeschichtlicher Zeit verdrängt, während es in Deutschland noch zur Zeit Cäsars lebte und in Nordschottland noch im 12. Jahrhundert gejagt wurde. Jetzt ist es in Skandinavien über den 60. Parallel zurückgedrängt, in Asien geht aber seine Äquatorialgrenze viel weiter herab und erreicht an der Ostseite der Alten und im Westen der Neuen Welt $46^{\circ}$ B. Das Elen, das noch zur Zeit der sächsischen Kaiser die deutschen Wälder bewohnte, ist daraus verschwunden und kommt mit Ausnahme einiger preußischen Forste, wo es gehegt wird, nur noch in Skandinavien vor. Die Hasen, Hirsche, Rehe, Wildschweine und Gemsen vermindern sich zusehends; der Steinbock, früher im ganzen Alpengebirge zu Haus, findet sich jetzt nur noch am Monterosa. Notwendig war der Vertilgungskrieg gegen die Raubtiere, von denen Wolf, Luchs und Bär aus Mittel- und Westeuropa zum größten Teil verschwunden sind. Der Löwe, der sich noch zur Zeit der Perserkriege über ganz Griechenland bis nach Thrakien verbreitete, ist jetzt aus Europa gänzlich verwiesen. Im dichtbevölkerten China finden die Raubtiere selbstverständlich auch keinen Platz mehr. In Nordasien und in Nordamerika vermindern sich die Pelztiere stetig, und auch der nordamerikanische Bison, der manchmal in Herden von 20000 Individuen die Prärien durchstreifte, ist wild fast ganz ausgestorben.

Die Entwaldung großer Landstrecken, die nun von Getreidefeldern eingenommen werden, gab Veranlassung zur Einwanderung östlicher Steppensäuger, die ihr Verbreitungsgebiet unter unseren 
Augen bis nach Rußland vorschieben, d. h. soweit als das kontinentale Klima reicht; ja der gemeine Ziesel ist sogar schon bis Sachsen und Böhmen gelangt. Noch ausgedehnter sind die Westwanderungen der Vögel, die gegen klimatische Unterschiede unempfindlich zu sein scheinen. Unsere ostdeutsche Vogelwelt hat sich durch russische und sibirische Zuzüge bereichert, ja die sibirische Berglerche sucht im Winter sogar schon England auf. Es ist unstreitig die Tendenz vorhanden, die Fauna der mittleren und höheren Breiten der Alten Welt immer gleichförmiger zu gestalten; Hand in Hand damit geht aber auch eine Artenverarmung unseres Tierbestandes.

Am augenfälligsten sind die Veränderungen des Tierbestandes in den Kolonialländern; die faunistische Physiognomie Südamerikas, Australiens und Neuseelands ist durch die Einführung unserer Haustiere völlig anders geworden. Auf den Inseln sehen sich die Organismen plötzlich vor einen neuen Kampf ums Dasein gestellt, in dem sie, geschwächt durch langen Frieden, bald unterliegen. Hier gehen die Veränderungen mit unheimlicher Schnelligkeit und Gründlichkeit vor sich. So haben auf St. Helena die eingeführten Ziegen den Urwald zerstört, und infolgedessen sind auch seine einheimischen Bewohner, Vögel und Insekten, zum großen Teil ausgestorben. So haben auf den Mascarenen die Zuckerpflanzungen die frühere Vegetation fast völlig vernichtet, so beschränken auf Neuseeland die siegreichen englischen Gräser die so merkwürdige alte Flora auf immer kleinere Flächen, so wurde die einheimische Pflanzenwelt auf Madeira durch den Wein, das Zuckerrohr und den Pisang bis auf $650 \mathrm{~m}$ Höhe, und auf den Canaren durch den Wein und die Opuntien bis auf $1000 \mathrm{~m}$ Höhe zurückgedrängt.

Literaturnachweise. ${ }^{1}$ Die allgemeinen Werke zit. S. 886, Anm. 1. $-{ }^{2}$ C. H. Merriasr, The Geographical Distribution of Life in North Ameriea; in den Proceedings of the Biological Society; Washington 1892, Bd..VII. ${ }^{3}$ W. D. Matthew zit. S. $887 .-{ }^{4}$ R. F. ScharfF, European Animals, London 1907; On the Evidences of a former Land-bridge between Northern Europe and North America, in den Proceedings of the R. Irish Academy, Bd. XXVIII, Sektion B, 1909. - ${ }^{5}$ Тн. Tновоddsen, Die Hypothese von einer postglazialen Landbrücke über Island und Färöer, in der Naturwissensehaftlichen Rundschau 1906, Bd. XXI. - ${ }^{6}$ J. B. Harrison u. A. J. Jukes-Brown, Notes on the Chemical Constitution of some Oceanic Deposits, im Quarterly Journal of the Geological Society of London 1895. - ${ }^{7}$ E. Phinrppr, Über das Problem der Sehichtung und über Schichtbildung am Boden der heutigen Meere, in den Verhandlungen der Deutschen Geologisehen Gesellschaft 1908, Bd. LX. ${ }^{8}$ Bericht von E. Phiцipp in den Veröffentlichungen des Instituts für Meereskunde 1902 , Heft $1 .-{ }^{9}$ E. v. Mossisovics, W. WaAgen und C. Diener, Entwurf einer Gliederung der pelagischen Sedimente des Triassystems; in den Sitzungsberichten der Wiener Akademie der Wissenschaften, Mathem.-naturwiss. Kl. 1895, Bd. CIV, Abteilung I. $-{ }^{10}$ M. Сн. Jerosch, Geschichte und Herkunft der 
Schweizerischen Alpenflora; Leipzig 1903. - ${ }^{11}$ O. Drude, Die hypothetischen vegetationslosen Einöden im temperierten Klima zur Eiszeit, in Petermans's Mitteilungen 1889. - ${ }^{12} \mathrm{~F}$. Zsснокке, Die Beziehungen der mitteleuropäischen Tierwelt zur Eiszeit, in den Verhandlungen der Deutschen Zoologischen Gesellschaft 1908. - ${ }^{13} \mathrm{~J}$. Wrmmer, Geschichte des deutsehen Bodens in seinem Pflanzen- und Tierleben von der keltisch-römisehen Urz̨eit bis zur Gegenwart; Halle a. S. 1905; ein für genauere Studien sehr zu empfehlendes, auf Urkunden gestütztes Werk. - ${ }^{14}$ Ausführlich haben die Veränderungen, die der Menseh in der Flora Chiles und Californiens bewirkte, R. A. Philippi und H. Semler geschildert (Petermans's Mitteilungen 1886 u. 88). - ${ }^{15}$ Diese Angaben verdankt der Verfasser der Mitteilung des + Prof. A. Kıгенног.

Die pflanzen- und tiergeographischen Einteilungen der festen Erdoberfläche (S. Karte XIX und XX).

Im folgenden fassen wir noch einmal übersichtlich zusammen was in den beiden letzten Kapiteln verhandelt wurde. Wir haben bereits verschiedene pflanzengeographische Einteilungen, die in ihren wesentlichen Grundzügen zwar übereinstimmen, in Einzelheiten aber sehr voneinander abweichen. Was der eine als Provinz bezeichnet, erhebt der andere zu dem Rang eines Reiches, und muß dann wieder eine höhere Einheit schaffen, um verwandtschaftliche Beziehungen zum Ausdruck zu bringen. Noch mehr Schwierigkeiten verursachen die Grenzen. Scharfe Florengrenzen gibt es in der Natur nur dort, wo sie mit einem Hochgebirge zusammentreffen, sonst tritt überall an den Grenzen Mischung ein, und die Linien unserer Karten tragen notwendigerweise den Stempel der Willkür und Unnatur. Auf Karte XIX sind einige solcher Mischgürtel hervorgehoben. Im großen und ganzen folgen wir der Einteilung DRUDE's, nur weichen wir in drei Punkten davon ab: 1. lassen wir die Gliederung in Zonen (DRudE's Gruppen) fallen, weil sie - man vergleiche z. B. die boreale und die Australzone keine gleichwertigen Einheiten darstellen; 2. scheiden wir Melanesien und Neuseeland nicht als eigenes Florenreich aus, und 3. ebensowenig das südliche Afrika, das früher auch ENGLER mit dem tropischen Afrika vereinigt hatte. Die Provinzeinteilung des nordischen Reiches führen wir vollständig auf, von den übrigen aber nur einige wichtigere.

A. Boreale Gruppe.

I. Nordisches Reich:

1. Arktische (zirkumpolare) Provinz,

2. Mitteleuropäische Provinz,

3. Russische Steppenprovinz,

4. Sibirische Provinz,

5. Amurprovinz, 

6. Columbische Provinz,
7. Canadische Provinz.

II. Mittelmeer- und Orient-Reich,

III. Innerasiatisches Reich,

IV. Ostasiatisches Reich,

V. Sonorisches Reich.

Wichtig die pazifische Provinz!

B. Paläotropische Gruppe:

VI. Afrikanisches Reich, Wichtig die Kapprovinz!

VII. Madagassisches Reich,

VIII. Indisches Reich.

C. Neotropische Gruppe:

IX. Neotropisches Reich.

D. Westaustralgruppe:

X. Australisches Reich,

Westaustralische Provinz!

E. Ostaustralgruppe:

XI. Andines Reich,

XII. Antarktisches Reich.

Die Neue und die Alte Welt berühren sich an der BeringstraBe und gehen nach Süden immer weiter auseinander. Diese geographische Anordnung spiegelt sich in den Floren beider Landfesten wieder. Im äußersten Norden eine zirkumpolare Provinz; dann verschiedene Provinzen, aber noch ein zirkumpolares Reich; dann verschiedene Reiche, die aber doch untereinander und mit dem nordischen Reich so viele Beziehungen zeigen, daB man sie zu einer Einheit höherer Ordnung, der borealen Gruppe, zusammenfassen darf. Innerhalb der tropischen Zone ist der Zug gemeinsamer Entwickelung viel schwächer ausgeprägt, denn hier lagern in ostwestlicher Richtung nicht bloß Reiche, sondern auch Gruppen nebeneinander. Zwar erscheint im äußersten Süden wieder ein zirkumpolares Reich, aber ein Reich, das aus weit voneinander gelegenen Inseln besteht und daher natürlich anderen Gesetzen unterworfen ist als das kontinentale nordische Reich.

In bezug auf das Alter und die Entwickelung der Floren lassen sich unterscheiden:

1. Alte Floren:

a) die tropischen Kontinentalfloren, die sich seit der Tertiärzeit ungestört entwickeln konnten;

b) alte Inselfloren, zu denen wir die australische und die Kapflora zählen. 
2. Mischfloren in Ländern, deren Klima sich seit der Tertiärzeit allmählich geändert hat, wo aber die Entwickelung nicht ganz unterbrochen wurde (Mittelmeergebiet, Ostasien, atlantische Staaten von Nordamerika).

3. Junge Floren der Länder, die nach der Tertiärzeit mit Eis oder Wasser bedeckt waren:

a) Floren, die ganz entlehnt sind (z. B. die des norddeutschen Tieflandes);

b) Floren mit eigentümlicher Entwickelung (Steppenfloren).

Gegen tiergeographische Einteilungen hat sich in neuester Zeit, seit man den niederen Klassen erhöhte Aufmerksamkeit schenkt, eine scharfe Opposition erhoben, die insofern berechtigt ist, als in der Tat keine Einteilung für alle Klassen gilt. „Es muß,“ sagt Kobeut, „das Bestreben der Zoogeographen sein, für jede Abteilung des Tierreiches durch eingehende Untersuchung eine besondere Einteilung der Erdoberfläche vorzunehmen, zunächst ohne Rücksicht auf andere Tierklassen und auch auf das Pflanzenreich. Aus der vergleichenden Zusammenstellung derartiger Arbeiten wird sich dann von selbst die natürliche Gliederung der Erdoberfläche ergeben." Ein solches Programm ist nicht aussichtslos; wenn man die Einteilung nach Säugetieren und Vögeln mit der nach Regenwürmern in Mrchaelsen's Oligochätenwerk vergleicht, so wird man von der Übereinstimmung in den wesentlichsten Zügen überrascht. Indes wird es lange Zeit dauern, bis KoBELT's Zukunftspläne verwirklicht sind, und da der Geograph einer faunistischen Einteilung nicht entbehren kann, so muß er sie vorläufig auf die Verbreitung derjenigen Klasse gründen, die für ihn auch aus andern Gründen die wichtigste ist, nämlich der Säugetiere. Es trifft sich glücklich, daß die Einteilung der Erde in fünf „Faunenregionen“, die Sclater sen. im Jahre 1857 auf Grund der Vögelverbreitung vorgeschlagen hat, von WALLACE auch für die Verteilung der Säugetiere als durchaus zutreffend befunden wurde und dadurch zu hohem Ansehen gelangte. WALLACE teilte seine „Regionen“ weiter in "Subregionen“, anderseits faßte auch er schon die Regionen nach ihren verwandtschaftlichen Beziehungen zu Einheiten höherer Ordnung zusammen. BuANFORD und ZITTEL haben diesen Gedanken noch schärfer ausgesprochen und kennen nur drei Säugetierreiche. Wir nennen sie, um wenigstens eine gewisse äußere Gleichartigkeit mit der von uns adoptierten Floreneinteilung zu erzielen, Gruppen, und teilen sie in Reiche; diese können wieder in Provinzen aufgelöst werden, wofür sich Anhaltspunkte in unseren bisherigen Ausführungen ergeben. ${ }^{1}$ 
Die heutige Säugetierwelt - und im großen und ganzen gilt dies auch von den übrigen höheren Tierklassen - geht von drei Zentren aus: der Arktogäa oder der nördlichen Halbkugel, Südamerika und Australien. Die arktogäische Fauna verbreitet sich nicht nur über alle Nordkontinente, sondern auch über Afrika. Diese Wanderung und die Unterbrechung der nordischen Entwickelung durch die Eiszeit sind die beiden großen Ereignisse, die die tiergeographischen Verhältnisse der Gegenwart, wenigstens soweit es sich um die höheren Formen handelt, bedingen. Wir können darnach eine förmliche Altersreihe der Faunenreiche entwerfen:

\section{Gruppe Arktogäa.}

1. Das boreale Reich

2. Das sonorische Reich $\}$ Jugendliche Faunen.

3. Das indische Reich mit den Abkömmlingen der Tertiärfauna ohne starke Beimischung nordischer Formen.

4. Das afrikanische Reich südlich der Wüste, mit mangelhafter arktogäischer Tertiärfauna und einigen sonst ausgestorbenen Formen.

5. Das madagassische Reich mit ärmlicher arktogäischer Zuwanderung und alten Typen.

Südamerikanische Gruppe (Neogäa).

6. Südamerikanisches Reich, eine alte Fauna mit spärlicher arktogäischer Beimischung.

Australische Gruppe (Notogäa).

7. Australien mit einer Säugetierfauna von wesentlich mesozoischem Charakter,

8. Polynesien ohne Säugetiere.

Umstehende Tabelle dient zum Vergleich unserer pftanzenund tiergeographischen Einteilungen.

Im großen und ganzen ist die Übereinstimmung durchaus befriedigend. $\mathrm{DaB}$ die Grenzen nicht immer zusammenfallen, hat wenig zu sagen, denn die leicht bewegliche Tierwelt kümmert sich darum noch weniger als die Pflanzen, und die Grenzgebiete tragen in der Regel einen gemischten Faunencharakter. Die beiden einzigen tiefgreifenden Unterschiede sind folgende: 1. die weite Ausdehnung der Arktogäa, die zwei Florengruppen umfaßt, und darauf beruht, daß die Verbreitung der höheren Tiere weniger als die der Pflanzen durch das Klima beeinflußt wird; 2. die Stellung der Südseeinseln, die floristisch zum indischen, faunistisch zum australischen Reich gezählt werden. Dagegen tritt in beiden Einteilungen 
Die pflanzen- und tiergeographischen Einteilungen der festen Erdoberfläche $\quad 909$

\begin{tabular}{|c|c|c|c|}
\hline & Flora & Landfauna & \\
\hline & Nordisches Reich & & \\
\hline 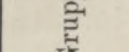 & Mittelmeer u. Orient & Boreales Reich & \\
\hline$\stackrel{0}{\varrho}$ & Innerasien & & \\
\hline 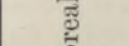 & Ostasien & & B \\
\hline$\stackrel{0}{n}$ & Sonorisehes Reich & Sonorisches Reich & के \\
\hline b 융 & $\begin{array}{l}\text { Indisehes Reich } \\
\text { (mit Polynesien!) }\end{array}$ & $\begin{array}{l}\text { Indisches Reich } \\
\text { (obne Polynesien!) }\end{array}$ & \\
\hline ๘ँ & Afrika & Afrika & \\
\hline 5 & Madagaskar & Madagaskar & \\
\hline 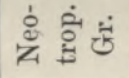 & Neotropisches Reich & Südamerikanisches Reich & Ž \\
\hline & Andines Reich & & : \\
\hline జై & Australien & Australien & a. za \\
\hline$\overbrace{4}^{\frac{a}{4}}$ & - & Polynesien & है \\
\hline & Antarktisches Reich & - & \\
\hline
\end{tabular}

das Grundgesetz der zunehmenden Differenzierung von Nord nach Süd mit gröBter Deutlichkeit hervor. In dieser Richtung wird die Gliederung mannigfaltiger und der Endemismus ausgeprägter. Der Grund liegt in dem kontinentalen Zusammenschluß auf der Nord- und der Zersplitterung auf der Südhalbkugel; nur vereinzelte Spuren deuten noch auf einen längstvergangenen Kontinentalzustand der antarktischen Hemisphäre hin.

So spiegeln sich in der organischen Welt die beiden großen geographischen Gegensätze wieder: die Alte und die Neue Welt, die Nord- und die Südkontinente. Und überall begegnen wir auch hier im positiven, aber mehr noch im negativen Sinn den Spuren der Eiszeit, und nur in den beglückteren südlicheren Ländern finden wir noch Reste einstiger Tropenfülle.

Literaturnachweise. ${ }^{1}$ Einen Überblick über die bisherigen tiergeographischen Einteilungen gibt Тн. АвLDT in der Geographischen Zeitschrift Bd. XII, 1906, S. 212. 


\section{Register.}

Die Autorennamen sind gesperrt gedruckt. * bei der Seitenzahl bedeutet eine Literaturnotiz. Namen, die man unter $\mathrm{C}$ nicht findet, suche man unter $\mathrm{K}$ oder $\mathrm{Z}$ und umgekehrt. Desgleichen suche man Namen, die man unter J nicht findet, unter Y.

Aachener Quelle 495.

Aachquelle 736 .

Aare 737.

Abdachungstäler 544, 545.

Abdämmungsstufen 555 .

Abegg, R. 289, 290*.

Abercromby, R. 129*.

Abessinien, Gewitter 179, Morphologie 398, 638, Ambas 633, Waldgrenze 829, Flora 897, Fauna 900.

Abessinischer Typus 643 .

AbfluB der Seen 758.

AbfluBfaktor 499, 501 .

AbfluBlose Gebiete 158, 732, 733, 734.

AbfluBmengen 499.

Abfuhr 466.

Abgegliederte Halbinseln $\mathbf{7 6 6}$.

Abgliederungsinseln 787 .

Abich, H. 181, 759 .

Abkehrflüsse 546 .

Ablagerung 466, 467.

Ablation 196, 467, 572, 586 .

Ablenkung sich horizontal bewegender Körper 22.

Abplattung der Erde 4, 5, 6, 372.

Abrasion 468, 586, 591, 683, 772 .

Abrasionsterminante 591 .

Abschleifende Gletschererosion 550.

AbschlieBungsküsten 804 .

Abschmelzung der Gletscher 196, 212.

Absolute Feuchtigkeit 147, 149.

Absolutes spezif. Gewicht des Meerwassers 287.

Absorptionstemperatur 320 .

Absteigende Quellen 488.

Abtragung 514.

Abukir, See von, 599.

Abu Moharik 578.

Abweichung der Temperatur 113.

Abyschkansee 760 .

Abyssische Region 46.

Achatinellen 883.
Achenschwankung 246.

Aclettagrat 476.

Adamello, Kare 552.

Adams, F. A. 647.

Adda 722,760 .

Adelsberger Grotte 538.

Aden, Golf von, 279, 336, 398.

"Adlergrund" (Schiff) 318.

Adobe 581 .

Adour 455.

Adriatisches Meer, Areal und Boden 258, 261, 270, Geschichte 456, 457, Strömung 597.

Afar 398.

Affatakha-Wadi 104.

Affen 860, 864, 867, 873, 874, 875, 877.

Affenbrotbaum 822 .

Afghanisch-turkestanisches Grenzgebirge 676.

Afrika, höchste Breite 31, Grenzen 35, Areal 36, Oberfläche 47, Höhe 47, 51, Temperatur 89, 90, 93, Temperaturschwankung 104, 106, 107, Luftdruck und Winde $130,134,137$, Regen 161-164, 175, Regenwahrscheinlichkeit 168, Gletscher 219, Klimaprovinzen 232f., Eiszeit 243, Wasserabnahme 252, Vulkane 393, 398, Grabengebiet 397, Erdbeben 430 , 432, Laterit 482, Bodenarten 601, 602, 603, Morphologie 620, 684, 697, Flüsse 731, 739, abfluBlose Gebiete 732, 734, Wasserscheiden 733, Abdachungen 734, Depressionen 752, Seen 757, Halbinseln 766, Küsten 793, Küstenabstand 807 , Küstenentwicklung 807,808 , Vegetation 817 , 849, Palmen 818, 819, Wald 834, 836, 837, Mangrove 837, Busch 840, Savanen 844 , Steppen und Wüsten 848 , Nahrungsgewächse 852,855 , 857 , tierische Schädlinge 867 , Flora 
$872,875,886,899,905,906,909$, Fauna $872,873,875,884,886,899$, 900, 908, 909, alte Landverbindung 885. (S. auch Ost- u. Südafrika.)

Ägäisches Meer 261, 270, 397, Geschichte 456, 771, Küsten 796.

Agassiz, A. 781, 782, 783, 792*.

Agassiz, L. 198, 205.

A gassizsee 761 .

Agaven 823, 843, 848, 872, 902.

Agh Sibyr 408.

Ägina 397.

Agostini, G. 764*.

Agramer Erdbeben 421, 425.

Agulhasströmung 334.

Ägypten, Klimaänderung 244.

Ahorn 838.

Aintal, Veränd. d. Aussichtsweite 462.

A iry, G. B. 311, Formel 296.

Aitken, J. 151.

Aitrach 728.

Ajan, Temperatur 145.

Akaba, Golf v., 398.

Akanthus 889.

Akazien 837, 838, 840, 841.

Akis-See 748.

Aktische Region 46.

Aktive Niveauveränderungen 18.

Alakul 760.

Alang-Alang 843.

Alangordlek 548.

Alaschan, Wald 161, 847.

Alaska 40, Vulkane 393, 395, Niveauveränderung 439, Waldgrenze 825 .

Albaner Gebirge 396.

Albanien, Bora 143.

Albano, Thermen 495.

Albert-Edward-See 398 .

Albert-See 398 .

Albrecht, Th. $140^{*}$.

Albtypus 643.

Albuenfjord 802.

Aldabra 782 .

Aletschgletscher 185, 195, 205, 220, Pflanzen 832.

Alëuten 395, 769.

Alëuten-Graben 267.

Alexabank 266, 783.

Alföld 623, 629.

Algier, Föhn 145, Regen 171, Kalkkruste 473, Küste 599, 795.

Alken 865.

Alleghanies 38, Föhn 145, Bau 688, 689 , 691, Beziehung zum Vorland 675 , Geschichte 690, Durchgangstäler 719 .

Allier 738.

Alligator 864 .

Allochthoner Torf 763 .

Alluvium 26, 467, 602, 603.
Almera, J. 658*.

Aloë 821, 824, 840, 902.

Alpaka 87.

Alpeinerferner 215.

Alpen 38, Unterschied zwischen Sonnenu. Schattentemperatur 78, vertikale Temperaturabnahme 76, 79f., Winde 133, Föhn 144, Regen 156, 160, 166 , 175, Hagel 181, Schneegrenze 185, 189, Gletscher 193, $195 \mathrm{ff}$., 199, 214, $216,217,219,220,221,237$, Eiszeit 243,246 , angebliche Klimaänderung 253, Seen $343,751,756$, $761 \mathrm{f}$., Vulkane 397, Erdbeben 429, 430, 431, Verwitterung 472, höchste Quelle 494, AbfluB 501, 502, Klammen 524, Talbildung $553 \mathrm{ff}$., 560, Kare 552, LöB 581, Moränenlandschaft 604 , Fazies 609, Bau u. Geschichte $647 \mathrm{ff}$., $654,655,656,662 \mathrm{ff} ., 669,672,687$, Abgrenzung 672, Einteilung 674, Beziehung zum Vorland 675, Gipfelhöhe 692, Talverlegung 713, Längstäler 715, Gliederung 717, 718, Durchgangstäler 719 , Talwasserscheiden 726 , Verhältnis zur europ. Hauptwasserscheide 735, Flora 814, 897, Waldgrenze 830, Getreidegrenze 853, 854 , Fauna $865,899,900$. (S. auch Ostalpen, Schweiz, Westalpen.)

Alpenrosen 840.

Alpensystem 38, 673.

Alpen-Windröschen 814

Alpine Gletscher 193, 221, 225.

, Pflanzenregion 813, 831, 897.

" Tiere 899.

"Waldgrenze $828 \mathrm{ff}$.

Alt 716, 719 .

Alt, E. $181^{*}$.

Altai 853,898 .

Altdorf, Temperatur 144.

Alte Floren 906.

Alter Hut 586.

Altertum der Erde 24.

Alte Welt s. Ostfeste.

Altstätten, Temperatur 105.

Alttertiär 25.

Altwasser 508.

Alvordtal 641 .

Amahei, Regen 176.

Amazonas, Gezeitengrenze 309, Wassermenge 504, Mündungsform 565, 570, System 737, Größe 739, Barre 806. Amazonasebene, Regen 161, 177, Bodenarten 603, Bau 628, Vegetation 810 , $819,834,835,836$.

Ambas 633 .

Ameisen 863, Humusbildung 474.

Ameisenbär 874.

Ameisenigel 877. 
Amerika, höchste Breite 31, Zweiteilung 34 , Oberflächenformen 39 , Temperatur $89,91 \mathrm{ff}$., Temperaturabweichung 113, Temperaturveränderlichkeit 114 , Niederschläge 166, Regenwahrscheinlichkeit 168, Schneegrenze 188, Gletscher 219, 224, Klima 233, 235, Vulkane 393, Erdbeben 431, LöB 605, Wasserscheiden 733, Küste 793 , Palmen 818, 819, Mangrove 837, Vegetationsformationen 849,850 , Nahrungspflanzen 851, 852, 853, 854, $855,856,857$, Flora 872 . (S. auch Nord- u. Südamerika.)

Amerikanisches Mittelmeer 259, Areal und Tiefe 260, Bodenrelief 269, 455, Strömungen 328, FluBgebiet 734 .

Amerikanische Zyklone 137.

Amiens, Schwelle 682.

Amorphophallus titanum 822 .

Ampferer, 0. $370,376^{*}, 556,564^{*}$. Amphibien 861.

Amphidromie 315 .

Amplitude 103.

Amsterdam 806.

Amsterdam-Inseln s. Neu-Amsterdam: Amu 740, 742 .

Amundsen, R. 356, 357.

Amur 506, 571, 739.

Amurland, Pflanzen 844, 905.

Amur-Liman-Strömung 335.

S. Ana, Vulkan 709 .

Anakonda 863.

Ananasgewächse 835,872 .

Ancylussee 445.

Andalusisches Gebirge, Vulkane 397, Bau 673, 675, 679 .

Andamanen 772, 788 .

Andamanisches Meer 259, 260.

Anderson, T. 384 .

Andersson, G. 52*, 227, 241, 256*, $464^{*}, 471,475,483^{*}, 588,589,600^{*}$, $827,833^{*}$

Andes, vertik. Temperaturabnahme 76, Schneegrenze 188, Gletscher 193, 220, 224, Klima 233, Eiszeit 243, Vulkane 395, 707, Erdbeben 420, höchste kalte Quelle 494, Täler 542, Gebirgsfazies 609, Hochflächen 624, Bau 669, Gipfel 692, Wasserscheide 735 , Seenzone 755 , Flora 819,875 , $899,906,909$, Wald $828,829,847$, Getreidegrenzen 853, 854, Fauna 875, 900. (S. auch Bolivien, Chile, Columbia, Ecuador, Feuerland, Peru.) Andesit 377, 386.

Andrews. Ch. W. 782, 792*.

Andrews, E. C. 792*.

Androsace lactea 814 .

Andrussow, N. 759, 765*.
Anemone alpina 814.

Aneroïd 616, 617 .

Angara 506.

Angefügte Ebenen 628, 629.

Angegliederte Halbinseln 766, 767.

Angot, A. 63, 69*.

Anhäufungstheorien 3 .

Anhydrit 471.

Aniggokfjord 798 .

Anio 494, 722.

Ankogel, schneefreies Gebiet 186.

Annecy, Quertal v., 728.

Anomale Durchgangstäler 719.

Anomale Wasserscheide 719 .

Anotherm 345.

Ansatzanschwemmung 597.

Anschwemmung des Meeres $595 \mathrm{ff}$.

Anschwemmungsflächen 622 .

Ansiedlungszentrum 869.

Antananarivo, Regen 176.

Antarktika 34, 36, 41, 48, 51, Gletscher $200,219,227$, Niveauveränderung 453, frühere Ausdehnung 884.

Antarktische Eisberge 229.

Antarktisches Florenreich 883, 906, 909.

Antarktisches Gebiet, Temperatur 89, 94, 111, Luftdruck u. Winde 126, $130 \mathrm{f}$., 145, Niederschlag 154, 182, Gletscher 219, Klima 234, Flora 826, 906, 909, Fauna 865 .

Antarktisches Hochdruckgebiet 126.

Antarktisches Meer s. südl. Eismeer.

Antarktische Waldgrenze 825.

Antecedenztheorie 721 .

Antholzer See 747.

Anthurien 872.

Antiklinale 645 .

Antiklinalkamm 645 .

Antiklinaltal 646, 715 .

Antilibanon, Karstphänomen 540 .

Antillen s. Westindien.

Antillenkontinent 455 .

Antillenströmung 328 .

Antilopen 860, 874, 890, 891, 893 .

Antipassat 125, 128.

Antisana, Temperatur 77, rel. Feuchtigkeit 149 .

Antizyklonaler Föhn 144.

Antizyklonen 117, Temperatur 120.

Anutschin, D. 764 *.

Anziehung von Sonne und Mond 21. Äolische Ảblagerungen 575 ff., 602, 604, 608.

Äolische Aufschüttungsbecken 622 .

Äolische Ausräumungsbecken 749, 750 .

Äolischer Felsboden 601, 602, 607, 608.

Aphel 59.

Appalachen 38 .

Appenninen 38,675, Eiszeit 243, Vulkane 396, Erdbeben 431, Bau 651, 669, 
679, Grenze 672, Peneplain 691, Getreidegrenze 853, Flora 897.

Apuanische Alpen 679.

Apulien 768.

Äquator, Umfang 6 .

Äquatoriale Depressionszone 126.

Äquatoriale Gegenströme 327, 334.

Äquatoriale Pflanzenwelt 813 .

Äquatorialer Regengürtel 161, 168.

Äquatoriales Barometerminimum im

Winter 131, im Sommer 136.

Äquatorialhalbmesser 6 .

Äquatorialklima 106, 107, 109.

Äquatorialseite der Zyklonen 119.

Äquatorialströmungen 327, 334, 790.

Äquatorialtypus des Regens 176, 177.

Äquatorialwinde 118.

Arabien 41, 767, Winde 134, Niederschläge 164,181 , Wüste u. Steppe 244, 848, Vulkane 398, Erdbeben 430, Bau 620, Tafelberge 633, Wald 837 .

Arabischer Meerbusen 259.

Arakan, Inselbildungen bei, 408.

Aral-kaspisches Tiefland, vertikale

Temperaturabnahme 82, tägl. Temperaturschwankung 104, Regen 165, 170, Klimaprovinz 232, Pluvialperiode 244,608 , Seen $253,758,760$, Dünen 578, 579, Bau 628, Verdunstung 760, Pflanzenwelt 847 .

Aralsee 628, 751, 759, 760, Wachstum 253.

Aräometer 283.

Araukarien 824, 837, 888.

Arbroath, Riffreihe 591.

Archäisches Zeitalter (Formationsgruppe) $24,25$.

Archenhold, F. S. $317^{*}$.

Archhelenis 885 .

Archinotis 883, 884 .

Archipel 769.

Ardêche, Naturbrücke 540.

Ardennen 700.

Arecapalme 820.

Aregoase 752.

Aretin, Frh. v., 481.

Argan, E. $657^{*}$.

Argastoli, Quelle 491.

Argäus 397.

Argentinische Ebene s. Pampas.

Argentinisches Becken 269, 354.

Argon 54.

Arica, Bucht v., Erdbeben 297.

Arizona, Sonnenscheindauer 65, Busch 841.

Arkansas, Cañon 525, Seen 749.

Arkatag 160.

Arktische Inseln 787, 801.

Arktische Mulde 269.

Arktisches Gebiet 28, 29, Temperatur
$89,90,92,93,94,832$, Niederschläge 157, Gletscher 204, 219, Klima 233, Küste 794, Vegetation 826, Fauna 892, Flora 898, 899, 905.

Arktisches Hochdruckgebiet 134.

Arktisches Meer s. nördl. Eismeer.

Arktische Waldgrenze 824.

Arktische Windscheide 132.

Arktogäa 908, 909.

Arktowski, H. 229, 364*, 453.

Arlberg, Regenverteilung 166.

Arldt, Th. 43, 52*, 774, 791*, 896, 909*.

Armenien, Vulkane 397, Getreidegrenzen 854 .

Armorikanisches Gebirge 696.

Arno 567, 568, 743.

Arongewächse 821, 835 .

Aronswurzel 855 .

Arrhenius, S. $7^{*}, 12,13,14,17^{*}, 56^{*}$, $69^{*}, 149,152,247,257^{*}, 405$.

Artesische Brunnen 488.

Artischockendistel 902.

Aruinseln 879.

Arundarien 823.

Arve 513, 725 .

Asakak-Gletscher 198.

Asar 604.

Ascension 769, tägliche Temperaturschwankung 106, Flora 818.

Aschenkegel 390 .

Asdjer, Schnee 182.

Asien, höchste Breite 31, Grenzen 35, Areal 36 , Oberflächenform $37 \mathrm{ff}$., Höhe 47, 51, Temperatur 90 ff., Juftdruck und Winde $131,133,134,135$, 137, Regen $162 \mathrm{ff} ., 168,173,177,240$, Gletscher 219, 222 ff., Klimaprovinzen 232, Eiszeit 242, 245, Vulkane 393, Erdbeben 430, 432, Bodenbeschaffenheit 602, 603, 605, Faltung 652, 653, abfluBlose Gebiete 732, 734, Wasserscheiden 733, Abdachungsgebiete 734, Flüsse 739, Depressionen 752, Halbinseln 765, Küste 793, Küstenabstand 807 , 808, Vegetationsformationen 817, 849, 901, Palmen 819, Grenze der immer- und sommergrünen Laubbäume 823, Mangrove 837, Nahrungspflanzen 851, 852, 853, 854, 856, 857, Getreidegrenze 853, 854, Flora 889, 890 f, 905, 906, 908, 909, Fauna 872, $873,879,889,890,891,908,909$, alte Landverbindungen 885,894 .

Askabad, Bodentemperatur 473, Profil 625.

Asowsches Meer, Eisbildung 359, Strandlinie 458.

Asphodilen 822.

Aspirationspsychrometer 73 .

Assai 820. 
Assalsee 752.

Assmann, R. 73, 83*.

Astatisches Pendelseismometer 418.

Ästuarien 570.

Ästuariumbäfen 806 .

Asymmetrische Gliederung 718.

Asymmetrische Täler 521 .

Atacama, Vegetation 848.

Atacama-Graben 267.

Atamigeysir 498.

Atlantische Abdachung 733, 734.

Atlantischer Küstentypus 793.

Atlantischer Ozean 32, 33, Areal 34, 260, Tiefe 47, 51, 260, Lufttemperatur 88, 90, 109, Luftdruck u. Winde $130 \mathrm{ff}$., Regen 154, 167, Küstenabstand 258, Muldenbreite 262, Bodenrelief 264, 268, Bodenbedeckung 274, Mittelwasser 281 , Salzgehalt 283,285 , absol. spez. Gewicht 287, Farbe 288, Wellen 293, 294, Gezeiten 308, 309, 310, Gezeitentafeln 312 , Strömungen $327 \mathrm{ff}$, 334 , Oberflächentemperatur 340,341 , Tiefentemperatur 349, 350, 351, 352, Mitteltemperatur 350, Zugangsdimensionen 353, Treibeis 362, Vulkane 393, FluBgebiet 733, 734, Bodenbewegung 896 , Geschichte 897 (s. auch Nordatlantischer Ozean).

Atlantische Schwelle 268.

Atlantische Sippe der vulkan. Gesteine 405.

Atlantische Strömung 331, 332, 341.

Atlas 38, Vulkane 397, Erdbeben 431, Bau 651, 671, Richtung 673, Beziehung zum Vorland 675, Flora 899.

Atmosphäre s. Luft.

Ätna s. Etna.

Atoll 777.

Attika, Flußdichte 734.

Aubry, A. 638,614 *.

Auchenien 875 .

Auckland, Vulkane 710.

Auerochs 903.

Aufgedeckte Vulkanberge 618, 705, 706,710 .

Aufgesetzte Berge 618.

Aufgesetzte Ebenen 621, 629.

Aufgesetzte Vulkanberge 705, 706, 709.

Aufschließungsküsten 804 .

Aufschüttungsbecken 746, 750 .

Aufschüttungsboden 602, 603 .

Aufschüttungshäfen 804 .

Aufschüttungsinseln 770 .

A ufseB, O. v. u. z., 288, 289, 290, $363^{*}$.

Aufsteigende Luftströme 70.

Aufsteigende Quellen 488.

Auftriebwasser 335 .

Ausfüllungsdelta 567 .
Ausfüllungsterrassen $558 \mathrm{f}$.

Ausgeglichene Küste 796 .

Ausgleichsströmungen 317, 326, im

Erdinnern 373.

Ausräumungsbecken 749, 750 .

Außenküste 793.

ÄuBere Zone 86, im Januar 90, im Juli 93.

Aussichtsweite, Veränderungen 462.

Austen, E. E. 867, 868*.

Australalpen, Eiszeit 243, Bau 697, 698.

Austral-asiatisches Mittelmeer 259, 261, Areal und Tiefe 260, Bodenrelief 268, Salzgehalt 286, Tiefentemperatur 354 .

Australe Ländergruppe 37, 40, 41.

Australien 34, höchste Breite 31, Areal 36 , Oberflächenform 41, Höhe 47, 51, Temperatiur 93, Temperaturschwankung 104, Temperaturveränderlichkeit 110 , Luftdruck u. Winde 123 , 135, Wüstenwinde 146, Regen 162 , $163,164,168,173,176,178$, Hagel 180, Klimaprovinzen 233, Eiszeit 243, 246, Niveauveränderungen 453, Erdbeben 431, Flüsse 504, 739, Bodenarten $602,603,605$, Ban 620, 633, 684, 697, abflußloses Gebiet 732, 734, Wasserscheiden 733, Abdachungen 734, Binnenseen 746, 758, Moore 764, Halbinseln 766, Riffe 777, 781, Küste 793, Küstenabstand 807,808 , Palmen 818,819 , Flora $817,823,878,897$, 902, 906, 909, Eukalyptenwälder 838, Skrub 840, Steppen und Wüsten 847, Vegetationsformationen 849 , Nutzpflanzen 852, 857, Fauna 877, 884, 904, 908, 909, alte Landverbindungen 885,885 , (s. auch Ost- und Westaustralien).

Australische Bögen 39.

Australisches Riff 781.

Australmonsum 135.

Autochthone Gebirge 650 .

Autochthoner Torf 763 .

Auvergne 377, 472.

Aye-Aye 877 .

Azoren 789, 790，791, Vulkane 393, Flora 889 .

Babinet's Barometerformel 616 .

Bach, H. $69^{*}$.

Bäche 498 .

Baden-Baden 495.

Bad land erosion 633 .

Badoureau, A. 452, 464*.

Baëff, B. $517 *$.

Baer, K. E. v., 741, 742, 860.

Baffinbai 259, 330 . 
Baffinland 606 .

Bagnères-de-Bigorre 495.

Bagnères-de Luchon 495.

Bahama-Inseln 540, 783.

Bahr-el-Ghasal 758.

Baikalsee 345, 751, 752, 753 .

Bakerfjord 800 .

Bakerinsel, Regen 154.

Baku, Sehlammsprudel 408, 409.

Balch, E. S. 547*.

Bali 879 .

Balkan 38, Vulkane 397, Bau 673, Durchgangstal 719, Völkerscheide 729 .

Balkanhalbinsel 766, 768, 771, Eiszeit 243, 245, Erdbeben 431, Gebirge 672, 674,680 , Täler 717, Vegetation 841 .

Balkaschsee 253, 758, 759, 760 .

Ball, J. 832.

Ballonfahrten 73 .

Baltiseher Schild 682.

Baltische Seenplatte 627, 733.

Baltorogletscher 209.

Baltzer, A. 213, $218^{*}, 548,549,550$, $563^{*}, 649$.

Bambus 821, 823, 841.

Banana, Regen 162.

Bananen 820.

Banda-Inseln 772 .

Bandaisan 382, 389 .

Bandlicht 66.

Bandstruktur der Gletscher 204, der Bergabhänge 479 .

Banjanen 821 .

Bank 266.

Bant 593.

Barabasteppe 845 .

Baratta, M. $410^{*}$.

Barbados 895.

Barbour, E. H. 497.

Barchane 576, 579.

Bären 873, 893, 903.

Bäreninselstrom 332 .

Barnaul, Luftdruck 134, Regenschwankungen 240.

Barometerschwankungen 138.

Barometrische Höhenmessung 616 .

Barometrisches Maximum 118.

Barometrisches Minimum 118.

Baron, R. 877.

Barren 271, 564, 806.

Barriere-Eis 228.

Barrierequellen 488.

Barriereriff 776.

Barrygletscher 211.

Barth, H. 105.

Bartholmew, J. G. 56*.

Bartold, W. W. 740 .

Barus, C. 407, 411*.

Barysphäre 13.

Basalt 377, 387, 587, 894.
Basehin, O. 140*, 576, 578, 583*.

Basedow, H. $52 *$.

Basel, jährl. Temperaturschwankung 108.

Basische Eruptivgesteine 377.

Basses-Alpes 658, 671.

Batate 855 .

Batavia, tägl. Temperaturschwankung 106, Regen 178.

Batemann 14 .

Bates, H. W. 863 .

Batholithen 712 .

Bätisches Gebirge s. andalusisch. Geb.

Batchelder, S. F. $95,102 *$.

Bauer, M. $482,484^{*}$.

Bauerngraben 537.

Baulig, H. 515, 517*.

Baumann, 0. 398, 411*.

Baumfarn 821.

Baumfrüchte 855 .

Baumgärtel, H. 466*.

Baumgrenze 687, 831 .

Baumstachelschwein 874 .

Baumsteppe 842 .

Baumwolle 855 .

Baur, G. 791, 792 *.

Bauxit 482.

Bayern, Hochebene, Klima 112, 142, Alpen, Regen 160, Seen 762.

Bayrischer Wald 898.

Beadnell, H. G. L. 576, 579, 583*.

Beaumont, Elie de, 42, 652 .

Bebber, J: van, 69*, 102, 103*.

Beck v. Mannagetta, G. $832,833^{*}$.

Becke, F. 405, 411*.

Becken (Meer) 265.

Beckenseen 745, 750 .

Becker, G. F. 17 *.

Beelfoot Lake 749 .

Beerensträucher, Zone der, 855 .

Behr 840.

Bekaâ 398.

Belar, A. 416.

Belcher, Sir Edward, 776.

Beleuehtungszonen 61 .

„Belgica“-Exped. 29, 131.

Belgicastraße 453.

Belgien, Winde 133, Regen 171, Niveauveränderung 454, Fauna 785, Wald 902.

Belize, tägl. Temperaturschwankung 105.

Bell, J. M., 410*.

Bell, R. 452, 765*.

Bell-Rock 585 .

Belutschistan, Erdbeben 459 .

Beneš, J. 7, 8*.

Bengalen, vertikaleTemperaturabnahme 76, 77, Regen 163.

Bengalen, Meerbusen v., 258, 259. 
Benguelastrom 334, 336.

Benndorf, H. 14, 17*,415, 437*.

Ben Nevis, Temperaturabnahme 76 .

Benthonische Wellen 297.

Benthos 273.

Berendt, G. 202, 577, 744.

Beresow, Sommertemperatur 854 .

Berg 612.

Berg, L. 257*, 765*.

Bergeat, A. 405, 410*, 411*, 709, 713*.

Bergeidechse 900 .

Bergeron, J. 658*.

Berghaus, Heinrich 806.

Berghaus, Herm. 56*, 275*, $375^{*}$, $735,854,857^{*}$.

Bergklima 77, 79, 108, 109, 111, 116.

Bergkrankheit 55 .

Bergland 613.

Berglauf 731.

Bergreis 851.

Bergschatten 64 .

Bergschrund 201.

Bergsturz 481.

Bergwind 140, 141.

Bergziege 893 .

Beringmeer 259, 268, Areal und Tiefe 260, Eisbildung 359 .

Beringstraße 32, 269, 890, 894 .

Berkeley Hills 405.

Berlin, Temperatur 101, 241, Zahl der heiteren Tage 152, Grundwasser 487, Mächtigkeit des Diluviums 626.

Bermudas 540, 759, 783, Flora und Fauna 790, 791, 837.

Bern, tägl. Temperaturschwankung 105. Berner Oberland, Flußdichte 734 .

St. Bernhard 80, 105 .

Bernina, Temperatur 78, Wald 831.

Berson, A. 55, 74, $83^{*}$.

Bertrand, L., $657^{*}$.

Bertrand, M. $38,42,648,651,652$, $653,657^{*}, 658^{*}$.

Beschleunigung d. Erdbebenwellen 422 .

Besenstrauch 812.

Bessarabische Depressionen 751.

Bessel, F. W. 6.

Besteck 320.

Bestrahlung 57.

BetelnuB 820.

Beul, 0. 52*.

Beutelratten 874 .

Beuteltiere 871, 873, 876, 877, 880, 884,890 .

Bevelling hypothesis 689 .

Bevers 80, 105, 108.

Bewegungslinien 208.

Bewölkung 96, 152.

Beythien, H. 51*.

Bezdek, J. 154, 155, 169*.

Bezingigletscher 222 .
Bezold, W. v., 129*, 147, 181*.

Biafogletscher 223.

Biber 893 .

Biegungen 365, 367 .

Bienen 863.

Bifurkation 735 .

Bigelow, F. H. $81,84^{*}, 119,120,129 *$.

Bighorn Mts. 660.

Billwiller, R. jun. 144, 146*.

Billwiller, R. sen. 142, 144, 146*.

Bimsstein 383.

Bingöldagh, Getreidegrenze 854 .

Binnendelta 564 .

Binnendepressionen 751, 752 .

Binnenlanddünen 575, 577.

Binnenländische Niveauveränderungen $438,459 \mathrm{ff}$.

Binnenmeere 259, Salzgehalt 286, Gezeiten 309, Strömungen 324.

Binodale Wellen 300.

Birger, S. $792 *$.

Birke 811, 827, 838, 839, 901.

Birket el-Kerun 752 .

Birstal 720 .

Biseh of K. G. 11.

Biskra 152, 179.

Bismarck-Archipel 395.

Bismarkgletscher 209.

Bison 893, 903.

Bittere Kreuzblume 815.

Bitterseen 759 .

Bjelowjescher Wald 903 .

Bjerknes, V. 321, 338*.

Bjerlykke, K. O. $256^{*}$.

Black Hills 681 .

Blackwelder, E. $702 *$.

Blake, J. F. 264, 276*.

Blanc, E. 583*, $745^{*}$.

Blanckenhorn, M. $52^{*}, 244,256^{*}$, $608,610^{*}, 677^{*}$.

Blanford, H. F. $140,146^{*}, 255$.

Blanford, W. T. 907.

Blatt, Gletscher 204, geologisch 367.

Blattnasen 874,890 .

Blaueis 194, antarktisches 230.

Blauer Schlick 271, 275.

Blaues Eis 205.

Blink, H. 740, 745*.

Blitz, Zerstörung durch, 471.

Blocklava 382 .

Bludau, A. 733, 739, 745*.

Blumberger Wasserscheide 728 .

Blümcke, A. 196, 198, 199, 200, 202, $208,209,217^{*}, 218^{*}, 549^{*}, 555,563^{*}$.

Blunt, A. 848.

Blutregen 572.

Blytt, A. 241, 256*, 441, 442, 463*.

Boa 885 .

Boabab 844 .

Boceas 403. 
Bocche di Cattaro 803.

Bochorno 142.

Bodden 794 .

Bodenarten 474.

Bodenbewegungen 466 .

Bodeneis 99.

Bodensee 455, 461, 740, 753, 757, 761.

Bodentypen 600 ff.

Bodenversetzung 466, 468.

Bodenwasser des Meeres 353, des Lan. des $484 \mathrm{ff}$.

Bodman G. 231.

Bodmer, A. 560, 564*.

Bogdanowitsch, K. $245,665,676$, $677^{*}$.

Bogendünen 576 .

Bogenförmige Abrasionsküsten 590 .

Bogenförmige Faltengebirge 672, 675 .

Bogoslovinseln 401.

Bogota 179, 829.

Boguslawski, G. v., 328.

Böhm, A. v., 209, 218*, 243, 372, $376^{*}, 442,484^{*}, 551,678^{*}, 755,765^{*}$.

Böhmen, Winde 133, Kreide 698.

Böhmer Wald 477.

Böhmisches Massiv 654, 696.

Böhmisches Mittelgebirge 397.

Boiumgletscher 225 .

Bolgen, Strandterrasse 587.

Bolivia 395, 853.

Boller, W. 69*.

Bolsena, Kratersee 396.

Bombay 101.

Bomben 378.

Bonin, Ch. 746.

Bonneville-See 244, 761.

Bonney, Th. G. 779.

Bonnier, G. $871,886^{*}$.

Bonsdorff, A., 464*.

Boothia Felix, Niederschläge 182.

Bora 143.

Borabora 776.

Boraxseen 759 .

Bore 308.

Boreale Ländergruppe 37, 40, 41.

Boreale Pflanzengruppe 905, 909.

Boreales Faunenreich 908, 909.

Börgen, K. 312, 362.

Borissjak, A. 644*, 658, 676*.

Borissow, A. 92.

Borkum 148, 592, 785.

Bormiotherme 494.

Borne, G. v. d., 376 *.

Borneo 772, Inselbildung bei, 408, Erdbeben 430 , Fauna 786,879 , Waldgrenze 830 .

Börsch, A. 281.

Borstenferkel 874 .

Borstenigel 876 .

Bos 873 .
Böschungen auf dem Meersboden und Festland 265, im Gebirge $478 \mathrm{ff}$.

Bosporus 359, 595.

Botner 551.

Bougainville-Graben 268.

Boule, M. 652, $887^{*}$.

Bourdaloué 461.

Boussinesq 507, 513, 517*.

Bouvet-Insel 94, 225.

Bowman, J. 257*, 728, 730*.

Bozel, Überschwemmung 511.

Bozen, Erdpyramiden 480 .

Bra, Erdpyramiden 480.

Braak, C. $256^{*}$.

Bracciano, Kratersee v., 396, 749.

Brachyantiklinale v. Peyruis 658 .

Brackwasser 564 .

Brahmaputra 569, 739.

Branca (früher Branco), W. 371, $376^{*}, 377,396,399,410^{*}, 411^{*}, 437^{*}$, $634,635,644^{*}$.

Brandis, Sir D. 833.

Brandt, K. $868^{*}$.

Brandung 296, 585, 586.

Branner, J. C. 483*.

Bransfieldsund 355 .

Brasilianisches Becken 354 .

Brasilien, Gebirge 41, 620, 697, Laterit 482, Riff 591, Strandseen 748, Küste 793, 796, Vegetation 813,819 , Wald 836, 837, 838, 888, Campos 842, 843, 844, Reis 851, Fauna 886.

Brasilstrom 334.

Brauer, A. 892.

Braun, G. $337^{*}, 466,691,702^{*}, 764^{*}$.

Brauner Jura 25.

Bravais, A. 445 .

Brechungsexponent d. Meerwassers 283

BreitfuB, L. 338*.

Breitnasen 873. 876 .

Brennecke, W. 276*, 333, 338*, 350.

Brenner 726, 729 .

Brenz 638.

Breschetäler 719 .

Breschin, A. $850 *$.

Breslau, Feuchtigkeit 148.

Bresson, A. $657 *$.

Bretagne 653, 690, 766, 771, Rias 797, $802,803$.

Breu, G., 762.

St. Bridesbai 590.

Brienzer See 761.

Brillouin, M. 129*.

Briquet, A., 457, 465*, 744, 745*.

Briquet, J. 242, 869.

Bristenstock 479 .

Bristolkanal, Hubhöhe 308.

Britisch-Columbien, Granitdiorit 712.

Britische Inseln 769, 771, Bewölkung 152, Regen 166, Eiszeit 246, Gezeiten 
314, Vulkane 399, Niveauveränderungen 451, Küsten 587, 590, 594, 597, Gebirge 652, Seen 751, Alter und Fauna 784, 786, Wald 902 (s. auch England, Irland, Schottland).

Brito, Wasserscheide 35.

Brocken 700, 712.

Brockmann-Jerosch, H. 244, 256*. Bregger, W. C. 463*.

Brohm, 600*.

Bromatorische Linien 857.

Bronzitchondrite 21.

Brooke, J. M. 261.

Brotbaum 820.

Brown, H. Y. L. $644^{*}$.

Bruce, W. S. 29.

Brüche 19.

Bruchformen 618.

Bruchnetze 366 .

Bruchstufen 638, 643.

Bruchzone 34, 43.

Brückner, E. 56*, 157, 169*, 186, $190^{*}, 191 *, 230,235,236,239,246$, $256^{*}, 279,290^{*}, 346,363^{*}, 450,464^{*}$, $466^{*}, 517^{*}, 551,554,557,561,563^{*}$, $757,765^{*}$.

Brücknersche Klimaperioden 235, 251, 279, 333, 448, 505 .

Brun, A. 379, 405, $410^{*}$.

Brunhes, J. 517, 518, 525, 546*, 555, $556,563^{*}, 573,583^{*}, 741,745^{*}$.

Brunnen 486.

Brüssel 155, 832 .

Brys on 496.

Bubendey, J. F. 516*.'

Buch, L. v., 399, 441, 708.

Buchan, A. 95, 102*, 129*, 140*, 290*, $363^{*}$.

Buchanan, J. J. 204.

Buche 811, 838, 901.

Buchsbaum 823 .

Buchtenländer $626,629$.

Bücking, H. 399, 411*.

Büffel 873 .

Büffelgras 845 .

Bug 569, Liman 803.

Bühlstadium 246.

Buhse, F. A. 848 .

Buise 593 .

Buitenzorg, Regen 155, 178.

Bulman, W. 28*.

Bumbum-Riff 775 .

Bunge, A. 256*.

Bunge, A. v., 848 .

Bunsen, R. W. 404, 496, 497.

Bunterden 482.

Buntsandstein 25.

Burckhardt, K, $669,676^{*}, 677^{*}, 887^{*}$.

Burckhardt, R. $884,887^{*}$.

Bürgermeistertor 589 .
Burma, Naturbrücken 540.

Burmester, H. 256*, 608, 610*,

Burrard, S. G., 666, $677^{*}$.

Burtscheid 495 .

Buru 772.

Busch 816, 834, 839 ff., 842 .

Büschelgras 845 .

Buschsteppe 842 .

BüBerschnee 220.

Buxton 862 .

Buys-Ballot, C. H. 97, 102*.

Buys-Ballotsches Gesetz 115.

Cabral 319

Cagni, U. 28.

Calabrien 679, 768, Erdbeben 421, 430 .

Calamus 820.

Calcutta-Hafen 806.

Caldera $707 \mathrm{f}$.

Calderaberge 391, 708.

Caledonischer Kanal 727.

Caledonisches Gebirge 696 .

Californien, Regen 176, Klima 233, unterseeische Täler 455, Erdbeben 450, Geysire 498, Tal 716, Depressionen 752 , Seen 760 , Halbinsel 767, Flora 823, 889, Vegetation 841, 844, Fauna 890 .

Californien, Golf v., 260.

Californische Strömung 335, 336.

Callaway, C. 508, 517*.

Callunaheide 901.

Caltabianco 523.

Campanula excisa 869.

Cam pbell, M. R. $546^{*}, 689,690,702^{*}$.

Campos 842, 843.

Canada, Flora u. Fauna 823, 893, 906.

Canadische Rumpffläche 682,685 .

Canadisches Berufkraut 869.

Canadische Seen $751,754,761$, Temperaturveränderlichkeit 112 , Winde 133, Fjorde 802.

Canaren, Wüstenwinde 146, Vulkane 393, 396, 707, Flora u. Fauna 789, $790,889,904$.

Cancani, A. 419, 423, 435, 436.

Candolle, Alph. de, 857 *.

Canidae 864 .

Cannes, unterseeische Quelle 491.

Canoe 726.

Cañons $525 \mathrm{f}, 631$.

St. Canzian-Höhle 539.

Capeder, G. $480,484^{*}$.

Capoës 844.

Capverdesche Inseln 773, Passatstaub 272, Vulkane 393.

Caracas, Erdbeben 421.

Carandapalme 837.

Carez, L., 517*, 575.

Cariacus 893. 
Caribisches (Karibisches) Becken 269. Caribisches (Karibisches) Meer 876.

Caribische (Karibische) Strömung 328, 329.

Carpenter, G. H. 892.

Cassiquiare 735 .

Castasegna, Winde 143.

Castenedolo, Dislokation 656 .

Castens, G. 338.

Castellamonte, Erdpyramiden 480 .

Castilianischer Typus 643.

Castilien, Plateaus v., 624.

Casuar 878, 884.

Casuarinen 812, 837, 878.

Catalonisches Gebirge 719.

Catena metallifera 679.

Catingas 844.

Cauca 738.

Causses 540, 541, 698.

Caviana 799 .

Cavonedelta 567.

Caye ux, L., 458, 459, 465*.

Cayman-Graben u. -Rücken 270.

Caziot, E., 457, 465*.

Ceboruco 395.

Celebes 772, 879, 880, Schlammsprudel 409, Fauna 786, 879.

Celebes-See 879, Temperatur 354.

Celsius, A. 441 .

Cenoman 25.

Ceram 772, Regen 178.

Cerro Llimpi 709.

Cerros de Yaruquies 710 .

Ceylon, vertikale Temperaturabnahme 76, Fauna 876, Gebirgsflora 899.

Chablaisalpen 648 .

Chaillexon, Lac de, 758 .

Chaîne de l'Etoile 651 .

Chaîne des Maures 697.

Chaix, E. 546*, 547* 548, 563*.

Chalkidike 768 .

"Challenger"-Expedition 10, 261, 276.

Chamaerops 819 .

Chamberlin, T. C. $3,8^{*}, 206,218^{*}$, $248,257^{*}$.

Chambérytal 728 .

Chamisso, A. v., 784 .

Champlain-Hudsontal, Winde 142.

Champlainsee 751.

Chanar 841.

Chaparal 841.

Chapman 768 .

Chargeh-Oase 244.

Charleston, Erdbeben 423, 429.

Chatangatal, Waldgrenze 825 .

Chathaminsel $837,881$.

Chaudesaigues 495 .

Chavanne, J. $52 *$.

Chemische Erosion 467, 585.

Chemische Verwitterung 471.
Cher 738.

Chérantal 724 .

Cherrapundji, Regen 163.

Chester, F. D. $454,465 *$.

Chevalier, A., 836, 850*.

Chianasee u, -tal 743, pliozäne Fauna 888.

Chile, Temperatur 81, Regen 176, Schneegrenze 188, Klima 233, Vulkane 395 , Erdbeben 432, Niveauveränderungen 439, 453, Andes 669, Seen 751, Flora 819, 823, Waldgrenze 829,830 , Waldland 838 , Steppen 848, Weizen 852, Getreidegrenze 853 , Fauna 875.

Chimborazo 392, 707, 709.

China, Regen 163, Klima 232, Erdbeben 430, Laterit 482, LöB 581, 624,633 , Bodenarten 603, 605, Tiefland 626 , Küste 793,802 , Flora 819 , $823,889,901$, Wald 838, Maquis 841, Fuuna 861, 890, 903.

Chinchillas 874, 875 .

Chinook 145 .

Chistoni, C. 153*.

Chlorgehalt des Meerwassers 282.

Choisy, A. 583*, 610*.

Cholnoky, E. v., 508, $517 *, 547,579$, $583^{*}$.

Chorigraphische Kurve 807.

Christ, H. $814,828,832,833^{*}, 901$.

Christmas Island 782 .

Christy, Miller $846,850 *$.

Chrystal, G. 299, 301*.

Chudeau, R. 643*.

Churchillhafen 452 .

Churfirsten 478 .

Cierzo 142.

Circekap 679 .

Clarke. A. R. 6.

Clausthal, Senkung 462.

Clemankette 660 .

Cleve, P. T., $338^{*}$.

Cloos, H., 642, 645*.

Coahuillatal 752 .

Coaz, J. 217*.

Coceolithenkalk 782 .

Cockayne, L., 576.

Codrington, T. $455,465^{*}$.

Coffey, G., 464*.

Coles, J. 495.

Colorado, Tafelland 631, 633, 639, 681, 711, Cañon 526, 631, Kare 562, Fluß 731,739 , Vegetation $831,847$.

Coloradotypus 643 .

Columbia (FluB) 570, 726, 739, Lavafeld am C. 621 .

Columbia (Staat) wärmster Monat 107, Vulkane 395, Höhengrenzen 828 , Getreidegrenze 853. 
Columbische Florenprovinz 906.

Commission internationale des glaciers 213.

Comoren, Vulkane 393.

Comosee 751, 756, 757.

Coneyinsel, Land- u. Seewinde 140.

Connecticut 558, 569.

Conway, W. M. 222, 223, 230*.

Cook, G. H. 454, 465*.

Cooper Creek 565 .

Cope 768.

Copernikanisches Weltsystem 1.

Copiapó, Regen 164.

Cordilleren s. Andes.

Cornet, J. 624.

Cornish, V. 295, 301*, 583*.

Cornwall 652, 696, 802.

Corralgletscher 221.

Corsica, Eiszeit 243, Erdpyramiden 480, Gebirge 697, Rias 797, 802, Maquis 841 , Flora 888.

Corstorphine, G. S. 28*.

Corypha umbraculifera 822 .

Coseguina 381 .

Costa Rica, Getreidegrenze 853 .

Cotidal lines 310.

Cotopaxi 381, 382, 706.

Cottonsoil 582.

Courbis, E. 579, 583*.

Crammer, H. 202, 205, 206, 207, 218*, $547 *$.

Crater Lake 709.

Credner, H. 28*.

Credner, R. 300, 301*564, 565, 566, $571^{*}, 749,752,765 *$.

Creeks 504, 838.

Creuse-Vienne 738.

Crkvice, Regen 166.

Croll, J., 249, 257*.

Cross, Wh. 713*

Cryptoproctidae 877 .

Culbertson, G. 471, 483 *.

Cuneo, Aussichtsweite 462.

Curtis, G. E. 151.

Cuxhaven, Gezeiten 302.

Cvijić, J. 243, 256*, 535, 537, 541, $547 *, 674,678^{*}, 685,686,690,693$, $702^{*}, 724,730^{*}, 765^{*}$.

Cyperaceen 763 .

Czuchower Bohrloch 8.

Dachs 893 .

Daemonorops 820.

Dahna 848.

Dall, W. H. 269, 825.

Dalmatien, Bora 143, Regen 166, Rumpffläche 541, Küsten 585, 797, Inseln 771, Waldgrenze 829,831 , Maquis 841 .

Daly, R. A. $702 *$.
Damaraland 848.

Dammbecken 746, 750 .

Dämmerung 62, 273.

Dammriff 776.

Dampfdruck 147.

Dampfquellen 495 .

D ana, J. E. 28*, 387, 410*, 558, 586, $711,713^{*}, 774,778,792 *, 801$.

Danakilland 752 .

Danckelman, A. v., 145, 170*, 181*, 619*.

Dänemark, tägl. Temperaturschwankung 104, Winde 133, Torfmoore 241, Hebung 447, Küste 802, Wald 902.

Danziger Bucht 598.

Daressalam, Regen 162.

Darling 505, 738.

Darß 795 .

Darton, N. H. 702*.

Darwin, Ch. $4,8^{*}, 439,455,474$, $483^{*}, 531,776,778,779,780,781$, $782,783,784,789,791 *, 860$.

Darwin, G. 3, 13, 17*, 304, 317*, 369.

Dastarjan, See bei, 758 .

Dattelpalme 152, 820, 856 .

Daubrée, A. 399, 411*, 498*, 527.

Dauergebiete 605.

Dauernd regenarme Gebiete 173.

Daunstadium 246.

Dauphiné, Flora 813.

David, E. 781.

Davidson, G. 456. 465*.

Davis, W. M. $257^{*}, 470,508,517 *$, $519,530,531,532,545,546 * 547^{*}$, $551,555,560,563^{*}, 564^{*}, 618,619^{*}$, $636,644^{*}, 683,693,703^{*}$.

Davison, Ch. $421,437^{*}, 475,483^{*}$, $582,583^{*}$.

Davisstraße 132, 330.

Davos 78, 854 .

Death Valley 752.

Debundja, Regen 162.

Déchy, M. v., 190, 191*, 230*.

Deckengebirge 650 .

Deckentheorie 647, 650 .

Deckert, E. 477 .

Deeley, R. M. 203, 549, 563*.

Deflation 468, 573.

Deime, Niveauveränderung 461.

Dekan 41, Regen 163, Felssäulen 385, Trappplateau 338, 621, 698, Erdbeben 430, Massiv 697, Halbinsel 767, Fauna 876, Zusammenhang mit Afrika 885.

Delabarre, E. B. 451, 464 *.

Delaware, Niveauveränderung 454 .

Delebecque, A. 764*.

Delebpalme 837.

Delta 564 ff., 584 . 
Deltaküsten 569 .

Demawend 392, 395, 396.

Deniquil 104.

Denudation 466, 467, 475 .

Denudationsterrassen 479 .

Denudationsniveau 469,686 .

Depéret, Ch. 457, $465^{*}$.

Depressionen 751.

Derborence, Seen v., 747.

Derby, O. A. 702*.

Ders ch, O. $146^{*}$.

Deschampsia antaretica 826.

Desmoplankton 321.

Destruktion 466, 467, 468, Maß 21.

Destruktionsberge 643 .

Destruktionsformen 618, der Flachschichtung 629, der Falten $681 \mathrm{ff}$,, 700, 701.

Destruktionsstufen 634,643 .

Deuben, Glazialflora 898.

Deuerling, O. 517*.

Déusi 689 .

Deutsche Seewarte 276*.

Deutsches Mittelgebirge, Regen 171, Eiszeit 243, 609, Abfluß 501.

Deutsche Südpolar-Expedition 130, 286, $355,895$.

Deutschland, Sonnenscheindauer 65, Temperaturabweichung 113 , Winde 133, Regen 171, 173, Eiszeit 242, 246, Weinbau 253, Erdbeben 431, Niveauveränderungen 454,461 , Flüsse $499 \mathrm{ff} ., 516^{*}$, Löß 581, 582, Faltengebirge 653, Fauna 785, 863, 904, Küste $794 \mathrm{ff}$., Heide 841, Wald 902 (s. auch Deutsches Mittelgebirge, Nord- und Süddeutschland).

Devon 25, 27.

Dewdarokgletscher 199.

Diagonale Stromzerlegung 527.

Diathermanität der Luft 62 .

Diatomeen 858.

Diatomeenschlamm 274, 275.

Diavolezza, Temperatur 78 .

Dichotherm 345 .

Dichte der Erde 13.

Dichte des Meerwassers 279, 283, 346, als Erzeugerin von Strömungen 317, 322 , des Süßwassers 346 .

Dichtigkeitsfläche 280 .

Didica 401.

S. Diego, Temperatur 93.

Diels, L., $817^{*}$.

Diener, C. $677^{*}, 720,904 *$.

Dietrich, F. $276^{*}, 781,792 *$.

Differentialtiden 316.

Diffraktionstheorie 289.

Diffusion 62.

Dikotyle Angiospermen 872.

Dilatationstheorie 198.
Diller, J. S. 708, 713*.

Dilolosee 758.

Diluvialterrassen 558 .

Diluvium 26.

Dimensionen der Erde 6.

Dinarisches Gebirge 685, 690, 717.

Dingo 878.

Dinklage, L. E. 272, 276*, 336, 337*.

Dinse, P. $809^{*}$.

Disjunktive Dislokationen 371.

Disjunktivtäler 542 .

Diskordante Küste 793, 796, 804.

Dislokationen 19, 365, Gegenwart 462, Alter 652 .

Dislokationsbeben $427,428 \mathrm{ff}$.

Distortionswellen 412 .

Dittmar, C. R. 282.

Djihar 743.

Djuba 569.

Djumna 743.

Dojepr 501, 738, 739 .

Dnjestr-Delta 567.

Dobrudscha-Küste 597.

Doelter, C. $407,411^{*}, 458,773,791^{*}$.

Dofane 398.

Dogger 25.

Dokutschajew, W. 582, 583*.

Dolinen 533, Vegetation 832.

Dollart 592 .

Dollfus, G. F. $658^{*}, 676^{*}$.

Dolomit 15, 470, 471, 489, v. Südtirol 669.

Domberge 391, 709.

Domeyko 432.

Domsten, Regen 166.

Donau 731, Geschwindigkeit 328, Eisbedeckung 506, Profil 512, Delta 570, Durchbruchstäler 719, 723, 724, Verbindung mit dem Rhein 736, System 737, 738, Größe 739, Ablenkung 742, 743, Veränderung des Gebietes 744 .

Donaubecken 622 .

Donez, Kohlengebiet am, 621, 652, 658.

Doppelinseln 769.

Doppelküsten 795 .

Doppellauf 731 .

Doppelseitig zusammengesetzte Faltengebirge 662, 701.

Doppeltäler 726 .

Doppelvulkane 402 .

Dorfersee 747.

Dornsträucher $812,840,841$.

Dorscheid, 0. 102*.

Doss, B. $523,546^{*}, 762$.

Doubs 744.

Doughty, C. M. 643 *.

Douglastanne 839.

Dove, H. W. 94, 97, 102*, 113, 114*, $129,238,313$. 
Dover, Straße v., 595, 785.

Downs 682 .

Drache (in der Meteorologie) 73.

Drachenbaum 821, 824, 889.

Drakenberge 638 .

Drammengranit 712 .

Drance 554, 722 .

Draperien (Tropfstein) 539.

Drasche, R. v., 679.

Dratzigsee 345 .

Drautal 717 , vertikale Temperaturzunahme 80 .

Drei-Herrenspitze 675 .

Drepanididae 882.

Dribblet-cones 387 .

Drosseln 861.

Drude, $0.817^{*}, 819,833^{*}, 836,905^{*}$.

Drumlins 604.

Drygalski, E. v., 183, 189, 191*, 193, $198,199,200,203,204,218^{*}, 228$, $230^{*}, 348,359,364^{*}, 447,448,452$, $464^{*}, 547^{*}$.

Dscheren 891.

Dschungel 835, 841.

Du Bois, G. C. $473,482,484^{*}$.

Duffart, Ch. $600^{*}$.

Du Fief, J. 547*.

Dumpalme 820, 837.

Düna, Eisbedeckung 506.

Dünen 575，576ff., 584, 596,.618, Vegetation 816.

Dünenseen 747.

Dünenwüste 847.

Dunkelmeer 337.

Dünung 295.

Dupare, L. 730 *.

D u Pasquier, L. 581.

Duppaner Gebirge 397.

Durance 743 .

Durchbruchstäler 719 .

Durchgangsmeere 260 .

Durchgangstäler $719 \mathrm{ff}$.

Durchgreifende Gebirge 676 .

Durchgreifende Wasserscheide 719.

Durchlässiger Boden 485 .

Durchschnittstemperaturen der Breitengrade 94, der Zonen usw. 97.

Durrha 852 .

Dutherford 372.

Dutton, C. E. $374,375,376^{*}$, 387 , $403,410^{*}, 411^{*}, 432,437^{*}, 526,546^{*}$, $640,644^{*}, 702 *, 713^{*}$.

Dwina 506, 738, 739 .

Dyas 25.

Dynamische Antizyklonen 118.

Dynamische Theorie der Zyklonen 120.

Eastman, Ch. R. 380 .

Ebbe 21, 302, 316.

Ebene (Ebenheit) 612, 614, 618.
Ebenmaß von Zerstörung und Fortschaffung 601.

Ebermayer, E. 486.

Ebrodelta 566, 567.

Ebrotal 719, Winde 142.

Eckert, M. 547*.

Eckert, R. v., $745^{*}$.

Ecuador, Gradmessung 5, Schneegrenze 188, Vulkane 391, 392, 395, 399, 708, Strandterrasse 587, Andes 669, Waldgrenze 829.

EdaphischeVegetationsformationen 816 . Edentaten 864, 873, 874, 876, 891.

Edmondstone 770.

Efeu 839.

Egertal 720 .

Egnell, A. 116.

Ehrenberg, Ch. G. 272.

Ehrenburg, K. 24*, 808, $809^{*}$.

Eiche 811, 839, 901.

Eichhorn, A. 65, 69*.

Eichhörnchen 860 .

Eide 799.

Eidechsen 863, 867.

Eiderdelta 569 .

Eifel, Maare 377, Vulkane 392, 400, Bau 700, FluBdichte 734 .

Eiffelturm, Temperatur 70 f., Wind 116.

Eigenmann, C. H. 887 *.

Einbruchshäfen 804.

Einfache Eruptionen 389.

Einfache Faltengebirge 660, 701.

Einfache Verwitterung 471.

Einhufer 873, 874.

Einjährige Pflanzen, Verbreitung 813.

Einkehrflüsse 546 .

Einseitige Randfaltung 676.

Einseitig zusammengesetzte Faltengebirge $662,701$.

Einsturzbeben 427,434 .

Einsturzbecken 749,750 .

Einsturztäler 540, 545 .

Eintagstiden 310 .

Eintiefungsbecken 746, 748, 750 .

Eis 20, Struktur 203.

Eisack 723, 729.

Eisbär 787, 864, 893.

Eisbedeckung der Flüsse 506 .

Eisberge 228, 359.

Eisbildung in Süßwasserseen 345 , im Salzwasser $346,359$.

Eisboden 601, 602, 606.

Eisbrecher 358.

Eisbrocken 359 .

Eisenbahnen, Einfluß auf die Pflanzenverbreitung 902 .

Eisfelder 359 .

Eisfjord 803.

Eisflarden 359.

EisfuB 445 . 
Eishöhlen 539.

Eismeerbecken s. Nordmeerbecken.

Eismeere 32, 358.

Eispressung 360 .

Eisschollen 359.

Eisseen 747.

Eiszeit $242 \mathrm{ff}$, Beziehungen zu den Niveauveränderungen $451 \mathrm{f}$., Einfluß auf die Oberflächenformen 535, $547 \mathrm{ff}$., $603 \mathrm{f} ., 607,609,729,754,801$, auf die Pflanzenverbreitung 888, 898, 899, auf die Tierverbreitung 862, $900,907$.

Eiszunge 192.

Ekholm, N. 248, 251, 257\%.

Ekliptik 248, 249.

Ekman, G. 338*.

Ekman, W. W. 301, 322, 323, 324, $337^{*}$.

Elastische Wellen 412.

Elbe 737, Gezeitengrenze 309, Eisbedeckung 506, Sedimentführung 515, Mündung 569, 570, Veränderungen 743 .

Elbert, J. 879, 880.

Elbsandsteingebirge s. Sächs, Schweiz.

Elbsandsteintypus 643 .

Elbtal 526, 733.

Elburs-Gebirge 396, 542, 847.

Elefanten 867, 873, 874.

Elen 893, 903.

Elfenbeinküste, Temperatur 107.

Elfert, P. 152, 153*.

St. Elias-Alpen, Gletscher 224, Hebung 656.

Eliot, J. 171, 181*.

Elk Mountains 668.

Ellesmereland 227.

Ellice-Inseln 780 .

Ellipsoid 4.

Ellis, T. S. 508, 517*.

Elm, Bergschlipf 481.

Else 735.

Eltonsee 759.

Eluvialboden 602, 603, 606.

Eluvium 467.

Emden 203, 204, 218*.

Emersionswinkel 419.

Emerson, B. K. $44,45,52 *$.

Emmons, H. 458, 465*.

Emmons, S. F. $668,677^{*}, 723$.

Ems 568.

Emser Quelle 495.

Emu 884.

Enaresee, Temperatur 345, Getreidebau 852 .

Endemismus 785, 870.

Endmoränen 212.

Endmoränenlandschaft 604 .

Endogene Phänomene 365 .
Endrös, A. 301*.

Endverkettung v. Faltengebirgen 673 . Energiequellen 18.

Engadin, vertikale Temperaturzunahme 80, Berg- und Talwind 142, Seen 761, Getreidebau 854.

Engelbrecht, Th. H. $857^{*}$.

Engelhardt, R. 338*.

Engell, M. C. 123, 799, 809*.

England, Temperaturveränderlichkeit 111, Temperaturabweichung 113, Höhe der Zyklonen 119, Winde 133, Regen 156, 173, Erdbeben 421, Mineralgehalt derQuellen 493, Küsten 587, 590, 594, 597, Trennung vom Kontinent 595, 773, Tiefland 636 , 637,638 , Fauna 785, 863 .

Engler, A. 816, 817*, 836, 842, 844, $850^{*}, 869,872,881,886,887^{*}, 890$, 905 .

Enns 722.

Enock, C. R. 191*, $484^{*}$.

Ensete-Pisang 822.

Enten 861, 865.

Entwicklungszentrum 869 .

Enversac 491.

Eogen 25.

Eozän 25.

Ephesus 598.

Epigenetische Täler 544, 545, 722 .

Epiphyten 835, 838, 839.

Epirogenetische Niveauveränderungen 374.

Epizentrum 413, 415, 417, 418.

Epomeo 396.

Erdachse, Schwankungen 139.

Erdbahn 60, 249.

Erdbeben 19, $412 \mathrm{ff}$., 434, Bergstürze 481, Temperaturänderung $\mathrm{d}$. Quellen 495, Seenbildung 749 .

Erdbebenachse 419 .

Erdbebenbrücken 426 .

Erdbebenfluten 297.

Erdbebenherd 413, Tiefe 432.

Erdbebeninseln 426 .

Erdbebeninstrumente 413.

Erdbebenkern 419.

Erdbebenperiode 421 .

Erdbebenphasen 415.

Erdbebenschwarm 421.

Erdbebenstatistik $435 \mathrm{f}$.

Erdbebenwellen $413 \mathrm{ff}$.

Erde, Geschichte 2, 3, 24, Gestalt 4, 369, 442, Dimensionen 6, Teile 8, mittlere Dichte 13, Verhältnis von Wasser u. Land 30, Temperatur 97 , 107, Luftdruckverteilung 124, 126, 128, Winde 128, Kreislauf des Wassers 158.

Erdenluft 54. 
Erdferkel 876.

Erdinneres (Erdkern), Beschaffenheit 8 ff., Gezeiten 21, 316.

Erdkrume 474.

Erdkruste $15 \mathrm{ff}$, 402, vertikaler Auf bau 45,46 , mittlere Höhe 49,50 .

Erdkunde s. Geographie.

Erdmagnetismus 69.

Erdmann, H. 765*.

Erdpyramiden 479 .

Erdrotation, Ablenkung 22, der Winde 115,156 , der Flutwelle 313 , Erzeugung der Meeresströmungen 328, Ablenkung der Meeresströmungen 318, 323, Schwankungen 441, Ảblenkung der Flüsse 741 .

Erdwellen 416.

Erdwolf 876.

Eredia, F. $436,438^{*}$.

Erg 579.

Ergene 502.

Erica cinerea 823.

Eriekanal, Eisbedeckung 506.

Erigeròn canadense 869 .

Erkmann, 319.

Erle 839.

Erloschene Vulkane 392, 393.

Ernst, A. 792*.

Erosion 466, 467, 468, 510 .

Erosionsbasis 520, 532 .

Erosionsgebirge 633, 643 .

Erosionsspuren 526.

Erosionstäler 518ff., 543, 545 .

Erosionsterminante 519.

Eruption der Vulkane $379 \mathrm{ff}$.

Eruptionsperiode 382.

Eruptionsprodukte 377.

Eruptivgesteine 15, 377, 470, Höhlen 540, Areal 703.

Erythräischer Graben 397, 398.

Erzbach 722.

Erzgebirge, Temperaturabnahme 76, Temperaturveränderlichkeit 112, Böschung 263, Vulkane 397, Erdbeben 436, Bau u. Geschichte 696, 698, Granit 712.

Esche 901.

Escher v. d. Linth, A. 716.

Esker 604.

Estavellen 537.

Esterel 697.

Esthland 529.

Etage (geologisch) 24.

Etewald 835.

Etmal 320.

Etna 396, 709, vertikale Temperaturabnahme 76, jährl. Temperaturschwankung 108, vulkanische Tätigkeit 382, moderne Talbildung 523,
Höhe 703, Krater 707, Getreidegrenze 853 .

Etsch 512, 711.

Etschtal 561, 747.

Etzold, F. $437^{*}$.

Euböa, Gebirge 681 .

Eukalypten 812, 822, 838, 878, 902.

Eulenpapagei 881 .

Eupelagische Ablagerungen 270.

Euphrat 499, 569, 739, 740, 743.

Eurasien, Abdachungen 40, alter Scheitel von, 652 .

Eurasiatischer Faltengürtel 37 .

Euripus-Strömungen 300 .

Europa, höchste Breite 31, Grenzen 35, Areal 36, Oberflächenform 37, 41, Höhe 47, 51, Temperatur 91, Windgeschwindigkeit 116, Gradient 119, barometrische Minima 121, Luftdruck u. Winde $122,132,136,137$, Tau 150, Bewölkung 152, Regen 166, Regenwahrscheinlichkeit 168, Gewitter 179, Hagel 180, Gletscher 219, 221, Klimaprovinzen 232, Regenschwankungen 240, Eiszeit 242, Vulkane 393, 396, Erdbeben 430, 431, Thermen 495, Dünen 577, LöB 581, Bodenarten 602, 603, 604, Faltungsepochen 652, Wasserscheide 733, abfluBloses Gebiet 732, 734, Abdachungsgebiete 734 , Flüsse 739 , Kryptodepressionen 751, Seen 754, Halbinseln 766, Küste 793, Küstenentwicklung 807, Küstenabstand 807 , 808, Palmen 819, Grenze der immergrünen Gewächse u. sommergrünen Laubbäume 823, 824, Wälder 838, 839, 901, Heide 841, Vegetationsformationen 849, Getreidegrenzen 852, 853 , Obst 855 , tertiäre Fauna 861 , 888, Flora 888, 902, Umgestaltung der Fauna 892, 902, 903, Verbindung mit Amerika 894 (s. auch Mitteleuropa, Mittelmeerländer).

Eustatische Niveauveränderungen 19, $440,443$.

Euterpe oleracea 820.

Evorsion 468, 748.

Evorsionsbecken 748, 750, 754 .

Ewiger Schnee 191.

Ewiger Schneeberg 225.

Exaration 468.

Excelsior-Geysir 497.

Excessives Landklima 107.

Exogene Wirkungen 466.

Explosionsbecken 749, 750 .

Exzentrizität der Erdbahn 64, 249.

Fabre, L.-A. 522, 546.

Fächerstruktur 646 . 
Fadenalgen 858 .

Fairchild, H. L. 3, 8*.

Falken 861 .

Falkeninsel 401 .

Falklandinseln 453, 787, 825 .

Falklandstrom 334.

Fallinie 689 .

Fallwinde 143.

Falten 367, 370, 618, 645, 655 .

Faltengebirge $645 \mathrm{ff}$., $658 \mathrm{ff}$., 701 .

Faltengürtel 37 .

Faltenland 368, 645, 700 .

Faltenschollengebirge 680, 701 .

Faltenschollenland 680 .

Faltenzonen 652 .

Faltung der Schichten 19, 27, 367, 370.

Faltungsbecken 749,750 .

Faltungsepochen 27.

Faltungsintensität 656 .

Faradayhügel 266.

Farbe der Gewässer 287.

Farben der Tiere 860 .

Farne $790,821,835,841$.

Faro 778.

Färöer 788, 789, 854, 894.

Fasanen 861, 878, 890 .

Fasolt, E. 546 .

Fastebene s. Peneplain.

Faulenbach 728 .

Faulhorn 472, 477, 832 .

Faultier 874.

Faunenreiche $907 \mathrm{ff}$.

Faziesgebiete $605 \mathrm{ff}$.

Federbarometer 617 .

Feigenbaum 889.

Feinerdige äolische Ablagerungen 602, $604,608$.

Feldermethode 48 .

Felsbecken 754 .

Felsboden 601, 602, 606, Vegetation 816.

Felsdolinen 533.

Felsengebirge, vertikale Temperaturabnahme 76 , Temperaturschwankung 105, 108, Zyklonen 121, Föhn 145, Gletscher 224, Gipfelbildung 477, Bau 667, Talwasserscheiden 726, Waldgrenze 829,831 , alpine Flora 899, Getreidegrenze 853.

Felsenmeere 477 .

Felsnadel 385 .

Felsstufen 555 .

Felssturz 481.

Felsterrassen 558, 560, 657.

Felswüste 573 .

Fennema, R. 410*.

Fennoskandia 41, 447, 685, 765 .

Fenster 651.

Ferdinandea 401.

Fernando-Noronha 385.
Fernando-Po 787.

Fernbeben 415 .

Ferner 194.

Fernpaß 730.

Ferrel, W. 126, 128, 129*, 313.

Ferretto 581.

Festland s. Kontinente.

Festländische Inseln 769.

Festlandnahe Inseln 770 .

Festlandsseen 750 .

Fettpflanzen 815,840 .

Feuchtigkeit der Luft 147.

Feuchtpflanzen s. Hygrophyten.

Feuerland, Wald $829,830,838, \mathrm{Ge}-$ birgsflora 899 .

Fichte $839,901$.

Ficker, H. v., 84 *.

Fidschi-Inseln 773，780，783，788，791, Flora u. Fauna $880,882,883$.

Fiederförmige Gliederung 717.

Fietschergletscher 221.

Figee, S. 156.

Filicudi 709.

Filippi, F. de $217 *, 230 *$.

Fineman, C. G. 449.

Finken 878 .

Finlay 726.

Finnland, Winde 133, Niveauveränderungen $447 \mathrm{ff}$., Höhe 685 , Seen 754, Fjärde 802, Gerste 827, Wald 902 .

Finsteraarhorn, Sehneegrenze, 184, 185, 187.

Finsterwald er, S. 199, 200, 207, 211, $218 *, 548,549,563 *$.

Firn 183, 192.

Firneis 204.

Firngletscher 192, 219 ,

Firnlinie 184, 214.

Firnschalen 213.

Firnsee (Karakorum) 223.

Fischer, F. J. $498^{*}$.

Fischer, Hans $190^{*}$.

Fischer, Theobald $473,483^{*}, 582,590$, $600^{*}, 658^{*}, 702 *, 795,833^{*}, 843$.

Fisher, 0, 373, 376*.

Fiskefjord 798 .

Fitzroy, R. 313.

Fiumaren 503.

Fixsterne als Wärmequelle 56 .

Fjällfras 864, 893.

Fjärde 802.

Fjeld 801 .

Fjorde 797, 798, 804.

Fjordinseln 796, 799 .

Fjordstraßen 799 .

Flachbogen-Küste 794 .

Flächenbeben $420,428,434$.

Flächenberechnung 7 .

Flächenhafte Destruktion 468. 
Flächenspülung 468 .

Flachküste $584,592 \mathrm{ff}$.

Flachland 612, 619, 701.

Flachlauf 731 .

Flachmoor 763 .

Flachschichtung 618, 619, 642 .

Flachsee 263.

Fiadenlava 382.

Fläming 627.

Flammen bei vulkan. Ausbrüchen 381 .

Flarden 359.

Flaschenreisen 319 .

Fläscherberg 671 .

Flattertiere s. Fledermäuse.

Flechtentundra 826 .

Fledermäuse $864,871,874,878,885$, 890.

Fleischer, A., 407, 411*.

Fletcher, L. 203.

Fleury, E., 525, 546*.

Flevosee 592 .

Flexur 367.

Flexurstufe 638, 643 .

Floeberg Beach, Temperatur 92.

Flora 810 , Einteilung 905, Alter und Entwicklung 906.

Florida 767 .

Floridastrom 328.

Flughörnchen 890 .

Flugsand 575, 602, 606 .

FluBbarsch 894 .

FluBdichte 734 .

Flußdünen 578 .

Flüsse $498 \mathrm{ff}$., $731 \mathrm{ff}$., jährliche Periode und Schwankungen $502 \mathrm{ff}$., Terminologie von Davis 545. Anschwemmung 603, 606, Veränderungen 739 .

Flußeis im Eismeer 359.

Flußgebiet 736,739 .

FluBgeschwelle 309.

FluBhöhlen 538.

FluBinseln 512 .

FluBperlmuschel 894 .

Flußpferd 873, 877 .

Flußschwamm 894.

Flußsedimente 511, 513, 564.

Flußspiegel 507.

Flußsysteme 736 f., Veränderungen 743 .

Flußufer, Veränderungen 508 .

Flußvermischung 735 .

Flußwasser, Salzgehalt 282.

Flut 21, 302, 316.

Flutbrandung 308.

Fluterzeugende Kraft 303.

Flutgrenze 308.

Flutlinien (Flutstundenlinien) 310 .

Fluviatile Destruktionspässe 730 .

Fluviatile Fazies 606.

Fluviatile Gebirgsfazies 609.

Föhn 144.
Folgeflüsse 546 .

Fontlongue 535 .

Foraminiferen 775 .

Forbes, J. D. 198, 201.

Förde 802 .

Forel, F. A. 215, 216, 218*, 299, 301*, $341,344,345,363 *, 422,550,764$ *.

For elsche Farbenskala 288, Erdbebenskala 422 .

Formation (geologisch) 24, 25 .

Förmerich 392.

Formosa 393, 395, 421, 786, 829.

Fornogletscher 206.

Förster, W. 56*.

Förstle, A. F. 722, 730 *.

Fortpflanzung der Wellen 291, 293, 294, der Erdbeben 415, 420.

Fortschreitende Wellen 291.

Fort Yukon, Wald 825.

Fort Yuma, Temperatur 93.

Fossile Dünen 579.

Fouqué, F. 410 .

Foureau, F. 105, 473, 576, 579 .

Fourier, J. B. 11.

Fournier, E. $658^{*}, 677^{*}, 741,745^{*}$.

Fourtau, R., 518, 546*.

Fraas, E. $371,376^{*}, 459,465^{*}$.

Frakturformen 618, des Flachlandes 638, des Faltenlandes 679, 701.

„Fram"-Expedition 16, 28, 269, 330, 358,864 .

Franchi, S. $677^{*}$.

S. Franciseo, Erdbeben 424, FluB 739, Hafen 805 .

Franco, P. 709.

Fränkisch-schwäbische Stufenlandschaft 636,637 .

Frankland, E. 78 .

Franklin, B. 328 .

Frankreich, Länge eines Meridiangrades 5, Fläche 7 , Temperaturabweichung 113, Höhe der Zyklonen 119, Winde 133, Regen 156, Niveauveränderungen $279,457,461$, Maare 377 , Vulkane 400, Flüsse 502, Talbildung 523, Küste 584, 597, 794, Tiefland 637, 767, Zentralmassiv $653,696,698$, Waldfläche 902 (s. auch Pariser Becken).

Franz-Josef-Fjord 799.

Franz-Josef-Gletscher (Neuseeland) 225.

Franz-Josef-Land 787, Gletscher 201, $219,227,228$, Pflanzen 826, 827, Renntiere 864.

Franzius, L. 516*.

Fraser 726 .

Frauenfelder, K. $517 *$.

Fraunberger, G. 169*.

Frech, F. 246, 247, 256*, 257*, 438*, $651,658^{*}, 670,677^{*}$. 
Freiburg i. Sch., Riesentöpfe 517.

Freie Anschwemmungen 597.

Freie Strömungen $325,326$.

Freie Wellen 311.

Freshfield, D. W. 230 *.

Freydenberger, H., 758 .

Frieker, K. $364^{*}$.

Friedel, Joh. 2, $7 *$.

Friederichsen, M. $644^{*}, 693$.

Friedrich, M. 190*.

Friesische Inseln 592 f., 770 .

Friesische Küste 596, 795.

Frische Nehrung 598, Dünen 577.

Fritsch, K. v., 404, 707, 708, 712*.

Fritz 791*.

Fritz, H. 66, 69*.

Fritsch, M. 187.

Fritzche, R. 154, 158, 169*, 733, 745*.

Frosinone, Vulkane 396.

Frost, Zerstörung durch, 471, 472.

Frostisgletscher 551 .

Früh, J. 610*, 765*.

Fuchs 787, 893 .

Fuchs, K. 436, 496.

Fuehs, Th. 78, 473, 814, 858, 868*.

Fugger, E. 517*.

Fujiyama 704.

Fumarolen 392.

Funafuti 779,781 .

Fundybai, Flut 308, Zerstörung 594. Furten 509.

Futterer, K. 581, 583*, 722, 730*.

Gabelantilope 893.

Gabelung der Flüsse 735 .

Gäbris, tägl. Temperaturschwankung 105.

Gagel, K., 708, 712*.

Gaiola 299.

Galapagosinseln 393, 788, 790, 791, 818.

Galdhötind 548.

Galeriewälder 837.

Galicia, Rias 797, 802.

Galunggung 709.

Gambierinseln 776.

Ganges 504, 731, 738, 739, Gezeitengrenze 309 , unterseeisches Tal 455, Delta 569, 570, 571, Ablenkung 743.

Gannett, H. $375^{*}, 614$.

Gänsbrunnen, $\mathrm{PaB} 729$.

Gänse 865 .

Gardasee, Moränen 604.

Gardiner, J. St. 776, 778, 783, 784, $792 *$.

Garonne-System 737.

Gartenschnecke 894 .

Gärtner 488.

Garwood, E. J. '555, 557, 561, 563*

Gaskill, A. 850*.
Gastein 525, 528, Therme 494, 495.

Gault 25.

Gautier, A. 379, 406, 410*, 411*, 498*.

Gautier, E. F. 244, 643*.

Gavalin, A. $256^{*}$.

Gavazzi, A. 547*.

Gavial 864.

Gazelle 873, 890, 893.

"Gazelle"-Expedition 272, 276 *.

Gebirge 44, 612, vertikale Temperaturabnahme 75, tägl. Temperaturschwankung 105, järhrl. Temperaturschwankung 108, Temperaturveränderlichkeit 114, Windstärke 116, Zyklonen 121, Feuchtigkeit $147,149,847, \mathrm{Be}-$ wölkung 152, Regen 161, Wetterund Klimascheiden 161, jahreszeitliche Regenverteilung 171, Gewitter 179, Hagel 181, Schneedecke 182, Verwitterung und Denudation 472, 475, Fazies 608, Höhe 653, 687.

Gebirgsfuß 612.

Gebirgsknoten 673 .

Gebirgsland 612.

Gebirgsschutt 602, 603, 606, 607.

Gebirgsseen 755.

Gebirgssysteme 673.

Gebrochene Faltengebirge 680, 701.

Gebrochene Rumpfgebirge 691, 701.

Gebuchtete Küsten 794.

Gebüsch 816.

Geer, G. de, 256*, 446, 447, 448, 449, $451,463^{*}, 464^{*}$.

Gefälle 506 .

Gefällsströmungen 326 .

Gefrierpunkt v. SüB- u. Salzwasser 346.

Gegenflüsse 546.

Gegenständige Täler 521 .

Gegißter Standort 319.

Gehängeformen 477.

Gehängeregion 551 .

Gehölz 816.

Geier 878.

Geiger, E. 727, 730*.

Geikie, Arch. 399, 411*, 699, 703*.

Geikie, J. 246, 256*, 375*.

Geinitz, E. 246, 256*, 298, 301*, 463*, $468,587,588,600 *, 748,754,765 *$, Geïte 13.

Geitsegubib 705 .

Gekröslava 382.

Gelbes Meer, Farbe 290, Strömung 335.

Gemäßigter Temperaturgürtel 99 .

GemäBigter Typus der Süßwasserseen $344,345$.

GemäBigte Zone 99, 100, Zyklonen 120, Gletscher 221, Pflanzen. 813, 822, Wälder 838 .

Gemischte Eruptionen 389.

Gemischte Formen 533. 
Gemischte Niederschläge 181.

Gemse 900, 903.

Gemüsepflanzen 856 .

Geneseefall 529.

Genetisches System d. Morphologie617.

Genette 890.

Genfer-See, Wärmeumsatz 85, Seiches 299, Temperatur 341, 344, unterseeisches Tal 455, zum Donaugebiet 744, Areal und Tiefe 753, 761.

Gentil, L., 658*, 671, 677*.

GenuBmittel 855, 856.

Geographie 2, 611.

Geographische Methode der Schneegrenzenbestimmung 186 .

Geographische Zyklen 470, 530, 541, 561, 574, 599, 618.

Geoïd 6, 277, 278.

Geoisothermen 10, 11, Veränderungen 452.

Geologie 24.

Geologische Gegenwart 25.

Geologische Klimaperioden 242.

Geologische Orgeln 535.

Geometrische Erdbebentheorie 416.

Georgetown, Temperaturveränderlichkeit 110, Depression 751.

Georgiosvulkan 709.

Geosynklinale 653 .

Geothermische Tiefenstufe 9.

Gepard 890.

Gepatschferner 198, 215.

Geradlinige Faltengebirge 670 .

Geradlinige Küsten 794 .

Gerhardt, P. 516*, 577, 583*.

Gerke $466^{*}$.

Gerland, G. 157, 169*, 401, 411*, 414, 431, 438*.

Germesir 584.

Geröllboden 474.

Gerste 852.

Geschichtete Gesteine 15.

Geschichtete Vulkane 390, 704.

Geschleppte Schichten 367.

Geschwindigkeit der Gletscher 199, des fließenden Wassers 507.

Gestalt der Erde 4.

Gestaltungsgesetz 42 .

Gesteinshülle 8 .

Gesträuch 816.

Getreide $851 \mathrm{ff}$., 856 .

Gewitter 179, 381.

Gewundene Falten 674.

Gewürze 855 .

Geysir $495 \mathrm{ff}$.

Gezeiten 21, 302, 413, Einfluß auf die Rotation 369, 442, auf die Erdbeben 435, auf das Grundwasser 487, auf die Deltas 570
Gezeitenströme 316,317 , mechanische Wirkungen 594, 597, 794.

Gezeitentafeln 315 .

Gezwungene Strömungen 325, 326.

Gezwungene Wellen 311.

Gharsa 752.

Ghôr 398, 716, 752, Winde 142.

Gibraltar, Straße v., 673, Ausgleichsströmungen 318 , Fels 679 , 890, alte Landbrücke 873 .

Giens 599.

Gießen, Temperatur 78.

Giffretal 725 .

Gilawüste 164.

Gilbert, G. K. $256^{*}, 374,453,464^{*}$, $527,599 *, 711,749$.

Gilbert-Inseln 780 .

Giles, E. 847.

Gingko 870.

Gipfelformen $475^{*}$.

Gipfelhöhen 686, 687, 691.

Gips 471, 489.

Giraffe 860, 873 .

Girard, J. 595, $600 *$.

Girardot, L. A. 466*.

Gironde 570, 597.

Glarner Alpen 647.

Glärnisch 478, 646.

Glarus, vertikale Verbreit. d. Tiere 865.

Glatte Küsten 794.

Glatzer Gebirge, Flußdichte 734.

Glaukonitkörner 271.

Glaziale Destruktionspässe 730 .

Glaziale Erosionsbecken 748, 750 .

Glaziale Gebirgsfazies 609.

Glazialer Felsboden 601, 602, 606.

Glaziale Übergangsgebiete 606 .

Glazialpflanzen 899 .

Gornergletscher 221.

Glazialzeit s. Eiszeit.

Gleichartige Flüsse 731 .

Gleichförmige Faltengebirge 661, 701.

Gleichgewichtsgezeiten 304 .

Glencoe, Regen 166.

Gletscher $192 \mathrm{ff}$,, verschiedene Begriffe 194, Verteilung 218, Erosion $547 \mathrm{ff}$., Seenbildung $754 \mathrm{f}$.

Gletscherausbrüche 199.

Gletscherbach 196, 209.

Gletscherbewegung 197.

Gletschereis 203, 206.

Gletschergarten von Luzern 202.

Gletschergeschwindigkeit 199, 213, 224.

Gletschergruben 213.

Gletscherhöhlen 213.

Gletscherkonferenzen 206, 209.

Gletscherkorn 203.

Gletscherlawine 197.

Gletschermileh 211.

Gletschermühlen 202. 
Gletscherperiode 214.

Gletscherschutt 602, 603, 608 .

Gletscherschwankungen 213, 217.

Gletscherspalten 201.

Gletscherstruktur $203 \mathrm{ff}$.

Gletschertemperatur 202.

Gletschertheorie 200.

Gletschertisch 212.

Gletschertor 196.

Gletschertrichter 213.

Gletscherzunge 194.

Gliederferner 215.

Gliederung 808.

Globigerinenschlamm 274, 275, 895 .

Glossopterisflora 885 .

Gneis 15, 403, 587.

Gnirs, A. 458, 459, 465*.

Gobi 625, 697, Vegetation 847, 848.

Gobi-Altaï 652.

Gobischichten 675, 691 .

Gockel, A. $7 *$.

Goetze, W. $850^{*}$.

Gogarten, E. 561, 563*, 564*, 757, $765 *$.

Gogra 738.

Goktschaï, Getreidegrenze 854 .

Goldbergferner 215 .

Goldgebirge 224.

Goldmull 876.

Golfier, J. 52*.

Golfstrom 328, 331, 341.

Golfstrominseln 770 .

Gondwana 27.

Gondwanaland 885 .

Gorilla 875 .

Gornergletscher 205, 221.

Gornergrat, Temperatur 78 .

Gotachi, See 749 .

St. Gotthard, -Tunnel 10, -StraBe 729.

Götz, W. 251, 257*.

Götzinger, G. 475, 483*, 532 .

Graben (geologisch) 366, im Meer 266.

Grabentäler 542, 545, 716.

Gradient 115.

Gradientföhn 144.

Gradman n, R. 242.

Gradmessungen 5.

Grammagras 845 .

Granatbaum 889 .

Grand 511.

Grandidier, G. 887*.

Granit 587.

Grantland, tägl. Temperaturschwankung 106, Fauna 864.

Grasbäume 824, 878.

Grasflur 816, 834.

Grassittiche 878.

Grassteppe 816, 834, $844 \mathrm{f}$.

Graupen 180.
Gravelius, H. 498*.

Gray, Assa 839.

Great Basin s. Großes Becken.

Green, Lowthian $42,43,45,50,52 *$.

Green River-Tal 720, 723.

Gregory, J. W. $42,43,52^{*}, 398,411^{*}$, $712^{*}$.

Greim, G. 703, 712*, 765*

Griechenland, angebliche Klimaveränderung 252, Vulkane 397, Erdbeben 431, Niveauveränderungen 457, Gebirgsbau 680, Rias 797, Flora 889,899 , Waldfläche 902 , Veränderung der Fauna 903.

Griechischer Archipel 681.

Griesbach, C. L. $465^{*}, 625,644^{*}$, 655,676 .

Griesebach, A. $815,817 *, 845$, 889.

Grießbreccien 377.

Grimmia 815.

Grindelwaldgletscher 213, 222, 548, 549, 748.

Grinnellland, Vegetation 827.

Grissinger, K. 342, 363*.

Grönland, Nordlichter 69, Temperatur $72,80,89,90,92,94,108$, Luftdruck druck 123, Föhn 145, Niederschlag 183, Gletscher 198, 199, 200, 206, 219, 225, 249, 549, Eisberge 228, Tertiürflora 247, angebliche Klimaänderung 253, Seter 445, Niveauveränderungen 452 , Boden 601,606 , Moore 764, Areal 769, Geschichte 787, Fjorde 798, 801, Vegetation 826, 827, 840,854 , Fauna 864, Basalt 894 .

Grönländische Bucht 269 .

GroB-Arlbach 722.

Großbuchtige Küsten 794.

Grosse, W. 599*.

Grosser, P. 392, 410*, 708, 712*.

Großer Bärensee 751 .

Großer Chingan 652.

GroBer Geysir auf Island 495.

Großer Ozean s. Pazifischer Ozean.

Großer Plönersee 753.

Großer Salzsee 244, 759, 761.

Große Salzwüste 848 .

Großes Becken von Nordamerika 243 $641,697$.

Große Schneegrube, Sonnenscheindauer 64 , Kar 552.

Grosseto, Alte Bucht v., 796.

Großfußhühner 878 .

Großgerauer Erdbeben 428.

Großglockner, Waldgrenze 831 .

Grotten s. Höhlen.

Grund, A. $457,458,465^{*}, 490,491,498^{*}$, $600^{*}, 685,702^{*}$.

Gründe (Meer) 266. 
Grundlawine 191.

Grundluft 484, 487.

Grundmoräne 209, 211, 212, 228, 483.

Grundmoränenlandschaft 604 .

Grundwasser 486.

Grüner Sand 275.

Grüner Schlick 271, 275.

Gschnitzstadium 246.

Guadalquivir 503.

Guanako 900.

Guatemala, tägliche Temperaturschwankung 105, Hagel 180, Vegetation 818, Waldgrenze 829 .

Guayana, Massiv 41, 697, Küste 751, 796, Savanen 844 .

Guayava 855.

Guébhard, A. $677^{*}$.

Guineagolf $162,259$.

Guineagras 902.

Guineaströmung 327, 329.

Gultal 716 .

Gulliver, F. P. 567, 571*, 598, 599*, $794,809^{*}$.

G ümbel, K. W. 272, 407, 412*.

Gunnera gigantea 822.

Gunung-Gedé 385 .

Gunung-Sumbing 711.

Günther, A. 864.

Günther, R. T. $459,465^{*}$.

Günther, S. $8^{*}, 12,17^{*}, 56^{*}, 301^{*}$, $402,411^{*}, 479,480,484^{*}, 513,517^{*}$, $575,583^{*}$.

Günzeiszeit 246 .

Guppy, H. B. 782, 784, 788, 792*, $882,887^{*}$.

Gurgitello 495.

Gurgler Gletscher 183, Eissee 747.

Gürteltier 874, 891.

Güsgundag 759 .

Gübfeld, P. 220.

Guyot, A. 34 .

H a a ck, H. $52^{*}$.

Haacke, W. $483^{*}, 886^{*}$.

Haarmann, E., 653, 658*.

Haas, H. J. $410^{*}, 498^{*}, 702 *, 802$, $809^{*}$.

Haase, A. 731, 745*.

Habenicht, H. 52*.

Häberle, D., $610^{*}$.

Habituelle Stoß- oder Schütterlinien 429.

Hachika 726.

Häckel, E. 273.

Hadramaut 398.

Haehinel, G. 850 *.

Hafen 804.

Hafenzeit 310 .

Haff 598, 795, 804.

Hagel 180.
Hagen, G. $516^{*}$.

Hague, J. D. 154.

Hahn, F. 269, 463*, 791*.

Hainan, Fauna 786.

Hainbach 722 .

Haken 598.

Halaváts, J. 644*, 742.

Halbaffen 877, 885.

Halbausgebildete Gletscher 194.

$\mathrm{HalbfaB}$, W. 301*, 345, 363*, 753, $764^{*}, 765^{*}$.

Halbinseln $766 \mathrm{ff}$.

Halbmonatliche Ungleichheit der Gezeiten 306.

Halbwüste 816.

Halimeda 775 .

Halligen, Fauna 788.

Hallstatt, Sonnenscheindauer 64 .

Hallstätter See 753, 756 .

Halmahera 772 .

Halophyten $812,815,816$.

Hals 598.

Hamberg, A. 206, 218*, 320.

Hamburg 806.

Hammada 574, 603, 847.

H ammer, E. $376^{*}, 465^{*}$.

H ammer, R. R. J. 199.

Hängegletscher 193, 195, 197, 220.

Hängetäler 553 .

Hangflüsse 546.

Hangö, Wasserstand 450 .

Hann, J. 56* $70,74,80,83^{*}, 85$, $89,95,96,110,113,114^{*}, 118,120$, $129^{*}, 137,140^{*}, 144,146^{*}, 160,239$, $252,256^{*}, 341,484,498^{*}, 616,832$.

Hansen, A. M. $190,191^{*}, 444,445$, $449,452,463^{*}, 464^{*}$.

Hansen, H. J. 346.

Hansen, R. 593, 600*.

Han-sin-ling, Lößschluchten 632.

Harboe, E. 420, 437*.

Hardangarfjord 800 .

Hardangerjökel 584 .

Hargita 388, 397, 710, 713 .

Harmattan 146.

Harmonische Analyse 315.

Harrilaid 770 .

Harris, R. A. $313,315,317^{*}$.

Harrison, J. B. 52*, 904*.

Hartlaubhölzer 822 .

Härtling 531 .

Hartmann, G. 599*.

Hartung, G. 799.

Harz, Temperaturabnahme 76, Eiszeit 243, Bau 696, 698, 700, Täler 714,

Waldgrenze 829 , Glazialflora 898 .

Hasen 893, 903.

Hassinger, H. 622, 644*, 724, 730*.

Hatch, F. H. 28*.

Hatteria punctata 887 . 
Haug, E. 643*, 653, 658*, 677*.

Hauptbeben 415 .

Hauptflüsse 513, 731, 737.

Hauptwasserscheide 732 .

Hauptwindgebiete 138.

Hauptwindscheide d. nördl. Hemisphäre im Winter 132, im Sommer 136.

Hautes-Alpes, Talverlegung 713.

Hauthal, R. 209, 220, 411*.

Hawaii 774, 791, Antipassat 125, Klima 233, Vulkane 387, 393, Erdbeben 421, Cañons 526, Flora 813, 831,882 , Fauna 882.

Hayden, F. V. 477, 667.

Hayden, H. H. $677^{*}$.

Hayes, C. W. $35,668,689,690,702 *$.

Hayes, J. J. 864.

Hay ford, J. 290*.

Heardinsel, Schneegrenze 188.

Hébert, F. F. 145 .

Hebungen 441.

Hebungsinseln 770 .

Hebungsintensität 653 .

Heckenkirsche 839.

Hecker, O. 13, 16, 17*, 21, 24*.

Heddlam, E. J. 412*.

Hedin, Sven v., 37, 52*, 160, 199, $218^{*}, 578,745,747,765^{*}$.

Hedley, Ch. 878.

Heer, O. 865.

Hegau 396.

Hegyalja 397.

Hehl, R. A. 748 .

Heide 841, 901.

Heidenmyrte 883 .

Heiderich, F. 30, 48, 49, 50, 51*.

Heilpflanzen 856.

Heilprin, A. 385, 410*, $886^{*}, 892$.

Heim, A., 199，201，214，366，367, $375^{*}, 475,476,477,478,479,483^{*}$, $484^{*}, 514,516,536,551,560,561$, $564^{*}, 589,590,645,647,657^{*}, 665$, $677^{*}, 716,727,756,757,765 *, 801$.

Hekla 404.

St. Helena $769,791,885$, vertikale Temperaturabnahme und Regen 76 , 77 , Organische Welt $813,818,886$, 904.

Helgeland, Strandebene 591.

Helgoland 593, 626.

Helikon 681.

Heliopolis, Wasserscheide 727.

Helland, A. 199, 446.

Helland-Hansen, B. 321, 331, 338*, 356.

Heller, C. $866,868^{*}$.

Hellmann, G. 129*, 179, 181*, 241, $272,572$.

Helmert, F. R. 4, 6, $8^{*}, 277,279$, $281,290^{*}, 447$.
Helmholtz, H. v., 129*, 292, 301, 578.

Hemipelagische Ablagerungen 270.

Henkel, L. 517*.

Henry, A. J. 129*, 181*.

Henry, E. 486, 498*.

Henry Mountains 711 .

Hentzschel, O. 797, 809*.

Herbertson, A. J. 56*, 169*.

Herdlinien 420.

Hergesell, H. 71, 74, 83*, 447, 448, $464^{*}$.

Hermsburg, Regen 166.

Hernösand, Regen 159.

Hernadlinie 679.

Herrmann, K. 411*.

Herz, N. 248, 257*.

Herzegowina, Karst 541.

HeB, H. 186, 189, 190, 191*, 196, 197, $198,199,202,206,208,209,210$, $214,216,217^{*}, 218^{*}, 221,222,230^{*}$, $514,517^{*}, 549,551,554,562,563^{*}$.

Hessischer Typus 643 .

Hessisches Bergland 641.

Heteromorphe Faltengebirge 660 .

Heterotherm 345 .

Hettner, A., 546*.

Hibsch, J. E. 399, 411*.

Hilber, V. 521, 546*, 719, 730*.

Hildebrand $813,817^{*}$.

Hildebrandsson, H. 56*, 128, 129*, $153^{*}$.

Hilgard, E. W. 474, 483*, 850*.

Hill, R. T. $375^{*}, 636,644^{*}, 876,887^{*}$.

Hill, S. A. 160.

Hilpert, H., 547*.

Himalaya 37, 395, Schneegrenze 189, Gletscher 199, 222, Eiszeit 245, Erdbeben 431, höchste kalte Quelle 494, Erosionsspuren 526, Fazies 609, Bau $655,665,673,676$, Beziehungen zum Vorland 675, Gliederung und Täler $715,716,717,721$, Verhältnis zur Hauptwasserscheide 719,735 , Seen 755, 757, Palmengrenze 819, Pflanzenregionen 828, Waldgrenze 829 , Vegetation 847, Getreidegrenze 853, Flora 898, 899, Fauna 900.

Himmelsluft 54 .

Hindukusch 673 .

Hindustan, Winde 142, Maximalregion des Regens 160, Regenverteilung 163, Tiefenbohrung 623, Flora 901.

Hintereisgletscher 196, 198, 199, 200, 202, 209, 215, 216.

Hinterindien 767,771 , Laterit 482 , Gebirgssystem 766, Flora 819, Wald 836.

Hintersee, Wärmeumsatz 85.

Hipparch 59. 
Hirsche 860, 873, 874, 893, 903.

Hirsehwald, J., 483*.

Hise, C. R. van, $369,370,375^{*}$.

Hispargletscher 222.

Hoa-hai-tse 746.

Hoangho 737, 739, 740.

Hobart, Deklination 68.

Hobbs, W. H., 428, 437*, 553, 563*.

Hochgebirge 609, 613, 614 .

Hochgebirgsflora 897.

Hochgrassteppe 845 .

Hochjoch-Gletscher 215.

Hochland 614.

Hochland-Klimaprovinzen, Asien 232, Amerika 233.

Hochmoor 763 .

Hochschnee 183.

Hochseen 755 .

Hochstetter, F. v., 56*, 298, 301*, 380,704 .

Hochtäler-Klima 108, 109.

Hochwald 836, 843.

Hochwasser des Meeres 302.

Höck F., 857*.

Hoernes, R. 428, 677*.

Hoff, K. E. A. v., 4, 8*, 523, 597, 742.

Höffer, H., 412*.

Hoff $\operatorname{mann}$, H. 78, 83*, 813.

H off $\operatorname{mann}$, J. E. 247,257 *.

Höftsee 753,755 .

Hogbacks 667.

Hög bom, A. G. 447, 448, 464*.

Hoggar 182.

Höhenmessung 280, 615 .

Hoher Priel 182.

Hohe Tatra, Temperaturabnahme 76, Bau 679.

Hohe Tauern 651, 730.

Höhlen $538 \mathrm{ff.,} 589$.

Höhlenbär 903.

Höhlenhyäne 903 .

Höhlenlöwe 903.

Höhlentiger 903.

Höhlenwolf 903 .

Höhnel, L. v., 394, 398, 411*.

HolderneB, Küstenzerstörung 587.

Holland, T. H. 482, 484.

Hollender, A. 450, 464*.

Hollow, tägl. Temperaturschwankung 104.

Holmboe, J. 241, 463*.

Holmes, W. H. 498*.

Holmsen, A. 363.

Holmström, L. 464*.

Holoarktische Zone $891 \mathrm{ff}$.

Holstein, Seenplatte 627, 755, Förde 802.

Homogene Vulkane 390, 704, 706, 709.

Homöomorphe Faltengebirge 660 .

Homoseisten 419.

Homotherm 345 .
Honda, K. 498.

Honduras, Vulkane 396.

Hongkong, vertikale Temperaturabnahme 76 .

Honigsauger 878 .

Honolulu, Regen 160, Riff 782.

Hooge 594.

Hooker, Sir J. D., 483*, 883.

Hopfen 839.

Hopfner, F. 69, 95, 102*, 106.

Horizontaldislokationen 365,367 .

Horizontalpendel 21, 412, 415.

Hornemann's Trachylobium 837.

Hornindalsvand 752, 753 .

Hornitos 403.

Hörnli, Temperatur 78 .

Horpatsosee 755 .

Horst 366 .

Howesund 800 .

Hub (Hubhöhe) 302, 307, 308.

Huber, J. 504.

Hudson, unterseeisches Tal 455, Eisbedeckung 506 , Delta 569 .

Hudsonbai 259, Areal und Tiefe 260, Bodenrelief 269, Eisbildung 359, Hebung 452 .

Hudsonprovinz, Klima 233.

Hudsontal, Winde 133, 142.

Hüfigletscher 548 .

Hufpfötler 874.

Huftiere 876, 877, 893.

Hulesee 752.

Hull, E. 231, 244, 256*, 263, 276* 455, $465^{*}$.

Hülsenfrüchte 856 .

Hult, R. 255*.

Hum 541, 685.

Humber 738.

Humboldt, Alex. v., 48, 51, 82,180 , 329, 399, 409, 617.

Humboldt-Gletscher 227.

Humusboden 474.

Humussauere Alkalien 472.

Humussäuren 472.

Hunde 864.

Hundskopf-Fledermäuse 891 .

Hungerbrunnen 493.

Hungersee 537.

Hunte-Ems-Kanal, Moor 763.

Huntington, Ellsworth 257*.

Huronsee 751.

Hurrikane 122.

Hutton, F. W. $245,881,887$ *.

Huyghens'sches Prinzip 417.

Hvittisbofjärd, Hebung 449.

Hyäne 873,890 .

Hydrometrischer Flügel 499.

Hydrophyten 812.

Hygrophyten (hygrophyle Pflanzen) 812.

Hymettos 681 . 
Hyomoschus 875 .

Hypozentrum 413.

Hypsographische Kurve 46.

Hypsometrie 614.

Hypsometrisches System 613.

Iberische Halbinsel 766, 767, Luftdruck 137, Wüstenwinde 146, Regen 166, 171, Gewitter 180, Eiszeit 243, Hochland 697, 698, Küsten 793, 795, 802, Flora 815, 889.

Iddings Gesetz 404 .

Igapowald 835 .

Thering, H. v., 842, $850 *$, 872, 882, $883,885,887^{*}$.

Ihne, F. 813, 817 .

Ilaló 395 .

Ilopango-Vulkan 704.

Imamura, A. 435 .

Imbabura 392, 708.

Imh of, E. 830, 831, 833*.

Immergrüne dikotyle Laubbäume 814 , $823,838$.

Immergrüne Sträucher 814, 823, 824.

Indien s. Ostindien.

Indische NW-Provinzen, vertikale Temperaturabnahme 76 .

Indischer Ozean 32, Areal 34, 260, Tiefe $47,51,260$, Lufttemperatur 87, Zyklonen 122, Luftdruck u. Winde 130, 135, Regen 154, 167, Küstenabstand 259, Bodenrelief 267, Bodenbedeckung 274, 275, Salzgehalt 285 , absolutes spezif. Gewicht 287, Farbe 288, Wellen 293, 294, Gezeiten 310 , Strömungen $334 \mathrm{f}$., Auftriebwasser 336,337 , Oberflächentemperatur 340,342 , Tiefentemperatur 349,353 , Mitteltemperatur 350 , FluBgebiet 734, Korallenriffe 782, 783, Algen 858.

Indisches Florenreich 906, 909, Faunenreich 908, 909 .

Indre 738.

Indus 738, 739, unterseeisches Tal 455, Delta 569, 570, Veränderungen 740 , 743.

Indusprovinz, Klima 232.

Inlandeis 193, 225, Niveauveränderung 451 f., Erosion 550.

Innenküste 793 .

Innenmoräne 209, 211.

Innerasiatisches Florenreich 906, 909.

Innere Reibung des Seewassers 322.

Innere Zone 86, im Januar 90, im Juli 93.

Innerkontinentale Wüsten 173.

Innsbruck, Sonnenscheindauer 64, Temperatur 144.

Inntal, Schneedecke 182, Talbildung $720,727$.
Inschan, Wald 847.

Insekten $789,863,865,866,875$.

Insektenfresser 874, 877 .

Inselabgeschlossene Meere 259, Salzgehalt 286.

Inselberge 684 .

Inselberglandschaften 574, 684 .

Inseln 32, 266, 401, 408, 512, 597, $769 \mathrm{ff}$., Landfestwerden 599, organische Welt 904, 906.

Insequente Flüsse 545,546 .

Insolation 607.

Instantane Niveauveränderungen 365 , 438, 439, 462.

Interglazialzeiten 246,248 .

Interkolline Täler 542, 545, 716 .

Interkontinentale Ozeane 33.

Intermittierende Flüsse 502.

Intermittierende Vulkane 379.

Interne Wellen 300.

Inundationsbett 512.

Inundationsterrassen 558 .

Inversion 73.

Inyltschekgletscher 223 .

Iquique, Erdbeben 297.

Iranisches Hochland 39, Regen 165, 170.

Irischer Strom 330, 331, 341.

Irische See 260.

Irkutsk, Temperatur 92.

Irland, Winde 133, Regen 173, Gebirge 696, Durchgangstäler 722, Moore 764, Flora und Fauna 785, Talbuchten 801, 802, 803, Basalt 894 .

Irminger Strom 330, 331.

Isachsen, G. $361,364^{*}$.

Isanomalen 97.

Ischia 396, Erdbeben 427, 428.

Ischma 738.

Iseosee 756 .

Isèretal 561, 725, 728.

Isker, Durchgangstal 719, 720.

Island 769, 771, Nordlicht 69 , Gletscher $217,219,220,227$, Klimaänderung 242, 253, Eis 333, Vulkane 388, 393, 399, 404, 707, 894, Schlammsprudel 409, Böschungen 471, Geysir 497, Wald 825 , Getreide 854 .

Isländischer Rücken 269, 894.

Isobaren 115.

Isobarenkarten 129.

Isobasen 446.

Isobathen 45 .

Isobathenkarten 262.

Isohypsen 45 .

Isoklinalfalten 646,678 .

Isoklinalkamm 646 .

Isoklinaltal 646,715 .

Isortok 548 .

Isoseisten 425 .

Isostasie 15,374 . 
Isostatische Theorie 374, 443.

Isothermen 82, Meeresisothermen' 339. Issel, A., 463*.

Issykkul 253, 761 .

Istrien 766, Entkarstung 541, Rias 797, 803.

Italien, Temperaturabweichung 113, Regen 175, Schnee 181, Vulkane 396, Erdbeben 414, 424, 429, 431, 436, Niveauveränderungen 459 , Halbinsel 766, 767, 768, Inseln 771, Küsten 795, Wald 902.

Ivrea, Moränen 604.

Iw an ow, D. W. $665,677^{*}$.

Ixtlangeysir 497 .

Izalko 704 .

Jaceard, F., 744.

Jacobi, A. $886^{*}, 892,893$.

Jadebusen 592.

Jäderen 584 .

Jadrinzew, N. 760, 765*.

Jaeger, F., 220, 221, 230*, 644*.

Jaggar, T. A. $411^{*}, 497,498^{*}$.

Jagowalfall 529 .

Jaguar 874.

Jahresisothermen 86 .

Jahreszeiten 59, in den Tropen 173.

Jährliche Niederschlagsschwankung 172.

Jährliche Periode der Polarlichter 68, der Temperatur 106, des Regens $172 \mathrm{ff}$., des Grundwasserstandes 486, der Flüsse 502, der Pflanzenwelt 813, der Tierwelt 866 .

Jährliche Temperatursehwankung 107.

Jailagebirge 767 .

Jakobshavn, Föhntage 145.

Jakutsk, Temperatur 91, 92.

Jamaica, Karstphänomen 540 .

Jamies on, T. F. 451, 452, 464*.

Janatal, Waldgrenze 825 .

Jangtse-kiang 739, Hubhöhe 309.

Janina-Polje 537.

Jankó, J. 567, 571*.

Jan Mayen, Gletscher 219, Vulkane 393. Jan Mayen-Strömung 331.

Japan, Föhn 145, Regen 165, Gletscher 223, Klima 232, Maare 377, Vulkane 393,395 , Erdbeben $414,421,422$, $424,425,426,432,433,435,436$, 459, 460, Geysir 498, Gebirge 676, 699 , Fauna 786 , Küste 795 , Flora 823, 889, Wald 838, 839, Fauna 890.

Japanischer Graben 267.

Japanisches Meer 259, 260, 268.

Jarvis 780 .

Jasmin 889 ,

Jasmund, R. 516*.
Jaszewski, L. 23*.

Java 772 , relative Feuchtigkeit 149 , Hagel 180, Vulkane 393, 396, Waldgrenze 830, Wald 837, Fauna 879, Gebirgsflora 899.

Javasee, Salzgehalt 286, Riffe 777.

,Jeanette"-Expedition 28.

Jeff Davis Peak, Firn 224.

Jefferson, Mark $745^{*}$.

Jegerlehner, J. 189, 191*, 230*, 466*. Jehu, T. J. 764*.

Jelinek, C. 616 .

Jemen 176, 398.

Jena, Aussichtsweite 462.

Jenikale, Schlammsprudel 408.

Jenissei 737, 739, Eisbedeckung 506. Jenny, Fr. 720, 730*.

Jensen, A. S. 827.

Jensen, H. J. 407, 411*.

Jensen, J. A. D. 226.

Jergenihügel 659 .

Jerosch, Marie Ch. 897, 904*.

Jeschke, C. 792*.

Jessen 855 .

Jessen, A. 794, 809*.

Jessesche Wolken 54 .

Johnson, W. D. 553 .

Johnston-Lavis, H. J. $407,412^{*}$.

Jökelfjord-Gletscher 225.

Jökulsá 548.

Joly, J. 585, 599*.

Jonas 843 .

Jordan, W. 105, 619*.

Jordantal s. Ghôr.

Jorullo 403, 704.

Jostedalsbrä 225, 548 .

Ju dd, J. W. 571*.

Judikarienspalte, Täler 715 .

Juist 592.

Jukes, J. B. 722, 723.

Jukes-Brown, A. J. 52*, 304*.

Junge Floren 907.

Junghuhn, F. W. 149, 385.

Jungtertiär 26.

Jura, vertikale Temperaturabnahme 76, Veränderung der Aussichtsweite 462, Bau 618, 642 (Tafeljura), 650, 654, $656,660,670,672,678,686,687$, Beziehung zum Vorland 675, Täler 713, 716, 722, Gliederung 718, 729, Waldgrenze 830, Getreidegrenze 853, Flora 897, 898.

Juraformation 25, 27.

Jütische Halbinsel 767, 771, 794, 795, 802.

Juvenile Quellen 485.

Kaagan, Gletscher 201.

Kabelbrüche 263.

Kabretplateau 473 . 
Käfer $863,866,876,880$.

Kaffee 855 .

Kagosehima, Mangrove 837.

Kahle, P. 466*.

Kairo, tägl. Temperatursehwankung 105.

Kaiser, E. $791^{*}$.

Kaiser, M. 146*.

Kaisergebirge 727 .

Kaiserstuhl, Erdbeben 428.

Kaiser Wilhelm II.-Land 826.

Kakadu 878.

Kakao 855.

Kakteen 823, 845, 848, 872, 902.

Kalahari 732, Regen 164, Klima 233, Vegetation 849.

Kalanscho-Serir 574 .

Kalema 296.

Kalkalgen 775 .

Kalkkruste 473 .

Kalkpflanzen 814 .

Kalkreiche Quellen 494.

Kalkschlamm 274.

Kalkstein 15, 471, 472, 489, 533, 587, 646.

Kalmengürtel 124.

Kalte Quellen 494.

Kalter Wall 331, 337.

Kalter Wärmegürtel 101.

Kalte Schlammsprudel 409.

Kalte Seen 345,346 .

Kalte Zone 99, 100 (s. auch arktische und antarktische Zone).

Kama 738.

Kambrium 25.

Kamel 860, 873, 891, 893.

Kamerunberg; Regen 162, Flora 897. Fauna 900.

Kames 604.

Kammgebirge 612, 698, 701, 710.

Kammpaß 730.

Kammregion 551.

Kammwasserscheide 725 .

Kampine 842 .

Kamtschatka 767, Regen 165, Gletseher 223, Klima 232, Vulkane 393, 395, Erdbeben 431, Flora 824, Savanen 844, Getreidegrenze 853, Fauna 900.

Kanabcañon 523.

Kanal, Areal und Tiefe 260, Gezeiten 314.

Kanal der Korallenriffe $\mathbf{7 7 6 .}$

Kanalriffe 776 .

Kanaltheorie. 311.

Kanarischer Strom 329, 336

Kandelabereuphorbie 840 .

Kander, Sedimentführung 514 .

Kane, E. K. 864.

Kankersee 761 .

Känozoisches Zeitalter (Formationsgruppe) 25 .
Kansu, Löß 625.

Kant, Imm. 3.

Kap Ferret 595.

Kapflora 875, 906.

Kapformation 27.

Kapgebirge 40.

Kapillare Wellen 292.

Kapland, Klima 233, Vegetation 823, 840 , Weizen 852 , Flora und Fauna $875,906$.

Kapmulde 269, Bodentemperatur 354 .

Kap St. Martin, unterseeische Quelle 491.

Kar 551 f., 562, 609.

Karabugas 759 .

Kara-Dagh 397.

Karakaschtal, tägl. Temperaturschwankung 104.

Karakorum 673, tägl. Temperaturschwankung 104, Schneegrenze 189, Gletscher 220, 222, 223, Bau 667, Getreidegrenze 853 .

Karapiti 495 .

Karbon 25, 27.

Karleisfeld 215, 548.

Karlsbader Thermen 397, 495.

Karnische Alpen, Durchgangstäler 722.

Kärnten, vertik. Temperaturabnahme 76, Temperaturumkehr 80 .

Karolinen 781.

Karpathen 38, Vertikale Temperaturabnahme 76, Winde 142, Eiszeit 243, Vulkane 397, Erdbeben 431, Bau $651,654,664,673,679$, Beziehungen zu den Alpen 673, zum Vorland 675, Längstäler 715, Flora 814, 897, Krummholz 831.

Karpinsky, A. $643^{*}, 689$.

Karreeberge 633.

Karregion 551.

Karren 535 .

Karru 638, 840.

Karruformation 27, 698 .

Karsee 753, 755 .

Karst 489, 490, 533, 540, 541, 672, 673 .

Karsten, Georg $817^{*}$.

Karstens, K. 48, 51, $52 *$.

Karstgebirge als Fazies 608 .

Karstgerinne 490 .

Karstphänomen 489, $533 \mathrm{ff}$.

Karstquellen 491.

Karstwasser 489 .

Karstzyklus 541.

Kartenniveau 281.

Kartoffel 854.

Kasan, tägl. Temperaturschwankung 104.

Kaschgarien, lokale Winde 141.

Kaschmirtal 716 .

Kaskaden 528. 
Kaskadengebirge, Schneegrenze 188, Gletscher 224 .

Kaspische Depression 752.

Kaspische Schlammsprudel 408, 409.

Kaspisee, ehemalige Ausdehnung 244, Seehöhe 628, Dimensionen 751, 752, 753, Geschichte 758, Salzgehalt 759, Kaspimeer 769 .

Kassel, Sonnenscheindauer 64 .

Kassner, K. 169*.

Kastner, K. 517*.

Katarakte 528.

Katavothren 537.

Katotherm 345.

Katsch, Erdbeben 460.

Katzer, F. $490,491,498^{*}, 536,537$, $547^{*}, 644^{*}$.

Kaukasus 37, vertikale Temperaturabnahme 76, Hagel 181, Schneegrenze 189,190 , Gletscher 222, Vulkane 396, 707, Erdbeben 431, Bau 655, 670, Abgrenzung 672, Seen 757, Vegetation u. Flora 847, 897, Fauna 900, 903.

Kaymeni 390.

Kayser, Em. 28*.

Kea, Waldgrenze 831.

Keelinginseln, Ratten 785 .

Kees 194.

Kegelberge 613, 706 .

Keidel, H. 678*, 702*.

Keigraben 268.

Kei-Inseln 879.

Keilhack, K. 577, 590，604，610*, $627,732,745^{*}$.

Keilscholle 641,643 .

Keller, C. $483^{*}$.

Keller, H. 499, 500, 516.*

Keller, Ph. 540, 547*.

Kelter 596.

Kelvin, Lord, s. W. Thomson.

Kenia 398, 705, Eis 219, 243, Moore 764.

Kent, Saville 775 .

Kentern 316.

Kerguelen, Schneegrenze 188, Gletscher 225, Hebung 440, Strandterrasse 587, Tiere 789, Flora 825, 883.

Kerkamündung 569 .

Kermadec-Graben 268.

Kerner, F. v., 109, 114*，154, 155, $169^{*}, 190^{*}$.

Kerngebirge der Karpathen 664.

Kertsch, Schlammsprudel 409.

Kerzenfelder 220.

Kessel (Meer) 266.

Kesselbruch 366 .

Kettengebirge 613, 645, 701, 714, 719 .

Kettung 672.

Keulenbäume 878.

Keuper 25.
Key West 782 .

Khamsin 146 .

Kharga 579.

Kibo, Gletscher 219.

Kiefer 839, 901.

Kies 511, 575.

Kieselpflanzen 814.

Kieselsäurereiche Quellen 494.

Kiessling, J. 277*.

Kieswüste 574.

Kigelia 822 .

Kihlman, A. O. 824, 833*.

Kikuchi, D. 438*.

Kikuchi, J. $410^{*}$.

Kilauea 387, 404, 707.

Kilian, W. 555, 563*, 658, 676*, $677^{*}$.

Kilimandscharo 398, Schneegrenze 185, Gletscher 219, 220, 243, Moore 764, Flora 897, Fauna 900.

Kimura, H., 139.

Kinalady, Schlammstrom 764.

Kirchhoff, A. 56*, 786, 792*, 905*.

Kirgisensteppe 628 .

Kirman 848.

Kirunga 394, 399.

Kithäron 681.

Kittler, Ch. 479, 484*.

Kitzlochklamm 525 .

Kiwi 884.

Kiwusee 398.

Kjellén, R. 466*.

Kjerulf, Th. 444, 463*, 716.

Klagenfurt, Regen 252.

Klamm 520, 524.

Kleinasien 39, Regen 165, angebliche Klimaänderung 252, Vulkane 395, Erdbeben 431, Halbinsel 766, Flora 889.

Kleinbuchtige Küste 794.

Kleine Sunda-Inseln 879.

KleinfleiBgletscher 215.

Klengel, F. 190*.

Kletterpalmen 820 .

Kliff 584.

Kliffgletscher 194.

Klima 230, Schwankungen $234 \mathrm{ff}$., Tabelle der 35jähr. Schwankungen 237 , Änderungen 251, EinfluB auf die Denudation 469, auf die Pflanzen 810, auf die Tiere 861.

Klimaprovinzen 231, 251.

Klimatische Schneegrenze 184, 187.

Klimatische Vegetationsformationen 816.

Klimatypen 231.

Klingatsch, A. 140 *.

Klippen (geologisch) 648, 651 .

Klippenbrandung 297.

Klippschliefer 876.

Kljutschewskaja Sopka 404, 707. 
Klose, H. 445, 436*.

Klossowsky, A. 181*.

Kluftwasser 489 .

Knebel, W. v., 371, 376*,539, 547*, $708,712 *$.

Knipowitseh, N. 338*.

Knipping, E. 145.

Knocknageehan-Moor 764 .

Knollengewächse 812,854 .

Knop, A. 428, 736.

Knoten 300 .

Knott, C. G. 435.

Knudsen, M. 284, 290*, 346.

Kobelt, W. $788,872,882,886,{ }^{*} 887 *$, $888^{*}, 907$.

Koeh, Rob. $868^{*}$.

Kochertal 543.

Kochthermometer, Höhenmessung 617.

Koenig, Fr. 484, 498*.

Koh-i-tafdan 394.

Kohlensäuregehalt der Luft 55, 247, des Meeres 274, 287.

Koken, E. $245,371,376 *$.

Kokospalme 790, 820, 882.

Kola, Strandlinien 446 .

Kolderup, C. F. $463^{*}$.

Kolibri 862 .

Kolk 262.

Kombinationsfluten 315 .

Kombinierte Halbinseln 768 .

Kompensationsströmungen 326 .

Komplizierte Verwitterung 471.

Kompressionswellen 427 .

Kondensation 150.

Kondensationswellen 412 .

Konglomerat 15.

Kongo 455, 504, 564, 738, 739 .

Kongobecken 41, 624, Regen 162, Vegetation 836,843 .

Koniferen 812, 824, 838, 839.

König, H. 64, 69*.

König-Karl-Land 787.

König-Oskar-Fjord $798 \mathrm{f}$.

Königsberg, Feuchtigkeit 148.

Königsberger, J. 9, 17*.

Konkordante Küste 793, 795, 804.

Konschin, A. M. 745*.

Konsequente Flüsse 545, 546.

Konstante Temperatur, Schicht d., 9.

Konstruktive Pässe 730 .

Kontinentalböschung 46, 264.

Kontinentale Ablagerungen 270, 275.

Kontinentale Flüsse 731, 734.

Kontinentale Maxima u. Minima 138.

Kontinentalinseln 769, 770, 771ff., 781, $784 \mathrm{ff}$.

Kontinentaltafel 46.

Kontinente $34 \mathrm{ff}$.

Kontraktionstheorie 369, 370.

Konvektionstheorie 119.
Konvektive Niederschläge 151.

Kootenay 726 .

Kopenhagen, tägl. Temperaturschwankung 104.

Köppen, P. v., $850 *$.

Köppen, W. 100, 101, 102*, 117, $129^{*}, 138,140 *, 169 *, 170^{*}, 231,235$, $255^{*}, 256^{*}, 339,363^{*}, 741,745^{*}$.

Kopra 820.

Korallen 774.

Korallenboden 601.

Koralleninseln $774 \mathrm{ff}$., 775,781 , Theorie $779 \mathrm{ff}$.

Korallenriffe 775, Höhlen 540.

Korallenschlick u. -sand 272, 275.

Kordon, F. 552.

Korea 766, Regen 165, Gletscher 223, Küste 796, 797.

Korinth, Isthmus v., 768.

Korintji, Pic v., Waldgrenze 829.

Korrosion 467, 573, 586, 590.

Kosmischer Staub 21, 273.

Kotlava 382.

Koto, B. $368,375^{*}, 437^{*}$.

Kövesligethy, R. v., 416，436, $437^{*}$.

Krafla 404.

Krakatau 273, 382, 383, 387, 389, StoBwelle 298, Talbildung 522, Korallen 783 , Flora 789, 790.

Kranabetter Klamm 525.

Kranz, W., 465*.

Krassnow, A. $644^{*}, 850^{*}$.

Krater 380, 387, 390, 707, 710.

Kraterberge 708 .

Kraterseen 748.

Kraus, F. 540, $547 *$

Krebs, N., 498*, $547^{*}$.

Krebse bei d. Humusbildung 474 .

Kreichgauer, D. 44, 52*.

Kreideformation 25, 27, 895.

Kreidel, W. 312, $317^{*}$.

Kremser, V. 110, 114*.

Kreta, Niveauveränderungen 458, Flora 889.

Kretaceïsche Formation 25.

Kretschmer, K. $600 *$.

Kreuzfaltungen 672 .

Kriechtiere, Verbreitungsmittel 789.

Krigar-Menzel, O. 13.

Krim 766, 767, Niveauveränderungen 458 , Fauna 860.

Kristallinische Schiefer 15, 470, 479.

Kristiania, Flora 813.

Kristianiafjord 798 .

Kristiansund, Temperatur 97, Regen 159, Fjord 798.

Kritische Perioden 4.

Kritische Temperatur 12.

Krokodil 864. 
Kronfeld, M. $817^{*}$.

Kronstadt, Becken v., 673.

Kropotkin, Fürst P. A. 242, 251, 257*.

Kruber, A. 540.

Krümmel, 0. 30, 31, 33, 49, 50, 51*, $52 *, 85,260,262,270,274 *, 288$, $294,297,299,301 *, 313,315,317^{*}$, $319,323,325,326,328,329,330$, $332,334,335,337,338^{*}, 339,340$, $341,345,350,351,352,353,362$, $363^{*}, 545,547^{*}, 594,595 *, 600 *, 804$, $809 *$.

Krummholzregion 831.

Krustenriffe 777.

Kryokonit 227.

Kryptodepressionen 751 .

Kryptovulkanische Erdbeben 428.

Kryptovulkanismus 377 .

Kuhnert, W. $886^{*}$.

Kuipers, R. 484, 498*.

Kukunor 759 .

Kulan 891.

Kulissenfalten 659 .

Kulm 25.

Kulturfähigkeit des Bodens 474 .

Kulturland, Ausdehnung 849.

Kumani 408.

Kumanierschwelle 629 .

Kuntze, O. 329, 902.

Kunzen, Dünen 577.

Kuppeleis 228.

Kuppen (im Meer) 266.

Kuppenberg 477, 613.

Kuppengebirge 613, 710.

Kur 716 .

Kürflüsse 546 .

Kurilen 393, 395, 823.

Kurilenströmung 335 .

Kurische Nehrung, Dünen 577.

Kuroschio 335.

Kurowski, L. 186, 187, 190 *.

Kuruk-tag 676.

Kurz, S. 786 .

Kurzflügler $873,875$.

Küste 583, $792 \mathrm{ff}$., Länge 263.

Küstenabstand 258, 807 .

Küstendepressionen 751 .

Küstenentwicklung 806.

Küstenriffe 776 .

Küstenströmungen 585, 596, Einfluß auf die Deltas 567, 570, auf die Küste 794 .

Küstenversetzung 596 .

Küstenwüsten 163 .

Küstenzone 605 .

Kuyper, J. 600 *.

Kverve, Strandlinien 444.

Kwenlun 37，673，692, Schneegrenze 189, Gletscher 223, Getreidegrenze 853 .
Kykladen 771, 772, Vulkane 397.

Kysyl-Kum, Dünen 579.

Cabialeruptionen 388, 390 .

Labiles Gleichgewicht der Atmosphäre 72.

Labrador 767, 771, Temperatur 93, Fjorde 801 , Waldgrenze 825 , Nutzpflanzen 853.

Labradorstrom 330, 332.

La Caille 43.

La Crau 743.

Lacroix, A. 384, 410*.

Ladakkette 667.

Ladogasee 751, 753, 767.

Lady Franklin-Bai, Temperatur 89.

Lago-maggiore 761 .

Lago-morto 761.

Lagrange, Formel 296, 298, 311.

Lagunen 795, in Oberitalien 597, der Korallenriffe 777, 784, 804.

Lahntal 723 .

Lahontansee 244, 761.

Laibacher Becken 716 .

Laibacher Erdbeben (1895) 421, 425, 426.

Laibachfluß 492.

Lake Eyre 746.

Lake of the Woods 682 .

Laki 382.

Lakkadiven 780 .

Lakkolithen 370, 711.

Lalanne, L. 103.

Lallemand, Chr. 462, $466^{*}$.

Lama 875.

Lamarck, J. B. de, 4 .

Lamothe, L. de, 456, 457, 465*.

Lamplugh, G. W., 246.

Land, Areal und Verteilung 28, 30, 31 , Höhe $47,49,50,51$, Volumen 48 , thermisches Verhalten 84 , tägl. Temperaturschwankung 103, Windstärke 117, Luftdruck 138, Barometerschwankung 138, Regen 154, 155, 158, Kreislauf des Wassers 158, Regenwahrscheinlichkeit 168, 169, jahreszeitl. Regenverteilung 170, Gewitter 179, 35 jährige Regenperiode 239, Bodentypen 603, Abdachungsgebiete 734, Vegetationsformationen 849, Floreneinteilung 905, Fauneneinteilung 908.

Landblock 48.

Landes, Dünen 576, 577, Etangs 748, Küste 794 .

Landhalbkugel 31.

Landklima 85, 107, 110, 239.

Landlöß 580.

Landsäugetiere $861,864,866,871,873-$ $78,884,890-93,899,907,908$. 
Landschnecken $789,866,870,872,873$, $881,882$.

Landschwelle 612 .

Landsenke 612, $622 \mathrm{ff}$., 629.

Landstufe 613, 634, 638, 643, 681, 700.

Landvögel 789.

Landwind 140.

Langenbeck, R. 230*, 792*.

Langenbrücken, Jura 635 .

Langley $56,63,250$.

Längsbeben 419 .

Längsfjord 798 .

Längsflüsse 731 .

Längsgliederung 717.

Längskämme 646 .

Längsmoränen 212.

Längsschollen 681, 698, 701.

Längsspalten im Gletscher 201, bei Erdbeben 424.

Längstäler $646,714 \mathrm{f}$.

Languedoc, Mistral 143, Veränderungen 597.

Lapilli 378.

Laplace, P. S. de, 2, 308, 617.

La Plata 739, Delta 567, 569, Bai 570.

Lapparent, A. de, $21,24^{*}, 28^{*}, 43$, $51,52^{*}, 370,375^{*}$.

Lappland, Meridiangrad 5.

Lärche 811, 814, 839.

Lasaulx, A. v., 428.

Láskasche Regel 418.

Laspeyres, H. 705, 712*.

Lassen Peak 396.

Laterit 482, 602, 603, 606.

Latmischer Golf 748 .

La Touche, T. D. $540,547^{*}, 661$, $677^{*}$.

Laubbäume 812 .

Laufen 299, Senkung 461.

Laufenschwankung 246 .

Laufvögel 884 .

Lautensach, H. 256*; 554.

Lauterbrunnental 554 .

Lava 378, 381, 404.

Lavablöcke 382 .

Lavadecken 621, 703.

Lavaeruptionen 385, 389.

Lavaherd $377,402 \mathrm{ff}$.

Lavakegel 391, 705.

Lavasee 387.

Lawinen 191, vulkanische 384 .

Lawinenkegel 192.

Lawson, A. C. .411*, 682.

Laxefjord 798, 799.

Laysan 780.

Le Conte, J. 4, 8*, 374, 375, 376*.

Lee, G. W. 275, $276^{*}$.

Lee, W. T., $546^{*}$.

Legföhre 814.

Lehmann, Paul 243.
Lehmann, Rich. 444, 463*, 587, 600*.

Lehmboden 474, 602, 603, 606 .

Lehmige Zersetzung 482.

Lehnert, J. v., 775, 792*.

Leierschwanz 878.

Leipoldt, G. 52*.

Leira 548.

Leitner, H. 252, $257^{*}$.

Leiviskä, J. 463*.

Lemming 787, 864, 866, 893.

Lemoine, P. $744,885,887 *$.

Lemström, S. $68,69^{*}$.

Lemuria 885 .

Lena 739, Eisbedeckung 506, Delta 567.

Lendenfeld, R. v., 146.

Lentz, H. 309, 317*.

Lenz, O. 483*.

Leon, Vulkan bei, 704.

Leopard 873, 890.

Leprignano, Seebildung 749.

Lepsius, R. $644^{*}$.

Lescours 576.

Les Dous 736.

Lesetsche, Doppeldoline 533.

Lesjeskogs 726, 736.

Lesse, gelöste Substanzen 539.

Leste 146.

Leuckerbad 495.

Leveche 146.

Leverett, F. 246.

Lewis, F. J. 241.

Ley, C. $153^{*}$.

Leymerie 477 .

Lianen $835,838,839$.

Lias 25.

Libanon, Bau 660, Waldgrenze 829.

Libysche Wüste, tägl. Temperaturschwankung 104, Quellbildung 493.

Liechtensteinklamm 524.

Liegende Falten 646.

Lierau $600^{*}$.

Lilienbäume 823,845 .

Lima, Temperatur 94.

Liman 795, 797, 803.

Limpopo 570.

Linck, G. 706.

Lineare Destruktion 467, 468.

Lineare Erdbeben 419, 428, 434.

Linhardt, E. $465^{*}$.

Linné, K. v., 869.

Linth 511, 725, 761.

Liopelma 881.

Liparische Inseln 396, 401, 495, 709.

Liparit 377.

Liquidambar 869.

Liro 722.

Lissaboner Erdbeben 426, 495 .

Listad, Flora 813.

Listow, J. 671, $677^{*}$. 
Lithothamnien 775 .

Lithosphäre 8.

Litorale Ablagerungen 270, 275.

Litorale Niveauveränderungen 438, $439 \mathrm{ff}$.

Litorinameer u. -periode 445 .

Litzerbachtal 519.

Liukiu-Graben 268.

Liukiu-Inseln 395, 397, 773.

Liverpool, Gezeiten 309.

Livland, Karstphänomen 541.

Livno-Polje 499, 536.

Liznar, J. 237, 238, 256*.

Llanos 628, 843.

Loa 404, Waldgrenze 831.

Loanda, Regen 177.

Loangoküste 843 .

Loch Hourn 800.

Loch Lochy, Temperatur 344.

Loch NeB, Temperatur $342,344$.

Lockerboden 602.

Lockereruptionen 389.

Locker geschichtete Flächen 629 .

Lockyer, N. u. W. J.S. 3, 235, 238, $239,255^{*}, 256^{*}$.

Loczy, L. v., 508, 581.

Lodoicea Sechellarum 822.

Lofoten 609.

Loire 502, 739.

Lokale Niveauveränderungen 365 .

Lokale Winde 140.

Lok-Botan 408.

Lokris, Erdbeben 460.

Lo $\mathrm{m}$ bardini, E. 568 .

Lombokstraße 879.

London, Sonnenscheindauer 65, Hafen 806.

Londoner Becken 771.

Longitudinale Wellen 412, 416.

Longitudinalfalten 671 .

Loom is, E. 116, 122, 129*.

Lop-nor 630, 745, 758.

Lorbeer 889.

Lorentz, P. G. 841 .

Lorentzen, O. $52^{*}$.

Lorenz, J. v., 146*, 288, 491.

Lorenz, Th. 670, 671, 677*.

St. Lorenz-Golf 260.

Lorenzo, G. de, 403, 411*.

St. Lorenzstrom 739, Eisbedeckung 506.

Lorié, J. 241.

LöB 246, 580 f., 602, 604, 605, 608.

Lößmännchen 581 .

Lößmulden 624.

LöBschluchten 632.

Lotablenkung 277.

Lotlinie, Ablenkung 413.

Lötschenbergtunnel 556 .

Louderback, G. D. 403, 411*.

Loup Fork-Schichten, Fauna 873.
Low, A. P. $451,464^{*}$.

Löwe 860, 873, 875, 890, 903.

Löwl，F. $17^{*} ， 28^{*}, 379 ， 399,406$, $411^{*}, 443,463^{*}, 531,546^{*}, 561,721$, $730^{*}$.

Loxodromen 33.

Loyalty-Inseln 780.

Łoziński, W. v., 526, 534, 546*, 563, $564^{*}, 606,610^{*}, 633$.

Lucas, K. $765^{*}$.

Lucerna, R. 243 .

Luchs 893, 903.

St. Lucia 404.

Lückenpaß 730 .

Luedecke, O. 713*.

Lueger Grotte 538.

Luft 8, 53, Verschiebung 139.

Luftdruck 54, 96, 125, Verteilung auf der Erde 96, 124, 126, 128, Verteilung im Winter 130, 131, im Sommer 130, 135, Schwankungen 138, 35 jähr. Periode 238, Eintluß auf d. Meeresniveau 278, Verhältnis zu den Bodenbewegungen 413,436 .

Luftzirkulation 125 .

Lugan, tägl. Temperaturschwankung 106.

Lugeon, M. 648, 657*, 724, 725, 728, $730^{*}$.

Luksch, J. 288.

Luluaburg, Regen 162.

Lurche 788.

Lütschine 761 .

Luzon, Schlammsprudel 409, Fauna 900.

Lužci-Palanka-Polje 490.

Lydekker, R. 716, '878, 887*, 892.

Ly ell, Ch. 4, 8*, 480, 522, 523, 708, 747.

Lysefjord 798.

Väander 508 .

Mäandertäler 543 .

Maare $377,390,749$.

Maas, Terrassen 457, Sedimentführung 515.

Macacus 890.

Macaluba 408.

Mac Connell, R. G. 204.

Mac Gee, W.J. 374, 644*.

Machaček, F. 184, 185, 190*.

Mackenzie, G. S. 497.

Mackenzie, 733, 739.

Mackenziebecken, Klima 92, Weizen 852 , Gerste 853.

Mackinder, H. J. 230*.

Maclaren, J. M. 498*.

Maclean 43.

Macquarie-Insel 862,881 .

Madagaskar 41, 769, 786, Bodenarten 603, Riffe 777, Flora 790, 819, 877, 
906, 909, Wald 836, Fauna 877,884 , $885,908,909$.

Madeira, Wüstenwinde 146, Fauna 789, Flora 790, 791, 889, 904.

Madrid, Gewitter 179.

Maelstrom 317.

Maer-Hall, Humusbildung 474.

Magalhãesstraße, Schneegrenze 244, Klima 854.

Magdalenenstrom 738 .

Magma 15, 376, 377, 378, 379, 401.

Magnetischer Nordpol 65.

Magnolien 823.

Magot 890 .

Mailand, Regen 252.

Maine, FluBvermischung 735, Fjorde 802.

Mainka, C., $437 *$.

Maipure-Schnellen 530.

Maira 722, 727.

Mais 852 .

Makarow, J. $358,364 *$.

MakassarstraBe 879.

Makroseismisches Feld 419, 426.

Makuaweoweo 387.

Maladettagletscher 221.

Malaiischer Archipel 772, Temperaturschwankung 106, 107, Regen 161, 178, Vulkane 393, Erdbeben 430, Areal 769, Entwicklungsgeschichte und Fauna $656,786,874,879 \mathrm{ff}$., Flora $819,821,880$, Wald 836,837 , Savane 843 .

Malakka 768, 772 .

Malamocea 262.

Malaria 868 .

Malaspina-Gletscher 193.

Malden 780 .

Malediven 778, 780, 784.

Malfroy, C. $497,498^{*}$.

Mallet, R. 432.

Malm 25.

Malpighiaceenbäume 843 .

Malta, Regen 175.

Mammut 903.

Mammutbaum 870.

Mammuthöhle 540 .

Mandschurei, Vulkane 394, Wälder 839, Flora 889.

Mandschurische NuB 889.

Mangrove 596, 821, 837.

Manicaria saccifera 820 .

Manihiki-Inseln 780 .

Maniokpflanze 855 .

Manytschniederung 36 .

Map 773.

Maquis 841.

Marble-Cañon 526 .

Marcano $484^{*}$.

Marchand, E. 255 .
Marchi, L. de, 247, 257*, 407, 411*. Marder 893.

Marek, R. 830, $833^{*}$.

Margerie, E. de, $375^{*}, 546^{*}, 636$, $644^{*}, 677^{*} 686$.

Mariam-la 715 .

Marianen 393, 773.

Marianengraben 267.

Marindin, H. L. 596, 600 *

Marine Ablagerungen 595, 602, 603.

Marine Flüsse 731, 734.

Marinelli, G. 568 .

Marinelli, O. 262.

Marine Maxima und Minima 137.

Marioninsel 825.

Maritzatal 716.

Marmarameer 270.

Marokko, Kalkruste 473, Schwarzerde 582, Vegetation 843.

Marquardsen, H. 758.

Marr, J. E. $375 *$.

Marrobbio 299.

Marsabitgebirge 398.

Marschland 795 .

Marshall, W. $886^{*}$.

Marshall-Inseln 780 .

Martel, E. A. 534, 535, 540, 547*, 494, 526.

Martha's Vineyard 596.

Martin, D., 730*.

Martin, J., $465^{*}$.

Martin, L., 463*, 791*.

St. Martin (Tirol), Seebildung 747.

Martinique 383, 404.

Martins, Ch. 748, 832.

Martonne, E. de, $56^{*}, 231,243,255^{*}$, $550,552,556,557,563 *, 564 *, 686$, $687,688,690,702 *, 797,803,809 *$.

Masárang 710 .

Mascarenen, Fauna 877, Florenveränderungen 904 .

Mascaret 308.

Massengebirge 613.

Massengesteine 15, 549, 801.

Mäßige Niederschläge 161 .

MäBig periodische Niederschläge 172 .

Massiv 613, 707.

Masurische Seen 736.

Mathematische Zonen 61, 98, 100.

Matotschkin-Scharr 799.

Matragebirge 397.

Matteucci, R. V. 370, 376*.

Matthes, F. E. 553 .

Matthew, W. D. 884, $887^{*}, 894,904^{*}$.

Maui 711.

Maulwürfe 873.

Maurer, J. $83^{*}, 190^{*}$.

Mauritiapalmen 837 .

Maury, E. $457,465^{*}$.

Mäuse $788,864,870,875,878$. 
Maw, G., 473.

Maximalböschung 478.

Mazedonisches Gebirge 693.

Mazelle, E. 103*, 147, 153*.

Mechanische Erosion 467.

Mechanische Verwitterung 471.

Meckenburg, Küste 587, 794, Seenplatte 754.

Mecking, L. 131, 140*, 338*, 363*, $364^{*}$.

Meer, Areal u. Verteilung 30, 31, Einteilung 32, Tiefe $47,50,51,52$, 260 , Volumen 48 , thermisches Verhalten 84, tägl. Temperaturschwankung 104, Windstärke 116, Luftdruckverteilung 137, Barometerschwankungen 138, Regen 154, 155 , $156,167,169,170,239$, Feuchtigkeit 156, Kreislauf des Wassers 158, Gewitter 179, Gliederung 258, 266, Küstenabstand 258, Salzgehalt, spezifisches Gewicht und Dichte 284, absolutes spezif. Gewicht 287, Gasgehalt 287, Farbe 287, Gezeiten 302, Stickstoffgehalt 287, Temperatur $339 \mathrm{ff}$, 353, Temperaturschwankung 340, Gefrierpunkt u. Dichtigkeitsmaximum 346, Mitteltemperatur 350, Eisbildung $358 \mathrm{ff}$,, geologische Arbeit $583 \mathrm{ff}$., Ablagerungen 595, 602, organisches Leben 858, Permanenz 894.

Meereis 358, Küstenzerstörung 585 .

Meeresboden 261, 894, Bedeckung 270.

Meeresleuchten 290.

Meeresniveau 277, Schwankungen 19, $278,440$.

Meeresschwinden 491.

Meeresströmungen 20, $317 \mathrm{ff}$., Instrumente 320, Einfluß auf d. Salzgehalt 285, auf die Pflanzenverteilung 790.

Meermühlen 491.

Meerstrands-Milchkraut 815 .

Meerwasser $277 \mathrm{ff}$., innere Reibung 322.

Megascolecinen 880.

Mehadia 495.

Meinardus, W. 48, 52*, 95, 111, 140*, $158,332,338^{*}, 364^{*}, 572$.

Meinhold, F., 794.

Mekong 739, Waldgrenze 829.

Melanesien 905 .

Melbourne, Sandsteinsäulen 480 .

Melghir 752 .

Memel, Eisbedeckung 506, Delta 571, Veränderungen 744 .

Mensalehsee 598.

Meran, Klima 78.

Mercalli, G. 371, 376*, 393, 410*, $428,429$.

Mercerat, A. $453,640,644^{*}$.

Mer de Glace 221.
Mergelboden 474.

Mergen, Vulkane 394.

Meridiangrad, Länge 5, Umfang 6 .

Merriam, C. H. 892, 894, 904*.

Merril, G.P. 483*.

Mersey 569.

Meru 398.

Meruan 752 .

Merz, A., 503, 517*.

Merzbacher, G. 222, 223, 230*, 693, 717.

Mesas 633.

Meseta 697.

Mesophyten 812.

Mesopotamien 134, 168.

Mesotherm 345.

Mesozoisches Zeitalter (Formationsgruppe) 25, 26.

Messerschmitt, J. B. 8*, 278, $290 *$, $466^{*}$.

Messierfjord 800 .

Messina, Straße v., 768, Erdbeben 424.

Meteoritentheorie 3.

Meteorsteine 21.

Methana, Vulkan 390, 397, 704.

Meunier, St. $375^{*}$.

Mexicanischer Graben 267.

Mexico, Temperatur 107, 111, Gewitter 179, Klima 233, Vulkane 393, 395, 396, Geysire 498, Bodenarten 603, Hochfläche 624 , Sattelgebirge 659 , Flora 819, 899, Wald 836, Mimosengebüsch 841, Getreidegrenze 853 , Fauna 874.

Mexico, Golf v., 270, Gezeiten 310, Strömung 328 .

Meyer, Hans $185,191^{*}, 220,230^{*}$, $256 * 542$.

Meyer, Hugo 102*.

Mezzolasee 761.

,Michael Sars"-Expedition 288.

Michaelsen, W. $872,880,884,886$, $887 *, 907$.

St. Michel, Bai v., Hubhöhe 308.

Michel-Lévy 43.

Michigansee 751, Gezeiten 309, 311.

Middendorff, A. Th. v., 825 .

Midori, Dislokation 367.

Mikkelsen, E. 29.

Mikroseismische Unruhe 413.

Mikroseismische Zone 419.

Mileh, L. 399, 411*.

Mill, H. 764*.

Milledgeville, Talbildung 522.

Miller d. J., Hugh 560, 564*.

Milne, J. 13, 263, 276*, 431, 435, 437*, $438^{*}$.

Milos 397.

Mimosensträucher 823, 841.

Mina 55. 
Minas Gerães, Hagel 180.

Mindeleiszeit 246.

Mindel-Günz-Interglazialzeit 246.

Mineralboden 474.

Mineralquellen 493 .

Minnesota, Seen 736, 754.

Minutoli, H. v., 742 .

Miozän 25, 247, 888.

Mischfloren 907.

Mißfärbung des Meeres 290.

Mississippi 733, 739, FluBspiegel 507, Abtragung 515, Flußbett 519, Delta 567, 568, 571, Flußvermischung 736, System 737, 738, 744 .

Mississippital, Winde 133.

Missouri 736, 738, Cañon 525.

Mistral 142.

Mittelalter der Erde 24.

Mittelamerika s. Zentralamerika.

Mitteldeutsche Alpen 696.

Mitteldeutsches Erdbeben 427.

Mitteleuropa, vertikale Temperaturabnahme 74, Temperaturveränderlichkeit 111, Feuchtigkeit 148, Bewölkung 152, Klimawechsel 242, 246, Witterung 333, Thermen 495, AbfluB 499, Diluvialterrassen 559, Flora 888, 898, 900. 901, 905.

Mittelgebirge 609, 613, 614, Regen 171.

Mittellauf der Flüsse 511 .

Mittelmeer (eurupäisches) 259, Wärmeumsatz 85, Areal u. Tiefe 260, Gliederung 261, Bodenrelief 270, Mittelwasser 281, Salzgehalt 286, Farbe 289, Gezeiten 309, Strömungen 318, Tiefentemperatur 347 , Flußgebiet 734.

Mittelmeerländer, Temperaturveränderlichkeit 111, Zyklonen 121, Winde 135, Regen 161, 170, 175, Klima 232, Niveauveränderungen $456 \mathrm{ff}$., Deltas 569 , junge Dislokationen 656 , Küsten 794, Wälder 838, Maquis 841, Flora $810,814,819,823,889,901,902$, 906, 407, 909, Fauna 867, 890.

Mittelmoräne 209, 211.

Mittelwasser des Meeres 279, Schwankungen 440 .

Mittelwerte 53 .

Mittlere Beleuchtungszone 61 .

Mittlerer Küstenabstand 807 .

Möbius, K. 892 .

Mochleusis 434.

Modena, Föhn 145.

Mofetten 392.

Mohavewüste 146, 164.

Mohn, H. 89, 92, 93, 95, 102*, 118, $180,230^{*}, 280,290^{*}, 338^{*}, 442$.

Mohrenhirse 852 .

Mojsisovies, E. v., 670, 674, 904*.
Mokuaweoweo 387.

Molar Movement 419.

Moldau 722, 737.

Molecular Movement 419.

Molengraaff, G. A. F. $638,644^{*}$.

Möller, M. 129*.

Mollusken 866, 893, 900 (s. auch Landschnecken).

Mombasa, Hebung 459.

Monacokessel 264.

Monadnock 531 .

Mondflut $305 \mathrm{ff}$.

Mondphasen 306, Beziehungen zu den Erdbeben 435 .

Mongolei 483, 861 .

Monoantiklinalen 658 .

Monogene Vulkane 390, 391, 392, 704.

Monokotyle Laubbäume 818, 824, 835.

Monotropa uniflora 869.

Monsun 135.

Monsunregen 176, 177.

Monsunwald 836 .

Montagna grande (Pantelleria) 709.

Montagne Pelée $383 \mathrm{ff} ., 709$.

Montaigne 577.

Montblane 609, relative Feuchtigkeit 149, Regen 160, Gletseher 204, 216, Höhenvegetation 832 .

Monte Amiata 396.

" Argentario 599, 796.

, Cimino 396, 404.

„ dell' Uecellina 796.

" Gargano 768.

, Hermoso-Schichten, Fauna 873.

Montellohügel 656.

Montenegro, Klammen 524.

Monte nuovo 390, 396, 403, 704.

Monterosa 609.

Montessus de Ballore, F. de, 430, 431, 432, 436, 437*, 438*.

Moore 760, Ausbrüche 764, Vegetation 816.

Moostundra 826.

Moränen 209, 618.

Moränenlandschaft 604,754 .

Moränenseen 748 .

Morawatal 717 .

Moresby 784 .

Morphologie $611 \mathrm{f} ., 618$.

Moschusochs 864, 866.

Moseltal 543, 723, Terrassen 457.

Moser, L. K. 498*, 547*.

Moskau, tägl. Temperaturschwankung 104.

Moskitokette 668.

Moskitos 868.

Mosor 685.

Mosselbai, tägl.Temperaturschwankung 106.

Mossman, R. C. $362,364^{*}$. 
Mougin, P. 214, 218*.

Mount Bogong 243.

\# Edgecombe 395 .

" Egmont, Waldgrenze 829.

" Elias, Gletscher 193, 224, Moränenflora 898.

" Everest 46, 616.

", Hillers 371.

, Kosciusko 243.

" Mazama 708.

" St. Michael 770.

" Owen Stanley, Regen 160.

"Shasta 396, 708, Gletscher 224.

"Washington, Temperaturabnahme 76.

, Wrangell 395 .

Möven 865 .

Mud 271.

Mudlumps 409, 566 .

Mügge, O. 204, 218*.

Mühry, A. 149.

Muir-Gletscher 224, 548.

Mulde der Falte 645, am Meeresboden 265.

Muldenbreite 262.

Muldentäler 542, 545 .

Müller, Aloys $317^{*}$.

Muller, J. J. A. 523.

München, Deklination 68, Temperaturveränderlichkeit 111, Grundwasser 487, Moore 762.

Mündungsfälle 528 .

Mündungsformen der Flüsse 564 .

Mündungshäfen 806 .

Mündungsseen 745 .

Münstersehes Becken, FluBdichte 734 .

Muntz 472, 483*, 484*.

Mur 722.

Muren 481.

Müritzsee 752 .

Murmeltier 900 .

Murray (FluB) 505, 570, 738, 739, 743.

Murray, Sir John, 24*, 47, 51, 52*, $154,169 * 263,265,275,276^{*}, 340$, $344,353,363^{*}, 764^{*}, 784,792^{*}$.

Musaceen 820.

Muschelbänke in Norwegen 443, 445.

Muschelkalk 25.

Mustagata-Gletscher 199.

Mutationsformen 618, im Faltengebirge 678, 701.

Mygale 863.

Myrte 889.

Mythen 476, 648 .

Nachbeben 415, 421.

Nachfolgeflüsse 546 .

Nachtbogen, Berechnung 61.

Nachtigal, G. 105.
Nachträgliche Bodenbewegungen in Faltengebirgen 656 .

Nadelholz s. Koniferen.

Nadirflut 305.

Nagaoka, H. 420.

Nagelfluh 674.

Nagetiere 873, 874, 877, 893.

Nahbeben 415 .

Nahrungspflanzen 856 .

Namaland 848.

Nandu 884.

Nanga Parbat-Gletseher 222.

Nankou-Gebirge 639.

Nankoutypus 643 .

Nanosplateau 541.

Nanschan 692.

Nansen, F. 28, 29, 92, 102*, 157, 225, $226,230^{*}, 242,269,276^{*}, 322,330$, $332,338^{*}, 356,357,358,359,361$, $364^{*}$.

Nantucket 596 .

Naphtha 409.

Nappismus 647.

Nara 743.

Narasbüsche 848 .

Narentadelta 568 .

Narowafall 529.

Narzissen 822.

Nashorn 873.

Nasse Abfuhr 475.

Nathorst, A. G. 589, 864, 898

Nationalpark, Geysire 497.

Natronquellen 494.

Natronseen 759, in Ägypten 493.

Natterkopf 902 .

Natürliche Brücken 540.

Naturschacht 533, 534.

Naumann, E. 699.

Nebel 152.

Nebenflüsse 731, 737.

Nebenmeere 259, 260, 261, Bodenrelief 269 f., Bodenbedeckung 271, Salzgehalt 286 , Temperatur $347 \mathrm{f}$., 350 .

Nebubulartheorie 2, 3.

Necks 711.

Nefud 181, 848.

Negative Niveauveränderungen 441 .

Negris, Ph. 457, 458, 465*.

Nehrung 567, 598.

Nekton 274.

Nelson 739, 745 .

Nemorhedus 890, 893.

Neoarktisches Faunenreich 892.

Neocom 25.

Neogäa 908, 909.

Neogen 26.

Neotropische Florengruppe (Reich) 906, 909.

Nerobäder 495 .

Nerotief 268. 
Neu-Amsterdam 825, 883.

Neucaledonien $772,880,882$.

Neucaledonischer Rücken 268.

Neue Hebriden 393, 395.

Neu-England, Winde 141, Gebirge 689.

Neue Welt s. Amerika.

Neufundland 801.

Neufundlandbank 271, Nebel 152, Fischreichtum 337 .

Neuguinea $393,769,772,786$, Fauna u. Flora 879,880 .

Neuhebriden-Graben 268.

Neuhebridenrüicken 268.

Neumann, B. $745^{*}$.

Neumann, L. 734, 745*.

Neumayer, G. v., 146.

Neumayr, M. 28*, 428, 489*.

Neu-Mexico, Sonnenscheindauer 65 .

Neupommern 880 .

Neuschottland 767, 793, 802.

Neuseeland $769,770,772,786,883$, Temperatur 110, Föhn 145, Regen 165,168 , Gletscher 219, 225, Klima 233, Eiszeit 243, 245, Vulkane 393, 395, Sehlammsprudel 409, Erdbeben 426, Hebung 453, Geysire 497, Dünen 576 , Seen $751,755,757$, Fjorde 801, Küstenlänge u. Inseln 797, Flora 811, 881, 897, 904, 905, Palmen 819, Waldgrenze 829, Waldland 838, Farnfluren 841 , Fauna $880,881,884$, alte Landverbindungen 883 .

Neusibirische Inseln 787.

Neusiedler See 486 .

Neusüdwales, Wald 838.

Neutrale Küste 793, 794, 806.

Neuzeit der Erde 25.

Nevada, Boraxseen 760 .

Nevado de Toluea 709.

Nevados 141.

Newa 503, 506.

Newcomb 250.

New Madrid, Seebildung 749.

New Orleans, Strandseen 748.

New Red Sandstone 26.

Newton, J. 302, 308.

New York, Niveauveränderung 455.

Neyland Pill 455.

Ngai 398.

Niagarafall 529 .

Nicaraguasee 35 .

Nicolson, J. T. 647.

Niedercalifornischer Graben 267.

Niedergebirge 613.

Niederguinea, Küste 793, Savane 842.

Niederlande, Winde 133, Moore 241, Niveauveränderung 279, Küste 592, 595, Depression 751, Wald 902.

Niederschläge $20,55,153 \mathrm{ff}$., sanitäre Bedeutung 55, jährl. Periode 172,
Schwankung 179,35 jähr. Periode $237 \mathrm{ff}$., im Wald 254, Salpetersäuregehalt 482 , EinfluB auf die Talbildung 542 .

Niederschläge $z u$ allen Jahreszeiten 172.

Niederungarische Ebene s. Alföld.

Niedrigwasser des Meeres 302.

Niemeyer, J. $146^{*}$.

Nieuwveld-Berge 638 .

Nieve penitente 220.

Nigerbecken 41.

Niger 739, Delta 570.

Niischima 401.

Nikolski, A. M. 760.

Nil 499, 739, Wasserstand $503 \mathrm{ff}$., Sedimentführung 515, Riesentöpfe 518, Katarakte 530, Delta 564, 567, 568, 570, 571, Ablenkung 742.

Niltal 630 , Becken 41, Schotterbänke 527.

Nippoldt, A. $69^{*}$.

Nipptiden 306.

Nischen 525.

Nischne-Kolymsk, Föhn 145.

Niue-Insel 780.

Niveauveränderungen 18, 364, litorale $439 \mathrm{ff}$., binnenländische $459 \mathrm{ff}$. Ein$\mathrm{fluB}$ auf die Deltabildung 571.

Nivellement 281,615 .

Njassasee 753, 757.

Noë, G. de la, 546*, 636, 644*.

Nolde, E. v., 181.

Nölke, Fr. 250, 257*

Nordamerika, Grenze 34, Areal 36, Oberflächengestaltung $39 \mathrm{ff}$, Höhe 47,51 , Temperatur $81,91 \mathrm{ff}$., Temperaturschwankung im westlichen Hochland 105, Temperaturveränderlichkeit 110 , 111,112 , Temperaturabweichung 113 , Windstärke 116, barometr. Minima 119,120 , Luftdruck u. Winde 123, 131, $133,134,136,137$, Regen 164, 165, $168,174,176$, Schnee 181, Gletscher 219, 224, Klimaprovinzen 233, Eiszeit 243, 245, 246, Vulkane 393, 396, Erdbeben 431, Niveauveränderungen 451, 452, Diluvialterrassen 559, LöB 581 , 582, Bodenarten 601, 602, 603, 605 , Tafelländer 620 , westliche Hochflächen 624, abflußlose Gebiete 732, 734, Abdachungen 734, Flüsse 739, Seen 754, 761, Moore 764, Halbinseln 766 , Inseln 769, 771, 787, Fjorde 801, Küstenabstand 807, Flora 817, 889, 891, 902, Palmen 818, 819, Grenze der immer- u. sommergrünen Bäume 823 , 824, Waldgrenze 829 , Wälder $831,833,838,839$, Salzwüste 848 , Vegetationsformationen 817, 825, 849, Getreidegrenze 853 , Obstgrenze 855 , 
Nutzpflanzen 856, Fauna 890, 892 f., 903 (s. auch Amerika).

Nordatlantischer Ozean, Windgeschwindigkeit 116, Geschwindigkeit der barometr. Minima 122, Stürme 122, Antipassat 125, Hubhöhe 308, Strömungen 327, Temperatur 351, Eisgrenze 362 (s. auch Atlantischer Ozean).

NordatlantischerVerbindungsstrom 329.

Nordatlantische Zyklone im Winter 132, im Sommer 136.

Norddeutschland, Sterblichkeit 110, Temperaturabweichung 113, Böśchnngen 265, Niederschlag und Abfluß 498, fossile Dünen 579, glaziale Landschaftsformen 604, 605, Bau $626 \mathrm{f}$., alte Tallinien 627,725 , Flüsse 731,743 , abflußloses Gebiet 733, Durchgangstäler 743, Moore 764, Flora 888, 901, 907 (s. auch Deutschland).

Nordenskiöld, A. E. v., 21, 24*, 182, $358,489,589$.

Nordenskjöld, Otto 228, 230*, 453, $464^{*}, 809^{*}$.

Norderney 592.

Nordholland, Küste 595.

Nordisches Florenreich 905, 909.

Nordkapstrom 331.

Nordkontinente $34,36$.

Nordkrainisehe Ebene 762.

Nördliche Halbkugel, Wasser u. Land 30, Dauer des Winterhalbjahres 59, Tageslänge 61, Durchschnittstemperatur 97, Klima 108, 109, Temperaturveränderlichkeit 110 , Temperaturabweichung 114, Antizyklonen und Zyklonen 117, Luftdruck 128, Luftdruck und Winde im Winter $131 \mathrm{ff}$., im Sommer $135 \mathrm{ff}$., Barometerschwankung 138, Luftmassenverschiebung 139, Bewölkung 152, Regen 155, 164,168 , Sommerschnee 181, Treibeisgrenze 362 , Waldgrenze 824 , Vegetationsformationen 849 .

Nördliches Eismeer 32, 33, Tiefe 260, Bodenrelief 269, Strömungen 332 , Tiefentemperatur $355 \mathrm{ff}$., Eisbildung 360 fr., Flußgebiet 734 .

Nordlicht 65 .

Nordlichtbogen 66 .

Nord-Lincoln-Land 227.

Nordmann, Ch. 235, 236, 256*.

Nordmeer (europäisches), Niveau 280, Strömungen 331, Temperatur 355.

Nordmeer-Becken 269, $355 \mathrm{ff}$.

Nordost-Europa, Temperaturabweiehung 113.

Nordost-Monsun 135.
Nordpazifischer Verbindungsstrom 335.

Nordpazifische Zyklone im Winter 133, im Sommer 137.

Nordpol, unbekanntes Gebiet 29, Tagdauer 62,63 .

Nordpolares Hochdruckgebiet 126.

Nordsee 260, Areal und Tiefe 260, Salzgehalt 286, Gezeiten 314, Strandverschiebung 454, Dünen 576, Küstenzerstörung 592.

Nordstrand 593.

Nordwest-Monsun 135.

Normale 5 .

Normale Durchgangstäler 719 .

Normale Falten 645 .

Normale Flüsse 731 .

Normale Wasserscheide 719.

Normale Wellen 412.

Normalhöhenpunkt und Normalnull der preuß. Landesaufnahme 280 , der schwedischen Landesaufnahme 280.

Normalisothermen 86, 87.

Normalküstenlänge 806 .

Normaltemperaturen d. Breitenkreise 95.

Normalwerte (meteorologische) 240.

Normandie, Küste 597, 794.

Northers 113.

Notiodrilus 884.

Notogäa 908, 909.

Norwegen, vertik. Temperaturabnahme 76, Wintertemperatur 91, Winde 133, Regen 159, 166, Schneegrenze 190, Gletscher 199, 217, 225, Torfmoore 241, alpine Waldgrenze 242, 829, Witterung 333, Niveauveränderungen $443 \mathrm{ff}$., 448 , Erdbeben 437 , Kare 551， 552, Küste 584, 804, Strandebene 587, 590, Gebirge 652, Peneplain 690, Fjorde $698,797 \mathrm{ff}$,, 801 , 804, Seen 755, 757, 800, Küstenlänge und Inseln 771, 797, Gerste 827, Getreidegrenze 852, 853, 854, Wald 902.

Novaldosee 761 .

Nowaja-Semlja 769, 787, Temperatur 92, tägl. Temperatursehwankung 106, Gletscher 219, Eisberge 229.

Noworossisk, Bora 143.

Nukuss, Verdunstung und Regen 760.

Nulato, Wald 825.

Nulliporen 775, 776.

Nummulitenkalk 895.

Nunatak 226, Vegetation 827.

NuBbaum, F., 552, 557, 561, 563*.

Nutzpflanzen $850 \mathrm{ff}$., 856 .

Oahu 711, 782.

Oak 728.

Oasen 573, 846, 856.

Oatland Park, Temperatur 78. 
Ob 738, 739, Eisbedeckung 506.

Oberdeutsche Hochebene 630, Böschung 265.

Oberer See 751, 753 .

Oberfläche der Erde 6 .

Oberflächenmoräne 209, 211.

Oberfluten 315.

Oberguinea, Wüstenwinde 146.

Oberhalbsteiner Tal 722, 854 .

Oberitalienische Ebene s. Po-Ebene.

Oberitalienische Seen 347.

Oberlauf der Flüsse 511.

Oberrheinische Ebene 542, 622, 639, 716, Erdbeben 431 .

Obersulzbachferner 215 .

Obrutschew, W. A. 471, 542, 547*, $608,628,702 *, 848$.

Obsequente Flüsse 545, 546.

Obst 855, 856.

Obst, E., 606, 610*.

Ochotskisches Meer 259, 268, Areal und Tiefe 260, Eis 359.

Ochotskische Strömung 91.

Oddone, E., 438*.

Oder, Veränderungen 743.

Odertal 719.

Odessa, tägl. Temperaturschwankung 106.

Odland, Ausdehnung 849.

Oeschinensee 514.

O estreich, K. $689^{*}, 702^{*}, 724$, 730 *.

Oeta 681 .

Offene Mündungen 564 .

Offene Pflanzenformationen 816.

Ogiven 204.

Ohio 738, Winde 133.

Oise 744 .

Oka, Eisbedeckung 506.

Okada, T. 147, 153*, 203.

Ölbaum $813,822,889$.

Olbricht, K. 841 .

Old Faithful-Geysir 497.

Oldham, R. D. 417, 419, 434, 437*, $438^{*}, 644^{*}$.

Oléron 794.

Oligozän 25.

Ölpalme 820, 837, 870.

Omori, F. $413,417,421,423,435$, $436,437^{*}, 438^{*}$.

Onager 891 .

Onegasee 751, 761, 767.

Ooze 271.

Opilio glacialis 866 .

Opossum 877, 891.

Oppokow, E. 501, 503, 517*.

Optimum-Temperatur 811.

Oran, Strandlinien 456, 457 .

Oranje 739.

Orbitalbewegung 291.
Orchesis 434.

Orchideen 821, 835 .

Oregon, Bau 640.

Oregonzeder 839.

Organischer Schlamm 272.

Orien 245.

Orinoco 530, 735, 739, Delta 570, Wald 837.

Orizaba, Pik v., 706.

Orléans, Herzog Philipp v., 356, $357,363^{*}$.

Orleanskanal 826 .

Orogenetische Niveauveränderungen 374 .

Orographische Gletscher 194.

Orographische Niederschläge 151.

Orographische Schneegrenze 187.

Orographisches System 612 .

Orographische Täler 544, 545 .

Orologische Einheiten 618.

Orometrie 617.

Orometrische Methode der Schneegrenzenbestimmung 186 .

Orongo-Antilope 891.

Ortler Alpen, Schneegrenze 187.

Ortmann, A. E. $872,877,880,881$, $883,884,887 *$.

Orust 462 .

Osman-Dagh 408.

Osorno, Waldgrenze 729 .

Ostafrika, Vulkane 394, Gräben $397 \mathrm{f}$., Seen 757, Vegetation 834, 836, 837, $840,841,843,844$.

Ostalpen, vertik. Temperaturabnahme 76, Schneegrenze 182, 189, Gletscherareal 271 , Stoßlinien 429,430 , Täler 553 , 554, Bau 651, 662, 674, Abdachungen 717, Hochseen 755, Waldgrenze 830, Getreidegrenze 853, Fauna 899 (s. auch Alpen).

Ostasien, Bau 38, 670, Temperaturveränderlichkeit 111, Luftdruck u. Winde 134, 137, Winterklima 145 , Regen 163, 165, 174, Schnee 181, Deltas 569, Wälder 838, 839, Parklandschaft 844 , Tee 855 , Flora 889 , 890, 906, 907, 909, Fauna 890.

Ostaustralien, Bodenarten 603, Flora 906 (s. auch Australien).

Ostaustralisehes Randmeer 268.

Ostaustralische Strömung 335.

Ostehinesisches Meer 259, Areal und Tiefe 260, Wellen 294.

Österreich, Wald 902.

Osterschwelle 267.

Ostersund, Regen 159.

Osteuropa s. Rußland.

Osteuropäische Klimaprovinz 232.

Ostfeste 34, Temperatur 113, 114, Wüsten und Steppen 165, 847, Regen 
168, 173, Schnee 181, 188, Klima 232 , 235, Eiszeit $242 \mathrm{f}$., äolische $\mathrm{Ab}$ lagerungen 604, Palmen 818, 819, alpine Waldgrenze 829 , Wälder 839 , Vegetationsformationen 849,850 , Nutzpflanzen 851, 852, 853, 855, 856 , Flora 872,891 , Fauna 893.

Ostgrönländische Strömung 331, 332.

Ostindien, vert. Temperaturabnahme 76 , tägliche Temperaturschwankung 104, Winde 135, 137, 235, Regen 162, Klima 233, Eiszeit 245, Maare 377 , Erdbeben 417, 424, 425, 426, 460, Niveauveränderung 462, Bodenarten $482,582,603$, Flora $820,872,880$, Wald 833, 836, Dschungel 835, 841, Reis 851, Fauna 872, 873, 876 (s. auch Hinterindien, malaiischer Archipel, Vorderindien).

Ostindischer Archipel s. malaiischer A.

Ostisländische Strömung 331.

Ostküsten, Temperatur 88, thermische Anomalie 97, jährliche Temperaturschwankung 108, Temperaturveränderlichkeit 111, Regen 147, 160, $164,168,169$, jahreszeitliche Regenverteilung $171,176,178, W$ älder 839.

Östliche Halbkugel, Wasser u. Land 30.

Ostsee 259, Wärmeumsatz 85, Landu. Seewind 141, Areal u. Tiefe 260, Bodenrelief 269, Niveau 279, Salzgehalt 286, Farbe 289, Hubhöhe 309, Tiefentemperatur 348, Eis 359, Geschichte 445, angebliche Entleerung 450, Dünen 576.

Ostsibirien,Temperaturumkehr 80,Temperatur 91, 93, jährl. Temperaturschwankung 108, Temperaturveränderlichkeit 111, 112, Barometermaxima 131, 134, Regen 174, Klima 232, Deltas 569, Tafelberge 633, Wald 833 (s. auch Sibirien).

Ostströmung 335.

Otdia 777.

Othrys 681.

Ototzkij, P. 486.

Ötztal 554 .

Ötztaler Alpen, Form 613, Gliederung $718,727$.

Outlier 634 .

O wen, L. A., 583*.

Oxus 740 .

Oxytropis 810 .

)yaschio 335 .

Öyen (Eyen), P. A. 209, 218*, 548, $563 *$.

Ozean s. Meer.

Ozeanische Deltas 564.

Ozeanische Inseln 770.
Pacific Creek 736.

Packeis 359, 361.

Padua, Regen 252.

Paëchoigebirge 787.

Pahde, A. 338*.

Paläarktisches Faunenreich 892 .

Palache, Ch. 411*.

Palacky, J. 888 .

Paläokrystisches Eis 361 .

Paläotropische Florengruppe 906, 909.

Paläozoisches Zeitalter (Formationsgruppe) 24, 25.

Palaugraben 268.

Palermo, Verunreinigung der Luft 55. Palics-See 759.

Palma, Caldera 707.

Palmarola, Niveauveränderungen 458 .

Palmen 817, $818 \mathrm{ff} ., 823$.

Palmenöl 820.

Palmenwein 820.

Palmenzucker 820.

Palmerarchipel 826.

Palmieri, L. 381, 428, 709.

Pambuk-Kalesi, Travertin 494.

Pamir 37, 673, tägliche Temperaturschwankung 104, Winterlager 160 , Gliederung 719, Waldgrenze 829 .

Pampas, Klima 233, Löß 581, 605, 628, Flora 189, 902, Vegetation 841, 845, Weizen 852, Diluvialfauna 874 .

Pampasformation 628 .

Panama-Isthmus 35 .

Panaria 709.

Pandanus 821.

Pandjab, Regen 163, Erdbeben 419.

Pantanelli, D. $644^{*}$.

Pantelleria, unterseeischer Ausbruch 400.

Panzerung 402.

Papageien 862, 873, 875, 878.

Papaver nudicaule 827.

Pappel 839.

Para, Schmetterlingsfanna 863.

Parabeldünen 577.

Paradiesfeige 820.

Paradiesvögel 878.

Paragras 902.

Paraguay, Fluß 733, 738, Wald 837.

Parallaktische Ungleichheit der Gezeiten 307.

Parallelgliederung 717, 729.

Paramo de Pansache 709.

Paraná 733, 738.

Parasitische Vulkankegel 403.

Pâris, A. 299, 301*.

Paris, Becken 515, 653, 659, 771, Flora 813.

Parmas 676.

Parnes 681 .

Paroxysmen der Vulkane 380. 
Parsnip 727.

Partsch, J. 186, 243.

Pascoe 880.

Pasochoa 708.

$\mathrm{PaB} 730$.

Passarge, S. 244, 252, 256*, 467, 468, $473,483^{*}, 573,574,583^{*}, 608,610^{*}$ $684,685,702^{*}, 765^{*}$.

Passat 123, 156, im Winter 134, 135, im Sommer 136.

Passatische Wüsten 173.

Passatregen 176, 178.

Passatschauer 156.

Passatstaub 272.

Pässe (Mississippi) 568.

Passive Niveauveränderungen 18.

Pasterze 215, 220.

Patagónien, Regen 165, Vulkane 395, Niveauveränderungen 453 , Bau 640 , Seen 755, Küstenform 794, 801, Vegetation 841.

Patton, H. B. 713*.

Pauchata, Schneegrenze 189.

St. Paul-Insel (Atlantischer Ozean) 773, 788.

, (Indischer Ozean) 805, 825, 883.

Paulowsk, Sonnenscheindauer 64 .

Paulsen, A. F. W. 68, 69.*

Paumotu-Archipel 780, 782.

Pawlow, A. P. 582, 583*.

Payer, J. v., 67, 201, 229.

Pazifische Florenprovinz 889, 906.

Pazifiseher Küstentypus 793.

Pazifischer Ozean 32, Areal 34, 260, Tiefe 47, 51, 260, 298, Lufttemperatur 88, Zyklonen 123, Luftdruek und Winde 133, 134, 135, 137, Regen 167, Küstenabstand 258, Bodenrelief 267, Randmeere 268, Bodenbedeckung 274, 275, Mittelwasser 281, Salzgehalt 285, Wellen 294, Gezeiten 308, 309, 310 , Strömungen $334 \mathrm{f}$., Auftriebwasser 337 , Oberflächentemperatur 340,341 , Tiefentemperatur 349, 350, 353, Mitteltemperatur 350, Vulkane 393, 394, Flußgebiet 734, Leitlinien 772, Inseln 774.

Pazifische Sippe d. vulkan, Gesteine 405.

Pazifisch-indische Abdachung 733, 734.

Pazifisches Becken 267.

Peale, A. C. $498^{*}, 668,677^{*}$.

Pearce, F. 730*.

Pearson, H. W. 463.

Peary, R. N. 28, 29, 226, 269, 276*, 361.

Pechuel-Lösche, E. 842.

Pécsi, A. 437*.

Pekari 874, 878.

Peking, Temperatur 145 .
Pelagische Ablagerungen 270, $272 \mathrm{ff}$. 275.

Pelagische Fauna 749.

Peléetypus 383, 391.

Peloponnes 768 .

Pelztiere 903.

Penaudtal 562.

Penck, A. 45, 47, 48, 51, 52*, 231, $246,255^{*}, 256^{*}, 371,375^{*}, 376^{*}, 447$, $468,469,500,512,516^{*}, 517^{*}, 519$, $526,528,531,532,546^{*}, 547^{*}, 549$, $551,552,553,554,556,557,559$, $561,563^{*}, 564^{*}, 573,581,582^{*}, 607$, $610^{*}, 614,630,631,642,650,657^{*}$, $685,686,702 *, 721,722,723,730 *$ $747,748,750,751,752,753,754$, $757,764^{*}, 765^{*}, 777,807,809^{*}$.

Pendelbeobachtungen 4, 278.

Peneplain 551, 683, 684, 686, 687, 689, $690,691$.

Pentagonalsystem 42.

Pentelikon 681.

Pentland 189.

Perihel 59.

Periode, geologische 24.

Periodische meteor. Veränderungen 53, 103, 234.

Periodische Quellen 493.

Periodische Seen 537.

Periodische tägl. Temperaturschwankung 103.

Peripherische Flachländer 626, 629.

Peripherische Lavaherde 402.

Peripherische StoBlinien 429.

Perlewitz, P. 276*.

Perm 25, 246.

Permokarbonisches Zeitalter 394.

Pernter, J. M. 144,

Perret, F. A., 712*.

Perrey, A. 435.

Persien, Bodenarten 603, Boraxseen 760, Wüsten 848 .

Persischer Golf 259, 260.

Peru, Klima 94, 233, Vulkane 395, Senkung 439, Cordillere 668, Vegetation 848, Getreidegrenze 853.

Peruströmung 335, 336.

Pervinquière, L. $677^{*}$.

Peschel, 0. 375*, 719 .

Peters, K. F. 742, 759.

St. Petersburg, helle Nächte 62, Temperatur 101.

Petersquelle 495.

Petit Lake 736.

Petro-Alexandrowsk, Verdunstung und Regen 760.

Petrographische Gaue (Provinzen) 405.

Petropawlowsk, Gezeiten 309, 310.

Petschora 708, Delta 566. 
Pettersson, O. 333, 338*, 354, 355, $357,360,363^{*}$.

Peucker, K. 64, 69* 619*.

Peyruis, Gebirge bei, 658.

Pfaff, F. 585.

Pfävers, Therme 494.

Pfeiffer, E. $466 *$.

Pfingstinsel 778.

Pfitseher Joch 725.

Pflanzen, marine 272, Anteil an der Zerstörung 471, an der Landbildung 596, 762, Verbreitungsmittel 789, Abhängigkeit vom Klima 810 , vom Boden 813.

Pflanzenformationen 815.

Pflanzenregionen $811,827 \mathrm{ff}$.

Pflanzenzonen $811,817 \mathrm{ff}$.

Pfriemengras 845 .

Phalanger 879.

Phalasarna, Strandverschiebung 458.

Phänologie 813.

Pheretima 880.

Philippi, E. 19, 24*, 230*, 246, 257*, 896, $904 *$.

Philippi, R. A. 905*.

Philippinen 772, 777, Vulkane 393, 395.

Philippinengraben 268.

Philippson, A. $364^{*}, 458,465^{*}, 519$, $546^{*}, 591,596,597,599^{*}, 644^{*}, 726$, $791 *, 809 *$.

Philodendren 872.

Phlegräische Felder 396, 403, 404, 405, 710.

Phönixinseln 780 .

Phönix spinosa 837 .

Phönizische Häfen 805 .

Phreatische Wasserschicht 486.

Phryma Leptostachya 869.

Phylica nitida 825, 883.

Piacenza 55.

Pic du Midi, vertikale Temperaturabnahme 76 .

Pico, Vulkan von, 706.

Piedmontzone 689.

Pierre du Niton 281.

Pietse h, W., 503, 515, 517*.

Pikes Peak, Temperatur 77, 108, Fazies 609.

Pilar, G. 533.

Pilgrim, L. 154, 155, 169*, 249, 250.

Pillsbury, J. E. $338^{*}$.

Pindus, Waldgrenze 829.

Pinguine 865 .

Pinien 824.

Pinselzüngige Papageien 878.

Piombino 796.

Pirmasens, Kanzel 606.

Piroutet, M. $882,887^{*}$.

Pisa, alte Bucht v., 796.

Pisang $820,837$.
Pisciarelli, Thermen 495.

Pittinsel 818.

Piwowar, A. 479, 483*.

Planetesimaltheorie 3 .

Planimeter 7.

Planimetrische Methode 48.

Plankton 274, 321, 337.

Plateaugebirge 613, 643.

Plateauklima 108, 109, 111.

Plateaus 613, vertikale Temperaturabnahme 81, im Meer 265.

Platten 614.

Plazentale Säugetiere 871.

Pleistoseistes Gebiet 425 .

Pleistozän 26.

Plinianische Vulkantätigkeit 379.

Pliozän 26, 247, 888.

Plombières, Therme 494.

Plumandon, J. R. 151.

Plutonistische Theorie 369.

Pluvialzeit 244.

Po 512, 513, 731, 736, 737, 743, Delta $567,568,571$.

Pockels, A. $317^{*}$.

Podolische Platte 563.

Po-Ebene 623, 626, 767, Klima 112, 142, Regen 175, Böschung 265.

Poikilotherm 345 .

Pokorny, A. 56*.

Pola, Sonnenscheindauer 64, Temperatur 101, Strandverschiebung 458 .

Polarbär s. Eisbär.

Polare Beleuchtungszonen 61 .

Polare Hochdruckgebiete 126.

Polare Pflanzenzonen 826.

Polarer Typus der SüBwasserseen 344.

Polarer Wärmegürtel 101.

Polare Wüsten 173.

Polarfuchs 787, 864.

Polargebiete 28.

Polarhalbmesser der Erde 6.

Polarhase 864.

Polarklima 99, 101, 109, Temperaturschwankung 106, Veränderlichkeit 111, 112.

Polarländer, Temperaturabweichung 113, Feuchtigkeit 149, Niederschläge 157, 182, Gewitter 179, Hagel 180, Gletscher 225, Verwitterung 472, Küstenveränderung 585, Faziesgebiet 606 , Vegetation $813,826,849,855$, Fauna 861, 864.

Polarlicht 65 .

Polschwankungen 139, 436.

Polareeite der Zyklonen 119.

Polarströmungen im Atlant. Ozean 332, im Pazif. Ozean 335.

Polarwinde 118.

Polder 596.

Poljakow, J. S. 742. 
Polje 490, 536.

Polsterfeld 827.

Polygene Vulkane 390, 704.

Polynesien 774, 780, Klima 233, Erdbeben 431 , Flora und Fauna 790 , 821, 836, 880, 908, 909.

Polynja 358.

Pommern, Landrücken 265, Flußdichte 734, Küste 794, 795.

Ponoren 537.

Pont-du-Scex, Sedimente 514.

Pontinische Inseln 396.

Pontresina, Temperatur 78.

Pontus s. Schwarzes Meer.

Popocatepetl 706.

Pori 843.

Poriten 775.

Pororoca 308.

Poros 397.

Portland 599.

Port Nolloth, Föhn 145.

Portorico-Graben 269, 270.

Portugal, Küste 796, Wald 902.

Positive Niveauveränderungen 441, 804.

Postume Bodenbewegungen 656 .

Potamoninae 880.

Powell, J. W. 659, 667.

Pozzuoli, Niveauveränderungen 459 , Thermen 495.

Praeger, R. L. 464*.

Pramberge 633 .

Prärien, Löß 582, Gelände 614, 620,

Vegetation $819,844,845,846$.

Präriehund 893.

Pratt, J. H. 15, 16.

Präzession 59, 249.

Precht, W. 102*.

Pregel 743.

Pressey, H. A. 516*.

Preußen, Küste 795 .

Prim 728.

Primäre Gletscherschwankungen 217.

Primäres Zeitalter (Formationsgruppe) 24.

Primäre Wellen 311.

Primäre Windströmungen 326.

Prinz, W. 45, 52*.

Prinz Alfred-Gletscher 225.

Prinzeninsel 787.

Prinzip der Erhaltung der Flächen 22.

Prinz Patrick-Insel, Eis 361.

Procida 396.

Produktive Steinkohlenformation 25.

Profilmethode 48.

Pröscholdt, H. 702*.

Proteaceenbäume 843 .

Protuberanzen 235.

Provence, Mistral 143, Gebirge 648, 651.

Pruth 569, 743.

Przewalsky, N. 104, 746, 857.
Pteropodenschlamm 274, 275.

Ptolomäisches Weltsystem 1.

Puff, A. 338*.

Puia-Therme 497.

Pullar, L. $764 *$.

Puls, C. $338^{*}$.

Puls, E., $745^{*}$.

Pulsationen 413.

Puma 874.

Pumpelly, R. 257*, 482, 483, 484*, 748.

Pnnaregion 848.

Punktweise Destruktion 467.

Punta Arenas, Temperatur 244, Klima u. Getreidebau 854.

Purpursehwalbe 862 .

Pußta 579, 845.

Puy de Dôme 392.

Pyrenäen 38 , vertikale Temperaturabnahme 76, Föhn 145, Schneegrenze 189, Gletscher 219, 221, Eiszeit 243, Verwitterung 472, Gipfelformen 477 , Bau $651,665,670,671$, Gliederung 717, 719, Seen 757, Vegetationsregionen 828, Getreidegrenze 853, Flora 897, 899, Fauna 900.

Pyrenäische Halbinsel s. Jberische $\mathrm{H}$. Pythonschlange 891.

Quartäres Zeitalter (Formation) 25, 26. Queenslandrücken 268.

Quellen 485, $488 \mathrm{ff}$., Mineralgehalt 493, Temperatur 494.

Quelltrichter 521, 527, 544, 552.

Quelltümpel 486 .

Querbeben 420 .

Querfjord 798 .

Querflüsse 731 .

Quergliederung 717.

Querkämme 646.

Quermoräne 210.

Querschollen 681, 698, 701.

Querschütterlinien 430.

Querspalten im Gletscher 201.

Quertäler 646, 714, 716.

Quervain, A. de, 79, 83*, 127, 189. Quilindaña 709.

Quito, Winde 141, Regen 176, Gewitter 179, Getreidegrenze 853.

R a b ot, Ch. 217, 218*, 225, 551, 829, $831,833^{*}$.

Racoon Creek 744.

Radiale StoBlinien 429.

Radialspalten bei Erdbeben 424 .

Radioaktive Wirkungen 372 .

Radiolarienschlamm 275.

Radmerbach 722 .

Radom (Prov.), LöBlandschaft 633. 
Rahir, E. 547*.

Ramaer, J. C. $600^{*}$.

Ramann, E. $483^{*}$.

Ramsaý, A. C. $592,636,637,644^{*}$, $682,683,757$.

Ramsay, W. 447, 464*.

Randfaltungen 676 .

Randseen 757.

Randspalten der Gletscher 201.

Randzonen des Meeres 895.

Ransome, F. L. 702*.

Ratitae 884.

Ratschacher Wasserscheide 726 .

Ratten 788, 870, 874 .

Ratzel, F. 33, 56*, 187, 191*, 263, 736 .

Raubtiere 873, 874, 876, 877, 893, 903.

Rauhe Alb s. Schwäbische Alb.

Raupengebirge 40.

Ravenna 439, 598.

Ravenstein, E. G. $290^{*}$.

Ré 794.

Reade, Mellard 374, 376*.

Rebeur-Paschwitz, E. v., 21, 24*, 412.

Reclus, E. 736 .

Red River 736, 744.

" (Nbfl. d. Mississippi) 569, Cañon 525.

Reduktion der Temperatur 82, des Luftdrucks 115.

Reduziertes spezif. Gewicht des Meerwassers 284 .

Reed, F. R. Cowper 637, 644*.

Reeden 804.

Regelation 203.

Regelationstheorie 203.

Regelmann, C. $371,376^{*}, 465^{*}, 609$, 644.

RegelmäBige Wärmeschichtung 345 .

Regen s. Niederschläge.

Regenarmer Gürtel 163.

Regenarmut 161, 173.

Regenerierte Gletscher 197.

Regengebiete der Erde, Boden 606.

Regengrüne Wälder 836 .

Regenpfeifer 865 .

Regenreichtum 161.

Regenwahrscheinlichkeit 167.

Regenwälder 834.

Regenwürmer 872, 881, 884, 907, Humusbildung 474 .

Regenzeit (geologisch) 251.

Reger, J. 169*.

Regionale Niveauveränderung 365 .

Regressionstheorie 721 .

Regur 582.

Rehe 903.

Reibungstiefe 323 .

Reichelt, K. 253, 257*.

Reichenow, A. 865, 868*, 892.

Reid, H. F. 206, 224.
Reiderland 592.

Reif 150.

Reifeformen $470,530$.

Rein, J. J. 851.

Reindl, J. 290, 291*.

Reinecke, F. 882,887 *.

Reiner Triftstrom 323.

Reinke, J. 576, 583*.

Reintal 562.

Reis 851 .

Reiß,W. 220, 386, 391, 410*.

Reka 491, 537.

Rekonstruktionsformen 618, 701.

Rekstad, G. 256*.

Rekstad, J. 190, 191*, 218*, 242, 445, $446,464^{*}$.

Relaisbeben 433.

Relative Feuchtigkeit 96, 148, 149.

Reliktenseen 749 .

Reliktentheorie in derBiogeographie 870.

S. Remo, unterseeische Quelle 491.

Renard, A. F. $24^{*}, 275,276^{*}$.

Renntiere 787, 864, 867, 893, 903.

Reptilien 789, 861, 865, 876, 893.

Resaca 299.

Reschenscheideck 726 .

Reschensee 747.

Resequente Flüsse 545, 546.

Restberge 685 .

Restinseln 787.

Réthly, A., 438*.

Retropinna 831.

Retyezátmassiv 688 .

Reusch, H. 542, 546*, 547*, 589, $600^{*}$, $690,801,809 *$.

Reuschle 806 .

ReuB, Abtragung 514, Tal 561, 725.

Révil, J. $677^{*}$.

Revillagigedo-Inseln 789.

Reyer, E. $375^{*}, 391,427^{*}, 433,533$, $650,657^{*}$.

Rhät 25 .

Rhätische Alpen, Getreidegrenze 854.

Rhein 728, 731, 737, Geschwindigkeit 328 , Schwankungen des Wasserstandes 502, 503, 505, Delta 566, 568, $569,570,571$, Tal 722, 723, 725, Verbindung mit der Donau 736, Veränderungen 740, 744, Ablenkung 742.

Rheinfall 529.

Rheinische Erdbeben 421, 431.

Rheinisches Schiefergebirge 696, 699, $700,723$.

Rheintal 723, Terrassen 457.

Rheinwalder Tal 854.

Rhinozerosbusch 840 .

Rhodope 697.

Rhön 399.

Rhône 722, 725, 737, 743, Abtragung 513, 514, Delta 566, 571. 
Rhônegletscher 196, 197, 213, 214, 215, 550.

Rhônetal 716.

Rhynchocephalier 881 .

Rhyolith 377.

Rias 797, 802.

Riceo, A. 400, 431, 703.

Richarz, Fr. 13.

Richarz, St., 702*

Richter, Ed. 186, 189, 190*, 214, 216 , $217^{*}, 218^{*}, 230^{*}, 343,536,547^{*}, 551$, $552,553,555,561,562,563^{*}, 610^{*}$, $702^{*}, 764^{*}, 801,809^{*}$.

Richth of n, F. v., $38,52^{*}, 371,375^{*}$, $394,468,482,527,528,544,571,580$, $582^{*}, 592,600,601,608,613,624$, $625,626,632,639,643,644^{*}, 660$, $670,672,673,674,677^{*}, 683,699$, $703^{*}, 717,719,730,766,802,804$.

Richthofeneis 225 .

Ricinus 821.

Ried (Tirol), Muren 481.

Riedel 630.

Riedgräser 763 .

Riesengebirge, Kare 552.

Riesenhirsch 903.

Riesenquellen 492.

Riesentöpfe 202, 517, an Steilküsten 589.

Rieskessel 371.

Rîf 673 .

Riffe (Meer) 266, 775 .

Riffelberg, Temperatur 78.

Riffinseln 770, 774.

Riga, Seen b., 762 .

Riggenbach, A. 153*.

Rigi, Temperatur 79, 80, 105, 108, 111, Wasserrinnen 524.

Rikli, M. $480,484^{*}$.

Rila 245.

Rind $873,877$.

Riũinahue 704.

Rio de Janeiro, Hafen 805.

Rio Grande del Norte 739, Cañon 525.

Rio Grande-Rücken 269.

Rio Negro, Waldland 836.

Riontal 717.

Rippelmarken 301.

RiBeiszeit 246.

RiB-Mindel-Interglazialzeit 246.

Ritter, A. 12.

Riukiu s. Liukiu.

Roberts-Austen, Sir, 374.

Robin, A. $375^{*}$.

Robinson, B. L. 791, 792*.

Rocea Monfina 396.

Rocky Mountains s. Felsengebirge.

Rodmann, H. $276^{*}$.

Roger 688 .

Rogers, A. W. 547*.

Roggen 852 .
Rohboden 474.

Rohlfs, G. 574.

Rohrbach, C. $600,601,603,807$, $809^{*}$.

Rokitnosümpfe 736 .

Rolland, G. 493, 579, 583*, 608, 643*.

Rollier, L. 655, 658*, 660, 677*.

Rom, Schnee 181.

Romanchetief 268, 896.

Romieux, A. 466*.

Rosén, P. G. 449, 464*.

Rosenlauigletseher 202.

Rosenthal, E., 418, 437*, 438*.

Rosiwal, A. 411*.

Ross, John 865 .

Roßberg, Bergsturz 481.

Rossi-Forel'sche Erdbebenskala 422.

RöBler, K. 275*.

Rostförmige Gliederung 717, 729.

Rotangpalmen 820,835 .

Rotation 22.

Rotatorische Erdbebenbewegung 417.

Roteh, A. L. 74 .

Roteh, L. 129 *.

Roter Schlick 271, 275.

Roter Schnee 572, 832.

Roter See 759 .

Roter Ton 272, 274, 275, 895 .

Rotes Meer 259, Alter 35, Areal u. Tiefe 260, Salzgehalt 286, Farbe 289, 290.

Roth, J. 471, 483*, 759.

Roth, Santiago 628, 644*.

Rotholzbaum 839.

Rothpletz, A. $372,376^{*}, 663,677^{*}$, $678^{*}$.

Rotliegendes 25 .

Rotmoosgletscher 205.

Roussel, J. 671, 677*.

Rubyinsel 408 .

Rücken (Meer) 265.

Rückengebirge $391,613,643,698$.

Rückläufiger Passat 124.

Rückstau 512.

Rudolfsbahn 729 .

Rudolfsee 757 .

Rudolph, E. 273, 277*, 297, 299, 301*, $400,411^{*}, 433,435,438^{*}$.

Rudzki, M. P. 23* $416,437^{*}, 451$, $464 *$.

Rügen 584, 587, 626.

Rühl, A. $600^{*}$.

Rühlmann's Barometerformel 616 .

Rumänien, Wald 902.

Rumiñahui 708.

Rumpfflächen 682, 701.

Rumpfgebirge $685,691,692,701$.

Rumpfschollengebirge 693, 701, Täler 714.

Runcsrüfi 522 . 
Rundhöckerlandschaften 754 .

Rung, G. $140^{*}$.

Rung, R. 833*.

Runkelrübe 855 .

Rüsselbär 860 .

Russell, J. C. 231*, 256*, 411*, 483*, $516 * ; 581,583^{*}, 640,641,645 *$, 770 .

Russell, Scott 292.

Russisch-Zentralasien s. Aral-kaspisches Tiefland.

Rußland, tägl. Temperaturschwankung 104, 106, Temperaturveränderlichkeit 111, Temperaturabweichung 113, Zyklonen 121, Winde 133, Regen 167, 173, Temperaturschwankungen 236 , Niveauveränderungen 451 , Flüsse 501, 503, 742, moderne Talbildung 523, Bodentypen 582, 603, Bau 620, Hauptwasserscheide 735, Küsten $795,797,803$, Steppen $845,860,905$, Getreidegrenze 853 , Obst 855, Wald 901, 902, Fauna 900.

Rutenförmige Teilung d. Gebirge 672.

Rütimeyer, L. 524, 546*, 803, $809^{*}$.

Rutot, A. $465^{*}$.

Ruwenzori 219, 243, 828, 829, 728.

Saalachtal 728, Seebildung 747 .

Sabaleae 819.

Sabalpalme 819 .

Sabbioncello 771 .

Sabine-Insel, tägliche Temperaturschwankungen 106 .

Saceo, F. 462, 466*, 678*.

Sachalin-Strömung 335 .

Sachs, C. 843 .

Sächsische Saale 500.

Sächsische Schweiz, Gipfelformen 477, Talbildung 526, 632, Kare 562, Tafelberge 63:, 634, Flexur 638, Flußdichte 734,735 .

Sackhöhlen 539.

Sagasis, Bohrloch 567, 571.

Sagopalme 820 .

Sahara 41, 733, 734, Temperatur 93, tägl. Temperaturschwankung 104, Luftdruck u. Winde 134, 137, Niederschläge $161,164,169,173,182$, Klima 232, früheres Klima 244, 607, Verwitterung 473, Quellen 493, Karbildungen 562, Depressionen 573, 752, Windwirkung 573, Ablagerungen 574 , Dünen 576, 578, 579, Bodenarten 601, 607, Oberflächenformen 607, Bau 619, 653, Gebirge 697, Vegetation $819,846,847,856$, Fauna $861,867,873$.

Saifnitzer Wasserscheide 726 .
Saissan-nor 253.

Sajama, Schneegrenze 189.

Sajangebirge 652 , Waldgrenze $829, \mathrm{Ge}$ treidegrenze 853 .

Säkulare Klimaperioden 241.

„Niveauveränderungen 364,438 , $439,462$.

Säkularer Waldwechsel 901.

Säkulare Verwitterung 481.

Sala y Gomez 769.

Salisbury, R. D. 8*, 194, 217*, 248, $257^{*}$.

Salomo-Inseln 782, 880 .

Salomon, W. 550, 563*.

Saloniki, Bucht v., Eis 359 .

Salsen 409.

Salsvand i Fosnaes 753.

Saltonsee 746 .

Salt Range $\mathbf{2 4 5}$.

S. Salvador, Regen 162.

Salz 471.

Salzachtal $716,720,722,723,728$.

Salzboden 815 .

Salzburg, Temperatur 244.

Salzgehalt des Meerwassers $282 \mathrm{f}$,, des FluBwassers 282.

Salzkraut 815 .

Salzpflanzen s. Halophyten.

Salzseen 758, 759 .

Salzsteppe 580, Vegetation 846.

Salzwasser, Tiefentemperatur 346 .

Sambesi 529, 570, 739.

Sambesi-Kalahari-Becken 41.

Sambre 744 .

Samländische Küste 584 .

Samoa 398, 788, 882, 883.

Samum 146.

San-Andreas-Linie 461.

Sand 511, 575.

Sandbänke 271, 512, 564 .

Saudberg, G. 191.

Sandberg in Fessan 578.

Sandboden 474, Wärmeumsatz 85 .

Sandebenen 604 .

Sandgebläse 573 .

Sandinseln in Flüssen 512 .

Sandkegel auf Gletschern 212.

Sandler, Chr. 445, 463*, 801.

Sandr 212.

Sandstein 15, 470, 606, 646 .

Sandsteppen 846 .

Sandström, J. W. 321, 325, 338*.

Sandwüsten 578, 604.

Sansibar, Temperatur 106, 107, Regen 178.

Santa-Cruz-Schichten, Fauna 873.

Santiago (Chile), Temperatur 81.

Säntis 182.

Santorin 385, 396, 773.

Saônetal 716 . 
Sap per, K. $35,52^{*}, 396,410^{*}, 411^{*}$, $469,707,708,709,712^{*}, 818$.

Sarasin, P. u. F. $247,257^{*}, 710,879$, $887^{*}$.

Saraswati 743 .

Sara-urcu, Gletscher 220.

Sardinien, Gebirge 697.

Sargans, Wasserscheide 728.

Sargassoméer 329, Farbe 288.

Sargent, C. S. $850^{*}$.

Sargent, R. H. 702*.

Sary-Kamysch-See 740.

Saskatchewan 733 .

Sassafraslorbeer 823 .

sattel der Falten 645 .

Sattelgebirge $658,681,700$.

Sattelpaß 730 .

Sättigungsdefizit 148 .

Sattler, H. 67.

Saturn 2.

Sauer, L. $480,484^{*}$.

Sauerquellen 392, 494 .

Sauerstoffgehalt der Luft 54, 55 .

Säugetiere s. Landsäugetiere.

Sauglöcher 537.

Saumriffe 776 .

Saure Eruptivgesteine 377.

Saussure, H. B. de, 198.

Saussurea tridactyla 832.

Savane $816,842 \mathrm{ff}$.

Savanenwälder 843 .

Savetal 717.

Sawicki, L. 541, 547*.

Sehacht, T. 763 .

Schafe 873, 893.

Schaffer, F. X. 502, 517*.

Schala 607.

Schallphänomene b. Erdbeben 419 .

Schanghai, Wintertemperatur 91, 134.

Schansi, Karbonplateau 639, LöB 624, 625.

Schardt, H, 10,646, 648, 657*.

Schären 802 .

Scharff, R. F. $885,887^{*}, 892,894$, $904^{*}$.

Schartenpaß 730.

Scharung im Flusse 512, der Gebirge 673.

Schat-el-Arb 569, 743.

Schauja 653 .

Schaukelwelle 299.

Scheitelwert 101.

Schelch 903.

Schelf 263.

Schelfeis 228.

Schenck, A. $644^{*}, 712^{*}$.

Schenck, H. $817^{*}, 833^{*}, 887^{*}$.

Schensi, LöB 625 .

Scheu, E. 543, 547*, 637, 644*.

Schichtenstörung 19.
Schichtflüsse 546 .

Schichtflut 468 .

Schichtquellen 488 .

Schichtungstafeln 622, 629 .

Schichtwasser 487 .

Schiefe der Ekliptik 248.

Schiefe Falten 646.

Schiefer 15, 470, 549, 646.

Schimpanse 875 .

Schimper, A. F. W. $812,815,816$, $817^{*}, 818,830,836,844$.

Schiweljutsch 404 .

Schlackenkegel 390 .

Schlackenwälle 390 .

Schlafkrankheit 868 .

Sehlaggendorfer Spitze, Einsturz 481.

Schlagintweit, H. v., 494.

Schlammsprudel $407 \mathrm{ff}$.

Schlammströme 381, 481, 764 .

Schlammvulkane 407 .

Schlangen $863,867,875,881$.

Schlee, P. $170^{*}$.

Sehleppung (geologisch) 367 .

Schlern 670 .

Schlesien, Regen 255.

Schleswig, Dünen 576, 577, Flußdichte 734, Förde 802.

Schlick 271.

SchlitzrüBler 876 .

Schlocke 523 .

Schlosser, M., 678*.

Schlüter, W. $415,417,427,437^{*}$.

SchmauB, A. 83*.

Sehmelzle, K. $410 *$.

Sehmetterlinge 863, 866 .

Schmidt, August 412, 416, 437*.

Sehmidt, J. 435.

Schmidt, Karl 409, 412*.

Schmidt, Wilh. 102*.

Schmiedeberg, W. $8 *$.

Schmelzpunkt 12.

Schmutzbänder der Gletscher 212.

Schnabeltiere 877 .

Schnee 20, EinfluB auf d. Bodentemperatur 99, Verbreitung 181.

Schneeberge (Südafrika) 638.

Schneehase 900 .

Schneehuhn 900 .

Schneelinie (Schneegrenze) 184, 188, 687, in der Eiszeit 243, 245.

Schneemaus 900 .

Schneider, K. 803, 809*.

Schnepfen 865 .

Schokalski, J. de, 257*.

Schollen (geologisch) 366, 639 .

Schollenberge 643 .

Schollengebirge 701 .

Schollenländer 368 .

Schollenlava 382.

Schonen, Gerstenreife 827. 
Schopfhuhn 875 .

Schopfige Kreuzblume 815 .

Schorfflechten 472 .

Schott, G. 153*, 269, 275*, 276*, 283, $284,286,288,290^{*}, 293,294,295$, $301^{*}, 320,337^{*}, 338^{*}, 341,349,350$, $352,363^{*}$.

Schott-el-Djerid 752 .

Schottland, Temperaturabnahme 76, Winde 133, Regen 166, Gewitter 180, Hochland 697, 698, 699, Seen 757, 800, Talbuchten 801, Waldgrenze 829, Getreidegrenze 853, 854.

Schrader, F. $677^{*}$.

Schratten 535.

Schreiber, P. 254.

Schröter, C. 765*.

Schröter, W. 797, 809*.

Schrumpfungstheorie s. Kontraktionstheorie.

Schu, F. 363*.

Schubert, J. $85,102^{*}, 148,169^{*}$, $255,257^{*}$

Schubert, R. 541 .

Schuh, K. 345 .

Schulz, Aug. 241, 256*.

Schuppenstruktur 647.

Schuster, A. 194.

Schuster, W. 250, 257*.

Schütt 289.

Schuttboden 474.

Schütte, H. 454, 465*.

Schütterlinien 428 .

Schuttgebirge 608 .

Schutthalden 479 .

Schuttkegel $479,513,518$, in Binnenseen 566,750 .

Schuttströme 481 .

Schutzfarben der Tiere 860 .

Schutzrinde der Wüstengesteine 473.

Schwab, F. $190^{*}$.

Schwäbische Alp (Jura), vertik. Temperaturabnahme $\mathbf{7 6}$, Vulkanismus 377, 399, Entkarstung 541, Bau 634, 638.

Schwalbe, G. 181*.

Schwarz, E. H. L. 498*, 547*, 791*.

Schwarze, G. 191*, 230*.

Schwarze Flüsse 290.

Schwarzerde 582.

Schwarzer See (Vogesen) 753.

Schwarzes Meer 261, Wärmeumsatz 85 , Tiefe 270 , Niveauschwankungen 279, Salzgehalt 286, Sichttiefe 288, Name 290, Tiefentemperatur 347, Eis 359, Abrasionsküste 588, Geschichte 758.

Schwarzhorn 475 .

Schwarzwald 654, 696, 698, Kare 609,
Flußdichte 734, Glazialflora 898,

Getreidegrenze 853.

Schwarzwasser 858 .

Schweden, Höhe der Zyklonen 119, Winde 133, Gletscherareal 225, Klimaänderung 242, Niveauveränderungen $279,446 \mathrm{f}$., $449 \mathrm{f}$., Brunnen 489 , Seen 750,755 , Fjärde 802 , Wald 829, 902 (s.auch Skandinavien). Schwefelquellen 494 .

Schweine 873.

Sehweinfurth, G. 493, 610*, 837.

Schweiz, vertikale Temperaturabnahme 76, Temperaturverteilung 79, tägl. Temperaturschwankung 105, Temperaturveränderlichkeit 111, Temperaturabweichung 113, Föhntage 145, Hagel 181, Schneegrenze 187, 189, Gletscherareal 221, angebliche Bodenverschiebungen 452, Erdbeben 414, 420, 436, Abtragung 514, Kare 552 , Täler 554, 556, 561, Klippen 648 , Bau $648 \mathrm{ff.,} \mathrm{662,} \mathrm{Abhängigkeit} \mathrm{der}$ Pflanzen vom Boden 814, Pflanzenregionen 828 , Waldgrenze 830,831 , alpine Flora 897, alpine Fauna 900, Waldfläche 902 .

Schwelle (Meer) 265.

Schwemmland-Dolinen 533.

Schwerekorrektur 115.

Schwerkraft 18.

Schwimmer 499 .

Schwind, F. 797, 809*.

Schwingfäden 858 .

Seiroceo $145,146$.

Sclater, Ph. L. $887^{*}, 907$.

Sclater, W. L. $887^{*}, 892$.

Scottgebirge, Cañon 526.

Scrope, G. P. $380,410^{*}, 458$.

Scylla und Charybdis 317 .

Sebcha 607.

Sedimentgesteine 15, 470, 478, 479, 895 .

Seealpen 672 .

Seeaugen 486.

Seebach, K. v., 432, 704.

Seebär 299.

Seebeben 433,434 .

Seebecken 750 .

Seefelder $\mathrm{Pa} B 730$.

Seeland, F. 831.

Seelöß 580 .

Seeklima 85, 107, 109.

Seen 528, 557, 745 ff., 35jähr. Wasserstandsperioden 237, Farbe 238, 289, 290, Tiefentemperatur $341 \mathrm{ff}$., Regulatoren 503, Uferzerstörung 585, Anschwemmung 603, Umgestaltung der Seebecken 750 .

Seengebiete 753 .

Seenperiode 251. 
Seentheorie der Durchgangstäler 720 .

Seeotter 893.

Seewind 140, 150.

Seibt, W. $466^{*}$.

Seiche 299, Formel 300.

Seichte Korallenriffe 781.

Seichter Karst 490.

Seihun 743.

Seine 738 , Sedimentführung 515 .

Seismisches Feld 418.

Seismische Störungen 413 , weiteres s. Erdbeben.

Seismographen 414.

Seismometer 414.

Seismoskope 413.

Seismotektonische Linien 428.

Seisser Alpe 670.

Seitenmoräne 209, 211.

Sekiya, S. $383,410^{*}, 418,437^{*}$.

Sekundäre Gletscherschwankungen 217.

Sekundäre Minima 122.

Sekundäres Zeitalter (Formationsgruppe) 24 .

Sekundäre Wellen 311.

Sekundäre Windströmungen 326 .

Sekundenpendel 4.

Selbständige Riffe 776 .

Selkirkgebirge 224 .

Sello, G. $600 *$.

Semler, H. $905^{*}$.

Semon, R. $887 *$.

Semper, K. 858, 868*.

Semper, M. 896.

Senkungen $370,441,461,772$.

Senkungsbecken $366,749,750$.

Senon 25.

Sequoia $822,839,870$.

Serenaea serrulata 841.

Serie in der Geologie 24.

Seri-Kitlod-Gletscher 222.

Serir 574, 847.

SermerBuack 226.

Sernander, R, 241, 256*.

Serpentinen 508 .

Serra da Estrella, Temperaturabnahme 76, Regen 166.

Serre 654 .

Serval 890.

Seter 443.

Seymourinsel 247.

Shackleton, E. H. 29, 48, 453.

Shaler, N. S. 483.

Shaw, R. 104.

Sherzer, W. H. 217 *

Sibirien, Temperaturabweichung 113, Antizyklone 134, Regen 173, Gewitter 180, Niveauveränderung 451, Erdbeben 430, Flüsse 503, 731, 742, Bodenarten 603, Küste 794, Waldgrenze 824, 825, Getreidegrenze 852,
Obst 855, Flora 899, 905, säkularer Waldwechsel 901, Waldflächen 902 (s. auch Ost- u. Westsibirien).

Sibirische Berglerche 904.

Sichelkamm 477.

Sichota Alin 665 .

Sichttiefe des Meeres 288.

Sickerhöhlen 539.

Siebenbürgen 630,633 .

Siebenbürgischer Typus 643 .

Siebengebirge 705, 711 .

Siebenschläfer 867 .

Siebenthal, C. E. $230^{*}$.

Sieberg, A. 414, $437^{*}$.

Siedepunkt 617 .

Sieger, R. 213, 218*, 449, 464*.

Sierra de Gredos, Gletscher 221.

" Nevada (Californien), Gletscher 224, Vulkane 396, Erdbeben 419, Bau 692.

" Nevada (Spanien) 38, Gletscher 221, Erdbeben 430, Gipfelformen 477 , Bau 679, Seezone 755, Getreidegrenze 853, Fauna 900.

" Nevada de S. Marta, Waldgrenze 829.

Silberne Wolken 54 .

Silltal 713 .

Sils, Temperatur 79, 80 .

Silur 25, 27.

Simeto, Talbildung 523 .

Simferopol, Föhn 145.

Simmental 556 .

Simony, F. 481, 548, 563*.

Simplon 647, Tunnel 10, Glockenblume 869 .

Simultanbeben 433 .

Sinaihalbinsel 900 .

Sinclair, W. J. 887*.

Singapore, Temperatur 107.

Singvögel 861 .

Sinisches Gebirgssystem, Richtung 674.

Siphon 492, 539 .

Sirmurschichten 666 .

Siwalikschichten 665,676 .

Sizilien, Wüstenwinde 146, Regen 175, Strabe von 270, Erdbeben 429, Flora 889.

Sjögren, Hj. 412*.

Sjögren, O. 447, 464*.

Sjongheller Grotte 589.

Skagerak, Tiefe 260, Salzgehalt 286.

Skandinavien 767, Winde 133, Zyklone 137, Bewölkung 152, Regen $159,165,166$, Gletscher 219, 225, Eiszeit 242, 246, Klima 333, Niveauveränderungen $443 \mathrm{ff}$., 452, Wasserscheide 542, Gebirge 696, 698, Seen 751 , Küste 793,802 , Waldgrenze 829,831 , Fauna 900, 903; Wald- 
wechsel 901 (s. auch Norwegen, Schweden).

Skerryvore, Brandung 585.

Skorpione 863.

Skrub 840.

Skuphos, Th. 465*.

Skutarisee (Montenegro) 537.

Slichter, Ch. S. 369.

Smith, G. M. A. $887^{*}$.

Smith, G. O. 677*.

Smith, S. P. $410^{*}$.

Smithsund, Eismächtigkeit 361 .

Smyrna, Hafen von, 748.

Soffioni 495.

Sognefjord 798, 799 .

Sokol, R. 524, 546*.

Sokolów, N. 583*, 644*, 803, 809*.

Solares Klima 60.

Solare Wirkungen 19.

Solarkonstante 63 .

Sölch, J. 730, 731*.

Solenodon 874, 876.

Soley, J. S. 322, 328, 338*.

Solfatara $392,396$.

Solfatarentätigkeit 392 .

Solferino, Moränen 604.

Solifluktion 475 .

Sollas, W. J. 781.

Solger, F. 579, 580, 583*, 765*.

Solms-Laubach, H. Graf zu, 817*.

Somaliland, Regen 162.

Somma 380, 390, 391, 709.

Sommatypus 402 .

Sommergewitter 180 .

Sommergrüne Laubbäume 824, 838.

Sommerhalbjahr 170.

Sommerregen 159, 170.

Sonklar, K. v., 186, 205, 617, 747.

Sonnblick, Sonnenscheindauer 64 , Temperatur 77, Niederschläge 182, Schneedecke 182, 183, 184.

Soune 56, Absorption der Strahlen 818.

Sonne, E. 516*.

Sonnenferne 59.

Sonnenflecken 56, 236, 238, Beziehungen zu den Polarlichtern 69, zum Klima 235, zu Vulkanausbrüchen 407.

Sonnenflut $305 \mathrm{ff}$.

Sonnennähe 59 .

Sonnenscheindauer 64 .

Sonnenstrahlung 96 .

Sonorisches Faunenreich 894, 908, 909, Florenreich 906, 909.

Soog 296.

Soolquellen 494.

Sorata, Waldgrenze 829.

Soret, J. 289.

Sorghum 852.
South Cape 32.

Soyka, J. 485, 486, 498*.

Spaichinger Wasserscheide 728 .

Spaltenbildung im Gletscher 201, bei Erdbeben 424.

Spaltenfrost $471,547$.

Spaltentheorie der Vulkane 399, der Durehgangstälér 719 .

Spaltquellen 488.

Spanien, Wüstenwinde 146, Regen 166, Flüsse 503, Küste 793,795 , Wald 902 (s. auch Iberische Halbinsel).

Spartina arundinacea 883 .

Spartium 812.

Spechte 861, 873, 878.

Speilöcher 537.

Spencer, J. W. $455,465^{*}, 529,546^{*}$. Sperlinge 865 .

Spethmann, H. 230*, 712*.

Spezifische Feuchtigkeit 147.

Spezifisches Gewicht des Meerwassers 283, 287.

Spezifische Wärme 84, 340.

Sphagnum 763.

Spindler, J. B. $363^{*}$.

Spinnen 863.

Spitaler, R. 95, 97, 102*, 139, 140*. Spitzbergen 769, 787, Gradmessung 5, Höhe des Nordlichts 68, Temperatur 89, Gletscher 206, 219, 225, 227, Eisberge 229, Tertiärflora 247, Moore 764 .

Spitzbergen-Becken 269.

Spitzbergenströmung 332 .

Spitzmaus 874.

Splitternde Gletschererosion 550.

Spratt, T. A. B. 458.

Sprecher, F. W. 191, 214*.

Spring, W. 289, 291*.

Springtiden 306.

Sprung, A. 170*.

Sprunghöhe d. Verwerfungen 365 .

Sprungsehicht $343,350$.

Sprungwelle 308.

Spülendes Wasser 468.

Stabiles Gleichgewicht der Atmosphäre 72 .

Stachelschwein 890 .

Staff, H. v., 659, 660, 677*.

Staffelbruch 366.

Stahlquellen 494.

Stalagmiten 539.

Stalaktiten 539.

Standortsformationen 816 .

Stanowoigebirge, Waldgrenze 829.

Stara Apnenca 534.

Starbuck 780 .

Stationärer Gletscher 207.

Staub 511, 575.

Staubablagerungen 580 . 
Staubfälle 272, 572.

Staublawine 191.

Staukegel u. -kuppen 385, 709.

Staustrom 324.

Stauungsbögen 670 .

Steamboot-Geysir 497.

Steck, Th. 514 .

Steenstrup, K. J. V. 199.

Stefanović, J. v., 506.

Steffen, H. $437^{*}, 463^{*}, 712^{*}, 800$.

Stehende Falten 645 .

Stehende Geysir 497.

Stehende Wellen 299, Anwendung auf die Gezeitentheorie 313.

Steilküste 584, $586 \mathrm{ff}$., 794 .

Stein, M. v., $257^{*}$.

Steinbock 900, 903.

Steineis 242.

Steinhauser, A. 32.

Steinkohlenformation 25 .

Steinmann, G. 243, 657*, 668, 669, $677^{*}$.

Steinschutt 474.

Steppen 816, 822, 842, 843, 844, 848, 849, Ablagerungen 608 .

Steppenflora 891, 907.

Steppentiere 860 .

Sterneck, R. v., 16.

Sternmaulwurf 893.

Stevenson'sches Gesetz 115.

Stickstoffgehalt der Luft 55.

Stiller Ozean s. Pazifischer Ozean.

Stilluppgrund 553 .

Stinktier 893.

Stint 881.

Stiný, J., 484*.

Stirnflüße 546 .

Stirnmoräne 212.

Stoek, J. P. van der, 310.

Stockbolm, Niveauveränderung 450 .

Stockhornalpen 648 .

Stolpe, P. 765*.

Storaxbaum 889.

Storfjord 801.

Störungen 413.

StoBförmige Erdbeben 417.

StoBlinien 428 .

Stobstrahlen 416 .

Strahlenförmige Gliederung 717.

Strahlenlicht 66 .

Strahlungsintensität 57 .

Strand 263, 583, 794 .

Strandbrandung 297.

Stranddünen 575 .

Strandlinie 443.

Strandriff 587.

Sirandsaum 597.

Strandseen 598, 748, 754.

Strandterrasse 587, 590.

Strandwall 597.
StraBburg, vertikale Temperaturabnahme 71 .

Stratosphäre 73 .

Stratovulkane 704, 706.

Strauchratten 874.

Strauehvögel 878.

Straub 884.

Strelbitsky, J. 7, 733, 739.

Streng-periodische Niederschläge 173.

Strichdünen 578 .

Strokkr 497.

Strom 498.

Stromboli 379, 396, 404, 707.

Stromer, E. $887^{*}, 888^{*}$.

Stromfläche 280 .

Stromkabbelung 337 .

Stromschnellen 528 .

Stromstrich 507.

Strömungskategorien 326 .

Strömungstheorie (Gletscher) 206.

Stromversetzung 319.

Stromwechsel 316 .

Struek, R. 802, 809*.

Strukturformen 618, der Flachschichtung 629, des Faltenlandes 701.

Strumatal 717.

Strutt 372.

Stübel, A. $220,386,390,391,392$, $399,402,403,406,410^{*}, 411^{*}, 427$, 704, 708, 709, 711, 712*.

Studer, Th. 587, 600*.

Stufe (geologisch) 24.

Stufentäler $555 \mathrm{ff}$.

Sturm, F. $546^{*}$.

Stürme 122.

Stürmer 308.

Sturmfluten 297.

Sturt, Ch. 146.

Sturzsee 293.

Stuttgart, Temperaturveränderlichkeit 111 .

Styehead-PaB, Regen 166.

Styliplankton 321 .

Subantarktische Depressionen 126,130, 131.

Subarktische Depressionszone 126.

Subantarktisches Windgebiet 130 .

Subnivale Region 866.

Subpolare Depressionszonen 127.

Subpolare Stromringe 330,335 .

Subsequente Flüsse 545, 546.

Subtropische Flüsse 503 .

Subtropische Hochdruckzonen 126, 127, 163, im Winter 130, 131, im Sommer 136, Bewölkung 152.

Subtropischer Regen 174, 179, 473.

Subtropischer Wärmegürtel 100.

Subtropische Stromringe 329, 334.

Succulenten 815.

Südafrika, Geologie 27, 638, Regen 
163, 164, 175, Eiszeit 244, Tafelberge 633, Flora u. Fauna $875 \mathrm{f}$.

Südafrikanische Mulde 354 .

Südalpen 663 .

Südamerika, höchste Breite 31, Grenzen 34, Areal 36, Oberflächengestaltung 41 , Höhe 47, 51, Temperatur 91, 93, 100, Regen 161, 162, 164, 165, $168,169,176$, Hagel 180, Schneegrenze 185, 188, Gletscher 219, 220, 224, Klimaprovinzen 233, Vulkane 393 , 395, Erdbeben 432, 435, LöB 581 , Bodenarten $602,603,605$, Tiefebenen 628, abfluBlose Gebiete 732, 734, Abdachungen 734, Flüisse 739, Halbinseln 766, Küste 796, Küstenabstand u. -entwicklung 807, 808, Palmen 818, 819, immergrüne Laubbäume 838 , Vegetationsformationen 841 , 849, Getreide 854, Nutzpflanzen 856 , Flora $872,875,883,909$, Fauna $872,873 \mathrm{f}, 875,884,904,908,909$, alte Landverbindungen $883, \quad 885$ (s. auch Amerika).

Sudan, Hagel 180.

Südatlantische Verbindungsströmung 334.

Südchilenische Klimaprovinz 233 .

Süddeutschland, Temperaturabweichung 113 (s. auch Deutschland).

Südearolina 851 .

Sudeten 696, Erdbeben 431, Krummholzregion 831, Getreidegrenze 853, Glazialpflanzen 898 .

Südeuropa, Sonnenscheindauer 64 , s. weiter Mittelmeerländer.

Südfrüchte, Zone der, 855 .

Südgeorginen, Temperatur 94, alte Landverbindung 884 .

Südkontinente 34, 36, Flora und Fauna $872 \mathrm{ff}$.

Südliche Halbkugel, Wasser und Land 30, Dauer des Winterhalbjahres 59, Tageslänge 62, Temperatur 97, Klima 108, Temperaturveränderlichkeit 111, Temperaturabweichung 114, Antizyklonen und Zyklonen 117, Luftdruck 128, Luftdruck und Winde 130, Barometerschwankung 139, Luftmassenverschiebung 139, Bewölkung 152, Regen 155, 164, 165, 168, Schneegrenze 182, 188, Gletscher 224, Treibeisgrenze 362 , Niveauveränderung 453 , Waldgrenze 825,828 , Vegetationsformationen 849 .

Südliches Eismeer 32, 33, Eis 229, $335,360,362$, Bodenbedeckung 271, 274 , Strömungen 335 , Tiefentemperatur 354.

Südlicht 65 .
Südorkney 884 .

Südpol, unbekanntes Gebiet 29, Tagesdauer 62, Temperatur 94 .

Südpolares Hochdruckgebiet 126, 131.

Südsee s. Pazifischer Ozean.

Südtirol, Maulbeerbaum 253.

Südwest-Monsun 135.

Suës, Golf v., 398.

Suës-Isthmus 35, Verwitterung 473.

Suëskanal 260 .

Suess, E. 13, 19, 27, 28*, 38, 40, 268, $369,370,371,375^{*}, 395,397,399$, $406,411^{*}, 429,440,441,443,444$, $445,450,453,454,456,458,459$, $463^{*}, 485,495,498^{*}, 620,652,653$, $654,658^{*}, 663,668,670,674,683$, $696,712,742,772,787,793$.

Suess, F. E. $437^{*}, 677^{*}$.

Sukkusorische Erdbebenbewegung 417.

Suldenerferner 215 .

Sulefjord 801.

Sulimangebirge 661 .

Sulusee, Tiefentemperatur 354 .

Sumatra, Bau 38, 772, Pluvialzeit 245, Vulkane 393, 396, Erdbeben 460, Schutzrinde 473, Hängetäler 563, Faziescharakter 605 , Klimaänderung 689 , Moore 764, Waldgrenze 830 , Fauna $87 \hat{9}$.

Sümpfe 505, 762 .

Sundagräben 267.

Sundainseln 393, 395, 772, s. auch malaiischer Archipel.

Sup an, A. 51, 52*, $102^{*}, 114^{*}, 140^{*}$, $169^{*}, 181^{*}, 276^{*}, 338^{*}, 438^{*}, 546^{*}$.

Suphellagletscher 214, 225.

Surinam 473, 482.

Süring, R. 55 .

Surrakrankheit 868 .

Susquehanna, Durchgangstal 719.

Süßwasserfauna $872,876,880,881$, 883,900 .

Süßwasserseen 758, Temperatur 341, Typen 344.

Sutley 738, 743 .

Suvadiva 777.

SuwanneefluB 768 .

Sverdrup, O. N. 29, 227.

Swamps 764 .

Swells 681 .

Sydney, Flutkurve (Aug. 1868) 298, Hafen 805.

\section{Syenit 587 .}

Symmetrische Gliederung 718.

Symons, G. J. 277*.

Sympathetische Nachbeben 434 .

Synklinale 645 .

Synklinalkamm 645 .

Synklinaltal 645, 715 .

Synoptische Witterungskarten 115. 
Syrien 41, Regen 168, angebliche Klimaänderung 252, Gräben 397, 398, 432, Erdbeben 430, 432, Seen 757, Küsten 794, Flora 889, Fauna 900.

Syrische Wüste 847 .

Syrten, Hubhöhe 309 .

Systeme in der Geologie 24.

Szegedin, Untergang 506, Seen 759.

Tabak 855 .

Tabora, Regen 162.

Tafelberge 613, $633 \mathrm{f}$., 643 .

Tafelbrüche 366 .

Tafelgebirge 613 .

Tafelland 614, 619 .

Tafelscholle 641, 643, 773.

Tafelschollenberge 643 .

Tafelschollengebirge 643 .

Tafelschollenland 643 .

Tag, Länge $61 \mathrm{f}$., 369 .

Tagliamentodelta 567.

Tägliche Periode der Temperatur 103, der Windstärke 116.

Tägliche Regenmaxima 156.

"Temperaturschwankung 103.

,Ungleichheit der Gezeiten 305, 310.

Tagschmetterlinge 863 .

Tahiti 791, Vulkan 705, Flora 882.

Taimyrland, Waldgrenze 825 .

Takufjord, Gletseher 224.

Takyr 607.

Talbecken 716 .

Talbuchten $796 \mathrm{ff}$.

Täler, Bildung $518 \mathrm{ff}$. , Einteilung 545, Einfluß der Gletscher 551, $553 \mathrm{ff}$, im Flachland $629 \mathrm{ff}$., Alter 713 .

Talfälle 528 .

Talgletscher 193, 195, 197.

Talklima 79, 80, 108, 109.

Talmäander 543 .

Talseen 755,756 .

Talstufen 553, $555 \mathrm{ff}$.

Talterrassen $558 \mathrm{ff}$., in Norwegen 444.

Taltrog 553.

Talübertiefung 528, 553, $554 \mathrm{f}$.

Talverlegung 713 .

Talwasserscheiden $725 \mathrm{ff}$.

Talweg 507, 513.

Talwind 140, 141.

Taman, Schlammsprudel 409.

Tamarisken 837.

Taminaschlucht 716, Lawinen 191.

Tammann, G. $12,17^{*}, 372,407$, $411^{*}$.

Tanfilew, G. I. $845,850 *$.

Tanganikasee 398, 751, 757, 758 .

Tangentialdruck 654 .

Tangkuban-prau 385.
Tannen 839.

Tanner, V., 464*.

Tapir 874.

Tarawera 383, 388, 389, 497.

Tarimbecken 625, 630, Regen 165, Seen 747 .

Tarnuzzer, Ch. 522.

Tarr, R. S. $463^{*}, 606,610^{*}, 689,702^{*}$, $791^{*}$.

Tasmanien 786, Regen 165, Eiszeit 243, Flora 882, 897.

Tateyama-Gletscher 223.

Tätige Vulkane 393.

Tau 150.

Tauben $861,878$.

Taube Tiden 306 .

Taucher 861.

Tauern, Längstal 713.

Taunusquarzit 700.

Taurisches Gebirge 671.

Taurus, Vulkane 397.

Tausendfüßer 863 .

Taylor, F. B. 765*.

Technische Pflanzen 856.

Tee 855 .

Tehuantepec, Landenge 34.

Teifun 122.

Teilminima 122.

Tein, M. v., 516*.

Teisserenc de Bord, L. 56*, 74, 124, $129^{*}, 153^{*}$.

Tektonische Becken 749, 750 .

„ Erdbeben 427.

, Formen 618.

" Landstufe 638 .

"Täler 544,545 .

" Theorien 368 .

Tekwälder 837 .

Telegraphenberg 461.

Teleki-Vulkan 394.

Temperatur 96 , vertikale Verteilung $70 \mathrm{ff}$., horizontale Verteiluug $84 \mathrm{ff}$., tägliche Periode 103, jährl. Periode 106, Veränderlichkeit 110, Abweichung 113, 35 jähr. Periode $237 \mathrm{ff}$., Temperatur des Erdinnern 8, im Wald 254, EinfluB auf d. Meeresniveau 278, im Wasser $339 \mathrm{ff}$, der Quellen 494.

Temperaturschwankung 103, 106, 470, $473,862$.

Temperaturzonen 98 .

Tenerife, Antipassat 125, Feuchtigkeit 147, Täler 542.

Tengger 707, 17 is:

Tennessee, Winde 133, FluB 743 .

Teplitzer Thermen 397, 495.

Terada, T. 498.

Teraiwald 836.

Terekdelta 568 . 
Termier, P. 657*.

Terra rossa 581 .

Tertiäres Zeitalter 25, 27, 247, 377, $394,861,872,877,885,886,888$, 897.

Tetarata 497.

Tethys 896,897 .

Tetraëdersystem 42 .

Texas, Prärien 636, Mimosengebüsch 811.

Texasfieber 868 .

Thar 575, Dünen 578.

Thaya 738 .

Theben (Ägypten), Seen 759.

Theiß 509, 629, 737, 742, Tal 684 .

Themse, Sedimentführung 515, Mündungsform 570, Talbildung 636 .

Theodolit 615 .

Thermen 392, 494.

Thermische Anomalie 97.

Thermische Antizyklonen 118.

Thermischer Äquator, im Jahresmittel 89, im Januar 90, im Juli 93.

Thermiseher Nordpol 90.

Thermische Seiches 344 .

Thermische Zyklonentheorie 119.

Thermoisodromen 109.

Thermoisopleten 103, 107.

Thessalisches Küstengebirge 681 .

Thiene, H. 17*.

Thomas, A. P. W. 388, 410*.

St. Thomas(Thomé)-Insel, tägl. Temperaturschwankung 106, Fauna 787.

Thomassen, T. Ch. 437, 438*.

Thomson, C. Wyville 276*.

Thomson, William (Lord Kelvin) $13,17^{*}, 316$.

Thorade, H. 337, 338*.

Thoroddsen, Th. $242,388,410^{*}, 411^{*}$, $471,483^{*}, 904^{*}$.

Thorshaven, Wintertemperatur 91 .

Thoulet, J. 275*, 276*, 573, 597, $600^{*}$.

Thuner See 761 .

Thüringer Wald, Böschung 263, Klammen 524, Bau $693 \mathrm{ff}$., 698.

Tiber 722, Delta 567.

Tiberiassee 752 .

Tibet 37, tägl. Temperaturschwankung 104, lokale Winde 141, Regen 165, Gletscher 194, höchste kalte Quelle 494, Bau 625, Waldgrenze 829 , höchste Blütenpflanze 832 , Tierwelt 857 , 891.

Tiden 302.

Ti-Drachenbaum 824.

Tiefe Korallenriffe 781 .

Tiefenregion 46 .

Tiefenstufen des Meeres 47.

Tiefer Karst 490 .
Tiefland 614.

Tiefsee 263, 264, 400 .

Tiefseeton 274.

Tiënschan 37, 394, 673, 675, 693, Schneegrenze 189, Gletscher 222, 253, Gliederung 717, Wald 847.

Tiere, im Meer 272, 273, 858, Seenzuschüttung 762, Verbreitungsmittel der Landtiere $785,787,789,790$, Beziehungen zur Pflanzenwelt 858, Färbung 860, Abhängigkeit vom Klima 861, Periodizität 866, Beziehungen der Tiere zueinander und zum Menschen 867.

Tietze, E. 396, 721 .

Tiger 860,862 .

Tight, W. G. 744, 745*.

Tigris 499, 569, 737, 739, 743 .

Tillo, A. v., 49, 50 51*, 52*, 97, 102*, $600,601,602,603,610^{*}, 643^{*}, 732$, $745^{*}$.

Timavo 491.

Timber line 831.

Timbuktu,tägl.Temperaturschwankung 104.

Timeus, G. 491.

Timoktal 720 .

Timor 879,880 .

Tipaza, Küste 590 .

Tirol, vertik. Temperaturabnahme 76 , Regen 175, Erdpyramiden 479, Bergstürze 481, Seenabnahme 761, vertik. Verbreitung der Tiere 866.

Tirsboden 582 .

Tittel, E. $600^{*}$.

Tivoli, Travertinablagerung 494.

Tjemorowälder 837 .

Toblacher Wasserscheide 726 .

Togo, permische Eiszeit 246.

Tokelau-Inseln 780 .

Tokio, Erdbeben 425, Bucht 796 .

Toll, E. Baron, 242, 256*.

Tolmatschew, J. P. 256*.

Tombolo 598.

Tonboden 474.

Tonerde 471.

Tongagraben 268 .

Tonga-Inseln 393, 772, 780 .

Tongarücken 267, 268.

Tonwüste 606 .

Topographic folios $375^{*}$.

Torell, 0. 862 .

Torf 763 .

Torfmoore 763, 814, mit Wurzelschichten 241, unterseeische 439 .

Torfmoos 763 .

Torghatten 589 .

Tornados 123.

Toroß 361.

Torsukatak 799 . 
Toskana, Inseln 679, Maremmen 751, Küste 796.

Totes Meer, ehemalige Ausdehnung 244, Höhe 752, Dimencionen 753, Entstehung 757, Salzgehalt 759 .

\section{Totes Tal 752 .}

Totwasser 300 .

Toula, F. $411^{*}$.

Trabert, W. 56, 77, 83*, 129*.

Trachycarpus Martiana 828.

Trachyt 377.

Trägheitsbahnglobus $24^{*}$.

Tragößbach 722 .

Transbaikalien 542, 652, 680 .

Transgression 27.

Transhimalaya 37 .

Transkei Gap 547*.

Translation 204.

Transsylvanische Alpen 552, 673, 686, 687, 690, 719.

Transvaalformation 27.

Transversale Schütterlinien 429 .

$$
, \quad \text { Wellen } 412,416 .
$$

Transversalfalten 671,725 .

Trapezunt, Föhn 145.

TraB 379.

Trautschold, H. 440, 463*.

Travertin 494.

Treibeis 359,362 , mechanische Wirkungen 585 .

Treibholz 319, 512, 566 .

Treitz, P. $644^{*}$.

Tremors 413.

Trent 738 .

Tres Virginies 395.

Treubert, F, 23*.

Triasformation 25, 26, 896 .

Trichoplankton 321 .

Trichterförmige Buchten 570 .

Trier, Feuchtigkeit 148.

Triest, Temperatur 101, Bora 143.

Triftströmungen 318,326 .

Trifttheorie $321 \mathrm{ff}$.

Trigonometrische Höhenmessung 615 .

Trinidad, Schlammsprudel 408.

Tristan da Cunha 773, 825, 883.

Trochoïde 291.

Trockene Abfuhr 475.

Trockenpflanzen s. Xerophyten.

TrogschluB 553, 562 .

Trompetenbaum 823.

Trondhjem, Regen 159.

Trondhjemfjord 798 .

Tronnier, R. 509, 517*.

Tropengürtet 61 , Temperatur 98, 100, 235, Temperaturschwankungen 105 , 106,107, Temperaturveränderlichkeit 110, Klima 109, 173, Zyklonen 120, 122 , Regen 156, 160, 176, 235, Gewitter 179, Hagel 180, Gletscher 218,
Eiszeit 243, Verwitterung 472, 474, Flüsse 503, 512, Dünen 577, Brandung 585, Moore 764, Vegetation $817 \mathrm{ff}$., 824, 834, Flora 813, 872, 906, Nutzpflanzen 851,856 , Fauna 860 , $861,863,867,868$.

Tropenregen 176, 179 .

Tropfstein 539.

Tropische Beleuchtungszone 61 . , Cordilleren, Klima 233

Tropischer Grenztypus der Niederschläge $176,177$.

TropischerTypus d.Süßwasserseen 344 . "Wald 834, 863.

, Wärmegürtel 100.

Tropophyten (tropophile Pflanzen) 812. Troposphäre 73.

Trümmerregion 609 .

Tschadsee 41, 751, 758 .

Tschagos 779, 780, 784 .

Tschalaat-Gletseher 222.

Tschermak, G. 405, 411*.

Tscherna-Reka, Einsturzbecken 673 .

Tschernosjom 582 .

Tschernyschew, Th. 464*, 689 .

Tschili, LöB 624, 625 .

Tschinschoscho, Temperatur 106, 107.

Tsetsefliege 867 .

Tsien-tang-kiang 308.

Tsinlingschan 717 .

Tuburisumpf 736 .

Tuff 378.

Tuffkegel 390, 707.

Tulpen 822.

Tulpenbaum 823.

Tundren 826.

Turanisches Tiefland s. aral-kasp. T,

Turbaco, Schlammsprudel 409.

Turfan, Depression bei, 752 .

Turner, H. W. 702*.

Turon 25.

Turuchansk, Temperatur 854 .

Tuttle, G. W. 465.

Two Ocean Creek 736.

Two Ocean- $\mathrm{PaB} 736$.

Tycho Brahe 251.

Tyndall, J. 203, 205.

Tyrrell-FluB 743 .

Tyrrell, J. B. 256*, 452, 464*.

Tyrrhenisches Meer 270.

Überdeckungsschollen 648 .

Überfallsquellen 488 .

Überfaltungstheorie 648 .

ÜberflieBende Geysir 497.

Übergangsklima 107.

Übergußtafeln 623,629 .

Überreife Formen 470, 530 .

Überschiebung 368 .

Überschwemmungen 506 . 
Übertiefung der Täler 528, 553, $554 \mathrm{f}$.

Udden, J. A. 575 .

Uetrecht, E. 517*.

Ufermoräne 212 .

Uferwälle 567, 570.

Ugogo 843.

Uhlig, V. 651, 657*, 658*, 664, $677^{*}$.

Uintagebirge 659,720 .

Ule, W. 288, 500, 517*, 755, 764*, $765^{*}$.

Umbrien, natürl. Brücke 540 .

Umfang der Erde 6.

Umkehrungsniveau 172.

Umlauf berge 543 .

Umptanumkette 660 .

Umwandlungsformen 618 .

Unaka 685 .

Undulatorische Erdbeben 417.

Undurchlässiger Boden 485.

Unebenheiten 618 .

Ungarn, Überschwemmung 506, Dünen 579 , Ebenen 622, Natronseen 759, PuBta 845, Wald 902.

Unger, F. 252, 850, 857*.

Ungleichartige Flüsse 731 .

Ungleichförmige Faltengebirge 661, 701.

Uninodale Wellen 300.

Unpaarzehige Huftiere 873.

Unperiodische meteor. Veränderungen $53,234$.

Unperiodische tägliche Temperaturschwankung 103 .

Unreife Formen 470, 530.

Unteraargletscher 221 .

Unteritalien, StoBlinien 429.

Unterlauf der Flüsse 511.

Unterloitsch, Doline 535.

Untermoräne 209.

Unterseeische Deltas 569.

"Eruptionen 400.

,. Moore u. Wälder 439, 454.

, Quellen 491.

" Täler 455 .

Untiefen 512, 564 .

Upernivik, Temperatur 77.

Ur 903.

Ural, Alter 40, Temperaturabweichung 113 , Bau 672, Beziehungen zum Vorland $675,677,689,691$, Talterrassen 713, Waldgrenze 829 .

Uranienborg, Temperatur 251.

Urbas, Wilh. 492.

Urmiasee 759 .

Urnersee 756, 761.

Ursprüngliche Ebenen 621, 629.

" Höhlen 540.

, Inseln 769, 770, $773 \mathrm{ff}$., $788 \mathrm{ff}$.

, Täler 542, 545.

Uruguay, Wälder 838 .
Urzeit der Erde 24.

Usambara, Wald 836 .

Usboi 740 .

Üsküb-Becken 537.

Ussa 738.

Ussing, N. V., 464*.

Ustjansk, Temperatur 91.

Ust-Urt 36.

Ütliberg, Temperaturveränderlichkeit 111.

Uvalas 536.

Vaagsfjord, Strandlinien 446.

Vaccinium 827.

Vacher, A., 543, 547.

Vadose Quellen 485.

Val de Bagnes, See 747.

Valence, Pliozän 656.

Valentia (Irland), Temperatur 109.

„Valdivia“-Expedition 130, 276*, 352, $354,363 *$.

Vallièresystem 741 .

Vallot, J. 204.

Val Mesoceo 557.

Valparaiso, Temperatur 81, Erdbeben $421,439$.

Vampyr 874.

Vanua-Levu 788.

Värdal 523.

Vardartal 717.

Varenius 326.

Variscisches Gebirge 696.

Vatnajökull 548.

Vauclusequelle 492.

„Vega"-Expedition 133.

Vegetation 810 .

Vegetationsformationen 815,849 .

Vegetationszonen $817 \mathrm{ff}$.

Velu 778.

Venezuela, Vegetation 813, Waldgrenze 829 , Llanos 843.

Venjukow P. N. 765*.

Veränderlicher Hase 900 .

Veränderlichkeit der Temperatur 110.

Verbeek, R. D. M. $410^{*}$.

Verbiegung 19, 367.

Verdoletsch, ehemaliger See 537.

Verdontal 526.

Verdunstung 147.

Vereinigte Staaten, Windgeschwindigkeit 116, Zyklonen 121, 122, Winde 133, 134, Regen 168, 171, Niveauveränderungen 454 , säkulare Verwitterung 482, FluBsedimente 515, Karstphänomen 540, Mündungsformen an der atlant. Küste 570, LöB 582 , Bodenarten 603, Küstenebene 628, Moore 764, Küste 794, Flora $819,823,889,901,902,907$, Wald 
838 , künstliche Bewässerung 850 , Weizen 852, Baumwolle 855 (s. auch Nordamerika).

Verfärbung des Meeres 290.

Verhältnis von Wasser u. Land 30 .

Verkehrte Wärmeschichtung 345.

Verlassene Täler 728 .

Vernagtgletscher 195, 199, 215.

Verschiebung 19, 367, 424, 459.

Verschwindende Flüsse 492.

Vertikaldislokationen 365 .

Verwerfung 19, 365, 459.

Verwerfungsquellen 488 .

Verwitterung 20, 466, 467, $470 \mathrm{ff}$.

Verwitterungserde 471.

Verwitterungsterrassen s. Denudationsterrassen.

Verwitterungstäler 545 .

Vesuv 371, 380, 390, 396, 403, 404, 405, 703, 709, Talbildung 522 .

Vesustypus 379

Vico, Kratersee 396.

Victoria regia 822.

Vidal Gormaz, F. 453, 465*.

Vidi 617.

Vierwaldstätter See 756, 761.

Vihorlat-Gutin-Gebirge 397.

Viktoria (Australien), Niveauveränderung 453 , Küste 589, Gebirge 698 .

Viktoriafälle 529.

Viktorialand, Temperatur 89, 145, Gletscher 227, Flora 826.

Viktoria Njansa 751, 757.

Villacher Alpe, Einsturz 481.

St. Vincent 384, 404.

Vintschgau, Stufenbau 555.

Virginien, Florenveränderung 902.

Virginischer Ebenholzbaum 823.

Virtuelle Reibung 323.

Viskositätstheorie 201.

Visptal 522, 554.

Viti-Levu 773, 774, 788.

Vivara 396.

Vochysien 872 .

Voeltzkow, A. 782, 792*.

Vögel 789, 861, 863, 864, 866, 871, 873, $875,878,880,881,890,893,904$, 907.

Vogelberge 865 .

Vogesen, Verwitterung 472, Gipfelformen 477, Kare 609, Bau 696, 698, Flora 814, Waldgrenze 829, Getreidegrenze 853, Glazialpflanzen 898.

Vogt, J. H. L. 600 *.

Vogtland, Erdbeben 437.

Volger, G. H. 427, 484.

Volkens, G. 835 .

Volz, W. 38, 52*, 245, 256*, $410 *$, $468,473,482,484^{*}, 563,564^{*}, 605$, $689,702 *, 772,791^{*}$.
Voralpen 647.

Vorbeben 415 .

Vorderasien, Hochland 37, Regen 171, 176 , Steppen 810, Palmen 819, Weizen 852, Vögel 890.

Vorderindien, Geologie 27, Regen 162, 225, vertikale Temperaturabnahme 76, Winde 135, 137, Eiszeit 245, Laterit 482, Tiefebene 623, 626, Küste 764, 796, Dschungelgebüsch 841, Flora 819, 901 (s. auch Dekan u. Hindustan).

Vorgeschobene Deltas 567.

Vorlandgletscher 193.

Vorpommern, alte Täler 445 .

Vortmann 491.

Voskule, G. A. 548 .

Voss, E. L., 169*.

Vranasee 537.

Vredenburg, E. W. 28*.

Vulcanello 401.

Vuleano 396, 401, 405.

Vulkane 377, 618, Einteilung 390, geographische Verbreitung 394.

Vulkanformen 389.

Vulkanische Ablagerungen 602, 603. , Asche 378, 381.

" Ausbrüche 19, $379 \mathrm{ff}$.

", Beben 381, 382, 427, 434.

" Berge u. Gebirge 388, 390, 618, $703 \mathrm{ff}$., 717.

, Blöcke 378, 386.

"Explosionen 382, 383.

"Gase 379, 392, 406.

", Gewitter 381.

Herde $402 \mathrm{ff}$.

"Inseln 401, 770, 773, 781, 804.

"Lawine 348.

"Meeresablagerungen 273, 275.

Vulkanischer Sand und Schlick 275, 378.

Vulkanische Tafeln 388, 390.

Vulkanismus, Theorie $370,373,401 \mathrm{ff}$.

Vulkankegel 385, 387, 390, 705, 706, 708.

Vultur 396.

Waadt, Veränderung d. Aussichtsweite 462.

W a gen, L., 491, 498*.

Waagen, W. $904^{*}$.

Wachspalme $819,837$.

Wackelsteine 574 .

Wadi-el-Araba 752.

Wadis in der Sahara 607.

Wadi Urirlu, Wolkenbruch 173.

Wagner, A. 73, 75, 83*.

Wagner, H. 8*, 30, 45, 47, 51*, 52*, $765^{*}, 766,849,850 *$. 
Wahaai, Regen 176.

Wahand 743 .

Wähner, F. 423.

Wahnschaffe, F. $610^{*}, 626,644^{*}$.

Wahre Oberfläche 7 .

Waimangu-Geysir 498.

Waitz, G., 497, 498*.

Waken 359 .

Wald $816,833,834,847,901,902$, EinfluB auf das Klima 254, unterseeischer 439, EinfluB auf d. Grundwasser 486, auf die Wassermenge d. Flüsse 502, Ausdehnung 849, 901.

Waldaihöhe 621 .

Waldgrenze auf d. nördl. Hemisphäre 824, auf der südlichen 825 , im Gebirge 687,828 .

Waldrebe 839 .

Waldtiere 860.

Walensee 761 .

Wales, Gebirge 652, 696.

Walfisch-Bai, Föhn 145, Regen 164.

Walfischrücken 269,354 .

Wallace, A. R. $785,786,792^{*}, 860$, $861,862,863,868^{*}, 874,879,884$, $886^{*}, 894,907$.

Wallace-Linie 879 .

Wallbecken 746, 750 .

WallpaB 730 .

Wallriffe 776 .

Walser, H. 762, 901.

W alther, Joh. $375^{*}, 468,482,483^{*}$, $572,573,576,578,579,582^{*}, 610^{*}$, $625,695,702 *, 740,745^{*}$.

Wangeroog 593.

Wanner, J. 880, 887 *.

Wansee 759,854 .

Wärme s. Temperatur.

Wärmedurchlässigkeit der Luft 62 .

Wärmegewitter 180 .

Wärmemenge 63 .

Wärmequellen der Erde 56, der oberen Luftschichten 69.

Warme Quellen 494.

" Schlammsprudel 408.

, Seen 345 .

Wärmeumsatz 85 .

Warme Zone 99, 100, 161, 472.

Wärmezonen Kö ppen's 100.

W a rming, E. $812,817^{*}, 835,841$.

Warrensee 761 .

Waschbär 893.

Wasser, Areal u. Verteilung 30, Verhältnis zur Wärme 85, 86, Kreislauf 158.

Wasserblock 48 .

Wasserdampf 55, 147, bei Vulkanen $379,405$.

Wasserfälle 528.

Wasserhalbkugel 31 .
Wasserhülle 8 .

Wasserpflanzen s. Hydrophyten.

Wasserscheiden 520, im Gebirge $718 \mathrm{ff}$., Veränderungen 522, 744 .

Wasserstoffgehalt der Luft 55 .

Wasserteilung 735 .

Watson, E. R. 344 .

Watt 596, 795 .

Wawerzik, E. 17*.

Weald, Bau 653, 681 .

Wealden 25.

Weber, Gebr. 295.

Weber, Max C. W. 879, 887*.

Weberknecht 866 .

Wechselboden 602 .

Wechselgebiete 605 .

Wechsellauf 731.

Wechselpaß 729 .

Wechselpflanzen s. Tropophyten.

Wechselständige Täler 521 .

W ed d ell, J. 29.

Weddellmeer 131.

We d derburn, E. M. 344, 363*.

Wegemann, G. 115, 129*, 330, $338^{*}$.

Wegener, A. $84^{*}$.

Weichsel, Wasserstand 502, Eisbedeckung 506, Delta 570, Durchgangstal 719 , Veränderungen 743 .

Weichtiere s. Mollusken.

Weide (Formation) 844.

Weiden 839.

Weihnachtsinsel 782 .

Weiho 737.

Weingürtel 855 .

Weinschenk, E. 17*.

Weißach 729.

Weiße Berge s. White Mountains.

Weißenbachkees 185.

Weißensee (Kärnten), Temperatur 342.

Weißer Jura 25.

Weißer See (Vogesen) 753.

Weißes Eis 205.

Weißes Meer, Name 290.

Weißtanne 839.

Weizen 852.

Wellenberg 292.

Wellenbewegung des Meeres 20, $291 \mathrm{ff}$.

Wellenböschung 293, 294.

Wellenförmige Erdbebenbewegung 417 .

Wellenfurchen 301 .

Wellengeschwindigkeit 291, 294.

Wellenhöhe 291, 294.

Wellenlänge 291, 294.

Wellenperiode 291, 294.

Wellental 292.

Wellentheorien 310 .

Wellingtonia 870 .

Wellungsebene 531 .

Weltbeben 419. 
Weltwasser 32 .

Welwitschia 848 .

Wendelstein, Temperatur 79.

Wenkchemnagletscher 194.

Werchnaja Mischikha 80.

Werchojansk, Temperatur 91, 92, 93, 854, jährl. Temperaturschwankung 108.

Wernoje, Erdbeben 424 .

Werratal 642 .

Werth, E., 600*, 802, 809*.

Weser, Gezeitengrenze 309, Mündung $569,570$.

Wespen 863.

Westalpen 664, 674, 853 (s. auch Sehweiz).

Westantarktischer Bogen 40.

Westaustralien 176, 847, 906.

Westaustralische Florengruppe 906.

Westaustralische Strömung 334.

Westerås, Temperatur 78 .

Westeuropa, Temperaturabweichung 113, Zyklonen 122, Klima 232, 333, Obst 855, Flora 888 (s, auch Europa).

Westfeste s. Amerika.

Westghats, Wald 836 .

Westgrönländische Strömung 330 .

Westindien $40,769,772,773,786$, Klima 233, Stürme 235, Vulkane 393, 397, Riffe 777, 783, Küste 793, Flora 819, 841, 901, 902, Fauna 876.

Westküsten, Temperatur 88, thermische Anomalien 97, jährliche Temperaturschwankung 108, Temperaturveränderlichkeit 111 , Regen 147,160 , $164,168,169$, jahreszeitliche Regenverteilung 170,176 , Wald 839 .

Westliche Halbkugel, Wasser u. Land 30.

Westphal, A. $464^{*}$.

Westsibirien, Temperaturveränderlichkeit 111,112 , Winde 133 , Regen 173, Klima 232, Tiefebene 628, Seen 760 , Moore 764 (s. auch Sibirien).

Wetterau 543.

Wettersee 289, 753 .

Wetterveränderlichkeit 122.

Wettstein, A. 560, 564*.

Weule, K. $809^{*}$.

Weyprecht, K. $359,361,364^{*}$.

Wharton, W. J. L. 792*.

Wheeler, W. H. 597, 600*.

Whewell, W. $310,311,314$.

Whitby, Temperatur 78.

White, Ch. A. $677^{*}$.

White Mountains, Waldgrenze 829, Glazialpflanzen 899 .

Whitney 846.

Whymper, E. 220.

Whymper, F. 825 .
Wichmann, A. $410^{*}, 773,791^{*}$, 792*.

Wick, Brandung 585 .

Wickenburg, tägl. Temperaturschwankung 105.

Wickenburg, Graf Ed., 398.

Widerhakentäler 542 .

Wiechert, E. $14,17^{*}, 413,418$.

Wiener Becken 622.

Wiener Thermenlinie 397.

Wies, Erdbeben 425.

Wiesbaden, Therme 495 .

Wiese $816,835,844$.

Wiesel 893.

Wiesner, J. 155, 156, 810, 817*, 824, $832,839$.

Wilander 589 .

Wild, H. 99, 148.

Wildbäche 518 .

Wildschwein 873, 903.

Wilkesland 884 .

Willis, B. $657^{*}, 685,688,691,702^{*}$.

Willkomm, M. 166.

Wilson, A. W. G. 702\%.

Wimmer, J. 905*.

Wimmera 743 .

Winde 20, $114 \mathrm{ff} ., 150, \operatorname{EinfluB}$ auf d. Meeresniveau 279, Erzeuger d.Meeresströmungen $321 \mathrm{ff}$., Einfluß auf die Zitterbewegungen 413 , geologische Arbeit $467 \mathrm{f}$., $572 \mathrm{ff}$., 607 , Einfluß auf Deltas 570, auf die Flüsse 741, auf die Pflanzenverbreitung 789.

Winderosion 572.

Windfläche 280.

Windgeschwindigkeit (-stärke) 115, 572.

Windgesetze 115 .

Windschatten-Wüsten 173.

Windstau 297.

Windstauströme 324,326 .

Windströmungen 326 .

Windsysteme 127.

Windt, Jean de, 258, 276*.

Windverteilung im Winter 131, im Sommer 135.

Windwellen $291 \mathrm{ff}$.

Winnipegsee 744, 761.

Wintergewitter 180.

Winterregen 159, 170.

Winterschlaf der Tiere 866 .

Wintungletscher 224.

Wirbelbewegung b. Erdbeben 417.

Wirbelgewitter 180 .

Wisent 903.

Wisotzki, E. 737, 745*.

Wisperwind 142.

Wissemann, W. 338*.

Witte, E. 336.

Witting, R. 318, 337*. 
Woeikow, A. $11,17^{*}, 56^{*}, 84^{*}, 92$, $99,105,134,137,145,153^{*}, 157$, $169^{*}, 253,254,257^{*}, 499,517^{*}, 765^{*}$, $833,850^{*}$.

Woerle, H. 426.

Woldřich $17^{*}$.

Wolf $860,864,893,903$.

Wolf, R. 56.

Wolf, Th. 382, 396, 435, 587.

Wolff, F. v,, 669, 677*.

St. Wolfgangsee $\mathbf{7 6 1}$.

Wolga 738, 739, Eisbedeckung 506.

Wolken 152.

Wollbaum 822 .

Wollhaariges Rhinozeros 903 .

Wollny 762 .

Wood, John 160.

Woodward, R. S. 448, 464*.

Woolacott, D. 464*.

Workmann, W. H. 230 *.

Wörther See, Temperatur 343 .

Woosnam, R. B., 833*.

Wrangel, F. F. $363^{*}$.

W rangell, F. v., 145.

Wrangelland 787 .

Wühlmaus 893.

Wulaschan 847.

Wundt, W. 63 .

Würmeiszeit 246.

Würm-Riß-Interglazialzeit 246.

Wurzelmaus 900 .

W urtengletscher 215.

Wüsten, Gewitter 179, Hagel 180, exogene Erscheinungen 470, 473, 572, $606 \mathrm{f}$, Q Quellen 493, Dünen 578, Bodenarten 601, Pflanzen 816, 822, $834,846,849$, Fauna 860.

Wüstengürtel der Alten Welt 764, 847.

Wüstensteppen $816,834,846$.

Wüstentafel 41, 619, 847, Regen 164, 168, 170 (s. auch Sahara).

Wüstenwinde 146.

Wutach 728.

Wyandotthöhle 540 .

Wyssotzkij, N. $628,644^{*}$.

Xerophilenklima 231.

Xerophyten (xerophile Pflanzen) 811, $812,814$.

Xerothermische Klimaperiode 242.

Yak 891.

Yakutatbai 439, Inseln 770 .

Yamasaki, N. 465*.

Yampa 720, 723.

Yamswurzel 855.
Yap 773.

Yapgraben 268.

Yarriambiack 743 .

Yataypalme 837.

Yellowstone-Nationalpark 497.

Yokohama, Erdbeben 421.

Yoldiameer 445 .

Yorkshire, Geologie 637.

Yosemitefall 529.

Yucatan-Becken 270.

Yucca 821, 824.

Yukon 739.

Zackenfirn 220.

$\mathrm{Zahn,} \mathrm{G.} \mathrm{W.} \mathrm{v.} \mathrm{51*,} \mathrm{586,} \mathrm{587,}$ $599 *$.

Zahnarme s. Edentaten.

Zannone 679, 773.

Zaunkönig 861 .

Zebra 860,873 .

Zechstein 25 .

Zeitalter, geologisches 24 .

Zeller, H. R. $677^{*}$.

Zenithflut 305 .

Zenker, W. 84, 85, 102*.

Zentralafrikanischer Graben 398, 432.

Zentralamerika 34 , tägl. Temperaturschwankung 105, wärmster Monat 107, Klima 233, Maare 377, Vulkane 393, 395, 396, Schlammsprudel 409, Erdbeben 432, Flüsse 503, Bodenarten 603, Pliozän 656, Wald 836, Fauna 873,885 .

Zentralasien 37, 39, Bodeneis 99, tägl. Temperaturschwankung 104, Winde 134, 141, 572, Regen 165, Gletscher 222 , Eiszeit 243, angebliche Klimaänderung 252, Erdbeben 430, Verwitterung 471 , Wüsten 576, 848, Bodentypen 603, 604, Schuttgebirge 608, 609, Hochflächen 625, Gebirge 676 , Felsbecken 748, Seen 758, 760, Getreidebau 853, Fauna 873, 891. Zentrale Erdbeben 419, 420, 428, 434.

Zentraleruptionen 388, 389, 390.

Zentralmassive der Alpen 662.

Zeppelin, Graf E., 299.

Zerealien s. Getreide.

Zerschnittenes Flachland 633, 643 .

Zerrungsbögen 670 .

Zeugenberge $618,634,639$.

Zibetkatze 890 .

Zickzackförmige Wasserscheide 521 .

Ziegen 893.

Ziemendorff, G. 276*, 443, 463*.

Ziemer, H. 169*.

Ziesel 904.

Zillertal 554 .

Zingst 795 . 
Zirknitzer See 537.

Zirknitzkees 185.

Zirkumpolares Faunenreich 892.

Zirkumterraner Ozean 33.

Zirkus 562.

Zittel, K. v., 493, 887*, 907.

Zitterungen 413.

Zonale Faltengebirge 664, 701.

Zöppritz, K. 12, 17*, 278, 321, 323, $324,325,338^{*}, 741$.

Zschokke, F. 900, 905*.

Zsigmondy, E. $644^{*}$.

Zuckerapfel 855 .

Zuckerkiefer 839.

Zuckerrohr 855.

Zugstraßen der Zyklonen 121.

Zuidersee 592 .

Zungenbecken 557 .

Zürcher, P. 671, 677*.
Zürich, Temperaturveränderlichkeit 111, Temperatur 144, Seen 762, Wald 901.

Züricher See 756, 757, 761, Tiefentemperatur 345 .

Zusammengeschweißte Rumpfschollengebirge 699 .

Zusammengesetzte Faltengebirge 662, 701.

Zweiflügler 865 .

Zwergpalmen $819,889$.

Zwiebelgewächse $812,846$.

Zwiebelstruktur der Vulkane 390 .

Zwillingsbeben 421.

Zwillingsgletscher 193.

Zyklonale Niederschläge 151 .

Zyklonen 118, indische 122.

Zyklus s. geographische Zyklen.

Zypressen 824.

\section{RBLLOTEMA POLITEGHIIZZMA




\section{Berichtigungen.}

S. 122 , Z. 13 v. u., statt Taifune lies Teifune.

S. 252 , Z. 5 v. u., statt HaHN lies HanN.

S. 260. Die größte Tiefe des Roten Meeres beträgt $2359 \mathrm{~m}$.

S. 296 , Z. 2 v. o., statt beträgt lies besteht.

S. 371 , Z. 4 v. u., statt L. Regelmann lies C. Regelmann.

S. 431 , Z. 15 v. o., statt 1899,1900 u. 1901 lies $1899-1907$.

S. 441 , Z. 21 v. o., statt "und das Land fest bleibe" lies ,und das Land bleibe fest"

S. 503, Z. 15 v. u., statt Merk lies Merz.

S. 563, Z. 2 v. u., statt Garword lies Garwood.

S. 599, Z. 2 v. u., statt W. v. ZAHN lies G. W. v. ZAHN.

S. 655 , Z. 5 v. o., statt ${ }^{23}$ lies ${ }^{24}$.

S. 671 , Z. 8 v. u., statt Altlas lies Atlas.

S. 722 , Z. 2 v. o., statt Förstel lies Förstle.

S. 724, In der Unterschrift zu Fig. 247 lies statt Lugeon ${ }^{13}$ Lugeon $^{15}$. 


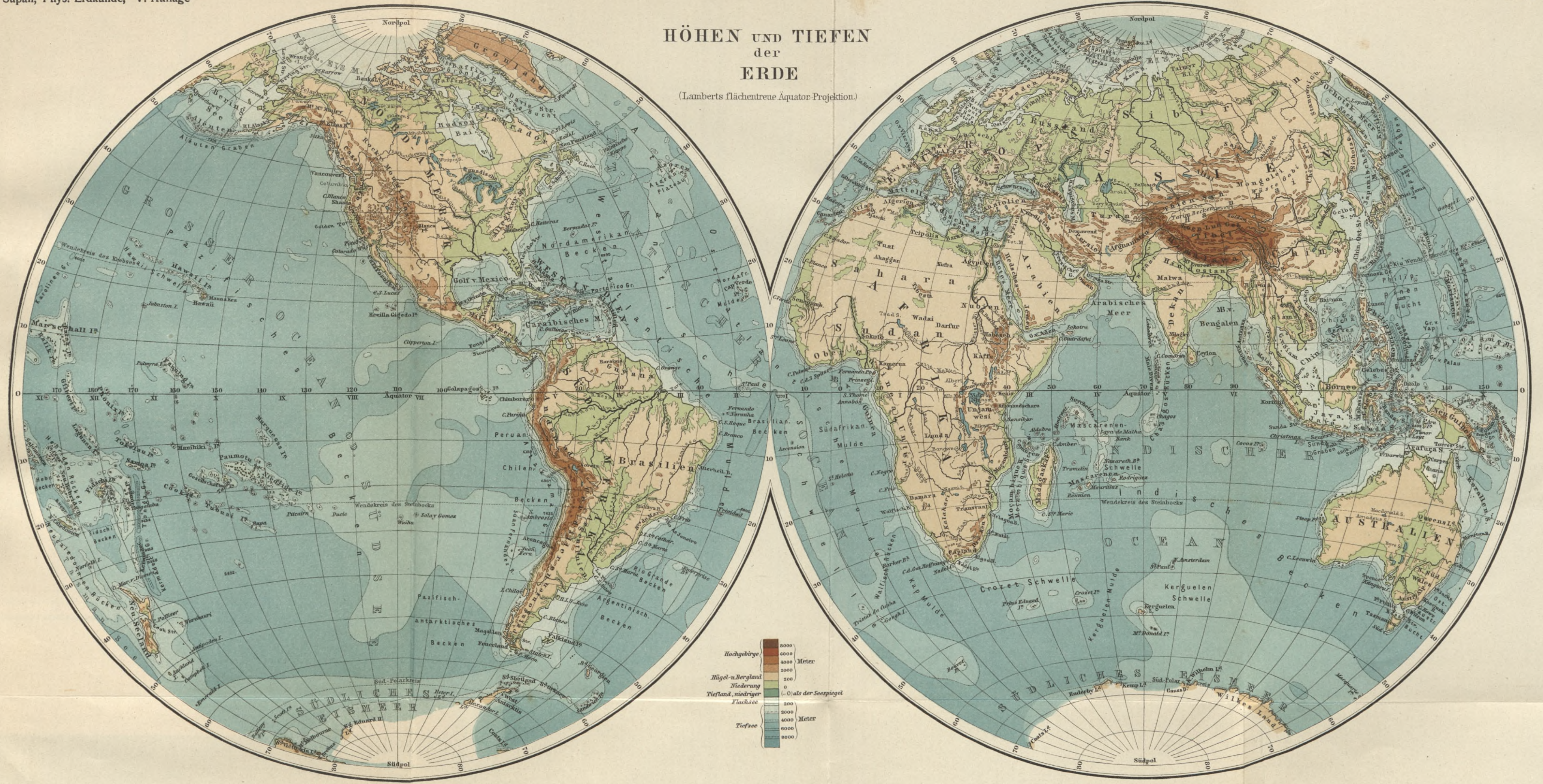




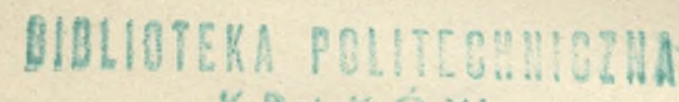

$6860.0 \%$ 


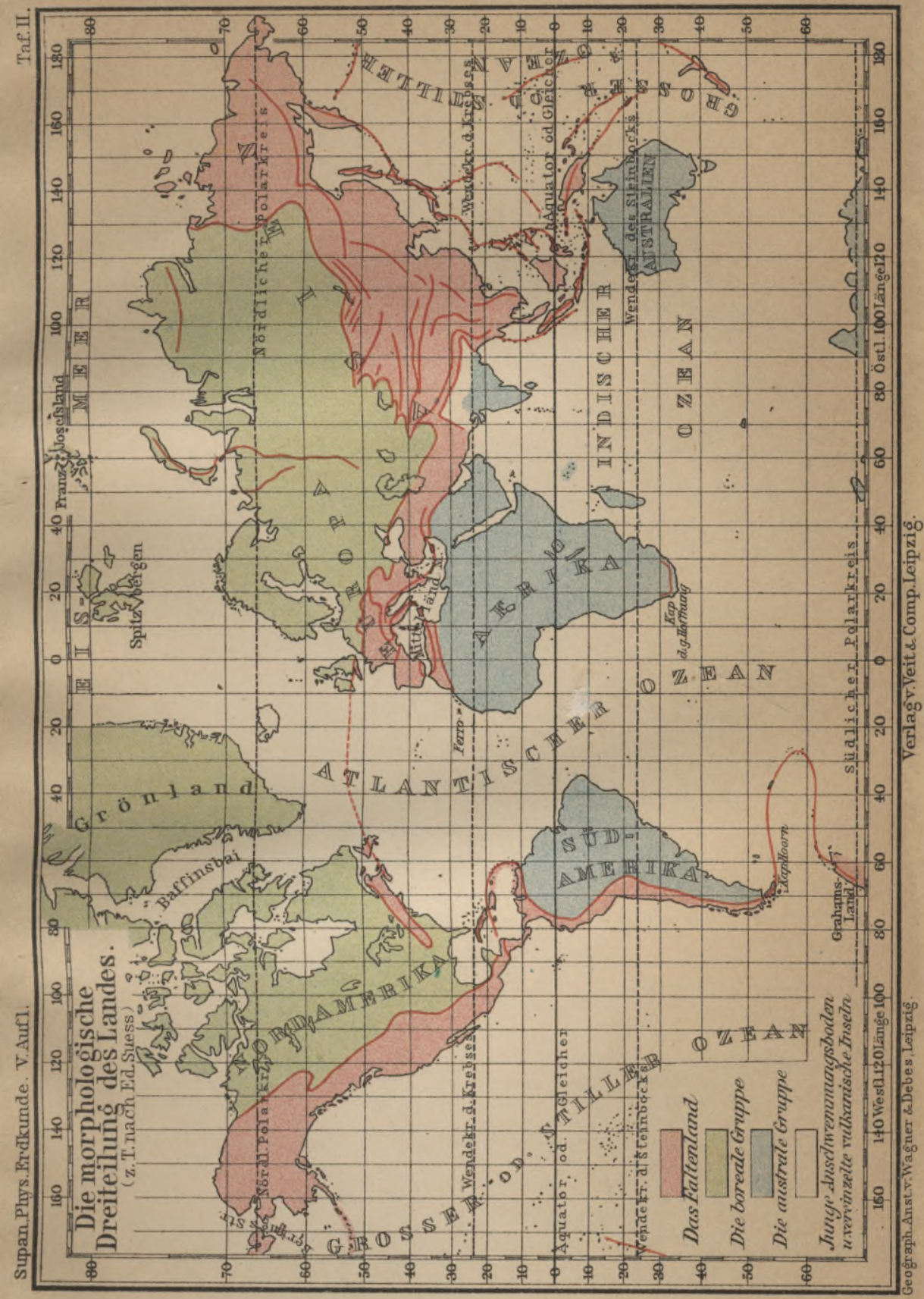


tain?

$\frac{5}{3 x}$

tive 


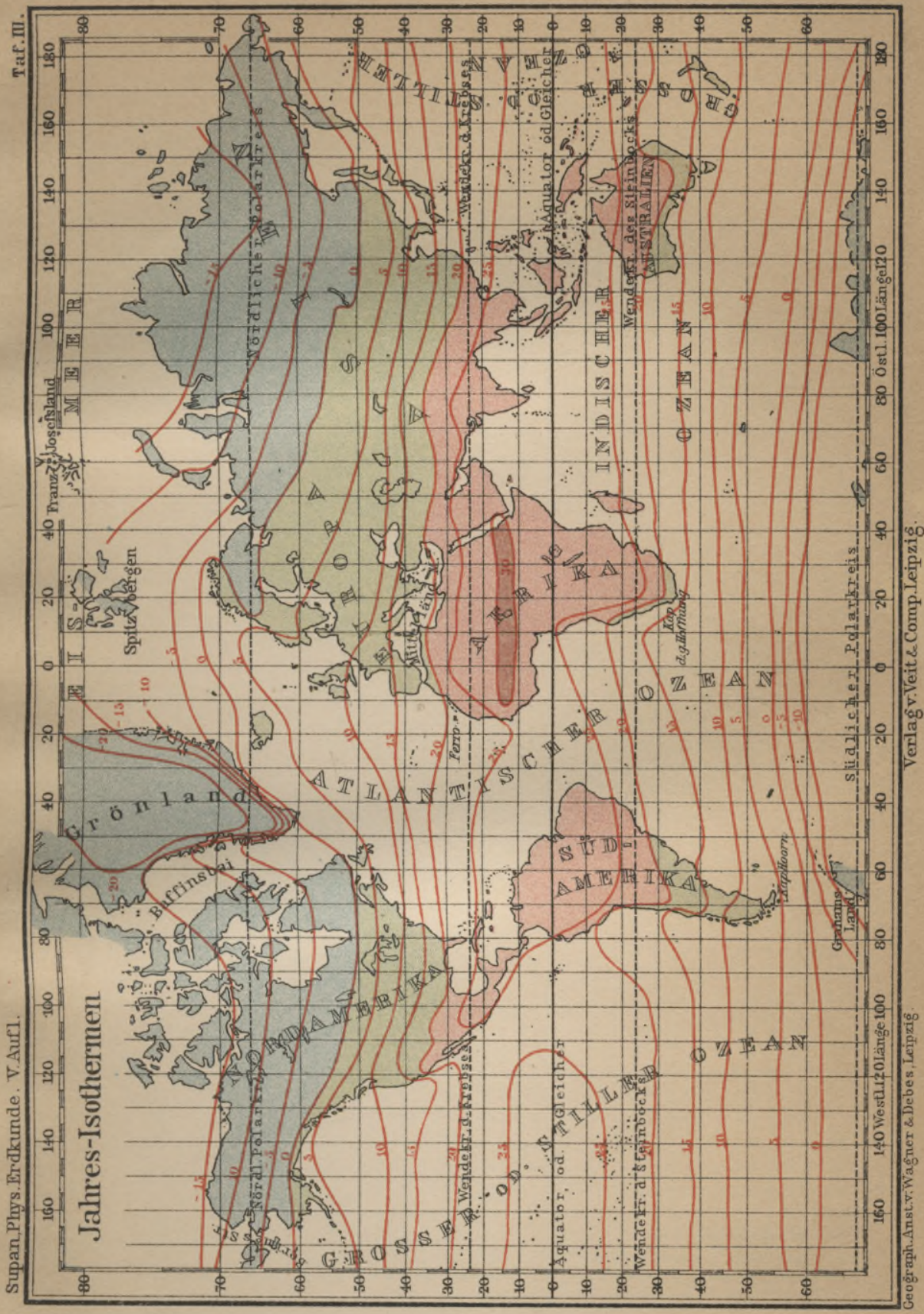





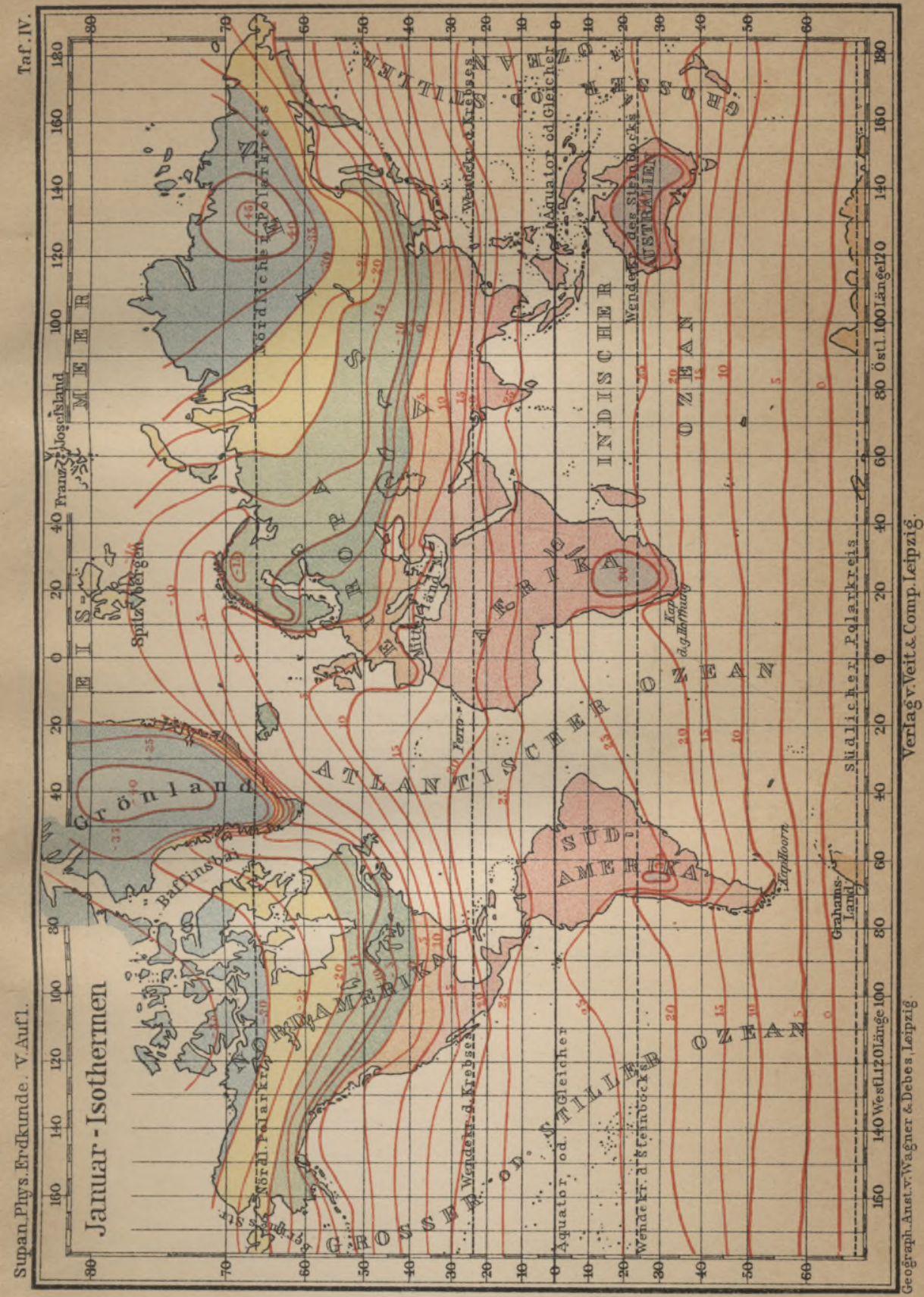


RBLIOTEMA POLITEQHMIGZMA KDAKOW 


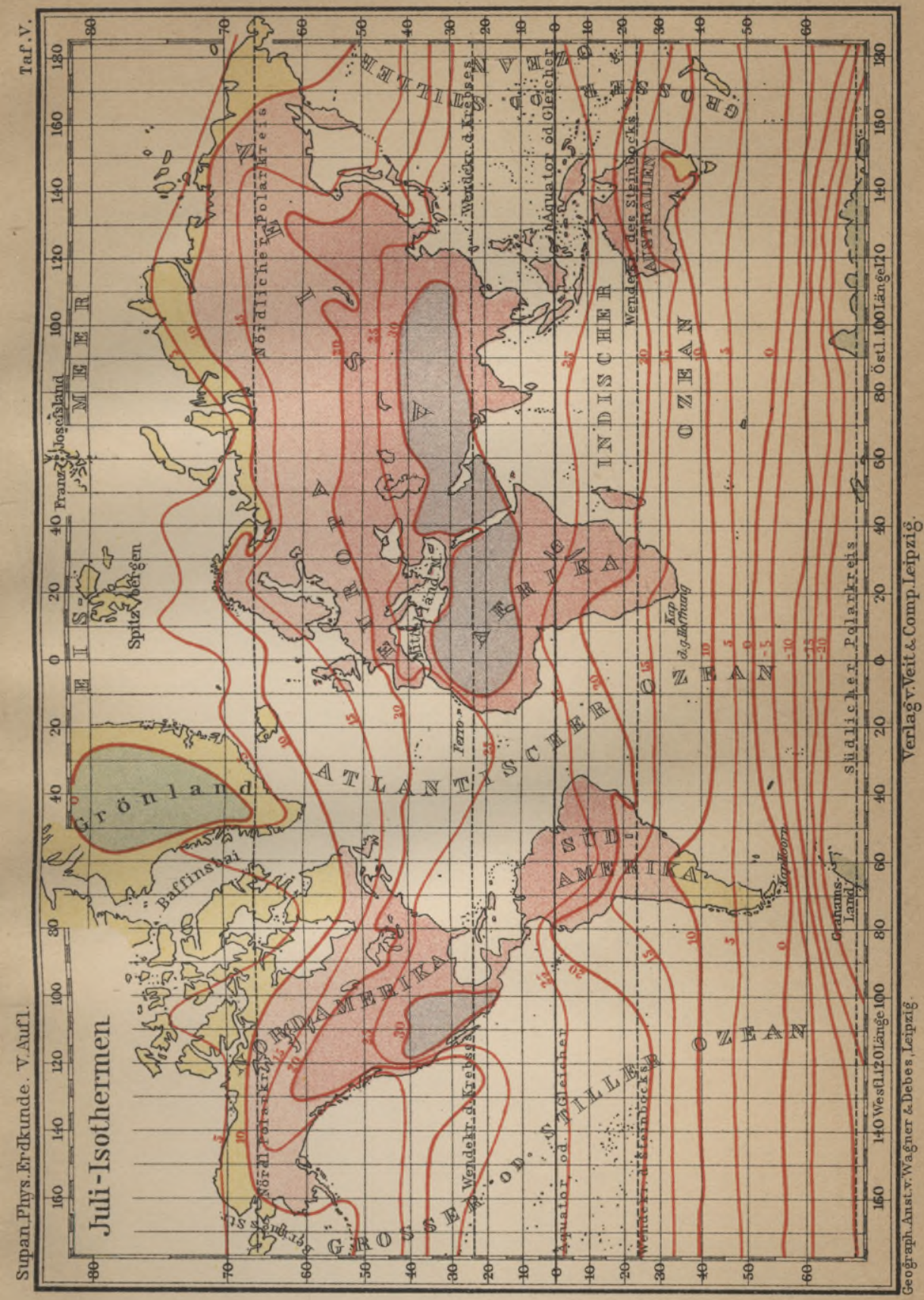


9.

KRAKO W 


\section{$\checkmark$}

Q.BLI, KesakO W 


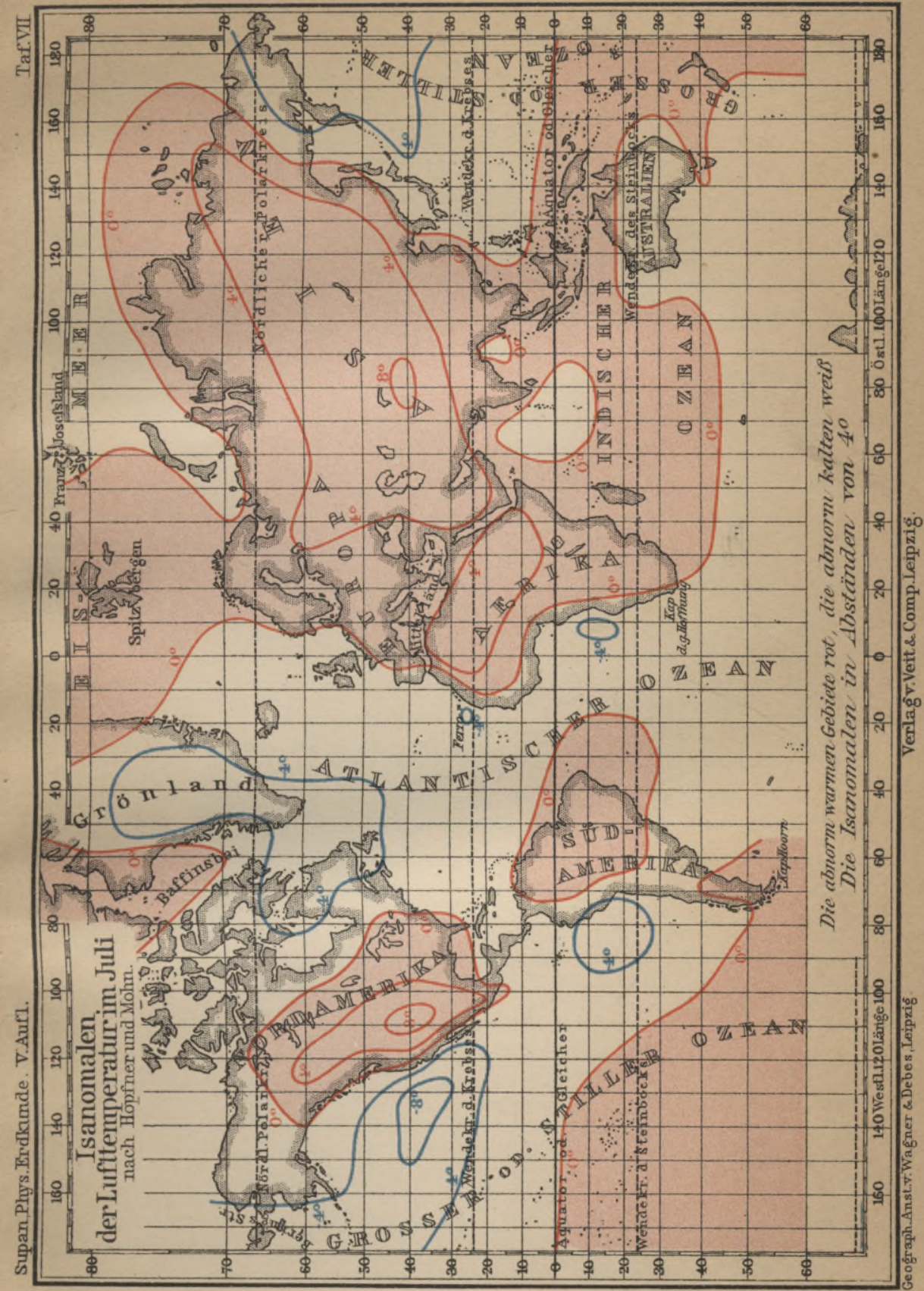


BiBLIBTEKA POLITECHWICZMA KRAKÓW 


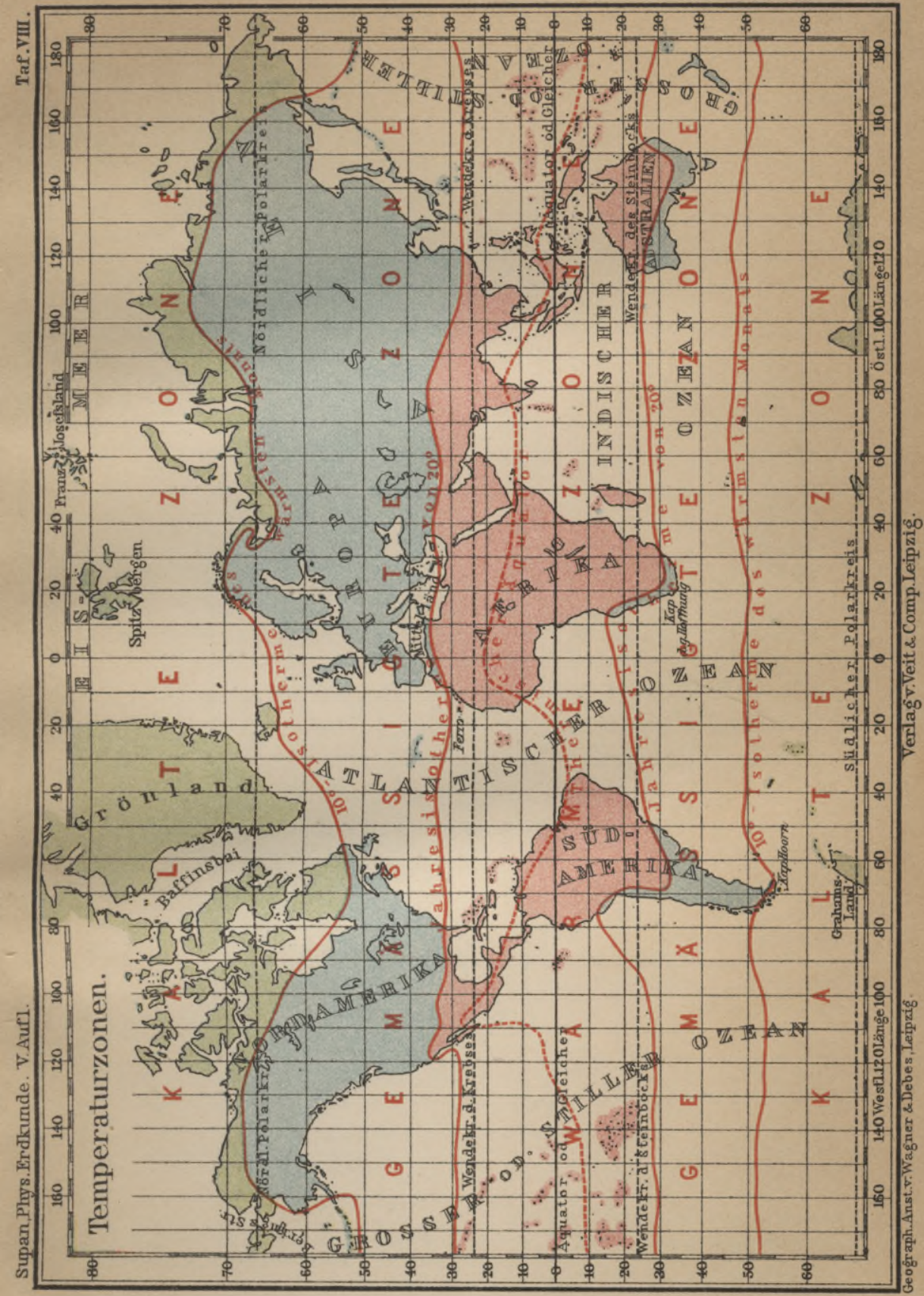


BIBLIOTEIIA POLITEGHWIZZMA KR A A KO W W 


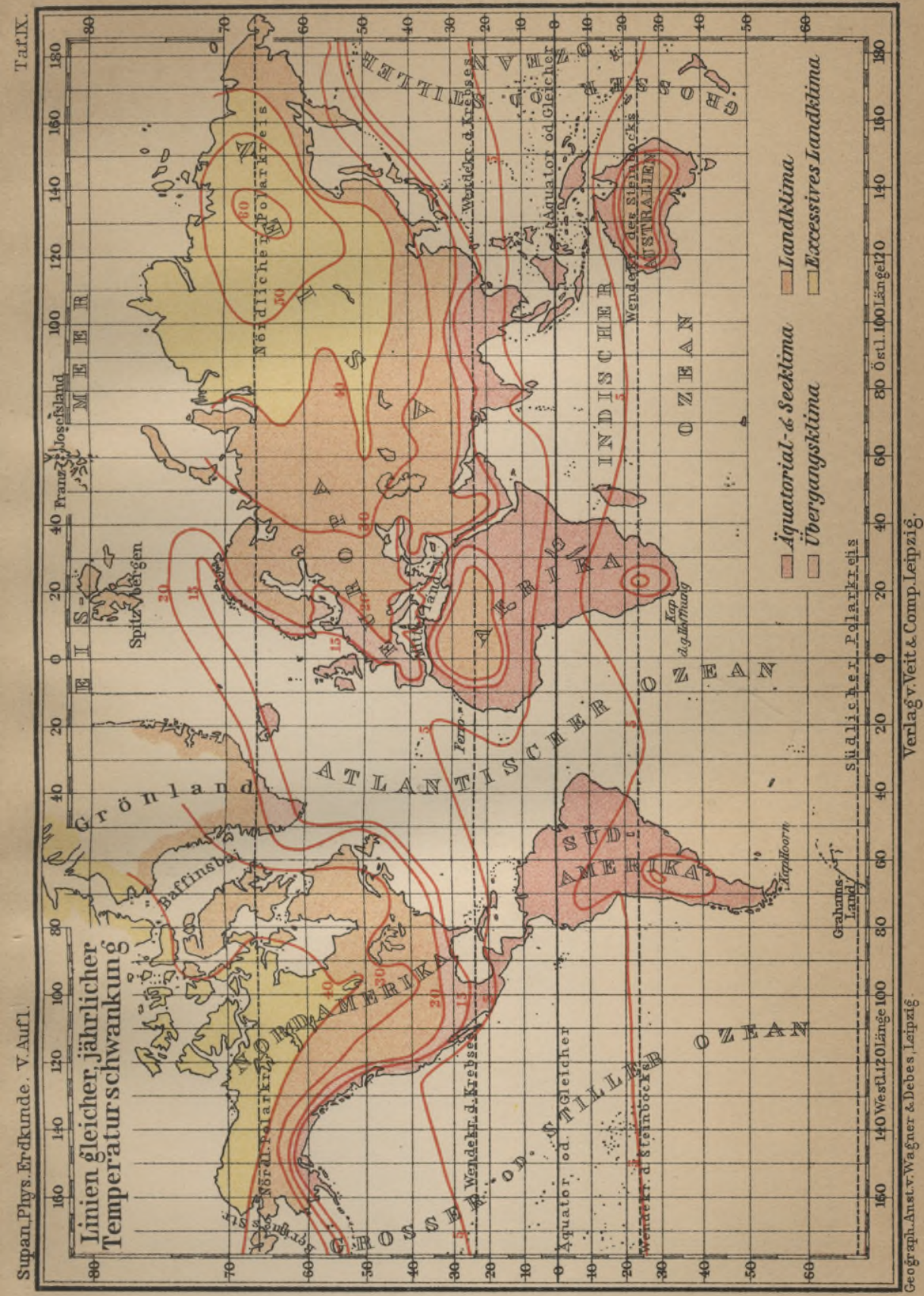




\section{BIBLIOTEKA POLITEGHMLZMA KRAKÓ W}




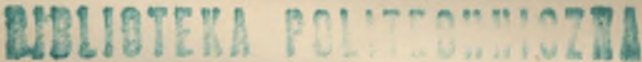 ababo W}




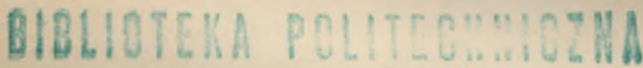 KRA Kó W}




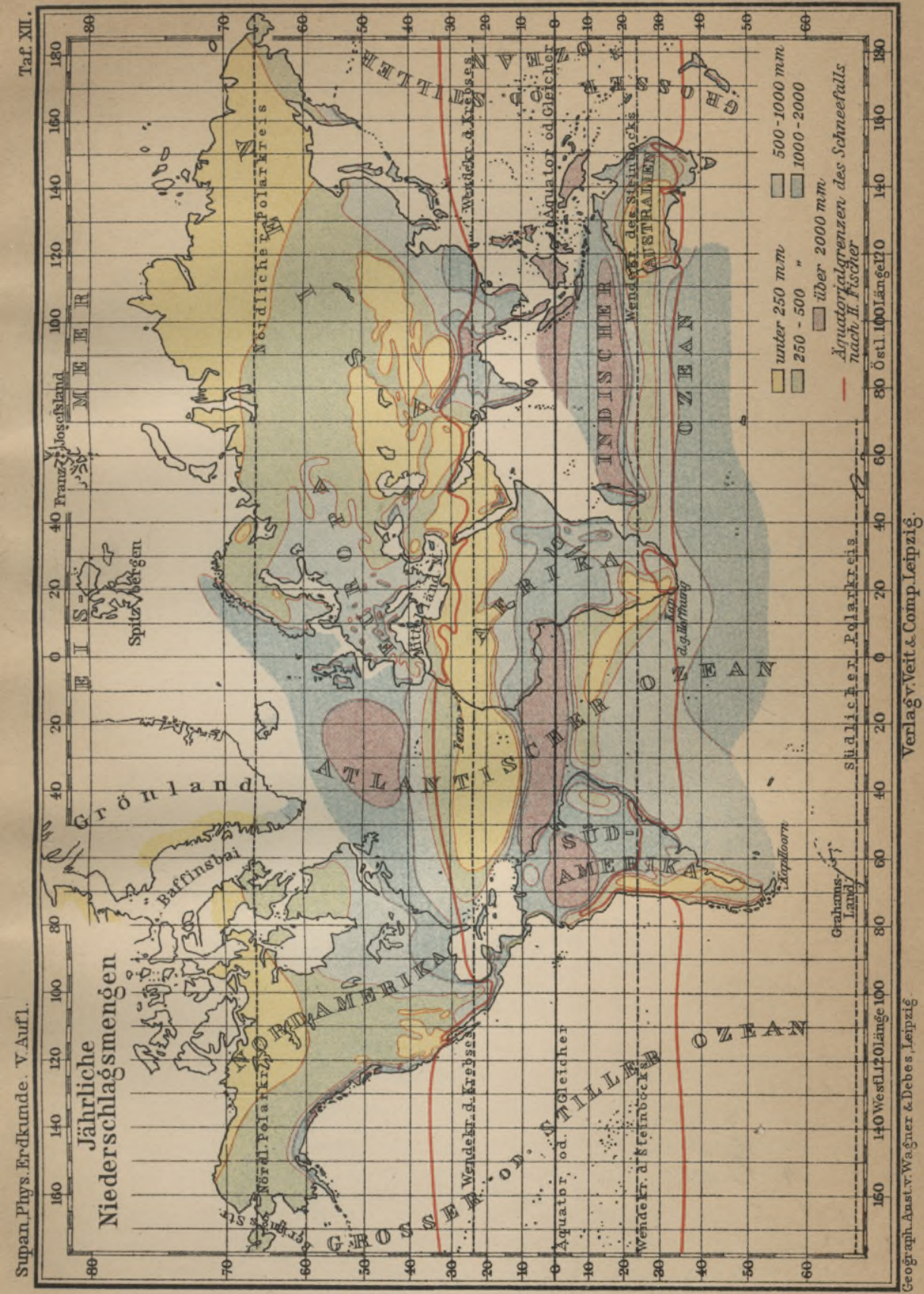


BIBLIOrELA PCUTECHUIGZMA KRAKÓ W 


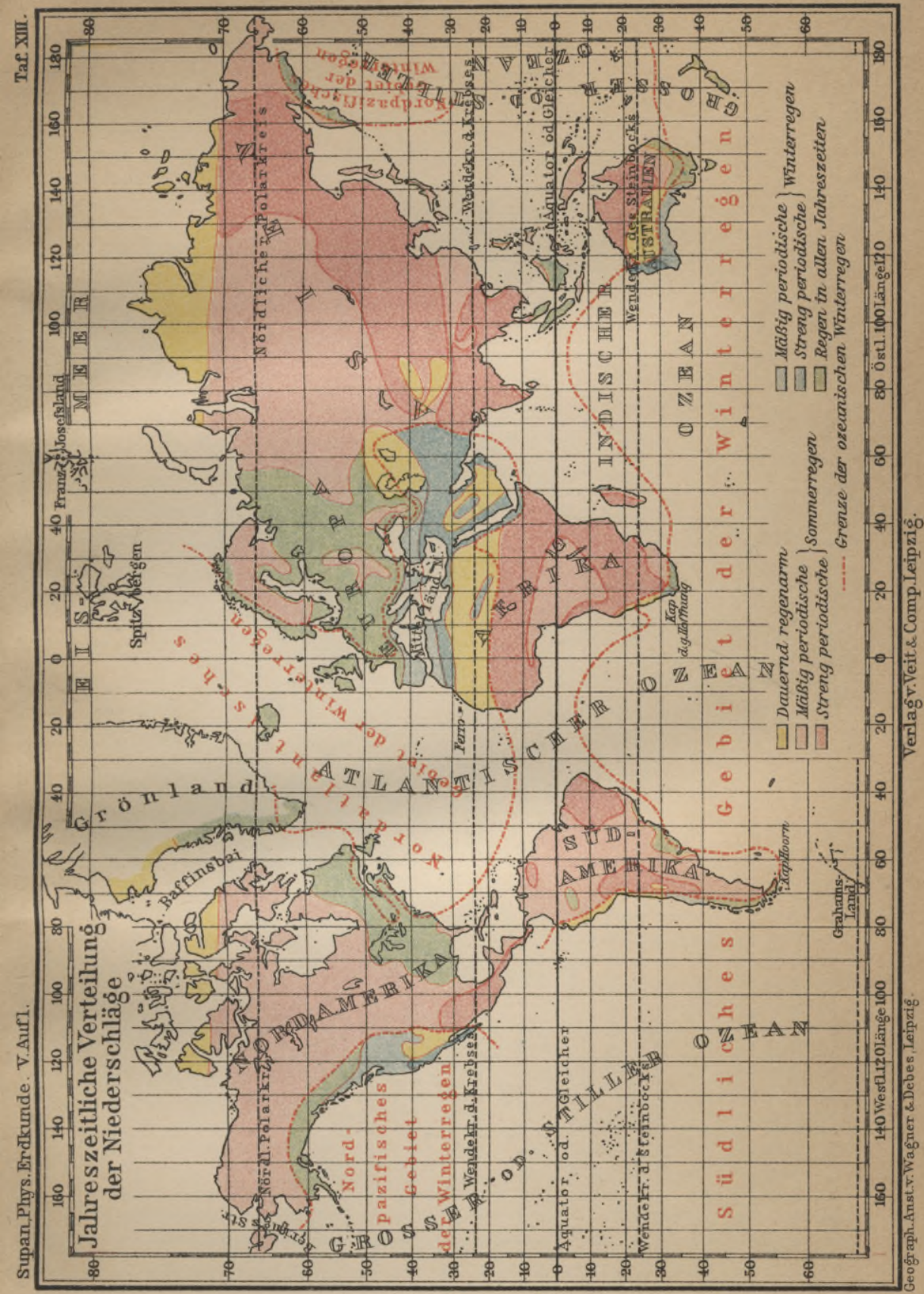




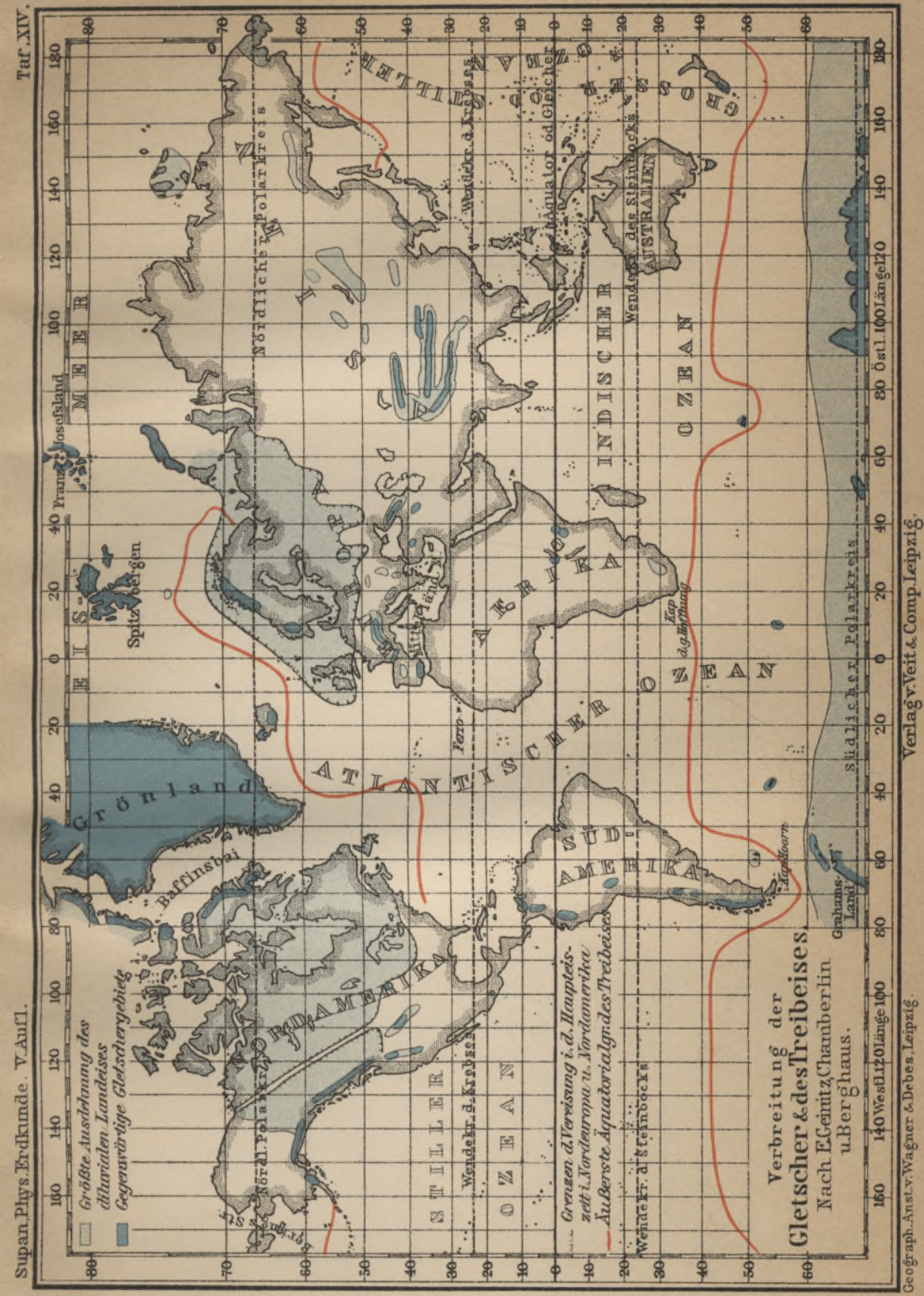




\section{BIBUIOTEMA POLITCEHWIOZZM Krakó W}




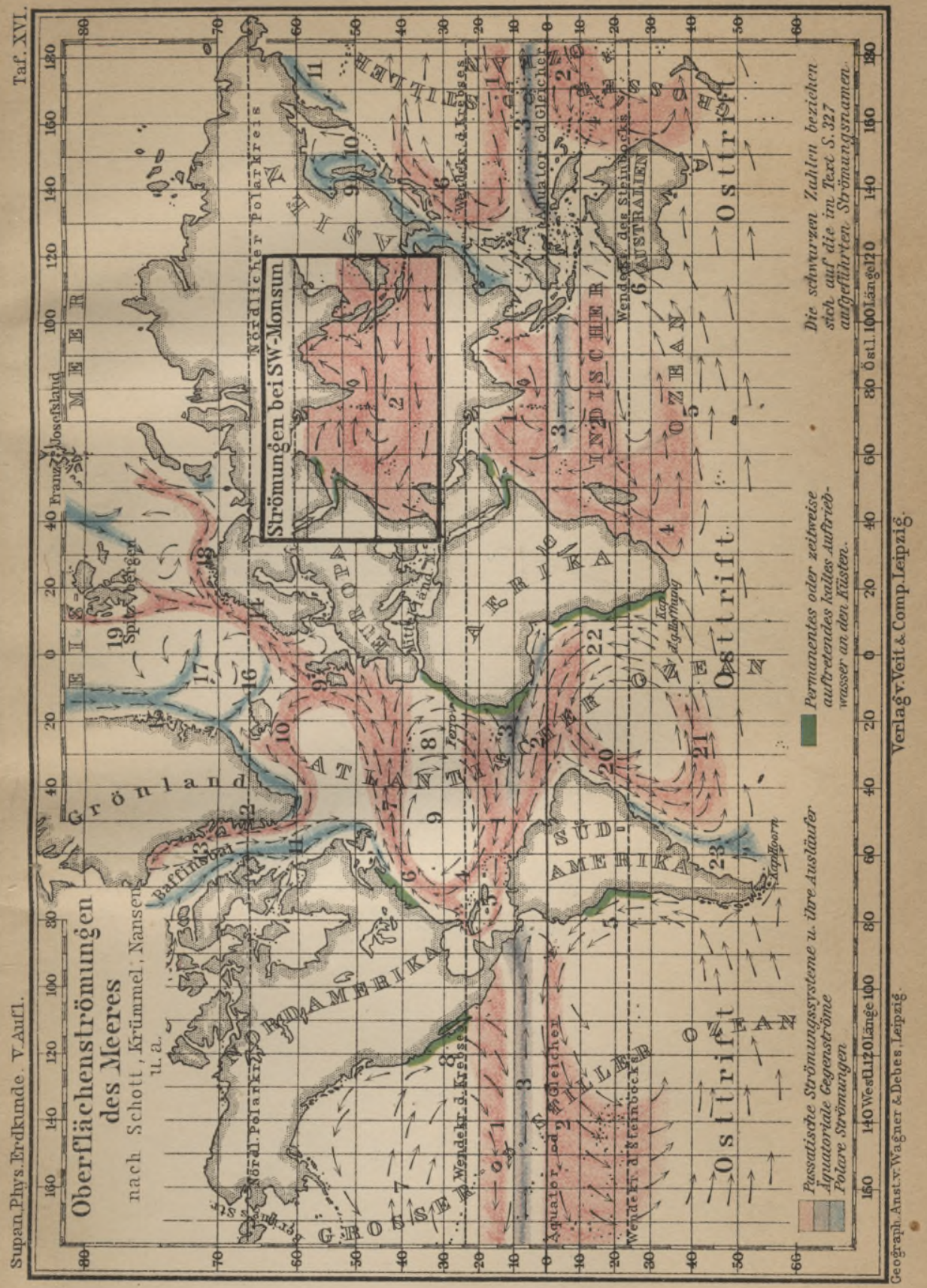




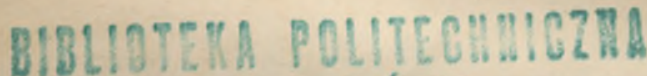
KaAKÓW 


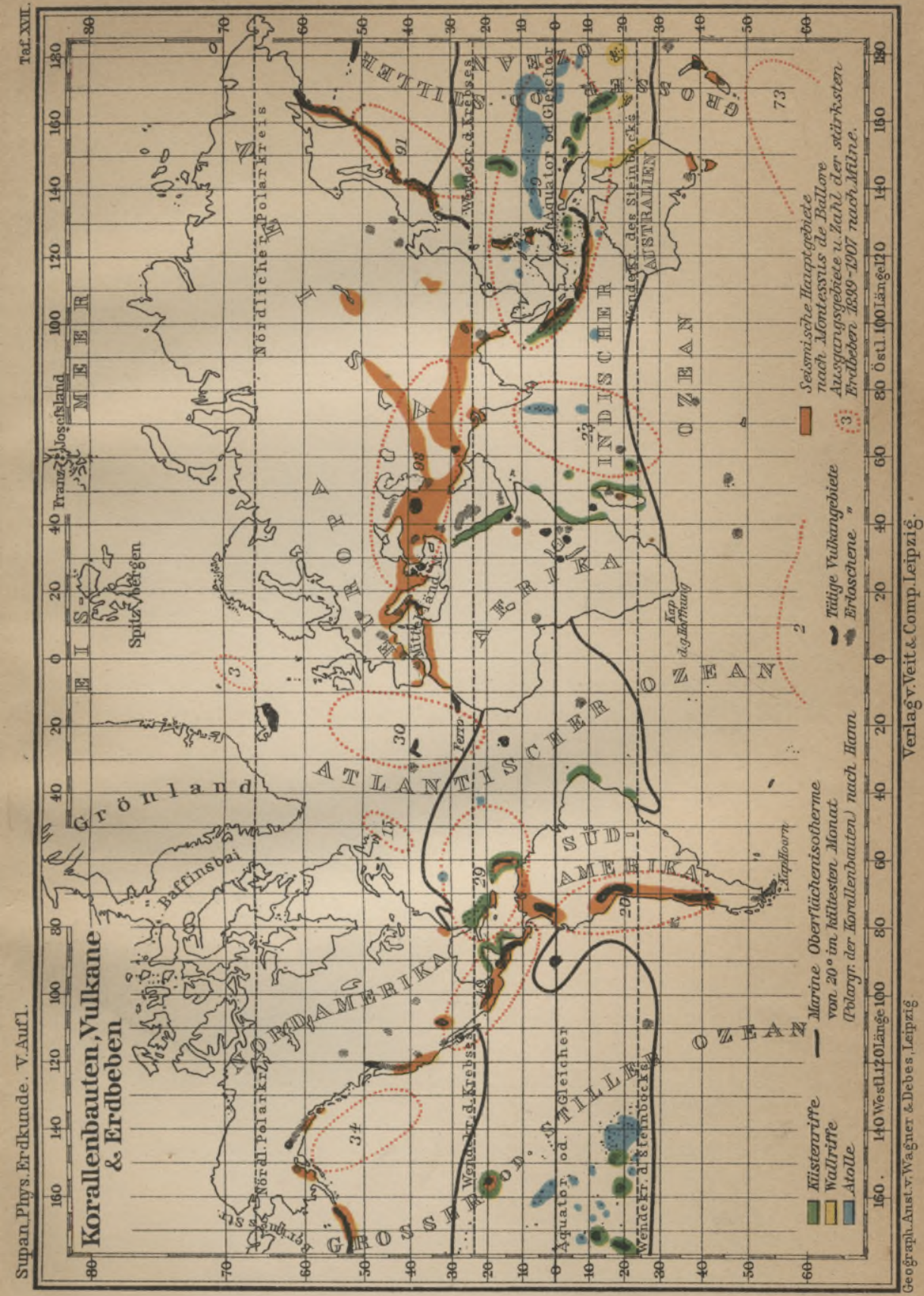





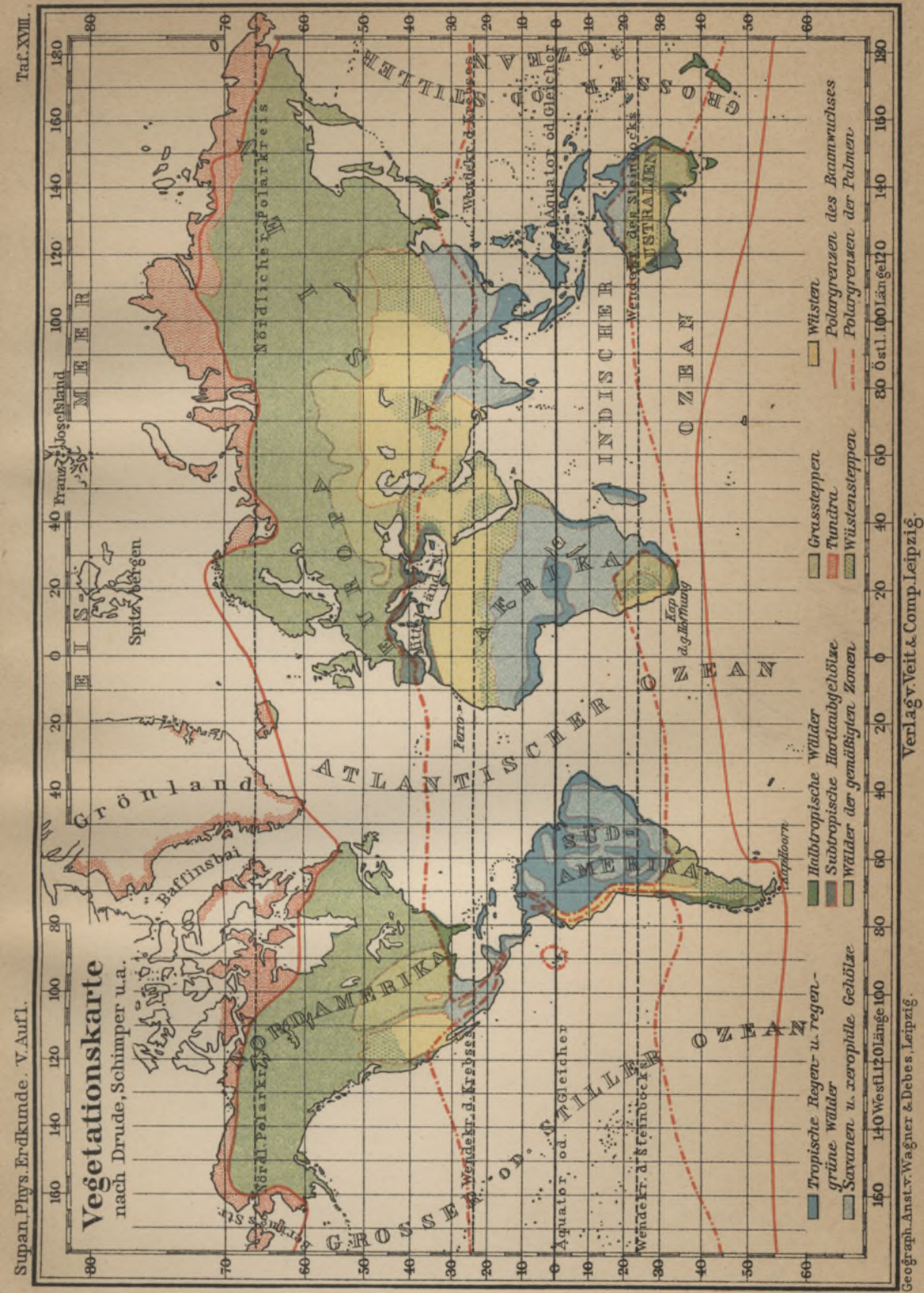




\section{BIBLIOTEMA POLITEGHAIOZM KRakÓW}




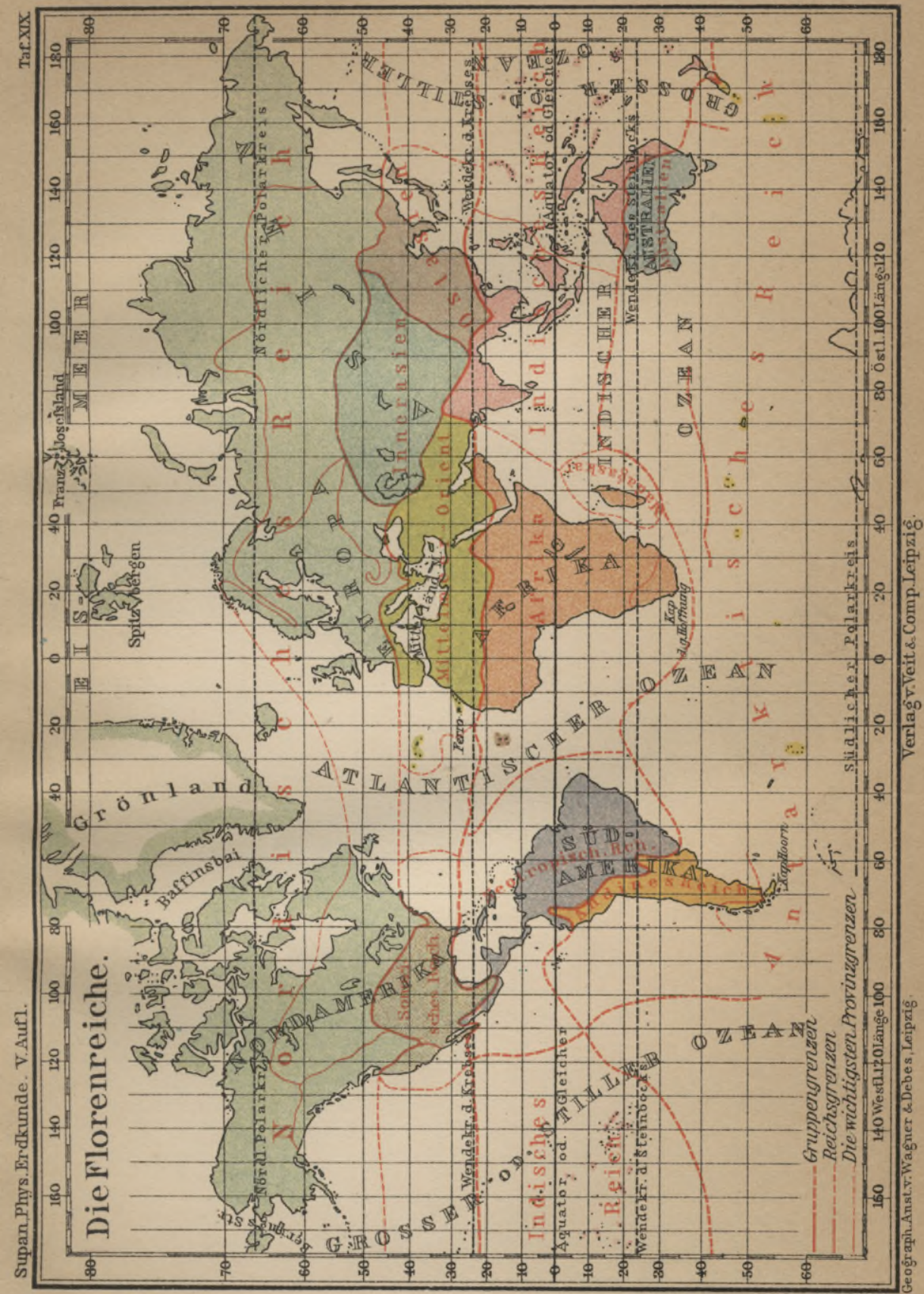




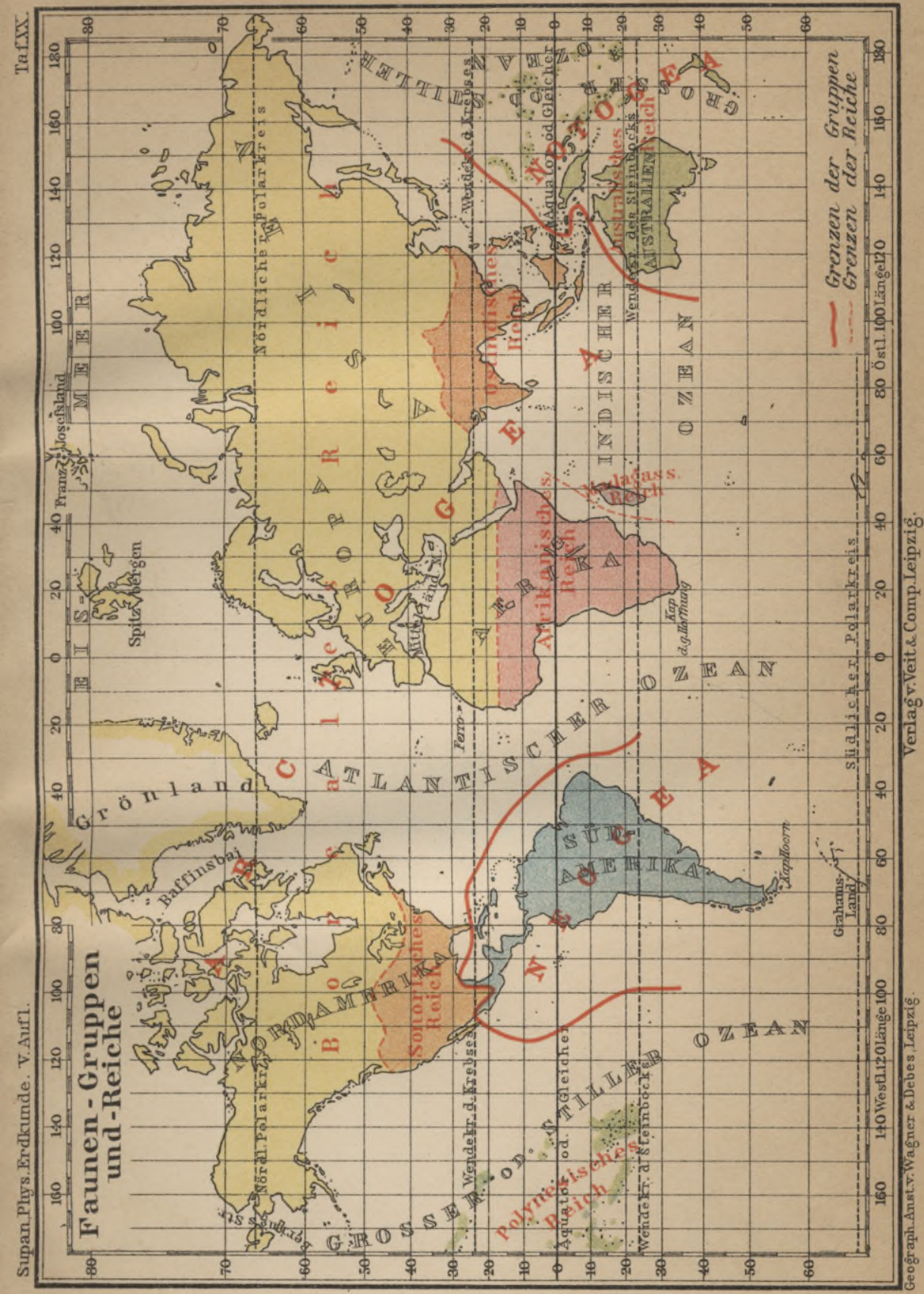




\section{BIBLIOTEKA POLITECHNICZMA} KRAKÓ W

$$
5-96
$$




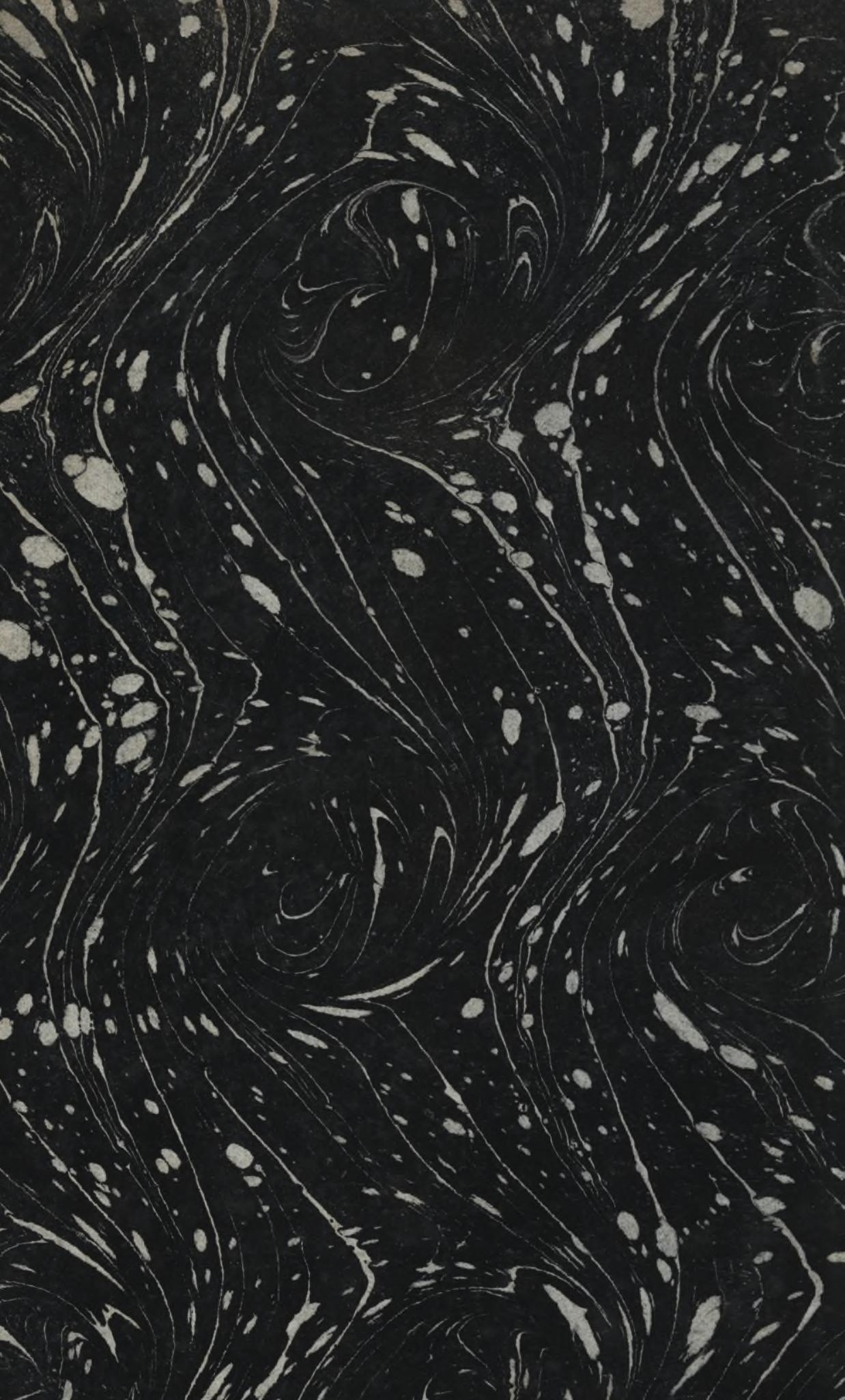




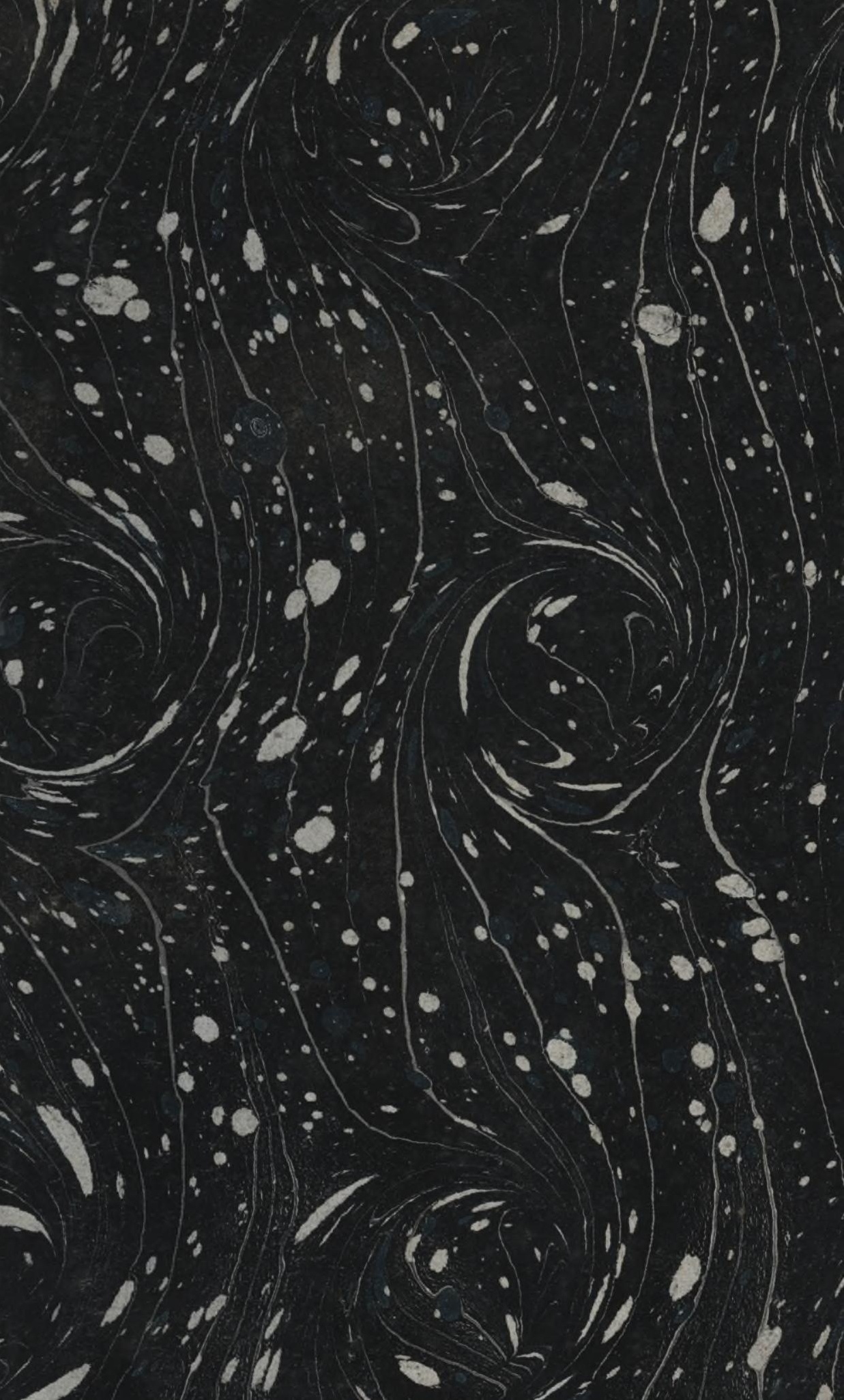




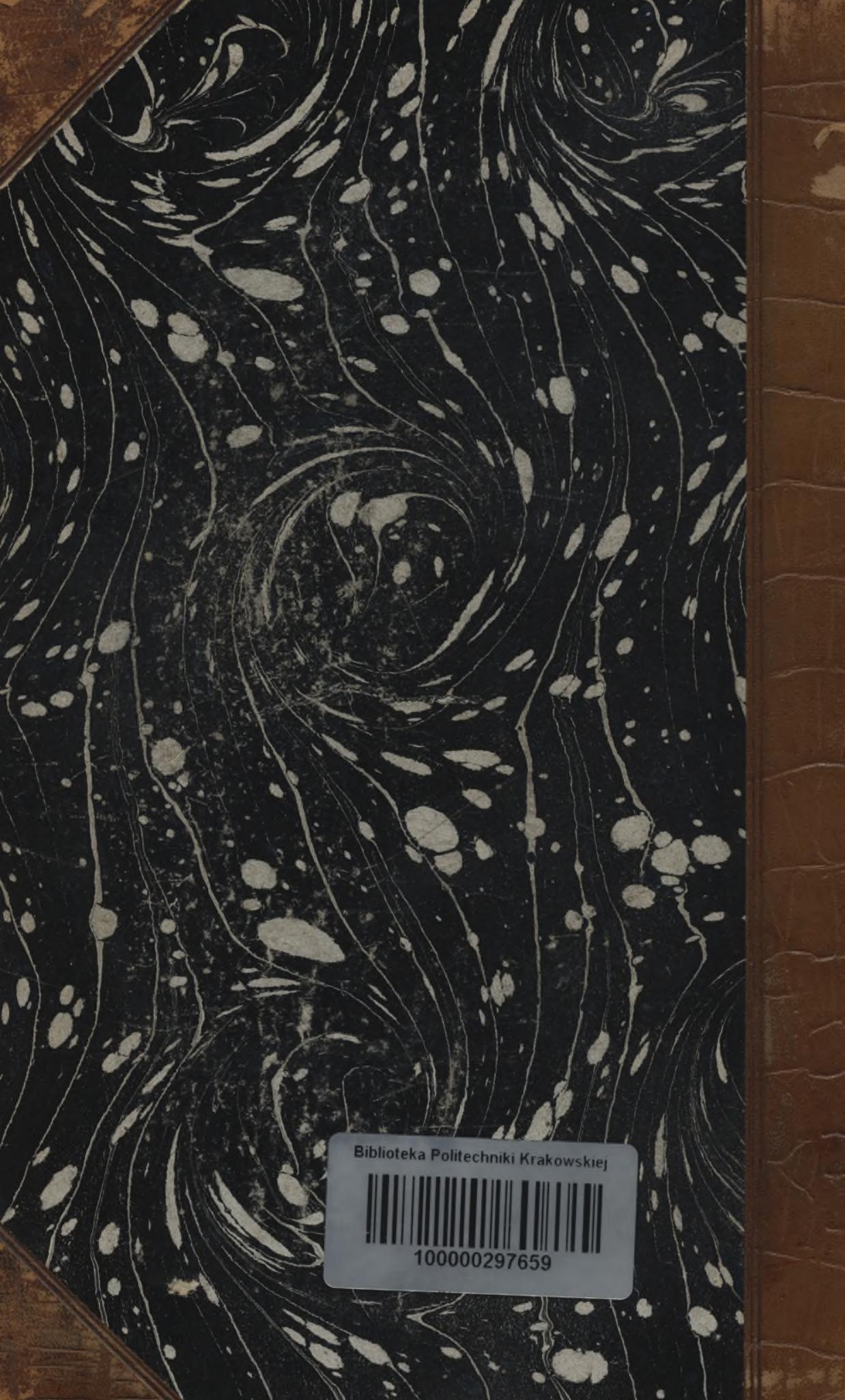

